


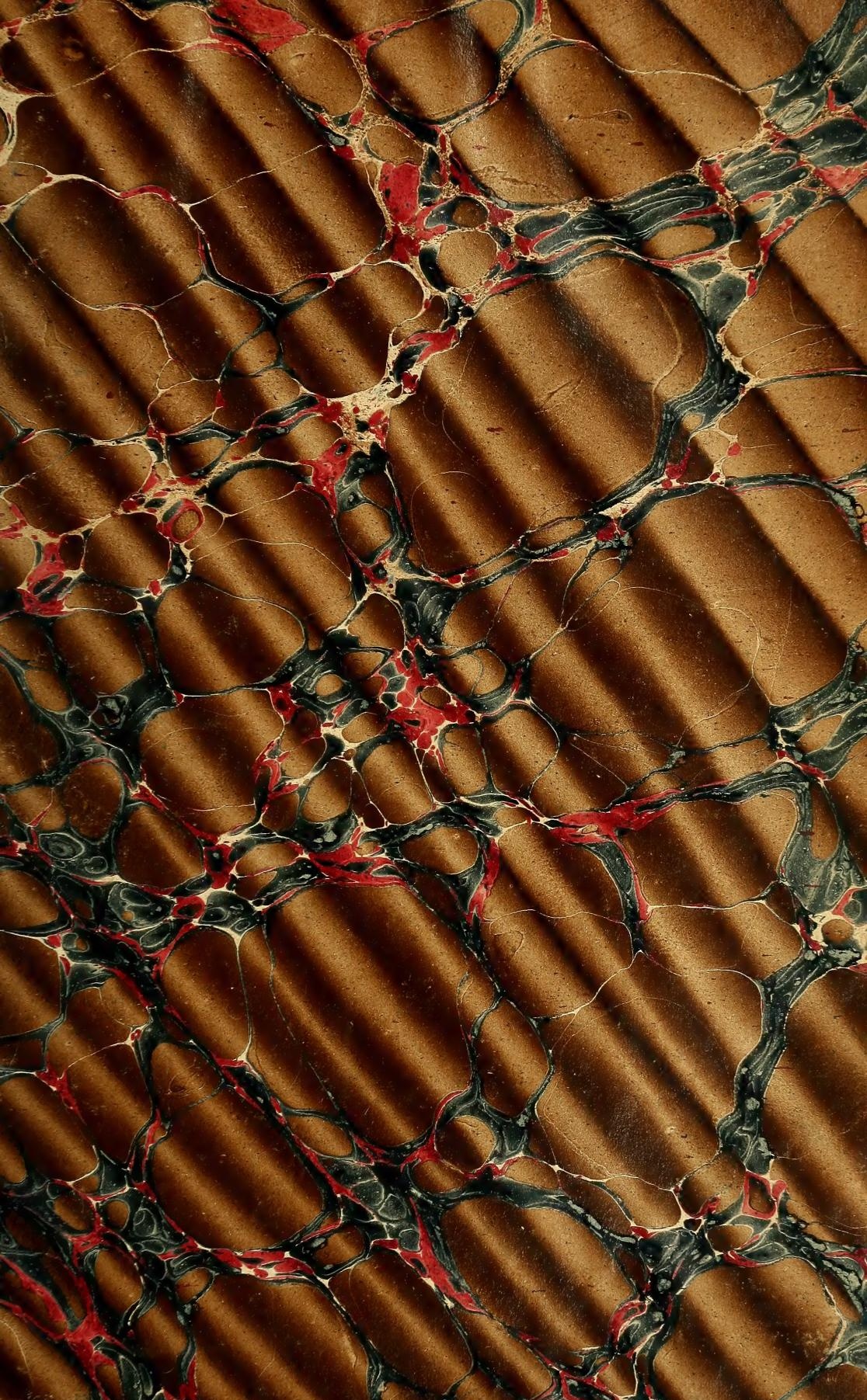










\title{
TECHNISCHES LEXIKON
}

für

\section{Gewerbe und Industrie.}

\author{
Friedrich Kick, \\ Dr. Wilhelm Gintl, \\ k. k. Reg.-Rath u. ord. Prof. der mech. Technologie, \\ ordentl. Professor der Chemie,
}

Herausgegeben von

am k. k. deutschen polytechnischen Institute in Prag unter Mitwirkung von:

Alter C., Brennerei-Ingenieur ;

Archleb J.. Fabriksdirector;

Balling C., Professor ;

Bellani Fr., Gussmeister;

Benade C., Fabriksleiter;

Benedikt F., Ingenieur;

Böck Rupert, Professor;

Brandeis F., Fabrikant;

Brauer E., Docent;

Brick Joh., Professor ;

Bussler, Director ;

Czuber, Professor;

Donath E., Adjunct;

Dwořaček, Director ;

Ernst C. Ritter v., Director;

Gebauer Otto, Ober-Inspector;

Gollner H., Professor ;

Grenzner C., Branerei-Ingenieur;

Grohmann H., Professor ;

Harlacher A. R., Professor;

Hartig Dr. Ernst, Reg.-R., Professor;

Haswell Robert L., Ingenieur ;

Hauer Jul. Ritter v., Professor;

Hausding A., Ober-Ingenienr;

Hausner J., Major ;

Herrmann Gust., Professor;

Hlasiwetz Dr. H.. Hofratli, Professor; ;

Hinkefuss, Ingenieur ;
Hojer E., Professor;

Ihl A., Professor ;

Janowsky J., Professor ;

Kässner B., Ingenieur ;

Kielmeyer Dr. E., Colorist:

Knaust, Fubrikant;

Koch J., Architekt ;

Kohlfürst L., Ingenieur;

Kohn Mor., Ingenieur:

Küpper Karl, Professor;

Kulmer Rudolf Freiherr v., Professor;

Lambl Dr., Professor;

Laube Dr. Gust., Professor ;

Lieblein Joh., Professor;

Lippich Ferd., Professor;

Lorey T., Professor;

Ludwik Cam., Ingenieur;

Marchetti, Inspector;

Markl A., Director;

Mikolaschek, Professor;

Niess B., Director;

Oldenburger, Ingenieur u. Lehrer ;

Ott v., Director;

Perels Dr. E., Professor

Pfuhl E., Ingenieur u. Lehrer ;

Polak F., Assistent:

Preis C., Professor:

Radinger Joh., Professor;
Richter J., Professor;

Ringhoffer Em., Professor;

Rittershaus Trajan, Professor;

Rochleder Dr. Fr., Reg.-R., Professor;

Royer John, Schiffobaumeister ;

Rziha F., Professor ;

Sablik, Professor;

Schmidt Gust., Reg.-R., Professor ;

Schneider R., Glashütten - Ingenieur ;

Schorlemmer C., Professor;

Schwarz Rob., Dr, der Chemie;

Schwarz-Flemming, Civ.-Ing. u. Doc.;

Seckendorf Frh. v., Reg.-R., Professor; Serlo Dr. Alb., Berghauptmann;

Skraup Dr. Zd., Assistent;

Specht C., Fabriksdirektor;

Stiubchen-Kirchner Franz, Assistent;

Trauzl Isid., k. k. Genie-Houptmann;

Vogl Dr. Aug., Professor;

Vorbach Emil, Hüttenchemiker;

Waltenhofen Dr. A von, Professor;

Weis Karl, Chemiker;

Wellner Georg, Professor;

Wersin Karl v., kais, Rath, Professor;

Willigk Dr. E., Professor ;

Winiwarter G. R. v., Fabrikant ;

Wunder Dr. G., Gewerbsehuldirector;

Zeller Jos., Ingeniem;

a $1 \mathrm{~s}$

\section{Auflage von Karmarsch und Heeren's}

techn ischem Wörterbuch.

III. Band.

Eisenerzeugung. - Giesserei.

\section{Prag 1878.}

Verlag der Bohemia.

Actien-Gesellschaft für Papier- und Druck-Industrie. 


\section{Karmarsch und Heeren's}

\section{TECHNISCHES WÖRTERBUCH.}

\section{Dritte A uflage}

ergänzt und bearbeitet von

Friedrich Kick,

k. k. Reg.-Rath u. ord. Prof. der mech. Technologie,
Dr. Wilhelm Gintl, ordentl. Professor der Chemie,

am k. k. deutschen polytechnischen Institute in Prag.

Mit über 2000 in den Text gedruckten Abbildungen.

III. Band.

Eisenerzeugung. - Giesserei.
249078

Prag 1878.

Verlag der Bohemia.

Actien-Gesellschaft für Papier- und Druck-Industrie. 


\section{Druck der Bohemia}

Actien-Gesellschaft für Papier- und Druck-Industrie.

Prag. 
Eisen-Erzeugung oder Eisen-Hüttenkunde. Von der E i s e n e r ze ng ung im Allgemeinen. Die zur Erzengung von Eisen verwendeten Eisenerze sind durchwegs Oxyde des Eisens, und handelt es sich bei der Eisenerzengung um eine Reduction der Erze, um ein reducirendes Schmelzen, bei welchem Holzkohle oder Koks (Coaks), selten andere Brennmaterialien als Reductionsmittel dienen.

Je höher die Temperatur des Processes ist, um so mehr nimmt das reducirte Erz Kohlenstoff auf, und wälrend wenig gekohltes Eisen teigig bleibt, wird mehr gekohltes flüssig. Die Erze sind aber äusserst selten reine Eisenoxyde, sondern enthalten sehr versehiedene Beimengungen, als Kalk, Magnesia, Thonerde, Kieselsäure, Schwefeleisen, phosphorsaure Thonerde, Schwefelkupfer, Manganoxyde ete. ete. Diese Beimengungen verhalten sich ausserordentlich versehieden; einige verwandeln sich beim Schmelzprocesse in eine flüssige, glasige Masse, Schlacke (scorie slag); andere (z. B. Schwefel, Arsen, Zink) verdampfen ganz oder theilweise; wieder andere mengen sich zum Theil dem erzeugten Eisen bei (so Mangan, Phosphor, Schwefel, Silicium) und wirken verändernd auf die Beschaffenheit desselben ein. Auch diese Beimengungen ändern ihr Verhalten mit der beim Processe herrschenden Temperatur.

Der Hiittenmann trachtet diese Beimengungen (das Mangan ausgenommen) möglichst zu beseitigen und wendet Zusätze, Zu schläge (fondant - fux) an, welche deren möglichst vollständige Ueberfïlırung in die Schlacke bewirken sollen, und welche der Schlacke auch den geeigneten Grad der Dünnfliissigkeit zu geben bestimmt sind. In friiherer Zeit verstand man nur wenig gekohltes Eisen (Schmiedeisen und Stahl) herzustellen, denn die Eisengewinnung wurde in kleinen Herden oder Oefen bei verhältnissmässig niedriger Temperatur durchgeführt. Dies Verfahren nennt man Rennarbeit, auch unmittelbare Eisenerzeugung, weil das Product unmittelbar Schmiedeisen oder Stahl war. Ein geringes Ausbringen ans Ien Erzen, eine kleine Productionsmenge und verhältnissmässig hoher Kohlenaufwand dieser Methode haben die spätere der mittelbaren Eisenerzengung zur fast allein gebräuchlichen gemacht. Bei dieser Methode reducirt, kohlt und schmilzt man das Eisenerz in grossen Oefen (Hochöfen) bei höherer Temperatur. Das so erhaltene Eisen, welches einen weit höheren Kohlenstoffgehalt besitzt, wird $\mathrm{fl}$ ii s s i $\mathrm{g}$ ans dem Ofen abgelassen, es heisst $\mathrm{Roheisen} \mathrm{(fer} \mathrm{fondu} \mathrm{-} \mathrm{pig} \mathrm{iron).} \mathrm{Der}$ Betrieb kann nun ein continuirlicher sein, die Productionsmengen sind gross, desgleichen das Ausbringen, der Aufwand an Brennmaterial verhältnissmässig klein.

Gewisse Roheisensorten gestatten eine Verwendung zum Gusse und werden Giesserei-Roheisen, Gusseisen genannt, wälrend andere Roheisensorten sich rorzugsweise zur Herstellung von Schmiedeisen eignen mo Frisch-oder P ud l e l- Ro h e i s en heissen.

Jie IIerstellung des Schmiedeisens aus dem Roheisen ist vorzigglich ein Entkrhllungsprocess, aber bei der durch Oxydation bewirkten Entkohlung - 
Frischprocess - werden auch manche im Roheisen enthaltene Beimengungen, namentlich Silicium und Schwefel entfernt. Diese Reinigung erfolgt im Allgemeinen um so vollkommener, je weiter die Entkohlung vorschreitet; daher wird das durch Frischen gewomnene Schmiedeisen im Allgemeinen reiner als Stahl sein. Dies ist der Grund, warum man sich zur Herstellung reinen Stahles gerne des Schmiedcisens bedient, und zwar durch Kohlung desselben Stahl erzeugt, welchen man auch - aber nicht so rein - erhalten hätte, wenn der Frischprocess früher unterbrochen worden wäre.

Die Processe der Eisenerzeugung sind daher mannigfaltig, und sollen durch die nachstehende Zusammenstellung iibersichtlicher gemacht werden sie zerfallen in:

I. Erzeugung von Eisen direct ans den Erzen.
II. Frze $\|\mathrm{g}\| 11 \mathrm{~g}$ selimiedbaren Eisens a 11 s Rolle is en.
III. Erzeng $11 n g$ ron $\mathrm{Stal} l \mathrm{l}$ a u $\mathrm{S}$ Sehmiedeisen.
A) Rolle isen-Erzeugung. Reducirendes Selımelzen der Eisenerze bei sehr hoher Temperatur in grossen Schachtöfen (H o ch ö fen).

$$
\text { Product: Roheisen }\left\{\begin{array}{l}
\text { Gusseisen, } \\
\text { Puddel Roheisen. }
\end{array}\right.
$$

b) Rennarbeit. Reducirendes Schmelzen der Eisenerze bei niedrigerer. Temperatur in kleinen Oefen, Herden ete.

Product: Schmiedeisen oder Stahl.

A) Frischarbeit. Die Oxydation des im Roheisen enthaltenen Krohlenstofies (und gewisser Vermureinigungen) erfolgt durch den Sauerstoff der Luft

mit zuhirc. ( a) in IJerden. Il er d fris chen, Frisclı en,

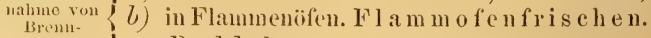
muateriale $\quad$ Puddeln.

Product: Schwe is se isen od. Schweissstall.

(Diesen Operationen geht läufig das F e in en (les Roheisens voraus.)

c) Durch Einpressen ron Luft in geschmolzenes Roheisen: Bessemern.

Product: Flusse isen und Flusstahl.

B) Dureh Gliihen ron Roheisen in oxydirenden Pulvern.

(i) A douciren, 'Tempern oder Herstellung von schmiedbarem Eisenguss.

b) Gliilistahl-Bereitung.

C) Durch Zusammenschmelzen von Roheisen mit Eisenerz oder Eisenoxyden (Breant- 11. Uchatzius-Stahl).

A) Kohlung des Schmiedeeisens durch Glihen mit Kohle in verschlossenen Gefässen:

a) Cementstahlbereituing.

b) Linsetzen (Cementiren eines fertigen Gegenstandes- ans Schmiedeisen. an der Oberfläche).

$B$ ) Kolılung des Schmiedeisens durch Zusammenschmelzen mit gutem Roheisen.

Martin-Stahl-Bereitung (in Siemens Regenerativ-Ocfen). (Hierher gehört anch der Spiegeleisenzusatz am Ende des Bessemer-Processes.) 
IV. R a f fin ir $n \mathrm{ng}$ des Sehmiedeisens und Stahles.

A) Durch Schweissen und Strecken oder Gerben des Schweisseisens und Schweissstahles:

a) Raffinirtes Eisen,

b) Gerbstahl.

B) Durch Umschmelzen des Stahles Guss stahl (Flussstahl).

I. A) Die Roheisenerzeugung, der Hochofenprocess. Die wenigsten Erze sind von solcher Beschaffenheit, dass sie unmittelbar zur Verschmelzung in den Hochofen gelangen; sie werden vielmehr gewöhnlich einigen rorbereitenden Operationen unterworfen, welche einerscits den Zweck haben, die Erze in Stuicke von tauglicher Grösse zu verwandeln, mechanische A ufbereitung, $\left.{ }^{*}\right)$ andererseits aber eine Auflockerung und Reinigung der Erze bewirken, und sie so zur Gewinnung eines guten Roheisens tauglicher machen. In dieser Richtung sind als wichtige Vorbereitungs-Operationen das Rösten, Verwittern und A uslaugen zu bezeichnen.

Beim Rösten (méthode de grillage - roasting process) findet eine Erhitzung, ein Glïhen der Erze statt. Hierdurch werden sie gelockert, das hygroskopische Wasser verdampft, das Hydratwasser des Spath-, 'Thon- und Kohleneisensteines, so wie jenes enthaltener Beimengungen (Gyps) wird ausgetrieben und auch die Kohlensäure der beigemengten kohlensauren Erden (des Kalks etc.) entfernt. Besonders wichtig ist, dass die, vielen Erzen beigemengten Kiese (Eisenkies, Kupferkies) durch das Gliihen einen grossen Theil ihres Schwefels verlieren, welcher als schweflige Säure entweicht, während die zuriickbleibende niedrige Schweflungsstufe durch das dem Rösten folgende Verwittern und Auslaugen grösstentheils entfernt wiru. Bei dem Rösten geht Brauneisenstein in Eisenoxyd, Spatheisenstein in Eisenoxyduloxyd iber. Es kommen uibrigens auch theilweise Reductionen und in anderen Fällen Oxydationen vor, je nachdem die Gase in den Röstöfen Kohlenoxyd oder Sauerstoff im Ueberschuss aufweisen.

Durch das Rösten also entweichen Kohlensäure und Wasser nebst dem grössten Theil des Schwefels (letzterer als schweflige Säure) und das Cyanoxydul (bei Sideriten, Chamoisiten, Magneteisensteinen) verwandelt sich in Eisenoxyd. Durch diesen Gewichtsverlust (Röstverlust, Röstabgang) werden die Erze specifisch leichter, also auch poröser; eine Eigenschaft, welche für den Hochofenprocess von liöchster Wichtigkeit ist.

Bei Thonerde-, Magnesia- oder kalkreichen Erzen ist die Entfernung des Schwefels, wie sie durch das Rösten derselben erreicht werden kann, nicht vollständig genug. Es nehmen die genannten Basen die entweichende schweflige Säure auf und bilden Sulfate, welche bei der Rösthitze nicht wieder zersetzt werden. In solchen Fällen miissen die Erze nach dem Rösten noch gelaugt werden.

Das Pösten findet in $\mathrm{Haufen}$, in Stadeln oder in $\mathrm{O}$ efen statt. Findet

*) Die mechanische Aufbereitung bezweckt eine Trennung der gehaltreichen von den unhaltigen (tauben) Erzpartien und eine Zerkleinerung zu grosser Stïcke, selten ein Zusammenbacken zu kleiner; sie erfolgt fast immer auf der Grube. Sollen die Eize geröstet werden; so lässt man sie faust- bis kopfgross; gelangen sie direct zum Verschmelzen, so zerkleinert man sie bis zur Nuss- oder Eigrösse.

Bei der gewöhnlichen $H$ ands cheidung findet die Zerkleinerung gleichzeitig mit der Trennung der unhaltigen Theile statt. Diese Scheidung erreicht den Zweck bei den meisten Erzen am besten, wenn sie auch thener ist; durch sie findet nicht so sehr ein Zerreiben in feine Theilchen statt wie bei der mechanischen Zerkleinerung durch Pochwerke, Walzen, Quetschen oder Steinbrecher. (Vergleiche die điesbezüglichen Artikel.) Gewisse Erze, z. B. die Bohnerze, haben jedoch unhaltige Partien in so feiner Vertheilung; dass die Handscheidung nicht ausreicht, und in diesem Falle muss zum Waschen gegriffen werden, welches am besten in rotirenden W a schtrommeln 'stattfindet. Nach Mengung des Erzes mit Wasser in Rührbottichen lässt man Ery und Wasser in die mit schraubenförmigen Rippen versehene Vorwasehtrommel gelangen, wo der Sehlamm sich rom Erz ablöst und in der Fertigwaschtrom mel durch einen entgegengefïhrten Strom klaren Wassers gesehieden wird. 


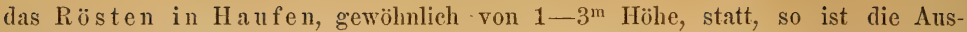
niitzung der Wärme des Brennmateriales eine schlechte, daher ist diese Röstmethode nur bei Kohleneisenstein, welcher in sich das Brennmateriale besitzt, angezeigt. Man hält die Haufen um so niedriger, je reicher dieses Erz an Kohle ist.

Die Röstung in Stadeln gewährt schon eine bessere Wärmeausnlitzung. Man versteht unter Stadel einen durch vier Mauern umschlossenen, viereckigen, gepflasterten Raum, häufig ohne Bedachung. In den bis $4^{\mathrm{m}}$ hohen Manern sind in regelmässiger Vertheilung Luftziige $\left(16^{\mathrm{cm}}\right.$ hoch und breit, $60^{\mathrm{cm}}$ von einander) angebracht, ofter auch solche in der Stadelsohle. Die eine Seitenwand hat zum bequemeren Einfahren des Erzes ein Thor, welches successive mit dem Anwachsen der Beschickung zugelegt wird. Die Beschickung besteht aus dem zu röstenden Erze und dem Brennmateriale, welche in horizontalen Schichten eingetragen werden. Man rechnet pr. Cubikmeter Erz $50 \mathrm{Kg}$. Kohle. Die Stadel bilden den Uebergang zu den Oefen, von welchen sie sich im.Principe nicht unterscheiden.

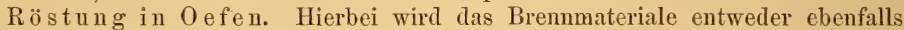
in Schichten zwischen das zu röstende Erz gegeben, oder es werden heisse brennbare Gase, z. B. die Gichtgase des IIochofens rorwendet, oder endlich die Flamme eines ausserhalb des Röstofens zum Zwecke des Röstens verbrannten Brennmateriales in den Ofen geleitet.

Indem die dritte Art der Heizung der Röstöfen (meist liegende Flammofen) eine minder gute Ausniitzung des Brennmateriales gestattet und mehr Arbeit beansprucht, sei hier nur auf die beiden ersten Röstofensysteme etwas näher eingegangen. Sie sind fast immer $\mathrm{Sch}$ achtöfen mit meist kreisförmigem Querschnitte. Gewöhnlich rermindert man unten die Teite des Schachtes, wenn das Brennmateriale in Schichten zur Anwendung kommt, weil die durch die Verbremnung des Bremmmateriales eintretende Volumsverminderung diese Form erwinschlich macht; es erweist sich abel die eylindrische Form auch fuir diesen Fall (bei Gasheizung ist sie fast ausschliesslich in Gelsrauch) (lamn als genïgend, wenn dem Ofen ein

Fig. 1212.

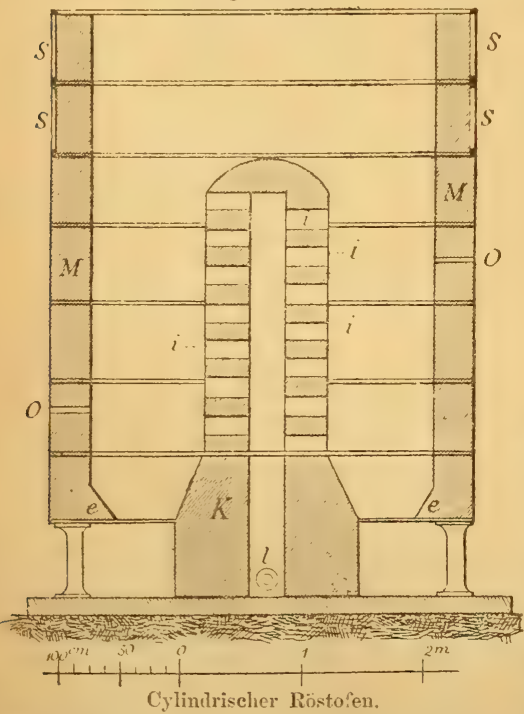
conischer Kern gegeben wird, weil damn dieser die Verengung bewirkt. Unsere Figur zeigt uns einen cylindrischen Röstofen; wie derselbe in Kladno*) in Anwendung steht. Im Betriebe wird täglich unten geröstetes Erz so lange abgezogen, bis man auf heisse Schichten stösst. Hierbei findet ein Niedersinken der Schichten statt. Oben wird nach erfolgtem Sinken eine Schichte Brennmaterial (Kohlenklein) und hierauf eine Schichte Erz aufgegeben. Fiir den erforderlichen Luftzutritt ist durch die Kanäle $i, i$ und $O, O$ gesorgt. Der durchbrochene Kernschacht $K$, welcher in abweichender Form auch bei dem oblongen Ofen (Fig. 1213) sich findet, gestattet eine vorziiglich gute Zuführung von. Luft und empfiehlt sich besonders bei kiesreichen Erzen.

Zur näheren Erlänterung unserer Figuren sei noch Folgendes gesagt.

Die gleichen Theile sind mit denselben Imchstalien bezeichnet. $I$ ider Mantel oder das Schachtmanerwerk, $K$ der Kern oder Kernschateht (Fig: 1212) oder $\mathrm{Ab}$ -

) Technische Blitter 1s70 S. 149 (Notizen aus der Adalbertshütte in Klatun ron J. Ze ma n). 
rutschliegel (Fig. 1:13), $i$ die Luftkanäle, $l$ die Hatuptluftzuführungsrohre. Dats Schachtmuturwerk ist aus feur. festen Steinen oder Zie: gelu, 0.32m stark, hergestellt; durch horizontale gusseiserne Platten und verticale Schienen $s$ armirt und ruht unten auf einer ringförmigen, vou einigen gusseisernen Fiissen getragenen Platte (beim oblongen Ofen auf einer Platte oblonger Form). Das Ausziehen des gerösteten Erzes ist daher rings um den Ofen ermöglicht.

Die Luftzuführumg erfolgt theilweise durch ausgesparte Oefinumgen $o$ im Schachtmaurrwerk, theils durch die Zitge $i$ im Kernschacht. Der unten erweiterte Durchmesser des Kernes $K$ Fig. 1212, so wie die conische Form von $K$ in Fig. 1213 und die Einziehung des Mauerwerkes des Schachtes bei $e$ verengt den Querschnitt des Ofens in seinen unteren Theilen zum Zwecke gleichförmigeren Niederganges. Der Oten Fig. 1212 fasst $42000 \mathrm{Kg}$. Erz und röstet täglich $8400 \mathrm{Kg}$.; der oblonge Röstofen fasst und röstet viermal so viel Erz, kostet aber nur die doppelten Anlagekosten.

Es sei hier bemerkt, dass Röstöfen ohne Keruschacht meist nach unten verjüngt hergestellt werden. Die Sohle des Ofens ist dann entweder eine feste oder aus einem Roste (Plan-oder Treppenroste) gebildete. Im ersteren Falle miissen geeignete Zuige angebracht sein und stets muss durch Ziehöffnungen oder Beweglichkeit des Rostes die Möglichkeit des bequemen Entfernens (Ziehens) des Erzes an der Ofensohle geboten sein.

Fiif. 1213 a. (1/128 n. (ir.)

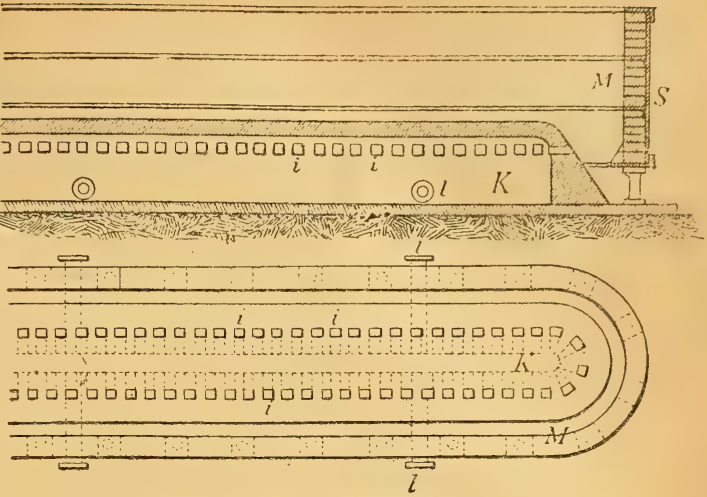

Oblonger Röstofen.

Fig. 1213 b.

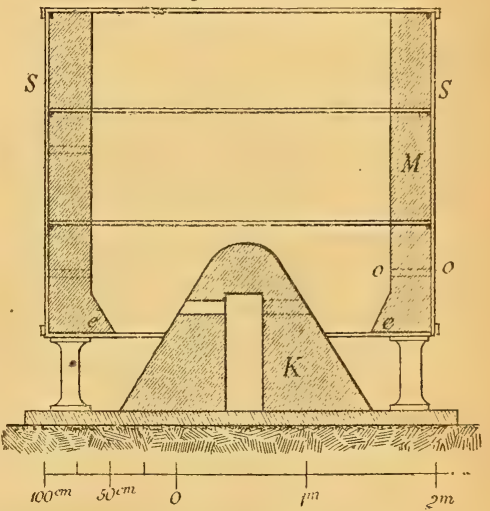

Bei Röstöfen mit Benützung von Gichtgasen leitet man die für die Verbrennung erforderliche Luft möglichst $n$ ahe an der Ofensohle ein, während die Gichtgase in einem etwas höheren Niveau zugeführt werden. Hierdureh wird die Luft, indem sie eine etwa $1 / 2-1^{\mathrm{m}}$ lohe, heisse Erzschichte passirt, vorgewärmt und die Verbrennung der Essengase findet intensiver statt. Eine genaue Regulirung der zugefïhrten Luftmenge gestattet die Anwendung von Gebläseluft, wie selbe beim Westmann'schen Ofen*) stattfindet.

Am leichtesten rösten sich Brauneisensteine und Siderite, am schwersten Magneteisensteine.

Das Verwittern (tomber en efflorescence - to effloresce) und Ausl a ugen (laver - to wash) folgt dem Rösten. Durch das Verwittern oder Aussetzen der gerösteten Erze der Linwirkıng der Atmosphärilien, daher auch dem Froste, findet cine weitere Lockerung der Masse und Oxydiren der Schwefelmetalle zu Vitriolen statt.

*) Siche WVrdding's Eisenhüttenkunde, in welcher sich eine grosse Zahl verschiedencr Röstofenconstructionen beschrieben finden. 
Eisen-Erzeugung (Auslaugen).

Durch das A uslaugen cntfernt man die lösbaren Vitriole durch die Einwirkung von Wasser.

Beide Operationen können in Halden, auf welchen die Erze $1-2^{\mathrm{m}}$ hoch aufgeschuittet werden, oder in Bassins vorgenommen werden. In letzterem Falle hat man den Process melır in der Gewalt, namentlich dann, wem die Wasserzufuihrung in die etwa $1 \frac{1}{\mathrm{~g}} \mathrm{~m}$ tiefen Bassins in der durch Fig. 1214 dargestellten Art erfolgt.*) Hierbei tritt das Wasser von unten ein, verdrängt die Luft, durchFig. 1214 a. Fig. 1214 b. Fig.1214c. weicht die Erze und löst dic beim Rösten
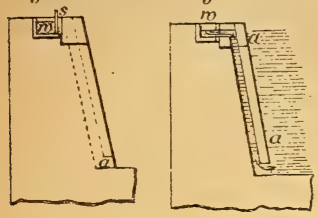

( $1 / 96$ nat. Gr.)

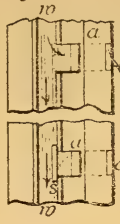

gebildeten schwefelsauren Verbindungen; beim Ablassen hingegen findet ein Saugen der Luft statt, welche alle. Zwischenräume füllt und oxydirend auf die Schwefelmetalle wirkt. Nach Analysen bringt das Rösten den Schwefelgehalt von circa $1.4 \%$ auf $0.6 \%$ und das folgende Auslangen auf $0.1 \%$.

Das Auslaugen durch s chw eflige

Säure zum Zwecke der Entfernung der Phosphorsäure aus den Erzen ist mit gutem Erfolge durch Director J. Jacobi in Kladno seit circa 3 Jahren eingefuilirt.

Das durch Rösten und Auslangen, manchmal auch durch Rösten allein, vorbereitete Erz wird auf Nussgrösse gebracht und gelangt nun zum Zwecke der Herstellung von $\mathrm{Roh}$ eisen in den $\mathrm{Hochofen}$ (haut foumeau - high frumace).

Fiq. 1215.

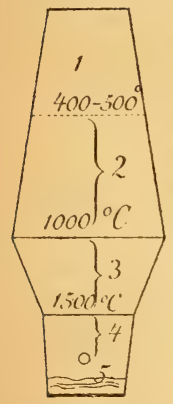

Der Hochofen (auch Hohofen) ist ein Schachtofen von bedeutenden Dimensionen, seine Höhe schwankt zwischen $8^{\mathrm{m}}$ (bei kleinen Holzkohlen-Hochöfen) bis $25^{\mathrm{m}}$ (bei grossen Kokshochöfen). Der Betrieb ist ein continuirlicher, d.h. es wird, so lange der Ofen intact bleibt, oben Erz sammt Zuschlag und Brenmmateriale in kurzen Zwischenzeiten aufgegeben, und unten Schlacke und fliissiges Roheisen abgelassen. Die Mengen des je in diesen Perioden aufgegebenen Erzes, Zuschlags und Brennmaterials begreift man unter dem Namen Gichten (charges - charges), abgesehen von dem Gewichte, wird die Bezeichnung Beschickung gebraucht.**) Das Brennmateriale, ferner Erz und Zuschlag werden hinter einander aufgegeben, ${ }^{* * *}$ ) so dass in dem Ofen schichtenweise Erz und Brennmateriale sich befindet. In dem obersten Theile (1) des Hochofens der Vorwärmezone findet ein Trocknen der Erze (Rösten) statt; im zweiten nächst tieferem Abschnitte wirkt das Kohlenoxydgas reducirend auf die Erze, daher dieser Theil Reductions-Zone genannt wird; in der 3. Zone - Kohlungs on e-nimmt der aus der Reductionszone niedersinkende Eisenschwamn Kohlenstoff auf, und erlangt dadurch einen

*) In unserer Figur ist $w$ die Wasserzuführime, aus welcher bei aufgezogener Schütze $s$ das Wasser durch a in das Reservoir dringt. Hat man genügend Wasser, so wird durch 6-8 Wochen das Anslaugen in der. Weise vorgenommen, dass van circa jeden 2. Tag das Laugewasser durch am Boden des Bassins befindliche Oefluungen ablässt und nach kurzer Zwischempause wieder frisches Wasser zuführt. Die Abfussöffimugen sind durch einen conischen Pfropf, dessen Stiel über das Erz hervorragt, verschlussen; damit beim Heben des Pfropfes nicht Erz in die 1 bflussöffinung fällt, ist an der Oeftinung um den Pfropif lrerum ein unten durchlöcherter Blechrvlinder angelsaclit. Hat, mau wenig Wasser zur Dispusition, so ist es zweckmässig, die Laugebassins, z. B. je vicr, derart anzuordnen und unter einander zu rerbinden, dass das Laugewasser ans dem ersten in das zweite etc. gebracht werden kann. Man lässt das frische Wasser dann in jenes Bassin truten, welches das bereits am neisten gelaugte Erz entlüit. Das frisch mit Erz beschickte Bassin erhält das Laugewasser aus jenem, welches näichst früher beschickt war.

*) Häutig wird unter Beschickung nur Erz und Zuschlag verstanden.

***) Bei fieier Gicht zuerst dis Brennmaterial, dann Erz nud Zuschlag. bei geschlossener Gicht umgekehrt. 
niedrigeren Schmelzpunkt, wodurch das Schmelzen des gekohllen Eisens in der Schmelzzone \pm ermöglicht ist. Das abtropfende Roheisen sammelt sich bei 5 , dem Eisenkasten, an.*)

Der Hochofenprocess ist mithin ein reducirendes Sehmelzen in Verb ind ung mit Kohlung.

Es ist leicht einzusehen, dass der natürliche Zug nicht ausreichen kann, dass durch ihn nicht die geniigende Luftmenge zutreten würde; man ist daher gezwongen, durch Gebläse atmosphärische Luft (Wind) unter höherem Druck in den Ofen zu treiben. Führt man der Luft beim Einblasen keine Wärme zu, so bläst man mit kaltem Wind; erhitzt man die Luft in sogenannten Winderhitzungs-Apparaten, dann bläst man mit heissem Winde.

Die Höhe des Hochofens, mithin auch die Höhe der Schichten, deren Widerstand für das Durchstreifen des Windes iiberwunden werden muss, bestimmt die Windpressung. Sehr leichtes Brennmateriale (Holzkohle) wiirde durch zu hohe Pressung vertragen; auch hielte die verhältnissmässig zartere Holzkohle den bedeutenden Materialdruck in hohen Hochöfen nicht aus, es ist daher begreiflich, dass jene Hochöfen, in welchen die Eisenerzeugung mit Holzkohle stattfindet die Holzkohlenhochöfen - relativ klein sind, während die sogenannten $\mathrm{K}$ oks- oder $\mathrm{Coakshoch} \mathrm{ö} \mathrm{fen,} \mathrm{deren} \mathrm{Brennmateriale} \mathrm{die} \mathrm{weit} \mathrm{widerstandsfähigeren}$ Koks sind, viel grösser gebaut werden können, wenn sie auch in den wesentlichen Theilen, welehe wir zunächst besprechen wollen, übereinstimmen.

Fig. $1216 a$ stellt den Verticalschnitt eines Kokshochofens moderner Construction dar. Die obere Oeffnung des Hochofens, die Gicht (gueulard - mouth) ist hier, der später näher zu besprechenden Nutzbarmachung der entweichenden Gase (Gichtgase) wegen, durch den Gasfang $C, E$ geschlossen. Das Mauerwerk $K$, welches, aus feuerfestem Materiale hergestellt, den Innenraun einschliesst, heisst Kernschacht, welche Bezeichnung auch dem Innenraum selbst (cheminée - fire room) zukommt. Die Theile des Kernschachtes (Innenranm wie Mauerwerk) heissen der $\mathrm{S} \mathrm{ch}$ a $\mathrm{cht} a$, Kohlensack (ventive - belly) $b$, die Rast

Fig. 1216 a. $\quad(1 / 192$ n. Gr. $)$

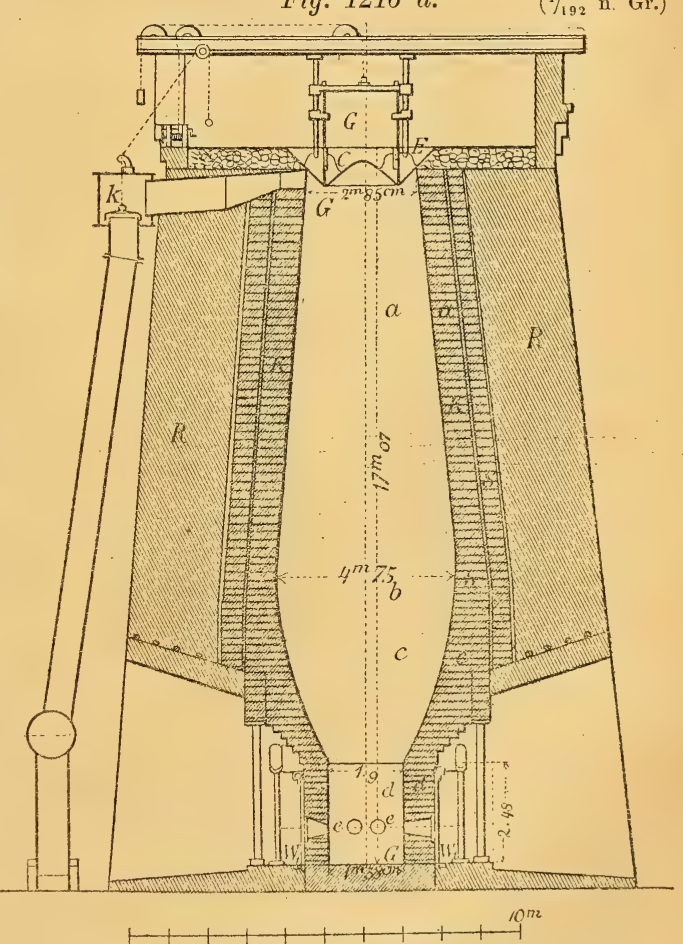

*) J. L. Be 11: Ueber die Entwicklung und Verwendung der Wärme in Eisenhochöfen von verschiedenen Dimensionen. Deutsch von P. 'Tunner, Leipzig 1870. Troska, Hochofen-Dimensionen, Weimar 1867. Schinz, Documente für den Hochofen, Berlin 1868. 
Fig. 1216 b.

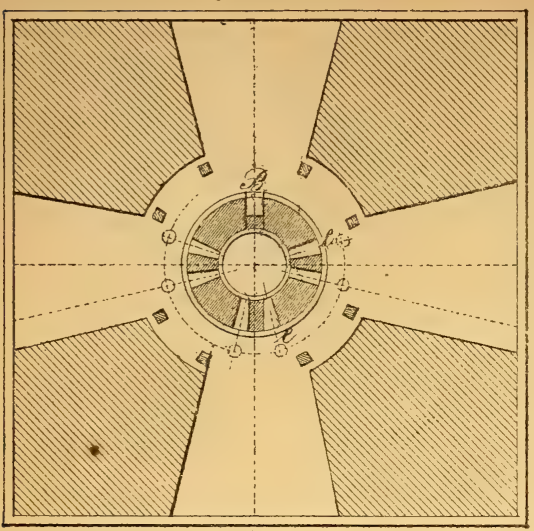

(étalages - boshes) $c$ und das G estelle (ouvrage - hearth) $d$.

Von der Gicht bis zum Gestelle ist das Kernschachtmauerwerk ununterbrochen. Im Gestelle wird dasselbe von den Oeffnungen Formen (tuyères - twyers) $e$ durchbrochen, welche zur Einführung des Windes mittelst der $\mathbf{D}$ ii se $\mathbf{n}$ (tuyères - blast-pipe) $f$ dienen. Gewöhnlich sind alle Formen in dem gleichen Niveau (der Formenebene), ihre Zahl ist verschieden; bei dem dargestellten Ofen sind 6 Formen (vgl. Fig. 1216 b) verwendet.

Der unterste Theil des Gestelles heisst $\mathrm{E}$ i s e $\mathrm{n} \mathrm{k}$ a s ten (creuset - crucible) $G$ und in ihm sammelt sich das geschmolzene Roheisen an. Der ober den Formen liegende Theil des Gestelles heisst auch $\mathrm{Ob}$ er geste1l, der unterhalb liegende Untergostell. Die vordere Seite des Gestelles bei $B$ (Fig. $1216 b$ ) heisst Brust (poitrine - breast), und man unterscheidet die Hochöfen, je nachdem die Brust offen oder geschlossen ist, in Hochöfen mit offener Brust (Sumpföfen) und Oefen mit geschlossener Brust (Blau-, auch Blaseöfen).

Die Skizze Fig. 1217 a zeigt das Gestelle eines Ofens der ersten Art, Fig. $1217 b$ der zweiten.*) Der in Fig. $1217 a$ mit $t$ bezeichnete Theil der Brust heisst T ia mpel, $u$ Wall- oder Dammstein (dame — dame). Beim Ofon mit offener Brust fliesst die Schlacke iiber $u$ ab, das Eisen hingegen durch $s$ aus,

Fig. $1217 a$.

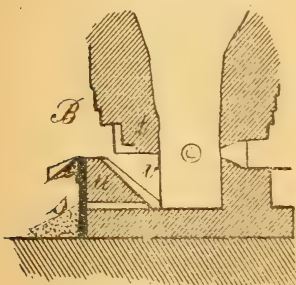

Fig $1217 \mathrm{l}$.

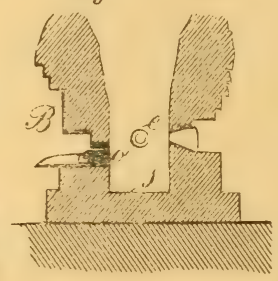

falls der das Stichloch (Stich) $s$ versckliessende Thonpfropf eingestossen wird; beim Ofen Fig. $1217 b$ ist $o$ der Kanal, dureh welchen die Schlacke abgelassen wird, hingegen $s$ das Stichloch. Ist der Wallstein bei den Oefen mit offener Brust weiter hinausgeriickt, so nennt man die dadurch bedingte Erweiterung $v$ des Eisenkastens Vorherd (aicunt creuset brectstpan). Das den Kernschacht umhiillende Manerwerk heisst $\mathrm{R}$ a u h s h a cht (chemise-rough-valling) und das

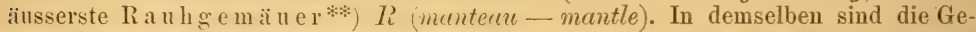
wölbe iiber den Formen, Formgew ölbe (encorbellement des soufflets - twyer

*) Perey- Tredding: Lehrbuch der Eisenhüttenkunde, Braunschweig 1S68 2. Abth S. 701. Teber die L ii rma nu'sthe Stichlochkiihlung s. Dgl, p. J. Bd. 217 S. 460 , von demselben eine Abhandlung ẗber Hochöfen mit geschlossener Brust. Dgl, p. J. 194 Bd. S. 106 и. 475, ferner findet sich eine sehr interessante polemische Ablandlung diescs hervorragenden Eisenhiittenmannes über die geschlossene Brust und Kühlung im 221. Bd. S. 28 d. J.

$\mathrm{Zu}$ erwähnen wäre hier, dass $\mathrm{D} u$ šanek in Althütten einen Hochofen baute, bei welchem das Gestelle aus Blechliästen (Steine genaunt) mit Wassereirculation hergestellt ist, die Schmelzung also hier unmittelbar vor der mit Wasser gekühlten eisernen Inmenwand erfulgt.

**) Beide Bezeichmugen, Rauhschacht und Rauhgemäner werd'n oft als gleichloeleutend gebrancht. In Fig. 1216 ist $\mathrm{K}$ der Keruschac!ıt, S der Rauhschacht, R das Rauligemäuer. 
(arch) und das Gewölbe auf der Seite der Ofenbrust, das Arbeitsgewölbe (encorb. de la tympe - working arch) angebracht. Zwischen Kernschacht und Rauhschacht, öfter auch zwischen Rauhschacht und Raulgemäuer ist die sogenannte F iillung, d. h. eine Schichte von Asche oder Schlackenklein ete. angebracht, welche als schlechte Wärmeleiter wirken. Ans Fig. $1216 a$ und $b$ ist ersichtlich, dass beim Ofengestelle das Rauhgemạuer vom Kernschacht zurüicktritt. Eiserne Säulen tragen dann die entsprechenden Theile des Rauhge: äuers, und es ist Raum gewonnen für eine später zu beschreibende Wasserkihlung des freistehenden Gestelles. Bei manchen Hochöfen ist das ganze Rauhgemäuer unten durch Säulen getragen, ja man stellt statt des Rauhgemäuers einen eisernen Mantel her, welcher den Kernschacht mit den Füllungen umgibt und zusammenhält, und welcher dann stets auf eisernen Säulen ruht.

Wir betrachten nun zunächst den Hochofen-Process während des Betriebes, mit Uebergehung des ziemlich lange dauernden Anheizens des Ofens, welches nur einmal stattfindet, da der Ofen, so lange Absatz fuir die Producte vorhanden ist, fortgesetzt im Betriebe ist und erst „ausgeblasen " wird, wenn er der Reparatur bedarf.

Ist die Gicht wie in Fig. 1216 a mit einem Abschlusse versehen, so muss beim Chargiren oder Aufgeben der Beschickung der Verschluss beseitigt werden, was beim Hochofen Fig. 1216 durch Heben oder Senken des Conus $C$ geschehen kann.*)

Um Erz und Zuschlag aufzugeben, fährt man mit dem in Fig. 1218 dargestellten Erzhund auf die iiber die Gicht gelegten Schienen (vgl. Fig. 1220) und lässt durch Heben des Mantels $m$ das Erz ringsum in den Trichter $E$ fallen; fährt hierauf mit dem den Zuschlag: (meist Kalk) enthaltenden Hunde, welcher dieselbe Einrichtung besitzt, über die Gicht und entleert ihn ebenfalls in den Trichter. Hierbei findet schon ein Mengen von Erz und Zuschlag (Möllerung) statt. welches aber erst dadurch vollständig erreicht wird, dass man den Conus $C$ senkt. Erz und Zuschlag: kollert hierbei tiber den Kegel gegen die Ofenwand.

Nun füllt man den Trichter mittelst der Kokshunde (Fig. 1219) mit Koks, indem man mit diesen Hunden an 4 Stellen den Trichter anfährt, und, wie aus der Figur ersichtlich, selbe entleert. Wird nun der Conus abermals gesenkt, so kollern die Koks, namentlich die grösseren Stiicke, über die an der Ofenwand anliegende Beschickung

Fï. 1218 a.
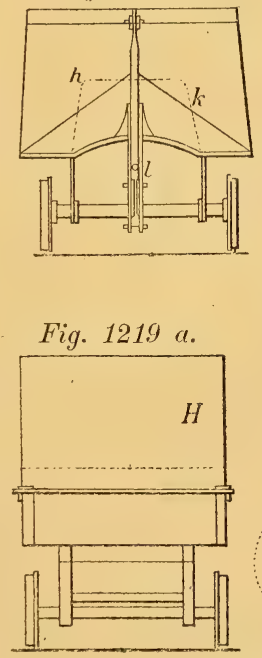

Kokshund.

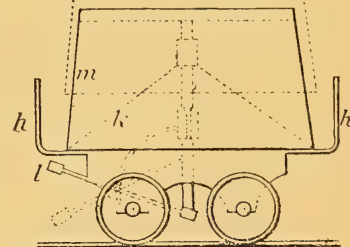

Erzhund.

Fig. 1219 b.

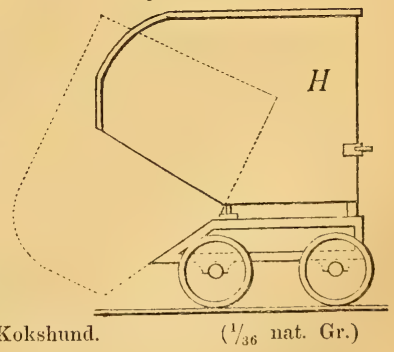

Fig. 1218 b.

* Wirr rer Conns gehoben, so füllt das im Trichter liegende Materiale gegen die Mitte des Ofens; wird er gesenkt, so fällt es gegen die Ofenwand. Da num das Erz als sperifisch schwerer stets rascher, also gegen die Mitte des Ofens sinkt, so sorgte man fïr einen gleichmässigeren Niedergang eben dadurch, dass man das Erz gegen die Wand, die Krhle gegen die Mitte autirah, worlurch in den tieferen Sclichten cine gïnstige Vertheilung stattfindet. Dasscllye kaun durch gecignete Folge der Beschickung erzielt werden. 
gegen die Mitte. Beim Niclergange des Materiales im Ofen erlangen dic specifisch schwereren Erze die Tendenz, gegen die Mitte des Ofens zu sinken, und es findet dann eine giinstigere Vertheilung des Materiales statt.

Bei dem allmäligen Niedersinken findet successive ein Erhitzen, ein Rösten urd eine Reduction der Erze statt. Im sogenannten Kohlensack (Fig. 1216) b ist das Erz reducirt, zu Eisenschwamm geworden, und nimmt nun Kohlenstoff auf.

Das gekohlte Eisen gelangt in die Schmelzzone und hier nun haben die $\mathrm{Z} \mathrm{u-}$ schläge ihre Aufgabe zu erfüllen.

Man darf sich allerdings die erwähnten Zonen nicht scharf von einander geschieden denken, aber zum Zwecke der iibersichtlicheren Darstellung des Vorganges ist ihre Annahme durchaus zulässig.

Die Reduction der Eisenerze beginnt schon bei verhältnissmässig niedriger Temperatur, wird aber erst vollendet, wenn Erze und Zuschläge keine Kohlensäure mehr gebunden enthalten, also bereits volle Gluth erlangt haben; und wenn die umgebenden Gase reich an Kohlenoxyd sind. So wie die Reduction beendet ist, beginnt die Kohlung, iiber deren Vorgang leider noch keine genïgende Erklärung gegeben ist (vgl. II S. 769); man weiss nur, dass Eisen mit Kohlenstoff in Berïhrung schon bei schwachem Gliihen sich kohlt, daher die Kohlung nicht erst in den tiefen Theilen des Ofens erfolgt, sondern sogleich nach beendeter Reduction.

Das himreichend gekohlte Eisen schmilzt bei der in der Nähe des Gestelles herrsclienden hohen Temperatur und kohlt sich hierbei höher durch unmittelbare Beriihrung mit glühendem Kohlenstoffe.

Je höher die Temperatur im Gestelle, einen um so höheren Kohlungsgrad erlangt das Eisen, und um so geneigter wird das Eisen, den Kohlenstoff nach dem Erstaren theilweise als Graphit auszuscheiden, d. h. graues Roheisen zu liefern. Bei relativ niedrigerer Temperatur bildet sich lieber we is ses Ro heis en.

Wenn die Kohlung des reducirten Erzes im Ofen beginnt, muss auch der Zuschlag auf die Gangarten der Erze einwirken, mit denselben eine schmelzbare Verbindung - Schlacke - eingehen und ziemlich gleichzeitig mit dem gekohlten Eisen niederschmelzen. Fiir dieses richtige Verhalten in der Schmelzung wird die Bezcichumg garer Gang oder Gargang gebraucht. Das Roheisen und die Schlacke sind diinnfliissig, letztere erstart, von lichter Farbe. Das beim Gargang erhaltene Roheisen kam grau oder weiss sein; das Wesen des garen Ganges liegt in der Art des Schmelzens von Erzen und Schlacke.

Ist hingegen der Zuschlag schlecht gewählt oder die Brennmaterialmenge zu gering, so dass die Schlacke vor der vollständigen Reduction der Erze schmilzt, wobei sie Eisenoxyde aufnimmt, so wirkt sie oxydirend (entkohlend) auf das Rohcisen durch die in ihr gelösten Eisenoxyde. Das Resultat ist damn stets ein weisses Eisen von wenig Kohlenstoffgehalt, daher hohem Schmelzpunkt. Dieser Gang fülırt die Bezeichnung Rohgang, auch kalter oder ii bersetzter Gang. Die Schlacke ist dunkel bis schwarz.

Nach Wedding ist es nothwendig, wenn in einem Ofen graues Eisen crzengt wird und man zu weissem iibergehen will, den Gargang durch Herabminderung der Brennstoffmenge zuerst in Rohgang zu rerwandeln und hierauf durch Aenderung oder Vermehrung des Zuschlages zu dem abgeänderten Gargang (auf weisses Eisen) zu gelangen.

Arbeitete ein Hochofen unter garem Gange auf weisses Eisen und vermehrt man in der Beschickung das Brennmateriale, so erhält man graues Eisen; arbeitete cin Hochofen unter Gargang auf graues Roheisen und rermehrt man das Brennmateriale, so erhält man ein sehr kohlenstoff- und siliciumreiches Eisen - ii bergares Roheisen - welches namentlich fuir den Bessemerprocess absichtlich erzengt wird. Das Kriterium des it bergaren Ganges ist daher die Verwendung von mehr Brennmaterial, als zum Gargang nöthig ist. Interessant ist es, dass ein iibergarer Gang stattfinden kamn bei gleichzeitiger Gewinnung weissen Eisens. Es riihrt dies ron den Erzen nicht angepassten oder zu schwer schmelzigen Zuschlägen her, wodurch eine Schlacke entsteht, die zu streng flüssig. ist, und nicht die Fähigkeit 
hat, die Eisentropfen bei ihrem Vorbeigange vor dem Winde durch Umhitillung vor der Entkohlung zu schiitzen. Es ist möglich, dass sich hierbei an den Ofenwänden Ansätze von gefrischtem Eisen bilden (Eisens äue), die Schlacke selbst kinn dureh Aufnahme von, vor den Formen oxydirten Eisens eisenhältig werden wie beim Rolgang. Dieser Fall zeigt ganz besonders die hohe Wichtigkeit der richtigen Wahl der Zuschläge (s. u.) und der richtigen Mengenverhältnisse der Beschickung.

Das Roheisen sammelt sich im Eisenkasten, über demselben die Schlacke. Da nun der Eisenabstich periodisch (etwa alle 4 Stunden) geschicht, das Niveau der Schlacke aber nie die Formen erreichen darf, so ist die Nothwendigkeit gesonderten Schlackenabstiches gegeben und sind bei den Oefen mit geschlossener Brust stets besondere Schlackenabstichkanäle vorhanden, durch welche man die Schlacke am besten in Schlackenwagen lanfen lässt, weil so der Transport zur Halde vereinfacht ist.

Der Abstich des Roheisens erfolgt nach Herstellung eines im Boden der Hütte (Sand) gemachten schmalen Grabens, des Masselgrabens, durch welchen das Roheisen entweder in eine vor dem Ofen befindliche grosse, sehr flache Mulde oder in offene, meist in Sand, seltener und nur für weisses Eisen aus Gusseisen hergestellte Formen, Rinnen von $\mathbf{U}$-förmigem Profil, geleitet wird.

Lässt man das Eisen in der Mulde erstarren und zerschlägt die dicke Platte in Stiicke, so erhält man die Flossen, Masseln (saumons - pigs), erstarrt das Eisen. in den Formen, so erhält man Stücke von Stangenform, Barren, Gänze (gueuses - pigs), giesst man auf das fliissige, in der Mulde (Sumpf) stehende Eisen Wasser, und reisst die erstarte Platte $a b-S c h e i b e n r$ issen — so erhält man Blatteln (blettes).

Ueber die Zuschläge. Aus der vorstehenden kurzen Besprechung des Hochofenprocesses konute schon entnommen werden, dass die rechtzeitige Bildung einer Schlacke von geeignetem Grade der Diinnfluissigkeit eines der wichtigsten Erfordernisse des Garganges ist. Da nur wenige Erze (selbstgehende) ein solches Verhältniss der Gangarten aufweisen, welches zur Bildung einer geeigneten Schlacke erforderlich ist, so muss entweder durch entsprechende Mischung: verschiedener Erze (Gattirung*) oder viel häufiger durch Zugabe solcher Materialien ( $\mathrm{Z} u \mathrm{~s}$ ch $\mathrm{l} \ddot{\mathrm{a} g \mathrm{~g}} \mathrm{e}$ ), welche mit den Gangarten der Erze zusammen eine Schlacke ron richtiger Beschaffenheit liefern, der gute, gare Gang erzielt werden.

Die Analyse der in dem Hochofen zur Verschmelzung kommenden Erze, in Verbindung mit der Kenntniss des Fliissigkeitsgrades und Schmelzpunktes der zu bildenden Silicate, lässt die Bestimmung der geeigneten Zuschläge zu und begreift man die hierher gehörigen Kenntnisse unter der Bezeichung Eisenprobirk unst.**) Ihre Aufgabe ist, aus den durch die Analyse bekannten Bestandtheilen der Gangarten der Erze solche billige Materialien — Zuschläge - zu bestimmen, welche eine Schlacke liefern, die beim Schmelzpunkt des herzustellenden Eisens

*) Gattiren der Erze. Unter diesem Ausdruck versteht man die zweckmässige Mischung verschiedener Eisenerze, wenn solche aus verschiedenen Gruben zu haben sind. Der Zweek hierbei kann ein mehrfacher sein. Einestheils ist es besser, gutartige, d. h. leicht zn verschmelzende Erze mit strengflüssigen zu mischen, um so einen stets gleichartigen Gang des Schmelzprocesses zu befördern, als bald die einen, bald die andern getrennt zu verschmelzen; sodann ist es sehr wichtig, durch Mischung ärmerer mit reicheren Erzen ein möglichst gleichbleibendes Verhältniss zwischen Eisen und erdigen Beimengungen zu erzielen; endlich ist es zuweilen möglich, solche Erze zu mischen, deren erdige Nebenbestandtheile ihrer chemischen Zusammensetzung nach geeignet sind, sich zu einer leichtflüssigen Schlacke zu vereinigen, so dass sich die verschiedenen Erze gegenseitig als Flussmittel dienen. Die zweckmässige Gattirung setrt nicht nur grosse Erfahrung, sondern genaue Kenntniss der verschiedenen disponibeln Erze und des chemischen Processes der Schlackenbildung voraus.

**) Ceber lierher Gehöriges kann in Schrötter's Chemie Bd.I, ferner in Bruno Kerl's Eisenuprubirkunst als Anhang zu dessen Handb. d. Eisenhüttenkunde nachgesehen werden. 
gleichfalls dünnfliissig ist. Zugleich darf aber aus ökonomischen Griinden dic Menge der Schlacke lı̈̈ chstens fünfmal jene der Eisenmenge sein; andererseits muss sie aber mindestens $2 / 5$ jener des Eisens betragen, weil unter diesem Verhältniss kein geniigender Schutz vor Oxydation stattfindet.

Da die Kohlung des Roheisens anfhört, wenn dasselbe mit einer Schlackenschichte bedeckt ist, so wird fur das mehr zu kohlende graue Roheisen die Schlacke schwerer schmelzig sein miissen, wie fii das weniger zu kohlende weisse Eisen.

Die gewöhnlichsten und wichtigsten Bestandtheile der Gangarten sowolıl, als der IIochofenschlacke sind: Kieselsäure, Kalk- und Thouerde. Ferner finden sich Magnesia, Baryt, Mangan und Alkalien. (Eisen als Oxydul kommt nur bei fehlerhaftem Processe in grösserer Menge in die Schlacke.) Alkalien finden sich meist 1 nur beim Holzkohlenbetrieb; manganhältige Zuschläge werden oft absichtlich be gegeben; Baryt, namentlich Schwerspath, wird gemieden; Magnesia wird oft statt des Kalkes im Zuschlag beigegeben und wirkt diesem ähnlich, doch macht es die Schlacke schwerer schmelzig.

Das Verhältniss der Kieselsäure zu den Basen der Schlacke schwankt zwischen den Grenzen eines einfachen und eines Doppelsilicates, wie dies durch die Formeln $\mathrm{H}_{1} \mathrm{SiO}_{4}$ (nach der frïheren Schreibweise $2 \mathrm{IIO}, \mathrm{SiO}_{2}$ und $\mathrm{H}_{\mathrm{a}} \mathrm{SiO}_{3} \quad\left(\mathrm{HO}, \mathrm{SiO}_{12}\right)$ ausgedriickt ist. Hierin können zwei Wasserstoffatome durch ein Calcium-, Magnesium-, Mangan- oder Eisenatom, oder drei Wasserstoffatome durch ein Atom Aluminium vertreten werden.*) Die Thonerdesilicate sind schwerer schmelzbar als die gleichartigen Kalk-, Magnesia- oder Mangansilicate, und liegt in der Möglichkeit der Regulirung dieses Mischungsverhältnisses die Möglichkeit, den Schmelzpunkt der Schlacke in geeigneter Weise zu bestimmen. Der Gehalt an Caleium zu jenem von Aluminium wechselt zwischen $4: 1$ und $3: 2$, dariber hinaus wiirde die Schlacke zu leicht, resp. zu schwer schmelzig.

Als Zuchläge finden Anwendung:

ML a mor, gew. Kalkstein, Kreide, Kalkstoff.

Dolomit (Kalk mit bis fast der Hälfte kohlensaurer Magnesia).

Kalkste in merge l, Dolomitmergel (thonhältig).

Flusspath (Fluorcalcium), bei Vorhandensein von schwefelsauren Verbindungen und Ofenansätzen besonders wirksam, doch meist zu theuer.

B a ux it mit $35-70 \%$ Thonerde wird dort, wo er zu haben ist, damn als Zuschlag gegeben, wemn derselbe zumeist aus Thonerde bestehen soll.

Thouschiefer, Sehieferthon, Mergel werden als Zuschlige verwendet, wem die Erze einen Thon- und Kieselsäurezuschlag fordern.

Quarz oder Sandstein allein wird selten verwendet, läufig hingegen Schweiss-, Frisch- und Puddel-Schlacken, um ilnen Gehalt an Eisen zu gewinnen. (Diese Schlacken werden häufig vorher geriistet.)

II och of enschlacken, wemn es sich um blose Vermehrung der Schlackenmenge handelt.

Manganoxydul und Alkalien werden selten, dann aber zum Zweck. der Erniedrigung des Schmelzpunktes der schlacke beigegeben (Manganoxydul wird meist durch Gattirung manganhältiger Eisenerze zugesetzt, um manganhältiges Roheisen zu crhalten); dies macht anch erklärlich, dass es schwierig ist, aus manganhiiltigen Erzen granes Rolieisen herzustellen, welches eine schwerer schmelzige Schlacke (s. oben) erheischt.

Es ist fast selbstverständlich, dass es bei sehr reichen Erzen durch Zuschläge, welche die ökonomisch znlässige Menge nicht iiberschreiten, möglich ist, Shliacken von sehr verïnderlichem Schmelzpunkte zu erzeugen, d. h. auch versehieden e Roheisensorten zu erzeugen; während dies bei armen Erzen, deren Gangarten an sich schon eine Schlacke ausgesprochenerer Qualität liefern, nicht so

\$) Dir betreftionlen Verhältnisse finden sich eingelıender in Artikel Kieselsäure alıgehandelt. 
leicht möglich ist, daher für arme Erze ganz besonders der Erfahrungssatz gilt, dass sie nur fuir eine Roheisenart mit dem ökonomisch besten Erfolge zu verschmelzen sind.

Wir haben im Vorstehenden den wesentlichen Einfluss der Zusehläge a $u f$ die Schlacke charakterisirt. Da die Schlacke von Einfluss anf dic Roheisenbildung ist, so ist hierdurch allerdings den Zuschlägen ein indirecter Einfluss auf das Product des Hochofens zuerkannt; sie besitzen aber auch theilweise einen directen, und hiervon soll zunächst die Rede sein.

II ang an, sei es durch manganhaltende Erze, oder als Zuschlag (Braunstein) in den Hochofen gelangt, bewirkt nicht nur eine leichter schmelzbare Schlacke, sondern bewirkt, indem es einen Bestandtheil des Roheisens bildet, dass dieses den Kohlenstoff nur chemisch gebunden aufnimmt, gibt also zur Bildung we is sen Eiscns, resp. bei höherem Procentsatz zur Spiegeleis enbildung Anlass.

Silicium, aus der Kieselsäure reducirt, gelangt in das Roheisen namentlich bei hoher Temperatur. Die Bedingungen, welche die Ofentemperatur erhöhen, befördern auch die Aufnahme von Silicium in das Roheisen, und wird die Kieselsäure um so eher reducirt, je weniger basisch die Schlacke ansfällt. Koksroheisen ist daher siliciumreicher als Holzkohlenroheisen.

Der die Qualität des Roheisens wesentlich verschlechternde Schw efel und Phosphor wird durch Rösten der Erze, Auslaugen ete. von der Beschickung des Hochofens nach Thunlichkeit fern gehalten. Zwar gelingt es, durch starken Kalkzuschlag (auch durch Mangan enthaltende Zuschläge), so wie durch Flussspath den Schwefel grossentheils zu entfernen; doch gelang es bisher nicht, den noch schädlicheren Phosphor im Hochofenprocess zu beseitigen; er geht in das Roheisen ïber.

Brennmaterial, Wind und $\mathrm{Hochofengase}$ in ihrem wesentlichsten Eiufluss auf den Hochofenprocess. (Vergl. d. Artikel: Brennstoffe, Gebläse, K oks ete.)

Das im Hochofen zur Verbrennung gelangende Brennmateriale muss drei Bedingungen erfiillen. 1. Es muss die hinreichende Widerstandskraft haben, den grossen Druck der Materialien auszuhalten, ohne zerdriickt zu werden; 2. es darf bei seiner Verbrennung die Temperatur des Ofens nicht zu sehr herabmindern, wie dies bei nassem und solchem Brennmateriale geschehen wiirde, welches ror dem Gliihen einen grossen Theil seiner Bestandtheile durch trockene Destillation (namentlich Kohlenwasserstoffe) vergast; und 3. es darf nicht zu viele und namentlich keine schädlichen Aschenbestandtheile besitzen.

Der ersten Bedingung entsprechen Braunkohlen- und Torfkoks nicht (oder selten); der zweiten entspricht weder Holz noch gasreiche Steinkohlen; und un der dritten Bedingung Genüge zu thun, müssen viele aschenreiche (namentlich schwefelkiesreiche) Steinko!.len vor dem Verkoken einer nassen Aufbereitung unterworfen werden (s. Koks).

Wedding sagt: Ob eine Steinkohle im rohen oder verkokten Zustande anzuwenden ist, dariber entscheiden vor Allem die Eigenschaften derselben beim Verkoken (geniigende Reinheit vorausgesetzt). Lässt sich eine Steinkohle als Kleinkolile verkoken, so list es der Regel nach vortheilhafter, die grösseren Stiicke zur Flammofenfeuerung zu verwerthen; lässt sich die Kleinkohle dagegen nicht verkoken, so ist es zweckmässiger, die rohen Stiickkolılen anch für den Irochofen zu beniitzen. Stark backende Kohlen lassen sich im rohen Zustande im Hochofen nicht rerwenden, weil sie den Niedergang ungleichmässig machen.

Der Wind, đ. i. die unter erhöhtem Drucke in den Hochofen getriebene atmosphärische Luft, verbrennt den Kohlenstoff vor den Formen zu Kohlenoxydgas und Kohlensäure, welche letztere aber, da gliihender Kohlenstofi geniigend vorhanden ist, sich gleichfalls in Kohlenoxyd umsetzt.

Der Wind wird entweder kalt oder he is s angewendet. Im ersteren Falle fiilurt der gare Gang die Bezeichnung Kaltgar, im zweiten Heissgar. Bei 
Anwendung von heissem Winde wird weit mehr Brennmateriale im Hochofen erspart, als zur Erwärmung des Windes erforderlich war.*) Diese Thatsache, für welclie viele Erklärungsversuche vorliegen, scheint ihre Begründung darin zu finden, dass durch die Winderhitzung, ähnlich wie dies bei der Verbrennung in Si emen's Regenerativöfen der Fall ist, die Verbrennungstemperatur im Gestelle wesentlich erhöht und dadurch der Schmelzprocess so sehr gefördert wird.

Die Menge des Windes kann als proportional dem zu verbrennenden Kohlenstoffe genommen und hiernach bestimmt werden; die Pressung: soll derart gewählt werden, dass noch freier Sauerstoff bis gegen die Achse des Ofens gelangt, aber nicht dariiber hinaus. Soll die Production des Ofens vermehrt werden, so darf nicht die Windpressung, sondern es soll der Diisenquerschnitt, resp. die Zahl der Diisen, eine Vermelrung finden, weil nur hierdurch giinstig gearbeitet wird.

Die im Winde enthaltenen Wasserdämpfe werden zerlegt, wobei freier Wasserstoff und Kohlenoxydgas sich bilden; diese Zerlegung ist mit Wärmeverbrauch verkniipft, weil kein freier Sauerstoff vorhanden ist, welcher den freien Wasserstoff oxydiren könnte. Daher finden wir unter den $\mathrm{Hochofeng}$ asen ${ }^{* *}$ ) ausser

*) Eine sehr interessante Zusammenstellung der durch heisse Gebläseluft erzeugten Resultate ist schon vor 40 Jahren von Dufrenoy gegeben, der sämmtliche englische Eisenwerke, auf welchen das damals neue Verfahren eingeführt war, besucht hat. Er berichtet darïber Folgendes:

Auf den Clyde-Eisenwerken bei Glasgow wurden im Jahre 1829 bei kalter Gebläseluft pr. Ton Eisen verbraucht:

Zum Schmelzen 3 'Tons Koks, entsprechend 7 Tons 13 Ztr. () Pfd. Steinkohle

Zum Betrieb des Gebläises

Ferner Kalkstein

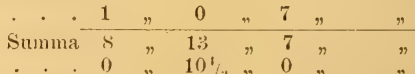

Im Jahre 1831 mit heisser Gebläseluft von $2322^{\circ} \mathrm{C}$. und Anwendung von Koks war der Verbranch:

Zum Schmelzen 1 Tons 18 Ztr. Koke entsprechend

Zum Erhitzen der Luft.

4 Tons 6 Ztr. 0 Pfd. Steinkohle

Zum Betrieb des Gebläises.

Kalkstein

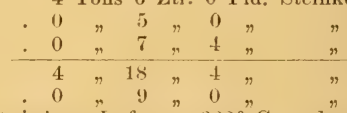

Im Jahre 1833 beim schmelzen mit heisser "Luft ron 32200 " C. und roluer, unverkokter Steinkohle ergaben sich:

Zum Schmelzen

2 Tous 0 Ztr, 0 Pfl. Steinkohle

Zum Erhitzen der Luft .

Zum Betrieb des Gebläses

Kalkstein .

\begin{tabular}{|c|c|c|c|c|c|}
\hline . . . & . & & & & \\
\hline . & . & & . & & \\
\hline . & 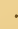 & & $\cdot$ & & \\
\hline unme & & & & & \\
\hline
\end{tabular}

"

0
2
0

Die tïgliche Production der Oefen hatte dabei um niehr als" $1 / 3$ zugrenommen nud also eine bedentende Ersparumg an Arbeitsloln gestattet, dabei war in der Menge der nöthigen Gehläischuft eine merkliche Verminderung eingetreten, dem ein Dampfgehlaise von 17 Pferdekräiten, das bei kalter Geblïseluft nur 3 Hochöfen versah, reichte jet»t zu 4 Oefen hin.

Auf den Eisenwerken von Caldex hat sich der Kohlenverbrauch in dem Verhältniss von $157 \mathrm{Ztr}$, zu $42 \mathrm{Ztr}$, der Kalksteinverbrauch von $13 \mathrm{Ztr}$, auf 5 1/2 Ztr. vermindert. Dats erfurderliche Luftrolumen ist von 3500 anf $2627 \mathrm{Kub}$.-F. pr. Minute gesumken, sellst die Pressung dieser geringeren Luftmenge kann in dem Verhältniss von $2^{3} / 4$ gegen $i^{1}$. Ptil. auf den Quadratzoll schwächer genommen werden.

;:k) Bunsen fand das Gas aus einem Holzkohlenofen folgendermassen zusammeugesetzt:

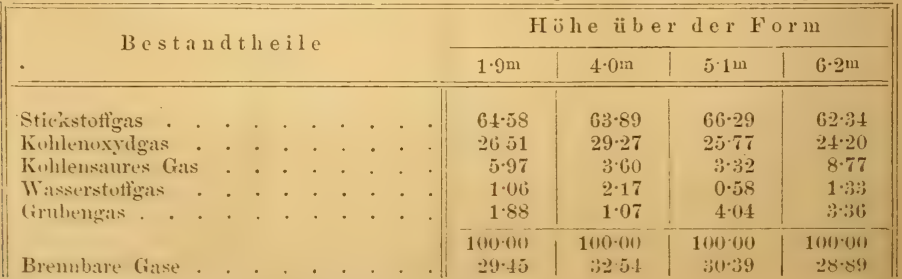


Kohlenoxyd und Stickst off auch Wasserstoff. Der Stickstoff diufte keinen wesentlichen Antheil an den Vorgängen im Hochofen nehmen, wenigstens beseitigen die Arbeiten $R$ ammelsberg's diesbezingliche frihere Vermuthungen und sind Cyanbildungen melı Ausnahme als Regel. Auch der Wasserstoff gelangt grösstentheils in die Gichtgase und fällt mithin die Hauptaufgabe dem Kohlenoxydgase $\mathbf{2 l}$, welches die Erze in den oberen Regionen reducirt und hierbei zum Theile zu Kohlensäure oxydirt wird. Die Gichtgase bestehen daher aus Stickstoff, Wasserstoff', Kohlenoxyd (circa 30\%), Kohlensäure (theilweise auch von den Zuschlägen und Erzen herrihrend), Wasserdampf (aus der Beschickung) und Kohlenwasserstoffen (aus manchen Brennmaterialien), wozu noch schweflige Säure, Zink dampf u. dgl. sich gesellen.

Die Gase haben vor den Formen eine Temperatur von circa $1600-1700^{\circ} \mathrm{C}$. und nimmt diese Temperatur in den höheren Schichten rasch ab, so dass sie in der Mitte der Ofenhöhe nur circa $600-800^{\circ}$ C. beträgt. Die im IIochofen erforderliche Wärmemenge wird vor den Diisen durch Verbrennen des Kohlenstoffes zu Kohlenoxydgas gewonnen.

Die Form des Hochofens ist durch nachstehende Momente bedingt. Das cylindrische und geschlossene Gestelle ist vortheilhaft, weil durch diese Form so wie durch die geschlossene Brust die Wärmestrahlung vermindert, daher die Temperatur im Gestelle erhöht wird. Die Wandstärke des Gestelles soll nicht iiber $0 \cdot 6-0 \cdot 7^{\text {m }}$ betragen, weil sonst die Wandungen innen abschmelzen, was stets ungleichmässig geschieht und zu nachtheiligen Aenderungen der IIerdform Veranlassung gibt, während bei der obgenannten Dimensionirung eine das Gestelle conservirende Wasserkühlung ermöglicht wird. Der lichte Durchmesser des Gestelles wird selten grösser als $2 \cdot 5^{\mathrm{m}}$ gemacht. Von diesem hängt gewissermassen die Productionsmenge ab, indem weiteres Gestelle mit rascherem Niedergang, engeres Gestelle mit langsamerem Niedergang (also geringerer Production) zusammenhängt. Von dem Gestelle erweitert sich der Ofen, wodurch den Gasen ein geringerer Widerstand entgegensteht, weil im grösseren Querschnitt die Bewegung derselben, wie der Beschickung langsamer stattfindet, wodurch die Einwirkung der Gase eine vollkommenere wird. An der Gicht wird der Schacht wieder verengt, um die noch vorhandene Wärme der Gase möglichst gleichförmig vorbereitend auf die Beschickung wirken zu lassen; doch soll die Spannung der Gase dadurch nicht erhöht werden, daher darf diese Verengung um so weniger betragen, je mehr Gase die Beschickung selbst entwickelt. Für rohe Brenmmaterialien wird daher eine weitere, fuir Holzkohle und Koks, so wie fïr gut geröstete Erze und gebrannte Zuschläge eine engere Gicht angewendet.

Erze, die schwer reducirbar sind, also länger der Einwirkung der Gase ausgesetzt sein miissen, erfordẹn einen weiteren Kohlensack, leicht reducirbare einen engeren.

Wedding charakterisirt die Hauptfälle nachstehend:

1. Die Erze sind leicht reducirbar, die Schlacke ist leicht schmelzbar (z. B. manganhaltige Spateisensteine), der Ofen erhält wenig Erweiterung in der Mitte, eine weite Gicht und weites Gestelle.

Nach Ebelmen ist das Gas eines Koksofens zusammengesetzt aus:

\begin{tabular}{|c|c|c|c|c|c|c|c|c|c|c|c|c|c|c|c|}
\hline \multirow{2}{*}{\multicolumn{13}{|c|}{ B estandthe ile }} & \multicolumn{3}{|c|}{ Tiefe unter der Gicht } \\
\hline & & & & & & & & & & & & & $0 \mathrm{~m}$ & $1^{m}$ & $4 \cdot 36^{\mathrm{m}}$ \\
\hline Stickstoffgas. & . & . & . & . & . & . & . & . & . & & . & . & $60 \cdot 70$ & $63 \cdot 59$ & $64 \cdot 66$ \\
\hline Kohlenoxydgas. : & . & . & $\therefore$ & . & . & . & $\vdots$ & . & . & . & . & . & $25 \cdot 24$ & $31 \cdot 83$ & 33.59 \\
\hline Kohlensaures Gas & . & . & . & . & : & . & . & . & . & . & . & . & 11.58 & $2 \cdot 77$ & 0.57 \\
\hline Wasserstoffgas. & . & . & . & . & . & . & . & . & . & . & . & . & $2 \cdot 48$ & $1 \cdot 81$ & $1 \cdot 38$ \\
\hline Brenubare Giuse & . & . & . & . & . & . & . & . & . & . & . & . & $\begin{array}{r}100 \cdot 00 \\
27.72\end{array}$ & $\begin{array}{r}100 \cdot 00 \\
33.64\end{array}$ & $\begin{array}{r}100 \cdot 00 \\
3497\end{array}$ \\
\hline
\end{tabular}


2. Die Erze sind schwer reducirbar und die Schlacke ist schwer schmelzbar (kieselsäurehaltige Rotheisensteine), der Ofen ist stark auszubauchen, mit enger Gicht und engem Gestelle.

3. Die Erze sind leicht reducirbar und die Schlacke schwer schmelzbar (gewisse Brauneisensteine), die Gicht ist weit, das Gestelle eng zu halten.

4. Die Erze sind schwer reducirbar und die Schlacke leicht schmelzbar (viele Magneteisensteine), die Gicht ist enge und das Gestelle weit zu halten.

Ueber Details der Hochöfen.

Die Gasfänge (cloche à gaz - gas-bell) haben den Zweck, die Gichtgase aufzufangen und einer nutzbaren Verwendung zuzufihiren. Es kann dieser Zweck auch bei offener Gicht erreicht werden, wenn man in die Gicht ein Rohr derart einlässt, dass zwischen ihm und dem Mauerwerk ein ringförmiger Raum bleibt, welcher oben abgeschlossen wird und seitlich mit Gasabzugs-Röhren communicirt. Das Innere des Rohres ist mit der Beschickung gefuillt, setzt daher den abziehenden Gasen mehr Widerstand entgegen, als sie anf ihrem Wege in den ringförmigen Zwischenraum und der weiteren Gasleitung finden; und da die Verbrennungsgase jenen Weg nehmen werden, welcher die kleinsten Widerstände bietet, so ist ihre Ableitung (allerdings mit Verlusten) möglich, anch ohne eigentlichen Abschluss der Gicht. Gichtglocken oder Trichterapparate, wie der nebenstehende, erfiillen die Aufgabe allerdings rorzïglicher; nicht nur der geringeren Verluste wegen, sondern hauptsächlich darum, weil die natiirliche Bewegung der Gase im Ofen nicht gestört wird, wenn die Ableitung oberhalb der Oberfäche der Beschickung erfolgt.

Der hier gezeichnete Gasfang *) ist nach dem früher Gesagten rerständlich. Bei $w$ ist die Winde, durch welche der Conus $C$ gehoben oder gesenkt wird. $G$ ist das Gasrohr, welches die Gase zu dem Winderhitzungsapparate (oder einer Fig. 1220.

$(1 / 6+$ nat. Gr.)

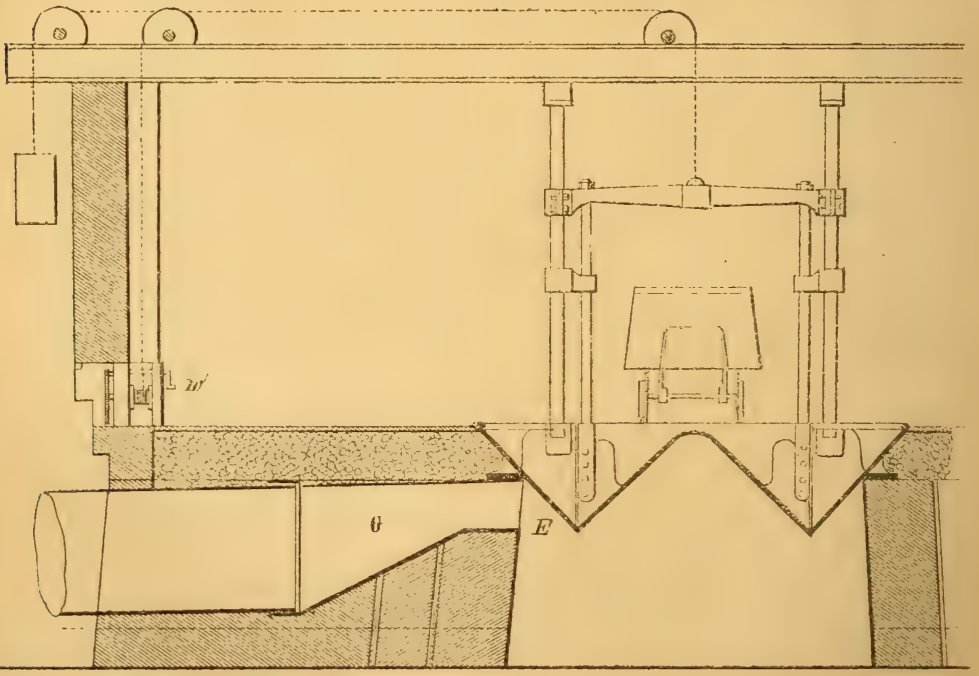

sonstigen Beniitzung) leitet. Conus und Trichter bieten an sich schon einen ziemlich guten Abschluss, welcher durch in den Trichter geworfenes Erz vervollständigt wird.

(4) Techuische Rlitter 1870 s. 155. 
Die Formen und Düsen. In das Mauerwerk des Gestelles sind die Formen $e$ (vgl. Fig. 1221) eingesetzt, in welchen die den Wind zuführenden Düsen $f$ ziemlich geschiitzt liegen. Um das Verbrennen der Formen zu verhindern, ist eine Wasserkiihlung vortheilhaft. Diese kann dann der Art angewendet werden, dass die Formen, wie aus unserer Figur ersichtlich ist, hohl sind; das Kühlwasser tritt am tiefsten Punkte ein, am höchsten aus.*) $\mathrm{Zu}$ den 6 Düsen unseres Hochofens gelangt der, vom Winderhitzungsapparate auf circa $350^{\circ} \mathrm{C}$. vorgehitzte Wind unter dem Drucke von $1 / 3$ Atmosphäre aus dem Rohre $R$ durch die Zweigröhren z. Bei $i$ ist ein kleines Guckloch, durch welches man den Process im Ofen beobachten kann. Hat sich das Auge durch längeres Hineinsehen an den Glanz der verbrennenden und schmelzenden Massen gewöhnt, so nimmt man den Vorgang vor den Dïsen nicht nur wahr, sondern ein geübtes Auge vermag den Gargang, Rohgang und iibergaren Gang aus der klaren und hellen, rothen und relativ dunkeln oder stark leuchtenden Verbrennung zu erkennen. Die Lage der Formen und Düsen ist nicht radial, d. h. die Achse der Formen schliesst mit dem vom Ofen- zum Formen-Mittel gezogenen Radius einen kleinen Winkel ein, wodurch eine bessere Vertheilung des Windes im Ofen erfolgt. Je nachdem das Ende der Duise dicht an die Form sich anschliesst oder nicht, unterscheidet man geschlossene oder offene Formeu. In unserer Figur 1221 ist die Form eine geschlossene.

Fig. 1221.

$(1 / 48$ nat. Gr. $)$

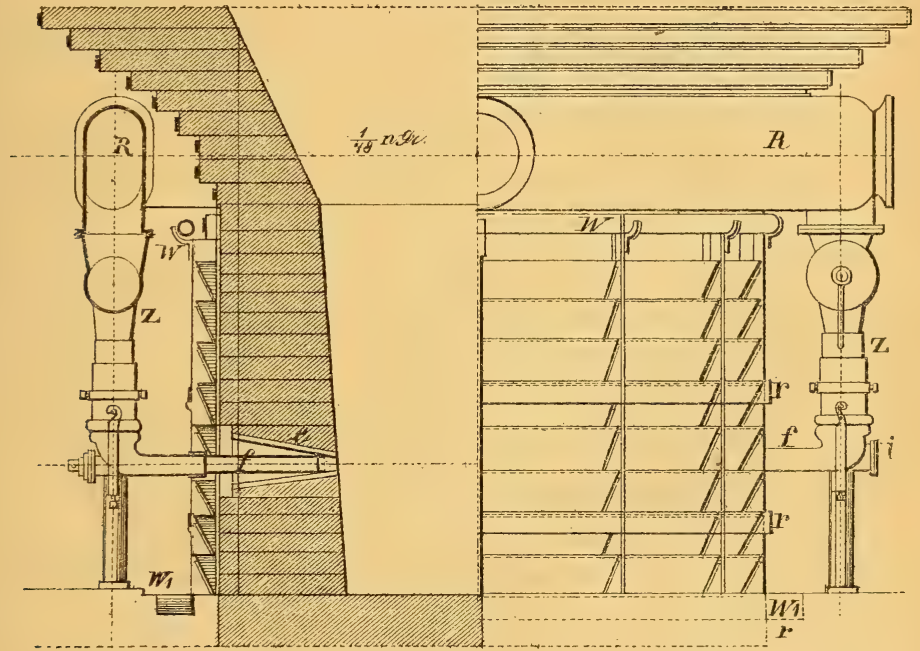

Die K ïhlung der Gestellwände bezweckt die längere Erhaltung derselben und wird durch Ueberrieslung der Aussenwände des Gestellmauerwerkes erzielt. Bei manchen Oefen wird auch das Schlackenabflussloch und das Stichloch durch directe Berieselung gekühlt, muss aber dann vor dem Abstich der Schlacke und des Eisens sorgfältig getrocknet werden. Dass die Kühlung des GestellKernschachtes durch Ueberrieselıng der Aussenwand das Abschmelzen der Innenseite

*) Eine der besten Düsenkühlungen besteht darin, aus einem spiralförmig gewundenen Kupferrohre, welches mit feinen Oeffnungen versehen ist. Wasser gegen die Innenseite der Düsenwände zu spritzen. Die Düse besteht aus zwei an der Vorderseite mit einander verbundenen, in einander gesteckten Hohlkegeln, zwischen welchen das Kupferrohr gelagert ist. Eine eintretende Undichtheit ist hier leicht zu bemerken, da die Düse rückwärts offen ist.

Karmarsch \& Heeren, Technisches Würterbuch. Bd. III. 
nur dann verhindern kann, wenn die Gestellwand keine zu grosse Dicke hat (circa $60^{\mathrm{cm}}$ soll nicht iberschritten werden), ist leicht begreiflich. Fig. 1221 lässt erkennen, dass rings um den Ofen acht horizontale Wasserrinnen herumgefuihrt sind. Der obersten Rinne läuft Wasser aus dem Rohre $W$ zu, welches nach Füllung derselben in die nächst tiefere iiberläuft u. s. f., bis das Wassèr, aus der untersten Rinne abfliessend, sich im Kanal $W^{i}$ sammelt. Die Aussenseite des Gestelles ist hịerbei mit Cement verkleidet, mit welchem auch die Fugen der Bleche, welche die Rinnen bilden, gedichtet sind.

Nebenerfordernisse des Hochofens sind die Gebläse, Winderhitzungsapparate und Gichtaufziige. Erstere liefern den Wind von erforderlicher Pressung (s. Gebläs e), die Winderhitzungsapparate (s. d.) haben die Aufgabe, den Wind zu erhitzen, und die Gichtaufzüge (s. He b e m e ch a n is m en), die Materialien. (Koks, Erz und Zuschlag) zur Gicht zu befördern.

Hochofen-Betriebsresultate. Kraftbedarf. Für einen Hochofen grösserer Dimension, welcher 800 Z.-Ztr. Koks pr. 24 Stunden verbraucht, ist eine Gebläsemaschine von 120-150 Pferdekräften erforderlich. Der Gichtaufzug beansprucht 5-10 Pferdekräfte.

Production. Bei circa $350^{\circ}$ C. Windtemperatur, basischer Schlacke und einem auf Puddelroheisen gerichteten Betriebe erhält man bei einem Koksverbrauch von 800 Z.-Ztr. pr. 24 Stunden, bei mittelmässigem E: z 500 Z.-Ztr., bei sehr gutem bis 900 Z.-Ztr. Roheisen.

Pro 125 Z.-Ztr. Koks oder 80 Z.-Ztr. Holzkohle kann man als Durchschnitt $100 \mathrm{Ztr}$. weisses Roheis en, pro 180 Z.-Ztr. Koks oder 115 Z.-Ztr. Holzkohle kann man als Durchschnitt 100 Ztr. graues Roheisen rechnen.

I. $B$ ) Die Rennarbeit oder das Rennen ist jene unmittelbare Darstellung schmiedbaren Eisens ans den Eisenerzen, auf welcher in friiherer Zeit die gesammte kisengewinnung berulite (ältere Rennarbeit) und welche in nenester Zeit den Gegenstand mannigfacher Versuche bildet (neuere Rennarbeit), die aoer bisher noch zu keiner durchschlagenden Bedeutung gekommen sind.*)

Bei der Rennarbeit findet eine Reduction der Erze zu Eisenschwamm und eine Kohlung dieses letzteren bei rerhältnissmässig niedriger Temperatur statt, daher die Kohlung nicht bis zur Roheisenbildung vorschreitet, das Product teigig bleibt (nicht diinnfliissig), und die Gangarten zu einer leichtfliissigen, sehr eisenreichen Schlacke verschmelzen, wodurch sich das geringe "Ausbringen " erklärt.

Die älteren Rennarbeiten wurden theils in Herden, theils in Schachtöfen vorgenommen, und nannte man das Rennen in Herden Luppenfrischerei, und zwar die Französische oder Catalonische, Corsikanische und Dentsche, je nachdem das Erz ron einer Seite des Herdes, oder mit Kohle gemischt rings um das ringförmig geschichtete Brennmateriale oder endlich in Schichten Erz und Kohle abwechselnd iiber die ganze Herdfläche aufgegeben wird. Uebrigens wurde die dentsche Luppenfrischerei auch öfter in kleinen Schachtöfen (Stïcköfen) und hierauf in Herden betrieben.

*) Eine interessante Abhandlung ïber die directe Darstellung des Eisens aus seinen Erzen und namentlich auch ïber die nemeren Methoden ron Blair und Dr. C. W. Siemens findet sich in T un ner: , das Eisenhüttenwesen der vereinigten Staaten von Nordamerika, " Wien 1877 S. 58 bis 74 .

Betreffend die in Nordamerika noch häufig in Herden durchgeführte Rennarbeit, welehe der alten deutschen Methode entspricht, gibt Tunner S. 60 an, dass pr. 1 Ztr. Luppeneisen nur 2 Ztr. Holzkohle verbraucht und aus $68-70 \%$ Erzen $57 \%$ Eisen gewonnen werlen, daher der Verlust nur $17^{\circ}$ beträgt. Betrett's der Siemens'schen Methode wird angegeben, dass selbe derzeit noch ziemlich im Versuchsstadium stecke, pr. Ztr. Eisen 3-4 Ztr. Kohle erfordert wẻrde, die Verschlackung noch $25 \%$ betrage, aber die Entphosphorung eine fast rollständige sei, daher angenommen werden könne, dass bei weiterer Entwicklung dieser Process sich für die Verarbeitung phosphorreichen Erzes eignen werde. Findet diese Erwartung ihre Bestätigung, so kommen wir unter Rennarbeit neuere nochmals auf diesen Process zu sprechen. 
Die französische Luppenfrischarbeit findet noch gegenwärtig hie und da in den Pyrenäen statt. Die kleineren Feuer, welche nur 3 bis 4 Ztr. Erze fassen, werden k atalon ische, die grösseren, in welchen 7 bis 8 Ztr. Erze gefrischt werden, biskay is che genannt. Das katalonische Feuer (denn hier sowohl wie bei allen übrigen zum Eisenfrischen dienenden Apparaten nennt man *den Apparat selbst ein Feuer) besteht aus einem flach viereckigen Herds von $0.5-3 \mathrm{~m}$ Länge und Breite und $23-70 \mathrm{~cm}$ Tiefe. Die Form liegt über der Herdsohle in schräg geneigter Richtung. Doch ist sie beweglich, damit ihre Neigung je nach dem Fortgange der Arbeit und der Menge des in dem Herde angesammelten Eisens geänlert werden könne. Sie wird durch untergelegte Thonklïmpchen oft selbst nach einem graduirten Instrumente regulirt, eine Sache, die von den Arbeitern als ein grosses Geheimniss bewahrt wird. Gewöhnlich liegen die Dïsen zweier Blasebälge neben einander in derselben Form. Die untere Herdplatte wird mit einer Sehicht von Lehm und Kohlenstaub bedeckt.

Das geröstete Erz wird zerstampft, und der feinste Staub davon abgesiebt, um später im Verlauf der Schmelzung zugesetzt zu werden; die Hauptmasse des Gröberen aber an der dem Gebläse gegenüber liegenden Seite zu einem sattelförmigen Hanfen aufgehäuft, und der übrige Raum des Herdes zwischen dem Erzhaufen und der Form mit Holzkohlen gefüllt. Um dem Erzhaufen mehr Festigkeit zu geben, beschlägt man ihn mit Thon und Kohlenklein. Während der ersten zwei Stunden lässt man das Feuer nur langsam angehen, wolsei der Arbeiter die Kohlen, so wie sie verbrennen, stets durch neue ersetzt, die er fest in den Herd eindrïckt, damit der Erzhaufen nicht zusammenfalle. Bei dieser mässigen Hitze tritt schon eine theilweise Reduction des Erzes, aber noch keine Schmelzung ein.

Etwa nach Verlauf von zwei Stunden aber lïsst man die Bälge mit ihrer vollen Gewalt angehen, um das Erz zum Sehmelzen zu bringen. Der Punkt, wo das Erz die zum Einschmelzen geeignete Beschaffenheit erlangt hat, lässt sich theils an der Flamme, theils auch an dem porösen Ansehen des Erzes leicht genug erkennen.

Um alle Theile gehörig zum ,Fluss“ zu bringen, sucht der Arbeiter die unteren Partien des Erzes von der Herdsohle abzulösen und sie der Form gegenüber zu bringen. Nach Verlauf einiger Zeit wird auch das abgesiebte Erzmehl, jedoch, um nicht zu verstäuben, feucht hinzugegeben und über die ganze Oberfläche der Kohlen ausgebreitet. Dieses Mehl soll, ausserdem, dass es die Eisenausbeute vermehrt, noch den Zweck haben, den Schlacken den angemessenen Grad von Schmelzbarkeit zu geben. Ist die Schlacke zu leicht- und dünnflüssig, so wird dieser Fehler durch den Zusatz des Erzmehles verbessert; hat sie dagegen eine sehr zähe Consistenz, so darf nur wenig Erzmehl aufgegelen werden. Die Schlacke selbst wird zum Theil durch einen Schlackenabzug abgelassen. Der ganze Process dauert 5 oder 6 Stunden, woranf der teigige Eisenklumpen aus dem Herde gehoben und unter den Hammer gebracht wird. Das Eisen, auf diese Art erhalten, ist als eine Mischung von Eisen und Stahl zu betrachten, doch kann man das relative Verhältniss beider nach Belieben abändern; denn wenn sehr reichlich Erzmehl, das offenbar mit zur Entkohlung des Eisens beiträgt, angewandt und die Form stark geneigt wird, so dass der Wind unter einem grösseren Winkel auf die Oberfläche des Eisens trifft, so bildet sich vorzugsweise reines Stabeisen; wird dagegen umgekehrt, bei sparsamem Erzmehlzusatz; die Form mehr horizontal gerichtet, und der ganze Process in die Länge gezogen, so entsteht ein stahlartiges Stabeisen, Das Gewicht der bei einmaligem Schmelzen erfolgenden Luppe beträgt etwa 2 bis $4 \mathrm{Ztr}$. Der Kohlenverbrauch ist aber sehr gross und beträgt mindestens das Dreifache von dem gewonnenen Eisen, daher die Luppenfrischarbeit, sowohl die jetzt beschriebene französische, als auch die italienische, nur allein in Gegenden betrieben werden kann, wo auf Kolenersparung nicht Bedacht genommen werden muss.

Die Ausbeute an Eisen beläuft sich auf etwa 33 Procent der rohen Erze (Spatheisenstein), so dass mithin, da der Spatheisenstein 54 bis 56 Procent Eisen hält, ein beträchtlicher Verlust eintritt.

Figur 1222 zeigt ein catalonisches Feuer, welches zuerst bis $e f$ mit Holzkohle gefüllt wird, rechts bei $A$ ist die Erzschicht, links bei $B$ die Kohlenschicht, $b d$ ist die mit Lösche bekleidete Trennungsfläche beider, $b c$ die natiirliche Böschung des Erzes. In unserer Figur stellt $D$ die Schlacke, $C$ die Luppe ror.

Italienische oder korsische Luppenfrischarbeit. Die Feuer oder Herde haben bei dieser, besonders auf Korsika heinischen Methode die Gestalt halbkreisförmiger, $16 \mathrm{~cm}$ tiefer, $47 \mathrm{~cm}$ im Durchmesser haltender Vertiefungen, die sich in einem niedrigen, $2 \cdot 5$ bis 3.1m langen, 1.6m breiten Mauerwerk befinden, und mit einer Esse überdeckt sind. Die, Form ist oberhalb des Herdes angebracht, und ein wenig abwärts geneigt.

Auf Korsika sowohl, wie in den Küstendistrikten Italiens wird am meisten Elbaner Eisenglanz verschmolzen, der nur sehr wenig Wasser, geringe Beimengungen von Spatheisenstein und etwas Schwefelkies enthält; Wasser und Schwefel müssen vor der Reduction durch eine Röstung ausgetrieben werden, wozu jedoch keine besonderen Oefen vorhanden sind, da diese anch in dem. Schmelzherd bewirkt wird; nur dass die ganze Arbeit in zwei getrennte $\mathrm{Ab}-$ theilungen zerfällt, In der ersten nämlich findet die Röstung einer Portion rohen Erzes und zugleich die theilweise Reduction einer zweiten, bereits früher gerösteten statt, in der zweiten Abtheilung dagegen die Verschmelzung so zwar, dass allemal zu gleicher Zeit sich ein Theil rohes Erz zum Rösten und das von dem vorhergehenden Processe erhaltene geröstete Erz zum Reduciren auf dem Herde befindet, nur dass das Letztere der stärksten, das Erstere einer 


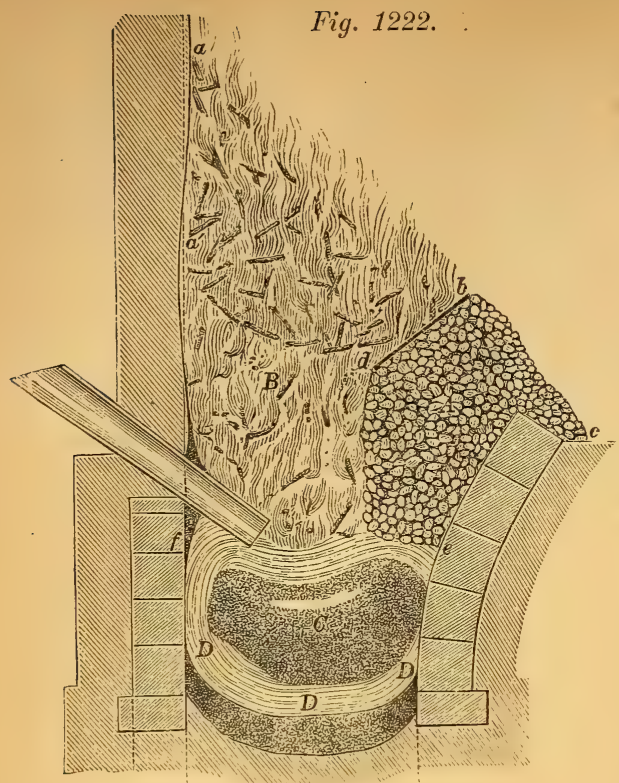

Catalonisches Feuer. schwächeren Hitze ausgesetzt wird, worauf dann in einer besonderen zweiten Operation das reducirte Erz verschmolzen und gefrischt wird.

Man fängt damit an, die Herdsohle und die Umfassungsmauer um den Herd mit einer $8 \mathrm{~cm}$ dicken Schicht von Lehm und Kohlenstaub zu bekleiden, und rund um den Herd eine ringförmige, $12 \mathrm{~cm}$ hohe Erhöhung aus derselben Masse zu bilden. Nunmehr formirt man in dem Herde zunächst vor der Mündung der Blasform einen halbkreisförmigen hohen Kohlenhaufen etwa von $16 \mathrm{~cm}$ Radius, und umgibt diesen mit einer Lage gerösteten Erzes in etwa nussgrossen Stücken, lässt auf diese wieder eine Lage Kohlen folgen, umgibt diese endlich mit dem zu röstenden rohen Erz, und bedeckt das Ganze mit einer starken Lage Kohlenklein. Die beiden Erzlagen erhalten eine Dicke von etwa $18 \mathrm{~cm}$, so dass die Gesammtbeschickung mít den Kohlen einen etwa $63 \mathrm{~cm}$ im Radius haltenden Haufen bildet, der den Herd um ein Bedeutendes überragt. Das rohe ungeröstete Erz kommt daher fast ganz ausserhalb des Herdes, auf dessen Umgebung zu ruhen, und wird in der Art angeordnet, dass die grösseren Stücke zu unterst, die kleineren zu oberst liegen. Ist so weit Alles fertig, so zündet man den mittleren Kohlenhaufen an, und lässt das Gebläse (fast allgemein ein Wassertrommelgebläse) angehen. So wie die Kohle in der Mitte des Haufens verbrennt, wird stets neue Kohle aufgegeben, die zu Anfang der Arbeit mit kurzen hölzernen, später nit wachsender Hitze, wo die Arbeiter dem Feuer nicht mehr nahe treten könmen, mit langen eisernen Stangen möglichst fest niedergedrückt werden muss, damit die Erzlagen so lange wie möglich in ihrer concentrisch cylindrischen Lagerung verharren. Nach drei Stunden pflegt diese erste Arbeit, bei welcher das innere Erz grösstentheils reducirt, dass äussere aber geröstet werden soll, beendigt zu sein, was man daran erkennt, dass das Letztere aufhört zu rauchen, das Erstere aber in mehr oder weniger zusammenhängende Klumpen zusammensintert. Das Gebläse wird nun abgestellt, die äussere, jetzt geröstete Erzschichte abgebrochen, behnfs der Zerkleinerung für die demnächstige Reduction vor den Herd geworfen, und nunmehr auch das reducirte Erz nebst den rückständigen Kohlen und Schlacken aus dem Herde entfernt.

Dieser wird hierauf wieder mit Kohlenstaub und Lehm ausgeschlagen und an der rechten und linken Seite zwei Haufen Kohlenklein und zwischen diese zwei oder drei Körbe Kohlen aufgeschiittet. Oben auf diese Kohlen werden einige Klumpen von reducirtem Erz gelegt, und mummehr das Gebläse angelassen. Sobald das Erz in Gluth kommt, tritt zwischen den erdigen Beimengungen und dem stets in Menge noch vorhandenen Eisenoxydul eine Wechselwirkung ein, in deren Folge sie sich zu einer ziemlich dïnnflüssigen Schlacke vereinigen, die man in Menge herabfliessen sieht. Bald fängt auch das reducirte Eisen an, in Fluss zu gerathen, und sich durch die Kohlen auf den Grund des Herdes herabzubegeben. Man fährt nun mit dem Aufgeben ron Erzstïcken fort, und lässt die Schlacke, wenn sie sich über dem Eisen in einer starken Schicht angesammelt hat, durch Oeftnung des Schlackenabzuges ablaufen, unterhält aber das Feuer, bis das Eisen durch Einwirkung des Gebläses eine gleichförmige zähteigige Consistenz angenommen hat, wo es dann in Gestalt eines Klumpens mit starken eisernen Haken aus dem Herde gekoben und unter den Hammer gebracht wird. Ein solcher Schmelzprocess damert durchschnittlich $3^{1 / 2}$ Stunden. Das gewonnene Stabeisen ist gewöhnlich von sehr guter Qualität; es ist weich, sehr dehnbar und wenig stahlartig. Vier Arbeiter sind gewölnnlich bei einem Herde beschäftigt. Die Ausbeute ist ziemlich gering, und beläuft sich auf etwa 4 Ztr. Eisen gegen $10 \mathrm{Ztr}$. Erz und $20 \mathrm{Ztr}$. Kohle, mit Buchen- und Kastanienholz gemengt.

Es werden also nur 40 Procent Eisen ron dem rohen Erz ausgebracht, so dass mithin, bei dem mittleren Eisengehalt von 65 Procent, etwa 25 Procent, d. i. reichlich ein Drittel des Eisens in Schlacke übergeht. 
Der Unterschied zwischen der katalonischen und der italienischen Luppenfrischarbeit besteht also ausser der geänderten Anordnung noch darin, dass bei der Ersteren das in Rösthaufen geröstete Erz in einer Operation reducirt, geschmolzen und gefrischt wird, während bei der letzteren ein jedes Stückchen Erz zu drei Malen auf den Herd kommt, einmal um geröstet, das zweite Mal um reducirt und das dritte Mal um eingeschmolzen und gefrischt zu werden.

Die in St ück-oder Wolfs öfen und hierauf in Herden ausgefihrte Luppenfrischerei bildet den Uebergang zum Hochofenprocess und dem auf dasselbe folgenden Frischen.

Diese Rennarbeit liefert schon grössere Quantitäten (iiber $500 \mathrm{~K}$.) auf einmal, während die in kleinen Schachtöfen $\left(1-2 \cdot 5^{\mathrm{m}}\right.$ hoch und $25-60^{\mathrm{cm}}$ weit) noch jetzt ausgeführte Rennarbeit mancher Völker Afrika's und Asien's nur ca. 70-90, ja auch oft selbst weniger als $10 \mathrm{~K}$. pr. Charge ergibt. Die kleineren Schachtöfen führten ehemals die Benennung Bauern- oder Osmundöfen.

Die Eisengewinnung in Stücköfen stimmt mit der Luppenfrischarbeit im Wesentlichen überein, insofern auch bei ihr das Frischen des Eisens gleich unmittelbar im Schmelzofen vorgenommen und das Eisen in einem zusammenhängenden Stück aus dem Ofen genommen wird, daher der Name Stückofen.

Es sind dies niedrige Schachtöfen von 3 bis $5 \mathrm{~m}$ Höhe und etwa $1 \mathrm{~m}$ innerem Durchmesser. Die Form des Schachtes hat zwar Aehnlichkeit mit jener der früher beschriebenen Hochöfen, doch ist der Herd verhältnissmässig weiter, der Kohlensack dagegen enger, die Unterschiede in der Schachtweite in verschiedenen Höhen sind daher nicht so gross als bei dem Hochofen. Der Querschnitt des Schachtes ist gewöhnlich quadratisch, die Blasform etwas geneigt, um den Wind behufs der Entkohlung auf die Oberfläche des Eisens zu treiben. Auch ist der Herd, d. h. der Raum unter der Blasform, weniger tief, dagegen aber, wie erwähnt, weiter, um das Eisen in einer mehr fachen, ausgedehnten Schichte dem Winde darzubieten, was beim Hochofen, dessen Bestimmung darin besteht, unentkohltes Roheisen zu liefern, zweckwidrig sein würde.

Da das Eisen nicht flüssig abgestochen, sondern in einem Stïck aus dem Herd gehoben werden muss, so erwächst hieraus eine der wesentlichsten Unvollkommenheiten des Stiickofenbetriebes: die Nothwendigkeit, um den Eisenklumpen (Guss) herauszubringen, bei dieser schon an und fïr sich beschwerlichen Arbeit die Ofenbrust jerlesmal zu öffnen und nach ausgehobenem Guss wieder zu vermauern. Die Arbeit selbst ist folgende: Hat man die Brust mit Mauersteinen und fettem Thon geschlossen, so füllt man den Ofen mit Kohlen, setzt diese von unten in Brand und lässt das Gebläse an. Hat sich nach einiger Zeit die Kohle bis zur Gicht hinauf entzündet, so fängt man an, das vorher geröstete Erz schichtweise abwechselnd mit Kohle aufzugeben, und fährt, so wie diese Gichten herabgehen, mit dem Aufgeben von Erz und Kohlen fort, bis das zu einmaligem Schmelzen bestimmte Erzquantum eingetragen ist. Sobald man bemerkt, dass die ersten Gichten zur Schmelzung gekommen sind, lässt man die über dem Eisen schwimmende Schlacke durch den in der beweglichen Ofenbrust angebrachten Schlackenabzug ab, um das Eisen von der schützenden Schlackendecke zu befreien, und es der Einwirkung der Gebläseluft vollständiger darzubieten. Hat sich das Eisen bis fast zum Niveau der Form. angesammelt, die in geringer Höhe über der Herdsohle in die neu gemanerte Ofenbrust eingesetzt wurde, so nimmt man sie heraus, und setzt sie etwas höher wieder ein, bringt auch einen neuen Schlackenabzug in entsprechender Höhe an, und rückt so in dem Masse, wie sich mehr und mehr Eisen im Herde ansammelt, mit der Form und dem Schlackenabzug weiter aufwärts, bis die letzte Erzgicht zur Schmelzung gelangt ist. Die Bälge werden nun ausgehängt, die Schlacke möglichst abgezogen, die Brustmauer aufgerissen, der Guss mit Haken und Zangen herausgeholt, unter den Hammer gebracht, zu einem 8-11 cm dicken Kuchen ausgereckt, in mehrere Stücke zerschrotet, und diese einzeln noch einem nachträglichen Frischprocess unterworfen. Man bringt sie nämlich auf einem eigenen Herde bei fast horizontal liegender Form zum Schmelzen, indem man sie mit einer grossen Zange gerade gegen den Wind in das Feuer einschiebt, und allmälig abschmelzen lässt. Das abgeschmolzene, hiebei dem Winde dargebotene und grösstentheils entkohlte Eisen sammelt sich auf dem Herdboden, wird hier durch Berührung mit dem Eisenoxydul der Schlacken noch weiter entkohlt und kommt nun abermals unter den Hammer, um zu Stabeisen ausgereckt zu weiden. Der bei diesem Einschmelzen in der Zange verbleibende, also nicht weiter entkohlte Theil wird ebenfalls unter den Hammer gebracht, und als Stahl in Stangen ausgeschmiedet.

Der in einem Stückofen von mittlerer Grösse entstehende Klumpen (Wolf) oder Guss wird gewöhnlich alle 24 Stunden ausgenommen, und wiegt 15 bis 20 Zentner. Um ihn herauszuheben und unter den Hammer zu bringen, sind mindestens 8 Mann erforderlich. Er wird hier in etwa zentnerschwere Stücke zerschrotet, die dann in der beschriebenen Art weiter verfrischt werden.

Die Eisengewinnung in Stuicköfen war früher besonders in Steiermark und Kärnthen in Gebrauch, ist aber gegenwärtig des grossen Kohlenverbrauches, des grossen Eisenverlustes und Arbeitsaufwandes wegen ganz abgekommen. Der Vortheil des Processes bestand in einem reinen, namentlich Phosphor und Silicium freien Producte, bedingt durch die niedrige Reductionstemperatur. 
II. Die Erzeugung sehmiedbaren Eisens aus Roheisen.

A) Durch die Frischarbeit im weitesten Sinne. Es ist Aufgabe der Frischarbeit, den Kohlenstoff des Roheisens grossentheils durch die Einwirkung des Sauerstoffes der atmosphärischen Luft zu entfernen; gleichzeitig aber auch die möglichste Abscheidung der im Roheisen enthaltenen nachtheiligen Substanzen zu bewirken. Bei der Frischarbeit befindet sich das Roheisen im geschmolzenen Zustande und kann der Process vorgenommen werden:

in Herden - Herdfrischen, Frischen im engeren Sinne (affinage - refining),

in Flammöfen -- Flammofenfrischen, P uddeln (puddler - puddling),

in Convertern - Windfrischen, Bessemern.

Beim Herdfrischen fallen die Tropfen des niederschmelzenden Roheisens durch den von der Diise kommenden Windstrom in den Herd, welcher mit Holzkohle beschickt ist. Die Holzkohle liefert die zum Einschmelzen erforderliche Wärme und kommt in unmittelbare Berührung mit dem Eisen.

Beim Puddeln wird das Roheisen durch die Flamme des von ihm getrennten Brennmateriales (meist Steinkohle) in einer Mulde des Ofens eingeschmolzen und die Einwirkung des in der Flamme enthaltenen freien Sanerstoffes und der Kohlensäure wird durch Rühren des Eisenbades befördert.

Beim Bessemern wird in die Retorte (Converter, Birne) fliissiges übergares Roheisen eingefüllt und Luft in möglichster Vertheilung durchgetrieben, welche durch Verbrennung des im Roheisen enthaltenen Siliciums und Kohlenstoffs jene Wärmemenge liefert, welche erforderlich ist, das gebildete schmiedbare Eisen in dünnflüssigem Zustande zu erhalten.

Zum Vergleiche dieser Methoden dienen nachstehende Durchschnittszahlen: $100 \mathrm{Ztr}$. Roheisen werden in einem Herde in 10 Tagen, in einem Puddelofen in $1 \frac{1}{2}$ Tagen, im Converter in 30 Minuten in schmiedbares Eisen verwandelt.

An Brennmateriale brauchen 100 Ztr. Roheisen beim Herdfrischen circa $60 \mathrm{Ztr}$. Holzkohle, beim Pud deln $100 \mathrm{Ztr}$. Steinkohle, beim Bess e mern fiir die Gebläsemaschine, das Einschmelzen und den Mehrbedarf beim vorhergehenden Hochofenprocess, welcher iihergares Roheisen liefern muss, circa $110 \mathrm{Ztr}$. St. K.

Aus $100 \mathrm{Ztr}$. Roheisen gewinnt man ca. $74 \mathrm{Ztr}$. gefrischtes Stabeisen, $75 \mathrm{Ztr}$. gepuddeltes Stabeisen und $80 \mathrm{Ztr}$. Bessemereisen.

Die chemischen Vorgänge beim Frischen. Beim Einschmelzen des Roheisens löst sich der in demselben als Graphit enthaltene Kohlenstoff im geschmolzenen Eisen und ist nun chemisch gebunden. Findet das Einschmelzen langsam und unter reichlichem Luftzutritte statt, wie dies im Frischherde und Puddelofen der Fall ist, so findet eine $O x y d a t i o n$ des grössten Theiles des im Eisen enthaltenen Siliciums statt, welches mit dem gebildeten Eisenoxydule eine Schlacke bildet. (Rohschlacke, Bisilicat $\mathrm{Fe}_{\mathrm{e}_{2}} \mathrm{Si}_{\mathrm{O}} \mathrm{O}_{6}$ oder nach der alten Schreibweise $\mathrm{Fe}\left(\right.$ ), $\mathrm{SiO}_{2}$.) Beim Bessemern findet die Oxydation des Siliciums im Converter selbst statt. Diese Periode heisst die 1. oder Fe in periode anch Periode der $\mathrm{S}$ ch la ck e n bild ung. Im weiteren Verlaufe des Processes nimmt die Schlacke mehr und mehr Eisenoxydul auf und geht in die Garschlacke (Singulosilicat $\mathrm{Fe}_{\mathrm{q}} \mathrm{SiO}_{4}$ oder $2 \mathrm{FeO}, \mathrm{SO}_{2}$ ) iiber. Diese Schlacke löst das weiter sich bildende Eisenoxyduloxyd anf, und dieses wirkt, da die Schlacke in Beriihrung mit dem geschmolzenen Eisen ist, entkohlend auf dasselbe ein, wobei sich Kohlenoxyd bildet. Ist das Roheisen manganhaltig, so enthält schon die Rohschlacke einen grossen Theil desselben, und die Garschlacke hat damn weniger die Fähigkeit Eisenoxyduloxyd zu lïsen, die Schlacke verzögert daun die Entkohlung. Diese Periode heisst die 2. oder Periode des Rohfrischens.

Die 3. Periode ist das Garfrischen. In ihr nimmt die Schlacke noch weiter Eisennyduloxyd auf, wirkt durch dasselbe weiter entkohlend und bedingt dadurch die Bildung von Schmiede isen, welches beim Frischen in Herden und Puddelöfen in teigiger Beschaffenheit, beim Bessemern fliissig erhalten wird.

Während des Roh- und Garfrischens oxydirt sich der im Roheisen enthaltene Phosphor und geht in die Schlacke, und zwar besonders dann, wenn die Tempe- 
ratur nicht zu hoch ist. Bei der hohen Temperatur des Bessemerprocesses findet entweder diese Oxydation nicht statt, oder sie wird durch nachfolgende Reduction aufgehoben. Auch der Schwefel oxydirt und entweicht als schweflige Säure, und zwar um so vollkommener, je länger der Process dauert. Die übrigen Verunreinigungen, Kupfer ausgenommen, werden durch den Frischprocess leicht oxydirt und gehen in die Schlacke.

Granes und siliciumreiches Roheisen wird, - wenn es im Frischherde verarbeitet werden soll (was höchst selten geschieht) immer, wenn es verpuddelt werden soll häufig, - dadurch vorbereitet, dass man es unter lebhaftem Winde in besonderen Oefen einschmilzt, welche Operation das Feinen, W eissen, R affiniren oder Läutern (finage - fining) heisst und weisses Roheisen liefert.

Die Entkohlung des Roheisens geht um so rascher vor sich, je höher die Temperatur und je reichlicher die Luftmenge ist; sie kann - namentlich beim Puddeln - alich dadurch beschleunigt werden, dass man dem Eisenbade Hammerschlag oder Garschlacke oder reine geröstete Erze zusetzt.

Das weisse Roheisen schmilzt langsam ein (gar), das graue und das Spiegeleisen plötzlich (roh); daher eignet sich das weisse Roheisen zum Herdfrischen und Puddeln weit besser, während für den Bessemerprocess nur graues und siliciumreiches Eisen, welches durch Verbrennung dieser Beimengungen die geniigende Temperatur liefert, verwendet werden kann.

Die Vorbereitung des Roheisens zum Frischen oder Puddeln. Sehr lichtgraues oder halbirtes Roheisen kann in weisses Eisen von brauchbarer Beschaffenheit durch rasche Abkühlung (A b s chrecken) des geschmolzenen Eisens iibergefuihrt werden; man erreicht dies entweder dadurch, dass man das geschmolzene Roheisen in eisemen Formen erstarren lässt, oder durch das Scheibenreissen oder Blattelheben s. III S. 11 oder endlich durch Einleiten in Wasser, Granuliren.

Wirksamer als das Abschrecken ist das Braten oder Glïhen. Gluht man graues Roheisen längere Zeit unter Zutritt der Luft, so oxydirt sich nicht nur die Oberfläche desselben, sondern es oxydirt sich das Silicium, und das Eisen geht aus der grauen in die weisse Modification über.

Rascher und vollkommener wirksam ist das Umschmelzen des grauen Roheisens unter kräftigem Winde. Bedient man sich hierzu des gewöhnlichen Frischherdes, so heisst die Operation auch Hartzerrennen; beniitzt man besondere mit Koks geheizte Feuer - Feinfeuer - so heisst der Process Feinen, Raffiniren, auch Affiniren.

Fig. 1223 und 1224 stellen ein Feinfeuer im verticalen und horizontalen Durchschnitt dar. Der Herd desselben $a$ besteht in einem länglich viereckigen Kasten, der an 3 Seiten durch kastenförmige, hohle, gusseiserne Wände $b$, die mittelst durehfliessenden Wassers kühl gehalten werden, eingeschlossen ist. Die vierte Seitenwand $c$, durch welche das Eisen abgestochen wird, besteht aus einer einfachen Eisenplatte. Der Boden des Herdes wird aus fettem Sand gebildet. An jeder der längeren Seiten liegen 3 Formen, so jedoch, dass sie einander nicht gerade gegenüber sind, und in ihnen die Düsen der aus der Figur deutlich ersichtlichen Windleitung. Die Formen sind hohl gregossen, so dass sie durch einen Strom hindurchfliessenden Wassers bestäudig kühl gehalten werden können. Zwei Rinnen $e$ e führen dem Apparate das nöthige kalte

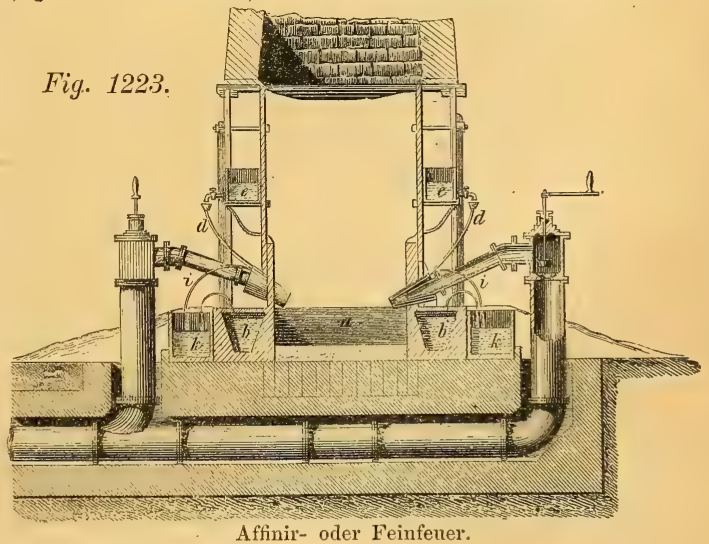

Affinir- oder Feinfener. 


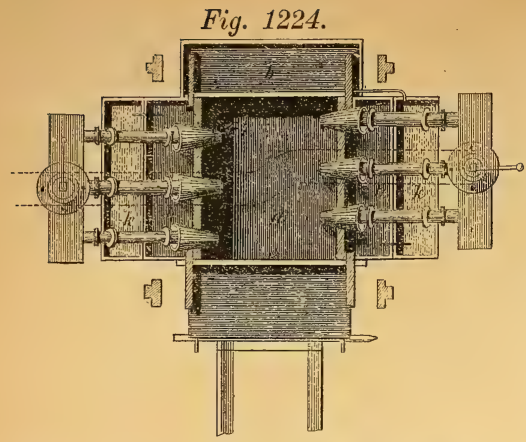

Wasser zu, welches theils durch die Röhrcen $d d z \mathrm{zu}$ den Formen und aus diesen durch die Röhren $i i$ in die Abflussbehälter $k k$, theils durch andere in der Figur nicht sichtbare Röhren in die hohlen Wände gelangt, um auch aus diesen in die Behäller $k k$ zu treten. Das ganze Affinirfeuer befindet sich unter einer 5-6m hohen Esse, deren unterer Rauchmantel etwa $1.3 \mathrm{~m}$ von dem Herde absteht.

Man füllt bei der Arbeit zuerst den ganzen Herd mit Koks an, und legt 6 Flossen (pigs) dergestalt auf sie auf, dass vier den vier Seiten des Herdes parallel und zwei in der Mitte quer über jene zu liegen kommen, worauf man sie mit einem Haufen Koks bedeckt. Das Feuer wird nun in Gang gebracht und nach Verlauf einer Viertelstunde das Gebläse angelassen, worauf das Eisen allmälig zum Fluss kommt und sich auf dem Sandbette des Herdes ansammelt. Hierbei werden die Koks in dem Masse, wie sie verbrennen, stets durch neue ersetzt und auch von Zeit zu Zeit neues Eisen aufgegeben, bis zur Gesammtmenge von 2 bis $2 \frac{1}{4}$ Tonnen.

Das herabgeschmolzene Eisen darf aber nicht aufgebrochen oder gerührt werden, wie dies bei der eigentlichen Frischarbeit geschieht, sondern man hat nur darauf zu sehen, die Temperatur stets auf dem richtigen Punkte und das geschmolzene Eisen flüssig zu erhalten. Man bemerkt hierbei eine eigenthümliche, gleichsam wallende Bewegung der Koks, die zum Theil von dem heftigen Luftstrom des Gebläses, zum Theil wohl auch von einer in dem Metalle vor sich gehenden Entwicklung von Kohlenoxydgas herrührt. Wenn nach Verlauf von etwa 2 oder $2 \frac{1}{2}$ Stunden alles Eisen eingeschmolzen ist, wird es abgestochen und fliesst nun nebst den Schlacken in eine vor dem Stich befindliche, von unten durch kaltes Wasser abgekühlte und mit Lehmbrei bestrichene flache eiserne Form von $2^{\mathrm{m}}$ Länge, $1 \mathrm{~m}$ Breite und $5-8 \mathrm{~cm}$ Eisenstärke.

Der Zweck dieser ganzen Operation ist ein doppelter: 1. das Roheisen durch das Umschmelzen unter Einwirkung der Gebläseluft theilweise zu entkohlen, und 2. keine Graphitabscheidung zuzulassen, zu welchem Ende man sogleich nach Ausfliessen die Platte durch Begiessen mit kalten Wasser auch oben kiihlt. Das bierdurch erhaltene Feinmetall ist sehr weiss und von fasrig strahligem Gefïge, zuweilen zellig, mit vielen kleinen runden Blasenräumen. Bei schwefelhaltigem Roheisen setzt man beim Affiniren wohl etwas Kalkstein zu.

Der Abbrand beim Feinmachen beträgt etwa 12 bis 17 Procent, der Verbrauch an Koks auf die Tonne (20 Ztr.) Eisen etwa 4 bis 5 Ztr.

Das Feinmetall wird nun zerschlagen, gewogen und dem Puddelofen übergeben, In einem gewöhnlichen Affinirfeuer können täglich 10 Tons Eisen fertig gemacht werden.

An manchen Orten wendet man auch Feinöfen mit Gasfeuerung an. S. Percy We d ding Eisenhuittenkunde

Die Herdfrischerei findet in den Frischherden oder Frischfeuern (forge d'affinerie - refining-fire) ihre Durchfuihrung.

Die beistehenden Figuren zeigen ein offenes Frischfener im Verticalschnitt und Grundriss. $a$ und $b$ sind Manern, welche das Fener gegen die Formseite und die Riickseite begrenzen. $c$ ist die Untermauerung. $a, b$ und die Säule $d$ tragen den Rauchmantel, welcher die Verbrennungsproducte zur Esse fuihrt. Der eigentliche Herd ist ein vertiefter Kasten e, welcher durch dicke Gussplatten begrenzt ist. Diese Platten fiihren besondere Bezeichnungen, n. zw. heisst $f$ der Fig. 1225 a.

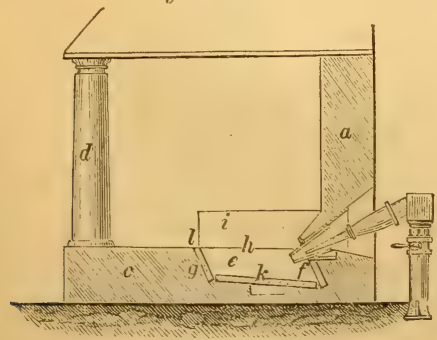

Fig. 1225 b.

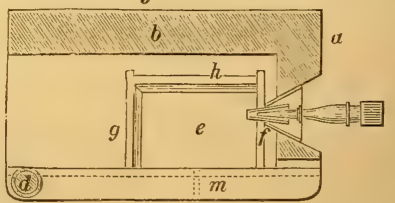

Formzacken, $y$ der Gichtzacken, $h$ der Hinterzacken, auf welchen zuweilen ein Zacken $i$ (Aschenzacken) aufruht, $k$ heisst Bodenzacken und $m$ Vorder- od. Schlaken- 
zacken, weil sich in ihm eine Oeffnung zum Ablassen der Schlacke befindet. Anf dem Vorderzacken ruht die breitere Arbeitsplatte $m$. Die durchschnittlichen Dimensionen sind $63-93^{\mathrm{cm}}$ Länge und Breite und $19-25^{\mathrm{cm}}$ Tiefe unter der Form. Der Bodenzacken ist durch Wasser, welches in dem unter dem Bodenzacken (Fig. 1225) befindlichen Hohlraum circulirt, gekühlt.

Um die abgehende Wärme in etwas auszuniitzen, überdeckt man den Herd - bedecktes Frischfeuer (Fig. 1226) — und gewinnt so einerseits einen Raum (Vorherd) $n$ zum Vorhitzen (Braten) des zu verfrischenden Roheisens, theils einen Raum $v$ zum Erhitzen der Gebläseluft. In unserer Figur hat $f, h, k$ die obige Bedeutung, $l$ ist der Schlackenzacken, $m$ die Arbeitsplatte und $p$ die Esse.

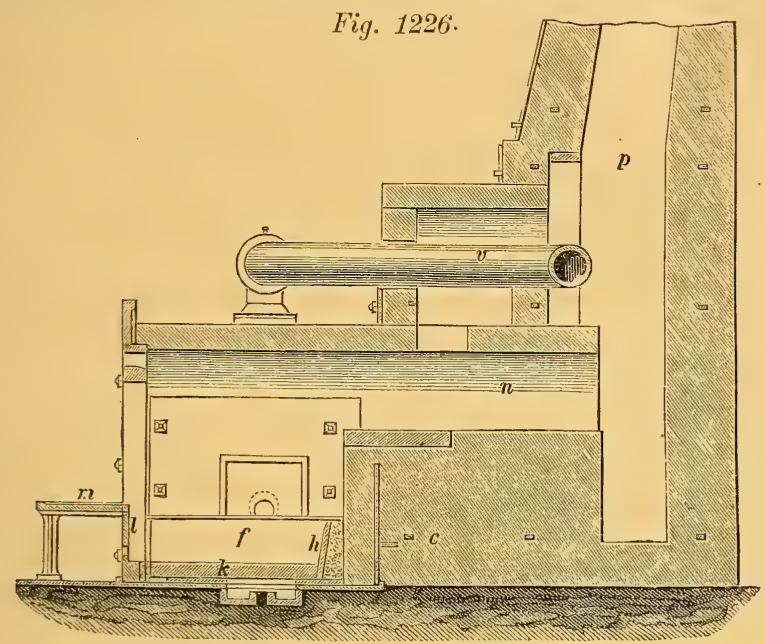

Je rohschmelziger ein Eisen ist, um so langsamer verläuft im Allgemeinen der Process. Bei rein em rohschmelzigen Eisen trachtet man denselben durch Verminderung der Herdtiefe, stärkere Neigung der Form, Neigung des Bodenzackens zur Form und durch kalten, schwächer gepressten Wind zu kürzen. Man nennt diesen Gang Gargang. Derselbe wird auch durch Zusatz oxydirender Mittel, namentlich Garschlacke von einem friiheren Processe, befördert.

Bei garschmelzigem, aber dabei unreinem Eisen verlangsamt man den Process durch die umgekehrten, die Herdform beeinflussenden Mittel.

Will man im Frischherde graues Roheìsen auf Schmiedeisen verarbeiten, so bat ein erstes Niederschmelzen die Aufgabe des Feinens, ein zweites die des Rohfrischens und ein drittes die des Garfrischens. Man nennt dann deses Verfahren Dreimalsehmelzerei oder deutsches Frischen.

Der bei der Dreimalschmelzerei beobachtete Vorgang ist folgender. Wenn der Herd mit Holzkohlen gefüllt, das Gebläse angelassen und das Feuer in Gang gekommen ist, so bringt man das in Gänze von $2-2 \cdot 6^{\mathrm{m}}$ Länge, $5-8^{\mathrm{cm}}$ Dicke und 23-26 $6^{\mathrm{cm}}$ Breite gegossene Roheisen der Form gegenüber auf den Gichtzacken und schiebt es so weit in das Feuer, dass sein vorderes Ende etwa $18 \mathrm{~cm}$ ron der Form entfernt ist. Das Eisen kommt nun bald zum Schmelzen und fliesst in den Herd, worauf man die Ganz weiter vorschiebt,bis sie gänzlich niedergeschmolzen ist. Auf diese Weise wird das zu einem Frischstiick bestimmte Roheisen, $2 \%$ bis 3 Zentner, niedergeschmolzen und schon hierbei durch die oxyrirende Einwirkung des auf das schmelzende und herabträufelnde Eisen einwirkenden Luftstromes einer anfangenden Entkohlung unterworfen, und dadureh zur dick- 
flüssigen Consistenz gebracht. Der Arbeiter untersucht das im Herde befindliche Eisen mit einem Spiess; zeigt es sich sehr fliissig (roh), so dass er den Spiess leicht hindurch bis auf die Bodenplatte bringen kann, so sucht er dadurch nachzuhelfen, dass er eine gewisse Menge Garschlacke in den Herd bringt und mit dem Eisen durchzuarbeiten sucht. Zeigt sich das Eisen im Herd von teigiger Consistenz, so dass der Spiess nur mit Mühe bis anf die Bodenplatte hindurchgestossen werden kann, so ist dies ein Zeichen von einem guten garen Gange. Sollte dagegen das Eisen sich hart anfuihlen, so ist der Gang zu gar, die Entkohlung für dieses Stadium des Processes schon zu weit vorgeschritten, und der Arbeiter muss durch Zufiigung von etwas Roheisen nachzuhelfen suchen. Bei diesem ersten Einschmelzen bildet sich eine sehr fliissige Schlacke, Rohschlacke, welche, da sie ihrer zu duinnfliissigen Beschaffenheit wegen sich mit dem Eisen nicht vermengt, daher nur wenig zur Entkohlung beiträgt, durch das Schlackenloch abgelassen wird.

Man schreitet nun zum $\mathrm{R}$ oh a ufbrechen oder Durchbrechen, indem man die Kohlen abräumt und bei ununterbrochenem Gange des Gebläses mittelst schwerer Brechstangen den -im Herde befindlichen weichen Eisenklumpen in die Höhe hebt und auf frische Kohlen über den Windstrom in umgekehrter Lage bringt, so dass die obere Seite jetzt zu unterst und die der Form vorher zugekehrte Seite an den Gichtzacken kommt. Das Eisen beginnt num wieder zu schmelzen und fliesst nach und nach wieder in den IIerd, wobei eine weitere Entkohlung und Schlackenbildung eintritt. Der im Herde entstehende Eisenklumpen zeigt nun schon grössere Consistenz, so dass der Spiess nicht mehr hindurch gebracht werden kann, und man nimmt ein abermaliges Aufbrcchen, Garaufbrechen, vor, wobei also jedesmal die aufgebrochene Eisenmasse über die Form gebracht und wieder niedergeschmolzen wird. Geht der Frischprocess gut von statten, so reicht ein zweimaliges Aufbrechen und Wiedereinschmelzen, Rohaufbechen und Garaufbechen, hin; doch kann, wemn das Eisen nach dem ersten Aufbrechen noch zu roh geblieben ist, ein zweites, ja selbst ein drittes Rohaufbrechen erforderlich sein. Das Einschmelzen nach dem Garaufbrechen erfordert eine sehr starke Hitze, weil durch die vorgeschrittene Entkohlung sich das Eisen in einem fast stabeisenartigen Zustande befindet. Die in diesem Stadium des Processes sich bildende, verhältnissmässig mehr Eisenoxydul und weniger Kieselerde enthaltende, daher weniger diunnfliissige Schlacke fuihrt den Namen Garschlacke; sie ist es, welche, wie schon erwähnt, bei der Entkohlung des Roheisens eine so wichtige Rolle spielt.

Bei dem letzten Niederschmelzen wird in einigen Eisenhitten das sogenannte Anla ufenlassen vorgenommen. Man hält nämlich einen geschmiedeten Eisenstab unter das herabfliessende Eisen und dreht ihn von Zeit zu Zeit, bis sich das auf seiner Oberfläche erstarrende Eisen zu einem Ǩlumpen, Anla ufkolben, von 16 bis $20 \mathrm{Pfd}$. vereinigt hat, der sodamn ausgeschmiedet ein Eisen von vorzuiglicher Guite liefert.

Nachdem sich alles iibrige Eisen im Herde zu einem zusammenhängenden weissgliihenden Klumpen, Deul oder Luppe, vereinigt hat, wird dieser ausgebrochen und nach dem Abklopfen der ihm äusserlich anhängenden Schlacke (Schwahl) sofort unter den Hammer gebracht, dessen Aufgabe darin besteht, die im Innern des Eisens noch befindliche fliissige Schlacke herauszupressen, und zugleich die Theile des Eisens durch Schweissung zu einer auch im Inneren vollständig zusammenhängenden Masse zu vereinigen, eine Aufgabe, die freilich bei diesem ersten Zängen nie vollständig erreicht wird. Das so durch angemessenes Wenden aluf dem Ambos gebildete prismatische Stiick wird hierauf mittelst des Setzeisens in 4 oder 6 Stiicke, Schirbel, zerschrotet, diese entweder in dem Frischfener oder einem besonderen Schweissofen wieder angewärmt, d. h. zum Weissgliihen gebracht, und unter dem Hammer zu Stäbèn von der verlangten Dicke und Gestalt ausgeschmiedet.

Der Frischprocess bezweckt den Kohlen- und Kieselgehalt des Roheisens durch Oxydation aus dem Eisen zu entfernen, wobei aber die vollständige 
Abscheidung des Kohlenstoffes keineswegs beabsichtigt wird, ja sorgfältig zu vermeiden ist, weil sie ein schlechtes, verbranntes Eiser liefern wiirde. Aber nicht nur der Kohlenstoff, sondern auch Kiesel und Mangan unterliegen derselben Oxydation, schmelzen mit dem im Ueberschuss vorhandenen Eisenoxydul zu einer schwarzen Schlacke zusammen, die sich zum Theil bei der Frischarbeit selbst, zum Theil beim nachherigen Zängen von dem reinen Eisen trennt. Soll jedoch diese Einwirkung des Eisenoxyduls auf die inneren Theile des Kohleneisens rasch erfolgen, so miissen beide Theile zur innigen Beriihrung und Mengung kommen, und hierin liegt der Grund, weshalb der Frischprocess bei allzugrosser Hitze weniger gut von statten geht. Bei sehr starker Hitze nämlich gehen Eisen und oxydulhaltige Schlacke (das Entkohlungsmittel) in diinnfliissigen Zustand iiber, trennen sich in Folge des rerschiedenen specifischen Gewichtes von einander, indem die Schlacke auf dem Eisen schwimmt, und kommen dabei nur in oberflächliche Beriihrung; während sie bei niedriger Ternperatur und geringerer Flüssigkeit sich besonders bei einigem Durchrühren innig mit einander mengen.

Im Anfange der Periode des Rohfrischens scheidet sich eine besonders phosphorreiche Schlacke ab, welche abgelassen werden muss. Das Product des Rohfrischens ist ein stahlartiges Eisen, jenes des Garfrischens Schmiedeisen.

Verarbeitet man bereits gefeintes oder sehr siliciumarmes, weisses Roheisen, dann fällt das erste Schmelzen (Feinen oder Gänzeschmelzen) weg; es genügen zur Herstellung von Schmiedeeisen zwei Schmelzungen, und dieses Frisch-

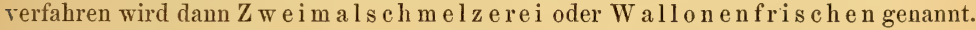
Es wird hierbei heisser Wind beniitzt und der Process durch Zusatz von Garschlacken beschleunigt.

Ist das verwendete Roheisen sehr arm an Kohlenstoff, manganhaltig und rein, so kann ein einmaliges Einschmelzen genïgen. Einmalschmelzerei. Es wird die Entkohlung hierbei beschleunigt durch Herstellung eines Garschlackenbodens im Herde, so wie durch Zusatz von Garschlacke beim Einschmelzen. Ist durch die Einschmelzung die Entkohlung noch nicht geniigend, so findet allerdings auch hier ein theilweises Aufbrechen - Nachrennen - statt.

Die richtige Führung des Frischprocesses - der in zahlreichen Abänderungen, woriber 'Tunner's "Stabeisen und Stahlbereitung" nachgesehen werden kann, durchgefuhrt wird — erfordert viele praktische Erfahrung; denn der Frischer muss aus dem Widerstand, den die Stange im Eisen findet, aus der Helligkeit der Funken und des Feuers, so wie aus der Beschaffenheit der Schlacke den Process beurtheilen.

Soll der Process nur bis zur Stahlbildung durchgeführt werden, so ist derselbe niclit einfach friiher (am Ende des Rohfrischens) zu unterbrechen; weil man so ein Product erhielte, welches meist nicht rein genug wäre. Man sucht vielmehr den Process durch die oben erwähnten Mittel, welche den Rohgang bedingen, namentlich aber durch Anwendung manganhaltigen Roheisens zu verlängern, d. h. die Entkohlung zu verzögern. In dieser Richtung wirkt auch ein, die $\mathrm{Ab}$ kühlung verzögernder, Sandsteinboden des Herdes. Durch dieses Hinausziehen des Processes, das Garen unter der manganhältigen Schlacke, steigt der Brennmaterialverbrauch über jenen zur Sehmiedeisenerzeugung erforderlichen.

Bei dem Frischen a u $\mathrm{Stahl}$ sind die Benennungen Zweimalsehmelzerei, Einmalschmelzerei nicht mehr so bezeichnend wie bei Schmiedeisenbildung; denn selbst daun, wenn rohschmelziges Eisen verarbeitet wird, findet nach dem Einschmelzen kein Aufbrechen statt, sondern es wird das gefeinte Eisen auf dem Boden des Herdes gar gemacht und zwar entweder durch Einrihren von Garschlacke, oder durch den auf das Eisenbad (resp. die Schlackendecke) gerichteten Wind.

Die gebildete Luppe (hier Schrei genannt) wird eben so gezängt, wie dies beim Schmiedeisen der Fall ist, und wie és später besprochen wird.

D as Puddeln. Dieser Process wird im Flammofen durchgefuihrt, in welchem das zu verpuddelnde Roheisen auf einer aus schwerschmelziger Schlacke gebildeten 
Mulde eingeschmolzen und durch die Einwirkung des, in der dariiber ziehenden Flamme enthaltenen, freien Sauerstoffs gefrischt wird. Die Einwirkung der Flamme wird durch Riihren des Eisenbades (to puddel, rïhren*) befördert.

Wir sehen beistehend einen Pud d e 1 o fen in Ansicht, Vertical- und Horizontalschnitt. Das einzuschmelzende Roheisen wird auf den Schlackenherd a gegeben, welcher auf den Herd- oder Bodenplatten aufgestampft ist. Bei $b$ ist die Arbeitsthiire, in derselben ist ein kleines Loch $c$ (Fig. 1227 a) ausgespart, durch welches der Puddler während des Processes mit den Riihrstangen (Krỉeken) in das Innere des Ofens gelangen kann; beim Einschmelzen ist $c$ zugelegt. Das Brennmateriale wird auf den Rost $f$ in den Verbrennungsraum $g$ durch die Heizthïre $i$ gebracht und die Flammen schlagen uiber die Feuerbriicke $l$ nach $a$.

Fig. 1227. a.

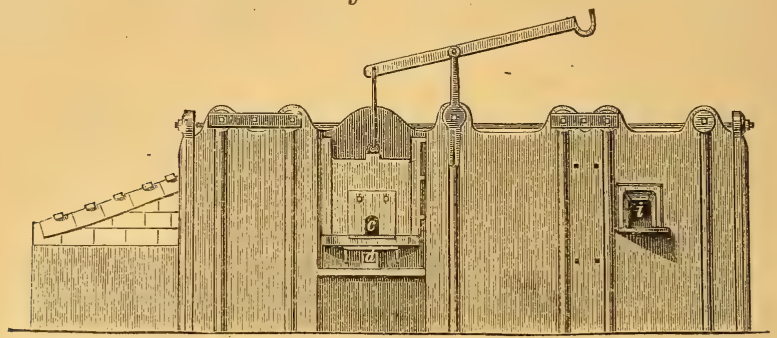

Einfacher Puddelofen.

Die Form des Ofengewölbes $h$ drückt hierbei die Flamme auf den Schlackenherd nieder. Gegen den Fuchs o ist der Herd durch die Fuchsbrü cke $m$ begrenzt. Die Fuchsbrücke $m$ liezt etwas niederer als die Feuerbrïcke und kann die anf dem Eisenbade schwimmende Schlacke iber $m$ nach $o$ abfliessen. Uebrigens ist zum Ablassen der Schlacke bei d (Fig. 1227 a) oder an anderer geeigneter Stelle ein Schlackenstichloch angebracht. Die Asche fält durch den Rost in den Aschenfall h. Die Feuer- und die Fuchsbricke bestehen aus einem hohlen Eisenkasten,

*) Die Benennumg diescs Processes stammt wie dieser selbst aus England. Das Verfrischen des Roheisens wurde frïher auch in England mit Holzkohlen nach dem deutschen Verfahren ausgefuihrt; als aber das $\mathrm{Holz}$ in England seltener und theurer wurde, fing man an, Holzkohlen mit Koks gemengt anzuwenden. Allein das Stabeisen fiel gewöhnlich von harter, schlechter Beschaffenheit aus und der Process ging so langsam von Statten, dass eine Eisenhïtte, die wöchentlich 20 Tons Stabeiseu zu liefern im Stande war, schon zu den bedeutenden gezählt wurde.

Es gelang (1787) den unausgesetzten Bemühungen Cort's, Roheisen dadurch zu Stabeisen zu verfrischen, dass er es auf dem Herde eines Flammofens einer lebhaften Steinkohlenflamme exponirte, wodurch er den doppelten Vortheil erreichte, einestheils mit Steinkohlen als Brennmaterial auszureichen, und zweitens, keines künstlichen Gebläses zu bedüirfen. Aber dieses Verfahren allein führte noch keineswegs zu dem gewünschten Resultat; es war sehr unsicher, gab mitunter einen sehr unbedeutenden, ein andermal wieder einen sẹr grossen Verlust; das Eisen fiel sehr verschieden aus, und eben so grosse Differenzen zeigten sich in der Jienge des Steinkohlenverbrauchs. Indessen gelang es Cort, anch diese Schwierigkeit dadurch zu überwinden, dass er vor dem eigentlichen Puddeln im Flammofen ein Feinen mit Koks vornahm. Das so vorbereitete Eisen nannte er finery metal oder fine metal (Feinmetall, Feineisen).

Statt der bis dahin gebräuchlichen Behandlung des gefrischten Eisens unter dem Hammer führte Cort das Walzwerk ein, wodurch die Stabeisenfabrication wieder eine ausserordentliche Erleichterung, wenn auch nicht Verbesserung erfuhr. Aber auch durch alle diese Mittel wurde ein brïchiges Stabeisen von sehr geringer Güte erzielt, das wenigstens unmittelbar keiner Anwendung fähig war. Um auch diesen Fehler zu verbessern und ihm die nöthige Consistenz zu geben, unterwarf er das gepuddelte Eisen einer nachtrïglichen sehr heftigen schweisshitze in einem besonderen Flammofen, wodurch es dann gelang, ein gutes verkäufliches Stabeisen herzustellen.

$\mathrm{C}$ ort ist nach den hier angedeuteten ausserordentlichen Leistungen nicht minder epochemachend in der Eisenindustrie aufgetreten als in der jüngsten Vergangenheit Bessemer. 
Fig. 1227 b.

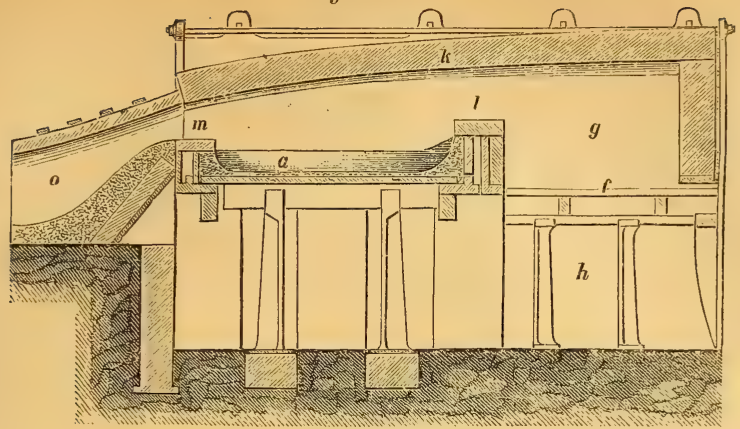

Fig. 1227 c.

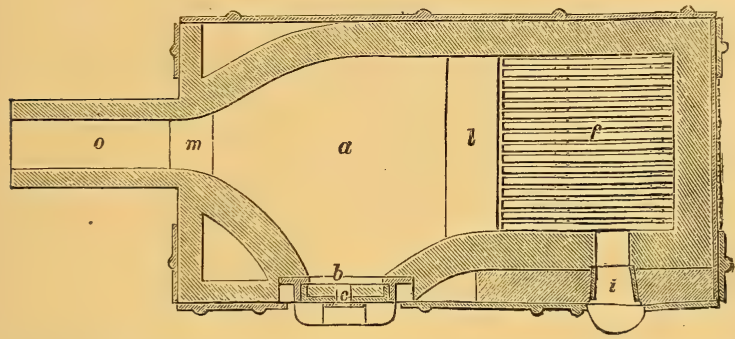

welcher durch feuerfestes Materiale aussen verkleidet und innen durch cirenlirendes Wasser gekühlt ist. Das Manerwerk des Ofens ist aus feuerfesten Ziegeln hergestellt und aussen durch Eisenplatten und Schliessen armirt. Die Länge des Schlackenherdes beträgt durchschnittlich $1 \cdot 6^{\mathrm{m}}$, die Breite $1 \cdot 5^{\mathrm{m}}$ und die Tiefe $15-20^{\mathrm{cm}}$ bei einem Einsatz von 3-4 Ztr. Roheisen und bei der nur für die Bearbeitung von einer Seite (einfache $\mathrm{O}$ efen) eingerichteten Anordnung. Oefen, welche eine Bearbeitung von beiden Seiten gestatten, heissen Doppelöfen. An den Fuchs schliesst sich der Schornstein an, dessen innerer lichter Querschnitt gewöhnlich quadratisch ist und die Verbrennungsproducte abführt. Die obere Oeffnung des Schornsteines ist mit einer Klappe (Deckel) versehen, welcher die Regulirung des Znges gestattet.

Zum Zwecke der Ausnützung der in den Verbrennungsproducten abgehenden Wärme werden manche Puddelöfen so construirt, dass sich an die auf den Schlackenherd anschliessende Vertiefung für den Abfluss der Schlacke ein zweiter ebener Herd anschliesst zum Vorwärmen des Eisens ( $\mathrm{vgl}$. Fig. 1226 S. 25). Oder man benützt die Verbrennungsgase zur Kesselheizung, wobei besonders die verticale Aufstellung, wie eine solche durch umstehende Skizze (Fig. 1228) dargestellt ist, häufig angetroffen wird.

Was die Puddelofenftuerung anbelangt, so kann dieselbe - abgesehen von der Form der Roste, in welcher Hinsicht zumeist Plan- und Treppenroste angetroffen werden - auch ganz vom Puddelofen getrennt werden und ist dann steț eine Gasfeuerung (s. d.). In dem sogenannten Generator wird aus Torf, S̈̈gespänen $u$. dgl. sonst schlechter rerwerthbarem Brennmateriale durch unvollkommene Verbrennung Kohlenoxydgas erzeıgt, und dieses in dem Schlackenherde des Puddelofens mit Luft gemengt verbrannt. Hierbei kann der Siemen s'sche Regenerativofen, welchen wir bei der Gussstahlbereitung besprechen werden, zur Anwendung kommen.

Es sei nun zunächst die Manipulation beim Puddeln auf Schmiedeeisen besprochen und hieranf jene Unterschiede im Gange dieses Processes, welche beim 
Fig. 1228.
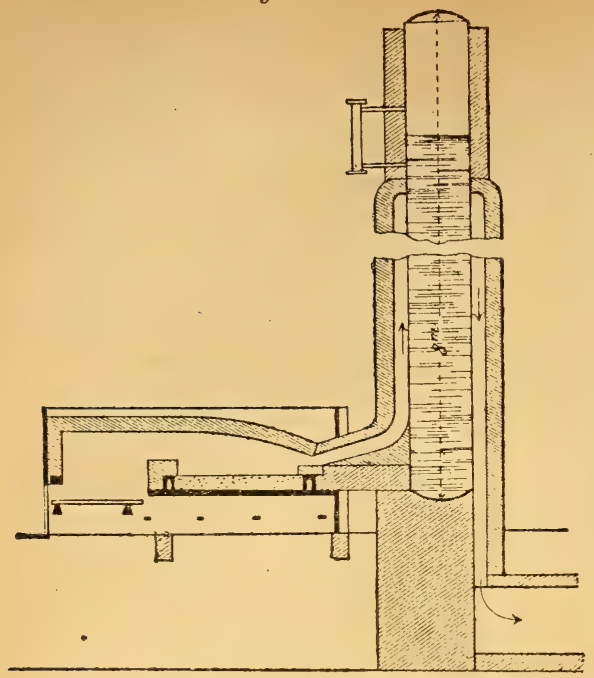

Puddeln sehnigen (Puddeln auf Sehne) oder körnigen (Puddeln auf Korni) Schmiedeeisens, so wie beim Stahlpuddeln beobachtet werden müssen.

Die Operation des Puddelns selbst erfordert viel Geschicklichkeit und Sorgfalt von Seiten des Arbeiters. Er bringt nämlich das Feinmetall oder Puddel-Roheisen mit einer Schaufel in den Ofen ein, und thürmt die Stiicke pfeilerförmig an den Seiten des Herdes bis fast unter die Wölbung des Ofens aufeinander, wobei die Mitte des Herdes frei bleibt. Die einzelnen Pfeiler oder Stapel miissen so viel wie möglich von einander getrennt bleiben, damit das Eisen von allen Seiten dem Zutritt der Luft und der Flamme dargeboten werde. Das Arbeitsloch wird nun mit seiner Fallthür versehlossen, Steinkohle auf den Rost gegeben, und das

Schïrloch damit zugelegt, dagegen aber die zum Oeffnen und Verschliessen auf der oberen Mündung des Schornsteins angebrachte Klappe geöffinet, so dass der Ofen in volle Gluth kommt. Nach etwa 20 Minuten wird das Eisen hellglihend und fängt an den herrorragenden Ecken und Kanten zu schmelzen und auf den Herd herabzutropfen an; so wie dieser Punkt eingetreten ist, öffnet der Arbeiter die kleine, in der Fallthiir eigens zu diesem Zweeke ausgesparte Oeffnung und sucht nun mit einem hakenförmigen Instrumente die Eisenstiicke so zu wenden, und je nach dem grösseren oder geringeren Hitzgrade so anzuordnen, dass das Eisen nicht zu raseh einschmilzt. Nunmehr beginnt das eigentliche Puddeln. Der Arbeiter sucht nämlich das geschmolzene Eisen mit zugesetzter Schlacke und der beim Einschmelzen gebildeten zu mengen, und arbeitet es beständig durch, umi stets neue Oberflächen mit der Luft in Beriihrung zu bringen. Das Eisen schwillt hierbei durch Entwicklung ron Kohlenoxydgas auf, das seinerseits, sobald es das Eisen durchbricht, in Gestalt kleiner Flämmchen abbreunt. In dem Masse, wie das Eisen seinen Kohlengehalt hierbei rerliert, nimmt es an Strengfliissigkeit zu, es wird in der Sprache der Eisenarbeiter trockner, allmälig rermindert sich die Entwicklung von Kollenoxydgas und hört endlich ganz auf. Während dem wird das Eisen beständig durchgearbeitet und umgewandt, bis es körnig-teigig (steif) ist. Wenn dieser Punkt erreicht ist, wird das Fener wieder verstärkt und die Klappe auf dem Schornstein geöffnet. Bei steigender Temperatur nimmt das Eisen jetzt wieder eine zähe Beschaffenheit an und backt oder schweisst sich zu einer kliimprigen Masse zusammen, wo dann der Process beendigt ist.

Es handelt sich jetzt nur noch darum, das Eisen in grössere Klumpen, Ballen, zu vereinigen. $\mathrm{Zu}$ dem Ende wird ein Kliimpchen, das hierbei gleichsam als Kern dient, auf der weichen Masse hin- und hergerollt, so dass es sich durch Anhäufung von Eisen mehr und mehr vergrössert, bis ein Ballen von 30 bis $50 \mathrm{Kg}$. entstanden ist. Dieser wird mit einer vorher heissgemachten Stange nach der heissesten Stelle des Herdes in der Nähe der Fenerbriicke gebracht, um hier noch weicher zu werden, mit Gewalt zusammengedrückt, damit sich die Schlacke möglichst herausquetsche. Wenn nach ungefähr 20 Minuten alles Eisen in Ballen formirt ist, wird auch das Arbeitsloch geschlossen, damit die Hitze ihren höchsten 
Grad erreiche, und die Theile des Eisens sich noch inniger und vollständiger rerbinden. Die Ballen werden nun einzeln mittelst einer grossen Zange aus dem Ofen 'gezogen und so schnell wie möglich unter dem Hammer oder der Presse, zuweilen auch direct zwischen Walzen, gezängt.

Der ganze Process des Puddelns dauert $1 \frac{1}{2}$ bis $2 \%$ Stunden, nämlich $1 /{ }^{+}$. Stunde zum ersten Erhitzen des Feinmetalls, bis es anfängt zu schmelzen, 1 bis $1 \frac{1}{2}$ Stunde zum Puddeln bis zur körnigen Zertheilung, in welchem Zustande das Eisen 1/2 Stunde erhalten wird, endlich 20 Minuten zum Formiren der Ballen. Etwa $3 \%$ bis $4 \frac{1}{2}$ Ztr. Feineisen kommen zur Zeit in den Puddelofen. Der Abbrand oder vielmehr Verlust an Eisen ist je nach der Geschicklichkeit des Arbeiters und der Beschaffenheit des Roheisens sehr verschieden und schwankt zwischen 8 und $15 \%$.

Der Sand- oder Schlackenherd muss schon 12 Stunden vor Anfang der Arbeit am Montag Morgen angewärmt, am Sonnabend aber nach dem letzten Puddeln durch ein lebhaftes Feuer ganz eingeschmolzen und als flüssige Schlacke durch den Abzulg abgelassen werden.

Das Puddeln a u Sehne ist in dem Vorstehenden, ein garschmelziges nicht manganhaltiges Roheisen, wie es verwendet werden soll, vorausgesetzt, bereits beschrieben. Die früher erwähnten Perioden des Feinens, Roh- und Garfrischens sind beim Puddeln, weil kein Aufbrechen erfolgt, nicht so dentlich unterschieden. Die Periode des Feinens ist die Zeit des Einschmelzens, die des Rohfrischens folgt unmittelbar auf das Einschmelzen und zeichnet sich durch die Bildung der Rohschlacke ans, welche allmälig in Garschlacke iibergeht. Die Periode des Rohfrischens soll um so mehr verlängert werden, je unreiner das Eisen ist; denn bei verhältnissmässig niedriger Temperatur gelingt die Abscheidung des Phosphors am besten, derselbe geht in die Schlacke, welche abgestochen wird.*) Ein Zusatz von Hammerschlag. und Garschlacke befördert das Entkohlen. Ganz wesentlich ist das Riihren mit der Kriicke (dem. Haken oder der Kratze), weil dadurch stets neve Theilchen dem oxydirenden Einflusse der Flamme ausgesetzt werden, die Rohschlacke rascher in Garschlacke iibergeht und diese dann lebhaft entkohlend auf das Eisenbad einwirkt.

Da nach 5-7 Minuten die Krïcke weissgliihend wird, aus dem Ofen genommen, in Wasser abgelöscht und durch eine frische ersetzt werden muss, so bezeichnet man an manchen Orten auch die Daner des Rohfrischens durch die Anzahl der Auswechslungen der Krücken und sagt „mit drei, fünf, zehn Krïcken gar". Man kann nun allerdings durch langes Hinausziehen der Rohfrischperiode auch sehr verunreinigtes Roheisen in taugliches, selbst gutes sehniges Eisen verwandeln, aber da hierdurch auch der Consum an Brennmaterial wächst, so ist es eine hauptsächlich ökonomische Frage, ob der Process bis zur Erzielung guten Produktes erstreckt werden kann. Steigt der Steinkohlenverbrauch pr. $100 \mathrm{Kg}$. Luppen gegen $160 \mathrm{Kg}$., so wird die Rentabilität meist schon fraglich.

Die Rohfrischperiode ist beendet, wenn das Eisen "steif" geworden, und nun schliesst sich die rascher verlaufende Garfrischperiode an. Das Eisen wird mit einer spitzen Brechstange zusammengebracht, der nun gesteigerten Erhitzung ausgesetzt und endlich zu Luppen geballt.

Die sich in reichlicher Menge bildende oder absichtlich zugesetzte Schlacke bedingt durch die oben beschriebene Wechselwirkung (S. 22) die Entkohlung. Dieses Puddeln, jetzt allgemein, führt auch die Bezeichnung Schlacken- oder Koch puddeln, zur Unterscheidung: der von Cort urspriinglich eingefiuhrten Methode des Trockenpuddelns, bei welchem sehr kohlenstoffarmes Roheisen teigig eingeschmolzen bei sehr geringer Schlackenmenge - trocken - verpuddelt wurde.

Puddeln auf Korn und Stahlpuddeln. Wie bei dem Stahlfrischen so ist auch beim Puddeln auf Feinkorneisen und $\mathrm{Stahl}$ ein manganhaltiges

*) Weil die Periode des Rohfriscliens bei grauem Roheisen länger wie bei weissem dauert, so verwendet man auch bei unreinem Roheisen lieber graues als weisses. 
Roheisen wesentlich, weil, wie oben erwähnt, der Mangangehalt der Schlacke die Aufösung des Eisenoxydoxyduls erschwert und so verzögernd auf die Entkohlung wirkt. Beim Puddeln auf Korn schmilzt man ras ch ein, um eine zu bedeutende Oxydation der äusseren Partien der Roheisenstücko zu hindern; man lässt ferner von der Rohschlacke so viel im Ofen, dass das. Eisenbad bedeckt ist und ein Garen unter der Schlacke möglich wird und endlich wird die Oxydation der Luppen dadurch verhindert, dass man die Brennmaterialschicht erhöht, wodurch die Behandlung der Luppen in rauchender (redoucirender) Flamme ermöglicht ist. Statt der garenden Zuschläge, welche beim Sehnepuddeln während des Einschmelzens gegeben werden, setzt man Rohschlacke, Sand, manganhältige Zuschläge und selbst Alkalien zu, um eine wenig oxydirende Schlacke zu erlangen.

Je kohlenstoffhaltiger das Product sein soll, um so la $\mathrm{ngs}$ a mer muss gegart werden, soll ein gleichförmiges Product hervorgehen. Daher ist die Chargedauer beim Stahlpuddeln länger als beim Puddeln auf Feinkorneisen.

Das mechanische Puddeln und die rotirendèn Puddelöfen. Die mechanischen Puddler sind Ruihrapparate, welche die Bestimmung haben, das überaus anstrengende Handhaben der Kriicken dem Arbeiter abzunehmen und von einem Mechanismus besorgen zu lassen, welcher, von dem Puddler beaufsichtigt, die Arbeit des Rührens vollbringen soll.

Wedding sagt, dass der Ersatz der menschlichen Arbeit nur dann Erfolg gewährt, wenn die Riihrperiode in Folge der Anwendung eines sich stets gleichbleibenden, ziemlich reinen, dabei rohschmelzigen Materiales bei geringer Aufmerksamkeit eine lange Dauer beansprucht. Zu den verbreiteteren Constructionen gehören die von Dumény und Lemut, ron Eastwood und für Doppelöfen von Whitham.*)

Weit entsprechender als diese Ruihrapparate sind die rotirenden Puddelöfen, von welchen die Constructionen von Menelaus und Danks**) wohl die bekanntesten sind. Die wesentlichste Schwicrigkeit macht das feuerfeste Materiale zur immeren Bekleidung, indem dasselbe den chemischen und mechanischen Einwirkungen der Schlacke und des Eisens bei dieser hohen Temperatur schwierig Stand hält und daher eine kostspielige und öftere Ernenerung erforderlich macht. Die beistehende Skizze zeigt den Rotator ron Sie mens, $\left.{ }^{* * *}\right)$ welcher allerdings zur directen Eisenerzengung verwendet wird, aber das Princip eines rotirenden Puddel-

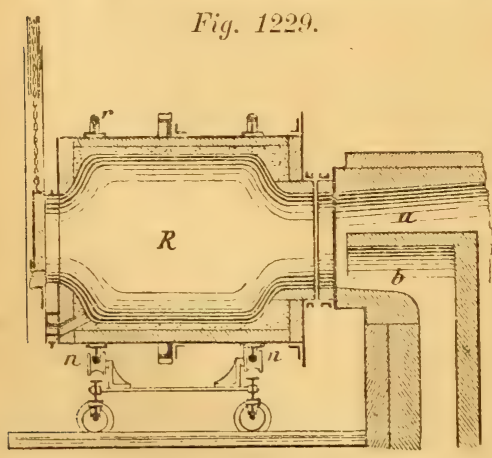
ofens ganz wohl darstellen kann.

$R$ ist der rotirende Herd (Rotator), welcher aus einem eisernen Mantel, einer aus feuerfesten Ziegeln und Steinen gemauerten Schichte und endlich aus einer $13-16^{\mathrm{cm}}$ dicken angeschmolzenen Schlakkenschichte besteht. Am äusseren Mantel desselben sind die auf den Rollen $n n$ laufenden Radkränze $r$ r angebracht, welchen die Bewegung mitgetheilt wird und die den Rotator sehr langsam, pr. Stunde 20- bis 40-mal, um seine Achse drehen. Der D a n k'sche Rotator macht pr. Minute 2 Touren.

$a$ ist der Zuströmungskanal für die den Ofen heizenden, von einem Generator

*) Vergleiche Zeitschrift d. leutsch. Ingenieure Bd. XI. u. Zeitsehrift für Berg-, Huittenu, Salineuwestn in Prenssen Bd. XVIII. Beziiglich Ponsard's Apparat s. Dingl. pol. Jumr. Bd. $19 x$ S. 302 , betreft's jenem ron Dornoy s. Jgl, p. J. Bd. 204 S. $2>7$.

(**) Dingl. p. Jom. Bd. 203 S. $277-286$, Bd. 204 S. 216 u. 282 .

*ar) S. Dingler's p. J. Bil. 209 S. 1; feruer Tunner's Bericht ${ }^{2}$ Das Eisenhüttenwesen der vereinigten Stauten von Nordamerika". 
kommenden Gase, hinter demselben befindet sich der Zuströmungskanal für die Luft. Gas und Luft, beide durch den Siemen'schen Regenerativofen (s. S. 46, 47) vorgehitzt, gelangen im Rotator zur Verbrennung und die Verbrennungsproducte gehen durch zwei hinter einander liegende Kanäle $b$ ab. Beim Dank'schen Rotator ist eine Rostfenerung vor demselben angebracht, und die Verbrennungsgase ziehen am Ende derselben durch einen (beweglichen) Fuchs ab.

Das den rotirenden Puddelöfen zu Grunde liegende Princip scheint uns vorziiglicher, wie die Ersetzung der Handarbeit durch Rührapparate, aber ebenfalls an dem Uebelstande zu leiden, dass sich das Puddeln mit diesen Apparaten schwer dem Materiale anpassen lässt, daher auch ein gleichbleibendes Roheisen voraussetzt.

Das Bessemern (nach dem Erfinder Heinrich Bessemer, welcher im October 1855 das engl. Patent erwarb, so benannt) oder die Erzeugung von Flussschmiedeisen und von Flussstahl mittelst Windfrischen findet dadurch statt, dass geschmolzenes übergares Roheisen in ein birnförmiges Gefäss, Birne, Converter, gebracht wird, in welches atmosphärische Luft unter so hohem Drucke gepresst wird, dass sie die Eisenmasse durchströmt. Hierdurch findet eine kräftige Einwirkung der Luft auf das Eisenbad, ein rasches Frischen, statt. (Die stabilen schwedischen Bessemeröfen sind veraltet.*)

Die beistehenden Figuren $1230 a$ und $b$ zeigen den Converter in zwei Ansichten und im Verticalschnitt.**) Es ist aus denselben ersichtlich, dass der Converter eine anssen mit Kesselblech armirte Retorte ist, welche im Inneren eine etwa $18^{\mathrm{cm}}$ dicke Verkleidung aus feuerfestem Materiale (1 Thl. feuerfester Thon, 6-7 Thl. Quarz) besitzt, welche sehr sorgfältig eingestampft werden muss. In dem Boden des Converters befinden sich etwa 10 Cylinder (Diisen) aus fenerfestem, gut umstampftem Thone, deren jeder etwa 12 Längskanälchen von $7^{\mathrm{mm}}$ Durchmesser besitzt, durch welche der Wind in das Innere des Converters aus dem am Converterboden angebrachten Windkasten $w$ strömt. Der Wind wird durch $b$ dem Windkasten zugeführt.

Die Drehachse des Converters a gestattet diesem Gefässe je nach Bedarf eine verschiedene Lage zu geben. An manchen Orten ist hierzu eine kleine Dampfmaschine $m$ vorhanden, welche die Welle des Schwungrades $s$ bethätigt. An dieser Welle sitzt eine Schraube ohne Ende, welche in das an $a$ sitzende Schraubenrad $r$ eingreift. Das mit Coulissensteuerung versehene Dampfmaschinchen gestattet eine Drehung der Schwungradwelle und dadurch auch des Converters nach beiden Drehungsrichtungen. Will man den Converter beim Fiillen oder Entleeren neigen, benützt man die eine $\mathrm{Be}$ wegungsrichtung; will man ihn heben, die andere.

Der erforderliche Wind von 80 bis $135^{\mathrm{cm}}$ Quecksilbersäule-Press ung wird von einer kräftigen Gebläsemaschine geliefert (200-250Pferdestärken);

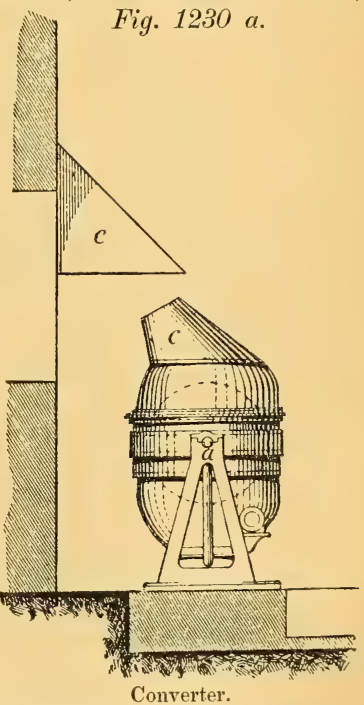
und zum Zwecke der Uebernahme des im Converter erzengten fliissigen Productes ist am hydraulischen Krahne $K$ die Pfanne (und ein Gegenwicht) angebracht.

*) Die erste grössere Specialschrift ist Boman: Das Bessemern in Schweden, Leipzig 1864, Felix.

**) Eingehende Beschreibungen von Bessemeranlagen finden sich in Rittinger's Erfahrungen Jg. 186,5 S. 37, Taf. 7-14; ferner im 5. Bd. „Oesterr. Eisenbalmen von E tzel, Wien 1867, Ḧ̈lder u. zw. Taf. 16-37 das Schienenwalzwerk in Graz, beschr. von. Paulus u. a. a. O. 
Fig. 1230 b.

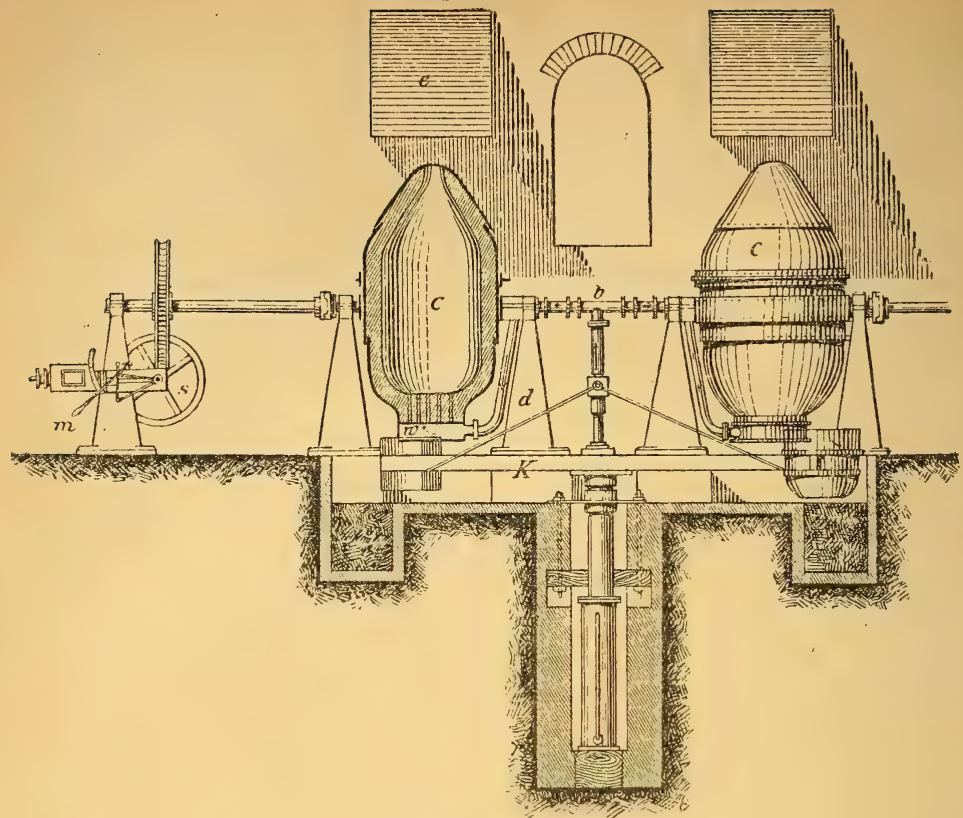

Bessemer-Anlage.

Der beistehende IIolzschnitt zeigt den oberen Theil des Krahnes im Schnitt. $a$ ist die Kolbenstange des Brahma- oder hydraulischen Kolbens, sie trägt an ihrem oberen Ende die drehbare Hiilse b, an welcher die Krahnarme befestigt sind. $G$ ist die Giesspfanne, deren Pfropf von $d$ aus bewegt werden kann. $R$ ist das Gegengewicht, welches in Führungen verschiebbar mit dem Krahnarm verbunden ist. Die Verschiebung kann von der Kurbel $n$ aus durch die Schraube, das Schraubenrad und ein an der Achse des letzteren sitzendes Stirnrad erfolgen, welches in eine mit dem Arm verbundene Zahnstange eingreift.

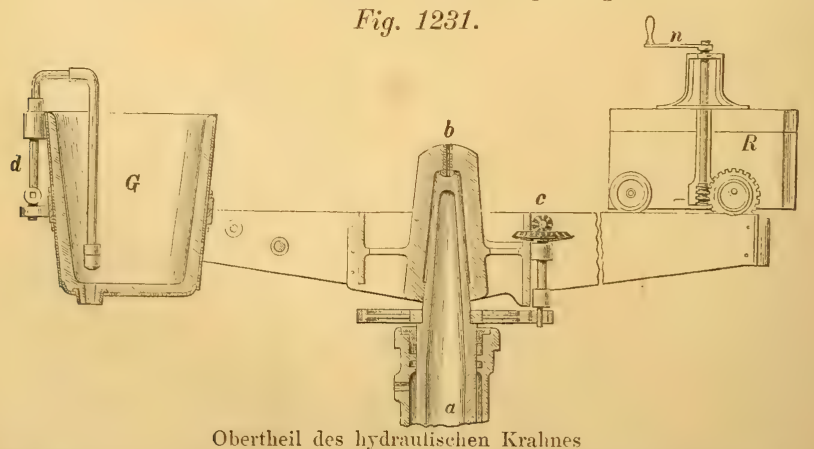

Die Drehung des Krahnes erfolgt von $c$ aus durch die Bethätigung einer Kurbel oder durch einen hydranlischen Kolben. 
Beschreibung des Bessemerprocesses. Ist die Bessemerhütte mit einer Hochofenanlage verbunden, so kann das übergare Roheisen unmittelbar aus dem Hochofen in den Converter geleitet werden. Ist diese Verbindung nicht vorhanden, so kommt das flïssige Roheisen von den Umschmelzöfen (Flamm- oder Cupolöfen). Der Converter muss gut durch Koks vorgewärmt und hierauf entleert sein. $\mathrm{Er}$ wird dureh Ingangsetzung des seine Achse bewegenden Mechanismus so geneigt, dass die Convertermündung in der Horizontalebene der Achsen steht, das Zuleitungsgerinne wird angeschoben, der Abstich erfolgt, das Roheisen fliesst in den Converter. Nach Zuruickziehen des Rohres hebt sich der Converter langsam, und gleichzeitig wird Wind gegeben, damit kein Verstopfen der Diisen stattfinden kann. Der Process ist im Beginne.

Sausend durchdringt der hochgepresste Wind das flüssige Roheisen und die glïhenden Gase entströmen der Converteröffnung untermischt mit Funken, aber ohne eigentliche Flamme. Diese tritt erst nach 2 bis 6 Minuten ein. Man nennt diese Periode jene des Feinens oder der Schlackenbildung. Sie geht mit Eintritt der Flamme in die Rohfriseh- (Koch-oder Eruptions-) Periode iiber, das aus dem Eisen entweichende Kohlenoxyd bedingt ein noch vermehrtes Wallen der Masse, der Funken- und Schlackenauswurf wird lebhafter, die Flamme allmälig lichter und länger, auch das Geräusch des durchströmenden Windes stärker. Das Spectrum entwickelt die grünen Streifen. Diese Periode hat meist die längste Dauer, circa 15 Minuten. (Soll direct Stahl erblasen werden, so kippt man den Converter im gehörigen Zeitpunkte, andernfalls fährt man mit dem Blasen bis zur vollständigen Entkohlung fort.)

Das Rohfrischen geht in die Garfrischperiode über, die Flamme wird bläulich-weiss und viel kürzer. (Bei Beginn dieser Periode schleudert ein kräftiger Arbeiter Abfälle von Bessemereisen in den Converter, welche in wenigen Secunden dem weissflüssigen Metalle beigemengt sind.) Die kurze, fast durchsichtig werdende Flamme und noch sicherer die Beobachtung durch das Spectroscop verräth dem dirigirenden Ingenieur, wann die Entkohlung beendet ist.

Der Converter macht wieder die Drehung, eine herrliche Garbe weisser Eisenfunken ausschleudernd, das Gebläse ruht einige Secunden, die Rinne wird in die Mïndung eingerïickt und bringt die zur Kohlung und Veredlung des Productes erforderliche Menge geschmolzenen Spiegeleisens, der Converter nimmt sie auf, erhebt sich unter gleichzeitiger Zufuihrung des Windes wieder, um nach einigen Secunden abermals zu sinken, denn nun ist der Process beendet.

Im Converter befinden sich jetzt statt der $100 \mathrm{Ztr}$. Roheisen circa $90 \mathrm{Ztr}$. geschmolzenen Stahles oder Flusseisens.

Der hydraulische Krahn bringt die Pfanne, gleichfalls gut vorgewärmt, zum Converter, derselbe wird weiter gedreht und entleert den weissheissen, wasserfluissigen Inhalt in die Pfanne. Die Masse erscheint wie kochend, sie wirft Blasen auf und man lässt sie etwas zur Ruhe kommen.

Hierauf lässt man den Krahn sich heben und führt die Pfanne über die erste der im Halbkreis aufgestellten eisernen Formen, Coquillen. Durch Heben des conischen Pfropfes fliesst der Stahl in die Coquille. Man füllt die Coquillen nun der Reihe nach, bis man sieht, dass die Schlacke, welche eine mehr rothgelbe Farbe hat, auszufliessen beginnt. Diese lässt man dann in die Grube ausfliessen.

Während des Processes beobachtet der Dirigent den Verlauf durch ein Spectroscop, und neben ihm steht der Arbeiter, welcher je nach Bedarf durch Drehen eines Handrades die Windmenge regulirt, durch Drehen eines zweiten den Krahn bethätigt, ja selbst auch das Neigen des Converters veranlassen kann, wenn diese Drehbewegung gleichfalls durch hydraulischen Druck bewirkt wird. So erfolgt dieser gigantische Process ohne un mittelbares Eingreifen des Menschen mit einer den Beschauer zur Bewunderung zwingenden Regelmässigkeit und Gewalt. Zur Zeit ist der Bessemerprocess unstreitig das schönste Beispiel der Beherrschung der Naturkräfte von Seite des Menschen. 
Der Bessemer-Process erfordert zu seinem richtigen Verlaufe ein übergares, siliciumreiches Roheisen,*) weil dieses durch Verbrennung des enthaltenen Kohlenstoffes und namentlich des Siliciums jene Wärmemenge zu liefern vermag, welche auch in der Periode des Roh- und Garfrischens das bereits kohlenstoffärmere und schwerer schmelzige Product in dïnnflüssigem Zustande erhalten kann. Das Gebläse drückt $30-31^{\mathrm{cbm}}$ Luft (auf normale Dichte bezogen) pro $100 \mathrm{Kg}$. Roheisen in den Converter. In dieser Luftmenge, welche $38.8 \mathrm{Kg}$. wiegt, sind $29.8 \mathrm{Kg}$. Stickstoff, welche mitgeführt werden, ohne direct am Processe betheiligt zu sein. Diese $29.8 \mathrm{Kg}$. Stickstoff werden den Converter auf circa $1000^{\circ} \mathrm{C}$. erhitzt verlassen und absorbiren circa 8000 Wärmeeinheiten. Durch Wärmeleitung und Strahlung geht gleichfalls eine grössere Wärmemenge verloren, es ist daher wohl einleuchtend, dass nur dann die Masse im Converter in dünnflüssigem Zustande verharren kann, wenn die durch die Verbrennung des Siliciums und Kohlenstoffes freiwerdende Wärmemenge diese Wärmeverluste nicht nur zu decken, sondern auch jenen Ueberschuss an Wärme zu liefern vermag, welcher erforderlich ist, um das schwer schmelzbare Endproduct in dïnnflïssigem Zustande zu erhalten. Würde ein silicium- und kohlenstoffarmes Eisen angewendet, so würde im Converter bald eine teigige, klumpige, theilweise verbrannte Masse entstehen, das Product wäre schlecht.

Durch den fluissigen Zustand, in welchem bei gutem Gange die Masse im Converter sich stets befinden muss, und durch die vielfache Vertheilung des eingepressten Windes findet der friiher im Allgemeinen besprochene Frischprocess in sehr kurzer Zeit statt. Das Feinen (Schlackenbilden), das Rohfrischen (Aufkochen) und das Garfrischen (weitere Entkohlen) nehmen zusammen einen Zeitraum von nur 20-35 Minuten in Anspruch; ersteres circa die Hälfte, letzteres ein Sechstheil dieser Zeit. Die Windpressung wird während der ersten Periode allmälig gesteigert, in der zweiten Periode ermässigt und gegen Schluss der dritten bis zu ibrem Maximum gebracht.

Anfänglich beurtheilte man den Verlauf des Processes nur nach der Beschaffenheit der Flamme, der Funken und der Qualität der ausgeschleuderten Schlacke und Eisens, es gehörte eine ausserordentliche Uebung und Beobachtungsgabe dazu, den Process gerade dann zu unterbrechen, wenn ein Product von der gewiinschten Beschaffenheit, ein Stahl von bestimmtem Kohlenstoffgehalte, gebildet war.

Leichter liess sich jenes Stadium des Processes, welches der Bildung von Flussschmiedeisen, also der fast vollständigen Entkohlung entsprach, aus den äusseren Erscheinungen ermitteln. Man kam daher auf die Idee, das Flussschmiedeisen durch $\mathrm{Zusatz}$ von $\mathrm{Spiegeleisen} \mathrm{wieder} \mathrm{zu} \mathrm{kohlen} \mathrm{und} \mathrm{hatte} \mathrm{durch}$ die Menge dieses Zusatzes den Grad der Kohlung in der Hand. Der Spiegeleisen- oder Ferromangan-Zusatz wirkt auch günstig durch den Mangangehalt, und wird gegenwärtig meist beibehalten, obwohl es durch die Anwendung des Spectroscopes (zuerst durch den österreichischen Chemiker Prof. Andreas Lielegg**) in der Bessemerhütte in Graz 1866 mit Erfolg angewendet) gelang, ein einfaches, wenn auch nicht immer sicheres Mittel für die Erkennung des Verlanfes dieses Processes zu erhalten.

*) Dasselbe darf weder schwefel- noch phosphorhältig sein.

**) Unsere Angabe ist richtig, obwohl Roscoe bereits im Beginn des Jahres 1863 in ,the Proceeding's of the Literary and Philos. Society of Manchester" V. III pag. 57 in wenigen Zeilen die Vermuthung aussprach, dass die Spectralanalyse berufen sein könne, beim Bessemern eine Rolle zu spielen. Die nächste (indirect) von Roscoe stammende Publication in dieser Sache, datirt rom December 1867 im Philosoph. Magazin, während Lielegg bereits im Juni 1867 in den Sitzungberichten der k. k. Akademie der Wissenschaften es aussprach und begründete, dass "Anfang und Ende der Entkohlung des Eisens mit dem Spectroscope durch das Erscheinen und Verschwinden gewisser Linien des Spectrums sicher erkannt werden könne." Die Verdienste Lieleggs wurden im Engeneer 28. Febr. 1868, und in Wedding's Arbeit „Das Spectrum der Bessemerflammen" Berlin 1869 (u. im 17. Bande der Zeitschr. f. d. Berg-, Hütten- u. Salinenwesen im pr. St.), durch $\mathbf{A}$. $\mathbf{H}$ abets in der Revue universelle d. M. T. 13 \& 14 p. 388 u. a. a. O, anerkannt. 
Die gegenwärtig angewendeten Spectroscope*) (sog. Westentaschenspectroscope) sind so einfach construirt, dass sie leicht (als etwa $18^{\mathrm{cm}}$ langes Röhrchen) in der Hand gehalten werden, die Beobachtung daher stehend stattfinden kann.

Im Nachstehenden sollen die Erscheinungen, wie man sie bei Beobachtung der Flammen durch ein Spectroscop empfängt, angegeben und später näher erörtert werden. Indem Referent noch nicht Gelegenheit hatte, diese Beobachtungen selbst zu machen, folgen selbe nach einer schriftlichen Mittheilung des Herrn Vorbach, Hüttenchemikers in Kladno.

Beim Aufgang des Converters, bei Eintritt der Flamme, bemerkt man nur ein mattes continuirliches Spectrum, in dem die gelbe Natriumlinie zeitweise aufleuchtet; sie nimmt aber mit Fortgang des Processes an Helligkeit zu und bleibt mit Eintritt der Flamme beständig.

Zugleich sieht man links von derselben (im Roth) eine oder auch zwei rothe Linien aufblitzen, die dem Kalium und Lithium angehören. Auch diese werden mit Anfang der zweiten Periode (Rohfrischperiode) stabil.

Die nächste Aenderung zeigt sich jetzt im grünen Felde. Hier erscheint zunächst am 59. Theilstrich der Millimeterscala (die Linie $D$ auf 50 gestellt) ein matter, grüner Streifen, der sich aber bald in eine Gruppe von Linien auflöst, die immer schärfer hervortreten. Kurze Zeit darauf tauchen rechts von dieser Gruppe eine grosse Anzahl neuer Streifen auf und entwickeln sich von links nach rechts. Bei Spectroscopen mit kleinem Gesichtsfelde unterscheidet man am Ende der zweiten und bei Beginn der dritten Periode vier Gruppen von grünen Linien, die sämmtlich rechts von der Natriumlinie liegen; ihre linke Seite ist mehr gelbgrün, die rechte blaugrün gefärbt. Sie sind der wesentlichste Theil des Bessemerspectrums, denn mit ihrem Verschwinden ist anch die vollständige Entkohlung des Bades erreicht. Das Verschwinden erfolgt aber bei verschiedenen Roheisengattungen auf ungleiche Weise. In manchen Fällen verlieren sie sich sehr rapid, wohingegen sie anderwärts nur langsam verschwinden. Im letzteren Falle werden immer die am rechts gelegensten matt und unsichthar, bis sich auch die der Natriumlinie am nächsten gelegene anfängt zu verdunkeln. Die Entkohlung ist dann erreicht und der Converter wird gewendet.

Manche Bessemerwerke halten sich an das Verschwinden nur einer bestimmten Linie und verfinstern dann den uibrigen Theil des Spectrums durch einen Schirm in den Apparaten.

Wie vorhin angedeutet, ist beim Verschwinden der grünen Linien das Stahlbad entkohlt. Es ergibt sich hieraus, dass der Gebrauch des Spectralapparates in der angedeuteten Weise nur dort zutreffend sein wird, wo man mit Spiegeleisen rückkohlt. Bläst man direct, so sind die Massgaben anders und jedenfalls schwieriger $\mathrm{zu}$ treffen.

Eben so verschieden ist das Blasen auf Werkzeugstahl, wo das erhaltene Product noch $0.6-0.7 \%$ Kohlenstoff halten soll.

Wie man jetzt schon einsehen dürfte, ist also der Gebrauch des Spectralapparates kein gleichartiger und auch kein unbedingter.

Hiezu kommt noch ein Umstand, wodurch sein Werth auf vielen Werken sehr herabgedrückt wird. Arbeitet man nämlich mit manganreichem Roheisen, so entwickelt sich am Ende der zweiten Periode so viel Rauch, dass die Flamme ganz eingehüllt erscheint und das Spectroscop lässt den Beobachter völlig im Stich. Es verschwinden die grünen Linien schon weit vor dem Ende des Processes und das Spectrum ist entweder continuirlich oder enthält nur die Natriumlinie.

Oft verschwinden die grünen Linien vorzeitig, kommen aber später, wenn das Bad durch geworfene Abfälle etwas gekühlt ist, wieder zum Vorschein; allein dies ist keineswegs immer der Fall.

*) Von Starke \& Kammerer in Wien, Hofmann in Paris, Herrmann \& Pfister in Bern, Brauning in London, Lüttieh in Berlin. (S. Art. Spectroscop.) 
Daher kommt es, dass während sich das Spectroscop beim Umschmelzbetrieb in den bei weitem meisten Fällen bewährte, es auf solchen Werken, die mit Koks arbeiten und ihr Roheisen direct dem Hochofen entnehmen, nur als ein Mithilfsmittel gebraucht wird. So auf der Königshütte in Schlesien, in Kladno in Böhmen u. a. a. 0 .

Ueber den Ursprung der einzelnen Linien ist man noch theilweise im Unklaren.

Dass die gelbe Linie vom Natrium, die zwei Linien links vom Kalium und Lithium stammen, ist sicher. Anders aber bei den Linien im griinen Felde. Diese hielt man längere Zeit für Kohlenstofflinien, und zwar für das Spectrum des Kohlenoxyds. Als es aber nicht gelingen wollte, mit dem letzteren Körper ein auch nur annähernd ähnliches Spectrum hervorzubringen, wurde diese Annahme zweifelhaft, und Brunner wies zuerst darauf hin (Oesterr. Zeitschr. f. Berg- u. Hüttenwesen 1868 pag. 226), dass die hellen, grünen Streifen möglicherweise dem Mangan zuzuschreiben wären. Er stiitzte seine Aussage auf die Beobachtung, dass jene Flamme, welche beim $\Lambda$ nwärmen eines schon gebrauchten Converters aus der Schnauze strömt, ein Spectrum mit grimen Linien gibt, während diese bei neuer Einmauerung ausbleiben. Đer directe Vergleich des Bessemer-Spectrums mit dem Manganspectrum ergab, dass die grünen Streifen zum grossen Theil Manganlinien sind.

Manche Werke wendeten nach Erlangung dieses Hilfsmittels die Kohlung durch Spiegeleisen nicht mehr an, sondern brachen den Process im geeigneten Momente ab. In der Mehrzahl der Fälle ist man jedoch bei dem Spiegeleisenzusatz (oder seinem Stellvertreter Ferromangan) geblieben oder wieder zu demselben zurückgekehrt, weil der Mangangehalt dieses Zusatzes zweifelsohne vortheilhaft auf die Qualität des Productes einwirkt. Das Spiegeleisen wird zu 5-12\% der verarbeiteten Eisenmenge gewöhnlich fliissig, selten nur glühend, zugesetzt. Der Zusatz anderer reiner kohlenstoffreicher Eisensorten, welche aber einen geringen Mangangehalt besitzen, bewährte sich nicht. Das Mangan scheint einerseits jeder zu weit gegangenen Oxydation entgegenzuwirken, gebildetes Eisenoxydul zu reduciren, andererseits zu bewirken, dass der Kohlenstoff nur chemisch gebunden im Producte auftreten kann. So wie manganhaltiges Roheisen zur Entwicklung eines braunen Rauches besonders in der letzten Periode Veranlassung gibt, welcher aus Manganoxyd und Eisenoxydul besteht, so bewirkt anch der Mangangehalt des Spiegeleisens diese Rauchbildung nach dem Zusatze desselben und deutet so auf eine reducirende Wirkung.

Der Spiegeleisen- resp. Manganzusatz macht das Product weniger blasig, was gleichfalls von Wichtigkeit ist. Ohne diesen Zusatz ist das Product nach vollständiger Entkohlung - Flussschmiedeisen - grobkrystallinisch, enthält oft etwas Eisenoxyde und erlangt technische Brauchbarkeit erst durch Zusammenschmelzen mit höher gekohltem Eisen oder durch Gliihen mit Holzkohle. Der ohne Spiegeleisenzusatz erhaltene Bessemerstahl ist nach dem Gusse, besonders wenn die Gussformen olne einiges Ruhenlassen der Masse gefiillt wurden, stark blasig und erfordert eine kräftige Dichtung mittelst des Dampfhammers. Hierbei geben oxydirte oder angelaufene Blasen unganze Stellen.

Von der Umwandlung der Luppen und Ingots in Stabeisen. Die vom Frischherde oder dem Puddelofen kommenden Luppen werden gezängt, d. h. durch verschiedene mechanische Mittel derart verdichtet, dass sich die lockere Eisenmasse, deren Zwischenräume mit flüssiger Schlacke gefüllt sind, unter Auspressen der Schlacke zu einer dichten, compacten Masse verschweisst. Das Auspressen der Schlacke hat um so vollkommener zu geschehen, ein je vorzüglicheres Product man anstrebt. Die kleineren Luppen des Frischherdes erfordern eine schwächere Bearbeitung als die grösseren der Puddelöfen, dafür soll die Arbeit um so rascher beendet sein, je kleiner die Luppe ist, weil selbe dann auch schneller die Schweisshitze verliert.

Der Eisenh ammer für gepuddeltes Eisen unterscheidet sich von dem für die kleineren Luppen aus den Frischherden durch viel grösseres Gewicht und daher 
auch durch massivere Construction aller Theile, daher wandte man hier häufiger Stirn- und Aufwerfhämmer als Schwanzhämmer (vgl. I S. 564) an.

Fig. 1232 zeigt einen Stirnhammer, bei welchem der Angriffspunkt zum Heben vor dem Hammerkopfe liegt. $a$ der $\mathrm{Helm}$, in welchem vorn der Hammer $b$ eingesetzt ist. Beide Theile zusammen haben gewöhnlich ein Gewicht von 60 bis $80 \mathrm{Ztr}$. $c$ c die Daumen oder Frösche, welche an der starken Welle $d$ sitzen, die mit einem Schwungrade $f$ versehen ist, und durch Wasserkraft oder häufiger durch eine Dampfmaschine gedreht wird. $e$ der Ambos, $g$ der auf einem durch Federn unterstiitzten Lager ruhende Drehpunkt des Helmes.

Fig. 1232.

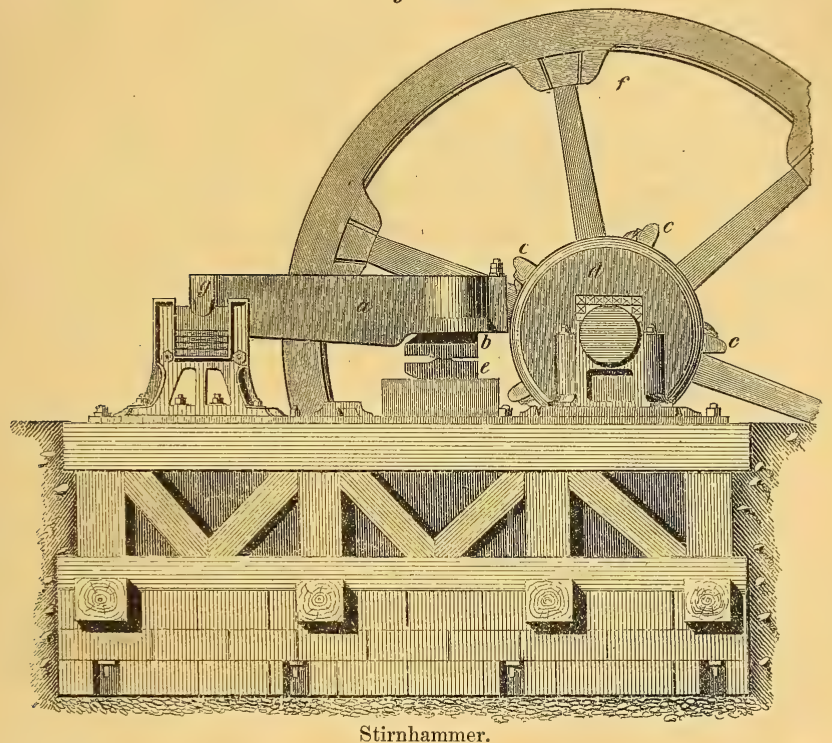

Fig. 1233 ist eine Abbildung eines $\mathrm{A} u \mathrm{fwerfhammers.} \mathrm{Er} \mathrm{unterscheidet}$ sich von dem vorhergehenden dadurch, dass der Angriffspunkt zwischen Hammerkopf und Drehpunkt, obwohl dem ersteren näher als dem letzteren, liegt. Die Hebung wird durch drei auf der Welle befindliche, in der Figur zum Theil durch Punktirung angegebene Excentriks $h$ bewirkt, welche den Fuss $i$ des Hammers heben. Man ersieht leicht, dass hier eine sanftere allmälige Hebung des Hammers erfolgt, während bei dem vorhin beschriebenen Stirnhammer eine stossweise Hebung stattfindet, die bei dem grossen Gewicht des Hammers eine nachtheilige Erschütterung bedingt.

Statt der Hämmer wendet man auch Quetschen an, welche nicht schlagend, sondern drïckend wirken. Eine solche durch Fig. 1234 dargestellte Maschine wirkt wie eine Zange, zwischen deren grosses Maul die Luppe gebracht wird. Die Bewegungsweise ist ohne weitere Beschreibung aus der Figur ersichtlich. Die Zahl der Hiibe beträgt durchschnittlich $40-50 \mathrm{pr}$. Minute und geniigt eine Luppenquetsche für circa 15 Puddelöfen. Kraftbedarf circa 8 Pferdekräfte.

Die Luppe erlangt hier nicht eine ausgeprägt parallelopipädische Form wie unter dem Hammer, sondern nur eine sehr rohe Form, hinreichend, um von den weiten Kalibern einer Luppenwalze erfasst und ausgewalzt werden zu können.

$\mathrm{Zu}$ dem gleichen Zwecke verwendet man auch $\mathrm{Luppenmühlen,} \mathrm{welche}$ aus einem gerippten gusseisernen Mantel $a$ Fig. 1235 und dem gerippten Cylinder 
Fig. 1233.

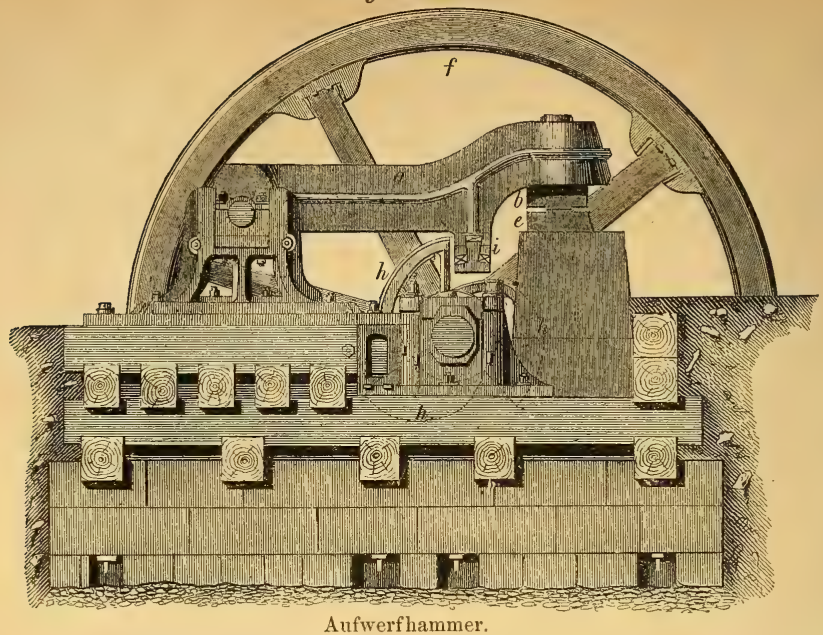

(Walze) $b$ bestehen. Die Luppe wird bei $c$ eingefiihrt, von der rotirenden Walze $b$ weiter bewegt und dadurch, dass sie den stets enger werdenden Raum $c d$ zwischen Walze und excentrischem Mantel passiren muss, rerdichtet. Der Raum $c d$ ist mit einer Eisenplatte bedeckt, welche der Luppe nicht gestattet, nach oben auszuweichen. Die Arbeit der Luppen-Quetschen und Mühlen ist in Bezug auf die Qualität des Productes nicht von derselben Giite wie die IIammerarbeit, auch lässt es sich nicht so leicht wie beim Hammer beurtheilen, ob die Verdichtung eine geniigende war; und die ausgepresste Schlacke wirkt leicht störend auf die Mechanismen ein.*) Kraftbedarf bei gleicher Leistungsfähigkeit circa 11 Pf.

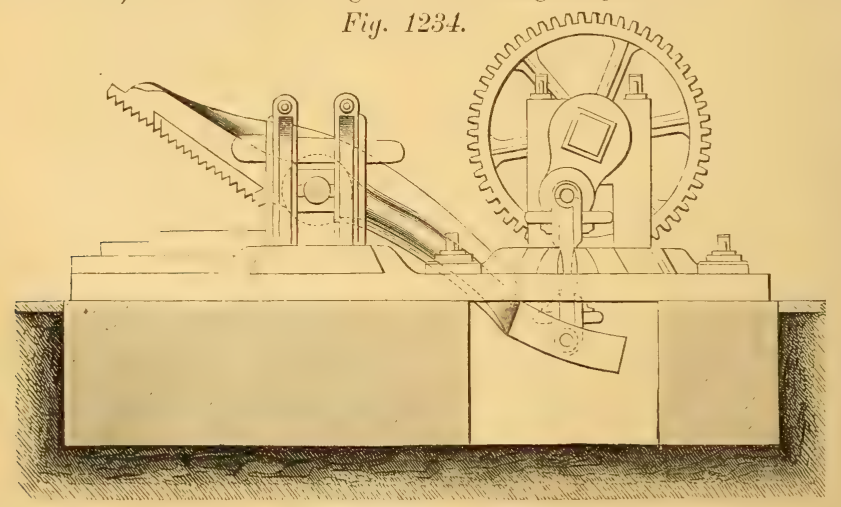

Luppen-Quetsche (Aligator).

Presshämmer, obwohl von vorziiglicher Wirkung, werden zum Zängen doch selten verwendet, sie stimmen im Wesentlichen mit den liydraulischen Schmiedepressen (s. Pressschmieden) überein. Ein sehr rollkommenes Zängen kann auch unter dem Dampfliammer (s. d.) stattfinden.

*) Ueber Dank's Luppenquetsche s. Dingl. p. J. Bd. 204 S. 281. 
Die Ingots von Bessemerstahl müssen, wenn sie grösserer Dimension sind, unter kräftigen Dampfhämmern verdichtet werden. Kleine Ingots können unmittelbar zum Walzen gelangen.

II. $B) \mathrm{D}$ arstellung schmiedbaren Eisens durch Gliihen von Roheisen in oxydirenden Pulvern.

Hierher gehört die Herstellung schmiedbaren Eis engusses, auch A do uciren oder Tempern genannt, und die Bereitung von Glïlistahl.

Das zu beiden $Z$ wecken zu verwendende Roheisen soll rein, lichtgrau und feinkörnig sein. Grap!ithältiges oder graues Eisen liefert schlechte Waare,

Fig. 1235.

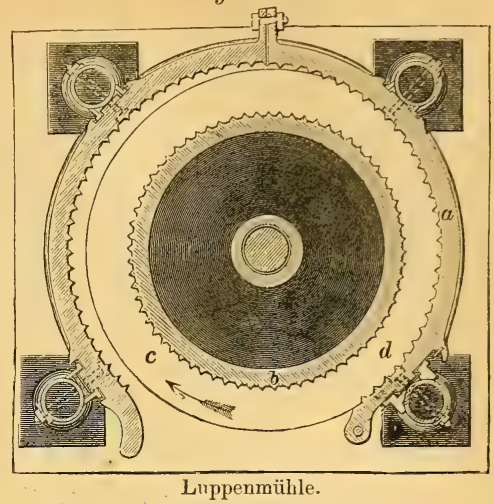
Mangangehalt verzögert die Entkohlung. Weisses Roheisen ist verwendbar, doch wird es schwieriger so dünnflüssig, als reine Güisse erheischen und daher wählt man meist lichtgraues Holzkohlenroheisen.

Indem die Glühstahlbereitung aufgelassen ist, können wir uns hier darauf beschränken, vom Adouciren (vgl. I S. 48) zu sprechen. Man schmilzt das Materiale in geschlossenen Tiegeln in Windöfen, oder falls es sich um ordinärere Waare handelt, auch in Cupolöfen (s. Eisengiesserei) ein. Das Einsehmelzen in Tiegeln liat den Vortheil, dass das Materiale seine Qualität besser behält. Das Formen und Giessen erfolgt wie gewöhnlich. Die Gussgegenstände werden hierauf in Tiegel, Gusseisenkästen oder Blechbiichsen mit Adoucirpulver so eingeschichtet, dass sie rings von demselben umgeben sind. Als Adoucirpulver wählt man verkleinerten Rotheisenstein oder Eisenglanz, von minderer Guite ist gerösteter Spathoder Brauneisenstein.

We dding sagt, es seien diese Materialien in Kornform von etwa $1^{\mathrm{mm}}$ Durchmesser anzuwenden, doch scheint auch feineres Pulver in Anwendung zu stehen. Auch finden andere oxydirende Substanzen, z. B. Braunstein, Zinkoxyd, Anwendung.

Wesentlich ist langsames Anheizen bis zur Rothgluth, genïgend langes, gleichmässiges Glïhen, so wie langsames Abkuihlen. Die Glühzeit beträgt circa 5 Tage, unter Umständen jedoch mehr. Die Angaben hieriiber weichen sehr von einander ab (vgl. Tunner's Eisenhiittenwesen der verein. Staaten, Wien 1877, S. 116, u. WV edding's Grundriss d. Eisenhüttenkunde, Berlin 1871, S. 237). Die Oefen, in welchen das Gliihen erfolgt, sind verschiedener Construction, meist Flammöfen. Anch hier sind bereits continuirliche Oefen in Gebrauch gekommen, auf dem Principe der für Ziegeleien verwendeten Ringöfen basirend.*)

Der getemperte Eisenguss lässt sich kalt sehr gut bearbeiten, bei schwacher Gliihhitze schmieden und nimmt beim "Einsetzen" (s. u.) leichter als gewöhnliches Schmiedeisen Kohlenstoff auf. Der schmiedbare Eisenguss ist zwar minder zäh und fest als Schmiedeisen, auch rostet derselbe leichter, dafiir aber kann er leicht verzinnt, vernickelt etc. werden, und stellen sich die Herstellungskosten kleiner Stïcke namentlich bei complicirter Form weit billiger als durch Schmieden.

II. C) Darstellung von Flusstahl - Erzstahl - durch Zusammensehmelzen von Roheisen mit Eisenerz oder Eisenoxyd.

Schmilzt man reines weisses, granulirtes Roheisen in Tiegeln mit geröstetem reinem Eisenerze zusammon, so erhält man bei richtig gewähltem Verhältnisse 
einen Stahl, welcher in seiner Beschaffenheit vom Tiegelgussstahl kaum zu unterscheiden ist.

Uchatzius schmolz 100 Thl. Roheisen, 24 Thl. gerösteten Spatheisenstein und $1 \frac{1}{2}$ Thl. Braunstein zusammen. Weichere Stahlvarietäten wurden bei Anwendung dieses Gemenges durch Beigabe von 12-20 Thl. Schmiedeisen erhalten. (Siehe iiber den Uchatziusstahl Dingl. p. J. Bd. 142 S. 34 u. 146 S. 313.$)$

Statt des Erzes verwendete Breant durch Gliihen oxydirte Schmiedeisenspäne (Breantstahl). Hierdurch weicht man der Schwierigkeit der Beschaffung reiner Erze aus, es bleibt aber die kaum geringere, so reines Roheisen zu erhalten, wie es hierzu Bedingung ist.

Dies ist wohl auch die Ursache, dass die Erzeugung des sogenannten Erzstahles, obwohl sie schon von Réaumur ausgeführt wurde, eine auf wenige Orte beschränkte ist.

Hierher gehört auch der sogenanute Landore-Process, welchen wir als Varietät des Siemens-Martin-Processes bei diesem S. 45 beschreiben.

III. Erzeugung von Stahl aus Schmiedeisen.

A) Durch Gliihen in Pulvern, welche dem Schmiedeisen Kohlenstoff abgeben. Hierher gehört die Erzengung von Cementstahl und das Einsetzen.

Der Cementstahl (acier à cémentation - steel of cementation) wird durch Glühen schmiedeisener Elachstäbe (reines Feinkorneisen) in Holzkohle hergestellt. Die Dauer des Gliihens beträgt 9-10 Tage bei einer Dimension der Stäbe von circa $20^{\mathrm{mm}}$ Dicke und $78^{\mathrm{mm}}$ Breite.

Die beistehende Figur zeigt einen Cementir-Ofen (fourneau ¿̀ cémenter. - cementing furnace) im Schnitte. Die Kästen oder Kisten $k$, aus feuerfestem Materiale gemauert, werden zuerst mit einer etwa $60^{\mathrm{mm}}$ hohen Lage von dichter Holzkohle - von Erbsen- bis Hasehussgrösse - besetzt (häufig mit Zusatz von

Fig. 1236 .

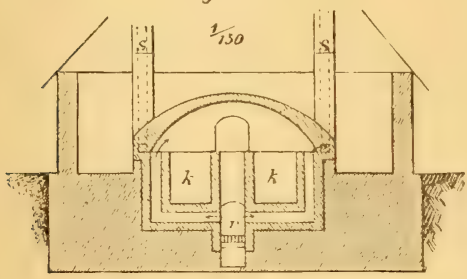

einem Alkali und thierischer Kohle), hierauf kommen die Schmiedeisenstäbe hochkantig im Abstande von beiläufig $15^{\mathrm{mm}}$, hierauf eine Kohlenschichte von 10 bis $15^{\mathrm{mm}}$ Höhe, dann wieder eine Lage Stäbe u. s. f. Oben wird eine dickere Kohlenschichte und zum Abschluss Sand gegeben. Diese Besetzung muss so erfolgen, dass jeder Stab ringsum von Kohle umgeben ist. Durchaus frische Kohle würde $\mathrm{zu}$ kräftig wirken, man mengt daher ein Viertel bis die Hälfte bereits gebrauchter Kohle bei. Der Kohlen:ufwand beträgt circa $27 \%$ vom Eisengewichte. Am Roste r wird nun mit Holz, Steinkohle oder Trockentorf Feuer gemacht, welches binnen 24 Stunden so gesteigert wird, dass die Kisten rothglïhend werden, in welcher Temperatur sie nun durch die ganze Dauer des Processes zu erhalten sind. Die Verbremungsproducte gehen, nachdem sie durch entsprechend gefïhrte Ziige die Kisten umspielt haben, zur Esse $s$. Die Torderwand eines der Kästen, so wie des Ofens ist an correspondirender Stelle mit einer Oefhinung, welche während des Proeesse's wohl zugelegt ist, versehen; es kann durch dieselbe eine Probestange herausgenommen und durch Abbrechen auf den Grad der Kohlung untersucht werden. Die Kohlung muss bis in den Kern der Stäbe vorgeschritten sein, darf aber andererseits nicht zu weit getrieben sein. Die Gewichtszunahme der eingesetzten Stäbe soll $0.5-0.75 \%$ betragen. Im Bruch erscheint das Product grobkürnig bis grobblättrig, die Oberflache zeigt Blasen, daher der rohe Cementstahl auch die Benemmung Blasenstahl fiihrt; und diirfte sich die Entstehung der Blasen dadurch erklären, dass im Eisen enthaltene Schlackentheilchen durch Reduction zur Bildung von Kohlenoxydgas Veranlassung geben. 
Das Einsetzen ist im Wesen nichts anderes als ein Cementiren fertiger Schmiedeisenstiicke auf eine gewisse Tiefe. Feinkorneisen und besonders adoucirter Guss cementirt hierbei leichter als sehniges Schmiedeisen. Man bettet die Stiicke, welche man durch Einsetzen oberflächlich in Stahl verwandeln will, am besten in gutes Spodium von Hanfkorngrösse in Eisenblechbüchsen, welche nicht zu rasch erhitzt und hierauf ein Paar Stunden in Rothgluth erhalten werden sollen. Die Buichsen sollen hierbei durch einen Lehmbrei verschlossen sein. Statt des Spodiums bedient man sich anch gerösteter Knochenspähne oder eines Gemenges von Holzkohle mit Kohle von Horn, Klauen u. dgl. Ein Zusatz von Cyankalium oder Blutlangensalz beschleunigt den Vorgang; so wie man eine ganz dünne Stahlschichte dadurch erhalten kann, dass man die gliihenden Schmiedeisenstücke in die Pulver dieser Salze eintaucht oder damit bestreut. Man kann ferner glühendes Schmiedeisen durch Eintauchen in geschmolzenes Roheisen, ja selbst nur durch Reiben mit einem Stiicke Guss- eisens oder durch Eintauchen in Gusseisenfeilspäne schwach verstählen.

Wenn man nach diesen Operationen die Stïcke noch gliuhend in kaltes Wasser wirft oder taucht, so nehmen sie an der Oberfläche Härte an; und da zum Zwecke dieser Härtung das Einsetzen oft vorgenommen wird, so bezeichnet man auch den ganzen Vorgang durch die Benennung Einsatz- oder Oberflächenhärtung (trempe en coquille ou en paquet - case-hardening). Das Einsetzen ist von grosser Wichtigkeit für manche Maschinenbestandtheile, z. B. Gleitstiicke, Kreuzköpfe etc., welche hierdurch viel längere Dauer erlangen; für Fräsen, Walzen etc., weil man der Gefahr des Springens beim Härten entgeht; endlich auch für kleine Schmuekgegenstände, sogenannten Stahlschmuck, weil durch die Einsatzhärtung die Politurfähigkeit wesentlich erhöht wird.

Es ist leicht möglich, die eingesetzten Stiicke nur partiell zu verstählen und zu härten, man braucht dieselben nur beim Einsetzen theilweise in Sand, theilweise in Cementirpulver zu betten. So z. B. werden "Stahlstiftchen " mit polirten und façettirten Köpfchen, aber weichem Stifte dadurch erhalten, dass man die Drahtstifte mit ihren Schäften in eine Sandschichte einsteckt und die vorstehenden Köpfe mit Cementirpulver bestreut. Man kann in der Blechbüchse eine grössere Zahl solcher Schichten anordnen und nach Verschluss der Biichse, wenn selbe geniigend lange glïhend gemacht wurde, den ganzen Inhalt durch Wegschlagen des Deckels in Wasser werfen. Es härten sich die Köpfchen, die Schäfte bleiben weich; erstere lassen sich schleifen und poliren, letztere kalt vernieten.

B) Stahlbildung aus Schmiedeisen durch Verschmelzen mit Kohle oder mit Roheisen.

a) Durch Schmelzen von Schmiedeisen mit Kohle. Es wird in Indien aus dem durch Rennarbeit gewonnenen Schmiedeisen mit Beigabe von Holzspänen und Blättern in kleinen Tiegeln ein Stahl erzeugt, welcher unter dem Namen Wo otz berihmt ist. Da die Schmelzung eine unvollkommene ist und nach derselben noch ein anhaltendes Glïhen des Stahles stattfindet, so zeigt sich das Product als ein Gemenge verschieden stark gekohlten Eisens, welches, zu Messern etc. ausgeschmiedet und geätzt, oft sehr hïbsche Zeichnungen aufweist (D a mast). Seine Giute ist der Reinheit zuzuschreiben, welche einerseits durch die Qualität der Erze, andererseits durch die Rennarbeit bedingt ist. - Der Parry-Stahl wird durch Schmelzen von Schmiedeisenabfällen im Cupolofen und hierauf folgendes Bessemern erhalten. Man erhält ein reines, aber theueres Product.

b) Schmilzt man Schmiedeisen mit reinem Roheisen im entsprechenden Mengenverhältnisse zusammen, so erhält man Stahl. Nicht selten werden hierbei zum Zwecke der Erlangung des richtigen Kohlungsgrades oxydirende Zusätze, als: Hammerschlag, geröstete Erze u. dgl. mit verwendet und der Process ist dann der Erzstahlbereitung ähnlich.

Hierher gehört das von M ushet eingeführte Kohlen des Bessemerfusseisens durch Spiegeleisenzusatz (s. S. 35, 36). Erfolgt das Zusammenschmelzen von Roh- 
und Schmiedeisen in Tiegeln, so erhält man Tiegel-Flussstahl; erfolgt dasselbe in Flammöfen, wobei man sich der Siemens'schen Regenerativöfen bedienen muss, um die ausreichende Temperatur zu erhalten, so erhält man den Flammofen-Flussstahl oder Martinstahl.

Martin gebührt das Verdienst, den Siemens'schen Regenerativofen zum Zwecke des Zusammenschmelzens von Roh- und Schmiedeisen beniitzt und dadurch diese Art Stahlerzeugung im Flammofen möglich gemacht zu haben, welche frïher stets misslang. Die Anwendung des Siemens-Ofens ist daher wesentlich, und so führt diese Stahlerzeugung auch mit Recht den Namen des SiemensMartin-Processes (open-hearth process).

Der Siemens'sche Regenerativofen gestattet, wie erwähnt, die Hervorbringung eines besonders hohen Hitzegrades im Schmelzraume, weil die zur Verbrennung gelangenden, von einem Generator kommenden Gase, $\left.{ }^{*}\right)$ so wie die atmosphärische Luft bereits auf circa $800^{\circ}$ vorgehitzt in den Schmelz- und Verbrennungsraum treten. Dadurch muss die Verbrennungstemperatur der Generatorgase, welche sich unmittelbar beim Eintritt in den Ofen mit der Luft mengen, eine ungewöhnlich hohe, $2000^{\circ} \mathrm{C}$. nahekommende werden. Wir unterlassen die Besprechung des zum Siemens-Martin-Processe angewendeten Ofens, weil derselbe im Wesentlichen mit dem S. 46 dargestellten Tiegel-Gussstahl-Ofen uibereinstimmt. Die Länge des Herdes beträgt zwischen $4-5^{\mathrm{m}}$, die Breite $2-3^{\mathrm{m}}$, die lichte Höhe $0 \cdot 8-1^{\mathrm{m}}$.

Beim Siemens-Martins-Processe arbeiten gewöhnlich zwei solcher Oefen zusammen. In dem ersten schmilzt man circa $500 \mathrm{Kg}$. Roheisen ein; in dem zweiten wird das Schmiedeisen nahe zur Weissgluth gebracht und dann partienweise bis zu $200 \mathrm{Kg}$. in den ersten übertragen, etwa in Intervallen von 30 Minuten, bis der Gesammtzusatz an Schmiedeisen (bis $2400 \mathrm{Kg}$.) im Roheisenbade gelöst ist. Ueber dem Roheisen bildet sich beim Einschmelzen eine Schlackendecke, welche bei Beginn des Schmiedeisenzusatzes abgelassen wird. Statt des Schmiedeisenzusatzes kann auch Stahl genommen werden, in welchem Falle die Menge des einzuschmelzenden Roheisens eine kleinere wird. Ist das Bad nach circa 6 Stunden gleichförmig, so zieht man eine Probe (Schöpfprobe). Man führt den Process gewöhnlich so, dass durch den Schmiedeisenzusatz, so wie durch die oxydirenden Einfliisse der Flamme ein kohlenstoffärmeres Product entstanden ist, als man herstellen will, und kohlt dasselbe durch spiegeleisen oder Ferromanganzusatz entsprechend auf, worauf abgestochen wird. Nach den einzelnen Eisenzusätzen wird mittelst der Krïcke untersucht, ob die Auflösung im Bade vollständig erfolgt ist, und erst dann ein neuer Zusatz gegeben, wenn dies der Fall. Dass der Schlusszusatz von Spiegeleisen wie beim Bessemerprocess auch durch seinen Mangangehalt auf das Product günstig einwirkt, ist begreiflich.

Der Siemens-Martin-Process gewährt bei billiger Anlage **) den grossen Vortheil, mit ihm bedeutende Quantitäten alten Materiales, z. B. Altschienen (mögen sie Schmiedeisen-, Stahlkopf- oder Stahlschienen sein) aufarbeiten zu können; sein Product ist dabei wenig theuerer als das Bessemereisen und kann leichter von bestimmter Qualität erhalten werden. Auch gestattet dieser Process die Benützung mannigfacheren Materiales.

Es bedarf kaum der Erwähnung, dass der Process mannigfach abgeändert werden kann, ja je nach den verwendeten Materialien abgeändert werden muss.

Siehe den Artikel Gas feuerungen.

**) Kupelwieser hat im berg- u. hüttm. Jahrluch (hieraus Dingl. pol. Journ. Bd. 190 S. 104) eine interessante Vergleichung des Bessemerprocesses mit jenem von SiemensMartin gegeben, woraus hervorgeht, dass fuir den Bessemerprocess, falls derselbe nicht mit dem Hochofen derart verbunden ist, dass ein neuerliches Schmelzen des Roheisens entfällt, ein eben so grosser Aufwand an Brennmaterial erforderlich ist. Vgl. auch Dingl. pol. Journ. Bd. 188 S. 46. Diese Betrachtung stellt sich jedoch für den MartiuProcess etwas zu gïnstig, weil seither die Erfahrung gezeigt hat, dass man graues Roheisen wählen muss. 
Auch wird bei geeigneter Ofengrösse bis $250 \mathrm{Ztr}$. pr. Charge verarbeitet. Martin hat schon im Anfange seiner Versuche garende Zuschläge, geröstetes reines Erz, Hammerschlag etc. beigegeben. W. Siemens hat in Landore einen Betrieb eingeführt, den Landore-Process, welcher im Nachstehenden aus Tunner's wiederholt erwähnten Bericht (S. 105) in Kürze besprochen werden soll. Es werden 106 Ztr. Bessemerroheisen und bis 53 Ztr. Abfalleisen in einem Ofen eingeschmolzen, wozu 4-5 Stunden erforderlich sind. Die Schlacke bleibt uiber dem Eisenbade, welchem allmälig während weiterer 4-5 Stunden circa $27 \mathrm{Ztr}$. Erz (Magneteisenstein von Mokta 60-62-procentig) in ziemlich grossen Stücken durch Einwerfen zugesetzt wird. Ist die Entkohlung durch den Erzzusatz nun erfolgt, so nimmt man die Schöpfprobe; kühlt die Probe unter Wasser, bricht sie und beurtheilt die Qualität. Hierauf erfolgt der Spiegeleisen- oder Ferromanganzusatz; ersterer, wenn das Product noch eine Kohlung erhalten, letzterer, wenn es weich bleiben soll. Die Menge dieses Zusatzes wird so bestimmt, dass das Product $0.3 \%$ Mangan enthält. Dieser Mangangehalt soll den Stahl vor Rothbrüchigkeit schuitzen. Die ganze Chargedauer beträgt 10 Stunden. Pro $100 \mathrm{Kg}$. Ingots werden beim Siemens-Martin-Process $70 \mathrm{Kg}$., beim Landore-Process $75 \mathrm{Kg}$. Steinkohle gebraucht. Bei ersterem Processe, wo die Schlacke abgelassen wird, beträgt der Abbrand circa $6 \%$.

Die beim Siemens-Martin-Processe verwendete hohe Temperatur so wie geringe Oxydation des Eisenbades bedingt, dass dieser Process $\mathrm{n} u \mathrm{r}$ bei Anwendung reinen Roheisens und reiner Stahl- oder Schmiedeisenabfälle angezeigt ist, weil eine Abscheidung des Phosphors und Schwefels nicht stattfindet; daher der Puddelprocess durch ihn auch nicht verdrängt werden kann.

\section{Das Raffiniren oder Veredeln und die Formgebung.}

Schweisseisen in jenem Zustande, wie es durch das Hämmern der Luppen erhalten ist, bedarf für viele Verwendungen allerdings nur eines nochmaligen Erhitzens und Auswalzens, um unmittelbar als Stabeisen in den Handel gebracht werden zu können; eben so genügt häufig dieselbe Operation bei den durch Hämmern verdichteten Ingots von Rohstahl; für andere Zwecke aber müssen die Ungleichförmigkeiten und Ungänzen durch die $\mathrm{Schweissarbeit} \mathrm{oder} \mathrm{das} \mathrm{Um}$ schmelzen behoben werden; und zwar wendet man erstere bei kohlenstoffärmeren Eisensorten, letztere bei kohlenstoffreicheren an.

Werden Frisch- oder Puddel-Luppen nach dem Zängen unmittelbar durch Walzen in die Form von Flachstäben gebracht, so zeigen diese, Rohschienen (mille bars) genannt, ein so rauhes, schuppiges, unegales Aussehen, sind noch so unganz, dass sie keine unmittelbare Verwendung zulassen. Man bricht diese Schienen in gleich lange Stiicke, bildet daraus ein Packet, welches im Schweissofen zur Weissgluihhitze gebracht, hierauf unter dem Dampfhammer verschweisst und unmittelbar hiernach in Walzwerken weiter verstreckt wird. Oder man lässt diese schweissheissen Packete auch sogleich durch Walzen gehen. Hierbei wird noch viel Schlacke ausgepresst, die Masse dichter und gleichförmiger; das Product ist raffinirtes Eisen. Die Bildung des Packets ermöglicht auch verschiedene Eisensorten zu packetiren, wovon später beim Walzen ausfiihrlicher gesprochen werden soll. Hier ist die Veredlung des Productes mit der Formgebung unmittelbar verbunden.

Schmilzt man hingegen Stahl um, und giesst die umgeschmolzene, dadurch auch verbesserte Masse in einfache Gussformen, wodurch man Ingots erhält, so haben wir hier eine Veredlung des Productes ohne wesentliche Veränderung der Form. Diese Veredlung findet bei der Gussstahl-Erzeugung statt und wir wollen daher zunächst von dieser sprechen.

A) Gussstahl-Erzeugung. Gussstahl wird durch Umschmelzen fertig gebildeten Rohstahls in Tiegeln erhalten. Dem durch den Bessemer- oder den Siemens-Martin-Process erhaltenen Stahle wird irriger Weise 
wohl auch zuweilen die Bezeichnung Gussstahl beigelegt, er ist jedoch ein Rohstahl, welcher erst durch Umschmelzen in Tiegeln*) zum Gussstahl wird.

Das Materiale zur Fabrication von Gussstahl kann jeder nicht allzu kohlenstoffarme Rohstahl sein. Für die Fabrication von Werkzengstahl wird rorwiegend Cementstahl; für Achsen, Radreifen (Tyers) etc. Puddelstahl, für Kanonen u. d. Bessemerstahl genommen.

Der entsprechend ausgewählte, in Stücke gebrochene Stahl wird in die Tiegel gegeben, entweder vor deren Anwärmung in einem Glihofen, oder auch nach derselben. Nach dem Einsetzen des Stahles in die Tiegel werden dieselben durch einen Deckel geschlossen.

Hie und da wendet man Zuchläge an. Holzkohlenstïckehen, welche kohlend wirken; Schmiedeisenstïcke, welche weicheren Stahl liefern; metallisehes Mangan, Wolfram, Titan etc., welche die Aufgabe haben, einen feinkörnigeren, härteren Stahl zu liefern. Um die Schlacke recht dünnflüssig zu machen, 'setzt man manchmal Braunstein zu.

Die Schmelzung des Stahles erfolgt theils in kleinen Schachtöfen verschiedenster Bauart, wie selbe auch theilweise für den Tiegelguss und zu anderen Zwecken Anwendung finden und bezüglich deren auf den Artikel Schmelzöfen verwiesen wird; theils in Flammöfen, von welchen sich nur die Siemens-Oefen vortheilhaft bewährten und jetzt auch in den meisten grösseren Gussstahlfabriken in Gebrauch stehen, und deren Princip bereits S. 44 besprochen wurde.

Die Figuren 1237 $a$ und $b$ zeigen uns einen solchen Ofen im Vertical- und Horizontalschnitt. Die Tiegel $b$ stehen in dem kanalartigen Raume $a a$ auf Unterlagen, den Käsen. Das den Raum a deckende Gewölbe ist aus einzelnen abhebbaren Segmenten $c$ bestehend, durch deren Entfernung das Ein- und Ausheben der Tiegel ermöglicht ist.

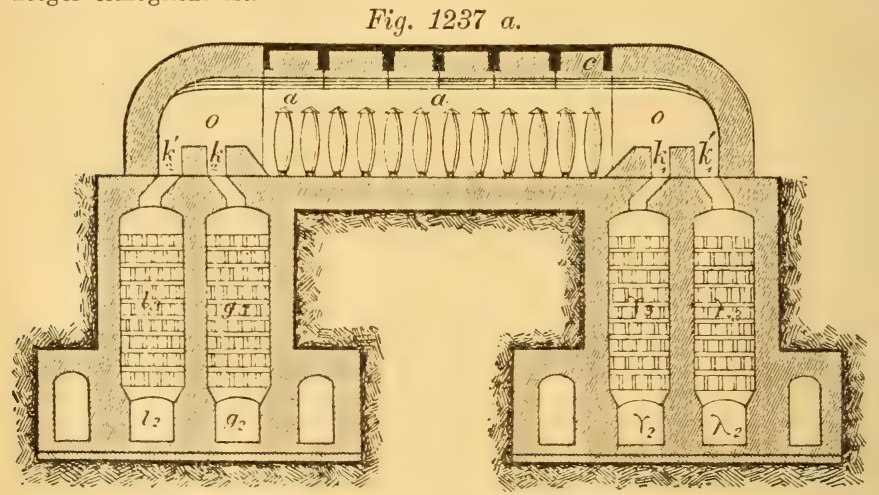

Die in a zur Verbrenuung gelangenden Gase kommen von einem Generator (s. Art. Gasfeuerungen), durchziehen den Kanal $g_{1}, g_{2}$ in der Richtung der Pfeile, gelangen in den mit einem Fachwerk feuerfester Ziegel versehenen verticalen Kanal $g_{3}$ und durch $k_{1}$ in den Ofen. Die zur Verbrennung erforderliche Luft ist gezwungen, den Weg $l_{1}, l_{2}, l_{3}$ zurïckzulegen und gelangt durch $k_{1}{ }^{\prime}$ in den Ofen. Dic Mengung beider findet bei $o$ statt und es erfolgt die Verbrennung. Die Verbrennungsproducte ziehen durch $k_{2}, k_{2}{ }^{\prime}$ ab und nehmen ihren Weg zum Theile durch $\gamma_{3} \gamma_{2} \gamma_{1}$, zum Theile durch $\lambda_{3} \lambda_{2} \lambda_{1}$ zur Esse. Diese abziehenden Gase erhitzen nun das Ziegelfachwerk in $\gamma_{3}$ und $\lambda_{3}$ bis zum Glühen. Stellt man nun die Klappen $p_{1}$ und $p_{0}$ um, d. h. verdreht man sie um $90^{\circ}$. so gehen die Generatorgase durch $\gamma_{1} \gamma_{2} \gamma_{3}$ nach $k_{\Omega}$, die Luft durch $\lambda_{1} \lambda_{2} \lambda_{3}$ nach $k_{2}{ }^{\prime}$, in $\gamma_{3}$, beziehungsweise $\lambda_{3}$ findet eine Abgabe der aufgespeicherten Wärme an Gas, resp. Luft statt,

*) Ueber die erforderlichen Eigenschaften der Tiegel und deren Fabrication s. den Art. Schmelztiegel. 
Fig. 1237 b.

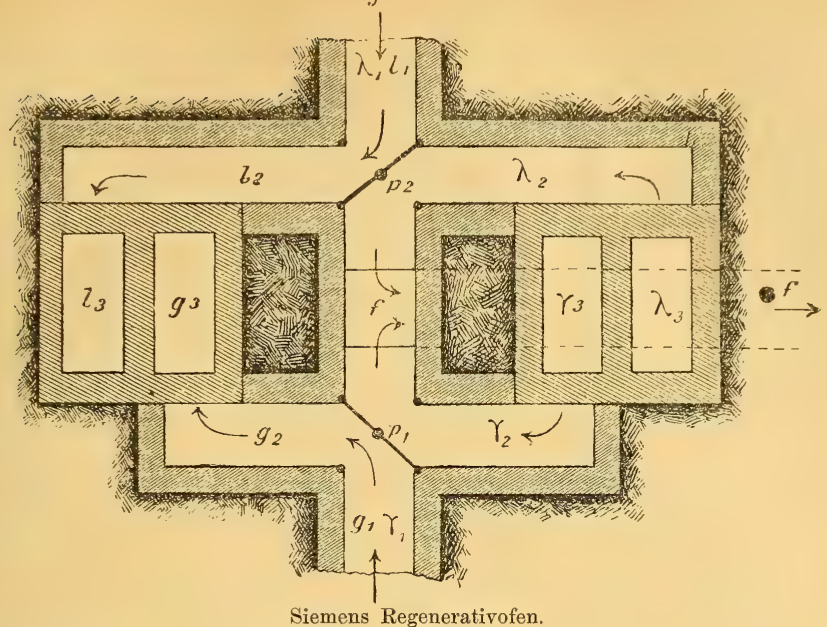

Siemens Regenerativofen.

beide treten daher nun anf etwa $800^{\circ}$ erhitzt in den Ofen; die Verbrennungstemperatur wird hierdurch auf $1500-2000^{\circ}$ C. gebracht. Die Verbrennungsproducte ziehen nun durch $k_{1} g_{3}, g_{2}, g_{1}$ und durch $k_{1}{ }^{\prime} l_{3}, l_{2}, l_{1}$ ab und erhitzen wieder das Fachwerk in $g_{3}$ und $l_{3}$. Nach einiger Zeit - circa 30 Minuten - verstellt man die Klappen wieder in ihre Anfangsposition und dann nehmen Gas und Luft ihre Vorhitzung aus den Fachwerken $g_{3}$ und $l_{3}$. Vor den Vertheilungsklappen $p_{1} p_{2}$ sind noch Klappen angebracht, durch welche man iiberhaupt die Generatorgase und die Luft absperren oder ihren Zutritt auch regeln kann. Der Name Regenerativofen stammt von dem Zurückgewinnen (regenere) der im Fachwerke gleichsam deponirten Wärme. Hieraus darf aber nicht geschlossen werden, dass diese Feuerung iiberhaupt ökononomisch vortheilhaft ist.*) Sie empfiehlt sich nur dort, wo man hoher Hitzegrade benöthigt; in dieser Richtung aber ist ihre Leistung unübertroffen.

Die Schmelzung dauert 3-4 Stunden; und man untersucht, ob der Stahl in den Tiegeln zum vollen Flusse gelangt ist, oft auch dadurch, dass man einen Eisendraht durch ein im Deckel des Tiegels angebrachtes Loch einfuihrt oder bestimmt durch die Erfahrung allein den richtigen Zeitpunkt. Nach dem Ausheben der Tiegel, welche circa 15 , selten bis $25 \mathrm{Kg}$. Stahl enthalten, findet das Giessen in Gusseisenformen statt, deren im Querschnitt achteckiger, prismatischer Hohlraum sich mit Stahl füllt und daher achteckige Ingots liefert.

Zuweilen werden die Tiegel in Façonformen entleert und dadurch Gussstiicke bestimmter Gestalt erhalten. Giesst man grosse Stiicke, so sammelt man sich die erforderliche Stahlmenge in einer Gusspfanne durch Entleeren einer entsprechenden Zahl Tiegel in dieselbe. Hierbei kann die Schwierigkeit eintreten, gleichzeitig die erforderliche Tiegelzahl mit flüssigem Stahle in Bereitschaft zu haben, welche sich nur durch entsprechende Grösse der Anlage und Leitung des Schmelprocesses beheben lässt.

Beim Gusse selbst findet eine geringe Sauerstoffaufnahme statt, welche sich nicht verhindern lässt, da der Strahl des flüssigen Metalles mit der Luft in Beriihrung kommt. Diese Sauerstoffaufnahme gibt zur Bildung von Kohlenoxydgas Anlass, welche bewirkt, dass der die Form füllende noch fliissige Stahl sein Volumen

*) Dingl. polyt. Journ. Bd. 166 S. 270 u. 167 S. 439 . 
vermelirt - steigt — wodurch blasige Güsse entstehen, wenn dieses Steigen nicht durch einen kräftigen Gegendruck gehindert wird. Am einfachsten lässt sich dieser Gegendruck dadurch herstellen, dass die Form nicht ganz gefuilt, sondern rasch auf die Stahloberfläche im Einguss eine Sandschichte gegeben wird, welche man mit einer eisernen, hinreichend beschwerten oder sonst fixirten Platte niedergedrïckt. Meist wird durch Steigröhren gegossen (s. Eis engiesserei).

Die Gussstahlingots werden, um sie in Forın von Stahlstäben zu bringen, in Herden oder Flammöfen zunächst hellrothglïhend gemacht, wobei in den Herden es zu vermeiden ist, den Stahl vor den Wind zu bringen, und in Flammöfen die Feuerung so geleitet sein muss, dass die Flamme etwas rauchig ist.

Die gliihenden Ingots werden hierauf entweder unter Hämmern*) oder Walzen a usgereckt. Findet das Ausrecken unter Hämmern statt, so wird (hier ist die Erhitzung in Herden angewendet) zuerst die eine Hälfte unter dem sehr rasch gehenden Hammer gestreckt, dann abgehauen, hierauf gelangt die zweite Hälfte zur Erhitzung in den Herd zurück und wird dann gleichfalls ausgeschmiedet. Die so erhaltenen Stäbe werden in Stiicke halber Länge geschnitten, neuerlich glii!end gemacht und hierauf zur verlangten Endform - von cirea $1 \frac{1}{2} \square \mathrm{cm}$ im Querschnitt - ausgeschmiedet.

Findet das Ausrecken unter Walzen statt, dann muss der ganze Ingot zur gleichförmigen Glühhitze in den Glïhofen gebracht sein, und passirt dann rasch hintereinander die Walzen ( $\mathrm{K}$ a l i b e r), bis der gewiinschte Endquerschnitt erhalten ist.

B) Die Schwe is s a rbeit. Jene Veredlung des Schmiedeisens oder Stahles, welche durch die Schweissarbeit stattfindet, setzt die gute Schweissbarkeit des zu veredelnden Materiales voraus; kohlenstoffreicher Stahl ist daher hier ausgeschlossen.

Das Wesen der Schweissarbeit ist gekemneichnet durch die Worte: Packetiren, Schweissen und Strecken. Ist es Aufgabe, ans Schmiedeisen-Rohschienen (millebars) durch die Schweissarbeit ein verbessertes Product, sog. doublirtes oder raffinirtes Eisen (corroyé) herzustellen, so werden die langen Rohschienenstangen, wie sie durch das Walzen erhalten werden, auf der Schere in circa $1^{\mathrm{m}}$ lange Stiicke geschnitten und diese in ein Packet (paquet - bundle of iron bars) zusammengelegt, wie es durch beistehende Figm dargestellt sein mag. Des besseren Zusammenhaltens wegen wird dasselbe gewöhnlich durch Binddraht

Fig. 1238.

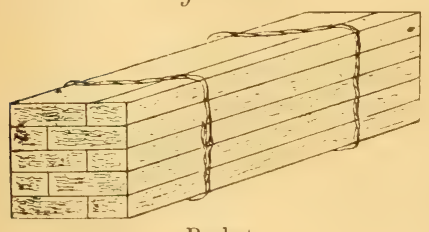

Packet. umbunden. Diese Arbeit nennt man P a cketiren. Das Packet kommt nun in den Schweissofen und wird zur Schweisshitze gebracht: dann aus dem Ofen genommen und auf einem kleinen eisernen Wägelchen dem Walzwerke (friher auch zuweilen dem Dampfhammer) zugefuihrt und verstreckt. Indem das schweissheisse Packet das erste Kaliber (s. u.) der Walzen passirt oder einigen Schlägen des Dampfhammers ausgesetzt wird, findet die Verschweissung der Lamellen statt. Die weiteren Durchgänge durch die Walzen haben die Aufgabe des Streckens bis zur gewïnschten Endform des Querschnittes. Statt der Walzen können auch Hämmer zum Strecken verwendet werden.

Ganz ähnlich ist die Anwendung der Schweissarbeit anf weiche Stahlsorten, nur werden hier gegenwärtig häufiger, als dies beim Schmiedeisen der Fall ist, statt der Schweissöfen theils offene, theils bedeckte Fener, Schweissfeuer, in Anwendung gebracht. Der durch Packetiren, Schweissen und Strecken veredelte Stahl führt die Bezeichnung Gerbstahl und heisst 1-, 2-, 3mal gegerbt, weun diese Operation nur einmal, zwei- oder dreimal durchgefiihrt ist. Der zweimal gegerbte Stahl wird daher durch Packetirung, Schweissung und Streckung des bereits einmal gegerbten Stahles erhalten, der dreimal gegerbte Stahl durch dieselbe Bearbeitung des zweimal gegerbten. Es heisst die Schweissarbeit auf Stahl an-

*) Vergl. Prechtl, techn. Encyclop. Bd. 15 S. 538. 
gewendet Gerben (auch Gärben), das Stahlpacket heisst Garbe; bei Schımiedeisen wird die Bezeichnung Gerben nie gebraucht, es heisst diese Arbeit dann Raffiniren.

Die Bildung des Packetes, der G a rbe, muss beim Stahle, welcher schwieriger schweisst, vorsichtiger erfolgen. Die Stahlstäbe werden nach dem Aushämmern (Plätten) gerade gerichtet (geschient), damit sie sich dicht aneinander legen und keine Lufträume bleiben.

Die vollkommene Vereinigung, das gute Schweissen, erfordert reine Flächen. Da die zu verschweissenden Stäbe aber an ihrer Oberfläche gewöhnlich schon eine dünne Oxyduloxydschichte besitzen, selbe übrigens in den Schweissfenern und Oefen auch allsogleich erhielten; so muss man durch Zugabe von Kieselsäure, Sch we is ss and, bei Schmiedeisen oder durch Zugabe von Schweisssand, Lehm, gestossenem Glase, Flussspath, ja selbst Borax und Alkalien bei Stahl dafür Sorge tragen, dass sich eine leichtfluissige Schlacke bildet. Dieser fällt die Aufgabe zu, das gebildete Eisenoxydoxydul von der Oberfläche der zu verschweissenden Stäbe aufzunehmen, so dass bei dem folgenden Hämmern oder Walzen die Stäbe, indem die Schlacke ausgedriickt wird, sich metallisch rein berïhren und verschweissen. Meist werden diese Schweisspulver trocken auf die Packete oder Garben gestreut, zuweilen (bei Stahl) rührt man das Schweisspulver mit Wasser an und bestreicht damit die Stäbe. Um die Oxydation bei der Erhitzung zu hindern, setzt man in diesem Falle wohl auch kohlende Substanzen, als Blutlaugensalz, Kolophonium dem Schweisspulver bei. (S. hierüber Näheres bei Sensen.)

\section{Zur Erhitzung}

derSchweisspackete, so wie der Ingots aus Bessemerstahl werden gewöhnlich Flammöfen, sogen. $\mathrm{Seh}$ weis - O fen verwendet, wie einen solchen Fig. 1239 $a$ und $b$ im Vertical- und Horizontalschnitt darstellt. $h$ ist der Herd, $b$ die Feuerbrücke, $f$ der Verbrennungsraum, $r$ der Rost, $a$ der Aschenfall, $t$ die Feuerthüre, $s$ der Schlackenkanal und $u$ der Fuchs.

Bei Bildung der Packete wird für gewisse Zwecke auch verschiedenes Materiale an-
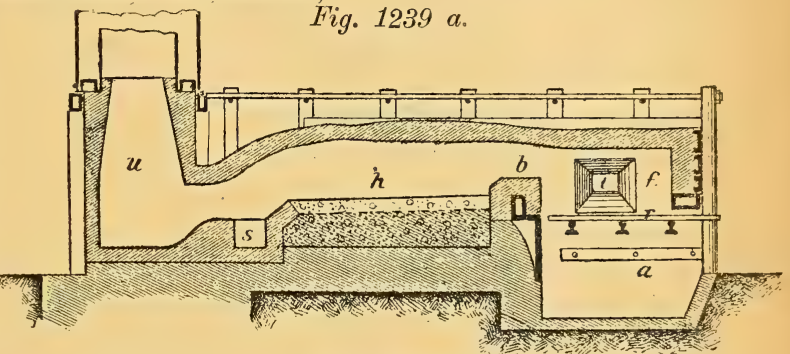

Fig. 1239 b.

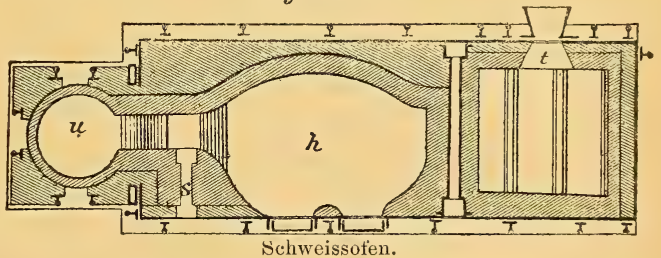

gewendet. So z. B. werden die Packete für Schmiedeisen-Eis enbahnschienen gewöhnlich so packetirt, wie Fig. 1240 zeigt; oben eine Platte aus Feinkorneisen, die Kopfplatte $k$, hierauf folgen die Rohschienen $r$ aus ordinärem Eisen und unten kömmt die Fussplatte $f$ aus sehnigem Eisen. Kopf- und Fussplatte bestehen aus bereits einmal raffinirtem Eisen. Soll eine $\mathrm{S}$ tahl$\mathrm{kopfschiene} \mathrm{hergestellt} \mathrm{werden,} \mathrm{so} \mathrm{besteht} \mathrm{die} \mathrm{Kopfplatte}$ Fig. 1240. aus Stahl. Indem jedoch die Verschweissung von Stahl und Schmiedeisen schwierig erfolgt, so sind gewisse Vorsichten zu beobachten.*)

*) Das Packet wird z. B. mit der Kopfplatte nach unten in den Schweissofen gelegt und in Sand eingebetet, damit die Erhitzung derselben nicht zu bedeutend wird. Siehe über 
Werden Eisenabfälle und Alteisen packetirt, so ist eine so regelmässige Anordnung, wie sie Fig 1240 darstellt, natürlich nicht möglich und lassen sich grössere Hohlräume im Innern des Packets nicht vermeiden. Doch schadet dies dem Endproducte dann nicht, wenn Fig. 1241 .

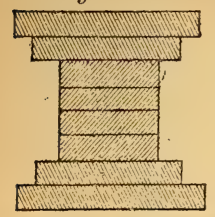
man recht "saftige Schweisshitze" gibt und durch Schweisssand fïr genïgenile Schlackenbildung sorgt. Das aus Abfällen guter Qualität hergestellte, sogenannte Ramasseisen ist sogar als vorzügliches, zähes Eisen beliebt. Sollen alte Eisenbahn-Schienen zur Packetirung verwendet werden, so lassen sich unliebsame, grössere Zwischenräume gleichfalls nicht vermeiden; falls man nicht $\mathrm{zu}$ dem etwas kostspieligen Umwalzen der Schienen, d. h. Verwandlung derselben in Flacheisen, greifen will. Für die Herstellung von Façon-Eisen, z. B. für H-Eisen, werden zuweilen Packete gebildet, welche nicht die rechteckige Querschnittsform haben, soudern eine solche, welche der angestrebten Endform näher kommt und dadurch die Zahl der erforderlichen Caliber vermindert. Fig. 1241.

Packete für Nasenplatten, so wie solche für besonders zähes Kesselblech werden aus querliegenden Schienenstücken zwischen einer Fuss- und Kopfplatte zusammengestellt.

Die Grösse des Packetquerschnittes steht zur Dimension des Schlussproductes in keinem bestimmten Verhältnisse, so ist z. B. der Querschnitt eines, ausgeschmiedeten Massels (Zackels) 100-mal grösser als jene: des daraus hergestellten Walzdrahtes, während eine Eisenbahnschiene etwa den 5. oder 6. Theil des Querschuitts ihres Packetes besitzt.

C) Die Formgebung durch Walzen. Obwohl auch der Hammer und die Presse*) zur Formgebung der Schweisspackete verwendet werden kann, so soll hier doch nur die zur Zeit für die Herstellung von Eisenstäben verbreitetste und wichtigste Methode, das Walzen (cylindrer - rolling), besprochen weíden.

Die Maschine, welcher die Aufgabe des Walzens zufällt, heisst Walzwerk (cylindie - roll). Hat dasselbe die Aufgabe, die Luppen zu zängen oder die bereits unter dem Hammer gezängten Luppen zu Rohschienen auszuwalzen, so führt es den Namen Präparir-, Luppen-, Zäng- oder Rohschienen-Walzwerk(cylindres d̀ cingler - blooming-rolls); ist seine Aufgabe, ans den Packeten Stabeisen herzustellen, so heisst es $\mathrm{Stab}$ is $\mathrm{enwalzw}$ erk (cylindres à étireurs - merchant-rolls).

Gewönlich sind mehrere Walzenpare, wie die beistehende Skizze zeigt, derart rerbunden, dass sie gemeinsamen Antrieb von der Schwungradachse $a$ erhalten. Eine solche Anorlnumg heisst Walzenstrasse oder W.-Strecke. In nnserer Figur bedenten $s$ die Stander des Schwungrades, $l_{i}$ ist die ausrickbare Kupplung zwischen $s$ und $s^{\prime}$, hierauf folgen die zwischen den Ständern $s^{\prime \prime}$ liegenden Getriebe (Krauseln) und zwischen $s^{\prime \prime}$ sind dic Walzen gelagert. $a b$ ist die untere, c d. die obere Welle, diese Wellen laufen jedoch nicht durch, sondern sind durch die Brechköpfe $v$ und Zwischenstiicke o verbunden, worauf wir sogleich zuriickkommen.

Fig. 1242.

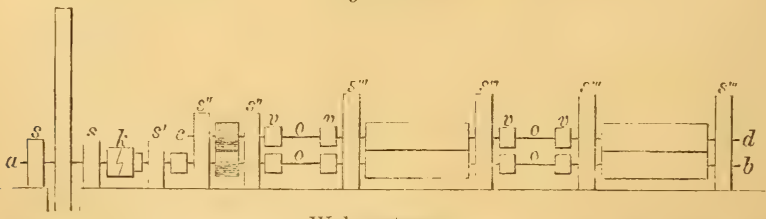

Wil\%enstrasse.

Die Walzen bestehen aus dem mittleren Theile, dem sog. Walzenbunde $a$ (Fig. 1243), den Lagerzapfen $\zeta$ und den Kupplungszapfen c. Der Walzenbund $a$ ist bei Blechwalzen und Universalwalzen glatt, bei den Rohschienen- und Stabeisenwalzwerken aber mit Einschnitten oder Calibern (Kalibern) rersehen. Die Liange des Bundes ist $2 \frac{1}{2}-3 \frac{1}{2}$-mal dem Walzendurchmesser gleich. Der Querschnitt der Kuppelzapfen oder auch Krenzzapfen ist aus Fig. $1243 l$ und Fig. $1243 a$ zu entnehmen. Deil gleichen Querschnitt hat auch die kurze Kupplungswelle

hierher Gehöriges: Petzholdt, Falorication, Prïfung und Tebrnahme ron EisrnbahnMaterial Wiesbaden, Kreidel, 1872.

*) Vergleiche die Artikel Dampthammer, Pressschmieden und Schmieden. 
Fig. 1243 a.

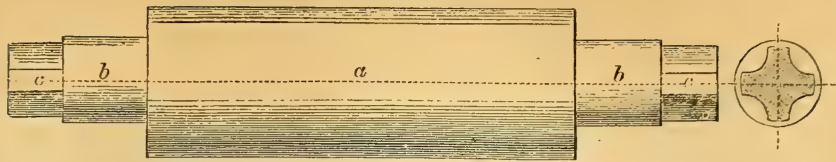

Walze mit glattem Walzenbunde

(o Fig. 1244 u. $d$ Fig. 1244 b), der Muff $f$ (Fig. $1244 b$ ) ist dazu passend gemacht und uiber $c$ und $d$ so aufgeschoben, dass er die Verbindung beider herstellt. Um die Verschiebung der Muffen zu hindern, sind an die Kupplungswelle $d$ Stäbe $e$ angelegt und mit Riemen oder Reifen $g g^{\prime}$ festgehalten. Der Muff oder Brechkopf wird gewöhnlich schwächer gehalten, damit bei einem vorkommenden Stoss - Klemmen des Walzstiickes - kein Brechen der Walzen, sondern ein solches des billigen Brechkopfes erfolge.

Fig. 1244 a.

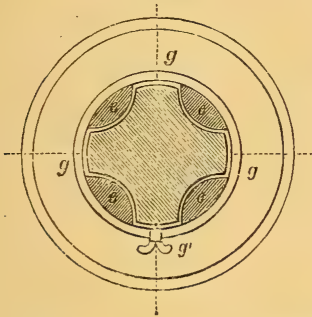

Walzenkupplung ( $f$ Brechkopf).

Zwei zusammengehörige Caliberwalzen sind in Fig. 1245 dargestellt. $k_{1}, k_{2}$ sind die Caliber, also jene Nuthen, durch welche das Walzstück durchzugehen hat, $r r$ sind die Walzenringe. Fig. 1245.

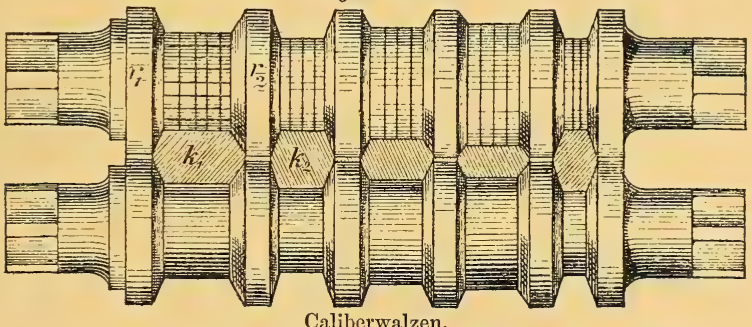

Es sei zunächst die fïr verschiedene Zwecke erforderliche Mannigfaltigkeit der Form der Caliber ausser Betrachtung gelassen, und nur im Allgemeinen die Wirkungsweise betrachtet.

Indem die Walzen im Sinne der Pfeile (Fig. 1246) rotiren, fassen sie das Walzstiick und zwängen dasselbe durch den geringeren Caliberquerschnitt. Dieses Fassen findet aber nur dann statt, wenn das Walzstiick nicht breiter ist, als das Caliber, und auch nur dann, wenn die Zugkraft der Walzen grösser ist, als der vom Walzstück gegen die Formveränderung in der Durchzugsrichtung geleistete Widerstand. In seiner Höhendimension wird das
Fig. 1246.

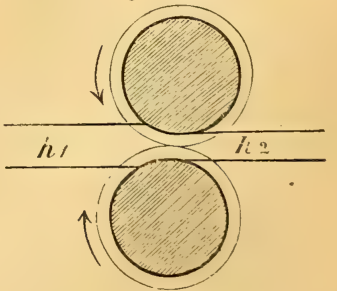


Walzstïck von $h_{1}$ auf $h_{2}$ gebracht, es findet also eine Höhenabnahme statt. Der Länge nach erfolgt ein Strecken, eine Längenvermehrung; der Breite nach aber ist die Einwirkung, Breitung, gering, und zwar um so geringer, je leichter das Materiale sich strecken lässt.*) Indem der Zug der Walzen, d. i. die Reibung derselben am Walzstück, dieses zwischen den Walzenoberflächen durchdrängt, wirken die Walzen drïckend auf das Walzstïck, und man kann daher ganz wohl von einem Drucke in der Richtung der Höhe, vom sogenannten Höhendrucke reden.

Will man von einem bestimmten Anfangsquerschnitt (des Packets) zn einem gleichfalls bestimmten Endquerschnitt gelangen, z. B. von $A B C D$ zu $a b c d$, so ist die Anwendung einer Reihe von Calibern nöthig, welche das Walzstiick abwechselnd in gewendeter Lage, d. h. die Breite als Höhe gesetzt passiren muss, Es wird dies sogleich klar werden. Wollte man $A B C D$ den Walzen zuführen,

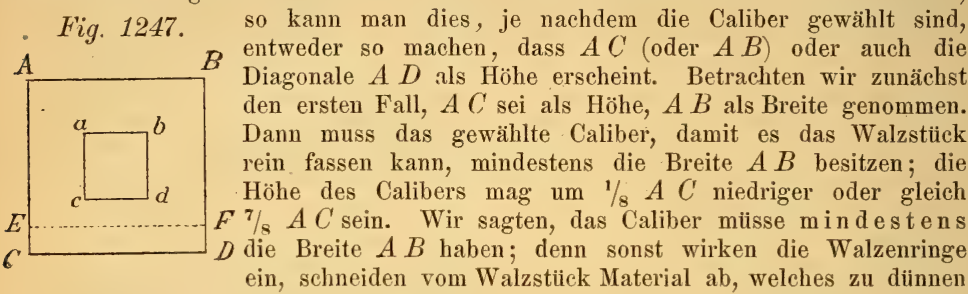
Lamellen ansgewalzt mit dem Walz-stuicke rechts und links zusammenhängen und die richtige Form beeinträchtigen wiirde. Auch dann, wenn das Walzstiick genau einpasst, driickt sich durch die Breitung etwas Materiale zwischen die Walzenringe und bildet die Walznähte. Aus diesem Grunde macht man das Caliber stets etwas weniges breiter. Durch den Durchgang erhält man nun ein Walzstiick von geringerer Höhe, aber derselben oder etwas grösserer Breite und durch analoge Wiederholung des Walzens durch mehrere Caliber könnte man endlich zur Form $C D E F$ des Quersehnittes kommen. Man sieht aber wohl, dass auf diesem Wege die verlangte Endform $a b c d$ nicht zu erzielen ist. Denkt man sich jedoch nach jedem Durchgang das Walzstiick gewendet, so dass, was Höhe war, zur Breite gemacht wird, so hat die Breite jedes nächsten Calibers stets um geringes die Höhe des vorhergehenden zu übersteigen, und man gelangt so zu einer Abnahme der Breiten- und Höhendimensionen, kann also die Schlussform $a b c d$ erzielen.

Wird die Diagonale $A^{\circ} D$ zur Höhe, $C B$ zur Breite gemacht, beim nächsten Durchgang $C B$ zur Höhe, das reducirte $A D$ zur Breite, so kann man durch geeignete Fortsetzung auch zum Schlussprofil gelangen.

Es sieht nach dem Gesagten die Aufgabe, die richtigen Caliber in den Walzen anzubringen, die Calibrirung, sehr einfach aus; aber doch bietet sie grosse Schwierigkeiten, welche einerseits darin liegen, dass man in einer Hitze vom Packet bis zum Endproduct zu gelangen strebt, daher die Zahl der Caliber möglichst herabzumindern hat, und mit möglichst wenig: Walzen möglichst viele Endformen herstellen soll; andererseits aber bei Herstellung ron Façoneisen die dann ungleich streckende Wirkung ein॰lnd desselben Calibers mit der Beschaffenheit des Materiales in Einklang bringen muss.

Die Caliber sind sowohl beziiglich ihrer Aufgabe, Form und Lage in den Walzen sehr verschieden. In ersterer Hinsicht, also bezüglich des $\mathrm{Z}$ we ckes oder der A ufgabe, lassen sich die Caliber eintheilen in:

*) Dirs erklärt die antänglich überraschende Erscheinung, dass weicheres (oder heisseres) Materiale eine geringere Breitung aufweist als härteres. Daher bei gleicher Glühhitze Schmiedeisen weniger in die Breite zunimmt als Stahl. Die theoretische Betrachtung des Walzprocesses bringen wir im Artikel Walzen. 
1. Schweisscaliber. Sie haben die Aufgabe, die Verschweissung der einzelnen Schienen des Packetes zu bewirken.

2. Streck- oder Vorbereitungscaliber, welche thunlichste Streckung des Walzstïckes bewirken sollen.

3. Entwicklungs-Caliber, welche die Endform allmälig bilden.

4. Vollend- oder.Fertigcaliber, welche die Endform namentlich mit Riicksicht auf das Schwindmass ausbilden.

Eine specielle Art der Entwicklungs-Caliber sind:

5. Die Breitungs- oder Stauch-Caliber, durch welche gewisse Theile des Walzstiuckes (z. B. der Schienenfuss bei Eisenbahnschienen) ausgebildet werden.

Zu den Vollend-Calibern gehören:

6. Die Adjustir-Caliber, bestimmt zur Ausbildung der Kanten o. dgl.

Der Form nach unterscheidet man:

1. Die Spitzbogencaliber. Figur 1248 zeigt seine Construction. Gegeben ist $a b$ und $c d$, die Bogenmittelpunkte $m$ bestimmen sich, indem man von $b$ und $c$ (eben so von je zwei anderen Eckpunkten) Kreisbogen vom Radius $a b$ beschreibt; es ist daher $m b=m c=a b$.

2. Quadratcaliber. (Fig. 1249 a u. b.) Die erste Figur zeigt ein Quadratcaliber als Streckcaliber, die zweite als Vollendcaliber.

3. Flachealiber. (Fig. $1250 a$ u. b.) Die erste Figur zeigt ein offenes, die zweite ein geschlossenes Flachealiber.

4. Ovalcaliber. (Fig. $1251 a$ u. b.) Es besteht dasselbe aus den beiden Kreisbogensegmenten $a b c$ und $d e f$, welche; wie die zweite Figur darstellt, dadurch erhalten werden, dass man durch die Punkte $m$ und $n$ des verticalen Durchmessers Sehnen zieht; wobei $b m=m n=n e$ ist.

5. Rund-oder Kre is caliber (Fig. 1252) ist stets nur als Vollendealiber zu verwenden.

6. Polygoncaliber. (Fig. 1253 a u. b.) Fig. $1249 a$. Fig. 1248.
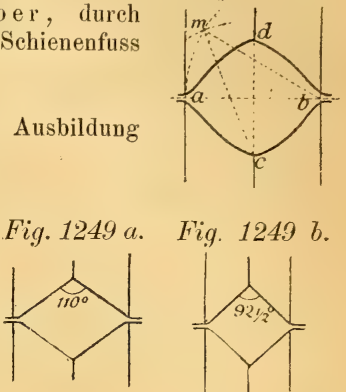

Fig. 1249 b.

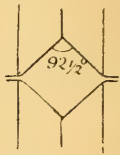

Fig. 1250 b.

Fig. $12 \hat{\jmath} 0$ a.

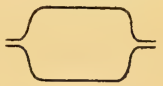

Fig. 1251 a.

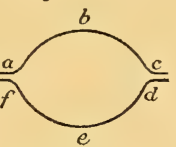

Fig. 1252.
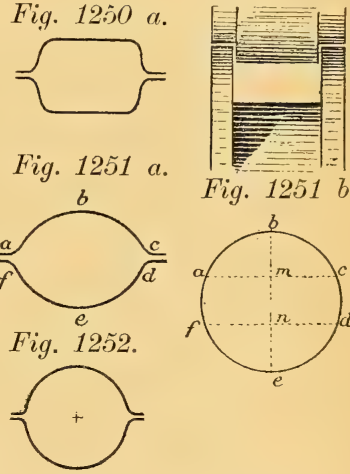

Fig. $1251 \mathrm{~b}$.

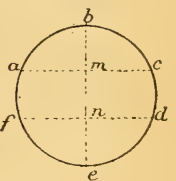

Die erste Figur zeigt ein Vorbereitungs-, die zweite ein Vollendealiber.

\section{Façoncaliber.}

In Bezug auf die L a g e der Caliber in den Fig. 1253 a.

Fiq. $1253 b$.
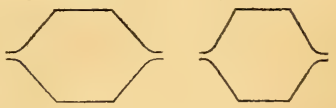
Walzen unterscheidet man:

1. Offene oder getheilte Caliber.

2. Geschlossene oder versenkte Caliber.

3. Theils geschlossene, theils offene Caliber. gehören.

4. Excentrische Caliber, zu welchen auch die unterbrochenen und periodischen

Die offenen oder getheilten Caliber können betreffs der Form allen diesbeziiglich angegebenen 7 Hauptformen angehören; beziiglich ihrer Aufgabe sind es sowohl Schweiss-als Streck-Caliber, öfter auch Entwicklungs und Vollendcaliber, seltener Adjustirealiber. Die in Fig. 1245 gezeichneten Caliber sind durchgehends offene. 
Die geschlossenen oder versenkten Caliber sind durch beistehende Skizze dargestellt. Der Form nach können es Flach- und Façoncaliber sein. Fig. 1254. Eine specielle Art der geschlossenen Caliber sind die Brei-

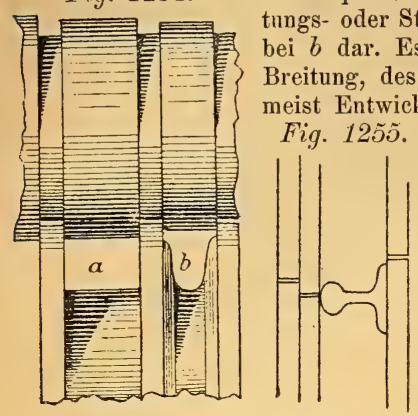
tungs- oder Stauchcaliber und stellt ein solches unsere Figur bei $b$ dar. Es hat dieses speciell den Zweck der. Ausbildung, Breitung, des Schienenfusses. Die geschlossenen Caliber sind meist Entwicklungs- oder Vollend-Caliber.

Fig. 12 วั.

nen und theils offenen Calibers mag Fig. 1255 dienen, es ist dies ein Adjustircaliber zur Abrundung des Schienenkopfes.

Alle diese Caliber lanfen centrisch zur Walzenachse und sind nach Schablonen in den Walzenbund eingedreht. Ist jeder einzelne Querschnitt durch die Walze zwar ein Kreis, liegt derselbe abei excentrisch zur Walzenachse, so nennt man ein solches Caliber ein excentri s ches. (Hierher gehören die Caliber für die Fischbauchschienen.) Hören die Querschnitte auf, Kreise zu sein, só werden die Caliber unterbrochene, und falls die Unterbrechung im Walzenumfang sich 2-, 3-..n-mal wiederholt, periodische Caliber genannt. (Unterbrochene und periodische Caliber finden bei Feilenwalzen, Zuspitzen von Draht ete. Anwendung:)

Das Abnahmsverhältniss ist das Verhältniss eines Caliber-Querschnittes zum nächstfolgenden oder das Verhältniss des Querschnittes des eintretenden Walzstiuckes zu jenem des austretenden. Es ist dieses Verhältniss von der Beschaffenheit des Walzstiickes, von der Dimension und Form abhängig; es kann für grössere Stiicke bei Flachcalibern $5: 4$, bei sehr heissem und weichem Materiale selbst $4: 3$ bis $3: 2$ betragen, ja für kleine Querschnitte selbst anf $2: 1$ steigen, wenn die Formen einfache sind, die Streckung daher gleichmässig erfolgt. Die Abnahme des Querschnittes findet hingegen bei Façoneisen viel langsamer statt, weil das Caliber dann insbesondere die Aufgabe der Formgebung zu erfüllen hat, der Höhendruck, resp. die Streckung des Walzstiickes eine ungleiche ist und das Materiale dieser ungleichen Anspruchnahme ohne Reissen Folge leisten muss.

Bei Spitzbogen-Calibern findet für Schmiedeisen die Abnahme durch nachstehende, in Millim. ausgedruickte Werthe des Constructionskreisdurchmessers ( $a, b$ Fig. 1248) seinen Ausdruck: 158, 132, 112, 98, 86, 75, 72, 66, 59, 53, 46.

Durch die beistehende Figur ist in $1 / 2$ n. Gr. die Aufeinanderfolge der Caliber fiur die Herstellung einer Grubenschiene dargestellt, und sind hierbei die Caliber in jener Lage gezcichnet, in welcher sie in den Walzen liegen. $I$ ist das Schweisscaliber, $I I$ bis $V$ sind Entwicklungscaliber (hierbei ist $I V$ das Stauchcaliber), VI ist das Vollend- und VII das Adjustircaliber zum Zwecke der Abrundung der Kante bei $k$.

Fig. $1256^{\prime} a$.
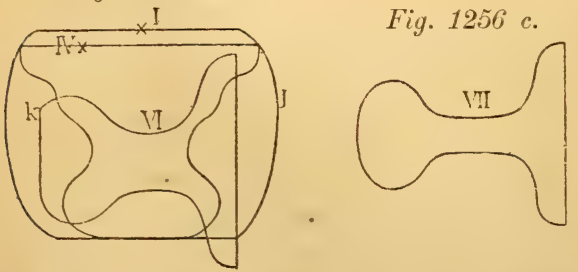

Fig. $12 \tilde{6} 6$.

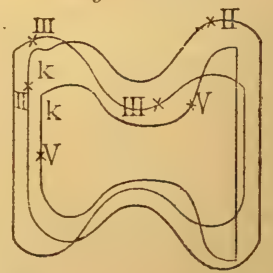

Was die Vertheilung des Caliberquerschnittes in den Walzen betrifft, so wäre es zwar scheinbar am natürlichsten, beide Walzen gleichviel ein- 
zudrehen und so rom Caliberquerschnitt je die Hälfte in jeder Walze anzubringen; aber in diesem Falle könnte das austretende Stück gleich leicht sich gegen die obere oder untere Walze ausbiegen, ja selbst wickeln. In den Schweisscalibern könnte ein Spalten des Packetes eintreten, ein Wickeln des einen Theiles um die obere, des anderen um die untere Walze, wodurch ein Bruch fast unvermeidlich würde. Man miisste an beiden Walzen Abstreichvorrichtungen anbringen, was für die Arbeit unbequem wäre. Dies wird vermieden, und die Abstreichvorrichtungen (Walzenbank, Abstreifmeissel) kömnen auf die untere Walze beschränkt bleiben, wenn man das Caliber mehr in die untere Walze einlässt, weil dadurch das Walzstiick die Tendenz erhält, sich gegen die untere Walze auszubiegen, um diese zu wickeln, woran es eben durch die Abstreichbank gehindert ist. Indem man die Mittellinie des Walzstiickes mehr in die untere Walze einlässt, wird der Caliberdurchmesser der oberen Walze grösser. Bei getheilten Calibern erhält die obere Walze um $2-3^{\mathrm{mm}}$ grösseren Durchmesser, bei versenkten Flachcalibern wird der Durchmesser der Matrize um $2-8^{\mathrm{mm}}$ kleiner als der Durchmesser der Patrize gemacht, bei Façoncalibern legt man hingegen öfter über $2 / 3$ des Calibers in die untere Walze, besonders dann, wenn die Form ein leichteres Hängen an der Oberwalze gestattet.

* Einspringende Winkel, welche das Freilassen des Walzstiickes verhindern, dürfen nie vorkommen, und bei der Herstellung von Walzstücken, welche dies scheinbar unvermeidlich machen, wie z. B. die Nasenplatte (Fig. 1257), walzt man das Stiick so aus, wie Fig. 1258 zeigt, und biegt die Nase dann um, wobei der Raum unter der Nase frei bleibt, die Calibergrenze entspricht der punktirten Linie in Fig. 1257.

Wir haben hier noch jene Mittel zu besprechen, durch welche eine wesentliche Ersparniss an Calibern, namentlich bei der Herstellung der verschiedenen Flacheisensorten, erzielbar ist. In dieser Beziehung sind die Stufen-oder Staffelwalzen und die Universalwalzwerke zu nennen.

\section{Die Stufenwal-}

zen, deren zwei von gleicher Gestalt, wie selbe durch die beistehende Figur gekennzeichnet ist, zusammenwirken, werden ausschliesslich als Vorwalzen fiir Flacheisen beniitzt.

Fig. 1259.

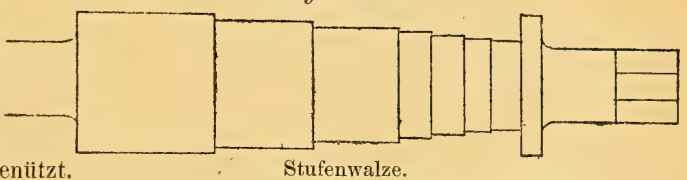

Indem die Stufenwalzen keine seitlich begrenzten Caliber aufweisen, so ist ihre Wirkung eine weniger vollkommene. Die Seitenflächen des Walzstïckes nehmen keine gezwungene Gestalt an, sondern bilden sich (durch das sogenannte Fliessen des Metalles) unrein aus. Als Vollendcaliber muss daher mindestens ein versenktes Caliber angewendet werden.

Die Universalwalzwerke besitzen ausser den gewöhnlichen zwei horizontalen Walzen noch zwei verticale. Das Walzstuick passirt zuerst die horizontalen Walzen und hierauf die verticalen. In diesen Walzen sind keine Caliber angebracht, sondern die Walzenbünde sind flach. Hiervon machen die verticalen Walzen nur dann eine Ausnahme, wenn das Universalwalzwerk als Vorwalzwerk für Doppelt - $T$ - Eisen dient. Die Walzen $a$ und $c$ sind gewöhnlich fix gelagert, die Walzen $b$ und $d$ (hinter $c$ liegend, daher in der

Fig. 1260.

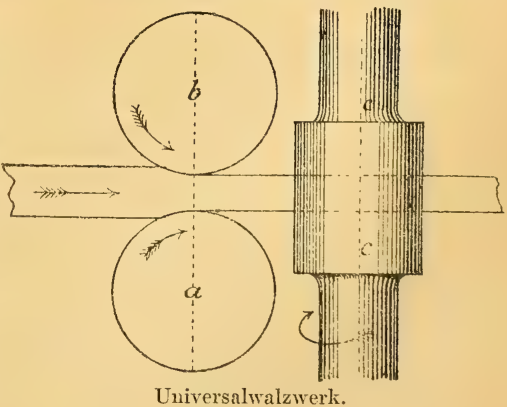


Figur nicht sichtbar) sind parallel zu sich selbst gegen $a$ resp. $c$ verstellbar. Die Wirkungsweise ist vollkommener wie jene der Stufenwalzen, weil alle vier Seitenflächen gepresst werden, kann aber doch keine so reinen Formen liefern als die Calibrirung, weil die Pressungen nicht in derselben Verticalebene ihr Maximum erreichen, sondern die verticale Pressung in $a, b$, die horizontsle in $c c$. Hierdurch ist die Bildung reiner Seitenflächen und namentlich reiner Kanten nicht möglich. Das Universalwalzwerk kann daher nur als Vorwalzwerk gebraucht werden.

Der Lösung der Aufgabe, vom Packet bis zur Schlussform in ein e r Hitze zu gelangen, ist bei der Anwendung nur zweier, nach der gleichen Richtung laufender Walzen, dem Zw e iw a l zens y s t em, der Zeitverlust hinderlich, welcher durch das Zuriickbringen des Walzstiickes zur Einlassseite entsteht. Nach dem Durchgang des Walzstiickes wird derselbe auf die obere Walze gehoben und dadurch auf die Einlassseite zuriickgefiihrt, es erfolgt dies zwar eben so rasch wie der Durchgang, aber doch findet während dieser Zeit eine Abkühlung statt.

Diesem Uebelstande begegnet man durch Umkehrung der Walzenbewegung*) oder, noch besser, durch das Dreiwalzensystem, beim Drahtwalzen aber durch die im Art. D raht II S. 649 beschriebene Anordnung.

Fig. 1261.

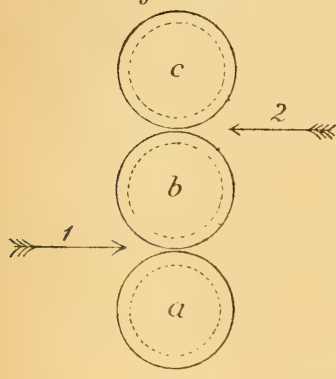

Das Dreiwalzensystem ist durch drei über einander gelagerte Caliber-Walzen charakterisirt. Das Walzstiick tritt in der Richtung 1 durch das erste Caliber, welches in den Walzen $a$ und $b$ angebracht ist, und gelangt dann in der Richtung zwei in das 2. Caliber, daher durch $b$ und $c$ wieder auf die frühere Seite zuriick. Das 3., 5., 7. Caliber liegt wieder in $a b$, das 4., 6., 8. in $c b$, ès findet das Walzen daher nach beiden Richtungen statt. Die Schwierigkeiten dieses Systems liegen in der Stellung der Walzen und in der Vertheilung der Caliber, sie sind aber überwunden und das Dreiwalzensystem gewinnt immer mehr Verbreitung.

Zum Schlusse seien noch einige Specialitäten erwähnt.

Walzen, deren wirksame Theile iiber das Walzengeriiste vorstehen (ähnlich den Bd. I S. 550 ete. beschriebenen), und das Auswalzen eines Ringes oder Reifens gestatten, heissen Kopfwalzen (s. d.). Sie finden z. B. Anwendung bei der Fabrication der Tyres.

Collarwalzen werden zum Walzen der Glieder fü Kettenbriicken verwendet (s. Berg- u. hiittenmännisches Jahrbuch neue Folge XII. Bd. S. 144).

Ueber Röhrenwalzen s. den Artikel Röhrenfabrication, auch obgen. Jahrbuch IX. Bd. S. 176.

Literatur der Eisenhiitenkunde. Die Wiederholung der bereits im Ver-

lanfe dieses Artikels genannten Werke kann vermieden werden, auch sollen hier nur einige die Eisenhiittenkunde im Allgemeinen behandelnde hervormgende Werke genannt sein. - Karsten's Eisenhiittenkunde, Berlin 1827. Percy-Wedding", Eisenhiittenkunde, Braunschweig 1864 bis 1876 . _ We ding, Darstellung d. schm. Eisens, Braunschweig Vieweg 1875. Tunner, Stabeisen- und Stahlbereitung auf Frischherden, Freiberg $1858 . \quad K k$.

Eisenalaun, s. A la un I pag. 77.

Eisenamianth, Eis en a sbest nennt man die in den Fugen der Sohlsteine und des Gestelles bei Hochöfen sich nicht selten findende Kieselsäure, welche schneeweisse faserige Massen bildet, die dem Amianth ähnlich sehen. Gtl.

*) Vorrichtungen zum Vor- u. Rückwärtswalzen sind u. a. beschrieben in Dingl. p. J. Bd. 200 S. 3 u. Bd. 203 S. 338. - Booth's Schnellwalzwerk für Draht Bd. 197 S. 9. 
Eisenapatit, s. Z Zwieselit.

Eisenasbest, s. E i s en a mi an th.

Eisenbahn (chemin de fer - rail-way). Eisenbahnen sind kïnstliche Strassen von einer derartigen Einrichtung, dass die den Fuhirwerken sich entgegenstellenden Widerstände auf ein geringes Mass herabgedrückt werden. Beinahe ausschliesslich besteht diese Einrichtung aus 2 parallelen, neben einander liegenden Schienen, auf welchen die Fahrzeuge mit einem Spurkranze, der ihnen zur Führung dient, laufen.

Die Geschichte der Eisenbahnen datirt zurïck bis in das alte Griechen- und Römerthum, in welcher Zeit wir bereits Spurbahnen vorfinden; diese verschwinden dann durch volle 1\% Jahrtausende aus der Geschichte des Verkehrs, bis die Spurstrassen als Holzbahnen in den alten Gruben im Harze und in England wieder erschienen; eine Krise in den Eisenpreisen v. J. 1767 gab Veranlassung zur Herstellung eines gusseisernen Bahnstranges und Benjam in Curr legte im J. 1776 die erste Bahn mit gusseisernen Schienen. Der letzte grosse Schritt in der Entwicklung geschah durch die Erfindung des Schienenwalzens durch John Berkinshaw im J. 1828; Robert Stephenson verwendete Schienen mit parallelen Ober- und Unterfächen und Charles Vignoles gab den Schienen endlich jene Gestalt, in welcher sie gegenwärtig auf eirea $40 \%$ der europäischen Bahnen im Gebrauche sind. Eine ungleich schnellere Ausbildung erlitten die Fahrzeuge selbst (s. Eisenbahn-Fahrbetriebsmittel).

A usbreitung der Eisenbahnen. Mit der Einfuhrung der Locomotivbahnen eröffnete England den Reigen, in welchem Lande 1830 die erste LocomotivEisenbahn in Europa zwischen Liverpool und Manchester dem öffentlichen Verkehre iibergeben wurde; in demselben Jahre folgten die Vereinigten Staaten Nordamerikas; 1835 folgte Belgien und Deutschland, 1837 Frankreich und Oesterreich, 1838 Russland, 1839 Holland und Italien, 1844 die Schweiz und Dänemark, 1848 Spanien, 1850 Mexico, 1851 Schweden und Peru, 1853 Ostindien und Norwegen, 1854 Portugal und Brasilien, 1855 Australien, 1856 Aegypten, 1860 Rumänien, 1864 Kleinasien, 1867 Java, 1875 die europäische Türkei.

Nach den neuesten, mit Ende 1871 abgeschlossenen Nachweisen von St ur m er zählen wir:

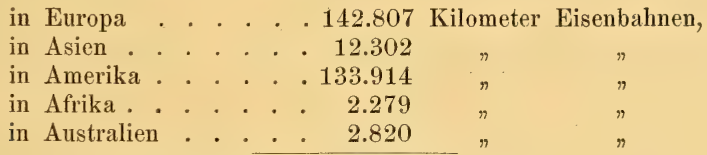

Zusammen . . 294.122 Kilometer.

Spurweite (largeur de la voie - gan̈gè). Hierunter versteht man die Entfernung der beiden Schienenstränge gemessen zwischen den beiden Innenseiten der Schienenköpfe (Fig. 1262). Ueber die Grösse dieser Spurweite entspann sich besonders in England ein langer Kampf, aus dem die Spurweite Stephensons $\left(4^{\prime} 8 \%{ }^{\prime \prime}\right.$ engl. $\left.=\mathbf{1} \cdot \mathbf{4 3 6}{ }^{\mathrm{m}}\right)$ siegreich hervorging. Dieselbe ist die verbreitetste und wird daher Normal-Spur genannt. Kleinere Spurweiten kommen nur in Ländern mit wenig entwickeltem Verkehr oder isolirt von Hauptbahnen vor. In Europa sind 4 Länder, welche eine grössere Spurweite haben: Spanien und Portugal $\left(1 \cdot 68^{\mathrm{m}}\right)$, Russland $\left(1 \cdot 525^{\mathrm{m}}\right)$ und Irland $\left(1 \cdot 60^{\mathrm{m}}\right)$. Die aussereuropäischen Länder zeigen in Betreff der Spurweiten erhebliche Verschiedenheiten: In den Vereinigten Staaten Nordamerikas ist das Mass $1.436^{\mathrm{m}}$ vorwaltend, es kommen aber daselbst noch andere Weiten bis $1.83^{\mathrm{m}}$ vor; in Ostindien und in Chili findet man Spurweiten von $1.68^{\mathrm{m}}$, in Brasilien solche von $1 \cdot 60^{\mathrm{m}}$. 
Eintheilung der Eisenbahnen. Dieselbe kann nach verschiedenen Richtıngen geschehen, und zwar:

1. Nach der Grösse des Verkehrs in Hauptbahnen (lignes principales main lines) mit grossem und in Secundärbahnen (lignes secondaires, lignes d'embranchements - secondary lines) mit kleinerem, untergeordnetem Verkehr.

2. Nach der Spurweite in normalspurige (chemin de fer à voie normale normal gange railuays) und in schmal- (eng-) spurige (chemin de fer à voie étroite - narrow gange railways) (letztere werden auch irrig Secundärbahnen genannt).

3. Nach der Art der die Fuhrwerke bewegenden Kraft in solche mit animalischer Zugkraft und in solche mit Wasser-, Luft- oder Dampfkraft.

4. Nach den Anforderungen, die der Verkehr stellt, in Bahnen für den gesammten Verkehr, in solche für ausschliesslich Personen- oder Frachtentransport, ferner in Materialtransport-, Arbeits-, Interims-, Strassen-, Pferde- und Locomotivbahnen.

5. Nach der Beschaffenheit der Erdeberfläche, längs welcher sich die Bahn hinzieht, in Bahnen in der Ebene (mit regelmässigem Grundriss und unregelmässigem Profil), Bahnen im offerien Thal (unregelmässigem Grundriss und regelmässigem Profil), Bahnen im Hiigellande (Umwege, schärfere Curven und stärkere Steigungen), in Gebirgsbahnen (grosse Umwege, noch schärfere Curven und Steigungen).

6. Nach der Construction des Oberbaues in Bahnen mit 2 parallelen Schienensträngen, mit einem Schienenstrang, System Fell, Riggen b a ch, Wetli, Zschok ke, Köstlin \& Lebret, Larmanjat etc. (siehe weiter unten).

Bei nachfolgenden Auscinandersetzungen sind stets normalspurige Bahnen mit dem gewöhnlichen Locomotivbetriebe in's Auge genommen und werden am Schlusse derselben die aussergewöhnlichen Bahnsysteme einer Besprechung unterzogen. Die Cotirung der Figuren bezieht sich anf das Metermass.

Alignement- und Neigungsverhältuisse (alignement et disposition des pentes et rampes - gradients) der Eisenbalmen. Diese beziehen sich auf die Richtung der Bahn und auf die in derselben rorkommenden Steigungen und Gefälle; die Wechselwirkung zwischen Bahn und Fuhrwerk tritt bei Bestimmung: dieser Verlältnisse in bemerkenswerther Weise hervor, eben so wollen auch hiebei die Verkehrsverhältnisse, der Bahnbetrieb und die Beschaffenheit des Terrains beriicksichtigt sein.

Nach den "Grundzigen für die Gestaltung der Eisenbahnen Deutschlands" (herausgegeben vom Vereine deutscher Eisenbahnverwaltungen) soll das Längengefälle nicht iiberschreiten: in flachen Lande 1:200, d. i. 5\% (d. h. auf 200 Längeneinheiten Länge 1 Längeneinheit Steigung), im Hugellande 1:100, d. i. $10 \%$, im Gebirge $1: 40$, d. i. $25 \%$.

Die Kriimmungshalbmesser der Curven sollen wo möglich im flachen Lande nicht unter $1100^{\mathrm{m}}$, im Higgellande nicht unter $600^{\mathrm{m}}$, bei Gebirgsbahnen nicht unter $300^{\mathrm{m}}$, ausnahmsweise mindestens $180^{\mathrm{m}}$ betragen. Durch die Steigungen wird eine Vermehrung der Zugkraft nöthig. Während durchschnittlich pro Tonne (1000 Kilogr.) Zugsgewicht $4 \mathrm{Kgr}$. Zugskraft benöthigt wird, steigert sich letztere anf Steigungen $u m 1 \mathrm{Kgr}$. für je ein pro mille; es ist daher auf Steigungen von $1: 100\left(10^{\circ}{ }_{00}\right)$ der Mehrbedarf an Zugskraft $10 \mathrm{Kgr}$. pro. Tome, also im Ganzen 14 ligr. pro Tome Zugsgewicht.

Bcim Befahren ron Curren werden die Fahrzeuge durch die Centrifugalkraft an dic äusseren Schienen angepresst, wodurch einestheils Widerstände entstelien, andreseits eine Abniitzung der Schienen und Fahrbetriebsmittel herbeigeführt wird. Weiters bedingt das Befahren in Curven, dass das äussere Rad in derselben Zeit einen grössereu Weg zuriicklegt als das innere. Man begegnet diesen schädlichen Einfliissen, indem man in Curven den äusseren Sclienenstrang gegen den inneren erhöht je nach dem IIalbmesser des Bogens und der Geschwindigkeit, mit welcher die Bahm befalıren wirl, bis $150^{\mathrm{mm}}$ ), die Geleiseweite vergrössert (bis $25^{\mathrm{mm}}$ ) und den Ralkränzen cine conische Fläche mit der Neigung $1 / 7$ bis $1 / 1$ g gibt. 
In Betreff der Alignements- und Höhenverhältnisse der Stationen bcstimmen oben erwähnte "Grundzüge": "die Bahnhöfe sollen eine horizontale Strecke erhalten, welche im flachen Lande wenigstens $550^{\mathrm{m}}$, im Gebirge wenigstens $180^{\mathrm{m}}$ lang ist. Im flachen und HügelLande muss wenigstens ein Theil dieser Strecke eine gerade Linie von $180^{\mathrm{m}}$ Länge erhalten Grössere Steigungen als 1:400 sollen auf Stationen nicht vorkommen."

Normalprofil des lichten Raumes. Die Wechselwirkung zwischen Bahn, Fuhrwerk und den neben den Geleisen befindlichen Baulichkeiten bedingt eine Grenzregulirung, welche, bildlich dargestellt, unter dem Namen "Normalprofil des lichten Raumes" bekannt ist, welches auf der freien Bahn und auf jenen Ge. leisen, auf denen Züge verkehren, mindestens einzuhalten ist. (Fig. 1264.)

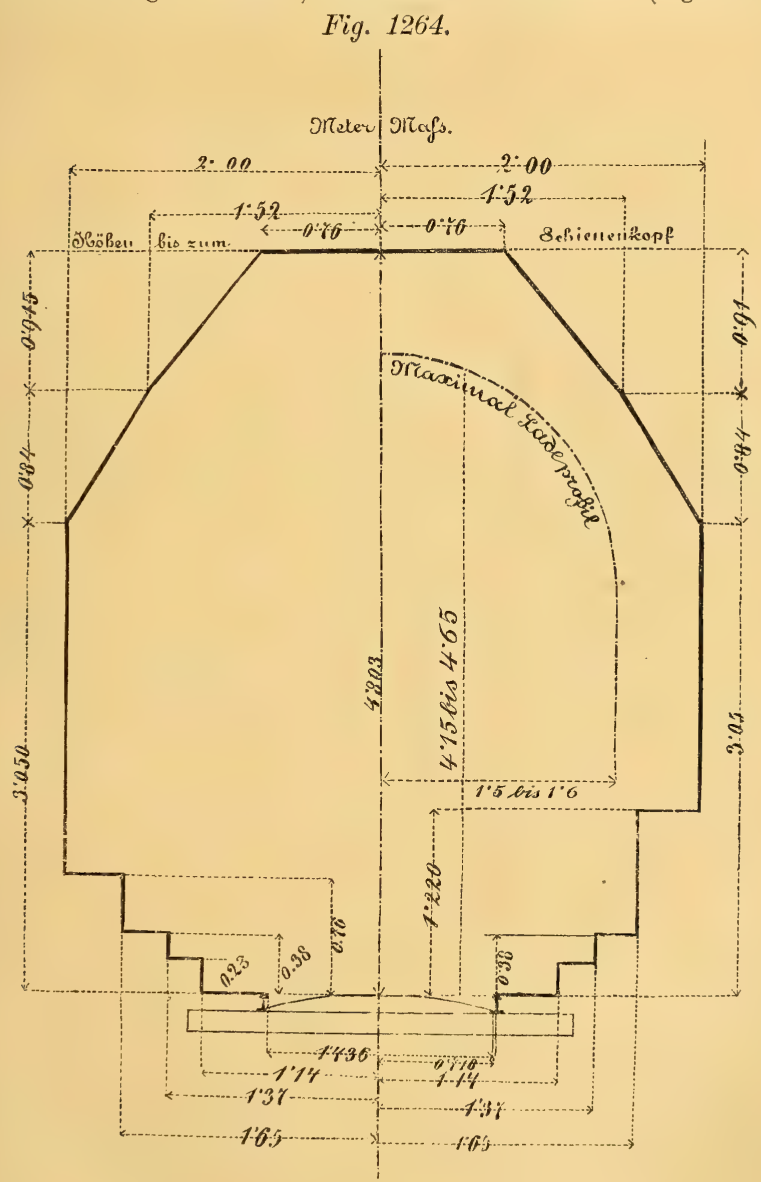

Tracirung (tracé - survey, tracing) nennt man die Ermittlung der Eisenbahnlinie und deren Absteckung auf dem Felde; als Grundlage dienen Höhen- 
und Längenmessungen in jenem Terrain, welches von der Bahn durchschnitten werden soll; mit Hilfe derselben wird die Bahntrace ermittelt und abgesteckt. Die hiezu nöthigen Behelfe sind Situationspläne, Nivellir-Instrumente, Nivellirlatten, Messketten oder Messbänder. (Hierïber Werke von He y n e, S t u m m e r u. K a v en.)

Die Ergebnisse der Tracirung werden durch Einzeichnen der Linie in die Situationspläne, so wie durch ein sogenanntes Längenprofil, welches die Gestaltung des durchschnittenen natürlichen Terrains, so wie die Steigungs- und Richtungsverhältnisse der. Bahntrace darstellt, ersichtlich gemacht.

Fig. 1265.

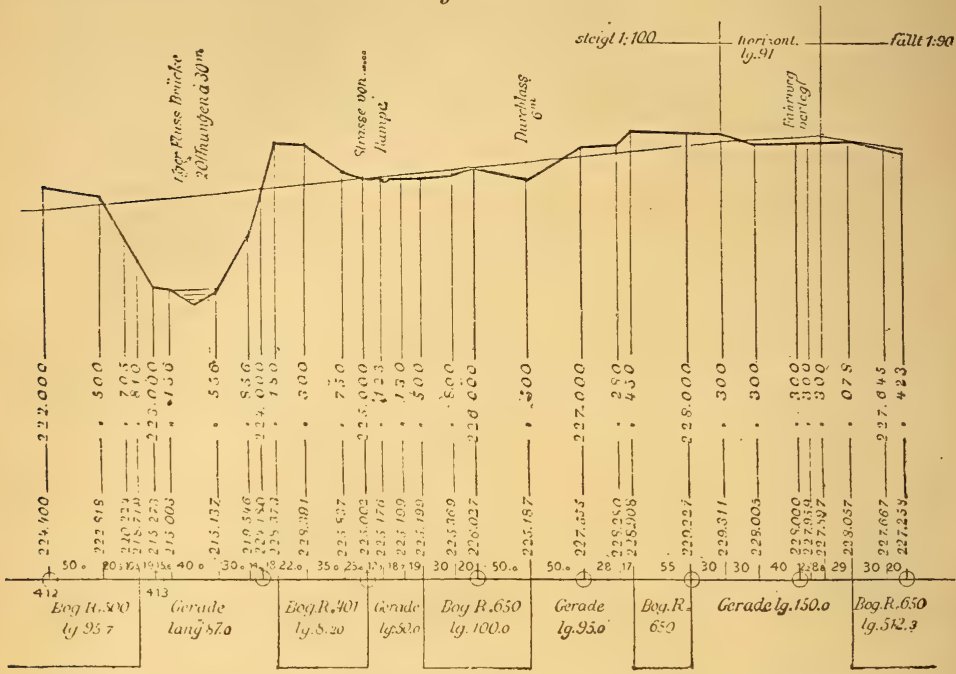

Fig. 1265 stellt ein Stück eines Längenprofils dar; das natürliche Terrain soll mit schwächeren Strichen, die Bahntrace, d. i. die sogenannte Nivellette mit stärkeren Strichen ausgezogen sein; die auf das natiirliche Terrain sich beziehenden Coten sollen durch liegende Schrift, hingegen die Nivellettecoten durch eine stehende kräftige Schrift, eben so auch die Richtungs- und Steigungsverhältnisse und die Kunstbauten gekennzeichnet sein. (Vom Xylographen in unserer Figur zu wenig hervorgehoben.)

Auf Grundlage dieser Aufnahmen werden die Pläne und Kostenvoranschläge für den gesammten Bahnbau verfasst. Letzterer lässt sich eintheilen: 1. in Unterbau, 2. Oberbau, 3. Hochbau, 4. Ausriistung der Bahn, 5. diverse Árbeiten.

Unterba u (terrassement et travaux d'art - way and works). Hierunter versteht man denjenigen Theil der Bahn, weleher die Schienen mit ihren Lagern nebst deren Lnterbettung trägt. Es gehört sonach hieher die Construction des Erdkörpers (Dämme, Einschnitte), der Durchlässe, Brïcken, Viaducte, Tunnels.

Die Form des Erdkörpers, d. i. sein Querprofil bestimmt sich 1. durch die Kronenbreite, 2. durch die Böschungen, 3. durch die Anlagen zum Schutz und zur Erhaltung des kidkörpers.

Die Kronenbreite soll nach den Beschliissen des Vereins deutscher Eisenbahnverwaltungen in einer durch die Unterkante der Schienen gelegten Linie vom Durchschnittspunkte der Böschungslinie bis zur Mitte des nächsten Geleises nicht unter $2^{\mathrm{m}}$ betragen (Fig. 1267); die Doppelgeleise in der freien Bahn sollen von Mitte zu Mitte nicht weniger als $3 \cdot 5^{\mathrm{m}}$ von einander entfernt sein. In der Regel sind die Kronenbreiten grösser als obiges Mass, wie umstehende Figur nachweist. 
Bei Einschnitten wird die Breite des Erdkörpers um den Raum für die auf beiden Seiten des Bahnkörpers herzustellenden Gräben grösser als bei Dämmen. Die Tiefe dieser Gräben ist $0.64-0.94^{\mathrm{m}}$, deren Breite richtet sich nach dem abzuführenden Wasserquantum und beträgt durchschnittlich $0 \cdot 30^{\mathrm{m}}$. Die zulässige Neigung der Böschungen ist bedingt durch die Art des Materials und durch das Verhalten desselben gegen die Einwirkungen der Atmosphäre und des Wassers. Bei vielen Bahnen gilt als Regel, die Dämme $1 \frac{1}{2}$-füssig (d. h. das Verhältniss der Höhe $h$ zur Breite $b=1: 1 \frac{1}{2}$ ), die Einschnitte einfüssig zu böschen (s. Fig. 1266 u. 1267). Die Böschungen werden zuweilen durch sog. Bermen (b Fig. 1266), d. i. durch horizontale Absätze unter-

Fig. 1266 .

$(1 / 25$ nat. Gr.)

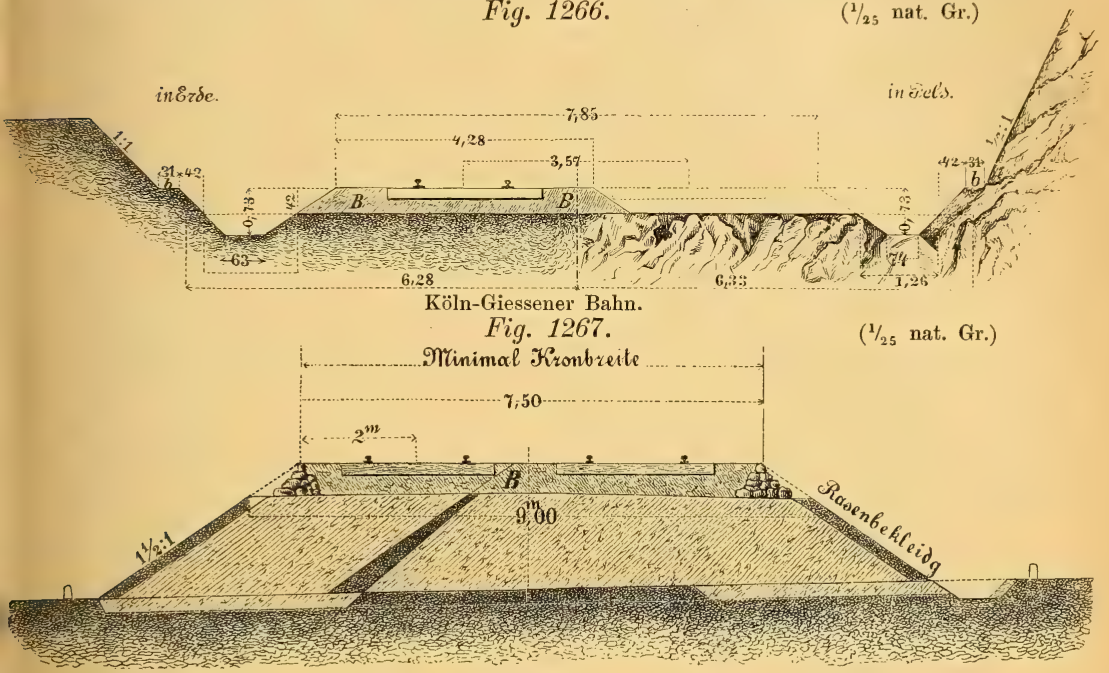

brochen, über deren Zweckmässigkeit dic Ansichten getheilt sind. Sollen die Böschungen, um mit dem Material oder mit dem zum Bahnbau nöthigen Grund zu sparen, steiler angelegt werden, so geschieht es durch Bekleidung mit Rasen (Fig. 1267), durch Abpflasterungen, Stiitz- und Futtermauern (Fig. 1268 u. 1269). Die Mittel, um Störungen in der Form der Einschnitte vorzubeugen, oder sie zu beseitigen, bestehen in der Entfernung des Bodens, welcher durch den Einschnitt seine Stiitze verloren hat (Entlastung) oder in dem Ersatz dieser verloren gegangenen Stiitze durch Stiitz- und Futtermanern, Strebepfeiler u. s. f. Weiter sind Mittel gegen die schädlichen Einflüsse des Wassers, der Atmosphäre, des Windes anzuwenden; diese bestehen in Herstellung der Einschnittsgräben, von Gräben oberhalb der Einschnitte, von Rigolen, Abteufen von Brunnen, Drainirungen, in dem Berasen,

Fig. 1268.
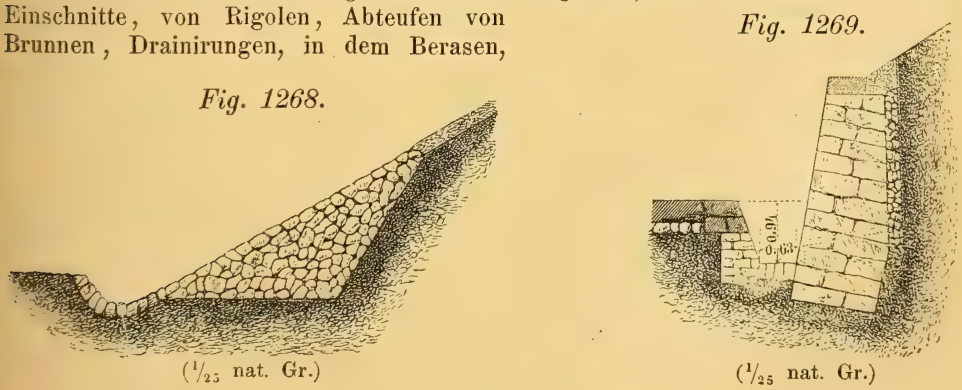
Bepflanzen und Abpflastern der Böschungen, Herstellen von Stuitzmauern. Letztere Mittel werden auch zur Erhaltung der Dammböschungen angewendet. (Werke iiber den Erdbau: Becker, Baukunde des Ingenieurs, Winkler und Rziha Unterbau, He us inger von Wa l d e g g Eisenbalınban, H en z, S ch m itt, Erdbau.)

Die von der Bahnlinie zu übersetzenden Wege und Strassen werden, insoferne sie nicht im gleichen Niveal liegen, mit Brïcken (Durchfahrten, wenn die Strasse unter, Ueberfahrten, wenn die Strasse über die Bahn gefuihrt wird) übersetzt, deren Spannweite von der Breite des Weges oder der Strasse abhängt; Wasserläufe, Quellen, Bäche werden mit Kanälen, Durchlässen, Flüsse und Schluchten mit Briicken und Viaducten uibersetzt; unterirdische Theile der Bahn werden als Tunnelbauten hergestellt. Wege, Strassen etc., welche von der Bahn im Niveau gekreuzt werden, werden mit sogenannten Rampen übersetzt; die Herstellung eines solchen Niveau-Ueberganges umfasst gewöhnlich: die Ausfihrung der Rampe, die Herstellung der Rampenkanäle für den Abfluss des Wassers in den beiden Seitengräben der Bahn, die Abänderung des Oberbaues in der Breite der Fahrbahn, die Abpflasterung des Ueberganges, die Verschlussvorrichtungen, welche den Passanten den Uebergang nur zu Zeiten, wo kein Zugsverkehr stattfindet, erlaubt.

Oberbau (superstructure - permanent way). Dies ist die eigentliche Schienenbahn; er besteht aus 3 Haupttheilen: 1. aus der Bettung, 2. aus den Unterlagen, 3. aus den Schienen sammt deren Befestigungs- und Verbindungsmitteln.

$\mathrm{D}$ i e B e t tu ng (chaussée, lit en dessous des traverses - ballast) (B Fig. 1266 ı. 1267) besteht entweder aus einer Steinpflasterung von circa $25^{\mathrm{cm}}$ Stärke und einer darüber befindlichen Schotterschichte von $15-20^{\mathrm{cm}}$ Stärke oder blos aus einer Schotterschichte von $0 \cdot 4-0 \cdot 5^{\mathrm{m}}$ Höhe.

Die Unterlagen sind grösstentheils Schwellen, und zwar heissen sie $\mathrm{L}$ angschwellen (longrines - longitudinal timbers), wenn sie den Schienen in ihrer ganzen Länge zur Unterstützung dienen, und Quers chwellen (traverses

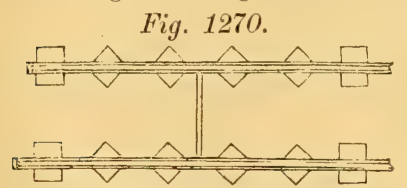
- sleepers), wenn sie senkrecht zur Richtung des Schienenstrangs unter demselben gelegt werden; weiter gibt es noch Einzeln-Unterlagen von Holz, Stein oder Eisen, welche die Schienen nur in einzelnen Punkten unterstiitzen und keine Querverbindungen zwischen den Schienen herstellen (Fig. 1270).

Auf diesen Unterlagen liegen die Schienen (rails - rails), welche unter einander mit Lappen (éclisses - fishplates) (Laschen) und Polzen (boulons nuts and bolts) und mit den ersteren mittelst Unterlagsplatten (Stoss-, Mittelund Zwischenplatten) und Nägeln (attaches - spikes) befestigt sind. Die Schwellen sind beinahe ausschliesslich aus Holz, und zwar aus hartem oder weichem; erst in neuerer Zeit wendet man solche aus Eisen an. Um die hölzernen Schwellen vor Fäulniss zu bewahren, werden sie zuweilen conservirt, und zwar geschieht dies durch Austrocknen des Holzes an der Luft oder in höherer Temperatur (Dürröfen), durch Entziehung des Saftes durch Auslaugen im Wasser oder durch Dämpfen und schliesslich durch Imprägnirung, d. i. Durchdringung der Schwellen mit Fäulniss verhindernden Stoffen. Die Imprägnirung geschieht nach mehreren Methoden, von denen hervorzuheben sind jene nach K y a n mit Chlorquecksilber, nach B ou cherie mit Kupfervitriol, nach Burnett mit Zinkchlorid, nach Bethell mit Kreosot. (Ueber Conservirung des Holzes: Sc heden, Organ fuir Fortschritte des Eisenbahnwesens 1866 u. 1868, Heusinger v. W. Eisenbahnbau V. Kap.)

Die Schienen sind entweder Eisenschienen oder solche mit Puddelstahlköpfen, Puddelstahlschienen, Eisenschienen mit Bessemerstahlkopf, Bessemerstahl-, Martinund Gussstahlschienen. (Ueber Fabrication der Schienen im Organ 1850, 1851, 1864, 1866, 1867, He u sing er v. W. Eisenbahnbau VI. Kap.)

Die bis jetzt angewendeten Schienenformen sind: Flachschienen (Fig. 1271 u. 1272) auf Langschwellen, Brïckenschienen auf Lang- und Querschwellen 
Fig. 1271.

Fig. 1272.

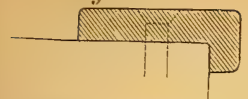

Amerik. Flachschiene. Wien-Glogguitz. E.-B. Fig. 1273.
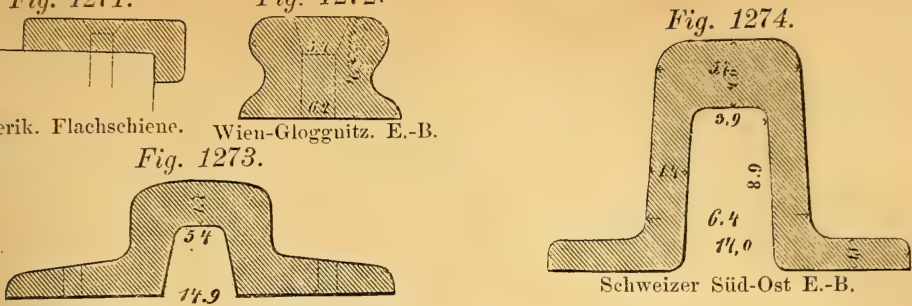

Brunel's Schiene der Great-Western E.-B.

(Fig. 1273 u. 1274), Sattelschienen auf Langschwellen (Fig. 1275), Stuhlschienen, und zwar mit einem Kopf (Fig. 1276) und mit 2 Köpfen (Fig. 1277), breitbasige (Vignoles) Schienen auf Lang- und Quersehwellen (Fig. 1278 u. 1279), zusammengesetzte Schienen, die aus mehreren Theilen bestehen (Fig. 1280).

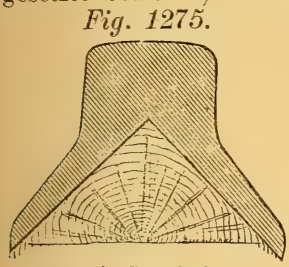

Seaton's Sattelschiene.

Fig. 1278.

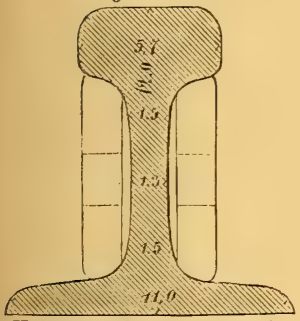

Kaiser Ferdinand-Nordbahn.
Fig. 1276.

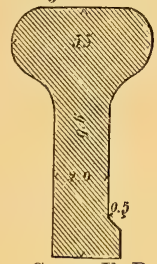

Oest. Staats-E.-B. alt. Fig. 1279.

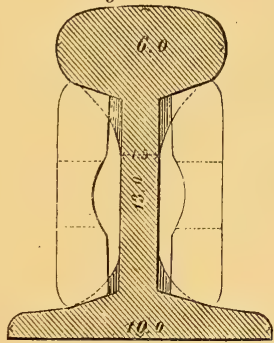

Orleans Central-E.-B.
Fig. 1277.

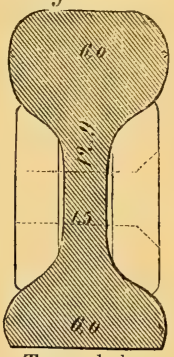

Taunusbalın.

Fig. 1280.

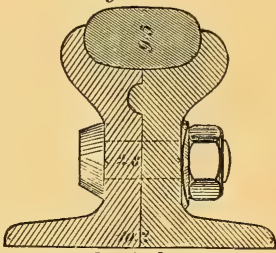

Amerikanische E.-B.

Die Höhe der Schienen soll für Hauptbahnen nicht unter $114^{\mathrm{mm}}$ betragen (in Amerika beträgt sie bis $90^{\mathrm{mm}}$ ), deren Länge beträgt gewöhnlich zwischen 6 und 7 Meter (in Amerika selbst über $9^{\mathrm{m}}$ ). Bei den breitbasigen Schienen soll der Kopf, d. i. jener Theil der Schienen, auf welchem die Räder der Fahrzeuge laufen, aus hartem Material sein, während der Fuss derselben, mit welchem sie auf die Lnterlagen aufruhen, eine sehnige Structur haben soll. Das Gewicht eines cur. Meters Schienen für Locomotivbetrieb variirt zwischen $26-36 \mathrm{~K}$ \%r. (in Amerika abwärts bis $20 \mathrm{Kgr}$.).

Bei der Anwendung des Querschwellensystems unterscheidet man 2 verschiedene Lagen der Schienenfläche: 1. ruhende (feste). Stösse, wenn der Stoss zweier Schienen auf eine Schwelle kommt; 2. schwebende Stösse, wenn derselbe zwischen 2 Schwellen kommt. Die letztere Art des Stosses wird nach übereinstimmenden Urtheilen als die bessere bezeichnet.

In neuerer Zeit fing man an, statt der hölzernen Unterlagen eiserne zu geben; es geschieht dies mit Rücksicht auf das verhältnissmässig schnelle Schadhaftwerden 
der hölzernen Schwellen, auf die hieraus entstehenden Störungen im Betrieb bei

Fig. 1282.

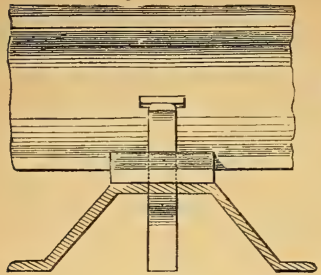

System Vautherin.
Fig. 1281.

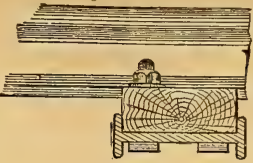

System Cosyns.
Auswechslungen, auf die unvollkommene Unterstiitzung und Verbindung der Schienen. So entstand das eiserne Quersehwellen- und Langschwellen-System. Querschwellen wurden nach verschiedenen Querschnitten angewendet; es sind hieher gehörig zu bezeichnen jene nach Cosyns (Fig. 1281), Vautherin (Fig. 1282), Le Crenier (Fig. 1283), Laz ar mit T-förmigen Querschnitt, Breite $200^{\mathrm{mm}}$, Höhe $65^{\mathrm{mm}}$. Die ConFig. 1283.
( $1 / 10$ nat. Gr.)

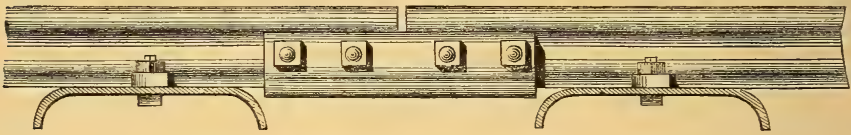

Stoss und Querschnitt der Schwellen nach Crenier.

structionen des eisernen Langschwellensystems lassen sich eintheilen: 1.) in eintheilige; hieher gehört die B arlow-Schiene (Fig. 1284), a die Laschenbleche bei den Schienenstössen, $b$ Querverbindung an den Stössen, die H a r twi ch-Schiene (Fig. 1285), a Laschen an den Stössen, $d$ und $c$ Querverbindungen, $b$ Unterlagsplatten an den Stössen, ferner das System Winkler ähnlich der Hartwich-Schiene; bei diesen Constructionen sind Schiene und Unterlage zu einem einzigen Stück ver-

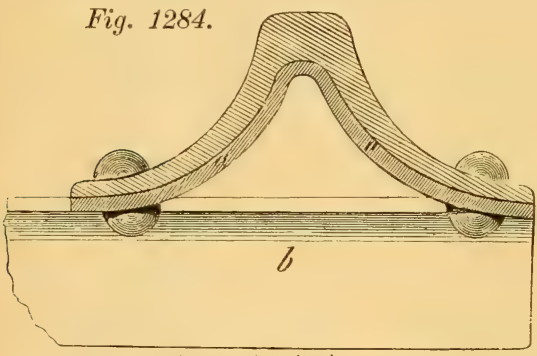

system IV. Barluw.

Fig. 1286 .

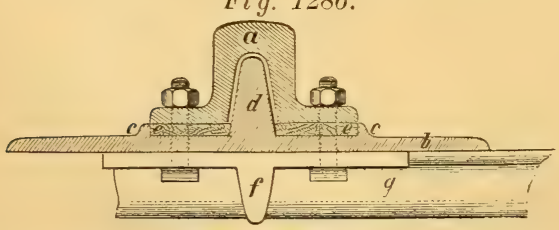

Srtsem Mac Donell. bunden. 2.) in $\mathrm{z}$ weitheilige, wohin das System Mac Donnel (Fig. 1286), a Schiene, $b$ Langschwellen mit 2 Leisten $c$ c und Rippe $d, f$ Unterlagsplatte mit Rippe am Stoss, $g$ Querverbindung, $e$ Holzunter-

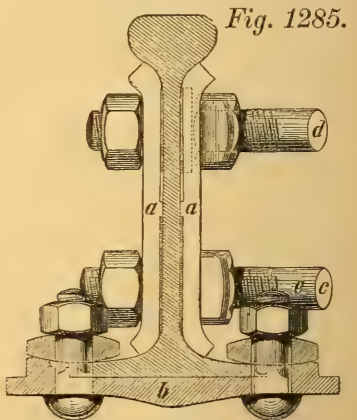

System Hartwich. Rhein-L.-B.

lage; das System Hilf (Fig. 1287) und System H o he n g g e r (die Langschwellen Fig. 1287. 
rom Querschnitte der Vautherin-Schwelle) einzureihen sind. 3.) in dreitheilige, hieher sind zu verzeichnen die Systeme von S ch effler(Fig. 1288), Kös tlin \& B a t tig (Fig. 1289), P a ulus, A tzing er, D a el en etc.; $b$ die beiden Unterschienen, $e$ die Oberschiene, $c$ Querverbindungen, $d$ Unterlagsplatten an den Stössen.

Die Erfahrungen iiber das Verhalten des eisernen Oberbaues sind jedoch noch nicht geeignet, dem einen Systeme vor dem anderen entschieden einen Vorzug zu geben.

Der Preis eines cur. Meters gewöhnlichen Oberbaues (mit hölzernen Schwellen) stellt sich auf circa 13 bis $15 \mathrm{fl}$., und jener eines cur. M. eisernen Oberbaues auf 15 bis $22 \mathrm{fl}$.

A usweichen, Drehscheiben und Schiebebihnen. A usweich en, Weichen (changements de voie - switches). Behufs Ausweichen von Ziigen und Uebergehen derselben von einem Geleise auf ein anderes sind eigene Vorkehrungen nöthig, welche man Ausweichen nennt. Jenes Geleise $H$, welches seine Richtung beibehält, wird Hauptgeleise (la voie principal main line) genannt, und jenes, das aus demselben abzweigt, $N$, Nebengeleise (la voie secondaire - siding), Fig. 1290.

Je nachdem dieses Nebengeleise nach rechts oder links abzweigt, entsteht eine rechts- oder linksseitige Ausweiche. Die Construction dieser Ausweiche ist für Eisenbahnen von grosser Wichtigkeit; eine solche besteht aus 3 Haupttheilen, und zwar: 1. aus dem Wechsel, 2. aus dem Herzstiick, 3. aus der Weichencurve. Der Wechsel $a, a, d, d$ ist jener Theil, welcher den Uebergang der Fahrzenge

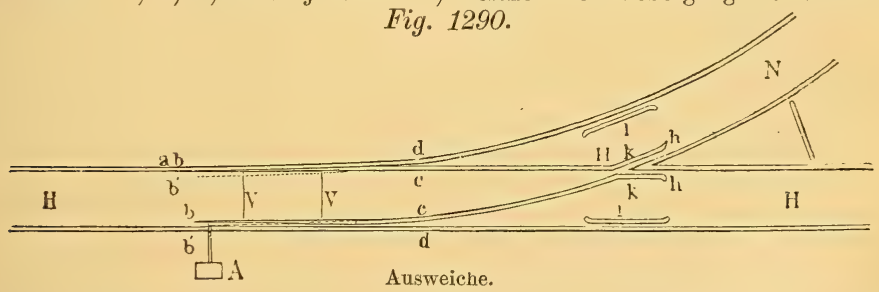

von dem Haupt- auf das Nebengeleise vermittelt. In Fig. 1291 (S. 66) ist er in Details dargestellt. Seine Hauptbestandtheile sind: 2 Stockschienen a (stockrail) und 2 um ihren Endpunkt $c$ bewegliche Spitz- oder Zungenschienen $Z$ (aiguille - switch-rail). Je nachdem letztere die Lage $c b$ oder $c b^{\prime}$ annehmen, ist der Wechsel für das Haupt- oder Nebengeleise gestellt, d. h. können die Fahrzeuge auf das Haupt- oder Nebengeleise übergehen. Die Bewegung der Zungen geschieht mittelst eines Hebels, welcher einen Theil des sogenannten Ständers $A$ bildet und mit welchem ein Gewicht in solcher Weise in Verbindung gesetzt wird, dass dessen Wirkung die eine Zunge in einer bestimmten Richtung gegen die Stockschiene presst und hiedurch die Stellung beider, mit Querstangen $V$ mit 
Fig. 1291.

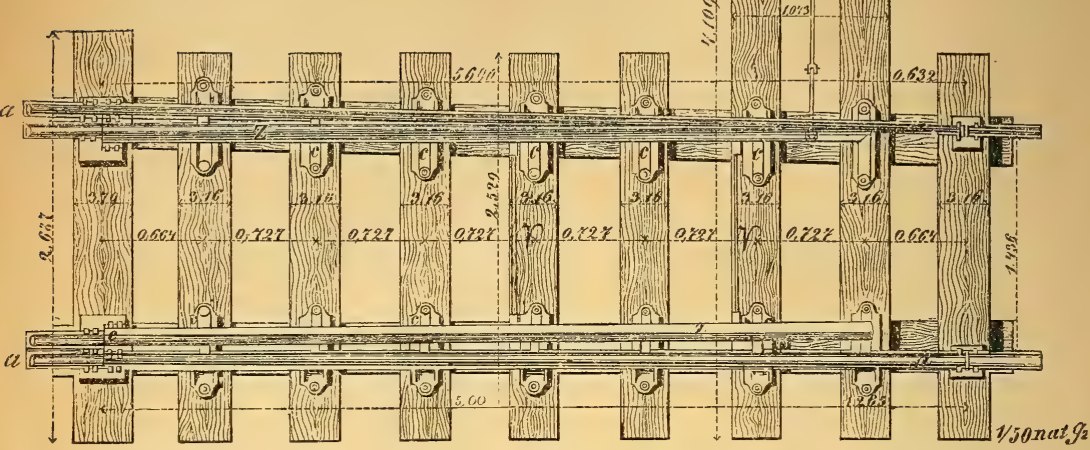

einander verbundenen Zungen sicher fixirt. Die Länge der Zungen beträgt in der Regel $4.5-5^{\mathrm{m}}$, der Stockschienen $5.5-6^{\mathrm{m}}$; die Zungen bewegen sich auf zum Schmieren vorgerichtete Unterlager $C$, welche man Chairs, Weichenstiihle, nennt.

Das Herzstii ck (pointe de coen - crossing) liegt an der Durchkreuzung der beiden Geleise; dasselbe ist entweder aus gewöhnlichen Schienen construirt, in welchem Falle die 2 Schienen $h$ die Herzschienen und die beiden Schienen $l$ die Knie- oder Fliigel- oder IIornschienen htissen, oder aber das ganze Herzstiick ist als Gussstiick (aus Gussstahl oder Hartguss) erzeugt. Gegeniiber dem Herzstiick liegen die 2 sogenannten Leit-oder $\mathrm{Z}$ wangschienen $l$, welche dem einen Rade des Fahrzenges während des Passirens iiber das Herzstiick die-Führung geben. Zwischen dem Techsel und dem Herzstiick liegt die Weichencurve, deren Radius nicht unter $180^{\mathrm{m}}$ sein soll. Sowohl Wechsel als Herzstick sollen stets in der Geraden liegen. Die ganze Ausweiche liegt nicht auf gewöhnlichen Schwellen, sondern auf sogenanuten Extrahölzern ron stärkeren Dimensionen nnd besser hergerichteten Formen. Soll eine Anzahl paralleler Geleise mit Weichen verbunden werden, so geschieht es mittelst eines schräg liegenden freleises, in welches jedes der parallelen Geleise mit einer Ausweiche einmündet; dieses schräg liegende Geleise heisst Mutter- oder Stammgeleise, die ganze Anlage eine Weichenstrasse (Fig. 1292). Ausweichen behandeln die Werke ron Baugut, Schule, Ernst \& Gottsleben, Terner, Pinzger.

Den Uebergang von einem Geleise anf ein zweites vermitteln ansser den Ausweichen noch Drehscheiben und schiebebïhnen.

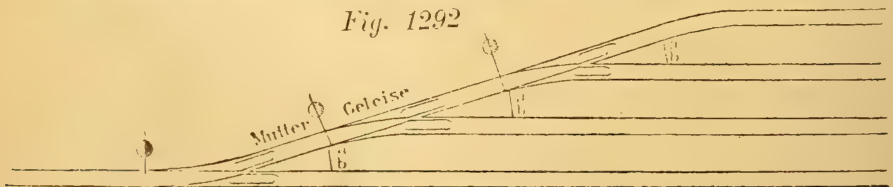

Wieichenstrasse.

Drehscheiben (plaque tournante - turn table) bestehen ans einem Gestell mit kräftigen Trägern, welche ein Stiick sclienengeleise tragen und dasselbr in seiner ganzen Länge unterstiitzen, ferner aus Verbindungsrippen am Umfange und einem starken Zapfen, um den sich die ganze Drehscheibe dreht. 
Soll ein Fahrzeug vom Geleise $a$ (Fig. 1293) auf jenes $b$ ibergehen, so wird es auf die Drehscheibe $I$ geschoben, dieselbe gedreht, wodurch das Fahrzeng in die Richtung $c d$ gelangt und in die Lage kommt, auf dem Geleise $c d$ weiter geschoben zu werden; durch ein Drehen der Scheibe II kann das Fahrzeug auf das Geleise $b$ iibergehen. Drehscheiben finden auch Anwendung zum Umdrehen der Maschinen und Wagen beim Rangiren der Züge. Die Grösse der Drehscheiben ist verschieden, je nachdem sie zum Umdrehen blos von Räderpaaren oder von Wagen oder von Locomotiven dient; sie wechselt von $3-12^{\mathrm{m}}$ und selbst bis $15^{\mathrm{m}}$. Das Material der Drehscheiben ist Holz, Guss-, in der Regel aber Schmiedeisen. Beziiglich der Unterstützungsweise des Scheiben-

Fig. 1293.

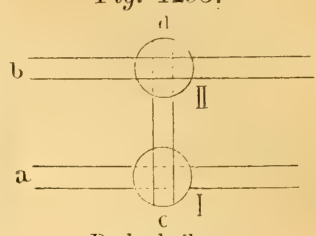

Drehscheiben.

körpers gibt es solche, welche im Zustande der Ruhe oder der Bewegung am Umfange von Rollen getragen werden, solche, welche theils am Centrum, theils am Umfang gestiitzt sind, solche, deren Belastung in der Mitte von einer Säule (Zapfen) getragen wird, solche, welche im Zustand der Ruhe am Umfang, bei der Bewegung im Mittelpunkte die Stiitze finden.

Die Drehscheiben liegen mit ihren Schienen im Niveau der Geleise und ist deren Construction somit in einer Grube versenkt; ihre Bewegung geschieht in der Regel mittelst eines Vorgeleges, das von Arbeitern bewegt wird.

$\mathrm{Schiebebiihnen} \mathrm{(pont} \mathrm{roulant,} \mathrm{chariot} \mathrm{roulant} \mathrm{-} \mathrm{platforms)} \mathrm{sind} \mathrm{Vor-}$ richtungen, welche ein Stïck gewöhnliches Geleise tragen, parallel zu sich selbst und senkrecht zu den zu verbindenden Geleisen $I, I I, I I I, I V \ldots$ bewegt und der Reihe nach in jedes der letzteren eingeschaltet werden kann (Fig. 1294). Die Schiebebiihne trägt das Geleise $a b$, und indem selbe in der Richtung $g h$ bewegt wird, erhält dieses Geleisestiick Anschluss an die Geleise $I I, I I I, I V \ldots$ Ein auf die Schiebebühne geschobener Wagen kañn auf diese Weise schnell auf eines der bezeichneten Geleise übergehen. Man unterscheidet zweierlei Constructionen: 1. die ältere, d. sind Schiebebühnen mit versenktem Geleise, 2. die neuere ohne versenktes Geleise; bei der ersteren Construction werden sämmtliche parallele Geleise durch eine Grube $g h$, in welcher sich die Schiebebühne bewegt, unterbrochen; bei bei der zweiten werden die zu verschiebenden Wagen iiber das Schienen-Niveau gehoben und sodann erst die Schiebebuihne fortbewegt.

Fig. 1294.

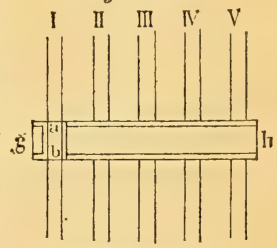

Schiebebühne.

$\mathrm{Bahnhofsanlagen} \mathrm{und} \mathrm{Hochbau}$ (gares et construction au dessus $d u$ sol - stations). Bahnhöfe (Stationen) sind Anlagen zum Befördern von Personen und Frachten oder zur Vermehrung oder Erneuerung der zur Bewegung erforder. lichen Kraft der Maschinen. Demnach unterscheidet man auch: 1. Personenbahn höfe für den Personenverkehr, 2. Frachtenbahnhöfe für den Frachtenrerkehr3. Bahnhöfe gemeinschaftlich für den Personen- und Frachtenverkehr, 4, Rangir-, (Manipulations-) Bahnhöfe, wo die Zusammenstellung, bezieh. Theilung der Ziige stattfindet; 5. Betriebsstationen, wo die Kraft der Maschine (durch Wasserspeisen und Ausrüsten mit Brennmaterial) vermehrt oder die Maschinen gewechselt oder sonstige Verkehrsmanipulationen vorgenommen werden; 6. Werkstättenbahnhöfe mit Anlagen für Reparatur oder Bau von Fahrbetriebsmitteln.

Nach der Lage der Bahnhöfe zur Hauptrichtung der Bahnlinie werden erstere eingetheilt: 1. Anfangs- oder Endstationen, welche an den Enden der betreffenden Bahnlinie liegen, 2. Zwischenstationen, 3. Durchgangsstationen $D$, wo die Richtung des Zugs bei der Ein- und Ausfahrt dieselbe bleibt; 4 . Kopfstationen $K$, wo der einfahrende Zug die entgegengesetzte Richtung des ausfahrenden hat (Fig. 1295). Aus Sicherheitsrücksichten legt man die Bahnhöfe in der Regel

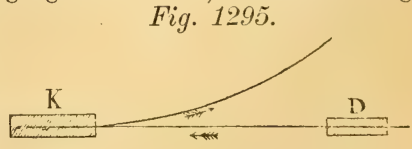


horizontal und in einer Geraden an; muss jedoch, wo es die Umstände erheischen (bei Gebirgsbahnen besonders), von dieser Regel abweichen. (Die diesbeziiglichen Bestimmungen des V. D. E. V. wie oben.)

Nach der Grösse des zu erwartenden Verkehrs und nach der Art desselben richtet sich die Einrichtung der Stationen, welche aus den Geleiseanlagen und in den Gebäulichkeiten bestehen. Die auf Bahmhöfen nach Bedarf vorkommenden Gebäude sind:

1. A u fnahms- (Empfangs-Stations-) Gebäude (bâtiment de départ et d'arrivée - station buildings), welche die für den Betriebsdienst nöthigen Räumlichkeiten und grösstentheils auch noch Beamtenwohnungen enthalten. Diese Räumlichkeiten sind: Vestibul, welches die Zugänge zu allen Localen vermitteln soll, Billet- und Gepäckscassa, Wartesäle, Restaurationen, Corridore, Betriebsbureaux, Bureaux für Zoll-, Polizei- und Postbehörden.

2. Perronsüberdachungen und Personenhallen (abris). Zwischen den für den Personenverkehr bestimmten Geleisen oder auch nur neben dem ersten dem Aufnahmsgebäude zugekehrten Geleise werden aus Erde oder auch gemanerte erhöhte Wege - Perrons - hergestellt, welche ein leichteres Ein- und Aussteigen der Passagiere erlauben. Diese Perrons oder auch nur die Vorplätze der Aufnahmsgebäude werden zum Schutz gegen Witterung durch sogenannte Perronsdächer überdeckt; werden sämmtliche für den Personenverkehr bestimmten Geleise iiberdacht, so entstehen die Personenhallen.

3. Frachten maga in e (magasin des marchandises - goods-shed, goodswarehouse), (Güterschupfen). Diese enthalten Lagerräume für die Guiter, ferner Bureaux für die Frachtenexpedition. Gewöhnlich sind an beiden Längenseiten des Magazins Perrons von $2-2 \cdot 5^{\mathrm{m}}$ Breite hergestellt, um ein Bewegen der Collis ausserhalb der Lagerräume zu gestatten; der Fussboden derselben, so wie jener des Magazins ist im Niveau der Böden der beladenen Wagen, um ein leichtes Einund Ausladen zu ermöglichen. Zuweilen sind gesonderte Zollmagazine erforderlich.

4. Locomotiv-Remisen (remise de locomotives - locomotiv shed) sind Gebäude zum Unterbringen der Locomotiven, wo dieselben angeheizt und in Betriebsfähigkeit gesetzt und kleinere Reparaturen vorgenommen werden. Sie enthalten Geleiseanlagen für die Maschinen und zwischen den Schienen sogenannte Putzkanäle $P$, welche vertieft sind, um ein leichteres Untersuchen der Maschinen zu gestatten. Ausserhalb der Locomotiv-Remise, in der Nähe des Ausfahrtsthores ist stets noch ein Putzkanal, um nach zuriickgelegter Fahrt der Maschine das im Fenerraum befindliche Feuer und die Asche entfernen zu können. Die Form der Remisen ist rechteckig mit parallelen oder kreisförmig mit radialen Maschinenstïnden (Fig. 1296 u. 1297).

Fig. 1296.
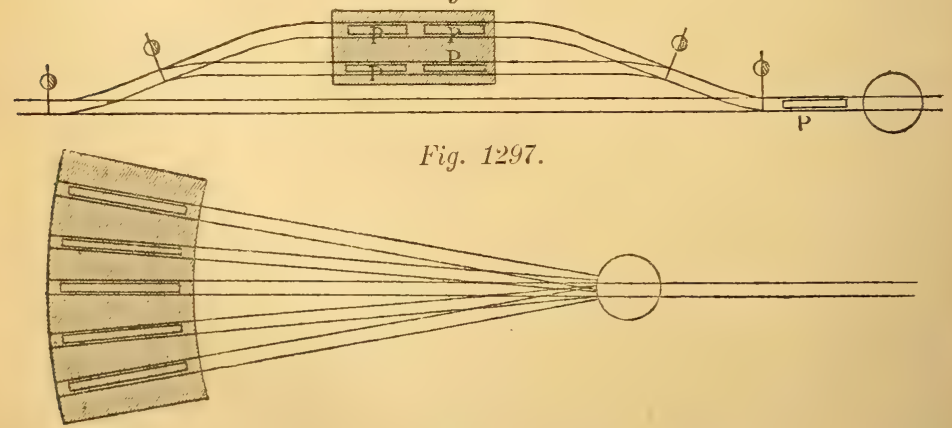

5. Wagenremisen (remise de wagons - carriages-shed) zur Unterbringung ron Tagen, und zwar gewöhnlich solcher, die kleinerer Reparaturen bedürfen, welche auch dort vorgenommen werden. 
6. Wasserstationen (station à eau - pumping station) dienen zur Versorgung der Locomotiven mit Wasser; sie bilden entweder einen Anbau an die Locomotiv-Remise oder befinden sich in deren Nähe. Sie enthalten einen Raum für den Brunnen und die Pumpe, welche das Wasser einem im obersten Stockwerke des Gebäudes befindlichen Reservoir zufïhrt; dasselbe steht durch Rohrleitungen mit den Wasserkrahnen der Station in Verbindung, aus welchen durch Oeffnen eines Hahnes das Wasser in den Tender abgelassen werden kann; eben so wird durch eine Rohrleitung das Wasser in die Locomotiv-Remise geführt, damit auch dort gespeist werden kann. Vor einem jeden Wasserkrahn sind zwischen den Geleisen stets gemauerte Putzkanäle angelegt, um das Reinigen der Maschine vornehmen zu können, während dieselbe Wasser nimmt.

7. Kohlenschupfen zum Aufbewahren eines genügenden Vorraths an Brennmaterial.

8. Werkstätten (ateliers - workshops), das sind Anlagen zum Baue und zur Reparatur der Fahrbetriebsmittel.

Deren Grösse richtet sich nach der Länge der Bahnlinie und der Anzahl der der Bahnanstalt gehörigen Maschinen und Wagen. Mit solchen Werkstätten sind gewöhnlich auch noch Magazinsräume zum Lagern der Materialien und Werkzeuge vorhanden.

9. Wächterhäuser (maisons de garde, guérités de garde - guardhouses) zur Unterbringung der Bahnwächter, wovon gewöhnlich je eines an den Enden des Bahnhofés, nach Bedarf auch mehrere situirt sind.

Die Geleis anlagen der Bahnhöfe richten sich nach der Grösse und Bedeutung des Bahnhofes; stets sind ein oder mehrere durchgehenden Geleise für die verkehrenden Zuige, dann Seitengeleise für die Aufstellung von Ziigen bei Kreuzungen, für Verschiebungen, für Aufstellung von ein- und auszuladenden Wagen, von Reserve- und reparatursbedürftigen Wagen; ferner Nebengeleise, wie z. B. Geleise zu den Locomotiv- und Wagenremisen, zu den Drehscheiben u. s. f. Dem Zwecke entsprechend gibt es daher Hauptgeleise, Geleise für den Personen- und Frachtenverkehr, Rangirgeleise, Locomotiv-Remisengeleise, Werkstättengeleise etc.

(Ueber Bahnhofs-Anlagen und Eisenbahn-Hochbau von Prof. Ed. Schmitt, Erbkam's Zeitschrift fuir Bauwesen, Heusinger von Waldegg "Specielle Eisenbahntechnik".)

A usrüstung der Eisenbahnen und diverse Arbeiten. Die Ausrïstung besteht, abgesehen von der Ausrüstung mit den erforderlichen Fahrbetriebsmitteln (s. weiter unten), aus den zum Eisenbahnbetriebsdienste und zur Sicherung und Regelmässigkeit desselben nothwendigen Einrichtungen, als:

1. Inventar in den Aufnahms- und Wächtergebäuden, soweit es der öffentliche Dienst erfordert.

2. Telegrafen apparate in den Stationen zur gegenseitigen Verständigung (s. unten Telegrafenwesen).

3. Signalisir ungsmittel (signal de chemin de fer - railway-signal), welche den Zweck haben, den Verkehr der Züge sicher zu stellen, zur Mittheilung verschiedener Kundgebungen und zur Verständigung der Bahnbediensteten unter einander dienen. Es gibt 2 Hauptgattungen: 1. op tis che (le signal optique the optical signal), sichtbare, 2. acustische (le signal acoustique - the acustic signal), hörbare.

Die optischen sind: a) rothe Handsignalfahnen und Handsignalscheiben (bei Tag) und die Handsignallaternen (bei Nacht) von den Bahnwächtern gehandhabt zum Signalisiren, ob der Zug ungehindert oder langsam oder gar nicht die Strecke befahren kann. b) Die feststehende Signalscheibe (Stationsdeckungssigual) in einer Entfernung von $200-500^{\mathrm{m}}$ vor und hinter einer jeden Station, um dem Zugspersonale anzuzeigen, dass Ein- und Ausfahrt in die bezieh. aus der Station erlaubt ist oder nicht. c) Wechselsignalscheiben und Laternen, um anzuzeigen, für welches Geleise die Ausweiche gestellt ist. d) Quittirungssignale, feststehende Signal- 
maste bei den Wächterhäusern, womit dem Zugspersonale dieselben Signale wie mit den sub $a$ ) angeführten Mitteln, jedoch auf grössere Distanz gegeben werden können. e) Die Zugssignallaternen vorn an der Locomotive und hinten an der Ruickseite des letzten Wagens im Zuge, mit welchen Mitteln auch ein vorhergehender Zug einen nachfolgenden oder einen entgegengesetzt fahrenden Zug signalisirt.

Die a custischen Signale sind: a) Kuallkapseln, welche von den Wächtern oder dem Zugspersonale auf die Schienenköpfe befestigt werden, und durch den Druck darüber gehender Räder explodiren; sie haben den Zweck, einem herannahenden Zug (bei Nacht oder trübem Wetter) das Signal zum Anhalten zu geben. b) Dampfpfeife der Maschine, von dem Maschin- oder Zugsführer gehandhabt, um das Streckenpersonale zu warnen und dem Zugspersonale Mittheilungen zu machen (Achtung, Bremsen anziehen, Bremsen los, Hilferuf). c) Handsignalpfeife für Signale beim Verschieben angewendet, auch vom Zugsfiihrer zum Zeichen der Abfahrt. d) Stationsglocke, um das Publikum zum Einsteigen in die Waggons aufzufordern und das Zeichen zur Abfahrt zu geben. e) Elektrische Läutewerke und elektrische Controlle-Klingelapparate in den Stationen und Wächterhäusern zur Signalisirung der Zïge und zu sonstigen Kundgebungen für das Streckenpersonale (s. unten Eise $\mathrm{n} b$ ahn-Signalè).

4. Wasserstationseinrichtungen (bereits oben beschrieben).

5. Stossvorichtungen an den Enden von Geleisen, um Wagen von dem Entrollen zu schützen.

6. Grenzmarken (Polizeistock) bei Kreuzungen und Ausweichen in Form weiss angestrichener Pfosten $a b$ (Fig. 1292), welche jene Punkte bezeichnen, bis zu denen Fahrbetriebsmittel ohne Hemmung der Bewegung der Ziige auf den nebenliegenden Geleisen aufgestellt werden können; die Entfernung der beiden Geleise an diesen Stellen von Mitte zu Mitte beträgt $3 \cdot 5^{\mathrm{m}}$.

7. Laderampen (rampe de chargement - platform for loading goods) zur leichteren Verladung von Frachten in die Waggons und umgekehrt.

8. Brï ckenwagen (bascule à pont - wajhing apparatus) zur Ermittlung des Gewichtes von Strassenfuhrwerken, Waggons und Locomotiven.

9. Ladeprofile, welche die geringsten inneren Weiten und Höhen der auf der Strecke und auf den Bahnhöfen sich befindlichen Objecte angibt.

10. Profilp flöcke (Kilometersteine), in Entfernungen von $100^{\mathrm{m}}$ längs der Balm gesetzt, und dieselbe sonach in 1/10 Kilometer eintheilen (Stationirung).

11. Niveautafeln (indicateur de nireau - gradient board), welche bei Gefällsbriichen auf der Strecke stehen und das Gefälls- (Steigungs-) Verhältniss unter $\Lambda$ ngabe der Länge ersichtlich machen.

12. Warnungstafeln (tableau d'avis) bei Strassen- und Wegübersetzungen, welche dem Publikum das Verbot des Betretens der Bahn kundgeben.

13. Weg- und Absperrschranken (barières et clotûres - gates and fenees) ebendaselbst, welche vor dem Eintreffen eines jeden Zugs geschlossen werden.

14. Einfriedung der Strecke, um ron derselben Menschen und Vieh abzuhalten.

A ussergêwöhnliche Eisenbahnsysteme. Dieselben haben den Zweck, entweder die Anlage- und Betriebskosten der Bahn zu verringern oder anssergewöhnlichen Schwierigkeiten und besonders starken Steigungen zu begegnen oder andere Motoren als Zugskraft zu beniitzen. Von den vielen Systemen, die zum Theil nur als Versuche gelten können, seien hier angefuhrt: 1. die normalspurigen Bahnen mit langsamer Fahrbewegung; 2. die schmalspurigen Eisenbahnen; 3. die Fell'sche Eisenbahn: 4. das System Riggenbach nnd Zschokke; 5. das System Wetli; 6. System Larmanjat; 7. System Köstlin \& Lebret (Superficiał-Eisenbahnen); 8. die Seilbahnen; 9. die atmosphärischen und pneumatischen Eisenbahnen.

Die beiden ersten srsteme, welche damn angewendet werden, wenn der anzuhoffende Terkehr ein schwächerer ist, die Bahn überhaupt nur lokalen Bedürf- 
nissen zu entsprechen hat, waren und sind noch immer gegenseitig Rivalen (sielıe WV. Nor d ling Stimmen iiber sehmalspurige Eisenbahnen, M. M. IV e b e r Secundärbahnen und neue Pfade der Volkswirthschaft), und wird bald dem einen, bald dem anderen Systeme der Vorzug gegeben. So viel kann jedoch mit Bestimmtheit angefuilırt werlen, dass die Schmalspur-Bahnen, welche den Uebergang ihrer Falırbetriebsmittel auf die normalspurigen und umgekehrt nicht erlauben, nur zu ganz localen Zwecken, für einen schwächeren Verkehr, welcher voraussichtlich lieine Steigerung erfährt, und bei Frachten, die keinen Schaden durch Ueberladungen erleiden, angewendet werden sollen. Die schmalspurigen Bahnen werden auch fälschlich Secundär- oder Vicinalbahnen genannt, obwohl auch weniger freruente normalspurige diese Benennung verdienen. Bei beiden Systemen werden in der Anlage der Bahn durch schärfere Krümmungen und Steigungen, und daher auch durch kleinere Grundeinlösung, Erdbewegung und durch geringere Kunstbauten, ferner durch einen leichteren Oberbau, durch kleine Hochbauten und geringe Ansrüstung bedeutende Ersparnisse gemacht. Das Anlagekapital wird hiedurch bis zu $30^{\circ}$; und dariiber niedriger.

Als eine Specialität erscheinen die schmalspurigen Bahnen mit F a ir li e'schem Maschinen-Betrieb, Doppelmaschinen mit beweglichem Untergestell, welche starke Krümmungen und Steigungen (bis Bögen von $20^{\mathrm{m}}$ Radius und Steigungen $1: 20$ ) ïberwindet und eine erhöhte Zugskraft hervorbringen kann. Ausgefuihrte schmalspurige Eisenbahnen in Europa: in Schweden, Norwegen, in Belgien die AntwerpenGenter Bahn, in England die Festining-Bahn, in Oesterreich die Lambach-Gmunducr und in Preussen die Bröhlthalbahn.

Die sub 3 bis incl. 7 angefïhrten Systeme haben den Zweck, grosse Steigungen auf Bahnen zu iiberwinden; auf grossen Steigungen reicht die gewöhnliche Adhäsion der Locomotive auf den Schienen, welche $1 / 4$ bis $1 / 10$ des auf den Triebrädern der Maschine ruhenden Gewichtes beträgt und für die Zugkraft massgebend ist, nicht mehr hin und ging das Bestreben dahin, diese Adhäsion zu vermehren, und zwar bei dem System Fell (Mont-Cenis-Bahn, 77 Kilom. lang mit Steigungen von $8 \%$, d. i. $1: 12 \cdot 5)$ sind ausser den gewöhnlichen Triebrädern der Maschine noch 2 Paar unter sich gekuppelte horizontale Triebräder, die mittelst Federn an eine 3., etwás höher als die Hauptschienen gelegene Mittelschiene (Fig. 1298) gepresst werden; durch diese Einrichtung wird die Adhäsion der Maschine und daher auch die Zugkraft derselben vergrössert, und die Möglichkeit geboten, grosse Steigungen $\mathrm{zu}$ befahren.

Bei dem System Riggenbaeh und $\mathrm{Zschokke(Rigibahn} \mathrm{in} \mathrm{der} \mathrm{Schweiz,} \mathrm{Kahlen-}$ bergbahn bei Wien mit Steigungen von $1: 4$, d. i. $25 \%$ ) geschieht die Uebertragung der Zugkraft nicht durch die 4 Räder der Locomotive, welche auf einem Geleise gewöhnlicher Spurweite rollen, sondern durch ein Zahnrad, auf das die Bewegung der Kolbenstangen iibertragen wird und welches in eine $z$ wischen den 2 Schienen des Geleises liegende Zahnstange eingreift (Fig. 1299).

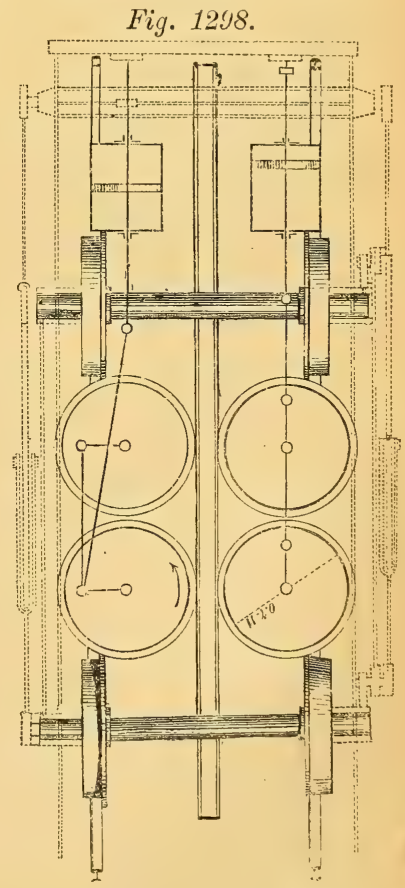


Fig. 1299.

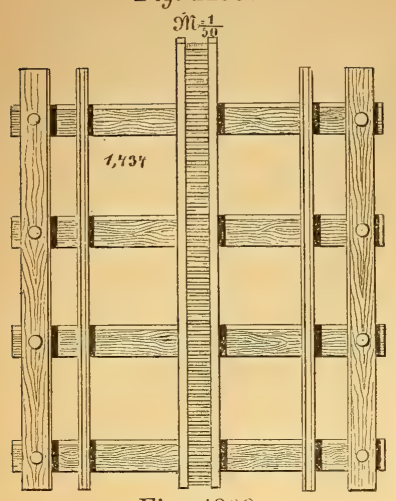

Fig. 1300 .

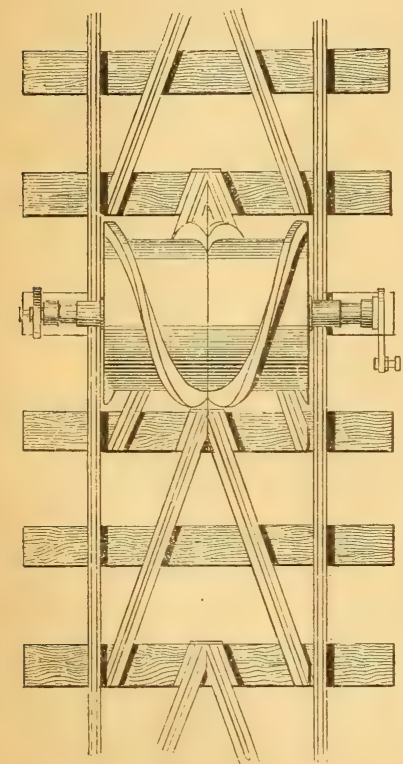

Bei dem Sy s tem We tli (Schweiz, Wädenzweil-Einsiedeln) hat die Maschine zwischen ihren gewöhnlichen Triebrädern und mit denselben gekuppelt ein Schraubenrad, $d . h$. eine Walze mit schraubenförmigen Felgen, welche auf den ziwschen den Hauptschienen liegenden Leitschienen rollen (Fig. 1300).

(Ueber die 3 letzt angeführten Systeme: Prof. Harlacher, das W e tli'sche Eisenbahn-

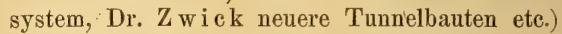

Bei dem System Larmanjat (in Frankreich ausgeführt) laufen die Triebräder der Locomotive auf einer Holz- oder Stcinbahn, während die Laufräder auf einer Schienenbahn, die blos aus einem Strang besteht, rollen. Die Reibung auf Holz oder Stein ist eirca $10 \mathrm{mal}$ grösser als auf Eisen und in demselben Verhältniss wächst die Adhäsion. Durch einen Mechanismus kann das Gewicht der Maschine bald auf den Trieb-, bald auf den Laufrädern ruhend gemacht werden, je nachdem man starke oder schwache Steigungen zu ïberwinden hat.

Im ersten Fall erhält man das Maximum, im zweiten das Minimum der Adhäsion. Die Wagen rollen ebenfalls mit 1 Räderpaar auf die Schienenbahn, mit dem 2. auf der Holzoder Steinbahn; jedoch ruht die ganze Last auf erst erwähnten Rädern, um die Widerstände so klein als möglich zu machen.

Dảs System Köstlin \& Lebret verfolgt ein ähnliches Princip wie das vorhergehende System; und zwar durch eine neben der gewöhnlichen Bahn erhöht gelegte Stein- oder

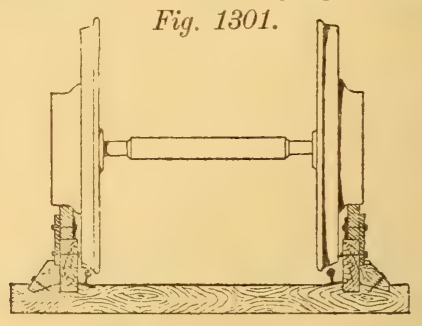

Holzbahn, auf welcher die Locomotive nicht mit ihren Triebrädern, sondern mit an der Achse derselben sitzenden Rollen (Walzen) rollt (Fig. 1301). An Stellen, wo die Balın keine so grosse Steigung hat, dass eine erhöhte Adhäsion nothwendig wird, hat die Bahn die gewöhnliche Einrichtung (ohne Steinbahn) und lauft die Locomotive mit ihren Triebrädern auf den Schienen, während die angegossenen Walzen ausser Thätigkeit kommen. Das System eignet sich besonders für Bahnen, welche bald geringere, bald stärkere Steigungen haben, also für solche, welche sich dem natiirlichen Terrain so viel als möglich anschliessen; deshalb werden sie : auch superficial-Eisenbahmen genannt. Eine solche Bahn hat daher 2 Typen, und zwar: 1. auf horizontalen und wenig geneigten Strecken die gewöhnliche Ein- 
richtung, 2. in den starken Steigungen nebst der Schienen- noch die Stein- (oder Holz-) Bahn; auf ersterer rollen die Wagen, auf der letzteren die Locomotive. Dieses System ist bisher nicht ausgefiihrt (s. Allgemeine Bauzeitung, Wien 1872).

Seilbahnen sind Eisenbahnen, wo die Züge durch feststehende Maschinen mittelst Seilen betrieben werden; derartige Anlagen bestehen unter anderem in Lyon $\left(500^{\mathrm{m}}\right.$ lang), zwischen Luittich und Ans in Belgien $\left(3860^{\mathrm{m}}\right)$, zwischen Diisseldorf und Elberfeld $\left(2450^{\mathrm{m}}\right)$. Sie lassen sich in 3 Gruppen eintheilen: 1. selbstthätige, wo die bergauffahrenden Wagen durch den absteigenden Zug bewegt werden; 2. in solche mit feststehenden Maschinen und endlosem Seil; beide dieser Arten sind zweigleisige Eisenbahnen; 3. System A gu di 0 , blos eingleisig; das Treibseil bewegt nicht direct den Zug, sondern einen Rollwagen, auf welchem um ein paar Rollen ein sogenanntes Schleppseil gewunden ist.

Indem diese Rollen durch das Treibseil gedreht werden, steigt der Rollwagen und mit ihm der vor bezieh. hinter ihm angehängte Zug auf-oder abwärts, indem sich ersterer längs des in der Mitte des Geleises liegenden Schleppseiles (welches mit der Zahnstange des Riggen bach'schen Systems verglichen werden kann) fortbewegt. (Ueber Seilbahnen Organ für Fortsch. d. Eisenb. 1849, F ör s ter's Bauzeitung 1842, Egen Betrieb stark geneigter Eisenbahnen, Heusing er von Waldegg Eisenbahnbau.) Vergl. d. Art. Drahtseilbahnen.

Die atmosphärisehen und pne umatischen Eisenbahnen unterscheiden sich von allen uibrigen Eisenbahnen durch die Verschiedenheit der Motoren; bei ihnen wird die atmosphärische Luft als Uebertragungsmittel der auf einem feststehenden Punkt entwickelten Kraft auf den in seiner Stellung veränderlichen Wagenzug benuitzt. Bei den atmosphärischen Eisenbahnen befindet sich die in einer längs der ganzen Bahn sich hinziehenden Röhre (Treibröhre) eingeschlossene Luft ausserhalb des Wagenzuges. Von allen den verschiedenen Systemen ist wohl nur jenes lebensfähig, wo die verdünnte oder verdichtete Luft in dieser Treibröhre einen Kolben treibt, welcher durch einen aus der Röhre hervorragenden Arm den Zug bewegt (System Medhurst, Pinkus, Clegg, Samuda). Hiernach ausgefiihrte Bahnen von Klingstown nach Dalkey (Irland), von London nach Croydon und Epsom, von Exeter nach Plymouth, von Narterre nach St. Germain (Frankreich).

Bei den pneumatischen Bahnen ist die Treibröhre (tunnelartig) so gross, dass sie den zu bewegenden Zug aufnimmt. Der Kolben hängt hier mit dem Wagenzug unmittelbar zusammen und wird ebenfalls von der verdichteten oder verdünnten Luft getrieben, deren Spannung jedoch von der atmosphärischen Luft nur wenig abweicht, da die grosse Kolbenfläche den erforderlichen Druck schon bei geringer Differenz der Spannungen erzengt.

(Ueber beide Bahnsysteme Eisenbahnzeitung 1846, Förster Bauzeitung Wien 1847, Heusinger von Waldegg Eisenbahnbau.)

$\mathrm{E}$ is en bahnbetrieb (Verkehrsdienst [exploitation des chemins de fertraffic]). Hierunter werden alle jene Vorkehrungen und Anstalten verstanden, welche zum Verkehr der gewöhnlichen und aussergewöhnlichen Zïge nöthig sind, als Beistellung der Fahrbetriebsmittel, Commandirung des erforderlichen Zugspersonales, Aufstellung, Rangirung und Ausrïstung der Züge, Verständigung und Avisirung des Maschinen-, Bahnaufsichts- und Streckenpersonales, Signalisirung und Beförderung der Züge, Ueberwachung, Hilfeleistung bei Störungen, Hand. habung der gesetzlichen Bestimmungen. Letztere sind in den betreffenden behördlichen Urkunden (Eisenbahnbetriebsordnung, Betriebsreglement, Strafgesetz) und in den besonderen Instructionen enthalten.

Sämmtliche Züge verkehren nach einer sogenannten Fahrordnung (Fahrplan [marche des trains - timetable]), welche die Ankunfts- und Abfahrtszeiten, so wie den Aufenthalt eines jeden Zugs in den einzelnen Stationen festsetzt. Die in Verkehr zu setzenden Züge sind: 1. regelmässige, welche nach der allgemeinsn Fahrordnung entweder täglich oder an bestimmten Tagen verkeliren. 2. Züge nach Erforderniss, welche wohl in der allgemeinen Fahrordnung enthalten sind, 
die aber blos dann in Verkehr gesetzt werden, wenn es die Masse des Transportes erheischt. 3. Separatzüge bei aussergewöhnlichen Anlässen oder im Nothfalle (bei Hilfs- und Schneepflugsfahrten). Nach der Bestimmung und nach der Fahrgeschwindigkeil lassen sich die Züge eintheilen: 1. in Eilzüge (trains à grande vitesse - express trains), 2. in Personen- (trains de voyageurs - passenger trains), 3. in gemischte (traïns mixtes), 4. in Lastzüge (trains de marchandises - goods trains). Um den Verkehr zu regeln, sind die Ziige in den Beziehungen zu einander derart gestellt, dass die einen Zïge den anderen untergeordnet sind. Dies nennt man die Rang o rdnung der Züge, welche in der Fahrordnung ersichtlich gemacht ist. In der Regel nimmt ein Hofzug den 1. Rang ein und im Allgemeinen geht der Eilzug dem Personen-, dieser dem gemischten und letzterer dem Last-Zuge vor. Weiters haben die Zïge in der einen Richtung stets den Vorrang vor den gleichnamigen Zügen der entgegengesetzten Richtung.

Die Zus ammenstellung der Züge (disposition des trains - making up trains) geschieht in der Abfahrtsstation; die Zugsmaschine muss sich in der Regel an der Spitze des Zugs befinden, hierauf folgt der Tender und sodann der Wagen, worauf der Zugsführer seinen Platz zu nehmen hat; in einem Zuge müssen zwischen dem Tender und dem ersten mit Passagieren besetzten Personenwagen wenigstens eben so viele mit Passagieren nicht besetzte Wagen (Sicherheitswagen) eingereiht werden, als geheizte Maschinen vorgespannt sind; in gemischten Ziigen sind die Personenwagen grundsätzlich gegen das Ende einzureihen, jedoch ist gestattet, dass der 3. Theil der Lastwagen hinter denselben gestellt werden kann. Bei Anwendung der Personenzugsgeschwindigkeit diurfen mit Ausschluss der geheizten Maschinen und ihrer Tender nicht mehr als 100 Achsen, bei Anwendung von Lastzugsgeschwindigkeit nicht mehr als 200 Achsen in einem Zuge gehen. Ausser der Tenderbremse der geheizten Maschinen, welche durch die Heizer gehandhabt werden, müssen in jedem Zuge eine gewisse Anzahl mit Bremsen versehener Wagen sein, die sich nach der Steigung der Bahnstrecke richtet; dieselbe beträgt bei Personenziigen den $1 / 3$ bis $1 / 8$ Theil, bei Lastzügen den $1 / 5$ bis $1 / 12$ Theil der gesammten Wagenzahl. Jeder Zug muss uibrigens mit dem Inventar (Einrichtungsgegenstände, Signalmittel), jeder Personen befördernde Zug mit einem Rettungskasten (zur ersten Hilfeleistung bei Unglücksfällen, enthaltend Arzneien und Instrumente) ausgerüstet sein.

Stundenpassfïhrung. Jeder Zug und jede leer oder mit Schneepflug verkehrende Maschine muss mit einem Stundenpasse versehen sein, welcher folgende Angaben enthält: Gattung des Zuges, dessen Nummer und Rang, die Ausgangsund Bestimmungsstation, das Datum, Namen des zur Ueberwachung und Bedienung des Zugs beigegebenen Personales und Nummern jener Wagen, die ihnen zugewiesen sind, Nummer oder Name der Maschinen und Tender, Namen der Stationen, Fahr-, Ankunfts-, Aufenthalts. und Abfahrtszeiten, Zahl der Personen- und Lastwagen, der Reisenden, Nummern der Ziige, mit denen gekreuzt wurde, Belastung des Zuges, Temperaturs- und Witterungsverhältnisse, Ursachen der Verspätungen, Unterschrift der expedirenden Beamten, Anmerkungen.

Diese Stundenpässe sind nur vom Zugsführer zu führen. Dem Stundenpass ist gleichzeitig ein Wagenbelastungsausweis beigegeben, welcher die Nummern eines jeden Wagens, so wie dessen Brutto- und Nettogewicht, usgangs- und Bestimmungs-Station angibt. Beide Documente werden in der Endstation an den diensthabenden Beamten abgegeben.

Vor der fahrordnungsmässigen Abfahrtszeit darf kein Zug eine Station verlassen; sind Verspätungen vorgekommen, so ist die Rangordnung der Züge die Grundlage der Verkehrsdisposition und muss festgehalten werden, dass ein Nachrangszug den Verkehr eines Vorrangszuges nicht beeinträchtigt. Die gegenseitige Verständigung über den Verkehr der Züge und die diesbezuiglichen Anfragen geschehen mittelst des Telegrafeg; ist die telegrafische Correspondenz unterbrochen, so richtêt sich das Ablassen der Ziige nach der spätesten (bei Nachrangs-), resp. der frïhesten (bei Vorrangszïgen) Abfahrtszeit. 
Die Fahrgeschwindigkeit (la vitesse de marche - velocity of trains) der Züge ist durch die Fahrordnung bestimmt; die höchst gesetzlich erlaubte ist fiir Personenziige mit 10 Meilen, für Lastzüge mit 5 Meilen pr. Stunde festgesetzt. Die Sicherheit macht es nothwendig, dass Ziige, welche in derselben Richtung verkehren, nur in bestimmten Zeitintervallen auf einander folgen duirfen, und zwar darf in der Regel ein Personen- oder gemischter Zug einem Lastzug erst nach 15 Minuten, ein Lastzug einem Personen- oder gemischten Zug erst nach 5 Minuten, Ziige von gleicher Eigenschaft einander erst nach 10 Minuten folgen.

(Ueber Eisenbahnbetrieb: Heusinger von Waldegg ${ }_{n}$ Die Technik des Eisenbahnbetriebs".) F. Benedikt.

Eisenbahn-Fahrbetriebsmittel. Zu diesen gehören zunächst die Motoren, welche zur Fortschaffung der Zïge dienen: die Dampfwagen - Locomotiven — sodann die Munitionswagen - Tender - welche den Brennstoff und das zur Erzeugung des Dampfes nöthige Wasser mitführen, und endlich die Wagen, welche zur Aufnalıme der Reisenden und der Frachtgüter dienen, schliesslich noch die Schneepflïge und Draisinen.

A) D a m p fwagen oder Lo e o motiven (machine locomotive - locomotive engine). Diese grossartige Erfindung und mit derselben die Eisenbahnen haben in dem kurzen Zeitraume eines halben Jahrlıunderts Verbreitung über den ganzen Erdball gefunden und das Culturleben der Völker völlig umgestaltet.

Ganze, mächtige Industriezweige, wie z. B. der Kohlenbergbau, die Eisenund Stahlindustrie, basiren in ihrer riesigen Entwicklung allein auf den Eisenbahnen, und es gibt wohl keine Industrie, welche nicht durch die Eisenbahnen einen starken Impuls zu ihrem Fortschreiten erhalten hätte.

Eine Hungersnoth ist, Dank den unermüdlichen, auf den Eisenbahnen dahin schnaubenden Dampfrossen und den durch sie allein zu bewältigenden Massentransporten, heute nicht mehr denkbar, und die noch im Mittelalter durch Jahrzehende wiithende Kriegsfurie wird, wenn entfesselt, in wenigen Monaten durch die alle Culturländer durchkreuzenden Schienenstränge in stählerne Bande geschlagen.

Diese Erfindung verdient es wahrlich, dass ihre Geschichte, trotz des beschränkten Raumes, mit wenigen Strichen skizzirt, und dass dabei jener Männer anerkennend gedacht werde, welchen sie ihren Ursprung und ihre Fortbildung verdankt.

Geschichtliches: England ist die Heimath der Locomotive; der Erfinder derselben ist Robert Stephenson und der Geburtstag der Locomotive ist der 8. October 1829.

Die Vorgeschichte dieser Erfindung ist dunkel. Beinahe zwei Jahrhunderte vorher kam 1637 Salomon de Caus aus der Normandie nach Paris, um dem König und dem allmächtigen Cardinal Richelieu auseinander zu setzen; wie die Dämpfe des siedenden Wassers zur Bewegung von Schiffen und Wagen benützt werden könnten. Er wurde als wahnsinnig im Bicêtre eingesperrt und starb dort. Auch Dionys Papin sprach um das Jahr 1690 die Ansicht aus, dass sich die Dampfkraft als Beförderungsmittel für Schiffe benützen lasse, und Savery wollte sie im Jahre 1708 für Wagen und Schiffe benützen. Cugnot baute 1763 das Modell eines Dampfwagens, sodann 1778 auf Kosten des Marschalls von Sachsen einen wirklichen Dampfwagen, welcher bei der Probe eine Mauer durchstiess und in Folge dessen für zu gefährlich gehalten wurde. Derselbe befindet sich noch heute im Conservatoire des arts et de metiers in Paris auf bewahrt. Im Jahre 1759 scheint Dr. Robinson in Glasgow die Idee gefasst zu haben, Fuhrwerke mittelst Dampf kraft in Bewegung zu setzen. Ein Jahrzehent später, 1769, verfolgte der geniale Erfinder der Dampfmaschine, James Watt, in Verbindung mit $\mathrm{Murdoch}$ diese Idee; wenige Jahre nachher beschäftigte sich 1772 Oliver Evans in Amerika erfolglos mit dem Baue eines Dampfwagens und 1784 nahmen Watt und Murdoch ein Patent auf eine Dampfmaschine zur Bewegung von Fuhrwerken auf gewöhnlichen Strassen.

Es war eine Niederdruckmaschine mit Condensation, welche nicht zur Ausfiihrung kam, da die Erfinder bei der Construction auf unüberwindliche Schwierigkeiten gestossen sein mochten. 
Oliver Evans erfand inzwischen die Hochdruckdampfmaschine ohne Condensation und wendete dieses Princip 1799 bei dem Baue eines Dampfwagens an, welcher 5 Jahre Zeit in Anspruch nabm und 1804 mit dem Namen Oructor Amphibolos in Philadelphia im Beisein von mehreren Tausend Zuschauern auf der gewöhnlichen Strasse in Bewegung gesetzt wurde. Oliver Evans fehlten die Mittel; seine Versuche fortzusetzen, so wio das Verständniss seiner Zeitgenossen und deren Anerkennung. Er starb 1819.

Gleichzeitig erbauten die Ingenieure Trevethick und Vivian in England einen Dampfwagen, welcher 1804 auf einer Eisenbahn in Süd-Wales in Gang kam.

Dieser hatte uur Einen horizontalen, im Dampfkessel liegenden, Cylinder von 200 Millimetern Durchmesser und 1370 Millimeter Hub. Die Bewegung des Kolbens wurde durch eine Kurbelstange und zwei Zahnräder auf die Triebräder vermittelt. Der gebrauchte Dampf wurde in den Schornstein geleitet, ohne die ausgesprochene Absicht, zur Zugerzeugung beniitzt zu werden. Diese Locomotive zog 10 Tonnen (ungefähr 10.000 Kilogramm oder 200 ZollZentner) mit 71/2 Kilometer (nahezu 5 englische oder 1 deutsche Meile) Geschwindigkeit. Eine regelmässige Verwendung derselben trat jedoch nicht ein, indem man bis 1813 der Ansicht war, die Reibung zwischen Rädern und Schienen sei so gering, dass die Räder sich auf demselben Punkte, ohne fortschreitende Bewegung, drehen würden. Dieser Irrthum wirkte lälmend auf die Verbesserung der Locomotive.

Um eine grössere Reibung zu erzielen, wollten Trevethick und Vivian die Radreifen rauh machen. Blenkinshop dagegen legte 1811 neben die Sclienen einer Eisenbahn bei Leeds eine gezahnte Stange, in welche rin gezahntes Rad des Dampfwagens eingriff.

Dieser Zahnrad-Dampfwagen wurde der erste als brauchbar erkannt und soll nahezu 23 Jahre Dienste geleistet haben.*)

Ein Jahr später, 1812, nahmen William und Edward Chapman eine Kette zu Hilfe, welche zwischen den Schienen lag und um ein Triebrad der Maschine geschlungen war. Wegen der ungemeinen Reibung der Kette und ihrer schnellen Abnützung gaben die Erfinder diese Idee bald auf, um so mehr, als auch der Dampfwagen oft aus der Bahn gerieth.

Dasselbe Schicksal hatte Brunton's Locomotive, welche 1813 erbaut wurde. Sie ruhte auf vier Rädern und war mit Einem Cylinder versehen. Die Kolbenstange bewegte sich in horizontaler Richtung nach hinten und war mit zwei Krücken in Verbindung, welche sich auf den Boden stützen und abwechselnd die Locomotive fortschoben, somit als mechanische Beine wirkten. In demselben Jahre machte zuerst Blackett Versuche, die Locomotive ohne Zahnrüder, ohne Kette, ohne mechanische Beine u. dgl. laufen zu lassen, um festzustellen, ob die Räder gleiten werden, was, wie gesagt, bis dahin als feststehend angenommen worden war. Blackett's Bemühungen waren von Erfolg gekrönt; es ergab sich, dass die Reibung zwischen Rädern und Schienen nicht nur so gross sei, um die Locomotive selbst eine fortschreitende Bewegung annehmen zu lassen, sondern dass auch noch ein Ueberschuss vorhanden war, um auf horizontaler oder gering ansteigender Strecke mehrere Wagen fortziehen zu können.

Die erste Maschine, bei welcher nur die Reibung der Räder auf den Schienen (die Adhäsion) wirkte, hatte auch nur Einen Cylinder und ein Schwungrad, um die unregelmässige Wirkung auszugleichen.

Wenn beim Stillstehen die Kurbel auf dem todten Punkte stand, musste der Dampfwagen mit Hebeln in Bewegung gesetzt werden. In dem folgenden Jahre 1814 baute Georgo Stephenson den ersten auf vorstehendes Princip sich stützenden Dampfwagen für die Stockton-Darlington Eisenbahn mit zwei vertical stehenden Cylindern von 200 Millimetern Durchmesser und 610 Millimetern Hub, wobei Zahnräder die Uebersetzung auf die Triebachse bewirkten. Durch den Kessel ging ein Feuerrohr. Diese Locomotive zog 30 Tonnen (ungefähr 30.000 Kilogramm) mit etwa 6 Kilometern (etwa $4 / 5$ deutsche Meilen) Geschwindigkeit in der Stunde.

George Stephenson baute nun in Verbindung mit Dodds und wieder allein noch mehrere Locomotiven, 1820 eine, wo der gebrauchte Dampf zur Erzielung eines besseren Zuges in den Schornstein geleitet wurde.**)

*) In unserem Jahrzehent ist dieses Princip (freilich nur für Steigungen, welche früher als unüberwindlich für eine Eisenbahn galten) zu Ehren gekommen; in Europa zuerst bei der Rigibahn mit Steigungen von 250 Millimeter auf einen Meter Länge.

**) In demselben Jahre baute Gryffiths nach dem Plane Prof. Arzbergers die erste Strassenlocomotive. 
Der Franzose Pelletan streitet mit George Stephenson und Hackworth um die Priorität der Erfindung, den gebrauchten Dampf als Zugerzeugungsmittel zuerst benützt zu haben.

Tim. Hackworth liess 1825 die zwei verticalen Cylinder seines neuen Dampfwagens zuerst zu beiden Seiten des Kessels auf Eine Triebachse wirken.

George Stephenson hatte nun schon in seiner Fabrik in New-Castle 16 Locomotiven gebaut, welche auf der Stockton-Darlington Bahn verkehrten, der ersten Bahn, auf welcher regelmässig und andauernd Personen befördert wurden.

Bis 1826 verwendete man Gusseisen für alle Locomotiv-Räder, welche sich auf der Lauffäche schnell abnützten, auch öfters sprangen und Unfälle veranlassten.

Nic. Wood versah zuerst auf der Killingworth-Eisenbahn die Räder mit Bandagen von Schmiedeisen, und es entstand 1827 in der Bedlington-Hütte das erste Walzwerk für Fabrication der schmiedeisernen Radreifen (bande-tyre).

Bis zum Jahre 1827 waren durchschlagend günstige Resultate mit den Dampfwagen nicht zu erzielen gewesen, indem die beschränkte Kesselanlage den verbrauchten Dampf nicht schnell genug ersetzen konnte. In diesem Jahre stellte der Franzose Marc Séguin auf der Bahn von Etienne nach Lyon Versuche mit einer englischen Locomotive an und kam zu der Ueberzeugung, dass nur durch Vergrösserung der Heizfläch€ bessere Resultate zu erzielen seien. Er machte den Vorschlag, eine grosse Anzahl Röhren von geringer Wandstärke im Kessel einzubringen und liess sich den „Röhrenkessel“ 1827 in Frankreich patentiren, jedoch kam derselbe erst mehrere Jahre nachher auf der Lyoner Bahn in Betrieb.

Im Jahre 1828 baute Robert Stephenson, der Sohn des George Stephenson, eine Locomotive mit 2 Cylindern, welche, unter einem Winkel von $45 \mathrm{Grad}$ geneigt, am Kessel befestigt waren.

Die Kolbenstangen wurden mittelst eines Kreuzkopfes zwischen zwei Parallelschienen gerade geführt und die Kurbelstangen griffen an den beiden um 90 Grad versetzten Kurbeln der Triebachse an; die Zapfen der zweiten Triebachse waren durch Stangen mit diesen verbunden; der Kessel hatte zwei Feuerröhren.

Dies war die erste Maschine mit vier gekuppelten Rädern. Das Kuppeln der Räder ist als ein wesentlicher Fortschritt zu bezeichnen, indem dadurch die Adhäsion verdoppelt werden kann.

Aber alle Locomotiven hatten einen so langsamen Gang, dass die Reisenden mit der Post doppelt so schnell vorwärts kamen.

Als nun 1829 die Manchester-Liverpooler Bahn beinahe fertig war, schrieb die Gesellschaft, welche lange geschwankt hatte, ob feststehende Motoren oder Pferde oder aber Locomotiven zur Zugförderung benützt werden sollten, auf den Rath ihres Oberingenieurs Ge org e Stephenson einen Preis auf die beste Locomotive aus. Man forderte Locomotiven, welche fähig wären, bei einem Gewichte von $10^{1} / 2$ Tonnen, inclusive Tender, einen Zug von 191/2 Tonnen Gewicht mit 10 englischen Meilen Geschwindigkeit in der Stunde zu befördern, d. h. eirca 20.000 Kilogramm mit 15 Kilometern Geschwindigkeit.

Am 8. Oetober 1829 concurrirten 4 Bewerber um den Preis von 5000 Gulden.

1. Burstall mit der Maschine Perseverance (die Beharrlichkeit). Diese Maschine kam defect an, entsprach mehreren Bedingungen nicht und wurde zu den Probefahrten nicht zugelassen.

2. Tim. Hackworth von Shild on mit der Maschine Sanspareil (die Unvergleichliche). Diese Maschine entsprach gleichfalls nicht allen Bedingungen; sie war zu schwer und es fehlten die vorgeschriebenen Tragfedern. Sonst hatte der Kessel eine doppelte Fenerröhre, welche von hinten nach vorn und wieder zurück ging, so dass Kamin und Rost an demselben Ende lagen. Dic Cylinder standen vertical über der Triebachse, welche mit der zweiten Achse gekuppelt war. Der gebrauchte Dampf wirkte in dem Schornstein saugend auf das Feuer.

3. Braithwaith und Ericson von London mit der Maschine Novelty (die Neuigkeit). Diese Maschine führte Wasser und Kohle selbst mit, war also eine Tendermaschine. Ein durch die Maschine getriebenes Gebläse führte die Luft unter den Rost. Der Kessel bestand aus Steh- und Langkessel. Vom Rost ging ein Flammrohr durch den Langkessel nach vorn, dann zurück, und endlich wieder nach vorn zum Schornstein. Von dem Feuerraum ging ein Rohr durch äen Stehkessel nach oben, durch welches das Brennmaterial eingeschüttet wurde. 
Die Maschine hatte vorn auf dem Kessel nur Einen Cylinder. Die Triebråder wurden mittelst Kurbelstangen und Winkelhebeln gedreht und konnten mít den Rädern der zweiten Achse gekuppelt werden.

4. Robert Stephenson von New-Castle mit der Maschine Rocket (Rackete). Diese allein entsprach allen Bedingungen, übertraf in ihrer Leistungen die gestellten Anforderungen und erhielt den Preis.

Figur $1302 a$ und $b$ zeigt diese Locomotive in Längenansicht und Querschnitt. Der Kessel a war cylindrisch mit flachen Enden, 2 Meter lang und etwa 1 Meter im Durchmesser.

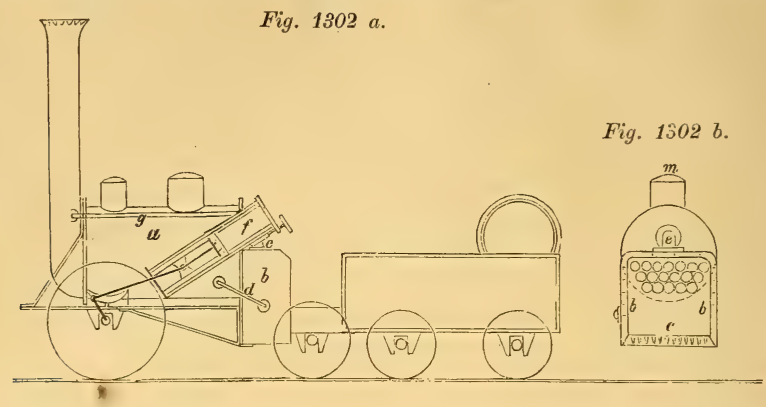

Mit dem einen Ende des Kessels war ein viereckiger Kasten oder Ofen $b$ verbunden, etwa 1 Meter breit und hoch, 0.7 Meter lang. Am Boden dieses Kastens waren die Roststäbe c Fig. 1302 a angebracht, und er war gänzlich ron einem Gehänse umgeben, ausgenommen am Boden und an der Seite des Kessels. Zwischen dem Gehäuse und dem Feuerkasten blieb nur ein Raum ron circa $\mathbf{7 5}$ Millimetern, welcher mit Wasser gefüllt war. Eine Röhre $d$ versah ihn mit Wasser aus dem Kessel und ein Rohr $e$ führte den Dampf in den Obertheil des Kessels, welcher oben mit Dampf, unten mit Wasser gefuillt war. Durch den Untertheil des Kessels gingen 25 kupferne Röhren ron circa 75 Millimetern Weite von einem Ende bis zum anderen.

Die 2 Cylinder wirkten, schief stehend, jeder auf nur ein Rad; sie hatten 200 Millimeter Durchmesser und 420 Millimeter Hub.

Der gebrauchte Dampf ging mittclst der Röhre $g$ in den Schornstein und erzeugte stossweise den Zug des Feuers. Die Triebräder hatten circa 1.250 Meter, die Laufräder 1 Meter

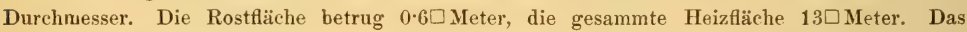
Gewicht der Locomotive war circa 4200 Kiloyramm, jenes des Tenders 3000 Kilogramm.

Die Maschine Rackete zog ausser dem Tender 2 beladene Wägen von $91 / 2$ Tonnen Gewicht und erreichte eine Maximalgeschwindigkeit ron 20 englisclien Meilen (circa 30 Kilometer oder 4 deutsche Meilen) in der Stunde, die mittlere Geschwindigkeit war 14 englische Meilen circa 21 Kilometer in der Stunde. Es war die glückliche Combination des Röhrenkessels von Seguin mit dem Exhaustor von Pelletan oder Hackworthoder George Stephenson welche die Maschine Rackete den Preis gewinnen liess.

Schon im Jahre 1830 baute man Maschinen mit 90 bis 130 Siederöhren von 40 bis 50 Millimetern Durchmesser und zwischen den Rädern liegenden Cylindern mit gekröpften Achsen. Die Räder waren von Holz mit schmiedeisernen Bandagen.

Edmund Bury war 1830 der erste, welcher die Cylinder ganz horizontal legte; in demselben Jahre erfaud W. Losh die schmiedeisernen Speichenräder. Nun wurden auch die Schienen tragfähiger gemacht und so konnte das Gewicht und die Leistungsfähigkeit der Locomotive gesteigert werden.

Robert Stephenson construirte 1833 die erste Dampfbremse. In demselben Jahre wandte Dix on zuerst Messingröhren statt der kupfernen an.

B ald u in in Philadelphia und Forrester in Liverpool vereinfachten und verbesserten 1834 die Steuerung behufs des Vor- und Rückwärtsganges.

Auch wandte man nun schon Triebrä er an ron mehr als 2 Meter ( 7 Fuss englisch) Durchmesser und Geschwindigkeiten von 40 bis 50 Kilometer per Stunde. 
Im Jahre 1835 erfand John Melling die Kugelventile der Speisepumpen statt der sich häufig festsetzenden conischen. Gleichzeitig baute Robert Stephenson Locomotiven mit aussen- und innenliegenden Cylindern mit drehbarem Vordergestelle.

Dieses letztere wurde namentlich durch William Norris und Balduin in Philadelphia ausgebildet und fast alle amerikanischen Locomotiven für Personenzüge haben noch hente ein drehbares Vordergestell (truck).

R. und W. Hawthorn construirte damals zuerst metallene Wasserleitungen zwischen Maschine und Tender mit Kugelgelenken, wie sie auch jetzt noch vorkommen.

Derselbe Ingenieur verbesserte auch die Steuerung durch Anwendung von 4 festen Excentrics, 2 für jeden Cylinder und je eines davon für den Vorwärts- und für den Rückwärtst gang, und wandten Triebräder von mehr als 3 Meter Durchmesser (10 englische Fuss) an, von welchen jedoch bald wieder, wegen der hohen Lage des Schwerpunktes, abgegangen wurde.

Gillingham und Winaus in Baltimore bauten die ersten Dampfwagen mit veränderlichen Expansion; jeder Cylinder batte 3 Excenter, eines für volle Füllung und 2 für eben so viele verschiedene Expansionsgrade.

Man hätte nun gern Maschinen von grösserer Leistungsfähigkeit gebaut, aber man kam nicht über $50 \square$ Meter Heizfläche, und glaubte, bei der nun einmal feststehenden Spurweite ron 1.435 Meter nicht mehr erreichen zu können, und es entstanden nun Bahnen in England ron 2.135 Meter Spurweite. In anderen Staaten und auch in England wandte man ein mittleres Mass von 1.500 bis 1.840 Meter an, ohne dass es gelang, kräftigere oder schnellere Locomotiven zu bauen.

Alle diese Verschiedenheiten sind verlassen worden und hat man derzeit in der ganzen Welt mit Ausnahme von Russland und Spanien alle Normalbahnen mit der Spurweite von 1·435, während die Secundärbahnen mit Spurweiten von 0.300 bis 1.200 Meter ausgeführt wurden.

Eastwick und Harrison bauten im Jahre 1839 eine Locomotive mit 8 Rädern, wovoń 4 gekuppelt und 4 in dem, uın Einen Punkt drehbaren Gestelle mit einer Federhängung so vereinigt waren, dass die ganze Maschine auf nur drei Punkten ruhte.

Gleichzeitig erzielte Clapeyron eine fixe Expansion, indem er den Excentern Voreilung und den Schiebern eine Ueberlappung gab.

$\mathrm{Pauwels}$ in Lille legte die Gleitflächen der Schieber zuerst vertical, was die Steuerung wesentlich vereinfachte.

Dr. Ridder erfand 1840 in Belgien die Wärmröhren, um den überschüssigen Dampf in den Tender zu leiten. Gooch nahm in demselben Jahre ein Patent auf verstählte Radbandagen.

Lud. Klein in Wien erfand 1841 die Funkenfänger, um die Feuersbrïnste zu beseitigen, welehe nicht selten durch Losomotiven veranlasst worden waren.

Rob. Stephenson baute im Jahre 1842 eine Locomotive mit nahezu 4 Meter langen Siederöhren aus Schmiedeisen und mit Coulissensteuerung behufs variabler Expansion, welche bis jetzt, trotz der sehr grossen Anzahl seitdem erdachter Steuerungen mit variabler Expansion, mit einem oder zwei Schiebern, nicht übertroffen worden ist. Die Speisepumpen wurden durch das Rückwärts-Excenter getrieben.

Die 3 Achsen (die mittlere Triebachse) lagen alle vor der Feuerkiste, die Maschine hatte somit einen kurzen Radstand und konnte scharfe Krümmungen durchfahren.

In Deutschland wurde die erste Locomotive (Saxonia) $1837 \mathrm{zu}$ Uebigau für die LeipzigDresdner Bahn gebaut; dieselbe Anstalt lieferte auch die zweite Maschine (Phönix). In demseiben Jahre erbaute Dr. Kü feld in Berlin eine Maschine für die Berlin-Potsdamer Eisenbahn mit verticalen Kesseln und Cylindern.

Dobbs und Pönsgen in Aachen bauten 1840 und Jacobi Haniel und Huysten in Sterkrade 1841 je eine Locomotive.

A. Borsig in Berlin stellte 1841 die erste Locomotive für die Berlin-Anhalter Bahn, Egels in Berlin folgte 1842.

Nun treten die Wien-Gloggnitzer Eisenbahn in Wien, Günther in Wiener-Nenstadt, Maffei in Hirschau bei München, Kessler in Carlsruhe als Locomotivfabrikanten auf.

Die Eisenbahnen (und mit ihnen der Locomotivbau) breiteten sich nun immehr mehr aus. Natürlich waren es Bahnen mit horizontalen oder wenig geneigten Strecken, welche man der leichten und billigeren Herstellungs- und Transports-Kosten wegen zunächst aus- 
führte: Thalbahnen, Flachlandsbahnen; allmälig ging man weiter und stieg aus den Thälern auf die Hügel und überschritt Wasserscheiden mit Steigungen von 10 Millimetern auf 1 Meter $(1 / 100)$, bis sich endlich zu Ende der vierziger Jahre das Bedürfniss zu einer Ueberschreitung der Alpen herausstellte, um die italienischen Provinzen Oesterreichs mit der Hauptstadt zu verbinden.

Die österreichische Regierung schrieb 1850 einen Preis von 20.000 Dukaten für die beste Locomotive aus, welche im Stande sei, die Bahn über den Semmering mit Steigungen von 25 Millimetern per 1 Meter $(1 / 40)$ und mit sehr scharfen Krümmungen mit einer Zugslast von 125.000 Kilogramm (2500 Zoll-Ztr. = 125 Tonnen) exclusive Tender zu befahren. Es wurden 4 Maschinen zur Concurrenz zugelassen, und zwar je eine von Maffei in München, von Günther in Wiener-Neustadt, von John Cockerill in Seraing und von der Maschinen-Fabrik der Wien-Gloggnitzer Eisenbahn.

Die Bavaria von Muffei in München erhielt den ersten Preis und auch die drei anderen wurden preisgekrönt, jedoch wurde keine als dauernd genügend für den Betrieb auf dem Semmering anerkannt.

Unter Zuhilfenahme der bis dahin gemachten Erfahrungen und der besten Constructionen projectirte Engerth in Wien seine Tenderlocomotive mit 3 gekuppelten Achsen, von welcher Fig. 1303 eine Ansicht zeigt. Die Maschine hat noch 2 Tenderachsen, von welchen eine vor der Feuerkiste und die zweite hinter der Fetterkiste sich befindet.

Der weit nach rückwärts überỉaute Kessel stützt sich mittelst der Stützen $p$, welche kugelförmige Zapfen haben und sich in Gussstahllagern drehen, auf den Tender.

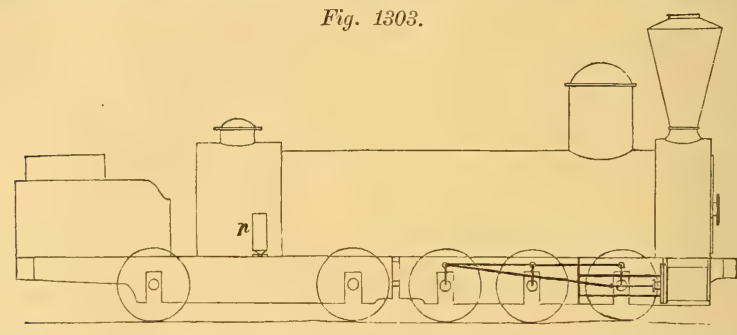

Während man früher bei starken Steigungen die Eisenbahn mit feststehenden Dampfmaschinen hetrieb, wie z. B. die schiefe Ebene bei Lüttich, erklimmen jetzt Locomotiven mit ihren Trains Steigungen von 35 Millimeter per Meter $(1 / 2 \mathrm{~s})$ mit glatten Bandagen nur rermittelst der Adhäsion.

Im Jahre 1850 erfand Giffard in Frankreich die Dampfstrahlpumpe (injecteur - injector), welche nummehr in den verschiedensten Constructionen bei fast allen neueren Locomotiven angewendet wird, da die früheren Speisepumpen allzuhäufig den Dienst versagten. Fs würde zu weit führen, alle möglichen Locomotir-Constructionen zu beschreiben, und wir begnïgen uns mit der Angabe, dass mit Schluss des Jahres 1874 nach authentischen Angaben auf den Eisenbahnen, welche zum Verbande des ${ }_{\pi}$ Vereines deutscher Eisenbahnverwaltung " gehören, der die deutschen, österreichischen, ungarischen, so wie mehrere Bahnen in Belgien, in den Niederlanden, Rumänien und Russisch-Polen umfasst, 13.237 Locomotiven im Betrieb waren. Die Anzahl der Locomotiven in allen Erdtheilen kann mit rund 50.00n Stück angenommen werden. Nimmt man den Preis einer Locomotive mit Tender mit 30.000 Gulden österr. Währ. an, so sind dafür F ïnf $\mathrm{ehn} H$ undert Millionen Gulden angelegt worden.

Organe der Locomotiven. Alle Locomotiven, mögen sie nun zur Beförderung von Courier-, gewöhnlichen Personenzïgen oder zur Fortschaffung von Frachten dienen, haben gewisse Hauptheile mit einander gemein, und unterscheiden sich nur in jenen Einzelnheiten von einander, welche ihre verschiedene Bestimmung erfordert.

Die allen Locomotiven gemeinschaftlichen Hauptorgane sind: der Da $\mathrm{mpf}$ kessel (generateur - steamboiler), der Wagen, welcher den erzeugten Dampf 
unmittelbar für Eisenbahnzwecke verfïgbar macht, und der Mechanismus, welcher Kessel und Wagen verbindet, die Maschine.

Diese 3 Elemente sind nach bestimmten Principien anzuordnen, und sollen zunächst getrennt aufgefasst und beschrieben werden.

I. K essel. Jeder Locomotivkessel besteht aus der Feuerkiste (bô̂te à feu - fire-box), in welcher sich der Rost befindet und der Brennstoff zur Verwendung gelangt, dann aus dem Langkessel von cylindrischer Form, welcher die Siederöhren enthält, endlich dem Rauchkasten mit dem Schornstein.

Die Feuerkiste oder der Feuerkasten hat meistens eine im Grundrisse oblonge Form mit abgerundeten Ecken; er ist auf allen 4 Seiten durch kräftige, mit einander vernietete Kupferplatten von $15-20^{\mathrm{mm}}$ Dicke gebildet und hat eine Decke aus Kupfer. In Amerika pflegt man häufig Stahl- oder Eisenplatten dazu zu nehmen, und man hat dies auch in Europa melrfach, jedoch mit ungiunstigem Erfolge versucht.

Bei dem hohen Dampfdrucke, welchen man bei Locomotiven aus ökonomischen Gründen zur Anwendung bringt, 8 bis 15 Atmosphären effectiv, müssen diese ebenen Flächen versteift werden, was durch die sogenannten Stehbolzen (entretoise - stay) geschieht, d. h. Schrauben aus Eisen, Stahl oder Kupfer, deren Gewinde in der Platte des Feuerkastens und des Stehkessels ihre Muttern und beiderseits noch runde Nietenköpfe haben.

Fig. 1304 zeigt einen S t e h bolzen im Schnitt. In der Mitte sind die Gewinde weggedreht, von der Seite ist der Bolzen angebohrt. Dies hat den Zweck, ein Abreissen des Bolzens durch das sodann herausspritzende Wasser bemerkbar zu machen. Dieser Uebelstand kommt häufig genug vor und bedingt natiirlich den Ersatz des Stehbolzens.

Der Stehkessel hat in der Entfernung von 80 bis $100^{\mathrm{mm}}$ mit dem Feuerkasten parallele Wände und Decke, und besteht aus Eisen- oder Stahlblech. Der Zwischenraum ist mit Wasser ausgefüllt, welches noch die Feuerkastendecke mindestens $100^{\mathrm{mm}}$ hoch bedecken muss.

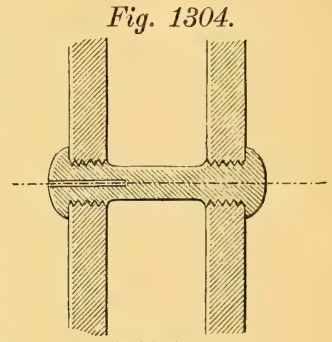

Stehbolzen.

Die Decke des Stehkessels ist entweder flach und muss dann gleichfalls mit Stehbolzen verankert sein wie die Seitenwände, oder halbcylindrisch.

In dem zweiten Falle muss die flache Decke, der Box, mit Ueberlegeisen und Schrauben versteift sein.

In den letzteren Jahren hat man Feuerkasten construirt, wo die Decke gewölbt ist und iiberdies aus gewelltem Kupferblech besteht, um die Deckenanker zu ersparen. Dies hat den grossen Vortheil, dass der bei den Locomotiven besonders lästige Kesselstein leicht entfernt werden kann, und dürfte auch die Dampfproduction eine bessere sein.

Im Jahre 1875 construirte $\mathrm{Kaselowski}$ in Berlin eine Feuerbüchse ohne alle Stehbolzen, Deckbarren und Deckanker. Wenn sich diese Construction, wie nicht zu bezweifeln, bewährt, so wird die Erhaltung der Locomotivkessel wesentlich billiger zu stehen kommen.

Auf der rückwärtigen Seite des Stehkessels befindet sich die Feuerthür, durch welche das Brennmaterial auf den Rost gebracht wird. Die Oeffnung ist von einem schmiedeisernen Ringe umgeben, welcher den Raum zwischen Box und Stehkessel ausfuillt und mit beiden Wänden vernietet ist.

Um das untere Ende der Feuerkiste geht ein starker, schmiedeiserner Rahmen, welcher mit den Platten der Feuerbïchse und des Stehkessels gleichfalls vernietet wird.

In der Nähe befindet sich der Rost (grille - grate). Er wird aus geraden, parallelen Stäben (barres du foyer - fire-bars), aus Schmied- oder Gusseisen 
gebildet, welche Luftspalten zwischen sich lassen, deren Breite von der Beschaffenheit des Brennmateriales abhängig ist und von etwa $10-50^{\mathrm{mm}}$ variirt.

Koks, Stiick-, backende oder schlackende Kohle erfordert weite, Kleinkohle oder sinternde, im Feuer zerfallende Kohle, braucht enge Spalten.

Unter dem Roste befindet sich der Aschenkasten, welcher vorn und rïckwärts mit Klappthüren versehen sein muss, durch welche die Luft unter den Rost treten kann. Dieser Kasten besteht aus Eisenblech, ist leicht abnehmbar und hat zur Verhütung von Schadenfeuern zu dienen, welche durch die noch gliihenden Kohlenstiicke leicht entstehen könnten, welche durch die Rostplatten fallen. Den Vordertheil der Feuerkiste bildet die Rohrwand. Sie nimmt das hintere Ende der Siederöhren auf (bouilleurs, tuyaux - boiler tubes, heating-tubes), deren Anzahl in den kräftigen Maschinen der Neuzeit uiber 200 steigt und deren lichte Weite $40-55^{\mathrm{mm}}$ beträgt: Die Siederöhren bestehen meist aus Messing, und dort, wo es die chemische Beschaffenheit des Wassers und des Brennstoffes gestattet, aus Schmiedeisen. Die Wandstärke beträgt $2-3^{\mathrm{mm}}$. Auch aus Stahl werden sie erzeugt, um ihnen ein geringeres Gewicht geben zu können; jedoch sind Stahlröhren zur allgemeineren Anwendung noch nicht gelangt.

Die Verbindung der Siederöhren mit der Rohrwand geschieht dadurch, dass durch eigene Werkzeuge die Wandung der Röhren an die Rohrwand angepresst wird. Die fruher allgemein angewendeten Brandiringe sind ganz ausser Gebrauch gekommen.

Häufig werden die eisernen und messingenen Siederöhren bei der Feuerkasten-Rohrwand mit Kupferstutzen versehen, um das bei schlechtem Speisewasser und nicht vorsichtiger Manipulation häufig vorkommende Rohrrinnen zu vermeiden. Diese Erscheinung tritt leicht ein, wenn während der Fahrt die Feuerthür aus irgend einem Grunde offen bleibt und kalte Luft in den Feuerkasten treten kann. Der in der Rohrwand befindliche Theil der Siederöhren zieht sich zusammen, die Dichtung wird aufgehoben und Wasser in den Feuerkasten gepresst. Rinnende Röhren müssen frisch gedichtet werden.

Der Holzschnitt Fig. 1305 zeigt ein Siederohr in Verbindung mit den Rohrwänden. Da die Röhren vom Rauchkasten aus in den Kessel gebracht werden, Fig. $130 \tilde{\text { o. }}$

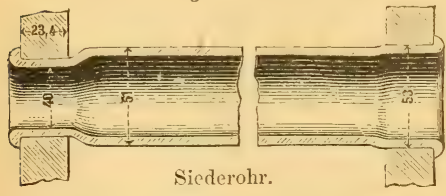
so müssen die Löcher in der vorderen Rohrwand grösser sein als die Röhren selbst; welche dann beim Eindichten an dieser Stelle etwas erweitert werden. Die Rohrwand muss dicker im Fleische sein als alle übrigen Kesselplatten, weil zwischen den Röhrenlöchern wenig Material stehen bleibt.

Der Lang-oder cylindrische Kessel ist mit den Stehkesselwänden durch Nietung verbunden, er besteht aus Eisen- oder Stahlplatten, welche nicht dicker als $15^{\mathrm{mm}}$ sein sollten und am vorderen Ende die Rauchkasten-Rohrwand aus Eisen, Stahl, seltener Kupfer, aufnehmen, mit welcher die Siederöhren eben so verbunden sind, wie mit der anderen. Der Durchmesser dieses Theiles beträgt selten iiber $1 \cdot 300^{\mathrm{m}}$, die Länge bis $4^{\mathrm{m}}$ und darüber.

Eigentlich nicht mehr zum Kessel gehörig, aber mit demselben durch Nieten verbunden, ist die Rauchkammer, der Rauchkasten (boite ì fumée - smoke box), durch welche die Verbrennungsproducte aus dem Feuerkasten und den Siederöhren zum Rauchfang (cheminée - chimney) gelangen. Er muss luftdicht geschlossen sein, damit in denselben keine kalte Luft eindringe. Die vorderste Wand des Rauchkastens wird fast ganz durch eine grosse Thiir eingenommen, welche dazu dient, die Siederöhren und den Rauchkasten von Russ und mitgerissenen Kohlentheilchen zu reinigen, die Reparaturen zu erleichtern u. s. w.

Behufs Vergrösserung des meist beschränkten Dampfraumes haben viele Kessel noch einen Dom (dome - dome), d. i. einen verticalen Cylinder aus Eisenplatten von rerschiedener Grösse, in dessen oberem Theile der Dampf für 
die Cylinder entnommen wird. Dies thut man gern, um möglichst trockenen Dampf zu erhalten und nicht unnuitz Wasser und Kohle zu vergeuden.

Bisweilen finden sich noch kleinere Aufsätze auf den Locomotivkesseln, um die Sicherheitsventile, Dampfpfeife u. dgl. aufzunehmen.

Der Schornstein ist gleichfalls ein cylinderförmiger oder wenig conischer Aufsatz, welcher die Verbrennungsgase und den Rauch, so wie den gebrauchten Dampf möglichst hoch in die Luft leiten soll, um die Belästigung der in der Nähe befindlichen Menschen u. dgl. zu verhïten.

Die Function des Schornsteines bei Locomotiven ist also nicht die, Zug zu erzeugen zu einer vollkommenen Verbrennung der Kohlen oder des Holzes, wie bei den Schornsteinen der stabilen Dampfkessel und sonstigen Feuerungsanlagen, indem der scharfe Zug durch den Strahl des ausgeblasenen Dampfes hervorgebracht wird.

Oft sind in demselben Funkenfänger angebracht, welche abweichende Formen bedingen, wie z. B. bei den Mantelrauchfängen. Alle diese Aufsätze sind mittelst Flanschen an den Kessel und an den Rauchkasten genietet oder geschraubt. Obwohl nun der cylindrische Theil des Locomotivkessels in Folge seiner Form an sich widerstandsfähig genug gemacht werden kann, um Verankerungen zu entbehren, obwohl ferner die Wandungen des Feuerkastens und des Stehkessels, so wie die Rohrwände durch die Stehbolzen und die Siederöhren hinreichend versteift sind, so bleibt doch noch der Obertheil der Feuerthürwand und der Rauchkasten-Rohrwand iibrig, welche flach sind und für sich allein den hohen Dampfspannungen nicht widerstehen könnten.

Man pflegte sie friiher mit einander durch Anker zu verbinden. Diese dehnten sich aber in Folge der hohen Temperatur mit der Zeit so aus, dass sie nicht gespannt blieben und absolut unwirksam wurden. Man ersetzte sie durch Winkeleisen, welche correspondirend am Cylinderkessel und Stehkessel und den früher erwähnten Wänden angenietet und durch starke Blechstücke verbunden sind und erzielt auf diese Art eine ganz solide Versteifung.

Die Figuren 1306 und 1307, welche den Längenschnitt und zwei Querschnitte einer Locomotive zeigen, machen alle Theile des Kessels ersichtlich.

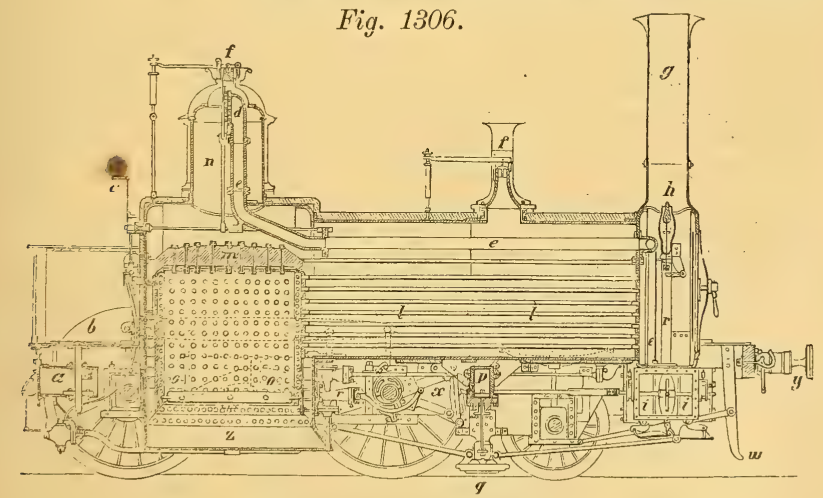

Längsschnitt einer Locomotive.

Die Buchstaben o, o bezeichnen den Feuerkasten mit dem Roste und dem Aschenkasten $z ; m$ die Deckelbarren, $l, l$ die Siederöhren, $u$ die Feuerthür, $r$ und $e$ die Dampfröhren, $e, r, h$ Rauchkasten, $g$ den Schornstein, $n$ den Dampfdom, $f$ den Aufsatz für die Sicherheitsventile.

Reinigung der Kessel. Die Reinigung der Locomotivkessel ist von ungemeiner Wichtigkeit. Die Vernachlässigung derselben wird bei den stabilen 


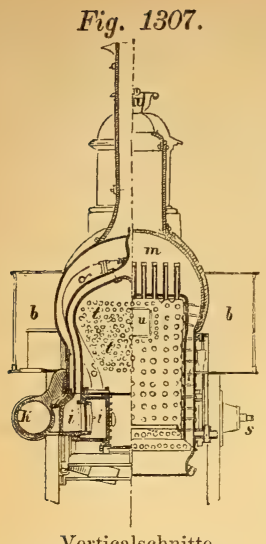

Verticalschnitte den Cylinder, die Feuerbichse.

Kesseln nicht mit so bedeutenden Reparaturen und so hohem Brennstoffverbrauch bezahlt als bei diesen.

Zugleich ist sie nirgend so schwierig durchzuführen als gerade hier, wo die Stehbolzen, die Siederöhren, die Wände von Feuerkasten und Stehkessel so kleine Zwischenräume bieten, dass die menschliche Hand keinen Raum findet.

Es muss also von vornherein beim Baue des Kessels auf Vorkehrungen gedacht werden, um das Innere möglichst zugänglich zu machen, und zwar vorzugsweise jene Stellen, an denen die Bildung von Incrustationen am meisten begünstigt wird, in den Kanten und untersten Ecken des Feuerkastens, so wie im Langkessel, auf dem Boden und zwischen den Siederöhren.

Man bringt deshalb Reinigungslöcher an dem unteren Rande des Feuerkastens, auf dem Boden, unter den Röhren, in den beiden Rohrwänden und in den Seitenwänden des Stehkessels oberhalb der Feuerbiichsdecke an. Diese Löcher werden mittelst Metallschrauben oder mittelst Deckel und Bïgel geschlossen.

Der Kesselstein wird sodann abgekratzt und durch einen kräftigen Wasserstrahl, welchen man nach allen Richtungen in die Lucken einfuihrt, abgespiilt.

Je schlechter das Speisewasser, um so häufiger ist das Auswaschen des Kessels vorzunehmen. Ausserdem soll man recht oft den Schlamm durch Ablassen des Wassers mittelst der Ablasshähne entfernen.

Ist das verfügbare Speisewasser chemisch sehr unrein, hat es nämlich einen grossen Gehalt an Gyps, kohlensaurem Kalk oder gar Säuren, so ist es trotz grosser Kosten vortheilhaft und nothwendig, eine chemische Reinigung in den Wasserstationen vorzunehmen, ehe das Wasser in den Kessel kommt. Die wegfallenden Reparaturen an Stehbolzen, Nieten, Siederöhren, so wie der geringere Kohlenverbrauch bringen die dafür aufgewendeten Kosten wieder herein.

Bewährt hat sich das Reinigungsverfahren des Dr. Ha ën in Hannover mittelst Chlorbaryum und Kalkmilch auf verschiedenen Eisenbahnen.

Verhiitung von Explosionen. Trotz der gesetzlich vorgeschriebenen Vorrichtungen, um den Wasserstand im Kessel zu controlliren, kann es bei unaufmerksamer Wartung doch vorkommen, dass der Wasserspiegel in dem Kessel bis zum Entblössen der Feuerbüchsdecke sinkt. Es bedarf dân nur weniger Minuten bis zum Augenblicke der höchsten Gefahr.

Für einen solchen Fall ist eine kleine Schraube von circa $20-26^{\mathrm{mm}}$ Durchmesser aus Blei oder einer leicht schmelzbaren Metalllegirung in der Decke des Feuerkastens die Rettung vor dringender Explosionsgefahr.

Ist nämlich die Decke von Wasser frei, so schmilzt der Pfropf durch die Hitze, der Dampf tritt in den Feuerraum und erstickt das Feuer.

Garnitur oder Armatur der Kessel. Gesetzliche Vorschriften in den verschiedenen Staaten, so wie die ,Technischen Vereinbarungen des Vereines Deutscher Eisenbahnverwaltungen" bestimmen die Apparate und Vorrichtungen, welche zur Verhütung von Gefahren an jedem Dampfkessel und somit auch bei den Kesseln der Locomotive vorhanden sein müssen. Diese sind:

Das Manometer zur beständigen Controlle der Dampfspannung im Kessel, zwei verschiedene Vorrichtungen zur Beurtheilung der Höhe des Wasserstandes im Kessel, zwei Sicherheitsrentile, welche selbstthätig Dampf aus dem Kessel treten lassen, sobald die normirte Dampfspannung überschritten ist, und endlich z wei Speisevorrichtungen, jede gross genug, um für sich allein den Kessel beim grössten Dampfrerbrauche hinreichend mit Wasser rersehen zu können. Ausserdem ist ein Ventil oder ein Hahn zum Ablassen des Wassers aus dem Kessel noth- 
wendig; Dampfventile für die Speisepumpen, dann für das Vorwärmen des Wassers im Tender, das Speiseventil und eine kräftige Dampfpfeife.

$\mathrm{D}$ as M a no meter (manometre - manometer) bei Locomotiven unterscheidet sich nicht von jenem bei stationären Dampfkesseln. Es wird daher nicht weiter behandelt; doch sei erwähnt, dass man, um Ueberschreitung der Dampfspannung durch leichtsinnige Locomotivführer zu verhüten, ausser dem gewöhnlichen Manometer noch sogenannte Maximalmanometer zur Controlle anwendet. Bei diesen bleibt der Zeiger stets auf der höchsten angewendeten Dampfspannung stehen, auch wenn diese ganz nachgelassen hat. Der Controllbeamte kann somit eine Ueberschreitung der erlaubten Dampfspannung noch nachträglich constatiren.

Zur Erkennung des Wasserstandes im Kessel dienen die Wasserstandsgläser (niveau d'eau - glass gauge), sodann die Probirhähne oder Probirventile (robinet d'epreuve, soupape d'epreuve - gauge cock, gauge valve). Auch diese unterscheiden sich nicht wesentlich von denen bei gewöhnlichen Dampfkesseln und ermöglichen die directe Beobachtung des Wasserstandes. Beistehende Figur 1308 verdeutlicht ihre Einrichtung. Die beiden Hähne $h, h^{\prime}$, wovon der untere in der Höhe des tiefsten, der obere in der Höhe des höchsten Wasserstandes zur Seite des Führers in die Rückwand des Stehkessels eingeschraubt, sind mittelst Stopfbüchse, Grundbiichse und Gummipackung durch die Glasröhren $r, r$ dampf- und wasserdicht verbunden. Sind beide Hähne geöffnet, so steht das Wasser im Glase gerade so hoch wie im Kessel, wenn die Kanäle gleich gross und nicht verstopft sind.

Unter dem Apparate befindet sich noch ein dritter Hahn $h_{2}$, welcher dazu dient, Verstopfungen der beiden Kanäle erkennen und beheben zu lassen. Das abfliessende Wasser wird durch das Röhrchen $k$ unter den Führerstand geleitet. Die Schräubchen $i, i$ dienen dazı, um hartnäckige Verstopfungen der Kanäle zu beheben.

Um bei dem nicht selten vorkommenden Springen eines Glases Verletzungen des Maschinenpersonals durch Glassplitter zu verhüten, umgibt man das Glas mit einem Gitter; um Verbrïhungen durch das Wasser zu vermeiden, hat man einen selbstthätigen $\mathrm{Ab}$ schluss durch ein Kugelventil construirt, welcher im Augenblick des Sprengens der Röhren einen sicheren Verschluss des unteren mit dem Wasserraume correspondirenden Hahnes bildet. Auch verbindet man die beiden Griffe der Hähne durch eine Zugstange und bringt einen Hebel so an, dass der Führer von seinem Platze aus mit Fig. 1308.

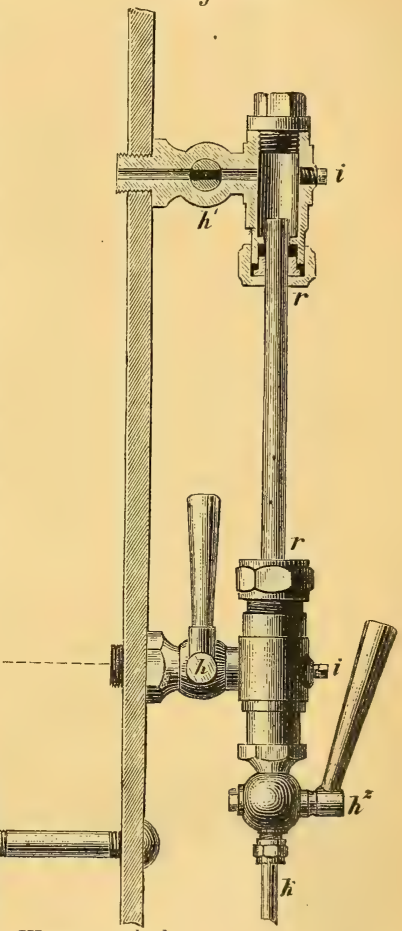

Ein em Griffe beide Hähne schliessen kann.

Die Glasröhren sollen recht dünn im Glase sein und iiberall gleiche Wandstärken haben. Auch soller. sie sehr langsam gekiihlt sein, indem sie andernfalls schnell, meistens schon beim Einziehen zu Grunde gehen. Es kommt vor, dass 10, selbst 20 Gläser mangelhafter Beschaffenheit hinter einander beim Einbringen brechen, olme dass dem Personal ein Verschulden zur Last gelegt werden kann. 
Probirhähne und Ventile hat man in verschiedenen Constructionen. Mindestens 2 Stuick sind so am Stehkessel anzubringen, dass sie der Führer oder Heizer leicht zur Hand hat. Eines muss in der Höhe des zulässigen niedersten Wasserstandes und eines $100-200^{\mathrm{mm}}$ höher angebracht sein. Der untere Hahn muss stets Wasser geben, geschieht dies nicht, so ist die Gefahr vorhanden.

Eine bequeme Construction zeigt Fig. 1309. Das Ventil $a$ wird durch den Dampfdruck im Kessel stets geschlossen gehalten. Das Oeffnen geschieht durch

Fig. 1309.

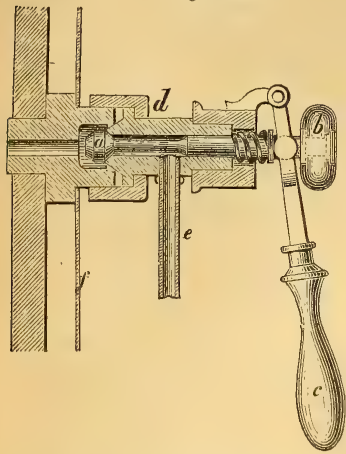

Probir-Ventil. den hölzernen Griff $c$ am Gabelhebel. Ausserdem dient ein am Ende des Ventilbolzens befindlicher, hölzerner Knopf $b$ zum Hin- und Herdrehen des Ventils, um während der Fahrt etwaige Unreinigkeiten des Ventilsitzes zu beseitigen.

Eine leichte Spiralfeder aus Messingdraht hält das Ventil geschlossen, wenn kein Dampfdruck im Kessel ist. Um die ganze Vorrichtung leicht abnehmen und reinigen zu können, ist dieselbe mittelst Conus und Verschraubungsmutter an einem besonderen Kesselstutzen befestigt. Das Röhrchen $e$ dient zum Ablasen des Dampfes oder Wassers, $f$ ist die Verschalung des Stehkessels.

Sicherheitsventile. Auch die Sicherheitsventile der Locomotiven (soupape de sureté - sufety valve) sind jenen bei den stabilen Dampfkesseln gleich und nur durch die Art der Zuhaltung verschieden.

Ein Sicherheitsventil ist eine runde Oeffnung im Kessel, auf die von aussen eine metallene Scheibe aufgeschliffen und so belastet ist, dass die Oeffnung geschlosssn bleibt, so lange der zulässige Dampfdruck nicht erreicht ist, welches sich aber hebt und Dampf austreten lässt, wenn er die erlaubte Spannung iiberschreitet. Bei Locomotiren wurden die Sicherheitsventile niemals direct mit Gewichten belastet, sondern meist mittelst einer Hebelübersetzung und Federn.

Die gebräuchlichste Art ist in Fig. 1310 dargestellt, Ventile mit indirecter Federbelastung.

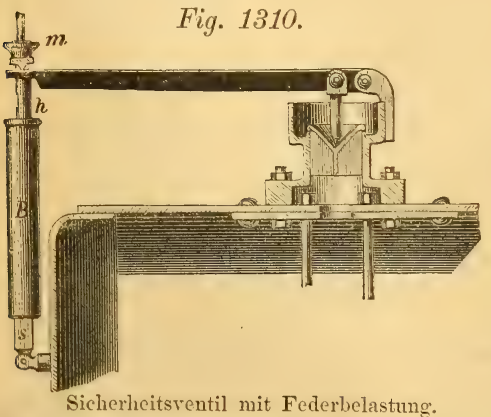
wendeten Hebelïbersetzung geringer, als er bei directer Belastung sein müsste. Eine wesentliche Verbesserung durch eine sinnreiche Hebelcombination hat an der Federwage $\mathrm{M}$ e g g e $\mathrm{n}$ h of e $\mathrm{r}$ angebracht, um zu vermeiden, dass bei geöffnetem Sicherheitsventil die Spannung der Feder zunimmt und somit das Ventil geschlossen werde, beror der Dampfdruck unter das gestattete Maximum gesunken. 
Ramsbottom und Kitson haben ganz abweichende Constructionen erdacht, welche auch schon Eingang gefunden haben.

Bei Revision der Sicherheitsventile ist Acht zu haben, dass es durch den leichtsinnigen Maschinisten nicht auf irgend eine Art unbeweglich gemacht sei, was leider häufig genug vorkommt.

Speisevorrichtungen. Die ältesten Locomotiven führten eine Handpumpe mit und mitsste das Personal stets dieselbe in Gang setzen, wenn der Wasserstand im Kessel gesunken war. Später wurden Sang- und Druckpumpen durch die Locomotive selbst, meistens von einem Excenter der Steuerung aus getrieben. Stand die Locomotive still, so konnte natiirlich nicht gespeist werden, man gab deshalb später noch eine dritte Pumpe bei, welche durch eine eigene kleine Dampfmaschine in Thätigkeit gesetzt wurde. In den letzten Jahren haben sich die Dampfstrahlpumpen immer mehr Eingang verschafft, welche bei stillstehender und bei in Bewegung befindlicher Maschine arbeiten.

Eine vom Excenter getriebene Speise pumpe (pompe alimentaire - feed pump) stellt Fig. 1311 a und $b$ dar. Wenige Worte werden zur Erklärung geniigen. Das Excenter $E$ zieht mittelst der Stange $s$ den Kolben $k$ in den Pumpen-

Fig. 1311 a.

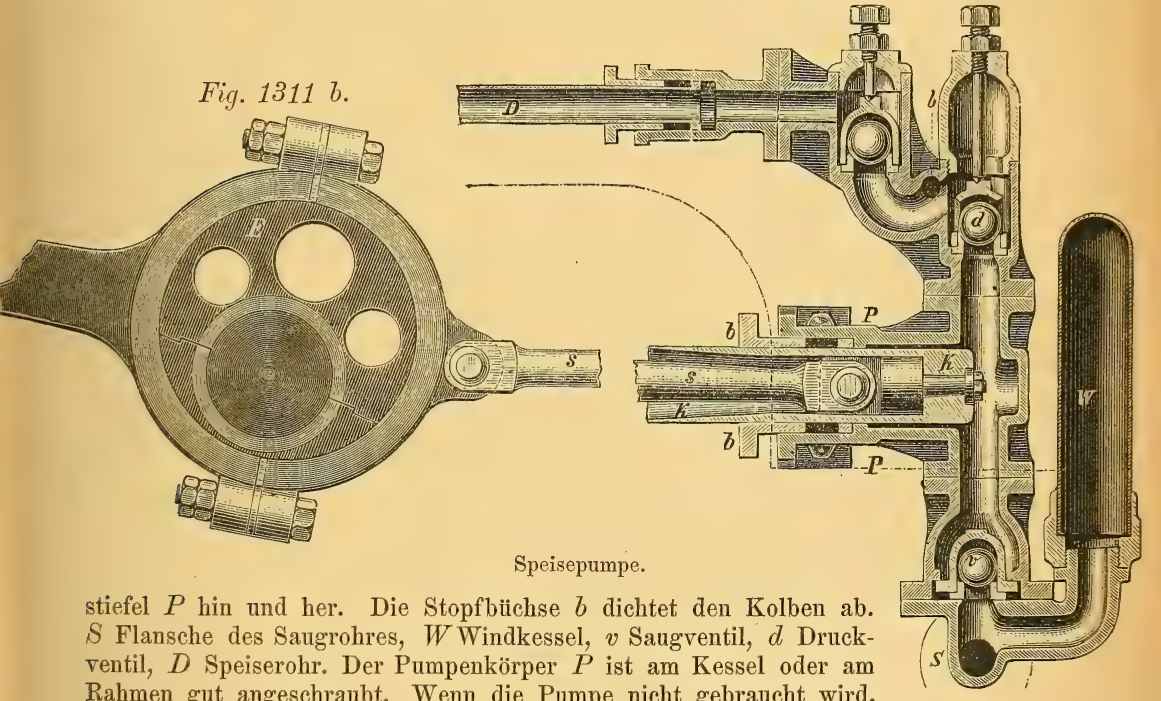
so wird sie nicht ausgeschaltet, sondern man setzt sie dadurch ausser Thätigkeit, dass das Wasser des Tenders durch einen im Saugrohr liegenden Hahn abgesperrt wird.

Injector. Die moderne Locomotivspeisevorrichtung ist die schon erwähnte, von dem Franzosen Giffard im Jahre 1858 erfundene Dampfstrahlpumpe (injecteur - injector). Sie hat vor den gewöhnlichen Pumpen viele Vortheile, namentlich Einfachheit, Billigkeit in der Anschaffung und Erhaltung, sie functionirt beim Stillstand und beim Gang der Maschine, ist betriebssicherer, bedarf wenig Aufsicht und liefert endlich nur heisses Wasser in den Kessel.

Diese Vortheile haben ihr auch in einem Decennium allgemeine Verbreitung: verschafft und derzeit dürften alle neuen Locomotiven ohne Ausnahme mindestens mit Einer Dampfstrahlpumpe versehen werden. 
Die Speisung findet einfach durch die directe Wirkung des im Kessel erzeugten Dampfes statt; indem derselbe in den Apparat geleitet wird, reisst er die darin befindliche Luft mit sich fort und die dadurch erzeugte Luftverdünnung bewirkt mittelst des den Apparat mit dem Tender verbundenen Rohres den Zutritt des Speisewassers.

In ausreichender Menge hinzutretend, condensirt dasseibe einen Theil des Dampfes, der aber demselben zugleich einen Theil seiner lebendigen Kraft mittheilt, wodurch sich eine Stosswirkung des Wasserstrahles ergibt, die bei entsprechender Construction der Diise kräftiger ist, als nöthig wäre, um den Eintritt in den Kessel zu ermöglichen. So einfach wie die eben beschriebene Wirkungsweise ist auch der Apparat selbst, welcher in Fig. 1312 dem Leser in der Construction von Schau speciell für Locomotiven vor Augen geführt wird.

Fig. 1312.

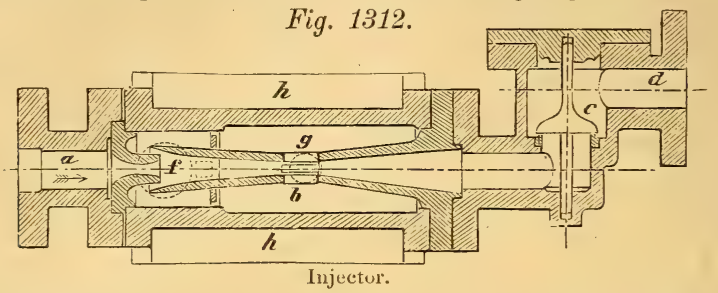

Mittelst der Platte $h$ ist er an der Locomotive befestigt; der vom Kessel hergeleitete Dampf tritt durch den Stutzen $f$, der seitlich einmündet und das Wasser vom Tender seitlich hereinleitet. Bei $g$ ist ein Ventil oder ein Hahn angeschraubt, wo mittelst der Schlitze $b$ Dampf entweicht, wenn der Apparat nicht speist. Dieses Ventil dient also dem Führer als Kennzeichen der guten oder mangelhaften Function des Apparates. Bei guter Function wird hörbar Luft eingesaugt, bei schlechter Dampf ausgestossen, beides in auffallender Weise. Es lässt sich denken, dass diese Erfindung bei ihrem ersten Auftreten Aufsehen erregte. Trotzdem stiess die Einfuhrung auf nicht geringe Hindernisse, welche theils durch die mangelhafte Uebung des Personals beim Anlassen, theils durch die sich allem Nenen entgegenstellenden Vorurtheile und theils endlich durch mangelhafte Construction entstanden. Alle diese Schwierigkeiten sind vollkommen uiberwunden und leben kaum in der Erinnerung; es gibt heute schon eine ganz beträchtliche Anzahl Locomotivführer, welche die alten Saug- und Druckpumpen nur vom Hörensagen oder aus Büchern kennen.

Alle civilisirten Nationen bemächtigten sich der Erfindung Giffard's, um sie zu rerändern, zu vereinfachen und zu verbessern. Namentlich waren es: Sharp, Stew art und Comp., Th. Hunt, G. T. Bonsfield, Andrew Barclay, Sellers, Schäffer und Budenberg, welche die saugenden Injectoren verbesserten; Flechter und Bower, Krauss, Schau, Friedmann, Körting, Fink, Haswell und $\mathrm{Webb}$ und Andere, welche die nicht saugenden Dampfstrahlpumpen erfanden und verbesserten.

Der Wasserablasshahn oder das Wasserablassrentil ist mit einer Flantsche an einem tief gelegenen Punkte des Stehkessels angebracht und sollte zum Abblassen von Schlamm und zum Ablassen des schmutzigen Wassers recht oft gebraucht werden. Auch die weiteren Armaturstiicke, als Dampfpfeife, Dampfventile für die Speisepumpe und das Vorwärmen des Tenderwasser's können nicht wohl mit Stillschweigen übergangen werden, da sie sich von anderen Dampfrentilen unterscheiden. Auch sei erwähnt, dass man bei Anwendung ron Dampfstrahlpumpen nicht eigene Ventile und Röhren für das Anwärmen des Tenderwassers braucht, sondern den Dampf auch durch den Injector in den Tender leiten kann, was ein weiterer Vortheil dieser genialen Erfindung ist.

Die Figuren 1314 und 1315 zeigen die sehr empfehlenswerthe Form eines Dampfrentils für Dampfstrahlpumpen von Rayl in Mährisch-Ostrau. Mittelst 


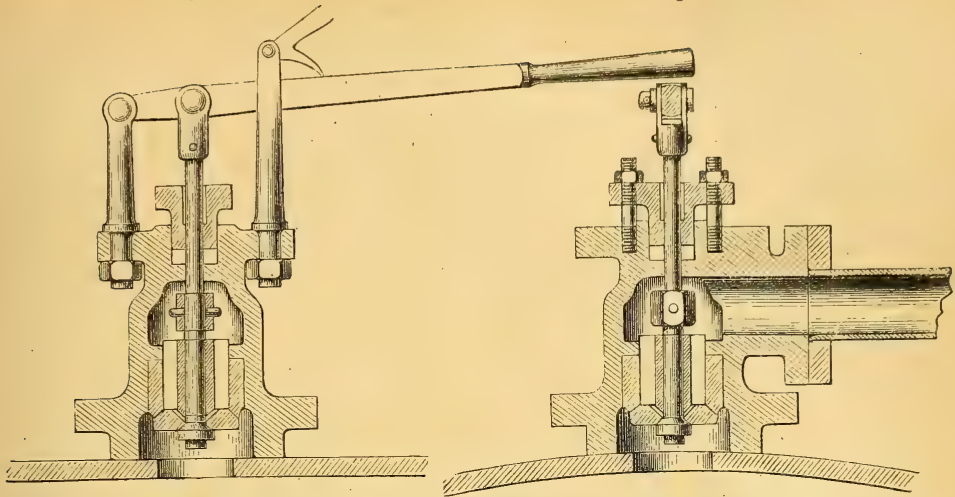

eines stark übersetzten Hebels wird zuerst ein kleines Hilfsventil geöffnet, und es strömt Dampf durch die nun frei gewordenen, kleinen Oeffnungen über das eigentliche Hauptventil, so dass die Oeffnung desselben nunmehr eine geringe Anstrengung erfordert. Da der von unten auf die grösste Oberfläche des Ventils stets wirkende Dampf jedoch das Ventil wieder schliessen würde, so wird dasselbe dann durch eine Art Sperrklinke niedergehalten.

Ein als kräftiges, akustisches Signalmittel unentbehrliches Armaturstiuck ist die Dampfpfeife (sifflet à vapeur - whistle), deren bald schrillen, ohrenzerreissenden, bald tieferen und höheren Ton wohl jeder Leser kennt. (Beschreibung siehe Dampfpfeife.) Manche Locomotiven haben 2 Dampfpfeifen mit verschiedenem Ton für bestimmte Signale.

II. Der Wagen. Durch ihre Eigenschaft als Wagen wird die Locomotive unmittelbar für Eisenbahnzwecke dienstbar gemacht.

Sie muss schwer genug sein, um durch ihr Gewicht eine hinreichende, der Zugkraft angemessene, Adhäsion auf den Schienen zu sichern, und dieses Gewicht muss so auf alle Räder vertheilt sein, dass bei der grössten Geschwindigkeit der grösstmöglichste Grad von S.abilität erreicht wird. Ausserdem ist das Arrangement des Wagens so zu treffen, dass die vom Bewegungsmechanismus der Maschine und von der Bahn selbst herrührenden, störenden Bewegungen möglichst ausgeschlossen werden.

Gewichts-Vertheilung. Das Gewicht der Locomotiven ist gegeben durch die für eine bestimmte Dampfentwicklung erforderliche Grösse der Heizund Rostfläche, somit durch das Gewicht des.Kessels, durch das Gewicht der Cylinder nebst Mechanismus, und endlich durch jenes der Räderpaare nebst Zugehör.

Unter Belastungsgewicht einer Achse oder eines Räderpaares versteht man die mittelst der Federn darauf ruhende Belastung, inclusive des Eigengewichtes dieser Achse, also den Druck, welchen die Räder auf die Schienen ausüben.

Rahmen. Der Wagen der Locomotiven wird gebildet zunächst durch zwei sehr kräftige, parallele Rahmen aus Schmiedeisen, welche vor dem Rauchkasten die Brust und die Buffer nebst Zugapparaten tragen und bis hinter den Stehkessel reichen, wo sie die Auflage des Platteaus für das Personal bilden.

Diese Rahmen (chassis cadre - frame) liegen entweder innerhalb der Räder (chassis interieur - inside frame) oder ausserhalb derselben (chassis exterieur - outside frame), und miissen durch starke Querverbindungen unverrickbar mit einander verbunden sein, da die Rahmen zwischen dem Mechanismus und dem Kessel das Verbindungsglied bilden. Mit dem Kessel muss die Ver- 
bindung gleichfalls sehr stark sein, aber sie muss gleichzeitig gestatten, dass der Kessel sich entsprechend den Temperatursgraden des Dampfes ungehindert ausdehnen könne. Dies wird bewerkstelligt, indem man den Rahmen an dem Rauchkasten gut anschraubt, dass jedoch die am Stehkessel befindlichen Kesselträger die beiden Rahmen so umfassen, dass sie parallel bleiben und den Kesselträgern sammt dem Kessel jedoch eine Verschiebung gestatten.

Auch unter dem cylindrischen oder Langkessel befindet sich eine oder mehrere Querverbindungen, welche einerseits zur Versteifung der Rahmen dienen, anderseits dem Langkessel Unterstuitzungen bieten, und endlich, so wie die Rahmen selbst, benützt werden, um gewisse Steuerungstheile daran aufzuhängen.

Auch diese Querverbindungen bestehen aus kräftigen Schmiedeisenplatten und sind mit dem Rahmen verschraubt; auch ruhen sie bisweilen behufs Entlastung der Bolzen mit einer Nase auf dem Rahmen. Von unten ist der Rahmen mit mehrfachen Aussparungen versehen, welche parallele Begrenzungen haben und die Lager für die A chsen aufnehmen, auf welchen letzteren die Räder festsitzen.

Die Rahmen sitzen nicht unmittelbar auf den Achslagern, sondern die Verbindung ist mittelst elastischer Stahlfedern hergestellt, so dass die von der Bahn auf das Fahrzeug ausgeiibten Stösse durch die Federn gemildert auf die Rahmen, den Mechanismus und den Kessel übertragen werden.

Vor der Brust des Rahmens sind die Bahnräumer aus Eisen kräftig hergestellt, welche wenige Centimeter von den Schienen entfernt sind und kleinere Hindernisse, wie Steine etc. von den Schienen wegdrängen und verhüten, dass die Räder aus der Bahn gerathen. Die amerikanischen Locomotiven haben vor der Brust die sogenannten Kuhfänger (cow - catches), welche so stark sind, dass sie die auf dem Bahnkörper befindlichen Büffel zur Seite schleudern. Am riickwärtigen Ende befindet sich zwischen den Rahmen der Kuppelkasten, wo die Verbindungsglieder mit dem Tender oder bei den Tenderlocomotiven mit den zu ziehenden Wagen befestigt werden.

Tenderlocomotiven müssen auch an hinteren Ende des Rahmens mit Buffern und Zugapparaten versehen sein, so wie vorn an der Brust. Die beistehenden Holzschnitte (Fig. 1316 a und b) zeigen das ganze Rahmengestell mit Brust, Bahnräumer, Rädern, Achsen, Lagern, Federn und Zugapparaten in Längenansicht und Eratifsicht.

Fig. 1316 a.

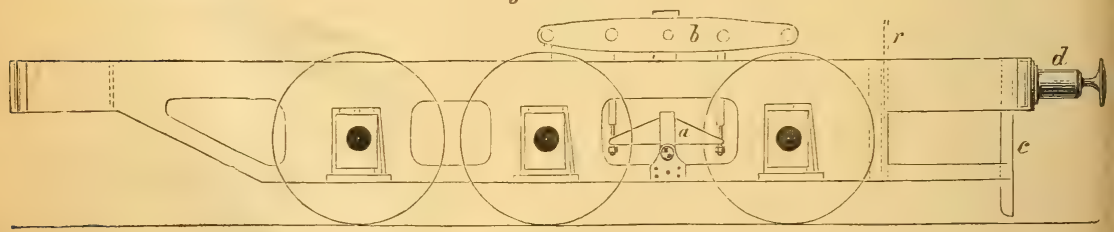

Fig. 1316 b.

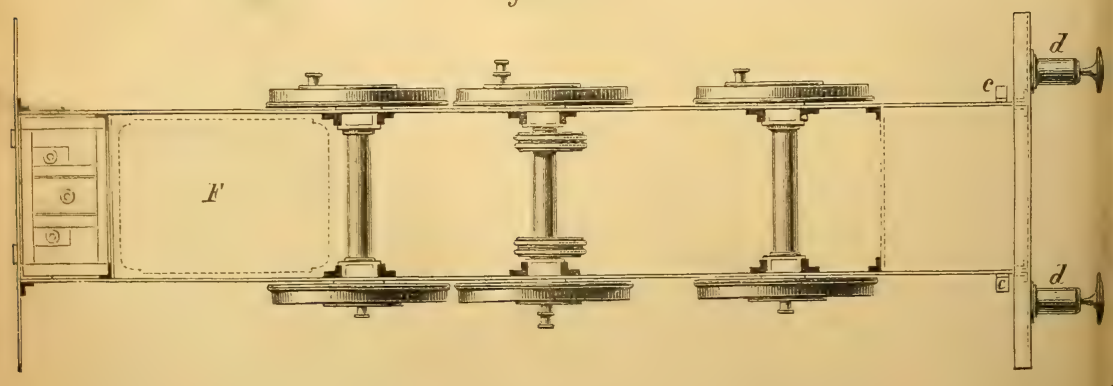


$F$ deutet die Lage des Feuerkastens an. Die Lage der Rahmen ist, wie man sieht, imnerhalb der Räder. Die Federn der 1. und 2. Achse sind durch einen zweiarmigen Hebel (balancier -- engine beam) verbunden, um eine gleiche Belastung beider Achsen zu erzielen.

Betreffend die als Kesselträger beniitzten Rahmenverbindungen unter dem Langkessel sei noch erwähnt, dass eine nachtheilige Wirkung dieser auf die Kesselplatten constatirt wurde, was Veranlassung gab, dass in den letzten Jahren der Cylinderkessel, welcher selbst ein steifer Träger ist, gar nicht mehr direct unterstiitzt wird, sondern dass nur der Rauchkasten und der Stehkessel die Verbindung mit dem Rahmengestell bilden. Da gewisse Theile aller Eisenbahnfahrzeuge mit einander ibbereinstimmen, so sollen dieselben gleich hier abgehandelt werden, und können wir uns dann bei den Tendern und Waggons schon darauf beziehen.

Diese Theile sind: Die Räder, die Achsen und die Federn, sodann die Zugsund Stossapparate.

Räder. Die Räder (roue - wheel) bestehen aus dem Radgestell (dem Radstern) und dem Radreifen. Nur bei Scheibenrädern, welche aus Schmiedeisen, Tiegel- oder Bessemergussstahl oder auch Gusseisen (Schalengussräder) bestehen, fertigt man Rad und Radreif aus Einem Stück an.

Die Anforderungen, welche an die Räder aller Eisenbahnfahrzeuge gestellt werden müssen, sind zu gross, als dass bei lose auf den Achsen sitzenden Rädern eine genügende Sicherheit erreicht werden könnte. Sie müssen demnach, abweichend von dem Gebrauche bei Strassenwagen, a uf den A chsen festsitzen und es machen somit die beiden Räder einer Achse in derselben Zeit dieselbe Anzahl Umdrehungen.

Die Figuren 1317 und 1318 stellen die Triebachse und die Triebräder einer Personenzugslocomotive für aussen liegenden Rahmen dar. $h$ bezeichnet den im Lager sich drehenden Kurbelhals. Eben so zeigen die Figuren die aufgesetzte Kurbel $K$ und die Kurbelwarze, das Gegengewicht $g$, von welchem weiter unten die Rede sein wird, die Speichen, die Radfelge, die Radreifen, Bandagen (bande-tyre) und die Schrauben zur Verbindung von Radgestell und Radreif.

Fig. 1319.
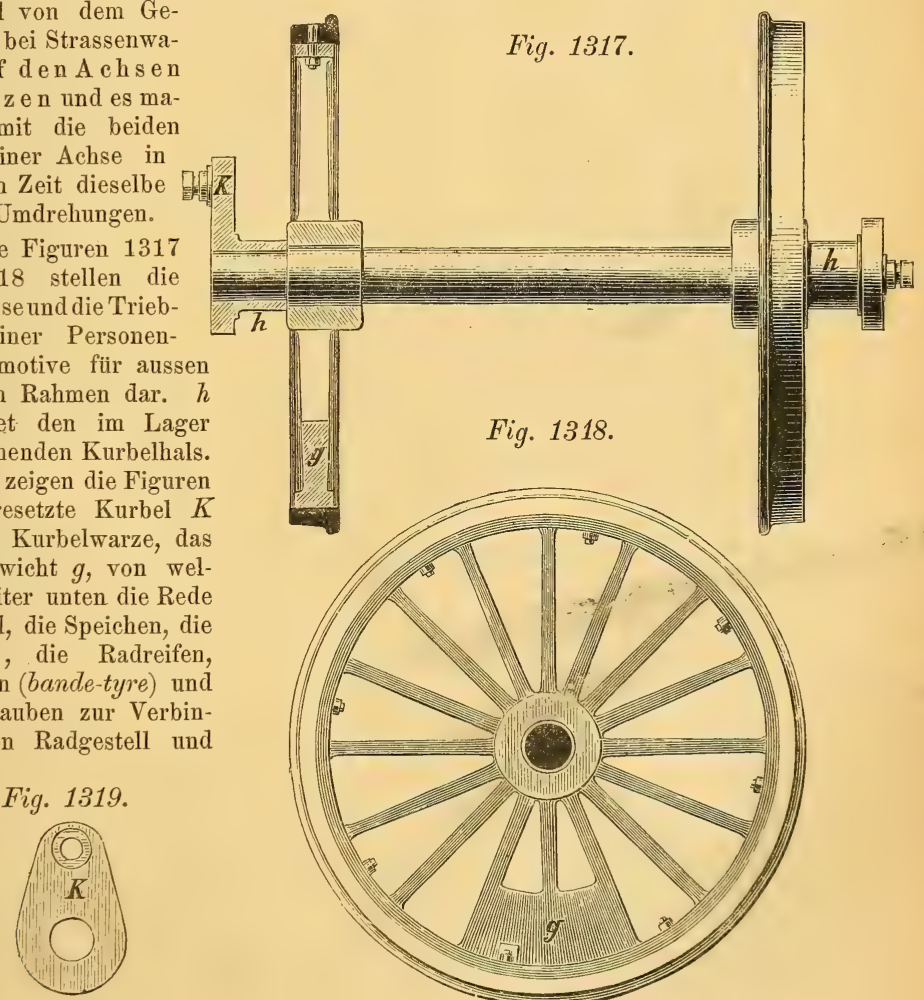
Alle Radreifen haben an der Innenseite eine Flansche, den sog. Spurkranz, um sie auf den Schienen zu erhalten und eine gewisse Neigung der Lauffäche, so dass der äusserste Rand der Bandage den geringsten Durchmesser hat.

In Bögen ist nämlich der äussere Schienenstrang etwas länger als der innere, und die Schienen liegen um ein gewisses Mass weiter auseinander. Da nun das äussere Rad einen grösseren Weg mit derselben Anzahl Umdrehungen zurückzulegen hat, so ist durch obige Einrichtung die Möglichkeit dazu gegeben, indem der Spurkranz des äusseren Rades sich in Folge der Centrifugalkraft an die äussere Schiene anlegt und sich auf einem grösseren Kreise umdreht als das innere Rad.

Bezeichnet $R$ den Radius einer zu befahrenden Bahncurve, $d$ den mittleren Durchmesser der Räder, $b$ die Geleisbreite $\left(1.453^{\mathrm{m}}\right), a$ die Geleiserweiterung in der Curve, $n$ der Radreife, so "findet allgemein die Relation statt: $n \cdot b \cdot d=2 \cdot a \cdot R$, woraus sich sowohl die erforderliche Geleiserweiterung, als auch in gegebenen Fällen der Conus berechnen lässt, welchen die Räder erhalten sollen.

Ist $R=500^{\mathrm{m}}, d=1 \cdot 000^{\mathrm{m}}, a=0 \cdot 026^{\mathrm{m}}$, so ist der Conus $n=17 \cdot 8^{\mathrm{m}}$.

Die technischen Vereinbarungen des ${ }_{\pi}$ Vereines Deutscher EisenbahnVerwaltungen" empfehlen, den Conus mindestens $1 / 20$, höchstens $1 / 12$ zu machen.

Die Speichenräder werden derzeit ausnahmslos aus Schmiedeisen hergestellt, entweder unter dem Dampfhammer geschmiedet oder mit der Schmiedepresse (von Haswell in Wien) gepresst. Die Radreifen, Bandagen, werden in eigenen Walzwerken nunmehr grösstentheils aus Einem Stiick (Ingot) Gussstahl erzeugt.

Denken wir uns von der dargestellten Triebachse die Gegengewichte und die Kurbeln weg, so haben wir das Bild einer Laufachse von Locomotiven, Tendern oder Waggons vor uns. Bei Locomotiven werden die Räder auf den Achsen mit Keilen befestigt, bei den Tendern und Wagen werden sie ohne Keile mit einer Kraft von $30.000-50.000 \mathrm{Kg}$. mittelst hydraulischer Pressen aufgepresst.

Achsen. Die Achsen (axe - axis, axletree) bestehen gleichfalls aus Schmiedeisen oder Stahl, sie werden gewalzt und unter Dampfhämmern behufs Erlangung grösserer Festigkeit bearbeitet. Von ihrer Festigkeit ist die ganze Sicherheit der Fahrzeuge abhängig. Sie müssen häufig revidirt, und bei dem geringsten Anbruche, der kanm mit einer guten Loupe zu entdecken ist, ausrangirt werden. Viele Eisenbahngesellschaften bezahlen fuir die Entdeckung von Anbriichen nnd Defecten bei Achsen, Radreifen, Rädern u. dgl. bestimmte Prämien. Ein Achsenbruch in einem Zuge gehört nummehr, Dank den verschiedenen Vorsichtsmassregeln bei der Construction, Erzengung, Ueherwachung und der Revision zu den Seltenheiten.

Eine sorgfältige Oelung der im Lager laufenden Achshälse ist von besonderer Wichtigkeit. Wird sie vernachlïssigt, oder verlegen sich die Oelzuführungskanäle, oder verharzen die Dochte, welche den Schmierstoff zu den reibenden Flächen führen, so tritt zumächst eine Erwärmung ein, welche, wenn nicht sofort Abhilfe geschieht, schmell zunimmt, bis die Achse und das Lager gliihend wird, Oel und Docht verbrennt und die gleitenden Flächen sich rerreiben, d. h. Riffe und Furchen bekommen. Durch den penetranten Geruch, der sich nun entwickelt, wird das Personal aufmerksam gemacht und das Fahrzeng wird rorsichtig und langsam bis zur nächsten Station gebracht und hier zurïckgelassen. Ist es eine Locomotive oder ein Tender, so muss eine Hilfslocomotive requirirt werden, um den Zug weiter zu befördern.

$\mathrm{Da}$ in vielen Fällen eine Nachlässigkeit des betreffenden Personals vorliegt, so wird dasselbe zur Verantwortung gezogen. Oft aber kann eine heisslaufende Achse ohne Verschuldung der Eisenbahnbediensteten eintreten, indem der aufgewirbelte Staub oder Sand in ein Lager geräth, oder sich rom Lager kleine Stiickchen loslösen in Folge ron Materialfehlern, welche so versteckt sind, dass sie bei der besten Rerision nicht entdeckt werden können. 
A chs lager. Fïr den guten Gang der Fahrzeuge sind die L a ger gleichfalls sehr wichtig. Sie bestehen aus der eigentlichen Lagerschale (auch Futter genannt), dem Lagerkasten und Unterkasten.

In den Holzschnitten (Fig. $1320 a, b$ und $c$ ) ist $b$ das Futter, $a$ der Lagerkasten, $c$ der Unterkasten, $e$ des Oelbehälter, $s$ der Federstift, punktirt angedeutet, $i$, $i$ Federn, welche das Schmierbrettchen $h$ und den Schmierpolster an die Achse driicken, und $g, g$ Bolzen, welche den Unterkasten mit dem Lagergehäuse verbinden, $n, n$ Röhrchen aus Kupfer, welche die Dochte für die Oelzufuhr aufnehmen.

Der Lagerkasten oder das Gehäuse besteht bei Locomotiven aus Schmiedeisen oder Gussstahl, der Unterkasten auch wohl aus Gusseisen, die Lagersehalen aus Kanonenmetall, Bronce, Phosphorbronce, häufig noch mit einem Einguss $d, d$ von verschiedenen härteren Metalllegirungen versehen. Die vier Ansätze an dem Lagergehäuse, welche im Grundrisse sichtbar sind, dienen zur Führung des Lagers in den Ausschnitten der Rahmen. Die Gleitflächen (schwarz) sind Beilagen von Messing oder Bronce. Die Lager müssen in ihren Fïhrungen auf- und niedergleiten können. Empfängt nämlich das Rad einen Stoss auf Fig. 1320 b.
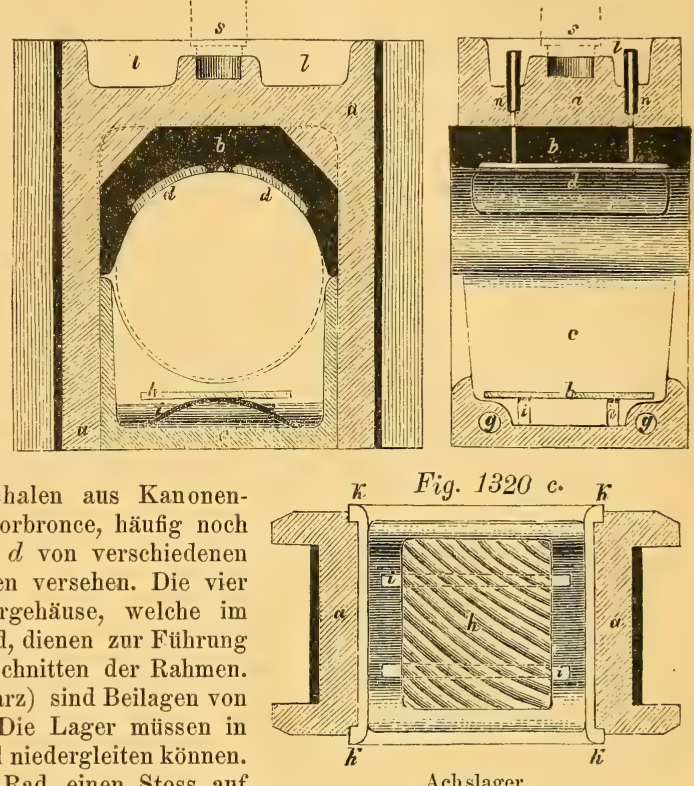
der Bahn, so wird das Lager und von diesem die Feder gehoben, worauf das Lager die Achse und die Räder durch die Feder wieder hinabgedriickt werden.

Feder und Federhängung. Mag die Bahn noch so gut unterhalten sein, beim Befahren derselben werden immer Stösse vorkommen. Dieselben treten dort ein, wo zwei Schienen zusammen stossen, und dort, wo die Schwellen nicht ganz vollkommen gelagert sind. Unter sonst gleichen Umständen nehmen die Stösse mit der Geschwindigkeit des Fahrzeuges zu, und wirken um so zerstörender auf die Bahn und auf das Fahrzeug. Um diese Stösse zu mildern, bringt man nun zwischen Achslager und Rahmen elastische Verbindungen an, die Federn (ressorts - springs), welche um so vollkommener sein müssen, je schneller das betreffende Fahrzeug verkehrt.

Schlägt Jemand z. B. mit einem Hammer auf eine Schiene, so wird sie bald zerstört wercien, während ein ruhig auf ihr liegendes Gewicht von hundertfacher Grösse ihr nichts anhaben wird.

Die Räder mit den Achsen und Achsenlagern schlagen ähnlich wie ein Hammer auf die Schienen, während die ibrigen Maschinentheile vermittelst der Federn nur drïcken. Aus diesem Grunde sollte man die Gewichte der Räderpaare und Achslager recht klein machen und also nur Material von ausgezeichneter Güte dazu verwenden.

Die Federn sollen stets möglichst lang gemacht werden, da die Durchbiegung mit dem Cubus der Länge zunimmt, d. h. eine Feder von $2^{\mathrm{m}}$ Länge biegt sich unter sonst gleichen Umständen achtmal so stark als eine Feder von $1^{\mathrm{m}}$ Länge. 
Man ist jedoch durch constructive und andere Rücksichten in der Federlänge eingeschränkt und kann über gewisse Masse nicht hinausgehen.

Bei Locomotiven und Tendern ist die Länge der Federn ungefähr $1^{\mathrm{m}}$, desgleichen bei Güterwagen, während sie bei Post- und Personenwagen bis zu $2^{\mathrm{m}}$ steigt.

Man nimmt zu den Federn Stahl oder vulcanisirten Kautschuk (gummi elasticum); da bei dem letzten Material allzuviele Schwindeleien vorkommen können, so hat die Verwendung von Stahl immer mehr zugenommen, nur in Amerika, dem Vaterlande des Gummi, wird dasselbe noch in grösseren Quantitäten verwendet. Die Figur $1321 a$ und $1321 b$ zeigt eine sehr gebräuchliche Form von Eisenbahnfedern. Sie besteht aus einer Anzahl Stahllamellen gleicher Dicke und Breite, jedoch verschiedener Länge, deren Ende spitzig zugeschnitten sind. a sind solche

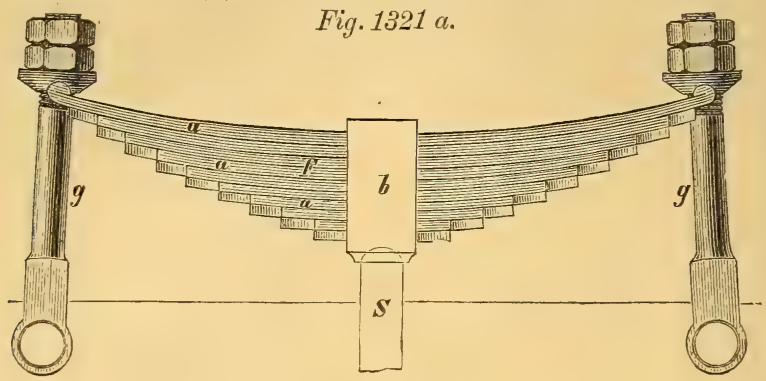

Fig. 1321 b.

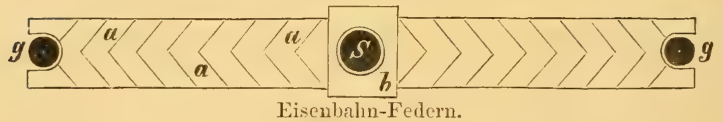

Lagen von Stahl, $b$ ist der Federbund, $g$ sind die Spannschrauben, welche zur Verbindung mit dem Rahmen und zur Regulirung der Federspannung dienen, $S$ ist der Stab oder die Stiitze, welche auf dem Lager ruht. Folgende praktisch erprobte Formeln zur Berechnung der Feder lassen erkennen, welche Functionen auf die Wirkung der Feder ron Einfluss sind. Ist $P$ das Belastungsgewicht, resp. die Tragkraft der Feder bei voller Sicherheit in Tonnen à $1000 \mathrm{Kg}$., $f$ die Biegung (Pfeilhöhe) per 1 Tomne Last, $l$ die Länge der Feder in Centimeter, $b$ die Breite der Feder in Centimeter, e die Blattdicke der Feder in Centimeter, $n$ die Anzahl der Blätter (Lagen), so ist für guten Tiegelgussstahl

$$
f=\frac{0 \cdot 0016 \cdot l^{3}}{b e^{3} \cdot n} \text { und } n=\frac{l \cdot P}{3 \cdot 56 \cdot b \cdot e^{a}} .
$$

Diese Formeln zeigen, dass die Anzahl der Blätter mit der Belastung und der Länge zunimmt, jedoch abnimmt mit der Breite und sogar im quadratischen Verhältniss mit der Dicke der einzelnen Lagen. Die Biegung nimmt zu mit dem Cubus der Länge, dagegen ab mit der Breite und der Anzahl der Blätter in einfachem, dagegen mit der Blattdicke im cubischen Verhältniss.

Da jede Eisenbahn suchen muss, so wenig als möglich Verschiedenheiten in ihrem Fahrparke zu haben, so pflegt man dieselbe Lamellenbreite und Dicke für alle Federn zu verwenden. Gebräuchlich ist die Breite von $60-90^{\mathrm{mm}}$ und eine Dicke von $10-14^{\mathrm{mm}}$.

Federhängung. Am häufigsten sind die Federn so am Rahmen angebracht, wie Figur 1321 a und $1321 b$ zeigt; oft befinden sie sich aber un ter h a l b des Lagers und mïssen dann durch Bolzen mit dem Lager verbunden sein. Bei kleinen Rädern und inneliegenden Rahmen ist man genöthigt, zu dieser Construction zu greifen; bei sehr vielen Locomotiven wendet man noch Balanciers an, welche auf 
sehr verschiedene Art angebracht sein können. Eine gewöhnliche Anordnung zeigt Fig. 1315 und 1316.

Auch Querbalanciers wendet man oft an, d. h. solche, welche zwei Lager einer und derselben Achse verbinden, dann Balanciers mit ungleich langen Armen, um z. B. bei Achsen, wclche vermöge ihrer Lage vom Schwerpunkte sehr verschieden belastet würden, eine gleichförmige Gewichtsvertheilung zu erzielen.

Stossapparate, Buffer. An jedem Ende eines Eisenbahnfahrzeuges (Maschine und Tender werden als Ein Falızeug betrachtet, da sie stets mit einander verkehren müssen) müissen sich elastische Apparate befinden, welche die die Stösse, die sie bei der Fahrt oder selbst beim Stillstande durch andere anfahrende Wagen empfangen, zu mildern und die Fahrzeuge zu schützen haben. Diese Apparate nennt man Buffer. Sie bestehen im Wesentlichen aus der Bufferhiilse $a$ aus Gusseisen oder Schmiedeisen oder auch Stahl, der Bufferstange $b$ und der Volutfeder (auch Spiralfeder genannt) $g, r$ ist die Bufferscheibe, welche den Stoss auffängt, $c$ ist ein Ansatz, welcher auf die Bufferhülse zu sitzen kommt, wenn die Feder die grösste gestattete Pressung erfährt, um sie vor Zerstörung zu schützen, $d$ ist eine ringförmige Scheibe zur Uebertragung des Stosses auf die Feder, $e$ ist eine Schraubenmutter, welche dazu dient, um die Feder zu spannen

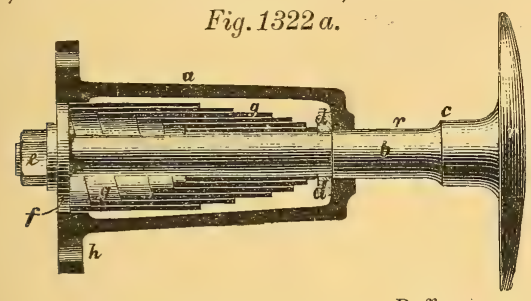

Fig. 1322 b.

Buffer.

und alle Theile des Buffers zusammen zu halten. Sie ruht auf der Schlussscheibe $f$, die sich wieder in einer Nuth der Bufferflansche befindet. Die Bufferhülse ist mit mehreren Schrauben $h$ an der Brust der Fahrzenge befestigt.

Zugvorrichtung. Jedes Eisenbahnfahrzeug muss an beiden Enden ferner mit Apparaten versehen sein, um mit anderen Fahrzeugen verbunden werden zu können. Dies sind die Zughaken und die Kuppeln. Im Gebiete des Vereines deutscher Eisenbahn-Verwaltungen sind die Form und Dimensionen der Zughaken und Kupplungen, so wie der Stossapparate einheitlich vorgeschrieben, eben so gewisse Maximal- und Minimalgrenzen gesteckt, damit sowohl jeder Wagen einer Eiserbahngesellschaft mit jedem Wagen aller anderen Gesellschaften des Vereines zusammengekuppelt werden kann, als auch alle Fahrzeuge einer Bahn auf sämmtlichen ïbrigen Vereinsbahnen ungehindert passiren können.

Am vorderen Ende der Maschine und am rückwärtigen Ende des Tenders befindet sich nun in der Mitte zwischen den Buffern der Zughaken und daran die Kupplung, bei den Waggons an beiden Enden.

Die Kupplung besteht in einer kräftigen, schmiedeisernen Schraubenspindel von $33^{\text {mim }}$ Durchmesser im Kern, mit rechtem und linkem Gewinde, in der Mitte mit einem Hebel zum Umdrehen. Die beiden Enden der Spindel greifen in Muttern, welche Zapfen haben und sich nicht drehen können, sodann einerseits in einem Loche des Zughakens aufgehängt sind, anderseits mittelst eines Biigels in den Zughaken des zweiten Fahrzeuges eingehängt werden.

Sollen die Fahrzeuge einander genähert werden, so dreht man die Spindel, noch Einhängen des Kuppelbügels, mittelst des Hebels so lange herum, bis die Scheiben der Buffer sich berihren, oder bei Personenziigen noch, fester. Will man auskuppeln, so schraubt man so lange zurick, bis man den Bügel leicht über die Spitze des Zughakens heben kann. 
Zwischen der Maschine und dem Tender befinden sich bisweilen auch Schraubenkuppelı, häufig jedoch auch steife Kupplungen oder solche mit Gelenken. Stets wird die Verbindung mit starken, verticalen Bolzen (den Reibnägeln) hergestellt, durch deren leicht $\mathrm{zu}$ bewerkstelligende Entfernung die Verbindung gelöst wird.

Ferner sind zwischen Maschine und Tender noch Vorrichtungen angebracht, um die Schwankungen zu verringern, indem durch Federn z. B. kleine Buffer vom Tender an der Brust der Maschine gedrückt werden, oder indem ein Zahn vom Tender in eine entsprechende Lücke der Maschine greift u. s. w.

Radstand. Die Entfernung der äussersten Achsen eines Fahrzeuges nennt man den Radstand. Je grösser der Radstand, desto ruhiger geht der Wagen. Allein bei den Eisenbahnen ist die Grösse durch die Krümmungen gegeben. Je kleiner der Halbmesser einer Krümmung ist, um so kleiner muss der feste Radstand der passirenden Fahrzeuge sein. Bei Flachlandbahnen mit wenigen und sanften Bögen hat man anstandslos den grössten Radstand, auf Gebirgsbahnen mit scharfen und häufigen Bögen muss man den Radstand auf das Aeusserste verkürzen, da andernfalls der Zugswiderstand allzusehr wachsen, die Fahrzenge und die Bahn selbst allzusehr leiden müssten.

Es ist zu empfehlen, für Bahnen, welche häufig Curven von $250^{\mathrm{m}}$ Radius haben, den festen Radstand bei Locomotiven nicht iiber $3 \cdot 5^{\mathrm{m}}$, bei $400^{\mathrm{m}}$ Radius nicht über $4 \cdot 7^{\mathrm{m}}$ und bei $600^{\mathrm{m}}$ Radius und dariiber nicht iiber $60^{\mathrm{m}}$ zu machen.

Radbelastung und Gewichts-Vertheilung. Im Zusammenhange mit dem Radstande steht auch die Belastung der Schienen durch einzelne Räder. Hier gelten folgende Grundsätze: Zur Verhiitung eines zu grossen Verschleisses von Radreifen und Schienen sollte kein Rad die Schiene höher belasten als mit $7000 \mathrm{Kg}$. Gekuppelte Räder sollen möglichst gleich belastet sein. Die Vorderachse soll bei dreiachsigen Personenzugsmaschinen mindestens 1/4 des Locomotivgewichtes tragen; ist die Hinterachse Laufachse, so ist derselben nicht unter $1 / 5$ des Locomotivgewichtes zuzutheilen. Setzt man für eine Maschine 3 feste Achsen voraus, so ergibt sich die Lastvertheilung nach Andentung der Figur 1323 wie Fig. 1323.

folgt: Bezeichnet $a, b, c$ das auf die einzelnen Achsen entfallende Be-

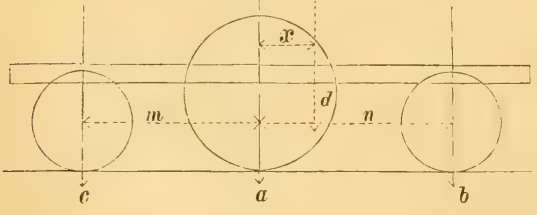
lastungsgewicht, $d$ die Summe dieser Gewichte, $m, n$ die Entfernung der Achsen von einander, also $m+n$ den Radstand, $x$ die Entfernung des Schwerpunktes von der Mittelachse, so ist $a x+c(m+x)=b$ $(n-x)$, woraus sich wegen $\bar{d}=$ $a+b+c$ findet $: x=\frac{b n-c m}{d}, b=\frac{c m-d x}{m}, c=\frac{b n-d x}{m}$, $a=d-b-c$. Sind bestimmte Belastungsgewichte gegeben, so kann man die Entfernung $m$ und $n$ bestimmen. Durch den Einfluss der Feder kann die Mittelachse auf Kosten der beideu anderen Achsen be- oder entlastet werden, weil ihre Lage mit der des Schwerpunktes ziemlich nahe zusammenfällt. Fig. 1324.

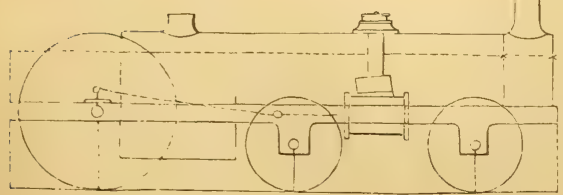

Arrangement des Wagens. Nachdem wir die Haupttheile des Wagens besprochen, können wir nun zu dem allgemeinen Arrangement desselben übergehen, welches sich je nach der Bestimmung der Locomotive und nach den Bahnverhältnissen richtet.

Fig. 1324 zeigt eine Eilzugslocomotive von $\mathrm{Cram}$ pt o n, welche die Triebräder hinter dem Feuer- 
kasten und die Laufräder vor demselben hat, die Cylinder liegen in der Mitte des Cylinderkessels. Dieses System ist verlassen, indem nach und nach die Eilziige schwerer wurden und das Adhäsionsgewicht der Triebachse in Folge ihrer grossen Entfernung vom Schwerpunkte sehr gering ist.

Auch hat es noch verschiedene andere Uebelstände, z. B. einen unruhigen Gang trotz des grossen Radstandes. Die gebränchlichste Form der Eilzugsmaschine ist auf dem europäischen Festlande derzeit auf Bahnen mit flachen Bögen (Fig. 1325) mit der Triebachse vor dem Feuerkasten, eine Laufachse vor und hinter dem Fenerkasten. Figur 1326 fiir Bahnen mit starken Krimmungen; bcide Laufachsen vor der Box.
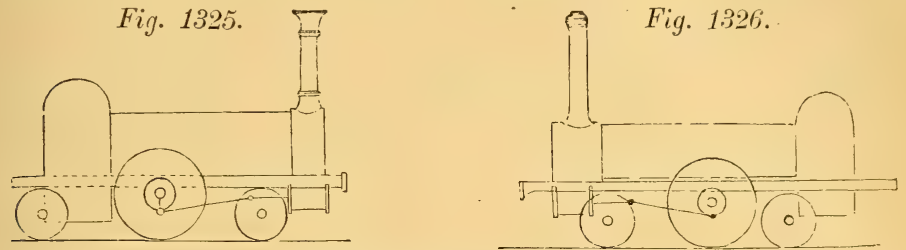

Fig. 1327 zeigt eine Schnellzugsmaschine für amerikanische Bahnen, Triebachse vor der Box und ein drehbares Vordergestell mit vier Rädern.

Einen guten Typus für kräftige Gebirgsmaschinen zum Frachtentransport zeigt Fig. 1328 mit acht geknppelten Rädern, alle vor der Box, die letzte Achse verschiebbar.

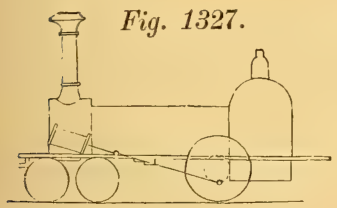

Fig. 1328.

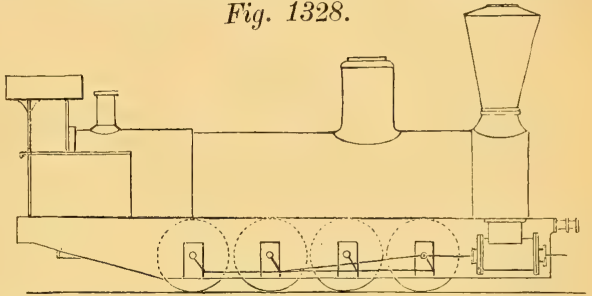

Alle diese Maschinen haben aussen liegende Cylinder.

In England haben die meisten Schnellzugslocomotiven innere Cylinder und die Triebachsen vor dem Feuerkasten; sie zeichnen sich durch den ruhigen Gang aus, haben jedoch mehrfach gekröpfte Achsen, welche häufiger brechen als gerade.

Fig. 1329 zeigt eine Engerthsche Tenderlocomotive mit 2 gekuppelten Achsen und einem Cylinder, welche auf der österreichischen Staatsbahn für Eilzüge und Personenziuge und selbst Lastzüge benuitzt werden.

Beliebte Typen für schwere

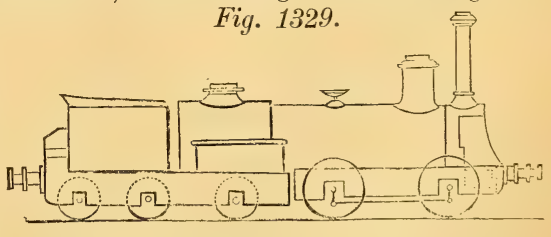
Personenzüge oder leichte Lastzïge sind in den Figuren 1330 und 1331 dargestellt.
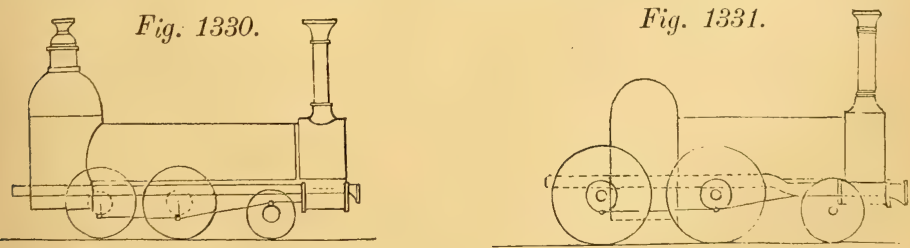
Beide Typen haben vier gekuppelte und zwei Laufräder, und unterscheiden sich nur daduch, dass Fig. 1330 alle drei Achsen vor dem Feuerkasten und einen

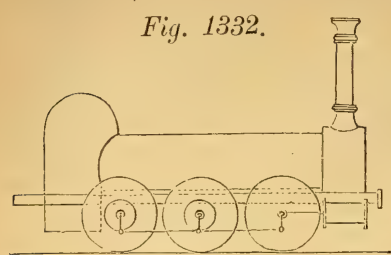
kurzen Radstand hat, und Fig. 1331 eine Kuppelachse hinter dem Feuerkasten und einen langen Radstand. Die Cylinder liegen aussen und horizontal.

Fuir gewöhnliche Lastzüge auf Hügcllandbahnen wendet man den Typus Fig. 1336 an. Sechs Räder gekuppelt, alle vor der Box, lileiner Radstand, Cylinder aussenliegend, letzte Achse horizontal verschiebbar.

Bremsen der Locomotiven. Die gesteigerten Anforderungen an die Eisenbahnen in Beziehung auf die Geschwindigkeit und das Gewicht der Züge bedingten auch wieder wirksamere Hemmrorrichtungen, und so wurden denn, namentlich in dem letzten Decennium, auch an den Locomotiven die verschiedensten Bremsen angebracht, um dem Fiihrer, welcher die Zugsgeschwindigkeit zu regeln hat, und der an der Spitze des Zuges eine herannahende Gefahr in den meisten Fällen zuerst erkennt, ein kräftiges, schnellwirkendes Mittel an die Hand zu geben, und dabei das grosse Gewicht der Locomotive nicht nur für die Fortschaffung, sondern auch für die Hemmung des Zuges zu benützen.

Nach der Natur ihrer Wirkung kann man die Bremsen zunächst eintheilen in Reibungs- und Compressions-Bremsen. (Vergl. Art. Bremsen II S. 1 bis 13.)

Reibungsbremsen. Die Reibungsbremsen wirken theils auf den Umfang der Räder (Radbremsen), theils auf die Schienen (Schlittenbremsen), sie werden theils durch Menschenkraft, theils durch Dampf in Thätigkeit gesetzt, und haben durch mechanische Einrichtung Reibung zu erzeugen, hiedurch das Bewegungsmoment der Locomotive zu absorbiren und dasselbe theils in Erwärmung der reibenden Theile, theils in mechanische Arbeit umzusetzen, durch welche die Zerstörung der reibenden Theile bedingt wird.

Die Radbremsen unterscheiden sich im Principe nicht ron den Wagenbremsen und werden dort behandelt. Man wandte sie zumeist bei Tendermaschinen an, um einen Ersatz fiir die entfallende Tenderbremse zu schaffen. Die Schlittenbremsen werden auch durch ein Hebelwerk mittelst Hand oder Dampf anf die Schienen gedriickt. Eine recht gute derlei Bremse ist in Fig. 1306 ersichtlich. $P$ bezeichnet einen kleinen horizontalen Dampfeylinder, welcher mitten unter dem Langkessel sich befindet. Der Kolben driickt beim Niedergange den Schlitten gf auf die Schienen, und hebt ihn ron den Schienen, wenn er hinaufgeht. Der Locomotivfiilurer hat nur einen Dampfhahn zu öffinen, um die Bremse wirksam zu machen.

Compressionsbremsen. Das einfachste und effectvollste Mittel, die Schuelligkeit einer Locomotive zu mässigen, ist die Anwendung des Contradampfes. Es besteht darin, dass man beim Vorwärtsgange der Maschine die Steuerung auf den Rückwärtsgang stellt (u. umgekehrt) und Dampf in die Cylinder strömen lässt.

Dies hat aber den Nachtheil, dass die Locomotive in der kuirzesten Zeit dienstunfähig wird, die Packungen rerbrennen und der Kolben nebst Cylinder durch die aus dem Schornstein und dem Rauchkasten eingesangten Gase verdorben werden.

Le Chatelier's Bremsen. Dies hat Le Chatelier auf den Gedanken gebracht, rom Kessel aus Wasser und Dampf in den Schornstein strömen zu lassen und in der That werden durch dieses höchst einfache Mittel die nachtheiligen Wirkungen des Contradampfes aufgehoben.

Nach den angestellten Versuchen und aufgenommenen Diagrammen ist schon die Rïckwiirsstellung der Steuerung allein ein sehr effectrolles Mittel der Hemmung, welches durch den Contradampf noch beträchtlich gesteigert wird. 
Le Chatelier's Bremse hat in Folge dessen auch eine sehr ausgedelinte Anwendung gefunden.

Repressionsbremsen. Bei den Repressionsbremsen wird die ganze lebendige Kraft, welche sie absorbiren, in Compression des Dampfes im Kessel und in Wärme umgesetzt. Dies wird dadurch erreicht, dass der Ausgangsregulator ganz geschlossen und der vor den Kolben geführte Dampf wieder vollständig in den Kessel zurückgeführt wird.

Die ausgefiihrten Bremsen dieses Systems sind die von L a d s e e und K r a us s. Die Repressionsbremse von Landsee ist bei Locomotiven der französischen Westbahn zur Ausfïhrung gekommen, jene von Krauss bei verschiedenen von ihm gebauten Locomotiven.

Die Zeh'sche Klappe. Diese besteht aus einem im Ausgangsrohre angebrachten Drosselventil. Beim Gebrauche dieser Bremse wird die Stenerung auf einen sehr hohen Expansionsgrad gestellt und die Klappe geschlossen, so dass nur ein sehr geringer Querschnitt für die Ausströmung des Dampfes erübrigt. Der Effect derselben ist nicht bedeutend.

Luftdruckbremse ron Bergue. Diese Bremse ist an einer Maschine angebracht, welche die schiefe Ebene von Pecq nach St. Germain befährt.

Wenn der Regulatorschieber geschlossen ist; sind die Cylinder in Verbindung mit einem Recipienten auf dem Kessel. Der Luftrecipient ist mit einem Sicherheitsventil, welches sich bei einem bestimmten Drucke öffnet, und mit einem Absperrhahn versehen, welcher vom Führerstande aus geöffnet werden kann. Das Dampfansströmungsrohr hat einen Absperrschieber und wird durch den Abschluss desselben gleichzeitig eine Communication des Schieberkastens mit der atmosphärischen Luft hergestellt. Schliesst man den Regulator und den Schieber im Blasrohre, so werden die Cylinder von dem Kolben mit dem Recipienten und hinter demselben mit der atmosphärischen Luft in Verbindung gesetzt und die Dampfmaschine in eine Luftpumpe verwandelt, welche die angesaugte Luft in den Recipienten drückt und durch die lebendige Kraft des Zuges in Bewegung gesetzt wird. Die Bremsarbeit wird durch die Belastung des Ventils regulirt, um ein Gleiten der Räder zu vermeiden.

Auch kann der Führer durch den erwähnten Hahn und durch verschiedenes Auslegen der Steuerung die Bremswirkung variiren.

Alle Umstände erwogen, so kann mit den Repressionsbremsen, welche ïberdies complicirt sind, und mit der gleichfalls complicirten Luftdruckbremse von B e r g u e ein wirksamerer Bremseffect nicht erzielt werden als mit den so viel einfacheren Contradampfbremsen und ist eine allgemeine Anwendung derselben in der Zukunft nicht anzunehmen.

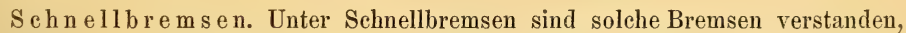
bei welchen die Bremskraft von der Locomotive auf den Tender und die Wagen des Zuges übertragen werden kann, so dass gleichzeitig alle Fahrzenge eines Zuges dureh den Locomotivführer gebremst werden können.

Bremse von Raux. Schon vor mehr als 20 Jahren hat A. Raux eine solche Bremse construirt; unter der Locomotive, dem Tender und den Wagen waren kleine Cylinder mit doppelten Kolben angebracht, welche direct mit den gegen die Räder wirkenden Bremsklötzen in Verbindung standen. Nach diesen Cylindern führte vom Locomotivkessel aus eine flexible Röhre, und wenn durch dieselbe der Kesseldampf in die Cylinder, und zwar zwischen die Kolben trat, so gingen letztere aus einander und bewirkten das Anpressen der Klötze gegen die Räder.

Bremse von Barker. Im Jahre 1871 führte Barker auf der. GreatEastern-Bahn in England einen Bremsapparat aus, bei dem Wasser zur Druckübertragung verwendet wird. An der Locomotive ist ein Accumulator angebracht, welcher voll Wasser gepumpt wird, und von dem aus jeden Moment die hydrau- 
lischen Pressen in Thätigkeit gesetzt werden können, welche die Bremsen des Zuges anziehen. Dieser Bremsapparat soll noch im Gebrauch sein.

Bremse von Heberlein. In demselben Jahre führte nach längeren Versuchen Heberlein eine Schnellbremse auf der bayerischen Staatsbahn aus, bei welcher das Bewegungsmoment des Fahrzeuges selbst zur Bremsung benützt wird, und die so eingerichtet ist, dass sie, wenn ansgelöst, automatisch wirkt.

Sie kann sowohl vom Locomotivführer, als auch von den anderen Zugsbegleitern in Thätigkeit gesetzt werden, und werden sodann die Räder der Locomotive, des Tenders und der Wagen gleichzeitig gebremst. Die Bremse des Tenders kann ausserdem, wie gewöhnlich, vom Heizer beḍient werden.

Soll der ganze Zug gebremst werden, so wird mittelst einer Leine eine Knagge zurückgedrückt, worauf eine Frictionsscheibe auf eine Rolle fällt, die sich auf einer Locomotivachse befindet. Die Frictionsscheibe dreht sich um und auf ilır wickeln sich Ketten auf, wclche die Bremsstangen so in Bewegung setzen, dass die Klötze an die Räder gedrückt werden. Die Bremse wirkt momentan und energisch. Tritt eine Zugstörung ein, so werden in Folge des Reissens der Zugleine die Bremsen in Thätigkeit gesetzt und verhindern so einen erheblichen Unfall.

Westinghouse's Bremse. Eine pneumatische Schnellbremse ist die in Nordamerika sehr verbreitete und auch in England eingeführte Westing houseBremse. Auf der Locomotive befindet sich eine separate kleine Dampfmaschine, welche eine Luft-Compressionspumpe betreibt, von der ein unter dem Führerstande liegendes Reservoir von circa $1 / 3$ Cub.-Met. Inhalt mit comprimirter Luft gefuilt wird.

Unter dem Tender und den Wagen des Zuges befinden sich 2 Luftröhren, welche mit diesem Reservoir communiciren. Zwischen diesen Röhren und dem Reservoir ist ein Dreiwegehahn eingeschaltet, durch welchen die Luftröhren mit der Atmosphäre oder mit dem Reservoir verbunden werden können. Zwischen den Fahrzengen sind die Luftröhren mittelst elastischer Schläuche und einer Metallkupplung nach Art des Bajonnetrerschlusses (s. I S. 279) in Verbindung gebracht.

In jeder Kupplungshälfte befindet sich ein Ventil und die Fiihrungsspindeln beider Ventile einer Kupplung stossen bei geschlossener Kupplung zusammen und halten die Ventile geöffinet.

Ist die Kupplung getrennt oder reisst der Zug, so schliessen sich sofort die Ventile und die comprimirte Luft kann nicht entweichen.

Aus den Luftröhren gelangt comprimirte Luft durch Zweigröhren und einen Ventilkörper zu den Bremscylindern. In dem Ventilkörper ist ein nach beiden Richtungen schliessendes Doppelrentil, welches gewöhnlich in der mittleren Lage sich befindet, so dass beide Luftröhren geöffnet sind und sich in ihnen die gleiche Spannung befindet. Wird das Gleichgewicht gestört, so schliesst das Ventil ein Rohr und es tritt nur aus dem anderen Rohr Luft in den Bremscylinder ein. Die comprimirte Luft treibt den Kolben vorwärts, und da die Kolbenstange direct auf den Bremshebel wirkt, so tritt die Bremse sofort in Thätigkeit. Jede vorhandene Bremse lässt sich als Luftbremse einrichten, und kann dabei noch separat durch den gewöhnlichen Bremser bedient werden.

Die pneumatische Bremse ist ganz in die Hand des Locomotivfïhrers gelegt, der einen Manometer bei sich hat, welcher ihm stets den Druck im Reservoir anzeigt und nach dem er den Gang der Compressionspumpe regulirt.

Die Erfolge dieser Construction sind giinstig und die grosse Verbreitung spricht auch fuir die Westinghouse'sche Bremse trotz des ziemlich complicirten Mechanismus.

Smith's Vacuumbremse. Diese Bremse beruht auf der ansaugenden Wirkung des Dampfstrahls, der mittelst eines sehr einfachen sogenannten Ejectors die Luft aus elastischen Cylindern heraussangt, die sich nur nach der Längsrichtung zusammenziehen können.

Der äussere Luftdruck bewirkt ein Zusammenklappen der Cylinder, und diese Bewegung wird mittelst an den Cylinderdeckeln vorhandenen Stangen und Hebeln auf die Bremsklötze ïbertragen. 
Die Lösung der Bremsen bewirkt der Locomotivführer durch Oeffnung eines hiezu bestimmten Lufteintrittventils. Der Locomotiv-Superintendent H. Stirling von der Great-Northern Bahn hat, wie auch andere Ingenieure, das System $\mathrm{Smith}$ zu vervollkommnen gesucht, da dasselbe für den Fall einer Zugstrennung nicht vorsorgt. Die Einfachheit desselben lassen ihm nur den besten Erfolg wiinschen. gefüihrt.

Die österreichische Siidbahn hat es im Winter $1876-1877$ probeweise ein-

Sandstreuapparat. Bei nebelfeuchten oder bethauten Schienen, oder bei nassem Schneewetter, oder auch dann, wenn die Schienen durch Fett, Letten u. dgl. verunreinigt sind, wird die Adhäsion sehr gering und es tritt das sogenannte Gleiten, Schleifen, Umhauen oder Trommeln der Räder ein. Dies besteht darin, dass sich die Räder der Maschine sehr schnell umdrehen, ohne ihren Platz zu verlassen.

Diese Erscheinung ist gleich nachtheilig für die Schienen, wie für die Bandagen und den ganzen Mechanismus, abgesehen von der störenden Wirkung auf den Zugsverkehr durch starke Verspätungen. Um dieses Gleiten möglichst hintanzuhalten, muss die Reibung künstlich vergrössert werden, und dieses geschieht durch den Locomotivführer, indem er einen stets auf der Maschine befindlichen Kasten voll Sand öffnet und einen Sandstrahl auf die Schienen fallen lässt.

Für Gebirgsbahnen und im Winter ist das Sandstrenen ein nothwendiges Uebel, denn die Schienen und Bandagen werden dadurch sehr angegriffen.

Reinigen der Schienen dureh heisses Wasser. Man hat versucht, um diese Nachtheile zu beseitigen, die Schienen durch Bespritzen mit heissem Wasser aus dem Kessel zu trocknen und zu reinigen, und die Versuche versprechen einen guten Erfolg.

Doch sind dabei noch manche praktische Schwierigkeiten zu überwinden, ehe dieses Verfahren allgemein werden kann.

Besondere Systeme der Maschinen. Um zur Erzielung eines ruhigen Ganges einen langen Radstand machen und doch scharfe Curven anstandslos durchfahren zu können, geben die Amerikaner ihren Locomotiven ein drehbares Vordergestell, wie bereits wiederholt erwähnt. Wenn aher alle Achsen gekuppelt sind, so ist die Anwendung desselben nicht möglich.

System Krauss. Dieses besteht in der Anwendung vierrädriger oder sechsrädriger T endermaschinen einfachster Construction, alle Räder gekuppelt. Aussen Cylinder, der Rahmen, welcher zwischen den Rädern liegt, wird durch den Wasserkasten gebildet, die Stenerung liegt aussen. Diese Maschinen haben ein gutes Aussehen und sind für gewisse Zwecke sehr empfehlenswerth.

System Fairlie. Fairlie hat zu diesem Behufe bei seiner Gebirgsmaschine einen sehr grossen. Kessel angewendet, nämlich in der Mitte des Kessels den Feuerkasten, dann zwei cylindrische Kessel, zwei Rauchkasten und zwei Schornsteine angewendet, und unter diesem Einen Doppelkessel und zwei drehbare Gestelle, jedes mit separaten zwei Cylindern und separater Steuerung angeordnet. Jedes Gestell hat nun nach Bedarf zwei oder drei gekuppelte Achsen.

Wir haben es somit eigentlich mit zwei Locomotiven zu thun, welche nur einen gemeinsamen Kessel haben. Mit zwei getrennten Tenderlocomotiven kann man dasselbe erreicheu, und hat dies noch den Vortheil, dass eine Locomotive Dienst machen kann, wenn die andere in Reparatur steht.

Solche Zwillingstendermaschinen mit je zwei gekuppelten Achsen werden seit zwei Decennien auf der schiefen Ebene von Giovi mit sehr gutem Erfolge benützt, diese Maschinen wurden in Seraing erbaut und haben Schlittenbremsen.

System Nowotny. Nowotny in Dresden hat eine Eilzugsmaschine für starke Steigung construirt, bei welcher zwei Achsen gekuppelt sind; die vordere Achse ist Laufachse und drehbar, zugleich so eingerichtet, dass sie sich in den Geraden normal stellt, in Bögen der Krümmung anschmiegt.

Dieses System hat den Vortheil vor Drehgestellen mit zwei Achsen, dass die vordere Achse besser belastet ist und das Fahrzeug eine grössere Stabilität besitzt. 
System Sturrock. Der Ingenieur Archibald Sturrock hatte die Idee, den Schlepptender mit Cylindern zu versehen und die Räder zu kuppeln, um die Leistungsfähigkeit der Locomotive zu erhöhen. Der Dampf für die Tendercylinder wird vom Locomotivkessel entnommen und wärmt das Tenderwasser vor. Auf flachen Strecken wird ohne Zuhilfenahme der motorischen Kraft des Tenders gefahren.

Der Director der Grande central belge, Maurice Urban in Löwen, führte neue solche Locomotiven aus, und auf einigen englischen Bahnen wurden ältere Locomotiven mit Motortendern versehen. Man soll damit zufrieden sein.

System Petiet. Auch die Locomotive von Petiet ist eine Zwillingstenderlocomotive mit zwei drehbaren Gestellen, jedes mit sechs gekuppelten Rädern und jedes mit zwei Cylindern. Die Eigenthümlichkeit liegt in dem Roste, welcher über dem Rahmen liegt, wodurch es möglich war, ihm eine lichte Breite von $1.8 \mathrm{~m}$ und eine Fläche von $3.33 \square \mathrm{m}$ zu geben. Die grosse Breite der Feuerkiste gestattete die Anwendung eines sehr weiten Cylinderkessels und sehr vieler Röhren; ferner hat Petiet ebenfalls an seinem Kessel noch ein separates, sehr grosses Dampfreservoir (circa 30 Cylinderfüllungen) angebracht, durch welches die heissen Verbrennungsgase in Röhren streichen und den Dampf trocknen. Die Leistungsfähigkeit dieser Maschine ist unübertroffen, der ästhetische Eindruck derselben ist jedoch kein günstiger, sie hat ein gar zu mammuthartiges Aussehen.

System François. Den Gegensatz zu diesem Colosse bildet die Rangirmaschine mit verticalem Kessel, welche vom Ingenieur Nicolas François in Seraing für den Dienst in dem ausgedehnten Etablissement mit sehr gutem Erfolge angewendet und von da aus verbreitet wurde. Zugsleistung 90 Tonnen Brutto auf der Horizontalen bei einem Dienstgewicht von 7.5 Tonnen.

System FelI. Alle anderen Locomotivsysteme mit gewöhnlicher Adhäsion fallen mit den erwähnten zusammen. Es gibt jedoch noch einige interessante Systeme, welche bei Secundär- oder Bergbahnen mit Erfolg angewendet wurden oder noch werden, welche sich von den vorigen dadurch unterscheiden, dass bei ihnen ausser der natïrlichen noch eine künstliche Adhäsion zur. Anwendung kam.

Das erste war das System Fell, es kam bei der Durchtunnelung des Mont-Cenis auf der gewöhnlichen Strasse mit Steigungen von 1:13 in Anwendung.

Das Wesen dieses Systems beruht auf der Anwendung einer erhöhten Mittelschiene (unter Beibehaltung der gewöhnlichen Aussenschienen), welche beiderseits zwei Horizontalrollen angreift, welche durch die Maschine gleichzeitig mit den Triebrädern in Rotation versetzt und an die Mittelschiene angepresst werden können.*)

System Riggenbach. Das System Riggenbach, welches zuerst auf der weltberiihmten Rigibahn zur Ausfiihrung gelangte, hat zwischen den Schienen eine Zahnstange, in welche ein auf der Triebachse festsitzendes, gewöhnliches Zahnrad eingreift. Es eignet sich nur für geringe Geschwindigkeiten, hat sich aber für diese seit Jahren bewährt, indem die Rigihahn Steigungen von $1: 4$ zu überwinden hat.

System Wetli. Dieses besteht in der Anwendung eines Schraubenrades bei der Locomotive, dessen Gewinde sich an, zwischen den Längs-Schienen liegende, gegen das Bahmuittel entsprechend geneigte Schienen stiitzen und durch dessen Rotationen dann die Maschine nnd der Train bergan bewegt werden. Dieses System ist sehr complicirt und in der Ausführung kostspielig. Eben so dürfte sich auch der Betrieb in Folge der theueren Bahnerhaltung kostspielig gestalten.

Im Herbste 1876 wurde die Strecke Wadenswyl-Einsiedeln bei Zürich zur Probe befahren, bei der Thalfahrt der zweiten Probe war die Locomotive nicht zu halten und es erfolgte eine schreckliche Katastruphe, bei welcher mehrere angesehene Personen das Leben verloren.

III. Maschine. Der dritte Haupttheil jeder Locomotive ist die Maschine, d. i. jener 'Theil, welcher den Dampf zur Umdrehung der Räder nutzbar macht. Wenn auch schon Stephenson eine Locomotive mit drei Cylindern, Haswell

*) Siche Eisenbahns. 71 u. 72 . 
eine Schnellzugslocomotive mit vier Cylindern gebaut hat, wenn auch in neucster Zeit eine Locomotive mit vier Cylindern nach Woolf'schem Dampfmaschinensystem construirt wurde, so sind dies doch nur vereinzelnte Fälle, und man kanı sagen, dass derzeit jede Locomotivmaschine eine Dampfmaschine mit Hochdruck, mit variabler Expansion und mit Vor-- und Rückwärtsgang ist, mit 2 Cylindern, welche auf die Triebachse unter $90 \mathrm{Grad}$ wirken, d. h. steht die Kurbel der einen Maschine auf einem todten Punkte, so ist die Kurbel der anderen Maschine um 90 Grad voraus und steht senkrecht.

Derzeit baut man alle Locomotiven mit horizontalen Cylindern, ob dieselben nun innerhalb oder ausserhalb der Räder liegen, und ist das Bestreben aller Constructionen dahin gerichtet, alle Theile so einfach, als nur möglich, anzuwenden und Reparaturen möglichst zu vermeiden oder dieselben wenigstens zu erleichtern.

Nan hat alle, nur einigermassen complicirten Constructionen, z. B. Kirchweger'sche Condensation, die Steuerungen mit 2 Schiebern, die Pumpen mit Kolben u. s. w. verlassen, um einfache Mechanismen zu erhalten, und was man dabei allenfalls an Breunstoff zusetzen sollte, wird wieder eingebracht, indem man Dampf von hoher Spannung verwendet. 10 Atmosphären Kesseldruck ist jetzt schon etwas Gewöhnliches, in Amerika, in England und in der Schweiz wendet man jetzt (1877) seit mehreren Jahren schon Dampf von 13 und selbst 15 Atmosphären Spannung an, und bei dem Fortschritte der Industrie ist man wohl noch nicht an der Grenze angelangt. Die Amerikaner spannen selbst bei ihren stabilen Dampfmaschinen die Kessel bis 10-12 Atmosphären und die Röhrenkessel für stabile Dampfmaschinen von Belleville, Root, How ard u. dgl. werden auf 20 Atmosphären Dampfdruck gepriift, und wer wollte behaupten, dass wir nun plötzlich stehen bleiben und nicht mehr fortschreiten werden?

Gehen wir jedoch zur Beschreibung der Maschine über.

Wie gesagt, ist die Locomotivmaschine eine horizontale Hochdruck-Zwillingsdampfmaschine mit variabler Expansion ohne Condensation, wobei die Triebachse mit den Triebrädern an die Stelle der Schwungradachse tritt.

Die Figuren $1333 a$ und $b$ stellen einen sehr verbreiteten Typus für eine Schnellzugslocomotive dar. Diese hat alle drei Achsen vor dem Feuerkasten, die erste Achse ist Laufachse, die zweite ist Tricbachse und die dritte Achse ist gekuppelt. Der Rahmen $A$ liegt ausserhalb der Räder, die Federn der letzteren zwei Achsen sind durch einen Balancier verbunden.

Auch die Stephenson'sche Steuerung liegt hier ausserhalb der Räder und des Ralımens, und ist somit leicht zugänglich. Wir wollen zunächst den Dampf auf seinem Wege begleiten. Der Dampf befindet sich, wie bekannt, in Obertheile des Kessels. Vom Dome $D$ strömt derselbe in der Richtung des Pfeiles in das offene Rohr zum Regulator $B$, von da bei geöffnetem Regulatorschieber durch die Einströmungsröhren in die Schieberkasten der Cylinder bei w. Der Vertheilungsschieber $v$ lässt ihn nun bald durch den Kanal $y$ in den Vordertheil des Cylinders $C$ treten, bald durch den Kanal $x$ in den rückwärtigen Theil, und von da tritt er nach vollzogener Arbeit durch die Kanäle und die Höhlung des Schiebers in den Ausströmungskanal $u$, von da durch das im Rauchkasten $L$ befindliche Ausströmungsrohr nach der Richtung des Pfeiles in den Rauchfang $L^{\prime}$ und durch den Funkenfänger, recte Funkenlöscher $T$ in's Freie. Der Theil $X$ des Rauchfanges heisst der Mantel. Der Raum zwischen Mantel nnd cylindrischem Rauchfang fiillt sich mit kleinen Kohlentheilchen und soll öfter gereinigt werden.

Die Maschine ist im Vorwärtsgange dargestellt. In dem durchschnittenen Cylinder $C$ drückt nun der Dampf (im Momente der Darstellung nur mittelst der Expansion) auf den Kolben, schiebt denselben zuriick. Die Kolbenstange $d$ schiebt den Kreuzkopf zwischen seiner Parallelfihrung gleichfalls zuriick und diese geradlinige Bewegung wird durch die Pleuelstange $b$ (auch Leit- und Fligelstange genannt) und die Kurbel $k$ in eine rotirende verwandelt und das Triebrad $R$, so wie vermittetst der Kuppelstange $c$ das Kuppelrad $R^{\prime}$, resp. die beiden Achsen a derselben, gedreht. 


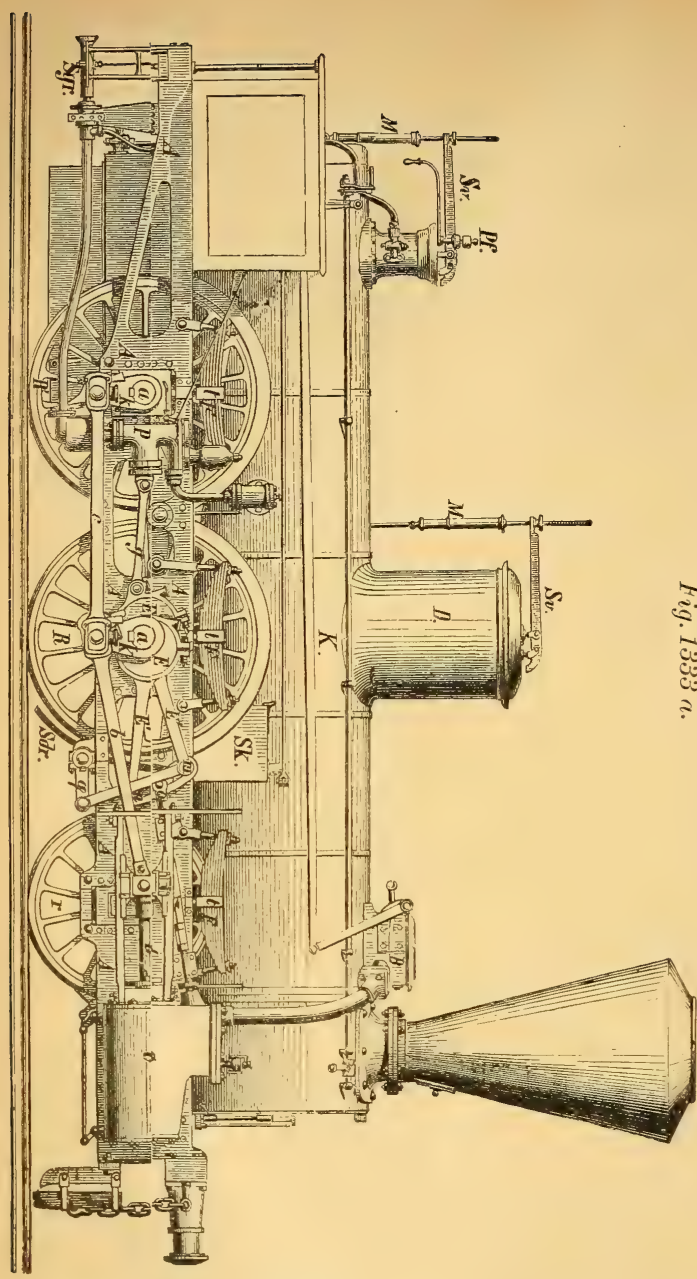

Auf der zweiten Seite der Maschine geht dasselbe vor, nur sind die Kurbeln um 90 Grad versetzt und stehen jetzt auf dem rückwärtigen, todten Punkte, d. h. horizontal nach riickwärts, während auf der sichtbaren Seite die Kurbeln vertical nach abwärts stehen. Hinter dem Kolben auf der sichtbaren Seite ist im Cylinder Compression; der Schieber hat den Kanal $x$ bereits geschlossen und die Ausströmung unterbrochen, in der nächsten Periode öffnet er wieder I. den Kanal $x$, bevor der Kolben ganz auf dem cu todten Punkte steht, und lässt frischen Dampf

₹ aus dem Schieberkasten hinter den Kolben treten, denselben weiter nach vorwärts treibend, der nun auf die Kurbel z i ehend wirkt.

Steuerung. Die Steuerung ist der wichtigste Theil, so zu sagen, die Seele der Maschine. Durch sie wird der Schieber so bewegt, dass er den Dampf nach Bedarf vor und hinter den Kolben treten lässt, ferner ihm gestattet, zur richtigen Zeit ans dem Cylinder zu treten. Wir wollen mit Hilfe der Figuren $1333 a$ und $b$ mit kurzen Worten dem Leser ein Bild geben, auf welche Art diese Wirkung hervorgebracht wird.

Es befinden sich auf der Triebachse fuir jede Seite der Maschine zwei KreisScheiben $E$, $E$, deren Mittel jedoch nicht mit dem Mittel der Achse zusammen fallt, sondern welche excentrisch aufgekeilt sind. Um diese Excenter $E, E$ herum geht je ein Ring, welcher sich auf einer Seite in eine Stange fortsetzt, die Excenterstangen $E^{\prime}, E^{\prime}$, welche wieder direct oder mittelst eines Hebels auf die Schieberstange $O$ wirken, welche mit dem Schieber $v$ rerbunden ist.

Dreht sich die Triebachse, so werden die Excenterstangen und mit ihr die Achieberstange und der schieber hin- und hergezogen. Je grösser der Abstand des Yittels der Triebachse von dem Mittel der excentrischen Scheiben, also ndie 
Excentricität " ist, desto grösser ist der Weg, welchen der Schieber zuriicklegt. Soll die Triebachse oder bei einer stabilen Dampfmaschine die Schwungradwelle sich stets nur nach einer Richtung umdrehen, so geniigt ein einziges Excenter, um den Schieber so zu bewegen, dass ein regelmässiger Gang der Maschine eintritt.*)

Die Excentricität muss in diesem Falle bei einem Schieber ohne Ueberlappung der Kurbel , um $90^{\circ}$ vorausgehen, bei den Schiebern mit Ueberlappung, welche fast ausnahmslos im Gebrauch sind, aber um $10-30^{\circ}$ mehr, d. h. um $100-120^{\circ}$.

\section{Diese Differenz}

der angewendeten Winkel gegen den rechten Winkel heisst die Voreilung und der entsprechende Winkel der Voreilungswinkel.

Soll dic Maschine aber auch in entgegengesetztem Sinne arbeiten, so ist, wie bei den Locometiven, noch ein zweites Excenter nötlig, welches wieder beim Rückwärtsgange der Maschine zu arbeiten hat und welches gleichfalls um einen gewissen Win$\operatorname{kel}\left(100-120^{\circ}\right)$ der Kurbel vorausgehen muss, wenn diese in entgegengesetzter Richtung bewegt wird.

Das erst erwähnte nennt man das Vorwärts-, das letztere das Rückwärts-Excenter. In der Figur $1333 a$ und $b$ ist das Excenter, dessen Stange nach oben geneigt zu $m$ geht, das Vorwärts- und das ein wenig nach abwärts geneigte, zu $n$ gehende, das Ruickwärts-Excenter.

Während man bei den ältesten Locomotiven die Excenterstangen direct mit den Schieberstangen in eine durch den Locomotivfuhrer jederzeit leicht auslösbare und wieder herzustellende Verbindung brachte (Gabelstenerung), sind seit 1843 die Enden $m$ und $n$ der Excenterstangen mit den Enden der sogenannten Coulisse 
gleiten oder des Schleifbogens verbunden, in welchem ein Backen auf- und niederkann, an dem die Schieberstange befestigt ist (Coulissensteuerung). Je mehr der Coulissenbacken sich dem Angriffspunkte der beiden Excenter nähert, desto grösser wird der Weg des Schiebers.

Auch wenn der Backen in der Mitte der Coulisse sich befindet, macht der Schieber noch eine, aber so kleine Bewegung, dass die Maschine dabei nicht aus der Ruhe kommt.

Bei der Gabelsteuerung tritt immer gleichviel Dampf in die Cylinder, man hat dabei constante Expansion; bei der Coulissensteuerung hat man eine in weiten Grenzen variable Expansion; je näher der Backen der Mitte der Coulisse ist, desto grösser ist die Expansion.

Geleitet wird die Steuerung vom Locomotivführer, welcher am Feuerkasten seinen Standort hat, indem er die Stenerungswelle dreht. Diese liegt vor dem Triebrade ziemlich tief, neben $q$. Mehrere Hebel sitzen auf ihr und werden mit ihr gedreht. Legt nun der Fiihrer den aufrecht stehenden Hebel am Stenerungsbogen (Reversirhebel) nach vorn, so senkt sich der Hebel $q$, durch Vermittlung der langen Zugstange, desgleichen das mit $q$ verbundene Hängeisen und die Coulisse, und der Backen kommt dem oberen Ende der Coulisse so nahe, als möglich, der Schieber macht den grössten Weg, der Cylinder bekommt die grösste Quantität Dampf und die Maschine kann die grösste Kraft im Vorwärtsgange entwickeln.

Zieht der Fihrer den Reversirhebel in seine äusserste Stellung nach hinten, so wird die Coulisse gehoben, der Backen kommt dem unteren Ende der Coulisse zunächst zu stehen, die Maschine arbeitet mit Rückwärtsgang, mit grösster Dampffüllung und geringster Expansion. Zwischen diesen beiden Extremen liegen sehr viele Variationen.

Steht der Reversirhebel anf der Mitte, so bleibt die Maschine in Ruhe.

Es ist eine grosse Anzahl den sinnreichsten Constructionen fuir die Steuerung der Locomotive erdacht; die bekanntesten sind die von Stephenson, Gooch, Allan, Heusinger von Waldegg mit Einem Schieber, dann die von Gonzenbach, Meyer, Polonceau mit 2 Schiebern, welche letzteren man wohl nicht melır anwendet, da man die möglichste Einfachheit in Allem und Jedem anstrebt.

Es ist theoretisch nachgewiesen, dass man mit der Stephenson'schen Stenerung bei richtiger Ausmittlung aller Dimensionen alle jene Vortheile erreichen kann, welche von den anderen gerühmt werden.*)

Man hat auch Stetierungen mit nur Einem Excenter für den Vor- und Ruickwärtsgang construirt, z. B. Fink, Watzka, Hackworth u. a., allein dieselben sind wohl interessant, aber haben verschiedene Nachtheile, welche ihrer Verbreitung hindernd in den IVeg treten. Der Schieber ist in der Regel ein gewöhnlicher Muschelschieber, welcher bei seinem mittleren Stande die beiden Einströmungskanïle so iiberdeckt, dass sowohl aussen als auch innen ein Uebergreifen stattfindet. Man kamn im Allgemeinen sagen, dass je grösser die äussere Ueberlappung ist, eine desto grössere Expansion mit dem Schieber erreicht werden kann.

Die imnere Ueberlappung ist weniger wesentlich, sie hat nur eine grössere oder cine geringere Compression des Dampfes im Cylinder zu Folge, welche erwiesener Massen auf den Dampf-, resp. Kohlenverbrauch von wenig merkbarem Einflusse ist.

Vergleichen wir die rerschiedenen Stellungen des Kolbens und des Schiebers und die Functionen des Dampfes mit Zuhilfenahme der Figuren $1334 a$ und $b$, welche in acht Stellungen einen Vertheilungsschieber zeigen, der bei $3 / 4$ des Kolbenhubes absperrt. Ueber jeder einzelnen schieberstellung ist der Stand des Kolbens im C'ylinder, unter jeder der Stand des Schiebers auf seinem Wege bezeichnet.

*) Vergleiche: Zeuner, die Schieberstenerungen, 3. Auflage, Freiberg 1862. 
Die Verhältnisse des Schiebers und der Dampfwege sind etwa die folgenden: Ist 0 die Länge der Einströmungskanäle, so ist die Länge der Stege zwischen Einströmungs- und Ausströmungskanal $b=3 / 40(o \mathrm{u} . b$ in der Richtung der Schieberbewegung gemessen).

Länge des Ausströmungskanals $=21 / 40$, Länge der äusseren Ueberdekkung $=0$, Lünge des Schiebers im Lichten $=3^{3}{ }_{4} 0$, Länge des Schieberhubes $=4.0$. Eine innere Ueberlappung ist nicht vorhanden.

Fig. $1334 a$ zeigt folgende vier Stellungen von Kolben und Schieber.

1. Kolben oben; Schieber im Begriff, die obere Einströmung zu öffnen, untere Einströmung mit der Ausströmung in Verbindung.

2. Kolben hat $1 / 4$ seines Hubes nach unten durch. laufen, obere Einströmung ganz öffnen, untere Einströmung mit der Ausströmung in Verbindung, Schieber nach unten ganz ausgeschoben.

3. Der Kolben hat $3 / 4$ seines Weges zurückgelegt; obere Einströmung geschlossen, Beginn der Expansion, untere Einströmung noch mit der Ausströmung in Verbin-

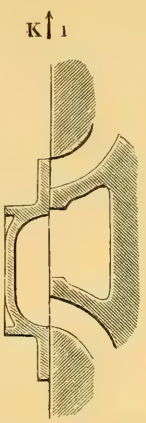
$\mathrm{S} \downarrow \frac{3}{4}$

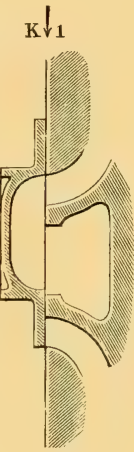

$S \uparrow \frac{3}{4}$

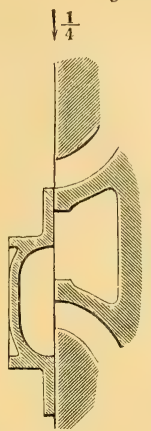

$\downarrow 1$

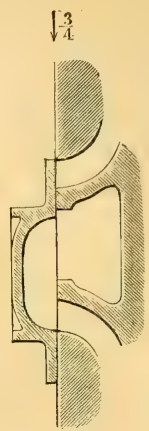

$\uparrow \frac{1}{4}$

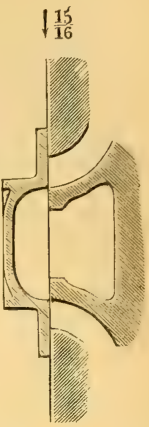

$\uparrow \frac{1}{2}$

Fig. 1334 b.
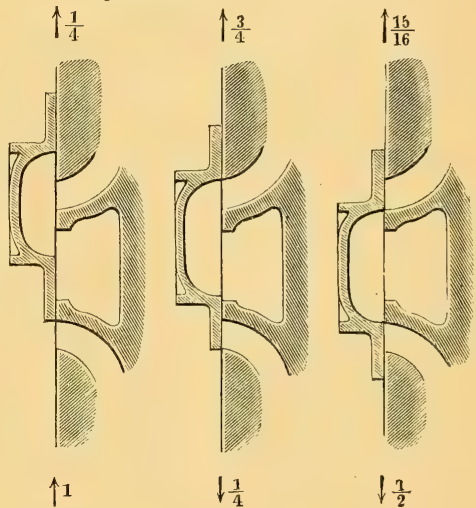
dung.

4. Der Kolben hat 15/16 seines Weges durchlanfen, die Expansion hat bis jetzt gedauert, beim Fortrícken des Kolbens und des Schiebers, und beginnt die Ausströmung - die untere Einströmung ist ausser Verbindnug mit der Ausströmung getreten. Beginn der Compression.

Fig. $1334 b$ zeigt die den vorigen Punkten entsprechenden Schieberstellungen beim Aufsteigen des Kolbens.

5. Der Kolben ist unten angelangt und beginnt aufzusteigen, der Schieber ist im Begriffe, die untere Einströmung zu öfnen und der Compression ein Ende zu machen, die obere Einströmung mit der Ausströmung in Verbindung.

6. Unten Einströmung, oben Ausströmung, der Kalben hat 1/4 seines Weges gemacht, der Schieber am Ende seines Hubes.

7. Unten Beginn der Expansion, oben Ausströmung, Kolben hat $3 / 4$ des Weges gemacht.

8. Unten Expansion und Beginn der Ausströmung, oben Beginn der Compression, der Kolben hat $15 / 1$, seines Schubes vollendet.

Würde der Schieber eine innere Ueberdeckung haben, so müsste die Compression früher beginnen, und da an der äusseren Ueberdeckung sich nichts ändert, so mïsste die Compression länger dauern. 
Man hat Locomotiven mit innerer Ueberdeckung von mehr als $2 / 50$ gemacht, ohne im Gange der Maschine oder im Kohlenverbrauche eine Aenderung zu merken.

Dies kommt einerseits daher, weil auch die Dauer der Expansion mit der inneren Ueberdeckung zunimmt und Compression und Expansion sich gegenseitig compensiren mögen; ferner die Einströmungskanäle und die kleinen Zwischenräume zwischen Kolben und Cylinderdeckel, welche nöthig sind, um das Zertrümmern der Cylinderdeckel zu verhindern, müssen von vornherein mit Dampf gefüllt werden, was immer eine gewisse, wenn auch noch so kleine Zeit erfordert; sie bilden die schädlichen Räume, der dort befindliche Dampf wird nur bei der Expansion ausgenützt. Compression füllt diese Räume mit Dampf, kann daher Dampf ersparen.

Wird der Weg des Schiebers verkleinert, so endet die Einströmung früher und die Expansion beginnt früher. Je nach der Witterung und den Steigungsverhältnissen der Bahn wird der Locomotivführer die Steuerung so stellen, dass er den Dampf durch die Expansion möglichst ausnützt.

Bei hohen Expansionsgraden wird dann der Einströmungskanal zu wenig geöffnet, und es kann zu wenig Dampf ausströmen, resp. derselbe wird zu sehr gedrosselt. Um die davon herrührenden Nachtheile aufzuheben, wendet man Schieber an, welche um die Muschel herum einen Kanal haben, so dass auch durch den Kanal des Schiebers Dampf aus dem Schieberkasten in den Einströmungskanal gelangen kann. (T'rick's Kanalschieber.)

Diese Schieber haben aber den Nachtheil, dass sie bei einiger Abnützung leicht brechen und dass die Bruchstücke in den Cylinder gelangen und eine Zertrümmerung der Cylinderdeckel herbeiführen können.

Schiebergesicht. Der Theil des Cylinders im Schieberkasten, auf welchem der Schieber gleitet, heisst das Schiebergesicht, es muss wegen seiner unausbleiblichen Abnützung etwas hervorragen und so eingerichtet sein, dass man mit leichter Mühe bei fortgeschrittener Abnützung ein neues Schiebergesicht einsetzen kann. Dies pflegt man dann aus Stahl zu machen. Die Cylinder werden derzeit ausnahmslos aus Gusseisen gemacht. Die Schieber in der Regel aus Bronce, häutig auf den Gleitflächen mit einer Legirung von Zinn und Kupfer $(80 \%$ Zinn, $20 \%$ Kupfer) gefüttert.

Alle anderen Theile der Steuerung, Welle, Excenterstange, Zugstange, Hängeeisen, Reversirhebel, Coulisse, Backen, Schieberstange, Bolzen macht man von Stahl oder Schmiedeisen, welches letztere man sodann aber auf der Oberfläche durch Cementiren anstählt und härtet. Nur die Excenterringe werden von Bronce gemacht oder mit Bronce oder einer Legirung ausgefüttert.

$\mathrm{Zu}$ allen Theilen der Locomotive ist das beste Material zu wählen, es erweist sich dieses mit der Zeit immer als das billigste.

In dem Bessemerstahl hat man ein Material gefunden, welches mit trefflicher $\mathrm{Be}$ schaffenheit den Vorzug eines niedrigen Preises vereinigt.

Reversirhebel. Der Reversirhebel, von welchem die Rede war, ist ein langer Hebel, welcher sich um einen Punkt in einem gewissen Winkel dreht, seine Bewegung erfolgt von Hand aus. Er muss an verschiedenen Punkten fixirt werden können. Dies geschieht durch Eingreifen eines beweglichen Zahnes in die entprechenden Lïcken eines Kreisbogens an seinem Ständer, dew sogenanten Steuerungsbock, welcher bei dem Fiihrerstande am Locomotivrahmen rerschraubt ist. Die Zugstange, welche die Stenerungswelle drehen kann, greift so am Reversirhebel an, dass eine zwei- bis dreifache Uebersetzung vorhanden ist.

Bei den jetzt iiblichen grossen Haschinen und dem hohen Dampfdrucke erleichtert man dem Fiihrer die Arbeit dadurch, dass der Hebel durch eine Schraube oder durch eine Combination von Hebel und Schraube ersetzt wird.

Regulator. Der Locomotivfihrer muss von seinem Stande aus natiirlich die Maschine in und ausser Thätigkeit bringen können, und es ist eine Forderung der Sicherheit, dass dies so schnell als möglich geschehe. Das Ventil, welches dem Dampfe den Weg zu den Cylindern öffnet, heisst das Regulatorventil, die Dampfschleusse, auch Regulator kurzweg. Es ist in verschiedener Construction ansgefuihrt. Die gebräuchlichste besteht in einem flachen Schieber, welcher iiber eine entsprechende Oefinung in Kopf des Dampfrohres geschoben wird. 
Diese Verschiebung bewirkt der Locomotivfuhrer durch einen Hebel oder eine Zugstange. Ein leichter Gang des Regulators ist aus Sicherheitsrieksichten und aus Griinden der längeren Dienstfähigkeit des Personals wichtig. Ein Hilfsschieber und eine rationelle Schmierung der Gleitfläche machen dieses möglich.

Blasrohr (Exhaustor). Ein wesentlicher Theil der Locomotive ist das Blasrohr. Dasselbe hat den Zweck, den gebrauchten Dampf aus den Cylindern in den Schornstein zu führen, und dadurch die im Schornstein und der Rauchkammer befindlichen Gase mit fortzureissen, wodurch dann in der Rauchkammer eine Luftverdïnnung entsteht, welche die Luft durch die Rostspalten zum Feuer und durch die Siederöhren in die Ranchkammer reisst, und endlich durch den Kamin in's Freie fiihrt. Diese Sangwirkung ist um so grösser, je schneller der Dampf ausströmt, somit abhängig von der Schnelligkeit der Maschine, der Grösse der Fillung der Cylinder und dem Querschnitte des Blasrohres. Geht die Maschine rascher, so verbraucht sie mehr Dampf, es strömt mehr aus und die Anfachung des Feuers ist eine lebhaftere; desgleichen, wenn die Maschine einen schweren Zug zu ziehen hat und mit starker Füllung arbeiten muss. Soll mehr Dampf producirt werden als unter normalem Verhältnisse, so verengt der Locomotivfiilırer das Blasrohr, und es hat nach $\mathrm{Z}$ e un er*) eine Verengung des Blasrohres um $30 \%$, eine Vermehrung der angesaugten Luftquantität um etwa $22 \%$ zur Folge und umgekehrt.

Diese Verengung ist aber in so fern nachtheilig, als die Pressung des ausströmenden Dampfes einen Riickdruck auf den Kolben ausibt, und in Folge dessen die Comsumtion des Brennstoffes in grösserem Masse zunimmt, als die Leistung eigentlich erfordern wïrde.

Die iibrigen Theile der Locomotive sind denen der Dampfmaschinen gleich und werden deshalb hier nicht besonders behandelt.

Bestimmung der Dimensionen und der Leistung der Locomotive.**) Es mögen hier noch einige praktisch erprobte Ziffern für die Bestimmung der Verdampfung und Leistung der Locomotiven Platz finden.

Erfahrungsresultate bezïglich der Verdampfung. Die Locomotivkessel verdampfen bei voller Leistung und guter Führung per $1 \square \mathrm{m}$ Heizfläche in der Stunde $27-33 \mathrm{Kg}$. Wasser und verbrauchen $3 \cdot 5-4 \mathrm{Kg}$. Koks, so das $1 \mathrm{Kg}$. Koks im Mittel $8 \mathrm{Kg}$. Wasser verdampft. Die grösseren Werthe gelten für ein Verhältniss der Rostfäche zur Heizfläche von 1:70 und 1:80, die kleineren für ein Verhältniss von $1: 90$ bis $1: 100$.

Eine weitere Erfahrung zeigt, dass die Locomotiven bei guter Erhaltung und bei ökonomischem Betriebe per Stunde und Pferdekraft 14-16 Kg. Dampf und $1 \cdot 7-2 \mathrm{Kg}$. Koks verbrauchen, was wieder 8 Kilo Dampf per 1 Kilo Koks gibt. Der Dampfverbrauch per Pferdekraft hängt bei gleicher, voller Leistung der Locomotiven hauptsächlich von der Dampfspannung im Kessel ab, und wird um so günstiger, je höher diese Spannung ist; der kleinere Verbrauch entspricht etwa 10 Atmosphären und der grössere etwa 8 Atmosphären absoluter Kesselspannung.

Z ugswiderstand. Erfahrungsresultate beziiglich des Zugwiderstandes. Ueber den Zugswiderstand wurden vielseitig Versuche angestellt und verschiedene Formeln zur Berechnung desselben ausgemittelt, welche meist von der durehschnittlichen, groben Annahme eines Widerstands-Coëfficienten $1 / 280$ bis $1 / 300$ für die gerade, horizontale Bahn bei der mittleren Geschwindigkeit von 34 Kilom. per Stunde wenig abweichende Werthe liefern.

Auf Steigungen nimmt der Zugswiderstand zu, u. zw. per Tonne bei $\frac{n}{1000}$ Steigung um circa $n$ Kilogramm.

*) Z e uner, das Locomotivblasrohr, Zürich 1863.

**) Vergleiche Pius F ink's Artikel hierüber in der Zeitschrift des österreichischen Ingenieurund Architekten-Vereines 1870. 
Alle Versuche zeigen jedoch, dass der Widerstand von der Witterung, von dem Zustande der Bahn, den Krümmungen, von der Construction, Schmierung und Erhaltung der Wagen, und endlich vorzüglich von der Geschwindigkeit des Zuges abhängig ist.

Diese Factoren sind jedoch nach Zeit und Ort so verschieden, dass es sehr erklärlich ist, wenn die Resultate der verschiedenen älteren und neueren Versuche wenig übereinstimmen und sogar ganz beträchtliche Abweichungen zeigen. Aus diesem Grunde wurde auch keine Formel aufgestellt, welche allgemein als zufriedenstellend betrachtet würde, und ein Abschätzen der Umstände ist unvermeidlich.

Von besonderer Bedeutung ist der Einfluss der Geschwindigkeit; und lässt sich derselbe, wie $\mathrm{Clark}$ gezeigt hat, genügend in der Formel $z=a+c v^{2}$ ausdrücken.

Zieht man den Widerstand eines Zuges ohne Maschine und Tender auf horizontaler Bahn in Betracht, so kann man nach den heutigen Erfahrungen und für die derzeitigen Bahnund Betriebs-Verhältnisse per Tonne Zugslast setzen:

1. Bei mittleren guten Verhältnissen (d. i. wenige Curven, und diese über 450 Meter Radius, scharfer Wind, Temperatur über $5^{\circ}$, Oel-Lager, gut belastete Züge mit mehr als 100 Tomen Brutto) $z=2.5+0.001 v^{2}, z$ in Kilogrammen, $v$ in Kilometern pro Stunde geuessen.

2. Bei mittleren sehlechten Verhältnissen (häufige Curven unter 450 Meter Radius, starker Wind, Temperatur unter 50, Lager mit fester Schmierung, schlecht belastete Züge mit weniger als 100 Tonnen Brutto) $z_{1}=1.5 \approx=3.75+0.0015 v^{2}$.

Diese Formeln liefern unter den gemachten Voraussetzungen mit den Erfahrungen gut übereinstimmende Resultate, doch wird nochmals bemerkt, dass man bei einzelnen Beobachtungen noch günstigere und auch noch ungünstigere Werthe erhalten kann, es kann namentlich beim Sturm und dem Zusammentreffen mehrever, der erwähnten, ungünstigen Umstände $z_{1}=2, z$ werden.

Leistung der Locomotive, Grösse der Kessel. Die Leistung der Locomotive wird fast ausschliesslich durch die Grösse der Heizfläche bedingt und spielen die iibrigen Verhältnisse der Kessel und der Maschine bei gleicher guter Fiihrung eine mehr untergeordnete Rolle.

Nach den obigen Resultaten folgt unter gïnstigen Umständen per Pferdekrift der Locomotive $0 \cdot 4$ m und unter weniger giinstigen Umständen $0 \cdot 58 \square \mathrm{m}$. Im Mittel kann man daher bei Locomotiven 0.5 m Heizfläche per Pferdekraft annehmen.

Daher auch, wenn $H$ die Heizfläche bedentet und $N$ die Anzahl der Pferdekräfte, $N=2 H$ gesetzt werden kann.

Driickt man die Leistung, wie es die Rechnung unmittelbar ergibt, durch die Gewichts- und Wegeinheit in Kilometer-Tonnen per Stunde aus (eine Kilometer-Tomme per Stunde ist gleich 3.7 Pferdekraft), und bezeichnet diese Einheiten zum Unterschiede von den transportirten gleichen Einheiten als effective, so ist die nöthige Heizfläche per effective Kilometer-Tonne annähernd $1 \cdot 8 \square \mathrm{m}$ und die Leistung, d. i. das Product aus der Zugkraft $Z$ in Tonnen in die Geschwindigkeit $v$ in Kilometer berechnet sich aus $N=\frac{Z v}{3 \cdot 7}=2 H$ oder aus $Z v=0.54 H$.

Betreffs der Beziehungen zwischen dem $\mathrm{Z}$ u gwiderstand der Geschwindigkeit und den Dimensionen der Maschine muss auf die am Schlusse angegebene Literatur rerwiesen werden, und sei hier nur bemerkt, dass die Geschwindigkeit ron 13 Kilometer für Lastzugs-M s chinen, 19 Kilometer für Gemischtezugs-Maschine, 40 Kilometer fiir Eilzugs-Maschinen als Maximalgeschwindigkeiten gelten können.

Verbrauch an Brennstoff und Wasser. Wie schon Eingangs erwïhnt, ist der Verbrauch an Koks per Stunde und Pferdekraft durchschnittlich circa $1.7 \mathrm{Kg}$., und die Menge des verdampften Wassers das Achtfache des Koksverbrauchs; der Verbrauch des Wassers im Tender aber ist verschiedener Verluste wegen ungefähr das $\mathrm{Z}$ ehnfache des Koksverbrauches.

Für eine stunde Verschubdienst (Rangiren der Zïge) erhält man den Koksverbrauch ammähernd genau, wenn man die Heizfläche durch $1 \cdot 7$ dividirt $=\frac{H}{1 \cdot 7} \mathrm{Kg}$. 
Fiir eine Stunde Dampfhalten kann man $10 \mathrm{Kg}$. per $1 \square \mathrm{m}$ Rostfläche rechnen.

B) Tender. Allgemeines. Der Tender bildet als Munitionswagen der Locomotive die nothwendige Ergänzung derselben; er hat den Brennstoff, das Wasser und noch ausser dem verschiedene Utensilien und Werkzeuge aufzunehmen.

Manche Locomotiven führen jedoch unter, neben oder auf dem Kessel das nöthige Wasser neben dem Kessel oder hinter dem Führerstande den Brennstoff mit sich, es sind dies die sogenannten Tenderlocomotiven. Wir sprechen hier ausschliesslich von den Schlepptendern.

Jeder Tender muss ausser den für jedes Eisenbahnfuhrwerk unentbehrlichen Achsen, Rädern, Lagern und Federn nebst Stoss- und Zugapparaten, den Behälter für Wasser und Brennstoff noch mit einer Bremse, der Vorrichtung zum Erwärmen, zur Abgabe und zum Empfange des Wassers, endlich den Behältern fuir die auf der Fahrt nöthigen Werkzeuge und das kleine Material und einer Plattform für das mitfahrende Personal versehen sein.

Die Grösse des Fassungsraumes für das Wasser und die Kohlen oder anderen Brennstoff richtet sich ganz nach localen und Betriebsverhältnissen. Im Durchschnitt haben die in Dentschland und Oesterreich-Ungarn gebräuchlichen Tender einen Wasserraum von 5 bis 7 , ausnahmsweise bis $10^{\text {eub-m }}$ und geniigend Platz fuir 2000 bis $5000 \mathrm{Kg}$. Kohle. Das Eigengewicht eines mittleren Tenders beträgt beiläufig $10.000 \mathrm{Kg}$. Je nach dem Fassungsraume und der Belastung ist der Tender mit 2 bis 3 Achsen versehen.

Das frihere Vorurtheil gegen zweiachsige Locomotiven und Tender wegen angeblicher Unsicherheit bei eintretenden Achsenbrïchen hat man fallen gelassen.

In Amerika baut man auch 4-achsige Tender, jedoch in 2 Drehgestellen, um die scharfen Bögen leichter zu befahren.

Beschreibung. Die beistehende Figur 1335 zeigt den recht guten Typus eines modernen Schlepptenders, wie er in Oesterreich-Ungarn beinahe als Normale betrachtet werden kann. Der Tender bildet einen Blechkasten, der zwischen den Rädern bis nahe an die Achsen reicht und durch die punktirte Linie $a, b, c$ in zwei Theile getheilt ist. Der obere Theil $A$ nimmt das Brennmaterial, der untere Theil $B$ das Wasser auf, welches durch das Saugrohr $S$ der Locomotive zugefuihrt werden kann.

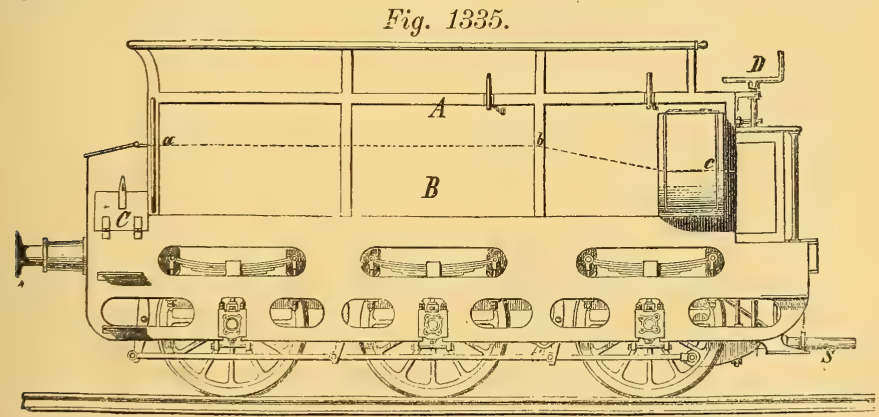

Durch dasselbe Saugrohr kann auch Dampf aus dem Kessel in das Tenderwasser gefuihrt werden, um dasselbe zu erwärmen. $C$ ist ein verschliessbarer Raum für die Hebewinden und Utensilien, $D$ die Kurbel für die Bremse, welche gleichzeitig auf alle sechs Räder wirkt.

Was von den Achsen, Rädern, Lagern, Federn, Buffern u. dgl. bei den Locomotiven gesagt ist, gilt auch fiir die gleichnamigen Bestandtheile des Tenders.

F'illvorrichtung. Der Wasservorrath des Tenders ist von Zeit zu Zeit zu erg̈̈nzen; dies geschieht durch die sogenannten Wasserkrahne (vgl. Art. Pumpen). 
Für die Nachfüllung des Tenders sind nach Umständen 5 bis 15 Minuten Zeit erforderlich. Man beschränkt sich daher thunlichst auf solche Stationen, wo aus Verkehrsrïcksichten ohnehin ein längerer Aufenthalt geboten erscheint.

Bei den sich steigernden Anforderungen an die Schnelligkeit, insbesonders der Courierund Express-Züge, hat man auf Mittel gesonnen, jene Aufenthalte zu vermeiden. Der Engländer Ramsbottom löste diese Aufgabe auf geniale Weise, so dass die Tender während der Fahrt ihr Wasser nehmen können. Das Prineip ist folgendes: Vom Boden des Tenders, etwa in der Mitte geht ein schlank nach vorn gebogenes Rohr, das sich nach unten zu verjüngt, bis zum Niveau der Schiənen. Der unterste Theil ist beweglich und kann vom Führer beliebig gehoben und gesenkt werden.

Im Innern des Kastens ist das Rohr senkrecht nach Oben fortgesetzt und endet in einen halbkreisförmig umgebogenen Ausguss, weleher die zehnfache Weite der unteren Mündung besitzt, um die Geschwindigkeit des in den Tender eintretenden Wasserstrahles zu vermindern.

An jenen Bahnstrecken, welche für die Füllung des Tenders bestimmt sind, befindet sich zwischen den Schienen ein Kanal aus Gusseisen, welcher oben offen und mit Wasser gefüllt ist. Der Kanal ist eirca $400 \mathrm{~m}$ lang.

Der Führer lässt nun das untere Ende in das Wasser tauchen, und es steigt in Folge der Geschwindigkeit des Tenders das Wasser im Rohre in die Höhe und ergiesst sich in die Cisterne.

Die erste Einrichtung wurde 1861 mit bestem Erfolge gemacht, so dass die Expresszüge von London nach Liverpool erst nach eirca 180 Kilometern Fahrt in Rugloy anhalten.

In 20 Secunden gelangen 5 eub-m Wasser in den Tender.

Es ist bedauerlich, dass die harten Winter des mitteleuropäischen Continentes eine ähnliche Anlage aussichtslos machen.

Hauptimensionen einiger Locomotiven.

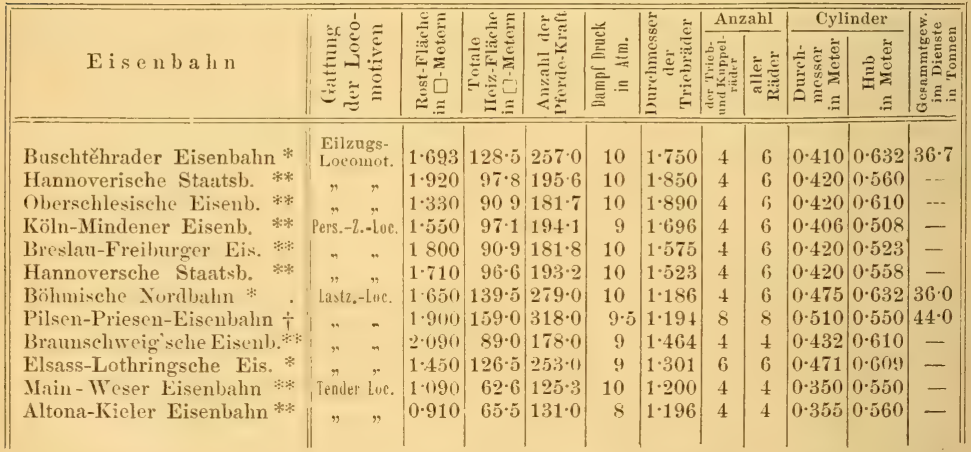

C) Eisenbahnwagen irniture, waggon - carrirge, waggon). Je nach dem Zwecke, welchem die Wagen dienen sollen, unterscheidet man 2 Hauptabtheilungen, u. zw.: Personenwagen und Lastwagen. Jede dieser Abtheilungen lässt sich je nach der speciellen Verwendung in Unterabtheilungen scheiden.

Wir führen im Nachstehenden die allgemein üblichen Benennungen der Eisenbahnwagen an: Personenwagen, Postwagen, Gepäckswagen, Pferdewagen, Borstenviehwagen, Hornviehwagen, ge deckte Giiterwagen, offene Giiterwagen, (i) mit festen hohen Wänden (Kohlenwagen), b) mit abnehmbaren niedrigen Wänden fiir den Trausport von schweren und voluminösen Gegenständen, Equipagen, Schotter ete., c) ohne Wände mit Drehschemmel zum Langholztransport.

\footnotetext{
*) System d(r. Struerung nach Stephenson.
} 
eisen mit gehärteter Lauffäche) besteht das ganze Rad blos aus Einem Stiicke. Holzscheibenräder, bei welchen die Speichen durch festes Holz ersetzt sind, sind seltener in Verwendung. In neuester Zeit wird in Amerika und England der Raum zwischen Nabe und Radreif mit Papierscheiben ausgefüllt.

Für die Constructionsverhältnisse der Achsen und Räder sind in den technischen Vereinbarungen des deutschen Eisenbahnvereins nachfolgende Bedingungen festgesetzt.

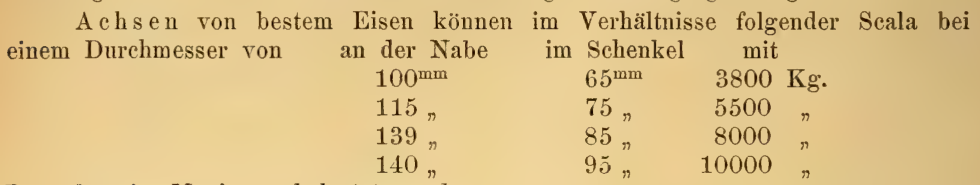

Bruttolast im Maximum belastet werden.

Bei Anwendung ron Gussstahl können diese Belastungen um $20 \%$ erhöht werden, für Achsen der Personenwagen sind der Sicherheit wegen die Belastungen um $20 \%$ geringer zu nehmen. Die Achsschenkeldurchmesser beziehen sich auf Schenkellängen bis zum $2 \frac{1}{3}-$ fachen des Durchmessers.

Bei den Achsen sind alle scharfen Ansätze zu vermeiden, und ist jeder Uebergang durch eine sanfte Curve zu vermitteln.

Die Radreifen müssen eine conische Form von mindestens $1 / 20$ Neigung haben. Die Breite derselben soll 130-145mm betragen. Sämmtliche Räder müssen mit Spurkränzen versehen sein.

Die geringste noch zulässige Stärke der Spurkränze soll an der Berührungsstelle der Schiene gemessen $19 \mathrm{~mm}$ betragen. Der lichte Abstand der Spurkränze beträgt normal $1360 \mathrm{~mm}$. Eine Abweichung bis zu $3 \mathrm{~mm}$ über und unter diesem Masse ist żulässig. Die Räder müssen in unverrückbarer Lage auf der Achse festgestellt sein.

Der Radstand (die Entfernung der Räder von einander) soll bei Bahnen, welche auf freier Strecke rielfach Curreu haben, nicht grösser sein als $4.5 \mathrm{~m}$ bei Curren ron $250 \mathrm{~m}$ Radius, $5.0 \mathrm{~m}$ bei Curven von $300 \mathrm{~m}$ Radius, $5.6 \mathrm{~m}$ bei Curven von $400 \mathrm{~m}$ Radius, $6.2 \mathrm{~m}$ bei Curven von $500 \mathrm{~m}$ Radius, $6.8 \mathrm{~m}$ bei Curven ron $600 \mathrm{~m}$ Radius, $7 \cdot 0 \mathrm{~m}$ bei Curven über $600 \mathrm{~m}$ Radius.

Bei Wagen mit 3 Achsen muss die Mittelachse eine entsprechende Verschiebbarkeit besitzen. Bei Wagen mit 4 Achsen werden immer je 2 in ein für sich drehbares Untergestell vereinigt.

Die fast allgemein verwendeten Blatt-Tragfedern bestehen aus mehreren Lagen von Stahlblättern gleicher Breite, jedoch verschiedener Länge, welche durch einen Stift oder einen Bund zusammengehalten werden.

Die Enden des obersten und längsten (Haupt-) Blattes sind umgerollt oder mit einem angeschweissten Ange versehen, um die Verbinclung mit dem Federgehänge mit Hilfe eines Bulzens herstellen zu kïnnen. Die Lïnge der Federn soll bei Personenwagen nicht unter $15^{\mathrm{m}}$, lei Lastwagen nicht unter $1^{\mathrm{m}}$ betragen. Die Blattstärke $\mathrm{kann}$ im Maximum $13 \mathrm{~mm}$ betragen.

Seltener als Blattfedern sind Volut- und Spiraltragfedern in Verwendung.

Um die Wagen anstandslos sowohl ziehen als auch schieben zu können, sind selbe mit Zug- und Stossvorrichtungen versehen.

An jedem Brustbaum befinden sich zu diesem Behufe 2 elastische Buffer, welche $1040 \mathrm{~mm}$ iiber den Schienen in einer horizontalen Entfernung von $1750 \mathrm{~mm}$ befestigt sind. Jeder Stossapluarat besteht wie bei Lucomotiven und Tendern aus der Bufferhülse, der Bufferstange sammt Stossplatte und dex elastischen Stossfeder, Gummi- oder Spiralfeder (ressort ù boudin - spivul-spring). Der in der Höhenlinie der Bufter liegende Zughaken befindet sich in der Mitte des Brustbaumes. Zu beiden Seiten desselben befinden sich die beiden Nothketten.

Die Zughaken finden ihre Fortsetzung in den Zugstangen, welche innerhalb des Gestelles mit dem elastischen Zugapparate (Fig. 1338) in Verbindung sind.

Zur Verbindung der einzelnen Wagen dienen die mittelst Bolzen am Zughaken befestigten Kuppeln (Schraubenkuppeln un Ketten). Die Wagenkasten bestehen aus einem, durch Winkel und Schraulen solid rerbundenem Rahmengestell (Säulen, Eck- und Thürsäulen, Oberahmen. Streheu, Bodens(hwellen etc.) ans Eichenholz oder Façoneisen, und sind mit 
dem Untergestell durch Consolen und Schrauben verbunden.

Das Kastenrahmengestelle wird bei den Lastwagen zumeist mit Holzverschalungen, bei Personenwagen innen mit Holz, aussen mit Blech (seltener Papiermaché) verkleidet.

Lastwagen mit eisernen $\mathrm{Ka}$ stenrahmen und Blechwänden sind stark verbreitet.

Das Dach der gedeckten Wagen ist nach einem flachen Bogen ausgeführt. Dasselbe besteht aus einer Holzverschalung, welche Fig. 13.38.

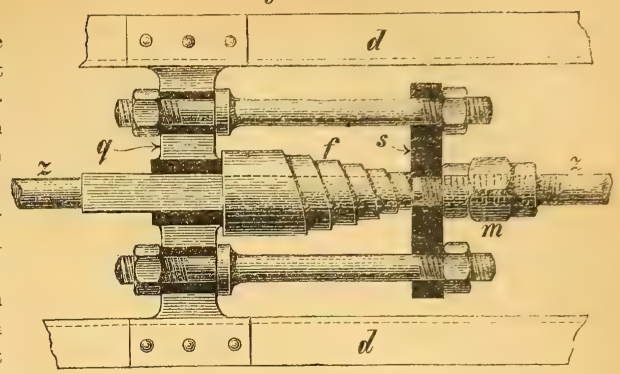

Elastischer Zugapparat. auf die Dachrippen (Bögen aus Holz oder Eisen) befestigt wird, und einer darïher gespannten Decke aus Blech (Eisen-, Zink- oder Kupferblech), Segeltuch, Dachpappe etc.

Bezüglich der im Eisenbahndienste so ausserordentlich wichtigen Bremsvorrichtungen verweisen wir auf das oben Gesagte und den Artikel Bremse, II. Bd. S. 1, und bemerken hier nur noch, dass ausser Holz und Schmiedeisen auch Gusseisen und Bessemerstahl zur Erzeugung von Bremsklötzen verwendet wird.

Die Handbremsen werden durch das Zugspersonal bedient, zu welchem Behufe an jedem Bremswagen ein offener oder gedeckter erhöhter Bremsersitz oder eine mit Geländer versehene Plattform angebracht ist. Da die Bremswagen auch zur Anbringung der Zugssignale verwendet werden, so müssen an jedem derselben die hiezu nöthigen Vorrichtungen (Laternstützen, Kloben) vorhanden sein. folgen.

Wir lassen nun eine kurze Beschreibung der einzelnen Wagengattung en

Von Personenwagen unterscheidet man 2 Systeme, u. zw.: a) Coupéwa g en (engl. System), b) Inter communicationswagen (amerik. System).

Erstere haben, da der innere Kastenraum durch Querwände in mehrere Coupés getheilt ist, die Thüren an den Längswänden, welche nach unten einwärts geschweift sind, um ein besseres Einsteigen zu ermöglichen. Diese Wagen haben Laufbretter und Fusstritte.

Die Intercommunicationswagen haben gerade Wände, einen Durchgang durch den ganzen Wagen, u. zw. in der Mitte oder seitlich. Die Thiiren führen von den Stirnwänden auf gedeckte Plattformen, welche durch bequeme Treppen bestiegen werden können.

Je nach der Ausstattung unterscheidet man: a) Wagen I., II., III. und IV. Classe. b) Combinirte Personenwagen (mehrere Classen vereinigt). c) Salonwagen (mit grösseren Räumen) für Gesellschaften. d) Hofwagen (für fürstliche Reisende mit mehreren in Verbindung stehenden Appartements).

Für den Localverkehr sind auch Wagen mit 2 Etagen in Verwendung.

Fig. 1339 zeigt den Grundriss eines Coupéwagens III. Cl.; Fig. 1340 eines combinirten Coupéwagens I. und II. Cl.; Fig. 1341 eines Intercommunicationswagens IV. Cl. mit Mittelgang; Fig. 1342 eines solchen mit Seitengang. Fig. 1339.

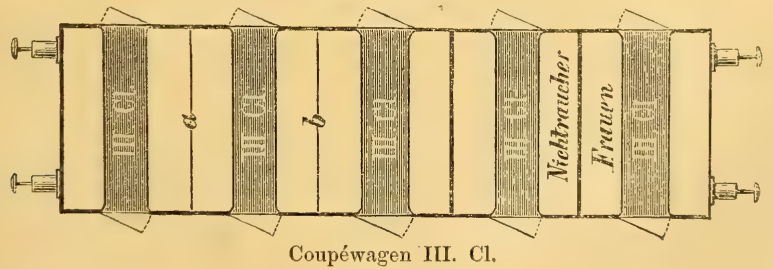


Fig. 1340.

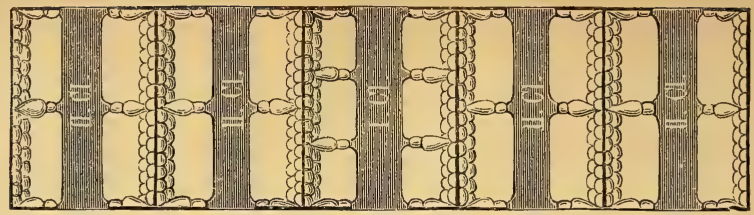

Coupéwagen I. und II. Classe. Fig. 1341 .

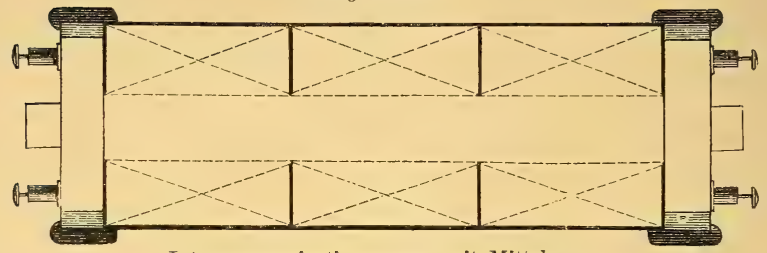

Intercommunicationswagen mit Mittelgang. Fig. 1342.

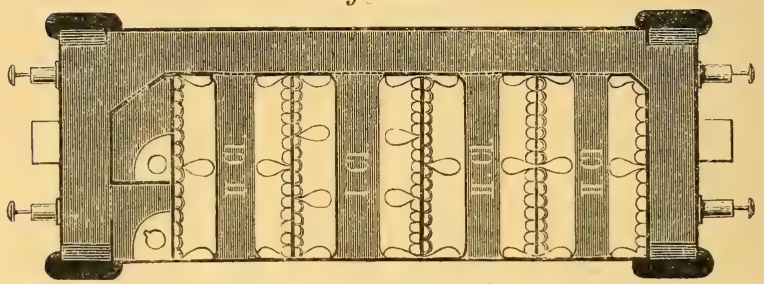

Intercommunicationswagen mit Seitengang.

Die Wagen verschiedener Classen unterscheiden sich hauptsächlich durch die innere Einrichtung und $\Lambda$ usstattung.

Die Anzahl Plätze per Coupé ist in Oesterreich und Dentschland in der I. Cl. 6 Sitzplätze, II. Cl. 8 Sitzplätze, III. Cl. 10 Siztplätze, IV. Cl. 20-25 Stehplätze.

Bei einzelnen Wagen I. Cl, werden in neuerer Zeit die Sitze so hergestellt, dass aus denselben eine bequeme Schlafstelle hergerichtet werden kann. Einige Bahnen besitzen eigene Hôtel- und Schlafwagen. Die Blechverkleidung der Personenwagenkasten ist lackirt.

Die Beleuchtung der Wagen vermitteln bei Tag die in und neben den Thüren angebrachten Fenster, bei Nacht aber Deckenlampen. Als Beleuchtungsmaterial dient zumeist Rüiböl, seltener Kerzen etc. Die Einfïhırung der Gasbeleuchtung auf verschiedenen Eisenbahnen gibt die besten Resultate.

Die Beheizung der Personenwagen im Winter geschieht auf mannigfache Weise, u. zw. mittelst Wärmflaschen, Fiillöfen, Dampfheizung, Luftheizung und Heizung mit comprimirter Holzkohle. Die billigste Heizung ist jene mit Füllöfen, die thenerste jene mit comprimirter Kohle.

Die Postwagen werden durch eine Scheidewand in 2 Räume getheilt. Niner derselben dient zur Dienstmanipulation, der andere zur Unterbringung grösserer Gepäcksstïcke.

Die Belenchtung geschieht durch Fenster und durch Deckenlampen, im Manipulationsraum ausserdem noch durch Wandhängelampen.

Fig. 1343 zeigt die Eintheilung eines auf deutschen Bahnen verwendeten Postwagens. Auf den Hauptlinien der österreichischen Bahnen hestehen die Postwagen aus 2 mit Drehnagel eng an einander gekuppelten 2-achsigen Wagen, von welchen der eine als Gepäcks-, der andere als Manipulationsraum dient. Den Cebergang von einem in den anderen Wagen rermitteln 
Fig. 1343.

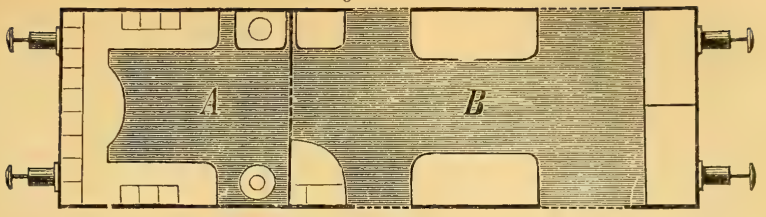

Postwaggon.

2 Thüren, der Zwischenraum zwischen beiden Wagen ist durch übergreifende Tritthleche gedeckt. Die beiden Thüröffnungen siıd mittelst eines wasserdichten, in Falten liegenden Gummistoffes verbunden, wodurch der Uebergang gegen Unwetter völlig geschützt wird.

Die Gepäckswagen sind durchwegs mit Bremse versehen; sie dienen zum Transport von Reisegepäck und Eilgut. Der Kasten wird durch 2 Scheidewände in den Manipulations-, den Gepäcksraum und den zur Unterbringung von 1 oder 2 Aborten nöthigen Raum geschieden.

Die Pferdewagen dienen hauptsächlich zum Transport von Luxuspferden, da die ibrigen Pferde in gedeckten Lastwagen transportirt werden.

Die Kasten dieser Wagen sind gewöhnlich kürzer als die der anderen Wagen und erbalten 2 durch eine Thür verbundene Abtheilungen, deren eine für 3 Pferde, die andere für den $\mathrm{P}$ ferdewärter bestimmt ist. In ersterer Abtheilung sind Seitenwände und Plafond mit Stroh gepolstert. Zwischen den 3 Ständen werden 2 ebenfalls mit Stroh gepolsterte Zwischenwände eingehängt. Für jeden Stand ist eine Krippe, welche vom Wärter bedient werden kann, angebracht. Die 2. Abtheilung enthält eine mit einem Deckel versehene, auch ads Sitzbank dienende Futtertruhe und einen Wasserbehälter. Thüren sind in den Stirnwänden, seltener auch noch in den Längswänden angebracht.

Der Eingang in die Wärterabtheilung geschieht über eine Plattform, zu welcher Fusstritte oder Stiegen führen.

Bei den Borstenviehwagen erhält der Kasten keine vollen, sondern durchbrochene Wände, und ist in 2 über einander liegende Abtheilungen getrennt.

Da das Holz durch den Unrath des Borstenviehs rasch zerstört wird, sind die Böden geneigt und so eingerichtet, dass eine Auswechslung derselben leicht möglich ist. Die Verschalungen sind überdies mit Blech beschlagen. Beide Abtheilungen erhalten besondere Schubthüren an beiden Langseiten und von Aussen zugängliche Wasserbehälter. Zwischen den Achsen ist am Untergestell oft noch ein Kasten angehängt, welcher zur Unterbringung von Jungrieh dient.

Die Hornviehwagen werden sowohl mit als auch ohne Dächer gebaut. Das circa $2^{\mathrm{m}}$ hohe Kastengerippe wird jedoch nur auf circa $1.4^{\mathrm{m}}$ Höhe verschalt. An beiden Langseiten befindet sich je eine Schubthüre.

Die gedeckten Lastwagen erhalten meist eine doppelte Verschalung, von welcher die innere jedoch nur bis zu einer Höhe von $1.5^{\mathrm{m}}$ reicht und als Schutz gegen die Beschädigung durch Transportstiicke dient. An den Längsseiten befindet sich je eine Schubthüre, an den Stirnwänden wohl auch je eine Flïgelthiire.

Da diese Wagen auch zum Militär-, Pferde- und Hornviehtransporte verwendet werden, erhalten sie an den Längsseiten 2 oder 4 Fensteröffnungen, welche entweder vergittert sind oder durch Klappen geschlossen werden können. Für den Thiertransport sind im Inneren Ringe und Kloben zum Anbinden angebracht. Durch Einstellen einfacher Sitzbänke werden diese Wagen zum Militärtransport eingerichtet.

Die Kohlenwagen erhalten je nach der Länge eine Höhe vou 0870 bis $1 \cdot 25^{\mathrm{m}}$, in den Längswänden-Thüren, welche entweder einfliglig nach oben aufklappbar sind oder zweiflïglig sich nach beiden Seiten öffnen lassen.

Der bequemeren Entladung wegen sind oft auch Stirnthiiren vorhanden. Die Oberrahmen dieser Wagen sind sehr stark ausgeführt und gewöhnlich in der Mitte durch ein Holz, Kette oder Stange abgesteift.

Die Lowries haben zum Abnehmen eingerichtete Wände von circa $0.450^{\mathrm{m}}$ Höhe. Die Stirnwände sind durch Einfallhaken mit den Längswänden verbunden. 
Haben diese Wagen gar keine Wände, so nennt man sie Platea uwagen.

Tragen diese Wagen in der Mitte einen Drehschemmel, so dienen sie zum L a n g holztrans port.

Die Drehschemmel aus Holz oder Eisen sind durch einen starken Drehnagel mit dem Wagengestell in sicherer und drehbarer Weise verbunden, tragen an beiden Enden zum Herausziehen eingerichtete eiserne Rungen, deren obere Enden durch Spannketten verbunden werden können. Auf die Drehschemmel und zwischen die Rungen zweier Wagen, welche entsprechend der Länge der zu verladenden Hölzer aufgestellt werden, wird das Holz aufgelegt. Dasselbe erhält eine feste Lagerung durch die am Schemmel befindlichen eisernen Schneiden, welche sich in das Holz eindriicken.

Eine Kupplung zweier mit Langholz beladener Wagen ist nicht erforderlich; steife lange Kuppelstangen $K$ (Fig. 1336) werden nur noch von einzelnen Bahnen verwendet. Von Wagen, welche zu besonderen Transportzwecken dienen, sind erwähnungswerth:

Bier- und Fleis chwagen. Es sind dies gedeckte Lastwagen mit doppelten Wänden, Fussboden und Decke.

Der Raum zwischen den 2 Verschalungen wird mit schlechten Wärmeleitern, Stroh, Häcksel etc. ausgefüllt. Die Fliigelthüren müssen sehr genau schliessen. An der Wagendecke sind 2 flache Eisreservoirs auf eisernen Querträgern gelagert. Die Reservoirs fassen $1-2 \frac{1}{2}$ Tons Eis, welches vom Wagendach durch gut verschliessbare Klappen eingefiillt wird. Jedes Reservoir ist mit 2 Abflussröhrchen fiir das Thauwasser versehen. Die Fleischwagen haben ausserdem noch an der Decke starke, eiserne Haken, damit das Fleisch frei aufgehängt werden kann. Wände und Dach erhalten einen lichten Anstrich.

Ein Bierwagen fasst circa 50 Hectoliter Bier, ein Fleischwagen circa 8 Tons Fleisch.

Die Bierwagen leisten den Brauereien auch im Winter gute Dienste, indem sie, was sonst öfter vorkam, das Einfrieren und somit Verderben des Bieres bei höheren Kältegraden verhindern.

Wagen zum Transport von Kalk, Cement, Thon, Gyps werden aus Kohlenwagen durch Anbringung fester, nach oben aufklappbarer Deckel hergestellt.

Wagen zum Transport von Theer, $\mathrm{O}$ el etc. sind ganz eiserne, oben geschlossene Lastwagen ron den Dimensionen der Kollenwagen. Der Boden ist gegen die Mitte zu geneigt, für den Abfluss resp. Entladung dient ein unterhalb des Wagenbodens angebrachtes Kreuzrohr mit Ventilen und Hähnen. Der Wagen erhält eine flach gewölbte, durch $T$-Eisen versteifte Decke, in welcher 2 gut schliessbare, zum Einfiillen der Flüssigkeit dienende Mannlöcher angebracht sind. Zum Transport von Fliissigkeiten werden auch Plateauwagen verwendet, auf welchen die Gefässe entsprechend befestigt werden. Anf diese Art wird in Amerika Petroleum in grossen Holzbottichen, in Oesterreich Schwefelsäure (aus der Aussiger (hem. Fahrik) in bleiernen Kesseln transportirt.

Im Nachstehenden lassen wir eine Tabelle der Eigengewichte, Tragfähigkeit und des Fassungsraumes neuerer Lastwagen folgen.

\begin{tabular}{|c|c|c|c|c|c|c|c|}
\hline \multirow{3}{*}{\multicolumn{2}{|c|}{ W a $g$ e $n$}} & & & Eige & vicht & Trag- & \multirow{3}{*}{ Fassungsvermögen } \\
\hline & & & & mit Brem & tne Bremse & fäligkeit & \\
\hline & & & & \multicolumn{3}{|c|}{ Tons } & \\
\hline Gepäckswagen . . & & . & & $6 \cdot \tilde{y}$ & - & 10 & - \\
\hline Pferdewagen . . & . & . & . & $5 \cdot 5$ & $5 \cdot 2$ & - & 3 Pferde \\
\hline Borstenviehwagen . & . . & . & . & $6 \cdot 9$ & $6 \cdot 4$ & 10 & - \\
\hline Hornviehwagen . & . . & . & . & $5 \cdot 9$ & $5 \cdot 4$ & 10 & 6 Stiick \\
\hline Gedeckte Lastwage & & . & . & $6 \cdot 0$ & $5 \cdot 5$ & 10 & 40 Mann od. 6 Pferde \\
\hline Kohlenwagen $\quad .$. & . . & . & . & $5 \cdot 2$ & $4 \cdot 5$ & $11 \cdot 3$ & - \\
\hline Lowries. . . . & . & . & . & $5 \cdot 2$ & $4 \cdot 8$ & $10--11 \cdot 3$ & - \\
\hline Langholzwagen . . & & & . & - & $5 \cdot 7$ & $11 \cdot 3$ & - \\
\hline
\end{tabular}


Schneepflïge. Die zur Entfernung des Schnees dienenden Schneepfliig e müssen so construirt sein, dass zuerst der Schnee gehoben und dann ähnlich wie mit einer Pflugschaar seitwärts gelegt wird. Um diese Wirkung zu erzielen, wird der vordere Theil des Schneepflugs nach eigenen Curven geformt. Die Schneepfliige bestehen aus einem kräftigen, hölzernen Rahmenwerk, welches mit Blech verkleidet wird; sie sind vorn mit einer steifen Kuppelstange, rïckwärts mit einer gewöhnlichen Kuppel, Nothketten und Buffern versehen.

Da das Eigengewicht der Schneepflüge für die nothwendige Stabilität und Widerstandskraft nicht ausreicht, werden dieselben durch Steine, Drehspäne, Schienenstiicke etc., welche in entsprechende, im Rahmenwerk befindliche Kästen gelegt werden, derart belastet, dass das Gesammtgewicht etwa 10-20 Tonnen beträgt. Beim Gebrauche werden die auf 2 oder 3 Achsen laufenden Schneepfliige vor eine Maschine gestellt, mit welcher dann gegen die zu entfernenden Schneemassen gefahren wird.

Zum Schlusse wollen wir noch der zu Bahnzwecken dienenden kleinen Wagen gedenken, welche nicht in Zïge eingestellt werden können. Es sind dies die Bahnwagen und Drais inen.

Erstere bestehen aus einem hölzernen, mit Brettern bedeckten Rahmen, welcher ohne Federn mittelst der Lager auf 2 schwachen Achsen ruht. Dieselben haben meist Schalengussräder von circa $0 \cdot 5^{\mathrm{m}}$ Durchmesser.

Die Bahnwagen dienen zum Transport von Schwellen, Schienen etc., welche auf der Strecke ausgewechselt werden sollen.

Die Draisinen sind sehr leichte vierrädrige Fahrzeuge mit einem Mechanismus zur Fortbewegung. Zumeist ist die eine Achse mit einem Krummzapfen versehen, welcher mit Lenkstangen, mit Hebeln oder Kurbeln in Verbindung steht.

Die auf der Draisine postirten Arbeiter setzen selbe durch Hin- und Herbewegung der Hebel oder Drehen der Kurbeln in Bewegung. Die Draisinen dienen als Beförderungsmittel bei Bahurevisionen, sind daher auch mit 2 Sitzbänken für die controllirenden Beamten und einer Bremse versehen.

Wegen des geringen Gewichtes und der bedeutenden Fahrgeschwindigkeit, welche mit den Draisinen erreicht werden kann, sind Entgleisungen derselben äusserst häufige Erscheinungen. Die Benützung derselben erfordert daher besondere Vorsicht und ist möglichst zu beschränken.

D) Kosten der Erhaltung der Fahrbetriebsmittel. Zu einer annähernden Beurtheilung möge die Angabe dienen, dass die Erhaltungskosten der Locomotiven und Tender per Jahr 3.5-7.2\%, im Mittel $5 \%$ der Anschaffungskosten beanspruchen, jene der Personenwagen $4 \cdot 1-5 \cdot 3 \%$, im Mittel $4.7 \%$, und endlich jene der Guiterwagen $2 \cdot 7-4.7 \%$, im Mittel $3.8 \%$.

Literatur: Hensinger von Waldegg: Die Locomotivmaschine. - Heusinger ron Waldegg: Handbuch für specielle Eisenbahntechnik. - Heusinger von Waldegg: Organ f. d. Fortschritte des Eisenbahnwesens. - Redtenbacher: Die Gesetze des Locomotivbaues. - Welkner: Die Locomotive. -- Weber: Die Schule des Eisenbahnwesens. - Brosuis \& Koch: Die Schule des Locomotivführers. - Paulus: Ban und Ausrïstung der Eisenbahnen. - Zeuner: Die Schiebersteuerungen. Zeuner: Das Locomotivblasrohr. - Scholl: Der Führer des Maschinisten. Hellfeld: Georg Stephenson. - Clark: Railway Machinery. - Colburn: Locomotive engineering. - Lechatelier, Etudes sur la stabilité des machines loco. motives en mouvement. - Armengaud ainé, Traité théoretique et practique des moteur à vapeur.

Otto Gebaner.

Eisenbahn-Alarmsignal, s. electrische Signale, Anhang zum Art. elektr. Tele graph.

Eisenbahnbewegung, s. II s. 144 (bei der Bewegung der Schriftform).

Eisenbahnbillet-Druckmaschine, s. I S. 522.

Eisenbahn-Brücken, s. Brii cken II S. 77.

Eisenbahn-Krahn, s. H e be m a s chin en. 
Eisenbahnschienen, s. Eis e n III S. 54.

Eisenbahn-Signale, s. Anhang d. Art. Electr. Telegraph.

Eisenbahn-Telegraphen, s. Electris cher T el egr a ph.

Eisenbahnwagen, s. III S. 112.

Eisenbahn-Zuggeschwindigkeit, s. Ges chwindigkeit.

Eisenband, s. B and I S. 286.

Eisenbeize, Eis en brühe (Schwarzbeize, Eisenrostwasser), syn. mit holzessigsaurem und essigsaurem Eisen, s. Eisen II pag. 760 und 763, vgl. a. Beize I pag. 372.

Eisenblau, natürl. Eisenphosphat, s. Vivianit.

Eisenblausäure und eisenblausaure Salze, s. Blutlaugensalze I pag. 662 , vgl. Cy an II pag. 459 .

Eisenblech, s. Blech I S. 537.

Eisenblüthe, s. Aragonit I pag. 179.

Eisenblumen, syn. mit wasserfreiem Eisenchlorid, s. Eisen II pag. 765 .

Eisenbromid und Eisenbromür, s. Eis en II pag. 766.

Eisencarburet, syn. mit Koblenstoffeisen, s. Eisen II pag. 769.

Eisenchamaeleon nannte man ein durch Vermischen von mangansaurem Natron mit schwefelsaurem Eisenoxyd hergestelltes Desinfectionsmittel (s. d. II pag. 604). Auch das eisensaure Kalium führt diesen Namen. Gtl.

Eisenchlorid und Eisenchlorür, s. Ei s en II pag. 765.

Eisencyanid und Eisencyanür, vgl. Blutlaugensalze I pag. 662.

Eisendraht, s. Draht II S. 643.

Eisenepidot, s. Epidot.

Eisenerde (grüne), s. Hy p o chlorit.

Eisenerz oolithisches, s. Eisenoolith.

Eisenerze gibt es nur vier Hauptarten, u. zw. : 1. Magneteisenerze, 2. Rotheisenerze, 3. Spatheisenstein, 4. Brauneisenerze. Siebe d. f. die betreffenden Artikel. $L b$.

Eisenfeilspäne. Eine Maschine zur Trennung der Eisenfeilspäne von Messingspänen hat V a vin construirt. Magnete in geeigneter Weise angebracht, bewirken die Scheidung. S. Dingler pol. Journ. Bd. 197.

Eisenfels, I t a b irit, dichtkörniges oder schiefriges Gestein aus Quarz, Magneteisen. Eisenglimmer und Eisenglanz bestelıend. Vorkommen in Brasilien (pic de Itabira). Gtl.

Eisenferridcyanid, syn. mit Turnbulls-Blau, s. Blutlaugensalze I pag. 667 .

Eisenferrocyanid, syn. mit Berlinerblau I pag. 667.

Eisengarn ist stark gedrehtes und mit Stärke appretirtes Baumwollgarn oder Zwirn, s. Garn-Appretur.

Eisengiesserei (fonderie en fer-iron-foundry). Zur Genüge kennzeichnet das Wort "Eisengiesserei", dass es sich hier darum handelt, fliissig gemachtes 
Eisen in friiher hergestellte Formen derart zu leiten, dass nach dem Erstarren des Metalles der verlangte Gusseisen-Gegenstand (Gussstiick) erhalten wird.

Da die Eisengiesserei mit ihren Erzeugnissen beinahe jerles industrielle. Wirken mehr oder weniger berührt, musste dieselbe darauf bedacht sein, den mannigfachsten Anforderungen gerecht zu werden, und vermag sie dies auch in Folge ihrer neueren Entwicklung in den meisten Fällen.

In dem Nachfolgenden soll nur dasjenige besprochen werden, was speciell fuir die Eisengiesserei gilt oder des Zusammenhanges wegen nicht fehlen darf, im Uebrigen sei auf den Artikel Giesserei verwiesen.

Das Roh-Material fuir die Gussstiicke der Eisengiesserei ist Roheisen, dessen Herstellung im Artikel Eisen II S. 771 genügend besprochen wurde.

Nach der Farbe des Giesserei-Roheisens unterscheidet man weisses und graues, das Gemisch beider Färbungen findet sich bei dem halbirten Eisen. Hier unterscheidet man wieder schwach und stark halbirtes.

$\mathrm{Schwach}$ halbirt ist jenes Giesserei-Roheisen, welches vorwiegend eine graue Färbung aufuweisen hat, stark halbirtes Eisen jenes mit vorwiegend weisser Farbe.

Je dunkler, das ist also, je mehr grau das Roheisen im frischen Bruche sich zeigt, desto besser verwendbar ist es im Allgemeinen zum Giessereibetrieb, aus dem Grunde, weil eben dieses Eisen nicht nur in. die schwächsten Theile der Form gleichmässig ausfliesst, sondern anch nach dem Erstarren weich, also leicht bearbeitbar bleibt. Doch nicht zu allen den verschiedenen Gegenständen, welche die Eisengiesserei herzustellen beauftragt wird, verlangt man absolut weich s graues Eisen. Beim Gusse eines Dampfeylinders z. B. wird man bei der Gattirung des Eisens wohl darauf bedacht sein miissen, ein schwach halbirtes, in seinem Gusse sich dicht zeigendes Eisen zu erhalten, denn ein solches Eisen hat nicht nur den Vortheil, dass beim Ausbohren des in Rede stehenden Stiickes die Innenfläche möglichst frei von Graphitausscheidung sich zeigt, sondern es liefert diese auch etwas härter, also mehr der Abnützung widerstehend. Das in seinem Bruche sich vollkommen weissstrahlig zeigende Eisen ist zum Giessereibetrieb im Allgemeinen nicht anwendbar.

Das Schmelzen des Roheisens geschieht in eigens hiezu hergerichteten Ofen (Cupol-, Flamm- und Tiegelofen). Der Cupolofen ((forneau à manche - cupolo furnace), welcher beim Giessereibetrieb zum Schmelzen des Roheisens die meiste Verwendung findet, ist der Hauptsache nach ein Schachtofen und als solcher dem Hochofen (s. III S. 7) ähnlich.

Auf einem wohlfundirten, gemauerten Untergestell ist eine kräftige Gussplatte aufgelegt und mit derselben ein verticaler Cylinder aus Kesselblech verbunden, weic! er der feuerfesten Ausmauerung als Armatur dient. Die Gicht des Ofens ist offen und die Ofenwände haben geeignete Durchbrechungen für die Formen und das Eisen- und Schlackenstichloch. Eine der einfachsten und zweckentsprechendsten Constructionen ist in Fig. 1344 dargestellt. $a$ ist die Bodenplatte, $b$ der Mantel

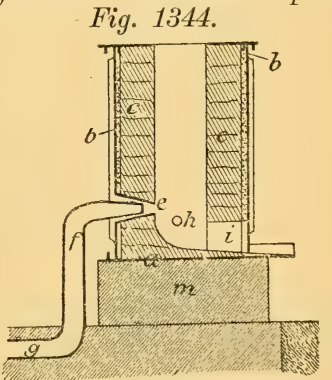

Cupolofen. oder Blechcylinder, $c$ die Ausmanerung, $e$ die Form, $f$ die Diise, $g$ das Windrohr, $h$ das Schlackenioch, $i$ die Ofenbrust, in welcher sich das Stichloch fuir das Eisen befindet.

Die zur Ausmauerung des Cupolofens in Verwendung kommenden feuerfesten (Chamotte-) Ziegeln werden je nach dem Durchmesser des Ofens in Keilform hergestellt und auf die Hochkante voll auf Fug gemanert. Als Bindemittel der Ziegel wendet man im Ofon schon gebranchte zermahlene ChamotteZiegelstiicke mit Wasser zu einem ziemlich fliissig gemachten Brei an. Die Fugen zwischen den einzelnen Ziegeln miissen möglichst dicht an einander schliessen. 
Zwischen der Mauerung des Ofens und dem Blechmantel wird ein schlechter Wärmeleiter (Asche) aufgestampft, um das Warmwerden der Blechhülle zu verhindern. Bei einem inneren Durchmesser des Cupolofens von $90^{\mathrm{cm}}$ wird man die Einströmungs-Oeffnung des Windes in eine Höhe von $40-45^{\mathrm{cm}}$ von der Sohle des Ofens legen.

Es genügt für diese Dimension eine Windpressung von $13-16^{\mathrm{em}}$ Quecksilber, um mit guten Koks pr. Stunde 60 Ctr. Eisen flüssig zu machen. Ohne dass die Mauerung des Ofens stark leidet, ist es bei diesen Dimensionen des Cupol-Ofens leicht möglich, 110-120 Ctr. Roheisen niederzuschmelzen. Die Beschickung des Ofens vor dem Anblasen geschieht auf folgende Weise.

Vorerst hat man die von der vorhergegangenen Schmelzung schadhaften Stellen des inneren Gemäuers thunlichst in guten Stand zu setzen, so wie den Herd von anhängenden Schlackentheilen zu befreien. Nachdem diese Ausbesserung mit feucht angemachtem feuerfesten Thon besorgt wurde, trocknet man den Ofen mit angemachtem Feuer langsam aus. So dies geschehen, beginnt man den Ofen bis an $25^{\mathrm{cm}}$ iiber der Windeinströmungs-Oeffnung mit Koks zu füllen, hierauf setzt man $10 \mathrm{Ctr}$. (500 Kg.) Eisen möglichst gut vertheilt auf die so entstandene erste Schüttung Koks, schichtet dann $35-40 \mathrm{Kg}$. Koks auf, dann wieder weitere 10 Ctr. Eisen u. s. w., bis schliesslich der Qfen, auf seine ganze Höhe gefuillt, fünf Gichten enthält. Zwischen die einzelnen Gichten setzt man etwas Flussspath, um einen leichteren Fluss der Schlacke zu erzielen. Sodann wird bei offener Brust die erste Fiillung des Ofens in Brand gesteckt und abgewartet, bis das Feuer sich über der Windduise gezeigt, dann die Brust geschlossen, das Windregister geöffnet. Nun ist der Schmelzprocess im Gange.

Ausser der oben dargestellten Form eines Cupolofens gibt es viele andere Constructionen, an welchen namentlich Abänderungen in der Anordnung der Windeinströmung getroffen sind.

Fig. 134 .
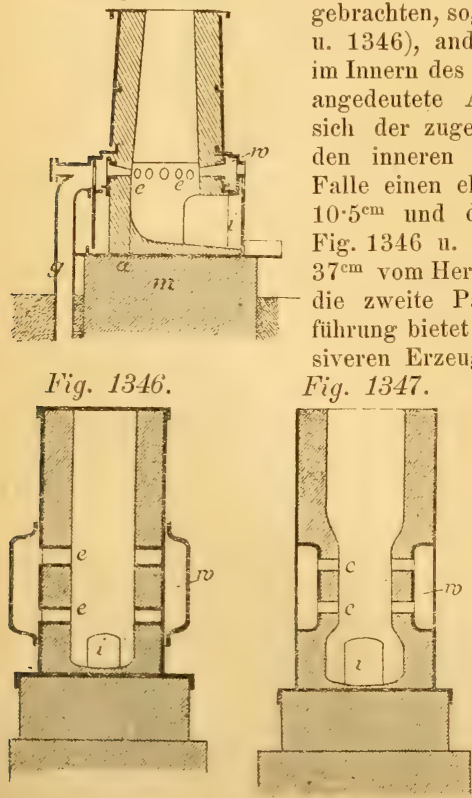

So wird der Wind in einen ausserhalb an den Ofen angebrachten, sogenannten Windmantel $w$ geleitet (Fig. 1345 u. 1346), anderntheils wieder befindet sich der Mantel im Innern des Ofens und bedingt dann eine nach Fig. 1347 angedeutete Ausmauerung. Aus diesem Mantel theilt sich der zugeführte Wind durch angebrachte Düsen in den inneren Ofenraum. Die Diisen haben in diesem Falle einen elliptischen Querschnitt, deren grosse Achse $10 \cdot 5^{\mathrm{cm}}$ und die kleine Achse $8^{\mathrm{cm}}$ beträgt und sind in Fig. 1346 u. 1347 derart in dem Ofen angeordnet, dass $37^{\mathrm{cm}}$ vom Herde die erste und weitere $37^{\mathrm{cm}}$ iber selbem die zweite Partie ihren Platz finden. Diese Windzuführ'ung bietet den Vortheil einer gleichmässigeren, intensiveren Erzeugung des Hitzegrades in der Schmelzzone des Ofens. Um das Ausscharren des Ofens nach geschehener Schmelzung des Eisens nicht nach gewöhnlicher Art bewerkstelligen zu müssen, hält man Cupolöfen in Verwendung, deren Boden durch eine Thür, welche sich nach abwärts öffnen lässt, ersetzt ist. Fig. 1348.

Selbstverständlich ruht dann solch ein Ofen nicht auf einem gemauerten Sockel, sondern wird von vier Füssen getragen. Der Uebelstand bei dieser Construction des Ofens ist wesentlich der, dass bei jeder stattzufindenden Schmelzung der Boden des Ofens neu hergestellt werden muss, in Folge dessen es auch 
nothwendig ist, unnöthig mehr Brennmaterial zum Austrockuen des Ofens in Anwendung zu bringen, als es bei anderen Oefen ohne dieser Vorrichtung nothwendig ist.

Fla m möf en (forneau ¿̀ réverbère - reverberatory furnace) werden zum Einschmelzen des Giesserei-Roheisens verwendet, wenn statt der Koks ein minder werthiges, billig zu beschaffendes Brennmateriale verwendet werden muss, oder wenn das Eisen länger im Fluss erhalten werden soll und auf bestimmte Gattirung ein besonderer Werth zu legen ist.

Das im Flammofen zu verschmelzende Roheisen wird direct am Herde durch die Flamme zum Schmelzen gebracht, sammelt sich dort in gehöriger Menge und wird endlich durch die Stichöfinung, welche am tiefsten Punkte des

Fig. 1348.

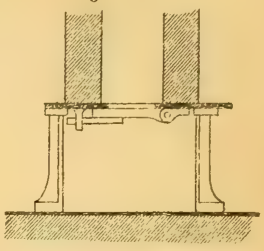
Herdes angebracht ist, abgelassen. Die Bd. III S. 28 und 29 dargestellten Flammöfen stimmen in den Hauptmerkmalen mit jenen zum Umschmelzen verwendeten iiberein und kann hier auf Beifugung einer Figur verzichtet werden. .

Um Roheisen in kleineren Quantitäten zum Schmelzen zu bringen, wird der Tiegelofen in Anwendung gebracht; hier kommt das zu verschmelzende Eisen nicht direct mit dem Brennmaterial in Berïhrung, sondern, wie schon der Name andeutet, in einen Tiegel, welcher, aus feuerfestem Thon oder Graphitmasse hergestellt, in das Feuer eingesetzt wird. *) Um das Feuer in dem Tiegelofen lebhafter zu erhalten, bringt man selben anch mit einem Gebläse (Fig. 1349 $a$ und $b$ ) in Verbindung und erzielt dabei ein rascheres Schmelzen des Eisens im Tiegel, als dies bei gewöhnlichem Fig. 1349 a. Fig. 1349 b.

Zug (Fig. $1350 \quad a$ und $b$ ) möglich wäre.

Das in einer dieser drei angefiihrten Oefen fliissig gemachte Eisen muss in entsprechende Formen geleitet werden, um dort zu erstarren.

Von dem F o r m en (moulage - moulding) oder der Herstellung der Form.

Die F o r m (moule - mould) für den Eisenguss wird gewöhnlich aus Sand, Lehm oder einem Gemisch beider Substanzen der Masse hergestellt; seltener ganz oder zum Theile a us $\mathrm{E}$ isen. Diesbezüglich unterscheidet man den S and-, Lehm, Masse- und Schalengiss.

Selten kann der Sand, wie selben die Natur bietet, zum Formen verwendet werden, und es wird beinahe jede Giesserei ihr Hauptaugenmerk darauf zu richten hajen, verschiedene Sandsorten

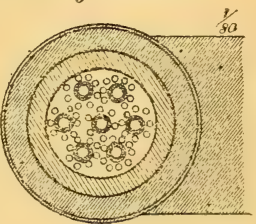

Fig. 1350 a.

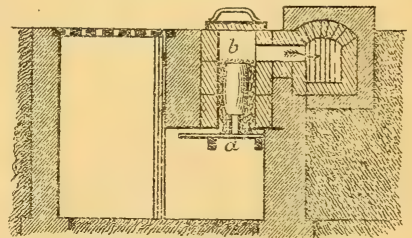

Fig. 1350 b.

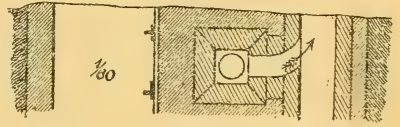
mit ihren bekannten Eigenschaften derart zu mischen, dass das Product eine homogene, unschmelzbare, die sich beim Guss bildenden Gase leicht durchlässige Masse bildet. In Allgemeinen wird von zwei sonst verwendbaren Sandsorten diejenigen zum Formen geeigneter sein, welche beim Beträufeln das meiste Wasser einsaugt (s. F o r m s a n d).

Bei den Sandformen unterscheidet man solche, in welche ohne vorheriges Trockner das Eisen gegossen (grüne Furm) wird, und solche, welche ror dem Gusse getrocknet werden. Um das Anschmelzen des Sandes möglichst zu rerhindern, wird bei den grïnen Formen die Oberfläche derselben mit gemahlenem 
Graphit oder Kohle, welcher in einen Leinwandbeutel gebracht wird, bestäubt; bei den getrockneten Formen aber vor dem Trocknen die Oberfläche mit im Wasser angemachten Graphit bestrichen (geschwärzt).

Gegenstände, welche besonders dicht im Gusse sein sollen, dabei stark im Eisen sind (Walzen, Pressköpfe u. s. w.), werden in Masse geformt. Dieses durch Mischung hergestellte Formmaterial besteht aus Lehm, Flusssand und Pferdemist zu gleichen Theilen. Pferdemist wird aus dem Grunde beigegeben, um den beim Abgiessen der Form sich bildenden Gasen leichteren Abzug zu gestatten.

Selbstverständlich wird die Masseform vor dem Gusse gut getrocknet.

Die Lehmformerei findet beim Eisenguss dann ihre Anwendung, wenn Abgüsse grösserer Dimensionen meist ohne Modell in Ausfuihrung zu bringen sind. Der Lehm wird auch hier mit Pferdemist gemengt und mit Wasser teigartig angemacht. Mit Vortheil mengt man in den Lehm auch Kuhhaare, um das Zerreissen der Form beim scharfen Trocknen möglichst zu verhindern.

Der Sch a lenguss wird überall dort angewendet, wo es sich darum handelt, eine oder mehrere Flächen des Abgusses gleichmässig hart zu erhalten (Schalengussräder, Hartwalzen u. s. w.). Das Giesserei-Roheisen besitzt nämlich mehr oder weniger die Eigenschaft, sich im flissigen Zustande an eisernen Wandungen (Schalen) abzuschrecken und dadurch weiss (hart) zu werden.

Die Herstellung guter Formen ist die wichtigste Arbeit des Giessers und sei "das Formen" daher an mehreren Beispielen besprochen.

Das Formen eines Rohres in grïnem Sande geschieht mittelst eines Modelles in eigens hiezu hergerichteten gusseisernen Rahmen (Formkasten), welche zuweilen, durch sogenannte Vorhänge in Fächer abgetheilt, den aufzustampfenden Sand aufnehmen. Das Rohr-Modell wird behufs leichteren Abformens seiner Länge nach aus zwei'Theilen hergestellt, welche durch das sogenannte Schloss verbunden sind, damit ein Verschieben der beiden Modellhälften nicht vorkommen kann. Man bringt zu diesem Zwecke an der einen Hälfte Führungsstifte an $s$ (Fig. 1351), während die andere entsprechende Vertiefungen enthält. Die Hälfte mit den Ver-

Fig. 1351 .

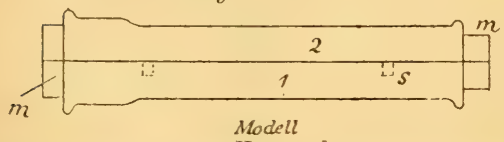

m sog. Kernmarken. tiefungen wird auf das Formbrett gelegt, der Formkasten darauf gestuirzt und der leere Raum zwischen Modell und Rahmen (nach Bestäuben mit Graphit) mit Sand aufgestampft, sodann wendet man den Formkasten sammt dem Modell um, glättet die Oberfläche der Form mittelst des Polireisens, bestäubt selbe mit pulverisirter Holzkohle, legt die zweite Hälfte des Moclells auf die erste, setzt die zweite Formkastenhälfte darauf, welche wieder durch Stifte $s$ (Fig. 1352 einerseits und Löcher andererseits eine Führung

Fig. 1352.

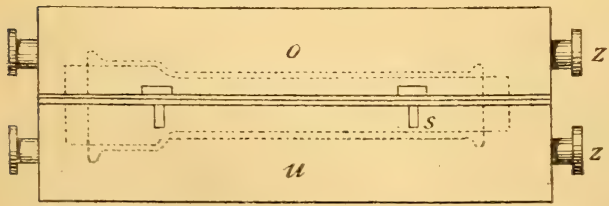

o Oberkasten, u Unterkasten. z Zapfen, an welche bei grossen Formkästen die Hebehaken eingehängt werden. erhält, und stampft wie früher den Formkasten auf. Die Kanäle zum Eingiessen des Eisens, so wie die nöthigen Steigtrichter werden im Sande ausgespart.

Nun schreitet man zum Abheben des Oberkastens vom unteren, wendet selben um, zieht, nachdem man früher noch die Berihrungsstellen des Modelles mit dem Sand befeuchtet und das Modell losgeklopft hat, dieses aus dem Formmaterial. Die schadhaften Stellen der Form, welche bei noch so rorsichtigem Herausziehen des Modells zu Tage treten, werden wieder mit Hilfe der diversen Former Werkzeuge reparirt und die Form mit Graphit bestäubt. Ganz dasselbe Verfahren wiederholt sich bei der unteren Formkastenhälfte. Beide zusammen geben den Mantel der Form. 
Je nach dem lichten Durchmesser und der Länge des Rolires werden Sandoder Lehmkerne in Anwendung gebracht. Erstere gelangen in sogenannten Kernb ü chsen oder Kernkästen zur Ausfuhrung, wo der Kern auf ein entsprechendes gusseisernes Gerippe aufgestampft wird. Da diese Kernkästen zwei- oder melırtheilig sind, so lässt sich der Kern leicht aus denselben nehmen. Fig. 1353.

Zur Anfertigung eines Lehmkernes bedient man sich eines, nach seiner Länge mit kleinen Löchern versehenen Gasrohres, welches mit einem dem Durchmesser, des Kernes entsprechend starken Strohseil umwunden wird. Auf diese so hergerichtete Spindel wird Lehm aufgetragen, dieser getrocknet, die Kernspindel sodann in entsprechende Lager gelegt, und wieder weiter so viel Lehm aufgetragen, als nach einem vorgelegten Schablonen-Brett nothwendig ist, um den Kern auf den verlangten Durchmesser zu bringen. Fig. 1354.

Der Sand-, so wie der Lehmkern wird mit Graphitschwärze überzogen und in der Trockenkammer vor dem Einlegen in die Form gut getrocknet.

Um das Rohr, wie es in den meisten Fällen verlangt wird; stehend zu giessen,

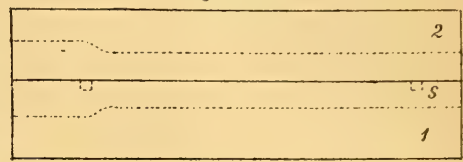

Kernkasten

Fig. 1354.

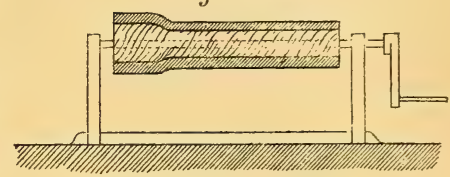

Herstellung eines Lehmkernes. muss auch die Form geschwärzt und getrocknet werden. Nach dem Einsetzen des Kernes in die Form ist selbe zum Guss fertig. Fig. 1355.

Nicht immer genügt zum Abformen diverser Gegenstände ein zweitheiliger Formkasten, bei einer Seilrolle z. B. wird, wie beistehende Figur 1356 $a$ und $b$ zeigt, ein dreitheiliger Formkasten nöthig sein oder doch das Formen wesentlich erleichtern.

$A$ Ober-, $B$ Mittel-, $C$

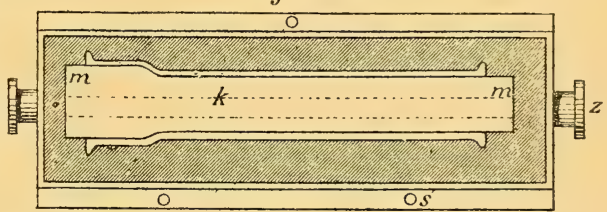

$k$ der Kern ist mit seinen Enden $m$ in die Kernmarken der Form eingelegt.

Unterkasten. Das zum Abformen in Verwendung zu bringende Modell muss selbstverständlich nach $a b$ getheilt sein.

Beim Formen legt man das Modell auf ein Modellbrett $c$, gibt darüiber den Mittelkasten $B$ und stampft den Sand zwischen Modell und Rahmen auf. Hernach glättet man mittelst des Polireisens die Sandfläche bei $d, f$, bestäubt selbe mit Holzkohlenstaub und setzt den Untertheil $C$ auf, stampft auch diesen mit Sand voll und wendet diese beiden Formkästen nebst dem Modellbrett um. Nachdem das Modellbrett abgehoben, die Fläche bei $g, h$ glatt gestrichen und bestäubt wurde, stampft man den Obertheil $A$ ein, in welchem auch der Gusskanal ausgespart wurde. Nach Abheben desselben zieht man die Modelllıälfte 1 aus dem mittleren Formkastentheil Fig. 1356 a.

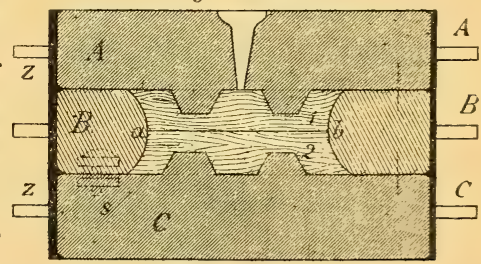

Fig. 13526 b.

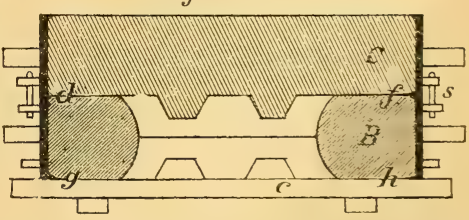
$B$, setzt dann den Kasten $\boldsymbol{A}$ wieder auf $B$, wendet die drei Formkastentheile, hebt dann den Theil $C$ von $B$ ab, und zieht die Hälfte 2 des Modells ans dem 
Kastentheile $B$. Nachdem der Kasten $C$ wieder aufgesetzt wurde, wendet man die drei Theile nochmals und der Guss kann vor sich gehen. Ist der Durchmesser der Rolle ein kleiner und die Stiickzahl der Abguisse eine mindere, dann lohnt es sich der Giesserei nicht, erst eigens hiezu passende Formkästen anfertigen zu lassen. Das Abformen solcher Rollen kann auch in zweitheiligen Formkästen vorgenommen werden.

Ist 1, 2 in Fig. 1357 das abzuformende Modell (wie früher getheilt), so legt man selbes vorerst auf das Modellbrett $c$, beschwert leicht das Modell, und

Fig. 1357.

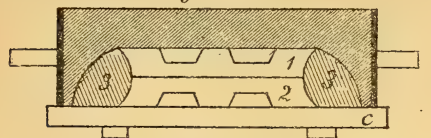

drückt den Sand, wie nach Fig. 1357 angedeutet ist, rings in die Nuth des Modelles ein. Glättet und bestäubt die so erhaltene Oberfläche des Sandes, setzt den Formkasten (A) darüber und stampft selben voll Sand, wendet den Kasten sammt dem Modellbrett, stampft den zweiten Theil $(\boldsymbol{B})$ des Formkastens voll; hebt, so selbes geschehen, diesen wieder ab und zieht die Hälfte 2 des Modelles aus dem Sande, setzt den Formkastentheil $B$ wieder darauf, wendet die beiden Theile, hebt den Kasten $A$, welcher jetzt nach oben gekommen, ab, und zieht die Hälfte 1 des Modelles aus dem Sandkörper 3, welcher bei dieser Art von Formerei die Stelle des mittleren Rahmens beim dreitheiligen Formkasten vertritt, setzt das Obertheil wieder darauf und die Form ist zum Abgiessen bereit.

Nach dem Gesagten ist das Einformen eines Topfes Fig. $1358 a, b, c$, einer Stufenscheibe Fig. $1359 a$ u. $b$, und der in Fig. $1360 a$ u. $b$ dargestellten kleinen Gegenstände ohne weitere Erklärung verständlich.

Fig. 1358 a. Fig. 1358 b. Fig. 1358 c.

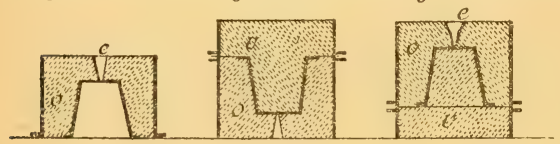

\section{Fig. 1360 b.}
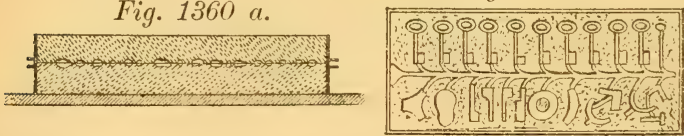

Fig. 1361 a.

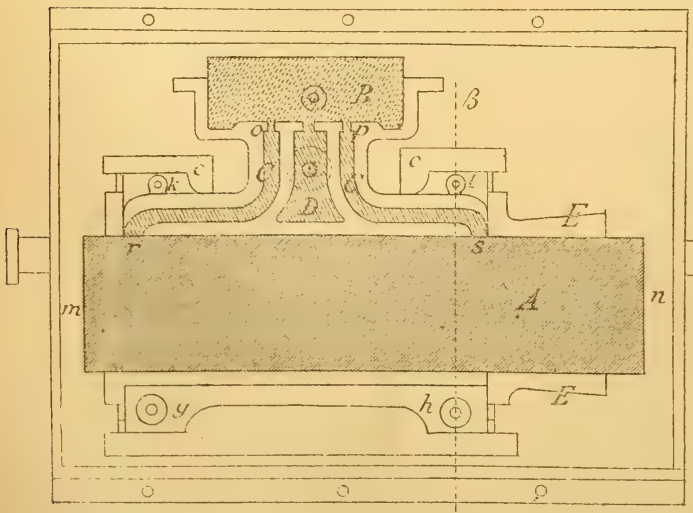

a
Fig. 1359 a.
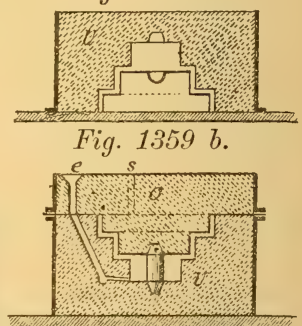

Um einen D a mpfcylinder mit angegossenen Pratzen, welche zum Befestigen an die Fundamentplatte dienen, nicht in einem dreitheiligen, ja je nach seiner Formkasten formen $\mathrm{zu}$ müssen, werden sogenannte falsche Theile der Form (Keilstücke) in Anwendung gebracht. Fig. 1361 a zeigt die Hälfte des Modelles in dem Untertheil des Formkastens eingestampft und Fig. $1361 b$ den Querschnitt nach re $\beta$. Nachdem bei $c$ der Sand entArt in einem viertheiligen 
sprechend der Form der Pratzen herausgehoben, die seitlichen Wandungen des stehen gebliebenen Sandes geglättet und bestäubt sind, setzt man ein schon friiher abgegossenes Kerneisen in den so entstandenen freien Raum und stampft dieses bis zur Hälfte des Modelles $e, f$ mit Sand ein, setzt die weitere Hälfte des Modelles über die bereits eingestampfte, stampft den Oberkasten ein, hebt diesen vom Unterkasten ab, und zieht die Hälfte des Modelles aus dem

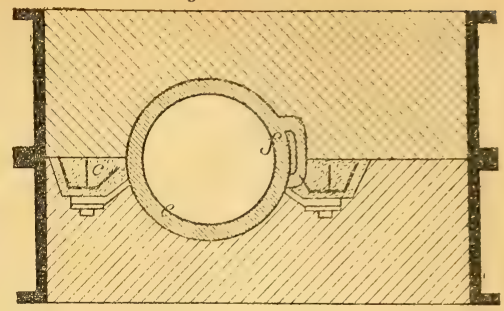
Formkasten. Das gleiche Verfahren wiederholt sich beim Untertheil, nur dass in diesem Falle die Pratzen $g, h, k, l$ vorerst vom Modell losgeschraubt werden müssen, um die falschen Theile sammt den Kerneisen aus dem Sand heben zu können. Schliesslich zieht man die so zn Tage getretenen Pratzen-Modelle aus der Form, reparirt diese so wie die falschen Theile, überstreicht selbe mit Graphitschwärze und trocknet die Form in der Kammer gut durch. Die weiter in die Form einzulegenden Kerne $B, C, D$ werden in Kernbüchsen hergestellt, der cylindrische Kern $A$ wird nach Art des oben beschriebenen Rohrkernes angefertigt.

Der Lehm fuir die Kanal-Kerne muss besonders gut durchgearbeitet und porös sein (mit Vortheil mengt man den dritten Theil Kuhmist zu, damit die sich während des Gusses bildenden Gase durch die sorgfältig. im Kern ausgesparten Abzugskanäle leichten Abgang finden. Ist die so nothwendige, fleissige Herstellung dieser Sandkerne ausser Acht gelassen, so wird es vorkommen, dass die Gase, welche dann nicht regelrecht entweichen können, sich durch das noch in der Form flüssige Eisen Bahn brechen und das Gussstuick bei der weiteren Bearbeitung sich in seinen Wandungen als blasiges zeigen wird. Zur Versteifung der Sandkerne selbst legt man je nach der Stärke des Kernes in die entsprechende Kernbiichse vorerst etwas Lehm und drïckt in diesen ein der Form des Kernes àhnliches Draht-Gitter ein, so dass, nachdem der Lehm bis auf die verlangte Stärke des Kernes aufgetragen wurde, dieses das Gerippe des Dampfkanal-Kernes bildet.

Die Abzugskanäle der Gase aus dem Kerne werden am sichersten ausgespart durch eingelegte Wachsdrähte, welche beim gelinden Trocknen des Kernes ausfliessen. Der zurüickbleibende Draht (Docht) kann dann leicht herausgezogen werden.

Das Einlegen der Kerne bei gut getrockneter Form des Cylinders beginnt mit dem Hauptkern $A$ in Fig. 1361, hierauf legt man in die Form den Kern $B$, welcher nach Abguss des Stiickes den inneren Raum des Schieberkastens bildet und reiht an selben und den Kern $A$ die beiden Sandkerne $C, C$. Diese werden zu ihrer Befestigung einerseits in den Kern $B$ bei o, $p$ in die ausgesparten Marken eingelegt, anderseits stumpf an den Kern $A$ angeschoben und mittelst eingesteckter Kernnadeln (Stipper) an selben festgehalten. Schliesslich wird der Kern $D$ des zu bildenden Dampfausströmungs-Kanales eingelegt und ebenfalls durch Marken und Stipper in der Form fixirt. Bei 'der Versteifung der Kerne unter einander wird man nur an jenen Stellen Kernnadeln (Stipper) in Anwendung bringen, deren Flächen durch Ausbohren oder Behobeln einer Appretur nicht unterliegen. Sind die Kerne, wie erwähnt, eingelegt, der Staub, der sich während des Einsetzens in die Formvertiefungen abgesetzt, sorgfältig herausgeblasen, dann setzt man den Obertheil des Kastens auf den Unterkasten, schraubt die beiden Theile zusammen, und stellt dann diese mit dem Aufguss $E$ (verlorenen Kopf) nach oben in der Dammgrube auf. Nachdem der Kasten sorgfältig in der Grube mit Sand eingedämmt wurde und die Gase aus der Form durch Kanäle um den Formkasten ihren Abzug erhalten haben, kann zum Gusse des Stückes geschritten werden. Rasches Abgiessen bei sonst sorgfältig hergestellter Form, so wie ein reines, nicht zu sehr iiberhitztes Eisen, wird einen dichten, porenfreien, gut bearbeitbaren Dampfeylinder liefern. 
Das Formen von Zahnrädern erfordert darum einer grösseren Aufmerksamkeit, weil meist die Zähne des gegossenen Rades ohne weitere Bearbeitung in die eines zweiten so eingreifen sollen, dass ein ruhiger Gang sich bemerkbar macht. Ein genanes Modell, ein vorsichtiges Einstampfen des Zahnkranzes bei gut zubereitetem Formsand, so wie ein gleichmässiges Losklopfen des Modells aus dem Sande, und schliesslich eine ruhige Hand beim Ausheben sind die Hauptfactoren, um einen gelungenen Abguss zu Stande zu bringen.

Da es hier zu weit führen wuirde, die Formerei der diversen Arten von Zahnrädern in's Detail zu beschreiben, so sei nur die Formerei eines Holzkammrades nach einem Modell und eines grossen Zahnrades mittelst Schablone besprochen.

In Fig. $1362 a$ und $b$ ist das Modell in dem Unterkasten eingestampft. Nachdem der Obertheil abgehoben wurde, wurden im Untertheil die Beriihrungsflächen des Fig. 1362 a.
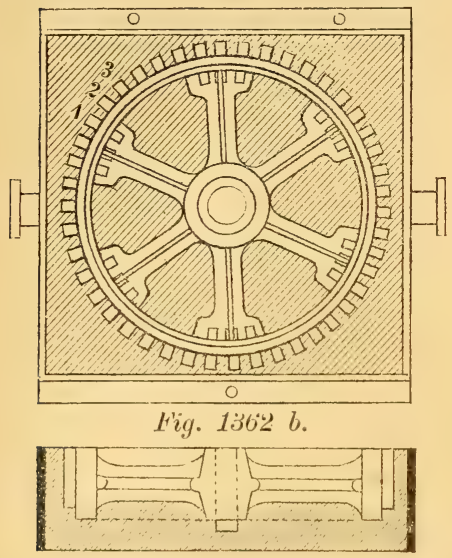

Fig. 1363.

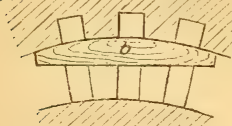
präciser Handlıabung ganz gelungene Abguisse erzielt. Sie ist in manchen Fällen den Radform-Maschinen vorzuziehen, weil der Durchmesser des zu formenden Rades hier kein beschränkter ist, und die Anschaffungskosten gegenüber denen einer Formmaschine viel geringer sind. Bei dem Formen eines grösseren Zahnrades ohne Modell sind es die nach Zeichnung geschnittenen Schablonen, welche durch Drehumg um eine rerticale Achse die verlangte Form in dem anfgestampften Sand herstellen helfen.

In Fig. 1364 ist $a$ die in ihren Lagern $c c^{\prime}$ senkrecht stehende abgedrehte Spindel und $b$ der Arm, welche auf derselben leicht anf- und abgeschoben werden kamn und nöthigenfalls während des Formens bei $d$ mittelst einer Schraube festgestellt wird. So geniigen weiter noch zwei Flugspindeln, eine kleine Schablone zum Ausziehen der Arme, so wie deren obere Rippen und eine Kernbiichse zur Herstellung der Zahnliicken, um mit der Formerei des Zahnrades beginnen zu können.

Die Grösse des in Rede stehenden auszuführenden Gussstiickes bedingt, dass selbes direct in der Herdsohle der Giesserei geformt wird.

Nachdem rorerst die Grube hiezu ansgehoben wurde, die Spindel $a$ nebst Arm $b$ auf ihr unteres Lager $c$ gestellt ist, wiri der Arm e, wie in Fig. $1364 a$ u. $b$ dentlich ersichtlich ist, in das Lager $c^{\prime}$ der Spindel niedergelassen. $e$ ist durch die beiden Streben $f, f^{\prime}$ gespreizt. So rorbereitet schraubt man das mit Blech- 
streifen beschlagene Schablonenbrett $S$ an den Arm $b$ der Spindel, vorausgesetzt, dass die Schablone auf das richtige, innere Mass des zu formenden Rades gestellt wurde. Stampft die Grube mit fein gesiebten Sand beiläufig der zu erhaltenden Form an, senkt den Arm sammt Schablone und dreht die Form nach Fig. 1364 rein aus. Glättet die so erhaltene Fläche mit dem Polireisen, bestrent selbe mit mageren trockenen Sand und reisst mittelst eines spitzigen Griffels

Fig. 1364 a.

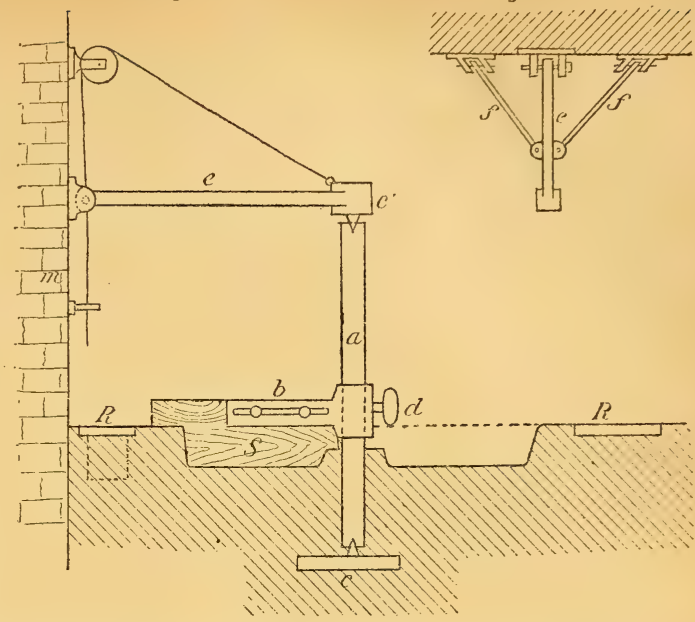

die Arme ihrer Figur nach auf das durch Ausdrehen so erhaltene Untertheil der Form. Nachdem die oberen Rippen (-Modelle) auf das Mittel der vorgerissenen Arme mittelst Drahtstiften fixirt wurden, setzt man den Formkasten dariber und stampft auf die friher eingelegten Kerneisen, die Felder zwischen den Armen, so wie weiter den Kasten mit Sand voll. Die in die Kerneisen eingeschraubten Oesen werden jetzt an die im Formkasten befindlichen Traversen festgekeilt; um den Kasten in die Herdsohle die Fihrungsstiften geschlagen und dann der Obertheil der Form abgehoben.

Fig. 1365 .

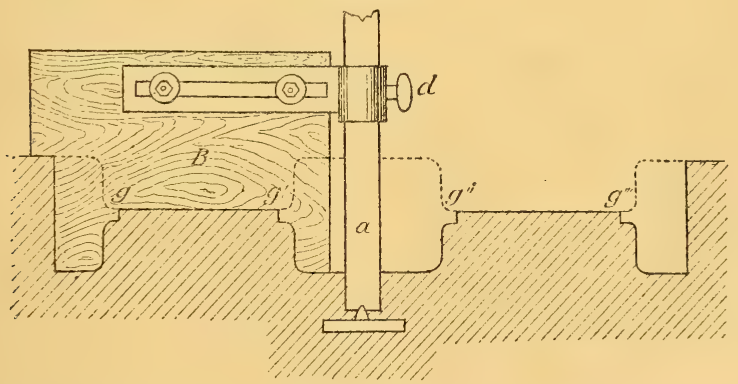

Die Spindel, welche während des Einstampfens des Obertheiles herausgehoben wurde, wird jetzt wieder in ihre Lager gebracht und an den Arm das zweite Schablonenbrett $B$ angeschraubt (Fig. 1365). Nach einmaliger Umdrehung der Schablone wird die Schraube bei $d$ geliiftet und der Arm sammt Brett um circa $4^{\text {mra }}$ tiefer gesenkt, dies wiederholt sich bei stetem Ausheben des Sandes so lange, bis die Schablone $B$ die schon früher nach Schablone $S$ in Fig. 1364 gebildete Fläche bei $g g^{\prime} g^{\prime \prime} g^{\prime \prime \prime}$ trifft, wie dies unsere Fig. 1365 zeigt.

Die Eintheilung der Zälne geschieht auf einem gusseisernen Ringe $R$, dessen Durchmesser grösser ist als der des zu formenden Rades. Man giesst auf ilın eine beiläufig $4^{\mathrm{mm}}$ starke Schichte Gyps, schabt diese nach dem Erstarren mittelst eines 
Fig. 1366.

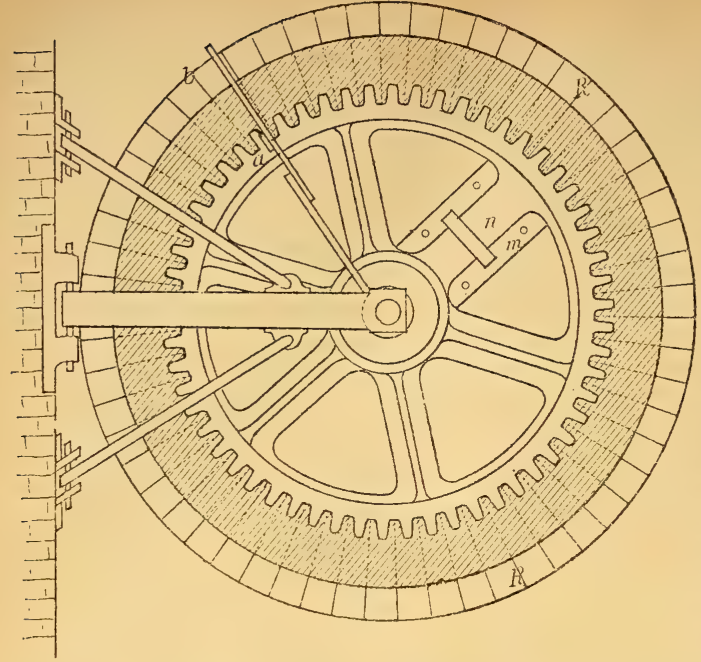

Fiq. 1368.

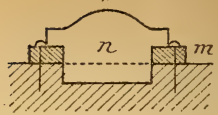

Messers ab und schwärzt den Gyps mit Holzkohlenstaub, um schärfer markirte Theilstriche zu erhalten. In die Form wird bei $a$ Fig. 1366 auf den verlängerten Arm der Spindel ein gehobeltes Lineal vertical aufgeschraubt, und an dieses die im Kernkasten aus fettem Sand angefertigten Zahnlücken, nachdem der Zeiger bei $b$ immer um einen Theilstrich weiter gegangen, nach einander von links nach rechts angelegt und durch die fruher

ausgesparten Oeffnungen an die ausgedrehte äussere Wandung der Form angestiftet. Fig. 1367.

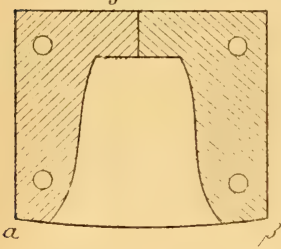

Fig. 1367 stellt die Kernbüchse der herzustellenden Zahnliicken in der Dranfsicht vor.

Die Rad-Arme werden, wie in.Fig. 1366 und 1368 ersichtlich ist, mittelst eines Schablonbrettchens $n$ zwischen zwei Linealen $m$ durch Herausheben des Sandes hergestellt.

Wurde die Form im Unter- und Obertheil reparirt, so überzieht man diese mit Graphitschwärze und trocknet sie gut durch. Mit dieser Art von Formerei ist man in den Stand gesetzt, alle Arten von Zahnrädern, Schwungrädern, Turbin- oder Riemscheiben u. s. w. mit geringen

Unter den verschiedenen Arten von mechanischer Formerei*) sei hier das Formen auf Modellplatten (welche gleichsam aus einer Vereinigung der Modellhälften mit je einem Formbrett bestehen) herrorgehoben, weil man mittelst derselben in den Stand gesetzt ist, die diversesten Gegenstände ras eh, g u t und billig herzustellen. Soll z. B. selbes zum Formen von massiven Kugeln in Anwendung gebracht werden, so miissen die hiezu nothwendigen Formkästen an ihren Beriihrungsflächen gehobelt sein, und deren Führungsstifte, so wie die entsprechenden Löcher derart genau in einander passen, dass das Obertheil eines Kastens auf sämmtliche Untertheile der anderen Kästen uud umgekehrt ohne im geringsten zu schlottern, gesetzt werden kann.

Der Ober-, so wie der Unterkasten wird jeder für sich auf seiner ihm zugehörigen Modell-Platte eingestampft, welche durch ein Schloss (vergl. $s$ S. 124) derart mit dem Kasten verbunden ist, dass eine gegenseitige Verschiebung nicht stattfinden kann.

Es kommt mithin der Lnterkasten auf die genau gehobelte erste Modellplatte, z. B. jene, welche nebst deu vier Halbkugeln auch die Erhöhungen für die Eingiisse aufgenietet trägt, der Oberkasten auf die eben so genau zugerichtete zweite

*) S. den Artikel Röhren. 
Modellplatte, welche mit den zur Ergänzung erforderlichen Modellhälften armirt ist; so dass, wenn beide Kastentheile mit Sand angestampft, von den Platten abgehoben und aufeinander gesetzt, nicht die geringste Verschiebung der ausgesparten Formtlieile bemerkbar ist. Zu bemerken wäre hiebei noch, dass die Eingusskanäle des raschen Formens halber auf der Formplatte des Unterkastens ein für allemal fest angemacht sind. Nach diesem angefuihrten Beispiel der Plattenformerei ist es ersichtlich, dass die verschiedenartigsten Gussgegenstände durch Austausch anderer Modellplatten mit denselben Kästen zur Ausführung gebracht werden köınen.

Bei der Lehmformerei ist das die Form bildende Materiale Lehm.

Die Lehmformerei wird durch das rationellere Herstellen der Formen in Sand und Masse immer mehr in den Hintergrund gedrängt. Das langsame Arbeiten der Formen in Lehm, so wie die kostspielige Herstellung haben die Eisengiessereien aufmerksam gemacht, dass man im fetten Formsand (Masse) schneller und eben so gelungene, verhältnissmässig billigere Abgiisse schaffen kann. Die Lehmformerei wird heute dort Anwendung finden, wo es sich handelt, Abgiisse anzufertigen, deren Modelle nicht nur wegen ihres grösseren Volumens sehr kostspielig kommen, sondern wobei auch die hiezu in Verwendung kommenden Formkästen aussergewöhnlich grosse Dimensionen annehmen müssten (z. B. Gebläsecylinder); und dort, wo schwere, massig in Eisen gehaltene Gussstiicke herzustellen sind, weil eben dieses Formmaterial dem flüssigen Eisen mehr Widerstand, in Folge dessen grössere Sicherheit während des Gusses bietet. Die zum Formen in Sand nothwendigen Formkasten fallen bei dieser Art von Formerei gänzlich weg und an deren Stelle treten Backsteine, und je nach der Figur des herzustellenden Gusses verschiedenartig gekrïmmte Eisenschienen.

Der Lehm, wie er an seinen Fundorten gegraben wird, muss immer vor Verwendung zum Formen eigens zugerichtet werden. Das Ausscheiden der im Lehm eingemengten Steinchen geschieht mittelst des Siebes. In den so gereinigten Lehm mischt man Flusssand, damit er poröser wird und die beim Guss sich bildenden Gase leichter entweichen lässt. Aus eben demselben Grunde gibt man, je nachdem der Lehm mehr oder weniger fett ist, Pferdemist bis ein Drittel hinzu. Um das Zerreissen des Lehms während des Trocknens bestmöglichst zu vermindern, mengt man Kuhhaare hinein. Nachdem die angefilhrten Theile im richtigen Verhältniss dem Lehm beigegeben wurden, feuchtet man das. Gemisch mit Wasser an und knetet die Masse am besten mit den Füssen so lange durcheinander, bis selbe eine teigartige Consistenz angenommen hat.

Um an einem Beispiel die Formerei in Lehm zu veranschaulichen, sei die Herstellung der Form einer Kühlpfannschale näher besprochen.

In Fig. $1369 a$ und $b$ ist $a, a$ ein gusseiserner Ring, dessen Durchmesser grösser ist als die abzugiessende Schale, $b, b$ sind Fiisse, auf welche der Ring bestmöglichst horizontal gelegt wird, $c$ ist eine vertical stehende Spindel in ihren Lagern $d, d$ laufend. An den Arm $e$ wird die Schablone $f$, welche den Kern der Form abzugleichen hat, angeschraubt. Das Aufmauern des Kernes geschieht mittelst halbgebrannten Backsteinen, als deren Bindemittel breiartig angemachter Sand verwendet wird. Auf den so hergestellten rohen Kern wird Lehm $1-2^{\mathrm{cm}}$ stark aufgetragen, hierauf trocknet man den Kern schwach, gibt dann eine weitere Lehmschichte von $2^{\mathrm{cm}}$, und gleicht diese dan mittelst des mit dem Blechstreifen $g$ beschlagenen Schablonenbrettes $f$ ab (Ausdrehen). Der so weit hergestellte K e r n wird nun getrocknet und nachher mit einem Gemisch von fein gesiebter Asche und Wasser bestrichen. Nun schreitet man zur Bildung des sog. Hemdes $h$, d. h. man trägt eine Lehmschichte auf, deren Dicke der nach dem Abguss verlangten Eisenstärke entspricht. Eine zweite Schablone dient zum Ausdrehen des Hemdes. Nachdem die Form (Kern und Hemd) abermals getrocknet wurde, setzt man nach Angabe der Werk-Zeichnung die eventuell am Guss verlangten Pratzen, Flanschen u. s. w. (aus Holz hergestellt) auf und bestreicht, um eine Trennungsfläche zu erhalten, die Oberfläche der neu hergestellten Lehmschichte wieder mit angemachter Asche. Nun beginnt das sogenannte Manteln der Form, die Herstellung des M a n t ls. 


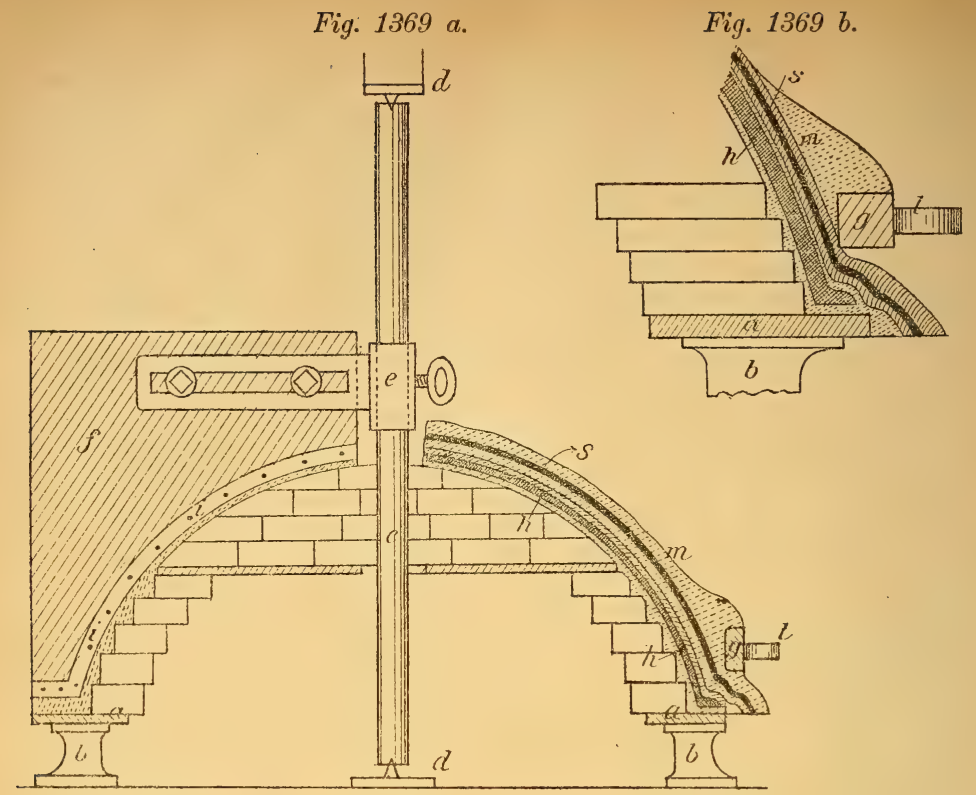

Ohne weitere Beniitzung der Schablonenbretter trägt der Former eine $1-2^{\mathrm{cm}}$ starke Schichte Lehm bestmöglichst gleichförmig auf die so hergestellte Eisenstärke oder das Hemd und trocknet sie abermals.

Die nach der Form gebogenen schienen $s$ werden jede einzeln wieder mit Lehm auf der der Form zugekehrten Seite auf $1 \frac{1}{{ }^{c m}}{ }^{\mathrm{cm}}$ hoch bestrichen und auf eine Entfernung von $10 \mathrm{zu} 10^{\mathrm{cm}}$ auf die so weit hergestellte Lehmform gut aufgerieben. Die entstandenen Felder zwischen den Eisenschienen werden nun wieder mit Lehm ausgefüllt und weiter dann der ganze Corpus mit einer $1 / \mathrm{c}^{\mathrm{cm}}$ starken Schichte Lehm iberzogen. Nachdem die Form so weit vorgeschritten und wieder getrocknet wurde, setzt man, wie nach Fig. 1369 ersichtlich ist, einen gusseisernen Ring $g$ iiber das Eisengerippe und verbindet selben wieder innig mittelst Lehm mit der zuletzt aufgetragenen Lehmsehichte. Der jetzt neu auf die Form gebrachte Lehm muss gut getrocknet werden, weil man widrigenfalls leicht Gefahr laufen könnte, dass beim Abheben des Mantels $m$ der King iiber die Form abglitte.

Bei vorausgesetzt vorsichtiger Manipulation kann dies nicht so leicht vorkommen, und olne Anstand lässt sich der Mantel der Form von der mit Asche bestrichenen Trennungsfläche des frïher anfgetragenen Hemdes (Eisenstärke) abheben. Nun schreitet man zum Ablösen der Eisenstärke und überzieht hierauf, nachdem man friiher den Kern von den anhängenden Aschentheilen befreit und die vorgekommenen Risse ausgebessert hat, mit Graphitschwärze und trocknet den Kern gut durch. Auch der Mantel wird jetzt ausgebessert, die etwa vorkommenden Modelltheile, Lappen, Stiitzen u. s. w. aus selben herausgezogen, und schliesslich so wie der Kern mit in Wasser angemachtem Graphit bestrichen und gut getrocknet. Beim Zusammensetzen der Form wird vorerst der Kern in die Dammgrube gebracht, der innere hohle Raum mit Sand angefiillt, die zuriickgebliebene Oeffinung nach der Form des Kernes mittelst Lehm geschlossen, und der Mantel nach den, vor dem Abheben angedeuteten Zeichen dariiber gesetzt. 
Friher unter den Ring $a$ in die Dammgrube gelegte drei Eisenschienen werden gegenïber den sechs angegossenen Lappen $l$ des Mantelringes g gebracht und durch Schrauben verbunden. Auf diese Weise wird der Mantel der Form mit dem Kern fest zusammengezogen. Weiter wird die Form vorsichtig eingedämmt und iiberdies noch mit Beschwereisen belastet. Durch ausgesparte Kanäle in dem Sand wird Sorge getragen, dass die während des Gusses sich bildenden Gase leichten Abzug aus dem Kern, so wie aus dem Mantel der Form erhalten. Die an der höchsten Stelle der Form angebrachten Gusskanäle sollen nicht zu stark sein, um dem Aussprengen beim weiteren Putzen des Gussstiickes vorzubengen. Dieser schwachen Gusskanäle bringt man 4 an, deren Durchmesser $19^{\mathrm{mm}}$ nicht übersteigen soll, vereinigt selbe ausserhalb der Form in eine Mulde und der Guss kann vor sich gehen.*)

Der Schalenguss wird in der Eisengiesserei, wie früher schon erwähnt, bei solchen Gegenständen in Verwendung kommen, von denen beansprucht wird, dass selbe Härte, also in Folge dessen weniger leicht sich abniitzende Flächen besitzen. Diejenigen Flächen des Gussstïckes, welche bearbeitet werden sollen oder überhaupt das ursprünglich graue Eisen aufzuweisen haben, werden in Sand abgeformt, jene Theile, welche hart werden sollen, erhalten als Begrenzung die gusseiserne Schale. Sandform und Schale miissen genau zusammengepasst sein.

Als Beispiel eines Schalengusses sei hier die Form einer $\mathrm{Hartwalze}$ näher in's Auge gefasst. Die ganze Form besteht der Hauptsache nach aus dem Unterkasten $a$ (Fig. 1370), der Schale $b$ und dem Oberkasten $c$. Vorerst wird der Unterkasten $a g$, welcher tangential einmündet, aufgestampft, der Eingusskanal mit Zuhilfenahme des entsprechenden Modelltheiles ausgespart und die Form gut getrocknet, am Boden der Dammgrube hingesetzt. Wie in der Figur ersichtlich, passt die Schale $b$ in den ausgedrehten Theil des Kastens $a$, wie auch in den analogen Theil des Kastens $c$. Mittelst angebrachter Schrauben werden diese drei Theile fest zusammengezogen und der Eingusskanal circa 6 bis $7^{\mathrm{cm}}$ stark an den Unterkasten angepasst. Um das Reissen der Schale möglichst zu verhindern, wird selbe vor dem Giessen der Walze gut vorgewärmt. Während des Eindämmens der Walzenform in die Dammgrube wird mit Vortheil rings um die Schale ein $2^{\mathrm{cm}}$ starker Ring irn Sande ausgespart, indem mit der Schale die später zu entfernenden Holzbrettchen $i$ eingestampft werden. In diesen Raum wirl knapp vor dem Guss Eisen gegossen. Dies hat lediglich den Zweck, best. möglichst von Aussen die Schale zu erwärmen und das Springen der Schale zu verhindern. $d$ und $f$ sind Formkästen für den Gusskanal, hier S t e igrohr genannt.

Mit dem Schalenguss verwandt ist der Schwenkguss.**) In die mehrtheilige, wohl zusammengefiigte, gut vorgewärmte eiserne Form wird geschmolzenes Eisen gegossen, einige Secunden ruhen gelassen, und durch Umstiurzen der Form der noch grossentheila flüssige Inhalt entleert. Man erhält hierdurch einen sehr diinnwandigen Guss, entsprechend der an den Wandungen der Form erstarten Kruste.

Beim Centrifugalguss wird das geschmolzene Eisen in eine rotirende eiserne Form, deren Innenfläche eine Rotationsfläche sein muss, gegossen. Durch die Rotation legt sich das flüssige Eisen an die Formwandungen an und erstarrt

*) In ganz älmlicher Weise findet die Herstellung der Form für Gebläsceylinder, grosse Säulen ete. statt. Bei sehr grossen Gussstiicken muss jedoch auf die beim Erkalten eintretende Zusammenziehung des Metalles Rücksicht genommen werden. Bei der Aufmausrung des Kernes z. B. einer grossen Säule, wie solche bei Balancirmaschinen vorkommen, werden eiserne, oben in einen Ring endigende Flachschienen eingemauert und wach eingetretener Erstarrung mittelst des Krahnes aus dem Kern gezogen, damit sich derselbe zusammenziehen kann. Eben so werden unter den Mantel für das Kapitäl der Säule segmentfürmige Eisenplatten gelegt, welche man gleichfalls nach eingetretenem Erstarren seitlich entfernt, und hierdurch ein Abreissen des Kapitäls von dem Säulenschafte verlindert.

**:) Dersolbe finclet in der Hütte in Badis ch-Wiesenthal zum Gusse ron Christus-Biisten 11. dgl. Anwendung, Dingl. polyt. Jouru. 167. Bd. S. 121. 


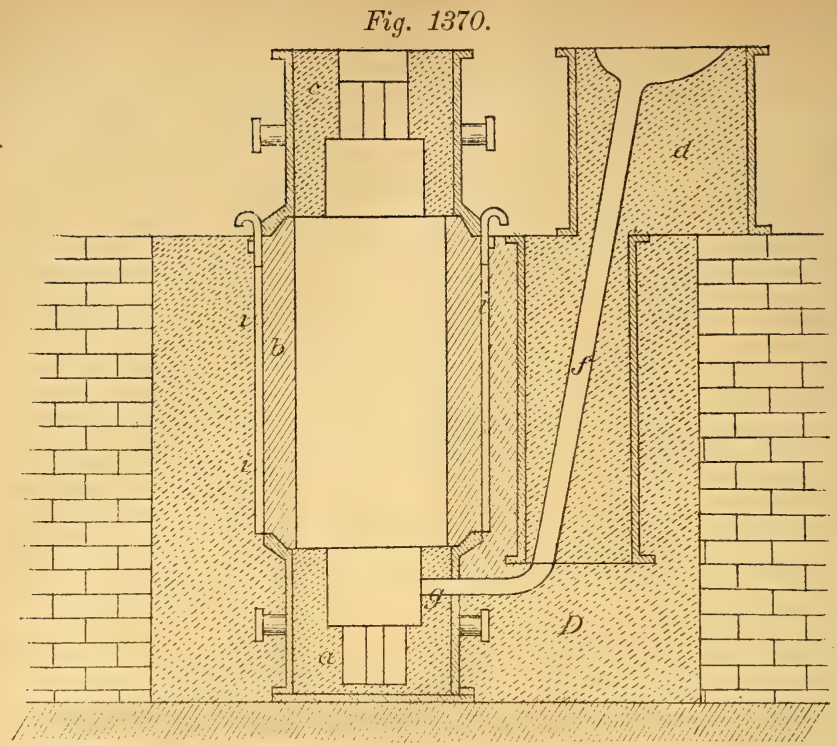

an denselben. Man hat durch Centrifugalguss Röhren und paraboloidische Hohlgefässe hergestellt. (Dingl. pol. Journ. Bd. 114 S. 326. )

Die beim Eisengusse selbst zu beobachtenden Vorsichten sind der Hauptsache nach die gleichen, welche auch beim Giessen anderer Metalle eingehalten werden mïssen; desgleichen bietet die Nacharbeitung oder Appretur der Gussstiicke nichts Eigenthiimliches, so dass beziiglich dessen anf den Artikel Giesserei verwiesen wird.

Literatur: Karsten's Eisenhittenkunde Bd. III. - Technol. Eneycl. von

Prechtl, Bd. V S. 70-121, Bd. 22 S. 613. - D iire, Eisengiesserei

2. Bd. Leipzig, Felix 1870-1875. - Ueber Formmaschinen siehe Kerpeli J. B. ii. Fortsch. in Eisenhittenwesen, ferner Dingler's polyt. Journ. u. A. Anton Belani.

Eisenglanz, s. Rotheis en erz.

Eisenglimmer, schuppige Form ron Eisenglanz, s. Rothe is en erz.

Eisenglimmerschiefer, ein schiefriges Gemenge ron mehr oder weniger Quarz mit schuppigem Eisenglanz, wodurch das Gestein glimmerschieferartig wird. Ist in Schweten ein sehr rerbreitetes Erz, kommt namentlich in der Gegend ron Nonberg reichlich vor, und ist hauptsächlich jenes, welches von den Schweden als "diirres Erz" (törr Maln) bezeichnet wird (wegen des Bedarfes von Zuschlägen zur Schmelzumg). In Brasilien und Siidcarolina bildet der Eisenglimmerschiefer zwischen Thonschiefer und Stakalemit mächtige Schichtensysteme. Sonst ist er sehr untergeordnet verbreitet. $L h$.

Eisenglühspan, Eisenhammerschlag, Schmiedesinter (ecailles scale), s. Eisen bei Eisenoxyduloxyd II pag. 764 .

Eisengranat, s. Granat, s. P yrop.

Eisenguss hämmerbarer oler schmiedbarer (fonte malléable - annealde cast iron), adoncirter Eisenguss, s. Bd. I S. 48 u. Bd. III S. 41. 
Eisengyps, s. Vivianit.

Eisenhammerschlag, s. Ei s englüh s a n.

Eisenhämmer, s. III S. 39.

Eisenhochofen, s. III S. 6 bis 18.

Eisenholz (bois de fer), Eisengrenadill, wird besonders hartes Grenadillholz genannt (s. d.), übrigens führen auch andere Hölzer den Namen Eisenholz, s. z. B. das Holz von Mesua ferrea, M. speciosa, Metrosideros vera, Cupania Sideroxyton, Siderodendron triflorum u. a.

Eisenjodid und Eisenjodür, s. Eis en II pag. 766.

Eisenkali blausaures, s. Blutlaugensalze I pag. 662.

Eisenkalkstein, o olithis cher Kalkstein, s. Eis enoolith.

Eisenkies. Man unterscheidet den hexaëdrischen Eisenkies oder Pyrit, dann den prismatischen Eisenkies, d. i. Markasit oder Wasserkies, und den rhomboëdrischen, d. i. Magnetkies, s. bei Pyrit, bei Markasit und bei Magnetkies, vgl. a. Eisen II pag. 767. Gtl.

Eisenkiesel, s. Quarz.

Eisenkitt, s. Kitte.

Eisenlack, gewöhnlich eine Auflösung von Asphalt in Terpentinöl oder Benzin. Vgl. Asphalt I pag. 216, s. a. Lacke. Gtl.

Eisenlegirungen, s. Eis en II pag. 769.

Eisenmangan, Ferromangan, s. Eisen bei Eisenlegirungen II pag. 769 .

Eisenmennige, s. Eisen bei Eisenoxyd II pag. 760 .

Eisenmohr (aethiops martialis), Eisenoxyduloxydhydrat, s. Eisen II pag. 764 .

Eisenmulm, syn. mit erdigem Rotheisenerz oder Magneteisenerz, s. d.

Eisennickelkies. Ein tesseral krystallisirendes, auch derb und in körnigen Aggregaten vorkommender Kies von der Zusammensetzung $2 \mathrm{FeS}+\mathrm{NiS}$ mit 36 Schwefel, 22 Nickel und 42 Eisen nach Scheerer. Härte $3 \cdot 5-4$, spec. Gew. $=4 \cdot 6$, Farbe licht tombackbraun, Strich dunkel, nicht magnetisch. Findet sich zu Lillehammer in Norwegen. $L b$.

Eisenniere, knollige nierenförmige Massen von Thoneisenstein, s. Brau ne is en erz.

Eisenocher, Eisenocker, s. Ocher.

Eisenöl, s. Eisen II pag. 766 .

Eisenoolith, Eis enrogenstein, o olithis ches Eisenerz. Eine Varietät des Rotheisenerzes oder auch Brauneisenerzes, bestehend aus kleinen gerundeten rothen oder braunen Körnern von Rotheisenstein und Brauneisenstein oder nur von einem derselben, namentlich des ersteren. Die Körner sind meist flach, linsenförmig, entweder selbstständig verwachsen, oder sie werden durch thonige oder kalkige Bindemittel zusammengehalten. Die Eisenoolithe bilden selbstständige Lager in Sedimentärformationen von der silurischen bis in die Kreideformation. Hierher gehören die Eisensteinlager des mittleren Böhmens bei Zdic, Zbirow, Neu-Joachimsthal n. s. w., die in Herkimes und Oreida Counti im Staate NewYork in N.-A. auftretenden aus dem Silur, die Eifler ron Lissingen bei Gerol- 
stein, Dollendorf u. s. w. aus dem Devon. Von beträchtlicher Mächtigkeit sind auch die bei Aalen in Württemberg im unteren Dogger auftretenden Eisenoolithflötze, welche gIeichfalls bergmännisch gewonnen werden. $L b$.

Eisenopal, so viel als Jaspopal, s. O pal.

Eisenoxyd und Eisenoxydsalze, s. Eis en II pag. 760.

Eisenoxydul und Eisenoxydulsalze, s. Eis en II pag. 756.

Eisenoxyduloxyd, s. Eis en II pag. 764.

Eisenpecherz; s. Triplit und Stilpnosiderit.

Eisenphosphorete, syn. mit Phosphoreisen, s. Eisen II pag. 768.

Eisenplatin, Platin mit einem Gehalt von 11-19\% Eisen, welches sich meist nur in kleinen Körnern von dunkelstahlgrauer Farbe, Härte 6, spec. Gew. $=14-15$, starkem Magnetismus in den Platingruben von Nischne Tapinsk am Ural findet. $L b$.

Eisenrahm, s. Rotheis en erz.

Eisenresin, $\mathrm{Humboldtin,} \mathrm{Ox}$ alit, Mineral, ist natülich vorkommendes Eisenoxalat, s. Eis en II pag. 760.

Eisenrogenstein, syn. mit Eis enoolith, s. d.

Eisenrose, eigenthïmliche rosen- oder rosettenförmige Krystallgruppen und polysynthetische Krystalle von Eisenglanz oder Titaneisenerz, welche durch regelmässige und parallele Verwachsung sehr flacher lamellarer Individuen entstehen, kommen besonders schön am St. Gotthard in der Schweiz vor. $L b$.

Eisenrost, s. Eisen bei Eisenhydroxyd II pag. 761.

Eisenrostwasser, Eisenbeize, s. Eisen II pag. 763.

Eisenroth, syn. mit Polirroth, Engelroth, Englisehroth etc., s. Eisen II pag. 761 .

Eisensaccharat, Eisenzucker, s: Eisen II pag. 764.

Eisensäuerlinge, Eis enwäs ser, Stahlwäs ser, s. W a s ser, vgl. a. Eisen II pag. 760 .

Eisensäure, s. Eis e n II pag. 765 .

Eisensafran, syn. mit Eisenoxyd und Eisenoxydhydrat, s. Eisen II pag. 760.

Eisensalmiak (flores salis martialis), s. Eis en II pag. 766.

Eisensau (renard - bear, horse), 0 f e n s a u (Wolf, Härtling, Büne). Huittenmännischer Ausdruck für die in dem Boden des Hochofengestelles eingeschmolzenen Eisenmassen, welche vorherrschend aus Eisen, oft neben Zink, Nikel, Kobalt, Mangan, Kupfer, selbst Silber und Gold, dann Schwefel, Phosphor, Arsen, Antimon, Kiesel, endlich Titan, gewöhnlich in der Form von Cyantitan-Stickstofftitan. Grtl.

Eisenschaum, Garschaum, hïttenmännische Bezeichnung für den im Roheisen enthaltenen, mechanisch beigemengten Kohlenstoff (Graphit), welcher beim Auflösen des Eisens in Säuren ungelöst zurïckbleibt. Gtl.

Eisenschlacken (laitier, scorie _ slag, iron-dross cinders), s. Eis enhittenkunde III pag. 12 und 22. Sie sind zumeist entweder Hochofenschlacken (scoric cinders) oder Frischschlacken (rifining cinder's). Erstere werden als Beschotterungs- und Baumateriale und zur Erzeugung ron Schlackenwolle, s. d., letztere selbst wieder zur Eisengewinnung verwendet 
Eisenschwamm, s. Eisen II pag. 756.

Eisenschwärze (gris de fer - iron liquor), Gemenge von löslichen Eisensalzen (Eisenbeizen) mit gerbstoffhältigen Materialien, welche zum Schwarzfärben, namentlich in der Lederfärberei, verwendet werden, vgl. Z e u g färberei. Denselben Namen fiihrt iibrigens auch der Graphit, welcher bekanntlich zum Einschwärzen von Eisenwaaren verwendet wird. Gtl.

Eisenschwarz (couleur de bronze - bronze paint) ist fein vertheiltes, durch Fällung von Antimonchloridlösungen mit Zink dargestelltes Antimon, welches als Farbe dient. Gtl.

Eisensinter, syn. mit A rseneisensinter oder Pittizit.

Eisenspaltwerk, s. bei S cheren.

Eisenspath, s. Spatheisenstein, vgl. a. Eisen II pag. 759.

Eisensteinmark, sächsische Wundererde, Teratolith, derbe, bolusartige Erde von bläulicher oder granlicher Farbe, worin lichte Flecken und Adern síchtbar sind. Strich gleichfärbig. Findet sich bei Planitz in Sachsen, und wurde ehedem wie die Terra sigillata in der Apotheke gebraucht, vgl. Bolus I pag. 724. $L b$.

Eisensublimat, syn. mit Ei is enchlorid, s. Eis en II pag. 765.

Eisensulfate, s. Eis en II pag. 756 und 759.

Eisensulfurete, s. Eis e n II pag. 767.

Eisensyrup nennt man eine wässrige Lösung von Eisensaccharat.

Eisenverband (assemblage en fer - iron-bond). Die Verbindung zweier Eisenconstructionstheile mit einander kann je nach den speciellen Fällen hauptsächlich durch folgende Mittel geschehen:

1. Nietverbindung, besonders für Bleche geeignet. Dieselben werden in bestimmten Abständen durchlocht oder durchbohrt, behufs Aufnahme des Nietbolzens. Die Verbindung der beiden Bleche geschieht entweder direct (einfache Nietnng) Fig. 1371, oder indirect, mit Zuhilfenahme von Blechstreifen (Laschennietung) oder Winkeleisen.

Fig. 1372 gibt ein Beispiel der Anwendung von Winkeleisen, wenn die Bleche rechtwinklig aneinander stossen.

2. Schraubenverbindung, zumeist dort anzu-

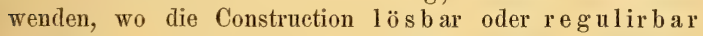
sein soll, z. B. wenn Röhren (Dampfleitungs-, Wasserleitungsröhren) mit einander verbunden werden, so geschieht dies an den Flantschen (d. s. scheibenförmige Ansätze am Ende des Rohres) mittelst Schrauben und zwischen die Flantsehen kommt eine Dichtung aus Kautschuk oder Bindfarlen.

Bei Verbindung von Zugstangen u. dgl. kann entweder der eine Theil die Schranbenspindel, der zweite die Mutter erhalten, oder beide haben SchraubenspindeIn (event.

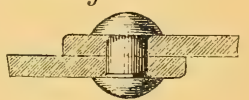

Fig. 1372.

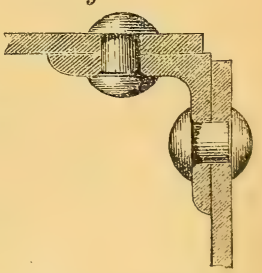
Mnttern) und durch eine Kupplungsschraubenmutter (event. Spindel) wird die Verbindung hergestellt. Fig. 1373 gibt die regulirbare Schraubenkupplung eines Zngstange für eine Dacheonstruction.

3. Keilverbindung. In entsprechende Oeffnungen der beiden zu verbindenden Eisenbestandtheile wird ein Keil (oder anch zwei Keile, nämlich Keil mit Gegenkeil) eingetrieben. Das Ineinandergreifen der Eisentheile kann verschieden stattfinden. Fig. 1374 zeigt eine Stangenverbindung, wo der eine Theil den zweiten gabelförmig umfasst. 
Fig. 1374.

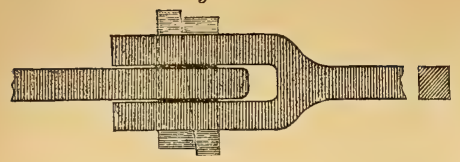

4. Muffenverbindung, nur bei Röhren (z. B. Wasser- und Gasleitungsröhren) angewendet. Das eine Rohr hat an einem Ende eine Erweiterung (Muffe), in welche das zweite Rohr einpasst. Die Fuge wird durch Kitt, Wergtau oder einen Bleiring gedichtet.

5. Falzverbindung, zumeist bei Dacheindeckung mit Blech verwendet; siehe Dachdeckung Bd. II S. 494 und Bd. I S. 545.

6. Z a p fenverbindung, bei schwachen Eisenconstructionen, z. B. bei Geländern, Fenstern etc. angewendet.

a) Der einfache gerade Zapfen des einen Eisens wird durch eine entsprechende Oeffnung des zweiten durchgesteckt und entweder auf der entgegengesetzten Seite umgenietet oder im Loche festgestemmt oder verschraubt.

b) Ist der Zapfen schwalbenschwanzförmig (trapezförmig), so muss \&r von der Seite eingeschoben werden; in vielen Fällen wird die Verbindung noch durch Vernietung oder Verschraubung gesichert.

c) Umfasst das eine Eisen das zweite theilweise oder vollständig, so heisst die Verbindung Gabelzapfen und muss verschraubt oder vernietet werden.

Fig. 1375 .

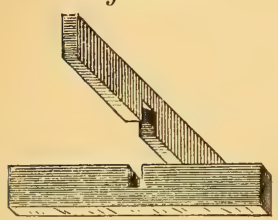

7. Verband durch Ueberblattung. Beide Eisen erhalten an der Kreuzungsstelle nach der halben Dicke Ausschnitte, so dass der übrig bleibende Körper des einen Theils in den Ausschnitt des zweiten einpasst. Fig. 1375 zeigt eine hochkantige Ueberblattung.

8. Verbindung durch Schweissung.

9. Verbindung durch Löthung.

10. Verbindung durch Verkittung. Siehe dariber die speciellen Artikel. Grohm.

Eisenverbindungen, s. Eis enverband, s. a. Eisen II pag. 755.

Eisenvitriol, grüner Vitriol, s. Eis en II pag. 756.

Eisenwalzen, s. III S. 50; iiber Theorie und Literatur s. Walzen.

Eisenzinkspath, Zinkspath ron einem grösseren Gehalt an kohlensaurem Eisenoxydul, s. Smith sonit. $L$.

Eisenzucker, Eisensaceharat, s. Eisen II pag. 764 .

Eisessig, s. Es sigsäure.

Eisglas (cerre cragnelé - craclile glass). Eine Glassorte, meist farblos, seltener gefärbt, welche an der Oberfläche durch zahlreiche, zum 'Theile wieder verflossene Spriunge zerkliiftet ist und dadurch ein eiskrustenähuliches Aussehen gewinnt, s. Glas. Gtl. S. 171 .

Eiskarton, Alabaster-oder Perlmutterpapier (papier nacré), s. I

Eiskeller, s. Eis-Keller II S. 749.

Eislebner Grün, syn. mit Schwe infurter Grỉn, s. Kupfer.

Eismaschine, s. II S. 743.

Eispunkt, Gefrierpunkt, Tha upunt (point de congélation freezing point), Fundamentalpunkt der Thermometerscalen (Celsius und Reanmur), welcher jener Temperatur entspricht, bei welcher das Eis unter gewöhnlichen Verhältnissen eben schmilzt, s. Wärmemessung. Gtl.

Eisschränke, s. II S. 753 . 
Eisspath, syn. mit Adular, s. Feldspath und syn. mit Sanidin (s. d.).

Eiweiss (blanc d'oeuf, albumine - white of eggs, albumen), s. Album in I. pag. 78 , s. Eiwe is skör per.

Eiweisskitt, s. Kitt.

Eiweisskörper (albumine - albumen), Protëinkörver. Mit diesem Namen bezeichnet man eine Gruppe von organischen Verbindungen, die sowohl im Thier- als auch im Pflanzenreiche vorkommen. Diese Verbindungen besitzen eine nahezu gleiche Zusammensetzung und haben viele Eigenschaften gemein. Gewöhnlich kennt man zwei Modificationen dieser Stoffe, eine lösliche und eine unlösliche; in ersterer Form finden sich die Eiweisskörper im Blut, in der Fleischflüssigkeit, Milch etc. gelöst.

Die Eiweissstoffe sind vielfach untersucht worden, doch ist die chemische Natur derselben noch wenig klar. Früher wurden diese Stoffe Protëinstoffe genannt, weil man von der Ansicht ausging, dass dieselben ein gemeinschaftliches Radical, das von Mulder "Protëin" genannt wurde, enthalten. Man hat aber, nachdem die Existenz des Protëins durch Liebig widerlegt wurde, den Namen Eiweisssloffe wieder aufgenommen.

Wie oben erwähnt, treten diese Körper in zwei Formen auf; man kann die lösliche Form meist leicht in die unlösliche Form durch Erwärmen, durch Einwirkung von Alkohol, Aether, Säuren etc. überführen. Alle löslichen Eiweissstoffe liefern nach dem Verdunsten amorphe gummöse Massen, nur das Hämatoglobulin kann unter geeigneten Umständen krystallisirt erhalten werden.

Von den im Thierkörper vorkommenden löslichen Eiweissstoffen unterscheidet man hauptsächlich drei Gruppen, die Fibrin-, die Albumin- und die Caseingruppe, wobei aber bemerkt werden muss, dass diese Eintheilung sich nur auf äussere Eigenschaften bezieht. Zur ersten Gruppe zählen wir diejenigen Stoffe, welche ohne besondere Reagentien, also scheinbar freiwillig in den unlöslichen Zustand ibergehen oder gerinnen (wie das Blutfibrin). Die zweite Gruppe umfasst Stoffe, die erst bei Einfluss der Wärme (bei $60-70^{\circ}$ C.) gerinnen, die letzte Gruppe endlich enthält jene Stoffe, welche durch die Schleimhaut des Kälbermagens (Lab) abgeschieden werden können.

Die löslichen Eiweisskörper geben mit verschiedenen Metallsalzen, wie Kupfer-, Quecksilber-, Blei-Salzen, ferner mit Gerbsäure, Phosphorsäure ete. Niederschläge (s. Albumin), auch mit anderen Substanzen gehen sie feste Verbindungen ein. Die wässrige Lösung hat einen faden Geschmack, reagirt nentral und dreht die Polarisationsebene nach links. Die Eiweisskörper verhalten sich wie indifferente Verbindungen, ihr Atomgewicht, das noch nicht festgestellt werden konnte, scheint, wie der geringe Schwefelgehalt $0.8-2 \%$ schliessen lässt, jedenfalls ein hoher zu sein.

Im Folgenden sind die Analysen der hauptsächlichsten Eiweissstoffe angefïhrt, alle enthalten ohne Ausnahme Kohlenstoff, Wasserstoff, Stickstoff, Sanerstoff und Schwefel. Andere Bestandtheile, wenn solche vorkommen, sind nur als Verunreinigungen $\mathrm{zu}$ betrachten.

\begin{tabular}{|c|c|c|c|c|c|c|c|c|c|c|c|}
\hline & & & & & & & $\begin{array}{c}\text { Kohlen- } \\
\text { stoff }\end{array}$ & $\begin{array}{c}\text { Wasser- } \\
\text { stoff }\end{array}$ & Stickstoff & $\begin{array}{l}\text { Sauer- } \\
\text { stoff }\end{array}$ & Schwefel \\
\hline Fleischfibrin & . & & & & & & $52 \cdot 6$ & $7 \cdot 0$ & $17 \cdot 4$ & $21 \cdot 8$ & $1 \cdot 2$ \\
\hline Blntalbumin & . & . & . & . & & . & $53 \cdot 0$ & $7 \cdot 1$ & $15 \cdot 6$ & $23 \cdot 1$ & $1 \cdot 2$ \\
\hline Eialbumin : & - & . & - & . & & - & $53 \cdot 4$ & $7 \cdot 0$ & $15 \cdot 7$ & $22 \cdot 4$ & $1 \cdot 6$ \\
\hline Pflanzenalbumin & & . & . & . & & . & $53 \cdot 4$ & $7 \cdot 1$ & $15 \cdot 6$ & $23 \cdot 0$ & $0 \cdot 9$ \\
\hline Legumin . . & . & . & • & . & & . & 51.5 & $7 \cdot 0$ & $16 \cdot 8$ & $24 \cdot 3$ & 0.4 \\
\hline Emulsin . . & . & . & . & . & . & . & $42 \cdot 9$ & $7 \cdot 1$ & $11 \cdot 5$ & $37 \cdot 3$ & $1 \cdot 2$ \\
\hline C'aseïn . . . & . . & . & . & . & & . & $53 \cdot 6$ & $7 \cdot 1$ & $15 \cdot 7$ & $22 \cdot 6$ & $1 \cdot 0$ \\
\hline
\end{tabular}


Die unlöslichen Eiweissstoffe zeigen im Allgemeinen ein gleichartiges Verhalten; Essigsäure und dreibasische Phosphorsäure, Alkalien und Alkalisalze lösen sie auf, auch durch Behandeln mit Wasser bei $160-170^{\circ} \mathrm{C}$. übergehen sie in Lösung, von Säuren, Alkohol, Aether werden dieselben aus ihren Lösungen abgeschieden.

Die löslichen und unlöslichen Eiweissstoffe zeigen noch folgendes Verhalten. Oxydationsmittel (chromsaures Kalium und Schwefelsäure, Mangansuperoxyd und Schwefelsäure) verwandeln dieselben in Fettsäuren (Ameisen-, Essig-, Propion-, Butter-, Valerian-, Capronsäure), A l d e h y de der Fettsäuren und B e n z o ësäure nebst anderen nicht näher untersuchten Producten.

$\mathrm{S}$ al petersäure (verdünnt) liefert Xanthoproteïnsäure $\left(\mathrm{C}_{36} \mathrm{H}_{54} \mathrm{~N}_{8} \mathrm{O}_{12}\left(\mathrm{NO}_{2}\right)\right.$, die als unlösliche gelbe Masse sich abscheidet, Zuckersäure und Oxalsäure bleiben gelöst. Chlorsaures Kalium und Salzsäure liefern gechlorte Verbindungen.

Schwefelsäure löst die Eiweissstoffe, mit Wasser wird eine weisse schwefelsäurehaltende Verbindung abgeschieden. Mit Zuckerlösung und Schwefelsäure werden sie roth-violett gefärbt. Jod färbt dieselben gelb, salpetersaures Quecksilber mit salpetriger Säure roth.

Durch Alkalien werden alle Eiweisstoffe unverändert gelöst, insofern die Temperatur von $30^{\circ} \mathrm{C}$. nicht überschritten wurde, bei $40-50^{\circ} \mathrm{C}$. entwickeln sie Schwefelwasserstoff und erleiden eine tiefer gehende Zersetzung, bei längerem Kochen mit Alkalien liefern sie Ammoniak, beim Schmelzen mit Kaliumhydroxyd flüchtige Ammoniakbasen und als Rïckstand valeriansaures und buttersaures Kalium neben Tyrosin und Leucin (s. d.).

Durch den Pankreassaft und Magensaft werden die unlöslichen wie die löslichen Eiweissstoffe in lösliche Stoffe, sog. Peptone verwandelt.*)

Beim Erhitzen schmelzen die Eiweissstoffe, blähen sich auf und verkohlen, bei der trockenen Destillation liefern sie Aminbasen und schwefelhaltige Oele.

Es sollen hier in Kïrze die wichtigsten Eiweisskörper betrachtet werden.

I. Fibrine.(fibrine - fibrin). Blutfibrin, Thierfibrin, Blutfaserst off genannt, findet sich im Blute der lebenden Thiere im gelösten Zustande. Sobald das Blut aus dem Körper austritt (oder aber nach dem Tode des Thieres), geht das lösliche Blutfibrin in die unlösliche Modification iiber. Das Blut gerinnt, die geronnene, aus Fibrin und allen im Blute vorkommenden festen Substanzen (Blutzellen, Lymphkörpern etc.) bestehende Masse wird Blutkuchen (cruor) genanut, die darïber stehende Flïssigkeit bildet das Blutserum. Das Fibrin kamn am besten durch Schlagen (Peitschen) des Blutes gewomnen werden, es scheidet sich in Form von Fäden ob, die mit Wasser gewaschen vollkommen weiss sind. Das unlösliche Fibrin ist in Alkalien, ferner in salpetersaurem Kalium löslich, anch von Wasser wird es bei $150^{\circ}$ C. unter erhöhtem Druck aufgenommen. Mit Wasser gekocht (bei $100^{\circ} \mathrm{C}$.) entwickelt es Ammoniak und liefert leimartige Substanzen. ${ }^{*}$; $)$

Muskelfibrin (Musculin, Syntonin) enthält Kohlenstoff 54.9, Wasserstoff $7 \cdot 3$, Stickstofi $16 \cdot 2$, Sauerstoff $20 \cdot 5$, Sehwefel $1.1 \%$. Findet sich im ungelösten Zustande in den Muskeln der höher organisirten Thiere in Form von feinen elastischen Fasern; durch Anslangen des Fleisches mit Wasser (wobei Kreatin, Xanthin, Fleischmilchsäure ete. entfernt werdeu) erhält man einen hauptsächlich aus Syntonin bestehenden Rïckstand. Wird derselbe mit sehr verdinnter Salzsäure behandelt, so lïst sich Syntonin auf, welches durch kohlensaures Natrium gefällt werden kanı. Die meisten Eiweissstoffe liefern mit Salzsäure behandelt ebenfalls Syntonin. Die Lösungen des Syntonins in Salzsäure besitzen ein bedentendes optisches Drehungsvermögen $\left(-72^{0}\right)$.

Neben Syntonin kommt im Fleische noch Myosin aber in löslicher Form vor, nach dem Tode findet es sich im geronnenen Zustande.

Chem. Contralhl. 1867 pag. 411.

**) Das Niblere dariiher wie iiber das run Denis Plasmin genannte s. Jahresb. der Chemie 1861 pag. 795, auch Chem. Centrallhl. 1865 pag. 759. 
Pflanzenfibrin kommt hauptsächlich in den Samen der Pflanzen vor, man gewinnt es aus dem Kleber, einem Körper, der beim Kneten von Mehl in einem Leinwandsäckchen unter Wasser als gelbgraue elastische Masse zurückbleibt. Der Kleber enthält hauptsächlich Pflanzenfibrin nebst Glyadin, Mucin und Legumin. Man kann das Pflanzenfibrin durch Auskochen des Klebers mit Alkohol in unlöslicher Modification gewinnen. Dasselbe löst sich in Ammoniak, Alkalien, Phosphorsäure, Essigsäure auf.

II. Albumine (albumine — albumen). Thieralbumin, Eiweiss, A Ib u min. Das Albumin kommt in löslicher Form in vielen thierischen Flüssigkeiten vor, hauptsächlich im Blutserum, im Weissen der Vogeleier, im Chylus, in der Lymphe, der Milch u. s. w. Abnormal findet sich dasselbe auch im Harn. Ueber die Eigenschaften und Gewinnung des Albumins siehe Albumin I pag. 78. In unlöslicher Form kann dasselbe durch Kochen oder durch Einwirkung von Mineralsäuren dargestellt werden. Die Lösungen des Albumins werden mit Bleiessig (bas.-essigs. Blei), Quecksilberchlorid, etc. gefällt, Eisenchlorid und neutrales Bleiacetat fällen die Lösung nicht (Drelungsvermögen 35\%). Mit Alkalien liefert das Albumin Verbindungen, welche frisch bereitet löslich sind. Eine zweite Modification des Albumins ist das Paralbumin, welches sich in den Ovarialcysten vorfindet. Dasselbe zeichnet sich durch ein ausserordentliches Drehungsvermögen $=\left(-70^{0}\right)$ aus.

Vitellin. Albumin aus dem Eigelb. Ein wesentlicher Bestandtheil des Eidotters, die Lösung desselben coagulirt bei $70^{\circ} \mathrm{C}$. und hat dasselbe im coagulirten Zustande dieselben Eigenschaften wie das gewöhnliche Albumin und Myosin.*)

Blutalbumin (Serin, Serosin, Serumalbumin) kommt neben gewölnnlichem Albumin im Blutserum vor, dasselbe ist dem Albumin ähnlich, besitzt aber ein grösseres Drehungsvermögen $=-56^{\circ}$. S. Albumin I pag. 78 .

Globulin (Krystallin, Blnteasëin) ist ein in der Krystalllinse enthaltenes Albumin, welches sich vom gewöhnlichen durch ein grösseres Lichtbrechungsvermögen unterscheidet, auch gerinnt dasselbe erst bei $93^{\circ} \mathrm{C}$.

Hämoglobin (Hämoglobulin), der wesentlichste Bestandtheil der Blutkörperchen des Blutes der Säugethiere; man kann diesen Körper aus Blut gewinnen, aus welchem man das Fibrin (durch Peitschen) entfernt hat, versetzt man so ein Blut mit Alkohol und Wasser, so scheiden sich rothe Krystalle von Hämoglobulin ab. Die Krystalle sind prismatisch oder tafelförmig, dichroitisch, u. zw. scharlachroth und bläulich. Die wässrige Lösung desselben zeigt 2 breite $\mathrm{Ab}$ sorptionsstreifen im Spectrum, u. zw. in gelb und griun. Diese Reaction ist sehr empfindlich und verlässlich. Mit Säuren und Alkalien spaltet sich das Hämoglobin in Hämatin und Globulin.

Das Hämatin (Blutfarbstoff) kann durch Zersetzung des Hämoglobins mit Kochsalz und Essigsäure gewonnen werden. Dadurch entsteht eine Salzsäureverbindung des Hämatins, die mit Ammoniak zersetzt reines Hämatin liefert. Dasselbe ist blauschwarz, in Alkalien leicht löslich, unlöslich in Wasser, Alkohol, Aether. Das Hämatin verbindet sich mit Mineralsäuren, die Verbindungen sind meist krystallisirt.

Pflanzenalbumin. Sitosin, Pflanzeneiweiss ist in den meisten Pflanzen enthalten, hauptsächlich in den Samen der Getreidearten, der Papilionaceen und in den Blättern der Cruciferen. Man kann es durch Auswaschen des Weizenmehls erhalten. Der Kleber bleibt zuriick, das Albumin löst sich auf, durch Erhitzen coagulirt das Pflanzenalbumin. Es ist dem Thieralbumin ähnlich.

Der Kleber enthält, wie oben bemerkt, Pflanzenfibrin neben M ucin und Gly a din, diese letzteren eiweissartigen Körper können durch schwachen Weingeist ausgezogen werden. Setzt man starken Alkohol zu der so bereiteten Lösung, so scheidet sich Mucin oder Mucedin aus, das Mucin liefert unter geeigneten Umständen mit Schwefelsäure erhitzt Glutaminsäure.**)

Chem. Centralhl. 1867 pag. 852.

** Journ. f. prakt. Chemie Bd. 99 pag. 454, Bd. 103 pag. 273 u. a. a O. 
Cas ëin (caséine - casein), Thiercasëin, Käsestoff, ist in der Milch der Säugethiere in löslicher und unlöslicher Form enthalten. Rein kann dasselbe durch Behandeln der Milch mit Salzsäure, Lösen des Rückstandes in lauem Wasser, Ausfällen mit kohlensaurem Natrium und Auswaschen mit Alkohol und Aether dargestellt werden. Auch durch Fällung der Milch mit Essigsäure, Abpressen, Auswaschen mit Aether erhält man ein reines Product. Das coagulirte Casëin ist nur bei Zusatz von Säure und Alkali im Wasser löslich (s. Cas ëin II pag. 427). Mit Alkalien und alkalischen Erden geht es Verbindungen ein. Mit Alkalien geschmolzen liefert es Leucin und Tyrosin.

Pflanzencasëin (Legumin) ist in den Samen der Hülsenfrüchte enthalten. Durch Behandeln der zerkleinerten Früchte mit Wasser geht dasselbe in Lösung über, mit Essigsäure scheidet sich das Legumin vollkommen ab, dasselbe ist in Aether und Alkohol unlöslich, Alkalien lösen es auf. Ueberhaupt verhält sich das Legumin dem Casëin ähnlich. Das aus den Mandeln u. a. Früchten dargestellte Casëin führt den Namen Conglutin. An diesen Körper schliesst sich die Synaptase, auch Emuls in genannt, ein in den Mandeln vorkommender Stoff, an; derselbe wird wie das Legumin gewonnen. Er wirkt auf Amygdalin und ähnliche Stoffe als Ferment. In Wasser ist er löslich, kann mit Säuren ausgeschieden werden. Aehnlich dem Emulsin ist die Diastase, ein Zersetzungsproduct des Klebers, welche ebenfalls als Ferment wirkt und Stärke in Zucker umwandelt (s. Bier).

J. V.J.

Eiweissleim (colle gluten, colle albuminö̈de -- gluten decomposed by putrefaction). Ueberlässt man den KIeber im ausgewaschenen Zustande bei einer Temperatur von $15-25^{\circ}$ C. sich selbst, so tritt alsbald Zersetzung ein, bei welcher sich zunächst ein Antheil von Milchsäure bildet. In Folge des Auftretens dieser Säure wird die Klebermasse flüssig und löst sich nach geraumer Zeit vollständig in Wasser. So veränderter Kleber wird gewöhnlich auf flachen Tassen getrocknet und bildet nach dem Trocknen (bei einer $30^{\circ} \mathrm{C}$. nicht iibersteigenden Temperatur) Tafeln ron Eigenschaften, welche ihn dem Leim ähnlich erscheinen lassen (Kleberleim). Er wird in 2 Thl. Wasser gelöst gleich dem Lein verwendet, dient wie dieser zur Bereitung von Schlichten, so wie für Zwecke der Appretur in der Färberei und Druckerei, endlich als Klärmittel für Flüssigkeiten u. s. w. Gtl.

Eiweisspapier, s. Album in papier I. pag. 84.

Ejector, s. Injector.

Eklogit, Omphacitfels, Smaragditfels, ein Gestein bestekend aus einem körnigen Gemenge von griinem oder gratem Smaragdit und rothem Granat. Hat nur eine geringe Verbreitung und bildet stockartige Einlagerungen in krystallinischen Schiefern. Z. B. an der Samalpe in Kärnthen, Bacheralpe in Steiermark, Eppenreuth bei Hof im Fichtelgebirge u. a. a. O. Lb.

Ektypographie, Blindendruck, s. I S. 641, feruer A etzen ,erhabene Manier" I S. 55.

Elaeolith, syn. mit Nephelin.

Elaeometer (eleométre - cleometer). Ein ron Berjot (Repert. de chim. appl. II pag. 160) zur Bestimmung des Oelgehaltes der Velsamen angegebener Apparat zur erschöpfenden Extraction gewogener kleiner Mengen von Oelsamen mittelst Schwefelkohlenstoft. Die Oelgehaltsbestimmung erfolgt durch Wägung des nach Verjagung des Schwefelkohlenstoffs hinterbleibenden Oeles.

Den Namen Elaeometer führt iibrigens auch ein von A. Vo gel (Dingl. pol. Journ. 168 pag. 267) construirter Apparat zur Bestimmung des Fliissigkeitsgrades eines fetten Oeles, der bekanntlich für die Beurtheilung der Eignung eines Oeles zu Beleuchtungszwecken insoferne in Betracht gezogen werden muss, als von dem 
Fliissigkeitsgrade die Quantität des in der Zeiteinheit in einem Dochte von bestimmter Qualität durch Capillarität aufsteigenden Oeles und also indirect der Beleuchtungseffect abh än ist. Der Apparat bestelit wesentlich aus einem mit einer Cub.-Centim.-Theilung versehenen Glasrohre von $4^{\mathrm{cm}}$ Weite und $34^{\mathrm{cm}}$ Höhe, dessen untere Oeffnung bis auf $3.5^{\mathrm{mm}}$ verengt und mit einem eingeschliffenen Glasstabe verschliessbar ist, so dass man durch Heben des Glasstabes eine in dem aufrecht stehenden Rohre befindliche Flüssigkeit plötzlich zum gleichıässigen $\mathrm{Ab}$ fliessen bringen kann. Dic Bestimmung des Flüssigkeitgrades, die selbstvenständlich nur eine vergleiehende sein kann, wird nun in der Weise vorgenommen, dass man genau die Zeit misst, inngrhalb welcher eine bestimmte Menge der zu prïfenden Flïssigkeit aus dem Rohre abfliesst, wozu man sich bequem einer kleinen Sandulır bedient. Als Basis für die Vergleichung wählt Vogel die Menge des in der Zeiteinheit ablaufenden destillirten Wassers ( $=100$ gesetzt). Laufen z. B. bei mittlerer Temperatur aus dem Messrohre in der Zeit von $1 / 2$ Minute $272^{\text {cc }}$ ab, während von raffinirtem Rapsöl $144^{\text {re }}$ und von rohem Rapsöle $122^{\text {ce }}$ in der gleichen Zeit abliefen, so wäre das Verhältniss der Flüssigkeitsgrade, wenn Wasser $=100$ gesetzt wird, für raff. Rapsöl $=52$ und für rohes Rapsöl $=44$. (Vgl. a. W agner, Jahr.-Bericht 1863 pag. 565.) Gtl.

Elaeopten (élaeoptène - elaoptene), Hygrusin, nennt man im Gegensatze zu Stearopten (d. i. dem bei der Abkühlung sich ans gewissen ätherischen Oelen abscheidenden festen Antheile) den bei der Abkühlung fliissig bleibenden Antheil gewisser ätherischer Oele. Gtl.

Elaërin (élaeérine - oleine in wool grease), nach Chevreul (vgl. Dingl. pol. Journ. 85 pag. 222) eine unverseifbare Fettsubstanz aus dem Wollschweisse. Schmilzt bei $15^{\prime \prime} \mathrm{C}$. und sieht dem Terpentin ähnlich. Gtl.

Elaïdin (elaidine - elaidine). Ein durch Einwirkung von salpetriger Säure auf Olëin entstehendes starres Umwandlungsproduct, das bei $32^{\circ}$ C. schmilzt und in Alkohol schwer, dagegen in Aether leicht löslich ist. Wurde seinerzeit als Materiale für Zwecke der Kerzenfabrication empfohlen (s. Olëin). Gtl.

Elaïdinsäure, s. bei 0 els äure.

Elaïn, s. $01 \ddot{\text { in }}$.

Elaïnsäure, s. O e ls ä ur e.

Elasticität und Festigkeit (élasticité et compacité - elasticity cund fastness). Die Elasticität (von $\varepsilon \lambda_{\imath}(\omega$, ich treibe), Spannkraft oder Federkraft ist jene Kraft, mit welcher die Körper einer vorübergehenden Formänderung widerstehen, oder jene Kraft, welche die Formänderung wieder aufzuheben suc't, wenn die äusseren Kräfte, welche diese veranlassten, zu wirken aufhören. Mau nennt den Inbegriff der auf einen Körper wirkenden äusseren Kräfte, die Belastung desselben und den Körper selbst den Träger dieser Belastung. Wird nach der Beseitigung der Belastung die ursp. ungliche Form des Trägers durch die Elasticität genau wieder hergestellt, so sagt man, der Träger verhalte sich vollkommen elastisch; ist dies aber nicht der Fall, d. h. verschwindet die Formänderung nach der Wegnahme der Belastung nicht gänzlich, so sagt man, der Träger verhalte sich unvollkommen elastisch. Die grösste Formänderung, welche ein Träger durch die allmälige Belastung erleiden kann und welche bei Beseitigung der Last verschwindet, heisst die Elasticitätsgrenze, und die Belastung, durch welche diese Grenze erreicht wird, die Elasticitätsgrösse oder Grenzbelastung.*)

*) Uebrig€ns wird die Bezeichnung Elasticitäts grenze gewöhulich auch für Elasticitätsgrösse angewendet und folgen wir diesem Gebrauche auch im Folgenden; weil stets leicht erkennbar ist, in welchem Sinne dieses Wort gebraucht wird. 
Es versteht sich von selbst, dass beide sowohl von der materiellen Beschaffenheit als auch von der Form und Grösse des Trägers abhängen.

Wird durch die Belastung die Electricitätsgrenze überschritten, so erfahren die einzelnen materiellen Punkte desselben eine bleibende Verrüickung, durch welche meist auch eine Aenderung der ursprünglichen Cohäsion bedingt ist. Jener Theil der Formänderung, welcher alsdann nach der Beseitigung der Belastung wieder verschwindet, heisst die elastische, während der zurïckgebliebene Theil die bleibende oder permanente Formänderung genannt wird.

Erfolgt endlich bei stetiger Zunahme der Belastung und der hiermit fortschreitenden Formänderung eine Trennung der materiellen Theilchen, d. h. tritt ein Bruch des Trägers ein, so wird die ganze Cohäsion des Materiales an der Bruchstelle überwunden und im Augenblicke des Bruches das Mass der sogenannten Festigkeit erreicht.

Festigkeit ist also der durch die Belastung eines Trägers in demselben hervorgerufene maximale Widerstand gegen die Trennung seiner Theile.

Je nach der Art der Belastung und der durch dieselbe erzielten Formänderung unterscheidet man mehrere Arten der Elasticität und Féstigkeit, wie z. B. die Zug-, Druck-, Schub-, Biegungs- und Drehungs-Elasticität, resp. Festigkeit.

Sollen die Träger die Belastung für die Dauer mit hinreichender Sicherheit tragen, so darf durch die Belastung die Elasticitätsgrenze nicht ïberschritten, ja in den meisten Fällen nicht einmal erreicht werden; denn die Träger sind ausser der Belastung mehr oder weniger momentanen Erschiitterungen oder Stössen ausgesetzt, die sich häufig eben so wenig wie die schädlichen Einflüsse der Atmosphärilien in Rechnung bringen lassen und doch berücksichtigt werden müssen. Es gilt daher bei definitiven Bauten als Regel, dass durch die grösstmögliche Belastung die Elasticitätsgrenze der einzelnen Constructioustheile des Trägers nicht erreicht werde.

Die zulässige Belastung darf also nur cinen aliquoten Theil der betreffenden Elasticitätsgrenze betragen. Bezieht man die Elasticitätsgrenze auf die Flächeneinheit, so heisst ihre Grösse der Grenzmodul (oder Elasticitätsgrenze), und dieser ist wieder ein aliquoter Theil des Festigkeitsmoduls, d. i. des Bruchwiderstandes pro Flächeneinheit.

Nach zahlreichen Versuchen liegt fiir die versehiedenen Eisen- und Stahlsorten das Verhältniss des Grenz- und Festigkeitsmoduls zwischen $0 \cdot 7$ und $0 \cdot 4$, beträgt also im Mittel circa 0.5 . Für Holz beträgt dieses Verhälniss circa $0 \cdot 3$. Da jedoch die Elasticitätsgrenze, resp. der Greuzmodul, für alle Baumaterialien noch nicht ermittelt wurle, so pflegt man die zulässige Beanspruchumg des Materiales (pro Flächeneinheit) gewöhnlich durch eimen aliquoten Theil des Bruchoder Festigkeitsnoduls anzugeben, und nennt die Zahl, mit der man den Festigkeitsmodul dividiren muss, $1 \mathrm{~m}$ die zulässige Beanspruchung pro Flächeneinheit zu erhalten, den Sicherheitscö̈fticienten. Er beträgt bei Trägern aus Metall 3 bis 6 , aus Holz 6-12, aus Stein 20-30. Der Sicherheitscoëfficient wird um so grösser gewählt, je mehr dic Belastung des Trägers variirt, je grösseren Erschiitterungen derselbe ansgesetzt ist und je mehr der Festigkeitsmodul des Materiales, ans welchem der Träger bestelit, schwankt. Die folgende Tabelle gibt die iblichen Werthe des Sicherheitscoëfficienten für die gangbarsten Baumaterialien und Belastungsweisen. ${ }^{*}$ )

*) In nenester Zeit wurken von mehreren herrorragenden Ingenieuren audere Bestinmmugsweisen der zulässigen Inansiruchnahme der Baumaterialien für voräuderliche Belastungen in Vorschlag gebracht, die wir im Anlange in dem Kapitel Arbeitsfestigkeit crwähnen werden. 


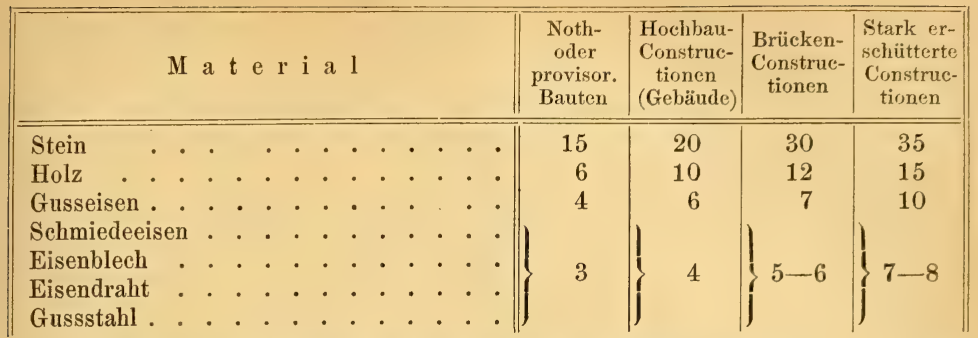

Die nachstehende Tabelle gibt die Werthe des Festigkeitsmoduls und der Elasticitätsgrenze oder des Grenzmoduls für mittelgute Materialien in Kilogramm per $\square$ em

\begin{tabular}{|c|c|c|c|c|c|c|c|c|}
\hline \multirow{2}{*}{\multicolumn{2}{|c|}{ Materiale }} & \multicolumn{3}{|c|}{ Festigkeitsmodul für } & \multicolumn{3}{|c|}{ Elasticitätsgrenze für } & \multirow{2}{*}{$\begin{array}{l}\text { Speci- } \\
\text { fische } \\
\text { Dichte }\end{array}$} \\
\hline & & Zug & Druck & Schub & Zug & Druck & Schub & \\
\hline & & \multicolumn{6}{|c|}{ In Kilogrammen pr. 1 $\square$ Centimeter } & \\
\hline Aluminium . & • & 2000 & $1-$ & - & 1000 & - & - & $2 \cdot 5$ \\
\hline Blei . . . . & . & 130 & 500 & 100 & 100 & - & - & $11 \cdot 4$ \\
\hline Bronze . . . . & . & 2300 & - & 1840 & 440 & - & - & $8 \cdot 8$ \\
\hline Eisen gegossen . & . & 1300 & 7000 & 1040 & 500 & 1400 & 400 & $7 \cdot 25$ \\
\hline " geschmiedet & & 4000 & 4000 & 3200 & 1400 & 1400 & 1100 & $7 \cdot 7$ \\
\hline$"$ Blech.. & . & 3000 & - & 2400 & 1400 & 1400 & 1100 & $7 \cdot 8$ \\
\hline " Draht.. & . & 6000 & - & - & 2200 & - & - & $7 \cdot 8$ \\
\hline Gold-Draht . . & . & 2700 & - & - & 1300 & - & - & $19 \cdot 26$ \\
\hline Holz-Faserrichtung & 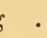 & 800 & 600 & 70 & 200 & 180 & 20 & 0.8 \\
\hline$₫$ radial .. & . & 120 & 270 & 100 & - & - & - & - \\
\hline Kupfer gehämmert & t & 2380 & 4100 & 1900 & 270 & - & 200 & $8 \cdot 94$ \\
\hline$"$ Blech. & . & 2100 & 一 & 1680 & 300 & - & 240 & $8 \cdot 94$ \\
\hline$\pi \quad$ Draht . & . & 4200 & - & - & 1200 & - & - & $8 \cdot 95$ \\
\hline Messing gegossen & . & 1240 & 1100 & 990 & 500 & - & 400 & $8 \cdot 6$ \\
\hline$\pi \quad$ Draht & & 3650 & - & - & 1300 & - & - & $8 \cdot 6$ \\
\hline Platin-Draht . . & . & 3400 & - & 2700 & 2660 & - & - & $22 \cdot 7$ \\
\hline Silber gegossen & . & 2900 & - & - & 1100 & - & - & $10 \cdot 47$ \\
\hline n Draht.. & . & 2975 & - & - & - & - & - & 10.51 \\
\hline Stahl ungehärtet & & 5000 & 5000 & 4000 & 2500 & 2500 & 2000 & $7 \cdot 6$ \\
\hline " gehärtet. & & 7500 & 7500 & 6000 & 2700 & 2700 & 2160 & $7 \cdot 8$ \\
\hline "Gussstahl & . . & 8000 & 10000 & 6400 & 6660 & 6660 & 3200 & $7 \cdot 87$ \\
\hline$"$ Draht(Gussst & tahl & 11000 & - & -- & 6500 & - & - & $7 \cdot 9$ \\
\hline Zink gegossen . & . . & 526 & - & - & 230 & - & - & $6 \cdot 8$ \\
\hline "gewalzt. & . & 480 & - & 一 & 230 & - & - & $7 \cdot 0$ \\
\hline Zinn gegossen . & 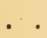 & 800 & - & 一 & 440 & - & - & $7 \cdot 29$ \\
\hline$"$ Draht . & . & 850 & - & - & 440 & - & - & $7 \cdot 3$ \\
\hline Basalt . . & . & - & 1200 & - & - & - & $\cdots$ & $2 \cdot 8$ \\
\hline Gneis, Granit . & $\cdot$ & 30 & 800 & 100 & - & - & - & $2 \cdot 8$ \\
\hline Kalkstein dichter & . & 27 & 300 & 70 & - & 一 & - & $2 \cdot 45$ \\
\hline Quarz . . . & & - & 1200 & - & - & - & - & $2 \cdot 62$ \\
\hline Sandstein dichter & . & 17 & 200 & 80 & - & - & - & $2 \cdot 35$ \\
\hline Ziegelstein . . & . . & 12 & 100 & 40 & - & 一 & - & $1 \cdot 6$ \\
\hline Mörtel gewöhnlich & er. & - & 40 & 5 & - & - & - & $1 \cdot 8$ \\
\hline Kalksteinmauer . & . . & - & 500 & - & - & - & - & $2 \cdot 4$ \\
\hline Sandsteinmauer. & . & - & 200 & - & -. & - & - & $2 \cdot 1$ \\
\hline Ziegelmauer . . & . & - *) & 40 & - & 一 & - & - & $1 \cdot 7$ \\
\hline
\end{tabular}

*) Wo die Rubriken nicht ausgefüllt sind, dort sind die betreffenden Moduls noch unbestimmt. 
Die Elasticitätslehre hat demnach im Allgemeinen die Aufgabe: zu ermitteln, welche Belastung die Träger mit hinreichender Sicherheit für die Dauer tragen können, oder welche Dimensionen sie erhalten müssen, um einer gegebenen Belastung fuir die Dauer zu widerstehen. Eine secundäre Aufgabe der Elasticitätslehre ist die Bestimmung der Formänderung, welche die Träger durch die gegebene Belastung erleiden.

Da sich alle Arten der Elasticität auf die Zug- und Druck-Elasticität zurüickfülıren lassen, so wird in der Elasticitätslehre zum Grundsatze das Gesetz der Formänderung gewählt, welches sich ergibt, wenn auf ein homogenes Prisma in Richtung seiner Längenachse eine Zug- oder Druckkraft einwirkt. Dieses Gesetz lautet: Die Verlängerung oder Verkürzung eines. Prismas steht innerhalb der Elasticitätsgrenze in geradem Verhältnisse zu seiner axialen Belastung $P$ und seiner Länge $l$, dagegen im umgekehrten Verhältnisse zur Querschnittsfläche $F$ und einem von der materiellen Beschaffenheit des Prismas abhängigen Coëfficienten, dem sogenannten Elasticitätsmodul E. Bezeichnen wir diese Längenänderung mit $\triangle l$, so ist demnach $\triangle l=\frac{P \cdot l}{F \cdot E}$

Für $P=1, F=1$ wird $\Delta l=\frac{l}{E}$ oder $E=\frac{l}{\Delta l}$.

d. l. der Elasticitätsmodul ist der reciprokeWerth der ralativen Längenänderung, welche von der als Zug oder Druck wirkenden Krafteinheit in einem Prisma vom Querschnitte Eins bewerkstelligt wird.

Mit der Längenänderung der Kanten des Prismas in axialer oder der KraftRichtung ist aber anch eine Aenderung des Querschnittes und somit der Querschnittskanten verbunden. Bei axialer Zugbelastung werden nämlich die Querschnittskanten verküirzt, dagegen bei axialer Druckbelastung verlängert. Das Gesetz dieser transversalen Längenänderung lautet analog wie jenes der longitudinalen, doch ist der Elasticitätsmodul der transversalen Elasticität circa 3mal grösser als jener der longitudinalen, so dass die transversale Längenänderung bei gleichen Umständen circa 3 mal geringer ist als die longitudinale.

Gewöhnlich ist nur vom Elasticitätsmodul der longitudinalen klasticität die Rede, dessen numerischer Werth nicht nur rom Materiale, sondern selbstverständlich auch von der Wahl der Kraft- und Flächeneinheit abhängt.

In der folgenden Tabelle (s. S. 147) sind die Mittelwerthe des Elasticitätsmoduls $E$ verschiedener Materialien pro Kilogramm unü Quadratcentimeter, so wie die relativen Längenänderungen $\frac{\Delta l}{l}$ für die Elasticitätsgrenze zusammengestellt.

Fig. 1376 .

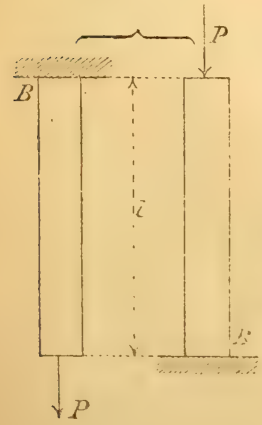

A) Zug-und Druck-Elasticität resp. Festigkeit gerader Stäbe (ehemals absolute, beziehentlich $r$ ï ckwirkend e Festigkeit genannt). Wir unterscheiden dabei zwei Fälle; entweder ist der Querschnitt des achsial belasteten Stabes constant oder veränderlich.

1. Ist der Stab prismatiseh (Fig. 1376) und bezeichnet $F$ den Querschnitt, $l$ die Länge, $\gamma$ das Gewicht der Volumseinheit, $k$ die zulässige Anspruchnahme pro Flächeneinheit und $P$ die axiale Belastung des Stabes, so wirkt auf denselben bei lothrechter Lage seiner Achse ausser $P$ auch sein Gewicht $G=\gamma F l$, so dass fur den Endyuersehnitt $L$ die Gleichung bestehen muss: $P+\gamma F l$ $=l_{i} F$, woraus die Belastung $P=F(k-\gamma l)$. . (3), oder der Querschnitt $F=\frac{P}{k-\gamma^{l} l}$. 


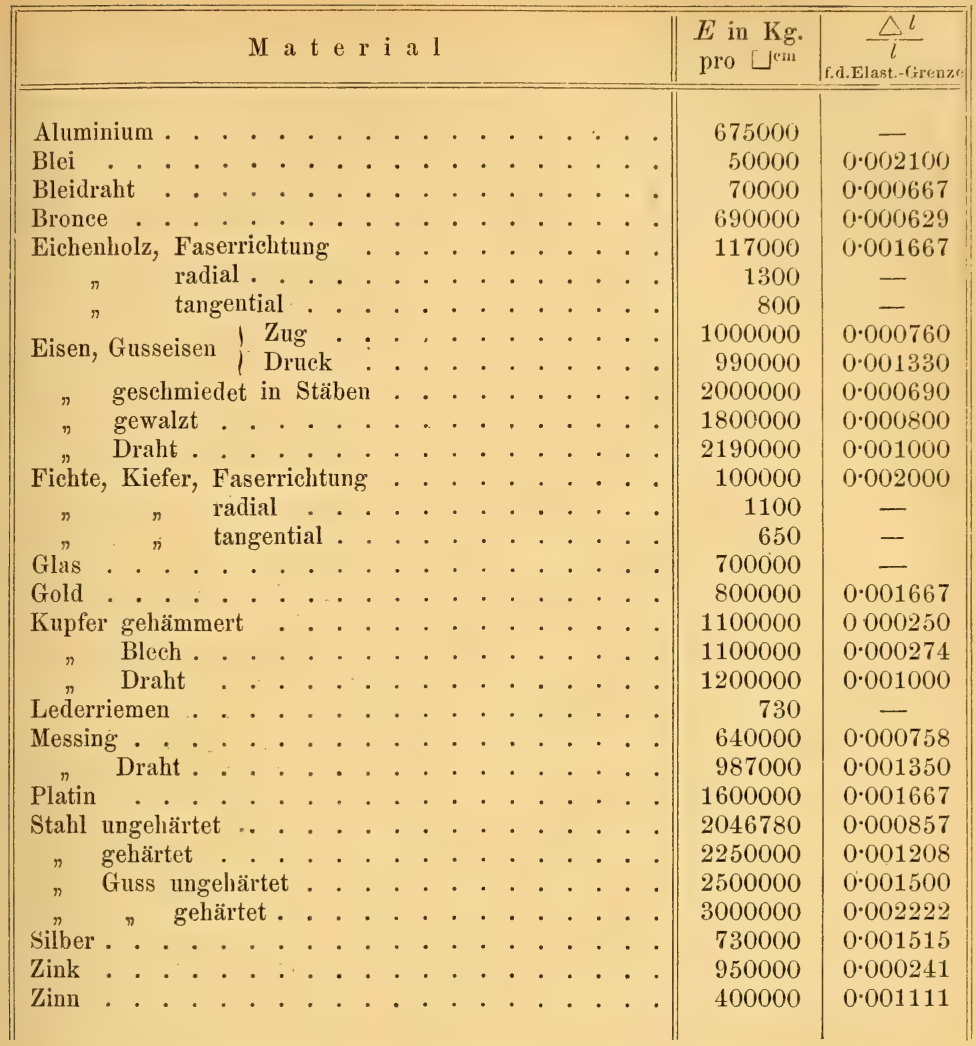

Die totale Verlängerung, resp. Verkürzung beträgt in diesem Falle

$$
\Delta l=\frac{l}{E F}\left(P+\frac{G}{2}\right)
$$

Ist der Stab so kurz, dass sein, im Verlıältniss zu seiner Belastung $P$, geringes Gewicht $G$ vernachlässigt werden kann, so wird
$I^{\prime}=k F$.
(6), $F=\frac{P}{k}$.
(7) und
$\triangle l=\frac{P l}{E F}$

2. Ist der Querschnitt des Stabes veränderlich, und zwar derart, dass alle Querschnitte desselben gleiche Zug- oder Druck-Spannung pro Flächeneinheit erleiden, so heisst der Stab ein Träger von constanter Zug- resp. DruckFestigkeit, und ist durch den geringsten Materialbedarf ausgezeichnet.

Bezeichnet $F_{0}$ den Querschnitt bei $A$ (Fig. 1377), so ergibt sich nach der Elasticitätslehre *) für einen beliebigen Querschnitt $F$, in der Entfernung $x$ ron A, die Formel

$$
F=F_{0} e^{{ }_{k}^{x}} \text {. }
$$

wobei $e$ die Grundzahl $2 \cdot 71828 \ldots$ der natiirlichen Logarithmen und $\gamma$ das specifische Gewicht des Materials bedeutet und $F_{0}$ dureh $F_{0}=\frac{l^{2}}{h}$ bestimmt ist.

*) S. Näheres z. B. in Ott's Baumechanik, II. Theil Seite 14. 
Die Längenänderung ist in diesem Falle $\Delta l=\frac{l . k}{E} \cdot . . .(10)$.

Da jedoch die stetige Aenderung des Querschnittes in der Praxis schwer ausfiihrbar ist, so pflegt man Stäbe von gleichem Widerstande annähernd dadurch zu erzielen, dass man, nach Fig. 1378, den Träger aus einzelnen prismatischen Stäben so formt, dass in den Endquerschnitten dieser Stäbe dieselbe Spannung $k$ pro Flächeneinheit herrscht.

Fig. 1377.

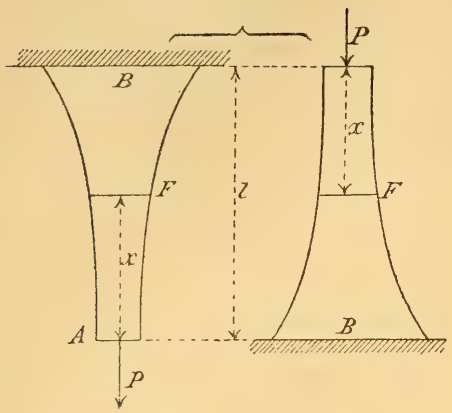

Fig. 1378.

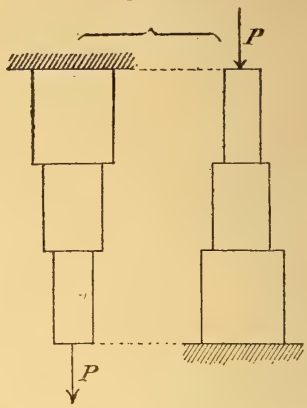

Sind $l_{1}, l_{2}, l_{3} \ldots$ die Längen der einzelnen Prismen, $F_{1}, F_{2}, F_{3} \ldots$ ihre Querschnitte und $P$ die axiale Belastung des Trägers, so ist:

$F_{1}=\frac{P}{k-\gamma I_{1}}, \quad F_{2}=\frac{P k}{\left(k-\gamma l_{1}\right)\left(k-\gamma l_{2}\right)}, \quad F_{3}=\frac{P . k^{2}}{\left(k-\gamma l_{1}\right)\left(k-\gamma l_{2}\right)\left(k-\gamma l_{3}\right)}$ u. s. w., daher allgemein: $F_{n}=\frac{P \cdot k^{n-1}}{\left(k-\gamma_{1}\right)\left(k-\gamma l_{2}\right) \ldots \ldots\left(k-l_{n}\right)} \cdot \ldots \cdot . \cdot$ (11).

Für den besonderen Fall, dass $l_{1}=l_{2}=\bar{l}_{3} \ldots=l_{n}$, wird allgemein

$$
F_{n}=\frac{P}{k}\left(\frac{k}{k-\gamma l}\right)^{n}
$$

Anmerkung. Es versteht sich wohl von selbst, dass sich die sämmtlichen Längen- und Qucrschnittstimensionen auf dieselbe Längeneinheit und die Kräfte oder Lasten auf dieselbe Gewichtseinheit beziehen muissen. Ist z. B. 1 Centimeter als Längen- und 1 Kilogramm als Krafteinheit gewählt, so ist $l$ in $\mathrm{cm} ., F$ in $\square^{\mathrm{cm}}, k$ in $\mathrm{Kg} . \mathrm{pr}$. $\square^{\mathrm{cm}}, \hat{i}$ in $\mathrm{Kg}$. pr. Cub. cm. und $P$ in $\mathrm{Kg}$. auszudrücken.

Beispiele. 1. Welchen Durchmesser muss eine cylindrische Zugstange aus Schmiedeeisen erhalten, weun sie mit 5facher Bruchsicherheit eine Last von $1000 \mathrm{Kg}$. (1 Tonne) tragen soll?

Nach Gleichung ( $(\overline{)})$ ist $F=\frac{P}{k}$. Darin ist $P=1000$ und bei 5 facher Bruchsicherheit $k=\frac{4000}{5}=800$ pro $\square^{\mathrm{cm}}$, somit $F=\frac{1000}{800}=1 \cdot 25 \square^{\mathrm{cm}}$.

Bezeichnet $d$ den Durchmesser der Stange, so ist $F=\frac{\pi}{4} d^{2}=1 \cdot 25$, woraus

$$
d=\sqrt{\frac{4 \times 1.25}{3.1416}}=\sqrt{1.5915}=1.26^{\mathrm{cm}} \text {. }
$$

2. Mit wie vielfacher Bruchsicherheit widersteht die unterste Ziegelschaar (lem Gewichte einer $30^{\mathrm{m}}$ hohen, unbelasteten Ziegelmauer, wenn $1^{\mathrm{clom}}$ der Mauer $1800 \mathrm{Kg}$. wiegt und die Druckfestigkeit der Ziegel pr. $\square^{\mathrm{cm}} 200 \mathrm{Kg}$., also pr. $\square^{\mathrm{m}} 2000000 \mathrm{Kg}$. beträgt?

Das Manergewicht pro $\square$ mer Grundfläche ist $P=30 \times 1800=54000 \mathrm{Kg}$.; dagegen die Iruckfestigkeit pro $\square^{\mathrm{m}} K=2000000 \mathrm{Kg}$., daher die Bruchsicherheit

$$
n=\frac{K}{P}=\frac{2000000}{54000} \doteq 37 \text {. }
$$


3. Welche Querschnitte wird ein $20^{\mathrm{m}}$ hoher Brïckenpfeiler von Granit crhalten, der ausser seinem Gewichte noch einen Auflagerdruck von 100 Tomnen (a $1000 \mathrm{Kg}$.) zu tragen und aus vier gleich langen prismatischen Stuicken zu bestehen hat, wenn $1^{\mathrm{cbm}}$ Granit $2 \cdot 4$ Tonnen und der zulässige Druck (bei 30-facher Bruchsicherheit) $27 \mathrm{Kg}$. pro $\square^{\mathrm{em}}$ oder 270 Tonnen pro $\square^{\mathrm{m}}$ beträgt?

Wählt man den Quadratmeter als Flächen- und die Tonne als Kraft-Finheit, so ist $P=100, k=270, \gamma=2 \cdot 4, l=5$, daher nach Formel (12) die einzelnen Querschnitte:

$$
\begin{aligned}
& F_{1}=\frac{P}{k}\left(\frac{k}{k-\gamma l}\right)=0.3876 \beth^{\mathrm{m}}, \quad F_{2}=\frac{P}{k}\left(\frac{k}{k-\gamma l}\right)^{2}=0.4056 \square \square^{\mathrm{m}}, \\
& F_{3}=\frac{P}{k}\left(\frac{k}{k-\gamma l}\right)^{3}=0.4244 \square^{\mathrm{m}}, \quad F_{4}=\frac{P}{k}\left(\frac{k}{k-\gamma l}\right)^{4}=0.4441 \square^{\mathrm{m}} .
\end{aligned}
$$

Das Gewicht des Pfeilers bei dieser Anordnung ist $G=19.9404$ Tonnen.

Hätte man aber unter denselben Bedingungen einen Pfeiler von constantem Widerstande construirt, so wäre, nach Formel (9) für $x=30^{\mathrm{m}}$ und $F_{0}=\frac{P}{F_{i}}=$ $0.3703 \square^{\mathrm{m}}$, an der Sohle die grösste Querschnittsfläche $F=0.4421 \square^{\mathrm{m}}$.

Aus $P+G=k \cdot F$ ergibt sich dann das Gewicht des Pfeilers $G=$ 19.367 Tonnen, welches gegen jenes im vorigen Falle um 0.5734 Tonnen oder $573.4 \mathrm{Kg}$. geringer ist.

$B)$ Schub- oder Abscherungsfestigkeit, resp. Elasticität. Ein Träger wird in einem Querschnitte auf Schub- oder Abscherungsfestigkeit (die auch Gleitungs- oder Scherfestigkeit genannt wird) in Anspruch genommen, wenn die Resultirende aller äusseren Kräfte in der Ebene des Querschnittes selbst wirkt und in dessen Schwerpunkte angreift. In der Baupraxis kommt die Scherfestigkeit, resp. Scherelasticität, nur dann ganz allein zur Geltung, wenn auf einen Stab zwei Kräfte auf beiden Seiten einer Querschnittsebene knapp neben dieser Ebene und parallel zu derselben nach entgegengesetzten Richtungen wirken. Diese Kräfte suchen dann den Stab in dem bezeichneten Querschnitte zu trennen oder, wie man sagt, abzuscheeren.

Der Widerstand gegen das Abscheren ist - wie jener gegen das Zerreissen - der Grösse der Trennungsfläche direct proportional.

Bezeichnet daher $P$ die Kraft, welche das Abscheren bewirken soll, $F$ die Grösse des Querschnittes und $S$ den Modul der Scherfestigkeit pro Flächeneinheit, so ist offenbar

$$
P=F . S \text {. . . . . . . (13). }
$$

Diese Gleichung gilt also für jene Fälle, in welchen die Trennung der beanspruchten Fläche bezweckt wird, also für das Abschneiden, Abstossen und Durchlochen der Materialien, welche Arbeiten mit den sogenannten Durchbruchmaschinen bewerkstelligt werden. Soll aber das Abscheren, z. B. der Döbeln, Nieten, Schrauben und dergleichen auf Scherfestigkeit in Ansprnch genommenen Verbindungsmittel, nicht erfolgen, so wählt man als zulässige Anspruchnahme $s$ pr. Flächeneinheit vom Modul $S$ bei Metallen den 5., bei Hölzern den 10. und bei Steinen den 20. Theil. Die Gleichung $P=F . s . . . . .(14)$ gilt demnach für jene Fälle, in welchen kein Abscheren erfolgen darf.

Bei Metallen beträgt der Abscherungsmodul $S$ etwa $3 / 5$ bis $4 / 5$ von jenem $K$ gegen das Zerreissen. Beim Holze ist der Widerstand gegen das Abscheren, wegen der Faserbildung, nach den verschiedenen Richtungen verschieden; während er z. B. in Richtung der Fasern sehr gering ist, ist er in radialer Richtung der Jahresringe verhältnissmässig gross.

Der Elasticitätsmodul $E^{\prime}$ für Schub beträgt circa $2 / 3$ ron jenem fuir Zug.

C) Biegungs-Elasticität, resp. Festigkeit, homogener Träger mit gerader A chse.*) Allgemein e Begriffe. Ein Träger $A, B$ (Fig. 1379)

*) Friiher durch die Benennung relative Festigkeit bezeichnet. 
wird auf Biegung-Elasticität, resp. Festigkeit, allein nur dann in Anspruch genommen, wenn die angreifenden oder äusseren Kräfte senkrecht stehen zur Längen-

Fig. 1379.

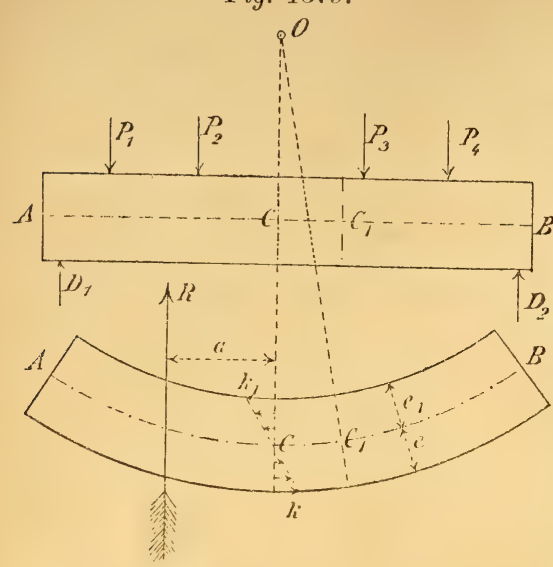
achse $A, B$ des Trägers und sämmtlich in einer Ebene - der sogenannten Kraftebene - liegen, die durch $A, B$ geht. $\mathrm{Zu}$ den äusseren Kräften gehören auch die Reactionen der Stïzzen, auf welchen der Träger auf. ruht, d. i. die sogenannten Stiitzendrücke $D_{1}, D_{2}$. Durch die Einwir$B^{\text {kung dieser Kräfte erfährt der Trä- }}$ ger, den wir uns als ein Bündel von parallel zu seiner Längenachse liegenden, unter einander fest verbundenen Fasern denken, eine Biegung. $B$ Die ursprïnglich parallelen, einander sehr nahen Querschnitte $C, C_{1}$ werden nach eingetretener Biegung nicht mehr parallel sein, sondern sie stehen dann, wenn die Durchbiegung innerhalb der Elasticitätsgrenze bleibt, auf den gekrïimmten Längenfasern nahezu senkrecht und schneiden sich in einer Geraden $O$.

Aus dem Umstande, dass die beiden Querschnitte $C, C_{1}$ bei eingetretener Biegung des Trägers cine convergirende Lage annehmen, folgt nun unmittelbar, dass die zwischen denselben befindlichen Fasern in den verschiedenen Faserschichten eine rerschiedene Länge haben miissen. Es werden daher, nach Fig. 1379, die auf der unteren oder convexen Seite liegenden Fasem ausgedehnt, somit gezogen, dagegen die anf der oberen oder concaven Seite liegenden rerkirzt, daher gedrickt. Demnach wird man beim Uebergange ron den gezogenen Fasern zu den gedriickten anf eine Faserschichte gelaugen, deren Fasern weder gezogen noch gedriickt sind, die also trotz der Biegung ihre ursprüngliche Länge beibehiclten; man nemnt deshalb diese Faserschichte die nentrale Schichte, ferner die Schnittlinie derselhen mit einer Querschnittsebene die neutrale Achse, und endlich die Schnittlinie der nentralen Fasersehichte mit der Kraftebene die elastische Linie. Von der nentralen Faserschichte aus nimmt die Faserspannung gegen die äussersten Fasem allmälig zu und erreicht somit in den änssersten Fasern ihren grössten Werth. Soll nun durch die Biegung die Elasticitätsgrenze nicht iberschritten werden, so diirfen die grössten Zug- und Druckspanmungen $k_{i}$ und $l_{1}$ der ïussersten Fasern den zulässigen Tragmodul für Zug und Druck nicht erreichen.

Widerstandsmoment. Betrachten wir nun ein beliebiges Fragment $A C$ des durch die äusseren Kräfte innerhalb der Elasticitätsgrenze gebogenen Trägers, und ist $R$ die Resultante der anf dieses Fragment wirkenden Kräfte $\left(D_{1},-P_{1},-P_{22}^{\prime}\right)$ und "der Abstand dieser Resultanten ron der durch $C$ gehenden neutralen Achse des Querschnittes, so muss für den Glcichgewichtszustand gegen Drehung des Fragmentes $A C$, beziiglich der neutralen $\Lambda$ chse $C$, das Drehungsmoment $R a$, das wir allgemein mit $M /$ bezeichnen, gleich sein der Summe der Drehungsmomente aller Faserspannungen des Querschnittes $C$ beziiglich derselben Drehachse $C$.

Aus dieser frleichsetzung des Drehungs- und Widerstands-Momentes ergibt sich die fiir Bailpraxis wielitige Formel:

$$
\left.\begin{array}{rl}
M & =\frac{k}{e} T \\
\text { oiler } M & =\frac{k_{1}}{e_{1}} T
\end{array}\right\}
$$


Hierin ist $k$ resp. $k_{1}$ die pro Flächeneinheit zulässige Zug-oder Iruckspannuing, $e$ resp. $e_{1}$ die Entfernung der äussersten gezogenen oder gerlriickten Fasern von der neutralen Achse, und $T$ das sogenannte Trägheitsmoment des Querschnittes beziiglich der neutralen Achse, die hier zugleich Schwerpunktardise des Querschnittes ist. Dieses Trägheitsmoment stellt die Summe aller Producte aus den einzelnen Flïchenelementen des Querschnittes in die Quadrate ihrer Al,stände von der neutralen Aclise vor.

Querschnittsform. Durch die Gleichstellung der beiden Wertle von $M$ aus (15), erhält man $\frac{k}{e}: \frac{k_{1}}{e_{1}}$ oder $k: k_{1}=e: e_{1}$, d. h. bei jedem rationell construirten Träger ist die Querschnittsform s o anzuordnen, dass die grösste zulässige Zug- und Druckspannung in den äussersten Fasern zu beiden Seiten der nentralen Faserschichte gleichzeitig erreicht wird. Da nun beim Stahle, Schmiedeeisen und Holze innerhalb der Elasticitätsgrenze nahezu $k=k_{1}$ ist, so sollen die aus einem dieser Materialien construirten Träger so geformt werien, dass die Querschnittsfläche durch die nentrale Achse halbirt werde. Beim Gusseisen ist dagegen die Druckfestigkeit wenigstens zweimal so gross als die Zugfestigkeit, weshalb bei gusseisemen Trägern der Querschnitt so anzuordnen ist, dass die äussersten gedriickten Fasern von der neutralen Achse wenigstens zwcimal weiter abstehen als die äussersten gezogenen.

Da iibrigens das Materiale zunächst der neutralen Schichte am wenigsten, dagegen in den von ihr am weitesten abstehenden Fasern am meisten in Anspruch genommen wird, so soll man das Materiale, um es ordentlich auszuniitzen, möglichst weit von der nentralen Schichte anordnen, wie dies bei den Blech- und Gitterträgern der Fall ist, deren Querschnitte ans zwei parallelen Gurten bestehen, die durch eine Blechwand oder durch Stäbe zweckmässig verbunden sind.

Querschnits-Berechnung. In der Gleichung $M=\frac{k}{e} T$ oder
$M=\frac{k_{1}}{e_{1}} T$ kommen vier verschiedene Grössen vor; soll daher eine derselben bestimmt werden, so miissen die drei anderen gegeben sein. Gewöhnlich ist die Länge $l$ des Trägers, die zulässige Spannung des Materiales $k$ pro Flächeneinheit und die Belastung des Trägers gegeben.

Aus der Länge $l$ und der Belastung lässt sich dann leicht das jedem Querschnitte zukommende Biegungsmoment $M$ bestimmen, und da auch die Höhe $h$ des Querschnittes und somit auch $e$ von der Länge des Trägers abhängig gemacht wird, so ist gewöhnlich nur das Trägheitsmoment $T$ des Querschnittes zu bestimmen, wobei im Allgemeinen die Form des Querschnittes und alle Dimensionen desselben bis auf eine gegeben sein müssen, die eben aus der Gleichung $M=$ $\frac{k}{e} T$ berechnet werden soll.

$\mathrm{Kurze} \mathrm{Tr} \ddot{g} \mathrm{ger}$ erhalten gewöhnlich wegen der leichteren Herstellung einen constanten Querschnitt, dessen Dimensionen aber für jene Stelle des Trägers zu berechnen sind, für welche das Biegungsmoment $\boldsymbol{M}$ der äusseren Kräfte den grössten Werth erreicht. Man nennt deshalb den Querschnitt an dieser Stelle den gefährlichen oder Brueh-Querschnitt. Die Höhe $h$ des Querschnittes wird, aus praktischen Griinden, bei Briickenträgern mit 1/s bis 1/12 der freicn Trägerlänge $l$, dagegen bei Hochbauträgern mit $1 / 16$ bis $1 / 32$ ron $l$ bemessen.

Träger von constantem Biegungswiderstande. Bei langen Trägern würde man durch die Wahl eines constanten Querschnittes nicht nur unnöthigerweise Materiale verschwenden, sondern auch die Tragfühigkeit verringern, weshalb man sie am rationellsten als Träger von coustantem Widerstande construirt, deren Querschnitte den bezïglichen Biegungsmomenten der äusseren Kräfte proportional gemacht werden. Hierbei ist jedoch zu bericksichtigen, dass die Querschnitte, fiir welche $M=0$ ist, so gross gemacht werden miissen, dass sie den in diesen Quersehnitten anftretenden Schubkräften himreichenden Wider- 
stand gegen Abscheren entgegensetzen. Die Schubkraft in einem Querschnitte $C$ (Fig. 1379) ist aber gleich der Resultirenden $R$ aller von einem Trägerende bis zu diesem Querschnitte auftretenden äusseren Kräfte, den Stiutzendruck mit eingerechnet.

Vertheilung der Schubspannungen. Wären die durch die Transversal- oder Schubkraft $V$ im Querschnitte $C$ (Fig. 1379) hervorgerufenen Schubspannungen über den ganzen Querschnitt gleichmässig vertheilt, so würde sich wenn $s$ die zulässige Schubspannung des Materiales pro Flächeneinheit bezeichnet - die Querschnittsgrösse $F$ für jene Stelle, an welc er das Biegungsmoment $M=0$ ist, aus der Gleichung $\dot{V}=s . F$ berechnen lassen.

Eine gleichmässige Vertheilung der durch die Biegung hervorgerufenenSchubspannungen kann jedoch deshalb nicht stattfinden, weil die zur neutralen Faserschichte parallelen Fasern zu beiden Seiten derselben entgegengesetzte und mit der Entfernung von der neutralen Achse zunehmende Spannungen erleiden. In Folge dieser entgegengesetzten Spannungen tritt offenbar in der neutralen Faserschichte die grösste Schubkraft auf, und es muss daher, damit die zu beiden Seiten der neutralen Faserschichte liegenden Trägerhälften nicht übereinander verschoben werden, der Träger in der neutralen Schichte eine gewisse Breite $z$ erhalten.

Sind $F_{1}$ und $F_{2}$ die Inhalte der zu beiden Seiten der neutralen Achse liegenden Querschnittstheile, ferner $a_{1}$ und $a_{2}$ die Abstände der Schwerpunkte der beiden Querschnittshälften $F_{1}$ und $F_{2}$ von der neutralen Achse, so ist die Schubspannung $s_{0}$ pro Flächeneinheit in der neutralen Faserschichte bestimmt durch $s_{0}=\frac{V \cdot F_{1} \cdot a_{1}}{z_{0} \cdot T}$ oder durch $s_{0}=\frac{V \cdot F_{2} \cdot a_{2}}{z_{0} \cdot T}$, wobei im Allgemeinen für Metalle $s_{0}=3 /{ }_{4} k$ und für Hölzer $s_{0}=\frac{k}{10}$. Es wird nun aus den obigen Gleichungen $z_{0}=\frac{V \cdot F_{1} \cdot a_{1}}{s_{0} \cdot T}$ oder $z_{0}=\frac{V \cdot F_{2} \cdot a_{2}}{s_{0} \cdot T}$.

Von der neutralen Faserschichte aus nimmt die Schubspannung mit der Ent. fernung $y$ von der neutralen Achse ab und ist stets in der Längenrichtung eben so gross, wie in der Querrichtung. Bezeichnet $z$ die Querschnittsbreite in der Entfernung $y$ von der neutralen Achse, so ist die in dieser Entfernung pro Flächeneinheit in horizontaler und rerticaler Richtnng auftretende Schubspannung $s$ bestimmt dureh $s=\frac{V}{z \cdot T} \int_{y}^{e} y \cdot z \cdot d y$, wobei $\int_{y}^{e} y \cdot z \cdot d y$ oder $\int_{y}^{e} y \cdot d F$ die Summe aller innerhalb der Grenzen $y$ und $e$ liegenden Flächenelemente $z \cdot d y$ oder $d F$ bezüglich der neutralen Achse bezeichnet.

Gleichung der elastischen Linie. Es wurde bereits erwähnt, dass man unter der elastischen Linie die durch die Biegung deformirte Längenachse $A, B$ (Fig. 1379) des Trägers versteht. Bezieht man dieselbe auf ein rechtwinkliges Achsenkreuz, dessen Ursprung z. B. im Punkte $A$ liegt, dessen $X$-Achse $A, B$ ist und dessen $Y$-Achse darauf senkrecht steht, so ist für einen beliebigen Punkt $C$ der elastischen Linie, mit den Coordinaten $x$ und $y$, die Grösse der Durchbiegung, nämlich $y$ aus der Differentialgleichung $\frac{d^{2} y}{d x^{2}}=\frac{M}{E T}$ durch zweimalige Integration zu bestimmen.

Hierbei bedeutet $M$ das Biegungsmoment $V . x$ fiur den Punkt $C, E$ den Elasticitätsmodul des Materiales und $T$, wie früher, das Trägheitsmoment des Querschnittes.

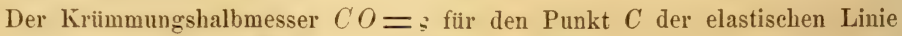
ergibt sich aus $\frac{1}{\xi}=\frac{M}{E \cdot T}$ oder aus $\frac{1}{\vdots}=\frac{k}{e \cdot E}$.

Trägheitsmomente. In der folgenden Tabelle sind die Trägheitsmomente $T$ der iiblichsten Querschnittsformen bezüglich der Schwerpunktsachse, so wie die Abstände $e$, resp. $e_{1}$, der entferntesten Fasern von derselben zusammengestellt. 
Elasticität (u. Festigkeit).

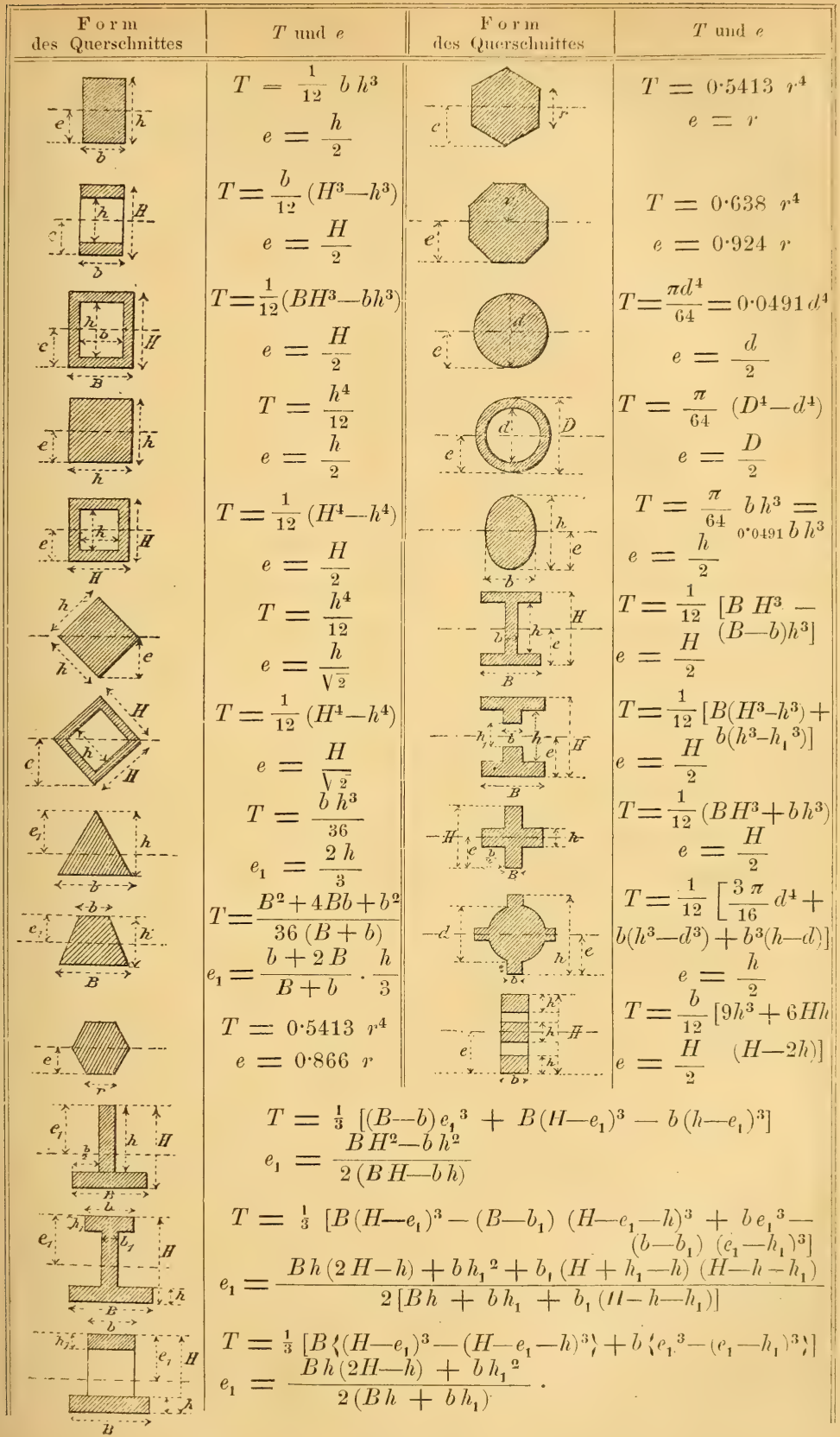


Besondere Belastungsfälle. In der folgenden Tabelle sind für eine Reihe von Belastungs- und Befestigungs-Arten eines prismatischen Trägers die Werthe der Tragkraft $P$ und der grössten Durchbiegung $F$ zusammengestellt. Hierbei bedeutet: $T$ das Trägheitsmoment des Querschnittes zu seiner neutralen oder Schwerpunktssachse, $e$ den Abstand der von der nentralen Achse am weitesten entferuten Fasern und $k$ die grösste zulässige Spannung derselben pro Flächeneinheit.

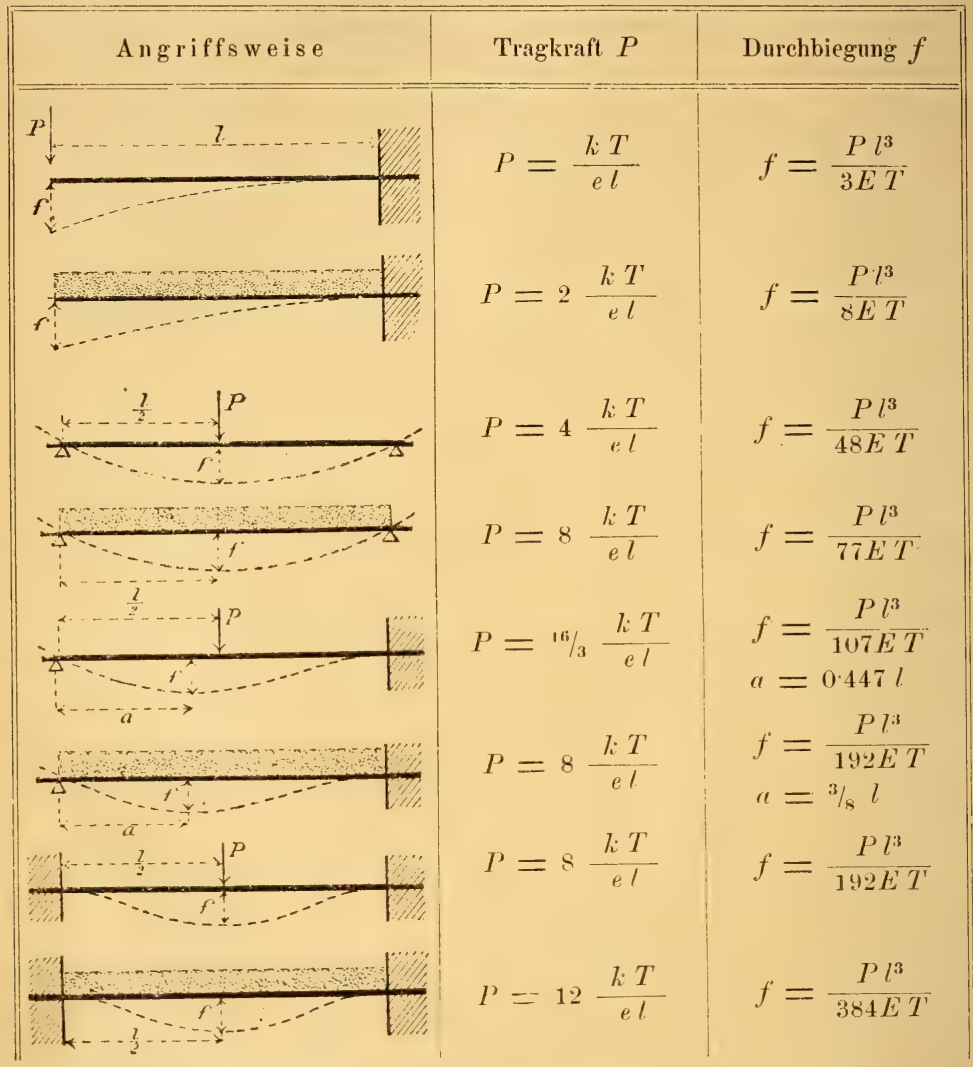

Fig. 1.380 .

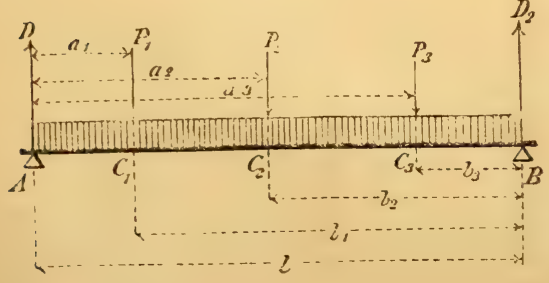

Specielle Berechnung $D_{2}$ eines a uf Biegungs-Elasticität beanspruchten Trägers. Wir wollen schliesslich die allgemeine Bestimmungsweise der Biegungs- und Widerstandsmomente eines auf zwei Stützen aufruhenden Trägers $A, B$ (Fig. 1380) durehfülıren, weleher durch mehrere Einzellasten $P_{1}, P_{\underline{y}}, P_{3} \ldots$ und durch eine iiber seine ganze Lïnge $l$ 
gleichmässig vertheilte Last beansprucht wird, die gewöhnlich vom Eigengewichte des Trägers herrihnt. Bezeichnet man die Abstände der Einzellasten $P_{1}, I_{a 2}, I_{3} \ldots$ von $A$ mit $a_{1}, a_{n}, a_{3} \ldots$ und von $B$ mit $b_{1}, b_{n}, b_{3}$, so ergeben sich mit Riicksicht anf die gleichförmig vertheilte Belastung, welche $q$ pro Längeneinheit des Träger's betragen soll, bei $A$ und $B$ die Stiitzendriicke

$$
\begin{aligned}
& D_{1}=\frac{q l}{2}+P_{1} \frac{b_{1}}{l}+P_{2} \frac{b_{2}}{l}+P_{3} \frac{b_{3}}{l}+\ldots \\
& D_{2}=\frac{q l}{2}+P_{1} \frac{a_{1}}{l}+P_{2} \frac{a_{2}}{l}+P_{3} \frac{a_{3}}{l}+\ldots
\end{aligned}
$$

Die Biegungsmomente ergeben sich am grössten in den Belastungspunkten $C_{1}, C_{0}, C_{3} \ldots \ldots$; bezeichnet man dieselben fiir die betreffenden Querschnitte mit $M_{1}, M_{2}, M_{3} \ldots$, so wird

$$
\begin{aligned}
& M_{1}=D_{1} a_{1}-\frac{q a_{1}{ }^{2}}{2} ; M_{2}=D_{1} a_{1}-P_{1}\left(a_{2}-a_{1}\right)-\frac{q a_{22}{ }^{2}}{2} ; \\
& M_{3}=D_{1} a_{3}-P_{1}\left(a_{3}-a_{1}\right)-P_{2}\left(a_{3}-a_{0}\right)-\frac{q a_{3}{ }^{2}}{2} \text { u. s. w. }
\end{aligned}
$$

Bezeichnet man die Trägheitsmomente der Querschnitte innerhalb der Fragmente $A C_{1}, C_{1} C_{2}, C_{2} C_{3} \ldots$ mit $T_{1}, T_{2}, T_{3} \ldots$, so würden die betreffenden Querschnitte zu bestimmen sein aus: $M_{1}=\frac{k}{e_{1}} T_{1} ; M_{2}=\frac{k}{e_{0}} T_{2} ; M_{3}=\frac{k}{e_{3}} T_{3} \ldots$, wobei $M_{1}, M_{2}, M_{3}$ die obigen Werthe und $e_{1}, e_{2}, e_{3}$ die Entfernungen der ron der neutralen Achse am weitesten abstehenden Fasern der bezïglichen Querschnitte bezeichnen.

Sollte der Träger durch seine ganze Länge einen constanten Querschnitt erhalten, so wäre selbstverständlich die Querschnittsgrösse aus maximum $M=\frac{k}{e} T$ zu ermitteln, wobei sich maximum $M$ in einem der Belastungspunkte $C_{1}, C_{2}, C_{3} \ldots$ ergibt.

Beispiel. Es sei nach Fig. 1380 die freie Spannweite $l=12$ Meter, $P_{1}=P_{2}=P_{3}=200 \mathrm{Kg} ., a_{1}=\frac{l}{3}, a_{2}=\frac{l}{2}, a_{3}=\frac{2 l}{3}$ und die gleichmässig uiber die Länge des prismatischen, hölzernen Trägers vertheilte Belastung pro laufenden Meter, d. i. $q=150 \mathrm{Kg}$. Welche Dimensionen muss der rechteckige Querschnitt dieses Trägers erhalten, wenn sich die Breite $b$ zur Höhe $h$ des Querschnittes wie 1 zn $\sqrt{2 *}$ ) verhalten, und bei 10 -facher Bruchsicherheit $k$, d. i. die grösste Anspruchnahme des Holzes pro $\square^{\mathrm{em}} 60 \mathrm{Kg}$. betragen soll?

Wegen der symmetrischen Anordnung der Belastung beziiglich der Auflager sind die Stiitzendrücke gleich, also

$$
D_{1}=D_{0}=\frac{q l}{2}+\frac{2}{3} P_{1}+\frac{1}{2} P_{\mathrm{a}}+\frac{1}{2} P_{3}=1200 \mathrm{Kg} \text {. }
$$

Der grösste Biegungsmoment ergibt sich hier in der Mitte des Trägers, nåmlich :

$$
M=D_{1} \cdot \frac{l}{2}-P_{1} \cdot \frac{l}{6}-\frac{q l^{2}}{8} .
$$

Sollen nun die Querschnittsdimensionen in Centimetern bestimmt werden, so miissen auch bei der Ermittlung von $M$ die Längendimensionen in Centimetern ausgedrickt werden; eben so ist der Werth von $q$, der sich anf einen Meter bezieht,

Fig. 1381.

) Ist aus einem Baumstamm vom kreisrunden Querschnitte (Fig. 1381) ein Balken mit rechteckigem Querschnitte. von grösster Tragfähigkeit zu zimmern, so theilt man den Durchmesser $A, B$ in drei gleiche Theile und errichtet in den Theilpunkten auf $A, B$ die Senkrecliten $1 C$ und $2 D$. Die Punkte $A, C, B, D$ sind alsdaun die Eckpunkte des gesuchten Rechteckes, in welchem sich die Breite $A, C^{\prime}$ zur Iröle $C, D$ wic $1 \mathrm{zu} V \overline{2}$ verhält.

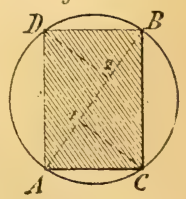


auf einen Centimeter zu reduciren, also statt $q$ nur $\frac{q}{100}$ in Rechnung zu nehmen. Hiemach wird $M=1200 \times \frac{1200}{2}-200 \times \frac{1200}{6}-\frac{150}{100} \times \frac{1200^{2}}{8}=410000$. In der Formel $M=\frac{k}{e} T$ ist nun $M=410000, k=60, T=1 /{ }_{12} b . h^{3}$ und $e=\frac{h}{2}$ einzufuihren, also $410000=\frac{60}{1 / 2 h} \cdot \frac{b h^{3}}{12}=106 h^{2}$, woraus $b h^{2}=41000$.

Da aber $b: h=1: \sqrt{2}$, also $b=\frac{h}{\sqrt{2}}$, so wird $\frac{h^{3}}{\sqrt{2}}=41000$ oder $h^{3}=41000 \sqrt{2}=57982 \cdot 2$, woraus endlich $h=\sqrt[3]{57982 \cdot 2}=39^{\mathrm{cm}}$ und $b=\frac{h}{\sqrt{2}}=28^{\mathrm{cm}}$.

D) Drehungs- oder Torsions-Elasticität resp. Festigkeit. Ein fester Körper wird auf Drehungs-Elastieität, resp. Festigkeit in Anspruch genommen, wenn ihn äussere Kräfte um seine geometrische Achse zu drehen suchen.

Der einfachste Fall tritt dann ein, wenn der Körper (Fig. 1382) an einem Ende $B$ festgehalten und am anderen Ende $A$ von einer Kraft $P$, die in der Ebene des Querschnittes $A$ liegt, derart angegriffen wird, dass sie ihn um seine Fig. 1382.

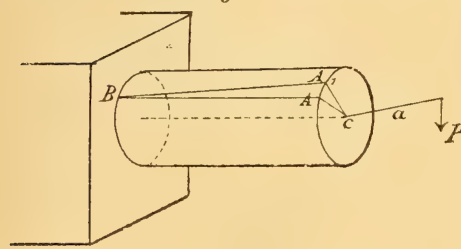
Längenachse zu drehen strebt. Ist $a$ der Abstand der drehenden Kraft vom Mittelpunkte des Querschnittes, so bildet das Product $P$. a das sogenannte Drehungs$\mathrm{m} o \mathrm{ment}$, welches die zur Längenachse des Stabes parallel gedachten Fasern zu verdrehen sucht. Da nun der Stab bei $B$ befestigt ist, so wird die Verdrehung: der Fasern von $B$ gegen $A$ zu nehmen und es werden die Fasern nach der Drehung die Lage von Schraubenlinien annehmen. Diese Deformirung der Fasern, resp. die Drehung der einzelnen Querschnitte des Stabes um seine Längenachse wird ım so grösser, je weiter die Querschnitte von der Befestigungsstelle $B$ entfernt sind, so dass der Querschnitt $A$ die grösste Drehung erleidet.

Zugleich wird die Verschiebung der einzelnen Querschnittselemente mit der Entfermung rom Querschnitts-Mittelpunkte zunehmen, so dass in Folge dessen auch die Verdrehung der Fasern mit der Entfernung ron der Achse wächst, während die Achse selbst neutral bleibt.

Da also das zunächst der Achse liegende Materiale am wenigsten in Anspruch genommen wird, so folgt daraus, dass hohle Cylinder bei gleicher Querschnittsgrösse eine grössere Torsionsfestigkeit haben als massive. Der Verdrehung der Fasern oder der Verschiebung ihrer Quersehnitte widerstehen die einzelnen Querschnittselemente mit ihrer Schub- oder Gleitungsfestigkeit, so dass die Torsionsfestigkeit von der Schubfestigkeit auf ähnliche Weise ablängig ist wie die Biegungsfestigkeit von der Zug- und Druckfestigkeit.

Demzufolge ist auch der Elasticitätsmodul für Torsion gleich jenem $E_{1}$ für für Schub, welcher mit $2 / 5 E$ bemessen wurde, wenn $E$ den Elasticitätsmodul für Zng bedeutet.

Ans der Gleichgewichtsbedingung zwischen dem Drehungsmomente $P$. $a$ und dem Widerstandsmomente der einzelnen Querschnittselemente bezüglich der Achse lässt sich die Formel ableiten: $P \cdot a=\frac{t}{r} T_{1}$.

Hierin bedentet $t$ die zulässige Torsionsspannung der äussersten Faserquerschnitte pro Flächeneinheit, $r$ den grössten Abstand der Fasern ron der Achse 
und $T_{1}$ das polare oder Torsions-Trägheitsmoment des Querschnittes, d. i. die Summe der Producte aus sämmtlichen Querschnittselementen $f$ in die Quadrate ihrer Entfernungen e vom Querschnittsmittelpunkte, alse $T_{1}=\Xi\left(f \cdot \epsilon^{2}\right)$.

Fuir einen quadratischen Quersehnitt von der Seitenlänge $b$ ist $\frac{T_{1}}{r}=\frac{b^{3}}{3 \bigvee \overline{2}}$, also $P a=\frac{t b^{3}}{3 \sqrt{2}}$ oder $P a \doteq 0.236 t b^{3}$

Für einen kreisförmigen Querschnitt ist $\frac{T_{1}}{r}=\frac{\pi r^{.3}}{2} \doteq 1.57 r^{.3}$, somit $P a=1.571 t r^{3}$, oder für $r=\frac{d}{2}, P a=0.1963 t d^{3}$

Für einen ringförmigen Querschnitt ist, wenn $r$ den äusseren und $r_{1}$ den inneren Halbmesser bezeichnet, $\frac{T_{1}}{r}=\frac{\pi\left(r^{4}-r_{1}{ }^{4}\right)}{2 r}=\frac{1.571\left(r^{4}-r_{1}{ }^{4}\right)}{r}$ also $P a=\frac{1.571 t\left(r^{4}-r_{1}{ }^{4}\right)}{r}$, oder für $r=\frac{d}{2}$ und $r_{1}=\frac{d_{1}}{2}, P a=$ $\frac{0 \cdot 1963 t\left(d^{4}-d_{1}{ }^{4}\right)}{d}$

$\mathrm{Zu}$ bemerken ist noch, dass $t$ circa $4 / 5$ von der zulässigen Zugsspannung beträgt, also $t=0.8 k$.

Die für das Torsionsmoment entwickelten Formeln gelten insbesondere zur Berechnung von Wellen und Achsen. auszudricken.

Bezieht sich $t$ auf den $\square^{\mathrm{em}}$, so ist selbstverständlich auch $a$ in Centim.

Bei Wellen ist aber das Drehungsmoment gewöhnlich durch die Arbeitsgrösse in Pferdekräften und durch die Anzahl der Umdrehungen der Welle pr. Minute ausgedriickt. Bedeutet also $\boldsymbol{N}$ die Anzahl der Pferdekräfte, welche durch die Welle übertragen werden soll und $\boldsymbol{n}$ die Anzahl der Umdrehungen pr. Minute, so ist, wenn eine Pferdekraft mit $75^{\mathrm{mk}}$ bemessen und $a$ in Centim. gegeben ist, $P \frac{2 \frac{a}{100} \pi n}{60}=75 \mathrm{~N}$, woraus $P a=\frac{6000 \times 75 N}{2 \pi n} \div 71620 \frac{N}{n}$ Met.-Kg.(20).

Führen wir diesen Werth des in Meter-Kg. ausgedriickten Kraftmomentes in die obigen Gleichungen ein, so ergibt sich für den quadratischen Querschnitt: $71620 \frac{N}{n}=0.236+b^{3}$. . . . . . . . . . . . (17 a) : für den kreisförmigen Querschnitt: $71620 \frac{N}{n}=0.1963 t d^{3}$. . . . (18 a), und für den ringförmigen Querschnitt: $71620 \frac{N}{n}=\frac{0 \cdot 1963 t\left(d^{4}-d_{1}{ }^{4}\right)}{d}$

Zur näheren Erläuterung der aufgestellten Formeln mögen die folgenden Beispiele dienen.

1. Wie gross muss der Durchmesser $d$ einer schmiedeisernen Welle werden, wenn durch ein auf der Welle aufgekeiltes Zahnrad von $1^{\mathrm{m}}$ Durchmesser eine Kraft von $2000 \mathrm{Kg}$. mit 8 -facher Sicherheit übertragen werden soll?

Nach Gleichung (18) ist das Drehungsmoment $P a=0.1963 t d^{3}$. Hieraus ergibt sich :

$$
d=\sqrt[3]{\frac{P \cdot a}{0 \cdot 1963 t}} .
$$

Es ist $P=2000 \mathrm{Kg}$., $\quad \iota=100^{\mathrm{cm}}, t=0.8 \mathrm{k}$, und weil fur 8 -fache Bruchsicherheit beim Schmiedeeisen pro $\square^{\mathrm{cm}} k=500 \mathrm{Kg}$., so ist $t=400 \mathrm{Kg}$. Für diese Werthe wird $d=\sqrt[3]{\frac{2000 \times 100}{0 \cdot 1963 \times 400}}=\sqrt[3]{2547,11} \doteq 13.65^{\mathrm{cm}}$.

2. Welche Wandstärke muss eine solche gusseiserne Welle erhalten, wenn sie bei einem Durchmesser von $20^{\mathrm{cm}}$ eine Arbeitsgrösse von 24 Pferdekräften 
übertragen und 36 Umdrehungen in der Minute bei 8-facher Bruchsicherheit machen soll?

Aus Gleichung $(19 a)$ wird $d_{1}=\sqrt[4]{d^{4}-\frac{71620 N d}{01963 t n}}$, wobei $d=20^{\mathrm{cm}}$, $N=24, n=36$ und $t=0.8 \mathrm{k}$; da nun für 8 -fache Bruchsicherheit $k=$ $163 \mathrm{Kg}$. per $\square^{\mathrm{em}}$ ist, so wird $t \doteq 130 \mathrm{Kg}$., daher für diese Werthe

$$
d_{1}=\sqrt[4]{160000-\frac{71620 \times 24 \times 20}{0.1963 \times 130 \times 36}} \div 18.71^{\mathrm{cm}}
$$

und die gesuchte Wandstärke $=\frac{d-d_{1}}{2} \doteq 0.65^{\mathrm{cm}}$.

E) Zusammengesetzte Elasticität resp. Festigkeit. a) Knickoder Stauchungs-Elasticität. 1. Fall. Der einfachste Fall des Widerstandes gegen Zerknicken eines prismatischen oder cylindrischen Stabes tritt bei axialer Belastung ein, wenn derselbe an beiden Enden frei beweglich oder um Scharniere drehbar ist und seine Länge $l$ (Fig. 1383), die kleinste Querschnittsdimension mindestens um das 3 -fache ïberschreitet.

Fig. 1383.

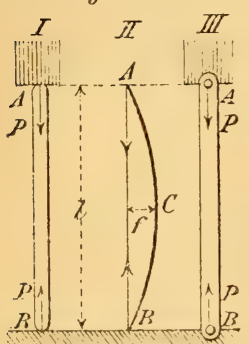

Die Curve $A, C, B$ sei die elastische Linie, d. i. die durch die Belastung $P$ deformirte Längenachse des prismatischen Stabes, dessen Durchbiegung im Allgemeinen in Richtung der kleinsten Querschnittsdicke derart erfolgt, dass die Durchbiegungsebene zugleich durch die Kraftrichtung geht. Der Stab erfährt durch die axiale Belastung eine Druckspannung, welche durch die Biegurg auf der concaven Seite vergrössert, dagegen anf der convexen Seite durch die Zugspannung vermindert wird.

Bezeichnet $l$ die Länge des Stabes, $F$ dessen Querschnitt, $T$ das kleinste Trägheitsmoment des Querschnittes in Bezug auf eine Scliwerpunktsachse und $\alpha$ einen von der materiellen Beschaffenheit des Stabes abhängigen Coëfficienten, so ergibt sich die durch die achsiale Belastung $P$ pro Flächeneinheit hervorgerufene grösste Druckspannung aus

$$
k_{1}=\frac{P}{F^{\prime}}\left(1+\approx \frac{l^{2} F}{T}\right)
$$

ferner die auf der convexen Seite entstehende grösste Zugspannung aus:

$$
k=\frac{P}{F}\left(-1+\varkappa \frac{l^{2} F}{T}\right)
$$

Für Schmiedeeisen ist $\alpha=\frac{1}{10000}$, für Gusseisen und Holz $\alpha=\frac{1}{5000}$.

Eine Zugspannung an der convexen Seite ist nur in solchen Fällen vorhanden, wo sich $k>0$, also $\frac{\iota^{2} F}{T}>1$ ergibt. Da übrigens $k_{1}$ stets grösser als $k$, so ist die Ermittlung ron $k$ nur bei Gusseisen erforderlich und für die Widerstandsfähigkeit erst dann massgebend, sobald $l_{i}>5 / 1+k_{1}$ wird.

In der folgenden Tabelle (S. 159) sind die für verschiedene Querschnittformen berechneten Werthe von $1+\frac{\iota^{2} \underline{F}^{\prime}}{T}$ und $-1+\frac{l^{2} F}{T}$ zusammengestellt, also $k_{1}$ und $k$ als Vielfache von $\frac{P}{F}$ ausgedriickt. Es bedeutet dabei $\frac{l}{d}$ das Verhältniss der Stablänge $l$ zur kleinsten Querschnittsdimension $d$.

Hierbei ist bei 5 -facher Bruchsicherheit pro $\square^{\mathrm{cm}}$ für Gusseisen $k_{1}=1400$ und $k=500 \mathrm{Kg}$., für Schmiedeeisen $k_{1}=800$ und für Holz bei 10 -facher Bruchsicherheit $k_{\mathrm{t}}=60 \mathrm{Kg}$. 


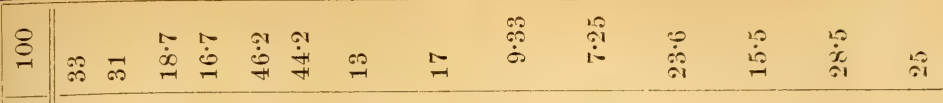

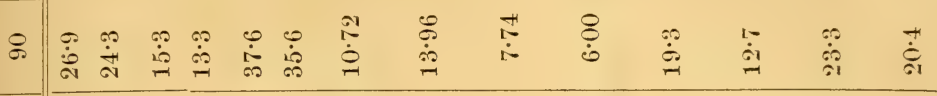

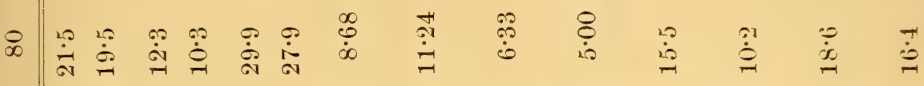

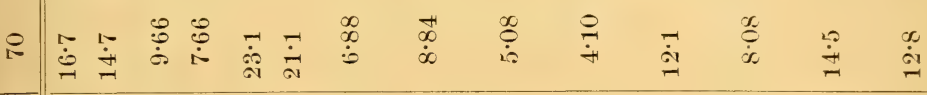

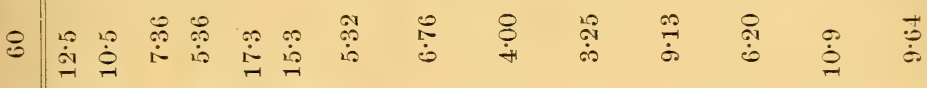

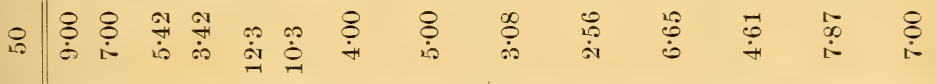

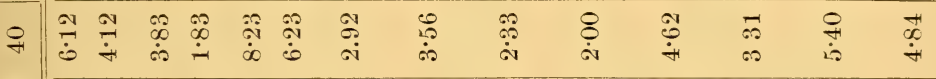

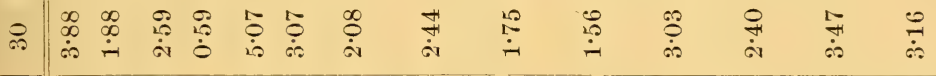

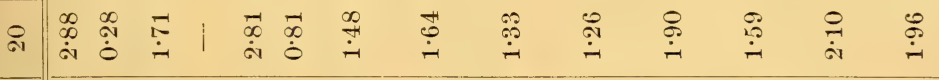

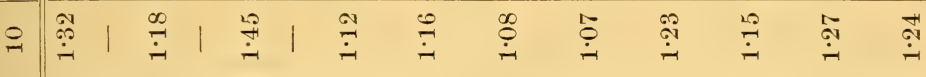

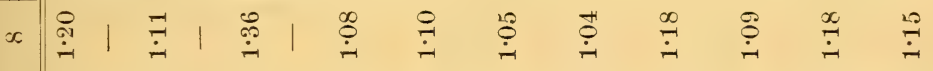

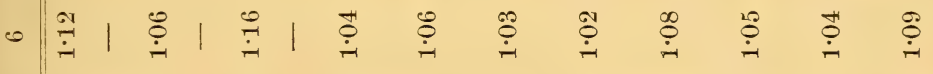

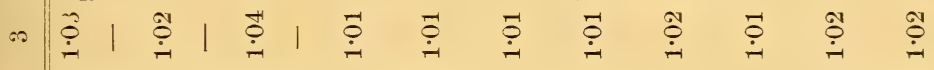

$\times \times \times \times \times \times \times \times \times \times \times \times \times$

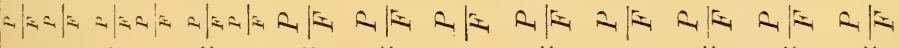

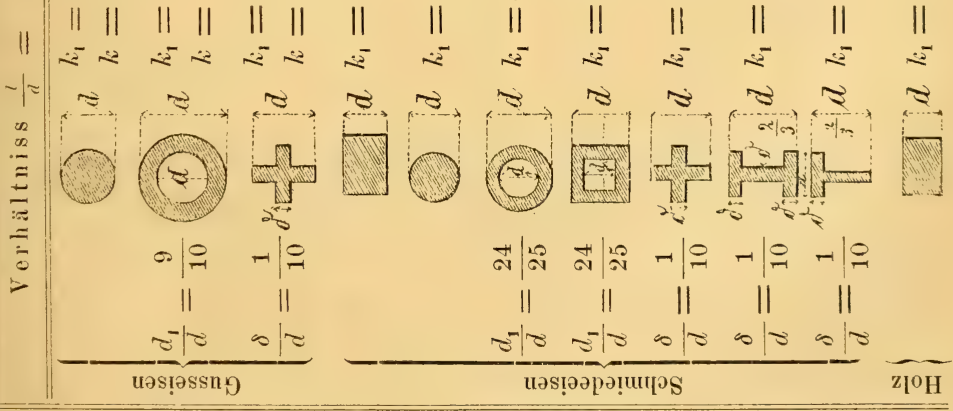


Beispiel. Wie gross ist bei 5 -facher Bruchsicherheit die zulässige achsiale Belastung $P$ einer an beiden Enden drehbaren, schmiedeisernen Strebe, deren rechteckiger Querschnitt die Breite $4^{\mathrm{cm}}$ und die Höhe $1^{\mathrm{cm}}$ hat, wenn die Länge $l$ der Strebe $40^{\mathrm{cm}}$ beträgt? Hier ist $\frac{d}{l}=40$, daher nach der obigen Tabelle für diesen Werth $k_{1}=\frac{P}{F} 2 \cdot 92$, woraus für $k_{\mathrm{l}}=800 \mathrm{Kg}$. und $F=4^{\mathrm{cm}}$, $P=\frac{800 \times 4}{2.92} \doteq 1092 \mathrm{Kg}$.

Fig. 1384. Fig. 1385.
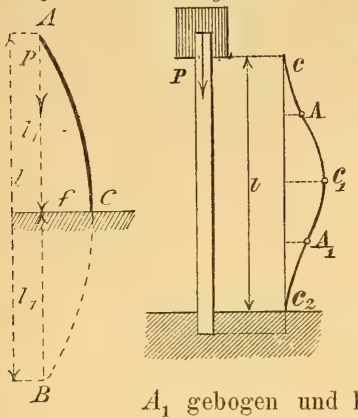

2. Fall. Der prismatische Stab $A, C$ (Fig. 1384) ist an einem Ende eingespannt und am anderen freien Ende achsial belastet.

Dieser Fall ist offenbar auf den vorigen zurickzuführen, wenn in den dortinge Formeln statt der Länge $l$ jene $2 l_{1}$ eingefuihrt wird; es wird dann $k_{1}=\frac{P}{F}\left(1+\frac{4 \alpha l_{1}^{2} F}{T}\right)$ und $\left.k=\frac{P}{F}\left(-1+\frac{4 \alpha l_{1}^{2} F}{T}\right)\right\}$.

3. Fall. Der prismatische Stab ist an beiden Enden eingespannt oder befestigt (Fig. 1385), so wird er dureh die achsiale Belastung nach einer Curve $C A C_{1} A_{1} C_{2}$ mit zwei Wendepunkten $A$ und man daher in den beiden letzten Formeln statt $l_{1}$ nur $\frac{l}{4}$, so erhält man

$$
\left.\begin{array}{rl}
k_{1} & =\frac{P}{F^{2}}\left(1+\frac{\kappa l^{2} F}{4 T}\right) \\
\text { und } k & =\frac{P}{F^{T}}\left(-1+\frac{\kappa l^{2} F}{4 T}\right)
\end{array}\right\}
$$

liig. 1386.

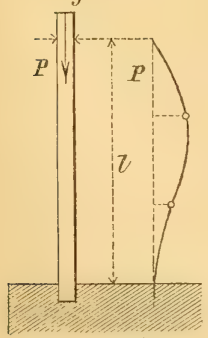

Fig. 1.387.

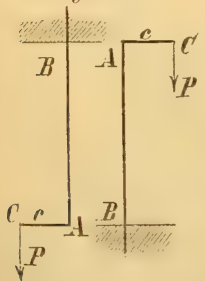

Dieser Fall findet die häufigste Anwendung bei der Berechnung der Säulen.

4. Fall. Der Stab ist an einem Ende eingespannt, am anderen Ende gegen seitliche Ausbiegung gesichert und mit $P$ achsial belastet. Fig. 1386.

Dieser Fall geht aus dem zweiten Falle hervor, wenn dort statt $l_{1}$ nur $\frac{l}{3}$ gesetzt wird; man erhält also:

$$
\left.\begin{array}{rl}
k_{1} & =\frac{P}{F}\left(1+\frac{4 k l^{2} F}{9 T}\right) \\
\text { und } k_{i} & =\frac{P}{F}\left(-1+\frac{4 k l^{2} F}{9 T}\right)
\end{array}\right\}
$$

b) Excentrische Zug-oder Druckbelastung. Ist die Durchbiegung der Längenachse $A B$ der prismatischen Stäbe (Fig. 1387) im Verhältniss zur Excentricität $c$ der belastenden Kraft $P$ sehr klein, so ist, wenn $F$ die ganze Querschnittsfläche, $T$ deren Trägheitsmoment in Bezug auf die Schwerpunktsachse normal zur Bildebene und $e$, resp. $e_{1}$ die Entfernung der äussersten gezogenen, resp. gedrückten Fasern von der Schwerpunktsachse bezeichnen, die pro Flächeneinheit auftretende grösste Zugspannung

$$
\begin{aligned}
r_{p} \cdot \boldsymbol{B} & =\frac{P}{F}\left(1+\frac{c \cdot e \cdot F}{T}\right) . \\
\text { und die grösste Druckspamnumg } k_{i_{1}} & =\frac{P}{F}\left(1+\frac{c \cdot e_{1} F}{T}\right) .
\end{aligned}
$$


Die Werthe von $T$ sind für verschiedene Querschnittsformen aus der Tabelle pag. $153 \mathrm{zu}$ entnehmen.

c) Achsiale und transversale Belastung. 1. Fall. Ist der Stab $A B$ (Fig. 1388) an einem Ende befestigt und am anderen Ende durch eine zur geraden Stabachse $A B$ schräg gerichtete Kraft $R$ belastet, so lässt sich $R$ in die beiden Componenten $H$ und $V$ zerlegen, und es wird die durch beide Componenten hervorgerufene grösste Zugspannung $k$ pro Flächeneinheit annähernd erhalten aus $k=\frac{H}{F}+\frac{V \cdot e \cdot l}{T}, .(27)$,

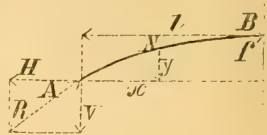
wobei wieder $F$ den Querschnitt, $T$ dessen Trägheitsmoment für die Schwerpunktsachse, $l$ die Stablänge und $e$ die Entfernung der äussersten gezogenen Fasern von der Schwerpunktsachse bedentet. Es wird hierbei jedoch vorausgesetzt, dass die durch $V$ eingeleitete Biegung des Stabes sehr gering, also der Biegungspfeil $f$ verschwindend klein sei.

2. Fall. Der prismatische Stab liegt mit beiden Enden auf Stiitzen $A, B$ (Fig. 1389), ist gleichmässig mit $g$ pro Längeneinheit und achsial durch die Kraft $H$ in Anspruch genommen.

Ist die Durchbiegung des Stabes Fig. 1389.

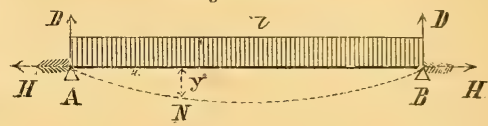
sehr gering, also $H$ im Verhältniss zu $g l$ gross, so ergibt sich die grösste pro Flächeneinheit auftretende Zugspannun $k$ annähernd aus

$$
k=\frac{H}{F}+\frac{e g l^{2}}{8 T}
$$

Die Grössen $e, l, F$ und $T$ haben hierbei dieselbe Bedeutung wie im vorhergehenden Falle. Der vorliegende Fall findet bei der Berechnung langer Zugstangen, deren Gewicht beriicksicht werden muss, häufige Anwendung.

d) B i e g n g s- und Torsionsbelastung. Fig. 1390.

Ist $M_{b}$ das Biegungs- und $M_{t}$ das Torsionsmoment einer Welle (Fig. 1390), so ergibt sich die grösste Anspruchnahme $k$ dieser Welle pro Flächeneinheit aus

$$
k=\frac{16}{\pi d^{3}}\left(2 M_{b}+M_{t}\right) . .(29) \text {. }
$$

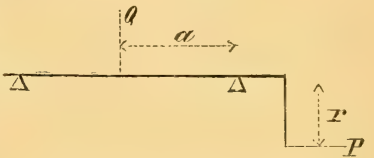

Hier ist $M_{b}=\frac{Q(l-a)}{l} a$ und $M=P r, d$ der Durchmesser der Welle, $l$ deren zwischen den Lagern liegende Länge und $\pi \doteq 3 \cdot 14$.

F) Elasticität, resp. Festigkeit der Gefässwände und Platten.*) Bezeichnet $p$ den auf die Gefässwand wirkenden Druck pro Flächeneinheit (nach Abzug des gegenseitigen), $k$ die in der Gefässwand zulässige Maximalspannung (pro Flächeneinheit), $\gamma$ und $\delta$ Gefässhalbmesser und Wanddicke, so ist für geringe Wandstärken :

1. beim cylindrischen Gefässe

Fig. 1391.

Fig. 1392.

(Fig. 1391)

$p=k\left(\sqrt{1+\frac{2 \delta}{r}}-1\right)$ und

$\frac{\delta}{r}=\frac{p}{k}\left(1+\frac{p}{2 k}\right) \cdot(30)$,

2. bei der Hohlkugel (Fig. 1392)

$p=2 k \frac{\delta}{r}$ und $\frac{\delta}{r}=\frac{p}{2 k} \cdot(31)$

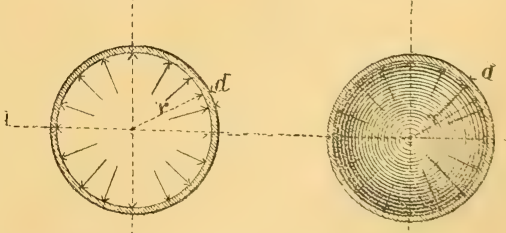

3. bei der kreisförmigen, lose aufgelegten Platte (Fig. 1393)

*) Vergleiche: Grashof, Festigkeitslehre.

Karmarsch \& Heeren, Technisches Wörterbuch. Bd. III. 
Fig. 1393.

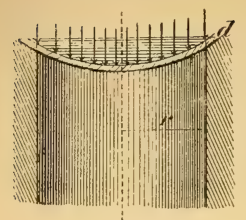

Fig. 1394.

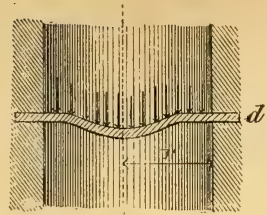

$$
p=k\left(\frac{\delta}{r}\right)^{2} \text { und } \frac{\delta}{r}=\sqrt{\frac{p}{k}}
$$

........ (32),

4. bei der kreisförmigen, am Rande fest. eingeklemmten Platte (Fig. 1394)

$$
\begin{aligned}
& p=\frac{3}{2} k\left(\frac{\delta}{r}\right)^{2} \text { und } \frac{\delta}{r}= \\
& \sqrt{\frac{2}{3} \frac{p}{k}} \cdot \ldots .(33) .
\end{aligned}
$$

Anmerkung. Bei Gefässen und Röhren, welche sehr hohen Pressungen ausgesetzt werden nnd demnach grosse Wandstärken erhalten müssen (z. B. bei Cylindern der hydraulischen Pressen), ist der Umstand zu berücksichtigen, dass das Material der Gefässwand in radialer Richtung in sehr ungleicher Weise (an der inneren Wand am stärksten) beansprucht wird. Mit Rïcksicht auf diesen Umstand erhält man nach Lamé fïr cylindrische Gefässe $p=k \frac{(r+\delta)^{2}-r^{2}}{(r+\delta)^{2}+r^{2}}$ und $\frac{\delta}{r}=\sqrt{\frac{k+p}{k-p}}-1$................................. (34); ferner für kugelförmige Gefässe

$p=2 k \frac{(r+\delta)^{3}-r^{3}}{(r+\delta)^{3}+2 r^{3}}$ und $\frac{\delta}{r}=\bigvee^{3} \frac{\overline{2(k+p)}}{2 k-p}-1$.

Beispiel. Wie gross muss die Wanddicke $\delta$ des gusseisernen Cylinders von $30^{\mathrm{cm}}$ lichter Weite einer hydraulischen Presse werden, wenn der Druck 100 Atmosphären oder nahezu $100 \mathrm{Kg}$. pro $\square^{\mathrm{cm}}$ beträgt und die zulässige Materialspamming $k=250 \mathrm{Kg}$. pro $\square^{\mathrm{cm}}$ betragen soll?

Ilier ist $r=15^{\mathrm{cm}}, l_{i}=250$ und $p=100 \mathrm{Kg}$, also nach obiger Formel (34)

$$
8=15(\sqrt{250+100}-1)=7 \cdot 9^{\mathrm{cm}}
$$

G) Elastische Federn.*) Die elastischen Federn gleicher Construction oder desselben Systems haben, wenn sie bei gleichem Material und gleicher Belastung (inmerhalb der Elasticitätsgrenze) dieselbe Formänderung erfahren, auch gleiches Gewicht. - Man unterscheidet im Allgemeinen: Blatt-, Spiral- und Schraubenfedern. Die ersteren werden auf Biegungs-, die letzteren auf Druck- oder Torsionsfestigkeit, resp. Elasticität beansprucht.

a) Einfache Blattfedern. Es bezeichnet $P$ die zulässige Belastung der Feder, $b, h$ und $l$ die aus den Figuren (s. nächste Seite) ersichtlichen Dimensionen, $k$ die zulässige Beanspruchung des Materiales pro Flächeneinheit, $E$ den Elasticitätsmodul und $\delta$ die grösste zulässige Durchbiegung.

4) Zusammengesetzte Blattfedern. Legt man mehrere der vorgeführten einfachen Blattfeclern aufeinander, so erhält man ein Blattfederwerk. Die Hauptbedingungen für ein gutes Federwerk sind:

1. dass es möglichst einen Träger von gleichem Biegungswiderstande bilde;

2. dass es bei der Biegung nicht klaffe, d.h. dass sich die einzelnen Blätter nicht von einander entfernen.

Diesen beiden Bedingungen entspricht nur das erste der folgenden Federwerke vollständig, während die anderen nur die letztere Bedingung erfüllen.

Das Trapezfederwerk. Denkt man sich die Dreieckfeder Fig. 1398, $I$, in eine gerade Anzahl gleich breiter Streifen zerschnitten und die mit gleichen Ziffern bezeichneten Stiicke so zusammengefiigt, dass hiedurch das Blattwerk II gebildet wirc, so erhält man das sogenannte Trapezfederwerk, welches offenbar dieselbe Tragfähigkeit hat wie die Dreieckfeder $I$.

: Vergleiclie: Relaux, Theorie der Federn. 
Elasticität (u. Festigkeit).

Tabelle der zur Berechnug der Blattedern nothigen Formeln.

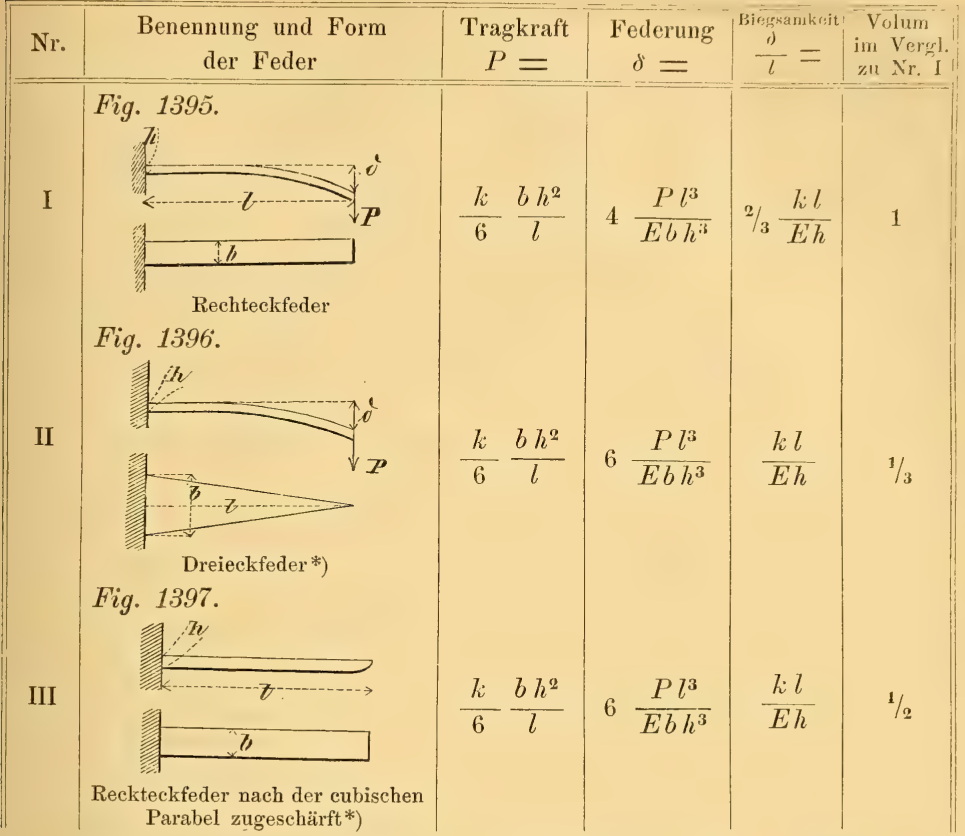

Statt die Enden der einzelnen Federn dreieckig zu machen, schärft man sie nach der cubischen Parabel zu (Fig. 1399), wobei sie dann überall gleiche Breite haben, oder man macht sie, nach Fig. 1400, trapezisch. In diesem Falle muss ausserdem noch eine Zuschärfung der Enden eintreten, die sich ans der folgenden Formel ergibt $z=h \downarrow^{3} \frac{b x}{b x+b_{\mathrm{\tau}}(a-x)}$. Fig. 1398.

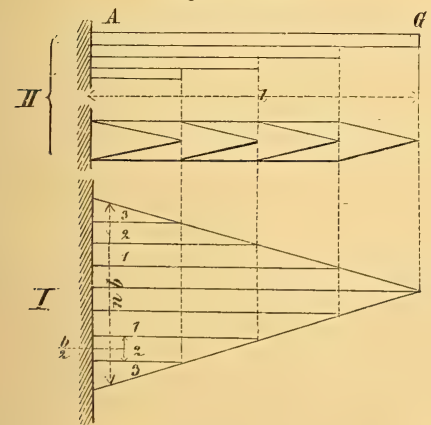

Fig. 1399.

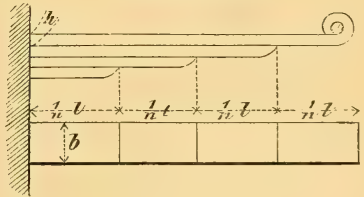

Fig. 1400.

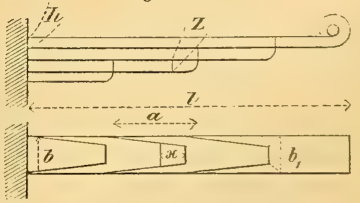

*) Die elastischen Linien der beiden letztgenannten Federformen bilden bei eintretender Biegung Kreisbögen, weshalb sich diese beiden Federn vorzüglich für die znsammengesetzten Federn eignen. 
In der Regel sind zwei Federwerke, nach Fig. 1401, mit einander verbunden

Fig. 1401.

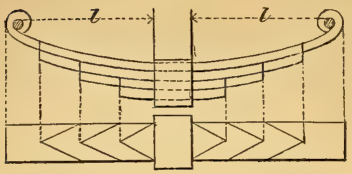

und erhalten eine geringe Krümmung, die man bei der Berechnung der Tragfähigkeit vernachlässigt.

c) Schrauben- und Spiralfedern. Hierbei bezeichne: $P$ die zulässige Belastung, $k$ die zulässige Anspruchnahme des Materials pro Flächeneinheit, $E_{1}$ den Elasticitätsmodul für Schub oder Torsion, der bekanntlich gleich ist $2 / 5$ von jenem für Zug (S. 147), $n$ die Anzahl der Windungen, $r$ den grössten Radius der Schraubenfeder bis zur Mitte des Drahtes, $\delta$ die durch $P$ hervorgerufene Längenänderung (Federung), $\frac{\delta}{r}$ den Werth für das Feuerungsverhältniss, $w$ die Grösse des Verdrehungswinkels und $l$ die Länge der gestreckt gedachten Federn (Fig. 1402 bis 1407).

Tabelle der zur Berechnung der Schrauben- und Spiralfedern nöthigen Formeln.

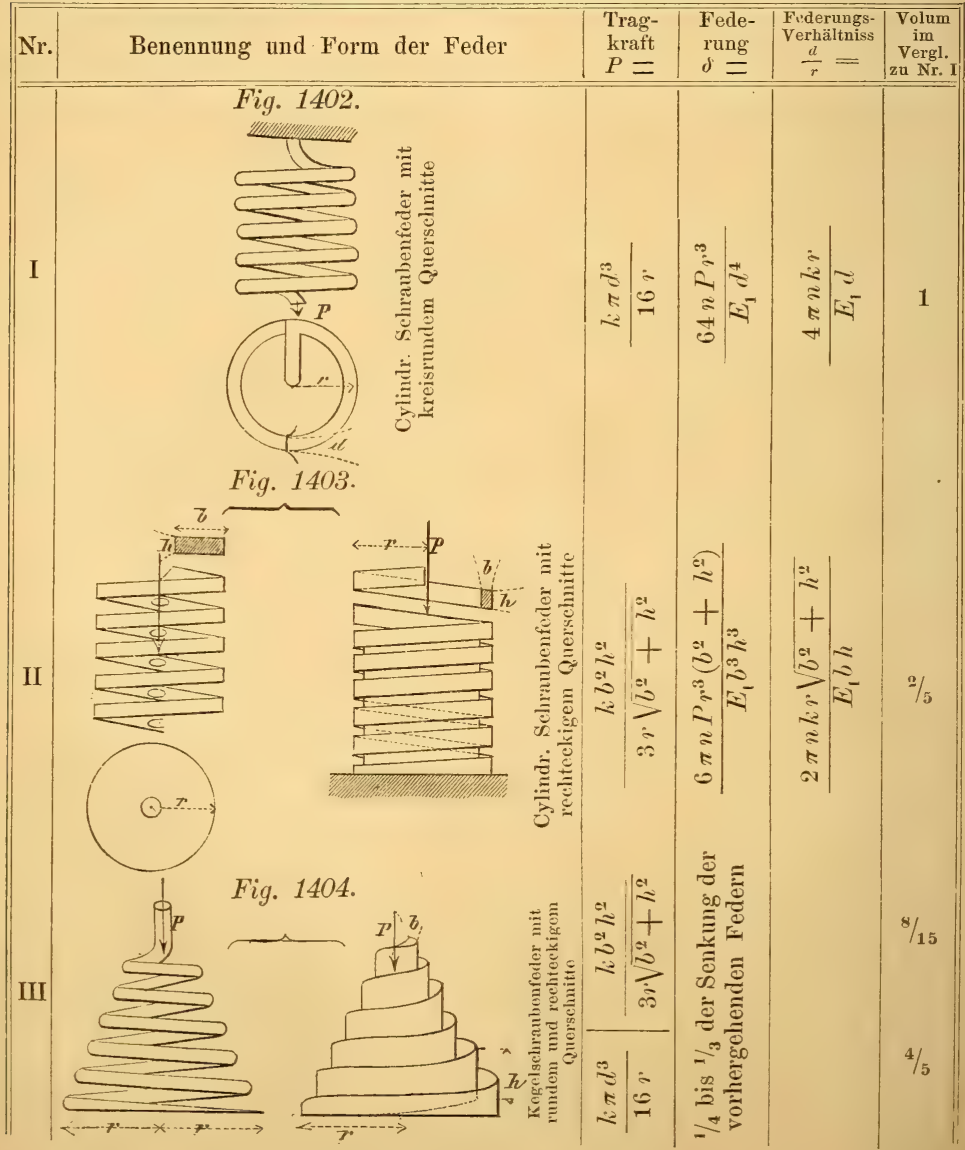




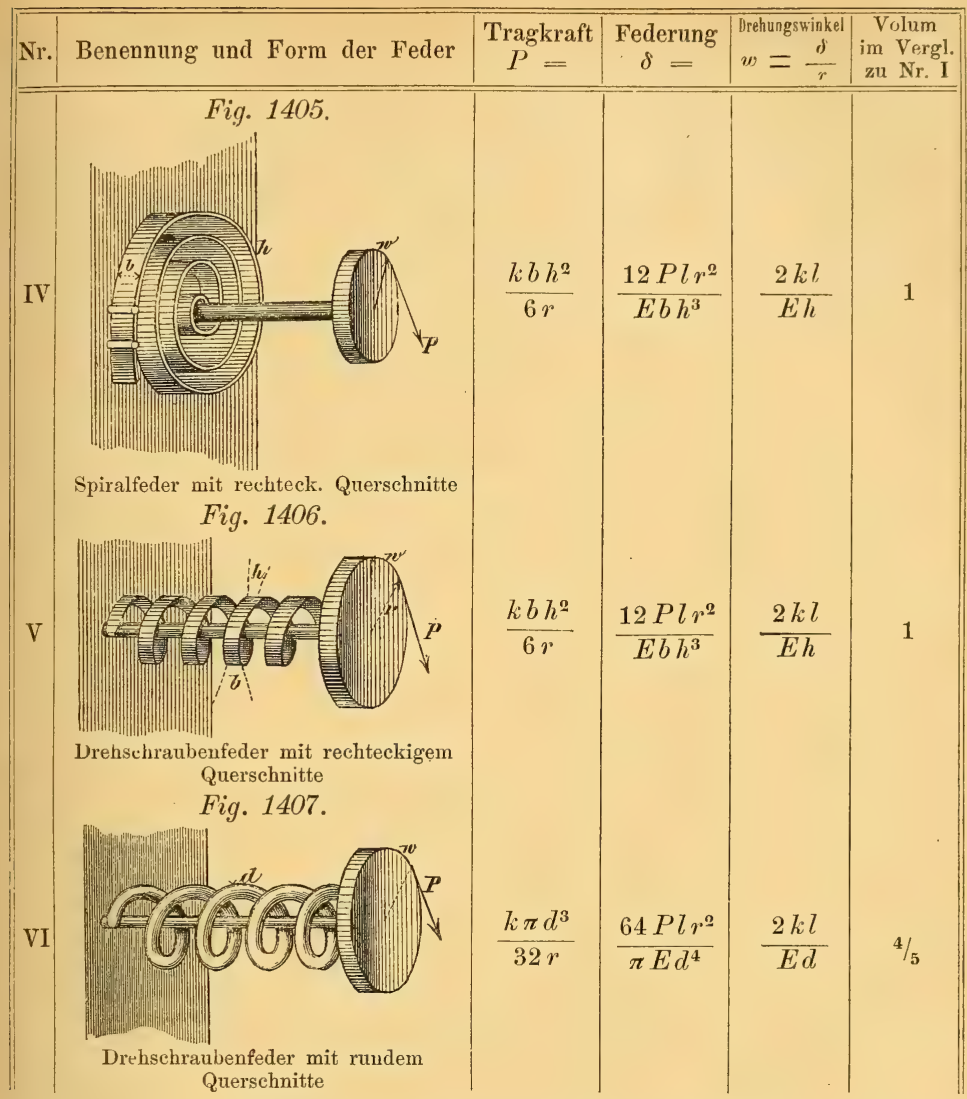

H) Arbeitsfestigkeit. Man versteht darunter, nach Launardt, die Maximalspannung $A$ pro Flächeneinheit eines Trägers, bei welcher erst nach einer grossen Anzahl von Belastungswiederholungen der Bruch des Trägers erfolgt. Nach den Versuchen von $\mathrm{W} \ddot{0} \mathrm{hler}$ ist die Arbeitsfestigkeit $A$ kleiner als der Bruch- oder Festigkeitsmodul $K$, bei dessen einmaliger Wirkung bereits der Bruch erfolgt.

Die von Wöhler mit Eisen und Stahl angestellten und von Prof. Spangenberg: fortgesetzten Versuche über den Einfluss wiederholter Beanspruchung der Träger führten zu den folgenden Wöhler'schen Gesetzen:

1. Der Bruch erfolgt bereits bei einer kleineren Spannung als bei ruhender Belastung, wenn man die Beanspruchung häufig wieederholt.

2. Die Anzahl der zum Bruche erforderlichen Beanspruchungen ist um so grösser, je kleiner hierbei - bei constant bleibender Minimalspannung - die Maximalspannung ist, oder je grösser - bei gleich bleibender Maximalspannung - die Minimalspannung ist.

3. Wenn die Maxinalspannung kleiner ist als eine von der Mininalspannung abhängige Grenze. so tritt nie ein Bruch ein.

4. Die Arbeitsfestigkeit ist um so grösser, je grösser die Minimalspannung ist.

Auf Grundlage der Wöhler'schen Gesetze wurden von den Ingenieuren und Professoren Backer, Gerber, La unhardt, M ïller, Schäffer, Weyrauch und E. Winkler in neuester Zeit Formeln zur Berechnung der Arbeitsfestigkeit 
und der zulässigen Inanspruchnahme der Eisen- und Stahlconstructionen aufgestellt. Wir wollen hier jedoch nur die von Weyrauch*) in Vorschlag gebrachten Formeln vorfuihren.

Bezeichnet min. $B$ die Minimal- und max. $B$ die Maximal-Belastung eines Trägers, so ist für Träger, die nur auf $\mathrm{Zug}$ oder nur a uf $\mathrm{Druck}$ beansprucht werden, die Arbeitsfestigkeit in $\mathrm{Kg}$. pro $\square^{\mathrm{cm}}$ : für Schmiedeeisen $A=2100\left(1+1 / 2 \frac{\min . B}{\max . B}\right)$, für Gussstahl $A=3300\left(1+9 / 11 \frac{\min . B}{\max . B}\right)$ ferner für Träger, die abwechselnd a uf Zug und Druck beansprucht sind, wenn max. $B$ das absolute Maximum der vorkommenden Beanspruchungen und max. $B^{\prime}$ die relativ grösste Beanspruchung im entgegengesetzten Sinne bezeichnet: für Schmiedeeisen $A=2100\left(1-1 / 2 \frac{\max . B^{\prime}}{\max . B}\right)$, für Gussstahl $A=3300\left(1-5 / 11 \frac{\max \cdot B^{\prime}}{\max . B}\right)$.

Uebrigens miissen die auf Druck beanspruchten Stäbe gegen seitliche Durchbiegung gesichert sein.

Schliesslich mag noch erwähnt werden, dass die zulässige Inanspruchnahme $k$ pro Flächeneinheit aller Constructionstheile, die wechselnden Belastungen hinreichenden Widerstand zu leisten haben, aus der Arbeitsfestigkeit $A$ bestimmt werden soll. Wählt man also nach Weyrauch die 3fache Sicherheit gegen den Bruch, so ist $k=\frac{A}{3}$.

Hiernach ergibt sich also die zulässige In anspruchnahme $k$ pro $\square^{\mathrm{cm}}$ in $\mathrm{Kg}$. bei Constructionstheilen, die $\mathrm{nur} \mathrm{Zug} \mathrm{oder} \mathrm{nur} \mathrm{Druck} \mathrm{zu} \mathrm{erleiden} \mathrm{haben:}$

$$
\left.\begin{array}{l}
\text { für Schmiedceisen } k=700\left(1+1 / 2 \frac{\min . B}{\max . B}\right) \\
\text { für Gussstahl } k=1100\left(1+9 / 1 \frac{\min . B}{\max . B}\right)
\end{array}\right\}
$$

dagegen für Constructionstheile mit entgegengesetzten Belastungen, also für Zug und Druck:

$$
\begin{aligned}
& \text { für Schmiedeeisen } k=700\left(1-1 / \frac{\max \cdot B}{\max \cdot B}\right) \\
& \text { für Gussstahl } k=1100\left(1-5 / 11 \frac{\max \cdot B^{\prime}}{\max \cdot B}\right)
\end{aligned}
$$

Bei Dach- und Briickenconstructionen wird gewöhnlich min. $B$ durch das Eigengewicht allein und max. $B$ durch die totale Belastung (Eigengewicht und zeitweilige oder mobile Belastung) hervorgerufen.

Zur Erläuterung mögen noch die beiden folgenden Beispiele dienen.

1. Beispiel. Wie gross ist die zulässige Inanspruchnahme $k$ und der Querschnitt $F$ einer schmiedeisernen Zugstange eines Fachwerkträgers, deren Minimalbelastung $=1000$ und deren Maximalbelastung $=6000 \mathrm{Kg}$. beträgt?

Nach (36) ist für min. $B=1000$ und max. $B=6000$

$$
k=700\left(1+1 / 2 \frac{1000}{6000}\right) \doteq 760 \mathrm{Kg} \cdot \text { pro } \square \mathrm{cm}
$$

daher der Querschnitt $F=\frac{\max . B}{k}=\frac{6000}{760} \doteq 7 \cdot 9 \square^{\mathrm{cm}}$.

2. Beispiel. Wie gross ist die zulässige Inanspruchnahme $k$ und der Querschnitt $F$ einer schmiedeisernen Diagonalstange eines Fachwerkträgers, deren durch die mobile Belastung bedingten entgegengesetzten Maximalbelastungen +7080 und $-1770 \mathrm{Kg}$. betragen?

*) Dr. J. We yraucli's Festigkeit- und Dimensionenberechnung der Eisen- und Stahlconstructionen, Leipzig, Teubner 1876. 
Hier ist $\max . B=7080$ und $\max . B^{\prime}=1770$, also nach (37)

und

$$
\begin{gathered}
k=700\left(1-1 / 2 \frac{1770}{7080}\right) \doteq 610 \mathrm{Kg} \cdot \text { pro } \square \mathrm{cm}, \\
F=\frac{\max \cdot B}{610}=\frac{7080}{610}=11 \cdot 6 \square^{\mathrm{cm}} .
\end{gathered}
$$

(Jtt.

Elasticitätsgrenze und Elasticitätsglösse, s. Elasticität III S. 143.

Elasticitätsmodul, s. Elasticität III S. 146.

Elastische Linie, s. Elasticität III S. 152.

Elaterin (élatérine - elaterine), Elatin. Bitterstoff aus dem Fruchtsafte der Eselsgurke oder Springgurke (Momordica Elaterium L.), welcher im eingedickten Zustande unter dem Namen Elaterium als Arzneimittel in Verwendung steht. Man unterscheidet im Handel zwei Sorten des Elateriums, u. zw. ein weisses und ein schwarzes Elaterium. Das erstere wird durch Verdunstung des aus noch nicht völlig reifen Frïchten durch Pressen gewonnenen und filtrirten Saftes bei gewöhnlicher Temperatur, das letztere durch Eindampfen des von völlig reifen Fruichten gewonnenen Saftes in der Wärme dargestellt. Das Elaterin stellt weissgraue bis grünliche (we is s e s oder en $\mathrm{gl}$ is ches), oder aber dunkel griinlichbraune (s chwarzes oder deutsches), bröckliche, am Bruche oft mattglänzende Massen von bitterem scharfem, bis brennendem Geschmacke dar, welche im Wasser so wie in Alkohol löslich sind und sich durch die heftig purgirende und brechenerregende Wirkung auszeichnen, die sie schon in geringer Dosis hervorrufen können.

Das Elaterin darzustellen, erschöpft man weisses Elaterium mit kochendem Weingeist und fällt aus dem durch Abdampfen concentrirten Auszuge mit Wasser das rohe Elaterin, das durch Waschen mit Aether und durch Umkrystallisiren mit Weingeist gereinigt werden kann (vgl. Z w enger, Ann. d. Chem. u. Pharm. 43 pag. 359). Bildet farblose, glänzende sechsseitige Tafeln, geruchlos, von scharfem und stark bitterem Geschmacke und neutraler Reaction. In Wasser unlöslich, schwer in kaltem Weingeist und Aether, leicht in kochendem Weingeist, Schwefelkohlenstoff, Amylalkohol und Chloroform. Aetzende Alkalien, so wie Aetzammoniak lösen es leicht, durch Säuren wird es aus diesen Lösungen wieder gefällt. In kohlensauren Alkalien unlöslich. Beim Erhitzen auf $200^{\circ} \mathrm{C}$. schmilzt es unter Gelbfärbung und erstarrt nach dem Erkalten zu einer gelblichen amorphen Masse. Concentrirte Schwefelsäure färbt es dunkelroth; wird es mit Salzsäure eingedampft und der Rückstand mit concentrirter Schwefelsäure befeuchtet, so färbt es sich amaranthroth (vgl. Köhler, Neu. Repert. f. Pharm. 18 pag. 578). Wirkt schon in geringen Gaben äusserst heftig purgirend. Seine Zusammensetzung entspricht der Formel $C_{20} H_{28} O_{5}$. Im weissen Elaterium sind nach $\mathrm{Walz}$ (N. Jahrb. f. Pharm. 11 pag. 21 u. 178) bis $50 \%$ Elaterin enthalten.

Neben dem Elaterin soll die Momordicapflanze nach Walz (s. oben) noch Elaterinsäure oder Ecbalin $\mathrm{C}_{20} H_{34} \mathrm{O}_{4}$ (?), eine harzartige bitterscharfe Substanz, dann Elaterid, Hydroelaterin und Prophet in enthalten, weicher letztere Körper sich nach Winckler auch im Safte der Friichte von Cucumis Prophetarum findet. Gtl.

Elaterit. Elastisches Erdpech, bildet derbe eingesprengte oder knollige Massen, auch Ueberzigge, ist elastisch, sehr weich, klebt zuweilen etwas, spec. Gew. $=0.8-1.23$, schwärzlichbraun, röthlich- bis gelblichbraun. Hat Fettglanz, ist kantendurchscheinend bis undurchsichtig, riecht stark bituminös. Chemische Znsammensetzung $\mathrm{CH}^{2}$. Findet sich auf Erzgängen zu Castleton in Derbyshire, so wie zu Nuahaven in Connecticut N.-A. S. Asphalt S. 213.

$L b$.

Elaterium, s. b. Elaterin. 
Elatin, s. Elaterin.

Elaylgas (gaz oléfiant - oil gas), ölbildendes Gas, A ethylengas, schweres Kohlenwasserst offgas. Ein Kohlenwasserstoff von der Formel $\mathrm{C}_{2} H_{4}$, welcher ganz allgemein unter den Producten der trockenen Destillation organischer Substanzen (Holz-, Stein- und Braunkohle etc.) angetroffen wird, s. Kohlenwasserstoffe. Gtl.

Elaylverbindungen, syn. mit A ethylenverbindungen, s. b. Kohlenwasserstoffe.

Elbeufschwarz, Sedanschwarz, ein Schwarz auf Wolle oder Seide, durch Ausfärben der in einer Indigküpe grundirten Zeuge in einem kochendem Bade von Campecheholz, Sumach und Eisenvitriol dargestellt. Gtl.

Electricität (electricité - electricity). So nennt man die ihrem Wesen nach noch nicht bekannte Ursache eines zuerst am Bernstein ( Electron) beobachteten Zustandes, der sich durch gewisse sowohl von der Gravitation als auch vom Magnetismus (s. d.) verschiedene anziehende und abstossende Kräfte zu erkennen gibt. Körper, welche sich in diesem sogleich näher zu erörternden Zustande befinden, nennt man electris ch.

A) Reibungselectricität. In sehr hohem Grade lässt sich der electrische Zustand an festen Harzen (z. B. Bernstein, Schellack, Schiffspech, Siegellack) durch Reiben mit Pelzwerk oder Flanell u. dgl. hervorrufen. Die genannten Körper erlangen auf diese Art voriibergehend die Eigenschaft, leichte Körperchen (z. B. Stiickchen von Hollundermark, Papierschnitzel) anzuziehen und nach erfolgter Berihrung wieder abzustossen.

Je zwei durch Beriihrung mit einer geriebenen Harzstange electrisirte Körper stossen einander ab.

Auch Glas wird durch Reiben (vornehmlich mit feinem Papiere, Tuch, amalgamirtem Leder) electrisch und bewirkt dieselben Erscheinungen, jedoch mit dem Unterschiede, dass zwei Körper, deren einer mit geriebenem Harze, der andere mit geriebenem Glase electrisirt worden ist, einander nicht abstossen, sondern anziehen.

Wir schliessen aus diesen und vielen ähnlichen Erscheinungen, dass es zweierlei Electricitäten gibt, die man als $\mathrm{H}$ arz-Electricität und Glas-Electricität unterscheidet. Insofern dieselben wie entgegengesetzte Grössen sich verhalten, pflegt man sie beziehungsweise als negative und positive Electricitäten $(-E$ und $+E)$ zu bezeichnen, wobei also die willkürliche Annahme zu Grunde liegt, dass man die Glas-Electricität als die positive gelten lässt . . . . . . I.)

Weiterhin folgt aus den angeführten Thatsachen noch der bekannte Satz, dass gleichnamige Electricitäten einander abstossen, ungleichnamige einander anziehen . . . . . . . . . . . . . . . . . . . . . II.)

Nähere Untersuchungen ïber die Electricitäts-Entwickelung durch Reibung haben gelehrt, dass dabei stets beide Electricitäten gleichzeitig und in gleicher Menge auftreten, so dass ron den beiden aneinander geriebenen Körpern der eine positiv und der andere negativ electrisch wird . . . . . III.)

Ferner hat sich herausgestellt, dass ein und derselbe Körper, je nachdem cr mit diesem oder jenem anderen Körper ("Reibzeug“) gerieben wird, bald positiv; bald negativ electrisch wird. So kann z. B. Glas, welches in den meisten Fiallen positiv electrisch wird, durch Reiben mit Katzenfell auch negativ electrisch gemacht werden. Es lässt sich iiberhaupt eine Reihe von Körpern so ordnen, dass bei der Reibung je zweier der in der Reihe vorhergehende stets positiv, der nachfolgende negativ electrisch wird. Eine solche Reihe wäre z. B. folgende: Katzenfell, Flanell, Glas, Bammolle, Seide, Holz, Schellack, Metalle, Schwefel, Guttapercha *) . . . . . . . . . . . . . . . . IV.)

*) Vergl. Bal four-Stewart, kurzes Lehrbuch der Physik. 
Der electrische Zustand eines Körpers kann, wie schon die angeführten Versuche erkennen lassen, auch anderen Körpern durch Beriihrung oder auch durch blosse Annäherung mitgetheilt werden. Dabei bestehen hinsichtlich der Leichtigkeit, mit welcher die Körper Electricität annehmen oder abgeben, grosse Unterschiede. So nehmen z. B. die Harze, Glas, Seide, wenn sie mit electrischen Körpern in Berïbrung kommen, die Electricität nur schwer und eben nur an der Beruihrungsstelle an, während dagegen ein Stiick Metall, mit einem electrischen Körper in Berührung gebracht, sogleich und auf seiner ganzen Oberfläche electrisch wird. Man schreibt deshalb den Körpern ein verschiedenes Leitungsvermög en für Electricität zu und bezeichnet insbesondere die Harze, das Glas, die Seide u. s. w. als schlechte, die Metalle aber als gute Leiter. Es mag bei dieser Gelegenheit schon jetzt bemerkt werden, dass gute oder schlechte Wärmeleiter (s. den Artikel Wärmemessung) im Allgemeinen auch gute oder schlechte Electricitätsleiter sind

Schlechte Leiter nennt man auch Is olatoren, und einen Körper, der mit keinem guten Leiter in Bertihrung ist, isolirt. Der leere Raum ist als absolut nicht leitend $\mathrm{zu}$ betrachten; trockene Luft als schlecht leitend. Feuchtigkeit erhöht ihr Leitungsvermögen sehr auffallend

Deshalb ist auch leicht einzusehen, dass electrische Versuche, bei welchen es darauf ankommt, die Electricität auf isolirten Körpern zu erhalten, $\mathrm{nur}$ in trockener Luft gut gelingen können. Eine höhere Temperatur ist dabei insofern vortheilhaft, als dieselbe bei gleichem absolutem Wassergehalte der Luft einen geringeren Feuchtigkeitsgrad (s. den Artikel Hygrometer) bedingt . VII.)

Von den Fliissigkeiten können die Säuren und Salzlösungen im Allgemeinen als ziemlich gute Leiter, Alkohol, Aether, fette Oele als sehr schlechte Leiter bezeichnet werden. Letzteres gilt auch vom chemisch reinen Wasser und rom Eise. Aeusserst geringe Beimischungen (Verunreinigungen) von Säuren oder Salzen erhöhen das Leitungsvermögen des Wassers schon sehr bedeutend*) . . . VIII.)

Uebrigens hängt das Leitungsvermögen der Körper auch von der Temperatur ab. Metalle werden durch Erwärmung schlechter, chemisch zusammengesetzte Flüssigkeiten besser leitend

Auch Glas wird in der Rothglühhitze leitend.

Um die electrischen Erscheinungen übersichtlicher zu machen, bedient man sich der Vorstellung, als wenn es zwei äusserst feine Flüssigkeiten.(Fluida) gäbe, $+E$ und $-E$ genannt, welche das im Satze II ausgesprochene Verhalten äussern. Im unelectrischen Körper denkt man sich dieselben gleichförmig und in gleicher Menge vereinigt und einander neutralisirend. Beim Electrisiren, z. B. durch Reibung, findet eine Scheidung der beiden Fluida statt, und zwar in einer dem Satze III entsprechenden Weise.

Wird ein mit $+E$ geladener Körper $K$ (z. B. eine geriebene Glasstange) einem isolirten Leiter $L$ (z. B. einer metallenen Kugel auf gläsernem Fusse oder einer Hollundermarkkugel an einem seidenen Faden) genähert, so wird die in $L$ enthaltene negative Electricität angezogen, die positive abgestossen und auf diese Art eine electrische Trennung, d. i. eine Electricitäts-Entwickelung bedingt, wobei eine Electricitätsmenge - $E^{\prime}$ auf der dem Körper $K$ zugewendeten und eine gleichgrosse entgegengesetzte Electricitätsmenge $+E^{\prime \prime}$ auf der von $K$ abgewendeten Seite des Leiters $L$ sich ansammelt. Wäre $K$ mit negativer Electricität geladen, so würden auf $L$ beziehungsweise die Electricitäten $+E^{\prime}$ und $-E^{\prime \prime}$ in der beschriebenen Anordnung auftreten. Man nennt diesen Vorgang der Electrisirung durch Fernwirkung electrische Influenz und bezeichnet die von der $E$ des influencirenden Körpers angezogene $E^{\prime}$ des influencirten Leiters $L$ als $I n f l$ ue nzelectricität der ersten Art, die abgestossene $E^{\prime \prime}$ als Influenzelectricität der zweiten Art.

*) Siche auch den Artikel Electrolyse. 
Theorie und Erfahrung lehren iibereinstimmend, dass das Innere eines durchaus gleichartigen electrisirten Leiters stets unelectrisch ist. Electrische Ladungen können sich also immer nur auf der Oberfläche eines Leiters befinden . . . . . . . . . . . . . . . XI.)

Es ist immer $\pm E^{\prime}=\mp E^{\prime \prime}$, d. h. die beiden Influenzelectricitäten sind immer von gleicher Menge aber entgegengesetzter Beschaffenheit . . . . XII.)

Die Electricitätsmenge $E^{\prime}$ (oder $E^{\prime \prime}$ ) ist nur dann der influencirenden Electricitätsmenge $E$ gleich, wenn der influenzirende Körper $K$ vom influenzirten Leiter $L$ ringsum (wie z. B. von einer metallenen Schale) eingeschlossen ist. In allen anderen Fällen ist $E^{\prime}$ (oder $E^{\prime \prime}$ ) kleiner als $E$. . . . . . . . . . XIII.)

Im ersten Falle des Satzes XIII üben die beiden eingeschlossenen Electricitäten $E$ und $E^{\prime}$ nach aussen gar keine anziehende oder abstossende Wirkung aus und es erscheint demnach $L$, wenn man $E^{\prime \prime}$ abgeleitet hat, ganz unelectrisch . . . . . . . . . . . . . . . . XIV.)

Annähernd gilt XIV auch von der abgeleiteten äusseren Belegung einer geladenen Leydener Flasche, wobei die innere Belegung den Körper $K$, die äussere den (theilweise) einschliessenden Leiter $L$ vertritt; so wie auch von einer zur Erde abgeleiteten Metallplatte $L$, hinter welcher sich der electrische Körper $K$ befindet, jedoch nur innerhalb des Raumes, welchen man den "electrischen Schatten" des Schirmes $L$ nennt . . . . . . . . . . . . . . . . . . . . XV.)

Bei dem Versuche $X$ wird, weil die Entfernung zwischen $E$ und $E^{\prime}$ kleiner ist als zwischen $E$ und $E^{\prime \prime \prime}$, die Anziehung zwischen $K$ und $L$ auch dann überwiegen, wemn $E^{\prime \prime}$ nicht abgeleitet worden ist. Ist $L$ beweglich, wie z. B. ein electrisches Pendel, und kommt es in Folge dessen mit $K$ in Berührung, so wird $E$ einen Theil von $E$ neutralisiren, und $L$, welches iiberdies noch einen Theil von $E$ aufnimmt, als gleichnamig electrisch abgestossen werden . . . . . XVI.)

Ist der influenzirte Leiter $L$ auf Seite des electrischen Körpers $K$ mit einer oder mehreren Spitzen (scharfen Kanten u. dgl.) versehen, so tritt die im Artikel Blitzableiter I pag. 641 und 642 beschriebene Ladung mit gleichnamiger Influenzelectricität durch Spitzenwirkung ein . . . . . . . . . . . . XVII.)

Nach demselben Principe ist leicht einzusehen, wie durch Spitzenwirkung auch der Electricitätsverlust eines Leiters an die Luft befördert wird, weshalb an isolirten Leitern, auf welchen man electrische Ladungen erhalten will (wie z. B. bei den leitenden Bestandtheilen ron Electrisirmaschinen, Leydener Flaschen u. s. w.), scharfe Kanten, Spitzen u. dgl. sorgfältig vermieden sein mïssen, mit Ausnahme der zur Vermittlung ron Ladungen bestimmten Spitzen, die man wegen ihrer scheinbar (XVII) saugenden Wirkung naugspitzen" nennt . . . . . . XVIII.)

Der electrische Körper $K$ kann (besonders wenn er selbst ein Leiter ist) bei hinreichend starker Ladung einen Theil seiner Electricität an einen angenäherten Leiter $L$ in der Form einer sogenannten Funkenentladung abgeben. Diese Erscheinung beruht darauf, dass die zwischen $K$ und $L$ befindliche Luftschichte, wegen ihres schlechten Leitungsrermögens, durch die iibergehende Electricität bis zum Glühen erhitzt wird . . . . . . . . . . . . . XIX.)

Im leeren Raume ist aus dem bereits in VI angegebenen Grunde eine electrische Entladung unmöglich, so wie wir ïberhaupt die Electricität immer nur an den Körpern (an denselben haftend oder ron denselben geleitet), niemals aber von den Körpern getrennt beobachten können . . . . . . . . XX.)

Die Strecke der Funkenentladung nennt man Schlagweite, wobei vorausgesetzt wird, dass $L$ mit der Erde leitend rerbunden ist. Nähert man $L$ verschiedenen Stellen von $K$, so erhält man unter ïbrigens gleichen Umständen rerschiedene Schlagweiten, nach Massgabe der sogenannten Dichte der Electricität an derjenigen Stelle der Oberfläche des Leiters $K$, von welcher der Funke ausgeht. Stärker gekrïmmten Stellen entspricht eine grössere electrische Dichte (und Schlagweite) als schwächer gekrimmten . . . . XXI.)

Deshalb ist z. B. an der Funkenstelle des Conductors der Winter'schen Electrisirmaschine ein hervorragender, abgerundeter Leiter angebracht. 
Ueber den Einfluss der Gestalt des Leiters L, welcher die Funkenentlariung aufnimmt, ist im Artikel Blitzableiter pag. 642 (unten) und 643 das Nöthige gesagt worden.

Von der Dichte der Electricität, welche anf der Oberfläche eines Leiters stellenweise verschieden ist, hat man die sogenannte Spannung der Electricität wohl zu unterscheiden. Diese ist, wenn Gleichgewicht besteht, auf der ganzen Oberfläche eines Leiters oder auch mehrerer mit einander leitend verbundener Leiter dieselbe. Man könnte sie durch die Electricitätsmenge messen, welche in eine kleine metallene Kugel iiberginge, die man mittelst eines langen dünnen Dralites mit der untersuchten Stelle des Leiters in Verbindung brächte. XXII.)

Zur genaueren Untersuchung des electrischen Zustandes der Körper dienen eigere Instrumente, die man Electroscope oder Electrometer nennt. Vom Electroscope wird nur verlangt, dass es das Vorhandensein von Electricität und deren Qualität $(+E$ oder $-E$ ) erkennen lasse, ohne jedoch genaue qualitative Bestimmungen zu gestatten. Ein Instrument, welches auch der letzteren Anforderung genügt und zur Messung von Electricitätsmengen geeignet ist, heisst Electrometer . . . . . . . . . . . . . . . . XXIII.)

Ein älteres, sehr einfaches, für viele $Z_{w e c k e}$ ausreichendes Electroscop ist das in Fig. 1408 abgebildete.

Durch den Deckel eines Glasgefässes geht, durch ein Glasrohr isolirt, ein dicker Draht, der oben eine metallene Kugel trägt, während an seinem unteren Ende entweder zwei feine Reisstrohhalme an feinen Häckchen angehängt oder zwei Streifen Blattgold angeklebt sind.

Nähert man der Kugel einen electrischen Körper, so wird bei starker z. B. positiver Ladung desselben die Influenzelectricität $+E^{\prime \prime}$ (siehe Satz $X$ ) in die Goldblättchen getrieben werden und durch gegenseitige $\mathbf{A b}$ stossung ein Auseinandergehen derselben, eine sogenannte "Divergenz" bewirken. Die Grösse der letzteren, zu deren Vergleichung in verschiedenen Fällen ein in der Zeichnung angedeuteter Gradbogen dienen mag, gestattet zugleich ein Urtheil über die Intensität der Ladung. Wird die Divergenz der Goldblättchen durch Annäherung einer geriebenen Siegellackstange an die Kugel des

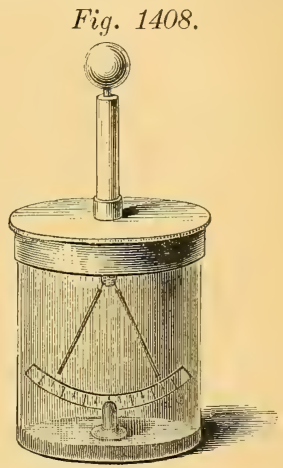
Electroscopes vermindert, so ist $E^{\prime \prime}$ positiv und somit auch die untersuchte Ladung $E$ positiv, wie im obigen Beispiele. Eine Divergenz, die durch Annäherung einer geriebenen Siegellackstange vermehrt wird, riihrt von negativer Electricität her. Schwach electrische Körper mïssen mit der Kugel des Electroscopes in Berührung gebracht werdeı, um eine Divergenz zu bewirken

Um den electrischen Zustand von Körpern nachzuweisen, deren Ladung auch bei Berührung des Electroscopes nicht ersichtlich wird, dient ein Hilfs-Apparat, der alsbald unter dem Namen Condensator beschrieben werden soll.

Auf die Beschreibung von Electrometern (siehe XXIII.) kann hier nicht eingegangen werden. Den meisten liegt das Princip der Coulomb'schen Drehwage zu Grunde, mittelst welcher das Gesetz der electrischen Anziehung und Abstossung nachgewiesen worden ist. Dieselbe ist, wie $\mathrm{Coulom} \mathrm{b}$ gefunden hat, dem Producte der auf einander wirkenden (in zwei Punkten concentrirt gedachten) electrischen Quantitäten ( $m$ und $m^{\prime}$ ) direct und dem Quadrate ihrer Entfernung $(r)$ rerkehrt proportional, entsprechend der Formel (Coulomb'sches Gesetz)

$$
p= \pm k \frac{m m^{\prime}}{r^{2}}
$$

Der Abstossung entspricht das positive, der Anziehung negative Vorzeichen. Der Coëfficient $k$ bedeutet die Wirkung zweier Quantitätseinheiten im Abstande der Längeneinheit $\left(m=m^{\prime}=1 ; r=1\right)$. 
Zur Erzeugung grösserer Mengen von Reibungselectricität dienen die Electrisirmaschinen, welche dem Principe nach von zweierlei Art sind.

Die gewöhnlichen Reibungsmaschinen haben bekanntlich eine solche Einrichtumg, dass in der Nähe eines Leiters (Conductors) von grosser Oberfläche eine Glasscheibe an amalgamirten belederten Reibkissen gerieben wird. Der in der Regel mit Saugspitzen versehene Conductor wird dabei in Folge des im Absatze XVII angegebenen Vorganges mit positiver Influenzeleetricität geladen. Die negative Reibungselectricität des Reibzenges wird gewöhnlich zur Erde abgeleitet, kann aber auch auf einem zweiten Conductor angesammelt werden, wenn man dafür den ersten Conductor mit der Erdleitung verbindet . . . . . . XXVI.)

Die neuere und für manche $Z$ wecke geeignetere Gattung von Electrisirma. schinen ist unter dem Namen Influenzmaschinen*) ( sie Electromaschinen) bekannt. Sie beruhen auf dem von Riess sogenannten Principe der Doppelinfluenz und zwar in folgender Weise.

Befindet sich zwischen einem negativ electrischen Körper $K_{1}$ (Fig. 1409) und einem mit Saugspitzen versehenen Leiter $L_{1}$, den wir uns zunächst mit der

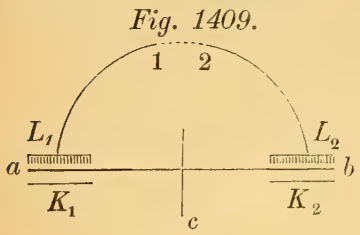
Erde verbunden denken, eine Glasscheibe $a b$, so wird dieselbe beiderseits positiv electrisch; diesseits durch unmittelbare Influenz $(\mathrm{X})$, und auf der anderen Seite dadurch, dass zugleich auch der Leiter $L_{1}$ influenzirt wird und seine positive Influenzelectricität aus den Saugspitzen auf die Glasscheibe (durch die dazwischen befindliche Luftschichte) übergehen lässt, wodurch die daselbst zuerst erregte negative Influenzelectricität mehr

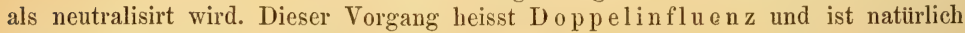
von einem Abströmen negativer Influenzelectricität aus $L_{1}$ in die Erde begleitet. Der Vorgang erneuert sich, wenn die Glasscheibe zwischen $K_{1}$ und $L_{1}$ bewegt wird.

Denkt man sich nun bei $K_{a}$ einen positiv electrischen Körper und auf der anderen Seite der Glasscheibe einen eben solchen Leiter $L_{0}$ wie $L_{1}$ angebracht, so ist leicht einzusehen, dass ron $L_{0}$ ein Strom positiver Electricität in die Erde abgehen wird, während man die Glasscheibe $a b$ um eine Achse $c$ dreht. Sind die Leiter $L_{1}$ und $L_{0}$ nicht zur Erde abgeleitet, sondern mit metallenen Bügeln verbunden, deren Enden 1 und 2 nicht zu weit von einander abstehen, so wird zwischen 1 und 2 eine Funkenentladung stattfinden, welche von den Influenzelectricitäten der Leiter $L_{1}$ und $L_{12}$ gebildet wird.

Bei der Influenzmaschine sind $K_{1}$ und $K_{2}$ mit Spitzen versehene Halbleiter und erhält $K$, seine negative Ladung durch einmalige Berübrung mit einer geriebenen Hartgummiplatte, $K_{2}$ seine positive Ladung durch die zwischen $K_{1}$ und $L_{1}$ positiv geladene Scheibe, die dann zwischen $K_{2}$ und $L_{2}$ negativ electrisch wird und $K_{1}$ nenerdings mit negativer Electricität versieht, dann wieder $K_{0}$ mit positiver u. s. w., so dass zwisehen 1 und 2 ein fast continuirlicher, bis zu einem gewissen Maximum anwachsender Funkenstrom ibergeht . . . . . . XXVII.)

Um die von einer Electrisirmaschine gelieferte Electricität in grösserer Menge auf einem auderen Leiter anläufen zu kömnen, bedient man sich der sogenannten A n s a m m l ung s a p p a rate. In diese Kategorie gehören vornelımlich die Leydener Flaschen und die aus solchen zusammengestellten Batterien, deren Einrichtung wir wohl als bekannt roraussetzen diirfen, ferner die Condensatoren, ron welchen schon im Artikel Condensator im Allgemeinen die Rede war.

Die im Obigen besprochenen Fundamentalgesetze gestatten, wenn auch nicht eine strenge Nachweisung, doch eine leichtere Beurtheilung der Verhältnisse, von welchen die Leistungsfähigkeit eines Condensators abhängt, weshalb wir die

*) Die Bezeichnung ist insofern nicht treffend, weil ja auch die Wirkmng der alten Electrisimasehinen auf Infneuz beruht. "Doppelinfluenzmaschinen" wäre passender. 
für praktische Anwendungen nöthigen Andeutungen hierüber diesem Artikel eingefuigt haben.

Man denke sich einen Streifen $A B$ (Fig. 1410 und 1411) von gut gefirnisstem Wachstaffet beiderseits mit Stanniolstreifen $C_{1}^{\prime}$ und $C_{12}^{\prime}$ belegt, die etwas kiirzer und schmäler sind, so dass vom Wachstaffet ringsum ein unbelegter Rand bleibt. Das Stanniol kann mit Schellackfirniss aufgeklebt werden. Um diese Vorrichtung, welche im wesentlichen nichts anderes als eine biegsame Franklin'sche Tafel ist, in eine compendiösere Gestalt zu bringen, legt man sie nach dem Schema Fig. 1412 zusammen und trennt die einzelnen Lagen durch dünne Brettchen oder Glastafeln oder sonst geeignete isolirende Substanzen.

Wird nun eine der beiden Belegungen, z. B. $C_{1}$ durch leitende Verbindung mit dem Conductor einer Electrisirmaschine oder einer anderen Electricitätsquelle positiv geladen, während $C_{2}$ zur Erde abgeleitet ist, so wird die von der Ladung $+E$ der Belegung $C_{1}$ herriihrende Influenzelectricität $-E^{\prime}$ der Belegung $C_{2}$ bewirken, dass der grösste Theil von $E$ auf der inneren Fläche der Fig. 1410 .

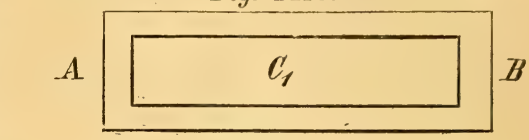

Fig. 1411.

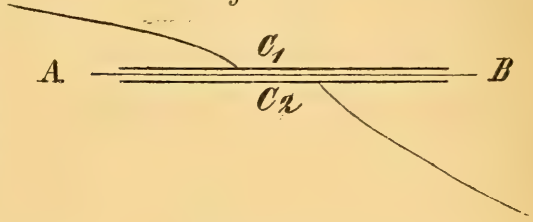

Fig. 1412 .

Belegung $C_{1}$ sich ansammelt und mit $-E^{\prime}$ zusammen (da sich beide Electricitäten gegenseitig anziehen) keine merkliche Wirkung in die Ferne ausiibt, oder, wie man sagt, "gebunden" wird. In Folge dessen kann $C_{1}$ noch weiter Electricität von der Maschine aufnehmen, wobei sich der beschriebene Vorgang mit einem Theile der nen aufgenommenen Electricität wiederholt, bis endlich die Ladung eine gewisse Grenze erreicht hat, bei welcher der Leiter $C_{1}$ viel mehr Electricität aufgenommen hat, als er ohne die Ruickwirkung von $C_{\mathbf{2}}$ für sich allein hätte aufnehmen können. Die Spannung der Electricität aber auf $C_{1}$ kann (vermöge XXII) in beiden Fällen nie grösser werden als auf dem Conductor der Maschine . XXVIII.)

Nennt man $F$ die Fläche der Belegung $C_{\mathbf{1}}$ (wir wollen $C_{\mathbf{2}}$ als gleich gross voraussetzen), $P$ die Spannung der Electricität auf dem Conductor der Electrisirmaschine oder der sonst angewendeten Electricitätsquelle, mit welcher der Condensator geladen wird, und $D$ die Dicke der isolirenden Zwischenschichte, so ist die Electricitätsmenge $M$ (Ladung), welche der Condensator aufzunehmen vermag, annähernd proportional dem Quotienten $\frac{F P}{D}$, also

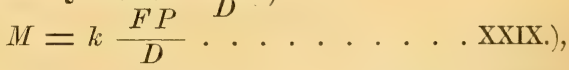

wobei $k$ eine constante Zahl ist, welche mit $F$ und $D$ die sogenannte Verstärkungszahl $\frac{k F}{D}$ des Condensators bildet.

Um also einen Condensator herzustellen, der möglichst viel Electricität aufnimmt, müssen die Belegungen sehr gross und das isolirende Diaphragma (so weit es mit der Widerstandsfähigkeit gegen durchbrechende Selbstentladungen vereinbar ist) sehr dïnn gemacht werden.

Soll der Condensator die nach XXIX berechnete Ladung anfuehmen, so ist ausser der besagten Widerstandsfähigkeit des Diaphragma auch ein himreichend 
breiter unbelegter Rand desselben erforderlich, damit nicht eine Selbstentladung: einer Belegung zur anderen um den Rand des Diaphragmas herum stattfinde. XXX.)

Dieselben Sätze gelten mehr oder weniger annähernd für alle electrischen Ansammlungsapparate, mögen diese nun Condensatoren, Leydener Flaschen, Franklin'sche Tafeln oder wie immer genannt werden.

Werden die beiden Belegungen des geladenen Ansammlungsapparates leitend mit einander verbunden, so findet jene Ausgleichung entgegengesetzter Electricitäten statt, die man Entladung nennt.

Die einer solchen Entladung entsprechende Arbeitsleistung $A$ ist dem Producte der Ladung $M$ und ihrer Spannung $P$ proportional . . . . . XXXI.) und kann mit Rücksicht auf die Formel XXIX auch durch die Gleichung

$$
A=c \frac{D M^{2}}{F} \text {. . . . . . . . XXXII.) }
$$

ausgedrückt werden, wobei $c$ einen constanten Factor vorstellt, und die übrigen Buchstaben die bereits angegebenen Bedeutungen haben. Man kann also auch sagen: die Wirkung der Entladung ist bei einem und demselben Condensator dem Quadrate der Ladung proportional.

Die Wirkung der Entladung besteht entweder blos in einer Erwärmung des Verbindungsleiters, oder, wenn derselbe unterbrochen ist, auch in der Bildung electrischer Funken (XIX) an den Unterbrechungsstellen, in welchen Fällen zugleich mechanische Wirkungen (Losreissen von metallischen Theilchen, Erschütterung der Luft, Durchbrechen eingeschalteter schlechter Leiter u. dgl.) anftreten.

Auf die chemischen Wirkungen, welche electrische Entladungen mit sich bringen können (z. B. Ozonbildung bei der Funkenentladung), wollen wir hier nicht weiter eingehen. (Vergl. den Artikel Electrolyse.) Eben so mögen die physiologischen Wirkungen iibergegangen werden. Auf die magnetischen Wirkungen kommen wir im Artikel Electromagnetismus zuriek.

Bei jeder Entladung findet in dem Verbindungsleiter ("Schliessungsbogen"), in welchem die entgegengesetzten Electricitäten zur Ausgleichung kommen, eine Bewegung derselben statt (beziehungsweise eine durch electrische Kräfte bewirkte Molecularbewegung), welche wir einen electrischen Strom nernen. XXXIII.)

Von besonderer Wichtigkeit sind die electrischen Ströme von längerer Dauer (continuirliche Ströme), insbesondere die constanten (oder stationären) Ströme, von welchen später die Rede sein soll. Die Reibungselectricität liefert uns in der Regel nur Ströme von sehr kurzer Dauer und rasch veränderlicher Intensität.

Ueber die Dauer electrischer Entladungsfunken hat Wheatstone Versuche angestellt; er fand diesclbe kleiner als ein Millionstel einer Secunde . XXXIV.)

Für die Fortpflanzungseschwindigkeit der Electricität in Leitern hatte Wheatstone 61000 Meilen pro Secunde gefunden. Kirchhoff berechnete auf Grundlage des Weber'schen Fundamentalgesetzes eine Geschwindigkeit von 41000 Meilen. Nach den in neuester Zeit auf Telegraphenlinien ausgeführten Werner Siemens'schen Messungen ergaben sich Geschwindigkeiten von durchschnittlich 30000 Meilen. Dieses letztere Resultat verdient am meisten Vertrauen und widerlegt zugleich die jedenfalls viel zu kleinen Geschwindigkeiten, welche ron Walker, Mitchell und Gould auf amerikanischen Telegraphenlinien gefunden worden sind. - Nach Kirch off wäre aus theoretischen Gründen anzunehmen, dass die Geschwindigkeit der Electricität in allen Leitern gleich gross sei

B) Berihrungselectricität. Wir haben bisher vorausgesetzt, dass der electrische Zustand durch Reibung hervorgerufen worden sei.

Zur Erzeugung der so erregten Electricität, welche man Reibungselectricität nenut, eignen sich, wie wir gesehen haben, schlechte Leiter. Bei guten Leitern geniigt eine blose Berihrung des einen mit einem anderen zur Electricitäts-Erregung, vorausgesetzt, dass beide nicht von gleicher Art sind, sondern entweder chemisch verschieden oder doch wenigstens von ungleicher Temperatur 
oder ungleicher Beschaffenheit der Oberfläche (z. B. der eine polirt, der andere matt). Man nennt die unter solchen Umständen durch Berihrung erregte Electricität: Ber ï hrungselectricität oder Contact-Electricität, oder auch galvanische oder volta'sche Electricität, endlich auch Galvanismus oder Voltaismus.

Die beiden letzteren Bezeichnungen riihren bekanntlich davon her, dass Galvani zuerst gewisse physiologische Erscheinungen (Zuckungen von Froschschenkeln bei metallischen Berïhrungen) beobachtete, von welchen Volt a später nachwies, dass dieselben von der Contact-Electricität der dabei angewendeten ungleichartigen Metalle verursacht worden sind ${ }^{*}$ ) . . . . . . . . XXXVI.)

Zur Erzeugung von Contact-Electricität eignen sich vornehmlich die Metalle, unter welchen am häufigsten Kupfer und Zink zu dicsem Zwecke benutzt werden, bei deren Berührung jenes negativ, dieses positiv electrisch wird.

Ganz analog dem für die Reibungselectricität geltenden Satze III treten nämlich auch bei der Electricitätsentwicklung durch Contact stets beide Electricitäten gleichzeitig und in gleicher Menge auf, indem jedesmal der eine von den beiden miteinander in Beriihrung gebrachten Leitern (z. B. Metallen) positiv, der andere negativ electrisch wird.

Alle einfachen und auch mehrere zusammengesetzte Körper lassen sich dergestalt in eine Reihe stellen, dass bei der Berihrung von je zwei beliebigen Gliedern dieser Reihe das vorhergehende positiv; das nachfolgende negativ electrisch wird. Diese Reihe nennt man Spannungsreihe.

Einige Glieder derselben, die besonders häufig in Betracht kommen, sind z. B. folgende: Zink, Z inn, Blei, Eisen, Kupfer, Silber, Gold, Platin, $\mathrm{K}$ ohle; oder mit chemischen Zeichen geschrieben: $\mathrm{Zn}, \mathrm{Sn}, \mathrm{Pb}, \mathrm{Fe}, \mathrm{Cu}, \mathrm{Ag}$, $A u, P t, C$. Das vorhin ausgesprochene Verhalten ist noch dahin näher zu präcisiren, dass die bei der Berihhrung zweier Glieder der Spannungsreihe erregte Contactelectricität mit desto grösserer Spannungsdifferenz**) auftritt, je weiter die beiden Glieder in der Reihe von einander entfernt sind. Es wird also z. B. Kupfer im Contacte mit Blei stärker als mit Eisen, noch stärker mit Zinn oder endlich mit Zink negativ electrisch, es wird hingegen positiv electrisch mit Silber, noch mehr mit Gold, stärker noch mit Platin oder endlich mit Kohle. Dieses Gesetz wird das erste Gesetz der Spannungsreihe genannt.

Ein zweites Gesetz der Spannungsreihe sagt, dass die Differenz der auf zwei Gliedern derselben auftretenden contactelectrischen Spannungen ganz dieselbe ist, man mag jene beiden Glieder unmittelbar mit einander in Berihrung bringen oder durch andere Glieder der Spannungsreihe in beliebiger Auswahl und Anordnung, mit einander leitend verbinden. Wenn also z. B. das eine Mal auf eine Kupferplatte unmittelbar eine Zinkplatte gelegt wird, das andere Mai hingegen auf die Kupferplatte zunächst etwa eine Platinplatte, auf diese eine Bleiplatte, dann vielleicht eine eiserne Platte und endlich die Zinkplatte, so werden die Contactelectricitäten auf den beiden Endplatten in beiden Fällen dieselbe Beschaffenheit und Spannungsdifferenz haben.

Die bei dem Contacte zweier Körper auf denselben auftretenden entgegengesetzten Electricitäten treten mit bestimmten Spannungen auf, deren Differenz nur von der materiellen Beschaffenheit, nicht aber von der Form oder Beriihrungsfläche der beiden Körper abhängt. Man nennt diese Differenz die electrische Differenz, welche den betreffenden Gliedern der Spannungsreihe entspricht. Wird einer der beiden Körper leitend mit der Erde verbunden, so wird die Spannung auf demselben gleich Null, steigt aber gleichzeitig auf dem anderen

*) Zum Theile kommt bei den von Galvani beobachteten Erscheinungen allerdings auch die später von Matteucei und Du Bois Reymond beobachtete Muskel- und NerrenElectricität (rhierische Electricität") in Betracht.

* *) Sei die Spannung auf dem einen Metalle $+p$, auf dem anderen $-p^{\prime}$, so ist die Spannungsdifferenz $d=+p-\left(-p^{\prime}\right)=p+p^{\prime}$. 
Körper um so viel, dass die electrische Differenz constant bleibt, also die Spannung auf dem nicht abgeleiteten Körper der ursprünglichen electrischen Differenz gleich wird.

Dagegen hängt die Electricitäts-Menge, welche sich beim Contacte entwickelt, von der Oberfläche und Berïhrungsfläche der im Contacte befindlichen Leiter ab. Es entwickelt sich eben auf beiden Körpern gleichviel Electricität in solcher Menge und Anordnung, dass die der Natur der Körper entsprechende electrische Differenz erreicht wird. Die Electricitäten verbreiten sich in Gemässheit des Satzes XI auf den Oberflächen beider Leiter, wobei die an den mit einander in Berührung stehenden Theilen der Oberflächen befindlichen Electricitäten eine ähnliche Wechselwirkung („Bindung“) auf cinander ausüben wie die Ladungen eines Condensators (XXVIII). Die Kraft, welche die Vereinigung der beiden Contactelectricitäten verhindert und also gewissermassen die Widerstandsfähigkeit eines Diaphragmas ersetzt, nennt man electromotorische $\mathrm{Kraft}$ und wird der electrischen Differenz proportional angenommen.

Aus dem zweiten Gesetze der Spannungsreihe lässt sich der Schluss ableiten, dass die electrische Differenz je zweier Glieder stets gleich ist der algebraischen Summe der electrischen Differenzen der Zwischenglieder.

Diejenigen Electricitätsleiter, deren Verhalten beiden Gesetzen der Spannungsreihe entspricht, werden Leiter erster $\mathrm{Ordnung}$, alle ïbrigen Electricitätsleiter hingegen Leiter zweiter Ordnung genant . . . . . XXXVII.)

Einen Leiter erster Ordnung, der im Contacte mit einem anderen Leiter erster Ordnung positiv electrisch wird, nennt man beziiglich des letzteren electropositiv, hingegen den letzteren gegeniiber dem ersteren electronegativ. So heisst z. B. Silber electropositiv gegeniiber dem Platin, aber electronegativ gegeniiber dem Zinn. In diesem Sinne bezeichnet man unter diesen drei Metallen Zinn als den electropositivsten und Platin als den electronegativsten Körper und nennt die Zwischenglieder desto positiver, je näher sie in der Spannungsreihe dem ersteren, oder, was dasselbe ist, desto negativer, je näher sie dem letzteren stehen.

Die Erfalırmng lehrt, dass die chemische Affinität des Sauerstoffes zu den Körpern, welche der Spannungsreihe angehören, desto energischer ist, je positiver die letzteren sind. Diese und viele andere analoge Thatsachen haben zu dem Schlusse gefiilnt, dass die chemische Affinität der Körper mit der electrischen Differenz beim Contacte derselben wesentlich zusammenhängt.

Auf dieser Grundlage ist es möglich geworden, allen Grundstoffen eine bestimmte Stellung in der Spannungsreihe mit mehr oder weniger Sicherheit anzuweisen. Die so erweiterte Spammugsreihe wird auch die electrochemische Reihe genannt.

In derselben erscheint das Cäsium als der positivste, der Sauerstoff als der negativste Körper. Im Lebrigen verweisen wir jedoch hinsichtlich der electrochemischen Reihe auf die Lehrbücher der Chemie, da in diesem Artikel nicht weiter darauf eingegangen werden soll . . . . . . . . . XXXVIII.)

Aus dem zweiten Gesetze der Spannungsreihe lässt

Fig. 1413.

$M$

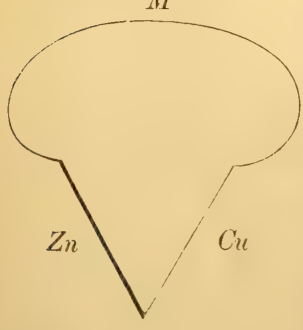

sich auch der Satz ableiten, dass in einem Cyclus von beliebig vielen einander beriihrenden Leitern erster Ordnung, wie immer dieselben angeordnet sein mögen (z. B. wie in Fig. 1413, wobei $M$ ein beliebiges zwischen Zink und Kupfer eingeschaltetes Metall bedeutet), immer nur electrische Spannungen, die im Gleichgewichte stehen, aber niemals ein electrischer Strom (XXXIII) auftreten kann, so lange in der Leiter-Combination überall dieselbe Temperatur herrscht : . . . . . . . XXXIX.)

Durch Einschaltung eines Leiters zweiter Ordnung, z. B. einer die Electricität leitenden (chemisch zusammengesetzten) Flüssigkeit kann das electrische Gleichgewicht aufgehoben und ein electrischer Strom hervorgebracht werden, der durch die fortdauernde Contactwirkung der 
Leiter erster Ordnung unter sich und mit dem Leiter zweiter Ordnung unterhalten wird. *)

Eine zur Stromerzengung geeignete Combination ron Leitern erster und zweiter Ordnuig wird eine galvanische (volta'sche oder hydroclectrische) liette genamnt, oder auch ein galvanisches Element.

Man erhält eine solche Kette in einfachster Form, wenn man z. B. je ein Stïck Kupfer und Zink (Fig. 1414), welche einander einerseits berühren, anderseits in verdiunnte Schwefelsäure taucht. Es geht in diesem Falle ein electrischer Strom vom electropositiven Zink durch die Fliissigkeit zum electronegativen Kupfer und von diesem durch die Beriihrungsstelle zum Zink.

Um von diesem Strome Gebrauch machen zu können, ist es zweckmässig, die Beriihrung der beiden Metalle durch einen Draht (Fig. 1415) zu vermitteln, welcher die Metalle leitend verbindet und Schliessungsdraht genannt wird. Vermöge des zweiten Gesetzes der Spannungsreihe ist es fuir die Contactwirkung zwischen Kupfer und Zink gleichgiltig, aus welchem Materiale der Schliessung'sdraht besteht. Zu dieser Contact-Wirkung gesellt sich in der Kette noch diejenige, welche durch die Beriihrung der Metalle mit der Fliissigkeit - wir wollen sie Ladungsflüssigkeit nennen - verursacht wird. So werden z. B. Zink und Kupfer durch Beriihrung mit verdünnter Schwefelsäure negativ electrisch, jedoch ersteres stärker als das letztere, weshalb die gleichzeitig anftretende positive Erregung der Flüssigkeit von der Art ist, dass sie eine Verstärkung des Stromes in derselben bedingt.

Diese und ähuliche Contact-Wirkungen zwischen Metallen Fig. 1414.
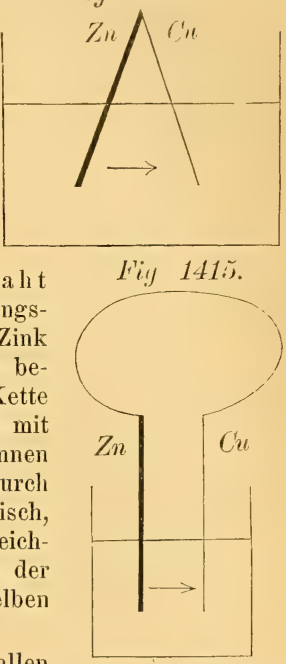
und Flüssigkeiten beruhen entweder darauf, dass ein Metall von einer Fliissigkeit angegriffen und in Folge dessen mit einer Gas- oder Oxyd-Schichte bedeckt wird, die im Contacte mit dem Metalle electromotorisch wirksam ist; oder aber darauf, dass, wenn kein directer Angriff stattfindet, eine der chemischen Affinitiit zwischen dem Metalle und dem electronegativen Bestandtheile der Fliissigkeit entsprechende electrische Differenz auftritt, wie z. B. beim Eintauchen von Platin und Gold in starke Säuren, wobei die genannten Metalle positiv electrisch werden.

Ein für practische Anwendungen wichtiger Vorgang ähnlicher Art ist das Passirwerden des Eisens beim Eintauchen in concentrirte Salpetersäure. Das blanke Eisen wird dabei bekanntlich nicht sichtbar angegriffen und verdankt dieses Verhalten, wie man annimmt, einer duinnen Oxydulschichte, mit der es sich im ersten Momente iberzieht. Diese Oxydulschichte verhält sich stark electronegativ und schiitzt in Folge dessen das Fisen gegen weitere Angriffe. Man nennt das in diesen Zustand versetzte Eisen passiv; es verhält sich gegeniiber dem gewöhnlichen Eisen electronegativ, ähnlich wie Platin, an dessen Stelle es anch bei der lıäıfig vorkommenden Zinkeisenkette, von welcher später die Rede sein soll, angewendet wird.

Fiigt man mehrere Zinkkupferketten der vorhin beschriebenen Art nach dem Schema der Fig. 1416 aneinander, so erhält man eine zusammengesetzte liette oder eine galranische (rolta'sche oder hydroelectrische) Batterie.

Es ist sofort ersichtlich, dass die positive Electricität der letzten Zinkplatte durch die Fliissigkeit in die letzte Knpferplatte iibergcht, welche man deshall, den positiven Pol (Kupferpol) der Batterie nemt. Aus analogem Grunde heisst die erste Zinkplatte, welche die negative Electricität der ersten Kupferplatte

Anf dic nährre Erklärung dieses Vorganges kommen wil slüter (LXVII) zuräck. 
Fig. 1416.

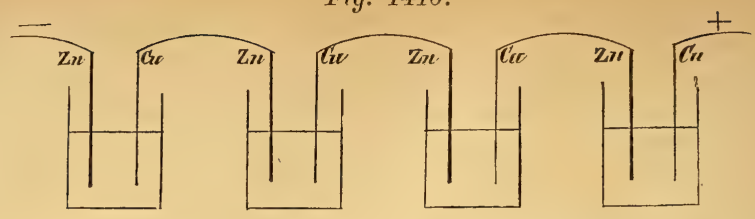

aufnimmt, der negative Pol (Zinkpol). Verbindet man beide Pole durch einen Schliessungsdraht, so rerläuft in demselben der Strom vom Kupferpole zum Zinkpole.

Auch bei einer einfachen Kette, wie Fig. 1415, wird die (obgleich im Contacte mit Zink negative) Kupferplatte als der positive und die Zinkplatte als der negative Pol bezeichnet, weil der Strom im Schliessungsdrahte von der ersteren zur letzteren geht. Es ist also zwischen dem positiven Pole und dem positiven Metalle einer Kette wohl zu unterscheiden.

Eine Kette oder Batterie, deren Pole nicht leitend verbunden sind, heisst offen, im entgegengesetzten Falle geschlossen.

Kette (oder Batterie) und Sclıliessungsbogen zusammengenommen, also die ganze Strombahn einer Kette, nennt man den Schli ess un g s kr e i s derselben . XL.)

In allen Fällen bewirkt der electrische Strom eine Wärme-Entwicke$1 \mathrm{ng}$ in allen Theilen des Schliessungskreises; ausserdem ist derselbe mit einer Zersetzung der im Schliessungskreise befindlichen Leiter zweiter $\mathrm{Ordnung}$ verbunden. Chemisch zusammengesetzte Fliissigkeiten leiten den Strom eben nur, insofern sie dabei zerlegt werden, wodurch, wie es scheint, die Stromleitung eigentlich vermittelt wird. Man nennt den Vorgang einer solchen Zerlegung durch den Strom Electrolyse ${ }^{*}$ ) und die dieser Zerlegung unterliegenden Körper Electrolyten.

Bei der Electrolyse der verdünnten Schwefelsäure, welche in der vorhin erwähnten Zinkkupferkette als Leiter zweiter Ordnung dient, wird das Hydrat $\mathrm{SO}_{4} \mathrm{H}_{2}$ in der Art zerlegt, dass $H_{0}$ an der Kupferplatte sich ausscheidet, an der Zinkplatte hingegen $S O$, mit einer äquivalenten Menge dieses Metalles zu Zinkvitriol sich vereinigt.

Hierans wird ersichtlich, dass einerseits eine gewisse Zinkconsumtion mit der Unterhaltung des Stromes unzertrembar rerbunden ist und anderseits cine Ablagerumg ron Wasserstoff an der Kupferplatte.

Der letztere Vorgang, bei welchem der Wasserstoff positive Contactelectricität annimmt, ist der Wirkmg der Kette offenbar abträglich, da rlie Wasserstoff-Schichte auf der Kupferplatte mit dem Zinke gewissermassen auch eine Kette bildet, welche jedoch eine dem Strome der Zinkkupferkette entgegengesetzte Stromrichtung herzustellen strebt.

Diese Gegenwirkung, Polarisation genannt, tritt noch stärker auf, wenn das Zink nicht durch Amalgamation gegen directen Angriff von Seite der Schwefelsäure geschützt ist.

Bei fortgesetzter Thätigkeit der Kette wird der dabei gebildete und in Lösung gegangene Zinkvitriol ebenfalls zerlegt und in Folge dessen Zink an der Kupferplatte ausgeschieden.

Diese Ablagerungen an der Kupferplatte, insbesondere die Polanisation, bewirken eine rasch eintretende Stromabnahme, weshalb man Ketten dieser Art inconstante Ketten nennt.

Das Wesen der sogenannten constanten Ketten, welche mit diesen Uebelstïnden nicht behaftet sind, besteht also in Einrichtungen, welche electro-positive Ablagerungen, insbesondere des Wasserstoffes, an der Kupferplatte verhindern.

$\mathrm{Zu}$ diesem $\mathrm{Zwecke}$ dienen oxydirende oder "depolarisirende Fliissigkeiten, welche man neben der verdiinnten Schwefelsäure, von dieser

*) Siehe d. Artikel. 
durch ein poröses Diaphragma getrennt, in der Art anwendet, dass die Zinkplatte in die Zelle mit verdiunnter Schwefelsäure tancht, wïhrend die mit der depolarisirenden Fliissigkeit gefuillte Zelle zur Anfnahme der Kupferplatte oder iberhaupt derjenigen Platte dient, welche mit der Zinkplatte als electronegativer Bestandthril der Kette verbunden wird

Zu den gebräuchlichsten constanten Ketten gehört vor Allem die D a n i ell'sche, bei welcher eine concentrirte Lösung von Kupfervitriol als depolarisirende Fliissigkeit die Kupferplatte umgibt. Die beiden Fliissigkeiten durchdringen das Diaphragma und der electrolytisch ausgeschiedene Wasserstoff der Schwefelsäure tritt im Kupferritriole an die Stelle des Kupfers, von welchem eine äquivalente Nenge an der Kupferplatte ansgefällt wird.

Die gewöhnliche Form des Daniell'schen Elementes (vergl. d. Artikel Telegraphie) ist folgende: Ein cylindrisches Glasgefäss wird zunächst mit verdiinnter Schwefelsäure (etwa $1: 15$ bis $1: 8$ dem Volumen nach) etwa zu einem Drittel angefüllt. In dieses Glasgefäss stellt man einen mit geringem Spielraum hineinpassenden Hohlcylinder aus dickem gewalzten Zinkblech, welcher Iurch Rundbiegen eines entsprechend grossen rechteckigen Stiickes Zinkblech erhalten worden ist. In den Hohlraum dieses Zinkeylinders kommt ein mit wenig Spiehraum hineinpassendes cylindrisches Gefäss aus nicht glasirtem feinem porösem Thon, welches das vorhin besagte Diaphragma bildet und mit der concentrirten Lösung von Kupfervitriol gefuillt ist. In diesen mit Kupfervitriollösung gefiillten Thoncylinder stellt man schliesslich ein cylindrisch zusammengebogenes Stiick Kupferblech, den Kupfercylinder. Dieser sowohl, wie der Zinkcylinder sind mit angenieteten Streifen aus Kupferblech oder dicken Kupferdrähten versehen, welche zur Anbringung des aus weiteren Drahtverbindungen bestehenden Schliessuugsbogens oder zur Vereinigung mehrerer Elemente zu einer Batterie dienen, wobei passende Schraubklemmen von verschiedener Form in Anwendung kommen.

Gibt man in die Thonzelle Salpetersäure, indem man gleichzeitig anstatt des Kupfers Platin anwendet, so erhält man die Grove'sche Kette.

Das Platinblech lässt sich, wie es zuerst der Engländer Cooper gethan hat, durch ein (cylindrisches oder prismatisches) Stiick Gaskohle (Retortenriickstand bei der Lenchtgasbereitung aus Steinkohle) ersetzen. Man erhält auf diese Art die riel weniger kostspielige und in dieser Form sehr häufig angewendete Zinkknhlenkette ron mindestens gleicher electromotorischer Kraft. Diese Kette wird gewiihnlich die Bunsen'sche genannt, obgleich diese Bezeichnung eigentlich auf eine andere Art der Zinkkohlenkette sich bezieht, in welcher statt der Gaskohle eine nach Bunsen's Angabe hergestellte künstliche Kohlenmasse die Stelle des Platins vertrat. Diese Kohlenmasse ist wegen ihrer grossen Porösität weniger empfehlenswerth als die Gaskohle, doch hat sie zur allgemeinen Verbreitung der Zinkkohlenketten sehr viel beigetragen, weshalb man eben diese Art von Ketten kurzweg Bunsen'sche nennt.*)

Die Salpetersäure wird in der Bunsen'sche Kette auch häufig durch eine Mischung von Schwefelsäure mit einer Lösung von doppeltchromsaurem Kali (12 Theile doppelt-chromsamres Kali, 25 Theile engl. Schwefelsäure und 100 Theile Wrasser ${ }^{*}$ ) ersetzt. Man vermeidet auf diese Art gänzlich die Dämpfe ron Lntersalpetersänre, deren Auftreten sich iibrigens schon durch reichliche Amalgamirung Ter Zinkrylinder (in deren Zellen man am besten etwas Quecksilber eingiesst, damit sich die Amalgamirung fortwährend selbst ernenert) sehr beschränken und fiir einige Stunclen fast mmerklich machen lässt.

Die Ketten ron Daniell und $\mathrm{B}$ unsen sind die gebränchlichsten constanten Ketten. Von ren ineonstanton hahen wir die einfache Zinkkupferkette bereits erwälnt. Ersetzt man in dieser das Kupfer durch platinirtes Silber (mit Platin-

*) Beri der ursuriunglichen Bunsen'schen Kette war ein hohler, mit Salpetersäure gefïllter Kohleneylinder in Anwendung; dor also zugleich die Stelle des Diaphragmas vertrat; rine Einrichtung, ven drer man später wider abgekommen ist.

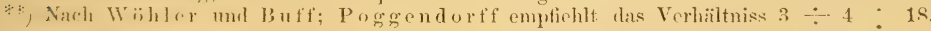


moor beiderseits galvanoplastisch bekleidetes Silberblech), so erhä̈lt man die sehr häufig angewendete Smee'sche Kette, welche also auch zu den inconstanten Ketten gehört, aber wirksamer ist als die Zinkkupferkette. Man verbindet gewöhnlich eine grössere Zahl von Smee'schen Elementen ( 6 bis 24$)$ zu Tauchbatterien, welche ihrer bequemen Handhabung wegen selur beliebt und rerbreitet sind.

Handelt es sich um eine Kette, welche selbst bei häufigem Gebranche monatelang aushalten soll, ohne erneuert zu werden, so bedient man sich einer der Modificationen, welche die Daniell'sche Kette namentlich durch M eidinger u. A. erfahren hat. Insbesondere sind die sogenannten Meidinger'schen BallonElemente sehr verbreitet. Wir verweisen diesfalls auf den Artikel Telegraphie. Selbstrerständlich ist (mit Riicksicht auf den Materialverbrauch) eine so lange Stromdauer nur bei verhältnissmässig geringen Stromstärken zu erzielen.

Wo es nur auf weniger ausdauernde Ströme ankommt, wie z. B. bei Haustelegraphen, leisten die Leclauchë'schen Elemente durch lange Zeiträume gute Dienste. Die neueste Construction dieser Elemente besitzt kein Diaphragma und hat folgende Einrichtung.

Ein massiver Cylinder aus einem Gemenge von 40 Theilen gepulvertem Bramstein, 55 Theilen Gaskohle und 5 Theilen Schellack, bei einer Temperatur von $100^{\circ} \mathrm{C}$. durch einen Druck von 300 Atmosphären in einer stählernen Form hergestellt, befindet sich nebst einem amalgamirtem Zinkstabe in einem mit Salmiaklösung gefuillten Glasgefüsse. Der Cylinder und der Zinkstab sind, durch eine hölzerne Zwischenlage von einander isolirt, mittelst zweier Kautschukbänder zusammengebunden und mit Fassungen versehen, welche die zur Aufnahme der Leitungsdrähte dienenden Schraubklemmen tragen.

Die Cylinder der oben beschriebenen Zusammensctzung crhalten noch einen 3- bis 4-procentigen Zusatz ron zweifach schwefelsaurem Kali, welcher sie besser leitend macht und als Lösungsmittel für die sich bildenden Oxychloriire dient.*)

Als ein constantes Element mit einer einzigen Flissigkeit und ohne Diaphragma verdient noch das Element ron $\mathrm{Pin} \rho \mathrm{us}$ erwähnt zu werden. Auf dem Boden einer mit rerdinnter Schwefelsäure gefiilten gläsernen Eprourette befindet sich eine silberne Kapsel, die etwas Chlorsilber enthäl, und in einiger Entfermung iiber derselben ein amalgamirtes Zinkklötzchen. Beide Metalle sind mit isolirten Zuleitungsdrähten versehen, welche durch einen die Eprourette verschliessenden Kork austreten.

Bei diesem sehr compendiösen Elemente ist die zweite Fliissiokeit durch Chlorsilber ersetzt, welches als depolarisirender Körper wirkt, indem es durch den electrolytisch ausgeschiedenen Wasserstoff redncirt wird. Die feste Form des Chlorsilbers macht ein Diaphragma iberflissig. . . . . . . . . . XLII.)

C) Thermoelectricität und Prroelectricität. Der Satz XXXIX gilt, wie ausdriicklich bemerkt worden ist, nur unter der Toraussetzung einer durchans gleichen Temperatur. Das electrische Gleichgewicht in einem Cyclus ron Leitern erster Ordnung kamn also nicht nur durch Einschaltung eines Leiters zweiter Ordnung, wodurch eine galvinische liette (XL) entsteht, anfgehoben werden, sondern auch durch ungleiche Erwärmung. Der im letzteren Falle anftretende Strom wirl ein thermoelectrischer genannt und die Leitercombination, welche ihn liefert, heisst eine Thermokette.

Man erhäl eine solche z. B., wenn man die Beribrungsstelle a (Fig. 1417) eines Wismuthstabchens $a b$ und eines Antimonstäbchens $a c$ erwärmt oder abkiihlt. Der Strom geht im ersten Falle in der Richtung $a c d b a$, im zweiten Falle entgegengesetzt. Dabei mag $b$ d c einen Schliessungsdraht rorstellen. Dașienige Metall, zu welchem der strom durch die erwärmte Contactstelle geht, wird das thermoelectrisch positivere genannt; im rorliegenden Beispiele also Antimon. 
Man kanu die Metalle nach diesem Verlualten in eine Reihe stellen, welche der Spannungsreihe (XXXVII) nachgebildet ist und die thermoelectrische Reilıe heisst. Einige Glieder derselben, vom positivsten angefangen, sind z. B. Tellur, Antimon, Arsen, Eisen, Zink, Kupfer, $\mathrm{Nickel,} \mathrm{Wismuth.} \mathrm{Uebrigens} \mathrm{gilt} \mathrm{eine} \mathrm{gewisse} \mathrm{thermo.}$ electrische Reihenfolge immer nur innerhalb bestimmter Temperatursgrenzen . . . . . . . . . . . . XLIII.)

Legirungen fallen in der thermoelectrischen Reihe nicht immer zwischen ihre Bestandtheile; so z. B. ist eine der empirischen Formel $\mathrm{Sb} \mathrm{Zn}_{3}$ entsprechende Legirung viel positiver als Antimon. Auch können sehr geringe Zusätze oder Verunreinigungen die thermoelectrische Stellung eines Metalles bedeutend verändern . . . . . . . . . . . XLVI.)

Durch eine Aneinanderreihung von thermoelectrischen Elementen in äln!icher Weise wie bei einer hydroelectrischen Batterie (XL) erhält man eine sogenannte Thermosäule, wobei entweder nur eiue Erwärmung der ungeraden $(a, c, e, g, i)$ oder auch zugleich eine Abkiihlung der geraden $(b, d, f, h, k)$ Contactstellen stattfindet. Siehe das Schema Fig. 1418, wobei $l a, b c$, de, $f y, h i$ die Stäbe des einen und $a b, c d, e f, g h$, ik die Stäbe des anderen Metalles beFig. 1418. deuten und $k l$ einen Schliessungsdraht vorstellt.

Die ungleichartigen Metallstäbe sind, wo sie sich berihren sollen, gewöhnlich zusammengelöthet, weshalb man die Contactstellen auch Löthstellen nennt.

Die electromotorische Kraft eines Thermoelementes $l a b c$ (Fig.1419) und in sofern auch die Stärke des von demselben gelieferten Stromes ist innerhalb gewissen Grenzen. stets der Differenz der Temperaturen, welche man den Contactstellen $a$ und $b$ ertheilt, proportional. XLV.)

Wir können in diesem Artikel nur die gebränchlichsten Thermoelemente und Thermosäulen beriicksichtigen.

Hierher gehören zunächst die fuir verschiedene Zwecke in den verschiedensten Grössen und Formen ausgeführten Wismuth-Antimon-Säulen. Die aus möglichst dünnen Stäbchen zusammengefuigten Säulchen dieser Art sind bei Untersuchungen iiber Wärmestrahlung unentbehrlich.

Grössere Thermosäulen zum Ersatze für hydroelectrische Ketten hat zuerst S. Marcus in Wien (1864) construirt, dessen Elemente eine nahezu sechsfache electromotorische Kraft im Vergleiche mit einem Wismuth-AntimonElemente besitzen. Noch zweimal kräftigere Elemente lieferte F. Nö̈ in Wien (1871), dessen Thermosänlen

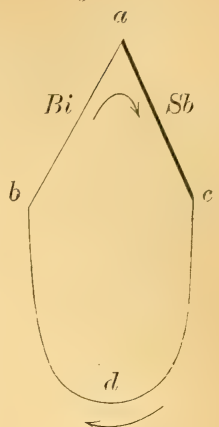
(2)

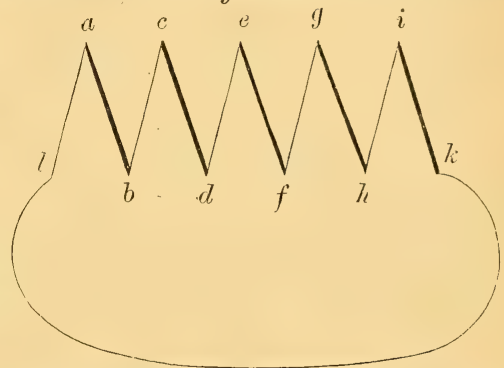
auch die ersten sind, die selbst für industrielle Zwecke (z. B. in galranoplastischen Anstalten) bereits Anwendung gefunden haben.*

Die chemische Zusammensetzung der $\mathrm{N}$ o ëschen Legirungen und deren Herstellung ist privilegirt und noch nicht veröffentlicht.

Bezüglich der neuesten Construction der Noëschen 'Thermosäulen, welche auf Gasheizung cingerichtet sind, keine nasse Fiihlung erfordern und in rer-

*) Siehe den officiellen Bericht der Wiener Weltausstellung 1873, Heft LX, Seite 101. 
schiedenen Formen und beliebigen Grössen geliefert werden, verweisen wir auf den Jahrgang 1877 des Dingler'schen polytechnischen Journals.

Vählt man Metalle von sehr hohen Schmelzpunkten, wie z. B. Eisen und Platin, so verträgt ein aus denselben gebildetes Thermoelement eine sehr starke einseitige Erhitzung. Der dabei entstehende Strom gestattet dann mit IIilfe des Satzes XLV eine amnähernde Beurtheilung der Temperatur, welcher die erhitzte Contactstelle ausgesetzt war. Man hat hierauf ein py rometrisches Verfal ren gegründet, von welchem im Artikel Wärmemessung die Rede sein soll . XLVI.)

Eine der Thermoelectricität nahe verwandte Erscheinung ist die Pyroelectricität. Dieselbe soll jedoch, da sie keine technische Anwendung tindet, hier nicht näher besprochen, sondern nur an einem Beispiele kurz erwähnt werden.

Bringt man einen Turmalin-Krystall aus einem kälteren in einen wärmeren Raum, so zeigt er sich mit zwei electrischen Polen behaftet. Das Ende $P$ des Krystalles, an welchem bei der Erwärmung der positive Pol auftritt, nennt man das analoge, das andere, gleichzeitig negativ electrisch gewordene Ende $N$ das antiloge. Wird sodann der Krystall abgekühlt, so wechseln die Pole; $P$ wird negativ und $N$ positiv. Dieses Verhalten zeigt sich auch an Bruchstiicken des Krystalles und kam mittelst eines empfindlichen Electroseopes leicht nachgewiesen werden

D) Inductionselectrieität. ( ) Wir denken uns, es liegen zwei geschlossene Drahtleitungen $I$ und $I I$ Fig. 1420 so nebeneinander, dass sie ganz Fig. 1420. oder theilweise in geringer Entfernung von
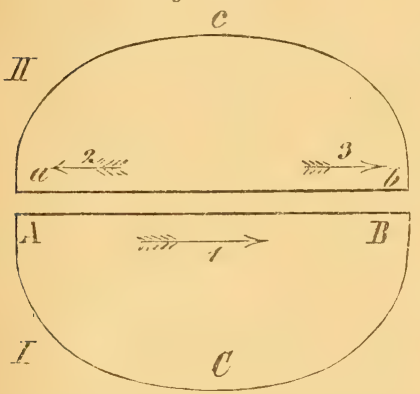
einander parallel lanfen, wie z. B. die Drahtstiicke $A B$ und " $b$. Erzengt man nun in der Leitung 1 , welche die primäre genannt werden soll, auf was immer fuir eine Art (z. B. durch Einschaltung einer Batterie) einen electrisehen Strom, so ist leicht erklärbar, dass in diesem Augenblicke anch im benachbarten Leiter II, welcher der s ee 11 ndäre heissen mag; eine Störung des bisher bestandenen (neutralen) electrischen Gleichgewichtszustandes eintreten muss; müisste ja doch z. b., wemn I electrisirt wird, nach dem Satze X auch der Leiter II durch Influenz electrisch werden. Die besagte Gleichgewichtsstörung in $I /$ gibt sich in der Furm eines clectrischen Stromes zn erkemnen, der, wemn der strom in I die lichtung $I$ hat, in der entgegengesetzten lichtung 2 verläuft. - Danert sollamn der in I crongte Strom 1 unveränlert fort, so ist krine Veranlas:mug zu einer weiteren stormug des electrischen Gleichgewiehtes in II, also aud keine Veraulassumg zu ciner Furtdauer des datselbst vorhin erregten Stromes 2z gegeben. Dieser Strom 2ै, welehen mall einen rom Strome 1 inducirten Strom neme, ist also ein angenblicklich voribergeliender sogenannter momentaner Strom, der nach äusserst kurzer Dauer sofort wieder verschwindet.

Eine nene electrische (ileichgewichtsstoirung in $/ 1$ muss alier cintreten, sobald der primäre strom (d.h. der strom $/$ im primären Leiter $I$ ) wieder verschwinctet. In der That tritt in diesem Angenblicke ein zweiter Inductionsstrom 3 im se('unlären Leiter $I I$ ant, dessen lidelitung jener des zucrst inducirten entgegen-

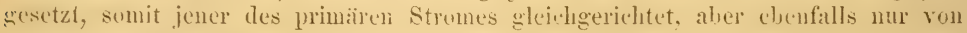
momentamer Daluer ist.

Insufern der Inductionsstmu 2 die Herstellung des stromes 1 durch Schliessung viner in $I$ cingeschalteten Batterie hegleitet, neme man ilm anch Schli essungsstrom, wihrend der das Auflüren des stromes 1 (bei Gefinung der Batterie)

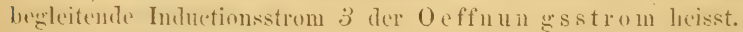

b) Inductionströme von der Richtung 2 oder 3 erhailt man auch, wenn nam den Leriter I des Stromes $I$ dem Leiter $I I$ rasch nailert, oder von demselben 
rasch entfernt, oder vielmehr die parallelen Stücke $A B$ und $a b$ beider Leiter rasch einander nähert oder von einander cutfernt.

c) Endlich bewirkt auch ein plötzliches Anwachsen oder Abnehmen des Stromes 1 eiuen gleichzeitig auftretenden Inductionsstrom, welcher bezichungsweise die Richtung 2 oder 3 liat.

Die inducirten Ströme sind desto stärker, je stärker der in $a$ ) und $b$ ) angewendete inducirende Strom ist, ferner je rascher die im Falle $b$ ) stattfindende Bewegung vor sich geht und je grösser und rascher die im Falle c) in Betracht kommenden Aenderungen (Schwankungen) des inducirenden Stromes sind. Man nennt die nuter $a$ bis $c$ aufgezählten inducirten Ströme electrodynamischinducirte . . . . . . . . . . . . . . . . . . XLVIII.)

d.) Denken wir uns den Draht $A B C$ entfernt und durch die Drahtschleife $a b c$ einen Magnetstab rasch bewegt, etwa mit dem Nordpol voraus die Zeichnungsebene durchdringend, so entsteht ebenfalls ein inducirter Strom und zwar in der Richtung 3; dagegen entsteht bei der rïekgängigen Bewegung des besagten Magnetstabes ein inducirter Strom von der Richtung 2.

e) Denkt man sich den Draht $a b c$ ganz oder zum Theile um einen Eisenstab herumgewickelt und den Eisenstab plötzlich magnetisirt oder entmagnetisirt, so treten ebenfalls Inductionsströme auf, deren Richtungen in der in $d$ angedeuteten Weise von der Lage der entstehenden oder verschwindenden Magnetpole abhängen.

f) Auch eine plötzliche Zu- oder Abnahme des Magnetismus im Falle $e$ wiirde das Auftreten inducirter Ströme von den bereits angedeuteten Richtungen zur Folge haben.

Die unter d) bis $f$ ) anfgezählten Ströme heissen magnetisch inducirte; ihre Stärke hängt von der Stärke der inducirenden Magnete und beziehungsweise ron der Schnelligkeit ab, mit welcher diese bewegt oder deren Magnetismus verândert wird .

XLIX.)

Eine besondere Art von inducirten Strömen, welche wir noch zu besprechen haben, sin丸 die sogenannten Extraströme. Sie gehören in die Kategorie der electrodynamisch indıcirten Ströme, erheischen jedoch mit Ruicksicht auf die eigenthiimlichen Verhältnisse, unter welchen sie zu Stande kommen, eine besondere Betrachtung.

Wemn in einer Drahtrolle der Strom einer beliebigen Electricitätsquelle hergestellt oder unterbrochen wird, so findet nicht nur eine inducirende Fernwirkung auf eine etwa vorhandene benachbarte Drahtrolle statt (in ähnlicher Weise wie bei dem in Fig. 1419 dargestellten Versuche), sondern es wirkt auch jede einzelne Drahtwindung auf alle iibrigen Windungen derselben Drahtrolle inducirend ein, wodurch in der Leitung des primären Stromes selbst sowohl ein Schliessungsstrom als auch cin Oeffnungsstrom entsteht. Diese von einem entstehenden oder verschwindenden Strome in seiner eigenen Leitung inducirten Ströme nennt man Extraströme.

Der Unterbrechungs-Extrastrom ist es, welcher den glänzenden und geräuschrollen Funken erzeugt, der bei der Unterbrechung eines in einer grossen Dralıtrolle circulirenden kräftigen Stromes auftritt. $\mathrm{Er}$ hat mit dem unterbrochenen Strome gleiche Richtung und macht sich insofern gewissermassen als eine Fortsetzung desselben geltend. Dieser Umstand kann in gewissen Fällen sehr störend sein, nämlich dann, weun es auf ein plötzliches und vollständiges Aufhören des primären Stromes ankommt, wie es z. B. zur Erzengung eines möglichst kräftigen Inductionsstromes in einer benachbarten (secundären) Drahtrolle erforderlich ist, wie später gezeigt werden wird.

In solchen Fällen muss der den primären Strom gewissermassen fortsetzenden Funkenentladung des Extrastromes vorgebeugt werden, was durch alsbald zu besprechende Hilfsmittel erzielt werden kann . . . . . . . . . . . . L.)

Die inducirten Ströme finden vielseitige Anwendungen im Gebiete der Plyysik, der Heilkunst und der Techuik und man hat daher zur zweckentsprechenden Er- 
zeugung inducirter Ströme die mannigfaltigsten Inductions-Apparate construirt. Sie lassen sich, den vorausgeschickten Principien (XLVIII und XLIX) entsprechend in zwei grosse Gruppen theilen, nämlich in electrodynamische und magnetoelectrische, wobei wir jedoch sogleich bemerken wollen, dass bei den sogenannten electrodynamischen Inductionsapparaten nebenbei auch das Princip der magnetoelectrischen Induction zur Verstärkung der Wirkung Anwendung findet.

Bei allen Inductions-Apparaten werden in rascher Aufeinanderfolge a bwechselnd entgegengesetzte Ströme inducirt, nämlich bei den Apparaten der einen Art Schliessungs- und Oeffnungsstrom, bei jenen der zweiten Art die entgegengesetzten Ströme, welche durch eine periodische (z. B. hin- und hergehende oder rotirende) relative Bewegung zwischen Magnet und Stromleiter zu Stande kommen.

In vielen Fällen (z. B. bei den meisten therapeutischen Anwendungen) ist dieser Richtungswechsel nicht störend; in manchen anderen Fällen, z. B. bei der Erzengung von Inductions-Funken, kommt er bei der Wirkung des Apparates insofern weniger zur Geltung, als Oeffnungs- und Schliessungsstrom, obschon sie gleiche Electricitätsmengen mit sich fiihren, doch sehr ungleiche Spannungserscheinungen zeigen, so dass der erstere vorherrscht. Häufig aber kommt es auf gleichgerichtete Ströme an. In solchen Fällen wird entweder (wie bei den älteren magnetoelectrischen Inductionsapparaten) jeder zweite Inductionsstrom ausgeschaltet, oder aber mittelst eines Stromwechslers, "Commutator" genannt, in die entgegengesetzte Richtung iibergefuihrt.

Wir beschreiben zunächst einen electrodynamischen Inductions.Apparat einfachster Art.

In Fig. 1421 stellt $I$ eine mit iibersponnenem Drahte bewickelte Holzspule vor. Durch diesen Draht geht der Strom einer Batterie $B$ (oder nach Umständen

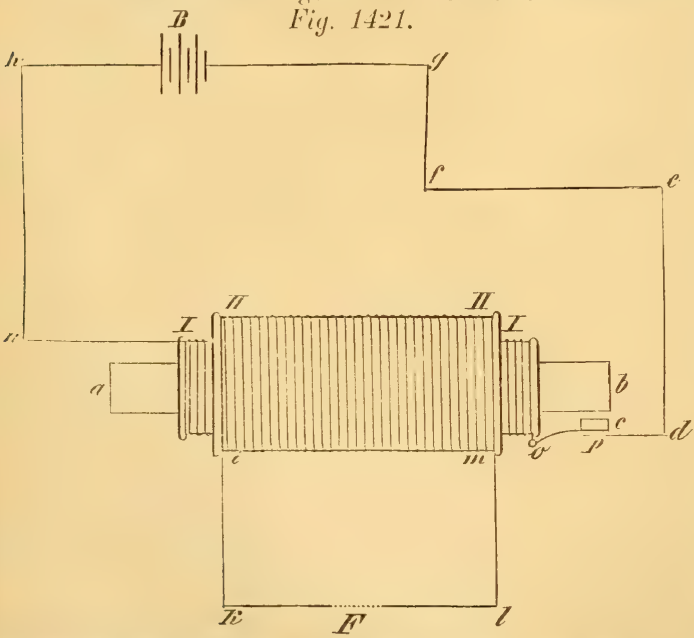
eines einzelnen Elementes) auf dem Wege Bh $\operatorname{loc} p$ de $f g B$, vorausgesetzt, dass der hammerartige, bei $o$ drehbare IIebel o $c$ anf der leitenden Un. terlage ( Ambos") $p$ aufliegt und auf diese Art die vorhin beschriebene Leitung schliesst. In der Spirale $I$ befindet sich ein Eisendraht-Buindel a b. Dieses wird, um. kreist vom Strome in der Spirale $I$, sofort magnetisch. In Folge dessen wird der eiserne Kopf $c$ des Hammers $o c$ vom Ende $b$ des besagten Eiseukernes angezogen und dadurch ron $p$ abgehoben. Auf diese Art wird die Stromleitung unterbrochen, das Eisen $a b$ also wieder unmagnetisch und der IIammer o $c$ fällt ant den Ambes zurick. Dadurch ist aber der strom wiecler hergestellt, der sofort anf die beschriebene Weise seine Selbstunterhrechung ncuerdings veranlasst.

Dieses Spiel des Apparates, welches so lange dauert, als die Kette $B$ einEeschlaltet ist, hat zur Folge, dass in einer weiteren Dralitrolle $I I$, wclche die friber erwïhnte umgiht, ein Ueffunngs- oder Schliessungsstrom entsteht, je nachdem der llammer " c abgehoben wird viler niederfallt. 
Die so erzeugten in rascher Aufeinanderfolge altemirenden entgegengesetzten Ströme können dann durch eine an den Drahtenden der zweiten Spirale angebrachte Leitung $i l k l m$ ihrer Verwendung zugefiihrt werden, indem man in dieso Leitung, z. B. bei $F$, den Körper einschaltet, welcher der Einwirkung der Inductionsströme ausgesetzt werden soll.

Die Drahtrolle $I$ wird die primäre, die weitere $1 I$, die secundäre genannt. Die beschriebene selbstthätige Unterbrechungs-Vorrichtıng ist unter dem Namen des Wagner'schen (oder auch Neef'schen) H ammers bekannt. Er kommt in den mannigfaltigsten Formen zur Anwendung.

Bei den sehr zweckmässigen Du $\mathrm{B}$ ois Reymoud'schen Apparaten fir Aerzte ist die secundäre Spirale über der primären verschiebbar, wodurch die Wirkung nach Bedarf verstärkt oder geschwächt werden kann. Solche Apparate (mit verschiebbarer Inductions-Spirale) heissen Schlitten-A p parate. Man hat iibrigens auch andere Vorrichtungen zur Regulirung des Wirkungsgrades, anf die wir jedoch, so wie anf die Hilfsgeräthschaften für medicinische $Z$ wecke, nicht eingehen. Auch unsere Zeichnung soll nur im Principe, nicht aber in den Details (welche in den mannigfaltigsten Modifieationen vorkommen) die Einrichtung der electrodynamischen Inductions-Apparate veranschanlichen.

Die Apparate für Heilzwecke befinden sich in verschliessbaren Kästehen, welche zugleich "die nöthigsten Hilfsgeräthschaften und bei kleineren Apparaten auch das galvanische Element enthalten . . . . . . . . . . . LI.)

Man hat in neuerer Zeit Mittel gefunden, Inductions-Apparate von äusserst intensiver Wirksamkeit herzustellen und damit Effecte zu erzielen, welche man früher wohl für unerreichbar gehalten hätte. In diese Kategorie gehören zunächst die auch in technischer Hinsicht wichtig gewordenen $\mathrm{Ruhmk}$ orff'schen Inductions-Apparate. Mau nennt dieselben häufig auch Funken-Inductoren, wcil sie Inductions-Ströme von so hoher Spaunung liefern, dass man mit denselben melır oder weniger kräftige Funken-Entladungen hervorrufen kann. Apparate dieser Art finden nicht nur in physikalischen und chemischen Laboratorien vielfache Anwendung; sie können auch zum Minenzitinden dienen; man verwendet sie ferner zur Entzïndung explosiver Gasgemenge bei manchen Gasmaschinen, und sie sind endlich bei den neuteren Chronographen (s. d.) in vielen Fällen unentbehrlich.

Die Fig. 1422 gibt das Schema eines solchen Apparates. Von der primären $(I)$ und secundären (II) Spirale gilt das bereits bei Fig. 1421 Gesagte; doch sehen wir hier auf dem Wege $B g h U c S n d e f B$ des von der Batterie $B$ kommenden Stromes einen Unterbrecher („Interruptor $\left.{ }^{\prime}\right) U$ eingeschaltet, der sich vom W a g n e r'schen Hammer zwar nicht im Principe, wohl aber durch seine besondere Einrichtung unterscheidet. Der stromleitende Draht $h$ taucht nämlich bei $U^{\prime}$ in ein mit Quecksilber gefuilltes Glasgefäss. In dieses Quecksilber Fig. 1422.

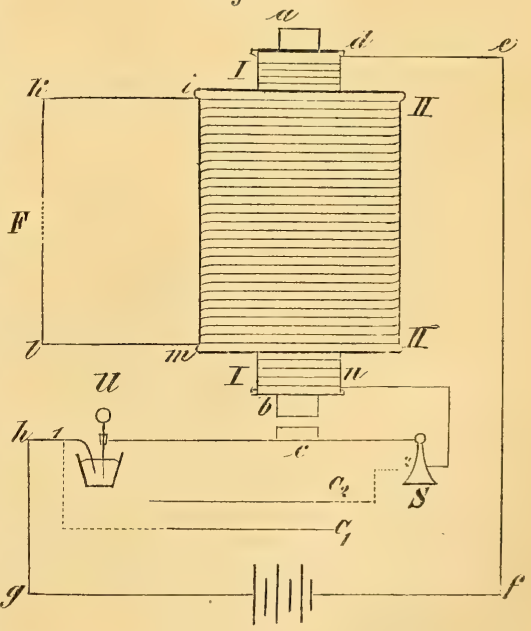
tancht anderseits auch eine Platindralıtspitze, die von einer an einem Säulchen $S$ festgemachten Feder gehalten wird. Auf diesor Feder ist das eiserne Kiötzchen $e$ befestigt, welches vom Ende $b$ des Eisenkernes $a b$ angezogen wird, sobald der Strom der Kette $B$ durch die primäre spirale geht. So wie dies geschieht, wird 
die Feder emporgezogen und dadurch die mit ihr verbundene Platinspitze aus dem Quecksilber ausgehoben. Auf diese Art wird der Batteriestrom unterbrochen, a $b$ wieder ummagnetisch, $c$ fällt zuriick, und damit auch die Feder, welche die Platinspitze wieder in's Queclsilber taucht und in Folge dessen nenerdings Stromschluss bewirkt u. s. w.

Diese von F ouca ult herrilirende Modification des W a g n er'schen Hammers hat vor der ursprünglichen Form desselben den Vorzug, dass beim Ausheben der Platinspitze ans dem Quecksilber, wenn sieh anf derselben eine Schichte vou Alkohol befindet, eine geringere Funkenbildung durch den Extrastrom stattfindet, was aus den im Absatze \& erörterten Gründen zur Verstärkung des von der secundären Spirale $I I$ dureh die Leitung $i k l m$ gehenden Inductionsstromes wesentlich beiträgt.

Ein anderer Kunstgriff, der Funken-Entladung des Extrastromes möglichst vorzubengen und dadurch die Intensität des Stromes in der Nebenspirale (II) zu begiunstigen, besteht in der Anbringung eines Condensators als Nebenschliessung: des Unterbrechers, d. h. in der Art, dass zu beiden Seiten des letzteren, z. B. bei 1 und 2, Drahtleitungen angebracht werden, welche zu den beiden Belegungen $\left(C_{1}\right.$ und $C_{0}$ ) eines Condensators (siehe die Beschreibung im Absatze XXVIII) fiihren. Durch diese Einrichtung wird Folgendes bewirkt.

Man kann sich den Extrastrom, so wie jeden electrischen Strom, in der Art gebildet denken, dass im Stromleiter gleiche Mengen positiver und negativer Electricitit gleichzeitig in entgegengesetzter Richtung sich bewegen. Denkt man sich also im vorliegenden Falle z. B. die positive Electricitait $(+E)$ des Extrastromes in der Richtung $B g h . U c S n$ u. s. w., die negative $(-E)$ in der Richtung $B$ fed $n$ $S c U$ u. s. w. verlaufend, so ist klar, dass ein Theil der gegen $U$ hinströmenden $+E$ bei 1 in die Belegung $C_{1}$ und eben so ein Theil der von der anderen Seite her nach $U$ zuströmenden $-E$ bei 2 in die Belegung $C_{n}$ des Condensators abgeleitet werden wird. Diese abgeleiteten Electricitäten werden also der im Unterbrecher stattfindenden Eutladumg des Extrastromes entzogen und können zu der (fiir den Oeffnumgsstrom in II nachtheiligen) Funkenbildung daselbst nichts beitragen; sie binden sich im Condensator, bis im nächsten Angenblicke der Platinstift des Unterbrechers wieder in das Quecksilber taucht, wobei sie sich damm atif dem Wege $C_{1}^{\gamma} 1 U_{C}, 2 C_{2}^{\prime}$ wieder ausgleichen.

Der Condensator ist das wirksamste Mittel zur Abschwächung: des Unterbrechungsfunkens und somit auch zur Verstärkung des Oeffung sstromes in der Inductionsspirale (II).

Durch den Condensator (seiue Anwendung in diesem Falle riihrt von F i z e a u her) und den Foucault'schen Quecksilber-Unterbrecher wird die Syannung des Oefthmosstromes so erhöht, dass eine sehr vollkommene Isolirmg des Induetionsdrahtes erforderlich ist, um zu verhindern, dass der Oeffinungsstrom in der Inductionsspirale (1I) ron ciner Drahtwindung zur anderen iibergehe. Die sehr zalhlreichen Windungen des sehr diumen Indurtionsdrahtes werden also nicht uur Iurch sehr sorgfaltige Ueberspinnumg wit Scide, sondern anch durch starkes Firnissen und die einzelnen Drahtlaeen selbst durch Schichten von Schellack isolirt. $\left.{ }^{*}\right)$

In dieser vollkommenen Isolirung des Iuductionsdrahtes besteht das dritte II:unterforderniss für die Erzielung von Inductionsströmen von sehr hoher Spannung.

Apparate dieser Art geben an einer Unterbrechungsstelle $F$ einer die Drahtend'n der Inductionsspiralen rerbindenden Leitung meh oder weniger lange Funken, von wenigen Millimetern bis zu mehr als 60 Centim., je nach der Grösse und constructiven Vorziiglichkeit der Apparate.

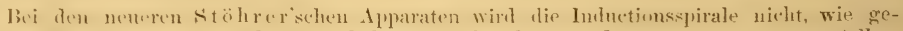
wöhnlich, aus ïbereinander gewickelten eylindrischen, sondern aus sogenannten "teller-

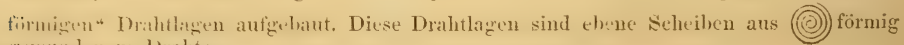
gewtundenem bralite. 
Auf die rerschiedenen Formen der Ausfiihrumg dieser zuerst von li ii ho k o off in P'aris zu Stande gebrachten Fumen-Inductoren, so wie iiberhaupt auf' construetive Details einzugehen, wiirde zu weit fiihren. Die gegebenen principiollen Erlinterungen geniigen zur Orientirung an jedem $\Lambda$ prarate dieser $\Lambda \mathrm{rt}$. . . . LII.)

Sehr gute, dauerhafte und preiswiirdige Fun. ken-Inductoreu hat Referent vom Herin Dr. E. St ̈̈hrer, Mechaniker in Dresden, erhalten.

Von magnetoelectrischen Inductions-Apparaten mögen hier nur zwei der neuesten Masehinen dieser Art erwähnt werden.

(c) Die Gram me'sche Maschine. Ihre Einrichtung ist durch das Schema Fig. 1423 anschaulich gemacht.

Man denke sich einen Ring aus weichem Eisen ${ }^{*}$ ) mit gut isolirtem. Kupferdrahte bewickelt, so dass der eiserne Ring den Kern einer gleichfalls ringförmigen Drahtrolle bildet, wie am Apparate Fig. 1424 ersichtlich ist. Diese in sich zurückkehrende Drahtrolle besteht aus mehreren Abtheilungen, die im Schema Fig. 1423 nur durch je eine einzelne Windung vorgestellt sind. Der beschriebene, mit Draht bewiekelte eiserne Ring (I nductor) ist mittelst cines Zahnradgetriebes $u m$ eine horizontale (auf der Ringebene senkrechte) Achse drehbar. Er läuft zwischen den Polen $N$ und $S$ eines kräftigen Stahlmagneten. In Folge dessen wird der eiserne Ring in der Art magnetisirt werden, dass er dem Nordpol $N$ s'egenüber (bei $s$ ) inmer siidlich und dem Siidpol $S$ gegeniiber (bei $u$ ) immer nördlich magnetisch wird. Weil die so erregten Pole $s$ und $n$ ihre Stellung gegeniiber $N$ und $S$ stets unverändert beibehalten, während die

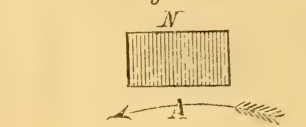

Drahtrollen sammt dem Eisen-Ring von rechts nach links umlaufen, so muss die Fig. 1.24 .

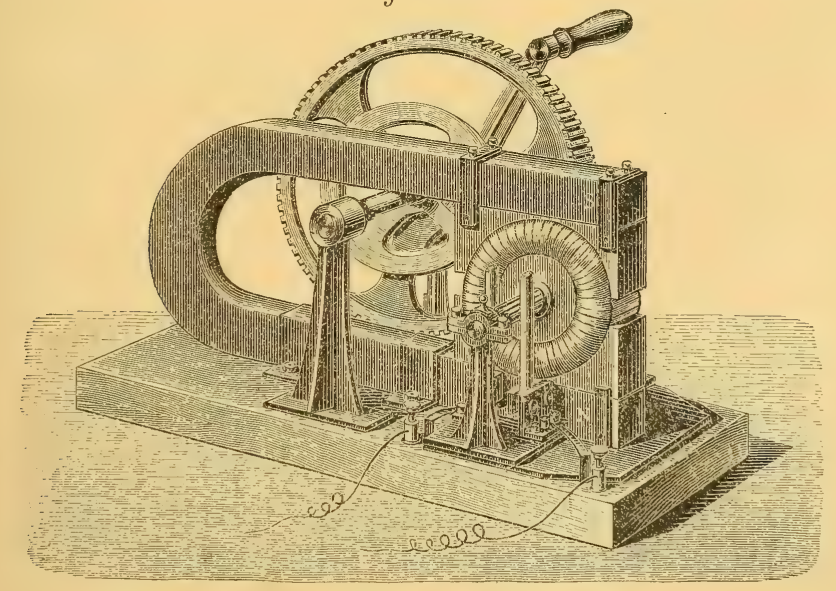

*) Man macht ihn atus Eisendralit. 
Wirkung dieses Vorganges dieselbe sein, als wenn die Drahtrollen stille ständen und im Innern derselben die Magnetpole $s$ und $n$ einen Kreislauf von links nach rechts machten. Eine solche Bewegung der Magnetpole $s$ und $n$ muss aber nach den unter Nr. XLLX angefuilrten Sätzen inducirte Ströme erzengen, welche in den Drahtwindungen so verlaufen, wie es die im Schema Fig. 1423 angefilhrten Pfeile anzeigen, nämlich sowohl in der oberen als auch in der unteren Hälfte des Inductors von $\zeta$ gegen $a$ hin. Denkt man sich bei $a$ und $b$ an den auf den eisernen Ring aufgewickelten Draht Kupferstifte 1 und 2 angelöthet, welche bei der Drehung an zwei punktirt angedenteten Federn (Contactfedern, Schleifern) anstreifen, so werden die bei a zusammenlaufenden Ströme bei 1 in die daselbst aufliegende Contactfeder iibcrgehen und durch die zwischen beiden Contactfedern eingeschaltete Leitung $L$ iiber 2 nach $b$ zurickkehren. Denkt man sich nun zwischen je zwei Abtheilungen des Inductorgewindes solche Ableitungsstifte angebracht, deren Enden 3, 4; 5, 6 u. s. w. bei fortgesetzter Drehung der Reihe nach paarweise mit den Contactfedern in Beriihung treten, so wird eine bei rascher Drehung fast ununterbrochene Folge von inducirten Strömen durch deu Schliessungsbogen $(L)$ gehen.

In Fig. 1424 sind die Schleifer als aufrechtstehende federnde Drahtbündel dargestellt, welche auf einem die Achse des Inductor's umgebenden Kranze gleiten, der aus eben so vielen ron einander isolirten kupfernen Klötzchen (Contactstiicken) zusammengefiigt ist, als das Inductorgewinde Abtheilungen (Drahtrollen) hat. Je zwei benachbarte Drahtenden von zwei neben einander liegeuden Abtheilungen sind (entsprechend den in Fig. 1423 durch 1 bis 6 angedeuteten Ableitungsstiften) mit je einem Contactsticke auf der Achse leitend rerbunden, so wie anderseits die Schleifer mit je einer Drahtklemme zur Aufnahme der Poldrähte.

Die Pole $N$ und $S$ des inducirenden Stahlmagneten sind mit starken eisernen Armaturen belegt, die so gestaltet sind, dass sie eine zur Aufnahme des Inductors dienende Höhlung umschliessen, wie auch ats Fig. 1424 ersichtlich ist . LIII.)

Die Gramme'schen Maschinen sind entweder, wie eben beschrieben worden ist, mit Stahlmagneten versehen (z. B. mit den seit der Wiener Weltausstellung bekannt gewordenen J a inschen Blätlermagneten oder sie sind nach dem später zu besprechenden dynamoclectrischen l'rincipe eingerichtet. Die grösseren Maschinen der letzteren Art (wie sie z. B. zur electrischen Beleuchtung dienen) können nicht mchr mit der Hand bewegt werden, sondern erfordern zu ihrem Betriebe eine Dampfmasehine oder Gasmaschine.

Die für den IIandhetrieb eingerichteten (i ram meschen Maschinen sind in Laboratorien als Ersatz fuir hydroelectrische Batterien sehr bequem.

6) Die Siemens \& II ilske sche magnetoelectrische Maschine. Dieselbe ist noch viel wirksaner als cinc G 1 an me sche Maschine ron gleichem Preise. Zwischen den in zwei horizontalen Reihen angeordneten Polen ron 50 Stahlmagneten, deren Wälhmgen abwechsehd nach aufwärts und nach abwärts gekehrt

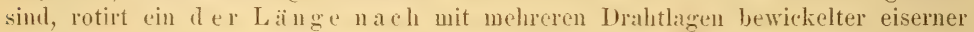
Cylinder. Dieser Inductor ${ }^{*}$ ) hat im Wesentlichen dieselbe (v. HefnerAltenceksche) Einrichtung wie bei den grossen dynamoelectnischen Maschinen von Siemens \& Halske, von welchen weiter unten die Rede sein wird. Die Anordnung der einzelnen Theile ist nicht so leicht iibersichtlich wie bei der Grammeschen Maschine, weshalb wir ohne allzugrosse Weitläufigkeit hier nicht auf eine nähere Beschreibung eingehen können ${ }^{*} * *^{*}$. . . . . . . . LIV.)

c) Die dyat moelectrischen Matichinen. So nemnt man eine besondere Art von hüchst leistungstähigen und auch bereits technisch wichtig gewordenen

Siehn den officiellen Austellungshericht Gruple XIV. I. ft LX, Scite 9!

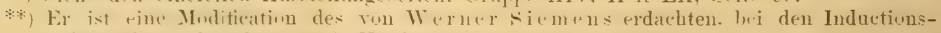

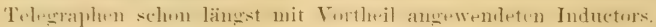

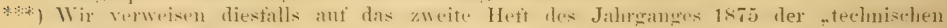

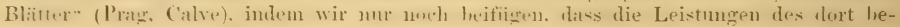

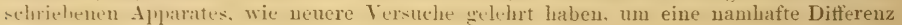
zul gring anteguhen sint. 
magnetoelectrisehen Induetionsmaschinen, deren eigenthiumliches (vor etwa 10) Jalıren ron Dr. Werner Sicmens erdachtes) Princip kurz in folgender Weise ansgesprochen werden kann.

Vorerst ist klar, dass als inducirender Magnet anstatt eines Stahlmagneten anch ein Electromagnet verwendet werden kann. Um einen solchen in Thüitigkeit zı erhalten, wïrde (nach der gewöhnlichen Ëinrichtung) eine galranische Battric erforderlich sein, die den magnetisirenden Strom liefert. Bei den dynamoclertrischen Maschinen hat der Eisenkern des Electromagneten schon von vornherein (als liickstand ron einer friheren Magnetisirung her) eine Spur von Magnetismus, die an sich sehon (auch wenn kein magnetisirender Batteriestrom in Anwendung kommt) rermögend ist, bei der Drehung des Induetors einen, wenngleich sehr schwachen, Inductionsstrom hervorzurufen. Man denke sich nun diesen Inductionsstrom (anstatt eines Batteriestromes) durch die Drahtwindungen des Electromagneten geleitet, so ist klar, dass derselbe den Magnetismus des Eisenkernes verstärken wird. Dies hat unmittelbar zur Folge, dass die bei fortgesetzter Drehung des Inductors nunmehr inducirten Ströme schon stärker sind. Wenn nun diese inducirten Ströme stets in gleicher Richtuug durch die Drahtwindungen des Electromagneten geleitet werden, so wird eine succesive Verstärkung desselben, und somit anch der inducirten Ströme selbst, eintreten müssen, bis ein gewisses der Beschaffenheit des Apparates angemessenes Maximum erreicht ist.

Das Princip der dynamoelectrischen Maschinen besteht also, kurz gesagt, in der succesiven Verstïkung magnetoelectrisch inducirter Ströme, indem diese selbst zur Verstärkung des inducirenden, urspringlich nur mit einem magnetischen Riickstande behafteten Electromagneten verwendet werten.

Hat der dynamoelectrisch inducirte Strom die erforderliche Stärke, so kann durch eine einfache Vorrichtung leicht die Leitung, in welcher der Strom zur Wirksamkeit kommen soll, in den Schliessungskreis des Apparates eingeschaltet werden.

Man hat auch doppeltwirkende, d.h. dynamoelectrische Maschinen mit zwei Inductoren construirt (einem grösseren und einem kleineren), die zwischen je zwei Magnetpolen so angeordnet sind, dass der kleinere Inductor zur Verstärkung des Magnetismus, der grössere hingegen zur Erzengung des nutzbaren Stromes dient.

Eine ähnliche Einrichtung hatte die bekannte Wild'sche Maschine, jedoch mit ilem wesentiichen Unterschiede, dass der kleinere Inductor zwischen den Polen eines Stahlmagneten rotirte und seine Ströme in die Windungen eines grossen Electromagneten entsendete, zwischen dessen Polen der grössere Inductor rotirte und den Nutz-Strom lieferte. Die Wild'sche Maschine ist also auch eine doppeltwirkende (mit Anwendung des Siemens'schen Inductors), aber keine „dyuamo-

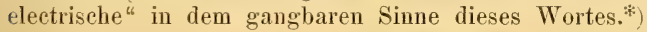

E) Allgemeine Gesetze des electrischen Stromes. Die Wirkungen, welche ein electrischer Strom hervorzubringen vermag, bestehen entweder nnmittelbar in einer Erwärmung des Leiters, in welchem sich der Strom bewegt, oder sie lassen sich (wenn sie chemischer oder mechanischer Natur sind, wie z. B. bei der Electrolyse oder bei dem Betriebe einer electromagnetischen Arbeitsmaschine) auf die Entwickelung einer äquivalenten Wärmemenge zuriickführen. Zerlegt z. B. ein Strom 1 Gramm $=0 \cdot 001$ Kilo Schwefelsäurehydrat, also 0.001

49 Acquiralente (auf Kilo bezogen) ron dieser Substanz, ${ }^{* *}$ ) so wird dabei eine

*) Wichtige Benerkungen über das Wesen und die Vorzüge dieser Maschinen im Vergleiche mit jenen mit Stahlmagneten enthält die Abhandlumg ron Dr. Wrernersiemens im Monatsberichte der Berliner Akademie rom Jïmer 1867.

*, $\mathrm{SO}_{4} H=49$. Aus Grïnden, welche im Artikel "Electrolyse" angefiihrt sind, bedienen wir uns bei der besprechung electruchemischer Fragen der ailteren Verhindungsewichte $(\sigma)=s$ statt ()$=16)$ und schreiloen demgemäss $S O_{4} I I$ statt $\$ O_{4} H_{2}$ fiir selwefolsäureHydrat. Dabei lassen wir die betreffende Aequivalentzahl (z. B. SOH $=49$ ) stets Kilo bedeuten. 
vom Strome gelieferte Wärmemenge im Betrage von $\frac{0.001}{49} .46462$ Calorien gebunden. *) Oder leistet ein Strom z. B. bei dem Betriebe einer electromagnetischen Maschine eine Brutto-Arbeit ron a Meterkilo, so ist die zur Bestreitung dieser Arbeit erforderliche äquivalente Wärmemenge $=\frac{a}{424} \quad$ Calorien, weil 424 bekanntlich das mechaxische Aequivalent der Wärme ist.

Joule u. A. haben (auf verschiedenen experimentellen und theoretischen Wegen **) nachgewiesen, dass die durch einen electrischen Strom in der Zeiteinheit bewirkte Wärme-Entwickelung dem Q u a rate der Stromstärke und zugleich einer von der Beschaffenheit des Leiters abhängigen Grösse, welche man Leitungswiderstand nennt, direct proportional ist.

Mit Beibehaltung der Jac obi'schen Stromeinheit (1 Cubic-Centimeter Knallgas-Entwickelung pro Minute) und der Siemens'schen Widerstandseinheit (d. i. der Leitung'swiderstand eines Quecksilberprisma's ron 1 Meter Länge und 1 Quadratmillimeter Querschnitt bei $0^{\circ}$ C.) findet man die Würme-Entwickelung $q$ in der Zeiteinheit (Secunde) mittelst der Formel

in Calorien.

$$
q=0.00000207 s^{2} u=\operatorname{cs}^{2} w \text {. }
$$

Die äquivalente Arbeit $a$ (Stromarbeit) in der Zeiteinheit ist demnach gegeben durch

$$
\left.a=424 q=0.000878 s^{2} u=\operatorname{sis}^{2} w \% \%\right)
$$

indem wir für die Zahleneö̈fficienten 0.00000207 und 0.000878 der Kiirze wegen bezichungsmeise die Bezeichmungen $c$ und $l_{i}$ ein fïr alle Mal einfïlıren. Der Satz LV wird das Joule'sche Gesetz genannt.

Versteht man unter wen Gesammtwiderstand des Schliessungskreises einer belicbigen Stromquelle (z. B. Batterie oder Inductions-Apparat), nämlich die Summe aller Widerstände innerhalb der Batterie und ausserhalb derselben in der eingeschalteten Leitung, so fundet man (so lange an der Stromquelle nichts geändert wird, also z. B. die Zahl und Beschaffenheit der Batterie-Elemente dieselbe bleibt, oder ein Inductions-Aplarat mit constanter Geschwindigkeit in Gang crhalten wird), dass $s$ in demselhen Verhïltnisse abnimmt, als man $v$ vergriossert und $u m$ gekehrt, dass also das Product beider Grössen eonstant bleibt. Man nemnt dieses Product $e=s$. . . . . . . . . . I IVII) die eleetromotorische Kraft der Strompuelle mol das so eben formulirte Gesetz das Oh m'sehe. + ) Es wire? gewöhnlich in der Form

geselirieben und ansgesprochen.

$$
s=\frac{\rho}{u}
$$

Befinden sich im Sohliessungskreise mehrere Strompnellen oder denkt man sich die vorhandene in mehreren zorlegt man kann z. P. jules Batterie-Element fiir sich oder jede Inductor-Windung für sich als eine Stromquelle betrachten), welchen einzeln genommen die electromotorischen Krifte $\rho_{1}, e_{9}, \rho_{3} \ldots \ldots$ zu-

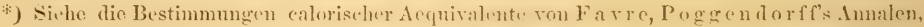
Bd. 135.

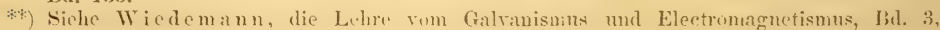
Achlusseatpitel.

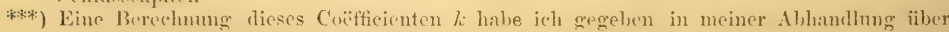

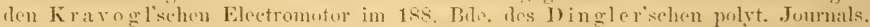

†) Mim kimn unter $\psi$ atuch den Widerstand eines Stïckes des Schliessungskreises (\%. B. cines eingeschalteten Drahtes) verstehen; dann bedentet e die Difiercuz der electrischen Spannmgen am Anfange mi am Eude des hetrachteten Leiterstiickes. In dieser allgemeineren Inttissung ist jenes (iesetz faut thenretisehem Wege) von $O$ hm zuerst irgriindet worlen. Zithlreiche exprimentelle Lntersuchmgen Ponillet, li. Kohlra useh

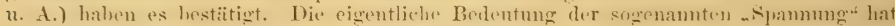
Kirchhoff dureh Einfühmug a

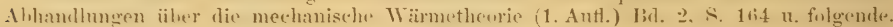
(I)ie zweite Antlage ist nueh nicht so weit erselienen.) 
kämen, *) und denikt man sich auch den Schliessungskreis in Theile von den Widerstiunden $w_{1}, w_{2}, w_{3} \ldots \ldots$ zerlegt, so wiirde das $O$ h m'sche Gesetz die Form $s=\frac{e_{1}+e_{0}+e_{3}+\ldots}{w_{1}+v_{2}+v_{3}+\ldots}=\frac{\Sigma e}{\Sigma v}$

annehmen.

Wirken nicht alle $e$ ibereinstimmend, so sind die entgergengesetzt wirkender mit den Vorzeichen + mol - in die algebraische Summe ze einzufiihn'ru.

Für Leiter von prismatischer oder cylindrischer Gestalt (z. B. für Drähte) ist der Widerstand $w$ der Länge $l$ direct und dem Querschnitte $f$ rerkelurt prorportional, so dass die Formel $\quad w=0 \frac{l}{f}$

Anwendung findet, wenn man unter dem Coëfficienten o den Widerstand vorsteht, welchen ein Stiick des Leiters von der Länge 1 und von dem Qnerschitte 1 halben würde. Diese Grösse $\varrho$ ist von der materiellen Beschaffenheit des Leiters abhängig und heisst sein specifiseher Widerstand.

Werden die Längen $(l)$ in Metern und die Querschnitte $(f)$ in Quadratmillimetern gemessen, so ist der specifische Widerstand des Quecksilbers glcich einer Siemens'schen Widerstandseinheit (gewöhnlich mit S. E. kurz bezeichnet). Dagegen wäre der specifische Widerstand des Quecksilbers $=0.000001$ S. L., wenn man die Querschnitte $(f)$ in Quadratmetern ausdricken wiirde.

Wir geben im Nachstehenden die Verhältnisszahlen der specifischen Widerstände für einige Metalle und Legirungen bei $0^{0}$ C.:

\section{Quecksilber . . . . . . 1.0000 Messing; gegliilit}

Reines Silber; ansgegliiht. . .0.0161

Reines Kupfer; ausgegliilit . . $0 \cdot 0179$

Silber $(\mathbf{7 5 0} \% \mathbf{1 0 0 0})$; ansgeglüht . . 0.0201

Peines Gold; gegliiht . . . 0.0227

Aluminium; gegliiht . . . 0.0324

Reines Zink; gehämmert . . 0.0621

Stahl; gegliiht

Reines Zinn

Eisen ; gegliilit

Platin; geglüht

Reines Blei

Neusilber; gegliilıt .
$0 \cdot 072: 3$

$0 \cdot 1149$

$0 \cdot 1214$

$0 \cdot 1272$

$0 \cdot 1647$

$0 \cdot 2075$

0.2775

\section{Reines Cadmium; gehämmert .0.0716}

Geringe Beimengungen verändern die specifischen Widerstände sehr bedentend. Dic Kupferdrahtsorten des Handels haben sämmtlich viel grössere Widerstände als reines Kupfer. Referent fand Widerstände von 0.0266 lis (1.0577. Aehnliche Verschiedenheiten fand man anch bei Neusilberdrahtsorten.

Der Leitungswiderstand der Körper hängt iibrigens von der Temperatur ab und wächst bei den Metallen mit zunehmender Erwärmung: Man findet den Widerstand $w_{t}$ bei $t^{\prime \prime} \mathrm{C}$. aus dem Widerstande $w_{0}$ bei $0^{0} \mathrm{C}$. annähernd durch eine Gleichung von der Form $w_{t}=w_{0}\left(1+a t+\beta t^{2}\right)$. Dabei ist z. B. fiir Platin $\iota=0.002454$ und $\beta=-0.000000594$. Uebrigens lässt sich der Zusammenhang zwischen Widerstand und Temperatur auch durch andere empirische Formeln darstellen; so gibt z. B. Siemens fuir Platin auch die Formel $w_{t}=w_{0}\left(\alpha^{1 / 2}+\beta T+\gamma\right)$. Dabei bedentet $T$ die sogenannte absolute Temperatur (so, dass $T=273+t$ zu setzen ist), während $r=0.039369$, $\beta=0.00216407$ und $\gamma=-0.24127$. Wir erwähnen diese Relation, weil sie dem in technischer Hinsicht sehr wichtigen Widerstands-Pyrometer zu Grunde liegt, von welchem im Artikel Wärmemessung die Rede sein soll ${ }^{*}$ ) . LXI.)

Die Widerstände der Leiter zweiter Ordnung (z. B. Salzlösungen, fliissige Säuren) sind verhältnissmässig sehr gross. So ist z. B. der Leitungswiderstand einer concentrirten Kupfervitriollösung etwa $210000 \mathrm{mal}$ gröisser als der des Quecksilbers. Uebrigens wird der Leitung'swiderstand der fliissigen Leiter Zw weiter Ordnung durch Erwärmung rermindert.

*) Nach LVII wïre also unter der electromotorischen Kraft einer Stromquelle die Strumintensität zn verstehen, welche die untersuchte Stromquelle bei einem Gesammtwiderstande $=1(w=1, e=s)$ hervorbringen wïrde.

**) Jahrbuch dex Erfindungen von Hirzel und Gretscliel, Bd. 10, S. 1s9 u. Bd. 9, S. 109 . 
Für möglichst rein dargestelltes Wasser fand F. K o hl ra u s ch den Leitungswiderstand $14000000000 \mathrm{mal}$ grösser als den des Quecksilbers. Ma n betrach tet daher jetzt das chemisch reine Wasser nieht mehr als einen Leiter, sondern als einen Isolator. Aehnliches gilt von Alkohol und A ether. Der Widerstand des ersteren beträgt etwa das Doppelte ron dem des oben erwähnten Wassers; der Widerstand des letzteren rerhält sich zu dem des Quecksilbers etwa wie eine Billion zu Eins. In diese Kategorie der flüssigen Isolatoren gehören auch noch viele andere Substanzen, z. B. Essigsäure (Eis-Essig), flüssige schweflige Säure, Kohlensäure, Schwefelkohlenstoff n. s. w., fette und ätherische Oele. Dureh Mischung zweier nichtleitender Flïssigkeiten kann eine leitende entstehen; so z. B. geben Essigsämre und Wasser beim specifischen Gewichte 1.022 Essig, der $38000 \mathrm{mal}$, beziehungsweise $2000 \mathrm{mal}$ besser leitet, als seine Bestandtheile. - Geringe Beimengungen ändern den Leitungswiderstand anch der Fliissigkeiten sehr bedeutend. Ein Tropfen Schwefelsäure in 60 Liter Wasser gebracht, vermindert den Widerstand etwa auf den zehnten Theil.*) Die fliissigen Leiter der zweiten Ordnung werden, indem sie den Strom leiten, durch denselben zugleich zersetzt. Man nennt sie deshalb auch Electrolyten (vgl. den Artikel Electrolyse). . LXII)

Eliminirt man $w$ aus den Gleichungen LV und LVII, so ergibt sich für die calorische Wirkung des Stromes in der Zeiteinheit (Secunde) der Ausdruck

und fuir die Stromarbeit

$$
\begin{aligned}
& q=c s e . . .2 . . .2 \text {. . . . . . . . . }
\end{aligned}
$$

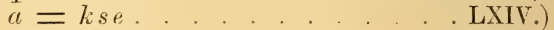

Bezeichnet man den Wärme-Effect der Stromeinheit $(s=1)$ in der Zeiteinheit mit $q_{1}$, so erhält man $q_{1}=c e$ und somit $e=\frac{q_{1}}{c}$. Eben so ergibt sich, wenn man die Arbeit der Stromeinheit $a_{1}$ nennt, der Ausdruck $e=\frac{a_{1}}{k}$.

Die im Schliessungskreise einer Stromqnelle thätige electromotorische Kraft ist also eine dem calorischen, somit anch dem mechanischen Effecte der Stromeinheit proportionale Grösse. In der That muss ja dic Wärme, welche bei der Erwärmung der Stromleiter durch den Strom in jeder Zeiteinheit abgegeben wird, durch die electromotorische Thätigkeit der Stromquelle in jerler Zeiteinheit geliefert werden. Man kann sich nämlich vorstellen, dass in der Secunde die Wärmemenge $q_{1}$ in der Strompuelle (z. B. einem galvanischen oder thermoelectrischen Elemente ${ }^{*}$ ) in Electricitiit umgesetzt wird, welche dann, indem sie den Schliessungskreis durchströmt, dieselbe Wärmemenge $q_{1}$ wieder abgibt . . . . . . . LXV.)

Bei einer hydroelectrischen Kette ist die in der Zeiteinheit für jude Stromeinheit entwickelte Wärmemenge $q_{1}$ leicht zu finden, sobald man die in der Kette vor sich gehenden chemischen Processe genau kennt.

Wir wollen die bei der chemischen Verbindung zweier Stoffe $A$ und $B$ frei werdende Wärmemenge durch das Symbol $+(A, B)$ und die bei der Zerlegung einer Verbindung $A, B$ in die Bestandtheile $A$ und $B$ gebundene Wärmemenge durch das Symbol - $(A, B)$ bezeichnen. Wir verstehen also z. B. unter $+\left(\mathrm{Zn}, \mathrm{SO}_{4}\right)$ die bei der Bildung eines Aequivalentes (d. i. $32.5+48=80.5$ Kilo) Zinkvitriol freiwerdende Wiirmemenge von 66296 Calorien; und eben so unter - (Cu, SO $\mathrm{C}_{4}$, die bei der Ausfillung ron 31.7 Kilo Kupfer ans Kupfervitriol gebundene Wärmemenge von 38950 Calorien.

Betrachten wir nun beispielsweise die Processe in einer Daniell'schen Kette und erwïgen wir, dass dabei für jedes (unter Bildung ron Zinkritriol) con-

*) Sithe F. Kohlrausch, über das electrische Leitungsvermigen des Wissers und der Nïuren. Sitzungsberichte der Münchener Akademie 1, $\mathbf{6 5}$.

**) Bei der Bewegung cines Inductionsapparates ist die mechanische Wechselwirkung zwischen inducirenden Magneten und den zu inducirenden Strümen zu überwinden; $f S$ muss also bei der Stromerzengung für jede Stromeinheit urd Zeiteinheit eine gewisse Arbeit $\boldsymbol{a}_{1}$ geleistet werden, die in Electricität ungesetzt und rom Strome sodann in Form einer äquivalenten Wärmemenge $q_{1}$ wieder abgegeben wird. 
sumirte Aequivalent Zink ein Aequivalent Schwefelsäurehydrat zerlegt wird, dessen freiwerdender Wasserstoff (unter Wiederbildung von Schwefelsäurchydrat) aus dem Kupfervitriol ein Aequivalent Kupfer ausfällt. Demnach entspricht einer Zinkconsumtion von 32.5 Kilo die Wärmeentwickelung

$$
+\left(\mathrm{Zn}, \mathrm{SO}_{4}\right)-\left(\mathrm{SO}_{4}, \mathrm{H}\right)+\left(\mathrm{H}, \mathrm{SO}_{4}\right)-\left(\mathrm{SO}_{4}, \mathrm{Cu}\right) \text {. . . LXVI. }
$$

Dieselbe reducirt sich mit Riicksicht auf die sich aufhebenden Glieder aut $+\left(\mathrm{Zn}, \mathrm{SO}_{4}\right)-\left(\mathrm{SO}_{4}, \mathrm{Cu}\right)=66296-38950=27346$ Calorien.

Wir wollen die so gefundene algebraische Summe der in der Kette entwickelten Wärmemengen kurz mit $\Sigma$ ? bezeichnen (indem wir uns die einzelnen Glieder von LXVI der Reihe nach mit $+\vartheta_{1}-\vartheta_{2}+\vartheta_{3} \ldots$ bezeichnet denken).

Von diesem $\Sigma \vartheta=27346$ wird jedoch durch die J a c o bi'sche Stromeinheit $(s=$ 1) in der Zeiteinheit (1 Secunde) nur ein kleiner Bruchtheil entwickelt werden. Diese Stromeinheit entwickelt nämlich in jeder Minute ein Cub.-Centim. Knallgas, zerlegt also in der Minute $\frac{1}{\mathbf{1 8 7 0}}$ Gramm Wasser,*) also in der Secunde $\frac{1}{1870 \times 1000 \times 60}$ Kilo Wasser. Dem entspricht eine Zink-Consumtion von $\frac{1}{1870 \times 1000 \times 60} .32 .5$ Kilo, also ron $\frac{1}{1870 \times 1000 \times 60 \times 9}=0.0000000009903$ Aequivalenten. Bezeichnet man diesen Coëfficienten mit $\alpha$, so findet man also die zur Unterlaltung dieser Stromeinheit in der Zeiteinheit erforderliche Wärmemenge $q_{1}=u \Sigma \vartheta$, somit die electromotorische Kraft der D a n i ell'schen Kette (vermöge LXV und LV)

$$
e=\frac{q_{1}}{c}=\frac{\alpha}{c} \Sigma \vartheta=\frac{0.0000000009903}{0.00000207} \Sigma \vartheta, \text { also }
$$

$$
e=0.000478 \Sigma \vartheta . . . . . . .4 X V I I),
$$

d. i. $e=0.000478 \times 27346=13$, was mit der durch Versuche ermittelten Zahl, welche etwas grösser als 12 ist, nahe ibereinstimmt.**)

In ähnlicher Weise lässt sich für jede hydroelectrische Kette, deren ehemische Processe man genau kennt, die electromotorische Kraft durch Rechnung mittelst der Formel LXVII finden.

Aus dem Joule'schen Gesetze und der daraus abgeleiteten Formel LXIV ist ersichtlich, dass die Arbeitsleistung eines electrischen Stromes (z. B. beim Betriebe einer electromagnetischen Maschine) nieht blos von der Stromstärke abhängt, sondern auch von der electromotorischen Kraft der Stromquelle, so wie z. B. die Arbeitsleistung einer sinkenden Masse nicht nur vom Gewichte derselben abhängt, sondern auch von der Hubhöhe. In der That bestimmt die Stromstärke wohl die Material-Consumtion, z. B. Zinkeonsumtion in einer hydroelectrischen Kette, aber die Consumtion eines und desselben Zinkquantums kann von sehr ungleichen Wärme-Entwickelungen begleitet sein, je nach der Einrichtung der Kette und dem dadurch bedingten Verlaufe der darin stattfindenden chemischen Processe. Je grösser die diesen Processen entsprechende Wärme-Entwickelung $q_{1}=\alpha \Sigma \vartheta$ (per Stromeinheit und Zeiteinheit) ist, desto grösser wird bei gleicher Stromstärke die Stromarbeit ausfallen . . . . LXVIII.)

Es ist gut zu bemerken, dass die in einem Stromleiter nach dem Jou l e'schen Gesetze stattfindende Wärmeentwickelung nicht verwechselt werden darf mit der im Stromleiter bewirkten Temperaturs-Erhöhung. Fiir den Grad der Erhitzung eines in den Stromkreis eingesclialteten Drahtstiickes fand J. Miiller gewisse empirische Gesetze, deren Zuriickfiihrung auf das Joule'sche Erwärmungsgesetz bisher noch nicht vollständig gelungen ist. So gelten z. B. fiur das Drahtgliihen folgende Erfahrungssätze.

*) Da das Wasser, wie wir oben (LXII) gesagt haben, den Strom nicht leitet, somit durch denselben auch nicht zerlegt wird, so ist diese Ausdrucksweise so zu verstehen, dass in der Minute ein Quantum Schwefelsïure zerlegt wird, welches 1/4rio Gramm Wasser äquivalent ist.

*:b) Die so berechneten electromotorischen Kräfte fallen stets etwas grösser aus als die experimentell ermittelt:n, aus Grïnden, deren Erörterung hier ïbergangen werden muss,

Karmarsch \& Hecren, Technisches Wörterbuch. Bd. III.

13 
Bezeichnet man mit $d$ die Drahtdicke in Millimetern und mit $s$ die Stromstärke, während $\gamma$ eine vom Materiale des Drahtes und rom Grade des Gliihens abhängige Constante ("Gliihwerth" genannt) bedentet, so gilt die einfache Relation

$$
\frac{s}{d}=i \text {. . . . . . . . LXIX.) }
$$

Dabei ist $\gamma$ fiir rothglihenden Platindraht $=172$, fiir weissgliihenden Platindraht $=220$, für rothgliihenden Kupferdraht $=430$, fiir rothgliihenden Eisendraht $=135$ u. s. w.

Sollte also z. B. ein $0.5^{\mathrm{mm}}$ dicker Platindraht rothgliihend gemacht werden, so wäre dazu (wegen $\frac{s}{d}=172$ ) eine Stromstärke rom Betrage $s=0.5 \times 172$ $=86$ nach chemischem Masse erforderlich. ${ }^{*}$ )

Der Widerstand $w$ im Schliessungskreise einer Stromquelle kamn als aus zwei Theilen bestehend betrachtet werden, die wir als inneren und äusseren Widerstand unterscheiden wollen. Unter jenem verstehen wir den Widerstand $u$ in der Stromquelle selbst, unter diesem den Widerstand $l$ im Sehliessungsbogen, so, dass man hat: $w=u+l$. Das 0 h m'sche Gesetz (LVIII) nimmt in Folge dessen die Gestalt an

$$
s=\frac{e}{u+l} \text {. . . . . . . . . . . . . LXX). }
$$

Wir wollen dabei voraussetzen, die Stromquelle sei ein Batterie-Element von der electromotorischen Kraft $e$ und vom Widerstande $u$. - Wie nun, wenn mehrere Elemente, z. B. $n$ an der Zahl, miteinander zur Batterie verbunden werden? Stellt man die $n$ Elemente in der üblichen Weise (wie Fig. 1425 andeutet) hintereinander, so erhält man eine Batterie ron der electromotorischen Kraft $n e$ und rom Widerstande $n u$. Die resnltirende Stromstärke würde damn sein :

Fig. 142;.

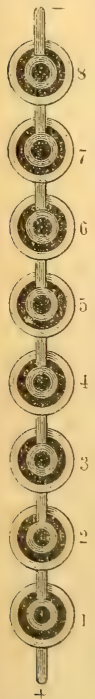

Fig. 1121 .

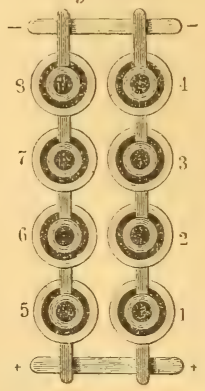

Fig. 14:-

$$
s=\frac{n e}{n n+1} \text {. }
$$
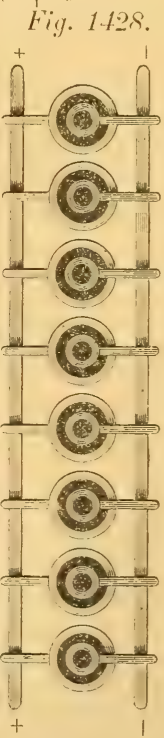

Aus Fig. 1426 bis Fig. 1428 ist nun aber ersichtlich, dass eine Anzahl ron Elementen in sehr verschiedener Weise zur Batterie angeordnet werden kann, so z. B. 8 Elemente zil einer 8-elementigen Batterie (Fig. 1425), damn zu zwei parallel geschalteten HalbBatterien von je 4 Elementen (Fig.1426), ferner zu vier parallel geschalteten Viertel - Batterien ron je 2 Elementen (Fig. 1427) und endlich zu acht parallel geschalteten Elementen (Fig. 1428). Sind die Elemente, wie wir annehmen wollen, einander gleich, so wirken die drei dargestellten Parallelschaltungen (Fig. 1426 bis 1428) so, als

*) Näheres über diesen Gegenstand fundet man in des Terfassers Abhandlung: "Teber die Gesetze des durch eleetrische Ströme luwirkten Dralıtgliheus". Sitzumgsberichte der kgl. bühm. Gesellschatt der Wissenschaften Jahrgang $1 \times i 4$. 
hätte man beziehungsweise 4 Doppel-Elemente (4 Elemente von doppelter Plattengrösse), 2 vierfache Elemente und endlich 1 achifaches Element genommen.

Es entsteht nun die, Frage, welche von den aufgezihlten ('ombinationen in einem gegebenen Falle die vortheilhafteste ist.

Es lässt sich zeigen, dass man die grösste Stromstärke erzielt, wenn man jene Batterie-Combination wählt, deren Wriderstand dem Widerstande im Schliessungsbogen am nächsten kommt.

Die Widerstände der anfgezählten vier Combinationen (den Widerstand eines Elementes $=u$ ) gesetzt) wïrden sein:

$$
8 u ; 4 \frac{u}{2}=2 u ; 2 \frac{u}{4}=\frac{u}{2} ; 1 \frac{u}{8}=\frac{u}{8} \text {. }
$$

Hätte man, um allgemein zu sprechen, $n$ Elemente in $m$ Batterien von je $r$ Elementen abgetheilt (wobei also $n=m r$ angenommen wird) und jene $m r$ elementigen Batterien parallel geschaltet, so wiirde diese Combination den Widerstand $r-\frac{u}{m}=\frac{n u}{m^{2}}$ haben. Die Stromstärke

$$
\left.s=\frac{v_{e}}{r \frac{u}{m}+l}=\frac{n e}{n \frac{u}{m}+m l} . . . . \mathrm{LXXI}\right)
$$

erreicht den grössten möglichen Werth, wenn

$$
\frac{n u}{m^{2}}=l \text {, also } m=\sqrt{\frac{n u}{1}} \cdot . . . \text {. 1.XXII) }
$$

gemacht werden kann. In den meisten Fällen wird $\sqrt{\frac{n u}{l}}$ keine ganze Zahl sein, welche in $n$ als Factor enthalten ist; man wählt dann von allen möglichen Parallelschaltungen diejenige, für welche $m$ der Grösse $\sqrt{\frac{n u}{l}}$ am nächsten kommt.

Beispiel. Es seien zum Betriebe einer electrischen Uhr von 8 S. E. Widerstand 6 Meidinger-Elemente von je 10. S. E. Widerstand zur Verfügung. Welche Combination wird den stärksten Strom geben? Man findet $m=$ $\sqrt{\frac{6 \times 10}{8}}=2 \cdot 7$; die nächstliezende in 6 als Factor enthaltene Zahl ist 3 . Man wird also bei der Parallelschaltung von drei Drittel-Batterien zu je zwei Elementen, oder, was auf dasselbe hinauskommt, bei der Combination der 6 Elemente zil 2 3-fachen Elementen einen stärkeren Strom erhalten als bei jeder anderen Combination. Es ist sogar möglich, dass eben nur die berechnete vortheilhafteste Combination iberhaupt geeignet ist, die Uhr in Gang zu erhalten, jede andere aber nicht . . . . . . . . . . . . . . . . . . . LXXIII.)

Die Formel LXXII zeigt, dass $m$ abnimmt, wenn $l$ wächst; es liegt aber in der Natur der Sache, dass $m$ nicht kleiner werden kann als 1 . Bei sehr grossen Schliessungs-Widerständen $(l)$ (z. B. beim Telegraphiren) wird man also keine Parallelschaltungen der Batterie-Elemente mit Vortheil anwenden können, sondern dieselben einfach hintereinander zur Säule anordnen. Wohl aber wird die Parallelschaltung bei kleinen Schliessungs-Widersländen angezeigt sein, wobei zu bemerken ist, dass $m$ nicht grösser als $n$ gemacht werden kann. Dies ist der Fall des kleinsten möglichen Batterie-Widerstandes. Er entspricht der Parallelschaltung aller $n$-Elemente, d. i. ihrer Combination zu einem einzigen $n$-fachen Elemente.

Um die Verbindung der Batterie.Elemente, ohne die letzteren verstellen zn miissen, nach Belieben in der Art abändern zu können, wie es den verschiedenen Combinationen (Parallelschaltungen) entspricht, hat man eigene Apparate construirt, die man Pachytrope (Querschnitswechsel) nemnt . . . . LXXIT.)

Bei der Beurtheilung des Material-Verbrauches (z. B. der Zinkeonsumtion) kommt immer nur die Anzahl der hintereinander gestellten Batterie-Elemente in 
Betracht, nicht aber die Zahl der parallel geschalteten Partialketten. Liefert z. B. die in LXXIII erwähnte Combination einen Strom von der Intensität $s$, so wird in jedem der beiden 3-fachen Elemente die Zinkmenge $\frac{s}{1870} \cdot \frac{32 \cdot 5}{9}$ Grammen*) in jeder Minute, im Ganzen also die Zinkmenge $2 \cdot \frac{s}{1870} \cdot \frac{32 \cdot 5}{9}$ Grammen in der Minute consumirt, gerade so, als wenn 2 einfache Elemente hintereinander gestellt denselben Strom liefern wiirden . . . . . . . . . . LXXV.)

Findet ausserhalb der Batterie eine Stromverzweigung statt, so lassen sich die entstehenden Zweigströme selbst in den complicirtesten Fällen dieser Art mit Hilfe der Kirchhoff'schen Gesetze**) berechnen. Wir können hier nur den am häufigsten in Betracht kommenden speciellen Fall einer Stromtheilung in zwei parallel geschaltete $\mathrm{Zweige} \mathrm{berücksichtigen.}$

Fig. 1429.

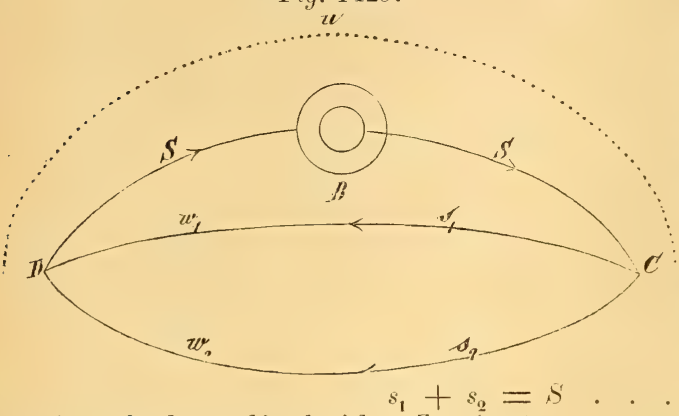

Wir denken uns einen von einer beliebigen Stromquelle $B$ (Fig. 1429), welche die electromotorische Kraft $e$ haben mag, ausgehenden Strom $S$, der bei $C$ in die Zweigströme $s_{1}$ und $s_{2}$ sich theilt.

Es ist leicht einzusehen, dass die Summe dieser Zweigströme dem ungetheilten Strome gleich sein muss, nämlich so wie auch, dass die beiden $\mathrm{Z}$ weigströme $s_{1}$ und $s_{2}$ sich verkehrt zu einander verhalten müssen, wie die Widerstände $w_{1}$ und $u_{2}$ der beiden $\mathrm{Z}$ weigleitungen $I$ und $I I$, welche zwischen den beiden Knotenpunkten $C$ und $D$ parallel geschaltet sind, also

$$
s_{1}: s_{2}=\frac{1}{w_{1}}: \frac{1}{w_{2}}
$$

Aus diesen beiden Relationen folgen (wenn man $\frac{1}{u_{1}}+\frac{1}{u_{2}}=\frac{1}{W}$ setzt) offenbar noch die weiteren

somit

$$
\begin{array}{r}
s_{1}: S=\frac{1}{u_{1}}: \frac{1}{W} \\
s_{2}: S=\frac{1}{u_{2}}: \frac{1}{W} \\
s_{1}=\frac{S W}{u_{1}} \\
s_{2}=\frac{S W}{u_{2}}
\end{array}
$$

Bezeichnet man den Widerstand des punktirt angedeuteten ungetheilten Theiles des Schliessungskreises mit $u$ und berücksichtigt, dass

$$
W=\frac{w_{1} u_{2}}{u_{1}+u_{2}} .
$$

*) $s$ Cuhic-Centimeter Krnallgas entsprechen nämlich $\frac{s}{18 \pi}$ Grammen Wasser, folglich $\frac{s}{1870} \frac{32 \cdot 5}{9}$ Gran.m'n Zink.

**) Siehe W i ede mann, Galvanismus, Bd. I S. 163 . 
den Widerstand der parallel geschalteten Zweige zwischen den beiden Knotenpunkten $C$ und I) vorstellt, dass also nach dem $O$ h m'schen Giesetze

$$
S=\frac{e}{u+W}
$$

sein muss, so gelangt man durch Einsetzung dieses Ausdruckes in LXXVIII und Substitution des Werthes fiir $W$ aus LXXIX leicht zu den Formeln

$$
\begin{aligned}
& s_{1}=\frac{e w_{12}}{u w_{1}+u w_{2}+w_{1} w_{12}} \\
& s_{12}=\frac{e w_{1}}{u w_{1}+u w_{2}+w_{1} w_{2}}
\end{aligned} \mid
$$

welche die Berechnung eines jeden der beiden $Z$ weigströme in zwei parallel geschalteten Stromzweigen sofort gestatten, wenn die electromotorische Kraft der Stromquelle und alle Widerstände $\left(u, w_{1}\right.$ und $\left.w_{2}\right)$ bekannt sind.

Jeder der beiden Zweigströme ist also proportional dem Producte der electromotorischen Kraft der Stromquelle mit dem Widerstande der Nebenschliessung.

Dieser Satz findet sehr wichtige Anwendungen in der Galvanometrie und in der Telegraphen-Technik.

Siehe auch die Artikel: Electrolyse und Electromagnetismus.

Electrische Telegrafie (telegraphe électrique - electric telegraph). Unter electrischen Telegrafen sind jene Fernschreib-Vorrichtungen (s. Telegrafie) verstanden, bei welchen die Zeichengebung mittelst Electricitit bewerkstelligt wird.

Das der Anlage eines electrischen Telegrafen Wesentliche ist ein isolirter, continuirlicher Schliessungsdraht, so weit gezngen, dass er durch zwei von einander entfernte Orte (Stationen) läuft, in welchen eine galvanische Batterie oder eine sonstige Electricitätsquelle entweder dauernd oder zeitweilig eingeschaltet werden kann. An einem dieser Orte ist ein Apparat aufgestellt, welcher eine Unterbrechung oder Schliessung der Kette, bezichungsweise die Ein- oder Ausschaltung der Electricitätsquelle oder ïberhaupt eine Aenderung des Schliessungskreises beliebig bewerkstelligen lässt, während am zweiten Orte ein anderer Apparat sich befindet, welcher diese, durch den ersteren Apparat verursachte Aenderung irgendwie wahrnehmbar macht. - Hiermit werden die Bedingungen für die Möglichkeit einer telegrafischen Correspondenz mittelst Electricität erfïllt sein. Die Signale können nun nach der Kürze und Länge und Anzahl der Schliessungen oder Unterbrechungen, Aenderung der Stromrichtung oder Stromstärke u. s. w. dargestellt. werden, je nachdem die Einrichtung des Zeichenapparates getroffen sein wird. Ein unbedingtes Erforderniss für jede, wie inmer geartete, electrische Telegrafenanlage ist sonach die Leitung, die Electricitätsquelle (Batterie, Inductor u. s. w.), die 'T a s tervor r c h t ung (Drucker, Taster, Schliissel, Manipulator; Commutator) und der Z eichengeber (Indicator, Schreibapparat, Receptor u. s. w.).

Die Electricitätsquellen, Tastervorrichtungen und Zeichengeber können nicht nur an einem, sondern an jedem beliebigen Punkte der Leitung zur Beobachtung und zum Gebrauche eingeschaltet werden. Bei hinlänglich kräftiger Electricitätsquelle wird die mittelst des Tasters ausgeiibte Action an allen Stellen des Schliessungskreises fast gleichzeitig erfolgen und also die eingeschalteten Zeichengeber in gleicher. Weise ebenfalls gleichzeitig in Thätigkeit setzen. Eine Reihenfolge soleher mit Electricitätsquellen, Taster und Zeichengeber ausgeristeter Stationen auf einer gemeinschaftlichen Leitung heisst schlechtweg Linie oder Section.

Schaltungssystem. Wird bei einem Telegrafensystenie der electrische Strom in der Art verwendet, dass er in bestimmten Intervallen in die Linie gebracht wird, um hier die einzelnen Signale zu erzeugen, heisst diese Anordnung: eine Schaltung auf Arbeits- oder Sprechstrom (courant en travail working-courrent); werden hingegen die Signale dadurch hervorgerufen, dass ein 
bei normalem Zustande des Schliessungskreises gleichmässig und dauernd circulirender Strom unterbrochen wird, nennt man dies eine Schaltung auf const anten oder Ruhestrom (courant constant - constant courrent).

Geschieht das Hervorrufen der telegrafischen Zeichen durch Vermelurung oder Verminderung eines vorhandenen Ruhestromes, heisst dies eine Schaltung auf Differenzstrom (courant differentielle - difference-courrent). Sind einander entgegengesetzte Ströme angewendet, welche sich im normalen Zustande aufheben, bei Action des Schliissels aber einzeln thätig werden, heisst die Schaltung auf G e genströme.

Telegrafen- und Erdleitung. Die wichtigsten Bedingungen für eine Telegrafen leitung sind: gute Leitungsfähigkeit, Continuität und Isolirung. Den beiden ersten Erfordernissen nach miisste also eine Telegrafenleitung aus einer isolirten Metall-Drahtleitung bestehen, die von der Anfangsstation bis zur Endstation und von der Endstation wieder zuriick zur Anfangsstation gezogen ist. Seit der Entdeckung der Erdleitung jedoch wird kein eigener Riickleitungsdraht gezogen, sondern statt eines solchen die Erde verwendet. Es werden nämlich die Enden der einen Drahtleitung vor der Anfangs- und hinter der Endstation unter die Erde auslaufen gelassen, und zwar, entweder an grosse Kupfer-oder Zinkplatten genietet, in Gruben, womöglich unter dem Niveau des Grundwassers, vergraben, oder an Eisenbalmschienen, Eisenröhren etc. befestigt, welche in den.Boden eingetrieben sind. Als vorziigliche Erdleitungen kömnen die Metallröhren der Gasund Wasserleitungen verwendet werden. Eine Erdleitung ist nur dann gut, wenn die Enden der Luftleitung, also die Erdplatten oder Erdschienen etc. in eine permanent feuchte Erdschichte zu liegen kommen. Wheatstone ${ }^{*}$ ) hat im Uebrigen nachgewiesen, dass die Erde nicht als leitende Verbindung der beiden Electroden einer galvanischen Batterie, sondern als Reservoir angesehen werden muss, in welches die galvanische Electricität abfliesst.

Je nachdem die Hinleitung auf Säulen oder Träger oberirdisch gezogen, oder unter der Erde, oder am Meeresboden gelegt wird, gibt es oberir is che, unterirdische und unterseeische Leitungen.

Oberirdische Leitungen (conducter d'électricité - conducting-wire). Für oberirdische Leitungen wurde urspriinglich das Kupfer als Leiter angewendet; aus ökonomischen Grinden sowohl, als auch deshalb, weil das Eisen eine grössere Festigkeit und geringere Dehmbarkeit besitzt, also weniger Stuitzpunkte bedarf, hat man bei oberirdischen Leitungen nummehr seit längerem schon von der Anwendung anderer Metalle, ausser Eisen und Stahl, Abgang genommen. Derzeit wendet man $3-5^{\mathrm{mm}}$ (in Ostindien und Bengalen sogar $8^{\mathrm{mm}}$ ) dicken Eisendraht, so wie auch Stahldraht an. Die laufende Leitung ist aus continuirlich verbundenen Drähten (sog Drahtadern) hergestellt; die Länge einer Drahtader beträgt 80 bis $\left.100^{\mathrm{m}}{ }^{*}\right)$ Die Enden je zweier zusammenstossender Atlern miissen selbverständlich so verbunden sein, dass sie nicht nur entsprechend fest an einander halten, sondern auch soliden metallischen Contact haben. In der Praxis des Leitungsbaues kommen die mannigfachsten Bundformen vor; die häutigste Anwendung finden: der in Fig. 1430 dargestellte Kropfbund, der in Fig. 1431 und 1432 dargestelle Bindedraht-Bund und endlich der Kkemmenbund (Fig. 1433). Die zwei ersteren

Fig. 1430.

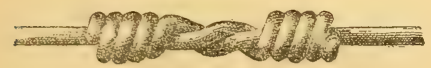

Fig. 1432 .

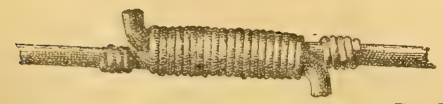

Fig. 1431.

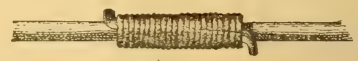

Fig. 1433.

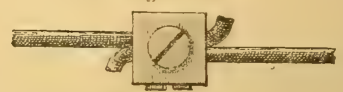

Bundformen.

" Rother's 'Telegrafenbau, pag. 21; Lu dewig, Bau v. Telegrf.-Linien, pag. 254. 
Bundformen sind jedenfalls die besseren, nur miissen sio gehörig hergestellt und die Bundstellen durch solides Verlöthen oder Ueberzichen von Blei- oder Guttaperchamuffen vor der Oxydation geschiitat werden. Nach den Messungen des Telegrafendirectors $\mathrm{L} u \mathrm{~d}$ wig*) belauft sich in einer gewöhnlichen risernen Telegrafenleitung die jähliche Abnalıme der Drahtslicke zufolge der Oxvdation nahezu auf $2 / 100^{m m}$. In Frankreich, Belgien, Deutschland und Amerika wurde deshalb versucht, einen Ueberzug von Zink als Sihutzmittel gregen das Oxydiren des Drahtes anzuwenden. In Deutschland hat man auch den Draht mit Gelfathen oder Theer iiberzogen, allein gleichfalls mit mehr Kosten als Erfolg. Ein giinstigeres Resultat erzielte man in Norddeutschland und in Oesterrcich mit der Methode, den Draht in Oel schwarz zu sieden oder in sehr heissem Zustande in Leinöl einzutauchen.

Eine neuere, in England und Amerika jedoch schon vielfach angewendete Erfindung ist der $\mathrm{Kupferstahldraht*}$ ) (compound telegraph wive). Derselbe enthält als Seele einen verzimnten Stahldraht von vorziglichstem Material, um welche zwei auf beiden Seiten verzinnte Kupferstreifen mittelst Zieheisen aufgepresst werden. Durch die bei der Pressung entstehende Hitze werden die Kupferstreifen gleichzeitig auch an den Stahldraht angelöthet. Das Gewicht eines solchen Drahtes beträgt nur $1 / 3$ des gewöhnlich verwendeten Telegraften-Eisendrahtes für gleiche Längen und Widerstände. Der von M. G. F a r mer und G. Milliken in Boston erfundene Kupferstahldraht wird in der Fabrik der New-Yorker Telegraph-Wire-Compagnie und in Woolwich von der Fabrik der Londoner Firma Gebriider Si emens erzengt und zeichnet sich dureh seine grosse Festigkeit und Dauerhaftigkeit aus.

Die in der Luft ausgespannte Telegrafen-Drahtleitung (fil conducteur telegiaph-wive) muss selbstverständlich in gewissen Abständen unterstiitzt oder aufgehängt sein; hiefiir stehen hölzerne, eiserne oder steinerne Säulen oder an Gebäuden guss- und schmiedeiserne Träger der mannigfachsten Construction in Anwendung. Am häufigsten sind für laufende Leitungen Holzsäulen, weniger häufig eiserne, ${ }^{*}$ ) selten steincrne Säulen im Gebrauche, doch ist vorauszuselien, dass mit der Abnahme des Holzes die Anwendung und Vervollkommnung der letzteren Systeme stetig zunehmen muss.

Die hölzeruen Telegrafensäulen, Telegrafenstangen (poteau télegraphiquetelegraph pole), die derzeit zumeist nach irgend einer der für Holz bestehenden Conservirungsmethoden behandelt (imprägnirt) werden, sind in Entfernungen ron circa $30-60^{\mathrm{m}}$ ron einander aufgestellt. Diese Entfernung ist näher bedingt durch die Anzahl und Schwere der aufgehängten Drahtleitungen, durch die Stärke der verwendeten T'elegrafenstangen und dureh den Kriimmungsradius der Linientraçe. Die aufgelıängte Drahtleitung darf nie unmittelbar mit den Stiitzen in Berihrung: kommen, weil sonst durch die Säulen, auch wenn sie nicht von Eisen, sondern von Holz oder von Stein sind, Nebenschliessungen entstehen, indem sie bei feuchtem Wetter dem Strome das Abgehen zur Erde ermöglichen.

An den Stiitzpunkten also sind solche Stoffe (Isolatoren) zwischen Träger und Draht zu bringen, welche letzteren vollständig isoliren. Diese Isolatoren werden aus Porcellan, Glas, Guttapercha u. s. w. hergestellt und haben die mannigfachste Gestalt; fiir alle gilt jedoch die Grundbedingumg, dass ihre Form das Abrinnen der feuchten Niederschläge bestens erlcichtert. Fast immer sind die Isolatoren glockenförmig (Fig. 1434 bis 1437) und auf cisernen Trägern, Fig. 1436 (Rundeisen), Fig. 1437 (Winkeleisen) aufgegypst oder mittelst firnissgetränktem Werg aufgekittet und aufgeschraubt ete. Dic Befestigung des Drahtes am Isolator geschieht, indem jener entweder um den Hals des Isolators umge-

Brix, Journ., Jhrg. IX, pag. 187.

**) Journal telegraphique Bd. 2, pag. 296; Polyt. Journal, Bd. 217, pag. 384; Organ f. d. Frt. d. Eisenbahuwesens 1876 -II, pag. 75.

W Dingler's polyt. Journal Bd. 2!4, pag. 199. 

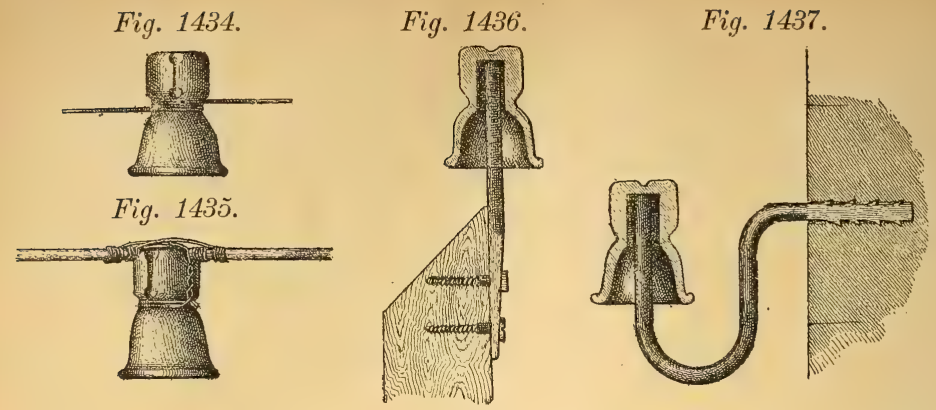

wunden (Fig. 1434) oder auf den Kopf aufgelegt (Fig. 1435) oder seitlich angelegt und mit einem zähen Bindedraht festgebunden wird. Bei Uebersetzungen von Fliissen oder an solchen Punkten iiberhaupt, wo die Unterstiitzungen der Leitung nur in besonders grosser Entfernung von einander angebracht werden können, ebenso an Gebäuden oder an den Vereinigungsstellen vieler Telegrafenlinien kommt mit Vorthesl Stahldraht zur Anwendung. An den Stellen, wo die Leitungen durch die Mauern in die Station eingefiihrt werden müssen, sowie im Bureau selbst, wird jedoch kein blanker Metalldraht verwendet, sondern Guttapereha-, Kautschuk- oder Gummi-Draht u. s. w., d. h. mit Guttapercha, Kautschuk oder Gummielastikum ete. iiberzogener Kupferdralıt. Fïr die Verbindungen der Apparate und Batterien untereinander innerhalb des Bureaus dient gewöhnlich diinner Kupferdraht, der mit Baumwolle iibersponnen und mit Wachs eingelassen ist; die Multi plicationen in den Apparaten sind aus Kupfer-oder Neusilberdraht, welcher durch eine Umspinnung von Seide isolirt ist, hergestellt.

Unterirdische Leitungen (conducteur d'électricité souterrain underground-cable). Einer noch sorgfältigeren Isolirung, als die oberirdischen Leitungen, bediirfen die unterirdischen. Solche werden aus einem oder mehreren Küferdrähten hergestellt, die vorerst eine glcichmässige Guttapercha- oder Kautschukumhiillung crhalten. Guttapercha und Kautschuk eignen sich deshalb besonder's als isolirende Umhiillungen für unterirdische Leitungen, weil sie von kaltem Wasser, Weingeist oder schwachen Säuren, selbst von der Salzsäure nicht und von der Schwefelsäure nur wenig angegriffen werden. Zum Schutze gegen Nagethiere und mechanische Einwirkungen wird der mit Kautschuk oder Guttapercha iberzogene Leitungstraht noch mit dicht aneinander liegenden Eisen-oder Stahldrähten spiralförmig umwunden, so dass er das Aussehen und die Gestalt eines Drahtseiles (Kabel) erhält.

Fig. 1438 gibt den Querschnitt der Wiener-, Fig. 1439 einer Pariser StadtFig. 1138. Fig. 1.339. leitung für den Fenertelegrafen, wobei immer die Kupfer-

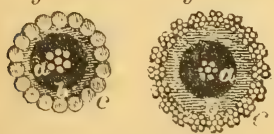
ader $a$ den eigentlichen Leitungsdraht, $b$ die Guttapercha-Umhiillung und $c$ den um die Peripherie d s Guttaperchadrahtes gewundenen Eisendraht darstellt. Es wurden ïbrigens unterirdische Telegrafenleitungen in mannigfach anderen Weisen herzustellen versucht; man lıat z. B. mit gutem Erfolge gewöhnliche, mit Kautschuk iberzogene Drähte in gemanerte Genimne eingelegt, welche dann mit Cement oder Asphalt ausgegossen wurden, so dass der Leitumgsdraht ringsum von der betreffenden isolirenden und schiitzenden Masse umgeben war.

Die submarinen Telegrafenleitungen (cîble sous-marin - submarime cable). In ganz verwandter Weise, wie die minterirdischen, sind die untersecischen oder submarinen Telegrafenleitungen hergestellt, nur dass sie entspredhend ihrer grösseren Abnitzung und Inanspruchnahme viel haltbarer construirt 
sein müssen. Sie hängen häufig auf weite Distanzen olne Stiitzpunkte frei, oder werden durch die Stiirme am Meeresboden hin- und hergeworfen; es miissen sonach ihre schiitzenden Umwindungen ans stärkerem Eisen- oder Stahldraht hergestellt werden, und zwar besonders an den beiden nächst dem Ufer liegenden Enden des Kabels. Fig. 1440 zeigt Querschnitt und Ansicht eines Stiickes dess letzten atlantischen Kabels, wie es im offenen Meere liegt; Fig. 1441 den Querschnitt eines Stuickes am Ende dieses Kabels (Strand- oder Kuistenkabel) in natürlicher Grösse; in der Mitte befindet sich der eigentliche Leiter, ein 7 facher Kupferdraht, denselben umgeben vier Lagen Guttapercha, $E$ ist mit Manillahanf Fig. 1440.
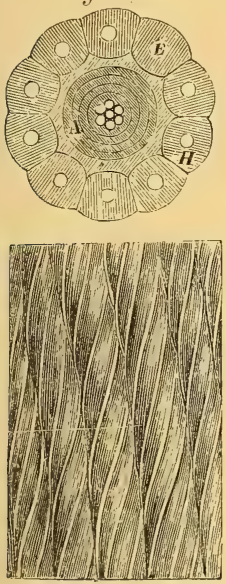

Fig. 1441.

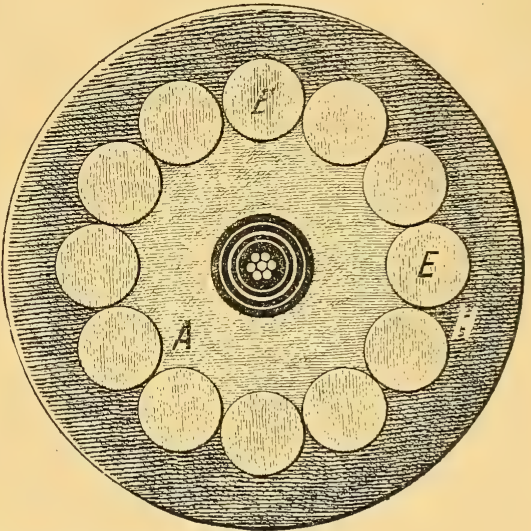

Submarine Kabel.

umsponnener, sorgfältig verzinkter Eisendraht, $H$ mit Catechu-Lösung gegerbtes Jutegarn und A Schmiermasse aus Asphalt. Die Kupferadern erhalten vor der ersten Guttapercha-Umhüllung einen isolirenden Ueberzug von Chaterton's Mischung, d. i. ein Gemenge von 3 Theilen Guttapercha, 1 Theil Harz und einem Theil Holztheer; ebenso erhält jede Guttaperchalage einen solchen Ueberzug bevor die nächste Lage daruber kommt, zu dem Zwẻcke, die Verbindung der Guttapcrehalagen um so dichter und undurchlässiger zu machen. Per Seemeile wiegt die siebenfache Kupferader $150 \mathrm{Kg}$., die Umhuillungen $1500 \mathrm{Kg}$., zusammen $1650 \mathrm{Kg}$., im Wasser $728.5 \mathrm{Kg}$.; die absolute Festigkeit des Kabcls ist $11 \mathrm{mal}$ so gross, als das Gewicht per Seemeile im Wasser.

Tragbare oder ambulante Leitungen (conducteur d'électricité trensportable - portative-contuctor). Wenn es sich darum handelt, provisorische Stationspunkte in telegrafische Verbindung zu bringen, u. zw. mittelst Leitungen, welche eventuell in kuirzester Zeit wieder für andere Traçen verwendet werden sollen, so miissen diese Anlagen einer raschen Herstellung und ebenso raschen Al,tragung entsprechen. Solche Telegrafen sind hauptsächlich in nenerer Zeit für militärische Zwecke in Aufselıwung gekommen, fast in allen grösseren Armeen bestehen eigene Truppenkörper, denen im Kriegsfalle die Herstellungen von Feldtelegrafen-Leitungen und Stationen obliegen. Das für Feldtelegrafenleitungen angewendete Materiale besteht aus dem Leitungsilaht und den Telegrafenstangen. Als Leitungsdraht wird entweder blanker Kupferdraht oder anch Kautschulidralst verwendet, der auf Trommelrollen, die sich auf Karren befinden, aufgewunden ist mul nach Bedarf abgewickelt wird. Die Telegrafenstangen sind 3.5 bis 5 Meter lohe, mit einem eisernen Schuh versehene Piquirstangen, an deren oberem Ende cin Kautschukisolator angebracht ist. In Distanzen von $50-70$ Metern werden 
diese Stangen möglichst tief in die Erde eingepresst und der Draht um den Kautschukisolator umgewiirgt.

Electricitätsquellen. Bei der Wichtigkeit, welche die Electricitätsquelle fuir den Betrieb einer Telegrafenanlage besitzt, wird es jederzeit eine Hauptaufgabe sein, eine möglichst entsprechende zu wählen und für deren vorziigliche Erhaltung Sorge zu tragen. Unter den feuchten Batterien verdient jene den Vorzug, welche bei langer Daucr kräftige und möglichst constante Ströme zu erzeugen vermag, gleichzeitig billig anzuschaffen und zu erhalten ist und dabei der möglichst geringen Pflege bedarf. Bei allen Schaltungssystemen oder Telegrafenanlagen iberliaupt, bei welchen langandauernde Stromschliisse verlangt werden, werden nur solche Batterien anwendbar sein, welche sich durch besondere Constanz auszeichnen; in Leitungen hingegen, wo nur momentane Schliessungen vorkommen, sind selbstverständlich Elemente vorzuziehen, welche einen energischeren Strom liefern, wenn sie auch nicht vollkommen constant sind, da ihnen die Intervalle zwischen den Stromschliissen Zeit zoir Erholung bieten.

Die Batterie muss gehörig zusammengesetzt, sowie richtig orientirt, $d . h$. mit den richtigen Polen eingeschaltet sein; ferner muss sie rechtzeitig durch nene ersetzt, respective während ihrer Inanspruchuahme in entsprechenden Zeiträumen mit jenen Stoffen wieder versehen werden, welche sie für ihre Thätigkeit nöthig hat.

Die Anwendung der Inductoren (vgl. S. 184) empfichlt sich besonders bei solchen Telegrafenanlagen, wo vom electrischen Strome grössere, mechanische Leistungen bei bedeutender Sicherheit gefordert werden, jedoch mit der Beschränkung, dass der Leitungswiderstand kein zu grosser und hauptsächlich nicht zu viel Multiplicationen eingeschaltet seien. Inductoren sind sonach fiir den Betrieb kurzer Telegrafenund Signalleitungen, z. B. bei Eisenbahnen, Fettertelegrafen u. s. f. von ganz ausgezeichneter Eignung und unbedingt jeder fenchten Batterie vorzuziehen. Die Nachtheile der letzteren gegenüber den Inductoren bestehen vorerst in dem Erforderniss einer sorgfailtigen Pflege und den deshalb auch noch auflaufenden, bedentenden Erhaltungskosten, sodann in den vielen Unterbrechungspunkten der Batterie selbst und den dadurch leicht möglichen Betriebsstörungen.

Dagegen ist wieder der Anschaffungspreis von Inductoren sehr hoch und die Möglichkeit der Verwendung eben eine beschränktere. Die beim Telegrafenbetriebe am liänfigsten rerwendeten, feuchten Batterien (batterie galranique - galornic battery) sind:

Das Smeesche Element. Dasselbe ist dort, wo es sich blos um kurz dauernde und ziemlich intensive Stromentwicklumg handelt, vortrefflich zu verwenden. Es besteht in der narh Straub und Schweizer *) verbesserten Form aus Fiy. 1142 .

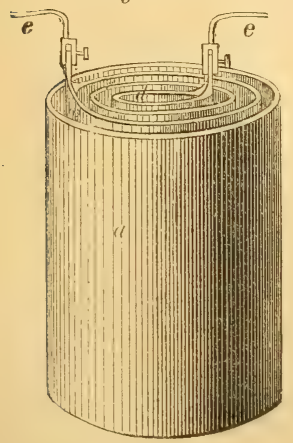
zwei amalgamirten Zinkplatten, zwischen welchen sich isolirt eine platinirte Silberplatte befindet; diese Platten werden in ein prismatisches Glasgefäss eingehängt und sind die zwei Zinkplatten immer mit einander (und mit der Silberplatte des nächsten Elementes) in metallischer Verbindung. Die verwendete Fliissigkeit besteht aus 10 Theilen Schwefelsäure und 90 Theilen Wasser.

Das Daniell'sche Element Fig. 1442. In einem cylindrischen Glasgefässe a steht ein kleinerer, oben offener Cylinder aus gebranntem, unglasirtem Thone $c$ zwischen dem ersteren und letzteren befindet sich ein der Gefässform angepasster Cylinder aus Zinkblech $b$, im Thongefässe ist ein kleinerer Cylinder aus Kupferblech $d$; der letztgenannte ist immer mil dem Zinkpole des nächsten Elementes durch einen angenieteten Kupferblechstreifen in Verbindung.

*) Dingler's polyt. Jumrual Bd. 162 pag. 418. 
Weiters wird der Raum zwischen Glas- mol Thongefäss bis zum obeeren Rimde des Zinkeylinders mit Wasser, welehem zuweilon retwas Schwefelsäure zugesetzt ist, gefullt, und in das Thongefïss Kupfervitriollösmog gebracht. Soll die Kette geschlossen werden, so wird der Zinkpol des letzten Elementes durch den Schliesungsdraht mit dem Kupfer des ersten verbunden. Dex im Elcmente stattfindende Vorgang ist Seite 192 letzte Alinea besprochen. Dieses Element arfiillt alle Bedingungen einer constanten Batteric und wird auch in der 'That als solithe angewendet. Ein Uebelstand bei den Daniell'schen Elementen ist die grosse P'flecte, welcher sie bedurfen. Der verbranchte liupfervitriol muss durch recelmässiges Nachfiillen sorgfailtig ersetzt und die Fliissigkeit zwischen Thonzelle und Glasgefïss rechtzeitig mit reinem Wasser verdünnt werden, damit die Lösung immer wieder den neuerzeugten Zinkvitriol aufzunehmen vermag.

Ein nachtheiliger Umstand ist noch der, dass die Poren der Thonzelle leicht durch das metallisch niedergeschlagene Kupfer verstopft werden, wodurch-die Verbindung zwischen den beiden Fliissigkeiten und folglich die Stromentwicklung gehemmt wird. Das Daniell'sche Element hat durch Sechi*) eine zweckmässige Abänderung erfahren.

Das Meidinger'sche Element**) unterscheidet sich von dem fríler angeführten durch den Mangel eines Diaphragmas. Es besteht (Fig. 1443) aus einem Glasgefässe, dem Standglase, auf dessen Boden concentrisch ein kleineres Glasgefäss eingekittet ist. In dem Standglase ist der Zinkeylinder so angebracht, dass er auf einem durch Verengerung des Standglases entstandenem Wulste feststeht. In das innere kleinere Gefäss wird ein Kupferblechcylinder eingesetzt, an dem ein mit Kautschuk iiberzogener Kupferdraht angenietet ist, welcher als Polanschluss dient, und einige Zoll iiber den Rand des Standglases hinausragt. Das ganze Element ist mit einem Holzdeckel verschlossen, in welchem sich Ausschnitte fiur die zwei Polanschliisse befinden; weiters ist in der Mitte des Deckels anch noch ein kreisrunder Ausschnitt, welcher dazu dient, einen Trichter aus Glas, welcher znm Festhalten den oberen Rand ïbergebogen hat, in das Element hinein zu hängen. Der Glastrichter, dessen unteres Ende mit einer ca. $2^{\mathrm{mm}}$ weiten, kreisrunden Ausflussöffnung versehen ist, reicht fast bis in die halbe Höhe des kleinen Glases, in welchem sich der Kupferpol be. findet, hinab. Das ganze Element wird bis zum oberen Rande des Zinkcylinders mit einer Lösung von Bittersalz $(1: 50)$ der Glastrichter jedoch mit Kupfervitriolkrystallen, gefiillt. Die sich daselbst bildende Kupfervitriollösung dringt ziemlich concentrirt durch die Ausflussöffnung in das Gefäss des Kupferpoles und sammelt sich als die specifisch schwerere Flüssigkeit dort so an, dass der ganze Kupferpol damit umgeben wird. Wenn diese Elemente ruhig stehen, so arbeiten sie sehr constant und ca. 12 Monate lang, ohne dass der Zinkeylinder ersetzt werden müsste; werden sie aber geriittelt, so dass die Kupfervitriollösung mit dem Zink in Berïhrung kommt, so wird die Stromentwicklung: bedentend geschwächt, in dem sich an dem Zinkpol metallisches Kupfer niederschlägt. Eine Modification dieses Elementes ist das sogenannte offene Meidinger-El ement (Fig. 1444). Fig. 1413.

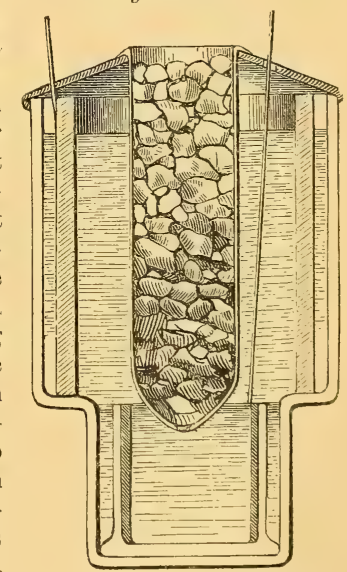
Bei diesem dient anstatt des früheren Glastrichters zur Aufnahme des Kupfurvitrioles

D ingler's polyt. Journ. Bd. 156 pag. 28.

\%) Pogg. Ann. CVIII, pag. 602; Brix's Journ. Jlurg. VII, lag. 5; Dingler's polyt. Journ. Bd. 155, pag. 109. 


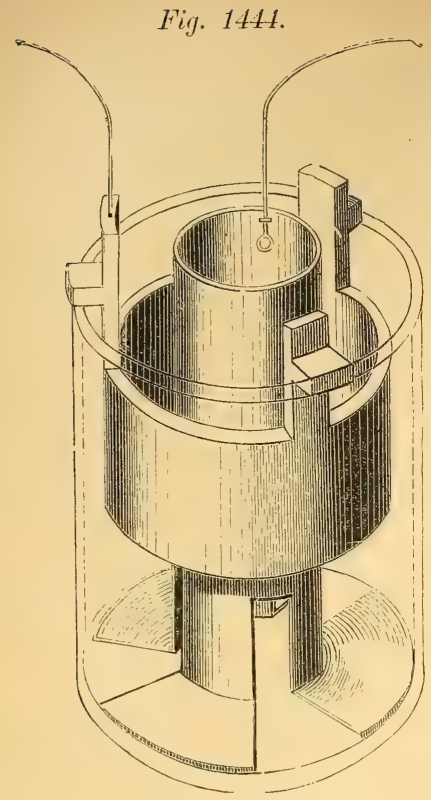

ein Glascylinder, der durch.Vermittlung des Kupferpoles feststehend erhalten wird. Der Kupferpol ist närnlich aus Blech cylindrisch geformt, unten mit ansgeschnittenen Fiissen und hat in seiner halben Höhe Einkerbungen, welche den Glascylinder, der in den Kupfercylinder genau hineinpasst, festhalten. Das zweite kleine Glas der früher beschriebenen Meidinger-Elemente wird hier also erspart. 'Die Kupfervitriollösung bleibt vermöge ihrer specifischen Schwere am Boden des Standglases. Der Zinkcylinder ist ein wenig höher angebracht, damit er nicht in die Kupfervitriollösung hinreiche. Diese Gattung ron Elementen findet bei dem Betriebe von Eisenbahn-Telegrafen selır verbreitete Anwendung, da es sich dureh seine Einfachheit auszeichnet und gegenüber dem Trichterelemente den Vortheil bietet, dass das Anflösen des Kupfervitrioles gleichmässiger vor sich geht als bei Anwendung der Glastrichter, bei welchen die Verstopfung der kleinen Ausflussöffnung häufig eintritt, was selbstverständlich die ganze Stromentwicklung gefährdet.

Eine weitere Abart des Meidinger-Elementes ist das B all on el emen t*) (Fig.1445). Die Einrichtung desselben ist fast ganz die gleiche, wie die des urspriinglichen Meidingerelementes, nur dass statt des Glastrichters eine Ballonflasche angewendet wird, deren Hals bis in die Mitte de's kleinen Gefässes hinabreicht. Die Ballonflasche ist iberdiess so gehlasen, dass sie eine, der Weite des Standglases entsprechende Einkerbung hat, vermöge weleher sie unverrickbar

liig. $144 i$.

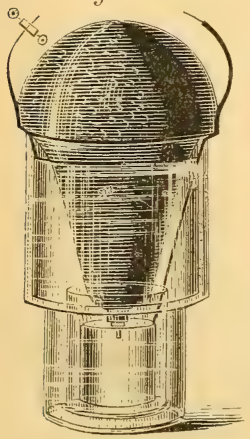
am Glasrande aufsitzt und so gleichsam als Deckel, beziehungsweise Verschluss des Elementes dient; ausserdem sind zwei Einkerbungen da, welche die Polanschlüsse durchlassen. Zum Gebrauche wird die Ballonflasche mit Kupfervitriol und Wasser angefiillt, mel dam mit einem Korkstöpsel, durch welchen ein Glasröhrchen oder ein Federkiel durchgesteckt ist, verschlossen. Das Standglas wird lingegen bis zur entsprechenden Höhe mit Bittersalzlösung gefiillt, sodamn erst die gefüllte Ballonflasche, mit dem Halse nach unten, eingesetzt. Die Kupfervitriolläsung, geht durch das Glasröhrchen oder den Federkiel in das kleine Gefäss des Kupferpoles. Die ziemlich voluminöse Ballouflasche bildet ein Reserroir für die Kupfervitriollisung wodurch das lästige Nachfüllen iiberfliissig gemacht wird. Ausserdem halun diese Elemente noch den Vortheil, dass bei ihnen der Consum des Kupfervitrioles auf ein Minimum beschränkt ist; dabei muss ihnen jedoch, gleich den Trichterelementen zur Last gelegt werden, dass sie sehr leicht durch Unreinigkeiten des Kupfervitrioles sich im Ausflussrölırehen verstopfen.

Das Leclanchi Element $\left.{ }^{*}\right)$. Seit Jahren beim Telegrafenherriebe in Frankreich in Anwendung, besteht aus einer Thonzelle, in der sich eine Kohlenplatte befindet, die ringsum mit grobkörnigem Braunstein und Kohlenstiickchen

*) R. Hundin. Mondes XI, pag. 184.

\$4) Brix's Journ. Jahrg. XIV, pag. 147; Jahrbuch d. Erfindg. 1575, pag. 204. 
umgeben ist. Ausserhalb der Thonzelle befindet sich im Batterieglase ein massiver, amalgamirter Zinkeylinder. Das Batterieglas wird mit wässeriger Salmiaklïsung gefuilt. Der chemische Vorgang in der Batterie ist nachstehender: Der Salmiak wird durch den galvanischen Strom in seine Bestandtheile, Chlor und Ammonium, zerlegt, das freie Chlor geht an den Zinkpol und bildet Chlorzink, das in Wasser lïslich ist; andererseits zerfällt auch der Braunstein in Manganoxydul und Saucrstoff, ein Theil des Sauerstoffes oxydirt das Ammonium zu Ammoniak, der andere Theil des Samerstoffes verbindet sich mit dem Wasserstoffe des ebenfalls zerlegten Wassers đer Salmiaklösung wieder zu Wasser, indem sich das gebildete Ammoniak theilweise auflöst. Der Ueberschuss des Wassers wird ebenfalls noch in seine Bestandtheile, Wasserstoff und Sauerstoff, zerlegt, der freie Wasserstoff zersetzt das gebildete Chlorzink in Salzsäure und metallisches Zink, während der Sancrstoff das Manganoxydul wieder zu Braunstein oxydirt. Die gebildete Salzsäure gibt mit der Ammoniaklösung wieder Chlorammonium (Salmiak) und Wasser. Diese Kette hat bei dem Vortheil eines geringen Materialverbrauches und einer bedeutenden electromotorischen Kraft hingegen wieder den Nachtheil, dass sie durch die entweichenden Ammoniakdämpfe sehr belästigt und einer ziemlichen Polarisation wegen keine langdauernden Schliessungen verträgt, jedoch ist in Boumans *) neuester Abänderung des Leclanchè-Elementes in Betreff des ersteren Uebelstandes Abhilfe geschaffen.

Verwendet werden weiters noch beim Telegrafenbetriebe: Elemente von Kramer, Minoto, Satory, Callot, Grove, Bunsen, Doit, Siemens, Halske ${ }^{*}{ }^{*}$ ), ferner neuerer Zeit sehr häufig Alaunelemente d. s. Zinkkohlen oder Kupferzinkelemente, bei welchen der feuchte Leiter aus einer Alaunlösung (6 Pfund Alaun in 12 Mass Wasser) besteht und Chromsäure-Elemente $\left.{ }^{* * *}\right)$, d. s. Zinkkohlenelemente mit einer Lösung von 3 Gewichtstheilen doppeltchromsaurem Kali, 4 Gewichtstheilen Schwefelsäure und 18 Gewichtstheilen Wasser als feuchter Leiter, endlich Victor Doat's Jodiire-Batterie ete. $\dagger$ )

Inductoren (inducteur - inductor). Sowohl electrische als magnetoelectrische Inductoren sind fiir die Telegrafie zu verwenden versucht worden. Unter allen diesen von Gauss, Saxton, Clarke, Faraday, Ettingshansen, Petřina, Siemens, Wheatstone etc. construirten Apparaten haben nur die letzten zwei, aber in um so ausgezeichneter Weise Anwendung gefunden.

Der Inductor von Siemens besteht $+\dagger$ ) aus einem in Fig. 1446 im Querschnitte dargestellten Eisencylinder $E$, welcher der Länge nach mit z wei einander gegeniiberstehenden, $7 / 16$ des Durchmessers tiefen, etwa $2 / 3$ des Durchmessers breiten Einschnitten versehen ist. Die dadurch entstandene Nut ist mit seidebesponnenem Kupferdrahte umwunden und ganz ausgefüllt. An den Enden des auf diese Weise Fig. 1446 . erzengten Cylinders werden die Metallhiilsen $F F^{1}$ befestigt, welche seine Lagerzapfen bilden. Die Enden der Umwindungsdrähte sind in $F^{\prime \prime}$, Fig. 1447 mit der kommenden und gehenden Linie oder mit der kommenden Linie und der Frte in Verbindung. Der beschriebene Cylinder dreht sich zwischen den Polen mehrerer $(10,12,14$ u. s. w.) in geringer Entfernung von einander anfgelegter Stahlmagnete $G G$. Die Lamellen dieser Stahlmagnete haben einen kreissegmentförmigen Ausschnitt $m m$ (Fig. 1446), welcher vom Cylinder $E$ fist ansgefiillt wird. $E$ dient als gemeinschaftlicher Schliessungsanker; bei jeder halben I'm-

Jahrbuch der Erfindungen 1874.

Brix's Journ., Jhrg. VI, pag. 53.

**, Wiede mann, Galvans, Cap. V; Dub, Anwendung d. Electromantism. \$. 3.

†) Brix's Jomm., Jurg. IV, pag. 10; Moigne Cosmos, Jhrg. 3, s, pag. 17t.

††) Schellen's Electromagnetischer Telegraf", pag. 38.2. 
Fig. $141 \pi$.

Inductor von Siemens.

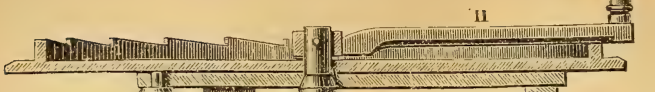

T

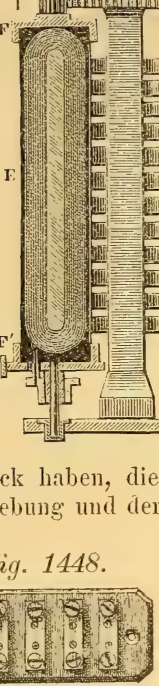

Fig. $144 \%$.

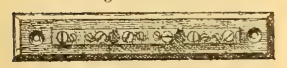
Fig. 1 tij $a$.

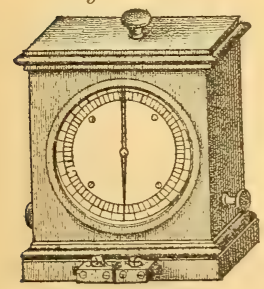

Fig. 1452 .

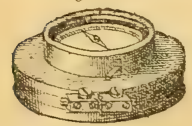

Fig. 1 tion a.

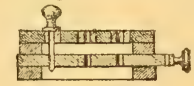

Fig. 14iol) b.

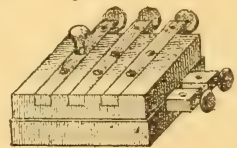

Fig. $14 ; 1$ b.

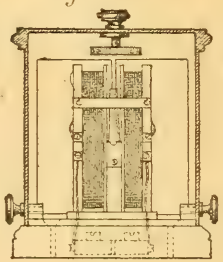

drehung desselben wird seine Polarität gewechselt und also dabei jedesmai in dem Drahtgewinde ein Inductionsstrom entsteher. Das Umdrehen des Cylinders geschieht mittelst einer Kurbel $D$ und der Räder $L$ und $T$, wie Fig. 1447 zeigt. Um die wechselnden Ströme in eine Richtung zu bringen, ist im Bedarfsfall bei $F$, ein Commutator (Stromwechsler) angebracht.

Neben apparate. Ausser den vorbesprochenen Apparaten, dem Schliissel, Zeichengeber und der Electricitätsquelle milssen auch mehrfache andere angewendet werden, welche

den Zweck haben, die Sicherheit, Leichtigkeit und Schmelligkeit der telegrafischen Zeichengebung und der Manipulation zu erhöhen. Hierher gehören: die A n s ch lus sklemmen (Fig. 1448), die zur leichteren Verbindung der Drähte unter einander dienen, dann die $\mathrm{B}$ a t t e ri eund Linienweehsel (Fig. 1449 11. $145($ ) a u. $b$ ), welche es ermöglichen, durch Einstecken von Metallstiften gewisse Leitungen mit einander beliebig und bequem zu verbinden, oder mehr oder weniger BatterieElemente einzuschalten (Ausschaltungs- und Einfiihrungsklemmen), weiter das G a l vanoscop oder die Bonssole Fig. $1451 a$ u. $b$ und Fig. 1452, welcher Apparat dazu eingeschaltet wird, um über die Stromstärke und den Zustand der Linie sofortigen Aufsehluss zu geben, ferner die Wecker, welche ertönen, sobald der Zustand des Schliessungskreises eine Aenderung erleidet, welche dem Telegrafisten zu wissen nothwendig ist, und endlich die Blitzableiter (s. Seite 208).

Störungen im Telegrafenbetriebe. Unterbrechungsstellen im Stromkreise, Nebenschliessungen oder Einwirkungen von atmosphärischer Electricität können bei sonst vollkommen gutem Apparatstande die Ursache von Störungen im Telegrafenbetriebe abgegeben. Un t e r b r e chung en entstehen durch Zerreissen der Leitungsdrähte, oder durch mangelhafte Anschlïisse an den Trechsellamellen, Apparaten, Batteriepolen etc. Eine Lnterbrechming äussert sich durch gänzliches Versagen der Sprechapparate; die eingeschaltete Boussole bleibt unter jedem Lmstande auf 0 . Unterbrechungen sind zumeist in Bureau und ist ihr Torhandensein leicht zu constatiren, indem man den hereinkommenden Draht mit 
dem hinausgehenden (bei der Endstation der Frolleitumg) verbindet, also einen kurzen Schluss herstellt. Bleiben die Fehlererscheinungen, so ist der Fehler im Bureau und muss durch successives Ausschalten der einzelnen Bureaubestandtheile aufgesucht werden; hören die Fehlererscheinungen nach der gemarhtru, kurzen Verbindung anf, so liegt der Fehler ansser dem Burean und wird dann dic Riclitung des Fehlerortes durch Erdeeinlegen*) leicht zu constatiren sein. Nobenschliessungen entstehen, wenn die Leitungen, Apparate orler Batterien mit

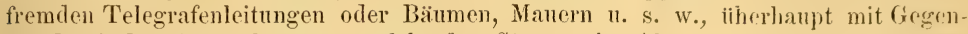
ständen in Beriihrung kommen, welche dem Strome eine Abzweigung in einen fremilen Leiter oder den Weg zur Erde gestatten. Bei einer solchen Störung arbeiten die eigenen Zeichenapparate schlecht oder gar nicht, sobald eine Station spricht, welche iiber die Fehlerstelle hinausliegt; die Nadel zeigt einen anormalen Ausschlag. Entsteht die Nebenschliessung durch Bcribhung der Leitung mit einer anderen Telcgrafenleitung, so kommen von der fremden Linie Zweigströme heriber, welche je nach Richtung und Stärke den eigenen Strom verstärken, aufhrben odcr vermindern, was das Galvanoseop dentlich anzeigt. Durch Erdeeinlegen kann sofort constatirt werden, nach welcher Richtung von der Station der Fehler liegt.

Ableitungen kommen selten im Bureau, meist nur auf der Strecke vor. Im ersten Falle sind es immer nur feuchtstehende Batterien oder mangelhaft isolirte Zufiihrungsdrähte, die den Fehler hervorrufen. Die Ableitungen in der laufenden Leitung kann man eingrenzen, indem man die Linie in bestimmten Punkten unterbrechen lässt, und dann den Schlïssel oder Taster so stellt, dass der Strom in der Linie sein sollte, wenn die angewendete Unterbrechung nicht vorhanden wäre. Zeigt die Nadel genau 0, so ist die Ableitung, beziehungsweise Beriihrung iiber die Unterbrechungsstelle hinaus; zeigt sie einen Ausschlag, so ist eine Ableitung zwischen der Beobachtungsstation und der Unterbrechungsstelle und eine fortgesetzte Prüfung in diesem Sinne lässt also die Fehlerstelle genau bestimmen.

Durch Gewitterwolken, welche über die Leitung hinziehen, oder durch den ungleichen electrischen Zustand der Atmosphäre der von der Telegrafenleitung durchlaufenen Gegend wird der Leitungsdraht mit Spannungselectricität geladen, welche dann plötzlich durch die Leitung in die Erde abströmt, sobald eine Entladung der Wolke stattgefunden oder der Spannungszustand der die Leitungsdrähte nmgebenden Atmosphäre sich geändert hat. Die durch solche Ströme hervorgerufenen Störungen sind vorzüglich bei Arbeitsstromsystemen höchst nachtheilig, weniger bei Ruhestromsystemen, so lange die Entladungsströme nicht gleich und entgegengesetzt dem vorhandenen Betriebsstrome sind. Die letztere Eventualität ist besonders bei elect. auf Ruhestrom geschalteten Eisenbahnsignalen ron grossem Nachtheile, da die Apparate unter dieser Voranssetzung arbeiten, als wie wenn sie absichtlich in Thätigkeit gesetzt würden. Zumeist sind jedoch derlei Entladungs-Ströme viel stärker als der in Anwendung stehende Betriebsstrom und statischer Natur. Noch weit kräftigere Ströme entstehen natiirlich bei directen Entladungen der Luftelectricität durch die Leitung, d. i. wemn der Blitz in den Leitungstraht schlägt. In diesem Falle wird die im Drahte gebundene, ungleichnamige Electricität zwar parallisirt werden, allein immer noch ein enormer Ueberschuss ron Electricität den Draht passiren, welcher auf die eingeschalteten Apparate rerderbend oder zerstörend einwirkt. Es zerstören solche Ströme gewöhnlich den Magnetismus der im Systeme etwa vorhandenen Magnetnadeln; häufig schmelzen sie auch die feinen Nultiplicationsdrähte der Electromagnete zusammen und machen letztere dadurch unbrauchbar, oder richten unter Umständen endlich alle jene Zerstïrungen an, welche Blitzschläge eben hervorzubringen vermögen. Bei Ge-

*) Errlepinlegen heisst: die Telegrafenlinie an irgend einer Stclle zwischen Anfang's- und Endstation mit dem Erdborlen in leitende Verbindung hringen. Jede Mittelstation ist mit einem zum Linienwechsel zugefïhrten Erdleitungsdraht versehen, also in der Lage, sich rurch das "Erdeeinlegen" im Bedarfistalle nach beiden Richtmogen hin zur Endstation zu machen 
wittern muss es strenge vermieden werden, mit den blanken Bestandtheilen der Apparate und Leitungen in Berührung zu kommen, weil leicht eine gefährliche Entladung durch den Körper stattfinden kann.

Als Schutz fuir das Bureau gegen die heftigen Entladungen der Luftelectricität sind eigene Blitzfänger oder Blitzableiter (paratonneur - contuctor of lightning) eingeschaltet. Alle diese Vorrichtungen sind darauf begriindet, dass

Fig. 14ij3.
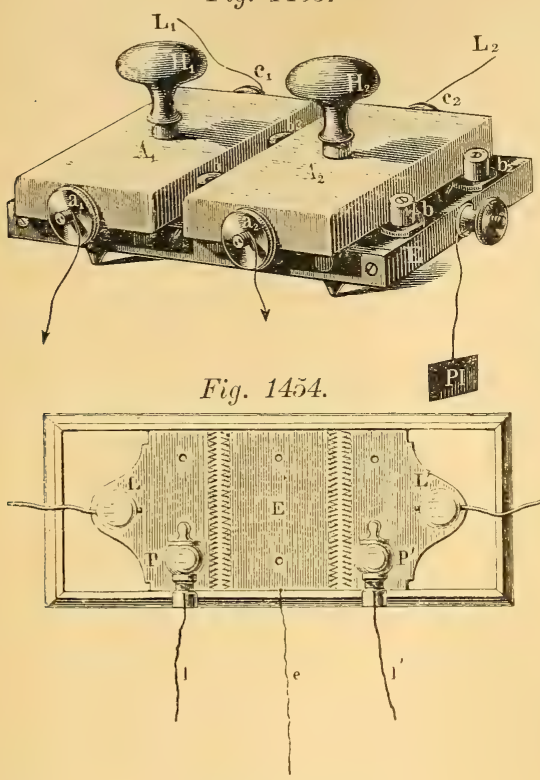

Blitzrorrichtungen. die atmosphärische Electricität ähnlich der Reibungselectricität grosse Neigmug besitzt, iiberzuspringen und den kiirzesten Weg zur Erde zu wählen, während die galvanische Electricität nicht die geringste Unterbrechungsstelle im Leiter zu iiberspringen vermag. Schon der erste von Steinheil *) 1846 construirte Blitzschutzapparat war nach diesem Princip eingerichtet. Die am häufigsten angewendeten Blitzvorrichtungen für Telegrafenbureaux sind derzeit die Me isner'schen Platten, die Siemens-Halskeschen Blitzplatten (Fig. 1453), die Brégu et'schen **): Spitzenableiter (Fig. 1454), K e r kh of s Saugspitzenableiter, E. W e n k eba ch's *w*) und M a sson's †) Blitzschutzvorrichtung etc. Bei allen ist die Luftlinie vor und nach ihrem Eintritte in's eigentliche Burcan an isolirte Metallplatten, Schneiden oder Spitzen angefuihrt, welche je einer ähnlichen, mit der Erde in V'erbindung stehenden Platte, Schneide oder Spitze, nahe gegeniiberstehen und dadurch dem atmosphärischen Strom einen Weg zum

Ueberspringen und zur Erde gestatten. In Fig. 1453 bezeichnet $L_{1}$ die von der Aufangsstation kommende, $L_{2}$ die zur Endstation weitergehende Luftlinie, bei $a_{1}$ schliesst die zu den Bureamapparaten gehende Leitung an, welche wieder bei $a_{a}$ zuriickkehrt. $I_{1}, H_{2}$ sind Handhahen aus isolirendem Material, um die sogenannten Lnft- oder Linienlamellen $A_{1}, A_{0}$ hohufs Lntersuchung oder Reinigung des Apparates vou der Erdlamelle $E$ ungefährdet abheben zu kïmnen. Dic unten mit Kautschukplättchen versehenen Klöbchens aus Hartgummi ouler Horn haben den Zweck, die Platten $A_{1}, A_{0}$ und $E$ ron einander zu isoliren. In Fig. 1454 sind wieder $L$ and $L_{1}$ die Linienanschliisse, $e$ und $e_{1}$ die Apparatanschliisse, hei e schliesst die Erdleitung an. Die drei messingenen Lamellen $P . P^{\prime}$ und $E$ sind anf einer Unterlagsplatte aus isolirtem Material befestigt. Bei den Kerkhof'schen Sangspitzen sind iiberdies in der Blitzrorrichtung Spiralen ron ganz dünnem Neu-Silberdraht dazwischen geschaltet, welehe der Entladungsstrom passiren muss und abschmilzt, wodurch seine zerstörende Wirkmmg anfgehoben oder wenigstens bedeutend abgeschwïht wird. Eine der neneren Blitzrorrichtungen, welche D igne y in Paris ††) erzengt, besteht aus einer U-fürmigen, mit Alkohol gefiillten Glasröhre,

Dingler's polyt. Jomrual Bd. 109 pag. $35 \%$.

**) Gararet. Telegrph. électrqu. 1859 pag. 83.

***) Brix's Journ., Jhrg. $V$ pag. 187.

†) Cosmos XII, Lirr. 16, pag. 425, Brix's Journ., Jhrg. V pag. 102.

††) Dr. Leander Dits eheiner. Ausstellumgsbericht. Wien 1sit. 
durch welche der kommende und gehende Liniendraht hindurchgezogen ist. Eine Drahtleitung zur Erde reicht jedoch gleichfalls in den Alkohol hinein. Sämmtliche Drähte sind durch zwei die Röhre verschliessende Kautschuk-Pfropfen durchgefïhrt und auf diese Weise vor der gegenseitigen Berührung geschiitzt. Da der Alkohol sehr schlecht leitet, nimmt der Linienstrom ohne merkbare Ableitung seinen Weg über den Liniendraht, eine atmosphärische Entladung aber schlägt durch den Alkohol in den Exddraht und geht unbeschadet der Bureauapparate zur Erde. Alle diese Blitzschutzvorrichtungen haben die Schwäche, nur jene Entladungsströme unschädlich zu machen, welche kräftig genug sind, die Distanz von Linienlamelle zur Erdlamelle zu iberspringen. Durch einen die Telegrafenleitung passirenden Blitzschlag wird jedoch noch eine dritte Gattung Ströme erzeugt. Der durchlaufende Eisendraht wird nämlich magnetisirt wie ein Electromagnet und kehrt nach der Entladung in den normalen Zustand zurück. Die Entmagnetisirung der Leitung ruft einen Inductionsstrom hervor, welcher der atmosphärischen Entladung unter Umständen nach einem, sogar merkbaren Intervalle folgt und nicht mehr kräftig genug ist, gleich dem Entladungsstrome überzuspringen; jedoch ist er stark genug, um auf die im Leitungskreise befindlichen Boussolen und Multiplicationen nachtheilig einzuwirken. Zur Unschädlichmachling dieses "Nachschlages" hat man Blitzvorrichtungen construirt, bei welchen durch den Entladungsfunken die Linienlamellen auf einige Momente leitend mit der Erde verbunden werden. Varley*) bringt zu diesem Zwecke zwischen die Luft- und Erdlamellen einer gewöhnlichen Blitzvorrichtung pulverisirte Holzkohle, Kohlfürst $50 \%$ Holzkohle und $50 \%$ Magnesia. Der von der Luftlamelle zur Erdlamelle iiberspringende Entladungsfunke bringt die dazwischen befindliche, im kalten Zustande gar nicht oder wenigstens so schlecht leitende Masse, dass dadurch ein nennenswerther oder störender Verlust des Betriebsstromes nicht herbeigefuihrt wird, zum Glühen und macht sie dadurch so leitungsfihig, dass der hinter der Entladung folgende MagnetInductionsstrom einen bequemen Weg zur Erde findet, ehe er in die Apparate dringen kann. Die fast momentan erkaltende Masse ist wieder so nichtleitend wie früher. Eine ähnlich wirkende, dabei höchst einfache und billige Blitzschutzvorrichtung wurde vom Telegrafensekretär $\mathrm{Schaak} \mathrm{k}^{* *}$ ) angegeben.

A p paratsysteme. Alle electrischen Telegrafensysteme beruhen auf der Ausnützung nachstehender eigenthümlichen Wirkungen des electrischen Stromes:

a) Bringt man die Polenden einer Schliessungskette zusammen oder trennt man sie, so bemerkt man hiebei einen Funken, der in seiner Intensität abhängt von der Art und Grösse der verwendeten Electricitätsquelle. Die Systeme ron Lesage $\mathrm{e}^{* * *}$ ) und Reissner sind die Repräsentanten für Telegrafen, welche diese Eigenschaft ausniutzen.

b) Fasst man die Poldrähte einer Schliessungskette mit feuchten Händen an, so fïhlt man ein höchst sonderbares Zucken in denselben und in den Armen, das mit der Stromstärke bis zur Unerträglichkeit gesteigert werden kann. Diese Eigenschaft benuitzte $\mathrm{Vos}$ selman de $\mathrm{Heer}$ zur Grundlage für seinen electrophysiologischen Telegrafen.

c) Viele Stoffe erleiden im Schliessungskreise einer electrischen Batterie chemische Veränderungen, die dem Auge durch auffällige Erscheinungen bemerkbar werden. Hierauf basirt seit $\mathrm{S} \ddot{\mathrm{mm}} \mathrm{mering's \dagger )}$ Telegrafen eine reiche Serie der hauptsächlich von Gintl, Davay, Stöhrer u. s. w. gepflegten electrochemischen Telegrafen.

d) Eine Magnetnadel wird, wenn man in der Nähe derselben einen electrischen Strom vorüberleitet, aus ihrer normalen Lage abgelenkt, u. $\mathrm{zw}$. um so mehr, je stärker der Strom ist und je näher und öfter er an derselben vorbeigeht.

*) Ingeneur, October 1870 .

*) D ingler's polyt. Journ. Bd. 217 pag 109.

***) Moigne Telegrph. électrqu. pag. 59.

†) Dinglex's polyt. Journ. Bd. 67 pag. 388.

Karmarsch \& Heeren, Technisches Wörterbueh. Bd. III. 
Von der Richtung des Stromes ist auch die Richtung der Nadelablenkung abhängig. Hierauf basiren die Nadeltelegrafen.

e) Ein Stiick weiches Eisen, um welches ein galvanischer Strom in einer spiralförmigen, mit einer isolirenden Hülle umgebenen Drahtleitung (Fig. 1455) geleitet wird, wird zum temporären Magnet (Electromagnet); die Pole eines solchen Fig. 1455 .

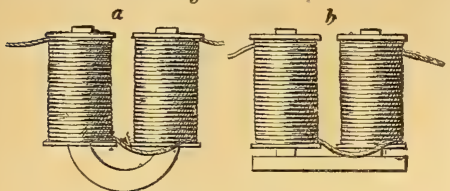
Electromagneten ändern sich mit der Richtung des über die Schenkel geleiteten Stromes, d. h. der Nordpol wird zum Siidpol und umgekehrt, wenn man den Strom in entgegengesetzter Richtung durch die Multiplication sendet. Wird ein Magnetstab mit einer Multiplicationsrolle umgeben, durch welche ein Strom geht, so wird der Magnetismus des Stabes entweder verstärkt oder auch geschwächt, ja bis zum gänzlichen Verschwinden parallisirt oder umgekehrt werden, je nach Richtung und Stärke des uiber die Multiplication geleiteten Stromes. Dicse Eigenschaft findet Anwendung bei den Zeiger-, Druck-, Typo-etc. Telegrafen, kurz bei den meisten, derzeit im Gebrauche stehenden Systemen. Wohl auch ist bei den jetzigen Telegrafen die eine oder andere der angefiihrten Eigenschaften combinirt angewendet und unter Zuhilfenahme scharfsinniger, mechanischer Apparate ausgenuitzt. Die' wichtigsten der noch heute in Anwendung und Entwicklung stehenden Systeme (Apparat- und Schaltungssysteme) sind nachfolgend erläutert, so weit, als es der Platz hier gestattet.

$\mathrm{Die} \mathrm{Nadeltelegrafen} \mathrm{(telegraphe} \mathrm{it} \mathrm{aignille} \mathrm{-} \mathrm{needle} \mathrm{telegraph).}$ Dieselben beniitzen, wie erwähnt, die Ablenkung der Magnetnadel durch den electrischen Strom als telegrafische Zeichen. Ein noch in Anwendung stehender

Fig. 1456 .

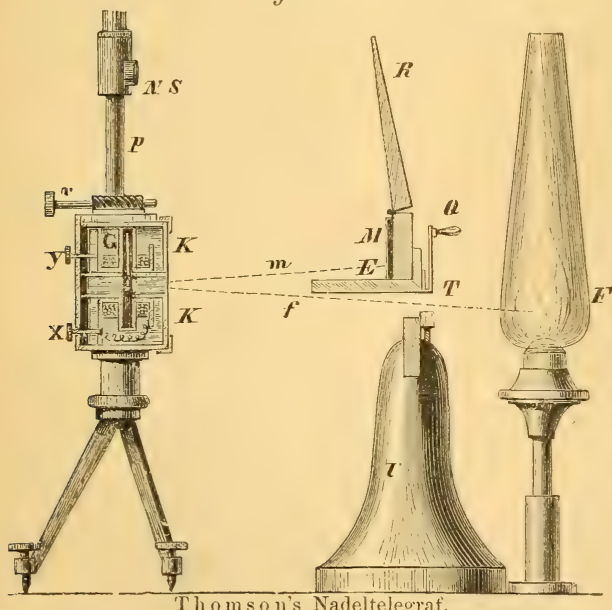
Nadeltelegraf ist der von Prof. Th $0 \mathrm{~m} \mathrm{~s}$ on in Glasgow (1858 fiir die transatlantische Linie nach den Principien des von G a us and Weber 1833 construirten Spiegelgalvanometers) eingerichtete Marinegalvanometer (Fig. 1456). Dieser Apparat steht auf einem solid erbauten Steinsockel in einem vor der bewegten Luft thunlichst geschiitzten und dunklen Raume. Es befindet sich in dem auf einem Dreifuss angebrachten Gehäuse $k k$ das mit zahlreichen, sehr dümnen Multiplicationswindungen versehene Galvanometer $S$. Die Enden der Multiplication $x$ und $y$ sind in die Leitung eingeschaltet. Die $12^{\mathrm{mm}}$ lange, $2^{\mathrm{mm}}$ dicke und $2^{\mathrm{mm}}$ breite Nadel des Galvano-

meters hängt auf einem Coconfaden in der Aufhängröhre $p$, wo auch der Richtmagnet $N, S$ angebracht ist. An den Magnetstäbchen ist im Aufhängepunkt ein kleines Spiegelchen aufgeklebt, dessen Spiegelebene mit der Ver.icalebene des Stäbchens zusammenfällt. Vor diesem Spiegelchen, welches bei normalem Stande mit der Nadel im magnetischen Meridian liegt, befindet sich anch eine kleine Sammellinse. Das Licht einer Lampe $F$ wird durch einen Schirm $R U$ rom Galvanometer abgehalten; nur durch cinen bei $T$ gelassenen Spalt kann ein 
Lichtstreifen bis zum Spiegel des Galvanoscopes gelangen und von diesem nach den Gesetzen der Reflexion auf die graduirte Elfenbeinplatte $M E$ zuruckgegeworfen werden. Da das ganze Instrument so gestellt ist, dass die Nadel bei stromloser Linie im magnetischen Meridian liegt, so ist das Einstellen des Spiegelbildes auf die Marke des Elfenbeinplättchens, welche normal auf die Nadel steht, durch Verdrehen des Richtmagnetes leicht möglich. Vor Beniitzung des Instrumentes muss diese Einstellung immer erfolgt sein. Kommt nun ein Strom in die Leitung, d. h. in die Multiplication des Galvanometers, so wird die Nadel und mit derselben das Spiegelchen abgelenkt; das Spiegelbild des Lampenstrahles wird von der Marke der Elfenbeinplatte seitlich abweichen, und zwar nach rechts oder nach links, je nachdem die Richtung des Stromes sein wird; und mehr oder weniger, je nachdem der Strom, also auch die Nadelablenkung stark oder schwach war. Diese Abweichungen sind die telegrafischen Zeichenelemente. Die Schlüssel für solche Apparate geben für je einen Impuls der Nadel mehrere ungleich gerichtete Ströme von verschiedener Zeitdaner ab, damit Ladungen des Kabels vermieden werden. Der Taster von Thom son und V a r ley gibt $\mathrm{z}$. B. $+100-156+80-325+26$ und damit einen Ausschlag nach rechts, die gleichen Ströme entgegengesetzter Richtung bringen den Ausschlag nach links. Diese Taster bestehen aus 2 Gleitrollen mit den entsprechenden Contactsegmenten, welche mittelst zweier Taster beliebig eingeschaltet werden können und pr. Umdrehung ein Zeichen (die Ablenkung nach rechts oder links) hervorbringen. Zur rascheren Abtelegrafirung hat man eigene Signalcodexe eingefiihrt, welche es gestatten, häufig gebrauchte Phrasen und Namen, statt sie erst durch Buchstaben langwierig abzutelegrafiren, mit einer einzigen bestimmten Zeichencombination kurz auszudriicken. Bei dem ersten atlantischen Telegrafen ist der Signalcodex des Capitän F. J. Bolton im Gebrauche.

Ausser dem Tho m so n'schen stehen noch die Einnadel- ${ }^{1}$ ) und DoppelnadelTelegrafen $^{2}$ ) von Wheatstone und Cooke, so wie der Bain'sche ${ }^{3}$ ) Nadeltelegraf, u. zw. ersterer bei den englischen Eisenbahnen und dem japanischen Staatstelegrafen, letztere bei einer österreichischen Bahn in Anwendung, während die Nadeltelegrafen ${ }^{4}$ ) von Stöhrer, Brett und Little, Henley und Forster, Bright, Siemens, Mapple und Brown, Highton, Varley, Glösener, Allan u. s. w. nirgends mehr praktisch verwendet werden.

Die Z eigertelegrafen. Dieselben sind leicht zu handhaben und empfehlen sich deshalb dort, wo weniger geschulte und routinirte Individuen als Telegrafisten verwendet werden müssen, also bei Eisenbahn-, Haus-, Fabriks- und Feuertelegrafen oder als Nothtelegrafen für Bahnwächter etc. Sie haben den Nachtheil, dass sie zu ihrem Betriebe sehr kräftige Ströme, also einen kostspieligen Batterieanfwand nöthig haben und wie die Nadeltelegrafen keine fixirbaren Zeichen geben. Thre Einrichtung besteht darin, dass sich ein Zeiger schrittweise iuber einer kreisrunden Scheibe dreht, auf welcher die Buchstaben und Ziffern oder sonstigen Schriftzeichen wie auf einer Uhrplatte angeschrieben sind. Das zu telegrafirende Zeichen markirt der Zeiger, indem er vor demselben einige Zeit stehen bleibt. Es geschieht dies, indem dieser Zeiger durch einen oder mehrere in die Leitung geschaltete Electromagnete, deren Anker und damit verbundene Hebel schrittweise in Umdrehung versetzt wird, oder indem die Electromagnete blos ein mechanisches Uhrwerk, das den Zeiger dreht, aus- und einlösen, je nachdem der Stromkreis geschlossen oder geöffnet wird. Der Erfinder des Zeigertelegrafen ist Ronulds und nach ihm haben denselben Cooke, Wheatstone, ${ }^{5}$ ) Drescher, ${ }^{6}$ )

1) Glös ener, Traité I pag. 93; Dingler 89 pag. 317; Z etzsche, Handb., Bd. I pag. 172.

$\left.{ }^{2}\right)$ Preece, Telegraphy, pag. 49; Zetzsche, Handb., Bd. I pag. 178; Sc heller, 5. Auf. pag. 352 .

3) Dingler's Journal 110, pag. 8; Zetzsche Handb., Bd. I pag. 183.

4) Zetzs che, Handb., Bd. I pag. 191-202.

5) Gavarret, Tlgrph. électrqu. pag. 161; Bix's Journ., Jhrg. XI pag. 64.

6) Zetzs che, Handb., Bd. I pag. 222-290. 
Leo nhardt, Fardely, Geiger, Poole, Lippens, Didie, Wilde, ${ }^{1}$ ) Kramer, ${ }^{2}$ ) Stöhrer, ${ }^{3}$ ) Breguet und Digney, ${ }^{4}$ ) Régnard, ${ }^{5}$ ) Schellen, ${ }^{6}$ ) Highton, Glösener, Brann, ${ }^{6}$ ) Froment, ${ }^{7}$ ) Mapple, Paul Garnier, ${ }^{8}$ ) Bain, Barlow, Henley, ${ }^{9}$ ) Nott, Yeates, ${ }^{10}$ ) Siemens ${ }^{11}$ ) ete. verLig. 1457 .

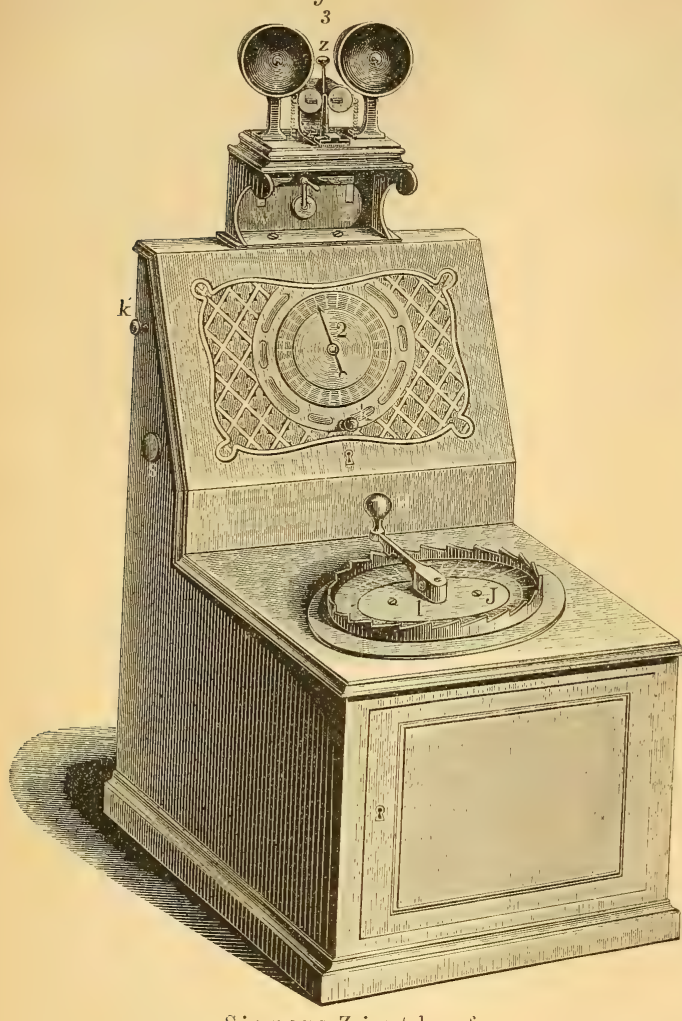

Siemens Zeigertelegrat. bessert, und war es besonders der Letztgenannte, welcher dieses System durch die ingenieuse Anordnung seines vervollkommten Zeigerapparates, ${ }^{11}$ ) zu dessen Betrieb er Magnetinductionsströme verwendet, lebensfähig gemacht und dieser Gattung Telegrafen hauptsächlich bei den deutschen Eisenbahnen eine grosse Verbreitung verschafft hat. Fig. 1457 stellt das Aeussere eines $\mathrm{S}$ i e m en s'schen 'Zeigerapparates dar, welcher der Hauptsache nach besteht aus dem Kasten 1 , in welchem sich der Inductor (s. Fig. 1446 u. 1447) befindet, dessen Antrieb-Kurbel $H$ ist, ferner aus dem Buchstabenblatt 2 mit dem rotirenden Zeiger, d. i. der eigentliche Zeichengeber; endlich aus dem Wecker 3 und dem Umschalter $W Z$. Auf der Zeigerplatte sind im Kreise die Buclistaben und Ziffern vertheilt. Jeder Stromimpuls, der in die Linie gelangt, bewegt den Zeiger um ein Feld von links nach rechts weiter. Die Stromentsendung geschieht durch Drehung der Kurbel $H$. Der anfnehmende Telegrafist hat den rotirenden Zeiger des Receptors (2) genau zu beobachten und jene Schriftzeichen, bei welchen der Zeiger Pausen macht, niederzuschreiben. Die Interralle zwischen je zwei Worten werden

1) Zetzsche, Handb., Bd. I pag. 223 290.

$\left.{ }^{2}\right)$ Schellen, der electr. Telegr. 5. Aufl. pag. 390; 1) nb, die Anwendung des Elect. Magnetismus, V. Abschnitt \&. 10.

5) Brix's Journ. II pag. 193.

4) Gavarret, Tlgrph. électrqu. pag. 114; D ub, Anwendg. d. Elect. mgt., V. Abschn. \$. 9

5) Zetzsclie, Haudb., Bl. I pag. 222290.

$\left.{ }^{6}\right)$ Bulletin d. 1. Societé d'encouragement 1851 pag. 319; Dingler, CXXI, pag. 37.

C) Zetsehe, Handb., Bd. I pag. $222-290$.

8) Brix's Journal, Jhrg. IX pag. 253.

9) Dinglexs pol. Jotrn. Bd. 214 pag. 291.

jo) Practical Vechanies Journ., Mai 1852; Dinglers Jumrn. CXXVII pag. 255.

11) Verhandlungen d. Vereines f. Eisenbahnkunde, März 1857 pag. 121. 
durch grössere Pausen markirt. Auch der Telegrafirende muss sein Zeigerblatt des Stromsenders $J$ genau im Auge behalten, damit er mit dem Drehen der Kurbel im richtigen Momente einhält. So lange die Station aufnimmt oder abtelegrafirt, ist der Umschalter auf $Z$ gestellt, d. h. dem Strome der Weg durch den eigentlichen Zeigerapparat gestattet, sonst steht der Umschalter auf $W$, d. h. der stromweg ist nicht durch den Zeigerapparat, dagegen durch den Wecker hindurch geöfthet. Die in die Linie entsendeten Ströme werden bei dieser Stellung des Umschalters nicht den Zeiger des Buchstabenblattes, dagegen den Klöpel $Z$ des Weckers in Bewegung bringen und an die daneben angebrachte Glocke anschlagen machen.

Die Schreibtelegrafen sind solche, bei welchen auf mechanischem oder chemischem Wege auf Papierstreifen bleibende Zeichen erzengt werden, die zwar nicht den in der Schrift gebräuchlichen Charakteren gleich sind, jedoch dauernde Aufschreibungen und Nachweise für die geführte telegrafische Correspondenz darbieten. Fast zu gleicher Zeit wurden in München von Steinheil*) und von Morse**) in Philadelphia Schreibtelegrafen erfunden. Ersteres System, welches auch unter die Nadeltelegrafen rangirt werden kann, ist längst ausser Gebrauche, letzteres jedoch derzeit das verbreitetste und hat durch Robinson, Siemens, Stöhrer, Steinheil, Digney, Matzenauer, Gintl etc. die mannigfachsten Modificationen und Vervollkommnungen erfahren.

Beim M o r s e'schen Systeme erhält der Zeichengeber - S chreiba p p a r a t (Fig. 1458) einen temporären Electromagnet $E$, dessen Anker o auf dem Hebel $n, h, n$ befestigt, von ihm abwechselnd angezogen und durch die Feder $f$ wieder abgerissen werden kann. Am anderen Ende dieses Hebels befindet sich ein stählerner Stift $S$ eingeschraubt, der beim jedesmaligen Anziehen des Ankers gegen einen Papierstreifen gepresst wird, den ein mittelst Federkraft oder durch ein Gewicht getriebenes Uhrwerk in gleichförmiger Geschwindigkeit voriiberführt. Der Papierstreifen läuft zwischen 2 Rollen durch, wovon die eine $W$ eine Furche hat, auf welche der Schreibstift $S$ genau passt. Wird ein momentaner Strom durch die Multiplication des Electromagnetes gesendet, so erfolgt eine kurzdauernde Anziehung des Ankers und der Stift $S$ drückt einen Punkt in das Papier. Dauert der Strom, also auch die Anziehung des Ankers länger, so presst sich der Stift in das ganze Stiick des Papierstreifens, welches während dieser Zeit passirt und erzeugt so einen Strich. Punkt und Strich geben die Grundzeichen der M or s e'schen telegrafischen Schrift.

D e r T a ster oder Schlïssel (Fig. 1459) ist ein metallener, zweiarmiger Hebel, der auf einer Achse in Lagern $B$ beweglich ist. In der normalen Lage zieht ihn die Feder $f$ so nieder, dass die an einem Ende des Hebelarmes angebrachte Contact-Schraube $s$ auf den unterhalb im Tasterbrette eingelassenen Metallambos $c$ angepresst ist. Dieser Ambos ist mit der Anschlussklemme 2 und das Lager $B$ mit der Anselılussklemme 1 mittelst isolirten Kupferdrahtes innerhalb des Fussbrettchens $A$ verbunden. Ein zweiter Ambos a steht mit der Anschlussklemme 3 eben so durch Draht in Verbindung. Am längeren Arme des Hebels sitzt das Klöbchen $a^{\prime}$ mit einem eingesetzten Platinkegel (Contact), dem Ambos $a$ genau gegeniiber, ohne diesen jedoch während der Ruhelage des Tasterhebels zu beriihren. $\mathrm{Zu}$ der Anschlussklemme 1 führt die Leitung, welche zum Schreibapparate durch die Multiplication desselben und dann weiter zur nächsten Station oder (in einer Endstation) zur Erde geht. Zu 2 schliesst die von der vorhergehenden Station kommende Leitung (in der Anfangsstation die Erde) an und ausserdem noch ein Draht, welcher zu einem Pole der Batterie geht; bei 3 endlich ist der zum anderen Batteriepole führende Draht angeschlossen. So lange in einer so geschalteten Morseleitung alle Taster in der Ruhelage sich befinden, wird also die Linie zwar continuirlich geschlossen, aber kein Strom in ihr vorhanden sein. Der vorhandene, jedoch nicht benïtzte Stromweg wïrde folgender sein:

**) Schaeffner, Electr. Telegrph. pag. 423; Brix's Journ. I pag. 196. 


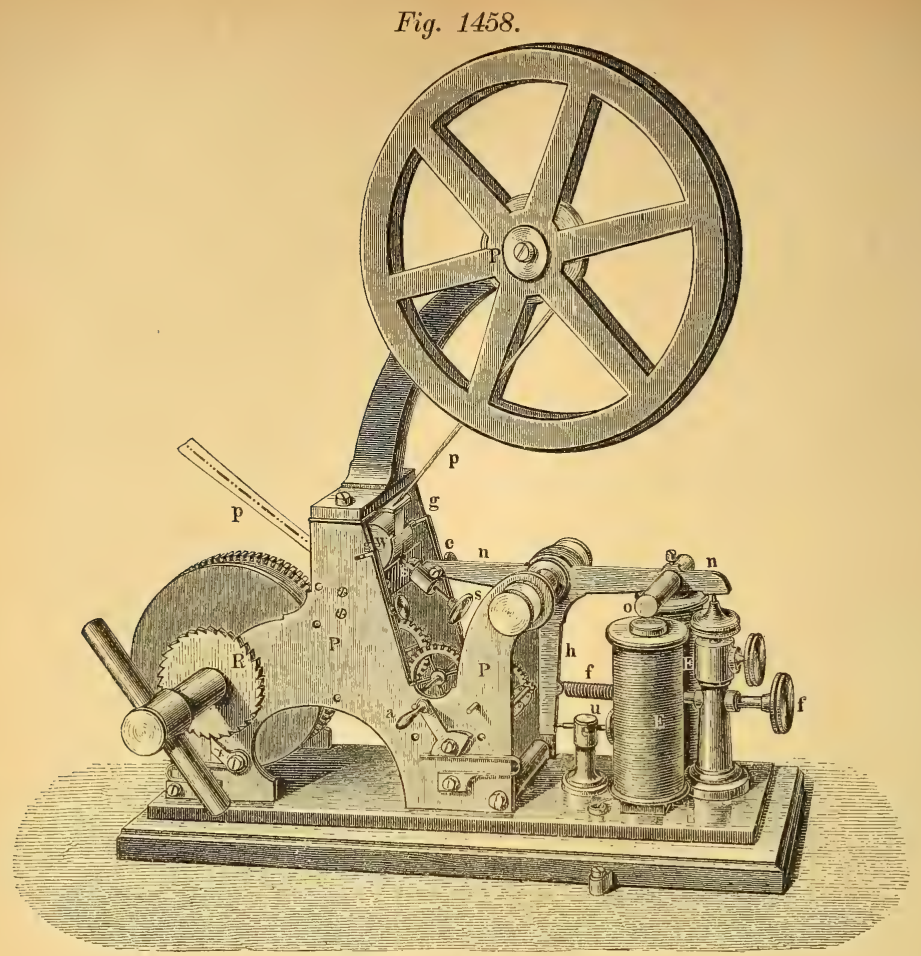

Morse's Schreibapparat.

Von der Erde oder der vorhergehenden Nachbarstation zur Klemme 2, durch den Drahtanschluss zum Ambos $c$ in die Contactschraube $S$, durch den vorderen Arm

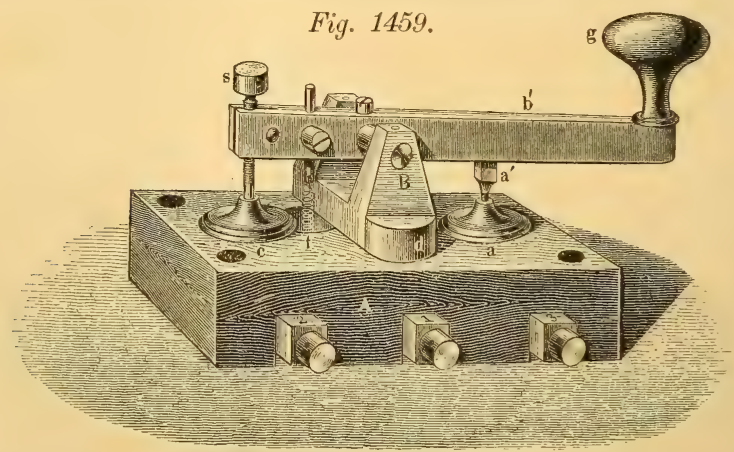

Taster (Schlüssel).

des Tasterhebels und die Drehachse in das Lager $B$, durch den Kupferdraht innerhalb des Tasterbrettchens zur Anschlussklemme 1, von da weiter zur Multiplication des Schreibapparates, durch diese weiter zur nächsten Station oder (bei 
der Endstation) in die Erde. Uebt man bei einem Taster auf den am längeren Arme seines Hebels befindlichen beinernen oder hölzernen Knopf $g$ einen Druck nach unten ans, so wird die Kraft der Feder iiberwunden, der Contact zuvischen $c$ und $s$ aufgehoben und dafiir der zwischen $a$ und $a^{\prime}$ lergestellt. Jetzt ist in der Station, wo sich der niedergedrïckte Taster befindet, der fiihere Weg von 2 uber $s$ und $B$ nach 1 aufgehoben, dagegen von 2 zu einem Batteriepole durch die Batterie und vom 2. Pol zur Anschlussklemme 3, von da weiter uiber $a$, $a^{\prime}$, $B$ und 1 die Linie continuirlich hergestellt, wobei die Butterie eingeschaltet und wirksam gemacht ist. In allen Schreibapparaten der Linie sind dann die Multiplicationen so lange vom Strom durchflossen, und in Folge dessen die Anker angezogen, als der Taster niedergedrückt bleibt. Ist die Telegrafenleitung lang oder sind viele Stationen auf eine Linie gemeinschaftlich geschaltet, überhaupt der Widerstand in der Leitung gross, so wuirde ein enormer Stromaufwand nöthig werden, um die Schreibapparate so zu betreiben, dass sie schöne, deutliche Zeichen geben. Man hat deshalb die Schreibapparate bei langen Linien nicht direct in dieselben eingeschaltet, sondern für dieselben einen viel empfindlicheren und selbst durch ganz schwache Ströme leicht beweglichen Apparat substituirt, der seine Bewegungen erst wieder durch Vermittlung eines anderweitigen, kleinen Stromkreises (Locallinie) anf den Schreibapparat iiberträgt. Dieser Uebertragungsapparat, das Relais (Fig. 1460) wurde zuerst von Cooke und Whe atstone 1837 für den Wecker ihres Nadeltelegrafen, von Morse 1844 bei seinem Schreibtelegrafen

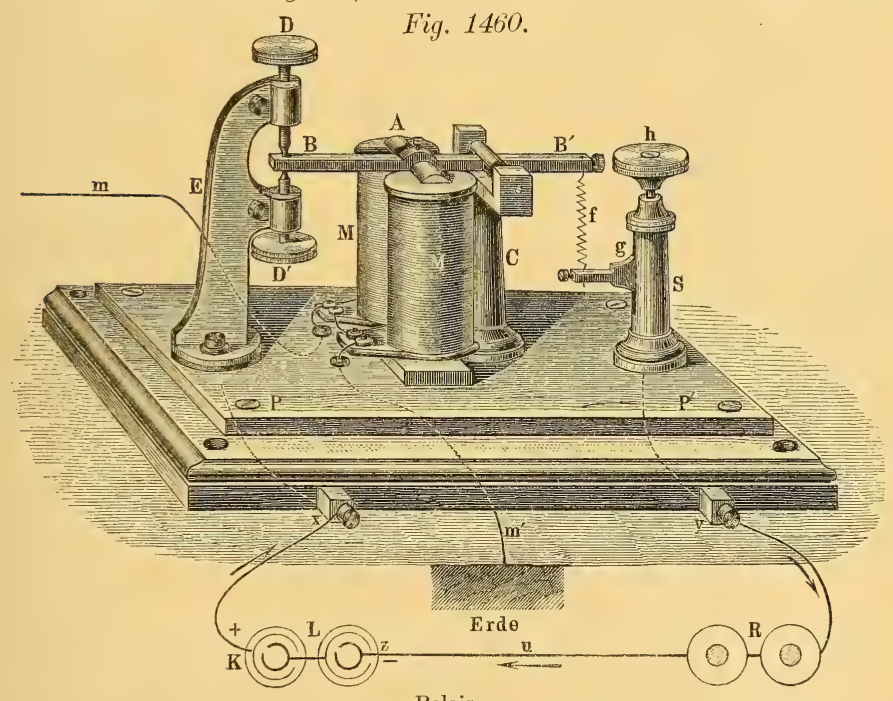

Relais.

in Anwendung gebracht. Ein Hauptbestandtheil desselben ist wieder ein Electromagnet $M$, dessen Multiplicationsenden einerseits mit der kommenden Telegrafenleitung $m$, andererseits mit der gehenden oder bei Endstationen, wie es die Zeichnung zeigt, zur Erde $m^{\prime}$ metallisch verbunden sind. Ueber den Kernen des Electromagneten ist ein eiserner Anker $A$ auf einem im Lagerständer $C$ drehbaren, messingenen Hebel $B, B^{\prime}$ aufgehängt. Die Bewegung dieses Hebels ist begrenzt durch die beiden Schrauben $D$ und $D^{\prime}$, wovon die obere mit einer Elfenbeinspitze, die untere mit einer Platinspitze (Contact) versehen ist. Der Arm $B^{\prime}$ des Relaishebels wird durch die Feder $f$, welche mit der Schraube $h$ stärker gespannt oder nachgelassen werden kann, niedergezogen, so dass der Arm $B$ normal gegen die isolirte 
Schraube $D$ drïckt. An den messingenen Federständer $S$ und an den Schwanenhalsständer $F$ schliessen die Enden der Locallinie an. Letztere ist ein besonderer Schliessungskreis, in welchem die sogenannte Local-oder Schreibbatterie und die Multiplication des Schreibapparates eingeschaltet ist. Die Ständer $E$ und $S$ sind von einander vollkommen isolirt, der Schraubenständer $S$ ist durch die messingene oder nensilberne Feder $f$ mit dem Relaishebel in Verbindung. Denkt man sich eine Morse-Telegrafen-Anlage, wie die vorhergeschilderte, nur mit dem Unterschiede, dass jetzt statt der Schreibapparate Relais eingeschaltet sind, u. zw. derart, dass in jeder Station eine so eben besprochene Locallinie sammt Localbatterie vorhanden ist, so werden, so lange kein Strom in die Linie kommt, beziehungsweise kein Taster niedergedrückt ist, alle Relaishebel "abgerissen " und die Schreibapparate in Ruhe bleiben. Wird hingegen ein Taster niedergedrückt, $d . h$. Strom in die Linie gebracht, so erfährt der Relaisanker eine Anziehung, da der Electromagnet durch den seine Multiplication passirenden Linienstrom magnetisch wird; die Kraft der Spiralfeder $f$ wird uiberwunden und der Relaishebel $B$ auf die Schraube $D^{\prime}$ niedergezogen. Die bis jetzt durch die nichtleitende Elfenbeinspitze $D$ unterbrochen gewesene Locallinie wird hierdurch geschlossen, denn von $S$ zu $E$ ist dem Strome der Localbatterie nun anstandslos der Weg über den Relaishebel zur Schraube $D^{\prime}$ gestattet; der Localstrom passirt die Multiplication des Schreibapparates und bringt demnach eben so oft und so lange die Anziehung des Sch: eibhebels hervor, als das Relais angezogen wird. Der Schreibapparat arbeitet also in rythmischer Beziehung gerade so, als wenn er direct in die Linie geschaltet wäre.

Die hier besprochene Morseanlage wäre eine solche mit Arbeitsstrom. Einfacher ist die Anlage für $\mathrm{R} u \mathrm{hestrom}$. Die Linienbatterien sind dann direct in die Leitung geschaltet. Der Schliissel hat blos die Klemmen 1 und 2, zul welchen einerseits der zum Relais gehende Draht $m$ (Fig. 1460), anderseits die von der Nachbarstation kommende Luftlinie anschliesst. Beim Relais für Ruhestrom ist die Schraube $D^{\prime}$ mit Elfenbein und dagegen die obere $D$ mit dem Contacte versehen. Bei normalem Zustande des Schliessungskreises sind nunmehr alle Relais angezogen und die Locallinien unterbrochen, durch das Niederdriicken des Tasterhebels wird der Linienstrom unterbrochen, die Relaishebel durch die Spiralfedern abgerissen und die Locallinien geschlossen, also die Schreibhebeln angezogen. Fig. 1461 stellt das Leitungsschema einer Morse-Telegrafenanlage fuir $\mathrm{Ruhestrom}$ dar. $A, B, C D$ sind die Stationen, $a$ die Relais, $\left.{ }^{*}\right) b$ die Taster, $c$ die Batterien, $d$ die Erdeleitung. Für das M or's e'sche System sind iibrigens

Fig. 1461 .

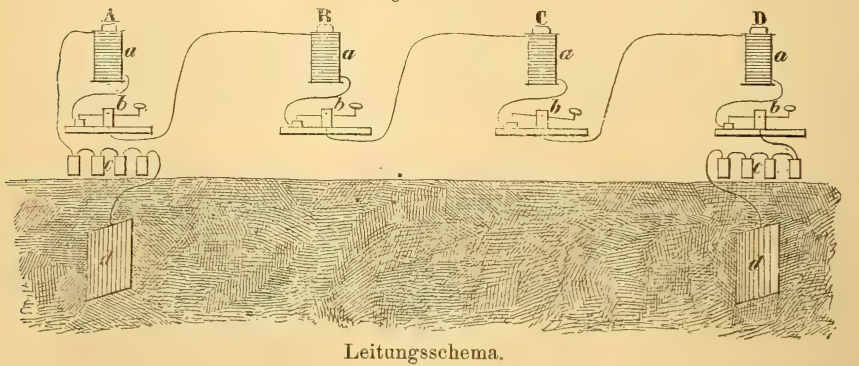

die mannigfachsten Schaltungssysteme in Anwendung, eben so auch der Betrieb mit Inductionsströmen. Die letztere Art, welche hauptsächlich von Siemens, ${ }^{* *}$ )

\footnotetext{
*) Es gibt auch Ruhestromsysteme, bei welchen keine Relais angewendet, sondern statt denselben die Schreibapparate, deren Schreibvorrichtung entsprechend construirt sein muss, direct in die Linie geschaltet werden.

* S chellen, Dub und Zetzschke.
} 
Varley und Wheatstone ihre Ausbildung erfahren hat, erfordert eigens construirte Taster, welche gleichzeitig als Inductoren thätig sind, und besonders eingerichtete (Inductions-) Relais oder Schreibapparate. Eine häufig angewendete Modification der Schreibapparate sind die Schwarz-, Blan-oder Farb-Schreiber, welche das Zeichen, statt in Relief, mit Farbe auf dem Streifen markiren. Wernicke und Siemens \& Halske*) in Berlin, Digney in Paris, G. Hasler, Wiehl, Brabender, Markus, Gebrider Digney und Andere haben solche Apparate in mannigfachen Varianten construirt oder ausgefuhrt.

Zuerst Stöhrer und Gintl und nach ihnen Andere haben weiters die Morsezeichen auf electrochemischem Wege hervorgerufen, indem sie den Papierstreifen mit diversen chemischen Stoffen, als Jodkalium mit Stärkekleister, Cyankalium mit Salzsäure und einer gesättigten Kochsalzlösung, salpetersaures Ammoniak mit Kaliumeisencyanïr etc. imprägnirten. Ein Strom, welcher über den Schreibstift durch das Papier gesendet wird, zersetzt den Stoff, mit welchem das Papier getränkt wurde und bringt färbige Zeichen hervor.

Eine vorzügliche Entwicklung haben die Relais erfahren. Es sind ausser dem geschilderten Schwanenhalsrelais ans der reichen Reihe dieser Apparate besonders zu erwähnen: das Dosenrelais von Siemens*), die polarisirten Relais von Siemens für Inductionsströme**), das Relais mit schwingendem Magnete von Frischen und Siemens, ***) das Relais von Nottebohm, *) von Borggreve, ${ }^{* *}$ ) ron Dr. Militzer, ${ }^{* * *}$ ) Edis o $n^{*}$ ), das polarisirte Relais mit zwei Hufeisen-Electromagneten, zwei Stahlmagneten und zwei Ankern von Siemens*), das Relais von Boivin, *) v. Froment, *) von d'Arlineourt†) etc.

Anschliessend an die Relais kommen die Translationsapparate zu erwähnen, welche den ersteren sowohl in Construction als Zweck ziemlich ähnlich sind und sich in letzterer Beziehung von jenen nur insoferne charakteristisch unterscheiden, als sie die Bestimmung baben, die auf einer Telegrafenlinie erfolgenden Stromimpulse, beziehungsweise Unterbrechungen nicht auf eine Locallinie, sondern auf eine zweite oder auf mehrere andere Telegrafensprechlinien zu übertragen. Bei langen Linien (etwa über 50 Meilen) erscheint es nämlich unter Umständen empfehlenswerth, wohl auch nothwendig, die Weiterbeförderung von Depeschen, welche für eine in der benachbarten Partiallinie eingeschaltete Station bestimmt sind, in der Weise zu bewerkstelligen, dass man die aneinanderstossenden oder sich kreuzenden Linien nicht direct verbindet, d. i. gleichsam zu einer einzigen macht, sondern dass zur Zeichenubertragung derlei Translationsapparate in Anwendung gebracht werden. Es wird damit den Schwierigkeiten, welche dem directen Functioniren der Telegrafenapparate durch die directe Verbindung zweier langer Leitungen, beziehungsweise die damit verbundene bedeutende Vermehrung des Widerstandes und der Fehlcrquellen bereitet würden, ausgewichen. Soll von einer Linie $I$ anf eine anstossende Linie $I I$ eine Depeschenuibertragung stattfinden, so werden in der gemeinschaftlichen End- oder Mittelstation für jede Linie ein Translator, für den gedachten Fall also zusammen zwei Uebertragungsapparate aufgestellt sein müssen. Stellt man sich das früher beschriebene Relais (Fig. 1460) als Translator vor, so müsste unter der Annahme einer Ruhestromschaltung zu den Linienanschlüssen des Translators $I$ die Sprechlinie I, zu Translator II die Sprechlinie II zugeführt, die Fortsetzung der Linie $I$ jedoch zum Localanschlusse des Translator $I I$, jene der Sprechlinie II, zum Localanschlusse des Translator $I$ angeschlossen sei.

Die Contacte im Schwanenhalsständer muissten selbstredend so angeordnet sein, dass der Stromweg uber den Relais - beziehungsweise - Translatorhebel während der Ruhelage des Translators hergestellt ist. Bei dieser Stellung des Translators $I$ wird also die Linie $I I$ ihren continuirlichen Weg finden, erfolgt jedoch in der Linie $I$ durch Niederdrücken eines Schliissels die Stromunterbrechung,

\footnotetext{
*) Schellen, Dub und Zetzsche.

**) Brix's Journal, Jahrg. VIII pag. 220 .

***) Dingler's polyt. Journ. Bd. 214 pag. 290

t) Ditscheiner, Ausstellungsbericht.
} 
also das Abreissen des Translatorhebels $I$, so wird damit auch die Linie $I I$ unterbrochen, u. zw. theoretisch genau so lange, als der Hebel des Translator $I$ abgerissen, beziehungsweise die Linie $I$ unterbrochen bleibt. Dieselbe Rückwirkung hat umgekehrt die Unterbrechung der Linie $I I$ auf die Linie $I$, da sie wie oben durch den Translator $I I$ fortgepflanzt werden wird. In der Praxis ist jedoch damit die Frage der Translation noch nicht gelöst, weil bei der geschilderten Anordnung durch die Zeiten, welche die Translationshebel brauchen, um den Weg von der Contactstellung in die Unterbrechungsstellung und umgekehrt zurïckzulegen, wechselweise Verzögerungen und in Folge dessen dauernde Unterbrechungen herbeigeführt werden. Es muss also das Translationssystem dahin ergänzt werden, dass der Translator $I$ immer, sobald er aus der Ruhelage kommt, die FolgeUnterbrechung des Translators $I I$ verhindert und der Translator $I I$ wieder dieselbe Einwirkung auf den Localschluss des Translators $I$ ausübt. Der Translator muss also aus zwei Relais oder einem Doppelrelais bestehen. Natuirlich muss in das Schema der Translationsstation stets ein entsprechender Linienumschalter eingeschaltet sein, der die willkürliche Ein- und Ausschaltung der Translatoren ermöglicht. Nach diesen hier angedeuteten Principien sind so ziemlich alle bestehenden Translatoren construirt und schematisirt. Für das Morse-System wird sehr häufig die Translationsvorrichtung direct am Schreibapparat angebracht, nämlich der Schreibhebel gleich als Translatorhebel ausgenützt. Unter der reichen Anzahl der im Gebrauche stehenden diversen Translations-Anordnungen wären hervorzuheben: das System von Steinheil ${ }^{1}$ ), Clark ${ }^{2}$ ), B ong greve ${ }^{3}$ ), Frischen ${ }^{4}$ ), Siemens-Halske ${ }^{4}$ ), Le opolder, Miglitzer, Jaite ${ }^{5}$ ). s. w. Auch die Tastformen sind zahlreich; Morse und Siemens haben z. B. statt Hebeltaster der geschilderten Art auch Tasttafeln angewendet, d. h. Tafeln aus Hartgummi, Horn oder trockenem Holze, in welche den Punkten und Strichen entsprechende Metallstiicke eingesetzt sind, die alle mit dem einen Pole der Batterie in Verbindung stehen, und iiber welche man nur einen mit der Leitung verbundenen Metallgriffel gleitend hinzuführen braucht, um die Batterie ebenso zu schliessen wie durch das Niederdrücken des Tasterhebels. Siemens ${ }^{\mathbf{1}}$ ) construirte ferner ein Lineal, in welches die Typen für Punkte und Striche eingesetzt werden, und welches durch eine den Contact vermittelnde Rolle und Feder gleiten gelassen wird, und auf diese Weise die sonst mit der Hand am Schliissel bewerkstelligten Oeffnungen und Schliessungen des Stromkreises automatisch besorgt. Um die in unterseeischen und unterirdischen Leitungen vorkommenden - von $\mathrm{Kramer}^{6}$ ), Guillemin ${ }^{7}$ ), Siemens ${ }^{8}$ ), F a rade $\left.^{9}\right)$, Wheatsto ne ${ }^{10}$ ), Varle $\mathrm{y}^{11}$ ) beobachteten und erforschten - Ladungserscheinungen, durch welche die telegrafische Zeichengebung bei gewöhnlicher Anordnung des Tasters gestört werden würde, zu parallisiren sind für derlei Linien eigens construirte Schliissel in Anwendung: darunter der Submarinschliussel von Siemens-Halske ${ }^{12}$ ) und der von Varley ${ }^{\mathbf{1 3}}$ ).

Mechaniker Stöhrer in Leipzig hat weiters einen Schreibtelegrafen construirt, der in seiner Wesenheit dem Morse'schen ähnlich ist; sein Schreibapparat hat jedoch zwei Hebel und schreibt also in zwei Linien. Der Taster ist ein zweiarmiger Commutator, der es zulässt, beim Niederdrïcken des einen oder

1) Schellen, V. Abschn. C. 4.

2) Brix's Journ., Jhrg. II pag. 145.

3) Brix's Journ., Jhrg. V pag. 216

4) Dub, Anwendung d. Electrs. Mgnt. VII. Abschnitt \&. 1, 13.

5) Brix's Journ., Jhrg. XI pag. 271.

6) Brix's Journ., Jhrg. I pag. 137.

7) Pogg. Annl. 79 pag. 333.

8) Pogg. Annl. 79 pag. 108 und 698.

9) Philos. Mag. (4) VIII pag. 1I7; Brix's Journ. I pag. 126.

10) Philos. Mag. (4) X pag. 56 Brix's Journ., Jhrg. II pag. 152.

11) Brix's Journ., Jhig. I pag. 188 x. 287; Engineer. 22. Februar 1867 pag. 169; Chemie al News, 1. März 1867 pag. 102; Dingler's polyt. Journ. 185 pag. 1.

12) Sehellen, V. Abschn. C. 5 § 209; Dub, Anwend. d. Electsch. Vi §. 4-2.

13) Schellen, V. Abschn. C. 5 §. 210 ; Dub, Anwendg. d. Electr. Mag. VI §. 4-3. 
anderen Tasterhebels den Strom in einer bestimmten oder entgegengesetzten Riclitung durch ein eigenthïmlich construirtes Relais zu senden und dadurch den einen oder anderen Schreibhebel in Bewegung zu setzen. Die Grundzeichen sind wieder der Punkt und der Strich, jedoch in zwei Zeilen; die Schriftzeichen dieses Systems können also doppelt so kurz sein wie die gewöhnlichen Morsezeichen. Dieses System war in Sachsen und Bayern beim Staatstelegrafen in Anwendung, wurde jedoch wieder aufgelassen, als des Durchspielens wegen, im deutsch-österreichischen Telegrafenverein der Einstiftapparat allgemein eingeführt wurde. Die Schreibtelegrafen von Hi p p*) (1851), V a rin*), Fribourg*), B o u rnes**), B onelli*) u. A. sind electrochemische und bestehen der Hauptsache nach in beiden Stationen (in der gebenden und nehmenden) aus einem oder mehreren Metallstiften, welche, durch ein Uhrwerk bewegt, beständig bestimmte Ziige auf einer mit chemisch-präparirtem Papier belegten Metallplatte beschreiben; durch Vermittlung des in entsprechenden Zwischenräumen hergestellten und unterbrochenen galvanischen Stromes schreibt der Stift oder schreiben die Stifte nur die Theile des Zuges auf das Papier, welche den beziiglichen Buchstaben liefern sollen, der iibrige Theil wird in die Luft beschrieben. Im praktischen Gebrauche stehen diese Systeme ihrer subtilen und heiklichen Construction wegen nirgends. Eine weit giinstigere Zukunft dürften indessen M a y e r's Multiplexapparat***;) und Bau er's Illimit-Telegraf zu gewärtigen haben. Beide diese Systeme bezwecken eine erhöhte Ausnützung der Telegrafenlinie dadurch, dass sie die Pausen, welche in einer Leitung mit nur einer Abgabe- oder Aufnahmsstation wegen der verhältnissmässig langen Vorbereitung zur Stromsendung zwischen je zwei auf einander folgende Stromimpulse eintreten, zum Betriebe mehrerer auf derselben Stelle angeordneten Aufnahms- und Abgabsapparate ausniitzen. Der Mayer'sche Multiplexapparat, mit welchem seit 1874 bei der österr. Staatstelegrafenanstalt Versuche gemacht werden, ist auf 4 Auf- und ebenso viele Abgabsstationen eingerichtet, d. h. auf ein und derselben Linie depeschiren. 8 Beamte (4 gebende, 4 aufnehmende) gleichzeitig. Die Empfangsapparate des Mayer'schen Multiplex schreiben die Zeichen, welche gleichfalls aus Punkten und Strichen bestehen, nicht wie beim Morse in einer Zeile der Länge des Papierstreifens nach, sondern es stehen die Buchstaben úntereinander und bildet jeder für sich eine Zeile. Die 4 Papierstreifen werden von einem durch ein Uhrwerk bewegten Walzenpaar fest bewegt. Die Schreibvorrichtung besteht aus einer rotirenden Welle, welche iuber die Streifen läuft und gleichfalls von demselben Uhrwerke wie die Zugwalzen bewegt wird. Auf dieser Welle sitzen genau den Papierstreifen gegenüber die 4 Schreibwalzen, von welchen jede eine Schneide trägt. Die vier Schneiden bilden zusammen eine Schraubenlinie, deren Höhe gleich dem Wellenumfange ist, so dass auf eine Schreibwalze ein Viertelschraubengang entfällt.

Diese schraubenförmigen Schneiden werden durch darïberliegende Farbwalzen fortwährend mit Druckfarbe befeuchtet und verrichten dieselbe Leistung wie die Schreibvorrichtung der Morse-Farbschreiber.

Unter den Papierstreifen liegt ein Rahmen, der so lange gehoben bleibt, und das Papier an die Schreibwalze driickt, als sich Strom in der Linie befindet.

Wird dieser Rahmen kurze Zeit angedrickt, so entsteht offenbar auf jenem Streifen, ïber welchem sich die Schneide der Schreibwalze soeben befindet, ein Punkt, bei längerem Andrïcken ein Strich. Die vier Tastervorrichtungen bestehen jede ans je 4 weissen und je 4 schwarzen Klaviertasten, von denen die ersteren Striche, die letzteren Punkte geben.

Der wichtigste Bestandtheil endlich ist der Stromvertheiler. Dieser ist eine aus 48 von einander isolirten Theilen zusammengesetzte, ringförmige ContactScheibe, auf welcher ein auf der Schreibwelle befestigter und mit der Linie ver-

*) Zetzs che, Katechismus.

**) Dub, Anwendg. d. Electr.-Mgt. VII. Abschnitt, §. 6, 6.

***) Dr. Leander Ditscheiner, Ausstellungsber, pag. 36; Zetzsche, Abriss d. Geschichte d. Tlgphie. pag. 59 . 
bundener Metallarm contactirend hinweggleitet. Die Taster der einzelnen Zeichengeber sind mit den Contacten je eines Quadranten des Stromvertheilers in bestimmter Weise verbunden und der Gleitcontact so eingestellt, dass die durch das Niederdrïcken der Taster eines Schliissels entstehenden Ströme gerade nur dann in die Linie gesendet werden, wenn die Schreibwelle iiber jenen Papierstreifen wegläuft, welcher dem gebrauchten Taster entspricht. Es können sonach hintereinander die Tastervorrichtungen in Gebrauch genommen werden und wird jede nun auf ihre correspondirenden Schreiber die Zeichen hervorrufen.

Bauer's Illimit-Telegraf*) ist wie der soeben erwähnte Multiplexapparat gleichfalls nach den Principien der Arbeitsvertheilung construirt, unter Anwendung von Stromvertheilern, nämlich synchronistisch rotirende Contactscheiben, von welchen sich eine in der Aufgabs-, die andere in der Abgabsstation befindet. Ein bestimmtes Segment der Contactscheibe entspricht je einer Apparatgarnitur.

Die Typendrucktelegrafen (typotélégraph - typotelegraph). Diese auch Lettern- oder Buchstaben-Drucktelegrafen genannt, bringen das Telegramm auf der Empfangsstation in Farben und Lettern auf Papier gedruckt fertig. Der erste solche Telegraf wurde von A l fred V a il 1837 in Nordamerika und gleichzeitig von Wheatston e erfunden, dann haben sich Fardely in Mannheim, Si emens in Berlin, M a y e $\mathrm{r}$ in Mühlhausen (jetzt Paris), H u gh e s in Philadelphia, Schw ärzl er in Bregenz, Greay in New-York**) etc. mit der Construction und Vervollkommnung solcher Telegrafen abgegeben und diese Aufgabe zumeist in wahrhaft ingenieuser Weise gelöst. Allein die Einrichtung solcher Apparate ist zu künstlich, die Behandlungsweise und Erhaltung meist zu schwierig und die Zuverlässigkeit zu gering, als dass sie in der Praxis eine grosse Verbreitung hätten finden können. Nur der von Hughes $* * *)$ hat in den letzteren Jahren, seiner grossen Schnelligkeit wegen, fuir lange Linien in Europa, wie Asien und Amerika grosse Verbreitung gefunden und Fig. 1462.

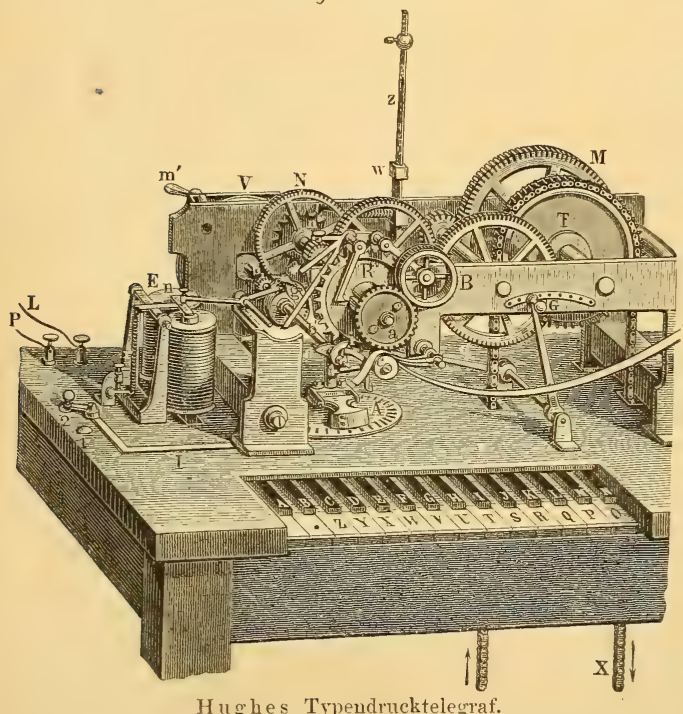
das Morse'sche System theilweise verdrängt.

Die Haupttheile des H u g h e s'schen Teie. grafen - Apparates (Fig. 1462 bis 1464) sind der Schlitten $S$ und die Klaviatur, das Laufwerk $\left(T, M, N, b, R, n_{1}\right)$, die Druckachse und das Druckwerk $(b, o)$, der Electromagnet $\boldsymbol{E}$, die Auslösung $n$ des Druckwerkes und der Regu. lator $G$. Das Abgeben der Depeschen geschieht mittelst Niederdrïcken der Taster der Klaviatur, welche je einem Schriftzeichen oder einer bestimmten Schriftpause entsprechen. Jeder dieser Taster ist ein zweiarmiger Hebel, der in einen Stift endigt. Jeder dieser Stifte läuft in einem be-

*) Dr. Leander. Dits cheiner, Ausstellungsbericht, Wien 1874; Ding ler's polyt. Journ. Bd. 213 pag. 17.

**) Dingler's polyt. Journal 1866, Bd. CLXXXII pag. 1.

**) Dingler's polyt. Journ. Bd. 217 pag. 468; Journal of the Telegraph, Bd. 8 pag. 193. 
stimmten Spalt eines ringförmigen Gehäuses $\Lambda$. Im normalen Zustande werden die Tasterhebel durch Federn derart gehalten, dass die Stifte nicht iiber die Gehäusfläche A hervorragen; driickt man aber eine 'Taste nieder, so heht sich das andere Hebelende und der entsprechende Stift tritt aus seiner Oeffinung ein Stiickchen herror. In der Mitte des Gehäuses $A$ befindet sich eine verticale Achse $Q$ (Fig. 1463 u. 1464), welche einerseits mit der Linie, welche durch die Multiplication des Electromagneten $E$ und dann weiter zur nächsten Station geht, andererseits mit der Erdleitung in Verbindung steht; von der besprochenen Büchse $A$ aber vollkommen isolirt ist. An der Achse $Q$ ist der Schlitten $S$ befestigt, welcher während der Rotation dicht über die Deckplatte des Gehäuses $A$ wegläuft. Wird eine Taste niedergedrickt und dadurch der entsprechende Stift iiber die Deckplatte emporgehoben, so beriihrt ihn der Schlitten, sobald er auf seiner Drehung diesen Punkt passirt und stellt zwischen der Achse $Q$ und der Taste eine metallische Verbindung her; gleichzeitig wird aber auch beim Aufsteigen des Schlittens die bestandene Verbindung der Achse $Q$ zur Erde unterbrochen.

Sämmtliche Taster sind mit einem Pole der Fig. 146.3.

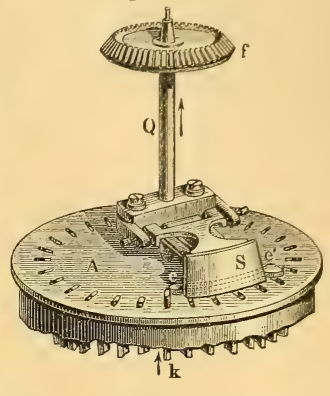

Linienbatterie verbunden, deren zweiter Pol zur Erdleitung anschliesst. So lange also in keiner Station eine Taste niedergedruickt wird, ist zwar, wie dies das in Fig. 1464 dargestellte Schema näher versinnlicht, die Linie continuirlich geschlossen, aber kein Strom in derselben vorhanden; wird jedoch eine Taste nieder gedriickt, so ist die Batterie in dem Momente eingeschaltet und wirksam, in welchem der Schlitten den emporgehobenen Tasterstift im Vorbeigehen streift. Die Schlittenachse $Q$ wird von einem durch Gewicht getriebenenUhrwerke in Rotation gesetzt und macht circa 110 Umdrehungen $\mathrm{pr}$. Minute; gleichzeitig mit derselben wird das Typenrad $a$ bewegt. Dieses Rädchen hat am Rande in derselben Reihenfolge, wie die Buchstabenstifte in der Buichse $A$ nebeneinFig. 1464.

ander liegen, die entsprechenden Typen eingeschnitten, und bewegt sich in der Weise, dass genau immer die Type jenes Buchstabens zu unterst sich befindet, welche dem Schlitze, beziehungsweise jenem Taster-Contactstift entspricht, iiber den im gleichen Momente der Contactschlitten hinstreift. Unter dem Typenrädchen, welches an seinem Rande durch ein darneben angebrachtes Farbrädchen immer mit der nöthigen Druckerschwärze befeuchtet wird, läuft in einem Schiffehen der Papierstreifen $p$. Kommt Strom in die Multiplication, so wird eine am Electromagnet angebrachte Armatur $n$ in Folge der plötzlich eingetretenen Aenderung im magnetischen Zustande des Electromagneten abgerissen und dadurch das Schiffchen mit dem Papier gegen den Rand des Typenrades gedriickt und dann um eine Buchstabenbreite weiter geriickt. Denkt man sich nun in der gebeuden 
wie nehmenden Station Typenrad und Schlittenachse ganz übereinstimmend bewegt, was durch eine genaue Regulirung der Laufwerke beider Stationen erzielt werden kann, so wird, wenn die depeschirende Station $A$ z. B. die Taste $x$ niederdrückt, in der aufnehmenden Station $B$ in dem Momente ein Strom die Multiplication passiren, als der Schlitten in $A$ den Schlitz $x$ passirt. Nach dem Vorhergesagten muss aber bei richtiger Einstellung der Typenräder in beiden Stationen in dem Momente der Stromerregung gerade der Buchstabe $x$ zu unterst liegen; in $B$ wird also das durc'ı die Stromerregung emporgeschnellte Papier den Buchstaben $x$ abdrucken und dann um ein Buchstabenintervall vorwärts gezogen. Sollen am Streifen Pausen markirt werden, so drïckt der Telegrafist eine besondere Taste nieder, für welche am Typenrad keine Type eingeschnitten ist; der Streifen wird bei dieser Taste also keinen Abdruck erzengen, sondern nur vorwärts riicken. Die hier nur im Principe gekennzeichneten Bestandtheile des Hughes'schen Apparates sind sehr complicirt, aber auch höchst genial ausgeführt und ermöglichen die staunenswerthe Leistung von 150 Buchstaben oder 25 Wörtern in der Minute.

Die Copir-, A uto- und Pan-Telegrafen ') telegrafiren Handschriften, Zeichnungen u. s. w. Sie beruhen im Allgemeinen darauf, dass auf eine leitende Platte mit einem nicht leitenden Materiale das Telegramm oder die zu telegrafirende Zeichnung geschrieben, beziehungsweise aufgezeichnet wird. Ist diese Platte mit einem Pole einer Batterie verbunden und wird mit einem Metallgriffel, welcher mit dem anderen Pol dieser Batterie in leitender Verbindung steht, iber die Platte hin- und hergefahren, so wird der Stromkreis offenbar abwechselnd geschlossen oder unterbrochen, je nachdem der Griffel über die isolirende Schrift oder über die leitende Platte gleitet. Denkt man sich in den Schliessungskreis den Empfangsapparat einer zweiten Station eingeschaltet und diesen so eingerichtet, dass bei ihm ein Schreibstift die ganz gleichen Bewegungen macht wie der Griffel in der Aufgabsstation und dabei jedesmal ein Zeichen auf ein Papierblatt hervorbringt, sobald Strom in die Linie kommt oder umgekehrt, so muss das Ensemble der erzeugten Zeichen endlich eine complette Nachbildung der Originaldepesche geben. Die Hauptbedingung für solehe Apparate, aber auch ihre Hauptschwäche, ist also der Synchronismus der Apparate in der Abgabs- und Ankunftsstation. Das Hervorrufen der Zeichen wird zumeist auf electrochemischem Wege erzielt, wie bei den Copirtelegrafen des Bain, $\left.{ }^{2}\right)$ Backewell, ${ }^{3}$ ) $\mathrm{Charles}^{4}{ }^{4}$ ) $\mathrm{Cros}^{4}$ ) $\mathrm{Caselli}^{5}$ ) u. s. w., oder auf electromagnetisch-mechanischem Wege, wie bei jenen von Hipp, ${ }^{4}$ ) Lenoir, ${ }^{4}$ ) Maycr, $\left.{ }^{6}\right)$ d'Arlincourt ${ }^{7}$ ) etc. So interessant und ingeniös diese Telegrafen sind, haben sie keine oder doch nur ephemere Anwendung in der Praxis gefunden. Im Jahre 1865 war Casellis System auf der Route ParisMarseille und Paris-Lyon in Anwendung, indessen wurde dasselbe 1866 durch M a yer's Pantelegraf, der auf der Strecke Marseille-Bordeaux Eingang fand, voriibergehend verdrängt.

A n to mat-Telegrafen sind solche, bei welchen die zeichengebenden Stromimpulse nicht direct mit der Hand rhytmisch abgegeben, sondern die Depeschen erst auf einem Vermittlungsapparate vorbereitet werden. Sie theilen sich ein in solche, bei welchen die Depeschenabgabe im Sendapparate mittelst Typen, welche In langen Schienen eingesetzt sind, geschieht, damn in solche, bei welchen dies mittelst durchlöcherten Papierstreifen bewerkstelligt wird, und endlich in solche, bei welchen das Vorbereiten der Depesche und das antomatische Abtelegrafiren ein einziger Apparat in Ausfülrumg bringt. Die erstere Art ist schon bei dem Morse'schen Apparatsysteme erwähnt worden und findet ihre wichtigsten Vertreter in dem magnetoelectrischen Typenschnellschreiber von Siemens-Halske

\footnotetext{
1) Dr. Zetzsche, Die Copir- u. Typendrucktelegrafen, Leipzig 1865.

${ }^{2}$ ) Mech. Mag. 1850, pag. 83; Dingler' polyt. Journ. 117, pag 40.

$\left.{ }^{3}\right)$ Mech. Mag. V., 50, pag. 544; Dingler's polyt. Journ. 119, pag 75.

Zetzsche, Katechismus.

Schellen. Y Absch., II. \$. 217.

6) Bulletin d. 1. Société de Mulhouse XL, pag. 197; Dingler's polyt. Journ. 124, pag. 488.

7) Dingler's polyt. Journ., Bd. 212, pag. 295.
} 
und in deren Typenschnellschreiber für Batteriestrom. ${ }^{1}$ ) 1846 machte Bain seine ersten Versuche, die Morse-Punkte und Striche in einen Papierstreifen zu stanzen, der dann zwischen einer Walze und Feder durchgefüht wurde. Die Rolle war mit dem Batteriepol, die Feder mit der Linie verbunden, und sobald ein Loch des Papierstreifens die Rolle passirte, konnte die Feder in Contact treten und Stromimpulse erzeugen. Nach diesem Principe sind auch die Automattelegrafen von Siemens, ${ }^{2}$ ) Schneider, Lacea, Gaspori, ${ }^{3}$ ) Little, ${ }^{4}$ ) Jaite ${ }^{5}$ ) und Wheatston ${ }^{6}$ ) construirt, unter welchen wieder hauptsächlich der letztgenannte beim Staatstelegrafen in England eine vorzügliche Anwendung findet. Sowohl der Siemens'sche als Wheatstone'sche Automattelegraf haben nachstehende Hauptapparate: Der Mittellochschreiber, ein Stanzapparat, welcher den Streifen mit einer Reihe in gleichen Intervallen von einander stehenden und in der Mittellinie des Papieres laufenden Löchern versieht. Diese Löcher haben den Zweck, den Papierstreifen zum Bearbeiten auf dem zweiten Apparate, dem $\mathrm{H}$ andschriftlocher geeigneter zu machen. Der Handschriftlocher ist ein Stanzappurat, mit dem nun die Schriftzeichenlöcher erzeugt werden, u. zw. beim Siemens'schen in einer Reihe, beim Wheatstone'schen in zwei Reihen. Die auf diese Weise vorbereiteten Streifen kommen nun in den eigentlichen Geber, das sind Walzwerke, welche wieder so eingerichtet sind, dass Ströme in die Linie entsendet werden, sobald ein Schriftloch passirt, und diese Ströme bringen in der Aufnahmsstation am Schreibapparate, der ein höchst leicht beweglicher, polarisirter Farbschreiber (Morse) ist, die entsprechenden Schriftzeichen hervor. Durch die colossale Geschwindigkeit, die mit solchen Apparatsystemen erzielt werden kann, ist der Aufwand von Vorarbeiten leicht hereingebracht. Eine Abart dieses Systemes ist das von Dumoulin-Froment, ${ }^{7}$ ) bei welchem statt Papierstreifen Staniolstreifen und statt der gestanzten Löcher mit Lack gemalte Zeichen, jedoch mit wenig Erfolg verwendet wurden. Der neueste automatische Telegraf ist der Siemens'sche Dosen-Schnellschriftgeber. ${ }^{8}$ ) Er erfüllt beide Functionen, nämlichdas Vorarbeiten und Abtelegrafiren der Schriftzeichen mittelst eines einzigen Apparates. Die Idee zu diesem Apparate gab v. Hefner-Alteneck, die Ausführung ist von Siemens. Der Dosenschnellschriftgeber hat seinen Namen von einer dosenartigen, sich sprungweise auf einer horizontalen Achse drehenden Trommel, die an ihrem ganzen Umfange mit dicht neben einander liegenden Stiften besetzt ist, welche die zur automatischen Beförderung nöthigen Typen dadurch bilden, dass eine bestimmte Anzahl derselben durch das Niederdrüicken je einer einzigen Taste verschoben wird. Solche Taster, knopfförmige Drucker sind zusammen 49 vorhanden und treppenartig in 7 Reihen auf einer pultartigen Tastertur untergebracht. Jede Taste entspricht einem Schriftzeichen; ihre Reihenfolge ist so getroffen, dass die am häufigsten vorkommenden sich besonders leicht und bequem greifen lassen. Das Niederdrïcken eines jeden Drïckers bringt am Empfangsapparat den entsprechenden Buchstaben in Morse-Schrift hervor. Der Empfangsapparat kann ein leicht beweglicher Farbschreiber sein. Es kann auf diesem Apparate ein routinirter Telegrafist ohne Schwierigkeit 5 Tasten hinter einander in 1 Secunde greifen; ist der Mechanismus dem entsprechend eingestellt, so sind das 300 Schriftzeichen in der Minute. Nimmt man den mittleren Bedarf per Depesche mit 200 Schriftzeichen, so entspräche das einer Leistung von 90 Depeschen, das Doppelte der mittleren Hughesleistung. Die praktischen Versuche

') $\mathrm{Uub}$, Anwendung d. E.-Magt. 2. Aufl. pag. 524; Zetzsche's Geschichte d. Telegrf. pag. 46.

$\left.{ }^{2}\right)$ Anwendung d. E.-Mgt. pag. 572; Zetzsche's Geschichte der Telegrf. pag. 44; Brix's Journ. XIV pag. 139.

3) D u b, pag. 579 .

4) Dr. Leander Ditscheiner, Ausstellungsbeticht, pag. 36.

5) Dingler's polyt. Journ. Bd. 214 pag. 446.

6) Dingler's polyt. Journ. Bd. 216 pag. 219

7) Dingler's polyt. Journ. Jahrg. 1867.

8) Ditscheiner, Ausstellungsbericht pag. 32; Zetzsche's Geschichte pag. 48. 
mit diesem Apparate auf der Linie Berlin Breslan haben jedoch gezeigt, dass die oben berchnete Leistung nicht zu erzielen ist, sondern eben nur eine solche, welche hinter der des Hughes'schen Apparates nicht zurïckbleibt. Ein anderer von Siemens construirter Automattelegraf ist der Kettenschnellschriftgeber, ${ }^{1}$ ) welcher die Steinheil'schen Schriftzeichen (Punkte in zwei Reihen) schreibt, und der Schnelldrucker. ${ }^{2}$ ) Letzterer ist ganz ähnlich dem Dosenschnellschriftgeber, nur dass bei ihm die Zeichen in Typenschrift hervorgerufen werden.

Die Doppel- und Gegensprech-Telegrafen. ${ }^{3}$ ) Darunter sind jene Systeme verstanden, welche die gleichzeitige Beförderung zweier Depeschen auf einem und demselben Draht entweder in gleicher (D o p pels precher) oder in entgegengesetzter ( $G$ egensprecher) oder auch in gleicher und entgegengesetzter Richtung gleichzeitig gestatten. Das erste dieser Telegrafensysteme wurde von Dr. Wilh elm Gint $1^{4}$ ) österr. Telegrafendirector, im Juni 1853 erfunden, nach ihm haben Kramer, ${ }^{5}$ ) Dr. Nedden, Rystor, Schreder, ${ }^{6}$ ) Frischen, Siemens, Dr. Stark, Edland, Kohl, ${ }^{8}$ ) Maron, ${ }^{9}$ ). Schakk ${ }^{10}$ ) und andere Doppel- und Gegensprechtelegrafen construirt. Das von Gintl zuerst angewendete Schema für Gegensprechtelegrafen ist das in Fig. 1465 dargestellte. Der 'Taster, welcher später in einen einhebeligen mit 5 Contacten umgeändert wurde, hatte ırsprünglich zwei Hebelsarıne, die durch Vermittlung eines isolirenden Querstiickes steif verbunden waren urd mittelst einem auf diesem Querstïcke festsitzenden Knopfe ganz gleichzeitig niedergedrückt werden konnten. Das Relais hat eine doppelte Multiplication, wovon die Enden der inneren aus dünnerem Draht hergestellten zur Leitung und zum Tasterlager l', die Enden der äusseren aus Fig. $146 \tilde{5}$.

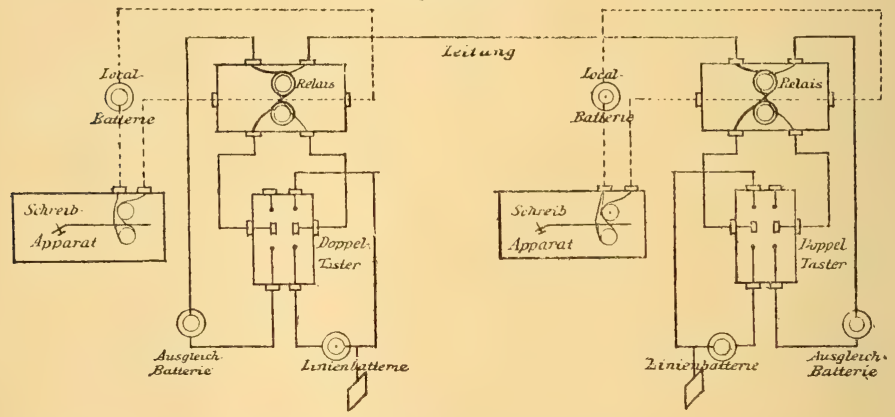

Giutl's S'chema zum Gegensprechen.

stärkerem Draht bestehenden zum 'Tasterlager $l$ und zu einem Pol der Ausgleichsbatterie anschliessen. Die iibrigen Verbindungen sind in der Zeichnung ersichtlich und zeigen, dass, so lange der Taster in der Ruhelage ist, die Linie direct uber die innere Multiplication weg und durch den vorderen rechtseitigen Tasterhebel in die Erde gelangt. Wird der Doppeltaster niedergedrückt, so ist erstens die Linienbatterie eingeschaltet und ein Strom wird in die Leitung entsendet. Dieser Strom kann jedoch nur das Relais der Station $B$ und nie auch das der Station $A$

3) Zetzsche's Geschichte der Telegrf pag. 53.

?) Zetzsche, Geschichte d. Telegrt. pag. 54; Dits cheiner, Ausstellungshericht pag. 35.

3) Dr. Zetzsehe, Zeitschrift f. Math. u. Physik, 10. Jhrg., Heft 3 bis 5.

$\left.{ }^{4}\right)$ Brix's Journ. II prg. 25.

5) Brix's Journ III pag. 4.

6) Brix's Journ. VII pag. 85 u. 258; Zetzsche, die Cop.- u. Typ.-Tlgrf., Lpzg. 1865.

7) Brix's Journ. IX pag. 241.

$\left.{ }^{8}\right)$ Brix's Journ. IX pag. 76.

9 Brix's Journ. X pag. 1 น. 125.

10) Brix's Journ. X pag. 5 u. 246. 
magnetisiren, weil in letzterer durch das gleichzeitige Niederdriicken der beiden Tasterhebel auch die Ausgleichsbatterie geschlossen wird, deren Strom iiber die ïussere Relaismultiplication länft. Die Stärke der Ansgleichsbatterie und die Multiplicationswindungen sind aber so bemessen, dass die magnetische Wirkung des Ausgleichsstromes eben so stark wie die des Linienstromes, jedoch entgegengesetzt polarisirt ist. Wenn also auch in beiden Stationen die Taster.zur selben Zeit niedergedriickt wiirden, so kann doch immer nur das Relais vom fremden Strome afficirt werden, niemals vom eigenen, und das gleiclizeitige Hin- und Zuriicktelegrafiren ist hiedurch also ermöglicht, gleichgiltig, ob die Linienbatterien gleich oder entgegengesetzt orientirt sind. Dieses System hat durch Gintl selbst und seine Nachfolger mannigfache Abänderungen und Verbesserungen erfahren.

Die Doppelsprecher basiren darauf, dass in der Sprechstation mit zwei Tastern Ströme ungleicher Stärke entsendet werden, und dass die Relais in den Aufnahmsstationen so eingerichtet sind, dass das eine nur durch den schwächeren, das zweite nur durch den stärkeren Strom thätig gemacht werden kam. Systeme, wo das Doppelsprechen mit dem Gegensprechen vereinigt ist, haben zuerst Dr. Stark, dann Dr. Bos ocha, Telegrafeninspector Maron etc. construirt. In der Praxis haben alle diese Doppel- nnd Gegensprechtelegrafen trotz ihrer eben so richtigen als ingenieusen Conception bisher wenig Ausniitzung gefunden, weil das denselben characteristisch anhaftende Bedurfniss der steten Stromausgleichung, besonders bei schlecht gebauten Linien, die Vortheile des Systems arg beeinträchtigt. Erst in nenerer Zeit fanden sie wieder Anwendung, u. zw. besonders in England und Amerika. Die jüngeren Gegensprechsysteme ') sind von Vans, Steares, Pracce, Winter etc, allein selbe diurften kaum vollkommener sein als die älteren, und wenn die Versuche damit sich günstiger herausstellten, so ist dies wohl nur darauf zurïckzufïhren, dass jetzt der Linienbau bedeutend besser und das Personale geschulter und geibter ist, als dies vor 20 Jahren der Fall war.

Entwicklung. Die electrische Telegrafie ist erst spät in die Reihe der Weltverkehrsmittel eingetreten, um so raschẹr hat sie jedoch ihren Entwicklungsgang durchgemacht, und um so grösser müssen die Erfolge genannt werden, welche in verhältnissmässig kurzer Zeit auf diesem Felde errungen wurden.

Die früheste literarische Notiz über die Idee einer electrischen Telegrafie findet sich 1753 in Seot's Magazin, $\left.{ }^{2}\right)$ 15. Band, pag. 73 , obwohl schon 1727 Stephen Gray, $\left.{ }^{3}\right) 1735$ bis 1737 Du Fay, ${ }^{4}$ ) 1746 Benjamin Franklin ${ }^{5}$ ) in Philadelphia und Professor Winkler ${ }^{6}$ ) in Leipzig Versuche gemacht hatten, die Electricität in Bezug auf ihre Fortpflanzungsfähigkeit zu prüfen und zur Versendung einzelner Signale anf grössere Distanzen auszunützen.

Im Jahre 1774 hatte Lessaye ${ }^{7}$ ) in Genf bereits einen electrischen Apparat zusammengestellt, welcher auf 24 Drähten, wovon jeder einem Buchstaben des Alphabetes entsprach, durch das Einschalten einer Leidnerflasche die Entladungsfunken erzeugte und dadureh den gewiinschten Buchstaben signalisirte.

Reusser ${ }^{8}$ ) suchte diese Idee 1794 weiter zu entwickeln. Ausserdem hatten Cavallo, Salva, Betancour ${ }^{9}$ ) ähnliche Versuche gemacht. Allein alle diese, so wie späteren auf Ausnützung der Reibungselectricität basirenden Systeme erwiesen sich für die Praxis als umanwendbar; und erst seitdem die Hol ta'sche Säule durch Dr. Sömmering ${ }^{10}$ ) (1808) und der

1) Zetzs cli e, Kritik der neuen tlgrt. Gegensprecher; D in g' l e r's polyt. Journ. CCXI pag. 111.

$\left.{ }^{2}\right)$ The Common Wealtb. 1854; Zeitschrift des deutsch-österr. Telegr.-Vereines 1. Jhrg: pag. 93; Zetzsche's Handbuch I pag. 21.

3) Robert Sabine, the hystory and progress of the elect. tlgrph. 2. Aufl. 1869 pag. 3.

4) Robert Sabine pag. 4; E. Higthon, London 1869 pag. 3.

$\left.{ }^{5}\right)$ Zetzsehe, Handbuch d. electr. Telegrf. Band I pag. 15.

5) Zetsche, Handbuch I pag. $\mathbf{1 5 .}$

7) Moigno, Telegrph. éléctrique pag. 59.

$\left.{ }^{8}\right)$ Lichtenberg's Magazin, Bd. 9 pag. 183; Kohn, Electricitätslehre pag. 825.

9) Gauss u. Weber, Resultate aus den Beobachtungen des magnetischen Vereines 1837 pag. 14.

17) Jingler's polyt. Journ. 67 pag. $38 s$.

Karmarsch \& Heeren, Technisches Wörterbuch. Bd. III. 
Magnetinductor durch Ronald (1816) als Electricitiitsquelle in Gebrauch kam, konnte das Problem der electrischen Telegrafie als gelöst betrachtet werden.

Von da arbeiteten Schillig, ${ }^{1}$ ) Beckmann, Liehtenberg, Cooke, ${ }^{2}$ ) Oerstedt (1832) etc. an der Weiterentwicklung. 1832 wurde von $\mathrm{Gauss}$ und $\mathrm{Weber}{ }^{3}$ ) die erste im Freien angelegte Telegrafenleitung erbaut und ein electrisches Sprachsystem, bei welchem die Nadelablenkung als Signalzeichen benützt wurde, zwischen dem physikalischen Cabinet der Göttinger Universität und der Sternwarte eingerichtet. Damit war die Serie der Nadeltelegrafen, welche später durch Steinheil, ${ }^{4}$ ) Wheatstone, ${ }^{5}$ ) Bain, Matzenaner, Eckling, Schefěik u. s. w. verbessert wurden, eröffnet und alle ersten Eisenbahn- und Staatstelegrafen in Europa waren ursprünglich mit diesem Systeme oder mit Zeigertelegrafen versehen. Letztere wurden 1816-1823 von Francis Ronulds aus Hammersmith erfunden, durch Wheatstone, ${ }^{6}$ ) Fardely, Drescher, Leonhard, Krome, Brégnet, ${ }^{7}$ ) Mapple, Froment, ${ }^{8}$ ) Stöhrer, ${ }^{9}$ ) Siemens und $\mathrm{Halske}{ }^{10}$ ) ete. verbessert und sind heute noch in Anwendung.

Alle diese Systeme wurden durch den von Morse ${ }^{11}$ ) 1837 in Amerika erfundenen Schreibtelegrafen in den Hintergrund gedrängt. Die Einführung des electrischen Telegrafen begann nun in England mit der 1840 von Cooke und Wheatstone erbauten 39 engl. Meilen langen Sprechlinie längs der Great-Westernbahn, in Anerika 1844 mit der 8 dentsche Meilen langen, von Morse erbauten Linie Washington-Baltimore, in Deutschland 1843 mit der von der Direction der rheinischen Eisenbahn bei Aachen errichteten Bahntelegrafenlinie, in Russland 1844 mit der Linie Petersburg-Zansko-Selo, in Frankreich 1845 mit der Linie Paris-Rouen, in Oesterreich mit der Linie Wien-Brünn. Bayern, Württemberg und Belgien folgten 1846, Baden und Holland 1847, Sachsen 1850, Ostindien 1851, Italien und die Sehweiz 1852, Schweden 1853, Spanien 1854, Norwegen, der Kirchenstaat 1855, Portugal 1857, Persien 1859, Japan 1864 u. s. w. Für den öffentlichen Verkehr, d. h. für die Beförderung von Privatdepeschen, wurden die electrischeu 'Telegrafen zuerst 1843 in Amerika, 1845 in Holland, 1847 in Deutschland (Linie Bremen-Vogesack), 1848 in England, 1849 in Preussen und Oesterreich, 1851 in Frankreich und 1854 in Dänemark ete. in Benützung genommen. In Bezug auf die allgemeine Gestaltung des Telegrafenwesens wären nachstehende Phasen als besonders weittragend zu bezeichnen: Die Entdeckung der Erdleitung durch Steinheil 1838, die Entdeckung Director Gintl's, dass es möglich ist, auf einem Drahte gleichzeitig nach beiden Richtungen zu telegrafiren (1853); die Anwendung ron Magnetinductionsströmen zum Telegrafenbetrieb, wieder eingeführt durch Siemens, nachdem schon Gauss und Weber 1832 und Steinheil 1837 ihre Telegrafen damit betrieben hatten; endlich die Einführung der submarinen Telegrafenleitungen, wovon die ersten nennenswerthen Versuche von O'Sehangkessy im Huglistrome (Indien) ans dem Jahre 1839 datiren.

Die Apparat- und Schaltungssysteme haben eine rasche und glänzende Entwicklung erfahren und der hier gebotene Raum gestattet nicht alle auf diesem Gebiete stattgehabten Wandlungen nominell zu registriren. Als letzte Glieder müssen nur noch erwähnt werden die Typotelegrafen, Copir-, Auto- und Pantelegrafen, die Gegen- und Doppelsprechtelegrafen, endlich die Automattelegrafen, die Multiplextelegrafen und die Ilimit-Telegrafen. Im Grossen und Ganzen hat unter den obigen Systemen wohl nur der Hughes'sche Typotelegraf eine bedeutende Verbreitung gefunden und im Laufe des letzten Decenniums fïir das Sprechen auf

1) Allgemeine Bauzeitung 1837 Nr. 52 pag. 440.

Schafner: The Telegraph manual, pag. 199

3) Pogg. Ann. 3? pag. 568; Göttg. glsrt, Anzeiger 1834, 128 Stïck.

Dingler's polyt. Journ. 70 pag. 292.

Mechanies Magazine 1839; Dingler's polyt. Journ. 74 pag. 394.

6) Gavarret Telegraph électqu. pag. 161.

Telegraphie électqu. p. Gavarret pag. 114

8) Bulletin d. I. Société d'encouragement 1851 pag. 319; Dingler's polyt. Journ. 122 pag. 37.

9) Brix's Journ. II pag. 193.

10) Verhandlung für Eisenbahnkunde 10. März 1857.

11) Moigno, Telegr. élect. 1852 pag. 75 ; Brix's Journ. I pag. 193; Sehossner, Electr. Tlgrf. pag. 423 . 
lange Linien den Morse fast verdrängt, aber auch ihm ist ein ïuerlegener Rival entstancien in dem Wheatstone'schen Automattelegrafen.

Die Thatsache, dass derzeit Europa mit Asien durch 3 Trlegrafenlinien, mit Amerika durch 3 Kabel, mit Afrika durch 4, bez. 5 Kabel, ferner Asien mit Australien durch 1 Kabel in Verbindung stelit, dass bereits ein Liniennetz von 623.742 Kilometer olserirdische Telegrafenlinien mit 1.375596:3 Klmt. Drahtleitungen und circa 100000 Klmt. unterseeische Leitungen die Welt umspinnt, obwohl die erste Anwendung der Telegrafen für den öffentlichen Verkehr aus dem Jahre 1843 datirt, lässt am deutlichsten ersehen, mit welch' wunderbaren Raschheit und in welcher colossalen Ausdehnung die electrische Telegrafie sich als Weltverkehrsmittel entwickelt hat.

Telegrafen der a usereuropäischen Staten.

\begin{tabular}{|c|c|c|c|c|c|c|}
\hline \multirow{2}{*}{\multicolumn{2}{|c|}{ St a a t e $n$}} & \multirow{2}{*}{$\begin{array}{c}\text { Leitungen } \\
\text { in } \\
\text { Kilometer }\end{array}$} & \multirow{2}{*}{$\begin{array}{l}\text { Flächeninhalt } \\
\text { in } \\
\square \text { Kilometer }\end{array}$} & \multirow{2}{*}{ Finwohner } & \multicolumn{2}{|c|}{$\begin{array}{l}\text { Entfallen an Lei- } \\
\text { tungen Kilometer }\end{array}$} \\
\hline & & & & & $\begin{array}{l}\text { auf } 100 \\
\text { Kilometer }\end{array}$ & $\mid \begin{array}{l}\text { auf } 1000 \\
\text { Einwohner }\end{array}$ \\
\hline Egypten . & . & 6488 & 559.350 & $5,000.000$ & $1 \cdot 160$ & $1 \cdot 299$ \\
\hline Brasilien . & . & 1600 & $8,347.515$ & $11,780.000$ & 0.019 & $0 \cdot 135$ \\
\hline Chili . . & $\ldots$ & 1648 & 343.090 & $2,085.000$ & 0.474 & 0.781 \\
\hline Algier . . . . & . . & 4000 & 389.510 & $2,921.000$ & $1 \cdot 052$ & $1 \cdot 711$ \\
\hline Canada . . & . & 8800 & 975.260 & $3,753.000$ & 0.909 & $2 \cdot 344$ \\
\hline Cap und Natal & . & 1080 & 548.900 & 760.000 & $0 \cdot 197$ & $1 \cdot 421$ \\
\hline Ostindien . . . & . & 20000 & - & -- & - & - \\
\hline Engl.-Australien . & . & 14736 & - & - & - & - \\
\hline Marocco . . . . & . & 360 & 671.550 & $3,750.000$ & 0.053 & 0.092 \\
\hline Niederl. Ostindien & . & 4184 & - & - & - & - \\
\hline Persien . . . . & . & 864 & $1,454.750$ & $4,400.000$ & 0.059 & $0 \cdot 191$ \\
\hline Cuba . . & . & 1272 & 118.600 & $1,370.000$ & 1.072 & 0.928 \\
\hline Tunis . . . . . & . . & 560 & 118.250 & $2,000.000$ & 0.473 & $0 \cdot 280$ \\
\hline Verein. St. v. Ame & rika & 149200 & $9,167.565$ & $38,650.000$ & $1 \cdot 628$ & $3 \cdot 860$ \\
\hline
\end{tabular}

Literatur. Deutsche Literatur: Sömmering, Ueber eine electrische Telegrafie, München 1811; Denkschriften der Münchener Akademie 1808 u. 1810. - Gaus und Weber, Resultate aus den Beobachtungen des magnetischen Vereines 1836, Göttingen 1837. - Steinheil, Ueber Telegrafie, besonders durch galvanische Kräfte, München 1838. - De reterum re telegraphia 1842. - Fandely, Der electrische Telegraf (aus dem Englischen), Mannheim 1844. - Drescher, Die electrische Telegrafie, Kassel 1848. - Pelcharim, Der electr.-magn. Telegrf., Berlin 1848. - V ail, Darstellung der electr. Telegrafen nach dem Systeme d. Prof. Morse (deutsch v. Gerke), Hamburg 1848. - Dr. Adolf Poppe, Die Telegrafie von ihrem Ursprung bis auf die neueste Zeit, Frankfurt 1848. - Schellen, Der electr.-magn. Tlgf. 1850, 6. Aufl. 1872. Steinheil, Beschreibung und Vergleichung der galv. Tlgf. Deutschland's, München 1850. - Josef Buerbanm, Die electro-magnet. Telegrf., Berlin 1851. - Gerke, Der practische Telegrafist, Hamburg 1851. - W. Siemens, Darstellung der mit unterirdischen Leitungen in Preussen gemachten Erfahrungen, Berlin 1851. - L. B e rg mann, Die Telegrafie, Leipzig 1853. - Lardner, Populäre Lehre von der electr. Tlgrf., deutseh von Hardtmann, Weimar 1856. - Galle, Katechismus der electr. Tlgf., Leipzig 1859, 5. Auflage, bearbeitet von Dr. E. Z etz s c h e, Leipzig 1873. - F a r d e ly, Der Zeigertelegraf für den Eisenbahndienst, Mannheim 1856. - K ri es, Der Tlgrf. als Verkehrsmittel, Tübingen 1857. - Vichelmann, Elemente der unterseeischen Telegrafie (nach Dela marche), Berlin 1860. - Dub, Die Anwendung des Electromagnetismus, Berlin 1862, 2. Aufl. 1873. - Dr. W. Sömmering, Der electrische Telegraf als deutsche Erfindung, Frankfurt a. M. 1863. - J. Richter, Morse's electro-magnet. Drucktelegrf., Reichenberg 1865. - Dr. Zetzs che, Die Copir- u. Typendruck-Telegrf., Leipzig 1865. - M. M. Freiherr v. We ber, Das Telegrafen- u. Signalwesen d. Eisenbahnen, Weimar 1867. - Lud wig, Der Bau von Telegrafenlinien, Dresden 1870. - L. F. W. Rother, Der Telegrafenbau, Berlin 1870. - Ludwig, Die Telegrafie in staats- und privatrechtlicher Beziehung, Dresden 1872. - H. Z a be l, Der electrische Feuertelegraf, Breslau 1873. - Dr. Zetz s e he, Kritik über die neueren Gegen- u. Doppeltelegrafen, Augsburg 1874. - Lohmaier u. Pohl, Leitfaden zum Selbstunterricht des Telegrafenwesens, 2. Aufl., Berlin 1874. Dr. Zetzsche, Beitrag zur Geschichte der electr. Tlgrf., Berlin 1874, - Dr. Leander- 
Stand des Telegrafen in den Staten

\begin{tabular}{|c|c|c|c|c|c|c|c|}
\hline \multirow{3}{*}{ S t a a $t$ e $u$} & \multirow{3}{*}{ Jahr } & \multirow{3}{*}{$\begin{array}{c}\text { Flüchen- } \\
\text { Inhalt } \\
\text { in } \\
\text { Qu^drat- } \\
\text { Kilometer }\end{array}$} & \multirow{3}{*}{\begin{tabular}{|c|} 
Gesammi- \\
Bevölke- \\
rung \\
(letzte \\
Zïhlung o. \\
Berechng.) \\
\end{tabular}} & \multicolumn{2}{|c|}{$\begin{array}{l}\text { Strats-Telegrafen- } \\
\text { Netz }\end{array}$} & \multicolumn{2}{|c|}{ Anstalten } \\
\hline & & & & Linien & Drähte & Staats- & $\begin{array}{l}\text { Eisenb. - } \\
\text { u. Privat }\end{array}$ \\
\hline & & & & \multicolumn{2}{|c|}{ Kilometer } & \multicolumn{2}{|c|}{ Stationen } \\
\hline Grossbritannien u. Irland & 1875 & 314.950 & $31,845.379$ & $38.850^{\circ} 0$ & $176.352 \cdot 7$ & 3.741 & 1866 \\
\hline Dännemark . . . . & 1875 & 38.237 & $1,784.741$ & 2780 & 7.653 & 114 & 89 \\
\hline Norwegen . . . & 1875 & 316.694 & $1,795.000$ & 7175 & 12.405 & 110 & 62 \\
\hline Schwe ien . . . & 1875 & 444.846 & $4,383.291$ & $7959 \cdot 4$ & $19.377 \cdot 4$ & 170 & 351 \\
\hline Russland (Gesammt) & 1874 & $21,750.943$ & $86,722.000$ & 62.3511 & 120.522 & 715 & 900 \\
\hline Oesterreich-Ungarn . . . & 1875 & 624.045 & $35,904.435$ & $36.262 \cdot 4$ & $108.147 \cdot 6$ & 1.341 & 1758 \\
\hline Gebiet d. Reichsrathes & 1875 & 300.191 & $20,394.980$ & $21.926 \cdot 0$ & $59.977 \cdot 9$ & 979 & 1233 \\
\hline „ d. ung. Krone & 1875 & 323.854 & $15,509.455$ & $14.336 \cdot 4$ & $48.169 \cdot 7$ & 362 & 525 \\
\hline Sehweiz. . . . . & 1875 & 41.418 & $2,669.147$ & 6334 & $15.442 \cdot 6$ & 892 & 110 \\
\hline Deut- Reichs-Tlg.-Gebiet & 1875 & 449.536 & $35,850.817$ & $35.708 \cdot 4$ & $132.009 \cdot 7$ & 1.945 & 2393 \\
\hline sches Bayern .... & 1875 & 75.863 & $5,024.832$ & $7598 \cdot 5$ & $19.665 \cdot 9$ & 734 & 140 \\
\hline Reich| Württemberg . . & 1875 & 19.508 & $1,881.505$ & $2480 \cdot 6$ & $6.236 \cdot 8$ & 328 & 10 \\
\hline Niederlande ...... & 1875 & 32.875 & 3.767 .263 & $3440 \cdot 4$ & $12.332 \cdot 5$ & 159 & 171 \\
\hline Luxemburg . . . . & 1874 & 2.587 & 197.528 & 290 & 445 & 16 & 22 \\
\hline Belgien . . . . . & 1875 & 29.455 & $5,253.821$ & 4959 & 21.094 & 503 & 83 \\
\hline Frankreich & 1875 & 528.577 & $36,102.921$ & $51.615^{\circ} 0$ & $135.944 \cdot 5$ & 2.767 & 1499 \\
\hline Portugal . & 1874 & 92.753 & $4,367.882$ & 3317 & 7.450 & 126 & 10 \\
\hline Spanien . & 1873 & 507.036 & $16,798.925$ & 11.754 & 26.728 & 196 & 26 \\
\hline Italien $\cdot \cdots$ & 1875 & 296.305 & 26.801 .154 & 20.756 & 62.224 & 1.128 & 825 \\
\hline Griechenland & 1875 & 50.212 & $1,457.894$ & 2565 & 3.165 & 60 & \\
\hline Türkei . . . . & 1875 & 369.257 & $9,791.582$ & 25.232 & 48.650 & 397 & 47 \\
\hline Romanien . . . . . . . & 1875 & 121.154 & $4,800.000$ & $3820 \cdot 6$ & $6.842 \cdot 4$ & 83 & 84 \\
\hline Serbien . . . . . . . & 1874 & 43.555 & $1,338.505$ & $1.461 \cdot 3$ & $2.145 \cdot 5 \|$ & 37 & \\
\hline
\end{tabular}

Ditscheiner, Die Telegrafenapparate, officieller Ausstellungsbericht, Wien 1874. Ludwig, Der Reichstelegrafist, Dresden 1874. - Joh. Krall, Handbuch des Telegrafendienstes, Marburg 1875. - Kovačevic, Betriebsstörungen oberirdischer Telegrafenleitungen, Agram 1875. - Dr. K. E. Zetzsche, Die Entwicklung der automatischen Telegrafie, Berlin 1875. - Dr. K. E. Zetzsche, Handbuch der electrischen Telegrafie, Berlin 1876 (I. Band 1. und 2. Heft, II. Band 1. Heft). - Grawinkel, Die Telegrf.-Technik, Berlin 1876. - W eiden b c h, Compendium der electr. Telegrafio, Wiesbaden 1877.

Journale und ausländische Literatur: Zeitschrift des österr.-deutschen Telegrafenvereines (bezieh. Brix-Journal) 1854-1867. - The Telegraphic-Journal, London 1850. - Annal, telegraphiques, Paris 1855. - Journal telegraphique, public par le bureau international des administrations telegraphiques, Bern 1872. - Vail, The american Electrotelegraph, Philadelphia 1847. - Highton, The elect. Telegraph, London 1852. - L. Turnbal1, The electric Telegraph, 2. Aufl., Philadelphia 1853. Sehaffner, The telegraph manual, New-York 1859, - Pressatt, History of the telegraph, London 1859. - Robert Sabine, The history and progress of the elect. telegraph, London 1869. - Culley, handbook of practical telegraphy, 6. Aufl. 1874. Douglas, a manual of telegraph construction, London 1875. - W. H. Preece and T. Sivewright, Telegraphy, London 1876. - Moigno, Traité de tlgrph. electrique, Paris 1853. - Blavier, Cours de telegraph, Paris 1860. - Breguet, Manual de tlgrph. electr., 5. Aufl. 1861. - Glös ener, Traitè general des application de Electr., Paris u. Brüssel 1870. - Alfred Etenaud, Telegraphie electrique en France et en Algérie, Paris 1872. - Gavarret, Telegraphie electr., Paris 1872. - Blavier, Nouv. traité de telegraphie elect., Paris 1876. - D u Moncel, De tlgrph. electr., Paris, 3. Aufl. 1876. (Sithe: Haus-Telegrafen, Telegrafie.)

An hang. Electrische Eisenbahnsiguale (les signeaux electriques de chemins de fer - the electric railuay signal) sind jene mittelst Electricitiat betriebenen Vorrichtungen, welche dem Zwecke dienen, bei Eisenbahnen den Verkehr der Züge zu sichern, indem sie durch leicht verständliche, die Aufmerksamkeit lebhaft erregende, in die Sinne fallende Zeichen eine rasche und klare Verstïndigung der Bahnbediensteten gestatten.

Das vornehmste, weil fernwirkendste und ausgebildetste electrische Eisenbahnsignalmittel ist der electrische Sprechtelegraf (s. Electr. Telegrafie). Eine Reihe ron Apparatsystemen waren und sind diesfalls in Anwendung. Derzeit dominiren in England noch immer 
Europa's*) mit Anfang des Jahres 1876.

\begin{tabular}{|c|c|c|c|c|c|c|c|c|}
\hline \multirow{2}{*}{$\begin{array}{l}\text { Per- } \\
\text { sonale }\end{array}$} & \multirow{2}{*}{$\begin{array}{l}\text { Appa- } \\
\text { rate }\end{array}$} & \multicolumn{4}{|c|}{ Correspondenz-Verkehr } & \multirow{2}{*}{$\begin{array}{c}\text { Ein- } \\
\text { nahmen }\end{array}$} & \multicolumn{2}{|c|}{ Ausgaben } \\
\hline & & interne & $\begin{array}{c}\text { inter- } \\
\text { national }\end{array}$ & \begin{tabular}{|} 
Gebühren \\
freie Dienst-
\end{tabular} & Zusammen & & ordentliche & $\begin{array}{c}\text { ausser- } \\
\text { ordentliche }\end{array}$ \\
\hline \multicolumn{2}{|c|}{ Anzahl } & \multicolumn{4}{|c|}{ Depeschen } & \multicolumn{3}{|c|}{ Gulden österr. Währ. } \\
\hline 11.605 & 11.988 & $18,433.092$ & $2,331.486$ & 298.400 & $21,062.978$ & $12,766.620$ & $10,414.780$ & $91,635.250$ \\
\hline 299 & 233 & 385.282 & 501.635 & 25.393 & 912.310 & 328.412 & 328.031 & 66.412 \\
\hline 637 & 297 & 486.779 & 248.456 & 46.247 & 781.482 & 495.451 & 540.516 & 354.634 \\
\hline 714 & 475 & 743.060 & 359.285 & 285.372 & $1,387.717$ & 782.838 & 739.453 & 119.733 \\
\hline 6.159 & 1.754 & $2,900 \cdot 330$ & 669.276 & 207.935 & $3,777.541$ & $7,820.924$ & $6,393.394$ & 605.120 \\
\hline 4.689 & 2.956 & $4,473.445$ & $1,717.035$ & 613.069 & $6,803.549$ & $3,799.256$ & $5,065.790$ & 229.511 \\
\hline 3.354 & 1.653 & $2,762.311$ & $1,398.429$ & 387.090 & $4,547.830$ & $2,755.090$ & $3,571.306$ & 229.511 \\
\hline 1.335 & 1.303 & $1,711.134$ & 318.606 & 225.979 & $2,255.719$ & $1,044.166$ & $1,494.484$ & . . . . \\
\hline 1.557 & 1.349 & $1,846.898$ & 834.486 & 68.079 & $2,749.463$ & 823.284 & 728.932 & 90.137 \\
\hline 4.610 & 4.477 & $7,114.095$ & $3,566.118$ & 515.414 & $11,195.627$ & $5,129.265$ & $6,749.214$ & $1,230.057$ \\
\hline 362 & $1 . \pm 14$ & 792.121 & 967.845 & 31.807 & $1,791.773$ & 525.746 & 504.960 & . . . \\
\hline 154 & 538 & 312.706 & 472.259 & 123.660 & 908.625 & 220.500 & 229.350 & 75.138 \\
\hline 1.082 & 379 & $1,601.711$ & 755.444 & 17.771 & $2,374.926$ & 632.486 & 957.651 & 66.525 \\
\hline 34 & 26 & 19.512 & 41.498 & 1.799 & 62.809 & 14.194 & 18.887 & 11.839 \\
\hline 1.769 & 1.088 & $1,929.945$ & 941.945 & $1,245.547$ & $4,117.437$ & 839.245 & 964.700 & 32.071 \\
\hline 5.410 & 5.069 & $6,988.832$ & $2,633.031$ & $1,360.000$ & $10,981.863$ & $6,402.855$ & $5,445.000$ & 428.000 \\
\hline 687 & 244 & 244.031 & 167.107 & 70.010 & 481.148 & 184.593 & 337.189 & 46.269 \\
\hline 1.826 & 385 & 1.124 .239 & 108.165 & 51.503 & $1,283.907$ & $1,037.813$ & $1,567.430$ & . . . . \\
\hline $\begin{array}{r}4.302 \\
\end{array}$ & 3.200 & $4,460.924$ & 904.978 & 205.944 & $5,571.846$ & $2,868.610$ & $2,330.364$ & 256.000 \\
\hline 333 & 120 & 191.523 & 52.391 & 5759 & 249.673 & 145.027 & 171.997 & 15.890 \\
\hline 2.894 & 1.240 & 491.898 & 230.338 & 448.520 & $1,210.756$ & $2,440.279$ & $1,960.264$ & 19.434 \\
\hline 988 & 212 & 615.812 & 196.212 & 165.245 & 977.269 & 292.453 & $1,276.229$ & 30.461 \\
\hline 255 & 52 & 95.002 & 56.800 & 13.374 & 165.256 & 59.617 & 134.595 & 11.136 \\
\hline
\end{tabular}

die Nadeltelegrafen, am europäischen Continent und in Amerika ist jedoch fast durchwegs der Morse'sche Schreibtel egraf im Gebrauche. Nur die französischen, belgischen und einige wenige deutsche Bahnen haben auch noch Z eigertelegrafen der Systeme Breguet Digney, Kramer, Fardely, Siemens und Halske etc. in Anwendung.

Von besonderem Werthe für die Eisenbahnzwecke sind die portativen Telegrafen, welche von den Zïgen mitgeführt werden. Es ist dies eine compendiös angeordnete Apparatgarnitur derselben Schaltung wie die betreffende Sprechlinie. Im Falle der Zug auf der Strecke anhalten muss und die Nothwendigkeit eintritt, sich mit der nächsten Station zu verständigen, bringt der Zugführer den ambulanten Apparat in die nächste Bahnwärterbude, wo er die nöthigen Anschlussklemmen vorfindet. Durch die entsprechende Verbindung dieser Klemmen mit seinem Apparat schaltet er letzteren in die Sprechlinie ein und kann nun seine Correspondenzen absetzen, eventuell auch solche empfangen. Statt einer completen Apparatgarnitur wird auch häıfig nur ein Automattaster angewendet. Dieser Taster enthält eine Reihe von Depeschen, die sich von selber abspielen, wenn ein bestimmter Knopf niedergedrückt, oder ein Zeiger eingestellt, endlich nebstbei eine Kurbel gedreht oder eine Schnur angezogen wird. Bei Beniitzung solcher Apparate braucht also der Zugführer nicht erst telegrafiren zu können, kann aber auch keine Antwort empfangen.

Die electrischen Läutewerke (cloche télégraphique - electric-signal-bell) dienen dazu, von einer Station aus auf einen gewissen Punkt der Strecke oder an alle Bahnwärter bis zur näphsten Station und vice versa Signale zu ertheilen. Es sind Glockenschlagwerke, die durch Vermittlung von Electromagneten zum Auslösen gebracht werden, wohl auch nur einfache Klingel auf einzelne Schläge, ein Electromagnet, dessen Anker gleich den Klöppel trägt, Klingel mit Selbstunterbrechung oder Selbstausschaltung, Klingel mit Relais, endlich kleine und grosse Glocken mit Uhrwerken. Bei letzterer Gattung lassen sich noch solche unterscheiden, bei welchen das Uhrwerk durch die Ankerbewegung blos ansgelöst wird, die Riick-tellung aber durch eine Person bewerkstelligt werden muss; die also so lange läuten, als dies letztere nicht geschieht und die Kraft des Uhrwerkes ausreicht; ferner solche, bei

*) Nachrichten über Industrie, Handel u. Verkehr des österr. k. k. Handelsministeriums. 
welchen nach der einmaligen Auslösung eine Anzahl von Schlägen abgegeben werden, nach welchem wieder eine Selbsteinlösung, die Arretirung des Uhrwerkes eintritt, und endlich solche, bei welchen die Einlösung (Selbstarretirung) nach jedem Glockenschlage erfolgt.

Die ersterwähnten Läutewerke finden eine wichtige Anwendung als Controlapparate für Distanzsignale aller Art, Drehbrücken- und Tunnelsignale, zur Controle der Stellung von Zugsschranken, Weichen etc. Sie werden an jenen Punkten angebracht, wo man über die richtige Stellung einer der vorgedachten S:gnalmittel oder Bahnrichtungen Gewissheit braucht, ohne dies der Entfernung wegen durch den Augenschein erreichen zu können. An den zu controlirenden Signalapparaten sind Contactvorrichtungen angebracht', welche entweder bei der "Sicherheits-Stellung" oder bei der "Gefahr"-Stellung den Stromkreis, in welchem die bezïgliche Klingel eingeschaltet ist, schliessen, im entgegengesetzten Fall unterbrechen. Das Läuten oder Schweigen des Controlklingelwerkes wird sonach die eine oder andere Stellung signalisiren. Zum Abgeben durchlaufender Streckensignale werden nur Läutewerke mit Schlaguhrwerk und Selbsteinlösung benützt. Nachdem nur ein Grundzeichen, der einfache Glockenschlag vorhanden ist, so ist die Zahl der ermöglichten Signalbegriffe eine ziemlich beschränkte, und steht dieselbe im umgekehrten Verhältniss zur Deutlichkeit, beziehungsweise Sicherheit der Signale.

In Deutschland werden mit den Läutewerken nur 4 Signale gegeben: Ein Zug geht $a b$ in diese oder entgegengesetzte Richtung - eine Gruppe, resp. zwei Gruppen von 5 oder 6 Glocken chlägen, „Feierabend“, drei solche Gruppen und „Alarm" mehrere wiederholte solche Gruppen.

In Oesterreich-Ungarn hingegen werden 9 bis 16 Signalbegriffe zum Ausdrucke gebracht.

Die in Deutschland angewendeten Apparate lösen sich immer erst nach einer Gruppe von 5 oder 6 Schlägen wieder ein, können mit Arbeitsstrom, z. B. mit Siemens'schen Magnetinductoren betrieben werden und bieten schon deshalb und der geringen Anzahl der Signalbegrifie wegen ein äusserst werthvolles, weil sicheres Signalmittel.

In Oesterreich-Ungarn ist durch die Anzahl der Signale und die verschiedene Gruppirung der Glockenschläge, sowie durch den Umstand, dass eine Reihe der Glockensignale vom Bahnwärter aus gegeben werden muss, die Schaltung auf Ruhestrom sozusagen bedingt, wenn auch (wie z. B. bei der Graz-Köflacher Bahn) die Anwendung des Inductors nicht absolut ausgeschlossen ist.

Von den in Benützung stehenden Läutewerkssystemen wären anzuführen: Kramer, *) Siemens-Halske $\left.{ }^{* *}\right)$ in mehrfachen Varianten, Scholz, Leopolder, ${ }^{* * *}$ ) Holub, Wenseh u. s. w.

Auf einigen schleswig'schen und holsteinischen Bahnen sind electrische Klingeln auch in Verbindung mit electrisch-optischen Signalen als durchlaufende Streckensignale in Anwendung. Bei jedem Streckenwächterhause befindet sich eine eigene Signalbude, in der der Apparat aufgestellt ist. Diese bei Nacht immer durch eine Lampe beleuchtete Signalbude hat an zwei entgegengesetzten Wänden viereckige Fenster ausgeschnitten, die verglast sind; die Glasscheiben haben rückwärts einen weissen Oelanstrich, so dass sie wie Milchglas erscheinen. In der Mitte jeder Scheibe befindet sich eine Oefthung für eine Achse, die vom Apparat heraus. reicht und auf welchen ein schwarz angestrichener Zeiger aus Blech anfgesteckt ist.

Durch die Erregung des Electromagneten im Apparate kann das Uhrwerk desselben ausgelöst und der Zeiger von der Station aus, wo ein Inductor als Stromerzeuger angewendet wird, von rechts nach links gedreht werden, u. zw. bei jedem Stromimpulse um $90^{\circ}$. Die vier möglichen Stellungen des Zeigers geben eben so viele Signale und erläutern erstens das mit der Klingel gekommene allgemeine Achtungssignal, und bedeuten den Bahnwärter noch nachträglich, dass ein und wofïr ein Signal gegeben wurde, wenn er auch das Läutewerk überhört haben sollte.

Solche electrische Zugsanzeiger sind übrigens auch ohne Verbindung mit electrischen Klingeln oder Läutewerken in Anwendung.

Ein wichtiges Glied in der Reihe der electrischen Eisenbahnsignale bilden die $\mathbf{D}$ is tan $\mathbf{z}$ signale (le signal protecteur). Wenn es gilt, einen bestimmten Punkt der Balın aus er-

*) Schellen, Electromagnetischer Telegraf, 4. Aufl. prag. 650; D ub, Die Anwendung des Electr. Magnetismus pag. 654 .

**) Schellen, Electromagnet. Telegraf, 4. Auf. pag. 654; D u b, pag. 655.

***) Oesterr. Bericht über die Weltausstellung zu Paris 1867, Heft V pag. 127. 
heblicher Ferne zu decken, stehen drehbare Scheiben oder Maste mit beweglichen Armen in Anwendung. Eine mit ihrer Fläiche zum Geleise parallel stehende Scheibe oder der $45^{0}$ schräg aufwärts stehende Arm des Mastsignales bedentet „frei“, die Fläche der Scheibe senkrecht auf die Richtung des Bahngeleises oder der wagrechte Arm des Semaphors bedeutet "halt".

Diese zwei Signale A und B sollen von dem zu deckenden Punkte aus gegeben werden umi wird hiezu die Electricitait mit Vortheil als Motor in Verwendung gebracht. Der Apparat ist wieder ein Laufwerk mit Uhrwerk oder Echappement uıd Selbsteinlösung, das durch den Anker eines tenıporären Electromagnetes ausgelöst und wieder arretirt wird. Jede Auslösung, die je nach der Schaltung durch Stromgeben oder Stromunterbrechen bewerkstelligt wird, ändert die Stellung des Signales von $A$ auf $B$, beziehungsweise umgekehrt von $B$ auf $A$.

Bei den electrischen Distanzsignalscheiben, welche für die Stations-Deckung benützt werden, lassen sich zwei wesentlich von einander abweichende Systeme unterscheiden.

Wenn die Scheibe bei Nacht blos zweierlei Licht, nämlich nur weiss oder roth zu zeigen hat, genügt eine stetige Bewegung um $90^{\circ}$ im gleichen Turnus; soll aber die Scheibe mehrfaches, nämlich rothes, weisses und grünes Licht zeigen, wie dies z. B. in Oesterreich-Ungarn vorgeschrieben ist, so wird eine Steuerung nothwendig, da sich die Scheibe alternirend bewegen muss, oder es wird bei Drehung nach einer Richtung abwechselnd eine Wendung um 90, dann wieder um $270^{\circ}$ nothwendig sein.

Unter den in Anwendung stehenden Systemen wären anzuführen: Hipp, ${ }^{1}$ ) Le opolder, ${ }^{2}$ ) Hohenegger, ${ }^{3}$ ) Langie, ${ }^{4}$ ) Kričik, ${ }^{5}$ ) Kleeblatt, Schönbach, Weyrich, Schäffler, ${ }^{6}$ ) Rikli, ${ }^{7}$ ) Teirich, Rommel u. s. w.

Electrische Distanzsignale sind fast stets in der bereits obengedachten Weise mit Controlläutewerken in Verbindung gebracht; ausserdem sind in die Controlläutewerkslinie auch noch häufig electrisch-optische Control-Apparate eingeschaltet. Ein solcher Apparat besteht aus einer Magnetnadel mit einer entsprechend reichlichen Drahtmultiplication, die in einem Gehäuse untergebracht ist. Das Gehäuse hat eine verglaste Oeffnung, hinter der jedesmal ein rothes, an der Magnetnadel befestigtes Seheibchen in Vorschein kommt, sobald das Distanzsignal die Contactstellung eingenommen hat, also in der Controlleitung Strom vorhanden und die Nadel abgelenkt ist. Für electrische Deckungssignale, welche, wie z: B. bei Bahnkreuzungen, in der Weise von einander in Abhängigkeit stehen sollen, dass eines nie auf "frei" gestellt werden kann, wenn nicht alle übrigen auf „halt" zeigen, sind die Bifurcations-Vorrichtungen von höchster Wichtigkeit. Es sind dies bei Ruhestromsystemen eigens angeordnete Taster oder Schlüssel, welche vermöge ihrer Schaltung nur solche Schlüsselbewegungen zulassen, durch welche immer blos eine einzige Signallinie für die Freistellung unterbrochen werden kann, während die Linie einer etwa früher frei gestandenen Scheibe gleichzeitig mit unterbrochen und dadurch das Signal anf „halt" umgestellt wird. Es ist nur noch eine zweite Schlüsselbewegung möglich, nämlich jene, durch welche alle Signalscheiben auf „halt" gestellt werden.

Bei Arbeitsstromschaltung muss für die Bifurcation zu jedem Signale eine zweite Leitung vorhanden sein. Die Bifurcationsvorrichtung ist in diesem Falle nach Art eines Relais oder Translators angeordnet.

Eine weitere Unterabtheilung der Distanzsignale sind die T'unnelsignale, welche den Zweck haben, die gleichzeitige Einfahrt zweier Züge in einen Tunnel zu verhüten. Die electrischen Tunnelsignale sind entweder auf Wecker, Glockensignale oder Distanzsche be eingerichtet, welche eventuell durch den an der einen oder anderen Tunnelmündung postirten Bahnwärter in Thätigkeit gebracht werden oder auch selbst thätig wirken.

Apparate letzterer Gattung hat z. B die französiscbe Nordbahn ${ }^{\text {s }}$ ) in Anwendung.

1) Technische Mittheilungen, Orell Füssli \& Comp., Zürich 1877.

$\left.{ }^{2}\right)$ Oesterr. Bericht über die Weltausstellung zu Paris 1867, Heft V pag. 119.

3) Zeitschrift des österr. Ingenieur- u. Architekten-Vereins, Bd. XXII pag. 103; Organ f. d. Fortschritt d. Eisenbahnwesens, Bd. VIII pag. 176.

4) Technische Blätter, Jahrg. 1873 pag. 228.

5) Dingler's polyt. Journal 1876, Bd. 222 pag. 59.

6) Organ f. Eisenbahnwesen 1875 Heft VI; Die Eisenbahn-Stations-Deckungssignale von Schäffler, Selbstverlag, Wien 1876.

7) Zeitschrift des österr. Ingenieur- u. Architekten-Vereins, Jahrg. XXIV pag. 307.

$\left.{ }^{8}\right)$ Oesterr. Bericht über die Weltausstellung in Paris 1867, Heft V pag. 121. 
Sobald der Zug in den Tunnel einfährt, wird durch ein am inneren Rand der Schiene angebrachtes Pedal, aufwelches das Rad der Zugsmaschine beim Vorüberfahren drückt, der Stromkreis geschlossen, welcher ein Glockenschlagwerk am Tunneleingang, sowie ein zweites bei der zweiten Tunnelmündung in Thätigkeit versetzt. So lange das Läuten der gedachten Glockenapparate anhält, ist jedem Zuge die Einfahrt in den Tunnel verboten. Dieses Läuten hält aber so lange an, als ein Zug im Tunnel ist, und hört erst dann auf, wenn durch das vorderste Rad der Maschine ein zweites Pedal niedergedrückt und der Strom wieder unterbrochen wurde. Die dabei angewendeten Pedalschlüssel sind Blasbalg-Contactunterbrecher (comutateur à soufflet).

In ähnlicher Weise kommen für die Deckung: besonders wichtiger Bahnpunkte oder für die Zugsdeckung auch selbstthätige Scheibensignale in Anwendung, sowohl für die Deckung auf Zeit als auf Raumintervalle.

Die ersteren sind in der Weise eingerichtet, dass der vorïberfahrende Zug den Strom schliesst oder unterbricht und dadurch die Armatur des Electromagneten der Scheibe auslöst, in Folge dessen sich letztere auf, halt" stellt. Eine in den Stromkreis geschaltete Uhr schliesst oder unterbricht nach dem gegebenen Zeitintervall (5, 10 odex $\mathrm{x}$ Minuten) den Stromkreis neuerlich, worauf der Electromagnet wieder ausgelöst und die Scheibe auf "frei" zurückgestellt wird.

Selbstthätige Deckungssignale auf Raumintervalle werden in gleicher Weise auf "halt" gestellt, während die Freistellung auch wieder durch den Zug selber erfolgt, indem das Maschinenrad desselben an einer entsprechend weit entfernten Gleisstelle wieder einen zweiten Pedalcontact niederdrückt, wodurch die zweite Auslösung des Electromagneten der Scheibe, also deren Rückstellung auf „frei" erfolgt.

Ein in der Schweiz mehrfach in Verwendung stehendes solches Signalmittel ist das von $\mathrm{Dr}$. $\mathrm{Hipp}^{1}$ ) construirte, welches aus einem auf einer Säule ruhenden quadratförmigen Eisenrahmen besteht, in welchem sich zwischen zwei Glasspiegeln jalousienförmige Blechstreifen öffnen oder schliessen und dadurch die Signale geben. Die Bewegung der Jalousien geschieht durch ein Uhrwerk mit Selbsteinlösung, das durch den electrischen Strom, beziehungsweise den Electromagneten ausgelöst wird.

Anzufïhren sind ferner die selbstthätig wirkenden electrischen Deckungssignal-Systeme: Lenoir, Brequet, Guillaume (französische Ostbahn), Verité (französische Nordbahn), Fragneau, de Foresta ${ }^{2}$ ) etc.

Wenn Deckungssignale an der ganzen Bahnstrecke in bestimnten Distanzen von einander aufgestellt und so von einander in Abhängigkeit gesetzt sind, dass sie immer nur erst dann dem Zuge die Einfahrt in die betreffende Theilstrecke gestatten können, wenn kein zweiter Zug sich mehr in derselben befindet, so heisst diese Anordnung ein Blocksignalsystem.

Die ersten solcher Signale hat $1843 \mathrm{Cooks}^{3}$ ) angegeben und bei der Eastern-CoutiesLondon-Chatham- und Dover-Bahn zur Amwendung gebracht. Er benütıte für seine Systeme einen einfachen Nadeltelegrafen. Die nach rechts ausschlagende Nadel bedeutete "Strecke besetzt", die nach links ausschlagende "Strecke frei".

Regnault ${ }^{4}$ ) führte 1847 auf der französischen Westbahn Blocksignal-Apparate ein, die im Wesentlichen nach den Principien des Wheatstone'schen Nadeltelegrafen construirt waren. Cook's System wurde durch Clark ${ }^{5}$ ) wesentlich verbessert und auf der Londonand North-Western-Bahn eingeführt, wo es durch 15 Jahre in Anwendung blieb.

Weitere solche Systeme sind von Walker ${ }^{6}$ ) (alt und neucres), von Tyer ile Dalton, ${ }^{7}$ )

1) Oesterr. Bericht über die Weltausstellung in Paris 1867, Heft V pag. 120; Dr. Sch mitt Signalwesen pag. 353.

$\left.{ }^{2}\right)$ Organ f. d. Fortschritt d. Eisenbahnwesens, Bd. V pag. 173

3) Dr. Schmitt, Signalwesen pag. 317.

4) D u M oncel, App. de L'Elct. II pag. 155; Gavarret, Télég. elect. pag. 221; Glä s en er, App. de L'Elet. I pag. 291; Dub, Electromagnetismus pag. 662.

5) Dr. Schmitt, Signalwesen pag. 319.

6) Kosmos, 1857 pag. 420; Brix's Journal IX pag. 5; D ub, Electr. Mgnts, 661.

7) Dingler's polyt. Journ. Bd. 217 pag. 468; Dr. Sehmitt, Signalwesen pag. 322. 
Bartolomew, ${ }^{1}$ ) Highton und Spagnoletti, ${ }^{2}$ ). Margfoy, ${ }^{3}$ ) Preece, ${ }^{1}$ ) SiemensHalske, $\left.{ }^{5}\right)$ Wiesenthal, Křičiku. s. w.

Am verbreitetsten darunter ist das Preece'sche System. Jede Preece'sche Blockstation enthält:

a) einen kleinen electrisehen Semaphor, der nur von der Nachbarstation gestellt und dessen Stellung in der Station selbst nicht geändert werden kaun;

b) eine Tastervorrichtung zum Stellen des Nachbarsemaphors;

c) einen optischen Controlapparat, der die gleiche Stellung zeigt wie der Nachbarsemaphor;

d) ein Läutewerk, das von der Nachbarstation in Thätigkeit versetzt werden kann, endlich

e) einen Taster, welcher dazu dient, das Läutewerk der Nachbarstation thätig zu machen.

Zum Betriebe dieser Apparate sind drei Leitungen vorhanden, zwei dienen zur Verbindung des Semaphore und dazu gehörigen Tastervorrichtungen, und in der dritten sind die Controlapparate, sowie die Läutewerke und dazu gehörigen Taster eingeschaltet. Die Handhabung des Signales ist folgende:

Passirt ein Zug die Signalstelle A, so drückt der Signalist den Taster $e$, wodurch das Läutewerk der Nachbarstation in Thätigkeit gebracht wird, was als Aufforderung gilt, den Semaphor $A$ auf "Gesperrt" zu bringen. In der Station $B$ wird dies mittelst des Tasters $(b)$ bewerkstelligt und gleichzeitig markirt daselbst der Controlapparat (c) die erfolgte „Halt"-Stellung. Der Zug bleibt nun solange durch das Haltsignal an der Signalstelle bei $A$ gedeckt, als der Signalist bei $B$ die Rückstellung des Semaphors nicht wieder vornimmt, was eben erst dann geschehen darf, bis der Zug die Signalstelle $B$ passirt hat. Die im Inneren der Stationskanzleien oder Wächterhänser erfolgenden electrischen Signale werden aussen auf den Stationsplätzen oder vor den Wächterhäusern mittelst optischen Telegrafen, welche dem Zugs- oder Maschinenpersonale auffällig sichtbar und deutlich erkennbar sind, wiederholt.

Im Falle von Linienstörungen stellen sich die electrischen Semaphore von selbst auf "Halt". Auf der London- und South-Western-Bahn hat das Preece'sche System in einer noch verbesserten Form Anwendung erfahren. Es ist da, um mögliche Irrungen fern zu halten, das Zurückstellen des Semaphors dem Signalisten nicht frei gegeben, sondern kann erst danu das einmal ertheilte Signal "Bahn blockirt" aufgehoben werden, wenn der Zug die Partialstrecke thatsächlich passirt und dabei durch den Druck der Räder eine mechanisch-electrische Sperrvorrichtung ausgelöst hat.

Die in Deutschland angewendeten Blocksignaleinrichtungen sind meist nach dem Systeme Siemens-Halske durehgefuilrt. An jeder Signalstelle befindet sich ein gussęisernes Kästchen, in welchem der ganze electrische Apparat untergebracht ist, weiters ein gewöhnliches Armsignal (Semaphor) mit zwei Flïgeln (für jede Richtung der Fahrt einen), welche letztere mittelst Ketten, die mit den Constructionstheilen des electrischen Apparates gekuppelt sind, dirigirt werden. Am Apparatkasten sind oben an der vorderen Wand zwei kreisrunde verglaste Oeffnungen, hinter welchen sich conform der Signalstellung eine weisse (Bahn frei) oder rothe (Bahn gesperrt) Scheibe zeigt Jede der Scheiben gilt für eine andere Fahrrichtung, was am Apparate durch Pfeile besonders angedeutet ist.

Am Deckel des Apparatkastens befindet sich über jeder der bezeichneten Scheibenöffnungen ein Tasterknopf, im Kasten selbst ein Magnetinductor, zu dem von Aussen eine Kurbel angesteckt ist. Unter der Inductorkurbel sind noch zwei weitere Kurbeln im Kasten vorhanden eine rechts, die andere links, auf welchen die zu den Semaphorflïgeln führenden Zugsketten befestigt sind. Dicse Kurbeln dienen zum Stellen der Semaphorarme und stehen mit dem Apparate derart in mechanischer Abhängigkeit, dass die Armstellung "Strecke frei" nicht gegeben werden kann, wenn nicht friiher von der Nachbarsignalstelle deblockirt (Sperrvorrichtıng durch den Strom gelöst) wurde, ndu dass umgeisehrt der Signalist die Nachbarstation auch nicht friiher zu deblockiren vermag, ehe er nicht seinen Semaphor auf "Strecke gesperrt" gestellt hat.

1) Dr. Schmitt, Signalwesen pag. 324 .

2) Engineering, 20. Jänner 1871.

3) Dr. Schmitt, Signalwesen pag. 326.

4) Oesterr. Bericht ïber die Weltausstellung zu Paris 1867, Hett V pag. 128; Seh mitt, Signalwesen pag. 328.

5) I $u$ b, Electromagnt. pag. 681; Schmitt, Signalwesen pag. 330; Ding ler's polçt. Journal, Bd. 213 pag. 89. 
Wären die Blockstationen $A, B, C, D$ vorhanden, und sei ein Zug von $A$ ab, so drückt der Beamte den entsprechenden Knopf nieder und dreht die Kurbel des Inductors, wodurch die bisher auf "weiss" gestandene Scheibe anf "roth" gestellt wird. Hiedurch ist die Strecke ron $A$ his $B$ fiir einen nachfolgenden Zug gesperrt, da $A$ so lange keinen Zng folgen lassen darf, bis nicht von $B$ ans die Scheibe auf "weiss" zurïckgestellt wurde. Dies geschieht vom Signalisten bei $\boldsymbol{B}$, sobald der Zug seinen Posten passirt, indem vorerst der betreffende Semaphorarm mittelst der Kettenkurbel horizontal (auf gesperrt) gestellt, sodann der betreffende Knopf am Apparatkasten niedergedriickt wird. In Folge dessen stellt sich nun die Scheibe in $A$, sowie die nach $A$ gerichtete Scheibe in $B$ auf "weiss", während sich die in $B$ befindliche, gegen $C$ gerichtete und die in C' befindliche, gegen $B$ gerichtete Scheibe auf "roth“ stellt. In $B$ ist der Semaphor nun so lange in der Haltstellung arretirt, als die Scheibe von $C$ her nicht auf "weiss" gestellt ist; erst dann kann der Bahnwärter den Arm auf die Freistellung zurückbringen.

Dieses System wurde von Frischen noch in der Weise rervollkommnet, dass durch Anbringung von zwei Weckern und zwei Contactvorrichtungen auf jeder Blockstation besondere Glockensignale zwischen denselben gewechselt werden können.

Fiir alle diese $Z$ wecke reicht ein Draht aus, nur in den letzten Streckensegmenten vor jedem Bahnhofe werden zwei Leitungen nothwendig. Eine Reihe von electrischen Vorrichtungen sind construirt und theilweise anch angewendet, welche den Zweck haben, die Fahrt eines Zuges zu controlliren. Den ersten Vorschlag für solche automatische Controllapparate machte Wouss 1845 und 1847 stellte Bréquet ${ }^{1}$ ) einen solchen her. Er brachte von 20 zu 20 Meter am Bahngeleise Pedalcontacte an, welche von den Rädern des vorbeifabrenden Zuges ge. schlossen wurden. Die eine Lamelle dieser Contacte war zur Erde, die zweite zur Linie verbunden, welche in der Controlstation durch einen Chronographen zur Batterie und dann zur Erde geleitet wird. Bei jedem Niederdruicken eines Pedalcontactes wird der Strom geschlossen und dieser Stromschluss am Chronographen maikirt.

Diese Vorrichtung wurde durch Ma iyrot ${ }^{2}$ ) dahin abgeändert, dass in der Coutrolstation bei einer Zählscheibe zwei verschieden gefärbte Nadeln angebracht sind, die sich in entgegengesetzter Richtung drehen, und wovon eine den Gang der sich nähernden, die andere der sich entfernenden Züge registriren. A hnlich eingerichtet ist der electrisch-automatische Zugsanzeiger von Bellemare. ${ }^{3}$ ) Steiulieil') liatte auf der Bahnstrecke München-Nanhofen ein ähnliches Signalsystem eingeführt, welches ausser der Controle der Fahrt des Zuges auch die Controle der Wächter verband, da diese die Unterbrechung der Controllinie nach Passirung des Zuges selbst bewerkstelligen mussten und sich jede solche Unterbrechung am Papierstreifen des in der Station aufgestellten Chronographen markirt. Auch Hipp ${ }^{5}$ ) hat mit seinem fruher erwälınten Ja'ousie-Sigmal einen electrisch-autonatischen Zugsanzeiger verluuden und auf einigen Strecken der schweizerischen Nordostbahn in Anwendung; ausserdem hat Hipp ${ }^{6}$ ) auch einen, dem Bréquetschen ähnlichen Zugsanzeiger, der nur die Besonderheit besitzt, dass auch jede Achse des Zures an den von 1000 zu 1000 Metern aufgestellten Tastervorrichtungen eine Stromunterbrechung erzeugt, wodurch am Chronograph nicht nur ersichtlich gemacht wird, an welcher Stelle sich der Zug befindet und mit welcher Schnelligkeit er verkehrt, sondern auch mit wie viel Achsen er führt, anf der Bahulinie Basel-Olten eingerichtet.

Die gleichfalls zahlreichen Versuche, Anordnungen zu treffen, wodurch der falrende Zug direct mit den zwei nächsten Stationen in telegrafische Verbindung gebracht wird, z. B. von Tyer de Dalton, ${ }^{7}$ ) Bonelli, Du Moncel, ${ }^{5}$ ) Manuel Fernandez de Castro, ${ }^{9}$ )

1) Du Moncel, Appl. de l'Ect. II pag. 181; Dub, Anwendung des Elect.-Mgnts. pag. 686.

2) D n b, Anwdg. des Electromagnetismus pag. 686

3) Glös ener, Appl. de l'Ectr. I pag. 303; D ub, Anwdg. d. Electromagnetismus pag, 687.

1) $\mathrm{Dub}$, Anwendung d. Electromagnetismus pag. 666.

5) Polyt Cont. Blatt 33 pag. 608; D a b, Anwendung des Electr. Magnet. pag. 699.

6) Schweizerische polytechnische Zeitschrift 1870 ; Zeitschrift des österr. Ingenieur- und Architekten-Vereins Jhrg. XXIII pag. 167.

5) Du Moncel, App. de l'Ect 2. Auf. II pag. 164; Glösener, App. de l'Ect. I pag. 306; $\mathrm{Dub}$, Anwendang des Electr.-Magnetismus pag. 688.

8) Du Moncel, App. d'Elct. 2. Aufl II pag. 185.

") Du Monce1, App. d'Elct. 2. Anf II pag. 198; Glösener, App. d'Elet. I pag. 320; Dub, Anwendung de l'Elect. pag. 693. 
ฯ. Ronneburg ${ }^{1}$ ) etc. haben zu keinem cigentlich praktischen Erfolg geführt. Werthvoller sind die Telegrafen am Zuge selbst, zum Zwecke der Verständigung der Zugsbeamten unter einander und des Publikums mit dem Zugsheamten, und wird besonders drn letzteren, den sogenannten Intercommunicationsignal'n neuerer Zeit eine erhöhte Aufinerksamkeit zngewendet. Bei solchen Einrichtungen wird der IIauptsache uach eine isolirte Dralıtlesitung nothwendig sein, welche vom Signalwagen aus über den ganzen Zug läuft, ferner in jerlem coupé ein Taster und im Signalwagen endlich, wo sich der Zugsführer auf hält, ein Alarmapparat und eine Batterie. Wird die Tastervorrichtung in einem Coupé in Anwendung gebracht, muss der Alarmapparat thätig werden.

Es wären als hieher gehörig anzuführen die Systeme von Brequet, ${ }^{2}$ ) Herman $n^{3}$ ) Gluekmann, Mirand, ') Prudhomme, ${ }^{5}$ ) David Lloyd Price, Preece, Tyer, Basin, Spagnoletti, Binney u. s. w.

In Verbindung mit Distanzsignalen findet in England eine electrisch-automatische Dampfpfeife Anwendung. Der Hahn einer Dampfpfeife ${ }^{6}$ ) auf einer Locomotive ist in Verbindung mit einem Electromagneten, der in einem Stromkreise eingeschaltet ist. Die Leitung ist $\mathrm{zu}$ einer unten an der Locomotive angebrachten Feder contact gefuihrt. So lange dieser Contact geschlossen, eventuell offen (je nachdem auf Ruhe oder Arbeitsstrom geschaltet ist), bleibt auch der Electromagnet in Ruhe, sobald aber die normale Lage der Contactvorrichtung geändert wird, erfolgt das Abreissen des Electromagnetankers, wodurch gleichzeitig auch der Hahn der Dampfpfeife geöffnet wird. Diese ertönt und zwar so lange, bis der Maschinenführer die Rïckstellung des Hahnes mit der Hand bewerkstelligt.

Das Oeffnen oder Schliessen der Contactvorrichtung wird durch daumenartige Pflöcke bewirkt, welche an richtiger Stelle in der Bahn festgemacht sind. Beim Darüberfahren des Zuges streift der Federcontact an den Daumen. Diese Daumen sind entweder stabil und dann hat das Pfeifen-Signal den Zweck, den Maschinenführer zu erinnern, dass er sich einer Stelle naht, wo die Signale besonders zu beachten sind, oder auch werden die Daumen erst durch die Haltstellung eines Deckungssignales auf mechanischem Wege in jene Lage gebracht, wo sie die darüber weggehende Controlvorrichtung erfassen und in diesem Falle gilt das Ertönen der Pfeife nicht nur als Avertirungs-, sondern selbst schon als Haltsignal.

So bedeutend der Fortschritt in der Anwendung der Electricität für den Betrieb von Bahnsignalen genannt werden muss, so darf doch nicht verkannt werden, dass diese für den leutigen Bahnverkehr ganz unentbehrlich gewordenen Signalmitteln in Bezug auf die wichtigste und nothwendigste Eigenschaft eines Eisenbahnsignales „die Sicherheit" Manches zu wünschen übrig lassen. Electrische Apparate können dem Einflusse atmosphärischer und tellurischer Einwirkungen nie ganz entzogen werden, ferner sind solche Apparate zart und subtil construirt und können sonach leicht schadhaft oder selbst auch durch Rost, Frost u. s. w. unbrauchbar gemacht werden. Endlich erfordern sie bei eingetretenen Fehlern die Hilfe eines Sachverständigen. Durch möglichst solide, separirte Leitungen, eventuell von ganz isolirten Drähten, durch die thunlichste Eliminirung feuchter Batterien und durch die möglichste einfache und kräftige Construction der Apparate dürfte aber auch in Bezug auf die Funktions-Sicherheit der electrischen Signalmittel noch höchst Erhebliches und Werthvolles zu erreichen sein.

Literatur: M. M. Frh, v. Weber, Das Telegrafen- u, Signalwesen der Eisenbahnen, Weimar 1867, - Heusinger u. Waldegg, Handbch. f. specll. Eisenbahntechnik, IV. Theil, Wiesbaden 1873. - Weber's Schule d. Eisenbahnwesens, 3. Aufl., Leipzig 1873. - Wink ler, Vorträge üluer Eisenbahnbau IX, Signalwesen von Dr. Ed. Schmitt, $1-4 H_{t} \mathrm{ft} 1874$.

L. Kohlfiirst.

Electrisirmaschinen (machine électrique - electrical machine), s. im Artikel Electricität die Absätze XXVI und XXVII.

I) Dingler's polyt. Journal Bd. 217 pag. 109.

2) Du Moncel, App. d'Elct 2. Aufl. II pag. 215; Dub, Anwendung des Elect.-Magnt. pag. 672 .

3) Dub, Anwendung des Elcctromagnetismus pag 672; Dingler's polyt. Journal Bd, 128 pag. 247.

4) Dub, Anwendung des Electromgt. pag. 673 .

5) Organ f. d. Fortschritt d. Eisenbahnwesens Bd. V pag. 61, 173.

6) Dingler's polyt. Journal Bd. 213 pag. 356. 
Electrode (électrode - electrode), Ein- oder Austrittsstelle eines electrischen Stromes, s. Electrolyse.

Electrograph (électrographe - electrographe). Diese Bezeichnung wird manchmal den electrochemischen Copir-Telegraphen (s. d. Art. Telegraphie) beigelegt und im weiteren Sinne iiberhaupt allen Apparaten, mittelst welchen auf electrischem Wege bleibende Zeichen, seien es nun Zeitmarken, Schriftzüge oder Zeichiungen, hervorgebracht werden können. (S. a. d. Art. Chronograph.) Den Namen Electrographie fiihren gewisse galvanoplastische Methoden, insbesondere das von D e vince n z i herrihlrende Verfahren, auf galvanokaustischem Wege erhaben geätzte Zinkplatten fuir die Buchdruckerpresse herzustellen. Hierher gehört auch die von F. v. Kobell erfundene Methode zur Erzeugung galvanoplastischer Druckplatten für Zeichnungen in Tuschmanier, welches Verfahren jedoch gewöhnlich Galvanographie genannt wird. (Siehe den Artikel Galvanoplastik.)

A. v. W.

Electrolyse (électrolyse ou électrolysation - electrolysis). So nennt man jede chemische Zerlegung durch einen electrischen Strom.

Jede chemisch zusammengesetzte Fliissigkeit, welche den electrischen Strom • leitet, wird durch denselben zerlegt oder electrolysirt, und heisst insofern auch ein Electrolyt. Die Stellen des Ein- und Austrittes des Stromes am Electrolyten heissen Electroden, und zwar Anode die Eintritts- und Kathode die Austrittsstelle. Die Electrolyse geschieht stets in der Weise, dass die Ausscheidung der Bestandtheile, das ist der sogenannten Jonen, des Electrolyten nur an den beiden Electroden stattfindet. Ein an der Anode ansgeschiedenes Jon nennt man Anion, ein an der Kathode ausgeschiedenes $\mathrm{K}$ ation.

Ein sehr bekanntes Beispiel von Electrolyse, welches zugleich die erste näher beobachtete Erscheinung dieser Art darbietet, zeigt sich beim Durchgange des electrischen Stromes durch verdünnte Schwefelsäure. Taucht man in diese Flüssigkeit zwei Platinplättchen, deren eines (als Anode) mit dem positiven, das andere (als Kathode) mit dem negativen Pole einer electrischen Stromquelle (z. B. einer hydroelectrischen Batterie) leitend verbunden ist, so beobachtet man an beiden Electroden eine nach Massgabe der Stromstärke mehr oder weniger lebhafte Gasentwicklung, und zwar in der Art, dass an der Anode Sauerstoff, an der Kathode Wasserstoff ausgeschieden wird.

Da beide Gase in dem Verhältnisse auftreten, in welchem sie Wasser bilden, so hat man den beschriebenen Vorgang als eine Zersetzung des mit der verdiinnten Schwefelsäure gemischten und dadurch besser leitend gemachten Wassers aufgefasst. Nenere Untersuchungen haben dagegen immer mehr zur Ueberzeugung gefiihrt, dass das Wasser für sich allein (in vollkommen reinem Zustande) den electrischen Strom fast gar nicht leitet, so dass ron einer directen Zersetzung desselben durch den electrischen Strom kaum die Rede sein kann. Man muss demnach den in einer wässrigen Lösung stattfindenden electrolytischen Vorgang lediglich als eine Electrolyse des gelösten Körpers betrachten, dessen Theilchen die Stromleitung vermitteh und durch das Wasser als Lösungsmittel eben nur den zur Electrolyse, wie wir bald sehen werden, erforderlichen Grad von Beweglichkeit erlangen.

Demnach wird das vorhin betrachtete Beispiel einer sogenannten Wasserzersetzung vielmehr als eine Zersetzung des Schwefelsäure-IIyilrates $\mathrm{HSO}_{4}^{*}$ ) anzusehen sein, welche in der Art vor sich geht, dass $H$ an der Kathode sich ausscheidet, wïlnrend ron dem an der Anode austretenden $\mathrm{SO}_{4}$, welches als solches nicht bestehen kann, $O$ frei wird und $\mathrm{SO}_{3}$ neuerdings ein $\mathrm{HO}_{\mathrm{O}}$ aus dem Lösungsmittel aufnimmt.

*) Wir bedienen ms in diesem Artikel, aus Grünten, welche alshald zur Sprache kommen werden. durchwegs der Aequivalentformeln, nicht aber der neuereu A tomgewichtsformeln. Wir schreiben also $H O=9$ und nicht $H_{2} O=18$ für Wasser u. s. w. 
Bei der electrolytischen Sanerstoff-Ausscheidung findet besonders in weniger verdïnnter Schwefelsäure und bei grosser Stromdichte (kleiner Anode) Ozonbildung statt. Die dadurch bewirkte Volumsverkleinerung (s. d. Art. O zo ui) und die im Vergleiche mit Wasserstoff viel grössere Alssorption des Sauerstoffes im Wasser bringen es mit sich, dass das an der Anodc entwickelte Sauerstoff-Volum oft weit unter dem halben Wasserstoff-Volum an der Kathode zuriickbleibt. Dicses Missrerhältniss kamn auch noch durch eine an der Anode stattfindende clurch niedrige Temperatur grosse Stromdichte und eine der Dichte 1.4 sich nähernde Concentration der Säure begiunstigte) Wasserstoffhyperoxyd-Bildung gesteigert werden.

Gar kein Sanerstoffgas wird entwickelt, wenn die Anode aus einem leicht oxydirbaren Metalle, z. B. Kupfer besteht. Der electrolytisch ansgeschiedene Sanerstoff verbindet sich in einem solchen Falle unmittelbar mit dem Materiale der Anode.

In Recipienten, welche mit der electrolysirten Fliissigkeit gefillt und in passender Weise über den Electroden angebracht sind, lassen sich beide Gase getremnt oder zu Knallgas vereinigt aufsammeln. Aus dem Wasserstoff-Volumen oder, insofern eine erhebliche Verminderung des Sauerstoff-Volumens vermieden ist, aus dem Knallgas-Volum lässt sich das electrolysirte Quantum von Schwefelsäure-Hydrat leicht berechnen, so wie anch die dem entwickelten Knallgase entsprechende Wassermenge $H O$, welche man gewöhnlich kurzweg (obwohl uneigentlich) als die durch den Strom zersetzte Wassermenge bezeichnet. Aus diesem Grunde wollen wir denn anch, dem herrschenden Sprachgebranche folgend, die Electrolyse der verdiunnten Schwefelsäure kurz als Wasserzersetzung bezeichnen und jeden zur Ausführung dieses Experimentes dienlichen Apparat einen Wasserzersetzungsappar at nen neu.

Gelit ein (von einer Batterie a b herrihrender) electrischer Strom gleichzeitig durch einen Wasser-Zersetzungsapparat $A$ und durch andere (aus $\mathbf{U}$-förmig gebogenen Röhren hergestellte) Zersetzungsapparate $B, C, D, E$ (Fig. 1466), welche z. B. geschmolzenes Bleioxyd, Chlorblei, Jodblei und Chlorsilber enthalten und hintereinander (mittelst eingetauchter Platindrähte) in den Stromkreis eingeschaltet sind, so treten an den Anoden in $A$ und $B$ Salterstoff, *) in C Chlor, in $D$ Jod, in $E$ Chlor und an den Kathoden in $A$ Wasserstoff, in $B$, $C$ und $D$ Blei und in $E$ Fig. 1466.

Silber auf; kurz: es werden die electronegativen ${ }^{*} *$ Bestandtheile an den Anoden, die electropositiven an den Kathoden ausgeschieden. Wendet man z. B. anstatt geschmolzenem Chlorblei gelöstes Chlorblei ${ }^{*}$ w*) an, so wird es in ganz gleicher Weise zerlegt. Salpetersaures Silberoxyd (s. unten bei Silber-Voltameter) zerfällt bei der Electrolyse in $A g$, welches an der Kathode sich ausscheidet, während der Rest $\left(\mathrm{NO}_{5}+O\right)$ an der Anode frei wird und sich, nach Beschaffenheit derselben, mit einer äquivalenten Menge ihres Metalles wieder zu einem salpetersaurem Salze verbindet. Bei der Electrolyse des Kupfervitriols wird in analoger Weise Kupfer an der Kathode ausgeschieden, während an der Anode $\mathrm{SO}_{3}+\mathrm{O}$

*) In $A$ eigentlich $\mathrm{SO}_{4}$, welehes in der bereits angedenteten Weise in $\mathrm{SO}_{3}$ und $O$ zerfïllt.

**) Siflie den Artikel Electricität, Absatz XXXVIII.

***) In kaltem Wasser ist es schwer lisslich; in vielem heissen Wasser löst es sich leichter. 
frei werden, deren weiteres Verhalten eben auch wieder von der materiellen Beschaffenheit der Anode abhängt. Salzsäure gibt bei der Electrolyse $C t$ an der Anode und $H$ an der Kathode.

Diese und viele ähnliche Thatsachen haben zu der Anschaunng gefiihrt, das Schwefelsäurehydrat, das salpetersaure Silberoxyd, den Kupfervitriol, kurz die sogenannten Samerstoff-Säuren und Salze im Gegensatze zur Berzelius'schen Schreibweise $\mathrm{SO}_{3} \mathrm{HO}, \mathrm{NO}_{5} \mathrm{AgO}, \mathrm{SO}_{3} \mathrm{CuO}$ nach Daniell in der Form $\mathrm{HSO}_{4}$, $\mathrm{AgNO}_{6}, \mathrm{CuSO} \mathrm{SO}_{4}$ auf den Typus der anderen vorhin erwähnten binären Verbindungen, namentlich der sogenannten Wasserstoff-Säuren und Haloidsalze $\mathrm{HCl}$, $\mathrm{PbCl}, \mathrm{PbJ}, \mathrm{AgCl}$ u. s. w. zuriickfiihren, und die (gleichwohl nicht isolirt darstellbaren) Atomencomplexe $S_{4}, N_{6}$ u. dgl. als dem Chlor, Jod u. s. w. analoge electronegative Jonen anzusehen. Daniell hat dafuir sogar die besonderen Benennumgen Oxysulphion für $\mathrm{SO}_{4}$, Oxynitrion für $\mathrm{NO}_{6}$, Oxyborion für $\mathrm{BoO}_{4}$ ll. s. w. vorgeschlagen.

Indem wir von dieser Daniell'schen Schreibweise weiterhin Gebrauch machen, wollen wir die derselben zu Grunde liegende Auffassung nicht als eine allgemein massgebende Typentheorie, sondern vorläufig nur als eine für die Uebersicht der electrolytischen Processe jedenfalls sehr bequeme Hypothese in Anspruch nehmen.

Im Sinne dieser Auffassung erscheint die Electrolyse als die electrische Zerlegumg fliissiger (geschmolzener oder gelöster) binärer Verbindungen, welche aus gleichen Aequivalenten zweier Grundstoffe (z. B. $\mathrm{HCl}, \mathrm{Ag} C l$ ) oder eines Grundstoffes mit einem der vorhin erwähnten Atomencomplexe (z. B. $\mathrm{HSO}_{4}, \mathrm{CuSO}_{4}$ ) zusammengesetzt sind.*)

Alle Verbindungen, welche nicht electrolysirt werden (mit Ausnahme der in die Spamungsreihe gehörigen Legirungen, Hyperoxyde und Schwefelmetalle) sind auch keine Stromleiter, ${ }^{* *}$ ) wie dies namentlich vom chemisch reinen Wasser bereits gesagt worden ist. Die Beobachtungen von $\mathrm{Carlisle,} \mathrm{Nicholson}$ u. A., welche eine Wasserzersetzung zu constatiren schienen, sind eben nicht mit chemisch reincm Wasser ausgeführt worden. Vielmehr haben die neuesten Untersuchungen von F. Kohlrausch einen so grossen Leistungswiderstand fuir das Wasser (14.000,000.000mal grösser als für Quecksilber) ergeben, dass wir mit Rücksicht auf die Schwierigkeit, dasselbe beim Versuche in absoluter Reinheit anzuwenden und zu erhalten, wohl berechtigt sind, es als nicht leitend zu betrachten. Hierher geliören auch noch flüssige schweflige säure $S O_{2}$ und Kohlensäure $C O_{\text {m, }}$ geschmolzene wasserfreie Schwefelsäure $\mathrm{SO}_{3}$, Borsäure $\mathrm{BO}_{0} \mathrm{O}_{3}$, Chlorphosphor $\mathrm{PCl}$, Chlorschwefel $\mathrm{SCl}_{3}$, Zinnchlorid $\mathrm{Sn} \mathrm{Cl}_{0} * *$ ) u. v. A.

Ausser der bereits angeführten allgemeinen Regel, dass der electronegative Bestandtheil des Electrolyten an der Anode (als Anion), der electropositive an der Kathode (als Kation) auftritt, haben sich noch andere Gesetzmässigkeiten ergeben, von welchen sofort die Rede sein soll.

Man denke sich in den Stromkreis einer Batterie $B$ (Fig. 1467) fünf Wasserzersetzungsapparate $a, b, c, d$ und $e$ nach dem beigefügten Schema eingeschaltet, so dass der Strom, nachdem er durch a gegangen ist, sich in zwei Zweige theilt, deren einer durch $b$ und $c$, der andere durch $d$ geht, worauf beide Zweige wieder zum urspriinglichen strome sich rereinigen, der endlich noch $e$ durchsetzt. Bezeichnet man mit $a, b, c, d$ und $e$ zugleich die Wassermengen, welche den innerhalb einer bestimmten Zeit, z. B. $1 / 4$ Stunde in den gleichnamigen Apparaten entwickelten

*) Eisen-Chlnriir $\mathrm{FeCl}$ gibt $\mathrm{Cl}$ an der Anode und $\mathrm{Fe}$ an der Kathode C'n Eisen-Chlorid $\mathrm{Fe}_{2} \mathrm{Cl}_{3}$ derselben Regel untcrzuordnen, muss es als $\mathrm{Fe}_{2} \mathrm{Cl}$ betrachtet werden, indem es $\mathrm{Cl}$ an der Anode und $\frac{2}{3} \mathrm{Fe}$ an der Kathode gibt. (W ie demann, Galvanismus, Bd. I S. 460 .)

**) Selbst bei dem durch Erhitzung leitend gemachten Glase hat Beetz Electrolyse nachgewiesen.

**:*, Siehe Wiedemann. Galranismus Bd. I S. 461 11. Art. Electricität Absatz LAII. 
Kinallgasmengen entsprechen, so zeigt sich, dass $a=e$, ferner $b=c$ und endlich $b+d=a$, also auch $b+d=c+d=a=e \cdot D_{a}$ nun die Summe der Zweigströme, wie immer dieselben zu einander sich verhalten mögen, stets dem ursprünglichen Strome gleich sein muss, so folgt hieraus, dass die innerhalb einer bestimmten Zeit zersetzte Menge des Schwefelsäurehydrates stets der Stärke des die Zersetzung bewirkenden Stromes proportional ist. Dasselbe gilt, wie Versuche gelehrt haben, auch fiir andere Electrolyte, so dass man allgemein sagen kann:

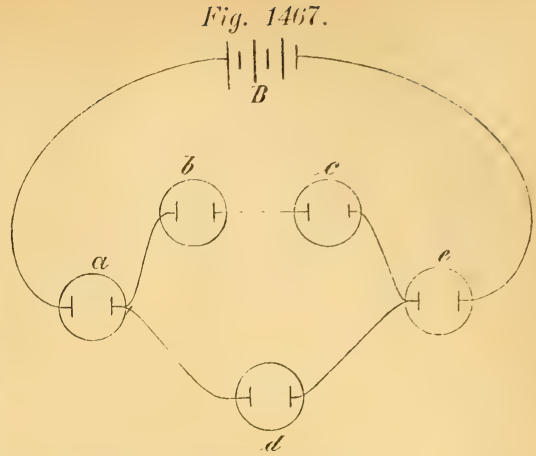
die innerhalb einer bestimmten Zeit zerlegte Menge eines Elec trolyten ist der electrolysirenden Stromstärke proportional. Dies ist das erste Faraday'sche Grundgesetz der Electrolyse.

Die so eben angeführte Beziehung zwischen Electrolyse und Stromstärke lässt erkennen, dass man die erstere zum Messen der letzteren benutzen kann. In der That dient der Wasserzersetzungsapparat (in verschiedenen Formen) schon längst als ein Instrument zur Messung electrischer Ströme, und wird deshalb anch häufig Voltameter genannt. Jacobi hat vorgeschlagen, jenen Strom als Einheitsstrom zu betrachten, der im Voltameter ein Cubic-Centimeter Knallgas, reducirt auf $0^{\circ}$ C. und $760^{\mathrm{mm}}$ Druck, in der Minute entwickelt. Wir wollen diese "chemische Stromeinheit" beibehalten; es entspricht diesem Knallgasquantum eine Wassermenge von nahezu $1 / 18$ iso Grammen.

Ein zu Strommessungen geeignetes Voltameter, welches von Mo h r herriihrt, zeigt Fig. 1468. Der eigentliche Zersetzungsapparat besteht ans dem Glasrohre $a$, welches zwei Platinplatten (als Electroden) in verdiinnter Schwefelsäure enthält, welche mittelst zweier unten angefügten Drahtklemmen in den Stromkreis der Batterie eingeschaltet werden können. Das entwickelte Knallgas tritt in die Flasche $b$, in welcher sich die Sperrfluissigkeit (Wasser, Quecksilber oder auch Chlorcalciumlösung) befindet. Das drehbare Ausflussrohr $c$ wird so lange geneigt, bis die Fluissigkeit im Innern der Flasche und in dem Trichterrohre $n$ gleich hoch steht. Die Luft in der Flasche befindet sich sodann unter dem Drucke der äusseren Luft (entsprechend dem Barometerstande). Hat man hierauf die Wasserzersetzung eingeleitet, so fliesst die durch das entwickelte Knallgas verdrängte Sperrflüssigkeit durch das Rohr $c$ aus, welthes man nach Beendigung des Versuches wieder so lange neigt, bis der vorhin angegebene Niveaustand wieder hergestellt ist. Das Volumen der ausgetretenen Flüssigkeit, welches entweder direct gemessen oder aus dem Gewichte berechnet werden kann, ist zugleich das entwickelte Knallgasrolumen. Reducirt man dasselbe nach den bekannten Formeln des M a r i o t t e-G a y-L u s s a c schen Gesetzes oder mittelst geeigneter Tabellen anf $0^{\circ} \mathrm{C}$. und $760^{\mathrm{mm}}$ Quecksilberdruck *)

*) wobei auch auf den Druck der Wasserdämpfe im Voltameter Riicksicht zu nehmen ist. 
und dividirt dieses reducirte Volumen durch die Anzahl der während der Zersetzung abgelaufenen Minuten, so erhält man die Stromstärke in chemischem Masse, insofern man eben amnehmen kann, dass der Strom während dieser Zeit sich nicht geändert hat.

Oft wïnseht man des Gewicht des in einer Minute entwiekelten Wasserstoffes zu wissen. Ist $V$ das verdrängte Fliissigkeits-, also auch das entwickelte Knallgasvolumen, $b$ der Barometerstand und $e$ das der herrschenden Temperatur entsprechende Druckmaximum des Wasserdampfes, folglich $b-e$ der eigentliche Druck des entwickelten Knallgases (in Millimetern Quecksilber ausgedriickt), so ist das auf $0^{\circ}$ C. und $760^{\mathrm{mm}}$ reducirte Volumen

$$
\left.V_{0}=V \frac{(b-e)}{(1+\alpha t) 760} \cdot \ldots . . . .1\right)
$$

wobei re den Ausdehnungscoëfficienten $1 / 073$ und $t$ die Beobachtungstemperatur bedeutet. Das reducirte Wasserstoffvolumen ist dann $v_{0}=2 / 3 V_{0}$ und das Gewicht $P_{H}$ desselben in Milligrammen

$$
\left.P_{H}=0.0896 v_{0}=2 / 3 V \frac{0.0896(b-e)}{(1+\alpha t) 760} \cdot \ldots .2\right),
$$

wemn die Volumina in Cubic-Centimetern angegeben sind.*) Dieses Gewicht ist dann noch durch die Zersetzungsdaner zu dividiren, um das bei constanter Stromstärke in der Zeiteinheit ausgeschiedene Wasserstoffquantum zu erhalten.

Ans dem ersten Grundgesetze der Electrolyse folgt unmittelbar, dass nicht nur die Wasserzersetzung, sondern anch andere electrolytische Processe zur Strommessung benutzt werden können. In der That ist für genauere Messungen das Poggendorff'sche Silber-Voltameter (Fig. 1469) sehr geeignet.

Fig. 1469.

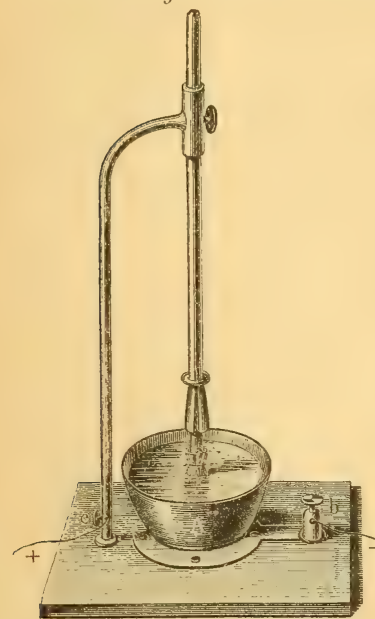

Der Strom tritt an der Klemmschranbe $c$ in ein messingenes Stativ, welches einen verticalen Silberstab trägt, der in die in der Platinschale $A$ befindliche Lösung von salpetersaurem Silberoxyd eintaucht. Die Platinschale $A$ steht mittelst einer messingenen Fassung mit der Klemmschraube $b$ in leitender Verbindung, bei welcher der Strom austritt. Das Silber scheidet sich auf der Platinschale, die als Kathode dient, in Blättchen $a b$ und kann nach dem Ausgiessen der Lösung mit Wasser gewaschen, getrocknet und sodann mit der Platinschale gewogen werden. Das Gewicht des innerhalb einer bestimmten Zeit ausgefällten Silbers ist der Stromstärke proportional.

Gleichzeitig löst sich von dem als Anode dienenden Silberstabe eine dem ausgefällten Silber gleiche Silbermenge unter Bildung von salpetersaurem Silberoxyd anf und der Stab zerfällt allmälig. Um dabei das Herunterfallen des gebildeten Pulvers in die Schale zu vermeiden, umgibt man den Stab am unteren Ende mit einem Läppchen von feinem Zeng. **)

Fiir weniger genaue Messungen eignet sich anch ein Voltameter, welches aus zwei gleich grossen in eine concentrirte Lösung von Kupfervitriol eingesetzten kupfernen Electroden besteht.

An der Anode wird Kupfer aufgelöst, an der Kathode Kupfer ausgefällt. Beide Kupfermengen können beziehungsweise aus der Gewichtsabnahme der Anode und Gewichtszunahme der Kathode durch Wägung der zuror mit destillirtem

*) Verrl. Tried e mann, Galranismus Bd. I S. 479.

**:) siehe Wiedemann, Galvanismus Bd. I S. 479 u. 480 . 
Wasser abgespiilten und mit Filtrirpapier getrockneten Electroden bestimmt werden. Man nimmt (nach Perrot) am besten das Mittel beider Gewichtsdifferenzen und dividirt dasselbe durch die Dauer der Electrolyse, um die der Zeiteinheit entsprechende Kupferfällung zu erhalten, welche dann als Mass der Stromstärke gilt.

Ein zweites electrolytisches Grundgesetz ergibt sich aus der folgenden gleichfalls durch zahlreiche und sorgfältige Versuche constatirten Thatsache.

Nehmen wir an, die Apparate $a, b$ u. s. w. in Fig. 1467 enthalten verschiedene Electrolyte (z. B. Schwefelsäure, Lösung von salpetersaurem Silberoxyd, geschmolzenes Chlorblei u. s. w.), deren Aequivalentzahlen wie $\iota, \beta, \gamma, \delta, \varepsilon$ zu einander sich verhalten, während $a, b, c, d, e$ wieder die Gewichtsmengen der innerhalb einer bestimmten Zeit in den einzelnen Apparaten zersetzten Substanzen bedeuten, so findet man, dass $\frac{a}{\alpha}=\frac{e}{\varepsilon}$, ferner $\frac{b}{\beta}=\frac{c}{\gamma}$ und endlich $\frac{b}{\beta}+\frac{d}{\delta}=\frac{a}{\iota}$, also auch $\frac{b}{\beta}+\frac{d}{\delta}=\frac{c}{\gamma}+\frac{d}{\delta}=\frac{a}{\alpha}=\frac{e}{\varepsilon}$. Dieses Resultat lässt sich dahin anssprechen, dass die von einem und demselben Strome innerhalb einer bestimmten Zeit zerlegten Gewichtsmengen verschiedener Electrolyte einander ehemisch äquivalent sind. Geht also derselbe Strom hintereinander z. B. durch verduinnte Schwefelsäure und gesehmolzenes Chlorsilber und zersetzt er innerhalb einer bestimmten Zeit 49 Milligramm Schwefelsäure (indem er dabei 9 Milligramm Knallgas entwickelt, oder, wie man sich ausdriickt, 9 Milligramm Wasser zersetzt), so zersetzt er gleichzeitig 143.5 Milligramm Chlorsilber, wobei die Zahlen 49, 9 und $\mathbf{1 4 3 . 5}$ eben die Aequivalentzahlen von $\mathrm{HSO}_{4}, \mathrm{HO}$ und $\mathrm{AgCl}$ sind. Ein Strom also, der in einem Wasserzersetzungsapparate binnen einer bestimmten Zeit 1 Milligramm Wasser zersetzt, ${ }^{*}$ ) wird, wenn er gleichzeitig durch Chlorsilber geht, von diesem $x$ Milligramm zerlegen, wobei $x: 1=143.5: 9$, also $x=15.9$ Milligramm ist. Dies gilt jedoch nur, wenn beide Zersetzungsapparate gleichzeitig eingeschaltet sind, nicht aber wenn man zuerst den einen und dann den anderen einschaltet, weil im letzteren Falle nicht anzunehmen wäre, dass auf beide Substanzen die gleiche Stromstärke wirkt.

Man kann das vorstehende Ergebniss auch so aussprechen: für jedes Milligramm Wasserstoff, welches im Voltameter innerhalb einer bestimmten Zeit entwickelt wird (s. Formel 2), scheidet derselbe Strom aus Chlorsilber 108 Milligramm Silber, aus Chlormagnesium 12 Milligramm Magnesium, aus Jodkalium 39 Milligramm Kalium, aus Kupfervitriol 31.7 Milligramm Kupfer u. s. w. aus.

Demnach lautet das zweite Faraday'sche Grundgesetz der Electrolyse auch so: dievon demselben Strome in verschiedenen Electrolyten gleichzeitig ausgeschiedenen Jonen sind einander chemisch äquivalent.

Durch die Wechselwirkung zwischen den ausgeschiedenen Jonen und der Substanz der Electroden oder des Electrolyten selbst werden in der Regel secundäre chemische Processe veranlasst, welche die Erkennung des urspriinglichen (primären) electrolytischen Vorganges oft sehr erschweren. Uebrigens gehen beiderlei Processe, wie die Erfahrung gelehrt hat, ganz unabhängig von einander vor sich. Auf diescm Verhalten und auf dem Umstande, dass die Wirkungen der Electrolyse nur an den Electroden sich äussern, während in allen zwischen denselben liegenden Schichten der Electrolyt keine unmittelbare Veränderung durch den Strom erfährt, beruht die Möglichkeit, die primären Resultate der Electrolyse von den secundären zu unterscheiden und mit Sicherheit zu ermitteln. Zu dem Ende gibt man den fiir electrolytische Untersuchungen bestimmten Zersetzungsapparaten eine solche Einrichtung, dass sie aus zwei oder mehreren durch Diaphragmen oder Canäle communicirenden Abtheilungen bestehen, deren Inhalt nach der Electrolyse getremnt

*) Wir haben bereits erläntert, in welchem Sinne diese Ausdrucksweise gestattet ist.

Karmarsch \& Heeren 'Technisches Würterbuch. Bd. III. 
(in Bezug auf seinc elementare Zusammensetzung) untersucht werden kann. Bei einer sehr einfachen und zweckmässigen, ron Wiedemann herrihrenden Einrichtung dieser Art besteht der Zersetzungsapparat (Fig. 1470) aus zwei durch einen Canal $d, e, f, e_{1}, d_{1}$ communicirenden Abtheilungen $a$ und $a_{1}$, welche die Fig. 1470 .

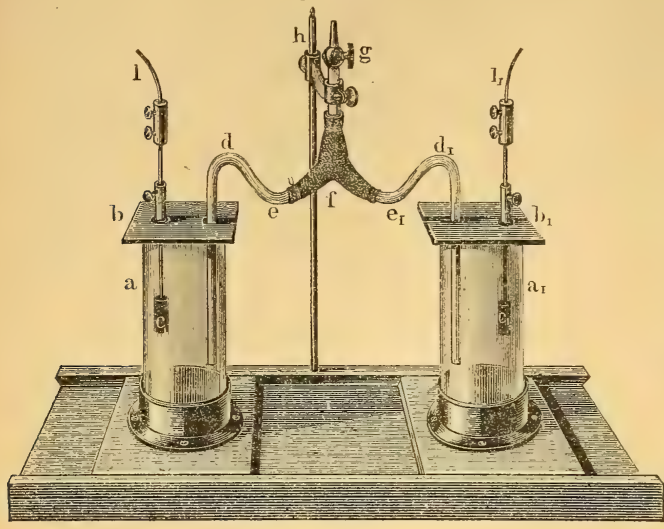

Electroden $c$ und $c_{1}$ enthalten, wobei angenommen werden kann, dass die in Folge der electrolytischen Processe an den Electroden auftretenden secundären Wirkungen nicht aus einer Abtheilung in die andere sich erstrecken können. Die zu den Electroden führenden Platindrähte $l$ und $l_{1}$ gehen durch die gläsernen Deč́el $b$ und $b$, der Glasgefässe $a$ und $a_{1}$; eben so die in der Mitte durch einen dreiarmigen Kautschukschlauch vereinigten gläsernen Arme des Verbindungs - Canals. Der mittlere Arm des Schlauches umfasst ein gläs ernes Hahnstïck $g$, welches von einem Stative $h$ verstellbar festgehalten wird und dazu dient, nach Füllung der Gläser durch Saugen bei geöffnetem Hahne auch den Verbindungs-Canal zu fuillen, woráuf der Hahm geschlossen wird. Nach der Electrolyse wird derselbe wieder geöffnet, um die in den Canal gehobene Fliissigkeit in zwei getrennten Partien zurickfallen zu lassen. Hierauf wird der Inhalt eines jeden der beiden Gläser fur sich untersucht und das Ergebniss mit der bekannten Zusammensetzung der Substanz ron der Electrolyse verglichen.

Wir übergehen die mannigfaltigen von Daniell, Miller und insbesondere von Hittorf construirten electrolytischen Apparate, indem wir diesfalls auf W i demann's Werk iiber Galranismus rerweisen, welches anch die betreffenden Originalabhandlungen citirt. Auf die Untersuchungen ron Hittorf und Wiedemann werden wir später noch zurückkommen.

Wir beschäftigen uns rorerst noch mit der Frage, wie man sich den Hergang. der Electrolyse vorstellen kann, um zu einer Erklärung der bisher angefulırten Thatsachen zu gelangen.

Nach einer älteren, ron Grotthus $(1805)$ anfgestellten Ansicht liätte man sich z. B. die Electrolyse von $H C l$ in folgender Weise zu denken.

Jedes $H C l$-Molecul $(I, I I, I I I$ u. s. w. Fig. 1471) besteht aus entgegengesetzt electrischen Atomen von $H$ und $C l$, indem beim Contacte der letzteren $H$ positiv und $C l$ negativ electrisch wird. Zwischen den Electroden $A$ und $K$ richten sich Fig. 1471.
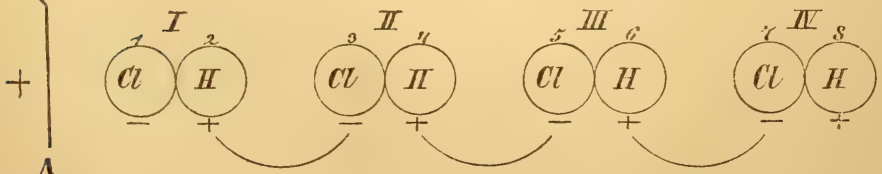

A

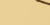


die (in Folge des fliissigen Zustandes des Electrolyten leicht beweglichen) Molecule dargestellt, dass die electronegativen Atome $(C l)$ der positiv electrischen Anode $A$ und die electropositiven Atome $(H)$ der negativ-electrischen Kathode $K$ zugewendet sind. Die Anziehung der Anode auf das Chloratom 1 bewirkt ein Losreissen desselben rom Wasserstoff-Atom 2; dieses, frei geworden, verbindet sich mit 3, 4 mit 5, 6 mit 7, während das Wasserstoff-Atom 8 der Anziehung ron Seite der Kathode $K$ folgt und an derselben sich ausscheidet.

Nach dieser Ansicht würde jedoch (wie Clausius mit Recht geltend gemacht hat) eine Electrolyse erst dann eintreten können, wenn die von den Electroden ausgehenden electrischen Kräfte eine gewisse zum Losreissen der angrenzenden Atome (1 und 8), d. i. zur Aufhebung des Zusammenhanges der Moleciile des Electrolyten erforderliche Intensität erreichen. Unterhalb dieser Grenze könnte kein Strom durch den Electrolyten gehen, nach Ueberschreitung dieser Grenze aber plötzlich ein sehr starker mil entsprechend lebhafter Zersetzung. Dagegen lehrt die Erfahrung, dass auch bei den schwächsten Strömen Electrolyse stattfindet.

Diese Schwierigkeit wird durch die von Clausius aufgestellte Annalıme behoben, dass die Moleciile des Electrolyten (wir wollen sie mit Clausius "Gesammtmoleciile" heissen)*) nicht als festverbundene Atomencomplexe zu betrachten sind, sondern dass die als Jonen auftretenden Bestandtheile ("Theilmoleciile") der einzelnen Gesammtmoleciile schon vor der Einschaltung in den Stromkreis in einem fortwährenden mehr oder weniger lebhaften Austausche begriffen sind, so dass z. B. ein $\mathrm{HCl}$-Molecïl nicht immer aus denselben Atomen $\mathrm{H}$ und $\mathrm{Cl}$ besteht, sondern dass bei den dem flïssigen Zustande (nach Massgabe der Temperatur) eigenthïmlichen Molecular-Bewegungen öfter ein Zusammentreffen ungleichartiger Theilmoleciile zweier benachbarter Gesammtmolecïle stattfindet, und in Folge dessen ein Losreissen und wechselseitiger Austausch der Theilmolecuile eintritt. $\left.{ }^{*}\right)$ Die Jonen sind also schon vor der Electrolyse in fortgesetzten Verbindungen und Zersetzungen begriffen. Beim Durchgange des Stromes werden diese Bewegungen mehr oder weniger in der Art geregelt, dass die freien positiven Jonen vorherrschend in der einen, die negativen in der entgegengesetzten Richtung sich bewegen.

Bei dieser Wanderung der Jonen kommt noch die weitere Frage in Betracht, ob man sich, was das Nächstliegende wäre, vorzustellen hat, dass Anion und Kation mit gleichen Geschwindigkeiten den betreffenden Electroden sich nähern oder nicht. Beide Annahmen sind mit einer gleich grossen Ausscheidung in einem gegebenen Falle vereinbar.

Nehmen wir z. B. an, es werden in einer Minute 222 Milligramm $\mathrm{CaCl}$ electrolysirt, wir wollen sagen: vier Aequivalente $\left(222=4 \times 55^{\circ} 5\right)$. Die Doppelreihe $I$ (Fig. 1472) soll uns 10 Aequivalente $C a C l$ vorstellen, indem die mit $A$ bezeichneten Punkte $C l$ und die mit $B$ bezeichneten kleinen Kreise $C a$ bedenten. Wir wollen der Einfachheit wegen 10 gleich weit von einander entfernte Gesammtmolecïle betrachten.

Man kann sich nun die Ausscheidung von 4 Aequivalenten $C l$ auf der einen und 4 Aequivalenten $\mathrm{Ca}$ auf der anderen Seite entweder in der Art bewerkstelligt denken, wie bei $I I$ angedeutet ist, nämlich so, dass die Theilmolecüle $A$ und $B$ gleich schnell (um je 2 Intervalle) nach entgegengesetzten Richtungen vorschreiten, oder auch, wie III andentet, durch ungleich schnelles Vorrücken (indem z. B. die

*) Diese Bezeichnungen: "Gesammtmolecül "s und "I'heilmolecuil" sind besunders fïr den allgemeineren Fall gewählt, dass die Jonen eines electrolysirten Molecüles selbst aus mehreren Atomen bectshen; so sind z. B. $\mathrm{SO}_{4}$ und $\mathrm{H}$ die Theilmolecïle des Gesammtmolecïles $\mathrm{HSO}_{4}$. (Siehe Clausius Abhandlungen Bd. 2 S. 205.)

***) Eine ähnliche (übrigens noch weiter gehende) Ansicht über das Verhalten zusammengesetzter fliissiger und luftformiger Körper hat schon Willia m son in einer Abhandlung über die Th orie der Aetherbildung ausgesprochen. 
$A$ um 3 Intervalle nach der Anode, die $B$ aber gleichzeitig nur um 1 Intervall nach der Kathode sich bewegen).

Fig. 1472.

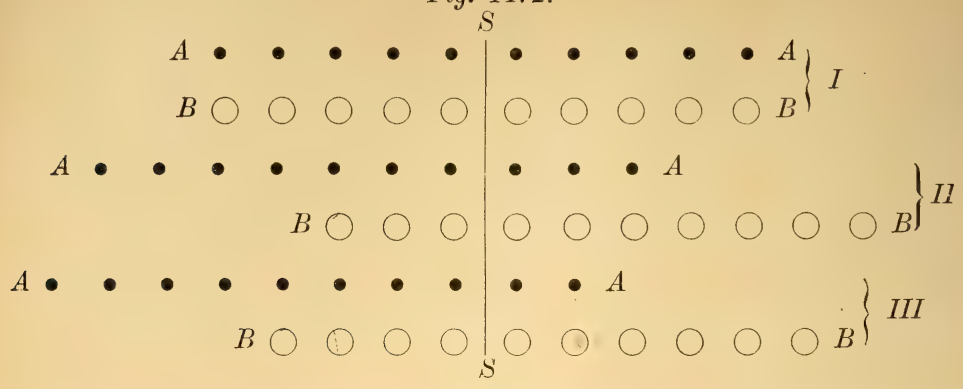

Würde man in beiden Fällen die Beschaffenheit des Electrolyten vor und nach der Electrolyse zu beiden Seiten eines bestimmten Querschnittes $S$ untersuchen (was bei Anwendung eines der oben erwähnten Zersetzungs-Apparate wohl geschehen kann), so wiirde man finden, dass der Gehalt an $A$ in der Abtheilung auf Seite der Anode im Falle $I I I$ mehr zugenommen hätte als im Falle $I I$; oder, mit anderen Worten, dass in dem einen Falle eine stärkere "Ueberfiuhrung" des Jones $A$ zur Anode stattgefunden hat als im anderen.

Hittorf hat die in diesem Sinne stattfindenden Ueberfürungen der Jonen zur Anode und Kathode in vielen Fällen untersucht und numerisch mit einander verglichen. Er fand, dass die diesem Verhältnisse entsprechenden sogenannten "Ueberfihhrungszahlen"*) fast nie einander gleich, sondern in der Regel ganz bedeutend von einander verschieden sind, und zwar in der Art, dass die Ueberföhrung zur Anode grösser ausfällt. So sind z. B. die Ueberführungszahlen von $C l$ und $C a \quad 0.78$ und 0.22 , d. h. an der relativen Wanderungsgeschwindigkeit participirt das Chlor mit $78 \%$, das Calcium mit $22 \%$.

Neueste Untersuchungen von F. Kohlrausch*) haben es sehr wahrscheinlich gemacht, dass die Leitungsfähigkeiten der Electrolyte mit den Ueberführungszahlen ihrer Jonen in einem sehr einfachen Zusammenhange stehen. Haben z. B. zwei Electrolyte einen Bestandtheil gemeinsam $(\mathrm{KCl}$ und $\mathrm{NaCl}$ ) und untersucht man dieselben in verdünnten wässrigen Lösungen, welche in gleichen Raumtheilen gleich viele Aequivalente enthalten, so zeigt sich, dass die Leitungsvermögen verkehrt (also die Leitungswiderstände direct) wie die Ueberfiihrungszahlen des in beiden Fällen gemeinschaftlichen Bestandtheils sich verhalten.

Da das Wasser selbst nicht leitet, kann es nur als Mittel betrachtet werden, in welchem die electrolytischen Verschiebungen vor sich gehen, so, dass der Leitungswiderstand der Lösung als der Reibungswiderstand sich darstellt, welchen die wandernden Elemente an den Theilchen des Wassers (und, wenn die Lösung nicht verdunnt ist, auch aneinander) finden.

Eine electrolytische Ueberführung anderer Art - man nennt sie die mechanische Ueberführung oder electrische Endosmose - findet statt, wenn ein Zersetzungsapparat durch eine poröse Scheidewand in zwei Abtheilungen getheilt ist. Es findet in diesem Falle eine Ueberfiuhrung der Fliissigkeit durch das Diaphragma nach der Kathode hin statt, und zwar desto mehr, je grösser einerseits die Stromstärke und anderseits der Leitungswiderstand der Flüssigkeit ist. Näheres

* Sind $v_{1}$ und $v_{2}$ die Wanderungsgeschwindigkeiten der beiden Jonen, so nennt man $n_{1}=\frac{v_{1}}{v_{1}+v_{2}}$ und $n_{2}=\frac{v_{2}}{v_{1}+v_{2}}$ ihre Ueberführungszahlen.

**) Siehe Carl's Repertorium der Experimentalphysik, Bd. 13 Heft 1, S. 10. 
iiber diese von Wiedemann und Quincke genauer erforschte Erscheinung findet man in Wiedemann's mehrfach citirtem Werke.*)

Die practischen Anwendungen der Electrolyse gehören grösstentheils der Galvanoplastik (beziehungsweise auch Galvanokaustik) an, die in einem besonderen Artikel abgehandelt wird. Hier wollen wir nur noch an die epochemachenden Versuche Davy's erimnern, welcher die Zerlegung der Alkalien und Erden auf electrolytischem Wege zuerst bewirkt hat und einige Worte ïber die electrochemische Gewinnung gewisser Metalle beifügen.

Kalium kann, bei Anwendung einer kräftigen Säule, an einer Platin-Electrode bekanntlich direct srhalten werden, wenn man ein feuchtes Stiickchen Aetzkali auf ein Platin-Blech als Anode legt und oben mit einem als Kathode dienenden Platin-Drahte beriihrt.

Leichter lässt sich Kalium-Amalgam erhalten. Um das Amalgam eines Alkali-Metalles electrolytisch darzustellen, dient ein Apparat wie Fig. 1473.

Am Boden eines Glasgefässes befindet sich Quecksilber, in welches das blanke Ende eines mit einem + isolirenden Ueberzuge versehenen Platin-Drahtes taucht, der mit dem negativen Batteriepole verbunden ist. Ueber dem Quecksilber befindet sich dann die concentrirte alkalische Lösung, in welche man die als Anode dienende Platinplatte taucht. Das ausgeschiedene Metall (z. B. Kalium) verbindet sich unter Erwärmung mit dem Quecksilber und das entstandene Amalgam erstarrt beim Erkalten.

Uebrigens können (nach Bunsen) selır leicht oxydirbare Metalle auch aus ihren Chlorverbindungen electrolytisch ausgeschieden werden, wenn man durch Anwendung einer Kathode von sehr kleiner Oberfläche (Platindraht) eine grosse Stromdichte erzeugt.

Die bei anorganischen Verbindungen betrachteten electrolytischen Gesetze finden auch oei den organischen analoge Anwendungen. So geben z. B. die Verbindungen organischer Säuren mit den Alkalien an der Kathode ein Aequivalent Metall, welches sich unter Wasserstoffentwicklung oxydirt oder nach Umständen auch reducirend auf das organische Salz wirkt. An der Anode tritt ein Aequivalent Sauerstoff und ein Aequivalent Säure (zunächst als Anhydrit) auf, die sich jedoch theils mit Wasser verbindet, theils durch den activen Sauerstoff oxydirt. Es entstehen auf diese Art secundäre Producte, die nach Massgabe der Stromdichte, Concentration und Temperatur sehr verschieden sein können.**)

Die secundären Producte der Electrolyse treten in gewissen Fällen (bald an der Arode, bald an der Kathode) in so dünnen Schichten auf, dass sie die sogenannten Farben dünner Plättchen (wie wir sie z. B. an den Seifenblasen sehen) zeigen. Hieher gehören z. B. die Nobili'schen Farben von Bleihyperoxyd an der Anode und die gleichfalls an der Anode entstehenden farbigen Niederschtäge von Manganhyperoxyd, welche Processe man zur Verzierung von Metallwaaren (z. B. Tischglocken, Briefschwerern u. dgl.) verwendet hat. Wir ver-weisen jedoch die näheren Angaben hierüber in den Artikel Galvanoplastik.

Electrolyte (électrolyte - electrolyte), s. Electrolyse. A. $v . W$.

Electromagnet (électro-aimant - electro-magnet), siehe Electromagne$\mathrm{t}$ is $\mathrm{mu}$ s.

Electromagnetismus (électro-magnétisme - electro-magnetism). Die im Artikel Electricität (Absatz XXXIII) erwähnten magnetischen Wirkungen eines electrischen Stromes (derselbe mag wie immer hervorgebracht sein) sind von zweifacher Art. Einerseits bewirkt der electrische Strom, indem er einen des

*) Bd. I S. 576 .

**) Siehe Wied emann, Bd. I S. 548. 
Magnetismus fähigen Körper (z. B. einen Eisenstab) umkreiset, eine Magnetisirung des Körpers; anderseits vermag er bewegliche Stahlmagnete (z. B. Magnetnadeln), die sich in seiner Nähe befinden, nach bestimmten Gesetzen abzulenken.

Beide Arten von magnetiscben Wirkungen sollen hier nur insoweit berücksichtigt werden, als sie bei wichtigen praktischen Anwendungen in Betracht kommen. Hierher gehören einerseits die Electromagnete und anderseits dic Galvanometer.

a) Magnetisirende Wirkung des Stromes. Die Gesetze derselben werden am besten aus folgenden Beispielen erhellen.

Ist ein Eisenstab mit einer rechtsgewundenen Drahtspirale bewickelt, so wird das Stabende an der Eintrittsstelle des Stromes stets siidlich magnetisch, wie $I$ und $I I$ in Fig. 1474 andenten. In einer linksgewundenen Dratlispirale entsteht an der Eintrittsstelle des Stromes der Nordpol. Siehe III und IV in Fig. 1474. Hieraus ergibt sich folgende allgemeine Regel. Man denke sich im Stromleiter eine menschliche Figur ${ }^{*}$ ) mit dem Strome schwimmend, das Gesicht gegen den Eisenstab gewendet. Der Nordpol entsteht dann stets zur Linken dieser Ampère'schen Figur. Ein durch einen electrischen Strom magnetisirter Eisenstab von was immer für einer Form heisst Electrom agnet.

Fig. 1474.

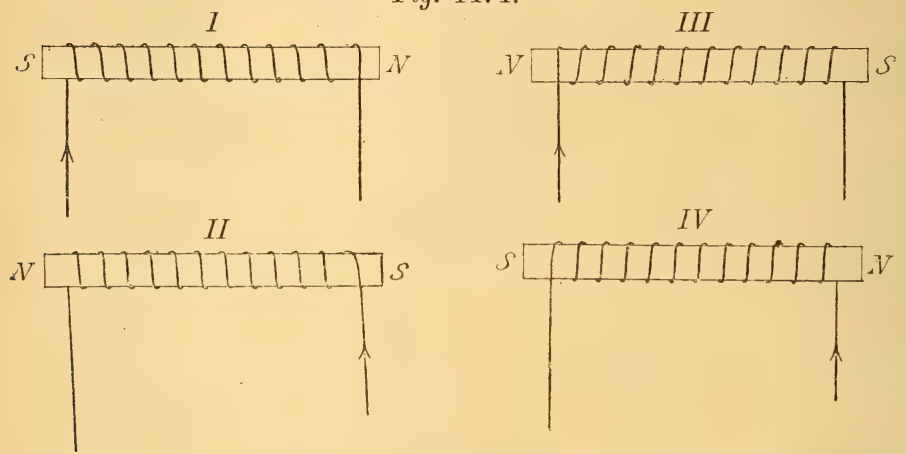

Zur Messing der Grösse des Magnetismus (z. B. eines magnetisirten Stahılstabes) dient bekanntlich die Beobachtung des Winkels $\omega=n_{0} n^{\prime}$, um welchen eine Magnetnadel $n^{\prime} s^{\prime}$ (Fig. 1475) von dem in bestimmter Lage und Entfernung angebrachten Magnetstabe NS aus ihrer urspriinglichen Stellung ns abgelenkt wird. War NS senkrecht auf $n s$ und der Abstand Oo (im Vergleiche mit Nadel und Stab) verhältnissmässig gross, so ist die Grösse des Magnetismus unter iibrigens gleichen Umständen der Tangente jenes Ablenkungswinkels amnähernd proportional. lïg. 1t7i.
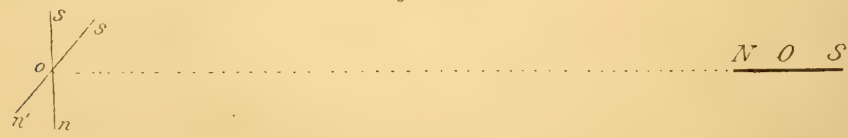

Mit Benutzung dieses Principes (in der Fig. 1476 angedeuteten IVeise) und gehöriger Beriicksichtigung des durch die magnetisirende Drahtspirale $S$ für sich allein (ohne Stab) bewirkten Theiles der Nadel-Ablenkung an der Bussole $B$ hat man gefunden, dass der durch einen electrischen Strom erregte Magnetismus (Electrom agnetismus) innerhalb zicmlich weiter Grenzen der Stromstärke

*) IIr wollen sie künftig kurz die Ampère'sche Figur nenuen. 
proportional ist. *) Bei stärkeren Magnetisirungen wächst der Magnetismus langsamer als die Stromstärke; man sagt dann: es trete nSätigung ${ }^{*}$ ein.**)

Ein ähnliches Gesetz gilt für den Zusammenhang zwischen der magnetisirenden Stromstärke und der Tragkraft von Electromagneten der gewöhnlich vorkommenden Form (Fig. 1477).

Dabei ist jedoch wohl zu beachten, dass der durch den Strom erregte Magnetismus, sobald man den Anker vorlegt, durch die Rïickwirkung desselben sehr bedeutend gesteigert wird, wesshalb eine Vergrösserung der Stromstärke bei vorgelegtem Anker eine viel rascher zunehmende Sättigung bewirkt als ohne Anker.****)

Während man die Tragkraft eines guten Stahlmagneten aus dem Gewichte desselben annähernd berechnen kann, $\dagger$ ) gibt es keine allgemeine Formel für die Tragkräfte der Electromagnete; doch ist es immer leicht, dieselbe soweit zu bringen, dass sie ein Vielfaches wird von der Tragkraft eines gleichschweren Stahlmagneten.

Eine verhältnissmässig noch grössere Tragkraft als die Electromagnete von der gewöhnlichen Hufeisenform haben die sogenannten Glockenmagnete (Fig. 1478, 1479 und 1480), welche man namentlich bei der Construction von electromagnetischen Maschinen (Motoren, siehe den Artikel Electromotor) mit Vortheil angewendet hat.

Wälrend bei gewölınlichen Electromagneten nur im Inneren der Magnetisirungsspirale ein Eisenkern sich befindet, haben Guillemin und Romershausen auch die äussere Fläche derselben mit ciner Eisenlitille umgeben, wie Fig. 1478, welche den Romer's h a us en'schen Glockenmagnet darstellt, beispielsweise zeigt. In den Raum zwisehen dem massiven und hohlen $\mathrm{Cy}$ Fig. 1479.
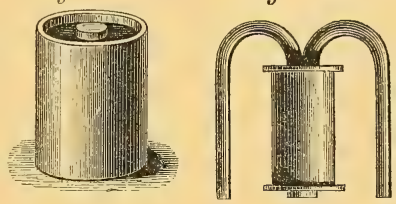

Fig. 1476 .
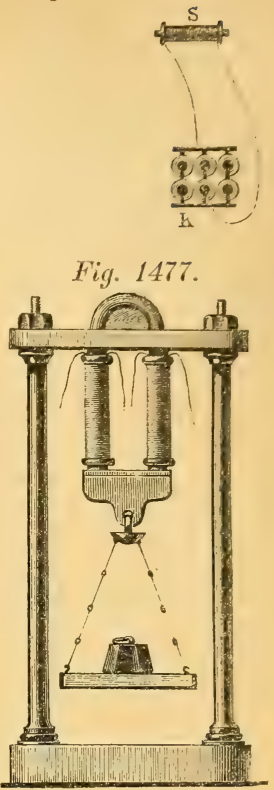

Fig. 1480.

linder kommt die Magnetisirungsspirale, wie auch in Fig. 1480 ersichtlich ist, wo anstatt der äusseren Hiille mehrere rings um die Spirale angeordnete Eisenstäbe angebracht sind, welche mit dem inneren Eisenkern auf einer gemeinschaftlichen eisernen Bodenplatte befestigt sind (System Nicklès). Eine solche gemeinschaftliche Bodenplatte verbindet auch den massiven und holilen Cylinder Fig. 1478. Eine oben aufzulegende eben solche Platte dient als Anker. Ein Nicklès'scher Magnet mit nur zwei äusseren Stäben ist Fig. 1479 abgebildet.

*) Nach meinen Untersuchungen ungeführ so lange, bis der Stab die Hälfte des Magnetismus, dessen er ïberhaupt fähig ist, angenommen hat.

**) Correcter wäre es zu sagen: Der Magnetismus iibersteigt die halbe Sättigung. Tergl. die vorhergehende Anmerkung.

* Die Resulate neuerer Untersuchumgen hierïber enthält W ïll u er's Lehrbuch der Physik (3. Aufl. 4. Bd. S. 825), wohei die mit $p$ bezeichneten Zahlen die Sättigungsprocente bedeuten.

†) Nach der II accker'schen Formel $T=103 P^{\frac{9}{3}}$, wobei $T$ die Tragkraft und $P$ das Gewicht des Magneten (ohne Anker, der bei $T$ eingerechnet wird) in Grammen bedenten. 
Man begegnet sehr häufig der Behauptung, dass die Tragkraft der Electromagnete bei schwachen Magnetisirungen mit dem Quadrate der Stromstärke wachse. Diese auf falschen Schlussfolgerungen beruhende Annahme wird durch die Erfahrung nirgends bestätigt. ${ }^{*}$ )

Die Tragkraft wächst bei beginnender Magnetisirung allerdings etwas rascher als die Stromstärke, aber nicht im quadratischen Verhältnisse; späterhin tritt innerhalb enger Grenzen eine annähernde Proportionalität ein, und bei noch weiter fortgesetzter Magnetisirung wächst die Tragkraft immer langsamer im Vergleiche mit der Stromstärke.

Nach Unterbrechung des magnetisirenlen Stromes verliert das Eisen den erlangten Magnetismus desto vollständiger, je weicher es ist. Stahl behält dagegen einen mehr oder weniger beträchtlichen magnetischen Riickstand, worauf eben die Herstellung permanenter Stahlmagnete beruht.

Zum Magnetisiren von geraden oder gebogenen Stahlstaben mittelst des electrischen Stromes dient die Elias'sche Magnetisirungsspirale (Fig. 1481), weiche Fig. 1481.

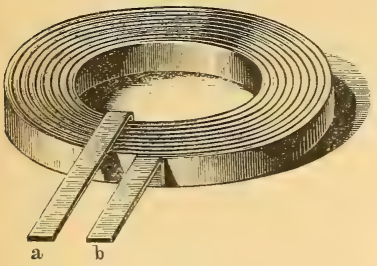
entweder aus sehr dickem (etwa $4^{\mathrm{mm}}$ ) iibersponnenen Kupferdrahte oder aus einem isolirend bewickelten oder übersponnen Kupferblechstreifen hergestellt wird. Ist die Spirale bis auf die Mitte des Stabes aufgeschoben, so wird der Strom geschlossen. Nachdem man die Polflächen mit weichem Eisen verankert hat, wird die Spirale etwa 10- bis 20 mal von Pol zu Pol und wieder in die Mitte zurïck hin- und hergeschohen (oder umgekehrt der Stab in der Spirale) und sodann der Strom wieder unterbrochen. Je härter der

Stahl ist, desto schwerer, aber auch desto haltbarer, ist er zu magnetisiren, $d$. . . desto weniger M: gnetismus nimmt er bei einer gewissen Stromstärke an, desto mehr Procente davon behält er aber auch zurück.

Aus glashartem Wolframstahl hat Referent durch Anwendung entsprechend starker Ströme sehr kräftige Magnete erzeugt. Ansserordentlich kräftig sind die (gleichfalls mit dem Strome magnetisirten) berílimten $\mathrm{H}$ a arlemer Magnete (namentlich jene von Wetteren). Ihre Tragkraft ist ein Mehrfaches von jener, welche nach Häcker den besten Stahlmagneten in der Regel zukommt und der Formel

$$
T=103 P^{\frac{2}{3}}
$$

entspricht, wobei $T$ die Tragkraft in Grammen und $P$ das Gewicht des Magneten in Grammen bedeutet. (Das Gewicht des Ankers wird natiirlich zu $T$ gerechnet.)

Noch kräftiger sollen die J a min'schen "Blättermagnete" (aus gebogenen magnetisirten dünnen Stahlfedern zusammengesetzt ${ }^{* *}$ ) sein.

Ungewöhnlich kräftig (d.h. mehr leistend, als die obige Häcker'sche Formel verlangt) sind anch die Magnete ron $\mathrm{S}$. M a r cus in Wien.

Die wichtigste Anwendung finden kräftige Stahlmagnete bei der Herstellung von magnetoelectrischen Inductionsapparaten fuir die Telegraphie, Sprengtechnik und andere Zwecke.

Der Electromagnetismus kann auch in der Art zur Herstellung künstlicher Magnete dienen, dass man die zu magnetisirenden Stahlstäbe an den Polen eines kräftigen Electromagn ten streicht. Man rerwendet dazu die grossen Electromagnete ron der in Fig. 1482 dargestellten Aufstellung, wie man sie in physicalischen Cabineten rormehmlich fuir diamagnetische Versuche gebraucht. ${ }^{* *}$ ) Eine

*) Siche die vorletzte Anmerkung.

**) Bei diesen Feder-Lamellen steht also die Breite der Lamelle anf der Biegungsebene senkrecht, währeud bei den gewöhulichen magnetischen Magazinen die einzelnen Lamellen so gebogen sind, dass die Breite der Lamelle in der Biegungsebene liegt.

***) Der in Fig. 1483 abgebildete Anker dient zu. Tragkraftsversuchen mit dem Electromagnete Fig. 1482 mittelst eines in die Stütze $a$ einzulegenden Abreisshebels, die Stütze b fängt den Hebel beim Losreissen. 


\section{Fig. 1482.}

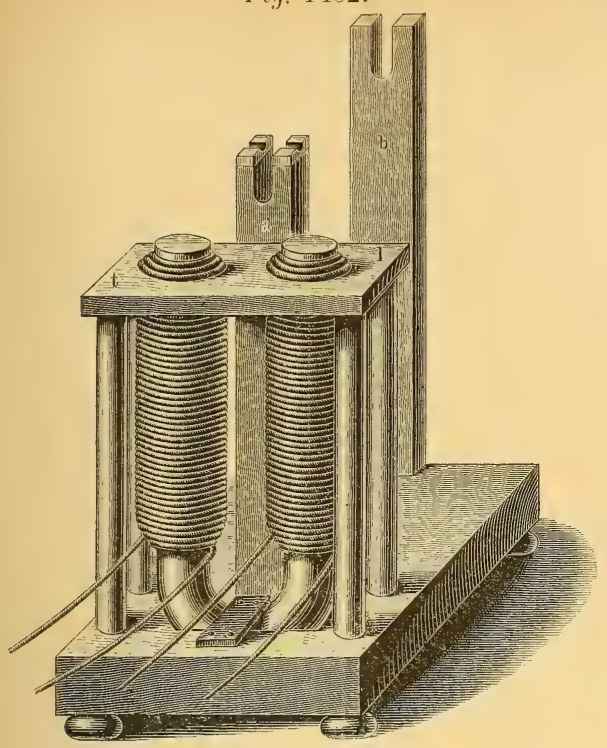

Fig. 148.3.

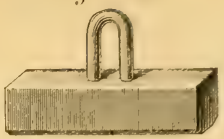

Hälfte des zu magnetisirenden Stabes wird auf dem Nordpol, die andere auf dem Siidpol des Electromagneten (von der Nitte aus nach dem Ende hin) mehrmals gestrichen. Die auf dem Nordpol gestrichene Hälfte wird südlich, die andere nördlich magnetisch. Ein weiteres Eingehen auf die verschiedenen Magnetisirungsmethoden (insbesondere auch für Hufeisenmagnete) wiurde uns zu weit fiihren und wir müssen diesfalls auf Frick's physikalische Technik verweisen. Gewöhnlich die nen Stahlmagnete als Streichmagnete.

b) Ablenkende IV i rkung des Stromes. Be-

findet sich eine Magnetnadel in der Nähe eines Stromleiters, so wird sie in der Weise abgelenkt, wie es Fig. 1484 für einige Fälle beispielsweise zeigt. Wie man sieht, erfolgt die Ablenkung des Nordpoles stets nach der Linken der mit dem Strome schwimmenden und mit dem Gesichte gegen die Magnetnadel gewendeten A mpére'schen Figur. *) So lautet die Ampère'sche Regel.

Liegt der auf die Nadel wirkende Stromleiter seiner ganzen Ausdehnung nach in der Ebene des magnetischen Meridians, und ist die Nadel sehr klein, selbst im Vergleiche mit dem Abstande vom nächstliegenden Theile des Stromleiters, so ist die Stromstärke der Tangente des Ablenkungswinkels annähernd proportional. Hierauf beruhen die sogenannten Tangenten bussolen. Bildet der Stromleiter einen kreisförmigen Ring, in dessen Mitte sich der Drehungspunkt der Magnetnadel befindet (Fig. 1485), so hat man im Wesentlichen die Anordnung: der Weber'schen Tangentenbussole, welche wohl als das einfachste, gebräuchlichste und unentbehrlichste Messinstrument für electrische Ströme (oder Fig. 1484 .

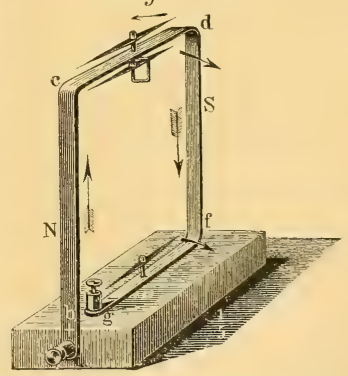
"Galvanometer") bezeichnet werden kann. Man findet mittelst dieses Instrumentes die Stromstärke $S$ nach ehemischem Masse nach der Formel

$$
S=1.05 \frac{H R}{2 \pi} \cdot \operatorname{tg} \omega
$$

Hier bedeutet $H$ die horizontale Componente der erdmagnetischen Krraft, nach

2) Man denkt sich nämlich zur leichteren Orientirung im Stromleiter eine mensehliche Fignr dargestellt, im electrischen Strome schwinmend, dass der Strom von den Fïssen nach dem Kopfe der Figur geht, wälırend das Gesicht der Figur der Magnetnadel. auf welche der Strom wirkt, zugewendet ist. 


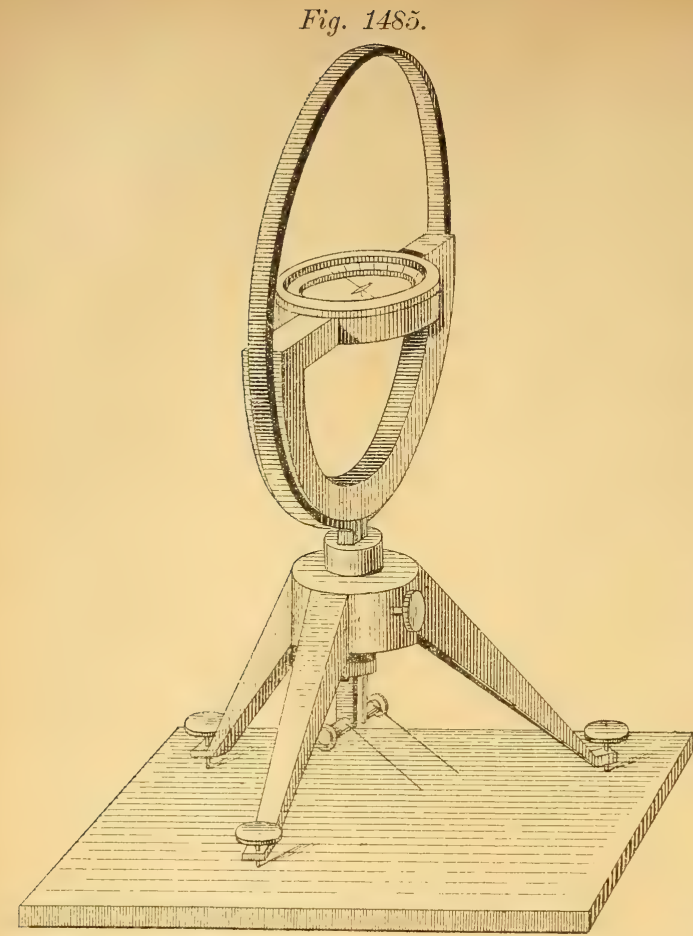

der iiblichen Gauss'schen Einheit gemessen, *) $R$ den Radius des strom. leitenden Ringes in Milli. metern, $\pi$ das Kreisverhältniss (3. 14...) und $\omega$ den Ablenkungswinkel.

Bei der Gaugainschen Tangentenbussole ist der Drehungspunkt der Magnetnadel ausserhalb der Ebene des stromleitenden Ringes im $\mathrm{Ab}$ stande von 1/4 des Ringdurchmessers. Diese Anordnung gewährt den Vortheil, dass die Proportionalität zwischen $S$ und $\operatorname{tg} \omega$ (,Tangentengesetz “) genauer zutrifft. Bedeutende Abweichungen vom Tangentengesetze treten ein, wenn die Magnetnadel zu lang ist. Auf die diesbeziiglichen Correctionen kann hier nicht eingegangen werden. Wir beschränken uns darauf, die Regel zu empfehlen, dass die Nadellänge $\%$, des Ringdurchmessers nicht be-

trächtlich iibersteigen soll. - Lin ungeachtet der Kiirze der Magnetnadel auf einer Kreistheilung ron grösserer Ausdehnumg die Ablenkungen ablesen zu können, rersieht man die Magnetnadel mit einem (gewöhnlich senkrecht zu ihrer Richtung angebrachten) leichten, geraden und gut äquililrirten Glasfaden oder Aluminiumdraht als Zeiger. Der stromleiter der Tangentenbussole kimn auch aus mehreren (entweder nach dem Treber'schen oder nach dem G a ug a inschen System angeordneten) Drahtkreisen bestehen, wodurch erzielt wird, dass die Ablenkung bei gleicher stromstärke grösser ausfällt, oder mit anderen Worten: dass der Reduetionsfactor kleiner ausfällt. Cuter diesem versteht man den Coëfficienten 7 in der Formel

$$
s^{\prime}=l: \operatorname{tg} \omega
$$

Fig. 1486.

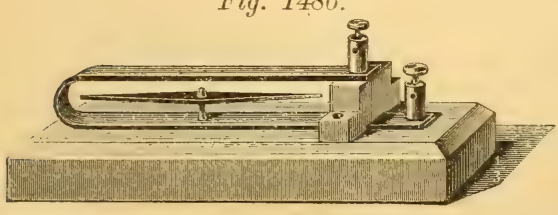

welche die Proportionalität zwischen Stromstärke und Ablenkungstangente ausclriickt. $\%$ )

Fiir starke Ströme, und wenn es sich nur darum handelt, die $\mathrm{Zu}$ oder Abnahme derselben zu beobachten ist das leicht herzustellende einfache ,Rheoscop" Fig. 1486

*) In unseren Gegenden kummt iler Werth rom $H$ der Zall 22 selur nahe.

*) In oliger Furmel (fiir eine Weber'sche Tangentenhusole mit einfiuhem Ringe) ist also der Reluctionsfactor fïr chemisches Strommass $l=10 \% \frac{I I R}{2 \pi}$. 
sehr bequem. (Wegen der grossen Länge der Narlel kann bei derselhen das Tangentengesetz natürlich nicht zutreffen).

Zur Nachweisung und Messung von selu schwarhen Strömrn dient eine eigene Classe von möglichst empfindlichen Galvanometern, die man M ultiplicatoren nenint.

Denkt man sich eine aufgehängte Magnctnadel $n s$ wie die untere in Fig. 1487 in der daselbst angedeuteten Weise von mehreren Drahtwindungen umgeben, so wird ein bei + eintretender und bri austretender Strom die Nadel mehrmals umkreisen. Die ablenkende Wirkung (welche im vorliegenden Falle den Nordpol hinter die Zeichnungsebene treibt) wird daher im Verhältnisse der Anzahl der Fig. 1487. Drahtwindungen verstärkt (multiplicirt) werden.

Zum Aufwickeln des Drahtes dient ein hölzerner Rahmen (Fig. 1488) innerlıalb dessen Höhlung die Magnetnadel sich befindet. Mit derseiben ist oft eine zweite entgegengesetzt gerichtete Magnetnadel, die sich ausserhalb der Drahtwindungen befindet, in der aus Fig. 1487 ersichtlichen Weise festverbunden. Diese Einrichtung (man nennt eine solche Doppelnadel eine astatische, weil der Erdmagnetismus auf dieselbe nur ein geringes Drehnngsmoment ausiiben kann) erhöht die Empfindlichkeit, d. h. die Ablenkarbeit durch sehwache Ströme aus dem bereits angegebenen Grunde und weil zugleich noch das Drehungs-

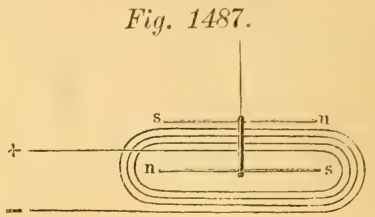
moment des Stromes auf beide Nadeln in gleichem sinne wirkt.

Die obere Nadel spielt, wie die Abbildung eines vollständigen Multiplicator's Fig. 148 ? zeigt, auf einer oberhalb des Gewindrahmens angebrachten Kreistheilung. Die Aufhängungsvorrichtung (zum Heben nnd Senken der Nadel eingerichtet) zeigt Fig. 1490 in grösserem Massstabe. - Zwei Drahtklemmen dienen zur Anbringung der Leitungsdrähte beim Gebranche des Instrumentes.

Vor dem Gebrauche wird das Instrument natiirlich so eingestellt, dass die obere Nadel auf dem Nullpunkte der Kreistheilung einsteht. Die freie Beweglichkeit der Nadel wird dadurch gesichert, dass man sie mittelst der Aufhängungsvorrichtung in solche Höhe bringt und das ganze Instrument mittelst der Stellschramben so richtet, dass die Nadel innerhalb des Rahmens nirgends anstreift.

Die feinsten Beobachtungen gestatten die sogenannter Spiegelgalvano. meter. Eines der einfachsten Instrumente dieser Art ist z. B. das W e be r'sche Fig. 1491. Der innerhalb des Drahtgewindes bewegliche, mittelst der Vorrichtung: $r r$ aufgehängte Magnetstab ist ausserhalb des Gewindes mit dem entsprechend äquilibrirten kleinen Spiegel $m$ fest verbunden. Denkt man sich uun von einer Flamme ein Strahlenbiindel auf den Spiegel fallend, so wird dasselbe rom Spiegel reflectirt und mittelst cines Schirmes aufgefangen, auf demselben ein Lichtbild erzengen, welches seinen Ort verändert, so wie der Magnetstab und mit ilım der Spiegel eine Drehung erfährt. Hier vertritt das reflectirte Strahlenbiindel gewisserruassen die Stelle eines langen Zeigers, der die Ablenkungen angibt. Auf dicse Art können Galvanometerablenkungen leicht einem ganzen Auditorium sichtbar gemacht werden.

Handelt es sich um genaue Messungen, so stellt man dem Galvanometerspiegel gegenuiber einen horizontalen Massstab auf und betrachtet das Spiegelbild desselben mittelst eines Fermrohres mit Fadenkreuz.

Beobachtet man, welche Theilstriche am Fadenkrenze erscheinen, so findet man aus der Anzahl der Scalentheile, um welche im Falle einer Ablenkung das Spiegelbild verschoben wird, und aus dem Abstande des Spiegels von der Scala 


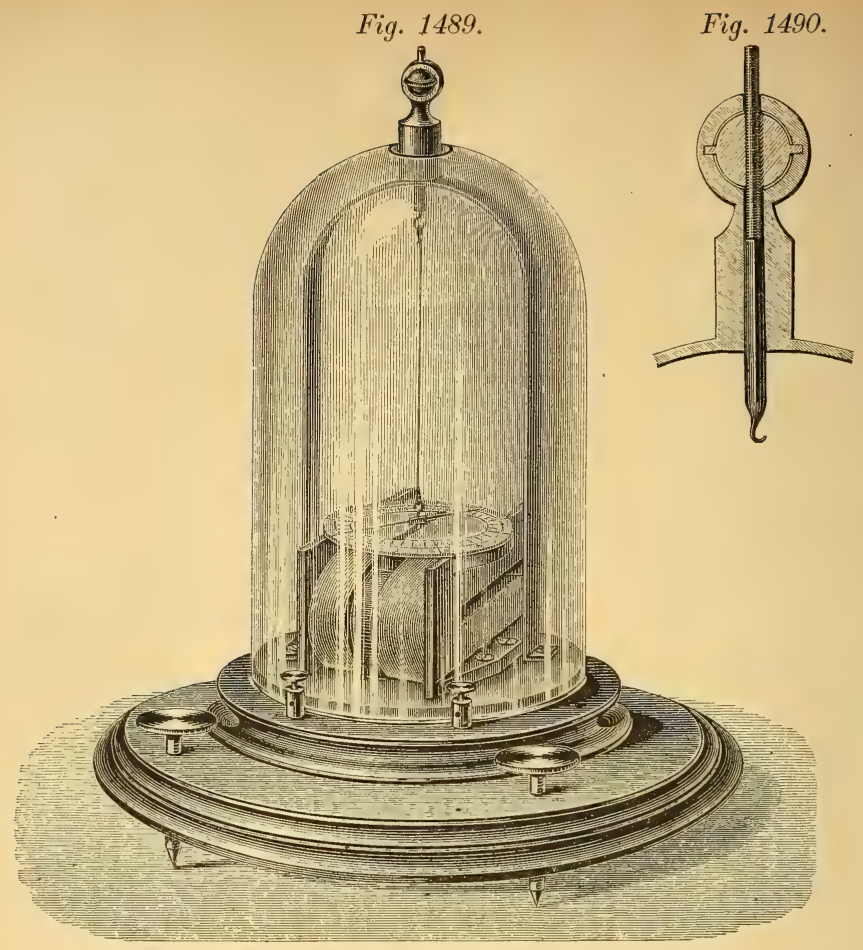

durch eine leichte Rechnung die Ablenkung in Bogenmass, worauf wir hier nicht weiter eingehen wollen.

Man hat Spiegelgalvanometer der verschiedensten Form und Construction je nach dem Zwecke, welchem sie dienen sollen. Auch beim transatlantischen Telegraphen ist ein Spiegelgalvanometer in Verwendung, welches durch grössere oder kleinere Ausschläge des reflectirten Flammenbildes ( Lichtzeigers“) zum Zeichengeben dient.

Bei manchen Instrumenten dieser Art vertritt ein magnetisirter Stahlspiegel zugleich die Stelle des abzulenkenden Magnetstabes oder der abzulenkenden Magnetnadel.

Oft ist es sehr störend und zeitraubend bei jeder Ablenkung abwarten zu müssen, bis der Magnet nach einer Anzahl von Schwingungen eine neue Gleichgewichtslage annimmt. Man hat desshalb auch Vorrichtungen erdacht, welche den Magnet mehr oder weniger rasch zur Ruhe bringen und Dämpfungen genannt werden. Man kann zu diesem Zwecke das Princip des Mittelwiderstandes anwenden, oder, was gewöhnlich geschieht und vorzuziehen ist, die Rückwirkung electrischer Ströme, welche der schwingende Magnet in benachbarten Metallmassen inducirt. Dass und wie eine solche Rïckwirkung stattfindet, lehrt schon der einfache Versuch, dass eine Magnetnadel viel schneller zur Ruhe kommt, wenn sie iiber einer Metallplatte als wenn sie z. B. über einem Brette schwingt. Nach den im Artikel Electricität abgehandelten Inductionsgesetzen (Abschnitt $D$ ) ist nämlich leicht einzusehen, dass die ron den bewegten Magnetpolen in der Metallplatte 
inducirten Ströme stets die entgegengesetzten Bewegungen der Magnetpole zu bewirken suchen.

Construirt man daher ein Galvanometer so, dass der schwingende Magnet von einer dicken kupfernen Hülse ("Dämpfer") umgeben ist, so wird er viel rascher zur Ruhe kommen, als wenn er frei schwingt.

Mian hat in neuester Zeit auch sogenannte aperiodische Galvanometer hergestellt, bei welchen die Dämpfung so stark ist, dass der Magnet, wenn er durch einen in das Gewinde eingeleiteten Strom abgelenkt wird, schon nach dem ersten Ausschlage zur Ruhe kommt, also gar keine Schwingungen mehr macht.

c) Spiralanziehung. Als eine dritte Form, in welcher der Electromagnetismus oft zur Anwendung kommt, mag noch die sogenannte ${ }_{n}$ Spiralanziehung" erwähnt werden.

Liegt in einer Magnetisirungsspirale Fig. 1492 ein Eisenstab, so wird derselbe, wenn in der Spirale Fig. 1492.
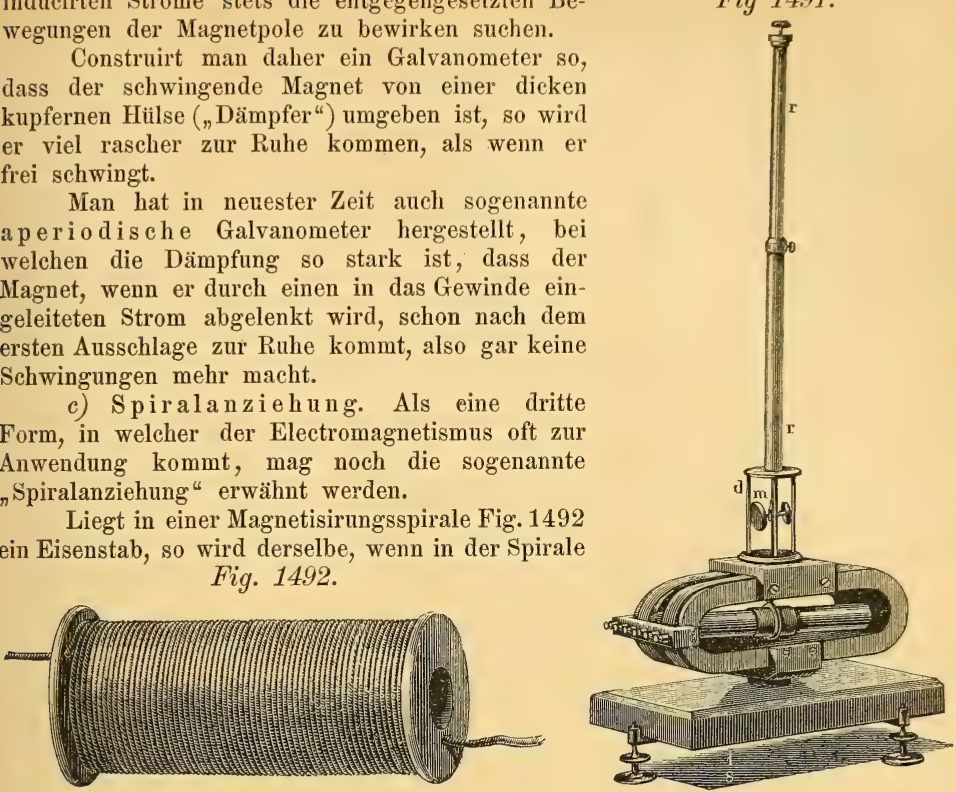

ein electrischer Strom circulirt, nicht nur magnetisch geworden sein, sondern auch nur mit einem gewissen Kraftaufwande aus der Spirale herausgezogen werden können. Lässt man ihn wieder aus, so wird er, bei entsprechend starkem Strome, kräftig in die Höhlung der Spirale zurickgezogen, bis er eine solche horizontale Lage angenommen hat, dass die Mitte des Stabes mit der Mitte der Spirale zusammenfällt (insoferne er daran nicht durch Reibung verhindert wird). Wir haben diese Erscheinung, die wir nicht weiter verfolgen wollen, nur erwähnt, weil anf diesem Principe einige oft zur Sprache kommende electromagnetische Apparate beruhen.

Wir wollen schliesslich noch hinzufügen, dass auch je zwei Magnetisirungsspiralen aufeinander magnetische Wirkungen ausüben, wie man leicht beobachten kann, wenn man sie entsprechend leicht beweglich aufhängt. Dasselbe gilt ron einzelnen Drahtwindungen. Die weitere Verfolgung dieser und ähnlicher Erscheinungen führt zu dem Resultate: dass gleich gerichtete parallele Ströme sich anziehen, entgegengesetzt gerichtete aber abstossen.

A. v. W.

Electrometer (électromètre - electrometer) nennt man Instrumente, welche zum Messen electrischer Spannungen oder Entladungen dienen. Gewöhnlich wird der Ausdruck Electrometer im Gegensatze zu Electroscop in dem im Artikel Electricität Absatz XXIII angegebenen Sinne gebraucht.

In analoger Weise werden die zur Untersuchung electrischer Ströme dienenden Instrumente entweder Rheometer ( = Galvanometer, siehe den Artikel El e ctr 0magnetismus) oder Rheoscope genannt.

$A . v, W$.

Electromotor (moteur électrique - electro-magnetic engine). Dieser Ausdruck wird in verschiedenem Sinne gebraucht, indem er bald anf die Electricitätserregung, bald auf die Anwendung der Electricität als bewegende Kraft bezogen 
wird. Im ersteren Sinne heisst "Electromotor" so viel als ,Electricitätserreger" (z. B. Kupfer und Zink beim Contacte. Daher anch der Ansdruck, „electromotorische Kraft"); siehe den Artikel ,Electricitä" Absatz XXXVI bis XXXVII. Im anderen Sinne, und dies ist der gewöhnliche Sprachgubranch, bedentet „Electromotor" eine electromagnetische Arbeitsmaschine (einen electrischen Motor), nämlich eine Maschine, durch deren Vermittelnng ein electrischer Strom mechanische Arbeit leistet.

Die grosse Tragkraft der Electromagnete hat bald nach deren Erfindung: grosse Hoffnungen erregt, den Electromagnetismus mit Vortheil als bewegende Kraft nutzbar machen zu können. Versuche dieser Art haben zu den mannigfaltigsten, mitunter sehr simmreichen und eleganten Constructionen dieser Art gefiihrt. Obgleich die meisten davon nur in kleinem Massstal)e hergestellt und erprobt worden sind, und nur wenige mit wissenschaftlichem Verständnisse gemachte Aufzeichnungen ron Versuchsresultaten rorliegen, so lässt sich doch mit Sicherheit behaupten*), dass selbst die besten bis jetzt construirten Electromotoren, bei den gegenwärtigen Hilfsmitteln zur Erzeugung electriseher Ströme, viel zu grosse Betriebskosten erfordern, als dass für jetzt an eine ausgedehntere practische Verwendung derselben oder wohl gar an eine Concurrenz mit Dampfoder Gasmaschinen (obgleich der Wirkungsgrad eines guten Electromotors den Wirkungsgrad einer gnten Dampfmaschine weit iibertrifft **) gedacht werden könnte. - Hicrbei kommt noch ganz besonders in Betracht, dass, wie die Erfahrung gelehrt hat und anch aus theoretischen Grüden begreiflich ist) der Wirkungsgrad eines nach einem bestimmten System construirten Electromotors bei der Ausfiihrung im Grossen sich immer kleiner heraustellt als bei den Versuchen mit einem kleinen Modell.

Fiir jetzt lïsst sich also von den electromagnetischen Arbeitsmaschinen noch kein practisch belangreicher Gebrauch machen, weshalb eine ausfilhrlichere Besprechmog derselben hier füglich unterbleiben kanu. Wir beschränken uns darauf, zunächst die Grundidee der electromagnetischen Maschinen an einem möglichst einfachen Modelle dieser Art (von Ritchie) zu erläutern und sodamn das Princip des besten bis jetzt construirten Electromotors (für die Pariser Weltausstellung im Jahre 1867 rom Mechaniker Johann Kravogl construirt***; in Kürze anzudenten.

Um zuvörderst im Allgemeinen eine Vorstellung davon zu geben, wie der Electromagnetismus als bewegende Kraft verwendet werden kann, betrachten wir das in Fig. 1493 abgebildete Rit chie'sche Maschinchen.

Zwischen den Schenkeln $N$ und $S$ eines Stahlmagneten befindet sich die verticale Drehungsachse eines mit isolirtem Drahte bewickelten Ankers ron weichem Eisen, dessen Enden $A$ und $B$ etwas nach abwïrts gebogen sind, jedoch so, dass sie beim Rotiren um jene Achse iiber den Magnetpolen $N$ und $S$ hinweggehen. Denkt man sich Magnet und Anker in der augenblicklich gezeichneten Stellung und $A$ sïdlich magnetisch (was dann der Fall sein wird, wenn ein Strom beim Drahtende o eintritt), so wird $A$ gegen $N$ und $B$ (Nordpol) gegen $S$ (Siidpol) gezogen werden. Dies hat eine Rotation des Ankers im Sinne eines Uhrzeigers

*) Die diesbezïglichen Nachreisungen hat Referent in seinen Abhandiungen im 183., 188. und 191. Bande von Ding ler's polytechnischem Journale geliefert. Diese Abhandlungen lehren zugleich die Ermittlung des Wirkungsgrades eines Electromotors.

**) Unter Wirkungsgrad versteht man bekanntlich den Quotienten des theoretischen Effectes durch den Nutzeffect, d. h. wenn z. B. $E$ den Arbeitswerth der zum Betriebe der Maschine (in der Feuerung oder in der Batterie) aufgewendeten Wärmemenge und $\Lambda^{\top}$ die wirkliche Arbeitsleistung bedeutet, su ist $\Pi=\frac{E}{I^{*}}$ der "Wirkungsgrad" der " Maschine.

**:*) Das ausgestellte, jetzt am Wiener Polytechnikum befinlliche, vom Referenten untersuchte Modell hatte im Maximum den Wirkungsgrad 1/4, etwa das Achtfache im Vergleiche mit den besten anderen Maschinen dieser Art. Siehe Dingler's polyt. Journal Bd. 183. 
zur Folge, bei welcher jedoch der Anker nicht plïtzlich iiber den darunter befindlichen Magnetpolen stehen bleiben, sondern diese Lage vermöge der Trägheit iiberschreiten wird.

Die Stromzuleitung ist nun so eingerichtet, dass in diesem Augenblicke ein Polwechsel stattfindet, in Folge dessen $A$ nördlich und $B$ siidlich wird. Die nunmehr zwischen $A$ und $N$ einerseits und $B$ und $S$ anderseits herrschende Abstossung veranlasst eine Fortsetzung der bereits beschriebenen Rotation, bis $B$ uiber $N$ und $A$ iiber $S$ zu stehen kommt. Bei Ueber schreitung dieser Lage (in Folge der Trägheit des rasch rotirenden Ankers) findet sofort wieder ein Polwechsel statt, und so setzt sich die beschriebene Bewegung fort.

Die erwähnten Polwechsel werden in folgender Weise bewerkstelligt.

An der Achse des rotirenden Ankers ist eine hölzerne Scheibe, deren Umfang mit zwei von einander getrennten kupfernen Halbringen belegt ist, auf welchen die den Strom leitenden Contactfedern gleiten, die ihrerseits wieder mit den Drahtklemmen + und - (zur Aufnahme der Leitungsdrähte) verbunden sind. Von dem Drahtgewinde des Ankers ist das eine Ende o mit dem Halbringe h, das andere mit dem zweiten Halbringe $i$ verbunden. Stelıt der Anker so, dass die Contactfeder $g$, bei welcher der positive Strom eintritt, anf dem Halbringe $h$ schleift, so wird $B$ nördlich, wenn aber $g$ anf dem entgegengesetzten Halbringe $i$ schleift, sîdlich magnetisch sein.

Im ersteren Falle geht der Strum ans dem Halbringe $h$ dureh das Gewinde des Ankers in den zweiten Halbring $i$ und aus diesem in die Contactieder $f$; im letzteren Falle aus $g$ iiber $i$ und $h$ nach $f$. Der Commutator (die Rolle mit den Halbringen) ist so gestellt, dass die beiden Contactfedern gerade auf die schmalen isolirenden Zwischenräume zwischen den Halbringen zu stehen kommen, wenn der Anker gerade iiber den Magnetpolen sich befindet. Es findet damn der vorhin beschriebene Polwechsel rechtzeitig statt.

Man kann sich nun leicht ein ähnliches grösseres Modell mit einem Schwungrade versehen denken, welches die Bewegung weiter überträgt.

Electromotoren, bei welchen, wie bei diesem und vielen anderen älteren electromagnetischen Maschinen, Polwechsel stattfinden, sind mit grossen Kraftrerlusten verbunden, theils weil die Polwechsel bei grösseren Eisenmassen nicht rasch genug erfolgen, theils weil sie Inductionsströme erzengen, welche dem Betriebsstrome entgegenwirken. Diese Uebelstände sind beim nachstehend beschriebenen Kravogl'schen Apparate vermieden.

Das im Schema Fig. 1494 dargestellte hohle eiserne Schwungrad enthält zugleich den electromagnetischen Apparat der Maschine. Dieser (längs eines anf der Drehungsachse $C$ senkrechten Schnittes zerlegbare) Radkranz umschliesst nämlich zunächst eine Anzahl von Magnetisirungsspiralen $a, b \ldots \ldots m$, innerhalb deren Iühlungen der hohle messingene Ping $r r^{2}$ sich befindet. In diesem messingenen Hohlringe befindet sich endlich der entsprechend gobogene (anf kleinen Rollen) sehr leicht gleitende Eisenkern $P p$ (in seinem Inneren mit Quecksilber beschwert). 


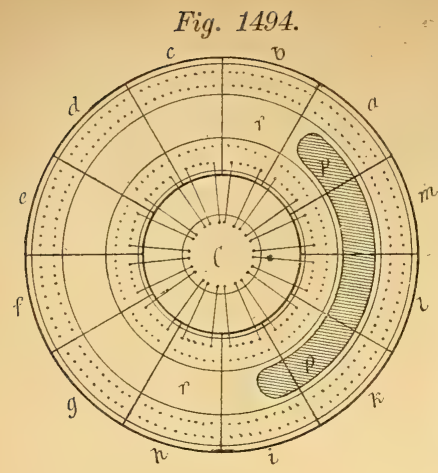

Die beiden Drahtenden einer jeden Nagnetisirungsspirale laufen radial gegen die Achse hin, an welcher eine eigenthïmlich construirte Contactvorrichtung ( Zuleiter" genannt) angebracht ist, welche den Batteriestrom immer nur in diejenigen Magnetisirungsspiralen übergehen lässt, welche während der Drehung des Rades in einer bestimmten Lage sind. Nehmen wir z. B. an, die Einrichtung sei so getroffen, dass immer nur die Spiralen, welche rechts liegen (bei $a$ und $m$ ) Strom bekommen, so werden diese stets den Eisenkern in ihre Höhlungen heraufziehen (siehe Electromagnetismus Abschnitt c). In Folge dessen wird das Rad immer einseitig beschwert sein und stets in der Richtung: $a m l \ldots .$. sich drehen müssen. Diese Bewegung des Spiralenrades, welches also zugleich Schwingrad ist, kann, wie die eines jeden anderen Schwungrades, leicht weiter uibertragen werden. A. $v$. $W$.

Electrophor (électrophore - electrophorus) heisst wörtlich Electricitätsträger. Diese Benennung führt eine einfache Vorrichtung, welche dazu dient, die Electricität einer (mit Pelzwerk) geriebenen Harzplatte lange Zeit zu erhalten, um dieselbe gelegentlich zu Funkenziindnngen (z. B. bei eudiometrischen Versuchen oder bei der electrischen Zündmaschine) verwenden zu können.

Böttger empfiehlt als Electrophormasse ein Gemenge aus 5 Theilen Schellack, 5 Theilen Mastix, 2 Theilen venetiauischem Terpentin und 1 Theil Marineleim (einer aus Schellack, Steinkohlentheer und Kautschuk bestehenden Masse).

Dieses Harzgemenge wird in eine niedrige cylindrische Form aus Blech eingegossen, um nach dem Erstarren entweder in derselben zu bleiben, oder herausgenommen und auf eine beliebige andere leitende Unterlage (z. B. ein mit Stanniol iiberzogenes Brett $c$, Fig. 1495) gelegt zu werden. (Um das IIerausnehmen leicht zu ermöglichen, kann die Gussform mit Papier ausgelegt werden. Die Unterlage Fig. 149.5 .

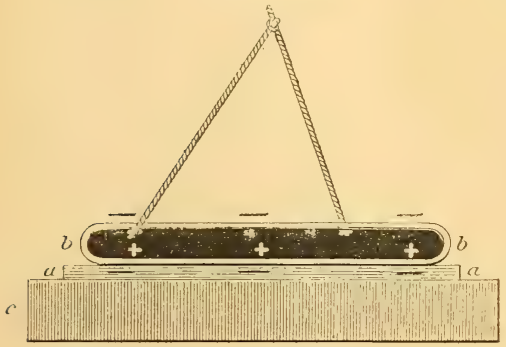
der Harzplatte muss ganz eben sein, damit sich jene nicht krümmt.)

Die Harzplatte $a$ (Fig. 1495) wird durch Reiben mit Pelzwerk (gewöhnlich durch starkes Schlagen mit einem Fuchsschwanz) negativ electrisch gemacht. Man setzt sodann einen an drei seidenen Schnïren hängenden metallenen Deckel 6 darauf. Derselbe ist entweder ein Hohlkörper aus Blech von der in der Zeichnung dargestellten Gestalt, oder in der Art hergestellt, dass man einen hölzernen Ring mit starkem Papier bespannt und das Ganze mit Stanniol iiberzieht.

Der Deckel wird beim Anflegen sofort durch Influenz electrisirt (s. Electricität Absatz X). Durch Beriihrung des Deckels wird die negative Influenzelectricität abgeleitet. Die positive bleibt gebunden zuriick *) und kann auf diese Art Monate lang in Bereitschaft gehalten werden. Sie wird frei, sobald man den Deckel mittelst der isolirenden Schniire abliebt, aus welchem sie anf einen angenäherten Leiter unter Funkenbildung iiberspringt.

A. v. W.

1)as schlechte Leitmngsrermïgen der Harzplatte verhindert, dass eine griissere Menge der negativen Harzelectricität mit positiver Influenzelectricität des Deckels zur Ausgleichung komme. 
Electroplate, Bezeichnung fuir versilbertes Neusilber, gleichbedeutend mit China-, Peru-Silber, Alfenide u. s. f., s. Argentan I S. 190.

Electroplaitiren, syn. mit galvanischer Versilberung, s. Galvan op las tik. Electroscop (électroscope - electroscop), s. Electricität Absatz XXIII.

Electrotyp, Voltatyp, ein mit auf galvanoplastischem Wege hergestellten Kupferplatten erzeugter Druck.

Electrum, syn. mit Bernstein s. I pag. 431.

Electrum (électre - electrum), silberhaltiges Golderz mit über $20 \%$ Silbergehalt. Hellgelbe Wiirfel oder Octaëder oder hexaëdrische Blättchen. Spec. Gew. 14·1-14*6. Columbien, Königsberg, Sibirien u. a. 0. Gtl.

Electrum, Name einer dem Silber ähnlichen Legirung aus 8 Thl. Kupfer, 4 Thl. Nickel und $3 \frac{1}{2}$ Thl. Zink. Gut polirbar. Gtl.

Elekta, besonders vorziigliche Schafwollsorte, s. Schafwolle.

Elektricität, s. Electricität.

Elektoral, jene Merino-Schaf-Race, welche das feinste Wollhaar liefert.

Elektrographie (Electrografie), ein von Devincenzi angegebenes Verfahren der galvanischen Aetzung von Zinkplatten für den Buchdruck, s. Holzschnitt.

Elektromotor, s. Electromotor III S. 253.

Element, chemisches (élément - element), Grundstoff, Urstoff, chemisch einfacher Stoff, einfaches Radical, nent der Chemiker die mit den bisher zu Gebote stehenden Mitteln nicht weiter zerlegbaren, also einfachsten Bestandtheile chemischer Verbindungen. Gegenwärtig sind 63 solcher Elemente oder elementarer Stoffe bekannt und isolirt. Man theilt sie je nach ihren Eigenschaften in metallische Elemente (Metalle) und in nichtmetallische Elemente ( $\mathrm{Nicht}$ metalle). Die ersteren zerfallen wieder in: I. die Leichtmetalle, deren Dichte unter 5 ist, und II. die Schwermetalle, deren Dichte iiber 5 ist. Die erste Abtheilung (Leichtmetalle) umfasst die Gruppe der

Alkalimetalle, n. zw. Kalium, Caesium, Rubidium, Natrium, Lithium, dann jene der

Metalle der alkalischen Erden, u. zw. Baryum, Strontium, Calcium, Magnesium. Endlich jene der

Erdmetalle, u. zw. Aluminium, Beryllium, Zirkonium, Yttrium, Erbium, Terbium (Norium), Thorium, Cerium, Lanthan, Didym.

Die zweite Abtheilung. (Schwermetalle) umfasst die Gruppe der

Unedlen Metalle, u. zw. Uran, Kobalt, Nickel, Eisen, Mangan, Chrom, Zink, Cadmium, Blei, Thallium, Kupfer, Zinn, Titan, Tantal, Niobium, Wolfram, Molybdaen, Vanadin, Wismuth, Antimon, Arsen, und die Gruppe der

Edlen Metalle, u. zw. Quecksilber, Silber, Gold, Platin, Palladium, Ruthenium, Rhodium, Iridium, Osmium.

Die Nichtmetalle pflegt man einzutheilen in die Gruppe der

Metalloïde, 11. zw. Wasserstoff, Stickstoff, Phosphor, Bor, Kiesel, Kohlenstoff, und die Gruppe der

Oxygenö̈de, n. zw. Sauerstoff, Schwefel, Selen, Tellur, Chlor, Brom, Jod, Fluor. Ausser dieser Eintheilungsweise ist heute auch die Eintheilung der Elemente nach ihrer Valenz (vgl. Atomigkeit I pag. 232) iiblich, wonach man sie in 6 Gruppen bringen kann.

Eine tabellarische Zusammenstellung der Elemente, ihrer chemischen Symbole, Atomgewichte und Aequivalente s. Atom I pag. 231. Gtl.

Element, galvanisches (élément galvanique - voltaic cell). So nennt man eine Combination von Leitern erster und zweiter Ordnung (z. B. zweier Metalle und einer Flissigkeit), welche zur Erzeugung eines continuirlichen elec- 
trischen Stromes geeignet ist. S. Electricität III pag. 177 und electrischc Telegraphie III pag. 202. Ueber thermoelectrisches Element s. Electricität III pag. 180.

A. $v . W$.

Elemi (resine élémi-elemi), Elemiharz. Unter diesem Namen kommen harzartige, zu medicinischen, vorzinglich aber zu technischen Zwecken verwendete Producte mehrerer Baumarten aus tropischen Gegenden verschiedener Weltheile im Handel vor. In unserem Handel findet sich nur das von den Philippinen uiber London und Hamburg eingefiihrte Manila-Elemi, eine Sorte, die man von dem Pechbaum der philippinischen Inseln, dem Arbol a brea, einer CanariumArt (Burseraceae) ableitet. Ausser dieser Sorte findet sich noch in den verschiedenen Preislisten z. B. von Londoner und Hamburger Droguisten ein Veracruzoder Mexikanisches Elemi (von Amyris elemifera Royle) angeführt. - Das Manila-Elemi bildet frisch eine zähe, fast terpentinartige, gelblichweisse, trübe, mit Pflanzenresten untermischte Masse von starkem gewiirzhaftem, an Fenchel und Macis erinnerndem Geruch und ähnlichem, nebstbei etwas bitterem Geschmack. Mit der Zeit trocknet die Waare zu einer blassgelblichen undurchsichtigen, am Bruche wachsglänzenden Masse ein.

Unter dem Microscop erweist sich das Elemi aus kleinen und grösseren prismatischen farblosen Krystallen zusammengesetzt, welche in eine formlose Masse eingebettet sind. Kalter Alkohol löst blos letztere; in heissem Alkohol, so wie in Aether ist Elemi bis auf fremde Beimengungen vollkommen löslich. Es besteht wesentlich aus einem ätherischen Oele (an 10\%) und Harz, das zum Theile amorph, zum Theile krystallisirbar ist (Amyrin und Bryoidin).

A. Togl.

Elephantenlaus (anacarde - acajou nut), Merknuss, Anakardie, A cajounuss, Malaccanuss. Nussartige Steinfrucht von Anacardium occidentale (auf den Westindischen Inseln und in Siidamerika einheimischer Baum), so wie ron Semecarpus orientalis (in Ostindien einheimisch). Die orientalischen (Malaccaniisse) sind glatt, herzfürmig bis stumpf dreieckig, dunkel- bis schwarzbraun, einen nussartigen, öligen, wohlschmeckenden Kern in der lederartigen Fruchtschale enthaltend. Die occidentalischen Niisse haben eine melır nierenförmige Gestalt und sind ron grauer bis graubramer Farbe. Die lederartige Fruchtschale enthält einen, im frischen Zustande lichtgefärbten, an der Luft rasch braun werdenden ätzenden Saft, der bald rerharzt und als wesentlichen Bestandtheil Cardol (s. II pag. 255) enthält. Man hat diesen Saft sowohl als Arzneimittel (blasenziehend) als auch wegen der Eigenschaft, sich intensiv braun zu färben und eine festhaftende brame Farbe zu liefern, zum Merken der Wäsche, in Ostindien auch zum Bedrucken von Cattunen verwendet. Gtl.

Elevator, s. H ebemaschinen.

Elexenholz, das Holz der Tranbenkirsche oder Elexe (Prumus padus) stimmt in seinen Eigenschaften mit dem Kirschbaumholz überein (s. d.).

Elfenbein (ivoire - ivory). Mit dem Namen Elfenbein bezeichnet man zunächst und hauptsächlich die Substanz, woraus die mächtigen Stosszähne der beiden, jetzt noch lebenden Elefantenarten, des afrikanischen und des asiatischen (indischen) Elefants bestehen, doch werden darunter im Handel und in den Gewerben häufig auch die analogen Gebilde noch einiger anderer Thiere (Flnsspferd, Walross, Narwal), so wie die unverändert erhaltenen Stosszähne vorweltlicher Elefanten (fossiles Elfenbein) verstanden.

Die grösste Menge dieses werthrollen Artikels liefert Afrika. Der afrikanische Elefant (Elephas Africanus Cur.) ist über den ganzen mittleren Theil dieses Continents rerbreitet; in grossartigem Massstabe wird hier, des Elfenbeins wegen, von allen Seiten der Vernichtmngskrieg gegen ihn gefuihrt, besonders in den Gegenden um die Nilquellenseen.

Der Hauptstappelplatz des hier erbenteten Elfenbeins ist Chartum, wohin es den Bachr el Ghasal und B. el Gebel heral, aus den weit in's Innere 
vorgeschobenen Niederlassungen (Seribas) der Chartumer Händler golangt. Fin wichtiger Elfenbeinmarkt ist in neuerer Zeit Zanzibar geworden für das im östlichen Afrika (in den Gegenden am Kilimandschuro, im Süden vom Ukereve-See, in den Gebieten des Nyassa-See's etc.) erbeutete Elfenbein. Von geringerer Bedeutung ist, was gegenwärtig die afrikanische Westküste und das Capland davon in den IIandel liefern. - Der asiatische Elefant (Elephas Asiaticus Cuv.) bewohnt Siid-Asien, zumal Hinterindien (Cochinchina, Siam, Pegu etc.), Ceylon und Sumatra. Aus diesen Ländern kommt anch das beste asiatische oder indische Elfenbein in den Handel.

Die Stosszähne des Elefanten sind gekrïmmt, gerundet, nach vorn allmälig spitz zulaufend; die des afrikanischen ausgewachsen bis armdick, bis $2 \frac{1}{2} \mathrm{~m}$ und selbst dariiber lang und $20-60 \mathrm{Kg}$. schwer; jene der asiatischen Art sind im Allgemeinen kleiner. Zähne junger Thiere sind bis gegen die Spitze zu hohl, während sie bei ausgewachsenen Thieren blos am Grunde eine Höhlung besitzen. Die Oberfläche zeigt eine meist hellbräunliche Farbe und soll möglichst glatt, frei von Sprüngen und Rissen sein. Die Substanz selbst ist weiss mit einem geringen Stich in's gelbliche; mit der Zeit nimmt die gelbliche Farbe zu, sie ist sehr hart und dicht und zeigt die eigenthïmliche Structur des Zahnbeins, so wie die chemische Zusammensetzung der Knochen überhaupt, indem sie wesentlich aus Knorpelsubstanz, phosphorsaurem und kohlensaurem Kalk besteht.

Die vielseitige Anwendung des Elfenbeins in Künsten und Gewerben ist allgemein bekannt. - Wie das recente verarbeitet man auch das fossile Elfenbein, d. h. die Stosszähne vorweltlicher Elefanten, der Mamuththiere (Elephas primigenius), wie sie durch die Kälte wohlerhalten im gefrorenen Boden des nördlichen Sibiriens zwischen dem $58^{\circ} \mathrm{n}$. Br. und dem Eismeere, insbesondere am unteren Lauf des $\mathrm{Ob}$, Jenissei und der Lena und an den Küsten des Eismeeres stellenweise in sehr grosser Menge vorkommen und entweder durch Meeresfluthen und strömendes Wasser ausgewaschen und blosgelegt oder durch Grabarbeit zu Tage gefördert einen wichtigen Handelsartikel jener Gegenden bilden, der iiber Russland zu uns gelangt. Die Stosszähne sind stärker gekrïmmt und noch kolossaler $\left(3-5^{\mathrm{m}}\right.$ und dariiber lang) als bei den lebenden Elefanten.

Ein sehr geschätztes, auch als "Hippopotam" bekanntes Elfenbein liefern ferner die bis $3 \mathrm{Kg}$. schweren, an $30^{\mathrm{cm}}$ und darüber langen, halbkreisförmig gekrümmten, stumpf-längsrippigen, unten hohlen, oben schief abgeschnittenen, äusserst harten Eckzähne des Nil- oder Flusspferdes (Hippopotamus amphibius $K$.), eines in den grösseren Flüssen und Seen Innerafrika's lebenden Dickhäuters. Nicht minder geschätzt sind die mehrere Decim. langen, 5-15 Kg. schweren Eckzähne des Walrosses (Trichechus Rosmarus L.), eines das nördliche Eismeer bewohnenden Flossenfüssers, deren sehr feste und dichte Masse eine an der Luft sich nicht ändernde, blendend weisse Farbe besitzt und unter Anderem zur Verfertigung künstlicher Zähne verwendet wurde.

Von geringerem Werthe ist die Elfenbeinsubstanz des gerade gestreckten Stosszahnes des im nördlichen Eismeere lebenden Narvals (Cerutodon Monoceros Briss.) aus der Ordnung der Walthiere, der eine Länge von $2^{1 / 2}-3^{m}$ und dariber erreicht, innen hohl und schraubenförmig gedreht ist. - Unter den Namen: ve g etabilisches Elfenbein, Elfenbeinniisse, Steinnïse, Tagna-N iis se, Corusconüsse (ivoire végétal - ivory nut) kennt man im Handel die Samen von Phytelephas macrocarpa R. et P., einer suidamerikanischen Pandanacee, welche vor etwa 50 Jahren zuerst in Europa als Ersatz des Elfenbeins eingefuihrt wurden und eine ausgedehnte Beniitzung zu verschiedenen Drechslerarbeiten, namentlich zu Stock- und anderen Knöpfen etc. finden. Der locker in einer dünnen spröden, aussen matt graubräunlichen Schale steckende Samenkern ron meist eirunder, etwas plattgedrückter, nicht selten fast gerundet-tetraëdrischer Form und Hühnereigrösse mit netzfurchiger, matt-rehbrauner Oberfläche besteht fast ganz aus einem beinharten, sehr dichtem, in der Mitte mit einem kleinen 
Hohlraum versehenen Eiweisskörper (Endosperm) von weisser Farbe mit einem Stich in's Grïnliche oder Bläuliche. Die Masse erweicht in heissem Wasser etwas.

Das Elfenbein wird bei seiner Verarbeitung häufig gebleicht und auch gefärbt. Um dasselbe zu bleichen, legt man die Stiicke in einen Brei aus 1 Thl. frischem Chlorkalk und 4 Thl. Wasser, lässt mehrere Tage darin liegen, wäscht ab und trocknet bei gewöhnlicher Temperatur (vgl. H. Angerstein, Dingl. pol. Journ. 137 pag. 155). Die Anwendung eines Säurezusatzes zum Chlorkalk ist zu vermeiden. Zum Färben des Elfenbeins verwendet man die verschiedensten Farben, wie solche auch für die Zwecke des Färbens von Holz und Bein in Anwendung stehen. Man färbt durch Einlegen in die etwas angewärmte, wohl auch zum Sieden erhitzte Brühe (vgl. a. Kellermann, Dingl. pol. Journ. 120 pag. 438 u. e. d. 141 pag. 67).

Die wichtigsten Farben erzielt man auf folgende Weise:

1. Schwarz. Soll eine in Elfenbein ausgeführte Arbeit im Ganzen schwarz gefärbt werden, so kocht man sie einige Zeit in einer durchgeseihten Abkochung von Blauholz, und legt sie darauf in eine Auflösung von schwefelsaurem oder essigsaurem Eisenoxyd.

2. Blau. Durch kurzes Eintauchen in eine verdünnte schwefelsaure Indigauflösung.

3. Gelb kann auf verschiedene Weise hervorgebracht werden. Man legt das Stiick einige Minute lang in Wasser, welchem eine kleine Menge salzsanrer Zinnauflösung zugesetzt worden, hierauf in heissen, durch Leinwand filtrirten Gelbholzabsud. Setzt man dem Gelbholz etwas Fernambukspäne zu, so wird die Farbe orange. Ein sehr dauerhaftes Gelb entsteht, wenn das Elfenbein etwa $1 / 4$ Stunde lang in eine Auflösung von Bleizucker, hierauf ebenso lange in eine Anflösung von chromsaurem Kali gelegt wird.

4. Roth. Zerriebene Cochenille wird mit Essig gemischt und darin das Elfenbein eine kurze Zeit, einige Minuten, gekocht. Statt der Cochenille bedienen sich einige Drechsler auch des theuerern Carmins. Das so erhalte Roth spielt in Purpur. Ein schönes lebhaftes Roth entsteht, wenn man Elfenbein einige Minuten lang in stark verdünnte Zinnauflösung und sodann in kochend heisses Decoct von Fernambuk einlegt. Durch Zusatz von etwas Gelbholz geht die Farbe in Scharlach iiber. Wird das auf die angegebene Art roth gefärbte Elfenbein in eine sehr verdiinnte Pottaschenlösung gelegt, so geht die Farbe in Kirschroth über.

5. Violett. Man färbt zuerst roth und taucht sodann auf einen Augenblick in Indigauflösung; oder durch Beizen mit sehr verdünnter Zimnlösung und nachheriges Einlegen in eine heisse Blauholz-Abkochung. Legt man das so gefärbte Elfenbein in Wasser, dem einige Tropfen Salpetersäure zugefiigt wurden, so entsteht Purpurroth.

6. Griin kann entweder durch anfeinander folgendes Gelb- und Blaufärben entstehen, oder indem man das Elfenbein einige Stunden in eine ziemlich gesättigte Auflösung von chromsaurem Kali legt, und es dann längere Zeit dem Sonnenlicht darbietet. Dunkelbläulich grün.

Sollten, wie z. B. bei Billardbällen, weisse Streifen auf gefärbtem Grund erscheinen, so legt man ein mit Wachs getränktes Band um die Kngel, bewickelt es noch ausserdem mit Bindfaden, und färbt den Ball, wobei die gewachsten Stellen weiss bleiben. Sollte sich die Farbe doch etwas in den weissen Streif gezogen haben, was leicht geschieht, so nimmt man durch vorsichtiges Schaben die Farbe weg.

Es ist noch zu erwähnen, dass alle Farben auf unpolirtem Elfenbein weit besser haften, als auf polirtem, weshalb man die Politur erst nach dem Färben gibt. Es geschieht dies durch Reiben mit Seife und Wiener Kalk mit der nackten Hand. Man darf beim Färben die Kochungen nie zu lange fortsetzen, weil das Elfenbein dabei leicht Sprünge bekommt, und legt die Stiicke, so wie sie aus der Flüssigkeit kommen, zum raschen Abkühlen in kaltes Wasser. 
Von besonderen Färbemethoden sei namentlich noch erwälnt die Herstellung von schwarzen Zeichnungen auf Elfenbein, die gewöhnlich in der Weise vorgenommen wird, dass man das zu ätzende Elfenbein mit einem Actzgrund überzieht, in denselben die gewïnschte Zeichnung radirt, und sodann eine Lösung von salpetersaurem Silber (1 Thl. in 10 Thl. Wasser) aufträgt. Man lässt diese etwa 1/2 Stunde lang einwirken, und setzt nach dem Entfernen derselben und leichtem Abtrocknen durch einige Stunden dem directen Sonnenlichte aus, wodurch die mit der Silberlösung benetzten Stellen des Elfenbeins eine schön schwarze Farbe annehmen. Man spült nun mit Wasser ab und entfernt endlich den Aetzgrund durch ein geeignetes Lösungsmittel. Dass man zum Färben des Elfenbeins auch die gegenwärtig so allgemein verwendeten Anilinfarben verwenden kann, ist selbstverständlich.

A. Vogl.

Elfenbein künstliches, s. El fen beinsurrogate.

Elfenbein vegetabilisches, s. E If en bein.

Elfenbein-Arbeiten, s. Kno chen bear beitung.

Elfenbeinkämme, s. Kä $\mathrm{mme.}$

Elfenbeinnuss, s. Eilfenbein.

Elfenbeinpapier (ivory paper) wird aus mehreren aufeinander geleimten aufgespannten Blättern guten Zeichenpapiers dadurch hergestellt, dass man die Oberfläche mit feinem Glaspapier abschleift, hierauf einen Anstrich von Gyps (mit Pergamentleim angemacht) gibt, diesen Anstrich abermals abschleift und hierauf noch ein Paar Anstriche dünnen Leimwassers aufträgt. Das Elfenbeinpapier wird bei der Miniaturmalerei verwendet. $K k$.

Elfenbeinschwarz (noir d'ivoire - ivory black), Bezeichnung für feinere Sorten von Beinschwarz, s. d. bei Knochen.

Elfenbeinsurrogate, kïnstliches Elfenbein. Für die Herstellung von kïnstlichem Elfenbein sind verschiedene Vorschriften gegeben worden. Eine der ältesten Elfenbeinimitationen erhielt man durch Einriihren von fein vertheilter Thonerde in eine genügend consistente Leimlösung, erstarren lassen und troeknen der erhaltenen Mischung. Weit besser und dem Elfenbein viel ähnlicher ist aber das Product, welches man erliält, wenn man Gelatine oder Folien von lichtem Leim in ein Bad von essigsaurer oder schwefelsaurer Thonerde einlegt, und längere Zeit in dem Bade belässt. Der Leim nimmt hiebei reichlich Thonerde auf, die Folien werden prall und dick, und liefern, nachdem sie vollständig von der Flïssigkeit durchdrungen sind, nach dem Trocknen eine Masse, die eine schöne Politur annimmt, und dem Elfenbein sehr ähnlich sich verhält. Eine plastische Masse, welehe die Farbe und das durchscheinende Wesen des Elfenbeins besitzt, dabei aber biegsamer ist, kann erhalten werden, wenn man 50 Thl. Kartoffelstärke mit 5 Thl. Zinkoxyd innig mengt und die Mischung mit einer Flïssigkeit aus 50 Thl. Chlorzinklösung (von $55^{\circ}$ B.), 1 Thl. Salzsäure und 1 Thl. Weinstein zu einer Masse anriihrt. Dieses Product widersteht jedoch nicht der Einwirkung von Feuchtigkeit, weshalb die daraus gefertigten Gegenstände mit einem schützenden Firnissiiberzuge versehen werden müssen.

Auch Kautschuk wird zu Elfenbeinimitationen verwendet. Nach einem von F. M a r quard (Dingl. pol. Journ. 183 pag. 498) angegebenen Verfahren erhält man eine solche, wenn man etwa 1 Kilo Kautschuk in der 15 fachen Menge Chloroform löst, die Lösung behufs vollständigen Bleichens mit Ammoniakgas sättigt, und hierauf unter fleissigem Rühren durch Erwärmen bis auf $85^{\circ} \mathrm{C}$. das Chloroform verdampft. Die riickständige, locker schaumige Masse wird nun nach vorherigem Pressen nochmals mit Chloroform zu einem Teige erweicht und diesem so viel von feinpulverigem phosphorsaurem Kalk oder kohlensaurem Zinkoxyd eingeknetet, dass die Masse das Anseher von feuchtem Mehl erhält. Die so er- 
haltene innige Mischung wird sodann in heisse Formen gebracht und stark gepresst, wodurch sie das Aussehen und die Politurfähigkeit des Elfenbeins annimmt. Gtl.

Eliasit, s. G u m mi erz.

Elimination, Ausscheidung; in der Algebra die Ausscheidung gewisser Grössen aus vorgelegten Gleichungen. Fehler-eliminirende Beobachtungsmethoden, bei welchen durch den Vorgang der Beobachtung selbst also ohne besondere Rechnung - die Einfliisse gewisser Fehlerursachen unschädlich gemacht (ausgeschieden) werden; z. B. die Umlegung des Fernrohrs bei Winkelmessinstrumenten, um die fehlerhafte Stellung der optischen Achse gegen die Drehachse des Fernrohres unschädlich zu machen; Ablesung der Kreistheilung an zwei diametralen Nonien, um den Einfluss der Excentricität der Alhidade zu beheben etc. Bei feineren Messungen kommen solche Methoden durchwegs zur Verwendung, weil an eine vollkommene Beseitigung der Instrumentenfehler nicht zu denken ist.

Czuber.

Elinsäure, Name einer von Chevreul im Wollschweisse entdeckten flüssigen Säure, deren spec. Gew. höher als das des Wassers ist. (Vgl. Dingl. pol. Journ. 171 pag. 480.) Gtl.

Ellagsäure (acide rufigallique - parellagic acid), B e zo arsäure, Säure der Formel $\mathrm{C}_{\mathbf{1 4}} \mathrm{H}_{\mathbf{6}} \mathrm{O}_{8}$, welche sich in den kalkigen Magenconcretionen der Bezoarziege und anderer Pflanzenfresser, den sog. Bezoarsteinen, dann im Biebergail, der Tormentillwurzel, den Galläpfeln u. a. O. findet. Wird durch Zersetzung des Tannins, wenn es in Lösung der Luft ausgesetzt ist, oder durch Kochen der Gerbsäure aus Granatrinden mit verduinnten Säuren, in letzterem Falle neben Zucker erhalten. Man erhält sie durch Gährenlassen von mit Wasser zu einem Brei angerïhrtem Galläpfelpulver, Auspressen des Breies, Kochen des Press-Rückstandes mit Wasser und Erkaltenlassen der abgeseihten siedend heissen Fluissigkeit, wobei sich rohe Ellagsäure als gelblichweisses Pulver abscheidet, das durch Auflösen in verdünnter Kalilange in ellagsaures Kali iiberfuihrt wird, welches durch Umkrystallisiren aus kochendem Wasser gereinigt und mit Salzsäure zerlegt die reine Säure liefert. Blassgelbes krystallinisches Pulver, seltener kleine gelbe, säulenförmige Krystalle oder hochgelbe seidenglänzende Nadeln. Gesckmacklos, von schwach saurer Reaction, zum Theile sublimirbar. In Wasser und Weingeist nur wenig löslich, gar nicht in Aether. Mit Eisenchlorid färbt sie sich allmälig tief schwarzblan. (Vgl. Bra c o n not, Annal. de Chim. et Phys. 9, 187; Wöhler, Annal. der Chem. 11. Pharm. 67 pag. 361, und Merklin u. Wöhler, Annal. d. Chem. u. Pharm. 55 pag. 129; F. Göbel u. A. Göbel, Annal. d. Chem. u. Pharm. 79 pag. 83 und 83 pag. 280.) Gtl.

Ellernholz, s. Erlenholz.

Ellernrinde, hie und da gebräuchlicher Handelsname für die gerbstoffhaltige Rinde von Alnus glutinosa, syn. mit Erleurinde.

Ellipse, s. Curven II S. 431.

Ellipsenzirkel, s. Zeichnen (Zeichen-Instrumente).

Ellipsoid, zu den Flächen zweiten Grades gehörig, hat einen im Endlichen selegenen Mittelpunkt, durch welchen die drei zu einander senkrechten Hauptachsen hindurehgehen. Heissen ihre Längen $2 a, 2 b, 2 c$, und verlegt man in dieselben die Achsen $I, Y, Z$ eines orthog. Raumcoordinatensystems, so lautet die Gleichung: des Ellips: $\frac{x^{2}}{c^{2}}+\frac{y^{2}}{b^{2}}+\frac{z^{2}}{c^{2}}=1$ (dreiachsiges oder allgemeines Ellips.). Alle ebenen Schnitte desselben sind Ellipsen, darunter zwei Schaaren von Kreisschnitten. - Wird insbesondere $2 a=2 b$, so hat man das Rotationsellipsoid (Sphäroid), dessen zu $Z$ senkrecht geführte Schnitte Kreise, während die durch $Z$ gelegten, congruente Ellipsen von den Achsen $2 a, 2 c$ sind, so dass 
man sich die ganze Fläche durch Umdrehung einer solchen Ellipse um $Z$ entstanden denken kann. Je nachdem $2 c \geq 2 a$, spricht man von einem oblongen oder abgeplatteten Ellipsoid. Der Gestalt des letzteren nähert sich unsere Erde, wobei (nach F. W. Bessel's Berechnungen) $a=6377397 \cdot 156^{\mathrm{m}}$ und $c=6356078.963^{\mathrm{m}}$ beträgt. Den Werth $\frac{a-c}{a}$ nennt man die Abplattung, er beträgt hier $\frac{1}{299 \cdot 153}$. Der Rauminhalt des $E$. ist $4 / 3 \pi a b c$, mithin der des Rotations-E. ${ }^{4} / 3 \pi a^{2} c$ (Kugel $4 / 3 \pi a^{3}$ ).

Czuber.

Elsbeerholz, Atlasbeerholz (alizier - service-tree), von Crataegus torminalis, ist ein feines, dichtes, hartes Holz, von jungen Bäumen gelblich, von älteren rothbraun und als Drechslerholz geschätzt. Sehr ähnlich ist das vom weissen Elsbeer- oder Mehlbeerbaume (alizier blanc - white-hawthorn), Crataegus Aria, stammende Holz. Kk.

Elsner's Grün, giftfreies Kupfergrün, durch Fällung einer Kupfervitriollösung mit einer Abkochung von Gelbholz, der man $1 \%$ Leim zugesetzt hat und die mit $10-12 \%$ Zinnsalz vermischt wurde, mit Natronlauge darstellbare griine Farbe, welche je nach der Quantität des angewendeten Gelbholzes mehr oder weniger gelb nuancirt erhalten werden kann. Gtl.

Elsner's Lampe, syn. mit Si eb-Gasbrenner, s. Le u chtgas, s. L a mpen.

Elvan, in Cornwales gebrauchte Bezeichnung für Porphyr, welcher in netzförmigen Gängen die dortigen Grauwackenschiefer durchsetzt. $L b$.

Email (émail - enamel), Schmelz oder Schmelzglas. Die Emaile sind Glasarten, die sich vom gewähnlichen Glase durch ihre leichtere Schmelzbarkeit und in den meisten Fällen durch ihre geringere Durchsichtigkeit*) unterscheiden. Sie sind entweder farblos (nur die durchsichtigen Arten) oder gefärbt und werden zum grössten Theile dazu verwendet, um metallische Oberflächen vor der zerstörenden Einwirkung verschiedener Flïssigkeiten (oder Dämpfe) und diese selbst vor der Verunreinigung durch aufgelöstes Metall zu schïtzen, und dienen anderntheils zur Oberflächen-Verschönerung verschiedener Luxusartikel. Eine unerlässliche Eigenschaft aller Email-Arten ist die, dass sie leichter schmelzbar sein mïssen als die Metalle oder Legirungen, **) zu deren Ueberzug sie verwendet werden sollen. Die Emailirungsarbeiten lassen sich in vier Hauptoperationen eintheilen, nämlich :

1. Die Bereitung der Emailmassen,

2. die Vorbereitung der zu emailirenden Gegenstände,

3. das Auftragen und

4. das Einbrennen der Emaile.

1. Die Emailbereitung. Die Erzeugung guten Emails erfordert viele Umsicht und genaue Kenntniss der Mischungsverhältnisse und Qualität der Materialien, des Verhaltens dieser Glasflïsse und der sie färbenden Metalloxyde in der Schmelzhitze, so wie der Haltbarkeit des Emails an der Oberfläche verschiedener Metalle.

Die Quantität und Qualität der Email-Bestandtheile richtet sich:

1. Nach dem Zwecke des Email-Ueberzuges; ob derselbe blos zur Verschönerung angebracht ist, oder ob er der Zerstörung der Metalle durch Chemikalien vorbengen soll, und im letzteren Falle wiederum, ob die emailirten Gegenstände erhöhter Temperatur ausgesetzt werden oder nicht.

*) Man unterscheidet durchsichtige Emaile, bei denen die Genr'ngtheile völlig geschmolzen siud, und undurchsichtige (opake), deren Bestandtheile entweder blos zusammengefossen oder, wenn sie geschmolzen sind, trübende Gemengtheile enthalten, so dass sie das Licht nicht hindurchdringen lassen.

**) Es soll hier blos von der Emailirung metallener Gegenstände die Rede sein. Ueber die Emailen für keramische Erzengnisse siehe den Artikel Thonwaaren. 
2. Nach dem zu emailirenden Metalle selbst. Der Ueberzug muss nämlich der verschieden starken Ausdehnung und Zusammenziehung verschiedener Metalle in der Hitze (des Emaileinschmelzens und beim Gebrauche) folgen, ohne abzublättern oder Risse zu bekommen.

3. Nach der beabsichtigten Färbung der Schmelze. So darf z. B. zu farblosen Emails kein eisenhältiger Sand, zu gefärbten kein kupfer- oder antimonhaltiges Bleiglas (den Fall ausgenommen, dass die Färbung ohnehin mit Kupferoder Antimonoxyd erfolgen soll), zu purpurroth zu färbenden Emailen iiberhaupt kein blei- oder zinnhaltiges Glas genommen werden u. s. f.

Die Basis des farblosen Emails ist stets das reine Kryst:llglas, dem man zur Erhöhung des Glanzes in einem gewissen Verhältnisse Zinnoxyd*) und Bleioxyd und unter Umständen auch Sand hinzufügt.

Die Materiale werden jedes für sich fein gepulvert, dann gesiebt und innig gemischt, worauf man sie in einem mittelst eines Deckels hermetisch verschlossenen feuerfesten Tiegel bis zur beginnenden Schmelzung erhitzt. Die so erhaltene zusammengebackene Masse - die Fritte - wird nach dem Erkalten (das man durch Einwerfen des heissen Tiegelinhaltes in kaltes Wasser beschleunigt) abermals gemahlen, gesiebt, gemischt und zum zweitenmale gefrittet, um eine recht innige, gleichförmige Vertheilung und Mischung der Bestandtheile zu erreichen.

Erscheint die Fritte uach erfolgter Sinterung missfärbig, so ist sie deshalb noch nicht immer zu verwerfen, da diese Verfärbung von eingedrungenem Rauch oder von Eisenoxydul verursacht sein kann. Es ist dann eine geringe Menge Braunstein (Glasmacherseife) vor dem zweiten oder dritten Fritten zuzugeben. Der Braunstein entwickelt in der Hitze Sauerstoff, der den etwa eingeschlossenen Kohlenstoff zu (entweichendem) Kohlenoxyd und das Eisenoxydul zu weniger färbendem Eisenoxyd oxydirt. **)

Als Basis färbiger Emaile eignet sich nach Clouet**; ) ein Gemenge von 3 Theilen gewaschenen Sandes, 1 Theile Kreide und 3 Theilen calcinirten Borax oder von 3 Theilen guten weissen Krystallglases, 1 Theil calcinirten Borax, 1/4 Theil Natronsalpeter und einem Theile Antimonoxyd, oder 60 Theile (kalkhältiger) Sand, 30 Theile Alaun, 35 Theile Kochsalz und 100 Theile Mennige.

Ein schwacher Eisengehalt dieser Bestandtheile ist weniger schädlich als das Vorkommen von Kupfer-oder Antimonoxyd, welche die Schönheit der Farben sehr beeinträchtigen würden.

Die färbenden Metalloxyde müssen stets in möglichst reinem Zustande und möglichst fein vertheilt in Anwendung gebracht werden.

Im Nachstehenden sei Einiges über dieselben erwähnt.

Zur Erzielung purpurother Schmelzflisse rerwendet man den CassiusGoldpurpur, den man durch Fällung einer Goldlösung mittelst Zinnsalz erhält und durch wiederholtes Waschen mit Wasser vollkommen gereinigt hat. Minder gut, jedoch mit noch zufriedenstellendem Erfolge, verwendet man das Gold. chlorid. Das Goldpräparat darf nur in cine zimu- und bleifreie Emailmasse eingetragen werden. Als Fritte eignet sich am besten ein Gemisch ron 3 Theilen Quarzsand, 1 Theile Kreide und วे Theilen calcinirtem Borax. Die Frittung muss bei möglichst niederer Temperatur rorgenommen werden. Die Tiefe des Farbentones hängt von der Menge des angewandten Goldpräparates ab.

Zur Rothfärbung verwendet man ein Thonerde-Eisenpräparat, welches man erhält, wenn man zuvörderst ein Gemenge von $2^{1 / 2}$ Theilen Eisenvitriol und 1 Theile schwefelsaurer Thonerde bis zur völligen Vertreibung des Krystallwasser's erhitzt, sodann aber die Hitze steigert und so lange gliiht, bis

*) Die Menge des Zinnoxydes muss so gering sein, dass sie keine Trübung der Schmelze hervorbringt.

30) Der Brannstein entlält meist sellsst eine gewisse Menge Eisenoxyd, die der Schmelze einen weingelben Ton eitheilt, den man aber durch einen geringen Smaltezusatz und wiederholtes Fritten parallisiren kann.

***) Muspratt, chemische Encyklopädie, II. Band Seite 431. 
eine herausgenommene Probe nach dem Erkalten eine gleichmässige braunschwarze Färbung zeigt, ein Zeichen, dass sämmtliches Eisenoxydul in Eisenoxyd überfiihrt worden ist. *)

Die Fritte fiir rothes Email besteht aus Alaun, Mennige, Kochsalz und talkhältigem Sande (Fayence Sand). Man nimmt je einen Theil des färbenden Oxydgemisches auf $2-3$ Theile Fritte. Das Eisenoxyd wird von der schmelzenden Fritte nicht gelöst, sondern bleibt als solehes im Glase schwebend erhalten; denn wiirde eine wirkliche Lösung desselben im Glasflusse erfolgen, so wiirde dieser anstatt roth schwarz oder gelb gefärbt werden.

Für die Gelbfärbung von Emailen erzeugt man sich die Farbe aus einem Gemenge von 1 Theile Bleiweiss, 1 Theile Alaun, 1 Theile Salmiak und 1 Theile Antimonoxyd, welche man sämmtlich zerreibt und in einem Gefässe über F(uer so lange erwärmt, bis aller Salmiak sublimirt ist und der Ruickstand eine gelbe Farbe angenommen hat.

Auch eine geringe Menge Eisenoxyd ertheilt bei hoher Temperatur den Glasflüssen eine gelbe Färbung.

Die für gelbes Email geeigneteste Fritte ist die aus Sand, Bleioxyd und Borax zusammengesetzte.

Die bla uen Schmelzen erzeugt man stets durch Zusatz von Kobaltverbind ingen, welche theils als reines Oxyd, theils als sogenannter Zaffer (Kobaltsaflor) im Handel vorkommen. Die Fritte darf kein Blei oder höchstens nur Spuren desselben enthalten, da eine grössere Quantität enthaltenen Bleioxyds die Farbe sehr alterirt.

Die violette Farbe wird dem Email durch einen Zusatz von Mangan. superoxyd (Braunstein) ertheilt. Beim Schmelzen der Fritte ist darauf zu achten, dass das Mangansuperoxyd nicht dazu beansprucht sei, etwa vorhandenes Eisenoxyd oder eindringenden Rauch oxydiren zu muissen, da es dadurch verhindert würde, auch gleichzeitig färbend aufzutreten.

Grïne Emails verdanken diese Färbung entweder der gleichzeitigen Anwendung blau- und gelbfärbender Metalloxyde oder der färbenden Eigenschaft von Kupfer- oder Chromoxyd, von denen man zu je 2 Unzen auf 4 Pfund gewöhnlicher Bleiglasfritte anwendet.

Endlich werden schwarze Emails crzielt, wenn man den Glasfliissen grosse Zusätze von Kupfer-, Kobalt- und Manganoxyd gibt, wodurch eine dunkle TonMischung von blau, griin und violett entsteht, die von schwarz nicht zu unterscheiden ist. Clou et will durch Zusammenschmelzen von leicht schmelzbarcm Thon mit $1 / 3$ seines Gewichtes Eisenoxydul ebenfalls ein schwarzes Email erhalten haben.

Die vorzuiglichste Sorgfalt muss auf die richtige Zusammensetzung der Emails zum Ueberzuge von Gefässen (Kochgeschirren) verwendet werden, da an diese Gattung von Schmelzen sehr vielfache, zum Theile ganz unerlässliche Anforderungen gestellt werden.

Wie bereits oben gesagt, müssen die Emaile der Einwirkung von Wasser und schwachen. Säuren vollkommen widerstehen, um dieselben nicht doch endlich zu dem zu schiitzenden Metall sich hindurchfressen zu lassen; und der Ausdehnung des Metalles folgen, damit sie keine, ihren Zweck ganz illusorisch machende Risse und Spriinge erhalten.

Diesen Anforderungen zu entsprechen, war zu Anfang ziemlich schwierig, weil die Ausdehnung zweier so heterogener Materien, wie es Metalle (gewöhnlich Gusseisen) und Glasfliisse sind, eine sehr ungleiche ist; doch wurde diese Aufgabe dadurch gliicklich gelöst, dass man zwischen das eigentliche, von den Flïssigkeiten berihrte Email und das Metall eine Schichte einschaltete, deren Ausdelm-

*) Wird lie Oxydation zu weit getrieben, so bildet sich durch theilweise Sauerstottabgabe Eisenoxyduloxyd, welches dem Schmelzflusse eine schwärzliche oder grïnliche Färbung ertheilen würde. 
samkeit in der Wärme zwischen jenen des Metalles und des Emails steht, so dass sie eine Vermittlung zwischen ersteren beiden bewirkt. Diese Zwischenschichte besteht aus einem nicht in den rollkommen glasartigen Zustand iibergegangenen porösen Email, dem sogenannten Grundemail oder der Grundmasse.

Nebst den oben angeführten unerlässlichen Eigenschaften ist es erwünscht, dass das Geschirremail eine möglichst glatte, von Blasen, Runzeln und Rissen freie Oberfläche und eine reine (meist weisse), gleichmässige, wolkenfreie Färbung habe, und nicht allzu spröde sei, um nicht bei geringen, gegen das Metall geführten Schlägen gleich abzuspringen.

Die Herstellung der Geschirremaile zerfällt also in die Erzeugung der Grundmasse und der Deckmasse.

Zur Darstellung der Grundmasse mischt man krystallisirten Borax mit Feldspath oder Kryolith und feinem Sand oder statt letzterem mit gepochtem Quarz, ${ }^{*}$ ) sämmtliche im feingemahlenen Zustande und bringt dieses Gemenge in einen an seinem Boden durchlöcherten Tiegel, in welchem man es einschmilzt.

Nebenstehende Figur $1496 a$ und $b$ zeigt einen für diese Operation geeigneten Ofen im Verticalschnitte. $A$ ist der hessische, mit einem Deckel verschliessbare Schmelztiegel, $B$ ein durchlöcherter Untersatz, der durch den Rost $D$ hindurchragt, Fig. 1496.

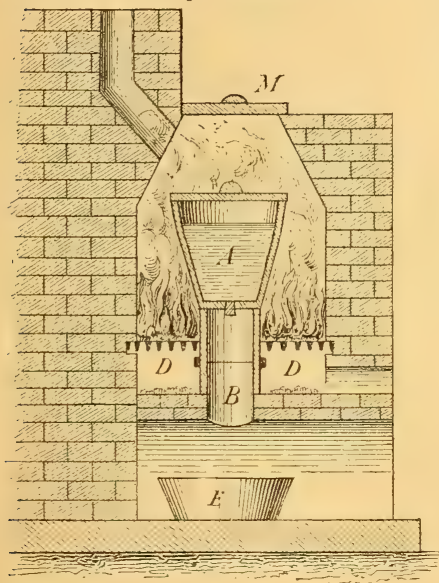

hier angeführt.

1.) 30 Thl. Quarzmehl, 16\% Thl. Borax und 3 Thl. Bleiweiss werden im Tiegel eingeschmolzen (und liefern 39 Gew.-Thl. Fritte) und nach dem Erkalten und Pochen der gewonnenen Schmelze mit 9 Thl. Quarzmehl, 8\% Thl. geschlämmtem feuerfesten Thon, 1/2 Thl. Magnesia alba und der nöthigen Wassermenge zu einer rahmartigen Fliissigkeit mittelst einer Glasurmiihle vermahlen.

2.) 30 Thl. Quarzmehl, 30 Thl. feingemahlener Feldspath, 25 Thl. Borax werden eingeschmolzen und nach dem Pochen der Schmelze zu dieser $10^{3} /$. Thl. Thon, 6 Thl. Feldspath und $1^{3} / 4$ Thl. gebrannter Magnesia zugemischt, worauf man unter Wasser vermahlt.

Die in diese Massen (Fritten) eingefiihrten Antheile von Thon und Thonerde (im Kryolith) bedingen, dass die Masse beim Einbrennen weniger diinnflüssig wird, vielmehr eine halbgeschmolzene, teigige Consistenz annimmt.

*) Derselbe wirl durch Glïhen und rasches Abschrecken in kaltem Wasser spröde gemacht, um leichter gepocht werden zu können. 
Die Deckmasse unterscheidet sich von der Grundmasse in ihrer Zusammensetzung nur durch ihren Mangel an Thonerde und durch die Anwesenheit von Zinnoxyd oder phosphorsaurem Kalke (als Knochenerde verwendet), welche die milchige Trübung des Schmelzflusses bedingen. Mit Uebergehung der als schädlich erwiesenen, bleihältigen Gemische sei hier die Zusammensetzung eines vollkommen unschädlichen Deckemails*) gehracht. 371/2 Thl. Quarzmehl, 271/2 Thl. Borax, 30 Thl. Zinnoxyd, 15 Thl. Soda, 10 Thl. Salpeter und 5 Thl. gebrannter Magnesia werden in feingepulvertem Zustande gemengt und, wie bei der GrundmasseErzeugung beschrieben, gefrittet (man erhält dadurch 92 Thl. Email), und diese Operation so oft wiederholt, als die abgelassene Masse noch blasig erscheint.

Nach beendeter Frittung, Abkühlung und Zerpochung mischt man das Emailpulver mit $6 \frac{1}{8}$ Thl. Quarzmehl, 3\% Thl. Zinnoxyd, $2 / 3$ Thl. Soda (calcinirt) und $3 / 4$ Thl. gebrannter Magnesia und vermahlt das Ganze auf einer Glasurmühle mit dem erforderlichen Wasserquantum zu einer rahmigen Fliissigkeit.

Eine besonders fuir Blechgeschirre und Säuregefässe sehr geeignete Emailmasse wird aus 12 Thl. ungebranntem Gyps und 1 Thl. Borax gemischt. Dieses Gemenge muss ebenfalls gefrittet, in Wasser abgelassen, getrocknet und vermahlen werden. $\left.{ }^{*} *\right)$

2. Vorbereitung der zu emailirenden Gegenstände. Die Mannigfaltigkeit der Formen und Verschiedenheit der Metalle bedingt verschiedene Vorarbeiten, doch lässt sich als allgemeines Erforderniss aufstellen, dass die mit Email zu iiberziehenden Flächen metallisch rein und doch rauh gearbeitet sein müssen, um die Adhäsion zwischen dem Email und dem Metall möglichst zu steigern.

Die zu Uhrzifferblättern, Schildern etc. bestimmten Kupferbleche werden theils einseitig, theils auf beiden Seiten emailirt, und müssen, nachdem sie in der richtigen Form zugeschnitten, concav ausgehämmert oder aber geebnet und mit den zur Befestigung bestimmten Löchern versehen sind, auf einer oder beiden Seiten mit verdünnter Salpetersäure blankgebeizt und sofort in Wasser geworfen werden, um sie vor der oberflächlichen Oxydation zu schïtzen. Im Wasser haben diese Bleche bis zur Auftragung und Einbrennung des Emails zu verbleiben.

Sehr grosse Sorgfalt und mehr künstlerische Ausfuihrung beanspruchen die Vorarbeiten an zu emailirenden Luxusartikeln. Auf dieselben wird das Email meist in mehreren nebeneinander angeordneten, aber scharf getrennten Farben aufgetragen, wodurch es nöthig ist, die Oberfläche solcher Gegenstände mit kleinen, zur Aufnahme des Emails bestimmten Behältnissen von entsprechender Form zu versehen. Das Erzengen dieser Behältnisse geschieht entweder derart, dass man auf eine gereinigte Platte die Contouren der im Email auszufiihrenden Zeichnung (d. h. die Grenzlinien der verschiedenen Farben) vorzeichnet, dann mittelst feiner Zängelchen Draht nach diesen Linien biegt und diesen schliesslich mit einem nicht zu weichfliissigen Lothe an die richtige Stelle auflöthet. Diese Manier führt den Namen Zellenschmelze (emaile cloisonne, von cloison, d. i. Verschlag oder Scheidewand) und liefert die am theuersten bezahlten Producte. Oder es werden die erforderten Grïbchen mit dem Gravirstichel aus dem vollen Metall ausgearbeitet. Diese Art bezeichnet man mit dem Namen Grubenschmelze (champ elevé).

Am raschesten und billigsten gelangt man zum Ziele, wenn man die Vertiefungen durch Einprägen mittelst starker Schraubenpressen erzeugt, oder durch Giessen der ganzen, schon mit den Zellen versehenen Gegenstände aus Metallen, die strenger fliissig sind als die zur Anwendung kommenden Emaile. Diese

*) Vom Hïttenmeister CuchuI in der k. Eisengiesserei in Gleiwitz erfunden und ebendaselbst im Gebrauche. S. Dingler's polyt. Journal Bd. 202 S. 502.

(k*) Dingler's polyt. Journal Bd. 203 S. 499. Dieses Email verwendet die Fabrik sog. ${ }_{3}$ Sanitätsgeschirre" des Emil Soltmann in Thale. 
beiden Verfahrungsarten sind natiirlich nur dann rentabel, wenn es sich um Anfertigung vieler gleicher Stiicke handelt, da die Beschaffung von Prägestempeln und scharfen Gussformen kostspielig ist.*)

Gleichgiltig, in welcher Weise vorgegangen wurde, muss auch hier ein $A b$ beizen mittelst Säuren dem Auftragen des Emails vorangehen.

Die ausgedehnteste Anwendung erleidet das Email als Ueberzug von Kuchgeschirren, Fliissigkeits-Leitungsröhren und als äusserlicher Schntz der Locomotivkessel-Siederöhren gegen die Ablagerung von Kesselstein.

Bei allen Arten Röhren ist das Material von der Bestimmung des fertigen Productes abhängig, bei Kochgeschirren aber ist es in den meisten Fällen Gusseisen, seltener Eisen- oder Kupferblech.

Die Gusseisengeschirre sollen an und für sich leicht sein und die Wärme rasch durchdringen lassen, beides Eigenschaften, die man durch entsprechend dünne Wandungen erzielt, wozu das beim Schmelzen sehr diinnflüssige weisse Gusseisen von Wiesenerzen sehr geeignet ist. Die Härte dieses Materiales thut der Verwendung keinerlei Eintrag, da die gegossenen Gefässe vor dem Auftragen des Emails keinerlei Bearbeitung mittelst Werkzeugen erfahren, sondern lediglich mittelst schwacher Säure (24 Thl. Wasser, 1 Thl. Schwefelsäure) abgebeizt, mit scharfem Sande und mittelst einer scharfen Biirste in kaltem Wasser geschenert und dann mit heissem Wasser ausgespïlt werden, worauf sie sofort trocknen.

3. A uftragen des Emails. Diese Operation erfordert einige Uebung, da der Emailiberzug überall möglichst gleichmässig sein muss. Zifferblätter u. s. w. werden mittelst eines Pinsels mit dem im Wasser vertheilten Emailpulver bestrichen oder in die rahmige Fliissigkeit, in welcher man das Emailpulver durch beständiges Rïhren gleichmässig vertheilt erhält, eingetaucht und der anhängende Ueberschuss durch mehrmaliges rasches Schwingen oder durch einige kurze, kräftige Stösse, die indess den Metallgegenstand nicht deformiren diirfen, abgeschleudert.

Ebenfalls mit einem Pinsel wird das Email in die Zellen von Luxusgegenständen eingefiillt.

Das Einbringen des Emails in Kochgeschirre muss in zwei getrennten Operationen vorgenommen werden, indem man zuerst eine Grundmasse aufträgt und erst nachdem diese eingebrannt ist, die Deckmasse dariber bringt. Beidemale wird die mit Wasser zu einer rahmartigen Fliissigkeit angeriihrte, fein gepulverte Emaile in die auf etwa $60-70^{\circ}$ in einem Vorwärmofen angewärmten Geschirre in hinreichender Menge eingegossen, durch geschicktes Wenden und Schwenken gleichmässig vertheilt, der Ueberschuss abgegossen und die Gefässe zum raschen Trocknen in einen Wärmofen gebracht. Neuer, wenn auch gewiss nicht besser, ist das Verfahren des Engländers Paris. $\left.{ }^{* *}\right)$ Die Gefässe werden innerlich mit einer diinnen wässrigen Lösung von arabischem Gummi ausgestrichen und auf diese klebrige Schichte das trocken feingemallene Emailpulver aufgesiebt und durch scharfes Trocknen befestigt.

4. Das Einbrennen des Emails erfolgt nie in offenem Feuer, sondern stets in Muffeln, um die Verunreinigung des Emailiberzuges dureh Rauch oder Flugasche zu verhiiten.

Die Gegenstände sind beim Einschmelzen stets so zu stellen, dass die möglichst geringste Tendenz des Abfliessens des breiig erweichten Emails vorhanden ist.

Die Einbrenn-Temperatur ist eine wechselnde und richtet sich nach der Schmelzbarkeit des Emails, die jedenfalls unter der des zu emailirenden Metalles oder an demselben vorkommender Löthungen liegen muss.

*) Vergleiche Dingler's polyt. Journal Bd. 211 S. 245 und "Verhandlungen des Vereiues fiir Gewerbefleiss" VI. Beilage, Vortrag vom Fabrikanten "Sussmann Hellhorn am 6. December 1875 .

*) Musspratt's chemisch-technische Encyklopädie. 
Die Einrichtung eines Muffelofens, wie derselbe zum Emailschmelzen für kleinere Gegenstände geeignet ist, zeigt nebenstehende Figur 1497. A ist die thönerne Muffel, die sich an den Einschnitt $C$ des Ofens schliesst und auf mehreren thönernen Stuitzen aufruht. $D$ ist eine durchlöcherte Thonplatte, die den Rost vertritt, $E$ der Aschenfall, $R$ die Oeffnung zum Einbringen des Brennmateriales und $B$ der von den Flammen erfüllte Ofenraum. Während des Email-Einschmelzens ist die Muffel bei $C$ mit einem thönernen Deckel verschlossen. Für Emailirung von Schmuckgegenständen eignet sich vorzïglich $\mathrm{P}$ er ro t's Gas-Muffelofen (s. G a s ö fen).

Nachdem das Email geschmol-

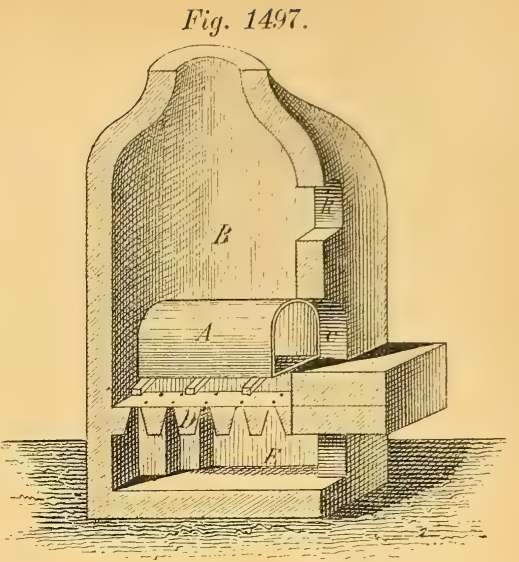
zen ist, wovon man sich durch zeitweiliges Herausziehen von Proben iiberzengt, lässt man den Ofen erkalten und nimmt die Gegenstände aus dor Muffel. Man findet nun, dass die Emailoberfläche mit vielen kleinen, geplatzten Blaschen iiberdeckt ist (diese Erscheinung tritt besonders stark auf, wenn das Fritten und Trocknen keine vollkommene Entwässerung des angewendeten Borax oder der Soda bewirkt hat). Man schleift dann die Oberfläche mit Schmirgel und Polirroth ab und bringt die Gegenstände nach erfolgter sorgfältiger Reinigung abermals in die Muffel zur zweiten Schmelzung, dem sogenannten Glanzschmelzen, wodurch sie eine glasglänzende Oberfläche erlangen.

Das Einbrennen des Emails in Geschirren erfordert wegen der bedeutenderen Grösse der einzelnen Stiicke, und weil die Procedur mit vielen Gefässen zugleich vorgenommen wird, Muffelöfen von bedeutenderen Dimensionen, doch dürfen diese nicht allzugross genommen werden, da es schwierig ist, dieselben dann gleichmässig auszuheizen.

Die Gefässe werden in diesen Oefen bis zur hellrothen Gluth erhitzt, wodurelı bei richtiger Zusammensetzung der Emailmasse nach 15-20 Minuten die Sinterung der Grundmasse oder Verglasung des Glanzemails vollständig erfolgt ist.

Die Geschirre müssen während des Einbrennens mehrmals gedreht werden, damit die Schmelze iberall gleichmässig erweicht werde.

Die Thüre der Muffel wird nur während des Einsetzens und Ausnehmens der Geschirre geöffnet; bleibt aber sonst verschlossen. Zur Einführung einer eisernen Gabel, mit welcher die Geschirre an den Henkeln gefasst und gewendet werden, ist in der Muffelthüre ein länglicher, wagrechter Schlitz.

Das Einbrennen der Deckmasse erfordert natiirlich mehr Sorgfalt als jenes der Grundmasse, wird aber im Wesentlichen in beiden Fällen gleich ausgefiihrt.

Alle emailirten Gegenstände, insbesondere voluminösere, sollen nach erfolgtem Einbrennen des Emails in Kühl-Oefen gebracht und mit diesen abkuihlen gelassen werden, um die Bildung von Hårrissen im Email zu verhiiten.

Geschirre und Röhren sind nach dieser letzten Operation fertig und werden nur zuweilen noch auf den nicht emailirten Flächen mit Firniss uiberstrichen.

Zifferblätter, Schilder und viele Luxusgegenstände aber erhalten eine Bemalung, welche man mit Emailfarben, die in höchst feingemahlenem Zustande mit Lavendelöl verrieben sind, mittelst eines Pinsels aufträgt und damn rorsichtig in Muffeln einbrennt. Es ist selbstverständlich, dass diese Emailfarben leichter schmelzen müssen als der Grund, um jedes Verfliessen hintanzuhalten. 
Auch Vergoldungen und Versilberungen werden auf den Schmelz angebracht und verweisen wir dieserhalb auf Porcellanmalerei im Artikel Thonwaaren. (Als hervorragende Fabriken emailirter Kochgeschirre sind zu nennen: Pleis chl Ad., Wien, Alserstrasse 25. (Emailirte Gussgeschirre.) Bartelmus A ug. \& Co., Brïnn (Em. Eisenblechgeschirre). Actiengesellschaft in $\mathrm{L}$ a $\mathrm{u} \mathrm{chhammer}$, Prov. Sachsen (bis zu em. Gährbottichen).

Moritz Kohn.

Emailfarben, Emailglas, Emailgrund, s. Email u. Glas.

Emailirofen, s. Email.

Embolit, Mineral. Tessulare Krystalle von gelber oder grïnlicher Farbe, diamantglänzend. Härte $1-1 \cdot 5$, spec. Gew. $=5 \cdot 79-5 \cdot 81$. Ist Bromchlorsilber von der Formel $2 \mathrm{Ag} \mathrm{Br}+3 \mathrm{Ag} C l$ mit $66.9 \%$ Silber. Findet sich zu Copiapo in Chili. Gtl.

Embrithit, Mineral. Derb, kuglige oder körnige Massen von bleigrauer Farbe bildend. Härte $2 \cdot 5$. Ist Schwefelantimon-Schwefelblei mit geringem Kupferund Silbergehalt. Vorkommen Nertschinsk. Gtl.

Emerald, s. S m aragd.

Emeraldin, s. Anilingrün bei Theerfarbstoffe.

Emeraldnickel, s. Nickels maragd, s. Tex a site.

Emerylith, s. m. Margarit.

Emetin (émétine - emetine). Das wirksame Princip der Ipecacuanhaoder Brechwurzel, vielleicht auch der Caincawurzel. Zuerst von Pelletier im Jahre 1816 dargestellt und von demselben im Vereine mit Magendie (s. Journ. Pharm. (2) III 145 u. IV 322), dann mit Dumas (Annal. d. Chem. et Phys. (2), XXIV pag. 180), weiter von Merk (Trmsdrf. n. Journ. f. Pharm. XX, 1. pag. 134), von Reich (Archiv f. Pharm. (2) CXIII pag. 193), Lefort (Journ. Pharm. (4) IX pag. 167 u. 241) u. A. genauer untersucht. Kann erhalten werden durch Extrahiren der zerkleinerten Ipecacuanhawurzel mit warmem Weingeist, zuerst mit stärkerem (86-grad.), dann mit schwächerem (56-grad.), Verdunsten der Ausziüge zur Syrupconsistenz und Versetzen des Verdunstungsrückstandes mit etwas Wasser und $2 \%$ ron dem Gewichte der Wurzel an Kalihydrat und Schuitteln dieser Mischung mit Chloroform. Nach dem Verdunsten der von der ïbrigen Masse getrennten Chloroformlösung hinterbleibt unreines Emetin, das in verdünnter Salzsäure gelöst und die Lösung durch eine eben zureichende Menge an Ammoniak gefällt wird. Der hiebei erhaltene Niederschlag wird nun zunächst mit Wasser, dann mit Aether gewaschen, wodurch die letzten Reste von Verunreinigungen entfernt werden (L efort). Es resultirt nach diesem Verfahren aus brasil. Ipecacuanhawurzel durchschnittlich $1 / 3-1 / 2 \%$ Emetin.

So dargestelltes Emetin bildet ein weisses, geruchloses Pulver von schwach bitter kratzendem Geschmack olme Spur ron Krystallisation. Es reagirt alkalisch. Löst sich in 1000 Thl. Wasser von $50^{\circ} \mathrm{C}$., leicht in Alkohol, sehr leicht in Chloroform, eben so auch in Benzol und Petroleumäther, dagegen fast gar nicht in Aether. Die angesänerte Lösung fluorescirt blau. Das Emetin schmilzt bei $70^{\circ}$ C. (Lefort) (nach Pelletier bei $50^{\circ}$ ), bei stärkerem Erhitzen verbrennt es mit russender Flamme. Von Säuren wird es gelöst unter Bildung neutraler Salze, welche nicht krystallisirbar, in Wasser meist leicht löslich und von scharfem, zugleich bitterem Geschmacke sind. Das Nitrat ist nach L e fort schwer löslich. Seine noch nicht mit Sicherheit festgestellte Zusammensetzung entspricht nach Reich der Formel $\mathrm{C}_{40} \mathrm{H}_{30} \mathrm{~N}_{2} \mathrm{O}_{10}$, nach Anderen wäre jedoch auf 30 bis 37 Atome Kohlenstoff blos 1 Stickstoffatom enthalten wie in der Formel $C_{32} H_{2}, N O_{10}$. Das Emetin wird aus den Lösungen seiner Salze sowohl durch Platinchlorid als auch durch Phosphormolybdänsäure, dann durch Gerbsäure, Quecksilberchlorid gefällt. Schwefelcyankalium fällt es gelblichweiss, Kaliumbichromat gelb, salpetersaure Alkalien weiss. Aetzende, so wie kohlensaure und doppelt kohlensaure Alkalien, Ammoniak und Magnesia fällen reines Emetin. Es wirkt schon in geringen Gaben 
heftig brechenerregend, in grösseren Dosen tödtlich. Unter dem Namen Emétine colorée (brune) kommt in Frankreich ein Prïparat in den IIandel, das nichts weiter als ein durch Verdunsten eines alkoholischen Wurzelauszuges, Auflösung des Riickstandes in Wasser und Eindampfen der nach Zusatz von etwas Magnesia filtrirten wässrigen Lösung zur Trockene bereitetes Extract der Ipecacuanha ist. Gtl.

Emmer, s. bei Dinkel II pag. 632.

Emmonit, kalkhältiger Strontianit, s. d.

Emoisin, Bezeichnung für Lexikon-Format.

Emplectit, rhombisches Mineral, welches in dünnen nadelförmigen, stark längsgestreiften Säulen in Quarz eingewachsen vorkommt. Mild, Härte 2, spec. Gew. $=5 \cdot 137-5 \cdot 263$, zinnweiss, gelb angelåufen. Chem. Zusammensetzung $C u^{2} S B i^{2} S^{3}$, 19 Schwefel, 19 Kupfer und 62 Wismuth. Vorkommen Schwarzenberg im Erzgebirge, Freudenstadt in Wiurttemberg, Copiapo in Chile. Lb.

Empyreuma (empyreuma - empyreume) bedeutet so viel als brenzlicher Geruch oder Geschmack, wie solcher den bei der trockenen Destillation organischer Substanzen sich bildenden Stoffen eigenthiimlich ist. Vgl. Destillation II pag. 613.

Emulsin, Synaptase, s. Amygdalin I pag. 141, s. Eiweisskörper III pag. 142.

Emulsion nennt man die innige Vermengung eines in einer Flïssigkeit nicht oder nur schwer löslichen Körpers mit derselben durch gleichmässige Vertheilung des feinzertheilten Körpers in der Flïssigkeit. Namentlich gebraucht man diese Bezeichnung für die durch feine Vertheilung eines Oeles oder Fettes, wohl auch eines Harzes in einer wässrigen Flüssigkeit entstandenen Mischungen, wie solche z. B. in der thierischen Milch, den Milchsäften der Pflanzen, dem Eidotter etc vorliegen und spricht in diesem Sinne von Oel-, Fett-, Harzemulsionen.

Für die künstliche Bereitung von Emulsionen wählt man schleimige Flïssigkeiten, welche der Wiedervereinigung der fein vertheilten Oel-, Fett- oder Harzpartikelchen einen grösseren Widerstand entgegensetzen. So kann man durch Anriihren von 1 Thl. Oel mit $1 / 2$ Thl. Gummi und allmäligen, unter fleissig fortgesetztem Verreiben erfolgenden Zusatz von Wasser (10-12 Thl.) eine Oelemulsion darstellen. Gummiharze liefern beim Anrühren mit Wasser direct eine Harzemulsion, auch durch Zerstossen ölreicher Samen, Anriihren des Breies mit Wasser und Abseihen der erhaltenen Emulsion von den festen Samentheilen erhält man Emulsionen (Samenemulsion), z. B. die Mandelmilch. Gtl.

Emydin. Stickstoffhältige und phosphorhältige organische Substanz, welche sich in Gestalt rundlicher Körner, nicht selten anch krystallisirt in den Schildkröteneiern findet. Gtl.

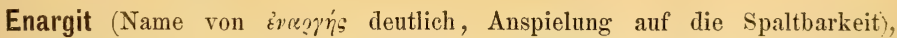
rhombisch-krystallisirendes Mineral, das jedoch meist derb, grobkörnig oder stenglig vorkommt. Spaltbar prismatisch, vollk. spröde. Härte 3, spec. Gew. $=4 \cdot 36$ bis 4.47. Eisenschwarz, Strich schwarz, Metallglanz. Chem. Zusammensetzung: $3 \mathrm{Cu}^{2} \mathrm{~S} \mathrm{As}^{2} \mathrm{~S}^{5}$ mit 48.60 Kupfer, 18.28 Arsen, 32.58 Schwefel. Zuweilen vicariirt etwas Antimon für Arsen, etwas Eisen und Zink für Kupfer. Im Kolben sublimirt erst Schwefel, woranf er schmilzt und dann Schwefelarsen gibt. Schmilzt anf Kohle leicht zu einer Kugel, Aetzkali entzieht dem Pulver Schwefelarsen. Fundorte Morococha in Peru, Chesterfield, Siid-Carolina, am Colorado, Coquimbo, Chile, Nengranada, Mexico. Lb.

Encaustik, s. Enkaustik.

Endlose Schraube, s. Schraube.

Endosirmaschine oder Abpress-M., s. Buchbinderei II S. 114. 
Endosmose, s. Diffusion II pag. 625 .

Engelroth, Englischroth, s. Caput mortum II S. 252 u. d. Artikel Poliren, s. a. Eisenoxyd II pag. 760.

Engelwurzel, Angelicawurzel (racine d'angélique - angelica root). Die Wurzel von Archangelica officinal. Hofim., einer im nördlichen Europa und Asien, seltener in Mitteleuropa, auf feuchten Wiesen und an Bächen rorkommenden Doldenpflanze, die nicht selten im Erzgebirge und in Thüringen cultivirt wird. Die Handelswaare bildet braune Stiucke, welche aus dem oft bis $6^{\mathrm{cm}}$ dicken, geringelten, mit den Scheidenresten abgestorbener Blätter besetzten Wurzelkopf bestehen, an dem zahlreiche, bis $0 \cdot 2^{\mathrm{m}}$ lange, $3-4^{\mathrm{mm}}$ dicke Nebenwurzeln sitzen, die häufig unter einander verschlungen sind. Die ziemlich lockere strahlige Wurzelsubstanz hat einen angenehmen, durehdringend aromatischen Geruch und schwach bitteren, gewürzhaften Geschmack, welche auf Rechnung eines ätherischen Oeles (von welchem die Wurzel $0.3-0.7 \%$ enthält) und einer balsamartigen Substanz $(-6 \%)$ zu setzen sind. Bu chner hat daraus das krystallisirbare Angelicin oder Angelicabitter erhalten, ansserdem findet sich Angelicasäure $\left(\mathrm{C}_{5} \mathrm{H}_{8} \mathrm{O}_{2}\right)$, etwas Valeriansäure, Zucker, Stärke, Wachs, ein Bitterstoff und Spuren von Gerbsäure.

Die Angelikawurzel dient einerseits als Arzneistoff, andererseits wird sie ihres angenehmen Aromas wegen zur Bereitung von Liqueuren und aromatischen Essigen verwendet. Gtl.

Englischblau, vgl. In dig 0 .

Englischgelb, Varietät von Casselergelb, s. d. I pag. 621.

Englischgrün, Mineralfarbe, welche durch Mischung vou Chromgelb mit Berlinerblau und Barytweiss erhalten wird. Vgl. griiner Zinnober bei Blei I pag. 603. Gtl.

Englisch-Leder, ein dichtes Baumwollgewebe, s. Satin, s. Weberei.

Englischpflaster (taffetas anglais - court plaster), S c hön h e it s p flas te r, Englisches Klebepflaster (Woodstock's), Táffetpflaster. Ein durch Ueberstreichen von Taffet mit Hausenblase oder Gelatine hergestelltes Pflaster, welches nach folgender Vorschrift dargestellt werden kann: 100 Gr. Blätterhausenblase in kleine Stiickchen geschnitten, werden in $2000 \mathrm{Gr}$. heissen destillirten Wasser's gelöst, die Lösung mit $100 \mathrm{Gr}$. 90-proc. Weingeist und $10 \mathrm{Gr}$. gereinigtem Honig gemischt und diese Mischung durch ein Tuch geseiht. Diese Menge der Mischung wird durch gelindes Erwärmen flissig erhalten und mit einem breiten Haarpinsel auf ein 1 Meter langes Stiick Taffet (ron schwarzer, rosarother oder weisser Farbe), welches auf eine Rahme glatt gespannt ist, nach und nach sehr gleichmässig aufgetragen, indem nach jedesmaligem Anstrich abgewartet wird, bis die aufgetragene Schichte völlig trocken geworden ist. Sobald die ganze Menge der Mischung aufgetragen und der Taffet völlig abgetrocknet ist, wird derselbe anf der Rückseite mit einem Anstrich aus einer Mischung ron 4 Thln. Benzoëtinktur (1 Benzoë zu 5 Thl. 90\% Alkohol) und 1 Thl. Perubalsam überstrichen und nach dem Abtrocknen dieses Anstrichs in Stiicke ron beliebiger Grösse geschnitten.

An Stelle der Hausenblase verwendet man fur geringere Sorten von Englischpflaster wohl auch weissen Lein (Gelatine), dem man etwas Glycerin $(1-2 \%)$ zusetzt. Gtl.

Englischroth, syn. mit Engelroth.

Englischsalz, syn. mit schwefels a urer Magnesia oder Bittersalz.

Englischschwarz, s. Z e ugfärberei.

Enkaustik (encaustique - encaustic painting), s. Thon w a ren. 
Enkaustiren nennt man das auf Gypsabgüsse angewendete Verfahren, des Einlassens (theilweisen Imprägnirens) derselben mit Stearin oder Paraffin, wodurch die Gypsgegenstände ein, gewissen Marmorarten ähnliches, schwach transparentes Aussehen gewinnen und eine weniger leicht schmutzende, abwaschbare Oberfläche bekommen. Man erreicht dies entweder durch Einlegen der vollkommen trockenen und auf $80-88^{\circ} \mathrm{C}$. erwärmten Gypsabgiisse in geschmolzene Stearnisäure oder Paraffin (in welch letzterem Falle man die Gegenstände blos auf $63-65^{\circ}$ C. zu erwärmen braucht), 3-4 Minuten langes Belassen in dem Fettbade und Bürsten der erkalteten Gegenstände mit einer weichen Bürste. Auch durch wiederholtes Bestreichen der auf den Schmelzpunkt des Fettes erhitzten Gegenstände mit dem geschmolzenen F'ette kann man den gleichen Zweck erreichen. Nach Wi e der hold kann man die Erwärmung der Gegenstände dadurch umgehen, dass man sie durch Tränken mit einer Lösung von 1-2 Thl. Stearinsäure in 10 Thl. Petroleumäther enkaustirt. Durch Anwendung einer mit etwas Drachenblut und Gummigutt gefärbten Stearinsäure kann man den enkaustirten Gegenständen eine angenehm röthlich-gelbe Farbe ertheilen. Die zu enkaustirenden Gegenstände müssen aus lem reinsten Gyps hergestellt sein, da sie andernfalls stets ein schmutzig weisses Aussehen bekommen. Vgl. Gyps bei Calcium II pag. 218, s. a. Gypsguss bei Giesserei. Gtl.

Enkrinitenkalkstein, körniger, mehr oder weniger dichter Kalkstein, der wesentlich aus zusammengehäuften Gliedern fossiler Crinoiden besteht, und in verschiedenen Formationen, namentlich im Kolılenkalk, Muschelkalk und Jura oft in beträchtlicher Entwicklung vorkommt. Da die Crinoidenglieder immer in Kalkspath rerwandelt sind, hat das Gestein ein mehr oder weniger späthig körniges, krystallinisches Aussehen, und liefert oft vorzïglichen Marmor (Lumachelle, Pietra stellaria z. Thl.). $L b$.

Enlevage (enlevages - chemical discharge), Aetzbeize, s. Beize I pag. 372. Vgl. a. Zeugfärberei u. Druekerei. Gtl.

\section{Enlevagedruck, s. Z e ugdruckerei.}

Enrouleur, Einrollapparat, eine Maschine zum faltenfreien Aufwickeln von Geweben (s. A ppretur'I pag. 169).

Enstatit, Min. rhombisch, in rechtwinkligen Säulen krystallisirend in Serpentin- oder Olivingesteinen eingewachsen. Prismatisch vollk. spaltbar. Härte $5 \cdot 5$, spec. Gew. $=3 \cdot 13-3 \cdot 29$, granlich oder grïnlich weiss. Perlmutterglanz auf den Spaltungsflächen, wenig durchscheinend. Chem. Zusammensetzung $\mathrm{MgOSiO}^{2}$, 60.6 Kieselsäure, 39.4 Magnesia. Ist vor dem Löthrohr unschmelzbar, wird von Säuren nicht angegriffen. Ursprünglich nur vom Zdjarberge in Mähren bekannt, lernte man den Enstatit als charakteristischen Gemengtheil des Schillerfelsens vom Harz, so wie zahlreicher Olivingesteine kennen; auch ist der Enstatit eines von jenen Mineralien, welche sich in Meteorsteinen finden, der Meteorit von Bishopville besteht vorwiegend daraus. $L b$.

Entfärben (décolorer - to decolour). Das Entfärben von Fliissigkeiten kann entweder durch Zerstörung oder durch Entfernung des färbenden Bestandtheiles erfolgen. Im ersteren Falle wird man es wesentlich mit einem Bleichprocesse zu thun haben und die anzuwendenden Mittel werden chemisch wirkende Mittel, Bleichmittel, sein miissen, vgl. Bleichen I pag. 622. Im zweiten Falle wird man Mittel anwenden müssen, welche die färbende Substanz aufnehmen oder binden und sie so zu entfernen gestatten. Von solcher Art ist die Wirkung der Mittel, die man läufig zur Entfärbung von Fliissigkeiten anwendet, welche die Anwendung chemisch wirkender Agenzien nicht gestatten. In diesem Sinne verwendet man am häufigsten Knochenkohle (Thierkohle od. Spodium), welche bei längerer Beriihrung mit gefärbten Fliissigkeiten, soferne dieselben sauer oder neutral reagiren, die Farbstoffe anfnimmt und nach dem Abfiltriren der Knochenkohle eine mehr oder weniger farblose Fliissigkeit liefert. Auch frisch gefälltes Schwefelblei, oder 
noch besser Schwefelblei, welches im Bereiche der zu entfärbenden Flïssigkeit selbst entsteht, reisst die meisten Farbstoffe mit nieder, wirkt also entfärbend, und man kann hiebei den günstigsten Erfolg dadurch erreichen, dass man eine zu entfärbende Flïssigkeit, falls dies angeht, mit etwas Bleizuckerlösung versetzt und sodann Schwefelwasserstoff so lange auf die Mischung einwirken lässt, bis alles Blei in Schwefelblei verwandelt ist. Auch frisch gefälltes Eisenoxyd und frisches Thonerdehydrat wirken nicht selten entfärbend. Gtl.

Entfärbungsmesser, vgl. Decolorimeter bei Colorimeter II pag. 385.

Entfärbungsmittel, s. Bleichen I pag. 622, vgl. Knochenkohle, vgl. Z e ugfärberei.

Entfernung (distance - distances), s. Distanzmesser II pag. 635.

Entfetten, s. Bleichen I pag. 623 u. 630.

Entfettungsmaschine oder Krappmaschine, s. Appretur I S. 170.

Entfuseln, s. Branntweinbrennerei I pag. 769, v. a. Alkohol.

Entfuselungspulver nennt Plattner ein ihm patentirtes Gemenge von 2 Thl. Stärke mit 1 Thl. Eiweiss und 1 Thl. Milchzucker, welches in feinpulveriger Form zur Klärung und Entfuselung von Liqueren dienen soll. S. Dingl. pol. Journ. 215 pag. 283. Gtl.

Entglasen, s. Glas.

Enthaaren und Enthaarungsmittel, s. Leder.

Enthülsungs-Maschinen, s. Land wirth seh a ftliche Maschinen.

Entkohlen, Decarbonisiren (décarbonisation - decarbonizing) bezeichnet das Gliihen von Stahlplatten (für Stahlstiche) zwischen Schmiedeisenfeilspänen zum Zwecke des Weichermachens der Platten durch Verminderung des Kohlenstoffgehaltes des Stahles.

Entkräuseln, s. K a m m g a rn spinn er ei.

Entladevorrichtungen, s. H e b e $\mathrm{m}$ a s $\mathrm{ch}$ in en.

Fig. 1497.

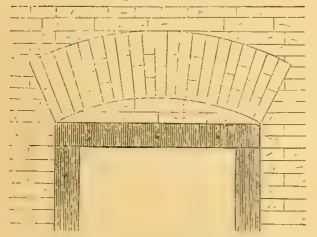

Entlastungsbogen (arc en décharge - discharging arch) ist ein Mauerbogen, um den Druck des Mauerwerkes (oder der Belastung) von einem darunter befindlichen horizontalen Steinbalken (Sturz) oder einem schwachen Matterbogen abzuhalten. Fig. 1497 gibt ein Bild davon. $G r$.

Entlastungs-Schieber, En tlas teter Schieber (soupape ì bascule - balance valere). Schieberentlastungen sind, wie schon das Wort besagt, Constructionen, welche bezwecken, den Druck, mit welchem Dampf-Schieber gegen ihre Bahn gepresst werdrn, zu verringern und dadurch den Reibungswiderstand thunlichst herabzumindern. Der entlastete Schieber wird natürlich complicirter und kostspieliger als der gewöhnliche, keine der bekannten Auordnungen kann als vollkommen entsprechend bezeichnet werden, und sie bediirfen, um dauernd wirksam zu bleiben, öfteren Nachsehens und Reparatur, so dass man derlei Constructionen, wo es nicht unbedingt geboten erscheint, lieber umgeht.

Das Beduirfniss der Schieberentlastung tritt aber ein, wenn man es mit grösseren Maschinen zu thun hat, deren Steuerungsapparat von Hand aus verstellt werden soll, wie bei Maschinen mit Umsteuerung und Handsteuerung. Wir sehen daher bei Schiff'smaschinen (wegen der grossen Schieberdimensionen) fast durchwegs Entlastungen angewendet, sehr oft auch bei Dampfhämmern (s. II pag. 520 ete.), während die Locomotiven und Förlermaschinen zumeist noch mit voll belastetem 
Schieber arbeiten, da die hierbei oft versuchten Entlastungs-Constructionen kein zufriedenstellendes Resultat ergaben.

Eine der gebräuchlichsten Schieberentlastungen ist jene mit Schlussring, wie eine solche Fig. 1498 zeigt. An dem Muschelschieber ist ein cylindrischer Theil $D$ angegossen, welcher oben eine Rinne $b$ eingedreht enthält. In letztere passt ein Gussring $R$, der durch Kautschuk oder Stahlfedern fortwährend gegen den bearbeiteten und gut gerichteten Schieberkastendeckel gepresst wird. Nach der Grösse, welche man dem Fig. 1498.

Cylinder $D$ gibt, kann die Entlastung in mehr oder minder hohem Grade erzielt werden, auf jeden Fall aber, und das gilt für alle Constructionen, muss noch ein Druck nach abwärts iibrig bleiben, der den Schieber gegen seine Bahn abdichtet. Die Entlastung ist im vorliegenden Falle dadurch erzielt, dass der Dampf vom Rïcken des Schiebers abgesperrt wird, und hört auf, sobald der Ring nicht mehr dampfdicht am Schieberkastendeckel schleift.

Auf einem ähnlichen Gcdanken beruht auch der Schieber von Holt, *) von Desgrange ${ }^{* * *}$ ) und noch zahlreiche andere Constructionen. ${ }^{* * * *}$ )

Eine andere häufige Anordnung zeigt Fig. 1499. Der Schieberkastendeckel bildet einen Cylinder $Z$, in dem sich dampfdicht der Kolben $K$ bewegt. Schieber und Kolben sind durch die Stange $L$, die in 1 und 2 mit Scharnieren versehen ist, verbunden. Indem der Dampf auch auf den Kolben $K$ (dessen Oberfläche stets etwas kleiner sein muss als die Schieberoberfläche) nach aufwärts drückt, entlastet er zum grössten Theil den Schieber. Bedingung ist, dass kein Dampf in den Raum $r$ gelange, sonst würde die Anordnung unwirksam. Liesse man den Deckel $E$ weg, was auch gesshen kann, so danert auch beim Undichtwerden des Kolbens $K$ die Entlastung fort, aber es ergeben sich bedeutende Dampfverluste. Während der Schieber hin- und hergeht, bewegt sich der Kolben unmerklich auf und ab, und es übt die Stange $L$ in allen Stellungen des Schiebers ausser der Mittelstellung einen schiefen Zug auf den Kolben aus, wodurch derselbe sehr bald schadhaft wird.

Auf dem Principe der Druckausgleichung beruht auch die Entlastung der Kolbenschieber, welche neuerer Zeit wieder häufiger in Aufnahme gelangen.

Fig. 1500 zeigt einen Kolbenschieber, construirt von Ös chgers. In einem cylindrischen Körper $H$ bewegt sich der Kolbenschieber und eröffnet die Dampfwege $a, b, c$, welche ihn ringförmig längs eines Kreisum-

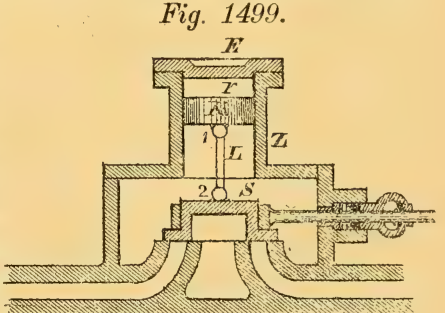

*) Radinger, Motoren der Wiener Weltausstellung.

*) Armengaud, Publication industrielle T. 8. 1853.

***) Eine grosse Anzahl von entlasteten Schiebern ist beschrieben von A. Lind $n$ er in der Zeitschrift d. österr. Ing.-V. Jhrg. 14. 1862. - Ueberdies ist noch zu erwähnen ein Artikel in der Révue universelle von Cuyper 'T. II 1857. 
fanges umgeben. Die Dichtung erfolgt bei grösseren Ausführungen durch Gussringe i. Sobald einer der Dampfkanäle, z. B. jener $a$ eröffnet wird, wirkt auf die äussere Mantelfläche des linksseitigen Gussringes allseitig der Dampfdruck. Um diesem entgegenzuwirken und so die Ringe auszubalanciren, dienen die Innenflächen $g$. Diese Construction soll sich bei Locomotiven vorziiglich bewährt haben.

Die Construction in Fig. 1501 ist die von Lindner, und sie fusst auf dem Gedanken, die Entlastung dadurch herbeizufibren, dass man die gleitende Reibung

Fig. 1501.

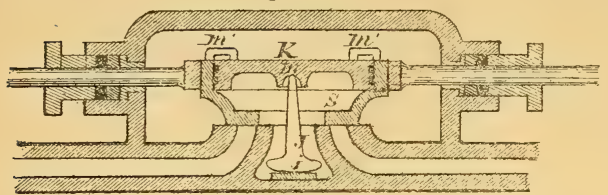

eines Schiebers zum grössten Theil in eine rollende verwandelt.

Der obere Theil des Schiebers ist cylindrisch und nimmt den Kolben $K$ auf, der durch Metallringe' gegen den Schieber abgedichtet ist. $K$ stïtzt sich in einem Stahllager bei $m$ auf den Sector $J$, dessen untere Bahn kreisförmig und aus $m$ beschricben erscheint.

Der Druck, den der Dampf auf den Kolben $K$ ausiibt, iiberträgt sich auf den Sector. Bei der Schieberbewegung bleibt $K$ relativ gegen den Schieber in Ruhe, und es ist nur die unbedentende Reibung, welche der Sector beim Rollen auf der im Auspuffkanal angebrachten Platte $i$ verursacht, zu iiberwinden. Der Sector $J$ wird durch einen Zahn (in der Figur nicht ersichtlich), der in einen Ausschnitt der Platte $i$ eingreift, vor zufälliger Verrickung geschiitzt. Die Anschläge $m^{\prime}$ verhindern ein Heraustreten des Kolbens aus dem Schieber. Anch diese Construction soll sehr gute Resultate ergeben haben.

Diese wenigen Beispiele geben nur typische Formen, Repräsentanten ganzer Gruppen, denn die Zahl der Constructionen ist iiberaus gross und schon seit dem Bestehen der Dampfmaschine cultivirt.

Behufs genaueren Studiums dieser Frage ist daher auf die bereits citirten Quellen zu verweisen.

Blaha.

Entoilage, ein den Spitzen ähnliches, gazeförmiges Gewebe, s. Weberei.

Entschälen oder Kochen der Seide s. d., s. a. Bleichen I pag. 632.

Entschlichten (macération - steeping), dem Bleichen rorhergehende, die Schlichte entfernende Reinigung der Gewebe. S. Appretur I S. 169.

Entschwefeln bezeichnet das Auswaschen der Seide nach der Bleiche (Schwefeln) mit schwefliger Säure. Entschwefeln der Erze vgl. z. B. K upfer u. Blei, s. a. Rösten.

Entschweissen, jenes Waschen der Wolle, durch welches der Fettschweiss entfernt wird, s. Kammgarnspinnerei u. Bleichen I pag. 630.

Entstehungszustand, Moment des Freiwerdens (stritus nascendi). Die Thatsache, dass einfache Körper, welche anf einen zweiten einwirken, sich anders verhalten, wenn sie bereits im freien Zustande sich fanden, wie sie zur Wirkung kamen, als wenn sie in dem Augenblicke zur Wirkung gelangten, wo sie eben aus einer Verbindung ausscheiden, hat schon friiluzeitig dazu gefilhrt, die Körper in dem Angenblicke ihres Freiwerdens in einem besonderen Zustande stehend anzusehen, und der Wirkung im Entstehungszustande eine besondere Energie beizumessen. In der That sind Erscheinumgen solcher Art nicht selten. So wirkt Sauerstoff z. B. weit weniger energisch oxydirend, wenn man ihn als Gas auf gewisse oxydirbare Substanzen einwirken lässt, als wenn man solche Snbstanzen mit Gemengen zusammenbringt, aus welchen sich eben Sauerstoff entwickelt. Eben so reducirt Wasserstoff als fertig vorhandenes Gas die verschiedensten Substanzen nicht, während er sie sehr leicht zu reduciren vermag, wenn man die 
Substanz mit einem Gemenge zusammenbringt, aus welchem sich Wasserstoff entwickelt u. s. w. Diese grössere Energie, die elementare Stoffe in dem Zustande ihres Freiwerdens zeigen, erklärt sich gegenwärtig aus der Annahme, dass auch die Molecule chemisch einfacher Körper sich in der Regel ans mindestens zwei Atomen der Substanz aufbauen, also gewissermassen als Verbindungen zweier Atome anzusehen sind, die sich in dem Momente ihres Freiwerdens zu einem Molecul vereinigt haben. Während man es also in einem bereits fertig vorhandenen Körper immer mit solchen zu Moleculen verbundenen Atomen zu thun habe, sei in dem Augenblicke, wo ein solcher Körper aus einer bestandenen Verbindung ausscheidet, also eben frei wird, Atom fïr Atom in noch unverbundenem Zustande vorhanden und diesem Umstande die grössere Energie des Körpers zuzuschreiben. Vgl. Atom I pag. 227. Gtl.

Entwässern, Trockenlegen (drainer - to drain), s. Landwirthschaft, Entwässern geistiger Fliissigkeiten (deflegmer - to dephlegmate), vgl. Alkohol I pag. 96.

Entwässerung, s. Wasserbau, s. Drainage II pag• 676 .

Entwickler, s. Hervorrufung" bei Photographie.

Entzündungstemperatur, d. i. die Temperatur, bei welcher ein brennbarer Körper unter sonst normalen Verhältnissen zur Verbrennung gebracht werden kann. Die Kenntniss dieser Temperaturen ist namentlich wichtig für die Beurtheilung der Brauchbarkeit von Leuchtölen, dann von Explosivstoffen u. dgl., s. Verbrennung, vgl. Explosivstoffe, vgl. Petroleum. Gtt.

Enveloppe- oder Papiersack-Maschine. Lockwood in Philadelphia hatte auf der dortigen Ausstellung eine E.-M. exponirt, welche ans einer endlosen Papierrolle die Enveloppen durch Schneiden, Formiren und Gummiren herstellt und in Packete von je 25 Stiick, welche von der Maschine abgezählt werden, bringt. Der Durchschnitt der täglichen Leistung soll nach Göldy's Bericht 60.000 Stück betragen. (Vgl. a. Falzkapselmaschine.) $K k$.

\section{Enzianbitter, Enziansäure, s. Gen ti anawurzel.}

Enzianwurzel (racine de gentiane - fell-uort), s. a. Gentinawurzel. Eoïdin, syn. mit Bixin, s. b. Orlean.

Eosin (eosine - eosina), Tetrabromfluorescëin-Kalium. Ein von A. B a e y e r und $\mathrm{H}$. Caro entdeckter, seit wenigen Jahren im Handel vorkommender stickstofffreier Farbstoff von prächtig morgenrother Farbe (daher der Name von $\eta \dot{\omega} s$, die Morgenröthe) und charakteristischer Fluoreszenz. Nach A. W. Hofmann (Ber. d. d. chem. Ges. 8 pag. 63) ist dasselbe als das Kalisalz des Tetrabromfluorescëin $\left(\mathrm{C}_{20} \mathrm{H}_{\mathrm{s}} \mathrm{Br}_{4} \mathrm{O}_{5}\right)$ anzusehen und kann sonach als ein Abkömmling des Resorcins $\left(\mathrm{C}_{6} \mathrm{H}_{4}(\mathrm{OH})_{2}\right.$ betrachtet werden, aus welchem das Fluorescëin $\left(\mathrm{C}_{\mathbf{2} 0} \mathrm{H}_{12} \mathrm{O}_{5}\right)$ durch Erhitzen mit Phtalsäureanhydrid $\left(\mathrm{C}_{8} \mathrm{H}_{4} \mathrm{O}_{3}\right)$ entsteht, das weiters durch Einwirkung von $8 \mathrm{Br}^{*}$ unter Abspaltung von $4 \mathrm{BrH}$ in Tetrabromfluorescëin uibergehen kann.

Das Eosin stellt im trockenen Zustande ein rothbraunes Pulver von grïnlichem metallischen Reflex dar, es ist in Wasser $(2 \cdot 2$ Thl. heissen und $2 \cdot 6$ Thl. kalten) sehr leicht zu einer prächtig rosarothen, im auffallenden Lichte grün fluorescirenden Flüssigkeit löslich. In Alkohol ist es schwerer löslich (in 11 Thl. kochendem Weingeiste), ferner löst es sich in Glycerin, Seifenlösungen, so wie in Lösmungen von ätzenden und kohlensauren Alkalien. In Aether, Benzol, Anilin, Phenylsäure, so wie in fetten Oelen ist es unlöslich.

Die wässrige Lösung wird durch Säuren (Essigsäure ausgenommen) unter Abscheidung eines ziegelrothen Niederschlages von Tetrabromfluorescëin zersetzt. Thonerde-, Zinn- oder Bleisalze crzeugen rothe, Silber- und Quecksilber-Salze violettrothe, Zinksalze gelbe, Kupfersalze braunrothe Niederschläge. Durch Natriumamalgam, so wie andlere kräftige Reductionsmittel wird die Lösung rasch entfärbt. 
Mit Kaliumhydroxyd versetzt färbt sich die Anfangs tiefroth gefärbte Lösung beim Erhitzen rasch schwarz-violett bis schwarz-braun. Zur Darstellung des Eosins kann man von der Benzoldisulphonsäure ausgehen, welche man nach Egli (Ber. d. d. chem. Ges. 8 pag. 817) leicht durch fortgesetztes Einleiten von Benzoldampf in auf $240^{\circ}$ C. erhitzte concentrirte Schwefelsäure erhält. Wird das Natriumsalz dieser Säure mit Aetznatron geschmolzen, so resultiren reichliche Mengen von Resorcin, die durch Extraction der mit einer Säure angesäuerten Lösung der Schmelze gewonnen werden können. Durch Erhitzen des Resorcins mit Phtalsäureanhydrid auf $195-200^{\circ}$ C. erhält man zunächst das Fluorescëin, das, in Essigsäure gelöst und mit Brom behandelt, endlich in das Tetrabromid übergeht. Es kommt westntlich darauf an, dass die Bromirung sorgfältig geleitet wird. Die fabriksmässige Darstellung ist bisher geheim gehalten.

Charakteristisch für das Eosin ist das von A. B a eyer (Ber. d. d. chem. Ges. 8 pag. 146) angegebene Verhalten desselben, beim Schiitteln mit Natriumamalgam und Wasser nach gelindem Erwärmen sich rasch zu entfärben, indem Fluorescin entsteht, dessen Lösung nach dem Verdïnnen mit Wasser und Zusatz von einem Tropfen Chamäleonlösung im auffallenden Lichte sofort undurchsichtig griin erscheint.

Das Eosin färbt Wolle und Seide sehr leicht und liefert schön rosafarbene Nuancen mit schwach gelblichem Stich. Eine kalte wässrige Lösung von $0 \cdot 1 \%$ Eosingehalt färbt noch lebhaft rosa. Auf Baumwolle lässt sich nach D épierre (Bull. d. l. soc. ind. de Rouen 11 pag. 273) selbst mit Anwendung der für Anilinfarben geeigneten Fixirungsmittel keine echte Färbung erzielen. Nach D urand (Monit. scient. 1876 Nr. 415 pag. 696) lässt sich Eosin auf Kattun in der Art verwenden, dass man mit der durch Gummizusatz verdickten Eosinlösung druckt, hierauf dämpft und endlich durch eine Bleizuckerlösung passirt. Derselbe erwähnt auch einer besonderen Sorte von Eosin, die er Primerose nennt, deren Bereitungsweise er jedoch nicht näher angibt und die sich namentlich für Erzielung dunklerer Töne eignen soll. Bins chedler und $\mathrm{Busch}$ (pol. Notizbltt. 31 pag. 240) stellen ein stark in's Blaue ziehendes Eosin dar, welches auf Wolle ein dem Cochenilleponceau im Tone gleichkommendes, aber reineres Roth liefert. Nach ihnen färbt es sich auf Wolle besonders leicht auf, wenn man dem Bade etwas unterschwefligsaures Natron zusetzt, vgl. a. Fluorescin und Res orcin. Durch Erhitzen des Eosins mit der 15-fachen Nenge von Alkohol und der für die Bildung eines neutralen Aethers berechneten Menge an ätherschwefelsaurem Kalium im zugeschmolzenen Rohre durch $4-5$ Stunden auf $150^{\circ} \mathrm{C}$. resultirt nach A. Baeyer (Annal. d. Chem. 1876, 183 pag. 1-74) das Monoäthyltetrabromfluorescëin oder das Erythrin $\left(\mathrm{C}_{20} \mathrm{H}_{6} \mathrm{Br}_{4} \mathrm{O}_{3} \mathrm{OC}_{2} \mathrm{OH}_{5}\right)$, welches in schön rothen Krystallen erhalten werden kann, und eine Kaliumrerbindung liefert, die in Wasser schwer, dagegen in warmem Weingeist $(50 \%$ ) leicht $\mathrm{zu}$ einer Anfangs rothgelben, beim Verdünnen in Rosa mit gelber Fluorescenz übergehenden Fliissigkeit löslich ist. Das Erythrin stellt ausgebildete (rhomboëdrische?) Krystalle ron starkem, metallisch grïnem Flächenschiller dar, welche beim Zerreiben ein dunkelrosafärbiges Pulver liefern. Es färbt Wolle und Seide roth mit deutlicher Nuancirung in Violett. Gtl.

Ephemeriden, Tagebücher iiberhaupt, insbesondere aber astronomische, welche die Erscheinungen am Himmel (Coordinaten der Himmelskörper für bestimmte Epochen etc.) für eine Folge von Zeiten und einen bestimmten Beobachtungsort im Vorhinein angeben. Insbesondere zu nennen sind der "Nautical Almanac" und das Berliner "Astronomische Jahrbuch".

Epicykloide, s. Curven II S. 444.

Epidosit, Gestein ron dioritartiger Beschafienheit, äpfel- bis pistaziengrün, ron bedeutender Härte. Besteht wesentlich aus Quarz und Pistazit. Tork. in Mähren (Blansko) und anf der Insel Elba. Vgl. Epidot. Gtl. 
Epidot (épidote - epidote), Pistazit, Bucklandit z. Thl., Eisenepidot, Piemontit (Akantikon, Achmatit, Delphinit, Thallit, Tautolith), Name von $\varepsilon^{\prime} \pi i \delta \circ \sigma(s$, Zugabe. Mineral mit horizontalsäulenförmigen, nach den Orthodiagonalen gestreckten Krystallen, monoklin, meist in Drusen, auch in Zwillingsformen, aber auch derb mit stengligem, körnigem und dichtem Gefïge. Spaltbar, nach der Basis sehr vollkommen, nach der Orthodiagonale vollkommen. Bruch muschlig bis uneben. Härte 6-7, spec. Gew. $=3 \cdot 32-3 \cdot 50$. Vorwiegend griin, gelb, grau, schwarz, selten roth. Glasglanz, durchsichtig in allen Graden, meist nur durchscheinend bis kantendurchscheinend. Die chemische Zusammensetzung ist schwankend und nicht auf eine bestimmte Formel zurückführbar. Im wesentlichen stellt der Epidot eine Verbindung von 36-40 Kieselsäure, 8-29 Thonerde, 7-17 Eisenoxyd und 21-25 Kalkerde dar. Demgemäss ist auch das Verhalten vor dem Löthrohr und zu Säuren verschieden. Alle werden nach heftigem Glühen oder Schmelzen melir oder weniger leicht von Salzsäure zersetzt.

Man unterscheidet:

1. Pistazit, Eisenepidot oder Epidot schlechthin, pistazienbis schwarzgrïn, oder auch öl- und gelbgrün, krystallisirt, aber meist derb mit stengligem, körnigem Gefüge, auch dicht und erdig. Ein häufiger Begleiter von Magneteisensteinlagern; im Erzgebirge bei Kupferberg, Schwarzenberg, Breitenbrunn, bei Striegen in Schlesien, in Arendal in Norwegen, in Finnland, Ural u. a. a. Orten vorkommend. Besonders schöne Krystalle kommen in den Alpen vor, berühmt die von der Knappenwand bei Sulzbach in Pinzgau.

2. Piemontit, Manganepidot, schwarzviolett oder schwarzröthlich mit rothem Strich und stengligem Gefiige. Statt der Thonerde findet sich Eisenoxyd und 14-24\% Manganoxyd. Schmilzt vor dem Löthrohr leicht, und gibt mit Borax die Manganreaction; von St. Marcel in Piemont.

3. Bucklandit, welcher in schwarzen Krystallen, im Kalkspath eingewachsen, bei Achmatowsk am Ural vorkommt.

Die schönen durchsichtigen Varietäten von Arendal, St. Gotthard, Sulzbach u. a. O. lassen sich als Schmucksteine verschleifen. Sonst wird der Pistazit da, wo er in grösserer Menge mit Eisenerzen vorkömmt, als Zuschlag beim Schmelzen verwendet. $L b$.

Epigenit, ein bei Wittichen in Baden vorkommendes Kupfererz von ähnlicher Zusammensetzung wie Enargit. $L b$. Glycerin.

Epihydrine, halogenhältige Abkömmlinge mehrwerthiger Alkohole, vgl.

Epistilbit, Mineral von der Zusammensetzung des Stilbits, d. i. ein Thonerde-Kalksilicat. Rhombisch, farblos oder schwach blau, durchsichtig oder durchscheinend, glasglänzend. Härte $4-4 \cdot 5$, spec. Gew. $=2 \cdot 25-2 \cdot 36$. Vorkommen Island, Neuschottland, vgl. Stilbit. Gtl.

Epsomit, Name vom Fundort Epsom in England, so viel als Bittersalz, s. M a gr esiu m.

Epsomsalz, Epsomer Salz, syn. mit Bittersalz, d. i. Magnesiumsulfat.

Epurateur, eine bei der Holzzeugfabrication verwendete Maschine, s. Holzzeug, s. Papierfabrication.

Erbium (erbium - erbium), Symbol Er, Atomgew. $=112 \cdot 6$ (?) (169). Das metallische Radical der Erbinerde, welche neben Yttererde sich fast nur im Gadolinit von Ytterby und Hitteroë, im Euxenit, Yttrotantalit und Orthit findet, ist bisher noch nicht isolirt dargestellt. Die von Mos ander 1843 entdeckte Erbinerde ist Erbiumoxyd $\mathrm{ErO}\left(\mathrm{Er}_{2} \mathrm{O}_{3}\right)$ und wird nach $\mathrm{Bunsen}$ und $\mathrm{Bahr}$ (Annal. d. Chem. u. Pharm, 137 pag. 1) aus dem Gemenge der Nitrate der Gadoliniterden erhalten, indem man dasselbe bis zur beginnenden Zersetzung erhitzt und 
sodann mit Wasser behandelt; aus der erhaltenen Lösung krystallisirt zunächst basisch-salpetersaures Erbiumoxyd, welches durch wiederholtes Umkrystallisiren gereinigt wird und nach heftigem Glihen Erbiumoxyd als rosenrothes Pulver liefert. Es ist unschmelzbar, ergliiht jedoch in Weissgliihhitze mit intensiv grünem Lichte. In Wasser ist es unlöslich, schwer löslich in Säuren, mit denen es sauer reagirende, süsslich zusammenziehend schmeckende Salze von blassrother Farbe liefert. Gut gekannt sind das Sulfat $3 \mathrm{E}^{2} \mathrm{SO}_{4}+8 \mathrm{H}_{2} \mathrm{O}$, welches in luftbeständigen röthlichen Krystallen erhalten werden kann, die in Wasser schwer löslich sind, aber mit Kaliumsulfat ein leichter lösliches Doppelsalz liefern. Dann das basische Nitrat $\operatorname{Er} O, \operatorname{Er}_{2} \mathrm{~N}_{6}+3 \mathrm{H}_{2} \mathrm{O}$, welches weisse Krystalle liefert, die in Wasser gut löslich, aber nicht zerfliesslich sind; ferner das Carbonat und das Oxalat, welche weisse, in Wasser unlösliche Niederschläge darstellen. Das Oxalat liefert beim Glühen in Wasserstoffstrom schwarzes Kohlenstofferbium $\operatorname{Er}_{2}$. Nach Delafontaine (Arch. de sciene. phys. et nat. 1864, 1865 u. 1866) kommen die eben beschriebenen Eigenschaften der Terbinerde (?) zu, während Erbinerde ein gelbes, durch Glühen im Wasserstoffstrome farblos werdendes Pulver darstellen soll, das in der Weissglühhitze in rein weissem Lichte erglüht. Gtl.

Erbsen (pois - peas). Sind die bekannten Samen zweier Pisum-Arten, u. zw. von Pisum sativum L., d.i.der weissbliihenden oder Acker-Erbse, und von Pisum arvense, der roth oder violett blïhenden Stockerbse. Die Samen stehen in der Hülse (Schote) in gedrängter Reihe, sind mehr oder weniger rund, im halbreifen Zustande grïn und dann sehr süss schmeckend (Zuckererbsen), im reifen Zustande gelb (weisse Erbsen), seltener auch griingelb und von eigenthümlichem, kaum mehr süssem Geschmacke. Die Erbsen werden fast nur als Nahrungs-, beziehungsweise Futtermittel verwendet und zu diesem Zwecke allenthalben noch gebaut, obwohl ihre Cultur seit der Verallgemeinerung des Kartoffelbaues ziemlich zurïckgegangen ist. Sie sind übrigens eine sehr nahrhafte, wenn auch namentlich im ungeschälten Zustande etwas schwerere Speise. Man pflegt sie deshalb wohl auch auf besonderen Maschinen zu entschälen (Erbsgraupen), oder im gekochten Zustande durch Siebe durchzureiben, wobei man das Erbsenmuss erhält, während die Schalen am Siebe zurickbleiben. Nach P ayen enthalten sie $27 \cdot 2 \%$ Stickstoffverbindungen, $43 \cdot 1 \%$ Stärkemehl, $12 \cdot 8$ Zucker und Dextrin, $2 \cdot 3 \%$ Fett, 11.6 Zellsubstanz und $2.9 \%$ Aschenbestandtheile. Nach P eligot beträgt der Wassergehalt im normalen Zustande $12.7 \%$. Der relativ hohe Fettgehalt, so wie der Reichthum an stickstoffhaltiger Substanz, endlich aber der in der Asche nachweisliche, nicht unerhebliche Gehalt an phosphorsauren Alkalien und alkalischen Erden bedingen ein sehr günstiges Nährwerthverhältniss. Gtl.

Erbsenstein, Pisolith, s. Aragonit I pag. 180.

Erdapfel, syn. mit Kartoffel s. d.

Erdalkalien oder alkalische Erden neunt man die Oxyde der alkalischen Erdmetalle: Baryum, Strontium, Calcium und Magnesium, s. d. G'tl.

Erdarbeit (travaux de terrassement-earth-workiny). Die Erdarbeit bildet bei vielen Bauunternehmungen den wesentlichsten Theil, und sei nur auf Strassenund Eisenbahnbauten hingewiesen, wo oft Abgrabungen und Anschiittungen von bedeutenden Massen zur Ausfïhrung gelangen. Olıne auf die theoretischen Deductionen iiber Erdarbeiten (Gleichgewichtsbedingungen und Bestimmung der Böschung eines Erdkörpers, Theorie rom Auf- und Abtrag und Transport der Erde) hier eingehen zu können, sei iiber die Ausfiiłırung der Erdarbeiten nur Einiges erwälmt.

Die Erdarbeiten zerfallen der Hauptsache nach in folgende Gruppen:

I. Erdgrabung oder Bildung des Abtrages. Abtrag oder Déblai nemnt man eine ron dem natürlichen oder gewachsenen Boden entnommene Erdmasse. Geschieht die Abgrabung derart, dass nur einerseits eine Erdwand iibrig 
bleibt, so entstelit ein Abschnitt; bleiben an zwei gegeniiberliegenden Seiten Erdwände, so heisst dies ein Eins chnitt.

II. Transport oder Förderung der Erde.

III. Erdauschütung oder Bildung des Auftrages. Auftrag oder Remblai nennt man die an irgend einer Stelle des Bodens künstlich abgelagerte Erdmasse.

Die Erdarbeiten beim Strassen- und Eisenbahnbau sollen so eingerichtet werden, dass Abtrag und Auftrag sich ausgleichen; daher ist es nöthig, den Kubikinhalt derselben genau festzustellen. Man bestimmt zu diesem Zwecke verticale Schnitte vom Erdkörper, die man Profile nennt und berechnet den Flächeninhalt derselben entweder analytisch, graphisch oder mit Hilfe eines Planimeters.

Zur Ausführung der verschiedenen Erdarbeiten dienen hauptsächlich folgende Werkzenge und Requisiten: die Schaufel, der Spaten, die Krampe (Kreuzpickel) Fig. 1502, die Breit-, Roth-oder-Erdhaue (Fig. 1503), die Spitzhaue oder Einspitze (Fig. 1504), die Planir- oder Scarpirhacke (Fig. 1505), die Sumpfhaue (Fig. 1506), die Wasenschaufel (Fig. 1507) zum Rasenstechen; ausserdem das Wasenmesser (zum Versetzen und Beschneiden der Rasenzicgel), die Erdramme, verschiedene Wagen und Karren.

Fig. 1502.

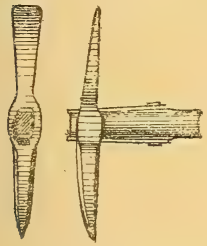

Krampe.

Fig. 150 รั.

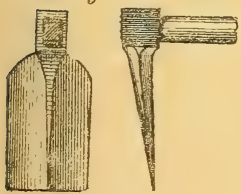

Planirhacke.
Fig. 1503.

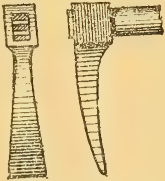

Breithaue.

Fig. 1507.

Fig. 1504.

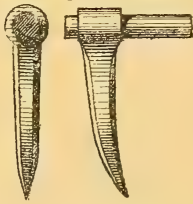

Spitzhaue.

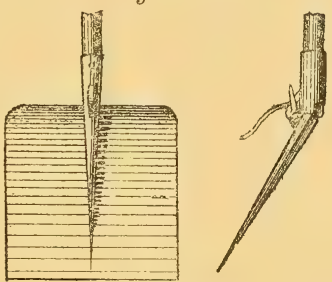

Wasserschaufel.
Fig. 1506.

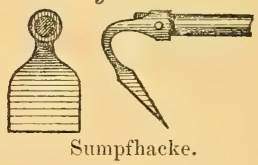

Die Arbeit des Erdgrabens ist verschieden je nach der Bodenbeschaffenheit, und man theilt dieselbe allgemein in 6 Kategorien.

1. Schaufelarbeit, geeignet für Sand, Dammerde, Moor, lockeren Lehm etc. Der Arbeiter wirft mit der Schaufel oder dem Spaten die Erde entweder zum Auftrag oder auf das zur Förderung bestimmte Fahrzeug. Man rechnet, dass ein Arbeiter in 10 Arbeitsstunden $15^{\mathrm{kbm}}$ lockere Dammerde oder Sand ansgraben und auf einen Karren oder Wagen zu laden im Stande ist. Die Entfernung der einzelnen Arbeiter darf behufs praktischer Durchfiihrung der Arbeit weder zu gross noch zu klein gewählt werden. Als Durchschnittsentfermung hat sich $1.5-1.8 \mathrm{~m}$ ergeben.

2. Krampenarbeit, für Fluss- und Grubenschotter, nicht sehr nassen Torf, theilweise erhärteten Lehm etc. Man verwendet hiezu die Krampe und die Breithane.

3. Arbeit mit Krampe und Spitzhane, für Bergschutt, Steingerölle, erhärtete Lehmerde, groben Schotter, feuchte Thonerde etc.

4. Arbeit mit Brecheisen, Spitzhane und Keilen, für Quader-, Mergel- und Thonschiefer, weichen Sandstein, verwitterten Kalkstein ete. Brecharbeit kommt l,ei lagerhaft gespaltenen Felsen ror nnd die Abarbeitung geschieht bankweise. 
5. Arbeit mit Brecheisen und Sprengung ausgeführt, fuir härtere Sandsteine, weiche Kalksteine, Feldspath, Hornstein, Grauwacke, weichere Porphyre etc.

6. Sprengarbeit mit Sprengpulver oder Dynamit, fur Urkalksteine, Granit, Gneis, Quarz, Basalt, quarzhaltige Sandsteine, Urporphyre ete.

Sehr wesentlich ist bei Beurtheilung der Erdarbeit, ob dieselbe im trockenen oder im nassen Boden (mit Wasseradern durchzogen) vor sich geht, da im letzteren Falle die Arbeit bedeutend erschwert wird. Das zuströmende Wasser muss entweder abgeleitet oder ausgepumpt werden, um im Trockenen graben zu können. Ist der Wasserzufluss nicht zu bewältigen, dann muss unter Wasser gegraben (gebaggert) werden. Siehe Artikel Baggern.

Fiir Aushebung grosser, gleichmässiger Erdmassen, in die Kategorie „Schaufelarbeit" gehörend, verwendet man mit Vortheil Erdaushebungsmaschinen, sog. Exeavatoren. Das Princip besteht darin, dass ein eisernes Gefäss mit schaufelförmigem oberen Ende (oder auch ein System ven Schaufeln) derart regulirt werden kann, dass es beim Herablassen mit der Spitze der Schaufel, vermöge des Eigengewichtes, sich in den Erdboden eingräbt. Beim Emporheben und gleichzeitiger Drehung des Gefässes (resp. des Schanfelsystemes) wird das Erdmaterial aufgenommen, gehoben und durch den beweglichen Boden des Gefässes; welchen der Arbeiter mittelst einer Kette löst, findet die Entleerung statt. Fig. 1508 zeigt eine

Fig. 1508 .

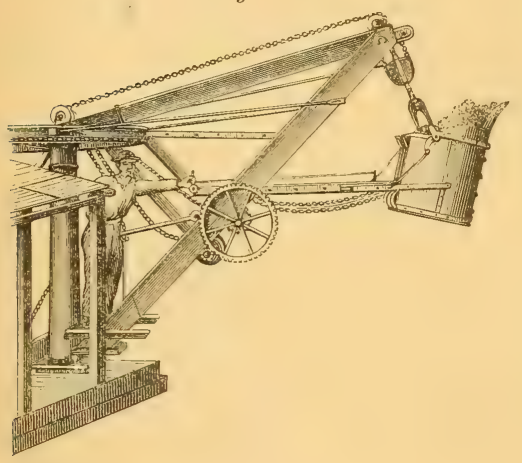

Excarator. Skizze des Excavators, wie er beim Erdbau der Central-Pacific-Bahn zur Verwendung kam.

Bei der Pfeilerfundirung der Clydebriicke auf der Glascower Verbindungsbahn *) verwendete man einen von Milroy construirten Excavator. Ein eiserner, achteckiger Rahmen trägt acht, um Scharniere drehbare Schaufeln von dreieckiger Gestalt, die in aufgeklappter, horizontaler Lage den Boden des Rahmens bilden. Das Rahmengestell hängt mittelst mehrerer Ketten an einer Hauptkette in lösbarer Verbindung; ausserdem sind an der Hauptkette, die an einer Aufzugsmaschine hängt, die Enden der Schaufeln mit je einer Kette befestigt. Beim Herablassen des Apparates stehen die Schaufeln rertical und durch das Gewicht des Rahmen-Gestelles, welches ans seiner Terbindung mit der Hauptkette gelöst wird, dringen dic Schanfeln in die Erde. Beim Wiederanziehen der Hauptkette drehen sich die Schanfeh um die Scharniere nach aufwärts (da der Apparat jetzt nur an den Ketten der Schaufel befestigt ist), und heben das Erdmaterial in die Höhe. Wird die Verbindung des Rahmens mit der Hauptkette wieder hergestellt, senken sich die Schaufeln und der Apparat entleert das Erdmaterial in den untergeschobenen Transportwagen.

Die Sicherung der Erdwände ist oft ein wichtiger Theil der Abgrabungsarbeit und ist besondere Vorsicht bei Lntergrabungen nöthig, welche mitunter, иm den oberen Theil zum Absturz zu bringen, in Anwendung kommen. Nicht selten ist der Einsturz durch einen Regen oder andauerndes fenchtes Wetter frither, als beabsichtigt wurde, erfolgt, zum Unheil der Arbeiter.

Ganz besondere Anordnungen sind zumeist dort zu treffen, wo das gegrabene Material ron unten nach oben geschafft werden muss, z. B. bei Fundament- und Kelleraushebung, Brunnengrabung etc. 
Zur Sicherung der iiber $1^{\mathrm{m}}$ tiefen, aus lockerem Material bestehenden Frdwände gibt man denselben entweder eine Böschung, 凡. l. die Wandungen miissen derartig geneigt angeordnet werden, dass keine Rutschungen entstehen, oder man lässt verticale Wïnde stehen und schützt dieselben durch sog. Bijlzungen. Es sind dies Verschalungen durch entsprechend starke Bretter, dis durch ein IIolzgeriist aus verticalen Pfosten und Spreizen oder horizontale Kränze aus Balken angepresst werden. Fig. 1509 gibt eine Schacht-Bölzung mit Anordnung ron Kränzen.

Bedeutende Arbeiten der Erdgrabung kommen vor: Beim Stollen-und Schachtbau (siehe Bergbau), beim Tunnelbau (s. d.), bei Bohrungen (Tiefbohrung s. d.) und bei Baggerungen (s. Baggern).

II. Transport des gewonnenen Erdmateriales. Die anzuwendenden Förderungsmittel hängen $a b$ von der Länge und Beschaffenlieit des Weges und von der Masse des Abtrages.

Der Transport kann geschehen:

1. Durch Werfen mit der Schaufel, vortheilhaft bis $6^{\mathrm{m}}$ Entfernung. Ein Arbeiter ist im Stande, anfgelockerte Erde mit der Schaufel $2-3^{\mathrm{m}}$ horizontal oder $1.2-1.8^{\mathrm{m}}$ vertical $\mathrm{zu}$ werfen, und vermag täglich $10^{\mathrm{kbm}}$ mit der Schaufel zu laden oder auf $3^{\mathrm{m}}$ Weite zu werfen.

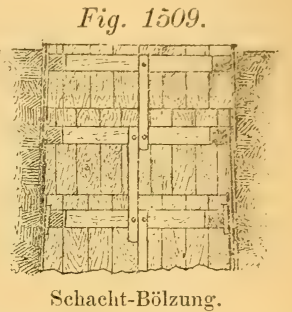

2. Mit dem Schubkarren, vortheilhaft bis $90^{\mathrm{m}}$ Entfernung. Der Schubkarren (ein einrädriges Fahrzeug) vermag $0 \cdot 03-0 \cdot 06^{\mathrm{kbm}} \mathrm{zu}$ fassen.

3. Mit dem Roll- oder Handkarren, vortheilhaft bis $190^{\mathrm{m}}$ Entfernung; derselbe ist ein zweirädriges Fahrzeug, fasst $0 \cdot 2-0 \cdot 27^{\mathrm{kbm}}$ und wird von 2 oder 3 Arbeitern bewegt.

4. Mit dem Wipp- oder Sturzkarren, vortheilhaft bis $200^{\mathrm{m}}$. Der Wippkarren ist ein zweirädriges Fahrzeug, fast $0.4-0.5^{\mathrm{kbm}}$ und wird von einem Pferde gezogen. Der Kasten ist zum Umkippen eingerichtet. Der Transport ist im Allgemeinen theuerer als der mit Handkarren.

5. Mit vierrädrigem Wagen, vortheilhaft iiber $200^{\mathrm{m}}$ Entfernung; das Ladvermögen desselben beträgt $0 \cdot 7-0 \cdot 8^{\mathrm{kbm}}$. Vgl. d. Art. F uh h w e rke.

6. Mit dem Haspel, bei der verticalen Schachtförderung von Erdmaterial angewendet. An der Welle eines Haspels sind durch Seile Kübel befestigt, welche das zu transportirende Material aufzunehmen haben. (Bei grösseren Anlagen sind statt der Haspel Pferdegöppel oder kleine Dampfmaschinen nöthig.)

7. Auf provisorischen Pferde- oder Locomotivbahnen, sog. Dienstbahnen, vortheilhaft für wenigstens $1000^{\mathrm{m}}$ Entfernung.

Zum Transport des Materials werden vierrädrige Kippwagen verwendet. Da die Dienstbahn nur ein Geleise erhält, sind von Strecke zu Strecke Ausweichbahnen (der Länge der Wagenziige entsprechend) nothwendig, damit die Zuige einander ausweichen können.

III. Erdanschüttung, Auftrag. Das durch Ab-oder Ausgrabung gewonnene Material soll zweckmässig zu baulichen Anlagen verwendet werden; kamn dies nicht sofort geschehen, so muss dasselbe einstweilen deponirt werden. Die Materialdeponirung hängt von localen Verhältnissen und den jeweiligen Materialien ab; es ist die Placirung so zu wählen, dass bei eventueller Verwendung die Kosten ein Minimum werden.

Für dauernde Erdanschiittung ist zunächst zu beriicksichtigen, dass der ron einem bestimmten Vol. Abtrag gewachsenen Bodens gewomene Vol. Auftrag bedentender als der erstere ist, und beträgt die Vermehrung bei Dammerde selbst nach der Verdichtung noch $1 / 12-1 / \mathrm{s}$.

Als Hauptgrundsatz gilt, nur Schichten von $0.18-0.30 \mathrm{~m}$ Höhe auf einmal aufzutragen, um ein möglichst gleichmässiges und rasches Setzen der Masse zu 
erzielen. Die Sohle ist möglichst horizontal (bei abschiissigem Terrain stufenförmig) herzustellen.

Die Dichtung des Auftrages geschieht entweder durch die darïber fahrenden Fuhrwerke, oder die Erdmasse wird durchwässert oder gestampft oder gewalzt.

Der Auftrag dient zur Herstellung von

Planirungen, d. s. Ausgleichungen der Terrainunebenheiten,

Beschotterungen, d. s. Beläge planirter Flächen mit festen kleinen Steinen oder Kies, und

D ämmen, d.s. feste Erdkörper, welche eine Strasse oder Eisenbahn tragen, oder als Schutz gegen andringendes Wasser dienen (Teichdamm, Flussdamm etc.).

Auf nassem Terrain ist die Dammherstellung erst zu bewerkstelligen, wenn dasselbe vollkommen durch Entwässerungsgräben, Ableitung der Quellen etc. trocken gelegt wurde.

Tabelle als Anhaltspunkt zur Bestimmung des Bedarfes an Arbeitskräften (bez. Kosten) einiger Erdarbeiten.*) (Um die Kosten zu erhalten, hat man die in der Tabelle angegebenen Taglohn-Bruchtheile mit der Grösse des Taglohnes eines Steinbrechers (Stbr.), resp. Handlangers (Hdlg.) bei täglich 10 Arbeitsstunden zu multipliciren und den Zuschlag fuir R quisiten (Req.) dazu zu addiren.

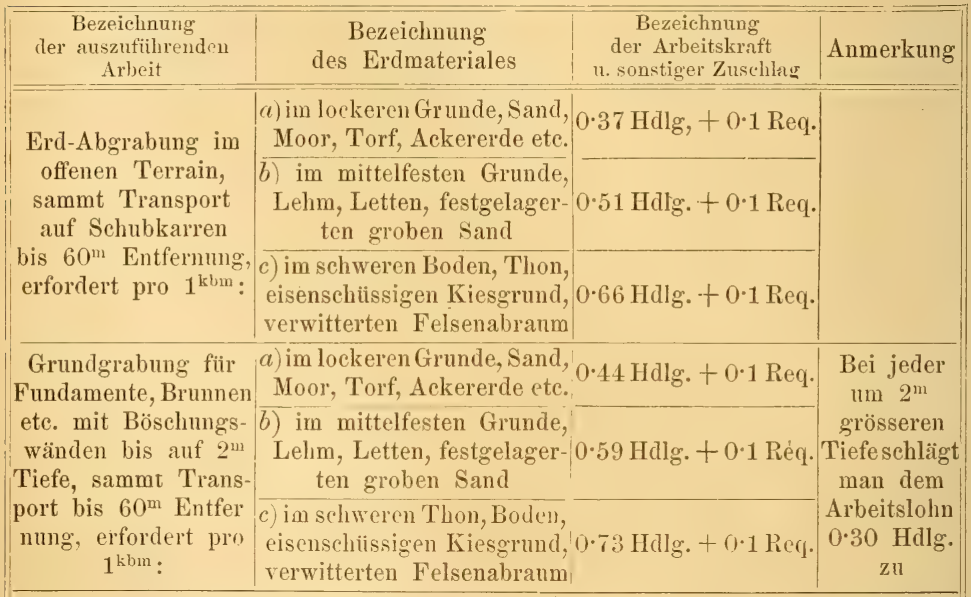

Für Aushebung mit Bölzung rechnet man zu dem jeweiligen Arbeitslohn 0.30 Hallg. hinzu.

Felsensprengung bis $2^{\mathrm{m}}$ Tiefe unter

dem Horizont, sammt Transport bis $60^{\mathrm{m}}$ Entfernung; erfordert pro $1^{\mathrm{kbm}}$ :

a) zerklüfteter Felsen ohne Sprengmaterial

$0 \cdot 30$ Stbr. $+0 \cdot 88 \mathrm{Idlg} .+0 \cdot 1$ Req.

b) zerkluiftete Felsen, bei $0.73 \mathrm{Stbr} .+0.59 \mathrm{Hdlg} .+0 \cdot 1$ Req. theilweiser Anwendung $+0.25 \mathrm{Kg}$. Pulver 0. $0 \cdot 11 \mathrm{Kg}$. von sprengmaterial Dynamit

c) mittelhart, wenig kluiftig: $1 \cdot 17$ Stbr.+0.37 Hdlg.+0.11Req. mit Sprengmaterial $+0.37 \mathrm{Kg}$. Pulv. 0.0.14 Kg. Dyn.

d) sehr hart mit Spreng- $1 \cdot 47$ Stbr. $+0.44 \mathrm{Hdlg}+0 \cdot 12$ Req. material $+0.41 \mathrm{Kg}$. Pulv. $0.0 \cdot 18 \mathrm{Kg}$. Dyn.

Bei jeder um $2^{\mathrm{m}}$ grösseren Tiefe gebe man pro Kbm. einen Zusclilag von $0 \cdot 07$ Stbr. $+0 \cdot 15$ Hdlg.

*) Nïheres siehe Wach's Baurathgeber, Tempsky, Prag. 1sit. 
Anschittung vom Erdhorizont in die Tiefe, bei Zufuhr auf $20^{\mathrm{m}}$ Entfernung und Stampfung erfordert pro $1^{\mathrm{kmm}}$. . . . . . . (5)40 IIdlg. + ().1 Perj.

Anschiitten und Planiren in Schichten und Stampfen . $0 \cdot 44 n+0 \cdot 1 n$

Anschïttung iiber Sturz- und Dippelboden, Gewölben, nebst

Aufladen und Planiren, bei Transport auf $60^{\mathrm{m}}$ horizontal

und $6^{\mathrm{m}}$ vertical, erfordert pro $1^{\mathrm{kbm}}$.

Für je $6^{\mathrm{m}}$ mehr Höhe einen Zuschlag pro $1^{\mathrm{kbm}}$ von . $0 \cdot 11$ "

$1^{\mathrm{kbm}}$ Erde im Grubenmass auf $60^{\mathrm{m}}$ horizontal mit dem

Schubkarren verführen, ohne Aufladen, erfordert $.0 \cdot 20-0.22 n+(0 \cdot 1$,

$1^{\mathrm{kbm}}$ feuchten Lehm $60^{\mathrm{m}}$ weit und $6^{\mathrm{m}}$ hoch, mit dem

Schubkarren verfiihren, erfordert . . . . . . $0 \cdot 29$

Für je $6^{\mathrm{m}}$ mehr Höhe rechnet man einen Zuschlag von $0.15 \mathrm{Hdlg}$.

$1 \square^{\mathrm{m}}$ Flachrasenverkleidung, sammt Stechung und Zufuhr

auf $60^{\mathrm{m}}$ Weite und Legung, jedoch ohne Pflöcke, erfordert $0 \cdot 11,+() \cdot 1$

$1 \square^{\mathrm{m}}$ Beschotterung, $16^{\mathrm{em}}$ hoch, nebst Zufuhr auf $20^{\mathrm{m}}$

Entfernung und Ausgleichung der Oberfläche, erfordert . $0.02 n+0.1$,

$1 \square^{\mathrm{m}}$ Besandung, $5^{\mathrm{cm}}$ hoch bei frisch beschotterten Strassen,

nebst Zufuhr auf $20^{\mathrm{m}}$ Entfernung, erfordert . . . $0.01 " 0.1$,

Literatur ïber Erdbau: Henz und Plessner, Anleitung zum Erdbsu,

Berlin 1867. - v. Etzel, Ausfuihrung grosser Erdarbeiten, Stuttgert 1859. -

Bernard, Annales des mines. 1862. - Piarron de Mondesir, Annales des ponts et chaussées 1847. - Ho ffm an n, Transportkosten, Zeitschrift des österr. Ing.- u. Arch.-Vereines, 1861. - v. K a ven, Vorträge über Ingenieur-Wissenschaften, Hannover 1870. - S ch mitt E., Der Erdkunstbau, Leipzig, Felix, 1871. - Becker, Allgemeine Baukunde des Ingenieurs, Stuttgart, Mäken, 1865. - Rziha, Der englische Einschnittsbetrieb. Technische Blätter (Vierteljahrschrift des deutschen polyt. Vereines in Böhmen), 1872, 1. Heft. - Heine, Der Erdban in seiner Anwedung auf Eisenbahnen und Strassen, Wien, Hölder, 1876.

Grohm.

Erdbeeräther, ein den Erdbeeren ähnlich riechendes Gemenge von Essigäther mit Essigsäureamyläther und Buttersäureäther, s. d.

Erdbirne, s. Topin ambur, vgl. a. Kartoffel.

Erdbögen (arc de fondation - retaining-arch in the grounduor $k$ ) sind die in verkehrter Lage (Scheitel unten und Bogenlinie nach aufwärts gerichtet) im Fundament angebrachten Gewölbebögen, welche die Fundamentpfeiler miteinander verbinden, behufs gleichmässiger Vertheilung des Druckes und Verhinderung der Senkung der Pfeiler bei schlechtem Baugrund. S. F undirnng.

Erdbohrer, s. Tiefbohrung.

Erde animalische, syn. mit Knochen as che.

Erde armenische, syn. mit Erde lemnische.

Erde blaue, syn. mit Eisenblau, Blaueisenerde, Vivianit s. Eisen II pag. 759 , s. a. Vivinit.

Erde braune, syn. m. Umbraerde, s. Umbra.

Erde casseler (van Dyke brown), s. Ca s s e I e r B r a un II pag. 265, s. U m b r a.

Erde cölnische, s. Umbra. 
Erde. - Erdmandeln.

Erde englische, syn. mit Englischroth, vgl. Bolus I pag. 725. Auch ein geschlämmter grauer Mergel, der zur Zimmermalererei verwendet wird.

Erde gelbe (neapolitanische), syn. m. Neapelgelb, s. Blei I pag. 603. Auch syn. mit $\mathrm{Ock}$ ererde.

Erde gesiegelte, s. Bolus I pag. 724.

Erde grüne, s. Grün erde.

Erde japanische, s. Catech u II pag. 266.

Erde lemnische (terre de Lemnos - terra lemnia), brauner Bolus von der Insel Lemnos. S. Bolus I pag. 724.

Erde nürenberger, rothe Erdfarbe, vgl. Bolus I pag. 724, s. Ockerde.

Erde persische, rothe Erdfarbe vgl., Bolus und Ockererde.

Erde preussische, rothe Erdfarbe, syn. mit Englisehroth.

Erde schmiedeberger, syn. mit Polirroth, Engli s chroth.

Erde sienische, siener (tera di Siena), ein brauner Bolus, der sich bei Siena im Toskanischen findet und als Malerfarben dient. Vgl. Bolus I pag. 724. pag. 724 .

Erde striegauer, brauner Bolus von Striegau in Schlesien. Vgl. Bolus I

Erde veroneser, s. Grïnerde.

Erden nennt der Chemiker die Oxyde der sogenannten Erdmetalle: Aluminium, Beryllium, Zirkonium, Cer, Lanthan, Didym, Yttrium, Erbium, Terbium (?), Norium, Thorium. Gtl.

Erdensalz, syn. m. Steppensalz, s. Chlornatrium bei Natrium.

Erdfarben, syn. mit farbigen Erden, Farberden.

Erdfernrohr, s. Fernrohr.

Erdgeschoss, parterre (rez-de-chaussée - ground-floor), ist das Gebäudestockwerk zu ebener Erde; gewöhnlich ist es um einige Stufen iiber das natiirliche Terrain erhöht. Ist die Erhöhung bedeutend, so nennt man es erhöhtes Erdgeschoss oder Hochparterre; Jann ist gewöhnlich ein Stockwerk theilweise unter dem natiirlichen Terrain angeordnet, welches man vertieftes Erdgeschoss oder Souterrain nennt. Bei Souterrainwohnungen soll die innere Fläche der Decke iiber das Strassen-Niveau wenigstens $1.25^{\mathrm{m}}$ erhöht sein.

Grohm.

Erdharz gelbes, s. Bernstein I pag. 431, schwarzes syn. mit Asphalt s. I pag. 211. Vgl. a. Elaterit und Ozokorit.

Erdkobalt, Kobaltbeschlag, ist arsenhaltige Kobaltbliithe, syn. Erythrin.

Erdkohle, s. Braunkohlc bei Brennst offe II pag. 27.

Erdmagnetismus, s. Magnetis mus.

Erdmandeln (amandes de tere - roumd cynerus root) sind die on den Enden der Wurzelansläufer von der in Nordafrika und Südamerika einheimischen, im Suiden Europas cultivirten Rieilgras-Art (Cyperus esculentus) sich findenden mehligen Ḱnollen. Sie sind etwa haselnussgross, unregelmässig kuglig oder eiförmig, graubraum, imnen weiss, mehlig, von süssem nussartigem Geschmack. Sie können sowohl roh als auch gekocht oder gebraten genossen werden und sollen im frischen 
Zustande $-16 \%$ eines haselnussähnlich riechenden, goldgelben fetten Oeles enthalten, von welchem die bei uns gezogenen Knollen indessen nie mehr als $4-50$ ") liefern. Nicht selten werden die Erdmandeln, von welchen eine einzige Pflanze oft bis 30 Stiick liefert, geröstet und gemahlen unter dem Namen Erdmandelc a ffe e als Caffeesurrogat in den Handel gebracht. Das Erdmandel al zeigt im reinen Zustande das spec. Gew. 0.918 und ist leicht verscifbar. (Vgl. Lesant Journ. Pharm. (2) VIII pag. 509.) Gtl.

Erdmannit, s. Cerin II pag. 300.

Erdmetalle, vgl. Erden.

Erdnüsse (pistaches de terre - ground wuts), Erdeicheln. Tie Frichte von Arachis hypogaea L., einer krautartigen, urspringlich wahrscheinlich dem tropischen Amerika angehörenden Pflanze aus der Familie der Caesalpineen, welche jetzt fast in allen heissen und wärmeren Gebieten der Erde, zumal in Sïd-Amerikil, West- und Ost-Indien und an der Westkiiste Afrikas als Oel- und Nahrungspflanze gebaut wird. Sie ist dadurch merkwiirdig, dass ihr Bliithensticl nach dem Verbliihen sich zu Boden senkt und der Stempel unterirdisch zu einer etwa $3^{\mathrm{cm}}$ langen walzlichen, in $\mathrm{der}$ Mitte meist etwas eingeschnuirten, nicht aufspringenden Hülse sich entwickelt, deren zähes, papierartiges, aussen netzig-geripptes, matt hellbraunes Gehäuse 1-3 eirunde, schief abgestutzte, mit dünner, vertieft-längsadriger braunrother Hülle versehene, sehr ölreiche, mandelartig schmeckende Samen enthält. Diese geben durch Auspressen bis 50\% eines gelblichen, geruchlosen fetten Oeles von 0.918 spec. Gew., welches wesentlich ein Gemenge der Glycerinverbindungen von 3 verschiedenen krystallisirbaren Fettsäuren (Arachinsäure, Hypogaeasäure und Palmitinsäure) ist und im Haushalte (als Speiseöl), besonders aber zu technischen Zwecken, sowie auch zur Verfälschung von Olivenund Mandelöl Verwendung findet.

A. Vogl.

Erdnussöl, s. Erdn iisse.

Erdöl, s. Petroleum s. Steinöl.

Erdöläther, der zwischen 60 und $100^{\circ}$ C. destillirende Antheil des RohPetroleums, s. Petroleum.

Erdorseille, s. Orseille, vgl. Flechtenfarbstoffe.

Erdpech, s. Asphalt I pag. 211. Erdpech elastisches, syn. Elaterit.

Erdpisé, s. Stampfbau.

Erdsalz, syn. Steinsalz, s. Chlornatrium bei Natrium.

Erdtheer, syn. Theer aus bituminös. Schiefer, s. Theer.

Erdthermometer, Geothermometer, vgl. Thermometer, s. Wärmemessung.

Erdwachs, s. Ozokerit.

Eremit, s. Monazit.

Ergänzungsfläche eines Kreiskegels ist wieder eine Kegeltäche, deren Erzeugende senkrecht stehen auf jener Erzengenden des ersten Kegels, welche sie an der gemeinsamen Basis (Ergänzungskontur) schneiden. Anf irgend ein Axoid ansgedehnt wird die Ergänzungsfläche zu der durch jene Normalebenen umhiillten Fläche, welche in den Punkten eines Querschnittes auf die Erzeugenden des Axoides gelegt werden können. $K k$. 
Ergänzungskontur bezeichnet Reuleaux die Schnittlinie der Oberfläche eines Axoides mit der Ergänzungsfläche desselben. S. Reuleaux Kinematik S. 86. (Vieweg 1875).

Ergotin (ergotine - ergotine) heisst der aus dem Mutterkorn (Secale cornutum) bereitete wässrige oder alkoholische Extract; mit demselben Namen bezeichnet man aber auch eines der Alkaloide, die in demselben enthalten sind. Der Extract wird auf verschiedene Weise bereitet. Nach Wiggers wird das gepulverte und mit Aether entfettete Mutterkorn mit Weingeist ausgekocht, der weingeistige Auszug abgedunstet, und der Verdampfungsriickstand mit Wasser behandelt, wobei Ergotin als rothbrames, scharf schmeckendes Pulver zuriickbleibt, das in Weingeist schwer, nicht in Wasser und Aether löslich ist. Bonjean's Ergotin wird durch Extraction des eingedampften wässrigen Mutterkornauszuges mit Weingeist und Eindampfen als Extract erhalten, der in Wasser und Weingeist löslich ist.

Letztere Darstellungsweise hat unter anderen auch die österreichische Pharmacopöe acceptirt. Der Mutterkornextract enthält ausser Trimethylamin nach Wenzell noch die Alkolaide Ergotin und Ecbolin, Tanret liat kürzlich noch ein drittes, das Ergotinin aufgefunden. Die ersteren zwei werden dargestellt, indem der kalt bereitete wässrige Auszug des Mutterkorns mit Bleizucker gefällt, das Filtrat entbleit, stark concentrirt und zunächst mit gepulvertem Quecksilberchlorid das Ecbolin vollständig ausgefällt wird. Das Filtrat mit Schwefelwasserstoff behandelt, dann mit Phosphormolybdänsäure versetzt, lässt einen alles Ergotin enthaltenden Niederschlag fullen, der mit aufgeschliimmtem kohlensauren Baryt digerirt wird; das Filtrat eingedunstet hinterlässt das Ergotin. Das Ecbolin wird aus seiner Quecksilberverbindung durch Zersetzen mit Schwefelwasserstoff, Schütteln der Lösung mit phosphorsaurem Silber, Behandlung der dann abfiltrirten Flüssigkeit mit Aetzkalk, endlich Entfernmg des iiherschiissigen Kalkes durch Kohlensäure und Eindunsten der Lösung als Riickstand erhalten. Beide Alkaloide sind amorph, firnissartig, bitter schmeckend, alkalisch reagirend und lösen sich leicht in Wasser und Alkohol, nicht aber in Aether und Chloroform. Sie bilden leicht zerfliessliche Salze, mit Kalilauge gekocht entbinden sie Ammoniak. Sie unterscheiden sich dadurch, dass Quecksilberchlorid das Ergotin nur in neutraler, das Ecbolin auch in saurer Lösung fällt, dass durch Platinchlorid Ecbolin dunkelgell, Ergotin erst nach Zusatz ron Acthermeingeist gelblich, durch Cyankalium nur das Ecbolin und zwar weiss gefällt werden kamn. II a n a s sewitz stellt fiir das Ergotin die noch sehr hypothetische Formel $C_{50} H_{50} \Lambda_{2} O_{3}$ aluf. Das Ergotinin von $\mathrm{T}$ an ret ist in Chloroform und Aether löslich, seine Darstellung sehr complicirt. W e nzell hat in wässrigem Mutterkornextracte die Ergotsäure nachgewiesen, die, mit Wasserdämpfen wenigstens, fliichtig ist und unkrystallisirbare Salze liefert. Skraup.

Erinit, Min. (Haidinger), amorphe, nierenförmige Massen von smaragdgrïner Farbe, kaum durchscheinend, $H .=1-5-5$, spec. Gew. $=4.01$, ist wasserhaltiges Kupferarsenat $=A s_{2} C_{u_{5}} O_{10}+{ }_{2} H_{2} O$, Vork. Irland, vgl. a. Cornwallit II pag. 415. Erinit (D a mour), Kupferglimmer, Chalkophyllit, bildet rhomboëder. Krystalle von smaragdgriner Firbe, durchscheinend bis durchsichtig H. $=\dot{2}$, spec. Gewicht $=2.4-2.66$, ist wasserhaltiges Kupferarsenat $=A s_{2} \mathrm{Cu}_{6} \mathrm{O}_{11}+{ }_{12} H_{2} O$. Gtl.

Eriometer, Instrument zur Bestimmung der Feinheitsnummer der Wolllaare, s. IT olle.

\section{Eriophoronwolle, s. Gespinnstfasern.}

Erker (fenêtre "n scillie - oriel-uindou, jut-uindou), ist ein geschlossener, balkonartiger Vorbau eines Gebäuderaumes, meist durch Consolen (aus Holz, Stein oder Eisen) getragen, oft durch melırere Geschosse reichend. Der 
Grundrissform nach kann der Erker polygonal oder rund sein, und soll stets in organischen Zusammenhang mit der Architektur des Gebäudes stehen. Grolım.

Erlangerblau, syn. Berlinerblau, s. Blutlaugensalze I pag. 667.

Erlenholz (aune, aulne - alder). Das Holz der gemeinen Erle (Betula alnus) ist ein weissgelbes bis gelbröthliches Holz, frisch ist es orangenroth. Dasselbe ist dicht, von mittelmässiger Härte, geringer Elasticität und Zähigkeit. Es wird seiner grossen Dauerhaftigkeit unter Wasser oder in feuchter Erde wegen zu Wasserbauten, sonst meist als Brennholz benützt. Uebrigens findet es auch zuweilen zu Holzschuhen, Leisten und Giessereimodellen Anwendung. Als Bauholz ist es seiner geringen Dauer im Trockenen, sowie seiner Sprödigkeit wegen nicht geeignet. $K k$.

Erntemaschinen, s. Landwirth sehaft.

Erstarrungspunkt, die Temperatur, bei welcher der Uebergang einer Flüssigkeit in den starren Aggregatzustand erfolgt. Vgl. a. Schmelzpunkt und Schmelzen. Gtl.

Erubescit, syn. m. Buntkupfererz, s. Kupfer.

Erucasäure (acide érucique), feste Fettsäure von der Formel $\mathrm{C}_{22} \mathrm{H}_{42} \mathrm{O}_{2}$, welche als Glycerinverbindung einen Bestandtheil des fetten Oeles der weissen und schwarzen Senfsamen, des Traubenkernöls und des Rapsöles (vgl. Brassinsäure) bildet. Farblose und geruchlose nadelförmige Krystalle bei $36^{\circ} \mathrm{C}$. schmelzend. Im Wasser unlöslich, löslich im Alkohol und Aether. Verfärbt sich an der Luft. Mit schmelzendem Kalihydrat zerfällt sie in Arachinsäure und Essigsäure. (Vgl. D a rby Annal. d. Chem. u. Pharm. 69 pag. 1, 0 t to ebenda 127 pag. 182. Gtl.

Eruptivgesteine. Allgemeine Bezeichnung jener Gesteine, welche aus dem Innern der Erde hervorgedrungen und erstarrt sind, wie alle Laven, Basalte, Trachyte, Porphyre u. s. w. $L b$.

Erweiterungsbohrer, s. I pag. 698, 709.

Erythrin, Farbstoff, s. Eosin III pag. 278.

Erythrin (érythrine - cobalt bloom), Kobaltblut the, Kobalt bes chl a g,

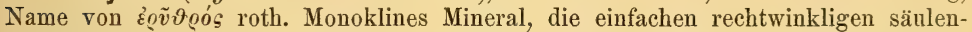
förmigen Krystalle selten, meist nadel-haarförmige, in büschel-, bündel- und sternförmige Gruppen verwaschene Individuen. Auch erdig als Ueberzug, Anflug oder Beschlag. Die Krystalle klinodiagonal sehr vollkommen spaltbar, wenig spröde. H. 2.5, spec. Gew. $=2.9-3.0$. Rosenroth, karmin-, pfirsichblüthroth, Strich rosa. Die krystallisirten Aggregate seidenglänzend, die erdige Varietät matt. Chem. Zus. $3 \mathrm{CoOAs}{ }^{2} \mathrm{O}^{5}+8 \mathrm{H}^{2} \mathrm{O}$, $37.8 \mathrm{Kobaltoxydul,} \mathrm{38.2 \cdot Arsensäure,} 24 \mathrm{~W}$ asser. Gibt im Kolben Wasser und wird blau, griin oder braun, im Reduct. F. auf Kohle Arsendämpfe und schmilzt dabei zu Arsenkobalt; Borax gibt damit ein blaues Glas. In Salpetersäure leicht zu einer röthlichen Solution löslich. In Kalilange wird er schwarz, während die Lauge sich blau färbt. Ein Begleiter ron Kobalterzen, namentlich des Speiskobaltes, und ein Zersetzungsproduct daraus. Unter Zutritt der Atmosphäre bildet sich der sogenannte Kobaltbeschlag oder die erdige Kobaltblüthe sehr rasch auf Kobalterzen, und ist ein charakteristisches Kennzeichen für solche. Fundorte Joachimsthal und Pribram in Böhmen, Schneeberg in Sachsen, Richelsdorf in Hessen, Saalfeld in Thüringen, Allemont Dauphiné. Wird mit anderen Kobalterzen zux Blanfarbenbereitung beniitzt. Lb.

Erythrit (erythrite - erytrite), Erythroglucin, Erythromannit, Erythroglycin, Eryglucin, Pseudoorcin, Phycit, ein in die Classe der Alkohole gehörender Körper, wird aus verschiedenen Flechten, so Roccella 
fuciformis, $R$. Montagnei, in denen er aber nicht als solcher vorkommt, am besten nach dem Verfahren von Stenhouse, der ihn zuerst darstellte, gewonnen. Hiernach wird die Roccella fucciformis kalt durch dünne Kalkmilch in der Art erschöpft, dass die zweiten und dritten Ausziige auf neue Flechte gegossen werden, während der erste so rasch als möglich durch Spitzbeutel filtrirt und mit Salzsäure zersetzt wird. Es fällt rohe Erythrinsäure heraus (s. Flechtenfarbstoffe), die mit Wasser durch Decantation gewaschen, mit Kalkmilch im geringen Ueberschusse durch eine halbe Stunde im Kolben gekocht wird, worauf die Lösung mit Kohlensäure oder Schwefelsäure vom uiberschïssigen Kalk befreit und fast zur Trockene verdampft wird. Der Rückstand mit Benzol (von 110-1500 Siedep.) wiederholt ausgekocht gibt an dieses Orcin (s. d), dann mit heissem Wasser behandelt an dieses Erythrit ab, der mit kaltem Weingeist gewaschen und nochmals aus Wasser krystallisirt rein erhalten wird. Die beschriebene Reaction geht in der Weise vor sich, dass die Erythrinsäure zunächst in Pikroerythrin und Orsellinsäure (resp. Aether der letzteren) zerfällt, dann das Pikroerythrin Erythrit und Orsellinsäure und letztere Orcin und Kohlensäure geben. Der Erythrit, nach Strecker $\mathrm{C}_{4} \mathrm{H}_{10} \mathrm{O}_{4}$, ist ein vieratomiger Alkohol, er krystallisirt in grossen farblosen glänzenden Krystallen des quadratischen Systems, schmeckt süss, ist in Wasser leicht, schwieriger in Alkohol, nicht in Aether löslich, ist nicht gährungsfähig und ohne optisches Drehungsvermögen. Er schmilzt bei $120^{\circ}$, auf $300^{\circ}$ erhitzt tritt unter theilweiser Zersetzung Caranelgeruch auf. Mit Jodwasserstoffsäure erhitzt gibt er Butyljodür vom Siedepunkt 120, in wässriger Lösung mit Platinmohr behandelt, oder vorsichtig mit Salpetersäure oxydirt auffälliger Weise nicht Weinsăure, sondern eine unkrystallisirbare Säure der Formel $\mathrm{C}_{4} \mathrm{H}_{8} \mathrm{O}_{5}$. Rauchende Salpetersäure führt ihn in eine Nitroverbindung, warme concentrirte Schwefelsăure in eine Erythritschwefelsäure iiber, mit organischen Säuren gibt er Ester, mit Aetzkali geschmolzen unter Wasserstoffentwickelung Essigsäure neben Oxalsäure. Nach Lamy und Wagner ist Phycit identisch mit Erythrit. Skraup.

Erythrobenzin, ein von Laurent und Castelaz (Repert. of. patent inrent. October 1862) dargestellter, noch nicht näher untersuchter, rother Farbstoff aus Nitrobenzol, welcher durch etwa 24 stiundige Digestion von Nitrobenzol (12 Thl.), mit Eisenfeilspänen (24 Thl.) und conentrirter Salzsäure (6 Thl.), Auslaugen der erhaltenen Masse mit Wasser und Fällen der wässrigen Lösung mit Kochsalz dargestellt werden kann und sich sowohl zum Färben als auch zum Drucken eignet. Gtl.

Erythrocentaurin, krystallisirbarer Bestandtheil des Tausendguldenkrautes (Erythrea centaurium), welcher aus dem wässrigen Extracte des Krautes durch Ausziehen mit Alkohol und Extrahiren des Rückstandes des Alkoholauszuges mit Aether erhalten werden kann. Farblose, geschmacklose Krystalle, in kaltem Wasser kaum löslich, leichter in siedendem, leicht in Alkohol und Aether, bei $136^{\circ} \mathrm{C}$. schmelzend. Färbt sich am Sonnenlichte rosa bis roth, wird aber beim Erhitzen wieder farblos. Durch Salpetersäure wird es nicht merklich angegriffen. Entspricht der Formel $\mathrm{C}_{27} H_{24} \mathrm{O}_{8}$. Vgl. C. Mèhu Journ. de Pharm. (4) 3, pag. 265 . Gtl.

Erythroglucin, s. Erythrit III pag. 289.

Erythroleïn und Erythrolitmin, s. L a e kmus.

Erythromannit, s. Erythrit III pag. 289.

Erythronium, syn. mit Van adin.

Erythrophyll, s. Blattfarbstoffe I pag. 533.

Erythrosin, syn. Tyrosinroth, durch Einwirkung ron Salpetersäure anf Tyrosin entstehender rother Farbstoff. Gtl.

Erythrozym, Ferment der Krappwurzel, s. K r a p p, rgl. A li z a rin I pag. 88. 


\section{Erzaufbereitung, s. A ufbereitung I pag. 234.}

Erze (minerais - ores). Der Begriff von Erz ist etwas schwankend. Im weiteren Sinne versteht man darunter alle jene Mineralkörper, welche als Hauptbestandtheil eines der sogenannten schweren Metalle enthalten, im engeren, melır gebräuchlichen Sinne aber nur jene Mineralien, aus welchen das darin enthaltene Metall mit Vortheil gewonnen werden kann, also die nutzbaren metallischen Minerale. Die Erze enthalten die Metalle entweder im regulinischen Zustande, oder in chemischer Verbindung mit anderen Substanzen, die oft ihre Eigenschaften als Metalle so verdecken, dass der Nichtkenner schwerlich ein werthvolles Metall darin vermuthen sollte. Die am hänfigsten vorkommenden Verbindungen der Metalle sind die mit Sauerstoff, also ihre Oxyde, und die mit Schwefel, seltener schon die Arsenikverbindungen. Die Oxyde wieder sind entweder rein oder mit Wasser, als Hydrate, oder mit Kohlensäure in Verbindung. Andere Metallsalze, so wie Phosphor-, Selen- und Chlorverbindungen sind so selten, dass sie den nutzbaren Erzen nicht zugezählt zu werden pflegen. Einige Metalle, so namentlich Gold und Platin, werden nur im regulinischen Zustande, wiewohl oft mit anderen Metallen legirt, angetroffen.

Ueber das Vorkommen der Erze in der Erdrinde und ïber ihre Gewinnung enthält der Artikel „B ergb a u " das Nähere, während die allgemeinen Verfahrungsarten ihrer Aufbereitung in dem Artikel "A ufbereitung“ (s. I pag. 234) nachzusehen sind. Ausserdem ist bei jedem einzelnen Metalle die Gewinnungsart im Grossen ausfiuhrlich behandelt. $K$. $H$.

Erzmetalle ist gleichbedeutend mit Schwermetalle, s. El e m e n t III pag. 257, s. Metalle.

Erzstahl, s. III pag. 41.

Eschel, s. S m alte.

Eschenholz (frène - ash). Das $\mathrm{Holz}$ der gemeinen Esche (Fraximus excelsior) weiss bis bräunlichgelb. Es hat breite Jahrringe und dem Eichenholz ähnliche Poren. Es ist sehr zäh und elastisch, spaltet schwer, aber gerade und ist im Trocknen sehr beständig. Es wird als Tischlerholz, zum Wagenbau und zu Stielen für Werkzenge, so wie zu Turngeräthen benützt. $K k$.

Esdragonöl (huile d'estragon - tarragon oil), Dragunöl. Das Oel der Blätter von Artemisia dracunculus hat den eigenthiimlich erfrischenden Geruch des Dragun- (Esdragon)- Krautes, ist blassgelb, vom spec. Gew. 0.935 und siedet zwischen 200-206 ${ }^{\circ} \mathrm{C}$. Es besteht wesentlich aus Anethol und Kohlenwasserstoffen. Vgl. Sternanis. Dient wie das frische Kraut zum Aromatisiren ron Essigen und Räucheressenzen. $G t l$.

\section{Esdragonsäure, s. bei Sternanis.}

Eserin, syn. mit Physostigmin, s. Calabarbohne II pag. 195.

Esmarkit, Min., durch Wasseraufnahme veränderter Dichroit. Auch führen diesen Namen Varietäten sowohl des Datolits als auch des Anorthits, s. Datolit II pag. 591. Gtl.

Esparto (sparte-esparto), Halfa, Espartogras. Unter dem spanischen Namen Esparto und dem arabischen Halfa versteht man ein vegetabilisches Rohproduct, welches in der Neuzeit als Papiermaterial zu grosser Bedentung gelangt, die getrockneten Blätter von zwei Grasarten darstellt, nämlich ron Macrochloco tenacissima Kth. (Stipa tenacissima Desf.) und Lygeum Spartum L. fil., die in grosser Menge auf dürrem Boden vom $41-32^{0} \mathrm{n}$. Br. in den Küistenprovinzer von Süd-Spanien, von Tunis, Maroceo und Algerien wachsen. 
Die zähen, $4-7^{\text {dcm }}$ langen, im Mittel etwa $1 \frac{1}{2} \mathrm{~mm}$ im Durchmesser betragenden Blätter dieser beiden in sonstigen botanischen Merkmalen wesentlich abweichenden Gramineen stimmen darin überein, dass sie nicht flach sind, wie wir dies an unseren Gräsern sehen, sondern von beiden Rändern her zusammengelegt, stielrund, binsenartig. Nur eine sehr feine Rinne, welche vom Grunde des Blattes bis zur Spitze verläuft, deutet dieses auffallende Verhalten der Blätter an, welche sonst an der Oberfläche kahl und glatt oder höchstens feinstreifig (bei Lygeum Spartum), etwas glänzend graugrünlich oder strohgelb gefärbt sind. Die Innenfläche zeigt eine matt graugrüne Farbe und mehr weniger tiefe Längsfurchen mit scharf vorspringenden (Macrochloa) oder mehr stnmpfen, gerundeten (Lygeum) Leisten (Nerven), welche mit kurzen konischen, an der Spitze etwas hakig gekrümmten Härchen besetzt sind. Histologisck besteht das Espartoblatt unter der derben Oberhaut aus einem Grundgewebe, welches theils parenchymatisch und diinnwandig, theils proxenchymatisch und dickwandig ist. Darin sind stärkere und schwächere Gefässbïndel vom Charakter jener der Monocotylen eingelagert. Bei Macrochloa sind diese im Allgemeinen schwächer, von spärlichem Parenchym umgeben, oder ganz in das Fasergewebe eingebettet, welches die Hauptmasse des Blattgewebes bildet, bei Lygeum sind die Gefässbündel stärker und das Proxenchym weit weniger, das Parenchym dagegen reichlicher entwickelt als bei Macrochloa. Jenes Proxenchym oder Fasergewebe, welches auch die Hauptmasse der fabriksmässig abgeschiedenen Espartofaser bildet, besteht aus bastzellenartigen Elementen, welche sich mit der Nadel leicht isoliren lassen. Sie sind kurz (bei einem Durchmesser von $0.007-0.02^{\mathrm{mm}} 0.5-4.5^{\mathrm{mm}}$ lang), glatt, beiderseits lang zugespitzt, oder an den Enden abgerundet, seltener abgestutzt oder gabelig, dickwandig, mit sehr engem Lumen; in Kupferoxydammoniak quellen sie stark auf und lösen sich darin schliesslich, Jod mit Schwefelsäure färbt sie blau.

Esparto dient schon seit den ältesten Zeiten in seinen Heimathsländern zur Verfertigung verschiedener Flechtwaaren (Sparterie), wie zu Körben, Matten etc. $\mathrm{Zu}$ diesen und anderen Zwecken, z. B. als Durchzugsstroh für Virginier-Cigarren wird es auch bei uns eingefuihrt. Durch eine entsprechende Behandlung wird daraus auch eine Rohfaser abgeschieden, die zui Fabrikation ordinärer Gewebe und zu Seilerarbeiten dient. In grossartigstem Massstabe aber wird Esparto, insbesondere in England in der Papierfabrikation verwerthet. 1872 exportirte Algerien 44 Mill. Kilo ron diesem Rohproducte (Spec. Catalog der Wiener Weltausstellung 1873. Algier). Die an Halfa (hauptsächlich Macrochloa) reichste Gegend hier ist das höhere Plateau ron Oran und die Hauptausfuhrplätze Sebdon, Daya und Saida.

Mit dem Namen Esparto bezeichnet man in Spanien auch die Binsenpfrieme, Spartum pinceum L., eine strauchige, in Siid-Europa einheimische, bei uns in Gartenanlagen ihrer schönen, grossen, goldgelben Blätter wegen häufig cultivirte Papilionacee, deren grüne zähe Zweige gleichfalls zur Anfertigung von Körben, Matten, Netzen, Tauen etc. dienen.

A. Vogl.

Espenholz (tremble - asp), auch Aspenholz, s. I pag. 211.

Esse (cheminée - chimney), Schornstein, s. II 549, s. Heizung.

Essence de Mirbane, Mirbanöl, künstliches Bittermandelöl, Nitrobenzol, vgl. I pag. 379, s. a. Nitrobenzol.

Essence d'orient, Perlenessenz. Unter diesem Namen kommt im Handel eine zur Imitation von Perlen verwendete Flüssigkeit ror, welche aus wässrigem Ammoniak besteht, in welchem der auf mechanischem Wege von den Schuppen genisser silberschuppiger Fische (namentlich des Weissfisches) abgelöste silberglänzende Beschlag rertheilt ist. Der Gehalt an Ammoniak dient wesentlich als Conservirungsmittel für die in reinem Wasser leicht reränderliche Substanz. 
Essenzen (essence - essence) nennt man im Allgemeinen geistige Ausziige oder Destillate aus aromatischen Pflanzentheilen oder sonstigen Substanzen, welche gewissermassen gesättigte Lösungen des riechenden Principes solch aromatischer Stoffe darstellen, seltener belegt man auch ätherische Oele mit diesem Namen. Vgl. a. Tincturen, s. Parfumerie. Gtl.

Essig (vinaigre - vinegar). Im Allgemeinen versteht man unter Essig eine sehr verdünnte Essigsäure, welche je nach der Art und Beschaffenheit des Materiales, aus welchem sie erzengt, andere Stoffe beigemengt enthält, die ihr den eigenthümlichen Geruch und Geschmack ertheilen.

Die Kenntniss des Essigs datirt seit den ältesten geschichtlichen Zeiten; schon den meisten alten Völkern war es bekannt, dass Fruchtsäfte (bes. Traubensaft), längere Zeit mit Luft in Berührung gebracht, sauer werden und die Eigenschaft erhalten, anf manche Steine und Metalle lösend zu wirken. Die Alchemisten, welche sich vielfach mit dem Essig beschäftigten, kannten bereits anch eine concentrirtere Essigsäure (sog. Kupferspiritus), das Wesen der Essigbildung aber war unbekannt; wurde auch nicht aufgeklärt, als Boerha ave in Leyden um das Jahr 1720 eine praktische Anleitung zur Weinessigfabrikation veröffentlichte, die als die eigentliche Grundlage der Wein- und Schnellessigfabrikation angesehen werden kann. Nachdem Priestley 1774 den Sauerstoff entdeckt und Lavoisier 1788 nachwies, dass Alkohol durch Oxydation in Essigsäure iibergehe, beschäftigte man sich eingehender mit der Erklärung des Vorganges der Essigbildung; es traten verschiedene Chemiker mit häufig wiedersprechenden Ansichten auf, die sich einerseits in der Behauptung, die Umwandlung des Alkohols in Essig sei ein reiner Oxydationsprocess, andererseits in der Ansicht, dieselbe geschehe nur durch Vermittlung eines Gährungserregers (Ferment, Essigpilz etc.), gipfelten.

Die Gewinnung des Essigs im Grossen geschieht:

1. Aus alkoholhaltigen Flüssigkeiten.

2. Aus zucker- und stärkmehlhaltigen Materialien und

3. Durch trockene Destillation des Holzes. Letztere siehe Artikel „Holzessig. “

Zur ersten Gruppe können gezählt werden: verdünnter Alkohol, Bier, Wein, gegohrener Malzauszug etc. Die zweite Gruppe umfasst alle jene Materialien, die durch ilıren Stärke- und Zuckergehalt befähigt sind, bei der Gährung alkoholhältige Flüssigkeiten zu liefern; hieher gehören z. B. Getreide, Riiben, Obst, Most ete.

Die erhaltenen Produkte bezeichnet man dann als: Branntwein- oder Spiritus-, Wein-, Bier, Malz-, Getreide- u. Rübenessig.

Soll iiberhanpt eine alkoholhältige Flüssigkeit in Essigsäure übergehen, so miissen gewisse Bedingungen erfiillt sein u. z.:

1. Eine bestimmte Concentration der zu säuernden Flüss:gkeit, deren Alkoholgchalt in den Grenzen von 3-12 Volumprocenten schwanken kann; die Erfahrung hat gelehrt, dass Fliissigkeiten, die unter $3^{0}{ }_{i 0}$ Alkohol enthalten, sehr langsam, solche mit mehr als $12 \%$ gar nicht säuern.

2. Hinreichender Luftzutritt; da der Uebergang von Alkohol in Essigsäure durch Aufnahme von Sauerstoff aus der Luft, die Säuerung stets von der Oberfläche der alkoholhältigen Flüssigkeit aus erfolgt, muss dem Luftzutritt eine möglichst grosse Beriihrungsfläche dargeboten werden.

3. Eine zwischen 20 bis $35^{\prime \prime}$ C. liegende Temperatur; obwohl die Essigbildung auch noch bei niederer Temperatur vor sich geht, erscheint dieselbe doch wesentlich verlangsamt, dagegen verläuft sie bei Temperaturen uber $35^{\circ} \mathrm{C}$. sehr rasch, jedoch mit bedeutenden, durch Verdunstung von Alkohol entstehenden Verlusten.

4. Die Gegenwart eines stickstoffhaltigen Körpers, eines Fermentes.

Zur Erklärung des Vorganges der Essigbildung machen sich verschiedene Ansichten geltend. Liebig*) fuihrt die Essigbildung auf einen einfachen Oxy-

*) Liebig, die Es-iggährung, Ann. der Chemie u. Pharm. 153 p. 137; Buchners Repert. 19 prg. 321, Dinglers polyt. Journal 196 pag. $5 \pm 8$. 
dationsprocess zurück und stiitzt seine Erklärung vorzüglich auf das Experiment von Döbereiner, nach welchem Alkoholdampf mit Sauerstoff oder Luft und feinvertheiltem Platin (Platinmohr) in Berïhrung gebracht in Essigsäure iibergeht, unter gleichzeitiger Bildung von Aldehyd, Acetal und Essigsäureäthyläther. Liebig nimmt also die Bildung von Aldehyd als Uebergangsstadium an, aus welchem sich durch weitere Aufnahme von Sauerstoff Essigsäure bildet:

$$
\begin{aligned}
& \underset{\text { Alkohol }}{\mathrm{C}_{0} \mathrm{H}_{6} \mathrm{O}}+\underset{\text { Sauerstoff }}{\mathrm{O}}=\underset{\text { Aldehyd }}{\mathrm{C}_{2} \mathrm{H}_{4} \mathrm{O}}+\underset{\text { Wasser }}{\mathrm{H}_{\mathbf{9}} \mathrm{O}} \\
& \underset{\text { Aldehyd }}{\mathrm{C}_{2} \mathrm{H}_{4} \mathrm{O}}+\underset{\text { Sauerstoff }}{\mathrm{O}}=\underset{\text { Essigsäure }}{\mathrm{C}_{2} \mathrm{H}_{4} \mathrm{O}_{2}}
\end{aligned}
$$

Aehnlich wie Platinmohr wirken nach Liebig viele in Zersetzung und Verwesung begriffene organische Körper, die durch diesen Process den Sauerstoff auf den Alkohol iibertragen; ebenso nimmt er an, dass Holzkohle oder Hobelspäne, als Sauerstoff verdichtend, in gleicher Weise wirken. P a ste ur (Etude sur le vinaigre, Paris 1868) dagegen vertritt die Ansicht, dass nur der Lebensprozess eines zur Essigbildung unumgänglich nöthigen Pilzes (Mycoderma aceti) auf analoge Weise wie bei der Alkoholgährung die Umwandlung des Alkohols in Essigsäure bewirkt, und beruft sich dabei auf das stetige Vorkommen jener Pflanze bei jeder Essigbildung, die nicht stattfindet, wenn im Essiggute nicht auch die Lebensbedingungen derselben (Proteinstoffe, phosphorsaure Salze) geboten sind. Diese Ansichten sind nach den Versuchen von W. v. Knieriem und Ad. Meyer (Chem. Centralblatt 1763 p. 666; Jahrbuch für Pharm. 187340 p. 326; Landwirthsch.-Tersuchstation 16 p. 327) in den Hauptpunkten vollständig bestätigt worden und bezweifeln sie auch die Möglichkeit der Verwandlung von Alkohol in Essigsäure durch ozonhaltige Luft. Lemaire (Compt. rend. 57 p. 625; Journal für praktische Chemie 92 p. 248) ist der Ansicht dass sich die Mycodermatten nicht als die Ursache der Essigbildung, sondern vielmehr als die Folge des Vorhandenseins von Essigsäure entwickeln, die durch directe Oxydation des Alkohols entstehe.

Man unterscheidet bei der Essigbereitung zweierlei Methoden:

1. Die ältere oder langsamere, nach welcher die Säuerung des Essiggutes in theilweise gefüllten, in warmen Localen liegenden Fässern vor sich geht; die vollständige Umwandlung erfordert wochen- bis monatelanges Lagern; gegenwärtig fast ausschliesslich nur zur Bereitung von Wein-, Bier- und Getreideessig verwendet.

2. Die neuere Methode oder Schnellessigfabrikation,nach welcher das durch sehr feine Vertheilung eine grosse Oberfläche darbietende Essiggut bei steter Luftzufuhr und erhöhter Temperatur sehr rasch in Essig iiberfihrt wird; hauptsächlich zur Erzeugung von Spiritus- oder Branntwein-, seltener des Malzessigs verwendet.

Im Folgenden geben wir eine Darstellung der wichtigsten Essigsorten und ihrer Bereitung:

a) Weinessig wird fast ausschliesslich in weinreichen Gegenden, besonders in Frankreich (bei Orleans), seltener in Deutschland producirt.

Nach dem ältern Vrfahren von Boerhaave benützt man zwei gleich grosse, oben offene Fässer, verschliesst das Spundloch, stellt dieselben auf Unterlagsbalken in ein warmes Local, fuillt nun beide mit Weinkämmen oder Trestern, das eine mit Wein ganz, das andere halbvoll an, entleert nach 24 Stunden das volle Fass so weit, dass hiemit das zweite, halbrolle, gefullt wird, nach 48 Stunden dieses und fährt so fort, bis aller Alkohol in Essigsäure verwandelt ist; die Säuerung geht hauptsächlich in dem halbrollen Fasse ror sich und dauert sehr lange Zeit.

Ausser diesem heutzutage fast gänzlich verlassenen Verfahren ist in Frankreich die sog. "Methode von Orleans" im Gebrauch, nach weicher ein Gemisch 
von Wein und Essig in warmen Localen sich selbst überlassen wird; Haupter. forderniss der Lagerräume ist steter Luftwechsel und möglichst constante Temperatur; die Wände derselben bestehen aus Ziegelsteinen und sind ausserdem mit Brettern und Gyps bekleidet; auch sind niedrige Räume am besten geeignet; die Temperatur beträgt 25 bis $30^{\circ} \mathrm{C}$. Die Gefässe, in denen die Säuerung vor sich geht, sind Fässer von 2 bis 4 Hektoliter Inhalt; grössere arbeiten zu langsam, kleinere erfordern zu viel Bedienung.

Man füllt die Fässer zu ca. $1 / 3$ mit siedendem starken Essig, fügt darauf 10 Liter Wein hinzu und uiberlässt die Mischung sich selbst; nach ca. 8 Tagen setzt man abermals 10 Liter Wein $\mathrm{zu}$, wiederholt diese Operation nach 3 bis 4 Wochen, und setzt dieselbe so lange fort, bis die Fässer iiber die Iälfte gefiullt sind, zieht sodann 1/3 des Inhaltes, in manchen Fabriken auch nur 40 Liter ab, setzt wieder 10 Liter Wein zu und fährt so fort.

Triiber. Wein muss vor dem Zusatze in die Säuerungsfässer durch mehrwochentliches Lagern in grossen, mit |Buchenholzspänen angefüllten Bottichen geklärt werden; triiber Essig wird derselben Operation unterworfen.

Von dem Fortschreiten der Gährung uiberzeugt man sich auf empirischem Wege, indem man einen weissen gebogenen Stab in die Flüssigkeit taucht; ist derselbe beim Heransziehen mit einem dichten weissen Schaume (Essigblume) bedeckt, so ist die Gährung beendet; ist der Schaum hingegen roth, so erhöht man die Temperatur bis zum Eintritte obiger Erscheinung.

Die in Verwendung stehenden Fässer bedürfen nach 6- bis 8jährigem Gebrauche in Folge des Absatzes von Weinstein und Essigmutter einer Reinigung, nach 20 bis 25 Jahren vollständiger Erneuerung.

Nach dem Verfahren von Pasteur (Compt. rend. 54 p. 265, 55 p. 28; Bulletin de la societé d'encouragement 1862 p. 615; Repert. de chim. appl. 1862 p. 70 und 279; Dingl. polyt. Journal 165 p. 299 und 303; Polytechnisches Centralblatt 1862 p. 1439 u. 1510) saet man auf eine Fluissigkeit, bestehend aus Wasser, dem $2 \%$ Alkohol, $1 \%$ Essig und etwas phosphorsaure Salze zugesetzt wurden, den Essigpilz aus; die kleine Pflanze entwickelt sich sehr rasch über die ganze Oberfläche, gleichzeitig säuert der Alkohol; sobald der Process im Gange und etwa die Hälfte des zugesetzten Alkohols in Essigsäure verwandelt ist, setzt man jeden Tag Alkohol, Wein oder mit Weingeist verselztes Bier zu, bis die Fliissigkeit so viel Alkohol erhalten hat, dass der resultireude Essig den erforderlichen Grad der Stärke besitzt.

Hiebei ist besonders zu beachten, dass es einerseits der Fliissigkeit nie an Alkohol fehlen, andererseits die Entwiklung der Pflanze nicht zu weit gedeihen darf, weil in beiden Fällen eine weitere Zersetzung der gebildeten Essigsäure (in Kohlensäure und Wasser) stattfinden wiirde. Wird die Wirkung der Pflanze schwächer, so wartet man die vollständige Säuerung ab, zieht den gebildeten Essig ab, wäscht die Pflanze und benuitzt sie von Neuem.

Dieses Verfahren wird in der Fabrik von Breton-Laugier in Orleans im Grossen ausgeführt. (Deutsche Industrie-Zeitung 1871 pag. 234; Dingl. polyt. Journ. 201 p. 67 ; Chem. Centralblatt 1871 p. 687 ; Polytechn. Centralblatt 1871 p. 1326.$)$

Der Weinessig enthält 6-9\% Essigsäurehydrat, daneben. Weinstein, Weinsäure, Citronensäure, Farbstoffe, Spuren von Aldehyd, Glycerin und Bernsteinsäure.

b) Bier-, Malz- oder Getreideessig. Die Erzeugung des Essigs aus Bier, resp. Malz oder Getreide ist heutzutage meist nur in Ländern gebräuchlich, in welchen in Folge der hohen Spiritussteuer solcher zur Erzeugung des Essigs nicht verwendet werden kann, wie z. B. in England und Schweden.

Bei der Herstellung des nöthigen Malzes ist es nicht nöthig, so genau und sorgfältig vorzugehen, wie es bei der Bierbranerei erforderlich ist; die T'emperatur beim Malzen kann etwas höher gesteigert, auch die Keimung weiter fortgesetzt werden; meist mischt man ungemalztes Getreide mit Malz u. z. am besten zu 
gleichen Theilen, wobei man das erstere sehr fein, das fertige Malz nur grob geschrotet anwenden kann; zur Mischung mit Malz kann mit Vortheil Hafer verwendet werden, weil die Treber dadurch aufgelockert werden und die Wiirze leicht abfliessen kann. Die erhaltene ungehopfte Maische wird auf Kühlschiffen bis 20 oder $25^{\circ} \mathrm{C}$ abgekühlt, in die Gährbottiche abgelassen und mit Hefe versetzt. Die Gährung kann als beendet angesehen werden, wenn das Saccharometer ca. $2^{0}$ zeigt und diese Anzeige constant bleibt. Die erhaltene vergohrene Maische wird in grossen, ganz gefüllten Fässern der Nachgährung unterworfen, welche ebenso wie die Hauptgährung um so rascher verlanfen wird, je höher die Temperatur der Flüssigkeit und der umgebenden Luft ist. Soll das erhaltene Bier nach dem älteren Verfahren in Essig umgewandelt werden, so kann die Nachgährung in ziemlich warmen Räumen oder in der Essigstube selbst vorgenommen werden; im letztern Falle jedoch resultiren sehr leicht trübe, nicht haltbare Producte. Soll das Bier nach der Methode der Schnellessigfabrikation gesäuert werden, so ist es vortheilhaft, den ersten Würzauszug oder die ganze Maische zur Abscheidung der Albuminate zum Kochen zu bringen, da ein zu grosser Gehalt an stickstoffhaltigen Körpern sehr bald eine Verschleimung der Späne im Essigbilder herbeiführen würde.

Nach dem älteren Verfahren wird die Maische oder das Bier, ganz ähnlich wie bei der Weinessigfabrikation beschrieben, in Fässer gebracht, die Temperatur der Essigstube möglichst constant auf 29 bis $30^{\circ}$ C. erhalten oder, wie in England gebräuchlich, im Freien auf sogenannten Essigfeldern die Sommermonate hindurch sich selbt iuberlassen. Durch Filtration uiber Traubenkämme, Trester, Hobelspäne oder Stroh reinigt man den fertigen Essig.

Nach der neueren Methode mischt man dem Biere oder der vergohrenen Maische verdünnten Alkohol und eine entsprechende Menge Essig zu, lässt aber die fruiher gebräuchlichen Zusätze von Brod, Sauerteig, Weizen- oder Roggenmehlteig mit Weinstein etc. weg.

Das Essiggut kann z. B. bestehen aus: 100 Liter Alkohol von 90\% Tr., 1900 Liter Wasser, 3600 Liter Bier und 900 Liter Essig, oder 100 Liter Alkohol von 90\% Tr., 1500 Liter Wasser, 700 Liter Bier, 180 Liter Essig, oder 100 Liter Alkohol v. $90 \%$ Tr., 1400 Liter Wasser, 100 Liter Bier, 300 Liter Essig, oder 100 Liter Bier und 15 Liter Essig ohne Alkoholzusatz.

Endlich kann zur Fabrikation von Bieressig eine der französischen Weinessigfabrikation nachgebildete Methode in Anwendung kommen; den regelmässigen Gang der Essigbildung verfolgt man durch Bestimmung der Zunahme des spezifischen Gewichtes, besser durch öftere Bestimmung des Säuregehaltes mittelst Titration. Ist ein Stillstand in der Essigbildung eingetreten und aller Alkohol in Essigsäure rerwandelt, so zieht man den gebildeten Essig ab und lässt nur so viel desselben zurück, als zur Herstellung des neuen Essiggutes benöthigt wird, ersetzt das Fehlende durch Zusatz der berechneten Menge verduinnten warmen Alkohols und Biers, worauf die Essigbildung sogleich wieder beginnt. Dem erhaltenen Essig setzt man behufs längerer Haltbarkeit eine geringe Menge Alkohol zu.

c) R übenessig. Die Fabrikation des Essigs aus Zuckerriibe ist in neuerer Zeit, besonders in Frankreich, vielfach in Anwendung. Nach dem Verfahren von $\mathrm{N}$ e a $\mathrm{l}$ und $\mathrm{D}$ u ye $\mathrm{k}$ (Zeitschrift des Vereins für Riibenzuckerindustrie 1867 p. 205 ; Polytechn. Centralblatt 1867 p. 208; Chemisches Centralblatt 1867 p. 512) wird durch die gegohrene Flüssigkeit mittelst eines Gebläses ein continuirlicher Luftstrom getrieben und dadurch die Säuerung in ziemlich kurzer Zeit bewirkt. Die grïindlich gereinigten und gewaschenen Rüben werden $\mathrm{zu}$ feinem Brei zerrieben, in Säcke gefiillt und in hydraulischen Pressen ausgepresst; das spezifische Gewicht des Saftes (ursprïnglich 1,035-1,045) wird durch Zusatz von Wasser auf 1,025 gebracht, derselbe kurze Zeit gekocht, rasch auf ca. $16^{\circ} \mathrm{C}$. abgekiihlt, in Gährbottiche gebracht, daselbst mit Hefe angestellt und die vergohrene Fluissigkeit in die Säuerungsgefässe gepumpt. Das Säuerungsgefäss ist ein starker Bottich von ca. 1000 Hektoliter Inhalt, in dessen unterm 
Theile eine Rose oder ein umgekehrter durchlöcherter kleiner Kegel, der mit einem Blaseapparate in Verbindung steht, angebracht ist; um die Fliissigkeit erwärmen zu können geht ein, an einem Ende offenes Dampfrohr bis auf den Boden des Bottichs. Um die vergohrene Wiirze in Essig zu verwandeln, bringt man zuerst 8000 Liter fertigen Essig in den Bottich, fügt eine gleiche Menge gegohrenen Saft und etwas Hefe hinzu und setzt den Blaseapparat in Bewegung. Wenn die Temperatur der Flüssigkeit unter $21^{\circ}$ C. sinkt, lässt man Dampf eintreten und erhält die Wärme zwischen 21 und $27^{\circ} \mathrm{C}$; der Alkohol wird auf diese Weise in wenigen Tagen oxydirt; man bringt sodann zum fertigen Essig 160 Hektoliter gegohrenen Saft und wiederholt diese Behandlung, wodurch die ganze Menge bald sauer wird.

Nach Leplay (Illustrirte Gewcrbezeitung 1862 Nro. 8; Polytechn. Centralblatt 1862 pag. 1167; Polyt. Notitzblatt 1862 pag. 183) lässt man nicht den Rübensaft, sondern die in Streifen geschnittenen Rüben gälıren, indem man dieselben in bereits in Gährung befindlichen Ruibensaft eintaucht; ist die Gährung vorüber, so zapft man die Flüssigkeit ab. Der Gährbottich ist nun mit Rübenstïcken gefiullt, welche mit grosser Begierde Sauerstoff absorbiren; nach einiger Zeit ist aller Alkohol im Zellgewebe der Rübe in Essigsäure iibergegangen, welche auf zweierlei Weise abgeschieden werden kann:

1 Die Riibenstiicke werden herausgenommen und in einem Destillirapparat mit Wasserdampf destillirt; man gewinnt destillirten Essig von sehr angenehmem Geruch und grosser Reinheit.

2. Der Essig wird durch Maceration ausgezogen. Ausser Zuckerriben können auch andere zuckerhaltige Pflanzenstoffe zur Fabrikation eines mehr oder weniger reinen Essigs verwendet werden, z. B. gewöhnliche Rïben, Möhren, Topinambours, Zuckerrohr etc.

d) Branntwein-oder Spiritusessig. Die ältere oder langsamere Methode der Erzeugung von Essig aus Alkohol, gegenwärtig wohl schon selten in Verwendung, bedient sich zur Säuerung entweder eichener Fässer oder Töpfe von Steinzeug; kleinere Fässer von ca. $6^{\prime} 0^{\prime}$ bis 90 Liter Inhalt sind grösseren vorzuziehen, Steintöpfe von 12 bis 18 Liter eignen sich besonders gut zur Erzeugung eines starken Essigs.

Das Locale in welchem die Säuerung vorgenommen wird, die sog. Essigstube, muss eine möglichst sorgfältige Regelung der Temperatur, des Luftzutrittes, Luftdurchzuges etc. gestatten, muss eine vor Wind und Luftzug geschiitzte Lage haben, gegen Süden gelegen und niedrig sein, Doppelthüren, möglichst wenig Fenster und starke Wände besitzen. Die Feuerung geschieht entweder durch ausserhalb des Locales angebrachte thönene, eiserne oder Meidinger'sche Oefen, vortheilhatter durch Kanalheizung; der Fussboden kann aus Holz oder Steinplatten mit trockener Unterlage hergestellt sein. Für genügende Ventilation wird durch mehrere kleine an der Decke und am Fussboden angebrachte, durch Schieber verschliessbare Oeffnungen gesorgt. Alle Eisentheile werden mit einem öfter zu erneuernden Anstrich von Asphaltfirniss (einer Lösung von Asphalt in Terpentinöl mit Zusatz von Leinölfirniss) versehen.

Dem zu säuernden verdünnten Alkohol wird zur Einleitung der Essigbildung fertiger Essig zugesetzt; die zu fuillenden Fässer werden vorher mit warmen Essig imprägnirt, indem man diesen mehrere Tage in denselben stehen lässt; mit dem bis auf die Temperatur der Essigstube, auch höher $\left(35-40^{0}\right.$ C.) vorgewärmten Essiggute werden die Fässer zur Hälfte oder $2 / 3$ angefüllt, die Spundlöcher mit Schieferplatten lose bedeckt und so gefüllt sich selbst iiberlassen; nach $2-3$ Wochen, je nach der Temperatur auch noch länger, ist die Säuerung beendet. Die Temperatur der Mischung, welche anfangs in Folge des Oxydationsprocesses über die Temperatur der Essigstube gestiegen, sinkt gegen das Ende desselben bedeutend herab, die Flüssigkeit nimmt einen rein samern Geschmack und Geruch an; sie wird nun auf die Lagerfässer abgezogen, wenn nicht ganz 
klar, durch Filtration iber Buchenholzspäne gereinigt, manchmal auch noch mit etwas Alkohol versetzt, um den resultirenden Essig stärker zu machen.

Die neuere Methode oder sog. Schnellessigfabrikation, 1823 von Schützenbach eingeführt, ermöglicht es, Alkohol binnen 24 bis 48 Stunden in Essig iiberzufuihren, und kann gegenwärtig, trotz ihrer Mängel, als die rationellste bezeichnet werden; sie erfordert grosse Umsicht des Betriebes, sorgfältige Regelung der Temperatur und grösstmögliche Reinlichkeit in allen Manipulationen; Nachtheile derselben sind: Produkte von geringerer Güte und grösserer Alkoholverlust.

Als Vertheiler der Fliissigkeit wendet man fast ausschliesslich Rothbuchenholzspäne an, welche aus ca. $30^{\mathrm{cm}}$ langen Stiicken grünen, durch Auslaugen mit Wasser von den löslichen Stoffen befreiten Holzes mittelst eines Stosshobels so gehobelt werden, dass sie sich zu Spiralen aufrollen, sodann nochmals mit Wasser ausgelangt und sorgfältigst getrocknet werden. Nach Mïhling soll die Essigbildung rascher verlaufen, wenn man abwechselnde Schichten von Buchenspänen und dünnen Weinreben anwendet. Statt Buchenspänen können auch Koks, welche durch Auslaugen mit Salzsäure und nachheriges Waschen mit Wasser von ihrem Eisengehalte befreit wurden, oder auch Holzkohle, besonders Lindenholzkohle, verwendet werden; letztere arbeitet sehr gleichförmig und mit geringem Alkoholverlust. Nach Pfund (Dingl. polyt. Journ. 211 pag. 280, 367 ; Polytechn. Centralblatt 1874 p. 518) wird dieselbe in möglichst trockenem, staubfreiem Zustande in etwa nussgrossen Stücken verwendet, hat aber den Nachtheil, dass ihre Säuerungsfähigkeit zu der Masse des erforderlichen Ansatzessiges in keinem sehr giinstigen Verhältnisse steht; die Kohlenfüllung eines mittelgrossen Essigbilders verschluckt $10-12$ Hektoliter Essig, liefert aber nicht mehr Fabrikat als ein Spanbilder mit 3-4 Hektoliter Ansäuerungsessig.

Die bei der Schnellessigfabrikation rerwendeten Säuerungsgefässe sind hohe cylindrische, nach unten ctwas verjuingte Bottiche aus Eichenholz, sogenannte Es sigbilder oder Essigständer. (Fig. 1510.) Dieselben haben folgende Einrichtung:

Fig. 1510.

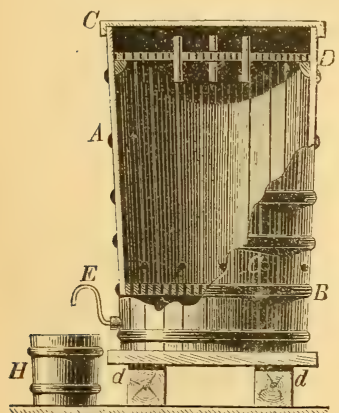

Essigbilder oler Essigständer. Ueber dem Boden befindet sich ein auf einem starken Holzrande liegender, durchlöcherter Deckel $B$. $5^{\mathrm{cm}}$ über diesem sind $6-12$ im Kreise gleichmässig vertheilte, $1 \cdot 5^{\mathrm{cm}}$ weite, nach abwärts gerichtete Zuglöcher $C$ gebohrt. Auf einem Holzrande, vom obern Deckel circa $30^{\mathrm{cm}}$ entfernt, befindet sich ein zweiter, mit zahlreichen Löchern (300-400) versehener, gut eingepasster Senk- oder Siebboden $D$, dessen Oeffnungen ea. $2 \cdot 5^{\mathrm{cm}}$ von einander entfernt sind; derselbe dient zur Anfnahme und gleichmässigen Vertheilung des Essiggutes über das Füllmateriale. Um diese Vertheilung langsam und gleichmässig zu erhalten, befinden sich in den Löchern starke, mit einem Knopfe versehene Bindfaden, die nur tropfenweise das Herabrinnen des Essiggutes gestatten; ausserdem sind noch $4-63^{\mathrm{cm}}$ weite Löcher gebohrt, in die kurze Glasröhren befestigt sind, welche den Zweck haben, die von unten durch die Zuglöcher $C$ eingetretene sauerstoffärmer gewordene Luft oben austreten zu lissen. Den Innenraum des Bottichs zwischen beiden Siebböden nimmt das Fiillmateriale ein. $\mathrm{Um}$ die Temperatur im Innern des Bilders genau beobachten und hienach den Process beschleunigen oder verzögern zu können, ist in der halben Höhe des Bildtrs ein Thermometer angebracht, dessen Kingel bis in die Mitte oder wenigstens $15^{\mathrm{cm}}$ weit ins Innere des Bottichs reicht. Den gamzen Bottich schliesst ein Holzdeckel $C$, der in der Mitte eine ca. $25 \square^{\mathrm{cm}}$ grosse Oeffinumg hat, die lose verschlossen oder offen gehalten werden kann; dieselbe gestattet das Auffiillen des Essiggutes in den Apparat und zugleich die Regulirung des Luftzuges in demselben. 
Im untern Theile des Bottichs, etwa $5^{\mathrm{cm}}$ iiber dem untersten Boden desselben ist eine S-förmig gebogene Glasröhre $E$ angebracht, welche bei einem gewissen Stande des Essigs denselben in ein unterstehendes Gefäss // abfliessen lässt. lage $d d$.

Der ganze Bottich ruht auf einer $45^{\mathrm{cm}}$ hohen Holz-oder Mauerwerksunter-

Die Dimensionen des Essigständers schwanken in der Höhe zwischen $0.8-6^{\mathrm{m}}$, in der Brcite von $0.8-2.5^{\mathrm{m}}$; in der Praxis jedoch hat sich eine Hölıs von $2-2 \cdot 5$ und eine Breite von $0.8-1 \cdot 5^{\mathrm{m}}$ am meisten bewährt. Zu grosse Bottiche ergeben einen grössern Abgang von Alkohol durch Verdunstung, zu kleine halten sich schwerer auf einer gleichmässigen Temperatur.

Neue Essigständer werden zuerst mit Fluss- oder weichem Brunnenwasser ausgelaugt, bis dasselbe geschmack- und farblos abläuft, hierauf mit den trockenen Spänen gefiillt und nun mit starkem angewärmten Essig gut durchitränkt. Sind die Bilder so vorbereitet, so erfolgt das Ansäuern, Einsäuern oder Ansetzen, indem man Essig von der zu erzielenden Stärke 3-4mal des Tages auf den Siebboden aufgiesst, 2-3 Tage auf den Spänen stehen lässt und dies so lange wiederholt, bis der ablaufende Essig dieselbe Stärke wie der aufgegossene hat; dies währt je nach der Grösse der Ständer 8-14 Tage. Nach Pfund benöthigt man für Bilder von $1^{\mathrm{m}}$ Durchmesser und $2^{\mathrm{m}}$ Füllungshöhe bei Anwendung von Buchenholzspänen 3-6, bei Lindenholzkohle 8-12 Hektoliter an Ansäuerungsessig.

Das Essiggut besteht aus Branntwein oder Spiritus, der durch Zusatz von Wasser auf einen Gehalt von $6-7 \%$ gebracht wird und dem man $1 / t_{*}$ oder $1 / 2$ Volum an Essig zusetzen kann. Oefter's gewählte und bewährte Zusammensetzungen sind z. B. 10 Liter Branntwein von 50\% Tr., 60 Liter Wasser, 20 Liter Essig, oder 10 Liter Alkohol von 90\% Tr., 120 Liter Wasser, 30 Liter Essig.

Der hiebei verwendete Essig enthält 6.25-6.5\% Essigsäurehydrat.

Das Auffïllen des Essiggutes geschieht alle Stunden mit 6-8 Liter, die, am Boden angelangt, zwar schon zum grössten Theile in Essig verwandelt sind, jedoch noch ein- oder mehreremal aufgegossen werden müssen, um die vollständige Oxydation des Alkohols herbeizufïhren. Man vertheilt diese Arbeit auch auf zwei oder mehrere Bottiche, die dann zusammen arbeiten; der erste erhält dann frisches Essiggut; mit 10 Bottichen kann man 750 Liter Essig pr. Tag erzeugen.

Statt des manche Nachtheile bietenden periodischen Aufgiessens wendet man häufig automatisch wirkende Apparate an, von denen insbesondere der sog. Schaukeltrog oder die Wippe gebräuchlich ist. Derselbe besteht aus einem auf seiner untern Kante ruhenden dreiseitigen Trog, der durch eine Längsscheidewand in zwei Hälften getheilt ist; das Essiggut fliesst aus einem höher stehenden Reservoire in eine der Hälften, die, wenn sie gefüllt, den Trog zum Umkippen und dadurch die andere Hälfte unter das Reservoir bringt, worauf sich das Spiel wiederholt. Auch kann zur Vertheilung des Essiggutes als feiner Regen iiber das Füllmateriale die in den englischen und schottischen Bräuereien zum Auslaugen der Treber verwendete Modification des Segnerischen Wasserrades mit Vortheil benützt werden.

Die 'Temperatur der Essigstube beträgt beim Beginne der Fabrikation $38^{\circ} \mathrm{C}$, die des Essiggutes $50-52^{\circ} \mathrm{C}$; ; bei erreichtem regelmässigen Gang erhält man die Luftemperatur auf 21, die des Essiggutes auf 26-270. Im Innern des Apparates steigt die Temperatur in Folge der raschen Oxydation des Alkohols auf $38-42^{\circ}$ C. Zur Erzeugung von stärkerem Essig oder Sprit setzt man dem Essig, nachdem er das Fass zweimal passirt, neuerlich Alkohol zu und wiederholt dies eventuell vier- bis fünfmal bis zur Erreichung der gewünschten Stärke.

Auf die Leistungsfähigkeit des Essigbilders iiben Einfluss: die Grösse desselben, Art und Beschaffenheit des Füllmaterials, Zusammensctzung und Vertheilung des Essiggutes, die Wärme in der Essigstube, die Ventilation derselben und wenn auch im untergeordneten Masse Sonnenlicht und Ozongehalt der Luft.

Statı Hobelspänen oder Lindenkohle wendet Artus (Dingl. polyt. Journ. 186, p. 158) zur schnelleren Säuerung und Darstellung eines angenehm 
riechenden Produktes platinirte Kohle an, die er durch Tränken von 1.5 Kilo haselnussgrosser Holzkohlenstiickchen mit einer Lösung von 15 Gramm Platinchlorid in 2.5 Liter Alkohol und nachheriges Glïhen in bedeckten Tiegeln darstellt.

Der bei der Schnellessigfabrikation resultirende Essig ist gewöhnlich milchig getriibt und lässt sich derart reinigen, dass man ihn mehrere Tage lang in einem Bottich mit Holzkohle oder Holzspänen anstellt, und nach dem Abziehen wenn nöthig durch Filzbeutel filtrirt. Nach einem in England ertheilten Patente wird Rohessig gereinigt, indem man denselben in Dampfform durch geschmolzenes $\mathrm{Pa}$ raffin leitet, welches die Verunreinigungen aufnimmt. (!)

Der bei der Schnellessigfabrikation entstehende Verlust durch Verdunsten von Alkohol kann auf etwa $6 \%$ veranschlagt werden.

Singer in Berlin will durch seinen Essiggenerator verschiedene Uebelstände des geschilderten Verfahrens beseitigt wissen und hebt als besondere Vortheíle seines Apparates geringeren

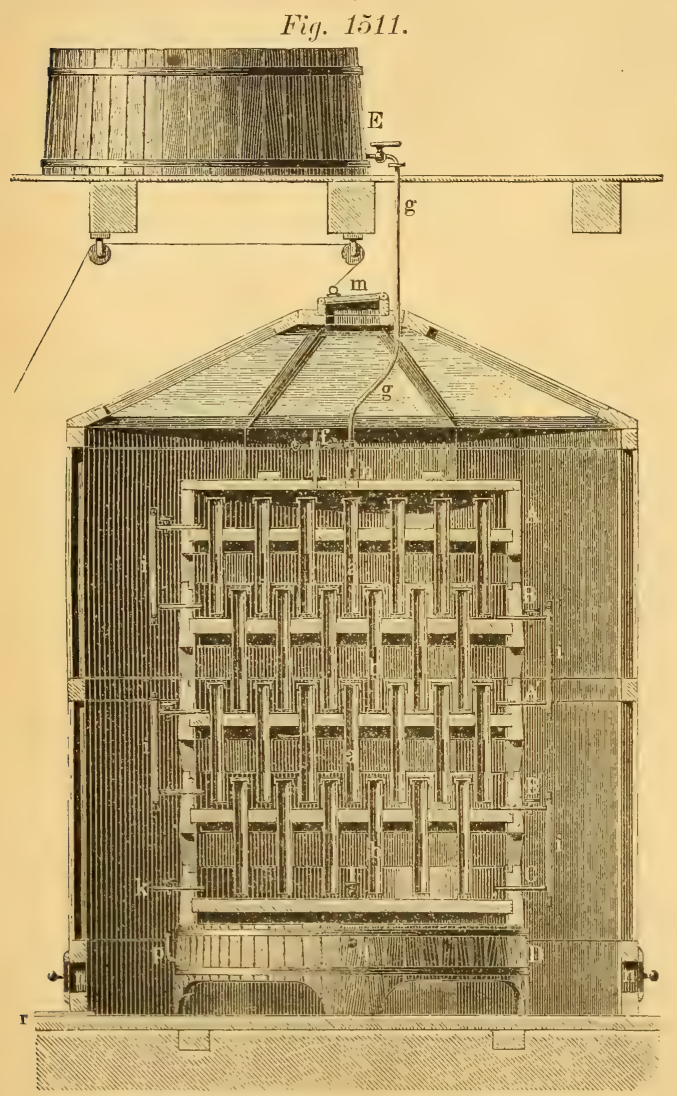

Alkoholverlust, Entfallen des Füllmaterials, einfache Manipulation, volle Sicherheit des Ganges und Erzeugung von Essig in jeder Stärke, hervor.

Nach Reimann (Dingl. polyt. Journ. 190, p. 314; Deutsche Industriezeitung 1868, p. 513) besteht derselbe aus einer Anzahl flacher lıölzerner Gefässe,welche durch hölzerne Röhren so verbunden sind, dass die Essigmischung tropfenweise aus einem Gefäss in das andere rinnt und dabei die Röhren passirt; dieselben sind zur Vergrösserung der Oberfläche der durchlaufenden Fluissigkeit im Innern mit horizontalen Riefen versehen, tragen ausserdem in der Mitte zwei Längsspalten, durch welche die Luft freien Zugang hat; diese bewirkt in den Röhren die Oxydation des fein vertheiltenAlkohols zu Essig, und da das Essiggut eine grosse Anzahl dieser Röhren wiederholt durchfliessen muss, wird die Essigbildung eine sehr rasche und vollkommene. Der Apparat steht in einem eigens construirten Gehäuse, das ihn vor Abkiihlung and starkem Luftzutritte schiitzt und heizbar ist. Fig. 1511 zeigt den- 
selben im Durchschnitt, Fig. 1512 die einzelnen Gefässe und ihre Verbinding durch die Röhren in grösserem Massstabe. Der Essiggenerator besteht aus fiinf übereinander befindlichen Bottichen, deren gleichmässige Zwischenräume durch die an den einzelnen Gefässen angebrachten, verlängerten Fassdauben ge. wonnen sind. In dem Boden der Gefässe $A$ u. $A_{1}$ sind 37 Röhren $a$ u. $b$ eingesetzt, durch welche dieselben mit den $\mathrm{Ge}$ fässen $B$ u. $B_{1}$ in Verbindung stehen; letztere tragen im Boden nuir 32 Röhren, welche nach oben das Gefäss $B$ mit $A_{1}$ verbinden, nach unten aber in das Gefäss $C$ einmünden. Das oberste Gefäss $A$ ist mit einem Deckel geschlossen, durch welchen der Schlauch $g$ aus dem Reservoir $E$ für das Essiggut führt; je 2 Gefässe sind aussen durch zwei Knieröhren $i$, die mit Hähnen verschliessbar sind, verbunden. Die früher genannten Röhren sind im Innern mit 6 ringförmigen Rillen versehen, oberhalb derselben sind 4 Oeffnungen angebracht, durch welche das Essiggut einfliessen kann. Die Röhren sind oben geschlossen, unten offen ; das unterste Gefäss $C$ hat zwei Abflussrohre, wovon $J$ am Boden, $k 3^{\mathrm{cm}}$ höher angebracht ist. Sämmtliche Gefässe ruhen auf dem Behälter $D$, der zur Aufnahme der Flüssigkeiten dient, die den Apparat passiren,

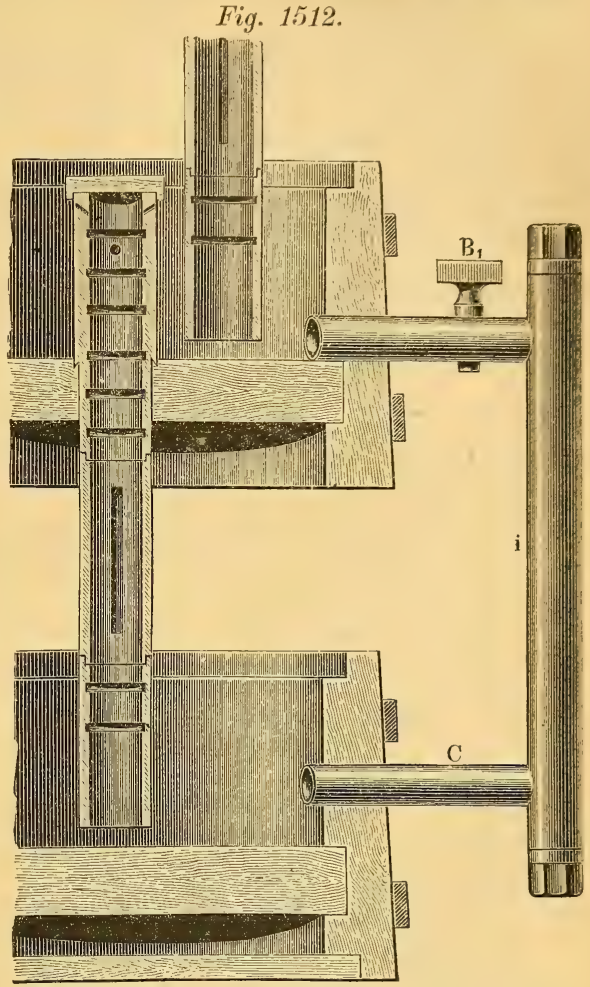

Lissiggenerator von Singer (ein Theil vergrössert).

und eine Oeffnung $q$ besitzt, welche vermittelst eines Schlauches vom Rohre $J$ mit dem Gefässe $C$ verbunden wird. Das Wasserstandsglas $p$ dient zugleich beim Umdrehen desselben zum Ablassen der Flüssigkeit aus $D ; m$ ist eine Klappe, $n$ sind Schieber zur Regulirung des Luftzutrittes.

Das Essiggut fliesst aus dem Reservoir $E$ durch $g$ nach dem elsten Gefässe $A$, tritt durch die Tropfröhren der Reihe nach in alle Bottiche, gelangt daselbst bei grosser Oberfläche mit stets neuen Luftmengen in Beriihrung und sammelt sich im Gefässe $D$ als fertiger Essig an.

K. E. Thiel (Hessisches Gewerbeblatt 1870, p. 161; Deutsche Iudustriezeitung 1870, p. 276) veröffentlicht einige ungünstige Urtheile iiber den Singer'schen Generator, bezweifelt die rasche Leistungsfähigkeit und hebt herror, dass einer Verdunstung von Alkohol nicht gesteuert wird.

Kurz erwähnt sei noch das Verfahren von C. Wied emann (Monit. scientif. 1872 Nro. 369 p. 733), welcher Alkohol (Whisky) durch Vermittlung ron Ozon in Essigsäure uiberfiihrt. Mayer und v. Knieriem (Chemisches Centralblatt 1873 p. 666) bestreiten jedoch, wie bereits erwähnt, die Fähigkeit ozonisirter Luft, Alkohol ohne Mitwirkung des Essigpilzes in Essigsäure rerwandeln zu können. 
Knapp beschreibt ein in England übliches Verfahren der Schnellessigfabrikation, bei welchem die Luft mittelst Pumpen (doppelt wirkendes Baader'sches Glockengebläse) durch die Essigbilder gesogen wird. Die aus den Pumpen tretende Luft passirt ein Gefäss mit Wasser, in welchem der mitgeführte Alkohol- und Essigdampf condensirt wird und das zum Ansetzen von neuem Essiggute verwendet wird. Die Bilder sind hiebei ausnahmsweise gross, $3 \cdot 7^{\mathrm{m}}$ hoch, $4-4 \cdot 5^{\mathrm{m}}$ im Durchmesser; die Füllung derselben geschieht mit gesägten Holzklötzchen. Im Verlaufe des Processes tritt eine solche Erwärmung ein, dass die Essigstube nicht geheizt werden muss.

A r o matis che- oder $\mathrm{Kr}$ äu teress ig e finden vorzüglich als Tafelessige, als cosmetische Mittel, zu Räucherungen etc. Verwendung. Man stellt sie entweder durch directes Aufgiessen des Essigs und Stehenlassen mit den betreffenden Pflanzen oder Pflanzentheilen, oder durch Destillation mit denselben unter Zusatz von Kochsalz (zur Erhöhung des Siedepunktes), oder endlich durch Beimischung von alkoholischen Lösungen ätherischer Oele dar. Die am meisten in Verwendung kommenden aromatischen Substanzen sind: Esdragonkraut und Esdragonöl (s. d.), Schalotten, Origanum, Boretsch, Sellerie, Piment, Pfeffer, Rosenblätter, Orangenblüthen, Senf, Himbeeren etc. und führen die erhaltenen Produkte die Namen Esdragon-, Himbeer-, Senfessig etc.

Das Färben des Essigs hat den Zweck, die durch die Schnellessigfabrikation erhaltenen farblosen Produkte dem Wein-, Malz- oder Getreideessig ähnlich zu machen und geschieht dies ausser durch Lagern des Essigs auf rohem Weinstein, Rosinen oder Rosinenstielen, durch Färben mit braunem Malz, Zuckercouleur, Malvenblättern, Heidelbeeren etc.

Im Allgemeinen sind die auf dem Wege der Schnellessigfabrikation erzeugten Essige von wesentlich weniger angenehmen Geschmack und Geruch als die nach der ältern Methode erhaltenen, was wohl daher kömmt, dass zu erstern destillirte, zu letztern bloss gegohrene Flüssigkeiten verwendet werden. Die Ursache des Geruches und Geschmackes sind verschiedene Aetherarten und verwandte organische Verbindungen. Der Gehalt an reiner Essigsäure beträgt bei Weinessig, der als der beste geschätzt wird, $6-8$, bei Malz- und Bieressig 2-5, bei Branntweinessig $4-6$, bei Sprit $12-14 \%$; das spezische Gewicht varirt von $1 \cdot 01-1.03$. Die sogenannten Krankheiten des Essigs entstehen durch Einwirkung der Luft auf die stickstoffhaltigen Substanzen desselben, wobei sich der Essigkahm oder Essigpilz (Mycoderma aceti), die Essigmutter (Hydrocrocis decti oder Ulvina aceti) und in den nach der ältern Methode dargestellten Essigen die Essigälchen (Vibrio aceti oder Anguillula aceti) bilden, welch letzere durch Kochen getödtet werden können. Ein Essig, der noch etwas Alkohol enthält, unterliegt in Folge der langsamen Neubildung von Essigsäure nicht so leicht dem Verderben.

Prïfung des Essigs, der Essigsäure und der essigsauren S a l z e. Die Bestimmung des Säuregehaltes im Essig durch das Araeometer gibt, da der Unterschied im spezifischen Gewicht bei verschiedenem Gehalte an Essigsäure ein sehr geringer ist, ausserdem stets andere auf das spezifische Gewicht Einfluss nehmende Substanzen vorhanden sind, nur ungenaue Resultate und kann höchstens zur Vergleichung von Essigen derselben Abstammung (und da nur bei Anwendung sehr genauer Araeometer und Einhaltung der Normaltemperatur) verwendet werden. Ebenso sind die in frühern Zeiten gebrauchten Methoden heute völlig unzureichend; die eine derselben bestand darin, dass man eine gewisse Menge des zu untersuchenden Essigs mit einem gewogenen Quantum reinen kohlensauren Kali's neutralisirte, den nicht verbrauchten Rest zurückwog und aus dem Verbrauch die Quantität reiner Essigsäure berechnete. Die andere auf ähnliche Weise und mit einem gewogenen Stïcke Marmor vorgenommene Probe führte man so aus, dass man nach dem Aufhören der Gasentwicklung den ungelösten Marmor reinigte, trocknete und aus der Gewichtsabnalıme $(5$ Thl. kohlens. Kalk $=6$ Thl. Essigsäurehydrat) den Säuregehalt bestimmte.

Um den Gehalt eines Essigs möglichst rasch und auch im Verlaufe der 
Fabrikation jederzeit bestimmen zu können, kann man sich des von 0 tt o construirten A cetometer's (Essigprobers) bedienen.

Dasselbe besteht aus einer graduirten, unten zugeschmolzenen, 30 $0^{\mathrm{m}}$ langen, $13^{\mathrm{mm}}$ weiten Glasröhre, welche vor unten nach oben folgende Eintheilung besitzt: Die erste Marke bezeichnet den Stand von $1^{\mathrm{ebcm}}$. Wasser, der Alsstand bis zum zweiten Theilstrich fasst $10^{\mathrm{cbcm}}$, der Raum über dieser Marke ist in 12 gleiche Theile getheilt, deren jeder $2 \cdot 07^{\mathrm{gm}}$ Ammoniakflussigkeit von solcher Stärke $(1 \cdot 369 \%$ fasst, dass damit gerade $0 \cdot 1 \mathrm{gm}$ Essigsäurehydrat neutralisirt wird. Man bringt nun bis zur ersten Marke neutrale Lakmustinktur, bis zur zweiten den zu prïfenden Essig (wodurch die Flüssigkeit roth wird), und setzt vorsichtig unter öfterm Umschütteln so lange von der Ammoniakflüssigkeit zu, bis die blaue Farbe eben wieder zum Vorschein kömmt; liest man nun den Stand der Fliissigkeit ab, so gibt die Zahl direct Procente, repective Bruchtheile derselben an Essigsäureliydrat an. Bei sehr starkem Essig füllt man nach dem Eingiessen der Lakmustinktur nur bis zur Hälfte des friher bezeichneten Standes, dann mit Wasser bis zur Marke und verdoppelt nach vollendeter Probe die abgelesenen Procente. Man kann auch die durch ein bestimmtes Gewicht Essig aus überschüssigem kohlensauren Natron ausgetriebene Kohlensäuremenge nach Gewicht oder Volum bestimmen und danach die Menge der Essigsäure berechnen.

Die genauesten Resultate liefert jedenfalls die Titrirmethode; zur Ausfiihrung derselben benöthigt man einer Normalsäure und einer Normalalkalilösung. Als erstere kann am besten die Oxalsäure, welche durch wiederholtes Umkrystallisiren aus der käuflichen dargestellt wird, verwendet werden; man wägt daron genau $63^{\mathrm{gm}} \mathrm{ab}$, löst in Wasser und verdünnt bei gewöhnlicher Tenperatur $\left(14^{0} \mathrm{R}\right.$.) auf 1 Liter $=1000^{\mathrm{cbcm}}$; ferner benöthigt man einer Normalalkalilösung von der $1^{\text {cbem }}$ genau $1^{\text {cbem }}$ der Normalsäure neutralisirt. Zur Herstellung derselben verdünnt man eine reine concentrirte (von 1.04 spec. Gew.) Natronlange mit Wasser, um eine der Normalsäure gleichwerthige Natronlösung zu erhalten; man misst z. B. $10^{\text {cbem }}$ der Normalsäurelösung ab, verdiunnt mit etwas Wasser, setzt Lakmustinktur zu und lässt aus einer Bürette die mit der noch zu concentrirten, richtig zu stellenden Lauge gefüllt ist, so lange von dieser zufliessen, bis der Neutralisationspunkt erreicht, d.h. die rothe Farbe der Fliissigkeit eben in Blau ibergegangen ist. Gesetzt den Fall, es seien auf obige Menge Oxalsäurelösung nur $8^{\mathrm{cbem}}$ Lauge verbraucht worden, so müssen je $8^{\text {cbem }}$ derselben mit $2^{\text {cbem }}$ Wasser oder 800 cbem durch Zusatz von 200 cbem Wasser auf einen Liter verdïnnt werden, um die richtige Concentration der Lauge zu erhalten; durch eine neuerliche Probe kann man sich von der Richtigkeit der so gestellten Normallauge überzeugen. 1 Liter derselben enthält nun $31^{\mathrm{gm}}$ wasser freies oder $4 \mathrm{cgm}^{\mathrm{gm}}$ Aetznatron und neutralisirt $51^{\mathrm{gm}}$ wasserfreie oder $60^{\mathrm{gm}}$ wasserhaltige Essigsäure.

Zur Prufung eines Essigs oder einer Essigsäure auf ihren Gehalt kann man entweder ein bestimmtes Volum oder ein bestimmtes Gewicht derselben nehmen ; im ersteren Falle hat man das Volumgewicht mit Berücksichtigung des spezifischen Gewichtes auf das absolute Gewicht zurïckzufuihren. Man titrirt nun nach rorherigem Färben mit Lakmus so lange mit der Normalnatronlösung, bis der Lebergang von roth in blauviolett stattfindet und berechnet aus der Anzahl der rerbrauchten Cubikcentimeter der Natronlösung den Säuregehalt. Hätte man z. B. 10 cbcm eines Essigs vom spezifischem Gewichte 1.010 abgemessen und $10.5^{\text {ebcm }}$ Natronlösung zur Neutralisation verbraucht, so ergibt die Rechnung: $10^{\text {cbcm }}$ rom spez. Gewichte 1.010 sind gleich $10 \cdot 10^{\mathrm{gm}}$ Essig; da nun $1^{\mathrm{cbcm}}$ Normalalkali 0.051 wasserfreier oder 0.06 wasserh. Essigsäure entspricht, so ergeben die rerbranchten $10.5^{\mathrm{cbcm}}$ Natronlösung $(10.5 \times 0.051$ oder $10.5 \times 0.06)=0.5355$ wasserfreie oder 0.63 wasserhaltige Essigsäure, d. h. es enthalten also $10.1 \mathrm{gm}$ Essig 0.5355 resp. $0.63^{\mathrm{gm}}$ Essigsäure, was in Procenten 5.302 wasserfreier oder 6.23 wasserhaltiger Essigsäure entspricht.

Bezeichnet allgemein mit $C$ die Anzahl der Cubikcentimeter Natronlauge, die zur Neutralisation von $10^{\text {ebcn }}$ Essig oder Essigsäure erforderlich sind, mit $s$ das spe- 
zifische Gewicht derselben, so wird der Gehalt $p$ an Essigsäurehydrat in Gewichtsprocenten durch die allgemeine Formel $p=0.6 \frac{C}{s}$ ausgedrückt.

Wägt man genau 5.1, resp. 6.0 gm Essig oder Essigsäure zur Probe ab, so gibt die Anzahl der verbrauchten Cubikcentimeter direct den Gehalt an Essigsäure in Procenten.

Ein ähnliches acetometrisches Verfahren beschreibt Pohl (Dingl. polyt. Journ. 163, p. 365). Man misst $5^{\mathrm{cbcm}}$ des Essigs ab, versetzt mit einigen Tropfen Lakmus, titrirt auf beschriebene Weise, bestimmt ferner mit einem genauen Araeometer (welches noch Differenzen von 0.005 anzeigt) das spezifische Gewicht und findet dann den Essigsäurehalt des Essigs ausgedriickt in Procenten wasserfreier Essigsäure nach der Forrmel: $p=\frac{5,1 . C}{5 D}=1.02 \frac{C C}{D}$ wobei $C$ die Anzahl der verbrauchten Cubikcentimeter Natronlauge, $D$ die gefundene Dichte (spez. Gew.) des Essigs bezeichnet. Zur raschen Ermittlung des Prozentgehaltes hat Pohl Tabellen für die verschiedenen Dichten des Essigs und die Zahl der verbrauchten Cubikcentimeter Natronlösung entworfen.

Nach Jaillard (Journal de pharm. et de chim. (3) 46, p. 419; Zeitschrift für analytische Chemie 1865 p. 222 ; Chem. Centralblatt 1865 p. 768) setzt man zu $20^{\mathrm{cbcm}}$ Normalnatron oder Kali $100^{\mathrm{cbem}}$ Wasser, 6 Tropfen Lakmus und titrirt mit Normalschwefelsäure; andererseits verdünnt man $20^{\mathrm{cbcm}}$ Normalalkali mit $190^{\mathrm{cbcm}}$ Wasser, färbt mit Lakmus und setzt $10^{\mathrm{cbcm}}$ des zu untersuchenden Essigs zu, welche natiirlich zur Sättigung des Alkalis nicht hinreichen, und beendet dieselbe durch Normalschwefelsäure; die Differenz der verbrauchten Schwefelsäuremengen in beiden Fällen gibt die gesuchte Menge an Essigsäure.

Bei stark gefärbten Essigen (Himbeeressig, Holzessig) verwendet man beim Titriren zur Erkennung des Neutralisationspunktes gutes Lakmuspapir, auf welches man hie und da einen Tropfen der Flïssigkeit bringt; bei sehr dunkel gefärbtem Essig ist auch diese Methode nicht verlässlich, und kann man in diesem Falle eine gewogene Menge desselben mit überschiissigem reinem kohlensauren Baryt von bekanntem Gewicht in der Wärme neutralisiren, den ungelösten kohlens. Baryt nach dem Auswaschen mit heissem Wasser und Trocknen entweder zurïckwägen oder die Menge desselben durch Titration bestimmen, um aus der Menge des verbrauchten kohlens. Baryts den Säuregehalt berechnen zu können.

Auch kann die Kieffer'sche Methode, die sich auf Titration mit einer richtig gestellten Kupferoxydammoniaklösung gründet, mit Erfolg angewandt werden.

Die Bestimmung der Essigsäure in essigsauren Salzen gründet sich auf die Eigenschaft derselben, beim Gliihen in kohlensaures Salz iiberzugehen (essigsaure Salze der Alkalien oder alkalischen Erden) oder Oxyde, resp. Metalle zu hinterlassen. Bei erst genannter Gruppe titrirt man das erhaltene kohlensaure Salz mit Normalsäure und berïcksichtigt dabei, dass 1 Molekiil kohlensaures Salz äquivalent ist 2 Molekiilen essigsauren Salzes. Nach Fresenius (Zeitschrift fiur analytische Chemie 1866 p. 315) kann man die Essigsäure in essigsauren Salzen (essigs. Kalk) durch Destilliren derselben mit Salzsäure abscheiden und durch Titration eines Theiles des gesammten Destiliates mit Normalnatron den gesammten Säuregehalt, durch Titration eines andern Theils mittels Silberlösung die mit übergegangene Chlor xasserstoffsäure bestimmen, und durch einfache Rechnung den Essigsäuregehalt finden. Mit Tortheil lässt sich Phosphorsäure bei dieser Methode besonders dann anwenden, wenn neben essigsaurem Kalk noch Chlorcalcium und andere Salze rorhanden sind.

Fresenius hat in neuester Zeit ein einfaches Yerfahren zur raschen Analyse des holzessigsauren Kalkes und Bleies reröffentlicht. Näheres hierüber s. seine Originalarbeit ${ }_{n}$ Zeitschrift für analytische Chemie" 1874 p. $153 ; 1874$ p. 30, Dingl. polyt. Journ. 213 p. 540 ; Polytechn. Centralblatt 1874 p. 1502.

Der Essig und die Essigsäure des Handels enthalten oft Verunreinigungen und Beimengungen, wie: Schweflige Säure, Schwefelsäure, schwefelsaure Salze, 
Chlorwasserstoffsäure, Chlorverbindungen, weinsaure Salze, Weinsäure, Kalk-, Natron- und Metallsalze, empyreumatische Stoffe, Gewuirze, Farbstoffe ctc.

Schweflige Säure kann bei Abwesenheit von Schwefelsäure nachgewiesen werden: mit Chlorbaryum, nachdem man den Essig mit Salpetersäure oder Chlorwasser erwärmt, worauf sich durch Bildung von Schwefelsäure, schwefeisaurer Baryt als weisser in Säuren unlöslicher Niederschlag abscheidet; oder man neutralisirt bis fast zur Sättigung der Essigsäure mit kohlensaurem Natron, fügt Zinkvitriol, Nitroprussidnatrium und einige Tropfen Ferrocyankalium zu, wobei sich die Gegenwart der schwefligen Säure durch Rothfärbung der Flüssigkeit zu erkennen gibt; eine Lösung von Chamaeleon (ïbermangansaures Kali) wird durch schweflige Säure enthaltenden Essig entfärbt; auch tritt bei Anwesenheit derselben die blaue Färbung der Jodstärke nicht auf oder verschwindet bald wieder. Ist neben schwefliger Säure Schwefelsäure vorhanden, so kann erstere in dem Destillate des Essigs, das man in verdünnte Salpetersäure leitet, nach dem Erwärmen dieser Flüssigkeit durch Chlorbaryum nachgewiesen werden.

Entsteht im Essig oder der Essigsäure durch Zusatz von Chlorbaryum sofort ein Niederschlag, so kann derselbe von Schwefelsäure, schwefelsauren Salzen oder von beiden zugleich berrühren. Freie Schwefelsäure kann nach Runge erkannt werden, wenn man etwas Essig mit Zucker in einer Porzellanschale langsam zur Trockene eindampft, wobei der Zucker zersetzt und geschwärzt wird. Auch kann man etwas Essig mit einigen Körnchen Stärke eine Zeit lang kochen, dann Jodtinktur zusetzen, worauf bei Anwesenheit von Schwefelsäure die blaue Jodstärkefärbung nicht auftritt, da das Stärkemehl in Traubenzuker verwandelt wurde.

Salzsäure oder Chlormetalle können im Destillate des Essigs an dem weissen, käsigen, in Ammoniak löslichen Niederschlag von Chlorsilber erkannt werden, wenn man einige Tropfen salpetersaurer Silberlösung zusetzt.

Weinsäure kann ermittelt werden, wenn man den Rückstand beim Abdampfen des Essigs mit Alkohol auszieht und der Lösung Chlorkalium zusetzt, wobei bei Anwesenheit von Weinsäure ein weisser krystallinischer Niederschlag von saurem weinsaurem Kali entsteht.

Dusart (Travaux de la soc. d'émul. pour les scienc. pharm. 3 pag. 174) wendet zur Auffindung von Weinstein im Essig ein Verfahren an, welches sich auf die Löslichkeit von weinsaurem Eisenoxydkali gründet. Setzt man zur Lösung des Essigextractes ein wenig Eisenchlorid zu, kocht, versetzt dann die Flüssigkeit mit überschïssiger Kalilauge, filtrirt und leitet Schwefelwasserstoff in das Filtrat, so fällt bei Gegenwart von weinsauren Salzen Schwefeleisen als schwarzer Niederschlag aus, während bei Abwesenheit derselben dies nicht erfolgt, da alles Eisen durch die Kalilauge ausgefällt wurde.

Um das Vorhandensein von Blei- oder Kupfersalzen zu erkennen, kann man den im Essig durch Schwefelwasserstoff entstehenden Niederschlag von Schwefelblei, resp. Schwefelkupfer beniitzen, während die Gegenwart von Eisen an dem durch Ferrocyankalium entstehenden blauen Niederschlag von Berlinerblau naclgewiesen werden kann.

Empyreumatische Stoffe können nach L ightfoot(Chemic. news. 1861 p. 290; Zeitschrift für analytische Chemie 1862 pag. 252 ; Dingl. polyt. Joum. 165 p. 240; Polytechn. Centralblatt 1862 p. 1392) nach geschehener Neutralisation durch Zusatz einer Lösung von iibermangansaurem Kali erkannt werden, die sich bei Gegenwart genannter Stoffe entfärbt; Eisessig (Acidum aceticum glaciale) muss vorher nach Merk (Neues Jahrbuch für Pharmacie 39 p. 1) mit seinem gleichen Gewichte Wasser verdünnt werden,

Der Zusatz von Gewuirzen (Pfeffer, Bertramwurzel, Senf, Seidelbast ete.) gibt sich nach der Neutralisation einer Partie Essig mit kohlensaurem Natron an dem auftretenden charakteristischen Geschmack und Geruch der betrefienden Pflanzenstoffe zu erkennen. K. Weis. 
Essigaelchen (anguillula aceti), s. Essig III pag. 302.

Essigalkohol, syn. mit Aceton, s. Essigsäure.

Essigäther, s. Essig s ä ur eäth er.

Essigbilder, Essigbildner, Essigständer, s. Essig III pag 298.

Essigblume, syn. mit Essigpilz, s. Essig III pag. 295. Z u cker.

Essigcouleur, syn. mit Zuekercouleur, s. Caramel II pag. 253, vgl.

Essiggeist, syn.m. Aceton, s. Ės igsäure.

Essiggenerator, syn. m. Essigbilder, s. Essig III pag. 300.

Essiggut, s. Essig, III pag. 298.

Essigkahm, s. Essig III pag. 302.

Essigmutter, s. Essig III pag. 302.

Essigpilz, Essigblume, s. Essig III pag. 294.

Essigprober, A ceto m eter, s. Essig, III pag. 303.

Essigsäure (acide acétique - acetic acid). $C_{2} H_{4} O_{2}$, Acetylsäure oder Acetoxylhydrat $C_{n} H_{3} O . O H$; Methylcarbonsäure $C_{3}$. CO.OH.

Die Essigsäure, in ihren Eigenschaften der Ameisensäure nahe verwandt, bildet das kohlenstoffreichere zweite Glied der sogenannten Fettsäurereihe und unterscheidet sich von ersterer durch einen Mehrgehalt von $\mathrm{CH}_{\mathbf{a}}$.

In der Form der verdïnnten Essigsäure ist dieselbe schon seit den ältesten Zeiten bekannt; Basilius Valentius (im 15. Jahrhunderte) lehrte eine concentrirte Säure (len sog. Kupferspiritus) durch Destillation des Griinspans erzeugen; er war es anch, der ganz richtig erkannte, dass bei der Destillation des Essigs die ersten Antheile schwächer, säureärmel sind als die nachfolgenden. Jedoch erst 1793 gelang es Wertendorf und Lowitz, die krystallisirte Essigsäure rein darzustellen.

Die Essigsäure findet sich in sehr geringen Mengen theils frei (in Hollunderbeeren und Tamarindenfrüchten), theils gebunden an Alkalien und alkalische Erden im Safte vieler Pflanzen; sie bildet cinen integrirenden Bestandtheil des Schweisses, der Fleischfliissigkeit der Säugethiere, des Magensaftes und anderer Fliissigkeiten des thierischen Organismus; in der Mileh, der Leber, im Harn und im Mineralwasser von Briickenau ist sie aufgefunden worden.

Sehr mannigfach sind die Bildungsweisen der Essigsäure. Eine grosse Reihe stickstofffreier organischer Verbindungen (Holz, Torf, Braunkohle, Cellulose, Stärke, Gummi, Zucker etc.) geben, bei Luftabschluss erhitzt, unter Abscheidung eines kohlenstoffireichen Riickstandes, ein Destillat, welches stets Essigsäure enthält. Dieselbe bildet sich ferner beim Keimen ron Samen (bes. Bohnen), bei der Fäulniss diverser organischer Stoffe (Casein, Fibrin, Albumin), bei der Einwirkung von Braunstein und Schwefelsäure, Chromsäure, Uebermangansäure oder Salpetersäure auf Albumin, Casein, Fibrin, Oelsäure, Terpentinöl ete., iiberhaupt von Oxydationsmitteln auf alle sog. Fettkörper, beim Schmelzen voß Kalihydrat mit Aepfelsäure, Weinsäure, Citronensäure, Milchsäure, Stärke, Zucker etc.

Wird rerdïnnter Alkohol oder eine alkoholhältige Flüssigkeit (Bier, Wein, vergohrener Rübensaft etc.) bei geeigneter Temperatur und Anwesenheit stickstofflıaltiger Körper Fermente) dem Zutritte der Luft ausgesetzt, so iibergeht der 
Alkohol in Essigsäure; dieselbe Umwandlung erleidet der Alkoholdampf in Beriihrung mit Platinschwamm und Sauerstoff oder atmosphärischer Luft (Döb e r e in er):

$$
\begin{gathered}
C_{2} H_{6} \mathrm{O}+\mathrm{O}=\mathrm{C}_{0} H_{4} \mathrm{O}+\mathrm{H}_{2} \mathrm{O} \\
\text { Alkohol Sauerstoff } \\
\mathrm{C}_{2} \mathrm{H}_{4} \mathrm{O}+\mathrm{O}=\mathrm{C}_{12} \mathrm{H}_{4} \mathrm{O}_{2}
\end{gathered}
$$

Auf synthetischem Wege kann Essigsäure gebildet werden durch Einwirkung von Kali- oder Natronlauge auf Methylcyarïr:

$$
\underset{\text { Methylcyanïr }}{\mathrm{CH}_{3} \mathrm{CN}}+\underset{\text { Wasser }}{\mathrm{H}_{2} \mathrm{O}}+\underset{\text { Natriumhydroxyd }}{\mathrm{NaOH}}=\underset{\text { Essigs. Natron }}{\mathrm{CH}_{3} \mathrm{CO} . \mathrm{ONa}}+\underset{\text { Ammoniak }}{\mathrm{NH}_{3}}
$$

Methylnatrium geht durch Absorbtion von Kohlensäure direct in essigsaures Natron über (Wanklyn, Ann. der Chem. und Pharm. 111 pag. 234):

$$
\underset{\text { Methylnatrium }}{\mathrm{CH}_{3} \mathrm{Na}}+\underset{\text { Kohlensäure }}{\mathrm{CO}}=\underset{\text { essigs. Natron }}{\mathrm{CH}_{3} . \mathrm{CO} . \mathrm{ONa}}
$$

Kaliummethylalkoholat durch Einwirkung von Kohlenoxyd in essigsaures Kali (Berthelot): $\mathrm{CH}_{3} \mathrm{OK}+\underset{\text { Kaliummethylalkoholat }}{\mathrm{CO}}=\underset{\text { Kohlenoxyd }}{\mathrm{CH}_{3} . \mathrm{CO} . \mathrm{OK}}$

Direct aus Essig lässt sich die Essigsäure nicht mit Vortheil gewinnen, da bei der Destillation desselben in Folge des ziemlich hohen Siedepunctes $\left(118^{\circ} \mathrm{C}\right.$. der reinen Säure die ersten Antheile immer wasserreicher und säureärmer sind, als das Rohmateriale selbst; wird die Destillation zu weit getrieben, so findet sehr leicht eine Zersetzung der fremden Bestandtheile des Essigs in der Destillirblase und hiemit eine Verunreinigung des Destillates selbst statt. Die Destillation wird in kupfernen Destillirblasen vorgenommen; handelt es sich hiebei um völlige Reinheit der zu erzeugenden Säure, so müssen Helm und Kïhlröhren aus Silber oder versilbertem Kupfer bestehen.

Immer erhält man nach diesem Verfahren eine für die meisten Zwecke zu schwache Essigsäure und muss zur Darstellung einer concentrirten Säure von der Zersetzung essigsaurer Salze durch Mineralsäuren ausgegangen werden. Die hiezu am geeignetsten Salze sind die Acetate des Natriums, Calciums, Baryums und Blei's, von welchen jedoch zur Darstellung im Grossen fast ausschliesslich nur die beiden ersteren verwendet werden. Das Nähere hierüber siehe Artikel "Holzessig."

Zur Darstellung des reinen Essigsäurehydrates kann der Bleizucker des Handels verwendet werden; man befreit denselben durch Schmelzen in einer flachen Schale von seinem Krystallwasser, steigert sodann die Temperatur bis eine vollkommen trockene, staubige Salzmasse erhalten wird; von diesem Salze werden in einer tubulirten Retorte 320 Theile $(1$ Mol.) mit 98 Theilen ( 1 Mol.) concentrirter Schwefelsäure unter Abkühlung gemischt, längere Zeit, bis alles Salz von der Schwefelsäure durchdrungen ist, stehen gelassen und sodann die gebildete Essigsäure vom Bleisulfat durch vorsichtige Destillation im Sandbade getrennt. Da sich das Bleisulfat leicht sehr fest an dem Boden der Retorte ansetzt, die abdestillirte Säure iiberdies leicht durch schweflige Säure verunreinigt wird, rerwendet man statt Schwefelsäure saures schwefelsaures Kali oder Natron und erhält dann im Riuckstande ein Gemenge von Bleisulfat und neutralem Kalium- oder oder Natriumsulfat, welches sich leicht aus der Retorte entfernen lässt.

Statt Bleiacetat kann mit Vortheil Natriumacetat verwendet werden. Der hiebei stattfindende Vorgang kann durch folgende Gleichung ausgedriickt werden:

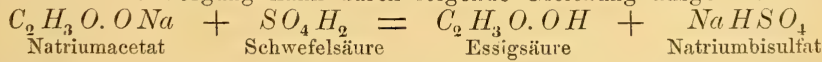

Zur Zersetzung von 1 Molek. oder 82 Theilen wasserfreien essigs. Natrons ist 1 Molek. oder 98 Theile Schwefelsäure erforderlich; das zu verwendende krystallisirte Natriumacetat $\left(\mathrm{C}_{\mathrm{u}} \mathrm{H}_{3} \mathrm{O} . \mathrm{ONa}+3 \mathrm{H}_{2} \mathrm{O}\right)$ wird durch Umkrystallisiren von seinem Chlornatriumgehalte, durch zweimaliges Schmelzen (bei ca. $240^{\circ} \mathrm{C}$.) von seinem Krystallwasser befreit. Man bringt nun 5 Theile des fein gepulverten Salzes in eine Retorte, fügt 6 Theile der cuncentrirten Schwefelsäure zu, sorgt durch kräftiges Umschwenken für sorgfältige Mischung beider, setzt sogleich die 
Vorlage an und unterstützt die sofort beginnende Destillation durch schwaches Erwärmen; man erhält für je 1 Mol. des verwendeten Natronsalzes 1 Mol. oder 60 Gewichtstheile Essigsäure.

Nach Melsens kann Essigsäure in der Form des reinen Hydrates erhalten werden durch Zerlegung des sog. sauren essigsauren Kali's, welches Salz sich bei $300^{\circ} \mathrm{C}$. in neutrales essigsaures Kali einerseits und Essigsäurehydrat andrerseits

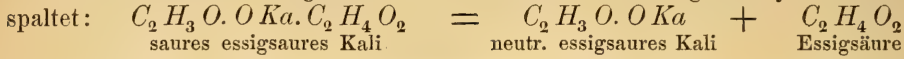

Eine reine, aber verdiinnte Essigsäure, der sog. concentrirte Essig, Acetum concentratum, Acidum aceticum dilutum der Pharmakopöen (spec. Gew. 1.040), wird erhalten durch Destillation von krystallisirtem essigsaurem Natron mit wasserhaltiger Schwefelsäure.

In den meisten Fällen ist jedoch die erhaltene Essigsäure nicht ganz rein, sie enthält Spuren von schwefliger Säure, entstanden durch Einwirkung von Schwefelsäure auf Essigsäure; um sie von diesem Gehalte zu befreien, kann dieselbe mit oxydirend wirkenden Substanzen, wie doppelt chromsaurem Kali, Braunstein oder Bleisuperoxyd der Rectification unterworfen werden.

Nach Buchholz soll eine, von schwefliger Säure vollkommen freie Essigsäure durch einmalige Destillation erhalten werden, wenn man dem Gemisch von Bleizucker und Schwefelsäure gleich von vornherein die erforderliche Menge Braunstein zusetzt.

Die reine Essigsäure ist eine farblose Fluissigkeit von scharfem, stechendem, zu Thränen reizendem Geruch, saurem Geschmack, oei gewöhnlicher Temperatur merklich fliichtig; auf die Haut gebracht, wirkt sie ätzend und erzengt schmerzhafte Brandblasen; reagirt nicht auf trockenes, wohl aber auf feuchtes Lacmuspapier. Ganz concentrirte Essigsäure raucht schwach an der Luft, zieht leicht Feuchtigkeit aus derselben an; erstarrt bei $+17^{\circ} \mathrm{C}$. zu durchsichtigen glänzenden Tafeln, die iiber $17^{\circ}$ wieder schmelzen. Man nennt nach dieser Eigenschaft die concentrirteste Säure Eisessig, Radicalessig (Acidum aceticum glaciale); ein sehr geringer Wassergehalt bewirkt eine beträchtliche Erniedrigung des Erstarrungspunktes, so dass sich nach F. R ü dorff*) in concentrirter Säure $0 \cdot 1 \%$ Wasser mit Sicherheit nachweisen lässt. Die Erniedrigung des Erstarrungspunktes ist dem Wassergehalt keineswegs proportional, dieselbe sinkt vielmehr langsamer, als der Wassergehalt zunimmt. So z. B. ist der Erstarrungspunkt der reinen conc. Säure nach Rüdorff bei $+16^{\circ} 7^{\circ} \mathrm{C}$, , der eines Gemisches von 100 Th. Säure mit $10 \mathrm{Th}$. Wasser bei $+4 \cdot 3^{\circ} \mathrm{C}$, , von $100 \mathrm{Th}$. Säure mit $24 \mathrm{Th}$. Wasser bei $7 \cdot 4^{0}$ C. gelegen.

Das specifische Gewicht der festen Säure ist $1 \cdot 10$ bei $8 \cdot 5^{\circ} \mathrm{C}$. (Persoz), das der flüssigen 1.0635 bei $16^{\circ} \mathrm{C}$. Mischt man Essigsäure mit Wasser, so nimmt das specifische Gewicht derselben unter Erwärmung zu, erreicht bei 1.0735 (77$80 \%$ Säure entsprechend) das Maximum der Dichte und nimmt dann allmälig wieder ab, so dass eine Flüssigkeit, die $54 \%$ Säure enthält, dasselbe specifische Gewicht zeigt, wie die reine Säure.

Der Siedepunkt liegt bei $118^{\circ} \mathrm{C}$, nach $\mathrm{R}$ ü dorff bei $117 \cdot 8^{\circ} \mathrm{C}$.; ihr Dampf ist mit blauer Farbe zu $\mathrm{CO}_{\mathrm{o}}$ und $H_{2} \mathrm{O}$ verbremnbar; Dampfdichte $=2 \cdot 09$. Mit Wasser, Alkohol und Aether ist sie in jedem Terhältnisse mischbar. Sie löst viele organische Körper, Campfer, Harze, Schiessbaumwolle, Albumin, Fibrin, ätherische Oele, ron welchen letzteren das Citronenöl am scliwersten löslich ist und ein Kemnzeichen für die höchste Concentration abgibt, indem es aufhört löslich zı sein. wenn die Säure mehr als $2 \%$ Wasser enthält. Die deutsche Pharmakopöe schreibt eine Essigsäure vor, von der 10 Theile 1 Theil Citronenöl zu lösen vermögen (1.04 spec. Gew.).

*) F. Rï orff, Poggend. Annal. 140, pag. 415; Berichte der deutsch. chem. Gesellsch. 1870 , pag. 390. Dingl. polyt. Journ. 196, pag. 545; Chem. Centralblatt 1870, pag. 320 ; Deutsche Industrie-Ztg 1870 , pag. 430. 
Den Zusammenhang zwischen Säuregehalt und specifischem Gewicht zeigt folgende Tabelle (nach Mohr):

\begin{tabular}{|c|c|c|c|c|c|c|c|}
\hline $\begin{array}{l}\text { Essigsäure } \\
C_{2} H_{4} O_{2} \\
\text { Proc. }\end{array}$ & $\begin{array}{c}\text { Spec. } \\
\text { Gewicht }\end{array}$ & $\begin{array}{c}\text { Essigsäure } \\
\mathrm{C}_{2} \mathrm{H}_{4} \mathrm{O}_{2} \\
\text { Proe. }\end{array}$ & $\begin{array}{c}\text { Spec. } \\
\text { Gewicht }\end{array}$ & $\begin{array}{c}\text { Essigsüure } \\
\mathrm{C}_{2} \mathrm{H}_{4} \mathrm{O}_{2} \\
\text { Proc. }\end{array}$ & $\begin{array}{c}\text { Spec. } \\
\text { Gewicht }\end{array}$ & $\begin{array}{c}\text { Essigsäure } \\
\mathrm{C}_{2} \mathrm{H}_{4} \mathrm{O}_{2} \\
\text { Proc. }\end{array}$ & $\begin{array}{c}\text { Spec. } \\
\text { Gewicht }\end{array}$ \\
\hline 100 & $1 \cdot 0635$ & 74 & 1.072 & 48 & 1.058 & 22 & $1 \cdot 031$ \\
\hline 99 & $1 \cdot 0655$ & 73 & $1 \cdot 072$ & 47 & $1 \cdot 056$ & 21 & 1.029 \\
\hline 98 & 1.0670 & 72 & 1.071 & 46 & $1 \cdot 055$ & 20 & 1.027 \\
\hline 97 & $1 \cdot 0680$ & 71 & 1.071 & 45 & $1 \cdot 055$ & 19 & 1.026 \\
\hline 96 & $1 \cdot 0690$ & 70 & 1.070 & 44 & 1.054 & 18 & 1.025 \\
\hline 95 & $1 \cdot 0700$ & 69 & 1.070 & 43 & 1.053 & 17 & 1.024 \\
\hline 94 & $1 \cdot 0706$ & 68 & 1.070 & 42 & $1 \cdot 052$ & 16 & $1 \cdot 023$ \\
\hline 93 & $1 \cdot 0708$ & 67 & $1 \cdot 069$ & 41 & $1 \cdot 051$ & 15 & 1.022 \\
\hline 92 & $1 \cdot 0716$ & 66 & $1 \cdot 069$ & 40 & $1 \cdot 051$ & 14 & 1.020 \\
\hline 91 & $1 \cdot 0721$ & 65 & $1 \cdot 068$ & 39 & $1 \cdot 050$ & 13 & $1 \cdot 018$ \\
\hline 90 & $1 \cdot 0730$ & 64 & $1 \cdot 068$ & 38 & 1.049 & 12 & $1 \cdot 017$ \\
\hline 89 & $1 \cdot 0730$ & 63 & 1.068 & 37 & $1 \cdot 048$ & 11 & $1 \cdot 016$ \\
\hline 88 & 1.0730 & 62 & 1.067 & 36 & $1 \cdot 047$ & 10 & $1 \cdot 015$ \\
\hline 87 & $1 \cdot 0730$ & 61 & 1.067 & 35 & $1 \cdot 046$ & 9 & $1 \cdot 013$ \\
\hline 86 & $1 \cdot 0730$ & 60 & $1 \cdot 067$ & 34 & $1 \cdot 045$ & 8 & $1 \cdot 012$ \\
\hline 85 & $1 \cdot 0730$ & 59 & $1 \cdot 066$ & 33 & $1 \cdot 044$ & 7 & $1 \cdot 010$ \\
\hline 84 & 1.0730 & 58 & $1 \cdot 066$ & 32 & $1 \cdot 042$ & 6 & $1 \cdot 008$ \\
\hline 83 & 1.0730 & 57 & $1 \cdot 065$ & 31 & $1 \cdot 041$ & 5 & $1 \cdot 007$ \\
\hline 82 & $1 \cdot 0730$ & 56 & $1 \cdot 064$ & 30 & $1 \cdot 040$ & 4 & 1.005 \\
\hline 81 & 1.0732 & 55 & $1 \cdot 064$ & 29 & 1.039 & 3 & $1 \cdot 004$ \\
\hline 80 & 1.0735 & 54 & $1 \cdot 063$ & 28 & $1 \cdot 038$ & 2 & $1 \cdot 002$ \\
\hline 79 & $1 \cdot 0735$ & 53 & 1.063 & 27 & $1 \cdot 036$ & 1 & $1 \cdot 001$ \\
\hline 78 & 1.0732 & 52 & $1 \cdot 062$ & 26 & $1 \cdot 035$ & & \\
\hline 77 & 1.0732 & 51 & $1 \cdot 061$ & 25 & 1.034 & & \\
\hline 76 & 1.0730 & 50 & $1 \cdot 060$ & 24 & 1.033 & & \\
\hline 75 & 1.0720 & 49 & $1 \cdot 059$ & 23 & $1 \cdot 032$ & & \\
\hline
\end{tabular}

Die Essigsäure findet vielseitige Verwendung, so in der Färberei zur Darstellung der Beizen, als Lösungsmittel für Farbstoffe, Harze, zur Bereitung von Anilinfarben, in grösster Menge zur Darstellung der essigsauren Salze; in der Medizin als belebendes Wasch- und Riechmittel (sog. Riechessig, ein Gemisch von Essigsäure und ätherischen Oelen), im concentrirten Zustande als Aetzmittel; der Eisessig in der Photographie.

Das sog. Essigsäur e a h y drid (anhydride acétique - acetic anhydride) $\mathrm{C}_{4} \mathrm{H}_{6} \mathrm{O}_{3}$ (zuerst von Gerhard 1852 dargestellt) wird erhalten durch Einwirkung von Chloracetyl oder Phosphoroxychlorid auf essigsaures Kali als wasserhelle leicht bewegliche Fliissigkeit, welche in Wasser in ölartigen Tropfen untersinkt, allmälig Wasser aufnimmt und sich in $2 \mathrm{Mol}$. Essigsäure spaltet. Spec. Gew. $=1.095$, Siedepunkt $138^{\circ} \mathrm{C}$.

Die Essigsäure ist sowohl als Hydrat, wie auch im wasserfreien Zustande bekannt. Das Hydrat, der empirischen Formel $C_{2} H_{4} O_{2}$ entsprechend, enthält in 100 Theilen:

$$
\begin{aligned}
& C=40.00 \% \\
& H=6.67 \% \\
& O=\frac{53.33 \%}{100 \cdot 00}
\end{aligned}
$$

Nach der älteren Anschauung als Verbindung der wasserfreien Essigsäure mit Wasser $\left(\mathrm{C}_{4} \mathrm{H}_{3} \mathrm{O}_{3}\right.$. $\left.\mathrm{HO}\right)$ betrachtet, leitet sich dieselbe vom einfachen Wassertypus 
${ }_{H}^{H}$ O durch Vertretung eines Wasserstoffs durch das Radical Acetyl $\mathrm{C}_{2} \mathrm{H}_{3} \mathrm{O}$ (für $C=12, O=16$ ) $\frac{\mathrm{ab}}{H_{3}}$; $O$

Typus Wasser

$$
\mathrm{C}_{2} \mathrm{H}_{3}{ }_{\mathrm{H}}^{\mathrm{O}} \mathrm{O}
$$

Essigsäure

aus dem Acetyl selbst durch Anlagerung einer Hydroxylgruppe $H O$ (Wasserrest) an die freie Affinität derselben (daher ihr Name Acetylsäure oder Acetoxylhydrat)

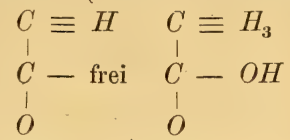

Acetyl Acetylsäure oder Es-igsäure.

In gewisser Hinsicht kann die Essigsäure auch als Abkömmling der Kohlensäure angesehen werden (daher auch Methylcarbonsäure).

Ohne den Charakter der Essigsäure wesentlich zu ändern, können sämmtliche Wasserstoffatome der Methylgruppe durch Chlor oder andere einwertige Elemente, der Wasserstoff der Hydroxylgruppe durch einwertige Metalle, Radieale (Methyl, Aethyl, Amyl etc.) oder Chlor vertreten werden.

Die Essigsäure ist durch Hitze nur schwierig zersetzbar; leitet man Essigsäuredampf durch ein glühendes Porzellanrohr, welches mit Bimsteinstiicken gefuillt ist, so findet theilweise Zersetzung derselben statt; unter den Zersetzungsproducten treten neben Kohlensäure noch Sumpfgas, Aceton, Benzol, Naphtalin und Phenol auf (Berthelot).

Salpetsrsäure, selbst concentrirte, wirkt weder in der Kälte noch beim Erhitzen auf Essigsäure ein; ebenso wird sie von Uebermangansäure nur schwer verändert, dagegen von Ueberjodsäure in Ameisensäure und Kohlensäure zerlegt.

Wird Essigsäure mit concentrirter Schwefelsäure erwärmt, so wird erstere theilweise zersetzt; das Gemenge färbt sich braun bis schwarz unter Entwicklung von Schwefligsäure- und Kohlensäureanhydrid. Erwärmt man wasserfreie Schwefelsäıre mit krystallisirbarer Essigsäure längere Zeit auf $75^{\circ} \mathrm{C}$., so bildet sich eine Doppelsäure, die Essigschwefelsäure oder Sulfoessigsäure.

Durch Einwirkung ron Chlorgas auf erwärmte reine Essigsäure können je nach der Daner der Einwirkung ein, zwei oder drei Wasserstoffatome durch Chlor vertreten werden; es entstehen auf diese Weise die Mono-, Di- und Trichloressigsäure, von welchen die beiden letzteren medicinische Verwendung finden.

Die D i chlores s ig s ii ur e $\mathrm{C}_{2} \mathrm{H}_{2} \mathrm{Cl}_{2} \mathrm{O}_{0}=\mathrm{CHCl}_{2}$.CO.OH, eine farblose Flüssigkeit von 1.52 spec. Gew. und $195^{\circ}$ Siedepunkt, hat sich nach A. Urner*) als ein ganz ausgezeichnetes Aetzmittel bewährt.

Die Trichloressigsäur e**) $C_{2} C l_{3} H_{0}=C_{2} C l_{3} \mathrm{CO} . O H$, welche durch Einwirkung ron überschüssigem Chlor auf concentrirte Essigsäure bei gleichzeitiger Gegenwart von Licht leicht erhalten werden kann, bildet in Wasser und Alkohol leicht lösliche, an der Luft zerfliessliche, rhomboedrische Krystalle, deren Schmelzpunkt bei $45^{\circ} \mathrm{C}$. liegt. Die Anwendung in der Medizin beruht auf der Eigen. schaft, durch Einwirkung ron Alkalien in gelinder Wirme Chloroform abzugeben und kamn sie statt Chloralhydrat da angewendet werden, wo man die Wirkung der Ameisensäure rermeiden will; die Wirkung der Trichloressigsäure als Anästheticum steht jedoch der des Chloralhydrates wesentlich nach.

Die Essigsäure ist eine einbasische Säure, d. h. sie enthält nur ein durch Metallatome vertretbares Wasserstoffatom; die allgemeine Formel der essigsauren

*) A. Lruer, Polytechn. Notizblatt 1868, pag. 239. Folytechn. Centralblatt 1868, pag. 1344 .

*) Schering, Mittheil. a. d. chem. Fabrik 1873 Nr. 5, pag. 4. Chem. Centralblatt 1873, pag. 272 . 
Salze ist daher $\mathrm{C}_{2} \mathrm{H}_{3} \mathrm{M}^{\prime} \mathrm{O}_{2}$ für einwertige, und $\mathrm{C}_{2} \mathrm{C}_{2} \mathrm{H}_{3} \mathrm{H}_{3} \mathrm{M}^{\prime \prime} \mathrm{O}_{2} \mathrm{O}_{2}$ für zweiwertige Metalle.

Ausser den neutralen Salzen bildet die Essigsäure auch basische und saure Salze. Die basischen können betrachtet werden als Verbindungen neutraler Acetate mit Oxyden oder Oxydhydraten, die sauren als neutrale, verbunden init Essigsäurehydrat.

Die neutralen essigsauren Salze sind meist krystallisirbar, fast immer farblos, grösstentheils in Wasser und Alkohol sehr leicht löslich; schwer löslich sind nur das Silber- und Quecksilberoxydulsalz. Die essigsauren Salze können theils durch Aufösen der basischen Hydrate, Oxyde oder Carbonate in Essigsäure, theils durch doppelte Zersetzung erhalten werden.

Die wässerigen Lösungen mancher Acetate, besonders jene des Blei- und Kupfersalzes verlieren beim Kochen etwas Essigsäure, das Ammonsalz hingegen Ammon. Im trockenen Zustande erhitzt zersetzen sie sich sämmtlich, u. z. unter Bildung von Essigsäure, Sumpfgras, Aceton und Zurïcklassung von Metall, Oxyd oder Carbonat, gemengt mit Kohle.

Die essigsauren Salze geben, mit verdünnter Schwefelsäure erhitzt, freie Essigsäure, die an ihrem stechenden Geruche, mit concentrirter Schwefelsäure und Alkohol erwärmt, Essigäther, der an seinem angenehmen, erfrischenden Geruche zu erkennen ist. Destillirt man ein essigsaures Salz mit verdunnter Schwefelsäure und digerirt das Destillat mit iiberschüssigem Bleioxyd, so erhält man eine alkalisch reagirende Lösung von basischem Bleiacetat (Bleiessig). Eisenchlorid gibt mit der Lösung eines neutralen essigsauren Salzes eine rothe Färbung von Eisenacetat; freie Essigsäure zeigt diese Reaction nicht. Salpetersaures Silber erzeugt in den Lösungen der neutralen Acetate einen weissen krystallinischen, in heissem Wasser löslichen Niederschlag von Silberacetat. Salpetersaures Quecksilberoxydul einen weissen, krystallinischen Niederschlag von Quecksilberacetat, der durch siedendes Wasser unter Abscheidung von metallischem Quecksilber zersetzt wird.

Wird ein essigsaures Salz mit arseniger Säure unter Luftabschluss erhitzt, so bildet sich Kakodyloxyd oder Alkarsin $\left.\left(\mathrm{As} / \mathrm{CH}_{3}\right]_{4} \mathrm{O}\right)$, dessen Gegenwart an dem durchdringenden penetranten, sehr charakteristischen Geruche erkannt wird. Dieses Verhalten kann verwendet werden, um die geringsten Spuren Essigsäure nachzuweisen.

Essigsäureäther (éther acétique - acetic ether). Die Essigsäure bildet, analog anderen Säuren mit Alkoholen eine Reihe von Verbindungen, sog. zusammengesetzte Aether oder Ester, welche angesehen werden können als Alkohole, in welchen der Wasserstoff der Hydroxylgruppe durch Acetyl, oder als Essigsäurehydrat, in welchem der Wasserstoff der Hydroxylgruppe durch ein Alkoholradical vertreten erscheint.

Die wichtigsten zusammengesetzten Aether der Essigsäure sind:

Essigsäureäthyläther, Essigäther, essigsaures Aethyl oder Essignaphta

$$
\mathrm{C}_{2} \mathrm{H}_{3} \text { O.O. } \mathrm{C}_{2} \mathrm{H}_{5}=\mathrm{C}_{4} \mathrm{H}_{8} \mathrm{O}_{2} \text { oder } \mathrm{C}_{2}^{\mathrm{C}_{2} \mathrm{H}_{3}} \mathrm{O}_{5} \mathrm{O} \text { oder } \mathrm{CH}_{3} \cdot \mathrm{CH}_{2} \cdot \mathrm{O} \cdot \mathrm{CO} \cdot \mathrm{CH}_{3}
$$

findet sich in geringen Mengen in manchen Weinen, im Weinessig und Franzbranntwein, deren Aroma bedingend.

Er entsteht durch Einwirkung von Aetherschwefelsäure auf essigsaure Salze:

$$
\underset{\text { Aetherschwefelsäure }}{\mathrm{C}_{2} \mathrm{H}_{5} \mathrm{SO}_{4} \mathrm{H}}+\underset{\text { essigs. Natron }}{\mathrm{C}_{2} \mathrm{H}_{3} \mathrm{O} . \mathrm{O} \cdot \mathrm{Na}}=\underset{\text { Essigäther }}{\mathrm{C}_{2} \mathrm{H}_{3} \mathrm{O} \mathrm{C}_{2} \mathrm{H}_{5} \mathrm{O}}+\underset{\text { saures sehwefels. Natron }}{\mathrm{SO}_{4} \mathrm{NaH}}
$$

Am leichtesten und in grösster Menge wird derselbe erhalten durch Destillation von 10 Theilen entwässertem, essigsaurem Natron mit einem Gemisch ron 15 Theilen englischer Schwefelsäure und 6 Theilen Alkohol von 80 bis $90 \%$; in das erkaltete Gemisch von Schwefelsäure und Alkohol wird das vorher fein gepulverte und vollkommen getrocknete Natriumacetat eingetragen, durch Umriihren gut gemischt und nun bei langsam steigender Temperatur die Destillation so lange fortgesetzt, bis das zuletzt übergehende Destillat nicht mehr brembar ist. 
Im Grossen wird die Destillation mit Dampf in eisernen Kesseln vorgenommen, die mit einem Helm aus Kupfer und einer im Wasser liegenden Kühlschlange verbunden sind.

Das Destillat enthält neben Essigsäureäther noch Alkohol, freie Essigsäure, Wasser und Spuren von schwefliger Säure; zur Entfernung dieser Verunreinigungen wird dasselbe mit Wasser versetzt, die sich abscheidende Aetherschichte zur Neutralisation der freien Säure mit Sodalösung geschüttelt, abermals mit Wasser gemischt und nun mit geschmolzenem Chlorcalcium so lange versetzt, als dieses noch gelöst wird, längere Zeit stehen gelassen und die sich oben abscheidende, entwässerte Aetherschichte fractionirt destillirt; der bei $74^{\circ} \mathrm{C}$. übergehende Antheil stellt dann reinen Essigäther dar.

Handelt es sich nicht um absolute Reinheit des Destillates, so genügt es das Rohdestillat mit Sodalösung zu neutralisiren und iiber Chlorcalcium zu rectificiren.

Nach Gros s ch opff*) eignet sich zur Darstellung des Essigäthers im grossen Massstabe folgendes Verfahren: Essigsaures Natron wird in gusseisernen Kesseln über freiem Feuer zur Trockeue verdampft, geschmolzen, hierauf gepulvert und noch warm gesiebt. Das Salzpulver bringt man in eine Kupferblase, die mit einer Rührvorrichtung und einer Oeffnung zum Nachfüllen versehen ist und gibt auf je 40 Kilo Salz ein erkaltetes Gemisch ron 46 Kilo englischer Schwefelsäure von 1.84 spec. Gew. und 37 Kilo fuselfreien Alkohol von $55^{0} \mathrm{~T}$. Nachdem alles gut gemischt ist, destillirt man unter fortgesetztem Umrühren so lange, als das Destillat nach Essigsäure riecht. Das Rohdestillat, von dem ca. 55 Kilo erhalten werden, vertheilt man in kleine Flaschen, die zu ca. $2 / 3$ hiemit gefüllt werden, gibt 1/4 Volum Wasser und etwas kohlensaures Kali zu, schüttelt einigemale kräftig durch, lässt sich scheiden, hebt die wässerige Flüssigkeit unter dem Aether heraus, und wiederholt diese Operation, indem man statt kohlensaurem Kali Chlornatrium nimmt. Den so entsäuerten und vom Weingeist befreiten Aether entwässert man mit zerstossenem Chlorcalcium, lässt einige Zeit stehen und rectificirt iiber gebrannte Magnesia. Man erhält ea. 36 bis 37 Kilo reinen Aether, der frei von jedem Nebengeruch ist. Die ganze Destillation dauert ca. 2 Stunden.

Die Waschwässer nehmen hiebei nicht unbeträchtliche Mengen von Essigsäure auf; sie werden gesammelt, rectificirt und geben ein alkoholhältiges Product.

Nach $\mathrm{Eghis}$ wird Schwefelsäure in einer tubulirten Retorte auf ca. $130^{\circ} \mathrm{C}$. erwärmt und nun tropfenweise ein Gemisch von Essigsäure und Alkohol zutreten gelassen; man erhält aus 1 Kilo Essigsäure fast 21\% Kilo rohen Essigäther, der, wie oben angegeben, weiter gereinigt wird.

Auch kann Essigäther erhalten werden durch Erhitzen eines essigsauren Salzes mit Jodäthyl in geschlossenen Gefässen auf ca. $200^{\circ}$ C. und Trennung des Aethers vom entstandenen Jodmetall durch Destillation.

Der Essigsäureäther stellt eine wasserbelle, dünne Fliissigkeit von angenehmem erfrischendem Geruche und brennendem Geschmacke dar, die angezündet mit gelblich weisser Flamme brennt, sich im trockenen Zustande nicht, im feuchten jedoch nach einiger Zeit in Essigsäure und Aikohol zersetzt; er ist leichter als Wasser, spec. Gew. $=0.917$, Siedepunkt $74^{0} \mathrm{C}$., Dampfdichte $=3.06$; er löst sich im 7 - bis 11 fachen Gewichte Wasser, ist mit Alkohol und Aether in jedem Verhältnisse mischbar. Durch Kochen mit ätzenden Alkalien wird er in Acetat und Alkohol, durch concentrirte Schwefelsäure beim Erwärmen in Essigsäure und gewöhnlichen Aether zersetzt.

Der Essigsäureäther findet in der Parfïmerie, zum Aromatisiren der Essige, als Lösungsmittel für Harze, Oele, Schwefel, Phosphor, manche Salze und mit dem zwei- bis dreifachen Gewichte Alkohol gemischt in der Medizin unter dem Namen spiritus a cetico a ethereus Anwendung. Im Verein mit Benzoesäure. äthyläther bildet er den sog. Kirschenäther.

*) Aun. der Chemie und Pharm. 63, pag. 258. Deutsche Industrie-Zeitung 1867, pag. 118. 
Essigs äureamyläther, essigsaures Amyl, Amylessigäther.

$$
\mathrm{C}_{2} H_{3} \text { O.O. } \mathrm{C}_{5} \mathrm{H}_{11}=\mathrm{C}_{7} \mathrm{H}_{14} \mathrm{O}_{2} \text { oder } \mathrm{C}_{5}^{\mathrm{C}} \mathrm{H}_{3} \mathrm{O}_{11} \mathrm{O}
$$

Er wird erhalten durch Destillation eines Gemenges von 2 Theilen essigsaurem Kali, 1 Theil Amylalkohol (Fuselöl) und 1 Theil concentrirter Schwefelsäure, Waschen des Destillates mit Wasser, dem etwas kohlensaures Natron zugesetzt ist, Trocknen über Chlorcalcium und Rectification über Magnesia oder Bleiglätte.

Nach Fehling kann derselbe ohne Destillation erhalten werden, wenn man 1 Theil Eisessig mit $1 / 2$ Theil Schwefelsäure und 1 Theil Amylalkohol mehrere Stunden auf $100^{\circ}$ C. erwärmt, den gebildeten Aether durch Wasserzusatz ausscheidet und wiederholt mit Wasser zur Entfernung der anhängenden Säure wäscht. Sehr rein erhält man den Amylessigäther nach Wurtz durch Erhitzen von Jodamyl mit Silberacetat.

Der Essigsäureamyläther stellt eine farblose, leicht bewegliche Flüssigkeit von angenehmem gewürzhaftem Geruche dar, in Wasser unlöslich, mit Alkohol und Aether in jedem Verhältnisse mischbar. Spec. Gew. $=0.857$ bei $21^{\prime \prime}$ C., Siedepunkt $133^{\circ}$ C. (Kopp), Dampfdichte $=4 \cdot 458$; wird durch . alkoholische Kalilösung in essigsaures Kali und Amylalkohol zersetzt.

Mit dem sechs- bis achtfachen Volumen reinen starken Alkohols gemischt, bildet er die in der Parfümerie und Liqueurfabrikation verwendete Birnen ess enz (Biruöl, Pear-Oil); gemeinschaftlich mit Essigsäure- und Buttersäureäthyläther den sogenannten Erdbeeräther.

Die nachfolgend angefiihrten Aether haben eine nur geringere Bedeutung, besitzen aber einen meist sehr angenehmen Geruch und finden deshalb auch Anwendung zur Darstellung der sogenannten Fruchtessenzen.

Essigsäuremethyläther, essigsaures Methyl, Methylessigäther oder essigsaurer Holzäther

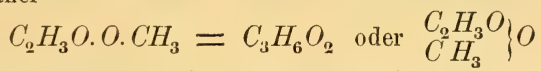

findet sich fertig gebildet im rohen Holzgeist und wird erhalten, wenn man ein essigsaures Salz mit einem Gemenge von Schwefelsäure und Holzgeist, oder 1 Th. Essigsäurehydrat, 2 Th. Holzgeist und $1 \mathrm{Th}$. Schwefelsäurehydrat, oder $3 \mathrm{Th}$. Methylalkohol, 5 Th. Schwefelsäurehydrat und 141/2 Th. Bleizucker der Destillation unter'wirft.

Farblose, angenehm ätherartig riechende Fluissigkeit von 0.956 spec. Gew. und $56^{\circ}$ C. Siedepunkt; in Wasser ziemlich leicht löslich, mit Alkohol und Aether in jedem Verhältnisse mischbar.

Essigsäurebutyläth er, essigsaures Butyl, Butylessigäther

$$
\mathrm{C}_{2} \mathrm{H}_{3} \text { O.O. } \mathrm{C}_{4} \mathrm{H}_{9}=\mathrm{C}_{6} \mathrm{H}_{12} \mathrm{O}_{2} \text { oder }{ }_{\mathrm{C}_{2} \mathrm{H}_{9}}^{\mathrm{C}_{3} \mathrm{H}_{1}} \mathrm{O}
$$

eine farblose, angenehm ätherartig riechende Flïssigkeit von 0.8845 spec. Gew. und $114^{\circ} \mathrm{C}$. Siedepunkt.

Essigsäureoctyläther, essigsaures Octyl, Octylessigäther

$$
\left.C_{2} H_{33} O . O . C_{8} H_{17}=C_{10} H_{20} O_{2} \text { oder } \begin{array}{l}
C_{2} H_{3} O_{i} \\
C_{8}^{1} H_{17}
\end{array}\right\} O
$$

farblose, angenehm ätherartig riechende, im Wasser unlösliche Fliissigkeit von 190-1930 C. Siedepunkt; bildet den Hauptbestandtheil des Oeles von Heracleum S'pondylium, im Verein mit dem Buttersäurehexyläther den, bei ca. $205^{\circ}$ siedenden Theil des ätherischen Oeles von Heracleum giganteum.

Essigsäurecetyläther, essigsaures Cetyl, Cetylessigäther

$$
\mathrm{C}_{2} H_{3} O . O . C_{16} H_{33}=C_{18} H_{36} O_{2} \text { oder } \begin{gathered}
C_{2} H_{3} O \\
C_{16}^{2} H_{33}
\end{gathered} \text { O }
$$

wird erhalten durch Sättigung einer Lösung von Cetylalkohol in Eisessig mit Chlorwasserstoff als weisse Krystallnadeln, welche bei $18 \cdot 5^{\circ}$ C. schmelzen.

K. Weis. 
Essigsäuresalze, A cetate, s. Essigsäure III pag. 311, s. die einzelnen Metalle.

Essigspinell (spinelle vinaigre — vinegar spinel), eine Varietät der brasilschen Spinell von blassbräunlicher Farbe, s. Spinell. Gtl.

Essigsprit, s. Essig III pag. 299.

Essigständer, Essigbilder, s. Essig III pag. 298.

Ester, syn. m. zusammengesetzter Aether, s. A ether I pag. 53.

Estrich wird jeder mit einer zusammenhängenden, künstlichen Steinmasse bekleidete Fussboden genannt. Speciell über den venezianischen Estrich erschien eine Schrift von Rödlich, Berlin, Trantwein, 1821. S. Decke II pag. 593, s. Cement II 273.

Etage (étage - stage), auch Stockwerk, Geschoss genannt, ist die horizontale Abtheilung eines Gebäudes. Mit bel-étage bezeichnet man das Hauptgeschoss, gewöhnlich den ersten Stock.

Grohm:

Etagenbruchbau, s. Bergbau I pag. 394.

Etagenrost, s. bei Treppenrost II pag. 534 .

Etalon (Normalmassstab). É. à bout, Endmassstab, welcher die zu definirende Länge durch die Entfernung seiner Endflächen angibt; é. à trait, Strichmassstab, bei welchem die Länge durch die Entfernung zweier parallelen Striche auf einer Seitenfläche definirt erscheint. Erstere sind letzteren im Allgemeinen vorzuziehen.

Czuber.

Etherzilin, syn. mit Schiessbaumwolle, s. Explosirstoffe.

Eucalin, Zuckerart, Zersetzungsprodukt der Melitose s. d.

Eucalyptol $\left(\mathrm{C}_{12} \mathrm{H}_{20} \mathrm{O}\right)$, Bestandtheil des äther. Oeles der als Fiebermittel verwendeten Bliithen von Eucalyptus globulus Lab. Farblose Fluissigkeit von angenehmem entfernt rosenähnlichem Geruche, siedet bei $175^{\circ} \mathrm{C}$., spec. Gew. 0.905 . Wirkt rechtspolarisirend. Kann aus dem äther. Eucalyptusöle durch Destillation iiber Kalihydrat erhalten werden. Das Encalyptusöl ist farblos, dünnflissig und von aromątischem, campherartigem Geruche, es siedet bei $170^{\circ} \mathrm{C}$. Durch Destillation iiber wasserfreie Phosphorsäure erhält man Eucalypten $\left(C_{12} H_{18}\right)$, bei $165^{\circ} \mathrm{C}$. siedend, und Eucalyptolen $\left(C_{10} H_{18}\right)$, bei $300^{\circ}$ C. siedend. Das Eucalyptusöl findet in grosser Menge Verwendung in der Parfumerie. Vgl. Clö̈z, compt. rend. 70 pag. 687. Vgl. a. A. Faust u. J. Homeyer Ber. d. d. chem. Ges. 1874 pag. 63 um 1429. Gtl.

\section{Eucalyptuszucker, s. Melitos e.}

Euchlorglimmer, syn. mit Kupferglimmer, Kupferschaum und Uranglimmer s. d.

Euchlorine, Euchloringas, s. Chlor II pag. 325.

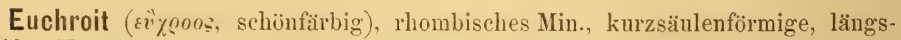
gestreifte Krystalle. Unrollkommen spaltbar. spröde. $\mathrm{H} .=3 \cdot 5-4$, spec. Gewicht $=3.3-3 \cdot 4$, smaragd- und lauchgrïn; Strich spangrïn, glasglänzend, durchscheinend. Chem. Zus. : $4 \mathrm{CuOAs}^{2} \mathrm{O}^{5}+7 \mathrm{H}^{2} \mathrm{O}$. 47 Kupferoxyd, 34 Arsensäure, 19 Wasser. Gibt im Kolben Wasser und wird lichter und locker. Schmilzt vor dem Löthrohr zu einer crkaltet krystallinischen Masse.. Schmilzt auf 
Kohle unter Arsengeruch, löst sich leicht in Salzsäure. Von Libethen in Ungarn.

Euchron, s. Euchronsäure.

Euchronsäure, Abkömmling der Mellithsäure (Honigsteinsäure). Bildet farblose, prismatische Krystalle, die in Wasser löslich sind. Entspricht der Formel $\mathrm{C}_{12} \mathrm{H}_{4} \mathrm{~N}_{2} \mathrm{O}_{\mathrm{s}}$. Durch Wasserstoff in Entstehungszustande wird sie in Euchron, einen tiefblauen, in Wasser unlöslichen, in Alkalien mit tief purpurrother Farbe löslichen Körper ïbergefiihrt. Gtl.

Eudiometer (eudiomètre - eudiometer), in seiner ursprünglichen Bedeutung so viel wie "Luftgütemesser", d. i. ein Instrument, bestehend aus einer einseitig geschlossenen, mit einer Raumtheilung versehenen Glasröhre, mit Hilfe deren man den Sauerstoffgehalt der Luft entweder durch Anwendung eines Absorptionsmittels oder durch Verpuffen mit Wasserstoffgas bestimmen kann (Endiometrie), zu welch letzterem Ende das Eudiometer nahe an seinem geschlossenen Ende zwei gegenüberstehende, in die Glaswand eingeschmolzene Platindrähte trägt, welche bestimmt sind den Entladungsfunken einer Leydenerflasche oder eines Funkeninductors im Innern der Glasröhre überspringen zu lassen und so das explosive Gemenge von Luft und Wasserstoff zur Verpuffung zu bringen, s. Luft. Gegenwärtig bezeichnet man mit diesem Namen allgemein Messröhren mit oder ohne eingeschmolzenen Platindrähten, deren man sich für die Zwecke der volumetrischen Gasanalyse bediente. S. Mess ge fässe. Gtl.

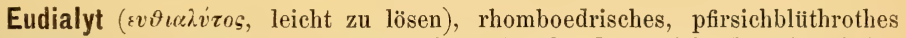
oder bräunliches Zirconsilicat, welches sieh im Kaukendluarsukfjörd und auf den Kittisutinseln in Grönland und der Arkansas in der Magnetlove findet. H. $=5-5 \cdot 5$, spec. Gew. $=2 \cdot 9-3 \cdot 01$. Eine cer- und lanthanhaltige Varietät des Eudialyts ist der Eukolit von Brewig in Norwegen. $L b$.

Eugenglanz, s. Polybasit.

Eugenin (eugénine - eugenin), weisse perlmutterglänzende Krystallblättchen bildende Substanz, welche sich aus dem iiber Gewiirznelken destillirten, mit Nelkenöl beladenen Wasser allmälig abscheidet. Ist geschmacklos, von schwachem Nelkengeruch, löst sich schwer in Wasser, leicht in Alkohol und Aether, wird an der Luft gelb, mit Salpetersänre bluthroth. Entspricht der Formel $C_{10} H_{12} O_{a}$. Vgl. Dumas Annal. d. Chem. et Phys. (2) 53 pag. 168; Liebig Annal. der Chem. u. Pharm. 9, pag. 72; B on as tre Journ. Pharm. (2) 20, pag. 565. Gtl.

Eugenol, syn. m. Nelkensäure, vgl. Gewïrznelken, vgl. Nelken.

Eugensäure, syn. mit Nelkensäure, vgl. Gewürznelken, vgl. Nelken.

Eukairit (Selen-Silber-Kupfer). Ein nur derb mit feinkörnigem krystallinisclen Gefüge vorkommendes Mineral von geringer Härte und blaugrauer Farbe mit glänzendem Strich. Chem. Zus.. $C u^{2} S e+A g^{2} S e$, 25.32 Kupfer, 43.13 Silber, 31.55 Selen. Sublimirt im Glasrohre Selen und selen. Säure, entwickelt auf Kohle Selendämpfe und schmilzt zu einer grauen, spröden Metallkugel, gibt mit Borax Kupferreaction, mit Blei abgetrieben ein Silberkorn; ist löslich in Salpetersäure. Findet sich zu Skrikerum in Smaland, in Chile und in der Wiiste Atakauen. Den Namen von ev"roupos, zur rechten Zeit, erhielt das Mineral von Berzelius, weil er es zur Zeit entdeckte, als er das Selen untersuchte. $L b$.

Euklas ( $\varepsilon \ddot{v}$ gut, $\varkappa \lambda \dot{c} \omega$ spalte). Monoklines Mineral, nach der Klinodiagonale und dem Hemidoma ausgezeichnet spaltbar, auch leicht zersprengbar, hat eine Härte von $7 \cdot 5$, spec. Gew. $=3 \cdot 0-3 \cdot 1$, blassgruin in blau und gelb verlanfend, Glasglanz, durchsichtig bis halbdurchsichtig. Chem. Zus.: $2\left(\mathrm{C}_{\mathrm{ClO}} \mathrm{O} \cdot \mathrm{SiO}^{\mathrm{2}}\right)+A l^{2} \mathrm{O}^{3} \mathrm{H}^{2} \mathrm{O}$, 
17.4 Glycinerde, 35.2 Thonerde, 40.3 Kieselsäure, 6.1 Wasser. Schmilzt vor dem Löthrohr in dünnen Splittern schwer und schwillt an. Wird mit Kobaltsolution geglüht blau, von Säuren nicht auflösbar. Findet sich sehr selten am Baikalsee in Sibirien, in den Goldseifen am südlichen Ural und in den Edelsteinseifen in Brasilien in losen Fragmenten und Krystallen. Schöngefärbte, durchsichtige Exemplare werden als Schmucksteine verwendet, und der Seltenheit wegen theuer bezahlt. $L b$.

\section{Eukolit, s. Eudialyt.}

Eulysit, ein in Schweden bei Tunaberg vorkommendes Gestein, bestehend aus einem Gemenge von einem olivinähnlichen Mineral, grünem Augit und braunem Granat. $L b$.

Eulytin ( $\varepsilon v^{\star} \triangleleft v \tau o s$, leicht schmelzbar), Kieselwismut, Wismutblende; ein Mineral, welches in sehr kleinen tesseralen, u. z. tetraedrischen Krystallen, welche einzeln aufgewachsen oder in kleine Drusen vereinigt, auch in Zwillingen vorkommen. Spaltbarkeit unbekannt, Bruch muschlig, H. $=4 \cdot 5-5$, spec. Gew. $6 \cdot 1$, nelkenbraun bis weingelb, Diamantglanz, durchsichtig bis durchscheinend. Chem. Zus.: $2 \mathrm{Bi}^{2} \mathrm{O}^{3} \mathrm{SiO}^{2}$, u. z.: $80 \cdot 6-82 \cdot 2$ Wismutoxyd und $15 \cdot 9-16 \cdot 2$ Kieselsäure nebst etwas phosphorsaurem Eisen. Schmilzt vor dem Löthrohr leicht unter Aufwallen zu einer braunen Perle, gibt mit Soda metallisches Wismut, mit Phosphorsalz ein Kieselskelett, Salzsäure zersetzt ihn unter Abscheidung von Kieselgallerte. Fundorte: Schneeberg und Freiberg in Sachsen. $L b$.

Euosmit, fossiles Harz aus dem Lignit von Bayershof im Fichtelgebirge, bildet gelbbraune pulverige oder erdige Massen, löslich in Alkohol und in Aether, bei $77^{\circ} \mathrm{C}$. schmelzbar, von angenehm aromatischem Geruch. Verbrennt angezündet mit Flamme und enthält 34 C., $29 \mathrm{H}$. und 20. Gtl.

Euphorbium (résine d'euphorbe - euphorbium), Euphorbiumharz, ist der eingetrocknete Milchsaft von Euphorbia resinifera Berg., einer cactusartigen Wolfsmilchart, welche im nördlichen Theile des tropischen Afrika einheimisch ist. Das Enphorbium wird namentlich im marokkanischen Atlas durch Anschneiden der Aeste der Pflanze vor dem Eintritt der Fruchtreife gewonnen, indem der den Schnitten entquellende Milchsaft an den Stengeln eintrocknet und nach dem Erhärten eingesammelt wird. Die Hauptausfuhrplätze für Euphorbium sind Sale und Mogadore. Das Euphorbium, welches gewöhnlich in mit Bastmatten eingehüllten Ballen zu Markte kommt, bildet undurchsichtige Stiicke von hell-graubrauner Farbe mit unebenem, rauhem Bruche, welche sich entweder aus zusammengeflossenen flachen Krusten oder keulenförmigen Stiicken gebildet erweisen und oft auch kurz dreiästige, innen hohle Formen eingeschlossen enthalten. Neben dieser eigentlichen Gummiharzsubstanz finden sich in der Handelswaare stets noch Bruchtheile der Aeste, Bliithen und Frïchte, so wie Stacheln der Stammpflanze. Das Euphorbium ist in Wasser kaum löslich und liefert damit auch keine Emulsion. In Alkohol ist es zum grossen Theile $(50-60 \%)$ löslich. Es ist fast geruchlos, doch wirkt der Staub heftig zum Niesen reizend. Der Geschmack ist anhaltend scharfbrennend. Beim Erwärmen zeigt es cinen schwach an Weihrauch erinnernden Geruch. Das Euphorbium hat schon in geringen Gaben eine heftig purgirende, zum Theile brechenerregende Wirkung, und wird dieser, so wie seiner reizenden Wirkung auf zartere Hautpartien wegen, als Arzneimittel verwendet. Es enthält nach Johnston (Journ. f. pract. Chem. 26, pag. 145) ein in kaltem Alkohol lösliches Harz $(38 \%)$ von der Zusammensetzung $C_{13} H_{22} O_{0}$, und eine krystallisirbare, in Alkohol, Aether, Chloroform und Benzin leicht, in Wasser unlösliche Substanz, das Euphorbon $\left(C_{13} H_{22} O\right)$, die geruchlos, aber ron scharfem Geschmacke und heftig purgirender Wirkung ist, wogegen das Harz den eigentlich reizenden (blasenziehenden) Bestandtheil bildet; überdies enthält es Gummi und Aepfelsäure, so wie morganische Salze. Nach Flü ekiger (Vierteljahrschrift f. pract. Pharm. 
17, pag. 82) beträgt der Euphorbongehalt $22 \%$, jener an Gummi $18 \%$, an äpfelsauren Salzen $12 \%$ und an Mineralsalzen $10 \%$. Vgl. a. Buchner's Repertorium 11, pag. 145 und Rose Pogg. Annal. 33, pag. 33, und 53 pag. 365 . Gtl.

Euphotide, syn. m. Gabbro s. d.

Euphyllit, s. Margarit.

Eupion (eupione - eupion). Ursprünglich wurde von Reichenbach mit diesem Namen ein bei der trockenen Destillation von Holz, fetten Oelen, Harzen, Kautschuk u. s. w. resultirender Kohlenwasserstoft bezeichnet, während nach Hesse das Product der Einwirkung von Schwefelsäure anf diese Producte der trockenen Destillation Eupion genannt wurde. Nach Frankland ist Eupion ein Gemenge mehrer Kohlenwasserstoffe, in welchem sich als wesentlicher Bestandtheil Amylwasserstoff $\left(C_{5} H_{12}\right)$ findet. Man kann es durch trockene Destillation des Rüböls, Behandlung des leichter flüchtigen Antheils des Destillates mit conc. Schwefelsäure, Destillation des von der Schwefelsäure und dem ausgeschiedenen Paraffin getrennten und durch nochmalige Destillation abgeschiedenen Oeles mit Schwefelsäure, Schitteln des Destillationsproductes mit Kalilauge und Rectification als eine farblose Flüssigkeit von angenehmem Blüthengeruche erhalten, die geschmacklos und in Wasser unlöslich ist. Das spec. Gew. $=0.655$ bei $20^{\circ} \mathrm{C}$., der Siedepunkt liegt bei $47^{\circ} \mathrm{C}$. Es ist mischbar mit Alkohol, Aether, Benzin, fetten Oelen und Schwefelkohlenstoff, löst Phosphor, Schwefel und verschiedene Harze auf und wird weder durch conc. Säuren, noch durch Alkalien und Chlor angegriffen. Auch aus den leicht fliichtigen Antheilen des durch trockene Destillation der Knochen (Thieröl), so wie des Kautschuks erhaltenen Destillates kann man Eupion darstellen. Es ist ein fast nie fehlender Bestandtheil der verschiedenen Theeröle. Gtl.

Eupyrchroit, ein zersetzter Phosphorit mit 46 Phosphorsäure, 50 Kalkerde und 2 Eisenoxydul, welche nierenförmiger faserige Massen von grauer Farbe bildet, und zu Hammoundsville in Essex, u. a. O. zur Erzeugung von Düngerphosphat gewounen wird. $L b$.

Eurit, s. Felsit u. Porphyr, vgl. a. Granulit.

Euritporphyr, syn. m. Felsitporphyr, s. Porphyr.

Eustilbit, Heulandit, s. Stilbit.

Eusynchit, ein dem Dechenit nahe verwandtes vanadinsäurehaltiges Mineral von Hofgrund bei Freiburg im Breisgau. $L b$.

Euxanthin, Bestandtheil des Pu r é e genannten gelben Farbstoffes, s. Purrée.

Euxanthonsäure, Zersetzungsproduct des Euxanthins, s. Purrèe.

Euxenit ( $\varepsilon v^{\prime} \zeta v^{\prime}{ }_{s}$, gastfreundlich, Anspielung auf die vielen Bestandtheile), ein gewöhnlich derb vorkommendes Mineral mit unvollkommen muschligem Bruch, unvollkommener Spaltbarkeit. Härte $=6 \cdot 5$, spec. Gew. $=4 \cdot 6-4 \cdot 9$, braunschwarzer Farbe, röthlichbraunem Strich, in Metallglanz geneigten Fettglanz, undurchsichtig. Chemische Zusammensetzung schwankend, im wesentlichen vorherrschend Niobsäure, dann Titansäure, Uranoxydul und Ittererde, im Verhältniss zur Niobsäure wie 15-20:39-32, ausserdem etwas Ceroxydul, Eisenoxydul, Kalkerde und Wasser. Im Kolben gibt er Wasser und wird lichter, vor dem Löthrohr ist er schmelzbar, wird auch von Säuren nicht angegriffen. Fundorte Jölster und Arendal in Norwegen. $L b$.

\section{Euzeolyth, s. Stilbit.}

Evacuiren, d. h. Ausleeren, pflegt man gewöhnlich das Auspumpen der Luft aus einem Recipienten oder einem Gefässe überhaupt zu nennen, s. Luftpumpe. 
Evaporiren, syn. m. Abdampfen s. I pag. 3.

Everninsäure, Evernsäure, s. Flechtenfarbstoffe.

Evolvente, s. Curven II pag. 447.

Evonymit, s. Duleit, II pag. 703.

Excavator, s. Erdarbeiten III pag. 282.

Excentrik, s. Kinematik, s. bei Dampfmaschine II pag. 560 etc.

Excess, sphärischer, heisst der Ueberschuss der Winkelsumme eines sphärischen Dreiecks über $18^{\circ}$. Wird derselbe, im Bogenmass, in Graden, Minuten, Secunden ausgedrückt, bezielungsweise mit $\varepsilon, \varepsilon^{0}, \varepsilon^{\prime}, \varepsilon^{\prime \prime}$, die Fläche des Dreiecks mit $F$, der Radius der Kugel mit $r$ bezeichnet, so hat man:

$\varepsilon=\frac{F}{r^{2}} ; \varepsilon^{0}=57.29578 \frac{F}{r^{2}} ; \delta^{\prime}=3437 \cdot 74677 \frac{F}{r^{2}} ; \varepsilon^{\prime \prime}=206264.806 \frac{F}{r^{2}}$.

Bei Dreiecken, wie sie bei Triangulirungen vorkommen, ist der sphär. $E$. immer nur gering; für ein Dreieck von 1 geogr. $\square$ M. beträgt derselbe in mittleren Breiten ca. $0 " .28$.

Czuber.

Exhaustor, Saugventilator (s. Ventilator), o. Blasrohr (s. Eisenbahnfahrbetriebsmittel III pag. 109); s. ferner Luftpumpe, s. Injector.

Exorateur, Name eines ron Kessler angegebenen Apparates zur Alkoholbestimmung im Weine auf dem Wege der Destillation. S. W ein, vgl. a. Alkohol I pag. 109. Grtl.

Exosmose, s. Diffusion II pag. 626.

Expansion, s. Dampf II pag. 504 etc., s. Damp $\mathrm{mmaschinen} \mathrm{II} \mathrm{pag.}$ 567,583 ete.

Explosionen bei Dampfkesseln, s. II pag. 551 .

Explosionsmaschine ist die Benennung der Drake'schen Gasmaschine s. daselbst.

Explosivstoffe (explosifs - explosives). I. Schiesspulver (poudre de guerre, de mine, de chasse -- gun pouder).

a) Zusammensetzung, physikalische und chemische Eigenschaften. Imniges mechanisches, gekörntes Gemenge ron Kalisalpeter, Schwefel und Kohle. - Mittleres Verhältniss der drei Bestandtheile: $7 \pm$ Salpeter, 16 Kohle, 10 Schwefel. - Bei feinem Jagdpulver nimmt der Salpetergehalt zu (französisches Jagdpulver: 78 Salpeter, 12 Kohle, 10 Schwefel), bei Sprengpulver ab (französisches Minenpulver: 62 Salpeter, 18 Kohle, 20 Schwefel). Das Mischungsverhältniss eines Pulvers heisst dessen Dosirung. - Das specifische Gewicht der einzelnen Körner (Massendichte) schwankt zwischen 1.4 (leichtes Minenpulver) und 1.82 (Geschiitzpulver), das specifische Gewicht des in einem Gefässe wohl eingeschiitteten Pulvers, also Körnerzwischenraum berücksichtigt (gravimetrische Dichte) zwischen 0.77 (französisches Yinenpulver) und 0.94 (sehr feines, dichtes Jagdpulver). Die Kömergrösse wechselt ron $0 \cdot 3-0 \cdot 5^{\mathrm{mm}}$ (feinstes Jagdpulver) bis zu $18-30^{\mathrm{mm}}$ (englisches Crlinderpulver): die sechsseitigen Körner des sogenannten prismatischen Pulvers haben sogar $40 \mathrm{~mm}$ Durchmesser.

Gutes Sehiesspulver muss folgende Eigenschaften haben: Schieferfarbe mit mattem Glanz (blaugrauschwarz); zu dunkle Farbe weist auf zu viel Feuchtigkeit, weisse Flecke auf Salpeterausscheidung. - Jagdpulver, welches absichtlich mit Rothkohle erzengt wurle, hat bräunlich schwarze Farbe. Beim Reiben der Körner auf der flachen Hand mit dem Finger müssen die Körner ganz bleiben, beim Zer- 
driicken zwischen den Fingern knirschen, nach dem Zerdriicken muss der Staub vollkommen gleiche Farbe haben und dürfen in ihm keine scharfen Theile fühlbar sein. Giesst man Pulver in hellem Licht von $1^{\mathrm{m}}$ Höhe aus, so darf kein Staub sichtbar werden, beim Rollen uiber reines Papier darf es nicht abfärben. Der Feuchtigkeitsgehalt darf $2 \%$ nicht uibersteigen. Auf weissem Papier entzündet muss es rasch, ohne Hinterlassung von Flecken und Rïckstand verbrennen. Pulver entziindet sich durch Temperaturerhöhung auf $250-300^{\circ}$, sehr leicht durch Beriihrung mit glïhenden Körpern, schwieriger durch Flamme, ausserdem aber auch durch Stoss, Reibung und Schlag zwischen gewissen Körpern, leicht durch Schlag von Eisen gegen Eisen, Eisen gegen Messing, Messing auf Messing, weniger leicht durch Kupfer gegen Eisen oder Kupfer, Eisen gegen Marmor etc. Der Entladungsschlag der Leidnerflasche entzïndet Schiesspulver nicht unmittelbar. - Um Pulverladungen durch den elektrischen Funken zu entzïnden, müssen daher eigene Zünder eingeschaltet werden. - Der durch galvanischen Strom gliihend gemachte feine Schliessungsdraht bewirkt aber directe Entziundung. Die Entzündung des Pulvers pflanzt sich rasch von einem Punkte durch die zusammenhängende Masse desselben fort. Die Geschwindigkeit dieser Fortpflanzung wechselt mit der Gattung des Pulvers, Grösse, Form und Einschluss der Ladung und der Entzündungsweise. In offenem Lauffeuer beträgt die Geschwindigkeit der Fortpflanzung $2-3^{\mathrm{m}}$, im Geschützrohre ïber $20^{\mathrm{m}}$, wenn die Entzïndung durch starke Knallsätze erfolgt (siehe später Detonationszündung) noch mit weit erhöhter Schnelligkeit. Die Verbrennungsgeschwindigkeit eines Kornes (Fortschritt der Verbrennung ron aussen nach innen) beträgt in freier Luft bei gutem Pulver etwa $12^{\mathrm{mm}}$ in der Secunde, nimmt ab mit der Dichte des Korns, aber rasch zu mit der Dichte und Temperatur der umgebenden Gase.

Die Verbrennungsproducte des Pulvers, die Menge, Temperatur und Spannung der gebildeten Gase wechseln mit der Gattung des Pulvers, der Grösse, und Form, dem Einschlusse der Ladung und der Entzïndungsweise. Die verlässlichsten der vorgenommenen. Versuche (von A. Noble \& F. A. Abel Compt. rend. 78 und 79) ergaben für den Fall, dass Pulver in fest verschlossenem Gefässe (Bombe) rerbrennt, folgende Resultate, berechnet fuir 1 Gramm Pulver: 1. Die Verbrenuungsproducte nach der Explosion sind ungefähr $43 \%$ permanente Gase, $57 \%$ fest werdende Producte. 2. Die permanenten Gase wiirden bei $0^{0}$ und $760^{\mathrm{mm}}$ Druck etwa 280 ${ }^{\mathrm{ec}}$, d. h. das 280fache Volumen des Pulvers betragen. 3. Die Spannkraft des Pulvers beträgt, wenn selbes den Verbrennungsraum ausfiillt und dieser fest umschlossen ist, circa 6400 Atmosphäreu, mit dem Wachsen des Verbrennungsraumes gegeniber dem des Pulvers nimmt die Spannung ab, so dass sie beispielsweise nur mehr circa 25 Atmosphären beträgt, wenn der Verbrennungsraum zehnmal so gross als das Pulvervolumen ist. 4. Die Temperatur der Gase beträgt circa $2200^{\circ}$ C. 5. Die Zersetzung von $1 \mathrm{Gr}$. Pulver entwickelt etwa 0.7 Calorien, d. h. 1 Gr. Pulver hat eine innere Arbeitskraft von circa $300^{\mathrm{km} u}$.

Als Zersetzungsproducte von $1 \mathrm{Gr}$. Pulver wurden bei den letztgenannten Versuchen gewonnen:

Kohlensaures Kali . . . . 0.3115

Unterschwefligsaures Kali . . 0.1163

Schwefelsaures Kali . ... 0.0843

Schwefelkalium . . . . . 0.0416

Sulfocyankalium . . . . . . 0.0005

Salpetersaures Kali . . . 0.0027

Anderthalb-kohlensaur.Ammoniak 0.0009

Schwefel . . . . . . 0.0034

Schwefelwasserstoff . . . . 0.0134

Kohlenoxyd . . . . . 00519

Kohlensäure . . . . . . 0 02577

Wasserstoff . . . . . 0.0007

Stickstoff

$0 \cdot 1151$

Summe der gasförmigen $\overline{\text { Pro- }}$

ducte....... . 0.1388

Summe der festen Producte. 0.5612

b) Entwicklung des Schiesspulvers. Der oder die Erfinder des Schiesspulvers sind unbekannt. Wahrscheinlich ist, dass die Entdeckung des Schiesspulvers durch die Araber in den ersten Jahren des 14. Jahrhunderts geschah; 
fast gewiss ist es, dass die Italiener schon in den ersten Jahrzehnten des 14. Jahrlunderts Schiesspulver fabricirten, und nachgewiesen, dass wenig später in Deutschland (1340 in Augsburg, 1344 in Spandau, 1360 in Luibeck) Schiesspulverfabriken bestanden. Die diversen Geschichten iiber die Erflndung des Schiesspulvers in China, über Berthold Schwarz u. s. f. halten unbefangener Priufung nicht Stich. Die wirkliche Verwendung des Schiesspulvers als Triebmittel für Geschosse und seine Fabrication in grössèrem Massstabe kann in Europa also mit Sicherheit in die 1. Hälfte des 14. Jahrhunderts verlegt werden, die erste Anwendung als Sprengmittel für Kriegszwecke fällt in das Jahr 1397, die ältesten verlässlichen Nachrichten über die Verwendung als Sprengstoff in Bergwerken in das Jahr 1613.*)

Schon die ältesten Zusammensetzungen des Schwarzpulvers weichen wenig von den heute iublichen ab. Beispielsweise zeigen dies folgende Daten:

1546 werden angegeben für Büchsen: 83.4 Salpeter, 8.3 Kohle, 8.3 Schwefel, 1649

1774 in "Preussen "fuir grobes Pulver: $74 \cdot 4$

heute meist übliche Verhältnisse: $74-75$

n $13 \cdot 3$

$13 \cdot 3$

$11 \cdot 2$

$" 15-16 \quad "$

$13 \cdot 3$

10

$n$

Das älteste Pulver wurde blos durch Mengung seiner Bestandtheile aus "freier Hand hergestellt, später benüzte man. Mahlmiihlen, die aber wegen ihrer Gefährlichkeit rasch verlassen und schon Mitte des 15. Jahrhunderts durch die heute noch zum Theil im Gebrauche befindlichen Stampfmïhlen ersetzt wurden. Im 16. Jahrhunderte findet man schon Walzmiihlen, nach Art der jetzt üblichen, zum Kleinen und Mengen der Materialien. 1791 wurde in Frankreich das Kleinen und Mengen in Trommeln eingefiihrt, das in mehr oder minder begrenzter Anwendung heute in den meisten besseren Pulverfabriken üblich ist.

Anfänglich wurde das Pulver nur in Mehlform verwendet. Die Nachtheile hievon bemerkte man bald und schon vor Mitte des 16. Jahrhunderts wurde in Frankreich, dann bald auch in allen anderen Staaten zur Körnung des Pulvers tibergangen. Mit dem Anfange des 18. Jahrhunderts hat die Fabrication des Schwarzpulvers in der Hauptsache bereits jene Entwicklungsstufe erreicht, welche sie um die Mitte des gegenwärtigen Jahrhunderts besass. Die Schwarzpulver. fabrication blieb also, wenn man von relativ untergeordneten, die Giite des fertigen Productes wenig beeinflussenden Veränderungen absieht, durch fast $1^{1} / 2$ Jahrhunderte stabil. Da entstand in Gefolge des letzten amerikanischen Bürgerkrieges der Wettkampf zwischen Geschiitz- und Panzerconstructionen, der zu den "Riesenkalibern der Gegenwart fülirte. Die grössten Metallstärken konnten nicht mehr den enormen Ladungen Widerstand leisten, es mussten Mittel und Wege gesucht werden, das alte Schwarzpulver zu verbessern oder zu ersetzen.

In Nordamerika wurde $1859-60$ zuerst durch Major Rodman, dann durch Professor Doremus in West-Point, 1858 durch das Geschützpulver-Comitẻ in England, später auch durch die grossen Militärstaaten Europa's energisch an die Lösung der Pulverfrage gegangen. Alle Versuche, das Schwarzpulver durch ein ähnliches mechanisches Gemenge zu ersetzen, in dem der Kalisalpeter durch analoge sanerstoffreiche Körper (Barytsalpeter, chlorsaures Kali), Kohle und Schwefel durch ähnlich wirkende Körper (Zucker, Holzstoff, Blutlangensalz etc.) substituirt sind, haben ungiunstige Resultate ergeben. Die alten Rohmaterialien haben sich als die besten erwiesen. Ferner hat sich gezeigt, dass jenes, seit uralter Zeit bestehende Mischungsverhältniss, welches fuir bestes Jagdpulver verwendet wird und welches die höehste Nutzleistung gibt, zugleich das beste Mischungsverhältniss für alle anderen Pulversorten ist, seien sie Minen- oder Geschützpulver. Das Vermehren des Kohlenstoffgehaltes gegeniiber dem Salpetergehalte, um geringeren Druck, langsamere Verbrennung zu erhalten, ist eine wahre Verschlechterung des Pulvers.

*) Zahlreiche Literaturnachweise und Notizen ïber die Geschichte des Schiesspulvers findet man im Lehrbuch der gesammten Tunnelbaukunst von F. Rziha I. Band 1867. Das Sehiesspulver, die Explosivkörper etc. von Dr. J. L T mann u Dr. E. v. Meyer. - Meyer, Handbuch der Geschichte der Fenerwaffentechnik. 
Dagegen haben umfassende Versuche nachgewiesen, dass die mechanische Constitution des Pulvers von höchstem Einflusse auf die Wirkungsweise ist, und dass richtig combinirte Veränderungen in der Grösse, Form, Oberflächenbeschaffenheit, Dichte und Härte der Pulverkörner vollkommen genïgen, auch den gesteigerten Anforderungen an die Triebkraft der Geschiitzpulver zu genügen, ohne die Pohre iibermässigen Spannungen auszusetzen. Indem man nur die stärkste Pulvermischung erzengt, erreicht man den grössten Effect des verbrennenden Pulvers, indem man je nach der Grösse der Ladungen dem Korn entsprechende Form, Dichte, Härte und Grösse gibt, kann man die Verbrennung der Ladung derart reguliren, dass der Druck während der ganzen Fortbewegungszeit der Geschosse im Rohr ziemlich gleichmässig wirkt, der Maximaldruck auf das Rohr also möglichst herabgesetzt wird.

Aus den hier angedeuteten Bestrebungen entstand 1862 in Amerika das II a m mout li pulver mit Körnern von $1 \cdot 5-2 \cdot 5^{\mathrm{cm}}$ Druchmesser; später das prismatis che Pulver, bestehend aus regelmässigen sechsseitigen Prismen von etwa $4^{\mathrm{cm}}$ Durchmesser und $2 \cdot 5^{\mathrm{cm}}$ Höhe. In Amerika aufgegeben, wurde das prismatische Pulver in Russland und Preussen um so ernsteren Versuchen unterzogen und schliesslich für die grössten Geschütze adoptirt. Die Dichte dieser Körner ist 1.66-1·76, ihr Gewicht bis zu $40 \mathrm{Gr}$. In England fiihrten die Versuche ebenfalls zur Anwendung stark verdichteter (gepresster) Pulversorten für schwere Geschütze; insbesondere gelangten zu umfassender Anwendung das Kieselpulver (pebble povder) durch die harte, glatt polirte Oberfläche, Form und Grösse der Körner Kieselsteinen ähnlich; 1867 das Cyliuderpulver (pellet powder), ein stark gepresstes Pulver in Form cylindrischer Scheiben. Zu analogen Resultaten gelangte man in den anderen Staaten. Auch fuir die Sprengarbeit wurden in letzter Zeit, besonders in Belgien und Frankreich, gepresste Pulver in Form cylindrischer Stangen eingeführt.

Der gesammte Fortschritt im Pulverwesen resumirt sich so in Folgendem:

1. Anwendung verbesserter Mittel, um eine möglichst homogene und innige Mischung der einzelnen Bestandtheile zu erzielen.

2. Starke Compression des Pulversatzes.

3. Bildung grosser Körner mit verschiedenen Formen und verschieden behandelten Oberflächen.

Diesem an sich geringen Fortschritte parallel läuft auch ein äusserst geringer Fortschritt in den Apparaten der Fabrication. Abgesehen von der Anwendung besserer Verkohlungsmethoden, der Einführung starker hydrauliseher Pressen und besserer Kornmaschinen ist man ziemlich auf demselben Standpunkte wie zu Anfang des Jahrhundertes. Und dass diese Fortschritte nicht wesentlicher Natur sind, dafür gibt das beste Beispiel, dass bei äusserst sorgfältig geleiteten Versuchen sich die Pulver einer kleinen schwedischen Fabrik,*) welche die primitivste Einrichtung besitzt, aber sehr sorgfältig arbeitet, als die besten zeigten.

c) Fabrication des Schiesspulvers. 1. Rohmaterialien. Es ist nothwendig oder doch sehr wïnschenswerth, dass Fabriken ihre Rohmaterialien selbst erzeugen oder wenigstens raffiniren.

Salpeter. Es wird nur Kalisalpeter verarbeitet, meist in Mehlpulverform, wie sie durch Störung des Krystallisationsprocesses bei der Läuterung entsteht (s. Salpeter). Der gereinigte Salpeter muss ganz frei von in destillirtem Wasser unlöslichen Stoffen sein, frei von schwefel- und kohlensauren Salzen (Prïfung durch Chlorbaryumlösung), von salpetersaurem Kalk und Magnesia (Prïfung durch oxalsaures Kalium und Ammoniak), und darf höchstens Spuren von Chlorverbindungen (Aequivalent $0.0004 \%$ Kochsalz) enthalten.

Schwefel. Mit Ausnahme Schwedens, wo zum Theile schwedische Schwefelkiese verarbeitet werden, wird nur sicilianischer Stangenschwefel genommen, der meist nochmals geläutert und in eine zum Kleinen passendere (sprödere) Modification übergeführt wird (s. S ch w e f e l). Der Schwefel muss frei von Erden und Oxyden (rïckstandslos verbrennen), frei von Schwefelsäure und schwefliger Säure (Prifung

*) A cker in Södermannland.

Karmarsch \& Heeren, Technisches Wörtorbuch. Bd. III. 
mit Lacmuspapier) und von Arsen (Kochen von feinem Schwefel mit Salpetersäure, Neutralisirung der salpetersauren Flüssigkeit mit kohlensaurem Ammonium und Zusatz von salpetersaurem Silber, darf keinen Niederschlag, Silberarseniat, geben) sein.

Kohle. Tanglich ist nur Kohle, die leicht entzündlich, sehr zerreiblich und rasch verbrennlich ist und sehr wenig Asche gibt; also nur Kohle von weichen, leichten Hölzern: Faulbaum, Weiden- und Erlenholz (Deutschland), Hundsbeer (Oesterreich), Haselholz (Schweiz) etc. Ausserdem werden sehr oft Hanfstengel (Italien), Weinreben (Spanien) und ähnliche Vegetabilien beniitzt. Ueber die verschiedenen Methoden der Verkohlung s. Verkohlung u. Holzkohle. - Für sehr feines Jagdpulver wird sogenannte Rothkohle (erzeugt bei etwa 270 $\mathrm{C}$.) genommen, da diese unter sonst gleichen Verhältnissen grössere Triebkraft gibt; die schwarze gewöhnliche Pulverkohle wird bei $340-350^{\circ}$ C. erzeugt. Die mittlere Ausbeute an Schwarzkohle beträgt 25-30\% des verwendeten Holzes.

Nach eingehenden Versuchen in England hat es sich gezeigt, dass sehr entzündliche Kohle aus Faulbaumholz, durch sehr langsame Verkohlung bei niedriger Temperatur erzengt, die besten Resultate gibt, und dass sich die Verbrennlichkeit des daraus erzeugten Pulvers durch entsprechende Dichte und Grösse des Kornes vollkommen regeln lässt. Die grössere Feuchtigkeitsanziehung solch schwach gebrannter Kohle lässt sich ebenfalls durch Dichte und Glätte des Kornes genïgend reduciren. Der Einfluss der Kohle ist besonders wesentlich. So ergab bei englischen Versuchen:

Pulver aus Waltham-Abbey mit Faulbanmholz erzeugt $439(437)^{\mathrm{m}}$, Anfangs-

" " mit Erlen- u. Weidenkohle "374 (391), Geschwindigk.

2. Mischungsverhältniss (Dosirung). Eine theoretische Festsetzung: des besten Mischungsverhältnisses ist nicht möglich, da hiefür eine ganze Reihe theoretischer und praktischer Faktoren fehlen. Dagegen ist durch eine höchst umfassende Reihe von Erfahrungen nachgewiesen, dass das praktisch günstigste, die vollkommenste Verbrennung gebende Verhältniss ungefähr jenes von 75 Salpeter, 10 Kohle und 15 Schwefel ist. Dieses oder ein nur wenig abweichendes Verhältniss kann heute für alle Gewehr- und Geschiitzpulver beibehalten werden.

Zweifelhaft ist es noch, ob dieses Verhältniss auch für Sprengpulver in jenen Fällen, wo eine langsam wirkende Kraft wünschenswerth ist (Riesenminen in relativ weichem Stein, wie Kalkstein), das richtige, und ob es nicht vorzuziehen sei, die Verbrennung solcher Pulver durch bedeutende Herabsetzung des Salpetergehaltes zu verzögern. Es sprechen aber auch hier sehr viele Gründe dafür, ${ }_{n} \mathrm{nur}$ die beste, d.h. am vollkommensten verbrennendePulvermischung zn verwenden" und durch Compression des Pulvers und andere, speciell der Sprengtechnik angehörende Mittel die gewünschte Modification der Wirkung zu erreichen. Immerhin wird noch in manchen Ländern sogenanntes Spreng-(Minen-) pulver mit vermindertem Salpetergehalt erzeugt. Das französische Minenpulver hat beispielsweise 62 Salpeter, 18 Kohle, 20 Schwefel.

4. Die Herstellung des Pulversatzes. Die Herstellung des Pulversatzes fordert das Kleinen der Rohmaterialien, deren vollkommen innige Mengung und endlich die entsprechende Dichtung (Pressung) des so entstandenen Gemenges. Die primitirsten Methoden sind jene, in welchen das Kleinen, Mengen und Dichten in einer Operation geschieht. Hiezı gehört in erster Reihe die Herstellung des Pulversatzes durch Stampfmiihlen, seit 1435 in Anwendung und auch gegenwärtig noch in einigen Ländern theilweise im Gebrauch (Oesterreich, Deutscbland, Dänemark ete.). In einer Reihe von mörserähnlichen Stampflö chern, in Eichenoder Buchenholz gehöhlt und etwa $0 \cdot 4^{\mathrm{m}}$ weit und tief und zur Aufnahme von etwa 8-10 Kilo Satz bestimmt, wird Salpeter, Kolle und Schwefel in Form groben Pulvers eingetragen und durch vertical auf- und abbewegte Stempel aus Holz, welche unten einen Bronceschuh tragen und $17-40 \mathrm{Kg}$. schwer sind, unter zeitweiser Befenchtung des Satzes zerkleinert und zugleich gemengt und gedichtet. Die Anzahl Stösse pro Minute ist 55-60, die Dauer der Bearbeitung je nach der 
Guite des Pulvers, der Schwere der Stampfen etc. 14-60 Stunden. Die Fallhöhe ist $0 \cdot 3-0 \cdot 5^{\mathrm{m}}$ (gewöhnlich $0 \cdot 432$ ). Diese Methode ist entschieden zu verwerfen. Sie fordert sehr viel Zeit, sehr viel mechanische Kraft (15-16 Millionen Kilogrammmeter pro 100 Kilo Pulver), viel Arbeiter (40 Arbeiterstunden pro 100 Kilo), liefert ein wenig homogenes, nicht sehr festes und poröses Pulver, und ist so gefährlich, dass sie in England ganz verboten ist. Das Gleiche gilt für eine analoge Arbeitsweise, die noch in der Schweiz in Verwendung ist und in der die Stampfen durch Hämmer ersetzt sind. Ein weit besserer Vorgang, um alle drei Operationen zu vereinen, ist die Bearbeitung durch Walzmühlen (Läufer-, Kollermühlen). Die Materialien werden auf eine Art horizontaler Stein- oder Eisenschale geschüttet, auf der im Kreise sich zwei schwere Cylinder von Stein, Bronze oder Gusseisen an einer horizontalen Achse, ähnlich wie bei Chocolademaschinen, bewegen und so die Materialien zerreiben, mischen und durch ihre Schwere (bis zu 5000 Kilo à Läufer) zugleich pressen. Die Detailbeschreibung einer solchen Construction folgt später. Aber auch diese Methode ist nicht rationell, fordert noch immer, besonders bei sehr feinem Pulver, viel mechanische Arbeit (9-10 Millionen K.-M. pro 100 Kilo guten Pulvers, feines englisches Pulver fordert sogar über 40 Millionen K.-M.) und ist ebenfalls höchst gefährlich.

Heute wird von der Vereinigung der Operationen des Kleinens, Mengens und Dichtens in allen rationellen Pulverfabriken abgegangen. Das Kleinen der Rohmaterialien wird jedenfalls getrennt von der Mengung und Dichtung, in den meisten Fällen sogar auch der Process der Dichtung getrennt von jenem der innigen Mengung vorgenommen.

$\mathrm{D}$ as K $\mathrm{K}$ inen der Substanzen (pulverisation, trituration des matières composantes - pulverizing the ingredients). Das Kleinen der einzelnen Bestandtheile für sich kann entweder in Stampfmühlen (älteste unrationellste Methode), in Walzmiihlen (ähnlich den Chocoladereibmaschinen, für Schwefel auch oft ähnlich den Kaffeereibmiuhlen), oder in sogenannten Pulverisir- oder Brechtrommeln geschehen. Die Walzmïhlen sind den später beschriebenen, zur innigen Mengung der Materialien bestimmten ähnlich, nur haben sie meist leichtere Läufer als diese. Die Brechtrommeln sind von sehr verschiedener Construction und Dimension. Eine gute Construction zeigt Fig. 1513. Die Trommel besteht aus einem Cylinder von starkem Eichenholz $\left(2 \cdot 2^{\mathrm{m}}\right.$ Durchmesser, $1 \cdot 6^{\mathrm{m}}$ Länge), der durch drei Eisenreifen zusammengehalten und durch Holzböden beiderseits geschlossen ist. Innen hat die Trommel 24 Leisten aus Weissbuchenholz, welche in gleichen Abständen von einander parallel mit der Achse der Trommel laufen. Die ganze innere Fläche der Trommel ist mit starkem Sohlleder bekleidet. Durch die Trommel geht eine eiserne, in Metalllagern ruhende Achse, welche im Innern der Trommel zuerst mit Holz und darüber mit Leder bekleidet ist. Durch entsprechende Transmissions-

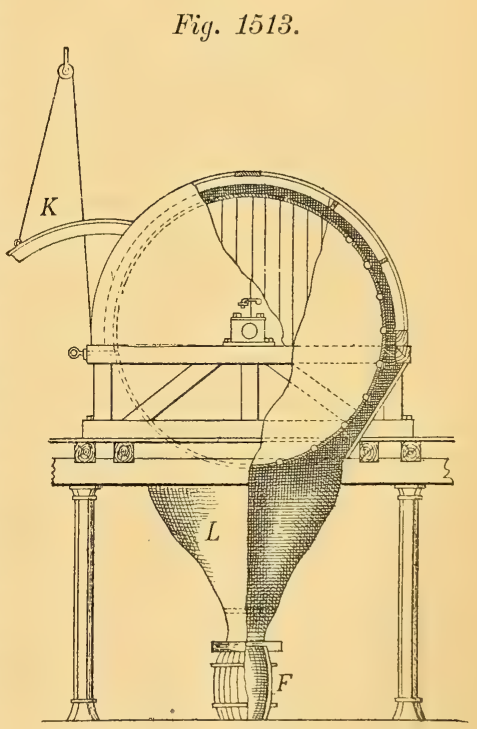
mittel kann die Trommel in Drehung versetzt werden. Das Ein- und Ausbringen der Materialien geschieht durch eine Oeffnung in der Mantelfläche, welche während des Kleinens durch eine massive Thüre verschlossen wird. Ueber der Trommel 
ist ein concentrisches Gehäuse aus Wachstaffet, das mit einer Klappe $X$ geöffnet oder geschlossen werden kanm und das Verstauben hindert. An dieses Gehäuse schliesst sich unten ein Drillichsack $L$, durch den die fertige Mischung in untergestellte Fässchen $F$ fällt. Das Kleinen in solchen Trommeln geschieht dadurch, dass die zu pulverisirenden Materialien mit kleinen Bronzekugeln von $4-15^{\mathrm{mm}}$ Durchmesser eingebracht und dann eine passende Zeit in Rotation erhalten werden. Da Schwefel sich sehr schwer durch diese Methode für sich kleinen lässt (er ballt und erhitzt sich), wird er gewöhnlich mit einem Theile Salpeter zusammengemengt. In Spandau werden in Trommeln der angegebenen Construction 50 Kilo Kohle mit 100 Kilo Bronzekugeln (von etwa $14^{\mathrm{cm}}$ Durchmesser) durch 900 Rotationen (8-10 pro Minute); 44 Kilo Schwefel mit 44 Kilo Salpeter durch 100 Kilo Bronzekugeln (ron $8-14^{\mathrm{cm}}$ Durchmesser) durch 1200) Umdrehungen gekleint. Ist eine Charge pulverisirt, so wird der massive Deckel abgenommen, an seine Stelle ein Messinggitter gesetzt, welches die Kugeln riickhält, die feinen Materialien aber in den Sack $L$ fallen lässt. Die feine, leicht selbstentzündliche Kohle wird zweckmässig in geschlossenen Blechkästen und fenerfesten Localitäten untergebracht. Wo man Salpeter und Schwefel schon in Form feinen Pulvers gewinnt, fällt natuirlich eine besondere Kleinung hinweg. Es ist ron Vortheil auch dort, wo man Trommeln zum Kleinen beniitzt, die groben Rolmaterialien zuerst mit Hämmern in Stuicke zu zerschlagen, damn unter einfachen Mühlen grob und dann erst in den Trommeln fein zu pulvern. Bei solchem Vorgang kann dann das Kleinen in Trommeln als die rationellste Methode angesehen werden.

In manchen Fabriken werden nur Mischungen von je zwei Rohmaterialien zusammengemengt, u. zw. Schwefel mit einem Theile der Kohle (Schwefelkohlensatz) uud Salpeter mit dem Rest der Kohle (Salpeterkohlensatz). Die Verhältnisse solcher „binärer" Mischungen oder Sätze miissen so sein, dass Schwefelkohlensatz und Salpeterkohlensatz, in passenden Verhältnissen zusammengemischt den richtigen Pulversatz geben.

Das M engen der gekleinten Materialien (melanger - mixing). Das Mengen der für sich oder binär gekleinten Substanzen findet, wo man Stampfmühlen hiefuir verwendete, in diesen, sonst aber in Mengtrommeln oder auf Walzmiihlen statt. Die Mengtrommeln sind ganz ähnlich den friher beschriebenen Brechtrommeln construirt, nur ist die äussere Holzverkleidung meist durch ein blosses Holzgerippe ersetzt, welches mit sehr starkem Sohlenleder überzogen ist; ausserdem werden alle Eisenbeschläge durch solche aus Bronze oder Messing ersetzt. In Spandau kommen in eine Trommel 20 Kilo Salpeterschwefel (s.oben), $6 \pm$ Kilo Salpeter und 16 Kilo Kohle mit 150 Kilo $8^{\mathrm{cm}}$ Bronzekugeln zusammen und werden durch 1440 Umdrehungen (8-10 ì Minnte) gemengt. Die vorgeschriebene Tourenzahl wird bei Brech- und Mengtrommeln meist durch Zählwerke controllirt. In mehreren der grössten Pulverfabriken, besonders in Frankreich, England und seinen Colonien geschieht das innige Mengen (the Incorporation) oft durch Walzmühlen (meules pesantes - incorporating mills), meist nachdem früher die drei Materialien oberflächlich in einer Art Mengtrommel, in der die Wirkung der Kugeln durch je mehrere an der Achse befestigter bronzener Arme ersetzt ist, gemengt wurden. Fig. $151 \pm$ zeigt eine Walzmiihle der kön. englischen Pulverfabrik zu WalthamAbbey. Die Mïhle besteht aus einem Paar grosser schwerer Läufer $L L$ (meules rerticales - edge-rumers) aus Eisen oder Stein, welche auf einer horizontalen Lagerschale $S$ desselben Stoffes laufen. Dic grössten Läufer haben bis zu $2 \cdot 5 \mathrm{~m}$ Durchmesser und $5-6000$ Kilo Gewicht. Die Läufer sind auf einer starken Horizontalachse $H$ befestigt, welche ihrerseits fest mit der MIuffe $m$ verbunden ist, die derart auf der Terticalwelle $T$ sitzt, dass sie sich wohl mit dieser drehen muss, sich aber längs derselben vertical senken und heben kann, wobei dann natiirlich die horizontale Achse und die Läufer an dieser Bewegung Theil nehmen. Die Achse $V$ wird durch eine passende Transmission unterhalb der Lagerschale in Drehung rersetzt. Die 2 Läufer sind in rerschiedenen Entfernungen von der verticalen Achse befestigt. Die Muffe $m$ trägt auf einem abwärts gehenden Arm 
ein pflugförmiges Streifmesser $R$ aus mit Filz oder Leder beschlagenem Holze, welches den Zweck hat, die Pulvermasse zu wenden und unter die Läufer zu bringen.

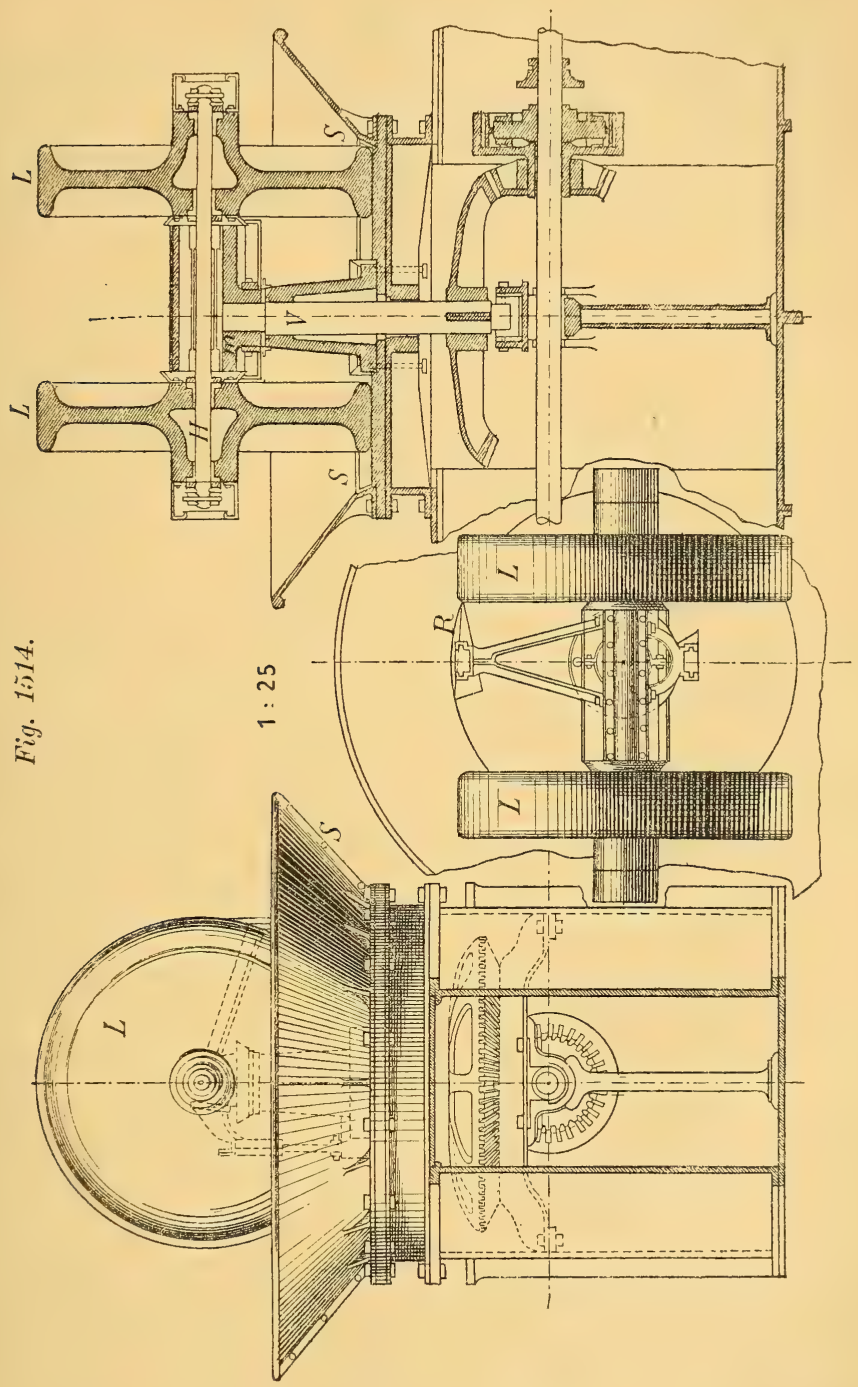

Während der Bearbeitung muss die Pulvermasse von Zeit zu Zeit mit destillirtem Wasser in dem Masse befeuchtet werden, dass sie am Schlusse der Arbeit $2-3 \%$ Wasser enthält. 'Trotz dieser Befenchtung wird die Masse gegen das 
Ende der Arbeit äusserst explosiv und die Arbeit somit sehr gefährlich. In England dürfen nur 25 Kilo auf einmal unter die Läufer kommen und dauert die Arbeit bei Gewehrpulver 5, bei Geschützpulver 3 Stunden.

In Form eines weichen Kuchens verlässt das Pulver die Walzmühlen und wird in hölzernen Fässern zur weiteren Verarbeitung aufbewahrt.

Es ist heute noch eine offene Frage, ob nicht die Mengung nur in Trommeln, welche weniger Arbeitskraft und viel weniger Anlagekapital fordern und weniger gefährlich ist, ein eben so gutes Product liefern kann, als die Bearbeitung durch Läufer.

Eine innige Mischung ist jedenfalls von sehr hohem Einflusse auf die Giite des Pulvers und bringt eine Verlängerung der Bearbeitungsdauer unter den Läufern innerhalb gewisser Grenzen eine bedeutende Steigerung der Anfangsgeschwindigkeit und eine Herabsetzung der Gasdrücke mit sich.

So ergaben Versuche in England:

\begin{tabular}{|c|c|c|c|c|}
\hline \multirow{3}{*}{$\begin{array}{c}\text { Mit Faulbaumholzkohle } \\
\text { erzeugtes Pulver von } \\
\text { Hall \& Sons }\end{array}$} & \multirow[b]{2}{*}{$\begin{array}{l}2 \text { Stunden } \\
\text { gemahlen }\end{array}$} & Korngrösse & $\begin{array}{l}\text { Anfangsge- } \\
\text { schwindigkeit }\end{array}$ & $\begin{array}{r}\text { Grösster } \\
\text { Gasdruck }\end{array}$ \\
\hline & & $\begin{array}{l}25^{\mathrm{mm}} \\
16^{\mathrm{mm}}\end{array}$ & $\begin{array}{l}450^{\mathrm{m}} \\
441^{\mathrm{m}}\end{array}$ & $\begin{array}{l}2142 \text { Atm. } \\
3154 \text { " }\end{array}$ \\
\hline & $\begin{array}{l}8 \text { Stunden } \\
\text { gemahlen }\end{array}$ & $\begin{array}{l}25^{\mathrm{mm}} \\
16^{\mathrm{mm}}\end{array}$ & $\begin{array}{l}462^{\mathrm{m}} \\
460^{\mathrm{m}}\end{array}$ & $\begin{array}{l}1897 \text { Atm. } \\
3106 \text { n }\end{array}$ \\
\hline
\end{tabular}

Mit der Zunahme der Mahlzeit sinkt die Dichtigkeit des Satzes.

Das Dichten oder Pressen des Pulversatzes (compression du mélange ternaire - pressing). Dichte und Härte des Pulvers sind von massgebendstem Einfluss auf die Wirkung, mïssen also genau eingehalten werden. Die entsprechende Dichte wird durch Volumverminderung (Pressen), die nöthige Härte durch Anwendung eines bestimmten Feuchtigkeitsgrades während der Pressung erreicht. Die moderne Pulverfabrication sucht grosse Dichte und Härte zu erreichen zur Schonung der Rohre und zur Vergrösserung der Widerstandsfähigkeit des Pulvers gegen mechanisehe Erschïtterungen und den Einfluss der Feuchtigkeit. Zu grosse Dichte kann aber ebenfalls schädlich sein und die Wirkung zu stark herabsetzen, so ergaben beim Feuern aus dem 10-zölligen Geschiitze;

$70 \mathrm{Pfd}$. pebble Pulver mit Dichte 1.84 . 1288 Fuss Anfangsgeschwindigkeit, 10

$n \quad n \quad n \quad n \quad 1 \cdot 81$,

Fïr jede Geschützgattung ist experimenteli die richtige Pulverdichte zu bestimmen.

Die Verdichtung des Pulvers geschieht durch Schrauben-, Walzen- oder hydraulische Pressen. Wurde der Pulversatz in Trommeln erzeugt, so muss er vor dem Einbringen in die Pressen angefeuchtet werden; wurde der Satz unter Läufern bearbeitet, wo er bereits eine ziemliche Consistenz erlangt hat, so muss er früher in Stiicke zerschlagen werden. Die Construction der Schrauben- und der hydraulischen Pressen ist im Wesentlichen ganz gleich jener gleichbenannter Pressen für andere Zwecke. Die Grösse der Pressung wird in beiden Fällen nur durch die crzielten Volumveränderungen gemessen, welche das Pulver während der Pressung erleidet. Man bringt das Pulver meist in 20-40, von einander durch feuchte Leinwand oder Metallplatten getrennten, $1-2^{\mathrm{cm}}$ hohen Schichten auf die Pressplatte und setzt es dann einem Drucke aus, der bis zu 130 Atmosphären steigt. Das Pulver wird hiebei etwa auf $1 / 3$ seines früheren Volumens comprimirt.

Eine eigenthiimliche Construction haben die Walzenpressen, welche besonders in Deutschland und Frankreich verbreitet sind. Fig. 1515 zeigt eine Walzenpresse dentscher Construction. Zwischen zwei paralellen Wänden $a \quad a$, deren jede aus zwei ron einander getrennten Balken $b b$ besteht, befinden sich 3 Walzen, von denen 
sich die oberen mit ihren Achsen in den durch die Balken $b \quad b$ in den Wänden a a gebildeten Führungen auf- und abbewegen können. Die unterste Walze $w_{1}$ (Triebwalze) hat feste Lager und wird von der Triebkraft der Fabrik durch eine passende Transmission in Bewegung gesetzt. Die mittlere Walze $w_{2}$ ist aus Papier, liegt frei auf der Triebwalze auf und wird von dieser durch Friction mitgenommen, die obere $w_{3}$ (Druckwalze) ist aus Metall. Zwischen $w_{2}$ und $w_{3}$ geht ein aus starkem Segeltuch gefertigtes Band ohne Ende, welches durch die kleine Walze $w_{0}$ in der Richtung des Pfeiles $f$ bewegt und so zwischen $w_{2}$ und $w_{3}$ durchgezogen wird. Ueber dem Bande ohne Ende sitzt ein Aufschüttkasten $K$, in welchen das angefeuchtete $\left(\mathbf{1 0} \%\right.$ Wasser enthaltende) Pulver kömmt, durch Oeffnen des Schiebers $S^{\prime}$ in mehr oder weniger dichter Schichte auf das Band fällt, mit diesem zwischen den Walzen $w_{2}$ und $w_{3}$ durchgezogen, durch den Druck der letzteren comprimirt wird und auf der anderen Seite in passende Aufnahmsgefässe fällt. Auf den Zapfen der Walze

Fig. 1515 .

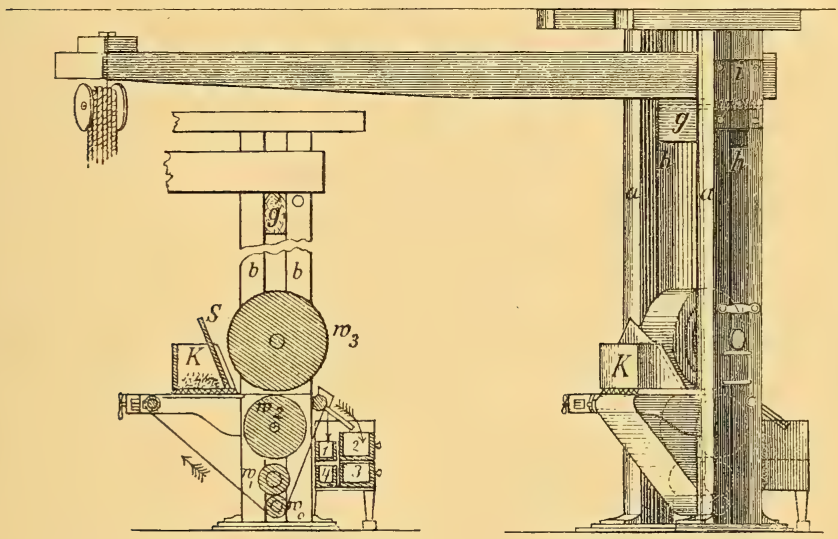

$w_{3}$ sitzen in den Schlitzen der Balken $b \quad b$ zwei Balken $h h$, über welche ein Querbalken $g$ greift, der als Auflager eines langen, um den festen Punkt $i$ drehbaren Hebels $H H$ dient. Indem man durch eine passende, aus Flaschenziigen und Hebeln combinirte Vorrichtuug das Ende $H$ entsprechend stark niederzieht, kann man auf die Walze $w_{3}$ und damit auf den Pulverkuchen einen sehr starken Druck ausüben. Passende Verhältnisse ergeben sich, wenn die Pulverschichte etwa von $30^{\mathrm{cm}}$ auf $10^{\mathrm{cm}}$ Höhe niedergepresst wird und die Druckwalze bei 10 Touren pro Minute ca. $10.000 \mathrm{Kg}$. Druck ausuibt. Eine solche Presse kann täglich bis 1000 Kilo Pulver pressen.

Gut eingerichtete hydraulische Pressen sind jedenfalls den Walzenpressen vorzuziehen.

Explosionen während der Pressung sind häufig und gehören zu den zerstörendsten und heftigsten.

Das Pulver verlässt die Pressen in Form fester, schieferartiger Kuchen und muss durch die folgenden Operationen zunächst in die entsprechende Form gebracht werden.

5. Das Körnen (le grenage-granulating). Das Körnen hat den Zweck, den harten Pulverkuchen in Körner bestimmter Grösse zu zertheilen. Die meisten der hiezu verwendeten Vorrichtungen lassen sich in 2 Gruppen theilen, in die 
Lefebere'schen und in die Congreve'schen Körnmaschinen. Die Construction der Ersteren, meist auf dem Continent in Gebrauch, zeigen die Fig. $1516 a$ u. $b$.

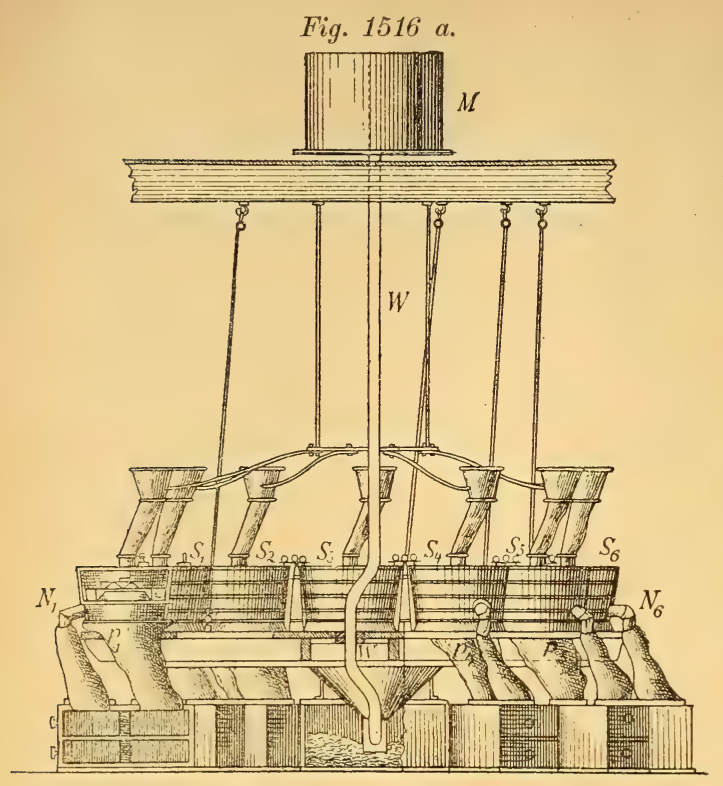
Der Hauptbestandtheil der Maschine ist eine Anzahl (8 bis 12 ) symetrisch um einen Mittelpunkt auf einem horizontalen Rahmen befestigter Siebsysteme $S_{1} S_{2}$ $S_{3}$, deren jedes folgende Detailconstruction hat (Fig. $1516 b)$. In einem cylindrischen Holzgestelle sind 3 Siebe eingesetzt $a_{1} a_{2}$ $a_{3}$. Das oberste Sieb hat ein Messinggewebe mit etwa $5^{\mathrm{em}}$ weiten Maschen, ausserdem enthält es zwei grössere Oeffnungen $o 0$, von welchen aus gekrümmte Kupferschaufeln $K$ nach dem 2. Siebe $a_{9}$ herabführen und

Fig. 1516 b.
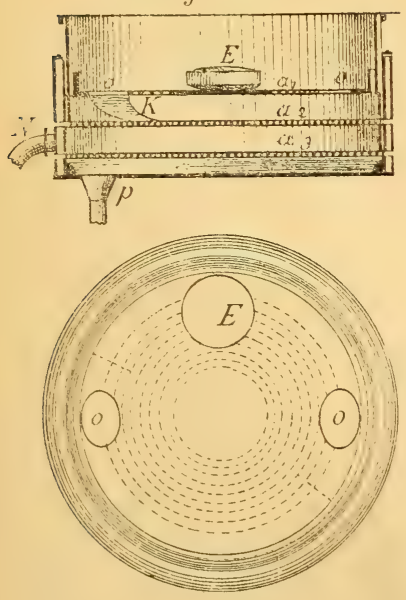

dieses tangiren. Auf dem Obersieb liegt frei eine Eichenholzscheibe $E$, welche an ihrer Unterfläche sternförnig ausgenommen und durch Bleieinguss immer im Gewichte von 3 Kilo erhalten wird. Die Maschenweite des Mittelsiebes $a_{\mathbf{g}}$ entspricht der zu producirenden Körnergrösse, während das Untersieb die zu feinen Theile durchlässt. Der Rahmen, auf dem sämmtliche Siebsysteme befestigt sind, kann durch eine Excenterwelle $W W$, welche in passender Weise (z. B. durch eine Trommel $M$ ) ihren Antrieb erhält, in eine schüttelnde, rüttelnde Bewegung versetzt werden, die sich den Sieben mittheilt. Jedes Sieb ist oben mit einem Deckel verschlossen, durch den je ein Lederschlauch $L_{1}, L_{0}$ nach einem Kupfertrichter $T_{1}, T_{2}$ fiihrt, der zum Einschütten des in grobe Stücke zerschlagenen Pulverkuchens dient. Der auf das Obersieb fallende Kuchen wird durch die Körnscheiben zerrieben, fällt auf das Mittelsieb und ron hier die entsprechend grossen Körner $N_{1}$ in die Aufnahmsgefüsse fiir das gekürnte Pulver. Die durch das Lntersieb gehenden Theile gelangen eben- 
falls durch Schläuche $P_{1}, P_{2}$ in separate Gefässe. Dic durch das Obersieb fallenden Theile, welche noch zu gross sind, um durch das Mittelsieb zu gehen, werden durch die Centrifugalkraft auf den schiefen Flächen $K$ aufwärts geschleudert, gelangen so durch die Oeffnungen $O$ wieder auf das Obersieb und unter die Körnscheiben. Eine bessere Construction, und vielleicht mit passenden Veränderungen auch für die grosskörnigen Geschützpulveranwendbar, ist die C ong réve'sche Körnmaschine(Fig. 1517). Vier mit entsprechend geformten Zähnen versehene Walzenpaare aus Bronze $v_{1} w_{2}$ $w_{3} w_{4}$ sind in geneigter Richtung uiber einander angebracht. Die Walzen jedes Paares können durch Stellschrauben passend von einander entfernt werden. Von einem Rollenpaar zum anderen führen geneigte kurze Drahtsiebe $s_{1} s_{\mathbf{2}} s_{3}$. Unter sämmtlichen Rollenpaaren hinweg, paralell zu einander, laufen zwei grosse Siebe $N N$ und $M M$ und eine volle Ebene $P P$, die sämmtlich durch einen Holzrahmen mit einander verbunden sind u. sammt den genannten kurzen Sieben in eine rüttelnde Bewegung versetzt wer-

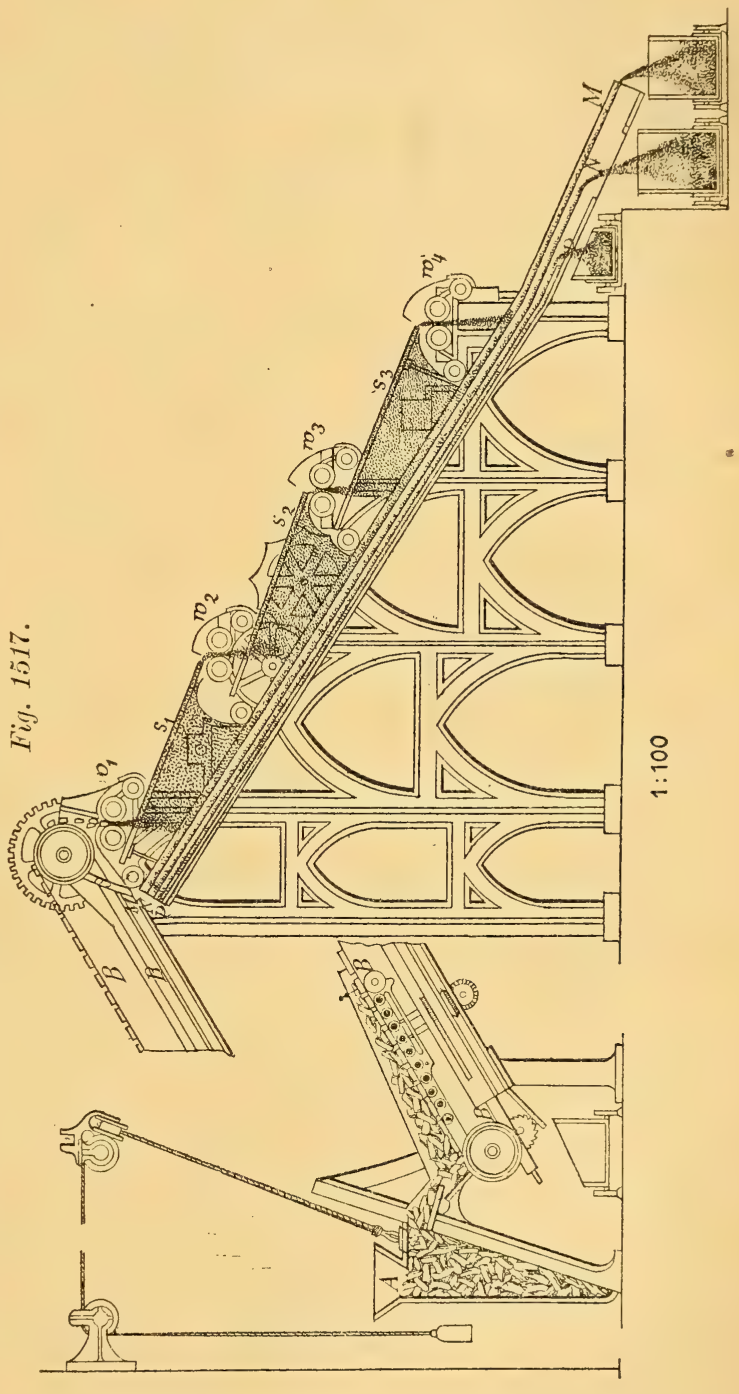
den können. Das

Pulver wird in ein Aufnahmsgefäss $A$ geschüttet und von hier durch ein Band ohne Ende $B B$ aufwärts und zwischen die Walzen geführt. Das weitere Spiel der Maschine ist selbstverständlich. 
Will man sehr grosskörniges Pulver (pelletpowder) erzeugen, so wird die Zertheilung des Pulverkuchens ebenfalls durch ähnliche, mit passend geformten Zähnen versehene Walzenpaare oder durch Schneidmaschinen, welche ähnilich grossen Zuckerscheeren sind, vorgenommen.

Auch die Körnung ist im Allgemeinen eine gefährliche Operation. Von 29 grossen Pulverexplosionen in England, zwischen Mai 1858 bis Juni 1870, entstanden eilf während der Körnung und verungliickten dabei 45 Menschen.

6. Erste Trocknung des Kornpulvers (séchage - drying). Das Pulver kömmt aus der Kornmaschine in geräumige Trockensäle, deren Construction guten Luftzug gestattet und wird hier in dünnen Schichten auf etagenförmig über einander liegenden hölzernen, gitterförmigen, mit Leinwand überspannten Trockentafeln ausgebreitet, und bleibt so lange liegen, bis es nur noch $2 \frac{1}{2}-3 \%$ Wasser enthält. Dieses Lufttrocknen dauert bei feuchter Witterung bis zu 14 Tagen.

7. Erstes Sortiren und A usstauben. Die Körnmaschienen liefern Körner sehr verschiedener Grösse und mit viel Staub gemengt. Nach dem Lufttrocknen wird deshalb ein vorläufiges Sortiren und Entstauben vorgenommen. Gut verwendbar hiezu sind grosse, an 4 Riemen hängende horizontale Siebkasten, welche durch verticale Wände in 12 Abtheilungen getheilt sind, deren jede ein Obersieb enthält, welches die zu grossen Körner rïckhält, während die anderen auf das darunter liegende Sieb fallen, welches die Geschützpulverkörner zuriickhält, die kleineren, für Gewehrpulver bestimmten, aber auf ein Haarsieb fallen lässt, welches den Staub allein durchlässt. Jede Abtheilung wird von oben mit etwa 4 Kilo beschickt, das Sieb von 2 Arbeitern in schiittelnde Bewegung versetzt und nach $1 \frac{1}{2}-2$ Minuten die Abtheilungen entleert.*)

8. Poliren der Körner(lissage - glazing). Die Operation des sogenannten Polirens hat den Zweck, die scharfen, sich leicht abbröckelnden Ecken und Kanten der Körner abzuschleifen, die Poren zu verstopfen und den Körnern eine feste glatte Oberfläche zu geben. Im Allgemeinen wendet man zum Poliren Holztrommeln an, die ähnlich den Mengtrommeln construirt sind, nur dass die Achsen meist nicht durch die Trommeln gehen, sondern an deren Stirnflächen direct befestigt sind. Das Poliren erfolgt einfach durch gegenseitige Reibung der eingebrachten Körmer aneinander während der Drehung der Trommeln. In Spandau haben diese Trommeln etwa $1.8^{\mathrm{m}}$ Durchmesser, $0^{\circ} 6^{\mathrm{m}}$ Länge, nehmen auf einmal 200 Kilo Pulver auf uud fordert deren Politur circa 3600 Drehungen, wovon 10 (bei Geschützpulver), 12-16 (bei Gewchrpulver) auf die Minute gehen, Graphitzusätze werden nur bei grobem Pulver genommen, bei feinem sind sie schädlich. Starker Glanz des Pulvers ist ohnedies kein Zeichen der Güte.

9. Trocknung des Pulvers. Obwohl das Pulver während des Polirens einen grossen Theil seiner Feuchtigkeit verliert, hat es bei Beendigung desselben doch noch immer $1 \frac{1}{2}-2 \%$ Wasser, von denen es befreit werden muss. In manchen kleinen Fabriken geschielit dies noch durch Trocknen an der Luft oder in sehr primitiven, blos durch Oefen geheizten Trockenstuben. In allen grösseren, besser eingerichteten Fabriken hat man nur Trockenstuben mit Warmwasserheizung, in denen der Feuerherd vollkommen vom Trockenraume getrennt ist. Meist ist die Einrichtung derart getroffen, dass die erwärmte trockene Luft in Trockenkästen tritt, welche oben mit Drahtgeflechten und darïber mit leinenen Decken überzogen sind, auf welche das Pulver in dünnen Schichten ausgebreitet wird. Die warme Luft strömt so durch die Pulverschichte und nimmt deren Feuchtigkeit leicht mit. Das Trocknen muss Iangsam geschehen, bei einer Temperatur, welche zwischen $50-60^{\circ}$ C. bleibt. Das Trocknen bei $58^{\circ}$ C. in $1-2^{\mathrm{cm}}$ hohen Schichten und unter fleissigem Umrühren dauert etwa 1 Stunde.

*) In manchen Fabriken wird das Ausstauben in rotirenden Sieben vorgennmmen. Das Lufttrocknen vor dem Ausstauben bleibt weg, wenn durch das Pressen ein sehr fester, wenig Feuchtigkeit enthaltender Pulverkuchen gewonnen wird. 
10. Das A us stäuben des trockenen Pulvers (époussetage-dusting). Sehr grobkörniges Pulver, z. B. das englische Rifle L arge Grain wird nach dem Trocknen sogleich in Fässer verpackt, feinere Pulversorten werden nach dem Trocknen nochmals entstaubt. Man beniitzt hiezu entweder wieder einfache Siebvorrichtungen oder in vielen Fabriken Leinensäcke verschiedener Form und Grösse, in welche das Pulver kömmt und in passender Weise in den Säcken einer schüttelnden Bewegung ausgesetzt wird. Das Ausstäuben in Säcken dauert circa 1 Stunde bei Geschitzpulver, 2 Stunden bei Gewehrpulver.

11. Das Sortiren des Pulvers. Die auf das 1. Sortiren folgenden verschiedenen Operationen verändern wieder derart die Korngrösse, dass ein 2. Sortiren, in ganz ähnlichen Apparaten wie beim 1. Sortiren, nothwendig wird, eine Operation, die für 25 Kilo Pulver die Arbeitskraft von 2 Mann dureh $5 / 4$ Minuten fordert.

12. Das Mengen der erzeugten Pulver. Um für die Verwendung möglichst gleichförmiges Pulver zu haben, wird das erzeugte Pulver noch derart in passender Weise zusammengemengt, dass die zufälligen unvermeidlichen Differenzen in Feuchtigkeitsgehalt, Dichte, Zusammensetzung etc. möglichst ausgeglichen werden, und man immer Mengen von 5000-10.000 Kilo erhält, welche praktisch genommen durchaus dieselbe Zusammensetzung haben.

13. Die Methode der Pulvererzeugung nach Champy. Eine für die Erzeugung von Minenpulver wichtige Abweichung von den bisher skizzirten Fabricationsmethoden ist das Verfahren nach Champy. Die gewöhnliche Methode, gekörntes Pulver herzustellen, ist zeitraubend, kostspielig und gefährlich, leider aber für alle Gewehr- und Geschützpulver nicht zu umgehen. Versuche zur Zeit der ersten französischen Revolution ausgeführt (in Vincennes 1795) zeigten, dass eine feuchte Pulvermasse schon durch Schütteln in Tonnen sich in Form runder Körner bringen lasse. Champy gründete hierauf folgende Körnungsmethode: Der Apparat der Körnung ist eine Trommel, ganz ähnlich jenè zur Erzeugung des Pulversatzes, nur führt durch eine der Stirnflächen in das Innere der Trommel ein Kupferröhrchen, welches mit einer Art Brause endet, und welches gestattet, genau abgemessene Wassermengen in feinen Strahlen in die Trommel einzuspritzen. In die Trommel kommen 50 Kilo Pulvermasse in Form sehr kleiner Körner, dann setzt man die Trommel in Bewegung, lässt etwa 5 Kilo Wasser durch die Brause zutreten, wodurch die Körner befeuchtet werden und bringt dann weitere 50 Kilo Pulver in Staubform zu. Die feuchten Körnchen werden von diesem umhüllt und vergrössern sich während der weiteren Drehung der Trommel bis zum gewünschten Masse. Man erhält so rundes Kornpulver, welches nur mehr getrocknet, sortirt und entstaubt wird. Die feinsten Körner kommen wieder zur nächsten Operation. Für Minenpulver ist diese Arbeitsmethode praktisch noch viel im Gebrauch, und lässt sich mit ihr Pulver von einer Dichte bis zu 1.5 erreichen.

14. Gepresstes Pulver. Die sogenannten comprimirten Kartätschen, nämlich ganze Ladungen, direct durch Pressung des Pulversatzes in die gewünschte Ladungsform erzeugt, haben durchaus ungiinstige Resultate ergeben und finden nur noch für Minenpulver Verwendung. Dagegen werden heute für alle schweren Geschütze nur Pulversorten verwendet, welche aus grossen Körnern stark gepressten Pulvers bestehen. Diese Körner werden entweder direct aus dem unter starken Pressen gewonnenen Pulverkuchen dadurch gewonnen, dass man diesen in Stiicke der gewünschten Grösse zerschlägt oder zerschneidet, diese Stiicke durch Siebe mit grober Maschenweite sortirt und dann weiter wie gewöhnlich in Polirtrommeln behandelt, oder aber man presst aus feinem Mehlpulver unter sehr hohem Drucke Körner in regelmässige Form. Zu den ersteren Sorten gehören das amerikanische Mammuthpulver (Körner von $1 \cdot 5-2 \cdot 6^{\mathrm{cm}}$ Durchmesser), das englische Kieselpulver (mit Körnern von $1 \cdot 7 \mathrm{~cm}$ Grosse), zu den letzteren Sorten das englische Cylinderpulver (regelmässige Cylinder von $1 \cdot 8^{\mathrm{cm}}$ Durchm., $1 \cdot 2^{\mathrm{cm}}$ Höhe), und das sogenannte prismatische Pulver (sechsseitige Prismen von $4 \cdot 0^{\mathrm{cm}}$ Durchmesser, $2 \cdot 5^{\mathrm{cm}}$ Höhe, welche paralell ihrer Achse mit 7 Durchbohrungen von etwa $0.45^{\mathrm{cm}}$ Weite versehen sind). Dieses gepresste grobkörnige Pulver hat eine Dichte ron 1.75 bis 
1.82. Um diese Dichte zu erreichen, muss das Pulver einem sehr starken Drucke ausgesetzt werden, der beispielsweise bei dem englischen Cylinderpulver etwa 80 Atmosphären beträgt.

Das Princip einer guten englischen Maschine zur Erzeugung von Pellet-Pulver ist folgendes (Fig $1518 a b$ ): In einer starken Metallplatte $A$ sind eine Reihe Durchbohrungen $B$ genau von dem Durchmesser der zu erzengenden Körner, welche unten durch bewegliche Stempel $C$ verschlossen sind, die ihrerseits durch eine dünnere Metallplatte $D$ gehen. Das Querhaupt $E_{1}$ trägt eine Reihe daran befestigter Stempel $T$; genau centrisch mit den Oeffnungen $B$. Quierhaupt $E_{1}$ und daran befestigte Stempel werden durch das Niedergehen des unteren Presskopfes $P_{2}$ herabgezogen. ( $P_{0}$ drückt auf $E_{2}$ und zieht dadurch $E_{1}$ herab.) Die Führungssäulen $S S$ haben Schultern $K K$, durch welche das Spiel der Querhäupter $E_{1} E_{2}$ begrenzt wird. Das Spiel der Maschine ist nun folgendes: Der ganze Theil $A, B, C, D$, welcher 200 Oeffnungen $B$ enthält, kann um eine horizontale Achse

Fig. 1518.
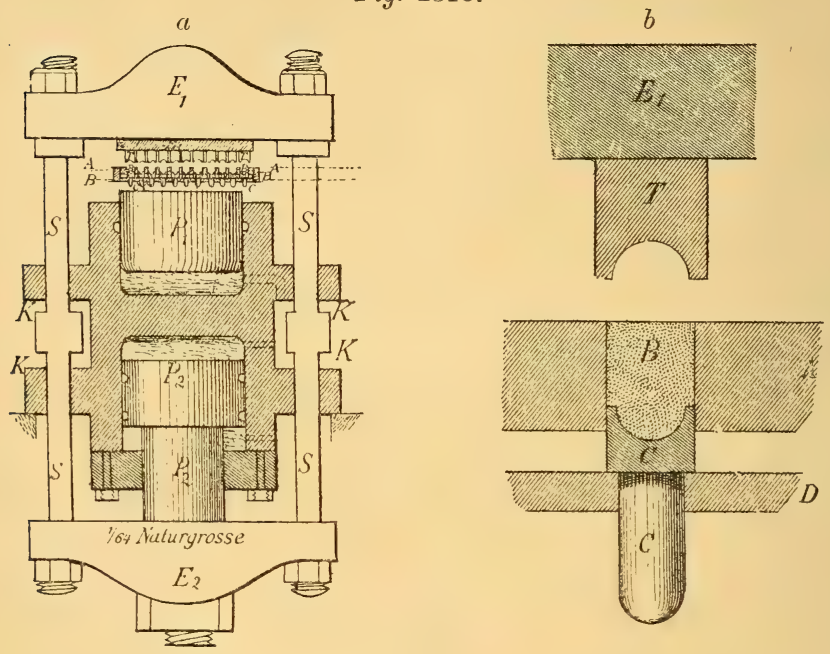

ans der Presse herausgedreht, dann leicht alle 200 Oefinungen $B$ mit Pulver gefiillt und dann wieder unter die Presse zurickgebracht werden derart, dass alle kleinen Stempel $C$ uber den oberen Presskopf $P_{1}$ zu liegen kommen. Beginnt die Presse ihr Spiel, so steigt das Querhaupt $E_{1}$ herab und alle Formen werden durch die Stempel $T$ oben fest verschlossen; gleichzeitig hebt sich der Presskopf $P_{1}$ und presst die unteren Stempel $C$ mit roller Kraft in die Formen. Ist das Pulver so in die entsprechende Form gepresst, so hebt sich $E_{1}$, die Stempel $C$ bewegen sich aber noch weiter nach aufwärts und pressen dabei die fertigen Körner aus den Formen heraus. Die Körner nähern sich der kugelförmigen Gestalt und sollen sich besser bewähren als rein cylindrische.

II. Surrogate des Schiesspulvers. Als solche soll jenes Pulver bezeichnet werden, welches in der Hauptsache ein mechanisches Gemenge sauerstoffund kohlenstoffreicher Körper ist.

a) Ersatz des Kalisalpeters: Natronsalpeter, vielfach versucht, gibt ein zu hygroscopisches Pulver; Barytsalpeter, besonders von Belgien und 
Preussen eingehenden Versuchen unterzogen, gibt Pulver, das zu heftig wirkt, mehr Feuchtigkeit als gewöhnliches Pulver anzieht und zu viel Riickstand erzengt; chlorsares (oder iiberchlorsaures) $\mathrm{Kali}$ ist viel zu heftig wirkend (zu brisant), auch im Verhältnisse zur Vermehrung des Nutzeffectes zu thener. Keines dieser Ersatzmittel hat sich als lebensfähig erwiesen. Bezüglich pikrinsaurem Kali siehe unten.

b) Ersatz der Holzkohle. Versucht wurden Zncker, Blutlaugensalz, feiner Holzstoff, Stärke, mineralische Kohle, Gerbsäure etc. Durchaus ohne praktischen Erfolg. Gute Holzkohle zeigte sich bisher als der beste kohlenstoffreiche Körper.

c) Pulver ohne Schwefel. In einer Reihe Pulver, die aber ebenfalls meist wenig Verbreitung erlangten, ist der Schwefel einfach weggelassen, ohne aber durch einen chemisch analog wirkenden Körper ersetzt zu werden.

d) Specielle Zusammensetzungen von Surrogatpulver.

Weisses Pulver von Augendre: Chlorsaures Kali..... . 40

Gelbes Blutlaugensalz . . . . . 25

Weisser Zucker ... . . . . . 25

Aus gleichen Stoffen besteht auch

Pohl's und Reveley's Pulver. Schwefel.

f . • • . . . . . . 2 Pulver von Sharp \& Smith:
Chlorsaures Kali. . . . . . . 2

Kalisalpeter . . . . . . . . . 2

Rothes Blutlaugensalz . . . . . 1

Weinsteinsaures Kali . . . . . . . 2

Schwefel ........... 2

Callo u's Pulver: chlors. Kali und Auripigment.

Spencer's Pulver: chlors. Kali, Stein- und Holzkohle, Sägespäne und doppelt-kohlensaures Natron.

Ehrhardt's Pulver: chlors. Kali, Kalisalpeter, Catechu und Holzkohle.

Kellow \& Short's Pulver: chlors. Kali, Kali- und Natronsalpeter, Schwefel, Lohe und Sägespäne.

Horsley's Pulver: 9 Thl. chlors. Kali, 3 Thl. Galläpfel.

N isser's Pulver: Ueberchlorsaures oder chlors. Kali, Ferro- oder Ferridcyankalium, Kali- oder Natronsalpeter, Pflanzenstoff, Steinkohle, Schwefel.

H a hn's Pulver: chlors. Kali, Schwefelantimon, Kohle.

Melland's Schiesspapier: Papier getränkt in Lösung von 9 Thl. chlors. Kali, $4^{1} / 2$ Thl. Kalisalpeter, $3^{1 / 4}$ Thl. gelbes Blutlaugeusalz, $1 / 16$ chromsaures Kali mit $3 \frac{1}{4}$ Thl. Holzkohle und $1 / 20$ Stärke.

D e 'Tret's Pulver (Pyronone): Natronsalpeter, Schwefel, Lohe.

Devey's Pulver: Natronsalpeter, Schwefel, Kohle und eine schleimige Substanz (Mehl, Stärke etc.) als Teig geformt, gekörnt und getrocknet.

Das Pulver von Orland, Eaton, Schwarz ist ein Gemenge aus Kaliund Natronsalpeter mit Stein- und Holzkohle; Sch äffer \& B u den berg's Sprengpulver hat ausserdem noch einen Zusatz von Seignettesalz.

Oller's Pudrolith besteht aus:

Kalisalpeter . . . . . . . 68

Natronsalpeter . . . . . . . 3

Barytsalpeter . . . . . . . 3

Schwefel . . . . . . . . 12

Holzkohle, Sägemehl, Lohe ... . 14

Carboazotine ist ein Gemenge von:

Kali- oder Natronsalpeter . . 50-60

Schwefel . . . . . . . 13-14

Kohle oder Sägemehl . . . 14-16

Russ . . . . . . . . $9-18$

Eisenvitriol . . . . . 5-6

Der P y r o lith e von Terré und Merca der ist ein Gemenge von Kalisalpeter, Sägemehl und Schwefel mit oder ohne Zusatz von Natronsalpeter und Steinkohle.

Typus eines Pulvers mit.Barytsalpeter ist Wynaud's Saxifragine bestehend aus: 76 Thl. Barytsalpeter, 2 Thl. Kalisalpeter und 22 Thl. Holzkohle. Schwefel.

Aehnlich ist Newton's und Küp's Pulver, nur enthält letzteres noch

Fehleisen's Haloxylin ist ein Gemenge von Kohle, Kalisalpeter und gelbem Blutlaugensalz. 
III. Die Nitroglycerinpulver oder Dynamite (la dynamite the dynamite).

a. Geschichtliche Notizen, Zusammensetzung und Eigens ch aften. Der neutrale Salpetersäureäther des Glycerins $C_{3} H_{5}\left(O N O_{2}\right)_{3}$, in der Technik Nitroglycerin oder Sprengöl genannt, bildet die Grundlage der wichtigsten Sprengmittel der Neuzeit. 1847 von Sobrero entdeckt wurde das Nitroglycerin erst 1863 durch Nobel, nachdem dieser eine praktische, wenig gefährliche Methode zur fabriksmässigen Erzengung gefunden hatte, in die Technik eingeführt. Es zeigte sich aber bald, dass Nitroglycerin im flïssigen Zustande ein so gefährlicher Sprengstoff sei, dass seine praktische Verwendung in diesem Zustande unzulässig wurde. Auch Nobels Vorschlag, durch Zusatz von 15-20\% Methylalkohol das Sprengöl während des Transportes unexplosiv zu machen und es am Gebrauchsorte durch Mischen mit Wasser von dieser Beimischung zn trennen, hat sich als unpraktisch erwiesen. 1864 machte Nobel die Entdeckung, dass Nitroglycerin, mit passenden porösen Körpern in bestimmten Verhältnissen gemischt, vorzïgliche Sprengstoffe gebe, welche die Verwendung der hohen Sprengkraft des Nitroglycerins, unter Vermeidung seiner bedeutenden Gefährlichkeit, zulassen. Diese Sprengstoffe, Nitroglycerin gemengt mit saugfähigen Körpern, haben von Nobel den Namen Dynamite erhalten.

Nitroglycerin, einer der stärksten bekannten Explosivstoffe, ensteht durch Einwirkung bestimmter Gemische starker Schwefel- und Salpetersäure auf Glycerin. Es ist eine hellgelbe, ölartige Flüssigkeit, geruchlos, von süsslichem, brennendem Geschmack, löslich in Alkohol und Aether, unlöslich in Wasser. Durch Flamme schwer entzïndlich, brennt es selbst in grösseren Quantitäten ruhig ab, bei vorsichtigem Erwärmen zwischen 100 und $150^{\circ}$ verdampft es, siedet bei $185^{\circ}$, detonirt bei etwa $250^{\circ}$. - Bei höheren Temperaturen kann wieder Zersetzung ohne Detonation eintreten. - Dagegen explodirt es in beliebig grossen Massen mit grösster Heftigkeit, wenn man in irgend einem Theile der Flüssigkeit eine geringe Menge bestimmter Knallpräparate (z. B. $0 \cdot 2-0.5$ Gramm Knallquecksilber in einem Kupferhuitchen eingeschlossen) zur Detonation bringt. - Diese Methode, gewisse Sprengstoffe dadurch zu vollständiger Explosion zu bringen, dass man die Detonation kleiner Mengen Knallsätze auf sie ïberträgt, wird die $\mathrm{Z}$ ï $\mathrm{n}$ d ung durch Detonation genannt. Sie bildet eine der fruchtbarsten Entdeckungen auf dem Gebiete der Sprengtechnik, die dem schwedischen Ingenieur A lfred Nobel zu danken ist. Die Geschwindigkeit der Fortpflanzung der auf solche Art erzeugten Explosion irgend eines Nitroglycerintheilchens durch die Masse des Nitroglycerins beträgt etwa 6000 Meter pro Secunde. Grosse Massen gelangen also fast momentan zu voller Explosion. Zwischen +8 und $+10^{\circ} \mathrm{C}$. erstart (gefriert) das Nitroglycerin zu farblosen, durchsichtigen Krystallen. Die Dichte des flüssigen Nitroglycerins ist $1 \cdot 6$, die des gefrorenen $1 \cdot 735$. Nitroglycerin ist giftig, verursacht in fliissigem Zustande und auch schon durch seinen Dampf heftigen Kopfschmerz, Mattigkeit, Schwindel. In diinnen Schichten explodirt es mit Heftigkeit, wenn es starken Schlägen oder Stössen zwischen harten Körpern ausgesetzt wird. Reines Nitroglycerin ist ein sehr stabiler Körper, bleibt Jahre lang unter den praktisch zu beachtenden Temperaturverhältnissen, selbst unter dem mehrwöchentlichen Einfluss von $50-60^{\circ}$ C. vollkommen unverändert. Die caustischen Alkalien zerlegen das Sprengöl unter Bildung salpetersaurer Salze und Glycerin. Die Zersetzungsproducte bei der Detonation sind noch umbekannt, wahrscheinlich sind es Kohlensäure, Wasserdampf, Stickstoff und Sauerstoff. Nach den heutigen theoretischen Anschauungen ist das Verhältniss der Energie des Nitroglycerins zu der des Schwarzpulvers ungefähr wie 2: 1; das Verhältniss der grössten Pressungen bei Explosion in allseitig greschlossenem Raume etwa wie 100: 8. Diesem letzteren Verhältnisse ist ungefähr die Sprengkraft gegen sehr feste Medien proportional. Da die Kraft des Nitroglycerins in weit geringerer Zeit zu roller Entwicklung gebracht werden kamn als die des Schwarzpulvers (Nitroglycerin weit brisanter als Pulver ist), kann Nitroglycerin zu bestimmten Zwecken (Sprengungen mit offen liegenden 
Ladungen) eine Kraft entwickeln, welche die des Schwarzpulvers noch weit mehr als in letzt angegebenem Verhältnisse iibersteigt. Dagegen vermindert sich das Kraftverhältniss zu Gunsten des Schwarzpulvers, wenn in weichen Medien (Erde) gewirkt werden soll. Das praktische Kraftverhältniss ist also von dem Materiale, in dem gewirkt werden soll, von der Art und Umschliessung der Ladungen abhängig.

Die Eigenschaften der Dynamite sind bedingt durch jene des Nitroglycerins und der zu dessen Aufsaugung verwendeten Stoffe. Im Allgemeinen sind es Pulver von grobkörniger, fettiger, mehr weniger plastischer Beschaffenheit, einem zwischen 1.0 und 1.6 wechselnden specifischen Gewichte und einer durch den Aufsaugestoff bedingten wechselnden Färbung. Gegen Feuer, glihende Kohlen, verhalten sie sich im Allgemeinen, wenn der Aufsaugestoff nicht selbst sehr verbrennlicher Natur ist, wie das Nitroglycerin. Geringere Quantitäten brennen meist ruhig ab, während bei grösseren Mengen auch durch blosse Entzündung eine Explosion herbeigefuihrt werden kann. Gegen mechanische Einwirkungen, wie starke Stösse und Schläge, sind gute Dynamite so weit unempfindlich, dass sie unbedenklich allen Erschütterungen des Transportes zu Wagen oder per Eisenbahn ausgesetzt werden können. Hierin liegt ihr ungeheuerer Vortheil gegeniiber dem flüssigen Nitroglycerin, welches eben während des Transportes enorm gefährlich ist.

Dynamite mit unorganischen Aufsaugestoffen geben im. Wasser das Nitroglycerin ab (hiezu gehören das Nobel'sche Dynamit I, dann alle sogenannten Salpeterdynamite, d. h. Dynamite, welche im Aufsaugestoff Salpeter enthalten). Dynamite mit blos organischen, passend präparirten Aufsangemitteln sind in Wasser vollkommen unverändert. (Cellulose-Dynamit und Schiesswolldynamit.)

Gleich dem Nitroglycerin bedürfen auch die Dynamite, um mit Sicherheit zu explodiren, einer besonderen Zündungsweise, der sogenannten Detonationszündung, welche meist darin besteht, dass man geringe Mengen $(0 \cdot 2-0 \cdot 4$ Gramm) Knallquecksilber, in einem Kupferhütchen eingeschlossen, in passender Weise im Innern des Dynamits zur Detonation bringt.

Wie das Nitroglycerin, so frieren (erhärten) auch die Dynamite bei Temperaturen unter $8^{\circ} \mathrm{C}$. und müssen dann vor der Verwendung in passender Weise aufgethaut oder durch sehr starke Kapseln oder besondere Zündpatronen zur Explosion gebracht werden.

Die Kraft der Dynamite ist abhängig von dem Aufsaugstoffe und der Menge des im Dynamite befindlichen Nitroglycerins.

Die verbreitetste Dynamitsorte, Nobel's Kieselguhr-Dynamit, bestehend aus $75 \%$ Nitroglycerin und $25 \%$ poröser Kieselerde, hat in sehr festem spröden Gestein die 6-7fache Kraft des Sprengpulvers. Je weicher der Stein, um so geringer wird die Ueberlegenheit dieser Dynamitsorte. Im Allgemeinen kann man aber mit Sicherheit annehmen, dass man durch passende Wahl der Dynamitsorte in allen Gesteinsarbeiten gegenüber dem Schwarzpulver wenigstens $25 \%$ an Kosten gewinnen und um $30-50 \%$ rascher arbeiten kann.

b) Fabrikation der Dynamite. 1. Erzeugung des Nitroglycerins. Die Rohmaterialien der Erzeugung sind: Salpetersäure von 1.5 spec. Gewicht, Schwefelsäure von 1.84 spec. Gewicht und Glycerin von 1.24 spec. Gewicht. Zur Bereitung von 1 Theil Nitroglycerin werden 1.5 Theil Salpetersäure mit $2 \cdot 6$ Theilen Schwefelsäure gemengt, dem abgekühlten Säuregemisch nach und nach unter beständiger Abkühlung und Bewegung der Flüssigkeit 0.5 Theile Glycerin zugesetzt und das so gebildete Gemenge in etwa die 10fache Menge Wasser ausgegossen. Es setzt sich dann das Nitroglycerin am Boden des Gefässes ab, wird abgezogen, mehrmals, zuerst mit Wasser und dann behufs völliger Entsäuerung mit Sodalösung gewaschen und endlich durch Filtrirung uiber Filzschichten von Wasser und Schlamm befreit. Hauptaugenmerk ist auf yöllige Neutralisirung des Nitroglycerins zu richten, da hievon in erster Reihe dessen chemische Stabilität abhängt. (Siehe Artikel Glycerin und Nitroglycerin.) Statt des Ausgiessens in Wasser kann man auch nach dem völligen Einbringen des 
Glycerins in das Säuregemische die Fliussigkeit ruhig stehen lassen, woranf sich nach $1 / 4-1$ Stunde das Nitroglycerin von den Säuren scheidet, sich auf diese.1 wie Oel anf Wasser absetzt und durch Decantiren von den Säuren getrennt werden kann.

Bei der fabriksmässigen Erzeugung wird meist der Process der Nitrirung in grossen Bleigefässen vollzogen, welche innen zahlreiche Schichten Bleiröhren enthalten, durch welche kaltes Wasser circulirt. Die Flüssigkeiten in den Gefässen werden durch comprimirte Luft in fortwährender Bewegung erhalten.

2. Erzeugung der Aufsaugestoffe. Die Erzeugung der Aufsaugestoffe variirt mit diesen. Der gebränchlichste und für viele $Z$ wecke beste Aufsaugestoff ist die sogenannte Kieselguhr, eine sehr leichte, mehlartige Infusorienerde, fast aus reiner Kieselsäure bestehend, welche bei Oberlohe in Hannover in grossen Lagern gefunủen wird. Die gegrabene Guhr ist sehr wasserhältig: und enthält organische Verunreinigungen. In grossen Flammöfen gebrannt, dann gewalzt und gesiebt saugt sie bis zu $76 \%$ Nitroglycerin und bildet mit diesem eine plastische Masse, welche das Nitroglycerin selbst unter grossem Drucke sehr gut festhält.

Für billigere oder weniger brisante Pulver, welche weniger (unter 70\%) Nitroglycerin enthalten sollen, werden als Aufsaugestoffe Gemenge, ähnlich dem Schwarzpulver, aus Salpeter und kohlenstoffreichen Körpern wie feiner Holzstoff, Kohle, Galläpfel ete. verwendet, die dann meist in ähnlicher Weise wie das Schwarzpulver erzengt werden. Gewöhnlich werden solchen verbrennlichen Gemengen dann noch, um die Saugfähigkeit zu vermehren, Guhr, Magnesia etc. zugesetzt.

Bei manchen Dynamiten werden endlich selbst feste Nitrokörper, wie Schiesswolle, zugemengt, deren Bereitung dann naturlich deren Natur entsprechend ist.

3. Erzeugung der Dynamite. Das Mengen der Aufsangestoffe mit dem Nitroglycerin. geschieht am sichersten und besten durch die primitivste Methode, nämlich durch Mengen des Pulvers mit dem Sprengöle mittelst Handarbeit in einfachen, mit Blei oder Kautschuk gefiitterten, Holztrögen. Ist die Mischung eine gleichförmig innige, so wird das gebildete Dynamit durch feine Siebe gedrïckt, um fremde Körper zu entfernen.

4. Patronirung des Dynamits. Des sicherern Transportes- und der leichteren Handhabung wegen wird das Dynamit für Bergwerkszwecke gewöhnlich schon in den Fabriken zu Patronen verarbeitet, d. h. in Pergamentpapierhiilsen eingepresst, welche den gewöhnlichen Bohrlochsdurchmessern entsprechen und wechselnde Längen haben.

c) Dynamitsorten. Die verbreitetsten und erprobtesten Dynamitsorten sind gegenwärtig die von der deutsch-österr.-ungarischen Dynamit-Actien-Gesellsehaft (vormals Alfred Nobel \& Comp.) erzeugten. Es sind:

1. Stärkste und im Wasser unveränderliche Sorte: Trauzl's CelluloseDynamit: $70-75 \%$ Nitroglycerin, $30-25 \%$ Cellulose.

2. Nobel's Kieselguhr-Dynamit: $75 \%$ Nitrogliyeerin, $25 \%$ Kieselguhr.

3. Salpeter-Dynamite obiger Gesellschaft:

Nr. II. Nr. III. Nr. IV.

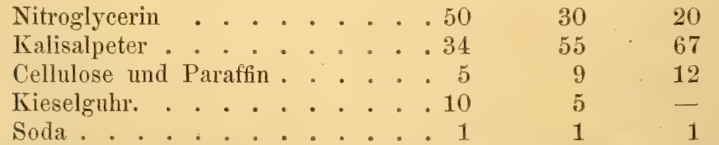

Ausser diesen Dymamiten existirt noch eine Unzahl Nitroglycerinpulver, welche theils ebenfalls den Namen Dynamit tragen, theils, obwohl sie Dynamite sind, unter anderen Namen in den Handel gebracht wurden. Die bekannten hievon sind:

Nobel's diverse Salpeterpulver und zwar: 1. 69\% Natronsalpeter, 4 Paraffin, 4 Holz- oder Steinkohle, 20 Nitroglycerin. 2. Barytsalpeter 70, Harz 10, Nitroglycerin 20 . 
Brain's Pulver: $40-50$ Nitroglycerin, $60-40$ einer Mischung aus 1 Theil Kaliumchlorat, 1 Theil Holzkohle, 1 Theil Zucker.

Lith of r a t e ur: Nitroglycerin 52, Kieselguhr 30, Steinkohle 12, Baryt-oder Natronsalpeter 4, Schwefel 2.

Col on i a u lver: Eine Art Schwarzpulver mit Nitroglycerin getränkt. (Wird nicht mehr erzeugt.)

Weisses Dynamit (nach Analysen von Schwarz in Graz): 57-67 Nitroglycerin, 42-30 Kreide und Sägespäne, 1-3 Feuchtigkeit.

Rhexite: Gemenge von $30-65 \%$ Nitroglycerin mit Kalisalpeter, Kreide, Sägespänen und geringem Zusatze von schlecht nitrirtem Holzstoffe, also zersetzlicher Natur.

D u a lin: Im Allgemeinen als Aufsaugestoff, Gemenge von nitrirtem oder unnitrirtem Sägemehl, Nitrostärke, Nitromannit und Kalisalpeter.

Ammoniakrut von Norbin: $80 \%$ Ammoniaksalpeter, $6 \%$ Kohle und $10-20 \%$ Nitroglycerin.

Seranine und Horsley's Pulver haben als Aufsaugestoff Gemenge von chlorsaurem Kali mit kohlenstoffreichen Körpern, wie Galläpfel etc.

IV. Schiesswolle (poudre-coton - gun-cotton). (S. Artikel Cellulose, Collodium und Schiesswolle.)

a) Geschichtliche Notizen, phisikalische und chemischeEigen$\mathrm{sch}$ aften. Branconnot entdeckte 1832, dass eine Reihe organischer Substanzen durch Behandlung mit Salpetersäure in explosible Körper verwandelt werden könne. 1846 entdeckte S chönbein ein praktisches Verfahren, um speciell Baumwolle durch Eintauchen in Gemenge von Salpeter- und Schwefelsäure in einen explosiven Stoff, Schiessbaumwolle genannt, zu verwandeln. Eingehende Studien von Regierungscommissionen in fast allen Staaten Europa's gaben zunächst kein praktisches Resultat und wurden Anfangs 1865 am Continent iiberall wieder die Versuche sistirt. Nur in England führte A bel das von dem österreichischen Feldmarschalllieutenant Baron Len $\mathrm{k}$ mitgetheilte Verfahren der Schiesswollerzengung fort, verbesserte es dadurch, dass er die Schiesswolle ähnlich wie Papiermasse maischte, sie stark comprimirte undihr endlich dadurch einen grossen Anwendungskreis wenigstens für militärische Zwecke sicherte, dass er zeigte, dass auch auf sie die Detonationszuindung anwendbar sei, und dass sie mit grossem Wassergehalte noch vollkommen explodirbar bleibe.

Schiesswolle unterscheidet sich im Aeussern fast gar nicht von gewöhnlicher Baumwolle, nur ist die Faser weniger elastisch und brichiger, knirscht beim Zusammendrücken und wird durch Reibung elektrisch.

Schiesswolle ist geruch- und geschmacklos, in Wasser vollkommen unveränderlich, unlöslich in Aether, Alkohol und weingeistigem Aether, widersteht den stärksten Säuren und Alkalien, wird aber durch concentrirte Schwefelsäure allmälig zersetzt. Vollkommen rein ist sie ein sehr stabiler, jahrelang unveränderlicher Körper.

Das spec. Gewicht ist abhängig von der Form und dem Compressionsgrade. In Flockenform hat sie 0.2 , in stark comprimirtem Zustande $0.9-1 \cdot 0$ spec. Gewicht.

Ihre Entziindungstemperatur schwankt zwischen 120 und $170^{\circ}$. Sie ist gegen Reibung ziemlich empfindlich, weniger gegen Stösse und Schläge.

Angezündet brennt sie in trockenem Zustande mit $4-5^{\mathrm{m}}$ Geschwindigkeit ab, im comprimirten Zustande ist die Verbrennung weit langsamer und können selbst Mengen von mehreren Centnern ohne Explosion abbrennen. Mit Knallpräparaten zur Explosion gebracht, detonirt sie auch ohne festen Einschluss mit voller Gewalt und einer $5000^{\mathrm{m}}$ iibersteigenden Geschwindigkeit.

Die Energie der Schiesswolle ist etwa 500.000 Kil. à 1 Kg., ihr grösster Druck bei Explosionen in eigenem Raume etwa das 4 fache von jenem guten Schwarzpulvers. Ihre Triebkraft in Gewehren ungefähr das 3-4fache von jener guten Schiesspulvers. Die Sprengkraft comprimirter Wolle ist ungefähr gleich jener der starken Dynamitsorten (mit 75\% Nitroglycerin).

Karmarsch \& Heeren Technisches Wörterbuch. Bd, III. 
b) Fabrikation der Schiesswolle (nach Lenk und Abel). Roh materialien sind: Abfälle der Baumwollspinnereien, die durch Kochen mit starken Alkalien vollkommen entfettet, ausgewaschen und dann scharf getrocknet werden, Salpetersäure von 1.52 spec. Gewicht und Schwefelsäure von 1.84 spec. Gewicht.

Die Säuren werden im Verhältniss von 1 Salpeter- auf 3 Schwefelsäure gemischt, abgekïhlt und dann die Baumwolle in kleinen Quantitäten in die Säure getaucht und wenige Minuten in der Säure belassen. Beim Herausziehen der Wolle aus den Säuren haftet ihr etwa das 9-10fache ihres Gewichtes an Säuren an und wird die Wolle in diesem Zustande etwa 24 Stunden zum Zwecke vollständiger Nitrirung in Steinguttöpfen belassen, welche von kaltem Wasser umspült sind. Nach dieser Zeit wird die anhaftende Säure durch Centrifugen von der nun in Schiesswolle verwandelten Baumwolle möglichst getrennt, die ausgedrückte Schiesswolle in Wasser getaucht und darin tüchtig ausgewaschen und dann das anhaftende Wasser wieder durch Centrifugiren entfernt. Die Schiesswolle wird nun in heissem Wasser unter Dampfzuleitung längere Zeit belassen, hierauf in einer Art Holländer fein zermahlen und hierauf noch in diesem fein vertheilten Zustande zur Entfernung der letzten Säurespuren einem neuen Waschprocesse, ähnlich jenem von Papierbrei, unterzogen. Zeigt sich nach 24-36stïndigem Waschen die Schiesswolle vollkommen säurefrei, so wird ihr noch ein neutralisirendes Agens (Soda etc.) zugesetzt und der Schiesswollbrei dann in die Pressen geleitet.

Je nach dem Zwecke wird nämlich die Schiesswolle durch starke hydraulische Pressen, welche einen Druck von etwa 1000 Kilo à $\square^{\mathrm{cm}}$ ausüiben können, in Cylinder- oder Scheibenform gepresst, welche ein spec. Gewicht von $0.9-1$ haben. Für Bergbauzwecke, haben die so erhaltenen Cylinder Durchmesser, welche den gewöhnlichen Bohrlöchern entsprechen, fuir militärische Zwecke hingegen werden Scheiben von $7 \cdot 8^{\mathrm{cm}}$ Durchmesser und $5 \cdot 25^{\mathrm{cm}}$ Höhe gepresst, welche mit einem Wassergehalte von $20 \%$ zur Verwendung gelangen.

Fiir Gewehrpatronen werden aus dem Schiesswollbrei Bogen, ähnlich wie bei der Papierfabrikation, geschöpft, getrocknet, dann in längliche Streifen zerschnitten und mittelst Maschinen zu Cylindern geformt, die durch ein Guttaperchahäutchen gegen Feuchtigkeit geschützt werden.

c) Surrogate der Schiesswolle. Ausser der möglichst reinen Cellulose, der Baumwolle, können eine Reihe verwandter Stoffe durch einen ähnlichen Process, wie bei der Schiesswolle angegeben, zu Explosivkörpern umgewandelt und fuir sich oder gemengt mit anderen Körpern verwendet werden. Solche Präparate sind :

Schultze's Pulver. (Weisses Schiess- und Sprengpulver.) Fein gekörntes hartes $\mathrm{Holz}$ wird mit Sodalösungen gereinigt, ähnlich wie Schiesswolle nitrificirt, dann mit einer Lösung von Kalisalpeter und Blutlaugensalz getränkt und getrocknet. Das sogenannte Collodin oder Volkmann'sche Pulver ist dasselbe Präparat. Aehnlich M us champ's Pulver.

Statt des Holzes kann man auch andere Pflanzenstoffe, Papier (Pyropapier), Flachs (Patent von Bicford \& Spoonor), Kleie (L annoy's Patent) etc. "verwenden.

Mackie's gekörnte Schiesswolle: Gewöhnliche, fein zermahlene Schiesswolle mit Salpeter- und Zuckerlösung getränkt und dann granulirt.

Hall's Sprengmittel: Schiesswolle mit Stärke.

U chatius - Pulver (Nitrostärke, Xiloidin): Stärke rerwandelt durch Nitrificirung in Nitrostärke, einem weissen, sehr hygroskopischen und sehr explosiven Pulver. Ohne praktische Bedeutung.

Nitromannit (Kuallmannit) entsteht aus einer bekannten Zuckerart, dem Mannit, ganz analog wie die Schiessbaumwolle. Stark explosives Präparat, mehrseitig als Ersatz des gefährlichen Knallquecksilbers zur Füllung von Zündhütchen vorgeschlagen. 
Aehnlich wie Mannit lassen sich auch andere Zuckerarten in Explosivkörper verwandeln und erhält man so Nitrorohrzucker, Nitromilchzucker etc.

V. Die Pikratpulver. Aus dem Phenol (Carbolsäure), so wie aus einer Reihe organischer Körper, wie Salicin, Harz, Indigo etc. erhält man durch entsprechende Behandlung mit concentrirter Salpetersäure die Pikrinsäure, die, an sich schon explosiv, mit einer Reihe Basen lösliche, kristallisirbare, rothe oder gelbe Salze bildet, welche zum Theile beim Erhitzen oder durch starke mechanische Einwirkungen heftig explodiren. Mehrere dieser Salze wurden zur Bildung von Explosivmitteln verwendet.

Designoll's Pulver besteht aus wechselnden Mengen von Kalisalpeter und pikrinsaurem Kali und Kohle.

Brugèrés Pulver, so wie Prof. A bel's Pikrinpulver aus pikrinsaurem Kali und pikrinsaurem Ammoniak.

Auch Bobeuf's und Fontaine's Pulver sind Pikratpulver.

Solchen Pulvern wird gegenüber dem Schwarzpulver nachgeriihmt: Gleichmässigere Wirkung, geringerer Druck im Rohre bei gleicher Triebkraft, geringere Hygroscopicität, wenig Rauch, unschädlicher Rückstand im Rohre etc.

Trotz all' dieser geriihmten Vorzïge haben sie bisher, ungeachtet sehr eingehender Versuche in Frankreich, keine grössere praktische Bedeutung erlangt.

Einige der Pikrinsäure und ihren Derivaten analoge Körper wie Knallanilin (salpetersaures oder chromsaures Diazobenzol) wurden als Ersatz des Knallquecksilbers vorgeschlagen.

VI. Knallpräparate (Fulminate). Zur Zündung für Gewehre und Geschütze, dann zur Detonationszündung bei gewissen Sprengmitteln (Dynamit, Schiesswolle etc.) bedarf man Präparate, welche durch Schlag, Reibung oder auch durch blossen Funken in heftiger Weise explodiren. Solche Präparate, meist Mischungen mehrerer explodirenden Substanzen, heissen je nach der Anwendungsweise, Percussions- oder Frictionssätze etc. Ihre Hauptbestandtheile sind Salze der Knallsäuren.

Am meisten Anwendung findet das Knallquecksilber $\mathrm{C}\left(\mathrm{NO}_{2}\right) \mathrm{CNHg}$. Es wird erzeugt durch Einbringen von 1 Theil Quecksilber in ein Gemische von 5 Theilen verdiinnter Salpetersäure (von 1:3 spec. Gewicht) mit 10 Theilen Alkohol (von 0.85 spec. Gewicht). Die nach Beendigung der Reaction abgeschiedenen kleinen, schwach grau gefärbten, nadelförmigen Krystalle des Knallquecksilbers werden auf Filtern so lange mit Wasser gewaschen, bis das ablaufende Wasser keine saure Reaction zeigt. Aus 100 Theilen Quecksilber werden 125 Knallquecksilber gewonnen. Das Knallquecksilber ist höchst explosiv und detonirt schon durch mässigen Schlag und Reibung zwischen harten Körpern. Feuer und der Induktions-Funke bringen es, besonders wenn es eingeschlossen ist, ebenfalls zu voller Detonation.

Es wird nur als Zündmittel verwendet, meist gemischt mit anderen Körpern. Vielverwendete Zündsätze sind:

$\mathrm{Z}$ ündsatz fü r Gew ehre: 100 Theile Knallquecksilber, 30 Theile Wasseı und 60 Theile Mehlpulver zu Brei vermengt, gekörnt und dann getrocknet, oder 100 Knallquecksilber, $62 \cdot 5$ Salpeter, 29 Schwefel.

$\mathrm{Z}$ ï ndsatz für österreichische Hinterlader: 3 Theile Knallquecksilber, 2 Theile chlorsaures Kali, 4 Theile Glaspulver, 1 Theil Leimlösung.

Zündsätze fürDynamit und Schiesswollkapseln: 3 Theile Knallquecksilber und 1 Theil chlorsaures Kali.

Dem Knallquecksilber analoge Verbindungen, wie das Knallsilber und Knallgold, sind noch empfindlicher wie das Erstere und haben keine bedeutendere praktische Anwendung gefunden. Ueber farbige Feuersätze s. Feuerwerkerei. J. Trauzl.

Liter atur. Das Schiesspulver, die Explosivkörper etc. von Dr. J. Upmann 1874 (enthält auch zahlreiche Literaturangaben.) - Ueber explosive Nitrilver- 
bindungen von I. Trauzl 1870. - Theoretische und praktische Chemie von Muspratt (mit zahlreichen Literaturangaben). - Die Explosivstoffe der Gegenwart von Isidor Trauzl 1877. Memorial de l' officier du génie Nr. 20 (höchst empfehlenswerthe Arbeit über die nenern Explosivstoffe). Guida pratique de la fabrication des Poudres par Steerk. - Les explosives modernes. Memoires etc., Paris 1876. Handbook of the Manufacture and Proof of Gunpowder. - Die wichtigen Arbeiten von F. A. Abel publicirt in den Phil. Transactions of the Royal Society. La Dynamite et la Nitroglycerine par Champion 1872. Sur la force de la Poudre par Berthellot 1872. - Gintl Ausstellungsbericht iiber Explosivstoffe, Wien 1873.

Exponent, in der Algebra in der primitivsten Bedeutung jene Zahl $n$, welche anzeigt, wie oft eine andere $a$ als Factor zu setzen ist (Potenz-Exp.), und im Gegensatze dazu jene Zahl $m$, welche angibt, in wie viele gleiche Factoren eine andere $b$ zerlegt werden soll (Wurzel-Exp.). Beide Definitionen gelten ihrem Wesen nach nur fuir eine positive ganze Zahl. Daher allgemeiner : „Der Exponent $n$ schreibt vor, eine Zahl $a$ solle zur Einheit so als Factor gesetzt werden, wie er selbst aus jener Einheit entstanden ist". Da -3 durch dreimalige Setzung des Gegensatzes der Einheit entsteht, der Gegensatz des Factors 8 aber der Quotient $\frac{1}{8}$ ist, so hat man $8^{-3}=1 \cdot \frac{1}{8} \cdot \frac{1}{8} \cdot \frac{1}{8}=\frac{1}{8^{3}}$; da ferner $\frac{2}{3}$ durch zweimalige Setzung des dritten Theiles der Einheit entsteht, dem dritten Theil der Einheit andererseits die dritte Wurzel des Factors entspricht, so ist $8^{\frac{2}{3}}=1 \cdot \sqrt[3]{8} \cdot \sqrt[3]{8}=\sqrt[3]{8^{2}}=4 ;$ da ferner $o$ aus der Einheit entsteht, indem man diese gar nicht setzt, so verlangt der Exponent $o$, man solle $a$ zur Einheit gar nicht als Factor setzen, d. h. $a^{0}=1 .-$ Operationsexponent, jene Zahl, welche anzeigt, wie oft an einer vorgelegten Grösse eine gewisse Operation auszufuibren ist; z. B. in $D^{n} f(x), D_{x}^{n} f(x, y)$ schreibt $n$ vor, man solle die Function $f(x)$ nmal nach einander ïberhaupt, resp. $f(x, y)$ ebenso oft nach der Variabelen $x$ allein differentiren. Brechungsexponent (s. Optik.) - Exponentialgleich n ungen, zu den transcendenten Gleichungen gehörig, enthalten die Unbekannte im Exponenten und können durch Logarithmirung in algebraische iiberfiihrt werden. So gibt z. B.: $a^{f(x)}=b^{4(x)}$ die algebraische Gleichung $f(x) \cdot l a=q(x) \cdot l b$, sofern $f(x), q(x)$ algebr. Funct. sind. - Exponentialgrösse, eine Potenz mit variablem Exponenten (z. B. $a x)$. Exponentialgrössen mit imaginär em Expon. fïhren den Namen Drehungs- o. Richtungsfunctionen, weil sie zur Darstellung der sogenannten Richtungszahlen (complexen Grössen) in die Algebra eingefiihrt wurden. So bedeutet reiq eine Strecke von der Länge $r$, welche um den Winkel of aus der Linie der positiv-reellen Zahlen gedreht wurde, oder jene complexe Grösse, deren reeller Antheil $r \cos q$, deren imaginarer Bestandtheil ir $\sin \varphi$, ist (alles auf eine bestimmte Einheit bezogen). - Exponentialreihe, d. i. die der Exponentialgrösse $a x$ äquivalente unendliche Reihe: $a x=1+\frac{x l a}{1}+\frac{x^{2}(l a)^{2}}{1 \cdot 2}+\frac{x^{3}(l a)^{3}}{1.2 \cdot 3}+\cdots \cdots$

Czuber.

Exsiccatoren (exsiccateurs) sind Apparate zur Trocknung von Substanzen ohne Anwendung von Wärme, s. Abdampfen I pag. 5, s. Trockenapparate. Gtl.

\section{Exstirpator, s. Landwirth sehaft.}

Extincteur nennt Cartier einen Apparat, welcher bestimmt ist zu Feuerlöschzwecken zu dienen, und dessen Wirkung darauf beruht, dass mit Kohlensäuregas gesättigtes und unter dem Drucke comprimirter Kohlensäure stehendes, in einem nach Art der Syphonflaschen (s. Kohlensäure, s. Sodawasser), 
eingerichteten, geniigend starkwandigen Gefässe aufbewahrtes Wasser, durch Oefinen eines Hahnes durch die Druckwirkung des comprimirten Gases in Gestalt eines Strahles herausgetrieben werden kann. Solche Apparate sind ausser von Cartier (vgl. Dingl. pol. Journ. 180, 199) auch von M as nata (d. Industrie-Ztg. 1867, pag. 118), dann von Bar agwan ath (d. Industrie-Ztg. 1867, pag. 187) angegeben worden, können aber nur zur Bekämpfung kleiner Brände mit Vortheil benützt werden, weil die verfügbare Wassermenge eine relativ nur geringe sein kann. Vgl. Feuerlöschwesen. Gtl.

Extracte (extraits - extracts). Durch an und für sich indifferente Lösungsmittel können aus organischen und insbesondere aus pflanzlichen Stoffen gewisse lösliche Substanzen gewonnen werden, während ein bedeutender unlöslicher Riickstand bleibt, welcher die Organisation der ursprünglich angewandten Stoffe besitzt. Dies Verfahren heisst die Extraction, das Ausziehen (s. Auslaugen). Die durch Extraction gewonnenen Lösungen führen in dem Falle, als dieselben zur mehr oder weniger dicklicher oder fester Consistenz eingeengt werden, den Namen Extracte oder A usziige. Das Verfahren ihrer Darstellung heisst die Extractbereitung. Die Lösungsmittel, deren man sich bei der Bereitung der Extracte bedient, und welche man deshalb Extractionsmittel nennt, sind: Wasser, Weingeist und Aether, selten kommen andere, wie Schwefelkohlenstoff, angesäuertes Wasser ete. zur Anwendung.

Die Extractbereitung bezweckt die Concentration aller, als chemisch oder medicinisch wirksam erkannten oder technisch verwendbaren Bestandtheile eines pflanzliehen oder thierischen Körpers behufs bequemer Aufbewahrung, Versendung und Verwendung.

Nach der Art der angewandten Lösungsmittel unterscheidet man wässe rige, weingeistige und ätherische Extracte. Saftextracte oder Störk'sche Extracte sind aus saftreichen Pflanzen oder Pflanzentheilen ohne Anwendung eines Lösungsmittels durch Auspressen und Eindicken der Pflanzensäfte erzeugt. Ihrer Wirkung nach sind die Extracte, narkotisch adstringirend, bitter etc. Hinsichtlich ihrer Verwendung könnte man sie eintheilen in solche, welche als Arzneimittel Verwendung finden, in solche, welche zum Gärben und Färben verwendet werden, und in Extracte, welche concentrirte Nahrungs- und Genussmittel vorstellen.

Man nennt die Extracte dii $\mathrm{n} n$, wenn sie die Consistenz des Honigs besitzen, dick, wenn man ihnen nach dem Erkalten die Pillenform ertheilen kann, und trocken, wenn sie entsprechend eingedickt nach dem Erkalten zerreiblich sind. Die Trockenform gibt man Extracten, die sich sonst ohne zu verderben nicht aufbewahren liessen, und welche beim Eintrocknen keinen Schaden leiden. Das vollkommene Austrocknen bei gewöhnlicher Temperatur gelingt nur unter einer Glasglocke über Schwefelsäure oder Chlorcalcium. Da Trockenextracte leicht Feuchtigkeit aus der Luft anziehen, müssen sie besonders sorgfältig aufbewahrt werden. Bei Extracten, welche sich ohne Zersetzung nicht völlig austrocknen lassen, wird das Austrocknen durch Vermengen mit indifferenten Stoffen (Zucker etc.) befördert.

Die Art der Extractbereitung ändert sich mit dem Lösungsmittel. In allen Fällen jedoch fordert man: 1. Die zweckmässige Zerkleinerung der organischen Substanz, damit das Lösungsmittel sie völlig durchdringen und energisch lösend wirken könne. Ob die organische Substanz zerschnitten, geraspelt, zerquetscht, zerrieben, zerstossen etc. werden soll, hängt von ihrer Art und ihrer Festigkeit ab. 2. Die sparsame Anwendung des Extractionsmittels. Das Gelöste muss vom Ungelösten etwa durch Abpressen getrennt und der Rückstand wiederholt ausgezogen werden. Je weniger Flïssigkeit verdampft zu werden braucht, desto eher kann einer etwaigen Zersetzung vorgebeugt werden. 3. Eine zweckmässige Temperatur, die sich zwar nach der Art des Extractes ändern, meist aber zwischen $20^{\circ}$ C. und $50^{\circ}$ C. bewegen wird. Das Auskochen wird nur bei holzigen Pflan- 
zentheilen angewendet, während Substanzen, welche viel Pectinstoffe enthalten und deshalb schwierig klärbare warme Extracte liefern, kalt extrahirt werden, die Löslichkeit der wirksamen Bestandtheile in kaltem Wasser vorausgesetzt. 4. Rasche Bereitung, da durch eine solche nachtheilige Zersetzungen vermieden werden. 5. Das Abdunsten und Eindicken des Extracts soll niemals über freiem Feuer, sondern immer auf dem Dampfbade und unter fleissigem Umrïhren vorgenommen werden. Jede Hautbildung auf der Oberfläche des Extracts ist ebenso zu vermeiden, wie unvorsichtiges Erhitzen. Zum Abjunsten sind am zweckmässigsten Apparate anzuwenden, welche die Verdunstung im Vacuum bei möglichst niederer Temperatur und in kürzester Zeit gestatten (s. Destillation). Zweckwiedrig ist es, dem ersten während des Eindampfens die folgenden Auszüge nach und nach zuzusetzen, der grösste Theil des Extracts bliebe dadurch längere Zeit einer höheren Temperatur ausgesetzt und litte Schaden. Wässerige Extracte bereitet man durch Maceration, Infusion, Digestion und Auskochen. Bei den meisten und insbesondere bei allen fleischigen und lockeren Pflanzengeweben (Blättern, Kräutern, Wurzeln) liefert die heisse Infusion eine grössere Extractausbeute als das Auskochen.

Die Extraction mit kaltem Wasser besteht darin, dass man die zerkleinerte Pflanzensubstanz etwa 24 Stunden mit kaltem Wasser macerirt, die abgepresste Flüssigkeit durch Stehenlassen klärt und zur vorgeschriebenen Consistenz eindampft. Die kalte Extraction nimmt viel Zeit in Anspruch, wodurch die Güte des Extracts beeinträchtigt wird. Mit Benuitzung der Real'schen Presse kann man dies Verfahren beschleunigen.

Die Real'sche Presse ist eine Vorrichtung, bei welcher der Druck einer höheren Wassersäule das raschere Extrahiren gestattet. Zu gleichem Zwecke bediente man sich früher weit mehr denn jetzt der Romershausen'schen Luftpresse: Vermittelst einer Handluftpumpe wird in einem sogenannten Evacuationsgefässe, welches mit dem oberhalb befindlicheu Extractionsgefässe luftdicht verbunden ist, ein luftverdünnter Raum erzengt, in Folge dessen der Druck der äussern Luft das Wasser mit grösserer Gewalt durch die zu extrahirende Substanz treibt und ein inniges Durchdringen des Zellgewebes derselben bewirkt, wenn die organische Substanz im Extractionsgefässe zusammengedrückt wurde, um das Wasser nicht wirkungslos hindurchfliessen zu lassen. In dem Evacuationsgefässe sammelt sich das Extract an.

Die Extractbereitung unter Anwendung von Wärme führt rascher zum Ziele. Der erste Auszug kann nach zwei Stunden abgepresst werden, während der immer wieder etwas aufzulockernde Riickstand noch ein oder zweimal mit heissem Wasser übergossen wird. Die Gesammtmenge des gewonnenen Auszugs wird aufgekocht, geklärt, geseicht und auf dem Wasserbade eingedampft. Zur Bereitung solcher Extracte verwendet man das Extractfass, ein Holzgefäss mit doppeltem Boden, das ein bequemes Auspressen der ausgelaugten Substanz gestattet, die Romershausen'sche Dampfpresse, eine Vorrichtung, darauf beruhend, dass der Druck des in einem geschlossenen Gefässe entwickelten Dampfes beim Oeffnen eines Hahnes Wasser durch eine dichte Schichte des zu extrahirenden Stoffes emportreibt, wodurch dieselbe binnen Kurzem vollständig ausgezogen werden kann, und weit häufiger eine von Rochleder angegebene Vorrichtung: ein ïberall siebartig durchlöcherter Cylinder aus Weissblech, auf drei kurzen Fuissen stehend, wird mit zerkleinerter Pflanzensubstanz angefuillt, mit einem Siebdeckel versehen in eine Destillirblase gestellt und der Einwirkung des siedenden Wassers und des Dampfes ausgesetzt; hierauf herausgenommen, die Pflanzensubstanz abgepresst und derselbe Vorgang mit neuen Partien Wassers wiederholt.

Farbextracte sind meist wässrige Extracte. Sie werden durch Auskochen der Farbhölzer und Eindampfen der erhaltenen Lösungen erzeugt. Farbholzextracte sind im Zeugdruck mit Vortheil zu verwenden, werden fabriksmässig dar- 
gestellt und namentlich von Frankreich und Suidamerika aus in den Handel gebracht.

Die zweckmässige Zerkleinerung der Farbholzscheite erfolgt mittels Maschinen. Das zerkleinerte Farbholz wird in einem von Aimé Bohra angegebenen oder einem andern ähnlichen Apparat extrahirt. Lin birnförmiges Gefäss von Kupferblech ist in Pfannen drehbar, welche auf Ständern ruhen; der birnförmige Kessel ist oben mittels einer Kappe luftdicht verschliessbar, im Innern bildet eine vielfach durchlöcherte Kupferplatte einen Boden, oberhalb dessen ein Sieb ans Kupferdraht angebracht ist; uiber dem Siebboden lagert ein gelochtes Schlangenrohr, das durch einen hohlen Zapfen eintritt, während ein zweites durch den entgegengesetzten hohlen Zapfen eintretendes Rohr bis an den Boden des Kessels reicht, welcher mit einem kurzen, mittels eines Hahnes abschliessbaren Rohre zum Ablassen des Kesselinhalts versehen ist. Der Kessel wird mit zerkleinertem Farbholze beschickt und aus dem unteren Rohre Wasser eintreten gelassen. Während aus dem Rohre oberhalb des Siebbodens Dampf strömt, gestattet man der Llift zu entweichen. Der eintretende Dampf bringt den Kesselinhalt zum Sieden, welches etwa eine halbe Stunde fortgesetzt wird. Beim Oeffnen eines Hahnes strömt der erhaltene Farbauszug in Folge des Dampfdrucks in einen Bottich, während neue Wassermengen bei Wiederholung des geschilderten Vorgangs die vollständige Erschöpfung des Farbholzes bezwecken. So erzeugt man drei verschiedene Abkochungen, welche mit einander vermengt entweder sogleich verwendet oder zur Trockene eingedampft werden.

Aehnliche zur Erzeugung von Farbextracten im Grossen beniitzbare Vorrichtungen älterer Art sind die Extractionsapparate von Suarce, $\mathrm{Kramer}$, Schlumberger, Meissonier, Payen u. a.

Der Payen'sche Apparat gestattet neben dem Ausziehen das sofortige Eindampfen und besteht aus einem Kessel mit doppeltem Boden, dessen Inhalt durch Dampf erhitzt wird. Mit dem Kessel stehen zwei Cylinder in Verbindung, die mit dem zerkleinerten Farbholz beschickt werden, welches der Dampf durchströmen kann. Die Anwendung zweier Extractionseylinder gestattet continuirlichen Betrieb; denn während der eine entleert wird, arbeitet der andere. Der aus dem Cylinder austretende Dampf wird in einem mit diesem in Verbindung stehenden Gefässe verdichtet und die dabei abgegebene Wärme zum Abdampfen des Extracts verwendet, was insofern geschehen kann, als der Boden des Abdampfgefässes den Deckel des Condensators bildet.

Wässerige Extracte sind: das Aloeextract, aus dem eingetrockneten und gepulverten Safte mehrerer Aloearten; das Chinarindenextract, aus der Rinde gewisser Cinchonaarten; das Enzianextract, aus kleingeschnittener Enzianwurzel; das Bitterkleeextract, aus den getrockneten Blättern von Menyanthes trifoliata L; das Löwenzahnextract, aus den getrockneten und zerschnittenen Blättern und Wurzeln von Taraxacum officinale Moench; das Opiumextract, aus dem eingetrockneten Safte unreifer Früchte von Papaver somniferum L.; das Quassiaextract, aus dem gestossenen Holze von Quassia amara L.; das Ratanhaextract, aus der Wurzel von Krameria triandra L.; das Fleischextract, aus dem vom Fettgewebe und den Knochen befreiten, zu einer grobbreiigen Masse zerkleinerten Ochsenfleisch; das Malzextract, aus geschrotetem Gerstenmalz; das Blauholzextract, aus dem zerkleinerten Kernholz von Haematoxylon campechianum L.; das Rothholzextract, aus dem Holze mehrerer südamerikanischer Cäsalpinien; das Quercitronrindenextract, aus der Rinde von Quercus tinctoria Willd.; das Gelbholzextract, aus dem Stammholz von Morus tinctoria L.; Eichenrinden-, Knoppern-, Galläpfelextract, Catechu etc.

Weingeistige und ätherische Extracte werden aus solchen frischen oder getrockneten Pflanzen oder Pflanzentheilen erzeugt, deren wirksames Princip sich im Alkohol oder im Aether löst. Zur Extractbereitung dienen diesfalls Verdrängungs- oder Deplacirungsapparate, gut schliessende Glas. 
oder Blechgefässe, welche die Verdunstung des Lösungsmittels verhindern, das dickere Schichten der zu extrahirenden Stoffe durchströmeu muss, nachdem es mit diesen längere Zeit in Berihhung gestanden, wodurch ein intensives Ausziehen des Löslichen ermöglicht wird. Solche Vorrichtungen sind von Mohr, Schiel, Jakobi, Robiquet, Pelouze u. a. angegeben worden und eignen sich theils zur kalten, theils zur warmen Extraction.

Apparate für die Extractbereitung mit Benützung von Wärme haben das gemeinschaftlich, dass man Aether und Alkohol sowohl in Dampfform, als auch im tropfbarfliissigen Zustande auf die zu extrahirenden Substanzen einwirken lässt. So besteht der Extractionsapparat nach $\mathrm{Mohr}$ aus einer zweihalsigen Wulf'schen Flasche, in deren einem Halse das Extractionsgefäss eingepasst ist, in welches ein nach abwärts conisch zulaufendes, mit kaltem Wasser gefülltes Gefäss hineinragt; aus dem zweiten Halse führt eine Röhre die Aether- oder Alkoholdämpfe in das Extractionsgefäss, wo sie mit den kalten Wänden des Kühlgefässes in Berührung flüssig werden und, die auszuziehende Substanz durchtränkend, am Boden der Flasche sich wieder ansammeln. Durch Erwärmen der Flasche von Aussen mittels eines Wasserbades werden die Lösungsmittel immer wieder verflüchtigt und bewirken, in der angedeuteten Weise circulirend, die Erschöpfung der Substanz.

Der Deplacirungsapparat von Pelouze für kalte Extraction verwendbar besteht aus einem spindelförmigen Glasgefäss, das mittels eines Korks in eine zweihalsige Flasche eingepasst und dessen unteres Ende mit etwas Baum- oder Glaswolle verstopft, oben mittels eines Korks geschlossen ist. Dieses fullt man zum Theil mit der zu extrahirenden Substanz und iibergiesst sie mit Aether; nach längerem Stehenlassen verbindet man den zweiten Hals der Flasche mittels eines Kautschukschlauchs mit dem oberen Ende der Glasspindel, das nun mit einem durchbohrten Korke versehen wurde, worauf der ätherische Auszug langsam nach abwärts fliesst, ohne dass Aetherdämpfe nach Aussen entweichen können. Weniger vollkommen wird das Entweichen von Aetherdämpfen bei dem folgenden Apparat vermieden, welcher dafür den Vortheil billiger und leichter Herstellung gewährt. Ein senkrecht gestellter Vorstoss aus Glas, dessen untere Oeffnung mittels eines Korkes geschlossen ist, während die obere bedeckt wird, ist das Wesentliche der Vorrichtung, das Extractionsgefäss. In diesem wird die organische Substanz ausgelaugt und das Extract durch Lüften des Korkes in ein untergestelltes Gefäss fliessen gelassen. Die Ausziige werden in hohen Glascylindern gesammelt, durch Stehenlassen geklärt, mittels eines Winkelhebels abgehoben, der Rest durch einen Flanellspitzbeutel und wenn nöthig durch Papier filtrirt, und die klare Lösung sofort eingedampft, was gleichzeitig mit dem Abdestilliren des Lösungsmittels erfolgt, welches auf solche Weise allemal wieder gewonnen wird.

Um grössere Mengen weingeistiger oder ätherischer Farbextracte zu erzeugen, kann man sich nach $\mathrm{Kopp}$ eines Apparats bedienen welcher aus drei durch Röhren mit einander verbundenen Theilen besteht. Die zu extrahirenden Pflanzenstoffe werden in einen verticalen Drahtcylinder gebracht, welcher in einem doppelwandigen Metallcylinder steckt; man bedeckt den Drahteylinder mit Werg und einer durchlöcherten Eisenplatte. In einem eisernen Behälter, der mit Wasserdampf gefüllt werden kann, steckt ein kugelförmiges Gefäss fur Weingeist oder Aether. Durch Wasserdampf erwärmt verfliichtigt sich das Lösungsmittel und gelangt in das mit einem durch Quecksilber abgesperrten Sicherheitsrohr versehene Kiihlrohr, aus welchem es, zur Flüssigkeit condensirt, auf die Siebplatte im Cylinder fliesst, um von hier aus gleichmässig vertheilt das Material vollständig zu durchdringen. Die Extraction wird dadurch befördert, dass zwischen die Doppelwand des Cylinders Dampf geleitet werden kann, vermittels dessen das Lösungsmittel erwärmt wird. Das Extract fliesst nach dem kugelförmigen Behälter und sammelt sich daselbst an. Das Lösungsmittel wird neuerdings verflichtigt und macht den beschriebenen Weg so oft, bis 
das Farbmaterial im Cylinder vollkommen ausgezogen ist. Die letzten Reste des Weingeists oder des Aethers werden durch Wasserdampf verdrängt, und das Extract durch Oeffnen eines auf der Unterseite des kugeligen Behälters befindlichen Hahnes in ein 'untergestelltes Gefäss abfliessen gelassen.

Weingeistige Extracte sind: das Sturmhutextract, aus den getrockneten und gepulverten Knollen von Aconitum napellus L.; das Malvenextract, aus den Blumenblättern von Althea rosea L.; das Tollkirschenextract, aus der getrockneten und gepulverten Belladonnawurzel; das Schöllkrautextract, aus dem zur Honigconsistenz eingedampften Safte von Chelidonium majus L.; das Coloquinthenextract, aus den von den Samen befreiten Früchten von Cucumis coloquinthis L.; das Safranextract, aus den getrockneten Blithennarben von Crocus sativus L.; das Cubebenextract, aus den gepulverten Früichten von Cubeba officinalis L.; das Bilsenkrautextract, aus den Blättern von Hyosciamus niger L.; das Brechnussextract, aus den grobgestossenen Samen von Strychnos nux vomica L. etc. Vorwiegend weingeistige Extracte sind auch die neuerer Zeit von einzelnen Erzeugern auf den Markt gebrachten Gewïrzextracte.

Die Giite und Zusammensetzung des Extracts lässt sich auf chemischem Wege nicht gut prüfen, da die wenigsten genau bekannte und analytisch nachweisbare Verbindungen enthalten. Bei Farbextracten bestimmt man das Färbevermögen durch den Versuch.

Die Extractausbeute ist unter sonst ganz gleicher Behandlung niemals dieselbe, weil die Beschaffenheit der Pflanze von den schwer bestimmbaren und sehr veränderlichen Vegetationsverhältnissen abhängt. Man pflegt den Extractgehalt in Grammen wirksamer Substanz anzugeben, welche aus 1000 Gramm des ursprïnglichen Pflanzenstoffes erhalten werden.

Von einem guten Extract fordert man den Geruch und Geschrnack des Pflanzenstoffs, aus welchem er bereitet wurde, bei pharmaceutischen Extracten hellbraune oder dunkelgelbe Farbe. Die grïne Farbe verräth die Anwesenheit von viel Chlorophyll, die schwarze Farbe eine fehlerhafte Bereitung. Wässrige Extracte müssen sich im Wasser fast vollständig lösen. Im Allgemeinen nennt man ein Extract um so besser, je grösser die relative Menge an wirksamer Substanz ist.

$$
R-c h-r \text {. }
$$

Extracteur, s. Centrifugaltrockenmaschinen II pag. 293.

Extrahiren, s. Ausziehen, s. Auslaugen I pag. 256.

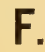

Fabrikgold, Doppelgold (or double - strong gold leaves), Handelssorte von Blattgold, s. Gold s chläg erei.

Fach (pas - lease), die Theilung der Kette, s. Weberei.

Fachwerk, s. Brücken II pag. 86, s. Dach II pag. 475.

Fackel (flambeau - torch), s. Le u chtstoffe.

Fackel bengalische, s. Feuerwerkerei.

Fackeldistel-Sprit ist Weingeist, welcher aus den Früchten von Cactus opuntia, einer in Algier einheimischen, auch im siidlichen Europa wildwachsenden Pflanze, d. i. der Fackeldistel oder algierischen Feige, durch Gährung und Destillation der vergohrenen Masse gewonnen wird. Diese Wein- 
geistsorte ist durch einen schwachen Feigengeruch ausgezeichnet. Vgl. Schub arth, preuss. Verhndlg. 1855, pag. 119, s. a. Jahrb. f. Pharm. 6, pag. 186. Gtl. W e in.

Fackelglanz, technische Bezeichnung für völlige Klarheit des Weines. S.

Façondraht, s. Draht II pag. 643 .

Façoneisen, s. Eisen II pag. 776.

Façon-Rum, syn. Rum künstlicher, s. Branntweinbrennerei I p. 741.

Fadenbruchwächter, s. S pulmas chinen.

Fadenführer, s. Spinnerei, s. a. Dingl. pol. Journ. Bd. 200.

Fadenglas, Filigranglas (verre filigrané - filigree glass), Spitzenglas, Petinetglas, s. Glas.

Fadenlinie, s. Kettenlinie b. Curven, II pag. 451.

Faecalsteine nennt Petri in Berlin (s. Dingl. pol. Journ. 213, pag. 258) ein durch Pressung in die Form von Ziegeln gebrachtes Brennmateriale, welches aus Excrementen (Faecalien) mit einem desinficirenden Zusatze hergestellt werden kann und eine nuitzliche Art der Beseitigung und Verwerthung solcher Auswurfsstoffe bezweckt. Das Brennmateriale soll in Bezug auf Brennwerth den Braunkohlen gleichkommen und eine wegen ihres Phosphorsäurereichthums als Düngmittel trefflich verwendbare Asche liefern. Gtl.

Fällen (précipiter - to precipitate), praecipitiren, niederschlagen, nennt der Chemiker jene Operation, bei welcher durch Zusatz einer geeigneten Substanz (Fällungsmittel) zu, einer Lösung ein in derselben vorfindlicher Körper oder ein Bestandtheil desselben in Gestalt eines sogenannten Niederschlages (Praecipitates) abgeschieden wird. Die Fällung erfolgt entweder dadurch, dass durch die Einwirkung des Fällungsmittels eine chemische Veränderung des gelösten Körpers sich vollzieht, und sohin eine neue, in dem vorhandenen Lösungsmittel nicht mehr lösliche Verbindung sich bildet, oder dass das Lösungsmittel in einer bestimmten Weise verändert und sohin sein Lösungsvermögen alterirt wird. Im ersteren Falle wird der niederfallende (gefällte) Körper offenbar chemisch verschieden sein müssen ron jenem, welcher in Lösung stand, in letzterem Falle kann ein in Lösung stehender Körper unverändert gefällt werden. So werden in Auflïsungen von Magnesia-, Kalk-, Baryt-, Strontian-, Thonerde-, Eisen-, Mangan-, Zink- und vielen anderen Metall-Salzen, z. B. durch Zusatz einer Lösung von kohlensaurem Natron Fällungen erhalten, indem sich durch Wechselwirkung desselben mit den genannten Metallsalzen ein kohlensaures oder basisch kohlensaures Salz des betreffenden Metalles bildet, das in der vorhandenen wässrigen Flüssigkeit nicht mehr löslich ist. In gleicher Weise fällt phosphorsaures Natron aus Lösungen der verschiedensten Metallsalze, unlösliches phosphorsaures Salz, Schwefelwasserstoff und Schwefelammonium, unlösliche Schwefelmetalle u. dgl. m. In allen diesen Fällen ist der entstehende Niederschlag von jenem Körper, welcher in Lösung war, verschieden. Ander's rerhält es sich in jenem Falle, wo durch das angewendete Fällungsmittel das Lösungsmittel beeinflusst wird, hier kann der in Lösung stehende Körper unter Lmständen unverändert abgeschieden werden. So entstehen Fällungen durch Zusatz vou Teingeist zu Aufösungen solcher Körper, welche in Teingeist röllig unlöslich sind, z. B. der verschiedensten Metallsalze. Beispielsweise fällt durch Zusatz von Weingeist zu einer Gypslösung Gyps; zu einer Eisenvitriollösung Eisenvitriol, zı einer Eiweisslösung Eiweiss u. dgl. m. Durch Zusatz von Wasser oder Aether kann man wieder die verschiedensten, in Alkohol löslichen Körper aus ihrer alkoholischen Lösung fällen, wenn sie an sich 
in Wasser oder Aether unlöslich sind. So lassen weingeistige Harzlösungen auf Wasserzusatz das gelöste Harz fallen, oder alkoholische Salzlösungen auf Zusatz von Aether, das in Aether unlösliche Salz. Auch durch Zusatz von Säuren zu wässrigen Lösungen kann man nicht selten das unveränderte Salz zur Ausfällung bringen, wenn die angewandte Säure wasserbindend wirkt und solin das Lösungsvermögen desselben verringert. So wird z. B. Chlorbarium aus seiner wässrigen Lösung durch Salzsäure als solches gefällt, salpetersaurer Baryt durch Salpetersäure, schwefelsaure Salze durch Schwefelsäure u. dgl. Die bei der Fällung entstehenden Niederschläge sind entweder feinpulverig und dann entweder amorph oder mikrokrystallinisch, oder sie sind flockig-gallertartig und dann immer amorph, doch können solche letztere unter Umständen, nach kürzerer oder längerer Zeit, krystallinisch werden, wobei sie dann immer das flockig-gelatinöse Wesen gegen ein pulveriges oder körniges vertauschen. Die Fällung kann entweder vollständig oder unvollständig sein. Ersteres wird immer dann der Fall sein, wenn der fällende Körper vollkommen unlöslich in dem vorfindlichen Lösungsmittel ist, und wenn von dem Fällungsmittel so viel verwendet wurde, als nothwendig, um die Gesammtmenge des in Lösung stehenden Körpers in die neue unlösliche Form ïberzufïhren; letzteres wird entweder bei ungenügender Anwendung von Fällungsmittèln oder bei nicht völliger Unlöslichkeit des entstandenen Niederschlages der Fall sein, und wird übrigens fast stets dann vorkommen, wenn die Fällung durch Veränderung des Lösungsmittels erfolgte, da in solchem Falle das Lösungsvermögen der Fliissigkeit meist nicht vollständig aufgehoben, sondern gewöhnlich nur mehr oder weniger stark vermindert werden kann. Bei unvollkommener Unlöslichkeit der gefällten Verbindung erfolgt die.Fällung in der Regel nicht sofort, sondern gewöhnlich erst allmälig, und ist dies insbesondere dann der Fall, wenn mit der Umwandlung eines amorphen Körpers in den krystallinischen Zustand eine Zunahme der Schwerlöslichkeit eintritt.

Man bedient sich der Operation der Fällung in ausgedehntem Masse zur Abscheiduug von gelösten Körpern aus ihren Lösungen, namentlich aber zur Trennung von mehreren nebeneinander in Lösung stehenden Körpern von einander, indem man Fällungsmittel anwendet, welche einen oder einzelne der gelösten Körper zur Ausscheidung bringen, während andere durch dasselbe Fällungsmittel unverändert bleiben. Hierauf beruhen die meisten Methoden der qualitativen sowie der quantitativen Analyse, sowie die Darstellungsmethoden der verschiedensten Körper. Auch kann man mehrere neben einander in Lösung stehende Körper auf dem Wege der Fällung von einander in der Weise trennen, dass man durch ein geeignetes Fällungsmittel, durch welches endlich alle vorhandenen Körper gefällt werden können, die Fällung partienweise vornimmt, wobei sich ergibt, dass derjenige Körper, welcher mit dem Fällungsmittel eine schwerer lösliche Verbindung gibt, immer friher abgeschieden wird als jener, der eine weniger schwer lösliche Verbindung liefert. Man nennt diese Art der Fällung die theilweise oder fractionirte Fällung, und wendet dieselbe namentlich zur Trennung einander sehr ähnlicher Körper an; so z. B. häufig bei organischen Substanzen.

Soll durch die Fällung eine Trennung von mehreren in einer Lösung vorhandenen Körpern erfolgen, dann muss nicht nur der gefällte Körper von der Flüssigkeit gesondert werden, was durch Decantiren oder durch Filtration geschehen kann, sondern es muss stets auch die den entstandenen Niederschlag durchtränkende Lösung durch Auswaschen (s. A uslaugen I pag. 256) entfernt werden, wobei selbstverständlich eine Flüssigkeit verwendet werden muss, die den auszulaugenden Niederschlag nicht oder doch nur spärlich löst, während sie den zu entfernenden Körper aufzulösen vermag. Gtl.

Fällung und Fällungsmittel, s. Fällen.

Färbelappen, s. Bezetten I pag. 455. 
Färben des Goldes (mise en couleur - colouring). Da die Goldarbeiten aus einem Gemische von Gold und Kupfer oder - noch gewöhnlicher - von Gold, Silber und Kupfer bestehen, so zeigen sie nach dem Blankschleifen und Poliren, ja selbst nach dem Absieden mit schwacher Salpetersäure, welchem man sie in der Regel unterwirft, eine von der reinen Goldfarbe sehr verschiedene Farbe. Sie erscheinen nämlich bleichröthlich oder bei vorwiegendem Silberzusatze blassgelb. Will man den aus legirtem Golde gemachten Artikeln ein hoch goldgelbes Ansehen ertheilen, so gesehieht dies durch das Färben, nämlich durch Kochen in einer Flüssigkeit, welche man $\mathrm{Farbe}$, Goldfarbe (couleur à bijoux - gold-colour) nennt.

Diese ätzend wirkende Flüssigkeit entfernt von der Oberfläche das Kupfer und Silber, und setzt durch eine electrolytische Wirkung das gleichfalls anfänglich gelöste Gold als feine gleichmässige Schichte anf der Oberfläche ab. Vor dem eigentlichen Färben wird die Waare durch Kochen in einer gesättigten Boraxlösung gereinigt.

Ein gebräuchliches Verfahren zu färben ist folgendes: Man nimmt auf einen Theil guter Goldwaare (s. diesen Artikel) 2 Gew.-Th. iiber Feuer abgeknistertes Kochsalz und 4 Thl. Salpeter, reibt sie trocken gut zusammen, lässt sie in einem irdenen Topfe mit ein wenig Wasser kochen, und rührt so lange, bis das Ganze zu einem trockenen Pulver geworden ist; dann giesst man 3 Thl. Salzsäure (von spec. Gew. 1.165) hinzu, lässt bis zu völliger Auflösung und sehr merklicher Entwicklung von Chlorgas sieden; bringt nun die Goldwaare hinein und bewegt sie fleissig herum, indem man sie nur zeitweilig auf einen Augenblick hebt, um das Hervorkommen der hochgelben Farbe zu beobachten. Gewöhnlich nach 5 bis 6 Minuten, während die Flüssigkeit stetig kocht und Chlorgas nebst salpetrigsaurem Dampfe ausstösst, ist das Geschäft vollendet; man spült die Gegenstände so rasch als möglich in zwei Gefässen mit kochendem Wasser, unmittelbar darnach in einer grossen Menge kalten Wassers, und taucht sie endlich noch einmal in reines kochendes Wasser, damit sie beim Herausziehen schnell von selbst abtrocknen. Wasser zuzusetzen, während die Waare in der Farbe verweilt, muss thunlichst vermieden werden, ist aber nöthig, wenn die Masse durch das Einkochen zu steif wird; das zugefügte Wasser muss jedenfalls kochend sein. Löthstellen färben sich anfangs schwärzlich, werden aber nachher ebenfalls gelb. Die gebrauchte Farbe kann nicht ein zweites Mal angewendet werden, wird aber wegen eines geringen darin befindlichen Goldgehaltes zuriickgestellt, und nach Ansammlung einer grösseren Menge dadurch zu Gute gemacht, dass man sie mit ein wenig Königswasser versetzt, durch zugefügtes reines Wasser ganz flüssig macht, filtrirt, und durch Eisenvitriolauflösung das Gold als metallisches Pulver niederschlägt.

Goldarbeiten von einem geringern Feingehalte als 14 Karat lassen sich nicht färben, sondern werden in der Farbe schwarz und unansehnlich, weil ibre Oberfläche dem auflösenden Chlor zu wenig Goldtheilchen darbietet. Rud. Wagner (s. Dingl. pol. Journ. 218 pag. 329) empfiehlt eine Lösuug von 1 Grm. Brom, 30 Grm. Bromkalium ( $=25$ Grm. Bromealcium) in 1000 Grm. Wasser als brauchbares Mittel zum Goldfärben.

Zur Erzielung bestimmter Farbentöne stehen mannigfache Goldfarben in Gebrauch, bei deren Anwendung es oft auf genaues Einhalten der Zeit ankömmt; dieselben werden meist geheim gehalten.

Färberalizarin (alizarine tinctoriale) nannte Kopp ein für Färbereizwecke dargestelltes, nicht völlig reines Alizarin, das durch Behandeln von Garancin mit auf $200^{\circ} \mathrm{C}$. erhitztem Wasserdampf, wobei sich Alizarin mit den Wasserdämpfen verflïchtigt, erhalten wurde. Gtl.

Färberblume, s. Färberginster.

Färberdistel, Stammpflanze des Safflors, s. d., s. a. Färberscliarte. 
Färberei (teinture - dyeing) ist im Allgemeinen die Kunst, Körpern der verschiedensten Art dauernd die Fähigkeit zu ertheilen, in unserem Gesichtsinne die Empfindung einer bestimmten Farbe hervorzurufen, im Besonderen aber versteht man unter Färberei die Fertigkeit, auf Geweben, sei es natürlichen, pflanzlichen oder thierischen Ursprungs, sei es künstlichen, wie solchen aus Baumwolle, Leinen, Wolle, Seide oder sonstigen Gespinnstfasern, zum Theile oder völlig bestimmte Färbungen hervorzubringen, welche der Einwirkung von Licht, Luft, Wasser oder sonstigen bei der Verwendung solcher Gewebe sich geltend machenden Einfliissen mehr oder weniger lange widerstehen können. Das Wesen dieser schon seit den ältesten Zeiten bekannten Fertigkeit liegt nicht so sehr in der Erzielung einer bestimmten Farbe auf der Gewebsfaser, sondern vielmehr in der Herstellung einer möglichst festen Verbindung zwischen der zu färbenden Faser und der die bestimmte Färbung hervorrufenden Substanz. Hiedurch unterscheidet sich die Kunst der Färberei im engeren Sinne des Wortes von der Malerei, der Anstreicherei, der Farbendruckerei, Buntpapierfärberei, deren Ziel zwar auch die Hervorrufung bestimmter dauernder Farbenerscheinungen auf der Oberfläche der Körper ist, die aber dieses Ziel durch einfaches Auftragen eines fertig vorhandenen Farbkörpers auf die zu färbende Fläche und Fixirung desselben mit Hilfe eines Klebemittels (Leim, Gummi, Stärkekleister, Firniss oder Lack) oder durch einfache Beimischung eines feinvertheilten Farbkörpers zu der zu färbenden Substanz (Färben der Papiermassen) oder endlich Durchtränkung einer porösen Substanz mit einer Farbstofflösung, die nach dem Verdunsten des Lösungsmittels den Farbstoff in den Poren der gefärbten Substanz hinterlässt (Färben von Steinen, Gyps, Bein, Holz), zu erreichen suchen. Gegeniiber einem solchen, rein mechanischen Vorgange der Färbung von Körperoberflächen oder Massen verwerthet die Färberei im engeren Sinne des Wortes die chemischen Beziehungen der farbegebenden zu den zu färbenden Körpern, indem sie entweder durch Einwirkung von geeigneten Agentien, die an sich nicht wie Farbstoffe sich verhalten, auf die zu färbende Gewebssubstanz eine solche Veränderung derselben hervorruft, dass diese nachmals gefärbt erscheinen (Reactionsfarben), oder dass sie die Fähigkeit der Faser beniitzt, gewisse Farbstoffe anzuziehen und zu binden (s ubstantive oder s ubjective F arben), oder dass sie zunächst Verbindungen der Faser mit Stoffen herstellt, welche ihrerseits Farbstoffe zu fixiren vermögen und sohin als Bindeglied zwischen der Faser und dem Farbstoffe (a d j e c tiv e F a r b e n) dienen (s. Beize I pag.370) oder endlich, dass sie die Faser mit Lösungen durchtränkt, aus welchen sich durch nachmalige Einwirkung eines dritten Körpers ein unlöslicher Farbstoff ausscheiden lässt und in fein vertheilter Form in der Faser abgelagert wird ( $\mathrm{K}$ ü p e $\mathrm{n}$ f a rben - Praecipitationsfarben). Seltener findet in der Färberei die Application fertiger Farbkörper auf die Faser und die Befestigung derselben durch ein eine mechanische Bindung bewirkendes Fixirungsmittel statt, wie das beispielsweise bei der sogenannten topischen Färberei oder dem topischen Druck der Fall ist, und anch hier muss wenigstens das Fixirungsmittel auf dem Wege eines chemischen Processes eine Umwandlung erfahren, der zu Folge es nach der Fixirung eine Veränderung seiner Löslichkeitsverhältnisse erleidet. So beispielsweise bei den Dampffarben und den Klotzfarben, die durch Auftragen von Mischungen der zu applicirenden Farbkörper mit Albumin oder Caseinlösungen und nachheriges Unlöslichmachen des Albumins durch Dämpfen (Erhitzen auf $100^{\circ} \mathrm{C}$.) oder des Caseins durch Einwirkung von Säurebädern, befestigt werden. Eine eingehende Besprechung der Methoden der Färberei geben wir in dem Artikel Z $\mathrm{Z}$ gdruckerei und Zeugfärberei, s. d. Gtl.

Färbereiche, Stammpflanze der Quercitron- oder Färbereichenrinde, s. Quercitron.

Färberflechten, s. b. Fle ch ten farbstoffe.

Färberflotte, s. Z eugfärberei. 
Färberginster (genêt de teinturiers - dyers broom), Färberblume, Gelbkraut, Geniste, Gloesen. Das zur Blithezeit gesammelte und getrocknete Kraut ron Genista tinctoria L., einer in lichten Wäldern in Europa und Mittelasien häufig wachsenden, vom Juni bis August blühenden Papilionacee, einen niedrigen Halbstrauch darstellend mit schlanken, unbewehrten, gestreiften zähnigen Zweigen. Die auf diesen zerstreut sitzenden Blätter sind lanzettlich oder länglich, spitz, ganzrandig, gewimpert, auf dem unterseits stark vorspringenden Mittelnerv spärlich behaart, glänzend grïn, getrocknet steif brïchig. Die Schmetterlingsblüthen mit kahler goldgelber Blumenkrone, deren zurückgeschlagene Fahne so lang als das sichelförmige Schiffchen ist, stehen in gedrungenen, fast rispenförmigen, endständigen Trauben. Das Kraut dient zum Gelbfärben von Wolle und Leinen, doch ist die Farbe von geringerem Werthe als Wau und Färberscharte. Der Farbstoff des Färberginsters soll sich dem Luteolin (dem Farbstoff des Waus) ähnlich verhalten. In Ungarn und Slavonien sammelt man zu demselben Zwecke die nahe verwandte Genista ovata W. K. - und wahrscheinlich rerhalten sich auch die anderen einheimischen Ginsterarten (Genista pilosa und germanica L.) ähnlich wie der Färberginster, nur sind sie farbstoffärmer.

A. Vogl.

Färberknötrich (Polygonum tinctorium), Stammpflanze einer Indigosorte, deren Blätter directe zum Blaufärben verwendet werden können. S. In dig o. Gtl.

Färberlack (lac de teinturiers - lac-dye), s. Lae-dye, s. Kermes, vgl. a. Carmin II pag. 256.

Färbermoos, s. b. Flechtenfarbstoffe.

Färberröthe, syn. Krapp s. d.

Färberscharte (herbe de cerette - sawwort), Färberdistel. Das getrocknete blühende Kraut ron Serratula tinctoria L., einer auf Wiesen sehr verbreiteten, ausdauernden Composite, hin und wieder (in Sachsen, Böhmen) auch angebaut. Der bis iiber $1^{\mathrm{m}}$ Höhe erreichende Stengel ist glatt, gestreift, oben doldentraubig-ästig; die wechselständigen Blätter sind länglich, spitz, ungetheilt, leierförmig oder fiederspaltig, scharf gesägt, die unteren langgestielt, die oberen sitzend, fast glatt. Die Bliithenkörbchen haben dachziegelförmige, nach oben violette Hüllblätter und röhrenförmige, mit einem Pappus versehene violette Blumen. Das Kraut enthält einen gelben Farbstoff, der sich dem Luteolin ähnlich verhalten soll; es dient zum Gelbfärben und zur Darstellung von Schiittgelb.

Färbersumach, s. Sumach (Schmack). A. Vogl.

Färberwau, syn. Wau, Gelbkraut s. d.

Fäulniss (pourriture - rot). Die Materie der abgestorbenen Organismen ohne Ausnahme und viele der organischen Substanzen als solche, erleiden in kürzerer oder längerer Zeit Veränderungen weitergehender Art, die man je nach den dabei auftretenden Erscheinungen als Gährung, Fäulniss (faulige Gährung), Verwesung oder Vermoderung bezeichnet.

Man weis jetzt nach eingehenderem Studium dieser Zersetzungsprocesse, dass zur Einleitung derselben umbedingt in der gewöhnlichen Atmosphäre stets vorhandene, lebens- und fortpflanzungsfähige Keime gewisser Organismen nöthig sind, die einmal eingeleitete Zersetzung aber weiters, wenn auch in modificirter Form, als Verwesung oder Vermoderung durch den Sauerstoff der Luft allein fortgesetzt und beendigt werden kann. Diese Fäulnissorganismen, die auch als organisirte Fermente ( $\mathrm{s}$. F ermente) bezeichnet werden, sind nun animalischer, vorzugsweise aber pflanzlicher Natur und jedenfalls die Producenten und nicht, wie man lange annahm, die Producte oder Begleiter dieser gewissermassen natiurlichen Zersetzungsprocesse. Bei den Pflanzen gehören sie ausschliesslich der chlorophyllosen und 
hier rorzugsweise der Klasse der Pilze an. Unter diesen gibt es insbesondere eine Reihe von Gattungen, die erwiesenermassen nur auf sich zersetzenden organischen Substanzen regetiren können und deshalb auch Fäulnissbewohner od s Saprophyten genannt werden. Sie umfassen nebst anderen die Hyphomyceten oder Fadenpilze, zu welchen die verschiedenen den Schimmel zusammensetzenden Schimmelpilze gehören, die Ascomyceten oder Schlauchpilze (worunter die Alkoholhefen Saccharomyces cerevisiae) und die besonders speciesreichen Schyzomyceten oder Schaltpilze, worunter die Bacterien, Bacteridien, Vibrionen, Zoogloen, Micrococcen und andere, die vornehmlich Fäulnisserreger sind.

Es gibt nun Stoffe, welche direct solcher Zersetzungsprocesse fähig, wahrscheinlich direct als Nahrungssubstrat diesen Fäulniss- und Gährungsorganismen dienen, wie z. B. die Eiweissstoffe, die Leimsubstanzen, viele Zuckerarten etc., sodann solche, die hiezu erst durch die Einwirkung gewisser unorganisirter oder katalytischer Fermente umgewandelt werden, wie z. B. der Rohrzucker, der durch einen Bestandtheil der Hefe vor der Gährung in Invertzucker iberführt wird, endlich solche, die iiberhaupt nicht fäulniss- oder gährungsfähig sind, wie z. B. die die Hauptmasse der festen Pflanzensubstanz bildende Cellulose, welche aber durch die Gegenwart der in Umlagerung befindlichen Molekuile der faulenden Stoffe und die dadurch hervorgerufene Erregung ihrer eigenen Atome zum mindesten schliesslich der Einwirkung des atmosphärischen Sauerstoffes zugänglicher gemacht wird und der Verwesung anheimfallen kann. Die Gährung ist ihren Ursachen nach von der Fäulniss nicht unterschieden, doch pflegt man nur die mit Entwickelung stinkender, flüssiger oder gasiger Substanzen verbundenen Zersetzungen speciell als Fäulniss ánzusprechen.

Die Bedingungen zur Fäulniss und Gährung (hier sei zuerst nur die erstere in's Auge gefasst) sind demnach:

I. Der Zutritt der atmosphärischen Luft, welche stets die fäulnisserregenden Keime (Sporen von Pilzen etc.) enthält. Hat die Fäulniss einmal begonnen, so setzen auch nach nachherigem Abschluss der Luft die inzwischen durch Fortpflanzung entstandenen Fäulnissgebilde diє Fäulniss fort.

II. Gegenwart einer hin reichenden Menge von Feuchtigkeit. Die fäulnissfähigen Stoffe sind als solche oder in wenig veränderter Form das Nahrungssubstrat der Fäulnissorganismen und können nur in wässeriger Lösung von diesen umgewandelt und assimilirt werden.

III. Eine bestimmte Temperatur. Die betreffenden Fäulnissorganismen bediirfen zu ihren Lebensfunctionen stets einer höheren Temperatur als $0^{\circ}$ C. und werden durch höhere Temperaturen, gegen $100^{\circ} \mathrm{C}$, getödtet, somit unwirksam gemacht.

Kömmt nun ein fäulnissfähiger Körper mit der atmosphärischen Luft in Berührung und sind die andern angeführten nöthigen Bedingungen zur Fäulniss vorhanden, so beginnt dieselbe in irgend einem Theile des Ersteren und setzt sich dann durch die ganze Masse fort. Wird die Luft nun nach begonnener Fäulniss ganz oder fast ganz abgesperrt, so macht sich unter den einmal in Bewegung gesetzten Atomen der Moleküle des faulenden Körpers ihre specifische chemische Affinität geltend. Der vorhandene Sanerstoff oxydirt einen Theil des Kohlenstoffes zu Kohlensäure, einem constanten Producte der Fäulniss, einen Theil des Wasserstoffes zu Wasser, wodurch der faulende Körper, wie leicht ersichtlich, immer relativ kohlenstoffreicher und-wasserstoff- und sauerstoffärmer wird. Der restirende Wasserstoff bindet weiters den Stickstoff zu Ammoniak, meistens vorhandenen Schwefel zu Schwefelwasserstoff, welche vier Verbindungen: Kohlensäure, Wasser, Ammoniak und Schwefelwasserstoff fast immer bei der Fäulniss auftreten. Ausserdem bilden sich aber verschiedene Kohlenwasserstofie, sowie gewisse übelriechende, bis jetzt noch ungeniigend erkannte fluissige und gasige Substanzen in wechselnden Quantitäten, welche die Fäulniss vieler Substanzen besonders charakterisiren. 
Ist die faulende Substanz aber dem ungehemmten Luftzutritte ausgesetzt, so sind die Veränderungen derselben wesentlich andere. Die faulende Substanz leistet weniger Widerstand dem Angriffe des Sauerstoffes, welcher dieselbe verhältnismässig rasch durch eine Reihe von ebenfalls wenig bekanntem $Z$ wischengliedern zu hochoxydirten Substanzen, Kohlensäure, Wasser, das erst gebildete Ammoniak sogar schliesslich zu Salpetersäure umwandelt, so dass, während bei der eigentlichen Fäulniss stets kohlenstoffreichere Reste zurückbleiben, bei diesem Vorgange der Verwesung (pourriture sèche — dry rot) die organische Substanz, freilich erst nach längerer Zeit, fast vollständig verschwindet.

Da die Wirkung des Sauerstoffes sich natürlich nur an der Oberfäche der faulenden Substanz geltend machen kann, so geht neben der Verwesung im Innern des Körpers stets zugleich eigentliche Fäulniss vor sich.

Wenn die Verwesung wegen ungenügenden Luftzutrittes langsam erfolgt, so wird sie als Vermoderung (carie - rot druxy) bezeichnet; ${ }^{*}$ ) deren Producte sind wesentlich dieselben wie bei der Verwesung, nur leistet der immer kohlenstoffreicher und deshalb dunkler werdende Rest der weiteren Einwirkung des Sauerstoffes einen so energischen Widerstand, dass er sich gewöhnlich als solcher durch sehr lange Zeit fast unverändert erhält, wie z. B. das Vermoderungsproduct gewisser Sphagnumarten, der Torf.

Man war natürlich aus vielen Gründen schon seit langer Zeit bemüht, diese gewissermassen natürlichen Zersetzungsprocesse der mannigfach verwertheten organischen Substanzen hintanzuhalten, dieselben davor zu bewahren, zu conserviren, und bedient sich einer Reihe von Mitteln, die man desshalb im weiteren Sinne als fäulnisswidrige, antiseptische Mittel bezeichnet. Aus den angefuihrten Bedingungen der Fäulniss ergeben sich von selbst die Principien der Conservirung organischer Substanzen. Diese kann daher erfolgen:

1. Durch Kälte, eines der kräftigsten und gewissermassen des natiirlichen Antiseptikums, von dessen hoher fäulnisswidriger Kraft die Erhaltung vieler vorweltlicher Thiere im Eise der Polargegenden das eklatanteste Beispiel liefert. Die Conservirung durch Kälte hat unbestreitbar unter allen Conservirungsmitteln die grösste Zukunft, weil sie die betreffenden Objecte mit durchaus unveränderten Eigenschaften erhält. Die gegenwärtig sehr vervollkommneten Maschinen zur directen Fabrikation von Eis und Hervorbringung niedriger Temperaturen haben, den verschiedenen Bedürfnissen gemäss construirt, nicht nur in grösseren Etablissements, wie Brauereien, Schlachthäusern, Conservenfabriken, sondern auch in Hotels und grösseren Haushaltungen Eingang gefunden. Neuester Zeit sind mit sehr günstigem Resultate Versuche zur Ueberschiffung grosser Quantitäten Fleisches von Australien nach Frankreich, conservirt durch Kälte mittelst einer am Schiffe befindlichen T elli e r'schen Kältemaschine (mittelst Methyläther, s. E is a p p a r a te II pag. 744), gemacht worden; diese berechtigen zu den Hoffnungen, dass ein grosser Theil der ungeheueren, bisher zur Fleischextractfabrikation verwendeten Quantitäten Fleisches von Siidamerika und Australien, als solches, durch Kälte conservirt, nach Europa wird gebracht werden können.

2. Durch Wasserentziehung, entweder durch directes Austrocknen oder durch Zusammenbringen der zu conservirenden Substanz mit wasserentziehenden Mitteln, z. B. Kochsalz, Salpeter, Zucker, Alkohol etc. Was das eigentliche Austrocknen anbelangt, so ist dieses zwar sehr wirksame, leider aber aus anderen Rïcksichten nicht immer empfehlenswerthe Verfahren nicht selten in Anwendung, wiewohl es einestheils bei grösseren Gegenständen, z. B. grösseren Fleischstiicken, schwierig ist, die Trocknung in der That vollständig und so schnell zu bewirken, dass nicht schon während derselben eine partielle Fäulniss eintritt; anderentheils aber, und hierin liegt ein weiteres Hinderniss, die Substanzen, zumal solche, die im frischen Zustande sehr weich und saftig waren, so stark zusammen-

*) In gewissem Sinne wird manchmal die Verwesung als die Veränderung der animalischen, die Vermoderung als die der vegetabilischen Substanzen aufgefasst. 
schrumpfen, dass sie nachher auch durch anhaltendes Kochen nicht wieder völlig zu erweichen sind. Endlich verursacht das Trocknen, zumal bei grösseren Quantitäten, auch sehr bedeutende Mühe und Zeitaufwand, und ist daher schon aus ökonomischen Rücksichten nicht immer vortheilhaft.

Fleisch, in dünne Streifen zerschnitten und an der Sonne getrocknet, wie dies in einigen Gegenden von Amerika geschieht (Tessajo und Pemmikan der Indianer), wird sehr hart, liefert jedoch eine jedenfalls schwer verdauliche und wenig schmackhafte Speise. Ein weit besseres, aber auch kostspieligeres Verfahren ist folgendes:

Man bringt in einem Kessel Wasser zum Sieden und legt das in etwa 100 Grm. schwere Stücke zerschnittene Fleisch auf einige Minuten hinein, nimmt es dann heraus, bringt es sofort auf Hürden in eine geheizte Trockenstube, deren Temperatur aber $50^{\circ}$ C. nicht übersteigen darf, und fährt mit dem $\mathrm{Ab}$ brühen frischer Portionen in demselben Wasser so lange fort, bis das letztere zu einer sehr dicken, concentrirten Fleischbrühe geworden ist, die man dann noch so weit eindampfen muss, bis ein Pröbchen auf einen kalten Körper gebracht, schnell zu einer steifen Gallerte erstarrt. Wenn nun nach Verlauf von etwa zwei Tagen das Fleisch völlig trocken ist, so erweicht man die Gallerte durch Erwärmen, taucht das Fleisch Stïck für Stiick in diese ein, und trocknet es wieder, worauf es auf seiner Oberfläche einen dichten Leimuiberzug erhält. Reicht die vorhandene Gallerte hin, so kann dieser Leimüberzug durch nochmaliges Eintauchen und Trocknen noch verstärkt werden. An einem recht trockenen Orte aufbewahrt, hält sich das so behandelte Fleisch völlig unverändert, und erlangt beim nachherigen Kochen seine anfängliche Weichheit, wenn auch nicht ganz, aber doch in genügendem Grade wieder. Verdeil dämpft das in Scheiben geschnittene Fleisch in Kammern von Eisen- oder Bleiblech mittels Wasserdampf von 3-4 Atm. Spannung durch 10-15 Minuten und trocknet das so abgedämpfte Fleisch bei $40-50^{\circ} \mathrm{C}$.

Am häufigsten wendet man die Trocknung bei Früchten an, die entweder in rohem, ganz unverändertem Zustande getrocknet werden, z. B. Weinbeeren zur Bereitung der Rosinen und Korinthen, Pflaumen, Kirschen u. dgl., oder vorher in Scheiben zerschnitten werden, wie z. B. beim Trocknen der Aepfel. Die Trocknung kann, zumal in wärmeren Klimaten, an der Sonne, sonst auch in einem Backofen oder in einem eigenen Trockenzimmer geschehen. Hierher gehört die freilich nur für gewisse Gegenden empfehlenswerthe Methode der RunkelruibenTrocknung für Zwecke der Zuckerfabrikation. Die durch eine Maschine in Scheiben zerschnittenen Rïben werden in einem Trockenhause getrocknet, und können so das ganze Jahr hindurch aufbewahrt werden, woraus sich für die Rübenzuckerfabriken der ausserordentliche Vortheil eryibt, dass die Fabrikation ununterbrochen das ganze Jahr hindurch betrieben werden kann, während bei Anwendung frischer Rüben sich die Fabrikationszeit auf den Winter und selbst nur einen Theil desselben beschränkt, indem die Rüben bei längerer Aufbewahrung der Verderbniss unterliegen; dass ferner die nutzbare Substanz der Riiben sich auf ein sehr kleines Volumen reducirt, wodurch nicht nur viel Raum zur Aufbewahrung erspart, sondern auch der Transport in dem Grade erleichtert wird, als getrocknete Rïben sich weit versenden lassen, mithin einen eigentlichen Handelsartikel bilden können, worin sowohl für die Zuckerfabriken, als auch für den Landbau ein grosser Vortheil liegt. Zwar verursacht das Trocknen der Rübenschnitte einen sehr grossen Aufwand an Brennmaterial, dieser aber compensirt sich fast ganz dadurch, dass bei der nachherigen Verarbeitung die zu feinem Mehl gemahlenen Schnitte mit einer verhältnissmässig sehr geringen Menge Wasser extrahirt, sofort einen sehr concentrirten und ziemlich reinen Zuckersaft liefern, dessen Verdampfung: nur noch wenig Brennstoff in Anspruch nimmt.

Die Conservirung von verschiedenen Gemïsen durch Trocknung hat in nenerer Zeit durch den Franzosen Masson eine bedeutende Vervollkommunng erfahren dadurch, dass er die getrockneten Blätter einer starken Pressung unter- 
warf und sie so in kleine viereckige Täfelchen von etwa $10^{\mathrm{cm}}$ im Quadrat und $1^{\mathrm{cm}}$ Dicke verwandelte, wodurch wegen des so sehr verminderten Volums die Einwirkung der Luft bedeutend herabgesetzt wurde (Comprimés). Es wurden auf diese Art von ihm gewöhnlicher weisser Kohl, Rosenkohl, Kerbel, Sellerie, Spinat und die Zuthaten zu der unter dem Namen „Julienne" bekannten Suppe gepresst und in blechernen Büchsen verlöthet verkauft. Ein Täfelchen solcher Comprimés wiegt $500 \mathrm{Grm}$. und liefert 20 Portionen, deren eine beim Kochen $150-180 \mathrm{Grm}$. Gemuise gibt. Ein Blechkästchen von $0.008^{\mathrm{cm}}$ Inhalt fasst 10 solcher Täfelchen, welche $5 \mathrm{Kl}$. Gemüse $=200$ Portionen à $25 \mathrm{Grm}$. entsprechen. Da den nach der M as son'schen Methode dargestellten Comprimés meist ein eigenthümlicher Hengeruch anhaftet und dieselben wegen der unvollständigen Coagulation des Eiweisses leicht bei längerer Aufbewahrung einen scharfen Geschmack annehmen, so hat man das Verfahren dadurch zu verbessern gesucht, dass man die zu conservirenden Gemüse zunächst mit ïberhitztem Wasserdampf behandelt und dann erst trocknet und presst. Dieser Art sind die Methoden von MorelFacio, Dolfuss und Verdeil, welcher letztere das Gemüse mit Dampf von $4-5 \mathrm{Atm}$. Spannung $\left(145-150^{\circ}\right.$ C.) in eigenen Kammern abdämpft und sodann in einem Strome von auf $32-40^{\circ}$ C. erhitzter Luft trocknet. Zum Gebrauch ist es nur nöthig, die Kuchen etwa $1 / 2$ bis $3 / 4$ Stunden in warmes Wasser zu legen, wodurch die Blätter bis zu ihrem früheren Volumen anschwellen und auch vollkommen das frühere Ansehen vieder gewinnen. Sie werden dann auf gewöhnliche Art gekocht und besitzen hiernach ganz den Geschmack der frischen Pflanze. Auch Kartoffeln in feine Streifen zerschnitten, getrocknet und in Blechbiichsen verlöthet, erhalten sich lange unverändert. Diese Erfindung ist besonders zum Verproviantiren der Schiffe in hohem Grade wichtig, weil es dabei hauptsächlich auf Raumersparung ankommt.

Getreidemehl, wie gewöhnlich feucht gemahlen, ist besonders bei fester Verpackung in Fässern der Verderbniss unterworfen. Zum Behuf der Weiterversendung oder langer Aufbewahrung ist es daher nothwendig, das Getreide nicht nur beim Mahlen nicht zu netzen, sondern es in möglichst trockenem Zustande zu verarbeiten. Auch ungemahlenes Getreide, so wie alle anderen Samen unterliegen in völlig trockenem Zustande durchaus keiner Verderbniss, wenn auch freilich ihre Keimkraft allmälig schwindet.

Auf dem Principe der Conservirung durch Trocknen beruht auch die Herstellung des Fleischzwiebacks (meat biscuit), wie sie von Gail-Bordes in Galveston (Texas) zuerst angewendet, später auch von Siemens in Hohenheim und Calamand in Paris ausgefuihrt wurde. Nach Siemens (vgl. Dingl. pol. Journ. Bd. 123 pag. 458) werden 12 Kilo Rindfleisch mit Wasser abgekocht und 4.5 Liter Brithe erhalten; diese nach dem Erkalten von dem aufschwimmenden Fett befreit und sodann bis auf etwa $1 / 4$ des Volumens eingedampft, sodann noch heiss mit 6 Kilo feinem Weizenmehl angemacht, zu Kuchen geformt und in einem Backofen gebacken. Es werden 6 Kilo Zwieback erhalten. Aus dem abgekochten Fleisch und den Knochen können anf gleiche Art noch 2 Kilo Zwieback erhalten werden.

Der Fleischzwieback ist zur Bereitung ron Suppen bestimmt, indem man ihn pulverisirt und mit Wasser unter Zusatz von Salz und Pfeffer kocht. Er ist so nahrhaft, dass 140 Grm. vollkommen zur täglichen Nahrung eines Menschen hinreichen.

Auf der wasserentziehenden Wirkung gewisser Salze, wie Kochsalz, Salpeter, weiters aber auch concentrirter Zuckerlösungen basirt das Conserviren z. B. des Fleisches, der Fische u. s. w. durch Einpöckeln und das Conserviren des Obstes durch sogenanntes Einsieden in Zucker. Das Einpöckeln des Fleisches ist sehr einfach und besteht darin, das Fleisch mit Salz stark einzureiben, es hierauf mit Salz stark bestrent einige Tage liegen zu lassen, dann unter Gewichten oder einer Hebelpresse auszupressen, dieselbe Behandlung noch einmal zu wiederholen, das Fleisch hierauf in Fässer zu verpacken und mit der ausgepressten 
Lake, die, wenn es sich um sehr lange Conservation liandelt, etwa bis auf die Hälfte eingedampft werden kann, zu ïbergiessen. Fische, so namentlich Häringe, werden mit Seesalz eingepöckelt. Man legt sie nach dem Ausnehmen und Abwaschen etwa 24 Stunden lang in Salzlake ein und verpackt sie endlich in die Fässer. Das Einsalzen von Gemiisen, Früchten u. dgl. ist eine zu bekannte Sache, als dass es einer näheren Beschreibung bedürfte.

Statt des Kochsalzes können auch andere Salze in Anwendung gebracht werden, was jedoch mit Ausnahme von Salpeter, der wohl beim Einsalzen in geringer Menge zugesetzt wird, ihres unangenelmen Geschmackes wegen nicht geschieht. Eines der am kräftigsten wirkenden Salze ist Alaun und schwofelsaure Thonerde. Eine concentrirte Lösung von schwefelsaurer Thonerde ist zum Einlegen der Leichen und Präparate bei anatomischen Arbeiten statt des Branntweins empfohlen worden, wird aber nur selten angewendet.

Eine sehr allgemeine Anwendung als Conservirungsmittel findet das Einmachen in Zucker. So sehr auch eine verdünnte Zuckerlösung geneigt ist, durch Vermittlung stickstoffhaltiger Substanzen, besonders der Hefe, in die Weingährung iiberzugehen, ebenso stark widersteht sie derselben in concentrirtem Zustande und schiitzt so auch andere damit imprägnirte Stoffe vor der Verderbniss. Das Einmachen der Friichte, Wurzeln und anderer Pflanzentheile in Zucker ist im Wesentlichen eine bekannte Sache, und ist dabei stets nur zu beachten, dass so viel Zucker angewendet werden muss, dass er die ganze Menge des vorhandenen Wassers fuir sich in Anspruch nimmt. Es ist daher immer Regel bei dem Einmachen in Zucker, an diesem letzteren nicht zu sparen.

Hierher gehört auch die Conservation der Milch, indem man etwa $1 / 3$ ihres Gewichtes Zucker darin auföst, und sie dann bis zur dicksyrupartigen Consistenz abdamptt. Sie nach der Methode von Fadeuil ganz zur Trockne abzudampfen, um sie so in Gestalt harter Kuchen aufzubewahren, ist nicht zweckmässig, weil sie sich beim Gebrauche nicht wieder im Wasser zu einer Emulsion fein zertheilt. (vergl. a. Milch.)

Endlich gehört zu den Conservirungsmethoden, welche durch Wasserentziehung wirken, auch das Einlegen in Alkohol (Rum u. dgl.). Diese bei anatomischen Präparaten, so wie beim Einmachen von Früchten iibliche Methode rerbindet den Vortheil der Einfachheit und Bequemlichkeit mit dem besonders fuir anatomische Präparate so wichtigen Umstande, dass die Theile in ziemlich unveränderter Gestalt und ihrem natiirlichen weichen Zustande verbleiben, und zugleich durch die völlig klare Fliissigkeit vollkommen gut beobachtet werden können. Leider gestattet dies so vortreffliche Aufbewahrungsmittel nur eine sehr beschränkte Anwendung auf die Conservation von Nahrungsstoffen, und man wendet es ausser zur Conservirung anatomischer Präparate wohl nur vereinzelt zur Obstconservation an. (Rumobst.)

3. Durch Absperrung der Luft, entweder durch entsprechende Einschliessung und Aufbewahrung in hermetischen Gefässen, oder durch Ueberziehen der zu conservirenden Objecte mit einer für die Atmosphäre undurehdringlichen Hülle. Beispiel für das erstere ist die so vielfach practicirte Appert'sche Methode der Conservirung durch Einschliessung und Verlöthung in Metallblechbüchsen, nachdem zuvor durch Erhitzen des Inhaltes bis iiber $100^{\circ}$ C. die Fäulnisskeime getödtet und die Luft aus den Büchsen rertriebén würde.

Nach dem Appert'schen Verfahren kann man sowohl zubereitete Speisen als auch Frïchte, Milch u. s. w. conserviren. Zubereitete Fleischspeisen z. B., die zu dem Ende möglichst stark eingekocht werden miissen, bringt man in cylindrische Blechbüchsen von angemessener Grösse, die damit grösstentheils gefüllt werden, löthet nun einen mit einer kleinen Oeffnung versehenen Deckel darauf, füllt durch diese Oeffnung den noch leeren Raum völlig mit Sance, und verlöthet endlich auch diese Oeffnung mit einem Stiickchen Blech. Die so weit fertigen Büchsen setzt man je nach ihrer Grösse $1 / 2$ bis 1 Stunde in einem Wasserbade 
der Siedhitze aus, wobei auch die letzten Spuren von Sauerstoff mit den Bestandtheilen der Brïhe zusammentreten, und dadurch ausser Wirkung kommen, worauf nach dem Erkalten die Büchsen noch mit einem Firnissanstrich versehen werden können.

So conservirte Speisen halten sich in der Regel lange Zeit völlig unverändert. Ist in einzelnen Büchsen ausnahmsweise Verderbniss eingetreten, so kann man diese schon äusserlich daran erkennen. dass die flachen Böden durch entwickeltes Gas bauchig aufgetrieben sind. Kleinere Gegenstände, als Erbsen, Bohnen u. dergl., werden in gläserne Flaschen gethan, diese mit sehr guten Körken fest verschlossen, und nun ebenfalls in einem Wasser- oder Dampfbade einer etwas iiber $100^{\circ}$ C. gehenden Temperatur ausgesetzt.

Um das Zerspringen der Flaschen zu verhüten, versieht man den Kessel mit einem durchlöcherten doppelten Boden, stellt die am besten in leinene Säckchen eingebundenen Flaschen darauf, und bringt nun das Wasser zum Kochen. Nach vollendeter Kochung bleiben die Bouteillen noch einige Stunden in dem Kessel, um damit langsam abzukiuhlen, worauf man sie herausnimmt und nach dem völligen Erkalten verpicht.

Erosen und andere Gemüse können zwar roh in die Flaschen gegeben werden, doch ist es zweckmässiger, sie vorher in heissem Wasser abzubriihen, indem sie dadurch auf ein kleineres Volumen reducirt werden, und die Flaschen mehr davon aufnehmen, mithin um so weniger Luft darin bleibt. Die Erhitzung in dem Wasserbade muss je nach der verschiedenen Beschaffenheit der Gemuise 1 bis 2 Stunden dauern. Auch Milch kann nach der Appert'schen Methode ziemlich lange conservirt werden, wenn man eine reine Flasche damit füllt, sie gut verkorkt und etwa $3 / 4$ Stunden im Wasserbade erwärmt.

Eine neuere, dem A ppert'schen Verfahren nachgebildete, sich aber doch von ihr wesentlich unterscheidende Methode, Fleischspeisen u. dergl. zu conserviren, ist von Willa umez erfunden. Es können dazu gläserne Flaschen gebraucht werden. Wesentlich ist hierbei ein kleines Werkzeug, der Dilator, ein ganz schmales, etwa 3 Linien breites und 2 Zoll langes Streifehen von Weissblech, welches in Gestalt einer flachen Rinne umgebogen ist; es wird beim Gebrauch an den Kork gelegt, so dass die Rinne dem Gase zugekehrt ist und beim Eindrücken des Korkes der in der Flasche enthaltenen Flüssigkeit und beim nachherigen Kochen den Dämpfen einen Ausweg gestattet.

Die zu conservirenden Substanzen, Gemiise oder Früchte, werden entweder roh, im natürlichen Zustande, jedenfalls aber so frisch wie möglich, oder auch im gekochten und zubereiteten Zustande in die Flaschen gebracht. Letzteres ist vorzuziehen. Der Zwischenraum wird entweder mit der beim Kochen erhaltenen Briihe oder mit gesalzenem Wasser gefült. Man stellt die Flaschen in einen hinreichend tiefen Kessel auf einen durchlöcherten hölzernen Boden, und füllt den Kessel mit einer Mischung von Wasser, Kochsalz und Zuckersyrup in dem Gewichtsverhältniss von $12: 2: 2$ an, welche bei $108^{\circ} \mathrm{C}$. kocht.

In diesem kochenden Bade lässt man die ganz gefiullten Flaschen etwa 1/a Stunde lang stehen und setzt nun die Korke auf. Diese mïssen von sehr gutem, dichten Korkholz angefertigt und durch Eintauchen in geschmolzenes Wachs völlig luftdicht gemacht sein. Wenn nun die Substanz in der Flasche sich im Kochen befindet, und der Dampf durch den Dilator in einem ununterbrochenen Strahl auströmt, so nimmt man die Flasche schnell aus dem Wasserbad, setzt sie in ein kleines Kasseroll mit kochendem Wasser, trägt das Ganze unter die Zupfropfe-Presse, zieht den Dilator heraus und presst den Kork mit Gewalt in die Flasche, worauf man sie langsam erkalten lässt.

Dasselbe Verfahren kaun auch bei Fleischspeisen angewandt werden, nur sind sodann Flaschen mit weiter Mündung erforderlich, und es entsteht die Schwierigkeit, so grosse, hinreichend dicht schliessende Korke zu finden.

Ganz analog ist das ron Fastier und Morel-Facio angegebene Verfahren, nach welchem man die Blechbüchsen zunächst nicht völlig verlöthet, 
sondern eine kleine Oeffnung an der Löthstelle belässt, durch welche beim Erhitzen der Büchsen die letzten Reste von Luft entweichen können, worauf man erst völlig verlöthet.

Beispiele für das zweite Verfahren sind das Ueberziehen von Fleisch und feineren Früchten mit einer Schichte von Paraffin, das Einlegen der Eier in Kalkwasser, welches in die Poren der Schale eindringt, sich hier bald in unlöslichen kohlensauren Kalk umsetzt, wodurch das Eindringen der Luft verhindert wird. Auch das Verfahren, die frischen Eier auf kurze Zeit, etwa 2 Minuten, in siedendes Wasser zu tauchen, so dass das Eiweiss bis zu einer gewissen, wiewohl nicht bedeutenden Tiefe hartgekocht wird, und somit eine schiitzende Decke für den uncoagulirten Theil abgibt, gehört hierher. Die Eier werden dann zwischen Sägespänen an einem kühlen Orte aufbewahrt. Noch sicherer würde es sein, die auf die eben erwähnte Art oberflächlich abgekochten Eier noch heiss mit einer starken Gummilösung, der man, um das völlige Austrocknen und Rissigwerden zu verhindern, ein wenig Zuckersyrup zusetzen könnte, zu bestreichen und nun in Kohlenpulver aufzubewahren.

4. Durch Anwendung von Substanzen, welche mit den zur Fäulniss am meisten geeigneten Stoffen, wie Eiweisssubstanzen, Leim etc., gewisse, wenn auch lose Verbindungen eingehen, in welcher Form diese der Fäulniss einen grösseren Widerstand entgegensetzen, wie z. B. Gerbsäure, Phenol und seine Homologen, Kreosol und Guajacol (im Holzrauch enthalten), gewisse Metallsalze.

Beispiele hiefür sind die Conservirung der thierischen Haut als Leder durch Gerbung mit Gerbsäure und Thonerdesalzen, das Räuchern des Fleisches, wobei eine Fixirung der Eiweisssubstanzen durch die Bestandtheile des Kreosotes des Holzrauches und zugleich eine Austrocknung erzielt wird, die Conservirung des Holzes durch Kupfervitriol, Chlorzink etc. (Letztere ist übrigens hierbei noch auf mehrere andere Momente zurückzufïhren.)

5. Durch Anwendung von Substanzen, welche geradezu Gifte für die Fäulnissorganismen sind, dieselben tödten, wie z. B. Arsenige Säure, Sublimat etc.

6. Durch Anwendung von Substanzen, welche die Fäulnissorganismen nicht direct tödten, aber die Umwandlung der fäulnissfähigen Substanzen in eine zur Ernährung der ersteren geeignete Form verhindern oder andere physiologischen Functionen dieser beeinträchtigen.

Hierher gehören unter anderen die in neuerer Zeit als vorzïglichstes Antisepticum erkannte Salicylsäure und einige ihr nahestehenden Verbindungen, deren ausgezeichneten antiseptischen Eigenschaften wahrscheinlich nur auf diesen Wirkungen beruhen; hierher gehört wohl auch die conservirende Wirkung der Benzoësäure, der Borsäure, endlich des Schwefelkohlenstoffs. Ed. Donath.

Fäustel, s. Bergbau I pag. 384, s. Bohren I pag. 696.

Fagin, flüchtiges Alkaloid, von Herberger in den Bucheckern (s. II pag. 161) aufgefunden, dürfte mit Trimethylamin identisch sein. Gtl.

Fahlerz, Schwarzerz, Graugiltigerz (Cuivre gris - Gray copper ore), Teträ̈drit. Ein unter die Kiese gehöriges Erz, welches tesseral, vorzüglich in tetraëdrischen Hemiedrien (daher der von $\mathrm{Ha}$ iding er gegebene Name) mit zahlreichen Combinationen krystallisirt, gewöhnlich aber derb und eingesprengt vorkommt. Unvollkommene Spaltbarkeit, Bruch muschelig, kleinkörnig, spröde. Härte $=3-4$, spec. Gcw. 4.36-5.36. Stahlgrau bis eisenschwarz, Strich dunkel fast schwarz. In der chemischen Zusammensetzung zeigen die Fahlerze verschiedene bemerkenswerthe Abweichungen, welche im Allgemeinen nach $H$. Rose Bildungen nach der Formel $4 R S Q S^{3}+2\left({ }_{4} C u^{2} S Q S^{3}\right)$ darstellen, worin $R$ Eisen und Zink, Q Antimon oder Arsen bedeutet. Das Kupfer fuihrt zuweilen (bis $10 \%$ ) Silber, auch wohl Quecksilber. Man unterscheidet:

1. Arsenfahlerze. Sie sind in der Regel heller von Farbe und dabei spröde, sie haben einen grösseren oder geringeren Silbergehalt, führen aber kein 
Zink. Sie geben im Kolben ein Sublimat von Schwefelarsen, schmelzen v. d. L. leicht zu einer Kugel, welche geröstet die Eisen- und Kupferreaction gibt. Salpetersäure zersetzt das gepulverte Erz unter Abscheidung von Arseniksäure und Schwefel. Salpetersalzsäure gibt eine Lösung, welche sich mit Wasser nicht trübt. Kalilauge extrahirt Schwefelarsen.

2. Antimonfahlerze. Dunkler von Farbe und etwas weicher, führen niemals Silber, haben dafür etwas Zink. Geben im Kolben ein dunkelrothes Sublimat, v. d. L. wie Arsenfahlerz. Salpetersalzsäure zersetzt das Pulver und scheidet dabei Antimonoxyd und Schwefel ab. Salpetersalzsäure scheidet Schwefel ab, die Lösung wird durch Zusatz von Wasser triibe. Kalilauge extrahirt in der Wärme Schwefelantimon.

3. Eine zwischen beiden stehende Gruppe Arsen-Antimonfahlerze, deren Reactionen keinen bestimmten Charakter haben, da sie nach 1 . und 2. schwanken.

Die Fahlerze sind weit verbreitet, finden sich bei Přibram, Joachimsthal, Freiberg, Clausthal, Zillerfeld, Andreasberg im Harz, Schwatz und anderorts in Tyrol, Herrengrund, Kremnitz, Schemnitz in Ungarn, Kapnik in Siebenbürgen, Cornwall in England u. a. v. a. 0.

Die Fahlerze werden theils zur Gewinnung des Kupfers, theils mit zur Erzeugung des Silbers verwendet. $L b$.

Fahlleder, syn. Lohleder, Schmalleder, s. Le der.

Fahlrohkupfer, s. Kupfer.

Fahlunit, syn. Dichroit von Fahlun, vgl. Dichroit II pag. 621 .

Fahnenhafer, Avena orientalis, s. Hafer.

Fahrgeschwindigkeit, III pag. 75.

Fahrkunst, s. Bergbau I pag. 410.

Fahrordnung, III pag. 74.

Fahrschacht, s. Berg bau I pag. 387.

Fahrten, s. Bergbau I pag. 409.

Fahrtonne, Boje, s. I. pag. 724.

Fahrung, s. Bergba u I pag. 409.

Falle (cadole - latch), s. Schlösser.

Fallen der Schichten, s. Einfallen II pag. 739.

Fallhämmer, s. Dampthammer II pag. 511, s. Schmieden.

Fallklotz, s. Bär I. pag. 273.

Fallprobe, s. Eisen II pag. 775 (Wurfprobe).

Fallschirmrakete, s. Feu erw erkerei.

Fallwerk, s. Blechbearbeitung I pag. 557.

Falscher Draht bezeichmet eine blos voribergehende Drehung des Vorgarnes, s. Streichgaruspinnerei.

Falsch-Schiefer, falsche Schieferung, auch secundäre oder transrersale Schieferming (Clerter/e), nemnt man eine cigenthimliche, vorwiegend im Thonschicfer- und Graurackengebirge wahrnehmbare Erschcinung, welche darin besteht, dass sich stellenweise, aber oft anf weite Strecken, eine Schieferung be- 
merkbar macht, welche nicht mit der eigentlichen Schichtung parallel geht, sondern auf deren Richtung mehr weniger senkrecht steht. Die Grauwacken- und Thonschiefermassen zerfallen an solchen Stellen in parallelopipedische Stuicke (Griffelschiefer z. B.), und die falsche Schieferung kann so ausgebildet sein, dass sie die ächte vollkommen unkenntlich macht. Die Ursache dieser Erscheinung ist jedenfalls in Störungen der Lagerung der Schichten durch seitlichen Druck zu suchen, und zeigt sich auch zumeist nur da sehr ausgebildet, wo durch Verwerfungen und Stauungen eine solche entstanden ist. $L b$.

Faltung der Schichten oder des Gebirgs nennt man die in einem Schichtensystem oder einem Gebirge mehrfach wiederkehrenden Biegungen der Glieder, welche hiedurch eine wellenförmige, zickzakförmige schleifen- oder fächerförmige Lage oder Faltung annehmen können. $L b$.

Falz, s. Holzverbindungen, s. Blechbearbeitung I pag. 545.

Falzen, s. Holzverbindungen, s. Buchbinderei II pag. 110.

Falzhobel, s. Holzverbindungen, s. Hobelmas chinen.

Falzkapsel-Maschine zur Massenerzeugung der in den Apotheken verwendeten Papierkapseln erzeugt W. R. Enzmann in Dresden.

Falzmaschine, s. Buchbinderei II pag. 110, s. Blechbearbeitung pag. I 546, 552 .

Falzzange, s. Blechbearbeitung I pag. 545 .

Fangspitze, s. Blitzableiter I pag. 641.

Fangvorrichtungen, s. Berg b a u I pag. 407.

Faradayin, ältere Bezeichnung für ein flüchtiges Product der trockenen Destillation des Kautschuks, siedet bei $33^{\circ}$ C., spec. Gew. $0 \cdot 65$. Ist ein gutes Lösungsmittel für Harze, Schwefel und Phosphor, und bei gewöhnlicher Temperatur schon äusserst flichtig. Gtl.

Farbe (couleur - colour) im Allgemeinen, ist die eigenartige, durch den Sehnerven vermittelte Empfindung, welche durch die Einwirkung einzelner oder auch mehrerer, einander aber nicht zu weissem Lichte ergänzender, Lichtwellen von bestimmter Wellenlänge auf die Netzhaut oder durch eine sonstige Reizung der Netzhaut erregt wird. Je nachdem diese Empfindungen ihre Quelle ausserhalb des die Empfindung vermittelnden Organes haben, und daher fuir mehrere von einander unabhängige Sehorgane gleichzeitig wahrnehmbar sind, oder aber in einem einzelnen Organe selbstständig zur Geltung kommen und dann für normale Sehorgane gleichzeitig nicht wahrnehmbar sind, unterscheiden wir die Farben in objective oder physische und in subjective oder physiologische. Es soll hier nur von den ersteren die Rede sein. Das von einem leuchtenden Körper ausstrahlende Licht, welches in unserem Sehorgane eine bestimmte Farbenempfindung nicht hervorruft und das wir weisses Licht nennen, ist, wie die Erfahrung lehrt (s. Licht), das Ergebniss mehrerer neben einander bestehender, wellenförmig sich fortpflanzender Schwingungsbewegungen der Lichtäthermoleküle. Da das Zustandekommen der Lichtempfindung iiberhaupt als die Folge der von den schwingenden Aethermolekïlen gegen die in der Netzhaut des Anges ausgebreiteten Endverzweigungen des Sehnerven geführten Stösse angesehen werden muss, so lässt sich denken, dass während die gleichzeitige regellose Einwirkung der Stösse mehrerer in verschiedener Weise schwingender Aethermoleküle auf die Netzhant die Empfindung des weissen Lichtes bedingen kann, die in einer gewissen Regelmässigkeit erfolgenden Stösse schwingender Aethermoleküle die Empfindung der Farbe bedingen, etwa so wie beim Tönen der Körper die gleichzeitige Einwirkung rer- 
schiedener Schallwellen in unserem Gehörorgane die Wahrnehmung eines Geräusches hervorrufen kann, während Schallwellen von bestimmter gleichartiger Natur die Wahrnehmung bestimmter Töne bedingen. Insoferne die physischen Farbenerscheinnngen sonach stets nur ihre Quelle in der Einwirkung bestimmter Lichtwellen auf die Netzhaut des Auges haben, kann man solche Lichtwellen selbst als farbige bezeichnen und demnach die Farbenempfindung als das Ergebniss der Einwirkung einzelner oder mehrerer, zwar gleichzeitig wirkender, sich in ihrer Wirkung aber nicht störender farbiger Lichtwellen bezeichnen. Die Art der Farbenempfindungen ist, ebenso wie die Art der Tonempfindung durch die langsamere oder raschere Schwingung des tönenden Körpers bedingt wird, abhängig von der grösseren oder geringeren Raschheit der Schwingung der Aethermoleküle, also von der Dauer der Schwingung und der mit dieser im engsten Zusammenhange stehenden geringeren oder grösseren Länge der Lichtwellen, uud wie jeder bestimmten Schwingungszahl eines tönenden Körpers ein bestimmter Ton entspricht, so entspricht jeder bestimmten Schwingungszahl der Lichtäthermoleküle eine bestimmte Farbe. Fresnel hat durch sehr genaue Versuche für verschiedene farbige Lichtwellen, welche die Hauptfarben repräsentiren, die Wellenlängen und die Schwingungszahlen der Aethermolekïle gemessen und wie folgt gefunden:

\begin{tabular}{|c|c|c|c|c|c|c|c|c|c|c|c|c|c|c|c|}
\hline Licht & & $\begin{array}{r}\text { W } \\
\text { Milli }\end{array}$ & & $\begin{array}{l}\text { länge ausge } \\
\text { heilen eines }\end{array}$ & $\begin{array}{l}\text { edrü } \\
\text { Mill }\end{array}$ & & $\begin{array}{l}t \text { in } \\
\text { eters }\end{array}$ & & & & & & & er Ser & cunde \\
\hline Rothes & . & . . & . & .645 . & & & & & . & & & & & 500 & Billionen \\
\hline efarbige & & . & . & .588 . & & & & & . & . & & & & 532 & \\
\hline . . & - & . & . & : 551 . & - & $\cdot$ & • & & & & & & & 563 & \\
\hline . . & . & . & . & 1. & . & . & . & & & & & & & 607 & \\
\hline aues & . & . & . & . & . & . & & & & & & & & & \\
\hline olaues & . & . & . & . 449 . & . & & & & & & & & & 691 & \\
\hline Violettes . . & . . & . . & . & . . 423 . & & & & & & & & & & 735 & \\
\hline
\end{tabular}

Wie man aus diesen Zahlen ersieht, unterscheiden sich die verschiedenen Lichtarten in Bezug auf ihre Wellenlängen und Schwingungszahlen sehr erheblich von einander, und es ist demnach begreiflich, dass die Empfindungen, welche sie hervorzurufen vermögen, um so verschiedener sein werden, je mehr die Schwingungszahlen von einander abweichen. In ihrer gleichzeitigen Einwirkung auf den Sehnerv bringen sie den Eindruck des weissen Lichtes hervor, und da man sohin im weissen Lichte die verschiedensten Arten farbigen Lichtes nachzuweisen vermag, kann man das weisse Licht als aus den einzelnen farbigen Lichtarten zusammengesetzt und demnach die unter dem Einflusse des weissen Lichtes auf gewisse Körper hervortretende Farbenerscheinung als das Resultat einer Zersetzung des weissen Lichtes bezeichnen. In der That nehmen wir Farbenerscheinungen nicht blos dann wahr, wenn das von einem leuchtenden Körper ausgestrahlte Licht von bestimmter Farbe direct in unser Auge gelangt (ursprüngliche oder permanente Farben), sondern weit häufiger werden Farbenerscheinungen bedingt durch den Einfluss, welchen die Körper bei der Einwirkung weissen Lichtes auf die Verhältnisse der Lichtwellen nehmen (a p parente F arben). Hierher gehören zunächst die Farbenerscheinungen, die bei der Brechung des Lichtes, d. s. Brechungsfarben (prismatische Farben), zu Stande kommen können und ilıren Grund in der durch die Verschiedenheit der Wellenlängen bedingten verschiedenen Brechbarkeit der einzelnen Lichtarten haben, weiters die Farbenerscheinungen durch die Einwirkung zweier unter einer schwachen Neigung sich so treffender Lichtwellen, dass bei dem Zusammentreffen derselben eine Gangverschiedenheit $\mathrm{um}$ eine ungerade Zahl von halben Wellenlängen besteht (Interferenz-Farben), endlich jene, welche durch die Vernichtung einzelner Lichtarten bei dem Durchgange oder der Reflexion der Lichtstrahlen durch verschiel dene Körper zu Stande kommen, d. s. Farben der Absorption. Zu deersten Art der apparenten Farbenerscheinungen zählen vornehmlich dic Spectrarfarben, dann die Farben bei Linsensystemen; die Farbenerscheinungen durch Interferenz finden sich in den Farben dünner Blätter, dann den irisirenden 
oder Perlmutterfarben, endlich die Polarisationsfarben, während zu den Farbenerscheinungen durch Absorption, die Farbenerscheinungen an farbigen, Licht durchlassenden Körpern, Gläsern, Mineralien, Flüssigkeiten, Gasen (dioptrische Absorptionsfarben), so wie jene an farbigen, für Licht undurchgängigen oder doch höchstens durchscheinenden Körper von natürlicher Farbe (katoptrische Absorptionsfarben) zu zählen sind.

Farbenerscheinungen, mit welchen es die Technik zu thun hat, sind vornehmlich Absorptionsfarben (nur verhältnissmässig selten kommen Farbenerscheinungen der Interferenz in Betracht), und diese Erscheinungen kommen dem oben Gesagten zu Folge in der Art zu Stande, dass das auf gefärbt erscheinende Stoffe auffallende weisse Licht vermöge der absorbirenden Wirkung die die Masse oder wenigstens die Oberfläche solcher Stoffe auf einzelne in dem weissen Lichte enthaltene farbige Lichtwellen ausuibt, zum Theile zersetzt wird und demnach nur der nicht absorbirte Antheil der das weisse Licht zusammensetzenden einzelnen Lichtarten zur Wahrnehmung gelangt. Der Eindruck, den dieser Antheil auf unser Auge macht, wird mehr oder weniger von jenem des weissen Lichtes abweichen muissen, und zwar um so ausgesprochener, je mehr von den einzelnen Lichtarten, die in ihrer Gesammtheit die Empfindung des Weiss hervorbringen, absorbirt worden ist; in der Regel aber wird dieser Eindruck nicht der einer einzelnen Lichtart, sondern meist noch der eines Gemenges von sich zu einer Farbenmischung vereinigenden farbigen Lichtwellen sein. Hat ein Körper die Eigenschaft, alle Lichtwellen bis auf eine von bestimmter Wellenlänge zu absorbiren, so wird seine Farbe rein (homogen) erscheinen, in allen anderen Fällen wird sie noch zusammengesetzt sein, also eine von der reinen Farbe abweichende Nuance (F a rbenton) haben, und es ist klar, dass ein solcher Körper bei der Beleuchtung mit allen Lichtarten von anderer Beschaffenheit oder mit einem Gemenge von solchen, welche die Lichtart, die er nicht absorbirt, nicht enthalten, dunkel erscheinen, und nur dann erhellt und wahrnehmbar sein wird, wenn er von der bestimmten Lichtart oder einem dieselbe enthaltenden Gemenge derselben getroffen wird. Es kann demnach ein Körper, welcher im weissen Lichte eine bestimmte Färbung zeigt, bei der Beleuchtung mit einer bestimmten anderen Lichtart, dunkel und ungefärbt erscheinen, oder wenn er wie gewöhnlich keine homogene Farbe zeigt, durch die Beleuchtung mit einem andern als weissem Lichte eine andere Nuance der Färbung zeigen, wie ja das die Erfahrung, z. B. das missfärbig erscheinen violetter oder blauer Körper bei Beleuchtung mit dem nicht rein weissen Kerzen- oder Lampenlicht, das ungefärbt erscheinen rother Körper in dem gelben Lichte der Flamme von mit Kochsalz vermengtem Spiritus u. s. w. sattsam lehrt. Die Beurtheilung der Farbe eines Körpers kann sich demnach im Allgemeinen nur auf die Beleuchtung mit weissem Lichte (Sonnen- oder helles Tageslicht) beziehen.

$\mathrm{Da}$ die Farbe eines Körpers, wie erwähnt, durch die Absorption eines Theiles farbiger Lichtwellen aus dem weissen Lichte zu Stande kommt, so ist klar, dass der zur Absorption gebrachte Antheil der farbigen Lichtwellen, mit jenem, welcher unabsorbirt geblieben ist und also die Körperfarbe bedingt, sich zu Weiss ergänzen müsste, wenn man beide wieder zusammentreffen lässt, und es folgt hieraus, dass es fuir jede Farbe eine entsprechende zweite geben muss, welche mit der ersten, in passendem Verhältnisse zusammentreffend, wieder Weiss liefert.

Diese eine bestimmte Farbe zu Weiss ergänzende Farbe nennt man ihre Ergänzungsfarbe oder Complementärfarbe, und Farben, die mit einander gemengt Weiss liefern, nennt man complementäre Farben. Von diesem Verhalten der Farben macht man mannigfachen Gebrauch; so z. B. benuitzt man die Complementarität dazu, um schwach gelb gefärbten Körpern durch Zusatz von einem geeigneten Blau ein rein weisses Aussehen zu ertheilen; hierher gehört das Bläuen der Wäsche, des Zuckers, der Stärke, das Weissmachen des Glases durch schwaches Anfärben mit Violett. Farblos erscheinende Mineralien verdanken ihre 
Farblosigkeit oft dem Umstande, dass sie zwei einander complementäre Farben enthalten u. dgl. m. Auf der Complementarität der Farben beruht auch die als Contrastwirkung bezeichnete Erscheinung, dass eine Farbe durch eine neben ihr gestellte zweite Farbe beeinflusst und in ihrer Nuance geändert werden kann, indem bei der gleichzeitigen Einwirkung zweier Farben auf die Netzhant, wenn dieselben neben einander wirken, das Auge die beiden Farben nicht nur unverändert, sondern jede einzelne so wahrnimmt, als wenn ihr die der nebenstehenden Farbe complementaire Farbe beigemengt wäre. So erscheint ein weisses Feld, das sich auf einem hellgrïnen Grunde befindet, schwach roth, oder umgekehrt schwach grün, wenn es sich auf rothem Grunde findet, schwach violett, wenn es vorherrschend eine gelbe Umgebung, und schwach gelb, wenn es eine violette Umgebung hat, schwach blau, wenn nebenbei vorherrschend Orange, und orange, wenn nebenbei vorherrschend Blau vorhanden ist $11 . \mathrm{s} . \mathrm{w}$. So wird Grin neben Violett gelblich, das Violett röthlich, Roth neben Gelb violett, das Gelb grünlich u.s.w. Solche scheinbare Farben pflegt man Contrastfarben oder Nebenfarben zu nennen, und ihrem Auftreten muss in der Färberei und Druckerei, ebensowohl wie in der Malerei ganz besonders Rechnung getragen werden.

Man kann die Farben nach den 7 Hauptfarben, welche das durch prismatische Zerstreuung zerlegte weisse Licht in dem sogenannten Spectrum (s. S pe ctros cop) zeigt (vgl. oben), in rothe, orange, gelbe, grïne, blaue und violette unterscheiden, welchen 7 Hauptgruppen als eigentliche Grundfarben wieder nur roth, gelb und blau zu Grunde gelegt werden können. Weiss und Schwarz erscheinen nicht als Farben, sondern es entspricht Weiss der Abwesenheit jeglicher Farbe und Schwarz dem Abgange des Lichtes uiberhaupt. Chevreul hat ein System der Farben aufgestellt, dessen wesentlichsten Grundsätze hier kurz angedeutet werden sollen.

Die Hauptfarben: roth, orange, gelb, grïn, blau und violett können verändert werden:

a) durch Weiss, welches sie heller und weniger intensiv macht, wodurch die helleren Töne einer und derselben Farbe entstehen;

b) durch Schwarz, welches sie dunkler erscheinen lässt, bei gleichzeitiger Schwächung der Intensität, wodurch die dunkleren Töne der Farbe erhalten wcrden. Die Reihenfolge aller Töne bildet die Farbenscala;

c) durch eine zweite Farbe, welche die Eigenthümlichkeit der Farbe ändert, ohne sie zu trüben, wodurch $\mathrm{Nu}$ ancen der Farbe entstehen;

d) durch eine zweite Farbe, welche die Eigenthümlichkeit der Farbe unter gleichzeitiger Trübung ändert und sie endlich in Schwarz oder in das Gemenge von Schwarz mit Weiss, d. h. in Grau abstumpft.

Durch Combination der in der Reilenfolge stehenden Hauptfarben mit einander in bestimmten Verhältnissen stellt Chevreul 72 Farbentypen dar, von deren jeder er durch Beimischung von $0 \cdot 1-0.9$ Antheilen an Weiss oder Schwarz 20 Töne herstellt. Er erluält in dieser Weise Scalen von je zwanzig Farben, mit Hilfe deren sich jede einzelne Farbe genau bestimmen lässt, indem man die Namen der Scala angibt, der sie angehört, und die Nummer ihres Tones, eventuell die Beimengung von Schwarz, durch welche sie gedämpft erscheint. (Vgl. E. Chevreul de conleurs et de leur applications ete. 1864.)

Als Erfahrungsregeln für die Mischung ron Farben ergeben sich folgende:

I. a) Mischungen ron Farbstoffen, deren einer Roth, der andere Gelb ist, beziehungsweise zwischen Roth und Gelb liegenden Nuancen des einen oder des andern liefern Orange oder orange Nuancen.

b) Mischungen von Farbstoffen, deren einer dem Roth, der andere dem Blau angehört, liefern Violett oder violette Nuancen.

c) Mischungen von Farbstoffen, deren einer dem Blau, der andere dem Gelb angehört, liefern Grïn oder grïne Nuancen.

II. a) Roth, Gelb und Blau liefern in passendem Verhältnisse gemischt Schwarz oder durch Schwarz gedämpftes Weiss, d. i. Grau. 
b) Ist in der Mischung eine Farbe iiberwiegend, so entstelit, je nach dem Vorherrschen des Roth, Gelb oder Blau, ein röthliches, gelbes oder blaues Grau. Vgl. iib. a. Färberei III pag. 349, s. a. Farbstoffe. Gtl.

Farbendruck, s. Buntdruck II pag. 157, s. Kupferdruck, s. Litographie. Eine eigenthümliche Methode des Farbendruckes von J. M. Jolinson \& Son im London ist kurz beschrieben in der Zeitschrift d. nied.-ijst. Gew.-Ver. 1874 pag. 49 . $K k$.

Farbenmass, syn. m. Colorimeter, s. II pag. 379.

Farbenspectrum, s. Spectroseop.

Farberden, syn. m. Erdfarben, s. bei Erde III pag. 285.

Farbereiben (pulvériser des couleurs - to powder colour). Das Reiben der Malerfarben geschieht sehr häufig noch jetzt aus fieier Hand mit Farbstein und Läufer, ist aber eine höchst zeitranbende und langweilige Arbeit. Sie liesse sich ungemein erleichtern, wenn die Farben, besonders das Bleiweiss, welches in so grossen Quantitäten gebraucht wird, gleich als hinlänglich fein gemahlene Pulver in den Handel kämen.

Der Farbstein ist eine horizontal gestellte, ebene Platte aus dichtem Marmor, Porphyr, Granit od. dgl. Der Reiber oder Lä ufer ist ein kegelförmigei Stein derselben Art mit glatter Grundfläche.

Wo es sich um kleine Quantitäten handelt, empfiehlt sich allerdings das Reiben mit Farbstein und Läufer durch Einfachheit, sowie dadurch, dass die ganze Menge der geriebenen Farbe leicht und vollständig abgenommen werden kann. Beim Reiben grösserer Quantitäten einer und derselben Farbe aber verdienen Reibmaschinen jedenfalls den Vorzug.

Eine Farbreibmaschine, deren Wirkungsart mit jener der Handarbeit ziemlich nahe ibereinstimmt, besteht in einem grossen runden Reibsteine auf welchem ein kleinerer, dessen Durchmesser etwa $1 / 3$ von dem des grossen beträgt, durch einen Mechanismus im Kreise herumgefuihrt, und während dem beständig um seine eigene Achse gedreht wird.

Recht wirksam und durch vielfältige Anwendung erprobt ist die in Fig. 1519 abgebildete Farbenreibmaschine von $\mathrm{Rummel}$. Auf einem gusseisernen Gestelle $A B$ ist durch Schrauben das gleichfalls gusseiserne Bodenstïck $C$ befestigt, auf welchem sich der auf der Innenseite gefurchte gusseiserne Läufer $E$, Fig. 1519.

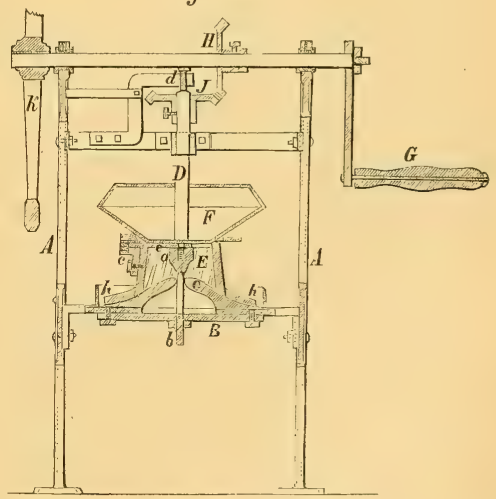
dessen Gestalt sich aus der Zeichnung ergibt, dreht. Derselbe ist durch die Mutter $a$, den dreiarmigen Stern $e$ und die Winkelstiicke $c$ an der stehenden Welle $D$ befestigt und trägt zugleich den Aufgebetrichter $F$. Die Drehung der Welle wird mittelst der Kurbel $G$ und der konischen Räder $H$ und $J$ bewirkt: ein Schwungrad $K$ dient zur Erzielıng gleichförmigeren Ganges. Tm den Druck des Läufers gegen das Bodenstiick beliebig reguliren zu können, dienen die beiden Stellschrauben $b$ und $d$. Die in den Trichiter gegebene Farbe geht langsam zwischen Läufer und Bodenstiick hindurch, sammelt sich in der kreisförmigen Rinne $h$ und fliesst von hier ab. Auf einer Maschine mit $36^{\mathrm{cm}}$ Durchmesser des Läufers kann täglich $50 \mathrm{Kg}$. Oelfarbe gerieben werden. 
Zum eigentlichen fabriksmässigen Betriebe eignen sich besonders die Maschinen mit Walzen, deren zwei oder drei, fest an einander gedrïickt, sich mit ungleicher Geschwindigkeit umdrehen. Solche Walzmaschinen haben Aehnlichkeit mit den Chocolade-Reibmaschinen, welche Bd. II pag. 338 etc. beschrieben wurden. Diese Maschinen werden namentlich zum Reiben der Buchdruckerfarbe benützt. Auch excentrische Mühlen finden Anwendung. Hierbei sitzt eine Eisen- oder Steinscheibe auf einer vertikalen, von unten hebbaren Achse und rotirt. Oberhalb derselben ist fest eine zweite Scheibe angebracht, welche excentrisch zu der ersteren steht und durch deren Auge (durchbohrte Mitte) die zu reibende Farbe zufliesst. (Vgl. Art. Pulverisiren.)

F arben reibmaschinen verfertigen: Herrmann in Paris, Carl A. Specker in Wien, Joh. Ph. Klein in Offenbach a. M., Michaelis \& Mïller in Chemnitz, H. Brückner in Berlin u. v. A.

Farberze oder Farbenerze, im weiteren Sinne alle Erze, welche zur Farbenbereitung gebraucht werden, wie: Brauneisenerz, Rotheisenerz, Chromeisenerz, Uranpecherz, Kobalt- und Nickelerze. Im engeren Sinne werden namentlich letztere drei, im sächsischen Erzgebirge wohl auch die Kobalterze allein, weil zur Blaufarbenerzeugung gebraucht, als Farberze bezeichnet. $L b$.

Farbhölzer, s. Blauholz, s. Gelbholz, s. Rothholz u. A.

Farbholzextracte, s. Extracte III pag. 341, vgl. a. d. einzelnen Farbhölzer.

Farbholzmühlen, s. Hobelma s chinen, s. Fräs en.

Farbkörper, s. F a rbst offe.

Farblacke (laque des peintres - drop-lake), Lackfarben, Lacke, nennt man im Allgemeinen die Verbindungen von organischen Farbstoffen mit Thonerde, Zinnoxyd, Bleioxyd, Eisenoxyd u. s. w., wie solche durch Fällung gewisser Farbstofflösungen mit Thonerde-, Blei-, Zinn- oder anderen Salzen der schweren Metalle oft bei gleichzeitiger Anwendung eines Alkalis in Gestalt von in Wasser nicht oder nur sehr schwer löslichen Niederschlägen erhalten werden können. Gtl.

Farbmalz, s. Bier I pag. 476.

Farbmühlen, s. F arbereiben.

Farbreibmaschinen, s. F arbereiben.

Farbschreiber, Blauschreiber, s. Electricität bei electrische Telegraphie III pag. 217.

Farbstein, s. F a r bereiben.

Farbstoffe, F a r b materia lien (matières colorantes - colouring matters), Pigmente, Farbkörper, nennt man alle jene Körper, welche durch ihre Gegenwart anderen Körpern die Fähigkeit ertheilen, eine bestimmte Farbe zu zeigen, wobei sie die bestimmte Farbe entweder schon an sich haben ( $\mathrm{F}$ a r ben), oder dieselbe erst unter gewissen Umständen annehmen ( $\mathrm{Chromogene).} \mathrm{Man}$ kann die Farbstoffe je nach ihrer chemischen Natur in unorganische oder Mineralfarben und in organ is che $\mathrm{F}$ arbstoffe eintheilen, welche letatere Gruppe alle dem Pflanzen- und Thierreiche entstammenden natïrlichen Farbstoffe, sowie die künstlichen Farbstoffe (z. B. Phenol-, Anilin-, Naphtalin-, Anthracen-, Chinolin-Farben u. s. w.) nmfasst. Zwischen beiden stehen jene Farben, welche einen organischen Farbstoff in Verbindung mit einer unorganischen Substanz enthalten, d. s. die sogenannten Lackfarben (s. Farblacke). Je nach ihrer Verwendung unterscheidet man die Farbkörper in solche, welche vornehmlich für 
Zwecke der Färberei und Druckerei dienen (Zeugfarben oder Druckfarben), dann solche, welche wesentlich zu Zwecken der Malerei verwendet werden (Maler-oder Anstrichfarben); endlich solche, die zur Färbung von Glasflüssen Verwendung finden (Schmelzfarben).

Die Maler- oder Anstrichfarben unterscheidet man, je nachdem die durch Auftragen derselben herstellbare Farbschichte mehr oder weniger durchsichtig oder durchscheinend oder aber undurchsichtig und demnach den Untergrund verdeckend ist, in Lasur-oder Saftfarben und in Deckfarben (Körperfarben); je nach der Natur des Bindemittels, mit welchem sie auf der Unterlage haftend gemacht werden, in $\mathrm{O}$ el- oder Firnissfarben, in Wasserfarben (Leimfarben, Aquarellfarben) und in Kalkfarben (Mauerfarben), endlich Pastell- und Staubfarben, welche ohne besonderes Bindemittel aufgetragen werden. Eine besondere Art der Deckfarben bilden die Metall- oder Bronzefarben, bei welchen mit der bestimmten Färbung ein gewisses Mass von Metallglanz erzielt werden kann.

Die Schmelzfarben unterscheidet man je nach ihrem jeweiligen $\mathrm{Zwecke}$ in Glasfarben, Email- oder Glasurfarben und Porzellanfarben; dass man die einzelnen Arten von Farben überdies nach ihrer Abstammung, beziehungsweise nach ihre wesentlichsten Bestandtheilen gruppirt und entsprechend benennt, erhellt aus den bezüglichen Namen, wie An il in farben, A n th r a c en farben, $\mathrm{N}$ a $\mathrm{p}$ h talinfarben, B leifarben, $\mathrm{Kupferfarben,} \mathrm{Chromfarben} \mathrm{u.} \mathrm{dgl.} \mathrm{m.} \mathrm{Je} \mathrm{nach} \mathrm{der}$ Natur der charakteristischen Färbungen, die die einzelnen Farbkörper zeigen oder hervorzubringen gestatten, unterscheidet man schwarze, braune, rothe, orangegelbe, gelbe, grüne, blaue, violette, weisse und graue Farben. Von besonderer Wichtigkeit ist endlich die Unterscheidung in giftige (schädliche) und giftfreie (unschädliche) Farben, und insoferne diese Unterscheidung für die Praxis nicht selten von hervorragender Bedeutung ist, geben wir im Folgenden eine Zusammenstellung der gebräuchlichsten Farben, welche diesen Categorien angehören.

\section{Es sind giftig:}

S c hwarze Farben: Antimonschwarz (Eisenbronce), Quecksilberschwarz.

B ranne Farben: Bleibraun, Breslauer Braun (Chemisch Braun), Terra siena.

R oth e Farben: Zinnober (chinesisch Roth, Vermillon, Pariser Roth, Patent Roth), Antimonzinnober, Mennige (Bleiroth, Minium, Pariser Roth, rothes Bloioxyd), Chromroth (Chromzinnober, chroms. Blei), Mineralroth, rother Streuglanz, Schönroth, Florentinerlack (arsenhalt. Cochenilleroth), Corallinroth, gewisse Arten von Fuchsin, Kupferroth (Kupferoxydul).

Or a n geg e lbe Farben: Chromorange, Goldschwefel (Antimonorange).

Gelbe Farben: Rauschgelb (Auripigment, Opperment, Königsgelb, persisch Gelb, chinesisch Gelb, spanisch Gelb), Cadmiumgelb, Chromgelb (Kaisergelb, Neugelb, Krongelb, Kölner Gelb, Pariser Gelb, Leipziger Gelb, Gothaer Gelb), Neapel-Gelb, Casseler Gelb (Mineralgelb, Turners Gelb, Patent Gelb, Montpellier-Gelb, Veroneser Gelb, chemiseh Gelb). Zinkgelb (Zinkchromat), Ultramaringelb (Gelbin, Barytgelb), Antimongelb, Steinbühler Gelb, Wismuthgelb, Massicot (Bleigelb), Gummi Guttae, Pinkrinsäure (Pikringelb).

Grüne Farben: Grïnspan (Spangrün), Bremer Grün, Berggrün (Braunschweiger Kupfergrün), Barytgrün (Mangangrün), Zinkgrün (Rinmanns Grün), Kobaltgrüin, grüner Zinnober (Oelgrün, Resedagrün, Maigrün, Moosgrün, Laubgrün, Neapel-Grün), Chromgrün (Grignet's Grün, grünes Chromoxyd), Seheele's Grün (schwedisch Grün, Mineralgrün), Schweinfurter Grün (Kaiser-Grün, Königs Grün, Kurrers Grün, Kirchbergers Grün, Schober-Grün, Zwickaner Grün, Grundir-Grün, englisch Grün, Casseler Grün, Leipziger Grün, Neuwieder Grün, Originalgrün, Patentgrün, Pickelgrün, Mitisgrün, Maigrün, Moosgrün, schweizer Grün, Pariser Grün, Wiener Grün, Würzburger Grün, Papageigrün, Basler Grün), Casselmanns Grün, Smaragdgrün, Gelbholz- und Quercitrongrün, Jodgrün.

B la u e Farben: Bergblau (Mineralblau, Kalkblau, Kupferblau, Casseler Blau, Hamburger Blau, englisch Blau. Neuwieder Blau), Coeruleum, Kobaltblau (Thenard's Blau), Molybdaenblau (Mineralindigo), Smalte (Eschel), Berliner Blau (u. z. speciell Louisenblau und Mineralblau), blauer Erzglanz, blauer Streuglanz, manche Sorten Anilinblau.

$\mathrm{V}$ iolet te Farben: Alle aus giftigen blauen oder rothen Farben hergestellten violetten Gemenge, ferner manche Sorten Anilinviolett.

We is se Farben: Bleiweiss und bleiweisshaltige Mischungen (Schieferweiss, Kremser Weiss, Venetianer Weiss, Hamburger Weiss, Holländer Weiss, Tyroler Weiss, Thenards Weiss, Clichyer Weiss, französisch Weiss, Silberweiss, Perlweiss), Zinkweiss (Schneerreiss, Zinkblumen, Zinkoxyd), Barytweiss (Schwerspath, Spathweiss, Mineralweiss, Neuweiss, Bleiweisssurrogat, Permanentweiss, Blanc fixe), Satinweiss, Wismutweiss (spanisch Weiss, SchminkWeiss, echt Perlweiss). 
G ra ru Farben. Alle Mischungen; welche schädliche weisse oder schwarze Farben enthalten, dann Zinkgrau, Zinkblende.

Metall - oder Broncefarben: Schaungold, Schaumsilber, nnechtes Metallgold und Metallsilber, unechtes Malersilber, Kupferbronce, Broncelacke aus schädlichen Anilinfarben, Wolframbronzen.

Es sind nicht giftig:

Schwarze Farben: Frankfurter Schwarz (Rebschwarz, Weinschwarz, Drusenschwarz, Hefenschwarz), Russschwarz (Kienruss, Lampenschwarz), Oelschwarz, Beinschwarz, Korkschwarz' (spanisch Schwarz), Neutralschwarz, Kernschwarz.

B ra n n Farben: Umbra (Umbraun, KöInisch Braun, Kesselbraun, spanisch Braun, Van Dyks Braun, Eisenacher Braun, brauner Carmin), Biester (Sodbraun, Chemischbraun), Manganbraun (Mineral-Biester, Wad), Rothbraun, Mumienbraun, Sepia, Mahagonibraun, Modebraun, Russischbraun.

Rothe Farben: Eisenroth (rothe Ocker, Rouge, Engelroth, Berliner Roth, Nürnberger Roth, Indischroth, Neapel-Roth, Steinroth, Hausroth, rother Bolus, rothe Erde, Röthel, Polirroth, Todtenkopf, Caput mortuum, Colcothar, Blutstein), Freienwalder Roth, Rothlacke (Kugellack, Wiener Lack, Rosenlack, Karminlack, Blauholzroth, Rothholzroth, Rosenroth, Carmin), Bezetten, Sophienroth, Safflorroth (Tassenroth, Safflorcarmin), Anilinroth (giftfreies), Anthracenroth (Purpurin, Alizarin), Krapproth, Rothsäfte (Berberitzensaft, Alkermessaft, Malvenroth, Heidelbeerroth.

Orangegelbe Farben: Orlean (Saft-Nanquin), Gemenge aus unschädlichen rothen und gelben Farben.

G e lbe Farben: Ockergelb (Ockererde, Gelberde, Hausgelb, Goldocker, Satinocker, Chineser Gelb, Schöngelb, Kahlaer Gelb, Strigatuer Gelb, Lemnische Erde), Schüttgelb, Krappgelb, Curcuma-Gelb, Saftgelb, Berberitzen-Gelb. Saflor, Quercitron, Wau, Kreuzbeergelb, Gelbbeeren, Gelbholz, Gelbholzlack (Gelblack), Fustikholz, Saffran, Ringelblumengelb.

Grïne Farben: Saftgrün (Kreuzbeergrün, Pistaziengrïn, Apfelgrün), Ultramaringrün (Leykaufs Grün), Grünerde (Veroneser Grün, Seladongrüin, Steingrün, cyprische Erde, böhmische Erde, Kaadner Erde, französische Erde), Mischungen aus Berliner Blau mit Curcumagelb oder Ringelblumengelb, obenso aus Indigocarmin mit unschädlichen gelben Farben.

Bla ue Farben: reines Berliner Blau (Pariser Blau, preussisch Blau, Diesbacher Blau, sächsisch Blau, englisch Blau, Turnbulls Blau, Raymonds Blau, Erlanger Blau, Neublau, Waschblau, Hortensienblau, Miloriblau, Wasserblau), Indigo (Indigocarmin, blauer Carmin, Blautinktur), giftfreie Smalte (Eschel), Ultramarin (Lazurblau, Azurblau), Malvenblau, Lakmusblau, Holzblau, giftfreies Anilinblau.

Violette Farben: Veilchensaft, giftfreies Anilinviolett, Gemenge von unschädlichen rothen mit unschädlichen blauen Farben, z. B. Carmin und Indigo, Alkermes und Lakmus oder Indigocarmin.

Weiss e Farben: Geschlämmte Kreide (Schlämmkreide, Marmorweiss, Wiener Weiss, Bologneser Weiss), weisser Bolus (Pfeifenthon, Bol- oder Volerde), Gyps (Alabasterweiss), Talkweiss (Federweiss, Venetianer Talk, Speckstein). Krochenasche (Beinweiss, Hirschhornweiss), Porzellanthon (China Clay).

Meta 11- und Bronzefarben: Echtes Gold (Muschelgold) und Silber (Muschelsilber), Musivgold, Zinnstaub, Graphit, Eisenpulver, giftfreie Anilinfarben.

Ueber die einzelnen Farbstoffe s. die betreffenden Artikel. Gtl.

Farbwurzel, syn. Krappwrzel, dann auch fiir Alkannawurzel gebränchlich.

Farina, syn. m. Mehl.

Farinzucker, s. Z u cker.

Farrenkrautwurzel-0el, s. Filix öl.

Faschine (fascine - fascine), s. W a s serbau.

Faseralaun, natürlich vorkommonde Verbindung von sehwefelsaurer Magnesia und schwefelsaurer Thonerde. Enthält 25 Mol. Wasser. Nicht selten mangan- und eisenhaltig. Weisse oder gelblichweisse bis graue krystallinische Masse. Vorkommen am Bosjemanfluss in Siidafrika. Gtl.

Fasergyps, s. Gy ps.

Faserkalk, s. Arragonit I pag. 179.

Faserkohle, eine fasrige Varietät der Stein- oder Braunkohle, s. d. 
Fasern, s. Gespinnstfasern.

Faserquarz, s. Quarz.

Faserstoff, syn. m. Fibrin, s. Eiweisskörper III pag. 140 .

Faserzeolith, syn. Skolezit.

Fass, Fassfabrikation, s. Bötteherei I pag. 690.

Fassait, s. Pyroxen.

Fassbinderei, s. Böttcherei I pag. 677.

Fasseschel, s. Smalte.

Fassfüller, s. Kellerwirth sehaft.

Fassgeläger, vgl. Bier und Wein.

Fassglasuren nennt man Lösungen von Harzgemengen (Colophonium, Damarharz etc.), in Terpentinöl oder Alkohol, welche man zum Wasserdichtmachen von Holzfässern verwendet. (Vgl. Kanitz Dingl. pol. Journ. 212 pag. 351). Gtl.

Fasshahn, s. Kellerwirthschaft.

Fasshahnlegierung, von Vigoure ux empfohlene Legierung für Fasshähne, bestehend aus Antimon (19-21 Thl.), Zinn (71-80 Thl.) und Nickel (1.8-7 Thl.). Vgl. Dingl. pol. Journ. 178 pag. 242. Gtl.

Fassheber, s. Kellerwirths chaft.

Fatisciren, syn. m. Verwittern, s. d.

Faujasit, Min. kalk- und natronhaltiges Thonerdesilikat, wasserhaltig. Weisse bis braune, glasglänzende Krystalle (tessular), Härte 5-6. Vorkommen bei Giessen, Eisenach und Kaiserstuhl in Baden. Gtl.

Faulbaumkohle, s. Explosivstoffe III pag. 322, s. a. Kohle.

Faulbruch, s. Eis en II pag. 774.

Faust, Fausteisen, s. Blechbearbeitung, I pag. こ̌54.

Faustleier, s. I pag. 723.

Fayalit, Min. ist kieselsaures Eisenoxydul $\left(\mathrm{SiFe}_{2} \mathrm{O}_{4}\right)$ von Fayal in Irland, krystallinisch, messinggelb, grünlich schwarz, oft verschlackt und derb, undurchsichtig, magnetisch. Härte $=6.5$. Gtl.

Fayence, s. Thon waren.

Fayenceblau, s. Indigo.

Fayencedruck, s. Thonwaren.

Fayencefarben, syn. Porzellainfarben, Emailfarben, Schmelzfarben, s. Th o nwa a ren.

Fayencethon, s. Thon, s. Thonwaren.

Fecule, syn. m. Stärkemehl s. d.

Feculometer nennt Bloch (Polyt. Centrlblt. 1873 pag. 1486) ein ron ihm construirtes Instrument zur Bestimmung des Wassergehaltes eines Stärkemehls, beziehungsweise zur Prüfung der Stärke auf ihre Reinheit. Die Einrichtung des- 
selben basirt auf der Thatsache, dass Stärkemehl beim Benetzen mit Wasser eine bestimmte Volumsvermehrung erfährt, und besteht dasselbe wesentlich aus einem mit einer empirischen Scala versehenen Glasrohre, in welchem die Volumszunahme gemessen werden kann, welche eine bestimmte Menge der zu untersuchenden Stärke unter der Einwirkung des Wassers erfährt. Vgl. a. St ärke. Gtl. pag. 62 .

Federalaun, Haarsalz, natürlich vorkommender Alaun, s. Alaun I

\section{Federerz, s. Het eromorphit.}

Federglätte, Bleiglättekryställchen die sich beim Treiben des Silbers bilden, s. Silber.

Federhämmer, s. Schmieden, u. a. auch verfertigt von Schwabe W. \& Co. Wien Hernalserstrasse 121.

\section{Federharz, s. Kauts chuk.}

Federn. I. Federn der Vögel (plumage - plume). An einer Vogelfeder unterscheidet man zwei Hauptheile: die Fahne und den Schaft; das Ende des letzteren ist durch eine hornartige durchscheinende Röhre gebildet, die Pose, $\mathrm{Spule}$ oder der Kiel. Die Federpose ist an ihrem Ende offen und enthält im Innern das Mark (die Seele, eine Zusammensetzung von kleinen, häutigen Trichtern), welches einen Kanal von der Oeffnung des Kiels nach dem massiven Theile des Schaftes bildet und zur Ernährung der Feder dient. Die grössten Federn befinden sich an den Flügeln (Schwungfedern) und am Schwanze (Steuerfedern); kleinere, mit breiter Fahne und schwachem Kiele bedecken bei den meisten Vögeln fast den ganzen Körper (Deckfedern); die allerkleinsten, welche einen kaum bemerkbaren Kiel und eine ausserordentlich feine, wollige Fahne besitzen, stehen unter den Deckfedern, dicht auf der Haut (Fla umen, Fla umenfedern, Dunen oder Daunen). Die Benützung der Vogelfedern ist eine verschiedene, je nachdem sich dieselben durch grosse Elasticität der Fahnen, oder sehr elastische Kiele oder endlich durch schöne Form und Farbe der Fahne auszeichnen. Man verwendet demnach Vogelfedern zum Fiillen von Betten und Kissen (Bettfedern), zum Schreiben (Schreibfedern) und zum Schmucke Schmuckfedern).

1. Bettfedern. Als solche werden meistens die Flaumen und Deckfedern der Gänse benützt, welche sich durch Leichtigkeit, Weichheit und Elasticität vorzüglich brauchbar zeigen; seltener, weil theurer, verwendet man die Federn der Eiderente oder Eidergans (Anas mollissima) - die wegen ihrer ausgezeichneten Elasticität und Weichheit berühmten Eiderdunen - und die Dunen nnd Deckfedern des Schwanes und Pelikans. Von weit geringerem Werthe als die Gänsefedern sind dagegen die Federn der Enten und Huihner, weil sie weniger elastisch und schwerer sind. Man gewinnt die Gänsefedern theils von lebenden Gänsen, welche dreimal des Jahres - im Frühlinge, Sommer und Herbst - gerupft werden, theils von geschlachteten. Im Durchschnitte erhält man 12-14 ${ }^{\text {Dkgrm }}$ Deckfedern und $3.5^{\text {Dkgrm }}$ Flaumfedern von einer Gans.

Die Federn von lebenden Gänsen (Rupffedern oder Sommergut) sind dem Verderben weniger unterworfen, besitzen mehr Elasticität und sind gewöhnlich auch reiner als die von geschlachteten (IVintergut), wesshalb man die ersteren auch mehr schätzt; ebenso sind die Federn von ungemästeten Gänsen (Futtergänsen) besser als die von gemästeten.

Die eingesammelten Federn werden an der Sonne oder in einem geheizten Zimmer gut getrocknet, dann durch Schlagen mit leichten Stäbchen gut aufgelockert und durch Sieben von dem ausgeschlagenen Schmutze befreit. Das sorgfältigste Trocknen ist unerlässlich, weil ohne dasselbe die in den Kielen befindliche Feuchtigkeit in Fäulniss iibergeht. Federn, welche an diesem Fehler 
leiden oder durch den Gebrauch einen moderigen Geruch angenommen haben, können daron befreit werden, indem man sie 3 oder 4 Tage lang in Kalkwasser einweicht, mit reinem Wasser auswäscht, auf Netzen trocknet und durch Klopfen mit Stäbchen auflockert. Doch stauben solche Federn stets.

Zur Reinignng übelriechender Bettfedern wurde rom Hospitalverwalter J. Spahn in München ein Dampfapparat construirt, der in Fig. 1520 dargestellt ist.*) Derselbe besteht aus einem Ofen $A$ von Schwarzblech und einem in diesen eingehängten kleinen Dampfkessel $B$ von Weissblech. Dieser Kessel hat einen Probehahn $a$, dann eine Nachfüllöffnung $b$, die nach erfolgter Speisung des Kessels verschraubt wird, und endlich eine Oeffnung $c$, die mit einem verzinnten engmaschigen Drahtsiebe iiberdeckt ist. Dieses Drahtsieb bildet den Boden eines auf den Kessel $B$ aufgesetzten Schwarzblechtrichters $C$, in welchen die zu reinigenden Federn eingebracht werden. Während des Dämpfens ist der Trichter oben mittelst einer ïber einen hölzernen Reifen gespannten Leinwand abgeschlossen:

Wird der Ofen geheitzt, so entwickelt sich im Kessel Dampf, der ans $a$ austritt; sobald die Dampfentwicklung eine genügend starke ist, wird $a$ geschlossen und hiedurch der Dampf gezwungen, durch die in $C$ befndlichen Federn hindurchzustreichen und die Miasmen etc. abzuführen. Nach 5 Minuten langem Dämpfen wird der Leinwanddeckel abgenommen und die Federn mit einem hölzernen Stöckchen umgeriihrt. Mehr als handwarm darf man die Federn nicht werden lassen. Steigt die Temperatur zu sehr, so werden die Federn aus dem Trichter genommen und auf einer reinen Diele mittelst Besen bis zum völligen Erkalten durch einander gefegt, um eine Lockerung der Ballen zu bewirken.

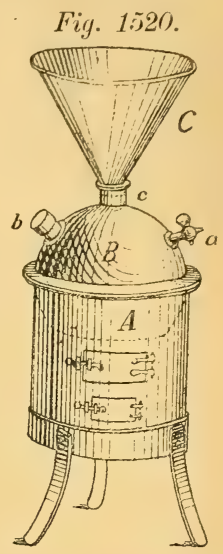

Flaumenfedern sind nach den oben beschriebenen Reinigungsoperationen unmittelbar zum Gebrauche geeignet; nicht so die Deckfedern. Die Stiele der letzteren vermindern die Weichheit einer grösseren Partie, indem sie, theilweise in der Richtung des etwa wirkenden Druckes stehend, einen weniger elastischen Gegendruck äussern, und leiden noch an dem Uebelstande, dass sie das Bettinlett durchstechen und heraustreten. Desshalb mïssen die Deckfedern von den steifen Kielen befreit werden, was durch Abreissen der Fahne mit den Fingern rorgenommen wird. Diese Operation heisst das Reissen oder Schleissen. Die Absonderung der Stiele zieht einen Verlust von $1 / 6$ bis $1 / 4$ vom Gewichte der Federn nach sich. Eine Arbeiterin kann in zehn bis zwölf Arbeitsstunden nicht leicht mehr als $25^{\text {Dkgrm }}$ Federn schleissen.

Im Handel werden die Bettfedern öfters verfälscht, theils durch Einmengung schon gebrauchter Federn (welche man an den abgeniitzten Spitzen erkennt), theils durch schlechtere Federn von anderem Gefliigel, theils endlich durch feinen weissen Sand, Gyps oder andere pulverige Körper, welche nur den Zweck haben das Gewicht zu vermehren, und sich durch Schitteln leicht erkennen lassen.

2. Schreibfedern. Die Schwungfedern aus den Flügeln der Gänse sind fast die einzigen, welche zum Schreiben gebraucht werden. (Untergeordneter und seltener ist die Anwendung von Fasanen-, Pfau-, Truthahn- und Rabenfedern.) Die besten sind diejenigen, welche den Thieren zur Mauserzeit (im Mai oder Juni) von selbst ausfallen oder ausgezogen werden; weil sie die völlige Reife erlangt haben. Weniger geschätzt sind die zu anderen Zeiten den Gänsen ausgerissenen, am schlechtesten die von geschlachteten Gänsen. Von den Schwungfedern in jedem. Gänseflügel sind blos die ersten fünf brauchbar. Die erste, welche Lckfeder (Eckpose, Ort-oder Endpose) genannt wird, ist kurz, sehr hart und nahezu kreisrund; die folgenden zwei - die Schlachtfedern (Schlachtposen) sind die allerbesten, während die Eckfeder nur von mittlerer Qualität ist und die nun folgenden Breitfedern (die 4. und 5.) der Güte nach zwischen der Eckfeder und den Sehlachtfedern die Mitte halten. Zwischen den Federn aus beiden Fliigeln findet ein kleiner Unterschied statt, den man leicht bemerkt; sie sind nämlich nach entgegengesetzter Seite gekrümmt. Wenn man eine Feder des rechten Flügels so auf den Rücken legt, dass das Kielende dem Beschauer zugekehrt ist, so befindet sich die breitere Seite der Fahne links, und der Schaft der Feder ist ebenfalls nach der linken Seite gekrümmt. Bei den Federn des linken Flügels ist beides

*) Polytechn. Centraiblatt, Jahrgang 1856, pag. 160; Kunst- u. Gewerbeblatt für Bayern, 1855 , pag. 667.

Karmarsch \& Heeren, Technisches Wörterbuch. Bd. III 
umgekehrt, daher dieso beim Schreiben durch ihre auswärts gerichtete Krïmmung manchen Schreibern bequemer in der Hand liegen.

Die rohen Gänsekiele müssen, um zum Schreiben brauchbar zu sein, eine Zurichtung erleiden, durch welche folgende. Zweeke erreicht werden sollen. 1. Vermehrung der Härte; 2. ein gewisser Grad von Sprödigkeit, vermöge derer gute Federn rein und ohne Zähne spalten; 3. Entfernung der dünnen Haut, womit die Kiele im natïrlichen Zustande überzogen sind, sowie des an ihnen sitzenden Fettes, welches das Anhaften der Tinte verhindern würde. Zur Erzielung der eben angedeuteten Zwecke unterzieht man die Federn nachstehenden Operationen:

a) Sortiren, wobei man die Federn des rechten und linken Flügels von einander trennt, sie nach Dicke, Härte und Länge zusammenlegt und besonders die Rangordnung beriicksichtigt, welche die Federn nach ihrer Stellung in dem Flïgel beobachten. In der Regel sind die schwersten Federn die besten.

b) Reinigen oder Putzen, wobei der Kiel ron allem Schmutze befreit und von der Fahne das Ueberflïssige, welches die Feder entstellen oder beim Schreiben hinderlich sein könnte, mittelst eines scharfen Glasscherbens oder eines Rasirmessers abgeschabt wird.

c) Das Ziehen, Härten oder Brennen ist die eigentliche Hauptoperation und besteht darin, dass man die Kiele bis zu einem angemessenen Grade $\left(62-85^{\circ}\right.$ C.) erhitzt, dann jeden einzeln der Länge nach mit einer Messerklinge abstreift. Durch die Wärme wird der Kiel zwar erweicht, aber wenn er dann wieder erkaltet ist, besitzr er eine viel grössere Härte als im ursprünglichen Zustande und seine ursprüngliche Zähigkeit hat einem gewissen Grade von Sprödigkeit Platz gemacht. Es kommt hier sehr darauf an, den richtigen Hitzegrad zu treffen und zu benützen. Ist die Hitze zu schwach, so bleiben die Kiele zähe und werden nicht hart genug, spalten sehr unrein und zackig; ist hingegen die Hitze zu stark, so erlangen sie eine zu grosse Sprödigkeit. Der richtige Wärmegrad ist daun eingetreten, wenn die Kiele gleichmässig erweicht sind, und die sie umkleidende Haut mit Leichtigkeit abgestreift werden kann. Das Erwärmen kann über freiem, nicht rauchendem und nicht flammendem Kohlenfeuer, oder in heisser Asche, auch in erhitztem feinen Sande oder endlich in heissem Wasser geschehen. Am gewöhnlichsten bedient man sich des heissen Sandes. Indem der Arbeiter die durch Einstecken in den Sand erwärmte Feder mit der linken Hand auf sein Knie legt, drückt er sie mit dem Messer, welches er in der rechten Hand hält, oben, wo als Fortsetzung des Schaftes der Kiel anfängt stark zusammen und zieht sie behende unter dem Messer durch, so dass sich die Haut grösstentheils abstreift. Dieses Drücken bewirkt ein Abgerissenwerden der Seele, welche daun beim Schneiden aus dem Kiele herausfällt. Ein geschickter Arbeiter kann in 10 Arbeitsstunden an 3000 Stiick Federn ziehen. Die Seiten, wo der Kiel von dem Messer und der Unterlage berührt wurde, machen sich durch zwei klare durchsichtige Streifen bemerkbar. Sollen diese rermieden werden, so muss in dem Messer ein halbrunder Ausschnitt sein, durch welehen der Kiel einigemal mit der gehörigen Wendung durchgezogen wird. Die resultirenden, ganz durchsichtigen Kicle führten im Handel, aus dem sie nun zum grössten Theile verschwunden sind, den Namen Glaskiel e.*) Unmittelbar nach dem Ziehen werden die Federn einige Zeit an einer Stelle in den Sand gesteckt, wo derselbe etwas kühler ist; zuletzt aber bringt man sie wieder in den ganz heissen Sand, um den gehörigen Grad von Härte zu erzielen. Um von den wieder ganz erkalteten Kielen die Reste der Haut und allen iibrigen Schmutz zu entfernen, werden sie gebürstet. Zwei flache, steife Bürsten sind zu diesem Behufe so angebracht, dass die eine, die Borsten nach oben kehrend, auf eincm Tische fest liegt, die zweite hingegen über jener sich befindet, mittelst eines Fusstrittes niedergedrückt und durch eine eiserne Feder wieder aufgehoben wird. Mehrere Kiele werden zugleich zwischen diesen Bürsten schnell hin und her gezogen, und erlangen auf diese Weise Glätte und Glanz.

Hierauf folgt das Binden und Verpacken. Es muss hier noch angefügt werden, dass manche Kiele mit sich vielfach durchkreuzenden Linien verziert werden, welche man durch Drïcken der erwärmten Federn mit der stumpfen Messerklinge hervorbringt (Kreuzkiele.) *:s)

Durch den Gebrauch der Stahlfedern (s. d.) ist die Zurichtung der Federkiele nur mehr in wenigen Fabriken in Anwendung.

Bevor wir auf die dritte Anwendungsweise der Vogelfedern übergehen, sei hier der Fabrik des Hrn. Bardin in Joinville le Pont bei Paris, ${ }^{*}{ }^{*} *$ ) $)$ welche früher ausschliesslich für die Zurichtung der Federkiele zu Schreibzwecken bestimmt war, gedacht. Daselbst sind über 150 Arbeiterinen damit beschäftigt, die aus Russland (Nischnei, Moskau, Kasan) kommenden Federn von Gänsen, Enten u. s. w, unter theilweiser Benützung sehr sinnreich construirter Maschinen zu verarbeiten. So z. B. werden mittelst Maschinen die Kiele nach Spiralen in ca. $\mathbf{1}^{\mathrm{m}}$ lange Streifchen zertheilt, diese mit Dampf erweicht und gestreckt, zu Blumen und Haarputz verarbeitet. Von den ïbrigbleibenden Bärten und Stielen werden die ersteren zu bunten Teppichen mitverarbeitet u. s. w.

*) Zur Erxielung höchster Durchsichtigkeit soll man die Kiele 24 Stunden lang vor dem Ziehen in Alaunlösung weichen lassen.

* Prechtl's technolog. Encyclopädie, Band V.

***) Dingler's julrt. Juurnal Bd. 193 S. 523 und Bulletin de la Société d'Encouragement, September 1860 . 
3. Schmuck - oder Putzfedern. *)

I. Die Bearbeitung der Schmuckfedern ist bei allen Sorten so ziemlich dieselbe; wir theilen hier als Beispiel die Zubereitung der Straussfedern mit. Es werden verschiedene Arten von Straussfedern unterschieden; im Allgemeinen sind die von dem Männchen die weissesten und schönsten. Die in der Nähe der Bürzeldrüse (am hinteren Ende des Rückens) wachsenden Biirzelfedern sind die rorziiglichsten; demnächst folgen die Schwungfedern von den Flügeln, die Schwanzfedern bilden die geringste Sorte. Die Stranssdunen von dem Baucl und anderen Theilen des Körpers sind kürzer; sie sind bei dem männlichen Vogel schwarz, bei dem weiblichen grau. Die schönsten weissen Federn der Weibchen sind stets nach den Enden zu ein wenig graulich, wodurch sie gegen die mänılichen Federn, die völlig rein weiss sind, in der Qualität, daher auch im Preise zuriickstehen. Der Haupthandel mit Straussfedern geht von Algier, Tunis, Alexandrien, Madagascar und der Mïndung des Senegal aus, unter ihnen liefert Algier die schönsten, Senegal die am wenigsten schönen Federn.

Um die Federn zu waschen, geht man folgendermassen zu Werke: Man löst 1 Theil klein geschnittene weisse Seife in 32 Theile warmen Wassers, das sich in einem recht geräumigen Behälter befindet, und schlägt das Seifenwasser zu Schaum. Man bringt nun zwei Bündel mit Bindfaden zusammengebundener Federn hinein, arbeitet sie etwa 5 Minuten lang mit den Händen durch, und wäscht sie darauf in reinem handwarmen Wasser.

Die Federn werden dann, um sie ganz weiss zu machen, zuerst auf ähnliche Art wie die Strohhüte geschwefelt (s. den Artikel Schwefeln), hierauf gebläut, indem man sie rasch durch kaltes Wasser, welchem ein wenig Indigauflösung beigemischt, hindurchzieht; dann noch in einem Bade von Wasser mit etwas eingerührter feiner Stärke oder geschlämmter Kreide herumgenommen; endlich in handwarmem Wasser ausgespült, auf Bindfaden zum Trocknen aufgehängt und dabei von Zeit zu Zeit geschiittelt.

Sind die Federn so weit fertig, so schabt man die Schäfte mit einem Glasscherben, um sie recht biegsam zu machen. Die Fahne wird dann mit der Schneide eines stumpfen Messers gestrichen, wodurch sie das hübsche gekräuselte Ansehen erhält.

Die Federn, die eine unangenehme, schmutzige Farbe besitzen und daher in ihrer natiirlichen Farbe nicht verkäuflich sein wuirden, werden meistens schwarz gefärbt. Zn dem Ende werden auf je 20 Kilogramm Federn $25 \mathrm{~K}$. Blauholz mit Wasser abgekocht, nach sechsstündigem Kochen das Holz herausgenommen und $3 \mathrm{~K}$. Eisenvitriol zu dem Decocte gegeben, dann noch 15 bis 20 Minuten gekocht, und nun der Kessel vom Feuer genommen. Jetzt bringt man die Federn in kleinen Portionen hinein, vertheilt sie so gleichmässig wie möglich in dem Bade, und lässt sie 2 bis 3 Tage darin liegen. Hierauf nimmt man sie durch eine ganz schwache alkalische Lauge und wäscht sie mehrere Male mit Seifenwasser. Wenn sie durch diese Behandlung die gehörige Weiche und Biegsamkeit angenommen haben, spült man sie in kaltem Wasser und trocknet sie. Ganz weisse Federn nehmen selten ein so schönes Schwarz an, als die von Natur gramen. Statt des Eisenvitriols soll auch essigsaures Eisen und zwar mit noch besserem Erfolge angewandt werden können.

Um andere Farben zu färben, müssen die Federn zuvor an der Sonne und im Thau gebleicht werden, wobei man sie mit den Kielen einzeln in den Rasen einsteckt. Nach 14 'Tagen werden sie gut mit Seife gewaschen und gefärbt. Zum Färben dienen (ausser Anilinfarben) gewöhnlich die folgenden Pigmente: zu Hellroth und Rosa Safflor, zu Dunkelroth Brasilienholz nach vorhergegangenem Anbeizen mit Alaun. Zu Karmoisin werden die Federn auf die zuletzt angegebene Art gefärbt und dann noch durch ein Orseillebad genommen.

*) Prechtl's technolog. Encyclopädie Band V pag. 499. 
Zu Violettbraun behandelt man die mit Brasilienholz gufïrbten Federn mit einer schwachen alkalischen Lauge.

$\mathrm{Blau}$ in allen Tönen wird in der Indigkïpe gefärbt.

Gelb, nach dem Beizen mit Alaun, in einem Wau- oder Curcumebade.

$\mathrm{Zu}$ erwähnen wäre noch das Dressiren, eine Arbeit, welche die Geradrichtung des Federschaftes, sowie die regelmässige Ausbreitung der Fahne zum Zwecke hat. Sehr dicke Federschäfte werden hierbei an der Unterseite zım Theil weggeschnitten und mit Glas glattgeschabt, um dieselben diinn und biegsam zu machen; endlich das Frisiren oder $\mathrm{Kräuseln,} \mathrm{welches} \mathrm{der} \mathrm{Feder} \mathrm{eine}$ angenehme Krümmung und der Fahne ein gelocktes Aussehen ertheilen soll. Diese Operation wird dadurch ausgeführt, dass man die Feder mehreremale zwischen dem Daumen und einer stumpfen Messerklinge hindurchzieht oder aber (was nur bei schwarzen Federn ausführbar ist) die Federn in den Rauch ron brennendem Zucker bringt, oder vorsichtig mit einem heissen Eisen behandelt.

II. Metallfedern (ressorts - springs). Ein Körper federt", wenn er rermöge seiner Elasticität sofort in seine urspriingliche Lage zurückkehrt, sobald die äussere Kraft, die ihn aus der Gleichgewichtslage gebracht hat, zu wirken anfhört. Ueber das mechanische Verhalten s. EI asticität und Festigkeit III pag. 162.

In Bezug auf die Verwendung lassen sich die Federn eintheilen in:

1. Triebfedern oder Gangfedern zur Hervorbringung einer Bewegung von Maschinen und Mechanismen.

2. Reactionsfedern, um Riuckkehr-Bewegungen hervorzubringen, d. h. um Theile von Maschinen und Werkzeugen, die durch äusseren Einfluss rerschoben worden sind, wieder an ihren Platz zuriickzufuihren.

3. Druckfedern. Zur Ausübung eines constanten Druckes, also um Theile von Werkzeugen und Maschinen auf ihrem Platze zu erhalten.

4. Spannfedern, um Schnïre, Bänder oder solche Maschinentheile, welche sich zeitweise locker befinden, anzuspannen.

5. Tragfedern zur Unterstiitzung von Körpern und Unschädlichmachung von Stössen.

6. Dynamometrische Federn. Um durch den Grad ihrer Deformation die Grösse der auf die Feder wirkenden Kraft zu bestimmen.

7. Ton- oder Sehlagfedern, die beim Vibriren einen Schall hervorbringen.

1. Triebfedern. Die Anwendung der Federn zur Hervorbringung andauernder Bewegmngen beschränkt sich auf Uhren, Bratenwender, Stahlspielwerke, kleine Automaten, Nähmaschinen u. s. w. In allen diesen Fällen dienen die Federn gewissermassen als Arbeitsreservoir, indem sie die zum sogenannten A ufziehen erforderliche Arbeit aufnehmen, und durch die so erzielte Spannung: auf gewisse Maschinentheile bewegend einwirken. Diese Federn bestehen aus einem dünnen Streifen gehärteten und bis zur blauen oder violetten Farbe nachgelassenen, elastischen Stahles (Federstahl). Dieser Streifen wird in einer Spirallinie zusammengerollt und in ein cylindrisches Gehäuse - das sogenannte Federhaus - eingelegt. Das Federhius ist seitlich mit zwei Scheiben abgeschlossen, damit cie Feder nicht herausfalle und hat eine durch die beiden Büden und die innerste Windung der Feder frei hindurchgehende Welle, die

\section{Fig. 15221.}

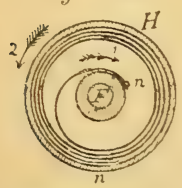

fürmig umbiegt dann in Rinnen, welche sich auf den eben genannten Hauptheilen befinden, einzwängt. Aus der Betrachtung der Fig. 1521 ist er- 
sichtlich, dass die Feder, vermöge ihres Bestrebcus sich aufzuwickeln, ihre Windungen möglichst nahe an den Federhausrand driickt. Denken wir uns das Federlıaus $H$ festgehalten (z. B. durch ein gehemmtes Räderwerk) und der Federstift $F$ werde in der Richtung des Pfeiles 1 umgedreht, oder umgekehrt, es sei $F$ festgehalten und das Federhaus werde in der Richtung der Pfeiles 2 umgedreht, so ziehen sich die Windungen der Feder gegen die Federwelle, wie dies Fig. 1522 zeigt. Die Feder ist in diesem Zustande a $u$ fgezogen und die ihr innewohnende Spannung hat das Bestreben, das Federhaus $H$ in der Richtung des Pfeiles 1 (Fig. 1522) umzudrehen, wenn der Federstift $F$ als nicht drehbar angenommen wird (oder den Federstift nach dem Pfeil 2 zu drehen, wenn das Federlhaus an der Drehung gehindert ist). Eine anfogezogene Feder läuft sofort ab, d. h. sie bewirkt die Drehung des drehbaren einen Theiles (entweder $F$ oder $H$ ), wenn diese nicht durch eine so. genannte $\mathrm{H}$ e $\mathrm{m} \mathrm{m} \mathrm{m} \mathrm{n}$ (echappement-escapement) verhiitet wird.

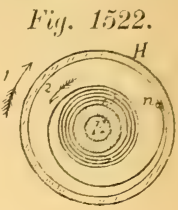
Diese $\mathrm{H}$ e $\mathrm{m} \mathrm{m}$ un $\mathrm{g}$ hat ein allmäliges Ablaufen der Feder zu bewerkstelligen, also die Wirkung der in der Feder angehäuften Arbeit auf eine längere Zeitdauer auszudehnen. Solcher Echappements gibt es verschiedene, und ihnen, inVerbindung mit den sogenannten Unruh efedern fällt die Aufgabe zu, in den Federulıren eine isochrone Bewegung eines Zahmräderwerkes einzuleiten, d. h. das Ablaufen der Feder so zu reguliren, dass die Uhrenräder stets gleiche Umdrehungszahlen in gleichen Zeiten laben.*) Da die spannende Kraft der Feder nach und nach geringer wird, so sind in den Uhren Vorrichtungen angebracht, die einen Ausgleich herste!len, d. h. den Isochronismus auch dann noch erhalten, wenn auch die Spannung der Feder geringer geworden ist. (Hieriber siehe den Artikel Uhren.) Zum Aufziehen einer Feder ist eine gewisse Anzahl Umdrehungen erforderlich; wird diese Zahl überschritten, so läuft man Gefahr die Einhängungshäkchen oder die Feder selbst zu reissen - abzusprengen. Solche Zufälligkeiten vermeidet man mit Hilfe der sogenannten Stellung (s. Uhren), welche ein Aufziehen iiber die zulässige Grenze verhindert.

Fabrikation der Uhrfedern. Da die Federn für Werke verschiedener Grösse und Feinheit gebrancht werden, so werden sie in mannigfachen Dimensionen erzeugt. Die Nummerirungen beziehen sich besonders auf Abstufungen der Breite. Diese variirt zwischen $1^{\mathrm{mm}}$ und $10^{\mathrm{mm}}$. Man bedient sich zum Messen des Federmasses. Die Breiten der Federn nehmen von Zehntel zu Zehntel Millimeter zu. Die Dicke der gewöhnlichen Taschenulırfedern beträgt zwischen $0.16^{\mathrm{mm}}-0.24^{\mathrm{mm}}$, endlich die Länge $400-700^{\mathrm{mm}}$. Letzteres Ausmass wird in der Regel reichlicher genommen, damit dem Uhrmacher die Freiheit bleibt, die Feder beliebig abzunelımen und dem Federhause anzupassen. Das Material für Federn für die Kleinuhrmacherei ist Gussstahl, für die Grossuhrmacherei Gerbstahl. Die Barren oder Stahlstäbe werden zuerst*:) in heller Rothgluth auf $1^{\mathrm{mm}}$ Dicke ausgewalzt und dann kalt (ofter ausgeglibit) bis zur erforderlichen Dicke gestreckt. Dic dabei verwendeten Walzen sind von Stahl, von $0.25^{\mathrm{m}}$ Länge und $0.15^{\mathrm{m}}$ Durchmesser. Die erzielten Streifen werden sortirt. Um dic Oberfläche blank zu machen, werden die Federn auf den Flächen und Kanten mit Schmirgelscheiben abgeschliffen, indem man sie langsam zwischen den rasch rotirenden Scheiben hindurchzieht. Das Härten beansprucht die grösste Sorgfalt. Die zu lıärtenden Federn einer Sorte werden um kammartig aus der Fläche einer Scheibe hervorragende Zähne gewickelt und mit Draht umbunden. Diese Scheiben werden in einem Ofen gleichmässig erhitzt und hierauf rasch und mitsammt den Scheiben in ein Ilärtebad von Rapsöl und etwas Seife gebracht. Nach rölligem

*) Londoner Preis-Schrift iiber den Isochronismus der Spiralfedern ron Muritz Immisch pract. Chrmacher. - Weimar 1873 Berml. Friedr. Voi ty t.

\%) Dingl. pol. Joum. Band 196 pag. 19. Arnengaud (renie industriel Jahr.. 1870 pag. 44. Ueber die Lhrfederfabrik von Montandon \& Sïlne in Paris 
Verkiihlen nimmt man die Federn von der Scheibe und schleift sie an einer Stelle blank. Hierauf erhitzt man einige Probefedern zu verschiedenen Anlauffarben, und wenn man die Temperatur fuir die Entstehung der gewünschten Anlauffarbe gefunden hat, spannt man etwa $1 / 2$ Dutzend Federn mit ihren Enden zwischen zwei Schraubkloben, welche an einer Spannvorrichtung befestigt sind und setzt sie der ermittelt. n Nachlasstemperatur aus. Die Anspannung zwischen den Schraubenkloben verhindert jedes Krummziehen. Zum Nachlassen wird auch die in Fig. $1523 a b$ dargestellte Maschine beniitzt. Von der Spule $N$ läuft der Stahlstreifen über die vom Ofen $J$ geheizte Gusseisenplatte $K$, und wird an diese von einem Sattel $k$ mit einer dem Zuge des Gewichtes $r$ entsprechenden Pressung

Fig. 1523 a.

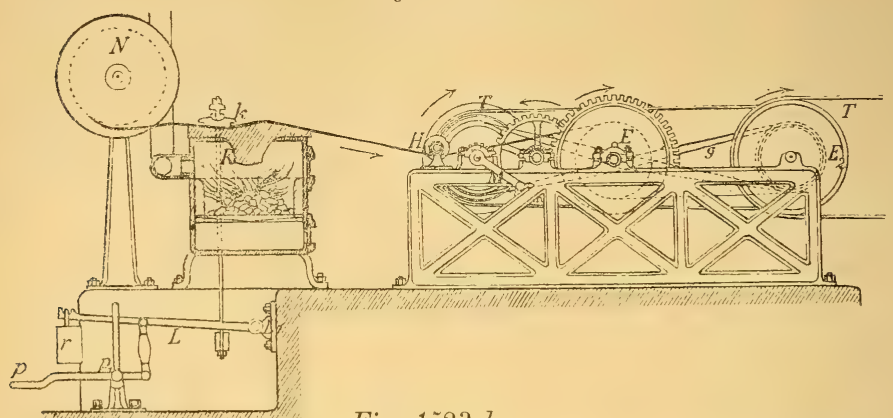

Fig. 1523 b.

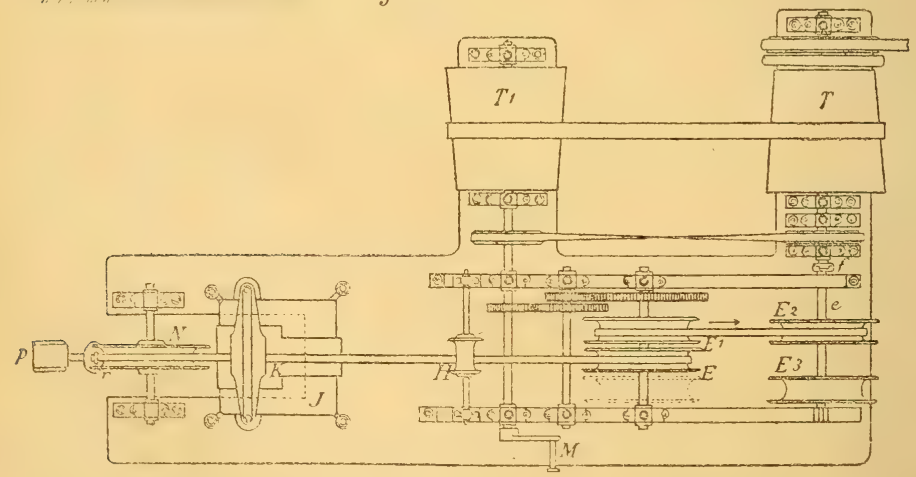

angedruickt. Von hier läuft das Stahlband unter einer Leitrolle $H$ auf eine Spule $E$. Ist diese rollgewunden, so wird das von $H$ kommende Stahlband auf eine zweite, neben $E$ befindliche spule $E_{1}$ gewickelt, während $E$ sich auf die Spule $E_{3}$ abwindet; ist nun wiederum $E_{1}$ voll, so kommt das Band wieder auf $E$, wihrend $E_{1}$ sein Band an $E_{a}$ abgibt 11. s. f. Nan hebt dann die Welle $e$ aus ihrem Lager, zieht die mit dem nunmehr völlig erkalteten Band bewickelte Rolle $E_{3} \mathrm{ab}$, und ersetzt sie durch eine neue. Die Conuse $T$ und $T_{1}$ dienen zur Regulirung der Geschwindigkeit, die Kurbel $I$ zum Betriebe der Maschine ron Hand aus und ier Tritt $p$ zur Aufhebung des Satteldruckes gegen die Gusseisenplatte $K$. Letzteres wird dann nöthig, wenn sich die Hitze der Platte iiber das Erforderniss gesteigert haben sollte. Die Bestimmung der übrigen 
Theile ist aus der Zeichnung verständlich. Nach dem Anlassen werden die Federn abermals geschliffen. Kleinere Federn passiren zwei Schleifmaschinen mit je drei Paaren Schmirgelwalzen, grössere 12 Schleifmaschinen mit je zwei Schmirgelwalzenpaaren. Die Schmirgelbelegung ist an den später zur Wirkung kommenden Walzen immer feiner, als an den vorhergehenden, so dass nach und nach ein Schleifen, Glätten und Poliren erfolgt.

Interessant ist die zum Härten gebrauchte Maschine von $\mathrm{Kugler}$ in Paris*) Fig. 1524. Nachdem der Stahldraht bis zur richtigen Verduinnung geplättct ist, wird er auf Rollen $N$ aufgewunden. Von $N$ läuft das Stahlband durch ein eisernes, aussen mit feuerfestem Materiale umgebenes Rohr von rechteckigem Querschnitt (etwa $100^{\mathrm{mm}}$ breit, $12^{\mathrm{mm}}$ hoch). Dieses Rohr liegt in cinem Ofen und wird daselbst mit einem Holzkohlenfeuer erhitzt. Das Stahlband erlangt bei dem langsamen Durchziehen durch das Rohr die Glühhitze und wird noch gliihend mittelst der Druckwalze $D$ in ein Oelbad $E$ gezogen und gehärtet. Da sich das Oel bald erhitzt, so wird es stetig durch einfliessendes frisches Oel erneuert, während das warme aufsteigende durch ein Ueberlaufrohr abgeleitet wird. Aus dem Oelbade tritt das Band zwischen

Fig. 1 ì24.

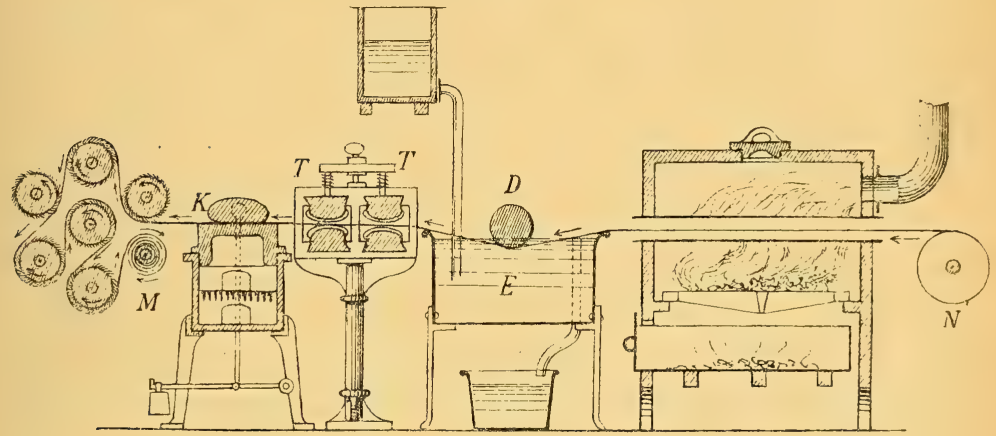

die Trockenballen $T$, die mit entsprechenden Gewichten belastet sind und eine langsame Querbewegung ausführen. Das abgestreifte Oel läuft in das Härtebad zuriick. Von den Trockenballen gelangt das Band auf eine von einem Ofen erhitzte Gusseisenplatte $K$, um nachgelassen und geradgerichtet $\mathrm{zu}$ werden, und endlich auf einen Schleifapparat, dessen mit Schmirgel belegte Walzen beide Seiten des Stahlbandes abschleifen. Zuletzt windet sich das Band auf die Spule $\boldsymbol{M}$.

Sind die Federn auf die eine oder andere Art so weit fertig gemacht worden, so schreitet man an ihre Rectification. Zuerst bringt man ihre Dicke durch ein nochmaliges Schleifen zwischen verstellbaren Schleifwalzen auf das richtige Mass und polirt sie, worauf man dasselbe Verfahren zur Egalisirung der Breite vornimmt. Hierauf zertheilt man die Stahlstreifen mittelst eines Proportionalmassstabes in entsprechend lange Stiicke, erwärmt deren Enden und lässt sie langsam erkalten, um sie weich zu machen, und schlägt dann in dieselben mittelst eines Durehschlages viereckige Löcher zum Einhängen. Die so vorbereiteten Stahlstreifen müssen nun spiralförmig gewunden werden. Man bedient sich hierzu des in Fig. 1525 dargestellten Federnwinders.

Man hat dieses Werk\%eug von verschiedener Grösse, nach der Stärke der Federn, für welche es bestimmt ist. Der Gehrauch dieses Instrumentes ist sehr einfach. Zuerst wird das

*) Polytechn. Centralblatt, Jahrg. 1860 pag. 1304; Genie industriel Juli $1 ऽ 60$ pag. 16. 
Ende der Feder mittelst einer Zange etwas rund gebogen, um es auf den Stift $q$ legen und in das Häkchen $r$ einhängen zu können; dann dreht man mit der rechten Hand die Kurbel $g$, während die linke Hand den Stahlstreifen so regulirt, dass die Windungen gehörig auf einander fallen. Ist die ganze Feder gerollt, so lässt man den Hebel $u v$ herab, und hängt das freie Federende auf den Haken $u$, danı verschiebt man die Feder $l$ so auf dem doppelten Sperrkegel $w k i$, dass er die Umdrehung des Sperrades $h$, also das Aufgehen der gewundenen Feder verhindert. Hierauf wird die Kurbel noch etwas weiter gedreht und die Federspannung um beiläufig so viel vergrössert, als beim Freilassen der Feder davon wieder verloren wird, indem sich die Feder aufzurollen strebt Der Federwinder wird beim Gebrauche mit seinem Ansatze $n$ in den Schraubstock befestigt.

Fig. 1525 .

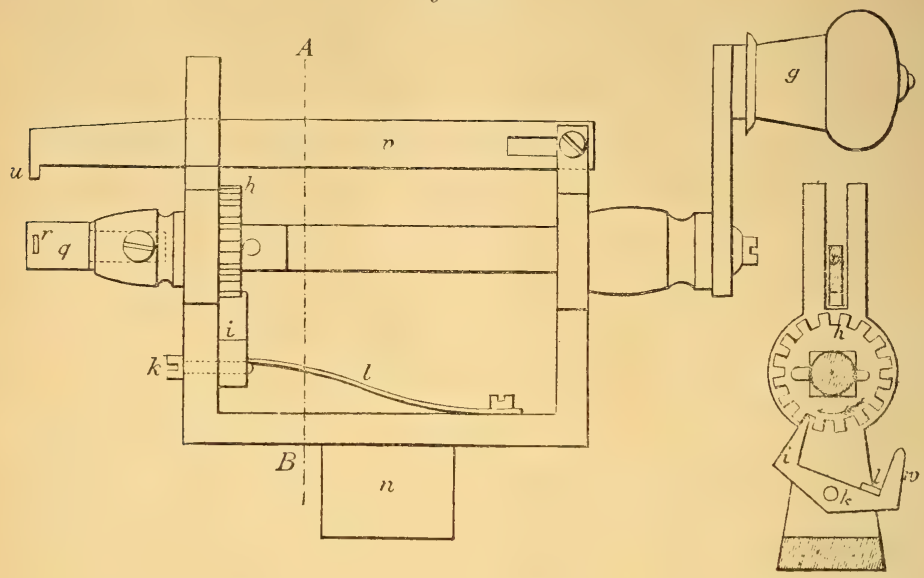

2. Reactionsfedern bestehen meistens aus gehärtetem und wiedei nachgelassenem Stahle, zuweilen auch aus Eisen oder Messing, welche durch Ziehen oder Hämmern hart und elastisch geworden sind. Die Federn werden durch Schmieden aus Stahlstangen oder Stahlstreifen hergestellt und die an ihnen vorkommenden Lappen zur Befestigung entweder angeschweisst oder mit Messing angelöthet oder gleich aus einem Stiicke ausgearbeitet.

Die Befestigung der Federn geschieht gewöhnlich mit einer Schraube; um sicher zu sein, dass sich die Feder nicht zufällig verdreht, oder um beim Wiederbefestigen einer etwa abgenommenen Feder ihre richtige Lage zu treffen, bringt man zwei Schrauben au oder eine Schraube und einen sogenannten Stellstift (Fuss) $b$ in den Figuren 1526 und 1527, welcher an der Feder befestigt ist und
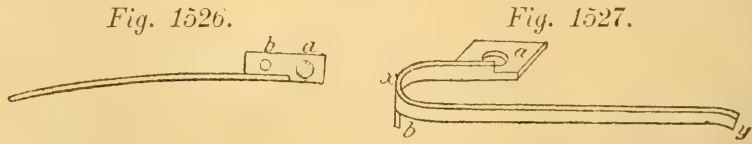

in ein Loch der Unterlage gesteckt wird, bevor man die Feder anschraubt. Die in Fig. 15:7 gezeichnete Eimrichtung ist dann geboten, wenn der Raum zwischen $x$ und $y$ gegeben ist und die Feder in demselben eine nöglichst grosse, frei spielende Länge erhalten soll, folglich die Befestigungsschraube nicht in der geraden Fortsetzung derselben angebracht werden kann. Grosse Länge des beweglichen Theiles der Feder bei beschränktem Raume wird anch dadurch erzielt, dass man dem festgemachten Ende einige Spiralwindungen gibt, wie dies die Fig. 1528 und 1529 zeigen. Die Befestigung geschieht dann entweder an 
einem vierkantigen Stift (Fig. 1528) oder in dem Querschlitze eines runden Stiftes (Fig. 1529). Um zwei Stiucke, die temporär gegen einander gedriickt werden (Backen- oder Flaschenschraubstöcke), nach Behchung der zusammendrïckenden Kraft von einander zu entfernen, legt man zwischen dieselben Blattfedern wie Fig. 1530. Dieselben sind kräftiger, wenn man den Theil zwischen beiden Schenkeln zu einer biigelförmigen Blattfeder gestaltet (Fig. 1531), wie dies bei Schafscheren und Federzirkeln gebräuchlich ist, oder aber wenn man die Feder an dieser Stelle mit einer vollen Windung versieht, Fig. 1532 (z. B. in Drehorgeln zum Zusammenpressen des Blasebalgs). Federn der eben vorgefïhrten Formen findet man in Schlössern und an vielen anderen Vorrichtungen.*,

Federn, wie in Fig. 1531 und 1532, machen den Uebergang zu den Spiralfedern, die ihrer ganzen Länge nach zu einer Spirale gewunden sind, und deren Windungen in einer Ebene liegen. Durch diese Gestalt werden die Federn, wic bereits oben erwähnt, geeignet, bei drehender Bewegung einer Kraft entgegen zu wirken. Ist nämlich das innere Ende $o$ einer Feder Fig. 1533 an einer Achse, das äussere Ende $n$ an einem Punkte ausserhalb der letzteren befestigt, so wickelt jede Drehung der Achse orler jeder Umschwung von $n$ je nach der Drehungsrichtung die

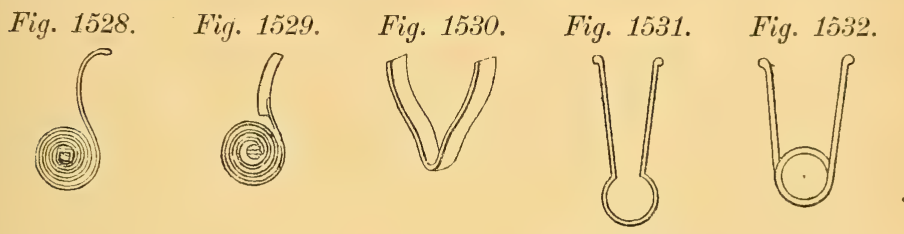

Fig. 1534.

Fig: 1533.
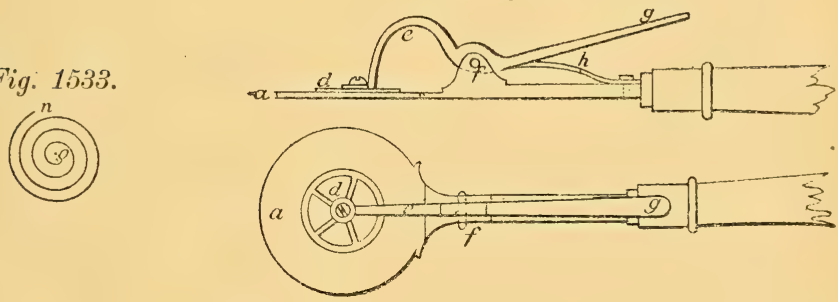

Feder enger zusammen oder weiter auseinander, und sobald die Kraft zu wirken aufhört, leitet die Elasticität eine Bewegung nach der entgegengesetzten Richtung ein. Die wichtigste Beniitzung finden diese Federn bei den Unruhen der Uhren. Die Unruhefedern werden aus hartgewalztem Stahlblech — dem sogen. Spiralfederblech - geschnitten, an den Rändern abgeglichen, dann mittelst eines feinen Zängelchens um einen runden Stift gewunden, und endlich gehärtet nnd nachgelassen. Zu letzterer Operation bedient man sich der in Fig. 1534 dargestellten Zange. Die gewundene Unruhefeder wird zwischen die Scheibe a und die durchbrochene Backe $d$ des Schenkels efg gebracht und durch den Druck der Feder $h$ festgehalten. Nun bringt man die Zange sammt der Spiralfeder in eine Weingeistflamme und erhitzt bis zum Glühen, resp. zu dem Erscheinen der gewiinschten Anlauffarbe.

Von den Spiralfedern sind die schraubenförmigen Federn dadurch unterschieden, dass ihre Windungen nicht in einer Ebene liegen, sondern eine

*) Band $I$ dieses Werkes: $f$ in Fir. 125, $F$ in Fig. 147, $f$. in Fig. 148, b in Fig. 425: Band II dieses Werkes: $e$ in Fig. $1103 a, e$ in Fig. $1104 a, f_{3}$ in Fig. 1105, $f$ in Fig. 1107 u. s. w. 
Kegel- oder Cylinderfäche umhïllen. Sie bestehen entweder aus Draht oder Blechstreifen. Sie können beansprucht sein auf Zug, Druck oder Drehung. Im ersten Falle liegen die einzelnen Windungen im ungespannten Zustande der Feder nahe an einander; das eine Ende der Feder ist an einem unbeweglichen Punkte befestigt, das zweite an jenem Theile, der nach einer Verschiebung auf seinen Platz zuriickgefïhrt werden soll. Im zweiten Falle ist die Feder zwischen einen festen Widerstand und den zu verschiebenden Theil eingeschoben. Ihre Windungen sind im unbelasteten Zustande von einander abstehend, und werden dureh die Verschiebung gegen einander gepresst. Bei diesen Federn ist eine grössere Zahl von Windungen leicht mit dem Nachtheile verbunden, dass der mittlere Theil derselben seitwärts ausweicht. Man verhuitet diesen Uebelstand dadurch, dass man den Windungen den grösstmöglichsten Durchmesser gibt, dass man die Feder auf einen Dorn steckt, oder in ein Rohr einschliesst u. s. w. Die kegelförmigen Federn sind von diesem Fehler frei. Die Fig. 1535, 1536 und 1537 zeigen uns drei Formen von schraubenförmigen Federn. ${ }^{*}$ )

Im dritten Falle endlich sind die beiden Enden der Schraube gerade gerichtet und mit diesen an den zu verschiebenden Gegenstand und anderseits an einen festen Widerstand gestemmt. Die Einschliessung der Feder in eine Röhre oder die Aufsteckung auf einen Stift ist auch hier, wie bei den Druckfedern nöthig. Diese Anordnung der Feder benuitzt man bei Springdeckeln von Dosen, als Thürschliesser u. s. w.

Die Herstellung der schraubenförmig gewundenen Federn geschieht in mannigfacher Weise. Am einfachsten durch Umwindung des Drahtes oder Blech-

Fig. 1535. Fig. 1536. Fig. 1537.

Fig. 1538.
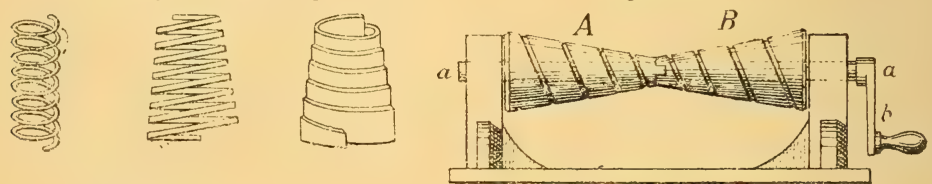

streifens um einen rotirenden cylindrischen oder kegelförmigen Körper. Eine etwas complicirtere Vorrichtung wird zur Herstellıng doppelt kegelförmiger Federn benuitzt, die in Fig. 1538 dargestellt ist. Sie besteht aus einer Welle $a$, die durch die Kurbel $b$ gedreht werden kamn. Auf $a$ sitzen zwei Holzkegel, auf deren Oberfächen eine Rinne, entsprechend der zu erzeugenden, doppelt kegelförmigen Feder, eingearbeitet ist. Der zu verarbeitende Draht wird an einem Ende dieser Riune befestigt, und während die rechte Hand die Kurbel dreht, wird der Draht von der linken Hand zugeleitet. Ist die Feder gewunden, so wird der Draht abgezwickt, indem die Welle aus ihren Lagern gehoben, der Conus $A$ abgezogen und dann die Feder vom Conus $B$ entfernt wird.

Interessant ist die von J. Harris on in New-York**) zum gleichen Zwecke construirte Maschine, welche in Fig. 1539 in del Seitenansicht dargestellt ist.

Das einem Spindelstocke einer Drehbank ähnliche Gestcll $A$ ruht auf den Füssen $B$. Es trïgt die Spindel $\ell$; welche sich in Lagern ss dreht und an dem vorderen Ende in einen Conus $D$ ausläuft. Der zwischen $S$ und $S_{1}$ betindliche stärkere Theil von $C$ trägt eine Schraube $J$, welche aus einem rechten und einem linken Gewinde gebildet ist. Die Hülse $Q$ umfasst die Schraube und trägt ein auf einem stifte drehbares Stïck $K_{1}$, welehes zwischen

*) Vergleiche dieses Werk Baud $I$; in Fig. $298, y y_{1}$ in Fig. 160, II. Band $F$ in Fig. $987,{ }^{\prime}$ in Fig. 988, s in Fig. $67 t$ und 677 u. s. $w$.

**) Patentirt für die vereinigt. Staaten 27. Januar 1857, für England 16. September 1857, veröffentlicht im Polyt. Centralblatt, Jabrgang 1858, pag. 782 und Dingler's Journ. Bd. 148, pag. 14. 
die Gewindg̈̈nge von $J$ passt. Wird die Spindel ( $C$ gedreht, so wiri die Hülse $Q$ wegen des Stückes $K_{1}$ von der Schraube vor- oder rückwärts bewegt. An den Enden der Schraube $J$ sind in die Gänge kleine Füllungen $c c_{1}$ eingesetzt und es wird das Stück $K_{1}$ bei seiner Bewegung von links nach rechts $z$. B. durch die Fiullung $c$ von dem rechten Gewinde in das linke ïbergeleitet und die Hülse $Q$ dadurch zu einer rückgängigen Bewegung veranlasst; während sich die Spindel fortwährend in demselben Sinne weiterdreht. Dasselbe findet hierauf am anderen Ende der Schraube $J$ statt, wo durch die Füllung $c_{1}$ das Stïck $K_{1}$ vom linken wieder in d.n rechten Gewindgang gewiesen wird. Die Hülse $Q$ bewegt sich daher hin und her, durch eine Länge, welche durch die Stellung der Füllungen $c c_{\mathrm{j}}$ regulirt werden kann. Oben greift die Hülse $Q$ über eine runde Stange $P$, welche sich vermöge der Zahnräder $m$ und $n$ zugleich mit der Spindel $C$ dreht, und mittelst zweier auf ihr augebrachten Stellringe $r$ und $r_{1}$ von der Hülse $Q$ der Länge nach hin und her geschoben wird. Die Stange $P$ hat

Fig. 1539.

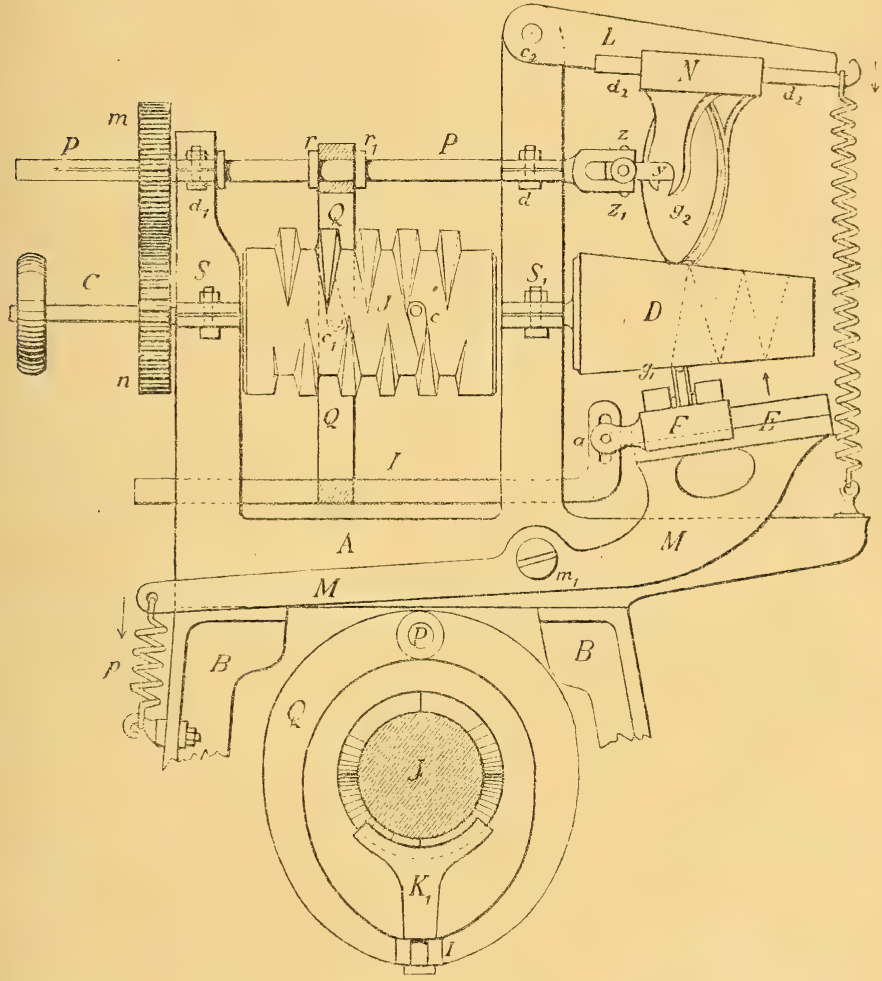

ihre Führung in den Lagern $d$ und $d_{\text {, }}$ und das Rad $n$ ist mittelst Keil und Nuth so mit $P$ vereinigt, dass es die Stange dreht and ihr zugleich die Längenbewegung erlaubt. Aut' dem vorderen Ende der Stange $P$ ist bei $y$ die Rolle $g_{2}$ aufgekeilt und zwei Charniere $Z Z_{1}$ (H ooke'scher Schlüssel) erlauben der Rolle $g_{2}$ einem Druck von oben nach unten zu folgen, ohne der drehenden Bewegnung der Stange $P$ etwas in den Weg. zu legen. Am oberen Ende des Ständers $d$ sind seitlich zwei Hebel $L$ um den Zapfen $c_{2}$ leicht drehbar, und diese Hebel haben an den unteren Seiten die Bahnen $d_{22}$, auf welchen sich ein Schlitten $N$ hin and her schiebt, welcher mittelst zweier Lappen über die Achse $y$ der Rolle $g_{2}$ greift. Vermöge der vorn an den Hebeln $L$ wirkenden Spiralfedern wird die Rolle $g_{2}$ nach unten gegen den Conus $D$ gedrüickt.

Das untere Ende der Hïlse Q trägt die Stange $I$, welche sich in viereckigen Löchern der Ständer $d \cdot d_{4}$ führt. Das vordere Ende von $I$ ist aufwärts gebogen, abgeflacht und mi 
einem Schlitze versehen, wodurch sie mittelst eines Stiftes $a$ mit dem Wagen $F$ verbunden werden kann. $F^{\prime}$ gleitet auf einer Bahn $E$ vor- und rückwärts, wie es die Bewegung der Stange $I$ mit sich bringt. Die Bedeutung von $M m$ und $p$ ist aus der Figur ohne Weiteres zu entnehmen. Der Schlitten $F$ trägt zwei Ansätze, in welchen die Rollen $y$ und $y_{1}$ gelagert sind.

Beim Winden der Federn mit dieser Maschine wird der Dralit auf eine Spule in sorgfältig neben einander gelegten Windungen anfgewickelt, um ein Verwirren zu verhüten, und dann sein Ende so um den Conus $D$ gewickelt, dass es durch die Rollen $g$ und $g_{1}$ von unten und durch die Rolle $g_{2}$ von ohen gehalten wird. Wird jetzt die Maschine in Bewegung gesetzt, so zwingt die vor- und rückwärts gehende Bewegung der Rollen $g g_{1}$ und $g_{2}$ den Draht sich auf dem rotirenden Conus in schraubenförmigen Linien aufzuwickeln, und es bildet sich, da hierbei die Aufwickelung abwechselnd auf engere und weitere Stellen des Conus stattfindet, eine Reihe von konisch gewundenen Federn, deren Länge durch $c c_{1}$ regulirt werden kann und deren Steigung sich nach dem auf der Spindel $C$ angebrachten Gewinde $J$ richtet. Durch Einschaltung eines steileren Patronengevindes $J$ kann man auch steilere Windungen des Drahtes erzielen. Die an einander hängenden Federn können entweder in die halbe Anzahl rechts gewundener und die halbe Anzahl links gewundener, einfach konischer, Federn oder in doppelt konische Federn zertheilt werden,

3. Druckfedern werden angewendet:

a) Statt Gewichten zur Belastung von Maschinentheilen, z. B. Ventilen, Walzen (bei Auswindemaschinen und Mangen, Satinirpressen etc. vergl. Bd. II pag. 170 Fig. 696 Feder a) etc.

b) Um die stete Berührung zweier Körper, welche sich an einander verschieben können, zu erzielen, oft zu dem Zwecke, zufällige unbeabsichtigte Ver-

Fig. 1540 .

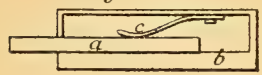
schiebungen zu hindern, z. B. die Schleiffedern, welche, am Schlossdeckel angebracht, den Riegel $a$ gegen den Schlossboden $b$ drïcken; die Schraubenfedern in den Wagenlaternen, welche die Kerze stets bis zum eingebogenen Rande ihrer Hiilse heben u. dgl.

c) Zum Zwecke der Erhaltung einer "gefälligen" Form eines Kleidungsstuickes - Miederfedern - oder bei gewissen Bandagen zur Erzielung eines "sanften" Druckes.

In ihrer Form sind sie häufig mit den Reactionsfedern (Fig. 1528 bis 1532) iibereinstimmend, und sind bei der Auswahl der Form zumeist Riicksichten des Raumes massgebend.

Hätte man z. B. die Aufgabe, ein lose auf einer Welle aufgestecktes Rad $\boldsymbol{\imath}$ gegen eine mit der Welle fest verbundene Scheibe $b$ zu driicken, so könnte man diese Frictionskupplung sowohl dadurch erzielen, dass man gegen die feste Wand $d$ eine Feder $c(A, B)$ stemint und anf $a$ wirken lässt, wie sie Fig. 1541 zeigt, oder man könnte zu demselben Zwecke auch Kegel- oder Schraubenfedern etc. verwenden.

Fig. 1542.
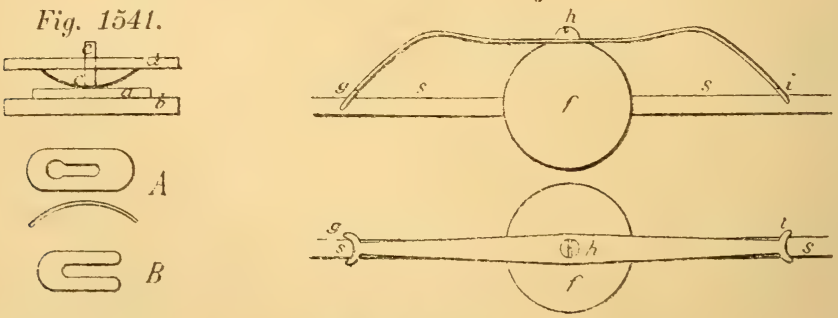

Fig. 1juti.

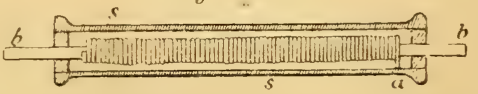

In Fig. 1542 wird durch die Feder $g$ h $i$ ein unabsichtliches Verschieben der Ansgleichskugel $f^{\prime}$ auf der Ausgleichstange $s$ verhindert. In Fig. 1543 ist 
eine Torrichtung dargestellt, welche dazu dient ein allzuleichtes Drehen der Spule $a$ in der Weberschiitze zu verhindern. Auf dem in der Schütze festgelagerten Stabe $b$ ist eine schraubenförmige Feder mit einiger Reibung drehbar. Das Ende a dieser Feder ragt in ein Löchelchen der Spule $s$. Wickelt sich nun der Faden ron $s \mathrm{ab}$, so bewirkt die Drehung der Spule zunächst eine Spannung der Feder und diese beginnt sich erst dann mitzudrehen, wenn die eben erwähnte Spanuung die Reibung der Feder an $b$ zu überwinden vermag; es wird also der Urehung der Spule ein gewisser Widerstand entgegengesetzt.

Spulen, welche sich gar nicht drehen sollen (wie in den Schnellschiitzen) werden, wie dies in Fig. 1544 dargestellt ist, entweder auf eine Achse aufgesteckt,

Fig. 1544.
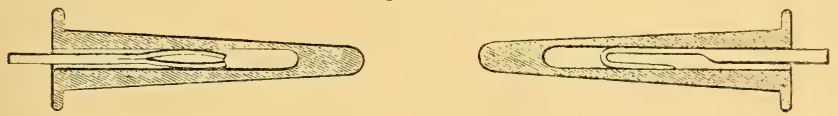

welche in zwei anseinander klaffende 'Theile gespalten oder in einen federnden Haken umgebogen ist. *)

4. Spannfedern. Bei den zuletzt angefïhrten Constructionen sehen wir schon die Absicht, durch erschwerte Umdrehung der Spulen den sich abwickelnden Faden gleichmässig anzuspannen. Es gibt jedoch Fälle, z. B. in Gürteln, Hosenträgern, Handschuhen u. s. w., wo schraubenförmige Drahtfedern o. dgl. direct eine Anspannung bewirken. Die Spiralfeder Fig. 36 pag. $149 \mathrm{Bd}$. I. beseitigt den todten Gang. Bei den Bohrbögen spannt der federnde Bogen die den Bohrer umschlingende Saite etc.

5. Tragfedern. Bei der Unterstiitzung schwerer Massen durch-Federn verfolgt man zweierlei $Z$ wecke; entweder den Druck anf die Unterlage anders zu vertheilen, oder die Stösse, welche ein bewegter Körper während seiner Bewegung erleidet, zu brechen und in unschädliche Schwingungen zu verwandeln.

In der erst angedeuteten Weise verwendet man Federn, um z. B. den Druck einer schweren aufrechtstehenden Welle (Königsbaum) auf deren Fusslager zu vermindern.

Zur Unschädlichmachung von Stössen wendet man die Federn an: bei Fuhrwerken und Eisenbahnfahrzengen; bei Grubenseilen, um das Reissen zu verhuiten; bei Kanonenlaffeten, um den Stoss der nach dem Schusse zuriickfahrenden Kanone fuir die Laffete unschädlich zu machen; bei den sogenannten Pferde. schonern u. s. w.

Die Formen der Federn sind sehr verschieden. Wir treffen da die in den Fig. 1535 bis 1537 dargestellten schraubenförmigen Federn, dann gewellte Scheiben- und Blatt- oder Lamellenfedern. Das Material der Federn ist fast durchwegs Stahl, nur in einigen vereinzelten Fällen mit Kautschuk, comprimirter Banmwolle**) ete. combinirt. Die einfachste, jetzt schon seltener anzutreffende, Form von Wagenfedern ist die in Fig. 1545 dargestellte. Wir sehen, dass dieselbe aus dem Hauptblatte $b a c$ und 5 immer kürzer werdenden Innenblättern 1, 2, 3, 4 und 5 besteht. Die sämmtlichen 6 Stahlblätter sind bei $a$ mittelst eines festen Bundringes zusammengehalten. Damit die einzelnen

*) Das Bankeisen, Fig. 117 pag. $290 \mathrm{I}$ Band, ist mit einer Klemmfeder versehen, damit es im Loche der Bankplatte dort stehen bleibt, wo man will.

**, Dingler's polyt. Jomrnal Bd. 174 pag. 419. 
Blätter bei der Durchbiegung nicht von einander abweichen, sind ihre aufwärts gekehrten Enden aufgeschlitzt und diese Schlitze gleiten iiber kleine Stifte der benachbarten Blätter. Die Feder ist bei $c$ und $d$ an das Wagenuntergestelle befestigt und der Wagenkasten ist an dem Haken $b$ des Hauptblattes aufgehängt. Diese Form bezeichnet man mit dem Namen a ufechte oder stehende Feder zum Unterschiede von den in den Fig. 1546, 1547 und 1548 dargestellten liegenden Federn. Fig. 1546 zeigt eine gerade liegende Feder, dieselbe ist bei $a$ an das Wagen. gestelle befestigt, während bei $b \quad b$ die zu unterstiitzende Last (Wagenkasten) driickend wirkt. Widerstandsfähiger wird diese Feder, wenn ihre Enden nach

Fig. 1546.
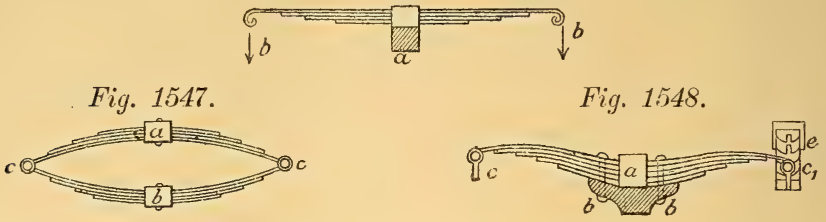

aufwärts gekrimmt werden, wie dies Fig. 1547 zeigt, wo zwei solcher Federn an ihren Enden mittelst starker Bolzen $c$ c vereinigt sind. Die Befestigung dieser Feder erfolgt bei $b$ an das Wagengestell, bei $a$ an den Wagenkasten, der senkrecht abwärts driickt. Fig. 1548 zeigt eine aus ungleich dicken Blättern bestehende Feder, dieselbe ist bei $b \quad b$ an das Wagengestelle befestigt. Der Druck des. Wagenkastens ist auf $c$ und $c_{1}$ vertheilt. Bei $c_{1}$ wird der Druck nicht direct vom Wagenkasten ausgeuibt, sondern durch eine bei $e$ an den Wagenkasten quer zur ersten Feder befestigte zweite Feder übertragen.

Da die Lamellenfedern gegenwärtig eine ausgedehnte Verwendung im Wagen- und Waggonban finden, sei ihre Fabrikation kurz skizzirt.

Die geeignetste Stahlsorte fuir Waggontragfedern ist der halbweiche Stahl (acier demi tendre) von $0.45-0.55 \%$ Kohlenstoffgehalt und einer Zerreissungsfestigkeit von $56-59 \mathrm{Kilo}$ pr. $\square^{\mathrm{mm}}$ (die Ausdehnung - allongement vor dem Reissen beträgt $10-20 \%$ der ursprünglichen Länge).

Die Grundlage bilden Bessemer-Rohgussstahlstiicke von 120-130 Kilo Gewicht; sie werden weissgliihend gemacht, unter einem Dampfliammer zu Prismen mit quadratischem Querschnitt (von $180^{\mathrm{mm}}$ Seite) ausgehämmert und auf einem Vorwalzwerk auf $80 \times 60^{\mathrm{mm}}$ ansgereckt. Hierauf wird auf einem Fertigwalzwerk (finisseur. nach und nach ein Band ron $13^{\mathrm{mm}}$ Dicke und $78^{\mathrm{mm}}$ Breite erzielt. Lamellen, welche nicht allerorten gleich stark sind, wie sie Fig. $\mathbf{1 5 4 8}$ zeigt, werden auf einem excentrischen Walzwerk fertig gemacht. Um die seitlichen Verschiebungen der Feder-

Fig. $1 \tilde{5} 49$. lamellen zu verhiiten, wird nicht immer die in Fig. 1548 gegebene Anordnung getroffen, sondern man versieht gleich die Stahllamellen mit Rinnen und Rippen, die in einander passen. Fig. 1549 zeigt den Querschnitt durch eine solche Feder.

Aus dem auf die eine oder die andere Art erhaltenen Profileisen werden nun Stiicke von der entsprechenden Länge mittelst einer Maschinenschere geschnitten. Die längsten, zu den Hauptblättern bestimmten Stricke werden hierauf rothwarm gemacht und zwischen zwei gusseisernen Blöcken, die mit Schrauben zusammengepresst werden, in die entsprechende Form gebogen. Zum Erhitzen bedient man sich eines Flammofens. Die folgenden Blätter werden hierauf immer nach den ihnen in der Feder voranliegenden gebogen, was mit Hilfe des in Fig. 1549 gezeichneten Walzwerkes geschieht. Das betreffende Blatt wird warm gemacht, auf sein Nachbarblatt gelegt, 
und nun beide zwischen die durch einen Hebeldruck von einander gehobenen Walzen eingebracht. Hierauf lässt man die Oberwalze herab und dreht mit der Kurbel so lange hin und her, bis die neue Lamelle sich der vorhergehenden vollkommen angepasst hat. Sind auf diese Art alle zu einer Feder gehörigen Lamellen gebogen, so werden sie provisorisch an einandergelegt, ihre Enden bezeichnet, dann wieder auseinander genommen und an die Adjustirung der Enden geschritten. Dieses Adjustiren besteht zunächst für alle Gattungen in einem Zuschneiden mit einer Maschinenschere, und für jene ohne Rippen und Rinnen in der Anbringung des Schlitzes und des Zapfens, welcher in den Schlitz der nächsten Lamelle passt.

Hierauf werden die Enden der Blätter (mit Ausnahme jener des Hauptblattes) abgeeckt oder seltener zugespitzt, die Enden der Hauptblätter $\mathrm{zu} 5 / \mathrm{s}$ zöliigen $\left(16^{\mathrm{mm}}\right)$ Augen umgebogen oder mit

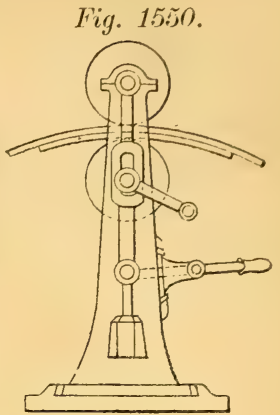
separat geschmiedeten Augen durch Schweissen verbunden.

Nach diesen Operationen werden die Blätter rothwarm gemacht und in Wasser von $25^{\circ}$ R. $\left(31^{\circ}\right.$ C. $)$ gehärtet, worauf man sie in einem eigenen Ofen bis zur himmelblauen Farbe nachlässt. Die nun fertigen Blätter werden in der richtigen Reihenfolge an einander gelegt, durch kaltes Hämmern der völlige Anschluss bewirkt und zuletzt mittelst eines durch ihre Mitte gehenden Bolzens oder eines in der Mitte anzubringenden Bundes vereinigt.*) Die fertigen Federn werden auf ihre Tragfähigkeit und Elasticität gepriift.

An die Blattfedern reihen sich die gegliederten Federn von J. B. Jolly, Ingenieur in Paris.**) Dieselben sind in Fig. 1551 dargestellt. Sie haben den Vortheil, dass man durch beliebige Aenderung ihrer Gliederzahl und deren Länge und Breite fast jeden gewünschten Grad von Elasticität innerhalb gewisser Grenzen erreichen kann; auch ist das Auswechseln einzelner Lamellen leicht gemacht.

Eine sehr ausgedehnte Verwendung finden die Spiralfedern und schraubenförmigen Federn theilweise zur Aufhebung der Stösse zwischen dem Wagenuntergestelle und dem Wagenkasten (Tragfedern), theilweise zur Unschädlichmachung heftiger Stösse beim plötzlichen Anziehen (Zugfedern), und endlich zur Aufhebung der Stösse beim raschen Aneinanderfahren der Eisenbahnfuhrwerke (Bufferfedern).

Im Nachfolgenden wollen wir einige Constructionen von Trag-, Zug- und Bufferfedern besprechen; verweisen aber betreffs der gewöhnlichen Volutfedern auf den Artikel Eisenbahnwesen III pag. 95 und 115, und den Art. Elasticität III pag. 164.

Fig. 1552 stellt Co chran s combinirte Stahl-Ka u t s chukFeder***) dar, die sich zu allen drei Anwendungsarten eignet.

Fig. $1 \tilde{5} 51$.

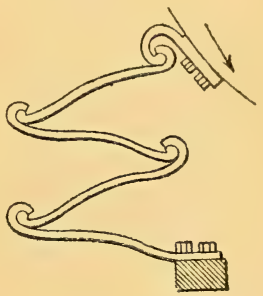

Fig. 1552.

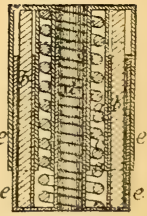
$a$ ist eine cylindrisch gewundene Feder, $b$ eine Kautschukröhre, beide sind ron

*) E. Heusing e $\mathrm{r}$ von Waldegg, specielle Eisenbahntechnik, 1875 Leipzig, Wilh. Engelmann, 4. Band pag. 220; Alphons Petzhold, Eisenbahmmaterial, 1872 Wiesbaden, C. W. Kreidl pag. 211; Polyt. Centralblatt Jahrg. 1861 pag. 924.

**) Dingler's polyt. Journal Band 183 pag. 186. Armengaud Gen. ind. November 1866 pag. 262.

**35) D ingler's polytechn. Journal Band 197 pag. 206; Mech. Magazin, Jahrg. 1870 pag. 188. 
einander durch teleskopartig in einander verschiebbare Blechröhren $c$ und $e$ getrennt, einestheils um ein Ausweichen von $a$, anderntheils aber um die schädliche Reibung und die durch sie bedingte Abnutzung des Kautschuks zu vermindern.

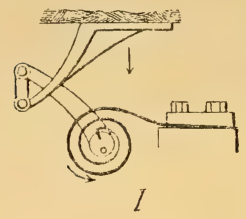

Fig. 155.5.

Fig. 1553 zeigt die Anordnung der Spiralfeder von Vaugin \& Chesn e a u in Paris*), u. zw. unter I als Tragfeder, II Zugfeder und III als Bufferfeder. In allen drei Fällen ist das eine Ende der Feder festgemacht, während das zweite Ende der Feder an eine drehbare Welle o befestigt ist. Die Stösse werden durch entsprechende Vorrichtungen anf die Welle o so iibertragen, dass sie eine theilweise Umdrehung ausfuhrt und dadurch die Spiralfeder spannt.

Fig. 1554 stellt die Bufferfeder von R. Chrimes in Rotherham**) vor. Sie ist eine Combination mehrerer verschieden langer schraubenförmig gewundener Federn, die in einander geschoben sind, und wegen ihrer verschiedenen Länge nach und nach zur Wirkung kommen. Die Federn bestehen entweder aus rundem Draht oder Stahlblechstreifen. Damit sich die Federn nicht in einander klemmen, ist immer eine Feder rechts gewunden und die in sie eingeschobene links, dann wieder rechts n. s. w.

Fig. 1554 .

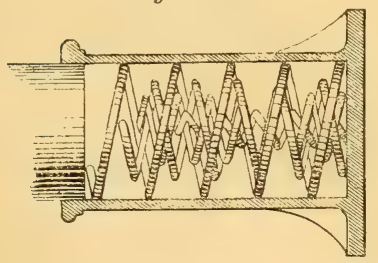

Fig. 1555.

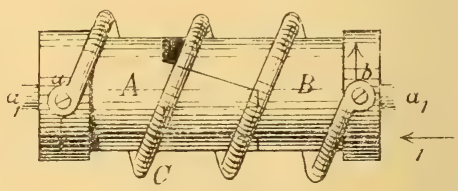

Interessant ist die Bufferfeder von Th. B. Turston \& J. Root in Shefield.**** Ans Fig. 1555 ist ersichtlich, dass auf einer Welle $a_{1}$ zwei cylindrische Körper $A$ und $B$ anfgeschoben sind. $A$ und $B$ sind auf den gegeneinander gekehrten Enden mit schiefen Ebenen versehen (ähnlich jenen an Zahnkuppelungen) die, wenn $A$ und $B$ an einander geschoben werden, in einander passen. Eine um $A$ und $B$ gelegte schraubenförmige Feder $C$ ist mit ihrem einen Ende $a$ an $A$, mit dem anderen $b$ an $B$ befestigt. Wirkt nun auf diesen Buffer ein Stoss in der Richtung des Pfeiles 1 , so werden zunächst $A$ und $B$ aneinander geriickt und hierdurch die Feder $C$ zusammengepresst. Das Gegeneinanderbewegen ron $A$ und $B$ hat aber auch zur Folge, dass die schiefen Ebenen anfeinander gleiten und dadurch die Drehung von $A$ und $B$ in den Richtungen der anf ihnen gezeichneten Pfeile, bewirken, wodurch die Feder $C$

*) Polytechn. Centralblatt Jahrg. 1855 Seite 257; Genie industriel Jahrg. 1854 pag. 284.

Polytechn. Centralblatt Jalırg. 1857 pag. 564; Pract. Mech. Journal Jahrg. 1857 pag. 317.

*:*) Polytechn. Centralblatt Jahrg. 1857 pag. 565; London Journal Jahrg. 1856 pag. 261. 
enger gedreht wird. Beide Elasticitätsäusserungen, nämlich jene gegen das Zusammendricken und jene gegen das Drehen der Feder wirken den auftretenden Stössen kräftig entgegen.

Fig. 1556 zeigt den Buffer von Meyers in Rotherham. ${ }^{3}$ ) In die ringförmigen Nuthen $a b c$ eines am Wagengestelle befestigten Gussstiuckes sind niedrige schraubenförmige Federn $A B$ und $C$ eingelegt. In dieselben Nuthen ragen ungleich hohe ringförmige Leisten des zweiten Buffertheiles. Die Wirkung der Federn beginnt nicht zugleich, was einestheils zu ihrer eigenen Schonung, anderntheils zur besseren Aufhebung des schädlichen Stosses beiträgt.

Die Bufferfeder von Richard Vose in New-York ${ }^{2}$ ) besteht aus einer schranbenförm:gen Stahlfeder von eigenthümlicher Querschnittsform $\frown$ und eincr zwischen die Gänge der Feder eingelegten Kautschukschnur. Der Zusammendriickung der Feder durch den Stoss wird zuerst von ihr selbst, dann aber auch durch den Kautschuk entgegengearbeitet.

Fig. 1556 .

Fig. 15.57 .
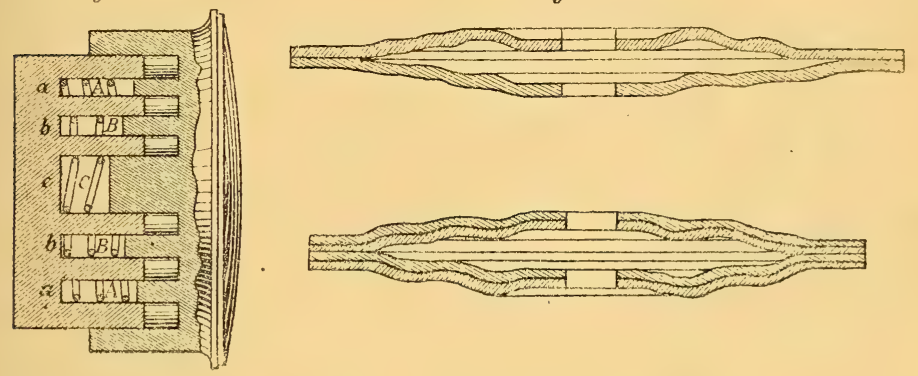

Fig. 1557 zeigt eine einfache und eine vorstärkte Bellevile-Scheibenfeder von Alfred Egan, Ingenieur der ung. Theiss-Eisenbahn. ${ }^{3}$ ) Die gewellten Scheiben sind von bestem Bessemerstahlblech gemacht. Die Erzeugung der Wellenscheiben gesehieht durch Pressen der rothwarmen Blechscheiben zwischen zwei entsprechend geformten Gusseisenstanzen. Mehrere solcher Doppelscheiben, mit ihrem Loche auf eine schmiedeiserne Stange geschoben und mit dieser in das Buffergehäuse gebracht, bilden einen selur kräftigen, aber auch sehr elastischen Widerstand gegen Stösse. Es wurde auch der Versuch gemacht, die Verbindung der Scheibenfedern an ihrem Rande luftdicht zu machen, die Löcher in der Mitte nicht anzubringen und so die zwischen zwei an einander gefügten Scheiben eingeschlossene Luft als Luftpolster (pneumatischer Buffer) zu beniitzen.

Black benützt anstatt der Wellenscheiben wellenförmige Platten. ${ }^{4}$ )

Von den Kautschukbuffern sind besonders hervorzuheben die Construction von Georg Richardson Fig. 1558.5) Die Kautschukringe sind abwechselnd mit Stahlringen in den Bufferkörper eingelegt; erstere sind, um gegen das Zersprengen gesichert zu sein, von G. Spen eer ${ }^{6}$ ) mit Stahlringen armirt worden,

Polytechn. Centralblatt, Jahrgang 1857 pag. 1417; Genie industr. 1857 pag. 6.

Dingler's polytechn. Journal, Band 176 pag. 418; Practical Mech. Journal 1865 pag. 16.

3) Dingler's polytechn. Jonrnal Band 184 pag. 229 und Band 204 pag. 273.

4) Dingler's polyt. Journal Band 184 pag. 303; Journal of the Frankl. Inst. 1867 pag. 46.

5) Polytechn. Journal Jahrgang 1857 pag. 564; The pr. Mech. Journ. Jahrgang 1857 pag. 317.

6) Dingler's polyt. Journal Band 207 pag. 358; Techn. Blätter 1872 IV. Heft pag. 254.

Karmarsch \& Heeren, Technisches Wörterbuch. Bd. III. 
wie dies Fig. 1559 zeigt. Sterne*) hat diesen Buffer in einen pneumatischen umgewandelt, indem er zwischen je zwei Kantschukringe eine ebene durchlochte Scheibe und von drei zu drei Kautschukringen eine volle Scheibe statt der gelochten anbringt; die zwischen den Ringen und den ganzen Scheiben eingeschlossene Luft wirkt dann als Luftpolster. Diese letztere Construction eignet sich vorziiglich als Buffer am Grunde von Förderschachten, zur Aufhebung des vom rasch nach abwärts fahrenden Förderkorbe ausgeiibten Stosses. Fig. 1560 zeigt diese Anordnung. Eine andere Art Tragfedern sind die sogenannten Torsionsfedern, deren Elasticität nicht durch Biegung, sondern mittelst Drehung in Anspruch genommen wird. Fig. 1561 zeigt eine aus mehreren geraden Stahlblättern bestehende Feder, die in der Mitte durch einen Band $\iota$ zusammengehalten sind und an den Enden in den drehbaren Hiilsen $c$ s stecken. Wirkt nun $z$. B. bei $d_{1}$ ein Zug nach einer Richtung und bei $d$ ein entgegengesetzter Zug oder Widerstand, so kommt die Torsionselasticität der Feder zur Wirkung. Solche Torsionsfedern eignen sich besonders gut zur Unterstützung von Wägen. Sie sind damn bei $a$ am Untergestelle befestigt, während der Zug der aufgehängten Masse bei $d$ und $d_{1}$ nach abwärts wirkt.**)

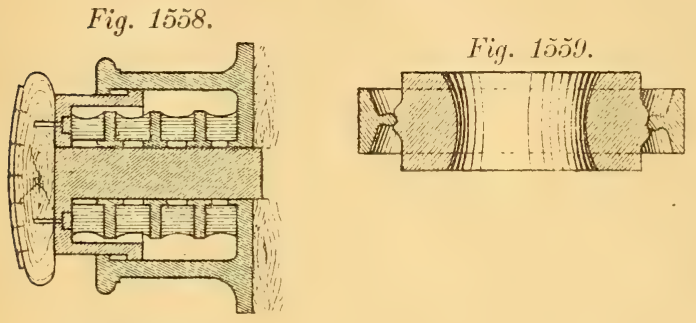

Fig. 1561 .
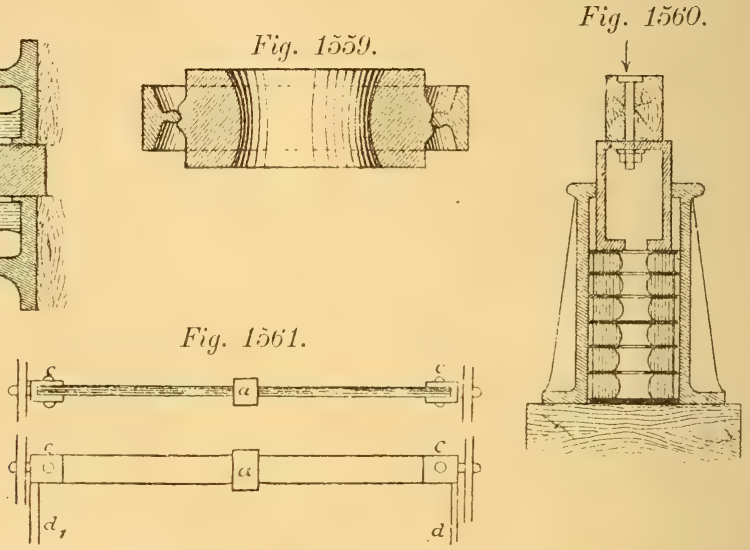

Von allen Trag-, Zug- und Bufferfederm, die im Wagenbau, insbesondere im Waggonbau verwendet werden, wird eine gewisse, von den Bahnverwaltungen normirte Qualität verlangt. Deshalb werden alle Federn vor ihrer Verwendung einer Belastungsprobe unterzogen, wobei insbesondere die roribergehende und bleibende Deformation der Feder bei einer gewissen Belastung beriicksichtigt werden. Federn, die bei dieser Probe entweder eine allzugrosse bleibende Formveränderung erleiden oder gar brechen, werden natiirlich als unbrauchbar rerworfen.

Die zum Probiren der Federn verwendeten Federprobirmaschinen sind manigfacher Construction. Die einfachste derartige Maschine ist die mit Hebeliibersetzung wirkende, wie sie in Fig. 1562 dargestellt ist. Die Feder ruht auf einer festen Unterlage; iiber sie ist der Hebel $A$ gelegt, dessen freies Ende ron dem Hebel $B$ herabgezogen wird. Der Hebel $B$ trägt an seinem freien Ende eine Schale zur Aufnahme eines Gewichtes, welches so schwer

*) Polytechn. Journal .Jahrgang 1886 pag. 553 u. 1369; Engineering 1868 pag. 235.

*: Dingler's polyt Journal Band 205̃ pag. 4s7; Zeitschrift des Vereines deutscher Eisenbahnverwaltungen. 
gewählt ist, dass es auf die Feder den bestimmten Druck ausübt. Die Schraube s dient zur Aufhebung der Hebel nach beendigter Prüfung jeder Feder. Bei der Probe wird die Höhe der unbelasteten Feder und dann der Höho wähıend der Belastung gemessen. Die Abnahme darf nur einen festgesetzten Procentantheil der urspriinglichen Federlänge betragen. Fig. 1563 zeigt die Federnprobirmaschine von John Dewrance \& Comp. in London. Dieselbe bestelit aus einem schweren Gussstïck $A$, den Säulen $B$, welche einen Wasserbehälter, ein l'umpwerk und eine feste hohle Kolbenstange $C$ tragen. Die Kolbenstange ragt in einen beweglichen entsprechend gefiihrten Cylinder $D$, welcher kräftig nach abwärts gedriickt wird, wenn mit Hilfe des Hebels $a$ das Pumpwerk bethätigt, also Wasser in den Cylinder gepumpt wird. Unterhalb des Cylinders wird die zu priifende Feder $F$ aufgestellt und nun das Pumpwerk in Bewegung gesetzt. Ein am Cylinder angebrachter Manometer reducirt den Druck, während die Verkiirzung (resp. die Einsenkung der Federn) an einem an der Maschine selbst angebrachten Massstabe $m$ abgelesen werden kann. Hierauf öflnet man einen Wechselhahn $h$, welcher das Zuriicktreten des Wassers aus dem Cylinder in das Wasserbehältniss gestattet und hebt den Cylinder durch Umdrehung des Zahnrades $c$, wobei man von der Elasticität der Feder unterstützt wird. An dem Massstabe $m$ kann nun leicht die bleibende Verkürzung (resp. Einsenkung) eben so wie vor der Probe die urspriingliche Länge (resp. Pfeilhöhe der gebogenen Federn) abgelesen werden. Gebrider T a n g i e in Birmingham construirten ebenfalls cine hydraulische Federnprobirmaschine (hydraulic spring tester) die horizontal wirkt. Der Ruickgang des Presskolbens wird durch sinkende Gewichte be-

Fig. 1562 .

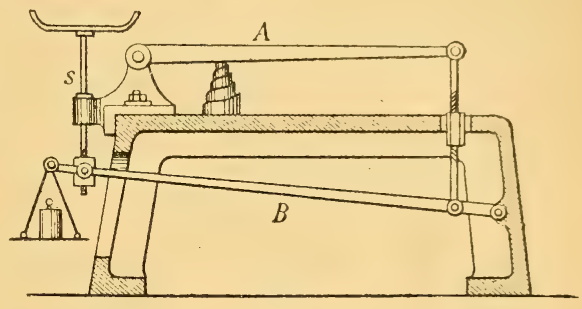

Fig. 1563.

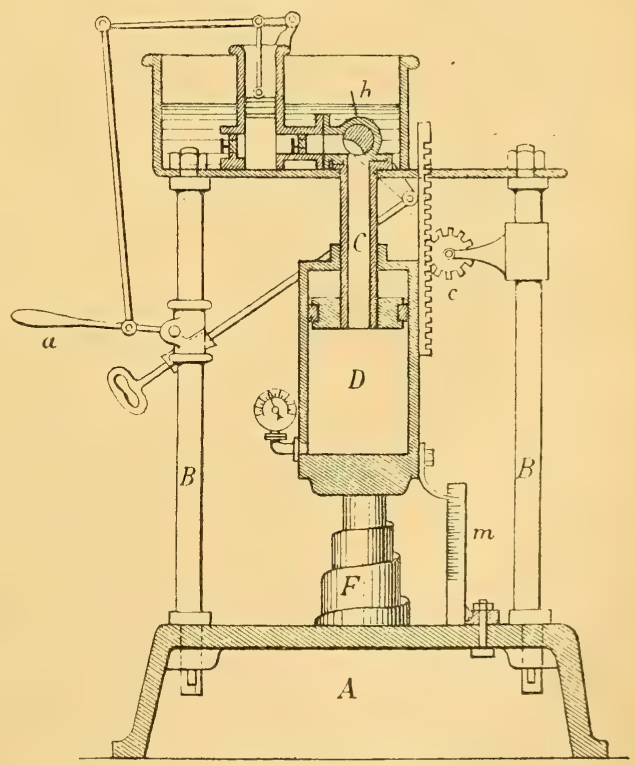
schleunigt.

VI. Dynamometrische Federn. Die Eigenschaften der elastischen Federn machen sie geeignet aus der Formveränderung einen Riickschluss auf die deformirende Kraft zu machen. Man macht hievon Anwendung bei den sogenann- 
ten Dynamometern (II. Band pag. 707). Eine ähnliche Anwendung finden die Federn in den Federwagen, s. Artikel Wagen.

VII. Tonfedern. Spiralfedern aus hartem Stahldraht von runden oder quadratischen Querschnitte, geben, mit einem Hammer angeschlagen, eineu Schall von sich, weshalb man sie zu Uhrenschlagwerken anwendet. Der Ton ändert sich mit der Zahl und Grösse der Umwindungen und dem Querschnitt des Federdrahtes. Die Tonfedern sind an ihrem inneren Ende an einen Lappen gelöthet und werden mit demselben auf dem sogenannten Stuhle (einem im Uhrkasten aufrechtstehenden messingenen Kloben) festgeschraubt oder in ein Loch desselben eingeschoben. Als Ersatz der Glocken hat man versucht Stahlstäbe in Form einer V, gegen deren Schenkel geschlagen wird, anzuwenden. Die Tam-tams der Japanesen sind ebenfalls hieher zu zählen. In den Stahlspielwerken befinden sich kurze gerade Stahlfedern verschiedener Länge und Dicke, wclche durch die Umdrehung einer mit Stiften besetzten Walze in tönende Schwingungen versetzt werden.

Moritz Kohn.

Literatur: Ausser den bereits citirten Quellen s. Galloway Anfertigung der Federn für Kutschen etc. Quedlinburg 1832 Basse.

Federsalz, syn. m. Federalaun.

Federschmückerei, s. Federn III pag. 372.

Federstock ist ein Hilfswerkzeng fuir Sammtweber, erfunden von Schmitz. (Verh. des Vereins für Gewerbfleiss in Preussen J. 1846.)

Federwage, s. W a gen, s. auch III pag. 86.

Federweiss (soap stone - craie de Briançon) nennt man gemeiniglich das in verschiedenen Gewerbszweigen als schliupfrigmachend verwendete Pulver verschiedener Speckstein- oder Talksorten. Denselben Namen fiihrt aber auch der sog. Fasergyps (satin spar), endlich auch der Amianth (s. d. I pag. 129). Gtl.

Federwerk, s. III pag. 161.

Federzirkel (compas à pompe, compas à ressort - spring compass), s. Messwerkzeuge.

Feigbohnen, Wolfsbohnen, sind die Samen von Lupinus albus L., einer im siidlichen Europa cultivirten Huilsenfrucht. Wie Bohnen verwendbar. Gtl.

Feigen (fignes - figs). Die getrockneten Scheinfriichte von Ficus Carica L., einem urspriinglich in Vorderasien einheimischen Baume aus der Familie der Moreen. Eine sehr frihe Cultur hat ihn über Nord-Afrika und Suid-Europa verbreitet und gegenwärtig wird er hier, sowie in vielen wärmeren und gemässigten Ländern der östlichen und westlichen Erdhälfte in zahllosen Abarten gezogen. In der Höhlıng des Blüthenbodens sitzen auf der Innenfläche zahlreiche gestielte, grünliche oder röthliche Bliithen, von denen nur beim wilden Feigenbaum einige wenige männlich, alle ïbrigen weiblich sind. Die cultivirte Feige besitzt nur weibliche Blüthen. Bei der Fruchtreife wird der Blïthenboden umfangreicher, saftiger und fleischiger, siissschmeckend, innen gelblich, röthlich bis purpurn, während seine Aussenfläche je nach der Spielart die grüne Farbe beibehält, oder aber eine bräunliche, violette bis blauschwarze Färbung annimmt; die Fruchtknoten verwandeln sich in etwa $2^{\mathrm{mm}}$ grosse Steinfriichtchen, oder gehen bei manchen Spielarten ganz ein. Die Friichte des wilden oder verwilderten Feigenbaumes (Caprifico) werden von einer kleinen Wespe, Blastophaga Psenes Löw, bewohnt, welche ihre Eier in die Fruchthöhlung legt. In Griechenland und in Süd-Italien ist allgemein der Glaube verbreitet, dass dieses Insekt, indem es sich auch auf die Bliithenstände der cultivirten Feigenbäume begebe, durch ein gesteigertes Zuströmen von Säften eine Vergrösserung der Frucht, Beschleunigung ihrer Reife bewirke, das zu frühe Abfallen derselben hintanhalte, kurz den Ertrag des Baumes steigere. Man hängt 
desshalb in jenen Ländern die mit Feigenwespen besetzten Fruchtstände des wilden Feigenbaumes auf die cultivirten Bäume auf, um die reifenden Feigen des letzteren desto sicherer dem Angriffe der ausschwärmenden Thierchen zugänglich zu machen, ein Vorgang, den man Caprification nennt und der bereits von den alten Römern und Griechen geübt wurde. Nach den Beobachtungen melirerer Forscher ist diese Caprification ganz nutzlos; in manchen Ländern wird sie gar nicht vorgenommen und doch liefern sie ganz ausgezeichnete Feigen.

Die gewöhnlichsten im Handel vorkommenden Feigensorten sind:

1. Smyrnaer Feigen (türkische Feigen), die grössten, sehr süss und fleischig; kommen aus Kleinasien mit Lorbeerblättern in Holzschachteln verpackt uiber Smyrna in den Handel.

2. Kranz-Feigen (griechische Feigen), ziemlich gross, flachgedriickt, dickhäutig, trockener und minder süss als die vorbenannten. Sie kommen aus Griechenland (Kalamata), auf Bastschnüre oder Cyperushalme gereiht und in grossen Fässern verpackt, meist iiber Triest zu uns. Die geschätzteste Sorte stammt von Corfu (Fraceazani).

3. Dalmatiner oder kleine Feigen (Istrianer Feigen), die kleinsten, sehr süss, aber bald austrocknend und wenig haltbar; gelangen in Fässern oder flachen Bastkörben aus Dalmatien und Italien in den Handel.

Ausser diesen hauptsächlichsten Sorten unterscheidet man noch im Handel die Malteser (puglieser, calabreser, sicilianischen) Feigen, die meist zwischen Lorbeerblättern oder auch in Kastanienmehl verpackt vorkommen; dann die Tyroler Feigen, die mit Lorbeer- oder Rosmarinblättern verpackt vorkommen (Laub- oder Rosmarin-Feigen); endlich die französischen (Marseiller und Comat-Feigen).

Die getrockneten Feigen haben meist eine graugelbliche, mit einem mehr oder weniger reichlichen, grobkörnigen, weisslichen Pulver bedeckte Oberfläehe. Letzteres besteht aus Krystallgruppen von Traubenzucker, denen sich häufig kleine hefenartige Zellen und Milben beigesellen. Dem Angriffe der letzteren sind die Feigen iberhaupt sehr unterworfen. Der wichtigste Bestandtheil der Feigen, die in südlichen Gegenden als Nahrungsmittel seit den ältesten Zeiten eine hervorragende Rolle spielen, ist Traubenzucker, von dem sie $60-70 \%$ entlıalten. Bei uns dienen sie bekanntlich hauptsächlich als Näscherei und in grossartigem Massstabe zur Fabrikation des Feigenkaffees (s. Kaffee-Surrogate).

A. Vogl.

Feilen (limes - files), F e il h a u m as ch in en (machines c̀ tailler, les limes file-cutting machines). Feilen und Raspeln sind Werkzeuge, die zum Abtrennen kleiner Materialtheilchen behufs der Formvollendung der Arbeitsstïcke bestimmt, demgemäss immer eine grosse Anzahl von eigenthümlich geformten Schneiden zeigen, deren Gesammtheit in ihrer entweder regelmässigen(Feilen) oder annähernd gleichmässig vertheilten Anordnung (Raspeln) der Hieb (taille, cut) heisst. Das Material zu diesen Werkzeugen ist grösstentheils Stahl, der sich in ausgezeichneter Weise hiezu eignet, es kommen aber doch auch Feilen aus Gusseisen, Eisen mit aufgeschweisstem Stahl oder selbst aufgelöthetem Stahl vor. Der Hieb, der durch das Eintreiben eines entsprechend geformten Meisels (s. pag. 395) erzengt wird, besteht, wie schon erwähnt, aus einer Reihe von halb aufgeworfenen, halb vertieften Schneiden die im Querschnitt nebenstehendes regelmässiges Bild geben. Fig. 1564.

Die Zähnchen der Raspeln sind im Querschnitt sehr ähnlich geformt, nur laufen sie nicht über die ganze Breite des Werkzengs, und folgen nicht in der Weise aufeinander, dass unmittelbar Zahn auf Zahn folgt, sondern zwischen den einzelnen Zähnchen befindet sich regelmässig ein Fig. 1564. ebener Theil des Werkzeugkörpers.

Die Gestalt der Feilen ist immer eine, im Verhältniss zu dem sehr mannigfaltigen Querschnitt, langgestreckte zu nennen, und characteristisch ist nur der schwach 
biconvexe Längsschnitt der Feilen, der, wie dies auch in Fig. 1565 ersichtlich ist, sich gegen das eine Ende (die Feilspitze) $a$ etwas stärker verjüngt, während das andere Ende etwas abgesetzt und zu einer Spitze $b$ (Angel), die zur Befestigung: in das Heft $c$ dient, ausgezogen ist. Der Grund zu der schwachen Krümmung der wirksamen Feilflächen liegt in der Führung der Feile durch den Arbeiter, der sie mit der rechten Hand am Hefte hält und mit einigen Fingern oder dem Ballen der Linken fuihrt. Bei dem Hin- und Herschieben der Feile über das Arbeitsstück fällt es dem Arbeiter in Folge der beim Vorschreiten der Feile von Stelle zu Stelle für beide Hände wechselnden Hebelverhältnisse ungemein schwer, den Druck auf beide Feilenden so zu variiren, dass die Bewegung eine genau geradlinig hin- und hergehende wiirde, was für den Fall gerader Feilen für exacte Arbeit unbedingt nöthig wäre. Die hier den Gliederungsverhältnissen der Arme am meisten entsprechende und namentlich bei schwerer Arbeit immer stattfindende Bewegung ist eine oscillirende, und zwar so, dass die drei Hauptstellungen die in Fig. 1566 mit $F^{\prime \prime} F^{\prime \prime} F^{\prime \prime \prime}$ markirten sind. Wie aus den beiden Figuren leicht ersichtlich, ergeben gerade Feilen convexe Oberflächen, während bei den gekriimmten Feilfächen viel leichter eine ebene Oberfläche zu erzielen ist.

Fig. 1565 .

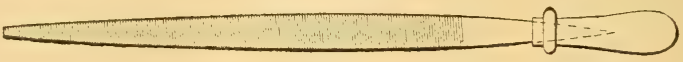

Fig. 1566 .
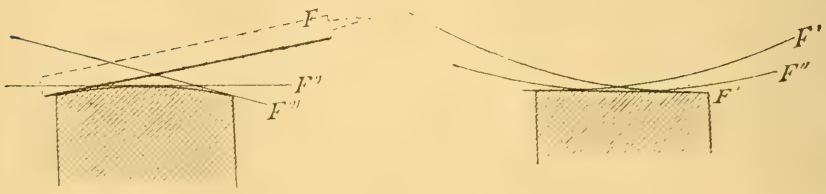

Das Arbeiten mit der Feile geht immer so vor sich, dass zuerst die gröbsten Feilen, die man verwenden will, beniitzt werden, um die Fläche zu elonen (das Bestossen), und hierauf in richtiger Stufenfolge die feineren Ftilen, deren Anwendung den Zweck hat, den groben Feilstrich durch einen stufenweise feineren zu ersetzen, whe aber viel zur Formveränderung beizutragen (das Schlichten:

Die feinen Feilen werden auf Schmiedecisen und Stahl mit Oel gebrancht, welches mit dem Feilicht (den Feilspänen) eine Art Paste bildet, die durch theilweises Terlegen des Hiebes einerseits cin sanfteres Angreifen der Feilen andererseits aber das Festsetzen gröberer Späne verhindert.

Sind Feilen durch Feilspäne rerlegt (rerstopft), so werden sie entweder durch Streichen des Hiebes mit tiner Stalılspitze, oder bei feineren durch Beniitzung ron Kratzbiirsten (siehe diese) oder durch ein auf ein Brettchen aufgenageltes Stiick Baumwollkratze gereinigt, wobei einige Tropfen Benzol, auf die Feile gebracht, durch Auflüsen des verdickten Oeles die Reinigung sehr arleichtern.

Fin richtiges Feilen (limer, filing) gehört zu den schwierigsten Arbeiten des Metallarbeiters. Gut gefeilte Arbeiten zeigen ebene glatte Flächen, scharfe Kanten, regelmässigen Feilstrich, d. h. lauter kleine, gleich tiefe, untereinander parallele Striche, die bei schmalen Gegenständen der Länge nach, nicht queriiber wher schief liegen sollen.

Als Hilfsmittel beniitzt der Arbeiter Winkelmass, Richtschiene und Richtflatte. Bei den Rumdfeilen kleinerer Gegenstände werden diese in Feilkloben Nitielkloben, eingespannt, in eine Rimne cines im Schraubstock eingespannten 
Holzes (Feilholz) eingelegt, und durch gleichzeitiges Drehen in dieser Rinne und Befeilen gerundet.

Bei den Raspeln ist die gekrümmte Oberfläche nicht von solcher Bedeutung fiir die Arbeit da diese Werkzenge seltener zur Erzeugung gerader Flächen, sondern mehr zur Abrundung, Schweifung etc. beniitzt werden, und auch der Druck, mit dem die Raspeln gefiihrt werden, in Folge des weicheren Materiales, für welches sie Anwendung finden, ein geringerer ist. Daher findet man meistens nur bei grossen und groben Werkzeugen dieser Art die schwach biconvexe Form. Bezuiglich der Gestalt der Raspeln wäre hier noch zu erwähnen, dass das eine Fnde nur selten zu einer Angel ausgeschmiedet ist, sondern dass entweder beide Enden stumpf abgeschrotet sind, oder dass wie bei den Flachspitzen das Heftende in der Weise geformt erscheint, wie es Fig. 1567 angibt.

Die Eintheilung und Benennung der Feilen richtet sich zumeist nach der Anordnung und Beschaffenheit des Hiebes und nach der Grund- oder Querschnittsgestalt des Feilkörpers, obwohl viele Feilen auch nach ihrer speciellen Verwendungsart benannt werden.

Je nach der Anordnung des Hiebes unterscheidet man Feilen mit einfachem Hiebe (limes à taille simple - single cut files) Fig. 1568 und mit Doppelhieb (limes ì deux trauchants - double cut files) Fig. 1569.

Fig. 1567 .

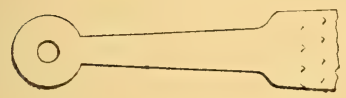

Fig. 1568 .

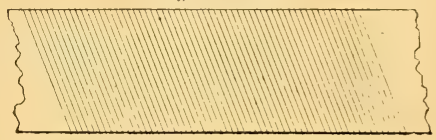

Bei den Feilen mit Doppelhieb führt der untere die Bezeichnung Grund- oder Unterhieb (premiére taille - first cut), der obere Kreuz- oder Oberhieb (second trille $-s$. cut). Durch die Kreuzung dieser Hiebe erscheint die Oberfläche der Feilen mit lanter kleinen Zähnchen bedeckt. Solche Feilen greifen etwas stärker an als einhiebige mit gleich tiefem Hiebe, da die Zertheilung in einzelne Zähnchen das Eindringen in das Material besser ermöglicht.

Eine selten vorkommende Abart der doppelhiebigen Eeilen sind die Spiegelfeilen Fig. 1570, bei welchen abwechselnd Grund- und Kreuzhieb oben liegt.

Fig. 1569

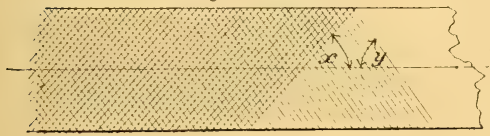

Fig. 1570.

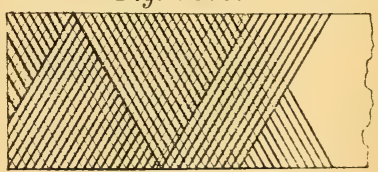

Der Winkel Fig. 1569, unter dem der einfache Hieb oder bei den doppelliebigen Feilen der Oberhieb gegen die Längsachse der Feile gefuihrt ist, soll ungefähı $70^{\circ}$ betragen, da es zwar vortheilhaft ist, ihn möglichst $\mathrm{klein}$ zu machen*), jedoch andererseits ein Hinschieben in der Richtung des Hiebes rermieden werden muss, da sonst ein Furchen Ziehen, Kratzen der Feilen eintreten wiìde. Genau betrachtet ist hier nicht der Winkel, den der Hieb mit der Läng'sachse der Feile, sondern jener, den der Hieb mit der Feilrichtung einschliesst, ron Bedeutung. Wie in Fig. 1571 veranschaulicht, setzt der Arbeiter die Feile $F$ gewöhnlich in etwas schiefer Lage anf das Arbeitsstiick $A$ und fiihrt sie beim

begen des sogenamnten rolucirten Schneidwinkels siehe Hojer mechanische Technologie Band I. 
Vorschieben so, dass sie auch etwas seitlich verschoben wird, damit die zu bearbeitende Fläche keine eingefeilten Absätze erhält, die ein richtiges schnelles Arbeiten sehr erschweren würden. Dann kom-

Fig. 1571.

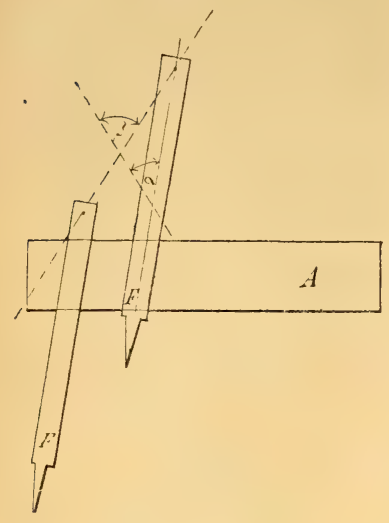
men aber die Schneiden, die mit der Feilachse den Winkel $\alpha$ einschliessen, nicht unter diesem Winkel, sondern unter dem Winkel $\beta$ zur Wirkung, und dieser Winkel soll so beschaffen sein, dass ein Gleiten der Feile längs des Hiebes nicht zu befürchten steht.

Bei den doppelhiebigen Feilen ist ausserdem noch zu beachten, dass die Winkel, unter denen Grund- und Kreuzhieb die Feilachse schneiden, nicht dieselben sind, damit die gebildeten Zähnchen nicht in mit der Feilachse parallelen Reihen hinter einander stehen, da in diesem Falle die Feilen gleichfalls leicht Furchen ziehen, nicht aber vortheilhaft arbeiten würden.

Was die Beschaffenheit des Hiebes betrifft, so kann dieser entweder grob (grosse taille - rough), mittel (moyenne taille - bastard) oder fein (douce taille - smooth) sein. $\mathrm{Zu}$ den Feilen mit grobem Hieb gehören die sogenannten Arm- und Strohfeilen, welch letztere den Namen nach der Art ihrer Verpackung tragen. Feilen mit mittlerem Hieb nemnt man Vorfeilen, auch wohl Bastardfeilen, die mit feinem Hieb Schlichtfeilen. Manchmal folgt noch eine Stufe, die sogenannten Feinschlichtfeilen. - Feilen, bei denen der Hieb wiederum beinahe gänzlich abgeschliffen ist, oder welche anstatt des Hiebes nur die leichten Ritze eines groben Schleifsteines erkennen lassen, werden als Polirfeilen verwendet.

Die obigen Bezeichnungen sind alle nur relativ zur Grösse der Feile zu verstehen, so dass der Hieb einer $40^{\mathrm{cm}}$ Schlichtfeile gleich dem einer $15^{\mathrm{cm}}$ Vorfeile sein kann; daher man nur aus der Zahl der Einschnitte pro Centim. auf die Feinheit einer Feile bestimmt schliessen kann.

Eine beiläufige Relation zwischen Hieb und Länge der Feilen gibt folgende, aus Karmarsch's Technologie entlehnte Tabelle:

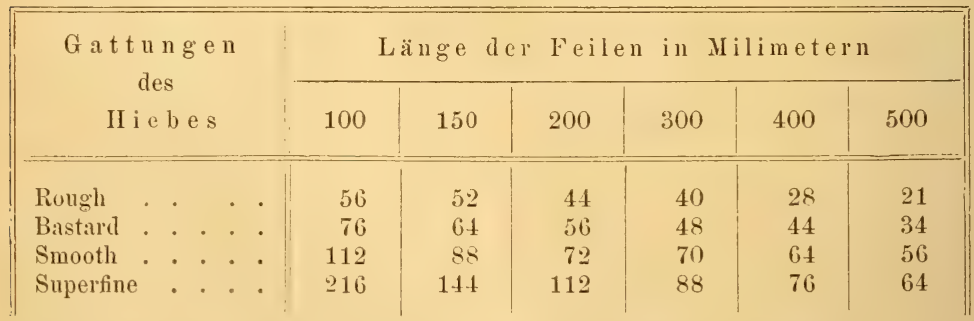

wobei die in den Rubriken stehenden Zahlen die Anzahl der Hiebe pro $25^{\mathrm{mm}}$ Länge der Feile angeben.

Die Benemung richtet sich ferner, wie früher gesagt, nach Grund- und Querschnittsgestalt des Feilkörpers. Was die Grundgestalt anbetrifft, so sind es hamptsächlich rier Formen, wie sie Fig. 1572 zeigt, die auftreten. Diese Figuren sind als Schnitte parallel zu den Arbeitsflächen der Feilen aufzufassen, während die daranf senkrecht geführten Längsschnitte mit wenig Ausnahme die schon in Fig. 1565 gegebene biconvexe Form ergeben. 
Ordnet man die Feilen der rerschiedenen gangharen Querschnitte nach ihren Grundgestalten, so erhält man somit vier Gruppen (Fig. 1572).

Die erste der Hauptformen

Fig. $1573 a b c$ findet sich bei besonders schweren Feilen, viereckigen oder rechteckigen Querschnittes (Arm-oder Strohfeilen). Sie ist dadurch bedingt, dass alle vier Seiten dieser Feilen Arbeitsseiten sind, daher etwas gekrümmt sein sollen. Die Feilspitze ist stumpf abgeschnitten, manchmal ohne Hieb, weil sie immer als Handgriff dient, da diese Feilen zur Fiihrung mit einer Hand viel zu schwer sind. Das Gewicht derselben variirt von $1-8$ Kilogr., ihre Länge von $35-70^{\mathrm{cm}}$. Als Mass für die Qualität des Hiebes können 5-8 Einschnitte pro Centim. Länge der Feilen angegeben werden.

Die zweite der Hauptformen Fig. 1574 ist für Feilen sehr verschiedener Grösse und mannigfachen Querschnittes in Verwendung, da sie in Folge der schlanken Verjuingung zur Spitze anch für schwerer zugängliche Stellen zu gebrauchen ist. Fei-

Fig. 1574.

len dieser Grundgestalt mit flachrechteckigem Querschnitt $b$ nennt man spitzflache, die mit Querschnitt $c$ einfach dreieckige. Bei dem Querschnitte der Sägefeilen $d$ sind die Ecken des Dreieckes abgeschrägt, und die dadurch an diesen Feilen sich vorfindenden schmalen Flächen haben nur einfachen Hieb. Querschnitt $e$ wird mit halbrund bezeichnet. Feilen mit Querschnitt $f$ fiihren den Namen Vogelzungen, während solche, bei denen die Krümmung beider Seiten nicht dieselbe ist, als Karpfenzungen $g$ bezeichnet werden. Da diese Feilen, wie schon erwähnt, sehr verschiedener Grösse sind, so sind auch alle Feinheitsstufen des Hiebes vertreten; zu erwähnen ist, dass die dreieckigen und die Sägefeilen häufig einfachen Hieb, die convexen Querschnittes aber einen Hieb zeigen, der aus schmalen Streifen einfachen Hiebes in einer der Arten, wie sie Fig. 1575 zeigt, zusammengesetzt ist.

Fig. 1575 .
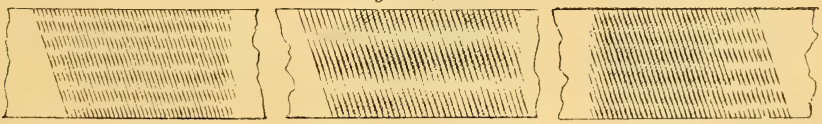

Gruppe drei mit der langgestreckt rechteckigen Grundgestalt zeigt (Fig. 1576) unter $a$ den Querschnitt der gewöhnlichen flachen Feilen; ist eine der Schmalseiten ohme Hieb, so heissen sie Ansatzfeilen. Es greift die ohne Hieb gelassene Seite natiirlich nicht an, was das reine Ausarbeiten winkelrechter Ecken, sogenannter An- oder Absätze ermöglicht. $b$ gibt den Querschnitt der sogenamnten Einstreichfeilen, die zum Einfeilen der Rinnen in Schraubenköpfen dienen. $c$ hat nnr an der geraden Seite Hieb, während die convexe geschlifien ist. Solche Feilen dienen theils als Wälzfeilen den Lhrmachern zum Abrunden der Zähne kleiner Räder, theils als Polirfeilen, wo ihre quergeschliffene convexe Fläche wie eine Feile mit äusserst feinem Hieb, wohl aber anch zugleich in der Art eines Polirstahls wirkt. Feilen, die zum Ausfeilen der Gabelzinken beniitzt werden 
- Gabelfeilen - haben den Querschnitt $d$, besitzen jedoch nur an den convexen Schmalseiten Hieb.

Was endlich die

Fig. 1578. Fig. 1579.

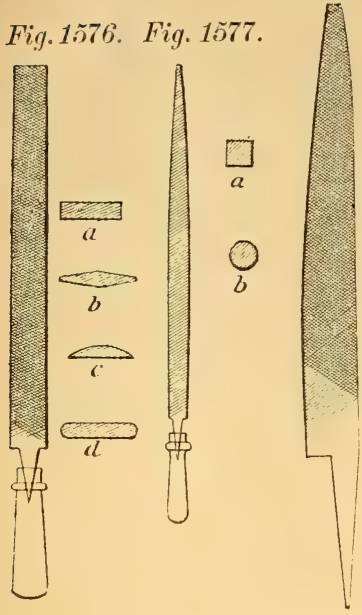

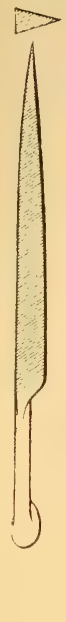
vierte Hauptform anbelangt, die langgestreckt cinerseits zur Spitze, andererseits zur Angel verjüngt erscheint, so ist sie gewöhnlich nur für Feilen in Anwendung, die zum Einfeilen schmaler Rinnen, Ausschweifen oder Ausweiten verschieden gestalteter Oeffnungen bestimmt sind. Die gebräuchlichsten Querschnitte sind die in Fig. 1577 unter $a$ und $b$ gegebenen. Kleine Feilen solcher Form mit rundem Querschnitt führen häufig die Bezeichnung R att ens c hw änze.

Zı erwähnen wären noch einige, vereinzelt dastehende, für specielle $\mathbf{Z}$ wecke verwendete Feilensorten.

Messerfeilen Fig. 1578, die Grundgestalt messerartig, Querschnitt nach Art einer Klinge dünn, keilförmig, alle vier Seiten mit Hieb versehen, zur Verfertigung schmaler Einschnitte, jedoch selten verwendet.

Schweiffeilen mit trapezförmigem Querschnitt, und nur an der grösseren Parallelseite mit Hieb versehen, von Schlossern zum Schweifen von Schliissellöchern verwendet.

Backenfeilen mit Längsfurchen und einem einfachen, querliegenden Hiebe, von den Messerschmieden zu dem Einfeilen der an den Metallbacken der Messerschalen als Verzierung dienenden Querfurchen benützt.

Liegefeilen, breite, flache Feilen, ohne Heft, von Gold- und Silberarbeitern in der Weise bentitzt, dass sie kleine Arbeitsstiicke mit der Hand ïber die auf dem Tisch liegende Feile hin und her führen.

$\mathrm{N}$ a delfeilen. Federfeilen Fig. $15795-10^{\mathrm{cm}}$ lange ungchärtete oder auch aus Eisen bestehende Feilen sehr verschiedenen Querschnittes, die, da sie sich leicht biegen lassen, zur Bearbeitung schwer zugänglicher Stellen ron Bijouteriearbeiten Anwendung finden.

Riffelfeilen, Fig. 1580, ähnlich den vorigen, aber etwas grösser, zum Gebranche für Silberarbeiter, Gürtler, Bildhauer, häufig aus Eisen und nur durch Einsetzen (s. III pag. 36) oberflächlich verstählt, so dass sie auch mittelst eines hölzernen Hammers beliebig gebogen werden können.

Putzfeilen sind die zum Eigengebrauch in Giessereien gegossenen Feilen, deren Zähne schon im Gusse erzeugt werden.

Spitzringe sind Scheiben, die entweder ganz von Stahl, oder nur an der Peripherie mit Stahl armirt sind, sie sind bis zu $10^{\mathrm{em}}$ dick, bei ungeführ 4()$^{\mathrm{em}}$ Durchmesser. Der Hieb befindet sich an der Cylinderfläche und ist mit dem der gewöhnlichen Feilen ganz gleich. Diesc Spitzringe dienen, auf eine raseh rotirende Welle aufgesetzt, zum Zuspitzen von Nadeln, kuzen Drähten iiberhanpt, deren einige der Arbeiter, sie zwischen seinen Handflächen haltend, dem 
Spitzringe wie einem Schleifsteine darbietet, während er durch Rollen zwischen den Händen das Angreifen an allen Seiten, also das Zuspitzen erzielt. Feilen fuir Uhrmacher, Drechsler, Kammmacher, Schuhmacher etc. siehe Prechtl's Encyclopäđlie Bd. 5. Was scheibenförmige Feilen anbelangt, siehe Fräsen.

$\mathrm{R}$ aspeln sind nur in wenigen Formen gangloar. Als solche sind die flachrechteckigen, flachrunden und die ganz runden hervorzuheben. Die ersteren gewöhnlich von rechteckiger Gestalt mit von der Mitte gegen beide Enden gerichtetem Hieb. Die beiden letzteren nähern sich in der Form den Feilen gleichen Querschnittes.

Gute Feilen sollen richtige, rein geometrische Form zeigen, ohne Sprünge, Flecken und Streifen sein, beim Anschlagen reinen Klang geben (was bei Härterissen nicht der Fall ist), der Hieb soll die grösstmöglichste Regelmässigkeit mit gehöriger Tiefe verbinden, die Oberfäche endlich von heller Farbe sein, da eine dunkle Gliihspan anzeigt, der der Schärfe der Feile nachtheilig ist.

Proben. Beim kräftigen Bestr eichen mit der Bruchecke einer guten, gebrochenen Feile soll kein Umlegen, sondern ein Ausbrechen des Hiebes erfolgen. Ein federhartes Stahlstiick soll auf dem Hiebe keine sichtbare Spur (weissen Strich) zuriicklassen und mit gleich bleibendem Widerstand über die Feile gleiten.

Feilenfabrikation. Selbe zerfällt in das Schmieden der Feilkörper, deren Ausarbeituug, das Hauen und Härten.

Als Material wird zumeist Gerbstahl oder fuir die mittleren und kleinen Sorten Gussstahl gewählt. Zuerst werden aus den Stahlstangen Stiicke von passendem Gewicht abgeschrotet und diese dann vom Schmiede in zwei Hitzen in die entsprechende Form umgewandelt. In der ersten Hitze bildet der Schmied, dem gewöhnlich zwei Gehilfen zum Feucrschüren und Zuschlagen beigegeben sind, den Feilkörper (blanket) meistens mit Zuhilfenahme von Gesenken (siehe Schmieden), während in der zweiten Hitze das Ausrecken der Angel, Richten und Einschlagen der Fabriksmarken erfolgt. Pro Tag und Feuer können auf diese Weise bis 25 Dutzend Feilen ausgeschmiedet werden. Die so ausgeschmiedeten Feilkörper (blankets) besitzen aber nicht jene Reinheit der Form und Oberfäche, dass sie unmittelbar dem Hauen unterworfen werden könnten, sondern sie miissen zu diesem Zwecke noch einer weiteren Ausarbeitung unterzogen werden. Diese geschieht gewöhnlich durch Schleifen auf Steinen von $1-1 \cdot 50^{\mathrm{m}}$ Durchmesser und $20-30^{\mathrm{cm}}$ Breite. Da diese Steine von der Transmission etwa 100 Touren pro Minute erhalten, so sind sie, um bei einem eventuellen Zerspringen jeder Gefahr vorzubeugen, mit einem starken, aus Bohlen gefügten Gehäuse umgeben, welches nur eine circa $35^{\mathrm{cm}}$ lange Arbeitsöffnung besitzt. Die Feilkörper werden dem Steine zuerst der Quere nach zugefuihrt, und damn der Länge nach, um den ersten Schleifstrich zu vertilgen. Bei grösseren Feilen übt der Arbeiter den nöthigen Druck auf den Feilkörper nicht durch die Hände aus, sondern durch ein etwas ober der Schleifstelle stehendes, schwach federndes Brett. Da der Arbeiter auf diesem Brette gleichsam reitet, mit den Fiussen aber auf dem Boden aufsteht, so hat er es ganz in der Macht den Druck zu variiren oder auch beliebig aufzuheben. Das Schleifen geht ziemlich rasch vor sich, und ist namentlich bei runden Feilen kaum durch ein anderes Verfahren zu ersetzen.

Eine bessere, d. h. genauere Ausarbeitung bietet das Feilen, es ist jedoch zeitraubender und daher auch kostspieliger.

Eine andere Methode der Herstellung der Feilkörper ist die von William Gray in Sheffield patentirte, durch Walzen mit Beniitzung unterbrochener Caliber. Diese Caliber (Fig. 1581) befinden sich in Scheiben, die anf den Wellen $B B_{1}$ eines Walzwerkes correspondirend anfgekeilt sind. Zur Fertigstellung eines Feilkörper's gehören gewöhnlich drei solche Façoncaliber, die je zur Hälfte in Ober- und Unterwalze eingelassen sind Ausnahmen hievon entstehen bei den dreieckigen und halbrunden Feilen). Zu bemerken ist, dass die Scheiben aus akonomischen Grinden aus mehreren Theilen zusammengesetzt sind, den eigent- 
lichen Calibertheilen (Gussstahl) $C C_{1}$, die nur mit Schwalbenschwanznuthen und Keilen mit den Scheiben $G G_{1}$ (Gusseisen) verbunden, somit auswechselbar sind.

Fig. 1581 a.

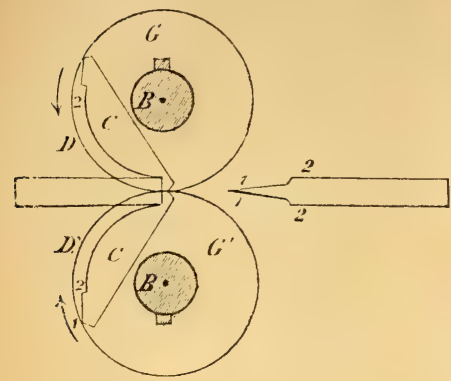

Fig. $1 \tilde{2} 81$ b.

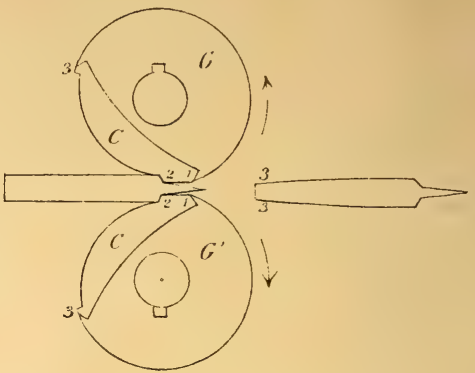

Seitlich werden die Caliber durch die Walzenringe $D \quad D_{1}$ abgeschlossen. Gewöhnlich sind in einem Walzwerke Caliber fül mehrere Feilenformen angeordnet. Art und Weise der Arbeit für Flachfeilen ist aus den Fig. $1581 a$ und $b$ sehr leicht zu entnehmen. Die passend vorgerichteten glühenden Stahllamellen passiren das erste Caliber nur zum Zwecke der Bildung der Angel. In das zweite Caliber werden sie mit der Angel voran in anf die hohe Kante gestellter Lage eingefuihrt, somit beim Durchwalzen der Breite nach verjünt, wobei jedoch in der Caliberform anf die im dritten Caliber erfolgende Verjiingung der Dickendimension, die eine ziemliche Streckung der Feilspitze zur Folge hat, Riicksicht zu nehmen ist. Die auf diese Weise fabricirten Blankets bediurfen nur sehr wenig Nacharbeit, was die Gestehungskosten wesentlich vermindert.

Anschliessend hieran sei auf die für das Nachhauen der stumpf gewordenen Feilen nöthigen Vorarbeiten hingewiesen, da das Hauen selbst mit dem der neuen Feilen ganz uibereinstimmt. Diese Vorarbeiten zerfallen in das Ausgliihen der Feilen und das Entfernen des alten Hiebes. Diese letztere Operation geschieht entweder durch Schleifen oder aber bei grobem Hiebe durch Abfräsen im glühenden Zustande, oder aber endlich durch Abhobeln mittelst eigens construirter Hobelmaschinen (Reinach in Berlin), bei denen der Schlitten durch Gleiten auf zwei zu einander geneigten (verstellbaren) Schienen in seinem mittleren Theil, an welchem die Feilen befestigt sind, die hier nöthige, schwach convexe Balın zuriicklegt.

Nach diesen Vorarbeiten werden die Feilen in Kalkwasser eingetaucht, um durch den dïnnen Ueberzug von kohlensaurem Kalk das Rosten zu verhindern. Dieser Ueberzug lässt sich, sollen die Feilen dem nun folgenden Hauen unterworfen werden, durch Abwischen leicht entfernen.

Fig. 1582.

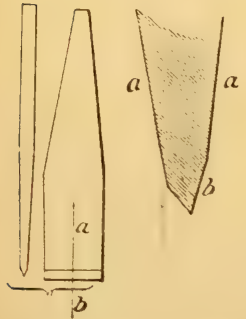

Das Hauen. Die Werkzenge, deren sich der Feilhauer hiezu bedient, sind Meissel und Hammer, ferner, als Unterlage für die Feilen dienend, Hauamboss, Haublei und rerschiedene Haugesenke. Der Arbeiter setzt bei der Arbeit den Meissel Fig. 1582 in der schon anfangs besprochenen, gegen die Feilachse schiefen Richtung, und zwar etwas gegen die Spitze iuberhängend, auf. Da die Schneide des Meissels, die immer etwas breiter ist als die zu hauende Feile, je nach Beschaffenheit des Hiebes mehr oder weniger zugeschärft ist, so ergibt sich daraus, dass, da wegen des guten Angreifens die Vorderflichen der Zähnchen bei allen Feilen ziemlich dieselbe Steilheit haben sollen, die Meisselstellung für feine Feilen eine aufrechtere sein wird als bei groben. Der Winkel, unter dem die Meissel aufgesetzt werden, variirt gewöhnlich 
zwischen 78-86". Letztere Grenze ist für die feinsten Feilen giltig. Ferner ist zu bemerken, dass namentlich bei den Meisseln für groben Hieb, um die Lage derselben nicht gar zu geneigt zu erhalten, die Zuschärfung der beiden Seiten der Schneide, wie aus Fig. 1582 ersichtlich, nicht unter gleichem Winkel geschieht.

Dass die Meissel auch in der Länge und Dicke je nach den zu hauenden Feilen stark variiren, ist selbstverständlich. Für convexe Feilflächen benützt man schmale Meissel mit ausgekrïmmter Schneide, deren Krïmmung aber viel geringer ist als die Convexität der Feile.

Die Hämmer des Feilhauers sind gedrungener Gestalt mit schwach convexer Bahn(Fig. 1583) mit eigenthïmlich gekriimmtem, der Handstellung angepasstem Griff. Für grobe Feilen steigt ihr Gewicht oft bis zu 5 Kilogramm. - Ist, wie oben angegeben, der Meissel von der linken Hand des Arbeiters richtig aufgesetzt, so treibt derselbe durch einen kräftigen Hammerschlag den Meissel ein, was in Folge der schiefen Stellung nicht nur ein Eindringen in die

Fig. 1583.

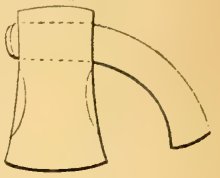

Feile, sondern auch ein Aufwerfen des anliegenden Materiales erzielt. Es entsteht so ein über die ursprüngliche Fläche erhabener Grat, an dessen Rïcken der Arbeiter den Meissel beim folgenden Hieb anlegt, und dadurch leicht den Parallelismus aller Hiebe erzielt. Die Arbeit geht somit nach dieser Methode (der englischen) von der Spitze zur Angel, während die alte deutsche, welche umgekehrt vorging, längst verlassen ist.

Als Unterlage dient, wie erwähnt, ein der Grösse der Feilen angepasster schmiedeiserner Haula moss, der wiederum auf einem massiven Holzblocke aufruht. Für halbrunde, dreieckige oder anders façonirte Feilen kommen noch zwischen Feile und Amboss die mit entsprechenden Rinnen versehenen $\mathrm{H}$ a ugesenke, die sich von den Gesenken der Schmiede nur durch etwas grössere Länge unterscheiden. Sind die Auflagsflächen schon gehauen, so miissen immer $\mathrm{H}$ a ubleie unterlegt werden. Diese sind Bleiplatten, deren 3 Dimensionen zwischen $1-6$ $10^{\mathrm{cm}}$ bis $3-8-15^{\mathrm{cm}}$ schwanken, natïlich haben jene fuir runde und dreieckige Feilen verwendeten die entsprechenden Rinnen.

Um die Feilen auf diesen Unterlagen festzuhalten, benützt der Feilhaner einen langen Riemen, welchen er so über die Feile legt, dass beiderseits eine Schlinge zu Boden liängt, in die er mit den Füissen tritt. Im Anfange der Arbeit, wo nur die Spitze auf den Hauunterlagen aufliegt, legt er den gedoppelten Riemen nahe der Spitze uiber die Feile und unterstiitzt die in ein provisorisches Heft eingeschobene Angel mit der Brust. Reicht das gehauene Stiick weit genug um den Riemen auflegen zu können, so legt er die Riemen beiderseits der Haustelle und hält die Feile so in ruhiger Lage.

Ist die Feile mit Grundhieb versehen worden und soll Kreuzhieb erhalten, so muss der äusserste Grat mit einer Feile etwas abgestrichen werden, weil er an und für sich nicht iiberall gleich ist, die Zähnchen daher einestheils ungleich ausfallen wïrden, andererseits aber durch Einbiegen die Furchen des ersten Hiebes auch theilweise geschlossen wiirden.

$\mathrm{Zu}$ der Feilhauerarbeit ist sehr viel Uebung erforderlich, besonders bei den feinsten Uhrmacherfeilen, die bis 100 Hiebe pro Centim. aufweisen.

Es scheint für den ersten Blick, dass keine Fabrication so auf maschinelle Arbeit hinweisen wuirde wie das Feilhauen. Demzufolge haben auch viele Constructeure sich bestrebt solche Maschinen zu erfinden, aber die wenigsten kamen zu guten Resultaten, und selbst gegenwärtig können sich diese Maschinen nicht allgemeine Verbreitung verschaffen.*) Die Scliwierigkeiten, mit denen man hier zu kämpfen hat, sind sehr verschiedener Natur. Besonders zu beachten sind folgende Umstände. Regelmässigkeit des Hiebes, Meisselfuihrung (Vermeidung des Prellens

*) Feilhaumaschinen stehen ausser in England auch bei Gebr. Di ckertma n $\mathrm{n}$ in Bi elefeld in Anwendung. 
und jeder Vibration), Aenderung der Schlagintensität je $\bullet$ nach Feilbreite. Unregelmässigkeit des Feilquerschnittes, ungleiche Härte im Material, Vermeiden jeder Beschädigung beim Ausheben des Meissels aus dem gebildeten Hieb. Rücksicht auf den constant sein sollenden Winkel, den der Meissel mit der convexen Feiloberfläche einschliesst, und noch andere mehr. Alle diese Umstände berücksichtigt der Arbeiter und eliminirt sie durch seine Uebung. Ausserdem verlangt man von den Maschinen, dass sie einfach, schnellarbeitend und keiner starken Abniitzurg unterworfen sind. Die hieher gehörigen Constructionen lassen sich in zwei Gruppen scheiden, und zwar in solche, die mit einem an einem Fallgewicht befestigten Meissel arbeiten und solche, die, mehr die Handarbeit imitirend, Meissel und Hammer getrennt anwenden.

Von den vielen Constructionen sollen hier nur zwei als Repräsentanten dieser beiden Gruppen Erwähnung finden.

Eine der gelungensten Maschinen der ersten Categorie ist die in Fig. 1584 dargestellte Feilhaumaschine von Bernot*) (Paris) herrihrende.

Fig. 1584.

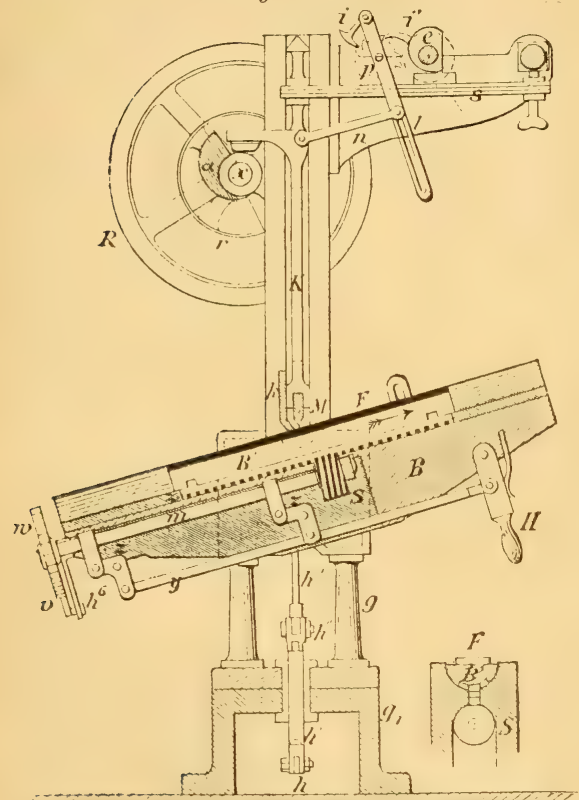

Die zu hauenden Feilen werden bei dieser Maschine durch Klauen an einen Schlitten $B^{i}$ befestigt, der seine Führung in dem auf Zapfen ruhenden Theil $B$ findet. Dieser Theil ist somit verstellbar, kann aber vermöge eines seitlich angebrachten Schlitzbogens und Stellschraube, je nachdem, wie es die Zuschärfung des Meissels erfordert, festgestellt werden. Der Meissel ist in dem vertical gefiihrten Theil $K$ festgeschraubt. Von der, von dem Motor aus angetriebenen Welle $x$ wird nun mittelst des Hebedaumens $\alpha$ der Theil $K$ gehoben, dabei aber auch gleichzeitig die aus mehreren Blättern bestehende Feder $s$ gespannt, lässt der Daumen $\alpha$ den Theil $K$ frei, so wird vermöge des Fallgewichtes von $K$ und der Beschleunigung durch die Feder ein kräftiger Schlag erfolgen, wobei durch Zusammenwirken von Feder und Fallgewicht ein Prellen verhindert wird. Von der Welle $x$ aus erfolgt aber auch nach jedem Schlage durch eine excentrische Scheibe eine Schwingung des Hebels $h$, welche durch die Hebel $h^{\prime}, h^{\prime \prime}$, $h^{\prime \prime \prime}, h^{4}, h^{5}, h^{6}$ (theilweise gedeckt) und den Sperrkegel $v$ anf das Schaltrad $w$ ubertragen wird, was eine intermittirende Rotation der Welle $m$ und Schnecke $S$ zur Folge hat. Da die Schnecke $S$ aber in eine Zahnstange eingreift, die mit Schlitten $B^{\prime}$ auf Verschiebung verbunden ist, so erfolgt daraus auch eine Verschiebung der Feile, und zwar um ein der Hiebdimension genau entsprechendes Stück. Durch Aenderung der Hebelverhältnisse oder Auswechslung des Schaltrades $v$ ist die Verschiebung leicht $\mathrm{zu}$ variiren. 
Lim die Nchläge des Meissels je nach der Grösse der zu hauenden Feilen variiren zu können, ist es möglich das eine Ende der Blattfeder, die sich in der Nitte gegen ein sofort näher zu besprechendes Stïck e stiitzt, durch eine Schraube zu spannen. Das Stiick e, eine excentrische Scheibe, wird je nach der Feilenform gewäblt, da es die Bestimmung hat, den Schlag des Meissels wälırend der Dauer des Hauens einer Feile entsprechend dem mit der Breite wachsenden Widerstand zu ändern. Von dem Theil $K$ wird nämlich durch $n$ bei jedem Schlage eine Oscillation des Doppelhebels $l$ vermittelt, die durch Sperrkegel $i$ eine ruckweise Drehung von $p$ und durch Zahnradiibertragung auch von $i^{1}$ erzielt. Dadurch kommen immer grössere Radien dieser Scheibe gegen die Feder zı stehen, und diese wird, da das auf $K$ ruhende Ende stets gleich loch gehohen wird, immer kräftiger einwirken. Um den Winkel, unter welchem der Hieb die Feilachse kreuzt, variiren zu können, besteht das Untergestell aus zwei Theilen $g$ und $g_{1}$, die durch die als Drehzapfen fungirende Biichse $o$ verbunden sind. Fiir das richtige Einstellen des im Querschnitt kreisförmigen Schlittens sorgt der federnde Taster $k$, der die jeweilig in Arbeit befindliche Stelle der Feile in mit der Meisselkante genau parallelen Lage erhält. Ist das Hauen bis zur Angel vorgeschritten, so wird durch den Hebel $H$ die Stange $y$ und die Winkel $z z_{1}$, Schnecke $S$ ausgeriickt, und der Schlitten in seine Anfangsstellung zurückgeschoben, um eine neue Feile aufzunehmen.

Als Repräsentant der zweiten Gruppe (Fig. 1585), d. i. jener Feilhaumaschinen, die die Handarbeit imitiren, sei hier die Maschine von A. Brand on*) beschrieben. Der Grundgedanke der Construction ist der, die Verschiebung der Feile durch den Meissei erfolgen zu lassen und zwar abhängig von der Beschaffenheit des Hiebes. Stellt Fig. 1586 I die Meisselstellung nach vollfuihrtem Hiebe dar, so folgt dann ganz wie bei der Handarbeit ein Heben des Meissels Aufsetzen in Position II und Vorschieben in dieStellung III. Da dabei der Meissel in seine Anfangslage zurïckkehren muss, so ergibt sich nothwendiger Weise eine Verschiebung der Feile. Die Construction ist nun in der Weise durchgefiihrt, dass der Meissel an einem

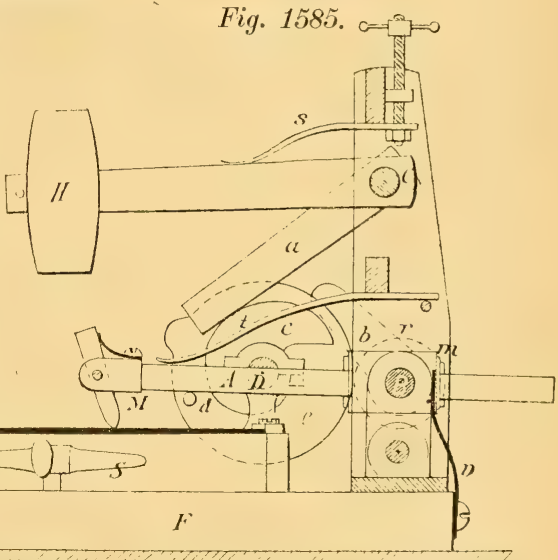

Stiele $A$ befestigt ist, der durch eine Muffe $m$ geht, in der er mit Friction durch zwei Seitenscheiben gehalten ist. Die Muffe $m$ hat zwei Zapfen, die in den Stiitzen $B$ gelagert sind. Einer der Zapfen trägt den Hebel $b$, der durch einen Bolzen $d$ der an der Welle $D$ sitzenden Scheibe $e$ bethätigt werden kann. Neben dem Hebel $b$ ist noch eine Rolle $r$ an der Achse $B$ angeloracht, und diese drückt, da die kräftige Feder $v$ anf die die Achse $B$ stiitzenden Theile einwirkt, continuirlich gegen den Umfang der Scheibe $e$. In dem Augenblicke, wo

*) London, Patent Office 1872 Nr. 628. 
Hebel $b$ durch $d$ gehoben wird, kommt eine Ausbanchung der Peripherie der Scheibe $e$ an die Rolle $r$, drïckt somit diese und den gehobenen Meissel zurick. Der Stift $d$ lässt aber den Hebel $b$ sinken, bevor die Ausbauchung die Rolle sänzlich passirt hat, und der Meissel muss in die Position II kommen. Hat sich Scheibe $e$ weiter gedreht, so kommt die Feder $v$ wieder zur Action, schiebt den durch die Feder $t$ auf die Oberfläche der Feile gehaltenen Meissel $M$ so lange vor, bis wiederum die Rolle $r$ an $e$ anliegt. In der allerletzten Periode dieses Vorschiebens kommt der Meissel an den beim vorhergehenden Schlage gebildeten Zahn, und schiebt sich, fest an diesen Zahn anlegend, die Feile sammt dem Schlitten um die Zahndicke vor. Das Verschieben des Schlittens geht ziemlich leicht vor sich, da die eine seitliche Fïhrungsschiene durch eine mittelst ciner Schraube zu spamende Federlamelle $F$ ersetzt ist. Hat das Verschieben stattgefunden so steht der Meissel in der zum Hiebe bereiten Stellung III. Der Schlag des durch eine Feder $s$ beschleunigten Hammers $H$ wird gleichfalls von der Welle $D$ durch den Hebedaumen $c$ abgeleitet. Auf der Welle $C$ ist der Hammerstiel, zugleich aber anch ein Hebel $a$ aufgekeilt, der die Wirkung des Hebedaumens auf den Hammer ïbermittelt. Auf eine selbstthätige Variation der Schlagstärke während des Hauens einer Feile ist hier nicht Riicksicht genommen, selbe kann jedoch von dem beaufsichtigenden Arbeiter durch Nachspannen der Feder $s$ erzielt werden.

Die Arbeit dieser Maschine soll ziemlich zufriedenstellend sein, ist jedoch nur für Flachfeilen zu verwenden. Dasselbe gilt von den Constructionen von Alfred Weed und Morgan Brown, London Patent Office 1873 Nr. 3680Nro. 1218, die nur Abänderungen dieser Maschine sind. Eine Maschine desselben Principes, aber in ziemlich rerschiedener Construction, welche selbst das Hauen der Feilen mit convexen Flächen gestattet, ist die von Maurice M ond on (London Patent Office $1874 \mathrm{Nr}$. 3426).

Sind die Feilen gehauen, so werden sie, um sie bis zu dem nun folgenden Härten vor dem Rosten zu bewahren, in Kalkwasser eingetaucht.

Das Härten der Feilen verlangt, aus Riicksicht anf den feinen Hieb, ziemlich viel Sorgfalt. Die Feilen werden, um sie vor den oxydirenden Einfliissen des Gliihens und des Härtewassers zu bewahren, mit einem Ueberzug versehen, dessen Zusammensetzung in verschiedenen Fabriken verschieden ist. Häufig wird hiezu ein Gemisch von verkohltem Leder (Horn, Knochen, Klauen), Ofenruss, Kochsalz und Töpferthon genommen. Dieses Gemenge wird mit Bierhefe angemacht und mit einem Pinsel auf die Feilen aufgetragen und langsam iiber einem Feuer getrocknet. Einfacher ist das Ueberziehen durch Eintauchen in einen Brei von Roggenmehl und Kochsalzlösung. (Vortheilhaft soll es sein, die Feilen vor dem eigentlichen Härten in dunkelroth gliihendem Zustande in gepulvertes Kochsalz zu stecken.) Ist der Leberzug trocken geworden, so werden sie entweder in einem Coaks-Feuer oder aber besser in geschlossenen Muffenöfen rothglühend gemacht und vertical in möglichst kaltes und reines Wasser (Regenwasser) eingetaucht.

Gut ist es die Angeln ungehärtet zu lassen, da sie sonst durch Anfassen mit einer glühenden Zange weich gemacht werden muissen.

Nach dem Härten werden die Feilen in stark verdiunte Schwefelsäure gelegt, um die nachfolgende Reinigung zu erleichtern.

Das Reinigen geschieht am besten durch eine mit Bürsten oder Karden besetzte Trommel, die in Wasser läuft. Die Feilen werden in verschiedenen Lagen gegen diese Trommel gehalten, und wenn sie rein sind, schnell auf erhitzten Eisenplatten getrocknet. Noch warm werden sie in Baumöl eingetaucht, und nachdem dieses genügend abgetropft ist, in Papier verpackt.

Ueber das Nachätzen stumpf gewordener Feilen siehe Karmarsch, Technologie Bd. I p. 295; D ingler's polyt. Journ. Bd. 192 p. $73 . \quad$ F. Polak.

Literatur: Prechtl's Encyclopädie Bd. 5; Karmarsch Technologie Bd. I; Hojer Technologie Bd. I. Ferner die schon bei den Feilenhaumaschinen angefiibrten Beschreibungen des Londoner Patent Office. 
Feilkloben, s. Schraubstock.

Feilkluppe, s. Schranbstoek.

Feilmaschine, s. Hobe $\mathrm{Im}$ as ehi

Feilspäne, s. III pag. 120 (Eisenfeilspäne), und pag. 390.

Feinbrennen, s. Silber.

Feineisen, Feinmetall, s. Eisenerzengung III pag. 24.

Feinen und Feinprocess, s. Eisenerzengung III pag. 23.

Feingehalt, s. Gold a rbeiten.

Feingold, s. Gold.

Feinkarde, s. Ba $u$ molls p innerei I pag. 334, s. Karden,

Feinkies, s. K ies.

Feinkorneisen, s. Eisen II pag. 773.

Feinkratze, Feinkrempel, s. I pag. 334, s. K a rde n.

Feinofen, Weiss ofen, s. Eis enerzeugung III pag. 23.

Feinprobe, s. Silber, s. Probiren.

Feinsilber, s. Silber.

Feinspindelbank, s. Ba u mwollspinnerei I pag. 345.

Feinspinnen, s. I pag. 351.

Feinspinnmaschine, s. B a $\mathrm{m}$ wollspinnerei I pag. 345.

Feinzeug, Ganzzeug, s. Papierfabrikation.

Fel vitri, syn. m. Glasgalle, s. Glas.

Felbel, Felpel, ein langhaariges, sammtartiges Gewebe, s. Weberei.

Feldahorn, s. A horn I pag: 60.

Feldbussole, s. Compass II pag. 390.

Feldkümmel, s. Q uendel.

Feldschmiede, s. Schmieden.

Feldspathe ("feldspath" - feldspar). Name einer Gruppe von Mineralien welche sich sowohl durch ihre bemerkenswerthe morphologische als chemische Uebereinstimmung auszeichnen. Die Feldspathe folgen namentlich zwei Typen, dem monoklinen und dem triklinen, sind ihrer chemischen Zusammensetzung nach Doppelsalze uud bestehen im Wesentlichen aus einer Verbindung von Kieselsäure, Thonerde, mit Kali-, Natron- oder Kalksilicat oder einem Gemenge der Letzteren in rerschiedenem Procentverhältnisse. Die ganze Reihe der Feldspathe besitzt nach $\mathrm{T}$ s c h e r m a k nur drei selbstständige Arten, nämlich den Orthoklas, Kalifeldspath $\left(A 7^{2} O^{3},{ }_{3} \mathrm{SiO}^{2}+\right.$ $\left.\mathrm{K}^{2} \mathrm{O},{ }_{3} \mathrm{SiO}^{2}\right)$, den Albit, Natronfeldspath $\left(\mathrm{Al}^{2} \mathrm{O}^{3},{ }_{3} \mathrm{SiO}^{2}+\mathrm{Na} \mathrm{CO}^{2}\left({ }_{3} \mathrm{SiO}^{2}\right)\right.$ und den Anorthit, Kalk(Natron)feldspath $\left(\mathrm{Al}^{2} \mathrm{O}^{3} \mathrm{SiO}^{2}+\mathrm{CaOSiO}^{2}\right)$; alle iibrigen Feldspathe, wie der Sanidin, Oligoklas (Plagioklas), Andesin, Labradorit sind nichts anderes als zum Theil mechanische, zum Theil isomorphe Gemische dieser drei Arten. Die Feldspathgruppe ist eine der wichtigsten im Mineralreich, da ihre Glieder einen wesentlichen Antheil an der Gestaltung der Gesteine nehmen. Die einzelnen Arten s. a. g. O. $L b$. 
Feldspath gemeiner, s. Orthoklas:

Feldspathgesteine nennt man die gemengten krystallinisch-kürnigen Gesteine, welche unter ihren Gemengtheilen ein Glied der Feldspathreihe besitzen. Die grösste Anzahl aller krystallinischen Massengesteine gehört hierher, da nur wenige untergeordnete Gesteinsarten feldspathfrei sind. $L b$.

Feldspath glasiger, s. Sanidin.

Feldspathporphyr, s. Qu arzporphyr.

Feldspathporphyrit, s. Porphyrit.

Feldspathporzellan, s. Thonwa aren.

Feldstecher, s. b. Fern rohr.

Feldstein, s. v. a. gemeiner Feldspath, s. Orthoklas.

Feldsteinporphyr, s. Qu arzporphyr.

Feldulme, s. U $1 \mathrm{me}$.

Felge (jante - jount, felly), s. Fuhrwerk.

Felle, s. Le der.

Fellinsäure, s. Galle.

Fellmaschine oder Pelzkrempel, s. Streichgarnspinnerei.

Felpel oder Felbe1, s. Weberei.

Felsenguano, s. Gu ano.

Felsit, ein dichtes Gestein, bestehend aus einem mikro- oder kryptokrystallinischen Gemenge von Quarz und Feldspath. Dasselbe kommt seltener für sich allein vor, sondern bildet häufiger die Grundmasse der Felsit- und Quarzporphyre, s. d. $L b$.

Felsitfels, Petroplex, s. Felsit.

Felsitische Grundmasse nennt man die mikro- oder kryptokrystallinische Grundmasse porphyrartiger Gesteine, wclche zumeist eine dem Felsit (s. d.) entsprechende Zusammensetzung hat, zuweilen wie bei den Phonolithen auch quarzfrei sein, und statt der Feldspathe ein lösliches Silikat aus der Reihe Nephelin, Leucit, Nosean, Hauyn haben kann. Lb.

Felsitpechstein, s. Pechstein.

Felsitporphyr, s. Quarzporphyr.

Felsöbanyit, Min. rhombisch, kleine kugelige Krystallirusen bildend, meist auf Schwerspath aufsitzend. Weiss bis grauweiss. Härte $=1 \cdot 5$. Ist bas. scliwefels. Thonerde, wasserhaltig. Vorkommen Felsöbanya in Siebenbiurgen. Gtl.

Femel, Fimmel, männliche Hanfpflanze, s. Hanf.

Fenchel (graines de fenouil-seed fennel graines), die getrockneten reifen Friichte von Foeniculum officinale All., einer ausdauernden, an trockenen, steinigen Orten in Siid-Europa, im Kaukasus und den siidkaspischen Ländern wildwachsenden, im gemässigten Europa viel gebauten und auch hie und da verwildert rorkommenden Doldenpflanze. Die Friichte sind im Umfange cylindrisch, an $8^{\mathrm{mm}}$ lang und $3^{\mathrm{mm}}$ breit, ron einer kegelfürmigen, zwei ganz kurze Griffel tragenden Scheibe gekrönt, glatt, braun, leicht in ihre zwei länglich-eiförmigen 
planconvexen Theilfrichtchen sich spaltend und zerfallend. Jedes der letzteren trägt auf seiner gewölbten Rïckenfläche fünf hervortretende stumpf-gekielte, grinlichgelbe Rippen, von denen die randständigen stärker und von den übrigen etwas entfernt sind. In jedem der breiten braun-grünen Thälchen liegt ein dunklerer Oelstriemen; zwei Striemen trägt iiberdies die blassbraune Berührungsfläche. Der aus Suid.Europa (besonders Siid-Frankreich) zugefiuhrte sogenannte R $\mathrm{i} \mathrm{m}$ is che Fenchel (süsser oder kretischer Fenchel), von Foeniculum dulce Ol., ist grösser, mit stärkeren, fast fliigelartig hervortretenden stroligelben Rippen und grüneı Theilchen. Der Fenchel riecht angenehm aromatisch und besitzt einen suisslichgewiirzhaften Geschmack; er gibt $3 \frac{1}{2}-4 \%$ eines ätherischen Oeles, und enthält ausserdem Zucker $(2 \%)$ und fettes Oel $(12 \%)$. Er findet eine ausgedehntes Anwendung als Gewiirz und Arzneimittel. - Das ätherische Fenchelöl wird durch Destillation der Samen mit Wasser oder Wasserdampf gewonnen. Es bildet eine farblose oder licht-gelbe Flüssigkeit von dem charakteristischen Fenchelgeruche und gewürzhaft süsslichem Geschmacke. Schon bei gewöhnlicher Temperatur etwas dickfliissig, erstarrt es bei $+10^{\circ} \mathrm{C}$. zu einer krystallinischen Masse. Das spec. Gew. $=0 \cdot 90-1 \cdot 0$, es destillirt zum grössten Theile zwischen 185 und $230^{\circ} \mathrm{C}$. Es besteht wesentlich aus Anethol, und verhält sich in Bezug auf seine Löslichkeitsverhältnisse ähnlich dem Anisöl (s. I pag. 152).

A. Vogl.

Fenchelholz, syn. m. Sass a frasholz.

Fenchelöl, s. Fen chel.

Fenian-Feuer (fenian fire), flüssiges Feu er, eine Lösung von 18 Thl. Phosphor in 1 Thl. Schwefelkohlenstoff, hinterlässt beim Verdunsten des Schwefelkohlenstofies Phosphor in so fein vertheilter Form, dass derselbe unter Zutritt von Luft freiwillig sich entzïndet. Brennbare Gegenstände mit einer solchen Lösung iibergossen, gerathen sonach, wegen der sehr rasch erfolgenden Verdunstung des Schwefelkohlenstoffes, alsbald in Brand. Man hat darum solche Lösungen zur Fiillung von Brandhohlgeschossen verwendet. Auf gepulvertes chlorsaures Kali aufgegossen, liefert eine solche Lösung eine nach dem Verdunsten des Schwefelkohlenstoffes selbstthätig explodirende und heftig detonirende Masse, die man fuir Petarden beniitzt hat. Vgl. iib. F enerwerkerei. Gtl.

Fenster (fenêtre - window) sind die durch eingerahmtes Glas abschliessbaren Licht- und Luftöffnumgen fiur die Räume der Gebäude. Man hat daher: 1. die Construction der Fensteröffnung, 2. den Verschluss der Oeffnung zum Schutz des Raumes gegen die Witterungseinflüsse, zu unterscheiden.

ad 1. Die Grundform der Fensteroffnung ist die eines hohen Rechteckes (Höhe zumeist gleich der doppelten Breite) und daraus entstehen viele andere Formen, wenn der Abschluss nach oben durch einen Halbkreis, Kreissegment, Spitzbogen etc. gebildet wird. Selbstverständlich kommen auch andere rerschiedenartige Fensterformen vor, z. B. kreisrunde etc. Im Allgemeinen ist durch die Stylrichtung des Gebändes und durch architektonische Riicksichten die Form bestimmt. Die Grösse und Zahl der Fensteröffnungen richtet sich nach der Grösse des zu beleuchtenden Raumes und dessen Bestimmung; auch begrenzt die Etagenhöhe das Mass der Höhe der Fenster. Die Begrenzung der Fensteröffinung geschieht unten durch die Sohlbank, zur Seite durch das Fenstergewände und oben durch den Fensterbogen, welcher, wenn an dessen Stelle ein horizontaler Steinbalken tritt, Sturz genannt wird. (S. Entlastungsbogen III pag. 274.) Alle drei Stïcke bezeichnet man anch mitunter als Fenstergestell.

Die Sohlbank hat den besonderen Zweck, das an das Fenster anschlagende Regenwasser abzuleiten; sie erhält daher einen Vorsprumg vor der Mauerflucht, ferner an der obern Fläche eine geringe Abschrägung und an der Unterseite eine Rinne (sog. Wassernase) oder auch eine etwas ansteigende Fläche, damit das Wasser abtropft und nicht vermöge der Adhäsion an der Mauer herabrinnt (s. 
Fig. 1589 bei $s$ ). Beim Vorsetzen einer steinerner Sohlbank auf der FensterBrüstungsmauer (gewöhnlich $0.45^{\mathrm{m}}$ stark und $0.80^{\mathrm{m}}$ vom Fussboden hoch, wenn das Fenster bequemen Ausblick gewähren soll) muss die Vorsicht gebraucht werden, dass zwischen beiden ein schmaler leerer Raum bleibt, bis das Mauerwerk sich vollständig gesetzt hat, da bei Ausserachtlassung ein Bruch der Sohlbank eintreten kann, indem die eingemauerten Enden sich mit der Mauer stärker setzen, während der mittlere unbelastete Theil nicht folgen könnte.

Das Fenstergewände wird entweder vollständig aus Ziegelmanerwerk hergestellt oder an der äussern Gebäudeseite aus Werkstiicken, nach Innen aus Ziegeln. Der Fensterbogen richtet sich ganz nach der herzustellenden Fensterform; die Anordnung eines steinernen Sturzes erfordert einen Entlastungsbogen (s. d. III pag. 274). Die einfache Umrahmung des Fensters in der Façade nennt man Chambrane (Fasche). Oft jedoch wird uber dem Fenster ein sog. Verdachungsgesims angebracht, welches nicht nur architektonischen Zwecken, sondern auch zum Schutze des Fensters gegen Regenwasser dienen soll.

ad 2. Die Construction zum Abschluss der Fensteröffnung besteht: a) aus dem Fensterstock, b) aus den Fensterflügeln (zusammengesezt aus Rahmen, Sprossen und Verglasung) und c) aus dem Fensterbeschlag.

a) Der Fensterstock ist der in Falze des Fenstergestelles eingesetzte, durch Bankeisen, Schrauben oder Bänder befestigte Holzrahmen, welcher die Fensterflügel zu tragen hat. Für unser Klima wird zumeist ein doppelter Abschluss (Doppelfenster) erforderlich. Davon bezeichnet man das äussere als Winterfenster, das innere als Sommerfenster (weil oft im Sommer das äussere durch Jalousien ersetzt wird). Zwischen dem Sommer- und Winterfenster ist ein Luftraum, welcher $0 \cdot 15-0.23^{\mathrm{m}}$ Tiefe besitzt; die dazwischen liegende Wandfläche heisst FensterLeibung.

Trägt ein Stock beide Fenster, dann geht er nach der ganzen Tiefe der Leibung und man bezeichnet ihn als Futterstock, Pfostenstock $\left(4-5^{\mathrm{cm}}\right.$ stark, $21-23^{\mathrm{cm}}$ breit). Siehe Fig. 1587, welche den Grundriss darstellt.

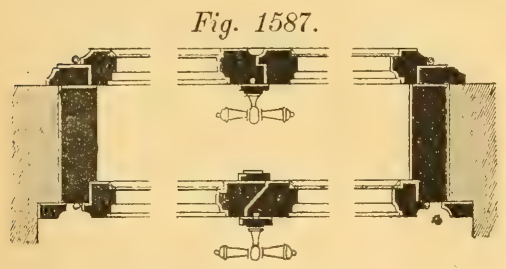

Winter-Fenster nach Aussen zu öffnen.

Erhält sowohl das äussere als auch das innere Fenster seinen separaten Stock (Blindrahmen mit ca. $5^{\mathrm{cm}}$ auf $6.5^{\mathrm{cm}}$ starkem Querschnitt, Fig. 1588), so wird bei eleganter Wohnungsaustattung die Fensterleibung durch das sog. Fensterfutter oder Steinfutter verkleidet.

Die Fenster der Wohngebäude erhalten zumeist 4 Flügel; zwei obere kleine und zwei untere grosse.

Die Trennung geschieht durch das horizontale Kämpferholz und L oosholz. Mitunter ist auch in der Mitte ein rertikal stehendes Holz festgemacht, welches mit dem Kämpferholz das Kreuz bildet. Man bezeichnet dies als Fensterstock mit Kreuz oder Kreuzstock. Bei eleganten Fenstern wird jedoch das feste Mittelstiick nicht angebracht und durch Schlagleisten ersetzt (offener Stock mit Kämpferstiick), oder nur an den oberen Flïgeln angewendet (Stock mit oberem Mittelstiick). Die äussern dem Schlagregen ausgesetzten Fugen zwischen Stock und Flügelrahmen miissen durch sog. Wetterschenkel gegen das Eindringen ron Wasser geschiitzt werden; derselbe ist ein am Stock oder event. Fensterrahmen angebrachtes schwaches, horizontales Holz, $1-2^{\mathrm{cm}}$ von den Fensterrahmen vortretend, mit einer Abschrägung und Wassernase versehen.

b) Die Fensterfligel bestehen aus Rahmen (mit ca. $4 \cdot 5^{\mathrm{cm}}$ starkem Querschnitt) und Sprossen $\left(2 \cdot 5^{\mathrm{cm}}\right.$ breit und wie die Rahmen stark), zwischen welche die Verglasung eingekittet ist. Bei stärkeren Rahmhölzern wird man möglichst nach der Tiefe des Fensters das Holz verstärken, da durch Verbreiterung des Holzes 
Fenster.

die Glasfläche verringert wird. Das Profil des Rahmens enthält hauptsäclllich zwei construetiv nothwendige Falze: den Anschlagfalz und den Kittfalz, ca. $1^{\mathrm{cm}}$ tief, welch letzterer immer an der Aussenseite des Fensters anzubringen ist. Die Untertheilung der Fensterflügel durch Sprossen muss der Ausstattung des Gebäudes entsprechen. Elegante Salonfenster erhalten für jeden Flügel nur eine Scheibe, so dass das ganze Fenster nur drei oder vier Scheiben besitzt.

Einen speciellen Fall bildet das Schaufenster, welches zumeist nur aus einer einzigen Spiegelscheibe, bis zu sehr bedeutenden Dimensionen, hergestellt wird.

Die innern Fensterflügel öffnen sich stets nach Innen, die äussern jedoch nach Aussen (Fig. 1587) oder Innen (Fig. 1588 und 1589). Im letzteren Fall darf natiurlich der innere Kämpfer dem Flügel kein Hinderniss zum Oeffnen bieten. Im Allgemeinen wird daher das innere Fig. 1588. Fenster in grösserer Dimension als das äussere herzustellen sein, und bezüglich der Kämpferanbringung sind folgende Anordnungen möglich: 1. Man mache den innern Kämpfer möglichst schwach, den äussern aber so breit, dass die äussern Fensterflügel nach Inven geöffnet werden können. Will man die Breite des innern Kämpfers auf ein Minimum reduciren, so geschieht dies am besten durch eine entsprechend geformte Eisenschiene, welche leicht mit Holz verkleidet werden kann. 2. Man mache beide Kämpfer in gewöhnlicher Stärke, bringe aber den äussern um so viel tiefer an, dass der untere Fensterflügel geöffnet werden kann; die äussern obern Flügel können dann nicht wie gewöhnlich in Bändern drehbar sein, sondern werden mit Feder und Nuth zwischen Stock und Kämpfer eingesetzt und
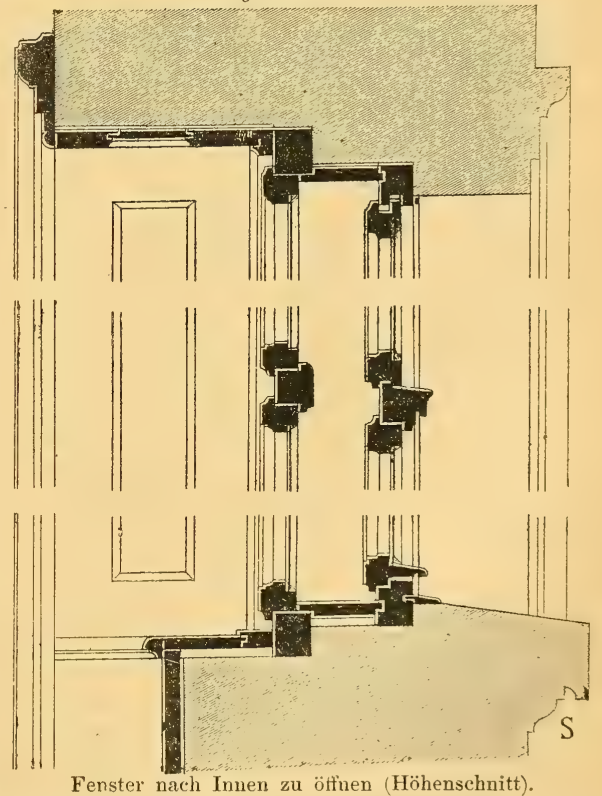
müsssen bei event. Entfernung gehoben werden. Siehe die Fig. 1588 und 1589, welche Grundriss und Höhen-schnitt darstellen.

Bei den nach Innen zu aufgehenden Fenstern wird der äussere Stock zumeist ca. $0 \cdot 15^{\mathrm{m}}$ nach Innen angeordnet; man nennt solche Fenster , z u rii ck- 
gesetzt". Im Sommer werden oft statt der Winterfenster Jalousien eingelängt. Sie bestehen aus zwei oder vier im gewöhnlichen Fensterstock eingehängten Fliigelrahmen (Hauptrahmen), drehbar wie die gewöhnlichen Fensterflügel; dieselben tragen im untern Theil Nebenrahmen, nach aufwärts drehbar oder aufklappbar unı Bänder, die am Kämpfer befestigt sind. Zwischen den Rahmen sind um Zapfen bewcgliche, mit ihrer Unterkante sich übergreifende Brettchen (ca. $9^{\mathrm{cm}}$ breit, $1.5^{\mathrm{cm}}$ stark) eingesetzt, welche mit Hilfe einer Zugstange gleichzeitig gedreht werden können.

Fensterläden. Man unterscheidet: ordinäre Fensterläden, welche aus gestemmten Flïgeln bestehen und am äussern Stock der Parterrefenster eingehängt werden; zum Schutz gegen Feuergefahr oder Einbruch werden dieselben an der äussern Seite mit Blech beschlagen.

Die Spalettläden haben einen ähnliehen Zweck, stehen aber immer innerhalb vor dem imnern Fenster und werden aus zwci Fliigeln, jeder aus mehreren zusammenlegbaren Theilen bestehend, hergestellt. Beim Zusammenlegen werden dieselben in eine Vertiefung der Fensterspalettirung (sog. Spalettkasten)zusammengeklappt.

Sehubfenster. Dasselbe besteht gewöhnlich aus zwei Theilen; die untere Hälfte ist immer nach aufwärts verschiebbar, während der obere Theil fest oder nach abwärts bewegt werden kann. Der verschiebbarc Rahmen ist durch eine Schnur, welche über eine Rolle führt. mit einem Gegengewicht in Verbindung, behufs leichterer Handhabung und damit das Schubfester in jeder Lage in Ruhe bleibt.

$\mathrm{Sch}$ a ufenster. Dieselben werden nicht drehbar angeordnet und müssen möglichst freien Einblick gewähren; daher werden zur Verglasung starke Spiegel. scheiben verwendet, welche mit anfgeschranbten Leisten im Falz des Stockes befestigt werden. Bei sehr grossen Oeffnungen theilt man die Scheiben durch vertikale Eisensprossen. Die Scheiben missen vor dem Beschwitzen und Befrieren geschützt werden. Es ist daher der eigentliche Schauraum nach Innen zu durch eine Glasthiir abzuschliessen und die äussere Luft mit demselben in Verbindung zu setzen, was am besten durch Oeffnungen (entsprechend verziert) im Fries oder Sockel der Schaufensterconstruction geschehen kann.

c) Fensterbeschläge bei gewöhnlichen Fenstern.

1. Die Befestigung des Fensterstockes im Anschlag geschieht entweder durch Bankeisen, oder durch Verbindung des äusseren und inneren Stockes durch Eisenbänder oder Schraubenbolzen.

2. Zur Verstärkung der Verbindung der Holzrahmen dienen sog. Scheinhaken, eiserne Winkel, je $10-12^{\mathrm{cm}}$ lang, $1.5-2^{\mathrm{cm}}$ breit und $2^{\mathrm{mm}}$ stark, an den Ecken in's Holz eingelassen und mit 5 Schrauben befestigt.

3. Das Aufhängen der Fensterflügel geschieht bei Wohngebäuden durch Fisch- oder Aufsatzbänder. Siehe Art. Band I pag. 287. Die Höle beträgt 12 bis $15^{\mathrm{cm}}$, der Durohmesser der Hülse $10-13^{\mathrm{mm}}$.

4. Fensterverschliisse: a) Einreiber, Litppenreiber, einfach und doppclt; ein Eisenplättchen wird in eine ausgestemmte Oeffnung des Fensterkreuzes ein-

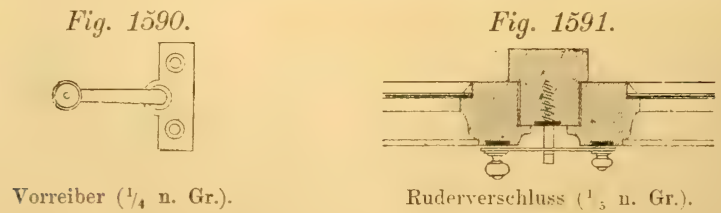

gedreht. 6) Torreiber (Kurbelreiber), einfach (Fig. 1590) und doppelt, je nachdem derselbe einen oder zwei Fligel festzuhalten hat. c) R u dervers ch l us s (Ueberwurf). Die Kurbel ist an einem Flügel. der Haken am festeu Mittelstück (Fig. 1591), oder wemn dies fchlt, am zweiten Fligelrahmen hefestigt. d) B a s c u l e-V e r s c h 1 u s s (Fig. 1592., s. I pag. 30.4). Beim Drehen des Griffels (Olive) greift ein kleines Zahnrad Triebrad) in zwei Zahnstangen ein, woron die eine oben, die andere unten schliesst; 
gleichzeitig bewirkt ein Einreiber in der Mitte den dritten Verschluss. Der BasculeVerschluss ist der am meisten iibliche. Statt durch Triebrad und Zahnstangen kann man auch durch Excenter die Bewegung der Eisenstangen erzielen (Patent Peyer in Wien). e) Espagnolette-Verschluss. Ein Ruderverschluss ist an einer vertikalen drehbaren Stange befestigt, welche, bei geschlossenem Zustand des Fensters, oben und unten mit gekrummten Haken in festgemachte Haken eingreifen. Fig. 1593 gibt eine Skizze. f) Schubriegel. Dieselben werden bei ordinären Fenstern aussen sichtbar angebracht, während bei besserer Ausstattung die Schieber ins $\mathrm{Holz}$ eingelassen und durch Bleche verdeckt werden (verdeckte sichubriegel.
Fiq. 1.0 .92$.
Fig. 1593.
Fig. 1594.
Fi. 15.95 .

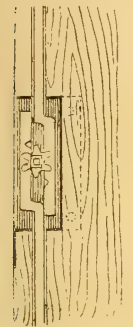
Basculeverschluss $(1 / 5$ n. Gr.).

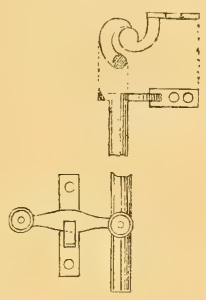
Espagnolettverschluss (1/5 n. Gr.).

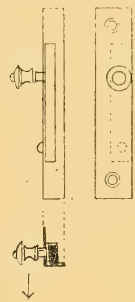
Innere Fensterspreitze (1/5 n. Gr.),

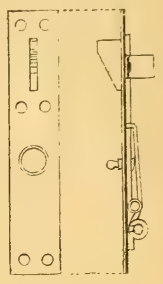
Fensterschnapper $(1 / 4$ n. Gr.).

5. Vorrichtungen, um die geöffneten Fenster in richtiger Lage zu erhalten: a) Für das nach Aussen zu aufgehende Fenster dienen eiserne Aufspreizstangen. b) Fiir das Festhalten der nach Innen zu aufgehenden Fenster verwendet man inwenaige Fensterspreitzen und Fensterschnapper. Diese Fensterspreitze ist ein Vorreiber, welcher am vertikalen Theil des Stockes befestigt wird. Fig. 1594. Der Fensterschnapper (Fig. 1595) ist im Fensterbrett derart eingelassen, dass die etwas vorstehende Falle in eine entsprechende Vertiefung an der Unterseite des Fensterrahmens beim Oeffnen desselben einspringt. Um das Fenster schliessen zu können, wird durch einen Drnck auf den Knopf die Feder sammt Falle hinabgedruiekt.

Für specielle Einrichtungen werden selbstverständlich mannigfache Anordnungen bedingt, z. B. für horizontal an Charnierbändern aufgehängte und verstellbare Fenster (Ventilationsklappen). Im Allgemeinen bringt man in der Mitte des Fensters eine kreisbogenförmige Zahnstange an, welche in cin Triebrad eingreift; durch Drehung des Triebrades öffnet oder schliesst sich das Fenster. Grohmann.

Fensterblei, s. Glas er a rbeiten.

Fensterglas, s. Glas.

Fenstersprosseneisen, ein durch Walzen erzeugtes Façoneisen.

Ferberit, s. Wo 1 framit.

Fergusonit (brauner Ittrotantalit), ein sehr seltenes, in kleinen, undeutlichen, tetragonalen Krystallen vorkommendes Mineral, welches undeutlich spaltbar, muschlig im Bruch und spröde ist, eine Härte $=5.5-6$, spec. Gew. $=4.89$ hat, dunkel-pechschwarz mit hell-braunem Strich, undurchsichtig ist, und wesentlich aus niobsaurer Yttererde besteht. Es findet sich in kleinen Kryställchen zu Schreibershau im Riesengebirge, bei Ytterby in Schweden und am Cap Farewele in Grönland. $L b$.

Fermentation, s. Gährung.

Fermente (ferment-ferment), Gährung s r reger, Gährungs mit tel. Substanzen, welche Zersetzungen oder irgendwie geartete Veränderungen anderer 
Substanzen zu bewirken im Stande sind, ohne selbst dabei eine durch eine chemische Gleichung ausdrückbare Veränderung $\mathrm{zu}$ erfabren, nennt man im Allgemeinen Fermente. Es gibt nun Fermente, welche niedere Organismen repräsentiren, bei welchen die durch sie bewirkten Zersetzungen gewisser Stoffe nur eine Folge ihrer Lebensfunctionen sind; sie werden als organisirte oder geformte Fermente bezeichnet, und die durch diese hervorgebrachten Veränderungen sind identisch mit den Fäulniss- und Gährungsprocessen.

Solche organisirte Fermente sind z. B. die Alkohol-Bierhefe, Saccharomyces cerevisiae M., die Milchsäurehefe, Oidium lactis etc. Es gibt sodann Fermente, welche bloss chemische Individuen, freilich bisher noch sehr ungenuigend gekannt, repräsentiren, ohne irgend eine Organisationsstructur, die durch blossen Contact mit anderen Substanzen bei Gegenwart von Wasser eine Veränderung derselben herbeiführen, derart, dass diese Substanzen entweder direct in mehrere Körper zerlegt werden, oder aber eine Spaltung erleiden und die Spaltungsproducte selbst durch Addition der Bestandtheile eines oder mehrerer Moleküle Wasser neue Substanzen bilden.

So z. B. wird der Rohrzucker (Saccharose) durch ein in der Bierhefe enthaltenes, ungeformtes Ferment, das Invertin, in zwei andere Zuckerarten iiberführt.

$$
\underset{\text { Rohrzucker }}{\mathrm{C}_{12} \mathrm{H}_{22} \mathrm{O}_{11}+\mathrm{H}_{9} \mathrm{O}}=\underset{\substack{\text { Dextrose } \\ \mathrm{C}_{6} \mathrm{H}_{12} \mathrm{O}_{6}}}{\underset{\text { Devulose }}{\mathrm{C}_{6} \mathrm{H}_{12} \mathrm{O}_{6}}}
$$

Dasselbe bewirken auch verdünnte Mineralsäuren, so dass man sieht, dass diese fermentösen Eigenschaften durchaus nicht an die organische Natur gekniipft sind. Das Amygdalin, ein Bestandtheil der bitteren Mandeln und vieler anderen Theile gewisser Prunusarten, wird durch ein sowohl in den bitteren als süssen Mandeln enthaltenes Ferment, das Emulsin, durch Aufnahme von Wasser gespalten in Bittermandelöl, Blausäure und Zucker.

$$
\mathrm{C}_{\mathbf{2 0}} \mathrm{H}_{27} \mathrm{NO}_{11}+\mathrm{H}_{22} \mathrm{O}=\underset{\text { Bnygdalin }}{\underset{\text { Bittermandelöl }}{\mathrm{C}_{7} \mathrm{H}_{6} \mathrm{O}}}+\underset{\text { Blausäure }}{\mathrm{CNH}}+\underset{\text { Zucker }}{2\left(\mathrm{C}_{6} \mathrm{H}_{11} \mathrm{O}_{6}\right)}
$$

Das myronsaure Kalium, ein Bestandtheil der Samen des schwarzen Senfs, wird durch ein ebenfalls in diesen Samen enthaltenes, dem Emulsin sehr ähnliches Ferment, das Myrosin, ohne Aufnahme von Wasser in folgender Weise zerlegt: $\mathrm{C}_{10} \mathrm{H}_{18} \mathrm{KNS}_{42} \mathrm{O}_{10}=\mathrm{C}_{4} \mathrm{H}_{5} \mathrm{NS}^{\mathrm{S}}+\mathrm{C}_{6} \mathrm{II}_{12} \mathrm{O}_{6}+\mathrm{KHSO}_{4}$ myronsaures Kalium Senföl Zucker saures schwefels. Kalium

Diese Fermente, wie das Emulsin, Myrosin, Invertin, Pepsin (im Magensaft), Diastase (im Malz) etc., werden als ungeformte oder unorganisirte Fermente bezeichnet; die durch sie hervorgerufenen Processe wurden fruher als Zersetzungen durch Contact oder Katalyse angesprochen und ihrer Ursachlichkeit nach sehr verschiedenartig erklärt.

Man kann sich hente dariber folgende urspriinglich zum Theil von Bunsen ausgesprochene Ansicht bilden. Die in einer Verbindung befindlichen Atome haben ihre Affinität vielleicht niemals ganz gesättigt; in Folge desen iiben sie auf jeden mit ihr in Beriihrung gebrachten Atomcomplex eine mehr oder minder grössere Anziehung aus. Diese Gegenwirkung kann entweder zu einer wirklichen Verbindung cinzelner oder aller constituirenden Theile der beiden Atomcomplexe oder zum mindesten zu einer Spamnung der Atome fülıren. Selbst im ersten Falle aber ist die eventuell entstandene Verbindung in Folge der grossen Anzahl der sie constituirenden Atome von so labilem Gleichgewicht, dass sie sich gewöhnlich entweder sofort bloss spalten, oder aber die Spaltungsproducte, da sie sich gewissermassen in Entstehmngszustand befinden, sofort mit anderen Atomen, z. B. in den angegebenen Beispielen mit den Bestandtheilen des Wassers in Verbindung treten. Einer der beiden in Action tretenden Atomcomplexe von stabilerem Gleichgewichte, in unseren Beispielen das Invertin, die schwefelsäure, das Emulsin etc., l. i. die fermentirende Atomgruppe wird keine Veränderung erleiden und kann daher wieder dieselbe Tirkung auf eine neue Menge der anderen Substanz ausiiben.

Ueber den allgemeinen Charakter der ungeformten Fermente haben uns insbcsondere die Untersuchungen ron $\mathrm{H}$ ïfner, Zulkowsky und König hoch- 
wichtige Aufschliisse ertheilt. Diesen zufolge sind die ungeformten Fermente ihrer Zusammensetzung nach wesentlich von den Protëinsubstanzen unterschieden, indem sie kohlenstoff- und stickstoffärmer sind als letztere; sie kommen fast in allen physiologisch wichtigen Thier- und Pflanzenfliissigkeiten vor, so dass sie jedenfalls als Vermittler sehr wichtiger Lebensfunctionen anzuschen sind. Viele von ihnen haben die Eigenschaft, im Wasser zwar nicht löslich, aber im lıohen Grade aufquellbar zu sein, in welchem Zustande sie z. B. von Aether in Eorm einer dickgallertartigen, an der Oberfläche schwimmenden Masse abgeschieden werden.

Die geformten Fermente spielen bei den mannigfachsten Vorgängen eine sehr wichtige Rolle; sie sind es, die den ersten Anstoss zu den Eäulniss- und Verwesungsprocessen geben; sie sind, wie unstreitig festgestellt, die Keime und Träger vieler epidemischer Pflanzen- und Thierkrankheiten. Die naturhistorische Stellung und insbesondere die physiologischen Eigenthümlichkeiten der geformten Eermente waren bis vor Kurzem sehr ungenügend gekannt, und nur diejenigen, die bei der Darstellung der geistigen Flïssigkeiten, den am längsten gekannten und geiibten Processen, auftreten, sind schon längere Zeit Gegenstand eingehender vielseitiger Studien gewesen.

Die meisten für die Technik wichtigen geformten Eermente kann man unter dem Collectivnamen Hefe (levûre, lies - lees, barm) zusammenfassen, und man spricht demnach von Alkoholhefe, Milchsäurehefe, Buttersäurehefe etc. Die wichtigste und bestgekannte ist die Alkoholhefe, welche die geistige Gährung verschiedenartiger Fliissigkeiten veranlasst. Dieselbe wurde zuerst als ein einfacher, nicht organisirter, aus den gährenden Flüssigkeiten sich abscheidender Niederschlag angesehen, 1680 aber von Anton van Leeuvenhoek zum erstenmale mikroskopisch untersucht und von ihm, aus lauter kleinen kugeligen und ellipsoidischen, verschieden an einander gereihten Körperchen bestehend, beschrieben. Desmazières reihte sie 1826 als Micoderma cerevisiae zu den Infusorien, und erst 1837 wurde ihr pflanzlicher Charakter gleichzeitig von CagniardLatour und Kitzing festgestellt; von dem Ersteren wurde sie als Cryptococcus fermenti den Algen eingereiht, vom Letzteren wurde ihre Fortpflanzungsweise durch Knospung entdeckt; als eigentliche Pilzspecies wurde sie von Schwann 1837 aufgestellt. Ihre organisirte Natur wurde aber trotzdem von den hervorragendsten Chemikern, wie Liebig und Berzelius, entsprechend den von diesen vertretenen Gährungstheorien bestritten, durch die eigenen Untersuchungen Mitscherlich's aber zweifellos erwiesen. Es haben sich sodann sehr viele hervorragende Botaniker, wie $\mathrm{B}$ ail, De Bary, Berkeley, Hallier, Hoffmann, Karsten und andere mit der Naturgeschichte der Hefe befasst, gelangten jedoch nicht zu ïbereinstimmenden Ergebnissen. Vorwiegend nahm man an, dass die Hefe eine besondere Entwicklungsform von Sporen vieler Hyphomyceten, wie Penicillium glaucum, Mucor mucedo etc. sei, bedingt durch die chemische Zusammensetzung der gährungsfähigen Flïssigkeiten als Nahıungssubstrate der letzteren, und dass unter Umständen aus der Alkoholhefe wieder diese Pilzspecies hervorgehen könnten. Erst die auf Anregung De Bary's erfolgten Untersuchungen von Reess 1869 in botanischer Richtung und noch später von Fitz in chemischer Richtung haben eine endgiltige Klärung der "Hefefrage" bewirkt, und $\mathrm{zu}$ folgender, gegenwärtig fast nicht bestrittener Anschauung gefiihrt.

Die Eigenschaft, geistige Gährung in geeigneten Flüssigkeiten hervorzurufen, kömmt selır vielen verschiedenartigen Pilzen zu. Sporen und selbst Mrcelstiicke von vielen Hyphomyceten, insbesondere der Mucorarten, können in zuckerhaltigen Flüssigkeiten eine Gährung bewirken, wobei vorzugsweise Alkohol und Kohlensäure gebildet werden. Allein die in der Gährungstechnik verwertheten Hefenpilze gehören einer anderen Pilzfamilie, Saccharonyces, zu, die gewiss in gar keinem entwicklungsgeschichtlichen Zusammenhange mit jenen Hyphomyceten steht. Diese specifischen Hefepilze Saccharomyces pflanzen sich bei Luftzutritt und in zuckerarmen Nahrungsmedien durch Ascosporenbildung (Ascuschlauch) fort, wälı- 
rend unter denselben .Umständen jene anderen ebenfalls Gährung bewirkenden Pilze Mycelien und Hyphen bilden.

In zuckerreichen Flüssigkeiten und bei beschränktem Luftzutritt aber findet die Vermehrung der Saccharomyces durch die schon lange bekannte Knospung statt, wobei sich an jeder Hefenzelle ein oder zwei Ausstiilpungen bilden, die mit fortschreitendem Wachsthum sich entweder schliesslich von der Mutterzelle lostrennen, oder aber, mit ihr in Zusammenhange bleibend, selbst neue Knospen treiben, wodurch eigenthiimlich rosenkranzförmige oder verzweigte Zellcolonien entstehen. Die Gährung der Bierwiirzen, sowie der Kartoffel-und Getreidemaischen wird durch Sacchuromyces cerevisiae Ileyen bewirkt, während bei der Gährung der versthiedenen Weinmostarten andere Saccharomycesspecies, wie S. ellipsoidens, S. apiculatus, S. pastoriamus etc. auftreten. Während man also unter Hefe alle gährungserregenden Pilze begreift, ist unter Hefepilz bloss Saccharomyces zu verstehen.

Die Mucorgährung ist iibrigens nach den Untersuchungen von Fitz wesentlich verschieden von der normalen, durch Saccharomyces bewirkten Alkoholgährung. Während Saccharomyces sehr widerstandsfähig ist gegen Alkohol, und selbst bei einem Gehalte der Fliissigkeit von $10 \%$ desselben noch lebhafte Gährung erfolgt; wird schon bei einem Alkoholgehalt von 3--4\% die Mucorgährung sehr träge und durch einen höheren Alkoholgehalt die Mucorhefe sogar getödtet. Auch soll nach Fitz bei der Mucorgährung das Verhältniss zwischen dem gebildeten Alkohol und der Kohlensäure ein anderes wie bei der Saccharomycesgährung, nämlich bei Nucor 123.1:100 gegen 96:3:100 bei letzterer sein.

Fiir die Praxis insbesondere wichtig ist das zweifache Auftreten der Alkohol-

hefe als Ober- und Uuterhefe. Bekanntlich zeigt die Hefe der alkoholischen Gährung, je nachdem diese bei niedrigen Temperaturen, $4-10^{\prime \prime} \mathrm{C}$, oder bei höheren, 12-240 C., vor sich geht, verschiedene Eigenschafteu. Im ersteren Falle scheidet sie sich zumeist am Boden der Gefässe ab (Unterhefe, Untergährung) und bestelıt aus einzelnen, unzusammenlängenden Zellen; im letzteren Falle scheidet sie sich fast vollständig an der Oberfläche der gährenden Fliissig. keit ab (Oberhefe, Obergährung), und besteht aus zusammenhängenden, gleichsam mit einander rerwahsenen Zellcolonien. In Folge dessen und da die durch Untergährung entstandenen geistigen Flissigkeiten weit weniger späteren nachtheiligen Veränderiugen ausgesetzt waren, hielt man Ober- und Unterhefe für typisch verschieden, und nalım insbesonders in Folge der Untersuchungen von Mitscherlich und Wagner an, dass die Oberhefe sich durch die bereits besprochene Knospung oder Sprossung, die Cnterhefe aber dadurch fortpflanze, dass die Mutterzellen platzen, einen körnigen Inhalt entleeren und die einzelnen Körnchen neue lose Hefezellen bilden. Die Untersuchungen ron Reess lassen nun alle diese Erscheinungen in anderer Weise richtig interpretiren. Nach ihm besteht zwischen Ober- und Lnterhefe kein typischer Lnterschied, und sind ihre Verschiedenheiten grossentheils durch die grössere oder geringere Gälıungsintensität bei den sehr verschiedenen Temperaturen und der dieser entsprechenden Kohlensäureentwicklung bedingt. Bei den niedrigen Temperaturen der langsamen Untergälırung aber sind die Existenzbedingungen für andere nicht nur Alkohol-, sondern auch Milch- und Essigsänregährung bewirkenden Pilzformen nicht gïnstig, in Folge dessen diese sich nicht entwickeln und fortuflanzen, und demnach auch späterhin diese nachtheiligen Processe nicht einleiten können. Bei den höheren Temperaturen der stiirmischen Obergährung aber entwickeln sich auch diese Pilzformen üppig und beeinträchtigen daher nicht nur das Wachsthum des echten Hefepilzes, sondern geben auch später zu den augefülırten schädlichen Gährungen Veranlassung.

Rees's bezeichnet daher die Tnterhefe als eine aus der gemischten unreinen Hefe wilder Selbstgährungen zumeist mit Hilfe nieđriger Temperaturen gezüchtete reine Raçe, und es lässt sich aus dem Angefiihrten wohl nicht schwer erklären, warum die thatsächlich gelungene Ueberfiilırung von Oberhefe in Unterhefe schwieriger erfolgt als umgekehrt.

E. Donath. 
Literatur: H i fuer Jahrb. f. pharm. Chem. 1872 5. Bd. pag. 372; 7 u I kowsky und König Sitzber. der kais. Akad. in Wien Bd. LXXI Märzheft 1875 ; Reess Zur Naturgeschichte der Bierhefe Bot. Ztg. 1869 pag. 105; Botanische Untersuchungen iiber die Alkoholgährungspilze 1870; F itz Berichte der deutsch. chem. Ges. 1873 pag. 48. S. a. Brefeld, landw. Jahrb. 1874 III Heft 1.

Fermentole nemnt man jene flüchtigen Principien, im Allgemeinen von der Natur sanerstoffhaltiger äther. Oele, welche ihre Entstehung einem durch Fermentwirkung eingeleiteten Zerfalle organischer (pflanzlicher) Substanzen verdanken. Solche Fermontole sind z. B. das Bittermandelöl, das Kirschlorberöl, das äther. Senföl, ferner die eigenthiimlichen Riechstoffe, die sich bei der Gährımg verschic. dener PHanzenblätter (Eichenblätter, Nesselblätter, Eschenblätter, Buclienblätter, Fliederblätter) oder Kräuter (Tausendguldenkraut), sowie anderer Pflanzentheile (Eichenrinde, Fichten- und Tannenrinde, Tannennadeln etc.) bilden. Gtl.

Fernambuk, Fernambuc, Fernambuk-Holz, s. Rothlolz.

Fernandine-Process nemnt Weil ein ihm patentirtes Verfahren (s. Bull. de la soc. chim. 1874, 21. Nr. 1 pag. 46) der Befestigung von Farbstoffen auf Zengen durch Ueberziehen der mit dem Farbstoffe bedruckten oder gefärbten Faser mit einer Schichte von Collodium. Gtl.

Fernrohr (télescope - telescope) heisst ein optisches Instrument, welches entfernte Gegenstände unter einem grösseren Gesichtswinkel (oder mit anderen Worten in einer geringeren scheinbaren Entfernung) und in Folge dessen deutlicher erscheinen lässt.

Die Einrichtung des Auges (insbesondere die anatomische Structur der Netzhaut) bringt es nämlich mit sich, dass eine Dimension (z. B. die Breite eines Striches oder Punktes u. dgl.) der Wahrnehmung sich entzieht, sobald der Gesichtswinkel derselben unter eine gewisse (übrigens auch von Nebenumständen abhängige und daher nicht allgemein angebbare) Grenze herabsinkt.

Eine solche die Wahrnembarkeit eines Objectes beeinträchtigende Kleinheit des Gesichtswinkels kann sich auf zweierlei Art ergeben. Es kann entweder das Object an sich so klein sein, dass es selbst bei der äussersten noch zulässigen Annäherung an das Auge noch immer nicht unter einem hinreichend grossen Gesichtswinkel dem Auge dargeooten ist, oder aber es kann die Entfernung des Objectes vom Ange so gross sein, dass der Gesichtswinkel, selbst bei beträchtlicher Grösse des Objectes, zu klein ausfällt. Im ersteren Falle dient uns das Microscop (s. den Artikel), im zweiten das Telescop*) oder Fernrohr zur erforderlichen Vergrösserung des Sehwinkels.

Im Folgenden soll zunäclıst von den dioptrischen Telescopen, nämlich von denjenigen Fernröhren die Rede sein, die nur aus Linsen (s. den Artikel) mit Ausschluss von Spiegeln zusammengesetzt sind. Die catoptrischen oder Spiegel-Telescope sollen später eine kurze Erwähnung finden.

\section{A. Dioptrische Telescope.}

Die dem betrachteten Objecte zugewendete Linse oder vielmehr Linsencombination heisst das Objectiv des Fernrohres. Dasselbe soll stets eine aplanatische Doppellinse**) (s. den Artikel) sein, deren Crownglaslinse nach aussen (gegen das Object) gekehrt ist. Die iibrigen Linsen bilden zusammen das sogenannte Ocular des Fernrohres. Abgesehen rom Galilei'schen Fernrohre

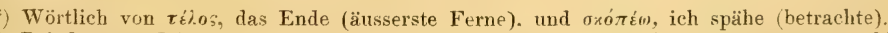

*) Bei den von Littrow berechneten und von Plössl ausgeführten sogenannten diaIytischen Fernöhren ist das Objectiv eine Sammellinse aus Crownglas, welche dureh eine von derselben durch einen grösseren Zwischenraum getrennte und desshalb entsprechend kleinere (also auch leichter vollkommen herzustellende) Zerstreuungslinse aus Flintglas (oder vielmehr durch eine zusammengesetzte Zerstreuunglinse) achromatisirt wird. Dialytisch komint von $\delta \iota \alpha$, auseinander, und $\lambda \imath^{i}($. ich löse. 
(z. B. Feldstecher, Theaterperspectiv), dessen Ocular eine einfache Zerstreuungslinse ist, sind die gangbarsten Fernrohr-Oculare Combinationen aus zwei oder vier Sammellinsen, je nachdem das Fernrohr ein sogenanntes astronomisches oder terrestrisches (Erdfernrohr)*) ist. Das astronomische Fernrohr zeigt die Gegenstände verkehrt, das terrestrische, sowie das Galilei'sche aufrecht.

I. Das astronomische Fernrohr. In der

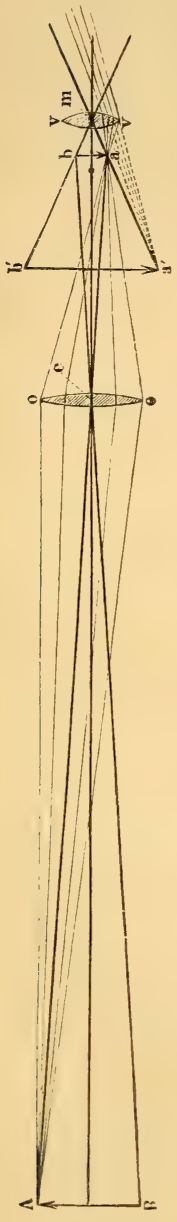
ursprünglichen einfachsten Form besteht das astronomische (oder Keppler'sche) Fernrohr aus zwei Sammellinsen, deren eine (Fig. 1596) oo als Objectiv, die andere mit $v v$ bezeichnet, als Ocular dient.

Das Objectiv einer Linse von verhältnissmässig grosser Brennweite hat die Aufgabe, von einem entfernten Gegenstande $A B$ ein Bild $b a$ zu erzengen, indem jeder Punkt des Gegenstandes, z. B. A durch die von demselben ausgehenden und auf das Objectiv fallenden Strahlen in einem entsprechenden Vereinigungspunkte $a$ jenseits der Linse abgebildet wird. (S. den Artikel Linse.)

Wir erhalten auf diese Art ein verkehrtes und verkleinertes, aber in unsere unmittelbare Nähe gerücktes Bild des Gegenstandes. Würden wir dieses Bild (falls es hinreichend lichtstark wäre) wie das Bild einer photographischen camera obscura auf einem transparenten Schirm auffangen und in der deutlichen Sehweite mit freiem Auge betrachten, so hätten wir mit dem 0 bjective allein schon eine Vergrösserung des Gesichtswinkels erzielt, weil die Verhältnisszahl der bewirkten Annäherung ב- an das Auge grösser ist als die Verhältnisszahl der gleichzeitig bewirkten Verkleinerung, sobald, was wir vorausor setzen wollen, die Brennweite $f_{0}$ des Objectives grösser ist als die Sehweite $s$ des Auges. Ist nämlich der $\mathrm{Ab}$ stand $a_{0}$ des Gegenstandes von der Linse im Vergleiche mit $f_{0}$ sehr gross, so wird das Bild nahezu in der Brennweite und sonach $\frac{a_{0}}{f_{0}}$ mal verkleinert erscheinen. Dafür ist es aber dem Auge $\frac{E}{s}$ mal näher gerückt als der Gegenstand, wenn $E$ die Entfernung des Gegenstandes vom Auge bedeutet.

Die Vergrösserung des Gesichtswinkels wird also überwiegen, sobald $\frac{E}{s}>\frac{a_{0}}{f_{0}}$, und zwar nach Massgabe des Quotienten $\frac{E}{s}: \frac{a_{0}}{f_{0}}=\frac{E}{a_{0}} \cdot \frac{f_{0}}{s}$, wofür man, insofern $a_{0}$ nicht viel kleiner als $E$ ist, auch $\frac{f_{0}}{s}$ setzen kann.

Diese Zahl

$$
V=\frac{f_{0}}{s} \text {. }
$$

nennt man die Objectivvergrösserung.

Im Fermrohre wird aber das Objectivbild $b a$ nicht mit freiem Auge in der Selıweite, sondern mit dem als Lupe dienenden Ocularglase von kurzer Brenn-

*) Die aus drei Linsen bestehenden Oculare sind in diesem Artikel, um denselben nicht zu sehr auszudehnen, nicht berücksichtigt. 
weite $f_{1}$ betrachtet, wodurch $\left.{ }^{*}\right)$ abermals eine $\left(\frac{s}{f_{1}}+1\right)$ malige, also annähernd $\frac{s}{f_{1}}$ malige Vergrösserıng erzielt wird, welche Zahl

$$
V^{\prime \prime}=\frac{s}{f_{1}^{\prime}} \cdot
$$

die 0 cularergrösserung heisst. Sie gibt, mit der Objectirvergrösserung multiplicirt, die Ges a m m trergrösserung

des Fernrohres.

$$
V=\frac{f_{0}}{f_{1}}
$$

Die Wirkung der Ocularllinse besteht darin, dass die nach der Kreuzung in einem Punkte (z. B. a) des Objectivbildes wieder auseindergehenden und auf das Ocular fallenden Strahlen so gebrochen werden, als wenn sie von einem entfernteren und auch weiter von der Achse abliegenden Punkte (z. B. $a^{\prime}$ ) herkämen. Die aus dem Oculare anstretenden Strahlen wirken also in ihrer Gesammtheit so auf das Ange, in dessen Pupille sie eindringen, als befände sich jenseits des Objectivbildes $b a$ ein demselben Hauptstrahlenwinkel (bma $\left.=b^{\prime} m a^{\prime}\right)$ entsprechendes, ebenfalls umgekehrtes Bild $b^{\prime} \alpha^{\prime}$. Dieses scheinbare (,imaginäre" oder "virtuelle") Bild muss in der deutlichen Sehweite $s$ erscheinen, wenn das Fernrohr deutlich zeigen soll. Da $s$ bei jedem nicht allzu kurzsichtigen Auge im Vergleiche mit $f_{1}$ sehr gross sein wird, so wird die Ocularlinse meist so zı stellen sein, dass der Abstand $a_{1}$ des Objectivbildes**) vom Ocular nicht viel kleiner als die Brennweite $f_{1}$ desselben ist, indem die nach einem Punkte des in der Regel 2-3 Decimeter weit entfernten imaginären Bildes gerichteten a ustretenden Strahlen nie stark divergiren können, und sonach annähernd parallel sein mïssen. Jedenfalls aber wird für verschiedene Sehweiten auch eine verschiedene Einstellung des Oculars nöthig sein; grössere $s$ erfordern grössere $a_{1}$ und umgekehrt, wesshalb das Ocular für den Weitsichtigen weiter ausgezogen werden muss als für den Kurzsichtigen.

Der Winkel, unter welchem das virtuelle Bild $b^{\prime} a^{\prime}$ dem Auge erscheint, heisst der künstliche Gesichtswinkel des betrachteten Gegenstandes $A B$. Er ist etwas kleiner als der Hauptstrahlenwinkel $b^{\prime} m a^{\prime}=\psi^{\prime}$, aber von diesem so wenig verschieden, dass man beide Winkel als nahezu gleich anzunehmen pflegt. Der natürliche Gesichtswinkel des betrachteten Gegenstandes $A B$ ist derjenige, unter welchem dieser nach Beseitigung des Fernrohres dem freien Auge erscheint. Dieser Winkel ist etwas kleiner als der Hauptstrahlenwinkel $A c B=\psi$, unter welchem der Gegenstand vom Objective aus gesehen erscheinen würde; da jedoch die Länge des Fernrohres im Vergleiche mit dem Abstande des Gegenstandes von dem (hinter dem Ocular gedachten) Auge kaum in Betracht kommt, so kann $\psi$ annähernd fiur den natiirlichen Gesichtswinkel gelten. Der Quotient des künstlichen durch den natiirlichen Gesichtswinkel

$$
V=\frac{\psi^{\prime}}{\psi} \text {. }
$$

ist die Vergrösserung des Fernrohres, die nach Formel 3.) auch durch den Quotienten der Brennweiten von Objectiv und Ocular ausgedriickt werden kann.

Es ist einleuchtend, dass kein grösserer Gegenstand oder, besser gesagt, keine grössere Dimension im Fernrohre erscheinen kann, als eine solche, für welche $\psi=v c v$ wäre, da sonst die im Objective sich kreuzenden Hauptstrahlen das Ocular nicht mehr treffen wïrden. Dieses grösste $\psi$, welches mit $\bar{\psi}$ bezeichnet werden mag, bestimmt also die Grösse des Sehfeldes, und wird desshalb

\footnotetext{
*) Siehe Linse, Lupe.
**) Nach den im Artikel Linse angeführten Formeln ist $a_{1}=\frac{s f_{1}}{f_{1}+s}=\frac{f_{1}}{\frac{f_{1}}{s}+1}$, also desto weniger von $f_{1}$ verschieden, je grösser $s$ im Vergleiche mit $f_{1}$ ist.
} 
geradezu das Gesichtsfeld genannt. Der dem $\bar{\psi}$ entsprechende scheinbare Gesichtswinkel $\bar{\psi}^{\prime}$ heisst das seheinbare Gesichtsfeld, und es gilt demnach vermöge 4.) die Relation

$$
\bar{\psi}^{\prime}=V \bar{\psi} .
$$

anf die wir später zurückkommen werden.

Hieraus ist ersichtlich, das das Gesichtsfeld eines Fernrohres nie grösser sein kann als der Winkel, unter welchem die Oeftnung (d. i. der Durchmesser) der dem Objective gegeniiberstehenden Linse vom Objective aus erscheint.

Ein astronomisches Fernrohr, dessen Ocular, wie wir bisher angenommen, aus einer einzigen Sammellinse bestände, wïrde sehr unvollkommen sein. Man gewinnt bei gleicher Vergrösserung an Gesichtsfeld und Schärfe der Bilder, wenn man anstatt einer einfachen Linse das von $\mathrm{Huyghens}$ herriihrende, häufig nach Campani benannte Ocular anwendet, dessen Einrichtung und Wirkungsweise in Fig. 1597 dargestellt ist.*)

Bedentet $f_{1}$ die Brennweite der grösseren und $f_{2}$ Fig. 1597.

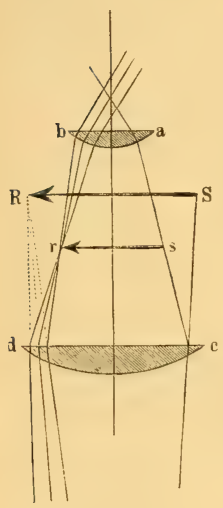
die der kleineren von den beiden (mit den Wölbungen nach dem Objectiv gekehrten) Planconvexlinsen, so ist $f_{1}=3 f_{2}$ und die Entfernung beider Linsen von einander $d=2 f_{a}$. Die grössere der beiden Linsen wird die Collectivlinse, die kleinere die Augenlinse oder 0 cularlinse genannt.

$R S$ stellt das Bild vor, welches rom Objectiv erzengt werden wiirde, wenn das Collectiv $d c$ nicht vorhanden wäre. Durch dieses Glas werden alle vom Objectiv kommenden Strahlenkegel gegen die Achse des Fernrohres gebrochen und zugleich stärker convergent gemacht, so dass z. B. die Spitze des am Rande bei $d$ auffallenden Strahlenkegels nicht nach $R$, sondern nach $r$ zu liegen kommt.

Auf diese Art entsteht anstatt des Bildes $R S$ ein kleineres und dem Collective näheres $r s$, und zwar, bei richtiger Einstellnng, nahezu in der Mitte zwischen beiden Linsen, aber jedenfalls innerhalb der Brennweite $f_{0}$ der Augenlinse. Diese empfängt die nach der Kreuzuug in $r s$ wieder divergirenden Strahlen und bricht sie dergestalt, dass z. B. der am Rande bei $b$ anftallende Strahlenkegel in ein gegen die Achse zu gebrochenes Bündel ron schwach divergirenden (nahezu parallelen) Strahlen tibergeht, die ron einem in der Zeichnung nicht dargestellten, in der deutlichen Sehweite erscheinenden imaginären Bilde (wie $b^{\prime} a^{\prime}$ in Fig. 1569) heraukommen scheinen.

$$
\mathrm{Da} \text {, wie sich zeigen lässt, } r s=\frac{2}{3} R S \text {, so ist die Vergrösserung eines }
$$

mit dem $\mathrm{Huyghens}$ 'schen Oculare rersehenen astronomischen Fernrohres ausgedriickt durch die Formel**)

$$
T=\frac{2}{3} \frac{f_{0}}{f_{2}}
$$

Die Fassung des Hughens'schen Oculars ist in Fig. 1589 dargestellt. Nahezu in der Mitte zwischen beiden Gläsern ist eine sogenannte Blendung, deren Weite zum Abstande beider Linsen in einem bestimmten V'erhältnisse steht. Da anderseits dieses Verhältniss, wie leicht einzusehen ist, fuir die Grösse des

*) Die Fassung der Gläser sammt Blendung zeigt Fig. 1589.

**) Die Vergrösserung des Huyghensischen Ocnlars ist nämlich $\frac{2}{3} \frac{s}{f_{2}}$; vergleiche die Formeln 2.) und 3.) 
seheinbaren Gesichtsfeldes $\bar{\psi}^{\prime}$ massgebend ist, so ergibt sich vermige 5.) fiir ein Fernrohr mit II $1 \mathrm{y} g \mathrm{~g}$ hens'schem Ocnlare die: Relation

$$
\Gamma^{*} \bar{\psi}=\text { const }{ }^{*} \text { ). . . . . . . . . . . . . }
$$

d. h. Gesichtsfeld und Vergriassernug sind einander rerkehrt proportional.

Grösseren Telescopen pflegt man eine Auswalll von mehreren Ocularen derselben Art (wie z. B. Fig. 1598) aber von verschiedenen Vergrösserungen beizugeben. Wendet man diese der Reihe nach an und betrachtet mit dem Telescope z. B. die Vollmondscheibe, so wird man einen desto kleineren Theil derselben im Sehfelde erblicken, zu je stärkeren Vergrösserungen man iibergeht, da das Gesichtsfeld nach Massgabe der Formel 7.) abnimmt. Berüicksichtigt man, dass der scheinbare Durchmesser (Gesichtswinkel) des Mondes beiläufig einen halben Grad beträgt, so kann man das Gesichtsfeld eines auf den Mond eingestellten Fernrohres leicht dem Augenmasse nach abschätzen. Wir werden später darauf zuriickkommen.

Hinsichtlich des Huyghens'schen Oculars**) ist noch zu bemerken, dass das Eadenkreuz (s. den Artikel Messinstrumente), wenn ein solches erforderlich ist, in der vorhin erwähnten Blendung (nämlich am Orte des durch die Augenlinse betrachteteu Bildes) angebracht wird.

Wird das Huyghens'sche Ocular gewechselt, so wird mit demselben auch das Fadenkreuz gewechselt, was manche Unannehmlichkeit mit sich bringt. Dieser Uebelstand entfällt bei Anwendung des Ramsden'schen Oculars. Dasselbe ist im Wesentlichen eine aus zwei getrennten (mit ihren Wölbungen gegen einander gekehrten) gleichen planconvexen Linsen zusammengesetzte Lupe, durch welche man das vom Objective erzeugte Bild (an dessen Ort sich das Fadenkreuz befindet) direct betrachtet***).

Die äussere Einrichtung des astronomischen Fernrohres ist in Fig. 1599 anschaulich gemacht.

Im sogenannten Objectivkopfe $k$ ist das achromatische Objectiv mit seiner (im Artikel Linse näher besprochenen) Fassung eingeschraubt. An die Röhre (Tubus), die einerseits mit dem soeben erwähnten Objectivkopfe endigt, ist anderseits eine engere Röhre $s$ angeschraubt, in welcher wieder eine andere Rölre $t$ mittelst des Triebes $r^{2}$ ein- und ausgeschoben werden kann. An diese letztere Röhre $t$ wird das Ocular $o$ angeschraubt, dessen Einstellung also mittelst des Triebes $r$ bewerkstelligt wird.

*) Für ein solches Fernrohr ist, wenn die $\psi$ in Graden ausgedrückt werden, ungefähr const $=28$, woraus dann auch das Gesichtsfeld $\bar{\psi}$, sobald die Vergrösserung, $\boldsymbol{V}$ bekannt ist, leicht in Graden berechnet werden kann.

**) Das Huyghens'sche Ocular wird auch häufig ,achromatisches" Ocular genannt. In der That wird, wie im Artikel Linse gezeigt werden soll, in dieser Linsencombination die Farbenzerstreuung fast vollständig anfgehoben. Im Gegen-

Fig. 15.98.

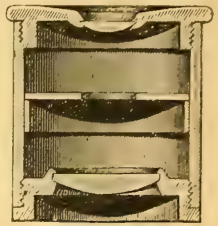

Fig. 1599.

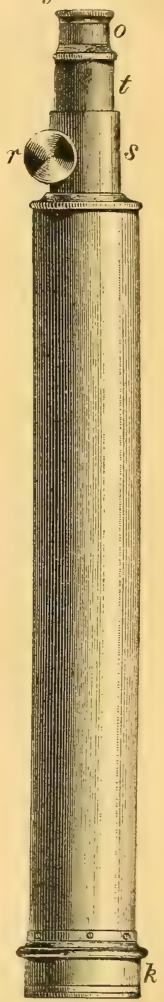
satze zu dem Ramsden'schen Ocular, welches später erwïhnt werien soll und positives" Ocular genannt wird, nennt man das Hnyghen s'sche auch oft das "negative". Diese Bezeichnung bezieht sich auf den Umstand, dass das Objectivbild bei jenem $v$ or, bei diesem hingegen (virtuell) hinter das Collectiv fällt.

**:) Plössl hat die beiden einfachen Planconvexlinsen des $\mathrm{R}$ a msden'schen Oeulars dureh achromatische Linsen ersetzt und so sein sogenanntes aplanatisches Ocular hergestellt. 
II. Das terrestrische Fernrohr. Das astronomische Fernrohr, sowohl mit einfachem als auch mit dem $\mathrm{Huyghens}$ 'schen oder $\mathrm{R}$ amsden'schen Oculare, zeigt umgekehrt. Bei der Betrachtung irdischer Objecte wäre dies sehr

Fig. 1600 .

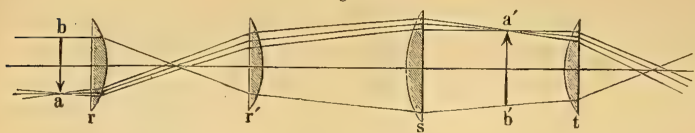

störend und muss daher durch ein Ocular vermieden werden, welches aufrechte Bilder gibt. Die Figur 1600 zeigt eine von den vielen Linsencomdem Objective zugekehrt, also die Linse $t$ dem Auge. Das rom Objective erzengte Bild $b a$ fällt innerhalb die Brennweite der Linse $r$ und wird durch die Wirkung der drei ersten Linsen, zu Folge der in der

\section{Fig. 1601.}

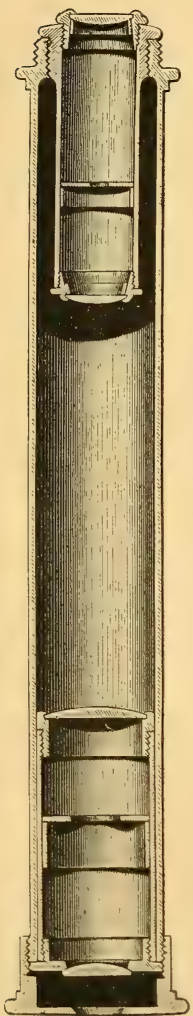

Zeichnung dargestellten Brechung der Strahlenkegel, umgekehrt, so dass ein aufrechtes Bild $a^{\prime} b^{\prime}$ entsteht. Dieses wird durch die letzte Linse $t$ als Lupe in derselben Weise betrachtet, wie es von dem Bilde $b a$ in Fig. 1596 gegeniiber der Augenlinse $v v$ erörtert worden ist. Man muss sich nämlich vorstellen, dass die aus der Linse $t$ anstretenden, etwas divergirenden Strahlen auf das (an der Kreuzungsstelle mit der Fernrohrachse befindliche) Ange so einwirken, als kämen sie von einem in der Sehweite befindlichen (imaginären) Bilde (wie $b^{\prime} a^{t}$ in Fig. 1596) her. Dieses scheinbare Bild ist natiirlich ebenfalls ein aufrechtes.

Ein mit einem solchen ("terrestrischen") Oculare ver sehenes Fernrohr wird ein terrestrisches oder Erdfernrohr genannt.

Die vollständige Eimrichtung des terrestrischen Oculars sammt Fassung ist aus Fig. 1601 ohne weitere Beschreibung ersichtlich. - Das Fadenkreuz, wenn ein solches erfordert wird, ist in der weiteren Blendung (ein wenig innerhalb der Brennweite der Augenlinse) anzubringen.

Bezeichnet man die Brennweite des achromatischen Objectives auch hier mit $f_{0}$ und der Ocularlinsen der Reihe nach mit $f_{1}, f_{2}, f_{3}$ und $f_{4}$, so gilt für die Vergrösserung die Formel

$$
V=m \frac{f_{0}}{f_{4}}
$$

wobei $m$ ein von der Einrichtung des Oculars abhängiger Coëfficient (bei den Fraunh of e r'schen Ocularen beträchtlich grösser als 1.) ist.**)

*) Bei einem von Fraunhofer construirten derurtigen Oculare, welches rom Verfasser untersucht wurde, waren die Brennweiten $f_{1}$ und $f_{1}$ der beiden äussersten Linsen unter sich amähernd gleich. also $f_{1}=f_{4}=f$. Ebenso die Brennweiten $t_{2}$ und $f_{3}^{\prime}$ der beiden mittleren Linsen, jedoch griisser als $f$, nämlich $f_{2}=f_{3}=F=\frac{3}{2} f$. Die Linse 2

hat die kleinste. 3 die grösste Oeffnung. Zwischen 1 und 2. sowie zwischen 3 und 4 befinden sich Blendungen. je im Abstande ron nahezu $f$ ron den äussersten Linsen. Die Alsstände 1,$2 ; 2,3$; und 3,4 waren beziehungsweise $f+\frac{F}{2} ; 2 F$ und $f+\frac{f}{2}$

**) Vergleiche Formel 6.). 
Das Gesichtsfeld wirl anch hier durch den Winkel bestimint, unter welchem die Oeffumg der Linse 1 (d. i. $r$ in Fig. 1600) rom Objective ans rrscheint.

Wenn die beiden Hiilsen, welche in dem Figur 1601 dargestellten terrestrischen Oculare je zwei Linsen enthalten, gegeneinander verschiebbar sind, so liegt darin ein Mittel, den Werth Fig. 1602. der Constanten $m$ in Formel 8.), also die Vergrösserung zu verändern. Ein solches, eine innerhalb gewisser Grenzen beliebig veränderliche Vergrösserung gewährendes Ocular wird ein pancratisches genamnt.

Wird das terrestrische Fernrohr als Standfernrohr (anf Stativ) gebraucht, so gibt man ihm die beim astronomischen Fernrohre beschriebene Form (Fig. 1599). Soll es bequem transportabel sein (z.B. als Touristen-Fernrohr), so wird es als sogenanntes Auszugsfernrohr oder Zug fernrohr (Fig. 1602) construirt.*)

Eine sogenannte Bamsehraube dient zur Befestigung des Fernrohres.

Die Auszüge eines Fermrohres bilden nach dem Herausziehen nie ein gerades Rohr und beeinträchtigen daher die für die Schärfe der Bilder so nothwendige "Centrirung ". Aus diesem Grunde werden nur kleinere Perspective als Zugfernrohre construirt.

III. Das holländische oder Galilei'sche Eernrohr. Ein aufrecht zeigendes Fernohr kann man auch herstellen, wenn man eine Zerstreuungslinse auf sogleich näher zu bezeichnende Art als Ocular anwendet. Lässt man nämlich die aus dem Objective austretenden Strahlen, bevor sie sich zu einem Bilde ba (Fig. 1603) vereinigen, so auf eine Zerstreungslinse fallen, dass der Ort des nicht zu Stande kommenden Bildes ausserhalb der (imaginären) Brennweite der Zerstreungslinse zu liegen kommt, so wird ein z. B. dem Punkte $A$ des betrachteten Gegenstandes entsprechender Strahlenkegel oao (der in $a$ das Bild von $A$ erzengen würde) dergestalt gebrochen und von der Achse des Fernrohres abgelenkt, dass die aus dem Ocular austretenden Strahlen nicht mehr nach dem Punkte $a$ des Hauptstrahles ma, sondern nach einem jenseits der Linse liegenden Punkte $a^{\prime}$ desselben Hauptstrahles convergiren, das heisst: die Strahlen treten (gleichwohl nur in geringem Grade) divergent aus der Linse und bewirken in dem dicht hinter dieser Linse angebrachten Auge den Eindruck, als kämen sie von einem aufrechten Bilde $a^{\prime} b^{\prime}$ jenseits der Linse her. Die scheinbare Entfernung desselben ist, bei angemessener Einstellung des Oculars, die deutliche Sehweite.

Setzt man auch hier fiir den natiirlichen Gesichtswinkel $\psi$ den Winkel $A c B=b c a$ und für den künstlichen Gesichtswinkel $\psi^{\prime}$ den Winkel $a^{\prime} m b^{\prime}=b m a$, so erhält man, da die Abstände des (nicht zu Stande kommenden) Bildes ba von Objectir

*) In Fig. 1593 sind die Linsen nur angedeutet, aber nicht genau gezeichnet.

Karmarsch \& Heeren, Technisches Wörterbuch. Bd, III. 
und Ocular nur sehr wenig die Brennweiten $f_{0}$ und $f_{1}$ dieser Linsen übertreffen, und insofern die Winkel $\psi$ und $\psi^{\prime}$ als sehr klein angenommen werden, $\frac{\operatorname{tg} \psi^{\prime}}{\operatorname{tg} \psi}=\frac{b a}{f_{1}}: \frac{b a}{f_{0}}=\frac{f_{0}}{f_{1}}$. Setzt man ferner annähernd $\frac{\operatorname{tg} \psi^{\prime}}{\operatorname{tg} \psi} \doteq \frac{\psi^{\prime}}{\psi}=V$, so erhält man für die Vergrösserung des holländischen oder Galilei'schen Fernrohres eine Formel von derselben Gestalt wie Formel 3.) fur das einfache astronomische Fernrohr, nämlich

$$
V=\frac{f_{0}}{f_{1}}
$$

Je schärfere Zerstreuungslinsen als Oculare angewendet werden, desto kleiner wird $f_{1}$, desto näher wird also auch das Ocular gegen $b a$ (welches nahezu in der Objectirbrennweite liegt) herausgezogen; die Distanz $\mathrm{cm}$ zwischen Objectiv und Orular (Länge des Fernrohres), welche im Allgemeinen $f_{0}-f_{1}$ ist, nimmt also zu.*)

Die Abweichung der aus dem Ocular austretenden divergenten Strahlenkegel von der Achse bringt es mit sich, dass, selbst wenn die Pupille des Auges dicht an der Linse sich befindet, nicht mehr Licht in das Auge dringen kann, als sinem der Pupille gleichen Theile der Ocularöffnung entspricht, während, wenn die Augenlinse eine Sammellinse ist, das im sogenannten A ugenorte (nämlich an der Kreuzungsstelle der austretenden Strahlenkegel mit der Achse) befindliche Ange auch Strahlen aufnehmen kann, welche in der Nähe des Randes der Augenlinse aus derselben austreten, also einem viel grösseren Theile der Oeffnung dieser Linse entsprechen.

Aus dem Gesagten ist zugleich ersichtlich, dass das Gesichtsfeld eines holländischen Fernrohres immer ein sehr beschränktes sein muss und ungefähr durch den Winkel bestimmt ist, unter welchem der Durchmesser der Pupille aus der Entfernung $f_{0}-f_{1}$ erscheinen würde.

Bewegt man das Auge am Oculare hin und her, so können immer andere Strahlenkegel ron der Pupille aufgenommen werden. Um dies zu erzielen, ist jedoch ein entsprechend grosses Ocular erforderlich, und hängt das Gesichtsfeld auch von der Oeffnung des Objectives ab.

Da im holländischen Fermrohre kein reelles Bild zu Stande kommt, so kann in demselben selbstverständlich auch kein Fadenkreuz (welches ja immer im Orte eines reellen Bildes sich befinden muss) angebracht werden. Es eignet sich daher nicht für Visir-Instrumente.

Wegen des beschränkten Gesichtsfeldes verträgt das Galilei'sche Fernrohr auch keine starken Vergrösserungen.

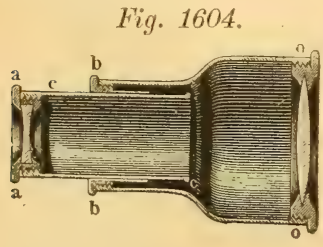

Die gewöhnlichste Form dieses Fernurohres ist das Theaterperspectiv (Fig.1604)**), welches gewöhnlich als Doppelperspectiv (Operngucker) in Verwendung ist und in der Regel nur eine 2- bis 3malige Vergrösserung besitzt. Uebrigens hat man auch Operngucker mit sogenannten Revolver-Oeularen construirt, bei welchen mittelst einer einfachen Drehvorrichtung drei verschiedene Oculare nach Belieben gewechselt werden können. Eines dieser Oculare gibt die gewöhnliche (etwa 2malige) Theater-Vergrösserung, die beiden anderen jedoch stärkere Vergrösserungen, z. B. 3- und 4malige.

Eine andere Form des Galileischen Fermohres ist der sogenannte

*) Beim einfachen astronomischen Fernrohre ist diese Distanz annähernd $f_{0}+f_{2}$.

**) Die Zeichnung ist insofern nicht ganz genau. als das Objectiv oo in Wirklichkeit keine einfache, sondern eine achromatische Sammellinse ist. 
Feldstecher. Er hat die Gestalt eines kurzen Auszugsfernrolires mit 1 bis 3 Auszuigen.

Beim Feldstecher können die Vergrösserungen mittelst einer Drehscheiłse gewechselt werden, welche etwa 4 Oculare zur Auswahl darbietet, deren Vergrösserungen je nach den Dimensionen des Feldstechers abgestuft sind, im Allgemeinen aber zwischen den Grenzen 4 und 30 liegen.

Die Baumschraube ist am Feldstecher häufig ein für allemal in compendiöser Weise befestigt.

Soll der Feldstecher (z. B. bei der Anwendung fuir militärische Zwerke) in freier Hand gehalten werden, so gibt man den Ocularlinsen (wie auch beim 'Theaterperspective) eine grössere Oeffnung, um das Aufsuchen der in's Auge zu fassenden Objecte zu erleichtern, was wegen der Kleinheit des Gesichtsfeldes bei kleinen Ocularlinsen sehr schwierig wäre.

Eine weitere Anwendung findet das Princip des holländischen Fernrohres bei der Brï cke'schen Lupe. Sie besteht aus einem achromatischen Doppelobjective und einer Zerstreungslinse, gibt (etwa $9^{\mathrm{rm}}$ lang) eine nahezu 7 malige Vergrösserung, und gestattet die Betrachtung von Objecten, die ungefähr $8^{\mathrm{rm}}$ weit vom Objective entfernt sind.

Der Gedanke, zwei Fernröhren zu einem binoculären Telescop oder Doppelperspectiv (binocle) zu verbinden, den wir an den bereits erwähnten Opernguckern realisirt sehen, ist in neuerer Zeit anch auf grössere Perspective (Erdfermrohre) angewendet worden.

IV. Allgemeine Bemerkungen über die Benrtheilung und Priifung der Leistungen eines Fernrohres.

Bei der Leistung eines Fernrohres kommen, abgesehen von der Vollkommenheit des Bildes, drei Momente in Betracht: die Vergrösserung, das Gesichtsfeld und die Helligkeit.

Von der Vergrösserung und dem Gesichtsfelde ist insofern bereits die Rede gewesen, als wir bei Besprechung der verschiedenartigen Fernröhren die constructiven Verhältnisse argegeben haben, von welchen jene Grössen abhängen.

Zur Erlänterung des Begriffes der Helligkeit diene folgende Erwägung.

Betrachten wir beispielsweise den Mond, das eine Mal mit freiem Ange, dessen Pupillenöffnung $=\omega$ sein mag, und das andere Mal mit einem Fernrohre von der Objectivöffnung $=0$.

Wir wollen annehmen, das Fernrohr sei ein astronomisches oder terrestrisches, und es kämen bei richtiger Stellung des Auges (an der Kreuzungsstelle der aus dem Ocular austretenden Strahlen mit der Achse) alle vom Monde dem Objective zugesendeten Strahlen in die Pupille. Dann verhalten sich die vom Auge aufgenommenen Lichtmengen in beiden Fällen wie $\omega^{2}$ zı $O^{2}$, d. h. das Ange empfängt bei der Betrachtung dureh das Fernrohr $\frac{O^{2}}{\omega^{2}}$ mal mehr Licht als bei der Betrachtung mit freiem Auge. Wäre das Netzhautbild des Mondes in beiden Fällen gleich gross, so wiirde die auf die Flächeneinheit desselben (des Netzhautbildes) entfallende Lichtmenge, die man eben $\mathrm{Helligkeit}$ nennt, bei Anwendung des Fernrohres eben auch $\frac{O^{2}}{\omega^{2}}$ mal grösser sein. Das Netzhautbild ist aber der Fläche nach in diesem Falle, wenn die (lineare) Vergrösserung des Fernrohres $=T^{r}$ ist, $V^{2}$ mal grösser als bei Anwendung des freien Auges, folglich entspricht der Hclligkeit bei der Betrachtung durch das Fernrohr nur der Werth

$$
H=\frac{O^{2}}{\omega^{2} V^{2}} \text {. }
$$

wenn die Helligkeit bei der Betrachtung mit freiem Auge $=1$ gesetzt wird.

Es lässt sich zeigen, dass

$$
V=\frac{O}{0}
$$


wobei o den Durchmesser des kleinsten Querschnittes des aus dem Ocular austretenden Lichtbïndels vorstellt. Man erhält sodann

$$
H=\frac{o^{2}}{\omega^{2}} \text {. }
$$

Wenn also die Pupillenöffnung (des freien Auges) jenem kleinsten Querschnittsdurchmesser gleichkommt, ist $H=1$, d. h. das Fernrohr gewährt, abgesehen von den Lichtverlusten beim Durchgange durch die Gläser, dieselbe Helligkeit, wie bei der Betrachtung mit freiem Auge. Man nennt diese die $n$ atii $r$ liche Helligkeit.

Diese Helligkeit findet auch statt, wenn $\omega<0$; denn wird z. B. o mmal grösser als vorhin (da es $=\omega$ war), so wird dadurch vermöge 11.) die Vergrösserung des Fernrohres und somit auch die Fläche des bei Anwendung des Fernrohres entstehenden Netzhautbildes $m^{2}$ mal kleiner, anderseits aber auch ron der Pupille nur der Bruchtheil $\frac{1}{m^{2}}$ des aus dem Oculare austretenden Lichtes aufgenommen, wesshalb die Helligkeit unverändert bleibt.*)

$H$ ist also gleich 1 , so lange $\omega \sum 0$; wird dagegen $\omega>0$, so fällt die Helligkeit im quadratischen Verhältnisse von $\frac{0}{\omega}$ geringer aus. ${ }^{*}$ )

Bei Fixsternen, die selbst im stärksten Refractor***) nur als scharfe Lichtpunkte ohne merkliche Ausdehnung erscheinen, entfällt der durch die Formel 10) ausgedruickte Einfluss der Vergrösserung (die hier eben nicht zur Geltung kommt) auf die Helligkeit und wächst diese demnach im Verhältnisse $\frac{O^{2}}{\omega^{2}}$.

Bezeichnet man die Helligkeit, mit der ein Fixstern dem freien Auge erscheint, mit 1, so wiirde dieselbe, wenn der Fixstern $\sqrt{h}$ mal weiter entfernt wäre, nach bekannten Gesetzen der Lichtfortpflanzıng $\frac{1}{h}$ betragen. Durch Anwendung eines Fernrohres von der Objectivöffnung $O=\omega \sqrt{h}$ empfängt das Ange $\frac{O^{2}}{\omega^{2}}$ mal $=h$ mal mehr Licht, und wiirde demnach der Eixstern in der $\sqrt{h}$ mal grösseren Entfermung ebenso hell erscheinen, wie dem freien Auge in der urspringlichen Entfernung. Desshalb nennt man nach $\mathrm{Herschel}$ die Grösse $\sqrt{h}=\frac{O}{\omega}$ die raumdurchdringende Kraft eines Telescopes.

Die zulässige Vergrösserung $T$, beziehungsweise die erforderliche Helligkeit $H$ hängt ron der Lichtstärke der zu betrachtenden Objecte ab. Beim terrestrischen Fernrohre pflegt man darauf anzutragen, dass $H$ nicht unter $\frac{3}{4}$ herabgeht. Mit derselben Helligkeit, $\left(\frac{3}{4}\right)$, begniigt man sich auch bei dem sogenannten Marine-E ernrohre zu Gunsten einer entsprechend stärkeren Vergrösserung. Bei astronomischen Telescopen pflegt man die Tergrösserungen, insofern es Lichtstärke und Gesichtsfeld gestatten, oft riel weiter zu treiben, $\dagger$ ) worauf wir später noch zurückkommen.

*) Die Formel 12.), nach weleher für $\omega<0, H>1$ werden müsste, gilt eben vermöge ihrer Ableitung nur so lange, als alles aus dem Ocnlar tretende Licht von der Pupille aufgenommen wird.

w*) Selbstverständlich immer unter der stillschweig'end zu Grunde gelegten Annahme, dass die Pupillenöffnung beim Durchsehen durch das Fernrohr dieselbe Grösse hätte wie bei der Betrachtung mit freiem Auge.

***) Man bezeichnet mit dem Ausdrucke Refractor ein dioptrisches oder Linsen-Teleseop. während man ein catoptrisches oder Spiegel-Telescop einen Reflector nennt.

$\dagger$ Hierbei kommt der Cmstand zu Gute. dass die meisten Himmelskörper eigenes Licht baben. 
Die schwächste Vergrösserung wählt man stets so, das $H=1$ ausfällt. Im Allgemeinen dient die Formel

$$
V=\frac{O}{\omega \sqrt{H}} \text {. }
$$

zur Berechnung der zulässigen Vergrösserung, sobald man über die einzuhaltende Helligkeitsgrenze im Reinen ist, und einen bestimmten Werth für $\omega$ angenommen hat. Nach Prechtl kann man $\omega=0.06$ W.-Zoll nehmen. Hieraus folgt, wenn $O$ und $\omega$ in Centimetern $(\omega=0.158)$ angegeben werden, annähernd

$$
V=100 \frac{O}{16 \sqrt{H}}
$$

Es entspräche demnach z. B. einem Eernrohre von $4^{\mathrm{cm}}$ (Objectiv-) Oeffnung, falls die natürliche Helligkeit $(H=1)$ nicht beeinträchtigt werden soll, eine 25malige Vergrösserung.

Ebenso leicht kann man die zur Erzielung einer gewissen Vergrösserung bei gegebener Helligkeit erforderliche Objectivöffnung berechnen, nämlich

$$
0=\frac{16 V \sqrt{H}}{100}
$$

Demnach wäre z. B. zur Erzielung einer 100maligen Vergrösserung bei $\frac{1}{4}$ der natiurlichen Helligkeit eine Oeffnung von $8^{\mathrm{cm}}$ erforderlich.

Nach einer von Fraunhofer herrührenden Regel für die Dimensionirung der Fernröhren sollen sich die dritten Potenzen der Ojectiv-Brennweiten wie die vierten Potenzen der Objectiv-0effnungen verhalten, wobei einem Objective von zwei Fuss Brennweite eine Oeffnung von 23.83 Linien (Wiener Mass) entspricht.*)

Es ergibt sich hieraus, dass ein terrestrisches Fernrohr bei einer nicht viel mehr als 40 maligen Vergrösserung (die natürliche Helligkeit vorausgesetzt) schon die Länge von etwa $1^{\mathrm{m}}$ erreicht. Da ein Auszugsfernrohr von grösserer Länge schon nicht melir gut centrirt bleibt, so erscheint es nicht zweckmässig, bedeutend stärkere Fernröhren noch mit Auszügen zu construiren, wesshalb denn auch die Objective der grössten Zugfernrohre eine Oeffnung von $6^{\mathrm{cm}}$ kaum überschreiten.

Für astronomische Telescope gibt Prechtl**) die Regel an, dass man als stärkste zulässige Vergrösserung das $4 \%$ fache der in Wiener Zollen ausgedrïckten Objectiv-Brennweite annehmen könne. Die Helligkeit wird dabei selbstverständlich entsprechend weit unter den Betrag der natuirlichen Helligkeit herabgesetzt.

Fermröhren von grosser Helligkeit und grossem Gesichtsfelde können natürlich nur eine verhältnissmässig schwache Vergrösserung haben. Man braucht solche Insrumente zum Aufsuchen lichtschwacher Objecte. Sie haben grosse Objectivund Ocular-Oeffnungen. Hieher gehören die sogenannten $\mathrm{Cometensucher}$.

Fermröhren mit Vorrichtungen zur genauen Messung des scheinbaren Sonnendurchmessers heissen Heliometer.***)

Die an grossen Telescopen parallel mit denselben angebrachten kleinen Fernrölıren, welche zur vorläufigen annähernden Einstellung dienlich sind, werden Su cher genannt.

Beí der Prüfung eines Fernrohres kommt es nicht nur auf die Ermittlung der Vergrösserung des Gesichtsfeldes und der Helligkeit an, sondern auch

*) Veberträgt man diese Zahlen auf Metermass, so kommen auf $5 \mathrm{~cm}$ Oeftnung sehr nahe 60 (genauer $59.52 \mathrm{~cm}$ ) Brennweite.

\%) Prechtl, Dioptrik pag. 176. Die Regel beruht auf der Annahme einer gewissen Minimal-Brennweite des Oculars mit Rücksicht auf Gesichtsfeld und Deutlichkeit des Bildes.

***) Bei Beobachtungen der Sonne pflegt man gefärbte Dunkelgläser, sogenannte Sonnengläser hinter dem Ocular (d. h. zwischen Ocular und Auge) anzubringen, 
auf die Erprobung der Vollkommenheit des Bildes, wie sie durch Beseitigung der chromatischen und sphärischen Abweichung, gute Centrirung, Gleichförmigkeit und passende Wahl der Glassorten und genaue Einhaltung der richtigen dioptrischen Verhältnisse in der Dimensionirung und Anordnung der Linsen und Blendungen erzielt wird.

Es würde zu weit führen, auf die Methoden zur Aufsuchung einzelner Fehlerquellen einzugehen. Wir begnügen uns, in Kürze die Proben anzuführen, nach welchen sich im Allgemeinen die Qualität und Leistung eines Fernrohres beurtheilen lässt.

Betrachtet man durch das Fernrohr die Kante eines dunklen Gegenstandes auf hellem Hintergrunde, so sollen bei richtiger Einstellung des Oculars keine farbigen Säume an der betrachteten Kante erscheinen, auch dann nicht, wenn dieselbe aus der Mitte des Sehfeldes gegen den Rand desselben gerückt wird.

Schiebt man das Ocular aus seiner richtigen Stellung nach einwärts oder auswärts, so treten auch beim besten Fernrohre Farben auf (das sogenannte secundäre Spectrum); *) diese sollen jedoch keine grellen Farben (z. B. feuerroth oder tiefblau) sein, sondern z. B. purpurroth beim Hineinschieben und weingelb beim Herausziehen des Oculars. **)

Ist das Objectiv eines Fernrohres zwar von der chromatischen, nicht aber von der sphärischen Abweichung gehörig befreit, so erkennt man dies an einer nebelartigen Trübung, in welcher es die Gegenstände zeigt.

Ein vorzügliches Prüfungsmittel eines Fernrohres in Bezug auf die Schärfe der Bilder liegt in der Betrachtung eines Fixsternes durch das Fernrohr. Ein solcher darf nicht wie ein Comma oder in anderer Weise verzerrt und auch nicht wie ein von einer Hülle umgebener heller Kern, sondern muss als ein scharf markirter glänzender Punkt ohne Ausdehnung erscheinen. Je vollkomenner ein Fernrohr dieser Probe genügt, desto leichter wird es auch sein, mit demselben Doppelsterne als solche zu erkennen, oder, wie man sagt, naufzulösen ", worin, so wie in der Auflösung von Sternhaufen und Sternnebeln, ebenfalls ein scharfes Prüfungsmittel zur Vergleichung von Telescopen der verschiedensten Grössen besteht. ****)

Auch schwarze Flecke ron verschiedener Form (kreisförmig, dreieckig und quadratisch) auf weissem Papier, oder Systeme von Parallelstreifen in Abstufungen verschiedener Breite und Distanz, oder endlich ein beliebiger Letterndruck, in angemessenen Entfernungen betrachtet, sind gut brauchbare Probeobjecte zur Beurtheilung der Guite und Leistung eines Fernrohres.

Die Vergrösserung eines Fernrohres ermittelt man sehr häufig durch directe Vergleichung des natïrlichen und kiinstlichen Gesichtswinkels anf folgende Art.

Ein entfernter Gegenstand, welcher eine Anzahl von gleichen Unterabtheilungen darbietet (wie z. B. eine eingetheilte Latte, eine Reihe von Dachziegeln, ein Gartengeländer u. dgl.), wird mit dem einen Auge durch das Fernrohr und gleichzeitig mit dem andem Ange unmittelbar betrachtet. Man beobachtet dabei, wie viele mit freiem Auge gesehene Abtheilungen auf eine im Fernrohr vergrössert gesehene kommen. Ebenso vielmal vergrössert das Fernrohr.

Das Gesichtsfeld eines Fermrohres findet man, indem man z. B. ermittelt, wie oft der Durchmesser der im Fernrohr betrachteten Mondscheibe im Durchmesser des Sehfeldes enthalten ist, oder, was fiir ein aliquoter Theil des

*) Dasselbe riilnt daron her, dass mit.nur zwei verschiedeuen Glassurten r Crownglas und Flintglas) ein vollkommener Achromatismus nicht erzielt werden kann. Siehe den Artikel Achromatismus.

*) Vgl. Kellner, das orthoscopische Ocular.

***) Die Firma Merz in München liefert Telescope wit aplanatischen Objectiven bis nahezu einem halben Meter Oeffinung und sieben Meter Brennweite. Noch grössere Dimensionen haben die amerikanischen Refractoren der neuesten Zeit. Die relative Vollkommenheit derselben im Vergieiche nit jenen mag hier dahingestellt bleibes. 
Durchmessers der Mondscheibe dem Durchmesser des Sehfeldes entspricht. Dabei kommt in Erwägung, dass der Gesichtswinkel des Mondes annähernd einen halben Grad*) ausmacht. Das Gesichtsfeld eines Fernrohres beträgt also etwa $1 \frac{1}{2}$ Grade, wenn der Mond, im Fernrohre betrachtet, 1/3 vom Durchmesser des Sehfeldes deckt. Das Gesichtsfeld wäre dagegen etwa 1/4 Grad, wenn schon die halbe Breite der Mondscheibe den ganzen Durchmesser des Sehfeldes einnehmen würde. Auch mittelst der getheilten Latte, wenn man deren Entfernung kennt, lässt sich, wie leicht einzusehen, das Gesichtsfeld ermitteln.

Andere lind genauere Methoden zur Bestimmung der Vergrösserung und des Gesichtsfeldes zu erörtern, würde uns hier zu weit führen. Wir verweisen diesfalls auf Specialwerke.**)

\section{B. Catoptrische Telescope.}

Vor der Erfindung aplanatischer Linsensysteme****) suchte man theils die Unvollkommenheiten des Oculars durch sehr starke Objectiv-Vergrösserungen, also durch sehr grosse $\mathrm{Ob}$ jectiv-Brennweiten (welche die Anwendung schwacher Oculare gestatten) weniger ffihlbar zu machen $\dagger$ ), theils die Unvollkommenheiten des Objectives dadurch zu umgehen, dass man die Linse durch einen Hohlspiegel ersetzte. So entstanden die Spiegeltelescope, die durch fortgesetzte Verbesserungen und vergrösserte Ausführung auch späterhin neben den achromatischen Refractoren immer noch eine hervorragende Rolle gespielt haben.

Die verschiedenen Constructionen derselben unterscheiden sich in der Hauptsache nur hinsichtlich der Anordnung und Einrichtung des Oculars, d. h. in der Art, wie das vom Objectivspiegel erzeugte Bild der Betrachtung durch ein Linsensystem zugänglich gemacht wird.

In der That wollen wir uns im Folgenden darauf beschränken, beispielsweise nur eines dieser Instrumente etwas näher zu beschreiben.

Wir wählen das sehr leicht übersichtliche Gregory'sche Telescop, welches Fig. 1605 in der inneren Einrichtung und Fig.

Fig. 1605.

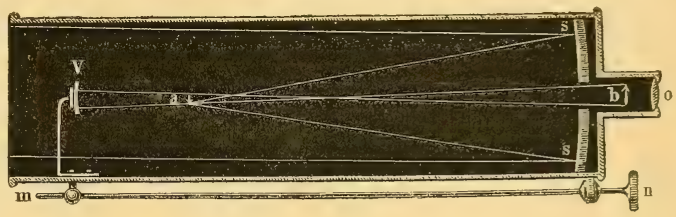

Fig. 1606 .

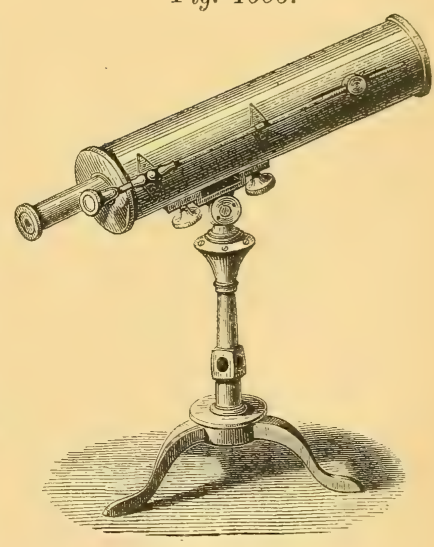
1606 in der äusseren Form dargestellt ist.

*) Er variirt zwischen $29^{\prime} 22^{\prime \prime}$ und $33^{\prime \prime} 31^{\prime \prime}$.

**) Man findet Näheres hierïber in ausführlicheren Werken über Geodäsie; ferner in $\mathrm{K}$ o h 1rauseh, praktische Physik, nnd endlich in den diesbezüglichen Abhandlungen des Verfassers (Abhandl. der k. böhm. Gesell. der Wissensch. VI. Folge 5. Band. und Carl's Repertorium der Experimentalphysik 8. Band).

****) Siehe den Artikel Aplamatismus.

†) Daher die enorme Länge alter Telescope, wie man sie in Museen noch häutig antriftt. so wie das Anbringen von Objectiven an hohen Gebäuden. - Die seit Dolloud coustruirten Telescope mit achromatischen Objectiven werden auch "Achromaten" genannt. 
In der Mitte des Objectivspiegels $s s$ ist eine kleine Oeffnung, von der wir vorderhand absehen wollen. Der Spiegel erzeugt ein verkehrtes Bildchen bei $a$. Dieses spiegelt sich in einem dem grossen gegeniiberstehenden kleinen Hohlspiegel $V$, der mittelst der Triebstange $m n$ so lange verstellt wird, bis ein verkehrtes Bild $b$ von $a$ (also ein aufrechtes bezüglich des betrachteten Gegenstandes) hinter dem Ausschnitte des Objectivspiegels entsteht, und zwar in solcher Entfernung vor dem Ocular o, dass es einem durch dieses Ocular sehenden Auge deutlich erscheint. Je näher die betrachteten Objecte sind, desto weiter muss des kleine Spiegel vom Objectivspiegel entfernt werden.

Beim Cassegrain'schen Telescop werden die vom Objectivspiegel kommenden Strahlen, bevor sie sich zu einem Bilde vereinigt haben, von einem Convexspiegel reflectirt, so dass sie mit verminderter Divergenz zu einem Bilde sich vereinigen, welches, so wie beim Gregory'schen Reflector, durch das Ocular betrachtet wird.

Der centrale Ausschnitt des Objectivspiegels muss als ein Uebelstand bei diesen Telescopen bezeichnet werden, weil gerade die mittlere Partie des Spiegels (nächst der Achse) die vollkommensten Bilder liefert.

Newton und F. W. Herschel haben dies bei ihren Spiegeltelescopen vermieden. Beim ersteren werden die vom Objectivspiegel kommenden Strahlen, bevor sie sich zu einem Bilde vereinigt haben, durch einen Planspiegel seitwärts reflectirt, und das so abgelenkte Bild durch ein seitlich in den Tubus eingesetztes Ocular betrachtet.

Bei den Herschel'schen Telescopen ist der Objectivspiegel etwas schief eingesetzt, so dass die Achse des Spiegels mit der Achse des Tubus einen Winkel bildet. Ein zweiter Spiegel ist nicht vorhanden, sondern das Objectiv-Bild entsteht in der Nähe des Randes der Tubus-Oeffnung und wird mit einem daselbst angebrachten Oculare betrachtet. Dass hierbei der Kopf des an der TubusOeffnung in das Ocular sehenden Beobachters zwischen Object und Spiegel kommt, bringt bei sehr grossem Spiegeldurchmesser keinen merklichen Nachtheil mit sich.

Die älteren Spiegel bestanden aus einer Legirung von Kupfer und Zinn, mit einem Zusatze von Arsen. - Rosse construirte bekanntlich einen Reflector mit einem Objectivspiegel von 6 Fuss Durchmesser und 50 Fuss Brennweite.

Steinheil und Foucault haben mit Benutzung gläserner Hohlspiegel, welche nach einem von Liebig herribrenden Verfahren versilbert wurden, ausgezeichnete Spiegeltelescope hergestellt. Spiegel dieser Art vertragen wegen der grossen Schärfe und Lichtstärke ihrer Bilder eine starke Ocularvergrösserung und können daher im Vergleiche mit den älteren Spiegeln bei gleicher Leistungsfähigkeit kleinere Dimensionen haben.

A. $v . W$.

Ferolenholz, syn. m. Atlasholz, s. Satinholz.

Ferricum-Verbindungen, syn. m. Eisenoxyd-Verbindungen, überhaupt Verbindungen der Atomgruppe $F e_{2}$, welche sechswerthig ist; s. Eisen II pag. 760.

Ferridcyan und Ferridcyanmetalle, s. Blutlaugensalze I pag. 666, 8. a. C y an II pag. 459 .

Ferrid-Ferrocyanid, syn. m. Ferrocyaneisen, ist der bei der Fällung von Eisenoxydsalz durch Ferrocyanwasserstoffsäure entstehende tiefblaue Niederschlag $\left(2 \mathrm{Fe}_{2}, \mathrm{Fe}_{3}, \mathrm{C}_{\mathrm{y}_{6}}\right)$.

Ferridprussianide, syı. m. Ferrideyanide; vgl. Cy an II pag. 459.

Ferridsalze (Ferrisalze), syn. m. Eisenoxydsalzen. s. Eisen II pag. 760 .

Ferrocyan und Ferrocyanmetalle, s. Blutlaugensalze I pag. 662, v. a. Cyan II pag. 45 . 
Ferro-Ferrideyanid, syn. m. Turnbullsblau oder Ferrideyaneisen $\left(\mathrm{Fe}_{3}, \mathrm{Fe}_{2}\right.$, $\left(y_{12}\right)$, s. Blutlaugensalze I pag. 667.

Ferrokalium-Ferridcyanid, syn. m. Wiallmsonsblau oder lösl. Berlinerblau, s. Blutlaugensalze I pag. 667.

Ferromangan (Feromanganese), s. Eisen II pag. 769 und 773.

Ferroprussianide, syn. m. Ferrocyanide, s. Cy a n II pag. 459.

Ferrosalze, syn. m. Eisenoxydulsalze, s. Eis e n II pag. 756.

Ferrosum-Verbindungen, syn. m. Eisenoxydul-Verbindungen, uberhaupt Verbindungen des Eisenatoms $\mathrm{Fe}$; s. Eis en II pag. 756.

Ferrum, syn. m. Eisen.

Ferulasäure, s. As an t I pag. 203.

Fes, Fez, türkische Kappe (fez). Diese Kopfbedeckung wird durch Wirken aus Schafwollgarn, nachfolgendes Walken, Färben, Scheren, Dämpfen, Pressen etc. hergestellt. Wesentlich abweichend von den bei der Tuchfabrikation verwendeten Vorrichtungen sind nur in Bezug auf äussere Form und Bewegungsmechanismen die Scheermaschinen und Raulımaschinen. U. a. liefern Maschinen für Fesfabrikation: Bernard in Karolinenthal bei Prag, Sternickel \& Gülcher in Bielitz-Biela. Vergl. die Artikel Tuch und Wirken. $K k$.

Fesen, eigentlich Vesen oder Dinkelvesen, s. Dinkel II pag. 632.

Festigkeit (resistance des materiaux - strength of materials), s. Elasticität III. pag. 143.

Festigkeitsmaschinen sind mechanische Apparate, mit welchen Materialien fiir das Bau- und Maschinenwesen auf ilı'e absolute oder Zerreissfestigkeit, ihre riickwirkende oder Druckfestigkeit, ferner auf Biegung und Torsion etc. in Anspruch genommen werden. Manche dieser Maschinen ist für die eine oder andere Aufgabe speciell construirt, andere sind für mehrere Arten der Inanspruchnahme gebaut. Ueber Werder's F. M. (auf Zug, Druck, Biegung, Torsion und Abscheren) s. $\mathrm{Kronauer}$ 's Zeichnungen von Maschinen Bd. 4, Lief. 7 und 8. Grafenstadener F. M. (Biegung, Zug, Druck) Dingler's polyt. Journ. Bd. 215, pag. 306. Gollner's F. M. (Zug, Druck, Biegung, 'Torsion, Abseheeren) s. Jahrb. d. Bergakad. Oesterr. 1878 Heft II. Vergl. Art. Stos s. $K k$.

Festungsachat, Varietät des Achat, s. d. I. pag. 45.

Festungsbau (fortification - building of fortifications), fällt über den Rahmen dieses Werkes und sei daher nur verwiesen auf: Bless on's "Die grosse Befestigungskunst", Berlin 1830; F esca's Handbuch der Befestigungskunst, Berlin 1852-53; Bl u m enhard t's "Die stehende Befestigungskunst“, Darmstadt 1864 bis 1866 .

Fettbol, eine Varietät des Bol, welche sich fettig anfühlt und nicht an der Zunge klebt. Kommt anf den Erzgängen Freiberg's vor. Vergl. Bolus I pag. 724. $L b$.

Fette (graisse - fat). Mit diesem Namen bezeichnet man im Allgemeinen die durch die allgemein bekannten Merkmale charakterisirten Glieder einer ganzen Classe organischer Körper, welche aus Kohlenstuff, Wasserstoff und Sauerstoff bestehen, sämmtlich stickstofffrei sind, und sich fast ausnahmslos als aus Fettsäuren oder Oelsäuren und Glycerin gebildete Ester des Glycerins, d. i. als filyceride erweisen. Fette im engeren Sinne des Wortes nennt man gewöhnlich nur jene dem Pflanzen- oder Thierkörper, u. z. vorherrschend letzterem, 
entstammenden Glyceride oder Gemenge solcher, welche im Gegensatze zu den fetten $\mathrm{O}$ elen oder flüssigen Fetten bei gewöhnlicher Temperatur starr oder doch nur halbweich (in welchem Falle man wohl auch die Bezeichnung Butter oder Schmalz gebraucht) sind.

Alle eigentlichen Fette sind dadurch ausgezeichnet, dass sie specifisch leichter als Wasser und in demselben nicht oder doch nur spurenweise löslich sind, sie schmelzen bei höherer Temperatur und zwar sämmtlich unter $100^{\circ} \mathrm{C}$. In Alkohol sind sie wenigstens in der Kälte schwer, dagegen beim Erwärmen bis zur Siedhitze leichter löslich, leicht werden sie von Aether, Schwefelkohlenstoff, Chloroform, Benzol und vielen aetherischen Oelen aufgenommen. Sie sind ferner im reinen Zustande neutral reagirend, geschmacklos und zeigen einen nur schwachen, aber eigenthïhmlichen Geruch, der namentlich beim Erwărmen deutlich wird. Durch Zersetzungsproducte verunreinigt nehmen sie indess einen deutlichen, unangenelm kratzenden Geschmack und einen charakteristischen, unangenehmen (ranzigen) Geruch an, der mit zunehmender Zersetzung, welcher alle Fette unter dem Einflusse der Luft mehr oder weniger ausgesetzt sind, immer deutlicher wird. Im reinen $\mathrm{Zu}$ stande sind ferner alle Fette farblos, im rohen Zustande dagegen können sie in Folge eines Gehaltes an fremden, aus dem Thier- oder Pflanzenkörper stammenden Beimengungen die verschiedensten Färbungen zeigen. Im geschmolzenen Zustande, so wie in dünnen Schichten sind sie durchsichtig oder stark durchscheinend, und bringen daher auf Papier, wenn sie von der Masse desselben aufgesaugt werden, einen durchscheinenden Fleck (Fettfleck) hervor, der sich dauernd erhält. Durch Erwärmen geschmolzen zeigt jedes bestimmte Fett einen bei einer bestimmten Temperatur liegenden Schmelzpunkt. Durch Abkiihlung geht das geschmolzene Fett wieder in den starren Zustand uiber, doch liegt der Erstarrungspunkt in der Regel bei einer niedrigeren Temperatur als der Schmelzpunkt. Beim Erstarren, bei welchem einige Fette undeutlich krystallinisch zu werden vermögen, während andere ganz allmälig, durch alle zwischen der Fliissigkeit und dem starren Zustande liegenden Grade der Consistenz hindurchgehend, in den starren Zustand zurïckkehren, findet fast ausnahmslos eine, wenn auch geringe, so doch nachweisliche Temperatursteigerung statt, welche in einzelnen Fällen fast den Schmelzpunkt erreicht. Beim stärkeren Erhitzen, etwa auf $300^{\circ} \mathrm{C}$. gerathen sie in's Kochen, sind jedoch nicht unverändert flïchtig, sondern werden hiebei zersetzt, wobei als Hauptproducte Aeroleïn, dann Kohlenwasserstoffe und flüchtige Säuren neben Kohlensäure und Wasser entstehen; gleichzeitig findet eine Ausscheidung von Kohlenstoff statt und tritt in Folge derselben eine mehr weniger deutliche Braun- bis Schwarzfärbung der erhitzten Fette ein; da die beim Erhitzen der Fette auftretenden Zersetzungsproducte bremnbar sind, so fangen stark erhitzte Fette Feuer und verbrenmen mit leuchtender Flamme.

Unter Zutritt der Luft erleiden die Fette, wie schon erwähnt, Veränderungen, u. z. um so leichter, je weniger rein sie sind. Namentlich vermag die Gegenwart geringer Mengen von Eiweissstoffen thierischen Schleimes u. s. w. die Zersetzbarkeit der Fette wesentlich zu begünstigen und scheinen solche Körper auch in dieser Beziehung als Fermente zu wirken. Die Veränderung der Fette crfolgt in der Regel unter Aufnahme von Sauerstoff, und besteht einerseits in einer Spaltung der Glycerinverbindungen unter Abscheidung freier Fettsäuren, anderseits in einer Oxydation der rorhandenen Säuren. Namentlich energisch erfolgt diese Oxydation, wenn Fette im feinvertheilten Zustande der Einwirkung der Luft ausgesetzt werden und die hiebei frei werdende Wärme kann sich so weit steigern, dass eine Selbstentzïndung des fein vertheilten Fettes eintritt. Daher die Selbstentziindungen von gefetteten Geweben, wenn sie dicht aufeinander lagern, von fetten Putzlappen, Wolle u. dgl. Mit verdünnten Alkalilösungen geschüttelt oder innig gemengt bilden sie Fettemulsionen, in welchen sich das Fett, namentlich bei schleimiger Beschaffenheit der Fliissigkeit in fein rertheiltem Zustande aufgeschlämmt erhält. Mit Alkalien, alkalischen Erden oder basischen Metalloxyden, bei Gegenwart ron Wasser in Berührung, werden sie namentlich leicht beim Er- 
wärmen zersetzt, indem sie in Glycerin und Salze der vorhandenen Fett- oder Oelsäuren (Seifen) zerfallen, d. h. sie werden verseift. Auch beim Erhitzen mit Wasserdampf allein auf ca. $310^{\circ} \mathrm{C}$., so wie mit Wasser bei derselben Temperatur tritt Zersetzung unter Bildung von Glycerin und freien Fettsäuren ein, und dasselbe ist der Fall bei der Einwirkung von Schwefelsäure oder Chlorzink. Im ersteren Falle bilden sich zunächst Sulfofettsäuren, die jedoch bei Einwirkung von Wasserdampf unter Abscheidung freier Fettsäuren zersetzt werden.

Als Bestandtheile der eigentlichen Fette finden sich vornehmlich die Glyceride der Oelsäure, dann der Palmitinsäure und der Stearinsäure, weiters vereinzelt jene der Buttersäure, Capronsäure, Caprylsäure, Caprinsäure, Laurinsäure, Myristinsäure, Arachinsäure, so wie der Crotonsäure, Angelicasäure, Moringasäure, Hypogaeasäure, Döglingsäure und Erucasäure. Fast in allen Fetten vorhanden sind die Glyceride der Oelsäure, der Palmitinsäure und Stearinsäure, u. z. die sogenannten neutralen Glycerinäther dieser Säuren (s. Glyeerin), d. i. das Trioleïn oder Oleîn, das Tripalmitin oder Palmitin und das Tristearin oder Stearin, die übrigen Fettsäuren und Oelsäuren treten meist nur in geringen Mengen als Bestandtheile der Fette auf. Ausser solchen Glyceriden finden sich als Bestandtheile einzelner Fette auch Verbindungen von Fettsäurealkoholen und Fettsäuren, so wie auch freie Fettalkohole vor, wie dies z. B. bei dem gemeiniglich auch den Fetten zugezählten festen Antheil des Wallraths (Sperma-Ceti) der Fall ist, der aus Palmitinsäure-Cetyläther besteht. Auch die Wachsarten enthalten keine Glyceride und sind demnach den eigentlichen Fetten, von denen sie auch in ihrem Verhalten nicht unwesentlich abweichen, nicht beizuzählen.

Was das Vorkommen der eigentlichen Fette anbelangt, so stammen die meisten festen Fette aus dem Thierkörper, und nur zum geringeren Theile sind sie pflanzlichen Ursprungs.

Im Thierkörper, der fast in allen Theilen die Gegenwart von Fetten nachzuweisen gestattet, finden sich dieselben stets in Zellgewebe eingeschlossen (Fettgewebe), meist in grösseren Mengen an den Eigenweiden, dem Gedärme, den Nieren eingelagert oder zwischen Haut- und Muskelgewebe eingebettet, wohl auch in den Höhlungen der Knochen (Mark) vor. Sie sind Producte des Stoffwechsels im thierischen Organismus und verdanken ihre Entstehung wesentlich einer Umbildung der mit der Nahrung dem Körper zugefülrten Kohlehydrate (Fettbilder), zum Theile wohl auch jener der Eiweisstoffe und der diesen verwandten Bestandtheile der Nahrungsmittel. Im pflanzlichen Organismus, in welchem feste Fette weniger häufig, häufiger dagegen flüssige Fette (f et te $\mathrm{O}$ ele s. d.) vorkommen, finden sich die grössten Mengen derselben in den Samen und Frïchten abgelagert, doch sind auch andere Pflanzentheile nicht völlig frei von Fett. Auch im pflanzlichen Organismus scheinen die Fette wesentlich durch Umbildung früher vorhandener Kohlehydrate (Stärke, Zucker) zu entstehen, u. z. durch Desoxydationsprocesse, vielleicht unter gleichzertiger Bildung von Wasser und Kohlensäure.

Die Gewinnung der Fette pflegt im Allgemeinen nach zwei verschiedenen Methoden zu geschehen, u. z. entweder durch das Ausschmelzen oder durch das Auspressen; ausser diesen kann auch noch eine dritte, erst in neuerer Zeit auch praktisch angewendete Gewinnungsmethode verwendet werden, d.i. das Extrahiren der Fette mit Lösungsmitteln (Schwefelkohlenstoff).

Aus Theilen thierischer Organismen werden die Fette gemeiniglich nur durch Ausschmelzen gewonnen, das entweder ohne Zusatz von Wasser oder mit Wasserzusatz (Auskochen) vorgenommen werden kann. Aus Pflanzentheilen dagegen pflegt man die Fette fast stets nur durch Auspressen zu gewinnen, indem man die vorher zerkleinerten Pflanzentheile, wenn sie fettreich sind, vorher auf den Schmelzpunkt des Fettes erhitzt und warm presst; seltener wendet man auch bei Pflanzentheilen das Ausschmelzen mit Wasserzusatz an. Näheres über die Gewinnungsweisen der einzelnen Fettarten ist bei den betreffenden Fetten besprochen. Im Folgenden sollen die wesentlichsten Eigenschaften der wichtigsten Fette erörtert werden. 


\section{A. Thierische Fette.}

Von diesen sind die sogenannten Talgarten, d. s. die mehr oder wiger starren Fette der verschiedensten Thiergattungen, weiters die Butter, das Schweineschmalz und das Knochenfett zu nennen.

1. Talg (suif - tallow, suet), Unschlitt, Inselt. Mit diesem Namen bezeichnet man die bei gewöhnlicher Temperatur völlig starren Fette verschiedener Säugethiere, namentlich der Rinder, der Schafe, der Ziegen, der Hirsche und verwandten Thiere, vorherrschend der Pflanzenfresser, deren Fett im Allgemeinen nicht blos fester und dichter, sondern auch weniger leicht zum Ranzigwerden geneigt ist als das weichere Fett der Fleischfresser. Uebrigens hängt die Beschaffenheit eines Fettes bei gleicher Abstammung auch ganz wesentlich von dem Alter des Thieres, dem Geschlechte und der Jahreszeit ab, in welcher das Thier getödtet wurde. Auch das Klima, unter welchem das Thier lebte, ist von Einfluss. So ist das Fett junger Thiere stets weisser und garuchloser, aber auch weicher als das älterer Thiere, die in der Regel ein gelblich gefärbtes, aber auch festeres Fett haben. Das Fett mänulicher Thiere ist meist fester als das weiblicher Thiere, und das Fett von im Winter getödteten Thieren besser als das Sommerfett, wäbrend Thiere, die in heissen Klimaten leben, ein festeres Fett liefern als solche aus kälteren Zonen. Dass übrigens auch die Nahrung des Thieres, sowie der Gesundheitszustand desselben die Beschaffenheit des Fettes beeinflusst, ist selbstverständlich, ebenso wie es begreiflich ist, dass bei ein und demselben Thiere an verschiedenen Theilen des Körpers Fette von verschiedener Beschaffenheit sich finden. In letzterer Hinsicht lehrt die Erfahrung, dass jedes thierische Fett um so fester ist, je weiter von der Oberfäche des Körpers entfernt es sich findet.

Für Zwecke der Industrie kommen wesentlich nur der Rindstalg und der Schaftalg in Betracht.

Der Rindstalg (Ochsentalg) ist bei gewöhnlicher Temperatur hart und fest, von schwach gelblicher Farbe und schwachem Geruch. Er schmilzt je nach der Abstammung zwischen $37-50^{\circ} \mathrm{C}$. und löst sich in 40 Thl. Alkohol von 0.821 spec. Gewicht bei Siedhitze vollständig auf. Er lässt sich durch Pressen bei ca. $30^{\circ} \mathrm{C}$. in etwa $75 \%$ völlig starres Fett (Stearin) und etwa $25 \%$ flüssiges Fett (Talgöl, Olein) trennen. Das erstere ist weiss, körnig, krystallinisch, schmilzt bei $44^{\circ} \mathrm{C}$. und erstarrt bei $39^{\circ} \mathrm{C}$, in 7 Thl. absoluten Alkohol ist es löslich. Das letztere ist farblos, fast geruchlos und vom spec. Gew. 0.913. Es löst sich in . etwas weniger als dem gleichen Gewichte siedenden absoluten Alkohols.

Der S ehaftalg (Hammeltalg, Schöpsentalg). Weisser als Rindstalg, hart, brüchig, fast geruchlos, schmilzt zwischen $41-50^{\circ} \mathrm{C}$, ist in kochendem Alkohol schwerer löslich als Rindstalg. Auch der Schaftalg lässt sich in einen festen $(74 \%)$ und einen flüssigen Antheil $(26 \%)$ trennen. Der erstere, wesentlich aus Tristearin und Tripalmitin bestehend, ist krystallinisch, weiss, bei $38^{\circ} \mathrm{C}$. erstarrend und in Alkohol schwer löslich, der letztere ist farblos, von eigenthümlichem Hammelgeruche und löst sich in 1.2 Thl. kochenden Alkohols.

Die genannten beiden Talgsorten bilden den hauptsächlich zu Zwecken der verschiedenen Gewerbe (Seifensiederei, Kerzenfabrikation) in Verwendung kommenden Talg und stellen einen wichtigen Handelsartikel dar.

Man gewinnt den Talg durch Ausschmelzen der in den Schlächtereien ausgelesenen Fettgewebe der Ochsen, Kühe, Kälber, Schafe und Hammeln, welche zunächst einer mechanischen Zerkleinerung unterworfen und sodann ausgeschmolzen werden. Das Zerkleinern geschieht entweder mittels Handmessern oder es wird durch besondere Schneidemaschinen besorgt; in England bearbeitet man das Fettgewebe auf eisemen Kollermühlen, neuerer Zeit wohl auch zwischen Quetschwalzen. Die gehörig zerkleinerte Masse wird sodann gewöhnlich auf offenen Kupfer-Kesseln über freiem Fener geschmolzen (trockenes Schmelzen), wobei das Fett aus den theilweise durch die vorherige Bearbeitung zerrissenen, theils durch den Druck des bei der Erhitzung sich bildenden Wasserdampfes zurn Platzen gebrachten Zellen des Fettgewebes ausfliesst, während die Gewebssubstanz in dem Masse, als durch fortyesetztes Erhitzen die Gesammtmenge des in dem Fettgewebe eingeschlossen gewesenen Wassers entfernt ist, zusammenschrumpft und in Gestalt der sogenannten Griefen (Grieben) sich grösstentheils vom Fette scheidet und durch Abseilen und endliches Auspressen völlig von dem nun klar erscheinenden Fette getremnt werden kann. Statt der offenen Kessel kann man sich geschlossener Kessel bedienen, wrlehe mit Abzugsschläuchen versehen sind, die die entweichenden Dämpfe entweder 
directe in eine höhere Esse oder in eine Fenerung abführen, in der sie zerstört werdenkönnen. Es ist dies eine Einrichtung, die wegen der hiebei erreichbaren Verhütung der durch den beim Talgschmelzen in der Regel auftretenden höchst iiblen Gruch bedingten Belästigung der Arbeiter und Nachbarn empfehlenswerth ist, doch hat man hiebei darauf Bedacht zil nehmen, dass eine passende Rïhrrorrichtung in den Kesseln angebracht werde. da ein öfteres Umriiluren der auszusehmelzenden Masse bei dem Ausschmelzen über freiem Feuer unerlïsslich ist. Statt des trockenen Schmelzens kann man das Aussehmelzen mit Dampf oder das Auskrochen mit Zusatz ron gewissen chemischen Mitteln anwenden. Das Ausschmelzen mit Dampf kann entweder durch einfaches Zuleiten von Wasserdampf zu der anszuschmelzenden Masse geschehen oder man wendet gespannte Dämpfe an, die man entweder directe auf die Fettmasse wirken lässt, oder zur Erhitzung der dann doppelwandig construirten Schmelzkessel verwendet.

Zum Ausschmelzen mit gespannten Dämpfen, die directe auf die Fettmasse wirken, eignet sich besonders der von Wils o n angegebene Apparat, weleher einen cylindrischen, aufrechtstehenden Kessel aus starkem Eisenblech darstellt, der durch eine im Deckel angebrachte, dicht verschliessbare Füllöffnung beschickt werden kann und in seinem Tntertheil einen falschen Siebboden eingesetzt enthält, auf dem die eingetragene Fettmasse ruht. Ton der Mitte dieses Siebbodens aus führt ein weites, mit einem von Aussen zu handhabenden Ventile verschliessbares Rohr nach unten in ein unter dem Cylinder aufgestelltes Gefäss, das zur Entleerung der entfetteten Griefen bestimmt ist. Unter dem Siebboden liegt der mit Oefinungen versehene Rohrkranz, durch welchen die gespannten Dämpfe in den Cylinder eintreten, während eine Reihe von in verschiedener Höhe über dem Siebboden angebrachten Hähnen zum Ablassen des ausgeschmolzenen Fettes dienen. Ein Sicherheitsventil und ein Manometer bilden die übrige Armatur des Apparates. Man füllt den Cylinder bis etwa $\mathrm{zu}_{3}^{2}$ seiner Höhe nit dem zerkleinerten Fettgewebe an, verschliesst die Füllöffnung und lässt durch den Rohrkranz allmälig Dampf ron 4-5 Atmosph. Spannung in den Cylinder eintreten, bis die gleiche Spannung auch im Schmelzcylinder erreicht ist, in welchem man sie nun durch etwa 10 Stunden erhält. Nach beendigtem Dämpfen, während welchem man von Zeit zu Zeit das sich unter dein Siebboden ansammelnde Wasser durch einen hiezu bestimmten Hahn ablassen muss, zieht man durch Oeffnen der Abflusshähne das ausgeschmolzene Fett ab, während man das im Cylinder znriickgebliebene Wasser und die durch die Einwirkung des Dampfdruckes fast vollkommen entfetteten Griefen durch Oeffnen des das nach unten mündende Rohr verschliessenden Ventils abfliessen lässt.

Sehr empfehlenswerth ist der von Fouché construirte Apparat zum Ausschmelzen des Talgs mittels Dampf, bei welchem jedoch der Dampf nicht directe auf den Talg wirkt, sondern nur zur Erhitzung desselben, vermittelst einer Rohrspirale, welche vom Dampfe durchströmt wird, verwendet wird. (Vgl. Polytechn. Centralblatt, 1857, pag. 130.) Andere Apparate sind von Buff (Ding 1. polyt. Journ. 176 pag. 143), dann von Lockwood und Everett (vgl. Ott in D ingl, polyt. Journ. 213 pag. 493), endlich von Vohl (s. Dingl. polyt. Journ. 198 pag. 29) angegeben.

Vielfach wendet man beim Ausschmelzen, bez. Auskochen des Talgs Zusätze an, welche einerseits eine Lockerung des Zellgewebes und sohin eine vollkommenere Abscheidung des Fettes von dem Gewebe, andererseits eine Verminderung der bei der Talgschmelzerei anftretenden höchst ïblen Gerüche bezwecken sollen. So empfiehlt Rorard einen Zusatz ron Sodalauge und zwar 1 Thl. Soda, 200 Thl. Wasser auf 300 Thl. Talg; d'Arcet empfiehlt Schwefelsäure und zwar auf 100 Thl. Talg, 1 Thl. Schwefelsäure von 1.848 spec. Gewicht und 50 Thl. Wasser. Auch Zusätze von chromsaurem Kalium und Schwefelsäure, iibermangansarurem Kalium und Schwefelsäure u. a. m. hat man empfohlen. Das Rorard'sche Verfahren ist nach Stein weder geeignet den Geruch des schmelzenden Talgs wesentlich zu verminderm, noch -ist es sonst empfehlenswerth, da sich das Fett nicht rein von der Lange trennen lässt, ein Mangel, der auch dem sonst recht wirksamen Zusatze von chromsaurem Kalium und Schwefelsäure anhaftet. Empfehlenswerth ist dagegen das Verfahren von dAr cet, insofern als vollständige Abscheidung des Fetts von dem Gewebe durch das länger fortgesetzte Kochen mit der verdünnten Säure herbeigeführt und dadurch das Auspressen der Griefen röllig entbehrlich wird. Dagegen hat dasselbe gleich allen Schmelzmethoden, bei welchen chemische Zusätze gemacht werden, den Nachtheil, duss die Griefen, die andernfalls als Futtermateriale für Hunde, Schweine u. dgl. sehr gut verwerthet werden können, nicht mehr verwendbar sind. 
Der ausgeschmolzene Talg wird gewöhnlich, namentlich für Zwecke der Kerzenfabrikation vor seiner weiteren Verwendung einer Läuterung unterworfen, welche in der Regel durch Umschmelzen mit Wasser, mitunter bei gleichzeitiger Anwendung von Bleichmitteln erreicht wird. Man bringt zu diesem Ende den ausgeschmolzenen Talg, entweder noch flüssig oder nachdem er erstarrt ist, anf einen grösseren Kupferkessel, setzt 20-25\% Wasser zu und erhitzt unter fleissigem Aufrühren etwa eine Stunde lang zum Kochen, sodann wird der Kessel bedeckt der Ruhe ïberlassen, wobei sich die dem Fette noch beigemengten Unreinigkeiten zu Boden setzen, so dass das reine Fett abgeschöpft werden kann. Von bleichenden Zusätzen wendet man entweder chromsaures Kalium und Salzsäure $(1-2 \%)$ oder ïbermangansaures Kalium und Salzsäure $(1-2 \%)$ an, auch ïbermangansaures Kalium und wässrige schweflige Säure sind sehr wirksam. Bei Anwendung dieser Zusätze gilt als Regel, dass man das anzuwendende Salz zunächst im Wasser auföst, dann dem Fette zusetzt, und erst nach längerer Einwirkung desselben in der Wärme, wobei man durch fleissiges Rühren die Wirkung' wesentlich begünstigt, die Sänre zufügt. Nicht selten wird der geläuterte Talg durch Zusat\% einer entsprechenden Menge eines blauen Farbstoffs (Indigo mit Oel angerieben) geblendet, $\mathrm{d}$. $\mathrm{h}$. die schwach gelbe Färbung desselben durch Blau gedämpft. (s. Farbe III pag. 361.) (Vgl. a. die Bleichmethoden von Treutlen in Dingl. pol. Journ. 207 pag. 516 und Bourgey \& Comp. in Bull. de la soc. chim. $1875 \mathrm{Nr} .11$ pag. 526.) Im Handel kommen Rindstalg (gelber Talg), so wie auch Schöpsentalg (weisser Talg), theils rein, theils mit einander gemengt vor, die härteren Sorten des Talgs bilden den Lichtertalg, während die weichen und stark gelben Talgsorten gewöhnlich als Seifentalg bezeichnet zu werden pflegen. Die grössten Mengen von Talg liefert Russland, und zwar Schöpsentalg, aus dem Süden meist aus den Häfen des schwarzen Meeres (Odessa, Taganrog), zu Markte gebracht, während der Norden und das Innere Russlands, meist via Petersburg und Archangel, Rindstalg liefert. Der beste weisse Lichtertalg kommt von Woronesch. Ausser Russland liefert auch Amerika (aus den Laplata-Staaten) und Australien erhebliche Mengen von Talg, welcher aber von geringerer Qualität ist als der russische. Gute Sorten von Talg liefern auch Holland, Dänemark, Deutschland und Polen. und steht der Talg dieser Provenienz meist höher im Preise als russischer.

Von anderen Talgarten sind noch zu nennen:

Der Ziegentalg, welcher dem Rindstalg ähnlich, aber von charakteristischem, unangenehmem Bocksgeruche ist, welchen er dem Gehalte an einer flüchtigen Fettsäure (Hircinsäure) verdankt. Dieser Talg schmilzt zwischen $37-40^{\circ} \mathrm{C}$. und lässt sich ebenfalls in ein starres und in ein flüssiges Fett trennen. Dem Ziegentalg sehr ähnlich ist

der Hirsehtalg, der sich durchBehandeln mit kochendem Alkohol in einen löslichen und einen unlöslichen Antheil trennen lässt.

2. Butter (beurre - butter). Dieses der Kuhmilch entstammende Fett ist halbhart, von mehr oder weniger gelber Farbe, hat im frischen Zustande einen von der Fütterungsart und dem Alter des Thieres abhängigen charakteristischen Geruch und milden Geschmack, es schmilzt bei $29-34: 5^{\circ} \mathrm{C}$. und erstart bei $19-24^{\circ} \mathrm{C}$. heginnt jedoch schon bei $17^{\circ} \mathrm{C}$. ein körnig krystallinisches festes Fett abzuscheiden.

Das durch Umschmelzen der Butter gereinigte Butterfett führt gemeiniglich den Namen Butterschmalz oder Schmalz. Das Butterfett besteht wesentlich aus ca. $68 \%$ Palmitin, $30 \%$ Oleïn und $2^{\circ} \cdot$ der Glyceride der Buttersäure, der Capron-, Capryl- und Caprin-Säure Im Soinmer gewounene Butter ist reicher an Oleïn. Dem Gehalte an den Glyceriden der flüchtigen Fettsäuren verdankt die Butter ihren charakteristischen Geruch. Ausser den genannten Säuren und den im Palmitin und Oleïn enthaltenen, d. i. der Palmitinsäure und der Oelsäure, enthält die Butter auch Stearinsäure und Arachinsäure (Butinsäure). endlich eine Oelsäure von geringerem Kohlenstoffgehalte als gewöhnliche Oelsäure.

Die Butter ist sehr leicht dem Verderben unterworfen, so lange sie nicht durch Umschmelzen von dem beigemengten Wassergehalte, sowie den der Milch entstammenden Resten eiweissartiger Körper (Caseïn) völlig bef̉eit ist. Dieser Neigung zum Ranzigwerden kann durch iffteres Auswaschen, dann durch Einkneten ron Kochsalz, endlich durch Ausschmelzen gesteuert werden, in welch' letzterem Falle sich die dem Butterfette beigemengten Milchbestandtheile nebst dem Wasser (ca. $20 \%$ ) abscheiden und von dem nun reinem Fette getrennt werden können. 
WVas die Gewinnung der Butter anbelangt, so erfolgt diese, wie allgemein bekannt, durch eine mechanische Behandlung des nach längerer Ruhe (36--48 Stunden) an der (J)erfläche: der Milch sich ansammelnden $R$ ahm's, der dis Ilauptmenge der in der Milch enthaltenen Butterfett-Tröpfchen enthält, die als specifisch loichter in der Flüssigkeit sirh in dir Höhe erheben und cine etwas consistentere Schichte auf der Oherfläche der Milch bilden. Diese mechanische Behandlung der Rahmmasse lat stets nur den Zweck, die in der Fliissigkeit schwebenden Fettröpfchen in eine heftige Bewegung zu versetzen, durch welche sic an einander gerieben und so veranlasst werden zu grösseren Klümpchen zusammenzufliessen, die sich dann leicht von der Flüssigkeit trennen lassen. Die zu diesem Zwecke in Anwendung stelıenden Apparate, von denen verschiedene Formen und Constructionen bekannt sind, lassen sich sämmtlich in drei Gruppen einreihen. Die 1. Gruppe wird gebildet von solchen Apparaten. bei welchen die Butterausscheidung durch Stoss oder Schlag erzielt wird. Die 2. Gruppe umfasst jene Vorrichtungen, bei welchen durch kräftiges Riihren der Fliissigkeit die Vereinigung der Fetttröpfchen erreicht wird, während die 3. Gruppe solche Apparate umfasst, bei welchen die Abscheidung durch Schütteln der Flüssigkeit herbeigefuihrt werden soll.

In die I. Gruppe fallen das bekannte gewöhnliche oder dentsche Butterfass, ein kegelförmiges Fass mit Deckel, in dessen Oeffnung eine Stange auf- und abbewegt wird, dic an ihrem unteren Fnde eine durchlöcherte Holzscheibe trägt, mit welcher der Rahn geschlagen wird. Hierher gehören auch das Butterfass von Gussander, bei dem an Stelle der durchlöcherten Scheibe eine durchlöcherte Glocke von Weissblech zum Schlagen dient, und das amerikanische Butterfass (s. Ding1. polyt. Journ. 131 pag. 5), bei welchem die zum Schlagen dienende dnrchlöcherte Glocke von Blech an einer Röhre von Eisen befestigt ist die an ihrer oberen Mündung ein sich nach Innen öffnendes Ventil trägt, durch das sich die Glocke bei der Aufwärtsbewegung mit Luft fiillt, welche beim Niederdrüicken in Form ron Bläschen durch die Flïssigkeit hindurchgetrieben wird und so dieBewegung derselben erhöht. Hieher zählt ferner die Buttermaschine von Rennes (bez. Drummond), bei welcher zwei mittelst einer Kurbel bewegbare abwechselnd auf- und niedergehende Stempel auf die Flüssigkeit wirken, die sich in einem Gefässe befindet, welches durch eine durchlöcherte Zwischenwand in zwei Abtheilnngen getheilt ist.

In die 2. Gruppe sind zu zählen die Buttermaschine von Brochardt (s. Dingl. polyt. Journ. 160 pag. 109), dann das von Stjernsvärd angegebene Turbinen- oder Centrifugal-Butterfass (s. polyt. Centralblatt 1858 pag. 127), bei welchem, wie bei mehreren anderen auf ähnlichen Principien beruhenden Vorrichtungen die Flüssigkeit durch ein an einer verticalen Achse stehendes Rührwerk mit Kurbelbetrieb kräftig gerührt werden kann, während z. B. bei der unter dem Namen $\mathrm{K}$ a stenkarre bekannten Maschine, dann bei der Buttermaschine ron Lavoisy (Pariser Ausstellungsbericht 1856 pag. 179. Berlin) das Rührwerk an einer horizontal liegenden Achse befestigt ist. In die 3. Gruppe gehört die Buttermaschine (Diagonalkarre) von Tindall (s. Dingl. polyt. Journ. 131 pag. 97), bei welcher durch Drehung eines schräg gestellten Fasses die Flüssigkeit heftig geschüttelt wird, dann das wiegenförmige Butterfass von Weisse (s. Löbe, Encyclop. der Landwirthschaft, Leipzig 1851, III pag. 569) bei welchem durch die wiegenartige Hin- und Herbewegung eines anf Walzen stehenden, durch Fächer in mchrere Abtheilungen getheilten Holzkastens gleichfalls eine lebhaft schiittelnde Bewegung der denselben erfïllenden Flïssigkeit erreicht wird. Ueber Buttermaschinen s. auch Petit (polyt. Centralblatt 1858 pag. 202), Girard (Dingl. polyt. Journ. 160 pag. 110), Johnson. (Dingl. polyt. Journ. 159 pag. 263) u. s. w.

Bei dem Ausbringen der Butter aus der Milch kommt es, gleichgiltig welcher Vorrich. tung man sich hiezu bedient, wesentlich auf die Einhaltung grösster Reinlichkeit und Sorgfalt sowohl in Bezug auf die Aufbewahrung der Milch behufs Abscheidung des Rahms, als anch in Bezug auf das eigentliche Butterschlagen (Buttern) an, denn kaum irgend eine andere Substanz nimmt so leicht einen fremdartigen Geruch oder Geschmack an als die Butter. Die wohlschmeckendste Butter erhält man immer ans frischem Rahm, doch ist solche Butter weniger haltbar als eine aus vorher gesäuertem Rahm dargestellte. Es kamn ferner als Regel gelten, dass die Butter desto wasserhaltiger und schaumiger erscheine je rascher sie abgeschiedeu wurde, während sie bei langsamer Abscheidung wesentlich wasserärner und geschmeidiger erhalten wird. 
Die geschlagene Butter wird nun noch durch Auskneten im Wasser von dem eingeschlossenen Rückhalte an Milchbestandtheilen möglichst befreit, wobei man das Waschwasser so lange, wechselt, bis dasselbe bei dem Auskneten der Butter sich nicht mehr merklich trübt, sodann wird sie zu grösseren Klumpen zusammengeknetet und in bestimmte Formen, wie sie eben landesïblich sind, gebracht, um so dem Consume zugeführt zu werden. Gilt es die Butter längere Zeit aufzubewalıren, so legt man entweder die einzelnen Stïcke in eine starke Salzlösung ein, und zwar so, dass dieselben völlig von der Lösung überdeckt werden, oder man salzt die Butter ein, indem man ihr eine bestimmte Menge von Salz durch Kneten einverleibt. Die Menge des zugesetzten Salzes, die zwischen $2-5 \%$ zu betragen pflegt, soll für Butter, welche längere Zeit aufbewahrt werden soll, nicht geringer als $4 \%$ sein, wïhrend fiir Butter, welche nur auf kurze Zeit conservirt werden soll, $2 \%$ Salzzusatz genügen. Un das Einsalzen der Butter auszuführen, breitet man dieselbe zu flachen Stücken aus, bestreut dieselben sodann mit der bemessenen Menge an fein geriebenem Salz, rollt die Masse mit der bestreuten Fläche nach innen zusammen und knetet nun so lange durch, bis das Salz völlig gleichmässig in der Masse vertheilt ist. Empfehlenswerth ist es, dieses Einsalzen nicht in einer Operation auszuführen, sondern zunächst nur die Hälfte des Salzes einzukneten, dann durch 24 Stunden liegen zu lassen, und sodann erst die zweite Partie des Salzes.einzukneten. Die Butter wird so gleichmässiger gesalzen und gewinnt ein wesentlich schöneres Ansehen, als wemn man ihr das ganze Salzquantum auf einmal einverleibt.

Was die erzielbare Butterausbente anlangt, so variirt diese wesentlich mit dem Alter und der Ernährungsweise, sowie endlich der Raçe der Thiere, denen die auf Butter verarbeitete Milch entstammt. Die mittlere Butterausbeute aus Milch von guten Kühen beträgt $4.8-5.5 \%$; bei guter Ernährung liefert eine gesunde Kuh pro Tag ca. $500 \mathrm{Grm}$. Butter, in Mittel rechnet man pro Jahr per Kuh einen Ertrag von 150-160 Pfund Butter (vgl, von Hinn ïber Journ. fiir Landwirthschaft 1853 pag. 11 und 1854 pag. 95).

Die Butter wird nicht selten verfälscht oder doch durch Einkneten grösserer Wassermengen oder grösserer Mengen von Kochsalz ihr Gewicht in hetriigerischer Weise vermehrt. Von eigentlichen Verfälschungen kommen Zus:̈tze an Mehl, Gyps, Kreide, Schwerspath, zerriebene Kartoffel u. dgl. vor, deren Vorhandensein sich beim Ausschmelzen der Butter mit etwas Wasser sehr leicht erkennen lässt, da solche Beimischungen sich damn dem Wasser beimengen und sich allmälig aus demselhen abscheiden. Allzı grosser Trassergehalt (der normale schwankt zwischen 14-20\%) gibt sich daran zu erkennen, dass solehe Butter an der Schnittfäche dentliche Wassertropfen zeigt, während ein grïsserer Salzgehalt sich dureh den stark salzigen Geschmack verräth. Auch fremde Fette, mamentlich Talg und Schweinefett kommen, als Verfälschungen der Butter vor. Erstere ist an dem höhcren Schmelzpunkte kenntlich, den ein irgend grösserer Zusatz an Talg bedingt: letzteres verräth sich schon durch den Geschmack. Häufig wird die Butter, um ihr eine schön gelbe Farhe zı gehen, gefürbt, zu welchemZwecke in der liegel Orlean verwendet zu werden pflegt.

Kunstbutter (Sparbutter). Schon seit mehr als 50 Jahren wird in Deutschland unter d'm Namen „Kunstschmalz* (Ochehmalz) ein Surrogat fïr Butterfett erzeugt, des aus frisch gepressten Rüböl und Rindstalg hergestellt wird. Es wird zu diesem Ende das Rüböl zunäichst durch starkes Erhitzen mit zerschnittenen Zwiebeln oder Kartoffeln gereinigt und ron dem Gehalte an dem den Träger des Geruches im Rüböle bildendenden schwefelhältigen iither. Oele befreit und das so gereinigte Oel mit frischem Rindsfett zusammengeschmolzen is. Strenz, Anleitung zur Schmalzöl- und Oelschmalzbereitung, Nürnberg 1855). Dieses Ermengniss ist jedoch wegen seines Gehaltes an dem unter allen Umständen zum Ranzigwerden leicht geneigten und daun eckelhaft riechenden Rüböl zum Ersatze der Schmelzbutter wohl nicht zu empfehlen. Ebensowenig waren es andere Fabrikate, welche wie das nach einem 1871 für Amerika patentirten Verfahren erzeugte Kunstschmalz, durch Erhitzen einer Mischung von Talg und Schweinefett in einem Dampfstrome, Schlagen und endliches Abschöpfen ron dem ausgeschiedenen Wasser bereitet wurde, oder das nach dem Patente von La Pérouse durch Auskochen des Fleisches mit Wasser (unter Zusatz von d'ppeltkolılensaurem Natron und Kochsalz) abgeschiedene und ron der Brihe durch Abschöpfen gewonnene Futt, oder endlich das durch Zusatz ron Orlean gelb gefärbte Schweinefett, das seit längerer Zt-it ron Amerika aus als Butterfett exportirt wurde. 
Erst während des letzten deutsch-französischen Krieges gah der in dem belagerten Paris fühlbar gewordene Mangel an Butter Veranlassung zu Versuchen, ein brauchbares Surrogat für Butter herzustellen, und es gelang Mége Mourier in dem von ihm mit dem Namen Oleo-Margarine belegten Präparate ein Product zu liefern, das sich alsbald als Buttersurrogat einbürgerte. Das von Mége Mourier gewählte Verfahren (vgl. Industriebltt, von Hager und Jakobsen, Berlin 1875 pag. 111) ist in Wesenheit folgendes: 1000 Kilo frisches Ochsenfett werden zunächst entsprechend zerkleinert, dann mit 300 Kilo Wasser, 1 Kilo kohlensaurem Kali und zwei klein zerschnittenen Schaf- oder Schweine-Mägen in einem Fasse mittelst Wasserdampf auf $45^{\circ} \mathrm{C}$. erwärmt. Nach 2 Stunden, während welcher Zeit öfter umgerührt werden muss, lässt man das völlig geschmolzene Fett nach einiger Ruhe von der abgeschiedenen wässrigen Flüssigkeit in ein zweites Fass ab, das durch Wasserdampf anf $30-40^{\circ} \mathrm{C}$. erwärmt gehalten wird, setzt $2 \%$ Kochsalz $\mathrm{zu}$, rührt tüchtig durch und lässt nach erfolgter völliger Klärung abe:mals ab. Die so erhaltene blass gelb gefärbte Fettmasse wird nun in einem anf $20-25^{\circ} \mathrm{C}$. erhaltenen Raume abkühlen lassen, wobei sie eine halbfeste Consistenz und ein körnig crystallinisches Gefüge a nimmt. Diese Masse wird nun bei ca. $25^{\circ} \mathrm{C}$. in einer hydraulischen Presse gepresst, wobei etwa $40-50 \%$ Stearin und 50-60\% Oleomargarin erhalten werden. Dieses letztere wird nun in einem Butterfasse mit einem Zusatie von $25 \mathrm{~L}$. frischer Kuhmilch und $25 \mathrm{~L}$. von mit $100 \mathrm{Grm}$. fein zerschnittener Kuheuterdrüse digerirtem Wasser auf je $50 \mathrm{Kilo}$ Oleomargarine, das mit etwas Orlean gelb gefärbt ist, bearbeitet, wobei anfänglich ein dicker Rahm, und endlich nach ea. 2 Stunden eine der frisch geschlagenen Butter völlig ähnliche Masse resultirt, die in reinem Wasser ausgeknetet, für den Consum fertig ist. Der bei dieser Procedur in Anwendung kommende wässrige Auszug der Kuheuterdrüse soll ganz wesentlich die Vertheilung(Emulsion) des Fettes in der wässrigen Flüssigkeit begünstigen, während durch den Milchzusatz dem Fabrikate ein der frischen Butter ähnlicher Geschmack verliehen wird. So dargestellte Kunstbutter, welche von einer guten Butter weder in Geschmacke, noch iı Geruche wesentlich abweicht, enthält 12-13\% Wasser, löst sich in Aether unter Hinterlassung eines nicht mehr als $1.2 \%$ betragenden Rückstandes und erstarrt nach dem Schmelzen zwischen $17-22^{\circ} \mathrm{C}$. Die auf diese oder ähnliche Weise erzeugten Buttersurrogate, welche, wenn aus frischem Rindstalg bereitet, anstandslos zum Genusse tauglich sind, kommen neuerer Zeit mit einem wesentlich geringeren Wassergehalt $(6-7 \%)$ in den Handel (Sparbutter), und erscheint demnach, abgesehen von ihrem geringeren Preise, die Verwendung derartiger Erzeugnisse in der Hauswirthschaft insof $r$ mit einer Ersparniss verbunden, als sie ob des geringeren Wassergehaltes ausgiebiger sind als echte Butter. Zur Unterscheidung echter Butter von solcher Kunstbutter kann man nach Moser (s. Dingl. polyt. Journ. 216 pag. 288) die Verschiedenheit der Schmelzpunkte benützen. Nach seinen Untersuchungen schmelzen verschiedene Sorten echter Butter zwischen $33-37^{\circ} \mathrm{C}$., während die geprüften Sorten der Wiener Sparbutter bei $27^{\circ} \mathrm{C}$, eine Pariser Kunstbutter bei $31 \cdot 7^{\circ} \mathrm{C}$. schmolzen. Das aus den einzelnen Sorten echter Butter ausgeschmolzene Schmalz zeigte Schmelzpunkte zwischen 29 und $36^{\circ} \mathrm{C}$. (nur bei Kärnthner Alpenbutterschmalz lag der Sehmelzpunkt bei $24 \cdot 5^{\circ}$ C.), wogegen das Schmalz aus Sparbutter bei $22 \cdot 5^{\circ} \mathrm{C}$, aus Pariser Kunstbutter bei $31.5^{\circ}$ C. schmolz. Nach Kunstmann (s. Dingl. pol. Journ. 216 pag. 288) soll man die Gegenwart von Talg durch den Geruch erkennen, den das mittels eines Dochtes zum Verbrennen gebrachte Fett beim Ausblasen der Flamme verbreitet.

3. Schweinefett (graisse de porc - pork's lard), Schweineschmalz. Das Fett des Schweines ist je nach dem Körpertheile, dem es entstammt, verschieden. Das in dem Unterhautzellgewebe eingelagerte Fet;, d. i. der sogenannte Speck, ist weicher und leichter schmelzbar als das in der Bauchhöhle abgelagerte Peritonäalfett, d. i. der sogenannte Filz. Das durch Ausschmelzen des Bauchfettes gewonnene Fett ist weiss, fast geruchlos, von schwachem aber charakteristischem Geschmacke. Es schmilzt zwischen $26-31^{\circ} \mathrm{C}$. und hat nach Saussure ein spec. Gew. $=0.938$ (bei $15^{\circ}$ C.). Es besteht aus 62 pCt. flüssigem und 38 pCt. festem Fett (Braconnot), löst sich in $36 \mathrm{Thl}$. kochendem Alkohol und enthält neben Oelsäureglycerid auch jene der Palmitin- und Stearinsäure. Durch Pressen in gelinder Wärıne lässt sich das flïssige vom festen Fette trennen. Das erstere, d. i. das Specköl oder Sc lmalzöl (lard oil) dient für verschiedene Zwecke der Industrie, namentlich als Schmieröl, dann auch zum Einfetten der Wolle, wird aber auch vielfach zur Verfälschung anderer Oele, namentlich des Olivenöls verwendet. Es ist flïsssig, meist klar, farblos, mitunter auch weiss 
truibe und besteht vorherrschend aus Oelsäureglycerid (Oleïn). Der feste Theil des Fettes, das sogenannte Solarstearin, ist durchscheinend, körnig crystallinisch und schmilzt bei $43^{\circ} \mathrm{C}$., dient namentlich als Materiale für Kerzenbereitung, wohl auch zur Verfälschung des Wallraths. Das Schweinefett bildet einen nicht unwichtigen Handelsartikel, der namentlich von Amerika, dann von Ungarn, der Militärgrenze und Serbien exportirt wird. In Amerika ist das Missisippithal die Hauptproductionsstätte für dieses Fett, für welches Cincinnati den wichtigsten Handelsplatz bildet. Manpflegt daselbst den Körper der geschlachteten Schweine, na ch Abtrennung der Schinken des Lendenspecks und des Salzfleisches, sammt den Knochen in Dampfupparaten mit Dampf von $46 \mathrm{Atm}$. Spannung auszukochen und auszupressen und gewinnt derart ein weiches, sehr oleïnreicher Fett, das zum Theile gebleicht und als solches zu Markte gebracht, zum Theile auf Schmalzöl und Solarstearin weiter verarbeitet wird. Das ungarische und serbische Schweinefett, welches gewöhnlich durch Ausschmelzen des Bauch- und Gedärmefettes gewonnen wird, ist besser und gesuchter als das amerikanische. Das Schweinefett des Handels ist nicht selten verfälscht. Namentlich häufig wird demselben eine grössere Menge Wassers (ivis 20\%) einverleibt, wohl auch zur Erzielung grösserer Weisse und besserer Bindung des Wassers Stärke oder Mehl zugesetzt, endlich finden sich nicht selten Beimengungen von Aetzkalk (bis $1 \%$ ) und Alaun (bis 3\%), deren Anwendung zum Theile eine Verzögerung des Verderbens des Fettes bezweckt. Auch weisse Pulver, wie Gyps, Schwerspath u. dgl. findet man nicht selten dem Fette beigemischt. Von solchen Verfälschungen läst sich zunächst der grössere Wasserzusatz durch Ausschmelzen bei gelinder Wärme, wobei sich das Fett vom Wasser trennt, erkennen. Mehl- oder Stärkegehalt erkennt man beim Ausschmelzen mit Wasser an der Blaufärbung, die das Wasser mit etwas Jodlösung annimmt, Kalk, Alaun, Gyps, Schwerspath an dem Aschenrückstande, der beim Verbrennen des Fettes hinterbleibt. Auch das Schmalzöl wird nicht selten durch Rüböl verfälscht, das man durch Anrühren mit $2-3 \%$ Stärke und mehrstündig es Erhitzen bis zur Verkohlung der Stärke bleicht.

Dem Schweinefett ziemlich nahestehend sind: Gänsefett, das $32 \%$ festes und $68 \%$ flïssiges Fett enthält, ferner das Dachsfett, das bei $30^{\circ} \mathrm{C}$ schmilzt, aber schon bei $9^{\circ} \mathrm{C}$. erweicht und salbenartig wird, das Hundefett, das bei $27^{\circ} \mathrm{C}$., und das Ziegenfett, das bei $25^{\circ} \mathrm{C}$. schmilzt. Das Fett des Menschen hat gleichfalls eine dem Schweinefett fast gleichkommende Consistenz und löst sich in 40 Thl. kochenden Alkohols. Das Fett des Pferdes ist gelb und wesentlich härter als das Schweinefett, es schmilzt bei $47 \cdot 5^{\circ} \mathrm{C}$. Besonders fest und schwer schmelzbar ist aber das Fett vom Halstheile des Pferdes, d. i. das Kammfett, das bei $60^{\circ}$ C. schmilzt und aus $25 \%$ Stearin und $25 \%$ Oleï besteht. Fuchsfett schmilzt bei $54^{\circ}$ C., Hasenfett bei $47 \cdot 5^{\circ}$ C.

4. Knochenfett (petit suif - fat of bones), Markfett. Gelblich weiss bis gelb, bei gewöhnlicher Temperatur körnig weich, resultirt als Nebenproduct beim Auskochen der Knochen gelegentlich der Leim- oder Spodiumfabrikation. Es schmilzt bei $45^{\circ} \mathrm{C}$. und bleibt selbst an der Luft ziemlich unverändert, weshalb es als Maschinenfett sich empfiehlt. Es ist in siedendem Alkohol nur theilweise löslich.

5. Klauenfett (huile de pied de boeuf - foot oil), Klauenöl. Dieses selbst bei niederen Temperaturen flüssige, erst einige Grade unter $0^{\circ} \mathrm{C}$. erstarrende Fett, eigentlich richtiger Oel zu nennen, ist weiss oder blassgelb und von ganz vorzüglicher Haltbarkeit. Man gewinnt es aus den Fussknochen der Rinder, welche man durch Einlegen in heisses Wasser von den anhängenden Fleischtheilen und Hufen trennt und sodann die so präparirten grossen Knochen durch Einwirkung von kochendem Wasser oder gespannten Dämpfen entfettet, wobei sich das Fett auf der Oberfläche der Brühe abscheidet und abgeschöpft werden kamm. Das so gewomnene Fett scheidet beim völligen Erkalten einen Theil eines salkenartigen Fettes $a b$, welches durch Abgiessen von dem die Hauptmasse bildenden flüssigen Fette, geschieden werden kann. Gutes Klauenöl ist fast geruchlos und wird nicht leich ranzig weshalb es sich besonders als Schmiermittel für Maschinen, Uhren $u$. s. w. emptiehlt.

\section{B. Pflanzenfette.}

Yon den technisch verwendeten starren Pflanzenfetten hat die grösste Bedeutung:

1. Das Palmfett, Palmbutter oder Palmöl (huile de palme - palm oil). Dieses Fetl stammt von der Frucht der an der Westküste Afrikas, dann in Centralamerika einheimischen Oelpalme (Elais guineensis Jacq., Avoira elais). Die Küstendistricte von Sierra Leone his an die Congoküste liefern die grössten Mengen dieser Oelfrucht, welche im reifen 
Zustande eine tief orangegelb gefärbte Steinfrucht von der Grösse einer Pflaume darstellt, deren eine grosse Anzahl in traubenartigen Büscheln vereinigt den Fruchtstand der Oelpalme bilden. Ein Palmbaum trägt oft Büschel von $40-50 \mathrm{~K}$. im Gewichte. Die einzelnen Früchte bestehen aus einem den Samen einschliessenden Kerne, welcher in ein fasriges Fruchtfleisch eingebettet ist. Sowohl das Fruehtfleisch als der Kern sind ölhaltig. Die Einheimischen sammeln die Früchte und lassen sie in flachen Gruben oder Trögen durch längere Zeit der Einwirkung der Sonnenhitze ausgesetzt, wodurch das Fruchtfleisch gelockert wird und sodann durch Kneten und Schlagen von den Kernen getrennt werden kann. Das so gesonderte Fruchtfleisch wird in irdenen Töpfen mit Wasser gekocht, wobei sich das Fett an der Oberfläche der Flüssigkeit abscheidet und in Gestalt eines Breies, der noch reichlich Theile des Fruchtfleisches beigemengt enthält, abgeschöpft werden kann. Dieses rohe Fett wird dann durch Einschlagen in Tücher und Ausringen oder einfaches Ausdrücken von der Hauptmasse der Fruchtfleischreste getrennt. Die Kerne werden gegenwärtig fast ausschliesslich nach Europa gebracht, wo sie nach dem Zerstossen in hydraulischen Pressen warm gepresst werden.

Das Palmfett hat bei gewöhnlicher Temperatur Butterconsistenz, ist von röthlichgelber Farbe und hat im frischen Zustande einen angenehmen Veilchengeruch und einen schwach süsslichen Geschmack. Es schmilzt, wenn frisch, bei $24-27^{\circ} \mathrm{C}$. An der Luft wird es leicht ranzig, wird dann allmälig blässer und schwerer schmelzbar $\left(30-35^{\circ} \mathrm{C}\right.$., sehr altes schmilzt sogar erst bei $41-42^{\circ} \mathrm{C}$.). Im Alkohol ist es bei Siedhitze leicht und vollständig löslich, Aether löst es schon in der Kälte, von Alkalien wird es leicht verseift. Es besteht wesentlich aus Oelsäure- und Palmitinsäure-Glycerid, enthält aber gleichzeitig eine mit dem Alter zunehmende Menge an freier Oelsäure und Palmitinsäure, neben freiem Glycerin. Der Gehalt an freien Säuren kann bis $80 \%$ betragen. Die gelbe Farbe rührt von dem Gehalte an einem in dem Fette gelösten Farbstoffe her, der durch Zersetzung eines Bestandtheiles des Fruchtfleisches entsteht. Es dient vornehmlich für Zwecke der Seifenfabrikation. Das nach dem Abpressen des Oleïns resultirende Palmitin wird übrigens auch directe zur Kerzenfabrikation verwendet. Uebrigens findet es Verwendung zu den Oelbeizen der Türkischrothfärbereien, als Maschinenschmiere u. s. w., im frischen Zustande auch als Nahrungsmittel.

Das aus den Kernen gepresste Fett, Palmkernöl, ist von chocoladebrauner Farbe und übrigens ähnlichen Eigenschaften wie das Palmöl. Es hat einen an Cacao erinnernden Geruch. Das Palmöl wird für die Zwecke der Seifen- und Kerzenfabrikation häufig gebleicht Nach Pohl kann man die Zerstörung des Farbstoffes durch blosses Erhitzen des rohen Fettes erreichen. Man schmilzt dasselbe in Kesseln von Gusseisen und erhitzt es möglichst rasch auf $220-240^{\circ} \mathrm{C}$., bei welcher Temperatur man es durch ca. 10 Minuten bis $1 / 2$ Stunde erhält Bei $115^{\circ}$ C. konımt das Fett anscheinend zum Sieden und beginnt zu steigen, weshalb man die Kessel zur Verhütung des Ueberlaufens nicht über 2 Dritttheile ibres Fassungsraumes füllen darf; ist die Temperatur bis $180^{\circ} \mathrm{C}$. gestiegen, dann hört das Sieden auf und es beginnt nun die Entwicklung sehr belästigender, stechend sauer riechender Dämpfe. Nach genügend langer Einwirkung der höheren Temperatur wird das Fett rein weiss und scheidet die in demselben enthalten gewesenen Reste der Fruchtfleischsubstanz, von der in besseren Sorten nicht mehr als $0.3-1 \%$ enthalten sein sollen, in Gestalt brauner Flocken ab. Das frisch gebleichte Fett hat einen brenzlichen Geruch, der sich jedoch nach längerem Lagern wieder vollständig verliert, während der ursprüngliche Veilchengeruch wiederkehrt (vgl. Dingl. pol. Journ. 135 pag. 140).

Auch durch länger fortgesetzte Einwirkung der Luft bei $100^{\circ}$ C. kann man das Palmfett bleichen, ebenso durch Erhitzen mit chromsaurem Kali und Salzsäure oder Schivefelsäure oder mit Braunstein und Salzsäure (s. Dingl. pol. Journ. 152 pag. 80). Auf $100 \mathrm{~K}$. Palmfett rechnet man $1-1.5 \mathrm{~K}$. chromsaures Kali, $3 \mathrm{~K}$. Salzsäure und $1 / 2 \mathrm{~K}$. Schwefelsäure. Das chromsaure Kali wird früher gelöst und diese Lösung mit den Säuren dem auf $50^{\circ} \mathrm{C}$. erwärmten Fette beigemengt und durch fleissiges Rühren damit vermischt. Wenn die Gelbfärbung verschwunden ist, lässt man klären und zieht das Fett ab, hierauf wäscht man mit heissem Wasser oder mittelst Dampf. Sollte das gewaschene Fett noch eine Grünfärbung zeigen, so kocht man dasselbe wiederholt mit salzsäurehaltigem und endlich mit reinem W'asser. Am besten lässt sich die Lagos-Waare bleichen, während die unter dem Namen Liverpooler Waare bekannten Sorten nach dem Bleichen oft eine schwache Graufärbung zeigen. 
Das Bleichen des Palmkernöls wird am vortheilhaftesten derart ausgeführt, dass man das Fett zunächst bei $100^{\circ} \mathrm{C}$. mit Salzlauge von $26^{\circ} \mathrm{B}$. innig vermengt und sodann der Ruhe überlässt, wobei sich die Salzlauge, welche dem Fette schon einen Theil des Farbstoffs entzogen hat, abscheidet. Das abgeschöpfte Fett wird nun bei $35^{\circ} \mathrm{C}$. mit Salzsäure und chromsaurem Kali in gleicher Weise gebleicht wie das Palmfett. Das gebleichte Palmkernöl (Palmnussöl) ist indess fast nie rein weiss, sondern zeigt fast stets eine blassgelbe Farbe.

2. Mafurratalg. Das Fett der Mafurrakerne (Mafutrakerne), d. s. die Samen einer in Mozambique einheimischen, nicht näher bekannten Pflanze, welche eine leichte, beim Drücken abspringende rothe Hülle, in der Mitte mit einem schwarzen Fleck haben, etwa so gross wie eine Cacaobohne und durchschnittlich $0.6 \mathrm{Grm}$. schwer sind. Diese Kerne, welche an der Innenseite flach, nach Aussen zu convex sind und sich leicht in zwei Hälften spalten lassen, sind sehr hart und haben einen stark bitteren Geschmack. Beim Pressen liefern sie nur geringe Mengen Fett, dagegen wesentlich mehr beim Auskochen mit Wasser oder beim Extrahiren mit Benzin, Aether oder Schwefelkohlenstoff. Durch solche Extraction kann man bis $65 \%$ eines gelblichen starren Fettes gewinnen, das der Cacaobutter ähnlich riecht und etwa denselben Schmelzpunkt zeigt wie Rindstalg. In siedendem Alkohol ist es nur unvollständig löslich, leicht dagegen in heissem Aether, aus welcher Lösung es in sternförmigen Crystallen sich ausscheidet. Es ist leicht verseifbar und besteht wesentlich aus einem Gemenge von Oleïn und Palmitin. Die Mafurrakerne können in grösster Menge von Mozambique und Madagascar bezogen werden (s. Journal f. pract. Chem. 67 pag. 286).

Dem Mafurratalg ähnlich verhält sich der Tinkawantalg, der aus Indien in den Handel kommt und von den Früchten eines in Borneo und Sumatra einheimischen Baumes stammt. Er löst sich nur zum Theile in kaltem, vollständig in kochendem Alkohol und besteht wesentlich aus Oleïn, Palmitin und Stearin (vgl. Ruge Jahrbuch der Chemie 1862 pag. 506.)

3. Die Muscatbutter (beurre de muscade - oil of mace), Muscatbalsam. Muscatnussbutter, das Fett der unter dem Namen Muscatnüsse bekannten Frïchteron Myristica moschata Thunb., das durch Auspressen der zerstossenen und gedämpften Früchte bei gelinder Wärme gewonnen werden kann. Die Nüsse liefern etwa $12 \%$ eines röthlich gelben, weiss marmorirten ziemlich festen Fettes, das einen starken Muscatnuss-Geruch und schwach aromatischen Geschmack hat, welche Eigenschaften es einem Gehalte von ätherischem O.I (etwa $4 \%$ ) verdankt. Schmilzt bei $41-51^{\circ} \mathrm{C}$., spec. Gew. $=0.995$. Löst sich in kaltem Weingeist schwer, leicht in kochendem (4 Thl.), Aether, Chloroform und Benzin lösen theilweise. Besteht vornehmlich aus den Glyceriden der Oelsäure und Myristinsäure neben etwas Buttersäureglycerid (s. Playfair, Annal. d. Chem. u. Pharm. 37 pag. 152 u. 163; a. Ricker, n. Jahrb. d. Pharm. 19 pag. 17). Die Muscatbutter kommt in wie Seife geschnittenen Stücken, die in Bast eingehüllt sind, meist von Java (bessere Qualität) und von Singapore und Penang (geringere Qualitär) in den Handel. Nicht selten wird dieses Fett verfälscht durch Zusätze von billigeren Fetten oder dureh Kochen von Talg mit etwas Muskatnusspulver und Färben mit Sassafras oder Safran imitirt. Auch die Muscatblüthe liefert ein ähnliches, aber dunkler gefärbtes Fett (Macisbutter).

4. Der Pinientalg, das Fett der Samen von Valeria indica, wird durch Auskochen der Samen mit Wasser und Abschöpfen des abgeschiedenen Fettes gewonnen. Ist fa-t weiss, bei $38^{\circ}$ C. schmelzend, fast geruchlos.

Ueber Cocosfett, Cocosbutter s. II pag. 371, iber Cacaobuter s. Cacao II pag. 187. Fliissige Pflanzenfette d. s. fette Oele s. b. O el e, iiber Wachsarten s. W achs. Gtl.

Fettgarleder, fettgares Leder, Sämischleder, s. Leder.

Fettgas, Leuchtgass, durch trockene Destillation der Fette gewonnen, s. a. 0 elgas, s. Leuchtsto ffe.

Fettkörper, allgemeine Bezeichnung für Fette überhaupt. In der org. Chemie bezeichnet man mit diesem Namen, im Gegensatze zu den aromatischen Körpern, jene organischen Stoffe, deren Kohlenstoffatome man sich reihenförnaig zu sog. offenen Ketten angeordnet denkt ( $\equiv C-C-C-C \equiv)$, während man in 
den aromatischon Körpern die Kohlenstoffatome in geschlossenen Ketten (Ringen) gruppirt denkt. Vgl. aromatische Körper I pag. 192, vgl. a. Benzol I pag. 377. Gtl.

Fettleder, s. Leder.

Fettquarz, s. Quarz.

Fettsäuren. Diesen Namen führen die organischen Säuren der allgemeinen Formel $C_{n} H_{2 n} O_{2}$, welche sich vorherrschend als Bestandtheile der natürlichen Fette finden, in denen sie theils als Glyceride, theils in Verbindung mit Alkoholen, als zusammengesetzte Aether, theils auch im freien Zustande enthalten sind. Die wichtigsten hierher gehörigen Säuren sind:

Ameisensäure $\mathrm{CH}_{2} \mathrm{O}_{2}$
Essigsäure $\mathrm{C}_{2} \mathrm{H}_{4} \mathrm{O}_{2}$
Propionsäure $\mathrm{C}_{3} \mathrm{H}_{6} \mathrm{O}_{2}$
Buttersäure $\mathrm{C}_{4} \mathrm{H}_{8} \mathrm{O}_{2}$
Valeriansäure $\mathrm{C}_{5} \mathrm{H}_{10} \mathrm{O}_{2}$
Capronsäure $\mathrm{C}_{6} \mathrm{H}_{12} \mathrm{O}_{2}$
Oenanthylsäure $\mathrm{C}_{7} \mathrm{H}_{14} \mathrm{O}_{2}$
Caprylsäure $\mathrm{C}_{8} \mathrm{H}_{16} \mathrm{O}_{2}$
Pelargonsäure $\mathrm{C}_{9} \mathrm{H}_{18} \mathrm{O}_{2}$
Caprinsäure $\mathrm{C}_{10} \mathrm{H}_{20} \mathrm{O}_{2}$

Laurinsäure $\mathrm{C}_{12} \mathrm{H}_{24} \mathrm{O}_{2}$ Myristinsäure $\mathrm{C}_{14} \mathrm{H}_{28} \mathrm{O}_{2}$ Palmitinsäure $\mathrm{C}_{16} \mathrm{H}_{32} \mathrm{O}_{2}$ Stearinsäure $\mathrm{C}_{18} \mathrm{H}_{36} \mathrm{O}_{2}$ Arachinsäure $\mathrm{C}_{20} \mathrm{H}_{40} \mathrm{O}_{2}$ Behensäure $\mathrm{C}_{22} \mathrm{H}_{44} \mathrm{O}_{2}$ Hyänasäure $\mathrm{C}_{25} \mathrm{H}_{50} \mathrm{O}_{2}$ Cerotinsäure $\mathrm{C}_{27} \mathrm{H}_{54} \mathrm{O}_{2}$ Melissinsäure $\mathrm{C}_{30} H_{60} O_{2}$.

Wie aus den Zusammensetzungsverhältnissen der Säuren dieser Reihe zu ersehen, unterscheiden sich die höheren Glieder der Reihe von den niedrigen durch einen Mehrgehalt von $n$ mal der Gruppe $\mathrm{CH}_{2}$ und können aus den niedrigeren Gliedern durch Vertretung von Wasserstoff in denselben durch die einfache oder selbst schon Substitutionen zeigende Gruppe $\mathrm{CH}_{3}$ entstanden gedacht werden. Sämmtliche Säuren dieser Reihe sind einbasisch und enthalten sonach nur eine Hydroxylgruppe, in welcher der Wasserstoff durch Metalle vertretbar ist. Man kann sonach die Säuren dieser Reihe durch die allgemeine Structurformel $\mathrm{CHO}, \mathrm{OH}$ ausdrücken, worin der Wasserstoff der Gruppe $\mathrm{CHO}$ durch $\mathrm{CH}_{3}$ oder $\mathrm{CH}_{2} \mathrm{CH}_{3}$, $\mathrm{CH}_{2} \mathrm{CH}_{2} \mathrm{CH}_{3}, \mathrm{CH}_{2} \mathrm{CH}_{2} \mathrm{CH}_{2} \mathrm{CH}_{3}$ u. s. w. vertreten sein kann. So erscheint die Essigsäure als $\mathrm{CCH}_{3} \mathrm{O}, \mathrm{OH}$, d. i. Methylameisensäure, die Propionsäure als $\mathrm{CCH}_{3} \mathrm{CH}_{2} \mathrm{O}, \mathrm{OH}$, d. i. Aethylameisensäure u. s. f. Es ist hiebei jedoch nicht bedingt, dass diese den Wasserstoff vertretenden Gruppen durch successive Vertretung von je einem Wasserstoffatom in den Gruppen $\mathrm{CH}_{3}$ entstanden sind, sondern es kann auch der Fall eintreten, dašs in ein und derselben Gruppe $\mathrm{CH}_{3}$ mehre oder alle Wasserstoffatome durch die Gruppe $\mathrm{CH}_{3}$ oder Abkömmlinge derselben vertreten sind, wodurch Säuren von gleicher Zusammensetzung, aber verschiedenen Eigenschaften (isomere Säuren) entstehen; so kann es zwei Säuren der Formel $\mathrm{C}_{4} \mathrm{H}_{8} \mathrm{O}_{2}$ geben, deren eine $\mathrm{CCH}_{2} \mathrm{CH}_{2} \mathrm{CH}_{3} \mathrm{O}, \mathrm{OH}$, die andere $\mathrm{CCH}_{\mathrm{CH}_{3}}^{\mathrm{CH}_{3}} \mathrm{O}, \mathrm{OH}$ ist, und solche Möglichkeiten sind bei den höheren Gliedern dieser Reihe natürlich iu vermehrtem Verhältnisse nicht nur denkbar, sondern es bestehen bezüglich aller höheren Formen auch entsprechend mehr Isomeriefälle.

Die Fettsäuren, welche bis zu dem Gliede $C_{10} H_{20} O_{2}$ flïssig und auch fast völlig unzersetzt destillirbar sind, während die höheren Glieder schon bei gewöhnlicher Temperatur starr und unter gewöhnlichem Luftdruck nicht mehr unzersetzt flüchtig sind, und demnach in flüssige und flüchtige und in feste und nicht flüchtige unterschieden werden, sind im Allgemeinen schwache Säuren, u. z. um so schwächer, je höher ihr Kohlenstoffgehalt ist. Die flïchtigen haben einen mehr weniger stechend säuerlichen Geruch und brennend saiteren Geschmack, lösen sich in Alkohol und Aether und bis zur Valeriansäure auch in grösserer Menge in Wasser. Die festen Fettsäuren sind dagegen fast geruch- und geschmacklos, in Wasser unlöslich, dagegen in Alkohol und Aether löslich. Sie zeigen eine in dem Masse, als ihr Kohlenstoffgehalt wächst, abnehmende sauere Reaction, dagegen 
steigen ihre Siede- und Schmelzpunkte im Verhältnisse der Zunahme des Kohlenstoffgehaltes u. z. die Siedepunkte im Allgemeinen für jede Zunahme um 1 Kohlenstoffatom um $19^{\circ} \mathrm{C}$.

Ueber die einzelnen Fettsäuren s. die betreffenden Artikel. Gtl.

Fettwachs (adipocire), Leichenwachs, ist ein Umwandlungsproduct der Fette, welches durch längere Einwirkung von Feuchtigkeit und Luft, bei gleichzeitiger Gegenwart von Basen aus Fetten sich bildet. Findet sich nicht selten in den Erdreiche, in welchem viele Cadaver angehäuft waren, also auf Friedhöfen, und besteht wesentlich aus zum Theil freien, zum Theil an Kalk gebundenen Fettsäuren. Gtl.

Feuer flüssige (feu liquide - liquid fire) nennt man im Allgemeinen flüssige Mischungen, welche entweder durch Lnftzutritt oder durch Zutritt von Wasser selbst zur Entzïndung kommen, und so directe als Zündmittel dienen können, oder bei ihrer Berührung mit entzündlichen Substanzen die Entzündung dieser herbeiführen und so mittelbar als Zïndmittel wirken können. Ausser dem bereits besprochenen Fenian-Feuer (s. III pag. 403) gehören hieher:

1. Die Mischung von Ni è p e e, welche durch Vermengen von Benzol oder Petroleum mit Kalium oder Phosphorcalcium hergestellt wird, so wie die Natriumzündmasse von Fleck (s. Dingl. pol. Journ. 190 pag. 306) beides Mischungen, welche durch Berührung mit Wasser zur Entzündung kommen.

2. Die Mischung von Chlorschwefel mit phosphorhaltigem Sehwefelkohlenstoff, welche unter dem Namen lothringisches Feuer (feulorrain) bekannt ist, und sich sofort entzündet, wenn sie mit Ammoniak (Salmiakgeist) in Berihrung kommt. (S. Dingl. polyt. Journ. 206 pag. 78.) In gleicher Weise verhält sich auch Phosphortrichlorid (dreifach Chlorphosphor) und ebenso Bromschwefel, wenn sie mit Ammoniak oder Schwefelammonium in Berihrung kommen.

3. Die Mischungen von Schwefelsäure mit chlorsauren Salzen oder mit übermangansauren Salzen (3 Thl. concent. Schwefelsäure mit 2 Thl. übermangans. Kalium), welche bei Berührung mit brennbaren Körpern, als: Terpentinöl, Papier, Holz, Schwefel u. s. w. die Entzündung derselben herbeiführen. (s. Sophronius d. Industr. Ztg. 1867 pag. 36.) Gtl.

Feuer lothringisches, s. Feuer flü sig ige.

Feuerbeständig (apyre, fixe - apyrous, fix) nennt man Körper, welche bei höherer Temperatur nicht verbrennbar und auch nicht flüchtig sind. Unverbrennbare Körper bezeichnet man wohl auch als feuerfest (incombustible - fire proof), welche Bezeichnung indess correct nur für Körper angewendet werden soll, welche im Feuer fest bleiben, also unschmelzbar sind. Gtl.

Feuerblende, s. Zinkblende, s. a. Rothgiltigerz.

Feuerbrücke (pont - fire bridge), s. Eis enerzeugung bei Puddelofen III pag. 534.

Feuergeschränke, s. II pag. 534 .

Feuergewehre, s. Feuerwaffen.

Feuergrube, s. Schmiedeherd im Artikel Schmieden.

Feuerhahn oder Hydrant, s. Röhrenleitungen.

Feuerkasten (boîte à feu - fire-box), s. b. Locomotive III pag. 81.

Feuerlauge, s. b. Seife.

Feuerlöschdosen nennt man die von Bucher empfohlenen, zur Löschung vou bränden in geschlossenen oder gut rerschliessbaren Räumen bestimmten, mit brennbaren Gemengen gefüllten Dosen, welche dadurch löschend wirken, dass 
durch Verbrennung ihres Inhaltes eine grosse Menge von Gasen (Stickstoff, schweflige Säure, Kohlensäure) gebildet wird, welche zur Unterhaltung von Verbrennungen untauglich sind und sohin löschend wirken können. Nach verschiedenen Analysen besteht der Inhalt dieser Dosen wesentlich aus einem Gemenge von ca. 60) Thl. Salpeter, 36 Thl. Schwefel und 4 Thl. Kohle, und entwickelt ein Kilogr. dieser Masse durchschnitllich 298 Liter schwefliger Säure, 68 L. Kohlensäure und 84 L. Stickstoff.

Auch $\mathrm{Z}$ eisler hat ein ganz ähnliches Gemenge von 60 Thl. Salpeter, 36 Thl. Schwefel und 4 Thl. Kohle nebst einem geringen Zusatz an Kalk zu gleichen Zwecken angegeben, und empfiehlt das aus den gehörig zerkleinerten Gemengtheilen innig gemischte und in Pappendeckelhülsen fest eingestampfte Gemenge in das in einem abschliessbaren Raume entstandene Feuer zu werfen (u. z. $1 \mathrm{Klg}$. auf $15^{\mathrm{kbm}}$ Raum) und den Raum sodann möglichst gut abzuschliessen. Selbstverständlich ist bei Anwendung dieser Löschmittel zu berücksichtigen, dass die durch Verbrennung des Gemenges entstandenen Gase irrespirabel sind, wesshalb das Leben von Bewohnern angrenzender Räume durch Anwendung eines solchen Löschmittels unter Umständen gefährdet werden könnte. (Vgl. a. Lös chw es en.) Gtl.

Feuerlöschwesen, s. Lö s chwes e n.*)

Feueropal, s. Opal.

Feuerräder, s. Feuerwerkerei.

Feuerschwamm, s. Z ii $\mathrm{d} \mathrm{s} \mathrm{chw}$ a $\mathrm{m} \mathrm{m}$, s. a. S $\mathrm{chw}$ a $\mathrm{m} \mathrm{m}$.

Feuersetzen, s. Bergbau II pag. 385.

Feuerspritze (pompe à incendie - fire engine), s. Lös chw es en.*)

Feuerstein, s. Q u a rz.

Feuerstein-Bearbeitung hat jetzt nur mehr geringe praktische Bedeutung, indem die Anwendung des Feuersteines als Flintenstein, so wie als Stein zum Feuerschlagen auf wenige Kreise beschränkt ist. Der Feuerstein war in hervorragender Weise das Material der Werkzeuge der Alten und es kommt seiner Bearbeitung ein hohes historisches Interesse zu. Vgl. Hacquet B. phys. und techn. Beschr. der Flintensteine Wien 1792 Beck, s. f. Prechtl Encyclop. Bd. 6 pag. 34 und den Art. Steinbearbeitung. $K k$.

Feuerung (chauffage - fewel). Vgl. die Artikel: Brennstoffe II pag. 14, Dampfkessel II pag. 533, Eisenbahn-Fahrbetriebsmittel bei Locomotive III pag. 81, Gasfeuerung und Heizung, so wie betreffend die Feuerungen für andere specielle Zwecke die beztiglichen Artikel, z. B. Blei, Eisenerzeugung, Brodbackofen etc.

Feuerungs-Anlagen, s. F e ue rung.

Feuervergoldung, s. Vergoldung, s. Galvanoplastik.

Feuerwaffen. Unter dieses Schlagwort sind nicht nur die $\mathrm{H}$ andfeu erwaffen als Gewehre (fusil - musket) und Pistolen (pistolet - pistol), sondern auch die grossen Geschiitze als Mörser, Kanonen (canon — gun), Mitrailleusen etc. einzureihen. Es ist nicht möglich in diesem Werke alle die Abarten dieser Waffen zu beschreiben, wir wollen vielmehr nur eine Uebersicht iiber dieses grosse Gebiet liefern.

Nachdem die Wurfkraft des Schiesspulvers im 14. Jahrhundert bekannt wurde, machte man Versuche grosse Steine aus steinernen und metallnen starken, mörserartigen Gefässen in die Ferne zu schleudern, indem man in die Höhlung des Mörsers eine der gewïnschten Tragweite entsprechende Quantität Schiesspulvers

*) Zn dieser Verweisung sieht sich die Redaction durch den betreffenden Herru Mitarbeiter gezwungen. $K k$. 
schüttete und einen kugelförmigen Stein darauf legte. Durch eine feine, nahe am Boden des Gefässes angebrachte Bohrung ( $Z$ ii ndloch) erfolgte die Entzïndung (Explosion) des Pulvers und in Folge derselben das Auswerfen der Kugel.

Die parabolische Kugelbahn war aber, weil die Kugel keine sichere Führung: im Rohre des Mörsers erhielt, so unbestimmt, dass man den Einfall des geschleuderten Gegenstandes nicht einmal so genau bestimmen konnte, als es bei den bei Belagerungen seit vielen Jahrhunderten gebräuchlichen $K$ at apulten oder Wurfmaschinen der Fall war. So unvollkommen waren die ersten Mörser. Bald ist man jedoch zur Ueberzeugung gekommen, dass die Flugbahn bedeutend sicherer zu bestimmen ist, wenn das zu ladende Geschütz länger ist, und das Geschoss vor dem Austritte, durch eine längere Röhre, in die gehörige Richtung gebracht wird. Durch fortgesetzte Verbesserungen solcher primitiver Geschuitze gelang es in nicht geraumer Zeit die alten $\mathrm{K}$ at apulten und $\mathrm{B}$ allisten durch Mörser und andere mannigfach benannte grobe Gesch ïtze ersetzen. Diese Donnerbüchs en wurden theils von Eisen gewunden oder geschmiedet, theils in starke Baumstämme gebohrt, oder aus schwachen Eisenstäben, die um eine blecherne Röhre gelegt und mit Leder umnäht wurden, u. s. w. verfertigt. Die von minder festem Material, namentlich von Holz verfertigten $\mathrm{Feuerbü} \mathrm{chsen}$ wurden gewöhnlich durch starke Eisenreifen armirt. Später wurden dieselben aus Eisen oder diversen Legirungen gegossen. Am besten bewährte sich das Ka nonenmetall (s. Bronze II pag. 60), welches noch vor wenig Jahren, also beinahe vier Jahrhunderte nach seiner ersten Anwendung, meist zur Verfertigung der Kanonen benützt wurde.

Zugleich wurden auch Verbesserungen an den Geschossen getroffen, so dass die steinernen Kugeln den eisernen wichen; welche die $\mathrm{Rohrseele} \mathrm{genau}$ ausfullen konnten, wodurch die Treff- und Tragfähigkeit erheblich gewann. Bald nach der Einführung der Donnerbüchsen versuchte man auch kleinere derartige Waffen zu erzeugen, und schon das 14. Jahrhundert sah kurze Handbü chsen, Musketen, die mit der Zeit, wegen leichter Handhabung und ziemlich gutem Erfolge, die alten Bogen und die Armbrüste verdrängten.

Wegen besserer Handhabung befestigte man die Handkanonen, an verschieden geformte $\mathrm{Holzschäfte,} \mathrm{und} \mathrm{auch} \mathrm{die} \mathrm{schweren} \mathrm{Geschïtze} \mathrm{erhielten} \mathrm{hölzerne}$ Unterlagen wegen leichterem Richten beim Zielen, welche Unterlagen (Blöcke genannt) später mit Rücksicht auf den Transport wieder durch solid gebaute Karren (L a f etten) ersetzt wurden.

Anfangs wurden sämmtliche Fenerwaffen, kleine wie grosse, mit der Hand mittelst Lunte oder Feuerschwamm entladen, welcher Unstand das Zielen mit Handbüchsen sehr beeinträchtigte; deshalb wurden ganz einfache bewegliche Lunthalter (Drachen) angebracht, welche eine nicht gar starke Feder iiber der mit etwas Pulver bestreuten $\mathrm{Pf}$ anne hielt, und die der Schïtze, nachdem er gezielt, auf die Pfanne senkte. Bald nachher wurde eine besondere Vorrichtung getroffen, die es ermöglichte den Drachen durch einen einfachen Druck an die Pulverpfanne zu neigen, ebenso wie die alten Armbrïste durch dieselbe Bewegung abgedrïckt wurden. So wurde das Luntschloss, die erste mechanische Vorrichtung zur Entladung der Feuerwaffen.

In dieser Periode sind, wie es scheint, die Fenergewehre auch schon für die Jagd benützt worden.

Die Luntschlösser wurden nach geraumer Zeit durch die sinnreich zusammengestellten Radschlösser ersetzt. An die Stelle des Drachen trat der Hahn, in dessen M a u l e Schwefelkies befestigt wurde. Hat man den durch eine Schnappfeder festgehaltenen Hahn heruntergedrückt, so rieb das, vorher durch einen Schlüssel gespannte, am Umfange mit kleinen Einschnitten rersehene Rad beim Losdricken durch schnelle Drehung eine zur Anfeuerung des Zündsatzes genügende Menge Funken aus dem Schwefelkies.

Nach dem J. 1543 wurde das Radschloss der Präcisionswafien fast gewöhnlich mit 
der in München erfundenen Abzugvorrichtung, dem sogenannten Steclier verbunden, welchen wir später näher zu erwähnen Gelegenheit finden.

Das Radschloss, mit der Zeit wesentlich verbessert und vereinfacht, erhielt sich bis auf den heutigen Tag. Zudem besitzen auch die bei den meisten Hinterladern benützten Percusionsschlösser Feder, Studel, Schnappstange und $\mathrm{Nuss}$, wie diese dem ursprünglichen Radschlosse angehörten.

Das Radschloss fand bald erfolgreiche Concurrenz im Srhnapphahn schloss, welches bei sehr einfacher und wenig kostspieliger Construction den Vortheil hatte, dass die Pulverpfanne durch einen Deckel vor Regen und Ausschütten geschützt war. Der Hahn ist hier an die Stelle des Rades getreten und wird durch die Schlag- oder Schnappfeder stark gegen die Pfanne gedrückt, so dass er beim Loslassen (ohne Drücker) an die aufgeworfene Seite des P fann endeckels anschlägt, wodurch der rasch aufspringende Deckel den durch Anschlagen des Schwefelkieses auf Stahl erzeugten Feuerfunken freien Fall zu dem Zündsatz gewährt.

Später wurden die Vortheile des Schnapphahnes mit denen des Radschlosses, nämlich mit den Spannrasten und Abzugvorrichtung vereint; das Resultat war das Batterieschloss, welches mehr als 150 Jahre das Feld beherrschte. Der Schwefelkies des Radschlosses und Schnapphahnes wurde beim Batterieschloss durch den Feuerstein (altgerm. Flins) ersetzt. Das Wort ${ }_{n} F$ linte ${ }^{u}$ ist von Flins abgeleitet.

Mit diesen Schlossverbesserungen wurde auch der L a u und andere Gewehr. theile vervollkommt. So wurde vor Allem die Rohrseele mit parallel lanfenden geradlinigen Vertiefungen versehen, wodurch nicht nur die Tragweite, sondern auch die Trefffähigkeit bedeutend stieg, umsomehr als man die parallelen Riffe oder Zuige durch schraubenförmige ersetzte. Derartige Zuige sind bisher in ihrer Wirkung durch keine andere Vorrichtung ersetzt worden. Sie werden mit dem Namen Drall bezeichnet. Solche Läufe sind jedoch nur für den Kugelschuss geeignet.

Ferner wurde wegen sicherem Zielen das vordere Rohrende mit einem kleinen Ansatze versehen, der sich unter dem Namen Fliege, Korn, Mü cke bis heute erhielt. Die mit diesem Ansatze versehenen Fenergewehre bezeichnete man mit dem Worte "Musketen," welches von dem ital. "moschetta" (Fliege) abstammt.

Auch wurde der zu jeder Feuerbïichse nöthige hölzerne Ladstock durch einen eisernen ersetzt, welcher das Aufsetzen der Kugel durch seine Schwere bedeutend erleichterte, und nicht so gebrechlich war wie die plumpen Holzstöcke.

Bei derartigen Fortschritten war es ganz natürlich, dass die sämmtlichen alten Feuerwaffen den neueren Platz räumten, und diese als schwere wie als Handgeschütze neben den Hau- und Stichwaffen fast allgemein eingefiihrt wurden.

Fast gleichzeitig mit der Construirung des Batterieschlosses haben sich die Fachleute die alte Frage zur neuen Aufgabe gemacht, ob man nicht das Kugelrohr zugleich als Lanze benützen könnte. Dies war leicht geschehen. Man gab der kurzen Seitenwaffe einen runden hölzernen Griff, den der Kämpfer leicht in die Rohrmündung einstecken und so die Schusswaffe in eine Lanze verwandeln konnte. Bei derart verstopftem Rohre war es freilich nicht möglich, das Gewehr zum Feuern gleichzeitig zu gebrauchen. Die Schweden waren die ersten, die den Schuss bei aufgepflanztem $\mathrm{Bajonett}$ ermöglichten, indem sie nicht den Bajonettgriff in den Lauf, sondern umgekehrt den Lauf in den Griff einschoben, und die Stichklinge etwas seitwärts anbrachten.*) (Vgl. Bajonettverschluss I pag. 279.)

*) Die Idee, die Feuerwaffen mit einer anderen Waffe zu verbinden, ist bereits in den ersten Jahren der Benützung derselben, als man noch mit der Hand abfeuern musste, so wie auch später öfters vorgekommen; so war z. B. die Handwaffe zugleich ein Beil, Morgenstern etc., und in der Soltikoff'schen Sammlung bewundert man noch heute einen Saufänger, an welcbem über den Hellebardenhaken drei Läufe mit Radschlössern angebracht sind. 
Ausserdem wurden die für die Jagd bestimmten D op pelw affen erfunden, und zwar wurden solche anfänglich derart erzengt, dass jeder Lauf für sich, unabhängig von dem anderen, im Schafte befestigt war. Erst später wurden, und zwar wie es scheint in Schweden, die beiden Läufe zusammengelöthet.

Die Erfindung des explodirenden Chírkali durch den Chemiker Grafen Bertholet 1786 und die des Knallquecksilbers durch Howard 1799 hatte in der Waffenindustrie eine allgemeine Wendung hervorgerufen. Wie konnte auch die Erfindung dieser durch blossen Schlag sich entziindenden Stoffe besser benutzt werden, als für die Schusswaffen?

Schon im Jahre 1807 patentirte Forsyth in Birmingham ein Percussions$\mathrm{schloss}$. Der Hahn des Batterieschlosses wurde nämlich durch einen Hammer ersetzt, und auch die Pfanne hat andere Form und Bohrung erhalten. Jedoch wie alle neuen Erfindungen hatte auch diese mit vielem Misstrauen zu kämpfen. Man versah sehr oft einzelne Gewehre mit dem sinnreichen Doppelschloss (Batterieschloss und Percussionsschloss in einem verbunden), wie man vor einem Jahrhundert das Radschloss ebenfalls mit dem Batterieschlosse und noch früher das erstere mit dem Luntsehlosse vereinte.

Als jedoch später die Z ï nder, Z ündröhrchen, Z ï d hütchen (K a pseln) etc. auch die urspriinglichen $\mathrm{Z}$ ii ndpillen verdrängten, weil hier der durch blossen Schlag entzïndliche chemische Satz durch eine Metalldecke geschützt war, wurden die Percussionsschlösser, Schlagschlösser, fast allgemein angewendet, und erhielten solche Gewehre den Namen der Percussionsgewehre. Der Stecher der Radschlossflinten hat sich bei Kugelbüchsen gleich den, noch von der Armbrust geerbten einfachen Abzugziingel der Schrotflinten bisher erhalten.

$\mathrm{Zu}$ den Feuerwaffen wurde zu jeder Zeit nur das beste Material verwendet, namentlich ist dem "Rohrmaterial" die grösste Sorgfalt zu widmen. Der Lauf, als Haupttheil der Waffe, hat die Bestimmung, die Ladung aufzunehmen, und nach der Pulverexplosion dem Geschosse die Richtung zu geben. Die Rohrwände müssen daher genïgend stark sein, um den enormen Druck der Pulverexplosion aushalten zu können. Diese Widerstandsfähigkeit der Laufwände ist jedoch weniger von der Wandstärke abhängig, als von der Qualität des zum Laufe verarbeiteten Eisens, welcher Umstand die bewundernswerthe Danerhaftigkeit der verhältnissmässig schwacheu und leichten heutigen Läufe erklärt.

Am stärksten ist der Lauf immer an der Kammer, weil die Pulverkraft eben hier den bedeutendsten Druck auf die Rohrwände ausübt. Gegen die Mündung zu nimmt die Stärke des Eisens mehr oder weniger ab, so wie auch, freilich nur unbedeutend, der Durchmesser der Rohrseele (C aliber).

Die Fabrikation der Läufe geschieht auf mehrere Arten.

Früher verband man zwei rinnenartige Eisenschienen von entsprechender Länge, indem man die Seiten derselben zuerst in der Mitte um einen Dorn zusammenschweisste, und ron da zu beiden Enden derart fortschritt, bis aus den beiden hohlen Schienen eine Röhre entstanden war.

Später, als man bei Verwendung besseren Materials die iberfliissige Dicke der Rohrwände rermied, und noch jetzt findet man es für besser, die Läufe aus einer einzigen Schiene zu schweissen, indem man dieselbe derart hohl streckt, dass die beiden langen Seiten derselben sich berïhren. Hernach werden die Ränder der Schiene, wie bei ersterem Verfahren, zuerst in der Mitte und dann gegen die Enden zu iber einem Dorn geschweisst. Nach dem Zusammenschweissen wird der Lauf abermals erhitzt, und nachdem ein neuer Dorn in die Höhlung eingebracht wurde, nochmals so lange gehämmert, bis er gänzlich kalt geworden ist. Dadurch wird die Festigkeit und Elasticität des Eisens bedeutend erhöht. Ist anch dies geschehen, so wird durch die Höhle ein glatter, nach beiden Enden wenig zugespitzter, runler stählerner Dorn getrieben, und dadurch der Höhlung in ihrer ganzen Länge, cin ziemlich gleicher Uurchmesser ertheilt. 
Es gelang dem Schweden Wasström Gewehrläufe aus Stahldamast zu crzeugen (vgl. Damascener-Stahl Bd. II pag. 500), was in kurzer Zeit durch die Franzosen Delaunay, Cheaumette, Renier und Des Champs vervollkommt wurde, so dass man seit der Zeit Läufe aus verschiedenartigsten Damascirungen verfertigte. Meistens wurden die Läufe aus Draht und aus B andeisen erzeugt.

$\mathrm{Zu}$ diesem Behufe nimmt man eine gleiche Anzahl eiserner und stählerner Drähte oder Bänder, legt dieselben abwechselnd zusammen, schweisst und streckt sie sodann in eine einzige Stange. Diese wird in der Mitte der Länge gebrochen, beide Hälften wieder aufeinander gelegt, zusammengeschweisst, langgestreckt, welche Manipulation, nachdem man mehr oder weniger feine D rahtläufe erzeugen will, mehrmal wiederholt wird. Befeilt man eine Stelle der so zubereiteten Stange und befeuchtet diese mittelst einer ätzenden Säure, so erscheint auf der Oberfläche des Eisens eine Aderung wie Fig. 1607 zeigt, indem die weichen $\mathrm{E}$ is en stellen, durch die Säure in höherem Grade berührt, dunkel, die härteren Stahlstreifchen dagegen minder berührt, licht und glänzend bleiben.*)

Eine derart vorbereitete Stange wird, nachdem die Streifchen genü gend fein sich nuanciren, in eine lange, ungefähr 1 bis $1.5^{\mathrm{cm}}$ breite und $1 / 5$ bis $1 / \mathrm{g}^{\mathrm{cm}}$ starke Schiene gewalzt oder ausgeschmiedet. Diese Schiene wird dann um einen stählernen, dem gewünschten Caliber angemessenen langen Dorn schraubenförmig g ewunden, so dass die schmalen Seiten der Schiene fest aneinander liegen. (Fig. 1608.) Nachdem dies in gewünschter Länge geschehen, wird der Dorn beseitigt und das entstandene $\mathrm{Rohr}$ von einem Ende zum anderen in einem hohlen Ges enk e zusammengeschweisst. Während der Schweissung wird mit einem Ende des schweissenden Laufes gegen die Stirnseite des Ambosses angestossen, wodurch das Rohr nicht nur an der

Fig. 1608.

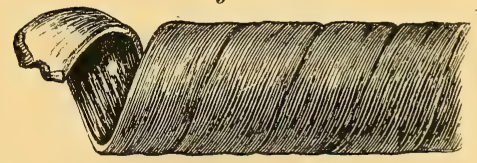
äusseren Oberfläche, sondern auch der Länge nach gestaucht wird, so dass die schmalen Seiten der Schiene in ihrer Schweisshitze um so fester zu einem Ganzen vereint werden.

Ist das Rohr der ganzen Länge nach gut geschweisst, so wird es nochmals dunkelroth erhitzt, und in einem hohlen Gesenke bis zum gänzlichen Erkalten mit kleinen Hämmern bearbeitet.

Solche Läufe heissen Drahtläufe oder Bandläufe und werden oft auch nur von Eisendraht, andere wieder blos von Stahldraht verfertigt. Sie kommen öfter im Handel unter dem Namen Rubanläufe und D'acier$1 \ddot{a} u f e$ vor, welche letztere wegen ungewöhnlicher Sprödigkeit nur selten zu Gewehren benützt werden.

Französische Canonieres (Rohrschmiede) recken das zu den Läufen bestimmte Eisen in kleinen Schmiedefeuern zu Bändern von nur $3^{\mathrm{mm}}$ Dicke, $4^{\mathrm{cm}}$ Breite und ungefähr 1 Meter Länge aus. Solcher Bänder werden nun 25 aufeinander und diese zwischen zwei etwas dickere gelegt, und das ganze, etwa 30 Kilo schwere Bündel, ans welchem nur zwei Läufe erfolgen, an zwei Stellen mit Eisendraht zusammengebunden. Die beiden dickeren Deckbänder haben den Zweck, die inneren während dem Schweissen vor dem Verbrennen

*) Es ist eine unter Chemikern eingewurzelte falsche Meinung, dass in diesem Falle nicht die lichten, sondern die dunkeln Stellen Stahl, die lichten dagegen Eisen sind, weil, wie gesagt wird, durch das Aetzen der Kohlenstoff des Stahles einen schwarzen Niederschlag bildet. Diese Theorie findet sich auch in den Beschreibungen des Brünirens; wer aber ein einzigesmal Gelegenheit hatte, einen eisernen und zugleich einen stählernen Lauf zu ätzen, der wird von der Richtigkeit unserer Angabe überzeugt sein. (Vergl. I pag. 54.) 
zu schützen, indem die vollständige Schweissung des Bündels, so wie das demnächstige Ausrecken zu einer $2^{\mathrm{cm}}$ breiten und $1.5 \mathrm{~cm}$ dicken Stange nicht anders als in wiederholten Hitzen ausführbar ist. Besondere Aufmerksamkeit wird bei dem Schweissen und Ausschmieden darauf verwandt, dass die einzelnen Bänder ihre anfängliche parallele Lage beibehalten. Die so erhaltene flache Stange wird nun umgebogen, und die beiden Hälften dergestalt wieder zusammengeschweisst und ausgeschmiedet, dass die Lage der ursprünglichen Bänder re chtwinklig gegen die neuerzeugten ist, dass also die Schweissnäthe der Dicke, nicht der Breite nach in dem neuerzeugten Bande fortlaufen. Das weitere Verfahren ist dasselbe wie oben beschrieben.

Besonders gute und schöne Läufe waren die noch vor wenig Decennien, namentlich in England massenhaft erzeugten $\mathrm{Hufnäge} 1 \mathrm{l} \ddot{\mathrm{afe}} \mathrm{f}$, und es ist bisher eine Frage, welches andere Material das Hufnägeleisen im Stande ist zu ersetzen. Es ist allgemein bekannt, dass das Eisen um so besser ist, je öfter es durch Glühen und Schmieden bearbeitet wurde. Durch diesen Grundsatz geleitet, wählten die Engländer die alten, wenn auch rostigen $\mathrm{Hufnägel}$ als das vortheilhafteste Rohrmaterial. Dies war freilich noch in der Zeit, als nur mit der Hand geschmiedete Hufnägel im Handel vorkamen; nachdem jedoch dieselben durch adoucirte $u$. a. ersetzt wurden, ist das Hufbeschlagen der Pferde freilich etwas billiger geworden, doch die Waffenindustrie erlitt hiedurch den beträchtlichsten Schaden. Wie in den $\mathbf{H} \mathbf{u}$ -

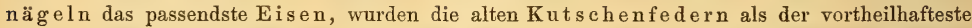
Stahl erkannt. Ehe man aus den Hufnägeln Eisen darstellte, wurden diese von Weibern genau sortirt und untersucht, um alle gusseiserne Nägel und andere Unreinlichkeiten auszuscheiden. Dann reinigte man die Nägel von Rost etc., indem man selbe in der Reinig ungstrommel (ein um seine Achse sieh drehendes Fass) unter schnellen Umdrehungen derselben so lange beliess, bis sie rein glänzend, wie polirt erschienen. Dieselbe Reinigungsmethode wurde auch bei den Kutschenfedern verwendet, nachdem selbe früher durch Scheere und Meissel klein gekörnt wurden.

In einer ähnlichen Trommel wurden dann Eisen und Stahl vermengt und zwar nach dem Gewichtsverhältnisse 5:3. Manche haben freilich mehr Stahl (ungefähr 5:5) vorgeschlagen, das alte Verhältniss hat sich jedoch immer am besten bewährt. Die so vermengten Eisen- und Stahlkörner wurden dann in Schmelztiegeln unter beständigem Umrïhren mittelst einer bereits fertigen Stange aus Hufnägeleisen einer starken Hitze ausgesetzt. Das dauerte so lange, bis die Körner, wie es schien, zusammenschmolzen und einen einzigen Klu mpen bildeten (Uebergang von der Schweiss- zur Flusshitze bei $1300^{\circ}$ C.), welcher nun auch an die Eisenstange angeschmolzen, mittelst dieser aus dem Tiegel gehoben, auf den Amboss geworfen und durch grosse Hämmer schnell bearbeitet wurde. Nach dem A usstrecken des Klumpens in eine lange Stange wurde diese gebrochen, wieder geschweisst und von neuem gestreckt, was ebenfalls je nach der gewünschten Feinheit mehrmals wiederholt wurde. Nach dem Abschleifen und Befeuchten durch ätzende Säure zeigte sich ungefähr dieselbe Zeichnung wie beim Drahteisen (Fig. 1607).

Aus dem Hufnägeleisen wurde Hufnägeldamast, ebenfalls wie aus Drahteisen Drahtdamast, durch nachstehendes Verfahren erzeugt. Nachdem das betreffende Eisen zu schwachen viereckigen Stäben gestreckt wurde, wurden diese an beiden Enden befestigt und in glühendem Zustande wie ein Strick gedreht. Drei so gedrehte Stäbe werden nebeneinander derart zusammengeschweisst, dass neben einem zur rechten Seite gedrehten ein links gedrehter Stab zu liegen kommt.

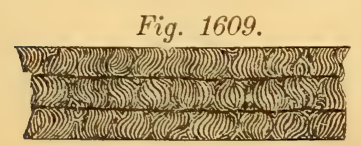

Nach dem Abfeilen und Aetzen erscheinen an der Oberfläche des Eisens gefällige Figuren (Fig. 1609). Je schwächer die gedrehten Stäbe waren, desto feinere und schönere Figuren zeigte dann die Oberfläche.

Diese Schienen wurden dann nach der vorher beschriebenen Methode zu Läufen verarbeitet.

Das Drehen ist freilich kein Vortheil für das Laufmaterial; die Schützen ziehen jedoch häufig die Schönheit der Giite ror, und zwingen also die Büchsenmacher die Güte dem gefälligeren Aeusseren zu opfern. Es ist nämlich bekannt, dass das Eisen in der Richtung des er s ten Streckens die meiste Daucrhaftigkeit besitzt, ebenfalls wie das Holz in der Richtung seiner Faser um vieles 
fester ist als quer iiber dieselben. Da aber durch das Drehen die Fasern des gestreckten Eisens gekrümmt, ja gerissen werden, kann man unmöglich von solchem Material dieselbe Festigkeit erwarten wie bei dem nichtgedrehten. Die Festigkeit des Eisens wird durch das Drehen um ungefähr 35\% beeinträchtigt, oder anders zu sagen: wenn die Kammer eines von Drahteisen verfertigten Laufes dem Drucke von 100 Atmosphären widersteht, wird die eines Drahtdamastlaufes bei gleichem Caliber und Wandstärke blos den Druck von 65 Atmosphären aushalten können. Deswegen sollen die Damastrohre am Pulversacke immer verhältnissmässig stärker gemacht werden.

Durch verschiedenartiges Behandeln des Eisens ist man mit der Zeit auf viele Abarten des Damastes gekommen, und würde uns zu weit führen, alle hier zu beschreiben. Beschränken wir uns deshalb auf die blosse Benennung der wichtigsten und gangbarsten:

Eisenband (damas ruban), Stahlband (ruban d'acier od. damas d'acier), Englischdamast (damas anglais), Moireédamast (damas moiré́), Rosen-oder Tïrkischdamast (damas turc), Bernarddamast (damast de Bernard), Blumendamast (damas fleurs).

Andere Damaste sind sämmtlich von den hier verzeichneten abhängig; so ist s. B. der heutige $\mathrm{Hufnägeldamast} \mathrm{eigentlich} \mathrm{grober} \mathrm{Rosendamast,}$ ebenso Garibald idamast; Damas L aminet sind abwechselnd liegende Stäbe von Rosen - und D'acierdamast. Durch nochmaliges Strecken fertiger Damaste erhält man damas alongé. Abarten des damas fleurs sind La ubdamast, Epheudamast u. s. w.

Wegen sehr kostspieliger Herstellung der Damaste haben die Rohrfabrikanten auch sparen gelernt, leider aber nur selten zum Vortheile ihrer Erzeugnisse. Sie verfertigen nämlich von ganz ordinärem billigen Eisen ein Rohr, und zwar nach der billigsten Methode, wie wir zuerst beschrieben haben. Dieser ordinäre Körper wird dann schwach mit Damast bekleidet, indem er mit der schwachen Damastschiene umgewunden und dann das Ganze zusammengeschweisst wird. Diese Idee ist freilich nicht schlecht, im Gegentheil sehr praktisch, muss aber gewissenhaft ausgeführt werden. Es wird nämlich darauf gerechnet, dass der innere schlechte Kern durch das nächstfolgende Bohren beseitigt, und so der thenere Damast geschont wird. Wie oft gelingt es jedoch, dass der schlechte Kern völlig ausgebohrt wird? Oft reibt in einem feinen Damastlaufe das Geschoss auf der einen Seite am ordinären äscherigen Eisen, auf der anderen am Damast. Bei solchen Läufen geschieht es nicht selten, dass sich das Schlechte vom Guten ablöst, und so in der Rohrseele ganze, oft centimeterlange Eisenfetzen sich abschälen.

Ist der Lauf geschweisst, so wird er regelmässig nochmals erhitzt, und bis zum gänzlichen Abkiihlen in einem hohlen Gesenke gehämmert. Nachdem man auch einen glatten Dorn durch die Rohrseele getrieben, und dieselbe hierdurch regulirt hat, wird das Rohr zur Bohrbank gegeben.

Das Bohren der Läufe hat den Zweck, das Innere des Rohres glatt, die Seele genau rund und das Caliber durchgehends genau und gleichmässig herzustellen, und bei feinen Läufen auch den schlechten Kern zu beseitigen.

Verschieden hievon ist das Bohren der aus Gusstahl oder Eisen ohne Schweissung verfertigten Läufe, welche meistens zu Kugelbiuchsen verwendet werden. Das Bohren dieser Läufe wird an einer grossen Drehbank verrichtet, und handelt sich in diesem Falle nicht um die weitere Ausarbeitung einer schon vorhandenen Höhlung, sondern um die Durchbohrung einer massiven Stahloder Eisenstange nach der Richtung ihrer Achse.

Der Bohrer zu geschweissten (also vom Schmieden her hohlen) Läufen ist ein vierkantiges, schwach pyramidal sich verjüngendes Stiick Stahl, ungefähr in Form einer Reibahle, welches an das vordere Ende einer runden eisernen Stange angeschweisst ist. Selır gewöhnlich lässt man nicht alle vier Kanten zugleich zur Wirkung kommen, sondern belegt eine der Seitenflächen mit 
einem dïnnen, an der Hinterseite cylindrisch convexen Holze (auch Messing oder Kupfer), wodurch dann zwei Kanten des Bohrers ausser Berührung mit dem Laufe gesetzt werden, und nur die zwei entgegengesetzten arbeiten. Dieses Verfahren gewährt den Vortheil, dass ein und derselbe Bohrer, successive mit immer dickeren Holzleisten belegt, zur allmäligen Erweiterung des Bobrlochs dienen kann, während bei Anwendung nackter Bohrer diese Erweiterung nur durch eine Reihenfolge mehrerer, in genauer Abstufung auf einander folgenden Bohrer zu erreichen ist. Und da bei dem so oft nöthigen Schleifen die Bohrer jedesmal ein wenig dünnel werden, so verlieren sie nach kurzem Gebrauch schon so viel ron ihrer Dicke, dass sie als unbrauchbar bei Seite gelegt werden müssen, was beim Belegen mit Holz oder Kupfer nicht so bald eintritt. Zum Einspannen des Laufes beim Bohren dient die Bohrbank, auf welcher der Lauf horizontal, auf einem zwischen zwei Schienen vor- und rückwärts verschiebbaren Schlitten liegend, in der Mitte seiner Länge befestigt ist.

Während man auf den ersten Blick zu der Vermuthung verleitet werden könnte, dass die Bohrung regelmässiger und vollkommener ausfallen und leichter von Statten gehen müsse, wenn sich Lauf und Bohrer in unverrückbar fester Lage befinden, zeigt die Erfahrung das Gegentheil. Dem Lauf muss Freiheit gelassen werden, in schlotternder Bewegung dem Eingreifen des Bohrers nöthigenfalls nachzugeben, daher denn auch dieser letztere ausser seiner Befestigung an der Triebwelle, durch die er seine Drehung erhält, seiner ganzen Länge nach freiliegt und nur am vorderen Ende durch den Lauf, in welchem er mit bedeutender Geschwindigkeit (150 bis 180 Umläufe pr. Minute) gedreht wird, die nöthige Fülurung erlangt.

Lauf und Bohrer befinden sich bei der Arbeit fast unaufhörlich in stark vibrirender Bewegung, wobei der erstere mittelst eines am vorderen Ende hakenförmig gebogenen Hebels, dessen anderes Ende der Arbeiter mit der linken Hand fasst, auf höchst einfache Art gegen den Bohrer gedrückt wird.

Nachdem der Lauf durch dieses Rauh-oder Schwarzbohren bis fast zur ealibermässigen Weite ausgearbeitet ist, folgt das Weissbohren oder Poliren, welches sich von dem Schwarzbohren nur darin unterscheidet, dass genauere, sehr scharfe und geradkantige, stets an einer oder auch zwei neben einander liegenden Seiten mit Kupfer oder Holz belegte Bohrer in Anwendung gebracht werden, die, um eine möglichst glatte Fläche zu erzeugen, nur wenig angreifen dürfen. Bei diesem Weissbohren, vorausgesetzt, dass es mit sehr guten Bohrern und mit Sorgfalt ausgefürt wird, erlangt die Rohrseele eine völlig hinreichende Glätte; beabsichtigt man jedoch die zarten Bohrringe völlig zu beseitigen, so nimmt man noch eine nachträgliche Bearbeitung mit einem feilenartig gehauenen, an einer Stange befestigten, stählernen $K 0 l b e n$, der unter langsamer Drehung durch den Lauf der ganzen Länge nach hin und her gezogen wird, vo:. Dieses Verfahren nennt man Frischen. Nach dem Frischen tritt an die Stelle des Frischkolbens ein Bleikolben, der mit $\mathrm{Oel}$ und Schmirgel bestrichen, ebenfalls in der Rohrseele hin und her gezogen wird, und dieser dadurch völlige Glätte ertheilt. Während des Rauhbohrens und des dabei ein tretenden Vibrirens des Laufes kann sich dieser, zumal bei geringer Wandstärke, krïmmen. Der Arbeiter muss daher von Zeit zu Zeit den Lauf prifen, indem er eine feine Darmseite hindurchzieht, in einen Bogen einspannt, und, indem er den Lauf gegen das Licht hält, untersucht, ob die Saite überall genau an die Rohrwände anliegt. Ergeben sich hierbei Biegungen, so wird der Lauf mittelst eines hölzernen Hammers oder an der Richtmaschine gerichtet.

Es folgt nunmehr die äussere Bearbeitung mittelst des Schleifsteins. Man gebraucht sehr grosse, wohl $1.7^{\mathrm{m}}$ im Durchmesser haltende und $0.3^{\mathrm{m}}$ dicke Steine, welche mit grosser Geschwindigkeit (bis 120 Touren pr. Minute) umgetrieben, und an deren Peripherie die Läufe horizontal (also der Achse des Steines parallel) angelegt und mit mässiger Kraft angedrückt werden. Indem nun die Reibung auch den Lauf, wiewohl mit geringer Geschwindigkeit, in Drehung setzt, 
wird er an allen Seiten gleichmässig abgeschliffen. In neuerer Zeit hat man mit grossem Vortheil angefangen, die Läufe auf einer eigenen Drehbank abzudrehen, wobei der Drehstahl durch einen Support gefuihrt wird.

Ist der Lauf so weit fertig, so wird das Gewinde für die Schwanzschraube eingeschnitten, bei manchen auch das Korn und die Schafth aften angelöthet, und dem Lauf durch $\mathrm{Abzi}$ eh en mit der Feile ein Längsstrich gegeben.

Nun wird der Lauf mit einer provisorischen Schwanzschraube versehen und der $\mathrm{Probirbank}$ übergeben.

Die Läufe werden nur in wenig Orten Europas fabricirt, da sich solche Etablissements nur bei gesicherten grossen Lieferungen rentiren können, und nichit sogleich routinirte Rohrschmiede zu finden sind. Die renommirtesten Fabriksorte sind hinsichtlich der Rohrwerkstätten: Birmingham, London, Lüttich, St. Etienne, obwohl uns auch $\mathrm{Ferlach}$ und andere, namentlich billige Fabricate massenhaft liefern. In solchen Städten sind gewöhnlich behördliche Anstalten zum Probiren der Läufe vorhanden. Jeder Rohrfabrikant und jeder Biichsenmacher ist in England und Belgien verpflichtet, seine Läufe nach dem Bohren und Schleifen, sowie auch nach dem gänzlichen A usarbeiten der completten Waffe, beschiessen zu lassen, und unterliegt einer grossen Geldstrafe, im Falle er gegen dieses Gesetz handelt.

In der Lüticher Probiranstalt (die uns als die vollkommenste der heute existirenden erscheint, weshalb wir unten meist nach dieser die Beschreibung richten) werden einfache Läufe nur einmal, Doppelläufe zu Vorderladern zweimal und zu Hinterladern dreimal probirt. Nach jeder Probe erhält der Lauf einen Punzen, so dass es immer möglich ist, sich zu ïberzeugen, wie vielmal ein Lauf die Probe bestanden hat.

Bei der Probe wird jeder Lauf mit einer Pulverladung gleich $2 / 3$ des entsprechenden Bleikugelgewichtes geladen. Wiegt daher eine für das bei uns beliebteste Jagdcaliber 16 (Durchmesser $17 \cdot 6^{\mathrm{mm}}$ ) passende Bleikugel $27^{1} / 2$ Gramm, so ist das Pulvergewicht der Probeladung auf 18 Gramm festzustellen. Auf die Pulverladung wird ein $\mathrm{K}$ artonpfropfen und auf diesen mittelst eines eisernen Ladstocks die Kugel aufgesetzt. Nach dem Laden werden alle zu probirenden Läufe in das stark gemauerte Probirhaus, dessen Wände mit starken Eisenplatten belegt sind, gebracht und auf eine mit Blei iiberzogene Bank (hievon „bunc d'epreuves") derart gelegt, dass die Zündlöcher der erwähnten provisorischen Schwanzschrauben nach oben gerichtet sind, in welcher Lage sämmtliche Läufe durch einen ebenfalls mit Blei bekleideten Eisenbalken befestigt werden. Nachdem man auf die Bank so hoch Pulver gestreut, dass die Zündlöcher hiemit gedeckt sind, wird das Beschiesshans verschlossen, und das gestreute Pulver durch eine kleine Oeffumng von aussen angeziindet, wodurch fast momentan die sämmtlichen Gewehrläufe entladen werden. Die Kugeln schlagen in einen Sandhaufen ein.

Nach der Probe werden die Läufe sorgfältig untersucht, und wenn keine Risse, Sprünge, Beulen oder sonstige Fehler vorhanden sind, mit einer provisorischen Marke am Pulversacke versehen. Diejenigen Läufe, die kleine Fehler zeigen, werden an der fehlerhaften Stelle zersägt. Den Schaden muss in jedem Falle der Rohrschmied tragen. Wenn der Lauf die bleibende Schwanzscliraube erhalten, oder bei Hinterladern, wenn er basculirt ist und abermals die Probe iiberstanden hat, erhält er erst die sogenannte grosse Marke. Doppelflintenläufe werden erst nach der ersten Probe zusammengelöthet, und zwar wählt man immer Länfe gleich feinen Damastes, jedoch immer so, dass wenn die Damastschiene des rechten Laufes zur rechten Seite gewunden ist, fuir die linke Seite ein in entgegengesetzter Richtung gewundenes Rohr gewällt wird. Das Verbinden der Rohre zu Doppelwaffen muss (oder soll wenigstens) sehr sorgfältig berechnet werden, damit die Schiisse beider Läufe auch auf grössere Distanz gleich hoch und auf ungefähr denselben Fleck anschlagen können. Nach der Verbindung der Doppelläufe, wenn selbe anch an der obcren 
Seite eine Visirschiene erhalten haben, müssen dieselben abermals der Probirbank vorgelegt werden.

Erst nach der Beschiessung dürfen die Läufe in England und Belgien weiter verarbeitet werden; in anderen Staaten, wo keine oder nur ungenügende Probiranstalten sich finden, kümmern sich die Regierungen wenig darum, ob die Büchsenmacher solide oder fehlerhafte Rohre zu ihren Erzeugnissen benützen, was freilich den sichtbar zunehmenden Verfall der Waffenindustrie solcher Staaten im hohen Grade unterstïtz1.

Die weitere Bearbeitung des bereits gestempelten Laufes hängt natïrlich davon $a b$, zu welchem Systeme derselbe benuitzt werden soll.

Für die sämmtlichen Abarten der Vorderlader werden die Läufe mit $\mathrm{Schwanzschrauben} \mathrm{versehen.} \mathrm{Die} \mathrm{Einrichtung} \mathrm{derselben} \mathrm{ist} \mathrm{sehr} \mathrm{verschieden,}$ doch ist es möglich, dieselben in drei Hauptarten zu theilen: 1. Die gewöhnliche Schwanzschraube alter Art Fig. 1610 besteht in einer gegen 1 Zoll langen eisernen Schraube $c$ mit ebener oder nur wenig concaver Endfläche, einem starken Kopfe $d$ und hieran befindlichen Lappen (S chwanz) e, der zur Befestigung des Laufes am Schafte dient. Sie reicht in dem Laufe $a$ a bis nahe an das Zündloch $b$ oder öfters sogar ein wenig darüber hinaus, in welchem Falle ihr vorderer Rand einen Ausschnitt enthält, um die Communication zwischen $b$ und der Laufbohrung herzustellen. Solche Schwanzschrauben waren meist bei Militär- und anderen ordinären Gewehren gebräuchlich. 2. Die Kammerscliwanzschraube Fig. 1611 unterscheidet sich von der vorhergehenden dadurch, dass ihre Vorderseite cylindrisch, conisch oder halbkugelförmig a us g e$\mathrm{h} o ̈ \mathrm{hlt}$ ist, so dass ein Theil der Pulverladung von dieser $\mathrm{K}$ a m m er aufgenommen wird. Auch hier bedeutet $a$ a die Wandung des Laufes, $c$ die Schwanzschraube, $d$ deren Kopf; der Zündkanal $b$ geht mitten von der Kammer aus, wendet sich unter rechtem Winkel und setzt sich durch den in $a$ und $e$ eingeschranbten Kern $e f$ fort, wo er in eine geräumigere cylindrische Höhlung $n$ mündet. In letztere wird schief gegen die Rohrachse der stählerne Z ïndkegel (auch Cylinder oder P iston genannt) eingeschraubt, vor dessen feiner Oeffinung bei $h$ die Zündung stattfindet, wonach der Feuerstrahl auf dem zweimal im Winkel ablenkenden und ziemlich langen Wege ins Innere dringt.

Fig. 1610.

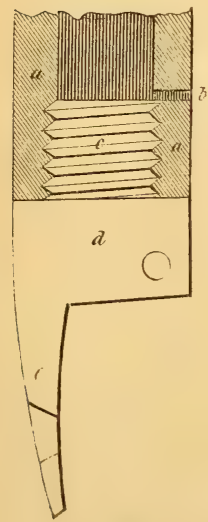

Fig. 1611.

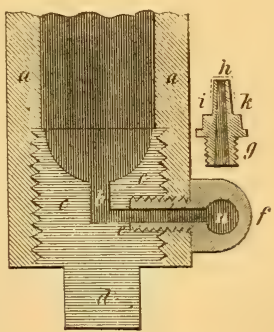

Fig. 1612.

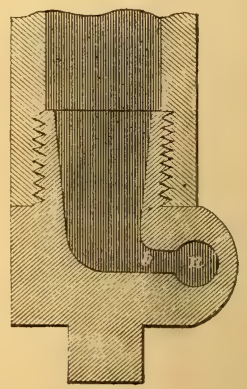

3. Die Patentschwanzschraube (Fig. 1612) enthält ebenfalls eine Kammer, diese aber von solcher Grösse, dass die Pulverladung vollständig hineingeht; sie bildet demnach den ganzen Pulversack. Die Zeichnung stellt zugleich 
eine von Fig. 1611 abweichende Anordnung des Zündkanals $b$ dar, welcher seitwärts von der Kammer ausgeht, viel kürzer ist und ohne Winkelbiegung zu der (in einer Verstärkung der Schwanzschraube selbst angebrachten) Bohrung $n$ fiihrt. Die Patentschwanzschrauben haben zugleich den grossen Vortheil, dass sie das Herausnehmen der Läufe vom Schafte bedeutend erleichtern, indem der sogenannte Schwanz nicht wie bei ersteren mit der Schraube vereint ist, sondern diese durch einen oder zwei Haken in den am Schafte fest angeschraubten Schwanz, hier Scheibe genannt, ein- und ausgehängt werden kann. (Deshalb wurde auch die ursprïngliche Benennung Patent- oder Kammerschwanzschraube in Patentschraube und Kammerschraube abgekürt.) Zugleich bietet diese Vorrichtung den grossen Vortheil, dass die Eisentheile des Schaftes sehr fest zusammengeschraubt werden können, und so zu sagen im Holze ein Ganzes bildend, die Erschïtterung beim Schusse eher aushalten können, ohne dass ein zelne Schrauben mit der Zeit locker werden.

Dies halten wir für genügend über den Rohrverschluss der Vorderlader, der regelmässig in die Laufbohrung eingeschraubt wird. Bei den meisten Hinterladern wird im Gegentheil der Lauf in das Verschlus g ehäus e eingeschraubt. Bei wenigen Jagdhinterladungssystemen, die auch zu Doppelläufen verwendbar sind, namentlich bei Lefauchex, Lancaster, Teschner's Zünd$\mathrm{n}$ adel etc., wird ein starker Eisenansatz ( $\mathrm{Haken}$ ) angelötliet, und sodann in ein eisernes, in Stärke dem Laufcaliber angemessenes B a s u l eingepasst. Die Läufe können durch diverse sebr einfache Druckvorrichtungen aus dem, am Bascul im Charniere beweglichen Schiffel herausgehoben und eben so leicht eingelegt werden; im geladenen Zustande werden die Läufe ganz einfach niedergedrückt, worauf sie durch verschiedene Schnappvorrichtungen oder durch Umdrehung einer $\mathrm{Kurbel}$ (Schlüssel) in dieser Lage festgehalten werden. Durch einfachen Druck oder rïckwärtige Umdrehung des Schlüssels wird dem Haken die Haltung entzogen, so dass sich die Läufe wieder durch eigene Schwere neigen, d. h. öffinen können.

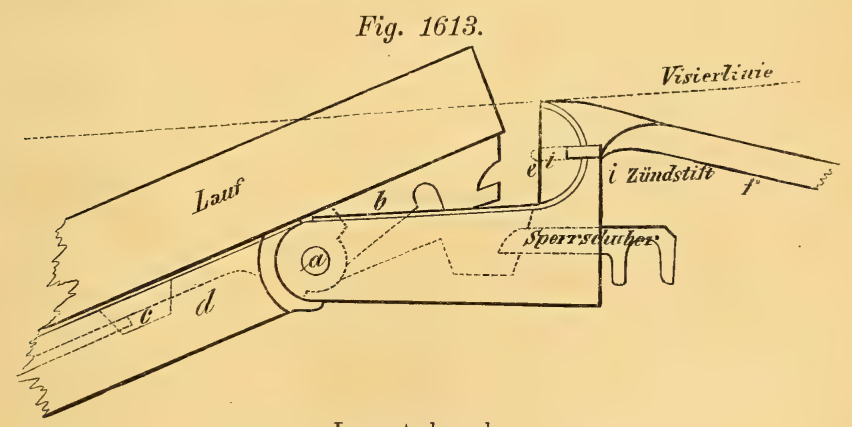

Lancasterbascul.

Obige Abbildung zeigt ein Lancasterbascul mit geneigtem Laufe. $a$ ist das Charnier, $d$ das bewegliche $\mathrm{Schiffel,} \mathrm{in} \mathrm{welchem} \mathrm{der} \mathrm{Lauf} \mathrm{durch}$ die $\mathrm{Hak}$ en $b$ und $c$ festgehalten wird. $e$ ist die Stossscheibe, auch Verschlussspiegel genannt, auf welche der geschlossene Lauf genau anliegen muss. $f$ ist der von der alten Schwanzschraube geerbte, zum Befestigen im Schafte bestimmte Schwanz.

Es wiirde uns hier zu weit führen, auch die Bearbeitung der tibrigen Verschlussarten der Hinterlader zu beschreiben und beschränken uns deshalb nur auf eine später folgende, kurzgefasste Beschreibung der wichtigeren Systeme.

Karmarsch \& Heeren, Technisches Wörterbueb. Bd. III. 
Ist der Rohrverschluss fertig, so wird auch das $\mathrm{Schloss}$, je nach der Construction, an- oder eingepasst. Die in der ersten Hälfte des 19. Jahrhundertes allgemein verbreiteten $\mathrm{Percussionsschlösser}$ haben wir bereits hinsichtlich ihrer Entstehung erwähnt und bleibt uns daher nur die Construction zu beschreiben iibrig.

Fig. 1614.

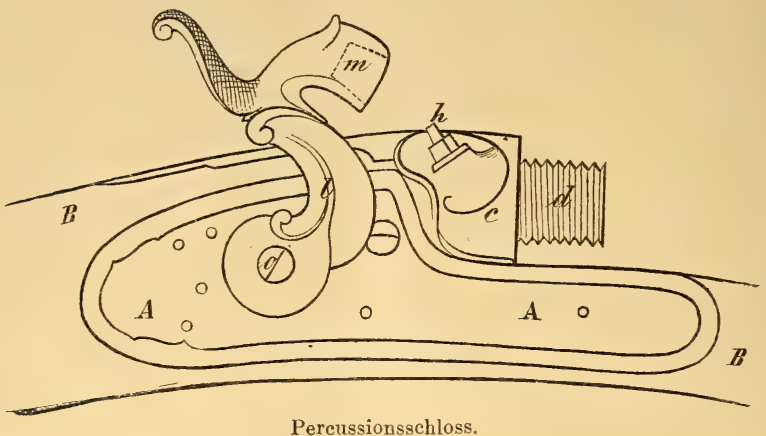

Figur 1614 zeigt die äussere Ansicht eines Percussions- oder Schlagschlosses. Man bekommt hier keine anderen Theile zu sehen, als das im $\mathrm{Schafthalse}$ eingelassene $\mathrm{Schlossblech} A A$ und der $\mathrm{Hahn} l$, welcher um die Nussachse $o$ beweglich ist, und in der $\mathrm{Schlagfläche} \mathrm{seines} \mathrm{Kopfes}$ eine Vertiefung $m$ enthält, die beim Aufschlagen den Piston und das Zündhütchen umschliesst, und dadurch das dem Schützen gefährliche Herumfliegen von Trümmern des zerschmetterten Zündhütchens verhindert. $c d$ bietet die äussere Ansicht der $\mathrm{P}$ at entschraube ohne Lauf, mit eingeschraubtem Cylinder $h$. $B B$ ist der Schaft.

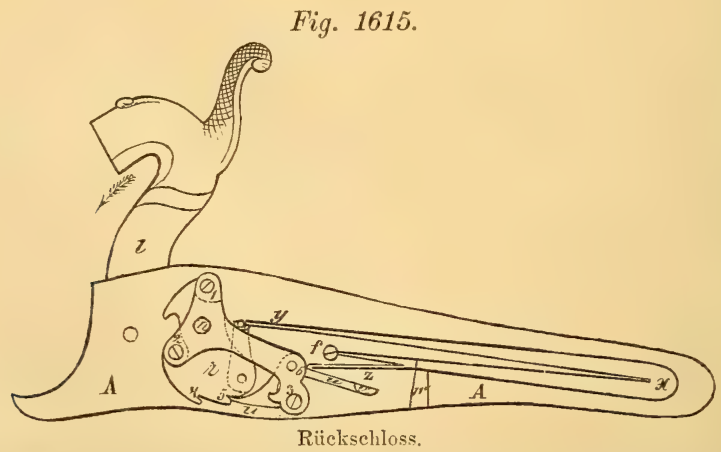

Zur Erklärung der inneren Schlosseinrichtung ist in Fig. 1615 als Beispielein Schloss derjenigen Art gezeichnet, welche man Rückschlösser nennt, weil hier die Schlagfeder rom Laufe rückwärts und nicht wie bei dem in Fig. 1614 abgebildeten Seitenschlosse zur Seite der Pulverkammer angebracht ist. Mit anderen Worten, bei einem Seitenschlosse ist die Schlagfeder vor, bei den Rück- oder Griffschlössern hinter dem Hahn befestigt. Im Uebrigen bleibt sich die Construction ganz gleich. $A A$ ist die Schlossplatte, $l$ der Hahn, $r$ die Nuss. Letztere besteht aus einer etwas dicken Platte von eigenthümlich 
geschweifter Gestalt, mit zwei runden $\mathrm{Z}$ apfen versehen. Der eine dieser Zapfen ist dick, geht durch ein passendes Loch des Schlossbleches, und endigt ausserhalb desselben in ein Viereck, auf welchem der Hahn mit einem entsprechenden viereckigen Loche steckt, so dass Hahn und Nuss nicht anders als gemeinschaftlich sich drehen können. Um das Abgehen des Hahnes von dem Vierecke zu verhindern, ist eine Schraube mit grossem Kopfe vorgeschraubt ( $o$ in Fig. 1614). Der Zapfen auf der inneren Fläche der Nuss ist bei $n$ sichtbar; er dreht sich in einem Loche der sogenannten Studel, welche mittelst der Schrauben 1, 2, 3 mit dem Schlossbleche vereinigt wird. Auf ihrem untern convex bogenförmigen Rande hat die Nuss zwei Kerben 4, 5, von welchen 4 die Vorderrast oder Ruhrast, 5 die Hinter- oder Spannrast heisst; letztere ist ganz seicht, erstere bedeutend tiefer. Ein Hebel $u$, welcher um den in Schlossblech und Studel eingebohrten Stift $b$ beweglich ist, und $\mathrm{Stange}$ genannt wird, fällt durch den Druck der Stangenfeder $f$ mit seinem vordersten Ende - Schnabel - in eine oder die andere der beiden Rasten ein (je nach der augenblicklichen Stellung der Nuss) und hält so Nuss und Hahn unbeweglich. Die Stange ist an ihrem hintersten Ende rechtwinklig vom Schlossbleche abgebogen; wird nun wegen Losdriicken des gespannten Schlosses der Abzug an diesen Stangenbalken $v$ gedrïckt, so wird der Schnabel aus der Spannrast gehoben, so dass die Nuss, resp. Hahn, dem Drucke der Schlag feder $y x$ folgend, in ebenso rascher, wie kraftvoller Bewegung an den Piston $h$ (Fig. 1614) schlägt. Die Schlagfeder ist durch einen nahe an $x$ befindlichen Stift in der Schlossplatte befestigt. Das Verfahren beim Spannen und Losdriicken ist genügend bekannt, als dass es einer Beschreibung bedürfte; und ebenso wird der innere Vorgang beim Spannen und Losdrücken aus Vorhergesagtem leicht zu verstehen sein. Wir bemerken nur, dass die Ruhrast so eingefeilt sein muss, dass es nicht möglich ist, den nur halb gespannten Hahn loszudrücken.

Eine ganz eigenthümliche Art der Percussionsziundung war in der österreichischen Armee eingeführt, wir meinen die $\mathrm{Z}$ ü $\mathrm{n}$ de r g e w e hr e. Diese entstanden durch die Console'sche Zündmethode, welche darauf beruht, eine geringe Menge Knallquecksilber in ein kleines Stückchen dünnen Messingblechs einzuwickeln und diese $\mathrm{Z}$ ünder in das Zündloch des Gewehrlaufes einzuschieben. Durch das Anschlagen des Hahnes explodirte das Knallquecksilber und zündete die Pulverladung des Laufes. Im Jahre 1840 verbesserte der damalige Feldmarschall-Lieutenant Baron Augustin diese Methode, indem er die alten Batteriedeckel durch $\mathrm{P}$ fannendeckel mit den beweglichen, mit grossen

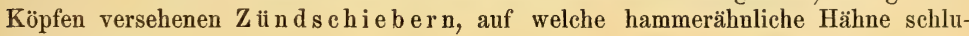
gen, ersetzte.

Um das gegen die Absicht des Schützen erfolgende, nur zu oft die grössten Unglücksfälle veranlassende Losschlagen des Hahnes zu verhindern, oder wenigstens unschädlich zu machen, hat man für Percussionsschlösser allerlei Sicherheitsvorrichtungen erfunden. Dem Zwecke ziemlich entsprechend war eine Bedeckung des Zündkegels, welche das Aufschlagen das Hahnes auf den Cylinder unmöglich macht, so lange sie nicht beseitigt ist. Ausserdem erscheinen die Gesperre bald in der Form eines verschiebbaren Riegels, eines Vorreibers, aus dem Schlossbleche beim Spannen a uspringenden Stiftes etc. etc.

Die Schlagschlösser hat man auch zu vielen Hinterladesystemen verwendet, doch wurden bei der Mehrzahl auch anders construirte Schlösser angebracht. Das Spiralschloss bei der Dreyse'schen Zündnadel (Vorderlader) 1827 angewendet, ist obwohl bei diversen Systemen auch verschiedenartig ausgefiilurt, im Princip aus Fig. 1616 leicht erkenntlich.

In einer langen, an beiden Enden nur mit kleinen Oeffnungen versehenen Hitse ist der Z iindstift $i$ hin und her beweglich und mit dem $\mathrm{Kragen} c$, der einen der Bohrung der Hülse entsprechenden Durchmesser hat, versehen. An diesen Kragen drückt von der dem Gewehrlaufe entgegengesetzten Seite 
eine Spiralfeder, mit dem hinteren Ende sich an die (mit der Oeffnung $f$ versehene) Hülsenmutter $d$ stützend. Beim Spannen des Schlosses wird der

Fig. 1616.

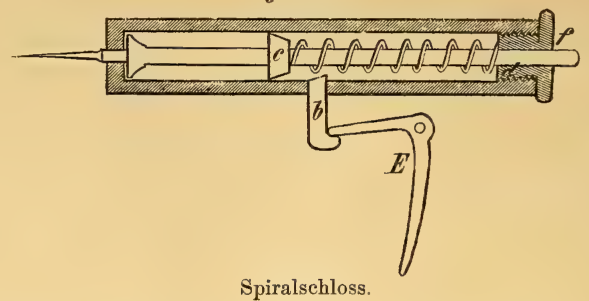

Zünd- oder Schlagstift so weit zurückgezogen, bis es dem Stollen $b$ möglich ist, vor den Kragen $c$ einzuschnappen und so den Schlagstift in dieser Stellung festzuhalten. Durch einen einfachen Druck auf den Drü cker oder Abzug $E$ wird der Stollen genïgend weit ausgezogen, um den Kragen des Zündstiftes zu verlassen, so dass der Stift durch den Druck der Spiralfeder gegen die Ladung getrieben wird, um so den Schuss zu bewirken.

Dies ist das Princip der Spiralschlösser, welche mit mehrfachen Aenderungen bei den meisten Hinterladern verwendet sind, und die, wie aus der Construction leicht erkenntlich, nur in der Mitte des Schafthalses, also in gerader Linie mit der Rohrseele angebracht werden können.

Indem wir die Beschreibung der Schlösser geliefert haben, sehen wir uus verpflichtet, auch den mit den Schlössern eng zusammenhängenden Abzugsvorrichtungen einige Zeilen zu widmen.

Der Abzug ordinärer und der Garnisons-Gewehre mit Schlagschloss ist aus Figur 1617, erkenntlich und es geniigt zu bemerken, dass der obere Rand $c$ beim Andriicken an das $\mathrm{Z} u ̈ n g e l ~ b$ die Schlossstange $v$ aus der Spannrast hebt, wodurch das ganze Schloss in die zum Schusse nothwendige Bewegung gesetzt wird.

Fig. 1617.

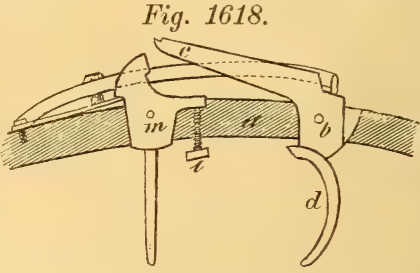

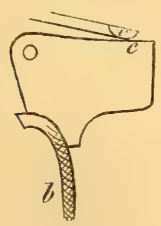

Abzug.

Stecher.

Complicirter ist der bereits bei Radschlössern erwähnte St ech er (Fig. 1618), der noch heute bei allen mit Percussionsschloss versehenen Scheiben bü chsen und auch bei vielen Hinterladern angebracht wird freilich auch mit verschiedenen Abweichungen). In der Abzugplatte $a$ ist an der Schraube $b$ ein langer Hebel $c$ mit Druckzüngel $d$ beweglich. Durch Andrücken an das Züngel neigt sich der obere Arm des Hebels $c$ so weit, dass die Stange $m$, durch eine schwache Feder gedrückt, mit ihrer Kerbe über das äusserste Ende des Hebelarmes schnappt und denselben in dieser Lage festhält. Bei blosser Berührung des nadelförmigen Theiles der Stange wird der Hebel seiner Haltung befreit, und dem Drucke einer starken Schnellfeder folgend ertheilt er der Schlossstange einen zum Abdrïcken des Schlosses genügenden Schlag. Durch die Stellschraube $i$ wird der Stecher regulirt, indem man das mehr oder weniger 
weite Uebergreifen der Stange hiemit bestimmen kann. Wesentlich verbessert und vereinfacht wurde der Stecher in dem sogenannten $R$ ü ckstecher oder franz. Stecher, bei welchem es möglich ist, auch auf gewöhnliche Art loszudrüicken.

Nachdem der Laufverschluss, Schloss und Abzugsvorrichtung fertig und aneinander gehörig angepasst sind, wird das Gewehr g e s chäftet. Die Laien sind gewöhnlich der Meinung, die Aufgabe des Gewehrschaftes sei, nur die einzelnen Bestandtheile beisammen zu halten, und dem Schützen als Griff zu dienen. Allein der Schaft spielt bei der Waffe eine viel wichtigere Rolle. Indem der Schütze das Gewehr in Anschlag nimmt (das Gewehr zum Schusse bereit zur Wange anlegt), will er die ganze Waffe schon in gehöriger Linie vom Auge zum Ziele wissen. Es ist also nicht gleichgiltig, wenn der Schaft zu lang oder zu kurz, zu krumm oder gerade verfertigt ist. Ein langarmiger magerer Schütze will einen langen, ein kurzarmiger dicker einen kurzen Anschlag am Gewehr haben. Ebenfalls bedarf ein langer Hals einen $\mathrm{mehr}$, ein kurzer dicker Hals dagegen einen weniger krummen Schaft. Es ist also kein Wunder, dass die Büchsenmacher während der Mode, hohe steife Halskrägen zu tragen, auch diese in Betracht nehmen mussten. Fig. 1619 zeigt dem Leser in verjüngter Zeichnung die

Fig. 1619.

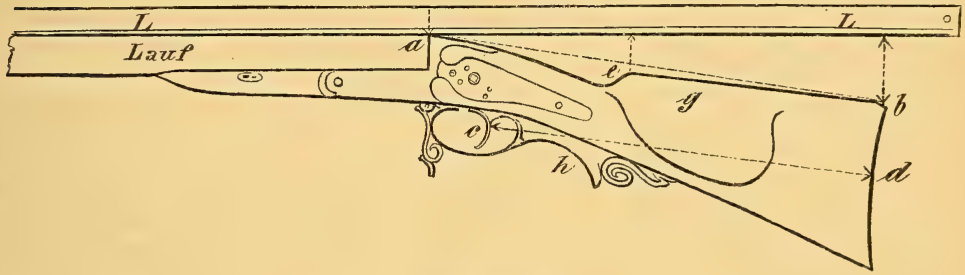

Gewehr-Schaft.

gewöhnlichste (mittelmässige) Form eines Gewehrschaftes. Die an dieser Figur sichtbaren punktirten Linien deuten die Art des Abmessens an, die Buchstaben die wiehtigsten Theile des Schaftes und des Kolbens, wie man den plumperen Hintertheil des Schaftes bezeichnet.

Die Länge eines mittelmässigen Schaftes ist vom hinteren Rohrende $a$ zum hinteren Schaftende $b$ gemessen $41 \frac{1}{4} \mathrm{em}$, vom Abdruckzüngel $c$ zur Mitte des hinteren Schaftendes $d 35^{\mathrm{cm}}$. Die Krïmme des Schaftes wird derart gemessen, dass man ein gerades Lineal $L L$ an den Lauf legt, und sodann seinen Abstand vom Schaftkolben bei der $\mathrm{N}$ ase $e$ und am Kolbenende $b$ genau abmisst. Dieser Abstand beträgt bei mittlerer Schaftkrümme bei $e 3^{\mathrm{cm}}$ und bei $b 6^{\mathrm{cm}}$. Im Schafthals e ist der ganze Schlossmechanismus und das hintere Laufende oder bei Ruickladern das Verschlussgehäuse (resp. Bascul) genau eingelassen und durch Schrauben befestigt. Das hintere Ende des Kolbens wird mit einer Eisenkappe versehen.

Bei den sogenannten deutschen Schäften macht man gewöhnlich eine zum Anlegen der Wange bestimmte Erhöhung Backenanlage, welche in unserer Zeichnung mit $g$ bezeichnet ist, und die um so voller sein muss, je magerer das Gesicht des Bestellers ist. Ausserdem haben die deutschen Schäfte noch einen Horngriff oder Hornbiigel $h$, der das feste Anhalten der Waffe beim Schusse erleichtert. Englische Schäfte haben weder Backe noch Griff und werden vom Schäfter ganz glatt ohne jeden Vorsprung abgerundet.

Nach dem Einschäften werden Versehluss- und Schlossmechanismus nochmals regulirt und auch die Rohrseele ihrer Bestimmung gemäss schliesslich bearbeitet. Schrotläufe werden nochmals gefrischt oder mit Blei geschmirgelt, und zwar so, dass die Rohrseele bei der Pulverkammer um ein Minimum erweitert wird, 
wodurch der Waffe bedeutendere Treff- und Tragfähigkeit ertheilt wird. Die Kugelrohre werden dagegen mit Drall versehen. Der Drall besteht aus einer gewissen Anzahl rinnenförmiger, in einer ganz schwach gewundenen Schraubenlinie fortlaufenden $\mathrm{Z}$ ï ge, deren Zweck darin besteht, der Kugel eine drehende Bewegung um ihre eigene Achse zu ertheilen, wodurch eine etwa unrichtige Lage ihres Schwerpunktes ansgeglichen und das Zusammenfallen der Kugelbahn mit der Achse des Laufes gesichert, auch eine vollständigere Ausnützung der Pulverkraft erzielt wird.

Das Ziehen der Läufe geschieht durch eine ebenso einfache wie sinnreiche Vorrichtung, die $\mathrm{Zugbank}$. Auf dieser wird der zu ziehende Lauf horizontal befestigt, während ein anderer, bereits mit Zügen (Drall) versehener Lauf (das Leitrohr) in geringer Entfernung von ihm so angebracht ist, dass die Achsen beider Läufe genau zusamme:fallen. In dem gezogenen Lauf ist ein genau passender Bleikolben (durch Eingiessen von Blei in ihn gebildet) beweglich, durch dessen Mitte eine mit dem Kolben fest verbundene Stange hindurchgeht. Es ist einlenchtend, dass diese Stange beim Vor- und Zurickziehen durch den an ihr festsitzenden Kolben, der sich in den spiralförmig gewundenen Zügen des Leitrohres fortschiebt, eine entsprechende Drehung erfährt. Das vordere Ende der Stange nun ist mit einem hölzernen Kolben versehen, welcher zwei oder drei wenig vorspringende feilenartig gehauene Schneideisen enthält, und in den zu ziehenden Lauf gebracht wird. Diese Eisen folgen natiirlich ganz genau der Bewegung des Bleikolbens und arbeiten somit genau iibereinstimmende Züge in dem Laufe aus. Ist ein solcher Zug bis zu der erforderlichen Tiefe fertig, so wird das Leitrohr mittelst einer getheilten Scheibe um einen, je nach der Anzahl der Zuige zu bestimmenden Winkel gedreht, wieder befestigt, und mit der Arbeit fortgefahren, bis sämmtliche Züge in genau gleichen Abständen von einander vollendet sind. Die Züge müssen vollkommen parallel neben einander fortlaufen, und nicht tiefer sein, als gerade nöthig ist, um der Kugel die bezweckte rotirende Bewegung $\mathrm{zu}$ ertheilen. Ist das Rohrziehen zu Ende, so wird die Rohrseele mittelst Blei und Schmirgel polirt und zugleich am Pulversacke derselben wenig grösserer Durchmesser ertheilt und sodann das Gewehr auf die gehörige Distanz e ing e s chos sen.

Nachher werden die kleineren Bestandtheile gehärtet, indem man selbe in blechernen Kästen mit Lederkohle bedeckt, bis zur Rothgluth dem Holzkohlenfeuer aussetzt, und sodann in stillstehendem kalten Flusswasser abkiihlt. (S. Einsetzen III pag. 43.) Die so behandelten Eisentheile, blank geschliffen und anlaufen gelassen, erscheinen in den schönsten Farben, welche (Ein s atzfarben) um so dauerhafter sind, je härter die Oberffäche der Bestandtheile. Durch Abwaschen mit Salzsäure werden die Eisentheile der Färbung (Moiré) beraubt, und erscheinen gleichmässig grau.

Die von aussen sichtbaren Bestandtheile der Luxuswaffen werden gewöhnlich vor dem Verstählen an der Aussenseite gravirt, künstlich ciselirt oder mit Gold und Silber ausgelegt. Dies gilt auch von dern Lauf, der aber nie gehärtet werden darf. Die Draht- und Damastläufe werden entweder durch ätzende Säuren gebeizt (wodurch die weicheren Eisentheile tiefer ausgeätzt, dunkel, die härteren dagegen der Säure widerstehend nur wenig berührt, fast in ihrer urspriinglichen Farbe erhaben erscheinen) oder sie werden gleich den Eisen- und Gussstahlläufen briinirt.

Die Brä un e zum Briniren der Rohre ist verschieden, und hat beinahe nicht nur jeder grössere Bïchsenmacher, sondern oft einzelne Arbeiter derselben eigene Recepte, und hält jeder sein eigenes für das beste. Die Laufbräune ist um so besser, je festere und dünklere Farbenkruste sie am Laufe bilden kann, ohne jedoch die Stahltheile des Damastes unsichtbar zu machen. (S. Bräunen I pag. 737.)

Bei Verfertigung von $\mathrm{P}$ istolen wird ganz ähnlich vorgegangen.

Die Hauptaufgabe der Schusswaffen im Allgemeinen ist die möglichst grösste Tragweite und 'Treffsicherheit. Jedenfalls kommt hier neben entspre- 
chender präciser Bearbeitung der Rohrseele und der von dem bestimmten Pulverquantum abhängigen Rohrlänge auch gutes Schiesspulver und namentlich die Form der $\mathrm{Kugel}$ in Betracht. Am besten bewähren sich mit Einschnitten versehene Spitzkugeln. Es wurde schon vor Langem eingesehen, dass die Schusserfolge um so besser sind, je strenger das Geschoss die Rohrseele ausfüllt, und sind deshalb bei den Vorderladern alle möglichen Vorrichtungen getroffen worden, um auch bei leichter Einbringung der Kugel in den Lauf die genaue Ausfüllung derselben zu ermöglichen.

Eine diesbezïglich wesentliche Verbesserung der Kugelbüchsen geschah durch den französischen Artilleriecapitän Delvigne, welcher zur Aufnahme der Pulverladung der Waffe eine verengte Kammer gab, bis zu deren Rand das Geschoss im Laufe nur hinabgleiten konnte. Das Geschoss (von, der Rohrseele entsprechendem Durchmesser) wurde mittelst eines Ladstockes, dessen Knopf mit einer der Kugelspitze entsprechenden Aushöhlung versehen war, so auf den Kammerrand aufgesetzt, dass es, durch diesen gestaucht, sich in die Ziige des Laufes einpresste.

Der franz. Art.-Oberst Thouvenin versah die Pulverkammer mit einem stählernen, oben zugespitzten D o rne, der uber die Pulverladung herausstehend die an ihn angestossene Kugel derart erweiterte, dass die Rohrseele gänzlich ausgefüllt war. Solche Gewehre nannte man Dorn-oder Stiftbü chsen. Bei Anwendung eines $3 \frac{1}{8}$ Loth $\left(55^{g}\right)$ schweren Geschosses miteiner Pulverladung von ${ }^{7 / 24}$ Loth $\left(5 \cdot 1^{g}\right)$ erreichte man bei diesen Gewehren eine bis auf 1000 Schritt gesteigerte Tragweite und eine Treffsicherheit, die auf die Entfernung von 800 Schritt der einer gewöhnlichen Büchse auf 300 Schritt gleich kam, wobei noch die Leichtigkeit des Ladens ein wesentlicher Gewinn ist. Durch hinreichende Versuche ist man auch zu der Ueberzeugung gekommen, dass es sehr vortheilhaft ist, die Geschosse mit einem in Talg getränkten Leinwand pflaster zu umwickeln.

Mit Rücksicht darauf, dass die Dornbüchsen namentlich beim Militärgebrauch im Felde sehr schwer zu reinigen sind, construirte im Jahre 1849 der Capitän Minié ein cylindrisches Geschoss, welches vorne abgerundet, hinten mit einer conischen Höhlung versehen war. In dieser Höhlung wurde ein eiserner Treibspiegel eingesteckt, welcher, durch den Pulverdruck in die Höhlung tiefer eindringend, die Kugel in ihrem Umfang genügend ausbreitete, damit sie die Zïge des Rohres ausfüllen kann. Nebige Fig. 1620 zeigt den Durchschnitt einer solchen Kugel.

Diese Kugeln vereinfachte der Belgier Timmerhans, indem er das eiserne $\mathrm{Culot}$ (Treibspiegel) beseitigte, die Wände der Höhlung schwächer machte, hingegen in der Mitte derselben einen massiven Kern beliess, der das Gleichgewicht der Kugel unterstützte. Diese in Fig. 1621 abgebildete Kugel war z $u g l e i c h$ mit der des Minié das Muster für

Fig. 1620.

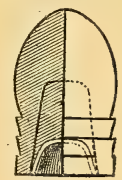

Fig. 1621.

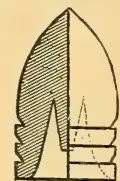
die späteren Versuche der expansiven Geschosse.

Am vortheilhaftesten bewährte sich für den Schusserfolg die $\mathrm{K}$ a mmerladung, die es möglich machte, ein Geschoss von grösserem Durchmesser als die Rohrmündung in die weiter gebohrte Kammer einzuführen und ausserdem auch das Laden weniger zeitraubend machte.

Obwohl schon seit den ersten Jahren der Benitzung von Fenerwaffen wiederholt Versuche gemacht wurden, die kleinen wie grossen Geschiitze von hinten zu laden, ist es doch erst dem 19. Jahrhunderte gelungen, diese so wichtige Frage eigentlich zu lösen. Den Alten mangelte es erstens an den sehr nothwendigen Patronenhülsen, so dass das Pulver nur lose in den Lauf geschüttet werden musste, wodurch auch der beste Verschluss als unvollständig erschien. Ferner war es schwer, ein noch so solid gebautes, von hinten geladenes Gewehr mittelst 
eines Lunt-, Rad- oder Steinschlosses zu feuern. Die Erfindung der durch blossen Schlag oder Stich zündbaren Stoffe hat erst zur Lösung dieser wichtigen Aufgabe gefiihrt.

Der erste Hinterla der unserer Periode war der im Jahre 1809 von P a uly in Paris construirte. Bald nachher erschienen ebenfalls in Frankreich die franz. Wallbüchse und die Rückladesystemé Robert und Lefaucheux; ausser diesen, das sogenannte $\mathrm{Kammerladungsgewehr}$ der norwegischen Infanterie nach Herzberger's Muster, und endlich das neuere Zündnadelgewehr von Dreyse in Sömmerda, welches eine grosse Reform in der gesammten Waffenindustrie hervorrief.

Das Charakteristische der Kammerladungsgewehre besteht iberhaupt in Folgendem: Um die Ladung von hinten in den Lauf zu bringen, muss dieser leicht und schnell geöffnet werden können. Verschliessung desselben durch eine Schwanzschraube ist also unzulässig. Die Oeffnung des Pulversackes kann auf dreierlei Art geschehen; entweder am oberen Theile, wie es bei der Amusette des Marschalls von Sachsen und bei dem Montalembert'schen Gewehre statt gefunden; oder an seinem vorderen Ende, wie bei der franz. W all bü chse (1831) oder schliesslich an seinem hinteren Ende, nach welcher Methode die Systeme Pauly, Robert, Lefaucheux, Dreyse und sämmtliche heute gebräuchlichen Hinterlader construirt sind. Die Bohrung des Pulversackes, hier $\mathrm{Kammer}$ genannt, ist etwas weiter als jene des Laufes, der sich noch gegen die Mündung zu unbedentend verengt. Dieser Umstand gewährt bei den Fenerwaffen der Cavallerie einen Vortheil dadurch, dass bei dem geladenen und mit der Mündung niederwärts hängenden Karabiner, selbst bei den schärfsten Gangarten des Pferdes, dem Vorgleiten und dadurch auch dem Versagen der Ladung vorgebeugt wird. Ueberhaupt ist es wegen der leichten Einbringung der Kugel von rückwärts und wegen ihres nach Entzündung des Pulvers folgenden Eindrängens in den engeren Vordertheil des Laufes möglich, aus den Gewehren ein dicht anliegendes Geschoss zu schiessen, ohne ein Pflaster anwenden zu miissen. Hiedurch wird jedenfalls die Friction des Geschosses in der Rohrseele bedeutend gesteigert, so dass solche Geschosse auf die grösste Distanz noch mit bewundernswerther Treffsicherheit das Ziel erreichen. Der unbequeme Gebrauch des Ladstockes fällt gänzlich weg, wodurch beim Laden Zeit erspart (die Geschwindigkeit des Feuerns vervielfacht) wird und die Länge des Laufes nicht mehr von der Grösse des Mannes abhängig ist, sondern nach der Ladung gerichtet werden kann.

Nach verschiedenen Versuchen, namentlich nach den mit dem norwegischen Kammerladungsgewehre, ergaben sich folgende Bedingungen als nothwendig zur Erreichung eines möglichst guten Schusses: Die Z ïge im Laufe mit abge flachten (gebrochenen) Kanten zu versehen und nicht tief $\mathrm{zu}$ machen, damit sich das Geschoss leicht nach dem Laufe formt; dem Pulversacke oder Patronenlager keine grössere Bohrung zu geben, als gerade der Geschossdurchmesser, resp. der der Patronenhiilse erfordert, und schliesslich das an den Pulversack sich anschliessende Laufende sehr schlank trichterartig zu erweitern, damit der Uebergang der Kugel aus der weiteren Bohrung in die engere nicht zu plötzlich stattfinde. Dic leichte Einbringung der Ladung von rüickwärts gestattet ohne Schwierigkeit jede Gattung von Geschossen anzuwenden.

Die ferneren Vortheile der Rïcklader bestehen darin, dass sie in jeder bewegten oder behinderten Stellung leicht und schnell geladen werden können *) $^{*}$ dass sich ferner die Geschwindigkeit des Feuerus bedeutend vergrössert, und

*) Dass das Laden daher exfolgen kann sowohl bei der geschlossen.n Gliederung der Intanterie, als auch vou dem im Laufen begriffenen, am Boden liegenden oder knienden Schützen, ferner bei der dem Reiter so lästigen Unruhe seines Pferdes und bei der unbequemen Handhabung der Wallbüchsen in den beschränkten Räumlichkeiten crenelirter Maueru. 
endlich das Entladen und Reinigen viel leichter als bei Vorderladern zu bewerkstelligen ist.

Eine ganz eigentlümliche Hinterladeconstruction war das preuss ische Z ündn a delgewehr, welches der Gewehr- und Ziindhiitchenfabrikant Dreyse in Sömmerda 1836 durch Umarbeitung seines im Jahre 1827 patentirten Vorderladers mit ZündnadeI und Spiralfeder herstellte.

Fig. 1622 stellt die äussere A nsicht des zum Laden geöffneten Zündnadelhinterladers, Fig. 1623 den Durch$\mathrm{schnitt}$ des schon geladenen vor.

Der Verschluss und Schlossmechanismus besteht bei diesem Systeme aus drei in einander geschobenen Cylindern und zwar der S e hw an zhülse $a$, die an den Lauf angeschraubt ist, und in welcherder V e rsehlusseylinder $b$ mit der $\mathrm{Kurbel} c$ in zwei Richtungen beweglich ist. Dieser Cylinder enthält den Schlosseylinder $d$ mit der Sp i$\mathrm{ralfeder}$ und dem Nadelbolz en.

Will man das ab gefeuerte Gewehr laden, so wird vorerst der stark vorstehende Ansatz der Sperrfeder $f$ niedergedrückt

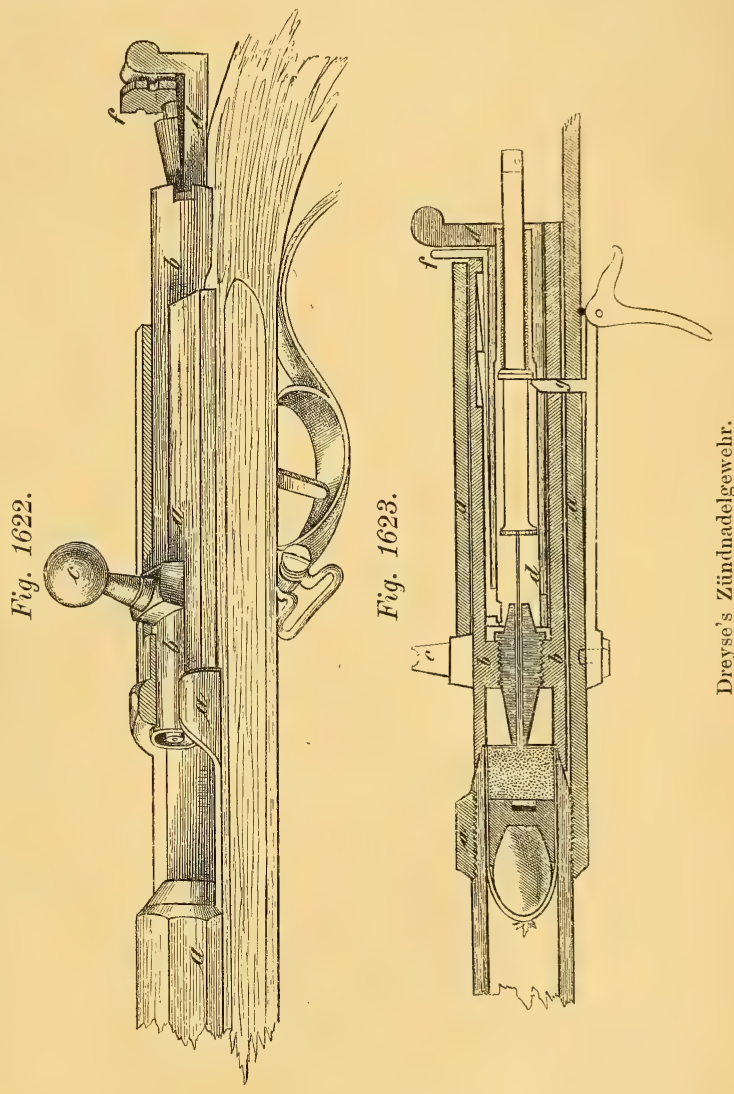
und der Schlosscylinder $d$ soweit herausgezogen, dass der Abzugstollen $g$ ïber den Kragen des Nadelbolzens iiberschnappen kann. Nun wird der Verschlusscylinder mittelst seiner Kurbel $c$ zur linken Seite gedreht und zurickgezogen, so dass zwischen dem Cylinder und dem Laufe ein genïgend weiter Raum zum bequemen Einschieben der Patrone entsteht. Nach dem Einstecken der Patrone in die Kammer wird der Verschlusscylinder wieder zugeschoben und rechts gedreht. In diesem Zustande kann das Gewehr beliebig lange belassen werden, ohne dass man besorgt sein müsste, es könnte vielleicht ein Ungliick durch zufällig erfolgte Entladung rorkommen. Erst wenn man schiessen will, wird der Schlosscylinder wieder eingedriickt, wo er durch das Eingreifen der Sperrfeder $f$ 
festgehalten wird. Dadurch wird erst das Schloss gespannt, indem der Nadelbolzen, durch den Abzugstollen gehalten, nicht mit dem Cylinder zugleich vorgeschoben werden kann. und so die Spiralfeder gepresst wird. Durch einfachen Druck auf den Abzug wird der Nadelbolzen seiner Haltung befreit, und, dem Triebe der Spiralfeder folgend, dringt er durch die ganze Pulverladung, um die $\mathrm{Z}$ ï ndpill e zu erreichen.

Das Dreysesystem war das erste, bei welchem die Einheitspatrone eingeführt wurde, d. h. eine Patrone, die Zündstoff, Pulver und Geschoss enthălt, so dass alles zum Schusse Nöthige auf einmal in den Lauf eingebracht werden kann.

Auch ist es das einzige Originalsystem, welches Kugeln von kleinerem Caliber als die Rohrseele schoss, und dessen Pulverladung von vorne und nicht von hinten entzündet wurde. Fig. 1623 zeigt zugleich den Durchschnitt einer Z iindnadelpatrone. Die Kugel, hier Langblei oder Eichel benannt, sitzt in einem dem Rohrcaliber entsprechenden Treibspiegel von gepresstem Papier, an dessen von der Kugel abgewendeter Fläche die Zündpille (in der Zeichnung schwarz) in der Mitte angebracht ist. Um diese Pille erreichen und durch ihren Stich zünden zu können, muss die Nadel die ganze Pulverladung durchdringen. Kugel, Propfen mit Zündpille und die entsprechende Pulverladung sind mit Papier umgewickelt. Der Treibspiegel hat hier die Aufgabe, die Zündpille in dem Centrum zu halten und beim Abfeuern der Kugel genügende F ïhrung zu ertheilen. Nachdem er die Rohrmündung verlassen fallt er zur Erde.

D reyse's Gewehr wurde, wie alles Gute, durch verschiedene unbedentende Umänderungen hier verbessert, dort verschlechtert. Von den Verbesserungen sind vortheilhaft zu nennen die Zündnadelgewehre: Doersch \& Baumgartner (Braunschweig 1861) und Chassepot (Frankreich 1866), ferner die Systeme Terry 1860, Carle \& Sohn 1867 (Russland), van der Popenburg 1860, Spangenberg \& Sauer 1860 und Carcano 1868 (Italien).

Ausser diesen diente die Dreyse'sche Construction und Verschluss- (Obturations) Idee einer grossen Mehrzahl verschiedener Hinterlader zum Muster.

Nach der Einführung von Metallpatronenhïlsen benütaten vom Dreyse'schen wenig abweichende Verschlusscylinder: H ïgel 1866, Norris 1868, Vetterli 1870, Berdan II. 1871, Beaumont 1871 und Brüder I a user 1871, welches letztere System bestimmt ist, in der deutschen Armee die siegreichen alten Zünđ̉nadeln zu ersetzen.

Fig. 1624.

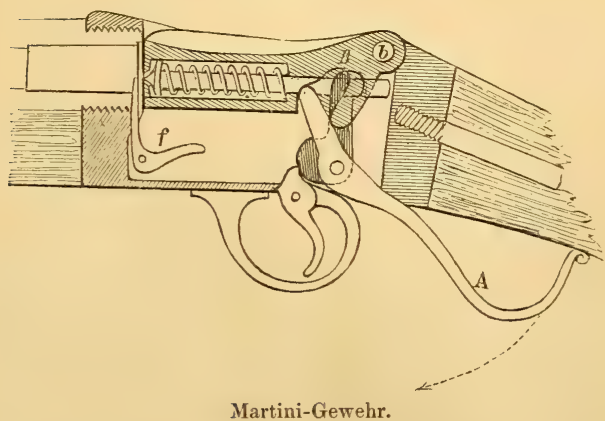

Einige dieser Systeme gestatten es, in $4 \mathrm{Be}$ we gungen schiessen zu können, und zwar: 1. Oeffnen des Verschlusses, wodurch zugleich das Schloss gespannt wird. 2. E in l egen neuer $\mathrm{Patrone}$ 3. Schliessung. 4 . $\mathrm{F}$ e u e r $\mathrm{n}$. Besonders sind ihrer Construction und Leistungsfähigkeit wegen die Systeme Vetterli und $\mathrm{Mauser}$ hervorzuheben.

Eine andere Obturationsvorrichtung ist der B lo e k e r s chluss, der bei manchen im Scharnier sich neigend, bei anderen wieder anders angebracht ist. Als Beispiel dienen hier die vorzüglichen Systeme Martini 1871 und Comblain 
1870, deren ersteres unter dem Namen Martini-Henry in England, das andere in der garde civique in Belgien eingeführt wurde. Fig. 1624 zeigt den Durchschnitt des Martini-, Fig. 1625 des Comblain-Gewehres. Der Verschlussblock $B$ des Martinigewehrs neigt sich beim Herabziehen des Hebels $A$, weil er an der Schraube $b$ beweglich ist; der Block hält ein Spiralschloss in der Mitte. Der Verschlussblock des anderen Gewehres wird ebenfalls durch Herabziehen des Hebels gesenkt, indem er an dem Hebel durch die Schraube $a$ befestigt und in der breiten Oeffnung $E$ in verticaler Richtung beweglich ist. Hiebei wird der Hahn $C$ durch den Ansatz $c$ des Hebels gespannt. Die punktirten Linien der Abbildung zeigen deutlich die innere Schlosseinrichtung.

Die Oeffnung und gleichzeitige Spannung des Schlosses geschieht also bei beiden Systemen durch dieselbe Handbewegung, und die abgeschossenen Hülsen werden durch die Extractors $f$ selbstthätig ausgeworfen. Nach dem Einbringen der neuen Patrone wird die Kammer durch Anziehen des Hebels $A$ eingeschlossen.

Ebenfalls wie Martini seinen Verschlussblock und Hebel dem amerikanischen Systeme Peab ody entwendete und nur mit neuer Spiralschloss-Vorrichtung versah, ahmte auch Comblain den Verschluss des Amerikaners Sharps nach, und ersetzte das alte Percussionsschloss durch ein einfacheres, in der Mitte des Blocks angebrachtes Schlösschen, wodurch er das Ganze für Metallhülsen anwendbar machte. Aber auch dem Amerikaner Sh a r p s gehört nicht die Ehre der ersten

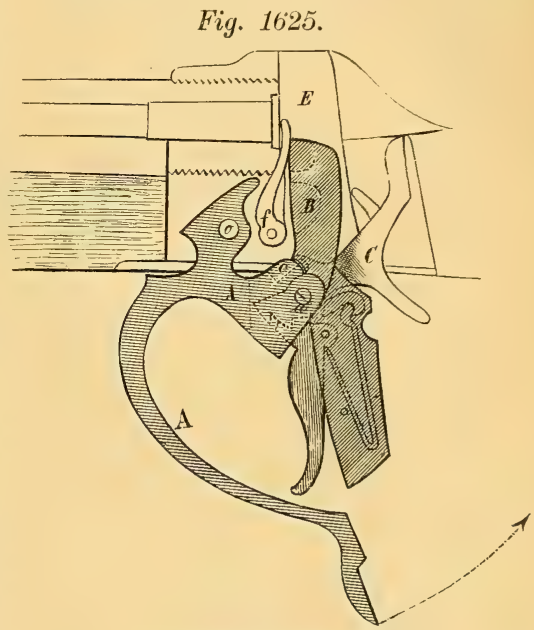

Comblain-Gewehr. Anwendung dieser Verschlussart, da noch alte Kammerlader vom Ende des 16. $\mathrm{J}$ ahrhundertes mit eben demselben Verschlussmechanismus vorhanden sind.

Peabody's Blockverschluss mit Charnier wurde 1872 wesentlich vereinfacht in der vom Fabrikanten Stahl in Suhl construirten Büchse. Dagegen

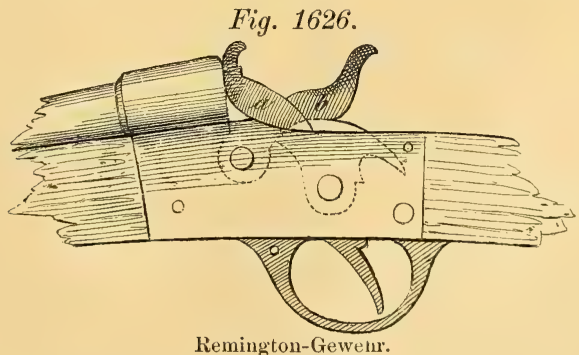

erscheint der ganze Mechanismus ziemlich complicirt im bairischen, ohne jegliche Werkzeuge zerlegbaren Werdergewehre (1869). Ausser diesen führen 
wir als wichtigere Blocksysteme an: Starr 1858, Cochrans 1866 und Schmidt 1873.

Von den übrigen verschiedenartigsten Verschlussarten, die grös stentheils mit gewöhnlichen Percussions sehlös sern versehen sind, können wir leider keine langen Beschreibungen vorlegen, und halten wir für genügend, das interessante amerik. Doppelhahnsystem Remington (1864) Fig. 1626 und das in der österreichischen Armee eingeführte Wörndelge weh r (1868) Fig. 1627 zur Ansicht zu bringen.

Der vordere Hahn a des Remingtongewehres bildet den Verschluss, und kann nicht eher von seiner Lage gehoben werden, als bis der zweite eigentliche Schlaghahn $b$ völlig gespannt ist. Ebenfalls kann der Hahn $b$ nicht losgedrückt werden, wenn der Verschlusshahn nicht an dem Laufe genau anliegt.

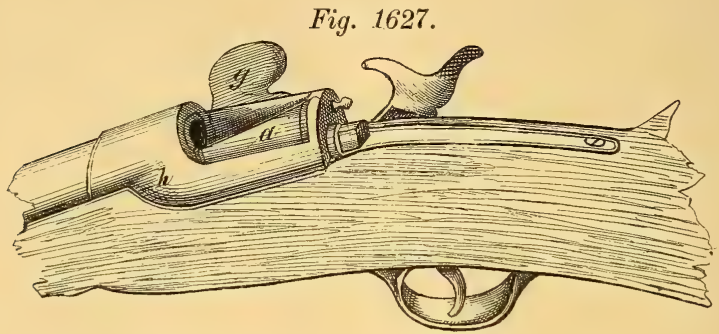

Wörndel-Gewehr.

Das österreichische W örn d l - Gewehr ist mit einem gewöhnlichen PercussionsRückschlosse versehen; den Rohrverschluss bildet hier eine von einer Seite löffel-

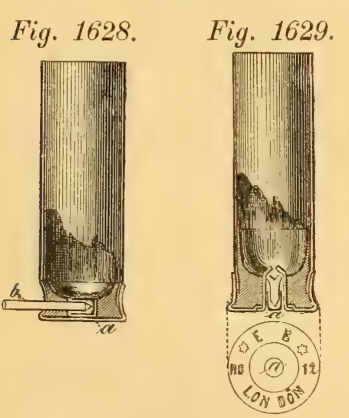
artig ausgehöhlte Walze $a$ von fast doppeltem Laufdurchmesser, die in dem V er schlussgehäuse $h$ um ihre Achse drehbar und mit dem Griff $g$ versehen ist. Der Schuss erfolgt durch Anschlagen des Hahnes an einen in der Walze eingebohrten, beweglichen Zündstift.

Für die Jagd werden meistens nur Doppelwaffen nach den Systemen $L$ efaucheux und Lancaster, freilich mit sehr verschiedenen Abänderungen erzeugt. Der Untersehied beider Systeme ist hier eigentlich nur in den verwendbaren Patronenhülsen zu suchen. Die Zündcapsel der Lefaucheuxpatrone (Fig. 1628) wird beim Anschlagen des Hahnes auf den Stift $b$ durch diesen gezündet; bei der Lanc aster patrone (Fig. 1629) zündet dagegen das im Centrum des Hülsenbodens sitzende Züindhiitchen durch unmittelbaren Anstoss des im Verschlussbascul des Gewehres beweglichen Zündstiftes. (Siehe Fig. 1613.) Ausser diesen findet auch das Z ïndnadeldoppelsystem nach Teschner (Frankfurt a. O.) Beifall, welches ausser der Ziindung nichts anderes mit dem Dreyse'schen Original gemeinschaftlich hat, und wird auch diese Zïndart sehr oft mit der nach Lancaster verwechselt.

Besonderer Erwähnung werth sind die sogenaunten Repetirgewehre, die theils im Schafte oder öfters unterhalb dem Laufe mit einer langen Röhre zum Einnehmen der Patronen versehen sind, welche Patronen sodann nach jedem Schusse durch besonderen Mechanismus einzeln zum Laufe gehoben und in das 
Patronenlager eingeschoben werden; daher kann man mit solchen einläufigen Gewehren, wenn sie einmal gefiillt sind, $9-12$ bis 15 mal nach einander feuern.

Wir liefern nebenbei nur die Abbildungen zweier Repetir-oder M a g a $\mathrm{z}$ ingewehre, und zwar zeigt Fig. 1630 das mit einem Percussionsschloss $u$. zweitheiligem Blockverschluss versehene S p en cer s ystem; (Boston Amer. 1860.) Das Schloss muss auf gewöhnliche Art gespannt werden; die abgeschossene Hülse wird mit einer neuen Patrone durch einfaches $\mathrm{Ab}$ - und Anziehen des unteren $\mathrm{He}$ bels ersetzt.

Die Function der einzelnen Constructionstheile ist aus der Abbildung leicht ersichtlich, indem dieselbe den Durchsehnitt des Gewehres in der Fig. 1630.

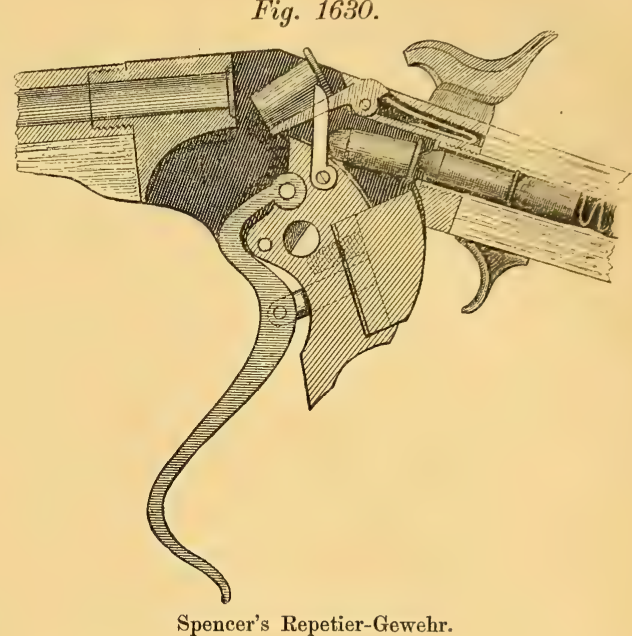

Stellung zeigt, als eben

die abgeschossene Hülse durch den (hier weiss markirten) am Verschlussblock befestigten Extractor aus dem Laufe beseitigt wurde, um der nächstfolgenden geladenen Patrone des Magazins Platz zu machen. Letztere wird bei der riickwärtigen Bewegung des Verschlussblockes durch die hier leicht bemerkbare Kante desselben am Rande erfasst, und sodann dem Patronenlager zugeschoben.

Das Henrygewehr Fig. 1631, (Newhaven, Conecticut, Amer. 1854) ist einfacher bezüglich der Handhabung,jedoch complizirter in der Construction.

Durch eine einfache Bewegung des Bügel$\mathrm{h}$ e bels wird vor allem die starke Verschlussstange vom Laufe zurückgezogen, wodurch auch der, an dem hinterem Ende der Stange Fig. 1631.

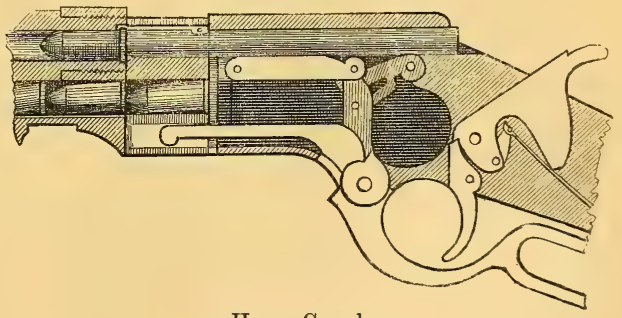

Henry-Gewehr.

anliegende Hahn in Bewegung gesetzt und gespannt wird. Zugleich wird anch die abgeschossene Hülse aus dem Laufe gezogen, indem sie durch die, an der Stange befestigten Krallen erfasst, die Bewegung mitmachen muss. Im selben Momente, als die abgeschossene Hïlse den Lauf verlassen hat, hebt sich ein eigens construirter Theil, der die nächste Patrone aus der hier unter dem Laufe angebrachten Magazinsröhre genommen, so dass die alte Hülse über den Rand des Gehäuses, die der Magazinsröhre entnommene neue Patrone dagegen in gleiche Linie mit der Rohrseele gehoben wird. Bei der Riickbewegung des Hebels wird wieder zuerst die Verschlussstange dem Laufe zugeschobeu, hiedurch also auch 
die neue Patrone in die Rohrkammer gedrückt, und schliesslich auch der Theil zum Einnehmen einer dritten Vorrathspatrone zur weiteren Repetirung herabgezogen. Alles dies geschieht durch einfaches Ab- und Andriicken des Bügelhebels - im Zeitraume von kaum einer Secunde.

Das System des Tyler Henry wurde durch Winchester verbessert, indem das Füllen der Magazinröhre vereinfacht wurde und diente so als Wegweiser zu den beiden Vetterli'schen Repetirsystemen (Schweiz 1867-1874), so wie auch zu den des Ball (Windsor 1863), Gamma \& Infanger (Altorf 1868), A. Thury (Bern 1874) und And.

Im Jahre 1872 construirte auch der Wiener Waffenfabrikant Fruhwirth ein vorzügliches Magazingewehr, welches in der österr. Gensdarmerie eingeführt wurde. Was die Einfachheit der Construction anbelangt, geziemt dem Herrn Thurỳ (1874) unbedingt der erste Platz.

Die Repetirgewehre sind jedenfalls das Vorzüglichste, was die Waffentechnik des neunzehnten Jahrhundertes dem Kriegswesen, sowie auch den passionirten Schützen bieten kann. Obwohl die ersten Repetirgewehre von Amerika zu uns kamen, ist doch der Ursprung derselben in unserem Continent zu suchen, da bereits vor mehr als 2 Jahrhunderten in Europa Versuche mit Repetition gemacht wurden, und wir können nicht umhin zu bemerken, dass auch Dreyse in den ersten Decennien seiner Thätigkeit sich mit dieser Idee befasste. $\mathrm{Da}$ er jedoch einsah, eher mit dem Zündnadelgewehre den Zweck erreichen zu können, gab er den Gedanken auf und erst sein Sohn hat die Idee wieder erfasst.

Es ist ganz natuirlich, dass während der Vervollkommnung der langen Handfeuerwaffen auch die kurzen Pistolen und Terzerole entsprechend verbessert wurden. Das Bedeutendste was hier geleistet wurde, ist der Revolver oder die Drehpistole. Wie alle wichtigen Erfindungen dieses Faches ist auch diese vor langer Zeit versucht worden. Hofantiquar Pickert in Nürnberg hat in seiner Sammlung einen Drehling, dessen Cylinder, Lauf und Schaftstellung denen des heutigen Revolvers sehr ähnlich sind. Diese Waffe ist mit Luntschloss versehen und wurde in Nürnberg in den Jahren 1480-1500 verfertigt. Ausserdem existiren noch mehrere alte Drehlinge.

\section{Fig. 1632.}

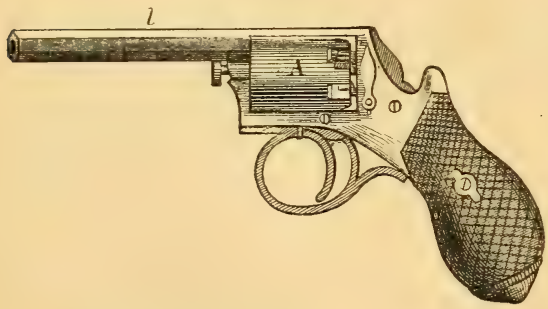

Die erste nachhaltige Erfindung im Gebiete der Drehlinge war die S a muel Colt's, der sein erstes Modell bereits als 15jähriger Schiffsknabe 1828 aus Holz schnitzte. Co l t's Revolver besteht (Fig. 1632) aus einem hinter dem Laufe $l$ um seine Achse drehbaren $\mathbf{C y}$ linder $A$ mit mehreren zum Aufnehmen der Ladung bestimmten Bohrungen, die auf der, dem Laufe entgegengesetzten Seite mitPistons versehen sind. Beim Schiessen stelt immer die eine Bohrung in gerader Linie mit der Rohrseele, so dass die geschossene Kugel aus der Walze in den Lauf gedrängt wird, um hier die bestimmte Richtung zu erhalten. Beim $\mathrm{Hahn-}$ spannen wird immer die nächstfolgende Bohrung dem Laufe zugedreht Ein anderer Drehling war der von Mariette (1842), der die Ladewalze oder den Cylinder nicht rom Laufe separirte; sein Rerolver besteht eigentlich aus 4 und noch mehr (bis 18) Läufen entsprechender Länge, die ebenfalls hinten mit Pistons versehen sind. Der Hahn wird gespannt und die Läufe der Reihe nach mittelst starken Drucks an den ringförmigen Abzug nach oben gedreht. Mit 
der Einfihrung der Riickladung haben auch die Drehlinge viele Verbesserungen erfahren.

Der beste und noch heute beliebteste Revolver ist der Lefaucheux's (Sohn) 1853, der die drehbare Walze von Colt mit der Hahnspannung mittelst Abzug von Mariette verbindet; es ist hier die sogenannte doppelte Bewegung (durch Hahn und Abzug) vorhanden. Die Patronen sind den Lef a u cheuxJag d p atron en ähnlich.

Nach Einführung der Central zü $\mathrm{n}$ ung nach Lancaster sind abermals neue Revolversysteme aufgetaucht. Von den heute bekannten Drehsystemen nennen wir ausser den oben angeführten: Gasser (Wien 1871, österr. Armeerevolver), der aber eine strenge Nachahmung des Lefaucheux-Revolvers und nur auf Wörndlpatronen gerichtet ist. Hauptmann K ropats chek hat den G a s se r'schen Revolver in Mass und Gewicht reducirt. Wirkliche Verbesserungen des Lefa ucheux sind die Revolvers: Drivon \& Birou (St. Etienne 1865), Spirlet (Littich 1869), Galand 1870, Smith \& Wesson 1867-70, Tackels 1871, Chamelot, Delvigne \& Schmidt 1873.

Bei dem allgemeinen Bestreben, alle Feuerwaffen in $\mathrm{Rücklader}$ zu verwandeln, wurde auch der groben Geschiitze nicht vergessen. Jedenfalls war es nicht möglich dieselben Verschlussarten wie bei Handgewehren hier in Anwen. dung zu bringen, und so entstanden meistens aus Guss tahl verfertigte Kanonensysteme mit: Kolbenverschluss (Wahrendorf), Keilverschluss (Kreiner), Schraubendeckelverschluss (Whitworth), Schraubenverschluss (Chay-Schalk), Riegelverschluss (Armstrong).

Am besten bewähren sich gegenwärtig die Krupp'schen und vor Allem die vor Kurzem in Oesterreich-Ungarn eingeführten Uchatius-Geschïtze, die, aus der sogenannten Stahlbronce verfertigt, bei nicht sehr grosser Metallstärke iiberraschende Schussresultate bieten.

Der Lafette wurde ebenfalls grosse Sorgfalt gewidmet und sind jetzt unzählige Lafettensysteme für Schiff, Land, Festungen, Gebirg etc. bekannt.

Gleich wie die von hinten zu ladenden groben Geschütze des 15. und 16. Jahrhundertes bei uns vervollkommnet und adoptirt wurden, sind auch die alten Orgelgeschïtze oder Todtenorgeln des 15. Jahrhundertes in den Mitrailleusen (auch Kugelspritzen) wieder zum Vorschein gekommen. Die Mitrailleuse besteht aus 25 bis 36 (auch noch mehr) Läufen, ziemlich grossen Calibers, die, mit einemmal geladen, durch Drehung einer Kurbel schnell hinter einander abgefeuert werden, so dass nur ein kurzes donnerähnliches Krachen vernehmbar ist. Von den bisher bekannten Mitrailleusen sind zu erwähnen die französische (1867) und die in Oesterreich und Belgien adoptirte Mitrailleuse Montigny's (1869).

Die drehbare, selbstladende Gatling-Kanone (1868) steht den Mitrailleusen würdig zur Seite. Brandeis.

Lit eratur. Betreffend die Gewehrfabrikation vergleiche: Furtenbach, Büchsenmeisterei, Ulm 1627. Prechtl, techn. Encyclop. Band 6. Alison G. Chr. der engl. Büchsenmacher, Quedlinburg Basse 1832. B ervaldo, Feuerund Seitengewehre, Wien, Gerold. 1829. Schmidt J., die Geheimnisse der engl. Gewehrfabrikation, Weimar 1824. S chmidt, Beiträge zur Büchsenmacherkunst, Weimar 1843. - Betreffend die Waffenlehre vergleiche: C. Rüstow, die Kriegshandfeuerwaffen, Berlin 1857; A. D u b, Handb. ï.d. K. d. Gewehre etc. Wien 1852. Neue Studien iiber die gezogene Fenerwaffe der Infanterie von W. v. Plönnies, 2. Bd., Darmstadt, 1861, 1864. Schott, Waffenlehre 1868, Darmstadt. Ferner zahlreiche Abhandlungen in Dingl. polyt. Juurnal u. a. a. O. Vergleiche Artillerie I. pag. 203.

Feuerwerkerei (pyrotechnic - pyrotechny), Pyrotechnik. Die Verwendung leicht entziindlicher, mehr oder weniger explosiver Gemenge hat seit Erfindung des Schiesspulvers ausserordentlichen Einfluss auf die Gesammtverhält- 
nisse des gewöhnlichen Lebens, besonders aber auf die Art der Kriegführung gewonnen, und die Kenntniss der Darstellung, Verwendurg und Wirkungsweise des Schiesspulvers bildet eine der wichtigsten Grundlagen der modernen Kriegskunst. Aber auch zu anderen wesentlich friedlicheren Zwecken kann das Abbrennen explosiver Mischungen dienen, insoferne man die bei dem Abbrennen entsprechender Mischungen erzielbaren Lichteffecte zur Erzeugung weithin sichtbarer Flammen verwenden und sohin für die Zwecke des optischen Signalisirungswesens geeignete Signallichter erzeugen kann, als man auch, sei es die mit solchen Mischungen erzielbare Farbenpracht der Feuer, sei es die mit Zuhilfenahme bestimmter Kunstgriffe erreichbare Vielgestaltigkeit und Mannigfaltigkeit in den Formen der Feuererscheinungen zur Hervorrufung brillanter Lichteffecte oder belustigender Schauspiele iiberhaupt verwenden kann.

Diese Art der Verwendung leicht entziindlicher oder explosiver Mischungen bildet den Gegenstand der Feuerwerkerei im engeren Sinne des Wortes, das ist der sogenannten Lustfeuerwerkerei, von der im Folgenden gehandelt werden soll.

Die meisten und schönsten Erfindungen im Gebiete der Feuerwerkerei verdankt man dem berühmten $\mathrm{Ruggieri}$ und seinem Sohne, die in Rom, Paris und den meisten übrigen Hauptstädten von Europa ihre bis dahin unbekannte, durch sie eigentlich begriindete Kunst der Ausführung brillanter Feuerwerke producirten, und deren Erfahrungen in dem $1821 \mathrm{zu}$ Paris erschienenen Werke "Eléments de pyrotechnic par Ruggieri" niedergelegt sind.

Die Hauptmaterialien zu fast allen Feuerwerksmischungen sind die Bestandtheile des Schiesspulvers: Salpeter, Kohle und Schwefel; ausser diesen dienen aber noch mancherlei Nebenmaterialien, als Feilspäne von Eisen, Stahl, Kupfer, Zink, dann Schwefelmetalle, ferner die verschiedensten Salze, meist solche, welche die Fähigkeit haben, den Flammen bestimmte Färbungen zu ertheilen, endlich auch Campher, Harze, Lycopodium etc. Schiesspulver selbst wird sehr häufig, und zwar zum Theil gekörnt, zum Theil ungekörnt, als Mehlpulver, angewandt; durch Beimischung bestimmter anderer Stoffe erzielt man besondere Effecte. So liefern Eisenspäne, besonders wenn sie rechtlang, aber fein sind (Lyoner Fäden), sprühende rothe und weisse Funken. Feil- und Bohrspäne ron Stahl und Gusseisen geben ein glänzendes, heftig sprühendes Feuer. Alle dergleichen Späne müissen, wenn sie die verlangte Wirkung machen sollen, ganz rostfrei sein. Ein Zusatz von Kupferspänen bedingt eine grüne, von Zinkspänen eine sehr schön grünlich blaue Färbung des Feners. Schwefelantimon wirkt ähnlich wie Zink, das Blau ist noch weniger griinlich, das Fener sehr stark rauchend. Bernstein und Colophonium, so auch Kochsalz färben die Flamme rothgelb oder gelb, das letztere muss aber, um die Verbrennung nicht $\mathrm{zu}$ hindern, sehr trocken angewandt werden. Lampen- oder Kienruss, mit Mehlpulver gemengt, erzengt ein dunkelrothes, mit Salpeter zusammengerieben, ein hellrothes Feuer. Man bedient sich eines solchen Satzes zum Groldregen. Auch gelber Glimmer wird wohl zugesetzt und bewirkt recht hübsche goldgelbe Funken. Durch Grïnspan entsteht Hellgrün, durch Eisenvitriol und Salmiak ein lichtes Palmgrïn. Campher bringt ein weisses Licht hervor, und wird auch wohl des Geruches wegen zugesetzt. $\mathrm{Zu}$ demselben $\mathrm{Z}$ weck dienen auch Benzoe und Storax. Durch Zusatz von Lycopodium entsteht eine schön rosenrothe Flamme.

Man kann die verschiedenen Feuerwerkskörper in 3 Hauptclassen eintheilen: 1. in solche, die ihre Wirkung auf der Erde zu machen bestimmt sind, 2. solche, die in höheren Luftschichten abbrennen sollen, und 3. solche, die auf dem Wasser abgebrannt werden sollen.

Fast alle Fenerwerkskörper bestehen aus einer papiernen oder pappenen Hiilse ron bestimmter Form, in welche die geeignete brennbare Mischung (der Fenerwerkssatz) eingefiillt ist. Die Hiilsen werden auf einem cylindrischen Stabe von angemessenem Durchmesser ans starkem Papier oder diinner Pappe, in mehreren Windungen iibereinander geleimt, angefertigt. Nicht selten wird das 
zur Verfertigung solcher Hülsen dienende Papier vorher mit einer Alaunlösung getränkt, um es vor dem Anbrennen zu schützen. Das eine Ende wird in der Regel dadurch fest verschlossen, dass man es mittelst eines umgewundenen starken Bindfadens, auch wohl mittelst einer besonderen Vorrichtung stark zusammenschnürt (würgt) und in die etwa noch vorhandene kleine Oeffnung einen papiernen oder thönernen Propf eintreibt. Bei Stiicken, wo sich nach dem Ausbrennen des Satzes die Entzuindung auf einen anderen Theil fortpflanzen soll, lässt man den kleinen Pfropf weg, und verbindet das hintere Ende der einen IIülse mit dem vorderen der anderen durch eine Zündschnur oder eine Brandröhre. Auch die vorderen Enden werden nach dem Einfüllen des Satzes gewöhnlich zugewïrgt und die so entstehende bedeutende Verengung nöthigt den Feuerstrahl mit grosser Heftigkeit hervorzusprïhen. Nur da, wo eine ruhige, geräuschlose Flamme verlangt wird, lässt man die Mündung der Hülsen ihrer ganzen Weite nach offen.

Der Satz, dessen Zusammensetzung je nach den verschiedenen Zwecken sehr verschieden sein kann, wird meistentheils, um das allzu rasche Abbrennen zu mildern, durch vorsichtiges Schlagen stark verdichtet, was zugleich den Vortheil gewährt, dass eine Hülse von bestimmter Grösse eine weit grössere Menge des Satzes aufzunehmen vermag, als ohn€ Verdichtung desselben möglich wäre.

Im Folgenden geben wir eine kurze Beschreibung der hauptsächlichsten Feuerwerkskörper und ihrer Herstellungsart.

1. Feststehende Feuerwerkskörper. Hierher gehören zunächst als einfachste Form die Bränder, d. s. einfache, mit irgend einem Brandsatze gefüllte und an dem vorderen Ende gewürgte Hülsen, die einen lebhaften Feuerstrahl auswerfen. Der gewöhnlichste Satz für Bränder von nicht über $2^{\mathrm{cm}}$ Durchmesser ist: 16 Mehlpulver, 3 Kohle; für grössere: 16 Mehlpulver, 4 Stahlfeilspäne. Durch Zusatz von Kupferfeilspänen erhält man grïne, durch Zinkfeilspäne blaugrüne Funken. Das chinesische Feuer, das mit prachtvollen blumenähnlichen Funken (Jasminblüthen genannt) brennt, wird für Bränder unter $2^{\mathrm{cm}}$ aus 16 Mehlpulver, 8 Salpeter, 3 feinem Kohlenpulver, 3 Schwefel und 10 feinen Gusseisenbohrspänen; für grössere Bränder aus 16 Mehlpulver, 12 Salpeter, 3 Kohle, 3 Schwefel und 12 groben Gusseisenspänen zusammengesetzt. Durch Verbindung mehrerer Bränder entstehen die feststehenden Sonnen, indem eine Anzahl von Brändern in der Richtung der Radien eines Kreises oder der Speichen eines Rades verbunden und zu gleicher Zeit in Brand gesetzt wird. Wenn, wie in dem vorliegenden Falle, mehrere, oft sehr viele Stücke gleichzeitig entziindet werden müssen, so geschieht dies mittelst der Ludelfäden oder Stopinen (étoupille - quickmatch), d. s. mit Pulver versetzte, in eine diinne papierne Röhre eingeschlossene baumwollene Dochte. Aus solchen Stopinen, deren jede die Länge eines Papierbogens oder auch mehrerer Bogen haben kann, und deren Hülsen man absichtlich an dem einen Ende ein wenig weiter macht, als an dem anderen, um bequem das dünnere Ende der einen in das weitere der nächsten einstecken zu können, bildet man dann eine vollständige Leitung nach allen zu entzündenden Punkten. Auch kann man sich zum gleichen Zwecke der gegenwärtig fabriksmässig dargestellten Zündschnüre oder aus Schiessbaumwolle gefertigter und mit einer Lösung von Salpeter getränkter Schniire bedienen.

Unter Glorien versteht man ähnliche Zusammenstellungen, wobei die Mündungen der Bränder nicht in einem einfachen Kreise, sondern in dreieckigen, sternförmigen oder anderen Figuren angeordnet sind, und die oft selbst mehrere Reihen von Brändern enthalten.

Der Fächer besteht aus mehreren, etwa 5 oder 7 , als Radien eines Viertel- oder Halbkreises verbundenen Brändern. Drei Bränder bilden den sogenannten $G$ äns efuss.

Mosaik entsteht, wenn mehrere, nicht zu weit, etwa 3 Fuss von einander entfernte Pfähle auf die Art mit Brändern besetzt werden, dass sich beim Bremen allemal vier Feuerstrahlen in einem Punkte vereinigen oder kreuzen, wodurch 
bei einer bedeutenden Anzahl solcher sich kreuzender Feuerstrahlen eine mosaikähnliche Erscheinung erzielt werden kann.

Cascaden werden durch eine Anzahl horizontal neben einander liegender Bränder nachgeahmt. Am besten eignet sich hierzu chinesisches Feuer. Auf gleiche Art, nur dass die Bränder nach abwärts geneigt sind, entsteht der Goldregen.

Fixsterne. Hierzu dienen Bränder von besonderer Einrichtung. Zu ihrer Herstellung werden die Bränderhülsen an beiden Enden geschlossen, dagegen aber bohrt man in der Nähe des einen Endes und zwar in einer und derselben Durchschnittsebene fünf Löcher durch die Hülse, welche, wenn der Bränder in horizontaler Lage in der Richtung seiner Achse betrachtet wird, beim Brennen einen aus fünf divergirenden Feuerstrahlen bestehenden Stern darstellen.

Zweckmässige Sätze zu solchen Sternen sind:

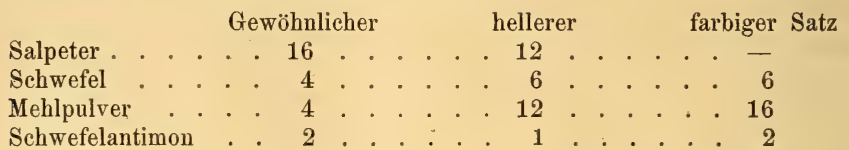

Die sogenannten bengalischen Flammen oder Theaterfeuer sind bunte Feuersätze, welche entweder in Papierhülsen, die nicht gewürgt werden, geschlagen sind, oder in Blechbüchsen von $6-10^{\mathrm{cm}}$ Höhe und $3-6^{\mathrm{cm}}$ Durchmesser, wohl auch in kleine Thontiegel eingestampft und nach dem völligen Trocknen angezündet werden. $\mathrm{Zu}$ ihrer Herstellung verwendet man die verschiedensten Mischungen, für welche unten passende Vorschriften angeführt werden sollen.

$\mathrm{Brändchen} \mathrm{sind} \mathrm{dünne,} \mathrm{oft} \mathrm{aber} \mathrm{ziemlich} \mathrm{lange,} \mathrm{mit} \mathrm{einem} \mathrm{Brandsatze}$ gefüllte Hülsen aus vierfachem Papier, von welchem aber nur die äusserste Lage geklebt wird, weil die Huilse, um das ruhige sanfte Fortbrennen des Satzes nicht in ein heftiges Sprühen zu verwandeln, gleichzeitig mit dem Satze verbrennen soll, hieran aber durch zu viel Leim oder Kleister gehindert werden würde. Sie werden aus demselben Grunde auch an der Mündung nicht verengt, sondern ganz offen gelassen. Solche Brändchen dienen zur Hervorbringung von Namensziigen und anderen Decorationen, als Tempeln u. dgl., die gewöhnlich den Schluss eines Feuerwerkes bilden. $\mathrm{Zu}$ diesem Zweck muss ein Rahmen oder Gerüst in der Gestalt der geplanten Decoration vorhanden sein, an welchem die Brändchen befestigt und durch Stopinen in Verbindung gesetzt werden, so dass sie sich gleichzeitig entzünden. Gewöhnlich bekommen diese Brändchen verschiedenfarbige Sätze, wobei dann der Feuerwerker die Vorsicht nicht ausser Augen lassen darf, die mit rasch brennenden Sätzen gefiillten Brändchen verhältnissmässig länger zu machen, als die mit langsam brennenden, weil die kunstgerechte Ausfïhrung der Decorationen nicht nur die gleichzeitige Entzündung, sondern auch ein möglichst gleichzeitiges Verlöschen sämmtlicher Lichter erheischt. Um die Brändchen sicher zur Entziindung zu bringen, bohrt man etwa zwei Linien vom vorderen Ende mit einer Pfrieme ein Loch quer hindurch, um die Verbindungsstopine, die an dieser Stelle bloss liegen und den Satz des Brändchens berühren muss, mit einem durch das Loch gesteckten Faden befestigen zu können. Für derlei farbige Brändchen empfohlene Brandsätze finden sich unten angeführt.

Hierher gehören auch die für Zimmerfeuerwerke verwendbaren ja p a nis $\mathbf{c h}$ en Stern-oder Blitz-A ehren, das sind etwa stricknadeldicke, am vorderen Ende ährenförmig verdickte Brändchen, welche aus feinem Seidenpapier gefertigt und mit etwa 0.04 Grm. einer Mischung von 3.75 Thl. Salpeter, 1.5 Thl. Schwefel und 1 Thl. Holzkohlenpulver, oder nach anderen Angaben 3 Salpeter, 6 Schwefel und 4 Holzkohle, oder 15 Salpeter, 8 Scliwefel und 3 Russ, oder 7 Salpeter, 4 Schwefel und 2 Lindenkohle (vgl. Dingl. pol. Journ. 175 pag. 481 und 189 pag. 87) gefiillt sind. Man schneidet zu ihrer Herstellung feines Seiden- 
papier in keilförmige, am breiteren Ende etwa $3^{\mathrm{cm}}$ breite, im G'anzen $9-10{ }^{\mathrm{m} m}$ lange Streifchen und wickelt die etwa 0.04 Grm. betragende Menge des Satzes so in den Streifen ein, dass die grösste Menge desselben vom breiten Ende eingeschlossen wird. Beim Anzünden an dem verdickten Ende bremen diese Aehrchen anfangs mit einer ruhigen, kaum leuchtenden, kleinen Flamme, bald aber beginnt sich an dem brenneden Ende ein rothglühendes Kügelchen zII bilden, aus welchem bei fortschreitender Verbrennung äusserst zarte glänzende Funken blitzartig hervorbrechen und eine prächtige Erscheinung gewähren.

Auch die japanischen Z Z̈̈ndstäbchen liefern eine ähnliche Erscheinung. Man erhält sie, wenn man 26-30 Thl. Mehlpulver, 11 Schwefel und 5 Lampenruss mit Weingeist zu einem steifen Brei anknetet, aus diesem kleine, etwa $1^{\mathrm{cm}}$ grosse Würfel schneidet und trocknen lässt. Zwängt man ein solches Würfelchen in ein gespaltenes Holzstäbchen ein, und brennt es an dem nach unten gehaltenen Sätbchen $\mathrm{ab}$, so bildet sich alsbald eine feurige Kugel, aus welcher gleichfalls blitzartige Funken hervorsprühen (vgl. d. Ind. Zeitg. 1865 pag. 48).

2. Feuerwerkskörper mit drehender Bewegung. Die Bewegung der meisten Feuerwerksstücke beruht auf dem Rückdruck, den die gasförmigen Verbrennungsproducte des Feuerwerkssatzes beim Ausströmen aus einer Oeffnung bedingen. Befinden sich nämlich in einem verschlossenen Gefässe stark verdichtete Gase, die also gegen die Wände des Gefässes einen starken Druck ausuiben, so bleibt nichts desto weniger Alles im völligen Gleichgewichtszustande, weil einem jeden Theile der Wand, der einen bestimmten Druck erleidet, eine gleich grosse Fläche gegenübersteht, die sich unter genau demselben Druck hefindet. Entstände nun plötzlich eine Oeffnung in dem Gefässe, so würde beim Ausströmen des Gases der Druck in der Oberfäche des Loches nicht mehr zur Wirkung kommen (weil hier keine Wand dem Drucke Widerstand leistet), während die gegenüberstehende Wand nach wie vor dem Druck unterworfen bleibt, daher denn also nach dieser letzteren Seite hin, d. i. in der dem Loche entgegengesetzten Richtung ein überwiegender Druck sich geltend machen muss, der eine Bewegung in der der Ausströmungsrichtung entgegengesetzten Richtung bedingen kann. Dieses Verhältniss tritt nun immer ein, wenn Feuerwerkshïlsen, welche mit Sätzen gefullt sind, die reichliche Mengen von Verbrennungsgasen entwickeln (Treibsätze), so angebracht werden, dass sie in Folge eines solchen, beim Abbrennen zur Geltung kommenden einseitigen Druckes, eine Bewegung erfahren können, wobei der der bewegten Hülse entströmende Fenerstrahl die Spur der Bahn kennzeichnet, welche von der Ausströmungsöffnung zurückgelegt wurde und so feurige Bewegungsfiguren beschreibt, welche in mannigfacher Weise combinirt und zur Erzielung prächtiger Effecte benutzt werden können.

Die einfachste Art derartiger beweglicher Feuerwerkskörper sind die F e u e r$\mathrm{räder}$, welche im Kleinen durch spiralförmiges Aufrollen einer mit Satz gefüllten Papierhülse um eine kleine hölzerne Scheibe, die beim Gebrauch mittelst eines Stiftes und um denselben drehbar an einen Pfahl befestigt werden kann, hergestellt werden. Im grösseren Massstabe werden die Feuerräder fast stets aus drei oder auch mehreren einzelnen Brändern angefertigt, die an der Peripherie eines dreieckigen oder polygonalen, um seinen Mittelpunkt drehbaren Brettchens so befestigt sind, dass ihre Achsen den Seiten des Polygons parallel laufen, und auf solche Weise mit einander in Verbindung gesetzt werden, dass der erste, nach dem völligen Ausbrennen, den zweiten, dieser den dritten u. s. w. entzündet, so dass jeder Zeit nur ein Bränder in Thätigkeit ist. Der Satz zu den Feuerrädern kann begreiflicher Weise die verschiedensten farbigen Fenermischungen enthalten, darf aber nicht zu stark verdichtet werden, um die nöthige Kraft zum raschen Umtreiben des Ganzen zu entwickeln; ein Grundsatz, der bei allen Stiicken Anwendung findet, die in eine lebhafte Bewegung versetzt werden sollen.

Gewöhnlich nimmt man zu Feuerrädern einen stark funkenspriihenden Satz.

So z. B. für einen Durchmesser der Bränder unter $2^{\mathrm{cm}}: 16$ Mehlpulver, 3 gröblich 
zerriebene Kohle; für grössere Durchmesser 20 Pulver und 4 Kohle; zu stark sprïhendem Feuer 16 Pulver und 2-3 gelben glimmerhaltigen Sand; oder 16 Pulver, 1 gestossene Steinkohle, 1-2 gelben Sand.

Doppelte Feuerräder werden aus zwei sich auf derselben Achse in entgegengesetzter Richtung drehenden Feuerrädern zusammengesetzt.

Capricen, ebenfalls aus einer Combination mehrerer Bränder bestehend, drehen sich in horizontaler Richtung abwechselnd bald rechts, bald links, was sich sehr leicht durch entsprechende Anordnung der Ausströmungsöffnungen der einzelnen, nach einander zur Wirkung kommenden Bränder erreichen lässt.

Etwas complicirter ist die Herstellung der Spiralen. Diese erfordern ein aus mehreren Stäben construirtes, möglichst leichtes, kegelförmiges Gerüst, das mit der Spitze auf einen verticalen Pfahl gehängt wird und sich in horizontaler Richtung um denselben dreht. Die untere ringförmige Basis ist mit einer Anzahl horizontaler Bränder ausgestattet, welche den Apparat in Drehung setzen, während eine spiralförmig sich bis zur Spitze des Kegels hinaufschlängelnde Reihe nahe zusammenstehender verticaler Brändehen sich zu gleicher Zeit entzündet. Dass besonders bei diesem Stiicke verschiedenfarbige Sätze eine ausgezeichnet schöne Wirkung machen, ist leicht zu begreifen.

Eines der effectvollsten Fenerwerksstuicke ist die von $\mathrm{Ruggieri}$ angegebene Schlange, welches den Eindruck einer feurigen Schlange macht, die in raschen Windungen einen vor ihr fliegenden Schmetterling verfolgt. $\mathrm{Zu}$ diesem Stück ist eine eigene mechanische Vorrichtung erforderlich. An den Ecken eines grossen achteckigen Gerüstes oder Rahmens sind grosse Räder angebracht, die sich sämmtlich in einer Verticalebene drehen. Um diese Räder oder Rollen schlingt sich ein endloses Band in der Art, dass es erst uiber die Aussenseite eines Rades, dann über die dem Centrum des Achteckes zugewandte innere Seite des nächsten, von diesem wieder uiber die äussere Seite des dritten u. s. w. fortläuft, mithin eine schlangenförmige, in sich zurücklaufende Curve beschreibt. Das Band ist ganz nach Art einer Uhrkette, natürlich in grossem Massstabe, ausgefuihrt und trägt in einem Theile seiner Länge verticale Plättchen oder Schilder, die sich dicht an einander anschliessen, und in ihrer schlangenförmigen Windung die Gestalt einer Schlange nachahmen. In einiger Entfernung von denselben trägt ein Kettenglied die den Schmetterling darstellende Platte. Indem nun die Schlange mit bunten, der Schmetterling mit weissen Brändchen besetzt in Bewegung gebracht wird, während der Zuschauer in der Dunkelheit der Nacht von dem mit schwarzer Farbe angestrichenen Mechanismus keine Spur bemerkt, entwickelt sich ein äusserst effectvolles Schauspiel. Ruggieri liess dieses Stuick gewöhnlich ohne menschliche Beihilfe durch das Abbrennen anderer Fenerwerksstiicke sich entzïnden, so dass es ans einem Flammenmeer sich selbst zu entwickeln schien. Die Drehung des Apparates bewirkte er dadurch, dass eines der Räder durch ein vorher aufgezogenes Gewicht angetrieben wurde. Er nannte dieses Feuerwerksstiick auch Sal a mander.

3. Feuerwerkskörper mit geradliniger Bewegung.

$\mathrm{Zu}$ diesen gehören vor allen anderen die $\mathrm{R}$ aket $\in \mathrm{n}$ (fusée volante, raquette - sky-rocket), die, so allbekannt und gebräuchlich sie sein mögen, dennoch immer eines der schönsten und interessantesten Stücke ausmachen und bei den kleinsten, wie bei den grössten Feuerwerken nicht fehlen dürfen. Besonders in grösserer Menge zugleich abgebrannt, gewähren sie ein überraschend schönes Schauspiel, das häufig als Schlussstïck und Höhepunkt grosser Fenerwerke benutzt wird. Man $\mathrm{u}$ terscheidet Girandolen und Pfauenschweife, erstere, wenn sämmtliche Raketen vertical, also im Allgemeinen parallel unter einander; letztere, wenn sie in divergirender Richtung, also nach oben sich ausbreitend aufsteigen.

Die Verfertigung der Raketen erfordert viele Sorgfalt und genaue Beobachtung mehrfacher Regeln, die besonders dahin abzielen, eine sehr gleichmässige 
Ladung und Verdichtung des Satzes zu erzielen, daher alch nur bei Beachtung aller Ruicksichten und entsprechender Uebung die Herstellung gut steigender Raketen gelingt.

Die Hülse der Rakete muss aus sehr festem Material angefertigt werden, um, ohne zu grosses Gewicht zu besitzen, dem starken inneren Druck der Feuergase des Treibsatzes zu widerstehen. Hinsichtlich der Ladung weicht die Rakete von allen anderen Feuerwerkskörpern darin ab, dass in ihrer Mitte der Länge nach, von der Mündung bis nahe an das entgegengesetzte Ende eine Höhlung (Seele) gelassen wird, die den Zweck hat, dass sich der Satz zu gleicher Zeit der ganzen Länge nach entziinde, und sohin durch eine reichliche Entwicklung von Feuergasen die erforderliche Triebkraft entwickle. Die Kraft eines gewöhnlichen Bränders, dessen Ladung sich vorn entzündet und gleichzeitig nur in der kleinen kreisförmigen Durchschnittsfläche brennt, reicht zwar zum Treiben eines Feuerrades und ähnlicher Apparate hin, wïrde aber für eine Rakete viel zu unbedeutend sein, wogegen die hohle, sich der ganzen Länge nach von der Achse aus entzündende Raketenladung eine sehr grosse, aber auch nur kurze Zeit andanernde Triebkraft entwickelt. Die Höhlung kann entweder, wie dies früher allgemein geschah und auch jetzt noch häufig geschieht, dadurch erhalten werden, dass man den Satz über einem Dorn mittelst hohler Stempel einstampft, oder dadurch, dass man in eine massive Ladung nachträglich auf der Drehbank ein Loch einbohrt, ein Verfahren, welches jetzt ziemlich allgemein in Verwendung ist, da man massive Ladungen viel leichter gleichmässig verdichten kann, als solche, die über einen Dorn geschlagen worden.

Diese Höhlung darf das vordere Ende der Rakete nicht erreichen, sondern lässt ein massives Stück der Ladung (die Z ehrung) übrig, welche nach dem Abbrennen die Entzündung auf die Versetzung, d. h. die zum Auswerfen bestimmten Leuchtkugeln, Schwärmer oder dergleichen iiberträgt. Die Versetzung, die oft nur aus einem einfachen Schlage (s. u.) besteht, befindet sich an dem vorderen, beim Steigen also oberen Ende der Rakete in der Kappe, einem in eine Spitze auslaufenden kegelförmigen Aufsatze aus dünnem Kartenpapier, dessen Durchmesser bei starken Versetzungen den der Rakete oft bedeutend übertreffen kann.

Als zweckmässiger Satz zur Raketenfiullung (Treibsatz) empfiehlt sich folgende Mischung:

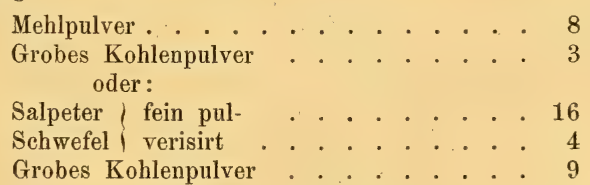

Der preussische Kriegsraketensatz besteht aus 32 Salpeter, 12 Schwefel, 32 Mehlpulver und 16 Holzkohle (von hartem Holze). In Frankreich hatte man eine Mischung von 21.1 Salpeter, $4 \cdot 3$ Schwefel und 12 Holzkohle in Verwendung.

Beim Laden muss sich die Hülse in einer genau anschliessenden, aus zwei Hälften zusammengesetzten kupfernen Form befinden, weil sie sonst bei dem gewaltsamen Eintreiben des Satzes zerplatzen würde. Ueber dem Satze wird eine durchbohrte Scheibe (Schlagscheibe) angebracht, auf welcher die V ersetzung, das ist der nach dem Aufsteigen der Rakete zum Abbrennen kommende Feutewerkssatz angebracht wird. Ist die Rakete fertig geschlagen, gebohrt, mit der Versetzung versehen, und mit der den Kopf bildenden Kappe, die wesentlich den Zweck hat, den Widerstand, den die Luft der aufsteigenden Rakete entgegeusetzt, leichtel uberwinden zu lassen, geschlossen, so bringt man einen Ludelfaden der ganzen Länge nach in die Seele ein, und versieht schliesslich die Rakete mit 
einem pyramidenförmigen Stabe von Weiden- oder Tannenholz, d. i. dem Raket enstab oderder Ruthe (panaceau - rocket stick), welcher den Aufstieg der Rakete zu regeln bestimmt ist. Die Länge dieses Stabes, welcher genau parallel der Längsachse der Rakete an dieser befestigt wird, muss für 1 pfündige Raketen*) $2 \cdot 66 \mathrm{~m}$, für $1 / 2$ pfündige $2 \cdot 35^{\mathrm{m}}$ betragen. Das Anbinden der Ruthe muss so vorgeno $m_{\text {men }}$ werden, dass der Schwerpunkt der mit dem Stabe armirten Rakete etwa $1^{\mathrm{cm}}$ unter die Raketenmündung fällt. Zum Abbrennen der Raketen wird ein etwa $4^{\mathrm{m}}$ hoher Pfahl möglichst fest (mindestens $1 / 2 \mathrm{~m}$ tief) in die Erde eingerammt, oben an der Seite desselben ein langer Nagel eingeschlagen, an welchem die Rakete mit einem schwachen Faden aufgehängt wird, während unten zwei kleine Nägel neben einander eingeschlagen werden, zwischen welchen das Stabende der mit der Mündung nach abwärts hängenden Rakete ruht; hierauf wird die Stopine mittelst einer langen Zündstange in Brand gesetzt und so der Satz entzündet.

Fig. 1633.

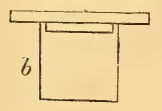

Fig. 1634.
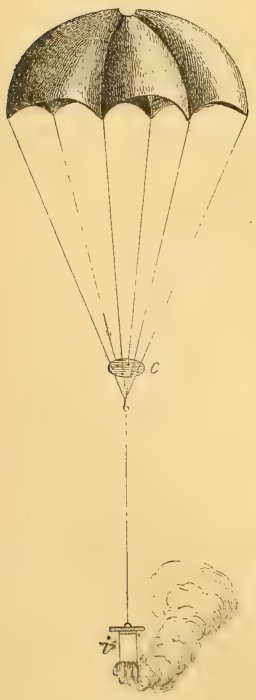

Fig. 1635 .

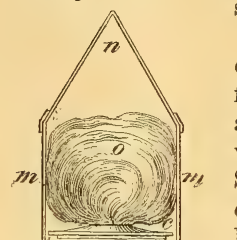

Die Versetzung oder Garnitur der Raketen kann mehrerlei Art sein ; die gewöhnlichen sind folgende :

Sterne, d. s. kleine runde oder würfelförmige Körperchen aus fein pulverisirtem und mit Spiritus angefeuchtetem Satz geformt. Zu weissen Sternen nimmt man 16 Salpeter, 8 Schwefel, 3 Mehlpulver; oder 16 Salpeter, 7 Schwefel, 4 Pulver. Zu goldgelben Sternen 16 Salpeter, 10 Schwefel, 4 Kohle, 16 Schiesspulver, 2 Kienruss; oder $\mathbf{1 6}$ Salpeter, 8 Schwefel, 2 Kohle, 2 Kienruss und 8 Schiesspulver.

Sehr häufig wendet man auch Leuchtkugeln an, s. u. Oft werden die Raketen auch nur mit einfachen Schlägen armirt, die nach dem Abbrennen des Raketensatzes mit kanonenschussähnlichem Knall explodiren.

Ganz besonders brillante Effecte geben die in neuerer Zeit häufiger in Verwendung kommenden Fallschirmraketen, die, sobald sie aufgestiegen sind, einen Fallschirm mit einem daran hängenden brennenden farbigen Leuchtsatz auswerfen. Da der sehr langsam sinkende Fallschirm in der Dunkelheit der Nacht nicht gesehen werden kann, so macht die Erscheinung den Eindruck eines geraume Zeit lang in der Höhe schwebenden, hellleuchtenden, farbigen Sternes. Besonders schön ist die Wirkung, wenn eine

grössere Zahl soleher Raketen gleichzeitig abgebrannt wird.

Man bezeichnet das Caliber der Raketen nach dem G:wichte einer Eisenkugel, welche den gleichen Durchmesser hat wie die Rakete. 
Die Einrichtung solcher Fallschirmraketen ist aus den nebenstehenden Fig. 1633-1635 ersichtlich. Ein in Fig. 1633 und Fig. 1634 a dargestelltes rundes Brettchen mit einem Ansatz, an welchen eine Hülse $b$ von Kartenpapier geleimt ist, trägt den in diese Hülse festgestampften Satz für ein Farbenfeuer. Der Fallschirm Fig. 1634 ist ein rundes Stück Taffet von $0.75-1^{\mathrm{m}}$ Durchmesser, mit einem Loch in der Mitte, an dessen Rand sechs Fäden befestigt sind, welche durch eben so viele Löcher einer kleinen, zweizölligen Pappscheibe c hindurchgehen und mittelst eines einzigen Bindfadens die mit dem Flammenfeuersatz geladene Hülse tragen. Fig. 1635 zeigt die ganze Rakete. e die Hiilse, $f$ den Satz, $g$ die Seele (die innere Höhlung), $h$ die Zehrung, $k$ eine an die Rakete geleimte Hülse von Kartenpapier, $l$ einen hölzernen Ring, der um die Hülse $k$, und um welchen wieder eine zweite, etwas weitere Hülse $m$ geleimt ist. In die Hülse $k$ wird die den Flammfeuersatz tragende Hülse hineingeschoben, so dass das Brettchen $a$ auf dem Ring $l$ aufliegt; die Pappscheibe $c$ kommt dann darüber und hierauf der Fallschirm $o$ in loser Weise zusammengefaltet. Endlich wird eine von Kartenpapier gemachte kegelförmige Kappe $n$ aufgesetzt und durch einige schmale Papierstreifchen leicht befestigt. Ist die Rakete aufgestiegen und die Zehrung zu Ende gebrannt, so theilt sich die Zündung dem vermittelst etwas Mehlpulver angefeuerten Leuchtsatz mit. Durch die dabei stattfindende geringe Explosion wird die Leuchthülse nebst dem Fallschirm ausgestossen. Letzterer öffnet sich sogleich beim Fallen durch den Widerstand der Luft, besonders wenn man Sorge getragen hatte, den Fallschirm erst am Tage des Gebrauches in die Rakete zu bringen, so dass die noch ungeschwächte Elasticität der Seide die Ausbreitung befördert.

Während die besprochenen Arten von Raketen wesentlich Zwecken der Belustigung zu dienen bestimmt sind, hat man in neuester Zeit von der Triebkraft der Raketen auch anderweitige Anwendung gemacht. So hat man Raketen von grösseren Dimensionen $\left(5-8^{\mathrm{cm}}\right.$ Durehmesser) dazu angewendet um Rettungsleinen von Uferstationen aus Schiffbrüchigen zuzufuihren und also die Verbindung von Wrack und Strand durch an derlei Raketen (Rettungsraketen) befestigte Leinen herzustellen. Auch zur Ërmöglichung des Abkommens von Rettungsboten vom Strande hat man die Triebkraft von Raketen (Ankerraketen) benützt.

Den Raketen wesentlich nahestehend sind die sog. Leuchtkugeln oder römischen Lichter. Bei diesen Feuerwerkskörpern wird eine an dem einen Ende ungewürgte Hülse abwechselnd mit einem langsam brennenden Satze (fauler Satz) und mit aus verschiedenfarbig leuchtenden Sätzen geformten Cylinderchen, von ähnlicher Art wie die Sterne gefiillt und an dem ungewïrgten Ende entzuindet. Man gibt den Cylinderchen an der Unterseite eine kleine Höhlung, die mit etwas Pulver ausgefüllt wird, und setzt sie mit dieser auf die vorher eingebrachte Schichte faulen Satzes auf, so dass man zu unterst in die Hülse etwas faulen Satz bringt, darauf einen Leuchtsatzcylinder setzt, der jedoch nur lose in die Hillse passt, hierauf den Zwischenraum zwischen Hülse und Cylinder mit faulem Satz ausfuilt und nun abermals eine Schichte faulen Satz iiber den Cylinder bringt, hierauf abermals einen Cylinder aufsetzt, wieder faulen Satz auffiullt und so fort, bis endlich die Hülse völlig gefüllt ist. Die oberste Schichte muss fauler Satz sein, der durch eine eingesetzte Stopine entzündet werden kann. Bei der Entzündung brennt zunächst die oberste Schichte ab, die Zündung pflanzt sich dann durch die faule Satzschichte um den 1. Cylinder nach der unter diesem liegenden Pulverladung, die etwas gedichtet sein muss, fort, und durch den Druck der bei der Verbrennung desselben gebildeten Gase wird der gleichzeitig entzündete Cylinder ausgeworfen, während sich die Zïndung der unter dem 2. Cylinder liegenden Schichte mittheilt, so dass dieser ansgeworfen wird u. s. f. Je nach der Wirksamkeit der gewählten Pulverladung, der Dicke und dem Grade der Dichtung derselben können die Cylinderchen höher oder weniger hoch ausgeworfen werden, und liefern, indem sie im Aufliegen abbrennen, die Erscheinung leuchtender 
Kugeln. Derlei im grösseren Massstabe gefertigte Feuerwerkskörper liefern die als Nachtsignale verwendeten Bombenröhren.

Von anderen theilweise freibeweglichen Feuerwerkskörpern sind zu nennen: die Serpentosen, die Schläge und Petarden.

Die Serpentosen oder Frösche sind kleine mit Treibsatz gefüllte Hülsen aus Kartenpapier, welche an beiden Enden zugewürgt und in der Nähe der Wiurgstellen mit zwei an entgegengesetzten Seiten angebrachten Oeffnungen versehen sind, aus welchen die Feuergase entweichen, und so ein Hin- und Herspringen der entzündeten Körperchen bedingen.

Schläge sind kleine mit Schiesspulver gefüllte viereckige Kästchen aus Pappe, welche mit einer Anfeuerung versehen, mehrfach mit Bindfaden umwunden oder leicht verklebt sind. Sie geben beim Abbrennen je nach ihrer Grösse einen starken Knall.

Man bringt sie entweder einzeln oder zu mehreren als Versetzung in Raketen oder brennt sie auf der Erde oder zur Erhöhung der Schallwirkung in leeren Fässern ab. (D o nnersehläge.)

Petarden sind kleine mit Schiesspulver gefüllte Hülsen, die beim Abbrennen mit einem heftigen Knall zerspringen.

Feuerwerkssätze.

Je nach dem Zwecke, dem ein bestimmter Satz dienen soll, haben die in der Feterwerkerei angewendeten Mischungen eine wesentlich verschiedene Zusammensetzung. Man unterscheidet wesentlich Treibsätze (solche, die durch Entwicklung von Gasen wirken sollen) und Leuchtsätze (die durch Erzeugung von hellen Lichteffecten wirken). Je nach der Raschheit, mit welcher die Sätze abbrennen, unterscheidet man rasche und faule Sätze, bei Leuchtsätzen, je nachdem der verbrennende Satz mehr oder weniger glühende Theilchen auswirft, oder aber mit mehr oder weniger ruhiger Flamme brennt, Funkenfeuer- und Flammfeuersätze. Die letzteren beiden werden mitunter vereinigt und liefern die $\mathrm{Zwitter-oder} \mathrm{Doppelsätze.}$

Fuir Treibsätze werden rorherrschend Schiesspulver oder demselben ähnliche Mischungen verwendet. Je nach der Raschheit, mit welcher der Satz wirken soll, rerwendet man entweder, u. z. für rasche Sätze gekörntes Schiesspulver oder man bringt das Pulver zur Mässigung der Raschbeit in Gestalt von Mehlpulver in Anwendung. Durch mehr oder weniger starkes Verdichten des Pulversatzes kamn man die Raschheit der Verbrennung noch weiter reguliren und endlich hat man in der Abänderung der Mischungsverhältnisse ein Mittel zur Verlangsamung der Terbremung. Den Mischungen, welche langsam verbrennen sollen, legt man gewöhmlich den Salpeterschwefel zu Grunde, d. i. eine aus 75 Thl. Salpeter und 25 Thl. Schwefel bestehende Mischung. Zur Sicherung des Fortbrennens dieser Mischung muss man jedoch immer wenigstens noch Kohle zusetzen. Durch Beimischung von Mehlpulver kann man je nach der Grösse des Pulverzusatzes eine zunehmende Raschbeit der Verbremnung erzielen. Sehr häufig wird eine unter dem Namen grauer Satz bekannte Mischung von 93.5 Salpeterschwefel mit 6.5 Mehlpulver verwendet. Durch Anwendung ron Mischungen mit chlorsaurem Kali kann man sehr rasch verbrennende Sätze herstellen und dient als Grundlage für solche Mischungen, der Chlorkalischwefel, d. i. ein Gemenge von 80 Thl. chlorsaurem Kalium und 20 Thl. Schwefel.

Die Funkenfeuersätze bestehen gewöhnlich aus Gemengen von Mehlpulver mit Kohle oder anderartige Mischungen von Salpeter, Schwefel und Kohle. Die Kohle wird zur Erzielung grösserer Funken zum Theile in Gestalt eines groben Pulvers angewendet. Ausser Kohle wendet man zu Funkenfeuersätzen auch Zusätze ron feinvertheilten Metallen, als Eisenspäne, Gussstahlspäne (rostfrei) oder zur Erzielung färbiger Funken Kupfer- oder Zinkspäne an. Kohle liefert 
röthliche, Eisen weisse, Kupfer grüne, Zink blaugrïne Funken. Sätze mit Metallzusätzen nennt man wohl auch Brillantsätze. Beliebte Funkenfeuermischungen sind:

\begin{tabular}{|c|c|c|c|c|c|c|c|c|c|c|c|c|c|c|c|c|c|c|}
\hline & & I & & & II & & & III & & IV & & & V & & & $\sqrt{1}$ & & VII \\
\hline . & . & 2 & & & 16 & & & 8 & & 12 & & . & 12 & & & 12 & & 12 \\
\hline el . . & & 3 & & & 4 & & & & & 3 & & & 1 & & & 3 & & \\
\hline grob). & & 5 & & & 9 & & & 3 & & 3 & & . & 1 & & & & & \\
\hline . & . & - & & & - & & & 1 & & 16 & & & - & & & & & \\
\hline äne & . & - & & - & - & & & 10 & & 12 & & & 2 & & & - & & \\
\hline ane. & . & - & & & - & & & - & & - & & & 一 & & & 6 & & \\
\hline kspäne . & & & & & - & & & - & & - & & & - & & & - & & \\
\hline
\end{tabular}

Für Flammfeuersätze kann entweder der graue Satz verwendet werden, der an und für sich ein weisses Licht liefert, oder ein ebenfalls weiss brennender Satz aus 75 Salpeter, 22.5 Schwefel und 2.5 Kohle. Auch das sogenannte Kaltgeschmolzenzeug, welches aus 85.6 grauem Satz, 29.4 Mehlpulver und 5 Thl. Schwefelantimon besteht, liefert einen guten Leuchtsatz.

Uebrigens wird als Grundlage für Leuchtsätze mit Flammfeuer auch nicht selten der Chlorkalischwefel (s. oben) verwendet. Für farbige Flammfeuer verwendet man Mischungen von einem dergleichen Leuchtsatze mit einem Salze, welches der Flamme die gewünschte Färbung zu ertheilen vermag, und variirt nicht selten die Mischungsverhältnisse in entsprechender Weise, wobei jedoch zu beachten ist, dass ein grösserer Gehalt an Kohle der Flamme stets eine röthliche Färbung ertheilt. Wir geben im Folgenden eine Anzahl bewährter Vorschriften für die Herstellung verschiedener Feuerwerkssätze zu farbigen Feuern, welche namentlich von $\mathrm{Websky}$ und $\mathrm{Ch}$ artier, so wie auch Anderen angegeben wurden.

\section{A. Zu Leuchtkugeln.}

Roth. a) Chlorsaures Kali 12, Salpetersaurer Strontian 39, Schwefel 12, Kienruss 2, Schellack 2; oder b) Chlorsaures Kali 10, Salpetersaurer Strontian 12, Schwefel 6, Schwefelantimon 3; oder c) Chlorsaures Kali 3, Salpetersaurer Strontian 4, Milchzucker 2; oder d) Chlorsaures Kali 25, Salpetersaurer Strontian 25, Milchzucker 12, Schwefelsaures Kupferoxyd-Ammoniak 3.

V i o l e t t. a) Chlorsaures Kali 9, Salpetersaurer Strontian 4, Schwefel 6, Bergblau 1, Calomel 1, Schellack $1 / 2$; oder b) Chlorsaures Kali 14, Kreide 5, Schwefel 6, Calomel 4, Schwefelkupfer 6, Schellack $1 / 2$.

B l a u. a) Chlorsaures Kali 4, Basisch Chlorkupfer 1, Milchzucker 2; oder b) Chlorsaures Kali 40, Schwefelkupfer 22, Calomel 32, Zucker 9, Talg 2.

Ge 1 b. a) Chlorsaures Kali 4, Oxalsaures Natron 2, Schellack 1; oder b) Chlorsaures Kali 4, Salpetersaurer Baryt 2, Milchzucker 2, Doppelt kohlens. Natron 1.

Or ange. Chlorsaures Kali 3, Salpetersaurer Strontian 10, Oxalsaures Natron 3, Schellack 3.

Gr ü n. a) Chlorsaures Kali 20, Salpetersaurer Baryt 40, Calomel 13, Schwefel 13, Kienruss 1, Schellack 1; oder b) Chlorsaurer Baryt 24, Calomel 9, Schwefel 1, Schellack 4; oder c) Chlorsaurer Baryt 3, Milchzucker 1, Schellack $1 / 2$.

W e is s. a) Mehlpulver 1, Arab. Gummi $1 / 2$, Salpeter 8, Schwefel 3, Schwefelantimon 2; oder b) Salpeter 70, Schwefel 14, Realgar 10, Schellack 1, Antimonmetall 12; oder c) Salpeter 9, Schwefel 3, Schwefelantimon 2; oder d) Chlorsaures Kali 16, Schwefel 8, Schwefelantimon 1, Salpetersaures Blei 16. 
Um aus diesen Sätzen Leuchtkugeln zu formen, werden sie mit etwas Weingeist, der Satz zum Weiss mit etwas Wasser, angefeuchtet und in einer Form zu kleinen Cylindern, wie oben angegeben, geformt.

\section{B. Sätze zu Brändern, Lichtchen und Sternen.}

R oth. a) Chlorsaures Kali 16, Salpetersaurer Strontian 24, Lycopodium (Hexenmehl) 4, Milchzucker 1; oder b) Chlorsaures Kali 15, Salpetersaurer Strontian 25, Schwefel 13, Mastix 1, Schwefelantimon 4.

V i o 1 e t t. Chlorsaures Kali 6. Salpetersaurer Strontian 4, Milchzucker 3, Bergblau 1, Salpeter 2, Salmiak 1.

B I a u. a) Chlorsaures Kali 8, Bergblau 2, Salmiak 1, Salpeter 2, Milchzucker 4 ; oder b) Chlorsaures Kali 40, Schwefelkupfer 22, Calomel 32, Zucker 9, Talg 2.

Gr rï n. a) Chlorsaurer Baryt 18, Calomel 7, Schellack 3; oder b) Chlorsaures Kali 3, Salpetersaurer Baryt 3, Schellack 1; oder c) Chlorsaurer Baryt 6, Stearin 1.

W e is s. a) Salpeter 4, Schwefel 1, Mehlpulver 1; oder b) Salpeter 4, Schwefel 1, Schwefelantimon 1.

C. Sätze zu bengalischen Flammen und Theaterfeuer.

Roth. a) Salpetersaurer Strontian 20, Chlorsaures Kali 2, Schwefel 5, Schwefelantimon 2, Feine Kohle 1; oder $b$ ) Salpetersaurer Strontian 24, Chlorsaures Kali 3, Schwefel 8, Schwefelkupfer 3, Calomel 6, Schellack 1; oder c) Salpetersaurer Strontian 40, Chlorsaures Kali 5, Schwefel 13, Kohle 2; oder d) Salpetersaurer Strontian 56, Chlorsaures Kali 20, Schwefel 24.

R o s a. Chlorsaures Kali 61, Schwefel 16, Chlorcalcium 23.

Purpurroth. Chlorsaures Kali 61, Schwefel 16, Kohlensaurer Kalk 23.

Vi o l e t t. a) Alaun 12, Kohlensaures Kali 12, Chlorsaures Kali 60, Schwefel 16; oder b) Alaun 16, Kohlensaures Kali 16, Chlorsaures Kali 54, Schwefel 14.

B 1 a u. a) Schwefelsaures Kupferoxyd-Ammoniak 15, Chlorsaures Kali 28, Schwefel 15, Schwefelsaures Kali 15. Salpeter 27; oder b) Schwefelsaures Kupferoxyd-Ammoniak 12, Geglïhter Alaun 12, Chlorsaures Kali 60, Schwefel 16.

Gr ü n. a) Salpetersaurer Baryt 8, Chlorsaures Kali 3, Schwefel 3; oder b) Salpetersaurer Baryt 40, Chlorsaures Kali 4, Calomel 10, Schwefel 8, Kienruss 2 , Schellack 1 .

G e 1 b. a) Salpetersaures Natron 48, Schwefel 16, Schwefelantimon 4, Feine Kohle 1; oder b) Kohlensaures Natron 23, Schwefel 16, Chlorsaures Kali 61.

IV e is s. a) Salpeter 32, Schwefel 10, Schwefelantimon 3, Ungelöschter Kalk 4; oder b) Salpeter 32, Schwefel 8, Antimon-Metall 12, Mennige 11.

Bei allen Fenerwerkssätzen, welche chlorsaures Kali und Schwefel enthalten, darf der letztere nur im Zustande von pulverisirtem Stangenschwefel, nie als Schwefelblumen genommen werden, weil sonst leicht Selbstentziindung eintritt, ebenso hat man sich zu hiiten, Mischungen welche chlorsaures Kali und Schwefel oder Schwefelmetalle enthalten, im trockenen Zustande zu reiben oder zu schlagen, da sie leicht explodiren. Das Mischen von chlorsaurem Kali mit Schwefel und den sonstigen Gemengtheilen sollte immer nur mittels eines Federbartes auf Papier oder durch Durchschlagen der für sich gepulverten Gemengtheile durch ein Sieb, vorgenommen werden.

Der salpetersaure Strontian muss vollständig entwässert, ebenso der salpetersaure und chlorsaure Baryt vollständig getrocknet sein. 
Dersalpetersaure und chlorsaure Baryt geben nur dann ein reines Grün, wenn sie chemisch rein, namentlich ganz frei von Kalk und Strontian sind.

Neuestens hat S. Kern (Jahrb. für chem. Technol. v. R. v. Wagner 1876) Vorschriften für Buntfeuer angegeben, bei welchen auch auf die Raschheit des Ablirenrens Rücksicht genommen ist. Eine Zusammenstellung dieser Vorschriften geben wir in folgrender Tahelle, wobei zu bemerken ist, dass die Vorschriften so geordnet sind, dass jeder Satz mit höherer Nummer auch langsamer abbrennt als einer mit niedrigerer.

\section{Für Grünfeuer.}

\begin{tabular}{|c|c|c|c|c|c|c|c|c|c|c|c|c|c|c|c|c|}
\hline & Numn & ex : & 1 & 2 & 3 & 4 & $\tilde{5}$ & 6 & 7 & 8 & 9 & 10 & 11 & 12 & 13 & 14 \\
\hline ט & & & 36 & 29 & 24 & 21 & 18 & 16 & 14 & 13 & 11 & 10 & 9.5 & 9 & 8.5 & \\
\hline - & Baryt & 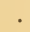 & 40 & 48 & 53 & 57 & 60 & 62 & 64 & & & & 69 & 69.5 & 70 & \\
\hline hwefel & - & 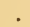 & 24 & 23 & 23 & 22 & 20 & 22 & 22 & 21 & 21 & 21 & 21 & 21 & 21 & \\
\hline
\end{tabular}

\begin{tabular}{|c|c|c|c|c|c|c|c|c|c|c|c|c|c|c|c|}
\hline & Nummer: & 1 & 2 & 3 & 4 & 5 & 6 & 7 & 8 & 9 & 10 & 11 & 12 & 13 & 14 \\
\hline Chlorsauses & Kali . . & 40 & 32 & 27 & 23 & 20 & 18 & 16 & 15 & 13 & 12 & 11 & 10 & 10 & 9.25 \\
\hline Salpetersaur & rer Strontian & 39 & 46 & 51 & 55 & 58 & 60 & 61.6 & 63 & 64 & 65 & 66 & 67 & 67.25 & 68 \\
\hline Schwefel. & . . . . & 18 & 19 & 20 & 20 & 20.5 & 21 & 21.2 & 21 & 22 & 22 & 22 & 22 & 22 & 22 \\
\hline Kohle . & $i$ & 3 & 2 & 2 & 2 & 1.5 & 1 & 1.2 & 1 & 1 & 1 & 1 & 1 & 0.75 & 0.7 .5 \\
\hline
\end{tabular}

Für Violettfeuer.

\begin{tabular}{|c|c|c|c|c|c|c|c|c|c|c|c|c|c|c|}
\hline & Nummer & 1 & & & 4 & 5 & 6 & 7 & 8 & 9 & 10 & 11 & 12 & 13 \\
\hline aures Kal & . & 52 & 52 & 52 & 52 & 52 & 52 & 51 & 51 & 51 & 51 & 51 & 51 & 51 \\
\hline Kalk & . & 29 & 28 & 26 & 24 & 23 & 21 & 20 & 18 & 16 & 15 & 13 & 11 & 10 \\
\hline . & . & 4 & 5 & 7 & 9 & 10 & 13 & 14 & 16 & 18 & 19 & 21 & 23 & 4 \\
\hline & . & 15 & 15 & 15 & 15 & 15 & 15 & 15 & 15 & 15 & 15 & 15 & 15 & 15 \\
\hline
\end{tabular}

Von sonstigen Buntfeuermischungen sind empfohlen, aber wegen grösserer Kostspieligkeit wenig angewendet:

Weissfeuer von Uhden.

\begin{tabular}{|c|c|c|c|c|}
\hline Salpeter & . . . & . . & . & \\
\hline Schwefel & .. & . & . & . \\
\hline Kohle . & . . . & & . & \\
\hline Schwefelca & admium & & & . \\
\hline
\end{tabular}

Grünfeuer nach D esignolle.

Pikrinsaures Ammoniak . . 48 Salpetersaurer Baryt . . 52
Grünfeuer nach Crookes. Chlorsaures Thallium*) . . 8 Calomel ....... . 2 Harz . . . . . . . 1

Grïnfeuer nach Brugè re. Pikrinsaures Ammoniak . . 25 Salpetersaurer Baryt . . . 67 Schwefel ...... 8

Rothfeuer nach Designolle.

Pikrinsaures Ammoniak . . 54

Salpetersaurer Strontian . . 46

Auch mit Chlorlithium lassen sich prächtige Rothfener herstellen, doch miissen solche Mischungen rasch verwendet werden, da sie ieicht feucht werden.

Durch Versetzen der einzelnen Buntfeuermischungen mit Stearinsäure (für Grïn und Blau auch mit Schellack) erhält man langsam breunende sätze. welche nach Thenius (Dingl. pol. Journ. 173 pag. 411) zur Herstellung der sogenannten bengalis chen $\mathrm{F}$ a ckeln verwendet werden, indem man dergleichen Sätze in Hülsen füllt, welche aus mit Salpeter getränktem Papier gefertigt und im Untertheile mit Sand gefüllt werden.

Furienfackeln (Theaterblitze) erzielt man durch Einblasen von Lycopodium in eine Weingeistflamme.

$\mathrm{Zu}$ bengalischen Lichteffecten besonders in geschlossenen Räumen eignet sich ferner vorzïglich das Magnesiummetall, welches in der Form von Bändchen oder

*) Auch Salpetersaures Thallium und Chlorthallium liefern zu Grïnfeuersätzen zugesetz eine brillante grüne Farbe. 
diunnem Draht leicht entzündet werden kann und mit ruhiger, glänzend weisser Flamme fortbrennt. Für Theaterbeleuchtungszwecke hat man besondere Lampen für Magnesiumverbrennung construirt, s. Mag n es i u m la mpen. Auch Legirungen von Magnesium mit anderen Metallen kann man zur Herstellung farbiger Flammen verwenden.

Ganz besonders eignet sich auch für bengalische Beleuchtnng die Verbrennung von chlorsauren Salzen in Weingeist- oder in Gasflammen. Wenn man in eine Flamme von Leuchtgas, das man ohne weitere Brennervorrichtung aus einer Röhre ausströmen lässt, auf einem halbrunden Eisenblechlöffelchen (das genietet sein muss) einige Gramm eines chlorsauren Salzes einführt, so tritt eine äusserst brillante Lichterscheinung ein, welche denselben Effect gibt wie ein bengalisches Feuer. Mit chlorsaurem Baryt erhält man in solcher Weise ein grünes, mit chlorsaurem Strontian ein rothes, mit chlorsaurem Natron ein gelbes, mit chlorsaurem Kali ein violettes Feuer, das namentlich bei den erstgenannten drei Salzen ziemlich lange anhält und den Vorzug hat, dass es keinerlei iiblen Geruch verbreitet.

Es ist hier auch am Platze von sonstigen Feuerwerkssätzen jener Erwähnung zu thun, die allerdings nicht zu Zwecken der Lustfeuerwerkerei, sondern wesentlich für Kriegszwecke Verwendung finden, wohl aber auch in bestimmten Fällen für aussergewöhnliche technische $Z$ wecke dienen können. Es sind dies die Brandsätze und Stankkugelsätze.

Die Brandsätze haben wesentlich den Zweck, brennbare Objecte auf Distanz in Brand zu stecken. Dem entsprechend muss ihre Mischung so gewählt werden, dass sie mit möglichst grossem Wärmeeffect und verhältnissmässig langsam abbrennen. Gewöhnlich stellt man solche Brandsätze durch Vermischen von grauem Satz (s. oben) mit Pech, Theer, Werg u. s. w. So besteht z. B. der preussische Satz für Brandgeschosse aus 76 Thl. grauem Satz und 24 Thl. Colophonium, der Satz für Brandbomben in Bayern aus einer Mischung von Schiesspulver, mit sogenanntem Warmgeschmolzenzeug, d. i. einer Mischung, welche durch Einrïhren von 22 Thl. Salpeter und $3^{3} / 4$ Mehlpulver in 22 Thl. geschmolzenen Schwefel erhalten wird.

Stankkugelsätze, welche den Zweck haben bei ihrem Abbrennen eine grosse Menge unathembarer Gase zu liefern, werden im Allgemeinen aus schwefelreichen Mischungen hergestellt, die sonach beim Verbreunen reiche Mengen schwefliger Säure liefern. Am einfachsten ist es Salpeterschwefel mit so viel von Kohle zu mengen als eben hinreicht um das Fortbrennen der Mischung zu sichern. Insoferne die schweflige Säure ein gutes Desinfectionsmittel ist (s. d. II. pag. 603) können dergleichen Sätze anch zu Desinfectionszwecken verwendet werden. (Desinfectionsschwärmer).

Schliesslich sei bemerkt, dass es ein Irrthum wäre zu glauben, man könne durch Vermischung von mit verschiedenfarbigem Lichte verbrennenden Feuersätzen alle Arten von Mischfarben in den Flammen erzielen. Das ist nicht oder doch nur in beschränktem Masse möglich, insoferne sich nur durch Mischen von Roth- und Blaufeuer ein violettes Feuer darstellen lässt, während z. B. Grün- und Rothfener oder Gelb- und Rothfener gemengt ein mehr weniger weisses oder weissgelbes, Gelb- und Blaufener ebenfalls weisse Feuer geben. Namentlich das Grïnfener ist besonders empfindlich gegen Zusätze von andersfarbigen Feuermischungen, da das Grïn wegen des Zusammentreffens complementärer (s. F a rbe III pag. 361) Strahlen ausgelöscht und in Weiss verwandelt wird. Dagegen lassen sich durch Nebeneinanderstellung von verschiedenfarbigen Feuern in Folge der Contrastwirkung sehr schöne Effecte erzielen. So erscheinen schwach grüne Feuer glänzend griin, wenn man ein starkes Rothfeuer neben ibnen abbrennt, und umgekehrt gewimnen schwache Rothfeuer an Effect durch Nebeneinanderstellung mit starkem Grïnfeuer; schwach blaue Fener gewinnen an Intensität durch Nebenstellung gelber oder rother Feuer u. dergl. m. 
Ueber Feuermischungen, welche im Wasser zur Entziindung kommen oder auf Wasser brennen s. bei Feuer flüssige III pag. 438. Ueber Griechisches Feuer vgl. Dingl. pol. Journ. 10, 125, 133, 280, 135 u. 155.

Ueber Feuerwerkerei vgl. a. A. Loden der Lustfenerwerker 1870; M. Meyer Lehrbuch der Pyrotechnik 1840; M. Websky die Luftfeuerwerkskunst. Winkelblech iiber farbige Fever im polytechn. Centralblatt 1850 pag. 1405 und 1851 pag. 107 etc. etc. Gtl.

Feuerwerksätze s. Feuerwerkerei.

Feuerzangen s. Schmieden.

Feuerzeug (briquet - tinder box), nennt man jede Vorrichtung, welche dazu dient, Feuer anzumachen, um mittels desselben die Entzündung brennbarer Körper zul ermöglichen. Die Feuerzenge lassen sich in mehrere Classen theilen, u. z. wesentlich in mechanische, in chemische und electrische. Die ersteren beruhen sämmtlich auf der Anwendung des Principes, durch Reibung (oder durch Druck) Wärme zu erzeugen. Die einfachste Form der Anwendung dieses Principes fand sich in dem Feuerzeug der Wilden, welche durch fortgesetztes, genügend heftiges Reiben zweier Holzstiicke, Feuer anzumachen pflegten. Dasselbe Princip liegt den bis zu Anfang dieses Jahrhunderts ziemlich allgemein im Gebrauche gewesenen Schlagfeuerzeugen zu Grunde, bei welchen man mittels Feuerstein und Stahl Feuer anmachte. Bei dieser Art von Feuerzeugen, die auch heute noch mehrfach in Verwendung stehen, werden durch heftige Reibung eines Stahlstiickes an der Kante eines harten Steins (Feuerstein) Theilchen des Stahls Iosgerissen, welche in Folge der durch die Reibung entwickelten Wärme zum Ergliihen, ja selbst zum Verbrennen gebracht werden und im glühenden Zustande auf ein leicht feuerfangendes Materiale (Zunder, Zündschwamm) fallend, dasselbe zum Glimmen bringen können. An dem glimmenden Zunder lassen sich mit Schwefel getränkte Baumwoll- oder Leinenfäden entflammen und mit Hilfe derselben die Zündung leicht auf andere brennbare Körper übertragen.

Die Feuersteinfeuerzeuge haben im Laufe der Zeit mannigfache Gestalten angenommen, indem man sich allenthalben bemühte, durch geeignete mechanische Vorrichtung die Arbeit der Reibung von Stahl und Stein zu erleichtern.

So entstanden die Feuerschlösser der alten Flinten (s. Feuerwaffen), die Radschlösser und die diesen verwandten Formen der besonders in England verwendeten Stahlradfenerzeuge, bei welchen ein an einer horizontalen Welle befestigtes Stahlrad mittels einer Kurbel oder eines Drehbogens in rasche Umdrehung versetzt und an dasselbe ein Stiick Feuerstein angedrückt wurde, unter welchem ein Stiick Zunder oder Feuerschwamm gehalten ward. Anf gleicher Grundlage beruht das in neuester Zeit von Herrm. Gläs er construirte Taschenfeuerzeug, bei welchem ein kleines, mit Riefen versehenes Stahlrädchen mittels eines kleinen Antriebes durch Anwendung mehrerer Zahnradübersetzungen in sehr rasche Rotation versetzt wird, und hiebei an einem in einem federnden Halter eingesetzten und an die Radperipherie angedrückten Stückcheu feinkörnigen Sandsteins Funken gibt, welche gegen eine Lunte geschleudert werden, die hiedurch zum Glimmen gebracht wird. Der ganze Apparat, der in einer Metallbüchse ron der Grösse einer gewöhnlichen Taschenuhr eingeschlossen ist, ist sehr handlich und namentlich zum Anmachen von Glimmfeuer im Freien sehr bequem.

Die Eigenschaft verschiedener Körper, durch die bei mässiger Reibung oder bei Schlag erzeugte Arbeitswärme zur Entzïndung gebracht zu werden, findet übrigens auch ausgedehnte Anwendung bei anderen Vorrichtungen, bei welchen durch die Wahl leichter entzïndlicher Körper schon ein geringer Schlag oder eine mässige Reibung zur Entzündung des brennbaren Stoffes zureicht. Solcher Art sind die Kapselfeuerzeuge und die Fenerzenge mit Zündpillen, bei welchen durch Vermittlung einer durch Schlag zur Explosion gebrachten Ziundkapsel oder Zündpille eine Lunte zum Glimmen gebracht wird, dann aber sind es insbesondere 
alle Arten von Streich- oder Reibfeuerzeugen, bei welchen die leicht entzindliche Züindmasse der Streichhölzer durch Reibung so weit erwärmt wird, dass sie zur Entzündung kommt (s. hierüber bei $\mathrm{Z}$ ün d wa aren).

In die Reihe der auf mechanischem Wege wirkenden Feuerzeuge gehört auch das Compressions- oder pneumatische Feuerzeug (Mollet's Pumpe, Luftfeuerzeug), das aus einem starkwandigen, an einem Ende geschlossenen Hohlcylinder besteht, in welchem ein Stempel luftdicht auf- und abbewegt werden kann und sohin die den Cylinder erfullende Luft zu verdichten gestattet. Wird an dem in den Cylinder passenden Ende des Stempels, an einem daselbst angebrachten Häkchen ein Stïckchen möglichst trockenen Zündschwamms befestigt und nun der Stempel möglichst rasch in den Cylinder hineingetrieben, was durch einen kräftigen Schlag auf den Griff des Stempels geschehen kann, so wird durch die rasche Compression der Luft so viel Wärme entwickelt, dass der Zïndschwamm Feuer fängt und nach dem Herausziehen des Stempels aus dem Cylinder fortglimmt.

Bei den chemischen Feuerzeugen ist es die durch die Einleitung chemischer Processe frei werdende Verbindungswärme, welche zur Entzündung brennbarer Körper herangezogen wird. Hierher gehört die 1823 von $\mathrm{D} o ̈ b$ ereiner erfundene und nach ihm benannte Zündmaschine (Platinfeuerzeug, Knallgasfeuerzeug).

Die Wirkıng dieses Apparates beruht auf der von Döbereiner entdeckten Eigenschaft des Platinschwamms (sehr porösen metallischen Platins), ein Gemisch von Wasserstoffgas und Sauerstoffgas zur chemischen Verbindung zu veranlassen, wodurch sehr schnell eine bis zum Glühen des Platins sich steigernde Hitze entsteht und die Gasmischung in Flamme ausbricht. Eine solche Zündmaschine einfachster Construction besteht aus einem cylindrischen Gefässe von Glas, Steingut oder dergl., welches oben durch einen metallenen, nur leicht aufgelegten Deckel geschlossen ist. Durch die Mitte des Deckels geht ein Loch, welches oben mit einem Hahn in Verbindung steht, der andererseits mit einer seitlichen, eine feine Bohrung tragenden Ausströmungsspitze communicirt. Nach unten communicirt dieses Loch mit einer Glasglocke, die an dem Deckel luftdicht befestigt ist und fast auf den Boden des äusseren Gefässes herabreicht. Auf einen kleinen Dreifuss von Blei wird ein Stück reines Zink gelegt oder mittels eines Bleidrahtes in der Glocke aufgehängt, und verdiinnte reine Schwefelsäure in das Gefäss gegossen, worauf man den Deckel mit der Glocke einsetzt. Durch Wechselwirkung des Zinks mit der Schwefelsäure entwickelt sich nun Wasserstoffgas und sammelt sich in der Glocke, aus welcher man es anfänglich durch Oeffnung des Hähnchens ausströmen lässt, um alle atmosphärische Luft damit zu entfernen. Glaubt man dies erreicht zu haben, so schliesst man den Hahn, worauf sich die Glocke mit Wasserstoffgas fuillt und die Schwefelsäure in ihr so weit herabgedrängt wird, bis sie ausser Berihrung mit dem Zink kommt, womit die Gasentwickelung aufhört. Nun erst wird ein kleines Stiickchen Platinschwamm innerhalb eines kurzen Rohres vor der Oeffnung der Ausströmungsspitze befestigt. Lässt man durch Oeffnung des Hahnes einen feinen Gasstrom gegen den Platinschwamm treten, so entzündet er sich sogleich. Wenn nach mehrmaligem Gebrauch so viel Gas entwichen ist, dass die Schwefelsäure wieder mit dem Zink in Beriihrung tritt, so beginnt sogleich von Neuem die Entwickelung von Wasserstoffgas, und der Apparat kann somit lange Zeit dienen, bevor es nöthig ist, ihn mit neuer Schwefelsäure zu rersehen. Sollte das Zink oder die Säure unrein, namentlich arsenikhaltig sein, so rerliert der Platinschwamm sehr bald seine Züudkraft. Derlei Zündmaschinen sind aber auch aus anderen Gründen dem Versagen leicht unterworfen. So verliert der Platinschwamm seine Zuindkraft leicht durch Aufnahme von Feuchtigkeit, sowie durch längere Beriihrung mit ammoniakhaltiger Luft, wie sie sich in Wohnräumen, namentlich solchen, in denen geraucht wird, in Schlafstuben, in der Nähe ron Stallungen u.s.w. gewöhnlich findet. Auf diese Weise 
unwirksam gewordener Platinschwamm gewinnt seine Wirksamkeit leicht wieder, wenn man ihn ausgliuht. Unwirksam wird der Platinschwamm auch, wenn das auf denselben wirkende Wasserstoffgas mit Schwefelwasserstoff, schwefliger Säure, salpetriger Säure, Phosphorwasserstoff, Kohlenwasserstoffen verunreinigt ist, was bei Anwendung von unreiner Säure oder stark verunreinigtem Zink leicht der Fall sein kann. So liefert eine mit schwefliger Säure verunreinigte Schwefelsäure bei Berührung mit Zink ein durch Schwefelwasserstoff, salpetersäurehaltige Schwefel säure ein mit salpetriger Säure verunreinigtes Wasserstoffgas. Bei Anwendung von rohem Zink kann sich leicht eine merkliche Menge von Kohlenwasserstoffen oder Phosphorwasserstoff entwickeln. Nach Böttg e r darf man keine rauchende Schwefelsäure anwenden, weil diese bei Berührung mit Zink leicht schweflige Säure entwickeln könnte, während nach Karmarsch eine bei Anwendung von englischer Schwefelsäure nicht mehr functionirende Zündmaschine bei Verwendung von Vitriolöl sofort wieder wirksam gemacht werden kann. Auch durch Verstaubtwerden allein, dann aber auch durch von dem Gasstrome mitgerissenes Zinksalz kann der Platinschwamm seine Wirksamkeit verlieren. In der Mehrzahl der Fälle lässt sich ein unwirksam gewordener Platinschwamm durch blosses Ausglühen in einer Weingeistflamme wieder wirksam machen. Heftiges Ausgliihen ist hiebei zu vermeiden, da der Platinschwamm durch Erhitzen auf Weissglühhitze seine Zündkraft verliert. Genïgt das einfache Ausgliihen nicht, dann kann man ihn durch Tränken mit einer Platinchloridlösung, nachherige Einwirkung einer Salmiaklösung und endliches Ausgliihen wieder wirksam machen. Wäre Unreinheit der Säure Schuld, dann kann man in Ermanglung reiner Säure, die Schwefelsäure durch Erhitzen mit Wasser und etwas Zucker reinigen, indem durch diese Operation sowohl ein Gehalt an schwefliger Säure, als auch ein solcher an salpetriger und SalpeterSäure aus der Schwefelsäure entfernt zu werden vermag.

Zündmaschinen ähnlicher Art, zum 'Theile blos in der Form von jener Döbereiner's abweichend, haben Eisen lohr (s. Dingl. pol. Journ. 72, pag. 27) und Schiele (Dingl. pol. Journ. 76, pag. 236) angegeben. Döberein er hat auch ein ähnlich wirkendes Iridiumfeuerzeug construirt (s. Schweiger's Jahrb. 3, pag. 467.)

Ein eminent chemisches Feuerzeug ist ferner das von Chancel in Paris 1805 erfundene fixe oder Stippfeuerzeug (Tunkfenerzeug), bei welchem Hölzchen, die an einem Ende mit Schwefel und daran mit einer kleinen Menge eines Teiges versehen sind, der aus chlorsaurem Kali (30 Thl.) und Schwefel (10 Thl.), dann etwas Hexenmehl, Tragantschleim und einem färbenden Zusatze von Zinnober oder Indigo hergestellt werden kann, dadurch zur Entzündung gebracht werden können, dass man das mit dem Teig belegte Ende derselben mit concentrirter Schwefelsäure benetzt, die der bequemeren Handhabung halber in einem Fläschchen, welches mit Asbest gefüllt ist, der mit concentrirter Schwefelsäure getränkt wurde, aufbewahrt wird.*) Die Entzündung dieser Hölzchen ( $T$ unkh ölzchen) wird dadurch bewirkt, dass concentrirte Schwefelsäure das chlorsaure Kali unter Bildung von Unterchlorsäure zersetzt, welche vermöge ihrer energisch oxydirenden Wirkung die dem chlorsauren Kali beigemengten oxydirbaren Substanzen (Schwefel, Hexenmehl, Zucker u. d. g.) oxydirt, wobei so viel Wärme entwickelt wird, dass die vorhandene brennbare Substanz zur Entziindung kommt. Dasselbe Princip lag den später in England eingeführten "Prometheans" zu Grunde, die aus dünnen Papierröllchen bestanden, in welchen eine geringe Menge einer Mischung von chlorsaurem Kali und Zucker und ein beiderseits zugeschmolzenes, dünnwandiges Glasröhrchen, das concentrirte Schwefelsäure enthielt, eingeschlossen war. Beim Quetschen solcher Papierröllchen sprang das Röhrchen

*) N ew to n brachte die Schwefelsäure in ein Fläschchen, das ohne Asbestfüllung zu 2/, mit concentrirter Schwefelsäure gefüllt und mit einem oben becherförmig ausgehöhlten, unten convexen, mit mehreren feinen Bohrungen versehenen Stöpsel aus Blei verschlossen wurde. Beim Schütteln des Fläschchens sammelte sich in der becherförmigen Aushöhlung etwas Schwefelsänre an, die zum Tunken verwendet wurde. 
und die ausfliessende Schwefelsäure brachte das entziindliche Gemenge zur Entflammung.

Eine andere Art chemischer Feuerzeuge sind die Phosphorfeuerzeuge, bei welchen die Selbstentzündlichkeit gewisser Phosphormischungen zur Zündung benuitzt wurde. Solcher Art war das Feuerzeug von Cagni ard d e la T ou r u. A. Etwas Phosphor wurde in ein kleines, mit Glasstöpsel verschliessbares Fläschchen gebracht und darin bis zur Entzündung erhitzt, während man durch ein Rohr etwas Luft einbliess, so dass der Phosphor einer unvollständigen Verbrennung anheimfiel. Die Innenwandung des Fläschchens überzieht sich hiebei mit einer Schichte von phosphoriger Säure, gemengt mit fein vertheiltem Phosphor, welche noch vor dem Erkalten mittels eines Glasstäbchens mit dem unverbrannten Phosphor gut durchgerihhrt und das Gläschen hierauf verschlossen wurde. Wurde etwas von dieser Masse mit einem in Schwefel getauchten Holzstäbchen aus dem Fläschchen genommen und an die Luft gebracht, so fing dieselbe Feuer, das sich dem Schwefelhölzchen mittheilte.

In ähnlicher Weise wirkten auch Mischungen von Phosphor mit anderen Substanzen, welche den Phosphor im Zustande feiner Vertheilung enthielten. Eine solche Mischung war es z. B., welche man durch vorsichtiges Zusammenschmelzen von 1 Thl. gelben Wachs, 8 Thl. Steinöl, 4 Thl. Phosphor und 1 Thl. feinen Korkfeilspänen darstellte. *)

Hierher gehören endlich auch die Pyrophorfeuerzeuge, bei welchen ein Pyrophor (z. B. ein durch Glühen von schwefelsaurem Kalium mit Mehl unter Luftausschluss dargestelltes und erkaltetes Gemenge von feinzertheiltem Schwefelkalium mit Kohle 0 . d. m.) in einem gut verschliessbaren Gefässe aufbewahrt wurde, und im Falle des Bedarfes etwas davon auf etwas Baumwolle, Zunder oder Zündschwamm ausgestreut wurde, die hiedurch sofort zum Glimmen gebracht wurden.

Endlich gehören hierher auch die Natriumfeuerzeuge Fleck's, bei welchen durch Beriihrung einer Natrium enthaltenden Ziindmasse mit Wasser eine Entzündung herbeigeführt werden kann (vgl. a. Feuer flüs sige III. pag. 438, s. a. $\mathrm{Z}$ ii $\mathrm{n} d \mathrm{w}$ a a ren).

Bei den electrischen Feuerzeugen wird die durch eine electrische Entladung oder durch einen galvanischen Strom bedingte Wärmewirkung zur Entziindung eines brennbaren Körpers verwendet.

Hierher gehört z. B. das 1770 von Fuirstenberg erfundene, 1777 von Brander verbesserte electrische oder electropneumatische Feuerzeug (Schnellfeuerzeug, Tachypyrion, Gasopyrion, Brennluftlampe). Dasselbe bestand wesentlich aus einem Wasserstoffentwicklungsgefässe von ähnlicher Anordnung, wie es sich bei der Döbereiner'schen Zündmaschine findet. In einem unter demselben angebrachten Holzkästchen ist ein Harzkuchen, Electrophor (s. Electrophor III. pag. 256) untergebracht, dessen Deckel dnrch einen geeigneten Mechanismus gehoben wird, wenn der Hahn des Ausströmungsrohres für das Wasserstoffgas geöffnet wird. Die durch das Abheben des Electrophordeckels und Beriihrung desselben mit einem Metalleontacte bewirkte electrische Entladung erzeugt das Ueberspringen eines electrischen Funkens zwischen zwei vor die Ausströmungsöffnung für den Wasserstoff gestellten Metallspitzen, so dass der beim Oeffnen des Hahnes austretende Wasserstoffstrom von dem überspringenden Funken getroffen und so zur Entzündung gebracht werden kann.

Bei dem von $\mathrm{H}$ a r e erfundenen $\mathrm{G}$ a l v a $\mathrm{n}$ o $\mathrm{ph}$ or wurde ein mittels einer galvanischen Batterie erzeugter Strom dazu benuitzt, einen dünnen Platindraht zum Glühen zu bringen, an welchem ein Zündfaden entzündet werden konnte. Das Erglühen

*) Die erst vor Kurzem empfohlenen, jedoch sehr gefährlichen Feuerzeuge, bei welchen kleine Fläschchen mit einer Lösung von Phosphor in Schwefelkohlenstoff gefüllt verwendet werden sollen, in welche man Papierstreifen eintaucht, die beim Verdunsten der Lösung an der Luft Feuer fangen, gehören auch hierher, inden die Entzïndung ebenfalls durch die Selbstentzïndlichkeit des beim Verdunsten des Lösungsmittels in fein vertheiltem Zustande hinterbleibenden Phosphors bedingt wird. 
eines dünnen Platindrahtes beim Durchleiten galvanischer Ströme wurde aucl als Zündmittel für Wasserstoffzündmaschinen, neuestens auch von Klinkerfues zur Entzündung von Leuchtgas (galvanisch-hydrostat. Zündmaschine) verwendet (vgl. Dingl. pol. Journ. 203 pag. 451 und polyt. Centralblatt 1872 pag. 1201). Auch Voisin und Dronnier (s. D. Industr.Ztg. 1874 pag. 418 und 187: pag. 4) haben dasselbe Princip zur Construction einer selbstzindenden Petroleumlampe (katalytisches Leuchtfeuerzeug) benützt. Ausführliches über Feuerzeuge s. H. W a gner, Licht und Feuer. Weimar 1869. Dr. H. Schmidt, der vollständige Feuerzeugspraktikant, Weimar 1840 und spät. Auflagen. C.B. A.Propst, Anweisung zur Verfertigung von allen Arten Zündapparaten, Quedlinburg 18:31 und A. Gtl.

Fibrilia nennt $\mathrm{V}$ at temare ein aus verschiedenen faserhaltigen Materialien componirtes Fasermateriale.

Fibrin, s. Eiweisskörper III. pag. 140. s. a. Blut I pag. 660.

Fibrinogen. Eisweissartiger Körper, welcher sich im Zustande der Lösung als Bestandtheil des Blutes, des Chylus, der Lymphe. sowie anderer thierischer Fliissigkeiten findet und ohne $\mathrm{Z}$ weifel in naher Beziehung zum Fibrin (s. d. III pag. 140) steht. s. a. Blut I pag. 661. Gtl.

Fibrinoplast s. Blut I pag. 661.

Fibroferrit, Min., ist strahlig krystallisirtes, bas. schwefelsaures Eisenoxyd. Vorkommen in Chile. Gtl.

Fibroïn (fibrö̈ne - fibroine) (Sericin), wesentlicher Bestandtheil der Seidensubstanz, sowie Bestandtheil der Spinnfäden gewisser anderer Spinner (Insecten, Spinnen etc.), z. B. der sog. Sommerfäden. Man erhält das Fibroïn am bequemsten aus Seidenfäden, indem man dieselben anhaltend und zwar am besten unter erhöhtem Druck mit Wasser kocht, den Rückstand mit Alkohol und Aether und endlich mit conc. Essigsäure erschöpft und schliesslich nochmals mit Wasser behandelt; auch durch Behandlung der Seide mit kalter Natronlange lässt sich das Fibroïn isoliren. Man erhält aus Seide 54-60 Procent reines Fibroïn.

Im reinen Zustande stellt dasselbe eine farb- und geruchlose, hellglänzende seidenähnliche Masse dar, die jedoch von geringerer Festigkeit aber auch geschmeidiger als Seide ist. In Wasser, Alkohol, Aether und conc. Essigsäure ist es unlöslich, dagegen löslich in conc. Mineralsäuren, in Auflösungen ätzender Alkalien, in Kupferoxydammoniak, sowie in Nickeloxydulammoniak, dann in conc. Chlorzinklösung $\left(60^{\circ}\right.$ B.). Aus den alkalischen Lösungen wird es durch Verdiummen mit Wasser, sowie durch Säuren, aus den Lösungen in Säuren nach dem Verdïnnen derselben mit Wasser durch Galläpfeltinctur (Gerbsänre) wieder als fasrige Masse gefällt. Beim Erhitzen bläht es sich auf und verbrennt mit hellbläulicher Flamme unter Verbreitung eines Geruches nach verbranntem Horn und Hinterlassung einer lockeren Kohle. Beim Kochen mit verdünnter Schwefelsäure wird es unter Bildung von Glycocoll, Leucin und Tyrosin zersetzt, Salpetersäure verwandelt es unter anfänglicher Gelbfärbung endlich in Oxalsäure. Die Zusammensetzung des Fibroïns entspricht der Formel $C_{12} H_{23} N_{5} O_{6}$ ( $(\mathrm{rramer})$, vgl. Vogel in Buchner's Repert. 8, pag. 1, Sehlossberger Annal. d. Chem. u. Pharm. 108 pag. 62, Schweizer Journ. f. pract. Chem. 76 pag. 544. Cramer, Untersuchung der Seide, Inaugural-Dissertation, Zürich 1863, a. Dingl. pol. Journ. 176 pag. 533 . s. a. Seide. Gtl.

Fibrolith syn. Sillimanit und Buehholzit.

Ficelliren syn. Verbinden der Champagnerflaschen s. W ein. 
Fichtelit (fichtelite - fichtelite), Min. Ein natürlich vorkommender, fester Kohlenwasserstoff, der in Gestalt kleiner, dem monoklinen Krystallsysteme angehörigen Krystall-Schuppen oder in krystallinischen Krusten im Lignit von Redwitz in Bayern, auch im Torf von Borkowitz in Böhmen, dann aber auch an den lebenden Stämmen von Pinus australis sich findet. Ist weiss, perlmutterglänzend, geruchlos und geschmacklos. Löst sich schwer in Alkohol, leicht in Aether, schwimmt anf Wasser; schmilzt bei $36^{\circ} \mathrm{C}$., in höherer Temperatur unzersetzt flüchtig. Seine Zusammensetzung entspricht der. Formel $n\left(C_{10} H_{16}\right)$. Gtl.

Fichtenharz (poix résine, pègle - common resin, firresin), g e m e in es Harz. Das an den Fichten, Kiefern und Tannen theils freiwillig, theils durch in die Rinde gemachte Einschnitte und Hiebe ausfliessende Harz führt in dem noch flüssigen Zustande den Namen Terpentin. Lässt man es so lange an dem Baume, bis der grösste Theil des Terpentinöls durch Verflüchtigung entfernt ist, so führt das so gewonnene, noch etwas Oel enthaltende Harz den Namen Fichtenharz. Galipot (brai sec) oder Barras. Es bildet mehr weniger unregelmässige Stiicke oder Klumpen von gelblich weisser, gelbrother oder brauner Farbe, die halbdurchscheinend, von terpentinartigem Geruch und etwas knetbar sind. Wird dasselbe geschmolzen und absetzen lassen oder durch Stroh oder Werg filtrirt, um Blätter, Rinde und andere Unreinigkeiten abzuscheiden, und dann in Fässern erkalten gelassen, so resultirt das weisse Harz (Weisspech) oder bei stärkerem Erhitzen das gelbe Harz, das eine mehr oder weniger gelbe oder bräunlich gelbe, durchscheinende, in der Kälte spröde Masse vor muschligem Bruche darstellt, die in der Wärme erweicht und klebrig wird. Beim Erhitzen mit Wasser resultirt das undurchsichtige, gelbliche oder gelblich weisse B urgunder Pech (poix de Bourgogne - Burgundy pitch). Dasselbe Product resultirt auch bei der Destillation des Fichtenharzes mit Wasser, wie sie zum Zwecke der Terpentinölgewinnung ausgeführt zn werden pflegt (s. Terpentinöl), als Retortenrïckstand.

Wird dieser stärker erhitzt, oder. die Destillation ohne Wasserzusatz ausgeführt, so resultirt das Colophonium oder Geigenharz (colophane colophony), das ron bräunlich gelber bis dunkelbrauner Farbe, durchsichtig oder durchscheinend, in der Kälte spröde und ron glänzendem muschligem Bruche, in in der Wärme aber klebrig ist. Es lässt sich leicht pulvern, doch hat das Pulver Neigung sich zusammenzuballen. Das spec. Gewicht des Colophoniums ist 1.01 bis 1.08 .

Wird die Destillation des Terpentins mit Wasserzusatz nicht so weit getrieben, bis der Rückstand wasserfrei ist, so resultirt der gekocht e Terpentin (terebintina cocta), ein noch Wasser und Terpentinöl enthaltendes, schmutzig gelbes Harz, das in der Wärme weich, in der Kälte hart ist, aber bei längerem Liegen der Stiicke noch zusammenfliesst. Auch durch Abtrocknen des freiwillig austliessenden Terpentins oder der nach der Terpentingewinnung in den Einschnitten der Stämme zurückbleibenden Terpentinreste bilden sich mehr weniger ähnliche Harzmassen. Solcher Art ist der Waldweihrauch, der in Gestalt kleinerer oder grösserer Stücke lıäufig ron Thränenform und gelblich weisser̈, gelber bis röthlich brauner Farbe in den Handel kommt, zwischen den Fingern erweicht, angenchm aromatisch riecht und terpentinähnlich bitter schmeckt. Nicht selten wird solcher Waldweihrauch in Ameisenhaufen gefunden, in welche die abfallenden Tropfen ron Ameisen vertragen werden, seltener ron den Bäumen selbst gesammelt. Das in den alten Einschnitten der Bäume angesammelte und dort eingetrocknete Harz, sowie jenes, welches sich nicht selten zwischen Rinde und Holz alter stämme findet, wird gesammelt und als gemeines $\mathrm{Har} z$ zu Markte gebracht. Es ist dem Waldweihrauch im Ganzen ähulich, doch gewöhnlich viel unreiner als dieser. Ein stark aromatisch riechendes Harz ist auch das sog. Lärchenharz, welches durch freiwilliges Abtrocknen des aus Pinus Laricio- 
Stämmen ausfliessenden Balsams entsteht und unregelmässig rundliche, aussen röthliche, innen weisse Harzkörner bildet.

Die reichsten Quellen für die Gewinnung des Fichtenharzes und der mit diesem allgemeinen Namen belegten Harzproducte anderer Coniferen sind einerseits die österreichischen, deutschen und russischen Wald̄gegenden, dann die Coniferenbestände im Süden von Frankreich (hauptsächlich von der sog. Meerstrandsfichte stammend), endlich aber vornehmlich die Wälder Nordamerikas, von wo jährlich hunderttausende von Tonnen Fichtenharz nach Europa exportirt werden. Alle Arten von Fichtenharz sind in Alkohol grösstentheils löslich, durch Alkalien verseifbar, bei höherer Temperatur leicht schmelzbar', bei starkem Erhitzen unter Luftzutritt mit hellleuchtender, stark russender Flamme verbrennbar. Sie enthalten neben Resten von ätherischem Oel und mehr oder weniger Wasser, mehrere Harzc von der Natur schwacher Säuren, die wesentlich theils das Hydrat, theils das Anhydrid einer Säure, der Abietinsäure $\mathrm{C}_{44} \mathrm{H}_{62} \mathrm{O}_{4}$ ( $\mathrm{Maly}$ ) sind. Das Fichtenharz findet in seinen verschiedenen Formen die mannigfachste Anwendung zu technischen Zwecken, insbesondere zur Herstellung von Lacken, Firnissen und Schmelzlacken (Siegellacken), dann zur Bereitung des Harzleims für Papierfabrikation, zu Kitten; Colophonium namentlich auch als Mittel zur Erzielung grösserer Reibungsmomente bei Maschinentheilen, Streichinstrumenten u. dg. m., endlich dient Fichtenharz als Rohmateriale für die Gewinnung der Harzöle, sowie auch zur Erzeugung eines Leuchtgases $u$. s. w. Nach $\mathrm{Hunth}$ und $\mathrm{P}$ ochin's patentirtem Verfahren lässt sich Colophonium durch Destillation mit ïberhitzten Wasserdämpfen auch gebleicht erhalten und ist dann weiterer Anwendungen, zu welchen das gewöhnliche Colophonium seiner Färbung wegen nicht verwendbar ist, fähig s. a. Pech und Forstwirthschaft. Gtl.

Fichtennadelöl (essence $d u$ coton de pin - pin needle oil), Kiefernadelöl, Waldwollöl. Das durch Destillation der Fichtennadeln mit Wasser, meist als Nebenproduct bei der Bereitung des Fichtennadelextractes gewoňiene ätherische 0el. Ist dem Terpentinöl nahe verwandt, von ăhnlichem, aber angenehmerem Geruche, farblos bis grünlich gelb, leicht beweglich, diinnfliissig. Spec. Gew. 0.88. Ist mit Alkohol und Aether mischbar. Gtl.

Fichtenholz (sapin, pin - red deal, pine) ist das Holz der Rothtanne oder Fichte (Pinus abies L.), welches in Mitteleuropa sowohl als "weiches" Brennholz, als auch als Tischler- und Bauholz die ausgedehnteste Anwendung findet. Es ist ein weiches, leicht spaltbares, unter der Axt gerne splitterndes Holz; etwas harzreicher als das Tannenholz, mit welchem es grosse Aehnlichkeit besitzt, aber lange nicht so harzreich wie das Holz der Föhre und Lärche. Die Jahresringe (das Frühlings- und Herbstholz) sind deutlich zu unterscheiden; die Farbe ist röthlich-gelblich-weiss. Ein Kubikmeter dieses Holzes wiegt ca. $475^{\mathrm{k}}$. $K k$.

Fichtenzucker s. P in it.

Ficinit, Min. Bildet dunkelfärbige, fast schwarze, kaum durchscheinende Krystalle des monoklin. Systems. Zu Bodenmais, als Begleiter des Cordierits sich findend. Ist Schwefelsäure und manganhaltiges Eisenphosphat rom spee. Gew. $3.4-3.5$ und der Härte 5-5.5. Gtl.

Fieberrinde syn. Chinarinde s. II pag. 309.

Fieberklee (herbe à la fièvre - fewer-few), Bitterklee. Die Blätter des anf sumpfigen Wiesen Mitteleuropas häufig vorkommenden Bitterklee's Menyanthes trifoliata $L$. zeichnen sich durch einen erheblichen Gehalt an einem intensiv bitterschmeckenden Extractivstoff Menyanthin aus, und wurden friher als Arzeneimittel, hie und da wohl auch als Hopfensurrogat zur Bierbereitung verwendet. Das von Lndwig und Kromayer (Arch. f. Pharm. 108 (2) pag. 263) isolirte Menyanthin stellt eine amorphe, gelbliche, anfangs weiche, allmiilig fest 
werdende Masse dar, die stark und rein bitter schmeckt, schwer in kaltem, leicht in kochendem Wasser und Alkohol, in Aether aber nicht löslich ist. Beim Erhitzen auf $110-115^{\circ}$ C. schmilzt es zu einer leicht beweglichen Flüssigkeit. Es ist stickstofffrei und ist der Formel $C_{22} H_{36} O_{11}$ entsprechend zusammengesetzt. Gtl.

Fiedelbogen, Bohrbogen, s. Bohren II pag. 710 Zeile 11.

Fikor syn. mit ostind. Arrow-Root, s. Stärkemehl.

Filanda (filature - silk-spinning-mill), S eidenspinnerei, s. Seide. s. Seide.

Filatorium (moulin d̀ soie - spinning mill), S eiden-Zwirnm as chine,

Filete, s. Buchbinder-Arbeiten II pag. 123.

Filigranarbeit (filigrane - filigrane) bezeiehnet man jene, namentlich im Oriente noch jetzt gebräuchliche Gold- und Silberarbeit, bei welcher die einzelnen Schmuckstücke aus mannigfach gebogenen, durch Löthen vereinigten Gold- oder Silberdrähten hergestellt sind. Um mannigfacheren Effect zu erzielen, verwendet man auch cordirten und dann geplätteten Draht, s. Goldarbeiten.

Filigranglas s. Glas.

Filigranpapier (papier filigrané -- paper filigrane) ist Papier mit zarten, durch Prägedruck (mit oder ohne Zuhilfenahme von Durchschnitten) hergestellten Zeichnungen. Vgl. Art. Buntpapier II pag. 177.

Filiren (moulinage - throwing), Zwirnen der Seide, s. Seide.

Filixgerbsäure s. Filixw urzel.

Filixsäure s. Filixwurzel.

Filixwurzel, Farrenkrautwurzel, die Wurzel von Aspidium filix mas. Sw., welche namentlich als Arzeneimittel geschätzt ist, enthält eine eigenthümliche Säure, die Filixsäure, dann eine Gerbsäure, Filixgerbsäure und ein fettes Oel, das Farrenkrautwurzelöl oder Filixöl.

Die Filixsäure $\mathrm{C}_{14} \mathrm{H}_{18} \mathrm{O}_{5}$ scheidet sich aus dem ätherischen Extracte der Wurzel in Gestalt krystallinischer, gelber Krystallkrusten ab, die durch Umkrystallisiren aus Aetherweingeist und endlich aus Aether gereinigt und in Form kleiner weisser Krystallblättchen erhalten werden können, die bei $161^{\circ} \mathrm{O}$. schmelzen, von schwachem Geruche und Geschmacke und scliwach saurer Reaction sind. In Wasser ist sie nicht löslich, leicht dagegen in kochendem Weingeist, dann in Aether und Schwefelkohlenstoff, sowie endiich in Fetten und äther. Oelen. Mit Alkalien bildet sie lösliche Salze. Sie ist ein Derivat des Phloroglucins u. z. Dibutyrylphloroglucin (rgl. Luck, Annal. d. Chem. u. Pharm. 54, pag. 119 und Grabowsky, Annal. d. Chem. u. Pharm. 143 pag. 279).

Die Filixgerbsäure, aus dem wässrigen Auszuge der Filixwurzel durch Fällen mit Bleiessig und Zersetzung des Bleiniederschlages mit Schwefelwasserstoff darstellbar, ist der Chinagerbsäure ähnlich, amorph, in Wasser unter Trübung, leicht in Alkohol löslich, fällt Leim und färbt Eisenoxydsalze grün. Durch Kochen mit verdiinnten Säuren wird sie unter Abscheidung dunkelziegelrother Flocken ron Filixroth $\left(\mathrm{C}_{26} H_{1 \mathrm{~s}} \mathrm{O}_{12}\right)$ zersetzt, wobei sich auch Zucker bildet (vgl. Malin, Annal. d. Chem. u. Pharm. 143 pag. 276).

Das Filixöl ist ein fettes, schwierig rerseifbares Oel von dunkel grasgrïner Farbe und ziemlich dicker Consistenz. Es schmeckt Anfangs mild, später kratzend und erstarrt in der Kälte nicht. Kann aus dem ätherischen Filixwurzelextracte dureh Schiitteln mit ammoniakalischem Wasser gewonnen werden. Gtl. 
Fillet, s. Baumwollspinnerei I pag. 332.

s. Seide.

Fillingmaschine ist eine in der Floretseidenspinnerei verwendete Maschine,

Filter, Filtrum, s. Filtriren.

Filterapparate, Filtrirapparate, s. Filtriren s. a. W a s s r.

Filterkohle, eine poröse Kohlenmasse zur Herstellung von Filterapparaten, namentlich für Wasserfiltration s. W as ser, vgl. Kohlenstoff. Gtl.

Filterpapier, Filtrirpapier s. Filtriren, vgl. Papier.

Filterpressen. Zur Abscheidung feiner, pulveriger Substanzen von Flüssigkeiten werden mit vorzüglichem Erfolge Filterpressen angewendet. So z. B. zum Auspressen des Porzellanmasse-Schlammes, des Stearins, der Hefe etc. S. hierüber Näheres im Art. Pressen, s.a. Zuckerfabrikation. Kk.

Filtriren (filtrage - filtering), Filtern (Durchseihen). Eine rein mechanische Operation, um Flüssigkeiten von darin aufgeschwemmten festen Theilchen zu sondern, sei es nun, dass man die Fliissigkeit oder die festen Theilchen oder auch Beides zu benutzen beabsichtigt. Das dazu dienende Mittel, das Filtrum (filtre - filter), besteht jederzeit aus irgend einem porösen Körper, wie z. B. Löschpapier, Filz, Zeugen, aller Art porösen Steinen oder thönernen Geschirren, Kohlenpulver, porösen Kohlenmassen, Sand, Amianth, Glaswolle u. dergl. Zu chemischen Versuchen im Kleinen wird fast nur feines Löschpapier (Filtrirpapier) genommen, welches entweder von vorn herein mit ganz reinem, sorgfältig gewaschenem Papierzeug und klarem Regenwasser angefertigt sein muss, oder das man noch besser dadurch reinigt, dass man es (am bequemsten die fertig zusammen gefalteten Filtra) in verdünnte Salzsäure einlegt, um alle Eisenoxydtheile und Kalk, die fast immer in geringer Menge im Papiere vorkommen, aufzulöseu, und dann wieder so lange mit destillirtem Wasser auswäscht, bis das ablaufende Wasser mit salpetersaurer Silberauflösung nicht die geringste Triibung gibt.

Die Art, das Papier zusammen zu legen, um es als Filter zu verwenden, besteht gewöhnlich ganz einfach darin, dass man ein viereckiges Stïck zweimal, nämlich in der Richtung der Diagonalen, zusammen faltet, und es dann an dem offenen Rande bogenförmig abschneidet, so dass eine kreisförmige Scheibe resultirt, die auf einen Viertelkreis zusammengelegt ist. *) Oder man legt ein Stück Papier einmal zusammen, und bildet nun durch fächerförmiges Zusammenfalten ein einem Fächer älınliches, halbkreisförmiges Falten-Filter (Sternfilter) (filtre à plis), bei welchem die einzelnen Faltenbüge radial gegen das Centrum der Kreisscheibe zusammenlaufen. Um die aus Papier gefertigten Filter, die man zur Ersparniss an Papier nach Stolba auch durch Zusammenlegen einer halbkreisförmigen $\mathrm{Pa}$ pierscheibe auf einen Viertelkreis und zwei- bis dreimaliges Zusammenfalten des offenen Randes erhalten kann, zu benutzen, setzt man sie entweder in eine Filtrirtasse oder in einen Trichter ein. Filtrirtassen sind flache Tassen aus Glas, Porzellan oder Holz, mit einem kreisrunden Ausschnitt in der Mitte, in welchen man das aufgerollte gewöhnliche Filter, das die Gestallt eines hohlen Kegel hat, mit der Spitze nach abwärts einsetzt, und die so mit dem Filter versehene Tasse legt man dann auf die Mündung des Gefässes auf, in welchem man die filtrirte Flïssigkeit auffangen will. Um ein gewöhnliches Filter aufzurollen, dreht man die in die Hälfte zusammengelegte Papierscheibe diitenförmig zusammen, indem man den Finger zwischen die beiden Hälften der Kreisscheibe dazwischen schiebt,

*) Zum Rundschneiden der Filter kann man sich bequem der von $\mathrm{M} \cap \mathrm{h} \mathrm{r}$ angegebenen Filterchablonen aus Weissblech oder einer Vorrichtung bedienen, welche Stevenson angegeben hat, und die aus einer Metallscheibe bestebt, auf welcher ein in einer Kreislinie beweglicher Arm mit verstellbarem Messer angebracht ist. 
so dass nach dem Aufrollen ein Hohlkegel entsteht, der an der einen Seite eine dreifache, an der anderen Seite eine fünfache Lage von Papier zeigt. Solcher Tassen kann man sich im Allgemeinen nur für kleinere Filter bedienen, da bei Anwendung grosser Filter der Druck der in das Filtrum eingegossenen Flüssigkeit zu gross ist, als dass ihn das, namentlich im feuchten Zustande leicht reissende Filtrirpapier, selbst wenn man es doppelt oder dreifach genommen hätte (doppelte oder dreifache Filtra), auszuhalten vermöchte *) Zweckmässiger, weil das Reissen des Filtrirpapiers, das, um für Flüssigkeiten möglichst gut durchgängig zu sein ungeleimt sein soll, besser vermeidend, ist es, die Filtra in Trichter einzusetzen. Man kann sowohl mit gewöhnlichen (glatten) als auch mit gefalteten Filtern (Sternfiltern) in Trichtern filtriren. Um glatte Filter in den Trichter einzusetzen, hebt man von der auf einen Viertelkreis zusammengelegten Kreisscheibe nur das oberste Blatt auf und formirt, während man die anderen 3 übereinander liegenden Blätter gemeinschaftlich fasst, einen Hohlkegel, den man nun in den Trichter einsetzt, so dass das Papier iuberall möglichst gut an der Trichterwand anliegt. Das Filter darf hiebei den Rand des Trichters nicht überragen. Die Trichter miissen so gewählt werden, dass der Winkel, welchen die Wände des Trichters einschliessen, nicht wesentlich mehr oder weniger als $60^{\circ}$ (für sehr grosse Trichter $50^{\prime \prime}$ ) beträgt, und der Trichterhals darf sich nicht allmälig erweitern, sondern soll mit einem möglichst scharfen Winkel absetzen. Andernfalls legt sich das Filter nicht gut an đie Trichterwand an und bleibt dem Reissen leicht unterworfen. In Folge des Umstandes, dass glatte Filter sich an der Trichterwand fest anlegen, wird die Filtration bei Anwendung solcher Filter in Trichtern nicht unwesentlich verlangsamt, und ist es daher, wenn rasche Filtration beabsichtigt wird, zu empfehlen, statt der glatten Filter, die gefalteten (Falten- oder Sternfilter) zu verwenden, die sich nu theilweise an der Trichterwand anlegen, und zwischen den Falten der Fliissigkeit den Ablauf gestatten, mithin eine grössere filtrirende Fläche bieten. Solche Filter muss man jedoch mit ihrer Spitze ziemlich tief in den Trichterhals eindrücken, da sie sonst leicht reissen.

Den Zweck einer Beschleunigung der Filtration erreicht man auch oei Anwendung glatter Filter, wenn man zwischen Filter und Trichterwand mehrere Glasstäbchen einstellt, oder Trichter anwendet, welche an ihrer Innenwand gerieft sind. Auch Trichter mit durchlöcherter Wandung kann man anwenden, und Wolff hat sogar empfohlen, an Stelle der Trichter kegelförmige Gestelle aus verzinntem Eisendraht anzuwenden, welche das Filter genügend stützen, ohne die Raschheit der Filtration zu beeinflussen.

Für die Filtration von Körpern, die nur bei höherer Temperatur genügend fliissig sind, um durch die Porren des Filters hindurch zu gehen, bedient man sich der sog. Warmtrichter, d. s. doppelwandige Trichter, gewöhnlich aus Metallblech, in die man entweder directe das Filtrum oder den dieses tragenden Glasoder Porzellantrichter einsetzen kam. Der Zwischenraum zwischen den beiden Wandungen des Trichters wird entwcder mit heissem Wasser gefült, das durch cine an der Aussenwand wirkende Flamme heiss erhalten wird, oder man lässt heisse Dämpfe durchströmen (Dampftrichter).

Filtrationen in etwas grösserem Masstabe werden häufig in Spitzbeuteln oder auf Seihetïchern vorgenommen; die ersteren können aus Leinwand oder Flanell genäht ouler auch aus Filz gleich in einem Stiick angefertigt werden. Dergleichen Filter befestigt man in sog. Tenakeln, d. s. aus $t$ zu einem Quadrat zusammensclegten Holzstäben gebildeten Fahmen, die an den Kreuzungsstellen der Stäbe lange Nägel tragen, deren Spitzen so weit aus dem Holze hervorragen, dass man len Rand les Spitzbentels ocler Tuches daran befestigen kann. Solche Eilzfiltra

pichot und Malapert haben ein Filtrinupier hergestellt, welches in der Mitte eines jeden Bugens eine runde Scheibe eines feinen Gewebes (Gaze) eingelegt enthält, wodurch die Festigkeit des Papiers wesentlich erhöht wird. 
finden z. B. Anwendung beim Filtriren des Brennöls nach der Behandlung mit Schwefelsäure. Eine andere Eiltrirvorrichtung, ebenfalls bei der Oelraffinerie gebräuchlich, besteht in einem Fass mit vielfach durchlöchertem Boden, durch dessen Löcher baumwollene Dochte, oben mit einem Knoten versehen, hindurchgezogen werden. Anch Werg sowie Stroh oder Strohgeflechte, dann Sicheerwolle wendet man im Grossen als Filtermaterial an.

In einzelnen Fällen, so namentlich beim Eiltriren concentrirter Säuren oder ätzender Laugen, oxydirend wirkender oder solcher Flüssigkeiten, die bei Berüllrung mit organischen Substanzen zersetzt werden würden, muss das Filtrum aus einer unorganischen Masse bestehen. Man bedient sich dann einer Lage von rein€m Sand, Glaspulver, Asbest, Bimsstein oder der gegenwärtig allenthalben leicht zugänglichen Glaswolle, welche jedoch aus einem Glase gefertigt sein muss, welches von dergleichen Flüssigkeiten nicht angegriffen wird. In manchen Fällen kann man mit Vortheil auch Schiessbaumwolle verwenden, die gleichfalls der Einwirkung gewisser ätzend wirkender Flüssigkeiten nicht unterliegt. Auch Bimsstein in Stïcken kann man als Filtermateriale in der Weise verwenden, dass man aus Bimsstein auf einer Drehbank kegelförmige Stiicke formt, die man innen bis auf eine schwache Wand aushöhlt. Eben solche Filter kann man auch aus porösem Thone (Bisquit) oder porösem Steinmateriale herstellen. Auch aus Asbestgewebe hat man ein Filtermateriale für ätzende Flüssigkeiten hergestellt, das ähnlich dem Filtrirpapier zu Filtern geformt werden kann, die man entweder in einem Trichter oder in einem anderen geeigneten Behälter, dessen Boden durchlöchert sein muss, anbringt. Um das Hindurchfallen des Sandes durch die Löcher zu verhindern, legt man über jedes ein Steinchen. Dergleichen Filtrationen kommen indessen seltener vor, oder lassen sich auf anderen Wegen umgehen.

Um sich die Miihe zu ersparen, sowohl bei den Filtrationen selbst die zu filtrirende Flüssigkeit, als auch besonders beim nachherigen Auswaschen das Wasser aufzugeben, bedient man sich mit grösstem Vortheil selbstwirkender Filtrirvorrichtungen, deren Aufgabe darin besteht, das Filtrum stets gefüllt zu halten. Eine bei Filtrationen im Kleinen sehr bequeme und zweckmässige Methode besteht darin, die Flüssigkeit mit dem Niederschlage in eine Flasche zu geben, den Hals mit dem Finger zu verschliessen, sie umzukehren und die Oeffinung: in das Filtrum zu bringen. Aus bekannten Grïnden hört das Ausströmen der Flüssigkeit auf, sobald sie in dem Filtrum bis zu der Höhe gestiegen ist, dass sie die Mündung der Flasche absperrt und sohin den Eintritt der Luft in die Flasche hindert. Die Flasche wird nun in dieser umgekehrten Stellung mittelst eines Trägers befestigt. Wenn aber im Verlauf der Filtration das Niveau bis unter die Mündung der Flasche sinkt, so gelangt, unter gleichzeitigem Ausfluss eines entsprechenden Volumens Flüssigkeit, Luft in dieselbe, bis abermals die Flaschenmïndung durch die Flüssigkeit abgesperrt wird. Zum Auswaschen von Niederschlägen, von welchen nichts verloren gehen soll, wie bei genauen Analysen, ist diese

Fig. 1636 .

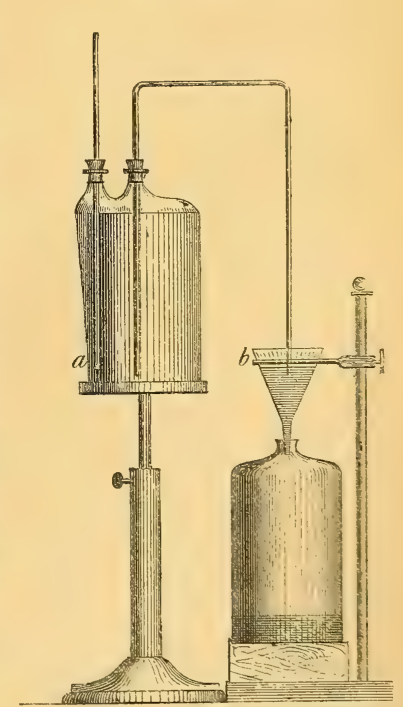
Vorrichtung aus dem Grunde unanwendbar, weil die Luftblasen bei ihrem Eintritt in die Flasche und dem Aufsteigen leicht eine kleine Menge des Niederschlages mit in die Höhe reissen und in die Flasche führen, wo sich derselbe damn an 
den Wänden festsetzen kann. Es sind daher wohl andere Vorrichtungen vorzuziehen, die diesem Uebelstande begegnen, unter welchen der in Fig. 1636 dargestellte, von Gay-Lussac empfohlene Aussïssapparat einer der ältesten und eben sowohl im Kleinen als auch im Grossen vollkommen anwendbar ist. Er besteht aus einer geräumigen Flasche, deren Mündung mit einem genau luftdicht schliessenden Pfropfe versehen ist, durch welchen zwei Glasröhren bis nahe auf den Boden der Flasche hindurchgehen. Die eine dieser Röhren ist heberförmig gekrïmmt, und an ihrem äusseren Schenkel so lang, dass das Ende, welches in das Filtrum $b$ hineinreicht, etwa um einen Centimeter tiefer liegt, als die untere Oeffnung $a$ der zweiten Röhre. Soll nun eine Aussüssung vorgenommen werden, so füllt man die Flasche mit reinem Wasser, verschliesst sie mit dem Pfropfe, bringt den Heber in das Filtrum, mit der Vorsicht, dass der Rand dieses letzteren um etwas höher liegt als die Oeffnung $a$ und setzt nun den Apparat dadurch in Thätigkeit, dass man in die gerade Röhre Luft einbläst, wodurch sich die Heberröhre mit Wasser füllt, das von da in das Filter abfliesst, so lang, bis die Mündung der heberförmigen Röhre etwa ebenfalls ein Centimeter tief in die Flïssigkeit im Filtrum eintancht. Indem das Flïssigkeitsniveau im Filtrum während des Ganges der Filtration sinkt, fliesst eine neue Menge Wassers aus dem Heberrohre nach, bis die Flüssigkeit im Filtrum wieder auf das urspriingliche Niveau gebracht ist u. s. f. Der Apparat wirkt also selbstthätig und hält, so lange noch Wasser in der Flasche ist, das Filtrum stets mit Wasser gefüllt. Aus physikalischen Gründen nämlich, deren Erörterung hier zu weit führen würde, fliesst der Heber, unter gleichzeitigem Eintritt von Luft durch die andere Röhre, nur so lange, bis das Niveau der ihn umgebenden Fliissigkeit in dem Filtrum bis zu der Höhe der Oeffnung a gestiegen ist, wo dann der Zufluss von Wasser aufhört.

Auf demselben Principe beruhen die meisten anderen selbsttlätigen Nachfuillapparate, die in den verschiedensten Formen angegeben wurden.

Die Natur des Niederschlages ist von dem grössten Einfluss auf die Schnelligkeit der Filtration. Grobkörnige, sandige Niederschläge filtriren am besten; nächst diesen folgen die fasrigen und flockigen, auf diese die feinkörnigen, und am schlimmsten von allen sind schleimig-voluminöse Niederschläge zu filtriren, daher man denn, zumal bei Arbeiten im Grossen, sich bemïhen muss, den. Niederschlägen eine geeigte körnige oder flockige Beschaffenheit zn ertheilen, sofern nicht etwa die Bestimmung derselben eine andere Beschaffenheit erheischt.

Insoferne die Raschheit, mit welcher eine Flüssigkeit die Poren eines Filtermateriales durchdringt, wesentlich abhängig ist von dem Drucke der auf die im Filter befindliche Fliissigkeit wirkt, ist es klar, dass man durch einseitige Erhöhung des Druckes eine wesentliche Beschleunigung der Filtrationsprocesse herbeiführen kamn. Ein solcher, und zwar am bequemsten ein hydrostatischer Druck, ist dadurch zu bewirken, dass man entweder dem Filtrum eine beträchtliche Tiefe gibt, oder dass man den Raum über dem Filtrum nach allen Seiten hin dicht verschliesst, mit einer aufsteigenden Röhre in Verbindung setzt, und diese mit Wasser oder der zu filtrirenden Flüssigkeit gefüllt erhält.

Eine grosse Unbequemlichkeit dieses an sich einfach erscheinenden Verfahrens liegt darin, dass der Niederschlag während der Filtration und der Auswaschumg röllig unzugänglich bleibt, sich also durchaus nicht nachsehen und aufriihren lässt, und dass auch das jedesmalige Oeffnen und Wiederverschliessen des Apparates zwischen zwei Filtrationen gewisse Schwierigkeiten darbietet. Ebenso unbequem und in der Praxis undurchfuhrbar ist es, durch Erhöhung des Luftdruckes iiber der Flïssigkeit im Filtrum die Filtration zu beschleunigen. Dagegen ist es rerhältnissmässig bequem ausführbar, den auf der Flüssigkeit im Filtrum lastenden Druck einseitig dadurch zu erhöhen, dass man den Atmosphärendruck unter dem Filtrum erniedrigt. Dies lässt sich am leichtesten in der Art bewerkstelligen, dass man den das Filtrum tragenden Trichter mittels eines doppelt durchbohrten Pfropfens luftdicht auf eine starkwandige Flasche aufsetzt, und nachdem man die zu filtrirende Fliissigkeit auf das Filter aufgegossen hat, durch Ver- 
mittlung einer in die zweite Bohrung des Pfropfens eingepassten Rölire die Luft aus der Flasche auspumpt oder doch wesentlich verdünnt. Man erreicht dies mittels einer Luftpumpe und wendet hiezu am vortheilhaftesten die neverer Zeit ganz Allgemein im Gebrauche stehenden Wasserluftpumpen (s. d. bei Luftpumpen) oder Aspiratoren anderer Art an. Bei Arbeiten im Grossen kann man die Luftverdïnnung anch wohl durch gewöhnliche Luftpumpen besorgen. Auf demselben Principe beruht auch die Einrichtung der Schnellfilter, welche man nicht selten bei Arbeiten im Kleinen verwendet, bei welchen an das Rohrende eines gewöhnlichen Filtrirtrichters mit Hilfe eines Kautschukschlauchstückes eine längere enge Glaspö̈hre angesetzt ist, die nahe an ihrer Verbindungsstelle mit dem Trichterrohre zu einer kleinen Schlinge gebogen ist. Die aus dem Filter ablaufende Flüssigkeit (das Filtrat), welches durch diese Röhre ihren Weg nehmen muss, bildet in derselben unter dem Einflusse der Schlinge, die sie passiren muss, kleine Flüssigkeitssäulen, die bei ihrem Fallen in der Röhre eine saugende Wirkung ausüben und sohin den unter dem Filter herrschenden Druck in einem, wenn auch nur geringen Grade vermindern.

Bei Arbeiten im Grossen kann man, soferne die zu filtrirende Flüssigkeit die Berührung mit heissen Wasserdämpfen verträgt, die Druckerhöhung über dem Flüssigkeitsniveau im Filter auch dadurch bewirken, dass man in das oben hermetisch abgeschlossene Filter gespannten Dampf eintreten lässt.

Dass bei allen Filtrationen mit Druck das Filtrum die nöthige Festigkeit besitzen müsse, um unter dem Drucke nicht zu zerreissen, bedarf kaum der Erwälnung. Man bringt desshalb zum Schutze der Filtra nicht selten kleine siebförmig durchlöcherte Hohlkegel aus Platinblech oder Pergamentpapier unter die Filterspitze oder wendet wohl auch ein durch eingelegte Gewebe (Gaze oder Battist) verstärktes Filtrirpapier oder sonstige dem Drucke leichter widerstehende Eiltermaterialien an. Bei manchen Niederschlägen ferner, namentlich bei schleimig-flockigen, ist Anwendung von Druck nicht immer zweckmässig, indem sich der Niederschlag gerade durch die Gewalt des Druckes auf der Oberfläche des Filtrums zu einer fast undurchdringlichen Kruste zusammensetzen kann, die den ferneren Durchgang von Flüssigkeit hindert.

Zweck der Filtration ist gerade nicht immer, eine Flüssigke it von einem darin enthaltenen fein zertheilten festen Körper zu trennen; es kommt auch in einzelnen Fällen der Zweck in Betracht, die Substanz des Filtrums chemisch auf die Flüssigkeit einwirken zu lassen, so z. B. bei der Salmiakfabrikation, wo man die rohe Lauge von kohlensaurem Ammoniak durch pulverisirten Gyps filtrirt, um eine gegenseitige Zersetzung zu kohlensaurem Kalk und schwefelsaurem Ammoniak zu erzielen; ferner bei der Filtration gefärbter oder riechender Stoffe durch Kohlenpulver oder über Spodium, um sie geruchlos zu machen oder zu entfärben.

Hierher gehört das Filtriren uber Spodium, wie es in der Zuckerfabrikation sowie bei verschiedenen anderen Zweigen der chem. Industrie in Anwendung steht; das Filtriren des fuseligen Branntweins uiber Holzkohle, um ihn zu entfuseln, das Filtriren schlechten Trinkwassers durch plastische Kohle, um es von riechenden und färbenden oder iiberliaupt fremdartigen Stoffen zu befreien. Ueber besondere Arten der Filtration im Grossen s. bei Was s er, s. b. Zuckerfabrikation. Ueber das Filtriren von Metallen, welches schon von $\mathrm{Lampadins}$ empfohlen wurde, hat nenestens Curter (vgl. Dingl pol. Journ. 215 pag. 469) nenere Arbeiten geliefert, vgl. üb. a. Leichsenring D. Industr.-Ztg. 1875 pag. 37 , s. a. b. d. einzelnen Metallen. Gtl.

Filtrirstein (pierve filtrante - filtering stone), Filtrirsandstein. Ein feinkörniger Sandstein von ziemlich poröser Masse, der sich als Filtermateriale gut eignet, insoferne er für Flüssigkeiten leicht durchgängig ist. Er wird gewöhnlich zur Wasserfiltration verwendet, u. z. in der Art, dass man grössere, unten geschlossene, oben offene, hohle Cylinder aus diesem Steine fertigt, die in das zu filtrirende Wasser eingestellt werden, das nun durch die poröse Sandsteinmasse in den Innenraum des Steines eindringt und hiebei filtrirt wird. Gtl. 
Filtrirtuch. Zum Auspressen des Stearins etc. in den Filterpressen wird ein dicker Schaffwollstoff verwendet, dessen Kettenfäden aus 8drähtigem und dessen Schussfäden aus 10drähtigem Kammgarnzwirne bestehen. Die Drehung der letzteren ist geringer. Diese Fäden sind zu einem dichten, dreibündigen Körper verwebt. $K k$.

Filz (feutre - felt) wird ein aus wirr durcheinander liegenden thierischen IIaaren bestehender Zeug genannt, welcher ohne Weben den Zusammenhang durch das Verfilzen oder Filzen erhalten hat. Nicht alle thierischen Haare besitzen die Verfilzungsfähigkeit in dem gleichen Masse und kann daher nur aus genügend verfilzungsfähigen Haaren ein guter Filz erhalten werden. Je feiner und elastischer das thierische Haar ist, um so dichter und fester lässt sich der Filz erhalten. Man kann das Filzen folgendermassen vornehmen. Eine Schichte gleichmässig gelockerter wirrer Haare, z. B. Schafwolle, Hasenhaare o. dgl., werde zwischen zwei Leinwandstïcke gebracht, welche zunächst nur die Aufgabe haben die Uebertragung der Haarschichte zu ermöglichen. Man bringt nun das Ganze in warmes Wasser oder eine warme Seifenlösung und drückt anfänglich sehr vorsichtig, später kräftiger. Die Haare werden sich bald unter sich derart verbinden, pass die Leinwand entfernt werden kann und ein weiteres Verfilzen durch kräftiges Kneten des Vliesses erzielbar wird. Man erhält so jene innige Vereinigung der Haare, welche Jedermann von den Filzhïten her bekannt ist. S. die Artikel: Hutfabrikation, Schafwolle und Tuch. $K k$.

Filzmalz, ein stark gewachsenes Malz, bei dem die langen Malzkeime so in einander verschlungen sind, dass die einzelnen Malzkörner eine verfilzte Masse bilden, s. Bier I pag. 465 bei Malzen. Gtl.

Filzmaschine, s. Tuch.

Filztuch, s. Tueh.

Fimmel, s. Bergbau-I pag. 384, s. a. Hanf.

Fingerhut (dé - thimble). Fingerhüte aus Metall werden gewöhnlich durch Stanzen (s. I pag. 557), selten durch Dricken, hergestellt und an der Drehbank mit Zuhilfenahme der Rändelrädchen etc. vollendet. Die Fingerhuite aus Elfenbein oder Bein werden auf der Drehbank durch Ausbohren und Abdrehen hergestellt und erlangen die feinen Grübchen durch Ausbohren, da hier das Rändelrädchen nicht anwendbar ist. $K k$.

Fingerhutkraut, wirksame Bestandtheile s. b. Digitalin II pag. 628.

Finirmaschine (machine ì chrondir - finishing engine), s. Wälzmaschine.

Finne, s. H a m mer.

Finnhammer, s. Blechbearbeitung I pag. 555 .

Finnish-Maschine, s. A ppretur I pag. 177.

Firmamentstein s. Opal.

Firneis, das aus dem Hochschnee iiber der Schneelinie der Hochgebirge gebildete, aus rundlichen, festen und harten Körnern bestehende Eis der Firnfelder der Gletscher, welches nach oben zu locker und hohl, nach unten hin zu einer festen compacten Masse sich verbindet, aus welcher nach und nach das Gletschereis entsteht. $L b$.

Firniss (remis - vamish). Lackfirniss, Lack. Mit dicsem Namen belegt m:m im Allgemeinen Fliissigkeiten, welche die Eigenschaft haben, in dünnen Schichten der Einwirkung der Luft ausgesetzt, mehr oder weniger rasch zı melir oder weniger harten, durchsichtigen oder doch durchscheinenden und einen 
melır oder weniger ausgesprochenen Glanz zeigenden Ueberzitgen einzutrocknen. Man benutzt Firnisse iberall da, wo es gilt der Oberfläche der verschiedensten Körper einen ihnen an sich nicht eigenthiimlichen Glanz zu ertheilen und ihnen hiedurch ein schöneres Aussehen zu geben (Lackfirnisse oder Lacke), sowie auch um die verschiedensten Körper mit einem dem Einflusse von Luft und Feuchtigkeit widerstehenden Ueberzuge $\mathrm{zu}$ versehen und sohin vor diesen Einflissen zu schützen. Diesen Zwecken entsprechend wendet man zur Herstellung von Firnissen fast ausschliesslich Harze oder diesen verwandte, der Einwirkung von Wasser und Luft widerstehende, Substanzen an, welche in geeigneten flichtigen Lösungsmitteln aufgelöst werden oder wenn sie an şich fliussig wären, so zubereitet werden, dass sie die Fähigkeit des Eintrocknens gewinnen.

Von Harzen oder Gummiharzen kommen am häufigsten Schellack, Copal, Dammar, Sandarak, Mastix, Fichtenharz(Colophonium), Bernstein, Asphalt, Elemi, Terpentin, Acaroidharz, seltener Benzoë, Gummi-Gutt, Drachenblut, Kautschuk u. d. g. in Verwendung. Als Lösungsmittel werden vornehmlich Weingeist, Holzgeist, methylirter Weingeist, dann Terpentinöl und Harzöl, Leinöl, Ricinusöl und Mohnöl, seltener Aether, Aceton, gewisse ätherische Oele, Benzol, Chloroform, verwendet. Man kann die Firnisse einerseits nach dem Harze, welches sie vorherrschend enthalten, eintheilen, andererseits classificirt man sie nach dem Lösungsmittel, welches in Anwendung kam. In letzterer Hinsicht unterscheidet man 1. Weingeistfirnisse (geistige Firnisse ïberhaupt). 2. Terpentinölfirnisse (Firnisse mit ätherischen Oelen). 3. Fette Firnisse (Leinöl-, Mohnölfirnisse). 4. Harzölfirnisse.

Haupterfordernisse für einen brauchbaren Firniss sind, dass die nach dem Eintrocknen hinterbleibende Schichte einen hohen Grad von Härte, dabei aber doch noch so viel Zähigkeit habe, dass sie bei Temperaturwechsel nicht rissig und klïftig wird, dass sie ferner einen schönen, haltbaren Glanz habe, sowie dass das Eintrocknen nicht allzu lange Zeit in Anspruch nimmt. Diese Eigenschaften werden theils durch die Wahl des Harzes oder der geeigneten Harzmischung, theils aber auch durch die Wahl des Lösungsmittels, sowie die Art der Herstellung bedingt. Im Allgemeinen sind die Weingeistfirnisse zwar durchwegs sehr rasch trocknend, und liefern hochglänzende Ueberziige, dagegen sind diese Ueberzüge meist nur von geringer Dauerhaftigkeit, indem sie zum rissig werden leicht geneigt sind, insoferne das gelöste Harz nach dem Verdunsten des Lösungsmittels in Gestalt einer mehr weniger spröden Schichte zurïickbleibt. Es kommt desshalb bei Herstellung derartiger Firnisse auf eine entsprechende Auswahl geeigneter Harzgemenge, bei welchen die Sprödigkeit des einen durch Zusatz eines weicheren oder zäheren gemildert wird, Alles an.

Die Terpentinölfirnisse, sowie jene, welche unter Anwendung anderer ätherischer Oele hergestellt werden, sind, was Raschheit des Trocknens anbelangt, den geistigen Firnissen sehr nahe kommend, unterscheiden sich aber von ihnen dadurch, dass sie, wegen der Fähigkeit solcher ätherischer Oele selbst zu verharzen und ein mehr weiches, erst allmälig spröder werdendes Harz zurücklassen zu können, weniger spröde Schichten liefern.

Weitaus vorzuziehen sind die fetten Firnisse zumal in Bezug auf Dauerlıaftigkeit und Widerstandsfähigkeit der Schichte, die sie nach dem Trocknen hinterlassen. Dagegen trocknen sie im Allgemeinen wesentlich langsamer als die Terpentinölfirnisse. Den fetten Firnissen an Widerstandsfähigkeit und Dauerhaftigkeit der Anstriche, die sie liefern, fast gleichkommend, dagegen aber weniger Glanz gebend, sind endlich die Harzölfirnisse, die iibrigens auch, was die Dauer des Trocknungsprocesses anbelangt, den fetten Firnissen ziemlich gleichstehen.

Im Folgenden geben wir eine Reihe bewährter Vorschriften fïr die Herstellung verschiedener Firnisse.

a) Geistige Firnisse (Weingeist, Holzgeist, Aether, Aceton, Chloroform als Lösungsmittel). Derlei Firnisse werden vorherrschend für Tischler- und Drechslerarbeiten, dann für Papier- und Buchbinderarbeiten, dann für Vergolderarbeiten und endlich fuiis Metallarbeiten verwendet. 
Firnisse für Tischler a r beiten sind:

Die Tischlerpolitur. 1 Thl. Schellack wird in 4 Thl. Weingeist von 90 Proc. gelöst. Für lichte Polituren wird eine blasse Schellacksorte gewählt. Die Auflösung erfolgt nach längerem Stehen in der Kälte, leichter beim Erwärmen auf $40-50^{\circ}$ C. Mody empfiehlt $1 \frac{1}{2}$ Thl. Schellack, 1\% Thl. Benzoë, 1/15 Thl. Drachenblut in 88 Thl. rectif. Holzgeist in der Wärme zu lösen.

Ein Firniss für Kunsttischler wird erhalten durch Auflösen von Gummilack $16 \frac{1}{2}$ Thl. in 900 Thi. Weingeist von 90 Proc. und Zusatz von 125 Thl. Kleber. Nach mehrtägigem Stehen in gelinder Wärme und oft wiederholtem Umschütteln wird filtrirt. Auch 250 Thl. Schellack oder Körnerlack und 1 Thl. Benzoë in 1000 Thl. Weingeist von 90 Proc. gelöst, liefert eine gute Tischlerpolitur. Ein guter Drechslerlack für Buchsbaumholz wird erhalten aus 20 Thl. Gummilack, 4 Thl. Elemiharz, 64 Thl. Weingeist (96 Proc.) und 3 Thl. venetian. Terpentin.

Für Papierarbeiten und Bilder:

Sandarak 6 Thl., Mastix 4 Thl. werden gestossen und zur Verhinderung des Zusammenballens bei der Auflösung 4 Thl. Glaspulver zugemischt. Das Ganze mit 32 Thl. Weingeist übergossen und bis zur vollständigen Lösung der Harze in der Wärme digerirt, schliesslich werden 3 Thl. geschmolz. venetianer Terpentin zugesetzt; oder 6 Thl. Sandarak in 24 Thl. Weingeist in gelinder Wärme gelöst und 4 Thl. Elemi zugesetzt. Nach Zinn liefern 10 Thl. Sandarak, 4 Thl. Mastix, und 1/2 Thl. Campher in 180 Thl. Weingeist von 90 Proc. aufgelöst, einen guten, in dïnnen Schichten aufgetragen, nicht abspringenden Bilderfirniss.

Für photographische Glasbilder (Negativ-Bilder) empfohlen, aber auch für Papierarbeiten verwendbar sind:

Weisser Schellack (gebleicht) 8 Thl., Sandarak 4 Thl., Canadabalsam 1 Thl., Weingeist von 90\% 120 Thl. Cooper's Firniss: 2 Thl. Benzoëharz (geschmolzen), $1 / 10$ Thl. Sandarak in 6 Thl. starkem Methylalkohol (Holzgeist) gelöst und zu dieser Lösung 40 Tropfen einer Lösung von 1 Thl. Mastix in 6 Thl. Terpentinöl zugesetzt; oder 2 Thl. Benzoë (geschmolzen) 1/10 Theil Sandarak, 2 Thl. Jalappaharz, 16 Thl. Holzgeist, 40 Tropfen Mastixfirniss. - Moczigay's Negativfirniss: 8 Thl. Sandarak, $1 \frac{1}{2}$ Thl. Terpentinöl, 11/2 Thl. Lavendelöl, $2 \%$ Thl. Eisessig, 40 Thl. absolut. Weingeist. - Lö cherer's Negativlack: 180 Thl. Weingeist, $11^{1 /}$ gebl. Schellack, $3^{3 / 4}$ Thl. Benzoë. - Spiritusfirniss von Schnauss : 20 Thl. gebl. Schellack, 1\% Thl. Sandarak, 160 Thl. Weingeist von 0.825 spec. Gew. (muss warm aufgetragen werden). Firniss für Zeichnungen: 16 Thl. gebl. Schellack, 8 Thl. Campher, 2 Thl. Canadabalsam in 130 Thl. Weingeist.

\section{Für Buchbinderarbeiten.}

1 Thl. Körnerlack in 7 Thl. Weingeist $(92 \%)$ gelöst, filtrirt und im Wasserbade auf die Hälfte eingedampft, sodann mit 1/16 Thl. Lavendelöl versetzt, liefert den braunen Buchbinderlack. Goldgelber Buchbinderlack wird erhalten aus 2 Thl. Körnerlack, 22 Thl. Mastix, 1 Thl. Gummigutt, 14 Thl. Weingeist $(90 \%)$ oder: 6 Thl. Sandarak, 4 Thl. Mastix, 1/2 Thl. Terpentin, 1/2 Thl. Gummigutt, 30 Thl. Weingeist $(90 \%)$ oder: 2 Thl. gebleichter Schellack, 1/8 Thl. Gummigutt in 12 Thl. Weingeist $(90 \%)$ gelöst, filtrirt und auf die Hälfte verdampft, oder: Colophonium (blass) 2 Thl., Mastix 1 Thl., Sandarack 1/\& Thl., Gummigutt 1/s Thl., venetianer Terpentin 1/s Thl., Weingeist $\left(90^{\circ} \%\right.$ ) 18 Thl. Ein schnell trocknender Buchbinderlack wird nach Krehan erhalten aus 5 Thl. Schellack, $2 \frac{1}{2}$ Thl. Sandarak, $2 \%$ Thl. Mastix, $2 \frac{1}{2}$ Thl. Benzoë in 32 Thl. absol. Alkohol gelöst.

Fiir Holzvergoldung:

25 Thl. Elemi, 25 Thl. Mastix, 250 Thl. Sandarak werden in einer Destillirblase mit 600 Thl. Weingeist zwei Stunden lang gekocht und nach erfolgter 
Lösung der in der Vorlauge aufgefangene Weingeist wieder zurückgegossen und mit der Lösung vermengt. (Dingl. pol. Journ. 131 pag. 238.) Für Sandarak und Mastix enthaltende Firnisse empfiehlt iibrigens Varrentrapp (Dingl. pol. Journ. 112 pag. 216) auch folgende Vorschriften: 6 Thl. Sandarak, 4Thl. Mastix, 1/2 Thl. Terpentin, 30 Thl. Weingeist, oder 12 Thl. Sandarak, 6 Thl. Mastix, $1 / 4$ Thl. venetian. Terpentin, 30 Thl. Weingeist. Einen Universalweingeistfirniss empfiehlt J. Miller (Dingl. pol. Journ. 130 pag. 358), bestehend aus 4 Thl. Sandarak, 2 Thl. Mastix, 2 Thl. Colophonium, 1 Thl. Campher, alles gepulvert, mit Glaspulver gemengt und mit 24 Thl. Alkohol von $90 \%$ in gelinder Wärme digerirt, bis Lösung der Harze erreicht ist. Durch theilweisen Ersatz von Sandarak durch gebleichten Schellack erhält man einen Firniss, der etwas härtere Anstriche liefert: z. B. 2 Thl. gebl. Schellack, 2 Thl. Sandarak, 2 Thl. Mastix, 2 Thl. Colophonium, 2 Thl. Campher, 24 Thl. Weingeist $(90 \%)$.

Für Goldleistenfirnisse speciell empfiehlt R. v. Pöppinghausen folgende Vorschriften:

1. 3 Pfd. Schellack (blond) in $2^{3} / 4$ Quart Alkohol gelöst, $1 / 2$ Pfd. Sandarak in $3 / 4$ Quart Alkohol gelöst, 1/4 Pfd. Mastix in 1/2 Quart Alkohol, 1/2 Pfd. Gummigutt in 1/g Quart Alkohol, 3 Lth. Drachenblut in 1/8 Quart Alkohol, 9 Lth. Sandelholz (hellstes) mit $3 / 4$ Quart Alkohol angesetzt, 12 Lth. venetianer Terpentin in 1/s Quart Alkohol. Jede Lösung für sich bereitet und wenn nöthig filtrirt und sodann alles zusammengegossen und gut gemischt. Der Firniss ist sehr hart und hat sehr viel Feuer.

2. $2 \frac{1}{2}$ Pfd. Schellack (blond), 1 Pfd. Sandarak, $1 / 2$ Pfd. Gummigutt, 11 Lth. hellstes Sandelholz, 8 Lth. Terpentin (venetianer), 5 Quart Alkohol.

3. $2 \frac{1}{2}$ Pfd. Schellack (blond), 1 Pfd. Sandarak, $1 / 4-1 / 2$ Loth Anilingelb, 11 Loth Sandelholz, 8 Loth venetianer Terpentin, 5 Quart Alkohol.

4. $1 / 2$ Pfd. Garancine, $21 / 2$ Pfd. Schellack, 2 Pfd. Sandarak, $1 / 2$ Loth Saffran, 5 Quart Alkohol nach mehrtägiger Digestion in gelinder Wärme zu filtriren. Ein Mattfirniss für matte, unechte Goldleisten wird erhalten aus $1 / 2$ Pfd. Schellack (blond) in 2 Quart Alkohol (absolut.) gelöst. Mit einem Theil dieser Lösung wird nach dem Filtriren etwa $1 / 2$ Pfd. geschlämmter Kreide fein abgerieben und der Brei mit der uibrigen Lösung verdünnt.

Für Metallwaren (Goldlackfirnisse).

12 Thl. Körnerlack, 4 Thl. gelb. Bernstein, 4 Thl. Gummigutt, 1/3 Thl. Sandelholz, $1 / 8$ Thl. Safran, 1/4 Thl. Drachenblut, gepulvert und mit 12 Thl. Glaspulver gemengt werden in 80 Thl. Weingeist von $90 \%$ in gelinder Wärme gelöst und filtrirt, oder es werden 2 Thl. Mastix, 1 Thl. Gummigutt und 2 Thl. Körnerlack in 14 Thl. Weingeist von $90 \%$ gelöst; oder 2 Thl. Schellack, 2 Thl. Körnerlack, 2 Thl. Orlean, 6 Thl. Gummigutt, 1 Thl. Safran in 15 Thl. Weingeist; oder 2 Thl. Gummigutt, 2 Thl. Drachenblut, 2 Thl. Körnerlack, 4 Thl. Elemi, 4 Thl. Sandarak, 1 Thl. Curcumawurzel in 45 Thl. Weingeist oder 4 Thl. Schellack, 4 Thl. Sandarak, 2 Thl. Mastix, 5 Thl. Terpentin (renetianer), 1 Thl. Colophonium, 4 Thl. Drachenblut, 4 Thl. Gummigutt in 70 Thl. Weingeist, $(90 \%)$.

Nach Morell kann man den Metallfirnissen eine besondere Haltbarkeit ertheilen und sie auf dem Metall sehr fest haftend machen, wenn man einem der Spiritusfirnisse z. B. obiger Vorschriften auf 100 Thl. 1/2 Thl. reiner krystallisirter Borsäure zusetzt und in demselben auflöst. Nach R ays e r erhält man einen sehr schönen Goldfirniss für Metallwaaren durch Auflösen von 1/2 kryst. Borsäure und reiner Pikrinsäure in einer hellen Schellacklösung. Je nach der Menge der zugesetzten Pikrinsäure kann man eine mehr oder weniger gesättigt gelbe Farbe des Firnisses erzielen.

Worlée (Dingl. pol. Journ. 184 pag. 377) empfiehlt fïr Croldlackfirnisse die Verwendung von Acaroïdharz, von dem namentlich die rothe Gattung eine 
alkoholische Lösung von schön rother Farbe liefert. Man verwendet vortheilhaft das Harz im Gemenge mit Schellack und setzt der alkoholischen Lösung, um die Sprödigkeit des Anstriches zu mildern, etwas Copaivabalsam und Lavendelöl zu.

Durch Zusatz verschiedener in Weingeist löslicher Anilinfarben zu lichten Weingeistfirnissen kann man Firnisse in allen Farben darstellen; die anzuwendende Menge der Anilinfarbe richtet sich nach der Intensität der Färbung, die man dem Firnisse ertheilen will. Solche Firnisse liefern auf blanke Metallfächen aufge strichen brillante Effecte, wenn sie völlig klare und durchsichtige Anstriche geben. Um solche zu erzielen, müssen die Firnisslösungen selbst vollkommen klar sein, was bei Schellack- sowie bei Körnerlacklösungen meist nicht der Fall ist, da ein geringer Gehalt dieser Harze an einer wachsähnlichen Substanz nach kiirzerer oder längerer Zeit eine Trïbung der alkoholischen Lösungen bedingt. Um solche Lösungen zu klären, empfiehlt Peltz (Deutsch. Industr. Ztg. 1875 pag. 175) dieselben mit $1 / 3$ ihres Volumens an Benzin zu schütteln und nach dem Abheben der Benzinschichte der nun klar erscheinenden Firnisslösung 1 bis 3 Proc. venetian. Terpentin zuzusetzen.

Die Auflösungen des Schell- oder Körnerlacks sind immer mehr oder weniger braun, wesshalb man zu solchen Firnissen, die recht hell erscheinen sollen, sich des gebleichten Schellacks bedienen muss. Hierbei trifft man häufig auf die Schwierigkeit, dass derselbe der Auflösung widersteht. Die Ursache davon liegt theils in dem Alter des Sehellacks, theils in der Art seiner Bleichung und es bleibt daher nichts uibrig, als den gebleichten Schellack, bevor man ihn ankanft, auf seine Auflöslichkeit zu prïfen.

Von sonstigen geistigen Firnissen sind zu nennen die mittels Aceton bereiteten Firnisse (vgl. Wi e d e rhold, Dentsche Industrie-Ztg. 1864 pag. 284). So liefert gepulverter und fast bis zum Beginn der Schmelzung gedörrter Copal in dem Verhältnisse von 1 Thl. zu 2\% Thl. reinen Aceton gelöst schon in der Kälte einen Firniss, der fast augenblicklich trocknet und einen Anstrich von dauerhaftem glasähnlichem Glanze liefert. Beliebig mit Aceton verdïnnt, erhält man aus einer solchen Lösung Firnisse von der verschiedensten Consistenz, die namentlich als Möbellacke und für solche Fälle verwendbar sind, wo der Firnissiiberzug nicht elastisch zu sein braucht. Sehr leicht lösen sich auch Mastix und Sandarak in Aceton und liefern schon in der Kälte sehr dicke Firnisse, die gleichfalls mit Aceton zu beliebiger Consistenz verdünnt werden können.

Auch mit Anwendung von Aether werden Firnisse bereitet. So empfehlen namentlich D. und F. Freudenberg für die Herstellung von Copalfirnissen folgende Vorschrift: \& Thl. westind. Copal, \& Thl. Schwefelather, 8 Thl. Terpentinöl, 8 Thl. Weingeist (84 Proc.) oder olne Aether \& Thl. westind. Copal, 8 Thl. Terpentinöl und 12 Thl. Weingeist (98 Proc.). Nach Karmarsch u. Heeren erhält man einen vorzïglichen Copalfirniss, wenn man 6 Thl. gepulverten westindischen Copal in eine Mischung von 6 Thl. Weingeist (98 Proc.), 4 'Thl. Terpentinöl und 1 Thl. Aether einträgt und in gelinder Wärme auflöst. Die Auflösung erfolgt sehr leicht, und der erhaltene Firniss bildet eine licht gefärbte dickfluissige Fliissigkeit, die durch Absetzen oder Filtriren vollkommen klar erhalten werden kann. Er trocknet in längstens 2-3 Stunden. Von Wichtigkeit ist aber, dass der angewandte Copal westindischer sei, da sich ostindischer Copal in diesem Lösungsmittel nicht auföst, sondern nur aufquillt. Um sicher zu gehen, ist es daher immer angezeigt, den zu verwendenden Copal vorher auf seine Löslichkeit in der oben angegebenen Mischung in einem kleinen Pröbchen zu prüfen. ${ }^{*}$ ) Auch mit Dammarharz lassen sich ätherische Firnisse herstellen, die weniger spröde Anstriche liefern als Copal.

*) Böttger (s. pol. Notizblatt 1867 pag. 209) empfiehlt Campher zur Vermittlung der Lösung des Copals in Aether-Weingeist. Er lïst 1 Thl. Campher in 12 Thl. Aether, digerirt mit dieser Lösung 4 Thl. feingepulverten Copal und setzt nach erfolgter theil-

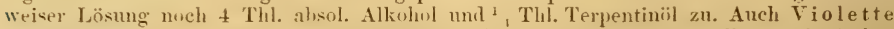

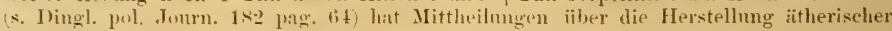
Cinglallacke gemacht. 
In einzelnen Fällen kann man auch Chloroform oder Essigätlier als Lösungsmittel fiur die Herstellung von Firnissen verwenden, doch ist die Anwendung derselben wegen des höheren Preises dieser Lösungsmittel, bei ersterem aber anch wegen der anästhetischen Wirkung, die die Einathmung der Dämpfe 'zur Folgch hat, für die Praxis nicht zu empfehlen.

b) Terpentinölfirnisse (Terpentinöl und verwandte ätherische Oele, dann niedere Kohlenwasserstoffe, als Benzin ete, endlich Schwefelkohlenstrofi als Lösungsmittel).

Terpentinöl wird namentlich zur Herstellung von Dammarfirnissen mit Vorliebe verwendet. Um solche darzustellen, muss das Dammerharz so lange mit Terpentinöl gekocht werden, bis alle Feuchtigkeit ausgetrieben ist, was man daran erkennt, dass die Masse ruhig ohne heftiges Aufwallen siedet. Man bringt zu diesem Ende 4 Thl. Harz in Stuicken mit 5 Theilen Terpentinöl in einen gusseisernen, emaillirten Kessel, und kocht so lange, bis der Firniss ruhig siedet, seiht dann durch ein Sieb, lässt absitzen und verdünnt die dickölige Flüssigkeit nach dem Erkalten mit so viel Terpentinöl, bis die gewünschte Consistenz erreicht ist. Soll der Firniss einen möglichst wenig spröden Anstrich liefern, so setzt man vor dem Kochen noch 2-3 Proc. Leinöl zu (vgl. M ü nz al, Dingl. pol. Journ. 131 pag. 141). Nach J. M üller (Dingl. pol. Journ. 128 pag. 58) soll man fuir die Herstellung eines guten Dammarfirnisses eine Sortirung des Harzes vornehmen, bei welcher alle undurchsichtigen, wachsglänzenden Stiicke ausgeschieden werden. Man bringt von dem sortirten Harz 1 Thl. im gepulverten Zustande in einen Topf aus Weissblech, rithrt dasselbe mit $1 \frac{1}{2}$ Thl. Terpentinöl zu einem dünnen Brei an, und kocht so lange, bis die Flüssigkeit klar geworden ist, hierauf nimmt man vom. Feuer und setzt noch 1 Thl. Terpentinöl unter fleissigem Umrühren zu. Da solcher Firniss ziemlich weiche, wenig widerstandsfähige Anstriche liefert, so kann man ihn dadurch härter machen, dass man $1 / 2$ Thl. reinsten Copal schmilzt und mit $1 / 4$ Thl. lichtem Leinölfirniss versetzt und dieser Masse 1 Thl. des obigen Dammarfirnisses zusetzt. Auch durch Auflösen von 10 Thl. Dammarharz in 12 Thl. Terpentinöl bei Siedhitze und Verdïnnen der erhaltenen Lösung mit 6 Thl. Weingeist (92 Proc.) erhält man einen guten Dammarfirniss, der sich namentlich zum Firnissen von Gemälden eignet. Mastix löst sich gleichfalls leicht in Terpentinöl in allen Verhältnissen und liefert einen sehr lichten Firniss. Ein mastixhaltiger Firniss mit Sandarakzusatz wird als Goldlackfirniss verwendet. Man erhält einen solchen, wenn man 4 Thl. Mastix, 4 Thl. Sandarak, beide gepulvert in einem Gemenge von 50 Thl. Terpentinöl und 6 'Thl. Spicköl siedend heiss auflöst und während des Siedens noch 1 Thl. Colophonium und 2 Thl Leberaloë zusetzt. Terpentinöl wird ïbrigens auch zur Herstellung der verschiedenen fetten Copal- und Bernsteinfirnisse als Verdiinnungsmittel verwendet (s. 11. fette Firnisse) und nach Violette (s. Dingl. pol. Journ. 183 pag. 402) löst Terpentinöl an sich sowohl Copal als auch Bernstein, wenn man dieselben vorher in einem geschlossenen Gefässe unter Druck geschmolzen hat. Von sonstigen Terpentinölfirnissen sind zu nennen die Firnisse, wclehe durch Anflösen ron Asphalt und Steinkohlentheerpech in Terpentinöl erhalten werden können (s. Asph alt I pag. 216).

Das Terpentinöl kann als Lösungsmittel für Harze zu Zwecken der Firnissbereitung sowohl durch Spicköl als auch durch Lavendelöl (beide jedoch kostspieliger), dann durch die bei der Harzdestillation resultirenden leichten Harzöle, endlich aber durch leichtes Steinkohlentheeröl ersetzt werden. Dieses letztere, welches im gereinigten Zustande wasserhell und vom spec. Gew. 0.850 ist (Benzin), ist leichter flüchtig als Terpentinöl und liefert daher rascher trocknende Firnisse, die ihren Geruch auch leichter verlieren als Terpentinölfirnisse. Da es iiberdies anch ein gutes Lösungsmittel für Kautschuck und Guttapercha ist, so wird es namentlich fiir die Herstellung ron derlei Substanzen enthaltenden Firnissen mit Tortheil verwendet. 
So erhält man einen guten Firniss für polirte Metalle, wenn man nach Ryder 32 'Thl. Guttapercha, 64 Thl. Colophonium und 1 Thl. Schellack in 544 Thl. Steinkohlentheeröl von 0.850 spec. Gewicht durch Erwärmen auf $60^{\circ} \mathrm{C}$. löst. Ein Kautschukfirniss kann nach Bolley (Dingl. pol. Journ. 156 pag. 465) erhalten werden, indem man Kautschuk mit Schwefelkohlenstoff übergiesst, und völlig aufquellen lässt. Die aufgequollene Masse behandelt man sodann mit Steinkohlentheeröl, worin sie sich gröstentheils auflöst, erwärmt die von dem Ungelösten durch Abseihen getrennte Lösung zur Verflüchtigung des Schwefelkohlenstoffs in einem Destillirkolben und verdiunnt die erhaltene Lösung bis zur gewïnschten Consistenz mit Steinkohlentheeröl. Auch ohne Anwendung von Schwefelkohlenstoff lässt sich Kautschuk auflösen, wenn man denselben in feingeschnittenem Zustande längere Zeit mit Steinkohlentheer digerirt und das Ungelöste abfiltrirt. Solcher Firniss trocknet sehr rasch und liefert an sich sehr elastische, nicht glänzende Anstriche; da er sich mit ätherischen Firnissen ebensowohl wie mit fetten in jedem Verhältnisse mischen lässt, so kann man denselben mit Vortheil als Zusatz zu solchen Firnissen verwenden, die an sich sehr spröde Anstriche liefern und diese hiedurch wesentlich verbessern.

Eine Vorschrift für einen eigenartigen Firniss hat C. Puscher (Deutsche Indust. Ztg. 1872 pag. 365) gegeben. Er empfiehlt eine Auflösung von Thonerdeseife in Terpentinöl als Firniss zu verwenden. Die Thonerdeseife kann leicht erhalten werden, wenn man eine dünne Lösung von Kernseife so lange mit einer Auflösung von Alaun oder schwefelsaurer Thonerde versetzt, als noch ein Niederschlag entsteht. Dieser wird mit siedend heissem Wasser gewaschen, getrocknet und sodann in warmen Terpentinöl gelöst. Der Firniss ist fast farblos und lässt sich namentlich, wo Biegsamkeit der Anstriche erforderlich ist, sehr gut empfehlen. Auch als Ueberzug auf Metalle, welche eine höhere Temperatur auszuhalten haben, wird er empfohlen, da der Anstrich mit demselben beim Erhitzen keine Blasen wirft.

Auch Wachs löst sich in Terpentinöl sowie in Steinkohlentheeröl und liefert einen Firniss, der namentlich zum Schutze von dem Rosten ausgesetzten Metallgegenständen sehr empfehlenswerth sein soll.

c) Fette Firnisse. Die einfachste Art fetter Firnisse bilden die trocknenden fetten Oele, wie Leinöl und Mohnöl, deren Fähigkeit an der Luft zu trocknen durch eine passende Zubereitung entsprechend erhöht worden ist. Die Mittel, deren man sich bedient. um die Trocknungsfähigkeit solcher Oele zu erhöhen, dieselben also in Firnisse umzuwandeln, sind entweder blosses Erhitzen derselben unter Luftzutritt (gekochtes Leinöl oder Mohnöl), oder Kochen mit Bleiglätte, oder Braunstein oder borsaurem Manganoxydul, oder endlich das Schitteln derselben mit bahisch essigsaurem Bleioxyd. Die gewöhnlichste Methode der Bereitung des $\mathrm{L}$ ein ölfirnisses ist folgende:

Man bringt 100 Kilo Leinöl in einen eisernen Kessel, der höchstens bis zu etwa $5 / 6$ damit angefült werden darf, erhitzt allmälig, steigert die Hitze, bis das Oel gelinde zu wallen anfängt. und erhält es in diesem Zustande zwei Stunden lang, wobei der grösste Theil der Feuchtigkeit ausgetrieben wird. Bildet sich Schaum auf der Oberfläche, so nimmt man ihn mit einer Schaumkelle ab, und thut ihn bei Seite, um ihn zu ganz ordinären Arbeiten zu verwenden. Man lässt nun die Hitze noch etwas steigen und schiittet sehr langsam und in kleinen Portionen 1.5 Kilo Bleiglätte, eben so viel Mennige und etwas türkische Umbra hinzu, welche sämmtlich scharf ausgetrocknet sein müssen, indem sie sonst das (Vel heftig aufschäumen machen und demselben eine trübe, dicke, zähe Beschaffenheit und die Eigenthïmlichkeit ertheilen würden, dass es nach dem Auftragen gewissermassen wie ein Stiick feine Blase auf der gestrichenen Fläche aufliegt und sich nach dem Trocknen leicht davon ablüst. Hat man nun diese Zusätze vollständig eingeriihrt, so hält man das Oel in steter Bewegung, damit sich Glätte und Mennige nicht zu Boden setzen. wodurch das Oel sehr leicht anbrennen und braun werden könnte. Nach dem 
Zugeben der Glätte lässt man das Oel noch etwa 3 Stunden gelinde fortkochen. Wenn es nun keinen Schaum mehr bildet, so untersucht man es ron Zeit zu Zeit mit einer Federfahne. Wenn diese sich ganz zusammenkriimmt und windet, so wird es als ein Zeichen angesehen, dass die Hitze hinlänglich hoch gestiegen ist, worauf man das Feuer möglichst rasch auslöscht, den Kessel mit dem Firniss aber wenigstens 10 bis 24 Stunden ruhig stehen lässt, damit sich die nicht gelöste Glätte und Umbra möglichst vollständig absetze.

Der so bereitete Firniss kann zwar sofort verwendet werden, aber ergewinnt sehr wesentlich an Güte, wenn er vor der Verwendung eine mehrmonatliche $A b$ lagerung erfahren hat, indem er hiebei alle beigemengten Unreinigkeiten absetzt und völlig klar erscheint, wie denn ïberhaupt längeres Lagern bei allen fetten Firnissen von ganz besonderem Vortheile ist. Die in früherer Zeit empfollenen Zusätze zu dem kochenden Leinöl, wie Brod, Zwiebeln u. s. w. sind durchaus nicht von Einfluss auf die Güte des resultirenden Firnisses und darum entbehrlich; selbst die Anwendung eines Umbrazisatzes kann ohne Nachtheil für das Product bei Seite gelassen werden. Ebenso ist es für die Erzeugung eines guten Leinölfirnisses keineswegs erforderlich, wie früher immer empfohlen, das Oel sich entzïnden und eine Zeit lang brennen zu lassen, da hiemit nur ein Verlust an Oel, aber kein Vortheil für das resultirende Product erwächst.

Auf kaltem Wege lässt sich durch Schütteln von Leinöl mit einer Lösung von basischem Bleiacetat Firniss bereiten. Löst man 1 Thl. Bleizucker in $4-5$ Thl. Wasser, erhitzt zum Sieden und trägt in die siedend heisse Flüssigkeit unter fleissigem Umrühren portionenweise 1 Thl. feinpulverige Bleiglätte ein, so erhält man nach dem Abfiltriren des Ungelösten eine Lösung von basischem Bleiacetat (Bleiessig). Verdiunnt man die erhaltene Lösung mit dem gleichen Gewichte Wasser und setzt sie zu $20 \mathrm{Thl}$. Leinöl zu, das man vorher mit 1 Thl. Bleiglätte abgerieben hat, und schïttelt nun das Ganze wiederholt heftig durch, so erhält man nach mehrstïndiger Einwirkung des Bleiessigs auf das Leinöl, die man durch öfter wiederholtes tiichtiges Schuitteln begïnstigt, eine Flüssigkeit, die sich nach längerer Ruhe in zwei Schichten trennt, von welchen die obere der Firniss, die untere eine Bleizuckerlösung ist, die man neuerdings zur Herstellung von Bleiessig verwenden kann. Der so dargestellte Firniss, welcher durch längeres Lagern oder durch Filtration geklärt werden kann, ist, da er ohne Anwendung höherer Temperaturen hergestellt ist, von lichter Farbe und trocknet innerhalb 24 Stunden vollständig. Er enthält $4-5$ Proc. an Bleioxyd.

Nach Winkler (Dingl. pol. Journ. 151 pag. 77) erhält man einen fast farblosen Leinölfirniss durch Kochen von 32 Thl. gutem alten Leinöl, mit 1 Thl. Bleispänen und 1 Thl. Spänen von engl. Zinn in einem Kupferkessel, unter Zu atz ron einem Stïck Blackfischbein, welches sich nach kurzem Kochen in dem Oele auflösen soll. Die noch heisse Masse wird sodann mit 2 Thl. feingepulverten, entwässerten Zinkvitriol vermischt, noch eine halbe Stunde gekocht, nach dem Erkalten filtrirt und in Flaschen, deren Boden mit einer Schichte von Bleispännen bedeckt ist, durch 4-6 Wochen aufbewahrt, nach welcher Zeit der fertige Firniss abgegossen werden kann.*)

Da die mit Blei oder Bleisalzen bereiteten Firnisse ob ihres Bleigehaltes schädlich wirken können und überdies die mit denselben hergestellten Anstriche zum Gelbwerden besonders geneigt sind, hat man vielfach andere Mittel zur Herstellung von Leinölfirnissen angewendet. Solche Mittel sind namentlich die Behandlung des Leinöls mit den Oxyden des Mangans oder mit borsaurem Manganoxydul. So erhält man nach Binks Leinölfirniss, wenn man Leinöl in einer mit Blei ausgekleideten Tonne mittels Dampf auf $40-66^{\prime \prime} \mathrm{C}$. erhitzt, anf je $240-250$ Thl. desselben 1 Thl. Manganoxydulhydrat zusetzt und in das auf circa $40^{\circ} \mathrm{C}$.

*) Walton (pol. Centralblatt 1860 pag. 1616) lässt auf mit 5-10 Proc. Bleizucker vermischtes Leinöl, das er durch ein feines Sieb in feine Strahlen vertheilt, heisse Lutt einwirken, wodurch die Firnissbildung wesentlich beschlemigt werden kann.

Karmarsch \& Heeren, Technisches Wörterbuch. Bd. III.

32 
erwärmt erhaltene Oel durch einige Stunden einen Strom von Luft einbläst. Unter Abscheidung von Manganoxyd erhält man schon nach 5-6 Stunden einen guten Firniss, der indess auch ohne das Einblasen von Luft sich schon nach $2-3$ Tagen brauchbar erweist. Man kann auch directe schwefelsaures Manganoxydul und Kalkhydrat oder Bleioxyd dem Oele zusetzen, wobei sich durch Wechselzersetzung Manganoxydulhydrat bildet, während der nebenbei gebildete Gyps oder das schwefelsaure Bleioxyd sich aus dem Firniss ablagert (vergl. Dingl. pol. Journ. 159 pag. 465).

Um mit borsaurem Manganoxydul Leinölfirniss zu bereiten, setzt man auf 1000 Thl. Leinöl 11/2 Thl. borsaures Manganoxydul, das man mit einem Theil des Oeles zu einem zarten Brei angerieben hat, zu und erhitzt durch eine Viertelstunde nicht ganz bis zum Sieden. Das borsaure Manganoxydul kann man einfach in der Weise herstellen, dass man Braunstein so lange mit conc. Salzsäure erwärmt, bis keine Chlorentwicklung mehr bemerkbar ist. Die erhaltene Lösung von Manganchlorür wird von dem ungelösten Antheil abgegossen, mit Wasserverdünnt und nun vorsichtig so lange eine Lösung von kohlensaurem Natron zugesetzt, als noch ein rostrother Niederschlag (von sich ausscheidendem Eisenoxyd. hydrat) sich bildet. Nach dem Abfiltriren dieses Niederschlags wird das Filtrat so lange mit einer Lösung von Borax versetzt, als noch ein weisser Niederschlag fällt. Dieser wird absetzen lassen, mit Wasser wiederholt gewaschen, endlich auf einem Filter gesammelt und getrocknet (vgl. B arruel u. Jean. Dingl. pol. Journ. 128 pag. 374 und Schubert Dingl. pol. Journ. 132 pag. 76).

$\mathrm{H}$ off $\mathrm{m}$ an $\mathrm{n}$ (Dingl. pol. Jour. $145 \mathrm{pag} 450$ ) reibt ein Loth weisses (in der Kälte gefälltes) borsaures Manganoxydul mit etwas Leinöl zu einem gleichmässigen Brei an, setzt 2 Mass altes Leinöl zu und erhitzt in einem Kupfer- oder Zinn-Kessel zwei bis drei Tage lang nicht iiber $100^{\circ} \mathrm{C}$. Auch kann man ein Theil borsaures Manganoxydul mit 3 Theilen Leinöl zu einem Brei anrühren und diesen zu 260 Thl, siedend heissem Leinöl zusetzen, einmal aufkochen lassen und nach dem Erkalten in einem geeigneten Gefässe durch 14 Tage lagern lassen, während welcher Zeit völlige Klärung erfolgt (vgl. Dingl. pol. Journ. 174 pag. 165).

Das borsaure Manganoxydul beschleunigt iibrigens, auch wenn es in der Kälte dem Leinöl zugesetzt wird, dessen Trocknung, und namentlich werden Leinölfirnisse sehr schnell trocknend gemacht, wenn man ihnen etwas borsaures Manganoxydul beimischt. So hat de la Rue empfohlen, der Buchdruckerschwärze, um sie rascher trocknen zu machen, einen Zusatz von 1 Proc. bors. Manganoxydul zu geben, und die Mischung etwa 4 Wochen lang lagern zu lassen, ehe man sie in Gebrauch zieht. Auch kann man vor der Fertigstellung der Schwärze dem zu ihrer Bereitung $z u$ verwendenden Firniss, nachdem man ihn auf etwa $350^{\circ} \mathrm{C}$. erhitzt hat, etwa 2 Proc. bors. Manganoxydul beimischen. (Dingl. pol. Journ. 141 pag. 317). Eine Mischung von Zinkweiss (95 Thi.) mit borsaurem Manganoxydul (5 Thl.) kommt als Siccatif zumatique in den Handel, von dem $2 \frac{1}{2}$ Proc. zu Leinölfirnissfarben zugesetzt dieselben rascher trocknen macht (s. Dingl. pol. Journ. 141 pag. 398).

Uebrigens soll nach einzelnen Beobachtungen das borsaure Manganoxydul nichts voraus haben vor der Anwendung von Manganoxyd oder Manganoxydhydrat, von welchen schon 1/s Proc., bei gelindem Erwärmen dem Leinöl beigemengt, einen sehr guten Firniss liefern soll (Dingl. pol. Journ. 142 pag. 452). Auch nach H e u man n (Dingl. pol. Journ. 149 pag. 200) stellt man einen sehr rasch trocknenden Firniss dar, wenn man ein Mass Leinöl mit 1/ع Loth Manganoxydhydrat bis zum schwachen Rauchen erwärmt und etwa $1 / 2$ Stunde lang bei dieser Temperatur erhält.

Ausser solchen Mitteln zur Darstellung ron Leinölfirnissen sind noch andere Verfahrungsarten angegeben und mehr oder weniger empfohlen worden. So kann man durch blosses Einkochen ron Leinöl unter Luftzutritt einen Firniss erzeugen, der, wenn auch langsam, so doch gut trocknet. Auch durch langes Lagernlassen 
von Leinöl unter Luftzutritt erhält man ein dickes, firnissähnliches, trocknendes Oel (Standöl). Für Zwecke, wo eine dunkle Farbe des Firnisses erwünscht ist, z. B. für den bei der Lederlackirerei verwendeten Blaulack empfiehlt Wiederhold (Dingl. pol. Journ. 168 pag. 457 und 169 pag. 147) das Kochen des Leinöls mit Berlinerblau, wobei ein tief dunkelbrauner dickflissiger Firniss erhalten wird. Uebrigens spricht die Erfahrung dafür, dass Leinöl durch blosse Einwirkung von Luft allein nur sehr allmälig in einen brauchbaren Firniss umgewandelt wird, selbst dann nicht wesentlich rascher, wenn gleichzeitig höhere Temperatur darauf einwirkt, und es scheint durch die Beobachtungen von $\mathrm{Clo} \ddot{\mathrm{z}}$ (pol. Centrallbl. 1866 pag. 118) erwiesen, dass die Umwandlung des Oeles in Firniss durch die Gegenwart einer gewissen Menge eines bereits entstandenen Oxydationsproductes wesentlich begünstiget werde. Die Bildung eines solchen Oxydationsproductes scheint aber wesentlich durch die Einwirkıng von Licht beschleunigt zu werden.

Mehrfach hat man sich bemiiht die Ueberführung von Oel in Firniss dadurch zu bewerkstelligen, dass man das Oel mit Luft unter Verhältnissen zusammenbringt, welche die Einwirkang der Luft möglichst günstig sich gestalten lassen. So wurde empfohlen das Oel in feinen Strahlen wiederholt durch Kammern durchfliessen zu lassen, welche fortwährend von einem Strome erwärmter Luft durchzogen werden. Dasselbe bezweckt auch Walton (Bericht d. d. chem. Gesellschaft 1874 pag. 1374) mit seinem patentirten Verfahren, wornach das in offenen Pfannen zum Kochen erhitzte Leinöl in von einem constanten Luftstrome durchzogene Kammern gehoben wird, in welchen es mittels Schaufelrädern zerstäubt wird, um so in möglichst fein vertheiltem Zustande der Einwirkung der Luft ausgesetzt $\mathrm{zu}$ werden.

Da beim Kochen des Leinöls in der gewöhnlichen Weise, also über freiem Feuer, eine theilweise Ueberhitzung des Oeles nur schwer vermieden werden kann, der zu Folge es sich mehr oder weniger bräunt, hat man vorgeschlagen das Kochen des Leinöls mittels Dampf vorzunehmen, von welchem Verfahren C. W. Vincent in London schon seit Jahren mit grossem Vortheile Anwendung macht. Sein Apparat (vgl. Dingl pol. Journ. 201 pag. 65) besteht aus einem halbkugelförmigen Kessel von Kupfer, der aussen mit einem Dampfmantel umgeben ist. Kessel und Mantel müssen einen Druck von $3 \%$ Atm. aushalten können. Der Kessel trägt einen aufgenieteten Dom mit einem Mannloch und einem Abzugsrohr für die Dämpfe. Ein mittels einer Stopfbüchse durch den Dom eingeführtes doppeltes Ruihrwerk und ein Rohr, durch welches Luft in den Kessel eingetrieben werden kann, vervollständigen die Einrichtung. Bei der Arbeit wird das Leinöl (etwa 40 Cent. pro Operation) in den Kessel gebracht, dann durch Einlassen ron Dampf in den Zwischenraum zwischen Mantel und Kesselwand mit dem Erhitzen begonnen und das Rührwerk in Bewegung gesetzt. Wenn der Dampfdruck im Kessel $35 \mathrm{Pfd}$. erreicht hat, wird Luft eingeführt. Nach etwa vierstiindiger Arbeit ist die Umwandlung in Firniss erfolgt. Das so erhaltene Product ist, wenn ohne Zusatz von Troekenmitteln bereitet, sehr lichtfärbig.

Leinölfirnisse, namentlich solche von dickerer Consistenz, werden nicht selten mit Terpentinöl verdünnt. Nach V arrentrapp (Dingl. pol. Journ. 108 pag. 74) erhält man auch einen Firniss durch Auflösen von Leinölbleiseife in Terpentinöl. Zur Herstellung dieses, namentlich in der Tapetenfabrikation zum Aufkleben des Goldes oder der Scheerwolle (für Sammttapeten) verwendeten Firnisses erhitzt man Leinöl zwei bis drei Stunden auf $200^{\circ} \mathrm{C}$., verseift es sodann durch Kochen mit einem möglichst geringen Ueberschusse von Kali oder Natronlauge, rerdünnt den erhaltenen Seifenleim mit Wasser und setzt so lange Bleiessig zu der Seifenlösung, als noch ein Niederschlag entsteht. Dieser wird ron der Flissigkeit getrennt, durch Auskneten in Wasser gewaschen und nach dem Abpressen des Wassers in 'Terpentinöl gelöst, so dass eine Fliissigkeit ron dieker Firnissconsistenz erhalten wird. 
Neben den einfachen Leinölfirnissen und denen aus Molınöl, das ganz so wie das Leinöl auf Firnisse verarbeitet werden kann und im Allgemeinen feinere Firnisse liefert, sind von fetten Firnissen namentlich die Copal- und BernsteinFirnisse von hervorragender Bedeutung.

Im Allgemeinen werden diese durch Auflösen von vorher geschmolzenem Copal oder Bernstein in kochendem Leinöl oder Mohnöl bereitet.

Für Copalfirniss, zu dessen Herstellung sich ostindischer Copal besser eignet als westindischer, da er beim Schmelzen sich weniger färbt, gibt $\mathrm{He}$ eren folgende Vorschrift:

Man bedarf hierzu zweier Kessel von angemessener Grösse, deren einer zum Kochen des Leinöles, der andere zum Schmelzen des Copals dient. Man bringt zuerst den Oelkessel mit z. B. $40 \mathrm{~K}$. Leinöl auf seinen Ofen und macht Feuer darunter an. Während sich das Oel allmälig erwärmt, wägt man den erforderlichen Copal in gleichen Portionen zu je $4 \mathrm{~K}$. ab, gibt dann eine davon in den Copaltopf und macht Feuer darunter an. In Zeit von 3 Minuten, wenn anders das Feuer lebhaft brennt, fängt der Copal zu schmelzen und zu rauchen an. Man rührt ihn nun beständig um und sucht die Stiicke so viel wie möglich zu zerkleinern. Zum Sschmelzen von $4 \mathrm{~K}$. Copal sind durchschnittlich etwa 15 bis 20 Minuten erforderlich, wo er dann wie klares Oel fliesst; doch richtet sich die Zeit sehr nach der Lebhaftigkeit des Feuers und der Geschicklichkeit, mit welcher der Arbeiter den ganzen Process zu leiten versteht. Während der ersten 12 Minuten, nachdem der Copal zu schmelzen angefangen hat, muss ein zur $\mathrm{Be}-$ aufsichtigung des Oeles angestellter Gehilfe mit dem Erwärmen desselben so weit vorgerückt sein, dass es gelinde zu kochen anfängt; denn es ist zum Gelingen des Firnisses sehr wesentlich, dass Oel und Harz beim Vermischen genau die richtige Temperatur haben. Zeigt nun das Oel durch das anfangende Aufwallen die richtige Temperatur an, so fassen beide Leute den Oelkessel an den Handhaben, heben ihn gerade in die Höhe und setzen ihn auf eine Schichte Asche. Der Arbeiter wendet sich nun sofort wieder nach dem Copaltopf, während der Gehilfe 3 Löffel roll (etwa $7-8 \mathrm{~K}$.) des gekochten Oeles in ein Giessbecken füllt und dieses, um es warm zu halten, auf dem Ofen neben dem Copaltopf aufstellt. Wenn nun der Copal so weit geschmolzen ist, dass die vollständige Schmelzung in wenigen Minuten bevorsteht, so gibt er dem Gehilfen ein Zeichen, der alsdann das Giessbecken mit beiden Händen, die eine unter dem Boden, die andere an dem Handgriffe, ergreift, den Ausguss über den Rand des Copaltopfes legt und wartet, bis der andere durch den Ruf ${ }_{n} O e l$ !" ihm einzugiessen befiehlt. Die 7-8 K. Oel des Giessbeckens werden nun unter stetem Umrühren zu dem geschmolzenen Copal gegeben, der Topf aber noch auf dem Fener gelassen, bis die Mischung ganz vollständig erfolgt ist, und ein Tropfen, auf eine Glasplatte gebracht, ganz klar erscheint. Ist dieser Punkt erreicht, so hebt man den Topf vom Feuer und stellt ihn vorläufig auf eine gemauerte Bühne, während der Gehilfe wieder 3 Löffel roll Oel $(7-8$ K.) aus dem Oelkessel in das Giesbecken und eben so riel zu einer dritten Copalschmelzung in ein zweites Becken füllt, so dass nach dem dreimaligen Ausfüllen von je $7-8 \mathrm{~K}$. in dem Oelkessel ron den anfänglichen $40 \mathrm{~K}$. nur noch $17-18 \mathrm{~K}$. zurückbleiben. Der Arbeiter ergreift nun den Copaltopf mit der Mischung der $4 \mathrm{~K}$. Copal und der ersten $7-8 \mathrm{~K}$. Oel, legt den Rand desselben iiber den des Oelkessels, und lässt den Inhalt zu jenen 17-18 K. Oel hinzufliessen; um den Inhalt völlig ausfliessen zu lassen, wendet er ihn zuletzt völlig um und hält ihn so etwa 1 Minute lang. Während dieser Operation muss der Gehilfe mit einem starken hölzernen Deckel in Bereitschaft stehen, um, falls das Oel während des Eingiessens des Copals Feuer fangen sollte, den Kessel sofort zu bedecken. Wenn nur der Copaltopf im Innern zu brennen anfängi, so hat dies weniger $z u$ bedeuten, weil die Flamme von selber wieder verlöscht, wenn man den Topf fortwährend in der umgekehrten Stellung erhält. Brennt aber das Oel im Kessel, so kann dies nur durch festes Auflegen des Deckels ausgelöscht werden. 
Gleich nachdem der Copaltopf entleert ist, gibt der Arbeiter $2 \frac{1}{2}$ K. Terpentinöl hinzu, wäscht mittelst eines Läppchens die Wände des Topfes so rein wie möglich und giesst das Oel in eine zinnerne Schale, um es später noch zu benutzen; mit einem anderen Läppchen trocknet er den Topf vollständig ab, gibt wieder $4 \mathrm{~K}$. Copal hinein, um ihn wieder zum Schmelzen zu bringen, ihn dann mit 7-8 K. Oel zu mischen, die Mischung in den Oelkessel zu geben, und endlich noch zum drittenmale $4 \mathrm{~K}$. Copal auf die nämliche Art zuzubringen. Man hat nun also eine Auflösung ven $12 \mathrm{~K}$. Copal in $40 \mathrm{~K}$. Leinöl. Diese wird in dem Oelkessel wieder zum Feuer gebracht und so stark erhitzt, dass sich die Oberfläche mit einem Schaume bedeckt, der plötzlich zu steigen beginnt. Ist dieser bis zu den Nieten der Handgriffe gestiegen, so wird der Kessel rasch vom Ofen abgehoben und auf die Asche gestellt, und nun die benöthigte Bleiglätte, falls solche angewandt werden soll, langsam und in kleinen Portionen eingeruhrt. Ist der Schaum gesunken, so bringt man den Kessel wieder auf das Feuer, setzt die noch vorhandene Bleiglätte allmälig hinzu, und hebt jedesmal, wenn der Schaum bis an den Rand zu steigen droht, den Kessel vom Feuer. Im Allgemeinen kann man annehmen, dass, wenn das Feuer im guten Gange ist, die zum Kochen nöthige Zeit, von dem dritten und letzten Copalzusatz an gerechnet, etwa $3 \frac{1}{2}$ bis 4 Stunden beträgt. Indessen darf sich zumal ein Anfänger keineswegs nach der Zeit richten, da diese nach dem Wetter, der Beschaffenheit des Oeles, des Copales und der Glätte, sowie nach der grösseren oder geringeren Lebhaftigkeit des Feuers sich richten muss. Wenn daher das Kochen etwa 3 Stunden fortgesetzt ist, nimmt man eine Probe und lässt sie auf eine Glasplatte tropfen. Zeigt diese beim Erkalten eine ziemlich feste und fadenziehende Consistenz, so ist die Kochung beendigt, der Kessel wird nun vom Feuer genommen und der Inhalt so lange gerührt, bis er hinlänglich abgekühlt ist, um den letzten Zusatz, nämlich das Terpentinöl, zu erhalten. Die zu diesem Abkühlen nöthige Zeit richtet sich gleichfalls nach Umständen; im Winter reicht eine halbe Stunde hin, im Sommer oft kaum eine ganze.

Der Zusatz des Terpentinöls muss unter stetem Umrïhren gegeben werden; die Menge hängt wieder von Umständen ab. War der Copal sehr gut, und ist die Schmelzung vollständig und richtig von Statten gegangen, so verträgt der Firniss wohl $75 \mathrm{~K}$. Terpentinöl; im entgegengesetzten Fall muss der Zusatz auf $60 \mathrm{~K}$., ja selbst noch weniger beschränkt werden. Es müssen daher von Zeit zu Zeit Proben gemacht werden, die darin bestehen, dass man eine flache Schale nimmt, und eine Portion Firniss hineingiesst. Wenn dieser erkaltet ist, so erkennt man leicht an seiner Consistenz, ob er eines ferneren Zusatzes von Terpentinöl bedarf oder nicht.

Die Mischung von Firniss und Terpentinöl kann begreiflicherweise nicht in dem Siedekessel geschehen, indem dieser nicht geräumig genug dazu ist; sondern es muss ein besonderer Kessel dazu vorhanden sein, in welchen man zuerst den Firniss füllt und dann das Terpentinöl hinzugibt.

Schliesslich wird der Siedekessel zuerst mit dem Terpentinöl, welches zum Ausspülen des Copaltopfes diente, sorgfältig ausgewischt, hierauf mit einem wollenen, in Bimssteinpulver getauchten Lappen blank gescheuert. Auf dieselbe Art werden alle ïbrigen gebrauchten Apparate und Werkzeuge geputzt, dann noch mit reinem Terpentinöl nachgespült und endlich mit reinen Läppchen vollständig getrocknet.

Das hier beschriebene Verfahren kann, mit Ausnahme der durch Abweichungen in dem quantitativen Verhältnisse der Materialien bedingten Modificationen, bei der Anfertigung von Copallack stets in Ausuibung gebracht werden.

Sehr wichtig ist die Auswahl des Leinöles. Am besten ist das Oel ron gutem ausgewachsenen reifen Samen. Dieses muss, in einem Glaskölbchen betrachtet, völlig klar und glänzend, dabei von recht hellgelber Farbe sein. Es muss einen milden, süsslichen Geschmack und wenig Geruch besitzen, nach dem 
Kochen und Klären schnell und fest eintrocknen und einen nur wenig gefärbten Firniss liefern.

Weit einfacher und bequemer ist die Bereitung fetten Copalfirnisses nach dem Verfahren von Violette. Nach seinen Untersuchungen (vgl. Dingl. pol. Journ. 167 pag. 70 und 371) löst sich Copal nur dann leicht und vollständig, wenn er so lange auf einer Temperatur von $360^{\circ} \mathrm{C}$. erhalten worden ist, dass er durch Verfluchtigung von bei dieser Temperatur destillirenden Antheilen circa 25 Proc. seines Gewichtes verloren hat. Kühlt man die hiebei resultirenden Dämpfe $a b$, so erhält man ein klares, gelbes, fliichtiges Oel von 0.80 spec. Gew. (Copalöl), das die Eigenschaft hat, die weicheren Sorten von Copal zu lösen und sich gleichwohl mit allen fetten und fluichtigen Oelen zu mischen. $\mathrm{Zu}$ diesem mit einer Destillation verbundenen Schmelzen des Copals, das vor der gewöhnlichen Art der Copalschmelzerei an sich schon den Vortheil voraus hat, dass die bei dem Schmelzungsprocesse sich verflüchtigenden Destillationsproducte gewonnen und verwerthet werden können, verwendet $\mathrm{Violette} \mathrm{kupferne,} \mathrm{innen} \mathrm{stark} \mathrm{ver-}$ silberte Trommeln (in Eisengefässen schwärzt sich der Copal), welche ähnlich den Rösttrommeln für Caffee um ihre Achse drehbar sind, oder kupferne, innen versilberte Destillirblasen mit eingesetztem Riihrwerk. Ein kupfernes Verbindungsrohr, welche bei den trommelartigen Apparaten in der Achse liegt, stellt die Verbindung des Innenraums des Schmelzgefässes mit einer Kühlvorrichtung. her, die nach Art eines Liebig'schen Kühlers (s. Destillation II pag. 607-608) construirt ist und zur Verdichtung der beim Schmelzen sich entwickelnden Dämpfe dient, deren Condensationsproduct (Copalöl) in einer Vorlage aufgefangen wird. Man trägt die abgewogene Menge des zu schmelzenden Copals durch eine gut verschliessbare Füllöffnung in das Schmelzgefäss ein, das iiber einer geeigneten Heizvorrichtung erhitzt werden kann, und beginnt, während man die drehbare Trommel fleissig wendet, oder in der Blase das Rührwerk in Betrieb setzt, mit der allmäligen Erhitzung, die man langsam steigert und sorgfältig unter Vermeidung jeder die Temperatur von $360^{\circ} \mathrm{C}$. iibersteigenden Ueberhitzung regulirt. Die Erhitzung wird so lange fortgesetzt, bis sich in der Vorlage eine 25 Proc. des angewendeten Copalgewichtes betragende Menge an Destillat angesammelt hat. Zur raschen Beurtheilung des Eintritts dieses Zeitpunktes ist an der Vorlage ein Fluissigkeitsstandmesser angebracht, an dem die den einzelnen Raumtheilen entsprechenden Gewichtsmengen des Copalöls er'sichtlich gemacht sind. Während des ganzen Schmelzprocesses muss die Trommel, bez. das Rïhrwerk unausgesetzt in Bewegung erhalten werden, damit die Copalmasse iiberall gleichmässig erhitzt werde. Ist der Schmelzprocess beendet, dann lässt man durch ein besonderes Abflussrohr die geschmolzene Copalmasse abfliessen und sammelt sie in kupfernen Kesseln oder in Steintöpfen, in welchen nunmehr die Lösung des Copals in dem Firniss oder dem Oele vorgenommen wird. Als Heizmateriale sowohl bei der Arbeit des Schmelzens als auch bei dem nachherigen Lösen im kochenden Firniss verwendet man vortheilhaft Holzkohle, da diese eine gute Regulirung des Feuers gestattet. Und auf diese kommt alles an, da Ueberhitzung nicht allein beim Schmelzen, sondern auch beim nachherigen Kochen mit Firniss eine mehr weniger dunkle Färbung des Firnisses bedingt, der zu Folge derselbe an Werth verliert. Man zieht desshalb vielfach Steintöpfe für die Arbeit des Firnisskochens den Metallkesseln vor, da sie wegen des geringen dVärmeleitungsvermögens des Steinzengs weniger leicht eine Ueberhitzung eintreten lassen als Metallgefässe. Doch kann man auch in den letzteren bei sorgfältiger Arbeit einer Ueberhitzung leicht aus dem Wege gehen, und hat den Vortheil, dass man das bei Steinzeugtöpfen so häufige Zerspringen nicht zu befürchten braucht.

Eine weitere wesentliche Verbesserung hat Violette (s. Dingl. pol. Journ. 183 pag. 402) in der Darstellung von fetten Firnissen dadurch angebalint, dass er nachwies, dass sowohl Dammar als auch Copal und selbst Bernstein die Eigenschaft erlangen, sich in fetten Oelen oder in Terpentinöl zu lösen, wenn man sie in einem geschlossenen Raume unter höherem Druck geschmolzen hat. Es ist demnach möglich durch Erhitzen von Copal oder Bernstein mit Leinölfirniss oder 
Terpentinöl in einem hermetisch geschlossenen Raum diese Harze nicht allein directe zu lösen, sondern zugleich auch jeglichen Verlust an sich verflüchtigenden Antheilen zu vermeiden. Die Erhitzung muss $350-400^{\circ} \mathrm{C}$. betragen, und erheischt insoferne einige Vorsicht, als die hermetisch geschlossenen Gefässe in Folge des bedeutenden Druckes, den sie zu erleiden haben (20 Atmosph.), dem Reissen leicht ausgesetzt sind. Diese Gefahr lässt sich indess durch Wahl passender Gefässe (Kupfercylinder innen versilbert) wesentlich verringern. Einen guten, farblosen Copalfirniss bereitet man nach Lefsel (s. Dingl. pol. Journ. 155 pag. 237) auch folgendermassen. Man verwandelt ostindischen Copal in ein ziemlich feines Pulver und lässt dasselbe ausgebreitet an einem trockenen Orte durch etwa 6 Wochen der Einwirkung der Luft ausgesetzt. Von dem so vorbereiteten Copal mengt man 1 Thl. mit 1 Thl. grobem Glaspulver, bringt das Gemenge in eine Flasche, übergiesst mit 6 Thl. Terpentinöl, bringt nun die Flasche auf ein Sandbad und erhitzt, bis das Oel zum Sieden kommt, während man öfter umrührt. Sodann setzt man der Mischung 1 Thl. Leinölfirniss zu, den man zum Sieden erhitzt hat, schiittelt gut durch und seiht nun die erhaltene Lösung von dem Ungelösten ab.

Zur Herstellung fetter Bernsteinfirnisse kann man im Allgemeinen in gleicher Weise verfahren, wie dies für Copalfirnisse angegeben wurde.

Von besonderen Vorschriften für Bernsteinfirnisse wäre, zu nennen: 18 Thl. Bernstein werden mit 2 Thl. Terpentinöl übergossen und so lange über freiem Feuer erhitzt, bis der Bernstein geschmolzen ist. $\mathrm{Zu}$ der etwas abgekühlten Masse setzt man sodann 24 Thl. vorher erwärmtes Terpentinöl zu, erhitzt neuerdings zum Sieden und mengt der erhaltenen Lösung endlich 7-8 Thl. Leinölfirniss bei. Dieser Firniss ist namentlich als Möbelfirniss empfohlen. Nach einer anderen Vorschrift schmilzt man 10 Thl. Bernstein, mengt der geschmolzenen Masse 9 Thl. Leinölfirniss zu und löst die Mischung in 32 Thl. Terpentinöl in der Wärme auf. Landerer und Di m ond (vgl. Dingl. pol. Journ. 151 pag. 78 u. 133 pag. 313) empfehlen Bernstein in geschmolzenem oder rohem Zustande in Chloroform zu lösen, wobei man einen sehr rasch trocknenden Firniss erhält.

Zum Kochen von fetten Firnissen hat ferner G. Feichtinger eine zweckmässige Vorrichtung angegeben, die namentlich dafür berechnet ist, die Belästigung zu beheben, der der Arbeiter durch die beim Sieden der Firnisse entweichenden Dämpfe ausgesetzt ist, und ferner die Gefahr der Entzündung der Firnisse, die beim Arbeiten in offenen Kesseln sehr leicht eintritt, zu beseitigen (vgl. Dingl. pol. Journ. 204 pag. 71).

Was endlich die Harzölfirnisse anbelangt, so sind diese wesentlich Lösungen von Copal, beziehungsweise Bernstein, oder aber von Colophonium und sonstigen billigen Harzen, in den schweren Destillationsproducten des Fichtenharzes. Die Darstellung dieser Art von Firnissen, die sich namentlich durch besonders niedrige Preise auszeichnen, ist derzeit noch das Geheimniss einzelner Fabriken, von welchen namentlich jene der Firma L e mme \& Co. in Stolp die erste war, die diese Fabrikate in den Handel brachte.

Um den Firnissanstrichen, namentlich solchen, welche mit fetten Firnissen hergestellt werden, die Eigenschaft zu ertheilen, möglichst rasch zu trocknen, setzt man den Firnissen nicht selten Trockenmittel (S i c e a tive) zu, von deren einzelnen bereits oben (s. pag. 489) die Rede war. Ausser solchen Zusätzen, die namentlich den Zweck haben, die Oxydation des trocknungsfähigen fetten Oeles zu begünstigen, hat man aber als Siccative auch andere Substanzen angewendet. Namentlich eignen sich Lösungen von Schellack in Borax oder Salmiakgeist vorziiglich zur Beschleınigung des Trocknungsprocesses und C. P useher (Dingl. pol. Journ. 191 pag. 174) empfiehlt eine Lösung, die aus 3 Thl. blondem Schellack, 1 Thl. Salmiakgeist und 6-8 Thl. Wasser und Kochen der zunächst durch 12 Stunden kalt digerirten Masse bis zur erfolgten Lösung des Schellacks bereitet werden kann, als Ersatz einer weingeistigen Schellacklösung für die verschiedensten Zwecke. 
Jü nemann (Dingl. pol. Journ. 178 pag. 160) empfiehlt als Siccativ eine Lösung, welche durch Kochen von 4 Thl. Borax, 12 Thl. Schellack und 100 Thl. Wasser, in einem Kupferkessel, bis alles gelöst ist, bereitet werden kann. Diese Lösung, welche, je nachdem lichter oder dunkler Schellack verwendet wurde, blass gelb bis braun sein kann, liefert an sich einen rasch trocknenden Firniss. Durch Zusatz von 1 Thl. desselben anf einen Theil eines fetten Firnisses oder einer Oelfarbe und inniges Vermischen kann man die Anstriche in 15-30 Minuten zum Trocknen bringen. Selbstverständlich darf man nicht mehr von fettem Firniss oder Oelfarbe mit diesem Sicativ vermengen, als eben zum Verbrauche kommt.

Eine ganz eigenthümliche Art von Firnissen und besonders ausgezeichnet durch Dauerhaftigkeit und Schönheit der Anstriche, die sie liefern, sind die ja panes is ch en Firnisse oder Lacke. Soviel man mit Sicherheit weiss, werden diese Firnisse aus dem Safte des Lackbaumes (Urushinoki) erzeugt, der allenthalben in Japan gedeiht, aber vorherrschend in den Provinzen Oshu und Oswari einheimisch ist. Man macht im Monate September Einschnitte an verschiedenen Stellen des Stammes dieser Bäume und hängt unter dieselben Gefässe, in denen sich der Lacksaft sammelt. Die gesammelte Flüssigkeit wird sodann durch ein Tuch geseiht, um sie von beigemengten Unreinigkeiten zu trennen und kommt so unter dem Namen Kidjomi in den Handel. Er wirkt ätzend und bringt auf die Haut gebracht bösartige Geschwïre hervor. Aus diesem Lacksafte werden nun durch verschiedene Zusätze die farbigen Anstrichfirnisse hergestellt. So wird schwarzer Firniss (Rairo) hergestellt, indem man zu 40 Thl. von dem Safte 1 Thl. eines Breies zusetzt, den man durch Schleifen eines Stiicks Eisen auf einem weichen Schleifstein unter Wasserzusatz bereitet. Das Gemenge wird dann am Sonnenlichte mit Holzschäufelchen so lange gerührt, bis es schwarz geworden und auf die Hälfte verdampft ist. Durch Zusatz von 15 Proc. des Oels von Sesamum orient. (Yenoabura) zu einem solchen Gemenge von Lacksaft mit etwas weniger Schleifbrei erhält man den glänzend schwarzen Hanaurushi-Lack. Ein rother Firniss (Shuurushi) besteht aus 100 Thl. Lacksaft, 30 Thl. Yenoabura und 1/300 Thl. Gummigutt an der Sonne gut umgerührt u. d. m. (vgl. hierïber P. Kemperm a n n, Industrieblatt v. Hager $u$. Jakobsen, Berlin 1874). *)

Ein eigenartiges Firnissmateriale ist auch das $\mathrm{Nienfett,} \mathrm{eine} \mathrm{fettälınliche}$ Ausscheidung eines in Amerika einheimischen Insectes (vielleicht von Coccus Axin), welches eine gelbbraune fettige Masse bildet, die an der Luft verharzt und sich in Terpentinöl, Benzin, Aether und Chloroform auflöst. Nach O. Buchner (s. D. Industr.-Ztg. 1870 pag. 479) wird die Lösung des Nienfetts in Terpentinöl von den Eingeborenen in Yucatan zur Herstellnng glänzender Firnissüberzüge, die sehr hart aber zugleich elastisch sind verwendet, (vgl. a. Chem. Centbl. 1870 p.679.)

Ueber Firnisse vgl. übg. auch $\mathrm{Creuzburg}$, Lehrb. d. Lackirkunst, Weimar 1865. Musspratt-Stohmann, Handbuch d. techn. Chem.-Gintl, Ausstellungsbericht über Appreturmittel u. Harzproducte, Wien 1873. - L. E. A n d é s, Jahrb. über Neuerungen etc. auf dem Gebiete der Lack- u. Firnissfabrikation. Leipzig 1877. Gtl.

Firnisspapier. Ein als Ersatz für Wachstafft verwendetes, mit Firniss getränktes Papier. Ueber Darstellung desselben, sowie der hierzu geeigneten Firnisse vgl. E. Thorey (Dingl. pol. Journ. 214 pag. 427). Gtl.

*) Es ist daher begreiflich, dass alle Versuche, die chinesischen, bez. japanesischen Lackarbeiten mit den bei uns üblichen Materialien an Firnissen und Firnissfarben nachzuahmen, wegen der Eigenartigkeit des in jenen Ländern verwendeten Materiales nicht von Erfolg sein konnten und wohl auch nicht sein werden, so lange man nicht selbst bei Anwendung desselben Materiales auch die Methode befolgt, die die japanesischen Arbeiter bei der Verwerthung ihrer Lacke anwenden. Versuche, japanesischen Lack nachzuahmen, sind vielfach gemacht worden. Eine der bekanntesten solcher Vorschriften ist wohl die der Marineartillerie der Vereinigten Staaten Nord-Amerikas, wonach 4 Thl. Bleiglätte, 6 Thl. Mennige, 1 Thl. Umbra, 8 Thl. Schellack, 2 Thl. Bleizucker und 1 Thl. Zinkvitriol unter allmäligem Zusatz von 17 Thl. gekochtem Leinöl unter fortwährendem Lmrïhren 5 Stunden lang gekocht und die Masce nach dem Abkühlen mit ¿ Thl. Terpentinöl vermfngt werden soll. 
First (fâte - ridge, top), s. Dach II pag. 463 Zeile 10.

Firstenbau, s. Bergbau I pag. 388.

Firstengewölbe, Firstenkasten, Firstenstirn, s. Bergbau I pag. 389.

Fischalbumin, Albumin aus Fischrogen, s. Albumin I pag. 80, vgl. a. L e u chs pol. Centralblatt 1861 pag. 286 und Wagn. Jahrbreht. der chem. Techn. 1861 pag. 595.

Fischangeln, A ngelhaken (hameçons, haims - fish-tooks). In Bezug auf die Beniitzung der Fischangeln zum Fischfange sei verwiesen auf: Boccius Die Fluss-, Bach- und Teichfischerei, a. d. Engl. 2. Aufl., Weimar 1861; B i ermann illustr. Fischereibuch, Berlin 1865; Sturz Der Fischfang auf hoher See, Berlin 1862. Betreffs des Fabrikation und Form der Fischangeln s. Prechtl's Techn. Encyclop. Bd. I pag. 277-282 und The Engineer Bd. 8 pag. 426.

Fischauge syn. m. Adular muschelförmiger, Wolfsauge, ceylon. Opal, Wasseropal, Girasol, vgl. Orthoklas.

Fischband, (fiche à vase - butt hinge) s. B and I pag. 287.

Fischbauchträger, s. Brü cken II pag. 89.

Fischbein (os de baleine - whale bone), d. i. Walfischbarten. Die Substanz der Walfischbarten (barbes - whale-pins) d. s. sensenförmig gestaltete hornartige Piatten, die in zwei Abtheilungen zu beiden Seiten eines Knochens, der der Länge nach unter dem Oberkiefer des Rachens der Walfische (Balaena mysticetus L, B. australis Desm.) und Finnfische (Balaenoptera borealis Less.) fortläuft und unter diesem Kiefer selbst befestigt sind. Die Länge dieser Barten hängt natürlicher Weise von der Grösse des Fisches ab, variirt aber auch sehr nach der Stelle des Rachens. Die mittleren sind im Allgemeinen die längsten und überhaupt die besten, und wohl bis zu 5 M. Länge vorgekommen, indessen gehört eine Länge von $4-4.5 \mathrm{M}$. schon zu den Seltenheiten. Die Breite beträgt in der Nähe des Anheftungspunktes etwa 3-3.5 Decim., von hier aus laufen sie in mässig bogenförmiger Krümmung in eine Spitze aus. Die Dicke ist am oberen Rande etwa $9-10^{\mathrm{mm}}$, nimmt aber gegen den unteren Rand, an welchem sich die Barte in eine Reihe loser Haare oder Fransen auflöst, sehr bedeutend ab. Jede der beiden Reihen zählt etwa 300 Barten, unter denen indessen nur etwa 250 brauchbar sind, so dass ein Fisch durchschnittlich 500 nutzbare Barten liefert. Die Substanz des Fischbeins (wesentlich Hornsubstanz) besteht aus einer Masse parallel neben einander liegender dicker Fasern, die seitlich durch eine ähnliche. jedoch etwas weniger feste Substanz aneinander geheftet sind, und sich ziemlich leicht von einander trennen lassen.

Dem Walfische dienen die Barten als eine Art Filtrirapparat; indem er nämlich das eingeschlürfte Wasser zwischen den Bartenreihen und dem Unterkiefer wieder herauspresst, bleiben kleine Seethiere und Fische in seinem Rachen zuriick.

Die Barten werden, nachdem sie von dem Oberkiefer abgelöst und von anhängendem Speck gereinigt und sortirt sind, in Packete von etwa 10 oder 12 Stiick gebunden und so nach Europa gebracht, wo sie in den Fischbeinreissereien, die in den meisten nordeuropäischen Hafenstädten, so wie anch in grösseren Fabriksstädten etablirt sind, in die handelsiiblichen Formen gebracht werden.

Die Verarbeitung des Fischbeins zu viereckigen oder flachen Stäben, das sog. Fischbeinreissen, wird, nachdem das Fischbein durch zweistiindiges Kochen mit Wasser erweicht worden, auf folgende Art bewerkstelligt. Man spannt die in Stücke von etwa 1-1 $1 / 2$ M. Länge zersägten Barten auf einer Art Tischlerbank mittels zweier Bretter so ein, dass sie auf der hohen Kante stehen, und spaltet nun mittelst eines eigenen bogenförmigen Messers oder Hobels, der je nach der Dicke der abzureissenden Stangen gestellt werden kann, diese davon ab. 
Nach dem Reissen werden die Stangen getrocknet, wodurch sie ihre natürliche Härte und Steifigkeit wieder erlangen, und nun auch an den Seitenflächen glatt geschabt. Die hierbei abfallenden Fischbeinspäne eignen sich als Surrogat der Rosshaare zum Ausstopfen der Betten und Möbeln.

Das Fischbein findet seiner Biegsamkeit, Elasticität, Festigkeit und seines geringen specifischen Gewichtes wegen mannigfaltige Anwendungen, besonders zu Schirmgestellen (Schirmfischbein), zu Corsets (Schneiderfischbein), zu Stöcken, Reitpeitschen, Galanteriewaaren, feinen Flechtarbeiten ete. Durch Dampf oder im Sandbad erhitzt, erlangt es einen solchen Grad von Weichheit, dass es sich wie Horn in Formen pressen lässt, und die so erhaltene Gestalt, vorausgesetzt, dass es innerhalb der Form abkiihlt, unverändert beibehält. Auf diese Art können mancherlei Luxusartikel, als: Tabakdosen, Messerschalen, Stockknöpfe u. dgl. aus Fischbein verfertigt werden.

Man polirt es gewöhnlich mit Bimssteinpulver, das mit Wasser auf einen Filz aufgetragen wird, und reibt es schliesslich noch mit zerfallenem Kalk ab.

Der relativ hohe Preis, den das Fischbein namentlich zu Zeiten, wo die herrschenden Damenmoden einen bedeutenden Consum an diesem Materiale bedingten hatte, hat Veranlassung gegeben, die Herstellung von Fis ch beinsurrogat en zu versuchen, deren einzelne noch zur Zeit, wo die Preise echten Fischbeins nicht mehr so hoch stehen, Anwendung finden. Ein solches wurde zuerst von Th. Vökler in Köln bei Meissen uuter dem Namen Wallosin in den Handel gebracht. Dasselbe wird in folgender Weise hergestellt: Gewöhnliches spanisches Rohr wird auf einer besonderen Maschine (vgl. Bayr. Kunst- u. Gewerbe-Blatt 1856 pag. 659) von seiner glatten Schale befreit, nach dem Entschälen mittels eines Blauholzabsudes und Eisenbeize schwarz gefärbt und nach dem Trocknen mit einer Lösung von Kautschuk, Guttapercha und Schwefel in Steinkohlentheeröl getränkt. Die so getränkten Stäbe werden nunmehr in einem Dampfapparate unter einem Druck von 2 Atmosph. gedämpft, wodurch die das Rohr durchtränkende Masse vollkommen gehärtet (vulcanisirt) wird, und endlich werden sie gewalzt, wodurch sie völlig dicht und in hohem Grade elastisch werden. Die Imprägnirumgsfiüssigkeit wird bereitet, indem man einerseits 1 Thl. Guttapercha in 2 Thl. Steinkohlentheeröl, dann in einem besonderen Gefässe 1 Thl. Kautschuk in 12 Thl. Steinkohlentheeröl, endlich 1 Thl. Schwefel in 12 Thl. Steinkohlentheeröl auflöst und sodann 24 Thl. der Guttaperchalösung mit je 12 Thl. der Kautschuk- und der Schwefellösung vermengt.

Nach Goodyear's Patent (Hamnov. Mitthlg. 1855 pag. 294) wird ein Fischbeinsurrogat wesentlich aus vulkanisirtem Kautschuk erhalten, indem Kautschuk mit einem Zusatz von geeigneten Vulkanisirungsmitteln durch Erhitzen auf $120-140^{\circ} \mathrm{C}$. gehäitet wirl. Er schreibt auf 1 Kilo Kautschuk eine Mischung ron $0.25 \mathrm{~K}$. Schwefel, $0.2 \mathrm{~K}$. Schellack, $0.2 \mathrm{~K}$. Magnesia und $0.25 \mathrm{~K}$. Goldschwefel (fünffach Schwefelantimon) als Vulkanisirungsmittel vor. Seit den in der neueren Zeit gemachten bedeutenden Fortschritten auf dem Gebiete der Kautschukindustrie (vgl. Ka utschuk) wird rulkanisirter Kautschuk ganz allgemein als Fischbeinsurrogat verwendet. Gtl.

Fischbein weisses, Blackfischbein s. Sepia.

Fischbein-Bearbeitung hat grosse Aelinlichkeit mit der Bearbeitung von Horn und wird hierauf verwiesen. Ueber die Verwendung des Fischbeins zur Erzeugung kïnstlicher Blumen schrieb B as se eine ,Anleitung “. Quedlinburg 1826.

Fischbeinsurrogate, Fischbein kinstliches, s. Fis chbein.

Fischguano s. Guano.

Fischhaut. Die eingetrocknete rauhe Hant einiger Haifisch-Arten, wird als Beleg ron Brustbäumen bei Webstiihlen, an Reibzeugen etc. verwendet. Vgl. Chagrin. 
Fischleim s. Ha usenblase.

Fischöl-Naphta. Ein Petroleumsurrogat, welches durch trockt-ne Destillation der Kalkseife des Thrans von einer Häringsart (Alosa menhaden) dargestellt wurde (vergl. Warren u. Storer, Ausz. in Journ. f. pract. Chem. 102 pag. 436). Gtl.

Fischsalz syn. m. Bühnensalz, s. Ka lium bei Chlorkalium, s. Natriu m bei Salz; auch Pöckelsalz zur Fischpöckelung.

Fischschuppen (écaille de poisson - scale). Die Fischschuppen finden ausser zur Herstellung der Perlessenz (s. Essence d'Orient III pag. 292) auch anderweitige technische Verwendung. Nach einem Patente von E. u. J. Huebner in Newark (Ver. Staaten) können frische. Fischschuppen von grösserer Form für die Herstellung von Schmucksachen, künstl. Blumen u. s. w. zubereitet werden, indem man sie zunächst durch 24 Stunden in Salzwasser einlegt, sodann wiederholt mit reinem Wasser auswäscht, dann einzeln mit Leinenlumpen abreibt und schwach presst. Sodann werden sie etwa 1 Stunde in Spiritus gelegt, abgerieben und wieder gepresst, bis sie trocken sind. So zubereitet haben sie ein perlmutterartiges Aussehen, sind sehr elastisch und widerstandsfälig und können leicht in den verschiedensten Nuancen gefärbt werden (vgl. pol. Centralblatt 1874 pag. 1246.) Gtl.

Fischschwanzbrenner, eine besondere Form der Leuchtgasbrenner, s. L e uchts t offe, vgl. L a m pen.

Fischthran s. Thran.

Fisetholz syn. Fustikholz u. Gelbholz.

Fixage u. Fixiren, so viel wie Befestigung und befestigen, namentlich von Farbstoffen auf der Faser, s. Beize I pag. 370, vgl. Zeugfärberei und Druckerei. dann auch das Haltbarmachen von Photographien s. Photographie.

Fixbleiche syn. Chlorbleiche s. Bleichen I pag. 622.

Fixirsalz syn. m. untersehwefligsauer. Natron, s. b. Natrium.

Fixöfen syn. Schneller-Oefen, s. b. Calciumoxyd Bereitung, II pag. 197.

Fisetin s. Fustikholz.

Fixsterne, s. Feuerwerkerei III pag. 466. Schiffes.

Flaak, Flack (platfond - flat), der unterste flache Boden eines

Flaake, ein Weidengeflecht zum Uferschutz.

Flachs. Unter Flachs versteht man die von den Gefässbüindeln der Stengel verschiedener, der Gattung Lein, Limum, angehörenden Pflanzen abgeschiedenen Bast-Fasern. - Nur wenige Arten dieser Pflanzen eignen sich jedoch geniigend zur Gewinnung einer als Spinnmaterial brauchbaren Faser und ist für den alten Continent in dieser Hinsicht von allein hervorragender Bedeutung die Art: Linum usitatissimum L., die sich in L. sativum oder Schliesslein, D reschlein (Rigaer Lein), bei welchem die reifen Samenkapseln geschlossen bleiben und in L. humile Mill. oder Springl e in oder K l a n gle in gliedert, dessen Samenkapseln bei ihrer Reife aufspringen. 
Der in manchen Gegenden gebaute, durch seine Länge ausgezeichnete $\mathrm{Königle} \mathrm{in} \mathrm{ist}$ ebenfalls eine Form des gewönlichen Leins und heisst L. us, regale.

Im mittleren und südlichen Europa, sowie im mittleren Asien wird noch L. perenne L., im südl. Europa, im westl. Frankreich und in West- und Süd-England L. angustifolium Huds. angebaut, von denen die erstere eine grobe, harte, die letztere eine etwas bessere Faser liefert.

In Nordamerika wird neben L. usitatissimum noch L. Levisii Pursh. gebaut.

In Europa zeichnet sich durch die Production eines hervorragenden, schönen Gewächses und Erzeugung der besten, feinsten Spinnfasern Belgien aus.

Der Lein gedeiht in allen Klimaten, wo Getreide angebaut werden kann, jedoch wechselt die Güte der unter sonst gleichen Umständen gewonnenen Faser nach Klima, und Lage und hält man gebirgige Gegenden und Meeresküsten mit feuchter, mässig warmer Atmosphäre als gute Vorbedingungen zur Erzeugung eines schönen Productes.

Der Lein ist eine Sommerpflanze mit dünnem 0.4 bis $1.2^{\mathrm{m}}$ hohem Stengel; der mit zarten lanzettähnlichen, wechselweise stehenden Blättern besetzt ist und in 2 bis 3 Aestchen endet, welche die

Fig. 1637. Fig. 1638.

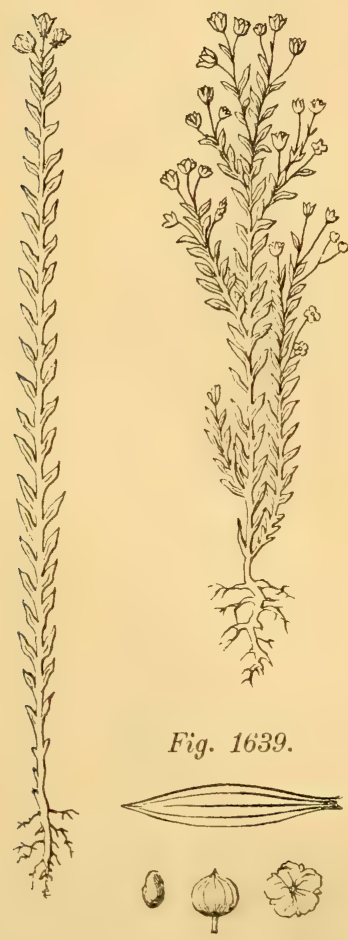
gewöhnlich blaue Bliithe tragen, aus der sich etwa erbsengrosse Samenkapseln mit 10, den länglich ovalen, platten, rothbraunen Samen enthaltenden Fächern entwickelt. - Der Kelch und die Blume ist fünfblättrig.

Der Lein hat eine Pfahlwurzel, die je nach der Art der Saat und der Ackerung, so wie der Witterung. $0 \cdot 1-0 \cdot 25 \mathrm{~m}$ lang wird. Soll der Lein besonders der Fasergewinnung wegen angebaut werden, so muss man ihn dichter säen, als wenn zur Aussaat geeigneter Samen gewonnen werden soll. Im ersten Falle zeigt dann der Stengel keine oder nur wenige Nebenäste mit geringer Anzahl Blüthen und eine längere Pfahlwurzel, im letzteren zweigt sich der Stengel verschiedentlich $\mathrm{ab}$ und enthält eine Pflanze viel mehr Blithen und eine kürzere, mehr geästete Wurzel. Die nebenstehenden Holzschnitte zeigen in Fig. 1637 den BastLein nach der Blüthe, in Fig. 1638 den Samen-Lein, in Figur 1639 in natürlicher Grösse die Blüthe, die Samenkapseln, das Samenkorn und ein Blatt des Leins.

Fester bindiger Boden und anderseits zu leichter Sand- und Torfboden eignet sich nicht zum Anbau des Leins, derselbe verlangt vielmehr einen mürben, tiefgründigen, in alter Kraft stehenden Boden und liebt auch gemischte Bodenarten.

Das Land muss ordentlich drainirt und wasserfrei sein und bis 0.4 Meter tief bearbeitet werden. Auf ein und demselben Boden darf der Lein nie öfter als alle 5 Jahre gebaut werden, doch ist es meist besser, erst nach Verlauf von 7 bis 10 Jahren wieder denselben Boden zur Flachstrzengung zu benutzen, und haben Gewohnheit und Erfahrungen eine gewisse Fruchtfolge und geeignete Diingung festgestellt.

Dic Zeit der Aussaat ist zwischen April und Juni, und spricht man desshalb von F r ühlein, Mittellein und spätlein. 
Der Frühlein wird im Allgemeinen bevorzugt, da er vor Erdfl̈̈hen mehr verschont bleibt und eine bessere, kräftigere Faser liefert, auch der Zeitpunkt der geeigneten Reife vor der des Getreides fällt, so dass man mehr Arbeitskriffte zum Abernten desselben in der Landwirthschaft bereit hat. Die schönen belgischen Flächse rühren meist von früher Aussaat her.

Je dichter gesäet wird - und man kann um so dichter säen, je tiefer geackert und je kräftiger der Boden ist - desto feiner, gerader, länger und frei von Nebenästen wird der Stengel - desto weniger Samen erhält man aber anderseits. Bei sehr dichter Anssaat und eingetretenem, länger andauernden Regenwetter kann ein Lagern der Pflanzen und Beschäidigung derselben durch Faulen eintreten, deshalb pflegt man in nanchen Gegenden, z. B. in Holland, Belgien und Frankreich - bei solcher dichter Aussaat - den Flachs dadurch zil stïtzen, dass man ihn zwingt, durch übergelegtes laubloses Reisig zu wachsen, welches auf seitlich gestützten, in geeigneten Entfernungen angebrachten Stangen ruht. Mun nennt diesen Process in Holland das "Ländern" und erhält durch denselben zarte, hohe Pflanzen, die eine feine und weiche Faser geben - in Frankreich unter lin ramé bekannt.

Der Lein muss, ehe die Samenreife eingetreten ist, abgeerntet (gerauft) werden, weil vor diesem Zeitpunkte die Faser weicher und zarter ist. - Der Samen ist alsdann wohl zur Oelgewinnung, aber nicht zur Wiederaussaat geeignet. Eine gleichzeitige Gewinnung guten Flachses und schweren, reifen Samens ist daher schon aus diesem Grunde nicht möglich.

Der geeignetste Zeitpunkt, wann der Lein geerntet, d. h. mit sammt der Wurzel aus dem Boden gezogen werden soll - welche Arbeit man das $\mathrm{R}$ a ufen der Flachsstengel nennt - hängt von der Absicht ab, in der man den Lein baute. Einige Tage nach der Bliithe geraufte Pflanzen geben einen sehr weichen, seidenähnlichen, aber nicht sehr festen Flachs; auch wird bei der Abscheidung der Fasern mehr Abfall gebildet. - Nach der Ausbildung der Samenkapseln wenn dieselben noch grün sind - geernteter Lein gibt eine festere, feine, weiche und helle Faser. Wartet man mit der Ernte, bis die Pflanzen von der Wurzel an bis zur Hälfte der Stengel gelb werden und die Leinenkörner in den Kapseln sich schwach zu färben beginnen - welchen Zeitpunkt man die "Gelbreife " nennt - so erhält man neben einem guten festen Mittelflachs zugleich auch Samenkörner zur Oelbereitung; wesshalb man in den meisten Gegenden in diesem Stadium die Einte vornimmt. Wenn man noch länger wartet, u. z. bis sich die Leinenstengel beinahe bis zur Spitze gelb gefärbt und bis die Samenkörner gleichförmig lichtbraun geworden sind - also bis zur sogen. "S a menreife" - so ist die Faser gröber und härter geworden, während der jetzt gewonnene Samen tauglich zur Wiederaussaat ist.

Dem Raufen folgt das Trocknen der Leinenstengel, das bei trockenem Wetter am einfachsten auf einer abgemähten Wiese oder einem Stoppelfelde durch reihenweise Lagerung der Stengel und öfteres Umwenden derselben erreicht wird.

Da aber starker Thau und eintretender Regen auch eine nicht beabsichtigte theilweise Röstung der Stengel hervorbringen kann, so ist das in Belgien, Westphalen und einigen anderen Orten übliche Trocknen in Kapellen, bei welchem dieser Umstand nicht leicht eintreten kann, vorzuziehen. Nach dieser Methode werden die gerauften Bïschel handrollweise mit einem dünnen Strohseile etwas zusammengebunden und dann mit den Wurzelenden nach unten in Form eines Satteldaches, bei welchem die Samenkapseln den First bilden, derart von Norden nach Süden aufgestellt, dass die schrägen Längenseiten desselben von der Sonne gleich stark beschienen werden können.

Sind die Stengel und deren Kapseln genügend getrocknet - rasseldürr geworden - so werden sie gesammelt und unter Dach gebracht, nachdem die Seitenäste, die Blätter, die Kapseln und die Wurzeln von den Stengeln entfernt worden sind, was auch manchmal sofort nach dem Raufen auf dem Felde geschieht.

Das Abstreifen der Aeste und Kapseln geschieht durch das Riffeln oder Reffeln, das mittels des Riffel- oder Reffelkammes, der R affel ausgefuihrt wird. Es besteht dies Instrument aus $8-10$ eisernen, $0 \cdot 2-0 \cdot 3^{\mathrm{m}}$ langen Zinken von der Form einer schlank zugespitzten Pyramide, welche in einem Brett oder einem Flacheisen so nebeneinander angeordnet sind, dass die Diagonalen des Querschnittes mit ihrer Aufstellungsrichtung zusammenfallen. Die Zinken haben an der Basis eine Dicke von etwa $15^{\mathrm{mm}}$ und lassen daselbst einen Zwischenraum von ca. $3^{\mathrm{mm}}$, der sich nach oben zu vergrössert. Mehrere solcher Kämme sind 
neben einander auf einer Bank - der Riffelbank - befestigt. Das Riffeln geschieht in der Weise, dass der Arbeiter eine Hand voll Stengel an den Wurzelenden fasst und festhält, während er die etwas ausgebreiteten Spitzen möglichst schonend und vorsichtig mehrmals durch den Kamm zieht. Nach Entfernung der Samenkapseln wird die Hand voll umgekehrt und mit den Wurzelenden ebenfalls einigemale durch den Kamm gezogen.

Es ergeben sich aus lufttrockenem Lein etwa $70-80 \%$ reine Stengel.

Auf das Riffeln sollte vortheilhafterweise stets das Sortiren der Leinenstengel - des Rohflachses, wie er jetzt heisst - nach ihrer Länge und Dicke erfolgen. Das erstere geschieht durch Aufstossen der Handvoll mit den Wurzelenden auf dem Sortirtische und durch Herausziehen der dann mit den Spitzen iiber die andern herausragenden Stengel. Man kann in dieser Weise bis vier verschiedene Sorten bilden, welche sich besser und vortheilhafter einzeln, als unsortirt verwenden lassen.

Der gewonnene Rohflachs (Flachsstroh) - also die lufttrockenen und abgeriffelten Leinenstengel - hat eine durchschnittliche Länge von $0 \cdot 6^{\mathrm{m}}$. Man erhält von eimer Hektare guten Ackerbodens unter giinstigen Umständen bis 5000 Kilo Rohflachs, meist aber bedeutend weniger.

Abscheidung der spinnbaren Faser, die Gewinnung des Flachses.

Um die zu diesem $\mathrm{Z}$ wecke eingeleiteten Processe besser beurtheilen zu können, möge zunächst eine nähere Betrachtung der Stengel folgen.

Die äusseren Schichten sind sehr schwach und dünn und bestehen aus der Oberhaut und der Rinde, unter welcher die Gefässbündel, der Bast - die eigent lichen Flachsfasern - liegen. Es umgeben diese Fasern einen holzigen Kern, den eigentlichen Stengel, der im Centrum von einer weichen Masse, dem Marke, erfuillt ist. Zwischen Fasern und holzigem Kern kann man noch eine Schicht unterscheiden, die sich je nach der Reife der Stengel mehr dem Faser- oder dem Holzgewebe anschliesst, die aber bei der Fasergewinnung selbst von untergeordneter Bedeutung ist. Die Bastfasern mit den dünnen obern Schichten betragen dem Gewichte nach etwa $20-30 \%$ des gut getrockneten Rohflachses.

Die Gefässbiundelchen haften durch eine Intercellularsubstanz besonders fest aneinander und an den umgebenden Geweben, und es soll der folgende Process eine Abtrennung derselben von diesen und ein Zerlegen in feinere einzelne Fasern bewirken und vorbereiten. Dies kann aber nur dadurch geschehen, dass die im Wasser unlösliche Intercellularsubstanz theilweise zersetzt wird, was man unter dem Einflusse einer Fermentation (Rotten) zu erreichen strebt.

Das Rotten oder Rösten (rouissage - retting, rating, steeping). Die älteren Methoden des Rottens sind die Thau-, Wasser-und gemischte Röste, und man hat sich erst seit den letzten 50 Jahren bemüht diese zeitraubenden und oft unsicheren Verfahrungsarten $\mathrm{zu}$ verbessern und in eigenen Röstanstalten durch andere zu ersetzen. Die Erfahrung hat jedoch gezeigt, dass die alten Methoden des Röstens allein die besten Resultate ergeben, dass sie also principiell die richtigsten sind, wesshalb sie auch jetzt noch, mit einigen Verbesserungen in Bezug auf die Art der Ausfiihrungen, fast ausschliesslich in Gebrauch sind.*)

*) Flachsiöstanstalten entstanden zunächst in Irland, dann in Deutschland und Oesterreich; und wenn sie auch keineswegs den gehegten Erwartungen entsprachen, so haben sie indirect doch den Weg erkennen lassen, auf dem allein dauernde Verbesserungen in der Gewinnung des Flachses zu erreichen sind. - Wir können hier nicht eingehend erörtern, warum derartige Unternehmungen nur selten lebensfähig sind, doch wollen wir wenigstens einige Momente hervorheben. - Es basirt eine derartige Anstalt vor Allem auf der Möglichkeit, geeigneten Rohflachs in genügender Menge preis w ürdig zu erlangen. Nun hat aberder Rohflachs in Bezug auf sein Gewicht ein sehr ledeutendes Volumen, weshalb sein Transport anf weitere Entfernungen als 30 bis 37 Kilometer ihn derart vertheuert, dass sein Bezug alsdann nicht mehr lohnend erscheint, und sind deshalb solche Anstalten auf einen ziemlich beschränkten Umkreis 
Die Röstmethoden können eingetheilt werden in

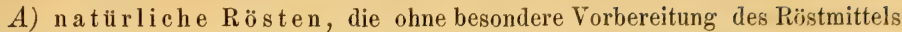
durchgeführt werden, wie: $a$ ) die Thauröste, $b$ ) die Wasserröste mit ihren Modificationen, c) gemischte Röste.

$B) \mathrm{K}$ ï nstliche Rösten. Sie sind stets Gegenstand besonderer Unternehmungen, welche den natiirlichen Zustand des Röstmittels in der Absicht verändern, den Röstprocess zu beschleunigen. H.geh.: $d$ ) die W armwasserr ijste, e) die Heisswasserröste, f) die Dampfröste,g) die Röste mit verdiinnter Schwefels äure.

Was zunächst den giinstigsten Z eitpunkt der Röste betrifft, so wurde frïher das Rösten der griinen, nicht getrockneten, abgeriffelten Stengel (Grünröste, noch jetzt in einzelnen Gegenden gebräuchlich) als empfehlenswerth angesehen, indem man annahm, dass einerseits der Röstprocess alsdann schneller verlaufe, anderseits ein besseres Product ergebe; doch hat sich das letztere als ein Irrthum erwiesen. Der getrocknete und manchmal bis zum nächsten Jahre und länger aufbewahrte Rohflachs röstet zwar etwas langsamer, gibt aber eine bessere, weichere Faser. So pflegt man in Belgien den in drei Qualitäten sortirten Rohflachs stets getrocknet und meist nur die geringsten Sorten noch in demselben Jahre, wo sie geerntet wurden, zu rösten; Flachs besserer und bester Qualität hingegen erst im Frühling des folgenden Jahres und den Process bei dem besten noch vor Beendung zu unterbrechen, um ihn erst im darauf folgenden Frihjahr zu vollenden.

a) die Thauröste (rouissage sur terre, rosage - dew-retting) ist jetzt noch sehr verbreitet und muss iiberall da angewendet werden, wo geeignetes Wasser zur Ausführung der Wasserröste nicht vorhanden ist. Sie liefert bei aufmerksamer Ueberwachung und gïnstiger Witterung einen glänzenden und weichen,

angewiesen. Hierzu kommt noch, dass die Leinpflanze nur etwa alle 7 Jahre wieder in demselben Boden gezogen werden darf, so dass nur ca. 1/7 des in dem erwähnten Bereiche vorhandenen Landes für die Cultur derselben übrig bleibt. Man kann aber nur in seltenen Fällen auf eine so concentrirte Flachszucht rechnen; - und auch da, wo sie vorhanden ist, gelingt es doch noch seltener, das sämmtliche Rohmaterial zu geeigneten Preisen für die Flachsbereitungs-Anstalt zu erwerben, weil der Landwirth, wo sich ihm nur irgend passende Gelegenheit dazu bietet, die Zubereitung des Flachses selbst übernimmt, indem er die hierauf verwendete Mühe und Arbeit nur sehr niedrig oder gar nicht in Anrechnung bringt und sich einen höheren Nutzen aus dem Verkaufe des abgeschiedenen Flachses als aus dem der rohen Stengel verspricht. Die gewerbsmässigen Flachsbereitungs-Anstalten, die eine theure Anlage zu verzinsen haben, können somit nicht in Coneurrenz mit dem mit sehr einfachen Mitteln arbeitenden Landwirthe treten, besonders da es ihmen nur ungenügend gelingt, ihre etwa feineren Producte entsprechend höher zu verwerthen, wie es die aufgewendeten Kosten verlangen. Bedenkt man ferner noch die nicht sehr selten eintretenden Missernten, wodurch der Bezug von Rohflachs manchmal für eine an einen bestimmten Ort gebundene Anstalt fast unmöglich werden kann, ferner noch den Umstand, dass der Rohflachs je nach der Art des Samens, des Bodens, der Cultur und des Reifestadiums, in dem er geerntet wurde - welche Umstände doch unmöglich den Flachsbereitungs-Anstalten genügend bekannt sein können - verschieden in der Röste behandelt werden muss, um das möglichst beste Product aus ihm zu erzielen, so lassen sich die Schwierigkeiten - welche einer fabriksmässigen Behandlung desselben entgegenstehen - ermessen und die Gründe erkennen, warum derartige Unternehmungen nur unter ganz besonders günstigen Verhältnissen und meist nur in Verbindung mit Spinnerei bestehen können. - Diese und noch andere hier nicht weiter verfolgte Punkte haben denn erkennen lassen, dass man nicht durch solehe Anstalten, sondern durch directe Belehrung der Landwirthe über beste Cultur und geeignete Verarbeitung der Pflanzen - die stets eine vortheilhafte, zum grössten Theil im Winter auszuführende Beschäftigung füir den Landwirth bleiben wird - eine Verbesserung der Flachsproduction und vermehrten Anbau der Pflanzen erreichen wird. - Die Bestrebungen in dieser Hinsicht, in Verbindung mit der Errichtung von Flachsmärkten, auf denen es dem Landwirth erst möglich ist, sein Product entsprechend zu verwerthe $\mathrm{n}$, sind denn auch bereits von Erfolg begleitet gewesen; doch können wir uns noch lange nicht messen mit dem noch unerreicht dastehenden Belgien, das Flachsbereitungs-Anstalten in dem besprochenen Sinne nicht kennt. 
meist dunkleren Flachs. Die geeignetste Zeit zur Ausführmng dieser Röste ist das Frïhjahr, und nur bei Fribflachs, der etwa im Monat Juli oder August geröstet werden könnte, kann man sie allenfalls noch in demselben Jahre in den Herbstmonaten zur Ausfuihrung bringen, - doch sollte man nur getrockneten, iiber Winter aufbewahrten Flachs in dieser Weise behandeln. In manchen Gegenden röstet man den Flachs im Herbst halbfertig und erst im folgenden Jahre ganz fertig.

Die Thauröste wird auf einer abgemähten Wiese oder einem Stoppelfelde vorgenommen, nie ąuf blosser Erde, weil sonst leicht ein Verderben der unten liegenden Stengel bei nur einigermassen nasser Witterung eintreten kann; doch darf der Erdboden nicht eisenhaltig sein, weil der mit demselben in Berïhrung kommende Lein hierdurch dunkel gefärbt wird und sich später sehr schwer bleichen lässt. Die Stengel werden in dünnen Schichten derart ausgebreitet, dass der herrschende Wind von den Wurzelenden nach den Spitzen zustreichen kann, und dann der Einwirkung von Thau, Sonnenschein und Regen mehrere Wochen unter wiederholtem Wenden der Schichten uiberlassen. Wechseln Regen und Sonnenschein häufig, so kann die Röste schon nach 14 Tagen beendet sein, während sie anderseits bei trockenem Wetter $7-8$ Wochen und länger dauert. Das Wenden des Flachses ist bei dieser Röste von grösster Wichtigkeit, um ein iuberall gleichmässiges Product zu erhalten.

Das beste Mittel zur Erprobung, wann die Röste beendet ist, besteht darin, dass man eine kleine Partie Leinenstengel an einem warmen Orte trocknet und die Abscheidung der Fasern mittels der Breche versucht. Findet dabei die Ablösung der Holzstengel leicht und vollständig statt, fühlt sich die Faser weich an, und sieht sie glänzend aus, hat sich dabei wenig Abfall gebildet, so ist die Röste gut verlaufen und vollendet. Hat sich viel Abfall gebildet, und zeigt die Faser wenig Festigkeit, so hat der Flachs bereits zu lange gelegen, er ist iberrottet. Geschieht hingegen die Abscheidung schwierig, und lässt sich die Faser kaum rein von Stengelresten erhalten, fühlt sich dieselbe hart an und zeigt eine grünliche Farbe, so ist zu wenig gerottet. Andere Methoden erfordern viel mehr Uebung, um die richtige Röstreife zı erkennen und bieten nicht die Sicherheit der vorher erwähnten. Es bestehen dieselben gewöhnlich in der Prïfung des Ablösens der Fasern, wenn man einige Stengel in der Mitte zerbricht und die eine Hälfte an der andern herunterzieht, oder in der Art des Abspringens des holzigen Kernes beim Zerreiben etlicher Stengel in der Hand und in der Beschaffenheit der zurïckbleibenden Faser.

Sind die Stengel röstreif, so müssen sie sobald wie irgend möglich und zwar dann, wenn sie gerade recht trocken sind, zu etwa armdicken Bündeln vereinigt, jedes mit einen Stengel quer umschlungen und mehrere derselben zusammengelegt zu grösseren Bunden durch Strohseile vereinigt und nach einem luftigen, trockenen Orte zur Aufbewahrung bis zur weiteren Behandlung gebracht werden. - Wenn aber anhaltend nasses Wetter eintritt, während die Stengel schon röstreif sind, so ist es am besten, dieselben im nassen Zustande zu sammeln und unter Dach und Fach zum Trocknen aufzustellen, um sie dann erst zu binden und aufzubewahren.

b) Die Wasserröste (rouissage à l'eau - water-retting, watering steeping) kann nur bei vorhandenem tauglichen Wasser und geeigneter Oertlichkeit angewendet werden; sie ist schneller und sicherer beendet als die erstere und liefert im Allgemeinen einen festern und schönern Flachs. Die Röste wird in besondern Gruben (Röstgruben) und sonstigen stehenden Wässern (Tïmpeln, Teichen), welche keinen oder nur schwachen Abfluss haben, ausgefuihrt und heisst dann Grubenröste oder Röste in stehendem Wasser (rouissage à l'eau stag. nante - pond-retting). Worden bei dem Einlegen der Stengel in Gruben ohne Wasserabfluss - die einzelnen Schichten mit Schlamm oder Rasen, dem wohl auch Erlenlaub und Klatschrosen beigemengt werden, bedeckt, so erhält man die Sch lammröste, in Belgien (Ostflandern) auch bla ue Röste genannt. Der anf letztere Art gerïstete Flachs hat eine silbergrane oft beliebte Farbe bei 
grosser Weichheit und Zartheit. Anderscits kann die Röste in Wässern mit mehr oder weniger lebhafter Wassercirculation, also in Bächen, Flüssen, wohl auch in Teichen mit schnellerem Wasserwechsel ausgefiihrt werden, und bezeichnet man dieses Verfahren mit Röste in fliessendem Wasser (rouissage ̀̀ l'eau courante - river-retting), in Belgien (Westflandern) auch weisse Rot te genannt, weil durch sie der Flachs eine hellere Farbe erhält.

Der Unterschied der beiden Methoden besteht hauptsächlich darin, dass bei der einen die Röstproducte gar nicht, oder doch nur langsam, bei der andern jedoch schneller aus dem Bereiche der röstenden Stengel linweggefülırt werden. Hierdurch wird aber im ersten Falle der Röstprocess wesentlich, allerdings unter erhöhter Gefahr des Ueberrottens, beschleunigt und der Flachs etwas dunkler gefärbt, - im andern Falle geht derselbe langsamer zu Ende und gibt dem Flachise eine hellere Farbe, aber auch etwas geringere Weichheit.

Am empfehlenswerthesten ist ein Mittelweg, ein Rösten mit langsamer Erneuerung des Röstwassers. Deshalb pflegt man auch, wenn irgend möglich, Riöstgruben so anzulegen, dass das frische Wasser von unten langsam zu- und das gebrauchte oben abfliesst.

Das Rösten in Flüssen, Bächen oder Teichen ist nicht überall gestattet und kann, in grösserem Massstabe an eine $r$ Stelle ausgeführt, durch die von dem Wasser aufgenommenen Gährungsproducte ein Aussterben der Fische und durch die Verengung des freien Flussbeetes eine Beeinträchtigung der Schifffahrt.

Als geeignetstes Röstwasser gilt ein weiches, nicht zu kaltes Wasser. Enthält dasselbe aber Eisenverbindungen gelöst, so ist es gänzlich zum Rösten unbrauchbar, weil es den Flachs dunkel färbt und derselbe sich dann nur schwer bleichen lässt. Hartes Wasser kann man im Allgemeinen dadurch zum Rösten geeigneter machen, dass man es einige Zeit vorher in dicht hergestellte Röstgruben leitet und sich selbst überlässt.

Ein Rösten in schnell fliessendem Wasser ist ganz verwerflich, da dasselbe, meist wenig erwärmt, die Röstung sehr verzögert und eine ungleiche Beenddiung des Röstprocesses bewirkt; auch verliert der Flachs wesentlich an Geschmeidigkeit und Weichheit.

Die Röstgruben werden, damit das Wasser in denselben oben und unten möglichst gleiche Temperatur hat, nicht tief, etwa $1 \cdot 2-1 \cdot 8^{\mathrm{m}}$ angelegt; sie werden entweder mit Brettern ausgelegt oder ausgemauert, wohl auch mit Thon ausgestampft, um sie wasserdicht zu machen.

Zum Rösten in Flüssen, Bächen oder Teichen wendet man Röstkästen an, etwa 3.75 bis 5 Meter lang und 1.25 bis 2.5 Meter breit und 1.25 Meter tief aus Latten, die unter einander einen Zwischenraum von 10 bis 12 Cent. lassen, hergestellt. - Werden dieselben in Flüssen oder Bächen gebraucht, so ist es empfehlenswerth, gegen die Strömung hin diese Kästen an 3 Seiten zu verschalen, um den Röstprocess möglichst wenig zu stören.

Die Gruben oder die Röstkästen werden nun in der Weise mit Rohflachs gefüllt, dass derselbe - wie er gewachsen ist - mit den Wurzelenden nach unten - bündelweise eingesetzt wird und soll er in den Gruben den Boden nicht berühren. Nach der Füllung wird manchmal eine Strohschicht iibergedeckt, dann Bretter und Stangen aufgelegt und das Ganze mit Steinen derart beschwert, dass das Wasser noch ea. $20^{\mathrm{cm}}$ über den Spitzen steht. Die Kästen werden natürlich am Ufer gefüllt, dann in's Wasser gelassen und nun erst mit Steinen beschwert, damit sie genügend untersinken.

Bei der Schlammröste wird der von dem Flusse mitgeführte fette Schlamm oder. auch in Ermanglung dessen abgestochener Rasen (Schlamm und Boden müssen aber eisenfrei sein) zwischen die einzelnen lose vereinigten Bündel und auf dem Boden der Grube nebst etwas Erlenlaub und Klatschrosen - letzteres geschieht der Farbe wegen - geschichtet, und das Ganze mit einer eben solchen Schichte Schlamm oder Rasen bedeckt. - Hebt sich im Verlaufe des Processes der Flachs, so muss er stets um so viel beschwert werden, dass er immer unter Wasser bleibt.

Die Dauer des Röstprocesses richtet sich zuerst nach den besonderen Ëigenschaften des eingelegten Flachses, sodann aber nach der Temperatur und der Beschaffenheit des Wassers. Je wärmer und je weicher das Wasser ist, um so schneller verläuft sie. Bei dem Rösten in stehendem Wasser ist der Process bei warmer Witterung bereits nach $2-4$ Tagen, bei kalter in 5-7 Tagen voll- 
endet, während er beim Rösten in fliessendem und hartem Wasser bei kalter Witterung oft 3 Wochen dauert.

Der Röstprocess besteht - wie erwähnt - in einer Fermentation und kündigt sich der Beginn derselben zunächst durch Färbung und Trübung des Wassers und Auftreten eines aromatischen Geruches an; es bilden sich Essigsäure, Pectinsäure u. s. w., und aufsteigende Blasen deuten auf die Bildung von Gasen, Kohlensäure u. s. w. Die Triibung des Wassers nimmt zu; es wird schmutzigbraun, und es tritt bei vermehrter Gasabsonderung ein starker unangenehmer Geruch auf; hierauf wird die Gasentwicklung wieder geringer und der Röstprocess ist nahezu vollendet. Der Flachs hat sich bei der stärkeren Gasentwicklung gehoben und muss auf's Neue beschwert werden, damit er unter Wasser bleibt.

In dem Stadium, wo die von der Gasentwicklung herrihirenden Blasen auf der Oberfläche zu verschwinden beginnen - was oft schon nach dem zweiten Tage eintritt - muss der Flachs fleissig untersucht werden, da jetzt die Intercellularsubstanz genïgend zersetzt und verändert ist, und ein zu langes Verweilen des Flachses im Wasser einen Fäulnissprocess hervorruft, der die Fasern selbst angreifen, ja unbrauchbar machen wiirde. Der Flachs ist dann "überrottet" oder "verrottet".

Die Untersuchung hat in dem letzten Stadium alle zwei Stunden stattzufinden, und erkennt man die Röstreife am besten wiederum durch rasches Trocknen und Abscheiden der Faser mittelst der Breche.

Doch hat man häufig hierzu nicht Zeit und Gelegenheit und begnügt sich dann durch Erprobung einiger anderen Kennzeichen, wie : a) Bildung eines Knoteus aus mehreren Stengeln, der in's Wasser geworfen ganz langsam bei Röstreife untersinken muss; $b$ ) leichtes Lösen der Fasern von den Stengeln, wenn man einige Stengel an den Wurzelenden fasst und sie mit den anderen Enden auf die Wasserfläche schlägt; c) leichtes Brechen und Knicken der Stengel; d) leïhtes Abziehen des Bastes in seiner ganzen Lünge, wenn man einen Stengel zwischen zwei angedrïckten Fingern hindurch zieht u. s. w.

Ist der Flachs genïgend geröstet, so entfernt man die aufgelegten Steine und Bretter, nimmt die Bündel heraus, schwenkt sie in reinem Wasser gut ab und stellt sie senkrecht an das Ufer des Flusses oder in Gestalt eines Kegels frei auf, um sie abtropfen zu lassen. Der Flachs ist in diesem Augenblicke so schwach, dass er das Ausbreiten auf der Wiese nicht aushalten, sondern unter den Händen zerbrechen würde, als ob er verfault wäre,

In dieser Lage bleibt der Flachs, bis er geniigend abgetrocknet ist, um das Ausbreiten auf der Wiese aushalten zu können.

c) Die gemischte Röste (rouissage à la methode mixte - mixed retting) ist eine Combination der Thau- und Wasserröste. Man legt den Flachs zuerst in's Wasser, nimmt ihn vor beendeter Röste heraus und breitet ihn auf dem Felde ans, bis er vollständig fertig geröstet ist. Hierbei geht man der Gefahr des Ueberrottens aus dem Wege und erhält einen schönen, weichen und hellen Flachs.

B) K ïnstliche Rösten. Dieselben verlaufen verhältnissmässig schnell und werden fast nur in Flachsbereitungsanstalten angewendet, weil sie zu ihrer Ausfïhrung besonderer Einrichtungen bedürfen und der Process auf das Sorgfältigste iiberwacht werden muss. Im Allgemeinen - etwa mit Ausnahme der Warmwasserriste - liefern aber diese Methoden ein weniger gutes Product, und pflegt man desshalb in den erwähnten Anstalten - wo sich irgend passende Gelegenheit hierzu bietet - stets nur die Wasserröste anzuwenden.

d) Die Warmwasseröste (rouissage à l'eau chaude - uarm-uater retting). Nach dieser Methode wird der Flachs in durch Dampf erwärmtem Wasser geröstet. Sie wurde ron $\mathrm{S} c h e n k$ aus Amerika zuerst nach England gebracht und heisst desshalb auch die S chen k'sche Methode. Bei diesem Verfahren beendet man den Process in etwa 80-90 Stunden, wenn das Wasser auf einer gleichmässigen Temperatur ron $20^{\circ} \mathrm{R}$. erhalten wird. Eine höhere Temperatur bewirkt zwar eine Abliirzung der Röstzeit, jedoch leicht auf Kosten der Qualität des Flachses. Es wird der Process in Bottichen oder in gemauerten, dichten Gruben ausgeführt. In beiden Fällen ist in etwa $15^{\mathrm{cm}}$ Entfernung vom Boden 
des Behälters ein Lattenboden eingelegt, auf welchen der Flachs mit den WurzeIenden zu stehen kommt. Unterhalb des Lattenbodens liegt in einigen Windungen ein Dampfrohr, in welchem Dampf circulirt, der scine Wärme an das Pijstwasser abgibt. Ist der Behälter gefüllt, so wird ein hölzerner Deckel aufgelegt, der durch Querbalken oder Steine niedergehalten wird, und jetzt lässt man kaltes Wasser zuströmen, bis dasselbe einige Cent. iiber dem Deckel steht. Durch Oeffnung des Dampfhahnes wird die angegebene Temperatur des Wassers erreicht und bis zur Beendigung des Processes beibehalten. Bei Eintritt der Riöstreife werden dic Stengel, ehe man sie herausholt, mit kaltem - besser jedoch mit warmem Wasser gespuilt und dann wie oben getrocknet.

In einigen Flachsbereitungsanstalten lässt man den herausgenommenen Flachs ein paar glatte Quetsehwalzen passiren, wodurch ein grosser Theil des Wassers und mit ihm zugleich noch eine Menge Schmutz entfernt wird. Durch einen wiederholten derartigen Quetschprocess, bei welchem immer frisch zufliessendes Wasser ein gründliches Abspülen bewirkt, erleichtert man die schliessliche Abscheidung der Fasern wesentlich.

e) Die $\mathrm{He}$ isswasserröste wird in selbstthätigen Apparaten ausgeführt, in welchen der Flachs wiederholt mit kochendem Wasser übergossen wird Es ist dieses Verfaliren, das in 4 Stunden beendet ist, von Buchanan angegeben worden, hat aber nicht den gehegten Erwartungen entsprochen (Dingl. pol. Journ. 133 pag. 59).

f) Die Dampfröste wurde von Watt 1852 angegeben und soll die Stengel - welche in verschlossenen eisernen Kästen der directen Einwirkung von Wasserdampf ausgesetzt sind - in 10 bis 12 Stunden vorbereiten. - Die anfänglichen günstigen Berichte über diese Methode müssen sich wohl nicht bestätigt haben, wenigstens ist dieselbe bereits wieder ziemlich in Vergessenheit gekommen.

g) Das Rösten mit verdünnter Schwefelsäure. Nach diesem von Gaultier de Claubry in Paris angegebenen Verfahren wird ein Bad, das dem Gewichte nach 1/. Proc. concentrirte Schwefelsäure enthält, hergestellt, in welchem der Rohflachs 5 bis 7 Tage lang eingeweicht wird, worauf ein sorgfältiges Spülen in reinem Wasser folgen muss, um jede Spur von Säure zu entfernen, die sonst unzweifelhaft die Faser angreifen würde. Das Fehlen jedes unangenehmen Geruches ist wohl der Hauptvorzug dieser Methode; die aber, recht vorsichtig angewendet, ganz gute Resultate ergeben kann.

Die gerösteten und getrockneten Flachsstengel (Rotte- oder Rösteflachs), bei denen also der Zusammenhang der Bastfasein unter einander und an den umliegenden Geweben gelockert ist, werden gewöhnlich in demselben Jahre - feinere Sorten auch später - verschiedenen mechanischen Arbeiten unterworfen; nämlich zunächst dem $\mathrm{Brech}$ - und $\mathrm{Schwingprocesse,} \mathrm{um} \mathrm{den} \mathrm{hol-}$ zigen Stengel zu entfernen und die Fasern-zu isoliren, hierauf dem Hechelprocesse, um letztere zu zerlegen; zu trennen, vollständig zu reinigen und zu ordnen. Diese Processe, so wie einige begleitende Arbeiten werden, je nach den Gegenden und je nachdem Hand- oder Maschinenarbeit, oder beide abwechselnd zur Anwendung kommen, verschieden ausgefiihrt.

Vor dem Brechprocesse wurde früher - und auch wohl manclımal jetzt noch - um denselben mit weniger Mühe ausführen zu können, ein künstliches Trocknen des Röstflachses in besonderen Darröfen oder gar über freiem, in Gruben angezündetem Feuer vorgenommen; doch schadet dasselbe - selbst wenn es noch so vorsichtig ausgeführt wird - stets mehr oder weniger der Faser; weshalb dieses verwerfliche Verfahren hier nicht näher beschrieben werden soll. - Andererseits aber erleichtert ein Auslegen der aus einem oftenen Schuppen kommenden Stengel in der Sonne oder in geheizten Rüumen, durch gründlichstes Austrocknen derselben, die folgenden Arbeiten nicht unwesentlich, ohne der Qualität der Faser zu schaden.

Das Brechen, Brechehn, Braken, Raken (macquer, macquage, broyer. broyage, teiller - braking, breaking) wird in vielen Gegenden ron den Landleuten fast ausschliesslich selbst besorgt. Man bedient sich dabei der Flachsbreche, Breche, auch Brake genannt (troie, macque, tillotte - brake). Dieselbe ist in umstehender Fig. 1640 in der Seitenansicht abgebildet, während Fig. 1641 die arbeitenden Theile im Querschnitt nach $A B$ wiedergibt.

Die Breche besteht aus der Lade $e$, dem Deckel oder Schlägel $f$ und dem Gestelle $a$, $c, d$. Die Lade ist aus 3 parallelen, an den oberen Enden zugeschärften, aber nicht sehnei- 
dig en Schienen von hartem Holze zusammengesetzt, die in den erwähnten Ständern horizontal befestigt sind. und erhalten diese durch einen schweren Klotz $b$ die nöthige Stabilität. Der mit Handgriff $h$ versehene Schlägel $f$ ist um den durch die Lade gesteckten Bolzen $g$ drehbar und besteht aus zwei ebenfalls stumpf zugeschärften Schienen, die so weit auseinander stehen, dass sie bei dem Auf- und Niederbewegen des Schlägels in die Zwischenräume der untern fassen.

Fig. 1640.

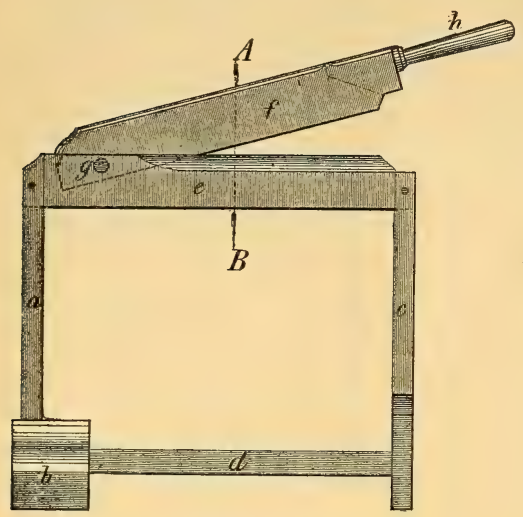

Flachs-Breche.

Fig. 1641 .

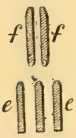

Fig. 1642.

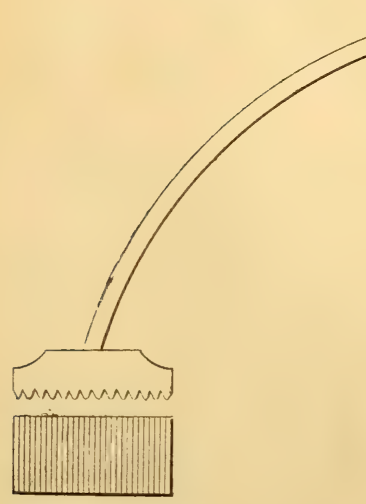

Botthammer.

Bei Ausführung des Brechprocesses wird der Schlägel $f$ an dem Handgriff $e$ erfasst und auf und nieder bewegt, während mit der anderen Hand eine Handvoll, eine Riste (poignée - strick) Stengel quer über die Lade gelegt und allmälig weiter bewegt wird, so dass dieselbe wiederholt in die Zwischenräume der Schienen gedriickt und der holzige Kern dabei zerbrochen, zerknickt und von den zäheren Flachsfasern zum grössten Theile abgelöst wird. Diese kleinen abfallenden Stengeltheilchen nennt man $\mathrm{Sch}$ äben, auch Schewen, Agen, Acheln, Annen (chènevotte - awn, chaff). Die Stengelristen werden zuerst von der Mitte nach den Wurzelenden zu bearbeitet, dann umgewendet und auf der andern Seite ebenso behandelt. Durch Ausschiitteln entfernt man schliesslich die noch hängen gebliebenen losen Schäben, muss jedoch meist zwei Brechen hinter einander anwenden, um auf der zweiten, mit enger aneinander gesetzten, manchmal aus Eisenblech hergestellten Schienen ein vollständigeres Abstreifen derselben durch mehrmaliges Durchziehen der Risten zwischen Schlägel und Lade zu erreichen. Häufig kommt der Flachs, nachdem er nur in dieser Weise behandelt worden ist, in den Handel.

In einigen Gegenden (besonders in Westfalen, Sachsen u. s. w.) pflegt man vor oder auch nach dem Brechen noch eine Hilfsarbeit - das Boken, Poken (piler - pilage) vorzunehmen, d. h. die Stengel einem Quetschoder Stampfprocesse zu unterwerfen, wodurch dieselben, wenn das Boken vor dem Brechen stattfindet, glatt gedrückt werden und sich dann auf der Handbreche die holzigen Theilchen leichter abscheiden lassen. Auch soll durch diese Vorarbeit der bei dem Brechen unvermeidliche Faserabfall - aus abgerissenen kür- 
mittels eines etwa $2^{\mathrm{k}}$ schweren Schlägels auf der Hirnfläche eines Holzklotzes, oder in besondern Bokmiihlen durch ein mechanisch bewegtes Stampfwerk auf Stein- oder Holzunterlagen. Durch diesen Process gewinnt die Faser an Weichheit, besonders aber dann, wenn derselbe $\mathrm{n}$ a $\mathrm{ch}$ vorausgegangenem Brechprocesse vorgencmmen wird. In Belgien wendet man das $\mathrm{B}$ otten oder $\mathrm{P}$ otten an und bedient sich zur Zerkleinerung der holzigen Stengel des Botthammers (Potthammers), mit welchem der Flachs gleichsam gedroschen wird.

Derselbe besteht - wie Fig. 1642 angibt - ans einen schweren Stück harten, viereckigen Holzes mit parallelen, nicht zu stumpfen Einkerbungen, welches an einem etwas gebogenen langen Stiele befestigt ist. Dieser Hammer wird in der Weise angewendet, dass der Arbeiter seinen Stand an den Spitzenden der dünn ausgebreiteten Stengel nimmt und zuerst die Wurzelenden mit der gekerbten Fläche desselben schlïgt und dann allmälig nach den Spitzenden vorrïckt. - Durch Umlegen der Stengel wird dann die andere Seite in derselben Weise bearbeitet.

Bei dieser Behandlung des Flachses soll lediglich ein vollstäidiges Knicken der Stengel stattfinden, während die Abscheidung der Schäben dem folgenden, alsdann stets nothwendigen Schwingprocesse vorbehalten bleibt. Die Faser wird hierbei sehr geschont und ihre Milde und Weichheit erhöht, und sollte man sich deshalb entschliessen, die vorerwähnte Breche bei Seite zu legen und zu diesem Verfahren iiberzugehen.

Das Schwingen (teiller, teillage, espader, espadage - swinging, suingling, swindling, scutching) (Schwingeln) soll die Abscheidung der von dem Brechen oder Botten her noch etwas fester an den Fasern haftenden Holztheilchen bewirken und wird mittelst des Schwing stockes (chevalet) und der S ch w ing e (Schwingmesser) (écang, dague, espade) ausgeführt. Der Schwingstock ist - wie die Figuren 1643 und 1644 zeigen - ein aufrecht stehendes, in der Bohle $b$ befestigtes, $5-6^{\mathrm{cm}}$ starkes und $1 \cdot 25^{\mathrm{m}}$ hohes Brett $a$, das $20^{\mathrm{cm}}$ von oben mit einem $18^{\mathrm{cm}}$ tiefen und $5-6^{\mathrm{em}}$ hohen Ausschnitte $c$ versehen ist, dessen untere Kante nach der Arbeitsseite hin abgerundet ist, wie dies bei $d$ in erwähnter

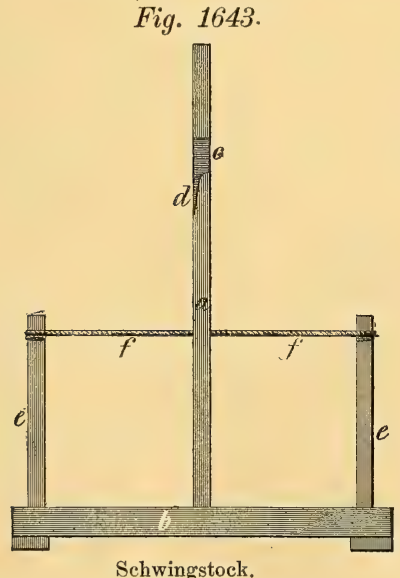

Fig. 1644.

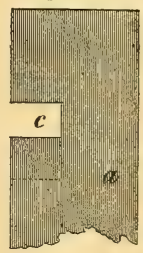

Fig. 1645.

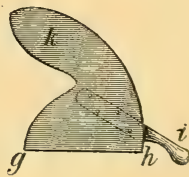

Schwingbeil.

Figur angegeben worden. Die Risten werden in den Ausschnitt $c$ gelegt und derart gehalten, dass die grössere Hälfte auf der abgerundeten Seite desselben herabhängt. Mit der andern Hand wird die Schwinge - ein schwertförmiges, $\left(0 \cdot 5-0 \cdot 6^{\mathrm{m}}\right.$ langes, etwa $10^{\mathrm{cm}}$ breites, mit einem Handgriff versehenes, an den Kanten stumpf zugeschärftes schwaches Holzstïck - gefasst und mit demselben an 
dem Schwingstock über den herabhängenden Flachs der Länge nach heruntergeschlagen.

Damit sich hierbei der Arbeiter nicht an die Beine schlägt und die Zurückführung der Schwinge erleichtert wird, ist an zwei Ständern $e e$ ein Strick $f f-$ oder auch ein Riemen - befestigt, welcher das 'Schwingmesser auffängt.

Ein anderes, besonders zweckmässig gestaltetes Schwingmesser, wie es in Belgien angewendet wird, ist in Figur 1645 abgebildet. - Das Messer besteht aus einem schwunggebenden, 35 Centim. langem Theile $k$ und dem eigentlichen, 25 Centim. langen Messer, das sich an der Kante $g h$ bis zu Messerrückenstärke verjüngt, mit dem Griffe $t$, welcher auf der Seite des Messers, die bei der Arbeit vom Schwingstock absteht, aufgeleimt und mit hölzernen Stiften befestigt ist. Ist zuerst die Wurzel- und dann die Spitzenseite einer Riste mittels dieses Instrumentes bearbeitet, dabei das Innere derselben wiederholt nach Aussen gebracht und in derselben Weise behandelt worden, so legt man, wenn durch die Entfernung der Holztheilchen die Riste so dünn geworden ist, dass sie mit der Hand nicht mehr gut gehalten werden kann, dieselbe bei Seite, bis eine zweite, ebensoweit behandelt, mit der ersten vereinigt und jetzt vollständig rein geschwungen werden kann, wobei man sich eines andern, feinern und mehr zugeschärften Messers - des Reinschwingmessers bedient.

Bei manchen Flachssorten, bei denen sich die Schäben etwas schwer abscheiden lassen, pflegt man nach dem Schwingen noch das Ribben oder auch das Risten anzuwenden, um diese fester anhängenden Holztheilchen zu entfernen.

Das Ribben wird mittels des Ribbmessers (racloir - flax-dresser'sknife), Fig. 1649, ausgeführt; einer dünnen Klinge $r$ von Eisenblech, welche in

Fig. 1646.

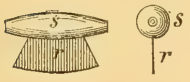

Ribbmesser. einem hölzernen Griffe $s$ gefasst ist. Der Flachs wird von dem sitzenden Arbeiter auf einem Stück Leder, das auf seinem rechten Schenkel bis zum Knie befestigt ist, ausgebreitet und mit der linken Hand gehalten, während die rechte das Messer fuihrt und das Abstreichen der letzten Schäbentheilchen bewirkt.

Bei dem Risten wird der Flachs an beiden Enden mit dẹn Händen gehalten und über eine horizontale, düinne, zugeschärfte, am besten aus Eisenblech bestehende Kante eines aufrecht stehenden Brettes (Ristebockes) hin- und hergezogen. Es ist stets empfehlenswerther die Entfernung der Schäben durch den Schwingprocess zu bewirken.

Wenn der Brech- und Schwingprocess in besondern Anstalten, auf grossen Giitern oder in Flachsspinnereien selbst ausgeführt wird, dann pflegt man sich stets mechanisch bewegter Brech- und Schwingmaschinen zu bedienen, von denen eine grosse Anzahl construirt worden ist. Kleinere Wirthschaften können oft mit Vortheil anstatt der gewöhnlichen Handbrake wenigstens eine Brechmaschine mit Handbetrieb anwenden, und schwingen dann den Flachs auf oben beschriebene Weise rein. Es kamn nun nicht in der Absicht dieses Aufsatzes liegen, die grosse Zahl der bis jetzt construirten Brechmaschinen hier ausführlich vorzuführen, und es sei deshalb auf die folgende Literatur verwiesen. *)

Die Hauptbedingungen guter Brechmaschinen sind:

Die arbeitenden Organe diirfen vor Allem niemals scharfe Schneiden oder Kanten haben, weil durch diese stets die Faser verletzt wird; auch müssen sie möglichst nur an einer Stelle auf die Stengel wirken, welche keinesfalls an meh-

Zusammenstellung der ïlteren Flachsbrechmaschinen von We in ling in Hülsse's allgemeiner Maschinen-Encyklopädie Bd. II, Leipzig 1844, Artikel Brechmaschinen. Artikel Flachs in Prechtl's technologischer Encyklopädie, 3. Supplenentband, Seite 95, Stuttgart 1861. Dr. H. Grothe: "Ueber die Bearbeitung des Flachses", Berlin, Verlag won Trieben, welche Brochure eine weitere reiche Quellenangabe enthält; ferner noch: Berichte ïber die Wiener Weltausstellung von Johann $\mathbf{Z}$ e $\mathbf{m a n}^{\text {" }}$ in Dinglers pol. Journ. Bd. 210 pag. 85 und ebenso von Prof. Gustav Herrmann, Zeitschrift deutscher Ingenieure 1874, pag 204; endlich auch Resultat des recherches et Experiences relatives au broyage et au teillage du lin à la Mécanique depuis 1856 jusqu’à ce jour, par P. Felboen-Pecquerian. Courtrai 1867 etc. 
reren Stellen gleichzeitig festgehalten werden dürfen, weil sonst ebenfalls Verletzungen der Fasern eintreten muissen. Der holzige Stengel darf ferner nicht in zu kleine Theilchen zerbrochen werden, weil diese sich nur schwierig durch den folgenden Schwingprocess abscheiden lassen, und es muss, wenn ein Brechen der Stengel in allen Theilen vorgenommen wird, stets ein grleiclizeitiges Abschaben, Abstreifen der Schäben von den Fasern stattfinden, während in beiden Fällen eine selbstthätige, continuirliche Beseitigung der abfallenden Schäbentheilchen und des Staubes aus den Arbeitsorganen der Maschine eintreten muss. Hierzu gesellen sich noch die an landwirthschaftliche Maschinen überhaupt zu stellenden Forderungen. - Keine der vorhandenen Brechmaschinen erfüllt alle diese Bedingungen vollkommen.

Die verschiedenen Constructionen lassen sich eintheilen in:

a) Brechmaschinen mit Poch-, Stampf- oder Hammerwerken, bei denen die untere Seite der Stampfen oder Hämmer, sowie die Unterlage geriffelt ist. Hierher gehört die Maschine von Payne und auch die von Friedländer, obgleich bei letzterer das Pochwerk untergeordneter Natur ist und die Hauptarbeit eine Schwingmaschine verrichtet.

b) Brechmaschinen mit Riffelwalzen, die auf geriffelten Platten hin und her bewegt werden (Terwagne, Mc. Pherson u. A.).

c) Brechmaschinen mit mehreren sich drehenden und gedrehten geriffelten Walzen, die mühlenartig unter einer cannelirten Platte arbeiten, und bei welchen die Flachsstengel, durch Schlitze in den Platten eingehalten, der Wirkung der Walzen ausgesetzt werden (Catlinetti und Kesseler).

d) $\mathrm{Brechmaschinen} \mathrm{mit} \mathrm{mehreren} \mathrm{cylindrischen,} \mathrm{in} \mathrm{gerader} \mathrm{Linie} \mathrm{oder}$ in einem Bogen hinter einander angeordneten, immer feiner in ihren Riffeln werdenden Walzenpaaren, oder mit mehreren Riffelwalzen, die um eine grössere Unterwalze herum angeordnet sind; bei welchen Constructionen aber sämmtliche Walzen nur eine einfache rotirende oder eine rotirende und transversale (Quer-) Bewegung haben. (Greenwood, Plummer, Coblenz \& Le oni, C. Maier, Lefebure, Kuthe - letztere Maschine kann auch unter $f$ angeführt werden - Warnecke u. A.).

e) Brechmaschinen mit derselben Anordnung wie unter $d$, bei denen aber die Oberwalzen bei ihrer Drehung hin und her schwingen Collyer, $\mathrm{Luft}$ u. A.).

f) Brechmaschinen mit derselben Anordnung vie unter $d$, bei denen aber Ober- und Unterwalzen eine Pilgerschrittbewegung annehmen, d. h. zusammen eine grössere Vorwärts- und dann eine geringere Rïckwärtsdrehung erhalten. Hierbei können noch, wie bei den unter $d$ genannten Maschinen, die zusammen arbeitenden Walzen eine Querbewegung, (also in ihrer Längenrichtung) ausfïhren (Kuthe, siehe oben, Guild, Narbuth, Warnecke, Felhoen u. A.).

g) Brechmaschinen, denen das Princip der Handbreche zu Grunde liegt und bei welchen der Flachs entweder mit der Hand gehalten (C. \& Th. Möller) oder durch ein cannelirtes Walzenpaar zugeführt wird (Ka selows $\mathrm{k}$ ).

Von diesen Maschinen sind die unter $a$ und $b$ genannten am verwerflichsten (mit Ausnahme etwa der Friedländer'schen, die aber mehr den Schwingmaschinen zuzurechnen ist). Die Maschinen unter $c$ und besonders die Maschinen Kesseler's sind von recht guter Leistung, jedoch schwerfällig und thener. Die Maschinen, bei denen vorzugsweise cannelirte Walzen zur Verwendung kommen, also die unter $d$ bis $f$ genannten, haben sich in höherm oder geringerm Grade hrauchbar gezeigt und sind einige Maschinen unter ihnen - wie z. B. die unter $f$ genannten Warnecke'schen - welche, bei geringem Kraftrerbrauch und einfacher Construction, anch weniger vertranten Händen iibergeben werden können. Von den unter $g$ genannten Maschinen sind zwar die von C. \& Th. Nölle in 
Brackwede ganz brauchbar, werden jedoch in vieler Hinsicht von den $\mathrm{K}$ a s e l o w s k yschen übertroffen, welche bei einfacher Construction und sehr geringem Kraftverbrauch eine vorzügliche Wirkung ergeben, und bei geringem Gewicht einen sehr niederen Preis haben, so dass sie sowohl für den Grossbetrieb wie in der Landwirthschaft gleich gut Verwendung finden können.

Fig. 1647 .

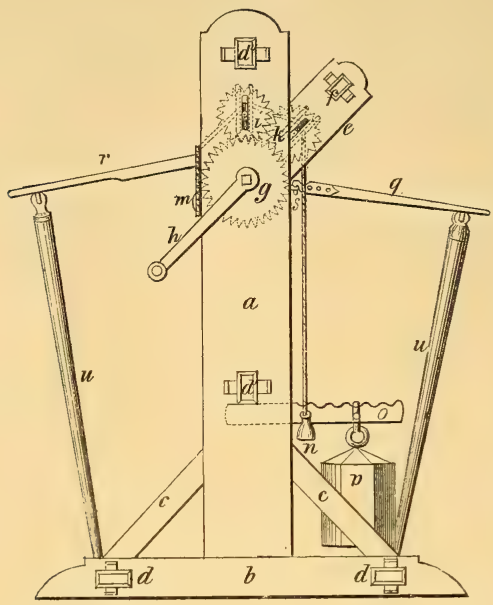

Fig. 1648.

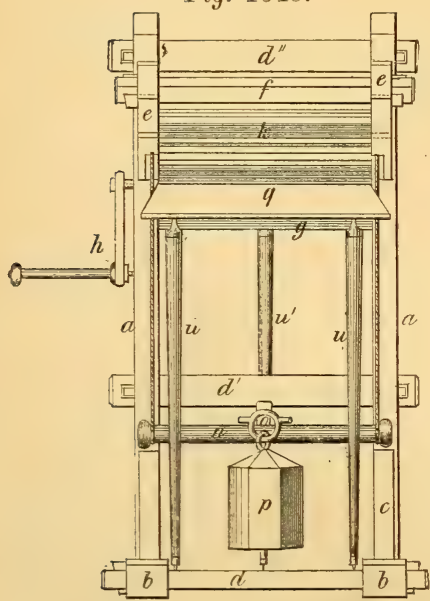

Fig. 1649.

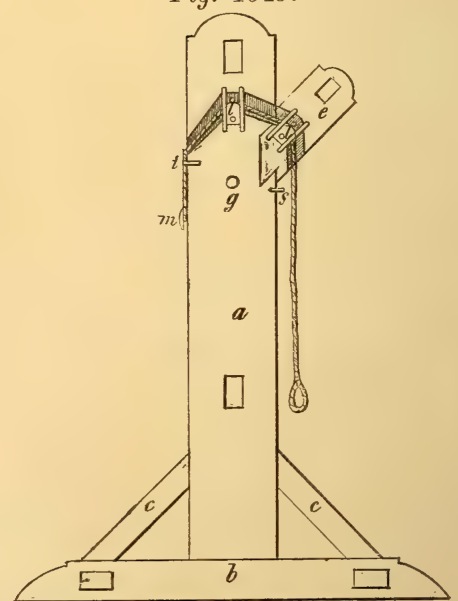

Kuthe s Flachsbrechmaschine.

Es mögen jetzt noch einige dieser Maschinen eine etwas nähere Besprechung finden.

Die Flachsbrechmaschine von $\mathrm{Kuth}$ e empfiehlt sich bei leidlich guter Wirkung besonders durch Einfachheit und Wohlfeilheit und vermag die Handbreche recht gut zu ersetzen. 
Fig. 1647 stellt dieselbe in der Längenansicht von der rechten Seite dar und Fig. 1648 in der Seitenansicht von hinten (wo der gebrochene Flachs heraustritt), Fig. 1649 gibt eine Ansicht der hintern Gestellswand. $g, i, k$ sind 3 Walzen von hartem Holze und mit eisernen Zapfen versehen; ihr Umkreis ist mit dreieckigen, etwas abgestumpften Rippen versehen, s. Fig. 1547. Wenn die grosse Walze $g$ mittels ihrer Kurbel $h$ umgedreht wird, so greift sie mit ihren Furchen und Rippen in jene der beiden andern Cylinder ein und versetzt also auch diese in Umdrehung. Die Zapfen von $g$ liegen in runden Löchern der Gestellswände (s. eines derselben bei $g$ in Fig. 1649); die beiden andern Walzen hingegen haben verschiebbare Lager (wie $l, l$ Fig. 1649), nämlich $i$ in den Ständern $a$ und $k$ in den Armen $e$, weil diese Walzen, wenn zwischen ihnen und $g$ der Flachs durchgeht, die Fähigkeit haben müssen, sich zu heben.

Der dabei fortwährend nöthige Druck wird mittelst eines Gewichtes $p$ ausgeübt, welches an einem von unten gegen $d^{\prime}$ sich stützenden Hebel $o$ hängt. Letzterer liegt selbst wieder auf einem Querholze $n$, an dessen Enden Stricke angebunden sind, welche über die Walzenlager $l, l$ nach ihren Befestigungspunkten $m$ an den Ständern $a$ hinlaufen. Eine Art schrägen Tisches $r$ dient zum Vorlegen des Flachses, ein ähnlicher Tisch $q$ zum Herausführen desselben aus den Walzen. Beide hängen mittelst eiserner Haken in Ringen $s, t$ an den Ständern $a$, und werden von Stützen $u, u^{\dagger}$ getragen. Fig. 1650 zeigt die Riffel in Naturgrösse.

Wenn die Maschine arbeiten soll, so legt man eine Hand voll Flachs auf den Tisch $r$, und breitet sie gleichmässig dergestalt aus, dass die Richtung der Stengel rechtwinkelig gegen die Walzenachsen ist. Indem man sodann die Kurbel

Fig. 1650.

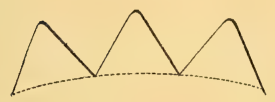
$h$ umdreht, wird der Flachs von den Walzen hineingezogen, zuerst zwischen $g$ und $i$, hierauf zwischen $g$ und $k$ gebrochen. Man dreht einigemal vor- und rückwärts, um den Flachs hin und her gehen zu lassen, und lässt ihn endlich auf den Tisch $q$ heraustreten. Die Schäbe fällt in sehr kleinen Theilen ab, der Bast wird weniger beschädigt, als es gewöhnlich auf der Handbreche der Fall ist.

Eine andere ir 1 änd ische, für einen Fabriksbetrieb bestimmte Brechmaschine besteht aus fünf horizontalen gusseisernen, geriffelten Walzenpaaren, welche so angeordnet sind, dass der durch das erste Paar eingeführte Flachs in einmaligem Durchgange von allen bearbeitet wird, und vollständig gebrochen aus dem letzten Paare austritt. Sämmtliche Walzen haben 0.65 Meter Länge und 20 Centimeter Durchmesser; ihre Rippen sind, bessern Eingriffs halber, nach Art von Radzähnen abgerundet; der untern Walze eines jeden Paares wird direct drehende Bewegung (vermittels eines Räderwerks) ertheilt, die obere Walze geht zufolge des Eingriffs der Rippen oder Riffeln mit. Die Riffeln sind an den Enden der Walzen auf etwa 1 Centimeter Länge etwas stärker gelassen, so dass sich dieselben an diesen Stellen gegenseitig berühren und nur in der Mitte - wo der Flachs hindurch geht - ein Zwischenraum bleibt, wodurch eine schonendere Einwirkung auf die Fasern erreicht wird. Die Flachsstengel werden wohlgeordnet auf einem Tische vorgelegt, von den ersten Walzen ergriffen, geknickt und den folgenden Walzenpaaren der Reihe nach überliefert, welche sie in gleicher Weise noch ferner bearbeiten. Um dies successiv auf möglichst vielen Punkten zu bewerkstelligen und eine stufenweise steigende Zerkleinerung der Holztheile zu erzielen, sind die später wirkenden Walzen feiner geriffelt als die vorausgehenden; es hat z. B. jede Walze im ersten Paare 14, im zweiten 18, im dritten, vierten und fünften 25 Rippen. Zugleich dreht sich das erste Paar am schnellsten, jedes folgende etwas langsamer, weil der Flachs beim Fortschreiten durch die feiner geriffelten Cylinder mehr Knickungen empfängt und nach Absonderung eines Theiles seiner Holzsubstanz auch tiefer in die Riffelung eintreten kann, mithin eine gewisse Verzögerung seiner Fortbewegang erfahren muss, wenn er nicht abgerissen werden soll. Zur Niederhaltung der obern Walzen auf die untern dienen Gewichte, welche auf zwei Hebel (an jedem Ende der Walzen einer) gesteckt werden.

Die Maschine erfordert zum Betriebe gegen 1 Pferdekraft, zur Bedienung 3 oder 4 Kinder, und bricht in 12 Stunden 2000 Kilo Stengel. 
Bei neueren Maschinen dieser Anordnung ist vor den ersten Riffelwalzen ein Paar glatte Walzen angeordnet, welches die Stengel erst breit quetscht, ehe sie zu den Riffelwalzen gelangen.

Die beschriebene Maschine ist sehr schwerfällig und theuer, erfüllt auch nur einige der vorher aufgestellten Bedingungen, und bleibt es selbst bei der sorgsamsten Construction nicht aus, dass einzelne Fasern zerrissen werden und in den Abfall übergehen.

Warnecke hat den Betrieb der sechs Unterwalzen seiner nach diesem Systeme gebauten Maschine durch Kurbelbetrieb bewirkt, doch sind auch bei ihr die gerügten Unvollkommenheiten vorhanden.

Eine Maschine neuerer Construction ist die von Collyer, die oben unter $e$ ) angeführt wurde (s, die erwähnten Wiener Weltausstellungs-Berichte) und welche in der folganden Fig. 1651 in der Längenansicht dargestellt ist.

Die grössere Riffelwalze $W$, welche von der Handkurbelwelle aus durch die Räder $a$ und $b$ nach einer Richtung hin bewegt wird, ist oberhalb von zwei kleineren Walzen $W_{1} W_{2}$ umgeben, diu mittels Gleitlager zu beiden Seiten in drehbaren, über die Achse $A$ der

Fig. 1651 .

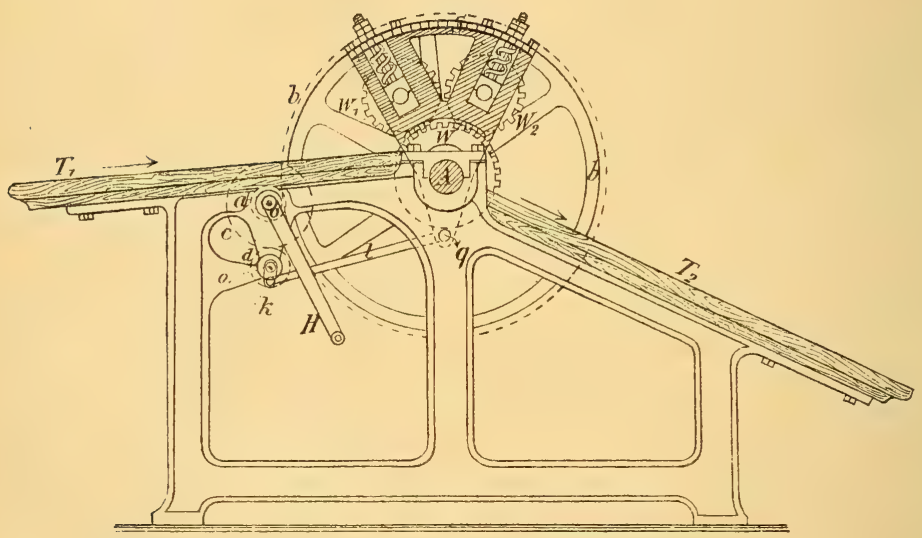

Collyer's Brechmasehine.

untern Walze geschobenen Ständern gelagert sind und die dureh Federn auf die untere aufgedrückt werden. Von der erwähnten Handkurbelwelle $o$ aus wird noch durch die Räder $c$ und $d$ die Welle $o_{1}$ bewegt, die mit einer Kröpfung $k$ versehen ist, von der aus durch die Lenkstange $l$ an den Querbolzen $q$ - der die Verlängerung der erwähnten beweglichen Lagerständer nach unten zu verbindet - und somit auch an diese Lagerständer und die oberen Walzen eine hin und her schwingende Bewegung übertragen wird.

Bei der Drehung der Handkurbel $H$ wird das auf den hölzernen Zufiihrungstisch $T_{1}$ ausgebreitete Flachsstroh von den Walzen erfasst, gleichıässig einwärts gezogen und auf den Abführungstisch $T_{2}$ abgeliefert. Da nun die durch Reibung und den Eingriff ilırer Riffeln mit gedrehten Oberwalzen zugleich eine hin und her schwingende Bewegung haben, so wird eine intensivere Bearbeitung der Stengel, ein vollständiges Knicken derselben und Ablösen der Schïben durch die reibende Wirkung erreicht, und zwar sind die Verhältnisse bei vorliegender Maschine so gewählt, dass die Stengel einer fünfmaligen Einwirkung jeder Brechwalze unterworfen sind. 
Bei dieser sonst recht gut arbeitenden Maschine fehlt besonders das genügende Ausschütteln der Schäben aus den geknickten Stengeln und müssen dieselben erst durch ein länger andauerndes Schwingen entfernt werden. Anderseits ist die Bearbeitung der Faser eine viel schonendere und mildere als bei der vorher erwähnten Maschine. - Bei Handbetrieb soll man mit dieser Maschine in einer Stunde 40 bis 50 Kilogr. Flachsstroh brechen können, während bei mechanischem Antrieb - in welchem Falle 3 schwingende Oberwalzen vorhanden sind - in derselben Zeit und bei einem Kraftaufwande von $1 / 2$ Pferden 130 bis $150 \mathrm{Kilogr}$. Flachsstroh verarbeitet werden.

Die ebenfalls unter der Rubrik $e$ angeführte Brechmaschine von $\mathrm{Luft}$ besteht aus 6 in einem Bogen gelagerten Walzenpaaren, und sind sämmtliche obere Walzen (Druckwalzen) in oscillirenden Ständern gelagert. Die Wirkung dieser Maschine ist ähnlich wie die der eben beschriebenen, doch bietet die Construction ihrer Walzen eine besondere Eigenthümlichkeit. Es sind dies nämlich Messerwalzen nach dem Patente Pini construirt, also aus radial stehenden, in der Breite viermal gestützten und seitlich durch Bundringe zusammengehaltenen, abgerundeten Messerschienen bestehend, welche ein leichtes Abfallen der Schäbentheilchen durch ihre Zwischenräume gestatten.

Von den unter $f$ erwähnten Brechmaschinen mit Pilgerschrittbewegung hat die Maschine von Narbuth 9 Paar Riffelwalzen, die von Guild nur 2 Paar (letztere Maschine ist von Prof. Dr. Hartig in seinem Werke: Ueber den Kraftbedarf der Maschinen in der Flachsund Wergspinnerei. Leipzig, Teubner, pag. 51, beschrieben und berechnet).

Die Maschine kommt in ihrer Leistung einer älteren Walzenbreche mit etwa 10 bis 12 Walzenpaaren gleich und bricht pro Tag 600 bis 700 Kilogr. Flachsstroh.

Bei sämmtlichen Maschinen mit Pilgerschrittbewegung ist die plötzliche Aenderung der Bewegungsrichtung stets mit bedeutenden Schlägen in den arbeitenden und transportirenden Theilen verbunden, so dass Brüche von Radzähnen u. s. w. nicht zu den Seltenheiten gehören, und daher diese Maschinen schon aus diesem Grunde eine besondere Empfehlung nicht verdienen.

Warneke hat bei seiner zweiten, nach dies em Princip arbeitenden Maschine, die für Handbetrieb eingerichtet ist, durch Anwendung von Keilrädern die Stösse bei dem Bewegungswechsel möglichst gemildert, weshalb diese Maschine bei ihrer Billigkeit (980 Mark) und verhältnissmässig grossen und guten Leistung (bei Handbetrieb täglich 600 Kilogr., bei Kraftbetrieb 1000 Kilogr.) vielfache Verbreitung gefunden hat. - Es hat diese Maschine 2 Paar in grösserem Abstande von einander gelagerte Brechwalzen, die durch ein Stirnräderpaar (an der unteren vorderen und der oberen hinteren) in Verbindung stehen. Vor den Stirnrädern sitzen auf den betreffenden Walzenachsen zwei Keilrädersectoren und auf der oberhalb gelagerten Schwungradwelle zwei eben solche von verschiedener Bogenlänge neben einander. Zuerst fasst der längere Keilsector in den an der Achse der oberen, hinteren Walze sitzenden Sector ein und bringt dadurch die Vorwärtsbewegung hervor, hierauf kommt der kürzere Sector mit den auf der unteren vorderen Brechwalze sitzenden in Eingriff und bewirkt die kürzere Zeit dauernde Rückdrehung u. s. w.

Brechmaschinen, denen das Princip der Handbreche zu Grunde liegt.

Bei der Maschine von Möller (Doppelrakmaschine) werden Risten zwischen 3 Paar feste, horizontal neben einander liegende, nach den Enden zu sich maulförmig erweiternde Fïhrungen gebracht, in deren Zwischenräumen von einer Kurbelwelle aus zwei Schlägergabeln senkrecht auf und nieder bewegt werden. Die Schlägergabeln sind ebenfalls paarweise vorhanden und knicken also einmal die Stengel von oben nach unten, dann von unten nuch oben, bei einer Undrehung der Kurbelwelle. Da diese nun 400 Umdrehungen in der Minute macht, so werden 800 Schläge in derselben Zeit ausgeführt, und hat man es in der Hand, durch langsameres oder rascheres Querdurchziehen der Risten die Schläge dichter oder weniger dicht auf einander folgen, den Flachs also verschieden bearbeiten zu lassen; auch kann durch Verstellung des Hubes die Kraft des Schlages, je nach Absicht, geändert werden. -- Die Maschine ist für Kraftbetrieb eingerichtet, bedarf etwa $1 / 2$ Pferdekraft, kostet 375 Mark incl. Aufstellung und Riemen und verarbeitet täglich etwa $300 \mathrm{Kilogr}$. Flachsstengel.

$\mathrm{Zu}$ den besten der vorhandenen Brechmasehinen gehört unstreitig die K a selow s ky'sche, welche bei einfacher Construction und niederem Preise, bei geringem Kraftbedarfe fast alle 
der vorher aufgestellten Bedingungen erfüllt, jedenfalls in schonender Behandlung der Faseru und gründlicher Ausführung des Brechprocesses von keiner anderen übertroffen wird.

Die Arbeits- und Betriebsorgane der Kaselowsky'schen Brechmaschine sind nach einer neueren Ausführung in der folgenden Fig. 1652 im Längenschnitt dargestellt. Die ersteren bestehen in einem Paar geriffelter Zufuihrwalzen $o_{\alpha} o_{1}$; einer grösseren Walze $W$ mit eingesetzten dünnen abgerundeten Leisten $l$ und aus einer Lade $L$ mit ähnlichen Leistchen. Die Hauptbetriebswelle $B$, welche durch die Riemscheibe $R$ - oder auch mit der Hand durch eine Kurbel - in Bewegung gesetzt wird, ist im höchsten Punkte der Maschine gelagert und zwischen den beiden Seitengestellen auf einer Länge, welche der Arbeitsbreite der Maschine (der Länge der Leisten) entspricht, gekröpft. Diese Kröpfung ist von den Lagerbacken der Lade $L$ umschlossen, weshalb letztere bei der Drehung der Hauptwelle eine auf und nieder gehende Bewegung annehmen muss. - Die Führung der Lade ist bei verschiedenen Maschinen etwas abweichend construirt.

Fig. 1652 .

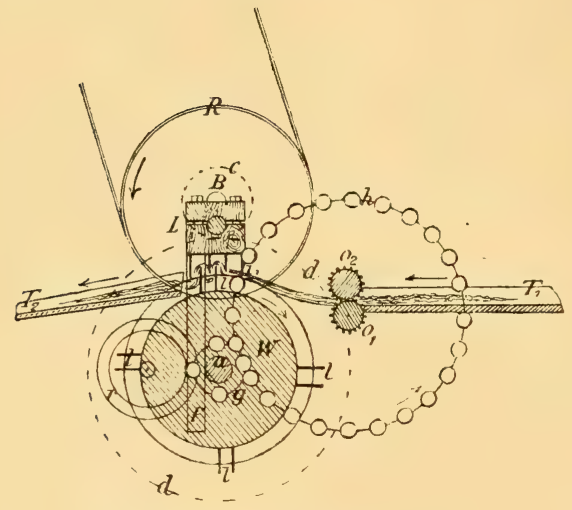

Kaselowsky's Flachsbrechmaschine.
Bei vorliegender Construction hat die Lade an ihren beiden Enden je eine Fïhrungsstange $f$, welche zwischen der Achse $\boldsymbol{a}$ der Leistenwalze und einer mit seitlichen Rändern versehenen, am Gestelle drehbar befestigten Führungsrolle $r$ hindurch geht. - Von der Betriebswelle $B$ aus wird durch die Räder $c$ und $d$ die Leistenwalze und von deren Achse durch die Stifträder $g$ und $h$ die untere Einziehwalze $o_{1}$ bewegt. Ist die Maschine im Betriebe, so wird auf den Zuführungstisch $T_{1}$ das Flachsstroh ausgebreitet und in den Bereich der Einziehwalzen $o_{1} o_{2}$ gebracht, welche dasselbe vorknickend allmälig weiter über die Leistenwalze schieben. Bei jeder

Undrehung der Hauptwelle stossen nun die Leisten der Latle in die Zwischenräume der dann stets unter ihnen befindlichen Leisten der Walze $W$ und drücken das Flachsstroh in dieselben ein, so dlass ein Kuicken der Stengel an mehreren Stellen - entsprechend der Anzahl der Walzenleisten - eintritt. Gewöhnlich pflegt man die Lade mit 4 Leisten, von denen die mittleren etwas kürzer sind, die Walze in 4 Abtheilungen mit 2 Leisten zu armiren, die aber dann nicht im gleichem Abstande von einander, sondern so stehen, dass sie einmal zwischen die ersten und dann zwischen die hintern Ladenleisten treten.

Die Ladenleisten haben neben ihrer senkrechten eine leicht oscillirende Bewegung und diese bewirkt, in Gemeinschaft mit der fortschreitenden der Walzenleisten, ein Abstreichen der geknickten Stengel, und fallen die Schäben, wenn nicht direct herunter, in die Zwischenräume der Leisten, aus denen sie bei der Drehung der Walze abgeworfen werden. Da aber ferner die Umfangsgeschwindigkeit der Leistenwalze viel grösser als die der Zufübrungswalzen ist, so wird bei dem Emporgehen der Lade und der weitern Drehung der Leistenwalze letztere noch fernerhin abstıeichend und abschüttelnd auf die aus den Zwischenräuıen der Leisten wieder herausgetretenen Stengel wirken und dadurch einen weiteren Theil der Schäben entfernen. In der That ist der auf den Abführtisch $T_{2}$ abgelieferte Flaclıs nur noch mit wenigen lose anhängenden Schäben behaftet, die sich durch einen leichten Schwingprocess - ein 
sogenanntes Reinschwingen - schon entfernen lassen, wenn der Flachs richtig vorbereitet war. Eine Verletzung der Fasern kann bei dieser Behandlung nicht gut eintreten, und ist der in dem Abfall sich findende Faserantheil sehr gering.

Die Maschine bedarf nur $1 / 4$ bis $1 / 3$ Pferdekrart zum Betriebe und verarbeitet bei 2 Mann Bedienung in 10 Stunden 500 bis 600 Kilogr. Flachsstroh. Der Preis derselben ist etwa 160 bis 180 Mark.

Schwingmaschinen. Es sind nur zwei verschiedene Arten derselben im Gebrauch : Bei der ersten Anordnung sind an der, auf einer horizontal liegenden, rotirenden Welle befestigten Nabe entweder direct oder mittels besonderer in dieselbe eingesteckten Arme gewöhnlich 4-12 hölzerne, besser aber eiserne, zugeschärfte und an der Schlagkante gut abgerundete Schlagscheiben (Leisten) befestigt, welche bei der meist aus Eisen hergestellten Schwingöffinung (Kante), ähnlich wie bei dem Schwingstock die Schwinge, vorbeistreichen und den übergelegten und fest gehaltenen Flachs unter wiederholten, rasch auf einander folgenden Streichen treffen. Eine ältere derartige charakteristische Anordnung zeigt die folgende Fig. 1653 in einem Querschnitt.

An der Nabe $c$ sind hierbei 5 schmiedeiserne Arme $b$ befestigt, welche die Schwingscheiben $a$ tragen. An dem gusseisernen Ständer (Stocke) $e$ ist im oberen Theile die nach den Schlagscheiben zu etwas gebogene und gut abgerundete Leiste bei $f$ (in unserer Figur verdeckt) eingesetzt, an welcher die Schlagscheiben ziemlich dicht vorbei schlagen. Die Leiste $f$ ist durch zwei Federn mit dem Ständer $e$ verbunden, wodurch ein gewisses Nachgeben derselben bei zu stark übergelegter Riste möglich ist und überhaupt der Flachs eine schonendere Behandlung erfährt. - Das in folgender Fig. 1653 angegebene Rad $d$ wird von der Schwingwelle aus durch ein Getriebe bewegt und dient zur Bewegung der Betriebs-

Fig. 1653.

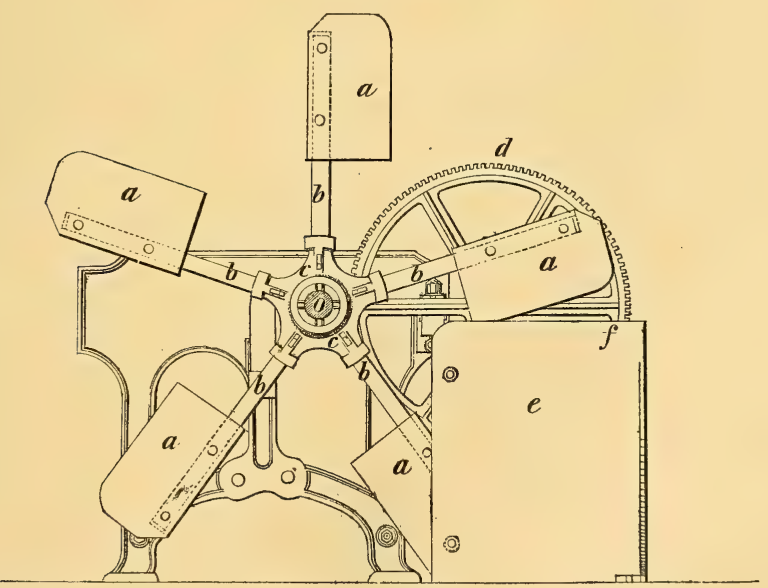

Schwingmaschine.

welle einer dahinter stehenden Brechmaschine. Sehr häufig fehlt diese Anordnung, indem die Brechmaschine besser direct von der Transmissionswelle aus bewegt wird. - In einer grösseren Schwingerei hat man sich nun mehrere der beschriebenen Schwingvorrichtungen hinter einander auf derselben Welle $o$ in solchen Zwischenräumen zu denken, dass in jeder entstehenden Abtheilung (einem sogenannten Schwingstande) ein Arbeiter bequem stehen und hantiren kann. 
Damit nun die Arbeiter vor Stanb und vor Verletzungen durch die Schlagscheiben möglichst gesichert sind, umgibt man die Maschine mit einem hölzernen Verschlage, aus dem nur die Auflegeleisten soweit wie nöthig herausragen.

Maschinen mit einer grösseren Anzahl Schwingständen construirt man doppelt, d. h. ordnet in genügender Entfernung von der ersten eine zweite Welle mit denselben Schlagvorrichtungen derart an, dass die äussersten Kanten der Schlagbretter immer dicht bei der andern Welle, und ohne die auf dieser sitzenden Schlagvorrichtungen seitlich zu treffen, rorbeigehen. Man erhält so die eine Hälfte der Schwingstände auf der einen Seite - und benutzt diese zum Vorsehwingen - die andere Hälfte auf der andern Seite - welche dann zum $R$ eins chwingen dient.

Nur bei intensiv wirkenden Brechmaschinen (K a selowsky) kann man sich mit einmaligem Ausschwingen der Risten begnügen. Die Anzahl der Umdre hungen der Schlagwellen schwankt sehr, liegt etwa zwischen 80 und 150 in der Minute und richtet sich nach der Grösse der Maschine und der Anzahl der Messer. Bei einer mehrständigen Maschine kaun man pro Stand etwa $0.1-0.2$ Pfcrde Betriebskraft rechnen, und erfordert beispielsweise eine Maschine von 8 Ständen und je 8 Schwingscheiben bei 90 Umdrehungen in der Minute etwa 1 Pferdekraft, dabei 12 Personen zur Bedienung. Vier um den gebrochenen Flachs zurecht zu legen und den acht an den Schwingständen Stehenden zuzureichen. Es werden täglich pro Stand etwa $35^{\mathrm{k}}$ gebrochener Flachs verarbeitet, der ca. $28^{\mathrm{k}}$ rein geschwungenen Flachs liefert.

Nach einer zweiten, besonders von Kaselowsky ausgebildeten Construction sind die Schlagscheiben tangential und gewöhnlich an beiden Enden von der Welle aus unterstützt angeordnet, so dass der iiber eine federnde Auflegeleiste gehaltene Flachs stets in voller Breite auf einmal - und nicht wie bei der vorigen Anordnung erst nach einander - getroffen wird. Bei diesen Maschinen ist es unbedingt nothwendig, die Auflegeleiste federnd und leicht verstellbar zu construiren, damit man fur jede Flachssorte sofort die Maschine richtig einstellen kann. Derartige Vorrichtungen hat $\mathrm{K}$ aselowsky in so vollkommener Weise angegeben, dass diese Schwingmaschinen die vorigen vielfach in schonender und dabei doch genügender Bearbeitung übertreffen. Diese Maschine gibt in Verbindung mit der Kaselowsky'schen Brechmaschine ausserordentlich zufriedenstellende Resultate.

Man hat an Arbeitskräften dadurch zu sparen gesucht, dass man Schwingmaschinen mit mechanischer Flachszufihrung construirte, jedoch wird dabei stets so viel Abfall erzengt, dass bis jetzt das Halten mit der Hand nicht entbehrt werden kann.

Der geschwungene Flachs ist von fast allen Holz- und Oberhautheilchen befreit, auch sind die an einander hängenden Fasern selbst bis zu einem gewissen Grade getheilt. Bei jenen Behandlungen hat sich eine Menge Abfall gebildet, der nicht allein aus Schäben, sondern auch aus einer gewissen Menge kürzerer oder längerer, mit Schäben vermengter Fasern in sehr verwirrtem Zustande besteht, die man, je nachdem sie beim Brechen, beim Vor- oder Reinschwingen abfielen, sortirt und entweder ungereinigt oder auf besonderen Schïttelmaschinen aufgelockert und gereinigt, als $\mathrm{Z}$ op fwerg, $\mathrm{S} \mathrm{chw}$ ingwerg, A b f allwerg" an Spinnereien oder Seilereien verkauft. Dieses Werg kann nur zu den gröbsten Nummern versponnen oder zu Seilerarbeiten verwendet werden.

Aus $1000^{\mathrm{k}}$ frisch ausgezogenen und geriffelten Leinenstengeln ergeben sich je nach Qualität der Stengel und Arbeitssorgfalt: $300-500^{\mathrm{k}}$ Iufttrockenes Flachsstroh, $190-430^{k}$ geröstete, lufttrockene Stengel, $90-360^{k}$ gebrochener Flachs, $65-160^{\mathrm{k}}$ geschwungener Flachs und etwa $5-90^{\mathrm{k}}$ Schwingheede.

Der Flachs kommt meist in geschwungenem Zustande ( $\mathrm{chwingflachs,}$ Reinflachs) in den Handel und muss in kiihlen, der Sonne nicht zugänglichen, nicht nassen, aber auch nicht zu trockenen Lagerräumen aufbewahrt werden. Er darf nicht auf dem blossen Fussboden, sondern muss stets auf einem Lattenboden 
gelagert werden. Eine mässige Feuchtigkeit der Luft erhöht die Weichheit und Milde der Faser und schützt vor Gewichtsverlusten durch Austrocknung.

Im Handel unterscheidet man den Flachs nach der Gegend, aus der er stammt und dann nach der Art der angewendeten Röste in "Rasenflachs, " der durch Thauröste, und in "Wasserflachs, " der durch Wasserröste gewonnen wurde.

Das H e ch eln (serancer, serançage, peigner, peignage - heckling, hackling). Die meisten Spinnereien verarbeiten fertig geschwungenen Flachs und es fallen daher die weiteren Arbeiten in das Gebiet der Flachsspinnerei. Da jedoch das Hecheln lediglich eine vorbereitende, die Faser isolirende Arbeit ist, so soll dieser Process - so weit er mittelst der Hand ausgefuihrt wird - an dieser Stelle besprochen werden.

Wir erwähnten, dass durch die vorangegangenen Processe die Fasern abgeschieden, bis zu einem gewissen Grade gereinigt und zertheilt werden, aber noch ist der Flachs nicht zum Verspinnen geeignet. Er enthält Reste von fester anhängenden Schäben und Oberhauttheilchen, auch sind die Bastfasern unter einander noch verbunden, vielfach verworren, längere befinden sich neben kürzeren u. s. w. Der Hechelprocess bezweckt die vollständige Abscheidung der Schäben, Zertheilung und Zerlegung der zusammenhängenden Faserbüschel unter gleichzeitiger Absonderung der kürzeren Fasern und ein Ordnen, Parallellegen der übrigen langen Fasern.

Zum Hecheln des Flachses bedient man sich der "Hechel" (séran, serin, serançoir, peigne - heckle, hackle), eines Werkzeuges, das aus einem System von Nadeln besteht, die in runden, concentrischen, oder wie iiblicher in mehrfachen, einfach versetzten, zusammen ein Viereck bildenden Reihen in einem Brett befestigt sind. Je nach der Feinheit des Flachses und dem Grade, bis zu welchem er ausgehechelt werden soll, stehen die Nadeln mehr oder weniger dicht zusammen und haben eine grössere oder geringere Feinheit und Länge. Sie sind aus Eisen oder besser aus Stahl, bilden schlank zugespitzte und polirte Kegel, im letzteren Falle mit stets rundem Querschnitt.

Der für die Maschinenspinnerei (von der später ausschliesslich die Rede sein soll) auszuhechelnde Flachs muss viel sorgfältiger behandelt werden als der für Handspinnereizwecke, weshalb man im erstern Falle eine grössere Anzahl von Hecheln hintereinander in zunehmender Feinheit anwenden muss als im letzteren.

Die erste Hechel, auf welcher der Schwingflachs zunächst behandelt wird, nennt man die Abzugshechel (Ruffer), die folgenden Mittelhecheln und die letzte, für einen bestimmten Fall benützte, die Aus machehechel.

In den Hecheleien der Fabriken sind die einzelnen Hecheln neben einander auf niederen Bänken entweder so, dass die Nadeln senkrecht oder etwas nach dem Arbeiter zu geneigt stehen, befestigt. Neben der Abzugshechel, die gewöhnlich besonders steht, ist noch ein 3 kantiger, einige Centim. langer Stift fest angeordnet. Von den anderen Hecheln stehen stets mehrere neben einander. Zu beiden Seiten eines Hechelsortiments sind weitere Bänke zur Lagerung und Sortirung des Flachses angeordnet, so dass sich einzelne durch die Bänke von einander geschiedene Hechelstände bilden, vor denen noch die Heedekästen stehen zur Aufnahme der ausgehechelten kürzeren Fasern, die das Material zur Wergspinnerei liefern. Zunächst findet das Spitzen der einzelnen Risten statt, d. h. die aus den Risten vorstehenden Enden der nicht richtig liegenden oder zu langen Fasern werden um den erwähnten Stift geschlungen und abgezogen oder abgerissen, so dass möglichst gerade Enden entstehen. Hierauf wird die Riste etwa in der Mitte gefasst, mit der andern Hand aus einander gebreitet, und auf die Spitzen der Vorhechel geworfen, worauf sie vorsichtig und langsam zuriickgezogen und dann dieses Verfahren mehrmals wiederholt wird, wobei man, immer tiefer in die Hechelnadeln eindringend, unter häufigem Wenden des Flachses, denselben erst an den Enden und schliesslich auch in der Mitte bearbeitet. Nachher wird die Riste umgekehrt und auf der anderen Hälfte in derselben Weise behandelt. 
Die kurzen und verworrenen Fasern bleiben zwischen den Nadeln sitzen, werden von Zeit zu Zeit herausgezogen und in den Handkasten geworfen, wobei die ersten in der Hechel sich ansammelnden Fasern, da sie länger als die später zurückbleibenden sind, abgezogen und zu einer besonderen Flachsriste zusammengelegt werden. Ist diese Bearbeitung auf der Vorhechel beendet, so gehen diese Risten gewöhnlich in die Hände des zweiten Hechlers über, der dieselben auf den Mittelhecheln und der Ausmachehechel ähnlich behandelt, bis der Flachs genügend gehechelt ist.

Das zuerst ausgehechelte Werg ist das gröbste und unreinste und wird das von den verschiedenen Hecheln stammende getrennt aufbewahrt.

Gleichzeitig mit dem Hecheln findet das Sortiren des gehechelten Flachses nach den weiter unten angegebenen Eigenschaften desselben statt, und ist es häufig üblich denselben in folgenden Nummern auslegen:

$$
1 \frac{1}{2}, 2,2 \frac{1}{2}, 3,3 \frac{1}{2}, 4,4 \frac{1}{2}, 5,5 \frac{1}{2}, 6,7 \text { und } 8 \text {, }
$$

(höhere Nummern kann man aus den in deutschen und österreichischen Spinnereien meist nur verarbeiteten Provinzial- und russischen Flächsen nicht auslegen), aus denen gewöhnlich die $10 \mathrm{mal}$ höhere Garnnummer gesponnen wird. Man kann also aus beispielsweise Flachs 3 Garn Nummer 30, aus Flachs $51 \%$ Garn Nummer 55 spinnen u. s. w. Es werden jedoch auch einzelne Flachssorten, je nachdem die Garnqualität ausfallen soll, etwas höher oder niedriger verwerthet.

Das Werg wird gewöhnlich direct nach den Nummern, zu denen es versponnen werden soll, sortirt, so dass also Werg 14 zuGarn Nummer 14 bestimmt ist $u$. s. w.

Eigenschaften der Flachsfaser, nach welchen ihr Werth bestimmt wird, sind: die Farbe, der Glanz, die Weichheit, Milde, Schmiegsamkeit, die Festigkeit, die Feinheit, die Länge und endlich der Grad der Reinheit.

Die Farbe des Flachses muss vor Allem gleichförmig sein. Man liebt die hellere, besonders die lichtblonde Farbe sehr, aber auch die stahlgraue Farbe ist vielfach geschätzt. Eine braune, rostige Farbe — von eisenhaltigem Dünger, Wasser oder Erde - eine grünliche, auf ungenügende Rotte, oder eine schwärzliche und ungleichmässige, auf Ueberrottung deutende Farbe gehören stets minderwerthigen oder ganz unbrauchbaren, werthlosen Flachssorten an.

Der Glanz ist neben geeigneter schöner, reiner Farbe ein sehr gutes Zeichen für die Güte eines Flachses. Derselbe steigert sich bei den besten kernigen Flächsen bis zum Seidenglanz.

Die Weichheit, Milde, Schmiegsamkeit ist meist ein Begleiter des Glanzes und gute Flachssorten müssen diese Eigenschaften im höchsten Grade zeigen. Geringere und schlecht in der Rotte behandelte Flächse sind harsch und rauh, und es fehlt diesen Fasern die Schmiegsamkeit fast gänzlich.

Die Festigkeit ist das Zeichen eines kernigen, gesunden, richtig in der Rotte behandelten Flachses und muss guter Flachs neben schöner Farbe, hohem Glanz; neben Weichheit, Milde und Schmiegsamkeit auch genügende Festigkeit zeigen. Ein Flachs, dem Festigkeit fehlt, ist fast werthlos.

Die Feinheit des Flachses, d. h. der Durchmesser der einzelnen Fasern, bestimmt bei sonstigen guten Eigenschaften den höheren oder niederen Werth desselben, weil besonders ron dies er Eigenschaft die Verwendbarkeit zu feineren oder weniger feinen Garnnummern abhängt. Selbst bei den feinsten belgischen Flächsen finden sich noch vielfach zusammenhängende Bastfasern und variirt die Breite (Durchmesser) der gehechelten Fasern zwischen 0.045 bis $0.062^{\mathrm{mm}}$.

Die Länge des Flachses wird oft in Zusammenhang mit der Feinheit der Fasern gebracht, aber meist sind feinere Flächse von geringerer Länge und nur bei Flächsen gleicher Feinheit und sonstigen gleich gu.ten Eigenschaften geniesst der von grösserer Länge dẹ Vorzug. 
Flachses:

Sonstige physikalische und chemische Eigenschaften des

Die Elasticität des Flachses ist geringer als jene der Banmwolle und lässt sich die Flachsfaser höchstens um $4 \%$ der natürlichen Lä̈ge ausdelinen, bis sie zerreisst. Im gewöhnlichen, lufttrockenen Zustande enthält der Flachs $5.7-7 \cdot 22 \%$ Wasser, der in mit Wasserdampf gesättigtem Raume bis zu $23,36 \%$ steigt.

Jod und Schwefelsäure färbt die Flachsfaser blau; Kupferoxydammoniak bringt zuerst eine blaue Färbung hervor und löst alsdann die Faser auf. Schwefelsaures Anilin färbt die Flachsfaser nicht. Bei schlecht geröstetem und gehecheltem Flachse wird das Oberhaut-Parenchim und Holzgewebe dadurch erkenntlich, dass dieses durch Jod und Schwefelsäure nicht blau, sondern gelb bis braun gefärbt wird, während Kupferoxydammoniak dasselbe nicht löst, das schwefelsaure Anilin dieses jedoch gelb färbt, so dass im letztern Falle dem unbewaffneten Auge die ganze Faser gelblich gefärbt erscheint. Das spec. Gewicht der reinen (gebleichten) Flachsfaser ist 1.5 , fast ebenso wie das der Baumwolle, der sie auch in der chemischen Zusammensetzung sehr nahe kommt.

Histologie der Flachsfaser. Die Bastfasern, wie sie nach dem Hecheln vorliegen, sind noch nicht einfache Pflanzenfasern, sondern erscheinen aus einzelnen kürzeren Bastzellen (Elementarfasern) von $2-4^{\mathrm{em}}$ Länge zusammengesetzt, welche mit einander durch den Rest des kleberartigen Bindemittels zusammenhängen. Nicht gut verarbeitete und schlecht gereinigte Flächse zeigen ausserdem noch Reste von Parenchym- und Oberhautzellen und des Holzgewebes, welche aber bei den besten und vollständig rein gehechelten Flächsen nicht mehr vorkommen.

Die Bastzellen selbst, welche sich durch Kalilauge oder Chromsäure die das Bindemittel lösen - isoliren lassen, erscheinen cylindrisch oder etwas plattgedrückt, aber nie bandförmig oder gewunden wie die Baumwolle (I. pag. 314) und haben stets spitz zulaufende Enden. Diese Enden fassen in der langen Faser dachziegelartig ibereinander und kann das Bindemittel auch durch heisses Wasser so weit erweicht werden, dass sich die einzelnen Bastzellen (Elementarfasern), wie dies beim Spinnen mittelst heissen Wassers geschieht, leicht von einander ziehen lassen, ohne dass ein eigentliches Abreissen der Fasern eintritt, und wodurch es - nebenbei bemerkt - möglich ist, den Flachs zu feineren Nummern als auf anderem Wege zu verspinnen. Auch bei dem der Wasserrotte unterworfen gewesenen Flachse zeigt sich diese Erscheinung, so lange der Flachs noch nass ist. Es gelingt nämlich in diesem Zustande sehr leicht die Bastfasern in kurze und äusserst feine Fasern aus einander zu ziehen, was nicht mehr möglich, sobald der Stengel getrocknet ist, weil alsdann das Bindemittel wieder erhärtet.

Die Elementarfasern sind hohl, jedoch ist die Höhlung sehr diinn und erscheint meist nur als dunkle Linie. Die Aussenseite der Elementarzellen des gehechelten Flachses ist häufig rauh. (s. Art. Gespinnstfasern). E. Pfuhl.

Flachs neuseeländischer s. Gespinnstfasern.

Flachsbaumwolle ( $f a x$ cotton) ist eine durch Nachrösten mit Aetzlauge, Behandeln mit Säure und Verkürzung durch Schneiden baumwollähnlich erhaltene und wie diese durch Krempeln bearbeitete Flachsfaser. Es ist dies eine entschieden verwerfliche Manipulation, welche nur auf Werg beschränkt in Zeiten Sinn haben könnte, wo Baumwolle sehr hoch im Preise stand. $K h$.

Flachsbereitungsanstalten s. F I a chs pag. 510 (Flachsröstanstalten).

Flachsbreche, Flachsbrechmaschine s. Flachs III. pag. 516, 519.

Flachsdarrhaus und Darrofen, s. Flachs pag. 515 (kiinstl. Trocknen'. 
Flachsdörre s. Flachs III. pag. 515 .

Flachsgarn s. Flachsspinnerei.

Flachsröste s. Flachs III pag. 510 bis 515 .

Flachsröstanstalien s. Flach s III pag. 514.

Flachsschwingmaschinen s. Flachs III pag. 525.

Flachsspinnerei (filature de lin - flax spinning). Hierunter verstelit man alle diejenigen Verrichtungen, durch welche aus dem gehechelten Flachse ein Faden von beliebiger Länge, Garn, erzeugt wird.

Geschichtliches. Bis vor etwa 60 Jahren wurde Flachsgarn lediglich mit der Hand mit Hilfe der bekannten Spindel oder des Spinnrades erzeugt und war dieser häusliche Industriezweig einer der ältesten und verbreitetsten. Ganz besonders auf dem alten Continente - in Russland, Oesterreich, Deutschland, Holland, Belgien und Frankreich - stand derselbe, in Verbindung mit einer ausgebreiteten Handweberei, in höchster Blüthe, ernährte Millionen von Menschen und bedingte den Wohlstand ganzer Provinzen und Länder.

In Preussen trug wesentlich Friedrich der Grosse zur Hebung der schlesischen Leinenindustrie und des Flachsanbaues bei, und in gleichem Masse Maria Theresia in Böhmen, wo besonders Graf Hatzfeld sich grosse Verdienste um die Hebung dieses Industriezweiges erwarb. - Früher war aber auch in Irland und Schottland die häusliche Handflachsspinnerei eingeführt und erhielt durch Errichtung der Linen-Hall in Dublin etwa um 1728 grösseren Aufschwung.

Während nun mit fortschreitender Entwickelung der Maschinenindustrie schon um 1767 und 1768 durch die Ausdauer der talentvollen Männèr James Hargreaves und Richard Arkwright Spinnmischinen für Baumwolle und Wolle mit dem besten Erfolge in Thätigkeit gesetzt wurden, gelang es doch erst viel später die weniger fiigsame Flachsfaser auf meehanische Weise, ohne Zuhilfenahme der bildenden Hand, in Garn umzuwandeln, und erst als das Uebergewicht der in England - und in geringerem Masse anch bereits in Deutschland und Oesterreich -. zu hoher Blüthe gelangten Baumwollenspinnerei mittels Maschinen für die häusliche Leinenindustrie auf dem Continente fast erdrïckend wurde, begann der Kampf dieser continentalen Industrie gegen die der Insulaner. Napoleon I. gebiihrt das Verdienst, die erste Anregung zur Einführung von Maschinen in der Leinenindustrie gegeben zu haben, indem er erkannte, dass es nur auf diesem Wege möglich sei, das einheimische Rohproduct, Flachs, in wirksame Coneurrenz gegen die fremdländische Baumwolle treten zu lassen. Er exliess am 12. Mai 1810 ein Decret an die Erfinder aller Nationen und setzte einen Preis von 1 Million Francs auf die beste Maschinenconstruction, welche die Verspinnung des Flachses auf mechanischem Wege in der für das Weben geeigneten Weise bewirkte.

Philipp de Girard war der Mann, welcher kaum 2 Monate nach dem Erlass dieser Auftorderung die gestellte Aufgabe löste, alle Principien für die erfolgreiche Lösung des Problems der Flachsspinnerei in einer seinem Patentgesuche beigefügten Beschreibung erklärte und die Wege vorführte, auf denen das Garu sowohl auf trockenem wie nassem Wege erzeugt werden könne. Er erhielt am 8. Juli 1810 ein Patent auf seine Erfindung, doch wurde der ausgesetzte Preis weder ibm, noch einem Andern ausgezahlt.

Bei Beginn der Maschinenspinnerei war jedoch wieder England - begünstigt durch eine bereits sehr entwickelte Maschinenindustrie - früher als andere Länder und selbst als Frankreich im Besitze von Flachsspinnmaschinen, obgleich der Erfinder derselben ein Franzose war. *)

Von der österreichischen Regierung wurde Philipp de Girard 1815 von Paris nach Oesterreich berufen und behufs Anlegung einer mechanischen Flachsspinnerei bedeutend

*) Man lese: Bilder und Studien zur Geschichte rom Spinnen, Weben, Nähen von Dr. Herrmann Grothe. 
unterstützt. Diese Spinnerei bestand in der Nähe von Wien (zu Hirtenberg) mehrere Jahre, arbeitete 1819 mit 20 Feinspinnmaschinen, producirte auch schöne Garne, hat aber niemals günstige ökonomische Resultate geliefert und ist später ganz eingegangen. Keinen bessern Erfolg hatten die anderen, sowohl in Frankreich wie in Oesterreich gegründeten Unternehmungen dieser Art.

Die Situation für die continentale Flachsspinnerei wurde jetzt immer bedenklicher. England hatte bereits durch ausserordentliche Verbesserungen in den Constructionen der Spinnmaschinen einen mächtigen Vorsprung vor allen anderen Ländern, und erst als man in diesen ebenfalls mit den verbesserten englischen Maschinèn mechanische Spinnereien anzulegen begann, konnte man der englischen Concurrenz wieder mit Erfolg begegnen.

Frankreich baut jetzt seine Flachsspinnmaschinen selbst und versorgt auch einen Theil der umliegenden Länder mit denselben. Die Maschinenindustrie Deutschlands und Oesterreichs wagt aber nur sehr vereinzelt gegen die englische, welche einen weiten Vorsprung hat, anzukämpfen, und so sehen wir diese Länder leider fast ausschliesslich nur mit englischen Maschinen arbeiten.

In Oesterreich verdankt die neuere, von Erfolg begleitete Flachsmaschinenspinnerei ihre Einführung dem Fabrikanten Johann Faltis, welcher im Jahre 1837 in der Mitte des böhmischen Flachsbaues und der Leinenweberei - nämlich in Jungbuch bei Trautenau - die erste Flachsgarn-Maschinenspinnerei mit englischen Maschinen errichtete. - In Deutschland war es die königl. preussische Seehandlung, welche durch Errichtung mehrerer derartiger Etablissements in Schlesien weitere Anregung zur Verbreitung der Maschinenspinnerei gab.

Jetzt hat dieser Industriezweig in allen industriellen Ländern weite Verbreitung gefunden. Er nahm in Folge des nordamerikanischen Krieges und des dadurch hervorgerufenen zeitweiligen Baumwollmangels einen ausserordentlichen Aufschwung, so dass beispielsweise in Oesterreich in dem kurzen Zeitraume von 5 Jahren die Zahl der Flachsspinnereien in dem Reichenberger Handelskammerbezirk von 18 im Jahre 1860 auf 36 im Jahre 1865 stieg, mit etwas mehr als 200.000 Spindeln, welche über 25.000 Arbeitern Lebensunterhalt verschafften und für etwa 12 Millionen Gulden Garn lieferten. - Doch machte die Flachscultur nicht gleiche Fortschritte mit der Entwickelung dieser Indussrie, so dass man in Oesterreich wie Deutschland meist auf den Bezug fremder Flächse angewiesen war und in missliche Abbängigkeit von ausländischen Flachsmärkten gerieth. Die Flachsindustrie erlitt zudem durch die Wiederkehr günstiger Verhältnisse in Amerika einen empfindlichen Stoss, dazu traten wiederholte Missernten im Flachsbau und in Folge dessen enorme Preissteigerungen des Rohmaterials, während dagegen gleichzeitig die Garnpreise sanken, einmal des wieder erfolgten Aufschwunges der Baumwollenmanufactur wegen, dann aber wegen des unmöglich gemachten Exportes von Leinenfabrikaten nach Amerika, welches auf die Einfuhr aller Leinenartikel einen Werthzoll von $25 \%$ legte. Die in den letzten Jahren wieder eingetretenen billigeren Rohflachspreise, so wio die Anfertigung neuer, früher nicht hergestellter Webeartikel aus diesem Material, haben die Verhältnisse wieder etwas gebessert; doch kann nur durch rationelle Flachscultur - indem mehr und besserer Flachs als bisher in den eigenen Ländern erzeugt wird - der Wiederkehr grösserer Calamitäten in diesem Industriezweige vorgebeugt werden.

Die Handspinnerei kommt jetzt nur noch sehr vereinzelt in den ländlichen Wirthschaften vor; sie ist fast gänzlich durch die Maschinenspinnerei, von der jetzt ausschliesslich die Rede sein soll, verdrängt worden.

Das Hecheln mit der Hand, vgl. pag. 527, ist auch jetzt noch in rielen Fabriken ausschliesslich im Gebrauch, in anderen jedoch hat auch die Maschinenhechelei Eingang gefunden, ohne dass man deshalb der Handarbeit dabei gänzlich entbehren könnte. - Bei der Anwendung von Hechelmaschinen - die erst in den letzten Jahrzehnten genïgend vervollkommt sind - verfährt man häufig in der Weise, dass die Flachsristen zuerst auf der Abzugshechel (Ruffer) an den Enden gerade abgerissen, vorgespitzt werden, hierauf den Hechelmaschinen ibergeben, und endlich noch durch eine oder zwei Ausmachehecheln gezogen und gleichzeitig: sortirt werden. - Geringere Flächse werden nur vorgespitzt, gehen dann aut. 
die Hechelmaschinen iiber und werden nach der Bearbeitung auf diesen, ohne nochmalige Anwendung von Handhecheln, gleich bei den Hechelmaschinen in verschiedene Sorten ausgelegt.

Die feinsten - gewöhnlich belgischen oder holländischen - Flächse, welche zu hohen Garnnummern für Zwirn- oder Spitzengarne verarbeitet werden sollen, werden in geschwungenem Zustande - noch vor dem Hechelprocesse - auf besonderen Zerreissmaschinen in 3 Theile zerrissen, von welchen Kopf- $\mathrm{u}$. Wurzelenden weniger brauchbar sind und nur der mittlere, gleichmässig starke Theil, zu dem besagten Zwecke verwendet wird. Frïher wurde fast jeder nur einigermassen lange Flachs in dieser Weise geschnitten, um gleich lange Theile zu bekommen und diese auf Maschinen von bestimmten Dimensionen verarbeiten zu können; jetzt baut man die Maschinen der natïrlichen Länge der Faser angemessen und zerlegt daher nur in dem zuerst erwähnten Falle den Flachs. Man nennt solchen Flachs geschnittenen Flachs (lin coupé - cut lin [flax]), im Gegensatz zu dem nicht geschnittenen, langen Flachse (long lin).

Die Zerreissmaschine ist ein- oder zweiseitig und hat dem entsprechend vier oder acht eiserne Einführungsscheiben, die $\mathrm{zu}$ beiden Seiten der Schneidescheibe auf zwei resp. vier parallelen, über einander liegenden Achsen paarweise befestigt sind. Die Einfïhrscheiben haben etwa einen Durchmesser von $0.3^{\mathrm{m}}$ bei $2^{\mathrm{cm}}$ Breite und es sind die oberen mit zwei ringsherum laufenden Stäbchen, die unteren mit entsprechenden Hohlkehlen versehen, um den Flachs fest zu fassen. Die Schneidescheibe, deren Achsé parallel den Achsen der Einziehwalzen in der Mitte zwischen den oberen und unteren, resp. vorderen und hinteren liegt, ist grösser, verstählt und mit einem gezackten Rande rersehen; sie bewegt sich mit bedeutend grösserer Geschwindigkeit als die Einführscheiben. Eine starke Riste geschwungenen Flachses wird mit beiden Händen gefasst und mit den zwischen liegenden Punkten den Einführscheiben übergeben. Letztere ziehen den Flachs hinein und führen ihn gegen die gezackte Scheibe, welche ihn schnell entzwei reisst. Bei doppelseitigen Maschinen wirkt alsdann die Schneidescheibe auf der einen Seite von oben nach unten, auf der andern von unten nach oben. Nach einem zweiten Systeme wird die Flachsriste um einen festen viereckigen und mit dem anderen Ende um einen sich drehenden Zapfen gewickelt, wodurch zwischen beiden das Zerreissen der Fasern erfolgt. Man muss diese Methoden und kann nicht etwa das Abschneiden mit einer Scheere anwenden, weil die Fasern, um sich leicht und gut spinnen zu lassen, keine stumpfen Enden haben dürfen. In Oesterreich und Deutschland wird der Flachs nur sehr selten in geschnittenem Zustande verarbeitet.

Ehe aber der lange oder der kurze (geschnittene) Flachs versponnen werden kann, muss er auf das sorgfältigste gehechelt und sortirt werden, wie dies schon im Artikel „Flachs" erwähnt wurde. Während eben daselbst die Handhechelei ihre Besprechung gefunden hat, erübrigt jetzt noch die Betrachtung der $\mathrm{M}$ aschinenhechelei.

Das Hecheln mittelst Maschinen*) geschieht durch Nadeln, welche auf Hechelstäben, gewöhnlich hölzernen, mit Blech iiberzogenen Leisten befestigt sind, während die Flachsristen in Kluppen oder Zangen eingespannt gehalten und so bewegt werden, dass die grössere hervorstehende Hälfte derselben zuerst an den Spitzen und allmälig nach der Mitte zu bearbeitet wird. Nach einmaligem derartigen Durchhecheln kommen andere, feinere und dichter stehende Nadeln zur Wirkung. Dieser Process wiederholt sich mehrmals, worauf die Risten nach genïgendem Aushecheln von beiden Seiten umgespannt und auf der andern Hälfte ebenso behandelt werden. - Es ist gleichzeitig eine Vorrichtung thätig, welche ron den Hecheluadeln das ausgehechelte Werg (Heede) abnimmt.

Die ältesten der angewendeten $\mathrm{He}$ ch el $\mathrm{m}$ a s $\mathrm{ch}$ in en (machine à peigner le lin, peigneusse - heckling machine) ron Peters bestanden aus einer Falze mit Hechelstüben besetzt. Die in Kluppen eingespannten Flachsristen, in horizontale Führungen eingelegt und über dieser rotirenden Tralze entlang geführt, wurden dadurch ausgebechelt, dass die herabhängenden Enden derselben sich in die Walzennadeln legten. Durch Umlegen der Kluppen und nachheriges Umspannen der Risten erreichte man die Bearbeitung von allen Seiten. Diese Maschinen sind in ihrer Wirkung sehr unrollkommen.

Siehe: Supplement zu Prechtl's technologiseher Eneyklopädie 3. Bd. pag. 108 bis 120 , ferner "Aufsatz über Hechelmaschinen" von Prof H. Falke in der deutschen IndustrieZeitmng 1877 Nr. 47 und 48 . 
Eine viel bessere Maschine ist die von Girard (1810) construirte, bei welcher der Flachs gleichzeitig von beiden Seiten bearbeitet wird. Die Narleln sind bei dieser Maschine in mehreren Reihen auf zwei Platten derartig angebracht, dass die Spitzen einander zugekehrt sind und liegen mehrere derartige Plattenpaare init imm' feineren Narlelgarnituren in einer Reihe neben einander. Oberhalb derselben sind Bahnen angebracht, zwischen denen sich Ketten fortbewegen, in welche die Kluppen mit den eingespannten Flachsristen ringehängt sind, diese werden somit langsam horizontal ïber den Hechelplatten fortbewegt, wodurch die herabhängenden Enden allmälig zwischen sämmtliche derselben gelangen. Den Platten wird von zwei gekröpften Wellen durch Schubstangen eine derartige Bewegung ertheilt, dass dieselben zunächst unter gegenseitiger Annäherung niedergehen, wodurch die Flachsenden erfasst und ausgehechelt werden, sodann sich von einander entfernen, aufwärts steigen, sich wieder nähern und auf's Neue abwärts gehen u. s. w. Obgleich diese Maschinen vielfach verbessert wurden, so von Decoster und von de Weight, und obgleich Valson, Levillard \& Chardot die horizontale Führung der Kluppen durch eine schräg abwärts gehende ersetzten, so dass zuerst die Spitzen der Risten und dann allmälig die Mitten derselben bearbeitet wurden, so ist dieses System doch ebenfalls bereits verlassen und durch einfachere und bessere Constructionen ersetzt worden.

Zu den neueren, Hechelmaschinen gehört die von Taylor, Wordsworth \& Comp. in Leeds gebaute Maschine, welche seit 1840 in österreichischen und deutschen Spinnereien vielfach Eingang gefunden hat, und deren Prinzip noch jetzt vielen Hechelmaschinen zu Grunde liegt.

Die hierbei gebrauchte Anwendung von zwei einander zugekehrten verticalen, endlosen Hecheltüchern, welche in der Längenrichtung aus mehreren Hechelfeldern mit zunehmender Feinheit und Dichtigkeit der Nadeln bestehen, zwischen welche die in Kluppen eingespannten Flachsristeu durch eine auf und nieder gehende Bahn eingeführt, erst an den Spitzen und dann weiter gegen die Mitte ausgehechelt, alsdann in ihrer höchsten Lage ausser dem Bereiche der Nadeln den folgenden Feldern zugeschoben werden, zeigen die neneren Maschinen fast sämmtlich und sind meist nur Aenderungen in den Bewegungsmechanismen und einigen Detailconstructionen zu erwähnen. Das

Emporbeben der Risten geschieht aber nicht plötzlich, sondern nur etwas rascher Fig. 165 4. als das Senken.

Von den neueren Hechelmaschinen sind ferner folgende zu erwähnen:

Die Combe'sche oscillirende Hechelmaschine mit Leistenapparat und Kammstäben zum Abstreifen der Heede (oscillating stripper bar hackling machine). Diese Maschine hat, wie die Figur 1654 in einem Querschnitt zeigt, zwei endlose Hecheltücher $a$ und $b$, die aber auf der einander zugekehrten Seite oben weiter als unten von einander abstehen; was einerseits durch die Stellung der obern Führungsrollen o gegen die untern $u$, anderseits durch die Bleche $i$ i bedingt ist. In der Längenrichtung sind sechs immer feiner werdende Hechelfelder vorhanden. Die Bahn $d$, in welche die Kluppen $c$ mit den eingespannten Risten gelegt werden, kann um den festen Zapfen $e$, wie die Pfeile andeuten, entweder nach der Richtung von $f$ oder nach der von $g$ schwingen. Die Wirkung ist folgende: div zwischen beiden Hechelfeldern senkrecht herabhängende Flachsriste wird bei der Bewegung der Bahn $d$ nach der Richtung $f$ zunächst an den Spitzen unł dann nach und nach mit der ganzen freien Länge au 
das Hechelfeld (sheet) $a$ angelegt und auf dieser Seite bearbeitet. Ist dies geschehen, so dreht sich die Bahn zurück in ihre mittlere Lage und dann weiter in der Richtung nach $g$, so dass jetzt in derselben Weise die Riste an das Hechelfeld $b$ angelegt und von diesem auf der anderenSeite bearbeitet wird. Hierauf stellt sich die Bahn in die Mitte und nun werden die Kluppen weiter in die Maschine hineingeschoben, worauf dieselbe Manipulation in der beschriebenen Weise auf dem zweiten Hechelfelde beginnt $u$. s. w.

Eine andere, neuere Hechelmaschine von Combe gehört unter die mit vertikalen Hecheltüchern versehenen Maschinen. Sie ist mit demselben Heedeabnehme-Apparat $m$ versehen wie die vorige (Vertical sheet stripper bar hackling machine). Die folgende Fig. 1655 stellt die arbeitenden Theile im Querschnitt dar. Wie aus dieser Figur hervorgeht, sind die beiden Hecheltücher $a$ und $b$ oben einander so weit genähert, dass die Nadeln des einen Tuches zwischen denen des anderen hindurch streichen, während dieselben unten etwas weiter von einander abstehen. Die in die Bahn $d$ eingelegten Kluppen $c$ mit den eingespannten Flachsristen nehmen eine auf- und niedergehende Bewegung an. Sind sie im höchsten Punkte, so bleiben sie daselbst einen Moment ruhig stehen und werden dabei in das folgende Hechelfeld, deren im Ganzen sechs vorhanden sind, hineingeschoben.

Der Bahnhub ist verstellbar, so dass die Maschine für längern und kürzern Flachs eingestellt werden kann. Das Heben und Senken der Bahn geschieht durch ein Excenter, und zwar so, dass $7 / 12$ einer Umdrehung desselben auf das Heben und $5 / 12$ auf das Senken verwendet wird. Die Fortrïckung der Zangen erfolgt von demselben Excenter aus durch eine Rolle, von der die Bewegung durch Hebel, Zugstangen und einen im oberen Theile angebrachten Winkelhebel auf Stosstangen übertragenwird,

\section{Fig. 165 5.}

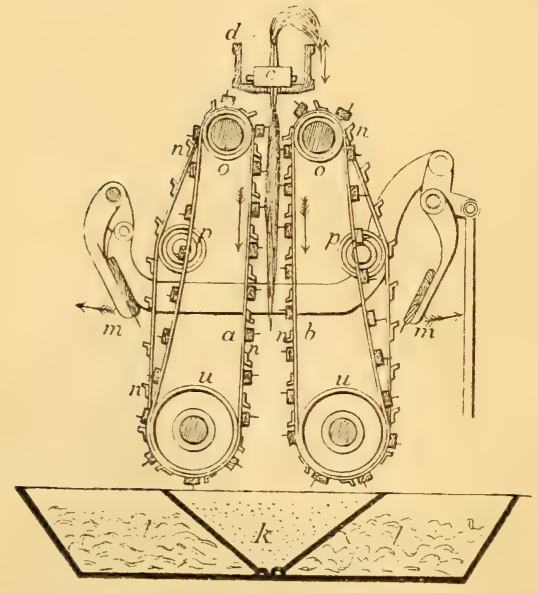

Combe's neuere Hechelmaschine. die gegen die Kluppen in der Bahn wirken. Die $\mathrm{Zu}-$ rückführung der Stosstangen geschieht durch ein Gewicht, wodureh erreicht wird, dass im Fall eines Steckenbleibens oder irgend eines anderen Hindernisses das 'erwähnte Gewicht sich nicht senkt, Beschädigungen der arbeitenden Theile also nicht eintreten können.

Damit das Einstechen der Hechelnadeln in die Risten möglichst rechtwinklich geschehe, sind die $\mathrm{He}$ chelleisten in den oberen Scheiben eigenthümlieh geführt, wie die Fig. 1656 angibt.

Die Maschine wird jetzt mit einer zweiten Schubstange auf der Kluppenbahn versehen,wodurch es möglich ist die Kluppen über die letzten Hechelfelder hinwegzuführen, olne dass ein Hechelu stattfindet, was die Anwendung ein und derselben Maschine für recht verschiedene Flachsgattungen, die mehr oder weniger gehechelt werden sollen, ermöglicht.

Das Abnehmen der ausgehechelten Heede von den Hechelnadeln bei dieser und der vorher erwähnten Combe'schen Maschine findet folgendermassen statt. Zwischen den Hechelstäben liegen die Abnehmeleisten n, entweder viereckige hölzerne Schienen wie in Fig. 1654, 
oder besser gewalzte Winkelschienen wie in Figur 1655, welche auf besondern, ebenfalls iiber die Rollen $o$ und $n$ gehenden Lederriemen befestigt sind. In dem abwärts gehenden Theile der zusammen arbeitenden Hechelfelaer liegen diese $\mathrm{Ab}$ nehmeleisten so tief, dass die Nadeln der Hechelstäbe vollständig über dieselben herausragen. Sobald diese aber die untere Rolle $u$ passirt haben und aussen aufwärts gehen, werden sie durch besondere Führungsrollen $p \quad p$ aus den Hechelstäben herausgehoben, wodurch die Heede von den Nadeln abgestrichen wird und in darunter befindliche Kasten fällt. Diejenige Heede indessen, welcke an den Abnehmeleisten etwa hängen bleibt, wird von dem anliegenden Kamme $m$ gefasst und bei jedem Spiel der Maschine, bei jeder Kluppenverschiebung, durch eine seitliche, rüttelnde Bewegung von denselben abgeschüttelt. Für sehr feineFlächse ist jedoch diese Abnehme-Vorrichtung nicht vollkommen geeignet, und wendet man dann einen Bürst- und Kammwalzen-Apparat an (vertical

Fig. 1656 .

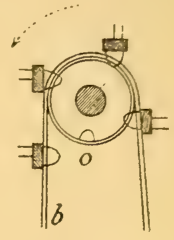
sheet lackling machine withbrush doffer).

Der untergestellte Heedekasten enthält drei Abtheilungen $l, k$ und $l$, von denen die beiden äusseren $l . l$ zur Aufnahme der Heede dienen, der mittlere $k$ hingegen nur die Schäben, welche bei dem Hechelprocess direct abfallen, auffängt. Bei dieser Anordnung bleibt die Heede viel reiner, als wenn eine derartige Trennung nicht vorgenommen wird.

An beiden Enden der Maschine sind Tische zum Ein-, Um- und Ausspannen der Flachsristen aus den Kluppen angeordnet, welche Arbeit gewöhnlich mit Hilfe von Schraubenschlüsseln mit der Hand vorgenommen wird, wobei die Kluppen horizontal auf den Tisch mit ihren Nasen in entsprechende Vertiefungen eingelegt und dadurch festgehalten werden. Das Auf- und Zuschrauben der Flachskluppen ist eine sehr ermüdende Arbeit, und wenn letzteres nicht sorgtältig und fest genug geschieht, so werden bei dem Hechelprocesse auch gute, nicht genügend festgehaltene Fasern mit aus den Kluppen herausgerissen. Dieser Umstand hat die Firma Combe \& Barbour in Belfast veranlasst, einen mechanischen Einspanner (Barbour's Patent) bei ihren Maschinen einzuführen.

Die folgende Figur $1657 *$ ) bringt diesen Apparat zur Anschauung. Die Kluppe wird auf den Tisch $T$ so gelegt, dass die Mutter, welche dieselbe zusammen hält, in den Schlüssel $a$ zu liegen kommt. Dieser Schlïssel ist vertikal drehbar gelagert und am untern Ende mit einem konischen Rade versehen, das mit zwei anderen, auf einer horizontalen Welle $c$ lose drehbaren Rädern in Eingriff ist. Die Welle $c$ wird während des Betriebes durch die Schnurscheibe $p$ in Drehung versetzt. Sobald nun die Zahnkupplung: $b$, die mittels Feder und Nuth verschiebbar auf der Welle $c$ angeordnet ist, nach links oder rechts mit den anderen Hälften der Kupplungen an den konischen Rädern in Verbindung gebracht wird, erfolgt die Drehung des Schlïssels $a$ nach der einen oder der andern Richtung, also das Oeffnen oder Schliessen der Kluppe. Die KupFig. 1657. plung steht gewöhnlich in der Mittellage und wird nach der einen oder der anderen Seite durch die Tritthebel $d d$ und den Winkelhebel $e$ gebracht und dann vermöge der unteren schrägen Flächen desselben durch den Gewichtshebel $f$ in dieser Lage gehalten. Das festere oder losere Einspannen hängt von der Grösse der Gewichte

*) Siehe Dingl. polyt. Journ. Band 210 pag. 88 . 
$a b$ und löst sich bei grösserem, als diesem Gewichte entsprechenden Widerstande die Kupplung $b$ von selbst aus, indem der. Winkelhebel $e$ in die Mittellage zurïckgeht.

Die Hechelmaschinen einer Reihe anderer Constructeure sind sämmtlich mit den verticalen Hecheltüchern versehen, so auch die von Rousselle \& Dosche, von Ward, von Stephen, Cotton \& Comp. in Belfast etc.

Schliesslich mag noch die Maschine von Horner in Belfast erwähnt werden, da dieselbe mehrere Eigenthïmlichkeiten zeigt. Die folgende Fig. 1058 stellt dieselbe im Querschnitt dar.*) Sie ist, wie aus derselben hervorgeht, eine Doppelmaschine mit zwei neben einander angeordneten, endlosen, verticalen Hecheltücherpaaren $a_{1} b_{1}$ und $a_{2} b_{2}$ und zwei Bahnen $d_{1} d_{2}$ zur Aufnahme der Kluppen $c$. Der bekanntermassen in die Kluppen gespannte Flachs wird zunächst in die linke Bahn $d_{\uparrow}$ eingelegt, vier- bis sechsmal - entsprechend der Anzahl der vorhandenen Hechelfelder - nieder- und aufgeführt und ruckweise weitergeschoben, bis er sämmtliche Hechelfelder passirt hat und am anderen Ende abgeliefert wird. Hier erfolgt das Umspannen der einmal gehechelten Risten, die dann auf derselben Seite in die zweite Bahn $d_{2}$ eingelegt und in entsprechender Weise bearbeitet, wieder auf der vorderen

Fig. 1658 a.

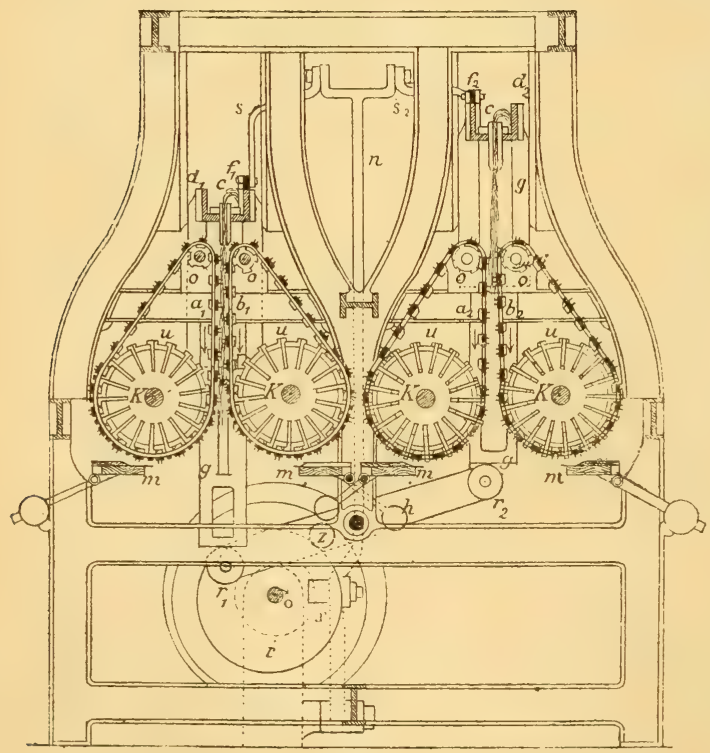

Horner's Hechelmascline.
Fig. 1658 b.

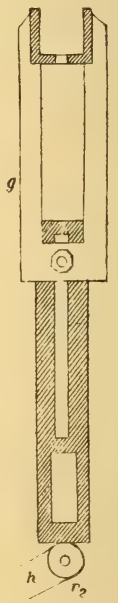

Seite abgeliefert werden. Das Transportiren der einmal bearbeiteten und umgespannten Risten nach der Eingangsseite, behufs nochmaligen Einlegens bei einfachen Maschinen, fällt also bei dieser Anordnung weg.

Die beiden Bahnen sind nahe an ihren Enden mit Schienen $g$ verbunden, die in obern Theile in den Gestellständern ihre verticale Fïhrung erhalten, während sie mit ihren unteren Enden lose auf den Rollen $r_{1} r_{2}$ der gleicharmigen Hebel $h_{c}$ ruhen. die auf einer gemeinschaft-

*) Siehe Prof. Hartig: Versuche über den Kraftbedarf der Maschinen in der Flachsund Werggarnspinnerei, Leipzig 1869. 
lichen, entlang der Maschine gehenden Achse fest sitzen. Die hierdurch abbalancirten Bahnen erbalten ihre auf- und niedergehende Bewegung durch die Hehel $h$. Der rine derselben fusst nämlich mittels eines Rollgapfens in die excentrische Nuth der Scheile i, durch deren Drwhng die Oscillation beider durch eine Achse verbundenen Hebel erreicht wird. Der erwähnte hollzapfen kanu in verschiedenen Entfernungen vom J)relpunkte des Hebrels festgrestellt, alsu, der Hub für verschieden lange Flächse verändert werden.

Damit aber auch bei verschiedenem Huhe die Hechelnadeln stets mïrglichst dicht an den Kluppen in den Flachs einstechen, sind die Schienen $g$ aus zwei iiber einander verschiebbaren Theilen hergestellt (Fig. 1658b), so dass man deren Länge verändern kann. Verschiedene Wechselräder erlauben ferner die Umdrehungszahl jener Welle zu ändern, von der aus der Hul, und die Kluppenverschiebung bewirkt wird, so dass bei gleich bleibender Geschwindigkeit der Hecheltiicher die Risten längere oder kürzere Zeit der Einwirkung dersellen ansgesetzt bleiben Ferner kanm auch noch die Geschwindigkeit der Hecheltiicher geäudert, also jerle nur irgend wünschenswerth erscheinende Bearbeitung erreicht werden.

Das Fortschieben der Kluppen geschieht durch den aufrecht stehenden, oben gabelförmigen Hebel $n$, der im tiefsten Punkte seinen Drehpunkt hat und Fig. 1659. etwas darüber mit einem Rollzapfen versehen ist, welcher in einem derartig schraubengangähnlich ausgeschnittenen Cylinder läuft, dass durch dessen Drehung der Hebel $n$ eine hin und her schwingende Bewegung mit kleinen Ruhepausen in den äussersten Stellungen erhält. Das gabelförmige Ende dieses Hebels ist mit den Schubstangen $s_{1}$ und $s_{2}$ und diese sind wiederum an den andern Enden mit den Führungsschienen $f_{1} f_{2}$ welche a uf den Bahnen durch Bügel gehalten horizontal verschiebbar sind - durch Gelenk verbunden. Die Schienen $f_{1} f_{2}$ sind mit Stossklinken versehen, welche direct auf die Stossknaggen der Kluppen wirken, und diese dadnrch in ihren Bahnen vorwärts bewegen, was jedesmal dann erfolgt, wenn die betreffende Bahn sich in ihrer höchsten Lage befindet, der Flachs also ausser dem Bereiche der Nadeln ist.

Die auf schmiedeisernen Schienen aufgenieteten Hechelstäbe, an den Enden und in der Mitte auf endlosen Riemen befestigt und dadurch zu einem fortlaufenden Hecheltuche vereinigt, gehen über grössere untere Scheiben $u$ und ïber kleinere obere $o$. Die letzteren sind eigenthümlich ausgezackt, wie Fig. 1659 erkennen lässt, und soll auch hierdurch ein möglichst senkrechtes Einstechen der Nadeln in die Risten erreicht werden,

Der Heedeabnehmapparat besteht aus Putzschienen und Kammleisten. Die unFig. 1660 . teren auf den Achsen $k$ sitzenden Scheiben $u$ haben nämlich radial stehende Schlitze, in denen die hölzernen, an den Enden mit Blech besetzten Putzschienen liegen. Auf der untern Hälfte der Scheiben $u$ treten diese Schienen, in Folge ihres Gewichtes, zwischen den Hechelstäben bis über die Nadeln heraus und streichen dadurch die zwischen sitzende Heede ab, die, so weit sie nicht direct herab in die Heedekästen fällt, noch von den Kammschienen $m$ aufgefangen und in bestimmten Zeiträumen abgeschüttelt wirl. Es tritt hei der Senkung der Kü̈mme $m$ ebentalls eine Schiene ïber die äussersten Spitzen derselben. Die Fig 1660 zeigt diese Einrichtung in etwas grösserem Massstabe. Da 
aber bei diesen Maschinen das sichere, Abstreifen der Heede von dem genügenden Vortreten der betreffenden Schienen, dieses aber lediglich von dem Eigengewichte derselben abhängig ist, so kann dasselbe bei grösseren Widerständen oder Klemmungen unterbleiben, weshalb das bei den Combe'schen Maschinen erwähnte Herausheben der Streichschienen zuverlässiger ist.

Die Horner'schen Maschinen werden übrig'ens auch mit Bürsten- und KammwalzenAbnahme ausgeführt.

Nach Beendigung des Hechelprocesses wird der gehechelte Flachs und das ausgehechelte Werg sortirt, in Magazinen als Material für die Spinnerei gesammelt und aufbewahrt, welche in Flachsspinnerei im engeren Sinne, die sich mit der Verarbeitung des ersteren, und in Wergspinnerei, die sich mit der Verspinnung des letzteren befasst, zerfällt.

\section{Die Flachsspinnerei im engeren Sinne umfasst:}

1. Vorbereitung. Die Bildung von Bändern durch Anlegen und das erste Verziehen und Doubliren derselben auf der Anlege- oder ersten Zugmaschine auch Anlegetisch, Anlege, genannt (table ì étaler, etaleur - spreader, first drawing).

2. Präparation. Das weitere Verziehen, Strecken und Doubliren auf den Zug-, Streck- oder Doublirmaschinen (Strecken, Durchziigen) (banc d'étirage, laminoir - drawing-frame).

3. Vorspinnen. Das letzte Doubliren und Verziehen und das Zusammendrehen der sehr verfeinerten Bänder zu Vorgarn auf der Spindelbank, der Vorspinnmaschine (bank à broches - roving-frame, flyer).

4. Das Feinspinnen bewirkt die Umwandlung des Vorgarns in Feingarn durch erneutes Strecken des ersteren und Ertheilen der bleibenden, festen Drehung an die zur genïgenden Feinheit ausgezogenen Fäden auf der Feinspinnmaschine (machine à filer en fin, métier - spinning frame).

5. Das Haspeln und $\mathrm{Nummeriren}$, das Trocknen des nass gesponnenen Feingarnes und das Packen der Garne. - Hierdurch wird das Garn von den Feinspinnspulen in eine für Verkaufszwecke geeignete Form gebracht. Wir besprechen zunächst noch allgemein:

Die Vorbereitung des Hechelflachses. - Bei allen Maschinen der Vorbereitung ist das Streckwerk gleich construirt. Es besteht zunächst aus den Einziehwalzen, auch Speisewalzen genannt (cylindre fournisseur - feeding or back roller), welche bei der ersten Zugmaschine den auf cndlosen Tüchern aufgelegten Flachs, bei den anderen Maschinen die ihnen zugeführten Flachsbander erfassen und den Streckwalzen (cylinder étireur - drawing or front roller) iibergeben, welche sich mit wesentlich grösserer Limfangsgeschwindigkeit als die Speisewalzen bewegen, und wodurch die Streckung, der Verzug der Bänder ausgeführt wird.

Die Entfernung der Einzieh- von den Streckwalzen - die Distanz (distance entre les axes de denx paires de cylindres successive - ratch reach), welche von der Mitte der unteren letzten Einziehwalze bis zur Mitte der unteren Streckwalze gemessen wird - hängt wesentlich von der Länge der Fasern in den zu streckenden Bändern ab, wie im Artikel Baumwollspinnerei (pag. 343 ) bereits näher auseinander gesetzt wurde. - Da nun der Flachs in sehr verschiedenen Längen ron $30^{\mathrm{cm}}$ bis $76^{\mathrm{cm}}$ (12 bis 30 Zoll engl.) vorkommt, so muss dem entsprechend auch die Distanz je nach der zu verarbeitenden Flachssorte wechseln, und man hat, da dieselbe sich bei den Flachsvorbereitungsmaschinen nur sehr wenig ändern lässt, in gut eingerichteten Spinnereien deshalb stets mehrere Systeme fuir kurzen, mittellangen und langen, er. auch für geschnittenen Flachs. Da der kiirzere Flachs auch zumeist der feinere ist, so sind die Maschinen mit kurzer Distanz für feinere Flächse, die zu höheren Garnnummern verarbeitet werden 
sollen, bestimmt. Bei jedem zusammen gehörenden Systeme von Maschinen hat aber das Streckwerk jeder folgenden Maschine stets eine geringere Distanz, da die Länge der Fasern mit fortschreitender Verarbeitung immer melr abnimmt.

Auf dem Wege zwischen Einzieh- und Streckwalzen werden die Bänder durch einen sich passend vorwärts bewegenden Hechelapparat unterstiitzt, durch welchen ein fortgesetztes Hecheln (Spalten, Zertheilen) und Reinigender Fasern, während sie von den Streckwalzen durch die Nadeln gezogen werden, dadurch stattfindet, dass die Schäbentheilchen und die bei dem friheren Hecheln noch nicht entfernten und bei der Spaltung neu entstandenen kürzeren Fasern - die sich zwischen den Nadeln des Hechelapparates und unter demselben ansammeln - abgestrichen und zuriickgehalten werden. - Der Hechelapparat zeigt je nach der Feinheit des Flachses und der zu erzeugenden Garnnummer Abweichungen in der Entfernung der Nadeln, der Feinheit und Länge derselben. - Die allgemeine Anordnung und Bewegung desselben ist jedoch bei allen Maschinen gleich und geschieht letztere jetzt ausschliesslich durch einen Schraubenmechanismus.

Gleichzeitig mit dem Strecken und auch nach Ausfiihrung desselben wird das Zusammenlegen, D o ubliren, mehrerer Bänder vorgenommen; jedoch iiberwiegt stets der Streck- den Doublirprocess, so dass die von den Ablieferungswalzen (réunisseurs ou débiteurs — delivering rollers) kommenden Bänder dünner und feiner sind, als die, welche urspringlich in die Maschine eingefiihrt wurden.

Wir gehen nunmehr zur näheren Besprechung der einzelnen Arbeiten und der bei denselben angewendeten Maschinen iiber.

1) Die Bildung eines Bandes auf der Anlegemaschine. Die folgende Fig. 1661 zeigt eine Anlegemaschine im Längsschnitt. Der Flachs wird derart ristenweise auf 4 bis 6 endlosen, $76-203^{\mathrm{mm}}$ breiten Ledertiichern $T$, den Speisetiichern (tablier - feeding cloth) ausgebreitet, welche sich horizontal neben einander, iiber dieselbe Treibrolle $a$ und Fubrungs- und Spannrolle $b$ fortbewegen, dass eine Auflage von möglichst gleicher Dicke entsteht. Auf derselben Tuchlänge muss stets dasselbe Gewicht Flachs ausgebreitet werden, zu welchem Zwecke man - wenigstens bei ungeibteren Arbeitern — stets dasselbe abgewogene Flachsquantum auf einer bestimmten markirten Tuchlänge niederlegt. Zugleich wird hier das Vermischen verschie dener Flachssorten vorgenommen, indem man die neben einander laufenden Tiicher mit denselben belegt und die gebildeten Bänder zı einem einzigen vereinigt.

Die endlosen Tïcher fiihren den aufgelegten Flachs zunächst iiber ein Leitblech $J$ zwischen Fiihrungen $l_{2}$ hindurch, welche die Breite begrenzen, nach den Einzugswalzen $p_{1}$ und $p_{2}$, von denen die untere ein glatter, eiserner, angetriebener Cylinder ist, während die obere, durch Gewichte beschwert, lediglich durch Reibung von der unteren mitgenommen wird. Zwischen diesen Walzen werden die Risten soweit zusammen gedriickt, verdichtet, dass sie von dem Hechelapparate vollständig aufgenommen werden können. Sowie die Einzugswalzen den Flachs abliefern, treten von unten sofort 4 bis 6, je nach der Anzahl der vorhandenen Auflegetiicher, auf Stäben (barrettes - fallers, heckle-bar's) befestigte Nadelsysteme (peigne - gill) in denselben ein, welche sich mit etwas grösserer Geschwindigkeit, als die Umfangsgeschwindigkeit der Einzugswalzen beträgt, in schräg anlaufender Richtung entfernen. Diese übergeben den durch die Führungen $l_{3}$ etwas zusammengezogenen Flachs den Streckwalzen $C_{0} C_{1}$, von welchen derselbe ausgezogen, gestreckt, wird. Der zwischen der Walzen herrschende bedeutende Druck veranlasst zugleich eine lose Vereinigung der Fasern, so dass ein fortlaufendes Band von geniigender Haltbarkeit entsteht. Der erste Hechelstab tritt, bei den Streckwalzen angekommen, senkrecht aus den Flachspartien nach unten und geht mit grösserer Geschwindigkeit zurïck, um, wieder bei den Einziehwalzen angekommen, auf's Neue in die Höhe gehoben, den Flachs zu fassen. Während sich der erste Hechelstab von den Einziehwalzen entfernt, treten fortwährend neue 
Hechelstäbe mit Nadelsystemen in den Flachs, so dass derselbe, wie die Fignr zeigt, zwischen $p$ und $C$ unterstiitzt und zugleich ausgehechelt wird.

Die untere Streckwalze $C_{0}$ ist ein glatter oder auch schwach geriffelter Cylinder, welcher zu beiden Seiten der Maschine gelagert ist und den Antrieb empfängt. Durch eine Putzleiste

Fig. 1661.

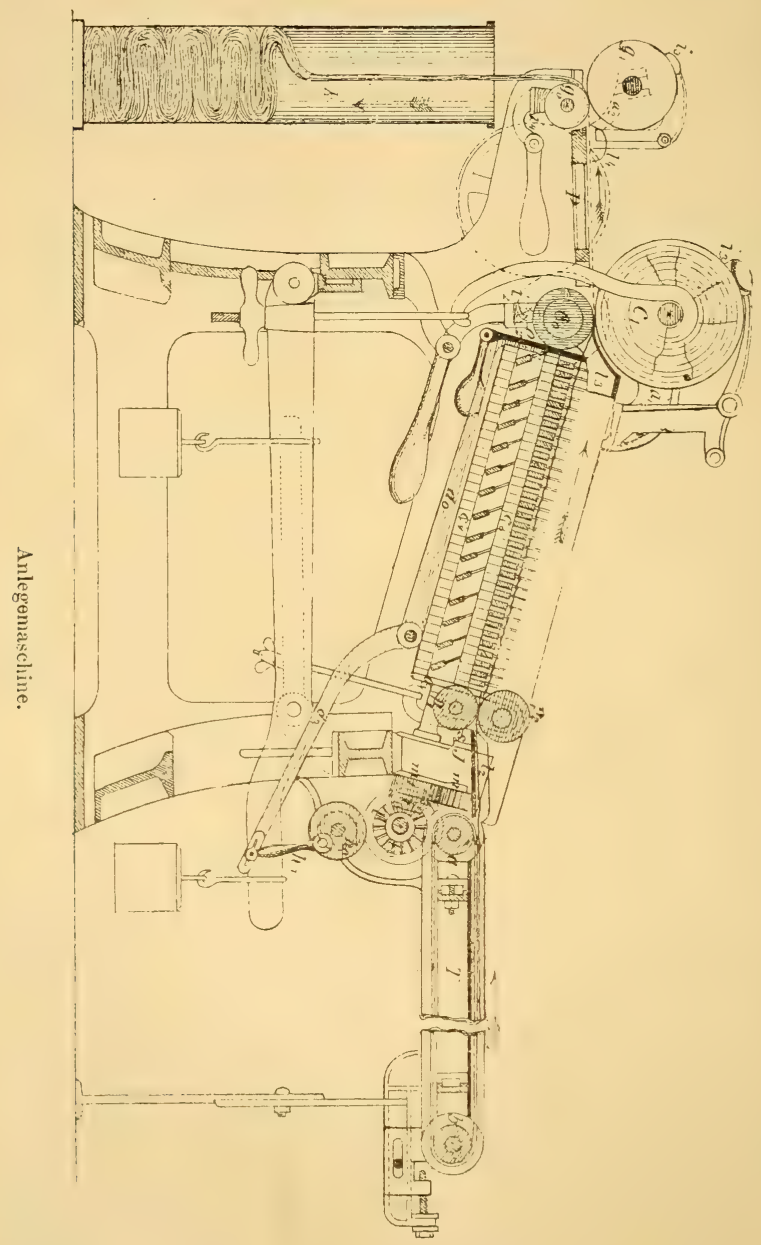

$i_{2}$ wird derselbe von etwa hängen gebliebenen Fäserchen gereinigt. 1)ie oberen Walzen, gewöhnlich ans Erlenholz hergestellt und parweise auf ein und derselben Achse befestigt, sind Druckilzen atrawing-or firontroller pressings, und werden nur durch Reibung ron den unteren mitgenommen. Neucrdings wendet man auch eiserne mit Leder überzogene Druck- 
Walzen an, wie sie in der Jute-Spinnerei beniitzt werden. Je nachclern die Maschine 4 oder (6) Anflagetiicher liat, sind 2 oder 3 Paar Druckwalzen vorhanden. Die Aclisenenden dersellsen laufen in Metall-Lagern, die ihrerseits durch prismatische Fïhrungen der Ständer a gehalten werden, und es wirkt das Belastungsgewicht mittels einer Hebelverbindung und eines Latgerbiigels in der Mitte der Achse. Nenerdings wird die Belastung der Achse an beiden Enden dicht neben den Lagern vorgezogen, da hierdurch eine glvichnässigers Vertheilung des J)rurkfs.s erzielt wird. Oberhalb der Druckwalzen sind Putzer $i_{3}$ zum Abstreifen der kïrøeren Füserchen angeordnet.

Die von den Streckwalzen ausgezogenen Bänder gleiten über die mit 4 oder 6, entsprechend der Anzahl der vorhandenen Bändler, unter 45" geneigten, abgerundeten Einschnitten versehene Doublirplatte $P$ herab, so dass es möglich ist, je 2 oder auch sämmtliche Bänder zu vereinigen und den Ablieferungswalzen $g_{0} g_{1}$ zuzufuhren - von denen entweder 2 Pare, oder, was gewöhnlicher, nur ein Paar vorhanden ist - welche das durch die Leistchen $l_{4}$ zusammengezogene Band in rorgesetzte Blechkannen abliefern. Es findet hierdurch also ein Doubliren von 2 bis 6 Bändern statt. Die unteren Ablieferungswalzen $g_{0}$ sitzen auf einer Achse, welche den Antrieb empfängt; während die oberen massiven gusseisernen Walzen Druckwalzen (delivering pressing rollers) sind, welche in den Ständern $a_{12}$ Führung haben. - Oberhalb dieser Walzen sind wiederum Putzer $i_{5}$ angeordnet. Die Ablieferungswalzen haben eine um sehr wenig grössere Umfangsgeschwindigkeit als die Streckwalzen (1:1.09), wodurch die Bänder stets straff angezogen werden; da aber die Entfernung zwischen Streck- und Ablieferungswalzen kleiner ist als die Länge der Fasern, so miissen die oberen Walzen $g_{1}$ etwas gleiten, was aber auf die Vereinigung der Bänder nur vortheilhaft wirkt.

Um nun stets eine bestimmte, von der Maschine abgelieferte Bandlänge zu erkennen und in den vorgesetzten Blechkannen immer gleiche Längen aufzufangen, um aus dem Gewicht derselben die weiteren Dispositionen zur Erzengung einer bestimmten Garnnummer treffen zu können, ist die Maschine noch mit einem Klingelapparat versehen, der von der Achse der unteren Abzugswalze $g_{0}$ aus in Bewegung gesetzt wird. Bei dem jedesmaligen Ertönen der Klingel wird das Band abgerissen und eine neue leere Kanne untergesetzt.

Die stündl. Einzugslängen betragen etwa 37 bis 122 Yards, die Lieferungslängen 1920 bis 3050 Yards. *)

2) Das weitere Strecken und Doubliren auf den Zug-, Streck- oder D o llblirmaschinen. Man wendet stets mehrere derselben und zwar zwei oder drei nach einander an. Die Bänder der Anlegemaschine zeigen nicht iiberall gleiche Stärke und müssen daher durch Doubliren und Strecken (s. Baumwoll. spinnerei I. pag. 341) ausgeglichen werden.

Eine erste Streckmaschine (premier etirage - first drawing frame) ist in Fig. 1662) im Lüngsschnitt abgebildet. Das Streckwerk ist bis auf die Einziehwalzen nahezu wie das der Anlegemaschine construirt. Der Hechelapparat liegt jetzt horizontal und es besteht die Maschine aus mehreren neben einander liegenden Abtheilungen, Köpfen (tête - heads), von denen der eine gleichsam die Wiederholung des anderen bildet. Jeder Kopf hat ein besonderes Hechelwerk und einen eigenen Mechanismus zum Treiben desselben, ferner eine besondere Doublirplatte und übereinstimmend angeordnete Abzugswalzen.

Die Maschinen zur Verarbeitung verschieden feiner (langer) Flächse weichen in der Anzahl der pro Kopf transportirten Bänder, in der Distanz, der Feinheit des Hechelwerkes und der Anzahl der Abzugswalzen ron einander ab. - Die Fig. 1663 zeigt den Grundriss eines Kopfes dieser Streckmaschine von den Streckwalzen bis zu den Abzugswalzen. Hieraus geht hervor, dass diese Maschine pro

T'eber weitere Details und Kraftbedart s. Zusammenstellung am Ende dieses Abschnittes. IIan sehe auch Prof. Hartig: Teher den Kraftbedarf der Maschinen in der Flachsund Werggarnspinnerei, Leipzig. 
Kopf 4 Bänder transportirt und 2 Ablieferungen hat. (Beispielsweise eine erste Streckmaschine $3 \mathrm{Köpfe} \mathrm{à} 4$ Bänder und 2 Ablieferungen. First dravoing 3 heads à 4 stivers and 2 deliverings).

Die Bänder aus den Kannen $k_{1}$ der Anlegemaschine gelangen uiber die Rollen $v$ Fig. 1662 durch die Führungen $l_{1}$ und seitlich begrenzt durch die verstellbaren Leistchen $l_{2}$ zu den, Einziehwalzen. Diese bestehen aus 3 Cylindern, von denen die unteren 2 durchgehende, zwischen jedem Kopfe der Maschine gelagerte glatte Cylinder $p_{1} p_{2}$ sind, welche durch Räderwerk bewegt werden, während die oberen $p_{3}$ aus kürzeren und zwar für jeden Kopf aus 2 bis 4

Fig. 1662.

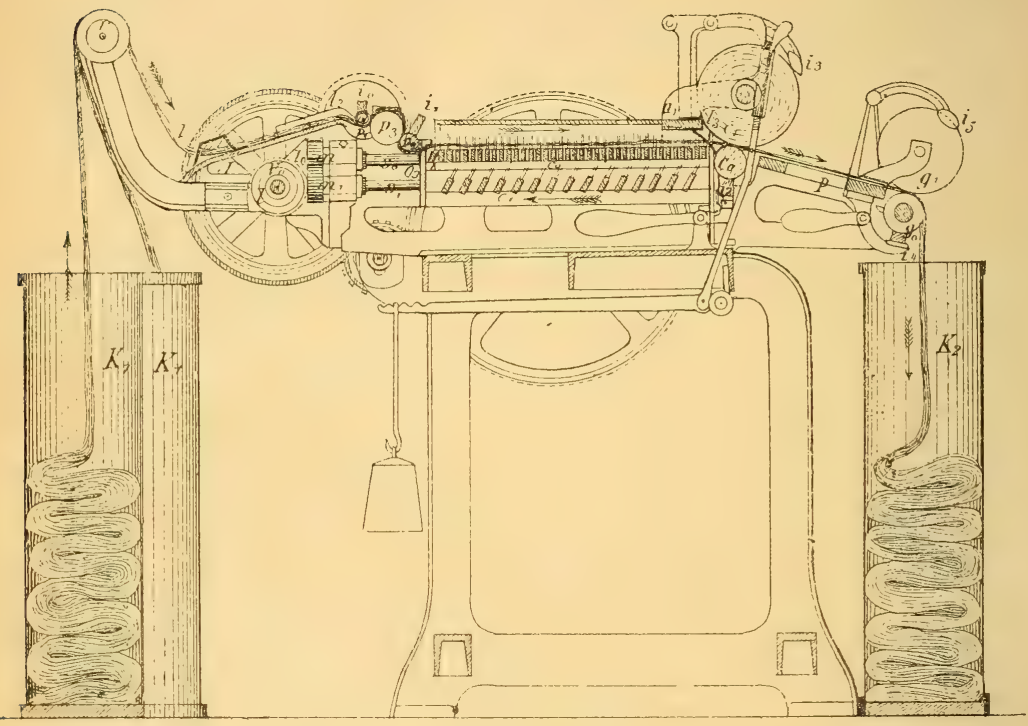

Strecke.

Enden bestehen, die, zwischen die ersteren eingelegt, von diesen nur durch Reibung mitgenommen werden. Zum Abstreifen der am Cylinder $p_{1}$ und $p_{0}$ etwa hängen geblicbenen kürzeren Faseru dienen die Putzleisten (dead rubbers) $i_{0} i_{1}$. Der Weg der Bänder ist aus der Figur ersichtlich, deren iibrigen Theile gleichartig denen der Anlegemaschine sind, und die gleichen Buchstaben aufweisen.

Die stiindlichen Einzugslängen pro Band betragen etwa 48 bis 123 Yards, die Lieferungslängen 957 bis 1720 Yards.

Es eriibrigt die nähere Beschreibung des Schraubenmechanismus zur Bewegung der Hechelstäbe. Fig. $166 t$ stellt den Schraubenmechanismus eines Kopfes der beschriebenen Streckmaschine im Querschnitt dar.

$\mathrm{Zu}$ beiden Seiten eines jeden Kopfes der Streckmaschinen ist ein Paar flachgängiger Schrauben, das eine links-, das andere rechtsgängig geschnitten, angeordnet. Je zwei sich gegenüber liegende Schrauben haben genau gleiche Steigung, doch ist die der untern bedentend grösser als die der obern. Zwischen diesen 
Schrauben liegen mittelst platter Köpfe, welche den Gängen der oberen Schrauben entsprechend an den Enden geneigt sind, auf den Fiihrungen $c_{0} c_{1}$ die Hechelstäbe $S$, und zwar derart, dass sie, ohne zu klemmen, in der Pichtung ihrer Länge möglichst wenig Spielraum haben. Auf diesen Hechelstähen sind die Narlelsysteme 1 bis 4 - entsprechend der Anzahl der Bander - befestigt. Die Hechelstäbe werden durch Drehung der oberen Schrauben $s_{0} s_{0}$ auf den Fiblurungen $c_{0}$ $c_{0}$ entlang gefiihrt. Ist ein oberer Hechelstab an dem Streckcylinder angelangt, so hören die Fig. 1663.

ihn unterstützenden Führungen auf, und zwei am Ende der oberen Schrauben sitzende Daumen $o_{0} \quad o_{0}$ werfen ihn nach unten. Ein Paar flache Federn $o_{0} \quad o_{0}$, welche sich hierbei in entsprechende Nuten der Köpfe des Stabes einlegen, geben demselben die nöthige Führung und hindern ein zu frühes Herabgleiten. (Bei der Streckmaschine sind es 2 flache drehbare, durch Gewichte geeignet beschwerte und angedrückte Schienen, welche diese Fiihrung bewirken.) Der Stab fällt auf die unteren Leisten $c_{1} c_{1}$ und in die Schraubengänge der unteren Schrauben $s_{1} s_{1}$ hinein, welche denselben, da ihre Drehrichtung der oberen entgegegensetzt ist, zurïckführen, und zwar vermöge ihrer gröberen Theilung wodurch an Hechelstäben gespart wird - mit grösserer Geschwindigkeit.

Ist der Stab am vorderen Ende in der Nähe der Einfiihrwalzen angekommen, so wird er durch die Daumen $o_{1} o_{1}$ der unteren Schrauben (Figur

Fig. 1664.

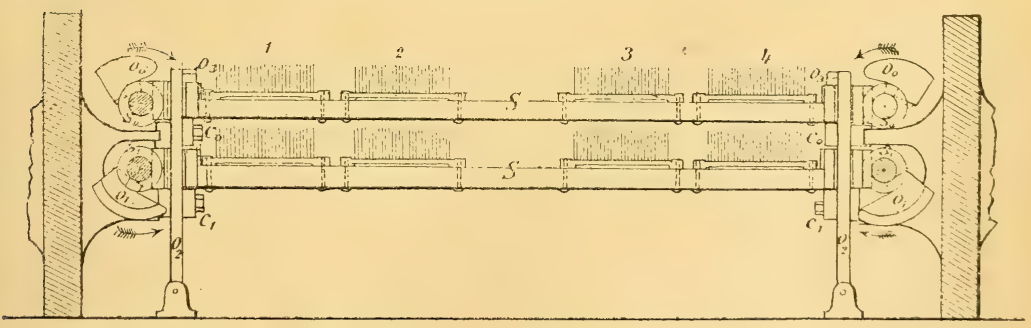

Schraubenmechanismus.

1664) an den Führungsstäben $o_{g} o_{\mathrm{g}}$ iiber die obere Kante der Führungen $c_{0} \quad c_{0}$ emporgehoben und so lange gehalten, bis die oberen Schrauben Zeit haben, ihn zu fassen und weiter zu führen. - Der an den oberen Fiihrungen anf der Seite der Einfuhrwalzen sichtbare Finger fasst dabei in die erwähnte Nut 
der Stabköpfe, in welche vorhin die Federn eingriffen, gibt bei dem Aufwärtsheben eine sichere Führung und gestattet zugleich ein leichtes Einschieben in die oberen Schraubengänge.

Die untern Schrauben werden von der Welle $V_{0}$ Fig. 1662 (back shaft) durch conische R:ider $l, l_{0}$ bewegt und übertragen die entgegengesetzte Drehung durch Stirnräder $m_{1} m$ anf die obern Schrauben. Denkt man sich jetzt Stab neben Stab in das Gewinde der Schrauben eingelegt, so muss bei jeder Umdrehung derselben ein Stab nach unten geworfen werden, während an dem andern Ende gleichzeitig ein Stab nach oben gebracht wird.

Bei den Anlegemaschinen sind, um das Auffallen der Stäbe bei ihrem Austreten aus den obern Schrauben auf die untern Führungen zu mässigen, Empfangshebel $d_{0}$ zu beiden Seiten oder auch nur einer in der Mitte angeordnet (Figur 1661), welche einmal empor und dann wieder niedergehen, wodurch das Inempfangnehmen und sanfte Niedersetzen der Stäbe erreicht wird. Die geeignete Bewegung der Hebel erfolgt von der Hinterwelle $\nabla_{0}$ ans. Diese treibt mittels zweier Räder eine Achse, welche die Excenterscheibe $h_{0}$ trägt, von der durch Schubstange $h_{4}$ der gebogene Hebel $d_{3}$ und durch diesen die horizontale Welle $w$ gedreht wird, auf der die Empfangshebel $d_{0}$ sitzen.

Der Doublir- und Streckprocess wird nun auf der zweiten, bei feinen Garnen anch noch auf der 3. Streckmaschine (second étirage - second drawing frame) wiederholt, das Ausgleichen der Unregelmässigkeiten in der Dicke der Bänder, das Verdiinmen, Verfeinern, das weitere Aushecheln derselben also hierdurch fortgesetzt. Je mehr man deshalb innerhalb praktisch zulässiger Grenzen den Streckund Doublirprocess ausdehnt, um so gleichmässiger und schöner werden die Bänder um so besser und egaler wird auch das aus ihnen gesponnene Garn.

Die neuerdings erhöhten Anspriiche, welche man an die Güte der Garne stellt, verlangen eine recht sorgfältige Vorbereitung und bedingen in Folge dessen anch schon zu weniger hohen Nummern (etwa von Nr. 50 an) die Anwendung ron drei Streckmaschinen hinter einander, auch muss die Anzahl der Köpfe der einzelnen Maschinen vermelırt werden, um geringe Belastung der Nadeln, nicht zu schnellen Gang der Streckwerke und starke Doublirungen - Umstände, die sïmmtlich vortheilhaft auf die Erzengung eines gleichmässig schönen Productes wirken - anwenden zu können.

Die zweiten und dritten Streckmaschinen sind im Princip ebenso wie die erste construirt; die Distanz wird bei jeder folgenden Maschine geringer, weil die Länge der Fasern immer mehr abnimmt, dabei steigt die Feinheit der Hechelwerke. Die Anzahl der pro Kopf eingefiihrten und abgelieferten Bänder nimmt zil und die untergestellten Blechkamnen werden, entsprechend der abnehmenden Stärke der Bänder, von geringerem Durehmesser gewählt. Einzugs- und Lieferungslängen stehen ebenfalls innerhalb der angegebenen Grenzen.

3) Das letzte Doubliren und Vorzielien und das Bilden des Vorgarnes auf der Spindelbank, der Vorspinnmaschine.

Die Bänder von dem Streckwerk der Vorspinmmaschine haben eine so geringe Stärke, dass sie das Verspinnen zu Feingarn, ohne auseinander zu gehen, nicht aushalten wiirden; deshalb erhalten die gestreckten Bänder sofort eine geringe Drehung und heissen dann Vorgespinnst, Vorgarn (rove).

Gewöhnlich werden die Bänder von der letzten Streckmaschine der Spindelbank einfach vorgesetzt; eine Doublirung findet also nicht mehr statt. Nur bei ganz feinen Nummern lässt man die Bänder doppelt in die Vorspinmmaschine gehen. - Die Zufiihrung der Bänder geschieht in derselben Weise wie bei den Durehziigen; auch ist das Streckwerk bis zn den Streckwalzen wie bei diesen construirt, hat nur geringere Distanz und feineres Hechelwerk. Die Streckwalzen liefern aber die Bändchen unmittelbar zu je einer Spindel, mit welcher ein fest anfgesetzter Flügel sich mit constanter Geschwindigkeit umdreht. Das Bändchen umschlingt den Fliigel oder geht, wenn derselbo hohl hergestellt ist, durch einen der hohlen Arme, um sich alsdam anf die Spule, nach Massgabe des Zuriickbleibens derselben gegenüber dem Fliigel, aufzuwickeln. Die Drehung des Vor- 
garnes darf nur eine geringe sein, damit es möglich ist, den Vorgarnfaden zwischen den Streckwalzen der Feinspinnmaschine noch weiter auszuziehen und schwankt dieselbe, je nach der Güte des Flachses, ungefähr zwischen den Grenzen: Drehung pro engl. Zoll $=0.3$ bis $0.5 \mathrm{~N}$; wo $\mathrm{N}$ die Nummer des Vorgarnes ist, ebensis bestimmt wie die des Feingarns.

Es ist nun wegen dieser schwachen Drehung nicht vortheilhaft, das Vorgarn auf eine durch die Spannung des Fadens allein bewegte und durch Reibung zuriickgehaltene Spule aufzuwinden, weil sich dasselbe hierbei ungleichmässig strecken würde und auch der Grad der Drehung nicht constant bleibt, sondern es müssen die Spulen wie bei dem Vorspinnen der Baumwolle (I pag. 347) durch einen besonderen Mechanismus bewegt werden, welcher bewirkt, dass in dem Masse, wie sich der Vorgarnfaden bildet, derselbe ohne erhebliche Spannung in dicht neben einander liegenden Lagen aufgewunden wird.

Die Spindelbank hat demnach auch hier folgende Functionen zll verrichten:

1. Das Strecken der eingeführten Bänder.

2. Das Drehen der gestreckten Bänder, um denselben die nöthige Festigkeit zu geben.

\section{Die regelrechte Aufwindung des Vorgarns anf Spulen.}

Die in der Flachsspinnerei angewendeten Spindelbänke haben Spulen mit Endscheiben, so dass sogenannte weiche Spulen entstehen und die Hubhöhe der Spulenbank stets dieselbe bleibt. Die Pressionsflügel und die Mechanismen, welche die Spulenbankhebung bei jedem Hube um etwas verkiurzen, wie sie zur Erzeugung von harten Spulen in der Baumwollspinnerei angewendet werden (pag. 345 und 347 ), fallen hier also weg.

Die sich mit constanter Geschwindigkeit bewegenden Spindeln haben dieselbe Bewegungsrichtung, wie die Spulen, und bewirken das Drehen des Vorgarnes, welches von den mit geringerer Geschwindigkeit, aber nach derselben Richtung bewegten Spulen gleichmässig aufgenommen wird.

Die mit zunehmender Bewickelung der Spulen nöthigen Aenderungen in der Umdrehungs- und Hebungsgeschwindigkeit derselben werden auch bei den Spindelbänken der Flachsspinnerei durch analoge Mechanismen, unter geringen Abweichungen, bewirkt, wie sie bei der Baumwollenspinnerei eingehend beschrieben wurden (s. Fig. 160 pag. 349 nebst Beschreibung).

Die Flachsvorspinnmaschinen von Samuel Lawson \& Sons in Leeds sind nach diesem Princip gebaut. Es sind aber auch vielfach Spindelbänke in Gebrauch, die mit anderen abweichend hiervon gebauten Regulirungsmechanismen versehen sind, und zwar sind dies Maschinen von Combe, Barbour \& Combe in Belfast und von P. Fairbairn \& Co. in Leeds, von denen wir die Combe'sche Maschine etwas näher besprechen wollen, während die Beschreibung der Fairbairn'schen im Artikel Jutespinnerei nachgesehen werden kann.

Die folgende Fig. 1665 zeigt eine Spindelbank im Querschnitt mit den Combe'schen Aufwindemechanismen. Fig. 1666 gibt eine perspectivische Ansicht der letzteren und Fig. 1667 stellt einen Theil der Spulenbank mit den Stossknaggen dar.

Aus Fig. 1665 erkennt man die mit den Durchzïgen übereinstimmende Construction des Streckwerkes, dessen einzelne Theile mit denselben Buchstabeu wie dort bezeichnet sind. Der untere Streckeylinder $C_{0}$ wird ron der Hauptwelle $I I$ ans, die durch die ganze Maschine geht, bewegt und zwar auf der (in Figur 1665 weggeschnitten gedachten) Seite. Dieser Antrieb ist anch in Fig. 1666 weggelassen worden. Vom Streckcylinder geht die Bewegung rückwärts nach dem Hinterschaft $V_{0}$, welcher die Schraubenmechanismen treibt, und ron diesem nach den Einziehwalzen.

Der gestreckte Vorgarnfaden geht durch die auf den Spindeln $S$ sitzenden Flïgel $f$ nach den Spulen e Fig. 1665. Die Spindeln werden von 2 horizontalen, im unteren soge- 
nannten Spindelkasten gelagerten Wellen durch die hyperbolischen Räder $r_{3} r_{3} \quad$ und $r_{2} r_{2}$ bewegt. Die Wellen stehen mit einander durch gleich grosse Räder $r_{r} r_{\mathrm{I}}$ in Verbindung und wird das eine derselben direct von der Hauptwelle $H$ aus durch die Räder $r$ und $t$ bewegt. Keines dieser Räder kann gegen ein anderes ausgewechselt werden, die Umdrehungen der Spindeln sind daher constant.

Fig. 1665.

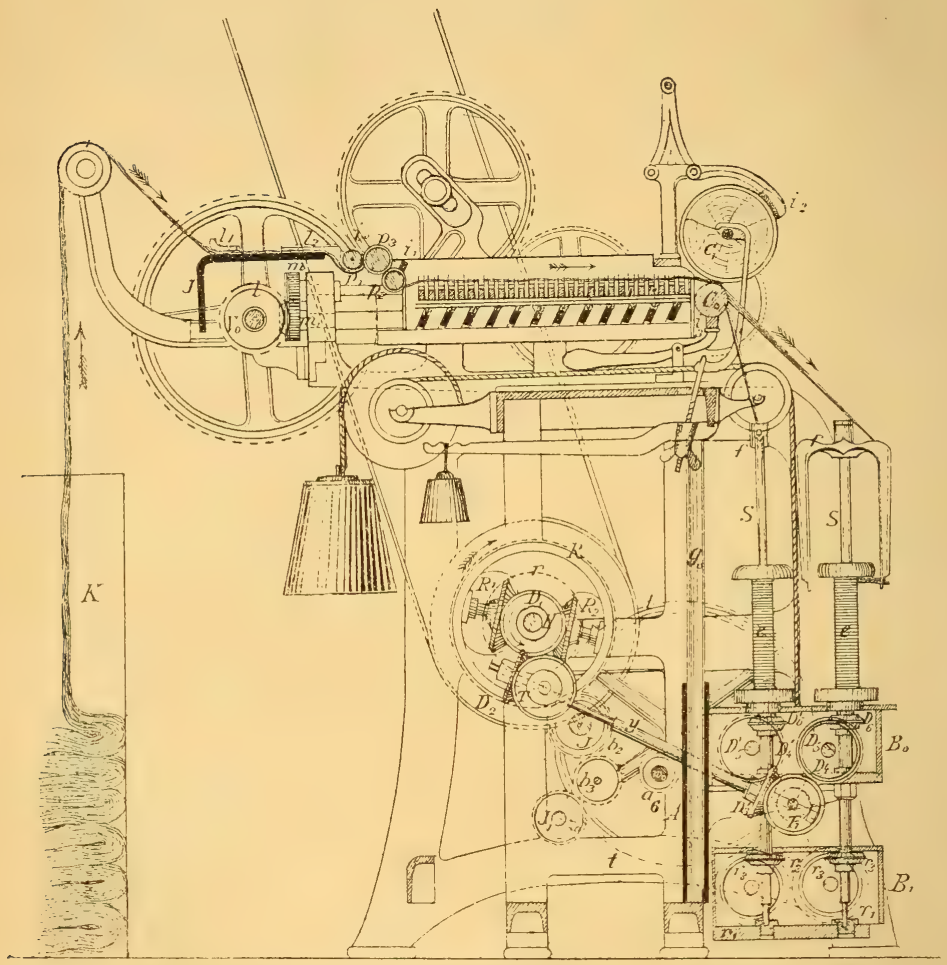

Cumbe's Spindelbank.

Bezeichnet man mit $S$ die constante Umdrehungszahl derselben, mit $L$ die constante Timfangsgeschwindigkeit der Streckeylinder in der Minute, d i. die in derselben Zeit gelieferte Fadenlänge, so ist die Drehung $D$ pro Längeneinheit $D=\frac{S}{L}$

Die Spulen ruhen sämmtlich auf einer durch Gewichte abbalancirten Spulenbank (oberer oder Spulen-Kasten) $B_{0}$, die mit dem ganzen zum Treiben der Spulen nöthigen Räderwerk mittels Zahnstange $A$ ron den anf der Welle $v_{0}$ sitzenden Rädern $a_{G}$ in Gradführungen $g_{0}$ auf und ab bewegt werden kamn, wodurch das Nebeneinanderlegen der Fäden in der Höhenrichtung der Spulen erreicht wird.

Der L'mfang der Spulen bleibt aber nicht constant, sondern wird nach jedem Auf- und Niedergang der Spulenbank in kleinen Abstufungen durch die Bewicklung grösser. Damit 
Flachsspinnerei.

nun das gleichmässig von den Streckeylindern abgelieferte und von den Spindeln aufgenommene Vorgarn ebenso gleichmässig aufgewickelt werde, muss sich hei constanter Umdrelungszabl der Spindeln die Tourenzahl der Spulen und die Geschwindigkeit der Helsung mul Senkung derselben mit ihrem zunehmenden Durchmesser ändern.

Fig. 1666.

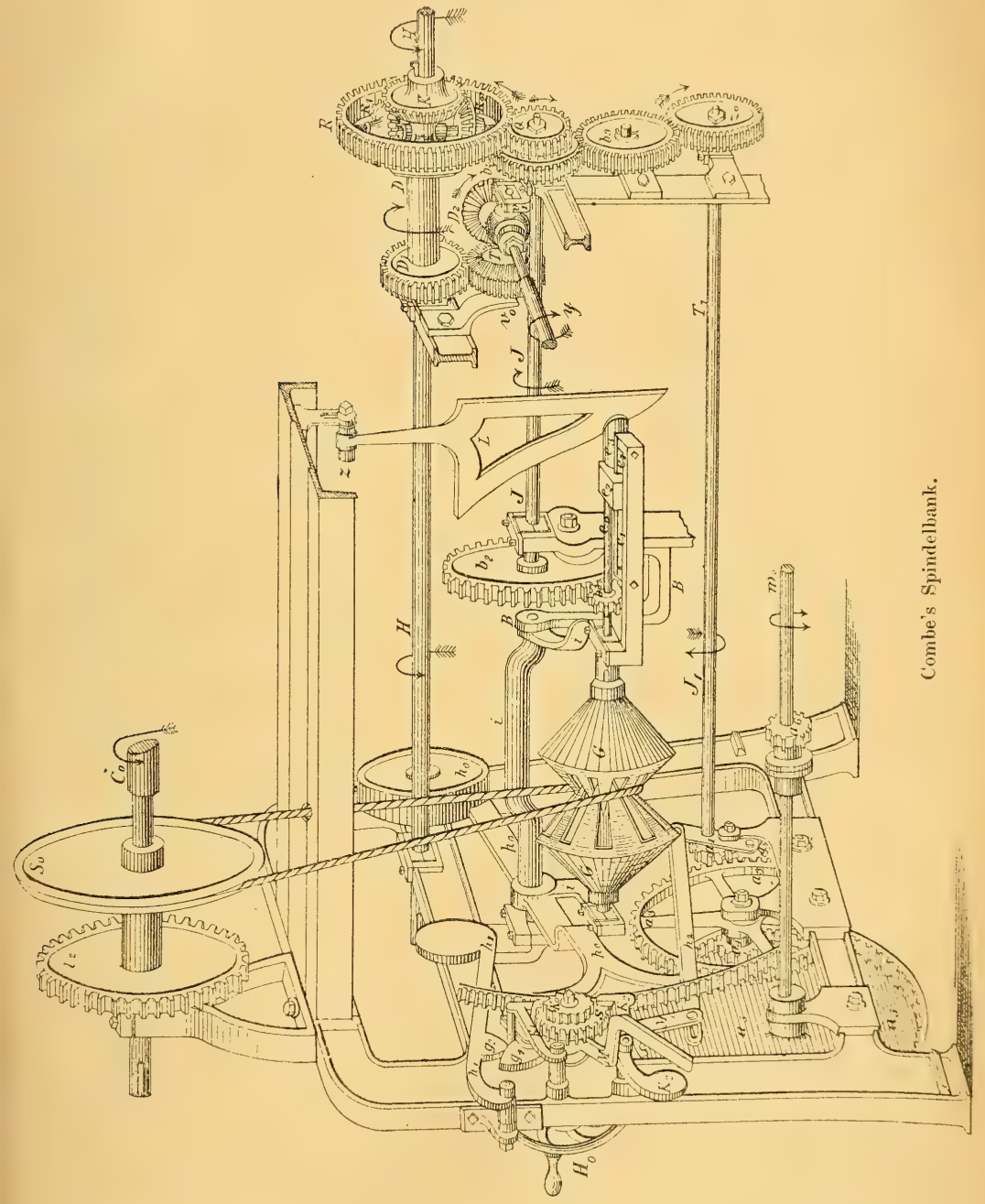

Bezeichnet naan den veränderlichen Spulenumfang mit $u$, die zugehörende Umdrehungszahl der Spulen mit $s$, so ist, da die Aufwicklung auf die Spule stets der gelieferten Faden- 
länge gleich sein muss (wie schon Bd. I Seite 347 erörtert wurde) $L=u(S-s)$ oder auch

$$
s=S-\frac{L}{u}
$$

Aus der ersten Gleichung ersieht man aber sofort, dass, wenn $u$ wächst, die Spule also voller wird, die Differenz zwischen Spindel und Spulenumdrehungen $(S-s)$ abnehmen muss, da $L$ constant ist. Diese Differenz kann aber bei constanter Spindelumdrehungszahl nur abnehmen, wenn die Touren der Spulen zunehmen. Mit zunehFig. 1667. mender Aufwicklung wächst also die Umdrehungs-

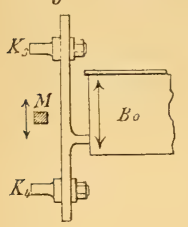
zahl der Spulen. Damit sich aber stets gleichmässig Faden neben Faden lege, muss die Geschwindigkeit der Hebung und Senkung der Spulen, also der Spulenbank proportional der Differenz der Spindel- und Spulenumdrehungszahl sein. Da diese aber bei fortschreitender Bewicklung abnimmt, so muss auch die Hebungsgeschwindigkeit der Spulenbank nach jedem Auf- und Niedergang derselben abnehmen. Die Geschwindigkeit der Auf- und Abwärtsbewegung der Spulen nimmt also mit wachsendem Durchmesser derselben ab.

Die eigenthümlichen Mechanismen, welche diese Bedingungen erfüllen, sollen jetzt näher betrachtet werden, und zwar zunächst die bei der Auf- und Abbewegung der Spulenbank thätigen Theile.

Auf der linken Seite des Streckcylinders $C_{0}$ Fig. 1666 sitzt die Schnurscheibe $S_{0}$ und überträgt ihre constante Geschwindigkeit mittels eines Lederseiles auf die expandible Schnurscheibe, den Expander $G$. Die Expanderwelle ist in der gekröpften Achse $i$ gelagert und diese einerseits in dem Bïgel $B$, anderseits im Gestelle links, so dass die Verbindungslinie der Drehpunkte mit der Mittellinie der Welle $J$ zusammenfällt, die Expanderwelle aber in einem Kreisbogen um die Drehpunkte der Lagerachse $i$ auf- und abbewegt werden kann. Bei leeren Spulen nimmt die Expanderwelle ihre tiefste Lage ein, und es geschieht die Aufwärtsbewegung sprungweise nach jedem Auf- oder Niedergang der Spulenbank. Dicht bei dem Gestelllager ist nämlich die Kropfachse mit Hebel $h_{0}$, der auf der Spindelseite in einen Zahnbogen ïbergeht und auf der hinteren Seite ein Gewicht trägt, fest verbunden. Der Zahnbogen ist mit einem Stirnrädchen $s$ im Eingriff, welches ebenso wie das daneben angeordnete Klinkrad $K_{0}$ auf einem drehbar gelagerten, mit dem Handrade $H_{0}$ versehenen Zapfen befestigt ist. Das an dem Hebel $h_{0}$ sitzende Gewicht wird das Bestreben haben, den Hebel um den Drehpunkt zu drehen, die Expanderwelle also aufwärts zu bewegen. Diese Bewegung hindern zwei Sperrklinken $k_{1}$ und $k_{2}$ ron denen die eine stets in den Zähnen des Sperrades liegt, rährend alsdann die andere durch ein besonders geformtes Gussstück $M$, das auf demselben Zapfen wie Rad $s$ und $k_{0}$, aber lose sitzt, ausser Eingriff gehalten wird. Die Spulenbank bewirkt nun. indem sie am Ende ihres Auf- oder Niederganges mittels zweier Knaggen $k_{3}$ und $h_{\downarrow}$ Fig. 1667 das Gussstück $M$ dreht, wodurch die eine der Klinken zunächst auf die Mitte eines Zahnes gelegt wird, die Auslösung der andern. Das Klinkrad kann sich daher jetzt um einen halben Zahn drehen, so dass bei jedem Auf-oder Niedergang der Spulenbank der Expander um einen bestimmten Bogen gehoben wird. Hierdurch wird aber die verschiebbare Hälfte des Expanders durch Gleiten an einem keilförmigen Lineal $L$ um ein bestimmtes Stïck in die andere Hälfte hinein geschoben - der Expander-Durchmesser also, nach jedem Bewegungswechsel der Spulenbank, rergrössert. Mit wachsendem Spulendurchmesser wird daher die Lmdrehungszahl der Expanderwelle eine geringere, und diese abnehmende Geschwindigkeit wird zunächst durch die Räder $b_{0} \quad b_{1}$ nach der Welle $J$ und ron dieser durch die Räder $b_{2} b_{3}$ und durch das Wechselrad $z_{0}$ anf die Welle $J_{1}$ fortgepflanzt, von welcher die AufAbbewegung der Spulenbank ausgeht.

Hierdurch wird aber die Bedingung erfüllt, dass dieGeschwindigkeit dieser Bewegung mit wachsendem Spulendurchmesser abnehmen soll. Da dureh das Wechselrad $z_{0}$ die Geschwindigkeit der Hebung und Senkung für jeden bestimmten Fall regulirt werden kann, so nennt man dasselbe das Hebungswechselrad.

Der Wechsel der Bewegung selbst geschieht in folgender Weise: 
Die Welle $J_{1}$ ist an ihrem linken Ende (Fig. 1666) in einer Scheibe gelagert und treibt durch das auf ihr sitzende Rädehen $a_{1}$ das ebenfalls in der Scheibe gelagerte gleich grossc Rädchen $a_{2}$. Entweder Rädchen $a_{1}$ oder $a_{2}$ ist im Eingriffe mit dem Uebersetzungsrade $a_{3}$ und dieses wiederum durch Rad $a_{4}$ mit dem Hohlrade $a_{5}$, das am Ende der durch die ganze Maschine gehenden Welle $w_{0}$ sitzt. Diese Welle treibt durch die an verschiedenen Stellen sitzenden Rädchen $a_{6}$ die mit der Spulenbank verbundenen Zahnstangen $A$, welche an den festerı Führungen $g$, auf und ab geschoben werden können (Fig. 1665). Je nachdem Rädchen $a_{\text {: }}$ oder $a_{2}$ mit Rad $a_{3}$ im Eingriff ist, wird dasselbe nach der einen oder der anderen Richtung, die Spulenbank also auf- oder abwärts, bewegt werden. Das Wechseln der Rïdchen muss nun jedesmal in demselben Momente geschehen, in welchem die Spulenbank einen Auf- oder Niedergang vollendet, also gleichzeitig mit der Vergrösserung des Expander-Durchmessers. $\mathrm{Zu}$ diesem Zwecke ist die Scheibe, in welcher die Welle $J_{\tau}$ mit den Rädchen $a_{\mathrm{r}}$ und $a_{2}$ gelagert ist, mit einer Zugstange $h_{2}$ versehen, welche den mit dem Gussstück $M$ fest verbundenen Hebel $M_{\mathrm{r}}$ mit ihrem schlitzförmigen Ende fasst. Das obere Ende des Hebels $M_{1}$ hat ein bogenförmig begrenztes Gleitstück $g_{\tau}$ und wird dasselbe auf einer Seite durch ein ähnliches Gleitstück $g_{2}$ des Gewichtshebels $h_{1}$ berührt. Gegen Ende des Aufganges der Spulenbank (bei der in Fig. 1666 gezeichneten Lage der Theile) wird nun, wie beschrieben, Gussstück $M$, mithin aber auch Hebel $M_{1}$ bewegt, bis sich die Spitzen der Gleitstücke $g_{\mathrm{t}}$ und $g_{2}$ berühren, ohne dass aber die Zugstange $h_{2}$ bewegt würde, da sie vermöge ihres Schlitzes von dem Stifte des Hebels $M_{\tau}$ stehen gelassen wird. Im nächsten Moment aber, während die Bank in ihrem höchsten Punkte angelangt ist, wird der Hebel $h_{\mathrm{r}}$ durch sein Gewicht das Gleitstiuck $g_{2}$ an der anderen Seite des Gleitstïckes $g_{\mathrm{r}}$ herabdrücken, den Hebel $M_{\mathrm{r}}$ noch weiter und mit ihm nunmehr die Zugstange $h_{2}$ nach der anderen Seite bewegen, wodurch das $\operatorname{Rad} a_{2}$ ausgerïckt und $a_{\mathrm{r}}$ in Eingriff kommt. Die Spulenbank geht nunmehr nach unten und findet am Ende des Niederganges wieder der entsprechende Wechsel statt.

Der Expander wird, wie erwähnt, stets um einen constanten Bogen gehoben, so dass das Lederseil bei dem Zusammenschieben stets dieselbe Spannung behält. Die Achse der Expanderwelle bewegt sich sonach in einem Kreiscylinder, dessen Halbmesser gleich der Entfernung derselben vom Drehpunkte der Kropfachse ist. Die verschiebbare Expanderhälfte (Fig. 1666) gleitet mittels eines Stiftes $\varepsilon$ in einem durch die Welle hindurch gehenden Schlitze. Gegen diesen Stift stösst in der Richtung der Mittellinie der Welle eine kleine Stange $e_{0}$, welche in entsprechender Bohrung der verlängerten Welle Führung hat. Der abgerundete Kopf dieser Stange legt sich an das in der Schiene $e_{1}$ gerade geführte Gleitstück $e_{2}$, welches in der Richtung der Achse der Stange einen geschlitzten drehbaren Kopf $e_{3}$ hat, der stets das keilförmige Lineal umfasst. Bei der Hebung des Expanders gleitet dieser Kopf an der schrägen Fläche des Lineals in die Höhe, und es wird dadurch das Gleitstïck und mithin auch die Stange und die verschiebbare Expanderhälfte in der Richtung der Achse verschoben, wodurch die successive Vergrösserung des Expanderdurchmessers erreicht wird. Damit das Lineal inmer von dem erwähnten Kopfe umfasst werden kann, muss es der Kreisbogenbewegung desselben folgen können, und ist deshalb um einen Zapfen $z$ normal zur Richtung, in welcher die Hebung stattfindet, beweglich. Das Lineal ist so gestaltet, dass der Expander nach jedem Auf- oder Niedergang der Spulenbank um ein gleiches Stück in einander geschoben wird, da die Vergrösserung des Durchmessers stets um ein constantes Stück erfolgen muss.

Die mit jedem Auf- und Niedergang der Spulenbank verminderte Geschwindigkeit der Expanderwelle wurde, wie beschrieben, auf Welle $J$ übertragen. Von dieser Welle aus geht nun die Bewegung durch $Q$ auf das Rad $R$ über, welches lose auf der Hauptwelle $H$ läuft und, zwischen Kranz und Nabe in Zapfen drehbar gelagert, zwei sich genau gegenüber stehende. gleich grosse konische Räder $R_{\mathrm{I}}$ und $R_{2}$ trägt. In diese Räder greift auf der einen Seite das fest mit der Hauptwelle verbundene, dieselbe Grösse habende Rad $K$ ein, und auf der andern $\operatorname{Rad} D$, welches aber lose auf der Hauptwelle sitzt und an seiner etwas verlängerten Nabe noch das Stirnrad $D_{1}$ trägt, durch welches die Bewegung auf das Zwischenrad $T$ und durch das an dasselbe angegossene gleich grosse konische Rad auf Rad $D_{2}$ überträgt. Das Zwischenrad $T$ läuft auf einem Zapfen, der bei $v_{0}$ und $v_{1}$ drehbar gelagert ist und eine kugelförmige Erweiterung hat, in deren Bohrung mittels langer Nabe sich das Rad $D_{2}$ bewegt. In diese Nabe fasst, mittels Feder und Nut verschiebbar, eine Welle $y$ (Fig. 1665 und 1666), welche nach der Spulenbank führt, und es kann also diese Welle der Auf- und Abberregung: 
der Spulenbank folgen. Die Welle $y$ pflanzt (Fig. 1665) ihre Bewegung durch Rad $D_{3}$ und und $T_{\mathrm{r}}$ auf $D_{4} D_{4}{ }_{4}$ und die beiben Betriebswellen im Spulenkasten fort, die ihrerseits durch Räder $D_{5} D_{5}^{\prime}$ die Spulenrädchen $D_{6} D_{6}^{\prime}$ bewegen. Diese Spulenrädchen haben lange Naben, welche iiber die Spulenbank herausragen und sich dort tellerförmig ausbreiten, um die Spulen aufnehmen zu können und sie mittels eines Stiftes und entsprechenden Loches im Fusse derselben zu kuppeln.

Die Rädercombination, welche an das Rad $D$ und $D_{1}$ und somit auch an die Spulen eine von der Umdrehungszahl des Rades $R$ und des Rades $K$ abhängige Tourenzahl überträgt, nennt man Differentialgetriebe, oder (nach H. Professor Reuleaux) Umlaufräder. Die eine durch $\operatorname{Rad} K$ von der Hauptwelle aus an dies Getriebe übertragene Bewegung ist constant, die andere von der Expanderwelle aus an Rad $\boldsymbol{R}$ abgegebene Tourenzahl nimmt, wie wir gesehen haben, mit jedem Hube der Bank ab. Bezeichnen wir daher mit $n$ die constanten Umdrehungen der Hauptwelle, mit $m$ die nur während eines Hubes constanten des Rades $R$, und berücksichtigen ferner, dass dieses Rad in demselben Sinne wie die Hauptwelle sich dreht, so wird an die Räder $D$ und $D_{\text {г }}$ eine Tourenzahl übertragen (vgl. Bd. I pag. 348 unten) von $f=n-2 m$, welche auf dem beschriebenen Wege nach den Spulen transportirt wird. Die Umdrehungszahl derselben ist demnach, wenn das gesammte constante Uebersetzungsverhältniss vom Rade $D$ aus mit $C$ bezeichnet wird, $s=C f=C .(n-2 m)$. Die veränderliche Umdrehungszahl $m$ des Umlaufrades $R$ ist aber abhängig von dem veränderlichen ExpanderDurchmesser $g$ und ausserdem bedingt durch das Uebersetzungs-Verhältniss von der treibenden Scheibe $S_{0}$ an his zu diesem Rade. Bezeichnen wir den constanten Theil dieses UebersetzungsVerhältnisses mit $C^{11}$, so ist also $m=\frac{C^{11}}{g}$ und daher auch $s=C^{\prime}\left(n-\frac{2 C^{1}}{g}\right)$.

Für das regelrechte Aufwinden des Vorgarnes war aber die allgemeine Bedingungsgleichung für die Umdrehungszahl der Spulen $s$ gefunden worden: $s=S-\frac{L}{n}$; damitnun der Mechanismus diese Bedingung erfïllt, müssen beide Werthe stets einander gleich sein, also $C n-\frac{2 C^{1} C}{g}=S-\frac{L}{u}$. In der Ausführung sind nun stets die Uebersetzungen so gewählt, dass $C^{\prime} n=S$ ist, alsdann folgt aber : $\frac{2 C^{1} C}{g}=\frac{L}{u}$ oder $g=\left(\frac{2 C^{3} C}{L}\right) u$, oder weun man die Constanten: $\frac{2 C^{1} C}{L}=A$ setzt, so ist stets $g=A u$, d. h. aber:

Der jeweilige Expander-Durchmesser ist direct proportional dem I'mfange $u$, also auch dem Durchmesser der Spulen und muss bei jeder vollendeten Wickelung um eine constante Grösse zunehmen, was wiederum bei geraden Expander-Armen nur dadurch geschehen kann, dass derselbe stets um dasselbe Stiick gleichmässig zusammen geschoben wird. Dieser Mechanismus erfïllt also ebenso vollständig die Aufwindebedingungen, wie der in Bd. I pag. 350 heschriebene, und ist besonders durch seine leichte Zugänglichkeit und Verstellbarkeit sehr heliebt. -

Die Maschine hat einen sehr geringen Kraftbedarf. Die stïndlichen Einzugslängen schwanken etwa zwischen 45 bis 126 Yards, die Lieferungslängen zwischen 950 bis 1800 Yards. Man baut jetzt die Maschinen bis 80 Spindeln, vertheilt in $10 \mathrm{Köpfen}$. - Die weiteren Details ergeben sich aus der folgenden tabellarischen Zusammenstellung.

Diese Zusammenstellung gibt die für verschiedene Garnnummern angewendeten Maschinensortimente, deren Hauptdimensionen, die Spindelgeschwindigkeiten der Spindelbänke und die Anzahl der Feinspindeln, welche eine Vorspindel zu versorgen vermag.

Der ungefähre Kraftbedarf der einzelnen Maschinen für mittlere Garnnummern beträgt nach Prof. Hartig:

Fïr eine Anlegemaschine pro Band 0.17 Pferdekraft; für eine erste Streckmaschine pro Kopf 0.29 Pf. und pro Band $0.026-0.096$ Pf.; für eine zweite Streckmaschine pro Kopf 0.25 Pf. und pro Band $0.022-0.069$ Pf.; fur eine Spindelbank pro Spindel: $0.023-0.038 \mathrm{Pf}$. 
Flachsspinnerei.

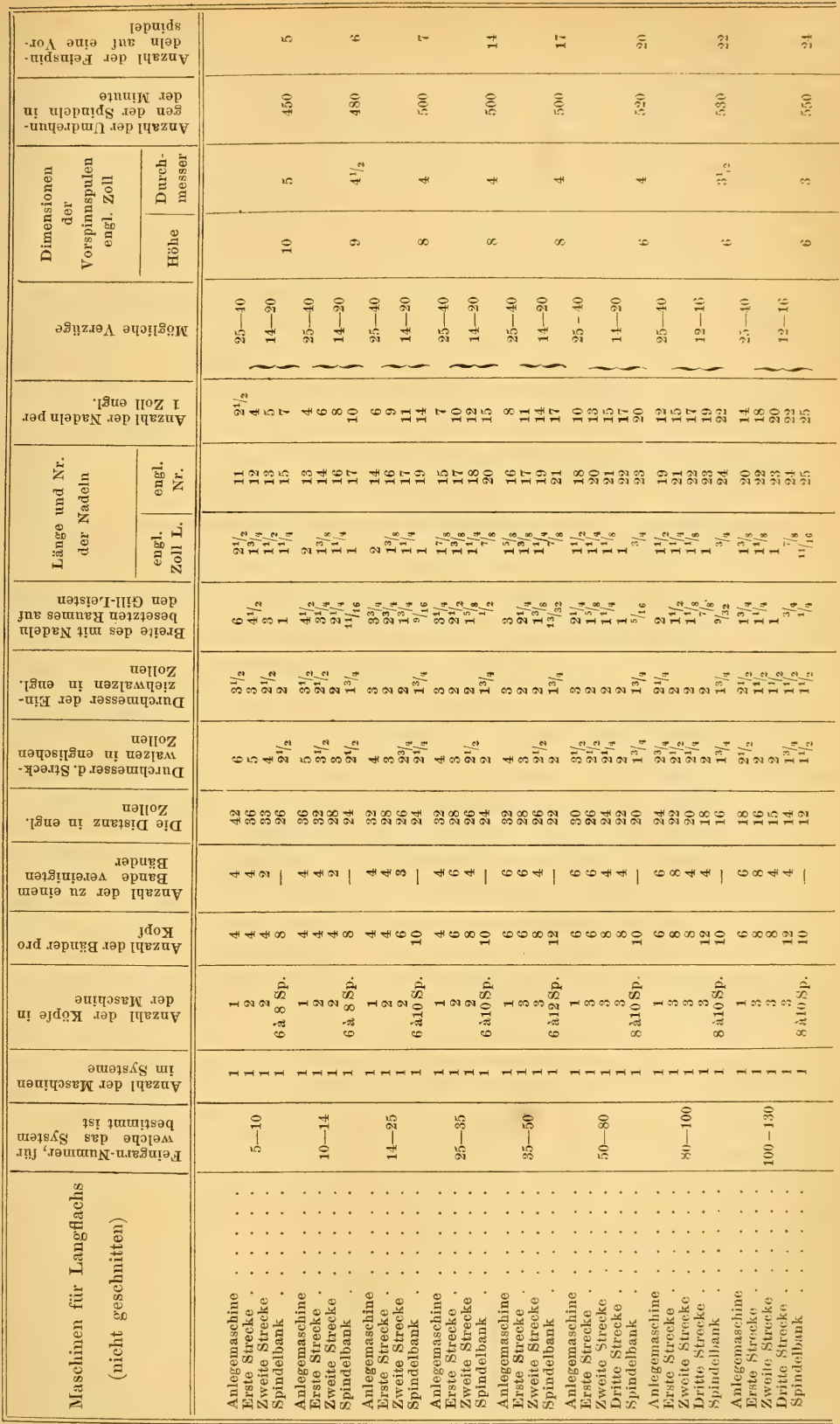


Der mittlere auf den Umfang der Streckwalzen reducirte Widerstand in Kilogr. ist etwa: Bei der Anlege 31.4, bei dem ersten Flachsdurchzug 15.3, beim zweiten Flachsdurchzug 9.87, bei der Spindelbank 7.81 .

Bezeichnet man daher nach Dr. Hartig mit $D$ den Durchmesser der Streckwalzen in Meter; mit $U$ die Umdrehungen desselben pro Minute; $n$ Anzahl der Bänder der Spindeln; $p$ obigen Widerstand auf den Umfang der Streckwalzen bezogen; $f$ Coefficient für die normalen Stillstände der Maschine; $N$ Betriebskraft der Maschine in Pferdestärken; so ist für sämmtliche Maschinen:

$$
N=f p \frac{D \pi U n}{60.75}=\frac{D U f p n}{1432} \text { Pferdestärken. }
$$

4) Das Feinspinnen auf der Feinspinnmaschine. Das Vorgarn wird bis zu einer dem Feingarne entsprechenden Feinheit ausgezogen, der gestreckte Faden, um ihm Zusammenhang, Festigkeit, zu geben, geniigend gedreht und schliesslich auf Spulen aufgewunden. Die Feinspinnmaschinen sind stets nach dem Systeme der Water- oder Drossel-Maschinen, bei welchem diese drei Verrichtungen in ununterbrochener Folge geschehen, gebaut (s. Baumwollenspinnerei pag. 352). Die Maschinen haben demnach ein Streckwerk zum Verziehen des Vorgarnes, dann Spindeln mit Fliigeln und Spulen zum Drehen des gestreckten Fadens und unmittelbarem Aufwinden des so gebildeten Feingarnes.

Das Streckwerk erhält aber bei diesen Maschinen eine verschiedene Anordnung, je nachdem das Vorgarn trocken, oder unter Anfenchtung mittels kalten Wassers (halbnass) oder endlich unter Anwendung von heissem Wasser (nass) versponnen wird, und kann man dem entsprechend unterscheiden: Trocken-, $\mathrm{Halbnass-}$ und $\mathrm{Nass-Feinspinnmaschinen.}$

Die Trockenspinnmaschine (metier ¿t filer ¿̀ sec - dry spinning frame, long reach spinning frame) hat eine der durchschnittlichen Faserlänge des Flachses im Vorgarn entsprechende Distanz im Streckwerk von 18 bis 22 Zoll engl. $=0.457$ bis 0.558 Meter. Da nun der Vorgarnfaden bereits etwas gedreht ist, so kann eine Unterstiitzung desselben zwischen Einzieh- und Streckwalzen durch ein Hechelsystem wie bei den Vorbereitungsmaschinen nicht stattfinden, sondern es genuigt, denselben ïber eine glatte Rinne aus Weissblech, oder zwischen einigen Walzenpaaren oder um einzelne Walzen herum und über eine verstellbare Platte bis zu den Streckwalzen zu fuihren. Es sind bei diesen Maschinen entweder drei Einziehwalzen wie bei den Streckmaschinen oder, was gewöhnlicher ist, nur zwei eiserne stark geriffelte vorhanden, ron denen entweder die vorderen oder hinteren die Druckwalzen sind. Die Druckwalzen der Streckcylinder werden gewöhnlich aus Holz hergestellt.

Eine Trockenspinmmaschine zeigt die Fig. $1668 \mathrm{im}$ Querschnitt. Die Maschine ist zweiseitig, während die Figur nur die eine Hälfte und die wichtigsten arbeitenden Theile vorfuhrt.

Auf einem Rahmen, im pbersten Theile der Maschine, sind neben einander iiber diinnere Drahtstifte die Vorspinnspulen A aufgesteckt, ron welchen die Fäden durch Oeffinungen der Führung $l_{1}$ hindurch nach den Einziehwalzen $p_{1} p_{0}$ gelangen. Die Walze $\nu_{1}$ ist durchgehend, auf ihrer ganzen Länge mehrmals gelagert und empfängt zugleich die Bewegung. Die hinteren Walzen sind Druckwalzen und sitzen zu je zwei auf einer gemeinschaftlichen Achse, die, an den Enden in Ständern gefiulurt, in der Mitte belastet ist. Beide Walzen sind aus Eisen und geriffelt. Die Lauftächen sind breiter als der Kern dick, und zwar etwa $3 / 4$ bis $1 \frac{1}{4}$ Zoll engl. $=19^{m m}$ bis $31.74^{\mathrm{mm}}$. - Damit nun der Vorgarnfaden nicht stets an ein und derselben Stelle diese Walzen passirt, ist die Fülırung $l_{1}$ sntweder verstellbar, oder erhält mittels Schnecke, Schneckenrad und einer mit letzterem excentrisch verbur.denen Schubstange eine selbstthätige, ganz langsam in der Längenrichtung hin und her gehende Bewegung, so dass die Vorgarnfäden alsdann allmälig die ganze Breite der Einzugswalzen entlang und wieder zurück 
gefiihrt werden, wodurch eine gleichmässige Abnutzung derselben auf der ganzen Breite erreicht und ein Einlaufen an einer Stelle vermieden wird.

Bei Anwendung von drei Einzielıwalzen sind zwei derselben u. z. die äusseren beiden glatte, durchgehende, angetriebene Cylinder, während die dritte zwischen liegende aus kürzeren, nur durch Reibung mitgenommenen Enden besteht. Diese Construction ist aber veraltet und wird jetzt nicht mehr ausgeführt.

Die weitere Führung des Vorgarnfadens nach den Streckwalzen $C_{0} C_{1}$ findet bei vorliegender $\mathrm{Ma}$ schine zunächst über den Cylinder $d_{0}$ und dann unterhalb $d_{1}$ uiber die Führungsplatte $g$ hinweg statt. Die beiden Cylinder $d_{0}$ und $d_{1}$ erhalten ebenfalls Drehung. Die Platte $g$ (guild plate) ist stellbar, um den Fäden eine grössere oder geringere Berührungsfläche zu bieten, wodurch das Aufdrehen derselben auf geringere oder grössere Länge begrenzt und der hiervon abhängende Zusammenhang der Fasern geändert werden kann.

Die äusseren Streckwalzen sind gusseiserne, an der Oberfläche ganz schwach eingerissene, etwa $13 / 16$ Zoll engl. $=20.5^{\mathrm{mm}}$ breite Cylinder, die sämmtlich auf einer durchgehenden und angetriebenen Welle befestigt sind. Die Druckwalzen sind aus hartem $\mathrm{Holz}$ hergestellt, und sitzen zu je zwei auf einer gemeinschaftlichen Achse, die, an den Enden in besonderen Ständern gefuihrt, in der Mitte entweder durch Federn oder mittels Gewicht und Winkelhebel belastet ist. Zwischen der Platte $g$ und den Streckwalzen wird jeder Faden über ein seitlich aufgebogenes Leitblech gefiihrt, welches an den Druckwalzen $C_{1}$ Führung hat, um einem Verlaufen des Fadens vorzubeugen, und sicher zu erreichen, dass derselbe stets vollständig von den Streckwalzen gefasst wird. Die Streckwalzen liefern dann den geniigend fein ausgezogenen Faden, nachdem derselbe durch die Augen des Fig. 1668.

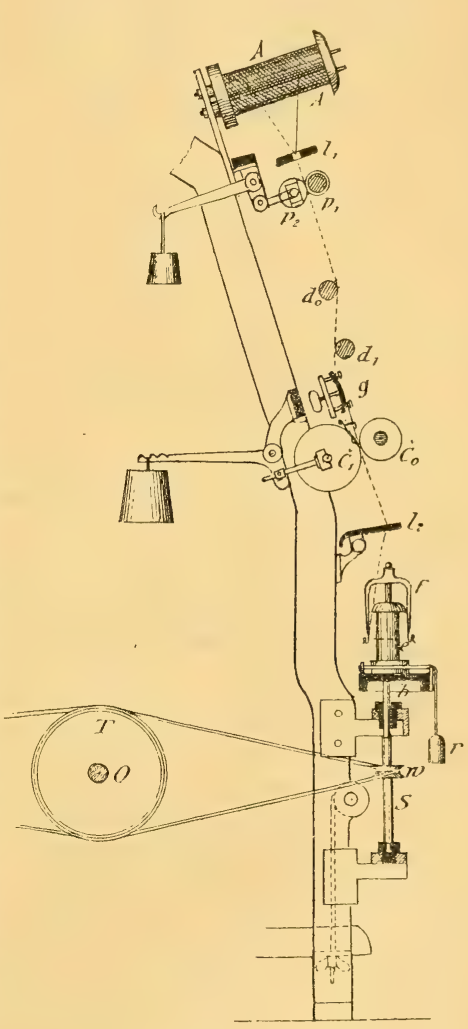

Trockenspinnmaschine.

Fiibrungsbrettes $l_{2}$ gegangen ist, nach den Flitgeln $f$, die mit den Spindeln $S$ hewegt werden, zu den Spulen $e$. Durch die Bewegung der Spindeln und Fliigel erhält der Faden die nöthige Drehung, und zwar ist dieselbe pro Längeneinheit $D=\frac{S}{L}$. wo $S$ die Umdrehungen der Spindeln in der Minute und $L$ die in derselben Zeit von den Sureckwalzen gelieferte Fadenlänge bedeuten. Die Spindeln mit Spulen und Flïgeln stehen in der Längenrichtung der Maschine dicht neben einander, soweit es die Dimensionen der Fliigel gestatten, und nennt man die Entfernung je zweier derselben die Theilung (pas, denture - pitch) der Maschine. 
Das Aufwinden des gesponnenen Garnes findet stets nach Massgabe des Zurückbleibens der Spule gegen die Spindel statt. Die Spulen erhalten keine besondere Bewegung, sondern werden durch die Spannung des Fadens allein mitgenommen. Das Zuruickbleiben derselben wird regulirt durch vermehrte oder verminderte Reibung, hervorgebracht durch beschwerte Bremsschnïre $r$, welche mehr oder weniger um den eingedrehten Fuss der Spule herumgelegt und durch zahnartige Einkerbungen der Spulenbank festgehalten werden. Sämmtliche Spulen ruhen auf einer Spulenbank $b$, welche eine auf und nieder gehende Bewegung annimmt und dadurch das schichtenweise Aufwickeln der Fäden auf den Spulen bewirkt. Die Auf- und Abbewegungsgeschwindigkeit bleibt während der Füllung der Spulen dieselbe und ist eine dem mittleren Durchmesser derselben angemessene; sie wird, meist von einer Herzscheibe hervorgebracht, durch Hebel und Ketten auf die Geradfiihrung der Bank iibertragen. Die Bewegung der Spindeln geschieht von der Trommel $T$ aus durch Schnüre, bei schwereren Maschinen durch baumwollene Bänder auf die Würtel $v$ derselben.

Von der Achse $O$ dieser aus Weissblech gefertigten Trommel aus, welche durch Riemscheiben angetrieben wird, geht die Bewegung unter Zwischenschaltung eines Uebersetzungsrades und Drehungswechselrades auf den Streckcylinder $C_{0}$ iiber, von diesem alsdann - auf der anderen Seite der Maschine - aufwärts nach den Walzen $d_{0} d_{1}$ und die Einzugswalze $p_{1}$ unter Einfügung des Verzugswechselrades.

Die Maschinen werden je nach den Garnnummern, welche auf ihnen gesponnen werden sollen, etwas verschieden gebaut. *)

Die Halbnasfeinspinnmaschine weicht nur wenig von der beschriebenen Maschine ab. Die Distanz des Streckwerkes ist auch hier, wie bei der vorigen, mit der Länge der Fasern übereinstimmend; es findet aber auf dem Wege zwischen Einzieh- und Streckwalzen oder zwischen den Streckwalzen selbst, ein Anfeuchten des Vorgarnfadens mittels kalten Wassers statt, wodurch ein glatteres, runderes Garn vor schönerem Aussehen erzeugt wird, das sich besonders zu solchen Geweben eignet, die roh bleiben sollen. Am häufigsten wird das Anfeuchten dadurch bewirkt, dass man die, wie in der letzten Figur 1668 angeordneten Streckdruckwalzen $C_{1}$ in einem Wassertroge sich bewegen lässt, so dass sie bei ihrer Umdrehung genügend Wasser mit empornehmen und an den zu streckenden Faden abgeben. Die Druckwalzen sind in diesem Falle aus Buchsbaumholz hergestellt, die vorderen Streckcylinder - des Rostens wegen - aus Messing.

Die Nassfeinspinnmaschine (métier à filer à l'au chaude, ou de décomposition - hot uater spinning, short reach spinning frame). Bei diesen Maschinen wird der Vorgarnfaden, ehe er zu den Einzugswalzen gelangt, durch heisses Wasser gezogen. Wir erwähnten im Artikel Flachs pag. 529 einer eigenthïmlichen Beschaffenheit und Eigenschaft der Flachsfaser, nämlich dass dieselbe aus kiirzeren Elementarzellen besteht, welche unter einander durch ein klebriges Bindemittel zusammengehalten werden, welches durch Chromsäure oder Kalilauge gänzlich gelöst, durch heisses Wasser aber so weit erweicht werden kann, dass ein Auseinanderziehen derselben - olne Abreissen der Fasern - möglich ist. Nachdem daher bei dem Spinnen mittels heissen Wassers die Vorgarnfäden dasselbe passirt haben, gelangen sie zu einem Streckwerk, das eine nur der Länge der Elementarzellen entsprechende Distanz ron 2 bis 4 Zoll engl. $=50.8$ bis $101^{\mathrm{mm}}$ hat, so dass das Auseinanderziehen dieser erfolgen muss. Die Priorität dieser Idee, welche es erst ermöglichte Flachsgarn höherer Nummern (grösserer Feinheit) maschinenmässig zu spinnen, gebiihrt Philipp de Girard, wie pag. 530 erwähnt wurde.

*) Die Redaction sah sich zu ihrem Bedauern durch den beschränkten Raum nicht nur zur Weglassung der dieshezüglichen Tabellen, sondern üherhaupt zu ganz bedeutenden Kürzungen dieses sehr eingehend bearbeiteten Artikels gezwungen. $K k$. 
Auf trockenem oder halbnassem Wege vermag man aus groben Flächsen Garn Nr. 1 bis 8 zu Sack- und Packleinen, aus feineren Flächsen Garn Nr. 10 bis 30 zu erzeugen; bei Anwendung von heissem Wasser spinnt man Flachsgarn von $\mathrm{Nr}$. 20 bis $\mathrm{Nr}$. 300, doch sind die höheren Nummern nur für bestimmte Zwecke, z. B. zur Herstellung von Zwirnen und zu Garnen für die Spitzenfabrikation etc. gebräuchlich. Auf dem Continente, wenigstens in österreichischen und deutschen Spinnereien, werden meist nur Garne bis Nr. 130 gesponnen. Die feinsten Garne aus geschnittenem Flachs (cut line) werden fast ausnahmslos in den irländischen Spinnereien und zwar in schönster Vollendung hergestellt, und gelingt es den deutschen und österreichischen Spinnern nicht, mit Vortheil in diesen Nummern zu concurriren.

Das Trocken- nnd Halbnassspinnen des Flachses kommt jetzt nur noch wenig zur Ausfuihrung, und sind die Garne in den Nummern 1 bis 8 durch die billigeren, schöneren, aber schwächeren, aus Jute gesponnen, in weiterer Ausdehnung bereits verdrängt worden.

Das Nassfeinspinnen ist daher iiberwiegend im Gebrauch. Die hierdurch mögliche vortheilhaftere Ausnutzung des Flachses stellt sich etwa so, dass Flachs trocken zu Garn Ni. 25, beim Spinnen mittels heissen Wassers zu Nr. 40 verarbeitet werden kann.

Eine Nassfeinspinnmaschine zeigt die folgende Fig. 1669 im Querschnitt. Die Maschinen werden stets doppelseitig, also mit 2 Reihen Spindeln gebaut und geschieht der Antrieb auf eine beiden Seiten gemeinsame Riemscheibe auf der Trommelachse 0 . Durch Ausriicken des Riemens kommen daher beide Seiten gleichzeitig zum Stillstande. Die Vorspinnspulen $A$ sind in 2 Etagen im Spulengestell (2 storys in Creel) angeordnet (die obere ist in der Figur weggelassen) und gehen die Vorgarnfäden zunächst über die Stäbe $v v$ in den Trog $D$, der zum grössten Theil mit Wasser gefüllt ist, welches durch das Dampfrohr $k$ auf einer bestimmten Temperatur (von $50^{\circ}$ bis $70^{\circ}$ R.) gehalten wird. Durch die Führungen $l l_{0}$ in diesem Wasser möglichst lange geführt, treten die Fäden über die vordere abgerundete, mit Messingblech bekleidete Kante des Troges zwischen die Einschnitte der Führungsleiste $l_{t}$, welche dieselbe Hin- und Herbewegung annimmt, wie bei den Trockenspinnstühlen erwähnt wurde; gelangen dann zu den Einzugswalzen $p_{1} p_{2}$ und von diesen direct zwischen die Streckwalzen $C_{0} C_{1}$.

Es sind hier stets die vorderen Walzen die Druckwalzen, und es wird je ein Einzugs- und Streckdruckwalzenpaar durch einen gemeinschaftlichen, in verschiedener Weise construirten Sattel mit Hilfe von Zugstange und Gewichtshebel, auf die unteren Walzen gedrickt. Die vorderen und hinteren Einziehwalzen, sowie die hinteren Streckwalzen sind stets aus Messing und zwar $u m$ einen Eisencylinder herumgegossen. Die Streckdruckwalzen werden entweder aus Buchsbaumholz, Gutapercha oder aus verschiedenen Compositionen hergestellt und sind zu je 2 auf einer Achse festgeschraubt.

Alle Walzen sind stark und rund geriffelt, um einem Gleiten der Fäden zwischen den Cylindern vorzubengen. Zur Berechnung der Umfangsgeschwindigkeit ist es aus diesem Grunde nöthig, den Umfang der Walzen durch Probiren zu ermitteln, da man denselben durch Rechnung auf gewöhnliche Weise wegen der Rifflung nicht finden kann. Man lässt desbalb sowohl zwischen den Einzugs- wie Streckwalzen einen genügend langen Papierstreifen hindurchgehen, nachdem man vorher einen Riffel der Unterwalzen mit Farbe bestrichen lat. Ist der Papierstreifen von den Walzen abgeliefert, so wird er ausgestrichen, geglättet, und es gibt dann die Länge zwischen je zwei Abdrücken des gefürbten Riff̈els den Umfang der Walzeu an. Zum Messen des Umfanges der Einzugswalzen, zwischen denen der dicke Vorgarnfaden hindurchgeht, muss man einen stärkeren, mehrmals zusammengefalteten Papierstreifen, der einigermassen mit der Dicke desselben übereinstimmt, anwenden, um die wirklich abgewickelte Länge zu erhalten. Bei den Streckwalzen ist diese Vorsicht nicht nöthig, da der Faden durch die Streckung hier bereits sehr dïnn geworden ist. Den Umfang der Walzen, wenn der äussere Durchmesser derselben (über die Riffeln gemessen) gegeben ist, findet man aunähernd 
durch Rechnung, wenn derselbe mit 3.44 multiplieirt wird. (Es ergab eine Messung bei den Durchmessern von $2^{1 / 2}, 1^{3} / 4,1 \frac{1}{2}$ Zoll engl. beispielsweise die Umfänge $8 \cdot 6,6.1$ und $5 \mathrm{Zoll}$, woraus obige Zahl folgt.)

Die Streckwalzen liefern den gestreckten Faden durch die Oeffnungen des Fadenfithrers $l_{\text {a }}$ nach den auf Spindeln $S$ sitzenden Flügeln $f$ und der durch beschwertes Bremsband $r$ gebremsten Spule $e$ ab, welche Anordnung also mit der bei den Trockenspinnmaschinen erwähnten uibereinstimmt. $B_{0} B_{1}$ sind Spritzbleche um das bei der Rotation der Spindeln umhergeschleuderte Wasser aufzufangen,

Fig. 1669.

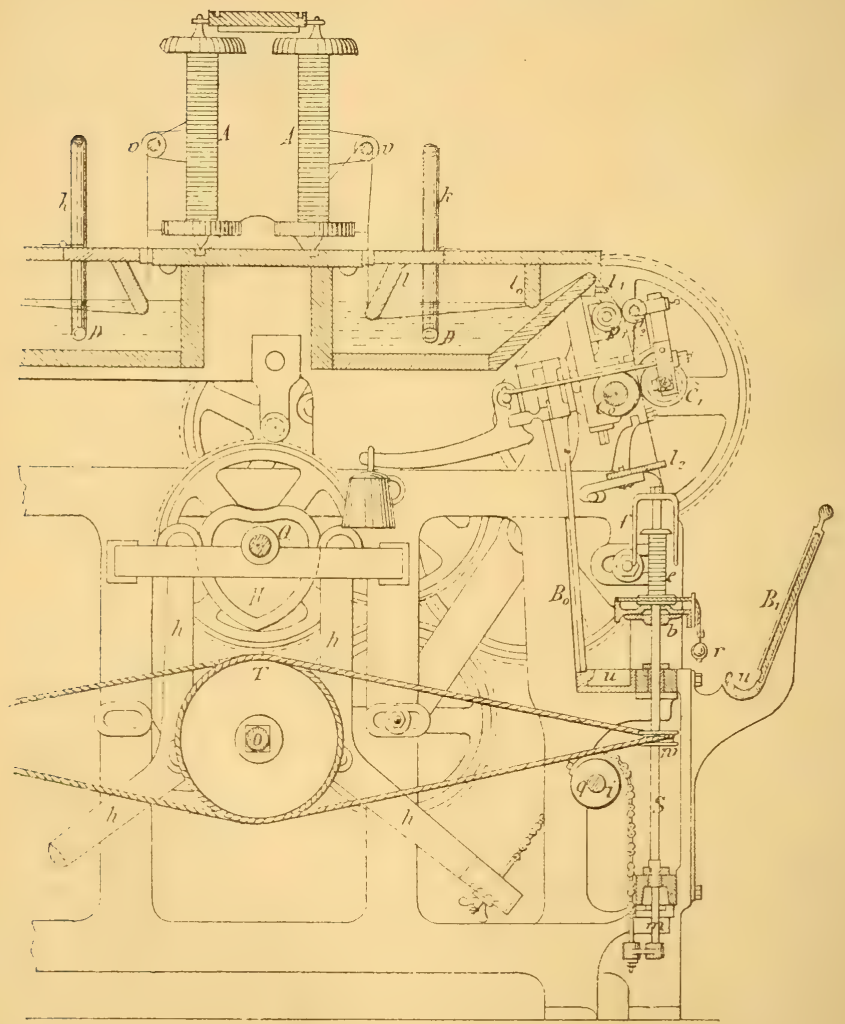

Nassspinnmaschine.

in Rinnen " zu sammeln und seitlich abzuleiten. Die Spindeln $S$ werden von der 'Trummel $T$ durch Wiirtel $u$ mittels Schnuren (oder Bänder) angetrieben. Die hinteren itreckeylinder erhalten ron der Trommelachse $O$ aus ihre Bewegung unter Zwischenschaltung eines Drehungswechselrades fuir beide Seiten der Maschine. Yon dem Streckerlinder aus geht, auf der anderen Seite der Maschine, die Be. wegungsibertraguing unter Zwischenfiigung des Verzugswechselrades nach oben zu 
dem hinteren Einzugscylinder. Die Auf- und Abbewegung der Spulenbank $\mathrm{b}$ ist in vorstehender Figur 1669 etwas näher angegeben. Die von der Trommelachse ausgehende, durch mehrere Uebersetzungsräder gelörig verlangsamte Bewegung geht auf die Achse $Q$ iiber, auf der das Herz $I I$ befestigt ist; durch dessen Drehung die Hebel $h h$ nach beiden Seiten hin immer in entgegengesetzter Richtung bewegt werden. Hebel $h$ pflanzt, wie rechts sichtbar, mittels Kette seine Drehung an eine Scheibe fort, welche auf der durchgehenden Achse q festsitzt und wodurch diese ihre Drehung bekommt. Auf dieser Achse sitzen in der Längenrichtung der Maschine mehrere andere Scheiben $i$, an denen Gelenkketten befestigt sind, deren untere Enden mit den Führungsstangen $m$ verbunden sind. Diese Stangen gehen zwischen den Spindeln durch bis unter die Spulenbank, die also mit ihren sämmtlichen Spnlen auf ihnen ruht. Die durch Hebel $h$ hervorgebrachte Drehung der Welle $q$ bewirkt ein Emporgehen der Stangen $m$, eine Hebung der Bank $b$, anderseits das Gewicht derselben ein Niedersinken und eine Rückdrehung der Welle $q$ und des Hebels $h$ in dem Masse, wie es das Herz bei seiner zweiten halben Drehung zulässt.

Anstatt dieser Herzbewegung findet man auch häufig eine Mangelrad-Construction angewendet.

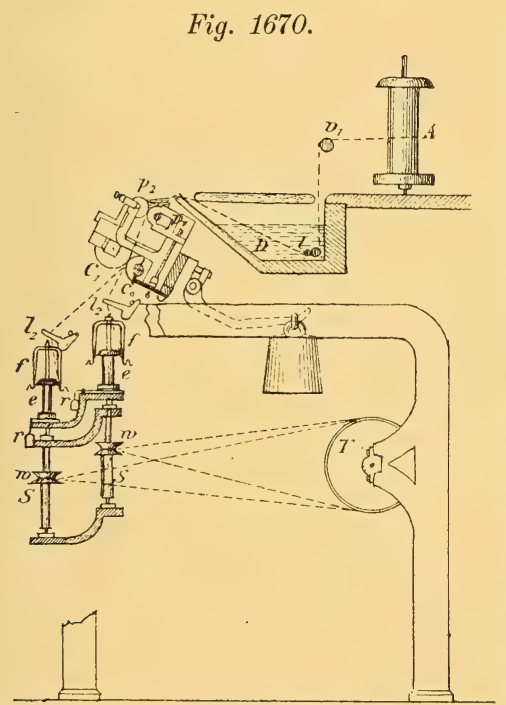

Wood's Nassspinnmaschine.

Hinsichtlich weiterer Details weichen nun diese Maschinen einigermassen von einander $a b$, namentlich in Bezug auf die Anordnung der Sattel, der Hebungsvorrichtung, der Spindel und Spulen u. s. W. Wir können an dieser Stelle hierauf nicht näher eingehen und erwähnen nur noch folgende, besonders eigenthümliche Anordnung, indem wir auf einige weitere in $\mathrm{Prechtl}$ 's techn. Encyclopädie III 153 beschriebene verweisen.

Nassfeinspinnmaschine von John Wood in Leeds, welche in der nebenstehenden Figur 1670 im Querschnitt abgebildet ist. Die Maschine ist ebenfalls zweiseitig, jedoch hat jede Seite zwei Reihen Spindeln, und zwar liegt die vordere Reihe derselben tiefer als die hintere, um letztere zugänglich zu machen. Jede Seite der Maschine hat eine besondere Trommel zum Antrieb. Durch diese Anordnung ist der zur Aufstellung einer bestimmten Spindelzahl nöthige Raum seh. vermindert. - Trotzdem haben diese Maschinen bei uns gar nicht Eingang gefunden.

Es erübrigt zunächst noch einige Worte iiber die Temperatur des Wrassers zu sagen. durch welches das Vorgarn gezogen wird, ehe es zu den Einziehwalzen gelangt. Wir sagten diese Temperatur liege etwa zwischen 50 und $70^{\circ} \mathrm{R}$. und ist die Wahl derselben abhängig. von der Beschaffenheit des. Flachses und dem Grade der Drehung des Vorgarnes. Die niederste Temperatur hat man bei schwachen, wenig haltbaren Rasenflächsen und lose gedrehtem Torgarn, die höchste Temperatur bei festen, kernigen Wasserflächsen und schärfer gedrehtem Vorgarn anzuwenden. Ist z. B. die Temperatux für einen bestimmten Fall zu hoch, so wird die Erzeugung eines gleichmässig dicken Garnes, wenn anch das Torgarn gut ist, länfig nicht 
gelingen, da die zu weit gehende Erweichung des Bindemittels der Elementarzellen die Haltbarkeit des Vorgarnfadens so weit beeinträchtigen kann, dass derselbe die Reibungswiderstände von den Spulen bis zu den Einziehwalzen nicht auszuhalten vermag, sondern sich auf diesem Wege entweder bereits ungleich streckt, oder ganz auseinander geht. Ist anderseits die Wassertemperatur für ein bestimmtes Vorgarn zu niedrig, so findet die Erweichung des Bindemittels nicht genügend statt; die Streckwalzen sind nicht im Stande das Ausziehen des Vorgarns richtig auszuführen; es tritt ein unegaler Verzug auf, oder das Vorgarn geht, ohne iiberhaupt gestreckt zu sein, durch die Walzen. Es ist deshalb Sache der Erfalirung, die richtige Temperatur für ein bestimmtes Vorgarn zu treffen, und sind die angegebenen Temperaturen etwa als Grenzwerthe anzusehen.

Alle Arten Flachsfeinspinnmaschinen werden je nach den Garnnummern, welche auf ihnen gesponnen werden sollen, verschieden in der Distanz und der Theilung (reach $u$. pitch), sowie in den hiervon abhängenden Riffelungen der Walzen, Walzendurchmessern, Geschwindigkeiten der Spindeln u. s. w. ausgefuhrt.

Ueber den Kraftbedarf der Trockenspinnmaschinen liegen zuverlässige Resultate nicht vor.

Für eine Nassfeinspinnmaschine zu den Garnnummern 25-40 beträgt die Betriebskraft nach Prof. Hartig pro Spindel $0.012-0.027 \mathrm{Pf}$. der mittlere auf den Umfang der Streckwalzen reducirte Widerstand in Kilogr. 10.8, und es gilt zur Berechnung der gesammten Betriebskraft einer Maschine dieselbe Formel, welche bei den Vorbereitungsmaschinen gegeben wurde.

Die auf das Feinspinnen folgenden Arbeiten stimmen mit denen in der Wergspinnerei überein und finden dort ihre Besprechung.

Die Werg- oder Heede-Spinnerei umfasst die Verarbeitung der beim Hecheln des Flachses ausgekämmten kiirzeren, verworrenen und vielfach verschlungen, durcheinander liegenden Leinenfasern, die mehr oder weniger mit Schäben und Staubtheilen verunreinigt sind, und wird das aus demselben eizengte Garn - im Gegensatz zum Flachsgarn - Werg-, Heede-(Tow) Garn genannt.

Die Verarbeitung der Leinenfaser in diesem Zustande beginnt zunächst mit einem Reinigungs- und Anflockerungs-Processe und der Bildung von Bändern aus den losen Fasern. Dieser Process kann je nach dem Grade der Verunreinigung des Materials in verschiedener Weise ausgeführt werden.

Bei sehr knotiger und stark rermmeinigter Heede wird zunächst ein Vorreinigen, ein Ausschitteln und alsdann ein ein- oder zweimaliges Kardiren oder Krempeln rorgenommen, während bei besserem Material nur ein einmaliges Kardiren nothwendig ist.

Abweichend hierron ist die Verarbeitung der Heede durch einen Kämmprocess mittels Heilman'scher Kämmmaschinen (man vergleiche später Kammgarnspinnerei), wodurch dasselbe zu feineren Nummern und zu einem dem Flachsgarne in Bezug auf Gleichmässigkeit röllig gleichwerthigen Garne gespounen werden kann. Dieser Methode steht bis jetzt noch die geringe Productionsfähigkeit der Kämmmaschinen entgegen, wodurch eine erhebliche Vertheuerung des Productes entsteht. Deshalb gehen wir auf diese immer noch im Versuchsstadium befindliche Verarbeitung nicht näher ein, sondern besprechen nur die zuerst erwähnte und bis jetzt allgemein gebräuchliche Methode.

Die Vorreinigung, der. Schüttelprocess der stark rerunreinigten Heeclen. Die zur Ausfïhrung dieser Arbeit bestimmten Maschinen sind meist Schlagmaschinen und ähnlich construirt wie die in der Baumwollenspinnerei zu diesem $Z$ wecke angewendeten. Die konischen Schlagwölfe (I pag. 323) eignen sich g:anz besonder's gut zur Auflockerung und Reinigung der Heeden und finden deshalb rielfach Verwendung, während durch andere Maschinen, wie beispielsweise durch die mit dem Oeffnen für Baumwolle ron Taylor, Lang \& Co. übereinstimmend construirte Schlagmaschine ron M. Frenzel in C'hemnitz, die Heeden stark angegriffen unc? die Fasern unnöthig verkïrzt werden. Abweichend von 
diesen Maschinen ist die Rack'sche Patent-Schüttel- und Auflockerungsmaschine (Victor Rack \& Co. in Zittau), die sich ganz besonders gut für kurze Heeden und Heeden-Abfälle eignet. Diese Maschine ist in 1/24 nat. Gröisse in folgender Fig. 1671 im Längenschnitt abgebildet.

Sie besteht aus einer Reihe von Nadellatten, die an den Enden auf je einem endlosen Riemen befestigt sind, der sich mit aufgenieteten Vorsprüngen in die zahnartigen Aussparungen der Walzen $S_{\mathrm{r}}, S_{2}, S_{3}$ einlegt. Walze $S_{\mathrm{r}}$ ist die Betriebswalze, $S_{2}$ nnd $S_{3}$ dienen zur Fuihrung und $S_{3}$ zugleich zur Spannung des Riemens. Auf ihrem Wege von Walze $S_{2}$ nach $S_{1}$ finden die Latten durch Fïhrungen $f$ Unterstützung, so dass ein System horizontal fortschreitender Nadelreihen entsteht. Durch die Zwischenräume je zweier Nadeln einer Reihe schlagen etwas stärkere in einer Reihe stehende Stäbe $o_{1}$ bis $o_{6}$, die in hölzernen, auf beiden Seiten im Gestell mit eisernen Zapfen drehbar gelagerten Achsen befestigt sind. In der Breitenrichtung der Maschine sind 25 Nadeln auf jeder Leiste und 24 Schlagstäbe in jeder Reihe vorhanden. Die hin und her schwingende Bewegung derselben geht von der Achse der Walze $S_{2}^{\prime}$ ans und wird

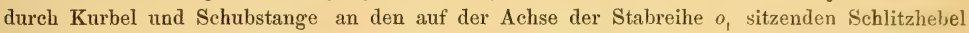
und von da durch zwei Kupplungsstangen auf die Schlitzhebel der anderen Stabreihenachsen

Fig. 1671 .

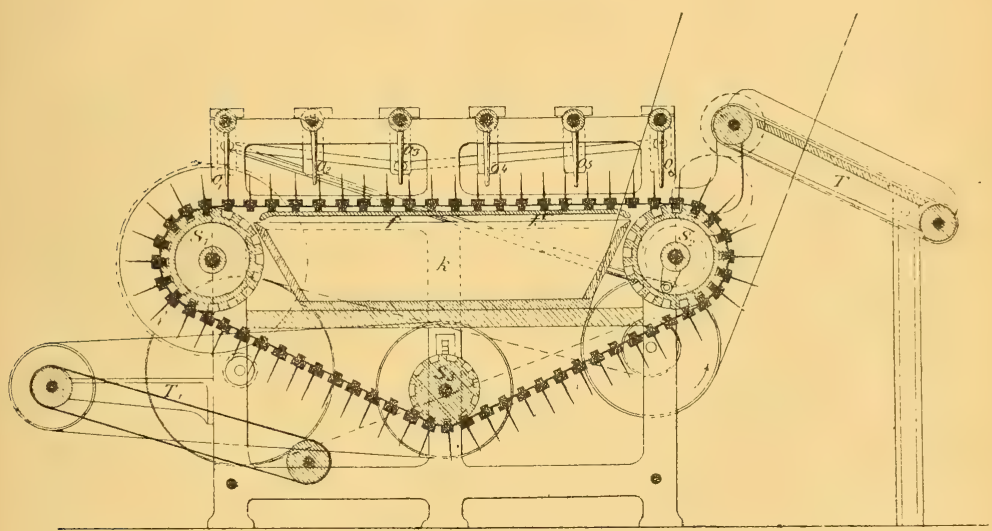

Rack's Schüttel- und Auflockerungsmaschine.

iibertragen. Diese Anordnung erlaubt den Ausschlag der Stäbe zu ändern. - In der gezeichneten Verbindung nimmt der Ausschlag der Stäbe von Reihe $o_{6}$ bis $o_{3}$ hin ab und von da bis $o_{1}$ wieder zu. Die Zuführung des Materials geschieht durch Auflegen auf das endlose Tuch T. Die ausgeschüttelten Schäben- und Schmutztheilchen fallen zwischen den Latten hindurch in den Kasten $K$, während die gereinigto Heede unterhalb der Walze $s_{\text {, }}$ aus den Nadeln herab auf Tuch $T_{\mathrm{I}}$ fällt und von diesem fortgefïhrt wird. Der Antrieb der einzelnen Theile geht ans der Figur hervor. Die Geschwindigkeit des Hecheltuches ist 30 Meter in der Minute.

Der Krempel- oder. Kardirungsprocess. Derselbe wird durch Karden oder Krempel (card - card) bewirkt, welche ähnlich wie die Baumwollenkrempel, aber stets Circular-Roller-Karden, d. h. auf dem ganzen Umfange der Haupttrommel mit Rollers umgeben sind. (Vergl. Baumwollsp. I pag. 334.) Die Aufgabe des Krempelprocesses ist zunächst die Entwirrung, Anflockerung und Zertheilung der Fasern, die Abscheidung der Schäben- und Schmutztheilchen und der ganz kurzen Fasern, die das zu erzengende Garn ranh und knotig machen 
wïrden, alsdann aber die gleichmässige Vertheilung und $\mathrm{Ordnung}$ der im Rohmateriale vollständig wirr und regellos durch einander liegenden Fasern, so dass sie in dem gebildeten Bande vorwiegend nach der Längenrichtung desselben zı angeordnet und ganz quer liegende Fasern nicht vorhanden sind. Je vollständiger diesen Bedingungen genügt ist, desto bessere Resultate ergibt der folgende Streckund Doublirprocess.

Den Krempelprocess pflegte man friiher meist zweimal, auf der Vorkarde (carde briseuse - breaking card) und der Feinkarde (card finisseuse - finishing card) vorzunehmen, begnügt sich aber neuerdings fast stets mit einem einmaligen Kardiren, indem man der Karde weniger Material in derselben Zeit zur Verarbeitung iibergibt.

Die Vorkarde unterscheidet sich von der Feinkarde meist nur durch minder feine Beschläge und weitere Stellung der Walzen. Häufig fehlt der Feinkarde der Zuführungstisch, indem die Bänder der Vorkarde auf Holzwalzen zu Wickeln (laps) mittels der Wickelmaschine gewunden werden, von denen stets drei neben einander in Gestellen eingelegt der Karde vorgesetzt werden. Ebenso häufig aber setzt man die Kannen der Vorkarde, wenn zweimal kardirt werden soll, der Feinkarde vor, die dann einen eben solchen Zuführungstisch wie erstere hat. Die. Wickelmaschinen sind übereinstimmend mit denen in der Jute-Spinnerei gebrauchten construirt und sollen daselbst näher besprochen werden.

Eine Karde mit Zuführungstisch ist in der folgenden Figur 1672 in $1 / 24$ natürlicher Grösse dargestellt.

Sie besteht aus einer Trommel $T$ von $1.52^{\mathrm{m}}$ (5 Fuss engl.) Durchmesser und $1.82^{\mathrm{m}}$ (6 Fuss engl.) Breite, welcher das auf drei endlosen Tüchern, Tischen $z$ (tablier - feeding cloth) ausgebreitete Material in dreiAbtheilungen durch die Speisewalzen $e_{1} e_{2}$ (cylindre fournisseurs - feeding rollters) zugeführt wird. Auf die Speisewalzen folgt eine dicht am Umfange der letzten $e_{\mathbf{a}}$ und der Trommel sich bewegende Walze $W_{0}$, Speisewendewalze (débourreur fournisseur-feeding stripper) genannt, alsdann folgen 7 Paar mit dem Umfange der Trommel und unter sich in naher Berührung befindliche Walzenpaare $W_{1} A_{1}$ bis $W_{7} A_{\tau}$, jedes aus einer Wendewalze $W$ (débourveur - stripper) und einer Arbeitswalze $A$ (travailleur - vorker) bestehend. Auf diese folgen drei grosse Walzen, die Abnehme- oder Kammwalzen $D_{1} D_{2} D_{3}$ (peigneurs - doffers).

Die Trommel und sämmtliche Walzen sind mit Beschlägen versehen, die von denen bei den Baumwollkrempeln benutzten insofern abweichen, als die Häckchen bedeutend stärker und nicht geknickt sind, also kein Knie haben, sondern in schräger ungebrochener Linie aus dem Befestigungsmateriale, meist Leder oder Holz, heraustreten. Nur die Nadeln der Speisewalzenbeschläge sind häufig bogenförmig gekrïmmt. Die Befestigung der Häkchen in den Lederstreifen ist dieselbe wie $\mathrm{Bd}$. I pag. 330 angegeben wurde. Die Trommelbeschläge bestehen neuerdings häufig aus ca. $6^{\mathrm{rm}}$ breiten Holzleisten mit schräg eingesetzten einzelnen Nadeln, die in 3 Abtheilungen neben einander auf dem Trommelumfange fest geschraubt werden. Die Holzleisten erlauben allerdings keine bedeutende Schrägstellnng der Nadeln, sind aber haltbarer und leichter zu repariren als die riel theurern Lederbeschläge. Die erwähnte Beschaffenheit der Beschläge gibt denselben eine grosse Widerstandsfähigkeit, sie sind starr und nicht wie die Beschläge der Baumwollenkrempel nachgiebig. Die Wirkung der Beschläge gegen einander ist aber im Uebrigen ebenso, wie I pag. 331 eingehend erläutert wurde, also abhängig ron der gegenseitigen Lage der Nadeln und deren Geschwindigkeiten.

Ebenso ist auch die Wirkung der Arbeiter und Wenderwalzen gleich der I pag. 333 besprochenen. Die Walzen $D_{1} D_{2} D_{3}$ entsprechen dem Filet der Baumwollkarde.

Damit die Abnahme der Heede müglichst rollständig geschehe, steht die erste Abnehmewalze $D_{1}$ am weitesten, nimmt daher die gröbsten, längsten, aber auch unreinsten Fasern von der Trommel ab; die zweite steht näher und die dritte am dichtesten, empfängt also die feinsten und reinsten Fasern. 
Aus den Nadeln der Abnehmewalzen werden die Fasern ibereinstimmend mit der in drei Abtheilungen bewirkten Auflage des Materials durch die rasch auf- und niedergehende Bewegung der $\mathrm{K}$ ä m m e $k_{i_{1}} k_{v_{2}} k_{k_{3}}$, auch II a c k e r genannt, (diinne, auf der Unterseite fein gezahnte Stahlschienen), ausgekämmt, und zwar in Form von drei für sich zusammenhängenden Fliessen, die durch Trichter $t_{1} t_{2} t_{3}$ zı Bändern zusammengezogen und durch die Abzugswalzen $g_{0} g_{1}, g_{i}{ }^{\prime} g_{1}{ }^{\prime}, g_{0}{ }^{\prime \prime} g_{1}{ }^{\prime \prime}$ verdichtet und weiter geleitet werden. Zur Reinhaltung der Nadeln der Abnelimewalzen dienen die Bürstwalzen $B_{1} B_{a} B_{3}$. $\mathrm{Zu}$ jeder Abnehmewalze gehören 3

Fig. 1672.

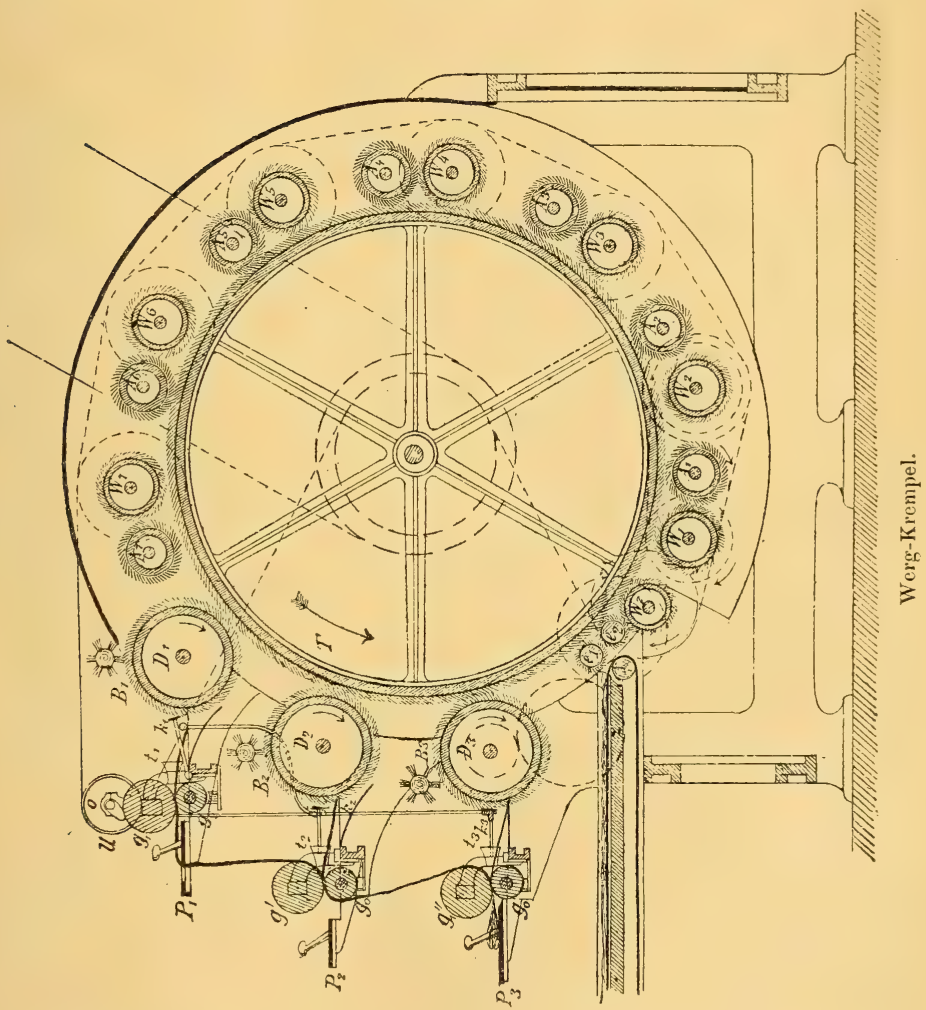

Paar Abzugswalzen, die eine Breite von $7.6^{\prime}$ bis $10.0^{\mathrm{cm}}$ haben und ron denen die unteren $g_{0}$ auf einer gemeinsamen Achse sitzen, während die oberen $g_{1}$ Druckwalzen sind. Von jeder Abnehmewalze kommen also drei, im Ganzen daher neun Bänder, die man in verschiedener Weise weiter leitet. Sollen je 3 Bänder einer Abnehmewalze für sich bleiben, so dienen die Doublirplatten $P_{1}^{\prime} P_{0} P_{33}$ mit sehräg eingesetzten 'Zapfen zur seitlichen Ableitung derselben. Man erhält alsdamn ein grobes, ein mittelfeines und ein feines Band, jedes zu verschieden feinen Garnnummern verwendbar. Sehr häufig aber lässt man, wie in der Figur angegeben, 
die Bänder der ersten Abzugswalzen mit denen der zweiten und diese wiederum mit denen der dritten zusammenlaufen, und erhält so von den letzteren 3 Bänder mittlerer Feinheit, die wiederum auf der Platte $P_{\mathbf{3}}$ rechtwinklich zu ihrer urspriinglichen Richtung abgeleitet und entweder getrennt, oder zu einem einzigen Bande vereinigt, durch seitlich stehende (in der Figur weggeschnitten gedachte) Abzıgswalzen in Blechkannen a ogeliefert werden.

Die Geschwindigkeiten der einzelnen Walzen sind vom grössten Einfluss anf die Art der Arbeit und können, mit Ausnahme der der Wendewalzen, durch Wechselräder innerhalb ziemlich weiter Grenzen geändert werden.

Trommeltouren zwischen 140-180, gewöhnlich 150 ; die

Umfangsgesclıwindigkeit der Trommel nahe $12^{\mathrm{m}}$

$\begin{array}{lll} & \text { Wender } & 2.7^{\mathrm{m}} \\ & \text { Arbeiter } & \mathbf{7 . 6}-\mathbf{4 4 . 5} \\ & \text { Abnehmewalzen } & 42.3-99^{\mathrm{mm}} \\ & \text { Speisewalzen } & 4-12.2^{\mathrm{mm}}\end{array}$

Soll das Material mit einmaliger Kardirung geniigend bearbeitet werden, so darf man anf einer Karde täglich nicht mehr als 200 bis 250 Kilogr. verarbeiten, und kann bei zweimaliger Kardirung bis 350 Kilogr. gehen.

Für Garn Nr. 8-14 hat die Trommel Bclag Nr. 13 oder 14; die später zur Wirkung kommenden Arbeiter und Wender sind um 2 bis $3 \mathrm{Nr}$. feiner, ebenso die Abnehmewalzen um 4-5 Nummern. Bei Garn Nr. 16-22 sind sämmtliche Belege $\mathrm{nm} 1-2 \mathrm{Nr}$., bei $\mathrm{Nr}$. 25-30 um 2-3 Nr. feiner.

Der Kraftbedarf einer Karde schwankt zwischen 1.5 bis 2.5 Pferdekräften.

Abweichend von den erwähnten Krempeln sind die von Dockrey construirten. Die Trommel hat den geringen Durchmesser von 0.8 Meter und ist nur von zwei Paar Wendeund Arbeitswalzen, auf welche 3 Abnehmewalzen folgen, umgeben. Die Zuführung des auf dem Anflegetische ansgebreiteten Materials erfolgt durch eine Muldenspeisewalze. Zwischen den Arbeitern und Wendern ist je eine gusseiserne, oben abgerundete stellbare Schiene angeordnet, welche bewirken soll, dass das vom Wender dem Arbeiter abgenommene und über diese hinweggezogene Material sich gleichmässiger ablösen und vertheilen soll. Das von der ersten Abnehmewalze von der Trommel abgenommene und durch einen auf- und niederschwingenlen Kamm von derselben ausgekämmte Material geht sofort wieder auf eine Muldenspeisewalze über und wird ròn der Trommel anf's Nene an der Kante der Mulde bearbeitet, worauf es durch die zwei letzten Abnehmewalzen definitiv abgenommen, aus diesen abgekänmt, durch Trichter zu je drei Bändern zusammengezogen und durch Abzugswalzen verdichtet wirl. Die Bänder jeder Abnehmewalze werden durch die Doublirplatte vereinigt und durch zweite Abzugswalzen weggeleitet. Bei einer andern Construction lauft je ein oberes Band mit dem untern zusammen, und gelangen die drei im Ganzen abgelieferten Bänder noch durch einen besondern Streckkopf, ehe man sie in Blechkannen auffïingt.

An verschiedenen Stellen der Trommel sind Holzschienen angebracht, um den Einflnss der Luftströmung auf die Fasern zu mildern.

Diese Karden sind bei uns nur in wenigen Exemplaren zur Anwendung gekommen und stehen in Bezng auf die Qualität der geleisteten Arbeit den zuerst beschriebenen bedeutend nach.

Die Kardenbänder werden mehrmals doublirt und gestreckt auf zwei oder drei Streckmaschinen und gehen alsdann auf die Vorspinnmaschine über.

Die Wergstreck- und Vorspinnmaschinen sind meist ebenfalls mit cinem aus Hechelstäben bestehenden und durch Schrauben bewegten Hechelapparat versehen, sind also im Princip gleich den Flachsmaschinen construirt, von denen sie nur durch einfachere Bandzuführung, direct über ein Zuführungsblech, durch kürzere Distanz im Streckwerk und leichtere Bauart abweichen.

Ausser dem erwähnten Hechelapparat benutzt man aber auch in der Wergspinnerei rotirende Hechelstäbe, die zusammen einen Cylindermantel bilden und durch deren Nadel Aus-und Eintritt in die Bänder durch excentrische Scheiben annähernd geradlinig bewirkt wird (circular gills), oder anch eine rotirende Hechelnadelwalze (rotary gill), die zwischen Einzieh- 
und Streckwalzen in der Nähe der letateren gelagert ist. Beide Anordnungen sind weniger gut als die erstere und werden nur selten angewendet. Die letztere erlaubt einen schnelleren Gang der Maschinen, also eine grössere Production, und findet deshalb bei Erzengung solcher Garne, bei denen es besonders auf möglichst billige Herstellung ankommt, Anwendung.

Das F e in s p in n e n des Wergrorgarnes findet ebenfalls entweder auf Trocken-, Halbnass- oder Nassspinnstuihlen statt. Die ersteren haben eine kleinere Distanz im Streckwerk, etwa 20 bis $25^{\mathrm{cm}}$, es fallen daher die bei den Flachsfeinspinnstiihlen dieser Art vorhandenen besonderen Fiihrungen des Vorgarnes weg und sind nur die früher erwähnten stellbaren Leitplatten und kurze seitlich begrenzte Bleche vorhanden, welche das Eintreten des Fadens zwischen den Streckwalzen sichern.

Zur Erzeugung dicker Garne ans der Schwing. und Abfallheede bedient man sich häufig eines sogenannten Abfallsystems, bestehend in einer $\mathrm{K}$ arde mit einer Trommel von $1.22^{\mathrm{m}}$ Durchmesser, bei $1.82^{\mathrm{m}}$ Breite und Streckkopf; dann folgt eine Streckmaschine mit 3 Köpfen à 6 Bändern und hierauf eine $\mathrm{H}$ e ch els p in nmaschine (gillspinning) oder Spindelbankspinnmaschine (roving-gillsp.).

Diese Feinspinnmaschinen werden in beiden Formen bis zu den Garnnummern 3 angewendet. Die Hechelspinnmaschinen besonders zu den gröbsten Nummern bis Nr. $1 \frac{1}{2}$ sind bis zu den Streckwalzen ebenso wie eine Vorspimnmaschine und von da ab in Bezug auf die Spindeln wie eine Feinspinnmaschine gebaut, haben also nur eine Reihe Spindeln und gebremste Spulen, während der besondere Bewegungsmechanismus derselben fehlt.

Die zweite Art der Feinspinnmaschinen, die häufiger angewendet wird, ist ebenso wie eine Vorspinnmaschine, also auch mit zwei Reihen Spindeln und gemeinsam bewegten Spulen construirt. Die Geschwindigkeit der Spindeln und die möglichen Drehungen per Zoll sind nur bedeutend grösser als die bei den Vorspinnmaschinen.

Bei Anwendung von Hechelspinnmaschinen, fehlt also im System die Vorspinnmaschine, und es folgt auf die letzte Streck-, die obige Maschine.

Ueber den Kraftbedarf*) ist zu bemerken, dass ein erster. Wergdurchzug: pro Kopf 0.32, ein zweiter pr. K. 0.25, ein Wergfleier pro Spindel 0.028 und eine Wergfeinspinnmaschine fuir die Nummern 14-16 pro Spindel 0.028 Pferdekräfte braucht.

Wird der mittlere Widerstand in Kilogr., reducirt auf den Umfang der Streckwalzen, mit $p$ bezeichnet, so ist derselbe für den ersten Durchzug 18.1, für den zweiten 12.2, für den Wergfleier 10.2 und für die Feinspinnmaschine zu Nr. 14-16 zu 11.9 zu setzen, und alsdann kann dieselbe Formel zur Berechnung der Betriebskraft wie früher (pag. 552) angegeben benutzt werden.

5) Das Haspeln, Numeriren und Troeknen der nass gesponnenen Flachs- und Werggarne, sowie das Packen derselben.

Das Haspeln der Garne findet auf dem Garnhaspel, der Weife, statt. Die Feinspinnspulen werden direct iiber feste, neben einander auf einem Brett angeordnete diinne Drahtstifte, oder besser (weil leichter drehbar) erst auf Messingliülsen und mit diesen dann über die Stifte gesteckt. Die Fäden verbindet man mit dem Haspel, bei dessen Drehung sie sich auf dem Umfange aufwinden (s. H a s p el).

Der Haspelumfang ist gewöhnlich $2 \%$ Yards $=90 \mathrm{Zoll}$ engl. $=2.286 \mathrm{~m}$. 120 Fäden heissen ein Gebind (lea) $=300$ Yards; 10 Gebinde geben einen Strähn $=3000$ Yards, 4 Strähn $=1$ Stiick $=12.000$ Yards: j Stiick $=$ 1 Biindel $=60.000$ Yards, 12 Bundel $=1$ Schock $=720.000$ Yards und ist ein Schock $=2$ Pack englisch.

Neben dieser Weife sind jedoch in Deutschland und Oesterreich noch andere hiervon abweichende im Gebrauch.

*) Siehe Dr. Hartig Versuche ii. d. Kraftbedarf etc. S. 11 u. 12. 
Die Garnnumerirung, also die Bestimmung der Feinheit des Fadens, findet, mit Ausnahme von Frankreich, ïbereinstimmend nach der englischen Methode statt. Hiernach ist die Garnnummer die Zahl, welche die Anzahl der in einem engl. Pfunde enthaltenen Gebinde oder leas à 300 Yards angibt. Ein Pfund Garn von der Nummer $N$ hat demnach eine Länge von $300 N$ Yards. Das Gewicht $G$ eines Biindels Garn in engl. Pfunden ist daher

$$
\begin{gathered}
G=\frac{60.000}{300 N}=\frac{200}{N} \\
G=\frac{90 \cdot 72}{N} \text { oder abgerundet } G=\frac{90}{N} \text { in Kilogr. }
\end{gathered}
$$

(s. Garnnumerirung).

Die Aufstellung des Spinnplanes ist jene Anordnung der Vorziige und Doublirungen auf den einzelnen Maschinen, welche aus einer bestimmten Menge Rohmaterial (Flachs oder Heede) ein Garn von gewïnschter Nummer liefert.

Der Spinnplan ist eingehend besprochen in der Spinnereimechanik von C. H. Schmidt und der Flachsspinnerei von Dr. Hülse, weshalb wir uns hier mit einigen Andentungen begnïgen kömnen. Verfolgen wir die Art und Weise der Verarbeițung des Flachses, so wird zunüchst die Grösse des Auflagegewichtes auf der Anlegemaschine, d. h. die auf die Längeneinheit des Zuführungstisches derselben ausgebreitete Flachsmenge, so gewählt, dass die durch den Klingelapparat angezeigte Bandlänge $k$ (gewöhnlich 500 Yards) ein durchschnittliches Gewicht $g$ besitzt, dessen Grösse innerhalh gewisser erfahrungsgemäss bestimmten Grenzen schwankt. Die durch ungleichmässige Auflage hervorgerufenen Differenzen im Gewichte der rinzelnen Klingellängen Band gleicht man nun dadurch aus, dass man $d_{1}$, je eine volle Klingellïnge Band enthaltende Kannen im Gesammtgewicht von $d_{1} g=P$ zu sogenannten "Ansätzen" (charges - sets) zusammensetzt, diese vor die erste Streckmaschine bringt, die Bïnder $v_{1}$ mal auf derselben verzieht und sämmtliche Bänder jeden Ansatzes durch die Bandplatto wieder zu einem einzigen Bande vereinigt. Hierauf werden $d_{2}$ soleher Bänder in ihren Kannen auf dem zweiten Durchzuge $v_{2}$ mal verzogen, wiederum zu einem Bande zusammengefithrt, und wiederholt man dieses Verfahren auf dem dritten Durchzuge mit $d_{3}$ Bändern, die man $l_{3}$ mal streckt. Gewöhnlich werden alsdann der Vorspinnmaschine die Bänder einfach, nehmc wir aber allgemein an $d_{4}$ fach vorgesetzt, $r_{4}$ mal verzogen, zu Vorgarn zusammengedreht, und dieses dann, nachdem es auf der Feinspinnmaschine $v_{5}$ mal gestreckt wurde, in Feingarn von der Nummer $N$ umgewandelt. Der aus $d_{1}$ Bändern bestehenảe Ansatz wird im t'ngl. Ptunde n eine Lünge von $\frac{k}{I^{\prime}}$ Yards und das aus demselben erzeingte Feingarn von der Nummer $N$ eine Lünge ron $300 N$ Yards haben. Der Ansatz muss deshalb eine totale Streckung $V$ erhalten von:

$$
r=\frac{300 N}{\frac{k}{P}}=\frac{300 N \cdot P}{k},
$$

welche demselben auf den Maschinen zu ertheilen ist.

Dor resultirende Verzug auf den Maschinen ist aber gleich dem Producte aus den einzelnen Verziigen, dividirt durch das Product aus den einzelnen Doublirungen, also

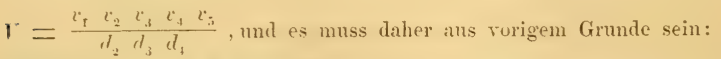

$\frac{\text { sul } x: P}{k_{i}}=\frac{r_{1} r_{2} r_{3} r_{1} r_{5}}{d_{2} r_{3} l_{4}}$, woraus sich beispiclsweise das Ansatzgewicht $P$ berechnet

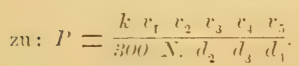

Da das Garn in Folge der Contraction durch die Drehung auf der Feinspinmmaschine an L:inge verliert. d. h, eben so viel an Gewicht gewimnt, anderseits aber durch den Algang an schïlsen- und stanbtheilchen leichter wird -- die Gewichtsmnahme aber iberwiegt, so ruchet man ron dem ermittelten Gewichte einen erfahrungsgemïss festgestellten Prncentsatz 
(etwa 8 Proc.) ab, oder vergrössert den Verzug anf einer Maschine - gewölunlich der Feinspinnmaschine - entsprechend, damit diese Gewichtszunahne ansgeglichen wird.

Im Allgemeinen geht hieraus hervor, dass man in verschiedener Weise doubliren und verziehen kamm und schliesslieh duch zu demselben Resultate kommt. Die Grenzen, welche man hier jedoch inne zu halten hat, sind einerseits durch die Grösse der Maschinen - indem die Anordnnng so zu treffen ist, dass jede folgende Maschine bei fortwährendem Betriche das Product der vorhergehenden möglichst vollstïndig aufarbeitet - inderseits durch die ljeschiaffenheit des Rohmaterials bestimmt. Gutes und kräftiges Material verträgt grössere Vorziige als schwächeres und kürzeres, und pflegt man meist auf der Feinspinnmaschine für Flachs keine höheren Verzüge als $9-10$, für Werg als $6-7$, auf den Vorspinnmaschinen und Durclızügen 14-16 für Flachs und 6-8 für Werg, anf der Anlegemaschiue und der Karde 25-30 zu geben, welche auch für geringeres Material anwendbar sind. Die Grösse des Ansatzes bei 500 Yards Klingellïnge ist etwa 55 bis 90 Kilogr. für Flachs und 30 bis 60 Kilogr. für Werg -

Die Anzahl der Drehungen, welche man dem Feingarne gibt, ist $D=\iota \sqrt{\bar{T}}$, wo bei Kettengarn ans Flachs $\alpha=1.8-2$ und aus Werg $\alpha=2-2.5$, "Schussgarn " $" \quad c=1.6-1.7, \quad, \quad, \quad \alpha=1.8-1.9$ ist.

Die nass gesponnenen und gehaspelten Garne miissen sofort, wie sie von der Weife kommen, getrocknet werden, um sie vor dem Verderben zu bewahren. Man wendet zum Trocknen der Garnsträhne an: a) Trockenkammern. b) Trockenapparate und c) Trockenmaschinen.

a) Die Trockenkammern werden meist in den obersten Etagen und zwar so angelegt, dass in demselbem Raume zwei durch einen $1.25^{\mathrm{m}}$ breiten Gang von einander getrennte Kammern entstehen. Die eine Kammer ist dann mit nassem Garne gefuillt und steht unter der Einwirkung erwärmter Luft, während dic andere von dem bereits getrockneten Garne entleert und damn mit neuem, nassen Garne voll gehangen wird. (Vgl. Art. Troeknen.) Bei guter Anlage kann man mit $200 \mathrm{~K}$. Kohle bis $1000 \mathrm{~K}$. Garn trocknen.

b) Trockenapparate. Es haben sich besonders zwei Apparate, die von Th. Calow \& Co. in Bielefeld gebaut werden, in verschiedenen Spinnereien eingefiihrt und bewährt, und zwar: der Canal-Trockenapparat und der Kasten-Trockenapparat. Beide bediurfen zum Trocknen desselben Garnquantums bedentend weniger Raum als die Kammern. Der Heizapparat besteht in beiden Fällen aus einem meist aufrecht stehenden, aus Schmiedeisen liergestellten, oben und unten geschlossenen Cylinder (etwa 1.5 Meter im Durchmesser und 3 Meter hoch), welcirer im Innern circa 500 Stiick durch beide Boden gehende $38^{\mathrm{mm}}$ weite liöhren enthält. In den Cylinder wird entweder directer Kesseldampf, durch ein Reductions-Ventil auf bestimmter Spannung gehalten, oder abgehender Maschinendampf eingefuihrt, der die kleineren Röhren umspielt und daher die in denselben circulirende Luft erwärmt, die man direct zum Trocknen der Garne benutzt. Die Bewegung der erwärmten Luft wird stets durch einen Ventilator beschleunigt.

Der Kanaltrockenapparat, welcher in der folgenden Figur 1673 im Grumlriss und Längenschnitt in $1 / 190$ nat. Grösse dargestellt ist, besteht aus zwei horizontalen neheu einander angeordneten, fenerfest gemauerten Kanälen $A$ und $B$ und ist nelon Kanal if noch eine offene Bahn $C$ angeordnet. Beide Kanäle $A$ und $B$ sind an den Enden mit eiseruen Schiebern geschlossen und communiciren mit einem Ventilator $V$, der die Luft ansaugt. $K K$ sind zwei Heizapparate, wie oben beschrieben, welche mit Kanal $B$ communiciren. Das Aufhängen der Garne an Stäben geschieht ausserhalb der Kanäle in der Balun ('ant kleine auf Schienen bewegliche Garnwagen. Die Garnwagen gelangen zumächst bei " in den kinal $A$ und rollen in demselben durch das Nachschieben never Wagen in der Richtung des Pteiles weiter. Aus $A$ werden die Wagen bei $b$ in den Kanai $B$ überführt, weleher geheizt ist und in welchem sich die Garnwagen nach links bewegen. 
Ist der Betrieb im Gange, also beide Kanäle gefüllt, so wird ein Wagen mit trockenem Garne aus $B$ herausgenommen, die Garnwagen werden nachgeschoben und ein neuer mit nassem Garn in $A$ eingeführt. Vor den Enden der Kanäle laufen sogenannte Querwagen, welche die Ueberführung der Garnwagen von dem einen Kanal zum andern vermitteln. Durch die angeführte Bewegung der Garne erst in dem ungeheizten und dann in dem geheizten Kanale wird das Trocknen der Garne unter geringem Kostenaufwande in verhältnissmässig kurzer Zeit erreicht. Die Leistung dieses Apparates ist 2500 bis 3000 Kilogr. Garn per Tag. Man verwendet auch je nach den Umständen zwei Ventilatoren oder auch nur einen Hejzapparat.

Fig. 1673.

Grundriss.
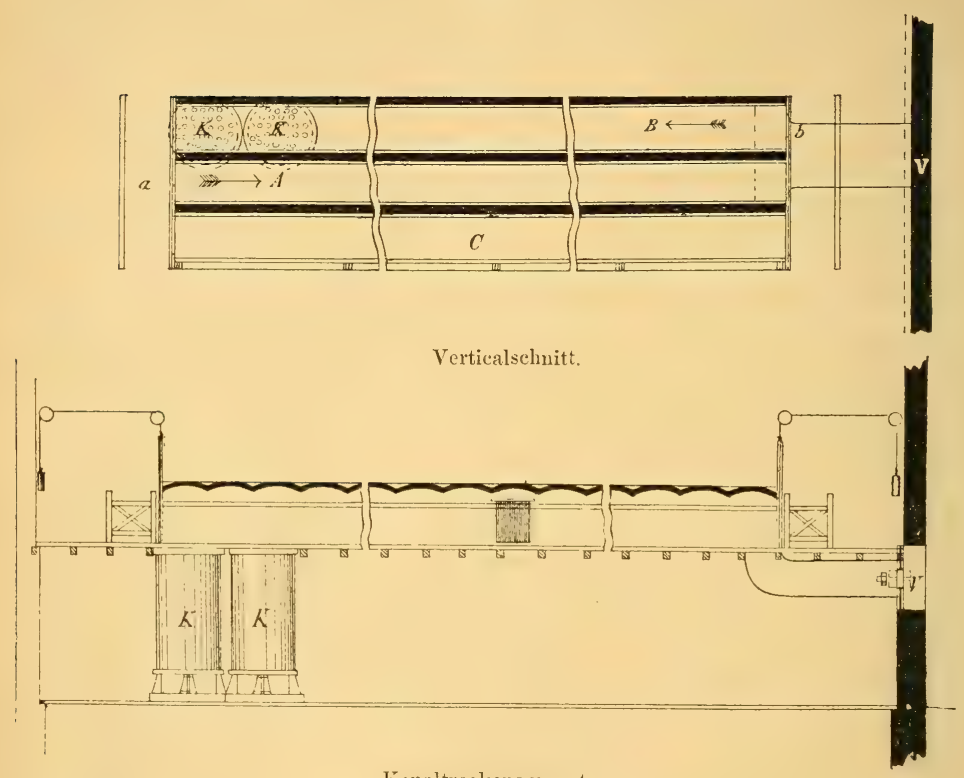

Kanaltrockenapparat

Der Kastentrockenapparat beansprucht noch weniger Raum als der vorstehend beschriebene nud wird deshalb gern bei sehr beschränkter Räumlichkeit angewendet. Zu jedem Apparat gehört ein Heizcylinder, der unter dem Fussboden des Trockenraumes entweder stehend oder liegend angeordnet ist. Oberhalb desselben ist ein ca. 125 Meter breiter, 1.4 Meter langer und etwa 3 Meter hoher hölzerner Kasten aufgestellt, durch welchen die erwärmte Lu't ron dem Heizcylinder von cinem im höchsten Punkte wirkenden Veutilator geführt und wegrgeleitet wirl. Die feuchten, auf Rahmen aufgespannten Garne gelangen im höchsten Punkte von der Vorderseite in den Kasten in welchem 36 Stück auf einander zu liegen kommen und schreitet demnach das Trocknen von oben nach unten zu fort. Die Rabmen werden in dem Kasten durch einen besonderen Mechanismus gehalten, welcher erlaubt, sobald das Garn des untersten hahmens trocken ist, diesen nach der Vorderseite zu herauszunehmen und auf eiceu Fahrstulil niederzulegen. Die Production eines solchen Apparates ist täglich 1250 Kilogr.

c) Trockenmaschinen. Am bekanntesten und in einigen deutschen Spinnereien (z. B. in der Flachsspinnerei von George Stelling, Gräber \& Co. in 
Hannover) seit langen Jahren mit bestem Erfolge angewendet, ist die (ylinderGarntrockenmaschine von Mather, Platt in Manchester, welche auf dem im Art. Appretur I pag. 171 besprochenen Prineipe beruht.

Das Garn wird in sechs Strängen neben einander auf der Maschine getrocknet, und jeder Strang fasst, je nach der Stärke des Garnes, 2 bis 6 Stiick, die mit einander durch bronzene Verbindungsstïcke (Fig. 1674 in $1 / 30$ nat. Grösse) an einander befestigt sind. Ein Mädchen hängt Fig. 1674 . die Strähne mittels dieser Verbindungsstiicke an einander, ein anderes am entgegengesetzten Ende der Maschine hakt die Verbindungen wieder ans und legt das getrocknete Garn geordnet nieder. Das Garn kommt sehr hübsch blank und glatt aus der Maschine und ist, nachdem es etwa 40 bis 45 Minuten auf derselben gewesen, völlig getrocknet. Man kann leicht 150 Bïndel von Nr. 10 bis 30 pro Tag auf dieser Maschine trocknen.

Das Packen der Garne geschieht entweder auf der Packbank oder mittels Pressen (s. Art. Garnpressen) und ist die Art der Packung, sowie die Grösse der gebildeten Packe sehr verschieden, je nach den Garnnummern und den Productionsgebieten.

Die Spinnereiabfälle, namentlich jene vom Feinspinnen, sind ein werthvolles Rohmaterial der Feinpapierfabrikation.

E. Pfuhl.

Flachstichel s. Graviren.

Flachzangen (pincettes, béquettes plyers) sind, wie die beistehende Figur zeigt, Zangen mit schmalem, flachem Maule, welche sich zum Festhalten dünner Gegenstände, zum Fassen und Biegen von Draht, Blechstreifen u. dgl. eignen. Vgl. Art. Z angen.

Flachwerk (couverture à claire voie), Eindeckung der Dächer mit flachen Ziegeln.

Flackmaschine und Schlagmaschine, s. Baumwollspinnerei, I pag. 327 .

Flader oder Maser, Mas erholz (madrure - speckled wood) bezeichnet jene unregelmässigen, gefaserten, oft astreichen Schnitthölzer (namentlich der Fournire), welche aus knorrigen, verkrüppelten Stämmen und Wurzeln erhalten werden, und ihres hïbschen Aussehens wegen für Tischlerarbeiten geschätzt

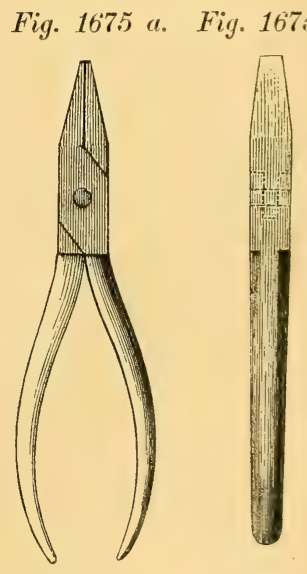
sind. $K k$.

Fläche (besoche - pichiaxe with two flut feuther's), ein Steinmetzwerkzeug zum Ebnen von Flächen, s. Ste inbe a rbeitung.

Fläche (surface - surface) als Raumgebilde, der Ort einer gesetzmässig bewegten Linie, welche während der Bewegung wohl anch ihre Gestalt continuirlich ändern kann, oder auch der Ort von Punkten im Raume, welche einer gewissen Forderung Geniige leisten. Den Eintheilungsgrund fiij die Flächen gibt ihre Entstehungsweise, vom analytischen Standpunkte die Natur der sie darstellenden Gleichung.

I. Nach der Entstehung unterscheidet man:

$A$. Regelflächen, entstanden durch die Bewegnng einer Geraden. Dieselben zerfallen in zwei Gruppen: 
a. Die entwickelbaren oder developpablen Regelflächen, bei welchen benachbarte Lagen der erzeugenden Geraden sich im Endlichen oder Unendlichen schneiden (in einer Ebene liegen). Dieselben lassen sich ohne Aufhebung ihres Zusammenhanges in eine Ebene - die einfachste Fläche dieser Gattung - ausbreiten (developpiren). Es gehören hieher:

«) Die Kegel- und Cylinderflächen, bei deren Erzeugung die längs einer Curve (Leitcurve) gleitende generirende Gerade durch einen festen Punkt im Endlichen - den Scheitel, - bezw. im Unendlichen - die Richtung lindurchgeht; die einfachsten Flächen dieser Art sind die Kreiskegel- und Kreiscylinderfläche.

ß) Die allgemeine developpable Regelfläche, der Ort der Tangenten oder die Enveloppe der Schmiegungsebenen einer Raumcurve (s. Curven, II. Thl.pag. 423); bezeichnet man nämlich mit $M_{1}, M_{0}, M_{3}, M_{4} \ldots$ benachbarte Lagen des eine Raumcurve beschreibenden Punktes, so sind die Verbindungslinien von $M_{1} M_{2}, M_{2} M_{3}, M_{3} M_{4} \ldots$ oder die Geraden $t_{1}, t_{2}, t_{3} \ldots$ Tangenten für die Elemente $\bar{M}_{1} \bar{M}_{2}, \bar{M}_{2} \bar{M}_{3}, \bar{M}_{3} M_{4}$... der Curve, die durch zwei auf einander folgende Tangenten $t_{1}$ und $t_{0}, t_{2}$ und $t_{3} \ldots$ bestimmten Ebenen $E_{1}, E_{12} \ldots$ Schmiegungsebenen fuir die Elementenpare $\bar{I}_{1} I_{2}$ und ${\overline{I_{2}}}_{M_{3}}, \bar{M}_{2} M_{3}$ und $\bar{M}_{3} \bar{M}_{4} \ldots$; der Ort der Tangenten $t_{1}, t_{2}, t_{3} \ldots$ oder die Enveloppe der Ebenen $E_{1} E_{2} \ldots$ wird die developpable Fläche der Raumeurve und diese selbst die R ü ckkehrkante der Fläche genannt. Wir nennen als Beispiel die developpable Fläche der Schraubenlinie auf dem Kreiscylinder, developpable Schraubenfläche oder Helicoid genannt.

Developpable Flächen, deren einhiillende Ebenen $E_{1}, E_{2} \ldots$ gegen eine feste Ebene gleiche Neigung haben, neunt man Flächen von gleichem Falle. Die Kreiskegelfläche und das vorgenannte Helicoid zählen hieher.

b. Die windschiefen Regelflächen, bei welchen benachbarte Lagen der erzeugenden Geraden sich kreuzen (nicht in einer Ebene liegen). Wir fiihren hievon an:

(6) Die windschiefen Regelflächen zweiten Grades: das hyperbolische Paraboloid, welches durch Gleiten einer zu einer festen Richtungsebene parallel bleibenden Geraden längs zweier sich kreuzender Geraden, und das II yperboloid mit einem Mantel, welches durch Gleiten einer Geraden längs dreier sich krenzender Geralen entsteht; beide Flächen enthalten zwei liegelschaaren, d. h. zwei Systeme von Geraden.

ß) Die Conoide, Flächen, welche durch Gleiten einer zu einer festen Richtungsebene parallel bleibenden Geraden längs einer Leiteurve (oder Leittäche) und einer Leitgeraden entstehen; steht letztere zur Richtungsebene normal, so spricht man von einem geraden Conoid. Wir nennen hier die gerade Schrauben- oder. Wendelfläche, deren Leitcurve eine Cylinderschraubenlinie ist; als Leitgerade dient die Achse derselben und die Richtungsebene ist zu dieser normal. Die Fläche tritt beim Steinschnitt schiefer Tonnengewölbe anf.

i) Die scharfe Schraubenfläche, welche entsteht, indem eine Gerade längs einer eylindrischen Schraubenlinie und der Achse des Schraubencylinders gleitet und letztere unter constantem Winkel schneidet.

Fiihrt man durch einen beliebig gewählten Punkt des Raumes Parallele zu den Erzeugenden einer Regelfäche, so haben diese zum geometrischen Orte eine Kegelfläche mit jenem Punkte als Scheitel, welche man den Directionskegel der RegelHäche nennt; derselbe spielt in der constıuctiven Theorie eine wichtige Rolle.

13. Rotationsflächen, welche durch Drehung einer Curve um eine mit ihr in fester Verbindung stehende Gerade, die Lmdreliungs- oder Rotations- 
achse entstehen. Alle durch die Achse gelegten Ebenen, Meridianchenen, schneiden die Fläche nach congruenten, zur Achse orthogonal-symmetrischen Curven, M eridianen, während die zur Rotationsachse normalen Ebenen Kreise liefern. Wir nennen hier:

a) Die Rotationsflächen zweiten Grades: die Kugel; das flache und oblonge Umdrehungsellipsoid, ersteres durch Drehung ciner Ellipse um ihre kleine, letzteres durch Rotation um deren grosse Achse entstanden; das einmantelige und das zweimantelige Umdrehungshyperboloid, das erste aus der Drehung einer Hyperbel um ihæe imaginäre, das letctere ans der Rotation um die reelle Achse hervorgehend; das Umdrehungsparaboloid aus der Parabel, wenn die Achse derselben als Rotationsachse gewälılt wird, hervorgehend.

$\beta$ ) Die Wulstflächen, durch Drehung eines Kreises um eine in seiner Ebene liegende, nicht durch den Mittelpunkt gehende Gerade entstanden.

C. Einhüllende Flächen, welche durch gesetzmässige Bewegung einer Fläche entstehen, wobei diese auch noch ihre Gestalt continuirlich verändern kann; je zwei Nachbarlagen der erzeugenden Fläche schneiden sich nach einer Curve, welche die Charakteristik der erzeugten Fläche genannt wird; offenbar kann letztere Fläche auch als Ort der Charakteristik aufgefasst werden. Wir nennen hier beispielsweise die Serpentine, erzengt durch Bewegung einer Kugel von constantem Halbmesser, deren Mittelpunkt eine Cylinderschraubenlinie durchläuft; ihre Charakteristik ist der Kreis.

D. Rückungsflächen, die man sich durch gesetzmässiges Fortrïcken einer Curve entstanden denkt, wobei dieselbe auch wohl ihre Form continuirlich abändern kann. Wenn beispielsweise der Mittelpunkt eines Kreises von constantem Halbmesser eine Cylinderschraubenlinie durchläuft und seine Ebene zur Cylinderachse normal bleibt, so beschreibt er diє Oberfläche der sog. gew undenen S äul e.

Selbstverständlich kann man sich jede Fläche auf mehrfache Art entstanden denken; alle Rotationsflächen z. B. entstehen auch durch Rücken eines Kreises oder durch Bewegung einer Kugel, die zugleich ihren Radius ändert etc.

II. Vom analytischen Standpunkte unterscheidet man die Flächen nach der Natur der sie darstellenden Gleichungen in algebraische und transcendente, erstere wieder nach dem Grade der Gleichungen.

III. Allgemeine Erklärungen.

1. Die durch zwei unendlich nahe Punkte einer krummen Fläche $F$ bestimmte Gerade $t$ wird eine Tangente der Fläche und die Vereinigung $M$ jener Punkte ihr Beriihrungspunkt genannt.

2. Dic durch zwei in einem Punkte $M$ an die Fläche $F$ gelegten Tangenten bestimmte Ebene $T$ wird $T$ angentialebehe fur den Punkt $M$ genannt; sie ist der Ort aller in $M$ an $F$ gezogenen Tangenten; von diesen berihren zwei, $t_{1}$ und $t_{\underline{a}}$, auch die Schnittcurve der Tangentialebene mit der Fläche, fiir welche $M$ ein Doppelpunkt ist, man nennt sie die $\mathrm{Haupttangenten}$ in $M$ und sie sind reell und verschieden oder reell und zusammenf:llend oder imaginär; darnach wird $M$ ein hyperbolischer, parabolischer oder elliptischer Punkt der Fläche genannt.

3. Die im Berührungspunkte $M$ zur Tangentialebene $T$ 'errichtete Senkrechte $N$ heisst Normale der Fläche für den Punkt $M$. Jede durch $N^{\top}$ gelegte Ebene heisst Normalebene und ihr Schnitt $S$ mit der Fläche ein Normalschnitt für $M$.

4. Jeder Normalschnitt des Punktes $M /$ hat im Allgemeinen in diesem Punkte eine andere Krümmung, mit anderen Worten: die Fläche ist in einem betrachteten 
Punkte in Richtung eines jeden Normalschnittes anders gekrimmt. Doch gibt es zwei zu einander senkrechte Normalschnitte $S_{1}$ und $S_{a}$, von denen der eine den kleinsten; der andere den grössten Krimmungshalbmesser oder der eine die grösste, der andere die kleinste Krïmmung in $1 /$ besitzt; man nennt $S_{1}$ und $S_{12}$ die Hauptnormalschnitte, ihre Krïmmungshalbmesser $r_{1}$ und $r_{2}$ (in $M$ ) die Hauptkrïmungsradien der Fläche in $M$. Die den Schnitten $S_{\text {, und }}$ $S_{\mathrm{a}}$ zukommenden, in $T$ liegenden Tangenten $\tau_{1}, \tau_{1}$ halbiren die Winkel der Haupttangenten $t_{1}, t_{20}$. - Ein Punkt der Fläche, in welchem dieselbe nach allen Richtungen gleiche Krümmung (wie die Kugelfläche) aufweist, heisst $\mathrm{Nabel}$ oder Umbilicalpunkt. Einfache Beispiele solcher Punkte bieten die Scheitelpunkte der Umdrehungsachse bei Rotationsfläehen.

IV. Von den einer Fläche a ufgeschriebenen Curven.

1. Errichtet man in den Punkten einer auf einer Fläche $F$ verzeichneten Curve $C$ die Normalen zur Fläche, so wird der geometrische Ort derselben eine Normalfläche von $F$ längs der Curve $C$ genannt.

2. Die asymptotischen Curven oder Curven der Haupttangenten sind jene Linien auf einer Fläche $F$, deren Schmiegungsebenen zugleich Tangirungsebenen von $F$ sind, deren developpable Flächen also der Fläche $F$ umschrieben erscheinen; sie berühren in jedem Punkte, durch welchen sie gehen, eine der Haupttangenten $t_{1}, t_{2}$. Es gibt solcher Curven zwei Schaaren, oder eine einfache Schaar, oder sie sind imaginär, je nachdem die Fläche an der betrachteten Stelle hyperbolische, parabolisch e oder elliptischePunkte enthält. Das hyperbolische Paraboloid und das einmantelige Hyperboloid besitzen zwei Schaaren asympt. Linien (in den beiden Regelschaaren); bei den Kegel- und Cylinderflächen gibt es deren nur ein System, repräsentirt durch die geraden Erzeugenden; auf den sämmtlichen Flächen zweiten Gerades ausser den beiden vorgenannten sind sie imaginär.

3. Geodätische Linien sind solche der Fläche aufgeschriebene Curven, deren Schmiegungsebenen zu den Tangentialebenen der Fläche normal sind. Es sind zugleich die Linien des kürzesten Abstandes in der krummen Fläche, in diesem Sinne also Analogon der Geraden in der Ebene. Bei den developpablen Regelfächen erscheint eine geodätische Linie in der Abwicklung als Gerade; daher ist beispielsweise auf einer Kreiscylinderfläche die Schraubenlinie eine geodätische Linie; auf Rotationsflächen sind die Meridiane derlei Linien.

4. Krïmmung linien sind Curven, welche in den Punkten, durch welche sie gehen, einen der Hauptnormalschnitte $S_{1}, S_{2}$ oder dessen Tangente $\tau_{1}, \boldsymbol{\tau}_{12}$ beriihren, daher in jedem Punkte die Richtung der maximalen oder minimalen Kriimmung der Fläche angeben. Es gibt deren zwei Schaaren, durch jeden Punkt der Fläche geht je eine aus jeder Schaar, die eine $\tau_{1}$ (oder $S_{1}$ ), die andere $\tau_{g}$ (oder $S_{u}$ ) berührend. Krimmungslinien d erselben Schaar begegnen sich nicht (ausser in Nabelpunkten), dagegen wird jede aus der einen Schar von allen aus der anderen Schaar rechtwinklig geschnitten. Durch beide Schaaren wird dic krumme Fläche in rechtwinklig-vierseitige Elemente getlieilt. Die Nor$\mathrm{malflächen} \mathrm{längs} \mathrm{der} \mathrm{Krïmmungslinien} \mathrm{sind} \mathrm{developpabel,} \mathrm{d.} \mathrm{h.}$ die in zwei benachbarten Punkten einer Krimmungslinie zur Fläche errichteten Normalen schneiden sich. Einfache Beispiele ron Krïmmungslinien bieten die Meridiane und Parallelkreise auf Rotationstlächen, die geraden Erzeugenden und die Normalschnitte anf Cylinderflächen.

Die Kriimnungslinien und ihre Normaltächen sind für den Steinschnitt der Gewölbe von Bedeutung.

V. Einige analytische Entwickelungen.

1. Die auf ein rechtwinkliges Raumeoordinatensystem $O(X Y Z)$ bezogene Gleichung einer Fläche stellt sich in einer der Formen 


$$
\begin{aligned}
& \text { к) . . . . . . } z=f(x, y) \\
& \beta) . \therefore F(x, y, z)=0
\end{aligned}
$$

dar; für manche Fälle (Rotations-, Schraubenflächen) empfiehlt sich die Einführung sog. Cylindercoordinaten mit Hilfe der Relationen

$$
\begin{aligned}
& x=r \cos \varphi \\
& y=r \sin \varphi \\
& z=z
\end{aligned}
$$

wodurch die Flächengleichung die Form

$$
\gamma) \cdot . \cdot . \cdot z=\Phi(r \varphi)
$$

annimmt. - Setzt man in $(x)$ oder $\beta$ ) der Reihe nach $x, y, z$ der Nulle gleich, so ergeben sich die Gleichungen der Schnittcurven der Fläche mit den Ebenen $Y Z, Z X, X Y$. Für $x=c$ erhält man die Gleichung des Schnittes einer im Abstande $c$ zur $Y Z$ parallel gelegten Ebene. Aehnlich für $y=c$ und $z=c$. Wird in Gl. $\gamma$ ) $z=0$ gesetzt, so erhält man die Polargleichung der Schnittcurve mit der $X Y$-Ebene, für $z=c$ die Gleichung des Schnittes mit einer im Abstande $c$ zur $X Y$ parallelen Ebene. Für ein constantes $\phi$ stellt $\gamma$ ) die Gleichung des Schnittes mit einer durch $O Z$ gehenden, zu $X Z$ unter dem Winkel of geneigten Ebene dar, während für ein constantes $r \gamma$ ) den Schnitt der Fläche mit einer Kreiscylinderfläche vom Radius $r$ repräsentirt, die $O Z$ zur Achse hat.

2. Sind $x, y, z$ die Coordinaten eines Punktes der Fläche $\alpha$ ) oder $\beta$ ), so hat die Tangirungsebene in diesem Punkte die Gleichung

bezw. $\quad(\xi-x) \frac{d F}{d y}+(\eta-y) \frac{d F}{d y}+(\zeta-z) \frac{d F}{d z}=0$

und ihre Stellungswinkel $\boldsymbol{\tau}_{x}, \boldsymbol{\tau}_{y}, \boldsymbol{\tau}_{z}$ sind bestimmt durch

$$
\begin{array}{lll}
\cos \tau_{x}=\frac{\frac{d z}{d x}}{N} & \text { oder } & \frac{\frac{d F}{d x}}{N^{\prime}} \\
\cos \tau_{y}=\frac{d z}{\frac{d y}{N}} & \text { oder } & \frac{\frac{d F}{d y}}{N^{\prime}} \\
\cos \tau_{z}=\frac{1}{N} & \text { oder } & \frac{\frac{d F}{d z}}{N^{\prime}},
\end{array}
$$

wobei

$N=\sqrt{\left(\frac{d z}{d x}\right)^{2}+\left(\frac{d z}{d y}\right)^{2}+1}, N^{\prime}=\sqrt{\left(\frac{d F}{d x}\right)^{2}+\left(\frac{d F}{d y}\right)^{2}+\left(\frac{d F}{d z}\right)^{2}}$.

Die Normale des betrachteten Punktes, wclche mit den Achsen eben diese Winkel einschliesst, hat die Gleichungen

$$
\xi-x=-\frac{d z}{d x}(\zeta-z) \quad \eta-y=-\frac{d z}{d y}(\xi-z)
$$

bezw.

$$
\frac{\xi-x}{\frac{d F}{d x}}=\frac{\eta-y}{\frac{d F}{d y}}=\frac{\xi-z}{\frac{d F}{d z}} .
$$

3. Die Coexistenz der Gleichungen zweier Flächen

$$
\begin{aligned}
& F_{1}(x, y, z)=0 \\
& F_{2}(x, y, z)=0
\end{aligned}
$$

repräsentirt die Durchdringungscurve dieser Flächen; die successive Elimi- 
nation von $x, y, z$ liefert die Gleichungen der Prujectionen dieser Curve auf die Ebenen $Y Z, Z X, X Y$. Sind $F_{1}$ und $F_{n}$ algebraische Flächen von der Ordnung $m_{1}$, bezw. $m_{2}$, dann ist die Durchdringungscurve im Allgemeinen von der Ordnung $m_{1} m_{12}$.

Die Coexistenz von drei Flächengleichungen

$$
\begin{aligned}
& F_{1}(x, y, z)=0 \\
& F_{0}(x, y, z)=0 \\
& F_{3}(x, y, z)=0
\end{aligned}
$$

fiihrt auf die allen gemeinschaftlichen Punkte, deren Zahl, wenn die Flächen von der Ordnung $m_{1} m_{2} m_{3}$ resp. sind, $m_{1} \quad m_{2} \quad m_{33}$ beträgt.

4. Bedeutet in der Gleichung:

$$
F^{\prime}(x, y, z, p)=0
$$

einer Fläche $p$ einen die Lage oder die Form oder beides zugleich beeinflussenden Parameter, so folgt durch Elimination von $p$ aus dem Gleichungspaare

$$
\begin{gathered}
F(x, y, z, p)=0 \\
\frac{d F(x, y, z, p)}{d p}=0
\end{gathered}
$$

die Gleichung $\boldsymbol{w}(x, y, z)=0$ der durch die continuirliche Variation von $p$ und die dieser entsprechende Orts- (und Form-) Aenderung der vorgelegten Fläche entstandene einhüllende Fläche oder Enveloppe. Die Coexistenz von

$$
\begin{aligned}
& F(x, y, z, p)=0 \\
& \text { 小) }(x, y, z) \underline{=}
\end{aligned}
$$

stellt die Charakteristik der einhiillenden Fläche dar.

5. Complanation der Flächen. Betrachtet man das Rechteck $d x$.dy in $X Y$-Ebene als Projection eines Elementes $d O$ der krummen Fläche

$$
z=f(x, y)
$$

und bezeichnet mit $w$ den Neigungswinkel der an das Element gelegten 'Tangirungsebene der Fläche mit der $X Y$-Ebene, so ist

$$
\begin{gathered}
d O=\frac{d x \cdot d y}{\cos u} \\
u=\tau_{z} \text { und } \cos \tau_{z}=\frac{1}{\sqrt{\left(\frac{d z}{d x}\right)^{2}+\left(\frac{d z}{d y}\right)^{2}+1}}, \text { so ist } \\
d O=d x \cdot d y \cdot \sqrt{\left(\frac{d z}{d x}\right)^{2}+\left(\frac{d z}{d y}\right)^{2}+1} \\
O=\int d x \cdot d y \mid \frac{d z}{\left(\frac{d z}{d x}\right)^{2}+\left(\frac{d z}{d y}\right)^{2}+1}
\end{gathered}
$$

und nachdem

und

Die Grenzen der beiden Integrationen richten sich nach der Ausdehnung des zu complanirenden Flächentheiles und werden aus der Projection seiner Umgrenzung auf die $X Y$-Ebene abgeleitet.

6. Cubatur durch krumme Flächen begrenzter Volumen. Wird der Inhalt des durch das frühere Rechteck $d x$. dy und das Element $d O$ der krummen Fläche, von welchem jenes die Projection ist, bestimmten prismatischen Raumelementes mit $d V$ bezeichnet, so kann

$$
d V=z \cdot d x \cdot d y=f(x, y) \cdot d x \cdot d y
$$

gesetzt werden, und es folgt hieraus

$$
V=\iint z d x \cdot d y=\iint f(x, y) \cdot d x \cdot d y
$$

wobei die Integrationsgrenzen wieder aus der Begrenzung der in der XY-Ebene liegenden Grundfäche des Volumens abzuleiten sind. 
Literatur. Fiir die constructive. Theorie der Flächen: In one, neçons de géométrie descriptive" (Paris, 7. Aufl. 1847); O. F. A. Leroy "'l'raité de géométrie deseriptive" (deutsch ron Kanffmann, 3. Aufl. 1873); J. A. Ii. M. de la Gournerie "Traité de géométrie descriptive" (Paris 1860-1864); Dr. W. Fiedler, "Die darstellende Geometrie in organischer Verbindung mit der Geometrie der Lage“ (Leipzig, 2 Aufl. 1875); J. Schlesinger "Die darstellende Geometrie im Sinne der neueren Geometrie" (Wien, 1870). Für die analytische Theorie: Dr. O. Böklen, "Anslytische Geometrie des Raumes" (Stuttgart, 1861); O. Hesse .. Vorlesungen uiber d. analyt. Geom. d. Raumes" (Leipzig, 1861 und 1869); G. Salmon, nAnal. Geom. d. Raumes" (deutsch von Dr. W. Fiedler). Ueber C o m p la nation und Cubatur sehe man anch Dr. O. Schlömileh's „Compendium d. höheren Analysis" (1. Bd., Leipzig, 4. Auft.). Ueber die geodätische Linie auf dem Sphäroid (flachen Rotationsellipsoid), welche für die Geodäsie von Bedeutung ist, vergl. man J. J. Baeyer "Das Messen auf der sphäroidischen

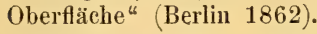

Czuber.

Flächeninhalt (ebener) begrenzter Figuren (aire - area); die Bestimmung desselben geschieht entweder auf rechnungsmässigem Wege aus den Masszahlen der Dimensionen oder mechanisch mit Hilfe von Planimetern (s. Messinstrumente). Die Flächenbestimmung von Grundstücken erfolgt entweder durch directe Messung der nöthigen Dimensionen (z. B. bei der häufig gebrauchten Aufnahme durch rechtwinklige. Coordinaten) oder aus einer graphischen Darstellung (einem Plane) mit Beniitzung des zu Grunde liegenden Massstabes. Was die hiebei erforderliche Genauigkeit anlangt, so besteht in Oesterreich (fuir den Kataster) die officielle Vorschrift, dass zwei unabhängige Flächenbestimmungen höchstens zeigen dürfen

bei einer Fläche von

$$
\begin{aligned}
1^{\mathrm{a}} & =100 \square^{\mathrm{m}} \\
10 & =1000 \\
1^{\mathrm{ha}} & =10000 \\
10 & =100000
\end{aligned}
$$

eine Differenz-von $0 \cdot 5 \square^{\mathrm{m}}$

500

(Vergl. Jordan, Handbuch der Vermessungskunde, 1877 pag. 177.)

Flächennivellement, s. Nivelliren.

Flächentheilung, die Theilung einer ebenen Figur in mehrere Theile, deren Flächeninhalte in einem gegebenen Verhältnisse stehen; in der Regel werden an die Theilungslinien gewisse Forderungen gestellt.

Flächenverwandlung - die Umwandlung der Begrenzung einer Figur mit Wahrung ihres Flächeninhaltes; es gehört hieher auch die Regulirung von Grenzen. Ueber die graphische Lösung derartiger Aufgaben, wie sie namentlich bei den Constructionen in der graphischen Statik vorkommen, sehe man den graphischen Calcul von L. Cremona (dentsch von M. Curtze).

Cz.

Flächenwirkung (Contactwirkung) nennt man die eigenartige, anf Flächenanziehung (Adhaesion) zurïckfuihrbare Wirkung, welche Körper von hoher Porosität, die demnach in einem verhältnissmässig kleinen Raume eine grosse Oberfläche haben, unter geeigneten Verhältnissen zu äussern vermögen. Hieher gehört die entfärbende Wirkung, welche z. B. poröse Kohle anf gefärbte Fliissigkeiten ausiibt, und die in einer Aufnahme des gelösten Farbstoffs durch die poröse Kiohle besteht. Ebenso können solche Körper auch andere Stoffe, insbesondere Bitterstoffe, sowie Riechstoffe aus Lösungen aufnehmen, ja sie vermögen sogar Zersetzungserscheinungen herbeizufuihren und sich mit einem der Zersetzungsproducte zu beladen. Hierauf beruht die Anwendung von Blut- oder Knochen-Kohle als Entfärbungsmittel (Spodium), als Mittel zur Abscheidung von Bitterstoffen aus 
Pflanzenausziigen, als Entkalkungsmittel z. B. für Zuckersäfte (s. b. Zuckerfabrikation), die Anwendung von Holzkohle als Mittel zur Entfernung von Riechstoffen u. d. g. m. Eine solche Flächenwirkung liegt auch jenen Erscheinungen zu Grunde, welche eintreten, wenn hochgradig poröse Körper Verbindungsvorgänge zwischen Gasen einleiten, die an sich bei gewöhnlicher Temperatur sich mit einander nicht zu verbinden vermögen. Hierher gehört z. B. die zündende Wirkung, welche Platinschwamm auf ein Gemenge von Sauerstoff und Wasserstoff ausiibt, sowie überhaupt die Einleitung von Oxydationsprocessen beim Zusammentreffen von Sauerstoff mit oxydirbaren Substanzen bei gleichzeitiger Gegenwart poröser Körper. So veranlasst poröse Holzkohle bei Berïhrung mit Luft und oxydirbaren Gasen die Oxydation dieser letzteren, und wirkt zum Theil anf diese Weise desinficirend für die Luft, so fülırt die Substanz der Buchenspäne im Essigbilder die rasche Oxydation des Alkohols durch den Sauerstoff der Luft herbei, so bedingt die Gegenwart von Bimsstein, Platinschwamm, platinirtem Asbest o. d. g., die Vereinigung von schwefligsaurem Gas mit Sauerstoff zu Schwefelsäureanhydrid u. s. w. Im Allgemeinen kann man die letztere Art der Flächenwirkung dem Umstande zuschreiben, dass die Oberfläche starrer Körper durch Adhäsionswirkung Gase zu verdichten vermag und dass derlei hochgradig verdichtete Gase energischere chemische Wirkungen zu äussern vermögen, als sie es im Zustande des Verdünnungsgrades zu thun im Stande sind, den sie unter gewöhnlichen Druck. verhältnissen zeigen. $\quad G$ tl.

Flamme (flamme - flame) nennt man die Erscheinung, welche ein in Verbrennung stehendes Gas darbietet. Das Entstehen einer Flamme bei irgend einer Verbrennungserscheinung setzt immer das Vorhandensein eines gas- oder dampfförmigen Körpers voraus, der der Verbrennung anheimfällt. Wenn daher ein der Verbrennung fähiger Körper bei seinem Verbrennungsprocesse eine Flam. menbildung zeigt, so hat dies seinen Grund darin, dass der Körper entweder an sich gas- oder dampfförmig war, oder dass er, wenn fliissig oder fest, bei einem unter seiner Verbrennungstemperatur liegenden Temperaturgrade sich in Dampf oder Gas verwandelt, oder aber eine Zersetzung erleidet, bei welcher brennbare Gase entwickelt werden Die Gestalt der Flamme ist wesentlich abhängig von den Verhältuissen, unter welchen der der Verbrennung anheimfallende gas- oder dampfförmige Körper mit der zur Verbrennung erforderlichen Luft zusammentrifft, und wird also wesentlich beeinflusst durch den herrschenden Druck, die Höhe der Verbrennungstemperatur, die Menge des verbrennungsfähigen Gases im Verhältnisse zur vorilandenen Luft-(Sauerstoft) Menge, den Dichtenunterschied zwischen Luft und dem rerbrennungsfähigen Gase, sowie endlich durch die Art und Grösse von Bewegungserscheinungen des der Verbrennung anheimfallenden Gases. Da jede Verbrennungserscheinung ein unter Licht- und Wärmeentwicklung sich vollziehender chemischer Verbindungs-Process ist, welcher unmittelbare Berührung der in die chemische Action eintretenden materiellen Theilchen voraussetzt, so ist es klar, dass bei Flammen die eigentliche Verbrennung lediglich an jenen Punkten sich vollziehen wird, bei welchen der mit dem Sauerstoff' der Luft verbrennende gasförmige Körper der Flamme mit der Luft in unmittelbarer Berührung steht, also an der Peripherie des Flammenkörpers. Demnach erscheint jede Flamme als ein Gebilde, an dem sich unter allen Umständen verschiedene Theile unterscheiden lassen, u. z. ein dunkler, aus noch unrerbrenntem Gase bestehender, im Allgemeinen auch eine niederere Temperatur zeigender $\mathrm{K}$ er $\mathrm{n}$, dann eine die Hïlle dieses Kerns bildende Zone, in welcher sich der Verbrennungsprocess vollzieht, und die demnach, als der eigentliche Herd der Wärme-und Lichtentwicklung, hohe Temperatur zeigt und Licht ausstrahlt, d. i. der- Fla m menmantel, endlich eine äussere IIülle von bei der Verbrennung gebildeten gliihenden, gasfürmigen Verbrennungsproducten, die eine gegenüber der Leuchtkraft des Mantels kaum wahrnehmbare Lichtentwicklung zeigt und demnach nur schwach sichtbar ist, d. i. der Flammenschleier. 
Die Lenchtkraft der Flamme ist abhängig ron der Natur, aber auch ron rer Dichte des verbrennungsfähigen Gases, endlich von dem Verhältnisse des Zutrittes an Sanerstoff. So lenchitet eine Wasserstoffilamme unter gewiilniechem Drucke kaum merklich, während sie bei höherem Drucke ein intensives Licht zu entwickeln vermag. Leuchtgas verliert wesentlich an Leuchtkraft, wenn man dem ausströmenden Gase gestattet sich vor dem Austritte in die Atmosphäre mit Luft zu mengen, so dass demnach die mit einer bestimmten Leuchtgasmenge in Beriilurung stehende Sauerstoffquantität grösser ist als bei dem einfachen Ausströmen des Leuchtgase's (s. Bunsens Lampe bei Lampen). Ans gleichem Grunde leuchten sehr kleine Flammen im Verhältnisse zu der verbrennenden Gasmenge weit weniger als grössere, weil das Verhältniss der Oberfläche zu dem Rauminhalte des Flammenkörpers ein relativ grosses und daher das Verhältniss des Sarerstoffs zur Gasquantität ein erhölıtes ist, ebenso zeigen flache Flammen eine grössere Lichtentwicklung als kegelförmige. Die Färbung der Flamme ist abhängig von der Natur der verbrennenden Körper, kann aber durch die Höhe der 'Temperatur nicht unwesentlich beeinflusst werden. Ueber Löthrohrfammen s. Löthrohr, vgl. auch Lenchtstoffe und Lampen. Flammen farbiges. b. Feuerwerkerei.

Gtl.

Flammenmergel, ein im nordwestlichen Deutschland in der unteren Kreideformation auftretender, mit eigenthïmlichen flammenartigen Zeichnungen versehener Mergel. $L b$.

Flammenopal s. Opal.

Flammenschutzmittel nennt man solche Mittel, welche geeignet sind verbrennbare Stoffe, wie Holz, Gewebe, Papier u. d. g. vor, dem Verbrennen mit Flamme zu schiitzen und dadurch die Fortpflanzung eines begonnenen Verbrennungsprocesses zu hindern. In Wesenheit gründet sich die Wirkung solcher Mittel darauf, dass sie entweder die verbrennbare Substanz mit einer den Luftzutritt abschliessenden, selbst nicht entziindlichen Schichte umhïllen, oder dass sie bei höherer Temperatur eine Einwirkung auf die verbrennbare Substanz in dem Sinne ausüben, dass Zersetzungsproducte geliefert werden, die nieht brennbar sind. Insbesondere hat man die Anwendung solcher Mittel empfohlen zum Unverbrennbar- (Unentflammbar-) machen des Holzes in Gebäuden, zur Herstellung unentflammbarer Stoffe fuir Damenkleider, zur Erzeugung unverbrennbarer Vorhänge oder Decorationen in Wohngebäuden, Theatern u. d. g.

Je nach dem zu erreichenden Zwecke können verschiedene Substanzen in Anwendung kommen. Für Holz hat man mit Erfolg die Imprägnirung mit Alaun, mit Eisenvitriol, anderen Vitriolen, mit Borax und mit kieselsauren Alkalien in Anwendung gebracht (v. Dingl. pol. Journ. 199 pag. 194). Besonders wirksam erweist sich das schwefelsaure Ammoniak, das phosphorsaure Ammoniak und das wolframsaure Natron. Die letztgenannten drei Salze sind es auch, welche für das sog. Unverbrennbarmachen leichter Kleiderstoffe, namentlich gefärbter oder gemusterter beinahe allein geeignet sind, da sie an sich indifferent die Farbe und Festigkeit des Gewebes nicht alteriren, worauf es gerade bei Kleiderstoffen ganz wesentlich ankommt. Im Allgemeinen genügt es die zu präparirenden Zeuge durch Lösungen von 1 Thl. des. Salzes in 10 Thl. Wasser hindurch zu nehmen und sodann zu trocknen. Sollen die Stoffe oder fertige Kleider und Wäsche mit heissen Plätteisen appretirt (gebiigelt) werden, was natürlich erst nach der Präparation mit der Salzlösung geschehen kann, so ist besondere Riicksicht darauf zu nehmen, dass sowohl schwefelsaures als auch phosphorsaures Ammon durch Einwirkung höherer Temperatur unter Verlust von Ammon zersetzt und Säure frei gemacht werden kann, deren Auftreten nicht allein die Farben zu alteriren rermag; sondern auch der Festigkeit des Gewebes abträglich werden kann. Es ist daher für solche Fälle gerathener sich des wolframsauren Natrons zil bedienen, das selbst bei Anwendung selır heisser Plätteisen den Zeugen keine Gefahr bringt 
und gleichwolıl die Unentflammbarkeit der Gewebe vollständig zu erreichen gestattet. Man wendet dasselbe in wässriger Lösung in dem Verhältnisse von 1:5 gelöst an und kann der Lösung wohl auch noch 3-4 Proc. phosphors. Natron zusetzen. Man hat nur darauf $z u$ achten, dass das angewandte Salz ziemlich rein und namentlich frei von einem höheren Gehalte an Soda sei (vgl. Vers: mann und 0 ppenheim im Auszg. in Dingl. pol. Journ. 158 pag. 66).

Von besonderen Vorschlägen für das Unentflammbarmachen von verbrennbarem Baumateriale und Zeugen wären noch zu nennen u. z. für Holz: Anstreichen des Holzes mit einer heiss gesättigten Lösung von 3 Thl. Alaun und 1 Thl. Eisenvitriol. Nach zweimaliger Wiederholung dieses Anstriches ein Anstrich mit verdünnter Eisenvitriollösung, in der Töpferthon anfgeschlämmt ist, oder Bestreichen des Holzes mit heissem Leimwasser, so lange dieses noch eingesogen wird; hierauf ein Anstrich von dickerer Leimsuppe, auf welchen, so lange derselbe noch fencht ist, ein Gemisch ron 1 Thl. Schwefel, 1 Thl. Ocker oder Thon und 6 Thl. Eisenvitriol als Pulver aufgestrent wird (vgl. Fr. Sieburger Deutsch. Industr.-Ztg. 1872 pag. 225). S. W. Mo o re (polyt. Centralbl. 1875 pag. 446) schlägt vor das Holz in einem Cylinder unter starkem Druck mit Kalkmilch und schwefliger Sänre zu imprägniren.

Fiir Gewebe: Ein Gemenge von schwefels. Ammoniak und Gyps oder ein Gemenge von Borax und Bittersalz in Wasser gelöst und die Gewebe damit imprägnirt (P a tera über Flammenschutzmittel, Wien 1872, s. a. Dingl. pol. Journ. 203 pag. 481 im Auszug). Nach Carteron und Rimmel (vgl. Deutsch. Industr.-Ztg. 1871 pag. 328) soll ein Gemenge von gleichen Theilen essigsaurem Kalk und Chlorcalcium in Wasser gelöst die mit einer solchen Lösung imprägnirte Zeugen unentflammbar machen. Nach den Erfahungen des Verfassers lässt sich auch thioschwefelsaures (unterschwefligsaures) Natron als Flammensuhutzmittel für Zeuge verwenden, ebenso Ammoniakalaun.

Vielfach hat man auch, um für die Zwecke der Hauswirthschaft die Vornahme einer besonderen Operation, welche die Imprägnirung der Zeuge mit der Lösung eines oder des anderen als Flammenschutzmittels empfohlenen Salzes erheischt, zu ersparen, Mischungen solcher Salze mit Stärke als Ersatz der gewöhnlich zu Appreturzwecken rerwendeten Stärke empfohlen und in den Handel gebracht, Feuersicherheits-Stärke (rpyrous starch). Leider hat auch diese beqneme Form eine allgemeinere Anwendung von Flammenschutzmitteln in den Kreisen der modernen Damenwelt nicht wesentlich gefördert (Gintl, Ausstellungsbericht 1873 iiber Appreturmittel, IVien 1874), s. üb. a. Stärke.

Gtl.

Flammiren, syn. flam men, chiniren chimu'e - chiné), Chinafärben. Eine Art der Garnfärberei, bei welcher die Garnstränge mit Knoten versehen und so ausgefürbt werden, wodureh die das Innere des Knotens bildenden Garmpartien ungefärbt bleiben und so zweifarbige Garnsträne erhalten werden können, s. a. Chiné II pag. 309. Gtl.

Flammirung, s. Chiné II pag. 309.

Flammirte Zange, s. Weberei.

Flammofen (fourneau pour les fontes crues - flaming furnace) im Allgemeinen jede Ofenanlage, bei welcher die Flamme des Bremmateriales iiber die zu erhitzenden Massen streicht und diese directe erhitzt. Flamm-o.Puddelof en (fournean ì réverbère, ¿̀ puddler — reverberatory furnace, puddling fornace) s. Eisenerzengung III pag. 28, 123, rgl. a. Blei I pag. 577, s. Gl ii h o fen.

Flanell (flanelle - flamnel) ist ein leinwandartiges oder geköpertes Gewebe aus Streichgarn, welches sehr wenig gewalkt ist und auf der rechten Seite ge- 
rauht wird. Die Kette ist oft Kammgarn, zuweilen aus Baumwollgarn, in welchen Fällen der Flanell beim Waschen weniger eingeht, als wenn Schuss und Kette aus Streichgarn besteht.

Flantsch, Flantsche (bourelet, collet - flange) nennt man den scheibenförmigen Rand an Rohrenden, welcher die Verbindung mit einem gleichfalls mit Flantsche versehenen zweiten Rohr durch Schrauben gestattet, s. Röhrenverb indungen. $K k$.

Flasche. a) Allgemein gebräuchliche Bezeichnung für Hohlgefässe mit ringsum verengter Ausgussöffnung(Hals). b) Flas che, F ormflasch e (châssis - flask) s. Eisengiesserei III pag. 124. c) Flasche (poulie - pulley) bedentet in der Mechanik die Verbindung zweier Flacheisen oder Bleche, zwischen welchen bewegliche Theile gelagert sind (so z. B. beim Flaschenzug die Rollen, beim Flaschenschraubstock der bewegliche Backen etc.). $K k$.

Flasche bologneser (fiole philosophique - Bologna phiol), Springkolben, s. Bologneser Fläschchen I pag. 724, vgl. a. Gl as bei Hartglas.

Flasche florentiner (récipient florentin - italian receiver). Eine Vorrichtung zur Aufsammlung ätherischer Oele, welche leichter sind als Wasser. Sie besteht aus einer grösseren Glasflasche mit weitem Halse, welche nahe am Boden mit einem nach aufwärts gekrümmten Rohre versehen ist, das etwas unter dem Rande des Halses mündet. Wird bei der Destillation von ätherischen Oelen mit Wasserdämpfen das aus Wasser und den Oeltröpfchen bestehende Destillat in einer solchen Flasche aufgefangen, so sammelt sich das specifisch leichtere ätherische Oel in der Flasche an, während das specifisch schwerere Wasser durch die Abflussröhre so lange abläuft, als durch neu eintretende Destillatmengen die Flüssigkeit in der Flasche ein höheres Niveau zeigt, als der Lage der Ausflussöffnung des Abflussrohres entspricht (vgl. Oele ätherische). Gtl.

Flasche leydener, s. Electricität III pag. 172.

Flasche Woulf'sche (flacon tubulé - necked bottle), eine mit 2 oder mehreren Hälsen (Tubulaturen) versehene Flasche für chemische $\mathrm{Zwecke,} \mathrm{insbe-}$ sondere als Gasentbindungs- oder Waschflasche in Verwendung. Gtl.

Flaschenbier, s. Bier I pag. 457.

Flaschenfüllapparate (appareils d'empli des bouteilles - bottlingapparatus). Das mühsame und zeitraubende Abziehen von Flüssigkeiten in Glasflaschen ist in neuester Zeit auf recht sinnreiche Art durch Füllapparate der Art erleichtert worden, dass die Handarbeit sich bloss auf das Anstecken der leeren Flaschen und das Wegnehmen der bereits gefuillten Flaschen beschränkt. Derartige Füllapparate können auch für jede beliebige Flaschenanzahl eingerichtet sein. Auf dem umstehenden Holzschnitte ist deutlich zu ersehen, dass aus der dem Fasse eingeschlagenen Pipe eine Röhre oder ein Gefäss $g$ mit der Fliissigkeit gefüllt wird. Aus diesem Sammelgefässe führen die Rohre $r^{\prime}, r^{\prime \prime}$ die Fliissigkeit jenen drehbaren Hebern $h_{1}-h_{4}$ zu, an welche die Flaschen gesteckt werden. (S. Fig. 1677.)

Diese Fïllapparate werden gewöhnlich aus England bezogen und die Firma Farrow \& Jackson in London, 18. Great Towerstreet, liefert diese Apparate in grösster Auswahl und besonderer Güte. (Vergl. polyt. Centralblatt 1858 pag. 66). G. $W$.

Flaschenglas s. Glas.

Flaschengrün s. Zeugfärberei und Druckerei, s. a. Glas. 
Flaschenkapseln (capsules des bouteilles - capsules of the bottle) sind aus mit Zinn plattirten Bleifolien auf Maschinen erzeugte Kappen oler Hiitchen zum luftdichten Verschluss ron rerkorkten Flaschen und zur Bezeichnung des Flascheninhalts. Tor ungefähr 40 Jahren (Ende des 3. Jahrzehents dieses Jahr-

\section{Fig. 1677.}

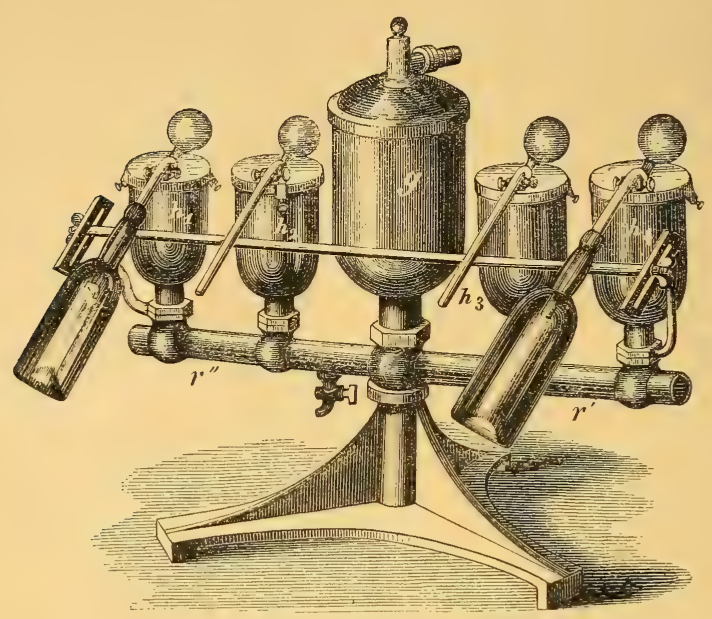

Flascheufüilapparat.

hunderts) wurde das Bediurfniss, die Flaschen der in Handel gebrachten Fliussigkeiten auf eine für den Export in warme Zonen danerhaftere Weise luftdicht zu verschliessen und die Echtheit der Fiillıng zu bezeichnen, zuerst in Frankreich durch Metallkappen statt der Verwendung von Siegelwachs oder Pech befriedigt.

In England wurde die Erzeugung von diesen Metallkapseln durch sinnreiche Maschinen vervollkommnet und der Gebrauch dieses metallischen Flaschenverschlusses so verallgemeinert, dass nun auch iberall anf dem Continent solche Elaschenkapseln bei der Tersendung von Mineralwässern, Weinen, Bieren, Liqueuren und Arzneimitteln in Verwendung gebracht werden. Das Wichtigste für die Erfiillumg des beabsichtigten $Z$ weckes ist die Möglichkeit, diese Metallkappen so fest iiber den Kork und Flaschenhals zu ziehen und anzuschmiegen, dass ein unverletzendes Abnehmen dieser Metallkappen und eine wiederholte Verwendung derselben Metallkappe unmöglich wird. Das feste faltenlose Anschmiegen der Flaschenkapsehn wird einerseits durch die Weichheit der verwendeten plattirten Bleifolie, andererseits durch die sinnreiche und einfache Methode, hiezu die Reibung einer Schlinge eines ledernen Bandes zu rerwenden, möglich gemacht. Die ausserdem empfohlene Verwendung ron harzigen, dünnflïssigen Klebemitteln ist dazu ganz iiberfliissig, und kann nur dort noch zum luftdichten Verschluss der verkorkten Flaschen nothwendig sein, wo zum Einpressen der Korke keine Stoppelmaschinen verwendet werden oder die Korke sehr porös und rissig sind.

Die fabriksmässige und gebotene billige Erzeugung der Flaschenkapseln ist natiirlich erst durch die vielfache Verwendung und den gesteigerten Absatz möglich geworden. Im Anfange hat man das Drucken der Kapseln aus den passenden 
Eolienscheiben auf mehreren von Knaben betriebenen Fussdrehbänken bewerkstelligt und erst Betts*) in England hat hiezu die complicirte automatische Kapselstanzmaschine eingefuhrt, welche durch entsprechende Veränderung der Matrizen und Patrizen auf einer Maschine in wenigen Secunden die längsten Flaschenkapseln zu erzeugen im Stande ist. Das Princip dieser Maschinen ist das im

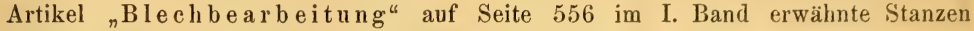
oder Pressen durch ruhigen Druck mittels Excentern, und es ist die von der Maschine selbst bewirkte Transportirung der durch ein Stanzenpaar vorbereiteten Kapsel zum nächsten Stanzenpaar durch eine Reihe höchst sinnreicher Bewegungen möglich gemacht. Wir müssen auf die Beschreibung dieser Maschine verzichten, und verweisen auf die Patentbeschreibung von Betts.

In Deutschland wurden diese Flaschenkapseln besonders von Vetter in Nürnberg, Gebrïder $\mathrm{P}$ ohle in Graupen bei Mariaschein in Böhmen und G. Winiwarter in Gumpoldskirchen in Niederösterreich der allgemeinen Verwendung zugänglich gemacht. Je nach der Grösse kosten 1000 Stück solche Kapseln $4 \mathrm{bis} 11 \mathrm{fl}$.

Eine besondere Art von Flaschenkapseln, welche leichten, guten Verschluss bei Champagnerflaschen gewähren sollen, werden von der Pat. Kork Company London, 1 Great Winchester steel Buildings, in den Handel gebracht. $G$. $W$.

Ueber Thompson's luftdichten Verschluss für weithalsige Flaschen, s. Dingl. polyt. Journal 203 Bd. pag. 8 .

Flaschenlack s. Siegell a ck.

Flaschenreinigung (rinser les bouteilles, bottle washing, rinsing). Die Versendung von Getränken in Flaschen bedingt eine grosse Aufmerksamkeit für die Reinigung der Flaschen, deren Fuillung mit geklärten und zur Versendung . geeigneten Fig. 1678. Flüssigkeiten und endlich die luftdichte Verkorkung mit neuen, ge. sunden Stöpseln.

Für die Flaschenreinigung ist nicht nur reines Spülwasser in genügender Menge erforderlich, sondern es miissen auch oft mechanische Hilfsmittel, reiner grober Sand oder eigene Flaschenbürsten mit in Anwendung gebracht werden, und was das Wichtigste ist : das letzte Spiilwasser muss in einem kräftigen Strahle in die Flasche geleitet werden, daher dieses a us einem $5-6$ Meter hoch stehenden Bottich mittels eines Spritzhahns die Flasche treffen soll.

Sind die Flaschen gebraucht gewesen, so muss auch eine Spillung mit verdünnter Salzsäure der Spülung mit reinem Wasser vorhergehen. Die mechanische Reinigung mit Bleischrot muss aber unbedingt als gesundheitsgefährlich vermieden werden.

*) Das I. Patent vom 12. Januar 1849. 
Die zweckmässigste Form der Flaschenbiirsten ans zwei rerzinkten eisernen, gabelförmig federnden Theilen zeigt beistehender Holzschnitt Fig. 1679.

Solche Bürsten werden aber nicht nur mit dem ein-

Fig. 1679 . fachen Drahtgriffe, sondern anch mit einer Kurbel und einer einfachen Radiibersetzung schneller und kräftiger gedreht, wie der Holzschnitt Fig. 1678 zeigt, und der Zweck der guten Flaschenreinigung wird dann um so leichter und schneller erreicht.

G. W.

Flaschenschraubstock, s. S chra ubstock.

Flaschenverkorkungsmaschinen. Obwohl mannigfache Maschinen die Aufgabe Flaschen zu verkorken lösen, so sei hier doch nur eines der angewandten Systeme kurz dargelegt, welches besonders gut die Aufgabe löst. Bei dieser Maschine wird der Kork durch den Druck eines von Hand aus bewegten Hebels, welcher den auf den Kork unmittelbar driickenden Stahleylinder bethätigt, in die Flasche eingepresst.

Damit die in der Flasche befindliche Luft oder falls dieselbe mit Flïssigkeit ganz gefiillt sein sollte, diese, dem eindringenden Korke keinen grossen Widerstand entgegensetzt, wird eine "Nadel" (zarte Blechrinne) vor dem Korke eingeschoben, neben welcher derselbe eingedrïckt wird und durch die Nadel Luft oder Fliissigkeit nach aussen treibt. Das Einführen des Korkes geschieht in einen konisch sich verengenden, in ein trichterartiges Rohr übergehenden Spalt. Der von einem Hebel bewegte Stempel, indem er den Kork niederdrïckt, zwingt denselben den geringen Durchmesser des (sehr dickwandigen) Trichters anzunehmen. Die auf einem beweglichen, durch selbstthätige Keilstellung feststellbaren, Untersatze stehende Flasche ist mit ihrem Halse genau an die Oeffnnng jenes trichterartigen Theiles gedrïckt und tritt der Kork also unmittelbar aus dem Trichter in den Flaschenhals ein, wo er sich entsprechend ausdehnt und den vollkommenen Abschluss bewirkt. Bei dem Heben des Handhebels wird die Nadel ausgezogen und die Festklemmung des Flaschentisches aufgehoben, so dass die Flasche entfernt werden kann, welche nun verkorkt ist.

Diese Maschinen sind schon seit lange in Champagnerfabriken in Gebrauch und bewähren sich rorziiglich. Als Bezugsquelle dieser und verwandter Maschinen kann die Administration der. Weinlaube in Klosterneuburg bei Wien empfohlen werden. (Vgl. die Artikel: Kellerwirthschaft und Wein). $K k$.

Flaschenverschluss, s. Flas chenkapseln.

Flaschenzug, s. Hebe mas chinen.

Flattirfeuern gleichbedeutend mit Anwärmen, Vorheizen, beim Einbrennen der Glasur des Porzellans, s. Thon wa a ren.

Flatterruss ist theerarmer, flockiger Russ von brauner oder schwarzer Farbe, je nachdem er bei der Verbrennung kohlenstoffärmerer oder kohlenstoffreicherer Brennmaterialien sich bildet, vgl. Russ, s. Kohlenstoff. Gtl.

Flaumhaar oder Grundhaar (poil follet - down, soft hair). Bei der Mehrzahl der Pelze oder der Behaarung der im wilden Zustande lebenden Thiere ist das weiche, feine Grundhaar deutlich von dem längeren gröberen Oberhaar zu unterscheiden und werden beide getrennt verarbeitet.

Flaus, Fries (frise - coating) ist ein tuchartiges Gewebe, welches sich ron dem gewöhnlichen Tuch durch grössere Dicke und längeres, gröberes Haar unterscheidet. $K k$. 
Flaveanwasserstoff, Cyansulfhydrat, Sulfoxalenid, ist eine Doppelverbindung von Cyan mit Schwefelwasserstoff von der Formel $\left(C_{2} V\right)^{2}+S H_{2}$. Entsteht bei der directen Einwirkung von Cyan und feuchtem Schwefelwasserstoff auf einander in Gestalt gelber Krystallnadeln. Gtl.

Flavin (quercitrine - flavine), Flavingelb. Diesen Namen führt ein namentlich in friherer Zeit für Färbereizwecke vielfach angewendetes Präparat (vgl. Dingl. pol. Journ. 140 pag. 297), das wesentlich ein aus Quercitron gewonnenes Extract darstellt, welches entweder durch Extrahiren der Quercitronrinde mit Wasser (vgl. König Dingl. pol. Journ. 145 pag. 304) oder durch Auslaugen der Rinde mit einem kohlensauren Alkali und Fällen des alkalischen Auszuges mit Schwefelsäure dargestellt werden kann (vgl. Hochstättler und Oehler polyt. Centralbl. 1857 pag. 1453). Es besteht wesentlich aus Quercitrin und Quercetin und stellt ein braungelbes Pulver dar, dessen Färbevermögen 16mal grösser ist als das der Quercitronrinde (s. Quereitron). Unter demselben Namen kam übrigens auch ein blassgelbes Farbstoffextract in den Handel, welches sich wesentlich als ein Gemenge von Morinsäure und Moringerbsäure erwies und offenbar durch Extraction von Gelbholz dargestellt war (vgl. G elb holz). Uebrigens belegt man auch das Diamidobenzophenon (Diphenylharnstoff) mit dem Namen Flavin. Gtl.

Flavindin. Ein Zersetzungsproduct des Indin's, sowie des Is a ty d's und der Sulfisatyde, welches durch Einwirkung von alkohol. Kalilauge auf einen dieser Körper entsteht und gelbe sternförmig gruppirte Nadeln bildet, vgl. I n digo und Is a tin. Gtl.

Flavinschwefelsäure. Sulf o flavin s äu re, Zersetzungsproduct des indigblauschwefelsauren Kali's (vgl. Indigo) durch Einwirkung von Kalkwasser bei Luftzutritt entstehend. Gtl.

Flavopurpurin nennen Schunk und Römer (s. Ber. d. deutsch. chem. Gesellsch. 1875 pag. 1628 und 1876 pag. 379) ein aus der, das künstliche Alizarin begleitenden Anthraflavinsäure darstellbares Purpurin, vgl. Purpurin. Es bildet goldgelbe, in kaltem Alkohol leicht lösliche, in Wasser, selbst bei Kochhitze wenig lösliche Krystallnadeln, welche sich in Kalilauge mit einer weniger rothen Purpurfarbe lösen als gewöhnl. Purpurin. Ihre Zusammensetzung entspricht der Formel $\mathrm{C}_{14} \mathrm{H}_{\mathrm{s}} \mathrm{O}_{5}$. $\mathrm{G} t \mathrm{l}$.

Flechtarbeiten, Flechten (tresser, cordonner, natter - to twist, to weave, to plait). Das Flechten ist zumeist Handarbeit und wird gewöhnlich mit kürzeren, biegsamen, band- oder ruthenförmigen Materialien, wie gespaltenem Stroh, gespaltenen oder ganzen Weidenruthen etc. ausgefuihrt. Die Verwendung der Strohgeflechte zu Hiiten, sowie die Korbflechterarbeiten sind bekannt. Sowie nun Stroh und Bast zu Flechtarbeiten verwendet werden kann, so können auch Haare und endlich auch Gespinnste hierzu Verwendung finden. Das Klöppeln der Spitzen ist eine mit dem Flechten im Wesentlichen übereinstimmende Operation, wenn durch dieselbe auch die mannigfachst gemusterten Fabrikate (s. Spitzen) erzielt werden. Manche Schnüre werden auch durch Flechten hergestellt, so Haarschnüre, Peitschenschnüre etc., doch bedient man sich hierbei mit Vortheil der Rundschnur oder Klöppelmaschine, s. d. vergl. auch Pos a mentierarbeiten und $\mathrm{Holzg}$ ew ebe. $K k$.

Flechtenblau syn. Lakmus.

Flechtenfarbstoffe. Eine grosse Anzahl von Flechtenarten (Lichenes) enthalten eine Reihe farbloser Verbindungen, die durch die Einwirkung verschiedener Agentien als Resultat ihrer Spaltung ein Product, das Orcin geben, welches als Chromogen den Ausgangspunkt für die Bildung der blauen und violetten Flechten- 
farbstoffe bildet; letztere sind der technisch verwerthete Bestandtheil der unter dem Namen $\mathrm{Orseille,} \mathrm{Persio} \mathrm{und} \mathrm{Lackm} \mathrm{us} \mathrm{im} \mathrm{Handel} \mathrm{vorkommenden} \mathrm{und}$ zur Färberei von Wolle und Seide Anwendung findenden Farbwaaren.

Andere Arten von Flechten enthalten fertig gebildete gelbe Farbstoffe, welche jedoch, hauptsächlich wegen ihrer Schwerlöslichkeit in Wasser, bisher noch keine technische Verwendung fanden.

Die hier in Betracht zu ziehenden Flechtenarten zeigen im Allgemeinen folgende Formen: Aus kleiner festsitzender Basis erhebt sich die baumähnlich verästelte $\mathrm{Pflanze}$, deren $\mathrm{Zweige}$ bald haarförmig spitz, bald mehr oder weniger dick, oder am Ende verbreitert, auch ganz flach gebildet sind; die Farbe wechselt zwischen grau und bräunlichweiss.

Die wichtigsten zur Fabrication der Farbstoffe verwendeten Gattungen und Arten sind:

Rocella tinctoria (Var. fuciformis), Rocella montagnei, Usnea florida, Usnea hirta, Usnea plicata, Usnea barbata, Lecanora tartarea, Lecanora parella, Variolaria dealbata, Variolaria lactea, Variolaria orcina, Parmelia furfuracea, Evernia prunastri, Ramalina calicaris, Cladonia rangiferina, Lecidia geographica, Cetraria vulpina, Gyrophora pustulata u. a.

Hauptfundorte genannter Flechten sind die Küsten des mittelländischen Mecres, Spaniens, Frankreichs, Hollands, Englands, Schwedens, die canarischen und capverdischen Inseln, zu denen in der neueren Zeit auch Südamerika (Lima, Valparaiso), Afrika (Madagaskar, Zanzibar, Angola) und Ostindien zu zählen sind.

Obwohl schon den Griechen und Römern das Färben mit Flechtenstoffen bekannt war und die Darstellung von Orseille bereits im 14. Jahrhunderte betrieben wurde, war doch bis in die neueste Zeit iiber das Wesen und den Zusammenhang der verschiedenen Flechtensäuren und der aus denselben gebildeten Farbstoffe nichts Näheres bekannt, bis die mühevollen Arbeiten von $\mathrm{H}$ e eren, Heldt, Hesse, Kane, Laurent und Gerhardt, Robiquet, Rochleder, Sehunck, Stenhouse, Strecker und Anderen Licht iiber diese Verbindungen verbreiteten und dieselben ihrem natiirlichen Zusammenhange nach erklärten.

In den obgenamnten Flechtenarten finden sich eine Reihe farbloser oder gelb gefärbter Säuren, deren wichtigste die Lecanorsäure, Erythrinsäure, Evernsäure, Vulpinsäure, Usninsäure, Rocellsäure und Parellsäure sind. Die meisten dieser Verbindungen liefern durch Kochen mit Wasser, Alkohol, wässerigen Lösungen von Alkalien und alkalischen Erden ein Endproduct, das $\mathrm{Orcin}$, welches als die eigentliche Grundsubstanz fuir die Bildung des Farbstoffes angesehen werden kann, indem sich dasselbe durch Einwirkung von feuchter Luft und Ammoniak in O r c e î verwaudelt, eine Substanz, die in allen, Orseille, Persio, Cudbear genannten Flechtenfarbstoffen offenbar das färbende Princip bildet.

Es seien hier nur kurz die wichtigsten Flechtenfarben angefuihrt und wird auf das Specielle derselben bei den einzelnen Artikeln verwiesen.

Orseille (orseille-orchal) wird aus verschiedenen Rocella- und Lecanoraarten durch Behandlung mit faulendem Harn oder wässerigem Ammoniak erzeugt und kommt im Handel als brei- oder pastenartige Masse von eigenthümlich ammoniakalischem Geruche, alkalischem Geschmacke und mehr oder weniger rothvioletter oder violetter Farbe vor. Man unterscheidet hauptsächlich zwei Sorten: Kratorseille (Orseille de mer) aus Rocellaflechten und Erdorseille (Orseille de terre) aus Variolaria orcina, Variolaria dealbata und Lecanora tartarea gewonnen.

Dureh Ausziehen des Farbstoffes der Orseille und nachheriges Eindampfen der Lösung oder durch Isolirung des farbstoffgebenden Orcins der Flechten und nachheriges Verwandeln desselben in den eigentlichen Farbstoff, gewinnt man die sog. Orseilleextracte.

Unter dem Namen französischer Purpur (Pourpre française-franch purple) kommt ein Orseillekalklack, d. i. ein durch Fällung der durch Einwir- 
kung der Luft kirschroth gewordenen ammoniakalischen Lösung der Flechtensäuren mit Chlorealcium erhaltener Niederschlag von schöiler ticfgranatrother Farbe im Handel vor. Persio, Cudbear oder rother. Indigo ist in geliniter Wärme getrocknete und fein gemahlene Orseille.

Lackmus wird ans Rocella-, Lecanora-, Variolaria-Arten durch Faulenlassen der zerkleinerten Flechten mit IIarn oder Ammoniak unter Zusatz von Pottasche oder Kreide bis zur vollständigen Blaufärbung der Masse und nacllherigen Zusatz von Kreide und Gyps, Formen in Täfelchen und Trocknen derselben gewonnen. Nach $\mathrm{K}$ ane ist der wesentlichste Bestandtheil des Larkmus das Azolitmin $\left(\mathrm{C}_{7} \mathrm{H}_{7} \mathrm{NO}_{3}\right)$, eine dunkelrothbraune Substanz, die aus dem Orcin durch Einwirkung von Ammoniak und Salterstoff entstanden gedacht werden kann.

Wie bereits erwähnt finden sich in den zur Farbstofffabrication verwendeten Flechten eine Anzahl Säuren, durch deren Zersetzung Orcin und weiter der eigentliche Farbstoff Orceïn gebildet wird; im Folgenden mögen die wichtigsten Flechtensäuren kurz charakterisirt werden.

Lecanors äur $\mathrm{e}^{*}$ ) (acide lécanorique - lecanoric acid) (Orsellsäure, Alphaorsellsäure, Lekanorin, Diorsellinsäure, Esteranhydrit der Orsellinsäure) $\mathrm{C}_{1 \mathrm{6}} \mathrm{H}_{14} \mathrm{O}_{7}$.

Zuerst 1842 von Schunck dargestellt, findet sich in Rocella-, Lecanoraund Variolaria-Arten, nach Hesse (Annalen der Chem. und Pharm. 89 p. 22; besonders in Rocella tinctoria und wird nach dem Verfahren von stenhouse erhalten, indem man den durch Maceration der zerschnittenen Flechten mit Kalk. milch erhaltenen gelblichen Auszug mit Salzsäure fällt, den erhaltenen weissen gallertartigen Niederschlag auswäscht, auf Gypsplatten trocknet und aus warmem Alkohol crystallisirt. Nach Hesse, indem man den durch Extraction der Flechten mit Aether erhaltenen Auszug verdunstet, den Riickstand in Kalkmilch löst, mit Schwefelsäure fällt und den mit Wasser gewaschenen Niederschlag wiederholt aus Alkohol krystallisirt.

Die Lecanorsäure bildet farblose, sternförmig vereinigte Nadeln mit 1 Mol. Krystallwasser, welche bei $153^{\circ}$ schmelzen; die Krystalle röthen Lackmus, sind im Wasser schwer, leichter in kaltem, leicht in heissem Alkohol löslich; sie bildet mit Alkalien lösliche krystallisirbare Salze. Ihre Lösung in wässerigem Ammoniak färbt sich an der Luft roth; die wässerige oder alkoholische Lösung mit Eisenchlorid purpurroth. Bildet beim Erhitzen Orcin und ein brenzliches Oel, hinterlässt nur wenig Kohle. Beim Kochen mit Wasser, Aethyl- oder Amylalkohol entsteht Orsellinsäure, resp. Orsellinsäureäthyl- oder Amyläther

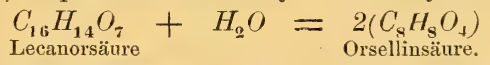

Die Orsellinsäure selbst zerfällt bei längerem Kochen in Orein und Kohle ns äure:

$$
\underset{\text { Orsellinsäure }}{\mathrm{C}_{8} \mathrm{H}_{8} \mathrm{O}_{4}}=\mathrm{C}_{7} \mathrm{H}_{8} \mathrm{O}_{2}+\underset{\text { Orcin }}{\mathrm{CO}_{0}}
$$

Rascher und vollständiger erfolgt diese Zersetzung der Lecanorsäure durch Kochen derselben mit verdiunnten Lösungen von Alkalien oder alkalischen Erden.

Die Orsellinsäure (acide orsellique - orchillic acid)

$$
\mathrm{C}_{\mathrm{s}} \mathrm{H}_{\mathrm{s}} \mathrm{O}_{4}=\mathrm{C}_{6} \mathrm{H}_{2}\left(\mathrm{CH}_{3}\right) \quad(\mathrm{OH})_{2} \mathrm{CO}(\mathrm{OH}
$$

krystallisirt aus Wasser und Weingeist in farblosen sternförmig gruppirten Nadeln von schwachsaurem, zugleich bitterem Geschmacke, welche bei $176^{\circ}$ schmelzen und hiebei unter Schäumen in Orcin und Kohlensäure zerfallen.

Die aus Rocella tinctoria vom Cap der guten Hoffinung dargestellte Betaorsellsäure ist von $\mathrm{Schunck}$ und Gerhardt als identisch mit Lecanorsäure

*) Vergl. hierüber Rochleder und Feldt, Ann. d. Chem. u. Pharm. 4s pag. 2. Stenbouse, Ann. d. Chem. u. Pharm. 6s pag. 57. O. Hesse, Ann. d. Chem. u. Pharm. 139 pag. 22. Schunck, Ann. d. Chem, u. Pharm. 41 pag. 157, $5 \pm$ pag. $: 61$. 
erkannt worden; ein Gleiches glaubt Gerhardt fiir die aus Gyrophora postulata dargestellte Gyrophorsäure annehmen zu müssen.

Erythrinsäure*) (acide érythrique - erythric acid) (Erythrin, Diorsellinsäure - Erythritester), $C_{20} H_{22} O_{10^{\circ}}$. Zuerst von $\mathrm{H}$ e e re $\mathrm{n}$ dargestellt, findet sich in den vollständiger entwickelten Formen der Valparaisoflechte Rocella fuciformis. Man digerirt die zerschnittenen Flechten mit Kalkmilch und fällt entweder die colirte gelbe Flüssigkeit mit Salzsäure, wodurch ein weisser gallertartiger Niederschlag erfolgt, oder man ieitet in die Lösung Kohlensäure, in welchem Falle kohlensaurer Kalk und Erythrin niederfallen. Der entstandene Niederschlag wird mit Alkohol erwärmt, mit Thierkohle entfärbt, filtrirt und mit so viel heissem Wasser versetzt, dass eine bleibende Trübung entsteht; nach dem Erkalten scheidet sich die Erythrinsäure ziemlich voliständig in krystallinischem Zustande aus. Sie bildet weisse, kugelförmig gruppirte feine Nadeln ohne Geruch und Geschmack, schwer in Wasser und Aether, leicht in kochendem Weingeist löslich; schmilzt bei $137^{\circ}$ und erstarrt beim Erkalten amorph; färbt sich mit Ammoniak an der Luft allmälig dunkelroth, mit Eisenchlorid in weingeistiger Lösung purpurroth. Sie verliert beim Erhitzen Krystallwasser und zersetzt sich unter schwacher Kohlensäureentwicklung; löst sich ohne Zersetzung in concentrirter Schwefelsäure und Salzsäure und wird durch Wasser unverändert abgeschieden.

Beim Kochen mit Wasser, Weingeist oder Amylalkohol, wässerigen Lösungen der Alkalien und alkalischen Erden zerfällt die Erythrinsäure in Pikroërythrin und Orsellinsäure, resp. Orsellinsäureäthyl- oder Amyläther.

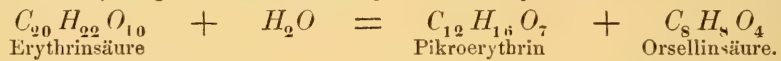

Das Pikroerythrin $C_{12} H_{16} O_{i}$, von $\mathrm{Heeren}$ als Erythrinbitter, von $\mathrm{K}$ an e als A marithrin beschrieben, bleibt beim Verdunsten der gekochten weingeistigen Lösung des Erythrins neben Orsellinsäureäthyläther zuriick; letzterer bleibt beim Vermischen dieses Riickstandes mit Wasser ungelöst, während aus der filtrirten Lösnng Pikroerythrin auskrystallisirt. Es bildet lange sternförmig gruppirte Nadeln mit $3 \mathrm{Mol}$. Wasser, wenig in kaltem, leichter in heissem Wasser, leicht in Weingeist und Aether löslich; schmilzt bei 158". Beim Kochen mit Kalk- oder Barytwasser zerlegt es sich in Orsellinsäure und Erythrit (Erythroglucin, Erythromannit oder Phycit), erstere in Orcin und Kohlensäure.

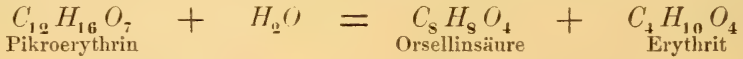

$$
\begin{aligned}
& \underset{\text { Orsellinsäure }}{\mathrm{C}_{\mathrm{s}} \mathrm{H}_{\mathrm{s}} \mathrm{O}_{4}}=\mathrm{C}_{7} \mathrm{H}_{\mathrm{s}} \mathrm{O}_{2}+\underset{\text { Orcin }}{\mathrm{CO}_{2}}
\end{aligned}
$$

Beim Kochen von Erythrinsäure mit überschüssigem wässerigem Kalk oder Baryt werden nur die Endproducte der Zersetzung, Erythrit, Orcin und Kohlensäure erhalten.

Betaerythrinsäure ${ }^{* *}$ ) (acide bétaérythrique - betaerythric acid) $\mathrm{C}_{121} H_{120} O_{10}$ findet sich an Stelle ron Erythrinsäure in verkimmerten Formen von Rocella fuciformis; bildet ein weisses krystallinisches Pulver, welches bei $116^{\circ}$ unter heftiger Kohlensäureentwicklung schmilzt. Beim Kochen mit Wasser, Weingeist, wässerigen Alkalien und alkalischen Erden entsteht neben Orsellinsäure Betapikroerythrin $\mathrm{C}_{13} \mathrm{H}_{16} \mathrm{O}_{6}$ und statt Orein das lomologe Betaorcin $\mathrm{C}_{8} \mathrm{H}_{10} \mathrm{O}_{2}$; letzteres krystallisirt in grossen glänzenden klinorhombischen

*) Vgl. Kane, Ann. d. Chem.u. Pharm. 39 pag. 31. Schunck, Ann. d. Chem.u. Pharm. 61 pag. 64. Stenhouse, Ann.d. Chem.u. Pharm. 68 pag. 72. O. Hesse, Ann. d. Chem. u. Pharm. 139 pag. 22. H e eren, Scliweigg. Journ. 59 pag. 313.

*) Vgl. Lamparter. Ann. d. Chemie u. Pharm. 134 pag. 243. Menschutkin, Zeitschr. fiii Chem. 8 prag. 112. 
Prismen von schwach süssem Geschmack; in kaltem Wasser schwerer löslich als Orcin; fïrbt sich, wenn völlig rein, durch Einwirkung von Luft und Ammoniak nur sehr langsam roth.

Evernsäure*) (acide évernique - evernic acid) $C_{17} H_{16} O_{7}$ findet sich nach Stenhouse und Hesse neben Usninsäure in Evernia prunastri; man zieht die Flechte mit Kalkmilch aus, fällt den filtrirten gelblichen Auszug mit Salzsäure oder Schwefelsäure, trocknet den mit kaltem Wasser gewaschenen Niederschlag, entzieht demselben die Evernsäure durch sclıwach erwärmiten Alkohol oder Aether und krystallisirt mehrmals aus Alkohol. Sie bildet weisse kugelige Krystallaggregate, die sauer reagiren, bei $164^{0}$ schmelzen, im Wasser schwer, leichter in Alkohol und Aether löslich sind; bei der trockenen Destillation entsteht neben Orcin ein brenzliches Oel. Die ammoniakalische Lösung färbt sich an der Luft dunkelroth. Beim Kochen mit wässerigen Alkalien oder alkalischen Erden zerfällt die Evernsäure in Everninsäure, Orcin und Kolllensäure.

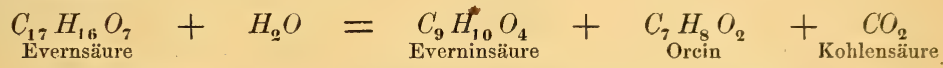

Everninsäure (acide éverninique - everninic acid) $\mathrm{C}_{9} \mathrm{H}_{10} \mathrm{O}_{4}$, eine der Orsellinsäure homologe Säure, krystallisirt in farblosen feinen Nadeln, in kaltem Wasser fast unlöslich, leicht löslich in heissem Wasser, Alkohol und Aether; schmilzt bei $175^{\circ}$, wird durch Eisenchlorid violett gefärbt. Beim Schmelzen mit Kali liefert sie neben Kohlensäure Orcin.

Vulpinsäure**) (acide vulpinique - vulpinic acid) (Chrisopikrin) $\mathrm{C}_{19} \mathrm{H}_{14} \mathrm{O}_{5}$ findet sich in Evernia s. Cetraria vulpina, nach Stein in den unentwickelten Formen von Parmelia parietina; sie wird der betreffenden Flechte durch lauwarmes Kalkwasser entzogen und scheidet sich beim Ansäuern des Filtrates in gelben Krystallen ab; krystallisirt aus Chloroform in dicken Prismen. In Wasser und kaltem Alkohol sehr schwer, leichter in kochendem Alkohol und Aether, leicht in Chloroform löslich. Schmilzt bei $110^{\circ}$, erstarrt beim Erkalten krystallinisch und sublimirt bei $120^{\circ}$ in glänzenden Blättchen, welche sich in Alkalien mit gelber Farbe lösen; bildet mit Alkalien gelbe lösliche, mit Metalloxyden unlösliche Salze.

Usninsäure***) (acide usnique - usnic acid) $C_{18} H_{18} O_{7}$, von $\mathrm{Knop}$, $\mathrm{Rochleder}$ und $\mathrm{Heldt}$ gleichzeitig entdeckt; gehört zu den verbreitetsten Flechtensäuren und findet sich in allen Arten der Gattung Usnea, ferner in Cladonia-, Parmelia-, Ramalina- und Lecanora-Arten. Besonders geeignet zur Darstellung sind Cladonia rangiferina, Usnea florida und Ramalina calicaris. Krystallisirt in hell schwefelgelben glänzenden Blättchen oder Prismen, in Wasser unlöslich, schwer löslich in Alkohol und Aether; leicht löslich in kochendem Aether, heissen ätherischen und fetten Oelen; schmilzt bei $200-202^{\circ}$ zu einer durchsichtigen harzartigen, beim Erkalten krystallinisch erstarrenden Masse. Die aus Cladonia rangiferina erhaltene Säure schmilzt nach $\mathrm{Hess}$ e bei $175^{\circ}$ und wird von ihm als Betausninsäure unterschieden. Die Usninsäure ist löslich in Alkalien, die Lösung bräunt sich unter Sauerstoff-Absorbtion sehr rasch an der Luft. Bei der trockenen Destillation liefert Usninsäure ein Destillat von B e t a $0 \mathrm{r}^{\circ} \mathrm{c}$ in $\mathrm{C}_{8} \mathrm{H}_{10} \mathrm{O}_{12}$; diese dem Orcin homologe Substanz, welche auch aus Betapikroerrthrin entstelıt, bildet grosse glänzende klinorhombische Prismen, welche unzersetzt in schönen weissen Nadeln sublimiren.

*) Vgl. Stenhouse, Ann. d. Chem. u. Pharn. 68 pag. 83. O. Hess a, Ann. d. Chem. und Pharm. 117 pag. 297.

**) Vgl. Bolley u. Kinkelin, Journ. f. pract. Chem. (2) 93 pag. 354. S te in, Zeitsch. Chem. 7 pag. 97; 8 pag. 47. Möller u. Strecker, Ann. d. Chem. u. Pharm. 113 pag. 56.

***) Vgl. Rochleder u. Heldt, Ann. d. Chem, u. Pharm, 48 pag. 9. Stenhouse, Ann. der Chem. u. Pharm. 68 pag 97. Hesse, Ann. d. Chem. u. Pharm. 118 pag. 343. Knop und Schnedermann, Journ. f. pract. Chem. 39 pag. 363. 
Chrys ophansäure (Rumicin, Lapathin oder Rhabarbersäure) von $\mathrm{Her-}$ berger, $\mathrm{Rochleder}$ und $\mathrm{Heldt}$ in der Wandflechte, Parmelia parietina entdeckt; findet sich auch in der Rhabarberwurzel und in Rumexarten; krystallisirt in goldgelben metallisch glänzenden Nadeln, welche bei $162^{\circ}$ schmelzen, bei höherer Temperatur unter theilweiser Zersetzung sublimiren (vgl. auch II pag. 359).

Die zuletzt angefiuhrten gelben Flechtenfarbstoffe haben bislang keine technische Verwendung gefunden. Chrysophansäure findet neuestens Anwendung als Heílmittel.

Rocellsäure*) (rocelline- rocellic acid) Rocellin $C_{1 ;} H_{32} O_{4}$ findet sich neben Erythrinsäure in Rocella tinctoria; bildet weisse silberglänzende Tafeln oder kurze Nadeln, in Wasser unlöslich, leicht löslich in warmem Alkohol und Aether; geruch- und geschmacklos. Schmelzpunkt 1320. Beim Erhitzen auf $220-280^{\circ} \mathrm{C}$. verwandelt sie sich in Rocellsäureanhydrit $\mathrm{C}_{17} \mathrm{H}_{30} \mathrm{O}_{33}$.

$\mathrm{Parells}$ äure (acide parellique - parellic acid) Parellin $\mathrm{C}_{9} \mathrm{H}_{6} \mathrm{O}_{4}$ findet sich nach Schunck neben Lecanorsäure in Lecanora Parella; krystallisirt in feinen stark glänzenden Nadeln, welche in Wasser fast unlöslich, in Alkohol und Aether leicht löslich sind.

$$
\begin{array}{r}
\text { Orcin (orcine - orcine) (Alphaorcin, Dihydroxyltoluol) } \\
C_{7} H_{8} \mathrm{O}_{2}=\mathrm{C}_{6} \mathrm{H}_{3}\left(\mathrm{CH}_{3}\right)(\mathrm{OH})_{2} .
\end{array}
$$

Orcin, das unmittelbare Chromogen der Flechtenfarbstoffe, findet sich vielleicht in sehr geringer Menge bereits fertig gebildet in den Flechten vor und entsteht durch Einwirkung von Wasser, Alkohol, Lösungen von Alkalien und alkalischen Erden auf Lecanorsäure, Erythrinsäure, Orsellinsäure etc.

Zur Darstellung von Orcin verfährt Stenhouse auf folgende Art: Eine Rocellaflechte wird mit Kalkmilch macerirt, colirt und die erhaltene Flïssigkeit mehrere Stunden gekocht; hiebei ïhergeht die Lecanorsäure in Orcin und Kohlensäure. Zur Entfernung des Kalkes wird Kohlensäure eingeleitet, filtrirt und die erhaltene Lösung zur Trockene verdampft; der Rückstand wird mit kochendem Alkohol extrahirt, aus welchem sich das Orcin nach einiger Zeit ausscheidet.

V. de Luynes, Dingl. polyt. Journal 169 pag. 220, a. Chem. Centralblatt 1863 pag. 1053) verfährt folgenderweise: Die Flechten werden eine Stunde lang mit Wasser macerirt, dann mit einer kleinen Menge gelöschten Kalk iiberstreut und gut durchgerihrt, hierauf decantirt und der Rückstand ausgeprosst; die erhaltene Flïssigkeit rasch filtrirt und mit Salzsäure in geringen Ueberschuss versetzt, wodurch alle Erythrinsäure als dicke Gallerte gefällt wird. Diese wird so lange gewaschen, bis die ablaufende Fliissigkeit nicht mehr sauer reagirt, an der Luft getrocknet und hierauf mit gelöschtem Kalk in luftdicht verschlossene Kessel gebracht und hier 2 Stunden auf $150^{\circ}$ erhitzt. Darauf wird die Flüssigkeit abgelassen und vom gebildeten kohlensauren Kalk filtrirt. Aus dem Filtrat scheiden sich beim Erkalten grosse beinahe farblose Krystalle von Orein ab.

Auf synthetischem Wege kann Orcin durch Behandeln von Aloë mit schmelzendem Aetzkali oder durch Schmelzen von chlortoluolsulfonsaurem Kali mit Aetzkali erhalten werden (Vogt und Henninger, Bullet. de la soc. chim. 1874, 21. Nro. 8 pag. 373.

Orcin bildet farblose 6 seitige monokline Säulen, ist in Wasser, Alkohol und Aether sehr leicht löslich. Beim Verdunsten aus Wasser erhält man Krystalle mit 1 Mol. Krystallwasser, aus Aether krystallisirt es wasserfrei; bei $58^{0}$ schmilzt das wasserhaltige Orcin und verliert sein Krystallwasser, destillirt bei $290^{\circ}$ unverändert als wasserhelle Flüssigkeit. Der Geschmack des Orcins ist widerlich siisslich, eckelerregend. Die neutrale wässerige Lösung wird durch Eisenchlorid dunkelroth, durch Bleiessig weiss gefällt.

Schunck, Ann. d. Chem. u. Pharm. 61 pag. 78. Hesse, Ann. der Chem. u. Pharm. 117 pag 332. 
Wird zerriebenes Orcin unter eine Glocke gebracht, unter welcher sich ein Gefäss mit Salpetersäure von $40^{\circ}=1.38$ spec. Gew. befindet und so bei gewöhnlicher Temperatur der Jangsamen Einwirkung von Salpetersäurerlämpfen ausgesetzt, so werden die Orcinkrystalle allmälich gebräunt und endlich vollständig in einen rothen Forbstoff verwandelt, welcher vom Orcein verschieden ist. Derselbe löst sich nach de Luynes (Compt. rend. 57 pag. 161; Dirgl. polyt. Journ. 170 pag. 237) in Wasser, Alkohol und Aether auf, färbt Wolle und Seide ohne Beize schön roth, wird von Ammoniak vorübergehend, von fixen Alkalien dauernd in einen violetten Farbstoff verwandelt durch Säuren aber wieder roth gefärbt; Chlornatrium fällt den Farbstoff aus seiner wässerigen Lösung, doch lïst er sich nach dem Auswaschen des Salzes wieder auf. Durch Chlorkalk wird Orcin tief violett, dann braun und gelb, an der Luft und im Lichte bald röthlich gefärbt; trockenes Orcin bleibt in ammoniakhaltiger Luft unverändert, im feuchten Zustande nimmt es Ammoniak und Sauerstoff auf und verwandelt sich in Orecïn und Wasser.

$$
\underset{\text { Orein }}{\mathrm{C}_{7} \mathrm{H}_{8} \mathrm{O}_{2}}+\mathrm{NH}_{3}+3 \mathrm{O}=\underset{\text { Orceïn. }}{\mathrm{C}_{7} \mathrm{H}_{7} \mathrm{NO}_{3}}+2 \mathrm{H}_{2} \mathrm{O}
$$

Das $\mathrm{Orceün} \mathrm{C}_{7} \mathrm{H}_{7} \mathrm{NO}_{3}$ kann leicht erhalten werden, wenn man zerriebenes fenchtes Orcin unter einer Glasglocke neben starker Ammoniakflüssigkeit stellt; sobald es braun geworden, löst man es in Wasser, dem einige Tropfen Ammoniak zugesetzt sind, und fällt durch Essigsäure. Aus Orseille kann es durch Versetzen mit Salzsäure, Abdampfen zur Trockene, Auskochen des Rückstandes mit Weingeist, abermaliges Eindampfen, Waschen mit Wasser und Aether erhalten werden. Es stellt ein dunkelrothbraunes Pulver dar, in Wasser sehr schwer, in Weingeist leic t mit scharlachrother, in wässerigen Lösungen der Alkalien mit prachtvoll purpurrother Farbe löslich. Chlornatrium fällt aus diesen Lösungen das Orceïn in Verbindung mit Alkali.

Nascirender Wasserstoff, ebenso Schwefelwasserstoff entfärbt ammoniakalische Orceïnlösungen, welche jedoch an der Luft wieder roth werden.

Durch Einwirkung von Chlor, Brom und Jod auf Orcin werden Substitutionsproducte desselben, durch Salpetersäure Nitroorcin erhalten.

Das Trichlororcin $\mathrm{C}_{7} \mathrm{H}_{5} \mathrm{Cl}_{3} \mathrm{O}_{2}$ oder $\mathrm{C}_{6} \mathrm{Cl}_{3}\left(\mathrm{CH}_{3}\right)(\mathrm{OH})_{2}$ krystallisirt aus Wasser in farblosen Nadeln von $59^{\circ}$ C. Schmelzpunkt. Das Tribromorcin $\mathrm{C}_{7} \mathrm{H}_{5} \mathrm{Br}_{3} \mathrm{O}_{92}$ oder $\mathrm{C}_{6} \mathrm{Br}_{3}\left(\mathrm{CH}_{3}\right)(\mathrm{OH})_{2}$ bildet farblose bei $103^{\circ} \mathrm{C}$. schmelzende seidenglänzende Nadeln. Das $\mathrm{Monojodorein} C_{7} H_{7} J O_{n}$ (Chem. News 29, 53; Ann. 1. Chemie n. Pharm. 171, 310) krystallisirt aus Wasser und Benzol in farblosen Prismen, die bei $86.5^{\circ}$ C. schmelzen. Das Trinitroorcin $\mathrm{C}_{7} \mathrm{H}_{5}\left(\mathrm{NO}_{2}\right)_{3} \mathrm{O}_{2}=$ $\mathrm{C}_{6}\left(\mathrm{NO}_{2}\right)_{3}\left(\mathrm{CH}_{3}\right)(\mathrm{OH})_{2}$ bildet gelbe bei $162^{0} \mathrm{C}$. schmelzende Prismen.

Nach W e s elsky (Berichte d. deutsch. chem. Gesellsch. 7 pag. 442) erhält man durch Einwirkung von salpetrige Säure enthaltender Salpetersäure auf Orcin neben einem Farbstoff zwei Nitroorcine, welche sich durch Destillation mit Wasser trennen lassen. Das Alphanitroorcin $\mathrm{C}_{7} \mathrm{H}_{7}\left(\mathrm{NO}_{\mathrm{a}}\right) \mathrm{O}_{\mathrm{a}}$ scheidet sich aus dem wässerigen Destillate in Krystallen ab und bildet nach der Sublimation orangerothe goldglänzende Nadeln. Das Betanitroorcin, im Destillationsriickstande enthalten, bildet nach dem Umkrystallisiren aus Wasser kurze citronengelbe Nadeln.

Durch Einwirkung von salpetrige Säure enthaltender Salpetersäure auf Orcin erhält man nach Weselsky (Berliner Berichte 7, 439) einen Farbstoff in Form dunkelbrauner krystallinischer Körner mit metallisch grünem Reflexe, welche in Wasser, das eine Spur Alkali enthält, mit prachtvoller Purpurfarbe löslich sind; die sehr verdünnte Lösung zeigt zinnoberrothe Flnorescenz; heisse concentrirte Salpetersäure löst den Farbstoff mit dunkelrothbrauner Farbe auf. Nach dem Erkalten der Lösung scheiden sich glänzende, fast zinnoberrothe Prismen aus. Diese Verbindungen scheinen im Zusammenhange mit dem durch Einwirkung von Luft und Ammoniak auf Orcin entstandenen Orceïn zu stehen. 
Orseille und Orseilleextracte werden hauptsächlich zum Färben von Wolle und Seide verwendet, und da der Farbstoff ein substantiver ist, so färben sich diese ohne Beize. Die erhaltenen violetten Farben sind ziemlich haltbar und können durch Zusatz von Alaun in verschiedenen Nuancen erhalten werden. Grössere Wichtigkeit hat Orseille zur Erzeugung von Mischfarben und von Braunuud Modefarben auf Wolle. Zum Drucken findet selbe wenig Verwendung, wohl aber französischer Purpur.

Die Methoden zur Bestimmung des Gehaltes an Farbstoff in Orseille und Flechten beruhen entweder auf dem Vergleiche der färbenden Kraft derselben oder auf der Bestimmung der farbengebenden Bestandtheile.

100 Gramm der zu untersuchenden Flechten werden mit alkalihältigem Wasser ausgezogen, auf 100 Gramm concentrirt, mit 30 Gramm Ammoniak versetzt und mit dieser Lösung directe Färbeversuche auf nicht mordanisirter Wolle angestellt, aus deren Vergleichung auf die Menge des gebildeten Farbstoffes geschlossen werden kann; die Prüfung der Orseille geschieht durch directe Färbeversuche auf nicht gebeizter Wolle.

Nach Gerhardt kann das Färbungsvermögen verschiedener Flechten vergleichsweise bestimmt werden, wenn man ein bestimmtes Gewicht derselben mit Kalkmilch extrahirt, filtrirt, die Fliissigkeit mit Salzsäure fällt und die ausgeschiedenen Flechtensäuren direct wägt.

Stenhouse (Annalen der Chem. und Pharm. 68 pag. 55; wendet eine titrirte Auflösung von unterchlorigsaurem Kalk an, mit der er die durch mehrmalige Maceration der Flechten mit Kalkmilch erhaltene Fliissigkeit so lange versetzt, als noch voriibergehende Rothfärbung eintritt und aus der verbrauchten Menge der Chlorkalklösung auf die Quantität des Farbstoffs schliesst. Statt Bleichkalk kann auch unterchlorigsaures Natron verwendet werden.

Nach Rey mann (Ber. d. deutsch. chem. Gesellschaft 1875 pag. 790 ; wird das Orcin in den Färbeflechten des Handels massanalytisch bestimmt. Durch Zusatz von Bromwasser zu verduinnter Orcinlösung entsteht unter Gelbfärbung zuerst Monobromorcin, das durch weiteren Zusatz von Bromwasser nach voribergehender Weissfärbung des in der Fliissigkeit suspendirten Niederschlags in gelbes Tribromorcin übergeht. Man versetzt die zu prüfende Lösung mit Bromwasser, bis der entstandene Niederschlag endlich wieder gelb geworden ist und nach einigem Schiitteln ein Ueberschuss von Brom durch den Geruch wahrnehmbar vorhanden ist; damn setzt man eine gemessene Menge Jodkalium zu und titrirt das durch den Ueberschuss von Brom ausgeschiedene Jod mit unterschwefligsaurem Natron, woraus sich berechnen lässt, wie viel Brom zur Bildung von Tribromorcin verwendet wurde oder wie viel Orcin in der Flüssigkeit enthalten war.

\section{K. Weis.}

Flechtengrün, der grïne Farbstoff der Flechten, s. Thallochlor.

Flechtenroth s. Orcëin, s. Flechtenfarbstoffe.

Flechtensäuren s. Elechtenfarbstoffe. Flechtensäure nennt man auch die Fumarsäures.d.

Flechtenspiritus (Moos-Spiritus). Ein neuerer Zeit namentlich in Schweden und Russland in grösserem Massstabe fabriksmässig gewonnener Alkohol, zu dessen Darstellung gewisse, an Flechtenstärke reichere Flechtensorten, zumal die Rennthierflechte durch Kochen mit verdünnter Schwefelsäure oder Salzsảure zur Gewinnung einer gälırungsfähigen Flüssigkeit verwendet werden, welche nach der Neutralisation der freien Säıre mit Kreide oder kohlensaurem Natron zur Gährung gebracht und nach der Vergährung entgeistet werden kann (vgl. Stenberg Journ. f. pract. Chem. 106 pag. 416), s. a. Chem. Centralbl. 1872 pag. 545, vgl. a. Branntweinbrennerei I pag. 739. Gtl. 
Flechtenstärke syn. Li clıen in, vgl. a. Stä rke.

Fleckenmergel, Allgäuschichten, Allgäuschiefer, dunkelgrane, diinnschiefrige Mergel mit von Fucoidin herrührenden Zeichnungen, welche im Lias der nördlichenAlpen namentlich im Allgäuer Gebirge vorkommen. $L b$.

Fleckenporphyr s. Qu arzporphyr.

Fleckenreinigung (détacher - to take out spots). Sowohl die Entfernung von Flecken aus Zeugen, besonders Kleidungsstiicken, als auch aus Papier und Holz, bildet den Gegenstand einer besonderen Fertigkeit, bei der es sich entweder darum handelt, einen den Fleck verursachenden fremden Körper aus dem zu reinigenden Stoffe zu entfernen (Oel-, Fett-, Harz-, Schmutz-, Rostflecke), oder darum, eine durch Einwirkung einer fremden Substanz bedingte locale Veränderung der Eigenschaften des fleckig gewordenen Zeugs zu beheben und die ursprüngliche Farbe wieder herzustellen (Laugen-, Säure-, Obstflecke). In allen Fällen setzt die rationelle Fleckenreinigung die Kenntniss der Natur der den Fleck verursachenden Substanz, dann aber auch die Kenntniss der Wirkungsweise der angewandten Reinigungsmittel und ihres Einflusses auf den zu reinigenden Stoff voraus, und es können demnach die im folgenden gegebenen Vorschriften nur als allgemeine angesehen werden.

a) Flecke in weissen Zeugen sind meistens leicht zu beseitigen, weil hier jede Art von Waschung und sonstiger chemischer Behandlung zulässig ist. Fettflecke sind durch Seife, welcher man bei hartnäckigen Flecken, z. B. eingetrockneter Oelfarbe, ein wenig ätzender Kalilange zusetzen kann, leicht fortzuschaffen. Theer, Wagenschmiere u. dergl. können ebenfalls durch Seife, besser noch durch vorheriges Einreiben mit Butter und darauf folgendes Waschen beseitigt werden. Zwar würden sich auch hier die weiter unten für gefärbte Zeuge angegebenen Mittel gegen Fettflecke in Anwendung bringen lassen, wo aber eine Waschung mit Seife irgend zulässig ist, geht sie in Sicherheit und Vollkommenheit des Erfolges allen anderen Mitteln vor.

Tintenflecke so wie Rostflecke vertilgt man aus weissen Zeugen am leichtesten durch Eintauchen oder Betupfen mit mässig verdiinnter Salzsäure, welche der Substanz des Zeuges nicht schadet, wenn nur nach der Zerstörung des Fleckes zuerst mit Wasser, darauf mit Seife gehörig gewaschen wird, um die Säure vollständig zu entfernen. Kleesäure und Sauerkleesalz wirken weniger kräftig, können aber auch dazu gebraucht werden. Sehr alte Rostflecke weichen mitunter der Einwirkung einer Zinnchlorürlösung.

Flecke von Fruchtsäften, z. B. Heidelbeeren, Rothwein und dergleichen weichen gewöhnlich schon einer kräftigen Waschung; sollte dies nicht der Fall sein, so tauche man die Stelle in eine schwache Lösung von Chlorkalk oder unterchlorigsaurem Natron (s. Bleichen I pag. 622), versäume aber nicht, hinterher durch sorgfältiges Waschen das Bleichmittel vollständig wieder zu entfernen. Dasselbe Mittel zerstört nicht selten die durch langes Liegen an feuchten Orten entstandenen sogenannten Stockflecke. Auch Flecke von blauer Tinte (Indiglösung), Blauholztinten, rothen Tinten, in weissen wollenen Stoffen werden durch Bleichwasser schnell zerstört.

b) Flecke in gefärbten Stoffen. Fettflecke entfernt man auch hier am besten durch Waschen mit Seife. Wo jedoch, wie z. B. bei seidenen Stoffen, eine Waschung nicht zulässig ist, sucht man das Fett durch Auflösung zu entfernen. Hierzu eignet sich am besten reiner Schwefeläther, Benzin, Chloroform oder Schwefelkohlenstoff (s. a. Fleckwasser). (Unreiner Schwefeläther oder verdorbenes, saures Chloroform ist zu vermeiden, weil die in ihm enthaltene Säure der Farbe schaden könnte.) Man legt die befleckte Stelle auf mehrfaches Löschpapier, tröpfelt etwas Aether o. d. g. auf den Fleck, betupft ihn mit einem weichen Bäuschchen, und wiederholt dieses bis zum Verschwinden des Fleckes. 
Denselben Zweck erfüllt auch Terpentinöl, vorausgesetzt, dass es ganz frisch rectificirt und dadurch von allem Harz befreit wurde; eine Bedingung, die nicht so leicht zu erfuillen ist, wesshalb dem Aether oder Benzin der Vorzug gebiihrt. Gewöhnlich findet man, nachdem der Fleck selbst verschwunden ist, in einiger Entfernung um denselben einen wolkigen Rand, von einem geringen Rest des Fettes herruihrend, das sich hier aus der Auflösung abgesetzt hat. Um diesen zu beseitigen, bestreicht man ihn mit in Wasser anfgeweichtem Pfeifenthon und lässt diesen trocknen. Das Fett wird von dem Thon eingesogen, der sich dann durch Klopfen beseitigen lässt. Oder, man umgebe den Fettfleck vor Anwendung des Aethers mit einem Rand von aufgelöstem Gummi arabicum, um die Poren des Stoffes hier zu verstopfen, lasse ihn trocknen und entferne nun den Fleck mit Aether. Ist dies geschehen, so beseitigt man das Gummi mit Wasser, worauf, wenn alles richtig ausgeführt wurde, kein Fettrand $\mathrm{zu}$ bemerken sein wird. $\mathrm{Zu}$ rathen ist jedoch, bei sehr empfindlichen Farben auf seidenen Stoffen vorerst einen Probeversuch mit einem absichtlich auf einem Läppchen desselben Stoffes gemachten Fettfleck anzustellen.

Bei weniger empfindlichen Stoffen leistet ein wiederholtes Betupfen mit zubereiteter Ochsengalle (m. s. Galle) gute Dienste; so wird dieses Mittel häufig beim Reinigen tuchener Kleidungsstücke in Anwendung gebracht, besonders um den im Kragen der Röcke sich ansammelnden, aus Fett und Staub bestehenden Schmutz zu entfernen. Auch durch Waschen mit verdünnten Aetzammoniak lassen sich Fettflecke, namentlich aus Tuchstoffen, gut eñtfernen.

Talgflecke beseitigt man leicht durch dieselben Mittel, nachdem durch gelinde Erwärmung das Fett zum Schmelzen gebracht worden; Wachsflecke durch Befeuchten mit Weingeist und darauf folgendes Reiben, wobei das Wachs in Pulverform sich ablöst.

Oelfarbe muss wo möglich sogleich und vor dem Eintrocknen mit Galle oder Terpentinöl weggenommen werden, wobei es jedoch nicht immer gelingt, die letzten Reste des in die Poren des Gewebes eingedrungenen Farbstoffes ganz zu entfernen. Ist Oelfarbe ein Mal erhärtet, so löst sie sich sehr schwer auf; am besten ist es denn, sie mit Butter zu bestreichen, diese melırere T'age lang darauf zu lassen und nun Terpentinöl in Anwendung zu bringen, auch mit Schwefelkohlenstoff lassen sie sich mitunter ausbringen. Ein besonderes Reinigungsmittel sind die Fleckkugeln. Diese werden folgendermassen verfertigt: Man nimmt durch Schlämmen ron allem Sande rollständig gereinigten Walkthon oder Pfeifenthon und mischt 1 Kilo daron mit 1 Kilo Soda, 1 Kilo Seife und einer durch anhaltendes Schlagen bewirkten Mischung von 1 Kilo Ochsengalle mit dem Gelben von 32 Eiern. Das Ganze wird auf einem Reibstein sorgfältig gerieben und zu kleinen Kugeln geformt. Beim Gebrauch schabt man ein wenig davon mit einem Messer ab, macht es mit etwas Wasser zu einem Teig und reibt damit den Fleck. Auf sehr zarten Farben sind diese Fleckkugeln ihres Alkali und Seifengehaltes wegen nicht anwendbar.

Tinte- und Rostflecke können aus gefärbten Zeugen nur dann entfernt werden, wenn die Farbe durch die nothwendig anzuwendende Säure (Kleesäure) nicht dauernd leidet; bei heiklen, durch Säure sich dauernd verändernden Farben ist die Vertilgung eines Tinten- oder Rostfleckes geradezu eine Unmöglichkeit.

Ist auf schwarz oder dunkel gefärbten Zeugen durch eine stärkere Säure, z. B. Schwefel- oder Salzsäure ein rother Fleck entstanden, so verschwindet er beim Betupfen mit Ammoniak (Salmiakgeist) augenblicklich; ist aber ein solcher Fleck sehr alt, so kann es sein, dass er nur unvollkommen oder gar nicht rerschwindet. Flecken von Salpetersäure lassen sich durch dieses Mittel ïberhaupt nur beseitigen, so lange sie ganz frisch sind.

Ist bereits wirkliche Zerstörung des Farbstoffes eingetreten, wie dies bei Einwirkung ron Salpetersäure oder durch Aufbewahrung ron gefärbten Stoffen in feuchtem Zustande (Stockflecke) geschehen kann, so bleibt kein anderes Aus- 
kunftsmittel, als die Stelle neu zu färben, wozı allerdings praktische Kenntniss der Färberei unerlässliche Bedingung ist.

Flecke auf Papier. Um Fettflecke von Papier zu vertilgen, bedient man sich am besten des Aethers. Man legt die Stelle anf eine Unterlage von Löschpapier, giesst einige Tropfen Aether auf den Fleck, bedeckt, ohne dem Aether zum Trocknen Zeit zu lassen, die Stelle mit mehrfach zusammengelegtem Löschpapier und bringt das Ganze sogleich unter eine kräftige Presse. Dieselbe Procedur wird so lange wiederholt, bis der Fleck verschwunden ist. Gleich dem Aether lässt sich anch Benzol oder Schwefelkohlenstoff verwenden.

Tintenflecke, wenn sie von Galläpfel- oder Alizarin-Tinte herruihren, zerstört man am besten mit einer concentrirten Auflösung von Kleesäure. Ist die schwarze Farbe verschwunden, so legt man das Papier zwischen Löschpapier und presst es, worauf man die Stelle mit reinem Wasser befeuchtet, dann abermals zwischen Löschpapier presst und dieses bis zur gänzlichen Entfernung sichtbarer Spuren der Operation wiederholt. Flecke von Blauholz-Indigo- oder Carmintinten lassen sich auf diese Weise jedoch nicht entfernen, zu ihrer Beseitigung ist in der Regel die Anwendung von Bleichkalklösung nothwendig.

Flecke auf Holz. Für. Fettllecke gibt es kein besseres als das allgemein bekannte Mittel zu empfehlen, den Fleck mit in Wasser oder Branntwein anfgeweichtem Pfeifenthon $\mathrm{zu}$ bestreichen, und denselben bis zur völligen Trocknung auf der Stelle zu lassen. Zeigt sich nach dem Ahnehmen des Thons der Fleck noch, so wiederholt man dieselbe Behandlung. Bürsten der Stelle mit heisser Sodalauge ist ebenfalls sehr wirksam; nur wird das Holz dadurch gelblich, welche Farbe sich freilich hinterher durch verdünnte Schwefelsäure beseitigen lässt.

Zur Zerstörung von Tintenflecken auf weissem Holz bedient man sich am besten der verdünnten Salzsäure, oder bei Blauholztinten etc, einer schwachen Bleichlauge. Ist der Fleck verschwunden, so suche man durch kräftiges Scheuern der. Stelle mit Regenwasser (nicht Brunnenwasser oder gar Seife) die Ruickstände der Operation zu entfernen, s. a. Fleckwasser.

Fleckkugeln (savonnette - scouring ball) s. Fleckenreinigung III. pag. 590.

Fleckschiefer, Frucht-, Garben-, Knotenschiefer. Sowohl sedimentäre als auch krystallinische Thonschiefer und selbst Glimmerschiefer, in welchen sich eigenthümliche Concretionen auf den Schieferflächen zeigen, welche oft nur einen mehr oder weniger scharfumschriebenen dunkelgefärbten Fleck bilden (Fleckschiefer) oder bei welchen dunkle Knötchen von unbestimmter Form (Knotenschiefer) auf den Flächen liegen, oder aber bei denen diese Flecken nach einer oder zwei Seiten hin sich ähren- oder garbenartig ausdehnen (Frucht- oder Garbenschiefer). Die knotenbildende Substanz hat keinen bestimmten mineralogischen Charakter, sie gemahnt zuweilen an Staurolith, u. a. a. Mineralien, ohne jedoch dasselbe zu erreichen. Nach Allem scheinen diese Knötchen oder Flecken die Folge der Einwirkung eines emporgedrungenen Eruptivgesteines zu sein, durch welches die umliegenden Schiefer bestimmt wurden eine Umkrystallisirung ihrer Gemengtheile einzuleiten, da man nur in unmittelbarer Nähe, an der Grä̀ze solcher Gesteine gegen die Schiefer, dergleichen Fleck- und Knotenschiefer findet. $L b$.

Fleckwasser (eau à détacher - scouring water). Von Mitteln zur Entfernung von Flecken aus Zeugen, namentlich von Harz-, Wachs-, Fett- oder Theerflecken, wohl auch von Säureflecken hat man die verschiedensten Mischungen empfohlen, wohl auch als Geheimmittel in den Handel gebracht. Von solchen sind zu nennen:

Brönners Fleckwasser ist wesentlich mehr oder weniger reines Benzin, wie es als leicht flichtiger Antheil bei der Rectification der leicht siedenden Theer- 
öle gewonnen wird, eignet sich nur für die Entfernung von Wachs-, Fett- oder 'Theerflecken.

Buchner's Fleckwasser ist eine Mischung von 3 Thl. Schwefeläther, 3 Thl. absol. Alkohol und 1 Thl. Salmiakgeist (auch für Säureflecke verwendbar). Benzol.

Englisches Fleckwasser, 6 Thl. 95\% Alkohol, 2 Thl. Salmiak, 1/10 Thl.

Le François's Mischungen: 1 Thl. Seife, 1/2 Thl. Ochsengalle, 1/10 Thl. Terpentin.

1 Thl. venet. Seife, $1 / 2$ Thl. Ochsengalle, 15/10, Honig, 1/10 Zucker und ein wenig Terpetin; endlich

64 Thl. Seifenwurzel und Seifenkraut, 45 Thl. geklärt. Citronensaft, 185 Thl. Weingeist, 1700 Thl. Flusswasser, als Waschmittel.

Winkler's Fleckwasser: 1 Thl. Pinolin, 1 Thl. Aether, 1 Thl. absol. Alkohol (das Ganze mit etwas Citronenöl und Bergamottöl parfumirt).

Aehnlich diesem ist die Mischung von 4 Thl. Terpentinöl (rectificirt), 1 Thl. Weingeist, 1 Thl. Aether.

Liqueur Bernhard ist eine Lösung, von 100 Thl. Ochsengalle und 50 Thl. Potasche in 1000 Thl. Wasser. Gtl.

Fledermausbrenner, s. Le u chts to ffe, s. L a m pen.

Fleisch (viande - meat). Unter diesem Namen begreift man die aus Muskelfasern, Bindegewebe und elastischem Gewebe bestehenden Antheile des Thierkörpers, in denen neben Gefässen und Nervenästen, stets Fettzellen und freies Fett eingelagert sind und die mehr oder weniger mit Blut und Blutflüssigkeit erfuillt sind. Im engsten Sinne des Wortes versteht man unter Fleisch auch nur die Bündel der Muskelfasern allein, welche sich aus mikroskopisch kleinen, meist quergestreiften Fäserchen aufbauen, die von einer aus Bindegewebe bestehenden Scheide umschlossen werden. Der Inhalt der einzelnen Muskelfasern (Primitivbündel) besteht wahrscheinlich im Wesentlichen aus Sy $\mathrm{n} t \mathrm{on}$ in einer dem Eiweiss ähnlich zusammengesetzten Substanz, während die das Muskelgewebe erfüllende Ernährungsfliissigkeit wesentlich eine Lösung von Eiweissstoffen und Myosin nebst Salzen ist. Der für das Fleisch der höheren Thiere charakteristische rothe Farbstoff ist identisch mit dem Blutfarbstoff (s. Blut I pag. 659), die die Scheiden der einzelnen Muskelfäserchen bildende Substanz, (Sarcolemma) besteht wahrscheinlich aus Keratin und Elastin. Von sonstigen charakteristischen Bestandtheilen findet sich im Fleische das Kreatin $\left(C_{4} H_{9} N_{3} O_{2}\right)$, das $\mathrm{Kr}$ e a t in in $\left(C_{4} H_{7} N_{3} O\right)$, die Inosinsäure $\left(C_{10} H_{14} N_{4} O_{11}\right)$ und Milchsäure (s. d.), ferner $\mathrm{S}$ arkin (auch Hypoxanthin $\left.\mathrm{C}_{5} \mathrm{H}_{4} \mathrm{~N}_{4} \mathrm{O}\right)$, X a n thin $\left(\mathrm{C}_{4} \mathrm{H}_{4} \mathrm{~N}_{4} \mathrm{O}_{2}\right)$, T a u r in (s. Galle), Harnsäure (s. d.), Inosit (Muskelzucker), gährungsfähiger Zucker, Dextrin, leimgebende Substanz, Fettsäuren und Salze nebst sonstigen Bestandtheilen des Blutes und der Nervensubstanz.

Wird Fleisch kalt extrahirt, so finden sich in dem Auszuge: Eiweiss (Al. bumin) Myosin, Kreatin, Kreatinin, Xanthin, Sarkin, dann Milchsäure, Inosinsäure, Harnsäure, Zucker, Dextrin, Inosit, Farbstoff endlich Salze u. z. z. Th. Salze der fliichtigen Fettsäuren, z. Th. Chloride und Phosphate der Alkalien. Ein heiss bereiteter Fleischauszug enthält nur wenig von Eiweisstoffen gelöst, da diese fast sämmtlich beim Kochen coagulirt und unlöslich werden, dagegen enthält er durch Umwandlung des leimgebenden Gewebes gebildete Leimsubstanz. Fein zerkleinertes Ochsenfleisch gibt an kaltes Wasser 6 Proc. Lösliches ab, wovon 2.9 Proc. coagulirbares Eiweiss sind, das beim Kochen des wässrigen Auszuges sich abscheidet. Hïhnerfleisch gibt 8 Proc. Lösliches ab, wovon 4.7 Proc. gerinnungsfähiges Eiweiss. Mit schwach salzsäurehaltigem Wasser mazerirt lässt das Fleisch eine erheblich grössere Menge an Substanz in Lösung übergehen, indem durch Einwirkung schwacher Salzsäure eine mehr oder weniger grosse Menge von Faserstoff löslich wird. Eine kochend bereitete Fleischbrühe, aus 
1 K. reinem Muskelfleisch durch fünfstündiges Kochen mit $3 \mathrm{~K}$. Wasser erhalten, enthält durchschnittlich 1.56 Proc. lösl. Stoffe, wovon etwa 1.27 Proc. organische Substanzen und 0.29 Proc. mineralische Stoffe. Diese letzteren, welche im Vittel 82 Proc. der gesammten Menge an unorganischen Bestandtheilen des Fleisches repräsentiren, bestehen wesentlich aus 31.8 Proc. Phosphorsäure, 42.9 Proc. Kali, 3.8 Proc. Kalk, Magnesia und Eisen, 3.5 Proc. Schwefelsäure und 17.9 Proc. Chlorkalium. Die Menge von Leim, welche beim Kochen des Fleisches gebildet wird, schwankt je nach der Daner des Kochprocesses nnd der Natur des Fleisches. So liefert ausgelaugtes Ochsenfleisch nur 0.6 Proc., Kalbfleisch 4.75 Proc. Leim.

Insoferne der Nahrungswerth des Fleisches einerseits durch den Gehalt desselben an stickstoffhaltiger organischer Substanz, andererseits aber durch die vorhandenen zur Blutbildung erforderlichen Salze bedingt ist, wird es klar sein, dass das Fleisch seinen wahren Nahrungswerth nur dann behält, wenn ihm bei der Zubereitung zur Speise keine für die Ernährung werthvollen Stoffe entzogen werden. Dies wird erreicht, wenn man ein compactes Fleischstuick entweder in siedendes Wasser bringt und durch längere Zeit für die Erhaltung der Siedetemperatur sorgt, oder es rasch über lebhaftem Feuer schmort; hiebei werden die coagulirbaren Eiweisskörper zum Gerinnen gebracht, noch ehe sie in Lösung überzugehen vermögen und durch die Ablagerung der geronnenen Eiweisssubstanz in dem Muskelgewebe bildet sich eine für Wasser nicht mehr durchgängige Schichte, welche auch der Auslaugung der Salze und sonstiger löslicher Fleischbestandtheile eine Grenze setzt. Umgekehrt muss Fleisch, wenn man möglichst viel von den löslichen Bestandtheilen desselben extrahiren will, zerkleinert, der Einwirkung ron kaltem Wasser ausgesetzt werden, und der erhaltene Auszug darf nicht iiber $60^{\circ} \mathrm{C}$. erhitzt werden, wenn man nicht durch Gerinnung den grössten Theil der werthvollen Eiweisssubstanz, die sich dann in Gestalt eines braunen Schaumes (Suppenschaum) ausscheidet, verlieren will. Zusatz von etwas Salzsäure (0.05-0.1 Proc.) zu dem zur Mazeration zu verwendenden Wasser erlöht die Menge der bei der kalten Mazeration in Lösung gehenden Antheile an stickstoffhältiger org. Substanz ganz wesentlich und liefert relativ sehr kräftige Fleischbriihen. Das günstigste Verhältniss für die Herstellung solcher Fleischbrühe ist: 1 Kilo fein gehacktes Ochsen- oder Hühnerfleisch (Kalbfleisch ist nicht empfehlenswerth) mit $2^{1 / 4}$ Kilo kaltem Wasser zu mazeriren, dem 16 Tropfen reine conc. Salzsäure und 12 Grm. Kochsalz zugesetzt sind. Die mit dieser Flüssigkeit ausgelaugte Fleischmasse wird endlich noch mit 1 Kilo Wasser ausgewaschen und abgepresst.

Schon seit längerer Zeit stellt man Fleischextracte im grossen Massstabe her, deren Werth je nach ihrer Gewinnungsart ein wesentlich verschiedener ist. Die älteste Form solcher Fleischextracte sind die sog. Fleischgallerten, Bouillontafeln (bouillon en tablettes - soupstock), welche durch Eindampfen einer Abkochung von Fleisch und leimgebenden Knochen bis zu einer Concentration, bei welcher die Brühe in Folge ihres Leimgehaltes gelatinirte, erhalten wurden. Häufig wurde auch Fleischbrïhe geradezu mit Leim versetzt und rerdampft. Der Werth dieser Extracte ist in Bezug auf den Nahrnngseffect ein relativ geringer, insoferne sie vorherrschend Leim und nur relativ wenig der Fleischsalze enthalten. Von wesentlich anderer Art sind die eigentlichen Fleischextrate, wie sie gegenwärtig in Gestalt einer braunen, salbenartigen Masse in den Handel gebracht werden. Diese Extracte repräsentiren allerdings auch nicht den vollen Nährwerth des Fleisches, aus dem sie erhalten wurden, aber insoferne sie den grössten Theil der Fleischsalze enthalten, die zur Blutbereitung erforderlich sind, liefern sie, mit entsprechenden vegetabilischen Nahrungsstoffen gemeinschaftlich genossen, eine Nahrung, welche insoferne dem Nahrungswerthe des Fleisches sehr nahe kommt, als die Gegenwart der zur Blutbereitung erforderlichen Salze den regetabilischen Nahrungsstoffen nahezu den Werth thierischer Nährstoffe verleiht. Die erste Fabrik solchen Fleischextractes ist eine Schöpfung des deutschen Ingenieurs Giebert, welcher unter Mitwirkung und unter dem Protectorate Liebig's den Gedanken, den Reichthum an Rindvieh in den Siidstaaten Amerikas dem Continente 
nutzbar zu machen, in der Art realisirte, dass er zu Fray Bentos in Uruguay eine erste Fleischextractfabrik in grossem Massstabe ins Leben rief. Die Fabrikation wird dort in der Art betrieben, dass das Fleisch der friiher fast nur der Häute wegen gezüchteten Rinder, nachdem es von Fett, Häuten und Sehnen befreit ist, kleingehackt und mit dem gleichen Volumen Wasser bei einer Temperatur von $75-80^{\circ}$ C. mazerirt wird. Die von dem Ungelösten geschiedene Fleischbrühe wird nun im Wasserbade möglichst rasch bis zu einer bestimmten Concentration verdampft, hierauf erkalten lassen und von den sich beim Erkalten ausscheidenden Fett und Resten an Eiweissubstanz durch Filtration getrennt. Das Filtrat wird sodann bei mässiger Hitze bis zur Salbenconsistenz verdunstet: sofort in Blechbüchsen von 20-25 K. Inhalt gefüllt und verlöthet, in welcher Form es nach Europa gebracht und in dem Hauptdepot in Antwerpen, nach vorheriger Controlle bezüglich seiner Güte, in glasirte Thontiegel von 1/2, 1/4, 1/8 Kilo Inhalt abgefuillt und so in den Verkehr gebracht wird. Von solchem Fleischextract, das also wesentlich eine concentrirte Fleischbrühe darstellt, entspricht $1 \mathrm{~K}$. einer Quantität von 34 Kilo reinen, fett- und sehnenfreien Muskelfleisches, oder $45 \mathrm{~K}$. des Fleisches sammt Fett, Sehnen, Haut und Knochen, wie es von den Metzgern verabreicht wird. Gutes Fleischextract soll sich zu mindestens 60 Proc. in Alkohol von 80 Proc. auflösen, in Wasser sôll es völlig klar löslich sein. Es enthält durchschnittlich 18-22 Proc. Asche, 10 Proc. Stickstoff und 16 Proc. Wasser, und soll frei von Fett und Eiweissstoffen sein und auch keinen Leim enthalten.

Der allgemeine Anklang, den dieses Fleischextract trotz des immerhin etwas hohen Preises beim Publicum gefunden, hat alsbald eine Concurrenz in der Fabrication dieses Productes wachgerufen und gegenwärtig sind nebst jener zu Fray-Bentos sowohl in Amerika als auch in Anstralien und selbst in Europa (namentlich Russland) Fleischextractfabriken im Betriebe, die grösstentheils das Liebig'sche Verfahren einhalten, wie es in Fray-Bentos im Gange ist. Die bedeutendsten dieser Fabriken sind nächst jener zu Fray Bentos die von R. Tooth zu Sydney in Australien, welche pro Lonat 4-5000 Kilo eines vorziiglichen Extractes liefert, u. z. gesondert Hammelfleisch- und Rindfleisch-Extract, und jene zu Buenos Ayres, welche gleichfalls in grossem Massstabe arbeitet. Von anderen Fabriken sind zu nennen jene der Firma Lucas Herrera y Obes y Co. zu Trinidad im Departem. San John (genannt Buschenthal), jene der San Antonio Meat Extract Company zu San Antonio in Texas, jene der Gebrider Robertson zu Baff le Creek in Queensland, Australien, des E. M. M. Bagot zu Adelaide in Suid-Australien, jene von Pedras Brancas zu Rio grande do Sul in Brasilien u. A. Eine besondere Art von Fleischextract liefert Georges in Montevideo, indem er das zur Conservation nicht geeignete Fleisch unter Druck mit Dampf kocht, den Brei abpresst und das so erhaltene Extract in Büchsen füllt. Der Pressrückstand wird als Brennmaterial verwendet und liefert eine Asche, die ein treftliches Düngmittel abgibt. Die schöneren Stücke des Flcisches werden in Stiicke ron $2-60 \mathrm{~K}$. zerschnitten und in einer Lösung von doppelt schwefligsaurem Natron, Glycerin und Salzsäure in Wasser (etwa 85 Procent Wassergehalt) mazerirt, sodann aus der Lösung genommen, mit doppelt schwefligsaurem Natron bestreut, in Blechbïchsen verpackt und verlöthet. Neuester Zeit ist auch Russland bezüglich der Fleischextractfabrication in Concurrenz getreten und liefert ein Fleischextract in Form von Tafelbouillon, aber von besonders guter Qualität. Dieses Extract soll aus dem Süden von Russland stammen und theils von gewöhnlichem Schlachtrieh, theils von Wild gewonnen sein. Auch in der Schweiz und in Frankreich, selbst in England sind Fleischextractfabriken entstanden. (Näheres über Fleischextract s. J. v. Liebig, Journ. f. pract. Chem. 63, pag. 312 und 94 pag. 293; W. Horn, pol. Centralblatt 1865 pag. 874; Wagner Jahrb. 1866 pag. 482 ; J. r. Lie big, Dingl. pol. Journ. 189 pag. 259; s. a. pol. Centralbl. 1869 pag. 622 ; E. Reichardt, Dingl. pol. Journ. 194 pag. 505 und 193 pag. 311 (iiber russische Bouillontafeln); 
Ge orges, polyt. Centralbl. 1870 pag. 719; Pettenk of er im Ausz. Dingl. pol. Journ. 209 pag. 378; O. Le ube, Dingl. pol. Journ. 210 pag. 319; E. Reichardt, Dingl. pol. Journ. 210 pag. 389 (ubber Prüfung und Zusammensetzung); Chandler und Cairns, Wag. Jahrber. 1874 pag. 802 (Zusammensetzung); E. Thiel, Amtl. Bericht über die W. Ausstellung, Wien 1873; Braunschweig 1874 Bd. I pag. 317 u. a. a. 0.)

Die Rüickstände von der Fleischextractfabrikation nach dem Liebig'schen Verfahren sind keineswegs werthlos, sondern lassen sich mit Vortheil noch als Futter verwenden, sowie sie selbstverständlich auch ein werthvolles Düngmittel darstellen. Gtl.

Fleischbearbeitungs-Maschinen, s. W urstf a brik ation.

Fleischcacao syn. Fleischchocolade.

Fleischchocolade eine mit Zusatz von nach dem Verfahren von H assal (s. Dingl. pol. Journ. 184 pag. 448) bereitetem Fleischmehl hergestellte Chocolade s. d

Fleischconserven syn. conservirtes Fleisch s. b. Fäulniss, III pag. 355.

Fleischextract s. Fleis ch, III. pag. 593.

Fleischfibrin s. Fibrin, s. Eiweisskörper III pag. 140.

Fleischhack- und Schneidemaschinen, s. Wurstfabrikation.

Fleischmilchsäure (Propylglycolsäure, Paramilchsäure, Aethylenmilchsäure), s. Milehsäure.

\section{Fleischzucker, s. In o sit.}

Fleischzwieback (biscuit de viande - meat biscuit) nennt man im Allgemeinen Gebäcke, welche aus Mehl unter Zusatz von Fleischbrïhe oder Fleischextract bereitet und demnach wesentlich nahrhafter als reine Mehlgebäcke sind.

Solcher Art sind Gail Borden's Fleischzwieback (s. amtl. Ber. der Londoner Ausstellung, Bd. I pag. 306, vgl. a. S i em en s Versuche, Dingl. pol. Journ. 123 pag. 248 u. 458), dann Call a mand's Fleischzwieback (s. Boussingault in pol. Centralbl. 1855 pag. 813, vgl. a. C. Thiel in Dingl. pol. Journ. 184 pag. 443), endlich das Fleischextract-Brod von Jacobsen, auch deutscher Fleischzwieback (s. Deutsch. Industr.-Ztg. 1870 pag. 409). Ein Kilo dieses letzteren Präparates entspricht an Nahrungswerth 4 Kilo Rindfleisch (vgl. a. Fäulniss III pag. 354). Gtl.

Fleur de garance, s. Garancine, s. Krapp.

Flexometer, ein Instrument zur Messung der Biegung der Briicken bei Probebelastungen von Amyot und Mallet. S. Wiener Banzeitung 1865 pag. 205.

Flickkupfer, Rollkupfer, ist Kupferblech von nur $0.5^{\mathrm{mm}}$ Dicke, in Rollen.

Fliederholz (lilas - lilac) ist das Holz des spanischen Hollunders (Syringa vulgaris), es ist gelblich- oder grauweiss, sehr hart und dicht und wird zu Drechslerarbeiten verwendet. Aehnlich ist das Hollunderholz (s. d.) ron Sambucus nigra.

Fliegen, s. Lufts chifffahrt.

Fliegen spanische, s. Canthariden II pag. 246.

Fliegende Angriffe, s. Schlös s er.

Fliegenholz, s. m. Quassiaholz. 
Fliegenstein syn. m. gediegen Arsen, s. Arsen I pag. 193.

Fliegenpapier (mort aux mouches - fly paper) Fliegentod. Die unter diesem Namen in den Handel kommenden, zur Vertilgung der lästigen Zimmerfliege bestimmten Giftpapiere werden allgemein durch Tränken von weissem oder gefärbtem Fliesspapier mit einer für Insecten giftigen Substanz hergestellt. Von solchen sind im Allgemeinen nur jene verwendbar, welche erfahrungsgemäss mit etwas Zucker gesüsst von den Fliegen genommen werden, als arsenige Säure, arsensaure Salze, Quecksilber-Sublimat, dann Abkochungen von Quassiaholz oder ron Kockelskörnern, sowie endlich ron Brechnüssen (nux vomica). Für den Gebrauch des grossen Publicums sind jedoch wohl nur solche Papiere zulässig, welche keine allzu heftigen Gifte enthalten, und sollten daher Papiere, welche mit Arsenpräparaten oder Quecksilberpräparaten vergiftet sind, nie verwendet werden. Am zweckmässigsten und ungefährlichsten sind die Quassiapapiere, welche bequem in jeder Hauswirthschaft hergestellt werden können, indem man Quassiaholz mit etwa der doppelten Menge von Wasser durch eine Viertelstunde kocht mit diesem Absude Kärtchen von Fliesspapier tränkt, und diese mit etwas Zucker bestreut, auf flachen Schälchen auflegt und von Zeit zu Zeit befeuchtet. Gtl.

Fliehkraft, s. Centrifugalkraft II. pag. 290.

Fliese (carreau - floor-stone) Flurziege l, Estrichplat te, sind Platten zum Belegen der Fussböden. Man verwendet sowohl natiirliche Steine (Marmor, Thonschiefer, Plattenkalk ete.) als auch künstlich hergestellte Platten aus gebranntem Thon (z. B. Mettlacher Pl.), Cement etc. oft mit verschieden farbigen Mustern versehen. Siehe auch d. Art. Fussboden u. Thonwaren. Grohm.

Fliess, Vliess (toison - fleece) s. Schafwolle.

Fliessofen, Ofen für das Rösten von Kiesen, s. b. Schwefel.

Fliesspapier ungeleimtes, lockeres (nicht sehr stark gepresstes) Papier aus Baumwolle oder Leinen und Baumwollbadern.

Flint s. v. a. Feuerstein s. Quarz.

Flinte, Gewehr, s. Feuerwaffen III pag. 439.

Flintenbohrmaschine, s. Feuerwaffen III pag. 445.

Flintenschrot (plomb de chasse, dragée - shot). Schrot, B I e ischrot werden Bleikïgelchen im Durchmesser von 1 bis $6^{\mathrm{mm}}$ genannt. Die Verfertigung des Schrotes geschah früher allgemein auf die Art, dass man das gehörig legirte Blei geschmolzen durch ein Sieb herabtröpfeln und in kaltes Wasser fallen liess, in welchem die Tropfen erstarrten; eine Methode, die nur sehr unvollkommenes Fabrikat liefern konnte. Wenn nämlich ein Tropfen flüssiges Blei plötzlich durch kaltes Wasser abgekühlt wird, so erstarrt im ersten Moment die äussere Oberfläche, während das innere Blei noch flüssig ist. Wenn dieses demnächst ebenfalls erstarrt und sich dabei zusammenzieht, so muss entweder im Innern eine Höhlung entstehen, oder aber es bildet sich an irgend einer Stelle der Oberfäche eine Vertiefung aus, wie man diese bei Untersuchung der uach dem alten Verfahren fabricirten Schrotkörner so häufig bemerkt.

Gegenwärtig ist allgemein ein weit rationelleres Verfahren angenommen. Man lässt nämlich das Blei ron einem hohen thurmartigen Gebäude herabfallen, so dass die Tropfen bereits in der Luft fest werden, und fängt sie nun, nur um sie vollends abzukiihlen, in einem Gefäss mit Wasser auf. Der höchste Schrotthurm ist wohl der zu Villach in Kärnthen, dessen Höhe 240 Wiener Fuss beträgt. 
In Ermangelung hinlïnglich hoher Giessthürme bedient man sich dazu eines Grubenschachtes. Das Schrotmetall ist eine Legirung von Blei mit wenig Arsenik. Das quantitative Verhältniss beider Theile richtet sich nach der Beschaffenheit des Bleies; je weicher und reiner das Blei, um so mehr Arsenik muss ihm zugesetzt werden. Auf 1000 Pfund Blei rechnet man hiernach 3 bis 8 Pfund weissen Arsenik oder Operment.

Meistens wendet man hartes Blei an, weil es wohlfeiler ist und dem Zwecke hinlänglich gut entspricht. Um die Legirung darzustellen, setzt man entweder bei jedem Schmelzen das nöthige Arsenik hinzu, oder man bereitet eine grössere Quantität einer stark arsenikhaltigen Legirung, und setzt nachher von dieser beim Bleischmelzen die nöthige Menge zu.

Als Kennzeichen der richtigen Zusammensetzung der Legirung kann die Forn der Schrotkörner dienen. Sind diese nämlich linsenförmig, so enthałten sie zu viel Arsenik; sind sie dagegen an einer Seite flach oder gar mit einer Vertiefung, so haben sie zu wenig Arsenik.

Die Erfinder des neuen Verfahrens, Ackerman und Martin, beschreiben dasselbe folgendermassen: Man schmelzt 1000 Kilo weiches Blei in einem grossen eisernen Topfe, und bedeckt es in der Nähe des Randes mit etwa zwei Schaufeln voll Holzasche, lässt aber die Mitte davon ganz frei, und trägt nun in der Mitte etwa 20 Kilo Arsenik ein. Man bedeckt dann den Topf mit einem eisernen Deckel und verstreicht die Fugen schnell mit Lehm oder Mörtel, um die arsenikalischen Dämpfe am Entweichen zu verhindern. So lässt man das Ganze unter mässigem Feuern etwa 4 Stunden lang stehen; nimmt dann den Deckel ab, reinigt die Oberfläche sorgfältig, und giesst das Metall in Blöcke von 75 Kilo. Beim Gebrauch wird von dieser Legirung ein Block mit 500 Kilo ordinärem Blei zusammengeschmolzen. Um zu untersuchen, ob das Metall von richtiger Beschafferiheit ist, nimmt man ein wenig davon in einen mit kleinen Löchern versehenen Schaumlöffel und lässt das durchtröpfelnde Blei aus einiger Höhe in einen Behälter mit Wasser fallen. Je nachdem sie nun $\mathrm{m}$ hr linsenförmig, oder an der einen Seite abgeplattet sind, muss entweder noch mehr Legirung oder reines Blei zugesetzt werden.

Zinnhaltiges Blei ist nicht $\mathrm{zu}$ brauchen, weil es Tropfen von länglich eirunder oder selbst nadelförmiger Gestalt liefert.

Das Giessen geschieht mittelst der Schrotform, einer etwa $260^{\mathrm{mm}}$ im Durchmesser haltenden hohlen Halbkugel von Eisenblech, die mit sehr genau runden, gleich grossen Löchern durchbohrt ist. $\mathrm{Zu}$ den verschiedenen gröberen und feineren Schrotsorten müssen begreiflicher Weise verschiedene Formen mit grösseren und kleineren Löchern vorräthig sein.

Der Durchmesser der Löcher muss betragen für Nr. 0 1/ ${ }_{50}$ Zoll engl.

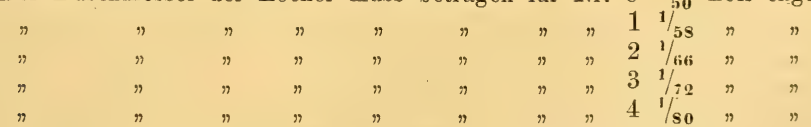

Von Nr. 5 bis Nr. 9 nimmt der Durchmesser in gleichmässigen Abstufungen $\mathrm{ab}$, bis er bei der letzteren nur noch $1 / 3$; Zoll beträgt.

Gewöhnlich wird mit 3 Formen zu gleicher Zeit gegossen, die in geringer Entfernung von einander sich in einem dreieckigen Kohlenbecken befinden. Während sich dieser Apparat an dem obersten Punkte des Giessthurms befindet, ist genau vertikal unter ihm der Wasserkasten aufgestellt, der bei der Arbeit zur Hälfte mit Wasser gefiillt wird. Durch umgelegte Kohlen wird das Blei in den Formen fliussig erhalten, wobei die angemessene Temperatur genau zu beriicksichtigen ist. Fiir grobe Nummern muss das Bleibad kaum so heiss sein, dass ein wenig Stroh, in dasselbe eingetaucht, sich schwach bräunt; für feinere Nummern darf sie schon heisser sein. 
Feinere Schrote erfordern natürlich, da sie weit leichter erstarren, eine weniger grosse Fallhöhe, als gröbere; so reicht für Nr. 4 bis 9 eine Fallhöhe von 32 Meter hin, während gröbere Sorten 45 bis 60 Meter erfordern. Soll nun das Giessen beginnen, so wird in grösseren Schrotfabriken gewöhnlich eine Quantität von 2000 bis 3000 Kilo Blei eingeschmolzen. Die Oberfläche desselben uiberzieht sich dabei mit einer weissen schwammigen Oxydkruste, welche bei dem Giessen eine wichtige Anwendung findet. Mit diesem Oxyd nämlich bedeckt man die Formen auf der Innenseite, um so die Löcher theilweise zu verstopfen; denn liesse man die Formen ganz rein, die Löcher ganz frei, so würde das Blei so schnell hindurchfliessen, dass die Tropfen eine längliche Gestalt erhielten. Gerade das langsame Hindurchsickern des Bleies durch die mit Bleiasche bedeckten Löcher ist eine der wesentlichsten Bedingungen zum Gelingen der Arbeit.

Ist nun Alles in Bereitschaft, so trägt der Arbeiter die Bleiasche in die Formen, und drückt sie überall in einer dünnen Lage an, giesst nur etwas Blei hinein und ersetzt dieses in dem Masse, wie es durchtröpfelt, stets durch neues.

Die Schrotkörner werden nachher aus dem Wasserkasten herausgenommen und durch Siebe sortirt; denn selbst wenn die Löcher der Formen von ganz gleicher Grösse sind, fallen doch die Schrote nicht von einerlei Grösse aus. Der mittlere Theil dieser Formen nämlich, der von den Kohlen weniger stark erhitzt wird, liefert jederzeit gröbere Schrote als die in der Nähe der Peripherie liegenden, stärker erhitzten Theile. Ausserdem wird auch oft mit mehreren Formen, von verschiedener Grösse der Löcher, zu gleicher Zeit gearbeitet.

Die zum Sortiren dienenden Siebe bestehen aus Eisenblech, und werden gewöhnlich zu je zwei Stïck, deren Löcher der Grösse nach aufeinander folgen, aufeinander befestigt.

Nachdem nun die Schrote der Grösse nach sortirt sind, ist es noch nöthig, sie auch der Form nach zu sortiren, um nämlich alle nicht genau runden Körner zu beseitigen. Diese auf den ersten Blick vielleicht schwierig scheinende Aufgabe wird durch ein eben so einfaches, wie unfehlbares Mittel gelöst. Man hat nämlich e bene, mit einem vorspringenden Rande versehene Platten von etwa $700^{\mathrm{mu}}$ Länge und $400^{\mathrm{mm}}$ Breite (geschliffene und polirte Spiegeltafeln eignen sich hierzu am allerbesten), welche genau horizontal gerichtet werden, und auf deren eines Ende man eine kleine Portion, etwa eine Hand voll, Schrot auflegt. Hierauf wird die Tafel sehr wenig geneigt, und sanft hin- und hergeschittelt, wobei denn die vollkommen runden Körner herabrollen, während alle ibbrigen zuriickbleiben, die man dann wieder einschmilzt. Gegenwärtig verwendet man Sortirapparate, welche auf demselben Principe beruhen aber ganz selbstthätig arbeiten.

Endlich folgt noch eine letzte Bearbeitung, wodurch die Schrote die nöthige Glätte und Politur erhalten. Sie werden zu dem Ende nebst einer Portion Graphit in ein kleines, horizontal liegendes, achteckiges Fass gegeben, das mittelst einer durchgehenden eisernen Achse gedreht wird. Indem sich hierbei die Körner an einander reiben, runden sie sich noch vollständiger ab und erhalten zugleich den feinen Graphitiberzug; der theils des Ansehens wegen, theils aber auch zu dem Ende gegeben wird, um das Blei bei längerer Aufbewahrung vor der Oxydation zu schützen.

Um die Anlage eines thurmartigen Gebäudes zu ersparren, ist der Vorschlag gemacht worden, zum Giessen einen niedrigen, vielleicht 13 bis 16 Meter hohen Cylinder zu benutzen, durch welchen von unten mittelst eines Ventilators ein so kräftiger Luftstrom getrieben wird, dass er das Blei, trotz der geringen Höhe, zum Erstarren bringt. Es ist aber kaum zu bezweifeln, dass die Betriebskosten eines solchen Ventilators die Zinsen der Anlagekosten eines hinlänglich hohen Gebäudes bei weitem übersteigen werden.

Ziemlich gut bewährt sich jedoch das Princip der Centrifugalschrotfabrikation. - Eine runde, ringsherum mit einer siebartig durchlöcherten Scheidewand 
von Messingblech versehene Metallscheibe wird mittelst Dampf- oder anderer Triebkraft mit einer Umfangsgeschwindigkeit von 6 bis 10 Meter pr. Secunde in Drehung gesetzt. Wird nun in die Mitte der drehenden Scheibe flüssige Blei legirung gegossen, so wird es in Folge der Centrifugalkraft in Form (den Löchern der Scheidewand entsprechender) runder Körner zu allen Seiten geschlendert, wo diese durch einen festen Leinwandschirm oder gepolsterte Bretterwand aufgefangen werden, und in unten befindliche Wasserkästen fallen müssen. Die durch Drehung der Scheibe ebenfalls in kreisende Bewegung gesetzte Luftmasse bringt die Bleitropfen zum Erstarren, noch ehe sie die Bretterwand erreichen. Zur Erzeugung gröberen Schrotes ist ebenfalls grössere Entfernung des Leinwandschirmes sowie geringere Hitze des Metalles erforderlich. Sonst ist die ganze Manipulation dieselbe, wie vorher beschrieben wurde.

Der Bleiverlust beträgt bei der Schrotfabrikation ohne Rücksicht auf die Methode $1^{3} / 4$ bis $2 \%$ Proc.; bei unregelmässiger Hitze und anderem schlechten Behandeln des Materials auch bis 4 Proc.

Flintglas, s. Glas.

Flintshirestein syn. Dinasstein, Quarzziegel, s. Dinassteine II pag. 631 , s. Thonwaren.

Flinz syn. Spathe is enstein.

Flittergold, Rauschgold, Knittergold (oripeau, clinquant -- dutch gold), ist dünnstes Messingblech, s. Messing.

Flittern (paillons et paillettes - spangles). Die Folie-Flittern (paillons) sind rundliche verschieden geformte Plättchen aus echter oder unechter Gold- und Silberfolie und Zinnfolie durch Ausschlageisen gefertigt, indem man auf einer bleiernen Unterlage Stückchen von runder, sternförmiger, rosenförmiger, blumenblattähnlicher etc. Gestalt aushaut.

Die Draht-Flittern (paillettes) sind flachgeschlagene Drahtringelchen, daher Scheibchen mit centrischem Loch. Die Drahtflittern, welche am meisten gebräuchlich sind, werden aus Ringelchen von echtem oder unechtem Gold- und silberdrahte gebildet, indem man diese auf einem fein polirten Ambosse mit einem ebensolchen Hammer flachschlägt; sie behalten dabei eine Oeffnung im Mittelpunkte, welche zum Aufnähen dient. Man lässt sie entweder glatt, wie sie sind, oder schlägt sie nachträglich auf einer Bleiunterlage mittelst eines stählernen Stempels, durch den sie entweder eine stark vertiefte Gestalt Hohlflittern) oder Verzierungen von Strichen, Punkten etc. bekommen (Krausflittern). Vgl. Le on is che A r beit.

Flocken, gleichbedeutend mit dem Füllen oder Füttern der Kratzen, s. d.

Flockseide (frisons - flock silk) beim Einsammeln der Cocons an den Brettchen oder Reisig hängen bleibende und später eingesammelte Seide, welche zu den Abfällen gegeben und zu Florettseide versponnen wird.

Flötz nennt man jenes Glied eines Schichtensystemes, welches aus einem nutzbaren Minerale besteht, daher z. B. Steinkohlen-, Braunkohlen-, Eisenstein-, Kalkstein-Flötz. $\quad L b$.

Flötzgrünstein so viel als Dolerit, s. d.

Flötzhund, s. Bergbau I pag. 403.

Flötzleerer Sandstein, ein in der pelagischen Steinkohlenformation an der Grenze über den marinen und unter den productiven Steinkohlengliedern liegender, sehr charakteristischer Sandstein, welcher keine oder nur unbedeutende Kohlen- 
flötze führt. Er wird in Ergland, wo er stellenweise aus hartem sogen. krystall. Sandstein besteht, vielfach zur Erzeugung von Mühlsteinen verwendet (millestone, grit), so in Yorkshire, Lancashire und Derbyshire, anch liefert er gute Gestellsteine. In Westphalen besteht er aus wechselnden Lagen von Sandsteinen und Schieferthonen, denen bauwïrdige Kohlenflötze fehlen. $L b$.

Flohsamen (graines de psillium - fly seed), sind die Samen von Plantago Psyllium und Plantago arenaria Wld. im südlichen Europa einheimischer, an sandigen Küsten wachsender Wegerich-Arten, von welchen namentlich die letztere im Süden von Frankreich behufs Gewinnung: der Samen cultivirt wird. Der Same ist etwa $2-3^{\mathrm{mm}}$ lang, gestreckt, einseitig gewölbt, anderseits flach und mit einer Längsfurche versehen, in deren Mitte ein punktförmiger Nabel sich findet. Sie sind von dunkel rothbrauner Farbe (Flohfarbe) und mehr oder weniger stark glänzend. Der Flohsamen, von welchem die geschätzteste Sorte von Frankreich aus auf den Markt kommt, während Italien eine zwar weniger schön aussehende, aber nicht minder brauchbare Sorte liefert, fand ehemals seines Gehaltes an Pflanzenschleim (etwa 15 Proc.) wegen, demzufolge er mit heissem Wasser eine consistente Gallerte liefert, als schleimiges Mittel Anwendung in der Medizin. Gegenwärtig wird er zur Herstellung von schleimigen Flüssigkeiten, namentlich für die Zwecke der Buntpapierfabrikation, dann wohl auch für die Zwecke der Zeugappretur und der Kattundruckerei in Verwendung gezogen. Gtl.

Flor, Trauerflor, ist jenes unter dem Namen Krepp oder Krepon bekannte Gewebe. S. Krepp. Auch bedentet dieses Wort die Pole (poil pile, na $)$, d. i. die haarige Decke der sammtartigen Gewebe. S. Weberei.

Florentinerlack, Carminlack, Wiener Lack, Pariser Lack, s. Carmin II pag. 257 und pag. 259. pag. 167 .

Flores Antimonii, Antimonblumen, syn. m. Antimonoxyd, s. Antimon I

Flores Benzoës, Benzoëblumen, syn. m. Benzoësäure I pag. 376.

Flores salis ammoniaci martiales, Eisenblumen, syı. m. Eis e nchlorid, s. Eisen II pag. 765.

Flores Sulfuris, Sehwefelblumen, s. Schwefel.

Flores viridcs aeris syn. mit Grïnspan s. b. Ku p fer.

Flores Zinci, Zinkblumen, syn. m. Zinkoxyd s. Zink.

Florettseide (fleuret, filoselle - floret silk, floss silk) aus den Seidenabfällen erzeugtes Seidengarn (s. Seide).

Floss (radeau, train de bois - Hout, raft) neben einander gebundene Stämme von Holz zur Flussschiffahrt.

Flossen (Roheisen-Handelsform), vgl. Eisenerzeugung III pag. 11.

Flottensalz syn. m. Borax, insoferne dieses Salz als Auflösungsmittel für Pigmente in Farbflotten dient, vgl. Borax bei Bor I pag. 728.

Fluavile, Bestandtheil der Guttapercha s. d.

Fluchtlinie. das Bild der unendlich fernen Geraden einer Fbene oder einer stellung, daher den perspectivischen Darstellungen eines Systems paralleler Ebenell gemeinsam. 
Fluchtpunkt, das Bild des unendlich fernen Punktes einer Geraden oder einer Richtung, daher der Vereinigungspunkt der Bilder eines Systemes paralleler Geraden. $C z$.

Fluder, Fluter, Vorrichtung zum Ablassen des Wassers ans Teichen.

Flügel oder S chaft (lame - lerıf), s. Weberei.

Flügelbremsen, s. R e gulat or.

Flügelort, s. Bergbau I pag. 387.

Flugmaschine, s. Luft s chiff a h r t.

Flugstaub der Hütten syn. Hütten rauch, s. Arsenige Säure I pag. 195. Flugstaub der Bleikammern s. Schwefelsäu re b. S chwefel. Gtl.

Fluid Ozon, Name eines als Geheimmittel in den Handel gebrachten Desinfectionsmittels, bez. Heilmittels, welches wesentlich eine 5 procentige Lösung von übermangansaurem Kali in Wasser ist. Gtl.

Fluocerit, hexagonales Mineral, kommt tafelförmig oder derb eingewaschen in Granit vor, hat einen unebenen Bruch, $H=4-5$, sp. Gew. 4.7, röthlich oder gelblich, wenig glänzend, undurchsichtig oder kantendurchscheinend. Chem. Zus. $C e F l_{2}+C e_{2} F_{6}$. Entwickelt beim starken Glühen im Kolben oder Glasrohr Flusssäure, ist auf Kohle unschmelzbar, gibt mit Borax und Phosphorsalz die Reaction von Cerium. Fundorte Finbo und Broddbo bei Falun in Scliweden. $L b$.

Fluor (fuor - fluor). Symbol Fl. Atomgew. = 19. Das Fluor bildet in Gemeinschaft mit Chlor, Brom und Jod die Gruppe der Haloide oder Halogene, monovalente Elemente, deren Wasserstoff- und Sauerstoffsäuren einbasisch, im Molekül nur ein durch Metall vertretbares Wasserstoffatom besitzen und nur eine Reihe, neutrale Salze, bilden. Von den Haloiden ist das Fluor das am wenigsten gekannte; es ist im freien Zustand nur unvollständig bekannt, da es sich im Momente seiner Abscheidung in Folge seiner grossen Verwandtschaft zu andern Elementen sogleich mit den Bestandtheilen der Gefäss-Substanzen verbindet; einigermassen grössere Mengen von Fluor im gasförmigen Zustande konnten bisher nur in Gefässen von Flussspath isolirt werden.

Durch Zersetzung von Fluorsilber (Davy) oder Fluorquecksilber ( $\mathrm{K}$ n $0 \mathrm{x}$ ) mit Chlorgas, durch Einwirkung von Jod (bei $70-8\left(^{\circ}\right)$ auf Fluorsilber in luftleer gemachten zugeschmolzenen Röhren ( $\mathrm{K}$ ä $\mathrm{mmerer}$ ), durch vorsichtiges Erhitzen eines Gemisches von Flussspath, übermangansaurem Kali und Schwefelsäure (Phipson), durch Elektrolyse von Fluorkalium etc. ist das Fluor als farbloses, in seinem chemischen Verhalten dem Chlor sehr ähnliches Gas von eigenthïmlichem Geruche erhalten werden, welches Wasser unter Bildung von Eluorwasserstoff und Entbindung von Sauerstoff sehr energisch zersetzt; die Versuche, es in grössern Quantitäten zu erhalten, scheitern eben an der grossen Verwandtschaft die das frei gewordene Fluor gegen fast alle Elęmente äussert.

In Verbindung mit andern Elementen findet sich das Fluor in grösster Menge im Flussspath $\left(\mathrm{CaFl}_{\mathrm{a}}\right)$ und im Kryolith $\left(6 \mathrm{NaFl}+A l_{\mathrm{g}} \mathrm{Fl}_{\mathrm{b}}\right)$; in geringerer Menge im Apatit, Topas, Amphibol, in den meisten natürlichen phosphorsauren Salzen, in den Knochen, im Email der Zähne, in sehr geringer Menge in der Milch, im Meerwasser etc.

Die Sauerstoffverbindungen des Fluors sind unbekannt; mit Wasserstoff bildet es die der Chlorwasserstoffsäure analoge Fluorwasserstoffsäure, welche den Ausgangspunkt für die Darstellung der Fluormetalle und anderer Fluor- 
verbindungen bildet. Die Fluorverbindungen der Alkalien sind im Wasser leicht löslich, die der meisten übrigen Metalle schwer löslich oder nnlöslich; Flıorsilber jedoch (im Gegensatz zu Chlor-, Brom- und Jodsilber) leicht löslich, Fluor calcium (im Gegensatz zu Chlorcalcium) unlöslich. Sämmtliche Fluorverbindungen oder Fluoride zersetzen sich mit Schwefelsäure unter Entwicklung von Fluorwasserstoff.

Näheres über Flussspath (Fluorit) und Kryolith siehe die betreffenden Artikel; über Fluorverbindungen bei den betreffenden Metallen.

Fluorwasserstoff (acide fuorhydrique - hydrofluoric acid), (Fluorwasserstoffsäure, Flusssäure), Symbol $F l H$, wird erhalten durch Zersetzung von Flussspath mit Schwefelsäure:

$\underset{\text { Flusspath }}{\mathrm{CaFl}_{2}}+\underset{\text { Schwefelsäure }}{\mathrm{SO}_{4} \mathrm{H}_{2}}=\underset{\text { Calciumsulfat }}{\mathrm{CaSO}_{4}}+\underset{\text { Fluorwasserstoff. }}{2 \mathrm{HFl}}$

Fluorwasserstoff ist ein farbloses ätzendes Gas von stechend saurem Geruche, welches an der Luft weisse Nebel bildet, leicht verdichtbar ist, eingeathmet höchst nachtheilig wirkt, von Wasser in grossen Mengen absorbirt wird. Da das Gas Gefässe von Glas, Porzellan, sowie die meisten Metalle angreift, so kann die Zersetzung des Flussspathes mit Schwefelsäure nicht in Glasgefässen oder beliebigen Metallgefässen bewerkstelligt, sondern es müssen hiezu Gefässe von Blei oder Platin verwendet werden.

Zur Darstellung der wässerigen Flusssäure in grössern Mengen kann der von Briegleb empfohlene Apparat verwendet werden. Die aus Blei gefertigte Destillirblase besteht aus zwei Theilen, deren unterer, zur Aufnahme der Beschickung mit Flussspath und Schwefelsäure bestimmt, mit dem obern 'Theile (Helm) gut verkittet wird. Die gleichfalls aus Blei gefertigte Vorlage hat seitlich einen Tubus zur Aufnahme des Helmhalses, ferner einen konischen uibergreifenden Deckel, von dem ein Ableitungsrohr abzweigt. In der Vorlage selbst befindet sich eine mit dem Absorbtionswasser gefüllte, auf einem Ringe von Blei stehende Platinschale. Sobald alle Fugen des Apparates verstrichen sind, beginnt man mit der Entwicklung des Fluorwasserstoffgases durch Erwärmen der in einem eisernen Sandbade stehenden Blase; man erhält so eine mehr oder weniger concentrirte, fast bleifreie Säure.

Zur Darstellung von wasserhaltiger Flusssäure in kleinen Mengen kann ein einfacher Apparat, bestehend in einer aus zwei Theilen gebildeten bleienen Destillirblase mit einem Abzugsrohr von Platin, verwendet werden. In den untern Theil der Blase bringt man concentrirte Schwefelsäure und rührt in diese so viel fein gepulverten Flussspath, dass die Masse noch vollständig flüssig bleibt, setzt sodann den obern Theil auf, verkittet und erhitzt nun den Boden der Blase mit einer kleinen Flamme. Das aus dem Platinrohr austretende Fluorwasserstoffgas lässt man in einen mit Wasser gefüllten und gekühlten Platintiegel eintreten.

Soll die erhaltene Flusssäure vollständig bleifrei sein, so müssen zur Darstellung derselben Gefässe von Platin verwendet werden, da die in den meisten Bleiapparaten dargestellte Flusssäure geringe Mengen von Blei enthält.

Lässt man das aus Flussspath und Schwefelsäure entwickelte Fluorwasserstoffgas in kleine, mit einer Kältemischung umgebene Gefässe von Platin, Blei oder Gold treten oder leitet man dasselbe durch eine U-förmige, gleichfalls gekühlte Röhre von Blei, so erhält man die Flusssäure im wasserfreien Zustande.

Die wässerige Flusssäure ist eine farblose, sehr saure, bei starker Concentration an der Luft rauchende Flüssigkeit, welche die meisten Metalle unter Entwicklung ron Wasserstoff auflöst, mit Metalloxyden Wasser und Fluormetalle bildet.

Die wasserfreie Flusssäure ist eine farblose, sehr flüchtige, rauchende, sehr saure, ätzende, bei ca. $15^{0} \mathrm{C}$. siedende Fluissigkeit ron 1.061 spec. Gewicht; auf die Haut gebracht, bewirkt sie lebhafte Entziindung derselben, und erzeugt 
schwer heilende Wunden. Durch Zusatz von wenig Wasser erhöht sich ihr spec. Gewicht auf 1.25 unter bedeutender Erhitzung.

Die Aufbewahrung der wässerigen Flusssäure geschieht in Gefässen von Blei oder Platin, wohl auch in Glasgefässen, deren Innenwände mit einer Schichte von Wachs oder Asphalt iiberzogen sind.

Von grösster Wichtigkeit ist die Einwirkung des Fluorwasserstoffgases sowohl als auch der wässerigen Fliisssäure auf Kieselsäure und Silikate.

Flusssäure setzt sich nämlich mit Kieselsäure um in gasförmiges Siliciumfluorid und Wasser,
$\underset{\text { Kieselsäureanhydrid }}{\mathrm{SiO}_{2}}+\underset{\text { Fluorwasserstoff }}{4 \mathrm{FlH}}=\underset{\text { Siliciumfluorid }}{\mathrm{SiFl}_{4}}+\underset{\text { Wasser }}{2 \mathrm{H}_{2} \mathrm{O}}$
$\underset{\text { Kieselsäureanhydrid }}{\mathrm{SiO}_{2}}+\underset{\text { Fluorwasserstoff }}{4 \mathrm{FlH}}=\underset{\text { Siliciumfluorid }}{\mathrm{SiFl}_{4}}+\underset{\text { Wasser }}{2 \mathrm{H}_{2} \mathrm{O}}$
$\underset{\text { Kieselsäureanhydrid }}{\mathrm{SiO}_{2}}+\underset{\text { Fluorwasserstoff }}{4 \mathrm{FlH}}=\underset{\text { Siliciumfluorid }}{\mathrm{SiFl}_{4}}+\underset{\text { Wasser }}{2 \mathrm{H}_{2} \mathrm{O}}$
$\underset{\text { Kieselsäureanhydrid }}{\mathrm{SiO}_{2}}+\underset{\text { Fluorwasserstoff }}{4 \mathrm{FlH}}=\underset{\text { Siliciumfluorid }}{\mathrm{SiFl}_{4}}+\underset{\text { Wasser }}{2 \mathrm{H}_{2} \mathrm{O}}$

mit Silicaten in Siliciumfluorid, Fluormetall und Wasser. Wirkt daher Fluorwasserstoffgas oder Flusssäure auf Glas, so wird demselben ein Theil der Kieselsäure in Form von gasförmigem Siliciumfluorid entzogen und je nach der Dauer der Einwirkung an der betreffenden Stelle eine mehr oder weniger starke Vertiefung erzeugt.

Diese zerstörende Wirkung der Flusssäure auf Glas wird benützt, um Zeichnungen, Schriftzüge, 'Theilungen, Photographien etc. auf Glas zu ätzen.

Bereits 1670 kannte $\mathrm{H}$. Schwankhardt in Nürnberg ein Verfahren, mittelst Flussspath und Schwefelsäure Glas zu ätzen; 1771 wies $\mathrm{Scheele} \mathrm{die}$ Existenz einer eigenthümlichen, der Chlorwasserstoffsäure ähnlichen Säure nach, welche sich aus dem Gemische von Schwefelsäure und Flussspath entwickelt und welcher Säure die ätzende Wirkung zukomme. Durch Hann, Böttg er und Bromeis, Kessler, Siegwart, Tessie du Mothay, Auer u. A. erbielt das Verfahren der Aetzung des Glases, namentlich in der Methode des sogenannten Glasdruckes, der Hyalographie etc. die grösste Wichtigkeit.

Man ätzt entweder mit Fluorwasserstoffgas, aus einem Gemisch von Flussspath und Schwefelsäure entwickelt oder mit wässeriger Flusssäure, wohl auch unmittelbar mit dem Gemisch von Flussspath und Schwefelsäure oder mit einer mit Salzsäure angesäuerten Lösung von Fluorwasserstoff-Fluorkalium oder endlich mit Fluorammonium. Je nach Wahl der einen oder andern Methode ist das Aussehen des geätzten Glases von verschiedener Art; Fluorwasserstoffoas und Fluorammonium erzeugen matte Aetzung, ebenso das Gemisch von Schwefelsäure und Flussspath, wenn es unmittelbar auf die zu ätzende Stelle aufgetragen wird; eine wässerige Lösung von Flusssäure hingegen hinterlässt die geätzte Stelle nicht matt, sondern hell und fast durchsichtig. Durch Abwechslung von matt und hell geätztenS tellen, durch verschiedene Tiefätzung, Wegätzen von Ueberfang etc. können die verschiedensten Arten geätzter Gläser von trefflicher Wirkung hergestellt werden.

Obzwar sämmtliche Glasarten von Fluorwasserstoff angegriffen werden, so eignen sich am besten weiche Bleikrystallgläser, indem die Aetzung der harten Kali- oder Kalikalkgläser nur sehr langsam vòn statten geht.

Um Zeichnungen auf Glasplatten, Scalen auf Thermometern, Eudiometern ete. zu ätzen, verwendet man die Methode der Aetzung mit gasförmigem Fluorwasserstoff. In die, mit einem Aetzgrunde von geschmolzenem Wachs und Terpentin oder Kupferstecherfirniss möglichst gleichmässig iiberzogene Oberfläche der Glasplatte oder Röhre wird die Zeichnung mittelst eines feinen Griffels, die Theilung für Thermometer und Eudiometer mittelst Theilmaschine eingeschnitten, um so die betreffenden Glasstellen der Einwirkung der Fluorwasserstoffsäure blosszulegen, hierauf durch längere oder kürzere Zeit je nach der gewünschten Tiefe der Aetzung den Dämpfen der Fluor- wasserstoffsäure ausgesetzt - wobei nur Sorge getragen werden muss, dass die Temperatur nicht zu hoch steigt, um nicht Stellen, welche nicht geätzt werden sollen, durch das Schmelzen des Aetzgrundes blosszulegen - und schliesslich durch gelindes Erwärmen und Abwischen der Aetzgrund entfernt. 
Da die Herstellung von Zeichnungen im Aetzgrunde viel Zeit und Mühe erfordert, für jeden einzelnen Gegenstand wiederholt werden muss, so wurde schon von $\mathrm{Hann}(1829)$, Böttger u. Bromeis (1844), Kessler (1855), S ieg wart, Tessié du Mothay und Maréchal etc. ein Druckverfalıren*) eingeführt, nach welchem die betreffenden Zeichnungen auf dem lithographischen Stein entworfen, der Aetzgrund auf Papier gedruckt und von diesem auf das Glas übertragen wird.

Nach Kessler wird zunächst die betreffende Zeichnung auf einem ebenen, polirten lithographischen Stein mittelst einer Tinte (Lösung von Asphalt in Terpentinöl) entworfen, nach dem Trocknen derselben der Stein mit stark verdünnter Salzsäure ca. $1 / 2 \mathrm{~mm}$ tief geätzt, mit Aetzgrund, bestehend aus $3 \mathrm{Th}$. Asphalt, 2 Th. Stearinsäure und 3 Th. Terpentinöl, iiberzogen und mittelst einer geradlinigen Metallschiene die erhabenen Stellen blossgelegt. Man bedeckt nun den Stein mit einem Blatte Halbseidenpapier und bringt ihn in die lithographische Presse behufs Uebertragung des Aetzgrundes auf Papier; auf diese Weise können von dem Steine eine beliebige Anzahl Abdrücke hergestellt werden. Hierauf erfolgt die Uebertragung des Abdruckes von Papier auf Glas; man legt das Papier mit der nicht bedruckten Seite auf ganz verdünnte Salzsäure, bis das Papier durchdrungen ist, breitet es hierauf mit der bedruckten Seite auf der Glasplatte vollkommen eben aus und entfernt das Papier durch vorsichtiges Abziehen, wodurch der Aetzgrund in Folge seiner klebenden Beschaffenheit auf dem Glase haften bleibt und die betreffenden Stellen vor der Einwirkung der Fluorwasserstoffsäure schützt.

Tessié du Mothay und Maréchal verwenden als Aetzbad eine Lösung von 250 Gramm Fluorwasserstoff-Fluorkalium und 250 Gramm käufl. Salzsäure in 1 Liter Wasser, Siegwart eine Lösung von 8 Thl. Fluorkalium, 1 Thl. Schwefelsäure in 100 Thl. Wasser.

Handelt es sich um die Herstellung grösserer matter Flächen, so wendet man häufig die directe Aetzung mittelst eines breiförmigen Gemisches von Flussspath und Schwefelsäure an; man erhält so mattirte Flächen, welche viel zarter und gleichförmiger sind, als dieselben durch Schleifen hergestellt werden können; besonders geeignet ist diese Methode zur Herstellung der matten Scheiben für die Camera obscura.

Um ganze Flächen zn mattiren werden diese nach $\mathrm{P} . \mathrm{W}$ e is k o $\mathrm{pf} * *)$ ca. $5^{\mathrm{mm}}$ hoch mit einem dünnen Teige von feingepulvertem Flussspath und concentrirter Schwefelsäure bestrichen, kleinere oder runde Gegenstände ganz eingehüllt, in einem eisernen Topf, dessen Boden mit Gyps oder Kreide belegt ist; durch zwei Stunden gelinde erhitzt, damit alle überschüssige Flusssäure abzieht. Das Ende der Operation erkennt man daran, dass sich die Dceke der Platte vollständig in harten Gyps verwandelt hat und sich nach dem Abkïhlen leicht und vollständig ablösn. Die Platten werden sodann in verdiinnter Aetzkalilauge und darauf in Wasster einigemal gewaschen, worauf die geätzten Stellen rein und intensiv matt erscheinen.

Will man Glasflächen nicht ganz matt, sondern nur eisartig glänzend (bes. fiir Fenster) herstellen so legt man die Glasscheibe vollständig horizontal, bedeckt dieselbe mit einer Lage sehr feiner Schrottkörner und ätzt nun mit stark verdïnnter Flusssäure; die Schrottkörner wirken als Deckgrund und bringen so auf dem Glase erhabene Punkte hervor.

Photographien lassen sich nach E. Siegwart (Dingl. polyt. Journal 190 pag. 426, 220 pag. 479; auf Glas ätzen, wenn die mit einer Chrom-Gelatine-

*) Vergl. Kessler, Dingl. polyt. Journ. 170 pag. 217 und 185 pag. 222 . Tessié du Il othay und Maréchal, Dingl. pol. Journ. 181 pag. 213. E. Siegwart, Dingl. pol. Journ. 199 pag. 222. M. Hock, Dingl. pol. Journ. 215 pag. 129.

**) S. Dingl. polyt. Journ. 206 pag. 469. 
schichte präparirte Platte dem Lichte exponirt, nach der Belichtung mit feinem Flussspathpulver bestreut (welches nur an den vor dem Lichte geschuitzten Stellen haftet), mit Rohcollodium iberzogen und hierauf in verdünte Schwefelsäure gebracht wird.

Zum Mattätzen und Mattschreiben mit der gewöhnlichen Feder empfiehlt Kessler eine Lösung von Fluorammonium.

Siliciumfluorid (Fluorkiesel, Fluorsilicium) SiFl 4 wird erhalten, wenn man ein Gemenge aus gleichen Theilen Flussspath und gepulvertem Quarz oder Sand mit 8 Thl. concentrirter Sehwefelsäure erwärmt:

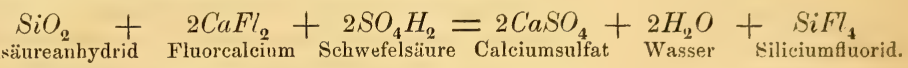

Das schon bei gelinder Erwärmung sich reichlich entwickelnde Gas muss iiber Quecksilber aufgefangen werden, da es von Wasser augenblicklich zersetzt wird. Es ist ein farbloses Gas von stechend saurem Geruche und Geschmacke, das an feuchter Luft starke Nebel bildet. Das spec. Gewicht des Gases nach $\mathrm{D}$ avy $=3.574$; bei einer Temperatur von $-106^{\circ} \mathrm{C}$. und einem Drucke von 9 Atmosphären zu einer farblosen leicht beweglichen Fluissigkeit verdichtbar.

Wird das Gas in Wasser geleitet, so findet Zersetzung desselben unter Abscheidung von gallertartiger Kieselsäure und Bildung von Kieselfluorwasserstoffsäure statt.

$$
\underset{\text { Siliciumfluorid }}{3 \mathrm{SiFl}_{4}}+\underset{\text { Wasser }}{4 \mathrm{H}_{2} \mathrm{O}}=\underset{\text { Kieselsäure }}{\mathrm{SiO}_{4} \mathrm{H}_{4}} \underset{\text { Kieselfuorwasserstoffsäure. }}{2 \mathrm{SiFl}_{6} \mathrm{H}_{2}}
$$

Die Kieselflu orwasserst offsäuré oder Kieselflussäure bildet eine farb- und geruchlose sehr saure Flïssigkeit, welche bei gewöhnlicher Temperatur nicht auf Glas wirkt, dasselbe jedoch bei höherer Temperatur, unter Rückbildung von Siliciumfluorid, angreift.

Die Kieselfluorwasserstoffsäure kann betrachtet werden als Kieselsäure von der Formel $\mathrm{SiO}_{33} H_{2}$, in welcher die drei zweiwerthigen Sauerstoffatome durch sechs einwerthige Fluoratome vertreten sind oder auch als Verbindung von Siliciumfluorid mit Fluorwasserstoff $\mathrm{SiFl}_{4}+2 \mathrm{HFl}$.

Die Kieselfuormetalle, durch Vertretung von Wasserstoff durch Metallatome entstanden, sind, mit Ausnahme des Kalium- und Baryumsalzes, in Wasser mehr oder weniger leicht löslich, einige auch krystallisirbar.

Ausser in der analytischen Chemie, in welcher die Kieselfuorwasserstoffsäure zur Erkennung der Kalisalze, Trennung der Baryum- und Strontiumsalze dient, ist dieselbe auch zur Entfernung der Alkalisalze aus Rübenmelasse empfohlen worden.

Näheres über Fluor, Fluorwasserstoff, Siliciumfluorid und Kieselfluorwasserstoffsäure siehe: Graham-Otto's ausführliches Lehrbuch der Chemie 2. Band 1. Abtheilung pag. $798-809$ und pag. 991-996.

K. Weis.

Fluorborsäure. Borfluorwasserstoffsäure, s. Bor I pag. 731

Fluoren, Name eines von Berthe lot in dem zwischen 300 und $340^{\circ} \mathrm{C}$. sied. Antheile des Steinkohlentheeres entdeckten, stark fluorescirenden Kohlenwasserstoffs, der nach B a rbier (Ber. d. d. chem. Ges. 1873 pag. 1264) bei $113^{\circ} \mathrm{C}$. schmilzt und der Formel $C_{13} H_{18}$ entspricht. Gtl.

Fluorescëin (fluoresceine) d. i. Resorcin-Phtalëin. Durch Einwirkung von wasserfreier Phtalsäure auf Resorcin beim Erhitzen auf $195^{\circ}$ C. entstehend, lässt es sich mittels Alkohol aus der Masse ausziehen und krystallisirt aus der Alkohol-Lösung, in Gestalt kleiner, zu Krusten vereinigter Kryställchen von dunkelbrauner Farbe. In Kalilauge lösen sich die Krystalle auf und aus der Lösung fällt durch Säurezusatz das Fluorescëin in Gestalt eines ziegelrothen Pulvers. Die Zusammensetzung entspricht der Formel $C_{40} H_{14} O_{6}$ oder $C_{20} H_{12} O_{5}$. Mit Schwefel- 
säure stark erhitzt liefert es bei Zusatz von Wasser einen rothen pulverigen Niederschlag, der sich in Alkalien mit blauer Farbe löst. Die Lösung liefert mit Zinkstaub eine Küpe mit der sich wie mit einer Indigoküpe blaufärben lässt. Doch sind die erzielbaren Farbentöne weder schön noch echt, (vgl. a. Eosin III pag. 277 , s. Ba eyer, Ber. d. d. chem. Gesellsch. 1871 pag. 558 u. 622, s. d. Ann. d. Chem. 1876,183 pag. $1-74$, s. a. Resorcinfarben). K r üg e r hat das Fluorescëin neuestens als Indicatorsubstanz für Maassanalyse vorgeschlagen, (vgl. Ber. d. d. chem. Gesellsch. 1876 pag. 1572). Gtl.

Fluorescin ist das Reductionsproduct des Fluorescëins, welches aus diesem durch Behandlung mit Zinkstaub in alkalischer Lösung erhalten werden kann.

Fluorescenz s. Licht.

Fluorid syn. m. Fluormetall.

Fluorit, Fluss spath, Flus s, Flöss der alten Bergleute, (chaux fluatée fluor spar, fluorite), krystallirt tesseral zumeist im Hexaeder oder Octaeder, aber auch im Rhombendodekaeder, Tetrakontaoctaeder, sowie in mancherlei Combinationen. Die in der Regel schön ausgebildeten, grossen Krystalle finden sich einzeln oder in Gruppen und Drusen, auch oft in sehr regelmässiger paralleler Verwachsung (Treppenoctaeder), Zwillinge nach einer Octaederfläche sind häufig. Auch derb, in grobkörnigen oder stängligen Massen, sowie dichte und erdige Varietäten finden sich. Spaltb. octaedrisch vollk. Bruch muschlig selten sichtbar, spröde. $H=4$, spec. Gew. 3.1-3.2, im reinsten Zustand wasserhell, gewöhnlich gefärbt in allen nur denkbaren Farben und Nuancen, auch nicht selten zwei- und mehrfach verschieden gefärbte Krystalle, daher auch von den Bergleuten "Erzblume oder Erzblïthe" genannt. Die Farbe soll von einer Beimengung von Kohlenwasserstoff herrithren, da sie beim Glühen verschwindet. Pulverisirt oder schon in gröberen Stiicken auf Platinblech erhitzt phosphoresciren die Flussspäthe lebhaft. Chem. Zus. $\mathrm{CaFl}_{2}=51.3$ Calcium und 48.7 Fluor. Zerknistert v. d. L. phosphorescirt und schmilzt nur in dünnen Splittern zu einem unklaren Email, wobei sich die Flamme röthet. Mit Gyps schmilzt er zu einer klaren Perle, welche erkaltet trüb wird. Von conc. Schwefelsäure wird er unter Entwicklung von Flusssäure vollständig zersetzt, in Salzsäure und Salpetersäure löst er sich schwer. Ist ein häufiger Begleiter von Erzen, z. B. von Zinnerzen zu Schlaggenwald, Zinnwald, Ehrenfriedendorf in Cornwall, auf Silbererzgängen in Weipert, Annaberg, Freiberg, Rongsberg, auf Bleigängen an vielen Orten in England, auch mit Rotheisenstein und Spatheisenstein findet er sich, bildet auch für sich oft ziemlich mächtige Gänge wie zu Wölsendorf im Bairischen Wald, Rothleberode am Harz u. a. a. 0. Eine eigenthümliche Varietät des Flussspathes ist der zu Wölsendorf in Baiern vorkommende "Stinkflussspath oder Antozonit." Er ist derb, dunkelblau bei schwarzblau, oft stänglig, und entwickelt beim Stossen oder Schlagen, noch mehr beim Zerreiben einen eigenthümlichen Geruch, welchen Schönbein als von Antozon herrührend erklärt, während nach anderer Ansicht dieser Geruch von einem Kohlenwasserstoff-Gehalt herrühren soll.

Der im Granit von Kararfoedt und Broddbo bei Falun sowie bei Amity in New-York, N.-A., vorkommende Yttrocerit, welcher violetblaue Ueberzïge und Krusten im Gestein bildet, besteht aus Fluorcalcium mit einem Gehalt von Fluorcerium und Fluoryttrium.

Der Flussspath findet mancherlei Verwendung in der Technik. Von Alters her findet er Anwendung als Zuschlag zum Schmelzen strengflüssiger Erze, sowie beim Probiren der Erze. El dient zur Erzeugung der Flusssäure, als Zusatz bei der Bereitung von Glasuren und Emailen. Die schöngefärbten englischen Flussspäthe werden zu Platten geschnitten, womit allerlei Luxusgegenstände belegt werden, auch werden ganze Ornamente und verschiedene Geräthe daraus gefertigt 
(Sparstone-Ornaments). Als Ringstein wird er seiner geringen Härte wegen nur selten verschliffen, und muss ir letzteren Falle mit einer Glas- oder Krystalldoublette versehen werden. Einige Archaeologen vermuthen, dass die von den Alten hochgeschätzten murrhinischen Gefässe (Vasa murrhina) aus Flussspath gemacht waren.

Lb.

Fluormetalle, Flu oride vgl. Fluor s. b. d. einz. Metallen.

Fluorwasserstoff s. Fluor III pag. 602.

Fluss syn. m. Fluorit.

Fluss, Flussmittel (fondant - flux), nennt man bei metallurgischen Processen im Allgemeinen Körper, welche man bei Schmelzoperationen den zu schmelzenden Stoffen zusetzt, um leicht schmelzbare Schlacken zu erzielen. In diesem Sinne dienen Flussspath, Borax, Glas oder sonstige Silicate als Fltisse. Den Namen Flus speciell führen aber auch besondere Flussmittel, die neben dem Zwecke als Verfliissigungsmittel zu dienen noch die besondere Aufgabe haben Reductions- oder Oxydationswirkungen auszuiuben.

Solche Flussmittel sind:

a) Der schwarze Fluss (flux noir - black flux), d. i. ein Product, welches durch Verpuffen eines innigen Gemenges von circa 2-3 Thl. Rohweinstein mit 1 Thl. Salpeter erhalten wird und eine schwarze Masse darstellt, welche wesentlich aus kohlensaurem Kali, fein vertheilter Kohle, etwas Cyankalium nebst geringen Mengen von kohlens. Kalk (aus dem Kalkgehalte des Rohweinsteins), Chlormetallen und schwefelsauren Salzen, oft auch brenzlichen Zersetzungsproducten der Weinsteinsäure besteht. Derselbe wirkt als reducirendes Flussmittel, und kann, je nachdem eine kräftigere oder weniger kräftige Reduction gewünscht wird, durch Aenderung des Mischungsverhältnisses von Weinstein und Salpeter variirt werden. So erhält man bei Anwendung von 2 Weinstein auf 1 Salpeter eine Masse von etwa 5 Proc. Kohlenstoffgehalt, von $2 \%$ Weinstein auf 1 Salpeter, von etwa 8 Proc. Kohlenstoffgehalt, von 3 Weinstein auf 1 Salpeter von etwa 12 Proc. Kohlenstoffgehalt und im Verhältnisse der Zunahme des Kohlenstoffgehaltes auch kräftiger reducirende Wirkung.

b) Grauer Fluss (flux gris - grey flux) ist ein Product der Verpuffung von 3 Thl. Weinstein mit 2 Thl. Salpeter, ist wesentlich ärmer an Kohlenstoff als der schwarze Fluss.

c) Weisser Fluss (flux blanc - white flux) wird erhalten durch Verpuffen eines Gemenges von 1 Thl. rohem Weinstein mit 1 bis 2 Thl. Salpeter. Er enthält vornehmlich kohlensaures Kali neben salpetrigsaurem und salpetersaurem Kali, dann geringen Mengen ron kohlens. Kalk (aus dem Kalkgehalte des Rohweinsteins) etwas an Chlormetallen und schwefels. Salzen. Er dient wegen seines Gehaltes an salpetrigsauren und salpetersauren Salzen als oxydirendes Flussmittel.

Diese Gemenge sind um so wirksamer, je vollkommenerer die Mischung: von Weinstein und Salpeter war. Sie miissen, da sie grosse Neigung haben Feuchtigkeit anzuziehen, in gut rerschlossenen Gefässen auf bewahrt werden.

Mit dem Namen Schnellfluss bezeichnet man eine von Ba ué angegebene Mischung aus 3 Thl. Salpeter, 1 Thl. Schwefel und 1 Thl. Sägespänen (von einem harzigen Holze), welche Metalle, die leicht in Schwefelmetalle rerwandelt werden können (Kupfer, Silber etc.), rasch zum Schmelzen bringt, indem sie dieselben in leicht flüssige Schwefelungstufen überfiihrt.

Fluss nennt man übrigens auch den Zustand der Verfliissigung fester Körper und unterscheidet in dieser Beziehung wohl auch zwischen wässrigem Fluss, 
d. i. das Schmelzen z. B. eines wasserhältigen Krystalls in seinem Krystallwasser, und feurigem Fluss, d. i. die Verflüssigung eines starren Körpers im Feuer, z. B. eines wasserfreien Salzes, eines Metalls u. s. w., vergl, anch Schmelzen. Gtl.

Flussbau, s. Was serbati.

Flusseisen, s. Eisen II pag. 771 und 777.

Fluss Mainzer syn. mit Strass, s. Glas.

Flussmittel s. F lus s.

Flusssäure syn. Fluorwasserst off, s. Fluor III pag. 602.

Flussschifffahrt, s. Schiff a hrt.

Flussspath s. Fluorit.

Flussstahl s. Eisen II pag. 778.

Flussstein s. Fluorit.

Fluxion ist der Grenzwerth, welchem sich das Verhältniss der Aenderung einer Function, zu der sie herbeifuihrenden Aenderung der unabhängigen Variablen, nähert, wenn letztgenannte Aenderung ohne Ende der Nulle zustrebt, also der sog. erste Differentialquotient oder die derivirte Function, welche ein Mass für die Aenderungsgeschwindigkeit der Function abgibt. $C z$.

Flyer, s. Baumwollspinnerei I pag. 345.

Flysch s. Wiener Sandstein.

Focus syn. m. Brennpunkt, s. b. Linsen, vgl. Licht.

Föhrenholz, Kiefernholz ( pin - fir), das Holz der Kiefer oder Föhre (Pinus silvestris); es ist meist röthlich gelb, an den Rändern der Jahrringe rothbraun, im Splinte weiss. Es gehört zu den weichen Hölzern, zeichnet sich jedoch durch seinen Harzreichthum aus, daher es anch in der Nässe dauerhaft ist und besonders gerne als Materiale zu Fensterrahmen, ferner auch zu Brunnenröhren beniitzt wird. Das Kienholz ist das besonders harzreiche Holz der Wurzeln der Föhre. Das Holz der Weymouthskiefer (Pinus strobus) ist sehr brichig und minder harzreich, daher nicht so verwendbar. $K k$.

Förderschacht, s. Bergbau I 387 .

Förderung, s. Bergbau I pag. 402, 407.

Folie (paillon, feuille - foil), dünnstes Blech, u. z. Silber- oder plattirtes Kupferblech, bei dem Fassen der Edelsteine in Gebrauch, und die Zinnfolie zur Belegung der Spiegel. Vgl. Goldarbeiten u. Spiegel. Kk.

Fonçirmaschine, Giundirmaschine II pag. 166.

Fontaine, s. Springbrunnen.

Fontaine-Pulver, s. Explosirst offe III pag. 339.

Forcherit, s. 0 pal.

Forellenstein, Forellenschiefer, s. Granulit.

Forlenholz, syn.m. Föhre nholz. 
Form (tuyère - twyer) s. Eis enerzeugung III pag. 8 und 17.

Form (moule - mould), s. Eisengiesserei III pag. 123, s. f. den Artikel Galvanoplastik, s. Glas.

Formaldehyd, Methylaldehyd ist der Aldehyd der Ameisensäure, der im reinen Zustande ein Gas darstellt, von der Formel $\mathrm{CH}_{2} \mathrm{O}$. Er liefert leicht Condensationsproducte. Zunächst entsteht der Paraformaldehyd $\mathrm{C}_{3}^{\prime} H_{6}()_{3}$, welcher eine krystallinische weisse Masse liefert, die unter $100^{\circ}$ C. sublimirt und bei stärkerem Erhitzen sich in drei Molekiile Formaldehyd spaltet. F. reducirt in einer schwach ammoniakal. Silbernitratlösung das Silber als metallglänzenden Spiegel und ist ïberhaupt ein energisch wirkendes Reductionsmittel, vgl. Aldehyd I pag. 84, s. a. Methylalkohol. Gtl.

Formamid, d. i. das Amid der Ameisensäure $\left(\mathrm{CHNH}_{2} \mathrm{O}\right)$, vgl. A mi de I pag. 130.

Formanilid, d. i. das Anilid der A meisensäure $\left(\mathrm{COH} \mathrm{NHC} \mathrm{CH}_{5}\right)$, rgl. Anilide I pag. 151.

Formatsalz, s. m. Blocksalz („Balwani"), s. Natrium b. Steinsalz.

Formen, s. m. Methylen s. d.

Formen, s. Eisengiesserei III pag. 123.

Formflasche, Formkasten, s. Eisengiesserei III pag. 124.

Formiate syn. m. ameisensaure Salze, s. Ameisensäure I pag. 128.

Formmaschinen. Jene Vorrichtungen, welche man unter diesem Namen begreift, haben die Aufgabe das Formen zu erleichtern, und sind meist auch nichts weiter, als mechanische Vorrichtungen, welche das Herausziehen der Modelle aus dem im Formkasten befindlichen Formsande ausführen, während das Einstampfen des Sandes nach wie vor Handarbeit ist. Für diesen Zweck genügt aber meist die im Artikel Eisengiesserei besprochene Anwendung der Modellplatten, so dass nur bei Massenfabrikation die Anwendung dieser Maschinen zu empfehlen ist. Näheres hierüber s. Dingl. polyt. Journ. Bd. 167, pag. 1-9; vergl. ferner Art. Röhrengiesserei. $K k$.

Formonitril syn. m. Cyanwasserstoff, s. Cy an II pag. 458, iibrig. auch syn. mit Carbylamin, s. II pag. 255, vgl. Cy a n II pag. 460.

Formplatten, s. B a umwolls pinnerei I. pag. 360 .

Formsand (sable de moulage - moulding-sand), ist bei Eis engiesserei III pag. 123 etc. in Bezug auf seine Anwendung besprochen. Hier sind noch dessen wesentliche Merkmale anzugeben. Guter Formsand soll sowohl den Druck des geschmolzenen Metalles, als die bedentende Erhitzung aushalten kömnen, und den beim Gusse entstehenden Gasen und Dämpfen den Durchgang gestatten. Die Merkmale guten Formsandes sind: Er soll dem Auge in der Korngrösse ziemlich gleichförmig erscheinen, anf $80-90$ Theile gröberen Kornes nur 10 bis 20 Theile feinen Kornes enthalten; er soll sich wenig scharf anfiihlen; er soll im trockenen Zustande nur sehr wenig staubige Theile enthalten; er soll mit 10-20 Proc. Wasser angemacht sich ballen lassen; die Ballen, welche man durch Drücken in der Hand bildet, sollen beim Fallen aus geringer Höhe auf Sand nicht zerfallen, aber sie sollen sich doch leicht brechen und zerdriicken lassen; endlich soll er sich wiederholt verwenden lassen. 
In letzterer Beziehung ist Quarzsand für die Eisengiesserei, Tuff für Bronzeguss vorziiglich. Feldspathsand zerspringt nach dem ersten Gusse in feine Theilchen und ist nicht verwendbar. (Verbrannter Sand.) Man findet selten in der Natur vollkommen verwendbaren Formsand. Meist muss man durch Sieben den gegrabenen Sand von den zu groben Steinchen befreien, oft auch muss durch Anwendung von Kollergängen (s. d.) eine entsprechende Verkleinerung derselben erzielt werden. Reiner Quarzsand hat, wenn auch gefeuchtet, zu wenig Bindekraft und muss in diesem Falle für Eisenguss mit ca. 2 Proc. Thon oder 4 Proc. Lehm gut gemischt werden, während Roth-, Gelb- und Bronzeguss eines grösseren Lehmzusatzes bedürfen.

Für Eisenguss findet zum Formsande ein Zusatz Kohlenpulver (Holz oder Steinkohle) statt, welcher die Eigenschaft hat, fetten Sand magerer und mageren Sand fetter zu machen. Vgl. die Artikel Masse und Sand. $K k$.

Formschneiden, Formstechen, s. Modelstechen, s. Holzschnitzen.

Formyl, Radikal der Ameisensäure, die demnach auch den Namen F o rmyls äure führt. Entspricht der Formel $C H O$.

Formylchlorid syn. Chlor of orm II pag. 330 .

Formylhydrür syn. mit Formaldehyd.

Formylsäure, s. A meisensäure I pag. 127.

Formyltrichlorid (Formylsuperchlorid), syn. Ch 1 or o for m, s. d. II pag. 330.

Forsterite, Min.-Varietät des Olivins aus alten Vesuvlaven vom Monte Somma, ist Eisenoxydul haltiges Magnesiumsilicat $\left(\mathrm{Mg}_{2} \mathrm{SiO}_{4}\right)$. $\mathrm{Gtl}$.

\section{Forstwirthschaft und Forstwissenschaft.}

I. Forstwirthschaft:

Der Wald soll einerseits bestimmte Producte - Holz (Hauptnutzung) und Rinde, Baumsäfte, Streu, Gras, Wild etc.(Nebennutzungen) - liefern, andererseits gewisse Einflüsse in klimatischer Hinsicht (Temperatur, Wind, Feuchtigkeit, Wasserstand der Quellen und Flüsse etc.) ausiiben. Möglichst vollkommene und dabei mit möglichst geringem Aufwand verbundene Erreichung dieser Ziele ist die Aufgabe der Forstwirthschaft.

In der Productenerzeugung ist das eigentlich privatwirthschaftliche Element der Waldwirthschaft gegeben, während hinsichtlich der Wirkung des Waldes auf Boden und Klima nicht der einzelne Besitzer (Staat, Gemeinde, Private etc.) allein und nur nach den eigenen Interessen entscheiden kann, sondern die Gesammtheit massgebend wird. Hieraus resultirt das Recht wie die Pflicht des Staates, durch die Gesetzgebung jene klimatischen Einfliisse des Waldes sicher zu stellen, eventuell zu schaffen - Staatsforstwirthschaft, (Waldschutzgesetze, Bildung von Waldgenossenschaften etc.). Eine, wenn auch innerhalb möglichst enger Grenzen zu haltende Beschränkung der freien Verfügung des Waldbesitzers über sein Eigenthum ist unvermeidich.

Die Productenernte setzt das Vorhandensein von Holzbeständen, bez. deren Begründung, Erziehung, Pflege und Beschützung voraus.

Der zur Productenerzeugung erforderliche Productionsfonds, welcher, wie in jeder Wirthschaft, auf eine relativ geringste Grösse reducirt werden soll, besteht hauptsächlich in dem Bodencapital, sowie einem Capital, aus dessen Zinsen die Culturkosten und die jährlichen Ausgaben für Verwaltung, Steuern etc. bestritten werden; handelt es sich um Waldungen, welche im sog. Nachhaltbetriebe bewirthschaftet werden, d. h. um solche, von denen man jährlich eine Nutzung verlangt, so tritt als wesentlicher, dem absoluten Betrag nach oft bedeutendster Factor ein bestimmtes Holzrorrathscapital hinzu, dessen Zins, neben den Zinsen 
der ïbrigen Productionscapitalien, in der jährlichen Nutzungsgriosse enthalten sein muss. -

Die Thätigkeit des Forstwirthes hat hiernach zunäclist zu bestehen in der Sorge fuir möglichste Steigermng des Waldertrags nach Masse und Werth der Producte bei gleichzeitiger Beschränkung des Productionsaufwandes, so dass dic Rentabilität des ganzen Betriebs die grösstmögliche wird. Dabei ist Sicherheit und Zuverlässigkeit des Ertragsanfalles, eine gewisse Stabilität und Nachhaltigkeit der Nutzungen zu erzielen.

Wie sich diese Thätigkeit im Einzelnen äussert, erhellt aus einer Uebersicht über die verschicdenen Disciplinen der Forstwissenschaft, welch' letztere, ganz allgemein, die systematisch geordneten Regeln der Forstwirthschaft begreift.

\section{Forstwissenschaft:}

Während man in frïhester Zeit (conf. z. B. des Tacitus Germania) in Mitteleuropa, speciell in dem jetzigen Deutschland und Oesterreich, Wald in Ueberfluss hatte, so dass ausser der den jeweiligen Bedarf befriedigenden Nutzung vorhandener Vorräthe kaum eine Verrichtung in den Forsten vorzunelimen war, gesellte sich bald - als Folge der Verminderung dieser Vorräthe und gleichzeitiger Vermehrung des Ackergeländes - die Sorge für Begründung neuer Bestrinde an Stelle der abgetriebenen, hinzu; die Vorstellung von der Unerschöpflichkeit der überkommenen Holzmassen musste sich mit der Zeit verlieren, die Pflege und Beschützung des Waldes, eine mehr und mehr ausgeprägte Regelmässigkeit der "Wirthschaft" gewann als Ersatz planloser Angriffe auf die Substanz der Forste allmälig Boden, und in stetem Fortschreiten bildeten sich diejenigen Wirthschaftsgrundsätze heraus, welche heute massgebend sind:

Conf. Bernhardt: Geschichte des Waldeigenthums, der Waldwirthschaft und Forstwissenschaft in Deutschland. 3 Bde. Berlin $1872-1875$.

Das Erstehen einer Forstwissensehaft fällt zusammen mit der Begründung einer eigentlichen Forstliteratur; energische Anfänge beider datiren erst aus der Mitte des 18. Jahrhunderts.

Seit dem Beginne des 19. Jahrhunderts ist die forstliche Literatur stattlich angeschwollen. Ein ständiger Meinungsanstausch wird durch zahlreiche Fachzeitschriften vermittelt, wie u. a.:

Die allgemeine Forst- und Jagdzeitung (red. Heyer in Münden), die Monatschrift für Forst- und Jagdwesen (Baur in Hohenheim), die Zeitschrift fiir Forst- und Jagdwesen (Dankelmann in Eberswalde), das Tharander Jahrbuch (Judeich in Tharand), das Centralblatt für das gesammte Forst- und Jagdwesen Hempel in Wien).

Zur Orientirung der Leser bringen alle diese Zeitschriften periodische Zusammenstellungen der literarischen Erscheinungen.

Eine gedrängte Uebersicht uiber das gesammte Gebiet der Forstwissenschaft gibt der Grundriss zu Vorlesungen iber Encyklopädie der Forstwissenschaft ron Dr. R. Hess, Giessen 1873, dessen einzelnen Abschnitten Literaturnachweise beigefügt sind; die wichtigsten forstlichen Werke finden sich sämmtlich darin rerzeichnet.

Man theilt die Forstwissenschaft sachgemäss in Productionslehre und Gewerbelehre. Erstere umfasst als Disciplinen den Waldban Forstproductenzucht), den Forstschutz (Sicherung der Waldungen gegen Gefahren), die Forstbenutzung (Nutzbarmachung der Forstproducte); die Gewerivelehre setzt sich zusammen aus der Ertragsregelung, Waldwerthrechnung und Statik, sowie der forstlichen Hanshaltungskunde.

1. Der Waldbau befasst sich im Wesentlichen mit der Begriindung und Erziehung der Bestände, wobei in den weitaus meisten Fällen das ITolz als dis Hauptproduct massgebend ist. 
Conf. in Betreff des Gesammtgebietes dieser Disciplin Heyer Dr. Carl: Der Waldbau oder die Forstproductenzucht. 3. Aufl. ed. Gustav Heyer, Leipzig 1877.

Der Wald setzt sich aus Boden und Holzbestand zusammen. Zwischen beiden bestehen mannigfache Wechselbeziehungen, aus denen sich die wichtigsten Regeln des Waldbaues ergeben.

Nächst dem Boden sind für das Gedeihen der Bestände die Lage (Meereshöhe, Exposition, geographische Breite etc.) und das Klima entscheidend.

Als Grundlage für eine wissenschaftliche Behandlung des Waldbaues muss hiernach erstlich specielle Kenntniss der Bodenkunde und Klimatologie, dann der Forstbotanik (der einzelnen Waldgewächse und ihres Verhaltens unter einander), sowie endlich des gegenseitigen Einflusses von Standort und Gewächsen vorausgesetzt werden.

Conf. Heyer Dr. Gustavi: Lehrbuch der forstl. Bodenkunde und Klima tologie, Erlangen 1856; Lorenz und Rothe: Lehrbuch der Klimatologie, Wien 1874; Döbner: Lehrbuch der Botanik für Forstmänner, Aschaffenburg 1865.

A. Anzucht der Hauptnutzung, des Holzes:

Die Holzbestände werden zunächst begrïndet und zwar natürlich (durch Besamung seitens des vorhandenen Bestandes oder durch Ausschlag, z. B. Stocklohden etc.) oder künstlich (mittelst Saat oder Pflanzung); dann sind die Bestände geeignet zu erziehen, zu welchem Ende insbes. Ausjätungen und Läuterungshiebe, Durchforstungen, Aufastungen, Unterpflanzungen etc. zu erfolgen haben.

Conf. Burckhardt: Säen und Pflanzen nach forstlicher Praxis, Hannover bei Rïmpler.

B. Die Anzucht der Nebennutzungen erfolgt meist gleichzeitig mit der Holzzucht; nur in besonderen Fällen ist sie Hauptzweck der Wirthschaft, wie die Anzucht der Lohrinde im Eichenschälwald, des Wildes in Thiergärten. Nächst diesen sind Gras, Samen, Futterlaub, Baumsäfte (z. B. Harz), landwirthschaftliche Gewächse (Waldfeldbau), Torf ete. zu beachten.

Der Anzucht der Forstproducte coordinirt steht im Waldbau:

C. Die Lehre von den forstlichen Betriebsarten, welche für Technik und Gewerbe insofern von Bedeutung werden, als durch die Wahl der Betriebsart (Hochwald, Mittelwald, Niederwald in ihren verschiedenen Formen) hauptsächlich die Gewährung der verschiedenen Nutzholzsortimente bedingt ist.

2. Der Forstschutz ibernimmt die Aufgabe, drohende Gefahren aller Art rom Walde fern zu halten und hereingebrochene auf ein Minimum zu reduciren.

Nach rer Art dieser Gefahren gliedert sich das ganze Gebiet in den Schutz gegen die organische und den Schntz gegen die anorganische Natur. In ersterer Hinsicht hat man den Wald zu rertheidigen gegen Menschen (Servituten, Forstfrevel), Thiere (Säugethiere, Vögel und insbes. In secten) und Pflanzen (Forstunkräuter, Pilze); in letzterer kommen u. a. Frost, Hitze, Wind, Schnee, Eis, Ueberschwemmungen, Feuer etc. zur Sprache.

Aus der genauesten Kenntniss des Cebels sind in jedem Falle die Vorbeugungsmittel und die Massregeh zur Bekämpfung abzuleiten.

Conf. Grebe Dr. C.: Waldschutz und Waldpflege als 3. Aufl. von Königs Waldpflege, Gotha 1875; Hess Dr. R. Der Forstschutz 3 Lieferungen 1876 bis 1878; Altum: Forstzoologie 3 Bde. Berlin 1872-1875; Hartig Robert: Die durch Pilze erzeugten Krankheiten der Waldbäume.

3. Die Forstbenutzung umfasst im weitesten Sinne (einschliesslich der Forsttechnologie) die systematisch geordneten Regeln für die Ernte, Aufbewahrung, Verwendung, Verwerthnng, Veredelung und den Transport aller Forstproducte.

Conf. Gayer Carl: Die Forstbenutzung 4. Aufl. Berlin 1876 (das ganze Gebiet begreifend). Zahlreiche Literaturnachweise enthält Hess Dr. R. Grundriss zu Vorlesungen über Forstbenutzung 1876. 
In diese Disciplin gehören also die in gewerblich-technischer Hinsicht jedenfalls wichtigsten 'Theile der Forstwirthschaftslehre. Bekanntschaft mit den Anforderungen der holzverbrauchenden Gewerbe ist ebenso unerlässliche Vorbedingung eines rationellen Ausnutzungsbetriebes, wie die Kenntniss der Eigenschaften des Holzes; letztere sind für dessen technische Verwendung ausschlaggebend (Farbe, Härte, Schwere, Dichte, Festigkeit, Elasticität etc. je nach Holzart, Alter, Zustand etc.)

Conf. Nördling e r: Die technischen Eigenschaften der Hölzer, Suttgart 1860.

Die Forstbenutzung im engeren Sinne behandelt

A. Die Ernte der Forstproducte, zunächst des Holzes (Holzhauereibetrieb), dann der Nebennutzungen, wie insbesondere der Lohrinde (conf. Neubrand: Die Gerbrinde, Frankfurt a. M. 1869; Hartig Theodor: über den Gerbstoff der Eiche und Wohmann, Neubauer und Lotichius: Die Schälung der Eichenrinde mittelst Dampf), des Harzes (conf. Grebe: Die neuere Harznutzung im Thüringer Walde, und B urckhardts "Aus dem Walde", Heft 1, 1865), des Futterlaubes, der Banmfrüchte, des Waldgrases, der Waldstreu (conf. E b e rmayer: Die gesammte Lehre von der Waldstreu, Berlin 1875), des Torfs, von Steinen und Erde, Seegras, Grassamen, Beeren etc.

Es gehört hierher auch der Betrieb der Jagd und Fischerei.

B. Der Transport der Forstproducte kann entweder zu Land oder zu Wasser stattfinden. Es handelt sich um das Verbringen derselben von dem Orte ihrer Gewinnung an den Ort ihrer Consumtion, zumeist nur, soweit dieser Transport innerhalb der Waldgrenzen erfolgt.

In die Lehre vom Landtransport ordnet sich naturgemäss der gesammte Waldwegbau ein.

Conf. Schuberg: Der Wald wegbau, 2. Bde. 1873 und 1875

Ausserdem kommen die charakteristischen Bringungsanstalten der Gebirgsforstwirthschaft (Holzriesen, Flösserei etc.) in diesem Abschnitte zur Besprechung.

C. Die A ufbewahrung und Verwerthung der Forstproducte.

Zur Forstbenutzung im weiteren Sinne gehören die Verwendung und Veredelung der gewonnenen Producte - Forsttechnologie.

Dieselbe umfasst die Veredelung des Holzes und der Nebenproducte. Zu ersterer gehört das

Imprägniren (conf. Buresch: Preisschrift iiber verschiedene Verfahrungsarten und Apparate, Dresden 1860; Nepomuck: Mittheilungen iiber Holzimprägnirung auf der Kaiser Ferdinand-Nordbahn, Wien 1874; v. Berg: über das Verfahren von Boucherie, allgem. Forst- und Jagdzeitung von 1858 und 1861), der Betrieb der Waldsägemühlen und Dampfsägen, die Anwendung sonstiger Holzbearbeitungsmaschinen, die Köhlerei (conf. v. Berg: Anleitung zum Verkohlen des Holzes, 2. Aufl. Darmstadt 1860), die Pottaschesiederei.

Als Verwendung und Veredelung von Nebenproducten sind zu nennen u. a.:

Die Theerschwelerei, Pechsiederei, Kienrussbrennerei, der Samenklengbetrieb (conf. Walla: Die Samendarren und Klenganstalten, Berlin 1874).

Gayer's "Forstbenutzung" enthält die Schilderung aller betreffenden Vorgänge, der Geräthe, Apparate, Baulichkeiten etc.

Der forstlichen Gewerbelehre fällt die Aufgabe zu, die wirthschaftlichen Momente des Betriebs klar zu stellen, insbesondere die Nachbaltigkeit der Nutzungen zu sichern, sowie einen regelrechten Gang und möglichste Rentabilität der Wirthschaft zu garantiren.

In diesem Sinne bezweckt:

4. Die Waldertragsregel ung. (Forsteinrichtung, Betriebsregulirung) die vortheilhafteste zeitliche und räumliche Regelung des Ertrags der Wälder, indem sie zunächst die Bedingungen eines idealen (Normal-) Zustandes derselben aufstellt und untersucht, auf welche Weise die concreten Waldverhältnisse sich am schicklichsten in normale überfiihren lassen. 
Die Lösung der Aufgabe fordert als Grundlage die Untersuchung des im Walde vorhandenen Thatbestandes, insbesondere der Standortsgiite (Bonitirung), Aufnahme der Bestände nach Masse, Alter und Zuwachs, Güite, Wüchsigkeit etc. Conf. H e yer Carl: Die Waldertragsregelung, 3. Aufl. von Gustar Heye (im Druck); Judeich: Die Forsteinrichtung, 2. Aufl. 1874; Baur Franz: Holzmesskunst, 2. Aufl. 1875.

5. Die Waldwerthrechnung lehrt die Berechnung der in der Waldwirthschaft arbeitenden Capitalien (Boden, Holzvorrath etc. etc.).

Conf. Heyer Dr. Gustav: Anleitung zur Waldwerthrechnung. 2. Aufl. 1876.

6. Die Statik zeigt als "Rentabilitätsrechnung der forstlichen Wirthschaftsverfahren," wie man in jedem Falle den Effect mit dem Productionsaufwand vergleicht und hiernach unter concurrirenden Betriebsoperationen stets die vortheilhafteste auswählt. (Bestimmung der Umtriebszeit, Holzart, Betriebsart, Bestandesdichte etc. mit Riicksicht auf höchste Rentabilität.)

Conf.: Heyer Dr. Gustav: Handbuch der forstlichen Statik. I. Abth. 1871.

7. Die Forsthaushaltungskunde endlich bespricht die Organisation des Geschäftsbetriebs.

Conf.: Micklitz Robert: Forstliche Haushaltungskunde 1859.

Alle bisher skizzirten Theile der Forstwirthschaft betreffen das Verhältniss des Waldbesitzers als solchen zu seinem Walde; sie geben die Massregeln an, welche der Waldeigenthïmer ergreift, um seine Wirthschaft in möglichst vollkommenen Zustand zu versetzen.

Die Beziehungen, in welchen der Staat zur Forstwirthschaft steht (conf. oben), finden in diesem System keine Stelle, sondern sind durch eine besondere Disciplin vertreten, welche als statsforstwirthschaftslehre oder als Forstpolizei neben den ïbrigen Fachzweigen herlauft und mit ihren Vorschriften iiberall mehr oder minder modificirend eingreift, wo.das Interesse der Gesammtheit dies erheischt.

Dir. Tuistio Lorey.

Forte-Piano, s. Musikinstrumente.

Fortification, s. F estungs bau IIL pag. 425.

Fossil (fossile - fossil), allgemeine Bezeichmung fiir durch Umwandlung organischer Substanzen entstandene Mineralien, als Mineralkohlen, Versteinerungen, Bernstein ete. Uebrigens gebraucht man den Namen Fossil (d. i. so viel wie Ausgegrabenes) auch von Mineralien schlechtweg. Gtl.

Foulard ist ein glattes seidenes Gewebe zu Kleidern und Taschentiichern, dessen Kette aus ungezwirnter Rohseide in einfachen Fäden und dessen Schuss entweder ans demselben Materiale oder gewöhnlicher aus feinem Florettseidengarn besteht. Die Bindung des Gewebes ist taffetartig. $K k$.

Fourcroye, s. Gespinnstfasern.

Fournire. Fournirblätter, Fournier, Furniire (plreques, feuillets, femilles de placuige - remurs), sind düme Holzblätter, meist aus edleren, gefladerten Hölzern mit der Fournirsäge ocler der Fournirhobelmaschine geschnitten. Betrefi der ersteren s. den Artikel Sägen bei Sägemuihlen und beziiglich der letzteren vergl. den Artikel $\mathrm{HobeImaschinen.} \mathrm{Die} \mathrm{Fournire}$ werden ron Tischlern und Kartonagearbeitern zu fournirten Arbeiten (s. d.) verwendet. $K k$.

Fournirte Arbeit, Fournirung (plaquer, placage - veneering). Der Zweck der Fournirung hölzeruer Gegenstände, durch Bekleidung derselben mit diinnen Blättern von feineren und thenereren Holzsorten, ist ein mannigfaltiger. 1. Die Arbeiten kïnnen billiger hergestellt werden und fallen im Gewichte kleiner aus als aus massirem Holze (bois plein), weil ihr Hauptkörper aus weichen, 
leichten und billigeren Holzarten verfertigt werden kann. 2. Das änssere Anselıen kann durch entsprechende Anordnung der Fournire schöner erhalten werden als bei massiven Arbeiten, weil grössere Holzstiicke selten eine gleichförmige Zeichnung zeigen, und 3. Die Nutzbarmachung schön gezeichneter, zu anderen Arbeiten unbrauchbarer kleinerer Holzstiicke, indem man dieselben auf Fourusire verschneidet.

Als Hauptgrundsatz beim Fourniren gilt: die einzelnen Blätter so nebeneinander anzuordnen, dass die Adern und Flammen derselben eine geschmackvolle, symmetrische und sich womöglich wiederholende Zeichnung ergeben. Natiirlich erfordern die beiden letzteren Eigenschaften das Vorhandensein mehrerer möglichst gleichgezeichneter Blätter, wie sie zu je zweien durch jeden Schnitt der Fournirsägemaschinen (s. d.) erhalten werden.

Die Erzielung der Symmetrie geschieht auf mehrfache Art: Entweder man bringt zwei gleiche Blätter parallel so neben einander an, dass ihre Figuren symmetrisch in Bezug zu der durch die Fuge bezeichneten Mittellinie stehen. (Wo eine Fläche mehr als zwei Blätter benöthigt, muss man fuir jede Fuge die eben angegebene Rücksicht auf Symmetrie nehmen.)

Oder man bildet den Fournirbelag so aus vier Blättern, dass sich die Fugen im Mittelpunkte der Fläche kreuzen, и. z. können hierbei die Fugen in diagonaler Richtung laufen oder den Seiten (viereckiger Flächen) parallel sein. Endlich werden ovale, runde oder polygonale Flächen sternförmig, auf spitze (en coeur, en rosace) fournirt, indem man die Blätter keilförmig zuschneidet und sämmtliche $(8-16)$ Fugen im Mittelpunkte der Fläche zusammentreffen lässt.

Bevor wir an die Beschreibung der eigentlichen Fournirarbeiten schreiten, sei Folgendes vorausgeschickt:

Zur Anfertigung des Grundkörpers - Blindholz (bâtis, ground) - ist solches Holz am besten geeignet, welches sich nach erfolgter Trocknung möglichst wenig verzieht, also Linden-, Pappel-, Tannenholz u. s. w.; das vorzüglichste aber ist astfreies schlichtes Eichenholz, welches nebst seiner Festigkeit noch die schätzbare Eigenschaft besitzt, den Leim sehr gut anzunehmen.

Die Verbindungen der Theile des Grundkörpers müssen solid und unverrückbar sein. Nirgend dürfen hölzerne Nägel oder unbedeckte Zinken mit ihrer Hirnseite in der Oberfläche des Blindholzes liegen, weil bei der Schwindung der umliegenden Partien das weniger schwindende Hirnholz stets die Veranlassung der Bildung von Buckeln ist. Endlich ist es erforderlich, dass das Blindholz eine etwas rauhe Oberfläche habe, um den Leim besser aufzunehmen.

Man erreicht dies durch Ueberfahren mittelst eines Zahnhobels in verschiedenen Richtungen, oder, wo Schweifungen etc. die Anwendung des Hobels nicht zulassen, mittelst einer Raspel.

Die Fournirblätter sollen möglichst egale Dicke haben und frei sein ron Rissen oder Löchern. Ihre Innenfläche (diejenige, die an das Blindholz zu liegen kommt) wird wie das Blindholz mittelst des Zahnhobels geraulit.

Die Holzfournire werden mittelst Maschinen erzeugt (s. d.). Das Fourniren erfolgt zuweilen mit im Voraus zusammengefügten Blättern, die in verschiedener Weise erzeugt werden: Aus verschiedenfarbigen Fournirblättern werden Stiicke mannigfaltiger Gestalt ausgeschnitten (mit dem Schnitzer, mit einer scharfen Reissahle, mit dem Stemmeisen, mit einer kleinen Säge, mit dem Schneidmodell, oder bei kreisförmigen Stücken mit einem Stangenzirkel, der eine zugeschärfte Spitze hat), und diese auf einem mit Leim bestrichenen Papierbogen zu einem Nuster zusammengestellt. Oder man vereinigt mehrere schmale Fournirstreifen mit ihrer breiteren Fläche zu einem Stabe, den man mittels quer zu den Stossfugen geführter Längenschnitte in mehrere, der Länge nach gestreifte Fournierbänder zertheilt. Werden Fournirplättchen zu einer Säule zusammengefügt und diese dann 'durch Längenschnitte zertheilt, so erhält man quer gestreifte Fournirbänder.

Die unter dem Namen Holz-Mosaik vorkommenden grösseren gemusterten Belegfournire werden in einer, der eben beschriebenen Manier ähnlichen, 
Weise hergestellt. Es werden nämlich quadratische, dreieckige oder rautenförmige, beliebig lange Stäbe aus verschieden farbigen Hölzern so durch Hobeln hergestellt, dass die Faserrichtung quer zur Länge der Stäbe liegt. Diese Stäbe werden entsprechend dem Muster zu einem Klotze an einander geleimt und dieser nach erfolgter Austrocknung durch quer zur Länge (also in der Richtung der Fasern) geführte Schnitte in Blätter (von $2-3^{\mathrm{mm}}$ Dicke) zersägt.*)

Das Verfahren ist bei Massenerzeugung billig, bietet aber weniger Freiheit in der Zusammenstellung der Zeichnung. Trockene Birkenreiser (ungeschält) auf dieselbe Weise zu einem Klotze an einander geleimt, wobei man die Zwischenräume durch den mit feinen Sägespänen vermengten Leim ausfüllt, liefern ebenfalls hübsche Mosaikfournire, die indess den Uebelstand haben, dass sie bei nachträglicher Glatthobelung leicht ausbröckeln, weil die Fasern quer gegen ihre Längsrichtung zerschnitten wurden.

Künstlicher und schwieriger auszuführen ist folgendes Verfahren: Auf ein Fournir wird ein Papier aufgeklebt und darauf die Zeichnung (aus in sich selbst zurückkehrenden Linien und Contouren) vorgezeichnet. Nun legt man unter dieses Fournir ein zweites von anders gefärbtem Holze und schneidet beide Blätter zugleich mit der Laubsäge aus freier Hand oder mittelst einer Decoupirsägemaschine nach den Umrissen der Zeichnung aus. Die aus dem unteren Fournire fallenden Stückchen werden in die Durchbrechungen des oberen eingelegt, und umgekebrt, so dass man zwei brauchbare vollständige Exemplare und, ausser den Sägespänen, keinen Abfall erhält (travail en contre partie, countrypart - sawing). Wenngleich die herausgeschnittenen Theile um die Breite des Sägeschnittes ringsum kleiner sind als die für sie bestimmten Oeffnungen der Fournire, so hebt sich doch dieser Fehler ganz, weil man die Vorsicht gebraucht, die beiden Fournire zum Ausschneiden so auf einander zu befestigen, dass ihre Fasern rechtwinklig gegen einander laufen. Beim Einleimen der Figuren in dic Oeffnungen quillt jedes Holz quer gegen die Fasern ein wenig an, und dem zu Folge schliesst sich die Fuge sehr gut, wenn der Sägeschnitt möglichst fein war. Manche Nürnberger Fabriken, die dieses Verfahren anwenden, gebrauchen auch folgenden Kunstgriff: Die Säge schneidet etwas schräg zur Fläche der Fournir (anstatt senkrecht darauf), wodurch die eine Figur bei entsprechender Schrägstellung der Säge um die Breite des Schnittes grösser ausfällt als die andere und dann sehr genau in die betreffende Oeffnung passt. Das zweite Stiick liefert dann natiiglich ein minder genaues, aber immerhin noch brauchbares Produkt.

Die höchst selten angewendeten Steinfournire oder Massefournire werden aus einem Teig aus Kreide, gebranntem Kalk und Leimwasser erzengt, den man mit Mineralfarben färbt. Die Steinfurnire müssen stets vor der Anwendung mit Wasser erweicht werden.

Das Fourniren ebener Flächen erfolgt durch Auflegen der Blätter auf das gerauhte, mit möglichst heissem, nicht zu dickflüsigem Leim bestrichene Blindholz und nachheriges Pressen. Man legt zu diesem Zwecke über das Fournirblatt ein etwas angewärmtes tannenholzenes Brett - die Zulage (cale, caul) - und passt es mit Schraubenzwingen fest. Sind zwei gleiche Stiicke zu fourniren, so erspart man die Zulage, indem man beide Stiicke rasch nach einander belegt, sie dann mit den Fourniren auf einanderlegt und mit Zwingen an einanderpresst. Erhält ein Stiick auf beiden Seiten Fournire, so legt man letztere ebenfalls rasch nach einander auf, dann auf jede Seite eine Zulage und presst ein, wodurch man bedentend an Zeit und Arbeit erspart. Bei dieser beiderseitigen Fournirung (Gegenfournirung contre plaquer) legt man auf die nicht ins Auge fallende Seite gewöhnlich ein Eichenholzfournir.

Bei besseren Arbeiten erfolgt zuweilen eine doppelte Belegung, wodurch dem Rissigwerden besonders gut vorgebeugt ist. Man belegt zuerst mit einem

*) Polyt. Centralbl. Jahrg. 1848 pag. 1212. 
Eichenholzfournir und nach dessen Antrocknung mit dem werthvolleren Aussenfournir.

An schmale Flächen pflegt man die Fournire nicht durch Einpressen zu befestigen, sondern man reibt den Fournirstreifen mit dem etwas angewärmten, glattbahnigen Fournirhammer (marteau à placage) auf das mit Leim bestrichene Blindholz, d. h. man iiberfährt das Fournir unter entsprechendem Drucke so lange mit dem Hammer, bis es fest haftet.

Das Eourniren der Kanten muss so vorgenommen werden, dass keine Euge bemerkbar ist. Man verfährt dabei in folgender Weise: Das Fournirblatt wird so gross vorgeschnitten, dass es für beide an einanderstossende Flächen ausreicht. Dann beklebt man es auf der Aussenseite mit einem starken Papierbogen und befestigt es durch Leimen und Anpressen zuerst auf der einen Fläche. Nach dem Trocknen schneidet man in die gegen das Blindholz gekehrte Seite gerade an der Stelle, wo das Fournir die zu belegende Kante überragt mit der sogenannten Kippsäge oder dem Kippeisen eine in der Tiefe winkelig zusammenlaufende, fast bis an das Papier dringende Furche in das Fournier, bestreicht die Fläche des Blindholzes mit Leim und befestigt das Eournir, nachdem man es um die Kante gekippt hat, auch auf der zweiten Fläche. Die so belegten Kanten fallen sehr rein aus und sind auch nicht aufgesplittert, da dies der Papierbelag verhïitet.

Das Belegen geschweifter und krummer Flächen unterscheidet sich von jenem ebener Flächen dadurch, dass man erst die Fournire, um sie biegsamer zu machen, verdïnnen muss. Man klebt sie zu. diesem Zwecke mittelst Leim auf ein mit Seife (gegen das Anleimen) bestrichenes Brett und hobelt bis zur erforderlichen Verdïnnung, dann erwärmt man mittelst eines heissen Eisens den Leim, löst das Blatt los und reinigt es durch Abwaschen von Leim.

Wesentliche Abweichungen zeigen die Zusammenpressungsvorrichtungen. Man benïtzt entweder Zulagen, die genau nach der Krümmung der Fläche ausgearbeitet sind, oder bei complicirten Formen Säcke, die mit feinem erwärmten Sand gefüllt sind, und mittelst hölzerner Zulagen und Schraubenzwingen angepresst werden oder endlich eiserne hohle, durch eingeleiteten Dampf erwärmte Zulagen*), letztere indess selten, wegen ihrer nur von Fall zu Fall zulässigen Anwendbarkeit.

Die grösste Aufmerksamkeit erfordert das Fourniren runder Stuicke (z. B. Säulen, Walzen etc.) Die Fournire müssen hierzu ebenfalls verdiinnt werden. Hierauf schneidet man sie etwas grösser zu, als der zu belegende Umfang erfordert, und hält sie mit der unrechten Seite ïber ein Feuer von Hobelspänen, wodurch sie schon eine Krümmung annehmen. Das Anpressen an das mit Leim bestrichene Blindholz kann nun entweder mittelst passend ausgehöhlter Zulagen geschehen, die freilich nur höchstens ein Drittel des Umfanges umfassen können oder durch spiralförmiges Umwinden mittelst eines straff angespannten Leinenbandes. Im letzteren Falle benützt man die Fournirmaschine (machine ¿̀ plaquer). Dieselbe besteht in einem Gestelle, welches einerseits eine verstellbare Dornspitze (Körner), andererseits ein ebenfalls verstellbares, an einer kurzen Welle sitzendes Spitzenfutter (s. Drehbankfutter) enthält. Zwischen den Körner und das Futter wird das zu belegende Blindholz eingespannt. Parallel und oberhalb der eingespannten Säule etc. dreht sich mit grosser Reibung eine Holzwalze, die mit einer Leinengurt spiralförmig umwunden ist. Ist das in der Wärme vorgebogene Fournirblatt auf das Blindholz gebracht, so wird es vorläufig befestigt und dann das Gurtende an das eine Ende der Säule. Bei der nachfolgenden Drehung wickelt sich die Gurte über das Fournir und bleibt daselbst bis zur völligen Trocknung. Hierauf wird der Leim mittelst eines erwärmten Eisens an der Stelle, wo die Ränder des Fournirs etwas iibereinander greifen, erweicht, die Eournirkanten sorgfältig zugeschnitten und durch wiederholtes Umwinden der Gurte festgehalten.

*) Polyt. Centralbl. Jahrg. 1850 pag. 775. Die mehrfach genannte Erwärmung hat den Zweck, den Leim vor dem allzu raschen Erstarren zu bewahren. 
Zuweilen treten kleine Fehler ein, welche vor der Ausfiihrung der Vollendarbeiten zu verbessern sind. Klebt z. B. das Fournir an einer Stelle des Randes nicht vollständig gut, oder ist es abgehoben, so führt man in die Spalte mittelst einer schmalen Messerklinge etwas Leim ein, und presst mittelst einer Leimzwinge und einer kleinen Zulage das Fournir gegen das Blindholz. Hat sich aber das Fournir in Form einer Blase abgehoben, so kann diese, wofern sie nicht von einer Unebenheit des Blindholzes herrïhrt, leicht beseitigt werden. Ist die Ursache ihrer Entstehung eine locale Mehranhäufung von Leim, so erweicht man diesen mittelst eines auf die Blase gehaltenen warmen Eisens und verstreicht die Unebenheit mit dem Fournirhammer; ist sie aber die Folge von zu wenig Leim (also eine wirkliche Blase), so muss man dieselbe durch einen feinen Schnitt mit einem Federmesser öff̈nen, dann etwas fliissigen Leim darein bringen und ebenfalls durch anhaltendes Reiben mit dem Hammer beseitigen.

Ein anderer Fehler sind Gribchen, Spalten und Löcher. Dieselben muss man mit einer Paste ausstreichen (cement stopping), wozu sich am besten sehr fein geschabte Spänchen derselben Holzgattung mit Leim vermengt eignen.

Zeigt eine Fournirbelegung zu viele Mängel nach dem Trocknen, so muss man sie wieder abheben (deplaquer). Zu diesem Ende überfährt man nach und nach die ganze Fläche mit einem erwärmten Eisen und hebt das Fournir in dem Masse allmälig $a b$, als dies der erweichende Leim gestattet.

Moriz Kohn.

Fowlerit Min. ist zinkhaltiges Kieselmangan (Rhodonit) ron Franklin in New-Yersey. Gtl.

Fowler's Lösung (solutio arsenicalis Fouleri) eine Lösung von arsenigsauerem Kali in Wasser, wird bereitet durch Auflösen von 1 Gramm gepulv. arseniger Säure und 1 Gramm kohlensaurem Kalium in soviel Wasser als nöthig, um im Ganzen 90 Gramm Lösung zı erhalten. Die Aufösung wird durch Kochen der Mischung begiinstigt. Als Fiebermittel geschätzt. Gtl.

Fradeln (Katten), Benennung der Ballen, in welchen Java-Indigo in den Handel kommt, s. Indigo.

Fräse (Fraise, Cutter). - Unter Fräse soll hier ganz allgemein ein Werkzeng verstanden werden, das gewöhnlich aus Stahl, selten aus Eisen angefertigt, auf der Oberfläche mit einer mehr oder weniger grossen Anzahl von Schneiden ausgestattet ist und durch eine drehende Bewegung zur Wirkung gebracht wird. $\mathrm{Da}$ die Fräse in einer grossen Zahl ron Fällen im Stande ist, nicht nur die theure und langwierige Arbeit des Feilens, sondern auch mit grossem Erfolg die. jenige des Grabstichels, des Bankmeissels, so wie namentlich auch des Profilhobels zu ersetzen, so ist sie in neterer Zeit zu einem der wichtigsten Werkzenge sowohl fiir Metall- und Holzarbeiter, als auch für Elfenbein-, Horn-, Hartgummiu. s. w. Arbeiter geworden.

Je nachdem die Fräse auf Metall oder auf $\mathrm{Holz}$ und event. auf Materialien in Verwendung kommen soll, die in ihrer Härte dem harten Metall oder dem Holze nahe stehen, sind die Schneiden in Bezug auf ihre Zuschärfung und Grösse u. s. w. ziemlich verschieden, weshalb zweckmässig die Metall-Fräsen von den Holz-Fräsen getrennt behandelt werden.

a) Ii tallfräsen. Diese werden mit wenig Ausnahmen in der Art angefertigt, dass man die stählernen Körper (die der Leichtigkeit halber oft hohl oder ausgehöhlt sind) auf der Oberfläche einkerbt, wie bereits bei den einhiebigen Feilen III pag. 366 angegeben, und zwar entweder durch Hauen und Feilen oder gewöhnlich wieder mit Fräsen oder mit Stossmaschinen. In der Regel sind die lierben dreieckig und je nach der Grösse der Fräsen sehr verschieden gross, von sehr verschiedener Theilung. Die Theilung richtet sich im Allgemeinen nach dem Durchmesser der Fräse und nach der Feinheit der Arbeit. Fräsen unter $6^{\mathrm{mm}}$ Durchmesser kommen selten vor, eben so solche über $100^{\mathrm{mm}}$, weil noch grössere 
sehr schwer zu härten sind, ohne dass sie sich werfen oder Risse bekommen. Als bewährte Theilung ist etwa anzunehmen bei Fräsen

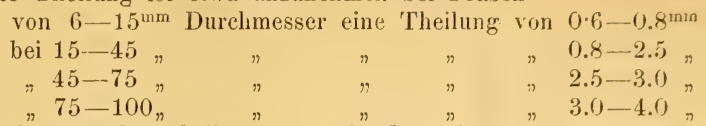

Mitunter macht man die "Theilung" so grob, dass sie an "Fräsen ron $75^{\mathrm{rm}}$ Durchmesser wohl $10^{\mathrm{mm}}$ beträgt. Namen.

Je nach der Gestalt und der Verwendung erhalten die Fräsen verschiedene

Die gewöhnlichsten Fräsen haben, wie Fig. 1679 A zeigt, eine cylindrische Gestalt und sowohl auf der Mantelfäche $a$ als auf der Stirnfläche $b$ Schnciden und heissen dann Stirnfräsen. Sie dienen zur Bearbeitung ebener Flächen, indem das Arbeitsstiick tangential an der Peripherie $a$ oder vor der Stirn $b$ hergeführt wird, und zur Ausarbeitung rechtwinkliger Ansätze, wie sie oft an Rahmwerk, als Führungsprismen u. s. w. vorkommen. - Wenn die Fräsen die Bestimmung haben, cylindrische Löcher zu erweitern (zu versenken', so nennt man sie demgemäss Senker (Versenker, Senkkolben, Ausräumer oder A usreiber, auch Fraiser, Fraise, Countersink). Je nach der Form der Ver-

Fig. 1679 .

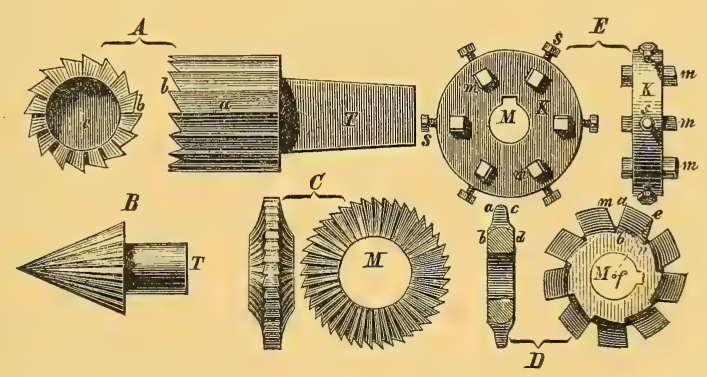

senkung ändert sich auch die Gestalt der Senker. Zu kegelförmigen Versenkungen dienen k on is che Fräsen Fig. $B$; zu cylindrischen Versenkungen gebraucht man cylindrische Senker oder Stirnfräsen, welche sich von denen in Fig. 1679 A dargestellten dadurch unterscheiden, dass die Schneiden auf der Mantelfläche $a$ fehlen, und dass auf der Mitte der Stirnfläche $b$ sich in der Regel ein Zapfen befindet, der zur Führung in das zu erweiternde Loch eintritt, wie beim Bohrer Fig. 504 pag. 709. - Hier schliessen sich die Fräsen an, welche die Gestalt einer Kugel besitzen, und zum Ausfräsen halbkugeliger Vertiefungen an Kugelzapfenschalen, der sog. Nuss an Thürschlössern, an den Kugel- und Hagelgiesszangen, so wie der oft vorkommenden halbkreisförmigen Rimnen dienen ( $\mathrm{K}$ u gelfräse Kugelknopf, Chemry). Ferner gehören hierher die Fräsen mit protilirter Oberfläche, welche als Rotationskörper zu betrachten sind, deren Oberflächen mit Schneiden besetzt sind, welche rechtwinklig zur Drehrichtung stehen, und zum Ausarbeiten profilirter Vertiefungen an Nähmaschinentheilen, Gewehrtheilen, an Spitzkugelgiesszangen u. s. w. uft vorkommen.

Mitunter sollen freistehende Erhöhungen, z. B. Zapfen oder ringförmige Vertiefungen oder auch nur Ränder vermittelst Fräsen gebildet werden; dann muss die Stirnfräse in der Achse mit einer entsprechenden Bohrung $C$ versehen sein Fig. A, in welche die Erhöhung eintritt. In diesem Falle liegen die Schneiden 
oft nach innen zu schräg gegen die Achse, also in dem inneren Mantel eines Hohlkegels, z. B. zum Anfräsen der Kegelfläche an versenkten Schraubenköpfen. Wenn die Fräsen sehr gross oder in der Achsenrichtung gemessen sehr dünn werden, so ist es gerathener, sie als Scheiben zu construiren und mit einem centrischen Loch auf die Welle zu schieben, welche sie in Umdrehung setzt, statt wie Fig. $1679 A$ und $B$ zeigen, mit Zapfen $T$ in eine achsiale Oeffnung dieser Welle zu stecken. - Solche scheibenförmige Fräsen (Schneidscheiben, Schneidräder) nähern sich, wenn sie dünn und auf der Peripherie gekerbt sind, den Kreissägen und finden vorzïglich Verwendung zur Herstellung von Nuthen aller Art. Hat die Fräse dann die Gestalt eines abgestumpften Kegels, so eignet sie sich zur Hervorbringung schräger Einschnitte, z. B. an Scheibenrändern, um Sperräder zu erzeugen; zur Fabrikation der Fräsen selbst; zur An fertigung von Schraubenbohrern, gekerbten Reibahien u. s. w. Ist die Kante der Schneidscheibe abgerundet, so wird die Nuth also auch halbrund. Da solche Nuthen an vielen Werkzeugen vorkommen, z. B. den amerikanischen Spiralbohrern Fig. 501 pag. 709, an Gewindbohrern etc., so wird die Fräse zur Anfertigung solcher Werkzeuge vielfach gebraucht.

In hervorragender Weise dienen die Schneidscheiben zum Einschneiden oder zum Egalisiren der Zahnlïcken an Stirnzahnrädern, in welchem Falle die Scheiben an der Peripherie des Zahnliickenprofils und auf der ganzen dies Profil bildenden Umfläche Schneiden besitzen und einen wichtigen Theil der Räderschneidmaschinen bilden. Fig. $1679 C$ zeigt in zwei Ansichten die Beschaffenheit einer solchen Rä derfräs e genügend deutlich.

Die Fräsen mit feiner Theilung lassen sich nicht nachschleifen (nur von $5^{\mathrm{mm}}$ Theilung aufwärts sollen Schmirgelscheiben anwendbar sein), sondern müssen, wenn sie stumpf geworden sind, weich gemacht, nachgeschnitten und neu gehärtet werden. Um dieser mühsamen und durch das häufige Zerspringen der Fräsen beim Härten verlustdrohenden Arbeit überhoben zu sein, wird in vielen Fällen die Theilung so gross genommen, dass ein Nachschleifen möglich wirä. Für Zahnschneidräder z. B. empfiehlt es sich dann, die Frässchneiden so auszubilden, dass wirkliche Meissel von dem Zahnluickenprofil entstehen. Mit Hilfe von Fig. $1679 D$ mag diese Art von Fräsen erklärt werden. Jeder Schneidzahn steht mit der Brust $a b$ fast radial, so dass der Winkel $b$ a e beinahe ein rechter ist. Die Linie $a$ e ist aber kein concentrisches Kreisstück, sondern der Punkt $e$ liegt dem Mittelpunkt $M$ näher als der Punkt $a$, so dass dadurch der Anstellungswinkel gebildet wird. Das Zahnprofil $a b c d$ ist an allen Stellen des Schheidzahnes kongruent, weil $b n$ mit $a$ e äquidistant ist, weshalb der Zahn bis zur Linie e $f$ abgenutzt, d. h. weggeschliffen werden kann, ohne dass sich die Zahnform ändert. Das Anschleifen der Brust findet aber wegen der grossen Zahnlücke a $m$ kein Hinderniss.

Bei sehr grossen Fräsen geht man noch weiter, indem man die Zähne als besondere Stiicke also als wirkliche Meissel oder Messer anfertigt und in ein anderes Stiick ( $\mathrm{K}$ op f, Fr ä s k o p f) einsetzt, entweder dauernd fest oder ausnehmbar und auswechselbar. Eine dauernde Vereinigung wird unter Anderem dadurch erreicht, dass man die Meissel in radialer Lage in einer cylindrischen Lehmform einformt und dann die Form mit Gusseisen ausgiesst, welches nach dem Erstarren die Meissel fest zusammenhält. Auch ist vorgeschlagen, die keilförmig ausgeschmiedeten, zu einem Cylinder zusammengesetzten Meissel durch eiserne Ringe $\mathrm{zu}$ rereinigen, die gluhend herumgelegt werden und dann durch Abkühlen sich verengend, eine starke Zusammenpressung hervorbringen. Am einfachsten und zweckmässigsten erscheint die Einrichtung, bei welcher die Meissel in den Fräs kopf eingesteckt und durch Klemmschrauben oder Keile befestigt werden. Stehen dabei die Meissel aus der Peripherie des Kopfes heraus, so gewinnt die Fräse grosse Aehnlichkeit mit dem Bohrkopf Fig. 518 pag. 719. Sollen sie aber auf der Stirnfläche sitzen, so erklärt Fig. $1679 E$ die Anbringung. Die Meissel $m$ werden quer durch den Kopf $K$ gesteckt und durch die Schrauben $s$ festgeklemmt. 
Bei dieser Anordnung ist es besonders leicht, die einzelnen Meissel zum Anschärfen aus der Frässcheibe herauszunehmen und sämmtliche Schneiden in eine Ebene zu bringen.

b) $\mathrm{Hol}$ z fräsen. Bei den Holzfräsen ist die Zahl der Schneiden in der Regel kleiner als bei den Metallfräsen, da die Schneiden mit ihren kleineren Schneidewinkeln tief eindringen, dickere Späne wegnehmen und desshalb eine grössere Theilung verlangen. Die Zahl beträgt gewöhnlich zwei bis sechs. Entweder werden die Holzfräsen aus einem Stuicke hergestellt oder sie bestehen aus einem scheibenoder cylinderartigen Kopfe, in welchen Messer eingesetzt oder auf welchem Messer befestigt werden. In beiden Fällen ist es oft geboten, die Schneiden so auszubilden, dass sie in beiden Drehrichtungen arbeiten, damit man durch Umsetzung der Bewegung im Stande ist, auch an krummen Holzflächen die Fräsen so zur Wirkung zu bringen, dass zur Vermeidung des Ausreissens die Arbeitsbewegungsrichtung mit dem Faserlauf zusammenfällt.

Wird auf diese letzte Anordnung Bedacht genommen, so erzeugt man die Fräsen in einem Stück aus stählernen Rotationskörpern von entsprechender Achsenlänge und Profilirung in der Art, dass man Fig. 1680 A Einschnitte $a$ macht, deren Seiten sich in der Achse $m$ schneiden. Je nach der Grösse des sich in der Achse bildenden Centriwinkels $b m c=\varnothing$ ist auch der Zuschärfungswinkel $m$ c $b=\alpha$ verschieden, indem ja dieser durch die geometrische Beziehung

$$
\alpha=90^{\circ}-\frac{\varphi}{2}
$$

bestimmt wird, wenn man die Fräse als Polygon ansieht. Sind demnach 3, 4, 6 Einschnitte vorhanden, so ist bei gleicher Theilung, und 6 Messern

$$
\begin{aligned}
\varphi & =\frac{360}{12}=30^{\circ} \\
\text { also } \alpha & =75^{\circ} .
\end{aligned}
$$

Ist die Zahl der Messer dahingegen 4 und haben die Einschnitte einen Winkel von $15^{\circ}$, so wird

$$
\begin{aligned}
\varphi & =\frac{360-4.15}{4}=75 \\
\text { und } \quad x & =90^{\circ}-37.5=52.5 .
\end{aligned}
$$

Da beim Härten dieser Fräsen aus Stahl leicht Bruch entsteht, so fertigt man sie oft aus Schmiedeisen an und härtet durch Einsetzen. Hierbei rerdient auch folgende Art der Anfertigung Beachtung. Man nimmt runde Scheiben von Eisenblech und treibt sie in Gesenken unter dem Fallwerk pag. 557 u. s. w. zu einem Rotationskörper oder einer Pyramide von verlangtem Profil aus. Sodann kerbt man sie vom Rande her so ein, dass in der Mitte eine Kuppe stehen bleibt, die eine centrische Durchbohrung zum Aufstecken auf die Frässpindel erhält und härtet die Fräse dann durch Einsetzen.

Stehen die Fräsen nur in einer Richtung auf den Schnitt, so werden sie in der Weise ausgebildet, wie Fig. $1680 \mathrm{~B}$ ohne weitere Erklärung zu erkennen gibt. 
Für grosse Fräsen ist wie bei Metallfräsen die Construction mit besonderen Messern aus denselben Grinden mehr üblich. Die beliebig profilirten Messer $m$ werden dann entweder quer durch den Fräskopf gesteckt, Fig. $1680 E$ und $F$, durch Klemschrauben $r$ oder Keile befestigt, oder auf einen prismatischen Körper von dreioder viereckigem Querschnitt gelegt Fig. $1680 C$ und $D$ und durch Schrauben $r$ gehörig fest gehalten. Durch Vertheilung einer Anzahl schmaler Messer $m$ iiber die Seiten des Prisma ist man, wie Fig. $1680 \mathrm{E}$ zeigt, im Stande, verschiedene Profile zu einem einzigen $c d$ zusammenzusetzen. Man sieht hierbei leicht ein, wie man hierdurch in der Wahl der Profile lediglich nur durch Unterschneidungen beschränkt ist.

Fräsmaschinen. (Machine à fraiser, Machine à shéper - Molling ma. chine, Cutting machine, Shaping machine.) Die Wirkungsweise der Fräse verlangt, wenn sie vortheilhaft zur Verwendung kommen soll, eine ziemlich bedeutende Arbeitsgeschwindigkeit. Die Frässcheiben haben auf Schmiecieisen 150 bis $180^{\mathrm{mm}}$; auf Gusseisen 180 bis $200^{\mathrm{mm}}$; die Messerkopffräsen auf Guss- und Schmiedeisen 200 bis $250^{\mathrm{mm}}$; die Räderschneidfräsen 300 bis $400^{\mathrm{mm}}$ Geschwindigkeit pro Secunde. Bei den Holzfräsen kann man sogar eine Peripheriegeschwindigkeit von 15 bis $20^{\mathrm{m}}$ pro Secunde annehmen, was einer Umdrehzahl von 3000 bis 4000 pro Minute für $100^{\mathrm{mm}}$ Fräsedurchmesser entspricht. Aus diesem Grunde erklärt sich auch namentlich die Unzweckmässigkeit, die Fräsen mit freier Hand oder einem einfachen Geräth, das nur geringe Geschwindigkeit zulässt, (Brustleier, Ratsche etc. pag. 712) zur Wirkung zu bringen, wenn zwar z. B. die Senker oft in der Brustleier gebraucht werden. Man bedarf vielmelır einer maschinellen Vorrichtung zur Erzeugung der gehörigen Geschwindigkeit, und so entstehen die Fräsmaschinen, die zunächst in zwei Kategorien: Netallfräsmaschinen und $\mathrm{Holzfräsmaschinen} \mathrm{zerfallen.}$

\section{Fig. 1681 .}

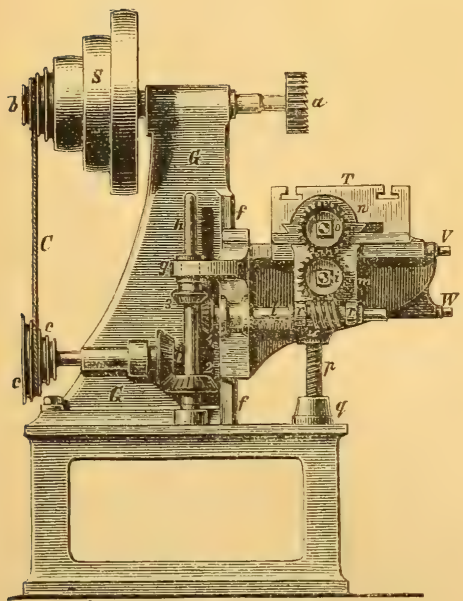

a) Metallfräsmaschinen. Dieselbe besteht in der Hauptsache aus einer gewöhnlich horizontal liegenden Fräswelle, welche die Fräse aufnimmt und in Bewegung setzt (Arbeitsbewegung); sodann aus einer Einrichtung für die Aufnahme des Arbeitsstiickes (E inspann $\mathrm{n}$ or richtung); und endlich aus dem Mechanismus der Relativbewegung zwischen Werkzeug und Arbeitsstiick (Schaltbewegung), um dem ersteren stets neue Arbeitsflächen darzubieten, wobei bemerkt werden mag, dass die Schaltbewegung fast ausschliesslich dem Arbeitsstück ertheilt wird und zwar entweder durch die Hand eines Arbeiters oder selbstthätig von der Maschine aus.

Zur näheren Erklärung mag die in Fig. 1681 dargestellte, sehr viel gebaute Fräsmaschine mit selbstthätigem Vorschub dienen. Das Werkzeng $a$ sitzt auf dem vorderen Ende der Fräswelle $a b$ und bekommt mit dieser die Arbeitsbewegung direct durch die Stufenscheiben S. Das Arbeitsstuick wird auf dem

Aufspanntisch $T$ durch Aufspannkloben etc. befestigt und mit demselben zunächst rertical auf- und niederwärts bewegt, um in die passende Lage zu der Fräse $a$ 
zu gelangen. Zu diesem Zwecke wird der Tisch $T$ von einer Console getragen, die an der Vorderseite des Gestells $G$ bei $f f$ Prismenführungen besitzt und nnterwärts durch die starke Schraubenspindel $p$ gestiitzt wird. Diese Schraube besitzt ihre Mutter in $q$ und ausserdem am oberen Ende einen Zapfen, der in ein umgekehrtes Spurlager an der Console eintritt. Die Bewegung der Śchraube erfolgt durch ein Schraubenrad, das am unteren Ende des Zapfens sitzt und durch eine Schnecke gedreht wird, die auf einer kurzen Schneckenwelle $W$ sich befindet. Die letztere wird an der vorderen Seite der Console durch eine aufgesteckte Handkurbel so lange nach links oder rechts in Umdrehung versetzt, bis das Arbeitsstïck die richtige Höhenlage erhalten hat. Zur Verschiebung in der Horizontalebene ist der Tisch wie am Kreuzsupport construirt.

Die Annäherung oder Entfernung an das Gestell $G$ wird mit Hilfe der horizontalen Schraube bewirkt, die bei $V$ durch eine Handkurbel bewegt wird, und die Bewegung vor dem Gestell entlang durch die Leitspindel o, welche fiir die erste Einstellung von einer aufgesteckten Handkurbel, zur continuirlichen Schaltbewegung aber von der Maschine aus gedreht wird. Für den letzten Zweck treten die Zahnräder $n$ und $i$ in Function, indem das Rad $i$ von der Schnecke $u$ gedreht wird, welche durch die Kegelräder 4, 3, 2, 1 von den Schnurscheiben $c$ den Antrieb erhält, die ihrerseits vermitteist der Schnur $C$ von den auf der Fräswelle sitzenden Schnurrollen $b$ in Umdrehung versetzt werden. Hierbei sind die Uebersetzungsverhältnisse so zu wählen, dass das Arbeitsstück etwa 0.5 bis $2^{\mathrm{mm}}$ Vorschub pro Secunde erhalten kann. Damit bei den verschiedenen Verschiebungen des Tisches und der Console die thätigen Organe niclıt ausser Eingriff kommen, werden diese von den sich verschiebenden Theilen mitgenommen und auf den Wellen in langen Nuthen verschoben. So hängt an dem unteren Tischschlitten das Lager $m$ zur Aufnahme des Rades $i$ und der Schnecke $u$, die zwischen den Armen $r$ liegt und anf der Welle $t$ verschoben wird. Desgleichen trägt die Console den Arm $g$, an dem das Zahnrad 3 hängt, durch welches die vertikale Welle $h$ sich verschieben kann.

Für bestimmte $Z$ wecke und namentlich auch für grössere Arbeiten werden Fräsmaschinen gebaut, welche in mancher Beziehung von dem eben beschriebenen Typus abweichen. So erfolgt der Antrieb bei Anwendung des Fräskopfes Figur $1679 E$ mit eingesetzten Messern, oft durch Rädervorgelege oder Schraubenrad mit Schnecke von Stufenscheiben aus, so dass ein Fräskopf von $200^{\mathrm{mm}}$ Durchmesser etwa 95 bis $260^{\mathrm{mm}}$ Peripherie-Geschwindigkeit pro Secunde erhält. Mitunter kann es bequem sein die Frässpindel vertical aufwärts mit der Fräse am unteren Ende über dem Arbeitstisch anzuordnen, wodurch die Maschine Aehnlichkeit mit ciner Bohrmaschine erhält. Bei manchen Maschinen sind zwei und mehr Fräsen auf einer Welle vorhanden, die dann entweder in der Mitte oder an beiden Enden gelagert wird, je nachdem die Fräsen an oder zwischen den Enden angebracht sind. Hierzu sind unter anderen die Mutterfräsmaschinen zu rechnen, welche mit zwei Fraisscheiben versehen sind, die ihre Arbeitsflächen einander zukehren und zwischen denen die Muttern oder die Köpfe von Bolzen etc. so hindurchgeführt werden, dass zwei einander gegenüber liegende parallele Seitenflächen gleichzeitig bearbeitet werden. Auch gehören hierher die Fräsmaschinen zur Bearbeitung $\perp$ förmiger Theile, wie sie vielfach für Artillerie-Ausriistungsgegenstände (Munitionswagen) nothwendig sind. Eine besondere Bedeutung haben die Fräsmaschinen zur Herstellung unregelmässiger Körper, Nuthen, Vertiefungen etc. für Nähmaschinen, Gewehrtheile und dgl. erhalten. Das wichtigste Stiick bildet bei diesen $\mathrm{Curvenfräsmaschinen} \mathrm{der} \mathrm{Führungsapparat,} \mathrm{welcher} \mathrm{in} \mathrm{den}$ meisten Fällen so eingerichtet ist, dass das Arbeitsstiick mit einem Schlitten, der zu seinem Festhalten oder Einspannen dient, vermittelst Schablonen ror der Fräse hin- und her- und an- und abbewegt wird. Zur Förderung der Arbeit werden dann zweckmässig gleichzeitig mehrere Fräsen angebracht und in Thätigkeit gesetzt. Ueber die bei den Fräsmaschinen anzubringenden Vorrichtungen zum Eintheilen wird das Nähere bei den Räảerschneidmaschinen angegeben. 
Sämmtliche Metallfräsmaschinen, besonders aber die Specialfräsmaschinen werden in vorzüglicher Ausführung von der Werkzeugmaschinen-Fabrik G. Justus in Hamburg gebaut.

b) Holzfräsmaschinen. Die oben beschriebenen Holzfräsen erfordern, wie dort bereits bemerkt, eine solche grosse Geschwindigkeit, dass sie nur mit Hilfe maschineller Einrichtungen zur Wirkung gebracht werden können. Sie stecken zu dem Zwecke auf Wellen o $p$ Fig. 1680, die entweder horizontal oder vertical gelagert und durch rasche Rotation denselben die Arbeitsbewegung ertheilen, während das Arbeitsstück die Schaltbewegung erhält, die entweder durch die Arbeiterhand oder selbstthätig von der Maschine erzeugt wied.

Nicht nur durch die verschiedenen Stellungen der'Triebwelle (vertical und horizontal), sondern auch durch Combinirung von Fräsen auf horizontalen Wellen mit solchen auf verticalen Wellen, so wie durch Anwendung mehrerer Fräswellen neben einander oder über einander u. s.w. erhält man eine grosse Verschiedenheit in der Construction dieser wichtigen Holzbearbeitungsmaschine, die jedoch in der Praxis wesentlich unterschieden werden als eigentliche Fräsmaschine und Holzhobelmaschine. Man versteht dann gewöhnlich unter Holzfräsmaschine eine Maschine mit Fräskopf zur Erzeugung profilirter Oberflächen und unter Holzhobelmaschine eine solche zur Hervorbringung ebener Flächen. Letzterer wird, der Anlage dieses Buches entsprechend, ein besonderer Artikel gewidmet.

Die Holzfräsmaschine hat durchgängig einen

Fig. 1682.

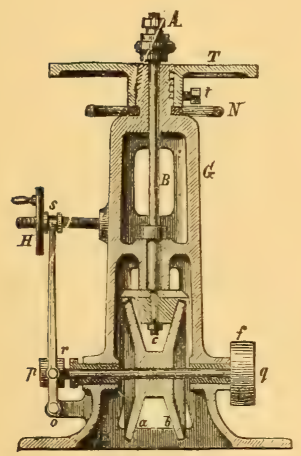
Fräskopf zwischen $30-100^{\mathrm{mm}}$ Durchmesser von der Art Fig. $1680 A$ oder in einer Richtung schneidend nach dem Princip Fig. $1680 \mathrm{E}$, der in der Regel unmittelbar über einem Tische auf einer durch den Tisch vertical abwärts gerichteten Welle sitzt, die deshalb auch unter dem Tisch den Antrieb erhält, während das auf dem Tische liegende Holzstïck tangential gradlinig oder in Bögen etc. an dem Fräskopf vorïber geführt wird. Der Antrieb der Welle erfolgt entweder durch Riemscheiben direct oder indirect, indem noch Reibungsräder eingeschaltet werden. Da die letztere Anordnung bedeutende Vorzüge voraus hat, so mag hier zur weiteren Erläuterung mit Hilfe der Fig. 1682 die Beschreibung einer Holzfräsmaschine mit Reibungsräder-Betrieb Platz finden. Der Fräskopf $A$, der nach beiden Drehrichtungen schneidend gedacht werden mag, sitzt auf der verticalen Welle $B$, welche wegen eines ruhigen Ganges und Vermeidung von störenden Erschütterungen in zwei langen Lagern läuft und bei $c$ einen Kegel aufnimmt, der durch die kegelförmigen Scheiben $a$ oder $b$ gefasst und angetrieben wird und zwar nach links oder rechts herum, je nachdem $b$ oder $a$ zur Wirkung gebracht wird. Wie die Zeichnung ergibt, bilden die Reibungsscheiben $a$ und $b$ ein Stiick, das auf der Welle $p q$ festgekeilt ist und durch die Riemscheibe $f$ vermittelst eines von der Haupttransmission abgeleiteten Riemens nach einer Richtung in Rotation versetzt wird. Wenn daher eine der beiden Scheiben $a$ oder $b$ an den Kegel $c$ angepresst wird, so erfolgt die Bewegung des Eräskopfes. Dies Anpressen vermittelt der in $o$ drehbare Hebel $\cap r s$, welcher mit dem gabelförmigen Ende $s$ um die mit dem Handrad $H$ rerbundene Schraubenmutter fasst und sich daher je nach der Drehung und Verschiebung der letzteren auf der Schraube nach links oder rechts bewegt und die Welle $p q$ mitnimmt, indem eine auf $p q$ befestigte Nuthscheibe $r$ von einem Stift des Hebels mitgenommen wird. Ausser der Möglichkeit, die Bewegungsänderung des Fräskopfes fast plötzlich eintreten zu lassen, gewährt 
der Hebel $o r^{*} s$ auch noch eine Druckregulirung zwischen den Reibungsrädern. $\mathrm{Da}$ in der Mittellage von $a b$ keine Berührung mit $c$ eintritt, so ist auch ein schnelles Stillstellen leicht. Der Arbeitstisch $T$ ruht um den oberen Theil des Bockes auf der Nabe des Handrades $N$, welche zugleich als Mutter für die in der Zeichnung leicht erkennbare Schraube ausgebildet, die Höhenlage des Tisches festlegt. Eine Klemmschraube $t$ schützt den Tisch gegen das nicht gewünschte Mitnehmen desselben durch das Arbeitsstück. Nach Lösung dieser Klemmschraube kann sich aber der Tisch drehen, was für manche Arbeiten erwünscht ist. Ausserdem lässt sich der Tisch leicht gegen Auflagen auswechseln, die z. B. bei Fräsen doppelter Krümmungen eine sicherere Führung des Arbeitsstücks verbürgen.

Von dieser neueren Construction sind die älteren wesentlich durch den Antrieb und das Gestell verschieden, indem der erstere fast ausschliesslich direct durch Riemen erfolgt, und zwar um die beiden Drehrichtungen hervorbringen zu können, oft durch einen offenen und einen gekreuzten Riemen, die abwechselnd angespannt werden, und indem das Gestell viereckig tischförmig ist. Diese Gestellform ist wegen der grösseren Stabilität namentlich für grössere Maschinen vorzuziehen.

E. Hoyer.

Fräsbohrer ist ein dem Schneidzirkel (s. d.) ähnlich gebautes Werkzeug zum Einschneiden kreisförmiger, schmaler Furchen. (Prechtl, Encyclop. II pag. 548.)

Fräsen (fraiser - shape, cut), s. Fräse.

Fraisen, Fraismaschine, s. Fräs e.

Frame ist ein aus dem Englischen entnommenes Wort, welches nicht selten auch vom Maschinenbauer zur Bezeichnung eines Rahmens, einer Einfassung oder eines Rahmengestells gebraucht wird. Es lässt sich dieses Wort meist deutsch eben so gut durch die Worte Rahmen, Gestell u. dgl. ersetzen. Kk.

Frangipani (Plumeriablüthen-Esssenz), Name einer höchst angenehm riechenden, auch himmlischer Geruch genannten Essenz, welche einer auf den westindischen Inseln einheimischen Plumeria-Art entstammen soll. Gtl.

Frangulasäure, s. m. Cathartin, s. Kreuzbeeren.

Frangulin, Avornin, Rhamnoxanthin, Glucosid aus der Wurzel und, Stammrinde, sowie den Beeren des Faulbaums (Rhamnus frangula $L$.), sowie des Kreuzdorns (Rh. cathartica) $C_{20} H_{20} O_{10}$, s. b. Kreuzbeeren, s. a. Lo-Kao.

Frankfurter Schwarz, Rebschwarz, Hefenschwarz etc. Durch Verkohlung von Weinhefe, Weintrestern oder Weinreben dargestellte schön schwarze Farbe, wesentlich feinvertheilter Kohlenstoff s. d. Gtl.

Franklinit, ein tesseral gewöhnlich in Octaedern oder Rhombendodekaedern krystallisirendes Mineral, dessen Krystalle aufgewachsen oder eingewachsen oder in Drusen vorkommen, das sich auch körnig derb und eingesprengt findet. Sehr unvollk. spaltb., Bruch muschlig, $H=5.5-6.5$, spec. Gew. $=5.0-5.069$, eisenschwarz mit braunem Strich und unvollk. Metallglanz, undurchsichtig. Chem. Zus. $R O \cdot R^{2} O^{3}$, worin $R O 21$ Zinkoxyd mit etwas (7) Eisen- und (0.7) Manganoxydul, $R^{2} O^{3} 59$ Proc. Eisen- und 8 Proc. Mangonoxyd vorstellt. v. d. L. unschmelzbar, gibt auf Kohle Zinkbeschlag, mit Soda auf Platinblech geschmolzen Manganreaction, mit Borax ein heiss rothes, kalt braunes Glas, löst sich in erwärmter Salzsäure unter Chlorentwicklung. Fundorte Franklin und Stirling Hill in New-Tersey, Nord-Amerika.

Lb.

Fransen (franges - fringes), s. Posamentierarbeiten.

Franzbranntwein, s. Cognac II pag. 373.

Karmarseh \& Heeren, Technisches Wörterbuch. Bd, III. 
schlägerei.

Franzgold, P a ris e r Gold, ist blassgelbes Blattgold, s. Gold-

Franzleinen ist ungebleichte, stark appretirte Futterleinwand.

Französischgrün, syn. mit Steingrün oder Grünerde.

Franzofen, Schliechofen für das Zugutemachen von Quecksilbererzen, s. Quecksilber.

Franzosenholz, Pockholz, s. Guajakholz.

Fraueneis, Frauenglas, s. G y ps.

Fraxetin, s. Fraxin.

Fraxin (fraxine - fraxine), Paviin. Glucosid aus der Rinde von Fraxinus- (Esche) und Aesculus- (Rosskastanie) Bäumen. Kann durch Auskochen der zur Blüthezeit gesammelten Eschenrinde mit Wasser und Fällen der Abkochung mit Bleizucker aus dem Filtrate vom B'einiederschlage erhalten werden, indem man dasselbe mit bas. essigs. Blei fracti : irt fällt und die letzten Antheile dieses Niederschlags mit Schwefelwasserstoff unter Wasser zersetzt. Die vom Schwefelblei abfiltrirte Lösung liefert beim Verdunsten Krystalle, welche aus Weingeist umkrystallisirt werden. (Vgl. S a l m-Horstmar, Pogg. Ann. 97 pag. 637, 100 pag. 607, 107 pag. 327). Aus Rosskastanienrinde erhält man es nach Rochle der (vgl. Pogg. Ann. 107 pag. 331, Ber. d. k. Akad. d. Wiss. zu Wien 40 pag. 37) durch Extrahiren derselben mit Weingeist von $35^{\circ}$ B., Fällen des Auszuges mit weingeistiger Bleizuckerlösung und Zersetzen des Niederschlags mit Schwefelwasserstoff unter Wasser.

Das reine Fraxin bildet farblose, dem Zinkvitriol ähnliche Krystalle, löst sich in 1000 Thl. Wasser in der Kälte, leichter in heissem Wasser und in Weingeist, welcher es namentlich bei Kochhitze reichlich aufnimmt. In Aether ist es unlöslich. Es schmeckt schwach bitterlich herbe. Seine Zusammensetzung entspricht der Formel $C_{27} H_{30} O_{17}$. Beim Erhitzen auf $320^{\circ}$ C. schmilzt es unter Wasserabgabe zu einer röthlichen Masse und weiter erhitzt tritt Verkohlung ein. Mit verdümnten Säuren erhitzt spaltet es sich in Fraxetin $\left(\mathrm{C}_{15} \mathrm{H}_{12} \mathrm{O}_{8}\right)$ und 2 Molekule krystallisirbaren Zucker $\left(\mathrm{C}_{6} \mathrm{H}_{12} \mathrm{O}_{6}\right)$.

Das Fraxin ist besonders ausgezeichnet durch die prächtig bläulich-grüne Fiuorescenz, welche die wässrigen und weingeistigen Lösungen desselben, namentlich bei Gegen rart rou geringen Mengen ron Ammoniak oder Alkalien zeigen. Säurezusatz hebt die Fluoressenz auf (vgl. auch Stokes Chem. Soc. Q. J. 11 pag. 17 und 12 pag. 126). Gtl.

Fraxinin wurde ron Keller ein als Mannit erkannter Bestandtheil der Eschenrinde genannt, s. Mannit.

Freie Achse (brayer d'une balance - axe of a balance). Rotirt ein Körper um eine Achse und heben sich die Fliehkräfte der einzelnen Moleküle derartig gegenseitig auf, dass diese Kräfte keine Einwirkung auf diese Achse ausiiben, also die Richtung der Rotations-Achse nicht zu verändern streben, dann neunt man dieselbe freie Achse.

Siehe z. B. Redtenbacher Principien der Mechanik pag. 117 und betreffs der Anwendung auf Mïhlsteine Kick Mehlfabrikation II. Aufl. pag. 159. Vergl. f. d. Artikel Rotation. $K k$.

Freie Hemmung, s. Uhren.

Freieslebenit, Schilfglaserz. Ein seltenes Silbererz, dessen monoklin-prismatischen, stark längsgestreiften Krystalle an Gras oder Schilf erinnern, daher 
der deutsche Name Schilfglaserz. Auch derb und eingesprengt kommt es vor. Ist nach der Säule und der Basis spaltbar, hat muschligen Bruch, ist wenig sprïde, hat $H=2-2.5$, spec. Gewicht $=6.19-6.38$, dunkelbleigrau. Chem. Zus. $2 \mathrm{Ag}{ }^{2} S . S b^{2} S^{3}+3 P b S . S b^{2} S^{3}$ nit 22.5 Silber, 32.4 Blei, 26.8 Antimon und 18.3 Schwefel. Schmilzt im Glasrohr unter Entwicklung von schwefliger Säure und Antimonsublimat. v. d. L. schmilzt er schnell und gibt unter Bildung von Bleiund Antimonbeschlag ein Silberkorn. Findet sich zu Přibram, Ratiborsehitz, Felsöbanya, Hiendelencina in Spanien. Ein in Pribram von dem Freieslebenit in der Krystallform etwas abweichendes Schilfglaserz wurde von v. Zepharovich Diaphorit genannt.

Freitreppe (perron -- open stairs) ist ein Stufengang, welcher ausserhalb des Gebäudes sich befindet. Die Auftrittsflächen erhalten eine ganz geringe Neigung nach vorn zum Wasserabfluss.

Grohm.

Friction, s. R eibung.

Frictionshammer, s. H a m m er.

Frictionshölzer, s. Z ü n d w a aren.

Frictionskalander, s. Appretur I pag. 179.

Frictionsräder, s. K in e m a tik.

Frictionsrollen, s. $\mathrm{R}$ e ib ung.

Frictionssätze, s. Explosivs t offe.

Friedrichsalz, s. m. Bittersalz, s. b. Magnesium.

Fries, Flaus (frise - coating), s. Flaus.

Fries (fries - plate-bande). Darunter versteht man im Allgemeinen Rahmen oder Streifen, welche eine Construction in Unterabtheilungen trennen, z. B. Friese bei Fussböden. In archetektonischer Hinsicht wird damit die Fläche im Gebälk der Säulenordnungen bezeichnet, welche zwischen Architrav und Kranzgesims liegt.

Grohm.

Frigoriféren, s. Eismaschinen II pag. 743.

Frischblei, Weichblei, Kaufblei, Glättblei (plomb raffiné - refined lead), s. Blei I pag. 569 .

Frischen, s. Eisenerzeugung III pag. 22.

Frischen (affinage - refining), hüttenmännische Bezeichnung, so viel wie Läutern, Garen, Reinigen, speciell im Blei- und Eisenhüttenbetrieb. Hierauf bezügliche Ausdrücke, wie Fris charbeit, Frischfeuer, Frisehherd, Frischmetall, Frischofen, Frischprocess etc., s. b. Blei I pag. 569 und bei Eisen III pag. 22.

Frischfeuer, Frischherd (forge d'affinerie - refining-fire), s. E is e nerzeugung III pag. 22.

Frischglätte (litharge conglomérée - hard litharge), s. Blei I pag. 569.

Frischluppe (loupe - bloom), s. Frischen.

Frischschlacke, s. b. Eis en III pag. 22 u. $f$., vgl. a. Schlacke. 
Frischstahl (acier brut - rough steel), s. Eisen II pag. 776 und Eisen erzeugung III pag. 27.

Frischvogel, hüttenm. Benennung des beim Stahlfrischen die Gare anzeigenden Ansatzes am Schlackenspiesse.

Frisè, Krausgespinnst, s. Leonische Arbeit.

Frisirmühle, Ratinirmaschine (friseuse, ratineuse), ist eine Appreturmaschine für den Ratin, ein tuchartiges Gewebe, dessen vorstehende Härchen zu kleinen Knoten mittelst der Ratinirmaschine geballt werden, indem das Tuch einer eigenthümlichen Reibung ausgesetzt wird. Armengand publ. ind. X. 366 .

Frisoletbänder sind geköperte Seidenbänder ziemlich schlechter Qualität, der Schuss ist meist Florettseide, die Kette dasselbe Materiale oder auch nur Baumwolle.

Frisoir, eine Punze mit ovaler ebener Fläche mit regelmässigen kleinen, halbkugeligen Vertiefungen, s. Goldarbeiten, s. Graviren.

Fritte (feretto - frit), allgem. Benennung für Glassatz oder Schmelzsatz, s. Glas, vgl. Email III pag. 264 .

Fritten (fritter - to frit), in der Glasmacherkunst das Vorglühen der Glasmasse bis zur beginnenden Sinterung. Im Allgemeinen das Erhitzen einer pulverförmigen Mischung bis zur beginnenden Erweichung und zum oberflächlichen Aneinanderhaften der erweichten Partikelchen. Gtl.

Frittenporzellan, s. Thonwaaren bei Porzellan.

Frosch, s. Böttcherei I pag. 685 .

Frösche, Hebedaumen, Däumlinge (cames, poucets - arms, knobs), vergl. I pag. 564, Fig. 360.

Frösche, s. Feuerwerkerei III pag. 472.

Frostmaschinen, s. Eis maschinen II pag. 743.

Frostmischungen, s. Kälte $\mathrm{m}$ is chungen.

Frottirapparat, Würgelapparat, s. Streichgarnspinnerei bei Vorspinnkrempel.

Frottirstoff, s. Ba dehand tü cher I pag. 271.

Fruchtäther, Fruchtessenzen, Fruchtöle (éther de fruit - essence of fruits), nennt man allgemein gewisse, meist zusammengesetzte Aether (Ester), s. A ther I pag. 50 oder Gemenge solcher darstellende Kunstprodukte, welche einen dem Aroma gewisser Obstarten ähnlichen Geruch zeigen, oder durch Zusätze von ätherischen Oelen anzunehmen vermögen. Die wichtigsten dieser Fruchtäther sind unter dem Namen der Früchte, deren Geruch sie zeigen, angeführt. Gtl.

Fruchtbranntwein, s. Branntweinbrennerei I pag. 741.

Fruchtessenzen, s. Fruchtäther.

Fruchtessige, s. Essig III pag. 293.

Fruchtgneis, Feldspathkörner führender Fıuchtschiefer, s. Fle ck s chiefer.

Fruchtöle, s. Fruchtäther. 
Fruchtsäure, s. m. A epfelsäure I pag. 49.

Fruchtschiefer s. Fleckschiefer.

Fruchtwein, s. Wein.

Fruchtzucker, Linksfruchtzucker, Levulose, s. Zucker.

Fuchsschwanz, Fuchsschweif (scie à mache - hand saw), s. Sägen.

Fuchsiacin, ält. Benennung für $\mathrm{Fuchsin.}$

Fuchsin, s. Theerfarbst of fe.

Fuchsinsäure, veralt. Bezeichnung für $\mathrm{Fuchsin.}$

Fuchsit, ein in Tirol vorkommender, durch einen geringen Chromoxydgehalt (bis 4 Proc.) schön gras- oder smaragdgrün gefärbter Kaliglimmer. $L b$.

Fuchsweizen, s. W e i z en.

Fucoidensandstein, ein in der Kreide im Flysch vorkommender Sandstein mit Resten von Meeresalgen (Fucoiden).

Fucusol, Produkt der Destillation gewisser Fucus-Arten mit verd. Schwefelsäure, ähnlich dem Furfurol, s. d.

Fuder (fudder), Bezeichnung für jene Wagenladung (Belastung), welche zwei Pferde ziehen können, s. Fuhrwerke.

Fügen (joindre - jointing) nennt der Tischler das Abhobeln der langen Kanten der Bretter (Dielen), welche Operation mit der $\mathrm{Fugbank}$ ołer des Fughobels (s. Hobel) und unter Beihilfe einfacher, die Bretter hochkantig haltender Gestelle, der $\mathrm{F} u ̈ \mathrm{~g} \mathrm{e} \mathrm{b} \ddot{\mathrm{c}} \mathrm{k} \mathrm{e}$, ausgeführt wird. $K k$.

Fühlhebel, s. Messwerkzeuge.

Führung (guide - guide), die Bezeichnung eines ruhenden Maschinentheiles, welcher einen bewegten zwingt, eine bestimmte Bahn zu durchlaufen, s. Kinem a tik.

Füllapparat, s. Flasehenfüllapparat.

Füllmasse, s. Zuckerfabrikation.

Füllofen, s. O efen.

Füllort (recette d'accrochage - pit-eye), jener erweiterte Raum in Schächten und Stollen, wo die Fördergefässe gefüllt werden.

Füllung (panneau - panel), die im Material schwächer gehaltene Ausfüllung eines Rahmens, s. Thüren, ferner bezeichnet das Wort F ü $11 \mathrm{ung}$ (remplage - backing) auch die Ausschïttung oder Anfüllung von Hohlräumen, häufig mit solchem Materiale, welches die Wärme schlecht leiten soll.

Fugbank, s. Böttcherei I pag. 680.

Fugenleiste, Deckleiste, ist eine schmale Leiste zur Ueberdeckung der Fuge zwischen Hölzer, oder Holz und Stein.

Grohm.

Fughobel (houvet - long-plane), s. Hobel.

Fuhrwerk (voiture - carriage). Allgemeine Grundsätze. Da der Name Fuhrwerk bekanntlich von den verschiedensten Vorrichtungen gebraucht wird, so ist ausdrücklich zu bemerken, dass hier darunter nur Karren und Wagen oder zweirädrige und mehrrädrige Transportmittel verstanden werden sollen. Um von der zweckmässigen Einrichtung dieser so höchst wichtigen Apparate dentliche 
Ansichten zu erwerben, ist es erforderlich, einige Sätze voranzuschicken, welche die Physik und Mechanik bei der Lehre von der Reibung näher entwickeln und beweisen.

Zwei feste Körper, welche mit ihren Oberflächen und einem gegenseitigen Drucke an einander herbewegt werden, zeigen - unabhängig von allen sonstigen Verhältnissen - einen Widerstand gegen die Bewegung, welcher mit dem Namen Reibung oder Friction belegt wird. Wenn die Theile der Fläche in Bewegung gerathen, so hat jeder Punkt eine augenblickliche Richtung, die normal gegen das Perpendikel der gemeinschaftlichen BerührungsEbene gerichtet ist, und die Richtung der Kraft, welche irgend einen Punkt wirklich forttreibt, muss ebenfalls rechtwinklig gegen die Richtung des gegenseitigen Druckes gestellt sein. Die Reibung als Widerstand gegen die Bewegung ist längs der Oberfäche der Richtung der Bewegung stets geradlinig entgegengesetzt, und also auch rechtwinklig auf die Richtung des Druckes. Neben der Reibung ist nun in manchen Fällen die Anhaftung oder Adhäsion der bewegten Flächen wesentlich mit zu berïcksichtigen; zunächst soll indessen davon abgesehen werden.

Man unterscheidet zwei Arten von Reibung, nämlich: gleitende und wälzende. Gleitende Reibung findet statt, wenn verschiedene Theile des einen Körpers mit demselben Theile des andern allmälig in Berührung kommen. Man pflegt dabei noch schiebende und drehende Reibnng zu unterscheiden; erstere zeigt sich bei dem einfachen Fortschieben eines Körpers auf einer Unterlage; letztere bei dem Bewegen eines Zapfens in seiner Pfanne. Bei der wälzenden Reibung, wie sie sich z. B. bei dem Fortrollen einer Walze zeigt, treten allmälig von beiden Flächen verschiedene Theile mit einander in Berührung.

Als Ursache der Reibung erkennt man die natürliche Rauhigkeit der körperlichen Oberflächen, welche durch Poliren und andere Mittel zwar bis zu einem gewissen Grade vermindert, jedoch nie ganz beseitigt werden kann. Es gibt für diese Rauhigkeit keinen Massstab, sondern sie lässt sich nur in ihrer Wirkung durch Vergleichung mit anderen Zuständen derselben Art auffassen. Im Allgemeinen zeigen gleichartige Körper stärkere Reibungen gegen einander als verschiedenartige, und es erklärt sich diese Thatsache sehr einfach daraus, dass beider ersteren die gegenseitigen kleinsten Erhabenheiten und Vertiefungen mehr und gleichmässiger in einander greifen und passen, als dies bei verschiedenartigen Körpern der Fall sein kann. Eine löhere Temperatur, wie sie besonders durch Reibung selbst eintreten kann, vermehrt den Widerstand oft sehr bedeutend.

Als wesentliche Sätze, welche die Erfolge der Reibung darlegen, kann man die nachstehenden ansehen:

a) Die Grösse der Reibung ist, unter sonst gleichen Umständen, dem Drucke proportional, mit welchem die Flächen an einander herbewegt werden.

b) Bei gleichem Drucke ist die Grösse der Reibung unabhängig von der Ausdehnung der sich reibenden Flächen, vorausgesetzt jedoch, dass diese nicht bis zu einer einschneidenden Kante oder Spitze rerkleinert sind. Diese sehr wichtige Thatsache findet ihre Erklärung darin, dass bei Vergrösserung der Fläche der Druck in entsprechendem Masse an jeder Stelle abnimmt, daher die gegenseitigen Rauhigkeiten nicht mehr so stark wie friher in einander greifen können; und dass bei Körpern, deren Theile in starrer Verbindung stehen, das Aufheben und Bewegen einer Stelle das gleichzeitige Loslassen aller anderen herbeiführt und bedingt.

c) Die Reibung, um aus der Ruhe in Bewegung überzugehen, ist grösser als diejenige, welche während der Bewegung wahrgenommen wird. Die Zeiten, welche bei ruhenden Körpern rerfliessen, ehe sich der grösste Werth des Reibungswiderstandes zeigen kann, sind übrigens so verschieden, dass eine allgemeine Angabe nicht möglich ist.

d) Gleitende Reibung zeigt einen ungleich grösseren Widerstand als wälzende, welches sich leicht daraus erklärt, dass bei letzterer ein hebelartiges Losheben der sich berührenden Theile stattfindet, welches bei ersterer offenbar nicht eintreten kann; vielmehr erfordert diese, um die Bewegung eintreten zu lassen, häufig ein gewaltsames Abbrechen und Ĺmbiegen der widerstehenden Theile.

e) Die rerschiedenen Geschwindigkeiten während der Bewegung zeigen nur einen unmerklichen Einfluss auf die Grösse der Reibung.

Man ist übereingekommen, den Werth oder den Widerstand der Reibung durch einen Bruch auszudrücken, dessen Nenner den jedesmaligen Druck angibt, womit die Flächen an 
einander gepresst sind, und dessen Zühler denjenigen verhältnissmässigen Theil dieses Druckes darlegt, welcher als bewegende Kraft angewendet werden musste, um die Bewegung eintreten zu lassen oder zu erhalten. Diese Zahlen, welche durch umfassende Erfahrungen in jedem besonderen Falle festgestellt worden sind, werden Reibungs-Coefficienten oder Reibungsfactoren genannt. So würde z. B. der Reibungs-Coefficient $1 / 4$ andeuten, dass bei zwei reibenden Körpern, denen diese Zahl angehört, jedesmal der vierte Theil des stattfindenden Druckes als Kraft verwendet werden müsse, um die Reibung zu ïberwinden. Natürlich sind jedoch alle Werthe, die auf diese Weise gefunden und in Tabellen niedergelegt sind, nur Mittelzahlen, welche innerhalb gewisser Grenzen einen genügenden Grad von Zuverlässigkeit für die Ausübung darbieten, ohne auf absolute Genauigkeit Anspruch zu machen, wie sich dies wegen der grossen Abweichung in der natïrlichen Beschaffenheit von solchen Substanzen derselben Art, wie sie hier vorkommen, zum Voraus denken lässt.

Ohne in Einzelheiten über die Auffindung der Reibungs-Coefficienten einzugehen, kann man folgende als die wichtigsten Mittelzahlen bemerken:

I. Gleitende Reibung der Ruhe.

1. Schiebende Reibung, zunächst in trockenem Zustande.

Eichen auf Eichen $3 / 7$; Kiefer auf Kiefer $7 / 12$; Ulmen auf Ulmen $6 / 13$; Eichen auf Kiefer $2 / 3$; Eichen auf Guajak $1 / 10$; Eisen auf Eisen $2 / 7$; Kupfer auf Eisen $3 / 7$; Eisen auf Eichen $1 / 5$; Kupfer auf Eichen $2 / r$; Messing auf Eisen $4 / 16$.

Mit Talg geschmiert ergaben sich folgende Zablen:

Eichen auf Eichen $2 / 5$; Kupfer auf Eisen 1/10; Eisen auf Eichen $1 / 12$.

2. Drehende Reibung.

Kupfer auf Eisen (trocken) $2 / 11$; mit Talg geschmiert $1 / 1 \mathrm{r}$; Eisen auf Guajak (trocken) $1 / 15$; mit Talg geschmiert $1 / 20$.

\section{Gleitende Reibung der Bewegung.}

1. Schiebende Reibung, trocken.

Eichen auf Eichen $1 / 2$; Kiefer auf Kiefer $1 / 6$; Ulmen auf Ulmen $1 / 10$; Eisen auf Eisen $2 / 7$; Kupfer auf Eisen $1 / 6$; Eisen auf Eichen $1 / 6$; Kupfer auf Eichen 1/12.

Mit Talg geschmiert:

Eichen auf Eichen $1 / 17$; Eisen auf Eisen $1 / 10$; Kupfer auf Eisen 1/11; Eisen auf Eichen $1 / 25$; Kupfer auf Eichen 1/41.

2. Drehende oder Zapfen-Reibung nach Morin.

\begin{tabular}{|c|c|c|c|c|c|c|c|}
\hline \multirow{3}{*}{$\begin{array}{c}\text { A ngabe } \\
\text { der } \\
\text { sich reibenden Körper }\end{array}$} & \multicolumn{7}{|c|}{ Zustand der Reibungsflächen und Gattung der Schmieren } \\
\hline & \multirow{2}{*}{ 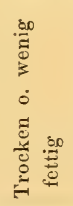 } & \multirow{2}{*}{ 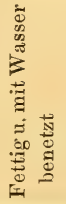 } & \multicolumn{2}{|c|}{$\begin{array}{l}\text { Oel, Talg oder } \\
\text { Schweinefett }\end{array}$} & \multirow{2}{*}{ 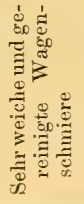 } & \multirow{2}{*}{ 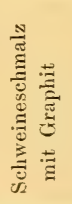 } & \multirow[b]{2}{*}{ 箬 } \\
\hline & & & 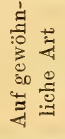 & 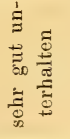 & & & \\
\hline Bronze auf Bronze. . & - & - & 0.097 & - & - & - & - \\
\hline Gusseisen auf Bronze. . & - - & - & - & 0.049 & - & - & - \\
\hline Schmiedeisen auf Bronze. & 0.251 & 0.189 & 0.075 & 0.054 & 0.090 & 0.111 & - \\
\hline Schmiedeisen auf Gusseisen & -- & - & 0.075 & 0.054 & - & - & - \\
\hline Gusseisen auf Gusseisen . & - & 0.137 & 0.075 & 0.054 & - & - & 0.137 \\
\hline Gusseisen auf Bronze. . & 0.194 & 0.161 & 0.075 & $0.05 t$ & 0.065 & - & 0.166 \\
\hline Desgleichen auf Guajakholz & 0.185 & - & 0.100 & 0.092 & - & 0.109 & 0.140 \\
\hline Guajakholz auf Guajakholz & - & - & - & 0.070 & - & - & - \\
\hline
\end{tabular}

Hieraus folgt insbesondere für die Praxis, dass es ganz gleichgiltig ist, sobald man nur sorgfältig schmiert, ob Zapfen aus Schmiede- oder Gusseisen auf Lagern (Pfannen) aus Gusseisen oder Bronze laufen, natïrlich ïbrigens dieselben Umstände, namentlich gute Beartung der Zapfen, vorausgesetzt. 
Der Widerstand der Adhäsion, welcher häufig ausser der Reibung stattfindet, wächst im geraden Verhältnisse mit den anhaftenden Flächen und scheint vom Drucke unabhängig zu sein; er ist im Allgemeinen und vergleichungsweise so gering, dass er bei bedeutenden Reibungen, mit denen derselbe verbunden erscheint, vernachlässigt werden kann. Es ist zu bemerken, dass die benutzten Oberflächen der Körper bei allen Versuchen möglichst polirt waren, und dass bei der Verwendung von fettigen Substanzen, wie Talg oder Oel, unter dem Namen von Schmiere, die dadurch eintretende, oft sehr bedeutende Abnahme der Reibung ganz einfach desshalb erfolgt, weil durch dies Zwischenmittel ein mehr oder weniger vollständiges Ausfüllen der natiirlichen Unebenheiten zu Wege gebracht wird. Auch der Erfolg dieses Mittels ist nach Beschaffenheit derjenigen Substanzen, wobei es benutzt wird, schr verschieden, und es muss von ihm nie mehr verwendet werden, als durchaus nöthig ist.

Es zeigt sich ferner aus Obigem, dass zwar einige harte Hölzer noch geringere Reibung geben als manche Metalle; al lein wegen der ungleich grösseren Festigkeit und Dauer der Letzteren werden sie dennoch zu Maschinentheilen und anderen Apparaten meistens vorgezogen.

Die wälzende Reibung zeigt sich stets ungleich geringer als die gleitende, sie steht bei den nämlichen Körpern im geraden Verhältnisse des Druckes und im umgekehrten Verhältnisse mit den Halbmessern oder Durchmessern der Walzen, so dass mithin eine ganz so einfache Bestimmung durch Coefficienten wie bei der gleitenden Reibung nicht thunlich ist. Eine Walze von $150 \mathrm{~mm}$ Durchmesser von Guajak auf eichener Unterlage erfordert bei 100 Kilo Belastung nur 0.3 Kilo zur Bewegung; eine von $50 \mathrm{~mm}$, also dreimal so viel, u. s. w. Eine Walze von $150 \mathrm{~mm}$ Durchmesser von Ulmen auf Eichen bei 1000 Kilo Belastung wurde durch 5 Kilo Kraft in Bewegung gesetzt; und ans diesen Angaben lässt sich durch einfache Rechnung die entsprechende Fortsetzung finden, wobei natürlich Alles auf dieselben Einheiten bezogen werden muss. Bezeichnet man die Belastungen durch $Q$ und $q$, die Halbmesser durch $R$ und $r$ und die Widerstände durch $W$ und $w$, so muss dem Vorigen zufolge nachstehendes Gesetz über die wälzende Reibung stattfinden:

$$
W: w=\frac{Q}{R}: \frac{q}{r}
$$

Setzt man hier $w, q$ und $r$ als durch Versuche bekannt voraus und bezeichnet $\frac{w r}{q}$ mit $q$, so wird $\phi$ der Coefficient der wälzenden Reibung genannt, und die Kraft $W$ zur Ueberwindung der wälzenden Reibung kann durch die Formel bestimmt werden:

$$
W=\varphi \frac{Q}{R}
$$

Wird $R$ in preussischen Zollen und $Q$ in preussischen Pfunden ausgedrückt, so ist nach sorgfältigen Versuchen:

$$
\left.\begin{array}{l}
q=0.0184 \text { für Walzen aus Pockholz } \\
\varphi=0.0311, n \text {, n Ulmenholz }
\end{array}\right\} \text { nach Coulomb. }
$$

Für gusseiserne Räder von 520mm Durchmesser, welche auf eisernen Schienen laufen:

$$
\begin{aligned}
& \varphi=0.0178 \text { nach Weisbach in Freiberg. } \\
& q=0.0187 \text { nach Rittinger in Schemnitz. }
\end{aligned}
$$

Endlich fand Pambour für Eisenräder von circa $1^{\mathrm{m}}$ Höhe auf schmiedeisernen Schienen :

\[ =0.019 \text { bis } 0.021 \text {. } \]
Bei der Formel $W=\varphi \frac{Q}{R}$ wird vorausgesetzt, dass die Kraft $W$ zum Ueberwinden des Reibungswiderstandes mit einem dem Walzenhalbmesser gleichen Hebelarm wirke, und daher mit der Walze einerlei Weg zurücklege; wirkt sonach diese Kraft an ein'm Hebelarme $2 R$, so ist auch der zurückgelegte Weg doppelt so gross und die Reibung unter sonstgleichen Umständen nur halb so gross: $d$. $h$.

$$
W^{\prime}=4 \frac{Q}{2 R}
$$

Die hauptsächlichste und entscheidende Bestrebung bei der Einrichtung aller Transportmittel ist bekanntlich dahin gerichtet, die Widerstände gegen die Bewegung so unbedeutend wie möglich zu machen, und abgesehen von der Beschaffen- 
heit der Wege und sonstigen Hindernisse, besteht das vorzïglichste Mittel, jenen Zweck zu erreichen, in der Verminderung der Reibung. Weil nun die wälzende Reibung so äusserst viel geringer ist als die gleitende, so liegt die Idee sehr nahe, wo möglich durch eine Umänderung der letzteren in die erstere sich dem vorgesteckten Ziele zu nähern, und es hat nicht an vielfachen Vorschlägen gefehlt, wie man geradezı jene Umänderung bewirken könnte. Allein die bis jetzt bekannt gewordenen Erfindungen dieser Art waren entweder ganz unpraktisch, oder ihre Anwendungsfähigkeit ist auf einzelne so seltene Fälle beschränkt, dass eine $\mathrm{Be}$ nutzung im Grossen davon nie zu erwarten steht. Untergelegte Walzen unter den fortzuschaffenden Lasten sind ein allbekanntes Mittel, welches nur für kleine Strecken brauchbar ist. Räderwerke, deren Zapfen selbst wieder auf dem Umfange anderer Räder liegen, sogenannte Frictionsrollen, eignen sich nur für geringe Belastungen und sind leicht zerbrechlich u. s. w. Es bleibt daher für jetzt nichts iibrig, als denjenigen Mechanismus kennen zu lernen und darzulegen, der seit Jahrtausenden schon zu diesem Zwecke benutzt ist, nämlich die Fortschaffung der Lasten durch Achse und Rad. Er überträgt die schiebende Reibung in eine drehende am Umfange der Achse, und in eine wälzende am Umfange des Rades. Dabei ist es zunächst gleichgiltig, ob die Achse mit dem Rade sich in einer Unterlage dreht oder, wie es gewöhnlicher ist, um die unbewegliche feste Achse sich das Rad allein dreht.

Gelegentlich mag hier angeführt werden, dass die grossartigste Verminderung der Reibung, welche bekannt geworden ist, diejenige sein dürfte, wodurch der Granitblock transportirt wurde, auf welchem die Bildsäule Peters des Grossen in Petersburg steht. Der Block wog iiber 1/2 Mill. Kilogramm und wurde auf metallenen Kugeln fortgeschafft, so dass mit Anwendung anderer mechanischer Vorrichtungen die gewöhnliche Kraft zum Bewegen einer so ausserordentlichen Last dennoch kaum 1000 Kilo zu betragen brauchte.

Wenn man sich eine Schleife mit ihrer Belastung auf Walzen gelegt denkt, und diese Walzen durch die Ausfiihrung als Räder bleibend macht, so hat man hierin die erste und allgemeine Vorstellung des Wagengestelles. Zweirädrige Fuhrwerke heissen bekanntlich $\mathrm{K}$ aren, vierrädrige Wagen; Gestelle mit mehr als vier Rädern kommen nur ausnahmsweise vor und verdienen hier keine besondere Berïcksichtigung.

Als Grundlage der ganzen Betrachtung sind natürlich die Verhältnisse an e in em Rad anzusehen, und $\epsilon s$ dienen zu ihrer Bestimmung, so weit dies ohne tieferes mathematisches Eingehen thunlich ist, die nachstehenden Sätze.

Eine oberflächliche Kenntniss der Theile eines Rades und ihrer Namen darf dabei als geläufig vorausgesetzt werden.

Man denke oder zeichne sich als Darstellnng des Rades einen Kreis auf horizontaler Grundlinie, und um seinen Mittelpunkt einen zweiten verhältnissmässig kleinen Kreis als Angabe des Achsschenkels oder der Oeffnung der Nabe. Im ruhenden Zustande pflanzt sich der Druck der Belastung, die auf der Achse liegt, in senkreehter Richtung von der Achse gegen die Nabe und am Umfange des Rades gegen den Erdboden oder die sonstige Unterlage fort. Es werde eine horizontale Zugkraft angenommen, deren Angriffspunkt die Mitte der Achse ist, und man fragt zunächst nach den Bedingungen des Gleichgewichtes zwischen Kraft und Widerstand. Nun leuchtet ein, dass der Widerstand am Umfange des Rades als eine nach rückwärts gestellte Kraft anzusehen ist, deren Ueberwindung nothwendig mit einem gleichzeitigen Vorrïcken der Achse oder einer eben solchen Rückwärtsdrehung des Rades verbunden sein muss. Denn wenn auf glatten Bahnen dieser Widerstand am Umfange fehlt, so dreht sich bekanntlich das Rad nicht, sondern es entsteht so lange eine bloss fortschleifende Bewegung. Alle Verhältnisse also, welche sich der Umdrehung des Rades widersetzen, sind in demselben Sinne Hindernisse des Fortriickens, und umgekehrt. Als erster Widerstand gegen die Drehung des Rades erscheint nun nothwendig diejenige Reibung am Umfange der Achse, welche als drehende Reibung nicht allein einen bestimmten 
Zahlenausdruck zum Reibungs-Coefficienten hat, sondern auch an einem $\mathrm{Hebel-}$ a rme wirksam ist, welcher mit dem Halbmesser der Achse übereinstimmt. Bei einem und dem nämlichen Werthe der unmittelbaren Reibung steht also, nach bekannten Sätzen, der Erfolg derselben, d. h. hier der Widerstand gegen die drehende Bewegung, in geradem Verhältnisse mit dem Halbmesser oder Durchmesser der Achse. Es wird daher, wenn alles Uebrige unverändert bleibt, der Widerstand in demselben Masse wachsen, wie die Achse dicker wird. Sodann ist als Folge des übertragenen Druckes, wie schon erwähnt, ein rückwärts gestellter Widerstand am Umfange des Rades zu berïcksichtigen. Zu seiner Ueberwindung, um die Drehung zu bewirken, hat die Zugkraft, wie leicht zu ersehen, einen Hebelarm, welcher dem Halbmesser des Rades entspricht, und die Bewältigung muss daher um so leichter erfolgen, je grösser dieser Halbmesser angenommen war.

Es sind also für jetzt die beiden Momente des Widerstandes, welche hier in Betracht kommen, um so leichter zu überwinden, je kleiner der Hebelarm der drehenden Reibung an der Aclse, d. h. je diinner der Schenkel ist, und auf der anderen Seite je grösser der Hebelarm der Zugkraft, d. h. der Halbmesser oder auch die Höhe des Rades ausgeführt wurde. In diesen höchst einfachen Begriffen liegt die theoretische Entwicklung ausgesprochen, wenn man eine vollständige mathematische Darlegung vermeiden will, und es darf dies um so mehr geschehen, als es sich bald zeigen wird, dass die mathematisch nachzuweisenden Verhältnisse des Widerstandes und die Gesetze des Gleichgewichts keineswegs diejenigen sind, welche im wirklichen Gebrauche entscheiden. Wenn also auch die vorstehende Erörterung nicht auf strenge Begrïndung Anspruch machen kann, so behält sie dennoch als Resultat die nämliche Wichtigkeit, welche einer weit ausgedehnteren Untersuchung zukommen könnte. Dabei ist auch noch der Einfluss der wälzenden Reibung am Umfange des Rades vernachlässigt, welches um so eher zu rechtfertigen ist, da derselbe vergleichungsweise zu den weit grösseren Widerständen, die sich noch nachweisen lassen, in der That als unbedeutend erscheint. Bezeichnet man den Halbmesser des Rades mit $R$, den der Achse mit $r$, die Belastung mit $Q$ und den unmittelbaren Reibungscoefficienten am Umfange der Achse oder des Schenkels mit $f$, so findet sich für den Fall des Gleichgewichtes die Zugkraft $K=f \frac{r}{R}$. Q, worin die vorhin entwickelten Beziehungen einfach ausgesprochen sind. Es sei z. B. die Belastung 2500 Kilo $=Q$; Halbmesser des Rades $R=1^{\mathrm{m}} ;$ Halbmesser der Achse $r^{\circ}=50^{\text {mm }}$ und der Reibungscoefficient $f^{\prime}=1 / 5$, so fände sich auf diesem Wege eine Zugkraft $K=1 / 5$ $511 / 1000 \cdot 2500=30 \mathrm{Kilo}$, und so in allen ähnlichen Fällen.

Eine vollständige Theorie muss mit einer genauen Erfahrung nothwendig und von selbst übereinstimmen. Nur freilich ist die Gewinnung der letzteren häufig ebenso schwierig, wie die Entwickelung der ersteren, und wenn einseitige Empirie mit gelehrter Einseitigkeit in Zusammenstoss geräth, so ist eine verständige Ausgleichung nicht füglich zu erwarten. Diese Bemerkung gilt in besonderem Grade von manchen Einrichtungen der Fuhrwerke, bei denen fast niemals eine erwägende Theorie dem arbeitenden Handwerker zu Hülfe gekommen ist. Wer z. B. die eben vorstehenden Zahlen näher betrachtet, wird leicht erkennen, dass kein Rad mit solcher Belastung durch eine so winzige Kraft bewegt oder auch nur in den Zustand des Gleichgewichts versetzt werden könnte. Und in der That sind in den früheren Herleitungen sehr wesentliche Umstände ausser Acht gelassen, welche für die Anwendung den entschiedensten Einfluss geltend machen. Hierher gehört zuerst die Vertheilung der Last auf wenigstens zwei Räder, wodurch zwar rein theoretisch Nichts geändert wird, desto mehr aber in einzelnen Fällen des wirklichen Gebrauches.

Sodann aber bewirkt die Beschaffenheit der gewöhnlichen Wege und die Construction der Achse (wovon später die Rede sein wird), dass fast ununterbrochen Reibungen an der Seite der Radfelgen, so wie an der Mittelachse oder 
am Lïnz stattfinden, welche unfehlbar viel grössere Widerstände gegen die Bewegung hervorrufen, als es die bisher erörterten Beziehungen thun konnten, und in diesen stets einwirkenden, aber auch stets veränderlichen Hindernissen liegt bei Weitem der Hauptgrund für die wirkliche Grösse der Zugkräfte, wie die Erfahrung sie fordert.

Ferner sollte die Zugkraft, wie sie durch die Reibung bedingt wird, sich verhalten wie die Quotienten, welche erscheinen, wenn man die Halbmesser der Schenkel (Achsenzapfen) durch die Halbmesser der Räder dividirt. Aber diese Behauptung ist nur rein mathematisch, nicht physikalisch richtig. Denn bei zu dünnen Schenkeln entstehen nothwendig Biegungen und dadurch Klemmungen von dem nachtheiligsten Einflusse, und bei zu hohen Rädern würde die Anbringung der Zugkräfte durch die Lage der Stränge nur unvortheilhaft geschehen können. Endlich aber ist wohl zu beriicksichtigen, dass ein möglichst hoher Grad von Beweglichkeit geradezu nur auf horizontalem festen Boden von unbedingtem Nutzen sein kann; dass aber bei solchen Verhältnissen des Bodens und der Wege, wo ein Streben des Fuhrwerkes sich rückwärts zu bewegen eintritt, der höchste Grad von leichter Beweglichkeit schon dadurch zum Theil aufgehoben und nutzlos gemacht wird. Nun aber bieten alle gewöhnlichen Wege eine zusammenhängende Kette von Erhabenheiten und Vertiefungen dar, jeder tiefsandige oder weiche Weg bildet vor dem Rade eine augenblicklich entstehende und wieder niederzudriickende Erhöhung, wodurch es dann sehr begreiflich wird, dass die möglichst dïnnen Schenkel im wirklichen Gebrauche keineswegs sich so günstig zeigen, wie es theoretisch der Fall sein sollte.

Für eine zweckmässige Anordnung der Theile des Gestelles der Fuhrwerke müssen nun noch verschiedene einzelne Umstände näher erörtert werden, durch deren Auffassung demnächst das Urtheil geleitet und bestimmt werden muss.

1. Verhältnisse beim Aufwärtsfahren.

So lange die Bewegungen auf einer horizontalen Ebene erfolgen, hat die Zugkraft keine anderen Widerstände zu überwinden, als die bisher verhandelt wurden. Wenn aber das Fuhrwerk bergan fahren soll, so tritt die Schwerkraft als neues Hinderniss, das mit überwunden werden muss, hinzu. Dieser Einfluss wird gefunden, wenn man das ganze Gewicht der Belastung und des Gestells mit der Sinuszahl des Neigungswinkels multiplicirt. Bei einem Ansteigen um $10 \mathrm{Grad}$ ist jene Zahl 0.1736; und wenn also das Gesammtgewicht 5800 Kilo beträgt, so entsteht dadurch ein neter Widerstand, welcher die erbebliche Grösse von $0.1736 \times 5800$ Kilo $=1006$ Kilo besitzen wird. Man kann hieraus leicht ermessen, welchen bedeutenden Einfluss auch die geringern Steigungsverhältnisse der Wege auf die Vermehrung der Zugkräfte haben. Etwas ganz Aehnliches, nur nicht so leicht darzulegen, findet in sandigen und tiefen Wegen statt, wo die Reibung an der Seite der Radfelgen noch hinzukommt. Daraus folgt sehr deutlich, wie ganz ausserordentlich die Kräfte der Zugthiere und diese selbst geschont werden, wenn die Beschaffenheit der Wege in dieser Hinsicht zweckmässig angeordnet und erhalten wird. Für das Bergabfahren müsste eine ebenso grosse Kraft als Hemmung entgegen treten, wenn nicht die Grösse der Reibung als vortheilhaft hier einwirkte und eine Verminderung zuliesse. Bei zweirädrigem Fuhrwerke zeigt sich beim Bergabfahren noch ein anderer Uebelstand, der später näher erörtert werden muss.

2. Uebersteigen von Hindernissen auf dem Wege.

Ein festes Hinderniss, welches sich anf dem Wege des Rades vorfindet, verlangt ein wirkliches Drehen und theilweises Heben der Last um die zunächst getroffene Kante desselben. Wenn man von dem Mittelpunkte des Rades nach dieser Kante einen Halbmesser zieht und den Winkel angibt, den derselbe mit der senkrechten Richtung einschliesst, so zeigt eine leichte Betrachtung, dass der so entspringende Widerstand gefunden wird, indem man das Gesammtgewicht mit der Tangentenzahl dieses Winkels multiplicirt. Ist z. B. der Halbmesser des Rades $1^{\mathrm{m}}$ und die Höhe eines Hindernisses $1 / 6 \mathrm{~m}$, so beträgt jener Winkel $33 \mathrm{Grad}$, und seine Tangente 0.6494 ; bei einem Gesammtgewichte von 5800 Kilo ergibt also dieser Widerstand den sehr bedeutenden Werth von $5800 \times 0.6494=3766$ Kilo. Wäre der Winkel 45 Grad, so wïrde bereits die Zugkraft der ganzen Last gleich sein mïssen. Man erkennt sofort, dass höhere Räder jenen Winkel bei sonst gleichen Hindernissen vermindern, also 
einen viel leichteren Gang geben; auch ersieht man eben so leicht, dass selbst unbedeutend scheinende Hindernisse vom nachtheiligsten Einflusse sein müssen. Obgleich die angefïhrten Zahlen allerdings sehr grosse Widerstände ausdrücken, so muss man dabei erwägen, dass für den ernstlichen Fall einige Beziehungen eintreten, welche die Ueberwindung möglich machen und erleichtern. Zuerst befindet sich das Hinderniss regelmässig doch nur vor einem Rade, und auf diesem ruht nur ein Theil der Last, entweder die Hälfte oder der vierte Theil; dabei bieten die anderen Räder Stïtzpunkte dar, so dass die zu hebende Last auf eine viel gïnstigere Weise in die nothwendige Drehung versetzt wird. Sodann kommt das Fuhrwerk nicht im Zustande der Ruhe vor das Hinderniss, sondern die Bewegung, die oft absichtlich vorher beschleunigt wird, bietet ein Moment dar, wodurch mit einer schwungartigen Bewegung die Drehung uud Uebersteigung sehr befördert wird. Endlich ist die Anstrengung der Pferde nur augenblicklich nöthig, und können daher oft ganz unverhältnissmässig grosse Kraftäusserungen von ihnen geleistet werden.

3. Fester Stand des Gestelles.

Nach bekannten Sätzen der Statik fällt ein Körper um, sobald die Serikrechte, welche von seinem Schwerpunkte herabgelassen wird, aus der Unterstützungs-Ebene hinausfällt. Wenn nun ein Körper um eine bestimmte Seite seiner Grundfläche gekippt oder umgelegt werden soll, so hängt der Widerstand, welcher sich dem entgegenstellt (die sogenannte Stabilität), zunächst von dem Gewichte des Körpers ab, und zwar so, dass ein grösseres Gewicht eine vermehrte Gewalt zum Umlegen erfordert; sodann von der Höhe des Schwerpunktes über der Unterstützungs-Ebene, indem mit zunehmender Höhe die Stabilität gleichmässig verringert wird; endlich von dem Abstande, welchen die Senkrechte aus dem Schwerpunkte von derjenigen Seite der Grundfläche hat, um welche das Kippen oder Umlegen erfolgen soll. Je grösser dieser Abstand ist, um so fester steht der Körper, weil alsdann eine stärkere Neigung eintreten muss, damit jene Senkrechte aus dem Bereiche der unterstïtzenden Fläche hinausfallen kann.

Wendet man diese einfachen Verhältnisse auf das Gestell eines Fuhrwerkes an, so ergibt sich sogleich, dass der Raum zwischen den Rädern hier als die Unterstützungsebene zu betrachten ist; dass die Gesammtlast den halben Abstand der Räder zu ihrem Hebelarme hat, um den festen Stand zu sichern, dass aber eine durch Umstände herbeigeführte umreissende Gewalt die Höhe des Schwerpunktes (welche über der Mitte der Achse liegend angenommen werden kann) vom Erdboden zu ihrem Hebelarme hat. Sobald nun das Fuhrwerk an eine seitwärts geneigte Ebene gestellt wird, so lässt sich sehr leicht der Winkel der Seitenneigung angeben, bis zu welchem hin das Fubrwerk schräg gestellt werden kann und dennoch nicht umfallen wird, weil die Senkrechte aus dem Schwerpunkte bis zu dieser Grenze noch innerhalb des durch die Räder bestimmten Raumes bleiben muss. Bei eincr halben Spurweite von $650 \mathrm{~mm}$ und einer Höhe des Schwerpunktes von $780 \mathrm{~mm}$ wird der Winkel, bis zu welchem die Seiten-Neigung vergrössert werden kann, ohne dass das Umwerfen erfolgt, zwischen 39 und 40 Grad betragen. Das Nämliche wird oftenbar eintreten, wenn ein Rad überhaupt niedriger steht als das andere, gleichgiltig, ob dies durch tine seitwärts abhängende B^hn oder durch Schlaglöcher, einseitige Hindernisse $\mathrm{u}$. dgl. herbeigeführt ist.

Allein in solcher Auszeichnung wird in den Fällen der Anwendung der feste Stand nicht gesichert sein. Das Fuhrwerk kommt in die betrachtete schräge Stellung nicht durch ruhiges Hinstelleu, sondern es ist im Zustande der Bewegung und oft der raschen Bewegung begriffen. Dadurch aber entsteht eine schwungartige Seitenbewegung, sobald das eine Rad plötzlich tiefer zu stehen kommt als das andere, und hierdurch wird die Gefahr des Umwerfens bei weitem grösser, als jene Rechnung sie ergab. Uebrigens bleibt es richtig, dass niedrige R̈̈der oder tiefe Lage des Schwerpunktes überhaupt, so wie eine breitere Spurweite den festen Stand wesentlich erhöhen. Es folgt ferner, wie sehr es gerathen ist, auf schlechten Wegen, wo Schlaglöcher und einzelne Hiudernisse vorkommen, langsam zu fahren, da jede rasche Bewegung den Seitenschwung und damit die Möglichkeit des Lmwerfens vergrössert. Endlich übersieht man schon jetzt, dass der Wagen in dieser Beziehung in überwiegendem Vortheile gegen den Karren steht.

4. Richtung der Zugstränge.

Ohne an dieser Stelle die Art und Weise zu berücksichtigen, wie die Zugthiere und namentlich die Pferde ihre Kraft äussern, wurde bisher angenommen, dass die bewegende 
Kraft parallel zur Unterlage gerichtet sein müssค. Die Richtung der Zugstränge ist nun gleichbedeutend mit der Richtung der Kraft, und es entsteht die Frage: was für Aenderungen die eigentlich thätige Kraft erleidet, wenn die Zugstränge die parallele Richtung gegen die Unterlage nicht haben? Der Verlust an Kraft ist wenig bedeutend; allein wenu der Angriffspunkt der Kraft höher liegt als die Brusthöhe des Pferdes, so wird der Verlust an Kraft unmittelhar dazu verwendet, um das Fuhrwerk noch fester gegen die Erde zu drücken, so dass dann die Pferde ihrer eigenen Thätigkeit entgegen arbeiten. Zudem lehnt sich das gut ahgerichtete Thier im Augenblicke des ersten Anziehens, wo der Widerstand der ruhenden Reibung zu überwinden ist, mit der Brust stets etwas über seine Vorderbeine hinaus, wodurch die Brusthöhe geringer wird; waren also die Stränge eigentlich parallel zur Lnterlage, so werden sie nun auf eine höchst ungünstige Weise sich etwas senken. Daher legt man den Angriffspunkt der Stränge an der Mittelachse gern um einige Zoll niedriger als die Brusthöhe der Pferde; dadurch sind die Stränge dann im gewöhnlichen Zuge etwas gehoben, was indess kein Lebelstand ist, und man vermeidet die nach unten geneigte Richtung im Augenblicke des ersten Anziehens. Durch diese Umstände wird wesentlich mit die zweckmässige Höhe der Rüder bestimmt, wie sich demnächst zeigen lässt.

Wenn man es versuchen wollte, eine vollständige mathematische Theorie auf diese höchst verschiedenartigen, einander gegenseitig bedingenden und stets veränderlichen Umstände der wirklichen Bewegung bei Fuhrwerken auf gewöhnlichen Wegen anzuwenden, so würde sich unfehlbar das Resultat ergeben, dass auch bei Zuziehung des höheren Kalkiils keine Uebereinstimmung mit der Erfahrung zu erreichen sein kann. Man denke sich nur die unendlichen und stets wechselnden Verschiedenheiten eines gewöhnlichen gepflasterten Weges, wo zahllose kleine Hindernisse nach vorn zu überwinden sind, daneben ein beständiges Abgleiten der Räder zur Seite und damit ein vorübergehendes Andrücken des Rades gegen die Mittelachse oder gegen den Lünz eintritt, so dass die Widerstände fast ununterbrochen wechseln; so wird man sich leicht überzeugen, wie undenkbar es ist, auf solche Thatsachen eine erschöpfende Theorie anzuwenden. Eben so schwierige Beziehungen bieten tief sandige und kothige Wege dar, besonders wenn ein $\mathrm{Zu}$ sammenschlagen des Erdreichs iber die Felgen hinzukommt, oder wenn man, wie es hier doch erforderlich sein würde, den Widerstand der Adhäsion mit hinzu zu ziehen versuchte.

Die beständige und grosse Verschiedenheit, welche in allen solchen Verhältnissen stattfindet, zeigt sich am deutlichsten bei Anwendung eines Kraftmessers, um die Zugkräfte in bestimmten Zahlen darzulegen. Selbst auf ganz ebenen und festen Wegen, bei dem vorsichtigsten Fahren schwanken die beobachteten Zahlenwerthe auf eine kaum glaubliche Weise. Auf Steinpflaster und in tiefen Wegen sind diese Schwankungen so gross, dass nur eine lange fortgesetzte Wiederholung der Beobachtıngen dazu führen kann, überhaupt eine Gesetzmässigkeit in der ganzen Erscheinung zu entdecken.

Die ausgezeichnetsten und umfangreichsten (dynamometrischen) Versuche sind jene, welche der Artillerie-Offizier Morin auf Anordnung und Kosten der französischen Regierung angestellt hat. Wir theilen im Nachstehenden die wesentlichsten Ergebnisse dieser Versuche mit, und verweisen übrigens auf unsere Quelle**)

Wir beginnen in tabellarischer Uebersicht mit dem Verhältniss des horizontalen Zuges auf horizontaler Bahn zur fortzuschaffenden Totallast.

(Dabei bezeichnet $l$ die Felgenbreite der Räder, $\varrho$ den Zapfenradius, $r_{1}$ den Radius der Vorderräder, $r_{2}$ den Radius der Hinterräder. Sämmtliche Masse sind Metermass.)

*) Expériences sur le tirage des voitures et sur les effets destructeurs qu'elles exercent sur les routes, par M. Morin, Paris 1842. 


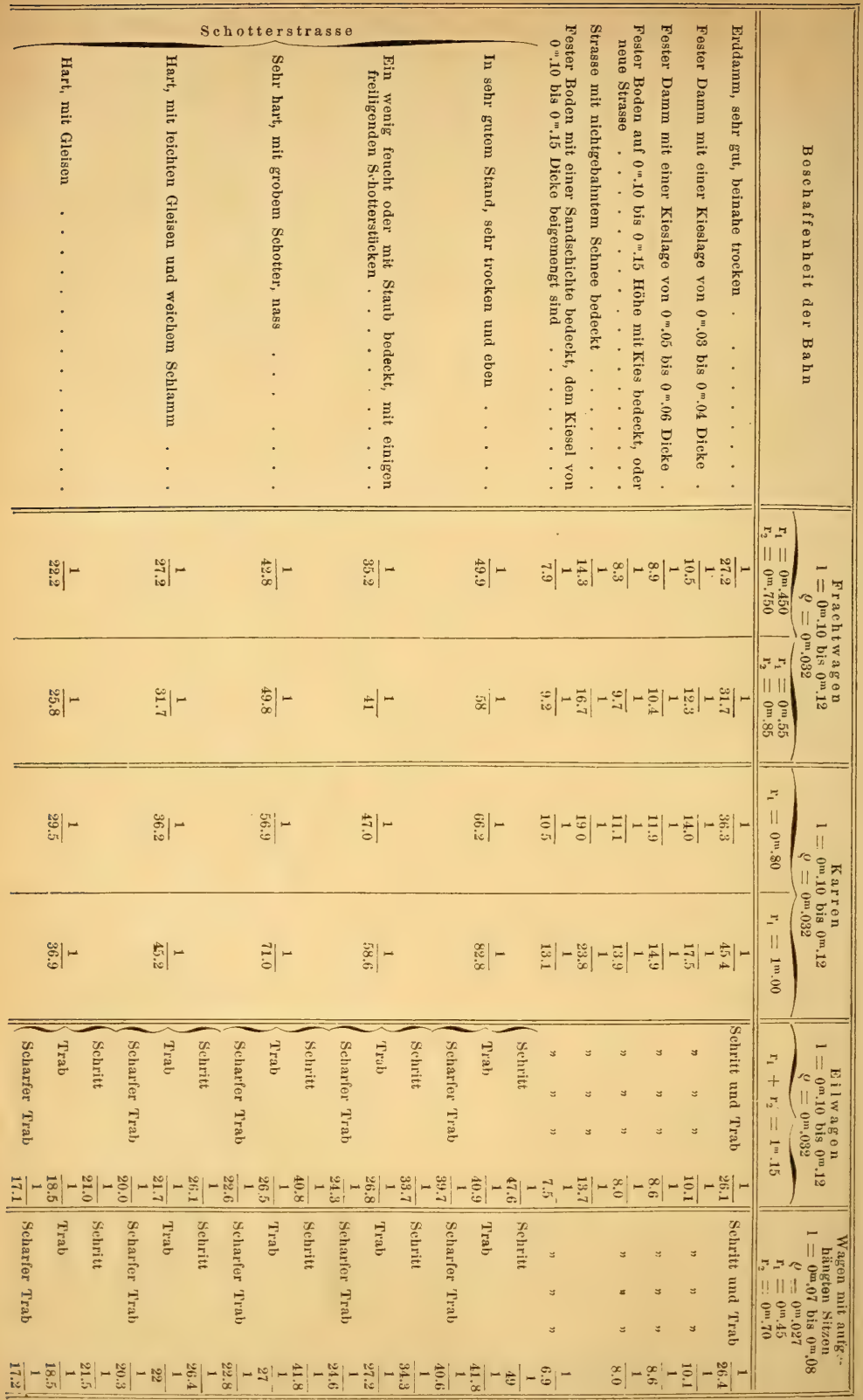




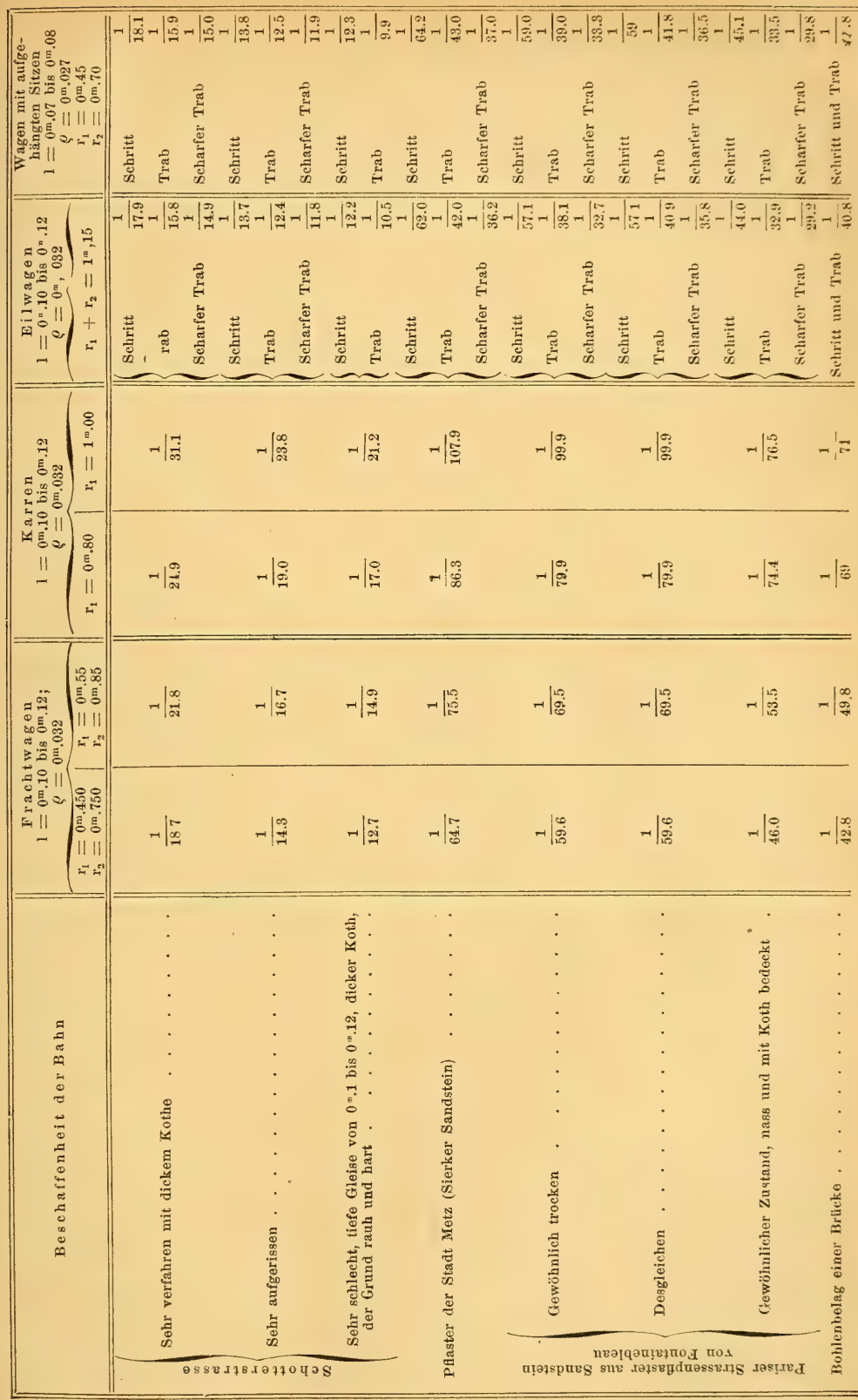


Die Znsammenstellung aller Morin'schen Resultate liefert mit Bezug auf vorstehende 'Tabelle Folgendes:

1. Bei allen Fuhrwerken ist der auf die Radachse reducirte, mit der Fahrbahn parallele Widerstand an der Letzteren proportional dem Drucke und umgekehrt proportional dem Radius des Rades.

2. Die Strassen werden desto mehr verdorben, je kleiner die Räder sind.

3. Auf dem Steinpflaster oder den Schotterstrassen ist der Widerstand nahezu von der Breite der Radfelgen unabhängig, sobald diese mindestens $0^{\mathrm{m}} .08$ bis $0^{\mathrm{m}} .10$ beträgt.

4. Auf zusammendrückbarem Boden, wie Erde, Sand, Kies, Ueberschüttungen von beweglichem Material und neuen Schotterstrassen nimmt der Widerstand in demselben Verhältnisse $a b$, wie die Breite der Felgen zunimmt.

5. Auf weichem Boden, wie Erde, Sand etc., die Bahn mag in gutem Zustande sein oder Gleise haben, in den tiefen Kieslagen auf festem Boden, oder den $0^{\mathrm{m}} .04$ bis $0^{\mathrm{m}} .06$ tiefen Aufschüttungen auf den Steinbahnen der Strassen ist der Widerstand bei aufgehängten und nicht aufgehängten Fuhrwerken von der Geschwindigkeit unabhängig.

6. Für den Schritt ist der Widerstand auf allen Strassen und selbst auf gutem Pflaster der nämliche für aufgehängte und nicht aufgehängte Fuhrwerke.

7. Auf Schotterstrassen und auf dem Steinpflaster nimmt der Widerstand mit der Geschwindigkeit zu, so dass die Aenderungen desselben den Aenderungen der Geschwindigkeit proportional sind, wobei von der Geschwindigkeit von einem Meter ausgegangen wird.

Die Vergrösserung des Widerstandes ist desto geringer, je weniger starr und je besser aufgehängt das Fuhrwerk ist; ferner je glatter die Strasse ist. Sie ist bei gut aufgehängten Eilwagen auf sehr guten Schotterstrassen, deren Oberfläche keine hervorragenden Steine darbietet, zwischen den Geschwindigkeiten des Schrittes und des starken Trabes ziemlich gering.

8. Auf einem guten Sandsteinpflaster, welches recht dicht und eben ist, wie das Metzer, ist der Widerstand bei der Geschwindigkeit des Schrittes nur ungefähr $3 / 4$ von demjenigen, welcher bei den besten Schotterstrassen stattindet; und für gut aufgehängte Fuhrwerke ist der Widerstand auf einem guten Pflaster bei der Geschwindigkeit des starken Trabes der nämliche wie auf einer guten Schotterstrasse, welche hier und da an der Oberfläche hervorragende Steine darbietet. Wenn das Pflaster dagegen nicht sehr gut unterhalten ist, so ist der Widerstand bei der Geschwindigkeit des Trabes grösser als auf guten Schotter. strassen, sẻlbst bei Fuhrwerken, welche möglichst gut aufgehängt sind.

9. Die nicht aufgehängten Fuhrwerke, welche im Schritt fahren, verderben die Strasse mehr als die aufgehängten Fuhrwerke bei der Geschwindigkeit des Trabes, und noch viel mehr werden die nicht aufgehängten Fuhrwerke bei der Geschwindigkeit des Trabes auf das Verderben der Strasse wirken.

10. Die Neigung der Zugrichtung, welche dem Maximum des Nutzeffectes correspondirt, soll im Allgemeinen mit dem Widerstande des Bodens zunehmen, und desto grösser sein, je kleiner die Vorderräder sind.

Ein Geste 11 bei Fuhrwerken besteht aus der Achse mit ihren beiden Schenkeln und zwei Rädern; jedes Rad bekanntlich wieder aus der Nabe, den Speichen und den $\mathrm{Felgen}$, welche letzteren vereinigt den $\mathrm{Kranz}$ bilden, wozu dann noch die verschiedenen Beschläge kommen.

An der Achse unterscheidet man den mittleren Theil unter dem Namen der Mittelachse; sie hat entweder gleiche Höhe und Breite, oder die Höhe ist grösser als die Breite; erstere Einrichtung kommt mehr bei eisernen Achsen vor, letztere bei hölzernen. Die Schenkel sind meistentheils abgekürzt kegelförmig, also vorn am Lünz dünner als an der Mittelachse, und man nennt diesen Unterschied ibre Verjüngung; am hinteren Ende stimmt ihr Durchmesser mit der Breite der Mittelachse uberein. Wenn der Querschnitt der letzteren kein Quadrat ist, 
so îberragt sie mit ihrer Höhe den Durchmesser des Schenkels, und dieser obere Theil heisst der Stoss. Auch bei eisernen Achsen kommt diese Stelle vor, weil zur Verbindung mit den übrigen Theilen die Achse in ein stärkeres hölzernes Achsfutter eingelassen werden muss.

Die Schenkel miissen immer so gestellt sein, dass ihre untere Begrenzung: mit der unteren Fläche der Mittelachse eine einzige gerade Linie bildet und also die vorhandene Verjüngung ganz auf der oberen Seite des Schenkels erscheint. Nur bei dieser Anordnung kann das Rad bei dem Drucke, welcher auf ihm liegt, eine ruhige und gleichmässige Stellung und Bewegung annehmen. Wollte man dagegen den kegelförmigen Schenkel so gegen die Mittelachse stellen, dass die Mittellinie desselben horizontal zu stehen käme, so wiirde der Schenkel veranlasst. sich beständig durch die Nabe zuriickzuziehen, so dass das Rad fortwährend gegen den Liinz geschoben wïrde und daselbst die nachtheiligsten Seitenreibungen entstehen müssten. Von anderen Mängeln, die sich dabei noch zeigen würden, wird weiterhin die Rede sein.

Die Verjüngung der Schenkel soll dazu dienen, durch den etwas geringeren mittleren Durchmesser den Erfolg der Reibung herabzusetzen, und an der Mittelachse grössere Sicherheit gegen das Zerbrechen zu gewähren. Bei sehr starken hölzernen Schenkeln muss man diesen Grund anerkennen, jedoch nicht bei eisernen, wo die Verjüngung viel zu unbedeutend ist, um irgend wesentlich einzuwirken. Nicht allein von dem rein mechanischen Standpunkte würden cylindrische Schenkel wegen des gleichmässigeren Ganges den Vorzug vordienen, sondern auch weil sie durch metallene Ringe, die an die Mittelachse hinter das Rad, oder zwischen dem Rade und Lïnz auf den Schenkel gesteckt werden, eine Veränderung der Spurweite zulassen, die man bei kegelförmigen Schenkeln nicht erreichen kann, ohne einen unsichern, schlottrigen Gang des Rades herbeizuführen. Fuir manche Fuhrwerke aber, die nicht blos auf Kunststrassen gehen, ist eine solche Anschliessung an die abweichenden Spurweiten in verschiedenen Provinzen eine wichtige Sache.

Die Länge der Schenkel hängt übrigens mit anderen Einrichtungen des Rades so genau zusammen, dass davon erst später gesprochen werden kann: sie beträgt von $37-63^{\mathrm{em}}$.

Die wirklichen Abmessungen von Achse und Schenkel sind natürlich durch das Material bedingt, woraus sie verfertigt werden. $Z u$ hölzernen Achsen wird vorzugsweise Eichenholz genommen, und nach Massgabe der Belastungen, wofür das Fuhrwerk bestimmt ist, macht man die Mittelaclise $79-132^{\mathrm{mm}}$ breit und 132 bis $184^{\mathrm{mm}}$ hoch; eiserne Achsen sind bedeutend dïnner und verhältnissmässig eben so breit wie hoch, im Allgemeinen wohl $50-100^{\mathrm{mm}}$. Es ist schon erwähnt, dass der hintere Durchmesser des Schenkels mit der Breite der Mittelachse ibereinstimmt, und bei gewöhnlicher Verjüngung ist der vordere Durchmesser etwa halb so gross. Am vorderen Theile des Schenkels befindet sich das Liinzloch oder sonst diejenige Vorrichtung, wodurch das Rad auf dem Schenkel festgehalten wird.

Eine hölzerne Achse muss immer stark und sorgfältig mit Eisen beschlagen werden. Dazu gehört das untere Achseisen oder Achsblech, welches den Schenkel bis zur Hälfte seines Umfanges und oft noch mehr umschliesst, und dann, in eine Stange ausgehend, unter die Mittelachse, ja selbst bei grossen Lasten ganz unter dieser hergeht, so dass der Beschlag fuir beide Schenkel aus einem einzigen Stiicke besteht. Die Befestigung geschieht durch Nägel, Schrauben und Bänder. Sodann ist noch ein oberes Schenkelblech nöthig, welches mit einem Bande das Lïnzloch umschliesst und einfasst; an der Mittelachse befindet sich das Stosseisen, welches oft pyramidal etwas vorspringt. Diese sämmtlichen Beschläge werden häufig verstählt.

Die eiserne Mittelachse wird durch Bänder in einem hölzernen Futter befestigt, um sie danerhafter mit dem Gestelle verbinden zu könuen. Eiserne Schenkel werden mitunter verstählt, oder es wird ihnen — so gut es gehen will - eine Stahlplatte angeschweisst. Eine cigenthiimliche und sehr vorziigliche 
Eimrichtung besteht bei den Fuhrwerken der englischen Armee. Die Schenkel sind ron Eisen und endigen in eine starke eiserne Stange, welche unter der hölzernen Mittelachse entweder ganz hergeht, oder die Stangen stossen von beiden Seiten unter der Mitte vor einander und werden durch starke Schrauben und Bänder befestigt. Durch Prüfung in den spanischen Feldzügen hat sich diese Einrichtung, die von belgischen Frachtkarren entlehnt ist, als vortrefflich bewährt, indem die mechanischen Beziehungen wie bei ganz eisernen Achsen sich ergeben, und doch die Widerherstellung einer zerbrochenen Achse eben so leicht und noch leichter als bei hölzernen geschehen kann.

Zur Vergleichung der hölzernen und eisernen Achsen wird man folgende Verhältnisse zu beriicksichtigen haben:

a) Das geringere Reibungsmoment, welches der dünne eiserne Schenkel zeigt, ist jedenfalls ein nur zweifelhafter Vorzug, indem Beweglichkeit vorwärts und Beweglichkeit riickwärts in gewissem Sinne dasselbe ist und einander entgegen treten kann. Wenn daher auf ganz ebenem festen Boden der eiserne Schenkel einen bestimmten Vorzug in den Zahlenwerthen der Zugkraft ergibt, so ändert sich dies sofort auf unebenem oder in tiefem Boden.

b) Ebenfalls zeigen diinne eiserne Schenkel bei geringen oder mittleren Belastungen vergleichungsweise oft grosse Vorziige, welche gänzlich verschwinden, sobald die Lasten bedeutend steigen. Diese wichtige Thatsache erklärt sich dadurch dass die dünne und melır elastische eiserne Achse für grosse Belastungen eine Biegung annimmt, was die hölzerne an sich und wegen ihrer Beschläge nicht thun kann.

Sobald aber die geometrische Mittellinie einer drehenden Bewegung mit der physikalischen Achse derselben nicht mehr zusammenfällt, zeigen sich Klemmungen, wobei an einzelnen Stellen heftige Pressungen und vergrösserte Hebclarme für die Reibung zu Stande kommen.

c) Die liölzerne Achse hat wegen ihrer Beschläge und wegen der Art, wie diese angelegt werden müssen, selten eine vollkommen regelmässige Form, und dieser Umstand ist, zumal bei stark verjüngten Schenkeln, ein wichtiger Nachtheil.

d) Es lässt sich die eiserne Achse bei der Uebernahme besser prïfen, aber sie ist auch schwieriger wieder herzustellen, wenn sie zerbrochen ist. Gerade in dieser Hinsicht erfiillt die vorhin erwähnte englische Einrichtung möglichst viele Bedingungen.

c) Bei strenger Kälte brechen die eisernen Achsen ungewöhnlich leicht; man schiitzt sie dagegen, renn man ror dem Gebrauche mit einem schweren Hammer oder einer Axt gegen die vordere Fläche des Schenkels einige kräftige Schläge fuihrt.

f) Der wichtigste Vorzug der eisernen Achsen ist ihre ungleich grössere Dauer. Es ist sehr wohl möglich, und die Erfahrung bestätigt es auf das Bestinmteste, dass eine gute hölzerne Achse im neuen Zustande völlig so stark sein kann wie eine eiserne. Allein nach wenigen Jahren, sowohl des Gebrauches, als des Nichtgebrauches, wird eine neue Probe ergeben, dass sich schon merkbare Unterschicde zeigen; und wemn beide Einrichtungen -- wie es doch oft gefordert wird - 20 bis 30 Jahre in Vorrath gehalten werden müssen, so ist nach dieser Zeit die eiserne Achse noch eben so diensttiichtig wie rorher, während die hölzerne durch die unabänderlichen Einwirkungen der Luft und sonstiger organischer Zersetzungen kaum noch brauchbar sein wird. Bei Fuhrwerken, welche sofort in steten Gebrauch genommen werden sollen, ist also dieser Umstand von geringerem Gewichte, allein ein anderer nachtheiliger Einfluss, der gleich (rwähnt werden soll, findet dennoch auch dann statt.

y) Es bedarf nämlich der eiserne Schenkel iberhaupt etwa nur den dritten Theil der Schmiere, welche ein hölzerner verlangt, theils weil letzterer an sich cinen grösseren Umfang hat, theils um rachtheilige Erhitzungen beim schnellen Fahren und Sclbstentziindungen zin veshüten. Num aber dringt dicse Schmiere mabwendlich in das Holz selbst ein, und dadurch wird der Schenkel allmälig 
und frîher zerstört, als es ausserdem geschehen wïrde. Auch hiervon abgesehen ist der viel geringere Bedarf an Schmiere und die grössere Unabhängigkeit ron diesem Stoffe ein recht wesentlicher Vortheil der eisernen Schenkel.

Als Resultat aller dieser Bemerkungen kann es nicht zweifelhaft sein, dass im Allgemeinen eiserne Schenkel, ungeachtet der grösseren Kosten, stets vorzuziehen sind, unbedingt aber dann, wenn dic Fuhrwerke längere Zeit unbenutzt hingestellt oder in Vorrath verfertigt werden, wie es zum Beispiel mit rem grössten Theile militärischer Fuhrwerke der Fall ist.

An der Nabe des Rades $\boldsymbol{A}$ Fig. 1683 unterscheidet man den mittleren und dickeren eylindrischen Theil, in welchen die Speichen eingelassen sind, er heisst der Busch oder Haufen $c$ Fig. 168.4; dann den abgekiirzt kegelförmigen Theil, der an die Mittelachse trifft und hier Stoss genannt wird a Fig. 1684, endlich den vorderen längeren Theil, welcher die Röhre heisst $b$ Fig. 1684.

Die Länge der Nabe ist von der Belastung nicht abhängig, wenn sie nur so lang ist, dass die Richtung des Druckes in ihr völlig unterstiitzt wird. Aus wichtigen, später zu besprechenden Gründen haben die Speichen $f$ keine senkrechte Stellung, sondern sind gegen aussen geneigt, und desshalb muss die Nabe eine solche Länge bekommen, dass das Perpendikel von dem oberen Theile des

Fig. 1683 .

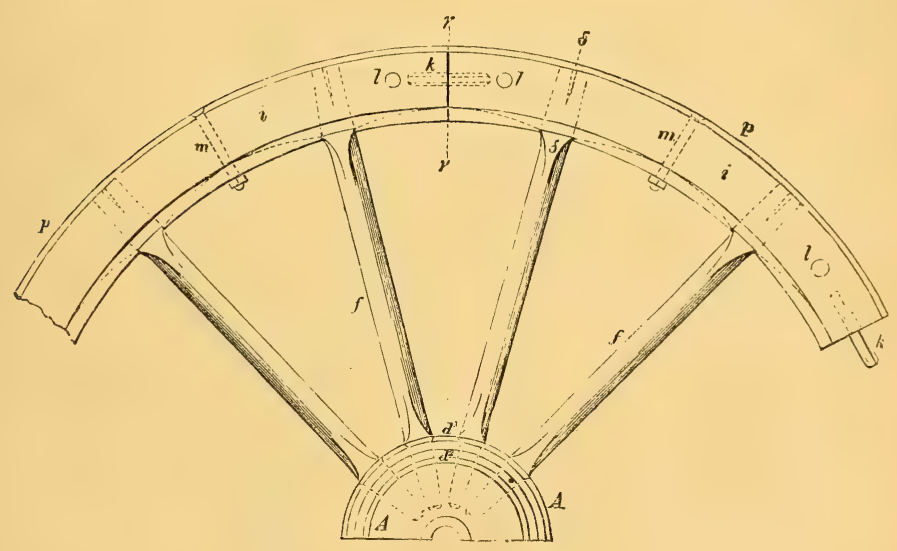

Rades auch bei Seitenbewegungen noch stets durch sic hindurchgelıt. Eine grössere Länge ist iiberfliissig, und obgleich die Schmiere dadurch mehr erhalten wird. so ist sie doch unbequem und störend wegen des Anneinanderfahrens mit anderen Fuhrwerken oder in engen Wegen. Damn macht man die Nabe wohl $65-75$ mm kürzer als den Schenkel, um die Stossscheiben zur Veränderumg der Spurweite anbringen zu kömnen; ähnliche Scheiben, auch ohne Beriicksichtigung dieses Zweckes, sind iberhaupt zur Verminderung der Seitenreibungen schr angemessen. Die Länge der Nabe wird etwa zwischen $34-63^{\mathrm{cm}}$ betragen. Die Iicke im Haufen oder Busch muss eine genigende Befestigung der Speichen an dieser Stelle zulassen, und daher verlangen hohe Räder oder grosse belastungen weil bei ihnen die Kräfte zum Losbiegen der Speichen grösser sind — stärkere Naben. Im Allgemeinen verdienen kurze und dicke Naben den Forzug, und eine Stärke derselben von $32-37^{\mathrm{cm}}$ wäre in vielen Fällen weit praktischer als die 
langen und dïnnen Naben, die rorkommen. Um die Nabe werden gewöhnlich eiserne Bänder $d^{1} d^{2} d^{3}$ Fig. 1684 gelegt, eins vorn an der Röhre und eins hinten am Stoss, und häufig auch noch an der vorderen und hinteren Seite des Haufens.

Wichtiger als jene Bänder ist die Art, wie die Bohrung dieses Theiles durch einen Beschlag ausgefuittert und gesichert ist. Man nennt ihn die $\mathrm{B}$ ü $\mathrm{chse}$ und er bestelit entweder nur aus zwei breiten Ringen, die vorn und hinten in die Bohrung eingelassen werden, oder besser lässt man die Büchse in Form einer Röhre B Fig. 1684 ganz durchgehen. Dann hat sie in der Gegend der Mitte eine geringe Erweiterung (die sogenannte $\mathrm{K}$ a m mer), um die Schmiere besser

Fig. 1684.

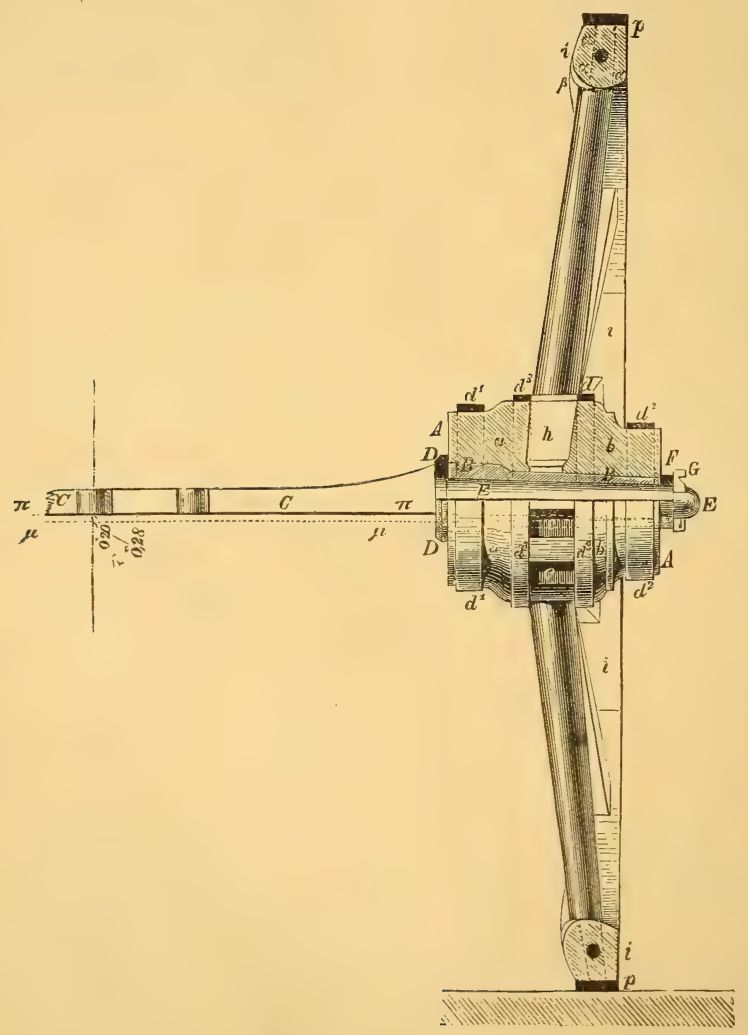

zu halten. Stets muss die Substanz der Biichse weicher sein als der Schenkel oder dessen Beschlag, damit bei den unvermeidlichen Abnutzungen der Schenkel so viel wie müglich geschont werde, indem Ausschleifungen der Buichse an sich weniger nachtheilig sind, und auch leichter rerbessert werden können als $\mathrm{Be}$ - 
schädigungen des Schenkels. Bei hölzernen Schenkeln mit gehärteten oder stählernen Achseisen kann man zu der Büchse Schmiedeisen nehmen, bei eisernen Schenkeln wählt man dazu Messing oder Bronze.

Bei neuen Rädern soll zwischen der Oeffnung der Büchse und der Dicke des Schenkels kein merkbarer Unterschied stattfinden, oder das Rad soll coline Spielraum auf den Schenkeln stecken. Nach einiger Zeit des Gebrauches tritt ein solcher Spielraum unvermeidlich ein, und er trägt späterhin besonders zum Ruin der Fuhrwerke bei, weil derselbe den Druck, den Achse und Rad eigentlichs erleiden sollten, in stossartige Bewegungen verwandelt, und dadurch die ergriffenen Theile ungleich mehr zu leiden haben.

Der nächste wichtige Bestandtheil des Rades sind die Speichen $f$; bei gewöhnlichen. Rädern sind deren 12, bei ganz hohen wohl 16 Stück. An der Speiche unterscheidet man das Blatt $h$, welches in die Nabe eingelassen wird, das Mittelstück $f$ und den Z a pfen $a$, der in die Felgen $i$ tritt. Das Blatt ist entweder vierkantig pyramidal geformt oder schwalbenschwanzförmig.

Die Oeffnungen im Busch heissen Stemmungen $c$, $c$, sie gehen ganz bindurch, und zum Einlassen der Speichen wird die Nabe mitunter in einer Lauge mehrere Stunden lang gekocht, in diesem erweichten Zustande kann selbst ein stärkeres Blatt eingetrieben werden. Die Befestigung in der Felge geschieht durch den Zapfen, in welchen nach dem Einsetzen ein Spalt gehanen wird, um einen Keil $d$ Fig. 1683 von weichem Holze nachzuschlagen. Das Mittelstiick ist in der Regel nicht völiig rund gebildet, sondern mit einem länglich runden Querschnitte, dessen grösserer Durchmesser die Stellung nach der Breite des Fuhrwerkes bekommt. Man wählt diese Form, weil die zerbrechenden Gewalten durch die Seitenbewegungen meistens nach der Richtung der Breite wirken, und also der Widerstand dann grösser ist als bei kreisförmigem Querschnitte. Das Mittelstück ist ferner häufig nicht ganz gerade, sondern so geformt, dass das äussere Ende etwas nach einwärts gebogen ist, damit diejenigen Speichen, welche eben unten stehen, mehr in ihrer eigenen Richtung in Anspruch genommen werden. Alsdann ist der Widerstand ihrer rückwirkenden Festigkeit weit grösser als derjenige gegen das Zerbrechen, wenn der etwas vor der senkrechten Stellung sich befindende Körper völlig gerade geformt wäre. Bisweilen werden die Speichen, einzeln abwechselnd, im Busch um etwa einen Zoll weiter vorwärts oder riickwärts eingelassen, welches man die Versetzung derselben nennt.

Endlich stehen mitunter je zwei Speichen einander etwas näher als den ihnen benachbarten, welches mit dem Namen gekuppelte S peichen bezeichnet wird. Man thut dies, um da, wo zwei Felgen zusammentreffen, die Speichen dieser Fuge näher zu bringen und so eine festere Verbindung zu erhalten.

Am wichtigsten für die Construction des Rades ist nun die Abweichung der Speichen von der senkrechten Stellung gegen Achse und Nabe. Man setzt sie nämlich so ein, dass - wie schon angefuihrt ist - sie sich vor der senkrechten Richtung befinden, und nennt diese Abweichung die Stürzung oder den Sturz derselben. Sie beträgt $1 / 12$ bis $1 / s$ des Radhalbmessers und wird bei lange gebrauchten Rädern allmälig schwächer. Diese Stürzung, wodurch also das Rad nicht mehr eine scheibenförmige, sondern im Allgemeinen eine kegelförmige Gestalt annimmt, hat wesentliche Vortheile gegen eine senkrechte Stellung. Ein Rad ron dieser Form, auf einen verjiingten Schenkel gesteckt, stellt sich nothwendig so, dass die unteren Speichen fast senkrecht stehen, also im Sinne ihrer riickwirkenden Festigkeit angegriffen werden, und ein Einbiegen der Speichen nach der Breite des Fuhrwerkes könnte nicht anders eintreten, als wenn gleichzeitig der Kranz des Rades aus einander gerissen würde. Nun ist aber dieser Kranz jetzt von einem geringeren Umfange, als er es bei der nämlichen Lage der Speichen in senkrechter Stellung sein wiirde, und mithin widersteht aus diesen beiden Gründen die ganze Vorrichtung weit sicherer, als es ohne Stürzung möglich wäre. Räder, dic mit starken Belastungen auf unebenen Bahnen gebraucht werden sollen, sind ohne Stürzung röllig untauglich 
weil die stossartigen Kräfte, welche seitwärts gegen die Speichen wirken, ein Einbiegen nnd Losbrechen derselben sehr bald zur Folge haben miissten. Ausserdem bewirkt die Stïrzung, dass der obere Theil des Rades weiter auswärts zu stehen kommt, wodurch der Raum zwischen den Rädern erweitert wird, was oft wichtig ist. Um bei Kutsch- und Reisewagen, zumal von geringer Spurweite oder bei meist cylindrischen Schenkeln, diese Annehmlichkeit noch mehr herbeizufiuhren, pflegt man sogar die untere Seite des Schenkels nicht in horizontaler Stellung zu belassen, sontern man biegt sie etwas abwärts, wodurch die unteren Theile der Räder anf dem Boden einander näher gebracht und die oberen Theile zur Aufnahme des Kutschkastens noch weiter von einander entfernt werden; dadurch wird jedoch der gleichmässige Gang des Rades gestört.

Eine zu grosse Stiurzung hat den Nachtheil, dass die Nabe länger werden muss und dass die zu schräg gestellten Speichen in tiefem Boden seitwärts gescheuert werden und die Geleise anfreissen.

Es ergibt sich hieraus noch schliesslich, dass: Stellung des Schenkels gegen die Nittelachse, Länge der Nabe und Stiirzung Anordnungen sind, die einander gegenseitig bedingen.

Der Kranz des Rades besteht bekanntlich aus den hölzernen Felgen $i$ Fig. 1683, deren Anzahl gewöhnlich sechs beträgt, welche unter einander bei $K$ verzapft sind, ihre eigentliche sichere Verbindung åber erst durch die Speichen und den Beschlag (Reifen $p$ ) erhalten. Um das Spalten der Felgen zu verhindern, sind die Felgenniete $l$ angebracht. Die Höhe der Felgen in der Richtung des Halbmessers beträgt etwa $75-100^{m m}$, mnd sie braucht bei höheren Rä̈lern nicht gerade grösser zn sein, weil sie nur dazu dient, die Spcichen lıaltbar zu binden. Lässt man den Kranz aus mehr als sechs Felgen bestehen, so wird jedes einzelne Stiick zwar giinstiger gewachsen sein und weniger iiberspänige Stellen besitzen, allein die dauerhafte Verbindung ist alsdann auch schwieriger zu hewerkstelligen. Vortheilhaft sind die Felgen ans gebogenem IIolze.

Fiir alle Fuhwerke, noch melr aber fiir die von ihnen befahrenen Wege, ist die Breite der Felgen ein höchst wichtiger Gegenstand. Die breitere Felge vertheilt natiirlich den Drack der Belastung auf eine grössere Fläche des Erdbodens, und wirkt d:sher weniger einschmeidend und weniger ungiinstig für die Bahn. Dies gilt anch noch von eigentlichen kinnststrassen, die bei manchen Wittermgsverhältnissen einem : ihnlichen Vurderben ausgesetzt sind. Auf unebenen oder anf geptlasterten Strassen deckt die breite Felpe die Lnebenheit mehr zu, verhindert daher in etwas das beständige IIin- und Herschleudern des Fuhrwerkes, wodurch dieses selbst und die fortzuschatienden Groenstände wesentlich geschont werden. Je mehr num der Staat fiir gute Kunststrassen sorgt, desto grösser, ja selbst zanz morerhältnissmässig. Werden die Lasten, die der Fuhrmam auf jedes Pferd ladet, und $1 \mathrm{~m}$ so sorgfiltiger sollten die rerderlblichen schmalen Felgen beseitigt werden. Eine geringere Breite als $100^{m m}$ (wie sie noelı so häufig an Frachtkarren vorkommt) sollte gainzlich von den Kunststrassen ausgeschlossen sein, uni es sollte durch Ileralosetzung des Weggeldes bei zunehmender Breite die Einfïhrung dieser letzter'n auch fiir Landfulnwerke befördert werden. Ausserdem wird der Beschlig des Rates bei breiterem Kranze weit mehr geschont als bei schmalem: endlich ist anch eine nicht ganz unerhebliche Verminderung der Zugkraft die Folge des gleichmässigeren Ganges der breitfelgigen Fuhrwerke.

Gegen die breiten Felgen hat man das grössere Gewicht der Räder angeführt; allein dieser Einwurf zerfällt in sich selbst. Als Nachtheil ist wohl zu nennen, dass auf Land- und Feldwegen bis jetzt die breiten Felgen nicht Spur halten und dass anf stark gewölbten Kunststrassen ein damit versehener Wagen bei glatter Bahn im Winter mit dem Hintergestell leicht seitwärts abgleitet, welches allerdings für die Pferde eine ziemliche Belästigung ist, oder wenigstens zur Vermeidung einen anfmerksamen Fulurmann fordert. Da man aber aus anderen 
Gründen von den früheren starken Wölbungen der Strassen mehr zuriickkommt, so wird auch dieser letzte Einwurf wenig Bedeutung behalten.

Es wïrde wegen aller dieser Verhältnisse eine gesetzliche Vorschrift, welche für eigentliche Frachtfuhrwerke die Breite der Felgen festsetzte, in jeder Hinsicht gerecht und lobenswerth sein.

Der eiserne Beschlag des Rarles besteht entweder aus einem Reif $p$ (bei breiten Felgen aus zwei neben einander liegenden) oder aus einzelnen Eisenstiick $\in$ n, welche Schienen genannt werden. In beiden Fällen geschieht die Befestigung auf den Felgen durch Nägel oder Schraubenbolzen $m$, deren Köpfe versenkt sein müssen. Der zusammenhängende Reif gibt - bei sonst richtiger Arbeit - dem Rade unfehlbar mehr Festigkeit, und besonders erhält er sicherer die so höchst wichtige, völlig runde Gestalt des Rades; mit Schienen beschlägt man meist nur solche Räder, die gewaltsamen Beschädigungen ausgesetzt sind, wie $z$. B. bei manchen Militär-Fuhrwerken, weil sie hierbei eine einfachere Ausbesserung zulassen als der Reif. Die Schienen müssen so gelegt werden, dass sie auf dev Mitte einer Felge zusammentreffen, damit die Fugen zwischen den Felgen desto mehr verdeckt und geschiitzt werden.

Geleitet durch die eisernen Räder der auf den Eisenbahnen gehenden Wagen hat man neuerdings versucht, die Räder auch anderer Fuhrwerke ganz von Eisen zu verfertigen. Abgesehen von den grösseren Kosten leidet es keinen Zweifel, dass eiserne Naben und Speichen sehr vorzüglich sein würden. Der Kranz von Schmiedeisen ist jedoch zu nachgebend, gestattet fortwährende Acnderungen in der Gestalt des Rades, und von Gusseisen wiirde er für grewöhnliche Wege wohl zerbrechlicher sein als gute hölzerne Felgen mit tüchtigem Beschlag'e.

Unter Spurweite versteht man bekanntlich den Abstand, den die Räiler auf dem Boden stehend von einander haben, und $\mathrm{zwar}$ ist man nicht allgemein dariiber einverstanden, ob es der innere Abstand oder der von der Mitte zu Mitte sein soll. Wenn man von der verschiedenen Breite der Felgen unabhängig bleibeu will, so ist es am besten, den innern Abstand zu nehmen, obgleich meistens der von Mitte zu Mitte gerechnet wird. Die Weite der Spur liegt in Mitteleuropa so ziemlich allgemein zwischen $134-158^{\mathrm{cm}}$, und die aus dieser verdriesslichen Verschiedenheit entspringenden Uebelstände in der Weite der Geleise anf Feldwegen und dergleichen sind leider hinlänglich bekannt.

Eine weite Spur hat grosse Vorzüge vor einer engen. Sie gestattet höhere Räder, ohne dass das Fuhrwerk an festem Stande verliert, und bei gleicher Höhe wird die Stabilität grösser; sie gewährt einen breiteren Raum für die Bepackung, so dass der Schwerpunkt derselben niedriger zu liegen kommt, welches ron Nenem den festen Stand erhöht. Aus den pag. 636 angegebenen Grïnden findet zwischen der Spurweite und der Höhe der Räder ein sich gegenseitig bedingendes Verhältniss statt, indem die Einfiihrung höherer Räder nothwendig eine weitere Spur fordert, wenn nicht die Stabilität bedentend gefährdet werden soll. Eine ungewöhnlich weite Spur kann nur in Gebirgspässen, wo regelmässig Fuhrrerke mit enger Spur gehen, ein grosses und vielleicht nicht zu besiegendes Hinderniss abgeben; in allen iibrigen Fällen, namentlich auf Kunststrassen, wo die landesuibliche Spurweite wenig in Betracht kommt, gewährt sie einleuchtende Vorzïge. Bereits pag. 641 ist gesagt, wie man bei cylindrischen oder wenig verjiingten Schenkeln durch aufgesteckte Ringe die Weite der Spur ändern könne, und wem eine solche Anschliessung auch nur die Grenzen von $50-63^{\mathrm{mm}}$ beträgt, so ist das unter Umständen schon ein wichtiger Gewinn.

In Beziehung auf die Höhe der Räder ist frúher (pag. 632 und 631) angefuilırt, dass das höhere Rad für die Zugkraft einen grösseren Erfolg, d. h. einen leichteren Gang herbeifuhrt. Hier ist noch zu bemerken, dass ein hohes Rad Unebenheiten, Vertiefungen, Gräben u. dgl. mehr zudeckt, Hindernisse leichter überwindet und, weil es weniger keilartig wirkt, auch in tiefem und sandigem Boden weniger einschneidet, als ein niedriges, und dies sind in dieser Hinsicht wichtige Vorziige. Höhere Räder machen beim Zuriicklegen desselben Weges 
eine geringere Anzahl von Umläufen, sie ruiniren also die Beschläge weniger, erhitzen sich nicht so stark wie niedrigere, verbrauchen weniger Schmiere, endlich werden Achse und Schenkel in tiefen Wegen nicht so leicht beschmutzt u. dgl.

Der einzige Einwurf von Belang gegen die höheren Räder ist in der That ihr leichteres Umwerfen; man wirkt ihm aber durch eine entsprechende Spurweite und zweckmässige Bepackung entgegen; dass sie etwas zerbrechlicher sein mögen, ist allerdings richtig, jedoch wird dieser Unterschied in den gewöhnlichen Grenzen wenig bedeuten. Wenn der Halbmesser des Rades die Brusthöhe der Pferde iibersteigt, so lässt man sehr zweckmässig die Zugstränge unter der Deichsel angreifen. Obgleich nun die Beschaffenheit ganzer Landstrecken, so wie die Grösse des Mittelschlages der zu verwendenden Pferde für diese wie für manche Einrichtung an Fuhrwerken mitsprechen, so leidet es doch keinen Zweifel, dass für Deutschland und einen grossen Theil des mittleren Europas iiberhaupt eine Höhe der Räder von 5 Fuss keineswegs zu bedentend ist, wobei nur beriicksichtigt werden muss, dass aus Grïnden, die sich bei der Zusammensetzung des Gestelles ergeben werden, die Vorderräler in der Regel etwas niedriger als die Hinterräder sein miissen.

Man kann noch hinzufiigen, weil bei Rädern mit breiten Felgen eine vermehrte Höhe in der einen Beziehung nachtheiliger einwirkt, dass das grössere Gewicht derselben beim Aufwärtsfahren (pag. 635) einen merkbaren Einfluss äussern wird, weil in diesem Falle jedes gesteigerte Gewicht eine nicht unerhebliche Vermehrung der Zugkräfte èrfordert.

Zum Schlusse dieser einzelnen Betrachtungen muss noch eine kurze Erwähnung der Methoden folgen, wie man das Rad anf dem Schenkel $F$ Fig. 1684 befestigt.

Die einfachste Vorrichtung dieser Art ist der Vorstecker oder Lünz $G$ ohne andere kiinstliche Mittel als allenfalls einen kleinen Riemen, der durch ein Oehr in dem unteren Theile desselben gezogen wird, um das Herausfliegen aus dem Lïnzloche doch einigermassen $z u$ verhiiten.

Nun folgt der Liinz oder Splint, welcher unten mit einer abstehenden Feder versehen ist, ohne deren Zerbrechen das Abfliegen nicht möglich ist; allein bei raschem Fahren anf hartem umebenem Boden zerbricht diese Feder auch ziemlich leicht. Von dieser Einrichtung des Liinzes gibt es iibrigens eine Nenge Abarten, theils mit, theils ohne Federn: ihre Anfiihrung hat keine besondere Wichtigkeit. Sodann hat man dem Schenkel an seinem vorderen Ende einen Schraubengang gegeben, anf welchen eine Mutter festgeschraubt wird, und vor dieser pflegt man noch einen kleinen Liinz amzubringen. Wäre diese Schraube an der linken Seite des Fuhrwerkes eine solche mit rechtem Gewinde, eine rechts eingeschnittene, so wïrde durch den Druck und die Seitenreibung der Vorderfläche der Nabe gegen die anfgeschranbte Mutter diese nothwendig und sehr bald gelöst werden. Man schneidet daher an der genannten Seite die Schraubengewinde links ein, wodurch die bezeichnete Reibmo die Lösung derselben nicht bewirken kann.

Eine sinnreiche und wichtige Verbesserung aller dieser Bemühungen bieten endlich die sogenamnten Patentbiichsen dar, und sie haben die Aufgabe völlig aufgelöst. Der Schenkel ist um etwas kiirzer als gewöhnlich, und würde durch die Nabe nicht völlig lindurchtreten; an der Stelle desselben, wo der Stoss der Nabe anfängt (also ungefähr auf $3 / 4$ seiner Länge von vorn) ist er mit einer cylindrischen oder linsenförmigen Verstärkung versehen, welche etwa $50-75^{\mathrm{mm}}$ mehr im Durchmesser hat als der Schenkel an dieser Stelle, und diese wulstartige Verstärkung mag eine Dicke von beiläufig $25-40^{\mathrm{mm}}$ haben. Die Nabe besteht aus zwei Theilen, nämlich dem Stosse für sich und dem Haufen oder Busch mit der Röhre für sich.

Der Stoss kann gleich bei der Zusammensetzung des Gestelles auf die Achse gebracht werden: jene cylindrische Verstärkung des Schenkels wird von ciner entsprechenden Erweiterung der Bïchse aufgenommen, welche sich am hinteren Ende des Haufens befindet. Vorn ist die Nabe durch eine starke Metall- 
platte geschlossen. Sind nun beide Theile der Nabe auf den Schenkel geschoben, so stossen sie hinter jener Verstärkung gegen einander und der Stoss bildet den Stiitzpunkt für die Verstärkung des Schenkels nach hinten; er kann daher einfacher in Form einer starken Platte gebildet sein. Zur Vereinigung beider Theile gehen nun drei Schraubenbolzen von hinten nach vorn der Länge nach durch die Nabe, und werden vor der vorderen Metallplatte durch aufgeschraubte Muttern gehalten. Man erkennt leicht, dass das Ablaufen eines so befestigten Rades ohne gänzliches Zerbrechen der Nabe unmöglich ist, und die Beweglichkeit bleibt eben so frei wie vorhin, ja der Gang wird eigentlich noch gleichmässiger als sonst ausfallen. Da ausserdem die Nabe ganz geschlossen ist, so wird ein Ablaufen der Schmiere verhindert, und man bedient sich nun mit vielem Erfolge dazu des Oeles; die Büchse hat eine etwas grössere Kammer als gewöhnlich, zwischen den Stemmungen zweier Speichen fïhrt ein Loch, welches durch eine Schraube geschlossen werden kann, in die Kammer, und durch dieses giesst man das Oel ein. Der Verbrauch und die Kosten sind ungleich geringer als bei jeder andern Art zu schmieren, da die Erneuerung begreiflicher Weise weit seltener nöthig wird. Weil diese Patentbiichsen indess den Preis eines Fuhrwerkes ziemlich beträchtlich erhöhen, so werden sie für jetzt nur bei iiberhaupt kostbaren Einrichtungen angewendet. (Näheres siehe unten.)

Auf dem gewöhnlichên Lünz, so wie an den Enden der Mittelachse bringt man gebogene starke Metallplatten zum Schutze des Schenkels gegen den vom oberen Theile des Rades herabfallenden Schmutz an; besser noch umgibt man zu eben diesem Zwecke die Nabe, sowohl vor der Rölıre wie hinter dem Stoss, mit einem ganz umhergehenden metallenen Ringe von einigen Zoll Breite, man nennt ihn die Kappe der Nabe.

Von den eben erwähnten Patentbïchsen seien zwei Arten näher beschrieben, welche unter dem Namen Collinge und Mail bekannt sind, und sich beide ganz vorziiglich bewährt haben. In nachstehenden Abbildungen stellen Fig. 1685 bis 1693 die Collinge-Achse und Fig. 1694 bis 1699 die Mail-Achse im 4. Theile wahrer Grösse dar.

Bei beiden Achsen und Büchsen sind gleiche Theile mit gleichen Buchstaben bezeichnet. So bedentet in sämmtlichen Figuren $A$ die Achse (im engeren Sinne genommen), d. h. den Theil des ganzen schmiedeisernen Körpers, welcher frei zwischen den beiden Rädern zu liegen kommt, während $B$ der sogenannte Achsschenkel ist, um welchen sich die Büchse (Nabenbiichse) $D$ dreht, die dem Schenkel $B$ zur Pfanne dient, in der Radnabe festgekeilt wird, und mit dem Rade zugleich um $B$ herumläuft. $E$ ist eine cylindrische Verstärkung der Achse, der sogenannte Stoss, wogegen sich, wie aus den Durchschnitten Fig. 1686 und 1695 erhellt, bei beiden Achsgattungen der hintere (weitere) Theil der gus s e is ernen Büchse $D$ lehnt. Zwischen beiden ist (Fig. 1686) eine ringförmige Lederscheibe $v$ gelegt, die sowohl zur Dichtung als auch dazu dienen soll, etwaige Seitenstösse minder schädlich zu machen. Die ebenfalls cylindrische Erweiterung $F$ der Büchse $D$ bildet in ihrem hohlen Raume die Kammer zur Aufnahme der Schmiere, zu welchem Raume man jedoch nur gelangen kann, wenn alle Theile der ganzen Patentbïchse auseinander genommen werden.*) Wie verhältnissmässig selten bei den Colling e-Patentbüchsen das Erneuern der Schmiere nothwendig wird, davon ist Referenten ein Beispiel bekannt, wo ein Wagen mit derartigen Achsen versehen über 1/2 Jahr (fast täglich) im Gebranche war, ohne dass die Schmiere

*) Auf der Londoner Industrie-Ausstellung 1851 hatten die Birminghamer PatentachsenFabrikanten Eykyn \& Millichap Collinge-Achsen und B̈ichsen ausgestellt, wo durch den Stoss $E$ für das Einbringen von Oel ein Loch gebohrt und durch eine Schriube verschlossen war. Ausserdem hatte man das hintere (stärkere) Ende des Schenkels $B$ mit zwei flachgängigen Schraubengewinden versehen, die beim Einbringen des Schenkels durch eine betreffende Mutter in die Büchse geschoben werden mussten, nachher aber frei in die Oelkammer $F$ zu liegen kamen. Beim Vorwärtsfahren des Wagens boten diese Gewinde ein neues Sicherheitsmittel gegen das Ablaufen dar. 
Fig. 1685.

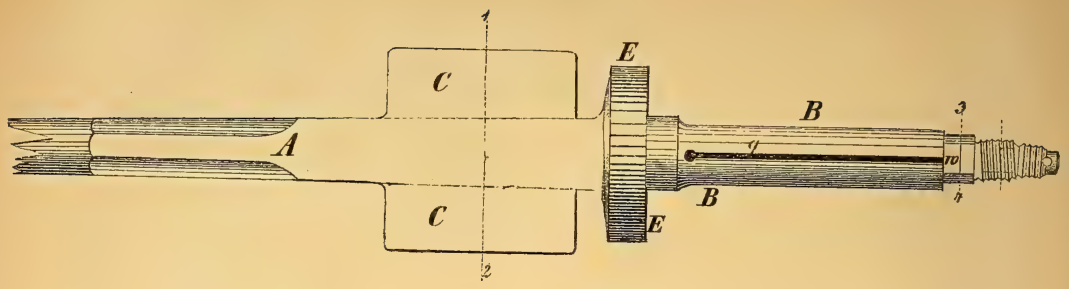

Fig. 1686.

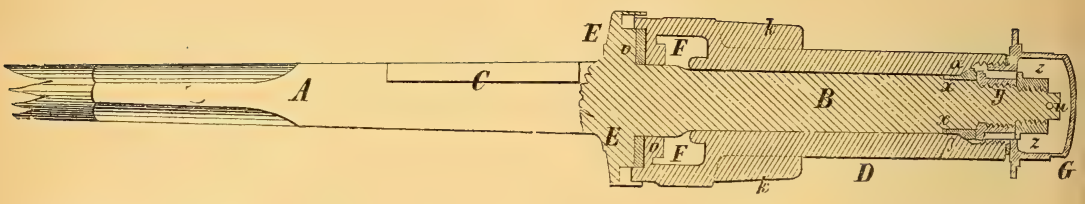

Fig. 1687. Fig. 1688. Fig. 1689, 1690.

Fig. 1696. Fig. 1698.

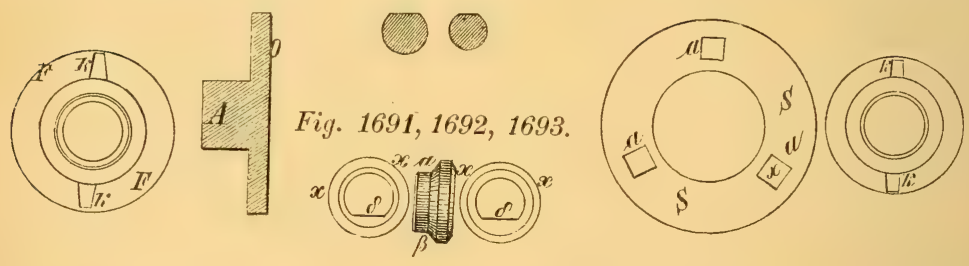

Fig. 1694.

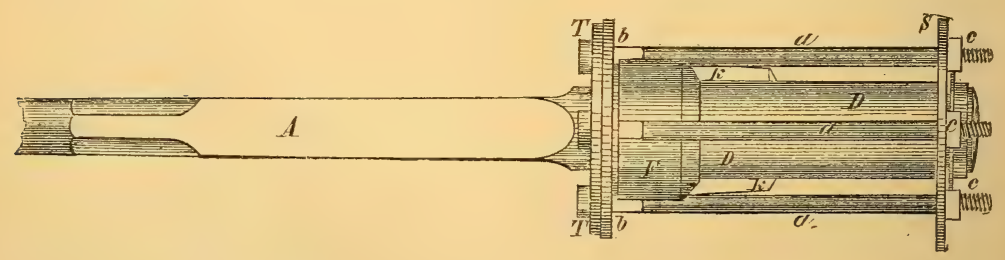

Fig. 1695.

Fig. 1697.

Fig. 1699.

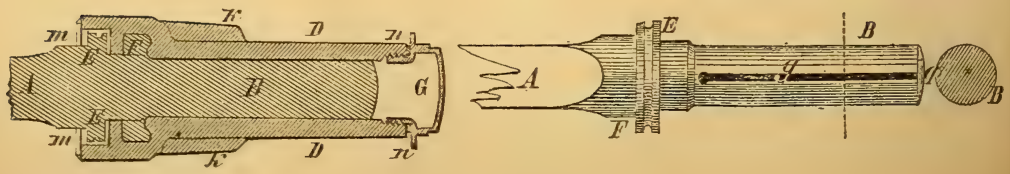


gänzlich verzehrt worden wäre. Der Hauptunterschied genannter beiden Patentachsen liegt in der Art nnd Weise, wie das Ablaufen der Achsbüchse $D$, respective des ganzen Rades, vermieden wird.

Bei Collinge ist der betreffende Haupttheil der sogenannte Kragen $x$ (Fig. 1691 bis 1693 in drei verschiedenen Ansichten gezeichnet), gegen dessen schiefe Fläche $\alpha \beta$ sich der vordere dünnere Theil der Büchse $D$ lehnt, wie Fig. 1686 hinlänglich erkennen lässt. Innerhalb ist dieser Ring nicht ganz kreisförmig, sondern an einer Stelle $\delta$ abgeplattet, welche Abplattung mit dem ebenso gestalteten Theil $w$ des Achsschenkels übereinstimmt,wovon Fig. 1689 den Durchschnitt nach der Linie 3.4 von Fig. 1685 zeigt. Man wird leicht erkennen, dass der $Z$ weck dieser Anordnung einfach der ist, das Drehen des Kragens zu verhindern, wenn derselbe auf der gehörigen Stelle aufgebracht wurde. Der Kragen $x$ wird wieder mittelst der beiden Schraubenmuttern $y$ und $z$ an dem Herunterschieben in der Achsenrichtung verhindert, wozu unter Umständen die Achsbiichse $D$ ein nicht geringes Bestreben hervorbringt. Dabei ist die eine Schraube $y$ eine rechts-, dagegen $z$ eine linksgängige, damit sowohl beim Vor- wie Rückwärtsfahren ein Losgehen nicht zu befürchten steht; endlich wird noch vor die Mutter $z$ ein Vorsteckstift $u$ eingebracht. Das ganze vordere Ende der Biichse $D$ wird überdies von einer Staubkapsel $G$ verschlossen.

Jede der Büchsen $D$ ist an ihrer Aussenfläche am stärkeren Theile mit zwei Nasen $k$ versehen, die zum Festkeilen der Büchse in der hölzernen Radnabe, und also dazu dienen, ein Umdrehen der Büchse in der Nabe zu verhindern. Schliesslich werde bemerkt, dass $q$ eine Schmierrille und $C$ der Lappen ist, auf welchem die Federn zum Tragen des Wagenkastens befestigt werden.

Bei der Mail-Patentachse wird das Ablanfen der Büchse $D$ nebst Rad vom Schenkel $B$ mittclst zweier schmiedeiserner Scheiben $S$ und $T$, Fig. 1694, vermieden, welche durch drei Schraubenbolzen a mit einander vereinigt sind und die Büchse $D$ zwischen sich fassen. Dabei ist $b$ wieder eine Lederscheibe, gegen welche sich der äusserste, besonders abgedrehte Rand $m$ (Fig. 1695) am weiten Ende der Buichse lehnt und beim Umdrehen der Biichse reibt. Von den in Fig. 1695 weggelassenen Scheiben $T$ und $S$ hat letztere ihren Platz in dem ringförmigen Raume $n n$ zwischen der Kapsel $G$ und der Bïchse $D$.

Ueber die Vorziige der einen oder anderen der beschriebenen Achsen ist man selbst in ihrem Vaterlande England noch nicht ganz einig.

Einleuchten dürfte jedoch die grössere Sicherheit der Mail-Büchse, weil hier ein Losgehen der drei Schraubenmuttern $c$ gewiss weit weniger zu erwarten ist, als dies bei den Schrauben $y$ u. $z$ der Collinge der Fall ist, we lche den ganzen Seitendruck der Buichse $D$ auszuhalten haben, der bei Mail von dem Ansatze $E$ gegen welchen sich im schlimmsten Falle die Lederscheibe $b$ lehnt, aufgenommen wird. Dagegen haben die Collinge-Biichsen den Vorzug des grösseren Dichthaltens gegen Schmutz und Staub, was sofort aus der Vergleichung der Durchschnittsfiguren Fig. 1686 und 1695 klar werden wird, wo bei der Mail der Achsschenkel $B$ völlig offen liegt, sobald die Staubbiichse $G$ entfernt wird, bei der Collinge dagegen der Kragen $x$ ein neues Mittel der Absperrung fü Unreinigkeiten bildet. welche bereits in die Büchse $G$ gelangt sein möchten. Dass Mail eine stärkere Nabe (unter sonst gleichen Umständen) als Collinge erfordert, dürfte namentlich fur elegante Stadtwagen gegen jene sprechen, so wie andererseits der jedenfalls höhere Preis der Collinge nicht ganz zu übersehen sein wird.

Nachdem im Vorstehenden die Anfangsgrïnde für die Einrichtung aller Fuhrwerke und ihrer allgemeinen Verlältnisse dargelegt waren, folgte eine Beschreibung der einzelnen Theile des Gestelles; und es ist nun die Verbindung dieser Theile zu dem Fuhrwerke selbst näher zu betrachten.

Dabei wird vorzugsweise der gewöhnliche und wichtigste Zweck, zum Transporte grösserer Lasten zu dienen, hier beriicksichtigt.

Man unterscheidet zunächst an jedem Fuhrwerke das Untergestill oder den Unterwagen und das Obergestell oder den Oberwagen. Von 
Wichtigkeit ist vorzüglich nur die Kenntniss des Untergestelles, weil dieses die Leistungen des Fuhrwerkes hauptsächlich bedingt; der Oberwagen ist einer allgemein zu bestimmenden Einrichtung gar nicht fähig, indem die verschiedenen Zwecke bald diese, bald jene Anordnung erfordern, welche häufig selbst auf dem nämlichen Untergestell ausgefiihrt werden kann.

Das Gestell eines Karrens ist höchst einfach; die Achse mit ihren beiden Rädern wird in zwei Trag- oder $\mathrm{Schwungbäumè} \mathrm{eingelassen,} \mathrm{und}$ durch Achsbügel, Bänder und Bolzen damit in feste Verbindung gesetzt. Diese Tragbäume bilden mit ihrem hinteren Theile den oberen Raum für die Bepackung und sind durch Querhölzer verbunden; ihre vorderen Theile kommen näher zusammen und geben die Gabeldeichsel, Kluftdeichsel oder Scheere zum Eispannen eines Pferdes. Sind mehrere Pferde nöthig, so müssen sie daher einzeln vor einander gespant werden, und diese Anordnung, so wie besonders die Lage des Pferdes in der Gabel ist für schnelle Bewegungen sehr hinderlich. Denn es leuchtet ein, dass dieses Pferd nicht allein den Theil der Last tragen muss, der die Bäume nach vorwärts niederdrückt, sondern beim raschen Fahren wird das Thier, besonders auf unebenem Boden, durch das Hin- und Herschlagen der Tragbäume auf eine gewaltsame Weise angestrengt und gequält.

Die Bepackung des Karrens sollte eigentlich so geschehen, dass der Schwerpunkt der Last genau über die Achse zu liegen käme, alsdann würde keine nach vorn niederdrückende Gewalt auf die Bäume wirken, und das Gabelpferd hätte in dieser Hinsicht nichts zu leiden. Allein bei einer solchen Bepackung würde beim Aufwärtsfahren die Senkrechte aus dem Schwerpunkte hinter die Achse fallen, dadurch eine Drehung des Gestelles nach oben entstehen, und das Pferd in der Gabel wäre wohl kaum immer im Stande, diesen Gewalten Widerstand zu leisten. Man muss daher von Haus aus die Belastung so packen, dass ihr Schwerpunkt vor die Achse zu liegen kommt, dadurch ist die eben angeführte Drehung, die man nicht gestatten darf, zu vermeiden; aber es wird nun auch dem Pferde für den gewöhnlichen $\mathrm{Z} u g$ auf ebenem Boden stets ëin Theil der Last zum Tragen aufgebürdet.

Wie iibrigens die Lage des Schwerpunktes in dieser Hinsicht regulirt werden soll, hängt von der Beschaffenheit der Wege ab, die man der Wahrscheinlichkeit nach passiren muss, und Gebirgsgegenden erfordern desshalb andere Massregeln als ein im Allgemeinen flaches Land.

Ein besonders ungünstiges Verhältniss tritt für den Karren dann ein, wenn derselbe - wie z. B. bei dem Durchschreiten von Gräben oder Vertiefungen eine Drehung der Last bewirken muss; das Gabelpferd befindet sich bereits auf der neuen Richtung des Zuges, der Karren aber noch nicht, und es ist klar, wie schwierig dieser Uebergang werden kann.

Endlich bietet das Karrengestell im Allgemeinen weniger Raum dar als das Wagengestell; bei Belastungen mancher Art, die viel Platz erfordern, rückt daher der Schwerpunkt höher; hierdurch, und durch den Umstand, dass die Last nur auf einem Gestelle liegt, ist der feste Stand des Karrens ungleich geringer als der eines Wagens unter sonst gleichen Verhältnissen. Andere VergleichungsMomente werden sich späterhin ergeben.

Das Untergestell eines Wageus besteht aus dem Hintergestell, dem Vordergestell und der Deichsel.

Zum Hinterğestell gehört die Achse $a_{1}$ und der Achsstock $b_{1}$ Fig. 1700, mit den beiden Rädern $r_{1} r_{1}$; auf $b_{1}$ wird noch eine $75-100^{\mathrm{mm}}$ hohe Verstärkung angebracht unter dem Namen des Achsschemels, und mit ilım durch Bänder vereinigt. Von ihm geht der Langbaum $l$ mit seinen beiden Streben oder Armen aus, und dient zur Verbindung des Hintergestelles mit dem Vordergestell; er gibt die Lenkung für das Hintergestell gerade so ab, wie die Deichsel dies fiir das Vordergestell thut.

Das Vordergestell besteht wieder aus der Achse $a$ mit den Rädern $r$ und einem Achsschemel auf dem Achsstocke $b$; durch letzteren gehen die beiden 
Deichselarme $d^{\prime} d^{\prime \prime}$ hindurch, welche vor der Achse die Deichselscheere zur Aufnahme der Deichsel $d$ bilden; hinter der Achse gehen sie beinahe bis zur Länge der Mittelachse auseinander, und sind an ihrem Ende - auf etwa 1 m Abstand von der Achse - durch einen Querarm, Reibscheit oder Lenkseheit $t$ verbunden. Eben weil von der Hinterachse der Langbaum, und von der Vorderachse die Deichselarme ausgehen, muss beiden jene angebrachte Verstärkung gegeben werden, um die Achse selbst nicht zu schwächen.

Der Langbaum des Hintergestelles geht iiber das Reibscheit weg, und tritt sodann in eine vierkantige weite Oeffnung in dem Vorder-Achsschemel, wo er durch den von oben durchgehenden $\mathrm{Reib}$ - oder Spann-Nagel $n$ gehalten wird. Das Reibscheit ist oben mit einer eisernen Schiene belegt, der vordere Theil des Langbaumes endigt in eine eiserne Kappe, und in dieser Verbindung muss das Vordergestell, d. h. die Deichselarme und die Deichselscheere, nothwendig eine wagerechte Stellung annehmen. Mit der Deichsel ist der Schwengel $s$ und an diesem sind die Zugscheite (Trittel) $z$ befestigt.

Zum Oberwagen gehört sodann der Wend- oder Lenks chemel, welcher in der Regel convex gekriimmt auf dem Vorder-Achsschemel drehbar ruht, und durch welchen der Spann-Nagel von oben hindurch geht. Dieser Wendschemel steht mit dem Kasten oder den sonstigen Theilen des Oberwagens in fester Verbindung, und auf der Hinterachse wird der Oberwagen ebenfalls durch entsprechende Vorrichtungen, $\mathrm{Rungen}, \mathrm{S}$ te mmleisten (auch wohl $\mathrm{N}$ ü sse genannt) festgehalten. Es kann daher die Vorderachse unter dem Wendeschemel und Oberwagen ihre

Fig. 1700 .

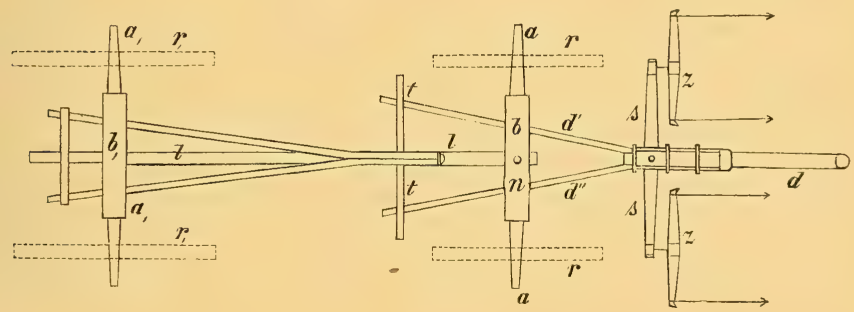

Stellung verändern, ohne dass dieser und die Hinterachse daran auf irgend eine Weise Theil zu nehmen brauchen. Soll daher der Oberwagen im Ganzen eine horizontale Stellung einnehmen, so muss der Halbmesser der Vorderräder um die Höhe des Wendeschemels kleiner sein als der der Hinterräder. Dies ist der gewöhnliche Grund der kleinen Vorderräder; eine andere Veranlassung, sie noch niedriger zu machen, findet statt, wenn man unterlaufende Räder haben will.

Von der hier beschriebenen Einrichtung des Vordergestelles ist das eigentliche $\mathrm{Kutsch}$ - oder Bockgestell völlig verschieden. Bei ihm muss ein grosser freier Raum über der Vorderachse zur Anbringung des Bockes u. s.w. gewonnen werden, in der Regel werden auch unterlaufende Räder angebracht, und darnach muss sich die übrigens höchst abweichende Construction sowohl des Unterwagens wie des Oberwagens in diesen Theilen richten. Der Unterwagen weisst z. B. in den Figuren 1701 u. 1702 keinen Langbaum auf, indem die betreffenden Verbindungsstiicke in den Oberwagen gelegt sind. Es liegt nicht in dem Plane dieses Artikels hiervon näher zu sprechen.

Als Material zum Unterwagen wird regelmässig Eichenholz genommen, weil dessen grössere Festigkeit und Dauer doch ein iiberwiegender Vorzug trotz des rermehrten Gewichtes ist. Bei leichteren Fuhrwerken benutzt man jedoch atuch 
Buchen und Ulmen. Ueberhaupt hängt die Festigkeit des Gestelles keineswegs von der Masse und Dicke des verwendeten Materiales ab, sondern mehr noch von der zweckmässigen Form, Gegeneinanderstellung und Verbindung der Theile.

Es dient die Deichsel und zunächst die einfache Deichsel dazu, um durch eine bestimmte Stellung derselben der Vorderachse eine veränderte Lage unter dem Wendeschemel und Oberwagen zu ertheilen. Wird̃ nun der Wagen in Bewegung gesetzt, so muss der veränderte Zng der Pferde gegen die Achse und die hierdurch bedingte seitliche Pressung des Langbaumes das Hintergestelle veranlassen in die neue Richtung iiberzugehen. Natürlich dient bei gleichmässiger Führung der Pferde die Deichsel dazu, die Richtung der Beweging iiberhaupt zu erhalten, wie zu lenken.

Fig. 1701.

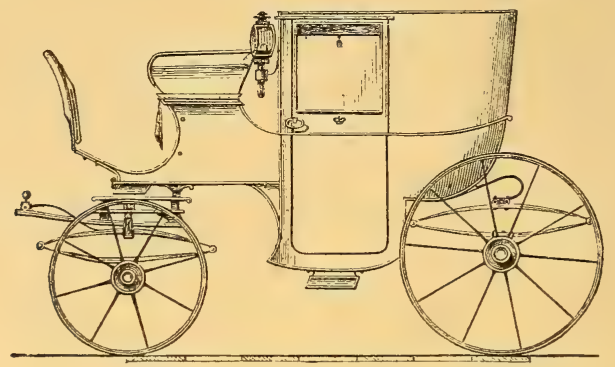

Auf vder unter der Deichsel, nach Massgabe der Höhe der Räder, liegt zur Verbindung der Zugstränge mit der Achse und dem Fuhrwerke die Wage (der grosse Schwengel), woran die kleinen Schwengel oder Zugscheite (Trittel) befestigt sind, an welche die Stränge angeschlungen werden.

Fig. 1702 .

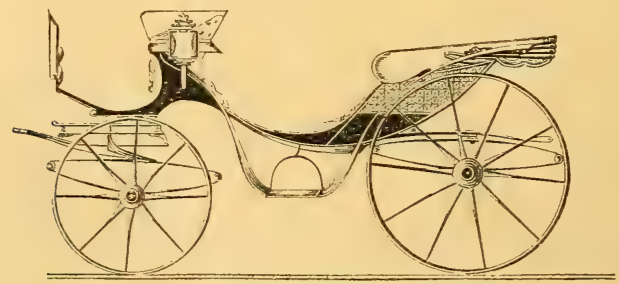

Bei allen Fuhrwerken ist ihre $L$ enk barkeit, d. i. die Fähigkeit der Richtungsinderung, ron besonderer Bedeutung. Indem die Richtungsänderung des ganzen Wagens keine plötzliche sein kann, sondern in einem Bogen stattfinden muss, welchen die Räder des Hintergestelles durchlaufen, so ist die Lenkbarkeit um so grösser, je schärfer gekrümmt dieser Bogen sein kann.

Wenn man das in Figur 1700 gezeichnete Untergestelle betrachtet und sich das Vordergestelle um den Reibnagel $n$ gedreht denkt, so ersieht man leicht, dass diese Drehung alsbald begrenzt ist, wenn eines der Vorderräder gegen 
den Langbaum stösst. Es bezeichnet dies die Grenze der Abweichung; und indem man die Vorderachse und Hinterachse so weit verlängert denkt, bis sie sich schneiden, so erhält man den Drehungsmittelpunkt, also auch den Radius des kleinsten Kreises, in welchem sich das Fuhrwerk bewegen kann. Es ist nun leicht ersichtlich, dass jener Radius grösser werden muss - also die Lenkbarkeit abnimmt - wenn der Langbaum bedeutende Länge hat, ferner wenn die Spurweite der Räder eine geringere ist.

In den wenigsten Fällen ist jedoch das Vordergestelle so weit beweglich, dass eines der Räder den Langbaum berühren kann, sondern meist wird die Bewegung durch den Oberwagen früher begrenzt. Daher ist auch die Breite des Oberwagens und die Grösse der Vorderräder von wesentlichem Einflusse auf die Lenkbarkeit; und trachtet man namentlich durch entsprechende Form des Oberwagens, z. B. Einschnitte am Wagenkasten, die Hindernisse zu vermindern.

Mit den Anforderungen, welche im Sinne der Lenkbarkeit an ein Fuhrwerk gestellt werden müssen, kreuzen sich die Forderungen, welche man betreffs der Stabilität stellen muss. Der Schwerpunkt der Last soll thunlichst tief liegen, es bedingt dies breite, niedere Oberwagen. Dieser Collision begegnet man durch solche Wahl der Dimensionen, wie sie die Erfahrung festgesetzt hat.

Beim Abwärtsfahren werden häufig Hemmungsvorrichtungen erforderlich, wohin die Hemmkette, der Hemm-oder Radschuh, die H emmschraube oder Bremse zu zählen sind. Vgl. den Art. Bremse II pag. 7 bis 10 .

Beziiglich der $\mathrm{Zugkraft}$ der Pferde und ihrer Ermittlung vergleiche die Artikel: Arbeit I pag. 188, Dynamometer II pag. 706 und Pferdekraft; hier sei nur bemerkt, dass man auf guten Strassen pr. 1 Pferd eine Belastung von 30-50 Zoll Cent. bei einer Geschwindigkeit (Schritt) von 1.1 bis $1.3^{\mathrm{m}}$ und von 5 Zoll-Cent. bei $3^{\mathrm{m}}$ Geschwindigkeit (Trab) rechnen kann, in welcher Belastung das Gewicht des Wagens nicht einbezogen ist.

Literatur. Rühlmann: Allgem. Maschinenlehre 3. Band. Braunschweig 1868.

Bickes: Anleitung z. Kenntniss aller Arten von Equipagen oder Darstellung

der Kutschenfabrikation. Freiburg i. Br. 1829. Lebrun: Manuel du Charron et du Carrossier, Paris 1833, übersetzt: Theor. pract. Handbuch des Wagners, Weimar 1835. Beckmann Handbuch der Wagenfabrikation, 4. Aufl. von Rausch, Weimar 1865. Zeitschriften für Wagenbau: Meitinger WagenbauZeitung München; Brice-Thomas le Guide du Carrossier. Paris ete.

Fuligo, s. m. Kienruss, s. b. Kohlenstoff.

Fulmicoton, s. Schiessbaumwolle, s. Explosivstoffe III pag. 337.

Fulminate, s. Knallsäure-Salze, s. d., vgl. Explosivs toffe III pag. 339.

Fulminatin, syn. Fuchs'sches Sprengpulver, ist Scheerwolle (möglicher Weise auch nitrirter Baumwollabfall), mit Nitroglycerin getränkt, s. Berg- und Hüttenm. Ztg. 1872 pag. 55, vgl, E. Kop p, Monit. scientif. 1874 Nr. 390, pag. 499, s. a. Gintl, Ausstellungsber. ü. Zündwaaren u. Explosivstoff, Wien 1874. Gtl.

Fulminatin, s. Bergbau I pag. 385.

Fulminsäure u. Eulminursäure, s. m. Knalls äure und Is ocyanursäure, s. Cyan II pag. 460, s. a. K nalls äure.

Fumarolen (soffioni), d. s. die in den Provinzen Pisa und Grosseto des ehemaligen Grossherzogthums Toscana der Erde entströmenden borsäurehaltigen Wasserdämpfe, welche zur Gewinnung von Borsäure dienen, s. Bor I pag. 726, vgl. a. C. M. Kurtz, Dingl. pol. Journ. 212 pag. 493 . Gtl.

Fumarin (fumarine - fumarine) das Alkaloid des Erdrauchs (Fumaria offic L.), kann aus dem frischen Kraute des Erdrauchs durch Zerstampfen, An- 
säuern des Breis mit Essigsäure und mehrstündige Digestion in der Wärme, Abpressen des Saftes und Extrahiren des im Wasserbade verdunsteten Saftes mit kochendem Alkohol zunächst in weingeistiger Lösung erhalten werden, aus welcher sich nach dem Entfärben mit Thierkohle beim Verdunsten farblose Krystallnadeln von essigs. Fumarin ausscheiden (vgl. Ha n n o n, Journ. Chim. med. (3) 8 pag. 705). Auch durch Auskochen des trockenen Krautes mit Essigsäure enthaltendem Wasser, Fällen des Decoctes mit Bleiessig und Fällen des vom Blei befreiten Filtrates nach starkem Ansäuren mittels Schwefelsäure mit metawolframsauren Natron erhält man einen Niederschlag der mit frischem Bleioxydhydrat vermengt und getrocknet an kochenden Alkohol Fumarin abgibt, welches durch Verdunsten des Alkohols, Lösen des Rüickstandes in essigsäurehältigem Wasser, Fällen der Lösung mit Bleiessig und Sättigen des vom Blei befreiten Filtrates mit Kalihydrat zunächst in Gestalt eines Niederschlags erhalten werden kann, der nach dem Waschen und Trocknen in warmen Schwefelkohlenstoff gelöst und nach dem Abfiltriren des Ungelösten aus dieser Lösung durch Schütteln mit salzsäurehaltigem Wasser die Base in Gestalt eines salzsauren Salzes liefert, aus welchem sich durch Vermengen mit kohlens. Baryt und Extrahiren des trockenen Gemenges mit absol. Alkohol das reine Alkaloid gewinnen lässt (vgl. Preuss, Zeitschr. f. Chem. 1866 pag. 414). Das Fumarin bildet farblose Krystalle (Prismen des klinorhb. Systems), löst sich wenig in Wasser, leicht in Weingeist, Amylalkohol, Schwefelkohlenstoff, Chloroform und Benzol, in Aether ist es unlöslich. Es schmeckt bitter und seine Lösungen reagiren alkalisch. Mit conc. Schwefelsäure färbt es sich dunkelviolett. Seine Zusammensetzung ist noch nicht festgestellt. Vergl. a. Peschier in Trommsdrff. n. Journ. Pharm. 17 (2) pag. 80. Gtl.

Fumarsäure (acide fumarique - fumaric acid), Flechtensäure, B oletsäure, Paramale in säure. Krystallisirbare Säure, findet sich als Bestandtheil des Erdrauches (Fumaria off. L.), des Krautes von Corydalis bulb. De C. und Glaucium lut. L., dann im isländ. Moos (Cetraria islandica Ach.), sowie in verschiedenen Schwämmen, insbesondere Agaricus und Boletus-Arten. Künstlich entsteht sie bei der trock. Destillation der Aepfelsäure, sowie beim Erhitzen dieser Säure mit Salzsäure oder Bromwasserstoff.

Aus Erdrauchkraut erhält man die Fumarsäure, wenn man durch Fällen der siedend heissen wässrigen Abkochung desselben mit Bleizuckerlösung zunächst Gerbstoffe und Farbstoffe entfernt und die noch siedend heisse Flïssigkeit vom Niederschlage abfiltrit. Aus dem Filtrate scheidet sich beim Erkalten fumarsaures Blei in Gestalt kleiner körniger Krystalle aus, die gesammelt und mit Salpetersäure zerlegt werden, wonach aus dem Zersetzungproduct durch kochenden Alkohol die Fumarsäure ausgezogen werden kann. Durch Ueberfuihrung in das Ammoniumsalz, Umkrystallisiren und abermaliges Zersetzen desselben mit Salzsäure lässt sich die Säure rein erhalten. Reine Fumarsäure bildet farblose prysmatische Krystalle, welche in 390 Theile Wasser ron $10^{\circ}$ C., reichlich in heissem Wasser, dann in 21 Theile 76 Proc. Alkohol, sehr leicht in Aether auflöslich sind. Sie ist geruchlos, schmeckt und reagirt stark sauer. Beim Erhitzen iiber $100^{\circ}$ C. schmilzt sie und sublimirt uiber $200^{\circ} \mathrm{C}$. in langen nadelförmigen Krystallen, während ein Theil sich unter Wasserabgabe in Fumarsäureanhydrid $\left(\mathrm{C}_{4} \mathrm{H}_{2} \mathrm{O}_{3}\right)$ verwandelt. Ihre Zusammensetzung entspricht der Formel $\mathrm{C}_{4} \mathrm{H}_{4} \mathrm{O}_{4}$, sie ist mit Malëinsäure isomer, in die sie z. Th. auch beim Erhitzen iiberzugehen vermag. Die Fumarsäure ist eine zweibasische Säure und liefert $z$. Th. krystallisirbare Salze. Das Silbersalz ist leicht zersetzbar und explodirt beim Erhitzen heftig. Beim Erhitzen einer mit Salzsäuregas gesättigten Lösung von Fumarsäure in Alkohol destillirt bei $225^{\circ} \mathrm{C}$. siedender Fumarsäure Aethyläther als eine farblose angenehm obstartig riechende Fliissigkeit $\left(\mathrm{C}_{4} \mathrm{H}_{2} \mathrm{O}_{4},{ }_{2}\left(\mathrm{C}_{42} H_{5}\right)\right.$.

Mit Jodwasscrstoff erhitzt oder mit Natriumamalgam behandelt, geht die Fumarsäure unter Aufnalıme von Wasserstoff in Bernsteinsäure über (vergl. a. Winckler, Rep. Pharm. 39 pag. 48 und 368 , dann 48 pag. 39 und 363 , 
Pasteur Annal. Chim. Phys. (3) 31 pag. 92, Pelouze Annal. Chim. Phys. (2) 56 pag. 72, Kekulé Annal. der Chem. und Pharm. 130 pag. 21, 131 pag. 85. Supplem. I pag. 129 und II pag. 108). Gtl.

Function. Hängt eine Grösse $u$ von einer oder mehreren anderen unbeschränkt und stetig veränderlichen Grössen $x, y \ldots a b$, so zwar, dass mit diesen auch $u$ seinen Werth ändert, so wird $u$ eine Function jener Grössen genannt und man schreibt $u=f(x), u=F(x, y) \ldots$ Die Grössen $x, y \ldots$, denen das Merkmal der unbeschränkten continuirlichen Veränderlichkeit als wesentlich anhaftet, werden die un abhängigen Variablen genannt; dagegen pflegt man $u$ auch die abhängige Veränderliche zu nennen. Der geometrische Repräsentant einer Function von einer Variablen ist eine ebene Curve, der einer Function von zwei unabhängigen Veränderlichen eine Eläche.

1. Dem Wesen nach theilt man die Functionen in algebraische und transcendente; in den ersten werden mit den Veränderlichen blos die sog. algebraischen Operationen - Addiren und Subtrahiren, Multipliciren und Dividiren, Potenciren und Radiciren mit constantem Exponenten - vorgenommen; in den zweiten sind die Variablen mit anderweitigen, sog. transcendenten Operationen behaftet.

2. Die algebraischen Functionen theilt man weiter ein in rationale und irrationale, je nachdem sie - nach Ausführung etwa angedeuteter Operationen - die Variablen nur mit ganzen oder auch mit gebrochenen Exponenten (unter einem Wurzelzeichen) enthalten; in ganze und gebrochene, je nachdem die Variablen nur im Zähler (mit positiven Exponenten) oder auch im Nenner (mit negativen Exponenten) erscheinen.

3. Eine Function $f(x)$ der unabhängigen Variablen $x$ - gleichgiltig ob algebraisch oder transcendent - heisst ein- oder mehrdeutig, je nachdem einem bestimmten Werthe von $x$ ein oder mehrere Werthe von $f(x)$ entsprechen; gerad oder ungerad, je nachdem sie für entgegengesetzt-gleiche Werthe von $x$ gleiche oder entgegengesetzte Werthe annimmt, je nachdem also $f(x)=f(-x)$ oder $f(x)=-f(-x)$; sie ist innerhalb eines Intervalls der unabhängigen Variablen $x=a$ bis $x=b$ continuirlich oder discontinuirlich, je nachdem für alle zwischen $a$ und $b$ gelegene Werthe von $x$ einer unendlich kleinen Aenderung dieser Grösse auch sie eine solche Aenderung erfährt. Periodisch heisst eine Function $f(x)$, wenn sie nach gleichen Intervallen der Variablen immer wieder denselben Werth annimmt, so dass, wenn mit a jenes Intervall bezeichnet wird, $f(x)=f(a+x)=f(2 a+x)=\ldots$; man nennt $a$ den Index der Periodicität.

4. Zu den einfachen algebraischen Functionen rechnet man nebst den einfachsten $a \pm x, b x, \frac{x}{c}$, in welchen die Variable mit den Constanten $a, b, c$ durch die vier Species verknüpft ist, die Potenz, d. i. die zu einem (ganzen oder gebrochenen, positiven oder negativen) constanten Exponenten erhobene Variable; zu den transcendenten die Exponentialgrösse $a^{\mathrm{x}}$, ihre Umkehrung, den Logarithmus a $\log x$; die goniometrischen Functionen $\sin x, \cos x, \operatorname{tg} x, \cot x, \sec x, \operatorname{cosec} x$, ihre Umkehrungen, die cyclometrischen Functionen $\arcsin x, \operatorname{arc} \cos x$, arc tg $x$, arc cot $x \ldots$ Lässt man für die unabhängige Variable auch complexe Werthe $\mathrm{zu}$, so können die goniometrischen Functionen aus der Exponentialgrösse, die cyclometrischen aus dem Logarithmus hergeleitet werden.

Literatur. Ausser dem hervorragenden Werke iber die Theorie der Functionen, Lagrange's "Theorie des fonctions analytique" (3. Aufl. v. Serret, Paris 1847) und dessen "Leçons sur le caleul des fonctions" ist auf die rerschiedenen Curse der höheren Mathematik zu verweisen, von denen wir hier nur Navier's "Leçons d'analyse" (deutsch v. Wittstein), Schlömileh's Compendium der höheren Analysis" (4. Aufl. Leipzig), Herr's Lehrbuch der 
höheren Mathematik" (3. Aufl. Wien, 1877) und Lipschitz's eben im Erscheinen begriffenes "Lehrbuch der Analysis" (Bonn 1877) anführen.

Czuber.

Fundament, s. Bergbau I pag. 400, s. Fundirung.

Fundamentalpunkte nennt man die durch directe Bestimmung festgestellten Siede- und Eispunkte an Thermometern, s. d. vergl. Wärmemessung. Gtl.

Fundirung (foundation - foundation). Die Gesammtheit jener Arbeiten, welche bei Herstellung des Fundamentes oder der Grundmauern eines Bauwerkes auszufiihren sind. Besondere Wichtigkeit im Brickenbau hat die p neumatis che Fundirung erlangt (s. hierüber d. Art. Was serbau).

Fungin, syn. Cellulose, s. d. II pag. 269.

Funkenfänger, werden bei Schornsteinen angebracht und sollen durch Krïmmung des Weges, welchen der Rauch bei der Ausströmung zurïickzulegen hat, die Ablagerung der mitgefuihrten glïhenden Stiickchen (Funken) bewirken. Vergl. III pag. 105, Fig. $1333 b$ bei $T$ u. $X$, vergl. ferner d. Art. Heizung.

Furfurin, s. Furfurol.

Furfurol (furfurole), A m e is e nöl, Pyroschleimsäure-Aldehyd. Name (von furfur, die Kleie und oleum, Oel, d. i. Oel aus Kleie) eines Zersetzungsproductes, das bei der Destillation von Kleie, Mehl, Gummi, Zucker, Holzspänen etc. mit verdiunnter Schwefelsäure, sowie bei der trockenen Destillation dieser Körper entsteht. Man stellt es dar durch Destillation eines Gemenges von 6 Thl. Kleie, 5 Thl. Schwefelsäure und 12 Thl. Wasser, oder durch Erhitzen eines Breies aus 15 Thl. Kleie und 5-6 Thl. Zinkchlorid mit so viel Wasser, als nöthig, um eine genïgend flüssige Masse zu erhalten, Neutralisiren des Destillates mit Kali und nochmalige Destillation, wobei ein wässriges Destillat erhalten wird, aus dem sich das Furfurol in Gestalt öliger Tropfen ausscheidet, die gesammelt und iiber Chlorealcium getrocknet werden.

Das Furfurol stellt eine Anfangs farblose, am Licht sich bald gelb und braun färbende ölige Flïssigkeit dar, ist von eigenthümlich gewürzhaftem Greruche und brennendem Geschmacke. Es hat das spec. Gew. 1.165 und siedet bei $163^{\circ} \mathrm{C}$. In Wasser, Alkohol und Aether ist es leicht löslich, färbt die Haut deutlich gelb und reducirt Silberoxyd zu metallischem Silber. Seine Zusammensetzung entspricht der Formel $C_{5} H_{4} O_{2}$. - Mit Ammoniak vereinigt es sich zu Furfuramid $\mathrm{C}_{15} \mathrm{H}_{12} \mathrm{~N}_{2} \mathrm{O}_{3}$, das beim Kochen mit Kalilauge in die isomere Base $\mathrm{Eurfurin}$ iibergeht, ebenso beim Erhitzen auf $120^{\circ} \mathrm{C}$. Diese Base bildet seidenglänzende farblose Nadeln, die geruch- und geschmacklos sind und sich schwer im kalten Wasser, leicht in Alkohol und Aether lösen. Die Lösungen reagiren alkalisch und liefern mit Säuren leicht krystallisirbare Salze. Bei $100^{0}$ C. schmelzen die Krystalle, dariber hinans erhitzt werden sie zersetzt. Das Furfurin ist giftig.

Mit Schwefelammonium liefert das Furfurol Thiofurfurol $\left(\mathrm{C}_{5} H_{4} \mathrm{OS}\right)$, in Gestalt eines weissen krystallinischen Niederschlags. Mit Anilin gibt es einen schön rothen, jedoch nicht beständigen Farbstoff, mit Pyrogallussäure oder Resorcin, auch mit Phenol unter Benetzung mit etwas Salzsäure gemengt, liefert es einen indigblanen Körper. Näheres s. in chem. Handbüchern. Gtl.

Furienfackeln, s. Feuerwerkerei III pag. 475.

Furniren, s. Fournirte Arbeiten.

Furnüre, s. Fournire.

Fuscin, organische Base aus dem Dippel'schen Oele, die sich an der Luft roth färbt, s. Thieröl, vgl. Knochen $\ddot{l} \mathrm{le}$. 
Fuscokobaltsalze sind Ammoniakkobaltsalze, s. Kobalt. wein.

Fuselcampher, der erstarrende Antheil des Fuselöls aus Getreidebrannt-

Fuselöl (fusel oil), Fusel nennt man im Allgemeinen die bei der Gährung der verschiedensten, einer Alkoholgährung fähigen Substanzen neben dem Alkohol in geringer Menge auftretenden anderweitigen Substanzen, welche dem Roli-Alkohol einen mehr oder weniger charakteristischen Geschmack und Geruch ertheilen und bei der Rectification desselben, als schwerer flüchtig, zurückbleiben. Die bei der Gährung der verschiedenen zur Alkoholgewinnung verwendeten Materialien resultirenden Fuselöle sind in der Regel entweder Alkohole von höherem Kohlenstoffgehalt oder Aether solcher Alkohole, oder Ester (s. A ether I pag.50), enthalten jedoch auch Säuren, mitunter Aldehyde und endlich sog. Fermentöle. So besteht das Fuselöl des Kartoffelspiritus wesentlich aus Amylalkohol neben etwas Propylund Butyl-Alkohol, wohl auch Spuren anderer kohlenstoffreicherer Alkohole und Fettsäuren. Das Getreide-Fuselöl enthält wesentlich Oenanthäther, Amylalkohol, Caprinsäure und Caprylsäure, sowie Ester dieser Säuren, endlich ein Fermentöl von eigenthümlichem, je nach der Getreideart verschiedenem Geruche (Kornöl). Das Fuselöl des Rüben-Melassen-Spiritus enthält Capron-, Caprylund Caprin-Säure, sowie Pelargonsäure neben verschiedenen Alkoholen. Das W e in fu s el öl (Drusenöl) ist wesentlich Oenanthäther (Pelargonsäure-Aethyläther), des $\mathrm{Rumfuselöl} \mathrm{wesentlich} \mathrm{Buttersäureäther} \mathrm{etc.}$

Mit dem Namen Fuselöl schlechtweg bezeichnet man nicht selten auch den A mylalkohol, der wie erwähnt den Hauptbestandtheil des Kartoffelfuselöls ausmacht und aus diesem durch Rectification gewonnen werden kann. Dieser der Formel $C_{5} / I_{11} \mathrm{OH}$ entsprechend zusammengesetzte Alkohol (Amyloxydhydrat) besteht in fünf verschiedenen Formen, von denen zwei im Fuselöl (Gälırungsamylalkohol) enthalten sind, u. z. der optisch inactive Amylalkohol, der als Isobutyl. carbinol aufgefasst werden muss, und der optisch active Amylalkohol, der vielleicht als Amylenhydrat anzusehen ist. Der durch wiederholte Rectification des Kartoffelfuselöls gereinigte Amylalkohol stellt eine farblose ölartige Flïssigkeit von eigenthümlichem Geruche und scharfem Geschmacke dar, die in Wasser nur wenig löslich ist, sich aber mit Alkohol in allen Verhältnissen mischt. Bei $-21^{0} \mathrm{C}$. erstarrt er, der Siedepunkt liegt bei $131^{\circ} \mathrm{C}$., das spec. Gew. $=0.818 . \mathrm{Er}$ erzeugt auf Papier einen erst nach einiger Zeit verschwindenden Fettfleck und brennt mit blauer Flamme. Die beiden durch ihr Verhalten gegen das polarisirte Licht sich unterscheidenden Modifikationen kann man nach $\mathrm{P}$ a steur durch Umwandlung in amylschwefelsauren Baryt und Trennung der Barytsalze durch Krystallisation von einander trennen. Das Salz des optisch wirksamen Alkohols, der links dreht (bei $50^{\mathrm{cm}}$ langem Rohre um $20^{\circ}$ ), ist schwerer löslich als das des Anderen. Dem Amylalkohol entspricht wie anderen Alkoholen der Fettreihe auch ein Aether $\left(\mathrm{C}_{\mathbf{1 0}} \mathrm{H}_{\mathbf{2}} \mathrm{O}\right)$, Aldehyd $\mathrm{C}_{5} \mathrm{H}_{\mathbf{1 0}} \mathrm{O}$, (Amylaldehyd, Valeral) und eine Säure, die Valeriansäure $\left(\mathrm{C}_{5} \mathrm{H}_{10} \mathrm{O}_{2}\right)$, die durch Oxydation des Alkohols leicht erhalten werden können. Mit Säuren liefert er Ester von meist angenehmen Obstgeruche (s. d. bei den einzelnen Säuren). Mit wasserentziehenden Mitteln (Chlorzink, Schwefelsäure) destillirt liefert der Amylalkohol Amylen $\left(C_{5} H_{10}\right)$, d. i. eine farblose, nach faulem Kohl riechende, kühlend schmeckende Fliissigkeit vom spec. Gew. 0.659 und dem Siedpunkte $35^{\circ}$ C., welche man ähnlich dem Chloroform als Anästheticum beniitzt hat. Die iubrigen isomeren Formen des Amylalkohols sind der sog. normale Amylalkohol (Pentylalkohol), der Normalbutyl-Carbinol (vgl. Buttersän re II pag. 181) ist und bei $137^{\circ} \mathrm{C}$. siedet; der Isoamylalkohol, d. i. Methylpropylcarbinol, ein secundärer Alkohol, der bei $120^{\circ} \mathrm{C}$. siedet, der Pseudoamylalkohol (Methylisopropyl-Carbinol) oder Amylenhydrat, ein secundär. Alkohol, der bei $105^{\circ} \mathrm{C}$. siedet, und der tertiäre Amylalkohol, Psendoamylalkohol (Dimethyläthyl-Carbinol), der bei $98.5-102^{\circ} \mathrm{C}$. siedet. 
Das Fuselöl findet ausser zur Herstellung verschiedener Fruchtäther anch als Beleuchtungsmateriale (Apolloöl), dann als Lösungsmittel für Alkaloïde praktische Verwendung, dient ferner zur Darstellung der Valeriansäure (s. d.) etc. Ueber Entfuseln des Alkohols s. Branntweinbrennerei. Gtl.

Fussarbeit, die Herstellung von Geweben, bei welchen die Schäfte durch Treten bewegt werden, Trittweberei (étoffes façonnées à la marche).

Fuss künstlicher, s. Gliedmassen künstliche.

Fussband, s. B and I pag. 285.

Fussbekleidung, s. Schuhmacherei.

Fussboden (aire - flooring), ist der Belag der Bodenfläche der Räume der Gebäude. Die Belegung erfolgt mit natiurlichen oder kiunstlichen Steinen (Pflasterung), oder mit einer weichen, breiartigen Masse, welche nach dem Erhärten ein festes Ganze ohne Fugen bildet (Aestrich, Estrich), oder endlich durch Holzconstructionen.

1. Pflasterung. a) Das gewöhnliche Steinpflaster ist entweder ein unregelmässiges, wenn wenig bearbeitete Bruchsteine verwendet werden oder ein Reihenpflaster (Wuirfelpflaster), wenn die Steine nach der prismatischen Form vorbereitet werden. Die Befestigung der Unterlage ist sehr wichtig und dient für Einfahrten, Stallungen etc. eine $8-15^{\mathrm{cm}}$ starke comprimirte Sandschïttung. Die Steine (ca. $10-15^{\mathrm{cm}}$ hoch) werden, nachdem sie mit unausgefüllten Fugen verlegt sind, mit einer Ramme (ca. 12 K. schwer) gestampft. Nach dem ersten Stampfen sind die Fugen mit feinem Sand auszufullen und erst dann ist das Stampfen fortzusetzen. Soll die Pflasterung Flüssigkeiten ableiten, so ist bei glatten Steinen ein Gefälle von mindestens $1 / 4 \%$ nothwendig.

b) Plattenpflaster zu Gängen, Vorplätzen, Küchen, Aborten, Trottoirs etc. Von natürlichen Steinen kommen besonders Sandsteine, Thonschiefer und Kalksteine, von kïnstlichen Steinen gebrannte Thonplatten (z. B. Mettlacher Platten), Cement- und Asphaltplatten zur Anwendung. (S. Asphalt, bautechn. Anwendung I. 216, 1. e.) Die Cementplatten werden aus einem Gemisch von Cement und Sand hergestellt und können leicht rerschieden gefärbte Zeichnungen oder Marmorincrustationen (Terrazoplatten) erhalten, welche den Platten eine hohe Eleganz rerleihen. Die Unterfläche der Platten bleibt rauh; die übrigen Flächen werden mehr oder weniger glatt hergestellt, selbst geschliffen und polirt. Als Untergrund nimmt man gestampften Schutt, Ziegelpflaster oder Béton. Die Platten werden zumeist in ein Mörtelbett gelegt und die Fugen mit dünnflüssigem Mörtel ausgegossen.

c) Ziegelpflaster. Hierzu verwendet man entweder gewöhnliche Mauerziegel oder eigene Pflasterziegel, Klinkerziegel (bloss $3-5^{\mathrm{cm}}$ stark). Bei Anwendung gewöhnlicher Mauerziegel unterscheidet man flaches oder liegendes Ziegelpflaster (Höhe des Pflasters gleich der Ziegeldicke) und hochkantiges oder stehendes Ziegelpflaster (Höhe des Pflasters gleich der Ziegelbreite). Letzteres wird bei grosser Belastung oder starker Abnützung rerwendet; mitunter ist demselben jedoch ein doppeltes Haches Ziegelpflaster, mit dazwischen liegender Sandschichte, vorzuziehen wegen leichterer Reparaturfähigkeit und geringerer Anzahl Fugen.

2. A estriche. Je nach dem Hauptbestandtheil der Masse unterscheidet man :

a) Lehmästrich. Lehm wird in feuchtem Zustande in dünnen Lagen aufgetragen und mit hölzernen Pracken geschlagen; ist der Lehm zu mager, bestreicht man ihn mit Rindsblut. Beim Schlagen werden Pausen ron ca. 24 
Stunden gemacht und beobachtet, ob sich Risse bilden. Man hat so lange zu schlagen, bis sich keine Risse mehr zeigen.

b) Gypsästrieh. Auf einer Sandunterlage wird der Gypsmörtel 2-5:m stark aufgetragen. Zur Erzielung gleichmässiger Dicke legt man genau horizontal Latten, mit Seifenwasser benetzt, in ca. $1^{\mathrm{m}}$ Entfernungen, füllt den $Z$ wischenraum je zweier Latten und streicht mit einem Richtscheit die Oberfläche gleich. Man entfernt dann die Latten und nach etwa 24 Stunden kann der Aestrich mit hölzernen Pracken geschlagen werden. Die von den Latten herrïhrenden Streifen werden mit Gypsmörtel ausgefüllt.

c) Venetianischer Aestrich, Battuta, auch terrazzo marmorino, ist ein aus drei Lagen bestehender Kalkanstrich. Die erste, ca. $8^{\mathrm{cm}}$ hoch, besteht aus gewöhnlichem guten Mörtel mit kleinen Ziegel- oder Steinstücken und wird mit eisernen Pracken gestampft; die zweite Lage, $4-5^{\mathrm{cm}}$ stark, wird áhnlich hergestellt, enthält aber nur Steinchen von ca. $1^{\mathrm{cm}}$ Durchmesser. Als letzte Schicht, ca. $1^{\mathrm{cm}}$ stark, wird ein Mörtel aus Kalk, Ziegel- und Marmorstaub aufgetragen, und so lange derselbe noch weich ist, Marmorstïcke nach verschiedenem Muster, als Mosaik, eingedrückt und die Fläche mit einer Walze geebnet. Nach gänzlicher Austrocknung wird der Aestrich mit Sandstein, dann mit Bimsstein geschliffen. Soll die Fläche Glanz erhalten so wird dieselbe mit einer stählernen Kelle bearbeitet und mit heissem Leinöl getränkt.

d) Bétonästrich und Cementästrich. Eine Masse aus hydraulischen Mörtel (oder Cementmörtel) mit erbsengrossem Kies wird auf eine gemauerte oder gut gerammte Unterlage $8-10^{\mathrm{cm}}$ hoch aufgetragen und gestampft. Der Bétonästrich eignet sich zur Herstellung von wasserdichtem Bodenbelag, z. B. für Küchen, Keller, Stallungen ete.

e) Asphaltästrich, siehe Asph., bautechn. Anwendung I. 216, 1.

3. Fussböden aus Holz. Die allgemeinen Anforderungen sind Ebenheit und Dichtheit, besonders gegen Staub. Für gewöhnliche Fussböden verwendet man Weiss- und Rothtanne; fiir stark der Abniutzung ausgesetzte Fussböden sind Eiche und Buche zu empfehlen. Die Lagerhölzer (Polsterhölzer), auf welchen der Fussboden befestigt wird, müssen genau horizontal liegen; das Füllmaterial (Schutt) muss trocken und frei von Gegenständen sein, welche zuir Erzengung des Hausschwammes Veranlassung geben, besonders vegetabilischen Stoffen. Es eignen sich hierzu trockener Sand, Bauschutt, Schmiedeschlacke, Kohlengrus. Bei Anwendung von Bauschutt müssen besonders Holztheile sorgfältig entfernt werden wegen Gefahr der Uebertragung von Ungeziefer. Zu gewöhnlichen Fussböden geniigt luftrockenes Holz; zu kostbaren Fussböden soll man gut in Trockenkammern vorbereitetes $\mathrm{Holz}$ verwenden.

a) Gewöhnlicher Bretterfussboden (Dielen). Die ca. $3^{\mathrm{cm}}$ starken Bretter werden mit glatt gehobelten Seitenflächen stumpf aneinander gestossen (gefugt). Die durch das eintretende Schwinden der Bretter entstehenden Fugen werden nach 1-2 Jahren ausgespant, d. h. durch eingeleimte Späne beseitigt. Die Verbindung der einzelnen Bretter durch Spundung (Feder und Nuth), Federung und Falzung bietet wohl anfangs grössere Dichtheit gegen Staub; da das Ausspanen nicht gut ausführbar ist, werden die Fugen später verkittet. Will man möglichst wenig Fugen erhalten, so leimt man mehrere Bretter zu Tafeln, so dass das Stammende des einen Brettes mit dem Wipfelende des anderen zusammentriffi: die Fugen werden in diesem Falle verhältnissmässig breiter werden. Um das Werfen der Bretter auf ein Minimum zu bringen, mache man dieselben möglichst schmal. Die Bretter werden durch Beniitzung von Klammern und Keilen fest aneinander getrieben und auf jedem Polsterholz mit zwei Nägeln befestigt.

b) Friesboden, eingefasster Fussboden. Fig. 1703. Die Bodenfläche wird durch Friese (Rahmen aus hartem Holz) in mehrere Felder getheilt, 
welche nach Art eines gewöhnlichen Fussbodens ausgeführt werden. Es miissen daher diejenigen Polsterhölzer, welche unter Friesen zu liegen kommen, um ca. $4-5^{\mathrm{cm}}$ breiter sein als letztere.

c) Stabfussboden, Wiener Fussboden, Schiffboden, auch mitunter Friesboden genannt.

Eichene Brettel, cà. $1^{\mathrm{m}}$ lang, $10-15^{\mathrm{cm}}$ breit und $2 \%-3^{\mathrm{cm}}$ stark, werden in verschiedener Weise in Verband gebracht und befestigt.

1. Die Brettel werden untereinander durch Falz verbunden und durch zwei Nägel an jedem Ende (u. z. der eine in der Mitte, der andere im Falz) an die Polsterhölzer befestigt. Fig. 1704.

2. Die Brettel haben an allen Seiten Nuthen und die Verbindung geschieht durch Federn; die Nagelung, auf einem Blindboden als Unterlage, findet innerhalb der Nuthen statt, ist daher vollständig verdeckt. Fig. 1705.

Fig. 1703.

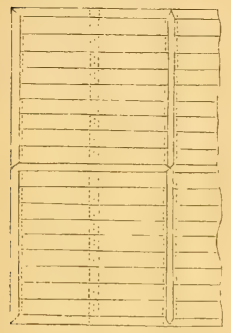

riesfussboden $1 / 100$ n. Gr.

Fig. 1704 .

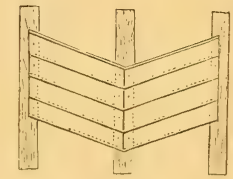

Stabfussboden $\eta_{100}$ 11. Gr.

3. Der Verband wird ohne Cnterlagshölzer und ohne Nagelung erzıelt. Die Brettel, nur ca. $50^{\mathrm{cm}}$ lang und $8^{\mathrm{cm}}$ breit, werden auf einer Asphaltunterlage mit Feder und Nuth verbunden und an den Stirnen der Brettel geschieht die Befestigung durch eiserne Plättchen, welche als Keile in eingesägte Nuthen getrieben werden.

d) Parketirte Fussböden. Dieselben erhalten als Unterlage einen gewöhnlichen Bretterfussboden (sog. Blindboden), auf welchen die Parketen ge-

Fig. 1706 .

$1 / 20$ n. Gr.

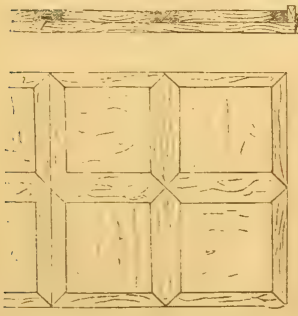
nagelt und untereinander durch eingeleimte Federn verbunden werden. Die Nagelung geschieht innerhalb der an den Stossflächen der Parketen angebrachten Nuthen $\mathbf{u}$. z. immer an zwei Seiten, während die anderen zwei Seiten nur durch die eingesetzten Federn befestigt sind. Jede Parkete besteht aus dem Rahmen, den Friesen und den Füllungen (sog. Steine), siehe Fig. 1706. Rahmen und Friese werden immer aus hartem Holz hergestellt und ersterer erhält die halbe Breite der letzteren. Sind die Steine aus weichem Holz, so nennt man die Par-

keten weiche; sind dieselben jedoch aus hartem Holz, so harte Parketen. Die ersteren sind nicht zu empfehlen, da das weiche Holz sich bald abnïtzt. Das 
Verlegen der Parketen geschieht entweder von der Mitte des Raumes aus oder am häufigsten aus der Ecke. Nach der vollständigen Legung wird der Fussborlen glatt gehobelt.

e) Fournirte Fussböden sind die reichsten und elegantesten und kommen-wohl nur bei Repräsentationsräumen zur Anwendung. Als Unterlage gibt man Tafeln aus Kiefernholz, die wie Parketen miteinander verbunden sind. Jede Tafel, ca. $0.50^{\mathrm{m}}$ breit, $4^{\mathrm{cm}}$ stark, besteht aus zwei Rahmen mit dazwischen eingeschobenen Brettchen. Auf diese Unterlage werden die $3-4^{\mathrm{mm}}$ starken Fournirhölzer, zu verschiedenen Mustern zusammengesetzt, geleimt.

f) $\mathrm{Holzpflaster}_{\mathrm{z}} \mathrm{Stöckelpflaster.} \mathrm{Auf} \mathrm{dem} \mathrm{genügend} \mathrm{festgerammten}$ Untergrund werden Holzwiirfel oder Klötzchen von polygonaler Form durch Diibel (Holzstifte) ( $2^{\mathrm{cm}}$ stark, ca. $8^{\mathrm{cm}}$ lang) verbunden. Soll das Holzpflaster wasserdicht sein, so wird dasselbe in Asphalt verlegt. Auf eine Bétonschicht kommt eine Asphaltlage und die durchgehenden Stossfugen der Holzklötzchen werden in der unteren Hälfte mit Asphalt gefuillt; die Fugen im oberen Theil erhalten Sandund Kiesfüllung.

Grohmann.

Fussbodenwachs, Fussbodenwichse, s. Bohnwachs I pag. 695.

Fussbüge, s. B and I pag. 285.

Fusspfund, s. A rbeit I pag. 188.

Fusspunktencurve ist der geometrische Ort der Fusspunkte der Senkrechten, welche man von einem als eine Art Pol gewählten Punkte auf die Tangenten einer Curve fällt. So ist beispielsweise die Cardioide die Fusspunktencurve eines Kreises, wenn ein Punkt seines Umfanges als Pol gewählt wird; die Lemniscate, die Fusspunktencurve einer gleichseitigen Hyperbel, wenn deren Mittelpunkt zum Pole gemacht wird; die Cissoide, die Fusspunktencurve der Parabel, wenn ihr Scheitel als Pol gilt. - "Ueber Fusspunktencurven der Linien zweiten Grades" von Dr. R. Wolf vergl. Crelle's Journal XX., uiber die hier genanuten Curven den Artikel "Curven" (II pag. 423.).

Cz.

Fussteppiche, s. Tep piche.

Fustet, syn. Fisetholz, s. Fustikholz.

Fustik alter, s. Gelbholz.

Fustikholz, Fis etholz (bois de fustet - ficet wood, fustic young), $\mathrm{Z}$ a n t eGelbholz, Tiroler-, Ungarisches Gelbholz, Periuckensumach, Schmackholz, Visetholz, junger Fustik. Das von Rinde und Splint befreite Kernholz des Perïckensumachs (Rhus cotinus L.) eines in Ungarn, Tirol, Dalmatien, Italien, Spanien, der Levante, den Antillen, Jamaika etc. wachsenden Strauches aus der Familie der Therebinthaceen.

Es kommt in Späne geschnitten oder in Gestalt von Kniippeln und Aesten, von aussen bräunlicher, innen gelbgriner Farbe, meist von Illyrien, Dalmatien und Ungarn, dann aber auch von Amerika aus in den Handel. Das amerikanische $\mathrm{Holz}$ ist geschätzter als das europäische. Es dient sowohl als Farbholz, sowie auch zum Gerben des Leders. Es enthält neben Gerbstoff und einer bramen Substanz namentlich einen gelben und einen rothen Farbstoff. Der zuerst ron Chevreul untersuchte gelbe Farbstoff, das Fisetin (Fustin) kann nach Bolley (s. schweiz. polyt. Zeitschrift 9 pag. 22) durch Verdampfen der wässrigen Abkochung des Holzes zur Trockene, Auslaugen des Trockenriickstandes mit Alkohol und Verdünnen der concentr. alkohol. Lösung mit Wasser in Gestalt eines krystallinischen Sedimentes erhalten werden, das durch Abpressen, Auflösen in Alkohol und wiederholtes Fällen mit Wasser in reinem Zustande resultirt. Es bildet kleine gelbe, nadelförmige Krystalle, die im kalten Wasser schwer, leichter im kochenden, leicht in Alkohol löslich sind, und der Formel $C_{15} H_{10} O_{6}$ (?) entsprechend zu- 
sammengesetzt sein sollen, aber nach B olley ohne Zweifel identisch mit Quercetin (s. d.) sind, da die Verschiedenheiten, welche dieser Farbstoff gegenüber dem Quercetin zeigt, wohl auf einen geringen Gehalt desselben an dem noch nicht näher untersuchten rothen Farbstoffe des Holzes zurïckzuführen sein dürften. Die Auflösung des Fisetins in Alkalien färbt sich rasch roth und wird durch Zinnchlorïr nicht gelb (wie bei Quercetin), sondern orangeroth gefällt. Die Thonerdeverbindung ist ebenfalls orangeroth. Vgl. a. Gelbholz. Gtl.

Fustin, s. Fustikholz.

Futter, s. Drehen II pag. 679, 682.

Futterbarchent, s. Barchent I pag. 291.

Futtermauer (contre-mur - retaining-wall) ist die Bezeichnung für eine Mauer, welche den Schub des auf der Rïckseite derselben befindlichen Erdreiches aufnehmen, und Abrutschungen verhindern soll. S. Rebhann: Theorie des Erddruckes und der Futtermauern, Wien, Gerold 1871, ferner Eytelwein und Gylly, Wasserbaukunst, 3. Heft, 2 Aufl. 1830, Berlin, Reimer.

Futterpresse, Futterschneidmaschine, s. L an d w ir th s ch aft.

Futtertafft, s. T afft.

\section{G.}

Gabanholz, Camholz, s. Cambaholz II pag. 235.

Gabbro (gabbro - diallage-rock),Urgrünstein, Zobtenfels, Schillerfels, Euphotide, Ophiolithe, Granitone, Granito di Gabbro, Verde di Corsica. Gabbro ist ein granitartig körniges, gemengtes, krystallinisches Massengestein, bestehend aus Labrador und Diallag oder Smaragdit. Der L a br a dor ist frisch glänzend, weisslich grau ins bläuliche geneigt, zeigt auf den grösseren Körnern deutlich die charakteristische Zwillingsstreifung, schmilzt vor dem Löthrohr, und wird von Säuren zersetzt. Statt desselben ist zuweilen ein anderes feldspathähnliches Mineral, S a u s s u rit, vorhanden, welches matt grünlich oder graulich weiss ist, vor dem Löthrohr suhwer schmilzt, und von Säuren nicht angegriffen wird. Der Diallag ist eine Varietät des Augites, er bildet blättrige graue, tombackbraune, tafelartige Krystalle, auf den Spaltungsfächen zeigt sich ein metallartiger Perlmutterglanz. Der S maragdit erscheint in grasgrünen perlmutterglänzenden Körnern. Je nach dem unterscheidet man Diallag- oder Smaragdit-Gabbro. Die Textur des Gesteines ist regellos körnig, bei Anwesenheit von Labrador ist das Gefüge gross- und grobkörnig. Bei der von Saussurit kleinkörnig oder porphyrartig. Seltener ist der Gabbro faserig oder schieferig. Serpentin ist häufig vorhanden, weitere Uebergemengtheile sind Hornblende, Glimmer, Sphen, Titaneisen, Granat, Magnet- und Eisenkies u. s. w. Das Gabbro braust zuweilen mit erwärmten Säuren. Das körnige Gabbrogestein sondert unregelmässig polyedrisch $a b$ und bildet oft mächtige Stöcke und Gangstöcke. Dem Alter nach scheinen die hierher gehörigen Gesteine sehr verschieden zu sein, da man solche an krystallinischen Schiefern, in Grauwacken, im Lias und selbst eocaenen Nebengesteinen kennt. Gabbrogesteine sind sehr verbreitet in Böhmen bei Komorau, Ronsperg, Kupferberg, in Sachsen, in den Vogesen, in Norwegen, in deu Alpen, auf Corsica u. s. w. Das Gestein (Gabbro, Euphodite, Verde di Corsica) wird in Italien wegen seiner Härte und schönen Farbe zu Ornamenten, kleinen Säulen, Tischplatten u. s. w. verarbeitet. $L b$.

Gabbromasse nennt J. v. Schwarz eine aus den Abfällen von der Fabrikation der Speckstein-Brenner gewonnene plastische Masse zur Herstellung von 
Gefässen, Luxusgeräthen, Statuetten u. d. g. Zur Darstellung dieser Masse werden die gemahlenen Specksteinabfälle mit geeigneten Zusätzen (geschlämmtem Thon u. dgl.) vermengt und mit Wasser zu einem Brei angestossen der äusserst plastisch ist und nach dem Brennen einen hohen Grad von Festigkeit und Härte gewinnt. Vgl. Bergan in Kunst und Gewerbe 10 pag. 177. Gtl.

Gabel, wird auch zuweilen statt dem Worte Flügel (épinglier, tréchoir - heck, $f(y)$ gebraucht, s. S pinn rad.

Gabelband, s. Band I pag. 287.

Gabelfeilen, s. Feilen III pag. 394. Gerste.

Gabelgerste, Bïs chelgerste (hordeum vulgare trifurcatum), s. b.

Gadolinit (Name nach dem Chemiker Ga dolin), rhombisches, nach Anderen monoklines Mineral, kommt selten und nur in undeutlichen Krystallen vor, findet sich zumeist derb und eingesprengt. Höchst unvollk. spaltb. Bruch, muschlig oder splittrig. H. $=6.5-7$. Sp. Gew. $=4.0-4.3$. Pechschwarz, Strich grau. Fettiger Glasglanz, gewöhnlich undurchsichtig. Chem. Zus. schwankend, die einen enthalten wenig oder keine Glycinerde, dafür Ceroxydul und wären halbkieselsaure Salze, für welche Berzelius die Formel $2\left({ }_{2} \mathrm{YOSiO}^{2}\right)+{ }_{2} \mathrm{ROSiO}^{2}$ aufstellte, sie enthalten etwa 27.1 Kieselsäure, 46.6 Yttererde, 15.7 Ceroxydul und 10.6 Eisenoxydul. Die anderen enthalten statt Ceroxydul Glycinerde, sind drittelkieselsaure Salze und entsprechen ungefähr der Formel

$$
3 \mathrm{ROSiO}^{2}, \text { worin } 3 \mathrm{RO}=2 / 3 \mathrm{YO}+1 / 3 \mathrm{FeO}+\mathrm{GlO}+1 /{ }_{6} \mathrm{LaO}
$$

mit 25.2 Kieselsäure, 48.8 Yttererde, 10.3 Glycinerde, 9.8 Eisenoxydul und 5.9 Lanthanoxyd. Gadolinite, z. B. die von Ytterby, glimmen vor dem Löthrohr lebhaft ohne $\mathrm{zu}$ schmelzen und schwellen dabei ein wenig an; andere, wie das von Hitteröe, zeigen dies Verhalten nicht. Salzsäure zersetzt ihn unter Abscheidung von gallertartiger Kieselsäure. Ytterby, Finbo, Broddbo in Schweden, Hitteröe in Norwegen, im Riesengebirge bei Schreibershau. $L b$.

Gaebeleshafer, Doppelhafer, Klumphafer, dreikörniger Haber (avena sativa alba trisperma), s. Hafer.

Gadoliniterde-Metalle nennt man die Metalle Yttrium, Erbium und (Terbium?), deren Oxyde in Verbindung mit Kieselsäure sich im Gadolinit finden, s. Erbium III pag. 279, s. Yttrium. Gtl.

Gährbottich, Gährfass, s. Bier I pag. 496.

Gährspund nennt Voss el er einen besonders construirten Spund, der während der Nachgährung zum Verschliessen der Fässer verwendet werden soll und so eingerichtet ist, dass er zwar das Entweichen der Kohlensäure gestattet, dagegen aber die Verflitchtigung des Aromas und des Alkohols, sowie das Eindringen von Luft in die Gefässe hindert und so zur besseren Conservirung gegohrener Getränke beitragen soll, vgl. Deutsche Ind.-Ztg. 1868 pag. 428 . Gtl.

Gährung (fermentation - fermenting). Die Gährungsprocesse unterscheiden sich ihrer letzten Ursächlichkeit nach nicht von den Fäulnissprocessen, deren Wesen und Bedingungen schon frïher (s. F äuln is s III p. 350) erörtert wurden. Man könnte höchstens reichliche Gasentwickelung bei Abwesenheit iibelriechender Producte als unterscheidende Kriterien derselben ansehen. In Folgendem mögen die Bedingungen und Erscheinungen der technisch wichtigsten Gährungsprocesse erörtert werden.

Die Alkoholgährung besteht in der Zerlegung gewisser Zuckerarten in eine Anzahl von Producten, unter denen Alkohol und Kohlensäure constant und als Hauptproducte auftreten. Es gibt nun eigentlich mehrere Arten der Alkohol- 
gährung, die durch die Sporen der verschiedeusten Pilzgattungen, z. B. der Mucorarten und anderer Hyphomyceten eingeleitet werden; die technisch wichtige Alkoholgährung aber, wie sie in den Gährungsgewerben auftritt, wird nur hervorgerufen durch einen zu den Ascomyceten (Scblauchpilzen) gehörigen Pilz, Saccharomyces, von dem eine Species, z. B. Saccharomyces cerevisiae, bei der Gährung der Bierwürze, verschiedene andere bei der Weinmostgährung auftreten. Die Zuckerarten sind nicht alle direct gährungsfähig. Der Rohrzucker z. B. muss vorher durch ein in der Hefe enthaltenes Ferment in Invertzucker iberführt werden; der eine Bestandtheil desselben, die Dextrose (Traubenzucker), ist viel leichter vergährungsfähig als der andere, die Levulose (Schleimzucker), in Folge dessen die Rechtsdrehung einer Rohrzuckerlösung im Verlaufe der Gährung allmälig in eine Linksdrehung iibergeht. Zum Eintritte der Alkoholgährung sind ausser dem Zucker noch andere Substanzen unbedingt nöthig, und zwar einerseits gewisse organische stickstoffhältige Substanzen, wie sie stets in der Bierwürze und im Weinmoste etc. enthalten sind; nach den Untersuchungen von A. Mayer sind vorzugsweise diejenigen stickstoffhaltigen Substanzen der Gährung förderlich, die mit sogenannten katalytischen Eigenschaften begabt sind, wie Diastase, Pepsin, Ptyalin, während die eigentlichen Eiweissstoffe wenig dazu geeignet sind. Ausserdem müssen aber noch gewisse Mineralsubstanzen, darunter vornehmlich Kali, Kalk und Phosphorsäuren, die ebenfalls in den in der Praxis zur Gährung gelangenden Flüssigkeiten enthalten sind, vorhanden sein.

Die organischen stickstoffhaltigen Substanzen können aber nach $\mathrm{P}$ asteur durch Ammoniaksalze, am besten mit organischen Säuren ersetzt werden, und eine Rolnzuckerlösung, die demnach noch ein Ammonsalz z. B., weinsaueres Ammon, und die angeführten Mineralsubstanzen in Form von Hefenasche enthält, wird durch Hefe sofort in Alkoholgährung versetzt.

Die constanten Producte der Alkoholgährung stammen nun jedenfalls ganz oder grösstentheils vom Zucker selbst ab; es sind dies: Alkohol, Kohlensäure, Glycerin, Bernsteinsäure, Cellulose und Eett. Ob das von $\mathrm{Oser}$ ) in mit Presshefe vergohrenen Zuckerlösungen gefundene Alkaloid $\left(C_{13} H_{100} N_{4}\right)$ und das von Ludwig in mehreren IVeinen gefundene Trimethylamin constante Producte der Alkoholgährung sind, ist noch nicht erwiesen.

Der Vorgang der Alkoholgährung lässt sich natiirlich nicht durch eine einfache chemische Gleichung ausdriicken, um jedoch die quantitativen Beziehungen zwischen den Gährungsproducten ersichtlich zu machen, kann man nach $\mathrm{Pasteur}$ annehmen, dass sich der grösste Theil des Zuckers $\left(94-95^{\circ} / 0\right)$ spaltet nach der schon friiher angenommenen Formel:

$$
\underset{\text { Rohrzucker }}{\mathrm{C}_{10} \mathrm{H}_{20} \mathrm{O}_{11}}+\underset{\text { Wasser }}{\mathrm{H}_{2} \mathrm{O}}=\underset{\text { Alkohol }}{4 \mathrm{C}_{2} \mathrm{H}_{6} \mathrm{O}}+\underset{\text { Kohlensăiure, }}{4 \mathrm{CO}_{2}}
$$

ein anderer kleiner Theil aber $4.5-6 \%$ nach einem complicirten Schema, nämlich

$$
\underset{\text { Rohrzucker }}{49 \mathrm{C}_{12} \mathrm{H}_{22} \mathrm{O}_{11}}+\underset{\text { Wasser }}{109 \mathrm{H}_{2} \mathrm{O}}=\underset{\text { Bernsteinsäure }}{24\left(\mathrm{C}_{4} \mathrm{H}_{6} \mathrm{O}_{4}\right)}+\underset{\text { Glycerin }}{14 t\left(\mathrm{C}_{3} \mathrm{H}_{\mathrm{s}} \mathrm{O}_{3}\right)}+\underset{\text { Kohlensäure. }}{60 \mathrm{CO}_{0}}
$$

Nach den Untersuchungen Pasteurs entstehen nämlich aus 100 Gewichtstheilen Rohrzucker, welche 105.23 Gew.-Thl. Invertzucker entsprechen, bei der Alkoholgährung:
51.10 Gewichtstheile Alkohol
49.20
Kohlensäure
3.40
n
Glycerin
0.65
Bernsteinsäure
$1.30 \%$ Cellulose und andere in die Zusammensetzung der Hefe eingehenden Substanzen

105.65 .

*) Sitzb. der W. Ak, Bd. 56. 
Ueber die Wirkung der Hefe in Bezug auf die Alkolılgährmng war bis vor Kurzem, vornehmlich begründet und gestiitzt durch die Untersuchungen und die Autorität P a steurs, fast allgemein die Ansicht geltend, dic Alkoloolgährung sei ein normaler physiologiseher Process. Die Hefe bediurfe nämlich, wie alle Pflanzen, zur Vollziehung ihrer Lebensfunctionen, des atmosphärischen Sauerstoffes und werde dieser durch Abschliessung der Luft ihr entzogen, so sei sie im Stande, denselben durch eine Zerlegung gewisser anderer Substanzen, also hier des Zuckers, sich anzueignen, wobei sie, Gährung hervorrufend, zugleich ganz normal wächst und sich fortpflanzt. Nach den Untersuchungen von O. Brefeld ist jedoch die Auffassung der Gährung eine wesentlich andere; nach Brefeld ist die Gährung ein abnormaler oder mindestens unvollkommener Lebensprocess; die durch $\mathrm{Ab}$ schliessung der Luft des freien Sauerstoffs entbehrende Hefe bewirkt die Gährung in Zuckerlösungen, die ausserdem die vorher angeführten andern Bestandtheile enthalten, aber sie kann den ihr nöthigen freien Sauerstoff nicht dem Zucker entlehnen und desshalb auch nicht normal wachsen und sich fortpflanzen.

Bei einer jeden Gährung, wie sie in der Praxis erfolgt, findet daher an verschiedenen Stellen Wachsthum und Gährung statt; das Wachsthum an der Oberfläche, wo freier Sauerstoff zutreten kann, Gährung im Innern, wenn der absorbirte Sauerstoff dort verzehrt ist.

Doch ist gegenwärtig die Gährungsfrage noch immer als eine strittige anzusehen.

Die Milchsäuregährung. Dieselbe bewirkt die Umwandlung mehrerer Kohlehydrate, wie Traubenzucker, Milchzucker, Dextrin in Milchsäure. Das Ferment derselben, ein Pilz Oidium lactis entwickelt sich vornehmlich gerne auf sich zersetzenden eiweissreichen Subştanzen wie z. B. faulendem Käse. Die Milchsäuregährung ist die Ursache der Gerinnung der Milch und des Sauerwerdens bei der Sauerkrauterzeugung. Sie tritt namentlich bei etwas höheren Temperaturen gerne neben der Alkoholgährung auf, so dass viele gegohrene Fliissigkeiten stets geringe Mengen von Milchsäure enthalten. Als Fortsetzung der Milchsäuregährung tritt, wenn bei sonstigen Bedingungen die Temperatur uiber $35^{\circ} \mathrm{C}$. gesteigert und erhalten wird, die But ters äu re gä h r u n ein, wobei die Milchsäure in Buttersäure umgewandelt und Kohlensäure und Wasserstoff entwickelt wird. Die Buttersäuregährung ist insoferne auch technisch wichtig, als die zur Erzeugung von buttersauren Aethern (behufs Fabrikation von Rumessenz) dienende Buttersäure häufig durch Gährung dargestellt wird.

Bei der schleimigen Gährung wird Traubenzucker in Milchsäure, Mannit und eine Gummiart umgewandelt. Die Bedingungen und das Ferment derselben sind noch ungeniigend gekannt.

Bei der Essigbildung wird die Aufnahme des Sauerstoffes durch den Alkohol, durch Micoderma aceti vermittelt.

Die Verhinderung der Gährungsprocesse, also die Conservirung vor Gährung, ist im Allgemeinen auf die bereits bei Fäulniss (s. o.) besprochenen allgemeinen Principien der Conservirung zurïckzufiihren. Doch, sind niedrige Temperaturen, wie sie schon zur Conservirung vor Fäulniss hinreichen, hier nicht anwendbar, weil die Gährungsfunctionen der betreffenden Organismen noch bei $3-4^{0} \mathrm{C}$. gar nicht beeinträchtigt werden. Höhere Temperaturen sind desshalb ein besseres und auch häufig ảgewendetes Mittel zur Verhinderung vieler Gährungsprocesse und hat z. B. die darauf beruhende Conservirungsmethode für Weine, das Pasteurisiren (nach Pasteur) grosse Verbreitung bereits gefunden und wird gegenwärtig auch bei Exportflaschenbieren angewendet.

Eine diesbezüglich wichtige Verwendung hat gegenwärtig die Salicylsäure und besitzt in dieser Richtung jedenfalls noch eine grosse Zukunft. Schon in geringen Dosen*) (z. B. 100 Gramm per 1000 Liter Most) ist sie im Stande,

*) Einschlägige Literatur über Salicylsäure. C. Neu b a u er, Journ. f. pract. Chem. 11. pag. 2 und 354 . E. v. Meyer und H. Kolbe, Dingl. Journ. 217 pag. 402. H. IV eidenbusch, Polyt. Centralb. 1875 pag. 582. 
die meisten Gährungsprocesse zu verhindern, ohne dabei einigermassen den Geschmack der betreffenden Fliissigkeiten zu modificiren oder gesundheitsschädliche Wirkungen auszuïben. Ueber Gährung der Bierwürzen, der Branntweinmaischen, des Weinmostes siehe bei Bier, Branntweinbrennerei und Wein.

Literatur. Pasteur: Memoire sur la fermentation alcoolique, deutsch übertragen von V. Griessmayer. J. v. Liebig: Ueber die Gährung und Quelle der Muskelkraft. Journ. f. pr. Ch. Bd. 109 pag. 35. Dr. Adolf Mayer: Untersuchungen über die Alkoholgährung etc., bei C. Winter in Heidelberg. Dr. Adolf Mayer: Lehrbuch der Gährungschemie. O. Brefeld: Wagners Jahresberichte f. 1874 pag. 700. Ed. Donath: Monographie der Alkoholgährung ete., bei C. Winkler in Brünn.

Ed. Donath.

Gährungsalkohole nennt man im Allgemeinen die bei Gährungsprocessen sich bildenden Alkohole, als Aethyl-, Propyl-, Butyl- und Amyl-Alkohole, von letzteren dreien selbstverständlich nur jene Formen, welche ihre Bildung eben dem Gährungsprocesse verdanken. Gtl.

Gährungserreger, s. Fermente III pag. 407.

Gährungsgummi nennt C. Scheibler eine besondere Art von Gummi, welche unter dem Einflusse einer eigenartigen Gährung des Runkelrubensaftes auf Kosten des Zuckers entsteht (vgl. Dingl. pol. Journ. 210 pag. 302). Gtl.

Gährungskupe, s. Indig o, s. Z e u g f är b e r ei.

Gänsekötigerz, G a n o matit, ein zu Joachimsthal, Andreasberg, Schemnitz vorkommendes Mineral, welches gelbgrïne oder bräunliche glänzende Ueberzüge auf anderen Arsen- und Silbererzen bildet, ist ein ähnliches Gebilde wie Arseneisensinter, ein Zersetungsproduct anderer Arsen-Eisenerze. $L b$.

Gänze (gueuses - pigs), Barren, s. Eisenerzeugung III pag. 11.

Gärben (raffiner, corroyer-rifining), s. Eis en erzeugung III pag. 49.

Gärbstahl (acier corroyé - refined steel), s. Ei s en erzeugung, III pag. 48 , s. Stahl.

Gagat (jayet, jais - jet), schwarzer Bernstein. Eine dichte, schwarze, von Erdpech getränkte Braunkohle, die fest und wenig spröde ist, $H$. $=1.3-1.4$, Spec. Gew. 3-4, hat den Bruch und den Glanz der Pechkohle, brennt lebhaft wie Asphalt und hinterlässt eine kohlige poröse Masse. Findet sich im unteren Jura zu Witby (Jet) in England, auch bei Rentlingen und anderwärts im schwäbischen Jura. In Frankreich findet er sich im Grïnsand von St. Colombe, Dep. Aude, auch in Aragonien und Asturien in Spanien kommt er vor.

Das Mineral wird seit langer Zeit zu Dourbon und Ségur in Languedoc fabriksmässig zu Trauerschmuck rerarbeitet, indem man es auf der Drehbank be. arbeitet oder ähnlich wie Bernstein auf Sandsteinen schleift und mit Tripel, Oel und Calcothar auf Leder polirt. Auch in England wird ähnlicher Trauerschmuck erzeugt, doch dient dort statt des ächten Gagat zumeist Cannelkohle als Materiale. $L b$.

Gahnit, A ut o molit Min., dunkelgriine oder blaue, fettglänzende Krystalle des tesseral. Systems, meist eingewachsen ist Eisen-, Magnesia- und Kieselerdehältiges Zinkaluminat $\mathrm{Al}_{2} \mathrm{O}_{4} \mathrm{Zn}$. H. 8, spec. Gew. 4.33-4.35. Vorkommen im Talkschiefer von Fahlun, Franklin in New-Jersey, Haddam in Connecticut, Querbach in Schlesien u. a. O. Dem Galınit sehr verwandt ist der Dysluit von Sterling in New-Jersey, ein dunkelbraunes Mineral, das neben Zinkaluminat 
reichlich Eisenoxyd, Eisenoxydul und Manganoxydul enthält, s. a. Aluminium I pag. 124.

Gtl.

Gahnitbeize nennt B olley (Dingl. pol. Journ. 149 pag. 142) eine zinkhältige Thonerdebeize für Baumwollfärberei, vgl. a. Spinellbeize. Gtl.

Gaidinsäure, s. m. Hy pog a e s äu re.

Gaize. In den Ardennen unter der Kreide vorkommendes Gestein, das wesentlich aus Kieselerde (80 Proc.), etwas Thon, Eisenoxyd, Kalk und Magnesia besteht und sich durch hochgradige Porosität und leichte Bearbeitbarkeit (es lässt sich mit dem Messer schneiden) auszeichnet. Es eignet sich mit Vortheil zur Herstellung von Schmelztiegeln und liefert nach dem Glühen sehr widerstandsfähige Ziegel für Schmelzöfen. Da ein grosser Theil des Kieselsäuregehaltes der Gaize in Alkalien löslich ist, so hat man das Gestein auch für die Fabrikation von Wasserglas empfohlen. Vgl. H. Deville und J. Desnoyers Compt.rend. 70 pag. 581, auch chem. Centralbl. 1870 pag. 244). Gtl.

Galacticum s. m. Milehzucker.

Galactinsäure, Galactin, nach Morin (Journ. de Pharm. (3) 25 pag. 423) eine in der Milch vorkommende eigenthümliche schleimige Substanz. Gtl.

Galactometer, Milchprüfer in Gestalt einer besonders construirten Senkwage von Silber oder verzinntem Eisenblech, s. Milch, vgl. Schlienkamp, Arch. d. Pharm. (2) 103 pag. 15. Gtl.

Galactose, Umwandlungsproduct des Milchzuckers, aus diesem durch Kochen mit sehr verdünnter Schwefelsäure sich bildend. Kleine warzenförmige Krystalle, leicht löslich in Wasser, gährungsfähig. Entspricht der Formel $\mathrm{C}_{6} \mathrm{H}_{12} \mathrm{O}_{6}$, stärker rechtsdrehend als Traubenzucker und wie dieser alkalische Kupferoxydlösungen reducirend. Mit Salpetersäure oxydirt liefert sie Schleimsäure, vgl. Milchzucker, s. Milch. Gtl.

Galactoscop, Milchprïfer, s. Milch.

Galambutter, s. Bassiabutter I pag. 305.

Galangawurzel, s. Galgantwurzel.

Galanteriewaaren: Alle zum Putz und Schmuck gehörigen Artikel, mit Ausnahme der Ellenwaaren, gleichviel ob sie Theile der Kleidung oder andere auch oft dem gewöhnlichen Gebrauche unterworfene Luxusartikel oder Theile davon sind (Spitzen, Fächer, Stockknöpfe, Dosen etc.), vergl. K u r zwa a ren.

Galazyme syn. für gegohrene Eselsmilch, vgl. a. A rs a I pag. 193.

Galbanum (galbanum-galbanum). Mutterharz. Ein durch Eintrocknen des Milchsaftes einer im nördl. und mittleren Persien, sowie auch in Mittelafrika vorkommenden Umbelliferen-Art, wahrscheinlich Ferula erubenscens Boiss., erhaltenes Gummiharz. Bildet rundliche, erbsen- bis haselnussgrosse, weissgelbe, gelbgrïne oder braungelbe, wachsglänzende Körner, welche am Rande durchscheinend, am Bruche schmutzig weiss oder gelblich sind (Körnergalbanum oder Galbanum in Granis) oder aus einzelnen Körnern zusammengeflossene, unregelmässige Stiicke von hellerer oder dunklerer grünlich-brauner Farbe, welche häufig fremdartige Gemengtheile (Pflanzentheile, Sandetc.) enthalten ( $K$ u e hengal ba n u $\mathrm{m}$, Galb. in massis). Es ist kalt ziemlich spröde, erweicht jedoch schon in der Handwärme und wird klebrig. Der Geschmack ist eigenthïmlich scharf bitter, der Geruch 
aromatisch. Mit Wasser angerieben gibt es eine weisse Emulsion, Alkohol löst es zum Theile etwa ${ }^{3} / 4$, auf. Das Galbanum gelangt theils aus Syrien, Arabien und Persien, theils von Ostindien zu Markte, Haupthandelsplätze sind Triest und Marseille.

Es besteht wesentlich aus Harz $67 \%$, Gummi $19 \%$, äther. Oel $6 \%$ neben 8 Proc. fremden Beimengungen (vgl. Pelletier Bull. Pharm. 4, pag. 97). Das ätherische Oel ist farblos, dem Terpentinöl isomer, rechtsdrehend, es siedet bei $160^{\circ}$ C. und hat das spec. Gew. 0.884. Das durch Auflösen des Destillationsrückstandes in Kalkmilch und Zerlegen des Kalkresinates mit Salzsäure isolirbare Harz bildet weissgelbe Flocken, die in Weingeist leicht löslich sind. Nach Mössmer u. Hlasiwetz (vgl. Annal. d. Chem. u. Pharm. 119 pag. 257 und Wien. Akad. Bericht 49 pag. 203) entspricht es der Formel $C_{24 i} H_{38} O_{5}$. Bei der trock. Destillation liefert es neben Wasser ein blaues dickes Oel, das bei $298^{\circ} \mathrm{C}$. siedet und der Formel $C_{20} H_{30} \mathrm{O}$ entspricht, und Umbelliferon $\left(\mathrm{C}_{6} \mathrm{H}_{4} \mathrm{O}_{2}\right)$ in seidenglänzenden, geschmack- und geruchlosen Nadeln. Beim Schmelzen mit Kalihydrat liefert es Resorcin neben Oxalsäure und fliicht. Fettsäuren. Das Galbanumharz, ehemals ein geschätztes Arzeneimittel, wird gegenwärtig nur selten als Zusatz zu Pflastern verwendet, auch bildet es einen Bestandtheil mancher Kitte z. B. des Diamantkittes. Gtl.

Galeerenöfen (galère - galley furnace), nennt man in Allgemeinen jene Art von Röhren- oder Retortenöfen, bei welchen eine Reihe rebeneinander eingesetzter, oft in Doppelreihen angeordneter Röhren oder Retorten, von einer gemeinschaftlichen Feuerung erhitzt werden kömnen. Gtl.

Galena s. m. Bleiglanz I pag. 570, allgemein auch synom. mit "Glanz", daher Galena inanis d. i. Zinkblende, Galena Wismuthi, Wismuthglanz.

Galenit, s. m. Bleiglanz I pag. 570. Galenit nennt E. David in Paris anch das Product, welches beim andauernden Rösten von Bleiglanz bei mässiger Temperatur erhalten werden kann (wesentlich Bleioxyd und schwefelsaures Bleioxyd), und das er als Ersatz des Miniums fuir Metallanstriche oder des Bleiweisses zur Grundfarbe fuir Oelanstriche empfiehlt. Es deckt gut und ist ein kräftiges Siccativ, vgl. Deutsche Industr.-Ztg. 1875 pag. 368. Gtl.

Galenoide, s. m. Glanze.

Galettam, Gallet (fantaisie), Chappe, Florettseiden-Gespinnst, s. Seide.

Galette, s. m. Cocon, s. Seide.

Galgantwurzel (galanga - galangal), kleiner Galgant, Galangaw urzel. Der Wurzelstock von einer in China cinheimischen Scitaminee (Alpinia chinensis Rosc.), bildet cylindrische $1-1.5^{\mathrm{cm}}$ dicke und $5-6^{\mathrm{cm}}$ lange, gebogene oder knieförmige, meist einzelne Reste abgeschnittener Stengel und Wurzeläste tragende Stiicke ron runzlichem Aussehen und aussen rothbrauner, innen zimmtbrauner Farbe. Die Trurzelsubstanz ist ron holzig zälrer Beschaffenheit und hat einen aromatischen, pfefferartig scharfen Geschmack und einen eigenartig aromatischen, entfernt an Ingwer erinnernden Geruch. Sie enthält Stärkemehl, ein scharfes Harz, Gummi, Bassorin, Gerbstoff und ein äther. Oel (etwa 0.5 Proc.), das durch Destillation mit Wasser gewonnen werden kann. Es ist gelb bis braungelb, ron bremnend anisartigem Geschmack und dem Cajaputöl ähnlichem Geruche (rergl. A. Vogel, Rep. Pharm. 83 pag. 22). Die als grosser Galgant im Handel nur mehr selten rorkommende Galgant-Sorte, welche dem kleinen Galgant vollkommen ähnliche aber stärkere, zugleich aber auch leichtere und weniger aromatische Wurzelstöcke darstellt, stammt nach einigen Angaben ron Alpinia Galangr Swrtz., nach anderen sind es lediglich ausgewählte grössere Stiicke der gewöhn- 
lichen Galgantwurzel. Der Galgant, ehemals als Arzneimittel geschätzt, wird gegenwärtig nur selten als Zusatz zu aromatischen Tincturen, Liqueuren u. d. g. hie und da auch als Gewürz, ähnlich dem Ingwer verwendet. Gtl.

Galipot, s. Fichtenharz, III pag. 482.

Galitzenstein blauer, s. m. Kupfervitriol, s. Kupfer.

Galitzenstein weisser, s. m. Zinkvitriol, s. Z ink.

Galläpfel, s. Ga 11 en.

Galläpfelgerbstoff, s. Gerbsäuren.

Galläpfeltinte, s. T in te.

Gallamid, Gallussäureamid, Tannigenamsänre, d. i. das Amid der Gallussäure $\left(\mathrm{C}_{7} \mathrm{H}_{7} \mathrm{NO}_{4}\right)$, welches durch Einwirkung von Ammoniak und saurem sehwefligsaurem Ammoniak auf Gerbsäure erhalten werden kann und grosse blättrige Krystalle liefert, die in Wasser und Salzsäure löslich sind. Gtl.

Galle (bile - gall), die in der Gallenblase höher entwickelter Thiere enthaltene grünlich gelbe Flüssigkeit. Sie ist schleimig-zähe, von salzig bitterem Geschmack, frisch nur schwach riechend, aber sehr leicht dem Verderben unterworfen und dann übelriechend.

Die Galle findet mehrfach technische Verwendung und pflegt zu diesem Zwecke gereinigt zu werden. Namentlich für die Zwecke der Aquarellmalerei, dann wohl auch als Reinigungsmittel für Zeuge muss sie völlig entfärbt werden.

Eine Reinigungsmethode ist folgende: Man nimmt ganz frische Ochsengalle, lässt sie etwa 12 bis 15 Stunden ruhig stehen, giesst nun die über dem Absatze stehende klare Fliissigkeit in eine porzellanene Abdampfschale, und lässt im Wasserbade bis zu dem Punkte abdampfen, wo die Galle anfängt eine dickliche Consistenz anzunehmen. Jetzt lässt man sie bei gelinder Wärme fast bis zur Trockne eindampfen, in welchem Zustande man sie in irdenen Kruken, die nur mit Papier bedeckt werden, unverändert jahrelang aufbewahren kann. Beim Gebrauch nimmt man ein Stückchen von der Grösse einer Erbse und Iöst es in einem Esslöffel voll Wasser auf.

Eine andere, weniger einfache, aber ein noch besseres Produkt liefernde Methode ist folgende. In 1 Liter gekochter und abgeschäumter Ochsengalle werden $40-50 \mathrm{Gr}$. fein pulverisirter Alaun anfgelöst, die Lösung in eine Flasche gegeben und diese, leicht verkorkt, bei Seite gestellt. In einem zweiten Liter Galle löst man 40-50 Gr. Kochsalz auf, und bewahrt auch diese in einer Flasche auf. In Verlauf von etwa 3 Monaten setzt sich in beiden Flaschen ein Bodensatz ab, während sich die ïberstehende Galle klärt. Man zieht diese von dem Sedimente ab, und mischt nun beide Portionen, wodurch der gelbe Farbstoff gefällt wird, nach dessen Abscheidung durch Filtration die Galle klar und farblos erscheint. Die so gereinigte Galle verbessert sich noch mit zunehmendem Alter, und ist der - Verderbniss nicht unterworfen.

Die so geklärte Ochsengalle mischt sich sehr gut mit Wasserfarben, und ist namentlich zum Anmachen von Ultramarin, Carmin, Griin und anderen empfindlichen Farben sehr nützlich, indem sie sie nicht nur eben so gut wie Gummi auf dem Papier befestigt, sondern ihnen auch die Eigenschaft ertheilt, sich vorziiglich gut und gleichmässig auszubreiten, ohne einen so starken störenden Glanz zu bewirken wie Gummi. Mit Galle aufgetragene Farben trocknen schnell und so fest cin, dass man sie ohne Gefahr des Wiederauflösens mit anderen Farben iibergehen kann. 
Geglühtes Lampenschwarz, mit Gummi und Galle angemacht, liefert eine sehr brauchbare Nachahmung des chinesischen Tusch. Sehr anwendbar ist sie auch, um Bleistift- und Kreidezeichnungen zu überziehen, um dem Verwischen derselben vorzubeugen.

Besonders für Miniaturmalerei ist die gereinigte Galle ein sehr wichtiges Hilfsmaterial. Auf Elfenbein nämlich haften die Farben nicht gut, indem es mit einer Fettsubstanz durchzogen ist. Dieser Mangel lässt sich durch Abreiben des Stückes mit Galle vollständig beseitigen, so dass sich die Farben auf dem Elfenbein eben so gut wie auf Papier auftragen lassen und befestigen.

Auch zu Transparenten kann Galle mit Vortheil angewandt werden. Wenn nämlich geöltes oder gefirnisstes Papier mit Galle bestrichen wird, so kann man so gut darauf malen wie auf ungeöltem.

Eine besondere Verwendung findet Galle auch in der Buntpapierfabrikation (s. d.) und als Fleckreinigungsmittel. Häufig wird Galle durch Zusatz von Essigäther conservirt (auf 1000 Thl. Galle 7-8 Thl. Essigäther) und hält sich mit diesem Zusatze, der auch den unangenehmen Geruch der Galle deckt, lange Zeit, ohne etwas an ihren Eigenschaften zu verlieren. Nach A. Vogel lässt sich die Galle auch durch Vermischen mit Torfkohle conserviren (vgl. Deutsch. Industr. Ztg. 1866 pag. 245).

Durch Kochen von frischer oder conservirter Galle mit caustischem Alkali oder durch Verkochen von 2 Thl. Talg oder Harzseife mit 1 Thl. Galle erhält man die Gallenseife, welche als Fleckreinigungsmittel verwendet wird (vgl. Ga ultier de Cla ubry in Dingl. pol. Jour. 159 pag. 159). A i mé Fich e mot (dtsch. Industr. Ztg. 1870 pag. 26) empfiehlt zum Waschen feiner seidener Zeuge, Bänder etc. eine Gallen-Seife, die man nach folgender Vorschrift erhält: $1 \mathrm{~K}$. Cocosnussöl wird in einem Kupferkessel erwärmt und mit $1 / 2 \mathrm{~K}$. ätzender Sodalauge von $30^{\circ} \mathrm{B}$. und $1 / 2 \mathrm{~K}$. weissen venetianer Terpentin vermengt, die Mischung durch 4 Stunden erwärmt gehalten und nun $1 \mathrm{~K}$. Ochsengalle eingerührt. Der so erhaltenen Masse wird endlich so viel gepulverte Kernseife beigemischt, bis sie völlig fest wird (etwa 1--2 K. Kernseife).

Die Galle enthält anorganische und organische Substanzen; von ersteren Alkalimetalle, Kalk, Magnesia, etwas Eisen, Mangan und Kieselsäure. Die organischen Bestandtheile, die zum Theil auch in anderen Organen aufgefunden wurden, sind nicht bei allen Thiergattungen gleich, stehen aber unstreitig in nahen Beziehungen. Ein grosser Theil derselben ist saurer Natur. Von ihnen sind an besten bekannt die Glycocholsäure $C_{96} H_{43} \mathrm{NO}_{6}$ und die Taurocholsäure $\mathrm{C}_{26} \mathrm{H}_{45} \mathrm{NSO}_{7}$, beide krystallisirte Säuren, die von Stre cker (Ann. Chem. Pharm.62,205) in der Ochsengalle nachgewiesen wurden. Beide liefern mit wässrigen Alkalien erhitzt Cholalsäure $\mathrm{C}_{24} \mathrm{H}_{40} \mathrm{O}_{5}$, die ersteren neben Glycocol (Amidoessigsäure) $\mathrm{CH}_{2}\left(\mathrm{NH}_{2}\right) \mathrm{COOH}$, die zweiten neben $\mathrm{T}$ a u rin $\mathrm{C}_{2} \mathrm{H}_{4}\left(\mathrm{NH}_{2}\right)\left(\mathrm{SO}_{3} \mathrm{H}\right)$. Die Glyeocholsäure dürfte auch in der menschlichen Galle vorkommen, von der Taurocholsäure ist es noch zweifelhaft. Bei anderen Thieren wurden besondere Gallensäuren gefunden, so die Hyoglycochols äure und H y otaurocholsäure der Schweinegalle, die ganz analog den obigen in Hyocholsäure und Glycocoll, respective Taurin zerfallen, die Chenotaurocholsäure der Gänsegalle u. a.

Das Cholesterin ist in allen Gallen höherer Thiere aufgefunden worden, es ist aber auch sonst im thierischen Körper und in pflanzlichen Produkten sehr verbreitet.

Es besitzt die Zusamensetzung $\mathrm{C}_{26} \mathrm{H}_{43} \mathrm{OH}+\mathrm{H}_{2} \mathrm{O}$, krystallisirt aus Alkohol in charakteristischen Blättern, ist seinem chemischen Verhalten nach ein Alkohol.

Von Gallenfarbstoffen, die auch in den Gallensteinen vorkommen, sind die relativ best untersuchten das Bilirubin, auch Gallenroth, ein rothes krystallinisches Pulver, dann das Bilive r din, Gallengrün, ein dunkelgrüner amorpher Körper, der auch aus dem Bilirubin erhalten werden kann. Diese und andere Gallenfarbstoffe werden am besten aus Gallensteinen dargestellt, die vorherrschend aus Cholesterin, Bilifuscin, Biliprasin, Bilihumin, Fett, Schleim, endlich cholsauren und choloidinsauren 
Salze des Kalks, neben kohlensaurem und phosphorsaurem Kalk, Magnesia, nicht selten Eisen, Kieselerde und Spuren von Kupfer etc. bestehen.

\section{K. H. und Dr. Skraup.}

Galleïn (galleine - galleine) nannte A. B a eyer (Ber. d. d. chem. Ges. 1871 pag. 457, pag. 555 und 658) das durch Erhitzen von Phtalsäureanhydrid mit Pyrogallussäure darstellbare Phtalein der Pyrogallussäure $\left.\left(\mathrm{C}_{20} \mathrm{H}_{12}\right)_{7}\right)$. Erhitzt man 2 Thl. Pyrogallussäure mit 1 Thl. Phtalsäureanhydrid durch einige Stunden auf $190-200^{\circ}$ C. bis zum Dickwerden der Masse, löst die Schmelze in heissem Alkohol, filtrirt und verdünnt mit Wasser, so erhält man einen reichlichen Niederschlag von Galleïn, der nochmals in Alkohol gelöst und umkrystallisirt, reines Galleïn liefert. Es bildet entweder ein braunrothes Pulver oder kleine metallisch grün glänzende Kryställchen, löst sich in kaltem Wasser kaum, in heissem mit rother Farbe jedoch schwer, leicht in Alkohol mit dunkelrother Farbe. Kalilauge löst es zu einer prächtig blauen, Ammoniak zu einer violetten Flüssigkeit. Erhitzt verkohlt es. Mit sehr verdünnter Schwefelsäure und Zink erhitzt liefert das Galleïn eine hellrothgelbe Lösung, aus welcher sich grosse braunrothe Krystalle ausscheiden, die aus trockenem Aether umkrystallisirt, grosse farblose Krystalle von Gallin $\left(\mathrm{C}_{20} \mathrm{H}_{18} \mathrm{O}_{7}\right)$ liefern, welche jedoch an der Luft rasch undurchsichtig werden und zu einem röthlichen Pulver zerfallen. Das Gallin, welches auch in einer wässrigen Lösung von Pyrogallussäure leicht löslich ist und aus einer solchen gut umkrystallisirt werden kann, löst sich in kaltem Wasser schwer, leichter in heissem, sehr leicht in Alkohol auf. Seine wässrigen Lösungen färben sich sehr leicht roth. Durch Erhitzen mit 20 Thl. conc. Schwefelsäure auf $200^{\circ}$ C. geht das Galleïn unter Veränderung der Anfangs rothbraunen Farbe der Lösung in eine grünbraune, in Coerule in über, das sich durch Verdünnen der Säurelösung mit viel Wasser in Gestalt eines voluminösen fast schwarzen Niederschlags ausscheidet, der nach dem Waschen mit Wasser zu einer bläulich schwarzen, gerieben metallglänzend werdenden Masse von reinem Coeruleïn eintrocknet. Das Coeruleïn ist in Wasser, Alkohol und Aether kaum, leichter u. z. mit schmutzig grüner Farbe in Essigsäure, mit olivenbrauner Farbe in heisser conc. Schwefelsäure und mit prachtvoll indigoblatier Farbe in heissem Anilin löslich; Alkalien lösen es mit schön grïner Farbe. Seine Zusammensetzung entspricht der Formel $\mathrm{C}_{\mathbf{2 0}} \mathrm{H}_{10} \mathrm{O}_{7}$. Durch Reductionsmittel geht es in $\mathrm{Coerulin}$ iiber, das sich in Aether zu einer gelben, schön grün fluorescirenden Flïssigkeit löst. Sowohl Galleïn, als auch Coeruleïn sind Farbstoffe und färben mit Thonerde-, Eisen- oder Chrom-Salzen gebeizte Zeuge schön und echt. Nach Versuchen von Kö chlin (Dingl. pol. Journ. 224 pag. 463) gibt Gallein sowohl auf dem Wege des Druckes als auch der Färberei rosa und violette Töne, welche Seife gut vertragen. Mit Chrombeiżen liefert es dunklere, mit Bleioxyd graue Nuancen. Coeruleïn liefert mit Thonerde- und Eisenbeizen olivengrüne Töne, die seifen- und lichtecht sind. Zur Herstellung einer für Färbereizwecke geeigneten Coeruleïnlösung setzt man dem Wasser eine der Farbstofimenge gleiche Quantität von doppeltschwefligsaurem Natron zu, worin sich das Coeruleïn vollkommen löst. Vgl. a. Phenolfarbstoffe bei Phenol, s. Theer. Gtl.

Gallen, Galläpfel (galles, noix de galle - nut galls), Gallus, sind gerbstoffreiche Auswïchse in kräftiger Vegetation stehender, jugendlicher oder bereits vollkommen entwickelter Pflanzentheile, welche in Folge des Einflusses ron im Innern ihres Gewebes oder an ihrer Oberfläche lebender Thiere sich entwickeln. Für uns hier haben nur jene eine Bedeutung, welche ihre Entstehung gewissen Gallwespen (Cynips-Arten) und Blattläusen (Aphis-Arten) verdanken und durchaus dicotylen Gewächsen angehören.

Die im Handel vorkommenden technisch und medicinisch verwendeten Gallen (namentlich in der Färberei und Gerberei) lassen sich demnach als Cynips-und Aphis-Gallen und nach den Pflanzen, von denen sie gesammelt werden, als Eichen-, Sumach-, Pistacien- und Tamarisken-Gallen unterscheiden. 
A. Eichengallen, durch Gallwespen auf verschiedenen Eichenarten in Asien und Europa erzeugte Gallen. Das eierlegende Weibchen dieser Hautflügler bohrt mit seinem Legestachel in die Rinde junger Zweige, in die Knospen oder in andere Theile und deponirt in der entstandenen Höhlung das Ei.

Dadurch, sowie durch den Reiz, den die später auskriechende Larve ausiibt, wird eine Vermehrung des Säftezuflusses, Neubildung und Wucherung von Gewebsmassen in Form eines geschlossenen, am häufigsten mehr oder weniger kugligen Auswuchses hervorgerufen, der in seinem Innern eine im Verhältniss zur Dicke der Wandung nur kleine Höhlung birgt, worin das Thier seine Metamorphose durchmacht und schliesslich als ausgebildete Gallwespe sich herausbohrt oder darin zu Grunde geht. In vielen Gallen findet sich im Innern ein aus sehr dichtem Gewebe bestehender, das Thier zunächst umschliessender, rundlicher Hohlkörper, die sogenannte Innengalle.

Nach ihrer Herkunft werden die Eichengallen des Handels als asiatische und europä ische unterschieden.

1. Asiatische. Die werthvollsten, weil gerbstoffreichsten unter den Eichengallen sind die sogenannten Levantiner oder türkischen Gallen (Gallae levanticae, Galle du Levant, Levant Galls). Sie entstehen durch Cynips Gallae tinctoriae Oliv. auf jungen Zweigen von Quercus Lusitanica Webb. Var. infectoria DC. (Q. infectoria Oliv.), einer immergrünen strauchigen Eichenart, die durch Kleinasien und Syrien bis Persien verbreitet ist und auch auf Cypern und in Thracien wächst. Der wichtigste Stappelplatz für diese Gallen ist Aleppo, und zwar werden sie theils im Elajet Aleppo selbst gesammelt, namentlich in der Gegend von Killis, Aintab und Marasch, nördlich von Aleppo, theils gelangen sie aus Kurdistan, wo sie sowohl östlich in den Bergen von Mosul, am Tigris, bei Zachu bis an die persische Grenze, bei Revandoz und Suleimania, als auch westlich bei Mardui und bei Diarbeker gesammelt werden, auf den Markt von Aleppo. Nach v. Z wiedinek kommen durchschnittlich jährlich von Mosul 900-1000 Kantar (à 200 Okken), von Mardui 500-600 und von Diarbeker 400-500 K., während die Jahresernte im Aleppischen Gebiet selbst ca. 200-250 K. beträgt. Der grösste Theil der auf den Markt ron Aleppo gelangenden Waaren wird über Alexandrette nach Marseille und Liverpool, ein Theil nach Triest, Genua und Livorno verschifft. In neuerer Zeit geht ein Theil des im östlichen Gebiet Gesammelten tiber Bagdad nach Indien und von hier aus wahrscheinlich in Verbindung mit Zufuhren aus Persien nach England (Bombay-oder ostind ische Gallen). Weniger belangreich ist die Production Kleinasiens an Gallen, die iiber $\mathrm{S}$ myrn a ausgeführt werden.

Die levantinischen Gallen sind kuglig, nach abwärts in einen kurzen Stiel verschmälert, mit einem Durchmesser von $1.5-2.5^{\mathrm{cm}}$, an der Oberfläche, zumal in der oberen Hälfte mit zerstreuten stumpfen oder ziemlich spitzen Höckern und leistenartigen Vorsprüngen besetzt, bald heller, bald dunkler olivengrün, grangrün, braungelb, gelblichroth oder strohgelb, häufig, zumal die lichter gefärbten mit einem seitlichen, $2-3^{\mathrm{mm}}$ weiten Flugloch versehen, schwer, hart, spröde, am Bruche bald dicht, fast hornartig, bald locker körnig-bröckelig, zuweilen strahlig oder zerkliftet. Der Durchschnitt zeigt eine von den Resten des Insectes und von Gewebsdetritus locker ausgefiillte oder eine ganz leere Höhlung, je nachdem die Galle geschlossen oder durchbohrt ist, selten findet sich darin die mehr oder weniger gut erhaltene entwickelte Gallwespe. Der Hohlraum ist zunächst von einem meist dunkleren und dichteren Kern (Innengalle) umgeben, während die tibrige Masse eine heller braune oder gelblich-weisse Farbe besitzt. Sie sind geruchlos und schmecken sehr zusammenziehend. Ihr wichtigster Bestandtheil ist die Galläpfelgerbsäure (Tannin), von der die besten 60 - 70 Proc. enthalten, neben etwas Gallussäure, Ellagsäure, Gummi, Zucker, Harz, einem pectinartigen Körper ete. 
Nach ihrer Provenienz, .Grösse, Schwere, Oberflächenfarbe unterscheidet man im Handel zahlreiche, im Preise ungleiche Sorten. Die werthvollsten im Allgemeinen sind die von Aleppo exportirten, aleppischen Gallen. Auf dem Markte von Aleppo werden die im Gebiete des Villajets gesammelten am höchsten geschätzt, ihnen reihen sich die von Mardui kommenden an, während die Mosul-Gallen in der Qualität nachstehen und als die schlechteste Sorte die von Diarbeker gelten. Weiter werden die aleppischen Gallen sowohl wie die aus Smyrna ausgefiihrten kleinasiatischen oder Smyrna-Gallen ( $G$. de l'Asie mineure ou $G$. de Smyrna) als schwarze ( $G$. noires, die dunkleren), grün e oder gr ünliche (G. vertes) und we iss e ( $G$. blanches, die heller gefärbten) unterschieden. Letztere bezahlt man durchschnittlich mit $2 / 3-3 / 4$ des Preises der schwarzen.

Die kleinsten (höchstens $1^{\mathrm{cm}}$ im Durchmesser), aus der naturellen Waare ausgelesenen aleppischen Gallen, in Farbe den schwarzen gleichend, zum Theil mit spitzen verlängerten, oft verbogenen Höckern, hart, meist ohne Flugloch, pflegt man als Sorian-Gallen zu bezeichnen.

Eine durch Form und Grösse sehr auffallende Sorte stellen die sog. B a s s ora-Gallen dar. Sie sind vorwaltend eirund oder etwas niedergedrückt kuglig, fast kreiselförmig, $5-5.5^{\mathrm{cm}}$ lang, oben kurz gespitzt, unten in einen kurzen dicken Stiel verschmälert, an der Oberfläche röthlich-braun oder braunroth, glänzend, oft wie lackirt, in der Mitte des Umfanges oder in der oberen Hälfte mit einem einfachen, meist aber mehrfachen Kreise ziemlich spitzer, gerade abstehender kurzer, heller gefärbter, von einander getrennter, selten zusammenfliessender Höcker und mit einem kreisrunden, relativ engen Flugloch versehen, sehr leicht, weich, innen schwammig, hell-lederbraun, in der Mitte auch einer eirunden glatten Höhlung. Ihre Abstammung ist nicht sicher erschlossen. Vielleicht werden sie von einer und derselben Cynips-Art auf verschiedenen Eichenarten erzeugt.

2. Europäische. Eichengallen. Auf verschiedenen Eichenarten (Quercus pedunculata Ehrh., sessiliflora Sm., pubescens Willd., Cerris L., Ilex L. etc.) durch verschiedene Cynips-Arten entstandene Gallen von mannigfaltiger Gestalt, Grösse und Oberflächenbeschaffenheit, leichter und ärmer an Gerbstoff als die asiatischen. Hieher gehören :

Die Morea-Gallen (angeblich von der Zerreiche Quercus Cerris L.), klein (höchstens $1.2^{\mathrm{em}}$ lang), kreisel- oder urnenförmig, in einen kurzen Stiel verschmälert oder fast zusammengezogen, an der Oberfläche etwas glänzend rothbraun oder graulich gefleckt, läıgs- oder unregelmässig netzrunzlig, im obersten Theile mit einem Kreise von spitzen oder ziemlich spitzen, seitlich verbundenen Höckern (ähnlich einem Fruchtkelche), am Scheitel flach gewölbt, seitlich mit einem auffallend grossen kreisrunden Flugloch. - Is tri an e r Gallen (wohl ron Quercus Ilex L.), klein (höchstens $1.5^{\mathrm{cm}}$ lang), kuglig, oben ohne Spitze oder kurz stumpf-gespitzt, nach abwärts in einen kurzen dicken Stiel verschmälert, an der Oberfläche matt rothbraun oder mehr gelblichbraun, grob unregelmässig, fast netzig-runzlig, gegen den Stiel zu längsrunzlig, ohne Höcker, hðchstens mit Andeutungen von stumpfen Leisten am Scheitel oder in der oberen Hälfte. Sollen 41.2 Proc. Gerbstoff enthalten.

Was als Abruzzo-Gallen im Handel vorkommt, stimmt im Wesentlichen mit den Istrianer Gallen iiberein. (Auch im Gehalte an Gerbstoff). - Die sog. Marmoregne- oder apulischen Gallen (G. Marmorigae, Marmonigae, apulicae), angeblich aus der Gegend von Puglia in Neapel, sind kuglig, kurz gestielt, von der Grösse der levantinischen, an der Oberfläche rorwiegend mattröthlich, grau-braun, mehr oder weniger runzlig, ohne Höcker oder höchstens mit einzelnen stumpfen Höckern versehen. Vielleicht werden sie von einer anderen Abart der Q. Lusitanica gesammelt.

Ungarische Gallen, von denen man kleine und grosse (Landgallus) unterscheidet. Die kleinen, durch Cynips lignicola Hart. auf der Stieleiche 
(Quercus pedunculata) und auf der Steineiche (Q. sessiliflora) entstanden, haben die Grösse etwa der Istrianer Gallen, sind kuglig, ungestielt, sehr grobrunzelig auf der etwas glänzenden, dunkel-rothbraunen, von weisslichen Schilfern fleckigen höckerlosen Oberfläche. Die grossen ungarischen Galläpfel, durch Cynips Hungarica Hart. auf Q. peducnulata erzengt, sind kuglig, oder nach abwärts etwas verschmälert, von der Grösse eines kleinen Apfels, an der Oberfläche matt oder schwach glänzend, hellbräunlich oder aschgrau, allenthalben mit Ausnahme des untersten flach-längs-furchigen Theils mit stumpfen 3-4 kantigen, mit den verlängert herablaufenden Kanten zum Theil zusammenfliessenden Höckern besetzt, dadurch unregelmässig kantig, höckerig, sehr leicht, im Innern mit lederbrauner korkartiger Wand, welche einen unregelmässigen Hohlraum umschliesst, in welchem sich, von einem kurzen Stiele getragen, eine sehr regelmässige ellipsoidische Innengalle findet. Ihnen verwandt, noch mehr aber den Bassora-Gallen sind die von Cynips argentea Hart. auf jungen Aesten von Quercus pubescens, seltener von Q. sessiliflora und pedunculata producirten Galläpfel. Sie haben etwa die Grösse der grossen ungarischen Gallus, sind kuglig oder urnenförmig mit einer ganz geringen Verjüngung nach abwärts, am Gipfel kurz stumpfgespitzt, im oberen Drittheil mit einem Kreise von wenigen (6-8) scharf ausgeprägten dreieckigen, etwas nach aufwärts gebogenen, seitlich durch einen schmalen Saum verbundenen Höckern versehen und dadurch an manche vom Kelche gekrönte Fruchtformen erinnernd, unter einem feinen aschgranen Ueberzuge rehbraun, mit einem kreisrunden Flugloch, sehr leicht, im Innern ganz wie die Bassora-Gallen.

Deutsche Gallen. Die durch Cynips Kollari Hart. auf Quercus sessiliflora, pubescens und wohl auch auf anderen Eichenarten hervorgerufenen Gallen sind regelmässig kuglig mit einem Durchmesser von $2-2.5^{\mathrm{cm}}$, aussen glänzend, hellröthlich oder gelbbraun und meist vollkommen glatt, selten etwas runzelig, sehr leicht, mit hellbrauner, nach innen zu radial gestreifter sehr weicher Wandsubstanz, die einen elliptischen Hohlraum einschliesst. Enthalten 25-30 Proc. Gerbsäure.

Eine besondere Art von Gallen bilden die als Gerbematerial bei uns viel beniitzten Knoppern, ungarische oder eigentliche Knoppern, (Gallons, Galles à bomnet - Acorn-Galls) (nicht zu verwechseln mit den sogenannten orientalischen Knoppern oder Valonen). Sie verdanken ihre Entstehung der Cynips Quercus Calycis Burgsdf., die ihr $\mathrm{Ei}$ in die junge Frucht von Quercus sessiliflora (und pedunculata) legt und kommen vorziiglich vor und werden gesammelt in Ungarn, Slavonien und in der Bukovina (in den Monaten September und October).

In günstigen (warmen trockenen) Jahren erhält man bis iiber $100 \mathrm{~K}$. von einem Baume. Fiinfkirchen, Temesvar, Pest, Oedenburg sind die Hauptmärkte fiir dieses Rohproduct, welches statt der Galläpfel in der Färberei und zum Gerben (besonders von Sohlenleder) rerwendet wird. Die Knoppern stellen sehr verschieden, zum Theil ganz unregelmässig gestaltete etwa $1.5-2.5^{\mathrm{cm}}$ lange stumpfhöckerige, furchige, kantig-geflügelte, leichte holzige Körper dar, von mattrothbrauner oder gelblichbrauner Farbe, die mehr weniger verkümmerte Frucht (Becherhïlle und Eichel) ganz einschliessend oder (bei einseitiger Entwickelung) der Frucht seitlich aufsitzend. Im Innern findet man zwei durch eine Querscheidewand getrennte Hohlräume, von denen der untere die eiförmige, an einem Ende offene Innengalle einschliesst; am oberen Ende der Knopper findet sich eine natiirliche Oeffinung zum Ausschliipfun des Insects. Je weniger Frïchte die Knoppern enthalten, desto geschätzter sind sie. Sie kommen auch gemahlen als Knoppernmehl im Handel vor. Auch ein Knoppernextract ist Gegenstand des Handels.

Im Anschlusse sei hier noch einer Sorte von Gallen erwähnt, die in jüngster Zeit angellich aus Griechenland unter dem Namen "Rove" eingefürt wurden. Sie haben (ine sehr mannigfaltige, zum Theil sehr abenteuerliche Gestalt; am häufigsten sind kreiselförmige oder fast becherförmige Stücke, manche erinnern 
einigermassen an Morea-Gallen, sind kelchförmig, oben am breitesten mit vertiefter, im Umkreise unregelmässig gelappter Scheitelfäche, aus deren Mitte sich ein kurzer spitzer Zapfen erhebt, nach abwärts in einen kurzen Stiel versclımälert, an der Oberfläche dicht gelblich granfilzig. Die harte, hornartige, glänzend schwärzlich braune Wand umgibt eine ziemlich weite, innen glatte Hölılung, in welcher lose eine eirunde oder längliche, sehr zerbrechliche Innengalle liegt. Meist sitzen diese Gallen zu mehreren endständig an den jungen Aesten. Ihre Abstammung ist nicht bekannt. Einigermassen erinnern sie in ihren Gestalten und der Beschaffenheit ihres Innern an die Gallen von Cynips polycera Gir. (s. M a y r, mitteleurop. Eichengallen Taf. III F. 23.)

B. Sumach- (Rhus-). Gallen. Durch Blattläuse auf verschiedenen Sumach-(Rhus-) Arten erzeugte Gallen. Hieher gehören als die wichtigsten die schon 1724 in Europa eingeführten, aber erst seit etwa 40 Jahren als regelmässiger Handelsartikel aus China und Japan auf dem europäischen, zumal dem englischen Markte vorkommenden chinesischen und japanischen Gallen (Gales de Chine ou du Japan - Chinese Galls.), blasige Auswiichse, welche durch Aphis chinensis Dubled. an den Blattstielen, angeblich von Rhus semialuta Murray einer in China und Nord-Indien, beziehungsweise in Japan einheimischen baumartigen Anacardiacee entstehen. Sie stellen hohle, blasenförmige, leichte, $2-8^{\prime m}$ lange, bis $4^{\mathrm{cm}}$ breite Gebilde dar von sehr mannigfaltiger, zum Theil sehr sonderbarer, schwer zu beschreibender Gestalt. Im Allgemeinen sind sie länglich oder verkehrt eiförmig ohne (Japanische G.) oder mit einzelnen bis zahlreichen kürzeren und längeren, geraden oder etwas gekrümmten, kugelförmigen, hohlen Fortsätzen und Höckern besetzt, aussen meist fein gestreift und von einem dichten, kurzen, grauen Filz aus einfachen, dickwandigen, steifen Haaren überzogen, darunter gelblich- oder röthlichbraun, mit $1-2^{\mathrm{mm}}$ dicker, hornartiger, ebenbrïchiger, durchscheinender, von Milchsaftgängen durchsetzter Wand. Die weite Höhlung enthält die Reste der in grosser Zahl vorhandenen schwärzlichen Blattläuse neben einer weisslichen, klumpig zusammengeballten, von den Insecten abgesonderten fädigen Masse.

Der Gerbstoffgehalt dieser Gallen, welche im Preise etwa $1 / 3$ billiger sich stellen als die besten türkischen und von denen auf dem Londoner Markt jährlich an $6000-8000$ Kisten verkauft werden, ist mindestens ebenso bedeutend, wie jener der besten türkischen, nämlich 65-77 Proc. Neben Gerbstoff enthalten sie auch Stärke (im verkleisterten Zustande) als Zellinhalt, etwas Gallussäure, Fett, Harz etc.

Hieher gehören auch die auf einer Sumach-Art (nach Dymook in Ph. d. a. Transact. 1876 Juni p. 1003 wohl nicht richtig auf Rh. succedanea) in Indien vorkommenden, im Gerbstoffgehalt den chinesischen kaum nachstehenden Kakrasinghee? G allen von flacher, scheibenrunder, eiförmiger, länglicher, häufig lappiger und verbogener Gestalt und $1-3^{\mathrm{cm}}$ Durchmesser, bei $4-6^{\mathrm{mm}}$ Dicke, an der hell bräunlich-gelben, gelbbraunen bis gelbgriinen Oberfläche kahl, längsrunzlig, mit etwa $1^{\mathrm{mm}}$ dicker, hornartiger, grïnlich-gelber bis brauner Wand und weiter Höhlung. Sie gelangen aus dem nördlichen Indien auf den Markt ron Bombay.

C. Pistazien-Gallen. Auf Pistazia-Arten durch Blattläuse erzengte Auswïchse. Hieher gehören die Terpentin-Gallen, Judenschoten, (Carobe de Giudea) Sie entstehen durch Aphis Pistaziae L., anf verschiedenen Theilen von Pistazia Terebinthus L. einer strauchartigen, im Gebiete des Mittelmeeres (in Oesterreich z. B. sehr häufig in der Suidspitze Istriens und auf den benachbarten Inseln) wachsenden Anacardiacee. Die meisten und grössten Auswïchse kommen auf der Spitze der Aeste vor, sind im Allgemeinen hiilsenfờrmig, nicht selten bis $1.5-2.0^{\mathrm{dm}}$ lang, nach abwärts etwas verschmälert, nach aufwärts zugespitzt, cylindrisch oder zusammengedriickt, die einjährigen hellgelb-grün, meist purpurn überlaufen, längs-ıdrig-gestreift, frisch klebrig von ausgetretenem Balsam 
und nach cyprischem Terpentin riechend, getrocknet hart, spröde. Die kaum $1^{\mathrm{mm}}$ dicke Wand enthält mit hellem Balsam gefüllte Kanäle, die weite Höhlung die Brut und eine weisse fädige Masse. Die vorjährigen Gallen sind schwarzbraun oder fast schwarz, meist klaffend, runzlig, sehr hart und spröde. Die Terpentingallen enthalten an 60 Proc. Gerbstoff, 15 Proc. Gallussäure, etwas Harz und ätherisches $0 \mathrm{el}$. Die auf den Blättern und Blattstielen der genannten Pistaziaart vorkommenden Gallen stimmen mit den gleichartigen Gallen von Pistazia atlantica Desf. und $P$. Lentiscus L., Arten, die gleichfalls in Süd-Europa, Nord-Afrika und im Oriente und zumal letztere häufig vorkommen, iberein, welche gewöhnlich als Busgundsch (in Marokko als $\mathrm{Igh}$ ) bezeichnet werden, und auf den letzten Weltausstellungen aus dem Oriente sowohl wie aus Marokko reichlich vertreten waren, in welchen Ländern sie gleich wie die Terpentin-Gallen zum Färben der Seide und zum Gerben dienen. Sie sind knollig, an kleine Kartoffeln erinnernd, erbsen- bis wallnussgross, nach abwärts in einen kurzen, stielartigen Theil verschmälert, an der Oberfläche mehr oder weniger runzelig, mit seichteren und tieferen Längsfurchen, etwas glänzend, braunröthlich oder gelblich-braun, nach abwärts purpurn. sonst mit den Eigenschaften der oben beschriebenen TerpentinGallen. Hieher gehören auch die von Pistazia vera L. stammenden e chten B okhara-Gallen (Gule-Pis tah auf dem Bombay-Markt, wohin sie von Persien, wohl auch aus Centralasien gelangen). Sie sind rundlich, eiförmig oder länglich, stumpf oder zugespitzt, 6-20mm lang, an der Oberfläche glatt, längsaderig, etwas glänzend, hellbraun-röthlich oder gelblich mit röthlichem Anflug, mit relativ dünner, hornartiger, braunvioletter, durchscheinender, einen weiten Hohlraum umgebender Wand, welche im Baue mit jener der Terpentin-Gallen iibereinstimmt. Ihr Gerbstoffgehalt soll 32 Proc. betragen.

D. Tamarisken-Gallen. In neuerer Zeit hat ein aus Marokko unter dem Namen Takout eingeführter Rohstoff die Aufmerksamkeit der europäischen Industrie auf sich gezogen. Aber nicht bloss Marokko, sondern auch Algier, Indien und Centralasien liefern (unter verschiedenen anderen Bezeichnungen) diesen Artikel in den Handel, und zwar wird diese Sorte von Gallen, wie es scheint, in den verschiedenen, eben bezeichneten Gebieten von einer und derselben weit verbreiteten Pflanze, der Tamarix articulata Vahl. (T. orientalis Torsk.), gesammelt. Der Takout besteht aus pfefferkorn- bis haselnuss- oder etwas darüber grossen sehr verschieden geformten Stiicken. Die meisten sind unregelmässig knollig, rundlich, annähernd eiförmig, länglich mit Einschnürungen etc., an der Oberfläche grob-warzig-runzlig, matt graubraun, gewaschen hell gelbbraun, purpurroth oder braumroth, hart, einzelne, namentlich die grösseren Stücke mürbe, zerreiblich, leicht, die kleinen ohne, die grösseren meist mit einem kreisrunden, glattrandigen Flugloche versehen. Die Innenmasse ist schwammig-zellig, gelblichbraun oder griin-bräunlich, an den grösseren mit einer unregelmässig begrenzten Höhlung oder mit mehreren derartigen Hohlräumen, in denen weisse Flocken, sowie Insectenreste, reichlich auch Pilzfäden sich finden. Ihr Gerbstoffgehalt beträgt über 43 Proc. A. Vogl.

Gallenfarbstoffe, s. Galle III pag. 672.

Gallenfett, s. Cholesterin, s. Galle III pag. 672 .

Gallensäuren, s. Galle III pag. 672.

Gallensteine, s. Galle III pag. 672.

Gallerte (gelée - jelly), nennt man im Allgemeinen jene eigenthümlich halbfesten, zitternden (sulzigen) Massen, welche sich beim Erkalten der Lösungen sog. Gallertkörper bilden. Solche Lösungen sind in der Hitze fast ausnahmslos schleimig zähe, mehr weniger klebrig und gestehen beim rollständigen Erkalten zu Gallerten (Sulzen). Körper, welche die Eigenschaft haben, Gallerten zu bilden, 
sind in erster Linie der thierische Leim und das leimgebende Gewebe (Hausenblase), s. d. Von Pflanzenstoffen haben namentlich gewisse Algen (s. Agar-Agar I pag. 59, Caragahéen s. II pag. 252), dann Flechten (isländ. Moos), endlich auch Samen (Flohsamen, s. III pag. 600, Quittensamen etc.), sowie andere reichliche Mengen von Pflanzenschleim enthaltende Pflanzentheile die Eigenschaft mit Wasser Gallerten zu liefern, Gtl.

Gallertfolien, s. Leimfolien bei Leim.

Gallertkapseln, s. Le i m.

Gallertsäure, s. m. P e ctin säure.

Gallette (cocon-cocoon), das Cocon genannte Gespinnst der Seidenraupe.

Gallhuminsäure, Metagallussäure, Melangallussäure, s. Gerbs äur en.

Gallin, s. b. Gallein III pag. 673.

Gallirbret (planche d'arcades - compass board), das Harnischbret an Zug- und Jaquardstühlen, s. Weberei.

Galliren (empoutage - becting), das Vorrichten des Harnisches, Harnischstechen genannt, s. Weberei.

Galliren, s. Beize I pag. 373.

Gallisiren, s. W e in.

Gallseife, Gallenseife, s. Galle III pag. 672.

Gallium (gallium - gallium). Von Lecoq de Bois ba udran im Jahre 1875 (27. Aug.) entdecktes neues Metall. Findet sich in der Zinkblende von Pierrefitte (Pyrenäen), in der schwarzen Blende von Bensberg, im Zinkstaube von Vielle Montagne und im Flugstaub der Röstöfen von Corphalie (Belgien), endlich auch im käuflichen Zink, spurenweise $\left(16^{\mathrm{mg}}\right.$ in $10^{\mathrm{k}}$ Zinkblende) vor. Ist grauweiss, vom spec. Gew. 5.93 und dem Atomgew. 69.9. Es schmilzt bei 29.5 bis $30.1^{\circ}$ C. (Handwärme) und kann wochenlang flüssig bleiben, bei langsamen Erkalten bildet es kleine Octaëder. Beim Erhitzen in reinem Sauerstoff auf $260^{\circ} \mathrm{C}$. oxydirt es nur wenig (D u pre), in dunkler Rothgluth stärker, wird bläulich grau und verliert seinen Glanz. Salpetersäure greift es in der Kälte nicht, wohl aber in der Wärme an. Salzsäure löst es unter Wasserstoffentwicklung, ebenso Aetzkali. Charakteristisch für das Gallium ist sein Spectrum, welches zwei schöne violette Linien zeigt. Es steht in Hinsicht der Eigenschaften seiner Salze einerseits dem Aluminium, andererseits dem Zink nahe. Schwefelwasserstoff fällt es nicht, ebenso werden reine Galliumsalzlösungen durch Schwefelammonium nicht gefällt. Zink fällt aus Galliumsalzlösungen Galliumoxyd, Ammoniak fällt unvollständig, Aetzkali und Aetznatron fällen, doch löst sich der Niederschlag im Ueberschusse des Fällungsmittels wieder auf. Aus den Lösungen von Galliumoxyd in ätzenden Alkalien kann durch Electrolyse das Metall gefällt werden. Näheres über Darstellung und Eigenschaften dieses Metalls, s. Lecoq de Bois ba udran, Compt. rend. 81 pag. 493, 82 pag. 1036 und 1098, 83 pag. 636. Derselbe und Jungfle is ch, Bull. d. l. soc. chim. 1877, 27, Nr. 3 pag. 144. D el a chanel und Mermet, Bull. d. l. soc. chim. 1876, 25, Nr. 5 pag. 197, im Auszug a. chem. Centralbl. 1875 pag. 658,$818 ; 1876$ pag. $393,451,452,705,721 ; 1877$ pag. 51. Gtl.

Gallus, s. m. Gaalläpfel, s. Gallen III pag. 673 .

Gallussäure, s. b. Gerbsäuren.

Gallussäureamid, s. m. Gall a mid III pag. 671. 
Gallustinte, s. Galläpfeltinte, s. Tinte.

Galmei (calaminec - alamine), kieselsaures Galmei, Zinksilicat, Kieselzinkerz, Hemimorphit, krystallisirt rhombisch in eigenthümlichen hemimorphen Krystallen, welche wie sie auch oben begrenzt sein mögen, unten eine Brachypyramide zeigen, wodurch sie einerseits zugespitzt, keil- oder spatenförmig werden. Die Krystalle sind meist klein, aufgewachsen und zu Drusen verbunden, häufig auch in kugel-, keil-, fächerförmigen Gruppen vereinigt, auch fein stenglig, faserig, körnig, dicht und erdig findet er sich.

Nach dem Prisma und dem Orthopinokoid vollk. spaltbar, $\mathrm{H}=5$, spec. Gew. 3.35-3.50, weiss, zumeist grau, gelb, grün, roth, bränn gefärbt; Glasglanz, durchscheinend bis undurchsichtig. Chem. Zus. $2 \mathrm{ZnOSiO} \mathrm{S}^{2}+\mathrm{H}^{2} \mathrm{O}, 67$ Zinkoxyd, 28.5 Kieselsäure, 7.5 Wasser. Im Kolben gibt er Wasser, v. d. L. schmilzt er nicht, färbt sich mit Kobaltsolution geglïht stellenweis grün. Säuren lösen ihn auf unter Abscheidung von Kieselsäure. Fundorte Raibl und Bleiberg in Kärnthen, Altenburg bei Aachen, Iserlohn, Tarnowitz in Schlesien, in England und Nordamerika an vielen Orten. Ist neben dem Zinkspath dạs wichtigste Erz zur Gewinnung des metallischen Zinks. $L b$.

Galmei edler, s. m. Zinkspath.

Galmei kohlensaurer, s. Zinkspath.

Galvanische Aetzung ist die wenig angewandte Methode der Aetzung durch den galvanischen Strom, wobei das zu ätzende Stück als Anode in dieZersetzungszelle kömmt (s. Galvanoplastik). Von dieser Aetzmethode wird meist nur zu dem Zwecke Gebrauch gemacht, um zu vergoldende oder zu versilbernde Metall-Gegenstände rauher zu machen, wodurch die Vergoldung, Versilberung etc. dann wesentlich fester anhaftet (s. pag. 684 und 686). Kk.

Galvanische Bronzirung, s. Galvan oplastik.

Galvanische Metallfärbung, s. Galvanoplastik.

Galvanischer Anstrich (peinture galvanique), wird ein Anstrich auf Eisenwaare genannt, bei welchem die Anstrichfarbe aus feinstem $\mathrm{Z} \mathrm{inkpulver}$, mit Leinölfirniss angerieben, besteht. Dieser Anstrich schützt durch den Firniss wie jeder Oelfarbenanstrich. $K k$.

Galvanismus, Beriihrungs-, Contact-Electricität, Voltaismus (galvanisme - galvanism), s. Electricität III pag. 175 .

Galvanisirtes Eisen ( $f e r$ galvanisé - galvanized iron) gleichbedentend mit verzinktem Eisen, d. h. durch Eintauchen in geschmolzenes Zink mit einer Schichte diesen Metalles überzogenes Eisen. Diese Benennung verführt manchmal zu dem Glauben, dass man es mit einem auf galvanoplastischem Wege hergestellten Ueberzuge zu thun hat, was nicht der Fall ist. Hiermit ist auch eine diesbezigliche Irrung $\mathrm{Bd}$. II pag. 49 š letzte Zeile richtig gestellt.

$K k$.

Galvanisiren (galvaniser - galvanizing), s. Verzinken.

Galvanoglyphik, s. Galvan oplastik pag. 686 , s. Holzschnitt.

Galvanographie, s. Galvanoplastik pag. 686.

Galvanometer, s. Electromagnetismus III pag. 249.

Galvanokaustik, galvanische Aetzung, s. oben und pag. 686 .

Galvanophor, s. Feuerzeug III pag. 480.

Galvanoplastik (galvanoplastie, hydroplastie - galvanoplastic, electrometallurgy) nennt man jenes Verfahren, durch welches mit Hiilfe des galvanischen Stromes aus Metall-Lösungen cohärente Metallniederschläge gebildet werden. Dieselben sind entweder bestimmt als Ueberzüge zu dienen (Verkupfern, Versilbern, 
Vergolden etc.) oder es werden diese Metallniederschläge von der Unterlage, Matrize, abgelöst und liefern negative Copien der Matrize von einer Genauigkeit, wie sie auf anderem Wege nicht erhalten werden können.

In beiden Fällen ist die Hauptforderung, welche an den Niederschlag gestellt wird, Homogenität und Cohärenz. Sollen Ueberzüge gebildet werden, so wird festes Anhaften an der Unterlage, an dem zu vergoldenden, versilbernden etc. Gegenstande verlangt; soll der Niederschlag von der Matrize abgenommen werden, so muss die Wegnahme ohne Beschädigung durchfihrbar sein; auch wünscht man den Niederschlag in einer dem Metalle entsprechenden, gefälligen F arbe. Sowohl das Ablösen, als die bei galvanischen Metallüberzügen oft verlangte Politurfähigkeit des Niederschlages erheischt endlich noch eine gewisse Zähigkeit des Niederschlages. Es handelt sich also um die Erzielung eines gleichförmigen, dichten, zähen und gut gefärbten Metallniederschlages.

Um einen Metall-Niederschlag zu erhalten, braucht man eine galvan ische Batterie (oder statt derselben eine Thermosäule oder eine dynamoelectrische Maschine) welche als Stromquelle betrachtet werden kann, ferner eine Z e r s e tz u n g sz elle d. i. ein Gefäss, in welchem sich die zu zerlegende Metalllösung, das Electrolyt, befindet und in dieser die Electroden d. $\mathrm{i}$. die mit der Batterie leitend verbundenen, den Strom selbst auch leitenden Körper, von welchen der eine, die K a thode, als Unterlage für den Metallniederschlag dient, während der zweite, die Anode, gewöhnlich aus demselben Metalle, welches gefällt werden soll, bestehend, zur möglichsten Erhaltung der Concentration des Electrolytes dient. Die Kathode ist leitend mit dem negativen Pole (Zinkpol) der Batterie, die Anode mit dem positiven Pole (Kupferpol) verbunden.

Die Principien, auf welchen die Galvanoplastik beruht, sind bereits in dem Artikel Electrolyse (s. III. pag. 236) dargelegt worden, und sei hier nur an das elektrolyti s.che u. Ohm'sche Gesetz erinnert, welche beide dem Galvanoplastiker als Fuihrer bei Beurtheilung des Vorganges dienen können.*)

Wir haben hier den praktischen Vorgang zu besprechen, welcher zum Zwecke der Erzielung guter galvanischer Niederschläge eingehalten werden muss. Als Regel ist $\mathrm{zu}$ beobachten, dass die Kathode, auf welcher der Metallniederschlag erhalten werden soll, meist Matrize genannt, aus einem Materiale bestehe, welches durch die angewandte Metallösung, also durch das Electrolyt, nicht angegriffen werde und von dieser Lösung auch nichts einsauge. Die Matrize muss entweder an sich leitend sein, oder durch einen Ueberzug mit einer leitenden Schichte in einen Leiter verwandelt werden.

Ferner ist die richtige Wahl des Electrolytes von besonderer Wesenheit und wenn sich auch diesbezüglich der Zeit keine allgemeine Regel angeben lässt, so kann doch bemerkt, werden, dass in der richtigen Wahl der Zersetzungsflüssigkeit das Schwergewicht des ganzen Verfahrens liegt. Die Stromstärke ist bei vielen Electrolyten von sehr untergeordnetem Einflusse auf die Qualität der Niederschläge**) und wenn sie bei manchen doch von Einfluss zu sein scheint, so rührt dies von secundären Vorgängen her, oder daher, dass die Metallabscheidung indirekt stattfindet. Die diesbeziiglichen Vorgänge sind noch nicht genügend erkannt und hieraus erklären sich die mannigfachen, oft abentheuerlichen Anschauungen einerseits, die Geheimnisskrämerei andererseits.

Die Zersetzungszelle muss aus einem Materiale bestehen, welches durch das Electrolyt nicht angegriffen wird, also aus Glas, Porzellan, Guttaperch a u. dgl.

*) Das electrolytische Gesetz lautet: Durch denselben galvanischen Strom werden äquivalente Mengen der Electrolyte (der durch den Strom zerlegten Substanzen) zersetzt und die Quantitäten der an beiden Electroden abgeschiedenen Stoffe stehen gleichfalls im Verhältnisse ihrer Aequivalente. - Das Ohm'sche Gesetz lautet: Die Stromstärke ist gleich der electromotorischen Kraft getheilt durch die Summe aller Leitungswiderstände.

**) Studien über Galvanoplastik von Fr. Kick, technische Blätter Jg. 1874, pag. 145. Dinglers polyt. Journ. Bd. 218 pag. 1 ; ferner 465 und Bd. 219 pag. $61,1+1$ und 313. 
Die Verbindungen zwischen der Batterie u. den Electroden, die Leitung sdrähte sind aus Kupfer herzustellen, die Contactstellen sind blank zu haltenund soll die Drahtstärke nicht unter $1^{\mathrm{mm}}$ betragen.

Als An o de wird häufig eine Platte desselben Metalles eingehängt, welches aus der Lösung gefällt wird, und dient dies zur Erhaltung der Constanz der Zersetzungsflüssigkeit. Doch wird dieser $Z_{w}$ weck bei länger fortgesetzter Arbeit nur dann ziemlich vollkommen erreicht, wenn die Oberfläche der Anode bedeutend grösser, wie die der Kathode ist, und auch nur dann, wenn die Anode rein ist, weil sonst entweder andere Metalle in Lösung kommen oder die Flïssigkeit verunreinigende Bodensätze entstehen.

Gleiche Dicke des Niederschlages lässt sich erzielen, wenn Kathode $u$. Anode horizontal in die Zersetzungsfluissigkeit eingehängt sind. Ist die Anode uiber der Kathode angebracht, dann soll zwischen beide ein Diaphragma (z. B. mit Pergament uiberzogener Rahmen) eingehängt sein, damit die von der Anode sich ablösenden pulverigen Verunreinigungen nicht auf die Kathode fallen. Meistens sind Kathode und Anode vertical in die Zersetzungszelle eingehängt, da dies für die Manipulation bequemer ist.

Wir haben bereits im Eingange erwähnt, dass die Galvanoplastik entweder zur Herstellung galvanischer Ueberzüge oder zur Herstellung von Gegenständen, welche von der Matrize abgelöst werden, verwendet wird, und wir wollen in dieser Richtung die weitere Besprechung sondern.

Die Herstellung galvanoplastischer Gegenstände. Soweit man durch Prägen, Stanzen u. drgl. Fabrikate herzustellen vermag, welche dem Zwecke entsprechen, kann die Galvanoplas tik nicht concurriren. Auf galvanoplastischem Wege hergestellte Metallknöpfe (durch Niederschlagung von Kupfer auf Guttapercha- oder Kautschuck-Matrizen) konnten z. B. trotz ihrer Schönheit und der Möglichkeit unterschnittener Partien (welche die elastischen Formen zuliessen) den Markt nicht erhalten, weil sie weit theurer als die gestanzten Blechknöpfe waren.

Hingegen für die Herstellung von $\mathrm{K} u$ p ferdruckp latt en, ga lva nis e hen Clichés u. drgl. ist die Galvanoplastik von hohem und bleibenden Werthe, desgleichen auch für die Reproduction von Kunstwerken in getriebener Arbeit.

Meist handelt es sich hier um die Darstellung eines galvanopl. Gegenstandes aus Kupfer und hierbei beniitze man Kupfervitriollösung mit einem Zusatze von Schwefels äure.*)

Als Zersetzungszelle lässt sich mit Vortheil ein mit Guttapercha gefütterter Holzkasten verwenden, an welchem Metallstäbe einerseits zum Anhängen der Anoden, auf der Gegenseite zum Anhängen der Kathoden angebracht sein können. Die Guttaperchafütterung ist zwar sehr theuer, aber weit haltbarer als eine Pechfütterung oder die Anwendung von Glaswannen:

Man kann auch die Zersetzungszelle mit der Batterie vereinen, indem man z. B. auf den Boden der Zelle die Matrize legt, ${ }^{* *}$ ) von welcher ein mit Lack iiberzogener Metallstab nach aufwärts bis oberhalb der Flüssigkeit reicht; in diese Zelle die oberwähnte Kupfervitriollösung giesst und dann einen Rahmen bis etwa $2 / 3$ der Höhe desselben eintaucht, welcher unten mit Pergament bespannt ist und in welchem eine Zinkplatte in sehr verdünnte Schwefelsäure ***) gelegt ist. Diese Zinkplatte wird mit der Kathode (Matrize) leitend verbunden. Durch die Fällung

*) Der Concentrationsgrad und der Zusatz an Schwefelsäure ist durchaus nicht an enge Gränzen gebunden. Man erhält geeignete Bäder, wenn man einer Kupfervitriollösung von $15-20^{\circ} \mathrm{B}$. so viel Sehwefelsäure zusetzt, dass das Areometer um 1 bis $2^{\circ} \mathrm{B}$. höhere Dichte zeigt. Der Schwefelsäurezusatz ist aber wesentlich, denn eine Kupfervitriollösung, welche keine freie Säure enthält, liefert schlechte, spröde, oft missfärbige Niederschläge.

**) Diese Anordnung stammt von Becquerel und ist u. a. in der k. k. Staatsdruckerei in Wien in Verwendung.

***n) Einige Tropfen Säure in destillirtes Wasser genügen. 
des Kupfers wird die Flüssigkeit ärmer an Kupfervitriol, und man thut daher gut, in dieselbe Leinwandbeutel gefüllt mit Kupfervitriol einzuhängen, welcher allmälig in Lösung kommt und die Flüssigkeit ziemlich constant hält.

Werden als Matrizen Kupferplatten (z. B. Original-Kupferstiche) verwendet, so reibt man die zu copirende Seite mit etwas Oel oder Wachs (in letzterem Falle auf erwärmter Platte) ein und wischt mittelst eines Baumwollbäuschchens scheinbar alles Oel oder Wachs wieder ab. Es bleibt doch so viel hängen, dass der erhaltene Niederschlag nach Erlaũgung der genügenden Stärke leicht abgezogen werden kann. Um dies zu erleichtern ist die Platte an der Rückseite und den Rändern mit Ausnahme der Contactstellen mit Pech oder Wachs oder Deckgrund*) überstrichen, wodurch der Niederschlag nur auf der zu copirenden Seite anfallen kann. Natürlich ist die erste Copie einer gravirten Kupferplatte eine sogenannte $\mathrm{Hochplatte}, d$. h. dieselbe zeigt die am Originale vertieften Linien erhaben. Von dieser Hochplatte wird eine neucrliche Copie gemacht und diese Ti f f latte ist dann eine getreue Wiedergabe des Originals.

Die Matrizen können aber auch aus den verschiedensten anderen Substanzen, z. B. aus Guttapercha, Wachs, Stearin, Gyps (mit Stearin getränkt), $\mathrm{G} I$ a s etc. etc. bestehen, es ist aber in diesem Falle erforderlich, diese Materialien leitend zu machen.

Die Erstgenannten werden durch Einreiben oder Einpinseln mit gutem englischen Graphit**) (Dix's Blacklead) oder Silberpulver (s. d.) leitend gemacht, Glas hingegen muss entweder mit Flusssäure matt geätzt und hierauf mit Graphit leitend gemacht werden, oder man gibt, wenn dies zulässig ist, einen dünnen Anstrich von Copalfirniss, und reibt diesen, wenn fast trocken, mit Graphit ein.

Für Gegenstände mit unterschnittenen Theilen oder einspringenden Winkeln werden auch elastische Formmassen angewendet, als welche sich die Bd. II. S. 137 erwähnte Walzenmasse sehr gut eignet. Durch Aufpinseln von Graphit werden sie leitend gemacht.

Die Wahl der Batterie ist durchaus nicht so wesentlich, als man meist annimmt. Man kann Elemente von Bunsen, Daniell, Smee, Meidinger etc. benützen (vergl. Bd. III p. 179 u. 202), und wird gleich gute Niederschläge erzielen. Da man für die Galvanoplastik so constante Ströme, wie sie für die electrische Telegrafie gebraucht werden, nicht nöthig hat, so sind hier besonders die Elemente von Smee und $\mathrm{Daniell} \mathrm{zn}$ empfehlen, welche einen hinlänglich kräftigen Strom ohne Entwicklung schädlicher Dämpfe liefern.

Vortheilhaft ist auch die Anwendung der in neuerer Zeit für längeren Gebrauch sehr vervollkommten No ë'schen Thermos äule***). Für grössere galvanoplastische Anstalten sind die dynamoelectrischen Maschinen $\dagger$ ) zu empfehlen.

Allen, welche sich mit Galvanoplastik beschäftigen, ist der Gebrauch eines Stromstärkemessers (Galvanometers, Galvanoskops, Rheometers oder der Bussole) auf das Angelegentlichste zu empfehlen, weil nur mit Zuhilfenahme dieses Instrumentes $\dagger \dagger$ ) erkannt werden kann, mit welchem Strome man arbeitet und wo etwaige Störungen oder Fehler ihren Grund haben. Was der Indicator bei der Dampfmaschine ist, das ist der Rheometer in der Galvanoplastik.

Es ist häufig wünschenswerth zu wissen, welche Qu antitäten Metalles man mittelst verschiedener Stromquellen galvanisch $\mathrm{zu}$ fällen vermag. Ist in den Stromkreis des galvanoplastischen Apparates der Rheometer eingeschaltet, so kann

*) Zwei Theile Asphalt, ein Theil Mastix.

**) Guter Graphit darf gar keine Sandtheilchen enthalten und muss an den Fingern oder auf Papier gerieben eine glänzende, glatte, bleigraue Fläche liefern.

***) Dingler's polytechn. Journal Bd. 200 pag. 10 und Bd. 224 pag. 267.

†) Siehe hierüber Näheres im Art. Electricität III pag. 182-189.

$\dagger \dagger$ ) Unter anderem zu beziehen beim Mechaniker Grund in Prag zum Preise von $12 \mathrm{fl}$ öst. Währ. 
man aus dem Grade der Ablenkung der Magnetnadel unmittelbar die Niederschlagsmenge jedes beliebigen Metalles nach dem electrolytischen Gesetze durch Auflösung einer einfachen Proportion leicht finden, wenn die den einzelnen Ausschlagswinkeln der Nadel entsprechende Wasserzersetzung oder Kupferfällung in einer Tabelle dem Apparate beigegeben ist. *) Natürlich ist bei Einschaltung des Rheometers in den Schliessungskreis darauf zu sehen, dass die Nadel auf Null zeigt, so lange der Strom nicht geschlossen ist, oder mit anderen Worten, der Leitungsbogen des Rheometers muss im magnetischen Meridian liegen.

Ohne Anwendung des Rheometers ist eine bestimmte Angabe der Niederschlagsmenge nicht möglich; wohl aber lassen sich zu annähernder Orientirung nachstehende Zahlen geben.

Es ist in 1 Stunde bei $0 \cdot 1 \square^{m}$ Electrodenzrösse eine $\mathrm{Kupferfällung}$ aus angesäuertem Kupfervitriolbade

durch ein Daniell-Element von . . . . . . . 1.2 gr. zu erhalten

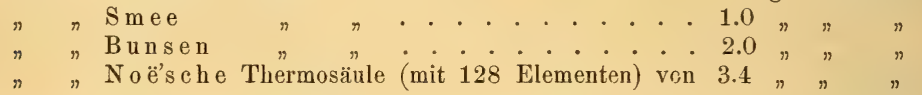

Es lässt sich die stündliche Niederschlagsmenge annähernd nach der von Prof. Dr. von Waltenhofen angegebenen Formel **)

berechnen.

$$
p=0.003565 \frac{e}{u+\varrho \frac{d}{n f}} \cdot M
$$

Hierbei wird $p$ in Grammen gefunden, wenn die electromotorische Kraft $e$ für ein Daniell'sches Element mit 12, für ein Smee'sches Element mit 6, für ein Bunsen-Element mit 20, für ein Noë'sches Thermoelement mit 1 in Rechnung gebracht wird. Ferner bedeutet $M$ das Aequivalentgewicht des gefällten Metalles (für Kupfer 31.7, für Gold 196 etc.); $u$ ist der vorher zu ermittelnde Widerstand in einem Element und $\varrho$ der Leitungswiderstand der Flüssigkeit, bezogen auf $1 \square^{\mathrm{cm}}$ der Electroden im Abstande von $1^{\mathrm{cm}}$ und beträgt bei concentr. Kupfervitriollösung 21 , bei mit 3 Proc. Schwefelsäure angesäuerter, auf $35^{\circ} \mathrm{B}$. verdünnter Kupfervitriollösung 12.3 u. s. w.

$d$ ist der Plattenabstand in Centimetern, $n$ die Zahl der Elemente der Batterie, $f$ die Plattengrösse (Electrodengrösse) in Quad.-Centm.

Galvanoplastische Ueberzïge (Galvanostegie). Die Herstellung galvanoplastischer Ueberzuige, auch Galvanostegie genannt, dient meistens zur Verschönerung der Metallwaaren und hierbei wird vorzïglich ein festes Haften des Ueberzuges verlangt. Dieses findet aber nur dann statt, wenn der zu überziehende (zu vergoldende, versilbernde, vernickelnde etc.) Gegenstand vollkommen frei von jeder Spur von Fett, Oxyd etc. und wenn er matt rauh ist. Dies wird durch Ausglühen und Abbeizen am besten erreicht.

Noch inniger findet das Anhaften statt, wenn man den zu überziehenden Gegenstand zuerst durch kurze Zeit als Anode einhängt und hierauf erst als Kathode. Durch diesen Vorgang werden die Bäder jedoch verunreinigt, und wendet man daher dies Verfahren nur ungern oder in besonderen, bereits mangelhaften Bädern an.

*) Ist dies nicht der Fall und kann man sich die erforderlichen Bestimmungen nicht durch einen Physiker durchfïhren lassen, so möge man selbst, bei Fällung von Kupfer aus den oberwähnten Lösungen, die Bestimmung der in gewissen kurzen Zeiten (während welchen die Stromstïrke ziemlich unveränderlich ist) gefällten Kupfermengen vornehmen. Die Stromstärke kann durch Einschaltung ron Widerständen für jede Probe geändert werden; auch durch Aenderung der Stromquelle.

**) Dingl. p. J. Bd. 224 pag. 274 . 
Ueber die Zusammensetzung der Bäder zur Herstellung verschiedener Metallüberzüge finden sich Angaben vor, von welchen wir einige folgen lassen, wobei aber bemerkt sei, dass z. B. die Zusammensetzung der Vergoldungsbäder, welche Goldniederschläge in bestimmten, beliebten Farbentönen liefern, noch als Fabriksgeheimniss *) betrachtet werden.

V e r g o l d un g s - B ä d e r sind gewöhnlich Lösungen von Goldcyanür-, Kaliumcyaniir oder Cyan-Gold, Cyan-Kalium, entweder bereitet durch Auflösen von Goldchlorid oder von Knallgold**) in einem Ueberschusse von Cyankaliumlösung (wässerige Lösung) oder auf electrolytischem Wege hergestellt, indem man als Kathode und Anode Goldblech anwendet, die Zersetzungszelle mit Cyankaliumlösung füllt und den galvanischen Strom durch ein, zwei Tage wirken lässt, bis hinlänglich Gold aufgelöst wurde. Beim Vergolden dient auch ferner reines Gold in Blechform als Anode. Es sollen 200-300' Gold auf 1 Kilo Cyankalium und 20 Liter Wasser kommen. Ein Zusatz von Aetzkali wird empfohlen.

Versilberungsbäder werden durch Auflösen von Chlorsilber in Cyankalium oder von salpetersaurem Silberoxyde in Cyankaliumlöșung hergestellt, wobei ca. 2'0 Gramm Silber anf 1 Kilo Cyankalium und 10 bis 14 Liter Wasser genommen werden.***)

Verkupferungsbäder für Stahl und Eisen. Diese Metalle, welche in Kupfervitriollösung direct angegriffen werden, erfordern ein Verkupferungsbad, welches aus einer Lösung von Cyankupfer-Cyankalium besteht und durch Auflösen von Kupferoxyd in Cyankaliumlösung, oder durch Auflösen von Kupfervitriol in jener Lösung oder endlich wie Gold- und Silberlösungen auch auf electrolytischem Wege bereitet sein kann.

Galvanische Platinirung. Obwohl das Ueberziehen von Metall-Gefässen mit Platin für chemischeZwecke von hoher Wichtigkeit wäre, hat man der Zeit noch keine geeigneten Bäder zum Verplatiniren aufgefunden.

Verstählen (Ueberziehen mit Eisen). Kupferdruckplatten werden mit einer dünnen Schichte Eisen überzogen, "verstählt", um mehr Abdrïcke zuzulassen, indem einerseits die Eisenschichte widerstandsfähiger ist und andererseits leicht erneuert werden kann, sobald sie schadhaft geworden ist. Durch Einlegen der Platten in verdünnte Schwefelsäure wird der schadhafte Ueberzug von Eisen in wenigen Secunden entfernt und dann frisch angebracht. Zum Verstählen kann man sich eines Bades bedienen, welches aus Eisen-Chlorïr, Chlorammonium besteht und dadurch bereitet wird, dass man in eine ziemlich concentrirte Chlorammoniumlösung als Kathode und Anode Eisenplatten einhängt und den Strom so lange einwirken lässt (ca. 24 Stunden), bis die Flüssigkeit griunlich (an der Oberfläche röthlich von Eienoxyd) geworden ist. Diese Fliissigkeit wird durch die Einwirkung des Lichtes zersetzt, daher keine Glasgefässe verwendet werden dürfen.

Vermessingen. Nach Heeren kann ein Bad znm Vermessingen bereitet werden, wenn 1 Theil Kupfervitriol in 4 Theile Wasser, 8 Theile Zinkvitriol in $16 \mathrm{Th}$. Wasser und $18 \mathrm{Th}$. Cyankalium in $36 \mathrm{Thl}$. Wasser gelöst und diese Lösungen gemischt werden. Der entstehende Niederschlag wird durch Zusatz

*) Ein Zusatz von Cyankupfer in das Cyangold-Cyankaliumbad soll den Goldniederschlag röthlich, ein Zusatz von Cyansilber soll ihn lichter (hellgelb) machen; doch fehlen genaue, verlässliche Daten.

**) Gold in Königswasser gelöst und die Lösung eingedampft, um die überschüssige Säure zu entfernen, liefert Goldchlorid $\mathrm{AuCl}_{3}$. Goldchloridlösung mit Ammoniak gefällt liefert als Niederschlag Goldoxyd-Ammoniak oder Knallgold.

***) Bei der Versilberung von Alpaka oder Argentan wird empfohlen, die zu versilbernden Gegenstïnde unmittelbar vor dem Kinhängen in die Zersetzungszelle in eiue sehr rerdïnnte Lösung von salpetersaurem Quecksilberoxyd zu tanchen. 
von Cyankalium gelöst und hierauf noch 250 Th. Wasser zugesetzt. Die Lösung wird auf ca. $80^{\circ} \mathrm{C}$. erhitzt verwendet.

Zum Bronziren von Eisenwaren soll man eine ähnliche Lösung anwenden, doch statt des Zink ein Zinnsalz (Zinnchlorid) verwenden.

Vergleiche ferner die Artikel: Vergolden, Versilbern, Verkupfern, Vernickeln etc.

Anwendungen der Galvanoplastik.

Es wurde schon oben erwähnt, dass die Galvanoplastik zur Reproduction von Holzschnitten (s. d.) und Kupferstichen (s. Kupferdruck) Anwendung findet. Eigenthühmliche, nur durch Anwendung der Galvanoplastik herstellbare Druckplatten erhält man bei der Galvanographie, Stilographie und dem Naturselbstdruck.

Bei der Galvanographie wird auf einer versilberten Kupferplatte mit dem Pinsel eine Farbe von Ocker und Leinöl in Tuschmanier aufgetragen, und hat der Künstler die Farbe um so rauher und dicker aufzutragen, je schwärzer im Druck die Stelle erscheinen soll. Nach dem Trocknen wird diese Platte durch Graphit leitend gemacht und im galvanoplastischen Apparat unmittelbar die Tiefplatte erzengt.

Die Stilographie benützt eine aus $1 \mathrm{Th}$. Stearin und 2 Theilen Schellack hergestellte, durch genïgenden Kienrusszusatz in der Masse schwarz gefärbte Platte. Diese Platte wird mit Firniss bestrichen und mit Silberpulver eingerieben. Hierauf wird mit dem Griffel die Zeichnung in die Platte radirt. Alle Theile, welche im Druck seiner Zeit schwarz erscheinen sollen, sind vertieft und daher die weisse Silber-Schichte an diesen Stellen entfernt. Nach vollendeter Radirung wird die Platte durch Graphit leitend gemacht, im galvan. Apparate zuerst eine Hochplatte und von dieser hierauf die Tiefplatte erzeugt. Während die Galvanographie Abdrücke in Tuschmanier liefert, gibt die Stilographie Drucke, welche ähnlich Radirungen sind.

Der Naturselbstdruck liefert Platten für den Buch- und den Kupferdruck, welche Pflanzen, Gewebe u. dgl. darstellen, zu welchen diese selbst die Originale bildeten, indem von ibnen der Abdruck entweder in Guttapercha oder Blei genommen und galvanoplastisch in eine Druckplatte umgewandelt wird. Soll z. B. eine Naturselbstdruckplatte von Spitzen gebildet werden, so klebt man diese mit dïnnem Gummiwasser auf eine Stahlplatte und legt nach dem Trocknen auf diese eine Bleiplatte. Beide Platten führt man durch ein Walzwerk unter mässigem Druck. Die Spitzen drücken sich in die Bleiplatte, welche als Matrize zur Herstellung einer Hoch- und hierauf einer Tiefplatte verwendet wird. Montirt man nun die Tiefplatte auf Holz für den Buchdruck, so empfängt die Platte die Farbe auf der Fläche und man erhält das Muster weiss auf färbigen Grunde. Für den Kupferdruck kommt die Farbe natürlich in die Tiefen.

In derselben Weise kann man Platten fii $\mathrm{r}$ künstliche $\mathrm{Narben} \mathrm{(Leder-}$ imitation) herstellen, indem man von dem genarbten Leder in Blei oder Guttapercha einen Abdruck macht. Auf diesem Wege bekommt man ein besseres Resultat, als wenn das Leder mit Firniss bestrichen und durch Graphit leitend gemacht, hierauf auf ein lackirtes Brett befestigt und mit Wachsrand versehen wird.

Hängt man eine mit Aetzgrund ïberzogene, hierauf radirte Kupferplatte als Anode in den galvanischen Apparat ein, so findet eine Vertiefung der blankgelegten Stellen statt, welches Verfahren man galvanische Aetzung oder Galvanokaustik nennt.

Ueber den mit Hilfe der Galvanoplastik möglichen Ersatz des Holzschnittes durch die sog. Glyphographie und Galvanoglyphik sprechen wir im Art. Holzschnitt.

Die Galvanoplastik wird ferner zur Herstellung sehr dichter Kupferplatten, zur Verbesserung von Fehlern an Kupferstichen etc. angewendet. 
Die Galvanochromie oder galvanische Färbung wird besonders zur Färbung von Messingwaaren angewendet. Hierbei wird die Waare als Anode in ein Bad eingehängt, welches bereitet wird, indem man 1 Kilo Aetzkali in 4 Kilo Wasser löst und in diese kochende Flüssigkeit einige Löffel Bleioxyd (Massicot oder gemahlene Bleiglätte) einträgt, und durch einige Zeit absetzen lässt. Es entsteht bei der galvanischen Zerlegung auf der als Anode eingehängten Waare ein dünner Ueberzug von Bleihyperoxyd, welcher je nach seiner Dicke verschiedene Farben (roth, blauroth, grïn, grau) liefert. Man muss den Gegenstand herausnehmen, wenn der richtige Farbenton erhalten ist. Da es schwierig ist bei starkem Strome gleichmässige Farbentöne zu erhalten, arbeitet man mit mässigen Strömen. Als Kathode wird Platinblech angewendet, und damit der Abstand der verschiedenen Oberflächenpartien des Gegenstandes von der Kathode nicht zu ungleich ist, biegt man selbe entweder zu einem den Gegenstand umfassenden Rohre oder hängt denselben öfter um.

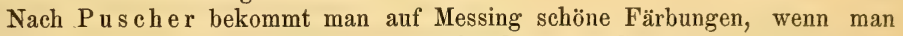
die Messingwaare in einer Flüssigkeit, bestehend aus $50 \mathrm{Gr}$. unterschwefligsaurem Natron in $1 / 2$ Liter Wasser und gemischt mit $16^{2} / 3$ Gr. Bleizucker gleichfalls in $1 / 9$ Liter Wasser gelöst, auf $85-100^{\circ}$ C. erhitzt; nur muss die Erwärmung gleichmässig erfolgen, was dadurch geschieht, dass man das Gefäss, in welchem die Flüssigkeit zum Kochen gebracht wurde, in eine Filzumhïllung setzt und die für sich in kochendes Wasser getauchten Gegenstände rasch einträgt, und nun das Gefäss mit einem Doppeldeckel oder Eilzscheibe bedeckt. (Vergleiche den Art. Bräunen (Brüniren) I pag. 737). $K k$.

Literatur: Jacobi: Galvanoplastik, Petersburg 1840. (Jacobi ist der Entdecker der Electrolyse und sein Werkchen von geschichtlichem Interesse.) Werner: die Galvanopl. in ihrer techn. Anwendung. Petersburg 1844. Martin: Repertorium der Galvanoplastik. Wien 1856. (Eine sehr reichhaltige Sammlung von Recepten, leider meist ungeprüft, wie sie in der Literatur zerstreut vorkamen). S mee: Elements of electrometallurgy, neue Aufl. London 1851, deutsch Leipzig 1851. R o s el e ur: Manipulations hydro. plastiques, Paris 1855, deutsch von Willich und Kasalowsky, Stuttgart 1862. v. Kress: die Galv. für industr. und künstl. Zwecke, Frankfurt 1867.

Galvanoscop, s. Electricität III pag. 171.

Gambeer, s. m. G a m bir.

Gambetta-Ballons sind Enveloppen aus dünnem, mit einer schwachen Lösung: von Kaliumbichromat oder einer verdünnten Lösung von Berlinerblau in Oxalsäure getränktem Papier, welche an ihrem oberen Ende angezilndet, ein Aschennetz hinterlassen, das nach dem Abbrennen gleich einem Ballon einige Fuss hoch aufsteigt (so lange die Erwärmung der Luft im Innern des Aschenballönchens nachhält), vgl. Dingl. pol. Journ. 200 pag. 158. Gtl.

Gambiensergummi, s. m. Kin o g u m i.

Gambir (gambir - gambir), Gambeer, Gambir-Catechu, gelbes, $\mathrm{kubisches} \mathrm{Catechu.} \mathrm{Eine} \mathrm{Catechu-Sorte} \mathrm{(vgI.} \mathrm{II} \mathrm{pag.} \mathrm{266),} \mathrm{welche} \mathrm{in} \mathrm{würfel-}$ förmigen Stiicken von $3-4^{\mathrm{cm}}$ Seitenlänge, von aussen dunkelbrauner, innen hellgelber bis graugelber Farbe, in den Handel kommt. Die meist ziemlich regelmässig geformten Würfel sind porös, leicht zerbrechlich, an der Zunge klebend und haben einen zusammenziehend bitteren, nachträglich siisslichen Geschmack. Das Gambir-Catechu, das in seiner Zusammensetzung dem Catechu bis auf einen geringeren Gerbsäuregehalt (36-40 Proc.) ziemlich nahe kommt, wird aus den jüngeren Blättern von Uncaria (Nauclea) Gambir, einer in Ostindien (Sumatra, Malakka, Singapore und molukkische Inseln) einheimischen, strauchigen Rubiacee, durch Auskochen mit Wasser und Eindampfen der Abkochung gewonnen und kommt von Singapore und Penang iiber London zu Markte. Gtl. 
Gambogiasäure, Bestandtheil des Gummigutt, s. d.

Gangspill, s. Ankerwinde I pag. 155.

Ganister, feuerfestes Materiale zum Auskleiden von Frischbirnen, s. Thon. Ganomatit, s. Gänseköthigerz.

Ganz, Gans, s. Barren I pag. 298 und III pag. 9.

Ganz-Holländer, s. Papierfabrikation.

Ganzholz (bois de brin). Holz in unbeschlagenen, also runden Stämmen oder kürzeren Stücken, Blöcken, ferner sogen. Stangenholz.

Ganzzeug (pâte raffinée - stuff), s. Papierfabrikation.

Ganzzeug-Holländer, s. P a pierf abrikation.

Gärbstahl, Gerbstahl, s. Eis en erzeugung III pag. 48.

Garbe, s. Eisenerzeugung III pag. 49.

Garanceux, s. Krapp.

Garancin, s. Krapp.

Gardeniazucker, Zuckerart, welche bei der Spaltung des Polychroits entsteht, s. S a fran.

Gardenin s. m. Crocin u. Polychroit, s. Safran.

Gargang, s. Eis enerzeugung. (Hochofenprocess) III pag. 10.

Gargouletten, Bezeichnung einer Form von Wasserkühlgefässen, welche nach dem Princip der Alkarazzas (s. I pag. 22) wirken. Gtl.

Garkupfer, s. Kupfer.

Garn $(f i-y a r n)$. Unter Garn versteht man die durch Spinnen zu einem Faderi vereinigten Gespinnstfasern, also eine durch Drehung erzielte Vereinigung von Fasern zu einem Faden möglichst gleichmässiger Dicke. Je nach der zur Garnbildung verwendeten Faser unterscheidet man Ba umoll-, Schafwoll-, F l a ch s-, J u t e-, H a n f-, S eiden- etc. Garn. In Bezug auf die Herstellungsmethode werden die Schafwollgarne in Streich- und $\mathrm{Kammgarne}$ unterschieden und sind für dieses Materiale nur diese Benennungen gebräuchlich.

Der von Cocons abgehaspelte Faden, Rohseide, ist kein Garn, sondern man hat unter Seidengarn das Gespinnst aus Seidenabfällen (die Florettseide) zu verstehen.

Der ziffermässige Ausdruck des Verhältnisses zwischen der Länge und dem Gewichte des Garnes liefert eine Zahl, welche das Garn n um er genannt wird. Ueber die zumeist in der Gegenwart noch gebräuchliche Numerirung siehe die Artikel Baumwollspinnerei, Flachsspinnerei, Kammgarnspinnerei etc. etc. Hier wollen wir nur die Vorschläge des zweiten internat. Congresses für einheit lich e Garn-Numerirung zu Brüssel 1874 kurz erwähnen, wenn auch dieselben noch der Einführung harren. Es wurde dort beschlossen:

1. Für Garne (Gespinnste) aus kurzfaserigem Materiale, Baumwolle, Schafwolle, Leinen, Chape, ist die Feinheits-Nummer die Zahl ron Metern, welche zur Erfiillung der Gewichtseinheit ron einem Gramm erforderlich ist. 
Hiermit ist die Nummer der reciproke Werth der Gewichtszahl von $1000^{\mathrm{m}}$ Garn Länge in Kilogrammen.

2. Für rohe und filirte Seide: Die Feinheitsnummer ist gleich dem absoluten Gewichte eines Fadenstïckes von $1000^{\mathrm{m}}$ in Decigrammen (1/10 Gr.) ausgedrückt. Oder die Nummer ist der 10 fache Werth der Gewichtszahl von $1000^{\mathrm{m}}$ Seidenfaden in Grammen gewogen. (Siehe diesbezïglich Näheres: Civilingenieur Bd. 21 Heft 1, Zeitsch. d. nied.-öst. Gewerbe-Vereines $1876 \mathrm{Nr}$. 30.)

Die Garne, welche vom Spinner entweder in Form von Strähnen (Schneller) oder als Kötzer oder auch auf Spulen in den Handel gebracht werden, werden nicht selten einer Appretur unterworfen, welche entweder ein Bleichen, Sengen (Gasiren) oder Knotenabstreifen oder Einreiben von Appreturmitteln (Liistriren) ist. Die Manipulationen sind je nach der Art der Garne, ob Baumwoll-, Flachs-, Seiden- etc. Garne, ziemlich abweichend. Das Bleichen der Baumwollgarne, selbst in Kötzerform, kann mit Vortheil in Kesseln ausgefuhrt werden, aus welchen zuerst durch eine Luftpumpe die Luft ausgepumpt und nachher durch den äusseren Luftdruck die Bleichflüssigkeiten eingetrieben werden. Es findet dies meist nur bei den für Strickzwirn (Baumwoll-Strickzwirn) verwendeten Garnen Anwendung (s. Zwirn). Das Bleichen der Flachsgarne findet theils auf chem. Wege in offenen Gefässen mit Chlorkalk und schwefelsaurem Natron, theils als Rasenbleiche statt; das Bleichen von Schafwoll- und Seidengarn findet in Bleichkästen statt, wo die feuchten Strähne den Dämpfen von schwefliger Säure ausgesetzt sind. (Vergl. Bleichen.)

Z um Sengen der Garne dienen Sengemaschinen. Die einzelnen Fäden streichen durch Gasflammen, bei welchen durch entsprechende Mengung des Gases mit Luft darauf zu sehen ist, dass die Flammen nicht russen. Diese Operation wird namentlich hänfig auf Florettseide (Chape) mit ausgezeichnetem Erfolge angewendet. (Dingl. polyt. Journ. Bd. 153 S. 21.)

Zum Abstreifen der Knoten zieht man das Garn durch einen Spalt feiner Metallblättchen, welche Operation meist mit der Weife verbunden ist.

Beim Lüstriren, namentlich der Baumwollgarne und Zwirne, wird auf die iiber rotirende Walzen gelegten Strähne das Appreturmittel aufgetragen, und durch rotirende, der Bewegungsrichtung des Garnes entgegenarbeitende Bürstenwalzen bis fast zur Trockene gebürstet und so glänzend gemacht. Als Appreturmittel verwendet man dünnes Stärkewasser mit Flohsamenabguss oder Seife u. d. gl. (Dingl. polyt. Journ. Bd. 122 S. 417, Bd. 123 S. 432 , Bd. 158 S. 255, Bd. 161 S. 20 ete.)

$K k$.

Garnerit Min. Im Serpentin von Neu-Caledonien vorkommendes Nickelerz, wesentlich aus wasserhaltigem Nickel- und Magnesium-Silicat bestehend, mit 18 Nickeloxydul, 15 Magnesia, 7 Eisenoxyd, 38 Kieselerde und 22 Wasser, rgl. Garnier Monit. scientif. 1876, Nr. 416 pag. 857, s. a. Nickel. Gtl.

Garnitur, s. Eisenbahn bei Locomotive, III pag. 84-89.

Garschaum, Eisenschaum, liüttenmännische Bezeichnung für den beim Auflösen von Roheisen in Säuren sich ausscheidenden Graphitkohlenstoft', siehe Kohlenstoff.

Garschlacke, s. Eis en erzeugung III pag. 26.

Gas der holländischen Chemiker, Elailgas, s. b. Kohlenwasser$\mathrm{st}$ off, s. Leuchtgas.

Gas ölbildendes. Elailgas, s.b. Kohlenwassers toff, s. Leuchtgas.

Gas (gaz - gas), allgemeiner Begriff, s. G a s e. 
Gasäther nennt man Mischungen von rectificirtem Terpentinöl (s. C a m phi n II pag. 239) mit Alkohol und Aether, welche als Leuchtmateriale empfohlen wurden. Gtl.

Gasbeleuchtung, s. Leuchtstoffe b. Leuchtgas.

Gasbehälter, s. Gas o m eter.

Gasbeleuchtung, s. Le u chtstoffe.

Gasbereitung und Gasbereitungs-Apparate, siehe Leuchtstoffe bei Leuchtgas.

Gasbrenner (brîleur a gaze - gas burner), s. Le uchtstoffe bei Le u chtgas.

Gasdruckregulatoren, s. L e uchtst offe bei Le uchtgas.

Gase nennt man, im Gegensatze zu den tropfbar-flissigen und nur innerhalb äusserst enger Grenzen elastischen Körpern, die a usdehnsam (elastisch) flü ssigen Körper.

In dem Gaszustande haben die Moleküle der Körper das Bestreben sich nach allen Seiten hin von einander zu entfernen, es besteht zwischen ihnen keine Anziehung mehr, wie sie bei den Molekülen im festen oder im flüssigen Aggregatzustande noch besteht; desshalb füllen Gase jeden ihnen gebotenen Raum vollständig aus (Ausdehnsamkeit) und vertheilen . sich in demselbem vollständig gleichmässig. Da jedes einzelne Molekül eines Gases sich in einer geradlinig fortschreitenden Bewegung befindet, die so lange währt, bis es auf ein zweites Molekiil oder an die feste, den Raum abgrenzende Wand stösst, wo dann die Bewegung entweder auf das zweite Molekiil uibertragen wird oder einen Ruickprall von der festen Wand bedingt, so ist begreiflich, dass ein in eine Gasatmosphäre eingeführter Körper (sowie natïrlich auch die einen mit Gas erfüllten Raum abschliessende feste Wand) fortwährend wiederkehrenden Stössen der bewegten Gasmoleküle ausgesetzt sein muss und das um so mehr, als die Geschwindigkeit der bewegten Gasmolekiile wäichst, oder die Anzahl der in einem abgeschlossenen Raume vorfindlichen und sich in demselben bewegenden Molekiile zunimmt; denn in dem einen Falle wird ein und dasselbe Molekül in gleicher Zeit öfter zum Anpralle kommen, in dem anderen Falle wird in gleicher Zeit eine grössere Anzahl von Molekïlen zum Stosse kommen.

Die Summe aller Stösse, welche von den Molekuilen eines Gases in der Zeiteinheit auf eine feste Wand ausgeïbt werden, gibt sich als Druck des Gases (Spaunung, Tension) zu erkennen und dieser wird, wie aus dem oben Gesagten erhellt, zunebmen mit der Verringerung des Raumes, der dem Gase zur Erfiillung geboten ist, und abnehmen mit der Vergrösserung desselben. Nennt man den von einem Gase erfüllten Raum das Volumen des Gases, so wird sich sagen lassen, dass der Druck und das Volumen eines Gases einander verkehrt proportional sind, d. h. dass der eine in demselben Verhältnisse wächst als das andere abnimmt und umgekehrt. Die Spannung der Gase, die selbst von dem auf das Gasrolumen ausgeiibten, ron aussen wirkenden Drucke abhängig ist, steht also im umgekehrten Verhältnisse zu dem Volumen desselben (Boyle'sches Gesetz, Mariotte'sches Gesetz).

Andererseits wird durch Tärmezufuhr die Grösse der lebendigen Kraft der in Bewegnng stehenden Molekiile und mithin ihre Geschwindigkeit erhöht, und sohin auf dem Wege der Vergrösserung der Molekïlgeschwindigkeiten in dem Falle, wo dem Gase die lï̈glichkeit der freien Ausdehnung benommen ist, also ein abgeschlossenes frastolumen in Betracht kommt, gleichfalls eine Erhöhung der Tension, bez. des Druckes herbeigefiilurt, oder diese im Falle der Wärmeabnahme rermindert. Temperatur und Druck eines Gases sind einander demnach gerade proportional (vgl. A us dehnung I pag. 250 und 251.) 
Der Mangel einer gegenseitigen Anziehung zwischen den cinzelnen Mrslekïlen, der den Gascharakter wesentlich bedingt, besteht nur innerhall, gewisser Druck- und Temperaturverhältnisse; und insoferne durch fortgesetzte Druckerhöhungen oder aber Temperaturerniedrigungen eine stetig zunchmende Annäherung der Moleküle herbeigeführt wird, kann diese endlich soweit gedeihen, dass die einzelnen Molekïle eine Anziehung auf einander auszuiben vermörcen und der Körper sonach aufhört gasförmig zu sein, d. i. den fluissigen orler festen Aggregatzustand annimmt. Es hängt wesentlich von der Natur der Körper al, unter welchen Druck- und Temperaturverhältnissen diese Aenderung des Aggregatzustandes eintritt und insoferne dieselbe bei einzelnen Körpern schon bei gewöhnlicher Temperatur und gewöhnlichem Drucke (Druck einer Atmosplıäre) erfolgt, unterscheidet man zwischen eigentlichen Gasen, d. h. solchen Körpern, welche unter gewölınlichen Verhältnissen noch gasförmig sind und $\mathrm{D}$ ämpfen, d. s. Gase, die nur bei höheren Temperaturen oder niedrigen Drucken bestehen. Die eigentlichen Gase selbst unterschied man bis vor Kurzem noch in solche, welche sich durch starke Abkiihlung und erhebliche Druckvermehrung verfliissigen (verdichten, condensiren) lassen, welche man condensirbare (coërcible) Gase nannte, und solche, bei welchen mit Hilfe der verfügbaren Mittel cine Verdichtung nicht erreichbar war, die man incoërcible oder permanente Gase nannte. Die neuesten Arbeiten von R. Pi ctet (Compt. rend. 85 pag. 1214 und 1220 und L. Cailletet, Compt. rend. 85 pag. 1016 u. 1213) haben aber gezeigt, dass auch die bisher für permanente erklärten Gase, Sauerstoff, Wasserstoff', Stickstoff etc., bei geeigneten Druck- und Temperaturverhältnissen condensirt werden können, so dass demnach diese Unterscheidung hinfällig ist. Ueber Ausdehnungscoëfficienten der Gase s. A usdehnung I pag. 250, iiber Absorption der Gase s. Absorption I pag. 35. Gtl.

Gasentbindungs-, Gasentwicklungs-Apparate, im Allgemeinen Vorrichtungen zur Darstellung und Isolirung gasförmiger Körper, deren Einrichtung je nach der Natur des Processes und der Art des Gases verschieden sein kann. Ueber die einzelnen Apparate s. bei den betreffenden Gasen. Gtl.

Gasfang, s. Eisenhüt enkunde III pag. 16.

Gasfeuerung (foumeau à gaz - gas furnace). Bei Beniitzung fester Brennstoffe $\mathrm{zu}$ industriellen Zwecken kommen im Allgemeinen drei Feurungssysteme zur Anwendung:

1. Der Brennstoff wird nur mässig hoch auf den Rost geschichtet. Die Verbrennung findet thunlichst vollständig bei Ueberschuss von Luft statt, welche jedoch theilweise unzersetzt mit den Verbrennungsproducten abzieht und sonach nutzlos erwärmt werden muss. Beispiele dieser Art sind z.'B. die meisten Dampt'kesselfeuerungen.

2. Der Brennstoff wird hoch auf den Rost geschichtet, die zutretende Luft bleibt so länger mit dem Brennmateriale in Berihrung und zieht nicht unzersetzt mit den Verbrennungsproducten ab. Diese enthalten jedoch in Folge der hier herrschenden, absichtlich hervorgerufenen unvollständigen Verbrennung vielleicht ebenso viel Kohlenoxyd als Kohlensäure. Trotzdem erzielt man hohe Temperaturen, weil sich die erzengte Wärmemenge auf eine geringere Mengè rón Terbrennungsproducten vertheilt. Dieses Verfahren kommt bei metallmrgischen Operationen nicht selten zur Verwendung (s. Brennstoffe II pag. 21 f).

3. Das Brennmateriale wird so hoch geschichtet, dass die das Bremnmateriale durchstreichende Luft zunächst nur Kohlenoxyd bildet. Diesem wird eine wcitere Quantität Luft zugefiihrt, gerade linreichend urn vollständige Verbrenumg zu Kohlensäure zu bewirken. Diese Art der Fenerung ist die Gasfenerung: Der principielle Unterschied zwischen Gasfenerung und gewöhnlicher directer Fenerung: besteht also darin, dass bei jener die Bildung ron Kohlenoxyd und dessen Ver- 
brennung zu Kohlensäure $\mathrm{nach}$ einander, bei dieser aber zugleich stattfindet. (Vgl. Brennstoffe II pag. 32).

Jede Gasfeuerung erfordert im Allgemeinen als wesentliche Theile den Gaserzeuger oder Generator (générateur de gaz - generator furnace) und eine Verbrennungsvorrichtung, den Brenner (bec - burner).

Zwischen beiden können noch eingeschaltet sein: Vorrichtungen zum Zurüickhalten mit fortgerissenen Flugstaubes (Rauchsammler, Gasreiniger), zur Condensation von Wasser- und Theerdămpfen (C o n densatoren), zur Vorerhitzung der Verbrennungsluft allein oder zugleich auch der brennbaren Gase (Regeneratoren) u. ähnl. m.

Die Zufuhrung der zur Gaserzeugung und zur Gasverbrennung nothwendigen Luft geschieht entweder durch natürlichen Zng oder durch Ventilatoren u. dgl.

Im Allgemeinen ist der Gasgenerator ein Schacht, in dessen Basis ein Rost eingebaut, doch variiren die Details entsprechend der vorliegenden Situation und insbesondere nach dem Brennmateriale und dessen Qualität. Als solches kommt Stein und Braunkohle, Torf, Holz und Sägespäne in Betracht. Den Eigenschaften genannter Brennstoffe nach wird die Schüthöhe, dem Agregatszustand entsprehend, gewählt; die Form und Grösse des Rostes - der übrigens nicht von so wesentlichem Einfluss wie bei directer Feuerung - bestimmt man mit Berücksichtigung der Reinheit des Brennmateriales derart, um die Rostreinigung mit Leichtigkeit handhaben und die nothwendige Luftmenge zuführen zu können u. s. w.

Anzustreben ist, dass alle durch die anfängliche Verbrennung erzeugte Kohlensäure wieder zu Kohlenoxyd reducirt wird und dass die Gaserzeugung möglichst regelmässig und ungestört stattfinde.

Zweckentsprechende Bedienung ist eine wesentliche Bedingung guter Function. Bei aschenreichem Brennstoffe und insbesondere bei stark backender, schlackender Kohle ist das Schüren und Abschlacken des Feuers eine wichtige, schwierige Arbeit, welche vollste Sorgsamkeit verlangt. Unregelmässige oder nngeschickte Bedienung ist häufige Ursache von Störungen in der Gasentwickelung; ein unzeitig gestörter Generator kann aber oft mehrere Stunden brauchen, um wieder in regelmässigen Betrieb zu gelangen.

Der Generator muss uibrigens so eingerichtet sein, dass er stets hermetisch geschlossen sei und Luft $\mathrm{nur}$ durch den Rost Eintritt finde. Desshalb ist besondere Vorsicht darauf verwendet, bei Beschickung des Schachtes mit frischem Brennmateriale, als auch bei Fortleitung der Gase nach dem Verbrennungsraume den Eintritt der Luft und dadurch schädliche Verdünnung der Heizgase zu vermeiden. Die Gaskanäle sind auch vor Fenchtigkeit bestens zu schiitzen und ist Eindringen von Feuchte in den Generator oder die Gasleitung für den Heizeffect höchst nachtheilig. Die Herstellung der Mauerung fiir Gasfeuerungen hat darum sehr sorgfältig zu geschehen.

Die Gasleitungen sollen möglichst kurz sein. Sind lange, bald ansteigende bald fallende Leitungen geboten, so sollen an geeigneten (tiefsten) Punkten bequem zugängliche, luftdicht verschliessbare Wasser- und Theerfänge angebracht sein. Die Züge miissen sich gut reinigen lassen und empfiehlt sich Anbringung von Schaulöchem und Sicherheitsklappen.

Âls Beispiel sei ein (Ferrini's Technologie der Wärme entnommener) Steinkohlengenerator von Siemens beschirieben, den Fig. 1707 zeigt.

Derselbe besteht aus einer etwa $2.5 \mathrm{~m}$ hohen überwölbten Kammer gebildet durch eine hintere Wand, zwci darauf senkrechte Seitenwände von $1.5 \mathrm{~m}$ bis $2 \mathrm{~m}$ Distanz und einer unter $50--60^{\circ}$ geneigten Vorderwand, welche in ihrem oberen Theile aus feuerfesten Ziegeln besteht und weiter ea. $800 \mathrm{~mm}$ über der Sohle einen Rost enthält, welcher sich in gleicher Neigung mit der Wand dieser anschliesst, bis er etwa $400 \mathrm{mn}$ ïber der Sohle mit einem zweiten horizontalen Roste zusammentritt't. Zwischen beiden Rosten lïst man um die Reinigung zu erleichtern, eine Oeftinung von $100-150 \mathrm{~mm}$. Eine Brennmaterialschichte von der richtigen 
Dicke liegt auf der schiefen Ebene und den Rosten. Im Gewöllse sind Oeffuungen angebracht, ïber denen sich Fülltrichter zum Einbringen des Brennmateriales befinden. Damit beinı Beschicken keine Communication mit dem äusseren Raume entsteht, haben die Trishter Deckel, deren Rïnder in eine mit Wasser oder Sand gefüllte ringförmige Rinne tauchen und der Boden des Trichters, der die Brennstoffcharge enthält, kann von Aussen mittelst eines Hebels vertical gestellt werden. Weitere Oeffnungen dienen als Schaulöcher lind sind so angeordnet, dass man durch dieselben auch mittelst eines Schürhakens die zusammengerackenen Stücke trennen und auflockern, so wie das Nachsinken des Brcnumateriales und dessen gleichnässige Vertheilung reguliren kann.

Die Ausströmung der Gase wird durch einen Schieber oder ein Ventil regulirt. Wenn das Gewölbe des Generators nicht mindestens um $3^{\mathrm{m}}$ tiefer liegt, als die Sohle des Verbrennungsraumes, so lässt Siemens die Gase erst in einen gemauerten oben geschlossenen Kamin emporsteigen. Etwas unterhalb der höchsten Stelle zweigt ein horizontales Blechrohr ab,

Fig. 1707.

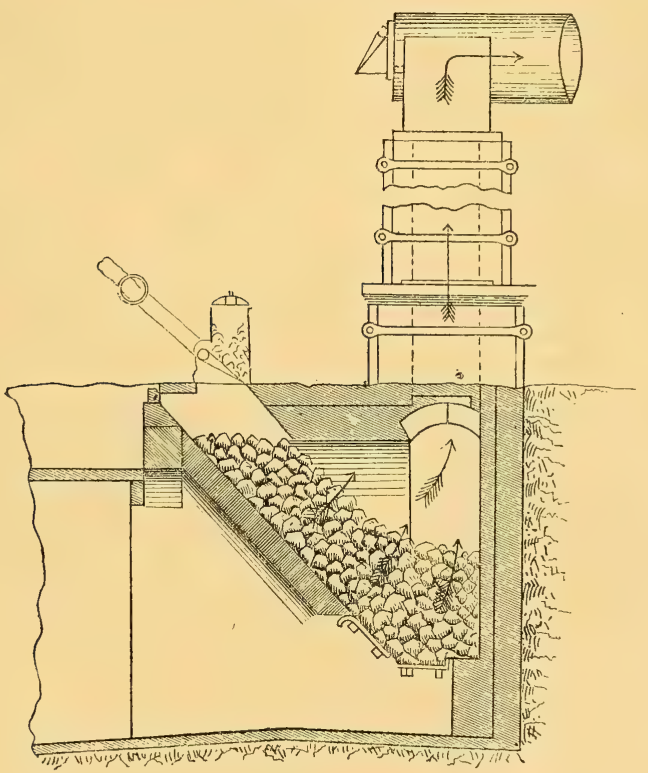

welches eine ziemliche Strecke weit hoch über den Boden geht, sich dann vertical abwärts bis zum Terrain des Ofens biegt. Dieses Kühlrohr (cooling tube) - wie Siemens es nennt - bewirkt durch die Spannungsdifferenz zwischen den heissen, vom Generator kommenden und den durch das Rohr abgekühlten Gasen constante Strömung zum Ofen hin, unabhängig vom Schornstein des letztern.

Ein solcher Generator soll je nach Grösse 1300 bis $1800 \mathrm{~K}$. Kohle in 24 Stunden destilliren. Genügt dies nicht, so ordnet man mehrere Generatoren an.

Die Generatoren stehen isolirt oder unmittelbar beim Ofen. Letztere Anordnung findet sich zumeist dort, wo ein Generator dem Betriebe geniigt, erstere empfiehlt sich für grössere Anlagen, sie lässt vollständige Trennung der Feuerungsvon der eigentlichen Ofenmanipulation zu. 
Die vom Generator kommenden Gase mischen sich im Brenner mit Luft und ziehen durch den Generator-Fuchs, wo die Flamme sich noch vollständig entwickelt, zum eigentlichen Herd oder Ofen.

Die möglichste Mischung von Gas und Luft wird durch sehr von einander abweichende, wohl noch wesentlicher Verbesserung fähiger, Constructionen angestrebt. Entweder bestehen diese aus einer Anzahl von paarweise und concentrisch in einander gesteckten Düsen, von denen die eme Gas, die andere Luft ausströmen lässt, oder man lässt gegen die aus einem Schlitze oder concentrischen Ringe austretenden Gase Luft unter einem gewissen Winkel aus einer Anzahl feiner Düsen oder schmaler Schlitze stossen und ähnl. m. Als bester Mischungsapparat dürfte in den meisten Fällen sich jener erweisen, bei welchem Gas und Luft nicht in paralleler Richtung, sondern unter einem Winkel auf einander treffen, weil die Mischung so schneller und inniger erfolgt. Wie selbstverständlich, muss Brenner und Fuchs aus allerbestem Materiale solidest hergestellt werden.

Die Art und Weise wie, und die Menge, in welcher dem Gase Luft zugefithrt wird, beeinflusst wesentlich die Beschaffenheit der Flamme und den Nutzeffect der Anlage. Durch diesbeziigliche Regelung kann man je nach Bedarf kurze oder langgestreckte Flamme erzeugen, ferner derselben mehr reducirenden oder oxydirenden Charakter ertheilen, je nach dem industriellen Zwecke, dem der Ofen zu dienen hat.

Wird dem Gase mehr Luft als nöthig zugeführt, so wird hiedurch Wärmeverlust hervorgerufen; wird nicht hinreichend Luft gegeben, so entsteht Rauch und ein Theil der Gase geht unbenützt verloren.

Nun ist gerade die Leichtigkeit, mit der man das Verhältniss zwischen Gas und Luft reguliren kann, ein wesentlicher Vortheil der Gasfeuerung. Es kann die beste Gasfeuerung mangelhaft arbeiten, wenn zur Vergasung oder zur Verbrennung nicht die angemessene Menge Sauerstoff zugeführt wird. Für die praktische Erkennung der Giite des Processes dient der durch Uebung geschärfte Geruchsnerv und die Beurtheilung der Art und der Farbe der Flamme, beste Controlle jedoch bietet die Untersuchung der Producte der Verbrennung, respective der Vergasung. Zu solchen Untersuchungen eignen sich die Gasanalysen-Apparate von 0 rsat (D. P. J. Bd. 217, S. 220, Bd. 221 S. 468), Winkler (D. P. J. Bd. 219 S. 413, Journal für prak. Chemie 1873 Bd. 6 S. 301), Schwackh ̈̈ fer (rerbesserter Orsat-Apparat, s. Wochenschrift der öst. J. u. A. V. II. Jahrg. Nr. 48 S. 299) u. a.

Zur Steigerung des Heizeffectes trägt die Erhitzung der Verbrennungsluft wesentlich bei. Selbe geschieht durch die ausstrahlende Wärme des Feuerungsraumes (in Kanälen der Seitenwände, in Rohren unter dem Rost u. ähnl.) oder des Ofens selbst u. z. beim Durchleiten durch die hohle Feuerbrücke, oder unter dem Ofenherd, oder in den Kanälen der Seitenwände, oder zwischen gitterförmig aufgestellten Steinen, welche von den abgehenden Feuergasen und in besonderen Kanälen dazwischen ron der Luft durchströmt werden. Letzteres ist bei den Vorrichtungen von Pons ard (D. P. J. Bd. 219, S. 125), Nehse (D. P. J. Bd. 220, S. 427 ) u. a. der Fall.

Fiv. 1708 und 1709 geben als Beispiel einen completten Gasofen mit Einzelnfeuerung (zur Terdampfung ron Laugen $u$, dgl.), wo die Verbrennungsluft in dem durch eiserne Platten gebildeten Raum $g$ erhitzt wird. $a$ ist der Gasgenerator, $d$ der mit dem Schieber $c$ versehene Fiilltrichter, dureh welchen die Braunkohle auf den Rost $b$ gelangt. Die Gase treten über die Fenerbrücke $e$ und mischen sich oberhalb derselben mit Luft, welche bei $f$ in den Gienerator eintritt und erhitzt bei $h$ austritt. Die Flamme rerbreitet sich gleichmässig ïber die gemanerte Pfamne 1, indem sie aus dem Brenner $l_{i}$ austritt. Behufs Entzündung der Gase bei Verwendung von feuchten Kohlen dient der kleine Yebenrost $h$. Die abziehenden Verbrennungsproducte münden durch den Kanal $o$ in den gut zichenden Schornstein $p$. Bei $n$ wird die concentrirte Lauge abgelassen, während des Ablassens werden die Fenergase durch die Neben. esse q abgeleitet. Dieser Gasofen functionirt im Alaunwerk bei Bonn (s. Alaun I pag. 67). 
Die höchsten Temperaturen erzielt man mit den Regeneratoren, wie sie C. W. u. F. Si emens eingeführt haben. Diese sind aus vielen engen Kanälen bestehende, aus feuerfesten Ziegeln hergestellte Kammern, welche abwechselnd von den Verbrennungsproducten (kurz ehe sie in den Schornstein entweichen) und von den zum Brenner strömenden Generatorgasen und der Luft durchzogen werden. In der ersten Periode werden also die Regeneratoren durch die Fenergase erwärmt, in der zweiten geben sie die aufgenommene Wärme an das Gas und die zur Gasverbrennung dienende Luft ab.

Für gewöhnlich sind die Regeneratoren paarweise gruppirt: die zwei Kammern eines Paares communiciren in ihrem oberen Theile fortwährend mit den

Fig. 1708.

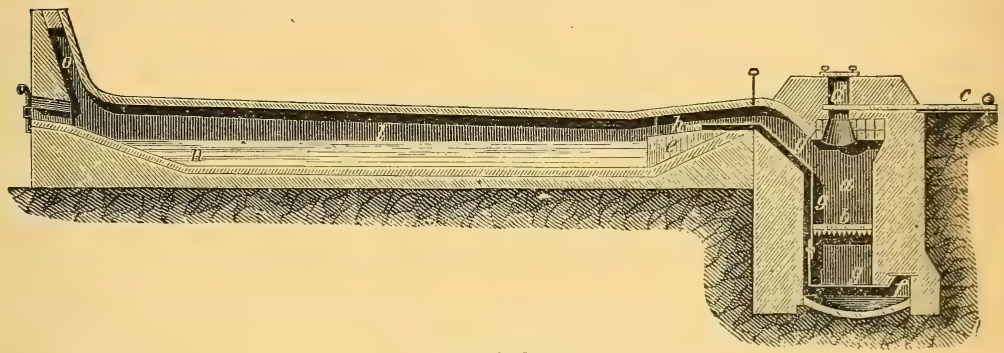

Verticalschnitt.

Fig. 1709.

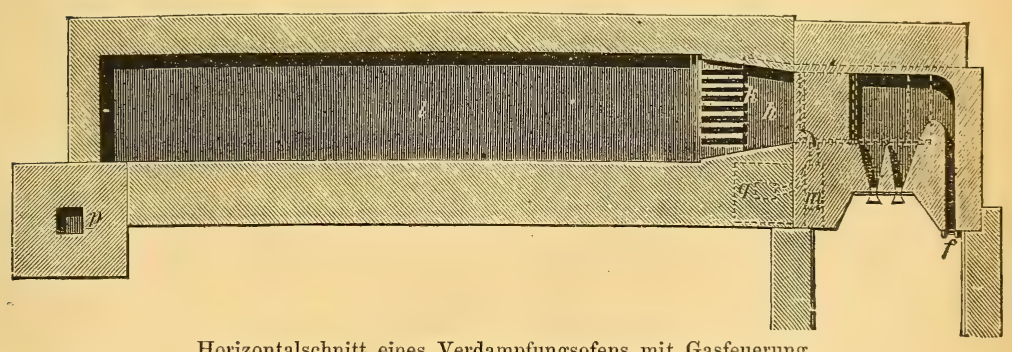

Horizontalschnitt eines Verdampfungsofens mit Gasfeuerung.

Oeffnungen in der Ofensohle oder Wand und nach unten mit dem Schornstein ; die zwei Kammern des zweiten Paares communiciren gleichfalls mit dem Ofen und zugleich die eine mit dem Generator, die andere mit der Atmosphäre. Mit Beziehung daranf sei bei jeder Gruppe die erstere die $\mathrm{G}$ a s $\mathrm{k}$ a $\mathrm{m} \mathrm{m} \mathrm{er}$, die zweite die $\mathrm{L} \mathrm{uft}$ a $\mathrm{m} \mathrm{m} \mathrm{er}$ genannt. Einen $\mathrm{Um}$ s te $11 \mathrm{ung} \mathrm{s}$ a p par at, durch welchen man die Communication eines Paares mit dem Schornstein herstellen, resp. unterbrechen und dafür die Verbindung mit dem Generator und der Atmosphäre herstellen kann, zeigt z. B. Fig. 1710. Zumeist hat man zwei solche, einen für die beiden Gaskammern und einen andern für die beiden Luftkammern. Die Saugwirkung des Schornsteines zwingt die Flamme, die im Ofen gewirkt hat, durch die zum ersten Paar fiihrenden Oeffnungen denselben zu verlassen und die in den Kammern angehäufte Ziegelmasse von oben nach unten zu durchströmen. Auf diesem Wege wird den Verbrennungsproducten allmälig 
ihre Wärme entzogen, während sich die Ziegel erhitzen. Inzwischen erhitzen sich in den Kammern des anderen Paares das eintretende Gas und die Luft durch die

Fig. 1710.

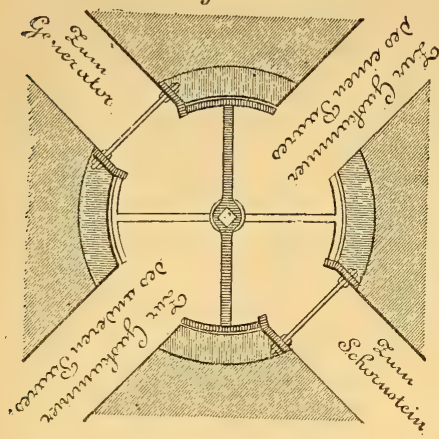

Berïlırung mit den Ziegeln, die kurz zuvor die Flamme umspülte, immer mehr und mehr. Natürlich kühlen sich die Ziegel in den vom Gas und der Luft durchströmten Kammern durch die Wärmeentziehung ab, allein unterdessen erhitzen sich die Ziegel des zweiten Paares und man hat nur dafür zu sorgen, dass zur rechten Zeit - etwa halbstündig - die Umschaltungsklappen umgeschaltet werden. Je häufiger die Umschaltung geschieht, um so geringer werden die Temperaturschwankungen im Ofen, allein um so höher ist auch die Temperatur der abziehenden Verbrennungsproducte im Schornstein.

Fig. 1711 und Fig. 1712 veranschaulichen einen Simens-Regenerativ-Schmelzgasofen (siehe Eisenerzeugung, Gussstahl, 3. Bd. S. 46). Die zur Verbrennung gelangenden Gase kommen von einem Generator durch $g_{1} g_{2}$ in der Richtung der Pfeile, gelangen in die Gaskammer $g_{3}$ und durch $k_{2}$ in den Ofen. Die Luft tritt durch $l_{1} l_{2}$ in die Luftkarmer $l_{3}$ und

Fig. 1711 .

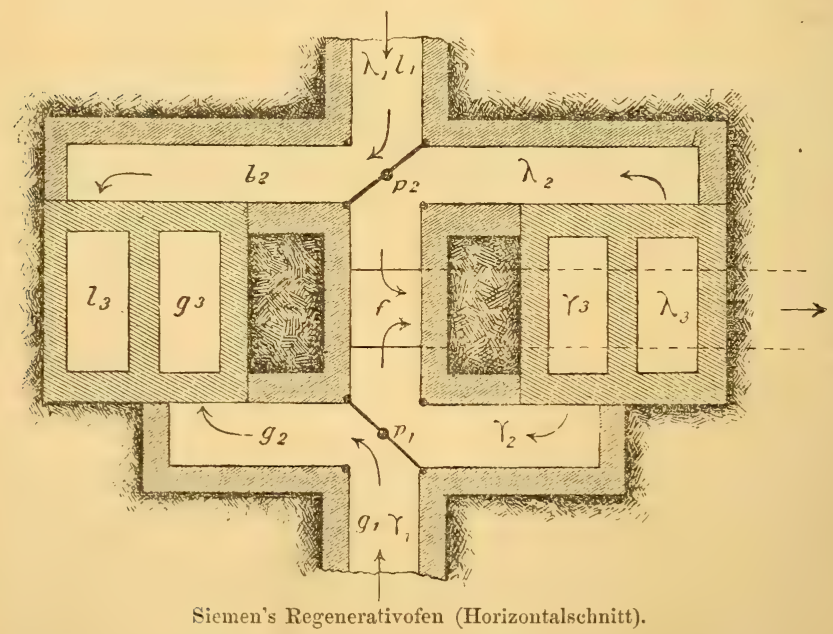

gelangt durch $k_{2}{ }^{\prime}$ in den Ofen. Die Mengung beider findet bei $o$ statt und es erfolgt die Verbrennung im Schmelzrame $a$. Die Verbrennungsproducte ziehen durch $k_{1} k_{1}{ }^{\prime}$ ab, und gehen durch $\gamma_{3} \gamma_{2}{ }_{1}$ und $\lambda_{3} \lambda_{2} \lambda_{1}$ zur Esse. Verstellt man die Klappen $p_{1}$ und $p_{2}$ um $90^{\circ}$, so gehen die Generatorgase durch $\gamma_{1} \gamma_{2} \gamma_{3}$ nach $h_{1}$, Luft durch $\lambda_{1} \lambda_{2} \lambda_{3}$ nach $l_{1}{ }^{\prime}$, in $\gamma_{3}$ ind $i_{3}$ findet Abgabe der Wärme an Gas resp. Luft statt, beide treten auf etwa $800^{\circ}$ erhitzt in den Ofen, die Verbren- 
nungstemperatur kann hiedurch auf 1500 bis $2000^{\circ} \mathrm{C}$. und mehr gebracht werden. Jie Verbrennungsproducte ziehen nun durch $k_{2} g_{3} g_{2} g_{t}$ und durch $k_{2} l_{3} l_{2} l_{t}$ ab und erhitzen wieder das Fachwerk der Kammer $g_{3}$ und $l_{3}$.

Was nun die Erfolge der Gasfeuerug anbelangt, so sind diese unbestritten vorerst da bedeutend, wo die Aufgabe gestellt ist, thunlichst hij chs te Ilitzegerade zu entwickeln. Die Regeneratoren ermöglichen die Erzielung sehr hoher Temperaturen, deren Gränze wohl in erster Linie nur durch die Widerstandsfähigkeit des Ofens normirt ist. Diese hohen Hitzegrade kann man mit IIilfe der Gasfeucrung selbst aus bloss geringwerthigem Brennmateriale - Torf, Braunkohle u. s. w. st ï ckreicher Beschaffenheit entwickeln.

Fig. 1712 .

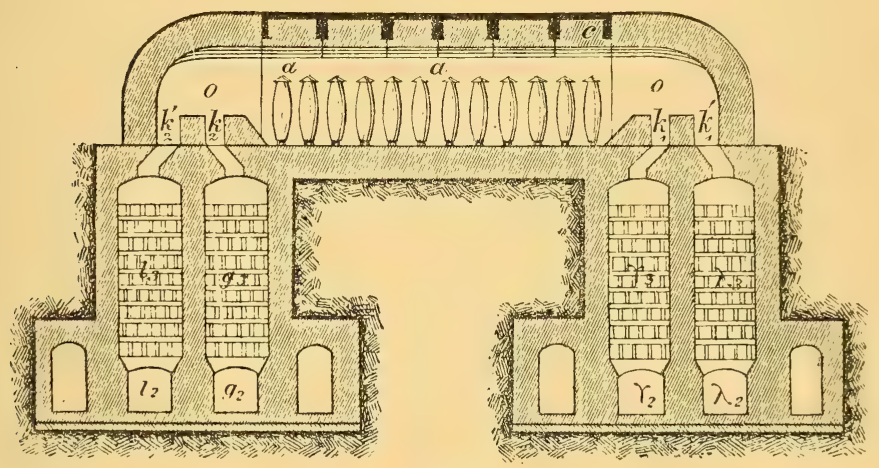

Siemen's Regenerativofen (Vertikalschnitt).

Nicht minder sind die Erfolge der Gasfeuerung dort fraglos, wo es gilt die Unreinigkeit des urspriinglichen Brennmateriales (Schwefel, Aschenbestandtheile u. dgl.) vom Arbeitsobject ferne zu halten, wie z. B. für keramische Zwecke. Fern zu halten dadurch, dass man eben aus dem unreinen natïrlichen Brennmateriale möglichst reines künstliches schuf. Auch ist es für gewisse Industriezwecke ein wesentlicher Vortheil der Gasfeuerung, dass sie vollständige Regelung der Flammc gestattet. Man kann die Länge derselben von $600-700^{\mathrm{mm}}$ bis $9^{\mathrm{m}}$ variiren.

Wo diese Bedingungen jedoch nicht zu erfïllen sind, hat bis jetzt die Gasfenerung dauernd sich nicht behaupten können, namentlich hat sie bisher wenig Anwendung gefunden zur Erzeugung mäs siger Temperaturen durch gutes Brennmateriale. Grund hiefuir ist, dass die Verbrennung guten Brennmateriales in unseren gewöhnlichen Feuerungsanlagen fast ebenso rationell bewirkt werden kamm, als mit Gasfeuerungen, während diese ungleich mehr Anlagekosten, Reparaturen und Intelligenz der Bedienung als jene verlangen. Desto mehr ist man bemiilit gewesen, das allergeringste Brennmateriale, also namentlich Kohlenlösche (Kohlengruss) u. Aehnl. durch Gasfenerungen zu verwerthen. Man hat hiebei die Erfahrung gemacht, dass der natüliche, durch einen Schornstein herstellbare Zug nicht ausreicht, um die Gase durch eine aus Lösche bestehende Kohlenschichte von solcher Mächtigkeit zu ziehen, wie sie zur Bildung von Kohlenoxydgas nothwendig, desshalb hat man den $\mathrm{Zug}$ auf künstliche Weise rerstärkt (Gebläse oder Pressungsgeneratoren). Der künstliche Zug macht Anlage und Betrieb thenerer, und droht mit Reparatursgefahr. 
Als Vortheil des künstlichen Zuges wird übrigens die Unabhängigkeit von Witterungsverhältnissen und in Folge dessen gleichmässigerer Betrieb hervorgehoben.

Wenn, wie im Vorstehenden enthalten, auch die Principien ziemlich unabänderlich feststehen, welche bei Errichtungen von Gasfeuerungen zu befolgen sind, so gibt es trotzdem zahlreiche Detailverschiedenheiten der Ausführung, welche theils durch die in jedem einzelnen Falle vorliegenden besonderen Verhältnissen geboten sind, theils nach den Anschauungen der einzelnen Constructeure variiren. So nennen wir beispielsweise die Anordnung von Benrath (für Holzgas, s. Ramdohr II), B i cheroux (mit gusseisernem Lufterwärmungs-Apparat am Generator selbst, S. D. P. J. Bd. 219 S. 220), B jörklund (mit besonderer Condensatorconstruction, s. Oest. Z. f. B. u. Httws. 1875, S. 77), Bö̈tius (s. Ramdohr II), G röbeL ï rmann (bringt die festen Brennstoffe vor deren Vergasung auf hohe Temperatur, s. Oest. Z. f. B. u. Httws. 1878 S. 125), Lebed off (s. D. P.J. Bd. 189 S. 378), Li e gel (bringt Schlacke zum Schmelzen und Selbstabfliessen, s. Ramdohr II., D. P. J. Bd. 223 S. 482 - A. Friedmann strebt das Gleiche an, s. D. P. J. Bd. 214 S. 355), Lundin (mit eigenthümlicher Condensator-Construction, angewendet für Gaserzengung aus Sägespänen, s. D. P. J. Bd. 183 S. 369, Ramdohr II S. 56, aus Torf, s. Oest. Z. f. B. u. Httws. 1877 S. 497), Möller u. Mendheim (s. Ramdohr II), Mïller u. Fichet (s. Rahmdor I), Nehse (s. D. P. J. Bd. 220 S. 427 , Ramdohr II S. 68 u. 123), Ponsard (s. D. P. J. Bd. 219 S. 125 , Ferrini S. 298 - in Anwendung für Dampfkessel s. D. P. J. Bd. 216 S. 199), H. Schäfer, Siemens (s. Fig. 1707, 1711 und 1712), Thum (s. D. P. J. Bd. 213 S. 121), Wils on, Wittenström (ordnet Regeneratoren uiber den Ofen an, s. Oest. Z.f. B. u. Httws. 1875 S. 75), R. Z i eb a rt u. $\mathrm{P}$ üts ch (s. deren " "verbesserte Gasfeuerung mit Regeneratoren ", Berlin 1865) u. a.m.

Oft werden die zu benützenden gasförmigen Brennmateriale nicht erst in besonderen Generatoren erzeugt, sondern sind entweder als Nebenproduct in gewissen metallurgischen Apparaten gewonnen (Gichtgase) oder kommen in der Natur vor. Die Gichtgase werden mittelst der G as änge (cloche à gaz gas bell), s. Eisenerzeugung Bd. III S. 7 und 16, abgefangen und an den Ort ihrer Verbrennung geleitet.

Betreffs der Benützung der von der Natur gebotenen Gase verweisen wir nur auf die in amerikanischen Eisenhiitten in neuester Zeit gemachten Fortschritte der directen Verwendung der mittelst Bohrröhren aus dem Innern der Erde abgeleiteten brenubaren Gase. Wir erwähnen als Beispiel, dass das Gas für den Betrieb der rotirenden Puddelöfen von Graff, Benett\& Co. in Pittsburg aus ca. $550^{\mathrm{m}}$ Teufe 20 engl. Meilen (ca. $32^{\mathrm{km}}$ ) Distanz geliefert wird und verweisen auf verschiedene diesbezügliche Mittheilungen (s. Oest. Z. f. B. u. Httws. 1875 S. 512, Z. d. öst. I. u. A. V. 1877 S. 79 u. s. w.)*) Vgl. a. Brennstoffe II p. 32.

Die Erfindung selbstständiger Gasfeuerungen ist deutschen und speciell österreichischen Technikern zuzuschreiben. Die Grundlage jedoch für die Idee der Construction selbstständiger Gasfeuerungen hat die Verwendung der Hochofengase für hüttenmännische Zwecke abgegeben, welche zuerst der Franzose Aubertot-1809 etwa - einführte, indem er Gichtflammen zum Schweiss- und Puddelprocess benützte. In Deutschland gingen die ersten diesbezïglichen Versuche 1837 von dem württembergischen Bergrath $\mathrm{F}$ abre du Faur in Wasseralfingen aus. Die Seitens der österreichischen Regierung nach Wasseralfingen abgesandten Hüttentechniker erkannten jedoch in der durch das System bedingten Abhängigkeit zweier so

*) In "Das Eisenhïttenwesen der vereinigten Staaten von Nordamerika" veurtheilt von P. Ritter v. Tunn'er heisst es S. 23: In Pittsburg traf ich zwei Eisenhütten, wo das in und nächst der Oelregion vorkommende, durch Bohrlöcher mit einer pro Quadratzoll 100 bis 120 Pfund betragenden Spannung zu Tage tretende brennbare Gas zum Betrieb von Puddlings- und Schweissöfen benützt wird. Die Verwendung dieses natürlichen Gases zu dem Endzwecke ist eine sehr einfache, sehr bequeme und würde auch eine sehr billige sein, wenn die Nachhaltigkeit des Gases aus dieser Quelle sich bewähren möchte. 
wichtigen Hüttenprocesse nicht unwesentliche Mängel und es erfolgten hierauf die Versuche mit selbstständigen Gasfeuerungen bei der k. k. Einsenhiitte zu Senbach in Tirol 1839 bis 1840. Wegen der nicht zu bewältigenden Explosionen sistirte man diese Versuche, fis sie 1842 auf dem k. k. Gusswerk zu St. Stephan in Steiermark wieder anfgenommen wurden und zwar mit besserem Erfolge. Sectionschef Carl v. Scheuchenstuhl hat um die Entwickelung der Gasfeuerung grosse Verdienste. Zu gleicher Zeit errangen Bis chof, welcher bereits 1839 den ersten Gasofen entworfen, sowie später Thoma, dann Schinz und besonders siemens wichtige Erfolge auf diesem Gebiete.

Literatur. Bischof, die indirecte, aber höchste Nutzung des rohen Brennmateriales, Quedlinburg 1856; F errin i R., Technologie der Wärme, deutsch v. Schröter Jena, Costenoble (S. 128, 175, 291); Neumann Fr., die Vergasung erdiger Braunkohle - Halle Knapp; R a m d o h r L., die Gasfeuerung I nach dem Französischen von Fichet (behandelt auch Gasfeuerungen für Dampfkessel); Ramdohr L., die Gasfeuerung II - Halle, Knapp; H. Stegmann die Bedeutung der Gasfeuerung und Gasöfen für das Brennen von Porzellan, Thonwaaren etc.; Reiche, Anlage und Betrieb der Dampfkessel, 2. Aufl. S. 85; Ste inm an n F., Compendium der Gasfeuerung, Freiberg, Engelhardt; Z errener Carl Dr., Einführung, Fortschritt und Jetztstand der metallurgischen Gasfeuerung im Kaiserthum Oesterreich, Wien, k. k. Staatsdruckerei 1856 (mit ausführlicher Literaturangabe über Gasfeuerung von 1841 bis 1855).

C. Ludwik. pag. 692 .

Gasgenerator (générateur de gaz - gas generator), s. Gasfeuterung

Gasheizung, s. H e i z ung.

Gaskalk (chaux gazière - gas lime), das aus den Reinigungsapparaten der Leuchtgasfabriken, welche Aetzkalk zur Gasreinigung verwenden, fallende Nebenproduct, enthält neben Kalkhydrat, Schwefelcalcium, Calciumsulfhydrat, Schwefelcyancalcium, Cyancalcium, kohlens. Kalk, unterschwefligs. Kalk, schwefligsauren Kalk, schwefelsauren Kalk, Ammoniak, Theerproducte ete. Wird vielfach verwerthet entweder an sich als Düngemittel, oder als Baumateriale (für Wegbauten), als Enthaarungsmittel für Felle (wobei der Gehalt an Calciumsulfhydrat und Schwefelcalcium wirkt), endlich als Rohmateriale für die Gewinnung von Schwefelcyanverbindungen und Cyanverbindungen (Berlinerblau), sowie von unterschwefligsauren Salzen, vgl. Le uchtstoffe bei Leuchtgas. Gtl.

Gaskohle nennt man einerseits solche Sorten fossiler Kohlen, welche besonders reiche Gasausbeuten liefern, andererseits bezeichnet man mit diesem Namen auch die in den Gasretorten sich ansetzende, äusserst dichte (spec. Gew. 2.356) und harte Kohle (Retortenkohle, Retortengraphit), welche namentlich zur Herstellung der Kohlenelemente für galvanische Batterien, vom Kohlenspitzen fuir electrische Lampen sich besonders eignet, aber auch fuir die Herstellung von Schmelztiegeln dienen kann, vgl. Kohlenstoff. Gtl.

Gaskoks, s. Koks, s. Brennst offe II pag. 29.

Gaskrug, Apparat zur Bereitung von mit Kohlensäuregas gesättigtem Wasser (Sodawasser), s. W a s s er.

Gasmaschinen oder Gaskraftmaschinen (moteur à gaz-gas poùer engine). Eine der baroksten Ideen, welche auf dem Gebiete des Maschinenwesens zur Durchführung gelangten, ist wohl die, explosive Gasgemenge als motorische Substanz, beziehungsweise als treibende Kraft zu verwenden.

Das Verdienst, diese Idee gefasst und sofort in gelungener Weise realisirt zu haben, gebiihrt Herrn Lenoir in Paris, uber dessen Erfindung in den technischen Journalen vom Jahre 1860 zuerst referirt wird, nachdem die von Herrn 
Chr. Reithmann in München und von Herrn C. Hugon in Paris erhobenen Prioritätsanspriiche nicht aufrecht erhalten wurden.

Die erste ausgeführte Lenoir'sche Maschine hatte den Typus einer gewöhnlichen liegenden doppeltwirkenden Dampfmaschine. Der Cylinder war mit Wasserkiihlung versehen und hatte oben einen Doppelschieber, welcher an ein oder dem andern Cylinderende den Eintritt des Gemenges von 2 bis 8 Proc. Gas mit 98 bis 92 Volumprocenten atmosphärischer Luft vermittelte, und unten einen Doppelschieber, welcher an dem entgegengesetzten Ende den Austritt des verbrauchten Gases in die Atmosphäre ermöglichte. Die Entziindung des in gefahrloser Weise explodirenden Gemenges erfolgte mittelst eines Ruhmkorff-Apparates derart, dass die beiden freien Enden desjenigen Drahtes, welcher den inducirten Strom leitete, sich nach den beiden Cylinderenden gabelten, und. dort so nahe an einander gestellt waren, dass in dem Momente, als der inducirende Strom durch Vermittlung des hin, und hergehenden Kreuzkopfes unterbrochen wurde, an der Innenseite der beiden Cylinderenden ein Inductions-Funken auftrat, welcher auf derjenigen Seite, wo eben das explosible Gemenge vorhanden war, die Entzündung bewirkte.

Diese Maschine war anch in der 2. Auflage von H. Boëtius "die Eriesson'sche calorische Maschine" 1861 beschrieben und wurde daselbst die französische Angabe von nur 1/g Kubm. Gasverbrauch per Pferd und Stunde als unmöglich bestritten.

Die Firma Lenoir setzte sich sofort mit dem renommirten Maschinenfabrikanten Hypolite Marinoni in Paris in Verbindung, welcher die Gasmaschine constructiv verbesserte und fabriksmässig erzeugte. Dic Marinoni'sche Maschine hat die beiden Schieber seitwärts liegend und ist so eingerichtet, dass die Mengung von Luft und Gas erst im Cylinder erfolgt, somit jede Explosionsgefahr ausgeschlossen ist.

Nach einer Mittheilung von Ingenieur Eyth im "Civilingenieur" 1861 versuchte der deutsche Maschinenfabrikant G. K $u$ h n die Marinoni'sche Maschine nachzubauen, erreichte aber keine guinstigen Resultate. Bei 7.1 Proc. Gasgehalt betrug die Leistung bei 100 Touren in der Minute 235 Fusspfund badisch $=35.25^{\mathrm{mk}}$ pro Secunde $=0.47$ Pferdestärken mit einem Gasverbrauch von 45 Kubikfuss $=1.215$ Kubikm. in 37 Minuten, also pro Stunde 1.97 Kubikm. und pro Pferd und Stunde 4.19 Kubikm., ja bei dem Mischungsverhältniss von 5.6 Proc. sogar $5.45 \mathrm{Kbm}$., also circa doppelt so viel, als nach den durch Professor C. H. S c h m idt in Stuttgart bekannt gewordenen ersten Versuchen des Herrn Tresca, Subdirector am conservatoire impérial des arts et métiers, abgeführt im März 1861, die französische Originalmaschine verbrauchte, bei welcher der durchschnittliche Verbrauch an Gas pro Stunde und Pferdestärke nur $2.74 \mathrm{Kbm}$. betrug.

Allein Herr Tresca setzte seine Beobachtungen an anderen derartigen Maschinen fort, und veröffentlichte im October 1861 einen ausführlichen interessanten Bericht im Bulletin de la Société d'Encouragement, welchen das polytechnische Journal B. 163 vollständig brachte.

Nach diesen Versuchen betrug der Gasverbrauch bei einer Leistung von 1.02 bis 1.85 Pferdestärken zwischen 2.7 bis $3.4 \mathrm{Kbm}$. pro Pferd und Stunde, und ergab sich insbesondere bei einer Jaschine mit 81 Touren 1.02 Pferdestärken und 2.878 Kbm. Gasverbrauch pro Pferd und Stunde, der Kiihl-Wasserverbrauch mit 800 Liter pro Pferd und Stunde, wobei dasselbe von 18 auf $40^{\circ} \mathrm{C}$. erwärmt wurle, also pro Stunde 17600 Calorien oder pro Secunde 4.89 Calorien, d. i. 27mal so viel wegfuihrte, als die der Nutzleistung äquivalente Wärmenenge beträgt. Ausserdem entwichen die Gase aus der Maschine mit $280^{\circ} \mathrm{C}$. Rechnet man beim giinstigsten, nicht zu schnellem Gang den Gasverbrauch nur mit 2.6 Kbm. pro Pferd und Stunde, so kommt man auf die Tresca'sche Angabe, dass ein Liter Gas 6 Calorien und eine Calorie $16.6^{\mathrm{mk}}$ Arbeit liefert.

Trotz dieser im Vergleich zu den Unterhaltungskosten einer kleinen Dampfmaschine, welche etwa pro Pferd und Stunde $5 \mathrm{~K}$. Kohle benöthiget, allerdings 
sehr ungünstigen Resultate, besitzt die Gasmaschine für den Gewerbetreibenden, der in seiner Werkstatt keine Dampfmaschine, wohl aber eine Gasmaschine aufstellen darf, einen grossen Werth, insbesondere dann, wenn er die Kraft nicht continuirlich benöthiget, sondern nur mit häufigen Unterbrechungen, denn sie consumirt während des Stillstandes keinerlei Betriebsinaterial, und kann fast mit derselben Bequemlichkeit in Gang gebracht werden, mit welcher man die Gasflammen anziindet. Die Maschine erfordert wenig Raum, die entweichenden Grase werden zum Heizen der Werkstatt und das erwärmte Külılwasser in der Haushaltung verwendet. Die Maschine kann auch gefahrlos dort zur Anwendung gelangen, wo in der Werkstatt feuergefährliche Materialien herumliegen, also eine calorische Maschine ausgeschlossen ist. Der einzige bedeutende Uebelstand ist, dass die Maschine einer sorgfältigen und reichhaltigen Schmierung bedarf, daher der hiemit beschäftigte Arbeiter in seiner sonstigen Arbeit sehr gestört ist.

Die seither noch mehrfach verbesserte Lenoir-Marinoni'sche Maschine wird bis heute fabriksmässig erzeugt, obwohl bei derselben der Gasverbrauch noch immer etwa doppelt so gross sein mag als bei der atmosphärischen Gaskraftmaschine System Langen und Otto, wo er nur $3 / 4$ bis $1 \mathrm{Kbm}$. pro Pferd und Stunde beträgt, und man zieht mit Recht die Lenoir-Marinoni'sche der LangenÓtto'schen Maschine in allen den Fällen vor, wo nicht die geringere Höhe der Betriebskosten, sondern der ruhige Gang für die Wahl des Systems entscheidend ist. Wo man sich aber eine Maschine gefallen lassen darf, welche einen Lärm wie etwa eine kräftig auspuffende Locomotive macht, da ist die der Wesenheit nach von dem deutschen Ingenieur N. A. Otto construirte „atmosphärische Gaskraftmaschine" am Platz.

Dieselbe, schon in der ersten Ausführung geistreich durchgeführt, gehört in ihrer jetzigen Form zu den vorziiglichst durchdachten Constructionen, welche der Maschinenbau aufzuweisen hat.

Die ersten Mittheilungen über diese Maschine finden sich im Journal für Gasbeleuchtung 1867 und hiernach in den anderen technischen Journalen. Eine vorzuigliche Beschreibung mit guten Zeichnungen derselben hat Prof. R e u le a u $\mathrm{x}$ in den Verhandlungen des Vereins für Gewerbfleiss in Preussen 1868 geliefert. In diesem Aufsatz wird die Idee, die Gasmaschine mit einer Wasser-Einspritzpumpe zu versehen, um einen Theil der Gaswärme zur Dampfbildung zu verwenden, Herrn Hugon zugeschrieben, während sie in Wieck's illustr. Gewerbezeitung 1861 (Polyt. Centralblatt 1861) schon als von Lenoir beabsichtiget angefiihrt wird. Desgleichen führt Reuleaux Herrn $\mathrm{H}$ u gon als Erfinder der Gasflammenentziindung an, welche jedoch erst bei der Otto und Langen'schen Maschine zur allgemeinen Anwendung gelangte.

Diese ist nicht horizontal liegend und mit Kurbelbewegung versehen wie die Lenoir'sche, sondern besitzt einen hohen verticalen, oben offenen Cylinder, der nur in seinem unteren Drittel mit Wasserkühlung versehen ist und nicht einmal steter Erneuerung des Kühlwassers bedarf, sondern mit der in passender Teise erzielten Wassercirculation ausreicht. Dieser wichtige Umstand wird dadurch erreicht, dass die nach eingetretener Explosion momentan entstandene hohe Spannung des sehr heissen Gases in möglichst vollständiger Weise ausgenützt werden kann, indem der schwere Kolben sammt der daran befindlichen verticalen langen also schweren Kolbenstange durch den starken Gasdruck, ohne hiebei in Terbindung mit der Arbeitswelle zu sein, also ohne Widerstand, mit grosser Beschleunigung in die Höhe geschleudert wird, und hiebei vermöge der erlangten lebendigen Kraft und zufolge des nach oben nicht begrenzten Hubes sich sehr bedeutend über jene Höhe erhebt, bei welcher diese Masse von dem darunter befindlichen Gase im Ruhezustande getragen werden könnte, derart, dass die Endspannung der Verbrennungsgase bei der höchsten Kolbenstellung sogar wesentlich geringer ist als die atmosphärische Spannung, was nur dadurch möglich wird, dass die expandirenden Gase Wärme an die durch Wasser und Luft beständig 
gekühlten Cylinderwandungen abgeben, wobei auch die bei der Verbrennung entstandenen Wasserdämpfe theilweise condensiren.

Bei Beginn des Kolbenniederganges ist daher nicht nur das bedeutende Gewicht des Kolbens sammt Zugehör wirksam, sondern überdies der Ueberdruck der atmosphärischen Luft über die Spannung der Gase im Cylinder, worauf der Name „atmosphärische Gaskraftmaschine“ basirt. Nur der Kolbenniedergang ist wirksam, indem hiebei die Zahnstange des Kolbens in ein auf der Welle loses Stirnrad eingreift, welches innen mit einem ganz eigenthümlich und sinnreich construirten Schaltwerk derart ver-

Fig. 1713.

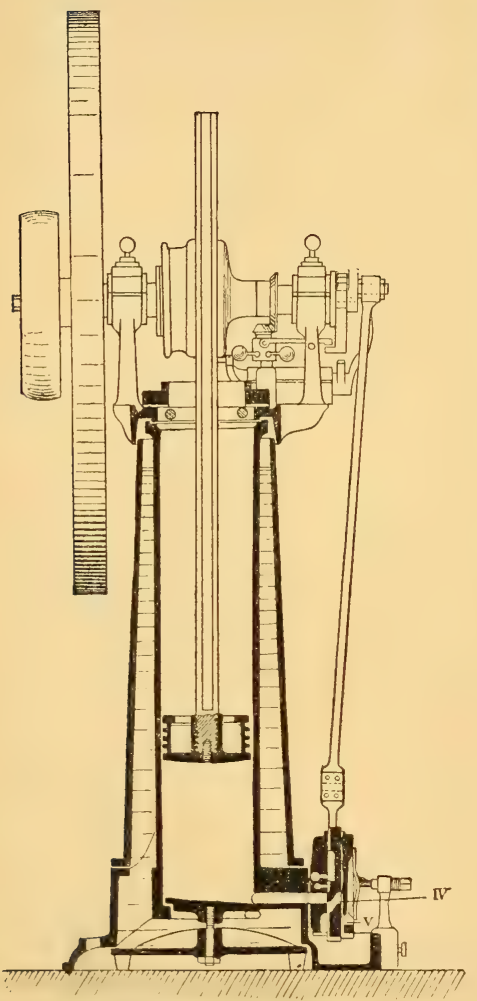

Atmosphärische Gaskraftmaschine. sehen ist, dass bei dem langsamen Kolbenniedergang der Zahndruck treibend auf die Arbeitswelle wirkt, während bei dem raschen Kolbenaufgang sich das Stirnrad entgegengesetzt der ziemlich gleichmässig fort rotirenden Schwungradwelle bewegt.

Die Abbildung dieses Schaltwerks findet man sowohl in der Reuleaux'schen Beschreibung der älteren Maschine, welche zur Bethätigung des Schiebers eine Vorgelegwelle hatte, wie auch in den Beschreibungen der neueren atmosphärischen Maschine ohne Vorgelegwelle und mit verbesserter Regulatoreinrichtung, welche $\mathrm{Be}$ schreibung in Alfred Musil "die Motoren für Kleingewerbe", Klagenfurt 1875, und in $\mathrm{M}$ iillerMelchior's vortrefflichem Bericht über die Weltausstellung in Phila. delphia 1876 im polyt. Journal, Band 223, Heft 6, Seite 557 zu finden ist.

In letzterer Quelle sind auch alle anderen ingeniösen Details der neueren Maschine, welche ohne Detail des Schiebers auch in Riedler's schätzbaren „Excursions-Bericht", Blatt 14, enthalten ist, deutlich beschrieben, und beschränken wir uns bei dem Umstande, als die atmosphärische Gaskraftmaschine seit Juli 1877 nur mehr auf $1 / 2$ und 1 Pferdekraft gebaut wird, während die grösseren Maschinen von 2 bis 8 Pferdestärken bereits nach dem neuesten System: „Otto's neuer Motor" ausgeführt werden, daranf, die ne uere atmosphärische Gaskraftmaschine Fig. 1713 nur mit einigen Schlagworten zu charakterisiren.

Da die Schwungradwelle mit dem Stirnrad seitwärts von der Mittellinie der Kolbenzahnstange liegt, so erhält natiirlich die Excenterstange und der Schieberkasten in der zweiten hier nicht dargestellten Projection eine schräge Stellung. 
Der Schieberspiegel ist in Figur 1714 dargestellt.

Der Schieber, Fig. 1715 enthält drei Muscheln. Bei Mittelstellung des Schiebers nimmt die mittlere Muschel II die durch eine Oeffinung zutretende Luft auf. Die rechts gelegene Muschel I ermöglicht den Austritt der gegen Ende des Kolbenniederganges comprimirten Gase durch ein Ruckschlagventil Fig. 1714, welches bei der darauf folgenden Periode des Kolbenaufganges und Ansaugens des Gasgemenges sich selbstthätig schliesst. Die links gelegene Muschel III füllt sich bei der Schiebermittelstellung mit der Gasmenge für den nächsten Hub. Der Schieber geht nach abwärts, das in III beflndliche Gas gelangt durch mehrere feine Löcher im Schieberspiegel in den mit Luft erfüllten Raum II, mengt sich mit derselben dort sehr vollkommen und tritt während der durch einen Hebelmechanismus erfolgenden langsamen Erhebung der Kolbenstange und während der Schieber aus der tiefsten in die Mittellage zurickgeht, in den Cylinder ein.

Eine tiefer liegende Durchbrechung IV des Schiebers ist beständig von dem Schieberkastendeckel bedeckt, ausser in einer

Fig. 1714.

Stellung oberhalb der tiefsten Schieberstellung, wo sie zusammtrifft mit einer Oeffnung im Deckel, vor welcher beständig eine kleine Gasflamme brennt. In der tiefsten Stellung des Schiebers wird der Raum IV mit Gas und Luft gefüllt. Bei Hebung des Schiebers ist er ringsum abgeschlossen, gelangt dann zu dem Fenster im Deckel V Fig. 1713, wodurch sich das abgeschlossene Gemenge entzündet, brennend sofort wieder abgeschlossen wird, und bei der höchsten Stellung des Schiebers zu dem Kanal gelangt, der mit dem Cylinder communicirt, und friher in Verbindung mit II war.

Hiedurch erfolgt etwa nach ein Fünftheil des Kolbenweges die Explosion, die Spannung der Gase steigt plötzlich auf circa 4 Atmosphären Leberdruck und der Kolben, welcher während der Füllungsperiode durch den Druck eines Hebels auf eine mit dem Hebel nicht verbundene Druckstange langsam gehoben wurde, wird nach der Explosion rasch hinauf geschleudert, und beginnt hierauf seinen wirksamen Niedergang. Auffallend ist die Erscheinung, sagt Reuleaux, dass die bedeutend unter dem atmosphärischen Druck liegende Spannung der Gase beim Niedergang des Kolbens so gleichförmig bleibt, ja sogar in der Regel noch sinkt, während und obgleich der Kolben die Verbrennungsgase zusammendriickt.

Man hat wohl eine rasche Ableitung der Wärme durch die gekühlten Cylinderwände und Condensation der Wasserdämpfe als Ursache dieser Erscheinung anzunehmen.

Im Durchschnitt betrug das Vacuum in der ersten Hälfte des Kolbenniederganges $3 / 4$ Atmosphären, so dass also eine absolute Spannung von $1 / 4$ Atmosphäre als Gegendruck blieb. Die Hublänge schwankte bei der $1 / \ldots$ pferdigen Maschine der Pariser Weltausstellung 1867 (älterer Construction) zwischen 0.88 und 0.95 Meter, je nach der etwas variablen Maximalspannung der Gase. Bei der älteren Maschine wurde jedesmal ein neuer Kolbenflug eingeleitet, sobald der Kolben an dem Boden des Cylinders ankam; die Regulirung der Anzahl Kolbenhube per Minute konnte also nur dadurch erfolgen, dass der Regulator auf das Riickschlagventil wirkte und die Ausflussöffinung der Explosionsproducte regulirte, beziehungsweise einen Verengungswiderstand einschaltete. Bei der neueren Maschine ist jedoch der Gasaustritt immer ganz ungehindert und der Kolben bleibt in seiner 
tiefsten Lage ruhig stehen, während die Schwungradwelle fortläuft, bis sich deren Geschwindigkeit so weit ermässigt, dass durch das Sinken der Regulatorkugeln auf eine Sperrklinke gewirkt wird, welche in ein auf der Welle befindliches Sperrad eingreift, wodurch erst diejenige Kurbel bethätiget wird, von welcher statt der sonst üblichen Excenter der Schieber bewegt und der Kolben behufs des Ansaugens angehoben wird. Daher wird der Schieber nur während der Beschleunigungsperiode der Welle bei Beginn des Kolbenniederganges von der Schieberkurbel mitgenommen und in die Mittelstellung gebracht, bleibt bei der ferneren Beschleunigung und darauf folgenden Verzögerung bei ausgelöster Sperrklinke unverändert in der Mittellage und wird erst, lange nachdem der Kolben schon unten angekommen ist, in Folge der unter das Normale sinkenden Geschwindigkeit des Schwungkugelregulators und des dadurch bewirkten Einklinkens des Sperrades weiter abwärts in die tiefste Lage geschoben und wieder aufwärts bis in die Mittellage zurück bewegt, während gleichzeitig der Kolben angehoben wird. Dieser sinnreichen Einrichtung verdankt man es, dass die Maschine je nach dem kleineren oder grösscren Widerstand an der Schwungradwelle nur 2 oder aber bis 30 Kolbenflüge pro Minute macht, während in beiden Fällen die Schwungradwelle eine gleiche in nur mässigen Grenzen schwankende Geschwindigkeit besitzt, und dass daher der Verbrauch an motorischer Substanz fast genau dem Widerstande bei unveränderter Geschwindigkeit proportional ist, ohne dass sich der Maschinenwärtcr darum zu kümmern braucht, eine Eigenschaft, die in so weiter Grenzen bei gar keiner anderen Kraftmaschine erzielt werden kann. In Folge dessen und wegen des ungehinderten Gasaustrittes beim Kolbenniedergang ist auch der Gasverbrauch weit geringer als bei der Lenoir-Marinoni'schen Maschine und beträgt nur $3 / 4 \mathrm{Kbm}$. pro Pferdestärke und Stunde. Die Betriebskosten stellen sich daher bei den gewöhulichen Preisverhältnissen des Gases und der Koks bei dieser Gasmaschine nur wenig oder gar nicht liöher als bei einer calorischen Maschine, abgesehen daron, dass letztere auch noch einen Heizerlohn erfordert, der bei ersterer wegfällt, und dass sich der Gasverbrauch immer der höchst verschiedenen Arbeitsleistung anpasst.

So ausserordentlich sinmreich auch diese atmosphärische Gaskraftmaschine in allen ihren Details construirt ist, und obwobl die Gasmotorenfabrik zu Deutz bei Cöln im Vereine mit ihren Zweigfabriken in verschiedenen Ländern bis Ende 1876 schon 4500 Exemplare dieses Motors verkauft hat, so leidet die Maschine doch an mehreren bedeutenden Uebelständen.

Vor Allem ist das unangenehme Geräusch beim Betriebe so störend, dass deswegen allein die Aufstellıng in vielen Localitäten unzulässig ist. Dann lässt sie sich nur als rertical stehende Maschine ausfiihren und gibt in Folge der complicirten Construction leicht zu Störungen und Reparaturen Anlass.

Diese Uebelstände sind durch die , Otto's neuer Motor" benannte Construction rollständig beseitiget. Dieser neu patentirte Gasmotor mit horizontalem Cylinder arbeitet so wie der Lenoir'sche Motor ähnlich wie eine kleine Dampfmaschine mit Plenelstange, Kurbel und Schwungradwelle ganz geräuschlos und verbraucht bei voller Arbeitsleistung $1 \mathrm{Kbm}$. Gas pro Pferd und Stunde, wohl mehr als die atmosphärische Maschine, was jedoch durch die sonstigen Vorziige voll aufgewogen wird.

Diese Maschine ist in Dingler's polyt. Journ. Bd. 228 S. 201 unter dem Titel: „Otto's geräuschlose Gasmaschine

Der Cylinder ist auf der Schwungsradseite offen, auf der anderen Seite wird der Cylinderdeckel durch starke Spiralfedern nebst zwei kleinen Sicherheits-Stellschranben an den zwischen Cylinder und Deckel sich in horizontalem Sinne senkrecht auf die Crlinderachse bewegenden Schieber angedriickt. Die Maschine ist nur halb wirkend, indem auf zwei Schwungradumläufe nur eine Cylinderfuillung stattfindet. Bei dem ersten Hingang des Kolbens erfolgt das Ansaugen des Gasund Luftgemenges, beim ersten Riickgang die Compression dieses Gemenges, 
beim zweiten Hingang die Explosion und Expansion und beim zweiten Rïckgang die Gasausströmung. Deshalb wird der Schieber von einer Zwischenwelle angetrieben, die nur halb so viele Umdrehungen macht als die Schwungradwelle, der Zutritt des Gases wird ausserdem selbstthätig durch ein Ventil regulirt. Die Entzündung also Explosion des Gasgemenges im Cylinder wird wie bei der atmosphärischen Maschine durch eine Gasflamme veranlasst. Zur Kuihlung des Cylinders ist eine geringe Menge kalten Wasser erforderlich. Die Maschine ist im Vergleich mit calorischen oder anderen Gasmaschinen auffallend klein, was wohl dem Umstande zugeschrieben werden darf, dass sie mit 170 Touren per Minute, also so wie eine sehr schnell gehende Locomobile arbeitet. Sie wurde bisher bis zu 8 Pferdestärken ausgeführt. folgende:

Die Dimensionen und Preise von Otto's geräuschloser Gasmaschine sind

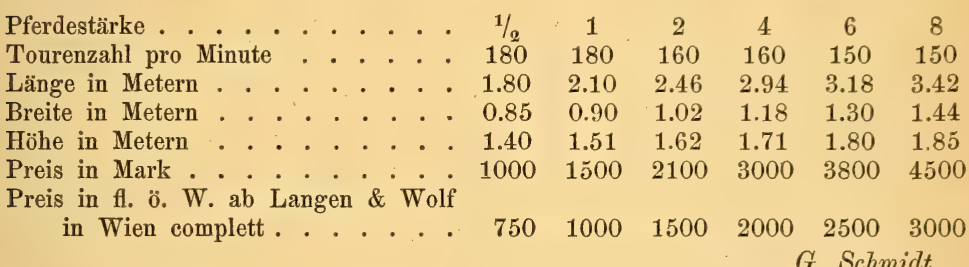

Gasmesser (compteur au gaz - gas counteur), Gaszähler, s. Gasuhren und Leuchtst offe.

Gasmuffelofen (fourneau d'émailleur à gas). P errot hat einen Gasmuffelofen construirt, welcher namentlich zur Emailirung von Schmuckgegenständen

Fig. 1716.

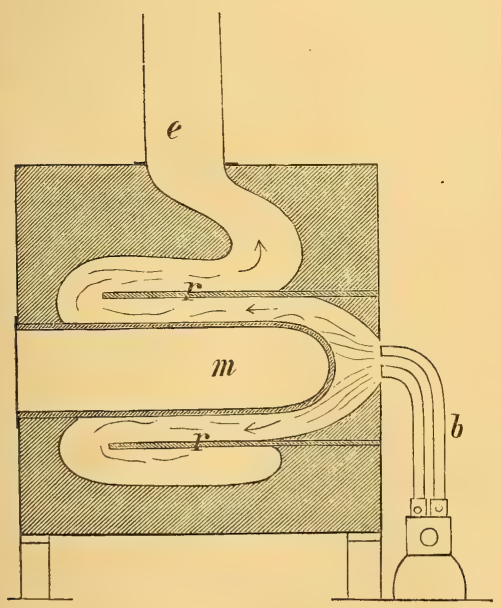

in Verwendung steht. Der ganze Ofen ist eine viereckige, auf kurzen Füssen stehende eiserne Kiste von $33^{\mathrm{cm}}$ Höhe und Tiefe und $44^{\mathrm{cm}}$ Breite. An der Rückwand ist eine Oeffnung, zu welcher die Mündungen der 6 Gasrohre des Brenners gebracht werden. Durch einen gemeinschaftlichen Schieber kann die Lufteinströmung in sämmtlichen Gasrohren des Brenners regulirt werden, der Gaszufluss hingegen durch Stellung eines Hahnes am Gaszuleitungsrohre. Die Muffel, deren Oeffnung auf der Vorderseite durch eiserne Thürchen verschlossen werden kann, steht von der Rückwand um ca. $6^{\mathrm{em}}$ ab. Sämmtliche Ofenwände sind mit einer Fuitterung von feuerfestem Materiale bekleidet und uiber die Muffe ist von der Rïckwand gegen vor gehend ein Rohr aus feuerfester Masse gesteckt, welches zwischen sich und der Muffel einen ringförmigen Raum von ca.

$14^{\mathrm{mm}}$ lichter Weite frei lässt. Durch diesen Raum streicht das Gas ron rückwärts gegen vor, und kehrt dann zwischen dem Rohr und der Fütterung der 
Ofenwand zurück, um endlich in das Rauchrohr zu gelangen, wie dies die vorstehende Skizze versinnlicht.

Beim Gebrauche dieser Oefen hat man darauf bedacht zu sein, dass die Erwärmung des Ofens eine langsame ist, auch muss vermieden werden Gas in den Ofen strömen zu lassen, bevor dasselbe entzündet ist, da sonst eine Explosion eintreten kann. $K k$.

\section{Gasofen, s. Heizung, s. Gasschmelzofen, s. Gasmuffelofen.}

Gasöl, ein als Schmieröl verwendbares Destillationsproduct der Braunkohle.

Gasolen, Handelsname der flüchtigen Destillationsproducte des Petroleums, s. Steinöl, s. a. Ga s o line.

Gasoline, in Amerika gebräuchliche Bezeichnung für den bei $77^{0}$ C. destillirenden Antheil der leichtflüchtigen Destillationsproducte des Rohpetroleums vom spec. Gew. $0.61-0.63$, s. Ste inö 1 .

Gasometer (reservoir à air — gas holder), Gasbehälter. Mit dem Namen Gasometer (d. i. Gasmesser) bezeichnet man im Deutschen unrichtiger Weise jene Vorrichtungen, die zur Aufsammlung und Aufbewahrung von Gasen verwendet werden und also streng genommen als Gasbehälter zu bezeichnen sind. Man unterscheidet zwei verschiedene Arten von Gasometern und zwar sogenannte Glockengasometer und Gefässgasometer. Beiden liegt das Princip zu Grunde, dass ein in einem Raume eingeschlossenes Gas, wenn auf dasselbe ein Druck ausgeübt wird, der grösser ist als der Druck in einem zweiten durch eine Röhrenverbindung mit dem ersten communicirenden Raume, in diesen überströmt, so lange bis Druckgleichheit in beiden Räumen herrscht.

Die Gefässgasometer, wie sie zuerst von Pepys angegeben wurden und in gleicher oder wenig abweichender Form noch gegenwärtig allgemein in Verwendung stehen, bestehen aus einen grösseren $30-40^{\mathrm{cm}}$ hohen und $15-20^{\mathrm{cm}}$ weiten Cylinder aus Kupfer- oder Zinkblech (das mitunter auch angewendete Eisenblech ist nicht empfehlenswerth), der allseitig geschlossen, in der Nähe seines Bodens eine kurze, etwas nach Aufwärts stehende, mit Stöpsel oder Verschraubung verschliessbare, etwa $3^{\mathrm{cm}}$ weite Abflussröhre, und nahe am obersten Rande eine für die Ausströmung des Gases bestimmte Hahnröhre mit enger Bohrung trägt und den eigentlichen Gasrecipienten bildet. Ueber demselben steht ein oben offenes Gefäss, gewöhnlich von gleichem Durchmesser, aber nur etwa $1 / 3$ der Höhe des unteren Cylinders, auf dessen etwas gewölbtem Deckel es mittels 3 bis 4 Tragsäulchen aufgesetzt und befestigt ist. Dieses zur Aufnahme des Wassers oder der geeigneten Druckflitssigkeit bestimmte Gefäss communicirt durch zwei mit Hähnen verschliessbare Röhren mit dem unteren Cylinder und zwar durch eine in der Achse der beiden Gefässe stehende kurze Röhre, welche vom Boden des Ober-Grefässes ausgehend unmittelbar unter dem Deckel des unteren Cylinders miindet, und eine zweite, seitlich gestellte, welche von dem Boden des Obergefässes ausgehend, bis nahe an den Boden des unteren Cylinders führt. Ueberdies trägt bei Gasometern aus Metallblech der als Gasrecipient dienende Cylinder noch eine am Boden und nahe am Deckel eingekittete Glasröhre zur Beobachtung des jeweiligen Flüssigkeitsstandes im Gasometer. Häufig, namentlich zum Gebrauche in chemischen Laboratorien, stellt man dergleichen Gasometer zum Theil aus Glas her (Eckling'sche Gasometer), indem man sowohl den unteren Cylinder als auch das Obergefäss durch Gefässe aus Glas ersetzt, die mit gut aufgekitteten Messingfassungen armirt sind, und bringt bei solchen Gasometern die Gasausströmungsröbre meist nicht an dem unteren Glasgefässe selbst an, sondern an der kurzen Terbindungsröhre zwischen dem oberen und unteren Gefässe, die man dann zweckmässig mit einem Dreiweghahne rersieht, um die Anwendung zweier besonderer Hähne zu ersparen. Endlich stellt man nach demselben Principe einge- 
richtete Gasometer für die Zwecke der Aufbewahrung von Gasen, welche, wie z. B. Chlorgas, Metalle heftig angreifen, auch ganz aus Glas her, indem man eine grössere zweihalsige Glasflasche, die nahe am Boden eine Tubulatur trägt, einerseits mit einer in die eine Halsöffnung gut eingeschliffenen, bis auf den Boden der Flasche herabreichenden Trichterröhre mit Glashahn (mit entsprechend grossem Trichtergefäss) versieht, während in die zweite Halsöffnung eine kurze, rechtwinklig gebogene und gleichfalls mit Glashahn versehene Glasröhre eingeschliffen ist, die unmittelbar unter dem Halse der Flasche mündet. Um solche Gasometer zu beniitzen, füllt man sie zunächst mit Wasser oder einer geeigneten anderen Flüssigkeit (für Chlorgasometer z. B. gesättigten Chlorcalciumlösung), indem man die Flüssigkeit auf das obere Gefäss aufgibt, während die Tubulatur am Boden des unteren Gefässes und der Hahn der kurzen Communicationsröhre geschlossen, die Hähne der Röhre für die Gasausströmung aber sowie der Hahn der bis an den Boden des Untergefässes führenden Communicationsröhre (Druckröhre) aber geöffnet sind. Während die den Gasrecipienten erfüllende Luft aus der seitlichen Ausströmungsröhre entweicht, füllt sich derselbe allmälig vollkommen mit Flüssigkeit an. Ist derselbe völlig gefüllt, dann schliesst man die Hähne der Druckröhre sowohl als auch der Ausströmungsröhre und öffnet hierauf allmälig die Tubulatur nächst dem Boden des Gasrecipienten, aus welchem nun, wenn alle Hähne gut schliessen und der ganze Apparat vollkommen dicht ist, bei sonst geeignet schräger Stellung des Tubulus, weder Flüssigkeit aus dem Gefässe ausfliessen, noch Luft in dasselbe eindringen darf. Führt man nun durch die Tubulusöffnung ein Rohr in das Innerne des Gasrecipienten ein, durch welches das in den Gasometer zu füllende Gas unter genügendem Drucke ausströmt, so füllt sich, wenn gleichzeitig die Flüssigkeit neben dem eingeführten Gasleitungsrohre frei abfliessen kann, der Gasrecipient mit dem Gase allmälig an. Man setzt die Füllung so lange fort, bis eben nur mehr so viel Fluissigkeit im Gasrecipienten enthalten ist, dass die Tubulatur nächst dem Boden durch dieselbe abgesperrt erscheint, zieht sodann die Gasleitungsröhre heraus, und verschliesst die Tubulatur mit dem zugehörigen Stöpsel oder der Verschraubung. Man hat nun das Gas in dem Recipienten völlig abgeschlossen und kann dasselbe, wenn der Apparat völlig dicht ist, und das Gas selbst nicht etwa in Folge der Berührung mit der Flüssigkeit eine Veränderung erleidet, beliebig lange aufbewahren. Will man dasselbe in Verwendung ziehen, so füllt man zunächst das Obergefäss mit Wasser oder einer sonst geeigneten Flüssigkeit und kann nun entweder nach dem Oeffnen des Hahnes der Druckröhre das Gas unter dem Drucke der Flüssigkeitssäule aus der seitlich angebrachten Ausströmungsröhre austreten und mittels geeigneter Röhrenleitungen in den Raum eintreten lassen, den man mit dem Gase füllen will, oder man kann dasselbe in andere Gefässe dadurch überfüllen, dass man dieselben mit Wasser oder der geeigneten Flüssigkeit völlig gefüllt, mit ihrer Mündung nach abwärts gekehrt über die Oeffnung der kurzen Communicationsröhre am Boden des oberen Gefässes bringt, und während der Hahn der Druckröhre geöffnet ist, nun auch den Hahn der kurzen Verbindungsröhre öffnet, worauf das Gas aus dieser entweicht und in Blasen, durch die das Obergefäss füllende Flüssigkeit aufsteigend, in dem gewünschten Gefässe aufgefangen werden kann.

Anstatt auf den Gasrecipienten directe das Wassergefäss aufzusetzen, kanu man, wenn eine Wasserleitung mit genügendem Wasserdrucke zur Verfügung steht, auch einfach hermetisch geschlossene und mit einem Ablasshahne, ferner einer Gasableitungsröhre und einer für die Zuleitung von Wasser bestimmten Druckröhre versehene Reservoirs als Gasometer benützen, die man nur mit der Wasserleitung in Verbindung zu setzen braucht, um sie in gleicher Weise zu verwenden wie Gasometer von der oben beschriebenen Construction. Von solcher Art sind die in Laboratorien mitunter in Verwendung stehenden grösseren Gasometer für Sauerstoff oder Wasserstoff und die neuerer Zeit von R. Muencke (Dingl. pol. Journ. 218 pag. 40) beschriebenen verbesserten Gasometer haben wesentlich dieselbe Einrichtung. 
Was die sog. Glockengas ometer betrifft, so ist die Einrichtung dieser verhältnissmässig älteren Vorrichtungen eine ziemlich einfache. Eine oben geschlossene, nach unten zu offene Glocke aus Metall oder Glas taucht mit ihrer Mündung unter die Oberfläche der in einem weiteren Gefässe befindlichen Sperrfliissigkeit, über welche die Mündung eines in das weitere Gefäss eingesetzten und mittels einer Hahnröhre nach Aussen mündenden Gasleitungsrohres einige Millimeter hervorragt. Wird die Glocke aufgesetzt, so sinkt sie, während die in derselben abgeschlossene Luft durch die Hahnöffinung der Gasleitungsröhre entweicht, vermöge ihrer Schwere in die Flïssigkeit ein und erscheint endlich selbst völlig mit Wasser gefüllt. Lässt man nun durch die Gasleitungsröhre einen Gasstrom unter genügendem Drucke unter die Glocke eintreten, so füllt sich dieselbe indem sie sich zugleich dem eingetretenen Gasvolumen entsprechend aus der Flüssigkeit hebt, mit dem Gase an, welches nach Abschluss des Zuleitungshahnes durch die die Glockenmuindung absperrende Flüssigkeit abgeschlossen erscheint. Will man das Gas wieder austreten lassen, dann hat man nur nöthig, den Hahn der Gasleitungsröhre zu öftnen und sofort strömt das Gas unter dem durch das Gewicht der Glocke (das man durch aufgelegte Belastungsgewichte beliebig vermehren kann) bedingten Drucke aus. Häufig sind solche Gasometer, die man wie begreiflich auch mit 2 Röhren, d. i. einer besonderen Zuleitungs- und einer besonderen Ableitungsröhre versehen kann, mit einem das gleichmässige Niedersinken und Aufsteigen bewirkenden Führungsgestelle versehen. Solche Gasumeter die man wohl auch in kleineren Dimensionen ausgeführt in Laboratorien (meist als Luftgasometer verwendet) antrifft, werden gewöhnlich zur Gasaufsammlung im Growsen, z. B. in Leuchtgasfabriken verwendet. Ueber die Einrichtung solcher grosser Gasbehälter, s. Le u chts to ffe bei Leuchtgas.

Dass man jede der beschriebenen Arten von Gasometern auch als Gassauger (Aspirator) beniitzen und mit Hilfe derselben Gase aus einem zweiten Gefässe in den Gasrecipienten einsaugen kann, ist begreiflich, wenn man erwägt, bei den Gefässgasometern der Abfluss der denselben erfüllenden Flüssigkeit nur in dem Masse erfolgen kann, als Luft oder ein anderes Gas die Flüssigkeit ersetzend eindringt, und dass ebenso ein gewaltsames Aufziehen der Glocke eines Glockengasometers bei geöffnetem Hahn der Gasleitungsröhre, ein Einsaugen von Luft oder Gas in die Glocke, u. z. in dem Masse statthaben müsse, als die dieselbe fiillende Flüssigkeit herabsinkt. In der That verwendet man denn auch Gasometer fuir die Zwecke der Gasaspiration. Eine für solche Zwecke geeignete Construction hat der Reversions - G a s o meter von A rendt. Derselbe besteht aus zwei gleich grossen cylindrischen Blechgefässen, deren jedes gleich dem Recipienten eines Gefïssgasometers hermetisch geschlossen ist, und die in der Richtung ihrer Längsachsen in einem Abstande von $20-30^{\mathrm{cm}}$ übereinander gestellt und durch entsprechend angebrachte Tragsäulchen fix miteinander verbunden sind. Durch zwei Röhren, deren jede mit einem Hahne rersehen ist, communiciren die beiden Gefässe so mit einander, dass die eine Röhre vom Boden des oberen Gefässes ausgehend bis nahe zum Boden des unteren Gefässes führt, während von der Decke dieses, eine Röhre in das obere Gefäss, u. z. bis nahe an die Decke dessclben reicht. Ausserdem trägt jeder der Cylinder, u. z. der obere, nahe seinem Boden, der untere nahe seiner Decke, ein mit einem besonderen Hahne verschliessbares Gasausströmungsröhrchen, deren Mündungen zweckmässig in ein gemeinschaftliches Ausströmungsrohr vereinigt werden können, während andererseits an jedem der Cylinder, u. z. an dem oberen beim oberen Rande, an dem unteren, nächst dem unteren Rande, je ein mit einem Hahn rerschliessbares Rohr eingepasst ist, welche als Saugröhren dienen und zweckmässig gleichfalls in eine gemeinschaftliche Saugröhre miinden. Der ganze Apparat ist in einem geeigneten Gestelle so befestigt, dass er im Mittelpunkt des Abstandes der beiden Grefässe um eine auf die Längsachse senkrechte Linie gedreht werden kann, so dass man bequem bald das eine, bald das andere der Gefässe nach oben, beziehungsweise unten stellen kamn. Wird nun z. B. das obere Gefäss mit Wasser gefuillt, der 
Hahn der Saugröhre an demselben geöffnet, zugleich aber auch der Hahn der bis auf den Boden des unteren Gefässes führenden Communicationsröhre und endlich der Hahn des Gasausströmungsröhrchens an dem unteren Gefässe geöffnet, während alle übrigen Hähne geschlossen bleiben, so wird das Wasser aus dem Obergefässe in das untere abfliessen und in dem Masse als es abfliesst, in das Obergefäss Luft oder ein anderes Gas eingesaugt werden, während das das untere G'efäss erfüllende Gas entweicht. Ist das Wasser abgeflossen, so hat man lediglich die geöffneten Hähne zu schliessen, den Apparat zu wenden, so dass das mit Wasser gefiillte Gefäss nach Oben zu stehen kommt, und kann nun durch Oeffnen der drei anderen Hähne den Process der Aspiration einerseits und der Gasausleitung anderseits in gleicher Weise vor sich gehen lassen wie früher. Dass solchen Apparaten auch die Einrichtung gegeben werden kann, dass der bei jedesmaliger Wendung erforderliche Wechsel der Hahnstellung durch die Wendung selbst besorgt wird, ist keinem Zweifel unterworfen (vgl. a. Aspirator I pag. 219).

Gtl.

Gasopyrion, s. m. electrisches Feuerzeug, s. Feuerzeug III pag. 480.

Gasprüfer, s. Le uchtst offe bei Leuchtgas.

Gassengmaschine, s. Appretur I pag. 175.

Gasschmelzofen (fourneau de fusion à gaz - gas smelting-furnace). Es sind in neuerer Zeit mehrere Constructionen von Gasschmelzöfen in die Industrie eingeführt worden. Die bekannteste Construction ist die von Perrot*), welche sich namentlich für die Gold- und Silberschmelzung vorziiglich eignet und von Goldarbeitern, Goldschlägern u. dgl. mit vorzüglichem Erfolge angewendet wird. Zeichnung und Beschreibung dieses Ofens findet sich im Artikel Golds chlägerei. $K k$.

Gasuhren, Gasmesser (compteur au gaz - gas-meter) sind Apparate, mittels welcher das von einer Gasfabrik producirte und das an einen jeden Consumenten abgegebene Gasquantum nach Kubikmetern gemessen werden kann.

Die Gasuhren lassen sich zur Zeit in zwei Abtheilungen bringen, indem man trockene von nassen Gasuhren unterscheidet.

Im Nordamerika und England sind vorwiegend die trockenen, in Oesterreich, Deutschland und Frankreich die nassen Gasuhren in Gebrauch.

Die trockene Gasuhr ist eine Erfindung des Johann Maclam, dem darauf im Jahre 1820 ein Patent ertheilt wurde. Maclam's Construction fand wohl viele Verbesserer, z. B. Edge, Defries, Croll, Glover und Andere, aber alle rerfolgten dasselbe Princip, welches darin besteht, dass dass durchgehende Gas durch blasebalgartige Kammern, die sich abwechselnd füllen und entleeren, mittels eines durch die Bewegungen der Bälge getriebenen Zählwerks gemessen wird.

Die Kammern der alten Uhr waren aus Leder gebildet, das mit Fett, später mit Glycerin präparirt wurde.

Lange Zeit waren die trockenen Uhren ausser Gebranch gesetzt, weil die elastischen ledernen Wandungen leicht spröde und brïchig wurden und deren Scharniere leicht die nöthige Beweglichkeit verloren, wodurch dann durch Druckwiderstand oder Durchlassen ungemessenen Gases Verluste für die Gasfabrik entstanden.

In neuerer Zeit, seit 1867, traten Verbesserungen in der Herstellung trockener Uhren auf, die ihnen den Eingang in einige französische und deutsche Städte verschafften.

$\mathrm{Zu}$ diesen Verbesserungen gehört die Erfindung des Ingenieurs $\mathrm{Sch}$ ï $1 \mathrm{ke}$, die darin besteht, dass er ein Gewebe, das man statt des Leders zur Herstellung:

*) In Oesterreich zu beziehen durch Scheeier \& Wolff in Wien. 
der Bälge anwenden kann, durch Niederschlag gerbsauren Leimes gasdicht machte. Dieses Gewebe besitzt bei grosser Elasticität die nöthige Festigkeit, wird durch die lösenden Bestandtheile des Gases nicht klebrig und verliert nicht seine Dichtigkeit und Elasticität, wie dies bei den ledernen Bälgen der Fall war.

Die nebenstehende

Fig. 1717.

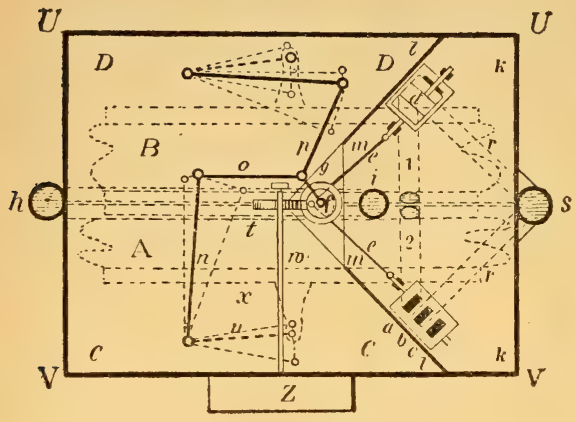

Glover's Gasuhr. Figur 1717 zeigt die Einrichtung der trockenen Gasuhr, wie sie von Glover construirt wurde.

Die Gasmenge wird in vier von einander getrennten Kammern $A$, $B, C$ und $D$, je eine äussere und eine innere, vertheilt. Durch die 3 Kanale $\quad a \quad b \quad c \quad$ wird immer von jedem der 4 gedachten Räume der eine gefuillt, der andere geleert. Die Bewegung der beiden Schieber. $d$ $d$ geschieht durch die rechtwinkelig auf einander stehenden Stangen $e e$, die mit einem kleinen Krummzapfen $f$ verbunden sind, auf dessen Welle noch die Kurbel $g$ aufgesteckt ist.

Das durch das Rohr $h$ kommende Gas tritt durch die Oeffnung $i$ in den abgeschlossenen Raum $k l m$ und durch einen der geöffneten Kanäle $a$ oder $c$ in das

Fig. 1718.

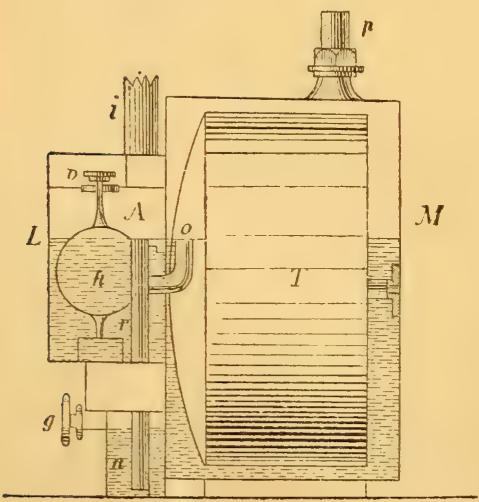

Innere eines der Bälge $A$ oder $B$ und zugleich in den entgegengesetzten Aussenraum $C$ oder $D$. Durch den Druck des Gases wird ein Druck gegen die Metallscheibe $x$ beim Füllen des Balges $A$ ausgeübt und dadurch die Scheibe nach auswärts gedrückt. Durch diese Bewegung wird der Winkelhebel $\quad n \quad n$ in Schwingung versetzt und diese Schwingungen mittels der Stangen $o$ und $p$ auf die Kurbel $g$ und den Krummzapfen $f$ übertragen, wodurch sich dann die Bewegung den Vertheilungsschiebern $d$ mittheilt.

Je nach der Stellung dieser Schieber strömt das Gas durch den Kanal $a$, in den bezüglichen Röhren 1 oder 2 fortgehend, in das Innere der Bälge $A$ und $B$ oder durch den Kanal $c$ direct abwärts in die Räume zwischen den beweglichen Scheiben $A$ und $B$ und den festen Wänden des Gasmessers $U U$ und $V V$. Das Abfliessen des Gases von da nach den Röhren $r r$ erfolgt mittels der mittleren Schieberöffnungen $b$. Der Abfluss des Gases zu den Brennern geschieht 
dann durch die Röhre $s$. Von der Krummzapfenwelle $f$ wird die Uebertragung der Bewegung durch das Schraubenrädchen $t$ und die Welle $w$ auf das Zählwerk in dem Gehäuse $z$ bewirkt.

Was die nassen Gasuhren betrifft, so unterscheidet man solche, bei welcher der Messapparat (wie bei der ersten, im Jahre 1815 von Clegg construirten Uhr und dem im Jahre 1861 von Hansen beschriebenen Gasmessapparat) aus abwechselnd vertical auf- und absteigenden Glocken besteht; und solche, deren Haupttheil aus einer mit Abtheilungen versehenen cylindrischen Blechtrommel besteht, die sich in einem grössern metallenen Gehäuse um eine horizontale Achse dreht (System der rotirenden Trommel). Die $\mathbf{n}$ as sen Gas uh ren mit Glocken sind weniger in Gebrauch, obwohl in neuester Zeit Friedr. Klingmüller eine solche Gasuhr construirt hat, deren Vertheilungsmechanismus sehr an den Figur 1717 dargestellten Apparat erinnert, und welche sehr gut functioniren soll.

Die nasse Gasuhr mit rotirender Trommel ist 1817 von Clegg erfunden und später von $\mathrm{Cros}$ ey sehr verbessert worden. In den Figuren 1718 bis 1720 wird eine solche nasse Gasuhr, welche häufig Anwendung findet, dargestellt.

In Fig. 1718 ist $T$ die Messtrommel; dieselbe bildet einen kurzen Cylinder, der an der rechten Seite offen und links eine ausgebauchte Endfläche hat. Bis

Fig. 1719.

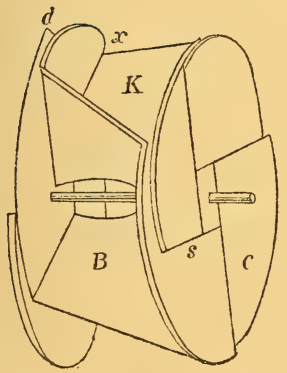

Fig. 1720 .

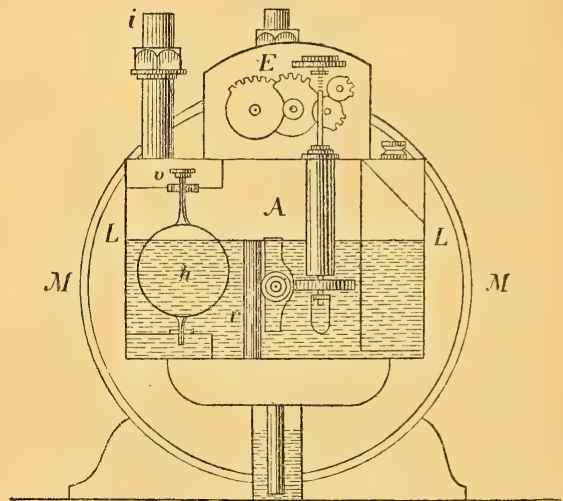

Gasuhr von Crosley.

zur Höhe $L$, also noch über die Hälfte taucht diese Trommel in Wasser oder eine andere Sperrflüssigkeit. Nach Hinwegnahme des Blechmantels $M$ sieht man, dass sich um eine im Centrum laufende Achse Figur 1709 der 4 fache Gang einer archimedischen Schraube aus Blech ohne Unterbrechung durch den Druck des durchströmenden Gases bewegt. Die verschiedenen Fliigelstiicke liegen nicht fest an einander, sondern lassen spaltförmige Zwischenräume übrig, wodurch das Gas ein und austreten kann. So tritt bei $s$ das Gas in die Kammer $K$ und unter $x$ wieder hinaus, ferner in $B$ durch $c$ ein und von da heraus durch den spalt $d$.

Das zu messende Gas tritt durch das Rohr $o$ in die Messtrommel und geht durch das Rohr $p$ ab Fig. 1718. Das kastenförmige Gehäuse $\boldsymbol{A}$ Fig. 1718 u. 1720 enthält die Sperrmechanismen und die Räder, die zur Bewegung des Zählwerks in $E$ dienen.

Das Gas wird durch das Rohr $i$ zugefuhrt und kann durch $r$ in $o$ kommen, wenn das Ventil $v$ genügend weit geöffnet ist. Da das Ventil durch den Schwimmer $h$ geöffnet wird, ist es für den Consumenten erforderlich, um Gas zu erhalten, dass stets so viel Wasser resp. Sperrflüssigkeit in dem Apparat sei, dass $v$ offen bleibe. $\mathrm{Zu}$ viel eingeschüttetes Wasser fliesst durch $r$ in das tiefer liegende Gefäss $n$, 
von wo es durch $g$ zu Zeiten abgelassen wird. Durch die Constanterhaltung der Flüssigkeitshöhe sind Producent und Consument vor Schaden gesichert. Bei zu niedrigem Wasserstand wiirde mehr und bei zu hohem Wasserstande weniger Gas durchgehen, als das Zählwerk anzeigt. Durch die sinnreiche Sperrvorrichtung ist der Consument gezwungen den Producenten vor Schaden zu schützen.

Die Trommel rotirt natürlich nur dann, wenn z. B. der Haupthahn einer Privatleitung geöffnet wird und der Brennerhahn geöffnet ist; sobald letzterer geschlossen ist, bleibt die Trommel der Uhr stehen.

Zur Controlle der Gasproduction hat jede Gasfabrik für sich einen Stationsgaszähler, der in jedem Momente die producirte Gasmenge angibt. Diese Gasuhr liegt zwischen dem Reiniger, aus dem das Gas fertig für den Consum herauskommt, und den Gasbehältern. Die Uhr ist ebenso eingerichtet wie die beschriebene Privatgasuhr. Sie soll so gross gemacht werden, dass die Trommel pro Stunde nicht mehr als 100 Umdrehungen mache, und man hat solche in Gebrauch, die in der Stunde $3000 \mathrm{Kbm}$. Gas durchlassen. Auf je $1000 \mathrm{Kbm}$. Maximalproduction in 24 Stunden soll die Fabriksgasuhr eine Capacität von je $50 \mathrm{Kbm}$. per. Stunde haben.

Die Sorge um die Constanterhaltung der Sperrflüssigkeitshöhe hat dem Consumenten nicht abgenommen werden können, so lange Wasser als Füllflüssigkeit verwendet wurde. Diesem Uebelstande kann man leicht abhelfen, wenn man statt Wasser reines säurefreies Glycerin nimmt. Dieses schiitzt die Uhren auch vor dem Einfrieren, wenn es anderweitig unmöglich ist, die Gasuhr vor Frost zu schützen.

Bei A ufstellung der Uhr ist zu beachten, dass man sie horizontal hinstelle, denn eine Neigung nach rückwärts hebt das Uförmige Rohr $r$ o höher über den Fliissigkeitsspiegel, erlaubt eine stärkere Wasserfüllung und schädigt den Consumenten, eine Neigung nach vorne schädigt den Fabrikanten. Vergl. a. Leuchtstoffe bei Leuchtgas.

Literatur: Dr. M. Riilılmann: Allgem. Maschinenlehre. R. v. Wagner: Handbuch der chemischen Technologie. J. Quaglio: Katechismus der Gasindustrie. Dingler: Polytechn. Journal. Band 218. Heft 1. Patentschriften.

G. Oldenburger.

Gaswasser, die bei der fabriksmässigen Erzeugung des Leuchtgases sich condensirende wässrige Fliissigkeit, welche wesentlich aus einer Lösung von kohlensaurem Ammoniak, Schwefelammonium, Syanammonium, Schwefelcyanammonium, flïchtigen oryan. Basen etc. in Wasser besteht und als Rohmateriale für die Gewinnung von Ammoniak und Ammoniaksalzen verwendet wird, vgl. Ammoniak I pag. 134, s. Leuchtstoffe bei Leuchtgas. Gtl.

Gatinois, Handelssorte des französischen Safrans (aus den Depm. Loiret, Pithivers und Orleans stammend), s. Safran.

Gatter, s. Sägen.

Gattiren (assortir - to mix), hiittenmännische Bezeichnung für das Mengen der Erze vor dem Ausschmelzen behufs Erzielung eines bestimmten Mittelgehaltes, bei welchem erfahrungsgemäss sich das Ausbringen des Metalls am günstigsten stellt, s. Blei, s. Eisenerzeugung, III pag. 11.

Gaufriren (gaufier, gaufrage - embossing), s. Moiriren, s. Blumen künstl. I, 654 .

Gault, s. m. blauer M ergel, Flammenmergel.

Gaultheriaöl (huile gaulthérique - wintergreen oil), Wintergrünöl, das ätherische Oel ron Gaultheria procumbens L. einer nordamerikanischen Ericinee, findet sich in den Blithen sowohl wie auch den ibbrigen Theilen der Pflanze, aus der es theils durch Destillation mit Wasser, theils durch Extraction mit Alkohol 
und Trennung durch fractionirte Destillation gewonnen wird. Es ist frisch farblos, an der Luft indess bald röthlich werdend, riecht angenehm aromatisch und schmeckt gewürzhaft, schwach süsslich. Es siedet zwischen 200 und $220^{\circ} \mathrm{C}$. und zeigt ein spec. Gew. $=1.17$. Es besteht wesentlich $(9 / 10)$ aus der Salicylsäureverbindung des Methyläthers, ist also Salicylsäure-Methyläther und enthält $1 / 10$ eines farblosen diunnfluissigen Camphens, das Gaultherilen, das bei $160^{\circ} \mathrm{C}$. siedet und nach Pfefferöl riecht (vgl. Cahours Ann. Chem. u. Phys. (3) 10 pag. 358). Es findet Verwendung zur Darstellung von Fruchtäthern und Parfumerien, in Amerika und England häufig auch als Geschmack verbessernder Zusatz. Gtl.

Gaultheriatinte, Name einer aus den ver. Staaten Nordamerikas eingefuihrten Tinte, welche, wie es scheint, eine Salicylsäure-Tinte ist.

Gautschen (coucher la feuille), s. Papier, s. Ka u ts chen.

Gayerde, Name einer in Ungarn vorkommenden, namentlich aus den Wohnungen der ärmeren Menschenclasse stammenden salpeterhältigen Erde, welche zur Gewinnung von Salpeter (Gaysalpeter) verwendet werden kann, s. K a li u m bei Salpeter. Gtl.

Gay Lussac Thurm, s. Schwefelsäure bei Schwefel.

Gaylüssit (Gay-Lussit - Natrocalcit) monoklines, in säulenförmigen, rauhen, einzeln in Thon eingewachsenen Krystallen vorkommendes Mineral. Unvollk. Spalth. Bruch muschlig, H. 2.5-3. Spec. Gew. $=1.90-1.99$, farblos durchsichtig oder weiss, Chem. Zus. $\mathrm{NaOCO}+\mathrm{CaOCO}^{2}+5 \mathrm{H}^{2} \mathrm{O}$. Ist langsam und nur theilweise in Wasser löslich, im Kolben verknistert er und schmilzt unter Abgabe. von Wasser, reagirt sodann alkalisch; schmilzt v. d. L. leicht zu einer trüben Perle und färbt die Flamme röthlichgelb. Fundorte Lagunilla bei Merida in NeuGranada, Salzsee bei Ragtawn in Nevada, N.-A.

$L b$.

Gaysalpeter, s. Salpeter bei Ka liu m, s. Gayerde.

Gaze, s. We ber ei.

Gebälk (empoutrerie - timberwork of a story), in constructiver Hinsicht die Gesammtheit aller zu einem Bautheil gehörigen Balken z. B. Dachgebälk, Deckengebälk. In architektonischer Hinsicht bezeichnet man bei den Säulenordnungen den von den Stützen (Säulen, Pfeiler) getragenen Theil, bestehend aus Architrav, Fries und Kranzgesims mit diesem Namen. Grohm.

Gebinde, Bind, Wiel, Wiedel, Fitze, Untertheil eines Strähns, s. Haspeln.

Gebläse (soufflets - blast-engine) gehören in die allgemeine Gruppe der $\mathrm{Luftbew}$ egungsmaschinen, welche bei der Ventilation von Bergbauen und anderen Räumen, ferner zur Erzeugung von comprimirter, als Transmissionsmittel dienender Luft (vergl. die Artikel "Bergbau", "Compressoren", "Ventilatoren") u. s w., dann insbesondere im Hütenwesen verwendet werden, um den Feuerungen die zur Verbrennung erforderliche Luft (den Wind) zuzuführen.

Die Gebläse der Hüttenwerke saugen atmosphärische Luft an und drïcken dieselbe in einen Röhrenstrang, die Windleitung. Zur Verbrennung einer gegebenen Menge Brennstoff in gegebener Zeit ist ein bestimmtes Luftquantum erforderlich; durch grosse Ausflussgeschwindigkeit desselben wird erfahrungsmässig der Effect der Verbrennung erhöht, daher man die Luft aus der Windleitung durch verengte Mündungen, D ï s en, in den Feuerraum treten lässt. Dieser Ausflussgeschwindigkeit entspricht aber eine die atmosphärische iibersteigende Spannung oder Pressung in der Windleitung, welche noch durch den Umstand erhöht wird, dass schon im Feuerraum die Spannung grösser ist als die äussere. Die Aufgabe eines Gebläses besteht daher in der Verdichtung einer gegebenen W in d- 
menge auf die erforderliche Pressung und in der Fortschiebung derselben in die Windleitung.

Die von einem Gebläse in bestimmter Zeit gelieferte Windmenge wird in der Regel dem Volum nach angegeben und letzteres auf $0^{\circ}$ Temperatur und den mittleren Meeresbarometerstand von 0.76 Meter Quecissilber reducirt gedacht. Sei $M_{0}$ die von 1 Düse pr. Minute gelieferte reducirte Windmenge, also das Volum, welches die in 1 Minute ausgeblasene Luftmenge bei $0^{0}$ Temperatur und $0.76 \mathrm{~m}$ Barometerstand einnehmen würde, so hat man $M_{0}=f M$, worin $M$ ein Nähe rungswerth und $f$ ein Correctionsfactor ist, welche Grössen die Werthe

$$
M=18740 d^{2} \vee \overline{h_{1}-h_{2}} \text {, und } f=1.127 \sqrt{\frac{b+h_{2}}{1+\alpha t_{1}}}
$$

besitzen. Das auf äussere Spannung und Temperatur reducirte Volum $M_{\mathrm{s}}$, d. h. das Volum, welches $M_{0}$ vor dem Eintritt in das Gebläse wirklich besass, ist

$$
M_{\mathrm{s}}=f_{1} M_{0}, \text { worin } f_{1}=0.76 \frac{1+\alpha t_{\mathrm{s}}}{b} .
$$

Bei Bessemergebläsen, wo die Spannung der Luft verhältnissmässig gross ist, sind die erhaltenen Werthe von $M_{0}$ und $M_{\mathrm{s}}$ noch zu multipliciren mit dem Factor

$$
f_{2}=1-0.03 \frac{h_{1}-h_{2}}{b+h_{0}} \text {. }
$$

In diesen Formeln ist $\varkappa$ der Ausdehnungscoëfficient der Luft $=0.003665$, die anderen Grössen haben folgende Bedeutung: $d$ der Düsendurchmesser; $h_{1} u . h_{2}$ die Quecksilber-Manometerhöhen, welche der Spannung der Luft in der Windleitung und ausserhalb der Düse, also im Feuerraum entsprechen (für die Manometerhöhe selbst wird kurzweg auch der Ausdruck ,Spannung" oder "Pressung" gebraucht); $b$ der Quecksilber-Barometerstand; $t_{1}$ und $t_{s}$ die Temperaturen der Luft in der Windleitung und der angesaugten Luft in Graden C.; bei Gebläsen mit Lufterhitzungsapparat ist $t_{1}$ die Temperatur, welche die erhitzte Luft in der Nähe der Düse besitzt. Die Längendimensionen sind dabei in Metern verstanden. Die angegebenen Werthe sind bei einem bestehenden Gebläse durch Beobachtung zu ermitteln. Die Grösse $h_{2}$ ist bei Hochöfen zugleich die Spannung im unteren Theil, im Gestelle, des Ofens und wird dadurch bestimmt, dass man durch eine der vorhandenen Oeffnungen, z. B. durch den Schlackenabstich ein eisernes Rohr einführt und am äusseren Ende desselben mittelst Kautschukschlauch ein Manometer anschliesst. Oder man notirt die Pressung $h_{1}$ in der Windleitung und die Zahl der Umgänge $n$ des Gebläses, zieht dann die Düse soweit von der Ofenwand zuriick, dass die Luft in's Freie ausgeblasen wird, regulirt den Gang des Gebläses derart, dass dasselbe wieder $n$ Umgänge beschreibt und beobachtet die nun sich einstellende Pressung $h_{\mathrm{x}}$ in der Tindleitung; hiemit ergibt sich $h_{\mathrm{a}}=h_{1}-h_{\mathrm{x}}$. Die Menge $M_{s}$ muss dann berechnet werden, wenn man den Windeffect des Gebläses, d. i. das Verhältniss der theoretischen, aus den Dimensionen und der Geschwindigkeit des Gebläses sich ergebenden und der ron den Düsen ausgeblasenen Luftmenge ermitteln will, zu welchem Zwecke das letztere Volum auf den Zustand zu reduciren ist, welchen das erstere besitzt.

Die Bestimmung der Windmengen, ein beim Hochofenbetrieb sich oft wiederholendes Geschäft, wird durch Tabellen erleichtert (die detaillirtesten Tabellen dieser Art sind die ron J. v. H a u er, Tien 1876, Verlag v. A. Hölder).

Unter den einzelnen Arten von Gebläsen spielen im Hüttenwesen weitaus die wichtigste Rolle die $\mathrm{Cylindergebläse,} \mathrm{welche} \mathrm{grosse} \mathrm{Pressungen} \mathrm{(bei}$ Eisenhochöfen bis zu $1 / \mathrm{g}$, bei Bessemergebläsen bis 3 Atm. Ueberdruck) zu erzielen gestatten. Sie bestehen nach Fig. 1721 aus einem glatt ausgebohrten, beiderseits mit Deckeln rersehenen Cylinder, in welchem ein mit Liederung rersehener Kolben sich hin- und herbewegt. An jedem Deckel sind Saug- und Druckventile 
angebracht; erstere öffnen sich gegen das Innere des Cylinders, letztere gegen Aussen. Von den Druckventilen sind Kanäle zum Windsammler $M$ geführt, an welchen sich die Windleitung $W$ schliesst. Bei Bewegung des Kolbens wird daher stets gleichzeitig auf einer Seite desselben Luft in den Cylinder gesaugt, auf der anderen zuerst verdichtet und dann in die Windleitung ausgeblasen.

Cylindergebläse werden aus denselben Gründen wie Dampfmaschinen fast durchgehends doppeltwirkend hergestellt; nur in Schweden waren und sind noch einfachwirkende Gebläse aus dem Grunde in Anwendung, weil bei diesen der Cylinder an einer Seite offen bleiben kann, daher der Kolben behufs Nachziehens der Liederung leicht zugänglich ist.

Der schädliche $R$ a um ist der zu Ende des Hubes zwischen dem Kolben und dem nächstgelegenen Cylinderdeckel befindliche, mit verdichteter Luft gefüllte Raum. Derselbe vermindert nicht, wie man glauben könnte, den Wirkungsgrad, Fig. 1721 . indem die vom Kolben zur Verdichtung der Luft des schädlichen Raumes aufgewendete Arbeit beim Rückgange des Kolbens durch Expansion dieser Luft wieder abgegeben wird, wohl aber den Windeffect, weil das Ansaugen neuer Luft erst beginnt, wenn durch das Fortschreiten des Kolbens die Luft des schädlichen Raumes bis unter die atmosphärische Spannung verdiunnt ist, so dass das Saugventil sich öffnen kann. Das Ansaugen beginnt daher erst nach einem Theil des Kolbenlaufes, der um so grösser ist, eine je höhere Spannung die verdichtete Luft besitzt.

Ist $M_{0}$ die von einem Gebläse zu liefernde reducirte Windmenge, $\varphi$ der Windeffect, $v$ die mittlere Kolbengeschwindigkeit, $s$ der Kolbenhub, so ergibt sich die Kolbenfläche $O$ und die Zahl $n$ einfacher Kolbenläufe pr. Minute

$$
O=\frac{f_{1} M_{n}}{60 \varphi v} \text { und } n=60 \frac{v}{s},
$$

wobei der Factor $f_{1}$ den früheren Werth besitzt und bei Berechnung desselben für $b$ und $t_{\mathrm{s}}$ voraussichtliche mittlere Werthe zu setzen sind. Der Windeffect $\varphi$ kann für Gebläse mit geringerer Pressung gleich 0.7, für Bessemergebläse mit 2 bis 3 Atmosphären Ueberdruck gleich 0.6 bis 0.5 gesetzt werden. Die Kolbengeschwindigkeit $v$ ist für einen Hub $s$ von 1 bis $3^{\mathrm{m}}$ gleich $0.8^{\mathrm{m}}$ bis $1.2^{\mathrm{m}} \mathrm{zu}$ nehmen; bei zu grosser Geschwindigkeit schlagen die Ventile zu heftig. Der Hub $s$ selbst wird in der Regel nahe gleich dem Cylinderdurchmesser gewählt; bei grossem Hub wird die Längenausdehnung des Gebläses grösser, im entgegengesetzten Falle ist der Einfluss des schädlichen Raumes um so fühlbarer. Ergibt sich $O$ zu gross, so nimmt man zwei oder mehrere Cylinder an, wobei auch der Gang und die Luftausströmung aus den Düsen gleichförmiger werden. Die grössten ausgeführten Cylinder besitzen Durchmesser bis $3.7^{\mathrm{m}}$; gegenwärtig geht man damit nicht uiber 2.5 bis $3^{\mathrm{m}}$.

Der Wirkungsgrad eines Cylindergebläses beträgt bei guter Construction 0.7 .

Der Kolben besteht meist aus Gusseisen, zur Verminderung seines bei liegenden Gebläsen nachtheiligen Gewichtes auch oft ganz oder theilweise aus Schmiedeisen. Wichtig ist eine dicht schliessende und doch wenig Reibung verur'sachende Liederung. Die ältere Hanf- und die Liederung mit Lederstulp sind wegen geringer 
Dauer fast ganz ausser Gebrauch gekommen. Leinwand ist dagegen viel in Verwendung und erweist sich bei Pressungen bis zu 12-15 Cent. Quecksilber als dauerhaft. Man schneidet aus Leinwand, welche in einer Mischung von Leimwasser und Grafitpulver getränkt wurde, diagonal zu den Fasern Segmente aus, und legt diese zu einem Ring von einigen Centimetern Höhe zusammen, welcher zusammengenäht, gepresst, aussen abgefeilt wird, und dann wieder in Stücke zer-

Fig. 1722.
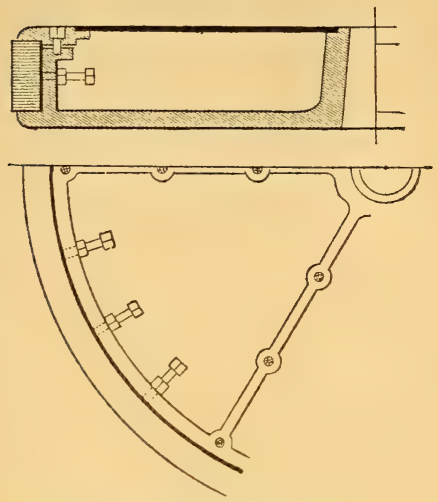

Kolben mit Leinwandliederung. schnitten auf den Kolbenrand zu liegen kommt. Durch einen geeigneten Mechanismus, z. B. durch Stellschrauben lassen sich die Segmente im Masse ihrer Abnützung nach aussen rücken. Ein Beispiel für eine solche Liederung zeigt Fig. 1722 im Verticalschnitt und im Grundriss ohne Kolbendeckel. Der Kolben besteht aus einer Bodenplatte mit Nabe für die Kolbenstange, radialen Rippen und einer am Umfang angegossenen cylindrischen Wand. Auf dem Rande der Bodenplatte liegen die Segmente des Leinwandringes und innerhalb des letzteren ein an einer Stelle getheilter Schmiedeisenring, gegen welchen Stellschrauben drücken. Diese sind in Gewinde der cylindrischen Wand eingedreht und mit Gegenmuttern versehen. Der Kolben ist durch einen Deckel geschlossen, bestehend aus einer Blechplatte mit einem Gusseisenring am Umfang, wodurch verhindert wird, dass die Höhlung des Kolbens als schädlicher Raum fungire. Schaltet man zwischen den Stellschrauben und dem schmiedeisernen Ring Federn ein, so wird die Liederung beständig nach Aussen gedrückt. Bei Völckner's Kolben sind die

Fig. 1723.

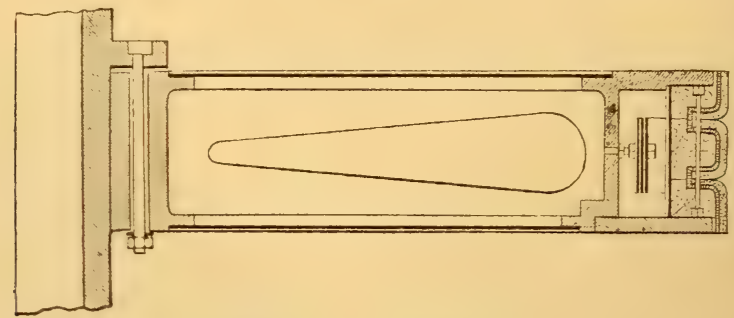

Kolben mit Lederliederung.

Stellschrauben durch Excenter ersetzt, deren Achsen parallel zur Cylinderachse liegen und ausserhalb des Kolbens mit Sperrädern versehen sind, um eine selbstthätige Riickdrehung zu hindern.-Als Schmiere für die Leinwandliederung dient Grafitpulver.

Figur 1723 stellt den Kolben der Georgs-Marienhütte bei Osnabrüek dar. Der Kolbenkörper besteht aus einer Nabe, welche an der hohlen Kolbenstange aufgeschoben und an einer Flantsche derselben festgeschraubt ist, aus Armen von 
I förmigem Querschnitt mit durchbrochener Mittelrippe und einem Kranz. Der Raum zwischen den Armen ist durch beiderseits aufgelegte Blechplatten, die Höhlung des Kranzes durch einen (in Fig. 1723 unten erscheinenden) Gusseisenring gegen Aussen abgeschlossen. Die Liederung besteht aus drei Stulpen aus Filz mit untergelegtem Leder; hinter denselben befinden sich drei Ringe aus Lindenholzsegmenten und dann ein Blechring; die Liederung wird durch Stellschrauben, welche auf Lamellenfedern wirken, gegen Aussen gedrückt. - Bei einem Gebläse in Kladno wurde mit gutem Erfolg eine Liederung angewendet, bestehend aus zwei am Kolbendeckel und Boden anliegenden Lederstulpen und einem dazwischen befindlichen Ring aus Segmenten von Weissbuchenholz, welche ähnlich wie im vorigen Falle gegen die Cylinderwand gedrückt werden.

Für hohe Pressungen, also besonders auch für Bessemergebläse geeignet erweist sich die Metallliederung. Sie besteht aus 2 bis 3 an einer Stelle getheilten Ringen aus Stahl, Schmiedeisen oder Messing, die durch Stellschrauben und Federn oder nur durch ihre eigene Elasticität nach aussen gedrückt werden. Sehr gebräuchlich ist die Ramsbottom'sche Liederung, bei welcher 4 bis 8 federnde Ringe von quadratischem Querschnitt mit nur 1 Cent. Seite in Nuthen der hier am äussersten Umfang des Kolbens befindlichen cylindrischen Wand gelegt sind; die Innenwand des Cylinders wird dabei weniger ausgerieben als durch starke Ringe. Auch verwendet man einen einzigen schraubenförmig gewundenen Ring mit mehreren Umgängen, der ebenfalls in einer entsprechend geformten Nuth liegt.

A utoclave, d. h. solche Liederungen, welche durch die Spannung der Gebläseluft selbst nach Aussen gedrückt werden, sind nicht besonders zu empfehlen, weil sie zu Anfang des Hubes, wo die Luft noch wenig verdichtet ist, nicht gut schliessen, dann aber, wenigstens bei höherer Pressung, eine zu grosse Reibung verursachen.

Die Kolbenstange erhält einen circa doppelt so grossen Querschnitt als bei Dampfkolben, welche dem gleichen Druck ausgesetzt sind, weil der Durchmesser des Gebläsekolbens bei gleichem Gesammtdruck bedeutend grösser ist.

Von besonderer Wichtigkeit für den guten Gang des Gebläses sind die Ventile. Um das Durchströmen der Luft zu erleichtern, soll deren Gesammtquerschnitt möglichst gross sein; so erhalten die Saugrentile an jedem Cylinderende zusammen $1 / 8$ bis $1 / 4$, die Druckventile $1 / 10$ bis $1 / 6$ des Cylinderquerschnittes, erstere mehr, um das Ansaugen möglichst zu erleichtern und dadurch den Windeffect zu erhöhen. Bei grosser Kolbengeschwindigkeit wird die ganze Deckelfläche zur Anbringung von Ventilen benuitzt, und $2 / 3$ davon für die Sang-, 1/3 für die Druckventile genommen, wodurch sich die obigen Verhältnisszahlen noch bedeutend steigern. Ferner soll der Hub der Ventile gering sein, damit dieselben sich rasch schliessen und nicht schlagen; bei Tellerventilen wird dies dadurch erreicht, dass man dieselben mit kleinem Durchmesser und in grösserer Zahl verwendet; bei Klappen durch Verminderung der senkrecht zur Drehungsachse gemessenen Breite, mit welcher Dimension man bis auf 5 oder 6 Centimeter herabgehen kann, während die Länge das 4 bis 6 fache beträgt. Endlich sollen die Ventile sich leicht öffnen, daher geringes Gewicht besitzen, und wenn sie Klappen sind, nahe vertical gestellt werden. Zur Erleichterung der Appretur verwendet man häufig besondere Ventilsitze.

Die gewöhnlichen Ventile bestehen nach Fig. 1724, welche ein Klappenv entil darstellt, aus einer durch Nieten zwischen zwei Blechtafeln eingeschlossenen Lederplatte. An einer der Langseiten ist die Lederplatte durch einen aufgelegten Blechstreif und Schrauben am Sitz befestigt; das Ventil öffnet sich bis in die punktirte Stellung, das Leder bewirkt dichten Schluss. Fig. 1725 zeigt eine Anordnung von Saugventilen, deren zwei an einem gemeinschaftlichen Sitz angebracht sind, für einen liegenden Cylinder; ähnlich werden die Druckrentile gestellt, doch müssen dieselben mit einem Ventilkasten umgeben sein (vergl. Fig. 1721). Den Uebergang zu den Tellerventilen bildet die Construction Fig. 1726, 
bei welcher am Ventil $v$ eine horizontale Schiene unveränderlich befestigt und mit zwei parallelen Hängschienen drehbar verbunden ist; das Ventil bewegt sich daher parallel zu seiner Stellung und lässt an seinem ganzen Umfange Luft durchströmen. Der Hub ist dadurch begrenzt, dass

Fig. 1724.

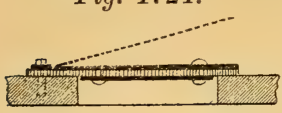
ein Ansatz der einen Hängschiene gegen einen in den Ventilsitz eingeschraubten Bolzen schlägt. Bei verticalen Cylindern kommen Tellerventile Fig. 1727 vor, deren Gewicht durch eine Feder oder ein Gegengewicht ausgeglichen sein mnss; das Ventil wird durch einen über seine Oeffnung gelegten Steg gerad geführt. Um die Gewichtsausgleichung $\mathrm{zu}$ vermeiden, ist es zweckmässiger, auch hier nahe vertical gestellte Klappen zu verwenden, wie Figur 1728 für das obere Druckventil

Fig. 1725.

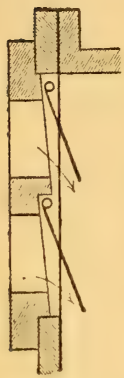

Fig. 1726 .

Fig. 1727.
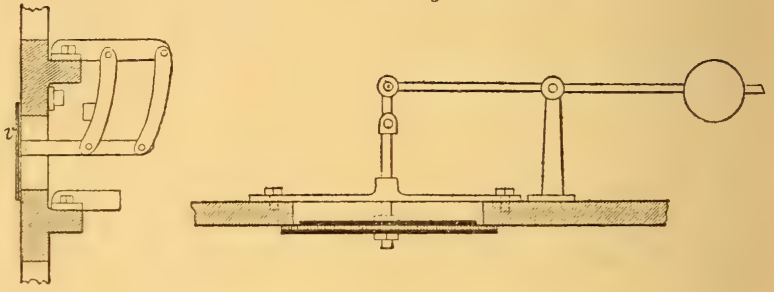

darstellt; an den Cylinderdeckel ist dabei ein Kasten angegossen, an dessen in den Windsammler eingetauchter Mündung das Ventil befestigt ist. Oft werden die Ventile, um ihre Dimensionen vermindern zu können, am ganzen Umfang des Cylinders vertheilt. Eine solche Einrichtung zeigt Fig. 1729. Zwischen der oberen

Fig. 1728.

Fig. 1729.
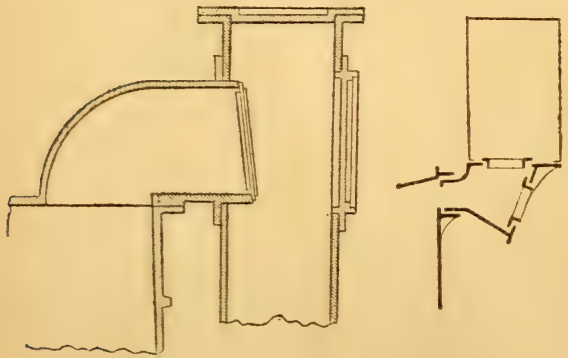

Fig. 1730 .

Cylinderflantsche und dem Deckel ist ein ringförmiges, gegen den Cylinder offenes Gehäuse angebracht, das am ganzen Umfang rertheilt die horizontalen Druck- und die geneigten Saugklappen enthält, welche sämmtlich mit besonderen Sitzen ver- 
sehen sind. Von den Druckventilen strömt die Luft in einen ringförmigen Blechkasten und aus diesem in die Windleitung.

Ventile aus biegs a m en Materialien, wie Kautschuk, Leder gefertigt, zeigen den Vortheil geringen Gewichtes, müssen aber sehr klein gemacht werden oder auf einem in der Oeffnnng befestigten Gitter ruhen, um von der verdichteten Luft nicht durchgedrückt zu werden. In Fig. 1730 ist in $1 / 3$ Naturgrösse ein Ventil skizzirt, aus einer kreisförmigen Kautschukplatte bestehend, welche durch einen Schraubenbolzen niedergehalten wird, dessen Kopf die Form einer Schuissel besitzt, und den Hub des ringsum aufsteigenden Ventilrandes begrenzt. In der Oeffinung befinden sich 4 radiale Stege.

Für Bessemergebläse hat man noch keine ganz befriedigende Ventilconstruction. Bei der ältesten, noch gegenwärtig viel verwendeten Einrichtung sind an jedem Ende des Cylinders in dessen Wandung 2 bis 3 Reihen Oeffnungen von 2.5 bis $3^{\mathrm{cm}}$ Durchmesser angebracht und mit einem Hohlcylinder aus Kautschuk umgeben, welcher sich in einem an den Cylinder angegossenen ringförmigen Kanal befindet, der mit der Windleitung communicirt; durch die verdichtete Luft wird der Kautschukring ausgedehnt und lässt daher die Luft austreten. Der Deckel ist mit grösserem Spielraum in den Cylinder eingelassen, der eingelassene Theil ebenfalls mit Oeffnungen am Umfang und einem diese umgebenden Kautschukring versehen, welcher als Saugventil fungirt. Der Nachtheil dieser Construction ist, dass die kostspieligen Ringe sich bald abnützen oder spröde werden und zerbrechen. Lederventile taugen ebenfalls nicht gut; Tellerventile mit einer ringförmigen $\mathrm{Kupferscheibe} \mathrm{als} \mathrm{Auflage} \mathrm{sollen} \mathrm{sich} \mathrm{bewähren.}$

Bei neueren Gebläsen werden öfters die Saugventile in Kästen eingeschlossen und diese mit einem Rohr in Verbindung gesetzt, durch welches die Luft von einem staubfreien Orte angesaugt werden kann.

Um die Uebelstände der Ventile zu vermeiden, hat man bei den Schiebergebläsen Schieber statt der Ventile in Anwendung, welche durch den Mechanismus der Gebläsemaschine bewegt werden. Dieselben besitzen meist die Form der Muschelschieber von Dampfmaschinen und werden durch Excenter bewegt; am Gebläsecylinder befindet sich der Schieberspiegel mit drei, wie bei einem Dampfcylinder angeordneten Kanälen. Der Schieber liegt entweder frei am Sitz und die verdichtete Luft wird in dessen Höhlung geblasen, welche durch den mittleren Kanal mit der Windleitung communicirt, oder es wird durch den mittleren Kanal angesaugt, und die verdichtete Luft gelangt durch die beiden äusseren Kanäle in einen Schieberkasten, in welchen dann die Windleitung mündet. Für einen guten Gang ist es nothwendig, dass der Schieber die Ausströmung erst öffnet, wenn die Luft bis auf die in der Windleitung vorhandene Spannung verdichtet ist, weil sonst Rïckströmung aus der Windleitung in den Cylinder stattfindet; ferner, dass das Ansaugen erst beginnt, wenn die Luft des schädlichen Raumes bis auf äussere Spannung verdünnt ist. Construirt man das Gebläse diesen Forderungen entsprechend, so ergeben sich entweder sehr grosse Schieber. dimensionen oder sehr kleine Durchströmung:squerschnitte für die Luft, auch arbeitet die Maschine nur bei derjenigen Pressung richtig, welche dem Entwurfe zu Grunde gelegt wurde. Nun ist gerade beim Bessemcrbetrieb, für welchen diese Gebläse vorzugsweise bestimmt sind, die hervorzurufende Pressung sehr veränderlich; aus diesem Grunde hat sich die anfängliche starke Verbreitung der Schiebergebläse wieder bedeutend reducirt.

Das Schwungrad erfordert verhältnissmässig geringe Dimensionen, da weniger eine gleichförmige Drehung der Wellen als eine gleichförmige Bewegung der Gebläsekolben wiinschenswerth ist, damit auch die Ausströmung der Luft aus den Düsen möglichst ungeändert stattfinde. Man kann bei Berechnung des Schwungradgewichtes den Gleichförmigkeitsgrad gleich 12 bis 15 setzen.

Zum Betrieb der Gebläse dienen Wasserräder, Turbinen und rorwaltend Dampfmaschinen. Letztere werden oft mit Expansion, dagegen namentlich bei Hochofengebläsen nur selten mit Condensation versehen, weil diese Einrichtung: 
die Maschine complicirter macht und zu Betriebsstörungen Anlass gibt, welche beí Hochöfen besonders nachtheilig sind. Expansionsmaschinen werden häufig nach dem $\mathrm{W}$ o olf'schen Princip ausgeführt.

Die Anordnung ist eine stehende oder liegende, je nachdem die Achse des Gebläsecylinders vertical oder horizontal ist. Letztere zeigt den Vortheil leichterer Fundirung, besserer Uebersichtlichkeit für den Wärter und geringerer Anlagskosten; bei grösserem Durchmesser wird jedoch der Kolben so schwer, dass wegen Biegung der Kolbenstange die Liederung an der Unterseite des Kolbens und die Stopfbüchsen sich mehr ausreiben, wenn man auch die Kolbenstange durch beide Cylinderdeckel führt und durch stellbare Gleitstïcke unterstitzt. Für mehr als $1.8^{\mathrm{m}}$ Cylinderdurchmesser empfiehlt sich daher die stehende Anordnung.

Ferner sind zu unterscheiden Balancier-, directwirkende und Gebläse mit Kurbelbewegung. Fig. 1731 zeigt die gewöhnliche Anordnung eines s tehenden

Fig. 1731.

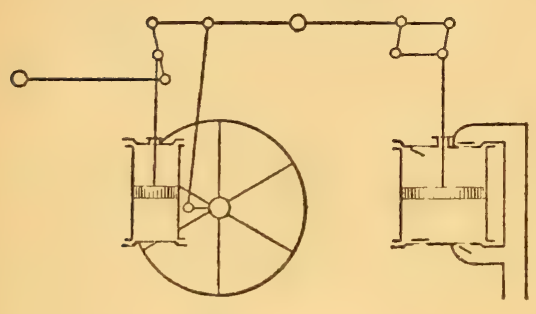
Bal anciergebläses; die Stange des Gebläsekolbens ist durch ein Parallelogramm, die des Dampfkolbens durch einen Gegenlenker geradgeführt; eine mit dem Balancier verbundene Schubstange setzt mittelst Kurbel die Schwungradwelle in Bewegung. Der Nachtheil dieser Anordnung ist, dass die Kurbel eine geringe Länge erhält, ihr Zapfen und die Schubstange einem starken Druck ausgesetzt sind. Gegenwärtig construirt man daher die Balanciergebläse meistnach Fig. 1732 (in dieser Figur ist eine Woolf'sche Maschine und Anordnung der Gebläseventile

nach Fig. 1729 angenommen); die Schwungradwelle ist dabei ausserhalb der Dampfcylinder verlegt. Bei der Mittelstellung des Balancier müssen die Linien, welche den oberen Endpunkt der Schubstange mit den Achsen des Balancier und der Schwungradwelle verbinden, senkrecht auf einander stehen, wodurch sich der hornartige Ansatz des Balancier ergibt.

Fig. 1732.

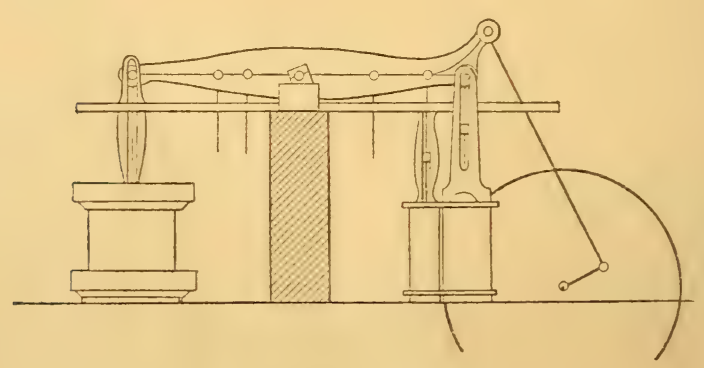

Bei directwirkenden Gebläsen sind die Kolbenstangen des Gebläseund des Dampfeylinders direct rerbunden. Die gewöhnliche Anordnung eines stehenden directwirkenden Gebläses zeigt Fig. 1733. Ganz oben ist dabei der 
Gebläsecylinder auf einen Rahmen gestellt, welcher von 4 Säulen gestützt wird. Letztere, sowie der Dampfeylinder ruhen auf einem mit seitlichen Oeffnungen versehenen Untersatz, und dieser ist mit dem Fundament verankert. Die Kolben. stangen beider Cylinder vereinigen sich in einer Traverse, welche zwischen den Geriistsäulen vertical geführt ist und an beiden Enden Zapfen besitzt, von welchen Schubstangen abwärts zu zwei anderen Zapfen laufen, welche in den Armen zweier Schwungräder befestigt sind. Die Schwungradwelle ist durch den Untersatz gelegt und bewegt mittest Excenter und einer Hebelumsetzung den Dampfschieber. Diese Einrichtung ist zweckmässiger als die umgekehrte, bei welcher der Gebläsecylinder unten, der Dampfcylinder oben steht, weil letzterer dann eine hängende Stopfbiichse erhält, an der sich stets condensirtes Wasser und Schmiere herabziehen und die unteren Theile verunreinigen. Gegenüber der Anordnung mit Balancier zeigt die eben beschriebene den Vortheil geringeren Raumerfordernisses und Anschaffungspreises, dagegen ist der Bau wegen grosser Höhe weniger solid; am grössten wird die Höhe, wenn man, wie es bei einigen neueren Gebläsen vorkommt, die Kolbenstange des oberen Cylinders auf- oder die des unteren abwärts verlängert und durch Schubstange und Kurbel mit der Schwungradwelle verbindet.

Dagegen ist für lieg ende, directwirkende Gebläse meistens die Einrichtnng Fig. 1734, welche der zuletzt besprochenen analog ist, in Verwendung, weil dabei das Gebläse am einfachsten ausfïllt, und eine etwas grössere Längenausdehnung keinen wesentlichen Uebelstand bildet. Neben dem Schwungrad ist in Figur 1734 das zur Bewegung des Dampfschiebers dienende Excenter angedeutet.

Gekuppelte Gebläse besitzen eine gemeinschaftliche Schwungradwelle mit unter 90 Grad verstellten Kurbeln zur Verbindung mit Fig. 1733.

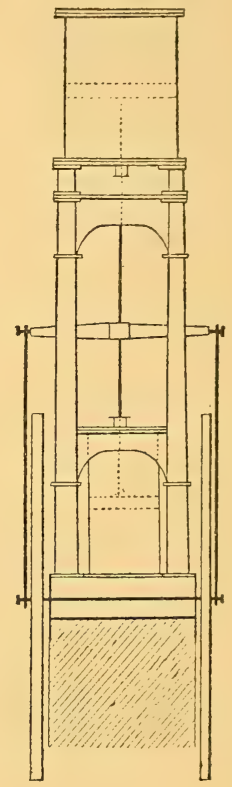

den beiden Balanciers, Dampf- oder Gebläsekolbenstangen. Zur Kupplung eignen sich die Anordnungen mit Balancier, dann das der Fig. 1734 analoge, stehende Gebläse.

Fig. 1734 .

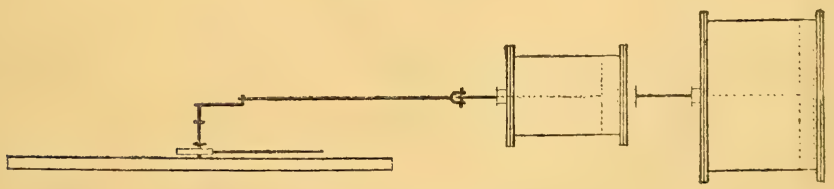

Bei Gebläsen mit Kurbelbewegung reicht nach Fig. 1735 ein einziger Dampfcylinder aus, um zwei beiderseits aufgestellte Gebläsecylinder mittelst einer Kurbelwelle zu betreiben, an welcher zwei Schwungräder zur gleichförmigen Tertheilung der Belastung angebracht sind. Die Cylinder sind zweckmässig oben, 
die Welle unten zu legen, weil letztere die solideste Befestigung erfordert. Fasst man die Fig. 1735 als Grundriss auf, so stellt sie ein liegendes Gebläse mit Kurbelbewegung dar. Da jedoch eine Welle mit Doppelkurbel oder zwei abgesonderte durch eine Schleppkurbel verbundene Wellen nothwendig sind, wird die Anordnung nicht oft benützt.

Endlich hatte man früher Gebläse ohne rotirende Welle, mit Knaggenoder wie Wasserhebmaschinen mit Kataraktsteuerung für die Dampfmaschine. Obgleich durch Weglassung des Schwungrades und seiner Welle die Construction sehr vereinfacht erscheint, ist man doch von solchen Gebläsen wieder abgekommen, weil bei denselben der Hub nicht genau begrenzt ist, daher entweder das Gebläse mit grossem schädlichen Raum arbeiten muss oder Buffer zur Verhinderung der Ueberschreitung des normalen Hubes erfordert werden, welche, wenn auch aus elastischem Material hergestellt, doch Stösse verursachen.

Turbinengebläse erfordern bei der grossen Umgangszahl der Turbinen eine Umsetzung in's Langsame, W a s s e rrad ge bläs e umgekehrt eine Umsetzung in's Schnelle. Beide werden liegend oder stehend, Wasserradgebläse zuweilen auch mit Balancier ausgefïhrt.

Fig. 1735.

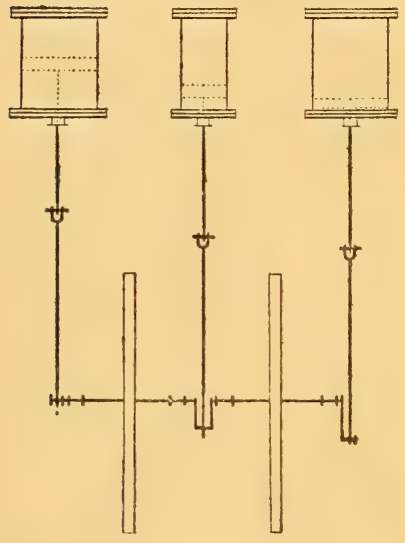

Die hüttenmännischen Processe erfordern eine gleichförmige Ausströmung der Luft aus den Düsen, daher eine eben solche Einströmung vom Gebläse her in die Windleitung. Um diesen Zweck zu erreichęn, werden bei zwei gekuppelten Cylindern deren Kurbeln um 90 ${ }^{\circ}$, bei dreien um 120 Grade gegen einander verstellt, damit die Perioden, in welchen der Kolben die Luft verdichtet, daher die Ausströmung unterbrochen ist, ferner die Momente der grössten und kleinsten Kolbengeschwin̨digkeit bei den einzelnen Cylindern mit einander abwechseln. Bei zweicylindrigen und um so mehr bei eincylinđrigen Gebläsen ist indessen die Luftausströ. mung noch so ungleichförmig, dass man in die Windleitung einen $\mathrm{Re}$ $\mathrm{gul}$ a tor einschaltet, d. i. einen Behälter, in welchem möglichst co nstante Spannung herrschen soll, damit die von dieser Spannung abhängige Geschwindigkeit des Ausflusses der Luft gegen die Duisen hin ebenfalls thunlichst ungeändert bleibe.

Dieser Zweck wird auf zweifache Art erreicht: entweder indem man den Behälter mit beweglichen Wänden rersieht, so dass dessen Volum sich bei stärkerer Zuströmung rom Ciebläse her rergrössert, im umgekehrten Falle rerkleinert; oder indem man dem Behälter feste Wände, doch ein so grosses Volum gibt, dass die Pressung darin ungeachtet des reränderlichen Zuflusses nahe constant bleibt. Es sind daher Regulatoren mit veränderlichem und solche mit unveränderlichem Volum zu unterscheiden.

$\mathrm{Zu}$ ersteren gehören der Kolbenregulator, aus einem verticalen $\mathrm{Cy}$ linder bestehend, in dessen Boden das rom Gebläse knmmende und das weiter zu den Dïsen fortgesetzte Windleitungsrohr münden. Im Cylinder befindet sich ein Kolben, welcher derart belastet ist, dass sein Gewicht dem mittleren Druck der Gebläseluft gleichkmmt. Strömt daher mehr als die normale Windmenge z11, so hebt sich der Kiolben; strömt weniger zu, so senkt er sich. Doch ist diese 
Regulirung unvollständig und der Kolben verursacht durch undicht schliessende Liederung Luftverluste. Der Wasseregulator ist ein unten offener, unveränderlich befestigter Kasten, der in ein Wasserreservoir taucht. In denselben münden oben das $\mathrm{Zu}$ - und Ableitungsrohr für die Luft. Das Wasser steht im Kasten niedriger als aussen, weil die innere Spannung grösser ist als die atmosphärische. Bei vermehrter Einströmung wird das Wasser theilweise nach aussen gedrängt; die Regulirung ist jedoch die unvollkommenste, weil bei Verdrängung des Wasser's auch der Höhenunterschied des äusseren und inneren Wasserspiegels sich ändert, was nur durch eine Pressungsänderung der Luft möglich ist. Daher haben auch diese Apparate wenig Verbreitung. Sehr empfindlich für Spannungs. änderungen ist der Wassertonnenregulator Fig. 1736, der dem Principe nach mit den in Gasanstalten gebrauchten Regulatoren iibereinstimmt und aus einem vertical beweglichen und geführten, unten offenen Blechcylinder besteht, welcher in den mit Wasser gefiillten Zwischenraum zweier schmiedeiserner oder hölzerner Cylinder taucht. In den Boden der letzteren münden $\mathrm{Zu}$ - und Ableitungsrohr fuir die Luft. Bei verstärktem Zufluss steigt der bewegliche Cylinder empor und es ist dazu nur eine sehr geringe Spannungsänderung erforderlich, da dieser Bewegung nur die Reibung gegen die Fuihrungen und gegen das Wasser entgegenwirkt. Die Belastung des Regulators muss wieder der mittleren Spannung der Luft entsprechen. Der Grund, warum auch dieser sonst sehr zweckmässige Apparat verhältnissmässig selten vorkommt, ist in der zu grossen Empfindlichkeit zu suchen, welche bei jedem Kolbenschub des Gebläses heftige Schwankungen auf- und abwärts zur Folge hat. Beide zuletzt beschriebenen Regulatoren sind übrigens nur für mässige Pressungen anwendbar, da sonst der Unterschied des äusseren und inneren Wasserspiegels und mithin die Höhe des Ganzen zu gross wird.

Fig. 1736 .

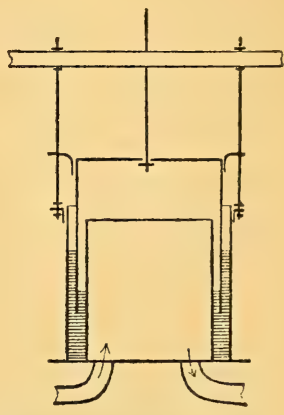

Wassertrommel-Regulator.

Bei allen neueren und grösseren Gebläsen kommen Regulatoren mit unveränderlich em Volum zur Anwendung, welche analog den Dampfkesseln aus zusammengenieteten Blechtafeln bestehen und keinen anderen beweglichen Theil als ein Sicherheitsventil enthalten. Die Grösse des Volums muss hier die Beweglichkeit der Wände ersetzen. Bei Hochofengebläsen nimmt man für zwei gekuppelte Cylinder das Regulatorvolum gleich dem 10fachen, und wenn zeitweise nur ein Cylinder in Betrieb ist, oder bei Vorhandensein nur eines Cylinders gleich dem 20fachen Cylindervolum, in welche Grösse jedoch auch das Volum der Windleitung einbezogen werden kann, daher bei grosser Länge der letzteren der Regulator entbehrlich wird, namentlich wenn man der Windleitung absichtlich eine grössere Weite gibt.

Diese Regulatoren sind meist cylindrisch geformt und werden liegend, wegen Raumverhältnissen zuweilen stehend angeordnet und im letzteren Falle auf einer Gusseisenplatte fundirt. Auch kommen kugelförmige Regulatoren vor, welche bei gegebenem Volum die kleinste Oberfläche besitzen, was jedoch nicht eben auf den geringsten Materialaufwand führt, weil die Wandstärke grösser sein und gegen unten zunehmen muss, um eine Einsenkung durch das Eigengewicht zu verhiiten; dieser wirken iubrigens auch hölzerne, im Innern aufgestellte Streben entgegen.

Endlich hat man gemauerte Regulatoren, unterirdisch angelegt, mit in Cement gelegten Steinen ausgefittert oder aus Béton mit einem bei der Auffiihrung als Stütze dienenden schwachen Ziegelgewölbe. Die Innenwände werden mit 
Cement beworfen und sodann mit mehrmaligem Theeranstrich rersehen. Dessen ungeachtet sind solche Regulatoren nur schwer luftdicht herzustellen und daher nicht besonders zu empfehlen.

Der Durchmesser der Windleitung soll so gross sein, dass sich die Luft darin mit nicht mehr als 10 Meter Geschwindigkeit bewegt. Sie wird mit Flantschenverbindung aus Gusseisen und bei grösserem Durchmesser jetzt meistens aus Blech hergestellt. Zur Dichtung der Flantschen dienen Kupferdraht oder Eisenkitt, bei kalter Gebläseluft auch Blei, Kautschuk, mit Fett getränkter Flanell oder Filz. Bei längeren geraden Röhrenleitungen sind, besonders wenn sie abwechselnd von kalter und heisser Luft durchströmt werden, Compensationen erforderlich. Röhren aus Asphaltpapier eignen sich nur fuir kalte Luft. Gemauerte Leitungen sind aus demselben Grunde wie gemauerte Regulatoren nicht vortheilhaft.

In der Nähe der Düsen ist eine Regulirungsvorrichtung, meist ein Schieber, eingeschaltet, um die ausströmende Luftmenge abzuändern. Der Durchmesser der $\mathrm{D}$ ü s en ergibt sich nach den Formeln für die Windmengen aus den Gleichungen

$$
M=\frac{M_{0}}{f}, d=\sqrt{\frac{M}{18740 \sqrt{h_{1}-h_{2}}}},
$$

worin die Grössen die früher angegebene Bedeutung besitzen, insbesondere $M_{0}$ die von einer Düse zu liefernde reducirte Windmenge ist, und im Werthe von $f$ für $b, h_{2}$ und $t_{1}$ voraussichtliche Mittelwerthe zu nehmen sind. In der Praxis wird iibrigens meist eine Abänderung des berechneten Werthes von $d$ nothwendig. Die Düse selbst ist ein Rohr aus Schmied- oder Gusseisen von schwach conischer Form (mit circa 6 Grad Seitenconvergenz).

Neben den Cylindergebläsen kommen beim Hüttenwesen noch zahlreiche andere Arten ror, welche jedoch grösstentheils von geringerer Bedeutung sind. Ziemlich verbreitet waren in den Alpenländern oscillirende Cylindergebläse, bei welchen wie bei oscillirenden Dampfmaschinen der verticale Cylinder um zwei horizontale Drehzapfen schwingt. Dadurch sind Schubstange, Gleitstiick und dessen Fiihrung erspart, doch lassen solche Gebläse nur eine geringe Kolbengeschwindigkeit zu und erfordern daher gross: Dimensionen. Die Ableitung der verdichteten Luft erfolgt älınlich wie bei den später betrachteten Wassertonnengebläsen.

Bei Kastengebläsen Fig. 1737 erfolgt die Verdichtung der Luft in einem hölzernen quadratischen oder rechteckigen, unten offenen Kasten, in welchem sich ein gleichfalls hölzerncr, mit Liederung versehener Kolben auf- und niederbewegt. Die Sangrentile befinden sich am Kolben und öffnen sich beim Niedergang, die Druckrentile sind am Kasten selbst angebracht und öffnen sich beim Aufgang, das Gebläse ist daher einfachwirkend. Da dasselbe grösstentheils aus Holz besteht, sind seine Herstellungskosten gering. Dagegen eignet es sich aus diesem Grunde nur für Pressungen bis zu 5 Cent. Quecksilber und unterliegt der Kasten einer baldigen Ausreibung.

Lederbälge (Spitzbälge) Fig. 1738 bestehen in der gewöhnlichen Construction aus drei hölzernen trapezförmigen Tafeln, deren Zwischenraum durch einen Ledermantel umschlossen ist. Die mittlere Tafel ist fix, enthält das Druckventil, und ist an der schmäleren ron beiden Trapezseiten mit einem Holzblock, dem Balgkopf, rerbunden, welcher durchbohrt und mit einer Düse versehen ist. Die beiden anderen Tafeln sind durch Charniere an dem Balgkopf befestigt; die untere enthält das Saugventil und wird auf- und niederbewegt, die obere ist mit Gewichten beschwert. Das Innere des Balges ist daher durch die fixe mittlere Wand in zwei Theile $B$ und $R$ geschieden, ron welchen der untere $B$ zum Aufsaugen und Verdichten der Luft, der obere $R$ als Regulator dient, um ein beständiges Ausströmen der Luft aus der Düse zu bewirken, obgleich der Balg selbst einfachwirkend ist. Hat man nämlich die Belastung des Regulatordeckels entsprechend regulirt, so wird beim Aufgang der unteren Platte mehr Luft in 
den Regulator $R$ gedrückt, als gleichzeitig durch die Düse austritt, daher auch der Regulatordeckel aufsteigt. Beim folgenden Nicdergang tritt frische Luft durch das Saugventil in den unteren Balgraum $\boldsymbol{B}$, das Druckventil ist geschlossen, der Regulatordeckel aber wird durch die Gewichte abwärts bewegt, daher die Luftausströmung fortgesetzt.

Die Trapezform ergibt sich aus der Forderung, dass die Charniere, bei welchen die Dichtung am schwersten herzustellen ist, thunlichst kurz sein sollen. Die Hebung der unteren beweglichen Tafel erfolgt durch Daumen an einer Wasserradwelle oder dureh Menschenkraft, mittelst eines zweiarmigen Hebels und einer Zugstange $Z$; der Niedergang tritt selbstthätig ein und wird erforderlichen Falles durch ein anhängendes Gewicht beschleunigt. Das Leder soll vor Erhitzung und Dnrchnässung bewahrt und durch ein fettes Schmiermittel geschmeidig erhalten werden. Damit dasselbe sich stets in die gleichen Falten legt, werden an den Kanten der letzteren Holzleisten befestigt.

Die Leistung der Bälge ist gering, für bedeutendere Windmengen fallen ihre Dimensionen wegen der eigenthïmlichen Form zu gross aus, die Pressung kann wegen Luftverlust nicht uiber $1 \cdot 2$ bis 2 Cent. Quecksilber gesteigert werden. Diese Gebläse sind daher nur bei Schmiedefeuern, dort aber allerdings wegen ihrer einfachen Einrichtung in ausgedehntester Weise in Anwendung; hie und da findet man sie auch bei Hammerwerken.

Fig. 1737.

Fig. 1738 .
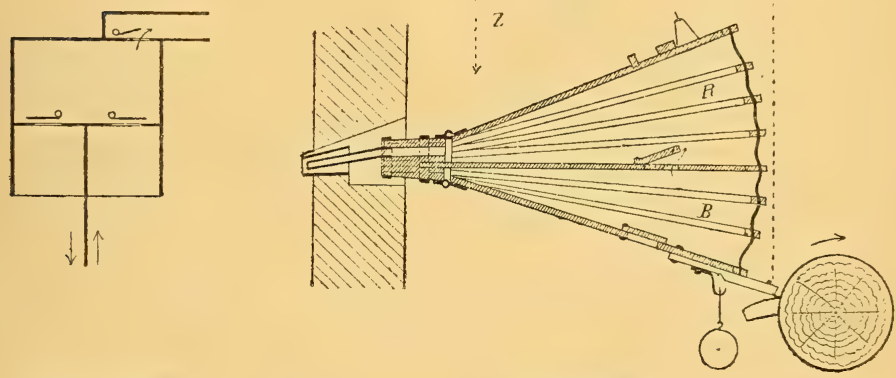

Kastengebläse.

Balggebläse.

Bei Holzbälgen. ist der Ledermantel durch ein hölzernes Gehäuse mit gekrümmter Riickwand ersetzt. In vervollkommneter Form standen solche Apparate unter dem Namen Widholmsgebläse in Schweden in Gebrauch.

Bei Cylinderbälgen sind die drei Holztafeln kreisförmig, der Ledermantel cylindrisch, die obere und untere Tafel bewegen sich parallel zu ihrer Stellung; am Rande der mittleren fixen Tafel ist eine cylindrische Holzwand aufgesetzt, in welche die Windleitung mündet. Die horizontale Ausdehnung eines Cylinderbalges ist kleiner als die eines Spitzbalges. Ein compendiöser Apparat dieser Art ist von En fe r für Schmiedefeuter construirt (Armengaud's génie industriel, 12. Bd.).

Von rotirenden Kolben mas chinen (bei welchen der Kolben eine drehende statt der hin- und hergehenden Bewegung erhält) haben in neuerer Zeit die Rootsschen Ventilatoren (Roots-Blower), zu der Gruppe der von R e ulea ux so benannten Kapselräder gehörig, einige Verbreitung gefunden. Die beiden Kolben $K$ Fig. 1739 sind ineinandergreifenden Zahnrädern vergleichbar, deren jedes nur zwei Zähne enthält. Dieselben rotiren in einem Gehäuse dicht anschliessend. in 
der Richtung der Pfeile mit gleicher Geschwindigkeit. Bei jeder Umdrehung werden von jedem Kolben zwei Volumen Luft von dem in der Figur schraffirten Querschnitte aus der oberen Saugöffnung entnommen und in die unten sich anschliessende Windleitung fortgefiuhrt. Die äusseren Enden der Kolben werden nach einem Kreisbogen gekrimmt, die Form des mittleren Theiles ist nach den Regeln der allgemeinen Verzahnung zu bestimmen. Um Klemmungen zu vermeiden, muss zwischen beiden Kolben etwas Spielraum belassen werden; der dichte Schluss wird durch eine consistente Schmiere aus 6 Gewichtstheilen Talg, 6 Th. Gips, 3 Th. Wachs und 1 Th.

Fig. 1739.

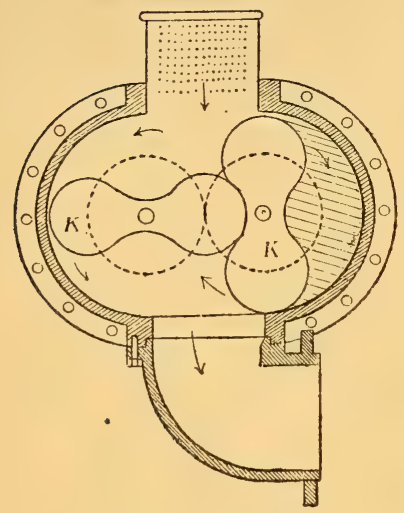

Roots Ventilator. Grafit erzielt. Die Achsen der Kolben ragen aus dem Gehäuse vor und es sind gewöhnlich an beiden Enden derselben Zahnräderpaare, dann an jeder Achse eine treibende Riemenscheibe, an entgegengesetzten Seiten des Apparates, befestigt, um eine möglichst gleichförmige Drehung zu bewirken. Nach Fig. 1739 kann an der Saugöffnung ein Kasten aus gelochtem Blech befestigt werden, welcher das Eintreten fremder Körper verhuitet. Die Kolben bestehen entweder ganz aus Holz oder aus eisernen Rahmen mit einer Holzhülle.

Die Vortheile solcher Apparate sind das Wegfallen der Ventile, einfache Construction und Unabhängigkeit der Pressung von der Umgangszahl; dagegen steigt mit der Pressung die Schwierigkeit der Dichtung, und es tritt Effectsverlust durch Rückströmung der Luft ein, da die angesaugte Luft bei atmosphärischer Pressung mit der verdichteten in der Windleitung in Berührung kommt. Die Spannung kann bei Kolben mit Holzuiberzug und Anwendung consistenter Schmiere bis 5 Cent. Quecksilber steigen, die Ventilatoren werden für Windmengen

Fig. 1740 .

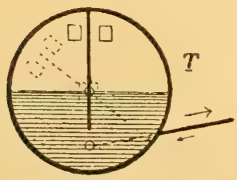

Wassertrommelgebläse. von 1.5 bis 200 Kubikmeter pr. Minute hergestellt und erhalten dabei 500 bis $200 \mathrm{Um}$ gänge pr. Minute; der Windeffect wurde vom Ingenieur Geiser in Mariazell zu 0.56 bestimmt. Man verwendet die Roots-Blower bei Kupolöfen, Schmiedfeuern u. s. w.

Bei einer Reihe von Gebläsen ist der Raum, in welchem die Verdichtung der Luft stattfindet, durch Wasser gegen Aussen abgeschlossen. Diese Arten bieten vorzïglich nur ein historisches Interesse; sie eignen sich sämmtlich bloss für geringe Pressungen, da sonst der Höhenunterschied der beiden Wasserspiegel, von welchen einer den atmosphärischen, der andere dem Drucke der Gebläseluft ausgesetzt ist, zu gross wird, die Dimensionen der Apparate zu sehr anwachsen. $\mathrm{Zu}$ denselben gehören das $\mathrm{B}$ a a der'sche Gebläse, welches im Princip mit dem bei Ventilation der Bergbaue verwendeten Harzer Wettersatz übereinstimmt, ferner das Wassertonnen-, das Schöpfradgebläse und die Cagniardelle.

Das Wassertonnengebläse Fig. 1740 ist ein hölzerner hohler Cylynder $T$, welcher um zwei in seiner Achse liegende und an seinen Stirnwänden befestigte Zapfen schwingt und durch zwei Kurbeln und Schubstangen eine oscil- 
lirende Bewegung erhält. Vom Scheitel der halb mit Wasser gefüllten Tonne $T$. ist bis nahe zum Boden eine Scheidewand herabgefuihrt, und beiderseits von dieser befinden sich an der einen Stirnwand die Druck-, an der anderen die Saugventile Bei Drehung der Tonne verbleibt das Wasser in deren unterer Hälfte, daher sich der freie Raum auf einer Seite der Scheidewand vergrössert, auf der anderen verkleinert; in dem ersteren findet daher Ansaugen, im letzteren Ausblasen der Luft statt. Diese Functionen wechseln in den beiden genannten Räumen mit einander ab. Der Wasserspiegel stellt sich beiderseits der Scheidewand verschieden hoch, weil sich auf einer Seite stets angesaugte, auf der anderen verdichtete Luft befindet. Von den Druckventilen ist ein Rohr herabgeführt, dessen Endstück in die verlängerte Achse der Tonne fällt, daher ebenfalls nur um diese Achse oscillirt und durch einen Lederschlauch oder eine Stopfbüchse mit der fixen Windleitung verbunden werden kann. Johnston's Luftcompressionsmaschine (Revue universelle 1874, 36. Bd. p. 343) ist eine Combination dreier auf einander folgender Wassertonnen, in welchen die Pressung der Luft successive gesteigert wird; der ganz aus Eisen bestehende Apparat ist ziemlich complicirt.

Fig. 1741 .

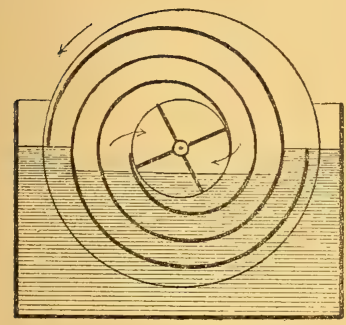

Schneckengebläse.
Fig. 1742.

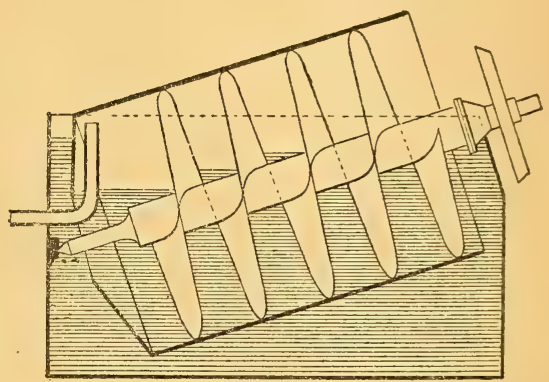

Cagniardelle.

Das Schöpfrad- oder Schneckengebläse, nach dem Erfinder, einem siebenbürgischen Bergbeamten, auch $\mathrm{D}$ e b r e c z e n y'sches Gebläse genannt, besteht nach Fig. 1741 aus kreisförmigen Holztafeln, welche mit einer centrischen Achse verbunden sind, und zwischen denen eiserne oder gleichfalls hölzerne, nach. einer Spirale gekrümmte Wände eingesetzt sind. Der Apparat taucht in ein Wasserbassin; eine der runden Tafeln ist mit einer centrischen Oeffnung und einem Ansatzrohr versehen, welches in einen Behälter mündet, an den sich die Windleitung anschliesst. Rotirt der Apparat in der Richtung des Pfeiles, so tritt in die Kanäle zwischen den Spiralwänden abwechselnd Luft und Wasser ein, das Wasser verbleibt stets in der unteren Hälfte der Windung, die Luft in der oberen, und schliesslich gelangen beide in den mittleren Raum und ron dort durch das Ansatzrohr in den erwähnten Behälter. Dieser communicirt unten durch eine Oeffnung mit dem gezeichneten Bassin, daher das Wasser wieder in letzteres zuriuckfliesst. Das Schneckengebläse stand in mehreren Provinzen Oesterreichs, besonders in Siebenbürgen, in Benützung; der Wirkungsgrad desselben beträgt nur 0.2 bis 0.3 , was dadurch zu erklären ist, dass stets ein Quantum Wasser ron den Spiralwänden bis in die Höhe der Achse gehoben werden muss und dann rom Austrittsrohre wieder frei herabfällt.

Die Cagniardelle Fig. 1742 (nach dem Erfinder Cagniard-Lato $\mathrm{ur}$ so benannt) oder Schraubengebläse ist in gewisser Beziehung dem rorbeschriebenen ähnlich. Sie besteht aus ciner schraubenförmigen Platte, welche 
an einer schrägliegenden Welle befestigt und mit einem cylindrischen Mantel umgeben ist, der unten in einen schwach ansteigenden Conus endigt. Das Ganze rotirt in einem mit Wasser gefüllten Behälter; das feststehende Windleitungsrohr taucht in eine Oeffnung des Conus. Durch die gekrümmte Platte ist ein schraubenförmiger Kanal gebildet, dessen obere Mündung sich bei der Drehung abwechselnd in der Luft und im Wasser bewegt, daher abwechselnd von beiden ein gewisses Quantum aufnimmt und allmälig nach unten führt, da in jeder Windung des Kanales das Wasser den unteren, die Luft den oberen Raum einnimmt. Schliesslich strömt die Luft in das Windleitungsrohr, das Wasser durch die Oeffnung des Conus in den äusseren Behälter zuriick. Der Höhenunterschied zwischen dem äusseren und dem Wasserspiegel im untersten Theil des Cylinders entspricht der Spannung der verdichteten Luft. - Die Leistungen der Cagniardelle sollen sehr befriedigend sein, doch hat die schwierige Herstellung derselben ihrer weiteren Anwendung eine Grenze gesetzt.

Bei einer anderen Gruppe, die man Was sergebläs e nennen kann, wird die Verdichtung und Fortschiebung des Wassers durch unmittelbare Wirkung des unter entsprechender Gefällshöhe zuströmenden Wassers erzielt. Es gehören dazu das Hensehel'sche Ketten-oder Paternostergebläs e, das von demselben Erfinder stammende W a s s e r ä ulengebläs e und das Alth a n s'sche Wasserstopfengebläse, von welchen nur je ein Exemplar ausgeführt wurde, und die beiden ersteren

Fig. 1743.

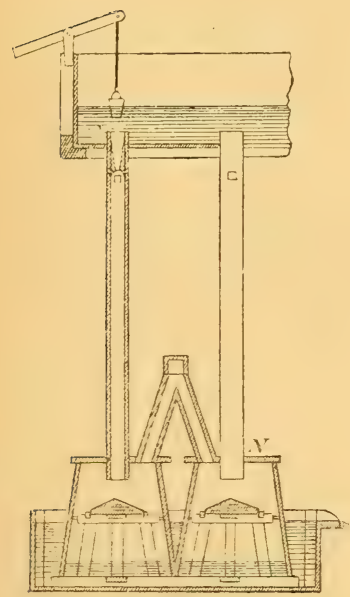

wegen zu complicirter Construction, das letztere wahrscheinlich wegen geringen Effectes keine weitere Verbreitung fanden, daher deren $\mathrm{Be}$ schreibung hier füglich übergangen werden kann.

Ferner sind zu erwähnen die W a s s e rund $\mathrm{D}$ a m p f trahlge bläs e, bei welchen Wasser oder Dampf mit so grosser Geschwindigkeit durch eine Röhre strömt, dass die Spannung in der letzteren unter die atmosphärische sinkt, daher durch seitliche Oeffnungen in der Röhre Luft eintritt, welche vom Wasser oder Dampf mechanisch mitgerissen und schliesslich durch Abgabe der lebendigen Kraft verdichtet wird. Hieher sind zu rechnen das Wassertrommel- und das Dampfstrahlgebläse.

Die $W$ assertrom melge bläs e sind nach Fig. 1743 gewöhnlich paarweise aufgestellt. An den Boden des oben befindlichen Gerinnes für das Kraftwasser schliessen sich die Einf a $11 \mathrm{röhren}$, von welchen in Figur 1743 die eine durchschnitten, die andere in der Ansicht erscheint; durch einen mittelst Hebel beweglichen Holzkegel kann die einströmende Wassermenge regulirt werden. Am Obertheil der Röhren befinden sich Oefinungen für den Eintritt der Luft, die sogenannten $\mathrm{Schlucklöcher.} \mathrm{Jede} \mathrm{Einfallröhre} \mathrm{mïndet} \mathrm{unten} \mathrm{in} \mathrm{eine} \mathrm{umge}$ stuirzte Tonne, die Trommel, welche in einem mit einer Abflusslutte versehenen Behälter steht, und an deren Deckel sich die Windleitung anschliesst. Indem das Wasser die Einfallröhre durchströmt, nimmt es eine gewisse Geschwindigkeit an, daher die Pressung im Obertheil der Röhre entsprechend kleiner wird als die atmosphärische. Die durch die Schlucklöcher eingetretene Luft gelangt mit dem Wasser in die Tonne und entweicht in die Windleitung, während das Wasser unter dem Rand der Tonne durch in den äusseren Behälter tritt und von dort continuirlich zum Abflusse gelangt. Um Wasser und Luft thunlichst von 
einander zu scheiden, ist in der Trommel ein Tisch mit flach kegelförmiger Platte, die sogenannte $\mathrm{Brechbank}$ aufgestellt. Die Verengung am oberen Ende der Einfallröhre hat den Zweck, die Geschwindigkeit des Wassers zu steigern und dadurch die Pressung um so mehr herabzusetzen. Die Wassertrommel ist das einfachste Gebläse, weil sie keine bewegten Theile enthält und ganz aus Holz hergestellt werden kann. Das Gefälle beträgt 3 bis $9^{\mathrm{m}}$, der Durchmesser der Einfallröhren 0.2 bis $0.26^{\mathrm{m}}$, die erreichbare Pressung ist nach dem Gefälle verschieden und steigt bis 4.5 Cent. Quecksilber, die gelieferte Windmenge beträgt 0.04 bis 0.07 Cubikmeter per Secunde. Der wesentliche Nachtheil ist der geringe Wirkungsgrad, der nicht höher als auf 0.05 bis $0.06 \mathrm{zu}$ veranschlagen ist. Die Anwendung dieses Apparates gehört daher auch mehr der Vergangenheit an.

Das D a m p f trahlgebläs e ist dagegen eine Erfindung der neueren Zeit, und ist der $\mathrm{G}$ i f $\mathrm{f}$ a $\mathrm{r}$ d'schen Dampfstrahlpumpe ähnlich, nur dass dasselbe Luft statt des Wassers saugt. Da die Luft mit dem Wasserdampf austritt, ist dieses Gebläse nur dort verwendbar, wo der Gehalt an Dampf dem betreffenden Hiittenprozess keinen Nachtheil bringt. Dasselbe kommt bei Gasgeneratoren, wo ein solcher Gehalt sogar vortheilhaft ist, zum Einblasen von Luft in den geschlossenen Raum unter dem Rost (Erzeugung von Unterwind) in Benützung. Bei dem Körting'schen Gebläse wird zuerst durch einen Dampfstrahlapparat das Gemenge von Luft und Dampf in einen Behälter geblasen, worin der Dampf sich theilweise niederschlägt, sodann in einen zweiten grösseren Apparat, um hier als Motor von Neuem Luft anzusaugen und mit dieser vereint in die Windleitung zu strömen. Im Allgemeinen lässt sich von den Dampfstrahlgebläsen analog den Giffard'schen Injectoren nur ein geringer Wirkungsgrad erwarten, und wird sich daher deren Anwendung nur auf specielle Fälle beschränken. (S. Injectoren.)

Auch die Centrifugalventilat oren spielen im Hüttenwesen eine verhältnissmässig untergeordnete Rolle. Der Grund davon ist, dass diese Maschinen sich zur Erzeugung höherer Pressungen nicht eignen. Die erreichbare Pressung hängt von der Umfangsgeschwindigkeit des Ventilatorrades ab, und je grösser erstere sein soll, desto grösser müssen Durchmesser und Umgangszahl sein. Bei grossem Durchmesser wird der Ventilator schwer und kostspielig, bei grosser Umgangszahl wachsen der Verbrauch an Schmiere und die Reparaturen. So kann eine Pressung von circa 3 Centimeter Quecksilber als die Grenze dessen betrachtet werden, was praktisch ohne grosse Uebelstände erreichbar ist. Ein Ritting e r'scher Ventilator z. B. erfordert dabei schon $1 \cdot 6^{\mathrm{m}}$ Durchmesser und 900 Umgänge pr. Minute oder $1 \cdot 2^{\mathrm{m}}$ Durchmesser und 1200 Umgänge. Dagegen fiihrt erst ein sehr grosses zu bewegendes Luftvolum auf Schwierigkeiten der Ausführung, weil dieses nur eine Vergrösserung der Breite des Ventilatorrades und des Durchmessers der Saugöffnungen, nicht aber eine Vermehrung der Umfangsgeschwindigkeit erfordert. Die sonstigen wesentlichen Vorzüge sind Einfachheit der Construction, bei welcher insbesondere die Ventile wegfallen, und gleichförmige Luftströmung. Centrifugalventilatoren werden dort angewendet, wo eine geringe Pressung genügt, wie bei Kupolöfen, Frisch- und namentlich bei Schmiedefeuern.

Der Wirkungsgrad der gewöhnlichen Ventilatoren beträgt 0.25 bis 0.35 , die Construction ist sehr verschieden und basirt nicht stets auf bestimmten Principien. In der Regel bestehen dieselben aus einem mit gekrimmten Flïgeln versebenen Rade, welches in einem Gehäuse eingeschlossen ist, an das sich tangential die Windleitung anschliesst. Im Gehäuse befindet sich auf einer oder auf beiden Seiten eine kreisförmige Sangöffnung, deren Mittelpunkt in die Achse des Rades fällt. Indem das letztere rotirt, erhält die zwischen den Flügeln eingeschlossene Luft ebenfalls eine drehende Bewegung und gelangt zufolge der Fliehkraft in das Gehäuse und von dort in die Windleitung. Durch den Austritt der Luft aus dem Flügelraum wird in diesem die Spannung kleiner als die atmospärische, und es findet daher ein stetes Nachströmen äusserer Luft durch die Saugöffinung statt. 
Bei Rittinger's Ventilator Fig. 1744 besteht das Rad aus einer massiven und einer mit einer Oeffnung in der Mitte versehenen Scheibe; zwischen diesen beiden parallelen Scheiben befinden sich die gekriummten Flügel, welche an der Innenseite eine derartige Richtung besitzen, dass der Eintritt der Luft ohne Stoss stattfindet, aussen jedoch radial auslaufen, da nach Rittinger's Theorie der Ventilatoren bei dieser Form die zur Erzielung einer gegebenen Pressung nothwendige Umfangsgeschwindigkeit am kleinsten wird. Die Oeffnung in der einen Ventilatorscheibe correspondirt mit der Saugöffnung in einer von den beiden ebenen parallelen Wänden des Gehäuses. Das letztere ist unter Berïcksichtigung des Umstandes, dass von gleichen Theilen des Radumfanges gleich viel Luft ausströmt, spiralförmig erweitert. Nach der genannten Theorie ergibt sich bei geringen Windmengen das Rad, parallel zur Achse gemessen, sehr schmal, wodurch der Nebenwiderstand gegen die Bewegung der Luft verhältnissmässig gross wird.

Fig. 1744.

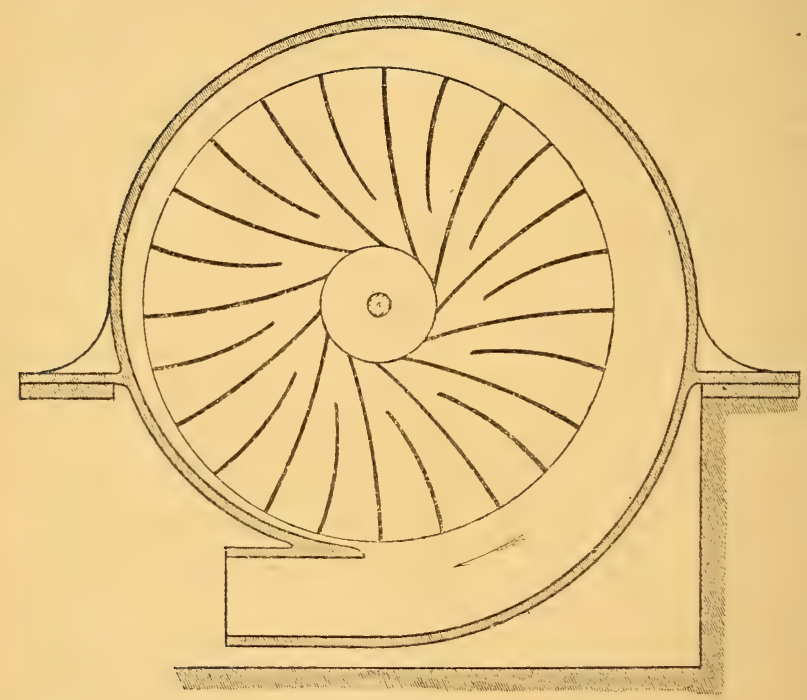

Rittingers Ventilator.

Ziemlich verbreitet ist die Ventilatorform, welche Fig. 1745 im Horizontalschnitte zeigt, und welche von $\mathrm{Colt}$, später von $\mathrm{Schiele}$ ausgefuihrt wurde. An die Achse schliesst sich das aus Nabe, Armen und dreieckigen Fliigeln bestehende Rad; das Gehäuse ist zweitheilig und besteht aus einem mittleren, beiderseits conisch zulaufenden und einem äusseren Theil in Form eines Ringes von kreisförmigem Querschnitt, an welchen sich tangential die Windleitung anschliesst. Die Verengung des Flügelraumes gegen Aussen hat den Vortheil einer allmäligeren $\mathbf{A b}$ lenkung und geringeren Contraction des Luftstromes, welcher parallel zur Achse eintritt und sodann eine radiale Richtung annehmen muss. Auch arbeitet dieser Ventilator ohne das Geräusch, welches nicht nur lästig ist, sondern auch auf weniger guten Gang und Effect schliessen lässt.

Bei L 1 o y d's Ventilator Fig. 1746 sind die Flügel etwas zurückgekrimmt, für welche auch sonst vorkommende Einrichtung verschiedene, nicht ganz stich- 
hältige Erklärungen gegeben werden. Die Austrittsgeschwindigkeit der Luft vom Rade wird durch diese Construction herabgesetzt, was zur Verminderung der Nebenhindernisse beitragen mag. Das Gehäuse besteht aus 4 in einer Horizontalund einer Verticalebene zusammenstossenden Theilen. Auch hier ist der Fliigelraum stark gegen Aussen verengt. Bei einigen anderen Arten sind die Flügel eben, jedoch ebenfalls nicht radial gestellt, sondern zurückgeneigt.

Eigenthümlich ist der Falliz e'sche Ventilator, dessen Rad statt der Flügel bloss eine Anzahl ringförmiger, in geringem Abstand von einander senkrecht zur Achse befestigter Scheiben enthält, von welchen die Luft nur durch Reibung mitgenommen und in Rotation versetzt wird, dann aber in Folge der Trägheit wieder in das umgebende Gehäuse entweicht.

Fig. 174 .̆.

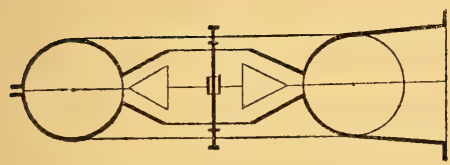

Colt's Ventilator.

(Horizontalschnitt.)

Fig. 1746 .

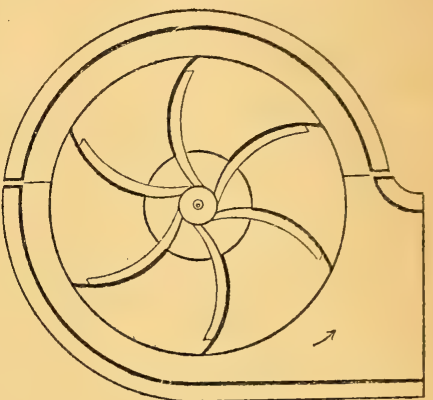

Lloyd's Ventilator.

Um die Umfangsgeschwindigkeit der Ventilatoren herabzusetzen, ist man auf die Idee verfallen, deren zwei oder mehrere derart zu combiniren, dass jeder die vom vorhergehenden gelieferte Luft ansaugt und dem folgenden wieder zubläst. Sind $n$ Ventilatoren vorhanden, so hat jeder die Pressung nur um den $n$ ten Theil der gewïnschten Gesammt-Erhöhung zu steigern. Sehr compendiös ist dieses Princip durchgefuihrt beim Hochdruckventilator von Clark (Polytechnisches Centralblatt 1870 , S. 736), bei welchem sämmtliche Räder auf einer gemeinschaftlichen Achse angebracht sind.

Die ausgedehnteste Bearbeitung des Capitels iuber Gebläse enthalten Jul. v. H a u e r's „Hüttenwesensmaschinen, “ II. Aufl., Leipzig 1876; ferner befassen sich mit dem Gegenstand, vorzugsweise beschreibend und vom Standpunkte des Hüttenmannes ans, die Werke über Eisenhüttenkunde; endlich enthalten die berg- und hüittenmännischen, sowie die sonstigen technischen Zeitschriften eine ausgedehnte Literatur über diese Maschinen.

J. v. Hauer.

Gebläselampe, s. Gla s blä s e rei.

Gebrochene Passage oder satzweiser Einzug (remettage interrompu) s. We berei.

Gedge's Metall. Legirung aus 60 Thl. Kupfer, 381/s Thl. Zink, 1.5 Thl. Eisen, dient zu Schiffbeschlägen, lässt sich hämmern und walzen. Gtl.

Geflechte, s. Flechtarbeiten III pag. 581.

Gefrierpunkt, E ispunkt, Nullpunkt der Celsius'schen und Reaumur'schen Thermometer, s. Wärmemessung. 
Gegen-Email (contre-émail) ist Email, welches auf der Gegenseite diinuer Metallbleche, z. B. Zifferblätter, aufgetragen werden muss, um das Verziehen zu hindern und das Object zu verstärken, s. Email III pag. 267.

Gegenmuttern, Contremuttern, s. Schraubenversicherungen.

Gegen-Punzen (contre-poinçons - counter-punches), s. P unzen.

Gegenwinder, s. Ba u mo ollspinnerei I pag. 353.

Gehänge, öfter gebrauchte Bezeichnung für Constructionstheile, an welche andere Theile angehängt sind oder hiedurch von oben oder der Seite her getragen werden, z. B. bezeichnet man so die Zwischenrahmen der Formkästen (Hängeisen), Theile am Webstuhl, welche Schäfte tragen (Rollen, Gehänge) etc.

Gehreisen, s. Ge is fuss.

Gehrmass, s. Gehrung.

Gehrung (onglet, anglet, biaisement, mitre - mitre). Der Tischler, Zimmermann und auch einige Metallarbeiter bezeichnen unter Gehrung den Winkel von $45^{\circ}$. In der Gehrung zusammengefiigte Theile sind dann solche, welche je unter $45^{0}$ zugearbeitet und dann zusammengefiigt eine rechtwinklige Ecke bilden. Namentlich für Holzarbeiten hat diese Verbindungsweise grosse Verbreitung und bedient man sich verschiedener Hilfswerkzenge, welche die Herstellung der Gehrung erleichtern. Hierher gehört das Gehrmass (équerre-onglet - mitre square), welches ein Winkelmass mit Anschlag ist, bei welchem beide Schenkel mit einander den Winkel von $135^{\circ}\left(90^{\circ}+45^{\circ}\right)$ einschliesseu, s. M esswerkzeuge.

Die Gehrungsschneidlade und die Gehrungsstosslade sind Hilfswerkzenge, bei welchen eine Säge, respective ein Hobel, unter $45^{0}$ gegen die Längskante des Arbeitsstiickes geführt wird und so die Herstellung, resp. Zuarbeitung der Gehrung erleichtert wird. Die erstere wird als Hilfswerkzeug bei Schneiden mit der Säge im Artikel Säge, letztere im Artikel $\mathrm{Hob}$ el besprochen.

$K k$.

Geigenharz, s. m. Colophonium, s. Fichtenharz III pag. 482.

Gëinsäure, A cker-, 'T orf-Säure, Bestandtheil der Moorerde, verhält sich ähnlich der Huminsäure s. d., vgl. Humus.

Geisfuss. Diese Benennung kommt verschiedenen IVerkzeugen zu. So heisst Geisfuss eine zum Bewegen von Lasten verwendete Eisenstange (Brechstange, Beisser), deren Ende etwas diinner und in zwei, einen kurzen Spalt zwischen sich lassenden Zinken ausgeschmiedet ist. Dieses gabelförmige Ende kann auch zum Ausziehen von Nägeln verwendet werden.

Geisfuss (carrelet, burin - corner chisel, parting tool) wird ferner ein schneidendes Werkzeug genannt, welches aus zwei geradlinigen, unter 45, 60 oder $90^{\circ}$ zusammenstossenden Schneiden besteht und in Form und Anwendungsweise zu den Stemm- und Stechzeugen (s. d.) gehört. Unter demselben Namen kömmt ein in den Schneiden ähnliches Werkzeug (b V), aber mit noch spitzerem Winkel, beim Schneidzeug für hölzerne Schrauben (s. d.) in Anwendung. $K k$.

Geistuhren, Controllapparate, s. m. Spiritusmessapparate.

Gekrätz, Arco (arcot-dross), s. Kupfer.

Gekrätz, Kr ätze, Goldkrätze (lavure, cendres — dross, sweepings) werden verschiedene Abfälle beim Goldschmelzen und der Goldbearbeitung genannt, z. B. Feilspäne etc., s. Go ld a rb eiten.

Gekrösestein, s. Anhydrit. 
Geländer (barrière, garde-corps — railing), die Einfassung eines Raumes an den Seiten, iiber welche man nicht hinaustreten soll; zumeist angewendet bei Stiegen, offenen Corridoren, Balkonen, Brïcken etc. Die Einfassung, ca. $0.90^{\mathrm{m}}$ hoch, wird entweder durch Holzstäbe (gedrechselt, Traillen genannt) oder durchbrochen geschnitzte Bretter, guss- oder schmiedeiserne Stäbe und Gitter, Stein-, Terracotta- und Cement-Brïstungen in mannigfachster Weise hergestellt. Siehe auch Balustrade I, 285.

Grohm.

Geläger, Kühlgeläger d. i. Absatz auf den Kihhlstöcken der Brauereien, s. Bier I pag 495. Fassgeläger, Absatz in den Lagerfässern, vgl. Bi er, vgl. We in.

Gelatine, s. Leim, vgi. a. Gallerte.

Gelatine chinesische, vgl. Agar-Agar I pag. 59.

Gelatine japanische, vgl. Ag a r-Aga r I pag. 59.

Gelatinefolien, s. m. Leim folie, s. Leim.

Gelatinpapier (papier glace, papier gélatine) ist Hausenblasenfolie, erhalten durch Aufgiessen einer warmen Lösung von Hausenblasenleim, welche man auf eine schwach geölte Spiegelglastafel giesst, eine zweite eingeölte Tafel darauf legt und nach dem Erkalten beide auseinander nimmt.

Gelbbeeren, Gelbkörner (graines de Perse - yellow berries), Avignonkörner, Kreuzbeeren, Persische Beeren. Unter diesem Namen kommen die getrockneten unreifen Beeren mehrerer in Italien, Spanien, der Türkei, KleinAsien, Persien einheimischer, im suidlichen Frankreich häufig cultivirter Rhamnus(Kreuzdorn-) Arten in den Handel und werden als Farbmaterialien verwendet. Die Beeren sind etwa erbsengross, rundlich mit drei oder vier halbkreisförmigen Einschnürungen, welche vom Stiel nach der Spitze zulaufen und den Zwischenräumen der in dem Fruchtfleische eingebetteten Samenkörner entsprechen. Die Farbe ist gelbgriin, bräunlich bis schwarz, sie haben einen eckelhaften Geruch und einen bitteren unangenehmen Geschmack.

Man unterscheidet namentlich folgende Handelssorten:

a) Persische Beeren, sind an Grösse etwa grossen Erbsen gleich, laufen gegen den Stiel spitz $\mathrm{zu}$ und zeigen eine schön grïne Farbe. Sie sind vierfächrig und enthalten in den Fächern fast dreieckige Samen. Der Geschmack ist stark bitter. Sie kommen meist von Aleppo und Smyrna, wohl auch Triest aus in den Handel und stammen von Rhamnus amygdalimus, oleö̈des und saxatilis.

b) Levantische oder türkische Gelbbeeren (Grenetten), sind etwa pfefferkorngross und nur dreifächrig. Sie kommen aus der Türkei und Natolien iiber Konstantinopel und Smyrna zu Markte. Man unterscheidet sie ihrer Abstammung nach in Adrianopel-, bessarabische und wallachische Beeren, ron denen die letzteren die geschätzteste Sorte sind.

c) Morea-Beeren, die grösste Sorte der Gelbbeeren von lichtgelber Farbe mit blos zwei Samenfächern.

d) Französische oder Avignon-Beeren (graines d'Avignon french berries), sind pfefferkorngross, plattgedrüekt, unten spitzig, zweifächrig, von dunkelgriner Farbe. Sie stammen von Rhammus infectoria und alatermus, und sind von geringerem Werthe als die persischen.

e) Spanische Be eren sind den französischen ganz ähnlich, aber ron gelber Farbe und werthvoller als jene. Stammen von Rhamnus saxatilis.

f) Italionische Beeren gleichen ebenfalls den französischen Beeren und stammen von Rhamnus infectoria. 
g) Ungarische Beeren, stammen von Rhamnus cathartica und saxatilis, sind etwa erbsengross und vierfächrig, ziemlich geschätzt.

h) Deutsche Beeren, welche von Rhamnus cathartica stammen, sind die geringwerthigsten (vgl. a. Kreuzbeeren).

Die Gelbbeeren liefern mit Wasser gekocht einen schmutzig gelben Absud, welcher sich an der Luft leicht verändert und mit verschiedenen Beizmitteln Nuancen liefert, welche den mit Quercitron erzielbaren ähnlich sind. Mit Quercitron und Gelbholzabsud gemengt und mit Alaun und Kreide gefällt liefert der Gelbbeeren-Absud einen gelben Farblack, das Schittgelb (stil de grain). Die Gelbbeeren werden hauptsächlich zur Herstellung von Dampf- und Tafelfarben benützt, meist gemeinschaftlich mit Gelbholz und Quercitron, auch für die Zwecke der Buntpapierfärberei u. d. m.

Lässt man den Absud von Gelbbeeren mit Wasser, der mit etwas Schwefelsäure angesäuert ist, einige Zeit stehen, so tritt alsbald alkoholische Gährung ein, bei der sich eine schwer lösliche krystallinische Substanz abscheidet. Die Gelbbeeren enthalten neben sonstigen allgemeiner verbreiteten Pflanzenstoffen namentlich Rhamnin (Rhamnegin, Xanthorhamnin) und Rhamnetin (Chrysorhamnin), von welchen das erstere ein Glukosid (Mannid), das letztere, das auch als Spaltungsproduct des Rhamnins entsteht, das eigentliche färbende Princip ist, das sich durchaus wie Quercetin verhält (s. Rhamnin und $R h$ amnetin). In den Beeren von Rhamnus cathartica findet sich das auch als Frangulin (s. III pag. 625) bezeichnete Chromogen, Rhamno-X anthin, dann ein unkrystallisirbarer Bitterstoff das Rhamnocathartin und die Rhamnogerbsäure. Vgl. a. Kreuzbeeren und Kreuzdornfarbstoffe, vgl. Kane, Journ. f. pract. Chem. 29 pag. 481. Fleury, ebenda 26 pag. 226. Winkler, Jahrb. Pharm. 24 pag. 1. Binsw anger, Repert. Pharm. 104 pag. 54. Gellatly chem. Centralbl. 1858 pag. 477. Ortlieb, Bull. soc. de Mulhouse 30 pag. 16. Bolley, polyt. Centralbl. 1860 pag. 1125. Le fort, Compt. rend. 63 pag. 840 u. 1081. Schützenberger, chem. Centralbl. 1868 pag. 806. Stein, polyt. Centralbl. 1868 pag. 1176 und 1869 pag. 41. Casselmann, Annal. Chem. u. Pharm. 104 pag. 77. Phips on, Compt. rend. 47 pag. 153. Enz, Viertelj. f. pract. Pharm. 16 pag. 106. F a ust, Arch. Pharm. 187 pag. 8. Gtl.

Gelbbeeren chinesische. Unter diesem Namen kommen seit einigen Jahren die getrockneten Bliithenknospen von Sophora japonica als Farbmateriale in den Handel. Gtl.

Gelbbleierz, s. Wulfenit.

Gelbbrennen, s. Abbeizen I pag. 1.

Gelbcomposition. Beize zum Gelbfärben mit Quercitron auf Zeugen, ist eine Lösung von Zinn in 3 Thl. Salzsäure und 1 Thl. Schwefelsäure, s. Z e u gfärberei. Gtl.

Gelbeisenerz (fer oxydé jaune - iron ochre), Gelbeis enstein, gelber Eisenocker, gelber Glaskopf, Xanthosiderit, Min., ähnliche Formen zeigend wie Brauneisenstein, goldgelb-braun bis braunroth, ist Eisenoxydhydrat $\mathrm{Fe}_{2} \mathrm{O}_{3}+2 \mathrm{H}_{2} \mathrm{O}$. Findet sich neben Brauneisenstein, bildet aber in juingeren Formationen auch selbstständige Lager (Ilmenau). Mit Thon gemengt bildet es das thonige Gelbeisenerz (im Steinkohlengebirge und Jura), findet als Eisenerz Verwendung. Den gleichen Namen führt auch das bei Kolosoruk und Tschermig in Böhmen, dann bei Modum in Norwegen vorfindliche Kalium-Eisen-Sulfat (das von Modum ist Natrium-Eisensulfat) $4 \mathrm{Fe}_{\mathrm{a}} \mathrm{O}_{3} \mathrm{SO}_{3}+\mathrm{Ka}_{\mathrm{a}} \mathrm{SO}_{3}+9 \mathrm{H}_{2} \mathrm{O}$, welches in nierenförmigen Knollen oder Platten auch derb sich findet, schön ockergelb, mattglänzend und wenig spröde ist. Härte $=2.5-3$, spec. Gew. 2.7-2.9. Gtl.

Gelbeisenstein, s. Gelbeis en er z. 
Gelberde, ein lichter Brauneisenocker, welcher sich hie und da in Brauneisenstein- oder Bohnerzgruben, auch als Absatz eisenhaltiger Säuerlinge findet, dann auch ein ockergelber, feinerdiger Thon, der bei Wehrau in der Lausitz und zu Amberg in Franken vorkommt. Sie brennen sich sämmtlich roth, sind in Säure theilweise löslich. Die Gelberde kommt geschlemmt in den Handel und dient als Anstrichfarbe.

$L b$.

Gelbgiesserei (fonderie de cuivre jaune - brass-foundry), Messinggiesserei (s. Giesserei).

Gelbgummi, s. Acaroidharz I pag. 45.

Gelbharz, s. Acaroidharz I pag. 45.

Gelbholz (murier des teinturiers - yellow wood), alter Fustik. Das rindenfreie Stammholz des Färbermaulbeerbaumes, Morus tinctoria L. (Maclura tinctoria Nutt., Broussonetia tinctoria Kunth.), einer in Ostindien, Südamerika, dann einzelnen Theilen Nordamerikas, Jamaika, Cuba, Tabago einheimischen Urticee, welche oft die Höhe von 50-60 Fuss erreicht. Das Holz ist blass citronengelb, fest und hart, fast spröde, ziemlich leicht, zuweilen von röthlichen Adern durchsetzt. Es kommt in Scheiben bis zu $50 \mathrm{~K}$. schwer in den Handel, welche beiderseits abgeschnitten sind. Auch gemahlen und geraspelt wird es zu Markte gebracht. Die beste Handelssorte ist:

a) Das Cuba-Gelbholz, das von Cuba stammend in kleinen, runden, ziemlich dicken Stücken von äusserlich brauner, innen schön gelber Farbe vorkonumt und in der Regel roth geadert ist.

b) Das Tampico-Gelbholz ist lichter gelb als das Cubaholz, mit dem es zumeist in den Handel kommt. Eine seltenere Handelssorte ist

c) das Brasilien-Gelbholz (gelbes Brasilienholz), das sehr hellfärbig, matt, meist wurmstichig und eine geringwerthige Sorte ist. Besser als dieses ist

d) das Jamaika-Gelbholz (Tuspanholz, ostindisches Gelbholz) von lebhaft gelber Farbe, am Schnitte deutlich glänzend, das in einzelnen Stücken dem Cubaholze an Werth fast gleichkommt, aber schwerer ist als jenes, und

e) das Portorico-Gelbholz (Carthagena-, Marakaibo-, San DomingoGelbholz), das ziemlich licht gefärbte, ungleich grosse, schwere Stücke bildet. Sehr geschätzte Sorten bilden endlich

f) das Siam-Gelbholz oder Kaleb (Kardarang der Malayen), das von Siam zu Markte kommt, und

g) das Madagora- oder Jungfernholz, das aus Indien stammmt.

Das Gelbholz enthält wesentlich zwei bei der technischen Verwendung desselben in Betracht kommende Stoffe, nämlich das Morin (Morinsäure) und das Maclurin (Moringerbsäure). Das Morin, zuerst von Chevreul ertdeckt, kann erhalten werden, wenn man den wässrigen Absud des Gelbholzes stark (etwa bis zur Hälfte des Gewichtes des verwendeten Holzes) eindampft und mehrere Tage stehen lässt. Es scheidet sich ein Bodensatz ab, der neben Morin auch die Hauptmasse des Maclurins enthält. Derselbe wird abfiltrirt, gepresst, zweimal mit Wasser ausgekocht und siedend heiss filtrirt. Der hiebei ungelöst bleibende Antheil ist rohes Morin mit etwas Morinkalk. Man erhitzt dasselbe mit Wasser und etwas Salzsäure, wäscht gut aus, löst den Rückstand in kochendem Weingeist, rermengt die Lösung mit $2 / 3$ des Volumens an heissem Wasser und lässt erkalten, wobei sich fast alles Morin in gelben Nadeln ausscheidet, das durch wiederholtes Umkrystallisiren aus Weingeist und endliches Entfärben mit Schwefelblei völlig gereinigt werden kann.

Es bildet glänzende, fast völlig farblose, 1-3 Linien lange Krystallnadeln, die häufig zu Büscheln gruppirt sind, von schwach bitterem Geschmacke und 
schwach sanerer Reaction. Es löst sich in 4000 Thl. kaltem und 1060 Thl. siedend. Wasser, leicht in Weingeist, schwer in Aether, nicht in Schwefelkohlenstoff. Alkalien lösẻn es leicht mit tiefgelber Farbe, wässrige Säuren lösen ebenfalls etwas leichter als reines Wasser. Die Zusammensetzung der Krystalle entspricht der Formel $\mathrm{C}_{12} \mathrm{H}_{\mathrm{s}} \mathrm{O}_{5}+\mathrm{H}_{2} \mathrm{O}$; sie verlieren ihren Wassergehalt erst bei $250^{\circ} \mathrm{C}$. vollständig. Beim Erhitzen über $300^{\circ}$ C. sublimirt ein Theil des Morins, während sich ein Theil in Kohlensäure, Phenol und Brenzcatechin zersetzt. Mit Eisenchlorid färbt sich die Lösung dunkelgrün. Mit Kali, Natron, Kalk etc. bildet sie salzartige Verbindungen, von denen das Morinkali $\left(\mathrm{C}_{12} \mathrm{H}_{9} \mathrm{KO}_{6}\right)$ sich in Gestalt weissgelber, nach dem Trocknen braungrün werdender Krystallnadeln aus einer heiss bereiteten Lösung des Morins in kohlensaurem Kali abscheidet. Morinkalk $\left(\mathrm{C}_{24} \mathrm{H}_{1 \mathrm{~s}} \mathrm{CaO} \mathrm{O}_{12}\right)$ bildet einen gelben Niederschlag, der durch Fällung von Morinkali mit Chlorcalcium erhalten werden kann. Mit Salpetersäure liefert es eine rothe Lösung die beim Verdampfen tafelförmige, gelbweisse Krystalle von Styphnins ä ure hinterlässt (vgl. Chevreul, Journ. chim. med. 6 pag. 158. R. W a gner, Journ. f. pract. Chem. 51 pag. 82, 52 pag. 449. Hlasiwetz u. Pfaundler, Journ. f. pract. Chem. 90 pag. 445 und 94 pag. 65).

Das Maclurin oder die Moringerbsäure kann aus dem durch wiederholtes Auskochen des, rohes Morin und Maclurin enthaltenden ersten Absatzes aus dem Gelbholzabsude (siehe oben), gewonnenen Filtrate durch starkes Eindampfen und Zusatz von etwas Salzsäure abgeschieden und durch wiederholtes Umkrystallisiren aus schwach angesäuertem Wasser gereinigt werden. Es bildet, wenn völlig rein, farblose Kryställchen von süsslich zusammenziehendem Geschmacke, wenn noch unrein, hellgelbe mikroskopische Nadeln, die bei $140^{\circ} \mathrm{C}$. ihr Wasser verlieren und bei $200^{\circ}$ C. schmelzen, bei weiterem Erhitzen tritt Zersetzung ein. Löst sich in 6.4 Thl. Wasser von $20^{\circ} \mathrm{C}$. und 2.1 Thl. kochendem Wasser mit gelber Earbe; leicht in Weingeist, Holzgeist, Aether. In wässrigen Alkalilösungen ist es leicht löslich, kohlensaure Alkalien werden unter Kohlensäure-Abscheidung zersetzt. Die Zusammensetzung entspricht der Formel $C_{13} H_{10} O_{6}$. Die Lösungen reduciren leicht alkalische Kupferoxydsalze, sowie Gold- und Silbersalze. Die alkalischen Lösungen färben sich an der Luft dunkelbraun, die wässrige Lösung liefert mit Eisenoxydsalzen einen grünschwarzen Niederschlag. Mit Kalihydrat geschmolzen zerfällt es in Phloroglucin und Protocatechusäure. Mit Zink und Schwefelsäure erhitzt liefert es eine Anfangs hochrothe, dann gelbe Lösung, in welcher neben Phloroglucin M a chromin $\left(C_{14} H_{10} O_{5}\right)$ enthalten ist, das sich durch Ausschütteln der Lösung mit Aether-Weingeist ausziehen und durch Fällen der wässrigen Lösung des Verdunstungsrückstandes mit Bleizucker, Zersetzen des Niederschlages mit Schwefelwasserstoff und Verdunsten des Filtrates nach dem Umkrystallisiren aus heissem wässrigen Weingeist in farblosen Kryställchen erlalten lässt, die sich unter Einwirkung von Luft und Licht bald dunkelblau färben; eine Erscheinung, welche auch die heiss bereitete wässrige Lösung sowohl an der. Luft als auch nach Zusatz von Ammoniak oder ätzenden Alkalien zeigt (vergl. R. W a gn er, Journ. f. pract. Chem. 51 pag. 82, 52 pag. 449. Delffs, n. Jahrb. f. Pharm. 14 pag. 166. Hlasiwetz und Pfaundler, Ann. d. Chem. und Pharm. 127 pag. 357).

Das Gelbholz in Spänen oder gemahlen wird in der Eärberei zur Herstellung von Farben verwendet, welche den mit Quercitron darstellbaren sehr nahe kommen. Seine Abkochungen liefern mit Alaun einen hellgelben, mit Zinnchlorür einen gelben, mit Bleizucker cinen orangegelben, mit essigs. Kupfer einen braungelben Niederschlag. Mit Eisenoxydsalzen liefern sie eine braune Färbung und einen grïnlich schwarzen Niederschlag. Die Blei-, Zinn- und Thonerdeniederschläge finden als Körperfarben Verwendung. Gtl.

Gelbholz tyroler, s. Fustikholz III pag. 663.

Gelbholz ungarisches, Zimte-Gelbholz, s. Fustikholz III pag. 663. 
Gelbin, s. m. chromsaurer Baryt, gelbes Ultramarin, s. Barytg e l b, I pag. 299.

Gelbkraut, s. W a u.

Gelbmenakerz, s. Titanit.

Gelbmetall, Münz's Verkleidungs-Metall, hämmerbares Messing, s. Mess ing, s. $\mathrm{K} u \mathrm{p}$ fer.

Gelbschoten chinesische (gousses de Chine - wongshy), Wongsky (HoangIschy), d. s. die Früchte von ('ardenia grandiflora Lour, einer in Ostindien einheimischen Gentianee. Die Schoten sind $2-3^{\mathrm{cm}}$ lang, bis $1^{\mathrm{cm}}$ dick, ungleichmässig röthlichgelb gefärbt und schliessen in der harten brüchigen Schale ein vertrocknetes Fruchtfleisch ein, in welchem zahlreiche harte Samen eingebettet sind. Sie riechen ausgesprochen safranähnlich, quellen im Wasser bedentend auf, werden schleimig und färben die Flüssigkeit deutlich gelb. Das Fruchtfleisch schmeckt bitter, die Samen scharf-süsslich-sauer. Sie kommen vornelımlich von Batavia aus in den Handel. Die Gelbschoten enthalten neben Pectin, Zucker, Fett und Aschenbestandtheilen wesentlich einen gelben Farbstoff, dann Rubichlorsäure und zwei Gerbsäuren, die sich mit Eisensalzen grïn färben und deren eine der Formel $\mathrm{C}_{23} \mathrm{H}_{36} \mathrm{O}_{17}$, die andere der Formel $\mathrm{C}_{46} \mathrm{H}_{58} \mathrm{O}_{27}$ entsprechend zusammengesetzt sein soll (vgl. v. Orth, Journ. f. prac. Chem. 64 pag. 10). Der Farbstoff, welchen man nach Rochleder und Mayer (Journ. f. pract. Chem. 74 pag. 1) durch Extrahiren der Gelbschoten mit kochendem Weingeist, Verjagen des Alkohols und Entfernung der Gerbsäuren aus dem Extracte mittels Thonerdehydrat, Fällen des Filtrates mit Bleiessig, Zerlegen des Niederschlages mit Schwefelwasserstoff und Auskochen des Schwefelbleies mit Alkohol in weingeistiger Lösung erhalten kann, die nach dem Abdampfen über Schwefelsäure im Vacuum den Farbstoff als ein lebhaft rubinrothes Pulver hinterlässt, das von Wasser mit rothgelber, von Alkalien mit gelber Farbe gelöst wird, ist nach Rochleder und Mayer identisch mit Crocin, dem Farbstoffe des Safrans (s. d.). Die Gelbschoten finden Verwendung zum Gelbfärben gebeizter Zeuge. Der mit warmem Wasser bereitete Auszug färbt Wolle sowohl ungebeizt als auch mit Thonerdesalzen gebeizt schön orange, mit Kalkwasser gebeizt schön röthlichgelb. Seide färbt sich im wässrigen Auszuge schön goldgelb, Baumwolle mit Zinnsalz gebeizt, orange. Die Farben sind seifenecht, werden aber am Lichte gebleicht. Säuren und Zinnsalz nuanciren sie röthlich, Alkalien gelblich (vgl. a. Stein, chem. pharm. Centralbl. 9 pag. 140). Gtl:

Gelbwurzel, s. Curcuma II pag. 422.

Geleisanlagen, s. Eis en bahn III pag. 62 ete. bei Oberbau.

Gelenkbewegung, s. K in e matik.

Gelenkketten, s. Ketten.

Gelenkquarz, s. It a columit, vgl. a. Diamant II pag. 617.

Gelese, Fadenkreuz (encroix, enverjure - lease), s. Weberei.

Gelfkupfer, Rohkupfer (cuivre brut - coase copper), s. Kupfer.

Gellert's Grün, ältere Bezeichnung für Rinman's Grïn, d.i. Kobaltgrïn, Zinkgrün, s. Kobalt, s. Z ink.

Gelose (Hä̈-Thao), Name eines für Appreturzwecke verwendbaren, der Gelatine sich ähnlich verhaltenden Pflanzenstoffs, der aus einer in Cochinchina und auf Mauritius einheimischen Alge gewonnen wird. Kommt in groben, platten Fasern von etwa $30^{\mathrm{cm}}$ Länge in den Handel, welche aus einer harten und zähen, farblosen, durchscheinenden, von einem Netz undurchsichtiger Aederchen (Falten) 
durchzogenen Masse bestehen, die geschmacklos und geruchlos ist, in kaltem Wasser stark aufquillt, in Wasser von $75^{\circ} \mathrm{C}$. theilweise, vollständig in kochendem Wasser bei längerer Einwirkung (etwa 10 Minuten) löslich ist. Die Lösung stellt eine dünne, schmutzig-weisse, nicht klebrige Fliissigkeit dar, die nach dem Abkühlen zu einer Gallerte erstarrt, welche keine Neigung zur Fäulniss oder Gährung zeigt. Eignet sich insbesondere zur Appretur feiner Gewebe, welchen man einen geschmeidigen, dabei aber körnigen Griff ertheilen will, nicht aber zur Erzielung eines steifen, schweren Apprets, s. J. J. Heilmann Bull. d. l. soc. industr. d. Rouen 1875 pag. 263, auch Dingl. pol. Journ. 218 pag. 522. Gtl.

Gemüseconserven, s. b. Fäuln iss, III pag. 353 und 354 .

Genadelte Arbeit, s. Stickerei.

Genauigkeit (exactitude - accuracy). Als Mass der Genauigkeit einer Messungsoperation betrachtet man den bei einer Messung zu fürchtenden mittleren oder wahrscheinlichen Fehler, und zwar ist die Genauigkeit diesem Fehler umgekehrt proportional. Ebenso versteht man unter der Genauigkeit eines Instrumentes den mittleren oder wahrscheinlichen Fehler, den man bei einer Messung mit demselben zu befürchten hat. Zum Zwecke leichter und rascher Vergleichung rechnet man die relative Genauigkeit entweder als auf den Zähler 1 reducirtes Verhältniss des mittleren (oder wahrsch.) Fehlers zur gemessenen Grösse, od er als mittleren auf die Einheit (z. B. bei Längenmessungen) entfallenden Fehler, oder man drückt den Fehler in Procenten der gemessenen Grösse aus. $C z$.

Generator, s. Gasfeuerung III pag. 692.

Generator, Gaserzeuger, s. b. Leuchtgas, s. Gasfeuerung.

Generatorgas, s. Gasfeuerung, s. a. Brennstoffe II pag. 32.

Genever (genièvre - gin), Wachholder-Branntwein (Steinhäger) ist ein namentlich in Holland (Schiedam) bereiteter, aus Gerste oder Roggen unter Zusatz ron Wachholderbeeren zur Maische erzengter Branntwein, der auch wohl durch Rectificiren gewöhnlichen Bramntweines iiber Wachholderbeeren und etwas Hopfen dargestellt wird, seine Eigenthümlichkeit aber wesentlich dem Umstande verdankt, dass die Maischen mit rerhältnissmässig wenig Wasser und wenig Hefe vergohren werden. Er wird nicht selten auch dadurch imitirt, dass man gewöhnlichen Branntwein mit Wachholderöl parfumirt. Solcher Branntwein trübt sich mit Wasser, was Genever nicht thut. Vgl. Branntweinbrennerei. Gtl.

Genipkraut, Alpenwermuth, das Kraut mehrerer alpiner Artemisia-Arten, namentlich A. Hutellina Till., A. glacialis L., A. spicata Wulf., ist sehr aromatisch, dem gewöhnlichen Wermuthkraut ähnlich riechend, aber weniger bittei schmeckend als dieses, wesshalb es mit Vorliebe zur Bereitung des AbsynthLiqueurs (extrait d'absynthe) verwendet wird. Gtl.

Gentele's Grün, ein durch Fällung einer Kupfervitriollösung mit ZinnoxydNatron darstellbares Griin, das wesentlich aus Zinnoxyd-Kupferoxyd (zinnsaures Kupferoxyd) besteht. Gtl.

Gentiana-Violet. Name eines von Töpke und Leidloff in den Handel gebrachten Anilinviolets das, billiger als Methylviolett, sich in kochend heissem Wasser leicht löst und ebenso brillante Nuancen gibt wie Methylviolett, rergl. Pharm. Centralhalle v. Hager, 16 pag. 157, s. a. The erfarben. Gtl.

Gentianawurzel (racine de gentiane - gentirne root), Enzianwurzel, heissen die hauptsächlich zu Tincturen und Extracten verwendeten Wurzeln mehrerer Gentianarten, so der G. lutea, G. purpurea, G. punctata und G. pan- 
nonica, unter denen jene der $G$. lutea am längsten und stärksten sind. Die Wurzeln sind je nach ihrer Abstammung aussen rothbraun bis rothgelb, innen braungelb bis gelblich-weiss gefärbt, und zeichnen sich durch ihren intensiv bitteren Geschmack und süsslichen Geruch aus. Die mitunter im Handel vorkommende Wurzel der $G$. asclepiadea zeichnet sich durch grössere Verholzung aus, die vollkommen verholzten Wurzelstiicke dieser Species sind ganz werthlos.

Die Enzianwurzel ist reich an Zucker, so dass sie in den Alpen und Juragegenden zu Branntwein vergohren wird.

Der wichtigste Bestandtheil derselben ist das Gentiopikrin, ein von Krom a y e (Arch. Pharm. (2) 110, 27) isolirtes Glucocid, das gewöhnlich zu den Bitterstoffen gerechnet wird. Es hat die Formel $C_{20} H_{30} O_{12}$, krystallisirt in farblosen, zu Körnern oder strahlig gruppirten farblosen Nadeln, welche leicht in Wasser und wässrigem, schwer in absolutem Weingeist, nicht in Aether löslich sind. Es schmeckt rein bitter. Mit verdïnnten Säuren gekocht spaltet es sich in gährungsfähigen Zucker und in amorphes Gentiogenin $C_{14} H_{16} O_{5}$. Frische Wurzeln der $G$. lutea geben eine Ausbeute von nicht ganz 0.2 Proc., trockene liefern fast gar nichts. Das gleichzeitig in der Enzianwurzel in höchst geringer Menge vorkommende Gentisin, auch Gentianin, Gentiansäure genannt, bildet gelbe, lange, geschmacklose Nadeln, besitzt die Formel $C_{14} H_{10} O_{5}$ und spaltet sich nach Hlasiwetz und Habermann (Wien, Acad. Ber. 70, 211) in Essigsäure, Phloroglucin und Gentisinsäure, die wahrscheinlich mit der Oxysalicylsäure identisch, in höherer Temperatur unter Kohlensäureabspaltung Hydrochinon liefert.

Skraup.

Gentianin, Gentiansäure, s. Gentian a w u rzel.

Gentiogenin, Gentiopikrin, s. Genti a n a w urzel.

Gentisin, Gentisinsäure, s. Genti an a w ur zel.

Geoceraïn, Name eines wachsartigen Körpers der sich zugleich mit dem ebenfalls wachsähnlichen G e omyricin und der Ge ocera ïnsäure durch Behandeln mit kochend heissem Alkohol aus sächsischen Steinkohlen extrahiren lässt. Aus dem alkohol. Auszuge scheidet sich beim Erkalten das Gemenge der drei Körper als eine Gallerte $a b$, die abgepresst und geschmolzen einen dem Bienenwachse sehr ähnlichen Körper darstellt. Schmilzt bei $82^{\circ}$ C., ist brennbar. Das Geoceraïn entspricht der Formel $C_{\mathbf{2}} H_{56} O_{a}$, démselben isomer ist die Geoceraïnsäure, während das Geomyricin der Formel $\mathrm{C}_{34} H_{6 \mathrm{~s}} \mathrm{O}_{2}$ entspricht. $\mathrm{G} t \mathrm{t}$.

Geodäsie (géodésie - geodesia). Die Geodäsie; auch Vermessungskunde oder praktische Geometrie genannt, hat die Messung kleinerer oder grösserer Theile der Erdoberfläche und in letzter Linie die Messung der Erde selbst zum Gegenstande.

Durch die bei den Messungen verwendeten Instrumente einerseits und die Rechnungsmethoden anderseits, tritt die Geodäsie mit der Physik, beziehungsweise Mathematik in enge Beziehung, und es haben die genannten Disciplinen in ihrer Wechselwirkung einander wesentlich gefördert. Namentlich war es die reine Geometrie, welche in den einfachsten Aufgaben der Geodäsie, die Feldmessung betreffend, ihren Ursprung nahm. Die höheren Gebiete der Geodäsie treten auch mit der Astronomie in enge Berührung.

Die übliche ältere Eintheilung unserer Wissenschaft ist die in die niedere und höhere Geodäsie. Erstere beschäftigt sich mit solchen Aufnahmen, bei denen von der Krümmung der Erdoberfläche abgesehen werden kann; bei den Arbeiten der letzteren dagegen muss die Erdkriimmung in Rechumng gezogen werden. Diese Eintheilung entspricht mehr dem praktischen Standpunkte, während vom wissenschaftlichen Standpunkte eine ebene, sphärische, sphäroidische und geoidische Geodäsie zu unterscheiden wäre. In der ebenen G. wird dem Vermessungsgebiete mit Rücksicht auf seine geringe Ausdehnung eine 
Ebene substituirt; in der sphärischen G. denkt man sich im Vermessungsgebiete an die Erdoberfläche eine ihrer Krïmmung möglichst angepasste berïhrende Kugelfäche gelegt; die späroidische G. betrachtet die Erdoberfäche als Rotationsellipsoid (Sphäroid); die geoidische G. endlich führt Messungen zur Bestimmung der Dimensionen dieses Sphäroids und der Abweichungen der thatsächlichen Erdoberfläche ron dieser idealen Fläche ans, hat also die Feststellung des sogenannten Geoid's zur Aufgabe; derlei Arbeiten fasst man unter dem Namen "Gradmessungen" zusammen und hat in ihnen die höchste Aufgabe der Geodäsie zu erblicken.

Bei den geodätischen Messungen handelt es sich entweder um die Aus $^{s}$ dehnung einzelner Theile der Erdoberfläche in Richtung des Horizonts oder in verticalem Sinne und man unterscheidet darnach Horizontal- und Verticaloder Höhenmessungen. Bei allen kommt es der Hauptsache nach auf Längen- und Winkelmessungen an.

Nach dem Zwecke der Arbeit richtet sich die erforderliche Genauigkeit und nach dieser wieder das zu wählende Instrument und Messverfahren. Es ist daher für den Geometer von wesentlicher Bedeutung, den mit jedem Instrument erreichbaren Grad der Genauigkeit zu kennen, sowie auch uber die Fehlergrenzen der erlangten Resultate im Klaren zu sein. Die Theorie der Beobachtungsfehler und ilırer A usgleichung bildet sonach eine der Grundlagen der praktischen Geometrie. Viele der neweren Werke über Geodäsie widmen diesem Gegenstande die gebührende Aufmerksamkeit, so Hartner's Lehrbuch, Bauernfeind's Elemente u. A., vor allen aber Jordan's Taschenbuch und Handbuch der Vermessungskunde; ausserdem sind als Specialwerke zu nennen:

Chr. A. Gerling, die Ausgleichungsrechnungen der praktischen Geometrie, Hamburg und Gotha 1843. Dr. A. Sawitsch, die Anwendung der Wahrscheinlichkeitstheorie auf die Berechnung der Beobachtungen und geodätischen Messungen; deutsch v. C. G. L a is, Mitau und Leipzig 1863. F. R. Helmert, die Ausgleichungsrechnung nach der Methode der kleinsten Quadrate mit Anwendungen auf die Geodäsie und die Theorie der Messinstrumente. Leipzig, 1872.

Betrachtet man dic Geodäsie als Gegenstand des Studiums, so lat man drei Stufen des Lehrganges zu unterscheiden. 1. Die Theorie der Messinstrumente, ilure Handhabung, Prifung und Bericlitigung; die genave Kenntniss der Instrumente ist erste Bedingung einer erfolgreichen Arbeit. 2. Die eigentlichen Messoperationen. 3. Die Rechnungsmethoden, durch welche aus den unmittelbaren Ergebnissen der Messung die angestrebten Resultate abgeleitet werden. An Stelle der Rechnungsmethoden oder auch zu denselben treten häufig Constructionsmethoden, welche die bildliche Darstellung der aufgenommenen Objecte bezwecken; iibrigens geht letztere zuweilen mit dem Messverfahren Hand in Hand (Messtischaufnahmen).

Die später anzufiihrenden Terke uiber Geodäsie behandeln in der Regel alle erwähnten Stufen melr weniger gleichmässig. Doch mögen als Specialwerke iiber die Messinstrumente genannt werden:

Dr. E. F. Schneitler, die Instrumente und Werkzenge der höheren und niederen Messkunde etc. Leipzig 1848 (2. Aufl. 1852). K. Engelbreit, Instrumente der niederen und höheren Geodäsie und der Hydrographie. Nürnberg: 1852. Dr. G. Chr. K. Hunäus, die geometrischen Instrumente der gesammten praktischen Geometrie, deren Theorie, Bes hreibung und Gebrauch. Hamnover, 1864. (Näheres s. Messinstrumente.)

I. Die niedere Geodäsie beschäftigt sich mit Aufnahmen, welche vorzugsweise für die Zwecke der Technik, der Land- und Forstwirthschaft, des Catasters u. dgl. bestimmt sind. Man könnte auch die Markscheidekunst hieher zählen, welche sich mit der Vermessung ron Grubenräumen mit den mit denselben zusammenhängenden Taggegenden (Abziehen) und mit der bildlichen Darstellung des Aufgenommenen (Zulegen) befasst; doch wird diese, wegen ihrer Beschränkung: auf ein einziges praktisches Gebiet, gewöhnlich als selbstständige Disciplin behandelt. 
Allgemeine Literatur: J. Lemoch, Lehrbuch der praktischen Geonetrie Wien, 1849. 2 Bde., 2. Aufl. 1857. Fr. Hartner, Handbuch der niederen Geodäsie. Wien, I. Aufl. 1852, II. 1856, III. 1864, IV. 1872, V. von Prof. J. Wastler bearbeitet, 1876 . C. M. B a uernfeind, Elemente der Vermessunerskunde. I. Aufl. 1856 -58, II. 1862, III. 1869, IV. 1873, V. 1876. Fr. B a n r, Lehrbuch der niederen Geodäsie. Wien, 1858. J. Rebstein, Lahrbuch der praktischen Geometrie, mit besonderer Beriicksichtigung der Theodolithmessungen. Frauenfeld, 1868. W. Jordan, Taschenbuch der praktischen Geometrie. Stuttgart, 1873. K. J. Schmarda, Lehrbuch der praktischen Messkunst, Wien, 1874. Dr. W. Jordan, Handbuch der Vermessungskunde. 2 Bde. Stuttgart, $1877-78$ u. s. w. A. Li ebenam, Lehrbuch der Markscheidekunst und praktischen Geometrie, Leipzig, 1876. B o r c h e r's, Die praktische Markscheidekunst. Hannover, 1870.

Die bildliche Darstellung der aufgenommenen Theile der Erdoberfläche und der mit ihr verbundenen Gegenstände, die Verkleinerung, Vergrösserung und Vervielfältigung von Plänen sind Gegenstand des Situationszeichnens. J. G. Lehmann, Das Situationszeichnen. Dresden 1843. Scheda, Situationszeichenschlüssel. Wien 1854. Muszynski und Prihoda, Terrainlehre in Verbindung mit der Darstellung, Beurtheilung und Beschreibung des Terrains. Wien 1872. J. Z a ffa $\mathrm{k}$, Populäre Anleitung für die graphische Darstellung des Terrains in Plänen und Karten, Wien 1875. V. R. v. Streffleur', Allgemeine Terrainlehre. Wien 1876. (Herausgeg. von GM. A. Neuber.)

Die Zeitverhältnisse brachten es mit sich, dass in den letzten Decennien namentlich die für das Ingenieurwesen wichtigen Partien des Vermessungswesens eifrige Pflege fanden und zahlreiche literarische Producte zu Tage förderten. Dies betrifft insbesondere das Nivelliren, namentlich das barometrische $(a)$, das Abstecken von Linien (b) und die Tachymetrie (Schnellmessverfahren) (c).

Ad a) C. M. Ba uernfeind, Beobachtungen und Untersuchungen über die Genauigkeit barometrischer Höhenmessungen. Mïnchen 1862. A. Elschnig, Kurzgefasste Auleitung zu barometrischen Nivellirungen mit Quecksilber- und Metallbarometern. Salzburg 1869. R ühlmann, Die barometrischen Höhenmessungen. Leipzig 1870. E. Herzog, Prakt. Anleitung zum Höhenmessen mittelst Dosenbarometer. Pest 1870. H. Schoder, Hilfstafeln zu barometrischen Höhenbestimmungen nebst einer Anleitung zur Untersuchung und zum Gebrauche der Aneroidbarometer. Stuttgart 1872. J. Höltschl, Die Aneroide von Naudet und Goldschmid, 1872 u. s. w.

Ad $b$ ) W. Heyne, Das Traciren von Eisenbahnen in vier Beispielen und einem Anhange. Wien 1865. F. R. Hel m e r't, Die Uebergangscurven für Bahngeleise. Aachen 1872. K. K n o 11, Taschenbuch zum Abstecken der Curven an Eisenbahnen und Strassen. Stuttgart 1873. L. W inckel, Handbuch zum Abstecken von Curven. Berlin, 1873. Absteckung des Mont-Cenis- und des Gotthard-Tunnels. Koppe. Pestalozzi, Zeitschr. f. Vermessungsw. 1875-76. Die Eisenbahn, 1877 u. s. w.

Ad c) C. Werner, Die Tacheometrie und deren Anwendung bei Tracestudien. Wien 1873. R. Jähns, Der Vielmesser, ein neues Feldmessinstrument. Deutsche Bauzeitung 1875. F. Kreuter, Das neue Tacheometer. Briinn 1876. Dr. W. Tinter, Das Tachygraphometer von Wagner, Zeitschr. d. öst. A.- und I.-V. 1876. J. Szeepaniak, Universal-Nivellir-Instrument als Tacheometer. Wien 1878 u. s. w.

In neuerer Zeit sind Nivellements mit sehr genauen Instrumenten und unter Anwendung besonderer Vorkehrungen zur Ausfïhrung gekommen. Es sind dies die sogenannten Präcisionsnivellements, welche namentlich für die Zwecke der Europäischen Gradmessung in sehr grosser Ausdehnung vorgenommen werten. Sie haben sich für verlässlicher und genauer erwiesen als die friiher bevorzugten trigonometrischen Höhenmessungen.

Hirsch \& Plantamour, Nivellement de précision de la Suisse. Genf und Basel 1867-74. C. M. B a u ern feind, Das baierische Präcisionsuivellement, 
1870-72. Dr. Chr. A. Vogler, Ueber Ziele und Hilfsmittel geometrischer Präcisionsnivellements. München 1873 u. s. w.

II. Die höhere Geodäsie beschäftigt sich mit jenen Operationen und Rechnungen, welche bei Vermessung grösserer Theile der Erdoberfläche zur Anwendung kommen und in letzter Linie zur Kenntniss der Grösse der Erde und ihrer wahren Form führen; wenn letzterer Zweck zu Grunde liegt, so spricht man von einer Gradmessung. (Für die geschichtliche Entwickelung der Gradmessungen sehe man: J. J. Ba yer, Ueber die Figur und Grösse der Erde. Berlin 1861; diese Schrift hat insoferne eine hervorragende Bedeutung, als durch sie die jetzt im Zuge befindliche Europäische Gradmessung angeregt wurde.)

Literatur. Bessel und Baeyer, Gradmessung in Ostpreussen und ihre Verbindung mit russischen Dreiecksketten. Berlin 1838. G a us s, Untersuchungen ïber Gegenstände der höheren Geodäsie. Göttingen 1844-47. $\mathrm{Ph} . \mathrm{F}$ is ch e r, Lehrbuch der höheren Geodäsie. Darmstadt 1845-46, 2 Bde. J. J. B a e ye r, Das Messen auf der sphäroidischen Erdoberfäche. Berlin 1862. Hansen, Geodätische Untersuchungen. Leipzig 1865. Bremiker, Studien ïber höhere Geodäsie. Berlin 1869. Dr. W. Jordan, Handbuch der Vermessungskunde. Stuttgart 1877-78. (Dieses Werk gibt eine vollständige Darstellung des gegenwärtigen Standes des gesammten V(rmessungswesens) u. s. w.

Die wissenschaftlichen Grundsätze für die bildliche Darstellung grösserer Theile oder der ganzen gekriimmten Erdoberfäche in einer Ebene bilden den Gegenstand der Kartenprojection oder Chorographie.

C. F. Gauss, Allgemeine Auflösung der Aufgabe; die Theile einer gegebenen Fläche so abzubilden, dass die Abbildung dem Abgebildeten in den kleinsten Theilen ähnlich wird. Schumacher's Astron. Abhandl. 1825. Wittstein, über conforme Kartenprojection, Astr. Nachr. 1868. Grets chel, Lehrbuch der Kartenprojection. Weimar 1873 u. s. w.

In Betreff der periodischen Literatur für Geodäsie ist besonders die seit 1872 (Stuttgart) erscheinende "Zeitschrift für Vermessungswesen, im Auftrage und als Organ des Deutschen Geometervereins herausgegeben von Dr. W. Jordan", zu newnen, welche Abhandlungen aus allen Gebieten des Vermessungswesens bringt. Zahlreiche Abhandlungen geodätischen Inhaltes enthalten ferner die seit 1823 erscheinenden "Astronomischen Nachrichten", die „Zeitschrift für Mathematik und Physik", Grunert's Archiv, die zahlreichen technischen Zeitschriften u. s. w. Seit 1864 erscheinen alljährlich "Generalberichte der Europäischen Gradmessung" (Berlin).

Auch ein speciell den Geodäten gewidmeter Kalender (anfangs „Deutscher Geometer-Kalender, " seit seinem 3. Jahrgange "Kalender fuir Vermessungskunde" betitelt) wird seit 1874 durch W. Jordan herausgegeben; derselbe brachte in einigen Jahrgängen dankenswerthe Zusammenstellungen der einschlägigen Literatur.

Czuber.

\section{Geoghégan's Salz ist Quecksilberjodid-Cyankalium $\mathrm{HgJ}_{2}+{ }_{2} \mathrm{KCy}$.}

Geoid. Denkt man sich die gesammte Oberfläche des Meeres im völligen Gleichgewichte und erweitert selbe unter den Continenten durch unter einander und mit dem freien Meere communicirende Canäle, so heisst diese dem hydrostatischen Gesetze der ruhenden Fliissigkeit entsprechende Fläche, welche das Loth überall rechtwinklig durchschneidet, das Geoid. Dasselbe bildet den Gegensatz zur idealen Form der Erdoberfläche, dem Rotationsellipsoid. (Vgl. Geodäsie.)

$C z$.

Geokronit, Min., meist derb, dicht mit undentlich streifiger Structur, selten rhomb. Krystalle, Härte 2-3, spec. Gew. 6.45-6.54, licht bleigrau, schwarz angelaufen. Ist wesentlich Schwefelblei-Schwefelantimon ${ }_{5} P b S+S b_{9} S_{3}$ mit 65 Blei, 1.6 Kupfer, 16 Antimon, 16.9 Schwefel. Vorkommen Sala in Schweden, 
Merodo in Spanien, Pietro santo in Toskana. Die Varietäten von Sala und Pietro santo enthalten auch Schwefelarsen. Gtl.

Geometrie (géométrie - geometry). Die Geometrie beschäftigt sich mit den Raumgebilden und betrachtet dieselben nach ihrer Entstehung, organischen Beschaffenheit und Verwandtschaft. Ihren Anfang nahm sie in den durch das praktische Beduirfniss gebotenen Aufgaben der Feldmessung, ilıre Elemente wurden zum ersten Male durch Euklid zu einem wissenschaftlichen Systern greordnet.

1. Die Ellemente der älteren Geometrie, welche die Grundlage jedes geometrischen Studiums bilden, sind in einer grossen Reihe von Werken behandelt, die besonders anzuführen wir für ïberflüssig erachten.

2. Die Trigonometrie (und Polygonometrie), welche sich mit der für die Praxis wichtigen Auflösung von Dreiecken (und Polygonen) in der Ebene, auf der Kugelfläche und dem Sphäroid (ebene, sphärische und sphäroidische Trigon.) befasst, überträgt ihre Aufgabe durch Einführung der sogenannten Winkelfunctionen auf das Gebiet der Arithmetik.

J. A. Grunert, Elemente der ebenen, sphärischen und sphäroidischen Geometrie. Leipzig 1837. J. Dienger, Handbuch der ebenen und sphärischen Trigonometrie mit Anwendungen. Stuttgart 1855. W. Brennecke, Trigonometrie für das Bediirfniss höherer Lehranstalten. Berlin 1856 u. s. w.

3. Die analytische Geometrie, durch Descartes im XVII. Jahrhundert begrïndet, unterwirft die geometrischen Gebilde durch Einfiihrung der sogenannten Coordinaten und Hinzuziehung des Begriffes stetig veränderlicher Grössen einer algebraischen Behandlung; die auf diesem Wege erzielten Resultate werden wiedes. auf geometrisches Gebiet uibertragen. Je nachdem man es nur mit ebenen oder mit Gebilden dreifacher Dimension zu thun hat, unterscheidet man eine analytische Geometrie der Ebene und des Raumes.

J. Plïcker, System der analytischen Geometrie auf neue Betrachtungsweisen gegründet. Berlin 1835. O. Fort und 0 . S chlömilch, Lehrbuch der analytischen Geometrie. 2 Bde. Leipzig, I. Aufl. 1855, II. 1863. L. O. Hesse, Vorlesungen aus der analytischen Geometrie der geraden Linie, des Punktes und des Kreises in der Ebene. Leipzig 1865. G. Salmon, Kegelschnittslinien. Deutsch von Dr. W. Fiedler. Leipzig 1860. J. Plücker, System der Geometrie des Raumes in neuer analytischer Behandlungsweise. Diisseldorf 1846. L. 0. Hesse, Vorlesungen über die analytische Geometrie des Raumes. Stuttgart, I. Aufl. 1861, II. Aufl. bes. v. Gundelfinger. O. Böklen, Analytische Geometrie des Ranmes. Stuttgart 1861. G. S a lmon, Grundriss der analytischen Geometrie des Raumes. Deutsch von Dr. W. Fiedler. Leipzig 1863 u. \&. w.

4. Die darstellende oder beschreibende Geometrie (géométrie descriptive) eigentlich erst durch Monge's im Jahre 1794 erschienenes Werk "Leçons de géométrie descriptive" begriindet, lehrt die Darstellung räumlicher Gebilde in der Ebene, wozu sie sich der sogenannten Projectionsmethoden bedient, und die Ableitung der aus der Gestalt und Lage der Raumgebilile entspringenten geometrischen Beziehungen aus diesen Darstellungen. - Fiir die Technik hat die darstellende Geometrie als Theorie des constructiven Zeichnens herrorragende Bedeutung; vom wissenschaftlichen Standpunkte bedeutet sie einen wesentlichen Fortschritt in der Entwickelung der Geometrie und bildet ein Seitenstiick des analytischen Verfahrens.

J. de la Gournerie, Traité des géométrie descriptive. Paris 1860-64. C. F. A. Leroy, Traité des géométrie descriptive. Deutsch von Kauffmann. I. Aufl. 1838, II. 1853, III. 1873. K. P o hlke, Darstellende Geometrie. Berlin, 1860, II. Aut. 1866. J. Schlesinger, Die darstellende Geometrie im sinne der neueren Geometrie. Wien 1870. Dr. W. Fiedler, Die darstellende Geometrie in organischer Verbindung mit der neueren Geometrie. Leipzig, 1871, II. Auf. 1875 u. s. w. 
5. Die nenere Geometrie, auch wohl projectivische, synthetische, constructive Geometrie oder Geometrie der Lage genannt, ist eine der neuesten mathematischen Disciplinen und hat seit ilırer durch Poncelet's "Traité des propriétés projectives des figures" (Paris 1822, II. Aufl. 1865-66) erfolgten Begrindung einen sehr bedeutenden Aufschwung erfahren. Ihr Ursprung ist in der ihr unmittelbar vorangegangenen darstellenden Geometrie zu suchen. Die Bezeichnung "projectivische Geom." hat ihren Grund darin, dass sich diese Disciplin mit solchen Eigenschaften der Raumgebilde befasst, die bei der Projection erhalten bleiben; die Bezeichnung "synthetische Geom." ist so aufzufassen, dass im Gegensatze zur rechnenden analytischen die neuere Geometrie ihre Gebilde construirt oder entstehen Iässt. "Geometrie der Lage" wird sie wegen der vorherrschenden Rücksichtnahme auf die Lagenverhältnisse, den. Grössenverhältnissen gegenüber, genannt.

Ueber die historische Entwickelung der neueren Geometrie lese man die vortreffliche Einleitung zu H. Hankel's „Die Elemente der projectivischen Geometrie in synthetischer Behandlung" (Leipzig 1875).

A. F. Möbius, Der barycentrische Calcul. Leipzig 1827. J. Plü cker, Analytisch-geometrische Untersuchungen. Essen 1828-31. J. Steiner, Systematische Entwickelung der Abhängigkeit geometrischer Gestalten von einander. Berlin 1832. K. G. Chr. v. Staudt, Geometrie der Lage. Nürnberg 1847. Th. Reye, Die Geometrie der Lage. Hannover 1866-68. J. Steiner's Vorlesungen iiber synthetische Geometrie. Herausgegeben von K. F. Geiser und H. E. Schrötèr. Leipzig, 1866-1867, II. 1875-76. H. Gretschel, Lehrbuch zur Einführung in die organische Geometrie. Leipzig 1868 u. s. w.

6. In neuester Zeit wurde die Geometrie in umfassender Weise zur Ausfiihrung algebraischer Operationen und für Zwecke der Mechanik (s. d.) hier im Gegensatze zll der im XVIII. Jahrhundarte auf diesem Gebiete beliebten rein analytischen Richtung - verwendet; so entstanden die unter den Namen ,graphisches Rechnen" (Arithmographie) und "graphisclie Statik" (Graphostatik) und "Dynamik" bekannten Disciplinen.

II. Eggers, Grundziige einer graphischen Arithmetik. Schaffhausen 1865. K. Culmann, Die graphische Statik. Ziirich 1866. K. v. Ott, Grundzïge des graphischen Rechmens und der graphlischen Statik. Prag 1871; IV. A. 1878. L. Cremona, Der graphisehe Calcul. Deutseh von M. Curtze. Leipzig u. s. w.

7. Praktische Geometrie, s. Geodäsie.

Czuber.

Geomyricin s. Geocerain.

Georgine, nemnt Max Singer in Tournai ein aus den Rïckständen der Fuchsinfabrikation dargestelltes Gelb, das sich auf Seide und Wolle ohne Beize, anf Baumwolle mit Anwendung einer Thonerdebeize oder einer Sumachpassage auffirben lässt und die Farbennuancen von Curcuma, Gelbholz oder Pikrinsäure zu erzielen gestattet ( $\mathrm{rgl}$. M ax S inger, Deutsch. Industrie-Ztg. 1872 pag. 478, val. a. Ko p p, Wiener Ausstellungsber. ïber Gruppe III, Baader's Verlag, Schaffhausen pag. 138 und 144 ), s. Theerfarben. $G(t$.

Georginenöl, das äther. Oel aus den Knollen der Georginen (Dahlia variabilis). Kann durch Destillation derselben mit Wasser gewonnen werden, hat einen starken, eigenthïmlicken Geruch, sïsslichen Geschmack, ist schwerer als W:asser, butterartig, krystallinisch (rgl. Payen, Journ. Pharm. (2), 9 pag. 384 und 10 pag. 239). Gil.

Gepräge (coinage - stamp, coinage), s. M ï nz en.

Geradeisen, ein Reifmesser mit gerader Schneide (draving linife).

Geraderichten (dressage: redressage - straightening), geschieht bei Stangen und Blech häufig mit dem Hammer im kalten Zustande, falls die Biegungen nicht 
zu bedeutende sind (vgl. Schmieden). Um Draht gerade zu richten, bedient man sich der sog. Draht-Dressur, eines aus 5 Rollen bestehenden Werkzeugs. Fig. 1747. Die drei Rollen $r_{1} r_{2} r_{3}$ sind in einer geraden Linie auf fixen Aclisen aufgesteckt, die beiden anderen Rollen $r_{4} r_{5}$ sind gegen die ersten stellhar, also senkrecht auf die Durchzugsrichtung zu verstellen, je nachdem die Drahtdicke dies erfordert. Sämmtliche Rollen sind am Umfange eingedreht. Solche Drahtdressuren stehen in Verwendung bei den Drahtstiften-Maschinen, den Kratzenund Drahtspiralwinde-Maschinen $u$. dgl.

Fig. 1747 .

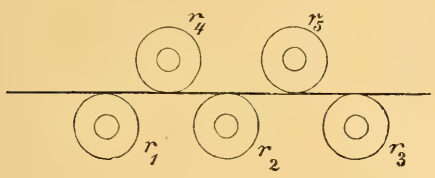

Fig. 1748.

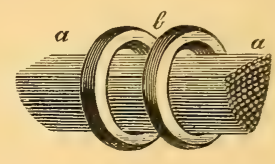

Das Geraderichten der Drähte für die Nähnadelfabrikation findet in der Weise statt, dass eine grosse Zahl der auf die Doppellänge der Nadeln geschnittenen Drähte zwischen zwei eisernen Ringen $r$ so eingelegt wird, wie es die Fig. 1748 zeigt. Man macht das Ganze dunkelroth gliihend und rollt den Pack, indem man mit den Schenkeln einer eisernen Gabel bei $a$ a niederdrückt, auf einem Eisentische hin und her. Hierauf schiebt man die Ringe etwas weiter auseinander und legt bei $b$ eine Flachschiene auf, mit welcher man den Pack wieder rollt. Hierdurch werden ein paar hundert Stifte in 2-3 Minuten genau gerade. Vergl. Artikel Drehen II 681 u. Art. W alzen (Geraderichtwalzen).

$K k$.

Geradführungen, s. K i n e m a tik.

Geradhäng-Maschine (machine à planter -- pitching tool.), eine $\mathrm{Uhr}$ macherei-M a s chine.

Geraniol, s. Ger an iumöl.

Geraniumöl (huile de géranium - geranium oil). Unter diesem Namen kommen mehrere von Andopogron und Pelargoniumarten stammende ätherische Oele in den Handel, welche wegen ihres rosenähnlichen Geruches vielfach als billigeres Surrogat für Rosenöl, sowie auch zur Verfälschung desselben verwendet werden.

Das echte Geranium- oder Rosenblattgeraniumöl, auch französisches Geranium- oder Palmae-Rosae-Oel stammt von Pelargonium Radula, aus dessen Blättern und Blüthen es durch Destillation mit Wasser gewonnen wird. Es ist farblos, mitunter auch grünlich oder gelblich, selbst bräunlich gefärbt und ist namentlich das letztere das am meisten geschätzte. Es siedet bei 216 bis $220^{\circ} \mathrm{C}$. und erstarrt bei $16^{\circ} \mathrm{C}$. Sein Geruch ist angenehm, dem Rosenöl ähnlich. Es polarisirt rechts. Dieses sowie das als algierisches Geraniumöl bezeichnete, aus den Blättern und Bliithen von Pelargonium roseum Willd. und $P$. odoratissimum, urspringlich im Oriente einheimischen, gegenwärtig aber mehrfach auch in Frankreich u. a. a. O. cultivirten Pflanzen, gewonnene Oel, welches dem französischen sehr ähnlich ist, aber links polarisirt, werden besonders häufig zur Verfälschung des Rosenöls verwendet, selbst aber auch mit dem Oele ron Andropogon-Arten (Grasöl) verfälscht, vgl. Citron ell ä̈l II pag. $36 t$.

Das türkische Geraniumöl (rosé - roshe oil, oil of rosegeranium, gingergrassoil) ist das äther. Oel von Andropogon Pachnodes Irin., einer in Ostindien, Persien und Arabien einheimischen Graminee, ist gelblich dünnflïssig, ron 
angenehm gewürzhaftem Geruche, nicht leicht erstarrend und kommt vorzüglich iiber Smyrna und Bombay in den Handel. Es wird angeblich in Mekka gewonnen.

Das Palmae-Rosae-Oel enthält Pelargons äure $C_{9} H_{18} \mathrm{O}_{4}$, eine farblose ölige Flüssigkeit, die bei niederer Temperatur erstarrt, bei $10^{0} \mathrm{C}$. schmilzt, bei $260^{\circ}$ siedet. Ist eine Säure aus der Reihe der Fettsäuren. Von weiteren Bestandtheilen des Geraniumöls sind zu nennen das Geraniol, das dem Borneol (s. d.) isomer $C_{10} H_{18} O$ ist und eine farblose, angenehm rosenartig riechende, bei $232^{\circ}$ C. siedende Fliissigkeit darstellt, die beim Eihitzen mit Zinkchlorid Geranien $C_{10} H_{16}$ als farblose, nach Möhren riechende Flüssigkeit liefert, welche bei $163^{\circ}$ C. siedet. Gtl.

Geranosin nannte Th. Luthringer einen ponceaurothen Farbstoff, der durch Einwirkung von Wasserstoffsuperoxyd oder von Baryumsuperoxyd und Schwefelsäure auf schwefelsaures Rosanilin erhalten werden kann, s. Monit. scient. 1868 pag. 39, auch d. Industrie-Ztg. 1868 pag. 75, vgl. a. The erfarben.

Gtl.

Gerbematerialien (tannins - tanning-materials). An Gerbstoff reiche, hauptsächlich in der Gerberei, zum Theil aber auch zu anderen technischen Zwecken, wie namentlich in der Färberei verwendete Rohproducte vegetabilischen Ursprungs. Die Zahl der Gewächse, welche in dieser Art beniitzte Stoffe liefern, ist eine beträchtliche und dieselbe nimmt natiirlich mit den sich erweiternden Kenntnissen Jahr für Jahr zu.

Gerbstoffe treten, und zwar in der lebenden Pflanze lauptsächlich als fliissiger Zellinhalt, in ober- und unterirdischen Theilen der meisten höheren Pflanzen auf. Sie können in den verschiedenartigsten Geweben vorkommen: in der Oberhaut, im Kork, im Parenchym und Prosenchym; am reichlichsten finden sie sich im Parenchym der Pinde dicotyler Phanzen, wie demn iberhaupt das Parenchym ihre vorzüglichste Ablagerungsstätte ist. Bald sind sie in allen parenchymatischen Zellen eimes Pflanzentheils, meist neben anderen Inhaltsstoffen, nicht selten selbst zwei versehiedene Gerbstoffe in einer Zelle vorhanden, bald ist ihr reichlicheres Vorkommen anf bestimmte, im Gewebe zerstreute oder zu netzförmigen Complexen zusammengestellte Zellen oder anf Schläuche beschränkt, welche die Crefässbündel begleiten, bald auf Zellschichten. Häufig finden sich Gerbstoffe auch im Holze, im Gewebe der Blätter, Bliithen und Friichte, seltener der Samen. Eine Uebersicht ler Gerbematerialien zeigt uns, diss es auch in der That Rinden dicotyler Holzgewächse sind, welche in grüsster Henge Verwendung finden, während die Zahl der in disser Richtung benüizten Friichte, Blätter. Hölzer und unterirdischen Theile eine weit geringere ist. Ausserdem gehören lieher gewisse durch Insecten hervorgerufene, durch grossen (ixhstoffgehalt ausgezeichnete Auswïchse (siehe den Artikel: Gallen) und eine Anzahl extractartiger Substanzen, wie Catechu, Gambir, Kino u. a., welche an den butreffenden Stellen eine besondere Besprechung finden Als die wichtigsten, Gerbeniterialien liefernden Pflanzenfamilien sind anzuführen: die Coniferen, Cupuliferen, Betulaceen, Ulmaceen, Salicineen, Artocarpeen, Casuarineen, Proteaceen, Ericaceen, Bignoniaceen, Rubiaceen, Rhizophoreen. Saxifragaceen, Malpigliaceen, Hippocastaneen, Rhamneen, Anacardiaceen, Combretaceen, Tamariscineen, Irrtaceen, Rosaceen, Amygdaleen und Leguminosen. Linter den Rinden spielen die wichtigste Rolle jene verschiedener Cupuliferen unt hier ror Allem die Rinden zahlreicher Eichenarten (Quercus). Ausser der Rinde der bei uns wachsenden (siehe: Eichenrinde) kommt auch jene verschiedener im Gebiete des Mittelmeeres einheimischen Arten, so ron Quercus Suber L., Q. Mirbectiii Dur., Q. castaneatolia Bor., Q. Psendo-Suber Desf., () Ilex L., Q. Ballota Dest., Q. coccifera L. in Betracht: für Nord-Amerika wichtige (ierberinden liefern dic dort einheimischen Quereus-Arten, insbesondere Q. Prines L. I'a1. 3. acuminata DC. (Q. Castanea Mulll.) ,White-Chestnut- 
Oak", deren Rinde ïber 16 Proc. Gerbstoff enthält und gleich dem daraus bereiteten flizssigen Extract (mit c. 28 Proc. Gerbstoffgehalt) das wichtigste (ierbematerial fuir die westlichen Unionsstaaten ist (W. Eitner in: Bericht iiber die Weltausstellung in Philadelphia 1876, Heft 18), ferner Quercus Prinus L. Var. $\gamma$. monticola (Q. montana Willd.) "Ruok-Chestnut-Oak", Quercus alba L. "White-Oak", Q. falcata Michx. "Spanish-Oak", Q. coccinea Wangenh. $\beta$. nigricans DC. (Q. tinctoria Michx.) "Black Oul:", Q. aquatica Walt. und Q. cinerea Michx. Von geringerer Bedeutung ist die Rinde anderer Cupuliferen, wichtiger dagegen die Weidenrinde, welche im Frühling von 2-4jährigen Trieben von verschiedenen Weidenarten gesammelt und nach sorgfältiger Trocknung in bandartigen Stïcken in den Handel gebracht wird. Ihr Gerbstoffgehalt, zwischen 3-16 Proc. schwankend, ist nach der Weidenart verschieden. Die gerbstoffreichsten Rinden liefern die sogenannten Bruchweiden (Salix fragilis L., S. alba L., S. pentandra L.), die Korbweiden (Salix viminalis L.) und Saalweiden (S. caprea L., S. cinerea L.). Die Weidenrinde (zumal jene von $S$. pentandra und caprea) dient schon seit Langem in Russland zur Bereitung des Juchtenleders und wird auch in neuerer Zeit in Deutschland zur Herstellung feinerer Ledersorten benützt. Besonders in den nordischen Ländern Europas, zum Theil auch in Deutschland spielt auch die Birkenrinde (von Betula alba L.), welche 5.5 Gerbsäure enthalten soll, eine Rolle. Weniger bedeutend ist die Erlenrinde (von Alnus-Arten) und die Ulmenrinde (von Ulmus campestris L.), dagegen ist die Rinde von verschiedenen Nadelbäumen (Coniferen) für manche Gebirgsgegenden Europas (Böhmen, Oesterreich, Deutschland) Gegenstand eines nicht unbedeutenden Handels. Hauptsächlich wird die Rinde der Fichte (Pinus Picea Dur.), seltener jene der Weisstanne (Pinus Abies Dur.), der Schwarzföhre (Pinus Laricio Poir.) und der Lärche (Pinus Larix L.) gesammelt. Nach Hartig liefern 60 - 80 Jahre alte Fichten die beste Rinde, deren Gerbstoffgehalt 8 Proc. beträgt. In Neapel und Sicilien, wohl auch in anderen Mediterranländern benïtzt man die Rinde von Pinus Halepensis Mill. und gewiss auch von anderen dort wachsenden Föhrenarten, so namentlich von Pinus $P i$ naster Sol., deren Rinde auf der Wiener Weltausstellung aus Marokko vorlag. In Nord-Amerika dienen gleichfalls die Rinden dort einheimischer Nadelbäume zum Gerben, namentlich jene von Pinus Canadensis L. "Hemlock", welche 7-8 Proc. Gerbstoff enthält und aus der man auch das in ausgedehnter Anwendung stehende, 18-30 Proc. Gerbstoff enthaltende Hemlock-Extract bereitet (Ausführliches im Bericht über die Weltausstellung in Philadelphia, 18. H. Lederindustrie von W. Eitner, Wien 1877) und jene von Pinus alba Ait. ,. White Spruce".

Als Gerberinden von beschränkter, localer Anwendung sind noch anzuführen: die Rinde des Rosskastanienbaumes, Aesculus Hippocastanum L. (in Italien), die Rinde des Myrtenstrauchs, Myrtus communis L, die Rinde von Pistacia Lentiscus L., von Rhus pentaphylla Desf., von Tamarix Gallica L. und Africana Poir, jene des Granatbaumes, Punica Granatum L. (in Algier, Jetztere auch im Oriente), die Rinde von Bignonia longissima Jacq. und IIalpighia spicata Cav. in Westindien, jene von Tectona grandis L. $f$. in Indien und viele andere.

In den letzten Jahren hat man zahlreiche neue gerbstoffreiche Rinden aus verschiedenen aussereuropäischen Gebieten näher kennen gelernt und der europäischen Industrie zugefuhrt. So um einige der wichtigsten zu nennen, die Rinde von Casuarina- und Terminalia-Arten, von Aleurites triloba Forst., Acacia Lebbeck $W$. aus Reunion, von verschiedenen Acacia-Arten wie $A$. dealbata Lk. ("Silver Wattle"), A. decurrens Willd. ("Black Wattle"), A. molissima Willd. u. a. aus Australien, die Rinde einer Balloghia-Art aus Neu-Caledonien, die Rinde von Phyllocladus trichomanoides Don. (23.2 Proc. Gerbst.), von Weinmannia racemosa Forst. (12.7 Proc. G.), von Coriaria ruscifolia I. (16.8 Proc. G.), von Elaeocarpus dentatus Vahl. (21.8 Proc. G.), von Eugenia Maire A. Cun., 
von Rhabdothamnus scabrosus Steud. u. a. aus Neuseeland (der Gerbstoffgehalt nach Angaben im Catal. der neuseel. Abth. der Wiener Weltausst. 1873), die Rinde verschiedener Leguminosen, namentlich jene der Cebil-Acacie, Acacia Cebil Gr. und anderer Acacia-Arten mit einem Gerbstoffgehalt von 9-14.4 Proc. (nach M. Siewert), die Quebracho-Rinde (siehe weiter unten das Quebracho-Holz), die Cedro.Rinde von Cedrela brasiliensis S. Hill. etc. aus der siidamerikanischen Republik Argentina, die Mango-Rinde von Mangifera Indica L., die MangleRinde (Mangle colorado) von Rhizophora Mangle L., die Rinde von Coccoloba uvifera L. (Uva de Playa) und Weinmannia glabra L. (Curtidor) aus Venezuela, die Rinden verschiedener Proteaceen vom Cap der guten Hoffnung, so von Protea mellifera Thbg. (Sugarbosh), Pr. grandiflora Thunbg. (Waagenboom), Leucospermum conocarpum $R . B r$. (Kreupelboom), Leucadendron argenteum $R$. $B r$. (Silverboom) etc. etc. Einige dieser Rinden haben bereits auch bei uns Eingang gefunden.

Von Fr i e h te $\mathrm{n}$ und Fruchttheilen sind als Gerbemittel von grosser Wichtigkeit die Fruchtbecher (Cupulae) verschiedener Eichenarten des Orients, welche unter dem Namen Vallonea (orientalische Knoppern) in den Handel gelangen (siehe den Art. Vallonea), ferner die sogen. Myrobalanen, die Früchte namentlich verschiedener Terminalia-Arten Indiens (siehe d. Art. Myrobalanen), die Hülsen verschiedener Leguminosen, so die als Dividivi (Libidibi) bekannten von Caesalpinia Coriaria $W$. (siehe den Art. Dividivi) und jene ron diversen Acacia-Arten, im Handel als Bablah bekannt (siehe den Art. Bablah). An sie schliessen sich die ans dem südlichen Amerika in den Handel gelangenden Hülsen von Acacic Paraguariensis Parody und wohl auch anderer Arten an, welche unter dem einheimischen Namen Algarobillo bekannt sind sowie die Hiilsen der in Argentina als "Espinillo" bezeichneten Acacia C'acenia Hook. et. Am., welche in ihrem Fruchtgehäuse uiber 32 Proc. Gerbstoff beherbergen. Eine ausgedehnte Anwendung finden im Oriente die bis 28 Proc. Gerbstoff enthaltenden Fruchtschalen des Granatbaumes (Punica Granatum L.). Lnter den Kräutern, Blättern, resp. jungen Zweigen baum- und strauchartiger Gewächse, welche hieher gehören, nimmt der S umach (s. d. Art.), die zerkleinerten beblïtterten $\mathrm{Z}$ weige verschiedener RhusArten, den ersten Rang ein. Der Aufmerksamkeit werth sind die Blätter verschiedener anderer Anacardiaceen, wie namentlich jene der in Siidamerika wachsenden, in Argentina (wo man sie zum Gerben und Färben verwendet) als "Molle" bezeichneten Lithraea Gilliesii (mit 8.5 Proc. Gerbst.) und Duvaua dependens DC. (mit 19- ¿0 Proc. (ierbst.), ferner die Blätter des Quajacan (Caesalpinia melanocarpa Gr. mit iiber 21 Proc. Gerbstoffochalt), die Blätter des als weisser Quebracho ron Salta bezeichmeten Baumes (Aspidospermu?), welche 27.5 Proc. Gerbstoff enthalten sullen (Siewert, Tauning materiales of South America. Pharm. J. a. Transact. 1878 Jänner p. 548). Auch die Blätter ron Pistacia-Arten, namentlich von $P$. Lentiscus $L$, jene ron Rhizophora Mangle und von TerminaliaArten sind in neuerer Zeit mehr berïcksichtigt worden. In Sicilien und Nordafrika spielen anch die jungen Aeste ron Tamarix eine Rolle. Kaum nennenswerth sind verschichene Ericaceen, wie der Sumpfporsch, Ledum palustre L., die gemeine Heide, Ericu rulgaris Salish., die Bärentraube, Arctostaplıyllos officinalis Trimm., die Heidel- und Preisselbeere, Vaccinium Myrtillus L. und T. Titis Idace $L$. ete., deren Kraut resp. Blätter hie und da zum Gerben dienen. Dasselbe gilt auch für rerschiedene unterirdische Theile, so die WasserSehwertlilienwurzel ( $I_{i}$ is Pseudoacorus L.), die Natternwurzel (Polygonum Bistorta L.), die Ruhrwurzel (Putentilla Tormentilla lestl.), die Wurzel von Statioe-Arten (so z. B. St. coriuria Hoffm. in Russland), von Eupatorium chilense Mol. in Chile etc.

Von Hölzern ist durch einen nambaften Gerbstuffgehalt 8 Proc.) ausgezeichnet und zumal in Frankreich gleich dem daraus dargestellten flüssigen Extract in der Gerberei rerwerthet das Holz der Kastanie Castanea vulgaris Lum. und ron in der argentinischen Republik einheimischen, näher untersuchten 
Pflanzen (vgl. Siewert 1. e.), das Holz der C'edrela Brasiliensis S'. IIill (j.61 P'ı.), des Walnussbaumes, Juglans nigra L. Var. Boliviana Dr: (5 Proc.), des Cochuchu oder Coco, Zanthxoylon Coco Gill. (6.13 Proc.), besonders aber das Quebracho-Holz, das bereits gleich dem daraus bereiteten festen Extract Gegenstand des europäischen Handels geworden ist und vor Kurzem viel be sprochen wurde. (W. Eitner in "der Gerber", Org. der chem. technischen Versuchsstation für Lederindustrie etc. 1878 , Nr. 83.) Mit dem Namen Quebracho bezeichnet man in der argentinischen Republik verschiedene Bäume und unterscheidet insbesondere einen Quebracho blanco und einen Q. colforado oder rosado. Ein Theil des Quebracho blanco betrifft das $\mathrm{Holz}$ wahrscheinlich ciner oder mehrerer Prosopis-Arten. Nach M. Siewert (l. c.), der als Stammpflanze einer Sorte des Q. blanco Aspidosperma Quebracho Schl. (?) nennt, eine Pflanze aus der Familie der Apocynacee (diese Ableitung ist indess durchaus unsicher. Vergl. A. Grisebach, die Vegetation der Erde. II. Band, Leipzig 1872, p. 619, 19), ist der weisse Quebracho von Salta verschieden von jenem aus der Provinz Cordoba. Als Stammpflanze des Quebracho colorado - es ist dies die auch bei uns schon eingeführte Sorte - fuihrt der Catalogue of the Arg. Republ. Intern. Exhib. Philadelphia 1876 Loxopterygium Lorentzii Gr. an. Es ist ein hartes Holz von 1.193 sp. G., aus kleinen Spänen bestehend von fast gleichmässig hell braun-röthlicher Farbe, auf der radialen Spaltungsfläche fast seidenglänzend, geruchlos, von herbem Geschmack. Der geglättete Querschnitt lässt ein dichtes röthlich braunes Grundgewebe erkennen, durchschnitten von feinen, scharf gezeichneten genäherten Markstrahlen von hellerer Farbe und dazwischen mit zerstreuten helleren Gefässpunkten. Es zeigt den Bau eines Leguminosenholzes und enthält (nach Eitner) neben einem rothen Farbstoff 16-17 Proc. Gerbstoff.

A. Vogl.

Gerben des Stahles, s. Eis enerzeugung III pag. 49.

Gerberei u. z. Lohgerberei (tannage - tanning), Weissgerberei (mégisserie -- tawing), Sämisch- oder Fettgerberei (chamoisage - chamoising), d. i. das Verfahren der Lederbereitung, s. Leder.

Gerberfett, syn. Dégras, s. Leder.

Gerberlohe, s. Leder, vgl. a. Gerbematerialien.

Gerbersumach, s. Gerbematerialien.

Gerbgang, Schälgang, Spitzgang, s. Mehlfabrikation.

Gerbsäuren, Gerbstoffe sind im pflanzlichen Organismus sehr verbreitete Körper, die vermuthlich in keiner höheren Pflanze fehlen dürften, und sowohl in ausdauernden als ein- und zweijährigen Pflanzen nachgewiesen wurden. Trotz ihrer ausgebreiteten Verwendung und ihrer wichtigen pflanzenphysiologischen Rolle sind sie aber nur sehr. unvollständig gekannt. So ist es noch ziemlich unentsclieden, ob in einer Pflanze, ja in einem Pflanzentheil stets nur eine Gerbsäure oder aber verschiedene gemeinschaftlich vorkommen. Dafiir steht es fest, dass die Gerbsäure einer Pflanze mit jener der auf ihr wie immer herrorgebrachten Auswiichse nicht identisch sein muss. (So Eichenrindengerbsäure und Gallusgerbsäure.) Andererseits haben insbesondere die zahlreichen Versuche Rochleder's dargethan, dass innerhalb eincr Pflanzenfamilie die gleichen oder doch höchst ähnliche Gerbsäuren auftreten.

Das allgemeine Kennzeichen der Gerbsäuren ist, dass sie amorph, farblos bis braun gefärbt, saurer Natur sind, einen adstringirenden Geschmack besitzen, in wässriger Lösung von Eisensalzen charakteristisch gefürbt werden (in der Regel grün oder blauschwarz, mitunter, so manche Gerbsäuren der Pinusarten aber auch braun). In alkalischer Lösung der Luft ansgesetzt werden sie unter Samerstoff- 
absorption braun gefärbt und zersetzt, in wässriger Lösung, rascher noch beim Kochen mit verdïnnten Säuren spalten sie sich, liefern hiebei sehr häufig, doch nicht immer, Glucose und andererseits Körper, die mitunter krystallisirt sind, wie Gallussäure und Ellagsäure, in der Regel aber roth bis braunroth gefärbte amorphe Substanzen darstellen, welch letztere den der betreffenden Pflanze angehörigen Phlobaphenen oder Rindenfarbstoffen sehr nahe stehen, wenn nicht mit ihnen identisch sind.

Alle Gerbstoffe reduciren Gold- und Silbersalze. Der weitaus grössten Zahl der Gerbstoffe kommt die Eigenthïmlichkeit zu, durch Leim- und Brechweinsteinlösung gefällt zu werden und in Wasser und Alkohol leicht, schwer dagegen in Alkohol und wasserfreiem Aether löslich zu sein. Die allermeisten sind glucosidischer Natur (siehe oben), doch ist es noch zweifelhaft, ob der Paarling wirklich Gluoose oder nicht etwa Gummi sei, das erst bei der Spaltung in Zucker übergeführt werde.

Mit Ausnahme der Gallusgerb- und Granatgerbsäure, die Gallussäure $\mathrm{C}_{6} \mathrm{H}_{2}(\mathrm{OH})_{3}(\mathrm{COOH})$ liefern, werden sämmtliche in dieser Richtung untersuchte Gerbstoffe, respective deren beim Kochen mit Säuren erhaltenen rothen Spaltungsproducte (China-, Chinova- etc. Roth benannt) beim Schmelzen mit Aetzkali in Protocatechusäure $\mathrm{C}_{6} \mathrm{H}_{3}(\mathrm{OH})_{22} \mathrm{COOH}$ ibergeführt, einige von ihnen, wie die Kaffee-, China- und Chinovagerbsäure liefern ausser jener noch Essigsäure, andere, so die Filix-, Ratanhia-, Tormentill- und Kastaniengerbsäure geben als zweites Spaltungsproduct Phloroglucin $C_{6} H_{3}(\mathrm{OH})_{3}$.

Als nicht glucosidischer Natur wurden mit Bestimmtheit die Tormentill-, die Kastanien- und die Gerbsäure der Rinde der Sauerkirsche erkannt, ebenso in neuester Zeit die Gallusgerbsäure oder das Tannin und die Ellagengerbsäure der Dividivischoten; die Zahl der nicht glucosidischen Gerbsäuren dürfte aber damit noch lange nicht erschöpft sein.

Aus all dem geht hervor, dass die unter dem Namen Gerbsäuren zusammengefassten Körper wohl gewisse Eigenthümlichkeiten gemein haben, aber sehr verschieden constituirt sind.

Ueber die umfassende Verwendung der Gerbstoffe, die allerdings nur beim Tamnin auch in Form der reinen Säure, sonst aber durch die betreffenden Rohmaterialien oder deren wässrige Extracte erfolgt, in der Medicin und Pharmacie, danı der Färberei, Gerberei, Tintenfabrikation, zum Schönen des Weines, zum Beschweren der Seide etc., siehe die betreffenden Artikel.

Der bestgekannte Repräsentant der Gruppe der Gerbsäuren ist das Tannin, oder die Galläpfel-, Gallusgerb-, Eichengerbsäure (acid tannique - tannin), das den Gerbstoff der verschiedenen Galläpfel, sowie der Knoppern ausmacht, dann aber auch im Sumach und in den Nyrobalanen (siehe nnten Ellagengerbsäure) nachgewiesen wurde, stets aber ron Gallussäure u. a. den Gerbstoffen sehr nahe stehenden Substanzen (im Sumach auch von der eigenthümlichen Catechugerbsäure, dann dem Catechin) begleitet wird.

Es kamn aus tïrkischen Galläpfeh am besten nach einem von Schmidt (Arch. Pharm. (2) 134, 213) empfohlenen Verfahren gewonnen werden. Hiezu werden jene mit einem Gemisch von 12 Thl. Aether und 3 Thl. 90-91 proc. Weingeist kalt extrahirt, das dann wiederholt mit einem Dritttheil Wasser geschiittelt wird, welches die Gerbsäure endlich vollständig aufnimmt. Durch Eindampfen der wässrigen Lösung wird ein ziemlich reines Präparat erhalten, die Ausbeute beträgt hiebei 50-77 Proc. der angewandten Galläpfel.

Zur Darstellung des Tannins aus chinesischen Galläpfeln hat Sch midt ein efwas modificirtes Verfahren angegeben, bezïglich dessen auf oben citirte Originalabhandlung verwiesen sei.

Um käufliches unreines Tamnin zu reinigen, soll dieses nach $\mathrm{Heinz}$ (Pharm. Zeitschr. f. Russ. 1867, VI, 469) in dem doppelten Gewicht warmen Wassers gelöst und daun mit $1 / 4-1 / 12$ des Volums Aether anhaltend geschüttelt werden, der die Verumreinigungen als coagulirte Massen fällt; durch Filtration von diesen 
und Eindampfen der Lösung wird ein schr reines Profluct gewonnen. Lnter vielen anderen Reinigungsverfahren sei auf jenes von $L u b o l d t$ (Jouru. f. prart. Chem. 77, 357), sowie anf die Arbeit von Löwe (Zeitsch. f. analyt. Chem. 1872, 365) aufmerksam gemacht.

Die reine Gallnsgerbsäure ist nahezu farblos, am Licht gelb werdend, amorph, leicht zerreiblich, wenig hygroskopisch, sie ist geruchlos, znsammenziehenr, aber nicht bitter schmeckend, besitzt deutlich saure Reaction, krin optisches Drehungsvermögen. Sie gibt im Wasser, das sie reichlich aufnimmt, eine schänmende Lösung, aus der Salze und Mineralsäuren sie wieder fällen. Wässriger Weingeist löst das Tannin reichlicher als absoluter, wasserfreier Acther lijst es nur wenig. wässriger weit besser, indem sich eine schwere, wässrige, viel Gerbsäure und etwas Aether und eine ätherische, nur wenig Gerbsäure haltende Schichte bildet. Die Zusammensetzung der Gallusgerbsäure wurde bis in die neueste Zeit mit $\left.C_{29}^{\prime} H_{22}{ }^{\prime}\right)_{17}$ angenommen (Strecker, Ann. Chem. Pharm. 81, 248 u. 90, 328) und sie als Glucosid betrachtet; als Frucht zahlreicher Untersuchungen von $\mathbf{K} n$ op (Chem. Centralbl. 1852-1860), von Rochleder u. Kavalier (Wien. Acad. Ber. 22, 558 , 29 28, 30 159), Hla siwetz (Ann. Chem. Pharm. 143, 295), dann Lö w e (Journ. f. pract. Chem. 102, 211) und Schiff (Ann. Chem. Pharm. 170, 43) hat sich aber herausgestellt, dass sie kein Glucosid, sondern der Formel $C_{14} H_{10} O_{9}$ entsprechend zusammengesetzt sei und als eine Digallussäure $C_{6} H_{2}(O H)_{3} \cdot C O \cdot O \cdot C_{t i} H_{i 2}(O H)_{20} C O O H$ aufgefasst werden miisse. Schiff gelang es auch das Tannin durch Einwirkung von wasserentziehenden Mitteln, wie Phosphoroxychlorid und Arsensäure (nicht aber von concentr. Schwefelsäure), auf Gallussäure synthetisch darzustellen, was schon durch Löwe als sehr wahrscheinlich hingestellt wurde. Schiff lıält es für wahrscheinlich, dass die in der Pflanze enthaltene Gallusgerbsäure doch ein Gilucosid u. z. der Formel $C_{34} H_{128} O_{22}$ sei, das sich aber schon während der Extraction $\mathrm{ja}$ in der Pflanze selbst, unter Aufnahme von $2 \mathrm{Mol}$. Wasser in $1 \mathrm{Mol}$. Glucose und 2 Mol. Digallussäure spalte.

Das Tannin liefert kein haltbares Leder, wird aber als adstringirendes Mittel medicinisch, dann zur Tintenfabrication, in der Färberei, besonders als Beize, zur Darstellung von Gallus- und Pyrogallussäure, als Reagenz auf Leim, Eiweissstoffe, Alkaloide, zum Entfärben von Polarisationszuckerlösungen etc. angewandt.

Die Gallussäure, das Product der Einwirkung von verdünnten Säuren auf Tannin, wird gewöhnlich aus dem Galläpfelextract dargestellt, indem dieses mit Natronlauge oder verdünnter Schwefelsäure gekocht, oder einer Art Gährung überlassen wird. Um auf letztere Weise Gallussäure zu bereiten, werden gewöhnliche Galläpfel zerstossen und mit Wasser befeuchtet mehrere Wochen lang der Luft ausgesetzt bei einer Temperatur von $20-28^{\circ} \mathrm{C}$. belassen, hierauf mit TIasser ausgekocht und die Lösung krystallisiren gelassen. Durch wiederholtes Umkrrstallisiren aus Wasser wird die Gallussäure gereinigt. Bei allen Operationen sind eisenhaltiger Staub etc. möglichst abzuhalten. Bei Anwendung chinesischer Galläpfel muissen gewöhnliche Galläpfel oder Fermente (Bierhefe) zugesetzt werden, da sonst die Ausbente eine sehr schlechte ist. Vorschriften wurden ron B r a con not (Ann. chim. phys. IX, 181), W it t s te in (Vierteljahrsch. pract. Pharm. II. 72), Steer (Wien. Akad. Ber. 22, 249) und Li ebig (Ann. Chem. Pharm. 53, 180) gegeben.

Die Darstellung der Gallussäure unter Mitwirkung von verdiunaten Säuren geschieht nach Wetherill (Journ. f. pract. Clem. 92, 247) am besten derart, dass 1 Thl. Gerbsäure mit $10 \mathrm{Vol}$. verdünnter Schwefelsäure $(1: 4)$ so lange gekocht wird, bis die Flüssigkeit nach dem Erkalten krystallisirt. Die Ausbeute beträgt dann gegen 87 Proc. Nach Liebig wird dasselbe durch Kochen mit Natronlauge erreicht, Kn op (siehe oben) erhielt beim Kochen von gleichen Theilen Gerbsäure nnd neutralen schwefligsauren Alkalien mit 12 Thl. Wasser gegen 80 Proc. Gallussäure. Die Gallussäure $C_{6} H_{2}(O H)_{3} . C O O H$ krystallisirt mit 1 Mol. $H_{2} O$, das sie bei $120^{\circ}$ verliert, bildet feine, weisse, scidenglänzende Nadeln des triklinischen Systems, die in kaltem Wasser schwer $(1: 100)$, leicht in heissem Wasser $(1: 3)$, 
leicht auch in Weingeist, schwer in Aether löslich sind. Leim und Pflanzenbasen fällt sie nicht, Eisensalze färbt sie schwarzblau. Vorsichtig erhitzt zerfällt sie in Kohlensäure und Pyrogallussäure $\mathrm{C}_{6} H_{3}(\mathrm{OH})_{3}$ (siehe diese), rasch erhitzt liefert sie Wasser und die kohlenähnliche Mel an- oder Metagallussäure. Sie reducirt mit Leichtigkeit Silbersalze, findet desshalb anch Anwendung in der Photographie, ist jedoch fast gänzlich hierbei durch die Pyrogallussäure verdrängt, zu deren Darstellung sie hauptsächlich bereitet wird.

Die Eichenrindengerbsäure ist weit weniger und seltener untersucht worden als das Tannin, mit dem sie nicht identisch ist, und von welchem sie sich ausser dem verschiedenen Verhalten gegen Säuren dadurch noch unterscheidet, dass sie, trocken destillirt, B ren z c a t e $\mathrm{ch}$ in $\mathrm{C}_{6} \mathrm{H}_{4}(\mathrm{OH})_{2}$, jenes aber Pyrogallussäure liefert. Nach Grabowski (Ann. Chem. Pharm. 145.1) bildet sie eine gelbbraune Masse, die sich gegen Leim-, Brechweinstein- und Eisensalzlösungen wie das Tanninverhält, die aber durch kochende verdünnte Mineralsäuren in Zucker und Eichenroth zerlegt wird, das dem Eichenphlobaphen sehr nahe steht. J. O ser (Wien, Acad. Ber. 1875,72$)$ zeigte in neuester Zeit, dass sie nach $C_{00} H_{20} O_{11}$ zusammengesetzt ist und oben erwähnte Spaltung nach der Gleichung

$$
\underset{\text { Eichenrindengerbsäure }}{\mathrm{C}_{20} \mathrm{H}_{20} \mathrm{O}_{11}}+\underset{\text { Zucker }}{\mathrm{H}_{2} \mathrm{O}}=\underset{\text { Eichenroth }}{\mathrm{C}_{6} \mathrm{H}_{12} \mathrm{O}_{6}}+\underset{14}{\mathrm{C}_{10} \mathrm{O}_{6}}
$$

vor sich gehe. Zahlreiche Bestimmungen zeigten ihm ferner, dass die Eichenblätter eben so viel Gerbstoff enthalten wie Spiegelrinde.

Die Eichenrindengerbsäure spielt in der Lohgerberei eine hervorragende Rolle, da ihre auf die thierische Haut niedergeschlagenen Verbindungen mit dem Coriin u. a. stickstoffhaltigen Faserbestandtheilen sehr widerstandsfähige Körper sind, was bei den analogen Substanzen des Tannins nicht der Fall ist.

Ob die gleichfalls in der Lohgerberei mit Vortheil angewendeten Gerbsäuren des Sumachs, der Valonia, verschiedener Rinden etc. mit der Eichenrindengerbsäure identisch sind, steht noch immer in Frage.

Nach Löwe (Z. analyt. Chem. 1875, 35 u. 44) ist die Gerbsäure der Dividivischoten und der Myrobalanen Ellagengerbsäure der Formel $C_{14} H_{10} O_{10}$, die unter erhöhtem Druck in wässriger Lösung erhitzt Ellagsäure, $C_{14} H_{6} O_{8}$, bei der trockenen Destillation, wie es scheint kein Brenzcatechin, sondern Pyrogallussäure liefert, gegen Reagentien ein der G.llusgerbsäure sehr ähnliches Verhalten zeigt, letzterer also im Ganzen sehr nahe steht.

Auch die Gerbsäure des Thees diirfte nach H lasiwetz (Ann. Chem. Pharm. 142, 233) dem Tannin näher stehen als der Eichenrindengerbsäure.

Eine ziemlich vollständige Beschreibung der Gerbsäuren und beziigliche Quellenangabe enthält A. und Th. H use m a n n's "Pflanzenstoffe", Berlin, Springer 1871.

Gerbsäurebestimmung. Alle bisher vorgeschlagenen Methoden der Bestimmung von Gerbsäuren kranken daran, dass dieselben der rerschiedenen Zusammensetzung der jeweilig zu bestimmenden Gerbsäure nicht Rechnung tragen, und sich darauf beschränken, ein bestimmtes chemisches Verhalten der zu prüfenden Gerbstofflïsung, welches natiirlich bei jeder rerschiedenen Methode anders gewählt ist, mit dem einer Taminlösung von bekanntem Gehalte zu vergleichen.

Derartige Methoden haben, wenn auch keine wissenschaftliche Schärfe, doch für bioss vergleichende Lntersuchung geniigenden Werth, vorausgesetzt, dass die dem Verfahren zu Grunde liegrende Normallösung einen bestimmten Titre hat. Dies trifft num bei den bisherigen Methoden desshalb nicht zu, weil sie zum Vergleich Tamnin des Handels nehmen, welches stets ron wechselnder Zusammensetzung ist. (Siehe Gerbsäuren.) Es diirfte sich wohl empfehlen, der Analyse von Gerbmaterialien reine Digallussäure zu Grunde zu legen, die nach dem Schiff'schen Verfahren, wahrscheinlich aber einfacher und wohlfeiler durch wiederholte Anwendung der von Rochleder rorgeschlagenen fractionirten Fällung mit Bleiacetat und Zerlegung mit Schwefelwasserstoff dargestellt werden kann. 
Von den vielen bekannt gewordenen Methoden seien nur folgende erwähnt: Nach Hammer (J. f. pr. Ch. 1860, 3, 159) wird der wässrige Gerbstoffauszug bis zu einem bestimmten Volumen eingedampft und sodann dessen spec. Gewicht ermittelt. Durch Eintragen von getrockneter, geraspelter thierischer Haut (4-5) Thl. auf 1 Th. vermutheten Gerbstoff) werden die Gerbsäuren niedergeschlagen. Wird hierauf die Flïssigkeit auf das ursprüngliche Volumen gebracht, abermals das jetzt geringere spec. Gewicht bestimmt, so erhält man eine Differenz, die dem Eigengewicht einer reinen Gerbsäurelösung der vorliegenden Concentration entspricht. Aus ron Hammer entworfenen Tabellen kann sodann der Procentgehalt direct abgelesen werden.

L ö w enthal (J. f. pr. Ch. 1860, 3, 150) titrirt die Gerbsäure mit ziemlich verdïnnter Chamäleonlösung, die auf eine $1 / 1000$ Lösung reiner, bei $100^{\circ} \mathrm{C}$. getrockneter Gerbsäure, und auch auf eine etwa $3 / 100$ Lösung von teigigem Indigcarmin gestellt wurde. Das Verfahren beruht darauf, dass Gerbsäure und Indigcarmin gleichzeitig oxydirt werden, also die blawe Farbe einer mit Indigo gefärbten Gerbsäurelösung erst dann verschwindet, wenn eben auch die erstere vollständig oxydirt ist. Die Stellung der Uebermangansäurelösung erfolgt zuerst auf reine Indiglösung, dann auf ein Gemisch dieser mit Gerbsäurelösung: Wird nun bei der Ausführung ein wässriges Gerbstoffdecoct mit einem gemessenen Volumen der Indiglösung versetzt und Chamäleonlösung bis zur Entfärbung zugesetzt, so weiss man die Menge letzterer, die zur Oxydation des Indigo's nothwendig war, und der Rest gibt auf Grund des Vergleiches mit der 1/1000 Gerbstofflösung die Menge des in der Probe vorhandenen Gerbstoffes, ausgedrïckt in Gewichtstheilen Tannin.

Bei beiden und allen älteren Methoden wirkt die Anwesenheit von Pectinstoffen, die in wässrigen Gerbstoffausziigen nie fehlen, störend. Selbe können entfernt werden, wenn man nach $\mathrm{L}$ öwe (Zeitsch. analyt. Chem. 4, 366) die wässrige Lösung eindampft, den Rückstand mit Alkohol aufnimmt, den von Pectinkörpern freien Auszug wieder eindampft, in Wasser aufnimmt und dann erst titrirt.

Speciell für die Löwenthal'sche Methode empfiehlt Neubauer (Zeitsch. für analyt. Chem. 10, 1) den Fehler derart zu umgehen, dass der Gerbstoffauszug einmal direct, das anderemal erst dann titrit wird, nachdem ihm durch Behandlung mit Thierkohle die Gerbsäure entzogen wurde.

Nach Carpene und B arbieri erhält man die sichersten Resultate, wenn mit überschïssiger ammoniakalischer Zinkacetatlösung die Gerbsäure heiss gefällt, die Flüssigkeit auf $1 / 3$ eingedampft, der von Gallussäure u. a. Stoffen freie Niederschlag nach dem Erkalten abfiltrit, mit heissem Wasser gewaschen, in verdiinnter Schwefelsäure gelöst und sodann mitauf $1 / 1000$ Tanninlösung gestelltem Chamäleon titrirt wird.

Ausführlichere Anleitung gibt u. a. "Bolley's technisch-chemische Untersuchungen", Leipzig, Arthur Felix, 1874.

Skraup.

Gerbstahl, s. Stahl bei Eisen-Erzeugung III pag. 48.

Gerbstoffe, s. Gerbsäuren, vgl. a. Gerbematerialien.

Gerbstoffe künstliche nannte man die durch Einwirkung von Schwefelsäure und Salpetersäure auf verschiedene organische Substanzen entstehenden Zersetzungsproducte, deren Natur bisher nicht völlig sichergestellt ist, die sich jedoch dadurch auszeichnen, dass ihre wässrige Lösung Leim fällt. Gtl.

Gerinne (chanée - trough), kiinstlicher Wasserlauf (Kanal) oder eine durch Rinnen bewirkte Wasserleitung.

Gerinnen, co agulire n, ge st e h en (coagulation - curdling), sagt man ron Eiweisskörpern, wenn sich dieselben aus ihren Lösungen durch einen geeigneten Einfluss (Erhitzen, Säurezusatz etc.) in unlöslicher Form ausscheiden. Das Aus- 
geschiedene bezeichnet man als Gerinnsel (précipité caillebotté - curcled precipitate), vgl. Albumin, vgl. Cas ëin. Gtl.

Germansilber, s. m. Neusilber; s. Argentan I pag. 190.

Gersdorffit, Nickelarsenkies, Nickelglanz. Krystallisirt tesseral ähnlich wie Pyrit, kommt gewöhnlich derb in körnigen Massen vor. Ist nach dem Würfel ziemlich vollk. spaltb., Bruch uneben, Härte $=5.5$, sp. Gew. $=5.95-6.9$, grauweiss, grau, dunkler angelaufen, Strich dunkel. Chem. Zus. NiAs ${ }^{2}+N i S^{2}$ mit 35.1 Nickel, 45.5 Arsen und 19.4 Schwefel, die Zusammensetzung ist jedoch nicht vollkommen constant, da ein Theil des Nickels durch etwas Eisen und Kobalt ersetzt sein kann (bis 14 Proc.), daher wird auch die Formel

$$
2 \mathrm{NiAs}+\mathrm{NiS}+\mathrm{FeS}^{2}
$$

aufgestellt, welche 28.1 Nickel, 8.9 Eisen, 47.7 Arsen und 15.3 Schwefel bedingt. Im Kolben decrepitirt er, sublimirt in stärkerer Hitze Schwefelarsen, der Rückstand ist Rothnickelkies. Im Glasrohr gibt er arsenige und schweflige Säure. Auf Kohle schmilzt er unter Abgabe von Arsendämpfen zu einer Kugel, welche mit Borax und Phosphorsalz die Reaction auf Nickel und Eisen gibt. Salpetersäure löst ihn theilweise unter Abscheidung von Schwefel und arseniger Säure. Fundort Schladming in Steiermark, Lobenstein in Reuss, Harzgerode im Harz, Müsen in Westphalen, Loos in Schweden. Wird zur Darstellung der Nickelmetall benutzt. $L b$.

Gerste (orge - barley). Eine schon in den frühesten Zeiten cultivirte Körnerfrucht, die, wie man glaubt, sich von Aegypten aus über Europa verbreitet hat. Sie hat die grösste Verbreitung und gedeiht noch in verhältnissmässig hohen Lagen. In Schottland baut man noch bis zu $500^{\mathrm{m}}$ Höhe Gerste, in den Alpen bis zu $1000^{\mathrm{m}}$, in der Provence bis zu $2000^{\mathrm{m}}$, auf der asiatischen Hochebene bis zu $5000^{m}$ Höhe. Sie verlangt aber zum Gedeihen einen kräftigen, nicht zu nassen und schweren Boden, der ziemlich rein sein muss und kein entschiedener Sandboden sein darf. Es werden hauptsächlich vier verschiedene Gerstenspecies gebaut, u. z. zwei sechszeilige und zwei zweizeilige. Bei allen Gerstensorten stehen immer je zwei aus drei Blithen bestehende Bündel einander gegenuiber, bei den sechszeiligen sind alle drei Bliithen jedes Bündels fruchtbar, während bei den zweizeiligen nur die mittlere Bliithe jedes Büdels befruchtet wirt. Man kann folgende Gerstenarten unterscheiden:

1. Die sechszeilige Gerste (Hordeum hexastichon) hat sechs regelmässige Zeilen, gedeiht nur in warmen Lagen und gutem Boden, gibt sowohl als Sommergerste, als auch als Wintergerste einen reichen Ertrag. In Deutschland weniger cultivirt, nur als Sommergerste. Sie ist in zwei Varietäten bekannt.

2. Die kleine oder ìierzeilige Gerste (Hordenm vulgare), gemeine Gerste. Ist unregelmässig sechszeilig, d. h. es liegt nur in zwei einander gegenïberliegenden Zeilen Korn auf Korn, während in den vier anderen Zeilen die Körner dachziegelförmig liegen, und durch die fast parallel anliegenden Grannen, der breitgedriickt viereckigen Aehre das Ansehen einer vierzeiligen Aehre geben. Sie wird hänfig u. z. sowohl als Sommer-, wie auch als Wintergerste gebaut. Winter- und Sommergerste unterscheiden sich iibrigens durch Grösse und Farbe der Körner, die bei der ersteren klein und bläulich bei der letzteren grösser und weisslich sind. Ausser der Sommergerste (Hordeum vulgare aestivum) und der Wintergerste (Hordeum vulgare hylermum), die beide beschalte Körner haben, unterscheidet man noch zwei Varietäten mit nackten Körnern, u. z. die namentlich im Orient, wohl aber auch bei uns als Sommerfrucht gebaute Himmels-Gerste (Hordeum vulgare mulum), Himalaja-Gerste, bei welcher die reifen Körner aus den Spelzen ausfallen, und die B ïschel-oder GabelGerste (Hordeum vulyare trifurcatum), welche der Himmelsgerste sehr ähnlich ist aber statt der Gramnen tragen die Spelzen drei kleine Spitzen, die wie Gabelzinken aussehen. 
3. Die grosse oder zweizeilige Gerste (Hordeumdistichon) hat eine flachgedriickte Aehre mit zwei gegenuiberstehenden Körnerreihen und weit gestellten, aufrecht gerichteten Körnern. Die langen Grannen sind fast parallel aufgerichtet. Die Körner sind grösser als bei den übrigen Arten. Man unterscheidet die grosse zweizeilige Gerste (Hordeum distichon nudum), auch Kaffeegerste oder ägyptischer Weizen genannt, mit nackten ausfallenden Körnem, die gemeinc zweizeilige Gerste (Hordeum distichon nutans) mit beschalten Körnern, die als Sommerfrucht in Deutschland am häufigsten gebaut wird, und die S piege Igerste (Hordeum distichon erectum) mit beschalten und dichter stehenden Körnern.

4. Die Reisgerste (Hordeum Zeocriton), Pfauen- oder Bart-Gerste, hat sehr gedrungene, zweizeilige Aehren, mit abstehenden Körnern und halbkreisförmig gestellten Grannen, ist der Spiegelgerste und der gemeinen Gerste sehr verwandt und wird namentlich in England viel gebaut. Ihrer grossen mehlreichen Körner wegen ist sie namentlich zur Bierbereitung sehr geschätzt.

Die Gerste enthält 10-17.7 Proc. Kleber und Eiweiss, 38 - 52 Proc. Stärke, 40-46 Proc. Holzfaser, Gummi und Zucker (nach Polson 4.2 Proc. Gummi und Zucker), 1.5-2.6 Proc. Fett, 12-16 Proc. Wasser, 2.1-5.5 Proc. Asche. Der mittlere Stickstoffgehalt beträgt 1.8-2.7 Proc., der Phosphorsäuregehalt 0.8 bis 1.13 Proc. Die Asche enthält 3-29 Proc. Kali, 1-16 Proc. Natron, 1.04 bis 4.9 Proc. Kalk, 28.5-52 Proc. Phosphorsäure, 0.1-5 Proc. Schwefelsäure, 1.3-33.3 Proc. Kieselsäure, 0.4-3 8 Eisenoxyd, je nach der Beschaffenheit des Bodens. Besonders charakteristisch ist für die Gerstenasche ihr hoher Gehalt an Kieselsäure, der in der Regel zwischen 20-30 Proc. zu schwanken pflegt. Die Gerste findet ausser zur Herstellung von Graupen, besonders für die Zwecke der Malzbereitung Verwendung, s. d. Bier. Gt?.

Gerstenzucker, s. Stangenzucker b. Canditen II pag. 243.

Gerüste, Baugerïste (échafaud - scaffold) sind diejenigen provisorischen Constructionen, welche nur als Mittel zum Zwecke dienen, nämlich zur Ausführung gewisser Bauarbeiten erforderlich sind. Die Gerüste werden im Allgemeinen aus Holz construirt und man unterscheidet beim Hochbau hauptsächlich folgende:

1. Haupt- oder Lantennengerüst, 2. Bock- oder Schragengeriist, 3. Ausschussoder fliegendes Gerïst, 4. Leitergerïst, 5. Hängegerỉst, 6. Laufgerüst, 7. Versetzgerüst, 8. Lehrgerüst.

1. Haupt- oder La antennengeriist. Fig. 1749. Hohe Baumstämme $a$, welche bis zum Hauptgesims des zu errichtenden Gebäudes reichen, werden in ca. $3^{\mathrm{m}}$ Entfernungen von einander (gewöhnlich gegenüber den Fensteröffinungen) und in $2.50^{\mathrm{m}}$ Entfernung vom Gebäude fest eingegraben; daneben werden Ständer $b$, von der Höhe eines Geschosses, aufgestellt, welche die Querriegel $c$, die einerseits auf der Mauer aufruhen, stützen. Die Querriegel nehmen Polsterhölzer, Streuhölzer $\left(8 / 10-10 / 12{ }^{\mathrm{cm}}\right.$ st.) auf und diese tragen einen doppelten Pfosten- oder Bretterbelag. Die Verbindungen werden sämmtlich durch Geriustklammern hergestellt; die Verbindung der Lantennen untereinander geschieht durch Sturmlatten, (sog. Schwerter). Für das obere Geschoss wiederholt sich die Anordnung. Mitunter vereinfacht man die Anordnung, indem der Ständer $b$ entfällt und ein Pfosten durch gute Verklammerung an den Lantennen befestigt wird; dieser nimmt zunächst

Fig. 1749.

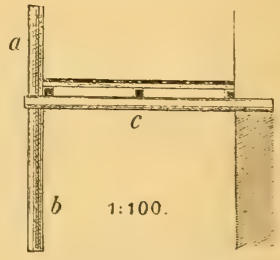

Lantennen-Gerïst. die Riegel auf. Auch verwendet man eiserne Tragklammern, die an den Lantennen befestigt werden (und verriickbar sind); dieselben nehmen Schweller auf, welche die weitere Geriistconstruction tragen. Das Gerüst kann gehoben werden. Bei leichten 
Geriisten kann man mitunter durch Anbinden der Schweller an die Lantennen und der Riegel an den Schweller mittelst Stricken auskommen; es ist jedoch vorsichtige Untersuchung der Stricke bezuiglich ihrer Guite nicht ausser Acht zu lassen.

Fiir bedeutend hohe Bauten und bei langer Bauzeit bilden die Geriiste zusammengesetzte Constructionen mit festen Holzverbindungen, welche nach Art der dauernden Holzconstructionen abgebunden werden.

2. Bock- oder Schragengerïste sind transportable Nebengeriiste, welche auf dem Hauptgerïste aufgestellt werden und bestehen aus den sogen. Böcken, über welche die Belagpfosten kommen Fig. 1750. Gegen das Umstiirzen werden die Böcke durch Strebehölzer und Klammern gesichert. Nan verwendet gewöhnlich Böcke von zwei verschiedenen Höhen, u. z. ca. $1^{\mathrm{m}}$ und $2^{\mathrm{m}}$ hoch.

Fig. 1750 .

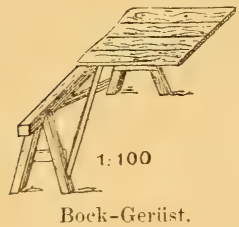

Fig. 1751 .

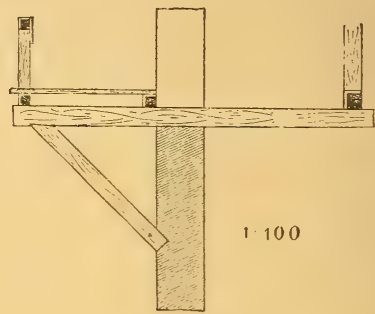

Ausschuss-Geriist.

3. Ausschuss- oder fliegendes Gerïst, Fig. 1751, kommt zumeist bei Restaurirungsarbeiten zur Anwendung. Durch Fensteröffnungen werden lange, starke Hölzer (Ausschussbäume) so weit hinausgeschoben, als die Gerïstbreite es erfordert und durch Streben gegen die Mauer gestiitzt. Im Innern müssen die Balken gut durch Verspreizung und Verstrebung niedergehalten werden.

4. Leitergeriste werden bei geringen Reparaturen, Färbelung der Façade etc. angewendet. Hohe Leitern mit eisernen Fussspitzen werden in 2 bis $2.50^{\mathrm{m}}$ Entfermungen ron cinander (die Sprossen senkrecht zur Mauerfä̈che) an

Fig. 1752 .

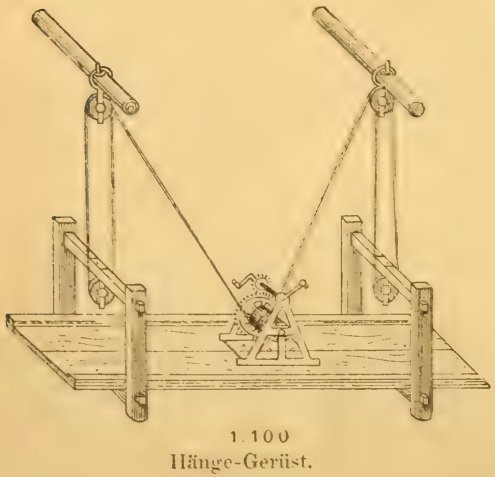

Fig. 1753 .

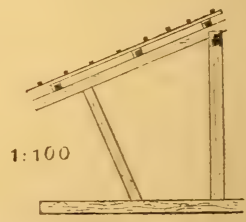

Lanf-Geriist.

gut rerspreizte (z. B. durch die Dachfenster herausgeschobene) Ausschussbäune mittelst neur Stricke angebunden. In den erforderlichen Höhen werden dann 
$4-5^{\mathrm{cm}}$ starke Bretter über die Sprossen gelegt. Dic Leitern miissen durch Sturmlatten kreuzweise verbunden werden. An den Seiten bilden Schutzbretter (mit Stricken angebunden)-das Geländer.

5. Hängegerüst, Verwendung wie das Leitergeriist. An Ausschussbäumen wird mittelst Rollen und Seile ein Kasten, fiir 1 oder 2 Arbeiter und das nothwendige Material, anfgehängt und derselbe kann nach Bedarf gehoben oder gesenkt werden. Wird ein kleiner Flaschenzug und ein kleiner Aufzugskralın angebracht, so können die Arbeiter den Apparat selbst reguliren. Fig. 1752 gibt ein Bild davon.

6. L a u f e riist, Fig. 1753, ist der schräge Aufgang zum Materialtransport in die Höhe, und wird dann verwendet, wenn keine besonderen Hebevorrichtungen (als Aufziige, Paternosterwerke etc.) zur Disposition sind. Die oberste Bretterlage erhält nach der Breite in Schrittentfernung Leisten wegen sicherem Gang. An regnerischen Tagen ist die Aufgangsfläche mit Sand zu bestreuen.

7. Versetzgerüst, dient dazu, die Bausteine zu heben und genau bis zur Versetzstelle zu schaffen. Die Constructionen sind mannigfarch nach den Objecten. Im Allgemeinen ist auf einem festen Gerist ein auf Rollen und Schienen beweglicher Wagen, der wieder Laufschienen trägt, deren Richtung senkrecht zur Hauptbahn ist. Auf dieser zweiten Bahn bewegt sich ein Aufzugskrahn, der die $\mathrm{zu}$ versetzenden Steine aufnimmt. Durch die zwei Bewegungsrichtungen kann der Stein innerhalb der Länge und Breite der Bahn auf jeden beliebigen Punkt leicht und sicher transportirt werden.

8. Lehrgerüst e oder Einrüstung behufs Ausfuihrung der Gewölbe. Bei Mauerbögen von geringer

Fig. 1754.

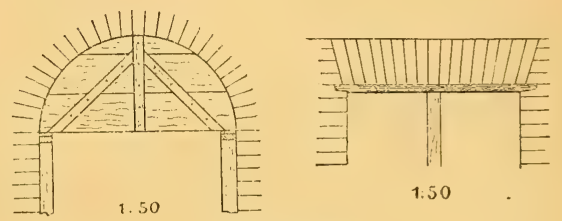

Lehr-Gerüste.

Spannweite, z. B. Thür- und Fensterüberwölbungen sind die Constructionen sehr einfach. Fig. 1754 zeigt die Einruistung für einen halbkreisförmigen Mauerbogen von geringer Tiefe. In diesem Falle ist keine Verschalung nothwendig, da Lehrbögen, in ca. $0.30^{\mathrm{m}}$ Entfernungen aufgestellt, genïgen. Bei Fig. 1755, welche die scheitrechte Ueberwölbung' einer Fensteröffnung angibt, genügt ein Brettchen, welches auf den Widerlagsmauern aufsitzt und in der Mitte gestiitzt ist.

Für grössere Gewölbe werden nach der Gewölbform L e h r bög e n hergestellt, indem Pfostenstiicke in 2-3facher Lage mit abwechselndem Stoss mit einander verbunden werden. Diese Lehrbögen werden in ca. $1-2^{\mathrm{m}}$ Entfernungen von einander aufgestellt (von einem Bogengeriist unterstiitzt) und durch aufgenagelte Latten wird die Form des Gewölbes genau fixirt. Fig. 1756 gibt ein Bild für die Ausführung eines Tonnengewölbes (s. Art. Gewölbe). Die Lehrbögen Fig. 1756 .

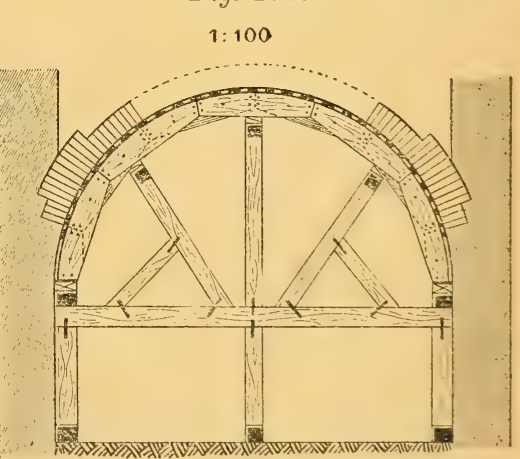

Lehr-Gerüst. werden durch Ständer, Durchzïge und Streben unterstiitzt und zwischen Lehrbögen und Durchzügen befinden sich Keile, welche bei der Ausrüstung des fertigen 
Gewölbes erst allmälig (vom Gewölbscheitel an) gelockert werden; erst wenu keine Setzung mehr bemerkbar wird, kann das ganze Lehrgerïst entfernt werden.

Die Art der Unterstützung der Lehrbögen hängt nicht allein von der Spannweite und dem Gewichte des Gewölbes ab, sondern auch, ob die Lehrbögen direct durch Ständer unterstiitzt werden können oder nicht; im letzteren Falle benützt man Häng- und Sprengwerke. Grohm.

Geschirr (équipage, harnais - mounting), das Werk, Z eug d. i., die Schäfte sammt ihrem Bewegungsapparate an den Webstiihlen (s. Weberei).

Geschlagene Arbeit (ouvrage martelé - hammered work), Treiben, s. Blechbearbeitung I pag. 554 . Wurfgeschoss.

Geschoss (etage - story), Stockwerk; Geschoss (projectile - shot),

Geschütze, s. Feuerwaffen III pag. 463.

Geschützmetall, s. Bronze II pag. 60 .

Geschützpulver, s. Explosivst offe III pag. 321 .

Geschur, s. m. Gekrätz, s. Blei I pag. 595.

Geschwindigkeit (vitesse - velocity). Unter Geschwindigkeit versteht man das Verhältuiss des Weges, welchen ein bewegter Körper in einem Zeittheilchen zuruicklegt, zur Dauer dieser kurzen Zeit. Bewegt sich der Körper mit gleicher Geschwindigkeit, dann ist dieses Verhältniss natïrlich ganz unabhängig von der Grösse des obigen Zeittheilchens, weil in der doppelten, dreifachen, nfachen Zeit auch der doppelte, dreifache, $n$ fache Weg zuruickgelegt wird. Bewegt sich aber der Körper mit variabler Geschwindigkeit, dann muss man den in einer unendlich kurzen Zeit zurïckgelegten Weg, der natiirlich auch eine sehr kleine Grösse sein wird, in's Verhältniss zum Zeittheilchen setzen und dies wird mathematisch durch die Gleichung:

$$
v=\frac{d s}{d t}
$$

ausgedriickt, welche besagt, die Geschwindigkeit des Körpers in einem Punkte seiner Bahn ist gleich dem Differentiale des Weges getheilt durch das Differentiale der Zeit. (Vergleiche Art. Bewegung Bd. I pag. 443.)

Mittlere Geschwindigkeit ist jener Werth, welcher durch Division des Gesammtweges durch die Gesammtbewegungszeit erhalten wird. Es ist jene Geschwindigkeit, welche ein gleichförmig bewegter Körper besitzen müsste, wenn er in derselben Zeit denselben Weg zurücklegen würde.

Indem der Mechaniker oft in die Lage kommt, Geschwindigkeiten, welche die Erfalıung für gewisse Bewegungen festsetzt, kennen zu muissen, so soll die nachfolgende Tabelle beigefügt sein. *)

a) Arbeits - Geschwindigkeiten in Metern pr. Secunde.

0.015 Schnittgeschwindigkeit bein Abdrehen von Hartgusswalzen.

0.015 Cmfangsgeschw. der Walzen an Blech- und Schienenbiegemaschinen.

0.018 Geschw. des bewegl. Scherblattes bei Parallelscheren, des Stempels bei Lochmaschinen.

0.030 Umfangsgeschw, an Gewindbohrern und den Backen von Schraubenschneidmaschinen.

E) Entnommen einer Zusammenstellung Hartig's, s. techn. Blätter 187t pag. 192. 
0.050 mittlere Schnittgeschwindigkeit beim Drehen, IIobchn, Ausbohren stählerner Arbeitsstiicke.

0.080 mittlere Schnittgeschwindigkeit beim Abdrehen, Hobeln, Aushohren gusseiserner Arbeitsstuicke.

0.15 mittlere Schnittgeschwindigkeit beim Abdrehen ete, von Bronze.

0.20 Geschw. beim Ziehen starken Eisendrahtes.

0.24 Geschw. der Eimerketten bei Flussbaggern.

0.25 Umfangsgeschw. hölzerner Arbeitsstuicke beim Abdrehen mit dem IIanrlstahı].

0.35 Umfangsgeschw. von Fräsen bei Bearbeitung von Guss- und SchmirdoeisenZahnrädern.

0.44 Arbeitsgeschw. der Stemmeisen bei Holzstemmmaschinen.

0.47 Umfangsgeschw. der Walzen von Erzquetschen.

0.70 mittlere Umfangsgeschw. der Quetschwalzen für Oelfruichte.

"0.75 vorth. Geschwindigkeit der Hechelstäbe bei Hechelmaschinen.

0.80 vorth. Geschw. der Schneidwalzen und Kreisscheren.

1.30 Arbeitsgeschw. beim Ziehen feinen Eisendrahtes.

1.50 vortheilhafteste Geschwindigkeit der Schienenwalzen und Grobeisenwalzen.

1.70 mittl. Arbeitsgeschw. der Walzwerke für Eisenblech.

2.08

" Mahlwalzen bei Walzenstublungen.

2.20 vortheilh. Geschw. der Schermesser an Getreidemähmaschinen.

$2.30 \quad " \quad$ "Walzenwalken für Stoffe.

2.50 mittl. " " " $"$ Gattersägen.

2.50 vortl. $\quad " \quad$ Feineisenwalzen.

3.00 grösste $"$ "Drahtwalzen.

4.50 mittl. Umfangsgeschw. des Schneidzahnes beim Fräsen ron Holzzähnen.

5.00 der Schleifsteine zum Schl. von Arbeitsstählen.

5.00 Umfangsgeschw. hölzerner Arbeitsstiicke beim Abdrehen auf Supportdrehbänken.

7.00 mittl. Umfangsgeschw. der Holländerwalzen.

7.43 vorth. Umfangsgeschw. der Messer bei Haderschneidern.

10.0

der feinkörnigen Schleifsteine in Schleifmaschinen.

10.0 " Geschw. des Blattes bei Bandsägen.

10.0 grösste rathsame Umfangsgeschw. der Miihlsteine.

10.0 "Umfangsgeschw. der grossen Schleifsteine in Fabriken.

$15.0 " n$ " $"$ Schmirgelscheiben zum Feinschleifen.

$18.0 " n "$ "Schneidköpfe bei Holz-Fräsmaschinen.

25.0 " zulässige Geschw." grosser Schleifsteine sehr guteri Materiales.

27.0 vorth. Umfangsgeschw. der Schmirgelsch. an Sägeschärfmaschinen.

40.0

60.0

"Kreissägen für Holz.

"Schlagscheiben bei Carr's Desintegrator.

b) Durehgangsgeschwindigkeiten von Materialien durch Arbeitsmaschinen. (Meter pr. Secunde.)

0.025 Geschw. der Schlagmaschinen für Baumwolle a. d. Zufuilurwalzen.

0.04

0.064

0.08

0.10

0.10

0.13

0.14

0.21

0.33

0.35

0.75

1.00 vorth. " bei Gassengmaschinen.

" Zwirnmaschinen für Streichgarn (Zwirnlänge p. S.).

$" n$

des Tuches "bei Tuchrauhmaschinen.

zweckm. Geschw. bei Blechspann- oder Bördelmaschinen.

mittl. Geschw. bei Tuchtrockenmaschinen mit endl. Spannketten.

$n n$

"Tuchbiirstmaschinen.

" Ketten-Scheermaschinen für Streichgarn.

des Papiers bei Glättkalandern.

bei Dampftrockenmaschinen fiir baumwollene Gewebe.

der Papiermaschine bei Herstellung diinnen Schreibpapiers.

des Stoffes beim Durchgang durch Kalander. 
1.10 vorth. Geschw. bei Tuchwaschmaschinen und Walzenwalken (PressprichWiede).

2.30 vorth. Geschw. der Walzenwalken. wähnt sind.

c) Umfangsgeschwindigkeiten, welche nicht unter $a$ und $b$ cr-

0.07 grösste zuläss. Umfangsg. der Messtrommel nasser Gasuhren.

0.06 Umfangsgeschw. der Lumpenkocher.

0.60 zweckm. Umfangsg. der Wasserschöpfräder.

$5-6^{\mathrm{m}}$ Geschw. der Trommeln bei Streichgarnkrempeln.

8 " " " Baumwollkrempeln.

8.5 der Schleifsteine für Holzstoff (Völter).

13-14 "der Trommeln bei Wergkarden.

30 grösste zulässige Geschw. an Schwungrädern.

35 Umfangsgeschw. der Schlagflïgel für Baumwolle.

50

"Centrifugen fiir Tuch.

d) Geschwindigkeiten bei Ortsveränderungen im gewöhnlichen Sinne und bei der Wirkung lebender Motoren.

$\mathrm{m} / \mathrm{Sec}$.

0.10 mittl. Fahrgeschw. der Berglente beim Ausfahren auf gew. Fahrten.

0.14

0.20

0.60

0.67

0.75

0.80

0.90

0.95

1.32

1.50

1.80

2.08

2.43

2.44

2.54 zweckmässige Fahrgeschw. bei Aufüigen in Fabriken. vorth. Geschw. der im Göpel g.henden Ochsen.
$n$
, Paternosterwerke oder Elevatoren für Mahlgut.

$n$

$n$

"von Menschen gedrehten Kurbelgriffe.

mittl. Geschw. der bei Fahrkïnsten" angewendeten Fahrten.

im Göpel gehenden Esel.

reglementmässige Marschgeschwindigkeit der Fusssoldaten mit vollem Gepäck. mittl. Geschw. eines Fussgängers ohne Belastung auf horiz. Bahn. vorth. Fahrgeschw. der Kettendampfer in todtem Wasser.

mittl." des Pariser Omnibus.
$n$
Londoner Omnibus.

höchste zulässige (ieschw. der Transportgurten für Hafer, Kleie, Mehl.

Beförderung.

2.68 vorth. Geschw. des 'Transportseiles bei der IIoogson'schen Seilbahn.

2.75 höchste zulässige Geschw. der Transportgurten für Weizen, Korn u. dgl.

3.10 mittl. Fahrgeschw. auf den Londoner Tramways eingerechnet der normalen

Unterbrechungen.

3.68 höchste zulässige Ausfahrgeschwindigk. der Fahrgestelle in Schächten (zur Menschen-Bef.)

4.00 mittl. Fahrgeschw. der Flussdampfer in todtem Wasser.

$5.00 " \#$ "Seedampfschiffe.

12.5 grösste zulässige Fahrgeschw. der Güiterzïge.

18.5 mittl. Fluggeschwindigkeit der Brieftauben.

20.8 grösste zulässige Fahrgeschw. der Personenzüge.

$25.0 ", \quad$, Schnellziige.

25.0 vortheilhafteste Geschw. des Treibseils bei Laufkrahnen m. Seilbetrieb. Vergl. Bıl. III pag. 75 betreffs Zuggeschwindigkeit.

e) Wasser- und Luftgeschwindigkeiten.

0.07 grösste Wassergeschw, bei welcher abgel. feiner Schlamm und Sand noch nicht weggefiihrt wird. 
0.10 Geschw. des aufsteig. Wasserstromes, bei welchem Quarzkïrner von $1^{\text {mu }} \mathrm{L}$. in fallender Schwebe gehalten werden.

0.14 Geschw. des aufsteig. Wasserstromes, bei welchem Quarzkijnor von 1.4 ${ }^{\text {mm }} \mathrm{L}$. in fallender Schwebe gehalten werden.

0.15 grösste Wassergeschw. in Fluissen, b. w. abgelagerter fotter Thon nicht weggefuihrt wird.

0.19 Geschw. des aufsteig. Wasserstromes, bei welchem Quarzkïrner von $4^{\text {mon }} \mathrm{L}$. in fallender Schwebe erhalten werden.

0.40 mittlere Wassergeschw. in Ober- und Unterwassergraben liydr. Mrstroren.

0.63 grösste Wassergeschw. in Flïssen, bei welcher Gerölle von 10 ${ }^{\text {mm }}$ D. noch liegen bleibt.

0.92 grösste Wassergeschw. in Fliissen, bei welcher Gerölle von 2(jm! I). noch liegen bleibt.

1.00 L u ftgeschw. bei kaum merkbarem Winde.

1.00 vorth. Geschw. des Wassers in Sang- und Druckröhren einfach wirkenrler Kolben-Pumpen.

1.60 vorth. Geschw. des Wassers in Saug-und Druckröhren doppelt wirkender Kolben-Pumpen.

$2.00 \mathrm{~L}$ u ftgeschw. bei mässigem Winde.

frischem
$"$ gutem Seewind.
starkem Wind.

Geschwindigkeitsmesser, Trochometer (trochometer - tachymetre). Die Schwierigkeiten, einen Apparat zum Messen der Geschwindigkeit zu schaffen, sind darum grosse, weil die Geschwindigkeit ein Zustand ist, welcher nicht nur innerhalb sehr weiter Grenzen der Grösse nach verschieden ist, sondern sich innerhalb kurzer Zeiten oder auch continuirlich ändern kann. Während man Längen mit Längen, Flächen mit Flächen etc. verhältnissmässig leicht messen kann, da während der Operation des Messens die zu messende Grösse sich nicht oder verschwindend wenig ändert, ist beim Messen von Geschwindigkeiten das zu Messende variabel, und man hat die Aufgabe, den in einer gewissen Zeit vorhandenen Werth zu messen. Hierzu gesellt sich eine zweite Schwierigkeit, welche darin liegt, dass man noch keinen Apparat aufgefunden hat, welcher die sehr verschiedenen Geschwindigkeiten der verschiedenen bewegten Körper, wie solche in der Technik, dem Eisenbahnwesen, der Ballistik etc. vorkommen, unmittelbar mit Geschwindig: keiterı, deren Grösse durch den Apparat feststellbar wären, vergleichın liesse.

Man misst daher die Geschwindigkeiten je nach ihrer Grösse und je nach der Art des bewegten Körpers und der Gattung der Bewegung durch mannigfache Apparate. Im Artikel Anemometer I pag. 146 wurden Apparate zur Bestimmung der Wind-Geschwindigkeit besprochen, im Art. Hydrometrie werden jene für die Bestimmung der Wassergeschwindigkeit angegeben. Zur Bestimmung der meist gleichförmigen $\mathrm{Um} \mathrm{fangsgeschwindigkeit} \mathrm{rotirender} \mathrm{Kürper}$ bedient sich der Mechaniker der Tourenzähler (s. d.) und findet die Geschwindigkeit aus der minutlichen Tourenzahl $n$ und dem Radius $r$ durch Rechnung, denn es ist $v=\frac{2 \pi r n}{60}$. Um die Geschwindigkeit eines Ei s e n b a hnzuges zu bestimmen, sind Apparate construirt (Hearson's Strophometer), bei welchen ein Centrifugalpendel mit einer Laufachse derart in Verbindung gesetzt ist, dass jenes ax Touren macht, wenn diese $x$ Touren ausfihirt. Die verschiebbare Huilse des Centrifugalpendels (ähnlich construirt wie bei Watt's Regulator, s. d.) bewegt einen Hebel, dieser wirkt auf ein Zahnsegment, welches in ein kleines Zahmrad eingreift, an dessen Achse ein Zeiger sich findet, welcher an einem empirisch getheilten Zifferblatte unmittelbar die Fahrgeschwindigkeit anzeigt. Die richtige Anzeige dieses Apparates hängt von der exacten Transmission der Bewegung, ron der Empfindlichkeit des Centrifugalpendels und der Richtigkeit der empirischen 
Theilung ab. In seinen Angaben wird dieser Apparat iiberdies dürch die Vibrationen des Waggons, in welchem er angebracht ist, beeinflusst. Die Geschwindigkeit eines Eisenbahnzuges kann auch in folgender Weise leicht bestimmt werden. Sei $u$ der Umfang des Triebrades der Locomotive und bewege sich der Zug mit $K$ Kilometer pr. Stunde, so werden $K$ Touren des Triebrades in irgend einer Zeit $t$ gemacht werden. $\frac{u K}{t}$ ist dann die Geschwindigkeit pr. Secunde. Dieselbe ist aber auch gleich $\frac{K \cdot 1000}{60.60}=\frac{10}{36} K$; hiernach wird $\frac{u K}{t}=\frac{10}{36} K$ oder $t=3.6 u$. Für $u=3^{\mathrm{m}}$ wird $t=10.8^{\mathrm{sec}}$ und man hat mithin nur die leicht zählbare Tourenzahl des Triebrades innerhalb der Zeit von 10.8 Sec. zu zählen, um in dieser Zahl unmittelbar die Anzahl der Kilometer pr. Stunde zu erhalten, mit welcher sich der Zug bewegt.

Die Geschwindigkeit einer Gewehr- oder Geschuitzkugel (zwischen 300 bis $500^{\mathrm{m}}$ ) kann in folgender Weise bestimmt werden. Mit einer horizontalen, sehr rasch (z. B. 300 Touren) und gleichförmig rotirenden Welle sind im Abstande von 2 oder mehr Metern zwei Papierscheiben entsprechend verbunden. Das Gewehr wird parallel zur Achse und iiber derselben gelagert, nahe vor der ersten Scheibe, und der Kugelschuss abgefeuert. Beide Papierscheiben werden Löcher aufweisen, aber die Lage derselben wird rersetzt erscheinen, entsprechend der Zeit, welche die Kugel zum Durchfliegen des kurzen Wegstiickes zwischen beiden Scheiben brauchte und entsprechend der Tourenzahl derselben.

Statt dieser Vorrichtung kann man (bei Geschiitzen) zwei Massen in einem gewissen Abstande von einander aufhängen und durch die Kugel die Fäden durchschiessen lassen. Die fallenden Stiicke schliessen oder muterbrechen einen electrischen Strom und ans der Zeit zwischen den Strom-Schliissen oder Unterbrechungen in Verbindung mit dem bekannten Abstand der Aufhängepunkte ist die Geschẉindigkeitsbestimmung leicht.

Die beiden letztgenannten Mittel gehen genauere Bestimmungen als das ballistische Pendel, welches darauf beruht, dass die Kugel gegen eine schwere aufgehängte Masse geschossen wird, deren Pendelschwingung gemessen und so die iibertragene lebendige Kraft $\frac{m v^{2}}{2}$ bestimmt wird, woraus sich $v$ ergibt (vgl. Art. Stoss), aber sie sind umständlicher, so dass z. B. zur Bestimmung der Pulverkraft doch die ältere Methode vorzuziehen ist. Vergl. auch Chronoskop II pag. 355 .

$K k$.

Gesenk (étampe, estampe - surage, hosse. shaper,) s. Schmieden.

Gesenkklotz, Gesenkstock (suage Llocki), s. Schmieden.

Gesenkschacht, s. Bergbau I pag. 387.

Gesims (moulure - moulding), aus einzeluen Profilgliedern zusammengesetzte architektonische Verzierumg, welche die Wechselwirkung einzelner Bautheile zum Ausdruck bringen soll, z. B. das Fuss-oder Sockelgesims soll den Abschluss des Bames (oder eines Bantheiles) nach Lnten ausdriicken, das Hauptgesims den Abschluss (Kröuung) nach Oben; das Gurtgesims bezeichnet eine Tremnung (Giirtung) der Hohe nach etc. In constructiver Hinsicht haben die Gesimse im Freien den Zweck. das Herabfliessen des Wassers an der Wand wenigstens theilweise zu rerhindern, daher im Profil die vortretende Hängeplatte mit einer Unterschneidung (Wassernase) wesentlich ist. In der Architektur bilden die Gesimse eines der wichtigsten Capitel: ein näheres Eingehen hierauf ist jedoch hier ausgeschlossen.

Grohmann.

Gesimshobel, s. Hobel. 
Gespann (trousse, fourrure, paquet - tongs), bei der Hammorarbeit vereinigte, gleichzeitig der Bearbeitung (dem Treiben) unterworfene Bleche.

Gespärre (chevrons - couple-close), die Gesammtheit aller in einem Dachprofil befindlichen Balken. Siehe über Bund- und Leergespärre Artikcl Dach II pag. 466 .

Grohm.

Gesperr (encliquetage - click and spring work) ein Sperrad mit Sperkegel. Uhrenbestandtheil, s. Uhren.

Gespinnstfasern. Die zu Geweben verarbeiteten Rohproducte entstammen theils dem Thierreiche, wie Wolle und Seide, theils dem Pflanzenreiche. Die vegetabilischen Gespinnstfasern sind entweder $\mathrm{Haarbildungen}$ und als solche einfache langgestreckte Zellen, wie die Baumwolle, die Wolle der Wollbäume, oder vielzellige Gebilde, sogenannte Zotten, wie die EriophorumWolle; - oder aber sie stellen Gefässbündel oder Bestandtheile von Gefässbündeln meist krantartiger, seltener baumartiger Gewächse dar, durch einen mehr weniger umständlichen Process theils aus der Innenrinde (Bast) dicotyler Pflanzen rein dargestellt, wie $\mathrm{Flachs}, \mathrm{Hanf}, \mathrm{Ch}$ in agras, $\mathrm{Sunn}$ und $\mathrm{Jute}$, theils aus den Blättern, Neuseelandflachs, Agavefaser u. a., aus Stängeln, Manillahanf, oder aus der Fruchthülle, Cocosfaser, monocotyler Gewächse. Die angeführten Beispiele von Gespinnstfasern sind zugleich solche, welche für die europäische Industrie eine grössere Bedeutung haben, nnd sollen bloss diese hier, mit Ausschluss der Baumwolle, welche bereits Band I. p. 308 dieses Wörterbuches abgehandelt wurde, mit Rücksicht auf ihre histologischen Verhältnisse besprochen werden. Verschiedene andere Faserstoffe finden eine Erörterung unter Papier-, Polstermaterial und Seilerei. Bezüglich einer eingehenderen Unterweisung verweisen wir auf folgende Schriften: H. Schacht, die Prüfung der im Handel vorkommenden Gewebe ete. Berlin 1853. - J. Wiesner, Einleitung in die technische Mikroskopie. Wien 1867. J Wiesner, die Rohstoffe des Pflanzenreichs, Abschnitt: Fasern. Leipzig 1873. - R. Schlesinger, mikroskopische Untersuchungen der Gespinnstfasern ete. Zürich 1873. — V étillart, Etudes sur les fibres végétales textiles employés dans l'industrie. Paris 1876.

Bei der Untersuchung der Gespinnstfasern mit mikrochemischen Reagentien empfiehlt sich ansser den sonst üblichen: Jodsolution (am besten Jodglycerin) mit Schwefelsäure, Kupferoxyd-Ammoniak und einer Lösung von schwefelsaurem Anilin, welche letatere durch Gelbfärbung die Anwesenheit von Holzstoff anzeigt, - auch Chlorzinkjodlösung, welche viel brauchbarer ist als Jod mit Schwefelsäure, und ferner eine Lösung von Phloroglucin, die in Verbindung mit einer Mineralsäure (am besten Salzsäure) in neuester Zeit als ein sehr empfindliches Reagens auf verholzte Zellmembranen erkannt wurde. Es ist wo möglich empfindlicher noch als das schwefelsaure Anilin, allerdings weniger bequem anzuwenden, insofern man das betreffende Object mit zwei Mitteln zu behandeln hat, während bei letzterem nur eines in Betracht kommt. Wir tränken bei der Anwendung des Phloroglucins das Untersuchungsobject mit der vorbereiteten wässrigen Lösung. dieses Mittels, tupfen die überschüssige Flüssigkeit ab und setzen sodann einen Tropfen Salzsäure zu. Verholzte Membranen färben sich nach dieser Behandlung: blass bis mehr weniger intensiv violett oder violettroth, je nach der Intensität der Verholzung, resp. der Dicke der verholzten Membranschicht. Bei den zahlreichen Untersuchungen, die an den im Nachfolgenden angeführten Fasern angestellt wurden, haben wir uns iiberzengt, dass nirgends die Bastfaserwandung in ihrer Totalität verholzt ist, sondern die Verholzung stets nur die äusseren mehr weniger dicken Partien der Zellwand betrifft. Dieser Limstand ist bei der Deutung der Erscheinungen, die man bei Anwendung der oben aufgezählten Reagentien beobachtet, wohl zu berïcksichtigen.

Sehr rein gehechelte Sorten des Flachses - aus den Stängeln von Linum usitatissimum L. (Lineae) gewonnen - bestehen bloss aus Bast- 
fasern (Fig. 1757); in weniger reinen Sorten sind diese begleitet von Resten des Rindenparenchyms und der Oberhaut (Epidermis), zuweilen auch von Resten des Holzgewebes. Noch reichlicher zeigen sich diese Beimengungen im

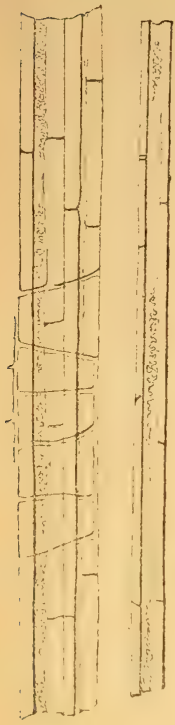

1
Fig. 1757 .

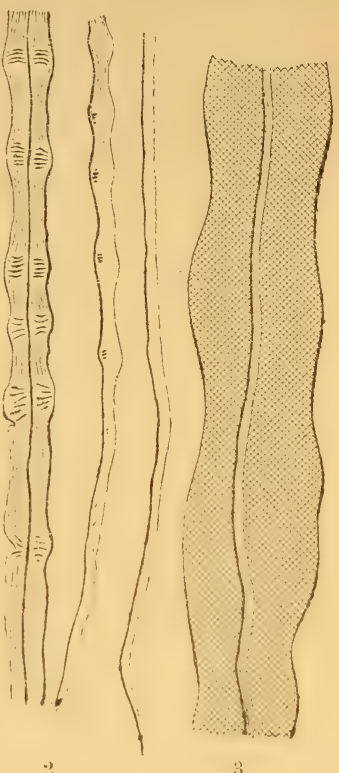

Flachs (Linum usitatissimum). Rohflachse, gewöhnlich neben Pilzfäden, Pilzsporen u. dgl. Im unveränderten Zustande, wie sie im sog. Flachsstroh vorkommen, stellen die Bastfasern 2-4 ${ }^{\mathrm{cm}}$ lange, 0.015 $-0.020-0.030^{\mathrm{mm}}$ dicke eylindrische oder fast cylindrische, nach den Enden zu beiderseits allmälig und meist sehr stark verjüngte, nicht selten in eine sehr lange, fast unmessbar dünne Spitze ausgezogene glatte farblose Faserzellen (Prosenchymzellen) dar mit sehr dicker, von einzelnen Porenkanälen durchsetzter Wand und meist sehr engem, oft nur als dunkle Linie sich darstellendem Zellenraume. Auf dem Querschnitte erscheinen sie gerundet: kreisrund, eirund oder mehr ellipsoidisch, oder gerundet polygonal mit engem kreisrunden, elliptischem oder spaltenförmigem Lumen und farbloser dicker geschichteter Wand. Das gleiche Verhalten zeigt die Bastfaser aus dem blos gerösteten Flachs. Die Fasern des gehechelten, also mechanisch bearbeiteten Flachses bieten dagegen zum Theil ein verändertes Aussehen dar; einmal findet man neben (der Länge nach) völig erhaltenen, zahlreiche abgerissene Bastfasern, ferner an viclen derselben die Verdickungsschichten der Zellwand auseinandergebrochen, die Zellwand in Folge dessen von längsverlautenden parallolen dunklen Linien durehsetzt. (2) Häufig zeigt sich diese Erscheinung nur an einzelnen aufgetriebenen Stellen. An der Obertliche der Bastfitsern des gehechelten Flachses sieht man iiberdies nicht selten Linien, welche senkrecht oder fast senkrecht zum Längsdurchmesser der Faser rerlaufen, veranlasst zum Theil durch Bruchlinien, welche die Zallwand yuer durchsetzen, zum Theil aber durch anhaftende Reste der Bastparenchymzellen (1). Kalilauge macht die Zellwand aufquellen ohne Farbenändermeg: Chlorzinkjod tairbt sie sufort violett, Jod mit Schwefelsäure schön blau, wiihrent die beigemengten Residnen der Rincle und des IInlzkörpers eine gelbbraune Farbe ammolhen. Schwefelsures Analin färbt die Bastfaser selbst nicht, ebensowenig wie Phloroglucin, dagegen werden dic etwa rorhandenen Reste des Holzgewebes durch ersteresReagens gelb, durch letzteres roth gefärbt. Kupferoxydammoniak macht unter Auftreten von Längs- und feiner spiraliger Streifung und unter lBlaufärbung die Wand zuerst stark aufuuellen und löst sie schliesslich bis ant die Innenanskleidung, welche längere Zcit in Gestalt eines dümnen glatten, stellenweise schraubenförmig gewundenen schlauchs zurickbleibt (3), um endlich auch aufgeriest zu werilen.

Der. II anf, - aus den Stingeln von Cannalis sutica L. (Cannabineae) crhalten -, besteht hauptsärhlich aus Bastfasern (Fig. 175s); danchen trifit man selbst in fein gehechelten Sorten noch in kleiner Menge Bastparenchymzellen. Ge- 
brochener oder unvollkommen gehechelter IIanf enthält iiberdies Reste der Oberhaut, des Rindenparenchyms und selbst des Holzgewebes. Dic IBastfaseru besitzen reine

Fig. 1758.

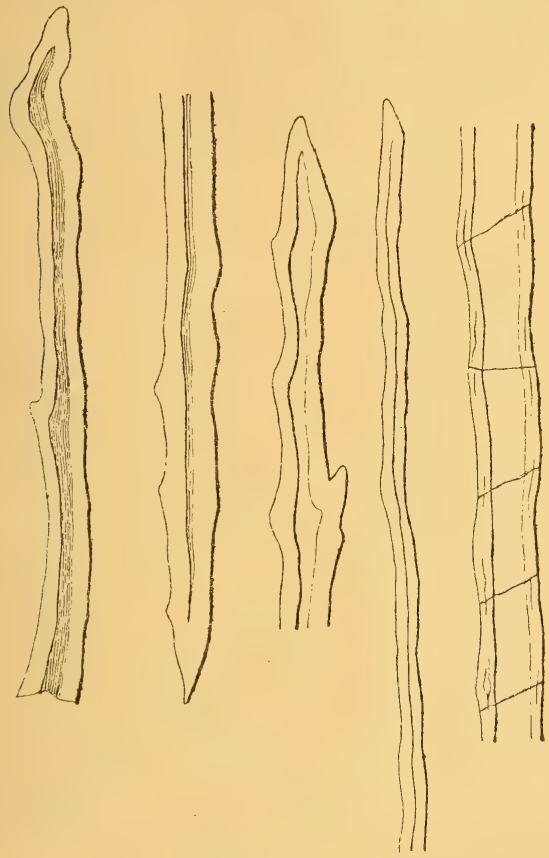

A

Hanf (Canabis sativa).

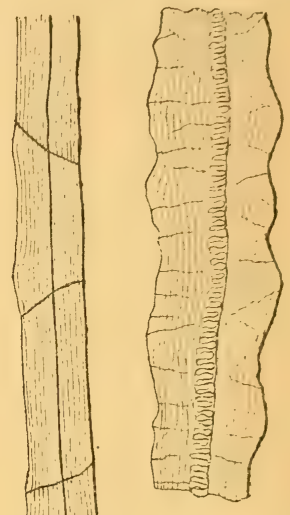

B

C

Länge von $1-5^{\mathrm{cm}}$ und dariber bei einem Querdurchmesser von $0.015-0.028^{\mathrm{mm}}$ : sie sind fast stielrund oder etwas flachgedriickt mit meist stumpfen, seltener mit spitzen oder selbst in eine lange Spitze vorgezogenen Enden $(A)$, zuweilen an einem Ende oder an beiden Enden mehr weniger knorrig mit einzelnen entfernten stumpfen Zähnen oder gerundeten Höckern, dabei leicht verbogen, selten kurzgabelig rerzweigt. Die ziemlich stark verdickte Zellwand zeigt hin und wieder einen schief verlaufenden Porenkanal und an der Faser des gebrochenen Hanfs stets grobe parallele Streifung $(B)$; der Zellenraum ist meist leicht zu erkennen. Auf dem Querschnitte erscheint die Hanfbastfaser gerundet, oder gerundet-polygonal mit farbloser geschichteter, ziemlich dicker Wand und engem spaltenförmigem einfachem oder strahligem, oder aber mit ziemlich weitem spitz-elliptischem Lumen. In Kalilange quillt die Wand farblos auf, Chlorzinkjod färbt sie violett, Jod mit Schwefelsämre die vollkommen gebleichte schön blau, sonst selten rein blan, sondern mehr weniger grünlich. Schwefelsaures Anilin färbt die unveränderte Bastfaser blassgelb. Phloroglucin viele schön violettroth, einzelne nicht. In Kupferoxydammoniak quillt die Wand zuerst unter Hervortreten grober Längs- und zarter querer oder schrïger Streifung und blangriner bis blaner Farbe mächtig auf; hiebei erscheint die innere Auskleidung als breiter, dicht ring- oder schraubenförmig gefalteter Schlanch $(C)$ 
und auch eine äussert zarte Schicht der Wand widersteht längere Zeit in Gestalt krausfaltiger Fetzen sich darstellend, während die eigentliche Zellwand bereits unter der Einwirkung des Reagens sich gelöst hat. Häufig sieht man bei dieser die Hanfbastfaser gleich der Leinenfaser und der Baumwollenhaare in Folge stellenweiser Einschnürnngen ein rosenkranzförmiges Aussehen annehmen.

Das sogenannte Chingras, aus dem Stängel von Boehmeria nivea Gaud. (Urtica nivea L.), und die Ramiefaser, aus dem Stängel von Bnehmeria tenacissima Gaud. (Urticaceae) gewonnen, enthalten ausser Bastfasern (Fig. 1759 A) Reste der Stängelrinde: sehr feine Siebröhren mit stark schräge ge-

Fig. 1759.

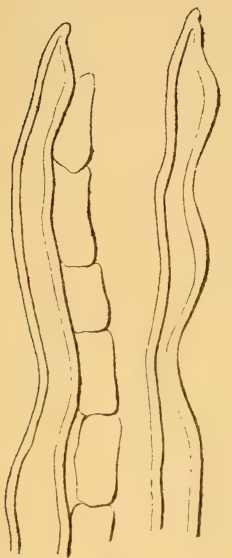

A

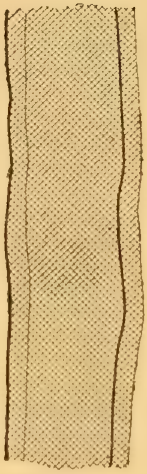

B

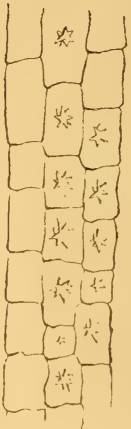

C

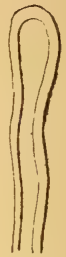

A

Chinagras (Buehmeria nivea).

stellten Siebplatten und Parenchym, und zwar sowohl chlorophyll-führende Zellen, als auch solche, welche kleine Krystalldrusen ron Kalkoxalat einschliessen. Die Bastfasern des unveränderten Chinagrases sind zunächst durch ihre ausserordentliche Länge ausgezeichnet; dieselbe beträgt $6-20^{\mathrm{cm}}$ und selbst dariber bei einem Querdurehmesser ron $0.04-0.08 \mathrm{~mm}$. Sonst sind sie ziemlich cylindrisch, beiderseits kegelförmig verschmälert mit abgerundeter, stumpfer, zuweilen lanzen- oder spatelfurmiger, selten gabelig getheilter spitze, im Allgemeinen mässig verdickt mit weitem Zellenraum (A), farblos, glatt, längsgestreift, nach Behandlung mit Kalilauge zwei sich fast rechtwinklich kreuzende feine, schief zur Längsachse der Faser verlaufende Liniensysteme in der Wandfläche zeigend $(B)$, einzelne einen feinkömigen gelblichen Inhalt einschliessend. Der Querschnitt ersch int gerundet: kreisrund, eirund, eiförmig oder elliptisch, meist mit buchtig eingebogenem Lmriss, mit deutlicher Wandschichtung und weitem rundlichem oder spitz-elliptischem Lumen. Chlorzinkjod färbt die Tand sofort schmutzig-riolett, Jod und Schwefelsäure kupferroth, violett oder schön blan; schwefelsaures Anilin färbt sie nicht, ebensowenig wie Phloroglucin; in Kupferoxydammoniak quillt sie unter Blaufärbung und Hervortreten eines breiten faltigen Innenschlauchs mächtig auf und löst sich schliesslich. Einzelne Bastfasern sind ganz oder theilweise ron LängsReihen kleiner zartwandiger, nahezu kubischer Zellen umsponnen, von denen jede eine Krystalldruse von oxalsaurem Kalk enthält $(C)$.

Die Bastfasern der Boehmeria tenacissima (Ramie) unterscheiden sich haupt- 
sächlich nur durch ihre Dimensionen. Nach W iesner beträgt ihre Länge höchstens

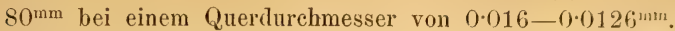

Die Faser des Sunns (braunen Hanfs, Madras-IIanfs), aus der Stängelrinds der einjährigen Papilionacee Crotalaria juncer $L$. grewonnen, besteht gleichfalls der Hauptsache nach aus Bastfaserbündeln, begleitet von mehr weniger reichlichen dïnnwandigen Zellen des Rindenparenchyms, von Sichröhren, Stiickrn der Oberhaut mit einzelligen kegelförmigen, nicht dickwandigen Haaren mi El menten des Holzkörpers. Die Bastfasern (Fig. 1760 A) zeigen eine Länge von 4 bi.s

Fig. 1761.

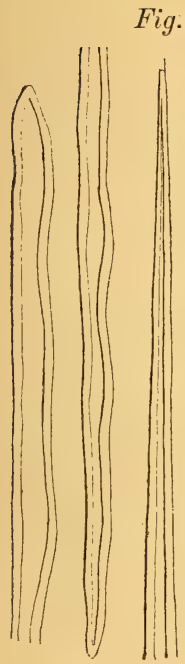

A
Fig. 1760 .

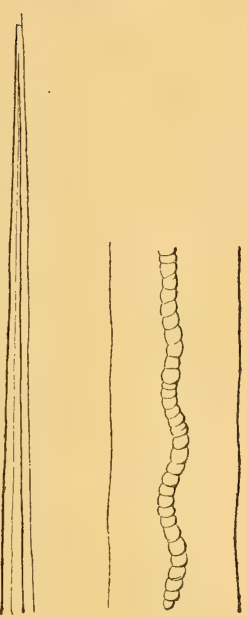

B
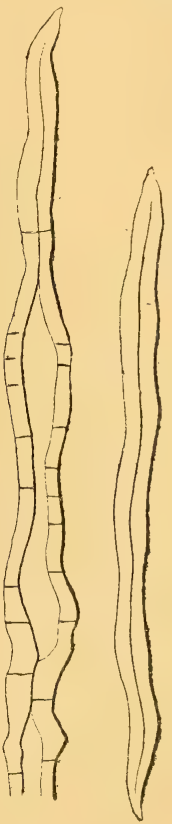
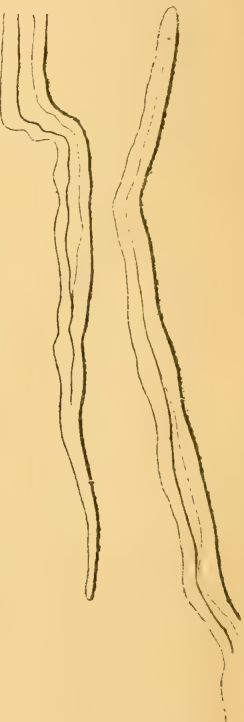

Jute (Corchorus capsul:uris).

Sunn (Crotalaria juncea).

$12^{\mathrm{mm}}$ bei einem Durchmesser von $0.02-0.05^{\mathrm{mm}}$; sie sind cylindrisch oder fast prismatisch mit allmälig verschmälerten meist stumpfen oder gerundeten, zuweilen fast spatelförmigen Enden, glatt, farblos; auf dem Querschnitt eirund oder gerundetpolygonal mit ziemlich dicker geschichteter Wand. Kalilauge färbt diese unter Quellung voribergehend gelblich, Chlorzinkjod sofort sehmutzig-riolett, Jod mit Schwefelsäure blau, schwefelsaures Anilin gelblich, Phloroglucin blass-violett, Kupferoxydammoniak blau unter Hervortreten einer deutlichen spiraligen Streifung, weiterhin folgt starke Quellung, wobei ein zarter krausfaltiger Innenschlauch bemerkbar wird $(B)$ und schliesslich Lösung.

Die Jute, aus dem Stängel mehrerer Corchorus-Arten, namentlich von C. capsularis L. (Tiliaceae) dargestellt, besteht aus Biindeln sehr innig mit einander verbundener Bastfasern (Fig. 1761) von nur $0.8-5^{\mathrm{mm}}$ (am häufigsten $2^{\mathrm{mm}}$ ) 
Länge und $0 \cdot 01-0 \cdot 03^{\mathrm{mm}}$ Dicke. Auf dem Querschnitte erscheinen diese polygonal, 5-6-seitig mit auffallend ungleichem, bald weitem, bald engem eirundem leerem Lumen und daher sehr ungleicher Wanddicke. Sie sind demnach in ihrem Körper prismatisch mit rasch zugespitzten, meist abgerundeten Enden, an den Seiten häufig knorrig, ausgeschweift oder gezähnelt, zumal gegen die Enden zu. Sehr auffallend ist die ungleiche Wanddicke im Verlaufe der Faser: an manchen Stellen ist sie nicht stärker wie bei der Baumwolle und dann der Zellenraum sehr weit, an anderen Stellen dagegen steht sie der Leinenfaser nicht nach. An einer und derselben Bastfaser sieht man sehr häufig den bis auf einen linienförmigen Kanal reducirten Zellenraum von Strecke zu Strecke plötzlich oder allmälig in eine Erweiterung übergehen; auch eine ungleiche Wandstärke in derselben Höhe e in e r Faser kommt vor. Chlorzinkjod färbt die Wand braungelb, Jod mit Schwefelsäure grïnlich-blau, schwefelsaures Anilin schön gelb, Phloroglucin sofort purpurn, Kupferoxydammoniak unter mässiger Quellung bläulich.

Der aus den Blättern von Phormium tenax Forst. (Liliaceae) abgeschiedene $\mathrm{Neuseeland-Flachs} \mathrm{besteht} \mathrm{der} \mathrm{Hauptmasse} \mathrm{nach} \mathrm{aus} \mathrm{Strängen} \mathrm{bast-}$ faserartiger Elemente (Fig. 1762) begleitet (wenigstens in der Rohwaare) von senkrechten Reihen kurzprismatischer derbwandiger

Fig. 1762.

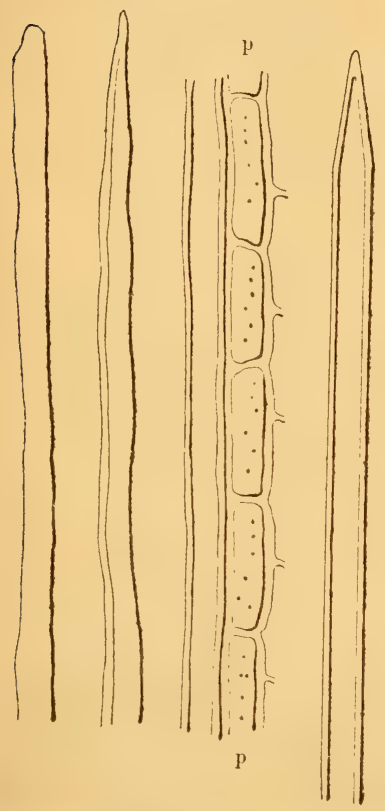

Neuseeland-Flachs (Pliormitm tenax) getiipfelter Parenchymzellen $(p p)$, von Bündeln sehr feiner Siebröhren (Cambiform) und mehr weniger reichlichen Resten von Holzgefässen: meist abrollbaren Spiralgefässen mit einfachem oder doppeltem Spiralbande, welche den im Manillahanf angetroffenen gegenüber nicht sehr weit sind $\left(0.05-0.07^{\mathrm{mm}}\right.$ mit etwa $0.007^{\mathrm{mm}}$ breitem Spiralbande). Hin und wieder trifft man Oberhautstiicke aus kleinen tafelförmigen Zellen mit einzelnen Spaltöffnungen. Die Bastfasern selbst sind 8-10 ${ }^{\mathrm{mm}}$ lang (Wiesner) mit einem Querdurchmesser von $0^{\circ} 008-0.016^{\mathrm{mm}}$, fast prismatisch, gleichmässig und eben nicht stark verdickt (jedenfalls aber relativ dickwandiger als jene des Manillahanfs) mit deutlichem, meist weitem Zellenranm, allmälig nach den Enden verschmälert und hier meist spitz oder zugespitzt, seltener stumpf oder in eine kurze Spitze vorgezogen, glatt, farblos; auf dem Querschnitte gerundetpolygonal mit meist kreisrundem Lumen. In Kalilauge quillt die Zellwand unter vorübergehender gelblicher Färbung auf, Chlorzinkjod färbt sie goldgelb, Jod mit Schwefelsäure grïnlichblau bis blau, schwefelsaures Anilin kaum wahrnehmbar gelblich (dagegen die Spiralbänder der Gefässe schön gelb; bei reichlicherer Anwesenheit dieser letzteren nimmt daher die Rohfaser eine gelbe Farbe an), Phloroglucin blassviolett, Kupferoxydammoniak nnter mässiger Quellung bläulich.

Dersog. Manillah an $\mathrm{f}$ (Abaca), die Faser aus dem Stängel von Musa textilis Nees auf den Philippinen (anch wohl ron andern Musa-Arten) darstellend, besteht gleichfalls rorwiegend aus bastzellenartigen Elementen (Fig. 1763) und daneben aus den wohlerhaltenen oder in Resten rorhandenen Gewebselementen, welche das Gefässbiindel jener Pflanzen zusammensetzen, namentlich aus s e hr we it en Gefïssen (Netz-, Ring- und abrollbaren Spiralgefässen sp) und Längsreihen kurzcylindrischer diunwandiger Parenchymzellen $(p p)$. Die Bastfasern selbst sind bei 
einem mittleren Querdurchmesser von $0 \cdot 024^{\mathrm{mm}} 3-12^{\mathrm{mm}}$ lang, fast cylindrisch oder gerundet-prismatisch mit wenig und gleichmässig verdickter Wanl murl weitem Zellenraum, nach den Enden allmälig verjüngt und hier spitz ofor stımpthich, nicht selten gegen das Ende zu mit etwas wellenfö̈rmigem Lmriss, sonst vollkommen glatt. Der Querschnitt erscheint gerundet-polygonal oder rundlich mit

Fig. 1763.

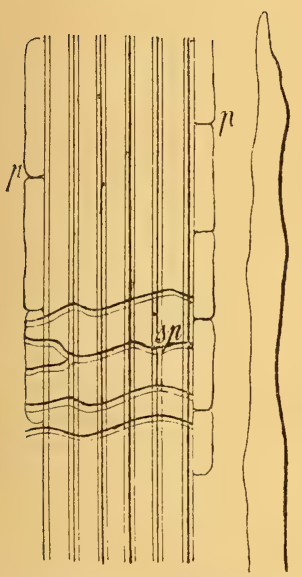

Manillahanf (Musa textilis).
Fig. 1764 .

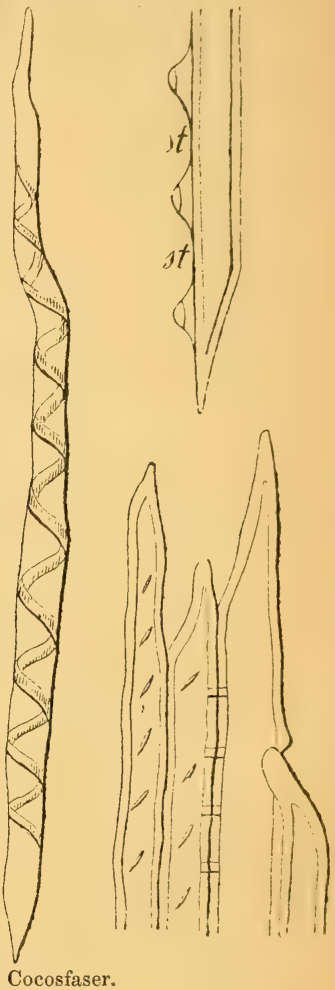

weitem Lumen. Gleich den Bastfasern des neuseeländischen Flachses lassen sie sich durch Kalilauge leicht isoliren. Chlorzinkjod färbt ihre Wand braungelb bis schmutzig-violett, Jod mit Schwefelsäure goldgelb, dann von innen nach aussen schön blau, Kalilauge vorübergehend unter Quellung gelb, Kupferoxydammoniak unter schwachem Aufquellen bläulichgriin. Weder schwefelsaures Anilin noch Phloroglucin bringt Färbung hervor.

Ganz ähnlich verhalten sich die Fasern anderer Musa-Arten. Musa paradisiaca soll etwas dickere Bastfasern besitzen.

Die Cocosfaser (Coir), aus der Fruchtschale der Cocosmuss gewonnen (siehe den Artikel: Cocos), besteht vorwaltend aus Bastfasern (Fig. 176t); daneben finden sich dünnwandige prosenchymatische Elemente (Cambiform), engräumige Holzgefässe (getiipfelte und Spiralgefässe), so wie in Längsreihen geordnete sehr kleine, mit der Wand der Bastfasern an der Oberfläche innigst verbundene Zellen, 
welche ungleich stärker an der Innenwand verdickt und hier stark verkieselt sind. Durch diese convex nach aussen vorspringenden, als Deckplättchen (Stegmata) bezeichneten Gebilde erhält die Bastfaser ein ganz eigenthümliches höckeriges oder warziges Aussehen (st st). Die Bastfasern selbst sind nur $0.4-0.8^{\mathrm{mm}}$ lang bei einem Querdurchmesser von etwa $0.02^{\mathrm{mm}}$, stielrund mit stumpfen oder abgerundeten Spitzen und häufig mit ausgeschweiften oder gezähnelten äusseren Grenzlinien; auf dem Querschnitte rundlich mit ziemlich dicker, hin und wieder von Porenkanälen durchbrochener Wand und weitem rundlichem Lumen. Die mit Kalilauge isolirten Bastfasern zeigen die aufgequollene Wand innen mit einem Spiralbande zierlich ausgekleidet. Chlorzinkjod färbt die Wand braungelb, Jod und Schwefelsäure grïn, schwefelsaures Anilin schön gelb, Phloroglucin blass purpurn, Kupferoxydammoniak unter schwachem Aufquellen gelbgrün.

Fig. 1765 .

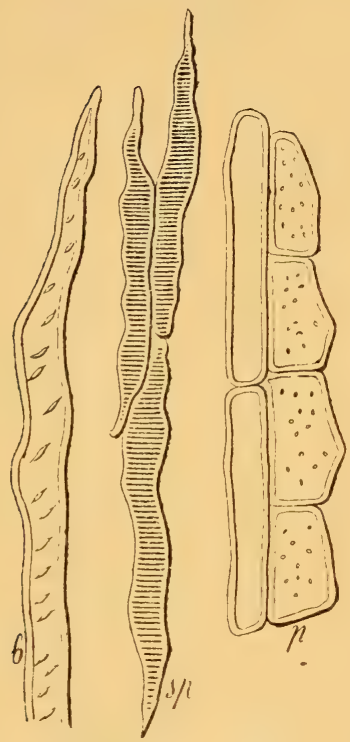

Agavefaser (Agave Americana).
Die Agavefaser, Pita, Chanvre Pita, Aloefaser, betrifft zunächst die aus den Blättern der Agave Americana L. (Pita) und anderen Agave-Arten (Famil. der Agaveen), wie namentlich aus Agave Mexicana Lam. (Maguey), Agave filifera Salm., A. vivipara L., A. (Fourcroya) foetida L., Agave Sisalana Mill. (Sisalhanf) etc. dargestellte Faser. Mit dem Namen Aloefaser oder Pita werden aber auch häufig im Handel die Blattfasern verschiedener Bromeliaceen, wie jene von Ananassa sativa Lindl. (Bromelia Ananas L.), Bromelia Karatas L. ete. und Liliaceen, wie jene von AloeArten (A. perfoliata Lour., A. littoralisu.a.), von $\mathrm{Yucca-}$ und $\mathrm{S}$ a ns e vi e r a-Arten (Yucca filamentosa L., Y. aloëfolia L.; Sanseviera Zeylanica Willd.) bezeichnet.

Die echte Agavefaser (Fig. 1765 ) besteht vorwaltend aus starken Bastfaserbündeln, begleitet von senkrechten Reihen längerer und kürzerer derbwandiger getuipfelter Parenchymzellen $(p)$, Cambiform, Bündeln enger treppen-, netz- und abrollbarer Spiralgefässe $(s p)$, abgerollten Spiralbändern, Resten eines sphäroidalen dünn-

wandigen grosszelligen Parenchyms und häufig ron grossen prismatischen Kalkoxalatkrystallen. Die Bastfasern $(b)$ sind prismatisch, meist einfach zugespitzt, mit häufig stumpfer oder schiefer, seltener kurzgabeliggetheilter Spitze $0.6-4 \cdot 0^{\mathrm{mm}}$ lang bei einem Durchmesser von $0.025-0.036^{\mathrm{mm}}$, derbwandig bis ziemlich dickwandig, mit nicht selten an einer und derselben Faser etwas veränderlicher Wanddicke, sehr deutlich spaltentüpfelig, mit deutlichem weitem Zellenraume, ganz glatt oder einzelne mit ausgeschweift-gezähnelter Begrenzung, auf dem Querschnitte polygonal mit rundlich-polygonalem Lumen. Chlorzinkjod färbt die Wand gold- bis braungelb, Jod mit Schwefelsäure gelb, dann grün und schliesslich von innen nach aussen blau, Kupferoxydammoniak unter starker oder ziemlich starker Quellung und unter Hervortreten einer deutlichen spiraligen Streifung bläulich. Anilin und Phloroglucin färben die Wand entweder gar nicht oder ganz schwach gelblich, respect. violett-röthlich; die Spiralgefässe werden dagegen meist deutlich gefärbt, 
daher bei reichicherer Anwesenheit derselben die Rohfaser selbst durch die beiden Mittel eine gelbe resp. röthliche Farbe annimmt.

Die Bastfasern der anderen oben angeführten Agave-Arten weichen zum Theil in Form, Grösse, Wanddicke, Verhalten gegen Reagentien etc. von den beschriebenen der Ag. Americana ab. Die echte Aloefaser, vom Aloe-Arten (zumal A. perfoliata), besteht nach W i es n er bloss aus Bastfasern von 1.3-3.72 Länge und $0.015-0.024^{\mathrm{mm}}$ Dicke. Dieselben sind regelmässig cylindrisch mit konischer Zuspitzung, einzelne gabeltheilig, sehr stark verdickt mit spärlichen Spaltentiipfeln, bei Quetschung oder Behandlung mit Kalilauge spiralige Streifung zeigend; mit Kupferoxydammoniak färben sie sich unter starker Quellung blau, mit Jod und Schwefelsäure die meisten rothbraun, einzelne grünlich oder gelb, stellenweise blau.

Die Yuccafaser, "Silkgrass" der Engländer, von Yucca aloefolia L., filamentosa L. etc. gewonnen, aus Amerika in den europäischen Handel gelangend, ist nach Vétillart von der Agavefaser sehr schwer zu unterscheiden. Ihre Bastfasern sind am Querschnitte polygonal mit engem gerundetem Lumen, dickwandig mit regelmässig verschmälerten Enden, bei $0.01-0.02^{\mathrm{mm}}$ Durchmesser $0 \cdot 5-6 \cdot 0^{\mathrm{mm}}$ lang.

Die Sanseviera-F aser, "Moorva", Bowstring-Hemp, von S. Zeylanica Willd., besteht nach demselben Gewährsmann aus $1.5-6.0^{\mathrm{mm}}$ langen, 0.015 $-0.026^{\mathrm{mm}}$ dicken, am Querschnitt polygonalen weitmündigen, nicht seh r dickwandigen, an den Enden lang ausgezogenen spitzen Fasern.

Die- echte Ananasfaser (Piña), von Ananassa sativa Lindl. (Bromelia Ananas L.) besitzt nach Vétillart sehr gleichmässig, aber verschieden dicke, glatte, am Querschnitte rundliche oder polygonale Bastfasern mit verlängerten spitzen Enden, sehr dicker Wand und engem Lumen, von $3-9^{\mathrm{mm}}$ Länge und 0.004-0.008 ${ }^{\mathrm{mm}}$ Durchmesser; die Faser der Bromelia Karatas L. nach W ie sn er duinnwandige, $1.4-6.7^{\mathrm{mm}}$ lange, $0.027-0.042^{\mathrm{mm} *}$ ) dicke, cylindrische, an den Enden zugespitzte, spaltentiipfelige, nicht spiralig gestreifte Bastfasern, die mit Jod und Schwefelsäure rostroth, mit Kupferoxydammoniak bläulich, unter schwacher Quellung, gefärbt werden.

Die Wolle der Wollbäume, verschiedener Arten der Gattung Bom bax, insbesondere von B. Malabaricum DC. und Bombax heptaphyllum L., sowie anderer verwandter Bombaceen stellt gleich der Baumwolle Samenhaare dar. Dieselben sind im Allgemeinen cylindrisch, nach der Spitze zu allmälig kegelförmig verschmälert, manche flachgedrückt oder ausserdem um die Achse gedreht, am Grunde etwas gekrïmmt und kolbig ausgebaucht, farblos (wenigstens bei $B$. Malabaricum), einzellig (ausnahmsweise zweizellig), dünnwandig, am Grunde zuweilen mit netzförmiger Wandverdickung, $1-3^{\mathrm{cm}}$ lang bei einem grössten Querdurchmesser von $0.02-0.04^{\mathrm{mm}}$, luftfuihrend. Jod mit Schwefelsäure färbt die scharf hervortretende Cuticula goldgelb, die eigentliche Zellwand, nachdem unter ihrer Quellung die Cuticula gesprengt ist, schön blau; Chlorzinkjod färbt die Haare gelb, Anilin blassgeblich, Phloroglucin schwach, aber deutlich röthlich, Kupferoxydammoniak bewirkt bloss eine schwache Quellung.

Die Wolle der Wollgras r ten (Eriophorum angustifolium Roth, E.latifolium Hopp., E. vaginatum L., E.gracile Koch, E. Scheuchzeri Hopp., E. alpinum L.; - insbesondere kommt jene der beiden erstgenannten Arten, die bei uns häufig wachsen, in Betracht) stellt die Frucht begleitende flache rielzellige, aus breitem, meist abgerundetem oder verwachsenem Grunde allmälig nach der Spitze verjüngte Zotten dar(Fig.1766). Das sie zusammensetzende, aussen von einer Cuticula iberzogene Gewebe besteht aus axial gestreckten, im Ganzen parallelepipedischen farblosen, meist lufterfüllten Zellen (5); ihre Wand ist dünn, nur der Grund eines jeden Haares wird aus derbwandigen, von Porenkanälen durchbrochenen Zellen gebildet und häufig sind auch die äussersten Spitzenzellen

*) Nach Vétillart Länge $=3.5-10 \mathrm{~mm}$, Durchm. $=0.020-0.032 \mathrm{~mm}$. 
stärker verdickt. Die Länge der Zotten schwankt nach den Arten zwischen $2-4^{\mathrm{cm}}$ (die kürzesten $\left[2-2 \frac{1}{2}{ }^{\mathrm{m}}\right]$ hat $E$. alpinum, vaginatum, gracile, Scheuchzeri, die längsten $\left[3-4^{\mathrm{cm}}\right]$ E. angustifolium und latifolium); die grösste Breite (über dem Grunde) liegt zwischen $0.0288-0 \cdot 1620^{\mathrm{mm}}$ (die breitesten hat $E$. vaginatum und E. alpinum - 0.108-0.1620mm, die schmalsten E. gracile - 0.0288 $-0.054^{\mathrm{mm}}$, in der Mitte stehen die Zotten von $E$ angustifolium, latifolium und Scheuchzeri mit $\left.0 \cdot 072-0 \cdot 108^{\mathrm{mm}}\right)$. - Die Zottenspitze ist meist einfach, aus 1 oder 2 neben einander liegenden Zellen gebildet, so bei $E$. angustifolium, latifolium, Scheuchzeri und gracile $(1-3)$; eine $2-3$ gabelige (in $2-3$ vorspringende Zellen endende) Spitze zeichnet die Zotten des E. vaginatum aus (4), während jene des $E$. alpinum sehr auffallend charakterisirt sind durch zerstreute gerade vorgestreckte oder spitzenwärts gebogene Zähnchen und durch eine mit derartigen

Fig. 1766.

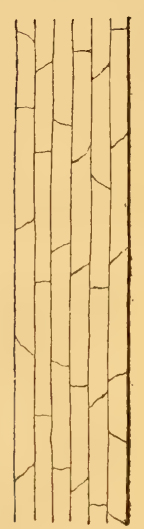

5
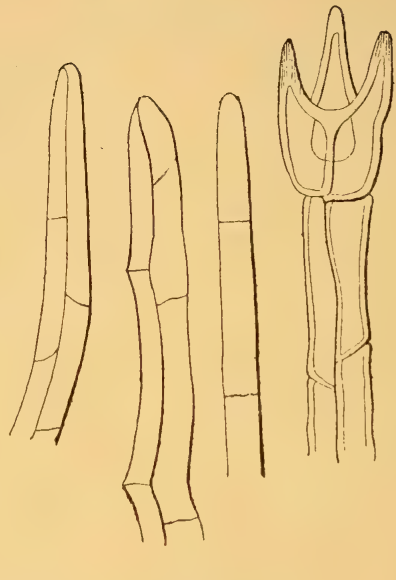

4

Haare der Wollgräser.

Zähnchen dicht besetzte und mit solchen endende Spitze. Jod mit Schwefelsäure färbt die Cuticula gelbbraun, die eigentlichen Zellwände schön blau, Chlorzinkjod färbt die Zotten geblich, Kupferoxydammoniak blass-bläulich-grün unter geringer Quellung der Zellwände. Weder Anilin noch Flıloroglucin bewirken eine Färbung.

Thierhare. Selten ohne Weiteres, meistens nach Behandlung mit gewissen Mitteln, wie Säuren und Alkalien oder am besten mit Kupferoxydammoniak, tritt an den Gespinnstfasern, welehe Thierhaare darstellen, die denselben cigenthümliche Structur hervor: zu äusserst eine dünne Hülle, das $O$ b erhäutchen (oder die Cuticula), welche aus sehr zarten glashellen, dachziegelförmig sich deckenden Epithelplättchen zusammengesetzt ist. Darunter folgt die Rinden-oder Faserschicht, die Hauptmasse des Haares bildend, von streifigfaserigem Aussehen, aus feinen, etwas flachgedrückten Faserzellen bestehend; endlich in vielen Fällen ein centraler Strang eines Gewebes von parenchymatischem Ausselien, aus kleinen gerundet-polyedrischen Zellen gebildet, das M a r k (Marksubstanz). Die natürliche Farbe der Haare hängt meist ab von einer Färbung der Rindenschicht, welche entweder gleichmässig oder fleckig ist, seltener von einem in den Zellen des Markes vorhandenen Pigment. Die weisse Farbe der Haare wird zumeist bedingt durch die mit Luft erfillten Markzellen oder durch die an und für sich farblosen Elemente, welche das Haar zusammensetzen. 
Die wichtigsten Anhaltspunkte zur Erkennung und Unterscheidung der verschiedenen Haare gewähren ihre Grösse, die relative Stärke der einzelnen Schichten, sowie Grösse und Form der sie zusammensetzenden Elemente, das Vorhandensein oder Fehlen des Markes etc. Die gewöhnliche Schafwolle besteht aus weissen oder gelbgefärbten, 4-32 $2^{\operatorname{cm}}$ langen, $\left(0 \cdot() 14-(0) \cdot() f^{\mathrm{mm}}\right.$ dicken Haaren, an denen man vnter Wasser gesehen in der Regel nur die scharfgezeichneten Epithelplättchen, zuweilen auch die Rindenschicht und ein Mark erkennt. Bei Behandlung mit Schwefelsäure tritt an vielen Haaren letzteres hervor; wo dies nicht der Fall ist, sind die Haare ursprünglich marklos. Concentrirte Schwefelsäure mit Salzsäure lösen nach Wiesner die Haare unter Rothfärbung, Kupferoxydammoniak bewirkt eine schwache Quellung unter Blaufärbung.

Das weisse Haar der A n g o r a z i g e (Hircus Angorensis), woraus die Angora(Mohair) Wolle besteht, hat nach Schlesinger eine Länge von $16^{\mathrm{cm}}$ bei einem Durchmesser von $0.02-0.03^{\mathrm{mm}}$. Es lässt ohne Weiteres grosse scharfeckige Epithelplättchen und meist leicht die Rindenschicht erkennen, dagegen ist ein Mark weder unter Wasser noch nach Behandlung mit Schwefelsäure sichtbar. Nur sehr selten treten kleine Inseln von Markzellen hervor.

Das weisse Alpacahaar (Alpacca-oder Pacos-Wolle) von Auchenia Paco Illig. zeigt jederzeit alle Schichten; das Mark erscheint graulich und durchzieht nur selten continuirlich, meist nur mit Unterbrechungen das Innere des Haares. Das braune und schwarze Alpacahaar lässt unter Wasser keinerlei Structur erkennen, nur am Rande lassen sich bei genauer Untersuchung die Epithelplättchen wahrnehmen. Nach $\mathrm{Schlesinger}$ hat das Haar eine Länge von $15^{\mathrm{cm}}$ bei einem Durchmesser von $0.02-0.034^{\mathrm{mm}}$.

Die Seide ist bekanntlich das erstarrte Secret zweier langer schlauchförmiger Drïsen (Spinndrüsen) des "Seidenwurms, " der Raupe des wahrscheinlich aus China stammenden Maulbeer- oder Seidenspinners (Bombyx Mori), welches in Gestalt eines sofort nach dem Hervortreten aus dem Körper der Raupe sich bildenden Doppelfadens ausgeschieden, in ununterbrochenem Zusammenhange zum Bau des Cocons verwendet wird. Durch das sogenannte Entschälen oder Degumiren wird der Kitt (Seidenleim), der die beiden zum Doppelfaden verbundenen Fäden rereinigt und iberzieht, in Lösung gebracht, wesshalb die degumirte Seide aus einzelnen Eäden besteht. Diese sind stets solid (innen nicht hohl) und rollkoinmen structurlos, cylindrisch, 0.009-0.021 $\mathrm{mm}$ dick; manchmal zeigt sich eine zur Längenachse parallele Zerklüftung. In Säuren und besonders in Alkalien quillt der Seidenfaden auf; concentrirte Schwefelsäure, Aetzkali und Kupferoxydammoniak lösen ihn nach einiger Zeit auf. Bruchflächen des Seidenfadens sind meist aus zwei bis mehreren treppenförmig über einander stehenden Flächenstïcken gebildet (Wiesner). Der Faden jedes Cocons bildet an diesem drei Schichten, aus welchen drei dem Werthe nach sehr verschiedene Seidensorten gewonnen werden. Die änsserste liefert die Florett- oder Flockseide, die mittlere die feine Seide, die innerste die Wattseide. Die Fäden dieser drei Sorten sind in Form und Grösse des Querschnittes nach Wiesner veränderlich. Florettseide ändert ihre Querschnittsform innerhalb längerer, Wattseide innerhalb kïrzerer Strecken, so dass an dieser die Begrenzungslinien stärkere Krümmungen zeigen. Der Querschnitt beider suhwankt zwischen $0 \cdot 009-0 \cdot 014^{\mathrm{mm}}$; feine Seide ist dicker als Florettund Wattseide und sehr constant in der Grösse des Querschnitts, der meist 0.018mm beträgt. - Die Seide des Ailanthusspinners (Saturnia Cynthia) lässt sich nach Wiesner mikroskopisch leicht ron echter seide unterscheiden. Der Durchmesser des Fadens liegt zwischen $0.011-0.025^{\mathrm{mm}}$, und zwar an den äusseren, mittleren und inneren Theilen des Cocons, ja selbst an einer und derselben Stelle des Doppelfadens besitzen dessen Theilfäden oft einen rerschiedenen Querschnitt; ferner besteht die Ueberkleidung des Doppelfadens aus einer körnigen Haut, der. Faden selbst zeigt eine zarte parallele Faserung und beim Zerreissen entstehen büschelige Faserenden. 


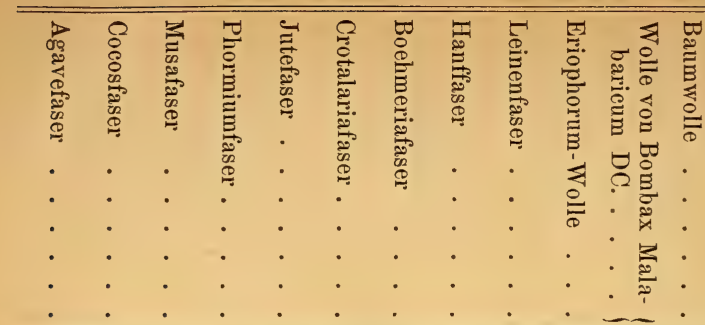

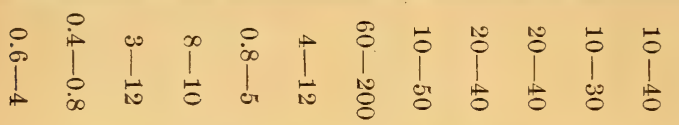

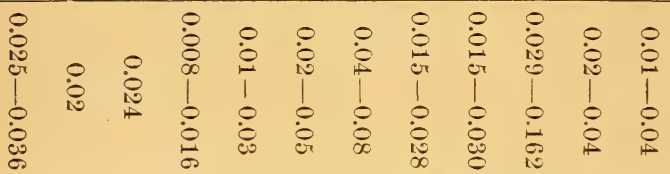

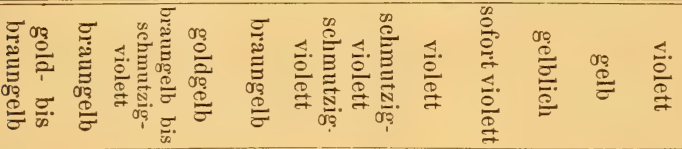

홈

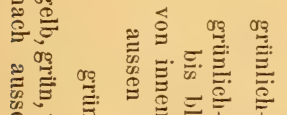

W

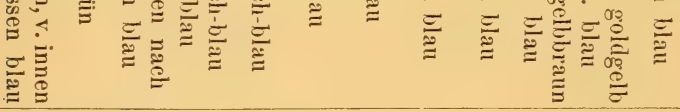

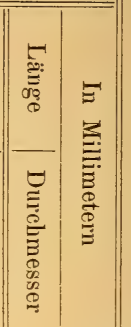

ลี

0
0
0
0
0
0
0
0
0
0
0
$\vdots$
0
0
0

욘

$\frac{\infty}{\infty}$

:

Е:

Ф)

象

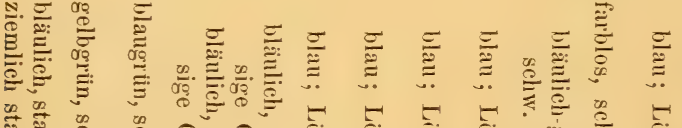

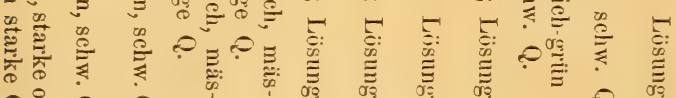

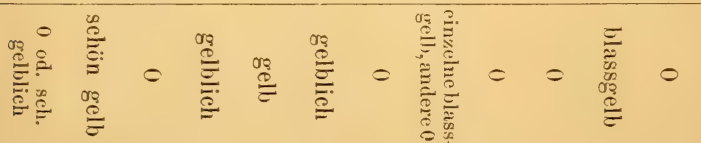


Gestänge (perches - poles). Mehrere zu einem Ganzen verbundene Stangen oder Balken, welche zur Uebertragung oder zur Leitung einer Bewegung dienen. In ersterem Sinne gebraucht man dieses Wort bei der Bezeichnnng $\mathrm{B}$ oh $\mathrm{r}$ - und Pumpen-Gestänge, im letzteren bei Fahrgestänge; bezeichnend die Summe jener parallel liegendén Balken, in deren Spur die Förderschale läuft. $K k$.

Gestängebewegung, Gestängbewegung, Hin- und II erbewegun g (mouvement de va-et-vient - see-saw-motion).

Gesteinarbeit, Stein arbeit (damboard), wird in der Weberei jene Art Muster genannt, welche aus quadratischen und rechteckigen Feldern bestehen, und namentlich bei ordinären Leinendamasten häufig vorkommen.

Gesteinbohrmaschinen, s. B o hren I pag. 699. Seit der Zeit, als jener Artikel, auf welchen wir hier verweisen, geschrieben wurde, ist durch Ingenieur Brandt in Zürich ein neues System in die Praxis eingeführt worden. Hierbei wird ein Stahlkronenbohrer verwendet, welcher durch hydraulischen Druck - an 100 Atmosphären - einerseits sehr kräftig gegen den Stein gepresst, andererseits langsam gedreht wird. Diese Maschine arbeitet sowohl auf harte als weiche Steine (Granit, Kalk) vorzïglich und ist in einer ausgezeichneten Monographie durch den Constructeur Riedler (Wien, Lehmann \& Wenzel, 1878) beschrieben. $K k$.

Gestell (bâti - stock), rahmenartige Gerüste; ferner in der Metallurgie (ouvrage - hearth) der untere, verengte Theil eines Schachtofens, s. III pag. 8

Gestemm, die von den Hirnrändern der Dauben gebildeten Fassränder.

Gesundheitsgeschirr, Sanitätsgeschirr, im Allgemeinen Thonwaaren mit bleifreier Glasur, für den Küchengebrauch; auch Porzellan fiihrt diesen Namen. Gtl.

Gesundheitshölzchen, d. s. giftfreie, auch schwedische Zündhölzchen, siehe Z ii d w a aren.

Gesundheitsstein, s. m. Schwefelkies o. Pyrit.

Getah Karet, s. Ka utschuk.

Getah Lahoe, s. Sumatrawachs.

Getee, Faser von Marsdenia tenacissima, dient als Flachssurrogat. Gtl.

Getretene Arbeit, Fussarbeit (étoffes façonnées à la marche), durch Bethätigung von Tritten hergestellte, gemusterte Stoffe.

fabrikation.

Getreide-Reinigungsmaschinen, siehe Landwirthschaft und M e h l-

Getreidestein, s. Bierstein I pag. 520.

Getriebe (pignons - pinions) sind die in den Uhren vorkommenden, aus Triebstahl hergestellten Zahnrädchen mit grosser Breite der Zähne; auch wird ein ganzer Satz zusammenwirkender Räder Getriebe genannt.

Getriebene Arbeit, Treibarbeit (repoussé), siehe Blechbearbeitung I pag. 554 und $\mathrm{C}$ iseliren II pag. 362.

Gettaniagummi, s. m. Gutta-Percha.

Geviere, s. Bergbau I pag. 399. 
Gevierte, s. Buchdruckerei II pag. 129; ferner Tafelglas von etwas grösserer Länge als Breite.

Gewände (jambage - jamb), Begrenzung einer Maueröffnung zur Seite ; je nach dem Material der Construction bezeichnet man dasselbe als Stein-, Ziegel-, Holzgewände und je nach der Art der Oeffnung als Fenster-, Thür- oder Thorgewände. Siehe auch Fenster III pag. 403.

Grohm.

Gewebe (tissu - web) ist im weitesten Sinne jedes flächenartig ausgedehnte Fabrikat, das durch regelmässige Kreuzung oder Verschlingung von Fäden oder fadenähnlichen Körpern mittelst einer maschinellen Vorrichtung hervorgebracht worden ist, s. Weberei, Wirkerei, Netzen und Bobbinnet (I pag. 667).

Gewehre, s. Fenerwaffen-III 439.

Gewehrpulver, s. Explosivst offe III pag. 322.

Gewehrfabrikation, s. Feuerwaffen III pag. 442 etc.

Gewehrläufe, s. Fe uerwaffen III pag. 442.

Gewehrschäfte, s. Feu erw a ffen III pag. 453.

Gewehrschlösser, s. F e u erwaffen III pag. 450.

Gewicht (pesanteur - gravity). Gewicht, als theoretischer Begriff, ist die Grösse des Druckes, den ein Körper auf seine Unterlage ausübt. Dieser Druck ist eine Folge der Anziehung, welche die Erde auf die Körper ausübt, und deren Stärke im geraden Verhältnisse des Productes der Massen des anziehenden (also des Erdkörpers) und des angezogenen Körpers und im umgekehrten Verhältnisse des Quadrates der Entfernung der Massen sich äussert. Die Grösse des Druckes auf seine Unterlage, welche ein bestimmter Körper auf der Erde zeigt, ist einerseits abhängig von der Grösse seiner Masse, andererseits aber von der Entfernung des Körpers vom Erdmittelpunkte, da die im Gefolge der Achsendrehung der Erde stehende Fliehkraft, deren Grösse mit der Entfernung vom Erdmittelpunkte wächst, der Anziehung entgegenwirkt. Es folgt hieraus, dass die Grösse des Druckes, den ein und derselbe Körper auf seine Unterlage ausübt, an verschiedenen Punkten der Erdoberfläche verschieden sein muss. Genaue Bestimmungen haben ergeben, dass für ein und denselben Körper die Grösse dieses Druckes an den Polen etwa 1/100 mehr beträgt als am Aequator. Mit Hilfe der Wage, welcher man sich allgemein zur Bestimmung des Gewichtes der Körper bedient, lassen sich nun diese Differenzen nicht ermitteln, insoferne an der Wage der zu wägende Körper sich unter denselben Verhältnissen befindet wie die Masse jenes, dessen man sich zur Herstellung des Gleichgewichtes bei der Wage bedient. Das, was man also im gewöhnlichen Leben Gewicht, absolutes Gewicht (poids absolu absolute ueight) nennt, ist kein Ausdruck für die wahre Grösse des Druckes, den ein Körper auf seine Unterlage ausịbt, sondern vielmehr nur ein Mass der Masse, welche den Druck ausiibt. Als Einheit dieses Masses gilt für wissenschaftliche Zwecke allgemein, für praktische $Z$ wecke auch in vielen cultivirten Ländern Europas das Gramm, d. i. das Gewicht eines Cub.-Cent. völlig reinen Wassers von $4^{0} \mathrm{C}$. Mehrfach sind jedoch auch noch andere Gewichtseinheiten im Gebrauche, deren Eintheilung und Verhältniss zum Gramm sich im Artikel Masse angegeben findet.

Zu der praktischen Ermittlung der Körpergewichte, wie sie mit Hilfe der Wage (s. d.) bestimmt werden, bedient man sich ganz allgemein abgemessener Massen ron bestimmter Grösse, d. i. der Gewichtsstiicke oder Gewichte (poids weight), welche entweder aus Metall (Eisen, Messing, Platin) oder aus anderem geniigend schweren Materiale (Stein), fuir feinere Gewichte namentlich anch Bergkrystall hergestellt sind. Sie sollen so geformt sein, dass sie sich bequem fassen 
lassen, und ihre Oberfläche soll so beschaffen sein, dass sich nicht leicht Schmutz und Staub an denselben festsetzt, so wie auch das Materiale möglichst widerstandsfähig gegen Abniitzung beim Gebrauche sein muss, damit sich beim fortgesetzten Gebrauche nicht allzugrosse Abweichungen vom Normalmasse herausstellen. Ueberdies müssen sie in gut erkennbarer Weise die Werthbezeichnung tragen. In Oesterreich, sowie in den meisten übrigen Staaten sind übrigens die für den Handelsverkehr bestimmten Gewichtsstiicke mit einer ihre Vollwichtigkeit bezeugenden Marke (Punze oder Aichstempel) versehen. Die gebräuchlichste Form für Gewichtsstücke ist die von abgestumpften Kegeln oder abgestumpften 4-6seitigen Pyramiden, seltener von Kugelsegmenten. Kleinere Gewichtsstücke verfertigt man nicht selten in der Form von abgestumpften Kegeln, die innen hohl und in ihrer Grösse so bemessen sind, dass immer das nächst kleinere Gewichtsstïck in die Höhlung des nächst grösseren passt (Schalgewichte oder Einsatzgewichte). Sehr kleine Gewichte, Gran-, Decigramm- oder Centigramm-Gewichte stellt man meist in Gestalt kleiner Bleche mit umgestuilpter Ecke (zum Anfassen), seltener aus dünnem Drahte (vergold. Messing, Platin oder Aluminium) her, welcher schneckenförmig aufgewunden und dessen Länge so bemessen ist, dass die Anzahl der Windungen die Anzahl der Decigramme, Centigramme oder Grane angibt, welche durch das betreffende Gewichtsstiick repräsentirt werden. Eine besondere Art von Gewichten sind endlich die La ufgewichte, deren man sich zu Wägungen an ungleicharmigen Wagen (Schnellwagen) oder zur Bestimmung sehr kleiner Gewichtsmengen auf sehr empfindlichen Wagen bedient. Grössere Laufgewichte haben meist die Form von Kugeln und sind mit einem an seiner Innenseite zu einer Schneide zugeschärften Haken versehen, mit welchem sie auf dem Wagebalken aufgehängt und an demselben verschoben werden können; kleinere Laufgewichte, z. B. Milligrammbaken, sind meist aus dünnem Metalldrahte gefertigte Reiterchen (Reitergewichte), welche mittels einer Pincette uder einer eigenen Vorrichtung (Reiterverschiebung) am Wagebalken hin und her geschoben werden können (vgl. üb. a. Wage).

Gtl.

Gewicht specifisches (poids spécifique - specific gravity). Durch Wägung erfährt man die Grösse der Masse eines Körpers ohne Rücksicht auf sein Volumen, d. i. sein absolutes Gewicht. Vergleicht man die absoluten Gewichte gleicher Volumen verschiedener Körper mit einander, so gelangt man zur Kenntniss der in gleichen Raumtheilen enthaltenen Massen verschiedener Körper, d. i. indirecte zur Kenntniss der Dichte der Körper (vgl. Dichte II pag. 622). Vergleicht man die Gewichte gleicher Raumtheile verschiedener Körper mit einander, indem man eines derselben zur Einheit wählt und darauf alle ibrigen Gewichte bezieht, so erhält man Verhältnisszahlen, welche man im Allgemeinen specifische Gewichte nennt. Als Einheit der spec. Gewichte fester und flïssiger Körper hat man das Gewicht der Volumseinheit des reinen Wassers gewählt, während man als Einheit der spec. Gewichte der Gase und Dämpfe das Gewicht der Volumseinheit der atmosphär. Luft angenommen hat. Das spec. Gewicht eines flüssigen oder festen Körpers ist demnach die Zahl, welche angibt, wie rielmal der bestimmte Körper schwerer oder leichter ist als ein gleich grosses Volumen Wasser, das spec. Gew. eines Gases die Zahl, welche angibt, wie vielmal das bestimmte Gas leichter oder schwerer ist als ein gleich grosses Volumen atmosphärischer Luft. Allgemein findet man demnach das specifische Gewicht eines Körpers, wenn man sein absolutes Gewicht durch das absolute Gewicht des gleichen Volumens Wasser (für flüssige oder feste Körper) oder des gleichen Volumens atmosphär. Luft (für gasförmige Körper) dividirt, oder durch eine allgemeine Formel ausgedrückt $S=\frac{P}{p}$, worin $S$ das spec. Gewicht, $P$ das absolute Gewicht des Körpers und $p$ das absolute Gewicht des gleichen Volumens Wasser (bez. Luft) ausdruickt. Weiss man z. B., dass ein Cub.-Zoll Eisen 210.6 Gramm, ein Cub.-Zoll Gold 520 Grm. wiegt, während das Gewicht eines 
Cub.-Zolles Wasser 27 Grm. beträgt, so erhält man das spec. Gewicht des Eisens $=\frac{210^{\cdot 6}}{27}=7 \cdot 8$, das des Goldes $=\frac{520}{27}=19 \cdot 26$.

Insoferne die Verschiedenheit der spec. Gewichte ihren Grund in der Verschiedenheit der Raumerfüllung einerseits und der Verschiedenheit der Moleculargewichtsgrösse andererseits hat, ist das spec. Gewicht bei festen und fliissigen Körpern, z. Th. ein Mass der Dichte; bei gasförmigen Körpern, bei welchen die Raumerfüllung unter gleichen Druck- und Temperaturverhältnissen als eine gleichartige angesehen werden muss, ein Mass der Moleculargewichtsgrösse und seine Kenntniss als eines wesentlichen Factors für die Charakteristik der Materie daher von besonderer Wichtigkeit. Zur Ermittlung des spec. Gewichtes eines Körpers bedarf man dem oben Gesagten zufolge einerseits der Kenntniss des absoluten Gewichtes des betreffenden Körpers, andererseits der Kenntniss des absoluten Gewichtes des gleich grossen Volumens Wasser oder atmosph. Luft. Am einfachsten ist die Bestimmung dieser Daten bei flïssigen oder gasförmigen Körpern, indem man nur nöthig hat, ein bestimmtes Gefäss, am besten ein solches, welches mit einem engen Halse versehen ist, an welchem eine Massmarke angebracht ist, zunächst zu wägen, sodann mit der zu untersuchenden Flüssigkeit bis genau zur Marke zı fiillen und zu wägen, wodurch man nach Abzug des Gewichtes des leeren Gefässes das absolute Gewicht des das Gefäss bis zur Marke erfüllenden Flüssigkeitsvolumens erfährt, um sodann dasselbe Gefäss mit reinem Wasser ebenfalls genau bis zur Marke zu fuillen und abermals zu wägen, wobei man nach Abzug des Gewichtes des leeren Gefässes das Gewicht des gleich grossen Wasservolumens erfährt. Da es bei solchen Bestimmungen auf möglichst genaue Ermittlung der absoluten Gewichte ankommt und oft nur geringe Mengen der zu untersuchenden Körper zur Verfügung stehen, so pflegt man solche Gefässe meist nur in kleinen Dimensionen $\left(5-10^{\text {cc }}\right.$ Fassungsraum) herzustellen und pflegt ihnen dann eine Einrichtung zu geben, welche möglichst sichere Erzielung der Volumgleichheit gestattet, was man erreicht, wenn man die Gefässe so einrichtet, dass sie vollständig mit Fliissigkeit gefüllt werden. Zu diesem Ende pflegt man die meist aus möglichst schwachem Glase hergestellten, meist ballonförmigen oder cylindrischen Gefässe entweder mit einem in der Längsachse mit einer capillaren Bohrung versehenen, gut eingeschliffenen Glasstöpsel verschliessbar zu machen, oder mit einer auf den Rand des Halses gut aufgeschliffenen Deckplatte, die selbst eine feine Bohrung tragen kann, zu versehen. Der Rand des Halses muss dann möglichst glatt abgeschliffen sein und keinerlei Vorsprünge oder Vertiefungen zeigen, in denen sich Flüssigkeit anzusammeln vermag. Solche Gefässe, welche man Pyknometer*) nennt, füllt man, nachdem man vorher ihr Gewicht genau bestimmt hat, beim Gebrauche mit der zu untersuchenden Flüssigkeit vollständig an, driickt dann den durchbohrten Pfropf langsam in die Halsöffnung ein, wobei das Uebermass der Flüssigkeit theils seitlich, theils durch die capillare Bohrung austritt, oder schiebt die aufgeschliffene Glasplatte ron der Seite her auf den Rand auf, und entfernt solann die an den Aussenwandungen adhärirende Fliissigkeit durch sorgfältiges Abtrocknen mit einem Tuche, wobei man sich jedoch davor zu hüten hat, das Gefäiss selbst mit der blossen Hand zu fassen, damit eine Erwärmung und hiedurch bedingte Ausdehnung der Fliissigkeit im Pyknometer, welches vollständig und ohne eine Luftblase einzuschliessen mit der Flüssigkeit gefüllt sein muss, nicht eintrete. Das so gefüllte Prknometer wird sodann gewogen und nun nach der Entleerung der zu untersuchenden Fliissigkeit lind entsprechender Reinigung in gleicher Weise mit destillirtem Wasser gefuillt und abermals gewogen. Da bei scharfen Bestimmungen iibrigens alles darauf ankommt, dass die rerwendeten Tolumina bei gleicher Temperatur gemessen sind, da ja jede Temperaturverände-

Eine sehr bequeme Form hat Gintl (D)ingl. pol. Journ. 194 pag. 42) angegeben. 
rung: eine dem Ausdehnungsvermögen des betreffenden Körpers entsprechende Volumsveränderung bedingt, hat man auch Pyknometer mit 'Thermometern in Verwendung (Geissler's Pyknometer), bei welchen ein genaues Thermometer zum Verschlusse des Pyknometerhalses verwendet ist, während eine seitlich angebrachte enge Röhre mit aufgeschliffener Kappe die Möglichkeit einer vollständigen Euillung sichert. Da die Körper undurchdringlich sind, und mithin ein in eine Flüssigkeit gebrachter Körper so viel von der Flüssigkeit verdrängt, als seinem Volumen entspricht, so lässt sich mit Hilfe des Pyknometers auch das spec. Gewicht fester Körper bestimmen. Man bringt zu diesem Ende ein oder mehrere Stücke des betreffenden Körpers, deren Grösse so bemessen sein muss, dass sie bequem in das Pyknometer gebracht werden können, und deren Gewicht vorher genau bestimmt wurde, in das Pyknometer, dessen Gewicht gleichfalls bekannt sein muss, und fiillt dasselbe, wenn der betreffende Körper von Wasser nicht angegriffen, bez. gelöst wird, vollständig mit Wasser an, sorgt dann mit Hilfe eines Federbartes oder eines feinen Pinsels (falls der feste Körper sehr porös wäre, durch wiederholtes Auskochen) dafür, dass alle an dem festen Körper haftenden Luftbläschen, bez. die die Poren desselben erfüllende Luft vollständig verdrängt und entfernt werden, und verschliesst das völlig mit Wasser gefüllte und, wenn ausgekocht wurde, wieder völlig erkaltete Pyknometer, wie oben angegeben, so dass es völlig mit Wasser erfüllt erscheint. Nach vollzogener sorgfältiger Reinigung der Aussenseite wägt man und erfährt hiedurch das Gewicht des Pyknometers mehr des festen Körpers und des den übrigen Raum erfüllenden Wassers. Entfernt man nun den festen Körper aus dem Gefässe, füllt dasselbe vollständig mit Wasser und wägt nach vorgenommener Reinigung wieder, so hat man das Gewicht des Pyknometers mehr jenem des den gesammten Innenraum erfuillenden Wassers. Zieht man von beiden gefundenen Gewichten nun zunächst das Pyknometergewicht ab und von dem Reste des für das den festen Körper nèbst Wasser enthaltende Pyknometer gefundenen Gewichtes das bekannte Gewicht des festen Körpers, so erhält man einen Rest, der, von dem Reste des für das bios mit Wasser gefüllte Prknometer gefundenen Gewichtes abgezogen, das Gewicht des Wassers angibt, welches denselben Raum erfüllt wie der feste Körper, und man findet sonach das spec. Gewicht dieses letzteren, wenn man das bekannte absolute Gewicht desselben durch das Gewicht des gleichen Wasservolumens dividirt.

Ist der auf sein spec. Gewicht zu untersuchende feste Körper in Wasser löslich oder wird er überhaupt von demselben angegriffen, dann muss man zur Bestimmung eine andere geeignete Fliissigkeit (Alkohol, Aether, Chloroform, Terpentinöl, Oel o. dgl.) wählen, hat jedoch, falls das spec. Gewicht derselben nicht an sich genau bekannt ist, die Bestimmung desselben nach dem oben angefiihrten Verfahren vorzunehmen, und hat, um das auf die Einheit Wasser beziigliche specifische Gewicht zu finden, das Ergebniss der übrigens genau so wie bei Anwendung von Wasser zu führenden Rechnung mit dem spec. Gewichte der verwendeten Flüssigkeit zu multipliciren.

Für die Bestimmung des spec. Gewichtes von Gasen und Dämpfen kann man sich eines gewöhnlichen Pyknometers nicht bedienen, sondern muss, wenn man Bestimmungen der spec. Gewichte solcher Körper nach demselben Principe vornehmen will, grössere mindestens $50-100^{\text {ce }}$ fassende Glasballons verwenden, die, wenn sie mit dem betreffenden Gase oder Dampfe gefüllt sind, zur Hintanhaltnng einer Aenderung in der Beschaffenheit des Gases (durch Diffusion) zugeschmolzen werden und sodann erst zur Wägung kommen. Man hat hiebei auf die Temperatur und den Druck, unter welchen das zu untersuchende Gas im Zeitpunkte des Zuschmelzens des Ballons stand, genan Riicksicht zu nehmen. Ermittelt man sodann genau, etwa durch Ausmessung mit Quecksilber, den Rauminhalt des betreffenden Ballons, so kann man, da man das Gewicht eines C. C. atmosphärischer Luft für $0^{\circ} \mathrm{C}$. und $760^{\mathrm{mm}}$ Barometerstand und den Ausdehmungscoefficienten der Gase nach der 'Temperatur, sowie die durch die Druckrerschiedenheit bedingte Volumsveränderung der Gase genau kennt (rgl. A us d e h n un g I. 
pag. 251), leicht das Gewicht des gleichen Volumens atmosphärischer Luft und sonach das spec. Gewicht des fraglichen Gases bezogen auf die Einheit Luft $=1$ berechnen, wenn man von dem Gewichte des mit dem Gase gefüllten Ballons das Gewicht des leeren Ballons weniger dem Gewichte des denselben, bei dem während der Wägung beobachteten 'Temperatur- und Barometerstand, erfuillenden Luftgewichtes (d. i. das Gewicht des luftleeren Ballons) abzieht und den Rest durch das Luftgewicht dividirt.

Ausser dieser Methode der Bestimmung spec. Gewichte kann man zu demselben Zwecke auch Anwendung von zwei Sätzen der Hydrostatik machen, deren erster, d. i. der archimedische Fundamentalsatz, dahin lautet, dass jeder in einer Flüssigkeit untergetauchte Körper so viel an seinem Gewichte verliert, als das Gewicht der durch ihn verdrängten Flüssigkeit beträgt, während der zweite lehrt, dass jeder in einer Flüssigkeit schwimmende Körper so tief in die Flïssigkeit eintaucht, bis das Gewicht des durch denselben verdrängten Fluissigkeitsvolumens so viel beträgt wie das Gesammtgewicht des schwimmenden Körpers.

Von dem archimedischen Fundamentalsatze macht man Gebrauch bei der sogenannten directen oder hydrostatischen Methode der Bestimmung spec. Gewichte, zu deren Ausführung man sich einer eigens hierzu adjustirten, genauen Wage bedient, die so eingerichtet ist, dass an dem einen Ende des Wagebalkens, statt der am anderen Ende vorfindlichen gewöhnlichen Wagschale, eine an nur sehr kurzen Schniiren oder Drähten aufgehängte, an der Unterseite u. z. in der Mitte mit einem Häkchen versehene Schale sich findet, deren Gesammtgewicht so bemessen ist, dass sie der anderen Wagschale genau das Gleichgewicht hält.

Will man mit Hilfe einer solchen Wage das spec. Gewicht z. B. einer Flïssigkeit bestimmen, so befestiget man mittels eines feinen Fadens oder Drahtes ein Stiick eines festen Körpers, am besten ein cylindrisches Glasstiick von möglichst glatter Oberfläche an dem Häkchen der kiirzeren Wagschale, bringt die Wage durch Auflegen von Gewichten auf die zweite Wagschale in völliges Gleichgewicht und bringt nun die zu untersuchende Flüssigkeit, in einem geeigneten Gefässe mit weiter Miindung, so unter die kürzere Wagschale, dass das an derselben aufgehängte Glasstiick, olme die Gefässwand zu berïhren, frei und vollständig in die Fluissigkeit eintaucht. Sofort wird sich die Abnahme des Gewichtes des Glaskörpers durch Störung des Gleichgewichts an der Wage bemerkbar machen. Um dasselbe wieder herzustellen, wird man auf die kürzere Wagschale genau so viel an Gewicht zulegen miissen, als der Gewichtsverlust des cintauchenden Glaskörpers betrug; da dieser gleich ist dem Gewichte des von dem Glaskörper verdrängten Flïssigkeitsvolumens, so ertälnt man in dem zur Wiederherstellung des Gleichgewichtes erforderlichen Zulegegewichte das Gewicht des dem Volumen des Glaskörpers gleichen Flüssigkeitsvolumens. Fiihrt man nun mit demselben Glaskörper, nachdem man ilın entsprechend gereinigt hat, in gleicher Weise eine Bestimmung des Gewichtsverlustes aus, den er in reinem Wasser erleidet, so erfährt man das Gewicht des gleichen Volumens Wasser und hat sonach die zur Berechnung des spec. Gewichtes der zu untersuchenden Flüssigkeit erforderlichen Daten.

Dasselbe Verfahren ist anwendbar zur Bestimmung des spec. Gewichtes fester Körper, soferne man dieselben in Stïckchen rerwenden kann, welche sich entweder directe mittels eines Fadens an dem Häkchen der kürzeren Wagschale befestigen oder in einem an demselben aufgehängten Tauchschälchen (aus feinem Platindrahtnetz o. dgl.) in die Fliissigkeit eintauchen lassen. Man bestimmt zunächst möglichst genau das absolute Gewicht des betreffenden festen Körpers und sodamn die Grösse des Gewichtsverlustes, welches er beim Eintauchen in reines Wasser (oder, falls er ron demselben gelöst oder angegriffen wiirde, eine andere Fliissigkeit) erleidet, und hat, da der gefundene Gewichtsverlust (Wasser als Tauchtliissigkeit rorausgesetzt) dem Gewichte des gleichen Volumens Wasser entspricht, ebenfalls wieder alle zur Berechnung des spec. Gewichtes erforder- 
lichen Daten. Dass man bei Ausfuhrung derartiger Versuche solır sorgfältig darauf zu achten hat, dass der feste Körper vollständig in die Flüssigkeit taucht und keinerlei Luftbläschen an demselben haften, bedarf wohl keiner Erörterungr, ebenso wie es begreiflich ist, dass die so ermittelten spec. Gewichte nur dann richtig sein können, wenn das Volumen des zur Auflü̈ngung benützten Fadens oder Drahtes im Verhältnisse zum Volumen des festen Körpers verschwindend klein und also zu vernachlässigen ist, was nur dann der Fall sein wird, wenn man sehr feine Fäden (oder haardünnen Draht) verwendet. Fiir Körper, welche leichter sind als Wasser und die demnach im Wasser nicht untertauchen, muss man entweder Flïssigkeiten von entsprechend geringerer Dichte verwenden oder man muss sie gemeinschaftlich mit einem zweiten schwereren Körper, dessen Gewichtsverlust für sich allein man vorher bestimmt hat, in die Flissigkeit eintauchen.

An Stelle einer gewöhnlichen hydrostatischen Wage kann man sich auch besonders eingerichteter Wagen bedienen, wie solche z. B. von Mohr, von Zenger in Prag u. A. angegeben worden sind. Die erstere ist eine ungleicharmige Wage, welche am Ende des längeren Armes ein an einem dünnen Platindrahte aufgehängtes cylindrisches Glaskörperchen trägt (das gewöhnlich gleichzeitig als Thermometer dient), während an dem kïrzeren Arme ein fixes Ausgleichsgewicht die Gleichgewichtslage herstellt. Der Abstand des Aufhängepunktes des Glaskörpers von dem Drehungspunkte des Wagbalkens ist durch eine auf dem lïngeren Arme angebrachte Scala in 10 gleiche Theile getheilt, und die 9 Theilstriche sind von dem Drehungspunkte gegen das Ende des Armes zu mit den Ziffern 1-9 bezeichnet. Die zur Ausfuihrung der Bestimmungen erforderlichen Gewichte, von denen 4 Stïck vorhanden sind, sind Reitergewichte und so bemessen, dass zwei derselben genau das Gewicht des durch den Glaskörper verdrängten Wassers repräsentiren, während das Gewicht des 3ten 1/10, des 4ten $1 /$ roo dieses Gewichtes beträgt. Wird man nun den Glaskörper in eine Flüssigkeit tauchen, welche schwerer ist als Wasser, und hängt dıs eine der schwersten Gewichte unmittelbar am Aufhängepunkte des Glaskörpers auf, so wird sich zunächst als erste Ziffer des zu ermittelnden spec. Gewichtes $=1$ ergeben, während die Wage noch nicht im Gleichgewichte steht. Uim nun das Gleichgewicht herzustellen, bringt man zunächst das zweite der schwersten Gewichte anf den längeren Arm nnd verschiebt dasselbe so lange auf demselben, bis Gleichgewicht herrscht. Fällt der Aufhängepunkt des Reitergewichtes hiebei genau mit einem Theilstriche der Scala zusammen, so gibt die Ziffer desselben genau die Zehntel des zu ermittelnden spec. Gewichtes an. Fällt der Aufhängepunkt jedoch zwischen zwei Theilstriche, so schiebt man das Reitergewicht auf den Theilstrich von niedrigerer Nummer, die man nun als Zehntel des spec. Gewichtes ansetzt, zurück, setzt das dritte Gewicht auf und verschiebt dasselbe ebenfalls wieder so lange, bis Gleichgewicht herrscht, wobei die Nummer des Theilstriches, mit welchem der Aufhängepunkt zusammenfällt, genau die Hundertstel des spec. Gewichtes angibt, während man endlich für den Fall, als der Aufhängepunkt dieses Gewichtes in der Gleichgewichtslage der Wage zwischen zwei Theilstriche fiele, durch Anwendung des 4ten und kleinsten Gewichtes die Ziffer der Tausendstel des spec. Gewichtes ermittelt. Würde z. B. in einem gegebenen Falle das grösste Gewicht auf dem Theilstriche 7, das kleinere auf dem Theilstriche 4 und das kleinste auf dem Theilstriche 3 hängen miissen, damit Gleichgewicht herrscht, währeud das zweite der grössten Gewichte an dem Aufhängepunkte des Glaskörpers aufgehängt ist, so entspräche das eirem spec. Gew. $=1 \cdot 743$. Bei der Prüfung von Flüssigkeiten, welche von geringerem spec. Gewichte sind als Wasser, bleibt das Verhältniss dasselbe, nur entfällt die Belastung des Aufhängepunktes des Glaskörpers, so dass sich dann als erste Stelle der zu ermittelnden spec. Gewichtszahl 0 ergibt, während der Werth der drei iibrigen, nun allein in Verwendung kommenden Reitergewichte derselbe bleibt wie früher. Wäre z. B. bei der Prüfung eines Alkohols zur Herstellung des Gleichgewichtes nöthig gewesen, das grosse Grewicht auf den Theilstrich 9, das nächst kleinere auf den Theilstrich 6, das kleinste auf den Theilstrich 5 zu setzen, so entspräche das einem spec. Gewichte $=0.965$. Wie man einsieht, gewährt diese Einrichtung der Wage den Vortheil, dass bei Bestimmung des spec. Gewichtes nicht nur alle Rechnung erspart bleibt, sondern dass man auch rerhältnissmässig rasch ein bei Berücksichtigung der erforderlichen Vorsichten bis in die dritte Decimalstelle richtiges 
Resultat erhält. Wagen solcher Art, welche in besonders empfehlenswerther Ausfülurung Mechaniker Westphal in Celle (Hannover) herstellt, haben übrigens auch den Vortheil, dass verhäiltnissmässig wenig Flüssigkeit $(4-5 \mathrm{cc})$ zu einer Bestimmung genügt.

Die Einrichtung der Z en g er's ch en Wage (Tangenten-Wage), welche vom Mechaniker F. Boschek in Prag in sehr exacter Ausführung geliefert wird, nähert sich im Allgemeinen der einer gewöhnlichen hydrostatischen Wage, doch wird die Grösse des Gewichtsverlustes nicht durch Aufgeben von Gewichten, sondern nach der Grösse des Ausschlagswinkels bemessen, den der aus seiner Gleichgewichtslage gebrachte Wagbalken beschreibt. Mit Hilfe von Tabellen lässt sich sodann das dem jeweiligen Ausschlagswinkel entsprechende spec. Gew. angeben (vgl. Phil. Mag. (4), 41 pag. 443). Ueber andere besondere Constructionen s. a. d. Art. Wage.

Von dem zweiten oben angeführten hydrostatischen Lehrsatze - „das Gewicht des von einem schwimmenden Körper verdrängten Flüssigkeitsvolumens ist gleich dem Gesammtgewichte des schwimmenden Körpers" — macht man Anwendung bei der Bestimmung des spec. Gewichtes mit Hilfe der Aräometer, von welchen man bekanntlich (s. d. I pag. 180), je nachdem sie zur Bestimmung des Volumens, bis zu welchem sie einsinken, eingerichtet und dann mit einer Scala versehen sind, oder aber durch Zulegen von Gewichten jeweilig bis zu einer bestimmten Marke eingesenkt werden müssen, Volum- (oder Scalen-) Aräometer und Gewichtsaräometer unterscheidet. Eine andere Anwendung von demselben Lehrsatze macht man bei der Bestimmıng der spec. Gewichte von Flüssigkeiten in solchen Fällen, wo man, wie in schmelzenden Körpern, erhitzten Fliissigkeiten u. dgl. m., nicht ohne Weiteres von einer der anderen Methoden Anwendung machen kann. Man verwendet dann kugelförmige Körperchen von verschiedener Grösse aus Glas oder Metall, deren Grösse im Verhältnisse zu ihrem Gewichte so bemessen ist, dass jedes derselben einem bestimmten spec. Gewichte entspricht, beziehungsweise nur in einer Flüssigkeit schwimmt, von welcher ein dem Körperchen gleiches Volumen dasselbe Gewicht hat wie das Körperchen selbst. Bringt man mehrere solche Körperchen, auf welchen die ihnen entsprechenden spec. Gewichte eingezeichnet sind, in eine zu untersuchende Fliissigkeit, und sieht zu, welches derselben sich in der Flïssigkeit eben schwimmend erhält, so gibt das Körperchen directe das spec. Gewicht der Flüssigkeit an. Fiir die Bestimmung spec. Gewichte von Gasen und Dämpfen, für welche sich allerdings auch die erwähnten hydrostatischen Principe mit entsprechenden Modificationen anwenden lassen, hat man ausser der oben angegebenen Methode ebenfalls andere Verfahrungsarten in Anwendung gebracht. So lässt sich aus der Geschwindigkeit, mit welcher zwei Gase unter gleichen Druck- und Temperaturverhältnissen aus einer Oefỉnung von bestimmter Grösse ausströmen, das Verhältniss ihrer spec. Gewichte ermitteln, ebenso ist hierzu die Bestimmung der Diffusionsgeschwindigkeit zweier Gase geeignet (vgl. II. pag. 626). M a ch und Gintl haben iibrigens auch versucht, aus der 'Tonhöhe, welche besonders construirte Pfeifen beim Anblasen mit verschiedenen Gasen und Dämpfen geben, die spec. Gewichte der Gase und Dämpfe, namentlich auch gesättigter Dämpfe auf eine bequeme Art zu bestimmen, doch sind die Versuche bisher noch nicht zun Abschlusse gebracht. Ausfiihrliches iiber spec. Gewichtsbestimmung s. in physikalischen Handbiichern.)

Da das spec. Gewicht eines Körpers das Verhältniss seines absol. Gewichtes zu seinem Volumen angibt, so ist klar, dass sich alle Angaben über spec. Gewichte auf bestimmte Temperaturen beziehen müssen, wenn sie einen Werth haben sollen, da ja jede Aenderung der Temperatur eine Aenderung des Volumens bedingt. Kann man bei festen Kürpern, wenn man nicht ausserhalb der Grenzen gewöhnlicher Temperaturverhältnisse die Bestimmung ihrer spec. Gew. vorgenommen hat, die Temperaturangabe wegen der innerhalb enger Temperaturgrenzen nur unbedeutenclen Volumsänderung auch vernachlässigen, so muss man dagegen bei Fliissigkeiten und insbesondere bei Gasen stets genau die Temperatur, bei Gasen iberdies auch den Druck (Barometerstand) angeben, auf welche sich das 
spec. Gewicht bezieht. Gewölınlich pflegt man iibrigens die spece Gewichte von Gasen auf $0^{\circ} \mathrm{C}$. und $760^{\mathrm{mm}}$ Barometerhöhe zu beziehen (vgl. iibrg. a. U ich te II pag. 622).

Gewichte, s. M a s s e.

Gewinde (filet - worm), Schraubengewinde, s. Schrauben.

Gewindebohror, s. Schrauben-Erzeugung.

Gewindestahl, s. Schrauben-Erzeugung.

Gewölbe (voûte - vault) ist die Ueberdeckung eines Raumes entweder durch keilförmig gestaltete Steine, welche so zusammengesctzt werden, dass jerler einzelne vermöge seiner Form und Lage von den benachbarten Steinen an einer Bewegung gehindert wird, oder durch eine auf einem eingeschalten Formgeriist aufgegossene breiartige Masse, welche bald erhärtet und ein festes Ganzes bildet. (Gussgewölbe.)

Die Ueberdeckung von Oeffnungen in Mauern durch Gewölbe nennt man Mauerbögen.

I. Benennungen der wichtigsten Theile eines Gewölbes. Fig. 1767. W Widerlager, sind die Begrenzungsmauern, welche dem Gewölbe als Stütze dienen; $S$ Gew ölbstirn, ist der dem Beschauer sichtbare Querschnitt des Gewölbes, $J$ Gewölbleibung (Intrados), ist die innere Fläche des Gewölbes, $E$ Gew ölbrücken (Extrados) heisst die äussere Fläche des Gewölbes, $x$ Gew ölbachse (in der Figur die Achse des halben Cylinders) ist die Linie, welche bei der Erzeugung der G. Leibung vom Mittelpunkt des Bogens durchlaufen wird, $a s b$ Bogenlinie, $s$ Scheitelpunkt, als höchster Punkt der Bogenlinie; Scheitellinie, die vom Scheitelpunkt bei Erzeugung der Leibungsfläche beschriebene Linie; Gewölb uss, G. Anfang, Kämpfer, heisst der unterste auf dem Widerlager ruhende Theil des Gewölbes. Die Durchschnittslinien der Leibung mit der Widerlagsfläche heissen Anlaufs - oder Kämpferlinien. Anfangs- u. Endpunkt der Bogenlinie heissen Anlaufspunkte. Gewölbweite, Spannweite $a b$ ist die Entfernung der zu einander gehörigen Anlaufspunkte. Gewölbhöhe, P feilhöhe $x s$ ist die grösste rechtwinklige Ordinate von der Spannweite bis zur Bogenlinie. Gew ölbschenkel sind die Theile, in welche eine lothrechte Ebene, durch die Scheitellinie, das Gewölbe zerlegt. Fällt eine Kämpferlinie mit der Scheitellinie zusammen, so entsteht ein einschenkliges Gewölbe. Der in einem Querschnitt im Scheitel befindliche Gewölbstein ist der Schlussstein, die am Anlauf liegenden heissen die A n fäng er oder Kämpfers te in e.

Fig. 1767

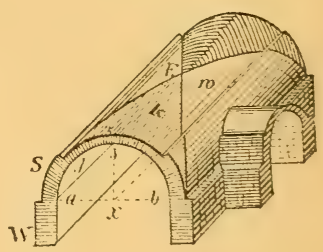

Die Gew ölbstärke wird durch die Länge der Gewölbfugen an der Stirntläche gemessen. Diese Fugen stehen normal auf den zugehörigen Bogenelementen und ihre Verlängerungen führen zu dem Mittelpunkte des Bogens.

Hintermauerung ist das Mauerwerk zur Ausfüllung des Zwickels zwischen dem Gewölbrücken und Widerlager.

II. Arten der Gewölbe. Man bezeichnet dieselben

A) Nach der Form der Bogenlinie.

1. Halbkreisförmiges, volles oder Rundbogengewölbe. 
2. Elliptisches Gewölbe, gedrïckt und überhöht. Ein Gewölbe heisst im Allgemeinen gedrückt, wenn die Pfeilhöhe kleiner ist als die halbe Spannweite. An Stelle der Ellipse wird gewöhnlich ein sog. Korbbogen, ein der Ellipse ähnlicher, aus Kreisbögen zusammengesetzter Bogen, angewendet.

3. Parabolisches Gewölbe, wenn der Bogen eine Parabel ist.

4. Segmentförmiges, Stichbogen- oder flaches Gewölbe, wenn die Bogen linie ein Kreissegment ist.

5. Spitzbogiges oder gothisches Gewölbe, aus zwei Segmenten.

6. Scheitrechtes Gewölbe, wenn die Gewölblinie eine Gerade ist.

$B)$ Nach der Form der Gewölbflächen. Diese Unterscheidung ist die wesentlichste.

1. Tonnengewölbe, Fig. 1767. Dasselbe entsteht durch Fortbewegung einer Bogenlinie nach der Richtung einer andern Linie, der Achse. Ist die Achse gerade, horizontal und senkrecht auf der Ebene der Bogenlinie, so entsteht das gerade Tonnengewölbe; ist die Achse geneigt zur Ebene der Bogenlinie, so entsteht das schiefe Tonnengewölbe.

Bei kreisförmiger Achse entsteht das ringförmige Tonnengewölbe, bei gerader und ansteigender Achse, - die steigende Tonne, und ist die Achse schraubenförmig - das Schneckengew ölbe oder die schraubenförmige Tonne. Denkt man sich ein Tonnengewölbe iiber einem rechteckigen Raum durch zwei diagonal gestellte lothrechte Ebenen geschnitten, so entstehen vier Theile; die, welche Anlaufspunkte und Scheitellinien haben, heissen $\mathrm{Kappen}(k)$, die mit Anlaufslinien und Scheitelpunkt heissen Wangen $(w)$. Aus diesen Elementen lassen sich noch andere weiter unten erörterte Gewölbformen zusammenstellen. Die Bezeichnung des 'Tomnengewölbes geschieht im Grundriss durch Einzeichnung der umgeklappten Bogenlinie des Gewölbes. Durchdringt eine kleine Tonne ein zweites 'Tonnengewölbe, so nennt man die erstere Stichkappe Fig. 1767. Kurze kräftige Tonnen, welche entweder zur Verstärkung eines Gewölbes oder zum Tragen von Mauern oder als Widerlager dienen, nennt man Gurten und bezeichnet sie demnach als Verstärkungsgurte, Traggurte, Widerlagsgurte.

A usführung der Tonnen-Gewölbe. Um iiberhaupt ein Gewölbe auszufiihren, sind mit wenig Ausnahmen Lehrgeriiste nothwendig, d. s. provisorisch aufgestellte Holzconstructionen, welche die Form der Leibungsfläche des Gewölbes entweder ganz oder theilweise bilden. Man unterscheidet ferner die Ausfiihrung nach dem Material 1. aus Werksteinen, 2. aus Ziegeln, 3. aus Cement oder Bétonmörtel (sog. Gussgewölbe).

Bei der Ausfihlung des Tonnengew ölbes mit Werkstücken werden die Steinschichten parallel zur Achse in Verband gesetzt; die Herstellung erfordert ein Lehrgeriist mit rollständiger Einschalung. Die Verstärkung des Gewölbes gegen das Widerlager findet im Allgemeinen nach einer krummen Linie statt. Siehe auch weiter unten: Stärke des Gewölbes.

Bei der Herstellung a u $\mathrm{Ziegeln}$ unterscheidet man drei verschiedene Einwölbungsarten :

Erstens Anordnung der Schaaren, wie mit Werkstiicken Fig. 1767 die vordere Kappe. Zweitens die Moller'sche Einwölbungsart. Die Schaaren werden senkrecht zur Achse in Verband gelegt. Man benöthigt in diesem Falle nur verschiebbare Lehrbögen und keine vollständige Verschalung, da jeder ausgefuihrte Bogen sich selbst erhält. Drittens die Schwalbenschwanzförmige Einwölbung. Man beginnt aus den Ecken und legt die Schaaren unter $45^{\circ}$ gegen die Achse gerichtet; die Schichten treffen in der Scheitellinie zusanmen und greifen schwalbenschwanzförmig in einander. Fig. 1767 die hintere Kappe. Hier wirken sämmtliche Umfassungsmauern als Widerlager und man benöthigt ebenfalls keine vollständige Einschalung. Die Verstärkung der Ziegelgewölbe gegen das Widerlager geschieht absatzweise, zu $15^{\mathrm{cm}}$ ( $1 / 2$ Ziegellänge). Als Widerlager für Tomnengewölbe dienen entweder volle Mauern, oder Widerlagsgurten oder eiserne Träger. Das Widerlager muss zur Aufnahme 
des Gewölbes entsprcchend vorbereitet werden. Man unterscheidet a ins pringende Widerlager, wenn in der Mauer entsprechende Rimnen hergestellt werden, und a u sspringende Widerlager, wenn durch Vorragen der Mauersteine, das Anflager für den Gewölbfuss vor die Mauerflucht hervortritt. Bei starken Gewölben werden ein- und ausspringende Widerlager combinirt, Fig. 1768 rechts; oder die Widerlager absatzweise angeordnet, Fig. 1768 links. Lange Tonnengewölbe erhalten in gewissen Abständen Verstärkungsgurten; dieselben sind entweder an der Leibungsfläche sichtbar oder sog. versteckte Gurten, wenn die Verstärkung nur im Rüicker des Gewölbes stattfindet. Die Anordnung, wenn ein Raum durch Quergurten (oder eiserne Träger) in kleine rechteckige Felder eingetheilt wird, welche mit flachen Tonnen gewölbt werden, bezeichnet man mitunter als preussische Kappengewölbe.

Herstellung aus Cement-Béton. Die Ausführung dieser Gewölbe erfordert selbstverständlich eine vollständige Eingerüstung nach der Gewölbform. Um den Seitenschub auf die Widerlager aufzuheben, empfiehlt Liebold*) ein horizontales Auflager dem Gewölbe zu geben, Fig. 1769, d. h. das Gewölbe als Platte aufzufassen, was keinen Schwierigkeiten unterliegt, da nach dem Erhärten das Gewölbe ein vollständiges Ganze bildet. Bei der Ausfuihrung ist nur so viel Material herzustellen, als conti-

Fig. 1768 .

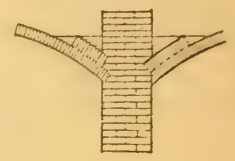

Fig. 1769.

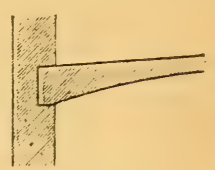
nuirlich verarbeitet werden kann; die gleichmässig ausge.

breitete Masse wird mit leichten Handrammen gestampft und comprimirt. Man hat auf die dadurch entstehende Schwindung Riicksicht zu nehmen und beim Auftragen die Masse entsprechend zu vermehren. Ein gewöhnlicher Cementbéton lässt sich circa um $1 / 4-1 / 3$ der Höhe comprimiren. Die Ausrïstung kann nach circa 4 Wochen geschehen.

2. Kreuzg ewölbe. Fig. 1770, welche ein spitzbogiges Kreuzgewölbe darstellt, entsteht durch die Zusammensetzung so vieler Kappen von gleicher Pfeilhöhe, als der zu überwölbende Fig. 1770. Raum Umfangsseiten hat. Bei einem rechteckigen Grundriss kann man auch sagen, dass das Kreuzgewölbe aus der Durchdringung zweier Tonnengewölbe von gleicher Pfeilhöhe entsteht. Die Duchschnittslinien der Kappen heissen Grate und die Flächen an demselben bilden einen einspringenden Winkel. Werden die Grate aus der Gewölbfläche vortretend ausgeführt und profilirt, so nennt man sie Rippen. Ist der Grundriss unregelmässig, so wird der Scheitel vertical über dem Schwerpunkt der Grundrissfigur angenommen.

Sind die Scheitellinien der einzelnen Kappen gerale und horizontal, sn entsteht das gerade Kreuzgew ̈̈lbe, - bei gerader aber ansteigender scheitellinie, Kreuzgewölbe mit gerader Stechung, - bei krummliniger Scheitellinie, Kreuzgewölbe mit bogenförmiger Stechung. Haben im letzteren Fall die Scheitellinien der Kappen im Scheitel des Gewölbes eine gemeinschaftliche. horizontale Tangente, so entsteht das sog. sphärische Kreuzgewölbe Fig. 1770. Werden die Gewölbfelder eines einfachen Krenzgewölbes durch Rippen abermals

*) Liebold. Der Cement in seiner Verwendung im IJochbau ete. Halle. Knapp. 1875. Karmarsch \& Heeren, Technisches Wörterbuch. Bd. III. 
gegliedert und diese neu entstandenen Felder selbstständig ausgeführt, so entsteht des Sterngewölbe (Liernen-Gewölbe). Die Rippen bilāen im Grundriss zumeist sternförmige Figuren, daher der Name für das Gewölbe, siehe Fig. 1771.

Die $\Lambda$ usführung geschieht: a) A us

Fig. 1771.

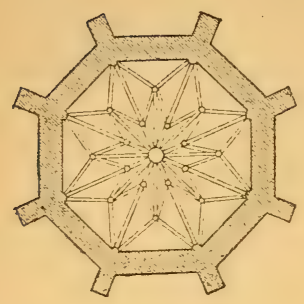
Werkstücken auf zweierlei Art. 1. Die einzelnen Kappen werden wie beim Tonnengewölbe hergestellt und es ergeben sich auf diese Weise besondere Gratsteine, welche in beide zugehörigen Kappen eingreifen. Der Schlussstein muss selbstverständlich mit allen Kappen in Verband gesetzt werden. 2. Die Grate werden selbständig als Rippen construirt und die zwischen denselben befindlichen Gewölbfelder separat mit Werksteinen oder Ziegeln eingewölbt. Es treten die Rippen als Widerlager auf und muss daher das Profil der Rippensteine darnach gewählt werden. Beim Sterngewölbe unterscheidet man Hauptrippen und Zwischenrippen (Neberrippen), welche die Hauptgewölbfelder in Unterabtheilungen theilen.

b) Herstellung aus Ziegeln. Hier unterscheidet man auch zwei Arten. 1. Einw $0 ̈ l b u n g$ a uf den $\mathrm{Kuf}$. Die Ziegelschaaren werden parallel zur Achse der Kappen gelegt. An den Graten übergreifen die Ziegel in die anstossende Kappe und miissen daher entsprechend zugehanen werden Fig. 1772 bei a. 2. Einwölbung auf den Schwalbensehwanz, welche zumeist angewendet wird. Fig. 1772 bei $b$. Die Fi. Ziegelschaaren werden senkrecht zur Gratlinie gelegt und nach derselben erhält das Gewölbe Verstärkungsgurten (Kreuzgurten, Diagonalgurten). Gewölbe und Kreuzgurten werden in Verband hergestellt. In den Scheitellinien greifen die Schaaren schwalbenschwanzartig in einander; diese Herstellungsart erfordert nur Aufstellung von Lebrbögen.

3. Klostergewölbe kann man sich entstanden denken durch die Zusammensetzung so vieler Gewölbwangen, als der zu überwölbende Raum Umfangseiten hat.

t. M uldengew ölbe, wegen der Aehnlichkeit mit einer Mulde so genannt. Der rechteckige Grundriss wird in der Richtung der Langseiten mit einer Tonne überspannt, welche an den Schmalseiten durch Gewölbwangen begrenzt wird. Die Ausfiihrung des Kloster- und Muldengewölbes erfordert Lehrbögen und vollständige Verschalung.

Die Anordnung der Ziegelschaaren ist entsprechend der Richtung der einzelnen Wangeu.

5. Spiegelgew ̈̈lbe. Nach allen Lmfassungswänden zu Gewölbwangen, in der Mitte jedoch ein scheitrechtes Gemölbe (der Spiegel. Bei der Fugenamordnung des scheitrechten (iewölbes wird immer ein Segmentbogen zu Grunde gelegt, welcher eine Pfeilhöhe ron ca. 1/16 der Spannweite erhält. Das Gewölbe selbst wird nach Art eines sehr flachen Platzel- oder Klostergewölbes ausgeführt. Der mit einem scheitrechten Gewölbe zu ïberdeckende freie Raum darf höchstens $3^{\mathrm{m}}$ Spaunweite besitzen. Durch Anwendung von Eisenträgern als Widerlager ist die Ausführung über grössere Räume sehr erleichtert.

6. Konisches Gew ïlbe, hat die Form eines abgestutzten halben Kegels, nach dessen Spitze die Ziegelschaaren gerichtet sind. 
7. Kuppelgewölbe. Die Grundrissform ist eine geschlossence Curve, gewöhnlich ein Kreis. Dariber wird entweder eine Ifalbkngel gespannt (rolle Kuppel), ein Rotations-Ellipsoid oder Paraboloid. Letztere getsen ii b e r h ijhte Kuppeln. Besteht die Ueberwölbung nur ans einem 'Theil ener vollen Kuppel (Kugelkappe), so heisst es flache Kuppel. Bei der IIerstellung werden dis: Steine in horizontalen Ringen zusammengesetzt mit central gerichteten (jewijlb. fugen. Jeder geschlossene Ring hält sich selbst, daher kïnnen die fiewijlthe im Scheitel offen sein; man nennt dann den obersten Steinring $1 \mathrm{i}$ be $\mathrm{l}$. Wird die Oeffinung zum Zwecke der Beleuchtung gelassen, so kommt noch ein thurmartiger Aufbau dariber, die sog. L a terne.

Zur Beurtheilung der imposanten Dimensionen zur Ausfiihrung gelangter Kuppeln seien einige Beispiele erwähnt:

Pantheon in Rom $43^{\mathrm{m}}$ Durchmesser im Lichten, vollendet 25 Jahre nach Christi, Sophienkirche in Constantinopel $31.4^{\mathrm{m}}$ Durchm. jm Lichten, vollend. $537 \mathrm{n}$. Chr., Santa Maria del Fiore in Florenz $43^{\mathrm{m}}$

Peterskirche in Rom 41.4 ${ }^{\mathrm{m}}$ Durchmesser" im "Lichten, vollendet 1563 " Set. Paulskirche in London $30.5^{\mathrm{m}}$ Durchm.

\section{Platzelgewölbe. a) Böhmisches} Platzelgewölbe. Fig. 1773. Dasselbe kann man sich aus einer Kuppel entstanden denken, welche durch verticale Ebenen nach den Seiten der Grundrissfigur geschnitten wird; der innerhalb der Ebenen liegende Theil des Gewölbes bildet das böhm. Platzel. Die Ausführung geschieht mit Hilfe von Lehrbögen für die Anlaufs- und Diagonallinien, ohne Verschalung. Man beginnt gleichzeitig aus den Ecken zu wölben, in Schaaren senkrecht zu den Diagonallinien. Die Gewölbzwickel im Rüicken des Gewölbes werden gleich nach Schluss des Gewölbes nachgemauert.

b) Preussisches, flaches, wälsches Platzel, welches sich besonders zur Einwölbung schmaler rechteckiger Räume eignet. Fig. 1774 gibt ein annäherndes Bild. Wir können das Gewölbe gebildet denken durch Bewegung eines Kreissegmentes längs eines zweiten. Die Ausführung erfordert nur Lehrbögen und geschieht entweder von den Ecken aus, wie beim böhm. Platzel, oder man legt an den Schmalseiten die Schaaren senkrecht zur Längsachse, die Schaaren des mittleren Theiles senkrecht zu den äusseren Schairen, wodurch diese verspannt werden.

9. Kuppel mit Pendentif ist eine Combination der Kuppel mit dem böhm. Platzelgewölbe iiber einem regelmässigen polygonalen Raume. Der Lebergang in den Grundkreis der Kuppel wird durch Gewölbzwickel, Pendentifs (welche dem böhm. Platzel entnommen sind) gebildet. Zwischen Pendentifs und der eigentlichen Kuppel wird gewöhnlich eine ringförmige Aufmauerung (mit Gesimsen geziert oder mit Fensteröffnungen versehen) cingeschaltet, welche $\mathrm{Tr}$ o m m e l, Ring. $\mathrm{T}$ a m b our heisst.

10. Chorgew ölbe nennt man ein halbes Kuppel- oder lilostergewülbe; nach einer Seite durch eine verticale Ebene begrenzt. Kleine Chorgewölbe innerhalb einer Mauerdicke heissen $\mathrm{N}$ is ch engew ölbe.

11. Trichter- oder Fächergewölbe. Fig. 1775. Denken wir uns bei einem quadratförmigen Raum die halbe Bogenlinie um den zugehörigen Eck- 
punkt gedreht und den mittleren durch vier horizontale Viertelkreise begrenzten Raum durch eine flache Kuppel oder nach Art eines böhm. Platzels eingewölbt, so hat man die Grundform eines Fächergewöl-

Fig. 1775.

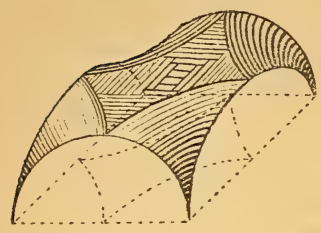
bes. Die vollständige Trichterform kommt erst zur Geltung, wenn mehrere Gewölbfelder aneinander stossen. Der Schlussstein wird durch eine herabhängende Rosette (Zapfen) verziert.

III. Stärke der Gewölbe und deren Widerlager. Es kann hier nicht der Ort sein, die vollständigen Theorien über die Gewölbe zu entwickeln und muss auf die zahlreiche Literatur in Lehrbiichern und Abhandlungen verwiesen werden. Es sollen hier nur im Allgemeinen die Wege angegeben werden, um für die Praxis anwendbare Werthe zu erhalten.

a) Die Bestimmung der $\mathrm{S}$ ch e it el s tärk e geschieht nach empirischen Formeln. Man kann sich der Näherungsformeln nach Schwarz bedienen:

Fiir Bögen und Gewölbe, Pfeilhöhe kleiner als $1 / 3$ der Spannweite, ist

$$
d=N+\frac{1}{6525} \frac{Q \cdot w}{k \cdot h} \text { in Meter. }
$$

Für Bögen und Gewölbe, Pfeilhöhe grösser als $1 / 3$ der Spannweite, bis halbkreisförmige Bögen ist $d=N+\frac{1}{2175} \frac{Q}{k}$ in Meter.

Fig. 1776 .

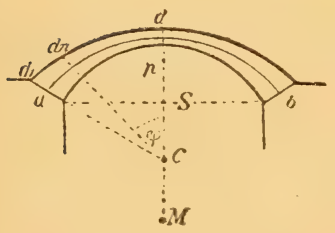

In den Formeln bedeuten: $d$ Gewölbstärke im Scheitel in Metern, Q Gewicht der Gewölbhälfte sammt Belastung für $1^{\mathrm{m}}$ Gewölbtiefe in Kg. $w$ Spannweite und $h$ Pfeilhöhe in Met, $k$ die in der Praxis zulässige Inanspruchnahme des Gewölbmateriales in $\mathrm{Kg}$. pro $\square^{\mathrm{cm}}$. $N$ eine Constante u. z. $0.24^{\mathrm{m}}$ für stark belastete, $0.16^{\mathrm{m}}$ für mittelstark belastete und $0.08^{\mathrm{m}}$ fuir wenig belastete Gewölbe.

Für halbkreisförmige Brückengewölbe, die Ausführung in Werksteinen vorausgesetzt, dient die Formel: $d=0.20+0.03 l+0.02 r$. Dabei bedeutet: $l$ lichte Weite, $r$ Radius, $d$ Scheitelstärke, alles in Met. ansgedrückt.

Unter Voraussetzung schon bestimmter Scheitelstärke wird die allmälige Verstärkung des Gewölbes gegen die Widerlager $a b$ nach der Gleichung:

$$
d_{\mathrm{n}}=\frac{d}{\cos \varphi}
$$

bestimmt, siehe Fig. 1776. Es bedeutet $d_{n}$ die Gewölbstärke in irgend einem Punkt, of den Winkel der beziiglichen Gewölbfuge mit der Lothrechten.

b) Nach einfachen, den Resultaten der Ausfuhrung annähernd entsprechenden graphischen Constructionen. Z. B. nach Rondelet für ein segmentförmiges Gewölbe aus Werksteinen nach Fig. 1776. $C$ ist der Mittelpunkt des inneren Bogens vom Radius $r, M$ der des äusseren Bogens und $C M=\frac{r}{2}$.

$$
\text { Für halbkreisförmige Bögen nimmt man } C M=\frac{r}{4} \text {. }
$$

c) Man nimmt die Gewölbstärke nach Erfahrungsdaten an und untersucht das Gewölbe auf Stabilität. Dies kann geschehen: 1. Man nimmt rorläufig an, 
dass die Drucklinie (Mittellinie des Druckes) in der Nittellinie des Gewöltrquerschnittes liege Fig. 1777 und geht von dem Satze aus, dass das Ioment der Horizontalkraft $Q$ im Scheitel in Bezug auf den tiefsten Punkt der Urusklinie gleich sein soll dem Moment der Kraft $P$ (Resultirende der Gesammtlast der Bogenhälfte für $1^{\mathrm{m}}$ Tiefe) in Bezug auf denselben P'unkt, also ( $)$. $\iota=I^{\prime}$. e.

$P$ ist genau bekannt, $h$ und $e$ annähernd.

Man erhält einen angenäherten Werth von Q. Durch Zusammensetzung von $Q$ mit den Theilbelastungen (als Componenten) lässt sich eine angenäherte Iruck. linie construiren, welche neue Werthe $h^{\prime}$ und $e^{\prime}$ licfert, folglich auch einen genaueren Werth $Q^{\prime}=P \frac{e^{\prime}}{h^{\prime}}$ Fiir den Zustand des Gleichgewichtes muss dieso annäherungsweise bestiminte Drucklinie innerhalb des Gewïlbes bleiben.

2. Man untersucht das Gewölbe in Bezug auf Stabilität durch Construction der Stiitzlinie mit Hilfe der graphischen Statik. *)

Die Stützlinie eines Gewölbes ist diejenige Linie, welche für jeden Normalschnitt $(\perp$ zur Achse) desselben die Lage und Richtung derjenigen Mittelkraft gibt, die man erhält, wenn man die ausserhalb jenes Schnittes auf den Bogen (auf einer Seite) wirkenden Kräfte (Eigengewicht, zufällige Belastungen undAuflagerreactionen) zusammensetzt. Beim Gewölbe darf die Stiitzlinie nicht aus dem inneren Drittel des Normalschnittes heraustreten.

Fig. 1777.

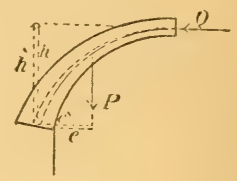

Fig. 1778.
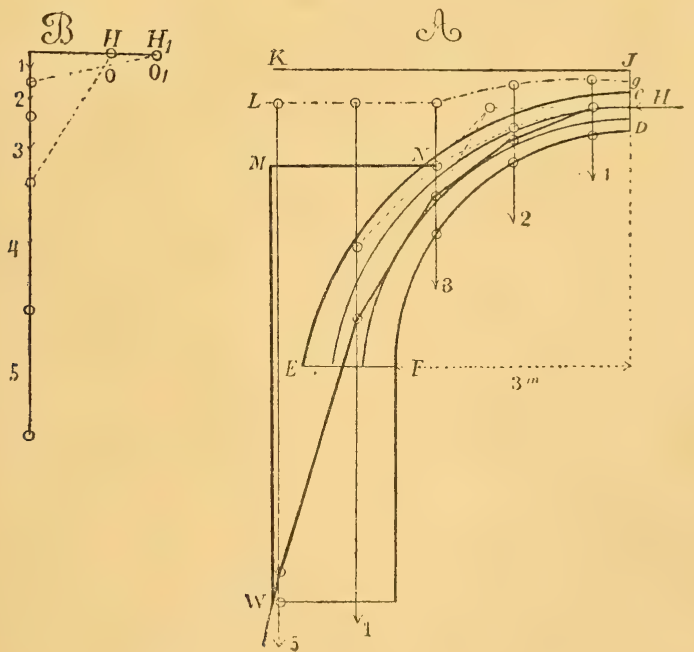

In der Praxis haben wir es mit denjenigen Fällen zu thun, wo die Belastungsverhältnisse und die Gewölbform gegeben sind und man die Stabilitït untersuchen soll durch Einzeichnen der Stiitzlinie. Es ist jedoch nicht nothwendig

*) Siehe Harlacher: Die Stiitzlinie in Gewölbe. Technisehe Blätter 18-0. 
durch Probiren die mittelste Stiitzlinie zu finden (ein directes Verfahren gibt es nicht), sondern es genügt zu untersuchen, ob es möglich ist, eine Stitzlinie einzuzeichnen, die das innere Drittel nicht über sehreitet.

Ohne auf die theoretische Begrindung der Construction hier eingehen zu können, sei die Untersuchung an einem Beispiel erläutert. Figur 1778 $A$ und $B$.

Es sei in Fig. $A$ (Massstab 1:100) die Hälfte eines halbkreisförmigen Gewölbes $C D E$ mit einer Nachmauerung bis zur Höhe $M I N$ angenommen. Das Auffuillungsmaterial zwischen $C N M$ und der Fahrbahn $J K$ sei um $1 / 3$ specifisch leichter als das Gewölbmaterial. Reducirt man die Höhen in demselben Verhältniss, so erhält man die Abgleichungslinie (Linie der reducirten Belastung) $G L$. Theilt man die Querschnittsfläche von der Mitte bis zur innern Widerlagslinie in Lamellen von gleicher Breite, so'sind die Gewichte der Prismen von $1^{\mathrm{m}}$ Tiefe proportional den Flächenlamellen; da diese annälırnd (für die Praxis genau genug) Trapeze ron gleicher Breite darstellen, so sind die Flächen wieder proportional der Länge der Mittellinien. Wir können also annähernd annehmen, dass die Längen der Linien in der Mitte der Lamellen proportional sind den Kräften 1, 2, 3 die eigentlich wieder in den Schwerpunkten der Lamellen, statt in der Mitte, angreifend gedacht werden sollten; doch ist diese Abweichung für die Praxis ohne Belang. Der Einfluss der weggedachten anderen Gewölbhälfte wird ersetzt durch die Horizontalkraft $H$ im Scheitel, welche wir im oberen Drittel angreifen lassen und bis zur Kraft 1 verlängern, dieselbe ist vorläufig noch unbekannt. Die zunächst willkuirlich angenommene Horizontalkraft $H$, im Kräfteplan Fig. $1778 B$ mit dem Pol O, wird mit den Kräften 1, 2, 3 zusammengesetzt u. z. gibt der Kräfteplan die Nittelkräfte in Lage und Richtung. (Um den Linienzug nicht zu lang werden zu lassen, wird im Kräfteplan oft ein aliquoter Theil der Kräfte aufgetragen, in vorliegender Figur die Hälfte.) Parallel zu den Mittelkräften im Kräfteplan werden nun in Fig. $1778 A$ die Seiten des Seilpolygones (welches nur die Lage der einzelnen Kräfte und ilıre Mittelkraft, angibt und hier als Stiitzlinie aufzufassen ist) gezogen u. z. von der Kraft 1 bis 2, von $2-3$, von $3-4$.

Die angenommene Horizontalkraft $I I$, liefert eine Stitzlinie, welche iiber das mittlere Drittel hinausgeht und in der Zeichnung punktirt wurde. Um zu untersuchen, ob eine Stuitzlinie möglich ist, welche das innere Drittel oben und unten beriuhrt zeichnet man eine zweite Stiitzlinie; da diese von der ersten nur dadurch sicl: unterscheidet, dass die Horizontalkräfte rerschieden sind, so gilt der Satz: die gleichnamigen Seilpolygonseiten der beiden Polrgone treffen sich auf der verlängerten Anfangskraft Horizontalkrafti. Anf diese Weise ergibt sich die ausgezogene Polygonseite zwischen den Kräften 3 und 4 als Tangente an die innere Linie des mittleren Drittels und im Kräfteplan hierzu eine Parallele gezogen, erhält man die Horizontalkraft $H$ mit dem Pol $O$, wodurch man wie friiher mit $H$, die Stiitzlinie ergänzt; dieselbe bleibt innerhalb des mittleren Drittels, daher ist das Gewölbe stabil.

3. Man beniitzt zur Bestimmung der Stärke und Fugenstellung des Widerlagers am zweckmässigsten die Stiitzlinie des Gewölbes, indem man dieselbe ins Widerlager fortfilurt. Siehe die Figur 1778 A und $B$. Man nimmt für das Widerlager doppelte Sicherheit an, d. h. zur Fortsetzung der Zeichnung der Stiitzlinie nimnt man die doppelte Horizontalkraft, oder, was dasselbe Resultat liefert, man trägt nur die halben Kräfte auf; da dieselben im Kräfteplan ohnehin schon zur Hälfte angenommen wurden, so sind die Kräfte 4 und 5 nur zum rierten Theil aus Fig. $A$ nach $B$ zu übertragen. Die in Fig. A gezeichncten Polygonseiten treffen die Basis des Widerlagers (welche gegeben ist) in $W^{r}$, welcher Punkt die Stärke des Widerlagers fixirt. Zur Bestimmung der Fugenrichtung im Widerlager benutze man die Stiitzlinie mit einfachem Hori- 
zontalschub; dieselbe darf mit den Fugenflächen keinen kleineren Winkel als $90^{\circ}$ minus dem Reibungswinkel bilden. Ein anderes Verfahren ist:

Die Bestimmung der Widerlagsstärke durch einfucho Construction nach Rondelet, welche Fig. 1779 für ein halbkreisförmiges Ciewölbe angibt. Man ziche co senkrecht zur inneren Gewölblinie, durch $d$ eine Horizontale ef, mache $d g=e d, a h=g f$ und $a l=2 k d$, schlage iber $h l$ einen Halbkreis; der Schnittpunkt $m$ der Horizontalen durch $a$ mit dem Halbkreis liefert die Widerlagsstärke.

d) Für Ziegelmaterial und die gewöhnlichen Dimensionen und Belastungen beim Hochbau haben sich annähernde Normen über Scheitelstärke, Verstärkung des Gewölbes gegen die Widerlager und Widerlagsstärke herausgebildet, anf deren Angabe hier verzichtet und auf die Hilfsbücher über Baukunde verwiesen wird.

lïg. 1779

e) Stärke der Cement-Bétongewölbe. Bei einer Spannweite bis $3.60^{\mathrm{m}}$ genügt nach den Resultaten ausgefiihrter Banten eine Gewölbstärke im Scheitel von 0.12 bis () $.15^{\mathrm{m}}$ bei einer Pfeilhöhe von $1 / 10^{-1 / 12}$ der Spannweite.

Zur Bestimmung des Kubikinhaltes des Gewölbmauerwerkes bedient man sich annähernder Formeln. Ist in Fig. $1776 U$ der Umfang des mittleren Bogens $a b$ (im Umfang breit), so nimmt man an:

Für Tonnengewölbe $U=S+p+3 / 2\left(\frac{d+d^{\prime}}{2}\right)$; für Platzelgewölbe $U=S+p+3 / 2 d$.

Es bedeutet $S$ die Spannweite, $p$ die Pfeilhöhe, $d$ Stärke im Scheitel, $d^{\prime}$ Stärke am Widerlager. Die mittlere Dicke $D=\frac{d+d^{\prime}}{2}$. Die Länge des Gewölbes $L$, dann ist der Kubikinhalt $K=U$. D. $L$.

Grohmann.

Literatur. Scheffler, Theorie der Gewölbe, Futtermanern und eiserne Brïcken. v. Ott, Vorträge über Baumechanik. Prag, Dominicus. Cu lmann, Graphische Statik. Ortmann, Statik der Gewölbe mit Rücksicht auf ihre Anwendung. Halle, Knapp. Heinzerling, Analyt. graph. Construction der Briickengewölbe. Zeitschrift für Bawwesen 1872.

Gewürzextracte und Gewürzsalze werden neuester Zeit namentlich ron L. Naumann in Plauen (Sachsen) und von H. Haensel in Pirna (Sachsen) für Zwecke des Haushaltes, sowie für Conditoreien und Nahrungsmittelfabriken erzengt und theils in fester, theils in flüssiger Form in den Handel gebracht. Atuch bestimmte Gewürzmischungen, z. B. Fleischgewiirze, Braten- und Fischgewiirze. Wurstsalze u. d. g. werden von diesen Fabrikanten erzengt. Näheres hieriiber s. deutsche Industr. Ztg. 1874 pag. 218, Industrie. Blt. 1876, $13 \mathrm{Nr}, 22,23$ u. 24, rgl. a. die chem. Industrie Dentschlands auf der Weltansstellung Philadelphia 18i6. Berlin 1876. A. Hirschwald - pag. 65. Gtl.

Gewürznelken s. Nelken.

Gewürznelkenöl s: Nelkenöl.

Gezogene Arbeit, specielle Art der Muster-Weberei, s. WT perei.

Ghittaiemou, alter Name für Gummigutt s. Gutti. 
Gibbsit, Hy drargillit, Min. in kleinen körnig. Krystallen des hexagonalen Systems, oder kugligen theils fasrigen, theils körnigen oder schuppigen Aggregaten, oft ganz Wawellit-älınlich; farblos bis röthlich weiss, Perlmutterglanz, theils Glasglanz, durchscheinend. Härte 2.5-3, spec. Gew. 2.34-2.39. Ist Thonerde-Hydrat $\mathrm{Al}_{2} \mathrm{O}_{3},{ }_{3} \mathrm{H}_{2} \mathrm{O}$ mit 65.5 Thonerde und 34.5 Wasser. Vork. Slatoust am Ural, Villa-rica in Brasilien, Richmond in Virginien. Gtl.

Gicht (gueulard, dame - furnace top, throat), Gichtgase (gaz perdu waste gas), Gichtfang (gueulard - top of a furnace) s. Eisenerzeugung III pag. 6 bis 16 .

\section{Gichten, s. Eisenerzeugung III pag. 6.}

Gichtrauch, Gichtsand, Gichtstaub, syn. Hütten rauch s. Eisen, s. Z in k, vgl. a. A r sen.

Gichtschwamm (tutie - tutia), zinkischer Ofenbruch, d.i. auf der Rast und im Schacht der Zinkhohöfen sich absetzende, in gelben oder grünen Säulen krystallisirte oder gelbgriue bis schwarze dichte Masse. Ist wesentlich Zinkoxyd meist mit Eisenoxyd und erdigen Massen verumreinigt, oft auch Chlorblei und Chlorkupfer enthaltend, s. Z ink. Gtl.

Giessen (fondre, couler - found, cast).

Giesserei, Giesskunst (fonderie — foundry). Alle jenen Operationen, welche erforderlich sind Metalle oder andere feste Körper in flüssigen Zustand zu bringen, in Formen zu giessen, in denselben erstarren oder erhärten zu lassen und hierauf in der so erlangten Gestalt (als Gussstiick) aus der Form zu nehmen, bilden zusammen die Giesserei. Oft wird dieses Wort auch dem Locale beigelegt, in welchem Giesserei getrieben wird.

In Bezug anf das Material, welches zum Gusse verwendet wird, unterscheidet man die Eisengiesserei (s. d. III pag. 121); die Bronze-, Messing-, Blei-, Zinn-, Gyps-, Cement-Giesserei ete.

Die Tombak-(iiesserei wirl auch als Rothgiesserei, die Messinggiesserei als Gelbgiesserei bezeichnet.

Die zum Guss beniitzten Metalle können in verschiedenen Oefen eingeschmolzen werden und in dieser Beziehung wird Tiegelguss, Flammofenguss, Cupolofenguss unterschieden.

Die Form, in welche gegossen wird, und deren Hohlraum durch das geschmolzene Materiale ansgefuillt wird und dadurch die Gestalt des Gussstückes bedingt, kann gleichfalls aus sehr verschiedenen Materialien bestehen, a!s: Sand, Masse (Cremenge aus Sind und Lehm), Lehm. Eisen, Messing, Stein, Holz etc. ete.

Diesbeziiglich unterscheidet man, namentlich als Arten des Eisengusses, den Sand-, Masse- und Lehmguss. Sand und Masse wird meist in Rahmen, "Kasten" oder "Flaschen" als Formmateriale angewendet und daher rïhrt die Benennung Kasten- vder Flaschenguss. Eiserne und überhaupt metallene Formen, Schalen genannt, geben Veramlassung zur Benennung Schalenguss.

In Bezug auf die Form oder die Art des Gussstickes sind die Beziehungen: Kuggel-, Räder-, Topf-, Lettern- oder Schrift, Kerzen-Giesserei u. d. gl. im Gebrauch. Enter $\mathrm{K}$ unstguss rersteht man die Herstellung von Figuren dureh den Giuss.

Zur Orientirung sei nachstehende Tabelle beigefügt.

So mannigfach hiernach auch die Arten der (iiesserei sind, so lassen sich doch gewisse Grundsätze angeben, welche das Verstäudniss des Vorganges erleichtern. 


\begin{tabular}{|c|c|c|}
\hline Guss-Materiale : & Eingeschmolzen in: & Die Form besteht aus: \\
\hline $\begin{array}{c}\text { Eis en } \\
\text { (Gusseisen) }\end{array}$ & $\begin{array}{l}\text { Cupol-Oefen } \\
\text { Flamm-Oefen } \\
\text { Tiegel-Oefen }\end{array}$ & $\begin{array}{l}\text { Sand (in der Herdschle, Herdynss, } \\
\text { Sand } \mid \text { in Kästen od. Flaschen } \\
\text { Masse } \\
\text { Lehm. } \\
\text { Es wird in feuchten (griinen, } \\
\text { Sand, in getrocknete Masse und } \\
\text { Lehm gegossen. } \\
\text { Eisen (Schalenguss, Hartguss). }\end{array}$ \\
\hline Stah 1 & $\begin{array}{l}\text { Flamm-Oefen od. } \\
\text { Tiegel-Oefen }\end{array}$ & $\begin{array}{l}\text { Sand, Masse, Lehm (trocken). } \\
\text { Schalen, Coquillen. }\end{array}$ \\
\hline Messing u. Tombak & Tiegel-Oefen & $\begin{array}{l}\text { Fetter Sand getrocknet oder } \\
\text { Lehm getrocknet. }\end{array}$ \\
\hline Bronze & $\begin{array}{l}\text { Flamm-Oefen od. } \\
\text { Tiegel-Oefen }\end{array}$ & $\begin{array}{l}\text { Fetter Sand getrocknet oder } \\
\text { Lehm getrocknet. }\end{array}$ \\
\hline Argentan & Tiegel-Oefen & $\begin{array}{l}\text { Fetter Sand getrocknet, Eisen- } \\
\text { Schalen. Feiner, feuchter Sand. }\end{array}$ \\
\hline Z in k & $\begin{array}{l}\text { Tiegel-Oefen } \\
\text { oder Einschmelzen in } \\
\text { einem eisernen Kessel. }\end{array}$ & Messing-, Eisen - Schalenformen. \\
\hline $\begin{array}{c}\text { Blei } \\
\text { Hartblei } \\
\text { Schriftmetall }\end{array}$ & $\begin{array}{l}\text { Tiegel-Oefen od. } \\
\text { (Pfannen, Kessel) }\end{array}$ & $\begin{array}{l}\text { Trockener Sand; Eisen oder Mes- } \\
\text { sing etc. Formen. }\end{array}$ \\
\hline $\begin{array}{l}\text { Z inn } \\
\text { 11. Zinnlezirungen, auch } \\
\text { Schriftmetall }\end{array}$ & $\begin{array}{l}\text { In Gusslöffel und Guss- } \\
\text { pfanne }\end{array}$ & $\begin{array}{l}\text { Sandstein-, Schiefer-, Serpentin-, } \\
\text { Messing-, Schalenformen ; Holz-, } \\
\text { Papierformen. }\end{array}$ \\
\hline Gold, Silber & Tiegel-Oefen (Gasöfen) & Eiserne Schalenformen. \\
\hline
\end{tabular}

a) Gusseisen, unter allen das wichtigste, in der grössten Ausdehnung angewendete (s. Eisengiesserei). Es ist zwar strengfliussig (bei starker Weissglühhitze schmelzend, aber doch nicht in solchem Grade, dass die nöthigen Anstalten zum Schmelzen grosser Massen desselben besonderen Schwierigkeiten unterlägen; dabei füllt es die Formen sehr gut, eignet sich demnach auch zu feinen Gïssen und besitzt nebenher grosse Festigkeit, wodurch es zu starken Gegenständen höchst anwendbar wird.

b) Die Mischungen des Kupfers mit Zink, welche unter den Namen If ssing und Tombak (oder Rothguss) vorkommen. Bei Rothglühhitze schmelzbar, dichten und festen Guss liefernd, gehören dieselben zu den schätzbarsten Materialien der Giesserei, wiewohl sie sich weit weniger fein ansgiessen als das Eisen und auch durch den höheren Preis ihre Anwendung beschränkt wird.

c) Die Zusammensetzungen aus Kupfer und Zinn, oder Kupfer, Zink und Zinu, welehe unter der Gesammtbenennung Bronze bekannt sind (s. Bronze), und nach Verschiedenheit ihrer Zusammensetzung bald durch besonders grosse Härte und Zähigkeit, bald dureh vorzügliche Tauglichkeit zu fein ausgebildeten Güssen sich hervorthun.

d) Das Argentan oder Neusilber, eine Legirung aus Kupfer, Zink und Nickel, von angenehmer weisser Farbe, von grösserer Härte und Zïligkeit als Jiessing, aber bedeutend the urer als dieses, weshalb seine Benutzung zn Gusswaaren auf Kleinigkeiten eingeschränkt ist.

e) Z in k, ist im gegossenen Zustande äusserst spröde, also zu Gussartikeln nur in so fern tauglich, als diese keinen Einwirkungen stossender oder brechender Gewalt unterliegen; Zinkguss findet desshalb nur Anwendung auf Gegenstände der Ornamentirung. als Reliefs. Vasen, Büsten, Bildsäulen u. dgl. Die Schmelzung des Metalls ist sehr leicht, da sie nicht einmal völlige Glühhitze erfordert; die Giisse kommen mit eben so grosser Schärfe und Sanberkeit aus den Formen, wie jene von Gusseisen.

f) Zinn, im reinen Zustande, füllt die Formen weit weniger leicht und gut, als eine Mischung aus Zinn und Blei, welche schon deswegen (ahgesehen von ihrer grösseren Wohlfeilheit) fast allgemein angewendet wird, Das Britannia-Metall (siehe diesen Artikel), 
welches hier anzureihen ist, da es zum allergrössten Theile aus Zinn besteht, liefert wohlausgebildete Güsse, die an Härte und Festigkeit das reine, noch mehr das bleibaltige Zinn übertreffen. Aus Zinn und Antimon, mit oder ohne Kupfersatz, giesst man vortreffliche Zapfenlager für Maschinen. Alle Zinnmischungen, sofern darin die fremden Zusätze den geringeren Antheil ausmachen, bieten für die Giesserei den Vortheil dar, dass sie zum Schmelzen eine sehr geringe Hitze erfordern.

g) Blei, dessen grosse Weichheit und geringe Festigkeit der Anwendung zu vielerlei Gegenständen im Wege stehen, bedarf zum Schmelzen einer wenig grösseren Hitze als Zinn, würde also aus diesem Gesichtspunkte zur Giesserei sehr geeignet sein. Platten, Röhren, Gewehrkugeln, Flintenschrot, Gefässe zu chemischen Zwecken und Plomben (Bleisiegel) für Zollämter sind jedoch die einzigen regelmässig vorkommenden Gusswaaren aus Blei. Durch Versetzung mit Antimon erlangt dieses Metall grössere Härte und Steifheit, anch in weit höherem Grade die Fähigkeit, durch vollkommene Ausfüllung der Formen sehr scharfe Abgüsse zu liefern; hiervon wird ein wesentlicher praktischer Nutzen gezogen, indem man allerlei kleinere Ornamente und Geräthe aus Hartblei (einem etwas antimonhaltigen Blei) giesst, und zum Gusse der Buchdruekerschriften eine Legirung von Blei mit grösserem Antheile Antimon (das Schriftzeug) zusammensetzt. Hierher gehört auch das Zapfenlager-Metall aus Blei und Antimon, oder Blei, Zinn und Antimon.

h) Silber und Gold werden ihrer Kostspieligkeit halber wenig durch Guss verarbeitet, da man gerade hier am meisten anf geringe Dicke der Gegenstände angewiesen ist, mithin fast alle Artikel von grösserem Umfange hohl aus Blech anzufertigen pflegt.

$\mathrm{Zu}$ feinen, verzierten Gusswaaren eignet sich im Allgemeinen ein Metall desto besser, je fähiger es ist, in alle Vertiefungen der Form, auch die zartesten, einzudringen. Diese Fähigkeit aber beruht auf natürlicher Dïnnflüssigkeit und auf dem Verhalten beim Erstarren und Abkühlen in der Form. In Ansehung ihrer Dünnflüssigkeit bieten die Metalle auffallende Verschiedenheiten dar; so z. B. ist das meiste weisse Roheisen auffallend dickflüssig im Vergleich mit dem grauen, ebenso das reine Zinn gegenüber dem mit Blei versetzten.

Das zum Giessen tangliche Metall muss ohne zu grosse Kosten schmelzbar sein, beim Erstarren dichte Gussstiicke liefern und die Form vollständig ausfüllen.

Der ersten Bedingung widersteht ron den teclinisch verwendeten Metallen nur das Schmiedeeisen, indem die Kosten der Schmelzung durch den Werth des Productes nicht anfgewogen wiirden. Die Schmelzung selbst unterläge keinen grossen Schwierigkeiten, kam man ja sogar Platin in ausgehöhlten Aetzkalkstücken mittelst Knallgas schmelzen; aber sie ist aus ökonomischen Griinden doch ausgeschlossen. Der zweiten Bedingung widersteht das Kupfer und es ist nur schwierig möglich aus Stahl und Aluminium dichte Giussstiicke herzustellen. Die Erlangung dichter Giisse erheischt ibrigens bei allen Metallen die Beobachtung gewisser Vorsichten. Der Grad der Erhitzung des geschmolzenen Metalles muss der richtige sein. Ist das fliissige Metall bedeutend iiber seinen Schmelzpunkt erhitzt, so entsteht meist blasiger Guss. Nur bei leichttliussigen Metallen, wenn selbe in Formen gegossen werden, welche die Wärme gut leiten, wiirde das Metall, ehe es die Form vollständig ausfuillt, erstarren, wenn es nicht stark überhitzt wäre. Es richtet sich die erforderliche Temperatur des flissigen Metalles daher nicht nur nach diesem, sondern auch nach dem Materiale und der Gestalt der Form. Die Form muss der Luft den Abzug gestatten, zu welchem Zwecke dieselbe entweder aus einem luftdurchlässigen Materiale (magerer Sand) bestehen oder mit Luftabzïgen (Windpfeifen) versehen sein muss. Lnnötige Ueberhitzung ist auch der meist eintretenden Oxylation wegen zu meiden. Zink und Zinklegirungen (Messing, Tombak) billen iiberhitzt Zinkoxyd. Das Zink verbrennt theilweise, einen Rauch aus weissen, leichten Flocken ausstossend. Zinklegirungen werden daher überhitzt ärmer an Zink, und dies um so mehr, je länger die Ueberhitzurg danert.

Das vollkommene Ausfïllen der Form längt von der Dünnflüssigkeit des Metalles ab. In dieser Bezichung zeichmet sich graues Roheisen (Gusseisen) und Zink besonders aus und liefern diese Metalle daher besonders reine Güsse. Denselben kïmmt noch die besondere Eigenschaft zu, dass sie sich unmittelbar vor oder bei dem Erstarren ausdehnen (quellen) und hierdurch die Formen um so vorziiglicher ausfüllen.

Im Allgemeinen folgen die Metalle dem Gesetze. sich bein Erwärmen auszudehnen, beim Erkalten zusammenzuziehen. Aus diesem Grunde ist das erkaltete 
Gussstiick kleiner als der Hohlraum der Form, wclchen das geschmolzene Ifetall ausfüllte, und hieran wird auch durch das oberwähnte Quellen nichts geändert, weil die Ausdehnung beim Erstarren weit geringer ist, als die nachfolgende Znsammenziehung beim Erkalten. Diese Volumsverminderung nennt man Schwinden und die Grösse derselben, ausgedrickt in Bruchtheilen der Lä̈ngendimensionen (lineare Zusammenziehung), heisst $\mathrm{S}$ e hw in d in as s. Wasselbe beträgt mach Karmarseh:

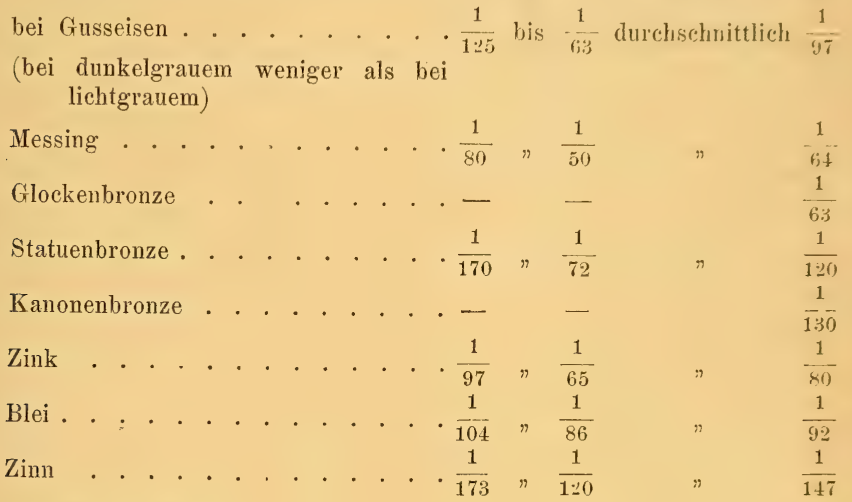

Um die Gussstiicke genau in verlangter Grösse zu erhalten, muss das Schwindmass für das anzuwendende Metall ermittelt und hiernach die Form entsprechend grösser hergestellt werden. Man verwendet hierzu in den Giessereien eigene Schwindmassstäbe, deren Theilung um den Betrag des Schwindmasses grösser ist.

Durch das Schwinden vermindert sich die Grösse des Gussstiickes im Allgemeinen. Es kann aber das ungleichzeitige Erstarren das Nachfliessen noch geschmolzenen Materiales zu Stellen, wo bereits die Volumsverminderung eingetreten ist, zur Folge haben und hierdurch können je nach der Form des Gussstiuckes an gewissen Stellen Löcher oder Vertiefungen entstehen. Diese Erscheinung bezeichnet man durch den Ausdruck Sa ugen (tassement) und falls dasselbe nur darin besteht, dass aus dem Anguss oder Gusszapfen Material nachgesogen wird, so benennt man es mit $\mathrm{Nachsacken.} \mathrm{Findet} \mathrm{die} \mathrm{Zusammenziehung.}$ derart statt, dass ebene Platten krumm, oder Theile, welche eine bestimmte Krümmung haben sollen, eine andere annehmen, so heisst dies Werfen.

Durch die richtige Wahl des Metalles, d. h. z. B. eines solchen Gusseisens, welches die ible Eigenschaft des Werfens nicht besitzt; durch entsprechende Erhitzung desselben; bei Schalenformen durch geeignetes Vorwärmen dieser ; ferner durch Anwendung hoher Anguisse (Gusszapfen); trachtet man correcte Gussstiicke zu erzielen.

Das Schwinden kann bei grossen, nicht genïgend nachgiebigen Formen (z. B. Lehmformen) auch ein $\mathrm{R}$ eis sen des Gussstiickes zmr Folge haben, welches bei grossen Stiicken durch Ausziehen von Keilen nach dem Erstarren, welche Keile Theile der Form bildeten, verhindert wird. Bei manchen kleinen stiicken öffnet man die Form nach dem Erstarren und ror der weiteren Abkiihlung.

Beim Schmelzen der meisten Metalle und Legirungen bildet sich, durch Oxydation oder durch Verschlackung beigemengter Theile, eine Schlacke bei Zinn "Asche", bei Gold "Krätze"), welche sich auf der Oberfläche der Gusspfamne oder des Tiegels sammelt und deren Eintreten in die Form beim Gusse durch Abstreifen oder durch Vorsetzen eiserner Schienen u. dgl. verhindert werden muss. Das Eingiessen des geschmolzenen Metalles muss in gleichmässigem, 
ununterbrochenem Strome geschehen, weil bei Unterbrechungen leicht $\mathrm{kalt}$ g ï s s ige (unganze) Stücke entstehen.

Die Form (moule - mould), in welche gegossen wird, soll dauerhaft und scharf sein, d. h. mindestens einen reinen Guss liefern. Im Allgemeinen ist es wünschenswerth, wenn das Materiale der Eorm ein schlechter Wärmeleiter ist, weil dadurch das Erstarren allmäliger und gleichnässiger geschieht. Aus diesem Grunde und aus ökonomischen Rücksichten wendet man für Eisen, Bronze und Messingguss meistens Sand-, Masse- und Lehmformen an. Das Materiale der Form muss das Herausheben des Gussstückes gestatten, es darf sich nicht an dasselbe anhängen oder anschmelzen.

Die Form ist entweder eine bleibende oder verlorene.

Bleibende Formen gestatten wiederholte Güsse und bestehen aus Gusseisen, Schmiedeisen, Messing, Sandstein, Schiefer etc., je nach dem Schmelzpunkt des Metalles, welches gegossen wird; sie sind zwei- oder mehrtheilig. Verlorene Formen dienen nur einem Gusse und werden aus Sand, Masse und Lehm hergestellt, entweder mit zu Hilfenahme eines Modelles oder einer Schablone.

Das Modell kann aus Holz oder Metall bestehen und ist entweder e inoder zwei-, seltener mehrtheilig.

Fig. 1780 .

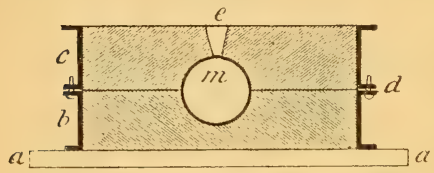

Formen mit eintheiligem Modell.

Fig. 1781 .

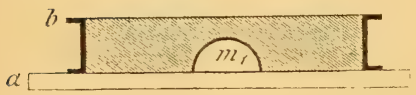

Fig. 1782 .

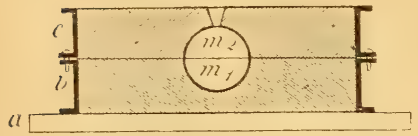

Formen mit zweitheiligem Modell.

Das Formen mit einem eintheiligen Modell erfolgt in Sand *) in folgender Weise. In den auf das Modellbrett $a$ gesetzten Formkasten $b$ wird Sand eingestampft und das Modell $m$ (beispielsweise eine Kugel) nach Bestauben des Sandes mit Kohlenpulver bis zum Mittelschnitte eingedrückt, der Sand abgeglichen und das Ganze neuerlich eingestaubt.

Hierauf wird der zweite Formkasten (Flasche) aufgesetzt, welcher auf den ersten mittelst des soge. nannten Schlosses $d$ genau aufgepasst und nicht verschoben werden kann. In den Kasten $c$ wird nun gleichfalls Sand eingestampft, welcher sich jedoch mit dem Sande in $b$ nicht verbindet, weil zwischen Kohlenpulver gestreut ist. Nachdem das Einstampfen des oberen Kastens vollendet und die Oberfläche abgeglichen ist, wird mittelst einfacher Werkzeuge (Formspateln, Formlöffel) der Einguss $e$ gebildet. Hierauf vorsichtig der obere Kasten abgehoben, das Modell entfernt, der Kasten $c$ wieder aufgesetzt und nun ist die Form zum Gusse fertig.

Das Abheben des oberen Kastens, sowie das Ausheben des Modells kann nur dann ohme Beschädigung der Form erfolgen, wenn die Kugel gen a bis zum Mittelschnitte in $b$ eingedriickt oder der Sand in $b$ genau bei dem Mittelschnitte der Kugel abgeglichen wurde. Erfordert dies schon bei so einfachen Formen, wie eine Kugel ist, einige Muhe, so wird die Sache bei complicirteren Formen noch schwieriger.

Aus diesem Grunde theilt man die Modelle durch einen Mittelschnitt in zwei Theile und formt dann in der Weise ein, dass die Modellhäfte $m_{1}$ auf das

*) Siehe Formsand III pag. 609. 
Formbrett a gelegt, darauf der Kasten b gestellt, mit Kohlenpulver bestaubt unr Sand eingestampft und endlich abgeglichen wird. Fig. 1781. Man legt mun cin zweites Formbrett auf, kehrt den Formkasten sammt don beiden Formbrettern um, hebt das erste, jetzt obere Formbrett ah, setzt die zweite Modellhialfte $m_{\text {g }}$ und hierauf den zweiten Kasten $c$ auf, bestäubt mit Kohlen, stampft Sand ein, schneidet den Einguss $e$ aus Fig. 1782, nimmt dann die beiden Kästen auseinander und entfernt aus jedem die Modellhälfte. Weitere Beispiele sind im Artikel E is engiess erei Bd. III pag. 124 nachzusehen.

Bei complicirteren Gussstiicken ist man nicht selten gezwungen ein mehrtheiliges Modell und mehrere Formflaschen oder Kästen anzuwenden. Die beistehende Figur soll uns die Herstellung Fig. $17 x: 3$. der Form eines Maschinentheiles darstellen, dessen Modell aus den Theilen $m_{1} m_{2} m_{3}$ besteht, und zu dessen Einformung vier Formkästen 1, 2, 3, 4 benützt werden. Schon aus der Numerirung ist ersichtlich, in welcher Reihenfolge das Formen durchgefulhrt wird oder werden kann. Der Kasten 4 dient als Boden oder je nach der Lage der Form beim Gusse, auch als Seitenwand oder Decke.

Ueber die Anfertigung und den Gebranch der $\mathrm{K}$ erne bei Herstellung hohler Gussstiucke ist im Artikel Eis engiesserei das Erforderliche mitgetheilt worden.

Das Formen in Lehm mit der Schablone statt des Modells.

Die Formerei in Lehm, welche sehr langsam von Statten geht und dadurch auch kostspielig wird, findet zu massiven Gegenständen fast niemals Anwendung. Man greift zu ihr gewöhnlich nur, wenn grosse Gefässe oder gefässähnliche Stiicke (Kessel, Thurmglocken, Dampfmaschinen-Cylinder ete.) zu giessen sind, zu welchen man keine hinlänglich hohen und weiten Formkästen hat, oder bei denen - weil sie nur in einem oder wenigen Exemplaren gegossen werden sollen - die Anschaffung eines hölzernen oder metallenen Modells zu viel Kosten verursachen würde. Denn die Lehmformerei bedarf (da der Lehm für sich Standfestigkeit genug hat) keines Formkastens und das Modell wird durch die weit billigere Schablone ersetzt oder, namentlich bei Kunstguss, durch ein Modell aus Lehm.

Der Formlehm muss nicht zu sandig, geniigend bildsam und bindend, aber auch nicht zu fett sein; demn gerade durch das richtige Mittel zwischen diesen entgegengesetzten Beschaffenheiten erlangt er einerseits die nöthige Standfestigkeit, andererseits die Eigenschaft, beim Trocknen und Brennen wenig zu schwinden, keine oder nur unbedeutende Risse zu bekommen. Nachdem man ihn von Steinen, Wurzeln u. dgl. gereinigt hat, wird er mit Wasser angefeuchtet. fleissig durchgearbeitet, mit gehacktem Stroh, Kuhhaar oder trockenem Pferdemist innig gemengt, und in der Consistenz eines weichen Brodteiges angeknetet.

$\mathrm{Zu}$ jeder Lehmform für einen hohlen Gegenstand miissen drei Haupttheile gebildet werden: der Kern, ein an Gestalt dem Innern des Gussstiicks entsprechender Körper; das Hemd oder Modell (die Dicke), eine den Kern dicht anliegend umkleidende Lehmschicht, welche äusserlich nach der verlangten äussern Gestalt des Gussstiicks gestaltet ist; endlich der M a n tel, eine starke Lehmmasse, mit welcher das Hemd gänzlich umhiillt und in der zugleich das Gussloch nebst den nöthigen Windp feifen (Luftausgängen) angelegt wird. Den Kern macht man hohl, um Material und Arbeit zu sparen; ist er von betrïchtlicher Grösse. so fithrt man ihn von lufttrockenen Lehmsteinen anf und bekleidet ihn nur 
schliesslich zur Berichtigung und Vollendung seiner Gestalt mit Formlehm; Eisenverstärkungen im Innern desselben sind oftmals nöthig. Den Mantel pflegt man äusserlich mit eisernen Reifen und Schienen zu armiren. $\mathrm{Zu}$ allen drei Bestandtheilen muss der Lehm in Schichten nach und nach aufgetragen und jede Schicht vor dem Auftragen der nächsten an der Luft getrocknet werden; zuletzt wird ein scharfes Austrocknen oder vielmehr ein gelindes Brennen an allmälig verstärktem Feuer vorgenommen, um alle Feuchtigkeit zu entfernen und der Form die gehörige Festigkeit zu geben. Mit der Anfertigung des Kerns wird der Anfang gemacht; die Oberfläche desselben bepinselt man dann mit in Wasser zerrührter Holz- oder Torfasche, manchmal statt dessen mit einer geschmolzenen Mischung aus Talg und etwas Wachs; ebenso verfährt man mit dem Hemde, wenn dieses auf dem Kerne vollendet ist. Dadurch wird erreicht, dass die Bestandtheile sich leicht von einander lösen lassen. Ist nämlich der Mantel fertig geworden, so hebt man ihn entweder im Ganzen, oder in zwei, auch mehrere Stücke zerschnitten, von dem Modelle $a b$, schneidet und bricht Letzteres vollständig vom Kerne los, setzt endlich den Mantel wieder über den Kern, und erhält so den bisher vom Modelle ausgefüllten Raum hohl. Vor dem Gusse muss der Kern äusserlich und der Mantel innerlich mit einer Brühe von Leimwasser und Kohlenstaub bestrichen oder über einem Kienholzfeuer angeräuchcrt werden, um das Anhängen von Lehmtheilchen an das eingegossene Metall zu verhindern.

Ist das Gussstiick von runder Gestalt, so wird der Kern, das Hemd und meist (wiewohl nicht streng nöthig) auch der Mantel durch A b drehen gebildet, wożu man sich verschiedener, nach den geforderten Profilgestalten ausgeschweifter Bretter (Schablonen, Drehbretter) bedient. Das Verfahren hierbei ist nach den Umständen verschieden. Kleine Formen dreht man auf einer Drehbank (Drehlade), indem man sie auf einer eisernen, horizontal in Lagern liegenden, mittelst einer Kurbel umzudrehenden Spindel bildet und hierbei das Drehbrett ruhig gegen den in langsame Drehung versetzten Lehmkörper anlegt. Die Höhlung des Kerns entsteht hierbei durch Bewickelung der Spindel mit Strohseilen. Formen, deren Transport zu schwierig und wegen zu fürchtender Beschädigung gefährlich sein würde, erbaut man an der Gussstelle selbst, und dann steht die Form unbeweglich und das Drehbrett wird im Kreise um dieselbe herumgefiihrt; hier findet danu die schon oben erwähnte Herstellung des Kerns aus Lehmsteinen seine Anwendung. Lehmformen von beträchtlicher Grösse (so wie auch mit Sand geformte sehr hohe Formkasten) muissen wegen bequemer Zuleitung des Metalls aus dem Stichloche des Schmelzofens in einer Erdgrube versenkt gegossen werden, und man hüllt sie hierin gänzlich mit trockenem Sand, trockener Erde oder zerpochter Steinkohlenschlacke ein, indem man diese Fiillung der Grube recht fest zusammenstampft, um einem Platzen der Lehmformen unter dem oft sehr bedeutenden Metalldrucke vorzubeugen.

Die Ausführung der Lehmformerei für grosse runde Gegenstände soll an einem Beispiele näher erläutert werden, wozn als etwas complicirtes Gussstiick eine Thurmglocke gewählt wird. Fig. 1784 zeigt im senkrechten Durchschnitte die zum Formen der Glocke erforderliche Veranstaltung. $a$ a ist der mit Ziegeln fundamentirte Boden der Formgrube; $b b$ ein Ziegelmauerwerk mit Canälen $c, c, c$, durch welche Luft in's Innere des Kerns treten kann, wenn man diesen durch darin angemachtes Feuer bremnt; $d e, d e$ der von Lehnsteinen mit Lehmverband aufgefïhrte Hauptkörper des Kerns; $f f$ dessen Hölllung; $g g$ die Lehmbekleidung, durch welche der Kern äusserlich seine Vollendung erhält; $h$ ein Pfahl im Mittelpunkte des Kerns, auf welchem das zugleich in dem Kern rermauerte Eisen $i$ i ruht; $k \cdot l$ die eiserne Spindel als Drehachse für die Schablone, welche mittelst eines Eisenbeschlages $n n$, o o daran befestigt wird. Die Spindel $k l$ hat an beiden Enden Zapfen, von welchen der untere in einem Loche des Eisens $i$, der obere in dem quer uiber die Formgrube gelegten Balken $m$ steckt. Die Schablone oder das Drehbrett $p q$ ist auf rerschiedene Teise fiur die drei Bestandtheile der Form ausgeschnitten. Die Schweifung der Kern-Schablone ergibt sich sofort durch 
die äussere Grenzlinie der Lehmschicht $g$ g; die Hemd-Schablone ist nach der punktirten Linie $r s$ ausgeschnitten, um dem Hemde oder Modelle die verlangte Gestalt $v \quad v$ zu ertheilen; endlich gibt die punktirte Linie $t u$ die Schweifung der Mantel-Schablone an. Der Hohlraum des Kerns wird nach dem Brennen mit Erde, Sand, Schlacken u. dgl. ausgefült, das Hemde $v v$ ohen durch dic Lehmplatte $w$ gehörig geschlossen; aber im Mantel bringt die Schablone oben eine regelmässige trichterartige Oeffnung hervor, in welche die aus Lehm iiber einem Holz- oder Wachs-Modelle aus freier Hand angefertigte Kronen-oder Henkel-Form eingesetzt wird. Aufschriften und Verzierungen der Glocke wurden friher von Wachs geformt oder bossirt und auf dem fertigen Hemde angeklebt, bevor man zur Anfertigung des Mantels schritt. Da diese Wachsreliefs beim nachherigen Feuern (welches stattfindet, um den Mantel zu brennen) ausschmelzen, so hindern sie die Ablösung des Mantels nicht, wenn dieser mittelst eines Krahns in die Höhe gezogen wird, damit man an das Hemd gelangen und dasselbe beseitigen kann.

Jetzt werden diese Vertiefungen meist durch Handarbeit im abgehobenen Mantel hergestellt und benützt man namentlich zu den erhabenen (im Mantel ver-

Fig. 1784.

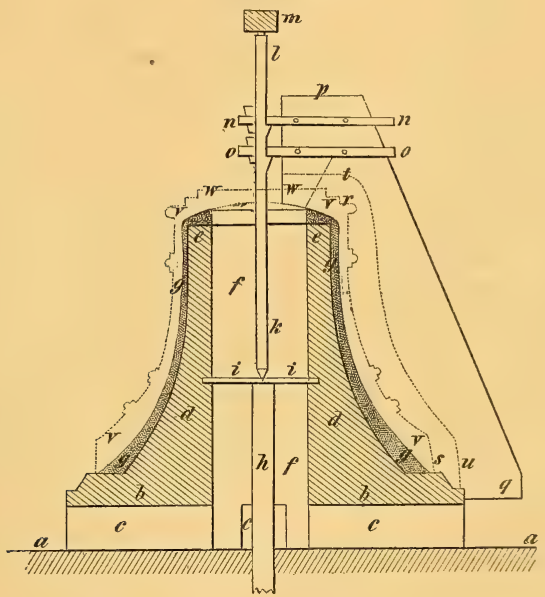

tieften) Buchstaben kleine Holz- oder Messingmodelle, welche in die Innenfläche des Mantels entsprechend eingeformt werden.

Figur 1785 ist die obere Ansicht und Figur 1786 die Seiten-Ansicht des Glocken-Mantels; $A$ der Körper der Glocke selbst, $B$ die Henkelform, $x$, $x$ der Eisenbeschlag mit Haken $y, y$ für die Ketten oder Seile zum Aufheben des Mantels, $z$ der Zuflusskanal für das Metall, $a^{\prime}$ das Gussloch, $b^{\prime}$, $b^{\prime}$ Miindungen der Windpfeifen der Henkelform. Vergl. Art. Eis engiesserei III pag. 132.

Schalen- oder Metallformen. Unter allen Arten von Giessformen sind diese die dauerhaftesten, aber gewöhnlich auch die kostspieligsten. Man gebraucht dergleichen zum Giessen des Eisens, Zinks, Zinns und Britamnia-Metalls, Bleies, Hartbleies und Schriftzenges. In der Eisengiesserei sind, wegen der dabei einwirkenden hohen Hitze, nur eiserne (gusseiserne) Formen anwendbar, welche man sehr dickwandig macht und mit Graphit oder Steinkohlentheer ausstreicht. Man nennt sie Schalen oder Schalenformen und bedient sich ihrer ans- 
schliesslich in denjenigen Fällen, wo die durch das schnelle Abkuihlen entstehende Härtung des Gusses ein Erforderniss ist. Sandguss aus Eisen kann durch dasselbe Mittel theilweise gehärtet werden, wenn man in die Sandform an der betreffenden Stelle ein Stück Gusscisen einlegt, durch. dessen Berührung gerade hier die rasche Abkühlung. (das Abschrecken) erreicht wird.

Aus Zink, mehr noch aus Hartblei werden öfters kleine Ornamente, Lampenfuisse, Leuchter etc. in gusseisernen oder messingenen Formen gegossen; aus Blei in guss- oder schmiedeisernen Formen die Plomben der Zollämter, die Gewehrkugeln, auch Röhren; das sogenannte Giessinstrument der Schriftgiesser ist die von Eisen, Messing und Kupfer zusammengesetzte Form fü Buchdruckerschriften (s. Schriftgiesserei). Am wichtigsten aber sind Metallformen beim Giessen des Zinns und des Britannia-Metalls. Man gebraucht hier sowohl Gusseisen- als Messingformen, und macht die Kerne zu hohlen Gegenständen manchmal aus Stahl; der Wohlfeilheit halber werden aber nicht selten auch Formen von Blei oder Zinn angewendet, welche freilich weit weniger dauerhaft sind. Die inneren

\section{Fig. $178 \tilde{5}$.}

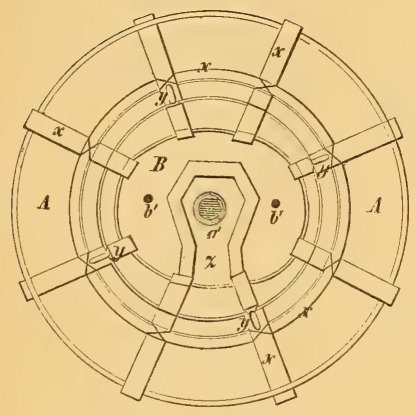

Fig. 1786 .

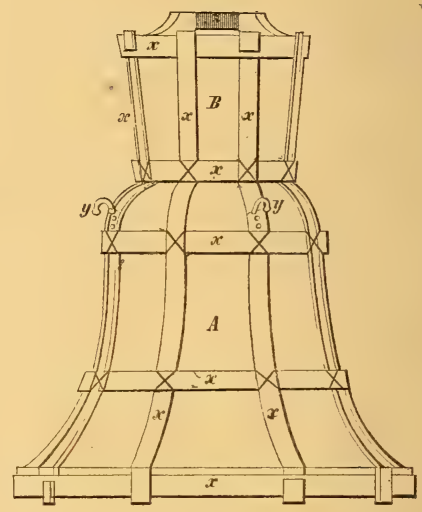

Flächen aller seiner metallenen Formen bestreicht der Zinngiesser mit in Wasser zerrihitem Bolus, Töpferthon, Lehm, Eisenocher, oder mit einer Mischung aus Kiemruss, Eiweiss und Essig; oder er beräuchert sie über einem Feuer von Kienholz, wenn sie sehr klein sind iiber einer qualmenden Licht oder Lampenflamme. Diese Formen bestehen wenigstens aus zwei, oft aber aus drei, vier und noch viel mehr Theilen. Am kiinstlichsten sind diejenigen zu bauchigen verzierten Gefässen, an welchen Ausgussrohr, Henkel, Füisse und ähnliche Nebentheile vorkommen. Da man aus einem bauchigen (innerlich sich erweiternden) Gefässe den Kern nicht als Ganzes fortnehmen könnte, so muss derselbe hier aus Stücken zusammengesetzt werden, welche man einzeln nach einander herausholt. Um die mit Anschaftung solcher vieltheiliger Formen rerbundenen grossen Kosten zu ersparen, giesst man sehr gewöhnlich die Gefässe in mehreren Stiicken, deren jedes für sich eine weit einfachere Form, erfordert, und welche nachher durch Löthung zu einem Ganzen rereinigt werden. Wenn bei kleinen hohlen Gegenständen das Innere nicht ins Ange fällt oder man aus anderen Gründen keinen Werth auf ein schönes glattes Ansehen der Iunenseite legt (wie bei Deckelknöpfen, Büsten, kurzen Röhren, Kinderspielzeng etc.), so wählt man die Methode des Stürzens, 
wobei ohne Kern hohl gegossen wird. Dann ist die Form von der liescliaffenheit, dass sie vollgegossen ein Stück ohne Höhlung liefer'n würde; man fiillt sir auch in der 'That gänzlich mit geschmolzenem Zinn, stiirzt sic aber nach wenigen

Fig. 1787.

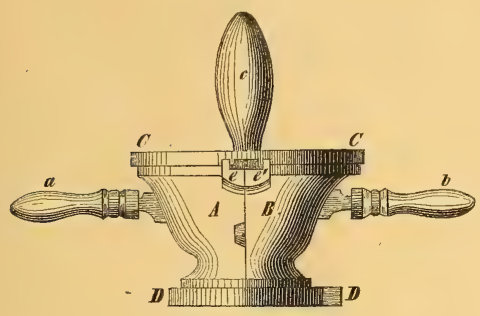

Fig. 1788.

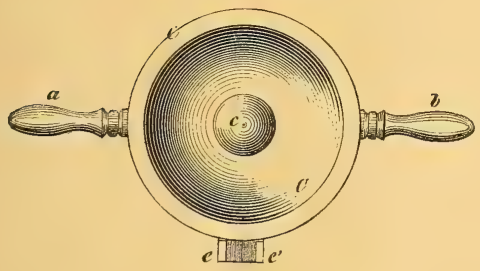

Fig. 1789 .

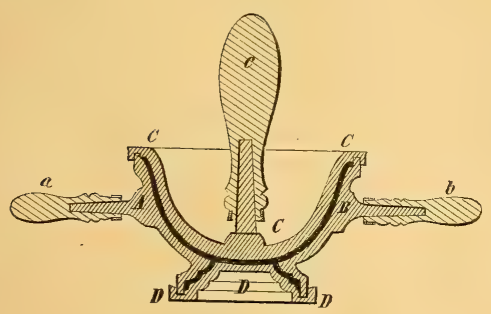

Augenblicken um und lässt len noch fliissigen Theil auslaufen, wobei eine bereits erstarte, den Hohlraum der Form auskleidende Kruste zuriuckbleibt.

Als Beispiel einer messingenen Zinngiesserform diene die zu einer Suppenterrine bestimmte, von welcher Figur 1787 die Seitenansicht, Figur $17 \times 8$ die (1) ere ansicht, Figur 1789 den senkrechten Durchschnitt darstellt. Sie besteht aus zwei Aussuntheilen $A, B$ und zwei Kernen $C, D$. Die dicke schwarze Linie in Fig. 1779 gibt den Raum zu erkennen, welcher von dem Zinn auszufuillen ist; zugleich erkennt man hier, wie die oberen und unteren Ränder der Seitentheile $A, B$ in Rimmen oder Furchen der Kerne $C, D$ eingreifen, um die richtige gegenseitige Stellung aller Theile zu sichern. $a b$, sind hölzerne Hefte, woran die drei grösseren Bestandtheile $A$, $B$, $C^{\prime}$ in ihrem erhitzten ' $\mathrm{Zu}$ stande bequem angefasst und gehandhabt werden können. Die Eingussöffnumg befindet sich am obern Rande des Gefässes und wird durch zwei aneinander passende Schnäbel $e, e$ der Seitentheile $A, B$ gebildet (s. Figur 1787, 1788).

Steinformen kommen in Zinngiesser-Werkstätten nicht selten ror und bestehen aus einem feinkürnigen festen Sandstein, aus dickspaltigem Thonschiefer, oder aus ser-

pentin. Die Sandsteinformen sind wohlfeil, aber schwerfällig und wie alle steinernen Formen empfindlich gegen unvorsichtige Erhitzung, welche sie zersprengt; sie erhalten immerlich einen Anstrich von in Wasser angerïhrter Kreide, damit der Guss sich nicht an der raulkörnigen Oberfläche festsetzt. Thonschiefer ist fein von Fläche, sehr weich und daher leicht zu graviren; die kleinen Soldaten- und Thierfiguren etc.: aus stark bleihaltigem Zimn, welche als allgemein bekanntes Spielzeng vorkommen, pflegt man in Schieferformen zu giessen. Serpentinformen sind ihres ziemlich hohen Preises wegen weniger gebräuchlich, liefern aber - da sie eine gute Politur annehmen - sehr glatte Güsse.

Holz- und Papierformen eignen sich zu manchen Zinn-Gegenständen ganz einfacher Gestalt, welche in wenigen Exemplaren zu giessen sind, also keine sehr dauerhaften Formen verlangen. Im Allgemeinen gehören sie zur Classe der Surrogate oder Nothmittel. Man kann z. B. Platten aus Zinn zwischen zwei mit glatten Pappblättern belegten Brettern 
giessen; kurze weite Röhren in einer Papierrolle, der man als Kern einen mit Kreide bestrichenen Holzzylinder gibt, u. dgl. m.

Gypsformen. Gussformen aus Gyps eignen sich nur für selır leicht schmelzbares Metall, da sie keine hohe Hitze aushalten köunen, olne zu zerspringen oder mïrbe zu werden und abzubröckeln. Man gebraucht sie daher kaum anders als in der Zinngiesserei, selbst hier aber ihrer Vergänglichkeit wegen ziemlich selten und ausschliesslich in solchen Fällen, wo niar zufrieden ist, pi ' ze Anzahl Abgüsse aus einer und derselben Form zu gewinnen. Sie gewå :. . . vch in einer Beziehung einen grossen Vortheil, nämlich dass sie sehr le: und mit geringen Kosten herzustellen sind, wenn man ein Modell des aus Metall zu giessenden Gegenstandes hat. Dieses Modell wird in einem leichten hölzernen Formkasten (statt dessen oft ein Schachtelrand, eine Einfassung ron Pappe etc. geniigt) eben so eingeformt wie mit Sand, nur dass man an des letzteren Stelle den Brei aus Gyps und Wasser eingiesst, welcher schnell erhärtet. - Durch einen Zusatz von feinem Ziegelmehl wird der Gyps fähig, etwas höhere Hitzegrade zu ertragen, aber zugleich auch mürber; man benützt eine solche Zusammensetzung nicht selten, um Kerne fuir Sandformen zu giessen, kann aber einen derartigen Kern nur einmal gebrauchen.

Die Gussstiicke bediurfen einer sehr verschiedenen Nacharbeit - Appretur - weil sie aus den Formen mit unreiner Oberfläche, mit Angiissen und Gussnähten kommen. Die erste Arbeit ist raher die Beseitigung des anhängenden Formsandes und Lehms, wenn die Form aus diesen Materialien bestand, das Ausschlagen der Kerne, das Abschlagen un ${ }^{7}$ Wegmeisseln der Gusszapfen und Nähte.

Zur Richtigstellung der Form wird nicht selten von Feilen und Schleifsteinen Gebrauch gemacht und bei Fein- und Kunstguss wird die Oberfläche durch Ciseliren (s. II pag. 362) mit dem Stichel und Schaber nachgearbeitet.

Feinerer Eisenguss wird geschwärzt, durch Anräuchern iiber Fener aus Kienholz und nachfolgendes Bürsten, oder durch Bestreichen mit Leinöl und Erhitzen der bestrichenen Stiicke bis zum Verschwinden der Flamme, worauf man gleichfalls bürstet.

Den Ständern der Maschinen und manchen Maschinentheilen gibt man einen Oelfarbenanstrich; andere Cussstiicke werden durch Verzinnen, Verkupfern, Vermessingen, durch Bräunen etc. verschönert (s. die betreffenden Artikel).

Das A douciren oder Tempern wird öfter auch zu den Appreturoperationen des Eisengusses gerechnet, wir haben es in Artikel Eisenerzeugung III pag. 41 besprochen.

Auf den Artikel Eisengiesserei wurde bereits wiederholt verwiesen, hier sei noch bemerkt, dass in den Artikeln: Gypsgiesserei, Kunstguss und Schriftgiesserei Einschlägiges zu finden ist.

Literatur. C. Hartmann: Handbuch der Metallgiesserei 4. Aufl. 2 Bd.,

Weimar 1863. Guettier: De la fonderie telle quelle existe aujourd'hui en France et de ses nombreuses applications á l'industrie, Paris 1844. Overmann: The moulders and founders pocket gnide. Philadelphia 1851. London 185:2. 







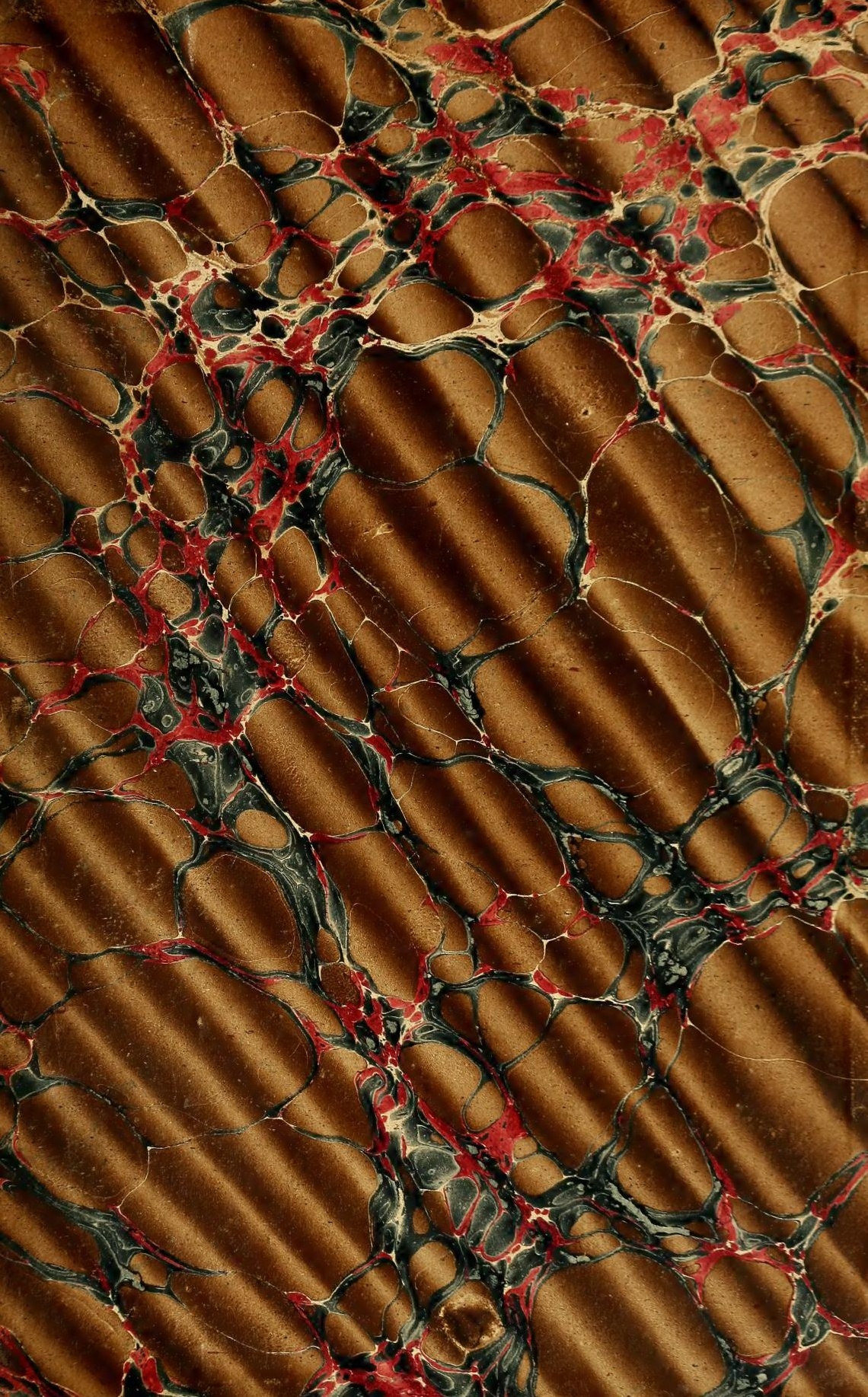


